Universidad deValladolid

PROGRAMA DE DOCTORADO EN EUROPA Y EL MUNDO

ATLÁNTICO. PODER, CULTURA Y SOCIEDAD

TESIS DOCTORAL:

\title{
EL ÍNDICE DE SAN ZOILO DE CARRIÓN: LA IMAGEN DE SU ARCHIVO A PRINCIPIOS DEL SIGLO XIX
}

Presentada por Dña. María José Díez Hermano para optar al grado de

Doctor/a por la Universidad de Valladolid

Dirigida por:

Dr. D. Mauricio Herrero Jiménez 



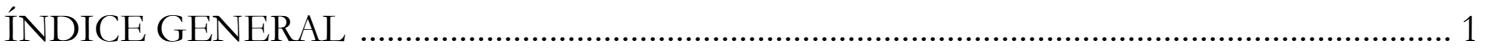

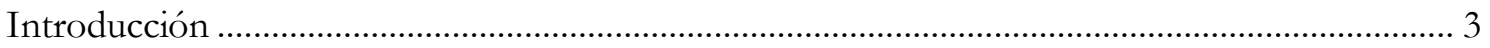

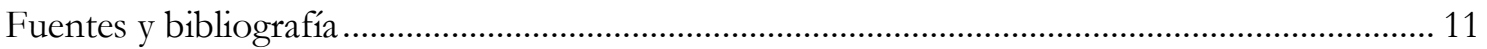

PRIMERA PARTE. ESTUDIO

1. HISTORIOGRAFÍA DEL MONASTERIO DE SAN ZOILO DE CARRIÓN ..................29

2. APROXIMACIÓN HISTÓRICA AL MONASTERIO DE SAN ZOILO DE CARRIÓN

2.1. Carrión en la historia ……………………………........................................................ 45

2.2. El monasterio de San Zoilo en el Condado de Carrión.......................................................... 50

2.3. Anexión a Cluny y formación del patrimonio................................................................ 52

2.4. San Zoilo en la Congregación de San Benito de Valladolid ................................................... 60

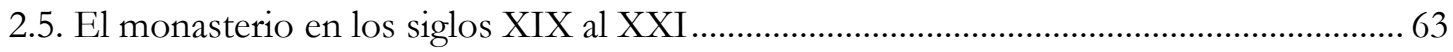

3. EL ARCHIVO DEL MONASTERIO DE SAN ZOILO DE CARRIÓN...............................67

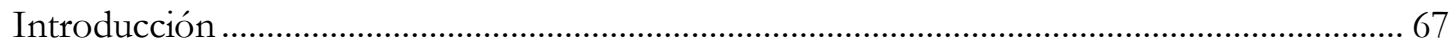

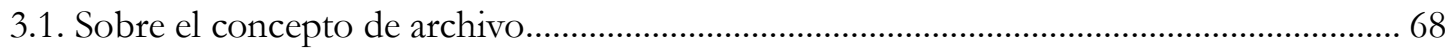

3.3. Periodización y evolución del concepto de archivo ............................................................. 77

3.2. El Archivo monástico a la luz de las Constituciones de 1701 .............................................. 82

3.4. La imagen del archivo de San Zoilo de Carrión a través del Índice .................................. 104

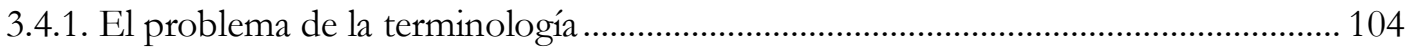

3.4.2. La organización de los documentos en el Índice de San Zoilo de Carrión. .............. 108

3.4.3. Las relaciones de los documentos en el Índice de San Zoilo de Carrión ................. 135

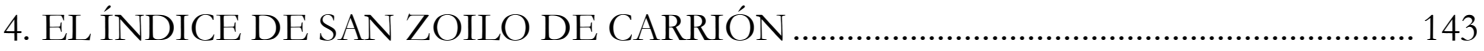

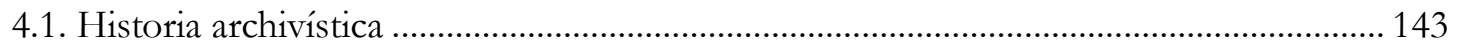

4.2. Comentarios codicológicos y paleográficos ……........................................................... 164

4.3. La construcción de los mensajes referenciales o labor sintetizadora................................. 178

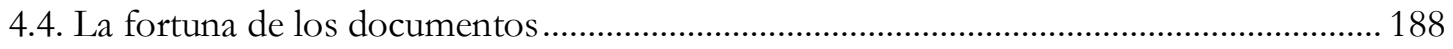

5. LA FORMACIÓN DEL PATRIMONIO Y SU ADMINISTRACIÓN A TRAVÉS DEL

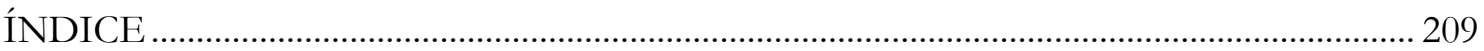

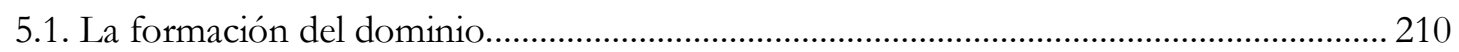

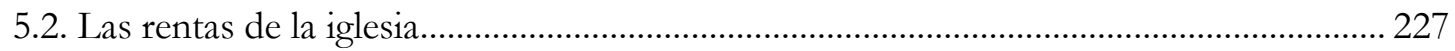

5.3. La administración y defensa del patrimonio …………………………………………........ 230

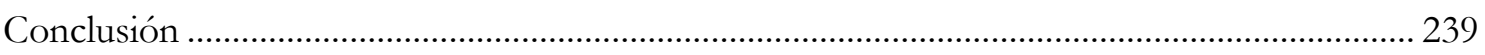

SEGUNDA PARTE. EDICIÓN DEL ÍNDICE DE SAN ZOILO DE CARRIÓN

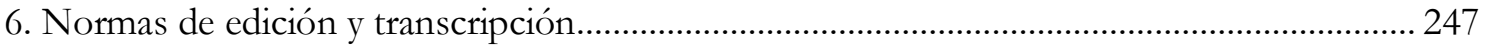

7. Edición del Índice de San Zoilo de Carrión..............................................................................249

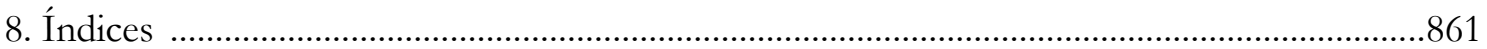

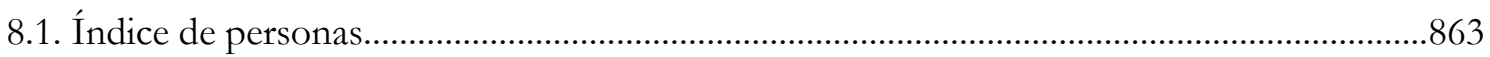

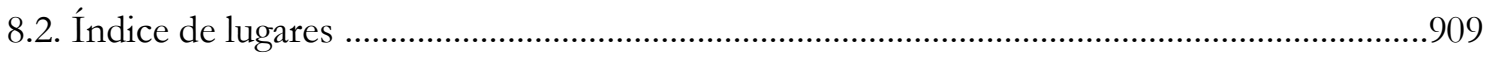





\section{INTRODUCCIÓN}

La realización de todo trabajo de investigación y, como no podía ser de otra manera, también de una tesis doctoral, reclama la relación de un aprendizaje y la puesta en escena de unos propósitos. Y en esta introducción realizaré ambas tareas. Este razonamiento gira en torno a una realidad de la que nos ocupamos, de una u otra manera, en varios de los capítulos de la misma aunque no en los primeros, siendo sin embargo su fundamento. Y esa realidad es el archivo, en el cual se halla no solo "el depósito y la garantía de los derechos reflejados en documentos custodiados entre sus muros" sino también una "cantera de informaciones para los diferentes modelos del oficio de historiador" ${ }^{1}$. Esta aserción de Diego Navarro Bonilla me sirve a la vez para explicar el hilo conductor del trabajo que presento como tesis doctoral: el análisis de un instrumento que acerca a lo que fue el archivo del monasterio de San Zoilo de Carrión.

En efecto, el legajo 112 de la Sección Desamortización del Archivo Histórico Provincial de Palencia contiene el "Índice del Archivo de San Zoilo" de Carrión, en el cual se describe toda la documentación que el monasterio había generado, recibido y sobre todo conservado desde su fundación hasta los años primeros del siglo XIX, momento en el que se redactó el manuscrito. Libro, pues, el Índice, esencial como instrumento de control de los documentos del archivo y de la información contenida en ellos, que si bien sí es conocida y ha sido citada, lo ha sido de forma muy parcial y nunca estudiada en su integridad.

Hasta hace unas décadas eran muy escasas, por no decir contadas, las monografías (no todas de igual fortuna y calidad) dedicadas tanto al cenobio carrionés como al estudio y edición de la documentación de lo que fuera su archivo (y su memoria), que en este caso además detuvieron la investigación en los documentos finimedievales. Esta ha sido una práctica común para los monasterios hispanos y con las colecciones diplomáticas de sus archivos. Se explica no sólo por el interés de los diplomatistas por los documentos anteriores a la Edad Moderna sino también y sobre todo porque se hace difícil la edición de

\footnotetext{
${ }^{1}$ NAVARRO BONILLA, Diego, La imagen del Archivo: Representación y funciones en España (siglos XVI y XVII). Gijón, 2003, p.43 (=NAVARRO BONILLA, La imagen del Archivo).
} 
la cuantiosísima documentación generada por estas instituciones partir del siglo XVI, que requieren por ello otro tipo de tratamiento y edición.

Pero en el Índice de San Zoilo se describen más de 3.000 documentos, muchos de los cuales, muchísimos en realidad, rebasan las fronteras del siglo XVI y llegan hasta los años primeros del siglo XIX. Hecho este que permitirá conocer el número y contenido de la documentación aún desconocida del monasterio, lo que, sin ningún género de dudas, permitirá conocer más profundamente la historia del monasterio carrionense, más allá de lo que sabemos para los siglos medievales y de la alta y baja modernidad.

El acercamiento a todo archivo requiere, en una buena aplicación de la metodología archivística, un conocimiento previo de su productor. Y para conocer al productor hay que acercarse a las fuentes. De ahí que la primera tarea y también las primeras páginas de esta tesis se dediquen a hacer un recorrido historiográfico, para conocer y presentar los trabajos dedicados al monasterio de San Zoilo, tanto como institución monástica como por el papel y la importancia que jugó como articulador del espacio carrionés. Sin ninguna duda, el rastreo y el paseo por las páginas a ello dedicadas permitirán reconocer el ámbito geográfico y el marco histórico en el que se desarrolló la vida de la comunidad, nunca aislada y en todo momento inmersa en las vicisitudes de la sociedad que la rodeaba, en la que fue intérprete destacado en no pocos momentos históricos.

Conocer el archivo, decía, requiere conocer al productor, su historia, las competencias y funciones que desempeñó a lo largo de su existencia. Y un monasterio es fundamentalmente un lugar de oración, un lugar para Dios. Pero a Dios llegan las oraciones de los monjes, que son hombres y precisan de casa en que cobijarse y ración con que alimentarse. No es posible la realidad de monasterio sin casa y sin heredad. Los papeles de Dios pueden pero no suelen estar en el archivo, o están de otra manera; los papeles del archivo son papeles del mundo. Y estos papeles (y pergaminos) sí están en el archivo. Es donde deben estar. Hay que cuidar las cosas del mundo porque si no se hará imposible alcanzar a Dios y rezar para que otros lo alcancen.

De ahí que dediquemos unas páginas al monasterio de San Zoilo y al archivo del mismo. Parte de lo que el archivo es cuando, a inicios del siglo XIX, se redacta el Índice de San Zoilo nos la proporciona este último, que es por ello la mejor imagen del archivo. El Índice, en efecto, proporciona una imagen admirable y precisa de lo que el archivo de la institución era en el siglo XIX y que, no puede ser de otra manera, es un reflejo del concepto de archivo, lo cual determinará su organización. La disposición, la ordenación de 
las descripciones de los documentos en el propio Índice, concebido para hacer más fácil, rápido y seguro el acceso a la información que contienen los diplomas, son reflejo de la organización del archivo en el siglo XIX. Y esa organización debía y mucho al concepto administrativo-patrimonial que se tiene del mismo. El archivo ha de permitir la recuperación de unos documentos que posibilitan no sólo una óptima administración del patrimonio sino también su defensa, así como la de los privilegios, exenciones y libertades ganadas con el pasar del tiempo.

Si para conocer el archivo hay que saber quién es su productor, a este se le conocerá más amplia y profundamente a medida que la información de los documentos de su archivo sea mayor. La bibliografía manejada nos ha permitido acercarnos al monasterio de San Zoilo de Carrión, pero el Índice nos permitirá conocer todo lo relativo a su patrimonio de una manera completa. Un recorrido bidireccional que tiene el objeto de alcanzar, una vez hecho, una visión del monasterio de San Zoilo de Carrión desde los orígenes del cenobio hasta el siglo XIX a través de un manuscrito escrito en esta última centuria.

Si bien del antiguo monasterio de San Zoilo hoy sólo son visibles algunos vestigios, sin duda custodios de su historia, una historia esplendorosa de la que habla cada una de las piedras que embellece el excepcional claustro plateresco, no es menos cierto que hay huellas invisibles, aun por rastrear, que informan también de esa historia y del esplendor del que hizo gala el cenobio en su largo devenir histórico. Una de esas huellas es el Índice al que me he acercado y que estudiaré en estas páginas.

Los más de tres mil documentos extractados en él permitirán, y esa es la propuesta de la Tesis, conocer:

a) el tiempo de formación del patrimonio y el modo en que se hizo; es decir, saber en qué momentos el cenobio se benefició de las donaciones y si estas se hicieron en remedio del alma o para ser enterrado en el cenobio; cuándo San Zoilo decidió comprar, cómo, cuándo y en qué litigios tuvo que defender sus heredades de las disputas de terceros; saber si las arrendó y cuándo lo hizo. El tiempo, pues, como eje fundamental para entender la formación del patrimonio monástico y su administración y defensa.

b) La tarea anterior está estrechamente ligada al estudio de los documentos y este con el proyecto diplomático-archivístico de la Congregación de San Benito de 
Valladolid. El análisis de los extractos de los diplomas permitirá conocer (más allá de la organización de los documentos) a los destinatarios de los mismos, puesto que no lo fue únicamente San Zoilo; determinar el momento y el motivo que explica el ingreso de los diplomas en el archivo. Es el caso de la incorporación de monasterios independientes a San Zoilo, como ocurrió con San Román de Entrepeñas y Nuestra Señora del Brezo, por citar dos de ellos.

c) Pero si hay un tiempo hay también unos espacios, y en ellos San Zoilo de Carrión tuvo sus tierras, sus viñas, sus casas, sus molinos. El Índice nos permitirá conocer el ámbito territorial en que el cenobio tuvo sus heredades.

d) Eso nos lleva al Índice, para comprobar que su organización, reflejo de la del archivo (no puede ser de otra manera), es la que se entendía mejor para la administración (y defensa también) de un patrimonio, sin el que se hacía imposible la función esencial del monasterio, la oración, formado a lo largo de los siglos en un territorio amplísimo. El Índice en sí mismo requiere un análisis codicológico y paleográfico, para conocer todo lo relativo a su factura; un análisis también de los resúmenes, para conocer la actividad documentaria. Hechura material y documentaria que no es ajena a las instrucciones de las diferentes Constituciones de la Congregación benedictina de Valladolid.

e) Y todo ello, por fin, permitirá que el enmarque, los apuntes de historia institucional que ofrezcamos se tornen en una historia que sólo se hace posible con la explotación de la información de las fuentes. Y el Índice se muestra como excepcional.

La metodología utilizada para la realización del trabajo viene dictada por la realidad del libro que estudiamos. En un instrumento de referencia y también de consulta que proporcione información sobre la documentación de archivo se ha de organizar la información del modo en que están organizados los documentos en los cajones del arca, del armario o del depósito. En definitiva, el Índice no es sino el "plano” del archivo de San Zoilo de Carrión.

Y el archivo del monasterio es deudor del propio concepto de archivo. El Índice es un libro que devuelve como un espejo la imagen del archivo, de sus miles de documentos y de la relación que hay entre ellos. Por esa razón y porque el manuscrito resume los documentos que formaban el archivo del monasterio a las puertas de las desamortizaciones burguesas que dieron paso a la Edad Contemporánea y acabaron con el monasterio, decidí transcribir los 
centenares de folios del manuscrito. La transcripción sería una de las claves que nos permitiría ir descubriendo la clasificación de los documentos regestados, su organización y ordenación, deudora, unas veces, del concepto administrativo-patrimonial del archivo; y otras, de una práctica archivística que siendo anterior al enunciado del principio de procedencia, muestra el respeto a la individualidad de los fondos de los diferentes monasterios anexionados a San Zoilo.

Conocer al productor (con la singularidad de que San Zoilo es tanto productor por su tarea de conservador como por ser, en efecto, propio productor de muchos de los diplomas), aplicar lo que la archivística italiana denominó en su día metodo storico, nos permitirá conocer no solo el origen institucional de muchos de los diplomas, llegados a San Zoilo de procedencias institucionales diversas: cancillerías regias, nobiliarias, episcopales, tribunales de justicia, etcétera, sino también el modo en que el cenobio los guardó en su archivo. Y lo hizo de una forma que entendía era la más propia para acceder a los documentos.

De ahí el trabajo de descripción llevado a cabo en el Índice, que se basó fundamentalmente en lo establecido en diferentes Constituciones de la Congregación benedictina de Valladolid, y que evidencia una afortunada técnica documental para lograr unas descripciones de documentos, expedientes y procesos que permitieran el acceso seguro y rápido al contenido documental.

La información que esta tarea proporciona resultaba igualmente idónea para conocer el proceso de formación y constitución de su patrimonio, tanto en el tiempo como en el espacio, logrando así establecer una serie de uniones temporales y territoriales que nos permitan confirmar cómo la organización del archivo estaba en directa armonía con el concepto administrativo-patrimonial que se tenía del archivo.

A la vez que transcribía los folios del Índice, trasladamos a diferentes campos de una Base de Datos que diseñamos ad hoc la información de las unidades de información de cada uno de los resúmenes de los documentos del archivo. La Base de datos se convirtió así en una herramienta precisa de gestión de la información.

Esta herramienta nos ha proporcionado la posibilidad de ordenar cronológicamente los diplomas, así como agrupar los documentos por su tipología documental, pudiendo saber de esta manera qué documentación se regestaba en el Índice y de qué manera, la importancia de los documentos que acreditaban sus propiedades y los pleitos que mantenían para asegurar la defensa de las mismas. La Base de datos ha sido un el recurso necesario para reconstruir 
todo lo relacionado con la formación del patrimonio y su administración, comprender y determinar los momentos de expansión y de crisis, reconstruir el modo de incorporación de iglesias ajenas y conocer el momento en que San Zoilo incrementó sus derechos de patronato en zonas alejadas de la propia villa de Carrión.

Ambas caras, el estudio del documento y sus relaciones en el archivo y el análisis de los documentos y la información que contienen, han exigido no solo la aplicación del método archivístico sino también del diplomático. Ambas metodologías nos han permitido analizar la realidad de lo que es el Índice: no solo resultado de análisis y tratamiento de la información, no únicamente consecuencia de la operación de descripción de los documentos, pensado para acceder más fácilmente a su contenido; sino también el resultado de trasladar a sus folios la organización del archivo a finales del siglo XVIII y principios del siglo XIX, la clasificación de los documentos en sus cajones, legajos y cuadernos, ajustada al interés por mantener el patrimonio del monasterio y su administración, fundamentales para su subsistencia.

La metodología archivística requiere además conocer cuál ha sido la suerte del documentos o documentos estudiado, lo que se conoce como la historia archivística, y la del Índice del monasterio de San Zoilo ha sido interesante. Eso explica que dedique un capítulo a este objeto: saber cuál ha sido no solo el trasiego del libro desde que salió del cenobio, sino también quién pudo ser su autor material y por qué razón no está en el que debiera ser su archivo de conservación una vez que los monjes dejaron de ser sus poseedores, y que no es otro que el Archivo Histórico Nacional, sino en el Archivo Histórico Provincial de Palencia.

Lo dicho hasta aquí, permitirá comprender que haya estructurado la Tesis en dos grandes bloques. Uno primero dedicado a los capítulos de Estudio, distribuido a su vez en distintos bloques en los que abordo cuestiones de Historiografía del monasterio de San Zoilo de Carrión (capítulo 1), de aproximación histórica al cenobio (capítulo 2), al archivo de San Zoilo (capítulo 3), al Índice de su archivo (capítulo 4), y a la formación del patrimonio monástico y su administración a través del Índice (capítulo 5), para concluir con unas páginas de conclusión. El segundo bloque de la Tesis se dedica principalmente a la Edición del Índice, que va precedida de unas normas de edición y transcripción y se cierra con unos índices de personas y lugares, pensados para acceder más rápidamente a la información contenida en el manuscrito. 
Se hacen siempre necesarias unas palabras de agradecimiento en todo trabajo de investigación. Palabras que nunca se escriben con intención de pagar, porque la estima, el afecto y el aprecio no tienen precio. Sirvan estas palabras de gratitud para expresar lo mucho que valoro todo lo que se me ha dado antes y durante los años de realización de la tesis doctoral.

Cuando hace ya algunos años, don José Manuel Ruiz Asencio me propuso acercarme al estudio de lo que por aquel entonces era para mí algo aún más que desconocido, el Índice de San Zoilo de Carrión de los Condes, no pude evitar que mi mente evocara el feliz recuerdo de aquellos calurosos domingos de verano en los que una niña con bañador de volantes y chanclas de goma azul marino, se bañaba en el río bajo la atenta y protectora mirada de su abuelo. Una niña que jamás habría imaginado que aquel edificio de piedra, cuya lejana torre podía intuir desde la otra orilla, se convertiría veinte años después, en el objeto central de estudio de su tesis doctoral.

Es por ello que únicamente puedo expresar hacia él mi más sincero y profundo agradecimiento por haberme brindado este precioso regalo. Gracias también a todos los miembros del área de Ciencias y Técnicas Historiográficas, doña Irene Ruiz Albi y doña Marta Herrero de la Fuente, cuyas indicaciones y apoyo durante estos años han enriquecido estas páginas; a Fran, Víctor y María, porque nuestras experiencias compartidas han hecho más amable y llevadera la en ocasiones solitaria tarea del doctorando. Gracias a todos por vuestra amistad sincera.

Gracias a mi familia por su apoyo incondicional. A mis abuelos maternos porque su recuerdo me ha insuflado fuerzas en aquellos momentos en los que más falta me hacían. A mi tía por su ayuda ilimitada y por estar ahí siempre que la he necesitado. A mi adorado y admirado hermano por su paciencia y ayuda infinitas y por enseñarme que, a veces, "una gráfica puede valer más que mil palabras". A Alejandro, por su espera callada y su calma capaz de serenar mis, en ocasiones, complicados ánimos; gracias por ser mi compañero todos estos años. Y gracias a mis padres por su dedicación y comprensión, en especial a mi madre, incansable y perseverante, gracias por tu amor, gracias por no dejar nunca que me rinda y por enseñarme, con tu ejemplo, que el esfuerzo y el trabajo siempre merecen la pena.

No podría acabar esta exposición sin mencionar a mi director de tesis, el doctor Mauricio Herrero Jiménez, hacia el cual únicamente puedo expresar un sincero y profundo agradecimiento, puesto que me ha enseñado todo lo imprescindible y necesario para llevar a cabo un trabajo de investigación riguroso, objetivo, digno y respetable, me ha guiado y 
continúa haciéndolo a través de sus impagables consejos y opiniones, transmitiéndome en cada momento un amor por el trabajo y una confianza en mis aptitudes y posibilidades que ha sido, sigue y seguirá siendo la base y fundamento tanto de este como de cualquier futuro trabajo que pueda realizar durante mi trayectoria profesional. Gracias, Mauricio.

GRACIAS infinitas a todos, porque el resultado de este trabajo es corolario de un trayecto recorrido con y por vosotros. 
FUENTES Y BIBLIOGRAFÍA

\section{FUENTES}

ARCHIVO HISTÓRICO PROVINCIAL DE PALENCIA (=AHPP).

-Sección Desamortización. Legajos 56, 106, 107, 108, 109, 110, 111, 112, 113, $170,171,435$ y 436.

—Inventario Legado Simón Nieto. Ilustre Colegio Oficial de Médicos de Palencia.

—Archivo Delegación Provincial de Hacienda. Libros-inventario de registro de entrada de documentos: 1890-1901 y 1971.

ARCHIVO HISTÓRICO NACIONAL (=AHN)

—Sección Clero. Carpetas 1700 (desde el doc. n. ${ }^{\circ} 6$ en adelante) y 1701 a 1717.

—Sección Clero. Libros 9580, 9558, 9569, 9574, 9581, 9882, 9552, 9555, 9556, 9557, 9559, 9560, 9562, 9563, 9564, 9566, 9567, 9568, 9578, 9579, 9583, 9584, 9588, 9589, 9590, 9565, 9585, 9586, 9587, 9570, 9561, 9573, 9553, 9571, 9572, 9582, 9554, 9575, 9576 у 9577.

COLEGIO SAN ESTANISLAO (SALAMANCA)

-Fondo Antiguo, Sala 2, Cajas 10 y 11.

ARCHIVO GENERAL DE LA PROVINCIA DE ESPAÑA DE LOS JESUITAS (ALCALÁ DE HENARES)

-AESI-A, Fondo Carrión, caja C 11, documento 26.

\section{BIBLIOGRAFÍA CITADA}

-ABELLA, Manuel, Noticia y plan de un viage para reconocer archivos y formar la colección diplomática de España, encargada por el rey. Madrid, 1795.

—ÁLAMO, M. del, Dictionnarie d'Histoire et de Géographie eclesiastique.París, 1912-1971.

-ALBERCH FIGUERAS, Ramón, Los Archivos entre la memoria histórica y la sociedad del conocimiento. Barcelona, 2003. 
—ALCALDE CRESPO, Gonzalo, Las Edades de Palencia. Burgos, 1999.

_ALVAR EZQUERRA, Alfredo (coord.), Imágenes Históricas de Felipe II. Madrid, 2000.

—ARA GIL, Julia, "Un grupo de sepulcros palentinos del siglo XIII. Los primeros talleres de Carrión de los Condes. Pedro Pintor y Roi Martínez de Burueva”, en II Curso de cultura medieval. Aguilar de Campoo, 1990. Alfonso VII y su época. Madrid, 1992, pp. 21-52.

-ARCHIVO HISTÓRICO NACIONAL, Clero secular y regular. Inventario de procedencias. Valladolid, 1924.

—BARREDA FERRER, Ángel Luis, "Restauración de la "Galilea" del Real Monasterio de San Zoilo": Peregrino: revista del Camino de Santiago, 147-148 (2013), p. 7.

—BARRET, Sebastien, La mémoire et l'écrit: l'abbaye de Cluny e ses archives (Xe-XVIIIe siècles). Münster, 2004.

-BARRIO GOZALO, Maximiliano, "El sistema beneficial en la España del siglo XVIII: Pervivencias y cambios": Cuadernos Dieciochistas, 2 (2001), pp. 73-107.

-BAUTIER, Robert- Henri, "La phase cruciale de l'histoire des archives: la constitution des dépots d'archives et la naissance de l'archivistique (XVI è-début du XIX è siècle)": Archivum. Revue Internationale des Archives, XVIII (1968), pp. 139-151.

—BECERRO DE BENGOA, Ricardo, “El Monasterio de Carrión”: La España Moderna, revista Ibero-Americana, 7 (1889), pp. 55-96 (=BECERRO DE BENGOA, "El monasterio de Carrión").

—_La Tierra de Campos: álbum de excursiones. Palencia, 2007 (=BECERRO DE BENGOA, Tierra de Campos).

_El libro de Palencia. Palencia: Imp. de Hijos de Gutiérrez, 1874, pp. 202-210.

-Becerro: libro famoso de las Behetrías de Castilla, que se custodia en la Real Chancillería de Valladolid: manuscrito del siglo XIV en el cual se espresan detalladamente la naturaleza y origen de la nobleza de España y se describe en todo su esplendor el feudalismo nacional en el último tercio de la Edad Media, $1^{a}$ ed. Santander: Librería de Fabián Hernández, 1866.

-BEJARANO RUBIO, Amparo-MOLINA MOLINA, Ángel Luis, El monasterio de San Zoilo (Carrión de los Condes) a fines de la Edad Media. Propiedades y rentas. Murcia, 1999.

—BELLO, Josefina, Frailes, intendentes y políticos. Los bienes nacionales (1835-1850). Madrid, 1997.

-BENDITO GONZÁLEZ, Carlos, Don Francisco Simón Nieto: medicina, antropología e bistoria. Palencia, 1992. 
—BERNAD, A-BRUEL, A, Recueil des chartres de l'abbaye de Cluny, 6 vol.. París, 1876-1903.

—BISHKO, Charles Julian, "Fernando I y los orígenes de la alianza castellano-leonesa con Cluny": Cuadernos de Historia de España , 47-48 (1968), pp. 31-135 (=BISHKO, Fernando I).

—_ "El abad Radulfo de Cluny y el prior Humberto de Carrión, camerario de España: tres cartas inéditas de hacia 117': Anuario de Estudios Medievales, I (1964), pp. 197-215 (=BISHKO, El abad Radulfo).

-BONELLI Giuseppe-VITTANI Giovanni, Ordinamento e Inventario degli Archivi. MilánRoma-Nápoles, 1908.

-BRENNEKE, Adolf. Archivistica. Contributo alla teoria e dalla storia archivística europea. Milán (1 $1^{\mathrm{a}}$ ed), 1953.

BURÓN CASTRO, Taurino, "Los inventarios de desamortización. Recurso para el seguimiento del patrimonio documental": Boletín de la $A N A B A D, 45-4$ (1995), pp. 25-50. “Archivología: una mirada hacia atrás": Boletín de la $A N A B A D, 43-1$ (1993), pp. 7-30. -CABALLERO GARCÍA, Antonio, "Desamortización y patrimonio documental: un ejemplo de tratamiento de archivos en el siglo XIX": Signo. Revista de Historia de la Cultura Escrita, 15 (2005), pp. 77-117.

—CANELLAS LÓPEZ, Ángel. Diplomática hispanovisigoda. Zaragoza, 1979.

—CANTERA MONTENEGRO, Margarita, Santa María la Real de Nájera. Siglos XI-XIV. 3 vols. Madrid, 1987.

—CÁRCEL ORTÍ, V., “La Iglesia en la España contemporánea (1808-1975)”, en Historia de la Iglesia en España, 5. Madrid, 1979, pp. 230-252.

-CASANOVA, Eugenio, Archivistica. Siena (1ª ed), 1928.

—CASTILLO GÓMEZ, A., Escrituras y escribientes: prácticas de la cultura escrita en una ciudad del Renacimiento. Las Palmas de Gran Canaria, 1997.

-COLOMBÁS, García M.-GOST, Mateo M., Estudios sobre el primer siglo de San Benito de Valladolid. Abadía de Montserrat, 1954.

- Constitvciones de la Congregacion de San Benito de la Obseruancia, que tuuo principio en el Real Monasterio de San Benito de Valladolid. Madrid, 1612.

—Constituciones de los monges de la Congregación de Sant Benito de V alladolid. Barcelona, 1575.

- Constituciones de la Congregacion de nuestro glorioso Padre San Benito de España e Inglaterra: augmentadas y añadidas con las nuevas difiniciones que desde el año de 1610 hasta el de 1701 han sido establecidas y aprobadas en diversos Capitulos y el día de oy tienen ya fuerza de leyes, recopiladas y 
reducidas a mejor methodo y orden por los Comissarios que la Santa Congregacion nombrò y señalò para su recopilacion, en su Capitulo General de 1701. Madrid: Oficina de la viuda de Melchor Álvarez, 1706 (= Constituciones 1701).

—CRUZ MUNDET, José Ramón, Manual de Archivística (4 edición, corr. y act.). Madrid: Fundación Germán Sánchez Ruipérez, 2005.

_ Archivística. Gestión de documentos y administración de archivos. Madrid, 2012.

- CUADRADO LOREnZO, M. ${ }^{a}$ Flora, "La Iglesia de Santa María de Carrión de los Condes y su programa escultórico": PITTM, 57 (1987), pp. 207-292.

-Definiciones cistercienses de la Sagrada Congregación de San Bernardo y Observancia de Castilla, etc. Valladolid: en la Imprenta de la Viuda de Santander, 1786.

_DEL ÁLAMO, M., Dictionnarie d'Histoire et de Géographie eclesiastique. París, 1912-1971.

—DE LA CRUZ HERRANZ, Luis M. "La Sección de Clero del Archivo Histórico Nacional", en II Jornadas cientificas sobre documentación de la Corona de Castilla (siglos XIII-XV). Madrid, 2003, pp. 373-432.

—_El archivo monástico. Entre la gestión de su administración y la gestión de su memoria histórica", en BALDAQUÍ ESCANDELL, Ramón (coord.), Lugares de escritura: el monasterio. Alicante, 2016, pp. 177-230 (=DE LA CRUZ HERRANZ, "El archivo monástico").

—DE LA FUENTE, Vicente, Historia eclesiástica de España. Tomo VI. Madrid, 1875.

-DEL VALLE CURIESES, Rafael, "Carrión de los Condes durante la guerra de la Independencia": PITTM, 84 (2013), pp. 7-83.

—DÍAZ-JIMÉNEZ Y MOLLEDA, Eloy, "Real Monasterio benedictino de San Claudio de Léon, 1885": Revista Erudición ibero-ultramarina, Descripciones bibliográficas, I-2,3,4 (1930); II5, 6, 7 (1931); III-9, 11 (1932).

—DÍAZ NAVA, Adolfo F., "Un claustro plateresco "San Zoil" en Carrión de los Condes": PITTM, 23 (1963), pp. 89-120.

—Diccionario de terminología archivistica ( $2^{\mathrm{a}}$ ed.). Madrid: Subdirección de General de los Archivos Estatales, 1995.

—DIEGO RODRÍGUEZ, Natividad de, "Fondos Monásticos en el Archivo Histórico Nacional": Memoria ecclesiae, 6 (1995), pp. 49-78 (=DIEGO RODRÍGUEZ, Fondos Monásticos). 
“La Desamortización y la sección de Clero del Archivo Histórico Nacional. Culto y Clero”, en Desamortización y Hacienda Pública. Tomo I. Madrid, 1986, pp. 45-55.

—DÍEZ HERMANO, M. ${ }^{a}$ José, "Escribir para conservar. El priorato de San Martín de Frómista a través del índice de San Zoilo de Carrión”, en Ramón BALDAQUÍ ESCANDELL (coord.), Lugares de escritura: el monasterio. Alicante, 2016, pp. 427-443.

—ENRÍQUEZ DE SALAMANCA GÓMEZ, Almudena, "El Archivo del Monasterio de Santa María de Nogales en el Tumbo de Astorga (1639)", Documenta e Instrumenta, 8 (2010), pp. 47-66.

—FERNÁNDEZ FLÓREZ, José Antonio, "La Congregación benedictina de Valladolid en el siglo XVIII", en Erudición y discurso histórico: Las Instituciones Europeas. (S. XVIII-XIX). Valencia, 1993, pp. 101-127 (=FERNÁNDEZ FLÓREZ, La Congregación benedictina de Valladolid).

—FERNÁNDEZ MARTÍN, Luis, "La diócesis de Palencia durante el reinado de José Bonaparte 1808-1813”: PITTM, 44 (1980), pp. 248-254.

-FERNÁNDEZ-RUIZ, César, Historia de la medicina palentina. Palencia, 1959, pp.123-129.

-FLÓREZ, Henrique, España Sagrada. Theatro geographico-historico de la Iglesia de España. Tomo X. De las iglesias sufragáneas antiguas de Sevilla: Abdera, Asido, Astigi y Córdoba. Madrid, 1753 (reimp. Madrid 1901) (=FLÓREZ, España Sagrada).

-FRANCIA LORENZO, Santiago, Anecdotario para la pequeña bistoria de un pueblo. Notas de archivo. 1. Palencia, 1985, p. 36.

_ "Documentación benedictina en la serie "Provisorato" del Archivo Capitular de Palencia”: Memoria ecclesiae, 6 (1995), pp. 415-428.

-FROCHOSO SÁNCHEZ, Rafael, "Las reliquias de San Zoilo, las arquetas y las telas árabes": Al-Mulk: Anuario de Estudios Arabistas, 14 (2016), pp. 19-49.

- GARCÍA GARCÍA, Lorena, Monasterio de San Zoilo de Carrión de los Condes: Arte e historia de un hito Cluniacense. Palencia: Asociación de Amigos del Camino de Santiago de Palencia: Centro de Estudios y Documentación del Camino de Santiago, 2014 (=GARCÍA GARCÍA, Monasterio de San Zoilo de Carrión de los Condes).

_Evolución del Patrimonio Religioso en Carrión de los Condes, Palencia, desde la Baja Edad Media hasta nuestros días. Tesis doctoral consultable en: http://uvadoc.uva.es/handle/10324/3026.

- GARCÍA GONZÁLEZ, Juan José, Vida económica de los Monasterios Benedictinos en el siglo XIV. Valladolid, 1972. 
—GARCÍA GUINEA, Miguel. Ángel, El arte románico en Palencia. Palencia, 1998.

—GENERELO LANASPA, Juan José, "Fuentes para la investigación en los Archivos Históricos Provinciales", en La investigación y las fuentes documentales de los archivos. I y II Jornadas sobre Investigación en Archivos. Vol. 1. Guadalajara, 1996, pp. 211-324.

—GÓMEZ GÓMEZ, Margarita, "Crítica histórica y archivos. El caso de España en el siglo XVIII”: Historia. Instituciones. Documentos, 12 (1985), pp. 199-232.

—GÓMEZ-LLERA GARCÍA-NAVA, Eduardo, "Los Archivos Históricos Provinciales": Cuadernos de historia moderna, 15 (1994), pp. 251-278.

-GARCÍA LOPEZ, Genaro Luis, Libros para no leer: el nacimiento de la política documental en España. Madrid, 2004.

—GOMÉZ MENDOZA, Josefina, "La venta de baldíos y comunales en el s. XVI. Estudio de su proceso en Guadalajara”, en Estudios Geográficos, 28 (1967), pp. 499-559.

-GÓMEZ PÉREZ, Enrique-PERAL VILLAFRUELA, Santiago, Carrión, la ciudad de los Condes. Palencia, 2003.

—GONZÁLEZ GONZÁLEZ, Julio. "Cuestiones de repoblación en Tierras palentinas", en Palencia en la Historia. Palencia, 1982, pp. 45-66.

__ "Siglos de Reconquista", en Historia de Palencia. I. Edad Antigua y Media. Palencia, 1984, pp. 155-215.

—GORDALIZA APARICIO, F. Roberto, Historias y leyendas palentinas. Palencia, 2001.

-GRUPO DE TRABAJO DE HACIENDA, "La documentación de las Delegaciones de Hacienda: valoración previa a la transferencia", en I Jornadas sobre Metodología para la identificación y valoración de fondos documentales de las Administraciones Públicas. Ministerio de Cultura, 1992, pp. 203-222.

—Guía de los Archivos de Castilla y León. Junta de Castilla y León, 2006.

—GUTIÉRREZ DEL ARROYO DE VÁZQUEZ DE PARGA, Consuelo, Privilegios reales de la Orden de Santiago en la Edad Media: Catálogo de la serie existente en el Archivo Histórico Nacional, Madrid: Junta Técnica de Archivos, Bibliotecas y Museos, 1945.

—HEREDIA HERRERA, Antonia, “¿Qué es un archivo?”: Revista ANABAD, 57-3 (2007), pp. 167-169 (=HEREDIA HERRERA, “¿Qué es un archivo?”). “Archivística. Inventarios y catálogos”: $A N A B A D, 2$ (1980), pp. 239-242.

__ Archivística General. Teoría y práctica. Sevilla: Diputación Provincial de Sevilla, 1986. 
"El nombre de las cosas o el valor de las palabras": Revista del Archivo General de la Nación, 25 (2005), pp. 27-32.

—ZQué es un archivo?. Gijón, 2007.

- HERRERO JIMÉNEZ, Mauricio, “Una llave para el tesoro de la catedral de León”, en RODRÍGUEZ DÍAZ, Elena-GARCÍA MARTÍNEZ, Antonio Claret (coords.), La escritura de la memoria: los cartularios, Huelva, 2011, pp. 197-216.

“La escritura mayúscula en el Tumbo Legionense", en MARTÍN LÓPEZ, M. ${ }^{a}$ Encarnación-GARCÍA LOBO, Vicente (coords.), Las inscripciones góticas: II Coloquio Internacional de epigrafía medieval. León del 11 al 15 de septiembre 2006. León, 2010, pp. 479-504.

—HEVIA BALLINA, Agustín, "Documentación monástica en el Archivo Histórico Diocesano de Oviedo. Benedictinos y canónigos regulares de San Agustín": Memoria ecclesiae, (6), 1995, pp. 361-396.

—HIDALGO DE LA VEGA, M. a José, "La crisis del siglo XIV en la Corona de Castilla" en Homenaje a Marcelo Vigil Pascual: la historia en el contexto de las ciencias humanas y sociales. Salamanca, 1989, pp. 217-236.

-índice de los documentos del Monasterio de Sahagún, de la Orden de San Benito y glosario y diccionario geográfico de voces sacadas de los mismos. Madrid: Imp. Aribau y Cía., Sucesores de Rivadeneyra, 1874.

- "Inventario de los Fondos o Procedencias del Archivo Histórico Nacional, con expresión del número de documentos que comprenden": Revista de Archivos, Bibliotecas y Museos, I-7 (1871), pp.102-106; I-8 (1871), pp. 118-124.

-JOVELLANOS, Gaspar Melchor, Obras completas. Tomo VII. Diario 2', Cuadernos V, conclusión; Tomo VII. Diario $2^{\circ}$ Cuadernos V, conclusión, VI y VII (desde el 1 de setiembre de 1794 hasta el 18 de agosto de 1797), Oviedo, 1999.

—La Regla de San Benito. Introducción y Comentario García M. COLOMBÁS. Traducción y notas Iñaki ARANGUREN, $3^{\text {a }}$ Ed. (reimpresión). Madrid: Biblioteca de Autores Cristianos, 2000.

—LEÓN TELLO, Pilar, "Los judíos de Palencia”: PITTM, 25 (1967), pp. 1-169.

—LINAGE CONDE, Antonio, Los origenes del monacato benedictino en la Peninsula Ibérica. 3 vols. León, 1973 (=LINAGE CONDE, Los orígenes del monacato).

— "Un caso de sucesión de familias religiosas en una misma sede: benedictinos y jesuitas en San Zoilo de Carrión de los Condes", en II Actas del Congreso de Historia de Palencia. Tomo3-2. Palencia, 1990, pp. 785-794. 
-LODOLINI, Elio, Archivistica. Principios y problemas, traducción de Mercedes Costa Paretas. Madrid, 1993.

— "El problema fundamental de la archivística: La naturaleza y la ordenación del archivo": Irargi, 1 (1988), pp. 27-61 (=LODOLINI, "El problema fundamental de la archivística”). _LÓPEZ-YARTO ELIZALDE, Amelia (coord.), El Catálogo Monumental de España (19001961). Investigación, restauración y difusión. Ministerio de Educación Cultura y Deporte, Secretaría General Técnica, 2012.

-MANSILLA REOYO, Demetrio, "La historiografía de los archivos eclesiásticos": Memoria ecclesiae, 1 (1990), pp. 7-32 (= MANSILLA REOYO, Archivos eclesiásticos).

-MARÍN MARTÍNEZ, Tomás-RUIZ ASENCIO, José Manuel, Paleografía y diplomática. Madrid: Universidad nacional de Educación a Distancia, 2011.

-MARTÍN MARTÍN, José Luis, "El clero rural en la Corona de Castilla", en MARTÍNEZ SAN PEDRO, María Desamparados-SEGURA DEL PINO, María Dolores (coords.) La iglesia en el mundo medieval y moderno. Almería, 2004, pp. 55-82

— "Beneficios y oficios del clero rural castellano (siglos XIII-XV)": Anuario de estudios medievales, 35-2 (2005), pp. 693-736

-MARTíN MÍNGUEZ, Bernardino, Catálogo Monumental de Palencia. 4 tomos. El manuscrito digitalizado del catálogo puede consultarse en la biblioteca del CSIC en: http://biblioteca.cchs.csic.es/digitalizacion_tnt/index_interior_palencia.html.

_L Las Dominicales del Libre Pensamiento. Ejemplar del domingo 16 de septiembre de 1883.

-MARTÍNEZ DÍEZ, Gonzalo, "Palencia en Castilla o la castellanidad de Palencia”, en Palencia en la Historia. Palencia, 1982, pp. 67-98.

_Libro Becerro de las Behetrías. 1 y 2 Estudio y texto crítico, 3 Índices y mapas. León, 1981.

“Años de crisis (1252-1369)”, en Historia de Palencia, I. Edad Antigua y Media. Palencia, 1984, pp. 245-272.

__ “La familia condal de Carrión”, en CALLEJA GONZÁLEZ, M. ${ }^{a}$ Valentina (coord.), Actas del III Congreso de Historia de Palencia. Vol. 2. Historia medieval: fuentes documentales, sociedad y economía e Historia de las Instituciones. Palencia, 1995, pp. 551-604.

-MARTÍNEZ SOPENA, Pascual, La Tierra de Campos occidental. Poblamiento, poder y comunidad del siglo X al XIII. Valladolid, 1985.

-MARTÍNEZ PINO, Joaquín, "La gestión del patrimonio histórico artístico en el siglo XIX. Fuentes para su documentación”: Tejuelo, 12 (2012), pp. 10-21. 
-MARTÍN-POZUELO CAMPILLOS, M. ${ }^{a}$ Paz. La construcción teórica en Archivística: el principio de procedencia. Madrid, 1996.

-MATÉ SADORNIL, Lorenzo, "Archivo de la Congregación de San Benito de Valladolid (1500-1835)": Memoria Ecclesiae, 6 (1995), pp. 313-332 (=MATÉ SADORNIL, Archivo San Benito).

_ Actas y constituciones de los Capitulos de la Congregación de San Benito de Valladolid (14971610): Stvdia Silensia, XXX-XXXI. Abadía de Silos, 2007-2008.

_ Actas y constituciones de los Capitulos de la Congregación de San Benito de Valladolid (16131721): Stvdia Silensia, XXXV-XXXVI-XXXVII. Abadía de Silos, 2012-2014.

-MENDO CARMONA, Concepción, "El largo camino de la Archivística: de práctica a ciencia": SIGNO. Revista de Historia de la Cultura Escrita, 2 (1995), pp. 113-132.

-MILLARES CARLO, Agustín, con la colaboración de José Manuel RUIZ ASENCIO, Tratado de paleografía española. 3 vols. Madrid: Espasa-Calpe, 1983.

-MORAL, Tomás, "Carrión de los Condes, San Zoilo", en Diccionario de Historia Eclesiástica de España. Tomo III. Madrid, 1973, p. 1543.

-MORALES, Ambrosio de, Crónica General de España. Madrid, 1574, libro 16, capítulo XVIII (=MORALES, Crónica España).

LLas antigüedades de las ciudades de España: que van nombradas en la Corónica con las averiguaciones de sus sitios y nombres antiguos. Tomo X. Madrid: Oficina de don Benito Cano, 1792.

-MORETA VELAYOS, Salustiano, Rentas monásticas en Castilla: Problemas de método. Salamanca, 1974.

—MOXÓ, Salvador, "Las desamortizaciones eclesiásticas en el s. XVI": Anuario de Historia del Derecho Español, 31 (1961), pp. 327-362.

-MÜLLER S., FEITH J. A., FRUIN R., Handleiding voor het Ordenen en Beschrijven van Archieven (traducción portuguesa, Manual de arranjo e descriçâo de arquivos). Río de Janeiro, 1960.

-MUÑOZ Y ROMERO, Tomás, "Inventario de los fondos y procedencias del Archivo Histórico Nacional con expresión de los documentos que comprenden": Revista de archivos bibliotecas y museos, 1 (1871), pp. 102-106 y pp. 118-124 (=MUÑOZ Y ROMERO, “Inventario del Archivo Histórico Nacional”). 
-NAVARRO BONILLA, Diego, La imagen del Archivo: Representación y funciones en España (siglos XVI y XVII). Gijón, 2003 (=NAVARRO BONILLA, La imagen del Archivo).

__Escritura poder y archivo. La organización documental de la Diputación del Reino de Aragón (siglos XV-XVIII). Zaragoza, 2004.

-NAVARro GARCÍA, Rafael, Catálogo Monumental de la Provincia de Palencia, por la Comisión provincial de Monumentos Históricos y Artísticos. Palencia, 1922.

-OCAMPO, F. de, Coronica general de España / que recopilaba el Maestro Florian de Ocampo Ique continuaba Ambrosio de Morales. Las antigüedades de las ciudades de España que van nombradas en la Corónica con las averiguaciones de sus sitios y nombres antiguos, que escribia Ambrosio de Morales...]. Madrid: Benito Cano, 1791-1792.

—PALACIO SÁNCHEZ-IZQUIERDO, M." Luisa, "Monasterio de San Zoilo y monasterios palentinos", en Palencia en la Historia. Palencia, 1982, pp. 145-166.

_ San Zoil de Carrión (siglos XI-XIV). Palencia, 1990.

_-El monasterio de San Zoilo de Carrión: Jurisdicción, franquezas y privilegios”, en Actas del I Congreso de Historia de Palencia. II. Fuentes documentales y Edad Media. Palencia, 1987, pp. 65-73.

—Colección diplomática del monasterio de San Zoil de Carrión (siglos XI al XV). 2 vols. Madrid, 1988 (=PALACIO, Colección San Zoil. I/II).

—PÉREZ CELADA, Julio A., Documentación del monasterio de San Zoilo de Carrión (10471300). Palencia, 1986 (=PÉREZ CELADA, Documentación San Zoilo, I).

—Documentación del monasterio de San Zoilo de Carrión (1301-1400). Palencia, 1987 (=PÉREZ CELADA, Documentación San Zoilo II).

_El monasterio de San Zoilo de Carrión. Formación, estructura y decurso bistórico de un señorío catellano-leonés (siglos XI al XVI). Burgos, 1997.

"La casa de San Pelayo de Toro y sus dependencias entre los siglos XI y XIV. Una aproximación al señorío cluniacense en la provincia de Zamora", en Actas del I Congreso de Historia de Zamora. T. III. Zamora, 1988, pp. 223-231

"Sobre la toma de posesión feudal en la Baja Edad Media castellana. El lugar de Benafarces en el año 1435”, en Actas de las I Jornadas sobre Fuentes y Métodos de la Historia Local. Zamora, 1990, pp.89-95.

—_Los conflictos jurisdiccionales en el barrio de San Martín de Frómista en los siglos XIV y XV": Cuadernos burgaleses de historia medieval, 3 (1995), pp. 155-185. 
_PÉREZ DE ÚRBEL, Justo, Historia del Condado de Castilla. I. Madrid, 1945.

-PÉREZ ORTIZ, G.-VIVAS MORENO, A., "Ensayo de organización de la documentación conventual: propuesta de cuadro de clasificación": Anales de Documentacion, 11 (2008), pp. 165-181.

—PESCADOR DEL HOYO, M. ${ }^{a}$ del Carmen, El archivo: instrumentos de trabajo. Madrid, 1982.

—PIGNOT, J.Henri, Histoire de l'Ordre de Cluny. Autun, París, 1868.

-PORRAS HUIDOBRO, Facundo de, Disertación sobre Archivos y reglas de su coordinación. Madrid: Imprenta de D. León Amarita, 1830.

—PUENTE, Ricardo, San Zoilo de Carrión: de la Edad Media al Renacimiento. León, 1998.

-QUADRADO, José M. ${ }^{a}$, Recuerdos y bellezas de España: Valladolid, Palencia y Zamora. Barcelona, 1885 (=QUADRADO, Recuerdos y bellezas).

-RAMÍREZ DE HelguerA, Martín, El libro de Carrión de los Condes (con su historia). Palencia, 1896 (reimp. 2007) (=RAMÍREZ DE HELGUERA, El libro de Carrión).

__El Real monasterio de San Zoilo de la muy noble y leal ciudad de Carrión de los Condes ante la Historia y el Arte. Palencia, 1900 (reimp. 2009).

—REAL ACADEMIA DE LAS BELLAS ARTES DE SAN FERNANDO ARCHIVO Y BIBLIOTECA, Inventario de los legajos de las Comisiones Provinciales y de la Comisión Central de Monumentos Histórico-Artístico. Madrid, 2001, con correcciones a diciembre de 2013.

—REDONDO CANTERA, M. José, “El programa iconográfico en el claustro bajo del monasterio de san Zoilo de Carrión de los Condes (Palencia)", en Actas del II Congreso de Historia de Palencia. V. Palencia, 1990, pp. 129-154.

—REGLERO DE LA FUENTE, Carlos M., Cluny en España. Los prioratos de la provincia y sus redes sociales (1073-ca.1270). León, 2008. (=REGLERO, Cluny en España).

_El monasterio de San Isidro de Dueñas en la Edad Media. Un priorato cluniacense hispano (9111478). Estudio y colección documental. León, 2005.

“El necrológico-obituario de San Zoilo de Carrión”, en HERRERO DE LA FUENTE, Marta-HERRERO JIMÉNEZ, Mauricio-RUIZ ALBI, Irene-MOLINA DE LA TORRE, Francisco J. (coords.), Alma littera. Estudios dedicados al profesor José Manuel Ruiz. Asencio. Valladolid, 2014, pp.525-533. 
—RELLÁN LÓPEZ, Avelino, "Libros del monasterio de San Andrés de Espinareda en el archivo de la parroquia de San Andrés de Vega de Espinareda (León)": Memoria ecclesiae, 6 (1995), pp. 473-480.

—REVUELTA GONZÁLEZ, Manuel, La exclaustración (1833-1840). Madrid, 1976.

—ROBERT, Ulysse, "Ėtat des Monastères Spagnols de l'ordre de Cluny aux XVIII è- XV è siècles, d'après les Actes des Visites et des Chapitres Generaux": Boletín de la Real Academia de la Historia, 20 (1892), pp. 321-431.

—RODRÍGUEZ DE DIEGO, José Luis, Instrucción para el Gobierno del Archivo de Simancas. Madrid, 1989 (=RODRÍGUEZ DE DIEGO, Archivo de Simancas).

“Archivos del Poder, archivos de la Administración, archivos de la Historia (siglos XVI-XVII)", en GENERELO, J.J., y MORENO LÓPEZ, A. (coords.), Historia de los archivos y de la archivistica en España. Valladolid, 1998, pp. 29-42.

_Colección Diplomática de Santa María de Aguilar de Campoo (852-1230). Valladolid, 2004.

__El Tumbo del monasterio cisterciense de La Espina. Valladolid, 1982 (=RODRÍGUEZ DE DIEGO, El Tumbo de La Espina).

—RODRÍGUEZ LÓPEZ-BREA, Carlos M., "Frailes y Revolución Liberal. El Clero Regular”, en España a comienzos del siglo XIX (1800-1814). Toledo, 1996

—RODRÍGUEZ MARTÍNEZ, Luis, Historia del Monasterio de San Benito el Real de Valladolid. Valladolid, 1981.

—RODRÍGUEZ MUÑOZ, Pedro, “Iglesias románicas palentinas”: PITTM, 13 (1955), pp. 36-38.

—ROMERO TALLAFIGO, Manuel, "El archivo y su función social": Boletín del Archivo General de la Nación, 114 (2006), pp. 15-36 (=ROMERO TALLAFIGO, El archivo).

"La historia de los archivos": Boletín del Archivo General de la Nación, 116 (2005), pp. 671-718 (=ROMERO TALLAFIGO, Historia archivos).

_ Archivistica y archivos: soportes, edificio y organización. Carmona, 1994.

—RUEDA HERNÁNZ, Germán, La desamortización de Mendizábal y Espartero en España. Madrid, 1986.

_La desamortización en España: un balance (1766-1924). Madrid, 1997.

—RUIZ, Elisa, Manual de Codicología. Salamanca, 1988.

-RUIZ ALBI, Irene, La reina doña Urraca (1109-1126). Cancillería y Colección diplomática. León, 2003. 
"Dos fragmentos de biblias visigóticas (San Zoilo de Carrión y Catedral de Zamora)", en CECILIO DÍAZ Y DÍAZ, Manuel-DÍAZ DE BUSTAMANTE, MercedesDOMÍNGUEZ GARCÍA Manuela (coords.), Escritos dedicados a José María Fernández Catón. 2 vols. León, 2004, pp. 1291-1316.

—RUIZ ASENCIO, José M.-RUIZ ALBI, Irene-HERRERO JIMÉNEZ, Mauricio, Los becerros gótico y galicano de Valpuesta. Madrid, 2010.

—RUIZ ASENCIO, José Manuel-RUIZ ALBI, Irene-HERRERO JIMÉNEZ, Mauricio, Colección documental del monasterio de San Román de Entrepeñas (940-1608). León, 2000.

—RUIZ GONZÁLEZ, Gregorio, "Los judíos de Palencia", en Palencia en la Historia. Palencia, 1982, pp. 116-142.

—RUIZ RODRÍGUEZ, Antonio Ángel, Manual de archivística. Madrid, 1995.

—SAGALÉS CISQUELLA, L., "Estructura institucional y legislación sobre archivos de la Congregación cisterciense de San Bernardo de Castilla", en HEVIA BALLINA, Agustín (edit.), Ordenes monásticas y Archivos de la iglesia (II): Santoral hispano-mozárabe en España: Actas del IX Congreso celebrado en Oviedo-Valdediós (13 al 16 de septiembre de 1993). Oviedo, 1995, pp. 187-206.

—SÁINZ RIPA, Eliseo, "El patrimonio documental eclesiástico en La Rioja”: Berceo, 128 (1995), pp. 291-306 (=SAÍNZ RIPA, "El patrimonio documental eclesiástico en La Rioja").

—SÁNCHEZ BELDA, Luis, Guia del archivo histórico nacional. Valencia, 1948.

—SÁNCHEZ DE FERIA Y MORALES, Bartolomé, Palestra Sagrada o Memorial de los santos de Córdoba: con notas y reflexiones críticas, sobre los principales sucesos de sus historias. Córdoba, 1772.

—SANDRI, Leopoldo, "La storia degli archivi": Archivum. Revue Internationale des Archives, XVIII (1968), pp. 101-113.

—SAN MARTÍN PAYO, Jesús, "La más antigua estadística de la Diócesis Palentina (a. 1345)" en Publicaciones de la Institución Tello Téllez de Meneses, nº7, Palencia, 1951, pp. 1-120.

SANTOS URBANEJA, Fernando, San Zoilo, un mártir cordobés en el Camino de Santiago. Carrión de los Condes, 2003 (=SANTOS URBANEJA, San Zoilo).

-SASTRE SANTOS, Eutimio, Una instrucción de Jovellanos para el arreglo del monasterio santiaguista del Sancti Spiritus. Salamanca, 1790. Madrid, 1995, p. 27. 
—SENRA GABRIEL y GALÁN, José Luis, “Algunas notas sobre la desaparecida iglesia románica del priorato cluniacense de Carrión de los Condes", en Actas del III Congreso de Palencia. IV. Palencia, 1996, pp. 439-451.

"La puerta como dogma: a propósito de un nuevo descubrimiento de la iglesia románica de San Zoilo de Carrión de los Condes (Palencia)": Archivo español de Arte, 81-322, (2008), pp. 139-150.

"Nuevos hallazgos románicos en el Monasterio de San Zoilo de Carrión de los Condes (Palencia)": Archivo español de Arte, 74-293 (2001), pp. 88-95.

_ “La portada occidental recientemente descubierta del priorato cluniacense de Carrión de los Condes": Archivo español de Arte, 67-265 (1994), pp. 57-72.

"Dos telas islámicas encontradas en el monasterio de San Zoilo de Carrión de los Condes": Goya. Revista de Arte, 303 (2004), pp. 332-340.

—SERRANO, Luciano, El Obispado de Burgos y la Castilla primitiva desde el siglo V al XIII. I. Madrid, 1932.

-SIMÓN NIETO, Francisco, Los Antiguos Campos Góticos. Excursiones histórico-artísticas a la Tierra de Campos. Madrid, 1895. (reimp. Palencia: La Editora del Carrión, 1998; Palencia: Región Editorial, S.L., 2006) (=SIMÓN NIETO, Campos Góticos).

_ Discurso leído por Francisco Simón y Nieto, doctor en medicina y cirugía, en la velada literaria celebrada el 13 de noviembre de 1904 con motivo de la terminación de las obras ejecutadas en el templo románico de San Martín de Frómista (1895-1904). Palencia: Comisión de Monumentos Histórico Artísticos de la Provincia de Palencia. Imprenta y Litografía de Alonso e Hijos, 1904.

—TEIJEIRA PABLOS, María Dolores, "Las Comisiones de Desamortización y la conservación del patrimonio histórico en el siglo XIX. La Comisión Civil y la Comisión científica y artística de Zamora (aspectos documentales)", en MORÁN SUÁREZ, María Antonia-RODRÍGUEZ LÓPEZ, María del Carmen (coords.), La documentación para la investigación: homenaje a José Antonio Martín Fuertes. Vol. 1. León, 2002, pp. 539-552.

-TOMÁS Y VALIENTE, Francisco, El marco político de la Desamortización en España, Barcelona, 1971.

-TORRES RODRÍGUEZ, C., "El P. Sarmiento como archivero y diplomático": Cuadernos de Estudios Gallegos, XXVII, 81-83 (1972), pp. 104-121.

-TROCHE Y ZÚÑIGA, Froilán, El Archivo cronológico-topográfico. Arte de archiveros. Coruña: Imprenta de Iguerreta, 1835. 
—ULLOA, Modesto, La hacienda real de Castilla en el reinado de Felipe II. Madrid, 1977.

—VALDEÓN VARUQUE, Julio, Los conflictos sociales en el Reino de Castilla en los siglos XIV y XV. Madrid, 1975.

"La crisis del siglo XIV en la Corona de Castilla", en HIDALGO DE LA VEGA, María José (edit.), Homenaje a Marcelo Vigil Pascual: la historia en el contexto de las ciencias humanas y sociales. Salamanca, 1989, pp. 217-236.

—VASSBERG, David E., "La venta de tierras baldías en Castilla durante el siglo XVI": Estudios Geográficos, 37 (1983), pp. 21-47.

-YEPES, Antonio de, Crónica general de la Orden de San Benito, edición abreviada por Fr. Justo Pérez de Urbel. 3 vols. Madrid, 1960.

_Coronica general de la Orden de San Benito, patriarca de religiosos. Tomo VI, centuria VI Vy séptima]. Valladolid, por Francisco Fernández de Córdoua, 1617 (=YEPES, Coronica San Benito).

—ZARAGOZA PASCUAL, Ernesto, "Abadologio del monasterio de San Zoilo de Carrión de los Condes (siglos XI-XIX) y libro de gradas de los monjes que profesaron en él (1593-1833)": PITTM, 64 (1993), pp. 273-322 (=ZARAGOZA PASCUAL, Abadologio San Zoilo).

LLos Generales de la Congregación de San Benito de Valladolid. Tomo 2. Los abades trienales (1499-1568). Abadía de Silos (Burgos), 1976.

—Los Generales de la Congregación de San Benito de Valladolid. Tomo IV. Abadía de Silos, 1982.

_Los Generales de la Congregación de San Benito de Valladolid. Tomo V. Abadía de Silos, 1984.

"Relación de los daños sufridos por algunos monasterios benedictinos españoles durante el Trienio Constitucional (1820-1823)": Stvdia Monástica, 30-1 (1988), pp. 121-163 (=ZARAGOZA PASCUAL, "Relación de los daños sufridos por algunos monasterios benedictinos").

—_Cronistas generales de la Congregación de San Benito de Valladolid": Boletín de la Real Academia de la Historia, 189-1 (1992), pp. 89-126.

—ZOZAYA MONTES, Leonor, "Una revisión de las periodizaciones archivísticas de la Edad Moderna Española: Documenta \& Instrumenta, 6 (2008), pp. 119-145 (= ZOZAYA MONTES, "Periodizaciones archivísticas"). 
EL ÍNDICE DE SAN ZOILO DE CARRIÓN 
PRIMERA PARTE.

ESTUDIO 



\section{HISTORIOGRAFÍA DEL MONASTERIO DE SAN ZOILO DE CARRIÓN}

Abordar el estudio de una institución cualquiera; acercarse a una biografía, a un paisaje urbano o a un simple edificio requiere como primera tarea saber quiénes, cuándo y de qué manera han contemplado esas realidades. No únicamente con la intención de allanar el camino sino también y sobre todo para tener una idea cabal de lo que se conoce o no sobre el objeto de estudio.

Así, pues, es natural que después de esa afirmación, inicie el trabajo con unas páginas dedicadas a conocer la historiografía del monasterio de San Zoilo de Carrión, o lo que es igual, con un repaso bibliográfico de lo que se ha escrito sobre la institución monástica y sus fuentes. Hacer tal revisión de la producción historiográfica permite reconocer, en primer término, que el interés por San Zoilo de Carrión está íntimamente unido al interés que ya desde su fundación, aunque más significativamente desde hace unas décadas, ha suscitado Cluny y la expansión del monacato benedictino en la Península Ibérica. Qué duda cabe, que el conocimiento del cenobio palentino exige este otro y este último se enriquece con el de aquel. La comprensión de lo que es San Zoilo se hace imposible sin conocer la realidad de Cluny.

El repaso a la bibliografía sobre San Zoilo permite adelantar dos realidades que, a primera vista, podrían ser entendidas como desalentadoras y que no lo quieren ser. Son, eso sí, significativas, reveladoras de una situación que no es ni singular ni única para el caso de San Zoilo de Carrión. La primera de ellas es la escasez de monografías sobre el cenobio, puesto que únicamente M. ${ }^{a}$ Luisa Palacio Sánchez-Izquierdo y Julio A. Pérez Celada se han ocupado por recoger y analizar la documentación conservada del monasterio, resultando de los trabajos de recogida de la documentación y estudio de la misma varios trabajos a los que después aludiré.

La segunda realidad a la que quiero aludir es compartida por no pocas instituciones monásticas, catedralicias, concejiles, municipales, universitarias y de otras índoles, tanto civiles como eclesiásticas. El caso de San Zoilo de Carrión no es paradigmático. Tanto Pérez Celada como Sánchez-Izquierdo, y lo mismo que ellos otros autores que se han acercado más superficialmente a la institución Carrionesa, centraron sus trabajos en los 
siglos medievales. La revisión historiográfica me ha permitido reconocer una evidente y considerable descompensación entre los estudios (y por tanto la información y conocimiento) que se tiene de San Zoilo en los siglos medievales y los correspondientes a la Edad Moderna. Añadiría más: resulta escasa, no me atrevo a calificarla de insuficiente, la información que se tiene al día de hoy del monasterio en los siglos de la Edad Moderna, tanto en lo que toca al ámbito eclesiástico, como al económico, al patrimonial, al relacional con el entorno, sea o no de conflictividad, lo sea en el plano civil o religioso. Mucha información desconocemos. Información que se hace indispensable y sin la cual se hace difícil, por no decir imposible, reconstruir la historia moderna de la comunidad carrionesa. Una historia, pues, que está por escribir.

Las primeras menciones del monasterio de San Zoilo las hallamos en las obras de los cronistas que, ya en la Edad Moderna, centraron su atención en el estudio de la historia eclesiástica y política de España. Evidente es que el interés de esos autores no era la construcción de una imagen particular ni una historia de San Zoilo, pero no dejó de contemplarse en sus crónicas por el interés que el centro tenía para la elaboración de las mismas y de sus disertaciones políticas o eclesiásticas.

Cuando en el siglo XVI Ambrosio de Morales $^{2}$ continúa la crónica inacabada de Florián de Ocampo, hace una mención breve aunque significativa del monasterio de San Zoilo, puesto que ofrece el momento de fundación del cenobio. Para proporcionar la información se sirve de lo anotado en un libro de concilios que escribió un monje llamado Juliano para el abad Teodomiro del monasterio, cuya redacción fecha en el año 948. Pero las afirmaciones de Ambrosio de Morales se han demostrado en alguna ocasión inexactas, cuando no dudosas, y hay que tener ciertas reservas cuando el cronista afirma haber visto libros y documentos que hoy se sabe que no vio, como ocurrió con el Becerro Gótico de Valpuesta que Ambrosio de Morales dice haber consultado, hecho que niega José Manuel Ruiz Asencio en su último trabajo sobre el manuscrito valpostano ${ }^{3}$.

Ya en la siguiente centuria el monje benedictino fray Antonio de Yepes ${ }^{4}$ se ocupará de llevar adelante la empresa de historiar la trayectoria de la Orden de San Benito. Lo hace

\footnotetext{
2 MORALES, Antonio de, Crónica General de España. Madrid, 1574. Libro 16, capítulo XVIII (=MORALES, Crónica España).

${ }^{3}$ RUIZ ASENCIO, José M.-RUIZ ALBI, Irene-HERRERO JIMÉNEZ, Mauricio, Los becerros gótico y galicano de Valpuesta. Madrid: Real Academia Española-Burgos: Instituto Castellano y Leonés de la Lengua, 2010.

${ }^{4}$ YEPES, Antonio de, Crónica general de la Orden de San Benito. Edición abreviada por Fr. Justo Pérez de Urbel, 3 vols. Madrid, 1960, volumen 3, pp. 48-78.

YEPES, Antonio de, Coronica general de la Orden de San Benito, patriarca de religiosos. Tomo VI, centuria VI $[y$ séptima]. Valladolid: por Francisco Fernández de Cordoua, 1617, pp.73-93, (=YEPES, Coronica San Benito); donde inicia el capítulo dedicado a San Zoilo con el siguiente título: "Año de Christo de 1047. Año de San
} 
en su Coronica General, en la que, no podía ser de otra manera, es destacada la presencia del monasterio de San Zoilo como uno de los prioratos cluniacenses más importantes de la Orden en la Península Ibérica. Y al remitirnos a su origen y fundación lo hace con el fundamento de la información recogida en escrituras que él mismo vio y manejó, aunque también con la revisión de la escasa bibliografía, mencionando entre otros a Ambrosio de Morales. Relata la llegada de monjes franceses alentados por la monarquía, pergeña la genealogía de sus fundadores, la formación de su patrimonio a través de donaciones e incluye una lista de los abades, un abadologio, de San Zoilo desde el siglo XIII hasta los años del siglo XVII en que él escribe su Crónica.

Las visiones de carácter general se continúan en el siglo XVIII de la mano del agustino Henrique Flórez, quien en el tomo X de su España Sagrada ofrece una visión panorámica, ligera del monasterio. Y si bien ofrece una colección de las leyendas y milagros de San Zoilo, lo cierto es que no proporciona ningún dato novedoso que permitiera ampliar los conocimientos que hasta entonces se tenían del monasterio ${ }^{5}$.

El siglo XIX se inauguraba convulso, por lo que habría que esperar hasta bien entrada su segunda mitad para ver resurgir el espíritu erudito de siglos pasados. Se promueve entonces una nueva querencia inclinada a realzar y revalorizar el carácter histórico y artístico de los monumentos, además de promover su protección y conservación a través del empleo de una serie de mecanismos como fueron, de un lado, la creación de academias, museos, comisiones de monumentos; y, de otro, mediante la elaboración de catálogos e inventarios donde aparecieran descritos y referenciados esos monumentos históricos.

Bajo estas directrices surge la obra Recuerdos y bellezas de España de José María Quadrado ${ }^{6}$. En el tomo dedicado a las provincias de Valladolid, Palencia y Zamora consagra un capítulo a Carrión y su distrito, en el cual, junto a diversas leyendas y descripciones de iglesias, realiza un recorrido por el monasterio de San Zoilo, analizando sus aspectos artísticos y su estado de conservación, desde el panteón de los condes hasta el claustro plateresco; detallando las características de sus esculturas y portadas, así como las

Benito 567. Los principios del insigne monasterio de San Zoil de Carrión, fundado por el Conde don Gómez Díaz y la Condesa Doña Teresa”.

${ }^{5}$ FLÓREZ, Henrique, España Sagrada. Theatro geographico-historico de la Iglesia de España. Tomo X. De las iglesias sufragáneas antiguas de Sevilla: Abdera, Asido, Astigi y Córdoba, Madrid, 1753 (reimp. Madrid 1901) (=FLÓREZ, España Sagrada).

${ }^{6}$ QUADRADO, José María, Recuerdos y bellez̧as de España. Valladolid, Palencia y Zamora. Tomo 10. Madrid, 1865. Esta obra se volvió a editar bajo el título España, sus monumentos y artes, su naturaleza e historia. V alladolid, Palencia y Zamora. Barcelona, 1885. (=QUADRADO, Recuerdos y bellezas). 
inscripciones de los antiguos sarcófagos, todo ello intercalado con datos de los primeros años de la historia del cenobio.

En esta línea se sitúa la obra de Ricardo Becerro de Bengoa El Monasterio de Carrión ${ }^{7}$. En ella realiza una exhaustiva descripción del claustro renacentista, buscando inclusive en su historia una explicación factible a que un monasterio tan pingüe desde sus inicios hubiera de esperar hasta el siglo XVI para poder construir el claustro; encontrando explicación en el "favor" que a la economía del monasterio hicieron los sucesivos abades cluniacenses, consistoriales y comendatarios.

Tras una centuria casi baldía, a excepción de las obras antes mencionadas, en el siglo XX se inaugura una manera diferente y nueva de estudiar el cenobio. Había pasado el tiempo de demostrar la vitalidad, el prestigio de los centros monásticos benedictinos, algo que había caracterizado los estudios de los siglos anteriores al movimiento desamortizador y al tiempo de las exclaustraciones.

A la producción bibliográfica se incorpora en el pasado siglo XX la propia de los historiadores palentinos, que en sus trabajos muestran un interés por la ciudad, por la historia de la provincia de Palencia y por la Tierra de Campos. Francisco Simón Nieto y Martín Ramírez de Helguera están entre ellos.

Simón Nieto ofrece en sus trabajos una perspectiva histórico-artística del que fue considerado centro de la vida política de Castilla, la Tierra de Campos, en la Edad Media ${ }^{8}$. Y en esa panorámica no podían faltar las notas que dedica no solo al monasterio de San Zoilo, sino también a otros cenobios como San Salvador de Nogal o Santa Clara de Astudillo. Centros que entendía como pilares vertebradores de su historia y su arte. Como miembro principal y secretario que fue de la Comisión de Monumentos Históricos y Artísticos de la provincia de Palencia, tuvo acceso a una parte importante de la documentación referente a dichos monumentos, lo que le permitió justificar y apoyar sus investigaciones en dichos documentos.

\footnotetext{
7 BECERRO DE BENGOA, Ricardo, “El Monasterio de Carrión”: La España Moderna, revista Ibero-Americana, 7 (1889), pp. 55-96. (=BECERRO DE BENGOA, “El monasterio de Carrión”).

El autor dedica unas páginas a la villa de Carrión y aporta una breve reseña del monasterio de San Zoilo en: BECERRO DE BENGOA, Ricardo, El libro de Palencia. Palencia: Imp. de Hijos de Gutiérrez, 1874, pp. 202-210.

8 SIMÓN NIETO, Francisco, Los Antiguos Campos Góticos. Excursiones histórico-artísticas a la Tierra de Campos. Madrid, 1895 (reimp. Palencia: La Editora del Carrión, 1998) (=SIMÓN NIETO, Campos Góticos).
} 
Martín Ramírez de Helguera, por su parte, dirige su mirada a la Cornica de Yepes para ofrecer su disquisición sobre el monasterio ${ }^{9}$, si bien no presta atención únicamente a la historia del mismo sino también y además a la propia villa en la que se asienta.

En el libro que dedica al monasterio, El Real Monasterio de San Zoilo: Carrión de los Condes ante la Historia y el Arte, desgrana aspectos artísticos y monumentales que acompaña en todo momento con anotaciones históricas. Sus poco más de cien páginas y un formato reducido podrían hacer pensar que se trata de un libro de carácter divulgativo, pero va más allá de esa intención y reúne atinadamente los datos geográficos, fundacionales y patrimoniales, a los que suma un capítulo de mayor desarrollo dedicado a tratar cuestiones de arte, llegando a afirmar que San Zoilo es "el mejor claustro de España". Afirmación que por sí sola permite muchas lecturas y una de ellas, evidentemente, será el interés del trabajo desde su concepción por realzar el pasado del centro como elemento esencial de la Historia que elabora.

Con una visión completamente diferente y con un interés por un espacio también distinto, podemos hacer referencia a un trabajo de Pascual Martínez Sopena que tuvo su origen en la que fuera su Tesis Doctoral, defendida muchos años después de que Martín Ramírez publicara su obra, y que centra su atención en la Tierra de Campos Occidental. Nada tiene que ver esta obra con las antes mencionados, pero la citamos en este momento para ofrecer una perspectiva distinta a la de los autores anteriores. Entre otras razones porque ofrece una idea no contemplada: la del ejercicio, la práctica, la acción de poder que en los siglos plenomedievales la Iglesia, y en ella están los monasterios benedictinos, establece sobre los campesinos y sus tierras. En el trabajo la presencia de la institución carrionesa es destacada porque es grande fue su influencia sobre algunas villas de la Tierra de Campos Occidental, entre las que cabe citar las hoy vallisoletanas Aguilar de Campos y Villafrechós ${ }^{10}$.

Sin que el monasterio de San Zoilo sea el objeto de sus trabajos, Julio González y Gonzalo Martínez Díez en sus investigaciones sobre la Historia de Palencia ofrecen una información muy concisa, unas notas rigurosas sobre el cenobio, que ensamblan con las exposiciones que hacen sobre la expansión cluniacense, su implantación en el ámbito

\footnotetext{
${ }_{9}$ RAMÍREZ DE HELGUERA, Martín, El libro de Carrión de los Condes (con su historia). Palencia, 1896 (reimp. 2007) (=RAMÍREZ DE HELGUERA, El libro de Carrión).- IDEM, El Real Monasterio de San Zoilo de la muy noble y leal ciudad de Carrión de los Condes ante la Historia y el Arte. Palencia, 1900 (reimp. 2009).

10 MARTÍNEZ SOPENA, Pascual, La Tierra de Campos Occidental. Poblamiento, Poder y Comunidad del siglo X al XIII. Valladolid, 1985.
} 
castellano y la importancia del señorío que ejercía San Zoilo sobre algunas de las iglesias de su entorno ${ }^{11}$.

La renovación de la Historia y las Ciencias Sociales que se produjo a mediados del siglo XX dio lugar a la aparición de trabajos dedicados monográficamente al estudio de instituciones. A ello habría que añadir el reconocimiento de la Paleografía y la Diplomática como ciencias que fijan en el tiempo y el espacio los documentos y determinan la tradición, tipología y veracidad o falsedad de los diplomas. Aspectos esenciales si se pretende que la información que contienen sea el soporte para la construcción de una historia científica. Conocer las circunstancias económicas, políticas y jurídicas que caracterizan la sociedad de una determinada época exige del manejo de los documentos que testimonian las actividades de la sociedad analizada. El trabajo de Martínez Sopena al que nos referimos anteriormente es un buen ejemplo de ello.

Y sin embargo, en los inicios de la década de los años ochenta del siglo pasado, concretamente en 1982, era aún escaso el interés histórico mostrado por la documentación de los monasterios palentinos. Esclarecedoras son las palabras de Gonzalo Martínez Díez: "La historia de los Benigómez y con ella la historia de Palencia de los siglos altomedievales no se ha podido escribir definitivamente porque las tres primeras colecciones documentales palentinas de los siglos X, XI, XII, a saber: San Román de Entrepeñas, San Zoilo de Carrión y Santa María de Aguilar están todavía inéditas; mientras perdure esta desidia y dejadez en la publicación de las fuentes históricas más importantes para el altomedievo palentino no es extraño que en vez de auténtica historia se escriban fábulas y leyendas" ${ }^{12}$. Afortunadamente, San Román, San Zoilo y Santa María tienen ya publicadas sus colecciones y los siglos medievales de las tres instituciones pueden conocerse de forma diferente. Distinta realidad es la de los documentos de la Edad Moderna.

Esa necesidad de superar la historia fabulosa y la leyenda; la exigencia de ampliar la historia de los aspectos religiosos y ofrecer las visiones de la realidad económica y los aspectos de la sociedad, explican y enmarcan los trabajos no solo de edición de los documentos sino también los dedicados a la institución en que se haen estas otras miradas.

Julio Antonio Pérez Celada es uno de los autores que se va a ocupar de la publicación de los documentos y del estudio del priorato de San Zoilo en distintas obras. Editará los documentos del cenobio en dos volúmenes. En el primero publica los 164

\footnotetext{
${ }^{11}$ GONZÁLEZ GONZÁLEZ, Julio, "Siglos de Reconquista”, en Historia de Palencia I. Edades Antigua y Media. Palencia, 1984, pp. 155-215.

12 MARTÍNEZ DÍEZ, Gonzalo, "Palencia en Castilla o la castellanidad de Palencia", en Palencia en la Historia. Palencia, 1982, pp. 69-91.
} 
diplomas que forman el conjunto documental del monasterio entre los años 1047 y $1300^{13}$. La mayor parte de esa documentación ha sido transcrita por el autor, aunque por la dificultad para acceder a algunos de los manuscritos y por la pérdida de otros, incluye algunas transcripciones que habían sido publicadas con anterioridad, como documentación francesa recopilada por Auguste Bernard y Alexandre Bruell en su Recueil des Chartes de l'Abbayé de Cluny, extractos de las Actas de las Visitas y Capítulos Generales Cluniacenses referentes a la Península Ibérica editados por Ulysse Robert, pasajes relativos al cenobio que se copiaron en el Becerro de Presentaciones de la Catedral de León que editó José Antonio Fernández Flórez, la copia de un Privilegio de Fernando III publicada por M. de Manuel y Julio González, y otros diplomas extraviados, perdidos o inaccesibles.

Más allá de la simple edición, Pérez Celada hace una clasificación de los diplomas del monasterio desde el punto de vista de su tipología, que relaciona con la cronología de los mismos, y sistematiza la información que contienen en un cuadro esquemático. Introduce la edición con un repaso a la exigua historiografía, haciéndose eco o destacando los escasos escritos sobre la historia y fuentes del cenobio hasta la fecha de la publicación de su trabajo. El capítulo central del mismo se articula o gira en torno al análisis de las cuestiones que permiten comprender el monasterio de San Zoilo en su contexto político, eclesiástico y patrimonial.

En el segundo volumen de documentos edita los correspondientes a los años comprendidos entre 1301 y 1400. Un siglo de crisis al que, claro está, no escapa el cenobio. Los documentos que publica Pérez Celada dejan ver la difícil situación que atravesó el monasterio. En la información de los mismos es destacada por el autor la de tipo económico, que explica el periodo crítico de San Zoilo ${ }^{14}$. La documentación editada en su mayoría era documentación inédita hasta el momento de aparición del libro. Y a esos diplomas inéditos de lo que fuera el archivo del monasterio, añade Julio Pérez Celada una serie de testimonios editados, como las ya mencionadas Actas de los Capítulos generales de la Orden de Cluny ${ }^{15}$, pero también otros como las cuentas de $1338^{16}$, el Becerro de los

\footnotetext{
13 PÉREZ CELADA, Julio A., Documentación del Monasterio de san Zoilo de Carrión (1047-1300), Colección Fuentes Medievales Castellano Leonesas, $\mathrm{n}^{\circ}$ 100, Palencia, 1986 (=PÉREZ CELADA, Documentación San Zoilo. I).

14 PÉREZ CELADA, Julio A., Documentación del Monasterio de San Zoilo de Carrión (1301-1400), Colección Fuentes Medievales Castellano Leonesas, no 101, Palencia, 1987 (=PÉREZ CELADA, Documentación San Zoilo. II).

${ }^{15}$ ROBERT, Ulysse, "Ètat des Monastères Spagnols de l'ordre de Cluny aux XVIII è- XV è siècles, d'après les Actes des Visites et des Chapitres Generaux": Boletín de la Real Academia de la Historia, 20 (1892), pp. 321431.
} 
beneficios eclesiásticos de la Diócesis palentina hacia $1345^{17}$ y el Becerro de las Behetrías ${ }^{18}$. Al igual que hace en el volumen primero, el autor propone una clasificación de la documentación que edita.

En 1997, diez años después de editar la colección diplomática del monasterio, Pérez Celada publica un nuevo libro sobre el monasterio de San Zoilo y el señorío del mismo ${ }^{19}$. Este tercer trabajo no sólo es corolario de lo que fuera su Tesis Doctoral sino también de la edición de los diplomas del monasterio. La visión ampliada, y renovada por ello, de lo que habían sido sus trabajos anteriores, se completa, y se muestra el monasterio en interacción con el ámbito geográfico, las condiciones en que se produjo la benedictización de la Cuenca del Duero y el proceso de configuración patrimonial desde el momento de su fundación merced a donaciones y adquisiciones.

Los capítulos esenciales del libro son los dedicados a explicar la estructura del dominio del monasterio de San Zoilo de Carrión y la explotación del mismo. El capítulo sexto, dedicado al análisis del entramado social como elemento esencial del dominio juega un papel destacado en el trabajo. En el mismo no sólo se presta atención al grupo monástico, sino que además se estudia la importante participación de los laicos en la explotación del servicio del monasterio. Todo ello estudiado en relación con lo que, de forma paralela, estaba sucediendo en ese momento en Cluny. También juega un papel importante el conjunto de cuadros y gráficos con interpretación de los datos de carácter económico en los que se hace un intento por sintetizar toda su investigación anterior, destacando principalmente las que hace para el siglo XVI, sobre todo porque es un segmento cronológico que en sus trabajos anteriores no había tenido cabida y por tanto son de interés sus aportaciones.

Ya hemos adelantado que el trabajo era en parte deudor, en cuanto a la información, a la colección de documentos que había editado en sus dos libros anteriores. Además de los documentos transcritos por él y los que toma de editores que le precedieron, que se habían perdido en el transcurso del tiempo o eran de difícil o imposible acceso, Pérez Celada explota la información de documentos que no transcribe pero que

\footnotetext{
16 El Libro de Cuentas del año de 1338 se conserva en el fondo documental del monasterio de Santo Domingo de Silos y constituye el apéndice documental de la obra de GARCÍA GONZÁLEZ, Juan José, Vida económica de los Monasterios Benedictinos en el siglo XIV. Valladolid, 1972.

${ }^{17}$ Editado por SAN MARTÍN PAYO, Jesús, "La más antigua estadística de la Diócesis Palentina (a. 1345)": Publicaciones de la Institución Tello Téllez de Meneses (=PITTM), 7 (1951), pp. 1-120.

${ }^{18}$ Custodiado en el Archivo General de Simancas y editado por MARTÍNEZ DÍEZ, Gonzalo, Libro Becerro de las Behetrías, 3 vols. León, 1980.

19 PÉREZ CELADA, Julio A., El monasterio de San Zoilo de Carrión. Formación, estructura y decurso bistórico de un señorío castellano-leonés (siglos XI-XVI). Burgos, 1997.
} 
consulta en el Archivo Histórico Provincial de Palencia. Me refiero a "El Libro Segundo de Apeos"20, ya editado, y al "Índice de San Zoilo",21, cuya edición y estudio constituye ahora el fundamento de esta Tesis Doctoral.

Otra monografía centrada en el estudio de San Zoilo de Carrión fue realizada en una tiempo paralelo al dedicado por Julio Pérez Celada a hacer su edición de la colección diplomática del monasterio. En esta ocasión la autora fue M.a Luisa Palacio SánchezIzquierdo y la obra tuvo sus orígenes en su Tesis Doctoral, defendida en 1987, año en que, como decimos, Pérez Celada publicó el segundo de los dos tomos de la colección de documentos de San Zoilo. La autora dedica los cuatro primeros capítulos al análisis de los aspectos relativos a la fundación del cenobio, la conformación del dominio monástico y cuestiones de renta y patrimonio del mismo ${ }^{22}$.

Las aportaciones más valiosas del trabajo de Palacio Sánchez-Izquierdo las encontramos en los capítulos que dedica al análisis de las cuestiones paleográficas y diplomáticas de los documentos, que no fueron tratadas con tanta profundidad por Julio Pérez Celada. Destaca asimismo el ensayo de reconstrucción de la organización de lo que fue el notable archivo del monasterio, ofreciendo además en la obra una clasificación de la documentación tomando como referencia el arreglo del archivo efectuado en el siglo XVII.

La monografía, dividida en dos volúmenes, presenta en el segundo de ellos (el primero es el descrito en el párrafo anterior) un apéndice documental en el que se editan 214 diplomas conservados en el Archivo Histórico Nacional, datados entre el siglo XI hasta comienzos del siglo XV, concretamente hasta 1409. Esas cifras y la cronología referida permiten deducir que la autora edita 65 documentos posteriores a 1400 que no había editado Pérez Celada. Publica además el interesante Manual del Archivo de San Zoil de Carrión elaborado en 1635 por fray Juan de Cisneros ${ }^{23}$ y parte del llamado "Libro Misceláneo", escrito entre finales del siglo XIII y finales del siglo XVII, conservado en la actualidad en el Archivo del Obispado de Palencia.

El primer volumen de la Tesis Doctoral de M. ${ }^{a}$ Luisa Palacio conoce en 1990 una nueva edición, publicada por el servicio de publicaciones de la Diputación de Palencia con

\footnotetext{
20 Archivo Histórico Provincial de Palencia (=AHPP), Sección Desamortización, Legajo 107. La edición fue hecha por BEJARANO RUBIO, Amparo-MOLINA MOLINA, Ángel Luis, El Monasterio de San Zoilo (Carrión de los Condes) a fines de la Edad Media. Murcia, 1999.

${ }^{21}$ AHPP, Sección Desamortización, Legajo 112.

22 PALACIO SÁNCHEZ-IZQUIERDO, M. ${ }^{a}$ Luisa, Colección Diplomática del monasterio de San Zoil de Carrión (siglos XI-XV), 2 vols. Madrid, 1988 (=PALACIO, Colección San Zoil I/II).

23 Archivo Histórico Nacional (=AHN), Sección Clero, Libro 9552.
} 
el título San Zoil de Carrión (siglos XI-XIV), en la que no se publican los documentos que la autora ya había editado ${ }^{24}$.

Los trabajos de Pérez Celada y Palacio Sánchez-Izquierdo tienen orientaciones diferentes. Los intereses de uno y otro autor también lo eran. Frente a Julio Pérez Celada, que no tenía en los documentos el objeto último de su obra, M. ${ }^{a}$ Luisa Palacios sí los tuvo en el suyo. La orientación de ambas obras es, pues, distinta, como distintos los resultados. Es natural entonces que mientras esta última autora esboce aspectos de índole socioeconómica, Pérez los aborde, sobre todo en su trabajo sobre el señorío del monasterio, de forma más honda, y que en ocasiones muestre su desacuerdo con las opiniones de la autora madrileña ${ }^{25}$. Como lo ha hecho también Carlos Reglero de la Fuente recientemente, que destacando las aportaciones de Palacio en las cuestiones de archivo, advierte errores de interpretación de algunos documentos ${ }^{26}$.

Lo dicho hasta aquí en este capítulo dedicado a referir lo aparecido hasta el momento sobre la historia y las fuentes del monasterio de San Zoilo de Carrión, advierte que tanto en lo que afecta a la edición de las fuentes como a los trabajos de análisis de carácter histórico estos no llegan más que hasta el siglo XVI. Esta es una circunstancia que no es exclusiva de San Zoilo. Lo cierto es que, recordando las palabras del padre Gonzalo Martínez Díez, para la Edad Moderna se está huérfano de muchas fuentes que aún no han visto la luz. Pero la explosión documental que se produce en la Castilla de la Edad Moderna hace prácticamente imposible la tarea de la edición de los conjuntos de los documentos al modo en que se han hecho para la Edad Media. Y en muchos casos la normalización tipológica y administrativa facilita la tarea de la descripción de series documentales que proporcionan la información que los historiadores precisan. Pero qué duda cabe que el estudio de los monasterios, los concejos, las universidades están necesitados de la edición de fuentes diplomáticas de la Edad Moderna. En cualquier caso se hacen necesarios para los monasterios trabajos que superen la limitación cronológica en los siglos medievales, que afecta no únicamente al monasterio de San Zoilo de Carrión, sino

\footnotetext{
${ }^{24}$ Con anterioridad a este trabajo realizó otras publicaciones. Destacamos entre ellas: PALACIO SÁNCHEZIZQUIERDO, M. ${ }^{a}$ Luisa, "Monasterio de San Zoilo y Monasterios Palentinos", en Palencia en la Historia. Palencia, 1982, pp. 145-166; IDEM, "El Monasterio de San Zoilo de Carrión, Jurisdicción, Franquezas y Privilegios", en Actas Capitulares del I Congreso de Palencia. II, Fuentes documentales y Edad Media. Palencia, 1987, pp. 65-73.

${ }^{25}$ PÉREZ CELADA, Julio A., El monasterio de San Zoilo de Carrión. Formación, estructura y decurso bistórico de un señorí castellano-leonés (siglos XI-XVI), Burgos, 1997, p.17.

${ }^{26}$ REGLERO DE LA FUENTE, Carlos M., Cluny en España. Los prioratos de la provincia y sus redes sociales (1073ca 1270). León, 2008, p. 81 (=REGLERO, Cluny en España).
} 
también a otros monasterios benedictinos, como es el caso de Santa María de Nájera ${ }^{27}$ o San Isidro de Dueñas ${ }^{28}$.

No obstante lo dicho, hay trabajos en los que se abordan asuntos puntuales en los que los límites de los siglos medievales son superados. Es lo que acontece con un artículo escrito por Ernesto Zaragoza Pascual, que se hace de imprescindible consulta al proporcionar una lista completa de todos los abades del monasterio ${ }^{29}$. El abadologio, en efecto, empieza con el abad Arnaldo (1047), que aparece en la Crónica de Yepes ${ }^{30}$, y concluye con fray Plácido Trevijano (1832-1835), mencionado como último abad por Tomás Moral ${ }^{31}$. Al dedicar el trabajo al abadologio, el autor buscó corregir algunos errores detectados por él en anteriores listados de abades del monasterio. Completa esto con una lista de los monjes profesos de San Zoilo de Carrión desde 1593 hasta 1833. Aportación necesaria, ya que la desaparición de los libros de gradas y profesiones con motivo de la exclaustración ha motivado la pérdida de esa información.

No es reducido el número de autores que se han dedicado al estudio del establecimiento de los prioratos cluniacenses en la Península Ibérica, Bishko ${ }^{32}$ y Linage Conde $^{33}$ entre ellos. El estudio más reciente y completo ha salido de la pluma rigurosa de Carlos Reglero de la Fuente, que ha dedicado una monografía a los prioratos de Cluny en la provincia española, y en la que de manera exhaustiva muestra la relación de los prioratos hispanos con su entorno social y político ${ }^{34}$. En el trabajo dedica un buen número de páginas a dar cuenta de una amplia historiografía con una selecta relación de los libros dedicados al estudio de Cluny, su implantación en la Península y las principales monografías dedicadas a los prioratos, así como las fuentes documentales que pueden consultarse para ahondar en estos y otros aspectos relacionados con Cluny.

\footnotetext{
27 CANTERA MONTENEGRO, Margarita, Santa Maria la Real de Nájera. Siglos XI-XIV, 3 vols. Madrid, 1987.

28 REGLERO DE LA FUENTE, Carlos M., El Monasterio de San Isidro de Dueñas en la Edad Media. Un priorato cluniacense Hispano (911-1478). Estudio y Colección Documental. León, 2005.

29 ZARAGOZA PASCUAL, Ernesto, "Abadologio del Monasterio de San Zoilo de Carrión de los Condes (siglos XI-XIX) y Libro de Gradas de los Monjes que profesaron en él (1593-1833)”: PITTM, 64 (1993), pp. 273-322 (=ZARAGOZA PASCUAL, Abadologio San Zoilo).

30 Podemos encontrar una lista de abades hasta 1613 en YEPES, Coronica San Benito, pp. 71-78.

${ }^{31}$ MORAL, Tomás, "San Zoilo de Carrión de los Condes", en Diccionario de Historia Eclesiástica de España. Tomo III. Madrid, 1973, p. 1543.

32 BISHKO, Charles Julian, "El abad Radulfo de Cluny y el prior Humberto de Carrión camerario de España: Tres cartas inéditas de hacia 1174": Anuario de Estudios Medievales, I (1964), pp. 197-215 (=BISHKO, El abad Radulfo).

33 LINAGE CONDE, Antonio, Los orígenes del monacato benedictino en la Peninsula Ibérica. 3 vols. León, 1973 (=LINAGE CONDE, Los origenes del monacato).

${ }^{34}$ REGLERO, Cluny en España.
} 
Son casi 900 páginas en las que destaca la claridad y concisión de ideas. Páginas generosas que permiten acercarse a la realidad de lo que fue la implantación cluniacense en España, el complejo sistema de relaciones con la monarquía, la nobleza y la jerarquía eclesiástica; así como su disputa por ejercer el control sobre los prioratos, de los cuales expone las características del personal monástico y la relación con la abadía borgoñona. Se incluye en la obra un apéndice documental, con el que el autor no busca dar a conocer documentos inéditos, sino ofrecer al lector la posibilidad de conocer las fuentes diplomáticas en las que fundamenta las tesis expuestas en la obra.

En la monografía de Reglero de la Fuente no extraña el protagonismo, la presencia del monasterio de San Zoilo. El cenobio de Carrión de los Conde fue uno de los primeros y más importantes prioratos que dependieron directamente de Cluny. Carlos Reglero ha trabajado además con documentos necrológicos y eso le ha permitido no únicamente identificar a alguno de los nombres inscritos en el Necrologio de San Zoilo de Carrión ${ }^{35}$ sino hacer un intento además por explicar la relación que los individuos inscritos en el documento necrológico mantuvieron con el cenobio carrionés.

El conocimiento de la historia del celebérrimo monasterio benedictino de San Zoilo se hace posible también y además de con la edición y el análisis de sus documentos, con el estudio de la arquitectura y escultura, del escenario artístico, en definitiva, del edificio que, junto con la comunidad conventual y el patrimonio y sus rentas, explican la realidad monástica. El escenario de arquitectura románica permite muchas interpretaciones, una de ellas está relacionada con el interés que para reyes y magnates tuvo el priorato.

La notoriedad del conjunto arquitectónico del monasterio descansa aún hoy sobre el admirable claustro plateresco. Ya lo advirtió Ramírez de Helguera en su obra "El Real Monasterio de San Zoilo: Carrión de los Condes ante la Historia y el Arte”. La notoriedad no se ha traducido en producción bibliográfica hasta tiempos recientes. Adolfo F. DíazNava hizo alusión a ello en un artículo que dedicó al claustro plateresco de San Zoilo ${ }^{36}$ y que concibió, precisamente, por la escasez de estudios dedicados al mismo. Literalmente

\footnotetext{
35 Recientemente Reglero de la Fuente ha publicado un estudio pormenorizado de dicho manuscrito, analizando su origen y composición, así como la importancia que este libro tuvo para el monasterio y su posible uso como obituario. Véase REGLERO DE LA FUENTE, Carlos Manuel, "El necrológico-obituario de San Zoilo de Carrión", en HERRERO DE LA FUENTE, Marta-HERRERO JIMÉNEZ, Mauricio-RUIZ ALBI, Irene-MOLINA DE LA TORRE, Francisco J. (coords.), Alma littera. Estudios dedicados al profesor José Manuel Ruiz. Asencio. Valladolid, 2014, pp.525-533.

36 DÍAZ NAVA, Adolfo F., "Un claustro plateresco "San Zoil" en Carrión de los Condes": PITTM, 23 (1963), pp. 89-120.
} 
escribió: “Al querer informarme sobre él apenas he encontrado más que someras referencias, sobre todo en lo que toca a su parte artística" ${ }^{37}$.

En las Actas del II Congreso de Historia de Palencia, celebrado en el año 1989, M. ${ }^{a}$ José Redondo Cantera, además de recoger las conclusiones expuestas por los dos últimos autores citados, las amplía en un capítulo que dedica al claustro bajo del monasterio, en el que describe minuciosamente el programa iconográfico del mismo y hace una relación del conjunto de los personajes representados (reyes, obispos, fundadores del cenobio) que proporcionan una visión de la tradición monástica e histórica ${ }^{38}$.

La notoriedad de San Zoilo no se agota en el claustro. Muy al contrario, y en ello inciden los últimos hallazgos, que permiten comprender la extraordinaria importancia de la iglesia románica. El autor que más se ha interesado en esta línea de trabajo, abierta tras los recientes descubrimientos, ha sido el profesor José Luis Senra Gabriel y Galán. Mucho dicen de su dedicación al tema y su aproximación a San Zoilo los artículos que ha dedicado a la soberbia portada románica ${ }^{39}$ y a las dos telas islámicas descubiertas en la última década ${ }^{40}$.

La iglesia era un lugar también para el enterramiento. $\mathrm{Y}$ en ella se buscaba el acomodo de los cuerpos para después de la muerte. La iglesia de San Zoilo tiene, como había de ser en un monasterio como el carrionés, una colección de sepulcros datados entre los siglos XI-XIII, en los cuales Julia Ara ha centrado su atención en uno de sus trabajos ${ }^{41}$.

El estudio histórico y artístico del cenobio parece haberse convertido en una fuente de inagotable producción científica, a tenor de las últimas monografías publicadas. La vallisoletana Lorena García publicó en el año 2014 el libro Monasterio de San Zoilo de Carrión

\footnotetext{
${ }^{37}$ Ibídem, p. 91.

38 REDONDO CANTERA, M. ${ }^{a}$ José, "El programa iconográfico en el claustro bajo del monasterio de San Zoilo de Carrión de los Condes (Palencia)", en Actas del II Congreso de Historia de Palencia. V. Palencia, 1990, pp. 129-154.

39 SENRA GABRIEL y GALÁN, José Luis, "La portada occidental recientemente descubierta del priorato cluniacense de Carrión de los Condes": Archivo español de Arte, Tomo 67, n. 265 (1994), pp. 57-72; IDEM, "Algunas notas sobre la desaparecida iglesia románica del priorato cluniacense de Carrión de los Condes", en Actas del III Congreso de Palencia. IV. Palencia, 1996, pp. 439-451; IDEM, "Nuevos hallazgos románicos en el Monasterio de San Zoilo de Carrión de los Condes (Palencia)": Archivo español de Arte, Tomo 74, n. 293 (2001), pp. 88-95; IDEM, "La puerta como dogma: a propósito de un nuevo descubrimiento de la iglesia románica de San Zoilo de Carrión de los Condes (Palencia)": Archivo español de Arte, Tomo 81, n. 322 (2008), pp. 139-150.

40 SENRA GABRIEL y GALÁN, José Luis, "Dos telas islámicas encontradas en el monasterio de San Zoilo de Carrión de los Condes: Goya. Revista de Arte, 303 (2004), pp. 332-340.

41 ARA GIL, Julia, "Un grupo de sepulcros palentinos del siglo XIII. Los primeros talleres de Carrión de los Condes. Pedro Pintor y Roi Martínez de Burueva", en II Curso de cultura medieval. Aguilar de Campoo, 1990. Alfonso VII y su época. Madrid, 1992, pp. 21-52.
} 
de los Condes: Arte e historia de un hito Cluniacense ${ }^{42}$; obra que tiene su punto de partida en su Tesis Doctoral: Evolución del Patrimonio Religioso en Carrión de los Condes, Palencia, desde la Baja Edad Media hasta nuestros días ${ }^{43}$, defendida en 2012. En ella realiza un completo estudio sobre el panorama histórico, económico y social de Carrión, así como de la huella que el arte ha ido dejando en dicha villa; poniendo especial incidencia en la evolución del patrimonio religioso. Y en este, como no podía ser de otra manera, destaca San Zoilo. Por siglos, analiza los hechos históricos más relevantes, así como los aportes artísticos que se producían en cada uno de ellos, elaborando una visión histórico-artística del monasterio desde el siglo XI hasta su declaración como Monumento Nacional en 1931 y su posterior reconocimiento como Bien de Interés Cultural en 2012.

En la misma línea, pero ya centrado en un aspecto mucho más concreto, aparece el monográfico Restauración de la "Galilea" del Real Monasterio de San Zoilo", publicado a raíz de las obras de restauración acometidas en la Sala Galilea, estancia concebida para ser atrio, vestíbulo o sala previa al claustro e iglesia del antiguo monasterio, destacando en ella la que fue puerta de acceso al conjunto románico.

En el 2016 se ha publicado una de las últimas obras referentes a San Zoilo y, aunque se centra en examinar las circunstancias que acompañaron el traslado de las reliquias del santo desde Córdoba hasta el monasterio carrionés y la suerte de las arquetas elegidas para contenerlas, es de destacar la utilización que hace, para soportar su investigación, del Martirologio del cenobio, el cual formaba parte de un libro Misceláneo que se encontró tirado detrás de una estantería en una de las dependencias una vez que los jesuitas abandonaron el monasterio ${ }^{45}$.

Sin embargo, lo que nunca deja de sorprender por lo casi ilimitado de sus recursos y posibilidades, es el ámbito reservado para los estudios de los documentos tanto en sus aspectos paleográficos como archivísticos. A este respecto destacamos dos de los trabajos más recientes. Uno, el ya citado Necrologio de San Zoilo estudiado por Reglero de la Fuente;

\footnotetext{
${ }^{42}$ GARCÍA GARCÍA, Lorena, Monasterio de San Zoilo de Carrión de los Condes: Arte e bistoria de un bito Cluniacense. Palencia: Asociación de Amigos del Camino de Santiago de Palencia: Centro de Estudios y Documentación del Camino de Santiago, 2014.

43 GARCÍA GARCÍA, Lorena, Evolución del Patrimonio Religioso en Carrión de los Condes, Palencia, desde la Baja Edad Media hasta nuestros días. Tesis doctoral consultable en: http://uvadoc.uva.es/handle/10324/3026 [Última consulta: 24 de febrero de 2017].

44 BARREDA FERRER, Ángel Luis, "Restauración de la "Galilea" del Real Monasterio de San Zoilo": Peregrino: revista del Camino de Santiago, 147-148 (2013), p. 7.

45 FROCHOSO SÁNCHEZ, Rafael, "Las reliquias de San Zoilo, las arquetas y las telas árabes": Al-Mulk: Anuario de Estudios Arabistas, 14 (2016), pp. 19-49.

Más información acerca de este mártir cordobés puede encontrarse en SANTOS URBANEJA, Fernando, San Zoilo, un mártir cordobés en el Camino de Santiago. Santiago de Compostela: Centro de Estudios y Documentación del Camino de Santiago, 2003. (=SANTOS URBANEJA, San Zoilo)
} 
el otro, un estudio realizado por la profesora Ruiz Albi del fragmento de una Biblia visigótica de San Zoilo que se encuentra en el Colegio de San Estanislao de Salamanca, formando parte del fondo que los jesuitas trasladaron del monasterio tras su salida del mismo ${ }^{46}$.

Por último, merecen especial mención, por lo anecdótico de su hallazgo, unos fragmentos que recientemente se han encontrado durante las últimas obras de restauración en la Galilea y la portada románica del cenobio, los cuales serán estudiados por la profesora Ruiz Albi.

Este recorrido historiográfico no ha hecho más que confirmar algunas de las afirmaciones que hacíamos al comienzo de este capítulo, en especial aquella que redunda en el hecho de que el visible vacío de monografías para los siglos modernos, en la generalidad de monasterios benedictinos y en el caso concreto de San Zoilo, nos va a permitir, al tener en nuestras manos un manuscrito, el Índice, que es un instrumento de control y acceso a los documentos del archivo del monasterio de San Zoilo (y por ende útil para la gestión del patrimonio), ofrecer una visión de conjunto desde la fundación hasta el declive del archivo de una institución clave para la comprensión del monacato benedictino y sus relaciones en la Península Ibérica como fue el monasterio de San Zoilo de Carrión.

\footnotetext{
${ }^{46}$ RUIZ ALBI, Irene, "Dos fragmentos de biblias visigóticas (San Zoilo de Carrión y Catedral de Zamora)", en CECILIO DÍAZ Y DÍAZ, Manuel-DÍAZ DE BUSTAMANTE, Mercedes-DOMÍNGUEZ GARCÍA Manuela (coords.), Escritos dedicados a José María Fernández. Catón. Vol. 2. León, 2004, pp. 1291-1316.
} 



\section{APROXIMACIÓN HISTÓRICA AL MONASTERIO DE SAN ZOILO DE CARRIÓN}

\subsection{Carrión en la bistoria}

De todos los monasterios hispanos que se erigieron en los siglos medievales y modernos y aún se asientan en la heterogénea geografía española, los cenobios cluniacenses $^{47}$ son al día de hoy algunos de los que cuentan con las historias más elaboradas y complejas de cuantas encontramos sobre el monaquismo hispano. Lo que, sin duda ninguna, permite reconocer la dilatada combinación de relaciones que se establecieron entre todos ellos, que se vio enormemente favorecida por la situación estratégica de los cenobios junto a las vías, calzadas y rutas de comunicación que habían sido construidas durante la etapa romanizadora y que vertebraron perfectamente el territorio, lo que convirtió a los monasterios en ciertos e inequívocos centros repobladores en los primeros siglos de reconquista cristiana. Esto llevó a la conversión de los monasterios en realidades inseparables del devenir histórico, económico y social de la zona de influencia, de las áreas en las que se encontraban y de los núcleos circundantes establecidos a su alrededor.

Esta circunstancia constituye, a mi parecer, una posición cardinal cuando se quiere afrontar la reconstrucción histórica de un monasterio. No pueden conocerse las vicisitudes que han conformado a lo largo de los siglos la realidad monástica si se aísla de su entorno, se ignora la historia del lugar en que se enclava y de sus habitantes. Por ello no podemos obviar esa realidad circundante en este capítulo, en el que nos proponemos abordar todas las cuestiones relativas a la formación y acontecer histórico del monasterio de San Zoilo de Carrión, uno de los más señeros prioratos benedictinos de la red cenobítica hispana.

No ignorarlo no supone que el epígrafe que dediquemos al entorno se convierta en eje de este capítulo que dedicamos a la historia del monasterio. No queremos, sin embargo, repetir lo hecho por algunos historiadores que se han acercado al monasterio de San Zoilo no sólo ignorando la trascendencia de la propia villa de Carrión, sino destacando que fue la

47 Véase REGLERO, Cluny en España, pp. 12-15, donde se hace eco de la controversia surgida en torno al uso del término «cluniacense» y señala que, siguiendo a Yepes, con este calificativo se podría designar "a los monasterios dependientes de Cluny en España, y a los monjes que en ellos habitaron", como fue el caso de Nájera, San Zoilo de Carrión, San Isidro de Dueñas, San Vicente de Salamanca, Santa Ágata de Ciudad Rodrigo, San Miguel de Zamora, San Román, San Boal, Pombeiro y otros. 
instalación de Cluny la que explica la circunstancia de esa importancia y realza el lugar a partir de entonces. Y lo cierto es que la historia de la villa de Carrión se acrecienta con el establecimiento monástico pero siempre poseyó una categoría y notoriedad evidente. Lo que justifica que algunos reyes decidieran instalarse en ella por el potencial económico y estratégico de la villa. Hechos como el que Carrión ostentara el título de ciudad así lo prueban $^{48}$, como también el que adquiriera nobleza no porque los reyes se instalaran en ella y la concedieran privilegios, sino por la riqueza del territorio.

Es por esto que considero necesario abordar el estudio del cenobio carrionés enmarcado en la historia de Carrión, para así poder comprender la significación que posteriormente adquirirá como sede de reyes, celebración de Cortes y $\operatorname{concilios}^{49}$, y baluarte de numerosas donaciones que convirtieron a San Zoilo en uno de los más significados centros monásticos de la diócesis palentina, asentado en la región circundante de las cordilleras del norte peninsular conquistada por los romanos a los vacceos indoeuropeos. Una riquísima vega agrícola, regada por el Duero y sus afluentes que facilitaron el desarrollo de una próspera economía de producción cerealista, que se acompañó pronto de una trashumancia ganadera que aprovechaba los valles y llanuras de la meseta central.

Pallantia fue uno de los centros neurálgicos de la Península Ibérica ${ }^{50}$, y Carrión, a la que los romanos llamaron Lacóbriga en el 78 a. C., la capital histórica de la comarca. Como tal centro y capital no fueron ajenos a los altibajos del propio Imperio ni tampoco a las

48 RAMÍREZ DE HELGUERA, El libro de Carrión, p. 34, sitúa en los años 1037 y 1050 a Carrión por primera vez con el nombre de ciudad, basándose en un documento del rey Fernando I, en el que entre otras poblaciones menciona la ciudad de Santa María, junto al río Carrión. No significa que dicho rey le concediese el título, esta es aún una cuestión sin aclarar.

Este mismo autor alude a otros testimonios que podrían ayudar a aclarar esta cuestión, entre los que destacamos, por su relación directa con el monasterio, aquel que se basa para su afirmación en una escritura hallada en el archivo de San Zoilo, en la cual se dice que dicho monasterio estaba fundado "justa civitatem Sanctae Mariae"; documento que se halla regestado en el Índice como "Testamento y donación, escrita en pergamino, que otorgó Sancha Ýñiguez y sus hijos e hijas, por la qual ofrecen al monasterio de San Juan, San Zoil y San Felices, que está fundado junto al río de Carrión iuxta cives Sanctæ Mariæ, que en aquel tiempo Carrión hera ciudad y se llamaba Santa María [...] Facta seriens testamenti kalendas maii, die sabato, era 1161, que es año de Christo de 1123 [...]"; incluye la siguiente nota al margen derecho: "Carrión se llamaba en este tiempo la ciudad de Santa María”. AHPP, Desamortización, Legajo 112, f. 355r, n. ${ }^{\circ}$.

YEPES, Coronica San Benito, p. 73, reafirma este hecho al referirse al pueblo Santa María de Carrión como "el qual en tiempos passados deuía de ser demás población que aora, pues le hallamos autoriçado con nombre de ciudad".

49 RAMÍREZ DE HELGUERA, El libro de Carrión, p. 56, donde lo confirma cuando se expresa de la siguiente manera al hablar de Carrión: “iQué importancia tenía esta población entonces! ¿Pero quién la protegía? El poder civil y el eclesiástico; así sólo se explica que fuera residencia regia y en la misma se celebrase Concilio y hasta más tarde Cortes".

50 Queda esto explícito en las palabras de Pomponio Mela: "In Tarraconensi clarisimae fuere Pallantia et Numantia”, refiriéndose a la categoría que representaba Palencia en la provincia Tarraconense. Tomamos la cita de SIMÓN NIETO, Campos Góticos, p. 8. 
invasiones tanto de los pueblos bárbaros en los momentos de debilidad como de los federados de Roma, los visigodos, que prestaron el auxilio a que estaban obligados. La presencia visigoda en el territorio no tuvo las connotaciones negativas de las otras incursiones. Autores como Francisco Simón Nieto entienden que la llegada del pueblo visigodo no puede traducirse en campañas de destrucción sino todo lo contrario, ha de entenderse su presencia como una "acción restauradora". La existencia de una firme y ambiciosa capacidad gestora y administrativa visigoda permitió el renacimiento de una Península devastada. Y eso es apreciable en el territorio conocido como Campi Gothorum, un espacio que se ajusta en buena medida con el área geográfica que hoy se conoce como Tierra de Campos ${ }^{51}$.

Tras la invasión del siglo 711 y el arrasamiento musulmán de los Campi Gothorum el único castillo que quedó en pie fue el de Monte Argel, en poder de los sarracenos. Cuando en el 796 ocupa el trono de Asturias Alfonso II el Casto, este llevó a cabo la reconquista de Carrión, liberando la fortaleza de Monte Argel, para lo que empleó un singular método de asalto, a modo de "caballo de Troya", que explica además, bien es cierto que en los espacios de la leyenda, el topónimo Carrión: el empleo de unos carros para conquistar la fortaleza ${ }^{52}$. No es este suceso el único aludido para explicar el origen del término Carrión; y así hay quienes explican el topónimo a partir de la fundación primitiva de los carios asiáticos, o bien le hacen proceder del nombre del río con el mismo nombre. Explicación esta última en torno a la cual se ha vertido un mayor número de argumentos. Ya el P. Yepes escribió: “[...] He visto disputar diferentes veces, quién dio nombre a cual, si la villa al río o el río a la villa. Sé que ambos tenían diferentes nombres antiguamente,

51 Esta región se extiende por el Norte hasta Carrión, al Sur hasta Palencia, al Oeste hasta las orillas del Pisuerga y al Este hasta Sahagún.

52 RAMÍREZ DE HELGUERA, El libro de Carrión, p. 23, relata el episodio de la siguiente manera: "[...] Convinieron cargar algunos carros de carbón con las armas encubiertas, mandándolos con los soldados más esforzados, aunque vestidos de carboneros. Hecho así, llegaron a las puertas de la fortaleza y preguntando a los árabes si necesitaban carbón, contestaron afirmativamente; convenidos en el precio, abrieron sus puertas y los carboneros y carros pasaron a descargarlo. Los soldados carboneros, aprovechando el mejor instante, sacaron sus armas y con ellas mataron a los árabes del fuerte. Los moros, apercibidos del hecho, pensaron hacer lo propio con los carboneros, que habían huido precipitada y cautelosamente, persiguiéndoles hasta una celada de cristianos preparada, en la que cayeron los moros, y todos perecieron siendo pasados a cuchillo. De esta manera, la fortaleza quedó libre y pasó a los cristianos, que seguidamente la destruyeron para jamás volver a pisar su suelo los invasores del Mogreb, arrojados posteriormente más allá del Duero [...]”. Helguera.

QUADRADO, Recuerdos y bellezas, p. 327, sintetiza el episodio narrado por Martín Ramírez de

Destaca el dato que refleja el Índice sobre esta cuestión cuando, al asentar una escritura sobre la hacienda que tenía San Zoil en Villaibáñez fechada en el año 1235, explica que "[...] el convento no tenía sello y pidió prestado para sellar el del concejo de Carrión, que es el carro; y el camarero selló con el suyo, que es el castillo"; y añade una nota indicando "[...] sellada con un sello de cera pendiente, que de una parte tiene un castillo, que son las armas y sello del camarero de San Zoil, que hera su prior mayor; y de la otra, un carro, que son las armas de la villa de Carrión, con que selló esta escritura el convento de San Zoil”. AHPP, Desamortización, Legajo 112, f. 353r. 
porque el río se llamaba Nubis y la villa Santa María, de lo cual he visto muchas escrituras en San Zoil de Carrión [...]"53. Sin embargo, señala la existencia de un privilegio de Alfonso VI en el que el rey llama Carrión al río; y al pueblo, Santa María. Se ha de entender entonces que Yepes se postula a favor de la hipótesis que entiende que es el río el que da nombre al lugar. Ramírez de Helguera se opone a esa tesis y afirma que los esgrimidos por el P. Yepes no son argumentos suficientes, apostando por la opción contraria, apoyándose en la posible fundación caria del lugar ${ }^{54}$.

Los acontecimientos que hemos esbozado configuran el escenario en el que se va a desarrollar la fundación y progreso del monasterio de San Zoilo. Un escenario en el que se sucedieron momentos de tolerancia (en los que a cambio de proteger sus prácticas y sus vidas, los cristianos tuvieron que pagar el impuesto adicional de la chizia) y de severidad, que fue evidente cuando en el siglo IX los emires musulmanes emprendieron una dura persecución, que motivó no únicamente conversiones masivas al Islam sino también el exilio de los mozárabes a las tierras cristianas del norte. En ese ambiente y circunstancias encontramos la figura de San Eulogio de Córdoba, fiel seguidor del culto peninsular a San $Z_{\text {Zoilo }}{ }^{55}$. Formado en la propia basílica del santo, su etapa final como ministro en esa iglesia le valió a Eulogio no sólo los recelos y críticas más áridos de los musulmanes sino también de algunos compañeros de fe. Tanto él como sus seguidores ejercieron una fuerte

53 YEPES, Coronica San Benito, p.73.

En el Índice de San Zoilo ha quedado reflejada la existencia de alguna de esas escrituras a las que alude Yepes y que evidencian cómo el antiguo nombre de la villa era de sobra conocido, al ser el mismo escribano del Índice quien introduce la explicación al nombre Santa María: "Concordia, escrita en pergamino, hecha entre el conde don Gómez Díaz, su muger, doña Theresa, y el obispo de Palencia don Miro, sobre las tercias de sus heredades, por la que habían tenido grandes barajas y diferencias ante don Fernando el $1^{\circ}$, rey de León. Juntáronse en Santa María (oy Carrión) y [...]. Facta cartula tertio nonas augusti, era 1089, que es año de Christo 1051". AHPP, Desamortización, Legajo 112, f. 107r, n. 1; "Escritura de venta, en pergamino, por la qual los vecinos de Villanueva, de Torre, de Ferreirolos, de Cestillos y de otras villas de Santa María (que así se llamaba en aquel tiempo Carrión) venden al [...]. Otorgose esta escritura $6^{\circ}$ idus novembris, era 1095, que es año de Christo 1057, reynando en Castilla y León don Fernando; y el conde don Gómez Dídaz, en Santa María y en Saldaña". AHPP, Desamortización, Legajo 112, f. 172r, n. ${ }^{\circ}$ 1; "Escritura de venta, escrita en pergamino, de letra gótica, [...]. Facta carta era 1119, que es año 1081, reynando en Castilla y León el rey don Alonso el $6^{\circ}$; y el conde don Pedro Ansures, (conde), en Santa María de Carrión, que esta villa se llamaba entonces la ciudad de Santa María". AHPP, Desamortización, Legajo 112, f. 434r, n. ${ }^{\circ} 1$.

${ }^{54}$ RAMÍREZ DE HELGUERA, El libro de Carrión, p. 25-26, no se detiene en este punto y ahonda en la procedencia del nombre de Santa María de Carrión, como fue conocida esta zona durante un tiempo. Si bien el nombre de Carrión se unió al de Santa María, este último procede a su vez de la iglesia de Santa María de la Victoria, fundada a raíz del milagro de las Cien Doncellas relatado por MORALES, Crónica España (libro 13, folio 142v). Más información sobre estas leyendas y otras en torno a Carrión de los Condes se encuentran en GORDALIZA APARICIO, F. Roberto, Historias y leyendas palentinas. Palencia: Cálamo, 2001.

${ }_{55}$ Dicho culto tiene origen en el año 303, cuando la publicación de un decreto romano ordena la persecución de los cristianos, que se hizo extensiva a Córdoba. Zoilo, un barón noble cordobés, se negó a aceptar la autoridad del emperador por encima de Cristo y fue martirizado junto a otros compañeros como Félix. Los restos de todos estos mártires se perdieron excepto los pertenecientes a San Félix, en cuyo honor se edificó una iglesia. En el año 613, el obispo de Córdoba, Agapio, recibió de San Zoilo la revelación del lugar donde se encontraban sus restos y los dispuso junto a los de San Félix; pasándose a denominar la iglesia a partir de entonces San Zoilo. 
oposición contra los dirigentes árabes, que en numerosas ocasiones se saldó con martirio y muerte; ninguno de ellos causó mayor impresión que el del propio Eulogio en el año 859.

En la figura de San Eulogio y su martirio se halla el detonante final que provocará un éxodo multitudinario de la comunidad mozárabe hacia los reinos cristianos del norte, donde el prestigio que gozaba el mártir era indudable. En esa migración hacia el norte dejaron abandonados numerosos monasterios, incluso las reliquias de San Zoilo fueron olvidadas en la que una vez fue la basílica que llevó su nombre.

En el momento en que esto ocurría, siendo Alfonso III el Magno rey de Asturias y León desde el año 866, algunos de esos monjes que llegaron al reino leonés huyendo desde Córdoba y fueron auspiciados por el patrocinio del monarca, construyeron, siguiendo el modelo repoblador de la presura, el monasterio de San Miguel de Escalada. Según Cuadrado, Alfonso III “conquistó o pobló” Carrión, trayendo consigo en la repoblación ${ }^{56}$ a algunos de los monjes Benitos que tras su huida del San Zoilo cordobés se habían instalado en San Miguel para fundar después el monasterio de San Zoilo en Carrión conocido como San Juan Bautista ${ }^{57}$. El lugar, Carrión, repoblado por Alfonso III se convertirá en núcleo divisorio entre Castilla y León, después de que, en el 939, el condado castellano alcance la independencia, como permite conocer el diploma de votos del conde Fernán González.

Lo cierto es que esas afirmaciones que los historiadores han apuntado no dejan de ser meras conjeturas, soportadas únicamente en las argumentaciones habituales esgrimidas cuando se habla de los monasterios de repoblación. La falta de fuentes no permite mucho más. Aun así, hemos de citar la fecha del 948 como fecha supuesta y defendida por Ambrosio de Morales como de ocupación del monasterio de San Zoilo con anterioridad a la llegada cluniacense. El hallazgo por el autor citado de un libro de concilios, datado en dicho año, le hace suponer que el monasterio debía de estar ocupado con anterioridad.

\footnotetext{
${ }^{56}$ Queda así reflejada de nuevo la importancia que Carrión poseía en esos momentos, a pesar de que pueda parecer caída en el olvido. Es un episodio reseñable la batalla entre Alfonso III y Caleb, el gobernador musulmán de "la frontera cristiana" (quizá Zamora). Al negarse Alfonso III tanto a convertirse al Islam como a pagar impuestos, se desencadena la "batalla del día de Zamora", de la cual saldrá victorioso el rey cristiano; elegirá Carrión como el lugar donde celebrar y dar a conocer su victoria, lo que señala la notoriedad que poseía la localidad. RAMÍREZ DE HELGUERA, El libro de Carrión, p. 28, sitúa Carrión como la residencia más habitual y visitada por el rey, lo que provocó su expansión económica y social y la transformación de su fisonomía urbana. Además, fue objetivo de numerosos privilegios; aunque esto sólo pueda ser presupuesto debido a la destrucción de su archivo municipal.

${ }^{57}$ MORALES, A. de, Las antigüedades de las ciudades de España: que van nombradas en la Corónica con las averiguaciones de sus sitios y nombres antiguos. Tomo X. Madrid: Oficina de don Benito Cano, 1792, p. 44, afirma que recibió dicha denominación porque era costumbre nombrar al monasterio por la reliquia que poseyera.

El Libro Misceláneo, conservado en el Archivo Diocesano de Palencia, recoge una "Memoria antigua de reliquias" entre las que aparecen las de San Juan Bautista: “[...] Item en esa misma archa están reliquias de Sant Juan Baptista [...]". La transcripción de este libro puede consultarse en PALACIO, Colección San Zoil. II, pp. 601-653, en concreto p. 633.
} 
Argumento que defiende asimismo el P. Yepes ${ }^{58}$. La cuestión de la primera ocupación y en general de los inicios del monasterio es un tema, sin embargo, cuestionado por la historiografía $a^{59}$ y que está aún por determinar ${ }^{60}$.

\subsection{El monasterio de San Zoilo en el Condado de Carrión}

La asimilación de Carrión como condado constituye un punto de inflexión en la vida del monasterio. Puede establecerse el comienzo de este distinguido periodo en el año 995 cuando doña Cristina, hija del rey de León Vermudo II, se casa con el infante Ordoño el Ciego, a quienes les fue donado el condado de Santa María de Carrión.

Cuenta el P. Yepes cómo la hija de los condes Ordoño el Ciego y Cristina, doña Aldonza, fue desposada con el infante don Pelayo ${ }^{61}$. No tendría esta unión mayor relevancia para el cenobio de no ser por el matrimonio que su hija, la condesa doña Teresa Peláez, contrajo con Gómez Díaz. Este, descendiente del linaje de los Banu Gómez ${ }^{62}$, era hijo del conde Diego Fernández, llamado en ocasiones conde de Carrión; en otras, nominado como cónsul, gobernador de provincia elegido por los reyes. Gómez Díaz heredó de su padre el gobierno del amplio territorio que poseía entre Liébana y Monzón,

58 YEPES, Coronica San Benito, p.74, indica lo siguiente al respecto: "Según dice Morales en el siglo XVI, había en él un libro de concilios en pergamino y letra gótica, en que se decía cómo a los 19 de enero de 948 se comenzó a escribir, [...] de donde se conjetura que [...] el monasterio estaba fundado y entonces se llamaba el monasterio de San Juan, y por estos en que ahora vamos se llamó de San Zoil".

59 QUADRADO, Recuerdos y bellezas, p. 337, considera insuficiente la existencia de dicho libro para afirmar que el monasterio estuviera habitado ya antes de la llegada de Cluny, puesto que no consta su procedencia y eran frecuentes los casos de monasterios con libros de otros lugares. RAMÍREZ DE HELGUERA, El libro de Carrión, p. 32, contradice esta explicación, aduce que no conocer su procedencia no significa nada, pues qué sentido tendría entonces llevar un libro a un monasterio deshabitado.

60 La documentación de San Zoilo nos aporta dos datos que, si bien no resultan determinantes ni esclarecedores a la hora de concretar la fecha exacta de la fundación del monasterio, contribuyen a reafirmar las informaciones en torno a esos posibles orígenes pretéritos.

El Índice de San Zoilo, en el cajón correspondiente a los documentos producidos por San Zoilo, señala la existencia de una "Lista de los superiores que ha tenido este monasterio desde el año de 948 en adelante”. AHPP, Desamortización, Legajo 112, f. 87v, n. ${ }^{\circ} 44$. Esta posible fecha de inicio, redunda en la ya señalada por Morales y enfatiza la posibilidad de situar en el siglo X ese primer establecimiento de la comunidad en Carrión.

La otra noticia procede del Libro Misceláneo. Aunque sin fechar, nos aporta una idea de la antigüedad de la fundación y de la importancia que tenía para los monjes el recuerdo de ese hecho al incorporarlo como parte de sus oraciones. Esa pequeña mención la encontramos en el Martirologio Antiguo, el cual formaría parte de esa "miscelánea", indicando lo siguiente: "[...] Eodem die fundatio monasterio Sancti Zoili [...]" concretando al margen: "Hac die 29 ianuarii fundatio monasterii Sancti Zoili". PALACIO, Colección San Zoil. II, pp. 601-653, en concreto p. 609.

61 YEPES, Coronica San Benito, p.74.

${ }^{62}$ Para una información pormenorizada del linaje de los condes de Carrión véase MARTÍNEZ DÍEZ, Gonzalo, "La familia condal de Carrión", en CALLEJA GONZÁLEZ, M. ${ }^{a}$ Valentina (coord.), Actas del III Congreso de Historia de Palencia. Vol. 2. Historia medieval: fuentes documentales, sociedad y economía e Historia de las Instituciones. Palencia, 1995, pp. 551-604.

Remitimos a REGLERO, Cluny en España, pp. 240-248, donde se aborda la posible existencia de una aristocracia filocluniacense, identificada en la familia de los Banu Gómez. 
en el cual se incluía el condado de Carrión. Gómez Díaz sería una de las figuras principales del reinado de Fernando I. El título de conde le fue concedido bien por la herencia mencionada de su padre o por su matrimonio con doña Teresa, pues supuestamente Gómez Díaz no debía de gozar del favor del monarca, al que no apoyó en su guerra contra Vermudo III de Támara para anexionarse el territorio de León; algo que sí hizo su hermano Asur Gómez.

Fuera de uno u otro modo, lo cierto es que Gómez Díaz y su mujer, doña Teresa, se encargaron de construir numerosas obras públicas, entra las que puede citarse el puente que permitía cruzar el río y entrar en Carrión; y otro tipo de empresas ${ }^{63}$, de las cuales alguna "ha quedado como memoria de su piedad, que puede serlo también de su opulencia" ${ }^{64}$, tal es el caso del monasterio de San Zoilo (aún San Juan Bautista), que fue reformado a sus expensas después de que fuera destruido en alguna de las razias cometida por Almanzor en el año 995. Esto puede inducir a la confusión de considerar a los condes Gómez y Teresa como fundadores del monasterio ${ }^{65}$; pero lo cierto es que, como he expuesto anteriormente,

${ }^{63}$ El ya mencionado Libro Misceláneo recoge además un "tractado de los bienhechores deste monasterio". En él nos indica que "[...] la condesa dio al monasterio muchas e ricas joyas e ricas cruzes, cálices e otras pieças de oro e de plata e muchos e muy ricos ornamentos [...]", y añade que sobre su sepulcro, se pueden leer los versos siguientes: "[...] Omnis eam merito plangere debet homo: ecclesiam, pontem, peregriniis optima recta fecit [...]"; haciendo referencia a la edificación de la iglesia de San Juan Bautista, el puente y el hospital de peregrinos. PALACIO, Colección San Zoil. II, pp. 601-653, en concreto p. 641.

64 SIMÓN NIETO, Campos Góticos, p. 23.

${ }^{65}$ A este respecto, resultan significativas las numerosas alusiones que encontramos a lo largo del Índice de San Zoilo en las que se menciona a los condes don Gómez Díaz y doña Teresa como fundadores o incluso reedificadores del monasterio, utilizadas estas por el autor del Índice a modo de memoria acerca de quiénes eran estas personas; puesto que, tal y como también aparece explicitado en alguno de los registros, no se conservaba escritura alguna de la fundación. Reseñamos a continuación alguna de estas menciones por el interés que suscita el hecho de que, al no poder refrendar su existencia en ningún documento tangible, acudan reiteradamente a sus fundadores como instrumento para autorreafirmarse: "La primera escritura es un testamento y donación de la condesa doña Yldoncia, hija del cónsul (sic) don Gómez Díaz, y de la condesa doña Teresa (a quienes tenemos por fundadores y primeros bienechores de este monasterio de San Zoil) [...]. Otorgose este testamento vndécimo kalendas januarii, era 1148, que es año de Cristo 1110, ante Raymundo, escribano". AHPP, Desamortización, Legajo 112, f. 1v, n. ${ }^{\circ}$ 1; "Donación, escrita en pergamino, del conde don Gómez Díaz, marido de doña Teresa, a quienes tenemos por reedificadores y fundadores de este monasterio. [...]. Facta carta donaciones era 1085, que es el año de Christo de 1047, feria sexta, ydibus martii". AHPP, Desamortización, Legajo 112, f. 35v, n. ${ }^{\circ}$ 1; "Privilegio del emperador don Alonso, escrito en pergamino, por el qual concede a don Gómez Cidiz y su muger, Elo Galiz (dicen ser estos señores nietos de los fundadores de este monasterio), [...]. Facta carta $13^{\circ}$ kalendas maii, era 1167, que es año de Christo 1129”. AHPP, Desamortización, Legajo 112, f. 91r, n. ${ }^{\circ}$ 1; "Sólo hay por tradición que como a esta casa la reedificaron los infantes que llamaron de Carrión (y nosotros nuestros fundadores), el cónsul don Gómez Díaz, la señora condesa doña Theresa, su muger, y los infantes, sus hijos; así entró esta hacienda de Toro con otras que dieron a este monasterio en su dotación y, como ni de aquellos nos han quedado esscrituras con ser tan constante en tradición, tampoco de esto". AHPP, Desamortización, Legajo 112, f. 339r; "Escritura de donación, escrita en pergamino, hecha y otorgada por la condesa doña Aldonza, que fue hija de los fundadores de San Zoil, juntamente con sus hijos Fernando Fernández y Elvira Moniz; [...]. Facta carta feria $6^{a}$ X6 (sic) kalendas septembris, era 1125, que es año 1087”. AHPP, Desamortización, Legajo 112, f. 408r, n. ${ }^{\circ}$ 1; “[...] vtilidad de su rey no tomó todas las heredades que el monasterio de San Zoil de Carrión tenía en Castromayor (que así se llamaba Aguilar, a título de un gran castillo que tenía aquella villa y era del patrimonio de los fundadores de este monasterio, en que le dotaron) [...]. Esto es lo que contiene el primer privilegio, 
siguiendo las argumentaciones de los autores que se han ocupado de la cuestión, el monasterio ya existía, y los condes lo que hicieron fue reformarlo y reedificarlo concediéndole, eso sí, una amplía dotación patrimonial ${ }^{66}$. Más adelante volveré sobre esta cuestión.

\subsection{Anexión a Cluny y formación del patrimonio}

El primer documento escrito que nos proporciona noticias sobre la existencia del monasterio de San Zoilo, a falta de un documento fundacional, data del año $1047^{67}$. Se trata

fecho en Castroxeriz, era 1219; y los demás, juntos con este, son confirmación". AHPP, Desamortización, Legajo 112 , f. $444 r$, n. $^{\circ} 4$.

66 Es reseñable la leyenda localizable en YEPES, Coronica San Benito, p.78, también recogida por RAMÍREZ DE HELGUERA, El libro de Carrión, pp. 38-39, sobre el origen de la devoción que impulsó a los condes a reconstruir el monasterio: "Dícese que la condesa doña Teresa tuvo celos del conde Díaz, su marido, por verle conversar muy de ordinario con una mujer casada, sucedió que esta parió una vez dos hijos con que se la confirmaron más a la Condesa las sospechas que traía de su marido, juzgando que si aquella mujer era casta, no pudiera parir más de un hijo de una vez, y que así el otro era de adulterio; pero ordenó nuestro Señor de ahí a algunos meses, que la condesa concibiese y pariese también dos criaturas y como ella había publicado que no era posible que tuviese una mujer dos hijos de un sólo hombre, temía que su marido se había de alborotar de aquel caso, y confiada de su inocencia se atrevió a pasar el río de Carrión para irse a socorrer de San Juan Bautista, cuya iglesia estaba en la otra parte del río y con singular milagro pasó por encima de las aguas $[. .$.$] y está publicado que fue la ocasión de fundarse el monasterio".$

${ }^{67}$ Destacamos el epígrafe señalado en el Libro Misceláneo como "Título de los sepulcros de los fundadores" donde ya se percibe el exhaustivo control que tenía el monasterio sobre su documentación y, por ende, sobre su archivo, al conocer perfectamente esta primera escritura a la que hemos hecho alusión: "[...] Este título es del sepulcro de Donna María. (Al margen: Sepulcro de una señora llamada doña María, pero no es la hija de los señores condes. An. D. 1043. Este epitafio es primero 4 años que la escritura más antigua de las que hay en el Archivo)". PALACIO, Colección San Zoil. II, pp. 601-653, en concreto p. 630.

Y por este mismo motivo, era bien sabido por el archivero de San Zoilo la inexistencia de aquella documentación acreditativa del origen de este monasterio, tal y como lo atestigua el Índice cuando explicita: "Porque como no tenemos cosa cierta de la primera fundación de este monasterio $[\ldots]$ y, como ni de aquellos nos han quedado esscrituras con ser tan constante en tradición [...]”. AHPP, Desamortización, Legajo 112, f. 339 r.

Barajamos la posibilidad de que algunos de estos "ynstrumentos principales que faltan de este archivo" fuesen remitidos a Cluny, por expresa petición de dicha abadía, quizás con el objeto de realizar un control más férreo sobre sus prioratos peninsulares. Para sostener esta hipótesis nos basamos en una serie de datos que, si bien no resultan definitorios, pueden servir como muestra para esta teoría.

El primero de ellos, y que resulta ser el más significativo aunque no por ello menos lógico, es el hecho de que tanto el documento de donación de San Zoilo a Cluny en el año 1076, como su confirmación un año después, no se hallaban en el archivo del monasterio; puesto que de haber sido así, habría quedado registro de estos en el Índice. La única noticia sobre estos diplomas procede de fuera de nuestras fronteras y nos la proporcionan BERNAD, A-BRUEL, A, Recueil des chartres de l'abbaye de Cluny. 6 vols. París, 1876-1903.

En el índice de San Zoilo encontramos la siguiente alusión, cuando en 1613 el abad fray Alonso Barrantes envía una carta a Cluny solicitando la devolución de algunas de sus escrituras:" $<$ Carta del reverendísimo Barrantes [...], en la que hace relación de los ynstrumentos principales que faltan de este archivo $>$. [...] En esta añade la falta de algunas escrituras tocantes a esta casa que fueron llevadas a Cluni desde que fue miembro de él este monasterio. Pide y suplica la remisión de ellas, para lo que la pone la relación de los instrumentos [...]”. AHPP, Desamortización,Legajo 112, f. 146v, n. ${ }^{\circ} 30$.

A esto se suma la estrecha relación de dependencia y sujeción a la que estaban sometidos los diferentes prioratos respecto a Cluny y su abad, pues así nos lo indica REGLERO, Cluny en España, pp.593642, en el capítulo dedicado a estudiar "La provincia de Hispania y Cluny", en el que nos hace relación de los diversos sistemas de control utilizados, entre los que se encontraban la institución de priores y las visitas de los camareros provinciales a los monasterios. 
de una donación por la cual el conde Gómez Díaz cedió al monasterio el cenobio de los santos Facundo, Primitivo y Cristóbal en Arconada ${ }^{68}$. La donación ha generado una doble controversia, la una relacionada con la incorporación del monasterio a la órbita de la Orden Cluniacense y la otra por haber colocado al monasterio bajo la advocación de San Zoilo.

La afirmación de que el monasterio se integraba en la órbita cluniacense en el año 1047 se ha planteado como una quimera, y autores hay que defienden que hasta 1076 el monasterio de San Zoilo no pasará a formar parte de la abadía borgoñona. Ya el P. Flórez dudaba del documento, y afirmó: "yo recelo que tiene yerros la escritura" ${ }^{69}$. Aun así, la duda respecto a la autenticidad del diploma sigue siendo al día de hoy una cuestión por resolver $^{70}$.

Pero además de la crítica a la data del documento y a la veracidad o sinceridad de la frase que relaciona a San Zoilo con Cluny, la suposición de que el monasterio albergara las reliquias del santo homónimo en esas fechas se cree asimismo incierta. La duda resulta de la existencia de un documento, datado en el 1051, por el que los condes de Carrión acordaron con el obispo de Palencia transferir la mitad de las tercias decimales de todas las iglesias de la ciudad de Santa María de Carrión, hasta 1405, al monasterio de San Juan de la Puente ${ }^{71}$.

Tal y como nos indica Pérez Celada esta referencia al monasterio como el de San Juan refuerza la idea de que el documento de 1047 al que nos estamos refiriendo sería una copia e incluso una falsificación con datos interpolados ${ }^{72}$, y redunda en la conjetura expresada por el Padre Flórez, que dudaba de que en el año 1047 estuvieran en el cenobio de Carrión las reliquias de San Zoilo. Tema este sobre el que volveré más adelante.

\footnotetext{
${ }^{68}$ AHPP, Desamortización, Legajo 112, f. 35v.

69 FLÓREZ, España Sagrada. Tomo X, p. 318

70 Serrano, Bishko y Linage Conde han manifestado su parecer al respecto. SERRANO, Luciano, El Obispado de Burgos y la Castilla primitiva desde el siglo V al XIII. I. Madrid, 1932, p. 259, indica que el diploma es falso porque la expresión Ordinis Cluniacensis no comenzó a utilizarse hasta el siglo XII; BISHKO, Charles Julian, "Fernando I y los orígenes de la alianza castellano-leonesa con Cluny": Cuadernos de Historia de España, 47-48, (1968), p. 47 (=BISHKO, Fernando I), señala que esta referencia es una interpolación, porque la donación a Cluny no se produce hasta 1076, y porque el texto se escribió en una época en la que "los monjes de Carrión eran fuertemente presionados para que defendieran su patrimonio contra la ocupación laica y episcopal"; LINAGE CONDE, Los orígenes del monacato. Tomo 2, pp. 941-942, coincide en los mismos argumentos.

PÉREZ CELADA, Documentación San Zoilo. I, p. 5, a diferencia de Bishko, cree que esta interpolación fue hecha con el objetivo de demostrar que San Zoilo era el priorato más antiguo de Cluny, lugar donde tradicionalmente debía instalarse el camerarius Hispaniae.

PALACIO, Colección San Zoil. I, p. 19, se basa en un análisis paleográfico, y no encuentra ningún indicio de interpolación pues en ese momento San Zoilo pertenecía a Cluny y afirma que "la donación del conde no se destinó al monasterio de San Juan Bautista escuetamente, sino a la orden de Cluny, adelantando en cerca de 30 años el asentamiento de la abadía borgoñona en Carrión”.

${ }^{71}$ AHPP, Desamortización, Legajo 112, f. 107r, n. ${ }^{\circ}$ 1. San Juan de la Puente era la advocación bajo la que se había acogido la comunidad antes de la traslación al mismo de las reliquias de San Zoilo; y así lo expresa el Índice al añadir "quedase al conde para San Juan de la Puente (que es este monasterio)".

72 PÉREZ CELADA, Documentación San Zoilo. I, p. 5.
} 
La incorporación del monasterio a la abadía de Cluny parece que ocurre no en 1047, sino unos años más tarde, en un contexto marcado por la política aliancista que el rey castellano-leonés Fernando I pretendía llevar a cabo, tanto para reforzar la unión dinástica que había logrado instaurar como para revitalizar el fervor religioso perdido por los monjes peninsulares, alzándose como "la punta de lanza de la reforma benedictina" 73 . Se pone esto de manifiesto y es testimonio de la intención del monarca el censo anual que asigna al monasterio, cuya cuantía será duplicada en 1090 por su hijo Alfonso $\mathrm{VI}^{74}$.

Fallecido el conde Gómez Díaz en el año 1057, el monasterio queda bajo la protección de su viuda, doña Teresa. En vida de esta última se va a producir un acontecimiento decisivo para la historia del cenobio. El suceso no es sino la cesión que hacen la condesa y siete de sus hijos, en el año 1076, del monasterio de San Zoilo de Carrión a la abadía borgoñona de Cluny, como muestra del apoyo profesado a la política procluniacense de Alfonso $\mathrm{VI}^{75}$. Dicha donación se hace bajo la triple advocación de San Juan Bautista, San Zoilo y San Félix y será renovada un año después, en $1077^{76}$.

Por esas mismas fechas parece que puede darse por segura la advocación del monasterio de Carrión como de San Zoilo. El primogénito de los condes Gómez Díaz y Teresa, el conde Fernando Gómez, participó en las disputas protagonizadas por los distintos reyes moros. Por un acto de valentía en Córdoba el rey árabe se ofreció a concederle lo que el conde Fernando deseara. Entre los deseos del conde se contó la

\footnotetext{
73 Ibidem, p. L.

${ }^{74} \mathrm{La}$ existencia de este censo aparece recogida en el Índice de San Zoilo formando parte de un cuaderno de nueve hojas, el cual recoge diversas escrituras, entre ellas este " $<$ Censo perpetuo de 2 mill monedas de oro que concedió el rey don Alonso el $6^{\circ}$ al monasterio de Cluni. Año 1090>. A folio $3^{\circ}$ está una escritura del rey don Alonso el $6^{\circ}$ (que la trae el maestro Yepes en el tomo $4^{\circ}$, p. 453), hijo de don Fernando el $1^{\circ}$, por el qual confirma un censo anual de mil monedas de oro (que él llama methales), que su padre había concedido al monasterio de Cluni, por la hermandad que tenía con dicho monasterio, y añade al dicho censo otras mill monedas de oro (que son dos mil) por la misma hermandad. Su fecha, en Burgos, en el año de 1090". AHPP, Desamortización, Legajo 112, f. 189r.

75 Probablemente, de haber estado presente el conde Don Gómez y a tenor de su rumoreada mala relación con la casa real, este no hubiera sido partidario de dicha cesión; y quizá la historia del monasterio habría sido muy distinta. Esto queda reflejado en que, tras su muerte, el condado de Carrión no pasó a manos de su descendencia directa sino que le fue entregado por Alfonso VI a Pedro Ansúrez, aunque se barajan varias explicaciones al respecto. RAMÍREZ DE HELGUERA, El libro de Carrión, p. 37, defiende que pudo tratarse, simplemente, de un título de gobernador o cónsul otorgado por el rey, mientras que el condado territorial quedaba para la familia de Don Gómez; SIMÓN NIETO, Campos Góticos, p. XXX, indica que le fue entregado el condado como premio a sus leales servicios; y PUENTE, Ricardo, San Zoilo de Carrión: de la Edad Media al Renacimiento, León, 1998, p. 4, dice que el condado habría pasado al hermano de Don Gómez, Asur, por el apoyo prestado; siendo su hijo, Pedro Ansúrez, el heredero. De no haber sido por el enterramiento de Don Gómez Díaz y sus hijos en el monasterio, posiblemente hubieran quedado estos en el olvido.

${ }^{76}$ Ambos diplomas, tanto la donación del año 1076 como su renovación un año después, han sido publicados en BERNAD, A.-BRUEL, A; Recueil des chartres de l'abbaye de Cluny. Tomo IV, pp.604-607, n. 3492; pp. 622$625,{ }^{\circ}{ }^{\circ} 3507$, respectivamente.
}

Véase PÉREZ CELADA, Documentación San Zoilo. I, docs. 7 y 8. 
entrega de los restos de San Zoilo ${ }^{77}$. Y junto a las reliquias del santo solicitadas, el rey cordobés le entregó también las de San Félix y las del obispo Agapio, que habían sido enterrados igualmente en la capital cordobesa. Todos los restos fueron trasladados a Carrión por el conde don Fernando el año $1070^{78}$. Así lo reseña el manuscrito del martirologio:

"Este señor D. Fernando Gómez primogénito de los dichos señores [...] tanto plugo al rey moro de Córdoba [...] el qual remuneraba magníficamente su servicio [...] en oro y plata [...] que si merced le quería hacer que le mandase dar el cuerpo de San Zuyl que era en Córdoba sepultado [...]. Entonces D. Fernando Gómez hizolo desenterrar e enbuelto en pannos limpios e decentes truxole a este sacro monasterio con mucha alegría donde está honoríficamente en una archa de plata en el altar mayor" ${ }^{\prime 79}$.

Es también ahora cuando se atribuye a la condesa doña Teresa, la viuda de Gómez Díaz y madre del conde Fernando Gómez, la construcción del hospital de San Zoil ${ }^{80}$. No fue una elección desatinada, porque la nueva construcción, levantada junto al monasterio en el conocido como camino francés, iba a convertirse en centro de acogida y cuidado de los peregrinos que acudían en peregrinación a visitar la tumba del apóstol Santiago en

\footnotetext{
${ }^{77}$ ¿Por qué el cuerpo de San Zoilo? En SANTOS URBANEJA, San Zoilo, se expone que tal vez “[...] Don Fernando hubiese oído muchas veces a su madre relatar las circunstancias que rodearon el martirio de San Zoilo, cuya historia y devoción [...] debieron llevar los monjes huidos de Córdoba, y pensase en la inmensa alegría que la posesión de las reliquias causaría a su piadosa madre [...]".

${ }^{78}$ Como la autenticidad del documento de donación del 1047 (aludido anteriormente) había sido indiscutida durante mucho tiempo, se pensaba que, puesto que la cesión se realizaba al monasterio de San Zoilo, las reliquias ya debían encontrarse aquí en esa fecha. Sin embargo, en FLÓREZ, España Sagrada. Tomo X, pp. 318-319, se indica que no pudo haber hecho la traslación de los santos, ya que en dicho año Don Fernando apenas habría cumplido los quince años, edad muy temprana para participar en guerras y mucho menos para lograr las hazañas que se le atribuyen; y que este episodio habría tenido lugar en el 1076, momento en el que rondaría los 36 años, edad propicia "para el fogoso espíritu de aumentar el honor por la milicia y juntamente más proporcionada para la madurez que manifiesta el deseo de anteponer reliquias a las riquezas".

Por otra parte, en SÁNCHEZ DE FERIA Y MORALES, Bartolomé, Palestra Sagrada o Memorial de los santos de Córdoba: con notas y reflexiones críticas, sobre los principales sucesos de sus historias, Córdoba, 1772, queda indicado que "[...] en el año 1070 el conde Fernán Gómez de Carrión llevó a su Villa los Cuerpos de San Zoilo y San Féliz y Santo Obispo Agapito [...]”. Cita tomada de SANTOS URBANEJA, San Zoilo, pp. 39-40. ${ }^{79}$ PALACIO, Colección San Zoil. II, p. 642. También alude a este hecho YEPES, Coronica San Benito, pp.74-75.

El índice de San Zoilo dedica a esta cuestión un cuaderno de uno de los cajones destinados a albergar la documentación producida por el monasterio, el cual lleva por título "Papeles pertenecientes a los cuerpos de los santos mártires, reliquias e yndulgencias que hai en esta iglesia" en el que destacan "Vn quaderno que contiene la vida, martirio, traslación, milagros y rezo de nuestro patrono San Zoil [...]” y "Otro quaderno que contiene la historia de la vida, muerte y traslación de nuestro compatrono San Félix monge y mártir [...]”. AHPP, Desamortización, Legajo 112, f. 117r, n. ${ }^{\circ} 2$.

FROCHOSO SÁNCHEZ, Rafael, "Las reliquias de San Zoilo, las arquetas y las telas árabes": Revista Al-Mulk, Real Academia de Córdoba, de Ciencias, Bellas Artes y Nobles Artes, 14 (2016), pp. 19-49, nos ofrece un recorrido por la trayectoria de las reliquias y las arquetas de las reliquias de los santos mártires, custodiadas en el monasterio de San Zoilo (Carrión).

${ }^{80}$ PALACIO, Colección San Zoil. II, p. 642. El “Tractado de los bienhechores de este monasterio”, señala, “[...] Ella como era sennora muy religiosa no sólo acabó las dichas obras començadas, pero también hedificó un noble hospital junto al monasterio copiosamente arreado e dotado”.
} 
Compostela. Eco se hicieron de la buena acogida en Carrión algunos viajeros que peregrinaron a Compostela siglos después, como lo hace el clérigo boloñés Domenico Laffi, que en 1673 testimonia que "a la salida de Carrión encontramos un gran convento, donde dan ración de pan y vino a los peregrinos”.

En el año 1080, obedeciendo una disposición de Alfonso VI, el conde don García Gómez $^{81}$, otro de los hijos de Gómez Díaz y doña Teresa, fue enviado a la abadía de Cluny como portador de una petición al abad don Hugo, al que el emisario solicitó que le permitiera acompañarse de monjes para que reformasen los monasterios, para que con su conocimiento y austeridad reavivaran la espiritualidad un tanto debilitada en la Castilla del siglo XI. La generosidad de los condes de Carrión con el monasterio era expresión de una religiosidad que se testimonia también en la decisión de los condes y sus hijos de ser enterrados en el monasterio: Gómez Díaz y sus primeros descendientes fueron sepultados en la capilla conocida como de los condes (antes galilea), al pie del monasterio; no así doña Teresa, quien yace dentro del cenobio ${ }^{82}$. Circunstancia esta que dice mucho de la relación de la condesa con San Zoilo.

Lo anteriormente expuesto, las referencias a las relaciones de los condes con el cenobio carrionés y las donaciones con que fue obsequiado ${ }^{83}$ permiten suponer una realidad patrimonial acorde al ambiente bosquejado. Y esa realidad se traduce en una aliviada posición económica en los primeros momentos. Estado que se acompaña con el establecimiento de viviendas y barrios alrededor del monasterio que mantendrán con el mismo una situación de dependencia. Testimonio de ello es que en el año 1073 Alfonso VI concediera al monasterio el señorío sobre el barrio anejo de San Zoles ${ }^{84}$.

\footnotetext{
${ }^{81}$ PALACIO, Colección San Zoil. II, p. 642; “[...] El segundo fijo que los dichos sennores ovieron obo nombre don García. Este fue a Cluni e alcançó a traer a este monasterio monjes de ella".

82 Según YEPES, Coronica San Benito, p. 56, la condesa fue dignificada por su santidad con el honor de ser enterrada dentro del monasterio, algo reservado en exclusiva a mártires o personas de conocida santidad.

83 No exclusivamente los condes "fundadores" dotaron espléndidamente al monasterio; sino que sus hijos continuaron esta tarea. Es el caso de la condesa doña Aldonza, hija de los condes don Gómez y doña Teresa, quien manda por su testamento que reciba el monasterio "la tercera parte de hacienda que tenía en Pharayones, en Fontezua, en San Juan de Tarador (que es Aguilar), en Villavera, en Villamaurel, en Villagonzalo, y en Villamayor; y si sus hijos no tubiesen sucesión, manda toda su hacienda al dicho monasterio de San Zoil”. AHPP, Desamortización, Legajo 112, f. 1v, n. ${ }^{\circ} 1$.

84 Ante la inexistencia de este documento de concesión, damos noticia de los dos testimonios en los que aparece reflejada. El primero de ellos es el Libro Misceláneo, en PALACIO, Colección San Zoil. II, p. 638, "[...] le dotaron muy magníficamente e el primero de su dote fue el varrio que agora llaman de Sant Zoles, hecho parrochia del dicho monasterio con sus diezmos enteros".

En este se hace un señero recorrido por todas y cada una de las donaciones y concesiones que se le fueron otorgando a este monasterio en concepto de bienes patrimoniales para el correcto y necesario desempeño de la comunidad monástica. Ibídem, pp.638-649.

El otro testimonio procede de la obra de RAMÍREZ DE HELGUERA, El libro de Carrión, p. 53, que fue el primero en dar a conocer esta noticia aunque sin fundamento documental.
} 
En los últimos años del reinado de Alfonso VI, San Zoilo no fue únicamente destinatario de las donaciones de la realeza sino también y además de otras muchas ofrendas de la nobleza, entre las que caben destacar las donaciones que hicieron al cenobio los miembros de la familia de Pedro Ansúrez. Los reyes, sin embargo, fueron en general poco generosos. Y sorprende que la reina Urraca sea una excepción. Aunque no fueran donaciones inocentes, sino el reconocimiento y agradecimiento del apoyo recibido tanto por la población como por los cluniacenses en la guerra que sostuvo contra su marido, Alfonso I el Batallador. Por ello, en 1118, nueve años después de ocupar el trono, puso a disposición del cenobio carrionés el monasterio de San Martín de Frómista ${ }^{85}$. Dos años más tarde, en 1120, la madre del emperador dona a San Zoilo todas sus heredades en la villa de Arconada ${ }^{86}$.

A la muerte de la reina Urraca, acaecida el año 1126, los vecinos de Carrión proclaman a su hijo, Alfonso VII, señor natural del lugar. Se determinó a partir de entonces que los reyes sólo acudirán a Carrión en caso de celebrarse en el lugar concilios o cortes, pero no por razones de residencia. Es así como en las cortes reunidas en Carrión en 1129 Alfonso VII confirmó los privilegios y mercedes que su madre le había concedido al monasterio y le exime además del pago del portazgo.

En ese mismo orden de patrocinio, Alfonso VIII promulgó una serie de disposiciones en favor de San Zoilo para que sus derechos fueran respetados ${ }^{87}$, además de conceder a los monjes del monasterio la facultad para celebrar una feria anual en el barrio de San Zoles y la concesión de percibir la mitad de los gravámenes que en concepto de portazgo en ella se recaudaran ${ }^{88}$. Si bien fue en el reinado de Alfonso VIII cuando de nuevo se hizo efectiva la separación entre León y Castilla, Fernando II de León permutará con el monasterio de Carrión las iglesias de San Cristóbal y San Pelayo de Villafrechós ${ }^{89}$ por las heredades que los monjes de San Zolio poseían en dicho lugar. Permuta que testimonia la

No obstante, en la confirmación que de ese fuero hace Alfonso VII en 1142, alude a la concesión de dicho barrio por parte de Alfonso VI; la cual puede consultarse en PÉREZ CELADA, Documentación San Zoilo. I, doc. 3, así como en AHPP, Desamortización, Legajo 112, f. 91r, n. ${ }^{\circ} 2$.

85 Levantado en 1066 por su bisabuela, la condesa Doña Mayor.

En el Índice, aparece formando parte del "quaderno e escrituras" de nueve hojas, AHPP, Desamortización, Legajo 112, f. 189r.

86 RUIZ ALBI, Irene, La reina doña Urraca (1109-1126). Cancillería y Colección diplomática. León, 2003, pp. 532533, doc. n. ${ }^{\circ} 110$.

87 PÉREZ CELADA, Documentación San Zoilo. I, docs. 54, 61, 63, 64, 72 y 73. Lo encontramos referenciados en AHPP, Desamortización, Legajo 112, ff. 88r, 97v, 112, 172r, 284r y 359r-359v.

88 PÉREZ CELADA, Documentación San Zoilo. I, doc. 41.

89 AHPP, Desamortización, Legajo 112, f. 358r. 
conjugación de los intereses estratégicos de la realeza con los del monasterio. Conjugación de intereses que no perjudicó al cenobio carrionés.

En este primer transcurso de la historia del monasterio se percibe de los testimonios conservados una relevancia y presencia del monasterio de San Zoilo en el plano político, administrativo y religioso. Lo que le lleva a ser sede frecuente de concilios, como el del año 1130. En el monasterio celebró Alfonso VIII los actos oficiados para solemnizar su mayoría de edad; y en él armó caballeros a su primo Alfonso IX de León en 1188; y a Conrado, hijo del emperador de Alemania, después.

La filiación de San Zoilo de Carrión a Cluny le confería independencia frente a la autoridad episcopal, pero le obligaba a mantener la disciplina monástica que establecían las consuetudines cluniacenses, como el resto de monasterios afiliados. Para lo cual la abadía madre de Cluny despachaba al camerarius Hispaniae, cargo que a partir de 1169 ostentará el prior de San Zoilo. El primer prior que ostentó el cargo de camarero fue el del monasterio de Carrión, Humberto ${ }^{90}$, que llevó a cabo una profunda reforma económica centralizadora del patrimonio del monasterio, tal y como muestran las tres cartas que se remitieron en torno al año 1174 el abad Radulfo y el prior Humberto de Carrión ${ }^{91}$.

Tras la muerte de Humberto, le sucedieron al frente de San Zoilo el prior Pedro y más tarde Juan, ambos camerarios de Cluny. En 1220, siendo prior este último, Fernando III el Santo concedió a los vecinos de San Zoles la exención de portazgo, y especificó que afectaba a todos los vecinos, bien fueran cristianos, judíos o moros ${ }^{92}$. Prueba de la convivencia de las tres religiones y del ambiente de tolerancia religiosa que se respiraba en esos momentos en la villa es también el hecho de que los monjes de San Zoilo poseyeran la mezquita de Carrión ${ }^{93}$. El privilegio de 1220 del rey Fernando al monasterio es una muestra del agradecimiento del monarca al prior carrionés, que había llevado a cabo valiosas gestiones en Alemania para el matrimonio del rey con Beatriz de Suabia. Pero no es la única prueba de agradecimiento, puesto que más adelante, en el año 1226, cederá a San Zoilo los monasterios de San Esteban de Villamayor y San Lorenzo de Villalpando ${ }^{94}$

\footnotetext{
90 AHPP, Desamortización, Legajo 112, f. 190r. donde se resume la " $<$ Confirmación de Humberto en prior de San Zoil y camarero de España de la donación de los zamarros>. A este mismo folio buelta está una escritura por la qual fray Radulfo, abad de Cluni, confirma a Hunberto en prior perpetuo de San Zoil y Camarero de España [...]".

91 BISHKO, El abad Radulfo, pp. 197-215.

92 AHPP, Desamortización, Legajo 112, f. 91r, n. 3.

${ }^{93}$ Encontramos constancia de la existencia de judíos en Carrión en RAMÍREZ DE HELGUERA, El libro de Carrión, pp. 78-79; LEÓN TELLO, Pilar, "Los judíos de Palencia": PITTM, 25 (1967); y RUIZ GONZÁLEZ, Gregorio, "Los judios de Palencia”, en Palencia en la Historia. Palencia, 1982, pp. 116-142.

94 AHPP, Desamortización, Legajo 112, f. 397r.
} 
Es en el siglo XIII cuando el periodo de formación del patrimonio monástico de San Zoilo se puede dar por cerrado. A partir del reinado de Alfonso X, los reyes que se sucedieron en el trono castellano hasta el siglo XV dedicarán sus disposiciones a la salvaguarda de las exenciones de la comunidad y a la defensa de sus derechos; pero no a acrecentar sus propiedades. Sin embargo, la suma de privilegios y mercedes reales no evitó que la comunidad de San Zoilo soportara una decadencia clara a partir de la segunda mitad del siglo XIII. Y una prueba evidente de ello es que el número habitual de religiosos, que estaba en torno a los veinticinco, descendió de forma considerable, de suerte que no eran más de diez los monjes del monasterio en el año $1349^{95}$.

En el siglo XIV, centuria de crisis, la situación económica del monasterio conoció uno de sus momentos peores. Los monjes se vieron obligados a empeñar una parte del tesoro litúrgico para sobrevivir, cuando los arriendos de algunas de sus heredades no fueron suficientes. Simón Nieto en Los antiguos Campos Góticos refiere el estado calamitoso y de destrucción del monasterio en 1376. En 1387 el dormitorio, el claustro y la casa del monasterio amenazaban ruina porque las crecidas del río llegaron a encharcar el monasterio. Por si fuera poco, empeoraron las relaciones con Cluny. Mucho tuvo que ver la relajación de las costumbres, como prueban las actas de los Capítulos Generales de la Orden; pero no fue causa exclusiva. Empeoró las relaciones la obligación que, desde la sujeción a la abadía borgoñona, los monjes de Carrión tenían de pagar a la casa madre parte de sus ingresos, obligación que se concretaba en una gabela de veinte florines de oro ${ }^{96}$; la cual sin duda se encargaban de hacer cumplir los abades que venían desde Cluny a explotar el monasterio y a someter a una comunidad por la que ni siquiera habían sido elegidos ${ }^{97}$.

\footnotetext{
${ }^{95}$ RAMÍREZ DE HELGUERA, El libro de Carrión, p. 174.

96 BECERRO DE BENGOA, Ricardo, La Tierra de Campos: álbum de excursiones. Palencia: Diputación de Palencia, 2007 (=BECERRO DE BENGOA, Tierra de Campos), pp. 45-46.

A partir del siguiente asiento de AHPP, Desamortización, Legajo 112, f. 241v-242r, n. ${ }^{\circ} 10$, puede inferirse esa relación de dependencia económica de San Zoilo respecto a Cluny: "Requirimiento que hizo un escudero de don Gómez de Venavides y doña María Manrrique (como protectores que dicen ser del monasterio de San Zoyl) al prior de San Boal, vicario y receptor del abad de Cluni, [...] para que pagase los florines que tenía obligación a Cluni por la defensa que aquella casa hacía en Roma a todos los monasterios que le estaban sugetos. [...] a 9 de junio de $1431[\ldots] ”$.

Inclusive las casas dependientes de San Zoilo debían hacer este pago a Cluny: "Obligación que hizo don Juan, prior del monasterio de San Salvador de Villaverde, a Fernán González de Velforado, procurador de don Pedro, por la gracia de Dios prior mayor de San Zoil de Carrión, visitador, camarero y receptor del abad de Cluniego, de darle en nombre de su monasterio 30 florines o mil y quinientos maravedís para paga de las pensiones a que estaba obligado por los años de 1422, 23 y 24. Fecha y firmada a 26 de abril de 1424". AHPP, Desamortización, Legajo 112, f. 448v, n. 22.

${ }^{97}$ Sirva como ejemplo de estas infames prácticas que tanto arruinaron al monasterio, la "venta" que el abad Juan III hizo del Barrio de San Martín de Frómista y que, por lo preciso de las explicaciones hechas en el asiento del Índice, reproduzco prácticamente en su integridad: "Escritura de arrendamiento por modo de encomienda del barrio de San Martín, por el qual don Juan, prior de San Zoil, dio en renta por diez años a Juan Fernández de Padilla, señor de Frómesta, el barrio de San Martín con jurisdicción, nombramiento de
} 


\subsection{San Zoilo en la Congregación de San Benito de Valladolid}

La situación en que se encontraba el monasterio de San Zoilo se hacía insostenible, por lo que los monjes no dudaron en solicitar al papa Eugenio IV $^{98}$ que aboliera su sometimiento a la abadía de Cluny; lo cual les fue concedido en 1435, convirtiéndose entonces San Zoilo en abadía independiente, de la que sus abades serían confirmados a partir de ese momento por el papa y no por el abad de la que hasta entonces había sido la casa madre de Cluny. Sin embargo, la autonomía no trajo la prosperidad presupuesta porque comenzó una etapa de abades comendatarios que no fueron capaces de sortear los tiempos de crisis.

Cluny siempre mostró una razonable preocupación porque los priores que designaba para que rigieran sus filiales fueran monjes que estuvieran bien preparados para el ejercicio del cargo. Por el contrario, a partir de la autonomía los abades elegidos para regir los destinos de los monasterios que abandonaron la relación filial con Cluny no fueron siempre los más idóneos, sino aquellos que, por la circunstancia que fuera, había que premiar, sin contemplarse la preparación y competencia para el cargo abacial como los más importantes de sus méritos. San Zoilo no fue una excepción, y algunos de los abades nombrados en este momento de independencia reciente de Cluny se caracterizaron por su

oficiales, diezmos mayores y todo quanto allí tenía el monasterio, [...] se arrendó por precio de 30 mill maravedís cada año, [...] La causa de hacer este arrendamiento y dar el varrio en encomiendo a Juan Fernández de Padilla dice esta escritura que fue porque este cavallero, como poderoso, les ofreció 30 mill maravedís adelantados de la renta para que pagasen sus deudas y en particular una que debían los monges al abad de Cluniago y para que desempeñasen y quitasen de la judería de Carrión un vaso de oro del monasterio que tenían empeñado para sustentarse, por la mucha necesidad en que se hallaban a causa de no haber cogido fruto ninguno el año anterior por los malos temporales y plaga de la langosta. Y para asegurar los vasallos y los frutos del barrio, aunque con gran pérdida del monasterio, diole en encomienda, de que se siguió la destrucción y pérdida del barrio y aún de la hacienda de toda la orden en España. Otorgose la escritura en Palencia, a 30 de abril, era de 1363, que es año de 1325, ante Domingo Pérez, escribano de dicha ciudad". AHPP, Desamortización, Legajo 112, f. 225v-226r, n. ${ }^{\circ} 4 .$.

La venta efectiva de dicho barrio llegará en 1574 cuando, tras casi dos siglos de pleitos con los señores encomenderos, el monasterio decida finalmente hacer efectiva la transacción del barrio al marqués de Frómista, don “Gerónimo de Venavides". AHPP, Desamortización, Legajo 112, f. 246v, n. ${ }^{\circ}$ 2. El Cajón $9^{\circ}$ (San Román) está destinado íntegramente a custodiar la documentación que dicho pleito generó AHPP, Legajo 112, f. 225r-251v.

Lo mismo ocurrió con la hacienda que el monasterio poseía en Benafarces, la cual vendió el abad don Pedro de Tosantos por un juro perpetuo de 4.000 maravedís. AHPP, Desamortización, Legajo 112, f. 338 r.

${ }^{98} \mathrm{El}$ mismo les concederá por Bula el uso de mitra y báculo.

AHPP, Desamortización, Legajo 112, f. 83r, n. ${ }^{\circ}$, recoge esa "Bulla del papa Eugenio 4", escrita en pergamino, con sello de plomo pendiente, por la qual, a instancia del rey don Juan el $2^{\circ}$ y de la reyna doña María, su muger, atento que el monasterio sustentaba 25 monges, extingue el oficio y dignidad de prior de él y le erije en abadía, y al superior de él en abad [...]"; con todos los privilegios y exenciones que tenían los abades cluniacenses. 
absentismo, visitando sólo el monasterio para cobrar las rentas que les correspondía entregar, sin ninguna o escasa preocupación por arreglar la situación del cenobio ${ }^{99}$.

El fracaso de la formulación de la encomienda con Cluny y los resultados calamitosos de los nefastos mandatos de estos abades ${ }^{100}$, provocaron el surgimiento de intentos de algunos conventos, una vez apartados de forma definitiva de la casa madre, por buscar filiaciones en las que la casa central no estuviera tan alejada como Cluny. Por ello en 1507, como testimonia la cédula de 26 de noviembre del rey Fernando el Católico, el monasterio de San Zoilo de Carrión se afilió al de San Benito el Real de Valladolid ${ }^{101}$. Filiación que no impidió al papado seguir reclamando las rentas y elegir los abades que rigieran la vida del cenobio carrionés ${ }^{102}$. Esta situación no cambia hasta 1532, cuando de forma definitiva se produce la unión de San Zoilo a la congregación vallisoletana. En esa

\footnotetext{
99 Indica BECERRO DE BENGOA, El Monasterio de Carrión, pp. 81-82, que los abades consistoriales sólo se mantuvieron hasta 1461, cuando fueron sustituidos por los abades comendatarios, nombrados por los reyes, los cuales elegían a obispos y arzobispos para un cargo del que no interesaba nada más que sus rentas. Este fue el caso de don Pedro González de Mendoza, obispo de Sigüenza; don Luis Hurtado, hermano del conde de Castro; don Bernardino de Carvajal, obispo de Ávila; don Juan de Fonseca, obispo de Palencia; y don Pedro Strozi, sobrino de Clemente VII; los cuales, entre 1469 y 1524, ocuparon el cargo de abad de San
} Zoilo.

Una relación más detallada de los nombramientos de abades consistoriales y comendatarios de este monasterio, así como de la disyuntiva a la que sometieron a este monasterio puede encontrarse en AHPP, Desamortización, Legajo 112, f. 83r-87v, bajo el título "Este quaderno contiene bullas de nombramientos de abades consistoriales y comendatarios de este monasterio, con otros papeles, hasta su vnión inclusive a la Congregación de San Benito de Valladolid".

100 Cabe aquí destacar la venta funesta de todas las haciendas que tenía el monasterio en Toro por 11.000 maravedís, realizada por el abad Gonzalo Martínez de Cervatos; lo que generó un pleito que duraría 148 años, desde 1443 hasta 1591, entre el monasterio y las familias interesadas en ella como los Vivero, los Fonsecas y los Ulloa. AHPP, Desamortización, Legajo 112, f. 338v- 344v.

101 AHN, Sección Clero, legajo 7739. Véase ZARAGOZA PASCUAL, Abadologio San Zoilo, pp. 273-322.

El Índice de San Zoilo da noticia de esto mediante un "Testimonio dado por Julián Martínez de Cortes, escrivano real, por el qual consta que, habiendo llegado al monasterio de San Zoil el abad de San Benito de Valladolid, reformador y visitador general de la Orden, requirió al alcalde Ronquillo, que estaba presente, con una bulla apostólica y cédulas de la reyna, para que le diese favor y ayuda para reformar este monasterio y unirle a la Congregación. [...] y el convento, habiendo consultado entre sí sobre el caso, dio la obediencia al abad de Valladolid y se sujetó a la reforma y visita, en 28 de septiembre de 1507, que es la fecha de este testimonio, siendo prior de San Zoil fray Diego de las Heras". AHPP, Desamortización, Legajo 112, f. $84 \mathrm{v}, \mathrm{n} .^{\circ} 14$.

Más información acerca del Monasterio de San Benito el Real de Valladolid y su reforma puede encontrarse en RODRÍGUEZ MARTÍNEZ, Luis, Historia del Monasterio de San Benito el Real de Valladolid. Valladolid, 1981; COLOMBÁS, García M.-GOST, Mateo M., Estudios sobre el primer siglo de San Benito de Valladolid. Abadía de Montserrat (Barcelona), 1954.

102 “[...] el año 1507. En que a solicitud de los Señores Reyes Catholicos le consiguió la unión de esta Casa a la Congregación suplicante, de que tomo posesión Fr. Pedro de Naxera, su Abad General con otros monges, y auxilio Real, que intervino. Sin embargo, tuvo 1a Abadía en encomienda Don Bernardino de Carbajal, Cardenal del título de Santa Cruz, y después D. Juan de Fonseca Obispo de Burgos hasta el año 1524. Aunque en este intermedio se governó la Casa por Superiores electos por sus monges, no obstante la mayor parte, o el todo de las rentas de la Mesa Abacial fe la llevaban los Comendatarios". Motivos legales, que reverentemente expone a la alta censura la Congregación Benedictina de estos reynos unida a su monasterio de San Benito el real de Valladolid en respuesta la real Cédula de 8 de noviembre de 1735 y demonstración de los títulos con que se eligen superiores regulares de sus monasterios, p.434. 
fecha el papa Clemente VII otorgó una bula que confería facultad a los monjes para que pudieran elegir libremente sus abades ${ }^{103}$.

En un primer momento, los abades eran elegidos en los Capítulos Generales de la Orden en Valladolid, pero a partir de mediados del siglo XVI la elección recaía directamente en la propia comunidad de San Zoilo ${ }^{104}$. Esta real autonomía en la administración y el gobierno permitió a los monjes de Carrión restaurar el monasterio. Restauración que se destinó tanto a la reconstrucción de las dependencias, que habían sido abandonadas en los tiempos de crisis y que estaban arruinadas, como a la erección de un claustro, que se encargó a Juan de Badajoz. El resultado es el claustro que hoy puede admirarse como una de las soberbias manifestaciones del renacimiento castellano ${ }^{105}$.

En el siglo XVII el monasterio adquirió notoriedad como colegio de artes donde se instruyeron personajes de renombre, entre los que podemos citar a Juan de Cisneros, notario apostólico, secretario que fue del Capítulo General de San Benito y archivero de San Zoilo, autor del manual del archivo de San Zoilo, a partir del que se confeccionará, en el siglo XIX, el registro que conocemos como el Índice de San Zoilo. En la centuria decimoséptima se sustituye la iglesia románica por otra de corte barroco, de mayor ostentación pero carente del valor artístico de la anterior construcción. Y es de destacar la controversia surgida en la centuria en torno al paradero de las reliquias del santo que da nombre al monasterio, San Zoilo, puesto que los cordobeses afirmaron que eran ellos sus poseedores $^{106}$.

${ }^{103}$ BECERRO DE BENGOA, Tierra de Campos, p. 47, explica que los monjes se expresaron de esta manera: "[...] demos gracias al Señor que nos libró de tan tirana esclavitud [...]".

En el Índice de san Zoilo se registra tanto un trasunto de la bulla de Clemente $7^{\circ}$ de la unión de este monasterio a la Congregación de San Benito de Valladolid, del año de 1532, como una cédula de consentimiento del emperador Carlos V y de su madre para que haga la unión de San Zoil a la Congregación, hecha también en 1532. AHPP, Desamortización, Legajo 112, f. 87v, n. ${ }^{\circ} 40$.

${ }^{104}$ En el Capítulo General celebrado el 12 de mayo de 1544 en San Benito de Valladolid se estableció lo siguiente respecto a las elecciones de los abades de los monasterios: "Otrosí, cerca de las elecciones de los Perlados de la Congregación, así de esta casa de San Benito de Valladolid como de todas las otras casas de la Congregaçión, por quanto en este presente Capítulo General por toda la Congregaçión fue reclamado de la forma y manera que se tenía en ellas, por les pareçer no ser cosa que les convenía, y que los conventos de los monasterios del modo de las tales elecciones reçibían algunos agravios, se ordenó y constituyó que las dichas elecciones se hiçiesen y celebrasen en los conventos según y de la manera que antiguamente se solía celebrar". MATÉ SADORNIL, Lorenzo, Actas y constituciones de los Capitulos de la Congregación de San Benito de Valladolid (1497-1610): Stvdia Silensia, XXX-XXXI. Abadía de Silos, 2007-2008, p. 266.

${ }^{105}$ DÍAZ NAVA, Adolfo F., "Un claustro plateresco "San Zoil" en Carrión de los Condes": PITTM, 23 (1963), pp. 130-158; REDONDO CANTERA, M. ${ }^{2}$ José: "El programa iconográfico en el claustro bajo del monasterio de San Zoilo de Carrión de los Condes (Palencia)", en Actas del II Congreso de Historia de Palencia. Tomo V, pp. 129-154.

106 SANTOS URBANEJA, San Zoilo, pp. 41-67 y 78.

Se registra en el Índice una serie de 9 cartas escritas en 1600 relativas a la pretensión que hizo la ciudad de Córdoba para que se le diesen unas reliquias de San Zoilo y, aunque no tuvo efecto la petición, 
Llegados a este momento de la historia del cenobio, no podemos dejar de mencionar que el monasterio de San Zoilo fue adquiriendo a lo largo de la misma nutridas propiedades, entre las que el Padre Yepes destacó los catorces monasterios de los que llegó a estar en posesión durante los primeros siglos de su existencia. Eran esos: San Román de Entrepeñas, San Pedro de Recueva, San Facundo y San Primitivo de Arconada, San Pelayo de Toro, Valcavado, San Martín de Frómista, San Martín de Villamayor, San Pelayo de Barcial, Santa María de Trigueros, San Juan de Aguilar, San Lorenzo de Villalpando, San Miguel de Ríos Menudos, San Salvador de Villaverde y Nuestra Señora del Brezo. Catorce monasterios que Ramírez de Helguera explica que se redujeron más tarde a seis: "San Román, Brezo, Frómista, Aguilar, Villalpando y Villaverde, por ser los demás erigidos en curatos, de los que sólo tenía la presentación" ${ }^{\text {107 }}$.

\subsection{El monasterio de los siglos XIX al XXI}

Desde finales del siglo XVIII y a lo largo de todo el siglo XIX, los distintos gobiernos de España buscaron resolver los problemas económicos de la nación mediante un proceso de desamortización que tiene muchas y diferentes lecturas. Con las actuaciones desamortizadoras se pretendió, en el plano político, abolir la tradicional estructura señorial y convertir el patrimonio amortizado de la Iglesia en bienes de titularidad nacional.

La desamortización de Mendizábal del año 1836 y la promulgación de las leyes de exclaustración provocaron que los monjes se vieran obligados a abandonar el monasterio de San Zoilo, quedando su último abad, Plácido Trebijano ${ }^{108}$, en calidad de párroco hasta su muerte en $1880^{109}$. Unos años antes, concretamente en 1851, el obispado de Palencia

consta que se abrió el arca y se registraron las reliquias que en ella había. AHPP, Desamortización, Legajo 112 , f. $117 \mathrm{v}$, n. $^{\circ} 4$.

No obstante, en 1708, vuelve el obispo de Córdoba a solicitar una reliquia del santo, a lo cual accede el monasterio haciendo entrega de "un hueso, al parecer canilla de un brazo, del santo de un jeme de largo", que es llevado a Córdoba. AHPP, Desamortización, Legajo 112, f. 119r, n. ${ }^{\circ} 21$.

107 En 1818, el monasterio únicamente contaba con esos seis prioratos, tal y como lo demuestra la organización del Índice de San Zoilo y las tipologías documentales registradas en cada uno de los cajones dedicados a estos prioratos. Aun así, cabe reseñar que en el Archivo Histórico Provincial de Palencia, entre los papeles procedentes del Fondo Desamortización únicamente existe la referencia a tres de esos prioratos, a través de la existencia de unos registros de fincas y censos realizados por las Comisiones de Amortización en 1840 para San Román de Entrepeñas, Nuestra Señora del Brezo y Villaverde; lo cual no excluye la posible vinculación del resto de prioratos para esas fechas. AHPP, Desamortización, Legajo 435 y 436.

Para un estudio más detallado de estos prioratos, así como de su momento de anexión a San Zoilo y su relación con el monasterio véase el capítulo que dedicamos a la conformación del dominio monástico.

${ }^{108}$ La relación más completa de todos los abades y priores que han ocupado dichos cargos en el monasterio podemos encontrarla en ZARAGOZA PASCUAL, Abadologio San Zoilo, pp. 273-322.

109 Becerro de Bengoa explica en su libro cómo conoció a este abad cuando fue a visitar el monasterio y cómo tomó debida cuenta de todas las historias que este le contaba, pues él era el último testimonio vivo de lo que en algún momento había llegado a ser la abadía de San Zoilo. Con su muerte, se ponía fin al elenco de los 
había entregado el monasterio a la Compañía de Jesús, la cual instituyó en él el primer colegio de primera y segunda enseñanza de España, con el nombre de Sagrado Corazón de Jesús. En 1868, año en que se inicia el Sexenio Democrático, se produjo la expulsión de las comunidades religiosas de España, entre ellas los jesuitas, que tuvieron que abandonar San Zoilo $^{110}$.

El establecimiento de la libertad de enseñanza que trajo el Sexenio convirtió a San Zoilo, en 1871, y tras haber sido utilizado como cárcel en 1869, en un instituto libre de segundas letras. Unos años más tarde, con la restauración monárquica de 1875, la Compañía de Jesús regresó a San Zoilo de Carrión y allí los jesuitas continuaron con la labor docente que habían desempeñado antes de su expulsión.

En 1891 el colegio se transformó en un noviciado, aunque ese mismo año se clausuró porque la Compañía tenía en esos momentos otros dos en funcionamiento en Gijón y Valladolid. Cuando Ramírez de Helguera escribió su libro de Carrión de los Condes en 1896, no pudo dejar de expresar su decepción ante los hechos ocurridos en la centuria que le tocó vivir. Lo hizo de la siguiente manera: "Y esto es ahora San Zoilo, después de lo que ha sido con frailes y colegio de segunda y primera enseñanza, sombra de lo que fue".

En 1918 los jesuitas volvieron su mirada a San Zoilo para convertirlo en Colegio Apostólico, un centro de enseñanza media para la formación de futuros jesuitas, ampliación del que habían creado anteriormente en Salamanca. Pero en 1926 se trasladaron el noviciado y los estudios jesú́ticos definitivamente a Salamanca, y el monasterio de San Zoilo se dedicó a Seminario Menor Diocesano y Escuela Apostólica de la Compañía. Durante la Segunda República, la protección del obispado evitó que los jesuitas fueran expulsados nuevamente del país. Aun así, la suerte de San Zoilo no mejoraría, y tras la Guerra Civil el monasterio quedó dedicado solamente a escuela apostólica, perdiendo la mayoría de sus funciones anteriores.

Treinta años más tarde, en 1948, los jesuitas planificaron su traslado a León, pero la aportación al monasterio en sus años de estancia en él ha resultado crucial. Así lo piensa Cuadrado cuando dice “[...] Sin los jesuitas, cuya modesta y sólida enseñanza vienen a buscar en aquel escondido rincón numerosos alumnos de todos los confines de España, el monasterio de San Zoilo yaciera probablemente confundido en un montón de ruinas

ochenta abades que había tenido el monasterio desde que lo fuese Thedomiro en el 948. BECERRO DE BENGOA, El Monasterio de Carrión, pp.93-94.

110 Se conserva en el AHPP, Desamortización, Legajo 435, un expediente de enajenación del Colegio de Jesuitas establecido en San Zoilo de Carrión, instruido por el Gobierno Civil (1868-1871). 
[...]"111. En 1959 el monasterio vuelve a manos del obispado de Palencia y se traslada a él el Seminario Menor de la Diócesis hasta 1988, momento a partir del cual San Zoilo permanecerá cerrado varios años.

La década última del siglo XX cambiará la suerte de San Zoilo. Y cambia porque el obispado de Palencia vendió la parte del monasterio que no tenía la condición de patrimonio histórico ${ }^{112}$ y se reservó para sí la iglesia del monasterio y el claustro renacentista. Dos circunstancias más que se sumadas a la anterior han sacado del olvido al monasterio: en agosto de 1993 se descubrió el pórtico de la iglesia románica ${ }^{113}$ y en 1999 se ubicó en él el Centro de Estudios Jacobeos, a raíz de la exposición itinerante "Camino de Santiago, mil años de historia... mil libros para conocerla".

Mención aparte requiere su declaración como Monumento Nacional, empresa que se logró el 3 junio de 1931, tras las numerosas demandas realizadas por la Comisión de Monumentos desde el año $1871^{114}$; lo cual fue ratificado cuando, siguiendo la disposición adicional primera de la Ley 12/2002 de Patrimonio Cultural de Castilla y León, la Junta de Castilla y León decide la adecuación del Bien de Interés Cultural del Monasterio de San Zoilo de Carrión de los Condes el 26 de julio del año 2012, por acuerdo 63/2012 ${ }^{115}$, definiendo sus límites y su entorno de protección, con una cartografía actualizada, incluyendo el conjunto de edificaciones que lo integran.

111 QUADRADO, Recuerdos y bellezas, p. 344.

${ }^{112}$ En 1991 el conjunto, excepto la iglesia y el claustro, fueron vendidos y el monasterio es transformado en la Hospedería de San Zoilo.

113 SENRA GABRIEL y GALÁN, José Luis, "La portada occidental recientemente descubierta del priorato cluniacense de Carrión de los Condes": Archivo español de Arte, 67, n. 265 (1994), pp. 57-72; IDEM, "La puerta como dogma: a propósito de un nuevo descubrimiento de la iglesia románica de San Zoilo de Carrión de los Condes (Palencia)": Archivo español de Arte, 81, n. 322 (2008), pp. 139-150.

114 GARCÍA GARCÍA, Lorena, Evolución del Patrimonio Religioso en Carrión de los Condes, Palencia, desde la Baja Edad Media hasta nuestros días, p.556. Tesis doctoral consultable en: http://uvadoc.uva.es/handle/10324/3026 [Última consulta: 2 de marzo de 2017].

${ }^{115}$ Este acuerdo está publicado en BOCYL n. ${ }^{\circ}$ 147/2012, de 01 de agosto de 2012. 



\section{EL ARCHIVO DEL MONASTERIO DE SAN ZOILO DE CARRIÓN}

\section{Introducción}

Si hay un hecho imposible de rehuir cuando se trabaja con documentos de archivo es el de la evidencia de que la información custodiada en los archivos es dúplice o, si se quiere, ofrece a la investigación dos dimensiones, puesto que permite conocer todo lo relativo al proceso y las circunstancias que afectan a la creación del archivo, pero también las realidades que se deriva de tal creación y la complejidad social de la institución productora $^{116}$; logrando así que el archivo no sea únicamente objeto de trabajo y estudio desde el ámbito de las ciencias auxiliares sino también y además que pueda ser objeto de reflexión en sí, en torno al cual operar y basar estudios completos ${ }^{117}$. Para una cabal comprensión de lo afirmado, se hace necesaria la lectura de los manuales que aparecen en el siglo XX, punto de inflexión de la Archivística, con la publicación de obras clásicas debidas a Adolf Brenneke, Eugenio Casanova, Elio Lodolini y Leopoldo Sandri, entre otros; autores todos ellos precursores en el intento de llevar a cabo una sistematización tanto de la teoría archivística como de la propia historia y el concepto de $\operatorname{archivo~}^{118}$.

Lo que realmente convierte a los archivos y sus documentos en instituciones excepcionales de cualquier sociedad no es sólo su carácter de almacén y herramienta donde rastrear las acontecimientos de unos momentos concretos o de un periodo determinado, sino el hecho de que ellos mismos supongan objeto de estudio en toda su amplitud

\footnotetext{
116 Véase HEREDIA HERRERA, Antonia, “QQué es un archivo?”: Revista ANABAD, n. ${ }^{\circ}$ 57-3, 2007, pp. 167-169 (=HEREDIA HERRERA, Antonia, “¿Qué es un archivo?”), donde la autora insiste en la conveniencia de no hablar de instituciones creadoras de documentos sino de instituciones productoras. Y así afirma que: "[...] hemos de entender que su producción [de los documentos] empieza en la tramitación administrativa [...], y cuando hablamos de creación de documentos nos estamos refiriendo a su concepción, a su diseño, momento en que todavía aquellos no existen [...]". Vuelve sobre ello en HEREDIA HERRERA, Antonia, ¿Qué es un archivo?, Trea, Gijón, 2007, p. 23, donde plantea la diferencia entre archivo como contenido documental y Archivo como institución: "Los documentos, los contenidos documentales, nacen inevitablemente, inexcusablemente. Tienen productor/es. Los Archivos, instituciones, se crean. Tienen creadores, titulares".

117 NAVARRO BONILLA, La imagen del Archivo, afirma que hasta los años medios del siglo pasado "la secular vinculación de los estudios sobre el archivo a las denominadas ciencias auxiliares [...] fue la tónica predominante $[\ldots] "$.

118 LODOLINI, Elio, Archivistica. Principios y problemas, traducción de Mercedes Costa Paretas. Madrid: 1993; SANDRI, Leopoldo, "La storia degli archivi": Archivum. Revue Internationale des Archives, XVIII (1968), pp. 101113; CASANOVA, Eugenio, Archivistica. Siena, 1928; BRENNEKE, Adolf. Archivística. Contributo alla teoria ed alla storia archivistica europea, traduzione italiana di Renato Perrella. Milán, 1968.
} 
científica: su estructura, el momento de producción, su evolución, el ligamiento con su institución y sus modificaciones ${ }^{119}$. El fin jurídico-administrativo, a raíz del cual se ven generados los documentos, constituye su valor más preciado a la hora de fundamentar las señas de identidad de la institución responsable.

$\mathrm{Al}$ hacerme eco de tales afirmaciones únicamente pretendo alinear la intención que persigo en este capítulo con la posición de los autores que defienden la actuación de la Archivística como ciencia en sí misma y no sólo por los resultados que de sus operaciones técnicas se extraigan. El hecho de que a través de la aplicación del método de la Archivística se facilite la búsqueda de un documento o un expediente en un archivo o puedan hacerse deducciones históricas son efectos producidos por una adecuada aplicación de la metodología archivística, pero no son su única finalidad ${ }^{120}$. Y así ocurre en nuestro caso.

El objetivo del estudio del Índice del monasterio de San Zoilo, del índice de su archivo, es tanto hacer progresar la información que conocemos en torno al propio archivo como emplear la información obtenida para posteriores fines; dándose como resultado la una de la otra, pues avanzar en la comprensión del archivo amplía la información histórica que contiene, y esta a su vez permite ahondar en las características que poseía el archivo en el momento concreto o en los diferentes momentos de su producción. Son ambas facetas un producto cruzado que constantemente enriquece a la una y a la otra.

\subsection{Sobre el concepto de archivo}

Apuntaba Troche y Zúñiga en su Archivo cronológico-topográfico. Arte de archiveros que el "índice o epacta no es más que un resumen de todos los documentos que contiene el archivo" ${ }^{21}$. Y ciertamente no es más, pero tampoco es menos; puesto que los índices, junto con otros instrumentos de descripción documental, se convirtieron ya desde el siglo XVI y

\footnotetext{
119 ROMERO TALLAFIGO, Manuel, "El archivo y su función social": Boletin del Arcbivo General de la Nación, año LXVIII, volumen XXI, n. ${ }^{\circ} 114$ (2006), pp. 15-36, especialmente p. 31. (=ROMERO TALLAFIGO, Manuel, El archivo).

${ }^{120}$ LODOLINI, Elio, "El problema fundamental de la archivística: la naturaleza y la ordenación del Archivo": IRARGI, 1 (1988), pp. 27-61 (=LODOLINI, Elio, "El problema fundamental de la archivística"), p. 56, se muestra radical en este aspecto: "[...] cuanto más progresa la archivística, mejor son satisfechas las búsquedas de los usuarios de los archivos. Pero esta, repetimos, es una consecuencia, no la finalidad, del progreso de la disciplina".

121 TROCHE Y ZÚÑIGA, Froilán, El Archivo cronológico-topográfico. Arte de archiveros. Coruña: Imprenta de Iguerreta, 1835, p. 69.
} 
sobre todo a partir del siglo XVIII ${ }^{122}$ en instrumentos fundamentales para llevar a cabo un control exhaustivo de la documentación garante del patrimonio, así como para proporcionar un acceso fácil y sencillo al contenido y localización de la documentación a través de un extracto o resumen de la información contenida en los diplomas del archivo descritos.

Esta considerable actividad archivística y documental podría parecer en cierto sentido anacrónico. Y no lo es, no solamente por su función de control sino también por la importancia que este tipo de registros poseía y que actualmente posee a la hora de reconstruir la organización del archivo del que son reflejo y que, en el caso que nos ocupa, se encuentra disperso en un considerable número de archivos españoles y franceses ${ }^{123}$. A este aspecto señalado debe sumarse otra posibilidad añadida, pues también nos facilitan el acceso al contenido de aquellos documentos de los que no se tiene noticia, bien por pérdida o porque ni se han descrito ni se han realizado estudios específicos en torno a ellos, como queda especialmente patente en el caso de la documentación del monasterio de San Zoilo de Carrión de la Edad Moderna.

Es este Índice de San Zoilo entonces una suerte de repertorio, un instrumento de consulta que facilita la localización de los documentos en el universo del archivo, el depósito de los documentos, el lugar destinado a la guardia y custodia de los mismos. No hay archivo sin documentos, sin los documentos que dan cuenta y razón de los negocios en los que el monasterio intervino. No hay memoria sin archivo, de ahí la importancia del mismo. Razón poderosa para ocuparme en la tarea de desentrañar lo que sobre el concepto de archivo se ha dicho y se ha escrito, antes de pasar al estudio del instrumento, el Índice, que fue concebido para acceder a la memoria guardada en el archivo.

Encuentro para ello un acertado punto de partida en la afirmación que José Luis Rodríguez de Diego hace en las páginas iniciales que dedicó al estudio y edición de la Instrucción para el Gobierno del Archivo de Simancas dada por Felipe II: "El archivo", escribe el que fuera director de la institución simanquina, "no es un producto aislado, un lujo cultural que surge sin más" "124; me atrevería a completar esta frase añadiendo que el archivo tiene

\footnotetext{
122 NAVARRO BONILLA, Diego, Escritura poder y archivo. La organización documental de la Diputación del Reino de Aragón (siglos XV-XVIII). Zaragoza, 2004, p. 168.

123 Véanse PALACIO SÁNCHEZ-IZQUIERDO, M. ${ }^{a}$ Luisa, San Zoil de Carrión: (1047-1300). Palencia: Diputación Provincial de Palencia, 1990, y PÉREZ CELADA, Documentación San Zoilo de Carrión I/II), Palencia, 1986/1987, que proporcionan información relativa a esta dispersión documental, y de la que me ocuparé en el epígrafe dedicado al archivo monástico.

${ }^{124}$ RODRIGUEZ DE DIEGO, José Luis, Instrucción para el Gobierno del Archivo de Simancas. Madrid, 1989, p. 13 (=RODRIGUEZ DE DIEGO, Archivo de Simancas).
} 
crédito per se, y no sólo por las consecuencias que de él se derivan ${ }^{125}$, como podrá comprobarse.

Afirma Antonia Heredia, en el artículo anteriormente citado, que responder a una cuestión tantas veces debatida como ¿qué era y es un archivo? "exige reflexionar sobre la evolución de la Archivística" ${ }^{126}$; es decir, comprender el carácter adaptable y maleable que posee esta disciplina, capaz de impregnarse de todos los cambios que acontecen en los comportamientos sociales, interdisciplinares y globales; todos esos comportamientos de los que un archivo es reflejo. Es esta misma evolución la que progresivamente fue otorgando al archivo un lugar importante dentro de una organización, la que le ha convertido en la unidad básica de la gestión documental, sea esta una gestión de documentos generados por instituciones de carácter sanitario, económico o educativo. Es este carácter voluble y cambiante del archivo lo que me lleva a querer precisar y perfilar una definición lo más exacta posible.

Archivar, según el DRAE, es guardar documentos en un archivo; pero también, añadimos, almacenarlos y conservarlos. Sin embargo, el archivo, tanto como unidad de gestión organizativa como custodio del patrimonio documental, no queda suficientemente demarcado por el verbo citado ${ }^{127}$; pues el archivo no está únicamente delimitado por su capacidad de almacenar o conservar. Por otro lado, si atendemos directamente a la voz “archivo", de nuevo el DRAE señala dos acepciones: “Conjunto ordenado de documentos que una persona, una sociedad, una institución, etc., producen en el ejercicio de sus funciones o actividades" y "lugar donde se custodian uno o varios archivos". Si bien supone una estimación más cercana a la definición que nos interesa, no deja de ser incompleta en algunos aspectos, pues un archivo ni es solamente un local de custodia ni es un conjunto de documentos sin más.

Los intentos por aportar una definición lo más precisa y acertada posible del término archivo han sido una constante, como es lógico, en la cada vez más amplia

\footnotetext{
${ }^{125}$ Es por esa razón por la que LODOLINI, Elio, "El problema fundamental de la archivística", p. 56, indica que eso mismo ocurre con la ciencia que tiene por objeto el estudio de los archivos, es decir, que "la finalidad de Archivística es el progreso de la misma".

126 HEREDIA HERRERA, Antonia, “¿Qué es un archivo?”, pp. 167-169. Una afirmación semejante puede encontrarse también en SANDRI, Leopoldo. "La storia degli archivi": Archivum, XVIII (1968), p.103, que afirma que: "podremos considerar que la historia de los archivos y la del mismo concepto de archivo, está en perfecta conjunción con la propia historia de la Archivística".

127 HEREDIA HERRERA, Antonia, “¿Qué es un archivo?”, pp. 167-169.
} 
bibliografía archivística ${ }^{128}$. Centrándonos en las definiciones aportadas dentro del contexto español cabría destacar los enunciados que nos propone el Diccionario de Terminología Archivística ${ }^{129}$, publicado por la Subdirección General de los Archivos Estatales, en el que se define el archivo como:

1. El conjunto orgánico de documentos producidos y/o recibidos en el ejercicio de sus funciones por las personas físicas o jurídicas, públicas y privadas.

2. La institución cultural donde se reúne, conserva, ordena y difunden los conjuntos orgánicos de documentos para la gestión administrativa, la información, la investigación y la cultura.

3. El local donde se conservan y consultan los conjuntos orgánicos de documentos.

Estas tres acepciones en el concepto de archivo han venido siendo apuntadas de modo general por la Archivística moderna y, aunque algún autor establece ciertas variaciones de significado que posteriormente analizaremos, esa triple definición está siendo desbancada en las definiciones de archivo más actuales por una concepción dual, tal y como sucede en las ofrecidas en las diferentes disposiciones legales de carácter estatal y autonómico españolas.

Nuestro objetivo es situarnos en un entorno próximo, tanto en el tiempo como en el espacio, por eso vamos a centrarnos en las definiciones de solo algunos de los trabajos más significativos así como en las incorporadas en los respectivos textos normativos.

A este respecto, cabe aludir en primer lugar, por orden cronológico, a las definiciones de algunas de nuestras disposiciones legales.

\footnotetext{
128 Algunas de las primeras definiciones a nivel teórico pueden encontrarse en monografías clásicas, entre las que destacamos las de LODOLINI, Elio, Archivística. Principios y problemas, pp. 24-25, donde el autor afirma que el "«archivo», en fin, nace espontáneamente, como sedimentación documental de una actividad práctica, administrativa, jurídica. Por eso está constituido por un conjunto de documentos, unidos entre sí recíprocamente por un vínculo original, necesario y determinado, por el que cada documento condiciona los demás y es por los demás condicionado"; CASANOVA, Eugenio, Archivistica, p. 19, donde el también autor italiano señala: "È quindi d'uopo che formuliamo, a nostra volta, una definizione dell'archivio che corrisponda al concetto che ce ne siamo formato: e diciamo che, per noi: «L'archivio è la raccolta ordinata degli atti di un ente o individuo, costituitasi durante lo svolgimento della sua attività e conservata per il conseguimento degli scopi politici, giuridici e culturali di quell'ente o individuo»"; y BRENNEKE, Adolf. Archivística. Contributo alla teoria e dalla storia archivística europea, p. 27, para el que la "parola 〈archiviò è presa in tre diversi significati; essa indica: 1. L'edificio adibito ad archivio, considerato come un insieme, quindi sia come il luogo di conservazione degli atti che come locale di amministrazione e di uso; 2. quella parte dell'edificio archivistico nella quale sono collocati gli atti, cioè il deposito (deposito, magazzino); 3. la consistenza del materiale archivistico che si trova nel deposito, o parti di essa che prima erano archivi autonomi (sezioni archivistiche, corpi archivistici)".

129 Diccionario de terminología archivística ( $2^{\mathrm{a}}$ ed.). Madrid: Subdirección de General de los Archivos Estatales, 1995.
} 
La ley de Patrimonio Histórico Español define los archivos, en su artículo 59, como “conjuntos orgánicos de documentos, o la reunión de varios de ellos, reunidos por las personas jurídicas públicas o privadas, en el ejercicio de sus actividades, al servicio de su utilización para la investigación, la cultura, la información y la gestión administrativa". “Asimismo", añade, "se entiende por Archivos las instituciones culturales donde se reúnen, conservan, ordenan y difunden para los fines anteriormente mencionados dichos conjuntos orgánicos" ${ }^{130}$.

La Ley 6/1991, de 19 de abril, de Archivos y del Patrimonio Documental de Castilla y León, como ocurre con no pocas de las normas autonómicas, define el «archivo» de manera muy similar a como lo hace la Ley de Patrimonio Histórico. Y así nos dice que:

1. "Se entiende por archivo el conjunto orgánico de documentos, o la reunión de varios de ellos, reunidos por cualquier entidad pública o privada, persona física o jurídica y conservados como garantía de derechos, como fuente de información para la gestión administrativa y la investigación o con cualquier otro fin".

2. "Asimismo se entiende por archivo aquella institución cuya función primordial es la de reunir, organizar, conservar, comunicar y difundir por medio de técnicas apropiadas dichos conjuntos de documentos para el cumplimiento de los fines antes enumerados" 131 .

Aunque a comienzo del siglo XXI eran ya muchas las comunidades autónomas que habían desarrollado sus propias leyes sobre Archivos; sin embargo, la ley de Archivos elaborada por el Ministerio de Cultura era solamente un proyecto, a pesar de que el Consejo de Europa había expresado, en el año 2000, la importancia de los archivos, recalcando que "constituían una parte esencial e irremplazable del Patrimonio Cultural pues preservan la perennidad de la memoria de la humanidad" $" 132$.

Casi doce años después, en el Real Decreto 1708/2011, de 18 de noviembre, que establece el Sistema Español de Archivos y regula el Sistema de Archivos de la Administración General del Estado y de sus Organismos Públicos y su régimen de acceso, tras advertir que para su elaboración han sido consultadas las Comunidades Autónomas, lo que permite deducir una colaboración que se echó en falta a mediados de los años ochenta del siglo pasado, se ofrece, "sin perjuicio de lo dispuesto en el artículo 59.1 de la Ley

\footnotetext{
130 Ley 16/1985, de 25 de junio, del Patrimonio Histórico Español (BOE n. ${ }^{\circ}$ 155, de 29 de junio de 1985), art. 59.1.

${ }^{131}$ Ley 6/1991, de 19 de abril, de Archivos y del Patrimonio Documental de Castilla y León (BOCYL n. ${ }^{\text {91, }}$ de 15 de mayo de 1991), art. $3^{\circ} .1$.

132 HEREDIA HERRERA, Antonia, ¿Qué es un archivo?, p. 25.
} 
16/1985, de 25 de junio, del Patrimonio Histórico Español, y de la correspondiente legislación autonómica”, la siguiente definición de archivo:

a) "El conjunto orgánico de documentos, o la reunión de varios de ellos, producidos o reunidos por las personas físicas o jurídicas, públicas o privadas".

b) "Las entidades, que de acuerdo con las normas internacionales de descripción archivística, comprenden instituciones, personas y familias, que reúnen, conservan, organizan, describen y difunden los conjuntos orgánicos y las colecciones de documentos" ${ }^{133}$.

Esta doble vertiente conjunto documental/institución es una constante en las definiciones mencionadas y en otras que pudiéramos traer a colación. Es de valorar que en las mismas se abandone el uso de la palabra "local" (DRAE) puesto que el archivo es mucho más que un local para la custodia, más aún hoy cuando la libertad de acceso y el uso de las nuevas tecnologías ha hecho posible que el contenido de los documentos pueda ofrecerse de muy diversas formas en una amplia variedad de servidores que agilizan y facilitan su acceso.

Antonia Heredia es una de las defensoras de esta bidimensionalidad, que ha sabido expresar certeramente al distinguir entre el archivo como "institución que conserva, trata y sirve los documentos de archivo que guarda" y el archivo como "contenido documental del archivo, identificado con todos los documentos conservados en él"134.

No obstante, el triple significado que en su momento ofrecía el Diccionario de Terminología Archivística, sigue siendo válido. Así lo manifiestan autores como Ramón Alberch $^{135}$ o José Ramón Cruz Mundet, el cual, en su manual de Archivística más reciente advierte que el concepto de archivo tiene distintas acepciones: "lugar, sistema, órgano, actividad y agrupación documental"136.

Por último, cabe destacar, por su peculiaridad, la definición como «colección» que Manuel Romero Tallafigo emplea para referirse al archivo: "Archivo sería una colección de documentos reunidos por una entidad en el ejercicio de una actividad práctica y necesaria,

\footnotetext{
133 Real Decreto 1708/2011, de 18 de noviembre, por el que se establece el Sistema Español de Archivos y se regula el Sistema de Archivos de la Administración General del Estado y de sus Organismos Públicos y su régimen de acceso (BOE n. ${ }^{\circ}$ 284, de 25 de noviembre de 2011), art. 2.1.

${ }^{134}$ HEREDIA HERRERA, Antonia, "El nombre de las cosas o el valor de las palabras": Revista del Archivo General de la Nación, n. 25 (2005), pp. 27-32, especialmente p. 29.

135 ALBERCH FIGUERAS, Ramón, Los Archivos entre la memoria histórica y la sociedad del conocimiento. Barcelona, 2003, p. 17.

${ }^{136}$ CRUZ MUNDET, José Ramón, Archivística. Gestión de documentos y administración de archivos. Madrid, 2012, p. 71.
} 
conservados en un lugar seguro como memoria fiel para servir de testimonio e información" ${ }^{\prime 137}$. Definición, sin duda, singular para un archivo por el empleo del término colección, que nos aleja de la producción natural de los documentos, del carácter orgánico del conjunto de los mismos, y nos evoca las colecciones artificiales de, por ejemplo, una biblioteca, creadas voluntariamente en contraposición a la condición orgánica de todo archivo.

Es innegable que la tarea de precisar el concepto de archivo es una tarea abierta, en constante cambio y progreso. Con las definiciones ofrecidas en estas páginas he pretendido mostrar únicamente una ínfima parte de la diversidad de autores que en diferentes monografías y trabajos se han preocupado por ofrecer el concepto de archivo, objeto asimismo de definición en una infinidad de normas legislativas.

Concepto del que, para el caso concreto del monasterio de San Zoilo, habrá que "reconstruir" porque hoy únicamente nos quedan sus documentos, puesto que la institución monástica perdió hace siglos su función religiosa y con ella la existencia de un local o estancia destinada a la guarda y custodia de la documentación recibida y producida a lo largo de siglos. Esto, a pesar de ser un contratiempo evidente, no supone ni mucho menos un lastre para la investigación, puesto que una imagen del archivo para los años últimos del siglo XVIII y principios del XIX nos la proporciona el Índice, que ha sobrevivido al paso del tiempo y ha llegado hasta nosotros y nos permitirá no solo conocer la institución productora y conservadora de los documentos, su historia, la formación y desarrollo de su patrimonio, y la administración del mismo; sino también, como digo, reconstruir el archivo no sólo como producto de la institución sino también como resultado de las circunstancias históricas que condicionan su existencia y finalidad, una triple funcionalidad a la que ya hacía referencia Rodríguez de Diego para el Archivo de Simancas ${ }^{138}$.

Otro aspecto importante acerca de lo que un archivo es el relativo a su naturaleza involuntaria ${ }^{139}$, aspecto sobre el que existe una aceptación completa y compartida por todos

137 ROMERO TALLAFIGO, Manuel, Archivistica y Archivos. Soportes, edificios y organización. Carmona, 1994, p.17.

${ }^{138}$ RODRIGUEZ DE DIEGO, José Luis, Instrucción para el Gobierno del Archivo de Simancas, p.14.

139 RODRÍGUEZ DE DIEGO, José Luis, "Significado del proyecto archivístico de Felipe II", en ALVAR EZQUERRA, Alfredo (coord.), Imágenes Históricas de Felipe II. Madrid, 2000, p.189, explica que esta involuntariedad de la producción de los documentos no está reñida con la existencia del archivo como consecuencia de su necesidad: "Existe, a mi modo de ver, otra causa que ha influido en esta reserva al lado histórico de los archivos: la involuntariedad de la producción documental. La insistencia en esta verdad inobjetable y a la que se acude para fundamentar el principio de procedencia ha dejado en penumbra la voluntariedad del archivo y, con ella, su historicidad. Da la sensación de que los archivos han nacido por 
los especialistas en la materia. La producción de un archivo es consecuencia directa de la existencia de trámites y prácticas administrativas constantes ${ }^{140}$, cualquiera que sea la época $\mathrm{O}$ la entidad responsable; el archivo surge de la necesidad de "documentar los actos jurídicos, organizarlos, describirlos y hacerlos accesibles", en palabras de Diego Navarro Bonilla ${ }^{141}$, quien además liga el progreso humano a la capacidad de registro y recuperación de datos escritos. Incide Lodolini en la idea y escribe que el archivo supone "la natural sedimentación documental"; de manera inconsciente e indeliberada, casi instintiva, la sola existencia de la persona física o ente lleva a originar un registro de sus actividades ${ }^{142}$. Un archivo jamás puede ser artificial; siendo artificial la recopilación de documentos aislados y de índole diversa, no puede ser esto llamado archivo por lo anteriormente expuesto.

Al concepto y naturaleza del archivo apuntados deben añadirse otras cuestiones que permitirán reconocer mejor la realidad del propio archivo y definirlo de manera más precisa. Y así, recogiendo las propuestas de autores como Romero Tallafigo, conviene ahondar en presupuestos como materia, forma, origen y finalidad del archivo ${ }^{143}$. Resulta lógico por ello entender el archivo como un conjunto de documentos reunidos naturalmente a causa de la actividad práctica desempeñada por una entidad, no para fines científicos sino con propósitos administrativos o gestores. De ahí que en ese conjunto, como refiere Lodolini, los documentos estén “indisolublemente unidos entre sí por un vínculo que es necesario, originario y determinado [...]"144.

El documento de archivo nació para convertirse en un instrumento de prueba e información, para documentar actividades de administración de muy diversa índole, no para ser difundido sino para ser garante incuestionable en caso de existir algún litigio. De nuevo recurrimos a Lodolini, para reconocer con él que solamente "[...] una vez que el curso del tiempo haya hecho decaer los originarios fines jurídico-administrativos, adquieran [los documentos de archivo] especial valor para fines culturales [...]"145. De hecho, señala el teórico de la archivística italiano, es su carácter de garantía administrativa estrictamente

generación espontánea y que en su creación y desarrollo ninguna voluntad ha existido. Nada más lejos de la realidad".

140 LODOLINI, Elio, El problema fundamental de la archivística, p.30, explica esta dimensión: "Usamos la expresión "administrativa" en la acepción más amplia, que comprende cada una de las actividades posibles: administración de Estado, de un ente, de una familia [...], también judicial, financiera, militar, religiosa [...]”.

${ }^{141}$ NAVARRO BONILLA, Diego, La imagen del Archivo, p.13.

${ }^{142}$ Esclarecedora es la afirmación hallada en ROMERO TALLAFIGO, Manuel, El archivo, p.17, que viene a proclamar que "en efecto, cada uno de ellos [los archivos] es testigo de la historia aunque sus actores eran normalmente ajenos a tal pretensión".

143 Véase ROMERO TALLAFIGO, Manuel, El archivo, p. 18.

${ }^{144}$ LODOLINI, Elio, El problema fundamental de la archivistica, p. 32.

145 Ibidem, p. 42. 
imparcial, creíble y fiable lo que hoy en día confiere al archivo mayor notoriedad cultural que la que puedan tener los textos no archivísticos redactados en su momento con exclusivo fin cultural.

Lo afirmado en el párrafo anterior nos lleva a otro nivel, que obliga, como acertadamente afirma Rodríguez de Diego, a “[...] estudiar el archivo como producto de la institución en la que nace; más aún como imagen de la misma [...] cristalizada en la organización de sus fondos" ${ }^{\prime 146}$. Es este, quizá, el punto en torno al cual más se ha resuelto y generalizado un consentimiento común que sitúa al archivo como conjunto orgánico, pues funciona como conjunto tanto de los documentos que lo forman como de las relaciones existentes entre los mismos. A partir de las afirmaciones de Giorgio Cencetti y Michel Duchein, Elio Lodolini manifiesta que el archivo tiene valor completo en sí mismo, lo que supone que si un documento es separado del resto perderá prácticamente toda su validez, pues se diluye el contexto en el cual fue originado. Las piezas de un fondo archivístico poseen un vínculo natural, una cohesión que se forma con el mismo avance de la gestión, pues cada documento tiene una causa de la que es reflejo, y esa causa se sitúa en un espacio y tiempo determinados, de los cuales debe existir constancia. Antonia Heredia postula, del mismo modo, que “[...] el carácter serial [es] una de las notas más significativas [de] los documentos de archivo [...]" ${ }^{\gg 147}$. Es decir, la producción archivística viene ligada a las actuaciones que la originan, normalmente reglamentadas y necesariamente continuas. La organización posterior dada por el archivero seguirá, entonces y necesariamente, un "principio de procedencia""

Principio que tras ser publicado por los archiveros holandeses Müller, Feith y Fruin se convertirá en uno de los paradigmas de la ciencia archivística, y que hace del archivo un

\footnotetext{
146 RODRÍGUEZ DE DIEGO José Luis, Instrucción para el Gobierno del Archivo de Simancas, p. 14.

147 HEREDIA HERRERA, Antonia, Archivística General. Teoría y práctica. Sevilla: Diputación Provincial de Sevilla, 1986, p. 90.

148 El término fue recogido por primera vez en un manual en 1898 por MÜLLER Samuel-FEITH Johan Adriann-FRUIN Robert, Handleiding voor het Ordenen en Beschrijven van Archieven, traduzione libera con note di Giuseppe BONELLI e Giovanni VITTANI, Ordinamento e Inventario degli Archivi, Milán-Roma-Nápoles, 1908. Consultable en http://www.icar.beniculturali.it/biblio/pdf/Muller/MullerCompleto.pdf; LODOLINI, Elio, El problema fundamental de la archivística, pp. 46-48, señala cierta controversia en torno a la expresión que inicialmente se adoptó, "principio de procedencia", ya que esta podía referirse tanto al orden original dado por el organismo productor, o bien tomar otro cariz y significar que no debían mezclarse documentos de origen distinto; de ahí que Lodolini prefierar la expresión "principio de respeto al orden original”. Por ello, en la resolución número 5 publicada en el Boletín Interamericano de Archivos, vol. 1, Argentina, 1974, se estableció una separación entre ambas acepciones. Puede encontrarse una profunda reflexión sobre todo ello en MARTÍN-POZUELO CAMPILLOS, M. ${ }^{\mathrm{a}}$ Paz, La construcción teórica en Archivística: el principio de procedencia. Madrid, 1996.
} 
centro documental diferente a bibliotecas y centros de documentación, como distintos son los conjuntos orgánicos de los documentos de archivo y las colecciones de bibliotecas.

La principal y más notoria diferencia es el carácter volitivo de las segundas, antitético al archivo. La colección implica la recogida voluntaria de documentos independientes, extraídos cada uno de su lugar original y dispuestos en otro conjunto artificial sin que pierdan su significado por ello; lo define Diego Navarro Bonilla como “[...] la adquisición de títulos [...] para satisfacer una curiosidad intelectual o [...] vanidad coleccionista" ${ }^{149}$. Otra de las diferencias que se destaca es la visión que del archivo se ha tenido durante siglos como un lugar inaccesible, en ciertos momentos por ser concebido como arsenal de la autoridad, por poseer vínculos con la administración; ostentando incluso cierto halo de arcano, por lo que era tenido como lugar de máxima guarda y custodia; todo ello lo alejaba de aquellos que eran ajenos a su creación ${ }^{150}$, lo que no era común que ocurriera con las colecciones bibliotecarias.

\subsection{Periodización y evolución del concepto de archivo}

El cambio del concepto que se ha tenido del archivo no ha estado separado de las cuestiones relativas a su evolución histórica. Y si importa conocer lo relativo al concepto de archivo para la mejor comprensión del Índice de San Zoilo, también conviene tener, si quiera, una idea de cuál ha sido esa evolución para entender mejor el escenario que explica la elaboración del Índice.

Estudiar la historia de los archivos permite, de un lado, conocer la influencia que las circunstancias históricas han ejercido sobre el concepto y uso del archivo hasta el siglo XX; y de otro, entender la evolución de la función de servicio de los archivos, que a pesar de mantenerse siempre como instrumentos que evidencian la acción administrativa y por tanto servir a la administración, pública o privada, han experimentado un gran cambio en cuanto a la modificación de la calidad y cantidad de usuarios. Atender a "la evolución que el concepto de archivo ha tenido en la sociedad que sirve" ${ }^{151}$ se hace necesario para entender la realidad del archivo y lo será para comprender el Índice que editamos y estudiamos, pues

\footnotetext{
${ }^{149}$ NAVARRO BONILLA, Diego, La imagen del Archivo, p. 22.

${ }_{150}$ ROMERO TALLAFIGO, Manuel, El archivo, p. 18, achaca esto a la posible duda en torno al origen de la palabra "archivo": "[...] No hay que derivarla del término latino arca (cofre o caja fuerte) que [...] ha implicado equívocamente al archivo con connotaciones esenciales de privacidad y secreto". Realmente, proviene del griego archeion (propiedad del gobierno).

${ }^{151}$ ROMERO TALLAFIGO, Manuel, "La historia de los archivos": Boletín del Archivo General de la Nación, n. 116 (2005), pp. 671-718.
} 
es reflejo de la organización del archivo del monasterio de San Zoilo de Carrión en el momento en que se escribió. Y si muestra la organización del archivo permite conocer el concepto que del mismo se tenía, más allá de que en sus folios se contenga la información documental de cerca de nueve siglos de historia de San Zoilo.

Se reconoce una dualidad principal de enfoques en cuanto al tratamiento de la periodización de la historia de los archivos y la archivística como parámetro de estudio, surgida esta a raíz de la contraposición realizada al planteamiento de división clásico ${ }^{152}$, a saber: o diferenciar fases en esa periodización en función de acomodar estas fases a los diversos momentos históricos o épocas universalmente aceptadas, o bien tener en cuenta la consideración de la evolución del concepto de archivo al margen de la periodización histórica clásica en Edad Antigua, Media, Moderna y Contemporánea ${ }^{153}$.

Si se atiende a una división de la historia de los archivos por edades clásicas, tendremos que decir que ya Eugenio Casanova y Adolf Brenneke establecieron segmentos cronológicos: Casanova otorgaba relevancia a cuatro períodos: desde la Edad Antigua hasta el siglo XIII; a continuación, del siglo XIII al XV; otro más desde el siglo XVI hasta el XVIII, para finalmente concluir con el período que abarca desde el siglo XIX hasta "nuestros días"154. Por su parte, Adolf Brenneke redujo a tres, en 1953, las épocas de división histórica. Según él, el nacimiento de la teoría archivística marca la primea época, basada esta en un "principio práctico intuitivo de clasificación" y comprendida entre los siglos XVI y XVII. El siglo XVIII es la segunda época, momento en que se empleaba un ordenamiento teórico deductivo. La última y tercera época abarcaría desde el siglo XIX en adelante, y enlaza con la teoría archivística del "principio de procedencia".

Más avanzado el siglo XX, la parcelación cronológica encontró acogida en las posturas de la denominada Escuela Francesa. Propuesta por el francés Robert Henri

\footnotetext{
152 Más información al respecto en NAVARRO BONILLA, Diego, La imagen del Arcbivo, pp. 26-28.

153 Véase ZOZAYA MONTES, Leonor, "Una revisión de las periodizaciones archivísticas de la Edad Moderna Española”: Documenta \& Instrumenta, n. ${ }^{\circ} 6$ (2008), pp. 119-145, donde la autora realiza un recorrido por algunas de las periodizaciones más conocidas en España. Trabajo recomendable en torno a las periodizaciones es el de MENDO CARMONA, Concepción, "El largo camino de la Archivística: de práctica a ciencia": SIGNO, Revista de Historia de la Cultura Escrita, n. ${ }^{\circ} 2$ (1995), pp. 113-132, publicado también en RUIZ RODRÍGUEZ, Antonio Ángel, Manual de archivística. Madrid, 1995, pp. 19-38.

154 ZOZAYA MONTES, "Periodizaciones archivísticas", pp. 123-124, puntualiza que dicho espacio temporal alcanza hasta 1928, cuando la obra de E. Casanova fue publicada por primera vez. Del mismo modo, remite a una edición de 1966 de dicha obra de Casanova, Archivistica, en cuyas pp. 291-388 trata el tema de los archivos europeos y españoles desde los inicios de la Edad Moderna. A pesar de ello, Zozaya Montes señala la existencia de ciertas imprecisiones y generalidades.
} 
Bautier ${ }^{155}$, esta periodización, también adoptada por algunos autores españoles, establece una división cuádruple de los archivos, a saber; Edad Antigua (Archivos de Palacio), Edad Media (Época de los tesoros de cartas o Cartularios ${ }^{156}$ ), Edad Moderna (Arsenales de la autoridad) y Edad Contemporánea (Laboratorios de la Historia). Sin embargo, ha sido este un método ampliamente debatido y objetado, como posteriormente detallaremos.

Frente a esta propuesta, surge una división de la historia de los archivos y la archivística propuesta por alguno de los miembros más conspicuos de la Escuela Italiana, con Elio Lodolini y Leopoldo Sandri como miembros más destacados. Con la pretensión de suprimir las edades y acentuar los niveles de valoraciones que la sociedad hace de los archivos, distinguen una primera fase, desde la antigüedad hasta el siglo XVIII, en la que prima una concepción patrimonial y jurídica de los documentos como conjuntos orgánicos y de acceso restringido a los mismos $^{157}$; un segundo momento, desde la Ilustración al Romanticismo, durante el siglo XVIII, en el que a la valoración anterior se añade la consideración de archivo como instrumento con fines de erudición y fuente histórica; y una tercera fase, que abarcaría los siglos XIX y XX (Romanticismo y Nacionalismo) y hasta la actualidad, cuando el archivo adquiere la total integridad de sus funciones como archivo en cuanto permite el estudio de la realidad histórica y a la vez es instrumento administrativo y de poder público ${ }^{158}$.

El archivo de San Zoilo de Carrión se organiza a partir de un claro concepto de archivo como herramienta fundamental para la administración del patrimonio y su propia conservación. $\mathrm{Y}$ aunque el Índice se redacte con la intención de convertirse en una herramienta de búsqueda que facilite el acceso a la información de los documentos del monasterio, refleja en su organización la del propio archivo y el concepto que del mismo se tenía en el cenobio del Carrión.

\footnotetext{
155 BAUTIER, Robert-Henri, "La phase cruciale de l'histoire des archives: la constitution des dépots d'archives et la naissance de l'archivistique (XVI ¿̀-début du XIX ${ }^{\grave{c}}$ siècle)": Archivum. Revue Internationale des Archives, XVIII (1968), pp. 139-151.

156 ZOZAYA MONTES, Leonor, "Periodizaciones archivísticas de la Edad Moderna Española", p. 125, prefiere la expresión tesoros documentales a la de "tesoros de cartas o cartularios", por ser estos últimos demasiado restrictivos, cuando realmente eran muy variados los documentos recogidos bajo dicha calificación: privilegios, actas, cuentas, contratos, etc. Esta y otras problemáticas en cuanto a traducciones terminológicas pueden consultarse en el Diccionario de terminología arcbivística, Madrid: Subdirección de General de los Archivos Estatales, 1995 ( $2^{\mathrm{a}}$ ed.).

${ }^{157}$ El carácter de secreto, custodia o tesoro que adquirió el archivo, especialmente a finales de esta primera fase, en los siglos modernos XVI y XVII, estaban "[...] fuertemente anclados en el pensamiento colectivo [...]", como afirma NAVARRO BONILLA, La imagen del Arcbivo, p. 23.

158 ROMERO TALLAFIGO, Manuel, "La historia de los archivos", p. 674, afirma que se "[...] produce una integración de la tradicional línea administrativa con la historicista [...], son archivos, no de un monarca o señor, sino de los ciudadanos, del pueblo o de la nación".
} 
Una vez revisadas las periodizaciones propuestas por los autores más significativos de la Archivística europea, creemos que merecen ser citadas las reflexiones, posteriores en el tiempo, de reconocidos autores españoles, como son José Luis Rodríguez de Diego, Manuel Romero Tallafigo o José Ramón Cruz Mundet, entre otros.

José Luis Rodríguez de Diego ahonda en los planteamientos de la escuela italiana y encuentra serios problemas en la periodización propuesta por el francés Robert Henri Bautier ${ }^{159}$. A partir de su adscripción a la postura que defienden Sandri y Lodolini, propone una triple integración de funciones, simultáneas, que reconoce ya en el siglo XVI y en el archivo simanquino; poniéndolo al servicio de la "administración, el gobierno y la historia" ${ }^{\text {160 }}$. Diego Navarro Bonilla, recogiendo las ideas del que fuera director del Archivo de Simancas, añade que "el archivo del reino de Aragón respondió al mismo planteamiento de simultaneidad de funciones" ${ }^{\prime 161}$.

Ese servicio a la administración, al gobierno y a la historia permite a Rodríguez de Diego, ver en Simancas un archivo de poder, es decir, una herramienta del dominio y el control ejercidos por el monarca, es decir, que el archivo es patrimonio del rey, de ahí el halo de secretismo e inaccesibilidad del que gozó. Pero Simancas fue también un archivo al servicio de una administración que vive una transformación, que Rodríguez de Diego califica de revolucionaria, con el afianzamiento del expediente en el inicio de la Edad Moderna y el paso de una administración judicial a otra gubernativa. Y Simancas fue, por último, un archivo para la historia, y es así por el creciente interés de los monarcas por la historia, como medio de representación del gobierno o, mejor, de su gobierno.

Manuel Romero Tallafigo, por su parte, considera la propuesta de Bautier conformista y confusa en cuanto a los términos elegidos para demarcar cada división histórica, ya que algunos pueden encontrarse en más de una de las barreras cronológicas $\operatorname{marcadas}^{162}$.

\footnotetext{
159 Puede leerse en RODRÍGUEZ DE DIEGO, José Luis, Archivo de Simancas, pp. 14-15, que "[...] el inconveniente mayor de la postura de Bautier radica [...] en que para la delimitación de esos ciclos ha atendido directamente a la evolución general histórica e indirectamente al desarrollo del concepto de archivo. [...] Es evidente que en los períodos señalados por Bautier se producen modificaciones en alguno de los aspectos archivísticos, pero no tan sustanciales como para cambiar el concepto de archivo".

${ }^{160}$ RODRÍGUEZ DE DIEGO, José Luis, "Archivos del Poder, archivos de la Administración, archivos de la Historia (siglos XVI-XVII)", en GENERELO, J.J., y MORENO LÓPEZ, A. (coords.), Historia de los arcbivos $y$ de la archivistica en España. Valladolid, 1998, pp. 29-42.

${ }^{161}$ NAVARRO BONILLA, Diego, La imagen del Archivo, p. 108.

162 Véase ROMERO TALLAFIGO, Manuel, Archivistica y arcbivos: soportes, edificio y organización. Carmona, 1994.
} 
Su propia propuesta se basa tanto en la que hicieron los autores de la escuela italiana como en la propia creencia de que "[...] tan arsenales de la historia eran los archivos de la Edad Antigua como los son los de cualquier ministerio o institución de hoy" "163. Así, aboga por dividir la historia de los archivos en dos categorías: Antiguo y Nuevo Régimen, el primero desde la antigüedad hasta la Revolución Francesa; el segundo, a partir de esta y sin límite claro. Es dicha revolución el punto de inflexión para Romero Tallafigo, cuando comienza a darse el paso de archivo real a nacional, cuando el derecho de los ciudadanos vence a la impenetrabilidad anterior, cuando "los archivos se convierten en esencia de nuevos estados, [...] de su legitimidad, naturaleza a identidad".

Acabamos este breve recorrido dedicado a los autores españoles haciéndonos eco del enfoque, más próximo a los pareceres franceses, de José Ramón Cruz Mundet, que divide la historia de los archivos y la Archivística en dos períodos, antes y después del principio de procedencia ${ }^{164}$. El primero, prearchivístico, sigue la división cuatripartita de Bautier, que recoge prácticas archivísticas que evolucionan al ritmo de otras ciencias y administarciones, sin poseer carácter definido ni firmeza científica alguna; el segundo, período de desarrollo archivístico, cuando la disciplina adquiere autonomía suficiente para considerar a la archivística como ciencia autónoma con total propiedad.

De todo lo dicho anteriormente en torno al concepto de archivo y periodización en la evolución de este puede extraerse una conclusión que nos servirá de nexo e introducción al próximo capítulo, y es que los archivos no son, como pueda creerse popularmente, concentraciones de papel. Y rescato como colofón una afirmación de Natividad de Diego Rodríguez, que resume a la perfección la esencia de lo que aquí he querido expresar cuando afirma que en los legajos de los archivos, “[...] en sus legajos polvorientos se siente palpitar la vida, lo cual les otorga la cualidad de ser base fidedigna de la historia privada y pública; así su estudio es la fuente más segura para indagar en la vida del pasado"165.

\footnotetext{
${ }^{163}$ ROMERO TALLAFIGO, Manuel, Historia archivos, p. 671.

${ }_{164}$ CRUZ MUNDET, José Ramón, Archivística. Gestión de documentos y administración de archivos, pp. 17-21.

${ }^{165}$ DIEGO RODRÍGUEZ, Natividad de, "Fondos Monásticos en el Archivo Histórico Nacional": en HEVIA BALLINA, Agustín (coord.) Órdenes Monásticas y Archivos de la Iglesia I. Santoral Hispano-mozárabe en España, Actas del IX Congreso de la Asociación. Memoria ecclesiae, n 6 , Oviedo, 1995, pp. 50.
} 


\subsection{El Archivo monástico a la luz de las Constituciones de 1701}

Comienzo esta cuestión con el subtítulo que puede leerse en la portada de la Disertación sobre Archivos ${ }^{166}$ de don Facundo de Porras Huidobro, y que reza como expongo a continuación: "útil para todos los que los tienen o manejan”. No podía ser más acertada la expresión elegida, pues es un extracto de dicho libro el que nos proporciona una de las más acertadas, si no la que más, aproximaciones al concepto de archivo monástico, que en estas páginas pretendemos aclarar: "Los monges desde su origen, á ejemplo de los obispos, formaron tambien sus Archivos, en que depositaron los diplomas de su fundacion, los instrumentos ó actas de donaciones [...] y obtuvieron tal grado de confianza, que con preferencia se llevaban á ellos para su custodia muchas actas públicas [...]"167. ¿Qué se extrae de estas palabras? Que todo lo escrito hasta el momento en torno al término "archivo" es aplicable sin excepción alguna a un archivo monástico.

$\mathrm{Y}$ es que es innegable que, respecto al total de la producción archivística documental a lo largo de los siglos y en la actualidad, es ingente la parte correspondiente a órdenes religiosas. La documentación que se conserva tanto en los monasterios que aún a día de hoy perduran como en aquellos en los que el paso del tiempo ha ejercido su mano ejecutora ha sido, es y seguirá siendo fuente inagotable de todo tipo de información, todos ellos custodiados y guardados en los llamados archivos monásticos-conventuales. Sin embargo, para comprender el gran valor y riqueza que tanto estos como los archivos diocesanos y catedralicios poseen, es necesario aclarar unas nociones esenciales al respecto.

Existe en torno al hombre, como persona jurídica capaz de ejercer derechos y cumplir obligaciones, documentos escritos que reflejan sus actividades a medida que las desempeña a lo largo de su vida: tanto el acta que recoge el momento de su nacimiento como el hecho de participar o adscribirse a cualquier tipo de ente u organización queda recogido y redactado en piezas que, dispuestas "ordenadamente", forman un archivo. Si bien esto puede parecer una reiteración sobre lo ya expuesto, es necesario recordarlo para poder observar una circunstancia importante, y que paso a relacionar ${ }^{168}$.

Mientras estas memorias privadas, de personas particulares, tienden a desaparecer y caer en el olvido, los archivos eclesiásticos se perpetúan y mantienen, se conservan. Cuando el productor privado muere, el vínculo y el interés práctico que suscitaba su archivo se

\footnotetext{
166 PORRAS HUIDOBRO, Facundo de, Disertación sobre Archivos y reglas de su coordinación. Madrid: Imprenta de D. León Amarita, 1830.

167 Ibidem, p. 28.

168 Seguimos de nuevo a DIEGO RODRÍGUEZ, Fondos Monásticos, pp. 49-50, en la introducción que realiza, muy acertada y acorde con lo que aquí se pretende argumentar.
} 
anula, disminuye su utilidad y es destruido en la gran mayoría de casos. Por el contrario, en el ámbito institucional, y por ende también religioso, no existe dependencia alguna respecto a sus componentes; es la comunidad la que necesariamente debe encargarse de proteger los documentos que acreditan su desarrollo y expansión históricos; es más, la existencia de dicho archivo confiere a la institución carácter y eminencia. No existe sociedad donde esto sea más decisivo - pues es en el ámbito religioso donde se encuentran las instituciones más antiguas- y donde la comunidad sea más ajena al devenir de cada miembro que en dicho ámbito.

Si bien esto es verdadero hasta comienzos del siglo XIX, momento en el cual los archivos eclesiásticos españoles, ya fuesen de clero secular o regular, gozaban de un perfecto e íntegro estado de conservación ${ }^{169}$; no pasa inadvertido para ningún estudioso sobre el tema que dicha situación cambió radicalmente a partir de la Guerra de la Independencia. Las desamortizaciones sucedidas en adelante provocaron que los documentos de las instituciones eclesiásticas desaparecidas se dispersasen, y terminasen en otros archivos o incluso en manos de particulares ${ }^{170}$, por motivos y circunstancias varias a lo largo de los años.

Cabe entonces realizar, brevemente, un repaso general de los sucesos más decisivos al respecto y que más han influido en el patrimonio documental eclesiástico ${ }^{171}$. Fue en la Guerra de la Independencia contra Napoleón, en 1808, cuando este inició las primeras medidas contra la Iglesia, incautando los bienes de la mayoría de los conventos que clausuraba (una tercera parte de los existentes). Al año siguiente, su hermano José Bonaparte se apoderó de muchas riquezas y tesoros de conventos tras suprimir todas las Órdenes religiosas por Decreto de 18 de agosto de $1809^{172}$-siendo esto confirmado en las

169 MANSILLA REOYO, Demetrio, "La historiografía de los archivos eclesiásticos", en VICARIO SANTAMARÍA, Matías y MARTÍ I BONET, Josep María (coords.), Actas del cursillo (Madrid, 12 al 15 de septiembre de 1988) y elenco de los Archiveros de la Iglesia: Memoria ecclesiae, 1 (1990), pp. 7-32 (= MANSILLA REOYO, “Archivos eclesiásticos”).

170 DIEGO RODRÍGUEZ, Fondos Monásticos, p. 51.

${ }^{171}$ Remitimos al capítulo de nuestra Tesis que titulamos El Índice de San Zoilo de Carrión, donde se hallará un estudio más detallado sobre la influencia que las sucesivas desamortizaciones ejercieron en la conformación de la historia archivística de San Zoilo y más concretamente del Índice.

172 FERNÁNDEZ MARTÍN, Luis, "La diócesis de Palencia durante el reinado de José Bonaparte 18081813”: PITTM, 44 (1980), pp. 165-275, especialmente pp. 248-254.

Más información acerca del proceso desamortizador francés puede encontrarse en DEL VALLE CURIESES, Rafael, "Carrión de los Condes durante la guerra de la Independencia”: PITTM, 84 (2013), pp. 783.

El Índice de San Zoilo refleja a la perfección esta exclaustración, puesto que entre los años 1810 y 1813 hay un completo vacío de documentación, reflejo de la nula producción documental que la falta de actividad por parte del monasterio ocasionó.

El último registro está fechado a 11 de junio de 1809: AHPP, Legajo 112, f. 437v, n. 17. 
Cortes de Cádiz-. Más adelante, una ley promulgada durante el Trienio Progresista o Liberal $^{173}$ (1820-23) suprimía todas las casas con menos de 20 miembros activos. Todas estas disposiciones, sin embargo, se vieron extremadas con la "Desamortización" de Mendizábal en 1836, que no sólo procedía a subastar los terrenos expropiados, sino que reducía a 12 el número de miembros exigidos para la supresión ${ }^{174}$.

Sin embargo, el Sexenio Democrático (1868-74) traería otra ofensiva fuertemente rigurosa y radical contra el patrimonio eclesiástico, con la violencia desatada por las Juntas provinciales creadas a raíz de la revolución burguesa conocida como la "Gloriosa". Promulgó en esos momentos Ruiz Zorrilla, perteneciente al gabinete de Prim ${ }^{175}$, un decreto por el cual se procedía a la confiscación por el Estado de todos los archivos, bibliotecas y demás colecciones en manos de monasterios, conventos, catedrales y órdenes religiosas ${ }^{176}$.

Esta supresión casi absoluta de las comunidades religiosas provocó que los archivos terminaran en manos del Estado, el cual, en palabras de Demetrio Mansilla, "[...] ni estaba preparado para hacerse cargo de una documentación tan voluminosa, ni le interesaba entonces su custodia [...], puesto que el único y principal objetivo era el financiero [...],

Figura en dicho documento como artífice de la presentación de un beneficio el que en esa etapa era abad del monasterio, fray Plácido Emelgo; el cual quedará como párroco de la parroquia del extinto monasterio hasta su destitución en 1810, tras ser injustamente acusado de hurto y ocultación de bienes, entre ellos las llaves del archivo y del dinero.

Un inventario de los bienes muebles y las alhajas, realizado el 18 de septiembre de 1809 en presencia de dicho abad, puede consultarse en AHPP, Desamortización, Leg. 435, s/f. Se encuentra bajo esta signatura la copia de otro inventario idéntico realizado el 25 de septiembre del 1809, en presencia del monje y exsacristán, el padre don Luis Sánchez, ante la ausencia del abad, copia realizada el 15 de enero de 1810.

El registro de la documentación se retoma en agosto de 1814 cuando, tras la salida de los franceses del cenobio, los monjes consideran segura la vuelta de las reliquias de San Zoil y San Félix al monasterio, después de haberse visto obligados a trasladarlas en 1810 a la parroquia de Santa María del Camino de dicha villa, por miedo a las consecuencias que sobre ellas pudiera ocasionar el expolio de los franceses. AHPP, Legajo 112, f. 119v, n. ${ }^{\circ} 25$.

173 Por decreto de 11 de octubre de 1820 todos los monasterios quedarían suprimidos, por lo que el 9 de marzo de ese mismo año la ocupación ya se había hecho efectiva y el convento fue suprimido en septiembre. Lo convulso de la época puede explicar el hecho de que los registros en el Índice cesen en 1818, al ser el archivo uno de los bienes sustraídos durante la dicha ocupación. AHPP, Legajo 112, f. 6v, n. 32.

El Listado de Quintín Aldea, al que haremos referencia más adelante en este capítulo, da noticia de la existencia de un "Inventario manuscrito hecho en 1820 de los muebles y enseres del monasterio de San Zoil por fray Plácido

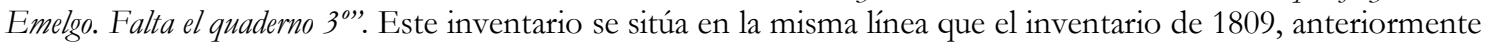
citado, y el que se hará en 1836 a raíz de la última desamortización que sufrió el monasterio, el cual estudiaremos en el capítulo dedicado a rastrear la historia archivística del Índice de San Zoilo.

174 MANSILLA REOYO, “Archivos eclesiásticos", p. 15, donde el autor se lamenta: "Si los archivos del clero secular y de las órdenes monásticas se hubiesen conservado [...] o se hubiera tenido más cuidado y precaución en su traslado, se habrían evitado muchas pérdidas hoy ya irreparables [...]”.

175 Ibidem, p. 12, nos remite a las palabras que Don Vicente de la Fuente, historiador coetáneo de los hechos, relata al respecto en su Historia eclesiástica de España. Tomo VI. Madrid, 1875, pp. 270-271: “[...] Ocurriósele, en mala hora, al señor Ruiz Zorrilla, ministro de Fomento y consejero de Prim, despojar a las iglesias de sus archivos y objetos arqueológicos [...]".

176 CÁRCEL ORTÍ, Vicente, “La Iglesia en la España contemporánea (1808-1975)”, en Historia de la Iglesia en España, 5. Madrid, 1979, pp. 230-252. 
apoderarse de los títulos de propiedad de los monasterios y cabildos catedralicios [...]" ${ }^{\text {"177 }}$. Es por esto que nace, por Real Decreto del 28 de marzo de 1866, el Archivo Histórico Nacional, que asume todas las funciones en cuanto a la custodia de archivos monásticos en propiedad del Estado y recoge los documentos que por entonces estaban en la Real Academia de la Historia ${ }^{178}$. Recibirá, a lo largo de más de 70 años, sucesivas remesas de documentos extraviados por las entidades eclesiásticas desamortizadas, así como documentación monástica y secular recogida en las Delegaciones provinciales de Hacienda.

Con lo referido se revela el incuestionable carácter eclesiástico que marca el Archivo Histórico Nacional, que nació para reunir todo ese patrimonio de la Iglesia y brindarlo a la investigación científica ${ }^{179}$. Es así como surge, entonces, la sección que nos atañe particularmente, que no es otra que Clero Secular y Regular ${ }^{180}$, así como Códices y Sigilografía; ambas forman el "conjunto documental de procedencia eclesiástica más importante y voluminoso de toda España" ${ }^{\text {181. }}$.

Dentro de la Sección de Clero, ocupa un lugar muy destacado y de especial interés para nosotros la documentación monástica, amplia en cuanto a volumen, contenido y cronología, procedente de las Órdenes Monásticas que en el siglo XIX tenían su sitio en España. Es por esto que la localización principal de los fondos pertenecientes a Son Zoilo es el Archivo Histórico Nacional, en el Fondo Pergaminos de la ya nombrada Sección Clero, y donde han obtenido su información los principales autores interesados en el estudio del cenobio a raíz de su producción documental: M. ${ }^{a}$ Luisa Palacio SánchezIzquierdo $^{182}$ y Julio A. Pérez Celada ${ }^{183}$.

\footnotetext{
177 MANSILLA REOYO, “Archivos eclesiásticos”, p. 13.

178 SÁNCHEZ BELDA, Luis, Guia del archivo histórico nacional. Valencia, 1948, pp. 7 y ss.

179 Nos informa DIEGO RODRÍGUEZ, Fondos Monásticos, p. 51, nota al pie, que este se trata del primer archivo español con la finalidad principal de ser centro de investigación histórica. Solamente con anterioridad, por R.O del 20 de abril de 1844, se abren a consulta pública los archivos estatales españoles.

${ }_{180}$ Véase ARCHIVO HISTÓRICO NACIONAL, Clero secular y regular. Inventario de procedencias. Valladolid, 1924, y MUNOZZ Y ROMERO, Tomás, "Inventario de los fondos y procedencias del Archivo Histórico Nacional con expresión de los documentos que comprenden": Revista de archivos bibliotecas y museos, 1 (1871), pp. 102-106 y pp. 118-124 (=MUNOZ Y ROMERO, "Inventario del Archivo Histórico Nacional”).

DE LA CRUZ HERRANZ, Luis M. "La Sección de Clero del Archivo Histórico Nacional", en II Jornadas científicas sobre documentación de la Corona de Castilla (siglos XIII-XV). Madrid, 2003, pp. 373-432.

181 DIEGO RODRÍGUEZ, Fondos Monásticos, pp. 51-53, donde informa que se realizó un traspase de casi 2.000 libros y documentos de Clero a Códices y Sigilografía.

182 PALACIO, Colección San Zoil. I, p. 615, nota 1, que escribe: "En el AHN, en la sección de Clero contienen documentación de San Zoil las carpetas n. ${ }^{\circ}$ 1700, desde el número 6 en adelante, 1701-1717. En total son 358 documentos que cronológicamente abarcan del 15 de marzo de 1047 al 27 de septiembre de 1700. En esta misma sección se hallan 40 libros, del siglo XV al XIX; y son los n. ${ }^{\circ}$ : 9580, 9558, 9569, 9574, 9581, 9882, 9552, 9555, 9556, 9557, 9559, 9560, 9562, 9563, 9564, 9566, 9567, 9568, 9578, 9579, 9583, 9584, 9588, 9589, 9590, 9565, 9585, 9586, 9587, 9570, 9561, 9573, 9553, 9571, 9572, 9582, 9554, 9575, 9576, 9577”.

183 PÉREZ CELADA, Documentación San Zoilo. I y II. En el cómputo de ambos volúmenes señala como fuentes utilizadas la documentación contenida en el Fondo de Pergaminos de la Sección Clero, carpetas 1701,
} 
Sin embargo, tras la marcha de la comunidad del monasterio, el archivo también se vio afectado por la dispersión de su documentación ${ }^{184}$. Siguiendo a Pérez Celada, los jesuitas que ocuparon el monasterio en 1851 conservaban en la Biblioteca del Colegio del Sagrado Corazón de León unos 70 documentos ${ }^{185}$, comprendidos entre el siglo XII y finales del siglo XVIII ${ }^{186}$. Además, conviene indicar que un lote documental estuvo en poder del médico palentino Francisco Simón Nieto ${ }^{187}$, quien a finales del siglo XIX lo utilizó para preparar su libro Los antiguos Campos Góticos antes de que él mismo lo donara al AHN, como revela la estampa que figura al dorso de alguno de los pergaminos: "donativo de F. Simón Nieto" ${ }^{\prime 188}$.

$1702,1703,1704,1705,1706,1708,1709,1710,1711,1714$ y que han proporcionado 132 unidades documentales, sean, en lo que atañe a la tradición diplomática, originales o copias. El Fondo Legajos de esta misma sección contiene una importante cantidad de copias y originales de documentos del periodo, pero indica que el estado de desorden de los legajos no permite realizar una identificación organizada, obligando a la búsqueda de epígrafes que responden unas veces al título que se dio en el momento de su realización o simplemente al contenido de la carpeta donde se encuentran. Destaca, además, el libro 9699, porque recoge noticias de documentos relativos a las posesiones monásticas en Frómista, y el libro 9552 o Manval del Archivo de San Zoil de Carrión.

${ }^{184}$ Para una información exhaustiva y más detallada de la que aquí expongo acerca de dicha dispersión, que incluso atravesó las fronteras españolas, remito de nuevo a PALACIO, Colección San Zoil. I, pp. 568 y 646-652, y PÉREZ CELADA, Documentación San Zoilo. I, p. XXXV.

${ }^{185}$ El padre Quintín Aldea, historiador jesuita, tuvo acceso durante su estancia en el monasterio de San Zoilo a aquellos documentos que habían permanecido en el mismo incluso después que las desamortizaciones hubieran provocado la salida del archivo de la mayor parte de su documentación. Y no solamente tuvo acceso a ella, sino que además la organizó en un fondo en el que catalogó 72 documentos pertenecientes a la etapa benedictina del cenobio. Tras la salida de los jesuitas del monasterio, estos se llevaron consigo la documentación al Colegio del Sagrado Corazón de León. Posteriormente, fue incluido en el Archivo de la Provincia de Castilla de la Compañía de Jesús, y en la última década trasladado al Colegio de San Estanislao en Salamanca. Actualmente dicho fondo se encuentra fraccionado, conservándose parte de la documentación en el Archivo General de la Provincia de España de los Jesuitas en Alcalá de Henares.

En Salamanca se conservan documentos del antiguo archivo monástico benedictino; en los Archivadores del Fondo Antiguo, Sala 2, hay once cajas con documentación diversa, dos de ellas de San Zoilo: la caja 11 contiene tres privilegios reales del siglo XII y la caja 10 dos cartas papales de 1423 y 1444, así como un fragmento de pergamino de la Biblia del monasterio. También en este archivo se conserva un tomo de la Cronología Benedictina de los años 480-800, igualmente incluido en el listado de Quintín Aldea.

Cotejando dicha documentación con los registros del Índice de San Zoilo, hemos comprobado que tanto los tres privilegios como las dos cartas papales aparecen extractadas en dicho manuscrito (Trueque Fernando II, AHPP, Legajo 112, f. 359r; Privilegio Alfonso IX, AHPP, Legajo 112, f. 359r; Privilegio Alfonso IX, AHPP, Legajo 112, f. 359r-v; Carta 1423, AHPP, Legajo 112, f. 20r; Carta 1444, AHPP, Legajo 112, f. $20 \mathrm{v})$

${ }^{186}$ Véase PALACIO, Colección San Zoil. I, p. 615, donde realiza una relación detallada de dichos documentos y manuscritos relativos a San Zoilo.

187 Francisco Simón Nieto, médico, historiador, antropólogo y arqueólogo palentino, fue secretario de la Comisión de Monumentos Históricos de la provincia de Palencia hasta su muerte en 1920, además de acérrimo protector de los intereses históricos y artísticos de Palencia, como así dejó demostrado a través de sus numerosos trabajos centrados en dar a conocer y ensalzar el valor de muchos de los monumentos que atesora dicha provincia, sirviéndose para ellos de la documentación que él mismo rescataba, puesto que sin su valiosa intervención dichos documentos quizás se hubieran perdido para siempre.

Véase sobre su vida y obra BENDITO GONZÁLEZ, Carlos, Don Francisco Simón Nieto: medicina, antropologia e bistoria. Palencia, 1992; una breve biografía del erudito puede encontrarse igualmente en FERNÁNDEZ-RUIZ, César, Historia de la medicina palentina. Palencia, 1959, pp.123-129.

188 PALACIO, Colección San Zoil. I, p. 617, donde aparecen recogidos los documentos donados, destacando el libro 9552, que es el Manual de San Zoilo escrito por Juan de Cisneros en 1635. 
En 1907, el profesor y archivero Bernardino Martín Mínguez es elegido para elaborar el Catálogo Monumental de la Provincia de Palencia ${ }^{189}$. Estos Catálogos Monumentales tuvieron su origen en el Real Decreto de 1 de junio de 1900, que ordenaba la catalogación completa y ordenada de las riquezas históricas o artísticas de la nación. Ello requería de una recogida exhaustiva de información sobre los bienes culturales y el patrimonio histórico-artístico y arqueológico de cada una de las provincias españolas, cuyo objeto era la publicación de cuarenta y siete catálogos, de los cuales se concluyeron treinta y nueve, pero tan solo diecisiete de ellos fueron publicados ${ }^{190}$.

En el tomo 3 de dicho Catálogo, entregado en 1909, encontramos las noticias relativas a San Zoilo bajo el título: "San Zoil. Monasterio de San Juan Bautista y San Zoil y San Felices de la obra benedictina extramuros" ${ }^{" 191}$. Manuscrita, en una especie de cuaderno de viaje, el autor realiza una descripción de los principales elementos del monasterio que va observando durante su visita, desde la fachada principal pasando por la iglesia, la galilea y hasta el claustro; e incluso incorpora una serie de fotografías. Pero la parte quizás más interesante es aquella que se refiere a "Algunos documentos de Carrión". Realiza una descripción de algunos de esos documentos que encuentra en el monasterio, indicando su fecha y en ocasiones su estado de conservación; pero no de todos, puesto que él mismo indica lo siguiente acerca del volumen documental:

"Más de trescientos son los documentos que encierran mucha importancia histórica y que recogido tengo, que de indicarlos todos aquí llevaría yo mucho papel y fuera nunca acabar. Les daré por suplementos poco a poco. La documentación llega hasta el año 1835. No obstante contaré algunas" ${ }^{192}$.

En el Archivo Histórico Provincial de Palencia hemos podido consultar un libro inventario actual con el título "Legado Simón Nieto, Ilustre Colegio Oficial de Médicos de Palencia”. El archivo de Nieto (que constaba de doce cajas) fue donado a finales de 1999 al Colegio de Médicos de Palencia por doña María Rodríguez Simón, nieta de don Francisco Simón Nieto. El inventario recoge, entre otras muchas, la referencia a algunas cajas con documentación concerniente a la Comisión Provincial de Monumentos Históricos y Artísticos, así como una enumeración detallada de las publicaciones del médico palentino conservadas en este legado.

189 MARTÍN MÍNGUEZ, Bernardino, Catálogo Monumental de Palencia. 4 tomos, sin publicar. El manuscrito digitalizado del catálogo puede consultarse en la biblioteca del CSIC en el siguiente enlace: http://biblioteca.cchs.csic.es/digitalizacion_tnt/index_interior_palencia.html [Última consulta: 17 de febrero de 2017].

190 Desde 2008 se ha llevado a cabo un proyecto de restauración y digitalización de los volúmenes de este Catálogo Monumental, que junto con la investigación histórica ha dado como resultado una obra cuyo objetivo es dar a conocer esta obra como instrumento de revalorización del patrimonio cultural.

Véase VV.AA., El Catálogo Monumental de España (1900-1961). Investigación, restauración y difusión. Ministerio de cultura. Ministerio de Educación Cultura y Deporte, Secretaría General Técnica, 2012.

191 MARTÍN MÍNGUEZ, Bernardino, Catálogo Monumental de Palencia. Cuaderno III, pp. 95-119.

192 Ante tal volumen de documentación en el monasterio a principios del siglo XX, y sabiendo que en el Listado de Quintín Aldea realizado unos años después únicamente se hace relación de 72 documentos, nos 
La Diputación de Palencia calificó este trabajo de "labor incoherente, confusa y de gabinete, como obra de decadente senectud, que está bien archivada donde está" y encargó la elaboración de un nuevo catálogo a Rafael Navarro García ${ }^{193}$, publicándose la obra en tres tomos, entre 1930-1939.

Incluso algunos periódicos de la época llegaron a hacerse eco de la existencia de documentos en manos de gentes del pueblo. Destaca el aviso que hace Bernardino Martín Mínguez en Las Dominicales del Libre Pensamiento del domingo 16 de septiembre de 1883, acerca de un Registro de Archivos, elaborado por el padre Cisneros del monasterio de San Zoil, que estaba en manos de un vendedor de pimiento en dicha villa.

"[...] Pero lo que en especial meceré la pena es un tomo en $4^{\circ}$ mayor, titulado Registro de Archivos, vol. VIII, por el P. Fray Juan de Cisneros, del Monasterio de San Zoil (Carrión de los Condes), manuscrito, y a lo que yo creo inédito. Se ha salvado de la destrucción de un vendedor de pimiento de esta villa. Contiene el manuscrito lo siguiente: Fundación de los monasterios de la Orden Benedictina en España, con sus documentos principales. Una Crónica Gothorum. Otra que empieza en 1504. Además hay en él unas hojas impresas con la orden del día en el sitio de Orbitelo. A manera de diario da cuenta de las operaciones"

Otra documentación de menor relevancia y cantidad se encuentra repartida en los Archivos Catedralicios de Palencia, León, Burgos y Valladolid ${ }^{195}$, así como un privilegio de Sancho IV custodiado en el monasterio de Las Huelgas de Burgos. A pesar de no ser estos los únicos dispersos, omito los restantes por aparecer ya detallados en las obras citadas y

mostramos escépticos de la veracidad de este testimonio, más aún cuando la misma Comisión que encargó el proyecto consideró este trabajo como incompleto y flojo.

Sin embargo, analizando algunos de esos documentos que refiere y su posible existencia, hemos encontrado la correspondencia a estos en el Índice; lo que nos hace pensar que si bien quizás la cifra de 300 es un poco desproporcionada, sí que estuvo en contacto con dicha documentación.

Nos llama especialmente la atención, la referencia que hace al documento de donación por la reina Urraca del monasterio de San Martín de Frómista, puesto que añade a este regesto una nota diciendo: "No ha pasado pues la frontera el documento, según imagina don Francisco Simón Nieto". Este documento aparece reseñado en el Índice formando parte de "un quaderno de nueve hojas (...)". Sin embargo, mientras que ese cuaderno se ha conservado, se desconoce la existencia del documento original al que hace referencia. Véanse MARTÍN MÍNGUEZ, Bernardino, Catálogo Monumental de Palencia. Cuaderno III, p. 118; AHPP, Legajo 112, f. 188r; AHN, Sección Clero, carpeta 1700, n. ${ }^{\circ}$ 13. RAMÍREZ DE HELGUERA, El libro de Carrión, p. 172, menciona esta donación y él mismo ya indicaba, a finales del siglo XIX, que esta era una escritura "cuya suerte se ignora".

193 NAVARro GARCÍA, Rafael, Catálogo Monumental de la Provincia de Palencia, por la Comisión provincial de Monumentos Históricos y Artísticos. Palencia: Imprenta Provincial, 1922.

194 MARTÍN MÍNGUEZ, Bernardino, Las Dominicales del Libre Pensamiento. Ejemplar del domingo 16 de septiembre de 1883.

195 PALACIO, Colección San Zoil. I, p. 615, refiere la situación dentro del ACP: Armario 8, legajo 15, n. ${ }^{\circ} 2,4,5$, 7, 11, 21. Para mayor accesibilidad: PÉREZ CELADA, Documentación San Zoilo. I, remite a los documentos 93, 94, 110, 114 a 126; 29, 11 y 19 para cada uno de los demás archivos, respectivamente.

FRANCIA LORENZO, Santiago, "Documentación benedictina en la serie "Provisorato" del Archivo Capitular de Palencia": Memoria ecclesiae, 6 (1995), pp. 415-428 
por no poseer ninguno de ellos mayor notoriedad para el conocimiento completo del archivo monástico que el Índice de San Zoilo, ubicado en el Archivo Histórico Provincial de Palencia ${ }^{196}$.

Paso ahora a centrarme, entonces, en describir los pormenores de dicho archivo a partir tanto de la información que nos ha proporcionado el estudio y edición del Índice, como la vertida y analizada en las investigaciones existentes.

La documentación monástica de San Zoilo no es sino fruto de la vida de una comunidad religiosa, que como cualquier otra institución, necesita asegurarse del cumplimiento de la función concreta que desempeña dentro de la sociedad en la que se creó; una función sí espiritual que, sin embargo, no podría alcanzarse o desarrollarse sin atender a lo temporal.

En el plano económico, la administración de su patrimonio y sus bienes era indispensable para asegurar el correcto funcionamiento de la comunidad, un dominio protegido por franquezas y privilegios y constituido mediante donaciones, privilegios, compras, ventas, permutas, de cuya administración dejan testimonio multitud de cartas de pago, apeos, arrendamientos, censos y todo tipo de documentación económica y hacendística. Dominio que, en cualquier caso, era necesario mantener y asegurar. Para lo cual, desde época muy temprana, el monasterio comenzó a organizar el archivo y conservar los documentos para garantizar que los títulos de propiedad, que avalaban sus derechos ante posibles negocios jurídicos, estuvieran dispoonibles ${ }^{197}$; convirtiéndose así en un órgano de defensa jurídica de sus títulos de propiedad, a la vez que instrumento esencial de gestión administrativa y depósito de documentación histórica ${ }^{198}$.

\footnotetext{
196 AHPP, Desamortización, legajo 112.

${ }^{197}$ El Índice refleja la conciencia de esta necesidad puesto que la pérdida de los documentos por negligencia o incuria podía suponer la pérdida de los derechos y propiedades que estos avalaban.

El monasterio (y el archivo) sabe distinguir el valor probatorio de un diploma de su valor testimonial o informativo, como se deduce de expresiones como las siguientes: "Esta escritura está cortada por abajo y sólo puede servir de memoria" (AHPP, Legajo 112, f. 190r, n. 1 ); "Memorial de los papeles que faltan y se presentaron en el pleito que litigó el monasterio de San Zoil... cuyos papeles faltan del archivo y no sé dónde habrán hido a parar, que fue buen descuido" (AHPP, Legajo 112, f. 399r, n. " 1); "Puede servir este papel de memoria de estas heredades y sus arrendamientos" (AHPP, Legajo 112, f. 405v, n. 10); "sólo puede servir de memoria de aquella hacienda, si bien confusa" (AHPP, Legajo 112, f. 433v, n. ${ }^{\circ}$ 1); "Estos papeles no se entienden por menor, por ser de poca importancia y de ninguna autoridad, n. ${ }^{\circ}$ " " (AHPP, Legajo 112, f. 28v.); "Memoria de los papeles, fundamentos y razones que tiene el monasterio, n. ${ }^{\circ}$ 10" (AHPP, Legajo 112, f. 60r.); "aunque en medio de estos faltan las de algunos años que, por descuido, no trageron al archivo..., pero supongo desde luego que no tendría mucha cuenta al monasterio y acaso menos utilidad” (AHPP, Legajo 112, f. 424).

198 SÁINZ RIPA, Eliseo, “El patrimonio documental eclesiástico en La Rioja”: Berceo, 128 (1995), pp. 291306, especialmente p. 292, (=SAÍNZ RIPA, "El patrimonio documental eclesiástico en La Rioja”), donde escribe que "Con idénticos fines pragmáticos, y no humanísticos, las instituciones eclesiásticas de seculares y regulares apilaron en arcas seguras los instrumentos notariales, las bulas papales, los diplomas regios, las cartas de compraventa o de permuta, contratos y avenencias... Se guardaban estos instrumentos porque a la
} 
La documentación del monasterio de San Zoilo fue escrita, a excepción de los diplomas y hasta la primera mitad del siglo XIII, por la schola monástica, tal como nos indica M. ${ }^{a}$ Luisa Palacio ${ }^{199}$. A partir de ese momento, el monasterio recurrirá también a la actuación de los notarios públicos y escribanos para la redacción de los documentos que recogían asuntos administrativos y judiciales: rentas, censos, diezmos, tazmías, pleitos, capellanías, hacienda. De esta manera, mientras que las funciones del primitivo scriptorium quedaron centradas en la nada desdeñable y ardua tarea de la copia y producción de libros, en su mayoría de carácter litúrgico, destinados a atender las necesidades espirituales y de lectura que la Regla de San Benito ${ }^{200}$ exigía a la comunidad; en el monasterio, la figura del archivero se tornó imprescindible en tanto en cuanto bajo su cargo y responsabilidad estaban quehaceres como el de organizar y archivar la documentación original, así como sus copias, necesarias frente a la posible desaparición del registro original ${ }^{201}$.

Si bien en otros monasterios en los que, para asegurarse la conservación íntegra de las piezas documentales que constituían el fondo archivístico del monasterio, se transcribían estas en volúmenes llamados “códices diplomáticos” (cartularios, tumbos o

hora de defender in re vel ad rem constituían pruebas fehacientes de privilegios, competencias, poderes, jurisdicciones".

199 Véase PALACIO, Colección San Zoil. I, p. 546; pp. 406-482, donde dedica un capítulo a la schola del convento.

200 La Regla de San Benito. Introducción y Comentario García M. COLOMBÁS. Traducción y notas Iñaki

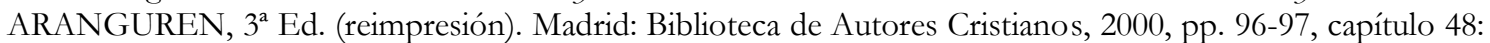
El trabajo manual de cada día, 1-25: donde se regula que desde Pascua hasta las calendas de octubre, "desde la hora cuarta hasta el oficio de sexta se dedicarán a la lectura"; "desde las calendas de octubre hasta la cuaresma se dedicarán a la lectura hasta el final de la segunda hora", y "después de comer se ocuparán en sus lecturas o en los salmos"; "durante la cuaresma dedíquense a la lectura desde por la mañana hasta finalizar la hora tercera". "En esos días de cuaresma recibirá cada uno su códice de la Biblia, que leerán por su orden y enteramente; estos códices se entregarán al principio de la cuaresma. Y es muy necesario designar a uno o dos ancianos que recorran el monasterio durante las horas en que los hermanos están en la lectura. Su misión es observar si algún hermano, llevado de la acedía, en vez de entregarse a la lectura, se da al ocio y a la charlatanería, con lo cual no sólo se perjudica a sí mismo, sino que distrae a los demás. Si a alguien se le encuentra de esta manera, lo que ojalá no suceda, sea reprendido una y dos veces; y, si no se enmienda, será sometido a la corrección que es de regla, para que los demás escarmienten". "Los domingos se ocuparán todos en la lectura, menos los que estén designados para algún servicio. Pero a quien sea tan negligente y perezoso que no quiera o no pueda dedicarse a la meditatio o a la lectura, se le asignará alguna labor para que no esté desocupado".

${ }^{201}$ SÁINZ RIPA “El patrimonio documental eclesiástico en La Rioja”, p. 293.

El Índice es una fehaciente muestra de que en San Zoilo estas tareas fueron desempeñadas con el máximo rigor y exactitud que la práctica archivística de aquella época permitía. En él encontramos numerosos ejemplos de cómo la expedición de copias se convirtió en un instrumento fundamental para la defensa del patrimonio.

Acerca de esta cuestión remitimos el capítulo dedicado al Índice de San Zoilo de Carrión, donde se aborda de forma más pormenorizada toda la cuestión relativa a las copias y trasuntos.

A modo de ejemplos citamos las siguientes referencias "Hay copia authorizada, sacada por don Antonio Martín García, traductor, año de 1783. El parecer original no tiene fecha” (AHPP, Legajo 112, f. 126v, n. . 5); "Trasumto simple de una sentencia dada en Roma contra quatro curas de Aguilar... El original de esta sentencia y sus executoriales están en el Archivo de San Claudio de León, y este monasterio pagó de las costas de este pleito, 368 maravedís, el año de 1578.” (AHPP, Legajo 112, f. 9v, n. ${ }^{\circ}$ 6). 
becerros, etc. $)^{202}$, en San Zoilo no queda constancia de la existencia de tales libros ${ }^{203}$. Únicamente se conoce la existencia de un cartulario ${ }^{204}$ o, en palabras de M. ${ }^{a}$ Luisa Palacio, "un inicio de cartulario o el inicio para su confección posterior [...] y parece como si se intentase recopilar aquellos documentos que consideró el monasterio de gran trascendencia para su historia" 205 . Ya se dio noticia de esto en el estudio histórico, recogiendo lo que en torno a dicho cartulario aporta Bishko, y en el cual indica cómo Julio González, en su obra El reino de Castilla en la época de Alfonso VIII, lo denomina "fragmento de cartulario del XIII"206. Por otra parte, se puede pensar que "El [libro] antiguo de las escrituras del archivo" 207 de que se da noticia en el Índice tal vez pudiera ser el cartulario del monasterio que hoy no tenemos.

Gracias a la celosa protección de su documentación, el monasterio carrionés fue capaz de protegerse de los numerosos litigios en los que se vio envuelto, de los cuales se tiene noticia por primera vez a finales del siglo XII. La defensa de su señorío jurisdiccional dio lugar a mucha documentación por los conflictos surgidos entre el monasterio y el cabildo, los concejos e incluso particulares, u otras instituciones que creían verse perjudicadas por la ampliación del ámbito de influencia del monasterio. Todo esto quedó testimoniado en querellas, pleitos, avenencias y concordias, entre otros muchos documentos ${ }^{208}$.

\footnotetext{
202 Baste como ejemplo RODRÍGUEZ DE DIEGO, José Luis, El Tumbo del monasterio cisterciense de La Espina. Valladolid, 1982 (=RODRÍGUEZ DE DIEGO, El Tumbo de La Espina), donde se puede encontrar una pequeña muestra de toda la bibliografía existente hasta ese momento en torno a códices diplomáticos.

${ }^{203}$ No obstante, consideramos que un monasterio de la talla de San Zoilo hubo de disponer necesariamente de algún becerro para la copia de sus escrituras más señeras. Rastreando esta posibilidad encontramos la siguiente mención en el Libro Misceláneo que nos podría poner sobre la pista de que dicha posibilidad fuese factible: "Las presentaciones de beneficios que esta casa de San Zoil tiene, sacado de vn libro antiguo del becerro el qual dice ansi". PALACIO, Colección San Zoil. I, p. 602.

${ }^{204}$ AHPP, Legajo 112, ff. 188r-190r.

Véase DÍEZ HERMANO, M. ${ }^{a}$ José, "Escribir para conservar. El priorato de San Martín de Frómista a través del índice de San Zoilo de Carrión", en Ramón BALDAQUí ESCANDELL (coord.), Lugares de escritura: el monasterio. Alicante, 2016, pp. 427-443.

205 AHN, Sección Clero, carpeta 1700, n.o 13.

206 Dicha afirmación aparece en BISHKO, El abad Radulfo, p. 404, y es del tenor siguiente: "González denomina al cuaderno fragmento de cartulario del XIII, pero la falta de criterio cronológico o geográfico en la selección de estos 13 textos tan dispares entre la masa de los pergaminos de San Zoil, hace difícil creer que fueran reunidos para su inserción en la clase de tumbo perfectamente organizado que podría esperarse encontrar en una casa tan importante y tan bien administrada como era Carrión hacia 1200."

207 AHPP, legajo 112, f. 471r, n. ${ }^{\circ} 4$.

${ }^{208}$ Los pleitos juegan un papel importante en lo que al volumen de documentación producida y registrada en el Índice se refiere. Estos litigios exigían además la presentación de aquellos documentos que avalasen y reforzasen los derechos que defendía como propios y sobre los que se litigaba, de ahí que las referencias que se hacen en el códice a pleitos sean unas de las más completas en cuando a grado de detalles y relación con otros legajos existentes en el archivo.

Véase como ejemplo el pleito que mantuvo el monasterio por la posesión del Barrio de San Martín de Frómista, que corresponde a todos los documentos contenidos en el Cajón 9 San Román. AHPP, legajo 112, ff. $225 \mathrm{r}-251 \mathrm{v}$.
} 
Junto a toda esta documentación, también pueden encontrarse libros y documentos relativos a la función espiritual y práctica religiosa. Es el caso del Libro Misceláneo ${ }^{209}$ que M. ${ }^{a}$ Luisa Palacio describió como “[...] un reflejo del estado de la vida del monasterio, y el

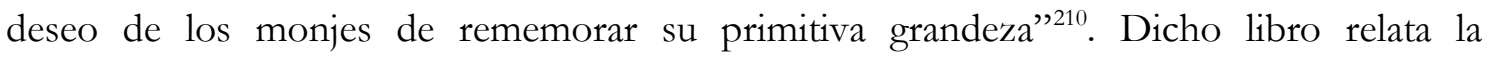
fundación y donación de San Zoilo, alabando la generosidad de los condes fundadores y su estrecha relación con la comunidad; exaltando la riqueza de las reliquias conservadas. Incluye una copia de la Regla de San Benito, donde se indicaban todos los preceptos que debían cumplir los monjes, especialmente la celebración del culto religioso, para lo que utilizaban un martirologio que también figura en el Misceláneo; y un laudo a la Orden, destacando la importancia de San Zoil. A estos se une la gran masa de documentación generada a raíz de la presentación y colación de los beneficios eclesiásticos, así como los numerosos pleitos que en torno a esta cuestión quedaron registrados en el Índice, en especial a partir del siglo XVI.

Además, en el ya citado "Fondo de San Zoilo de Carrión” inventariado por Quintín Aldea, se conserva documentación relativa a este tema, como una cronología benedictina, la vida de San Benito escrita por Juan de Cisneros, un libro del consejo, un calendario de los bienhechores de Cluny del monasterio de San Zoilo; así como numerosas bulas, que acreditan sus relaciones con la Santa Sede.

Existió también un necrologio ${ }^{211}$ del que, entre los miles de nombres, Reglero de la Fuente $^{212}$ realiza una identificación de diversos personajes hispanos que estuvieron relacionados con el monasterio. De la existencia de este libro en el archivo dejó constancia

\footnotetext{
209 PALACIO, Colección San Zoil. I, pp. 464-471, dedica un epígrafe en su capítulo sobre la schola monástica; en Colección San Zoil. II, pp. 601-633, realiza la transcripción del mismo.

Este libro, extraviado tras la salida de los jesuitas, fue encontrado en 1982 por el sacerdote don José Antonio Perrino, en una estantería de la biblioteca del monasterio. Actualmente, el libro se encuentra en el Archivo Diocesano de Palencia.

210 PALACIO, Colección San Zoil. I, p. 470.

211 Archivo General de la Provincia de España de los Jesuitas (Alcalá de Henares) AESI-A, Fondo Carrión, caja C 11, documento 26.

Este libro ha sufrido los estragos de la reciente dispersión documental producida en el "Fondo de San Zoilo de Carrión" que los jesuitas de San Zoilo se llevaron consigo. Al abandonar el edificio trasladaron este fondo al Colegio del Sagrado Corazón en León, donde aparecía catalogado en un listado de 72 documentos bajo el número 4 y descrito como: "Calendario de los bienhechores de Cluny y del monasterio de San Zoilo. En pergamino, letra gótica, sin fecha. Faltan algunas hojas". La última noticia acerca de la ubicación del Necrologio en Salamanca (Colegio de San Estanislao) nos la proporciona Reglero de la Fuente; si bien no es esta su localización actual puesto que el fondo se ha dispersado y fraccionado, llevándose una parte de la documentación al Archivo General de la Provincia de España de los Jesuitas en Alcalá de Henares, documentos entre los cuales se encuentra este códice.

212 REGLERO DE LA FUENTE, Carlos, “El Necrologio-Obituario de San Zoilo de Carrión”, pp. 525-533; REGLERO, Cluny en España, pp. 643-669.
} 
el padre Cisneros en su Manual ${ }^{213} \mathrm{y}$, de esta misma forma fue asentado en el Índice bajo la denominación de "Kalendario de bienhechores de Cluni y del monasterio de San Zoil y monges difuntos ${ }^{214}$ formando parte de un cajón reservado para "varios libros antiguos y curiosos".

Como en otros muchos monasterios benedictinos, San Zoilo también debió contar con un abadologio y un libro de gradas de los monjes que profesaron en él, pero como otros muchos documentos, estos, a consecuencia de la exclaustración, se extraviaron o se perdieron. Por fortuna el Manual de Juan de Cisneros nos da noticia de la existencia de un libro de los grados de habitos, profesiones y muertes de monges ${ }^{215}$; libro que, tal y como estaba indicado y ordenado en las Constituciones, debería encontrarse en los archivos de todos los monasterios benedictinos dependientes de San Benito ${ }^{216}$. No obstante, casi doscientos años después, no existe noticia explícita y literal alguna en el Índice de San Zoilo a este libro, a excepción del asiento que reza "libros de gradas e ynformaciones de monges y legos, e igualmente algunos testamentos de los mismos ${ }^{\wedge 17}$, cuyo uso puede que siguiera vigente en el momento de la redacción del códice, puesto que, de no haber sido así, habría sido registrado dentro del cajón destinado a custodiar "varios libros antiguos y curiosos" 218 . Para paliar la ausencia de dichos libros, abadologio y gradas, Ernesto Zaragoza Pascual nos ofrece una reconstrucción de lo que pudieron ser ambos libros ${ }^{219}$.

La conservación de toda esta documentación, desde el primer diploma hasta los últimos escritos antes de la desamortización, ha sido fruto de la fiel obediencia a las normas

213 Véase PALACIO, Colección San Zoil. II, pp. 553-554. Libro 1․ "Kalendario de bienhechores: Este es un libro antiguo escrito en pergamino. Al parezer es copia de otro que avia en San Pedro de Cluny, en que por los días del año están escritos y notados los hombres insignes y bienhechores de Cluny y de los monasterios de su congregación, notando las memorias que se hazían por ellos en aquella congregación, conforme a los beneficios recibidos. En este calendario están notados los bienhechores deste monasterio de San Zoyl con una $+y$ los aniversarios y memorias que ay obligación hazer por ellos. Conservanse deste libro escasas veinte y ocho hojas (...)".

214 AHPP, legajo 112, f.471r.

215 PALACIO, Colección San Zoil. II, pp. 555, donde da cuenta del 'Libro $4^{\circ}$ de los grados de hábitos, profesiones y muertes de monges".

216 Constituciones de la Congregacion de nuestro glorioso Padre San Benito de España e Inglaterra [...] 1701, pp. 166, 172: "El mismo día en que el novicio recibe el habito, escrivirá en el libro de las gradas del convento el día, hora, mes y año en que le recibe, en la forma acostumbrada, para que conste de su grada y tiempo de habito".

"Y que haya en cada casa un Libro Bezerro, en que el novicio escriva la forma de la profesión la letra, como la pronunció, cuando la hizo y la firme de su nombre (...) Y el escribano o notario en el mismo Bezerro, escriva el día, hora, mes y año en que el novicio hizo tal profesión (...) Este libro se guardará siempre en el archivo”. 217 AHPP, legajo 112, f.471r. Véase PALACIO, Colección San Zoil. II, p. 537.

También da noticia de una parte de este libro el padre Cisneros en su Manual (información de novicios y legítimos testamentos, por lo que no hay duda de que estaríamos hablando de dos libros que, en el siglo XVII se registraron por separado, pero que el autor del Índice registra como un único asiento, muy posiblemente porque así es como estarían descritos en el archivo.

218 AHPP, legajo 112, f.471r.

219 ZARAGOZA PASCUAL, Abadologio San Zoilo, pp. 273-321. Esta encomiable recopilación fue llevada a cabo mediante la consulta de documentación conservada en diversos archivos, destacando fundamentalmente aquella custodiada en el Archivo Histórico Nacional, así como las Actas de los Capítulos Generales de la Congregación de San Benito de Valladolid; sin excluir, por supuesto, otras muchas fuentes manuscritas e impresas. 
dictadas en la Regla de San Benito ${ }^{220}$ y a las sistematizaciones que, para organizar sus archivos, se dictaminaban en los capítulos de la Orden; fundamentalmente y para el caso específico de San Zoilo, desde su anexión a la Congregación de San Benito de Valladolid en 1532.

No poseemos ninguna noticia relativa a los primeros siglos de la existencia del Archivo de San Zoil ${ }^{221}$. Su pertenencia desde la donación de la condesa doña Teresa a la abadía de Cluny y la misma llegada al cenobio de monjes franceses hace suponer que, al igual que los monjes cluniacenses y siguiendo la Regla de San Benito, encontraron en el trabajo manual una de sus labores consideradas primordiales; ni qué decir tiene, la copia de manuscritos formaba parte de dicha labore manuum. Para ello, cada monje se valía de un punzón y unas tabletas, reservando para el trabajo un pequeño claustro, situado y construido para ofrecer la máxima tranquilidad posible a los encargados de esta tarea ${ }^{222}$.

La documentación custodiada era considerada de tal valía que, para evitar su pérdida y deterioro, se guardaba en una sala llamada armario. Linage Conde señala lo siguiente al respecto: "El gran benedictino y misionero gallego del pasado, Dom Rosendo Salvado, gustaba de repetir [...] que una abadía sin libros es como una fortaleza sin armas ${ }^{223}$ $[\ldots]^{3224}$; indicando tanto la importancia que para los monjes poseían sus libros y pergaminos como la conservación de los mismos en sus archivos.

Parece ser que en San Zoil existió, efectivamente, esta sala o armario. M. ${ }^{a}$ Luisa Palacio advirtió acerca de la aparición del término en un documento del año $1222^{225}$, aunque con anterioridad a esta fecha la existencia del archivo sólo haya podido basarse en

220 Resulta curioso el hecho de que no hayamos encontrado referencia alguna a la palabra "archivo" en la Regla de San Benito, aunque podamos deducir que para algunos aspectos de la vida monacal, el registro de determinadas informaciones hubiera sido casi imprescindible.

Seguimos a DE LA CRUZ HERRANZ, Luis M. de la, "El archivo monástico. Entre la gestión de su administración y la gestión de su memoria histórica", en Ramón BALDAQUí ESCANDELL (coord.), Lugares de escritura: el monasterio. Alicante, 2016, p. 193, DE LA CRUZ HERRANZ, "El archivo monástico") cuando hace mención a que "En la Regula magistri, al tratar de las herramientas del monasterio (Cap.17), se mencionan una serie de arcas, entre las cuales una era destinada a contener «diversis codicibus, membranis et cartis monasterii». Y nada más.”

${ }^{221}$ Para arrojar luz sobre este aspecto, resulta significativo el hecho de que la documentación registrada en el Índice comience en el año 940, al situarse también en el en el siglo X la posible fecha de fundación del cenobio. Esto hace que, aún sin noticias explícitas, podamos entender que tanto el monasterio como los que luego se convertirán en sus prioratos guardaran esas cartas fundacionales y de donación desde el principio como verdaderos "tesoros" por el valor probatorio del mismo documento y de la información que contenía. 222 PIGNOT, J. Henri, Histoire de l'Ordre de Cluny. Tomo II. Autun-París, 1868, pp. 417-419. Describe la tradición escriptoria de Cluny.

${ }^{223}$ Del proverbio cluniacense "Claustrum sine armario, sicut grex sine armentario".

224 LINAGE CONDE, Los orígenes del monacato. I, p. 384.

225 PALACIO, Colección San Zoil. I, p. 571, donde indica su ubicación en el AHN, Clero, carpeta 1702, n. 11. 
meras suposiciones ${ }^{226}$. Hay que entender, por lo tanto, que el archivo pensado como salvaguarda y custodia de los diplomas y títulos de propiedad existió desde el momento en que se inició la formación de su patrimonio, que, precisamente, testimoniaba dicha documentación, de ahí la necesidad de conservarla; sin embargo, su localización dentro del recinto monástico, así como su organización y ordenación serán desconocidos durante los primeros siglos de existencia del cenobio $^{227}$. No obstante, resulta lógico pensar que la relación de dependencia entre archivo e institución monástica generaba una recíproca necesidad entre ambos, que podría explicar el porqué de estas limitadas alusiones explícitas al archivo del monasterio ${ }^{228}$.

No cabe encontrar, sin embargo, óbice alguno en esta falta de información, pues simultáneamente a la realización de los documentos, en los reversos se redactaban unas anotaciones que reseñaban su contenido y no son sino muestra del afán sintetizador y descriptor que puede identificarse con esta acción ${ }^{229}$. Un afán que permitiría no solamente el acceso a la información sustancial del diploma de forma más rápida sino también una mejor conservación de los documentos, puesto que para el conocimiento de su contenido no sería precisa la manipulación de los mismos.

Esto, sin embargo, no ofrecía información alguna acerca de la primera organización, la cual tomó nueva forma en el siglo XVI ${ }^{230}$, cuando se llevaron a cabo las ordenaciones y catalogaciones de los archivos de todos los monasterios por orden de los Capítulos Generales ${ }^{231}$. Seguimos a Rodríguez de Diego cuando afirma al respecto que “[...] el hecho más determinante de la ordenación [...] fue la incautación por la corona no sólo de tierras de propios y baldíos, sino de propiedades pertenecientes al estamento eclesiástico. Los numerosos pleitos [...] obligaron $[\ldots]$ a una búsqueda de documentos

226 DEL ÁLAMO, M., Dictionnarie d'Histoire et de Géographie eclesiastique. París, 1912-1971, indica que la documentación archivada en San Zoil abarcaba de 1047 a 1647, custodiando el Libro de Concilios del siglo X y otro donde se narraba la historia del traslado de los cuerpos de San Zoilo, San Félix y San Agapio. Además, parecer ser que ya en el 1076 existían libros en el monasterio, tal y como se indica en el documento de donación de ese mismo año.

${ }^{227}$ La única noticia, aunque poco precisa, acerca de la posible localización del primitivo archivo de San Zoilo la encontramos en Statuts, chapitres généraux et visites de l'ordre de Cluny, I, pp. 284. Tomado de BARRET, Sebastien, La mémoire et l'écrit: l'abbaye de Cluny e ses archives (Xe-XVIIIe siècles), Münster: LIT, 2004, p. 149.

Nos la proporciona el Capítulo General de Cluny de 11 de mayo de 1264: "Priores Hispaniae coram visitatoribus expresse juraverunt et litteras super hoc patentes dederunt, que in prioratu karionensi sunt deposite, quod de cetero clericos seculares non reciperent, sed monachos loco ipsorum secundum facultades locorum instituent. Dominus abbas et definitores hoc approbant et confirmant."

${ }^{228}$ DE LA CRUZ HERRANZ, "El archivo monástico”pp.178, 179.

${ }^{229}$ PALACIO, Colección San Zoil. I, p. 571.

230 Véase DE LA CRUZ HERRANZ, "El archivo monástico”, pp. 183-184, donde el autor nos aclara como, fruto del cada vez mayor volumen de producción documental, a partir del siglo XIII "fue necesario recurrir a algún incipiente método de clasificación para facilitar la tarea de búsqueda".

${ }^{231}$ RODRÍGUEZ DE DIEGO, El Tumbo de La Espina, p. 166. 
acreditativos de sus derechos y, por consiguiente, a una ordenación y especial cuidado de los mismos"232.

A este contexto de crisis económica se le sumaba el hecho casi capital de las consecuencias negativas que en la hacienda de algunos cenobios habrían producido las numerosas negligencias en la conservación y vigilancia de la documentación; cuando, bien por extravío bien por deterioro, habrían visto mermada su capacidad para defender y preservar sus rentas y propiedades. El archivero o archiveros que redactaron el Índice fueron testigos directos de estas tribulaciones y, conocedores de sus nefastos efectos, dejaron constancia en sus registros del pésimo estado en que se habían conservado algunos documentos, así como la falta de otros muchos, traspapelados o perdidos en los ires y venires de pleitos y notarías ${ }^{233}$.

Todo ello dio lugar a que, tanto en las mismas Actas de los Capítulos Generales como en las leyes establecidas por la Congregación de San Benito de Valladolid ${ }^{234}$,

232 Ibídem, p. 24, donde Rodríguez de Diego realiza la afirmación basándose en las obras de GÓMEZ MENDOZA, Josefina, "La venta de baldíos y comunales en el s. XVI. Estudio de su proceso en Guadalajara": Estudios Geográficos, 28 (1967), pp. 499-559; ULLOA, Modesto, La hacienda real de Castilla en el reinado de Felipe II. Madrid, 1977, pp. 659-678; VASSBERG, David E., "La venta de tierras baldías en Castilla durante el siglo XVI": Estudios Geográficos, 37 (1983), pp. 21-47, y MOXÓ, Salvador, "Las desamortizaciones eclesiásticas en el s. XVI": Anuario de Historia del Derecho Español, 31 (1961), pp. 327-362.

233 Sirvan como muestra algunos de los siguientes ejemplos: "Esta escritura está cortada por abajo y sólo puede servir de memoria” (AHPP, legajo 112, f. 190r, n. ${ }^{\circ} 1$ ); “(...) esscrituras que el monasterio, quando litigó, no pudo descubrir por la malicia de los interesados que las tubieron ocultas; y después, pleiteando entre sí, las sacaron y presentaron" (AHPP, legajo 112, f. 338v.); "Proceso antiguo y maltratado (...)" (AHPP, legajo 112, f. 394r, n. 10 ); "Memorial de los papeles que faltan y se presentaron en el pleito (....) cuyos papeles faltan del archivo y no sé dónde habrán hido a parar, que fue buen descuido" (AHPP, legajo 112, f. 399r, n. ${ }^{\circ} 1$ ); “(...) faltan las de algunos años que, por descuido, no trageron al archivo (...)”(AHPP, legajo 112, f. 424v.); “(...) En esta añade la falta de algunas escrituras tocantes a esta casa que fueron llevadas a Cluni desde que fue miembro de él este monasterio. Pide y suplica la remisión de ellas, para lo que la pone la relación de los instrumentos” (AHPP, legajo 112, f. 146v, n. $\left.{ }^{\circ} 30\right)$; “(...) la qual bulla no está en este archivo y puede ser que esté en el de Sahagún, por haverse llevado a aquella casa para requirir al abad, quien usó de ella en pleitos que tubo este monasterio con los marqueses de Frómesta y clérigos de Aguilar y otros" (AHPP, legajo 112, f. 82v, n. ${ }^{\circ}$ 21); "(...) dice que el monasterio tiene carta executoria (la qual no parece en el archivo) (...)"(AHPP, legajo 112, f. 261r, n. ${ }^{\circ}$ ); "Ynformación antigua, escrita en pergamino (que tiene diez ojas y la faltan otras) (...)"(AHPP, legajo 112, f. 107r, n. ${ }^{\circ}$ 2).

${ }^{234}$ Los Libros de Actas de los Capítulos Generales de la Congregación de San Benito de Valladolid se conservan en el archivo del monasterio de Santo Domingo de Silos desde 1882. Abarcan una cronología que va desde el año 1500, fecha en la que se celebra el primer Capítulo General, tras la creación de la Congregación, por Bula del Papa Alejandro VI de 1497, hasta 1805, momento en el que los sucesos históricos posteriores (Guerra de la Independencia y sucesivas desamortizaciones) originaron la pérdida de las Actas de los Capítulos celebrados entre 1814 y 1832.

Véase MATÉ SADORNIL, Lorenzo, Actas y constituciones de los Capitulos de la Congregación de San Benito de Valladolid (1497-1610): Stvdia Silensia, XXX-XXXI. Abadía de Silos, 2007-2008; IDEM, Actas y constituciones de los Capitulos de la Congregación de San Benito de Valladolid (1613-1721): Stvdia Silensia, XXXV-XXXVI-XXXVII. Abadía de Silos, 2012-2014.

El último de los tres volúmenes, que corresponde a los Capítulos celebrados entre 1725 y 1805 aún está por publicar. 
denominadas Constituciones, se establecieran una serie de disposiciones concretas que regulaban la actuación a seguir por los monasterios sobre archivos y archiveros ${ }^{235}$.

Las Constituciones promulgadas en 1500 serán el punto clave de posteriores normativas. Así, en 1554, la "Primera Declaratoria de la Regla" establecerá los principales epígrafes sobre los que se incidirá reiteradamente en las sucesivas Constituciones y en los Capítulos Generales; entre ellas la obligación de que en cada casa hubiera un archivo para guardar las escrituras protegidas del fuego y la humedad, poniendo especial atención en aquellos documentos más valiosos para el monasterio, sus títulos acreditativos de propiedades, llegando inclusive a imponer graves penas si faltare alguna de ellas sin motivo justificado en el momento en que se realizase una visita. El comentario al capítulo 32 de la Regla de San Benito nos ilustra diciendo:

\section{“CAPUT 32: DE FERRAMENTIS MONASTERII.}

\section{Sustantiae monasterii in ferramentis etc.}

Acerca de este artículo, demás del ynventario general que allí se manda hacer, se acordó y ordenó que en cada casa se haga minuta de todas las escripturas que la tal casa tiene y se pongan en un archivo, el qual tenga dos llaves y esté seguro de peligro de fuego y de humedad y de otras cosas que le pueden dañar, y que las escripturas que fueren de ymportançia se cojan con zendales de manera que no se dañen, y espeçialmente se manda a Perlado de cada casa, que dentro de un año haga recoger todas las escripturas de la casa y las trayga al archivo, y las que no se pudieren en el dicho tiempo traer por alguna legítima causa, sea obligado de traer raçón dellas para que se sepa quantas son y quales y dónde están, so pena que pasado el dicho tiempo y no se huviere cumplido, le castiguen en la Visita gravemente por ello. Ytem, se acordó que se haga un índice o epítome de todas las bullas de la Orden, en el qual por orden del alphabeto se ponga sumariamente todo lo que

\footnotetext{
Nos ofrece un interesante recorrido por los avatares que "sufrieron" estos Libros de Actas, así como una valiosa información que nos permite trazar una imagen de la vida en la Congregación y el modo en que llevaban a cabo el gobierno y la administración del resto de monasterios y casas agregados. Véase MATÉ SADORNIL, “Archivo San Benitoq”, pp. 313-332, especialmente p. 317.

235 Simultáneamente a la Congregación de San Benito, otras comunidades realizaron su propia legislación en materia de archivos. Cabe citar el caso de la Congregación Cisterciense de San Bernardo de Castilla, cuyas Definiciones incluían unas normas muy similares a las establecidas por Valladolid. Véanse las Definiciones cistercienses de la Sagrada Congregación de San Bernardo y Observancia de Castilla, etc. Valladolid: en la Imprenta de la Viuda de Santander, 1786. Para una primera aproximación véase también SAGALÉS CISQUELLA, L., "Estructura institucional y legislación sobre archivos de la Congregación cisterciense de San Bernardo de Castilla": Memoria ecclesiae, 7 (1995), pp. 187-206.
} 
en ellas se conçede, y esto, nuestro muy Rdo. P. General lo encomiende a personas que dentro del término que él les mandare lo cumplan" ${ }^{236}$.

A lo largo del tiempo fueron tan frecuentes las reuniones en las que tomaban decisiones sobre las directrices que concernían a la normativa de la comunidad y por ende al archivo -el Capítulo General se celebraba cada tres años, hasta 1613, y cada cuatro a partir de esta fecha- que no hubo cambios relativamente significativos en su legislación. Los abades y delegados de los monasterios que acudían a estos capítulos revisaban las disposiciones y acordaban otras nuevas utilizando como referencia las noticias recopiladas por sus Visitadores Generales, los cuales recorrían los monasterios para asegurarse de que en todos ellos se estuviera aplicando la uniformidad de la observancia. Esta reiteración pone de manifiesto una vez más la “obsesión” por el control de toda la documentación, más aún cuando esta resultaba imprescindible para la defensa de su patrimonio.

Las disposiciones que en ellas se tomaban sobre archivos y archiveros continuaron con la línea ya iniciada sobre depósitos y encargados de ellos reforzando, aún más si cabe, la imagen del archivo como baluarte estratégico para la administración y gestión de los cenobios. A continuación, citamos algunas de ellas a tenor de su importancia y singularidad ${ }^{237}$ :

"Para conseruacion de las haziendas de los Monasterios y de sus calidades, priuilegios, y preeminencias, importa en gran manera el cuydado y diligencia en guardar con mucha fidelidad las escripturas en los Archiuos, y que en ellos en todos Tribunales tengan authoridad, no solo por su antigüedad, sino tambien por la fidelidad que constare se guarda en ellos" ${ }^{\prime 238}$.

Para garantizar la seguridad que tan valiosas escrituras exigían, pusieron en práctica varias directrices, entre ellas la que condicionaba el acceso al archivo a la necesaria presencia de dos personas diferentes -aunque en una época posterior serán tres-, para asegurarse que nadie ajeno a él pudiese acceder y dañar o sustraer la documentación, lo cual causaría un grave perjuicio al monasterio:

\footnotetext{
236 ZARAGOZA PASCUAL, Ernesto, Los generales de la Congregación de San Benito de Valladolid, 2, Los abades trienales (1499-1568). Abadía de Silos, 1976, p. 435.

237 Para realizar esta selección tomamos como referencia las Constituciones de 1575, 1610 y 1669; además de las Actas de los Capítulos recogidos en MATÉ SADORNIL, Lorenzo, Actas y constituciones de los Capitulos de la Congregación de San Benito de Valladolid (1497-1610): Stvdia Silensia, XXX-XXXI. Abadía de Silos, 2007-2008; IDEM, Actas y constituciones de los Capitulos de la Congregación de San Benito de Valladolid (1613-1721): Stvdia Silensia, XXXV-XXXVI-XXXVII. Abadía de Silos, 2012-2014.

238 Constituciones de la Congregacion de San Benito de la Obseruancia, que tuno principio en el Real Monasterio de San Benito de Valladolid. Madrid, 1612, pp. 152.
} 
"Que en todos los archiuos de la orden, los quales deuen estar en lugar muy seguro, aya dellos llaues diferentes de manera que no habra la vna sin la otra, e las tengan dos monges que tengan noticia de las escripturas del monesterio" 239 .

Además, para evitar el menoscabo que la pérdida de alguna escritura habría ocasionado al monasterio, se crean varios instrumentos de prevención, a cargo de los cuales estaría la persona del archivero, el cual se torna imprescindible tanto para la custodia de los documentos como en la elaboración de copias, traslados ${ }^{240}$ y registros ${ }^{241}$ que facilitarían la consulta y ubicación de los mismos:

"Otrosi mandamos que todas las escripturas del archiuo se visiten de quatro en quatro meses haziendo tabla dellas, para que vean las que faltan, e las bueluan al dicho archiuo.

Que los perlados tengan mucho cuidado que en sus casas se saquen las escripturas de poder de los escriuanos y se pongan en los archiuos, e que el Abbad e los que tienen cargo del archiuo tengan gran cuidado de que dentro de la semana que se haze la escriptura se traiga autorizada para ponerla en el archiuo" ${ }^{242}$.

"Ordenamos y mandamos, que quando alguna escriptura se presentare en algún pleyto, el Procurador tenga cuydado de pedir luego a los juezes, manden, que dexado en el pleyto vn traslado authorizado, y si fuere menester citada la parte, se buelua el registro original para ponerle en el Archiuo [...]"243.

"El Archiuero tenga vn libro en blanco, en el qual el que lleuare escriptura del Archiuo dexe conocimiento de la escriptura que lleua, con lo que en ella se contiene, con

\footnotetext{
239 Constitviones de los monges de la Congregación de Sant Benito de Valladolid. Barcelona, 1575, pp. 129.

240 En el índice de San Zoilo encontramos numerosas referencias a estas herramientas, como fueron las copias -simples o autorizadas-, los trasuntos y los traslados; gracias a las cuales, y en ocasiones únicamente a través de ellas, se tiene constancia de la existencia de algunos de los documentos: "Que el monasterio les dé traslados authorizados de todas las escrituras y privilegios del barrio y quede obligado a mostrar los originales quando fuere necesario" (AHPP, legajo 112, f. 238v, n. ${ }^{\circ}$ 20); "Hay un original y un traslado autoriza[do] por Juan de Castrillo, y de ambos copia autorizada por don Antonio Martín García, traductor" (AHPP, legajo 112, f. 436r, n. $\left.{ }^{\circ} 1\right)$.

${ }^{241} \mathrm{El}$ archivero era el responsable de que los diplomas fuesen fácilmente localizables dentro de la compleja estructura del archivo, de ahí que la elaboración de estas tablas se convirtiera en tarea primordial; también estaba bajo su responsabilidad el control de las salidas y entradas de documentación para cerciorarse que todas las escrituras que estaban fuera del monasterio, casi siempre a consecuencia de algún pleito, se devolviesen al archivo para poder servir como prueba cuando fuese nuevamente necesario.

El Manual de Cisneros nos ofrece una muestra de cómo ambos libros fueron elaborados y utilizados en San Zoilo. En el caso del libro de escrituras simplemente lo registra: "Libro $7^{\circ}$ de los conocimientos de las escrituras que se sacan del archivo; mientras que la tabla para organizar el archivo la elabora él como anexo a su manual: "Tabla Manual y Alfabética del Archivo de San Zoyl, por los títulos de los lugares y cosas que se incluye en sî”. Véase PALACIO, Colección San Zoil. II, pp. 560,561.

242 Ibidem, p. 129.

243 Ibidem, p. 153.
} 
día mes y año, ante que el escriuano, y para qué se saca la escriptura, y en qué día mes y año se saca, y en qué pleyto, y ante qué escriuano se ha de presentar [...",244.

"El archiuero ha de tener hecha vna tabla en vn libro con vn registro por orden Alfabético, de lo que contiene cada escriptura del Archiuo, y en qué caxon o parte del Archiuo está, para que con facilidad se halle la escriptura que se pretendiere, y se sepa lo que en ella se contiene. Y a de poner el día mes y año que se otorgó la escriptura, quien era Abbad, y ante qué escriuano se otorgó la escriptura" ${ }^{\text {245. }}$

Sin embargo, al iniciarse el siglo XVIII esta preocupación inicial parecía estar agotada, por lo que en el año 1701 se llevó a cabo una renovación de la legislación. Esto dará lugar a que en el año 1706 el Capítulo General publique las últimas Constituciones que rigieron la Congregación; como no podría ser de otra forma, este corpus dedica uno de sus capítulos, el 24, a legislar todo lo relacionado con los "archivos y archiveros de los monasterios" ${ }^{246}$. De este y otros me dispongo a exponer su contenido a continuación.

El capítulo 24 comienza con la siguiente materia: "Para conservacion de las haziendas de los monasterios, y sus calidades, privilegios, y preeminencias, importa mucho el cuydado, y diligencia en guardar con fidelidad las escrituras en los Archivos, de donde resulta que ellos tengan todo credito, y autoridad en los Tribunales, no solo por su antiguedad sino tambien por su fidelidad, que ay en ellos" ${ }^{247}$; es decir, concede al archivo una singular importancia por su condición privilegiada para conservar documentos, los cuales deben ser auténticos para que así, en caso de ser necesario, puedan cumplir su función como garantía del patrimonio que poseían.

En el Capítulo General de 1729 se observa cómo la atención por los fondos documentales continúa. En él se escribe: “[...] que teniendo necesidad muchos monasterios de la congregación de que sus archivos se hordenasen, pusiesen con claridad y se supiese lo que en ellos se incluía [...], y que teniendo sujetos idóneos [...] fuesen llamados a las casas que tubiesen esa necesidad" 248 .

\footnotetext{
244 Constituciones, 1601, p. 153.

245 Constituciones, 1610, f. 152v.

246 Constituciones de la Congregacion de nuestro glorioso Padre San Benito de España e Inglaterra: angmentadas y añadidas con las nuevas difiniciones que desde el año de 1610 hasta el de 1701 han sido establecidas y aprobadas en diversos Capitulos y el día de oy tienen ya fuerza de leyes, recopiladas y reducidas a mejor methodo y orden por los Comissarios que la Santa Congregacion nombrò y señalò para su recopilacion, en su Capitulo General de 1701. Madrid: Oficina de la viuda de Melchor Álvarez, 1706 (= Constituciones 1701).

247 Constituciones 1701 p. 237.

248 FERNÁNDEZ FLÓREZ, José Antonio, "La Congregación benedictina de Valladolid en el siglo XVIII", en Erudición y discurso histórico: Las Instituciones Europeas. (S. XVIII-XIX). Valencia: Universidad de Valencia, 1993, pp. 101-127 (=FERNÁNDEZ FLÓREZ, La Congregación benedictina de V alladolid), p. 112.
} 
Es por esta importancia por la que los lugares elegidos para albergar el archivo debían ser seguros contra los incendios y las humedades, como ya habían advertido en 1554. Para garantizar esta seguridad, las Actas de la Congregación anteriores a las Constituciones de 1706 habían establecido que el archivo debía tener dos llaves, guardadas por dos personas distintas. Estas Constituciones establecieron reiteradamente que "[...] en el Archivo aya tres llaves, [...], de manera, que no se pueda abrir el Archivo, sin que concurran todos tres" ${ }^{\prime 249}$.

Como punto cardinal, se indica que en el Archivo de la Congregación "[...] se han de guardar sus Bulas, privilegios y papeles [...]"250; añadiendo además que "un libro Bezerro de las Constituciones, y otro de las actas" debían guardarse siempre en el monasterio, "o en el Monasterio en que se celebrara el Capitulo General, y los otros dos en la Casa en que tuviere su Archivo la Congregación: que ordenamos esté en la Casa de San Zoil de Carrión" 251 , no debe esto ser considerado como algo baladí, ya que nos indica la relevancia que sobre los otros monasterios de la Congregación ostentaba San Zoilo ${ }^{252}$. Es más, en este archivo, que tenía tres llaves como indicaba la normativa para el resto de los archivos, una de ellas estaba en posesión del monje más anciano de San Zoilo ${ }^{253}$.

Y si he dicho que el archivo era fundamental, no menos lo era la persona encargada de su ordenación y mantenimiento. El archivero, nombrado por el abad, debía ser una persona versada en letras antiguas, tal y como se indica en el caso concreto del archivo de la congregación de Valladolid, pudiéndose hacer extensible al resto de monasterios: "Del qual Archivo tendra cuydado un monge inteligente, y versado en escrituras, y papeles, que tenga titulo de Archivero de la Congregacion" "254; quien estaría además acompañado de dos ayudantes: "que en cada Casa se nombren con parecer del Consejo tres monges de inteligencia de papeles, y de mucha confianza: uno para que sea Archivero principal, y exercite el oficio; y los dos, para que a falta suya substituyan por el"255.

\footnotetext{
${ }^{249}$ Constituciones 1701, p. 238.

250 Ibidem, p. 237.

251 Ibidem, p. 59.

252 Una enumeración de los monasterios que entre 1500 y 1835 formaron parte de la Congregación de San Benito de Valladolid nos la proporciona MATÉ SADORNIL, Archivo San Benito, p. 316.

253 En la reunión del Capítulo del año 1733, se tomó la decisión a propuesta del P. Berganza de que el Archivo de la Congregación pasase de San Zoil de Carrión a San Martín de Madrid. Véase FERNÁNDEZ FLÓREZ, La Congregación benedictina de Valladolid, pp. 112-113.

254 Constituciones 1701, p. 237.

255 Ibidem, p. 238.
} 
Por último, me remitiré a señalar, a modo de enumeración, las funciones que las Constituciones atribuían al cargo de archivero ${ }^{256}$, y que se cuentan entre las más variadas de todo el monasterio, aunque todas ellas estaban destinadas a evitar consecuencias negativas derivadas de la falta de documentación alguna en caso de litigio:

a) Debía procurar el adecuado mantenimiento de los documentos, para lo cual "mandamos al Archivero trate con mucha curiosidad las escrituras del Archivo, y las que estuviesen maltratadas, y de letra antigua, o poco legible, las trasladara de buena letra, para que se puedan leer con facilidad, cuando se ofrezca la ocasión, o lo advertirá al abad para que las mande copiar, y autorizar de nuevo, para que no perezcan y se pierdan del todo" ${ }^{257}$.

b) Por ello, era fundamental que cualquier documentación expedida por el monasterio estuviera correctamente refrendada por el escribano correspondiente, indicando así que, “[...]en otorgándose qualquier escritura en el convento, el Archivero procure traerla luego al Archivo, y la ponga en la tabla, y registro; y procure que no se le pague al escrivano hasta que la dé signada" 258 .

c) Si el litigio llegaba a producirse, quedó señalado que: “[...] quando alguna escritura se presentara en algun pleyto, el procurador tenga cuydado de pedir luego a los jueces, que dexando en el pleyto un traslado autorizado [...] se buelva el registro original, para ponerle en el Archivo"259. Además, los abades serían castigados durante un año si las escrituras originales no eran devueltas al monasterio en un plazo de tiempo establecido previamente.

\footnotetext{
${ }^{256}$ El padre Martín Sarmiento, uno de los grandes eruditos de la Congregación benedictina del siglo XVIII, señalaba como el cargo de archivero debía ser uno de los más importantes del monasterio, incluso más que el de abad porque "[...] Abad puede serlo cualquiera, pero para archivero se necesitan prendas singulares [...]". Esta carta ha sido publicada en C. TORRES RODRÍGUEZ, "El P. Sarmiento como archivero y diplomático": Cuadernos de Estudios Gallegos, XXVII, 81-83 (1972), pp. 104-121, especialmente 116-118.

GÓMEZ GÓMEZ, Margarita, "Crítica histórica y archivos. El caso de España en el siglo XVIII”: Historia. Instituciones. Documentos, 12 (1985), pp. 199-232, especialmente pp. 211-214, expone detalladamente el pensamiento archivístico del Padre Sarmiento e informa de la existencia de numerosos estudios sobre archivos realizados por él aún inéditos, destacando su obra Cualidades de un arcbivero.

${ }^{257}$ Constituciones 1701, 238.

${ }^{258}$ Ibidem, p. 238.

${ }^{259} \mathrm{Ibidem}, \mathrm{p} .238$.
} 
d) El archivero debe hacer relación ante el Consejo de "las escrituras que se han otorgado, y no se han traydo al Archivo, y de las que se an sacado, y no se han buelto" 260

e) Y para poder realizar esta relación, el Archivero debía llevar un registro preciso mediante "un libro en blanco, en el qual, el que llevare escritura del Archivo, dexe conocimiento de la escritura que lleva" ${ }^{261}$, indicando ante quién y cuándo se otorgó, para qué se necesitó, cuándo se sacaba y ante qué escribano se había de mostrar; todo ello debía hacerse con la licencia del abad.

f) Otra de las funciones que ostentaba el archivero era la de cronista del monasterio, pues era el encargado de redactar el llamado Dietario, "un libro [...] que sea como historia de los sucessos del monasterio" 262 , en el que se ha de incluir el fundador del monasterio, cuándo se fundó, qué mercedes han recibido de los reyes y de los pontífices, los abades del monasterio, las personas memorables, y los sucesos y generales de la congregación, qué personas toman el hábito y quién es nombrado abad, etc.

g) Debía asegurarse de que quedasen registradas como testimonio las visitas pasadas, que "aunque [...] no ayan de obligar a guardarse, no se rompan, ni borren; sino guárdense los libros dellas en el Archivo para memoria"263, reflejándose en lo que se conocen como Libros de Visitas.

h) Era otra de sus competencias la custodia de los Libros de Gradas con los nombres y las cartas de profesión de los monjes que tomaban el hábito, es decir, "[...] que aya, en cada Casa, un Libro Bezerro, en que el novicio escriva la forma de la profession [...] este libro se guardara siempre en el Archivo"264.

No se puede dejar pasar por alto, por la íntima relación que lo une a este trabajo, una de las premisas clave y que, por la claridad y exactitud conque sólo los mismos redactores de las Constituciones fueron capaces de explicitar, cito a continuación textualmente: "El Archivero ha de tener hecha una tabla, o índice en un libro por el orden

\footnotetext{
260 Ibidem, p. 239.

261 Ibidem, p. 239.

262 Ibidem, p. 239.

263 Ibidem, p. 125.

264 Ibidem, p. 179.
} 
del Alphabeto, de todas las escrituras del Archivo, dividido por los partidos, Iglesias, y jurisdicciones donde el Monasterio tiene sus haziendas. Y en este libro ha de estar escrito por mayor lo que contiene cada escritura, y en qué caxón, o parte del Archivo está, para que con facilidad se halle la escritura que se buscare. Y en dicho Alphabeto ha de poner el día, mes y año en que se otorgo la escritura, y ante que escribano paso"265.

Efectivamente, el Índice de San Zoilo responde en su mayor parte a esta estructura, así dictada en las Constituciones pero no sólo en ellas, como podrá comprobarse a continuación.

\subsection{La imagen del archivo de San Zoilo de Carrión a través del Índice}

\subsubsection{El problema de la terminología}

Como anticipamos al ocuparnos de todo lo que incumbe al concepto de archivo, una de las más valiosas posesiones del monasterio, era de suma prioridad para el monasterio elaborar un registro que certificara la existencia de los documentos que se guardaban en él, y permitiera la localización en el mismo de los diplomas, expedientes y procesos conservados y el acceso a la información que contenían. Ese preciado "obsequio", así llamado por el General Fray José Balboa ${ }^{266}$, se convertiría en un libro único que facilitaría la comprensión de la formación y administración del patrimonio (y por tanto del archivo) monacal en su conjunto a través de concisas regestas de sus documentos, así como en un instrumento clave para la localización y el uso de las escrituras por sus constantes referencias a la ubicación de los diplomas originales en el archivo.

No obstante, la multiplicidad y complejidad de este tipo de registros, surgidos de forma sistemática a raíz de las sucesivas disposiciones adoptadas por las Constituciones de San Benito desde el siglo XVII, puede provocar que en ocasiones nos resulte complicado

\footnotetext{
265 Ibidem, p. 238.

266 En 1731, Fray José Balboa, General de la Congregación de San Benito, muestra su preocupación por la formación intelectual de los monasterios benedictinos instándoles a centrar sus tareas en la lectura y la escritura, para soslayar la decadencia que venía siendo causada por la falta de estudio en algunos cenobios. En ella, dejaba en evidencia su interés por la protección de los archivos al expresar que "el único obsequio que pueden hacerme y que recibiré como especial es un índice exacto de lo que contienen los archivos". ZARAGOZA PASCUAL, Ernesto, Los Generales de la Congregación de San Benito de Valladolid. Tomo V. Abadía de Silos, 1984, p. 359.

La epístola en que se contiene aquella preocupación forma parte de un corpus de 33 cartas acordadas, escritas por diversos Generales de la Congregación en el siglo XVII y XVIII y que eran enviadas a los abades y monjes de los monasterios para comunicarles algunas de las disposiciones tomadas en el Capítulo General. Han sido publicadas por ZARAGOZA PASCUAL, Ernesto, Los Generales de la Congregación de San Benito de Valladolid. Tomo IV, Abadía de Silos, 1982; ZARAGOZA PASCUAL, Ernesto, Los Generales de la Congregación de San Benito de V alladolid. Tomo V, pp. 277-448.
} 
intuir su verdadero contenido y función, al conocer únicamente el nombre que a dicho instrumento le otorgó su propio autor, nesciente aún de lo que pudiera ser un tratamiento archivístico científico de los documentos, pero no de la conciencia archivística para reconocer la necesidad de conservar y organizar los documentos del archivo para poder administrar mejor el patrimonio y defenderlo. Será necesario, entonces, conocer y perfilar no sólo una definición adecuada al respecto, sino también ahondar en las diferencias existentes entre este tipo de índices y otros instrumentos de referencia y consulta ${ }^{267}$, a priori similares.

Empezamos así remitiendo a las definiciones que el DRAE nos ofrece y que, si bien no se ajustan al contexto archivístico en que deben ser tenidas en cuenta, sí permiten realizar una discriminación inicial válida.

De esta manera, encontramos que la tercera acepción del término Índice es la de "catálogo de las obras conservadas en una biblioteca, archivo, etc., clasificadas según diversos criterios". Cabría en nuestro caso particular descartar de esta definición lo relativo a obras de biblioteca y ampliarla con la que en el DRAE figura como palabra análoga a índice, es decir: Repertorio, que define como un "libro abreviado, índice o registro en que sucintamente se hace mención de cosas notables y otras informaciones, remitiéndose a lo que se expresa más latamente en otros escritos"; pudiendo ser estos otros escritos los documentos del archivo y el archivo en sí mismo.

Sin embargo esto no completa el auténtico significado que el repertorio o índice posee para la Archivística, donde podemos establecer una clara diferencia entre esta definición genérica y la que aquí pretendemos ofrecer. $\mathrm{Y}$ es que, como decíamos anteriormente, no cabe aquí alusión a biblioteca o colección alguna, pues estas le confieren un carácter de independencia y aleatoriedad inconveniente en nuestro contexto archivístico. Así, el repertorio no es sólo una obra localizadora, que proporciona las coordenadas por las que guiarse en el archivo de referencia, sino que además debe seguir un sistema determinado de organización de la información. Y, ya que los documentos de un archivo no pueden entenderse fuera del conjunto orgánico del que forman parte, el índice que los recoge debe también reflejar su organización, fruto del criterio primero a seguir: el concepto administrativo-patrimonial de archivo y la clasificación que resulta de su aplicación.

\footnotetext{
${ }^{267}$ Consúltense el Diccionario de terminología archivística ( $2^{a}$ ed.). Madrid: Subdirección de General de los Archivos Estatales, 1995, los términos "instrumento de consulta", "instrumento de control", "instrumento de descripción" e "instrumento de referencia"; aunque los dos últimos ya queden comprendidos en el primero.
} 
Atendamos entonces a una pregunta emergente, que puede surgir de lo anteriormente expuesto: ¿puede el índice tenerse en cuenta, entonces, como un inventario, o inclusive, como un catálogo? La respuesta a esta pregunta debe pasar necesariamente por las definiciones ofrecidas por el Diccionario de Terminología Archivística, pues sólo a partir de ellas es posible comprender el carácter que posee este Índice de San Zoilo.

Así, mientras se tiene en cuenta al inventario como un "instrumento de referencia que describe las series documentales de un fondo, siguiendo su organización” y al cual se le atribuye la función de "recoger, imprescindiblemente, una introducción histórica explicativa de la evolución del organismo productor de los documentos y el cuadro de clasificación del fondo descrito", así como "la signatura de la unidad de instalación, el nombre de la serie y las fechas que comprende"; el catálogo debe "informar sobre una materia u objeto específico" y describir "unidades documentales relacionadas por su autor en razón de una afinidad temática, cronológica, paleográfica o formal o por otro criterio subjetivo establecido de antemano".

Dejando a un lado las numerosas diferencias que separan ambos conceptos ${ }^{268}$, es posible reconocer desde un primer momento que la definición actual de catálogo no se ajusta al concepto que buscamos. En un catálogo el autor es libre de elegir los documentos que él valore primordiales dentro del bloque de afinidad designado, discriminando aquellos menos relevantes ${ }^{269}$; algo que no ocurre en el Índice que nos ocupa, en el que obligatoriamente se describió todo el archivo monástico ${ }^{270}$, entendiéndose así el carácter objetivo que prevaleció en su elaboración.

En cuanto a la definición actual de inventario, baste con afirmar que el Índice de San Zoilo no posee "introducción histórica explicativa de la evolución del organismo productor o cuadro de clasificación del fondo descrito" alguno; y si ambos le resultan

\footnotetext{
268 Un estudio en profundidad al respecto puede encontrarse en HEREDIA HERRERA, Antonia, "Archivística. Inventarios y catálogos": Revista $A N A B A D, 2$ (1980), pp. 239-242.

269 Podemos leer en RODRÍGUEZ DE DIEGO, El Tumbo de La Espina, p. 167: "Existen finalmente unos índices que bien merecen el calificativo de catálogos documentales, [...] brevísima regesta de los principales documentos existentes en el Archivo. Hernando de Aedo seleccionó, entre la gran masa documental, aquellas escrituras que por razón de su origen [...] o de su negocio jurídico [...] merecían un puesto especial en el Tumbo $[\ldots] "$.

${ }^{270}$ En el Índice encontramos numerosas alusiones que ponen en evidencia el grado de representatividad respecto a su archivo de referencia. A este respecto, es visible el hecho de que no se limita a registrar aquellas escrituras que pudieran serle de utilidad para la defensa de su patrimonio o la obtención de rentas, sino también aquellas que, en palabras del propio autor "sólo sirven de memoria" o "no sirven más que de memoria"; dando noticia incluso de papeles que "[...] no se entienden por menor, por ser de poca importancia y de ninguna authoridad" y de la existencia de un legajo dedicado exclusivamente a los censos ya redimidos por el monasterio. AHPP, legajo 112, f.2v; f. 28v; f. 456r.
} 
imprescindibles al inventario ${ }^{271}$ actual para ser considerado como tal, no puede nuestro índice entrar en esta clasificación.

Sin embargo, la realidad es que en el momento de redacción tanto de este como de muchos otros instrumentos de descripción, no existía terminología archivística alguna que pudiera calificarse de científica ${ }^{272}$, y la línea de separación entre cada instrumento enumerado se tornaba mucho más débil y difusa de lo que es a día de hoy. Considero que si bien existe una clara diferenciación entre lo que actualmente se consigue inventariando y realizando un índice, en el siglo XIX dicha diferencia no existía como tal, y probablemente lo que hicieron fue un inventario de la época, y que el calificativo de "Índice" le fue dado quizá de manera ajena a su propósito final273; cabe conjeturar incluso la posibilidad de que fuera nombrado así simplemente por ser la manera en que quedaba recogido en las Constituciones $^{274}$.

271 (DE LA CRUZ HERRANZ, “El archivo monástico”), pp. 184-185, redunda en la existencia, desde el siglo XIII, de inventarios destinados a recoger aquellos documentos imprescindibles considerándolos como "inventarios selectivos", ahondando así en la imposibilidad de utilizar "la terminología archivística actual para referirse a épocas pretéritas, desvirtuando completamente su significado al emplearla en un contexto histórico diferente".

272 Como ya hemos indicado, los primeros teóricos del principio de procedencia fueron los alemanes Müller, Feith y Fruin en 1898, fecha posterior a la redacción del Índice de San Zoilo. Del mismo modo, el antiguo Reglamento de archivos de 22 de noviembre de 1901 engloba bajo la denominación de "catálogo" todo instrumento de labor y descripción de fondos archivísticos.

273 Podemos observar el uso casi indistinto entre los términos inventario e indice en GUTIÉRREZ DEL ARROYO DE VÁZQUEZ DE PARGA, Consuelo, Privilegios reales de la Orden de Santiago en la Edad Media: Catálogo de la serie existente en el Archivo Histórico Nacional. Madrid: Junta Técnica de Archivos, Bibliotecas y Museos, p. 22. Indica cómo Fernando VI, en 1751, pide al prior del Convento de Uclés, de la Orden de Santiago, que informe sobre el estado del archivo y lleve a cabo un inventario, a lo que el prior responde que la tarea de redactar los indices es larga.

${ }^{274}$ Esta afirmación se sustenta en el hecho de que en el propio códice encontramos referencias relativas a la existencia de otros "índices" dentro del propio archivo, también señalados como "tablas" a modo de listas de lo que algunos libros indizados acopian; los cuales, estarían en consonancia con el significado del vocablo índice que más se maneja en la actualidad. Traemos aquí, las acepciones que, a este respecto, nos proporcionan tanto el DRAE como el Diccionario de Terminología Archivística, definiéndolo el primero como "[en un libro u otra publicación], lista ordenada de los capítulos, artículos, materias, voces, etc., en él contenidos, con indicación del lugar donde aparecen"; y como "instrumento de referencia formado por encabezamientos onomásticos, toponímicos, cronológicos y de conceptos contenidos tanto en los propios documentos como en los instrumentos de referencia y descripción”, el segundo.

Así, observamos alusiones a un "Quaderno de escrituras y apeos [...] con algunos otros papeles sustanciales, como se ve al principio dél, en un especie de índice que tienen”" (AHPP, Legajo 112, f. 387r, n. ${ }^{\circ}$ 15); "un quaderno de escrituras de compras de tierras, viñas, cuebas y trueques de unas viñas por otras [...]. Véase el índice que trae al principio y al último del dicho quaderno, en que hace relación de todo lo contenido en él y con distinción" (AHPP, Legajo 112, f. 423r, n. ${ }^{\circ}$ 21); así como a los libros de apeos recogidos en el Cajón 20, casi la mayoría de los cuales vienen acompañados de "el índice de este libro, que está al principio", "el índice o tabla de lo que contiene", "el índice de lo que contiene", "diversos lugares, los quales se hallan anotados en el forro de este libro, en forma de índice", "véase el índice que trahe al principio" (AHPP, Legajo 112, ff. $357 \mathrm{v}-458 \mathrm{v})$.

La variedad de estas referencias nos indica la posible utilización del término "índice" como un vocablo genérico para designar a aquellos "instrumentos de consulta" que se producían en el mismo archivo para facilitar el control y la adecuada localización de la información recogida en cada uno de estos libros. 
Si alguna relación cabe señalar, entonces, no es con un catálogo, como a priori podría parecerlo, entre otras razones porque en este se dejan fuera de la descripción algunos documentos (circunstancia esta que es impropia en un inventario). El catálogo además ordena la documentación descrita según un orden cronológico o alfabético, sin necesidad de una previa y primera organización de los documentos descritos en grupos que se forman en función de su pertenencia a una misma tipología, un mismo lugar o institución. En el catálogo, en definitiva, no es visible a simple vista (como lo es en el inventario y en el Índice), la organización (clasificación y ordenación) de los documentos. El Índice describe documentos y también los catálogos, pero estos frente a aquel no permiten ver la relación entre los documentos (simples o compuestos) que describen y los grupos documentales superiores, llámense como se llamen: cajones, legajos, cuadernos o en la terminología actual (y sin que se correspondan con los referidos): fondos, secciones, series. Una función similar a la del Índice es asimismo la del repertorio, aunque en este se puedan describir los documentos de manera más somera, pues permite el acceso a la información que los documentos contenían sí, pero sobre todo su localización en el $\operatorname{archivo}^{275}$.

\subsubsection{La organización de los documentos en el Índice de San Zoilo de Carrión.}

Pasamos ahora a ocuparnos de la cuestión de la estructura y organización y ordenación de los documentos descritos en nuestro manuscrito. Estructura que es deudora y está claramente condicionada por la propia organización del archivo del monasterio y del concepto administrativo-patrimonial que del mismo tenía, lo que hacía más fácil la gestión de las propiedades monásticas y su defensa. De ahí que el Índice sea, al modo en que pueden serlo hoy, y salvando las distancias, los cuadros de clasificación, fiel reflejo de la organización del archivo que representaba ${ }^{276}$, y sea por ello un instrumento de consulta y de control -una herramienta documental para el monje archivero- que facilitara el conocimiento y localización de la documentación descrita.

La organización del Índice, que refleja tanto el respeto a la individualización de los documentos (y archivos) de cada una de las instituciones que tuvieron entidad propia hasta su incorporación a San Zoilo como la dependencia jerárquica de unos grupos de

${ }^{275}$ HERRERO JIMÉNEZ, Mauricio, “Una llave para el tesoro de la catedral de León”, en RODRÍGUEZ DÍAZ, Elena-GARCÍA MARTÍNEZ, Antonio Claret (coords.), La escritura de la memoria: los cartularios, 2011, pp. 197-216.

276 Circunstancia que demuestra la inclusión en el mismo de algunos legajos producidos por el devenir de asuntos básicamente espirituales y librarios. 
documentos menores sobre otros mayores, se articula en torno a 27 cajones, cada uno de ellos identificado con el nombre de un santo vinculado a la tradición benedictina. Los cajones se dividen en legajos, y estos a su vez en cuadernos ${ }^{277}$, designados con las letras del alfabeto (ordenados de acuerdo a un orden alfabético-topográfico o a otro tipológicodiplomáticos, como veremos), y en los cuales se ordenan los asientos con las descripciones de los documentos, en un segundo nivel, a partir de elementos cronológicos ${ }^{278}$.

Atendiendo al criterio topográfico de organización, el Índice referencia aquellos lugares donde el monasterio tenía propiedades, jurisdicciones y derechos que se traducían en forma de diezmos, censos, juros, tercias, derechos de presentación y otros privilegios; patrimonio y derechos que el monasterio había ido acumulando por las donaciones de la realeza y otras muchas ofrendas de la nobleza, pero también por compras y permutas. Todo ello sin obviar la innegable realidad de que muchas de las pertenencias que pasaron a estar bajo su influencia lo hicieron como consecuencia de la anexión al cenobio de los prioratos de los que estos lugares eran dependientes.

Así pues, en la clasificación y ordenación de los documentos en el Índice (y por tanto en el archivo) se alterna la identificación de tipos diplomáticos concretos con la organización de la documentación en grupos mayores que resultan de la reunión de documentos provenientes de un lugar concreto o de una institución anexionada a San Zoilo, en cuyo caso se diferencian grupos de documentos no solo a partir de una tipología concreta (cartas de pago, por ejemplo) sino a partir del reconocimiento de funciones diferentes (hacienda, iglesia...). Ello permite reconocer archivos diferentes, procedencias diversas, anexiones, en definitiva, de prioratos distintos (cada uno con sus documentos); pero también controlar los documentos que testimonian la propiedad en los diferentes lugares en los que San Zoilo tenía posesiones, privilegios, derechos, y facilitar de esta forma la guarda y gestión de tales posesiones. El Índice resulta ser así fiel reflejo del concepto administrativo-patrimonial del archivo.

\footnotetext{
277 Señala Rodríguez de Diego que el archivo del monasterio de La Espina estaba organizado siguiendo el modelo comúnmente utilizado en aquella época: “[...] los documentos, numerados, se introducían en fajas o envoltorios y estos, a su vez, en cajones”. RODRÍGUEZ DE DIEGO, El Tumbo de La Espina, p. 166.

278 Tanto la enumeración de los asientos como la ordenación cronológica es individual para cada uno de los cuadernos. Sin embargo, sobre cada uno de los números, se observa la intromisión de otra numeración ajena a la original y manuscrita con posterioridad a bolígrafo, y que no es individual para cada asiento sino continua a través de los cajones. PALACIO, Colección San Zoil. I, explica que hasta el folio 465 se registraron 3048 documentos, siendo este el último número que aparece escrito a bolígrafo en el Índice. En realidad hasta el folio 471 se registraron 3088 documentos. Cifra concreta que conocemos por la base de datos que hemos creado para la realización de la Tesis Doctoral. Resulta indispensable señalar, que este número no se corresponde con el número de asientos, puesto que en ocasiones el autor inclúa bajo un mismo enunciado más de un documento, bien porque todos pertenecían a una misma causa o asunto o bien porque estos estaban recogidos en el archivo formando parte de una misma carpeta o cuadernillo. Por ello el número de registros se acerca a los 3.100 .
} 
Los cajones 1 hasta el 18 recogen la documentación que corresponde a los diferentes lugares donde San Zoilo tenía propiedades, ordenada según criterios alfabéticotopográficos, comenzando por Aguilar de Campos y terminando por Villaverde de Golpejera, así como la documentación de prioratos anexionados y tipos diplomáticos del archivo que fue propio del monasterio de San Zoilo. Los cajones 19 a 27, que, según el propio Índice, eran aquellos "donde comienzan las cosas comunes" documentación variada, cada uno de ellos relacionado con un tipo determinado: juros, apeos, censos, bulas y cédulas reales, escrituras de arriendo, libros de gradas e informaciones de monjes y legos, libros antiguos y curiosos, tazmías y cartas de pago. En alguno de estos, como es el caso del 20 (apeos) y del 21 (censos), la documentación era tan voluminosa que se ordenó de acuerdo a criterios alfabético-topográficos: censos de Abastas, Añozas, Arconada, etc.

Cada cajón se inicia con un breve esquema de los legajos que contiene; en cada legajo, los cuadernos que lo forman; y en cada cuaderno, una breve indicación de su contenido, siguiendo a continuación la regesta de los documentos existentes en cada una de esas partes en las que se divide físicamente el archivo.

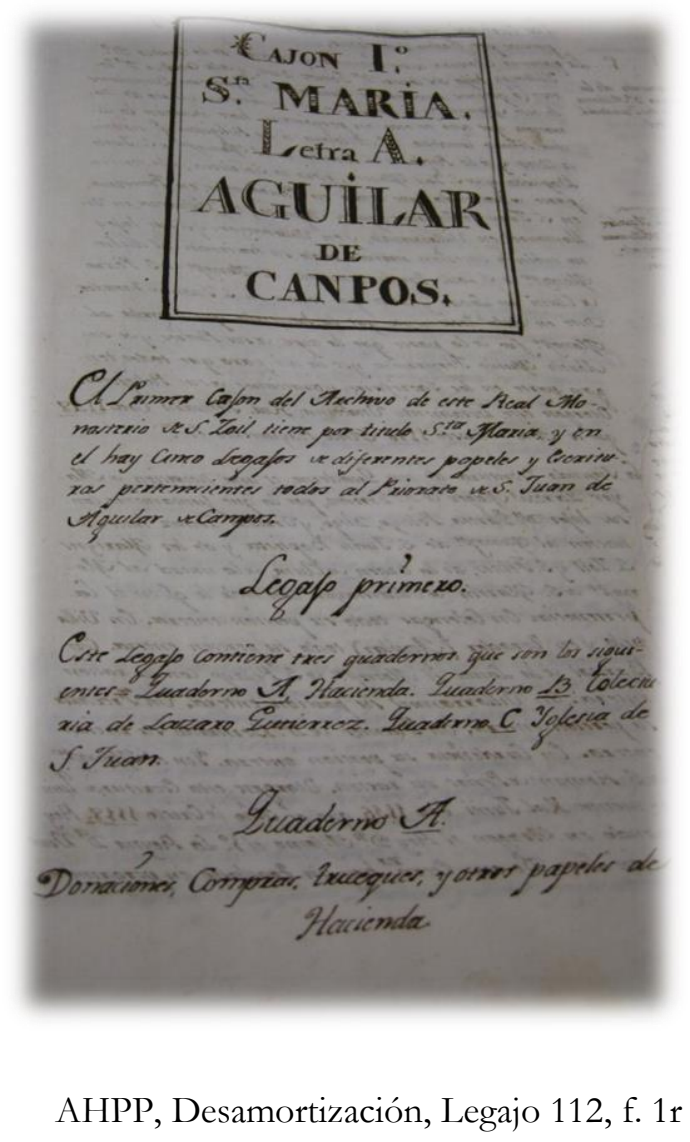

279 AHPP, Desamortización, Legajo 112, f. 454r. 
Esta organización y ordenación de los documentos que reflejan el concepto de archivo tiene otros objetos: favorecer la conservación de los documentos y posibilitar la localización de los mismos en el archivo. Se hace preciso, por tanto, que la información del Índice sobre cuadernos, legajos y cajones no solo nos lleve al documento, sino que en este último, en su verso, se anote una cota o anotación archivística idéntica a la que se escribe en el Índice cuando se resume el contenido del documento. De otra manera, toda esta clasificación y ordenación resultaría trivial y no tendría ningún efecto, ningún sentido en lo que a la localización de los diplomas en el archivo se refiere. Ya desde los inicios de la actividad escrituraria, y en algunos casos de manera casi sincrónica a la redacción de los documentos, pero sobre todo cuando a partir del siglo XIII la acumulación documental es mayor, los monjes acostumbraban a incluir en el reverso de los diplomas un breve resumen del tenor documental ${ }^{280}$; tarea que se fue consolidando y perfeccionando a la par que lo hacía el empeño y la entrega en la organización y custodia del archivo monástico, al incluir junto a ese resumen o extracto, las "coordenadas" exactas que indicaban la localización del mismo dentro del archivo y que, como no podía ser de otra manera, guarda, como hemos dicho, su correspondencia con el cajón que ocupaba dentro del Índice de San Zoilo en el momento en que este se escribió. Pero esas mismas anotaciones nos informan de organizaciones o reorganizaciones anteriores.

Ofrecemos aquí, por el grado de representatividad respecto a esta cuestión, la concordancia entre las notas y noticias de tres documentos que se conservan en el Colegio de San Estanislao de Salamanca ${ }^{281}$ y la descripciones de esos documentos en el Índice ${ }^{282}$, en el cuaderno A, del legajo 3ㅜㄹ cajón San Gregorio, haciendo mención a las posesiones del monasterio en Villafrechós.

En el verso de los documentos hallamos diferentes notas y noticias, regestos realizados en diferentes épocas, con diferentes tipos de letras, con pérdida de la cota más antigua de localización; pero con la nota de localización coetánea a la realización del Índice, la cota más reciente, bien visible e idéntica a la que aparece en el manuscrito que nos ocupa, con referencia exacta a su localización en un cajón, legajo, cuaderno y número concreto, lo que confirma que a la vez que se realizaba el Índice o por ello, se ordenó la documentación en el archivo. A esas noticias de archivo les acompaña información sobre la data

\footnotetext{
280 PALACIO, Colección San Zoil. I, p. 571. La autora nos informa que algunas de estas anotaciones incluían además interesantes informaciones acerca del estado en que se encontraban las posesiones mencionadas en el documento. Además nos refiere algunas de las cotas de localización que portan los diplomas conservados hoy en el Archivo Histórico Nacional, pp. 619 y 620, nota 20.

281 Colegio de San Estanislao (Salamanca), Archivadores del Fondo Antiguo, Sala 2, Caja 11.

282 AHPP, Desamortización, Legajo 112, f. 359r.
} 
-expresando la era y el año-, el lugar al cual concierne el documento y el asunto que se extracta o resume.

Lo que se escribe en el dorso de uno de los documentos del Colegio de San Estanislao es lo que sigue:

“Era 1222, año 1184. Villafrechós. Cauañas. Priuillegio del rrey D. Fernando $2^{\circ}$. Concede dos Iglesias en Villafrechós, [San Cristóbal y San Pelayo], y vasallos y hazienda en Cauañas. Quaderno A, Legajo 3, Cajón San Gregorio". "Murió el rrey don Fernando en Benauente, año de 1188" (puede observarse cómo la letra A, el número 3 y la palabra Gregorio fueron escritos en el siglo XVIII, mientras que el resumen se hizo en el siglo XVI).

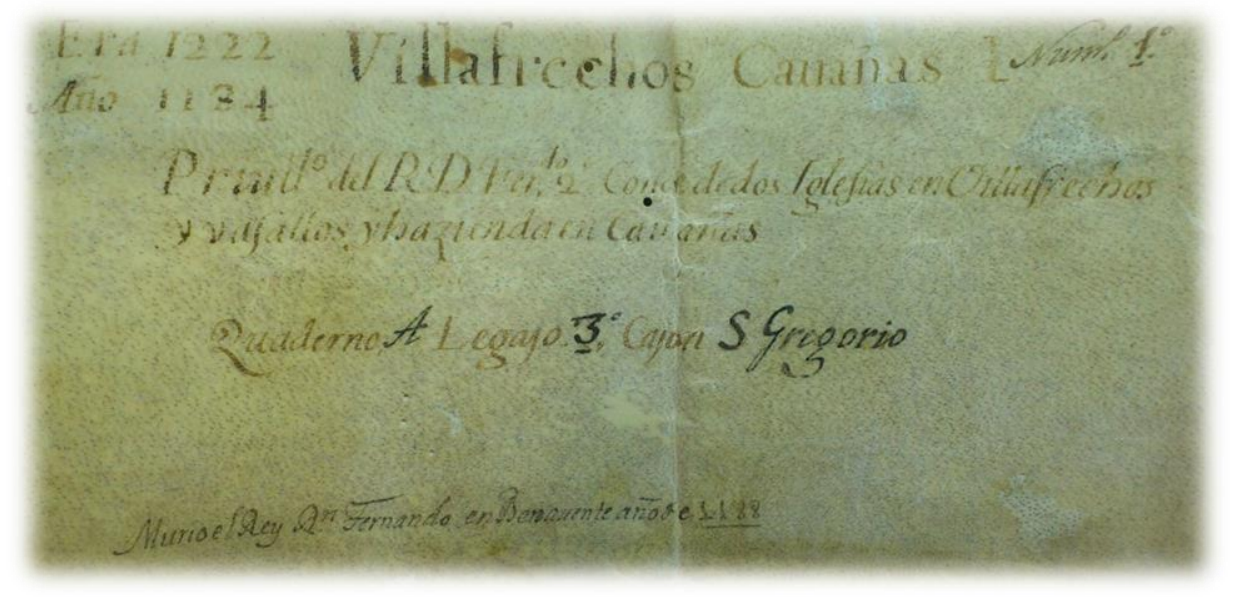

En el Índice se describió:

“1 ${ }^{\circ}$. <Privilegio del rey don Fernando el 2o. Era 1222. Año 1184>.

Privilegio del rey don Fernando el $2^{\circ}$, hermano del rey don Sancho el Deseado, hijo del rey don Alonso el $8^{\circ}$ (sic) llamado el Emperador, por el qual dice que, para la seguridad, fortaleza y defensa de su reyno, toma para sí toda la heredad que el monasterio de San Zoil tinía (sic) en Villafructuoso (ahora Villafrechós), la qual dio a los pobladores de aquella villa quando la pobló, excepto dos yugadas de tierras, quanto pudiesen arar para un año dos yugadas de bueyes, y excepto todas las viñas que tenía Estevan, procurador de la casa de San Salvador en su palacio quando el rey tomó esta hacienda, y tres huertas, todas las herrenes y una hera. Y en trueque da al monasterio dos yglesias en la dicha villa, que son la de San Christóval y la de San Pelayo, con sus viñas, heredades y parroquianos, con todo lo que les pertenece por derecho, y todas las demás yglesias que adelante se fundasen en la dicha villa, fuera de la yglesia del obispo, quæ venit cum parrochianis suis de Coreses. La qual / (f. 358v) manda que no reciva ningún parroquiano de las demás yglesias de los monges. Y para que esto sea firme y se guarde invi $<_{0}>$ lablemente, manda que se confirme por el obispo y cavildo y que se selle con su sello. Concede también que los monges posean perpetuamente juro hereditario todos los solares que el rey tenía y había dado a los vasallos que el monasterio tenía en el lugar de Cabañas, los quales havían venido a poblar a 
Villafrechós, y de allí adelante ser ayan y quiten del derecho real, y los monges tengan en tales solares el mismo servicio que en lo demás que tenían en Cabañas y tengan en ellos todo servicio, sumazga (sic) y pedido enteramente, y los monges hayan y cobren por su merino la mitad de los derechos que allí tenía el rey de pedidos, fonsecas (sic) y calumnias. Y si los vasallos que allí tuviere el monasterio no le quisieren servir y acudir como a sus señores con el pan, vino, pedidos y otros servicios, los monges tengan poder para quitarles los préstamos y darlos a quien quisieren. Manda que el concejo de Villafrechós no haga violencia alguna a los monges en las cosas que fueren necesarias para sus yglesias, si conforme al tiempo y posibilidad ellos las administraren. Concede que los capellanes y clérigos de los monges, los hombres de su palacio y los que se les hubieren encomendado por familiares, sean libres de todo derecho de concejo, de castillo, pedido, pecho y de toda hacienda, así del concejo como del rey. Y que la yglesia de San Lorenzo de Cabañas se haga en Villafrechós en buen lugar; y las yglesias de Santa María, que es de los herederos, y la del Obispo, les da una sentencia: que miren los sacerdotes de ellas no embían sus hombres por las heras y lagares a cobrar los diezmos de los monges; que se den 20 obradas de bueyes al señor que fuere del lugar o a quien tuviere la voz del rey, y los que dieren y los que recivieren vuelban doblado a los monges lo que tomaren de los muertos, de las ofrendas de diezmos y primicias y de qualquiera otra cosa que sea del derecho de la yglesia. Si en este trueque los monges recivieren alguna mejora, el rey se lo concede por remedio de su alma y la de sus padres y parientes. Concede que si en la población de Villafrechós reciviere algún disgusto, recivan los monges enteramente todas las heredades que tenían en Villafrechós y sus vasallos de Cabañas vuelvan a su lugar, y las yglesias / (f. 359r) de Villafrechós queden al derecho del rey. Prohive que los préstamos de Cabañas los tengan otros sino los vasallos de este monasterio y que no los puedan dividir si no fuere con voluntad de los monges. Las mejoras que dice el rey que hace a los monges son: que embíen por merino a sus vasallos de Cabañas a quien quisieren y sea merino todo el tiempo que los hombres quisieren; yten que ninguno de Cabañas tenga sino sólo un préstamo de 20 obradas de bueyes, y les manda que no vendan ni empeñen las tierras ni viñas de sus préstamos, ni tengan préstamo de que no den un par de bueyes para la serna. Facta carta en Zamora, VII kalendas novembris, era 1222 que es año de Christo de 1184. Este privilegio está escrito en pergamino, con sello de cera pendiente en correas de cuero y forrado en pergamino.

Hay copia traducida por don Antonio Fernández de Guzmán, nottario appostólico".

En el dorso del segundo de los documentos del Colegio de San Estanislao se resumió:

“Era 1226, año 1188. Villafrechos. Cauañas. Número 2․ Priuilegio del rrey D. Alonso el $9^{\circ}$, en que confirma la donación o cambio que el rrey D. Fernando el $2^{\circ}$ hizo al monasterio de San Zoyl de dos iglesias de Villafrechós: S. Saluador y S. Pelayo y ciertos en Cauañas, que auían sido del monasterio". Quaderno A, Legajo 3, Cajón San Gregorio" (puede observarse cómo la letra A, el número 3 y la palabra Gregorio fueron escritos en el siglo XVIII, mientras que el resumen se hizo en el siglo XVI). 


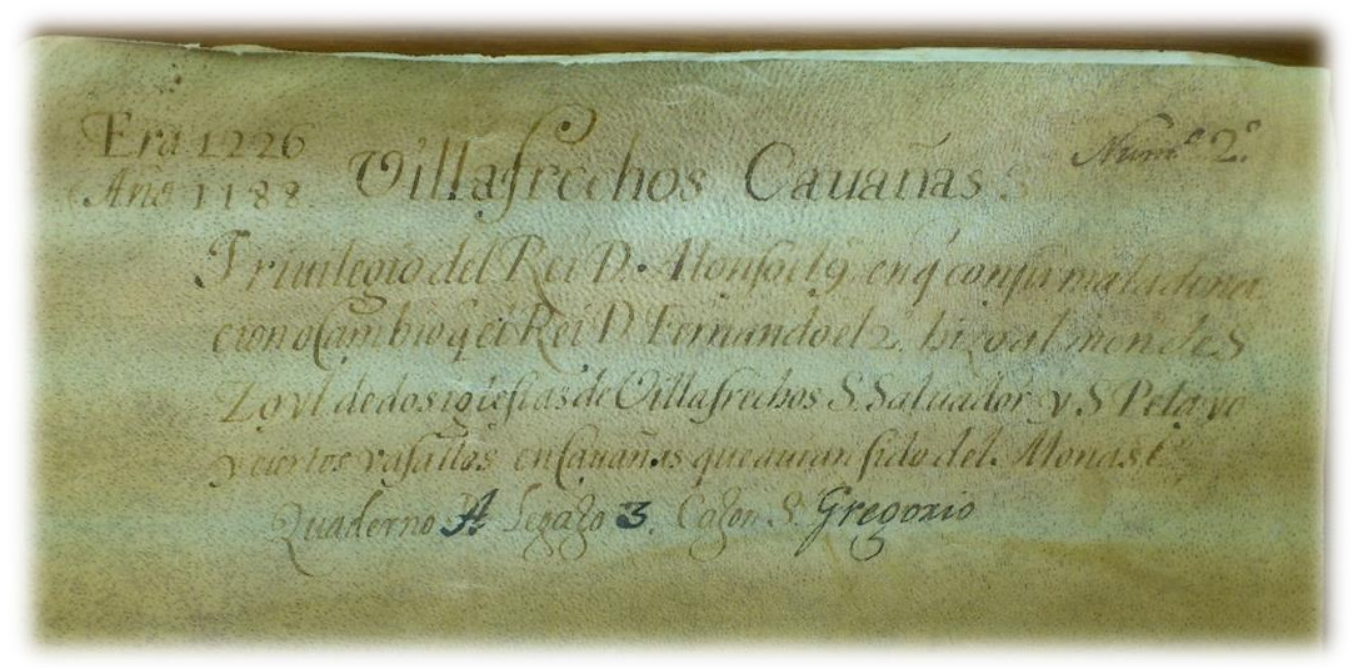

En el reverso del mismo documento, en el propio siglo XVI se añadió además otro resumen:

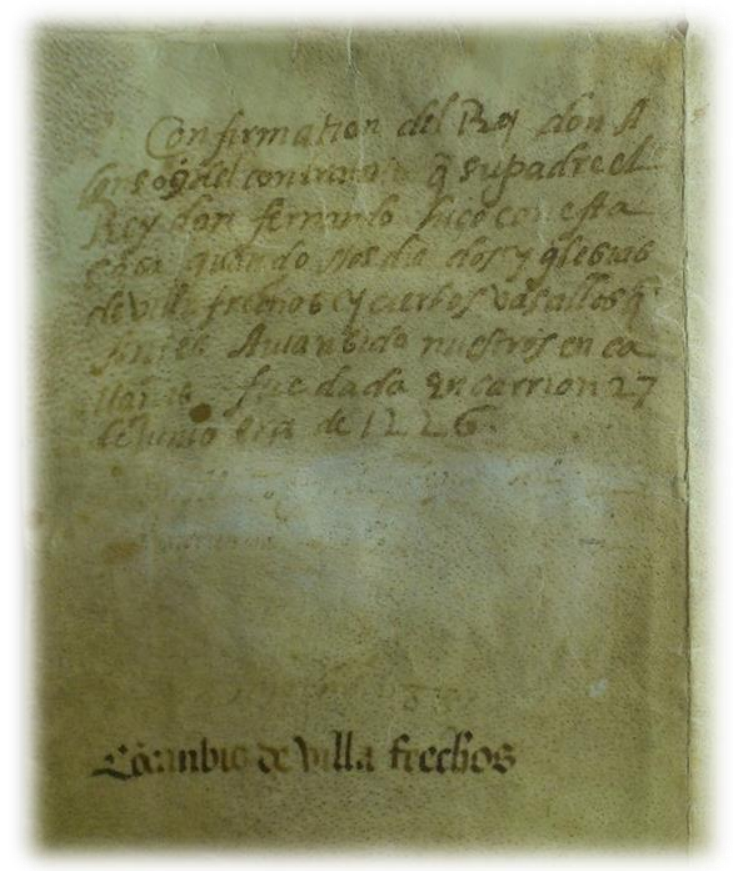

\begin{abstract}
"Confirmatión del rrey don Alonso $9^{\circ}$ del contrato que su padre, el rrey don Fernando, hiço con esta casa, quando nos dio dos iglesias de Villafrechós y ciertos vasallos que antes auían sido nuestros en Cauañas. Fue dada en Carrión, 27 de junio, era de 1226". "Can(n)bio de Villafrechós" (siglo XVI)
\end{abstract}

En el Índice se escribe:

“2 ${ }^{\circ}$. < Privilegio del rey don Alonso el $9^{\circ}$. Era 1226. Año 1188>.

Privilegio original del rey don Alonso el $9^{\circ}$, escrito en pergamino, con sello de cera pendiente en filos de seda de varios colores y forrado en pergamino, por el qual confirma el privilegio pasado del rey don Fernando el $2^{\circ}$, su padre, a Humberto, prior de San Zoil y camarero de Cluni, y a los monges y convento de San Zoil. Está en latín y refiere en relación todo lo contenido en él. Fecho en Carrión, V kalendas iullii, era 1226, que es año 1188”. 
En el tercer documento del Colegio de San Estanislao se resumió:

“Era 1234, año 1196. Villafrechós. Número 5. Priuillegio del rrey D. Alonso el $8^{\circ}$, en que concede al m[onasterio] las tercias de todas las Iglesias de Villafrechós, [saluo] una del obispo de León y otra de los Templarios. Quaderno A, Legajo 3, Cajón San Gregorio". "San Zoil" (puede observarse cómo la letra A, y la frase "Legajo 3, Cajón S. Gregorio" fueron escritos en el siglo XVIII, mientras que el resumen se hizo en el siglo XVI).

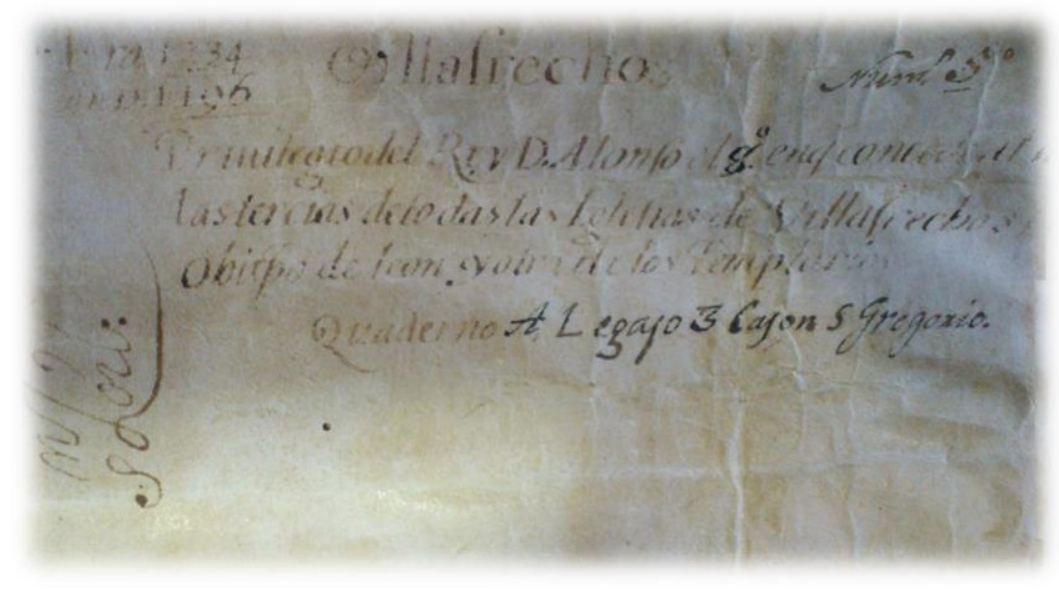

En el Índice se describió el documento de esta forma:

“5 $5^{\circ}$ < Privilegio del rey don Alonso el 9. Era 1234. Año 1196>.

Privilegio $3^{\circ}$ del rey de Castilla y de Toledo don Alonso el $9^{\circ}$, hijo de don Fernando el $2^{\circ}$, es rodado, escrito en pergamino y en latín, con sello de plomo pendiente, por el qual el rey don Alonso, junto con su muger, la reyna doña Leonor, y su hijo don Fernando, concede y confirma a Dios y al monasterio de San Zoil y a don Pedro, su prior y camarero de Cluni, y a todos sus sucesores las tercias de los diezmos de todas las yglesias de Villafrechós que enton/ (f. 359v)ces heran y que de allí adelante se fundasen, las quales ayan todos los años enteramente sin diminución alguna, excepto una yglesia del obispo que vino de Coreses y otra de los templarios que vino de Zalengas. Y por estas tercias y los derechos de los muertos no estén obligados a cosa alguna en las dichas yglesias. Fecha en Palancia, nonas februarii, era 1234, que es año 1191. Hay copia traducida por Antonio Fernández de Guzmán, nottario appostólico”.

Las motivaciones de estas referencias cruzadas se encuentran en la necesidad que el archivo tiene de acceder a la información del contenido de los documentos. De ahí las descripciones de los dorsos, que evitan además la manipulación innecesaria de los documentos que podrían deteriorarlos, con lo que se preservan los títulos de propiedad, los testimonios de privilegios y derechos, que se describen en el Índice para acceder a ellos de forma rápida y segura y facilitar además la devolución de los documentos que habían sido sacados de su lugar de conservación, y de esa manera localizarlos fácilmente si se precisaba 
que sirvieran como prueba en alguno de los litigios en los que el monasterio veía necesario su presentación como incuestionable aval de sus privilegios.

A partir de su creación, San Zoilo fue integrando en su estructura otros centros monásticos más pequeños y dispersos tanto por la actual provincia de Palencia como por las de Valladolid y Zamora. Cada uno de ellos había generado y generaba su propia documentación, primero como monasterio independiente y posteriormente formando parte de una entidad superior de la cual dependían y por la que eran administrados como prioratos satélites.

La organización del Índice nos sugiere que, cuando estos monasterios pasaban a estar bajo la órbita de San Zoilo, la documentación que habían generado hasta el momento pasaba también a formar parte del archivo de la casa principal, aunque respetando su procedencia original a modo de "fondos" independientes. Sin ni siquiera intuirlo, estaban experimentando con aquello que, en la teoría y práctica archivística actual, resulta básico a la hora de organizar los fondos de un archivo, el principio de procedencia. Al mantener unidos los documentos provenientes de los distintos centros dependientes, aseguraban su integridad a la vez que facilitaban la comprensión de cada diploma individual al idearlo como parte de un todo más amplio y complejo. Esta aseveración no se mantiene igual al intentar concluir si los documentos mantuvieron el orden que les había otorgado su entidad de origen, es decir, si nuevamente sin saberlo aplicaron el principio de respeto al orden original; puesto que no es imposible saber si las clasificaciones y estructuras administrativas visibles a través del Índice se mantuvieron desde su procedencia o se adaptaron a la ya existente en el archivo de San Zoilo.

La finalidad última de esta decisión de mantener los fondos separados viene a acentuar ese carácter administrativo y patrimonial del que hemos hablado con anterioridad al tratar del concepto del archivo, carácter que pasa al Índice, imagen del archivo. La organización de este y del Índice posibilita un control más preciso de la propiedad monástica y su evolución, de la del monasterio como de los prioratos, tanto en el momento de la anexión como después, cuando hubo que ocuparse de la gestión y defensa de las propiedades y parroquias anexionadas.

De no existir el Índice, de no conocer a través suyo la clasificación y ordenación de los documentos en el archivo en el momento en que el libro se escribe, y con motivo de la dispersión de la documentación sufrida tras las desamortizaciones, sobre todo las de Mendizabal y Madoz, tendríamos un panorama muy diferente, de desconocimiento de la forma en que estuvieron dispuestos los diplomas en el archivo. Más aún, no tendríamos la 
certeza de la inclusión conjunta de un priorato y su archivo en el momento de la anexión, y únicamente podríamos poner sobre el tapete meras suposiciones. Y la certeza mencionada se apuntala con la anotación encontrada en un Ynventario del ex priorato de Villaverde, hijuela deste monasterio de San Zoil de Carrión, realizado en 1809 para el control de los bienes monásticos durante la Desamortización francesa. En el último folio, unas ilustrativas palabras nos informan de lo que al parecer pudo haber sido una práctica habitual:

"[...] en este dicho Priorato de Villaverde, hijuela del Real Monasterio de San Zoil, extramuros de la villa de Carrión, a treinta días del mes de septiembre de este año de mil ochocientos y nuebe.

$<$ Nota $>$. Previénese que, según declaración del citado padre Granero y prior, todos los papeles y apeos correspondientes a este dicho priorato y su término y coto redondo, existen y se hallan en el archivo de el citado Monasterio, por los que constará que dentro de dicho territorio no se halla heredad de comunidad, ni particular alguno, por ser todo privativo de este dicho priorato.

Ante todo lo qual, yo el infraescripto escribano, me hallé presente [...]"283.

La documentación producida por la propia abadía de San Zoilo será la más abundante en cuanto a volumen y al espacio dedicado a ella en el archivo -tres cajones-. Pensados para albergar privilegios y gracias reales y apostólicas, la administración del barrio de San Zoles, la dirección de su parroquia y hospitales, así como aquellos instrumentos -donaciones, compras, trueques, foros- necesarios para conocer la formación de su patrimonio y administrarlo.

Completan el Índice las referencias toponímicas a aquellos lugares o circunscripciones territoriales en los que el cenobio estaba en posesión de alguna tierra, viña, dehesa, casa, heredad o iglesia, de la cual le correspondían el cobro de diezmos, la percepción de tercias o la presentación y colación de clérigos y capellanes.

Mención aparte requieren los "cajones comunes", cuyo doble propósito eran tanto aquellos instrumentos utilizados para la conjunta gestión del dominio monástico -apeos, juros, tazmías, censos, bullas, arriendos-, como otros de carácter espiritual y eventual; mostrándose ambos como imprescindibles para el alimento y sustento de la comunidad monástica.

Ofrecemos a continuación el contenido esquemático del Índice de San Zoilo, indicando el nombre de cada cajón, los legajos que conformaban cada uno de ellos y los cuadernos de cada uno de estos, aludiendo en cada caso a su contenido, con documentación agrupada por criterios tipológicos o topográficos. Una primera lectura de

283 AHPP, Desamortización, Legajo 436, s/f. 
conjunto pondrá en evidencia que el cuidado puesto en la conservación de los documentos, que se torna más difícil sin la clasificación, ordenación y descripción de los mismos, aseguraba la conservación y administración del patrimonio, con la certeza de que las rentas obtenidas de una buena gestión permitirá el mantenimiento de la casa, pensada para albergar la comunidad que había de ocuparse en el cuidado de las almas de los que vivían en el mundo.

\begin{tabular}{|c|c|c|c|c|}
\hline \multirow{8}{*}{$\begin{array}{c}\text { CAJÓN } 1^{\circ} \\
\text { Santa María } \\
\text { PRIORATO SAN } \\
\text { JUAN AGUILAR } \\
\text { DE CAMPOS }\end{array}$} & \multirow[t]{3}{*}{ Legajo $1^{\circ}$} & & QUADERNO A & $\begin{array}{c}\text { Hacienda: } \\
\text { donaciones, } \\
\text { compras, trueques, } \\
\text { y otros papeles }\end{array}$ \\
\hline & & & QUADERNO B & $\begin{array}{c}\text { Colecturía de } \\
\text { Lázaro Gutiérrez }\end{array}$ \\
\hline & & & QUADERNO C & $\begin{array}{c}\text { Yglesia de San Juan } \\
\text { de Aguilar }\end{array}$ \\
\hline & Legajo $2^{\circ}$ & $\begin{array}{c}\text { Pleitos con el } \\
\text { cabildo eclesiástico } \\
\text { de la villa de Aguilar } \\
\text { de Campos por la } \\
\text { parroquia e yglesia } \\
\text { de San Juan }\end{array}$ & & \\
\hline & Legajo $3^{\circ}$ & $\begin{array}{c}\text { Pleitos por la } \\
\text { parroquia e yglesia } \\
\text { de San Juan }\end{array}$ & & \\
\hline & \multirow[t]{2}{*}{ Legajo $4^{\circ}$} & \multirow[t]{2}{*}{$\begin{array}{l}\text { Feligresía, priorato e } \\
\text { yglesia de San Juan }\end{array}$} & QUADERNO A & $\begin{array}{c}\text { Concordias con el } \\
\text { cavildo y villa de } \\
\text { Aguilar }\end{array}$ \\
\hline & & & QUADERNO B & Papeles varios \\
\hline & Legajo $5^{\circ}$ & Informaciones & & \\
\hline
\end{tabular}




\begin{tabular}{|c|c|c|c|c|}
\hline & & & QUADERNO A & $\overline{\text { Añozas }}$ \\
\hline & Legajo $1^{\circ}$ & & QUADERNO B & $\begin{array}{l}\text { Arenillas de } \\
\text { Mazuecos }\end{array}$ \\
\hline & & & QUADERNO C & $\begin{array}{c}\text { Arenillas de Nuño } \\
\text { Pérez }\end{array}$ \\
\hline & & & QUADERNO D & $\begin{array}{c}\text { Arenillas de San } \\
\text { Pelayo }\end{array}$ \\
\hline & & & QUADERNO E & Astudillo \\
\hline & & & QUADERNO A & Hacienda \\
\hline & & & QUADERNO B & $\begin{array}{c}\text { Jurisdicción y } \\
\text { derechos }\end{array}$ \\
\hline & & & QUADERNO C & $\begin{array}{l}\text { Yglesia y beneficio } \\
\text { de San Facundo }\end{array}$ \\
\hline & Legajo $2^{\circ}$ & Arconada & QUADERNO D & $\begin{array}{l}\text { Yglesia y beneficio } \\
\text { de Santa María }\end{array}$ \\
\hline & & & QUADERNO E & $\begin{array}{c}\text { Tercias y noveno de } \\
\text { Santa María }\end{array}$ \\
\hline $\begin{array}{l}\text { CAJON } 2^{\circ} \\
\text { San Juan }\end{array}$ & & & QUADERNO F & $\begin{array}{c}\text { Visitas de los abades } \\
\text { de Santa María }\end{array}$ \\
\hline & & & QUADERNO G & $\begin{array}{c}\text { Capellanía intitulada } \\
\text { de Majo Mora }\end{array}$ \\
\hline & & & QUADERNO A & $\begin{array}{c}\text { Papeles } \\
\text { pertenecientes a la } \\
\text { hacienda que tiene } \\
\text { San Román en este } \\
\text { lugar }\end{array}$ \\
\hline & Legajo $3^{\circ}$ & Aviñante & QUADERNO B & $\begin{array}{c}\text { Iglesia, } \\
\text { presentaciones en } \\
\text { beneficio de este } \\
\text { lugar y derecho del } \\
\text { yantar }\end{array}$ \\
\hline & & & QUADERNO C & $\begin{array}{l}\text { Hacienda que tiene } \\
\text { Nuestra Señora del } \\
\text { Brezo en este lugar }\end{array}$ \\
\hline & & & QUADERNO D & $\begin{array}{c}\text { Hacienda que tiene } \\
\text { San Zoil en este } \\
\text { lugar }\end{array}$ \\
\hline
\end{tabular}




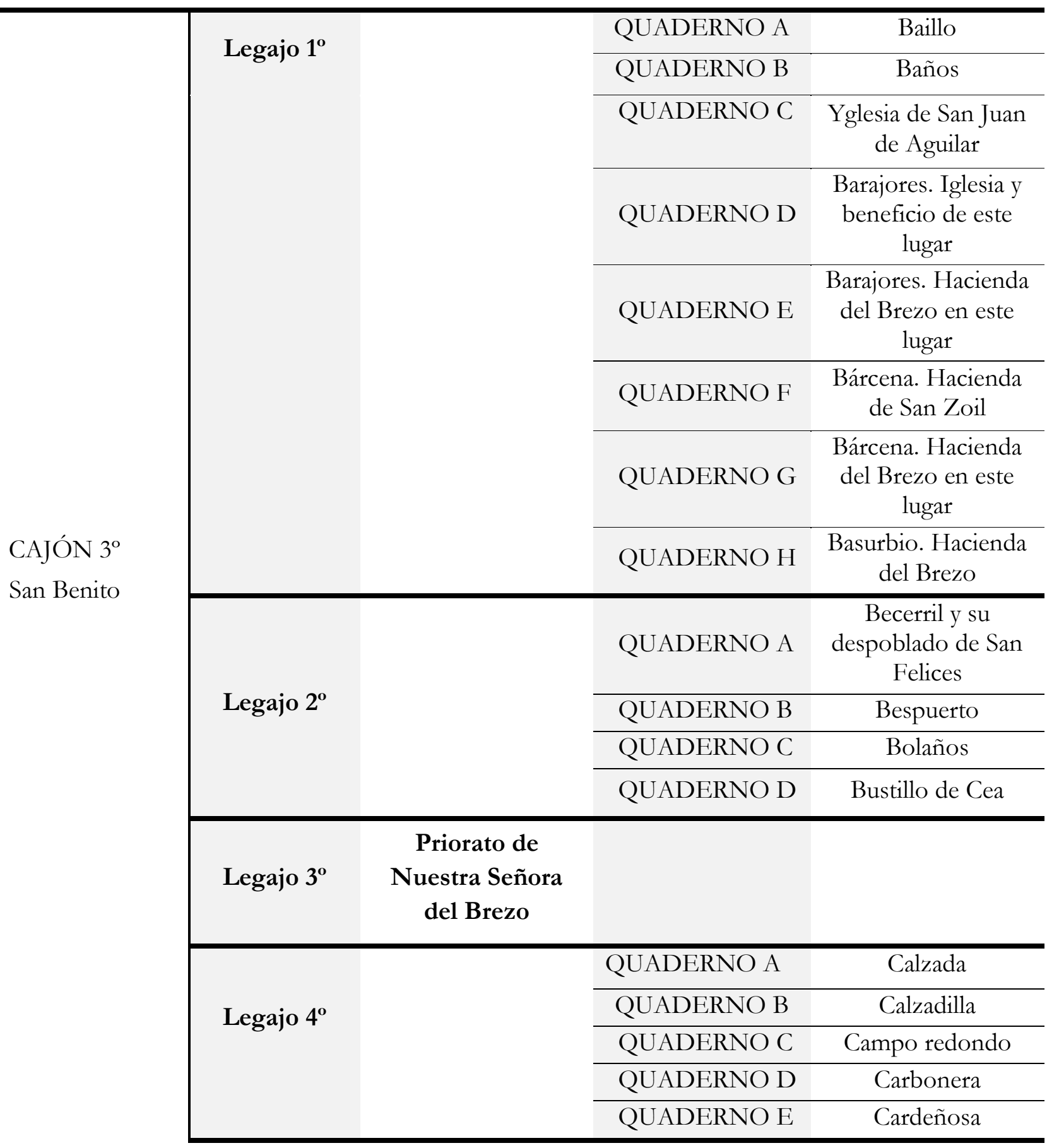




\begin{tabular}{|c|c|c|c|c|}
\hline \multirow{5}{*}{$\begin{array}{c}\text { CAJÓN } 4^{\circ} \\
\text { San Pedro } \\
\text { MONASTERIO } \\
\text { DE SAN ZOIL, } \\
\text { CARRIÓN }\end{array}$} & \multirow[b]{2}{*}{ Legajo $1^{\circ}$} & & QUADERNO A & $\begin{array}{l}\text { Bulas y concesiones } \\
\text { pontificias, y otros } \\
\text { papeles } \\
\text { pertenecientes a este } \\
\text { monasterio como } \\
\text { miembro de Cluny }\end{array}$ \\
\hline & & & QUADERNO B & $\begin{array}{c}\text { Bulas de } \\
\text { nombramientos de } \\
\text { abades } \\
\text { comendatarios de } \\
\text { este monasterio } \\
\text { hasta su unión } \\
\text { inclusive a la } \\
\text { congregación de } \\
\text { San Benito de } \\
\text { Valladolid }\end{array}$ \\
\hline & Legajo $2^{\circ}$ & Privilegios reales & & \\
\hline & Legajo $3^{\circ}$ & $\begin{array}{c}\text { Privilegios reales, } \\
\text { etc., jurisdicción del } \\
\text { monasterio en el } \\
\text { barrio de San Zoles, } \\
\text { y su venta a la villa } \\
\text { de Carrión }\end{array}$ & & \\
\hline & Legajo $4^{\circ}$ & $\begin{array}{l}\text { Privilegios Agua del } \\
\text { Cuérnago y al } \\
\text { arroyo forero }\end{array}$ & & \\
\hline
\end{tabular}




\begin{tabular}{|c|c|c|c|c|}
\hline \multirow{11}{*}{$\begin{array}{c}\text { CAJÓN 5o } \\
\text { San Andrés } \\
\text { MONASTERIO } \\
\text { DE SAN ZOIL, } \\
\text { CARRIÓN }\end{array}$} & \multirow[t]{3}{*}{ Legajo $1^{\circ}$} & \multirow[t]{3}{*}{$\begin{array}{c}\text { Parroquia. Diezmos } \\
\text { y visita de Iglesia }\end{array}$} & QUADERNO A & $\begin{array}{c}\text { Papeles } \\
\text { pertenecientes a la } \\
\text { parroquia de San } \\
\text { Zoles o Santa María } \\
\text { Magdalena }\end{array}$ \\
\hline & & & QUADERNO B & $\begin{array}{c}\text { Diezmos de dicha } \\
\text { parroquia }\end{array}$ \\
\hline & & & QUADERNO C & $\begin{array}{c}\text { Papeles sobre la } \\
\text { visita de la } \\
\text { parroquia }\end{array}$ \\
\hline & \multirow{4}{*}{ Legajo $2^{\circ}$} & & QUADERNO A & $\begin{array}{c}\text { Papeles } \\
\text { pertenecientes a los } \\
\text { cuerpos de los } \\
\text { Santos Mártires, } \\
\text { reliquias e } \\
\text { indulgencias que } \\
\text { hay en esta iglesia }\end{array}$ \\
\hline & & & QUADERNO B & $\begin{array}{l}\text { Pleitos y diferencias } \\
\text { con la villa y } \\
\text { clérigos de Carrión } \\
\text { sobre la procedencia } \\
\text { de asiento }\end{array}$ \\
\hline & & & QUADERNO C & $\begin{array}{l}\text { Obra pía de don } \\
\text { Francisco Barrio y } \\
\text { otras de Carrión }\end{array}$ \\
\hline & & & QUADERNO D & $\begin{array}{c}\text { Cofradía de la } \\
\text { Magdalena y otras }\end{array}$ \\
\hline & Legajo $3^{\circ}$ & $\begin{array}{c}\text { Hospital de Nuestra } \\
\text { Señora de la } O\end{array}$ & & \\
\hline & \multirow[t]{2}{*}{ Legajo $4^{\circ}$} & \multirow{2}{*}{$\begin{array}{l}\text { Hospitales de San } \\
\text { Lázaro y la Herrada }\end{array}$} & QUADERNO A & San Lázaro \\
\hline & & & QUADERNO B & La Herrada \\
\hline & Legajo $5^{\circ}$ & $\begin{array}{l}\text { Capilla de Doña } \\
\text { Constanza }\end{array}$ & & \\
\hline
\end{tabular}


CAJÓN

LEGAJO

CUADERNO

Donaciones hechas

Legajo $1^{\mathbf{o}}$ a este monasterio en

Carrión y San Zoles

\begin{tabular}{|c|c|c|c|c|}
\hline \multirow{6}{*}{$\begin{array}{c}\text { CAJÓN 6o } \\
\text { San Zoilo } \\
\text { MONASTERIO } \\
\text { DE SAN ZOIL, } \\
\text { CARRIÓN }\end{array}$} & Legajo $1^{\circ}$ & $\begin{array}{l}\text { Donaciones hechas } \\
\text { a este monasterio en } \\
\text { Carrión y San Zoles }\end{array}$ & & \\
\hline & \multirow{3}{*}{ Legajo $2^{\circ}$} & \multirow{3}{*}{$\begin{array}{l}\text { Compras, trueques } \\
\text { y molinos del } \\
\text { Huerto, de la Tapia } \\
\text { y de Guzmán }\end{array}$} & QUADERNO A & $\begin{array}{l}\text { Compras hechas en } \\
\text { Carrión y San Zoles }\end{array}$ \\
\hline & & & QUADERNO B & Trueques en ídem \\
\hline & & & QUADERNO C & $\begin{array}{c}\text { Molinos del Huerto, } \\
\text { de la Tapia y de } \\
\text { Guzmán }\end{array}$ \\
\hline & Legajo $3^{\circ}$ & $\begin{array}{l}\text { Foros corrientes en } \\
\text { Carrión y San Zoles }\end{array}$ & & \\
\hline & Legajo $4^{\circ}$ & $\begin{array}{c}\text { Foros no corrientes } \\
\text { en Carrión y San } \\
\text { Zoles }\end{array}$ & & \\
\hline
\end{tabular}

CAJÓN

LEGAJO

CUADERNO

\begin{tabular}{|c|c|c|c|c|}
\hline \multirow{11}{*}{$\begin{array}{l}\text { CAJÓN } 7^{\circ} \\
\text { San Felices }\end{array}$} & \multirow{2}{*}{ Legajo $1^{\circ}$} & & QUADERNO A & Castillo de Macintos \\
\hline & & & QUADERNO B & Cervatos \\
\hline & \multirow[b]{2}{*}{ Legajo $2^{\circ}$} & \multirow[b]{2}{*}{ Cestillos } & QUADERNO A & $\begin{array}{l}\text { Hacienda que este } \\
\text { monasterio tiene en } \\
\text { dicho término }\end{array}$ \\
\hline & & & QUADERNO B & $\begin{array}{c}\text { Iglesia y } \\
\text { presentación del } \\
\text { beneficio de } \\
\text { Cestillos }\end{array}$ \\
\hline & \multirow{7}{*}{ Legajo $3^{\circ}$} & & QUADERNO A & Cisneros \\
\hline & & & QUADERNO B & $\begin{array}{c}\text { Santa Comba dos } \\
\text { Dados }\end{array}$ \\
\hline & & & QUADERNO C & $\begin{array}{l}\text { Cornón y } \\
\text { Cornoncillo }\end{array}$ \\
\hline & & & QUADERNO D & $\begin{array}{l}\text { Santa Cruz de } \\
\text { Ventosilla }\end{array}$ \\
\hline & & & QUADERNO E & Entorcisa \\
\hline & & & QUADERNO F & Fontecha \\
\hline & & & QUADERNO G & Frechilla \\
\hline
\end{tabular}




\begin{tabular}{|c|c|c|c|c|}
\hline \multirow{11}{*}{$\begin{array}{c}\text { CAJÓN } 8^{\circ} \\
\text { San Agapio } \\
\text { FRÓMESTA }\end{array}$} & \multirow[b]{2}{*}{ Legajo $1^{\circ}$} & \multirow[b]{2}{*}{ Patrimonio } & QUADERNO A & Donaciones \\
\hline & & & QUADERNO B & $\begin{array}{c}\text { Compras, trueques } \\
\text { y foros }\end{array}$ \\
\hline & \multirow{5}{*}{ Legajo $2^{\circ}$} & \multirow{5}{*}{$\begin{array}{l}\text { Iglesia de San } \\
\text { Martín }\end{array}$} & QUADERNO A & $\begin{array}{c}\text { Iglesia y exención } \\
\text { diezmos }\end{array}$ \\
\hline & & & QUADERNO B & Santísimo Milagro \\
\hline & & & QUADERNO C & Cuentas de fábrica \\
\hline & & & QUADERNO D & Sacristía \\
\hline & & & QUADERNO E & $\begin{array}{c}\text { Hospital San Lázaro } \\
\text { e Iglesia }\end{array}$ \\
\hline & \multirow{3}{*}{ Legajo $3^{\circ}$} & \multirow{3}{*}{$\begin{array}{c}\text { Jurisdicción } \\
\text { eclesiástica y } \\
\text { derechos }\end{array}$} & QUADERNO A & $\begin{array}{l}\text { Presentaciones y } \\
\text { donaciones }\end{array}$ \\
\hline & & & QUADERNO B & Congrua y rezo \\
\hline & & & QUADERNO C & Visitas \\
\hline & Legajo $4^{\circ}$ & Contabilidad & & \\
\hline
\end{tabular}

CAJÓN

LEGAJO

\begin{tabular}{|c|c|c|}
\hline \multirow{5}{*}{$\begin{array}{c}\text { CAJÓN } 9^{\circ} \\
\text { San Román } \\
\text { BARRIO DE SAN } \\
\text { MARTÍN DE } \\
\text { FRÓMESTA }\end{array}$} & Legajo $1^{\circ}$ & Señorío antiguo del barrio de San Martín \\
\hline & Legajo $2^{\circ}$ & $\begin{array}{l}\text { Capítulos de concordia y dos } \\
\text { informaciones }\end{array}$ \\
\hline & Legajo $3^{\circ}$ & $\begin{array}{l}\text { Pleitos con los señores de Frómesta desde } \\
\text { el año de } 1414 \text { hasta el de } 1462\end{array}$ \\
\hline & Legajo $4^{\circ}$ & $\begin{array}{l}\text { Estado de los pleitos desde el referido año } \\
\text { hasta el de } 1572\end{array}$ \\
\hline & Legajo $5^{\circ}$ & $\begin{array}{l}\text { Estado de los pleitos desde el año } 1572 \\
\text { hasta el presente donde se halla la escritura } \\
\text { de censo perpetuo de } 100.000 \text { maravedís } \\
\text { sobre el dicho barrio }\end{array}$ \\
\hline
\end{tabular}




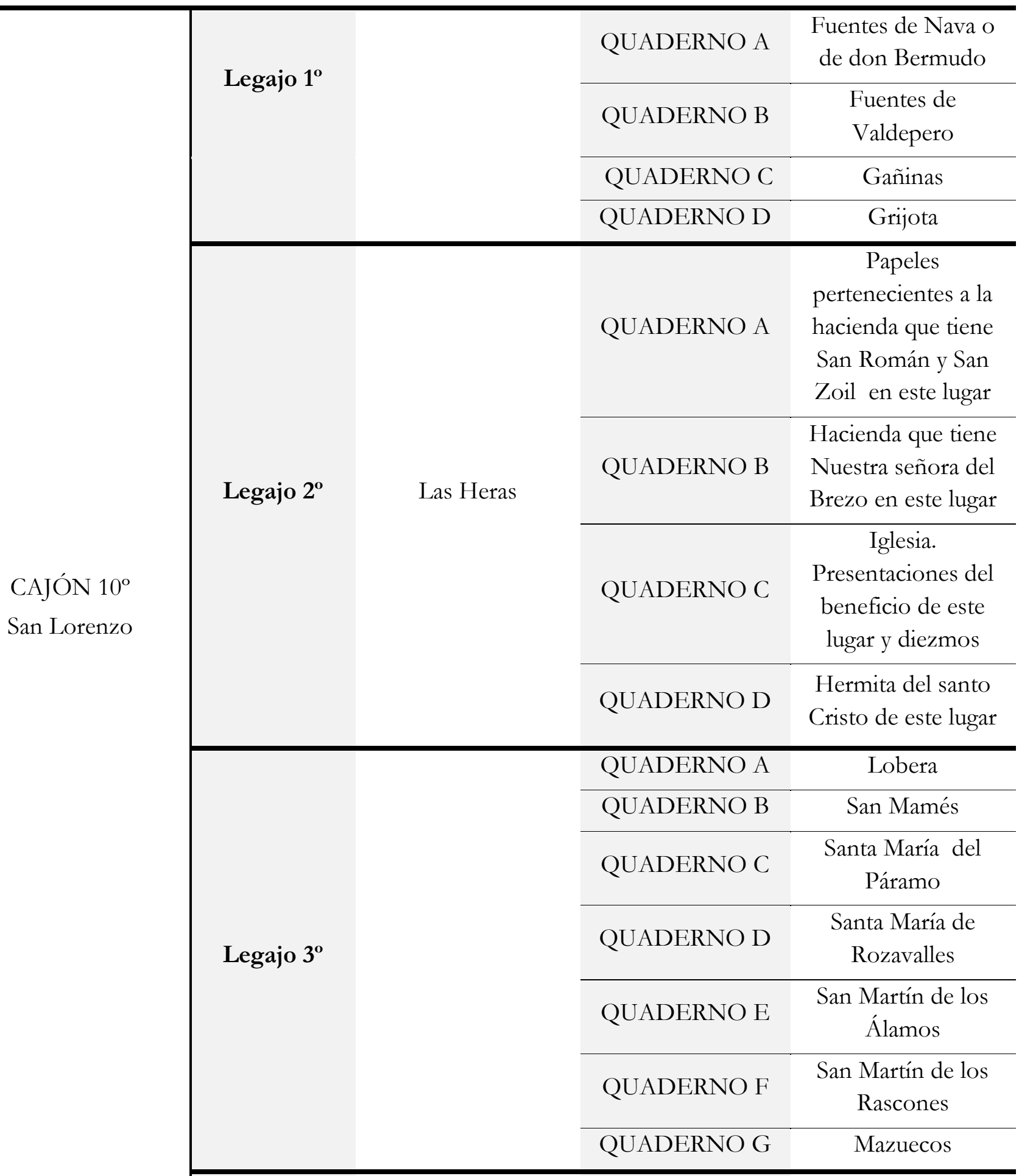

Legajo $4^{\circ}$ 


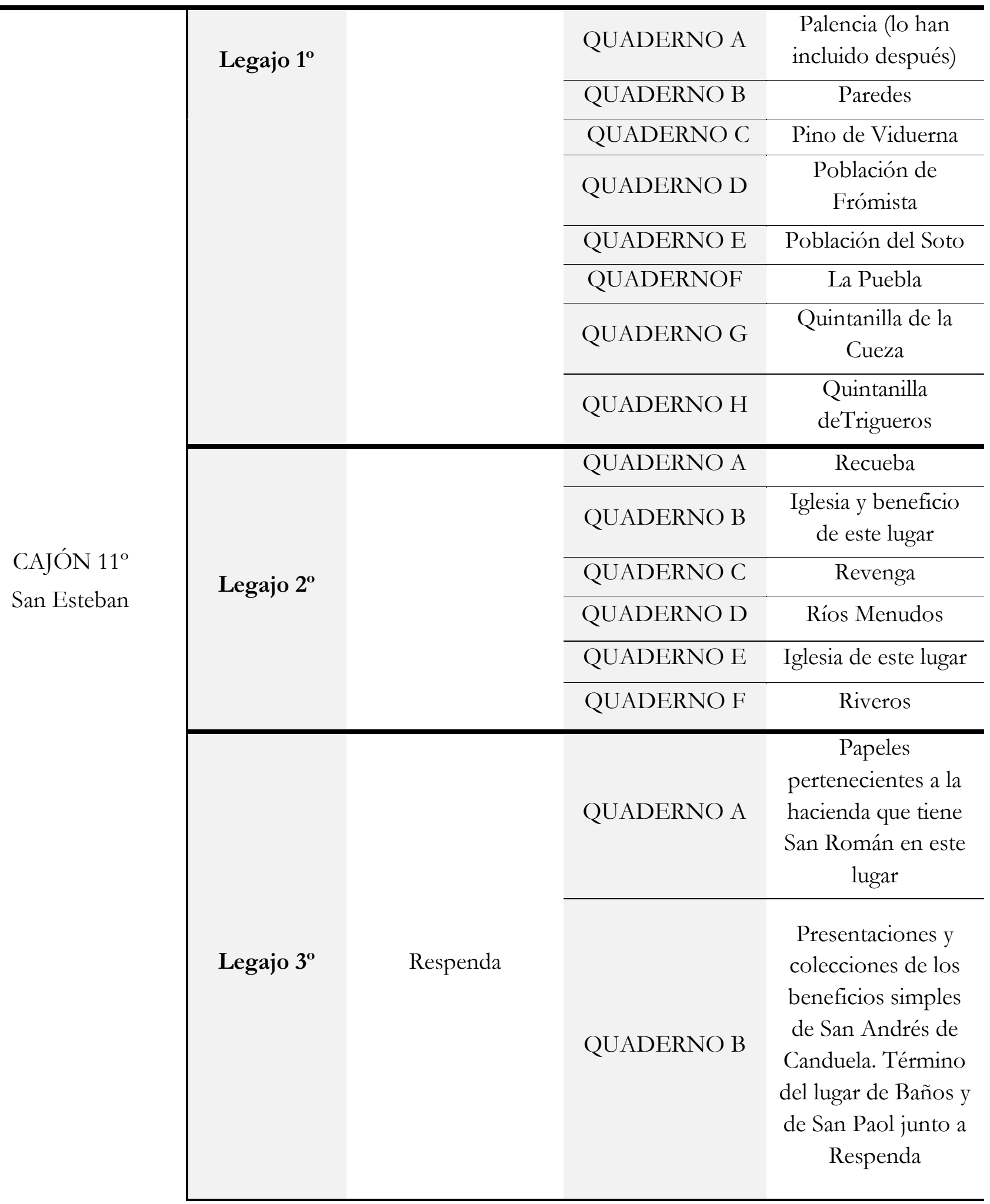


CAJÓN

LEGAJO

CUADERNO

\begin{tabular}{|c|c|c|c|c|}
\hline \multirow{12}{*}{$\begin{array}{c}\text { CAJÓN } 12^{\circ} \\
\text { San Martín } \\
\text { PRIORATO } \\
\text { DESAN ROMÁN } \\
\text { DE } \\
\text { ENTREPEÑAS }\end{array}$} & \multirow[t]{3}{*}{ Legajo $1^{\circ}$} & & QUADERNO A & $\begin{array}{c}\text { Donaciones hechas a san } \\
\text { Román en Santibáñez y } \\
\text { sus términos }\end{array}$ \\
\hline & & & QUADERNO B & $\begin{array}{c}\text { Compras, trueques y foros } \\
\text { en el mismo lugar }\end{array}$ \\
\hline & & & QUADERNO C & $\begin{array}{l}\text { Hacienda que tiene el } \\
\text { Brezo en Santibáñez }\end{array}$ \\
\hline & \multirow{3}{*}{ Legajo $2^{\circ}$} & & QUADERNO A & $\begin{array}{c}\text { Privilegios y jurisdicciones } \\
\text { de San Román }\end{array}$ \\
\hline & & & QUADERNO B & $\begin{array}{c}\text { Bula y papeles de la unión } \\
\text { de San Román a este } \\
\text { monasterio de San Zoil }\end{array}$ \\
\hline & & & QUADERNO C & $\begin{array}{c}\text { Curato de Santa María } \\
\text { Madre }\end{array}$ \\
\hline & Legajo $3^{\circ}$ & $\begin{array}{l}\text { Cartas de pago } \\
\text { relativos a San } \\
\text { Román }\end{array}$ & & \\
\hline & \multirow{5}{*}{ Legajo $4^{\circ}$} & & QUADERNO A & Santiago del Bal y Santoyo \\
\hline & & & QUADERNO B & Soles \\
\hline & & & QUADERNO C & Tabaneras \\
\hline & & & QUADERNO D & Tarilonte \\
\hline & & & QUADERNO E & Tavadillos \\
\hline
\end{tabular}

CAJÓN

LEGAJO

CUADERNO

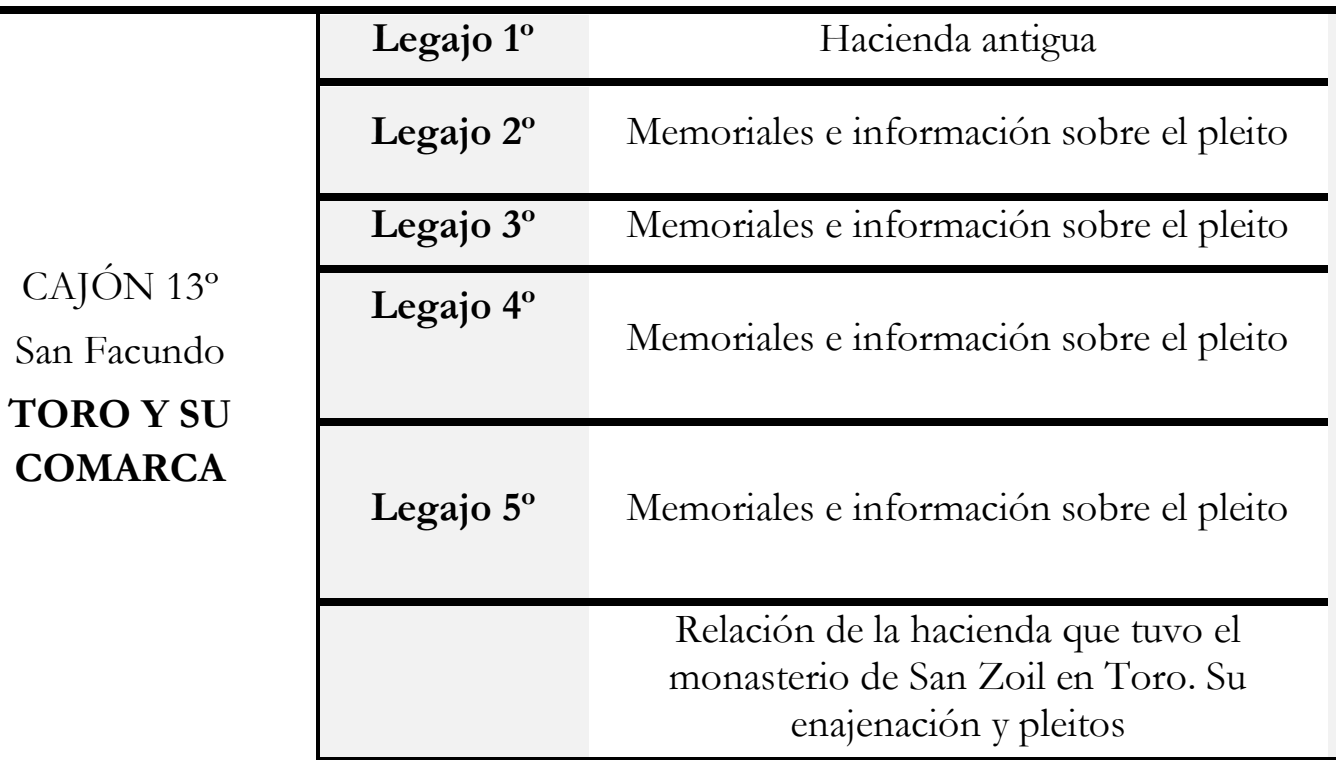




\begin{tabular}{|c|c|c|c|c|}
\hline & \multirow{3}{*}{ Legajo $1^{\circ}$} & \multirow{3}{*}{ Valcavado } & QUADERNO A & $\begin{array}{c}\text { Escrituras de censo } \\
\text { y foro perpetuas } \\
\text { hechas a favor del } \\
\text { monasterio por las } \\
\text { heredades que tenía } \\
\text { en el lugar de } \\
\text { Valcavado }\end{array}$ \\
\hline & & & QUADERNO B & $\begin{array}{l}\text { Pleitos que tuvo el } \\
\text { director Flores en } \\
\text { nombre del } \\
\text { monasterio }\end{array}$ \\
\hline CAJÓN $14^{\circ}$ & & & QUADERNO C & $\begin{array}{c}\text { Proceso en cinco } \\
\text { piezas que litigó el } \\
\text { dicho Flores en } \\
\text { razón de los } \\
\text { términos, tierras, } \\
\text { pastos y jurisdicción } \\
\text { de dicho lugar con } \\
\text { otros papeles } \\
\text { sueltos }\end{array}$ \\
\hline \multirow[t]{12}{*}{ San Gregorio } & \multirow{10}{*}{ Legajo $2^{\circ}$} & & QUADERNO A & Valcovero \\
\hline & & & QUADERNO B & Valderadue \\
\hline & & & QUADERNO C & Valheroso \\
\hline & & & QUADERNO D & Vega de Riacos \\
\hline & & & QUADERNO E & Velilla de Tarilonte \\
\hline & & & QUADERNO F & Villaherrín \\
\hline & & & QUADERNO G & Villaherreros \\
\hline & & & QUADERNO H & Villaibáñez \\
\hline & & & QUADERNO I & Villalveto \\
\hline & & & QUADERNO J & Villalumbroso \\
\hline & \multirow{2}{*}{ Legajo $3^{\circ}$} & \multirow{2}{*}{ Villafrechós } & QUADERNO A & $\begin{array}{c}\text { Privilegios y } \\
\text { escrituras tocantes a } \\
\text { las tercias y diezmos }\end{array}$ \\
\hline & & & QUADERNO B & $\begin{array}{c}\text { Hacienda que tiene } \\
\text { el monasterio en } \\
\text { Villafrechós }\end{array}$ \\
\hline
\end{tabular}




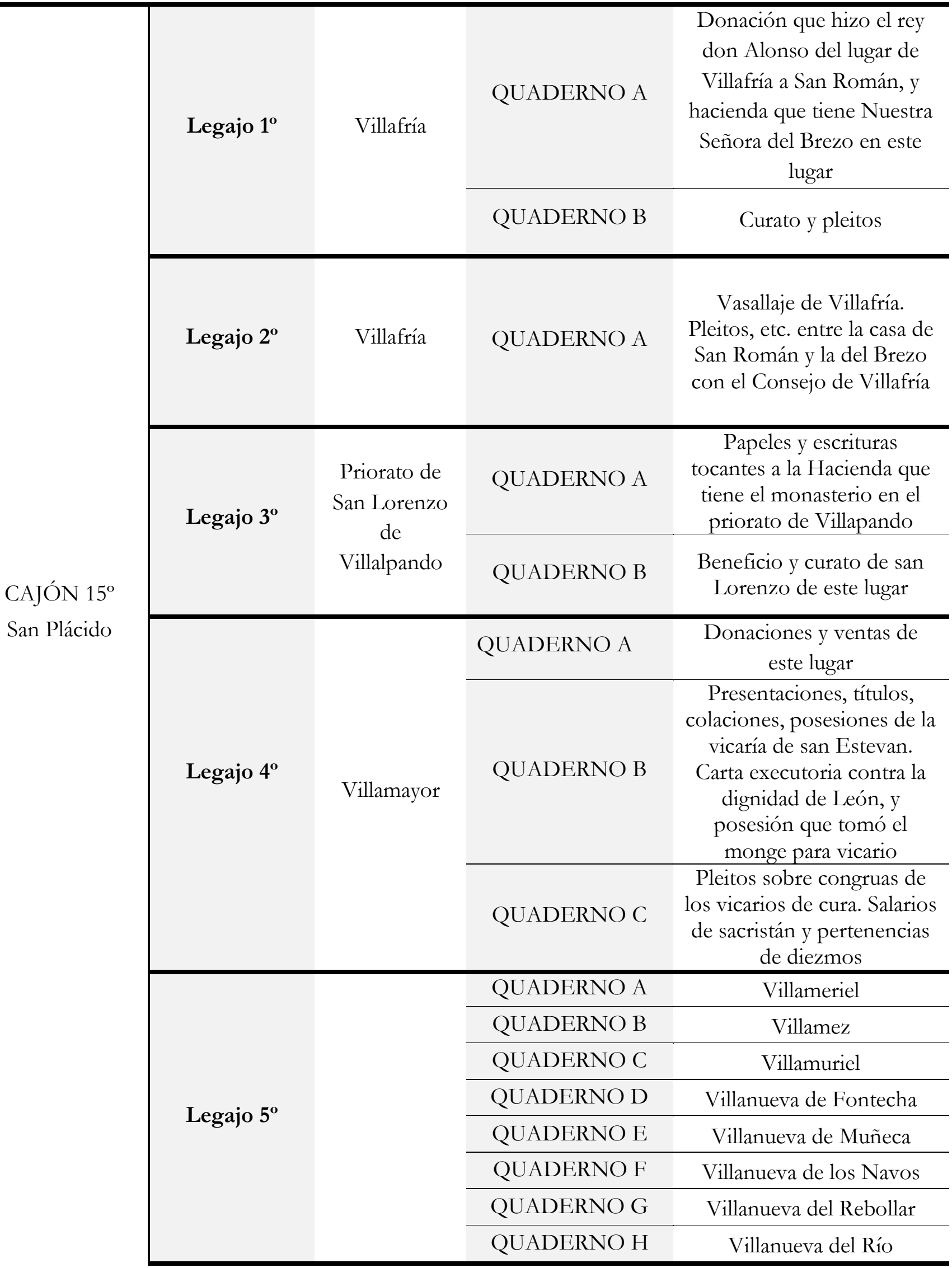




\begin{tabular}{|c|c|c|c|c|}
\hline \multirow{8}{*}{$\begin{array}{c}\text { CAJÓN } 16^{\circ} \\
\text { San Mauro } \\
\text { VILLAMUERA }\end{array}$} & \multirow[t]{3}{*}{ Legajo $1^{\circ}$} & \multirow[t]{3}{*}{ Señorío y hacienda } & QUADERNO A & $\begin{array}{c}\text { Privilegios y cartas } \\
\text { executorias de la } \\
\text { posesión y } \\
\text { propiedad de } \\
\text { Villamuera, su } \\
\text { jurisdicción, señorío } \\
\text { y vasallaje }\end{array}$ \\
\hline & & & QUADERNO B & $\begin{array}{c}\text { Escrituras tocantes } \\
\text { a la jurisdicción }\end{array}$ \\
\hline & & & QUADERNO C & $\begin{array}{c}\text { Hacienda de este } \\
\text { lugar }\end{array}$ \\
\hline & Legajo $2^{\circ}$ & $\begin{array}{c}\text { Residencias que se } \\
\text { toman cada } \\
\text { quadriento a los } \\
\text { alcaldes y ministros } \\
\text { de justicia de este } \\
\text { lugar }\end{array}$ & & \\
\hline & Legajo $3^{\circ}$ & $\begin{array}{c}\text { Pleitos por la } \\
\text { parroquia e yglesia } \\
\text { de San Juan }\end{array}$ & QUADERNO A & $\begin{array}{c}\text { Pleitos como } \\
\text { criminales por los } \\
\text { alcaldes de este } \\
\text { lugar, prestos los } \\
\text { abades de San Zoil }\end{array}$ \\
\hline & & & QUADERNO B & Lo mismo \\
\hline & & & QUADERNO C & Libros de Quentas \\
\hline & Legajo $4^{\circ}$ & $\begin{array}{l}\text { Propuestas para } \\
\text { alcaldes y demás } \\
\text { ministros de justicia }\end{array}$ & & \\
\hline
\end{tabular}


CAJÓN

\begin{tabular}{|c|c|c|c|}
\hline \multirow{17}{*}{$\begin{array}{l}\text { CAJÓN } 17^{\circ} \\
\text { San Bernardo }\end{array}$} & \multirow{9}{*}{ Legajo $1^{\circ}$} & QUADERNO A & $\overline{\text { Villaoliva }}$ \\
\hline & & QUADERNO B & Villadefellares \\
\hline & & QUADERNO C & Villarmiento \\
\hline & & QUADERNO D & Villabermudo \\
\hline & & QUADERNO E & Villamiel \\
\hline & & QUADERNO F & Villaserracino \\
\hline & & QUADERNO G & $\begin{array}{c}\text { Villasabariego y } \\
\text { Villovieco }\end{array}$ \\
\hline & & QUADERNO H & Villasirga \\
\hline & & QUADERNO Y & Villatoquite \\
\hline & \multirow{4}{*}{ Legajo $2^{\circ}$} & QUADERNO A & $\begin{array}{c}\text { Villaturde } \\
\text { Curato y diezmos. }\end{array}$ \\
\hline & & \multirow{2}{*}{ QUADERNO B } & Villaturde \\
\hline & & & Hacienda \\
\hline & & QUADERNO C & Villavaruz \\
\hline & \multirow{4}{*}{ Legajo $3^{\circ}$} & QUADERNO A & Villaumbrales \\
\hline & & QUADERNO B & $\begin{array}{l}\text { Villaverde de la } \\
\text { Peña }\end{array}$ \\
\hline & & QUADERNO C & Villavicencio \\
\hline & & QUADERNO D & Villotilla \\
\hline
\end{tabular}

CAJÓN

LEGAJO

CUADERNO

\begin{tabular}{|c|c|c|}
\hline CAJÓN $18^{\circ}$ & Legajo $1^{\circ}$ & $\begin{array}{l}\text { Privilegios y } \\
\text { jurisdicciones }\end{array}$ \\
\hline $\begin{array}{c}\text { San Yldefonso } \\
\text { PRIORATO DE } \\
\text { VILLAVERDE DE }\end{array}$ & Legajo $2^{\circ}$ & $\begin{array}{l}\text { Nombramiento de } \\
\text { alcaldes y pleitos } \\
\text { criminales }\end{array}$ \\
\hline & Legajo $3^{\circ}$ & $\begin{array}{c}\text { Hacienda y } \\
\text { amojonamiento }\end{array}$ \\
\hline
\end{tabular}


CAJÓN

LEGAJO

CUADERNO

\begin{tabular}{|c|c|c|}
\hline \multirow{3}{*}{$\begin{array}{c}\text { CAJÓN } 19^{\circ} \\
\text { San Leandro } \\
\text { JUROS }\end{array}$} & Legajo $1^{\circ}$ & $\begin{array}{c}\text { Juros y sus } \\
\text { privilegios reales }\end{array}$ \\
\hline & Legajo $2^{\circ}$ & $\begin{array}{c}\text { Escrituras tocantes } \\
\text { a los juros }\end{array}$ \\
\hline & Legajo $3^{\circ}$ & Censos redimidos \\
\hline
\end{tabular}

CAJÓN

LEGAJO

CUADERNO

Libro $\mathbf{1}^{\mathbf{0}}, \mathbf{2}^{\mathbf{0}}, \quad$ Apeos de Nuestra

$3^{\circ}, 4^{\circ}, 5^{\circ}, 6^{\circ} \quad$ Señora del Brezo

Libro $7^{\circ} \quad$ Apeos de San

CAJÓN $20^{\circ}$

San Millán

APEOS

$$
\text { Román }
$$

Libro $\mathbf{8}^{\circ}, \mathbf{9}^{\circ} \quad$ Apeos de San

Román

Libro 10 ${ }^{\circ}$ Apeos de Carrión y

otros varios lugares

Libro $1^{\circ}$ Apeos de Arconada 
CAJÓN

CAJÓN $21^{\circ}$

Santo Toribio

CENSOS
LEGAJO

\begin{tabular}{|c|c|c|c|}
\hline \multirow[t]{2}{*}{ Legajo $1^{\circ}$} & & QUADERNO A & $\begin{array}{c}\text { Abastas, Añozas, } \\
\text { Arconada, Autol, Calzada, } \\
\text { Cardeñosa, Carrión, } \\
\text { Cerbatos de la Cueza, } \\
\text { Congosto, Cuerno } \\
\text { Fuentes de don Bermudo, } \\
\text { Madrid, Polvorosa, } \\
\text { Roscales, Santoyo, } \\
\text { Santibáñez de la Peña, } \\
\text { Torre de los Molinos, } \\
\text { Villamez de Muñecas, } \\
\text { Villafría }\end{array}$ \\
\hline & & QUADERNO C & $\begin{array}{c}\text { Villalán, Villalumbroso, } \\
\text { Villamurco, Villaumbrales, } \\
\text { Aguilar }\end{array}$ \\
\hline Legajo $2^{\circ}$ & Becerril & & \\
\hline \multirow[t]{2}{*}{ Legajo $3^{\circ}$} & & QUADERNO A & $\begin{array}{c}\text { Villamayor de Campos, } \\
\text { Mantinos, Ríosmenudos, } \\
\text { Villamoronta, Villanueva } \\
\text { del Río, Villaturde, } \\
\text { Villorde }\end{array}$ \\
\hline & & QUADERNO B & Villamuera \\
\hline
\end{tabular}

CAJÓN

LEGAJO

CUADERNO

\begin{tabular}{l|cc}
\hline $\begin{array}{c}\text { CAJÓN 22 } \\
\text { San Vicente } \\
\text { BULAS }\end{array}$ & ${\text { Legajo } 1^{\circ}}^{\circ}$ & $\begin{array}{c}\text { Bulas comunes a la } \\
\text { religión y privilegios }\end{array}$ \\
\cline { 2 - 3 } $\begin{array}{c}\text { COMUNES A LA } \\
\text { RELIGIÓN Y } \\
\text { CÉDULAS } \\
\text { REALES }\end{array}$ & Legajo 2 $^{\circ}$ & $\begin{array}{c}\text { Papeles comunes a } \\
\text { la religión }\end{array}$ \\
\cline { 2 - 3 } & Legajo $3^{\circ}$ & Cédulas Reales \\
\end{tabular}


CAJÓN

LEGAJO

CUADERNO

\begin{tabular}{|c|c|c|}
\hline $\begin{array}{l}\text { CAJÓN 23 } \\
\text { San Rosendo }\end{array}$ & $\begin{array}{c}\text { Escrituras corrientes } \\
\text { de arriendo }\end{array}$ & \\
\hline CAJÓN & LEGAJO & CUADERNO \\
\hline $\begin{array}{l}\text { CAJÓN } 24^{\circ} \\
\text { San Veremundo }\end{array}$ & $\begin{array}{l}\text { Libros de gradas e } \\
\text { informaciones de } \\
\text { monges y legos y } \\
\text { algunos testamentos }\end{array}$ & \\
\hline
\end{tabular}

CAJÓN

LEGAJO

CUADERNO

\begin{tabular}{|c|c|}
\hline $\begin{array}{l}\text { CAJÓN } 25^{\circ} \\
\text { San Claudio }\end{array}$ & $\begin{array}{c}10 \text { libros antiguos y } \\
\text { curiosos }\end{array}$ \\
\hline
\end{tabular}

CAJÓN

LEGAJO

CUADERNO

CAJÓN $26^{\circ}$

Santo Domingo

Tazmías

CAJÓN

LEGAJO

CUADERNO

\section{CAJÓN $27^{\circ}$}

San Prudencio
Cartas de pago y

otros instrumentos 


\subsubsection{Las relaciones de los documentos en el Índice de San Zoilo de Carrión}

La clasificación y ordenación de los documentos de un archivo explican las relaciones que se producen entre los documentos que forman el mismo. Proponer un cuadro de clasificación que, tras la identificación de las series documentales, refleje la organización del fondo o fondos del archivo del monasterio de San Zoilo, permitiría comprender los grupos en que podrían reunirse los documentos procedentes de una determinada función, una actividad concreta o un asunto particular, y explicar así las relaciones establecidas de origen entre ellos. Podría clasificarse la documentación del archivo en secciones distintas: administración, gobierno o justicia, al modo que han propuesto Pérez Ortiz y Vivas Moreno, y dentro de cada una de ellas agrupar los documentos en series que resultan de actividades diferentes que permiten ejecutar esas acciones de gobierno, administración y justicia ${ }^{284}$. Si así lo hiciéramos, se alteraría la organización del archivo en el momento de escrituración del Índice.

Es cierto que en algunos casos se agruparon en los cajones, legajos y cuadernos del archivo del monasterio, los documentos en series muy reconocibles, caso de los pleitos, que podrían muy bien hacerse depender de un grupo mayor: la sección justicia; pero en el imaginario documental del archivero de San Zoilo no cabían conceptos como sección, función, serie, actividad y otros tan necesarios en al archivo y la archivística contemporánea. Eso no supone que en el momento en que se realiza el Índice no se individualizaran y reunieran los documentos porque pertenecían a un mismo tipo diplomático; pero el archivero del monasterio de San Zoilo no agrupó los pleitos porque resultaran de una actividad sino porque pertenecían a un mismo tipo diplomático, y no tuvo en consideración el conjunto de acciones y actividades del que resultan los documentos, ni la reglamentación y normalización del procedimiento, aunque sin ellos fuera imposible el documento. Al archivero, en definitiva, le importan los documentos que forman el archivo y el archivo como tal, en el que va a organizar los documentos de acuerdo al concepto administrativo patrimonial que de él tiene y sobre el que ya me he ocupado en otro lugar.

Esta percepción es fácilmente comprobable en los cajones $2^{\circ}$ (San Juan), $3^{\circ}$ (San Benito), $7^{\circ}$ (San Felices), $10^{\circ}$ (San Lorenzo), $11^{\circ}$ (San Esteban), parte del $12^{\circ}$ (San Martín), $14^{\circ}$ (San Gregorio), $15^{\circ}$ (San Plácido), $16^{\circ}$ ( San Mauro) y $17^{\circ}$ (San Bernardo), en los que dispone y organiza la documentación siguiendo un orden alfabético topográfico. En los

\footnotetext{
284 PÉREZ ORTIZ, G.-VIVAS MORENO, A., "Ensayo de organización de la documentación conventual: propuesta de cuadro de clasificación": Anales de Documentacion, 11 (2008), pp. 165-181, especialmente pp. 168177.
} 
diferentes cuadernos de esos cajones va agrupando la documentación que afecta a cada uno de los lugares en los que el monasterio de San Zoilo tiene alguna heredad, desde Añozas, en el cuaderno A del cajón San Juan, hasta Villotillo, en el cuaderno D del cajón San Bernardo.

Cuando la documentación de un determinado lugar o institución era más voluminosa se agrupó en un legajo, caso de Arconada y Avinante, en el Cajón $2^{\circ}$ (San Juan); Nuestra Señora del Brezo, en el cajón $3^{\circ}$ (San Benito); Cestillos, en el cajón $7^{\circ}$ (San Felices); Las Heras, en el cajón $10^{\circ}$ (San Lorenzo); Respenda, en el cajón $11^{\circ}$ (San Esteban); San Román, en el cajón 12 (San Martín); Valcavado y Villafrechós, en el cajón $14^{\circ}$ (San Gregorio); y Villafría, Villalpando y Villamayor, en el cajón $15^{\circ}$ (San Plácido). Y en estos casos, la documentación se ordenó en el legajo bien por pertenecer a un tipo diplomático concreto o a instituciones de cada lugar, que en principio se agruparon sin mezclarse.

Así ocurre en el caso de Arconada, donde la documentación de la hacienda y jurisdicción esta en los dos primeros cuadernos; separada de la iglesia y beneficio de San Facundo, que está en el cuaderno C; la de Santa María, en el D; mientras que los documentos relativos a las tercias y el noveno de la iglesia se agrupan en el cuaderno E y las visitas de dicha iglesia, en el F. En el legajo de Aviñante se organiza la documentación de acuerdo a que los documentos sean de la parte de la hacienda que en el lugar tiene San Román (cuaderno A) o Nuestra Señora del Brezo (cuaderno C).

Para Valcavado, sin embargo, se agrupan los documentos de acuerdo al tipo documental: censos (cuaderno A), pleitos (cuadernos B y C); y otro tanto ocurre en el legajo con documentación de Villamayor, al agruparse en el cuaderno A donaciones y ventas; en el B, presentaciones, colaciones y otros tipos; en el C, pleitos. En definitiva, en los legajos con documentación más abundante de un determinado lugar, el criterio cronológico de ordenación no es el principal aunque está presente, sino que los documentos se ordenan por las tipologías diplomáticas estructuradas sin distinción ni previa prevalencia.

En los casos en que la documentación ingresó en San Zoilo porque la institución que generó o recibió los documentos se incorporó al monasterio, se asignó un cajón para su guarda respetando la procedencia y singularidad del archivo de cada una de las instituciones incorporadas: cajón $1^{\circ}$ (Santa María), para el priorato de San Juan de Aguilar de Campos; $8^{\circ}$ (San Agapio), para la iglesia de San Martín de Frómista; $9^{\circ}$ (San Román), para el barrio de San Martín de Frómista; $13^{\circ}$ (San Facundo), para Toro y su comarca; $16^{\circ}$ (San Mauro), para Villamuera; y $18^{\circ}$ (San Ildefonso), para Villaverde de Golpejera. 
Una primera aproximación a estos cajones permite observar que la agrupación de cada documento en los diferentes legajos y cuadernos no es baladí. El monasterio de San Zoilo sabía perfectamente que la defensa de su patrimonio era la clave para el mantenimiento de sus funciones espirituales, por lo cual va a establecer una clara división entre aquellos documentos probatorios de derechos económicos y jurisdiccionales -donaciones, compras, truques y otros papeles como pleitos-, es decir, la memoria de la hacienda; y la documentación alusiva a la organización eclesiástica y la comunidad monástica y parroquial que, si bien concernían al cenobio, no ponían en peligro el sustento material de la comunidad.

En los tres cajones destinados a custodiar la documentación de San Zoilo de Carrión: $4^{\circ}$ (San Pedro), $5^{\circ}$ (San Andrés) y $6^{\circ}$ (San Zoilo), los documentos se agrupan en legajos y cuadernos a partir de la tipología diplomática: bulas, privilegios reales, donaciones, compras, trueques, foros, entre ellos; y por pertenencia a las instituciones dependientes del cenobio: Hospital de Nuestra Señora de la O, de San Lázaro y la Herrada, parroquia y capilla de doña Constanza.

El cajón $19^{\circ}$ (San Leandro) se dedica a los juros, con legajos diferentes según se trate de juros que proceden de concesiones reales, y entonces se asocian a privilegios; o bien se trate de juros redimidos, que se colocan en el legajo $3^{\circ}$; o bien de escrituras que tocan a los juros (que van al legajo $2^{\circ}$ ).

En el cajón $20^{\circ}$ (San Millán) se agrupan los apeos, y se individualizan en libros distintos de acuerdo a la institución a la que afectan: Nuestra Señora del Brezo, San Román, Carrión, Arconada; mientras que en el 21 (Santo Toribio), los censos se agrupan de acuerdo a criterios alfabéticos y toponímicos.

El cajón $22^{\circ}$ (San Vicente) se dedica a tipos diplomáticos bien definidos: bulas (comunes a la religión) y cédulas; y junto a ellos, en el legajo $2^{\circ}$ del cajón se agrupan documentos de tipología variada o inclasificable, es decir, papeles; continuando con el cajón $23^{\circ}$ (San Rosendo) en el que se agrupan escrituras de arriendo; el 26 ${ }^{\circ}$ (Santo Domingo), las tazmías; y en el $27^{\circ}$, las cartas de pago.

Finalizan la lista los cajones $24^{\circ}$ (San Veremundo) y 25\% (San Claudio), quizás únicos por su carácter menos documental y económico, destinados para la guarda fundamentalmente de algunos libros, imprescindibles estos en toda comunidad monástica, así como "algunos testamentos". 
En conclusión, hemos de afirmar que el esbozo de cuadro de clasificación que ofrecemos está realizado a partir de lo que el que el propio Índice nos ofrece, y que es reflejo de lo que fue el archivo del monasterio de San Zoilo; revelador, como no puede ser de otro modo, no únicamente de la complejidad de la historia del monasterio, sino también de sus continuas y constantes relaciones con el entorno en el que desarrolló su actividad.

Esta aludida complejidad es la causa de que en la de organización del archivo se vislumbre un concepto de archivo clásico para los archivos monásticos y se agrupen los documentos a partir de criterios alfabético-topográficos, pero también que se mantengan individualizados los fondo/archivos de los prioratos que se anexionaron. Una organización ${ }^{285}$ topográfica que se ajusta al concepto de archivo, pensado como depósito de documentos que hacen posible y más fácil la administración del patrimonio y su defensa.

Cuando alguno de esos lugares o territorios, ya fuesen prioratos -como el caso concreto de San Juan de Aguilar de Campos, San Martín de Frómista o San Salvador de Villaverde-, o simplemente villas -como Villamuera-, eran lo suficientemente importantes y habían generado o recibido un amplio volumen documental, les era asignado un cajón independiente para albergar toda la documentación por ellos producida. Los otros tres prioratos adscritos al monasterio en las fechas en las que se redactó el Índice (Nuestra Señora del Brezo, San Lorenzo de Villalpando y San Román de Entrepeñas) compartieron

${ }^{285}$ La clasificación que nos muestra el Índice era común sólo en parte a la organización establecida en los archivos de otros monasterios, en los que se destinaba un lugar aparte y primordial para aquellos documentos fundacionales y privilegios, especialmente cuando el libro en el que se recogían era un tumbo o becerro.

Troche de Zúñiga se refería a esta cuestión del "arreglo de los archivos" con estas palabras: “[...] documentos que traten del todo de los bienes, derechos o intereses [...] que a todas denominamos Documentos generales [...] Los documentos particulares necesitan de otro arreglo y división muy diferente que la de los generales, pero así mismo la más natural [...] Divídense así los documentos por provincias, corregimientos, jurisdicciones, alcaldías, parroquias, lugares, villas, $[\ldots]$ casas, fábricas, molinos, dehesas $[\ldots]$ sin que de esta regla se pueda esceptuar los archivos de comunidades y corporaciones religiosas y eclesiásticas [...] arreglados cronológicamente y con la precisa antigüedad de años, meses y días [...]”. TROCHE Y ZÚÑIGA, Froilán, El Archivo Cronológico Topográfico. Arte de Archiveros. Coruña: Imprenta de Iguereta, 1835.

En Sahagún, a mediados del siglo XVI, "Los monjes tenían distribuidos los documentos de este Archivo en dos grandes secciones. En la primera colocaron los privilegios y gracias reales y apostólicas, y en el segundo todos los demás, debidamente clasificados por orden alfabético de los pueblos ó monasterios á que se referían". Véase Índice de los documentos del Monasterio de Sabagún, de la Orden de San Benito y glosario y diccionario geográfico de voces sacadas de los mismos. Madrid: Imp. Aribau y Cía., Sucesores de Rivadeneyra, 1874, p. VII, nota 1.

Esta misma situación se observa en el Tumbo Legionense de la Catedral de León, aunque con la salvedad de que, una vez copiados los diplomas fundacionales y dotacionales, no se prosiguió con la copia de los documentos por orden alfabético de los lugares en los que la catedral poseía algún bien. Véase HERRERO JIMÉNEZ, Mauricio, "La escritura mayúscula en el Tumbo Legionense", en MARTíN LÓPEZ, M. ${ }^{a}$ Encarnación-GARCÍA LOBO, Vicente (coords.), Las inscripciones góticas: II Coloquio Internacional de epigrafía medieval, León del 11 al 15 de septiembre 2006. León, 2010, pp. 479-504.

El Tumbo de Astorga del Archivo de Santa María de Nogales organiza su documentación en cajones, pero colocando al comienzo los documentos de donación para luego continuar con la relación de demarcaciones territoriales en las que el monasterio poseía intereses. 
cajón con otras comarcas en las que el cenobio poseía heredades, mantenía negocios jurídicos o recibía y dispensaba los beneficios de alguna parroquia o capellanía.

Tanto para los prioratos como para esos lugares en los que las posesiones y su administración generaban más documentos, los legajos -aunque más esencialmente los cuadernos- se convirtieron en la categoría clave para agrupar los diplomas por su tipología o actividad, dando lugar a grupos muy cercanos a las hoy denominadas series, si bien guardando las distancias con el significado archivístico que esta subdivisión del fondo posee en la actualidad.

Algunas de estas "series" -reiterando que la ordenación del Índice se basa en el ámbito estrictamente diplomático y no archivístico- aparecen reseñadas como típicas de los archivos monásticos en el trabajo publicado por Vivas Moreno y Domínguez Ortiz ${ }^{286}$. En este sentido, conviene destacar aquellas que estos autores engloban entre las que permiten llevar la "economía espiritual" del monasterio, caso de los testamentos, donaciones, escrituras de patronazgo, fundaciones, compras, permutas o censos -entre otras muchas-, las cuales representarían "una especie de trueque entre protección y favor religioso"287 imprescindible para el sustento de la comunidad. Aunque también se registran en el Índice otros tipos como bulas, privilegios, reales decretos, visitas e incluso pleitos civiles y criminales, así como documentación exclusiva de las parroquias, como partidas sacramentales, capellanías y obras pías, a modo de ejemplo.

Cabe destacar una última cuestión, y es la relativa a la prioridad que supuso para el monasterio el mantener el orden de procedencia para aquellos fondos que se incorporaban a San Zoilo al anexionarse la institución productora, como ya hemos señalado en varias ocasiones en este mismo capítulo. La cuestión es si esta prioridad fue tal o pesó más en determinados casos la ordenación topográfica, motivada por la relevancia del lugar o por la cantidad de documentación que esas poblaciones generaban y recibían de manera individual. Nos estamos refiriendo al caso concreto de San Román de Entrepeñas y Nuestra Señora del Brezo, prioratos ambos indispensables para San Zoilo, a los que, sin embargo, no dedica un cajón para su documentación, sino que los incluye en los de aquellas poblaciones (siguiendo el orden topográfico) en los que San Román o Nuestra Señora tenían sus posesiones.

Esta realidad se observa en los siguientes casos y poblaciones:

\footnotetext{
286 PÉREZ ORTIZ, G.-VIVAS MORENO, A., "Ensayo de organización de la documentación conventual: propuesta de cuadro de clasificación”, pp. 441-467.

287 Ibidem, p. 456.
} 
- En Aviñante: el cuaderno A contiene papeles pertenecientes a la hacienda de San Román en este lugar; el cuaderno C, hacienda de Nuestra Señora del Brezo; y el cuaderno D, hacienda de San Zoil en este lugar.

- En Barajores: el cuaderno C, hacienda de San Román; el cuaderno E, hacienda del Brezo.

- En Bárcena: el cuaderno F, hacienda del San Zoil; el cuaderno G, hacienda del Brezo.

- En Basurbio: hacienda del Brezo.

- En Las Heras: el cuaderno A, papeles pertenecientes a la hacienda que tiene San Román y San Zoil en este lugar; el cuaderno B, hacienda que tiene Nuestra Señora del Brezo en este lugar.

- En Respenda: el cuaderno A, papeles pertenecientes a la hacienda que tiene San Román en este lugar.

- En Villafría: el legajo 1º, cuaderno A, donación que hizo el rey don Alonso del lugar de Villafría a San Román y hacienda que tiene Nuestra Señora del Brezo en este lugar; el legajo $2^{\circ}$, cuaderno A, pleitos entre la casa de San Román y la del Brezo con el Consejo de Villafría.

Existe la posibilidad de que fuese San Zoilo el que disgregara los documentos que le llegaban del fondo de estas filiales; aunque nos inclinamos más por la opción que, al incorporarse al monasterio más tardíamente estos prioratos -casi en el siglo XVI- ya poseerían sus archivos esta misma ordenación topográfica y que San Zoilo lo único que hizo fue acoplarla a su propia organización. Separando así por un lado aquellos diplomas producidos a raíz de la conformación y administración del priorato y su parroquia, y por el otro aquellos lugares en los que la hijuela poseía propiedades; aunque diferenciando que su hacienda pertenecía a uno u otro priorato, quizás con la sabida pretensión de que las rentas que estos generasen pudieran ir destinadas al mantenimiento de dichas casas sin necesidad de derivar algunas de las producidas por la casa principal.

Nuestro Índice del siglo XIX ofrece datos sobre la organización del archivo en los últimos años del monasterio ${ }^{288}$, pero con anterioridad existieron instrumentos y tablas

288 DE LA CRUZ HERRANZ, "El archivo monástico”, p. 230, señala respecto a una posible reconstrucción de los archivos monásticos que "El estado de desorganización en que nos han llegado la práctica totalidad de los archivos monásticos después de las sucesivas desamortizaciones hace que una hipotética reconstrucción de la organización original del archivo sea, nos atrevemos a decir, una misión imposible en la inmensa mayoría de los casos".

Esta afirmación nos permite enfatizar aún más la importancia de este instrumento clave para intentar, a partir de su estructura, esa "misión imposible" de reconstruir la organización del archivo del monasterio de San Zoilo. 
similares. De una de ellas al menos nos ha llegado constancia de su existencia. Nos referimos al Manual del Archivo de San Zoil de Juan de Cisneros, preparado por el monje en $1635^{289}$.

Este Manual, a diferencia de nuestro Índice, no realiza un resumen individualizado de cada unidad documental, sino que se limita a referir de manera general el contenido de cada cajón y sus legajos, que no se ordena alfabéticamente. Por ello, anexiona una tabla manual y alfabética, índice en el que ordena los títulos de los lugares y cosas que se incluían en el archivo, remitiendo al cajón y al legajo en que pueden encontrarse.

Sólo conociendo el esquema completo que refleja la organización del Índice podemos señalar algunas de las semejanzas y diferencias respecto al manual de Cisneros del siglo XVII, que nos proporcionan las claves para conocer la realidad del archivo que descubren estos dos instrumentos.

La diferencia más clara que se puede observar es que el Manual no sigue, como señalábamos, una ordenación alfabética, lo que supone que fray Juan de Cisneros no se atuvo a las normas dictadas por la Congregación de Castilla, que, por otra parte, él mismo incluye al comenzar el Manual. En ellas, se explicitaba que se organizase la documentación por cajones ordenados alfabéticamente por lugares, correspondiendo cada cajón a un lugar concreto.

Sin embargo, él pensó que esta ordenación presentaba una serie de inconvenientes: primero, la gran cantidad de lugares en los que el monasterio tenía posesiones haría necesario multiplicar el número de cajones, por lo que prefiere mantener los cajones ya existente en el archivo; segundo, y al que confiere mayor importancia, era que esta organización facilitaría el acceso a la información a personas ajenas al monasterio, decidiendo así titular cada cajón con nombres de santos e incluir un segundo libro o tabla alfabética que sirviera para "inteligencia del primero", haciendo imprescindible la presencia del archivero.

\footnotetext{
289 AHN, Clero, Libro 9552. El estudio y transcripción de este Manual puede encontrarse en PALACIO, Colección San Zoil. I, pp. 572-582; II, pp. 516-600.

Coetáneamente al manual, en el año 1620, se redacta para el monasterio de San Claudio un manuscrito que narra exclusivamente la historia de este centro benedictino que comienza con la "Fundación de la iglesia antigua y Martyrio de San Vicente, San Ramiro i sus doce compañeros", y termina así: "Yo también doy por concluido este manualico, que he acabado con infatigable trabajo, porque no he dejado papel en el archivo, grande ni pequeño, que no haya leído [...]". Por sus palabras y su cronología podríamos encajarlo en la órbita de la realización de este tipo de obras por parte de los archiveros de los monasterios benedictinos, que en parte reflejaría esa preocupación inicial por organizar la documentación.

Su transcripción ha sido realizada por DÍAZ-JIMÉNEZ Y MOLLEDA, Eloy, "Real Monasterio benedictino de San Claudio de Léon, 1885": Revista Erudición ibero-ultramarina, Descripciones bibliográficas, Madrid, 1930-1932.
} 
Viendo la ordenación de este Manual, se observa claramente que el Índice no se ajustó a la ideada por fray Juan de Cisneros, pues sólo conservó el nombre y el orden de cada cajón, aunque añadió a los 24 iniciales otros tres más, el cajón 25 (San Claudio), el 26 (Santo Domingo) y el 27 (San Prudencio).

Cabe señalar, por último, la ordenación que la propia M. ${ }^{a}$ Luisa Palacio propone, basándose para ello en las anotaciones encontradas en el reverso de los documentos, aunque limitándose a los años que comprendía su estudio, los siglos XI al XV. A pesar de que la autora realiza una ordenación alfabética según el nombre del santo que titula los cajones, se observa, haciendo una comparación con el Índice, cómo los documentos que incluye cada cajón corresponden a los mismos lugares mencionados en el Índice para ese cajón. Es decir, las notas que ella utilizó se correspondían, en mayor o menor medida, a la ordenación establecida en el Índice, como no podía ser de otra manera.

El secretismo y protección con la que el padre Cisneros concebía el archivo, y que se observa no sólo en la organización que él mismo planteó sino en sus propias palabras: "El primer aviso es que nunca se fie archivo de quien no tuviere este háuito", son testimonio del concepto de archivo, inaccesible por el valor probatorio de los documentos, y el incalculable papel que cobraban en la defensa del patrimonio monástico en esos momentos.

El Índice de San Zoilo es la prueba evidente de la concepción del archivo en el momento de su escrituración, establecido por las Constituciones de la Congregación, que pretende hacer más fácil el acceso (limitado a los encargados del mismo) a la información contenida en los documentos, facilitar la gestión del patrimonio y la defensa del mismo, porque más rápida era la localización de los diplomas a partir de la consulta del Índice, lo que hacía posible esa gestión y la defensa de la heredad monástica. 


\section{EL ÍNDICE DE SAN ZOILO DE CARRIÓN}

\subsection{Historia archivística}

El 28 de marzo de 1866 se crea el Archivo Histórico Nacional ${ }^{290}$, cuya preciada función no sería otra que la de hacerse cargo - con las consiguientes funciones de recogida, conservación y descripción que ello suponía- de aquellos documentos que, tras la supresión de las comunidades monásticas y junto con un sinfín de bienes y propiedades, habían sido expropiados e incautados por el Estado a consecuencia de las sucesivas Desamortizaciones eclesiásticas de las que el siglo XIX se había convertido en protagonista de excepción. Así lo expresa el artículo $1^{\circ}$ del Real Decreto fundacional del archivo, por el cual "[...] se declara Archivo público general del Reino, bajo la denominación de Archivo Histórico Nacional, al reunido con los documentos procedentes de las suprimidas corporaciones monásticas por la Real Academia de la Historia, en esta Corte, donde en adelante habrá de permanecer" ${ }^{\text {291. }}$.

Acepta esta ardua tarea, ante la solicitud de la Real Academia de la Historia para que se creara un nuevo archivo que se encargase de esa documentación que venía custodiando desde que, por la Real Orden de 18 de agosto de 1850, se derivaran a ella los fondos de los archivos eclesiásticos almacenados en los abarrotados -y pocas veces adecuados- locales

\footnotetext{
${ }^{290}$ La creación del Archivo Histórico Nacional se engloba dentro del conjunto de consecuencias indirectas que se derivaron del ambicioso programa de reformas administrativas del Estado, ideadas por los ministros de Isabel II; siendo la Hacendística una de las más incisivas al encontrar, en la confiscación y posterior venta de aquellas propiedades que durante siglos habían formado parte del patrimonio de la Iglesia, una solución eficaz a los graves problemas económicos que atravesaba el fisco Real. Como resultado, numerosas comunidades religiosas desaparecen y con ellas sus archivos, necesitados a partir de ese momento de un establecimiento que se encargase de realzar la nueva categoría adquirida, la histórica, por los documentos tras la pérdida de su original función jurídica como garantía de derechos y posesiones.

Véase DIEGO RODRÍGUEZ, "Fondos Monásticos", p. 51. La autora explica que el Archivo Histórico Nacional es el primero con función de centro de investigación histórica, indicando como precedente la apertura al público investigador de los archivos estatales españoles por Real Orden de 20 de abril de 1844, privilegio reservado hasta entonces para la Administración así como para algunos investigadores esporádicos (Gaceta de Madrid de 24 de abril de 1944).

Así lo establecía el R.D. de creación al indicar que "se le dé la consideración que merece, declarándole público, conservándole en esta Corte para que pueda ser más útil a la Academia a la vez que a los aficionados a los estudios históricos, y dotándole en fin del personal que se estime estrictamente necesario" (Gaceta de Madrid de 31 de marzo de 1866).

${ }^{291}$ Gaceta de Madrid de 31 de marzo de 1866.
} 
que para tal fin se habían habilitado provisionalmente en las Delegaciones de Hacienda ${ }^{292}$. Su pronta intervención resultó fundamental para la conservación de los diplomas, tal y como queda evidenciado al afirmar que la "ilustrada cuanto persistente iniciativa de la Real Academia de la Historia logró evitar en gran parte semejante daño, que habría impreso un negro borrón a la cultura de nuestra patria, obteniendo se le confiase por varias Reales disposiciones la conservación y custodia de los documentos históricos que pudieran recogerse de los Archivos de Hacienda, y la formación de índices"293.

A tenor de esta circunstancia, es lógico imaginar que la documentación del monasterio de San Zoilo, incautada en 1835 por la Comisión de Amortización, pasase también al Archivo Histórico Nacional a través del acceso de la documentación a una de las dos instituciones que para ello se establecerían sucesivamente en la capital; bien a partir de 1850, ingresando momentáneamente en la Academia de Historia para ser posteriormente trasladada al Archivo Histórico Nacional; o bien directamente a este archivo desde su ubicación provincial, hecho este que se habría producido en 1866 -al menos con parte de su documentación-, al ser esta la fecha en la que se registra una primera noticia de la existencia de documentación del cenobio carrionés en el archivo ${ }^{294}$. No obstante, los documentos de las instituciones que desbarató la Desamortización, y que para el caso de

292 DIEGO RODRÍGUEZ, Natividad de, "La Desamortización y la sección de Clero del Archivo Histórico Nacional. Culto y Clero”, en Desamortización y Hacienda Pública. Tomo I. Madrid, 1986, pp. 45-55.

293 Gaceta de Madrid de 31 de marzo de 1866.

294 En el "Inventario de los Fondos o Procedencias del Archivo Histórico Nacional, con expresión del número de documentos que comprenden": Revista de Archivos, Bibliotecas y Museos I, 7 (1871), pp.102-106, y 8 (1871), pp. 118-124., aparecen registrados un total de 474 documentos para la entrada: "Palencia, Benedictinos de San Zoil en Carrión de los Condes y de San Román de Entrepeñas", indicando que ese inventario estaba hecho en base a un recuento realizado en 1866 "después de haber sido declarado público el archivo”. Se publicó una edición aparte con el título Inventario del Archivo Histórico Nacional. Madrid, 1871.

Aunque los primeros fondos en ingresar en el Archivo Histórico Nacional fueran los procedentes de los archivos de los monasterios y conventos desamortizados, no será hasta principios del siglo XX cuando, una vez completados los trabajos de clasificación, surja la sección Clero Secular y Regular, bajo cuya denominación se conservará a partir de ese momento la documentación procedente de las instituciones del clero seglar y del sometido a una regla.

Un estudio completo sobre la formación de la Sección de Clero y sus fondos puede verse en DE LA CRUZ HERRANZ, Luis M. "La Sección de Clero del Archivo Histórico Nacional”, en II Jornadas científicas sobre documentación de la Corona de Castilla (siglos XIII-XV), Madrid, 2003, pp. 373-432.

En 1924 se publica ARCHIVO HISTÓRICO NACIONAL, Clero secular y regular: inventario de procedencias: Archivo Histórico Nacional. Valladolid: Imprenta de la Casa Social Católica, 1924. Esta se convertirá en la obra de referencia para conocer los fondos que componen esta sección.

Una relación completa de las fuentes para el estudio del Monacato Benedictino a través de la sección Clero Secular y Regular, y en concreto para San Zoilo, puede encontrarse en DIEGO RODRÍGUEZ, "Fondos Monásticos", pp. 68-78, especialmente p. 76.

Para un conocimiento exhaustivo de toda la documentación del monasterio que fue trasladada y que conforma actualmente algunos de los fondos más importantes del Archivo Histórico Nacional, remitimos al Portal de Archivos Españoles bajo el título "Monasterio de San Zoilo de Carrión de los Condes (Palencia). Benedictinos", "Monasterio de San Martín de Frómista (Palencia). Benedictinos", "Monasterio de San Román de Entrepeñas (Palencia). Benedictinos". 
San Zoilo es una realidad, se encuentran dispersos - dicha dispersión ya fue explicada en capítulos anteriores- tras las numerosas vicisitudes y circunstancias, que de manera individual y no siempre fortuita, decidieron la morada final de los diplomas que tan celosamente habían sido protegidos por los monjes durante siglos.

El Archivo Histórico Provincial de Palencia es una de estas "moradas" custodias de un conjunto, para nada desdeñable, de documentos producidos por el monasterio. Entre ellos se encuentra, como ya veníamos indicando desde el comienzo de nuestro trabajo, el códice denominado "Índice de San Zoilo". Así pues, llegados a este punto, no sería de justicia ignorar la pregunta cuya respuesta nos permitirá comprender y valorar, aún más si cabe, la trascendencia de este sobrio instrumento de consulta (y la importancia de la información que atesora) incluso fuera de los muros que fueron testigos de su escrituración. La pregunta que hemos de hacernos es ¿por qué si las órdenes de traspaso de la documentación al Archivo Histórico Nacional eran tan categóricas e imperativas, uno de los últimos manuscritos redactados en el monasterio prácticamente en los albores de la Desamortización -instrumento clave para el estudio de la historia de dicha casa-, nunca llegó a formar parte de aquellos documentos seleccionados para su transferencia?

La respuesta a esta pregunta la encontramos paradójicamente en el enunciado de la misma. Instrumento clave, sí, puesto que después de serlo para el archivo del que fue guía lo seguiría siendo para los nuevos administradores del patrimonio monástico, quienes, ávidos por obtener una rápida rentabilidad de sus propiedades, encontraron en esta suerte de Índice un "mapa" preciso con el que guiarse y conocer la vasta hacienda que durante siglos acaudaló y administró - de la manera más diligente que las circunstancias de cada época le permitieron- el cenobio carrionés y que ahora pasaría a engrosar las arcas del maltrecho Estado.

Basta con dirigirnos nuevamente al Decreto fundacional del Archivo Histórico nacional para encontrar entre sus líneas un aval factible que sirva de sustento para esta teoría. Dicho decreto, en el artículo $4^{\circ}$ y en lo atañente a estas cuestiones señala: "por mí, Ministro de Fomento, de acuerdo con el de Hacienda, se adoptarán las disposiciones necesarias a fin de que sean trasladados al Archivo Histórico Nacional todos los documentos procedentes de las suprimidas comunidades monásticas que existan en las Administraciones de Hacienda pública y no fueren indispensables para acreditar derechos de propiedad" 295 . Lo preciso y a la par razonable de estas palabras, torna casi innecesaria y

${ }^{295}$ Gaceta de Madrid de 31 de marzo de 1866. 
vana cualquier otra explicación; reservaron para sí aquellos instrumentos y documentos necesarios e imprescindibles para realizar correctamente y más fácilmente también sus funciones como organismos de amortización.

Una vez aclarada dicha cuestión, podría resultar baladí dedicar un apartado al estudio de la historia archivística del códice de San Zoilo; si no fuese por el hecho de que no hacerlo supondría dejar de lado, desatender dos elementos indispensables para la comprensión de los avatares históricos, archivísticos y, por qué no, económicos, de todos aquellos bienes desamortizados y templos abandonados desde las primeras décadas del siglo XIX, y que no son otros que los inventarios de desamortización y las Comisiones Provinciales de Monumentos históricos y artísticos.

El poder económico acumulado por buena parte de los monasterios desde su fundación hasta el siglo XVIII, basado tanto en las tierras y haciendas de las que eran propietarios como en el riquísimo patrimonio cultural y artístico del que eran depositarios, convirtieron a estas instituciones en el centro de acción de las políticas desamortizadoras practicadas durante el siglo XIX, encubriendo bajo la apariencia de un exacerbado anticlericalismo lo que en la mayoría de las ocasiones únicamente fue otro negocio más con el que obtener rentabilidad y beneficio para el Estado.

La primera de estas medidas llegaría a través del Decreto de 18 de agosto de 1809 $9^{296}$. En una España convulsa por los desastres que la invasión francesa estaba provocando, José Bonaparte, siguiendo la estela de su hermano, quien en 1808 había clausurado una tercera parte de los conventos existentes con la consiguiente incautación de sus bienes, ordena la supresión de todas las Órdenes religiosas. El monasterio de San Zoilo, que a principios del siglo XIX podía presumir de encontrarse en una posición económica privilegiada $^{297}$, va a sufrir los desmanes producto de su liquidación y de las malas artes de algunos de los empleados encargados de hacer cumplir las órdenes establecidas ${ }^{298}$.

Todas estas circunstancias adversas no impidieron que el archivo se conservase prácticamente intacto, tal y como lo evidencia la cronología de los asientos registrados en el Índice para estas fechas. Ya hicimos referencia en capítulos anteriores al sintomático vacío

\footnotetext{
${ }^{296}$ Gaceta de Madrid, n. ${ }^{\text {2 } 234, ~ d e ~} 21$ de agosto de 1809, pp. 1043 y 1044.

${ }^{297}$ FRANCIA LORENZO, Santiago, Anecdotario para la pequeña historia de un pueblo. Notas de archivo. 1, Palencia, 1985, p. 36, aporta la relación de rentas percibidas por el monasterio en 1804, con una cifra de 23600 reales anuales, lógica si consideramos que las heredades del cenobio se extendían por las actuales provincias de Valladolid, Palencia y Zamora.

298 FERNÁNDEZ MARTÍN, Luis, "La diócesis de Palencia durante el reinado de José Bonaparte 18081813", pp. 248-254.
} 
documental existente entre los años 1810 y $1813^{299}$; pero no dimos cuenta de aquellas dichosas situaciones que pudieron contribuir a su salvaguarda. Como hemos advertido ya, el proceso desamortizador iniciado por José Bonaparte no pilla desprevenidos a los monjes de San Zoilo, los cuales, a instancia del abad fray Plácido Emelgo, parten hacia Asturias el 8 de mayo de 1810, llevando consigo todos los libros, alhajas, trigo, cuadros y demás efectos que fueron capaces de portar; circunstancia esta que los pone a salvo del posterior saqueo hecho por las tropas francesas, auspiciados por don Manuel Merino de Castro, administrador de Bienes Nacionales ${ }^{300}$.

A esta circunstancia se une el hecho de que fray Plácido Emelgo, quien quedaría como párroco de la parroquia del extinto monasterio, será destituido de dicho cargo en junio de 1810, tras haber sido injustamente acusado de hurto y ocultación de bienes, entre ellos las llaves del archivo y del dinero, al no haber asistido a la entrega de bienes del monasterio cuando fueron requeridos por el mencionado administrador ${ }^{301}$. La fortuna hizo que los parroquianos del barrio de San Zoles así como algunos vecinos de otros prioratos, declararan a favor del depuesto abad en el expediente de ocultación de bienes del monasterio de San Zoilo y priorato de Villaverde abierto en su contra, argumentando que muchos de los bienes habían sido extraídos por particulares y permanecían ocultos o

299 El último regesto antes de las medidas desamortizadoras está fechado el 11 de junio de 1809: AHPP, Desamortización, Legajo 112, f. 437v. El registro documental se retoma en agosto de 1814: AHPP, Desamortización, Legajo 112, f. 119v.

${ }^{300}$ Unos meses antes de que se produjera la marcha de los monjes, y fruto del decreto de exclaustración, las autoridades francesas llevaron a cabo la inspección del monasterio en busca de aquellos bienes que pudieran ayudar a paliar los efectos de la deuda pública del Estado, así como contribuir al avituallamiento e intendencia de las tropas francesas enfrentadas a las guerrillas españolas. Fruto de este registro es un inventario de los bienes muebles y las alhajas existentes en la iglesia y sacristía, realizado el 18 de septiembre de 1809 en presencia del abad, junto con la copia (realizada el 15 de enero de 1810) de otro inventario idéntico realizado el 25 de septiembre del 1809. En la relación de bienes realizada el 18 de septiembre, el abad se hace responsable de que dicho inventario se hace "[...] sin que haia havido ocultación o extravío de alaxa alguna", quedando su custodia “[...] a su cargo bajo de toda responsabilidad”. AHPP, Desamortización, Leg. 435 s/f.

Muchos de estos efectos y alhajas registrados en estos inventarios habrían desaparecido ya del monasterio unos meses después cuando se proceda a la entrega de bienes; por lo que el administrador de bienes culpará de dicho extravío al abad, vertiendo sobre él toda una serie de insultos y acusaciones.

Se conserva además otro inventario, fechado el 25 de septiembre de 1809, de “[...] los bienes muebles, trigo y demás granos, halajas y efectos existentes en este priorato de Villaverde, hijuela del monasterio de San Zoil, en la villa de Carrión", hecho en presencia del padre prior, monje Granero y fray Melito Fernández. AHPP, Desamortización, Leg. 436 s/f. Este inventario es más completo que los anteriores, puesto que no describe solo lo que se hallaba en la iglesia y sacristía, sino que describe con detalle los objetos encontrados en otras dependencias como la cocina y la bodega, además de los aperos de labranza, grano y ganado ovejuno (poseía el priorato 163 ovejas de vientre, 67 corderas, 102 corderos y dos carneros primales). Destaca el dinero en metálico encontrado en la bodega y entregado al comisionado don Manuel Caballero por el prior, que ascendía a la nada desdeñable cifra de setecientos reales de vellón.

${ }^{301}$ Lo cierto es que el administrador de bienes Manuel Merino nunca contó con la presencia del abad para elaborar los inventarios, tal y como lo demuestra el hecho de que en los inventarios conservados para San Zoilo se haga constar que su realización se condiciona, precisamente, a que esté ausente el abad. 
"emparedados en los desvanes" 302 . Fuesen infundadas estas acusaciones o incluso si alguna de ellas pudo llegar a ser real -resulta lógico pensar que el abad quisiera proteger aquello que consideraba de vital importancia, aunque eso supusiera dificultar el acceso al mismo de las autoridades competentes-, lo cierto es que este cúmulo de condiciones permitió la salvaguarda de muchos efectos, entre los que pudo encontrarse el archivo y por ende el Índice de San Zoilo.

Tanto es así que, tras la salida de los franceses del cenobio y de manera prácticamente inmediata a la vuelta de las reliquias de San Zoilo y San Félix al monasterio, custodiadas desde 1810 en la parroquia de Santa María del Camino en Carrión, se registra en el Índice el testimonio de su traslado y colocación en el monasterio el 13 de agosto de 1814 303 ; prueba inequívoca de que el códice, y con este el archivo, probablemente nunca llegaron a estar en manos de las autoridades francesas, lo que permitió su pronta utilización y facilitó la vuelta al desarrollo de la actividad escrituraria y "archivística".

Habría que esperar solamente unos años para que el Trienio Liberal iniciase otro nuevo conato desamortizador, que sacudiría al monasterio de una forma trascendental y tan incisiva que las pérdidas ocasionadas en el patrimonio y en la documentación iban a ser difícilmente reversibles.

Por Decreto de 1 de octubre de 1820 se suprimían todos los monasterios de las órdenes monacales, entre los que, por supuesto, estaban incluidos los canónigos regulares de San Benito, pasando sus bienes muebles e inmuebles a ser considerados bienes nacionales susceptibles de ser aplicados al crédito público. El 11 de octubre se promulgaba de Ley de desvinculaciones, que suprimía todos los mayorazgos, fideicomisos, patronatos y cualquier otra vinculación de bienes; y que prohibía la adquisición de nuevos bienes inmuebles a todo tipo de "manos muertas". Todas estas reformas serían sancionadas definitivamente por Fernando VII el 25 de octubre de 1820, a través de la conocida como "Ley de Monacales".

El 9 de marzo de ese mismo año la ocupación del monasterio de San Zoilo ya se había hecho efectiva y el convento fue suprimido en septiembre, al igual que lo harían los

\footnotetext{
302 FERNÁNDEZ MARTÍN, Luis, "La diócesis de Palencia durante el reinado de José Bonaparte 18081813”, pp. 251-252.

$303 \mathrm{El}$ acto de entrega de la posesión del monasterio de San Zoilo a los monjes se realiza el 23 de junio de 1814, tras la solicitud realizada por el abad fray Fulgencio del Campo al intendente de la provincia de Palencia, fechada el 21 de junio de 1814. AHPP, Desamortización, Legajo 56.
} 
cenobios palentinos de Cardeñosa, Benavides, Benevívere o Arenillas de San Pelayo, entre $\operatorname{otros}^{304}$.

Una idea precisa de los perjuicios materiales y morales que este agresivo periodo trajo tanto para el monasterio y su hacienda como para la comunidad de monjes, legos y demás personal a él vinculado, nos la proporciona la minuciosa y detallada relación de los daños sufridos por el cenobio y sus monjes que fue enviada desde San Zoilo en 1823 a petición del General de la Congregación, Fr. Miguel Godos, deseoso de conocer el estado en que habían quedado todos los monasterios benedictinos de la congregación tras los desastres que el Trienio Liberal había provocado. El abad fray Plácido Emelgo ilustraba así el deterioro del convento: “[...] todas sus riquezas, grandeza y consideración desde lo material al edificio hasta la principal forma de su perfección, adorno y hermosura, todo lo perdió en los tres años de la rebelión" 305 .

Los comisionados del Crédito público se llevaron en primer lugar aquellos instrumentos necesarios para el control del vasto patrimonio que poseía el monasterio, comenzando por los libros de cuentas y el archivo, hasta llegar a las fincas y propiedades registradas en los libros de hacienda y apeos, sin olvidarse por supuesto de los valiosos libros de la librería y de todos los bienes muebles que encontraron a su paso por las dependencias de la casa ${ }^{306}$.

Para realizar tan infausta labor se valieron de una serie de cinco inventarios, prescritos por la Junta Nacional del Crédito Público ${ }^{307}$, que fueron falseados por los

304 GARCÍA GARCÍA, Lorena, Monasterio de San Zoilo de Carrión de los Condes. Arte e bistoria de un bito cluniacense, p. 273.

305 Recoge dicha carta ZARAGOZA PASCUAL, Ernesto, "Relación de los daños sufridos por algunos monasterios benedictinos españoles durante el Trienio Constitucional (1820-1823)": Stvdia Monástica, 30-1, (1988), pp. 121-163, especialmente p. 153-158.

Ésta carta y otras doce enviadas por algunos monasterios benedictinos se conservan en el Archivo de la Congregación de Valladolid, en el Monasterio de Silos.

306 GARCÍA GARCÍA, Lorena, Monasterio de san Zoilo de Carrión de los Condes, p. 273.

307 Uno de esos inventarios quedó en el monasterio tal y como lo indica la noticia que de su existencia nos proporciona el listado de QUINTÍN ALDEA: "Inventario manuscrito hecho en 1820 de los muebles y enseres del monasterio de San Zoil por fray Plácido Emelgo. Falta el quaderno $3^{\text {o". }}$

Otro de ellos, que recogía las obras de arte que atesoraba la biblioteca (hasta 50 lienzos de temática religiosa), puede consultarse en el Archivo Histórico Nacional, entre los papeles procedentes de la Desamortización, bajo la signatura AHN, Clero Secular-Regular, legajo 5343 s/f, papeles de desamortización. Proporciona esta información GARCÍA GARCÍA, Lorena, Monasterio de San Zoilo de Carrión de los Condes, p. 274.

RAMÍREZ DE HELGUERA, Martín, El libro de Carrión de los Condes, p. 172, parece estar consultando un inventario cuando realiza una enumeración de las fincas, censos y foros que poseía el monasterio al expresar: "Por multitud de donaciones tuvo fincas, según un inventario de 15 Enero de 1821".

La importancia que dichos inventarios radicaba en su propia naturaleza como sistema de recuento de aquellas propiedades de las que estaba en posesión cada monasterio o convento, puesto que estas constituían la base de la riqueza de la que el Estado pretendía apoderarse; tanto así que las directrices para su elaboración estaban perfectamente delimitadas y definidas, como nos lo muestra una "Ynstrucción para la formación de 
comisionados, lo que les permitió quedarse para sí cuantos efectos quisieron, sometiendo a vejaciones y amenazas al abad, que había quedado como párroco de la iglesia y sacristía, y al que obligaron a sancionarlo con su firma y suscripción con violencia.

La llegada en 1823 de los Cien Mil Hijos de San Luis puso fin a la experiencia liberal. La nueva ley obligaba a restituir todos los bienes y propiedades incautados, sin que por ello debieran recibir compensación alguna sus compradores. Sin embargo, dichos bienes fueron malvendidos en almoneda pública a precios ínfimos y sus fincas vendidas a personas poco cautas o arrendadas por una cantidad insignificante en comparación con los beneficios que de ellas había conseguido obtener el monasterio. Bienes con los cuales llegaron a sostener una comunidad de cincuenta monjes profesos, sin descuidar por ello la atención a sus obligaciones de misericordia y caridad.

A esto se une las elevadas sumas de dinero que el monasterio se vio obligado a invertir para recuperar su hacienda en los numerosos procesos judiciales y extrajudiciales, cuyos autos, testimoniados en formas de diligencias, testimonios, tomas de posesión, así como los derechos de escrituración requirieron unos desembolsos no pequeños.

ymbentarios de los combentos que quedan suprimidos en esta provincia por la reunión de regulares de ellos en conformidad con lo establecido por el govierno" elaborada por la Comisión Principal de Crédito Público de la Provincia de Palencia, con fecha de 9 de abril de 1821, y conservada en el Archivo Histórico Provincial de Palencia bajo la denominación "Monasterio de San Agustín. Cervera. Inventarios. 1821”. AHPP, Desamortización, leg. 436. Esta instrucción contenía los siguientes artículos y pautas:

"Ynstrucción para la formación de ymbentario de los combentos que quedan suprimidos en esta provincia por la reunión de regulares de ellos, en conformidad a lo resuelto por el govierno.

Artículo $1^{\circ}$. Los comisionados por el Crédito Público formarán los ymbentarios de todas las pertenencias de los combentos suprimidos, clasificándolas con la asistencia de la persona que nombre el señor intendente; que será en los partidos, los contadores de la Hacienda Nacional, y en los pueblos donde no haya contador, el alcalde constitucional o en su defecto el provisor jurídico, concurriendo también a la entrega y firmando los ymbentarios este representante con el comisionado del crédito público y el prelado persona que le represente.

Yd. $2^{\circ}$. Para mayor claridad se formarán de cada convento tres ymbentarios separados. El primero comprenderá todos los títulos de fincas, censos, foros, diezmos, prestaciones de todas clases, juros, efectos de villa, imposiciones en los fondos públicos y establecimientos mercantiles y particulares. El segundo de los vienes muebles y efectos semovientes, vales reales, créditos contra el Estado y particulares, las escrituras o contratos de arriendo, los libros de cuenta y razón; recogiendo los comisionados del estado todos estos efectos y conduciéndolos a esta capital con seguridad, escepto los vienes muebles, que se quedarán depositados en persona abonada bajo su responsavilidad hasta que se disponga la venta arreglando diligencia. El tercero conten/drá todas las fincas rústicas y urbanas, con espresión de si se hallan arrendadas, a quién, en qué precio y por quánto tiempo, lo que adeudan los colonos o arrendatarios, dónde radican su cavida y linderos y las cargas de justicia así civiles como eclesiásticas.

Yd. $3^{\circ}$. De los quadros, libros y demás efectos de viblioteca no se formará ymbentario y se custodiarán a disposición del señor gefe superior político de la provincia que es a quien corresponde su formación, depositándolo en las mismas casas suprimidas, encargando su cuidado a las justicias de los pueblos donde existan aquellas, y las que se hallen en despoblado a las del más inmediato vajo su responsabilidad.

Yd. $4^{\circ}$. Igual operación se hará con los efectos de yglesia y hornamentos destinados al culto, de los cuales deverá disponer el ilustrísimo señor obispo, escepto los comprendidos en la Real Orden de 31 de diciembre último, como son lámparas, ramos de plata y oro, custodias de mucho valor, coronas, diamantes y demás joyas; pues estos se depositarán, aun cuando se incluyan en el ymbentario de aquel, en personas de confianza vajo su responsabilidad, o se conduzcan a esta capital con toda seguridad hasta que las Cortes determinen el destino que deve dárselas." 
Lo convulso de la época explicaría el hecho de que los registros en el Índice cesen en $1818^{308}$, al ser el archivo uno de los bienes sustraídos durante la ocupación. Resulta innegable el hecho de que el Índice volvió al monasterio cuando lo hicieron el resto de bienes y propiedades incautadas -lo encontramos relacionado en un inventario realizado en 1835-, adquiriendo de nuevo su función de control del archivo; no únicamente porque permitía la localización física de las escrituras, sino también y además su localización intelectual en el fondo; es decir, era el instrumento que de una manera perfecta permitía situar el documento en el conjunto orgánico que es el archivo y que permite por ello conocer la organización y ordenación del mismo.

Podríamos imaginar las aciagas condiciones en que les fue restituido el archivo, puesto que así de nefastas fueron las acciones que llevaron a cabo para su sustracción, arrancando incluso para ello las rejas y ventana de la sala-archivo. Las pérdidas del archivo y de la biblioteca fueron incalculables ${ }^{309}$, tal y como lo relata el abad Plácido Emelgo en la relación de daños enviada al General de la Congregación en 1823:

"Del archivo faltan los preciosos códices del siglo XI, entre ellos uno [...] del monje Radulfo del mismo siglo, que traía en latín la historia de la traslación de los tres santos cuerpos San Zoilo, San Félix y San Agapio, obispo de Córdoba desde el monasterio cordobés famoso que fue cuna de este y otros santos, y cuenta entre sus hijos a San Eulogio; la mayor parte de las obras del padre Cisneros ${ }^{310}$, hijo de la casa y archivero de la religión de San Benito en España; infinitos privilegios de papas y reyes, con otros manuscritos de hijos de esta misma casa y papeles pertenecientes a las regalías del monasterio y de las casas de varios grandes de España, condes y marqueses, principalmente de [...] y Toro y Frómista"311.

La cantidad de documentos extraviados en el transcurso de esos tres desaventurados años, según señalaba el abad en su carta, nos lleva a plantearnos una hipótesis a partir de las nada triviales anotaciones encontradas a lo largo del Índice. La expresión "falta" aparece recurrentemente -en concreto la encontramos reseñada 129

\footnotetext{
308 AHPP, Desamortización, Legajo 112, f. 6v.

309 "En la biblioteca se llevaron toda la cajonería para el Crédito Público; los mejores libros se vendieron [...] el principal tesoro de los monjes era la librería que vino a perecer casi toda, juntada con tanto trabajo en tantos siglos". ZARAGOZA PASCUAL, "Relación de los daños sufridos por algunos monasterios benedictinos", p. 156.

310 Véase la lista de sus obras en ZARAGOZA PASCUAL, Ernesto, Los Generales de la Congregación de San Benito de Valladolid. Vol. IV. Abadía de Silos, 1982, pp. 419-420.

BECERRO DE BENGOA, Ricardo, "El Monasterio de Carrión”, p. 77, nos proporciona una relación de aquellas obras del "muy ilustre benedictino Fr. Juan de Cisneros" que a finales del siglo XIX aún se conservaban en el monasterio, en concreto dieciséis obras escritas "[...] en admirable y clara letra diminuta benedictina".

311 ZARAGOZA PASCUAL, "Relación de los daños sufridos por algunos monasterios benedictinos", p. 154.
} 
veces en el Índice - al margen derecho de algunos de los regestos y está escrita por otra mano diferente a la que redactó en origen los asientos de cada documento. No hay un denominador común, siguiendo un criterio tipológico o cronológico, que explique el motivo por el cual esa palabra había sido escrita para esa serie de documentos, exceptuando el hecho de que quizás, a la vez que utilizaban el manuscrito para organizar los documentos que les permitirían recuperar su hacienda y reconstruir el archivo, fueran anotando la falta de aquellos que no habían sido devueltos al monasterio tras la desamortización.

Señalando precisamente dicha falta al margen del registro de la escritura pretendían conseguir que, en el caso de que el documento pudiera ser necesario para algún pleito, no invirtieran su tiempo en intentar localizarlo sin éxito en el archivo; además de facilitarles las anotaciones de las pérdidas documentales la tarea del recuento, así como la evaluación del menoscabo que su extravío produciría para la correcta administración de los bienes del monasterio.

Con todo y a pesar de maltrecha situación en que habían quedado tanto el edificio como los contados pertrechos que pudieron recuperar, no iba a ser este el último de los reveses que acabarían definitivamente con la vida del monasterio de San Zoilo concebido como lugar de oración de una comunidad que vivía bajo la regla de San Benito.

La implantación a marchas forzadas del sistema liberal en España convirtió el proceso desamortizador en la clave para su consecución definitiva, y a los bienes del clero en el instrumento idóneo con el que lograrlo, al resultar imprescindible el cambio de régimen jurídico de la tierra para que se produjera el tránsito hacia la nueva sociedad de clases, lo que garantizaría al mismo tiempo el dinamismo necesario en la economía para hacer frente a la deuda del Estado ${ }^{312}$.

Sin embargo, no es la faceta económica y jurídica la única resultante de este proceso desamortizador. La exclaustración trajo consigo, como ya había ocurrido en casos anteriores, la nacionalización de todos los bienes y posesiones de la Iglesia; pero mientras que las fincas y propiedades inmuebles fueron progresivamente enajenadas, otros bienes -entre los que se encontraba el ingente patrimonio documental, bibliográfico y artísticofueron conservados, apelando para ello a su valor cultural y a la creciente conciencia sobre la necesidad de conservar el patrimonio histórico-artístico que ya la Ilustración venía impulsando y fomentando en España desde el siglo XVIII.

\footnotetext{
312 TOMÁS Y VALIENTE, Francisco, El marco político de la Desamortización en España, Barcelona, 1971, define la desamortización como "la nacionalización (conversión en Bienes Nacionales) y su posterior venta en pública subasta de tierras y otros bienes hasta entonces pertenecientes a las llamadas manos muertas".
} 
La única diferencia estriba en la consideración otorgada a la documentación de archivo, pues al ser esta justificante y aval de derechos de propiedad sobre los bienes sustraídos, primó temporalmente su valor primario. Los documentos quedaron en posesión de las Comisiones de Amortización, gestoras del patrimonio inmueble, hasta que pasaron a depender de las Delegaciones Provinciales de Hacienda. Una parte de esa documentación adquiriría una nueva consideración a partir de la segunda mitad del siglo XIX, al ser reclamada progresivamente por la Academia de la Historia y el Archivo Histórico Nacional como instrumentos imprescindibles para la investigación y la reconstrucción de la historia de la Iglesia en España. Otra parte de la misma permanecería en manos del Ministerio de Hacienda hasta la creación de los Archivos Históricos Provinciales encargados a partir de entonces de su conservación.

El monasterio de San Zoilo fue suprimido en noviembre de $1835^{313}$, en consonancia con el proceso desamortizador que había iniciado unos meses antes el ministro Mendizábal ${ }^{314}$. Todos los monjes se vieron obligados a abandonar el monasterio exceptuando su abad, fray Plácido Trevijano, quien lo era desde 1832 y permaneció vinculado al convento, en calidad de capellán, hasta su muerte, ocurrida en $1873^{315}$.

Por Decreto de 25 de julio del 35 se ordenó la supresión de aquellos conventos que tuvieran menos de doce religiosos profesos; la medida, adoptada a raíz de los brotes de violencia que habían estallado contra los religiosos, no afectó a San Zoilo, que contaba para esas fechas con un número de religiosos muy superior ${ }^{316}$. Esta orden no resultó del todo eficaz, por lo que el 11 de octubre ${ }^{317}$ se decretó la supresión de todos los monasterios,

313 RAMÍREZ DE HELGUERA, Martín, El libro de Carrión de los Condes, p. 176; GARCÍA GARCÍA, Monasterio de San Zoilo de Carrión de los Condes, p. 274, nos informa de que la enajenación fue comunicada al monasterio a través de una carta que el jefe político de Palencia, don Isidro Pérez Roldán, envió al convento el 18 de octubre de 1835; la cual se conserva en el Archivo de la Compañía de Jesús de Alcalá de Henares (ACJAH), C11, Carrión de los Condes, 10. Historia, fondo benedictino, visitas, inventarios.

314 Para el estudio y análisis del proceso desamortizador han sido consultadas las siguientes monografías: TOMÁS Y VALIENTE, Francisco, El marco politico de la Desamortización en España”. Barcelona, 1971; RUEDA HERNÁNZ, Germán, La desamortización de Mendizábal y Espartero en España. Madrid, 1986; RODRÍGUEZ LÓPEZ-BREA, Carlos M., Frailes y Revolución Liberal. El Clero Regular en España a comienzos del siglo XIX (18001814). Toledo, 1996; RUEDA HERNÁNZ, Germán, La desamortización en España: un balance (1766-1924). Madrid, 1997; BELLO, Josefina, Frailes, intendentes y politicos. Los bienes nacionales (1835-1850). Madrid, 1997; REVUELTA GONZÁLEZ, Manuel, La exclaustración (1833-1840), Madrid, 1976.

315 BECERRO DE BENGOA, Ricardo, "El Monasterio de Carrión”, p. 92, 94.

316 Según LINAGE CONDE, Antonio, "Un caso de sucesión de familias religiosas en una misma sede: benedictinos y jesuitas en San Zoilo de Carrión de los Condes", en II Actas del Congreso de Historia de Palencia. Tomo3, 2. Palencia: Diputación Provincial, 1990, pp. 785-794, especialmente p. 788, el monasterio contaba con cincuenta monjes cuando se lleva a cabo su exclaustración.

317 El Decreto fue publicado en la Gaceta de Madrid, n. ${ }^{\circ}$ 292, el 14 de octubre de 1835. Se iniciaba con una exposición de los motivos que habían abocado al estado a tomar esa decisión "[...] me hacen estimar indispensable y muy urgente, considerando cuan desproporcionado es a los medios actuales de la nación, el número de casas monásticas que queda, cuan inútiles o innecesarias son la mayor parte de ellas para la asistencia espiritual de los fieles, cuan grande el perjuicio que al reino se le sigue de la amortización de las 
independientemente del número de monjes con el que contasen, procediendo a la incautación de sus bienes y rentas que serían aplicados para la extinción de la deuda pública, exceptuando aquellos bienes -entre los que se encontraban archivos y bibliotecasque por su calidad cultural o artística se reservarían para otros fines ${ }^{318}$.

Para regular dicha actividad se estableció la confección de una serie de inventarios de cuya redacción quedaban a cargo los propios monasterios ${ }^{319}$, encomienda que realizarían bajo la supervisión conjunta de los intendentes de las provincias y los delegados de Hacienda. Una Real Orden de 29 de julio de 1835 dirigida a los gobernadores civiles, ordenaba la creación de comisiones en cada provincia para inventariar y recoger los bienes nacionales, definiendo además cuál debía ser el procedimiento de actuación:

“1”. Que V.S. al recibo de esta Circular y según la extensión de su provincia nombre una comisión de tres o cinco individuos inteligentes y activos, los cuales tengan a su cargo examinar, inventariar y recoger cuanto contengan los archivos y Bibliotecas de los monasterios y conventos suprimidos [...].

$4^{\circ}$. Nombrada la comisión y puesto V.S. de acuerdo con el intendente acompañará aquella a los comisionados de la Dirección de Amortización que pasen a hacerse cargo de los Conventos y de común inteligencia se formarán los inventarios de los objetos terminantemente excluidos en dicho artículo $7^{\circ}$ de la adjudicación al pago de la deuda pública.

$5^{\circ}$. Deberá V.S. mandar se formen inventarios separados de cada clase de objetos y tres copias autorizadas de cada uno de ellos para que se pueda quedar uno

fincas que poseen, y cuanta la conveniencia pública de poner estas en circulación para aumentar los recursos del estado y abrir nuevas fuentes de riqueza".

Firmado por la reina Gobernadora doña M. ${ }^{a}$ Cristina de Borbón, establecía la supresión de “[...] los monasterios de Órdenes monacales, los de canónigos reglares de San Benito de la Congregación Claustral, Tarraconense y Cesaraugustana; los de San Agustín y los Premostratenses, cualquiera que fuese su número de monjes o religiosos de que se compusieren".

318 El artículo $7^{\circ}$ del decreto de 25 de julio determinaba el destino de los bienes de las comunidades suprimidas como instrumento para "[...] la extinción de la deuda pública o pago de sus réditos". Se exceptuaban de dicha aplicación los "[...] archivos, bibliotecas, pinturas y demás enseres que puedan ser útiles a los institutos de ciencias y artes [...]”. REVUELTA GONZÁLEZ, Manuel, La exclaustración (1833-1840), p. 327.

319 Una orden de 29 julio procedente del Ministerio del Interior comunicaba al secretario del Despacho de Gracia y Justicia que los religiosos deberían colaborar en la conservación e inventariado de los bienes muebles -archivos, bibliotecas, pinturas y demás enseres- existentes en los respectivos monasterios, ordenando a los prelados "[...] que no sólo impidan bajo su responsabilidad que desaparezcan ninguno de dichos objetos, sino que formen lista separada de ellos, y la entreguen a los encargados de recogerlos [...]”. GARCÍA LOPEZ, Genaro Luis, Libros para no leer: el nacimiento de la política documental en España. Madrid, 2004, pp. 46-47. 
en el Archivo del Gobierno civil de cada provincia, otro en el de esta Secretaría de Despacho y el tercero en las Academias o Bibliotecas de esta Corte" ${ }^{320}$.

Esta Real Orden será confirmada a través de una Circular de 12 de agosto, dirigida a los gobernadores de provincia, estableciendo las normas precisas con arreglo a las cuales se debía realizar la toma de posesión y la formación de estos inventarios. Dichas normas serían comunicadas al comisionado principal y contador de Arbitrios de cada provincia que, junto con los delegados de la autoridad civil y eclesiástica, serían los encargados de llevar a término las órdenes del gobierno.

La fortuna ha hecho que uno de los inventarios confeccionado en San Zoilo ${ }^{321}$ haya llegado hasta nosotros conservado entre los papeles del fondo Desamortización que ingresaron en el Archivo Histórico Provincial de Palencia. Conformado por dos partes perfectamente diferenciadas - los bienes inmuebles ocupan una sección al margen de los enseres muebles-, recoge los siguientes apartados:

- Un inventario de las tierras propias del monasterio de San Zoilo de la villa de Carrión que se hallaban en arriendo, indicando su duración y rentas que pagan en especie corriente y los atrasos que se deben.

- Una relación de las rentas en dinero obtenidas a través de foros, censos y menudos; a las que se suman las conseguidas en capones, gallinas y cabritos.

- Un inventario de los efectos y muebles del cenobio, confeccionado entre el 19 de octubre y el 24 de noviembre de $1835^{322}$.

Por su relevancia y utilidad para conocer la historia archivística del Índice de San Zoilo, nos vamos a centrar en el estudio del tercero de estos inventarios, el cual comienza con las siguientes palabras:

'Ymbentario que los infrascritos S[eñore]S R[everendísimo] P[adre] Abad don Plácido Trevijano, el Padre Granero, don Joaquín Rodríguez; don Ylario Girón, subdelegado de rentas; don Justo Martínez Davalillos, contador de las mismas, y en representación de arbitrios de amortización de la provincia don

\footnotetext{
${ }^{320}$ Real Orden de 29 de julio de 1835, publicada en Gaceta de Madrid, n. ${ }^{\circ}$ 217, el 4 de agosto de 1835.

321 AHPP, Desamortización, Legajo 435. "Ymbentario del Monasterio de San Zoylo de Carrión. Tomada razón de lo perteneciente al Gobierno Civil”.

Su composición se ajusta fielmente al esquema de descripción que para estos inventarios proporciona BURÓN CASTRO, Taurino, "Los inventarios de desamortización. Recurso para el seguimiento del patrimonio documental": Boletín de la $A N A B A D, 45-4$ (1995), pp. 25-50, especialmente p. 31, donde señala que se comenzaba "por la descripción de fincas rústicas y urbanas, censos, foros, cargas. Luego se describen los muebles. En este apartado figura la relación del archivo, biblioteca y objetos de arte distribuidos por las diferentes dependencias".

322 Ofrezco la transcripción del inventario en el anexo que va al final del capítulo.
} 
Francisco San Martín, comisionado de dichos arbitrios de este partido, forman de todos los efectos y muebles pertenecientes a este suprimido monasterio de San Zoilo, con arreglo a la Real Orden Circular de doce de agosto de este año, habiendo dado principio a este ymbentario el día 19 de octubre de este año, según se nos prebino con fecha 18 del mismo en esta forma".

Toda la información que nos proporciona, tanto la relativa a las fechas como a las personas que intervinieron en su redacción, se corresponden a la perfección con las leyes dictadas para tal efecto; su confección se inicia tan sólo unos días después de la orden desamortizadora de 11 de octubre que afectó al monasterio, tomando como referencia para su correcta elaboración la circular de 12 de agosto ya referida ${ }^{323}$. Se contó para ello con la presencia de los representantes del monasterio -el abad y el padre Granero-, el comisionado de arbitrios, el contador de rentas y el subdelegado de las mismas en la provincia.

A lo largo de sus cinco folios incluye una relación de los diversos enseres que estaban distribuidos por la "casa combento con sus habitaciones altas y bajas, huerta y demás pertenencias", incluyendo la hospedería, cocina, cillería, refectorio, chopete, antebodega, bodega, cuadra, sacristía, iglesia, coro, sala capitular, claustro, panera y, como no podía ser de otra manera, la biblioteca y el archivo.

Resultarían significativas las escuetas cuatro líneas que dedica a los libros hallados en la biblioteca, que se reducen a unas nada desdeñables novecientas obras aunque todas incompletas; si no fuese por lastimoso testimonio del abad Emelgo, ya aludido anteriormente, en el que se duele por la pérdida que el Trienio Liberal había ocasionado de muchas de las más valiosas obras de su biblioteca.

No obstante, será en el archivo donde encontremos una de las relaciones más precisas y cuidadas, motivados en gran parte porque era en esta dependencia donde

\footnotetext{
323 BELLO, Josefina, Frailes, intendentes y políticos, p.87, describe cómo el proceso de intervención en los monasterios se desarrollaba con rapidez para impedir que los religiosos escondiesen algunos bienes u ocultasen la documentación de archivo, como ya había ocurrido en las anteriores experiencias desamortizadoras. Así, escribe, "llegados al convento a la hora acordada con las comisiones civiles y autoridad eclesiástica, reunirían a la comunidad en una de las dependencias más amplias del edificio y se les comunicaría el objeto de la visita leyéndoles las medidas acordadas en cuanto a la seguridad y conservación de los bienes que se iban a incautar a favor del Estado, e inmediatamente recorrerían, acompañados por el superior o prior, las distintas dependencias del edificio para conocer y asegurar, mediante inventario, todos aquellos bienes que se iban descubriendo. La parte más importante, y por ello a la que prestaría más atención la comisión sería el archivo y biblioteca donde se guardaban los títulos de propiedad de las fincas, escrituras de censos y demás rentas y en general todos los documentos acreditativos de propiedades y cuentas que les permitirían conocer el patrimonio que iban a incautar. Una vez hallados los libros, se rubricarían y asegurarían sellando el archivo por medio de carpinteros para evitar el acceso a los mismo; los documentos recogidos se custodiarían en la Contaduría de Amortización".
} 
encontrarían los títulos de propiedad y otros instrumentos que refrendarían la posesión de todas aquellas haciendas, rentas y propiedades que hasta ese momento había poseído y administrado el monasterio. Precediendo a su descripción se enumeró una relación de trece libros relacionados con la administración del convento, entre los que se encontraban un libro de granería, otro borrador, un manual de bodega, de molinos, de las cuentas de la sacristía, así como otros cuatro manuales correspondientes a los prioratos de las Heras, San Román, el Brezo y Villaverde.

Comienza esta descripción con el instrumento clave que, tal y como hubiera deseado para sí el general de la Congregación Fray José Balboa, se convirtió en un regalo para los comisionados de amortización, y que no era otro que el Índice del archivo: "Primeramente un manual que contiene el índice general de los papeles y demás documentos pertenecientes a este monasterio".

Es la primera mención explícita a la existencia de este manuscrito desde que se iniciase el proceso desamortizador a comienzos del siglo XIX; lo cual no resulta extraño teniendo en cuenta la protección que del archivo llevaron a cabo los propios monjes durante la invasión francesa y el escaso cuidado y atención que la desamortización liberal dispensó a la documentación.

La minuciosa descripción que hacen de cada uno de los cajones y legajos que contienen nos pone bajo la pista que, de forma simultánea al registro de la cajonería, estarían cotejando su reflejo en el Índice, con el que se correspondería casi de manera idéntica, con la excepción de algunos legajos y documentos sueltos ${ }^{324}$. La suerte del archivo en los casi veinte años que separan el último asiento registrado en el índice -el 21 de diciembre de 1818- de la redacción de este inventario, aparece reflejada en sus páginas; puesto que, aunque no se realiza una reseña individual para cada uno de los documentos, la sucesión de cajones y legajos nos indica que el orden del archivo se mantuvo prácticamente

\footnotetext{
324 Resulta sintomático el carácter estrictamente administrativo de aquellos documentos que, estando registrados en el Índice, no se encuentran en el archivo en el momento en el que se realiza el inventario. Las motivaciones de esta ausencia bascularían entre la posibilidad de que hubieran sido requeridos como prueba para alguno pleitos de los que nos informaba el abad Plácido Emelgo, tras la complicada experiencia de 1820 -destaca al respecto la falta del legajo $1^{\circ}$ del cajón $8^{\circ}$ correspondiente a las donaciones, compras, trueques y foros del priorato de San Martín de Frómista, actualmente conservadas en el Archivo Histórico Nacional-; y la posibilidad de que nunca volvieran al monasterio tras la desamortización de 1820, como pudo ser el caso de los juros del cajón 19, varios libros de apeos pertenecientes al cajón 20, las bulas y cédulas del cajón 22 destinado ahora para los arriendos que antes estaban en el cajón 23 y al que se ha añadido un censo en la localidad de Autol ubicado anteriormente en el cajón 21, así como el cajón 27 correspondiente a cartas de pago y otros instrumentos. Mención aparte requieren los cajones 13 y 14; al absorber el cajón 13, antes reservado a los papeles de Toro y su comarca, toda la documentación del cajón 14, quedando este reservado para los libros de granería y mayordomía antiguos y documentos de informaciones de monjes.
} 
intacto durante esos años, siendo este códice la guía que habrían utilizado en el caso que dicho archivo se hubiera visto necesitado de una reorganización.

Completa la enumeración un arquetón y mesa de pino viejo, referencia también única a lo que pudo ser el antiguo mobiliario del archivo de San Zoilo ${ }^{325}$ y que, tras su enajenación, fue sustituido por un mueble de finales del siglo XIX que los jesuitas instalaron para albergar los escasos testimonios del antiguo archivo benedictino que quedaron en el cenobio tras la exclaustración.

Finaliza este inventario el 24 de noviembre de 1835 con la rúbrica y aprobación de las referidas autoridades eclesiásticas y civiles anteriormente citadas. Incluye una anotación fechada en Palencia, el 22 de noviembre de $1836^{326}$, indicando que todos los muebles inventariados fueron vendidos en almoneda pública celebrada el 9 de noviembre de ese mismo año, con una enumeración aquellos que no habían conseguido venderse por falta de personas interesadas en adquirirlos.

Las medidas desamortizadoras provocaron la paralización del proceso de producción documental iniciado por el monasterio en el siglo X, así como la ruptura de la unidad y organización del archivo durante tantos siglos conservada; sólo quebrantada por la dispersión y el deterioro de la documentación una vez perdida la función jurídica y el valor probatorio e informativo por el que había sido creada y conservada. La atención se centró casi exclusivamente en aquellos documentos con vigencia administrativa y se descartaron otros muchos que hasta el siglo XIX habían permitido sustentar la vida espiritual y conventual de la comunidad.

Las nuevas instituciones encargadas de su administración, las Contadurías de Bienes Nacionales y las Delegaciones de Hacienda, toman el relevo de la producción documental, generando nuevas tipologías documentales a partir de la gestión de los bienes y propiedades enajenados, tarea para la cual resultaría imprescindible la posesión de los títulos de propiedad y de los documentos que acreditasen los fallos favorables cuando el monasterio pleiteó en defensa de su patrimonio. Para que esta labor fuese más realizable, dichas

\footnotetext{
325 Esta es la única mención que recoge el Índice al posible mueble que habría estado colocado en el archivo: "Véase la escritura de apartamiento en el libro de escrituras, ante Alonso Zapata, que empieza el año 1603, al folio 97 hasta el 102, que está en el estante tras de la puerta de yerro, donde está la cajonería”. AHPP, Desamortización, legajo 112, f. 448r, n. ${ }^{\circ} 21$.

326 Se observa un contraste entre la mano encargada de redactar el inventario y la que escribe esta anotación, siendo esta última mucho más cursiva, escrita en una caja de escritura de mayor tamaño, y con los astiles y caídos más pronunciado. Esta divergencia estaría producida por el hecho de que el inventario original, realizado en 1835, habría sido redactado por el propio abad o incluso por el padre Granero, que suscribía con él este registro; mientras que la nota, incluida un año después, se habría escrito fuera del monasterio por alguna de las personas encargadas de gestionar los bienes muebles desamortizados, valiéndose de este inventario para su control.
} 
oficinas procedieron a la confección de una serie de inventarios administrativos y contables en los que se recogían los datos de censos, foros, haciendas y fincas que generaban un beneficio al nuevo propietario de las mismas, el Estado ${ }^{327}$.

Las noticias relativas al Índice de San Zoilo desaparecen durante casi un siglo hasta que, en 1962 y por Orden Circular de la Subsecretaría del Ministerio de Hacienda de 12 de enero, se decrete el traslado de los fondos de Hacienda - administración de propiedades y derechos del Estado relativa a la Desamortización civil y eclesiástica del siglo XIX- de más de 25 años de antigüedad a los Archivos Históricos Provinciales ${ }^{328}$. El Archivo Histórico Provincial de Palencia recibirá en 1968 la documentación generada por la Desamortización que había permanecido custodiada en el archivo de la Delegación Provincial de Hacienda ${ }^{329}$.

${ }^{327}$ En el Archivo Histórico Provincial se conservan algunos de esos instrumentos que la administración de los bienes inmuebles enajenados a San Zoilo generó en la Delegación Provincial de Hacienda y que se convertirían en fundamentales para administrar de una manera más óptima las propiedades y rentas enajenadas: hojas de registro de censos y hojas de registro de fincas. Ambas consisten en unos cuadernillos apaisados formados por bifolios unidos por el margen izquierdo; la primera hoja se destina al título informativo del cuaderno, con indicación de la tipología -censos o fincas-, la fecha, así como del nombre del monasterio o priorato al que afecta. En su interior la información se organiza en columnas, indicando las personas o corporaciones que pagan, las fincas sobre las que gravitan, su situación, capital/rentas, época del pago, fecha de la escritura de imposición, pueblo en que se otorgó y ante qué escribano pasó, para el caso de los censos; y los establecimientos, clases de fincas, situación, renta anual y cargas, para los registros de fincas.

El AHPP recoge una "Hoja de registro de censos en fabor del monasterio de San Zoil de Carrión, orden de San Benito, 1841", una "Hoja de registro de censos del priorato de Nuestra Señora del Brezo, hijuela de San Zoil de Carrión, orden de San Benito, 1841" y otra "Hoja de registro de censos en fabor del priorato de San Román de Entrepeñas, hijuela de San Zoil, orden de San Benito, 1841". Además de una "Oja del registro general de fincas correspondiente al priorato de San Román de Entrepeñas, hijuela de San Zoil,", otra "Adicional de San Zoilo de Carrión (con registro de fincas)" y otra "Hoja de registro general de fincas de el Priorato Villaverde de Golpegera, hijuela de San Zoil de Carrión, 1840. AHPP, Desamortización, legajos 435, 436 (La hoja de registro de Fincas de Villaverde es la única que se guarda bajo la signatura 436). Completan esta enumeración los Expedientes de Arrendamiento de Fincas conservados para el priorato de Nuestra Señora del Brezo y San Román de Entrepeñas (1851), AHPP, Desamortización, legajo 170; y la "Razón de las fincas que se han de arrendar pertenecientes al estado por la subpresión del combento de San Zoilo de esta villa [...] del lugar del Villanueva de los Navos [...] 1837”, AHPP, Desamortización, legajo 171.

Esta ordenación y clasificación se llevó a cabo a raíz de la publicación de una Real Orden de 21 de febrero de 1840, de la Secretaría de Estado de Hacienda, y una circular posterior de la Dirección General de Rentas y Arbitrios de Amortización de 12 de marzo; directrices ambas necesarias por la acumulación de papeles y la incapacidad administrativa y archivística de los funcionarios para gestionarlos. BURÓN CASTRO, Taurino, "Los inventarios de desamortización", p.36-38; CABALLERO GARCÍA, Antonio, "Desamortización y patrimonio documental: un ejemplo de tratamiento de archivos en el siglo XIX": Signo. Revista de Historia de la Cultura Escrita, 15 (2005), pp. 77-117, especialmente pp. 81,82.

328 Más información acerca de los Archivos Históricos Provinciales puede verse en GENERELO LANASPA, Juan José, "Fuentes para la investigación en los Archivos Históricos Provinciales", en La investigación y las fuentes documentales de los archivos. I y II Jornadas sobre Investigación en Archivos. Vol. 1. Guadalajara, 1996, pp. 211324; GÓMEZ-LLERA GARCÍA-NAVA, Eduardo, "Los Archivos Históricos Provinciales": Cuadernos de historia moderna, 15 (1994), pp. 251-278, especialmente 257-258.

329 El AHPP se crea a partir del Decreto conjunto de los Ministerios de Justicia y de Instrucción Pública y Bellas Artes de 12 de noviembre de 1931, decreto que regulaba la creación de los Archivos Históricos Provinciales. No será hasta abril de 1932 cuando se constituya como tal con la inicial tarea de recoger y describir los protocolos notariales de la provincia. Guía de los Archivos de Castilla y León. Junta de Castilla y León, 2006, pp. 88-95. 
Dicho fondo estaría formado por dos series de documentos diferenciados por los cauces a través de los cuales llegaron a la Delegación de Hacienda: por un lado, aquellos diplomas que procedían de las instituciones desamortizadas, conservados por su valor probatorio de derechos y posesiones; y por el otro toda la documentación que el propio proceso desamortizador había generado, entre los que se encontraban los inventarios de bienes muebles e inmuebles y otra serie de registros producidos por las oficinas de Amortización en el desarrollo de sus funciones.

La creciente preocupación por el estado de conservación de la documentación procedente de los conventos y monasterios condujo a la creación en 1866 del Archivo Histórico Nacional, institución que recogería aquellos diplomas de carácter puramente histórico y que, con el paso de los años y la sucesiva ampliación de su capacidad y sus funciones, acrecentó al reclamar toda la documentación de aquellas instituciones desamortizadas que aún se encontraba en manos de la administración de Hacienda.

La existencia de expedientes y legajos de dicho proceso custodiados en el AHPP podría explicarse no tanto por una decisión deliberada de no colaboración con la Administración Central por parte de los encargados de Hacienda, difícil de entender si pensamos que a finales del siglo XX el grueso de la desamortización ya se había llevado a cabo, quedando dicha documentación sin vigencia jurídica, como por el hecho de que los Archivos Históricos Provinciales recogieron la documentación histórica de las administración central periférica. En otro sentido, cabría observar la consideración de los sucesivos olvidos de envío provocados por el amplio volumen documental que manejaban y del que eran responsables y en definitiva de unos inexistentes calendarios de transferencias periódicas al archivo histórico.

Sin embargo, las repetidas llamadas de atención por parte del Archivo Histórico Nacional $^{330}$ reclamando la documentación con valor histórica y por lo tanto susceptible de

Para más información acerca de la Delegación Provincial de Hacienda véase http://www.archivoscastillayleon.jcyl.es/web/jcyl/ArchivosCastillaYLeon/es/Plantilla100DetalleFeed/1253 861401355/FichaISAD/1257029865018/Archivo [Fecha de la última consulta: 29 de marzo de 2017]; GRUPO DE TRABAJO DE HACIENDA, "La documentación de las Delegaciones de Hacienda: valoración previa a la transferencia", en I Jornadas sobre Metodología para la identificación y valoración de fondos documentales de las Administraciones Públicas. Ministerio de Cultura, 1992, pp. 203-221.

330 El director del Archivo Histórico Nacional Vicente Vignau Ballester reclamó insistentemente a los Archivos Provinciales de Hacienda la remisión de aquella documentación con carácter histórico procedente de las órdenes monásticas suprimidas que no hubiera sido anteriormente remitida. Una Real Orden de 26 de agosto de 1898 y otra emitida el 11 de abril de 1899 incidían en estas reclamaciones, poniendo especial atención en algunas Delegaciones Provinciales de las cuales se sabía expresamente que estaban en posesión de este tipo de documentación, "ordenándoles que con la brevedad posible formen y remitan a este departamento la nota o relación de los documentos que pueden existir en sus archivos y se hallen comprendidos por su carácter en lo que determina aquella soberana disposición". El incumplimiento de dichas disposiciones queda patente en la documentación procedente del proceso desamortizador que 
una conservación permanente y un control que evitase su deterioro, inclina la balanza hacia la premeditación; teoría que quedaría confirmada con un somero análisis de la tipología documental de parte de esos diplomas que fueron transferidos al $\mathrm{AHPP}^{331}$ y que, junto con el Índice de San Zoilo, revelan que tanto aquellos como este seguían mostrándose

actualmente se conserva en los Archivos Históricos Provinciales. DE LA CRUZ HERRANZ, Luis Miguel, "La Sección de Clero del Archivo Histórico Nacional", pp. 379-380.

Los libros inventario de registro de entrada de documentación del Archivo Provincial de Hacienda de Palencia conservados en el AHPP reflejan la remisión de tales órdenes a los archivos provinciales y la insistencia que para llevar a cabo tal cometido puso el Archivo Histórico Nacional. Algunas de los registros lo expresan: "10 de octubre de 1898. Real Orden del Ministerio de Fomento trasladada al de Hacienda interesando de este que todos aquellos documentos históricos que se encuentren en los Archivos Provinciales de Hacienda sean trasladados al Archivo Histórico Nacional, en virtud de instrucciones que los archiveros reciban del jefe del mismo"; “<26 de noviembre [de 1898]>. Comunicación del Jefe del Archivo Histórico inquiriendo la situación en que se hallan los papeles referentes a las órdenes monásticas que obren en este archivo, según R.O. de 10 de octubre último, que se ordena sean trasladados al citado archivo"; "16 de diciembre de 1898. Comunicación del Jefe del Archivo Histórico Nacional indicando que, dadas las condiciones en que se halla este archivo y por tanto sus fondos, y a fin de dar cumplimiento a la Circular del Ministerio de Hacienda de $1^{\circ}$ de octubre último, para ello bastará hacer una nota de los legajos que comprenda la Sección de Órdenes Monásticas, manifestando que pertenecían en general a los combentos que tuvieron existencia en esta provincia en toda la Edad Media y principios de la Moderna".

La problemática sigue vigente en los años siguientes: "4 de agosto 1899. Recordando la R.O., fecha $1^{\circ}$ de octubre de 1898, sobre traslación al Archivo Histórico de documentos antiguos"; "13 de abril 1899. Orden del Jefe Archivo Histórico Nacional autorizándome para remitirle los documentos de las órdenes monásticas de esta provincia y demás de carácter histórico que existan en el de esta Delegación. Archivo Histórico Nacional, en 29 del mismo se hace la remisión; en 7 de mayo se devuelve el inventario con el recibí". El registro de entradas a este respecto finaliza el 7 de mayo de 1900 con el supuesto envío de toda la documentación requerida: "De un modo particular pregunta el jefe del Archivo Histórico Nacional si se han mandado todos los libros y documentos de órdenes monásticas, y en 8 del mismo se contesta por el mismo conducto de haberse enviado todos los libros y documentos de órdenes monásticas que se han encontrado"; lo cual no fue así a razón del amplio volumen documental que ingresó en el AHPP en 1968 procedente del Archivo Provincial de Hacienda.

Agradecemos la inestimable ayuda prestada por el Director del AHPP, Juan José Ruano Cerezo, para el conocimiento de esta fuente y otras informaciones relacionadas con la documentación procedente del proceso desamortizador en Palencia.

${ }^{331}$ En el AHPP se conservan, en el fondo Desamortización, junto con el Índice de San Zoilo, otros libros y documentos producidos por el monasterio y cuya tipología nos da una idea bastante fiable de las motivaciones administrativas que probablemente esgrimió el Archivo Provincial de Hacienda para no derivar dicha documentación al Archivo Histórico Nacional. Sirvan como ejemplo algunos de los siguientes documentos:

Legajo 113. Libro de apeos de 1586, imprescindible su manejo para conocer las lindes entre haciendas.

Legajo 111. Recoge más de 40 documentos fechados entre 1700 y 1841. Destacan por su predominio los censos, en los cuales encontramos, junto con una numeración diferente de la signatura proporcionada por el monasterio, algunas anotaciones hechas por los administradores de bienes (redimible, redimido, vendido) que nos informan del estado de dicho censo. Junto a estos, los juros, foros, trueques y arriendos, que quedarían completados por otros documentos más específicos, entre los que se encuentran: un Índice de bulas sueltas y de bulas y privilegios apostólicos, una Memoria breve del derecho que esta casa de San Zoyl tiene en la yglesia de nuestro priorato de San Joan Extramuros de la villa de Aguilar de Campos; "Lista de las tierras que labra y labró el monasterio de San Zoyl de Carrión desde el año de 96 y hasta el presente año inclusive de 1807"; "Lista de las tierras que labra el monasterio por haber muerto algunos que las llevaban en arriendo y haberse cargado el monasterio con ellas desde el año 1802"; "Lista de las tierras que labraba en monasterio de San Zoyl de Carrión en el año 1800 y que arrendó a sus feligreses del Barrio de San Zoles en el de 1801"; "Razón de las tierras que el monasterio de San Zoil labraba y que dio a renta en el año de 801"; "Relación [...] de San Martín de la villa de Frómista, de los bienes que posee dicho priorato, rentas y réditos que anualmente cobra y de las contribuciones que paga".

En los legajos 106 al 110, que no han sido revisados, se conserva asimismo documentación con información de interés sobre el monasterio de San Zoilo. 
indispensables para los administradores como pruebas que permitieron en otros tiempos el control del archivo de San Zoilo y la administración y guarda de su patrimonio.

Toda esa labor de protección y valoración del patrimonio documental, bibliográfico y artístico iniciada por la Academia de la Historia con el apoyo de la Real Academia de Bellas Artes de San Fernando ${ }^{332}$, se vio reforzado a mediados del siglo XIX con la creación, en 1844, de las Comisiones Provinciales de Monumentos Histórico Artísticos ${ }^{333}$. Estas comisiones estarían formadas por "cinco personas inteligentes y celosas por la conservación de nuestras antigüedades" y entre sus funciones estarían las de "1". Adquirir noticia de todos los edificios, monumentos y antigüedades que existan en su respectiva provincia y que merezcan conservarse; $2^{\circ}$. Reunir los libros, códices, documentos, cuadros, estatuas, medallas y demás objetos preciosos literarios y artísticos pertenecientes el Estado $[\ldots]$; y $5^{\circ}$. Crear archivos con los manuscritos, códices y documentos que se puedan recoger, clasificarlos e inventariarlos" 334 .

Su función como organismo garante de la conservación del patrimonio y el fomento de investigaciones en torno a este, se vio reforzada unos años después al poner bajo encomienda suya la custodia y reparación de las fábricas monumentales; encargándose en materia de archivos, de la adquisición de códices, diplomas, manuscritos y cualquier otro documento que pudiera contribuir al estudio histórico, así como del examen de los archivos existentes aún en las oficinas de la Hacienda Pública con el propósito de señalar los documentos que deberían pasar al Archivo Histórico Nacional.

En Palencia dicha Comisión tuvo especial relevancia desde su creación al actuar como intercesora ante el Ministro de Gobernación para impedir la venta en subasta pública del monasterio de San Zoilo, argumentando para ello la riqueza artística de su claustro renacentista. También se mostró activa en su preocupación por los libros de algunos conventos que se hallaban en la Sociedad Económica de Amigos del País de Palencia, así como por las pinturas procedentes de la sacristía de San Zoilo necesitadas de una

\footnotetext{
332 El Archivo de esta institución custodia un volumen importante de la documentación generada por las Comisiones de Monumentos Histórico Artísticos en el desempeño de sus funciones, como vigilante y protectora que fue del patrimonio histórico y artístico. Es fundamental la consulta de la obra: REAL ACADEMIA DE LAS BELLAS ARTES DE SAN FERNANDO ARCHIVO Y BIBLIOTECA, Inventario de los legajos de las Comisiones Provinciales y de la Comisión Central de Monumentos Histórico-Artísticos. Madrid, 2001, con correcciones a diciembre de 2013.

333 Información detallada acerca de la creación y labor de estas comisiones puede verse en TEIJEIRA PABLOS, María Dolores, "Las Comisiones de Desamortización y la conservación del patrimonio histórico en el siglo XIX. La Comisión Civil y la Comisión científica y artística de Zamora (aspectos documentales)", en MORÁN SUÁREZ, María Antonia-RODRÍGUEZ LÓPEZ, María del Carmen (coords.), La documentación para la investigación: homenaje a José Antonio Martin Fuertes, Vol. 1. León, 2002, pp. 539-552.

334 MARTÍNEZ PINO, Joaquín, "La gestión del patrimonio histórico artístico en el siglo XIX. Fuentes para su documentación”: Tejuelo, 12 (2012), pp. 10-21, especialmente pp.15-18.
} 
restauración por su pésimo estado de conservación ${ }^{335}$. Aun así, no será hasta finales del siglo XIX cuando, bajo la supervisión del médico palentino Francisco Simón Nieto, como secretario que fue de la Sociedad, se lleve a cabo la restauración del templo románico de San Martín de Frómista ${ }^{336}$ y la recopilación de buena parte de la documentación que se encontraba dispersa aún por los diferentes conventos y monasterios de la provincia ${ }^{337}$, destacando el lote documental correspondiente a San Martín de Frómista -como priorato dependiente de San Zoilo- que será donado al AHN, poniéndolo así a disposición de los investigadores.

Poder evaluar los daños producidos por la Desamortización en el archivo de San Zoilo haría necesario conocer cuáles fueron sus fondos documentales y poseer una descripción ajustada de su contenido, puesto que esto nos permitiría determinar con exactitud el volumen de documentación que se ha conservado y aquel que las adversas circunstancias han hecho desaparecer. Los inventarios de desamortización se convierten entonces en una fuente única para reconstruir el estado y la organización de los archivos monásticos y conventuales en los albores de este complejo proceso, el cual revalorizó la importancia económica de los documentos producidos por estas instituciones, descubriéndose al mismo tiempo su validez como fuente para reconstruir la historia. Esto traería como consecuencia la progresiva preocupación por la conservación de los fondos documentales y la puesta en marcha del germen de lo que sería la actual política archivística.

No obstante, la complejidad de dichas normativas, lo escueto en ocasiones de esos inventarios de desamortización y las consabidas pérdidas, deterioros y dispersión de la documentación sufridas al extraer los bienes de la protección y el cuidado con que hasta entonces habían contado, hacen del índice de San Zoilo un instrumento preciso y fiable que nos acerca a la realidad documental del archivo del Monasterio de San Zoilo, al aglutinar en un único libro toda la documentación, que el cenobio consideraba indispensable para su administración. Realidad esta que también supieron discernir los comisionados de Hacienda, al contar desde el principio con esta herramienta para conocer

\footnotetext{
335 GARCÍA GARCÍA, Lorena, Monasterio de San Zoilo de Carrión de los Condes, pp. 275, 276.

336 Discurso leido por Francisco Simón y Nieto, doctor en medicina y cirugía, en la velada literaria celebrada el 13 de noviembre de 1904 con motivo de la terminación de las obras ejecutadas en el templo románico de San Martín de Frómista (1895-1904). Palencia: Comisión de Monumentos Histórico Artísticos de la Provincia de Palencia. Imprenta y Litografía de Alonso e Hijos, 1904.

${ }^{337}$ Como miembro de la Sociedad Castellana de Excursiones realizó un estudio histórico-artístico de la Tierra de Campos mediante diversas excursiones en las que recogía aquellos documentos y papeles que encontraba, que utilizó para elaborar una construcción de la historia política, cultural y religiosa de esa comarca en su obra SIMÓN NIETO, Francisco, Los antiguos Campos Góticos: excursiones bistórico-artísticas a la Tierra de Campos. Palencia, 2006.
} 
y gestionar el patrimonio sustraído, haciéndole desempeñar de nuevo la función para la que había sido concebido por el monasterio.

\subsection{Comentarios codicológicos y paleográficos}

Instrumento extraordinario para la reconstrucción del antiguo archivo monástico, el Índice de San Zoilo presenta unos elementos externos e internos, unas particulares codicológicas propias de un manuscrito concebido en el monasterio para la descripción documental; cuestión que se ve reforzada a través del análisis de la estructura interna del libro y de su contenido textual.

El libro, conservado en el Archivo Histórico Provincial de Palencia, Sección Desamorización, e individualizado con la signatura: Legajo 112, tiene unas dimensiones de $330 \times 220 \times 85 \mathrm{~mm}$. Está escrito en tinta negra y en ocasiones sepia, en hojas de papel verjurado, y encuadernado con tapas de piel de becerro. Una encuadernación para un manuscrito de uso, que desde el origen y por su función está lejos de lo que pudiera entenderse como un libro de aparato.

Los cordones de cierre están realizados en cuero, uno se colocó en la parte superior y el otro en la inferior; atados cada uno de ellos con un nudo en la contraportada, quedando rodeados a modo de lazo por la propia cuerda de cuero, que da la vuelta completa al manuscrito. La longitud de ambas cuerdas es de $615 \mathrm{~mm}$; sin embargo, al estar dobladas, su longitud total sería del doble, aproximadamente. Esta encuadernación exterior se refuerza en el interior, y para unirlo al resto del libro, con dos bifolios, uno unido a la tapa y el otro a la contratapa, siendo de un color más claro que el resto de folios, con cierta tonalidad sepia.

El estado de conservación del volumen es óptimo, lo cual no resulta extraño considerando su relativamente reciente fecha de escrituración; así como las excepcionales y afortunadas circunstancias que rodearon su posterior preservación, al convertirse también para las oficinas de Hacienda en un instrumento con información completa sobre el archivo que acababan de incautar, quedando bajo su custodia y protección, aun habiendo perdido el valor inicial para el que había sido creado.

A lo largo del libro, la información no se distribuye en folios independientes. Por el contrario, estos se agrupan formando cuadernillos (quiniones y sexniones en su mayoría), aproximadamente unos cuarenta, sin poder precisar más porque el cosido de los fascículos 
hace imposible, sin desarmar la encuadernación, contabilizar los cuadernos, que se han unido mediante cuatro nervios, los interiores de cuero, y los exteriores más finos.

Consta de 471 folios con numeración arábiga ${ }^{338}$, colocada en el ángulo superior derecho de su cara anterior o recto. Redactado en el siglo XIX, tal y como permite concluir el documento más reciente registrado ${ }^{339}$ por una de las manos principales, está compuesto por una serie de regestos o resúmenes ${ }^{340}$ de todos los documentos conservados en ese momento en el archivo del monasterio.

A diferencia de otros códices pensados con la misma finalidad ${ }^{341}$, no hay ningún mensaje inicial que nos indique que nos encontramos ante un Índice a excepción del título que figura en el lomo, "Índice del Archivo". Sin embargo, tanto la organización de cada uno de los folios como la del propio manuscrito nos indica que desde un principio estaba claro cuál iba a ser la finalidad de este: un instrumento de consulta y de control que facilitara el conocimiento de la documentación descrita. La ausencia de un mensaje indicando la finalización de la obra redunda en la idea de que no era un instrumento cerrado, si no que estaba pensado para seguir creciendo en la medida que lo hiciera el $\operatorname{archivo~}^{342}$.

338 El primer folio es el único del libro en el que se observa una disposición diferente, puesto que en la parte superior derecha se indica no el folio sino la página no solamente con el número, sino con la abreviatura de la palabra: "pag. 1". Además, tanto el título del cajón como la letra y el topónimo aparecen enmarcados, lo que no vuelve a repetirse en todo el manuscrito.

339 Con fecha en 1818, se localiza en el folio 6v. Del mismo modo, el más antiguo queda fechado en el año 940, y se copió en el folio $78 \mathrm{v}$.

340 PESCADOR DEL HOYO, M. ${ }^{a}$ del Carmen, El archivo: instrumentos de trabajo. Madrid, 1982, p. 71, denomina a este tipo de índices "índices con personalidad propia", e indica que sería más apropiado llamarlos "relaciones de contenido". Pero la obra de esta autora es muy controvertida, prueba de ello es que la expresión "relaciones de contenido" aleja al instrumento de la realidad de un instrumento de descripción de un archivo, en el que, amén de la descripción del contenido, debe reflejar la de las relaciones entre los documentos. Y así ocurre en el Índice de San Zoilo.

${ }^{341}$ En el Monasterio de San Andrés de Espinareda se conserva un manuscrito que presenta el siguiente título en la primera hoja: "ÍNDICE ABECEDARIO, Y TABLA general de las Haciendas, Jurisdicciones, Diezmos, Presentaciones, Jantares, Patronatos, Luctuosas, Derechos y Pertenencias que este Real Collegio de San Andrés de Espinareda tuvo, tiene y debe tener, dispuesto por orden alphabetico en este año de 1728, siendo Abbad [...]". Véase RELLÁN LÓPEZ, Avelino, "Libros del monasterio de San Andrés de Espinareda en el archivo de la parroquia de San Andrés de Vega de Espinareda (León)”: Memoria ecclesiae, (6), 1995, pp. 473480, especialmente p. 477.

Un ejemplo similar se conserva para el monasterio de San Salvador de Cornellana en Oviedo en un libro titulado "Índice Principal de el Archivo de el Real Monasterio de San Salvador de Cornellana, [...] Orden de San Benito. Año de MDCCXXXII". Véase HEVIA BALLINA, Agustín, "Documentación monástica en el Archivo Histórico Diocesano de Oviedo. Benedictinos y canónigos regulares de San Agustín": Memoria ecclesiae, (6), 1995, pp. 361-396, especialmente p. 373.

342 ENRÍQUEZ DE SALAMANCA GÓMEZ, Almudena, "El Archivo del Monasterio de Santa María de Nogales en el Tumbo de Astorga (1639)": Documenta e Instrumenta, 8 (2010), pp. 47-66, especialmente p. 52.

Este códice, redactado en el Monasterio de Astorga en 1639, presenta un título, en el que señala qué tipo de documento es (un manual), su titular, su contenido y su data; un prólogo en el que justifica su finalidad y un colofón, dando cuenta de la conclusión de la obra. 
Cada folio $(310 \times 210 \mathrm{~mm})$ estaba organizado en dos columnas verticales. La de dimensión más reducida ocupa el margen izquierdo de $40 \mathrm{~mm}$, puesto que estaba pensado para recoger los resúmenes analíticos, que consistían en la expresión del tipo documental, así como la data; y que se obtenían del resumen informativo, que por su mayor amplitud, ocupaban el espacio central del folio, unos $130 \mathrm{~mm}$. El margen derecho tenía unas dimensiones idénticas al izquierdo, $40 \mathrm{~mm}$, y en él se escribieron notas de diversa índole, así como una serie de palabras claves que resultarían útiles para el archivero.

Los márgenes superior e inferior, de 20 y $30 \mathrm{~mm}$ respectivamente, pueden variar en función del volumen de información contenido en cada folio. El superior quedaba destinado para recoger una serie de datos que reafirman el carácter del Índice como instrumento localizador de documentos; datos que, a modo de descriptores, agilizarían y facilitarían la búsqueda de estos en el archivo al establecer una relación directa entre la información que los documentos aportaban y la que había sido recogida en los reversos de los documentos, suprimiendo la necesidad de recurrir constantemente al folio inicial de cada uno de los epígrafes, colaborando con ello en la conservación del manuscrito.

Entre los datos que se ofrecen están los referidos al lugar, la tipología documental donaciones, pleitos, compras, etc.-, y datos de localización (cuya disposición en el folio podía variar, alternando su colación en el recto o vuelto en función del lugar ocupado por el inicio del epígrafe): la letra y el cajón; el legajo, la letra y el cuaderno que informaba del lugar físico en que se hallaba el documento descrito.

Junto a estos datos, y siempre en el ángulo superior del recto del folio, se escribía el número de folio. Aunque resulta extraño en un instrumento de gestión con una elaboración tan cuidada, podríamos aventurar la posibilidad de que esta foliación no se hubiera realizado a la vez que se preparaba la caja de escritura y se redactaba el texto, al interferir en algunas ocasiones con el espacio superior destinado a las referencias de localización ya mencionadas. No creemos que esta circunstancia pudiera deberse a un descuido fortuito en el momento de redacción, o se explique por un olvido intencionado motivado por la falta de funcionalidad de la foliación, puesto que esta siempre es una guía necesaria para hallar la información y el documento que se busca. Pensamos que es un ejemplo más de que las foliaciones solían hacerse una vez concluida la escrituración del manuscrito. Y más en este

Si bien el Índice de San Zoilo no incluye ninguno de estos datos, la explicación a esta omisión habría que encontrarla en la evolución de la práctica archivística y de la redacción de estos instrumentos y libros que, al ser considerados como fundamentales para conservar íntegro el archivo, dejaron de necesitar de una justificación que argumentase su producción y explicase su finalidad de acceso y gestión de los documentos producidos por el monasterio. 
tipo de libros, en los que suele colocarse al inicio del mismo una tabla alfabética con el contenido del códice y el número de folios en los que se encuentra el correspondiente a cada epígrafe. En el caso del Índice de San Zoilo ni el libro tiene esa tabla alfabética ni tenemos noticia de su existencia.

La pretensión de ofrecer un momento concreto para fijar la redacción del Índice exige conocer o intentar conocer las causas que motivaron la escrituración del códice, puesto que en ellas están los condicionantes que llevaron al monasterio a decidir la realización de la empresa. Pensado para ser un instrumento de control de los documentos, de su localización física, para conocer su contenido y el reflejo de sus relaciones con el resto de los documentos, es decir su localización intelectual, su pertenencia a un grupo establecido a partir de la tipología diplomática o de su vinculación con un lugar concreto, ofrecía una visión completa del conjunto que era el archivo y además servía como guía para el control del mismo.

Si bien resulta sencillo determinar un momento de finalización del códice, al ser 1818 la fecha del último de los documentos que se describe en el mismo; establecer el momento concreto en el que se dio inicio a su redacción se convierte en una tarea más compleja, circunstancia esta motivada por la inexistencia de una referencia precisa al inicio de la copia del Índice. Se hace entonces necesario contemplar una serie de supuestos que nos aporten evidencias y argumentos para delimitar, de la forma más ajustada posible, cuál fue el tiempo de composición y quién pudo ser -al carecer el Índice de esta informaciónel encargado de la escrituración del manuscrito y, por ende, el artífice de la organización del archivo monástico. Había de ser, parece de sentido, el archivero del monasterio.

Una primera aproximación al estudio paleográfico del Índice pone de manifiesto la existencia de una serie de manos que participaron, unas de manera más o menos continua otras más ocasionalmente, en su redacción, quedando incluidas todas las grafías en un único tipo de escritura, la humanística de finales del siglo XVIII y principios del XIX. Todo lleva a pensar que la elaboración completa del libro se extendió durante un periodo inferior a veinte años. Serán las escrituras que llevan data las que nos proporcionen la información más fiable y precisa para poder inferir y acotar el tiempo de elaboración del manuscrito.

De entre los más de seis escribas que intervinieron en su composición, al menos dos resultan necesariamente reseñables ${ }^{343}$, ya que, a tenor del volumen de información y de

\footnotetext{
343 Rodríguez de Diego señala, al ocuparse de los escribas del Tumbo del Monasterio de la Espina, la falta de
} interés que tendría analizar detalladamente las grafías de los escribas que intervienen en su elaboración, al 
asientos copiados, habrían sido los principales encargados de la confección del manuscrito. El análisis de sus singularidades gráficas y de su intervención en el códice nos proporciona la siguiente información:

- Hasta el folio 322 predomina la escritura del llamado "escriba A", sin duda el más importante, quien dio comienzo a la obra y el que en efecto fue también el autor de la nueva organización del archivo, lo que obligó a redactar un instrumento que facilitase el acceso a la documentación descrita e hiciera más fácil el acceso al documento y el cuidado y administración del patrimonio.

Traza una escritura humanística cursiva ${ }^{344}$, inclinada ligeramente a la derecha, de excelente caligrafía y cuidada factura, acentuada por la casi ausencia de signos de reclamo y añadidos a excepción de las contadas ocasiones en las que utiliza el signo de la cruz para solventar algún olvido. Esta calidad se observa en detalles como la regularidad del tamaño de las letras, ajustadas a la caja del renglón, sin excesivo desarrollo de astiles y caídos, destacando caído en forma de 8 de la "g".

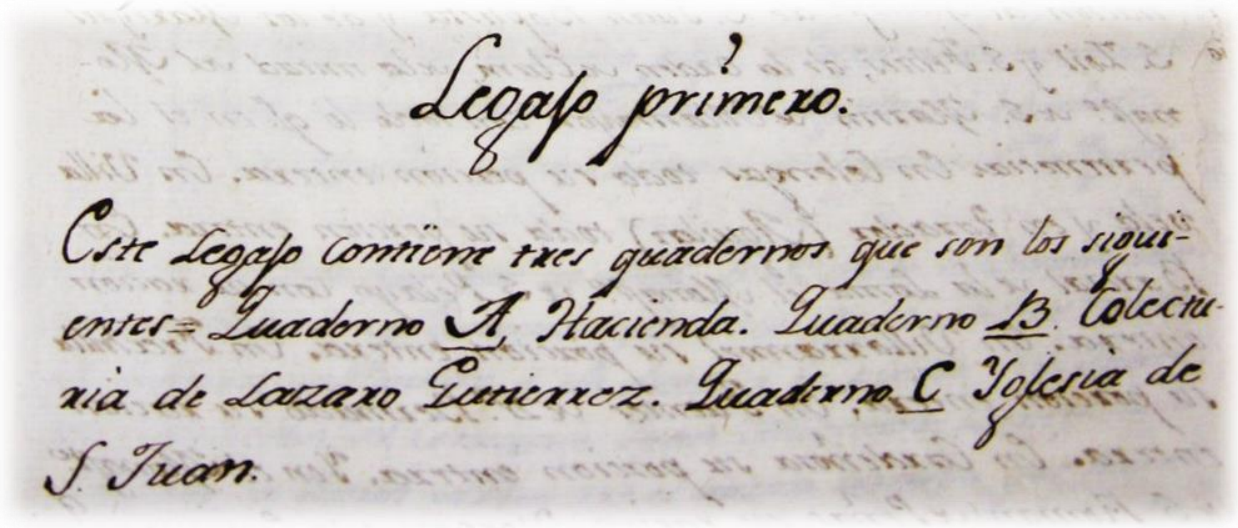

Escritura del "escriba A"

Es el encargado de preparar la página del códice, de establecer la disposición de los diferentes elementos en el folio, la cual será imitada por el resto de escribas, reservando el margen superior para las referencias de localización, el izquierdo para los resúmenes analíticos y el derecho para las anotaciones, procurando reservar siempre un espacio para el margen inferior. Subraya las fechas y las

incluirse todas ellas entre las humanísticas. RODRÍGUEZ DE DIEGO, José Luis, El Tumbo del Monasterio Cisterciense de la Espina, Valladolid, 1981, p.29.

344 MARÍN MARTÍNEZ, Tomás-RUIZ ASENCIO, José Manuel, Paleografía y diplomática. Tomo 2. Madrid: Universidad nacional de Educación a Distancia, 2011, pp. 63-83. 
cantidades importantes, aspecto este que también será continuado a lo largo del códice.

Es el autor de la primera página del Índice donde destaca el título del cajón, enmarcado por un rectángulo y realizado con letras capitales dispuestas en seis renglones, reservando para cada uno de ellos una decoración única y original.

Cronológicamente, sus registros abarcan hasta $1807^{345}$ y limita las remisiones -recurso que sitúa al final de cada epígrafe para relacionar el topónimo al que está dedicado con documentos que al respecto puedan encontrarse en otros cajones- hasta el cajón San Martín, que incluye hasta el folio $338, \quad$ coincidiendo prácticamente con el final de

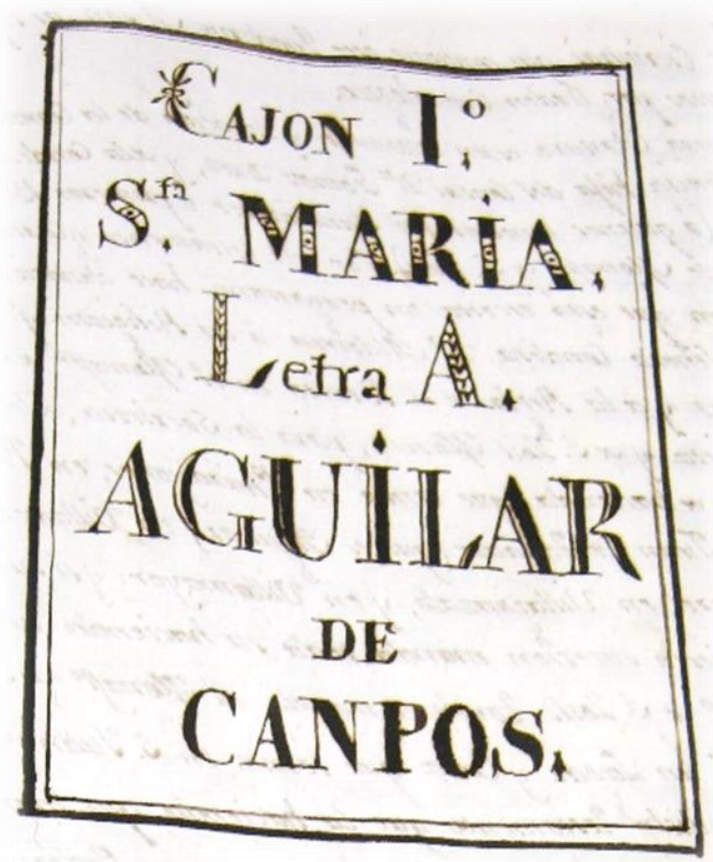
su intervención.

Títulos del "escriba A"

Cuando en ocasiones realiza la remisión a otro cajón posterior, no especifica el cuaderno, ni el legajo ni el número del asiendo, dejando un espacio que fue completado con posterioridad ${ }^{346}$.

Esto indica que, aunque la disposición por cajones ya estaba establecida con anterioridad -tal y como lo dispuso el padre Cisneros en su Manual-, la nueva ordenación no estaba aún definida, redactándose así el Índice a la par que se reorganizaba el archivo monástico.

Junto a la compleja labor de sistematizar y ordenar el enorme volumen documental, realizó además la ardua tarea de revisar toda la documentación, extrayendo un resumen lo suficientemente completo y preciso como para servir

\footnotetext{
345 AHPP, Desamortización, legajo 112, f. 101v.

346 AHPP, Desamortización, legajo 112, f. 187v: "Véase el cajón San Plácido, legajo 5, entre los papeles de Villamez, quaderno B, número 1 ", añadiéndose posteriormente "B" y " 1 "”.
} 
de noticia casi única del diploma que regestaba. Acorde a su rigor, no dejó de buscar referencias a obras impresas que citaran o transcribieran el documento ${ }^{347}$ y que, entendía, aportaban veracidad y legitimidad; sin limitar su labor de investigación al archivo de San Zoilo, remitiendo a otros archivos en los que se encontrasen aquellos documentos con los que poder probar o confirmar sus privilegios y posesiones ${ }^{348}$. Su letra también aparece en algunos de los regestos que se escribieron en los reverso de los documentos sueltos del archivo para facilitar el acceso a la información de los $\operatorname{mismos}^{349}$. Circunstancia que prueba su trabajo como archivero y reorganizador del archivo del monasterio, cuya identidad no aparece recogida de manera explícita en el códice -cuestión que será abordada más adelante-; pero cuyas funciones coinciden con los requisitos con los que, según las Constituciones, debía contar un monje para ocupar este cargo tan imprescindible en un monasterio para la gestión de la hacienda y la organización de su archivo ${ }^{350}$.

- Una ocupación tan ardua y compleja que con el tiempo hizo necesaria la intervención, de manera simultánea, de otros escribas que colaborasen con él y que, tal como indicaban las Constituciones, serían "tres monges de inteligencia de papeles, y de mucha confianza: uno para que sea Archivero principal, y exercite el oficio; y los dos, para que a falta suya substituyan por el’351.

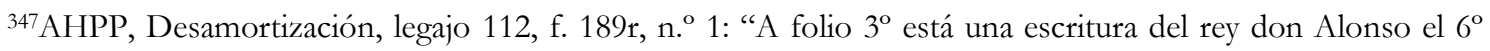
(que la trae el maestro Yepes en el tomo $4^{\circ}$, p. 453)".

348 Algunos de los ejemplos recogidos en el Índice así lo demuestran: "Esta causa se ventiló y sentenció en Roma y se sacaron executoriales, que están en el Archivo de San Claudio de León” (AHPP, Desamortización, legajo 112, f. 9r, n. ${ }^{\circ}$ ); "Relación simple de lo que se halla en los libros reales que están en los Archivos de Simancas, sobre las tercias del lugar de Arconada. Provisión real para compulsar unas partidas del libro Becerro de la cathedral de Palencia sobre las tercias de Arconada" (AHPP, Desamortización, legajo 112, f. 41r, n. $\left.{ }^{\circ} 3\right) ;$ " [...] la qual bulla no está en este archivo y puede ser que esté en el de Sahagún, por haverse llevado a aquella casa para requirir al abad, quien usó de ella [...]" (AHPP, Desamortización, legajo 112, f. 82v, n. . 21); "Memoria de algunas escrituras del archivo de Palencia tocantes a este monasterio" (AHPP, Desamortización, legajo 112, f. 109r, n. . 5); "Es papel curioso que se sacó de un libro antiguo de estas visitas, que está en el archivo de Cardeña” (AHPP, Desamortización, legajo 112, f. 146v, n. . 31); “[...] y mandó que esta sentencia se pusiese en el archivo de Saldaña con inventario [...]” (AHPP, Desamortización, legajo 112, f. $323 r$, n. $\left.^{\circ} 8\right)$.

${ }^{349}$ Entre la documentación conservada en el fondo Desamortización del AHPP, destaca un foro cuya portada ha sido escrita por la misma mano que la del "escriba A" y que indica: "Año 1770. Carrión. Foros corrientes. Cajón San Zoil. Legajo $3^{\circ}$. Número 18. Foro perpetuo de 4 reales sobre un solar en la colación de San Andrés. Paga este foro José Moslares en este año de 1802”. Tanto su referencia como el texto del documento coinciden de manera fidedigna con el regesto que proporciona el Índice, otra prueba más de la meticulosidad con que este escriba y muy posiblemente archivero llevaba a cabo su trabajo. Encontramos el original en AHPP, Desamortización, legajo 111, y su registro en el Índice en AHPP, Desamortización, legajo 112, f. $160 \mathrm{v}$.

350 Remitimos al capítulo Archivo del monasterio de San Zoilo de Carrión, donde analizamos detalladamente dichas funciones establecidas por las Constituciones.

351 Constituciones 1701, p. 238.
} 
A partir del folio 162 y hasta el 283, la mano del "escriba A" se alterna de manera simultánea con otras tres manos, aunque de una factura menos cuidada que la del escriba principal. Resulta especialmente sintomático el hecho de que la colaboración de estas manos se intensifique cuando comienzan a escribirse los registros en el cajón con los papeles pertenecientes al priorato de San Martín de Frómista, cuya documentación se extiende entre los folios 187 y 252.

Prueba de la importancia que Frómista representaba para la vida económica de San Zoilo es el amplio volumen documental que esta hijuela aportó, lo cual era fruto del dilatado patrimonio administrado y de los numerosos pleitos que la defensa y administración del mismo había generado. Fue precisamente el peso de su documentación en el archivo lo que pudo ocasionar la necesidad de apoyo por parte de otros monjes, quienes no parece que fueran personas tan expertas en las tareas de archivo, lo que explicaría el descuido en la calidad de la escritura.

Lo breve de su intervención en el Índice nos lleva a señalar únicamente algunos de los rasgos más singulares de sus escrituras. La primera de ellas se caracteriza por la inclinación a la derecha de sus letras con poco desarrollo de los astiles y caídos, destacando la grafía de la "E" derivada de una interpretación de la uncial, la " $\mathrm{t}$ " que prolonga el astil bajando el trazo hacia la izquierda y el signo utilizado para línea de la " $\tilde{n}$ ” y para las abreviaturas, con trazado muy ondulado.

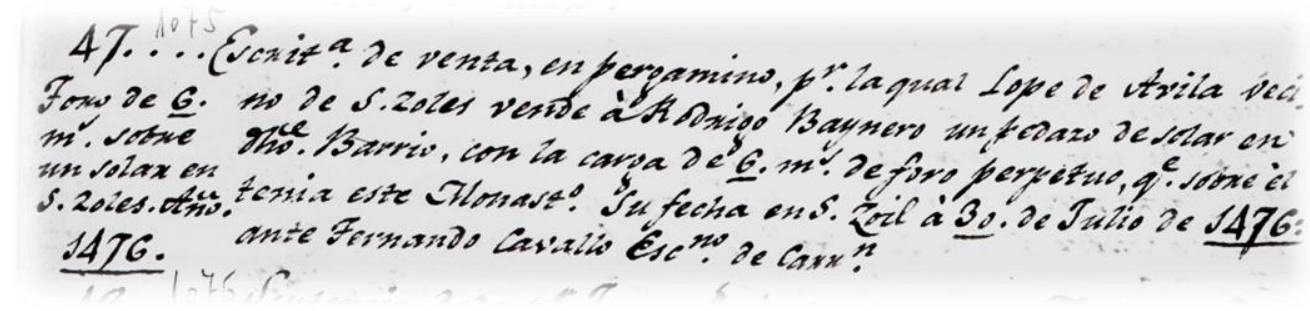

\section{Escritura del "escriba Frómista 1"}

La segunda escritura presenta un uso de "v" ante nasal (vno) de forma sistemática, normal en escritura gótica pero no tanto en humanística; una alternancia en la forma de abreviar la palabra maravedís entre maravedis y maravedis, así como el empleo de una línea quebrada en forma de triángulo $(\wedge)$ para el reglón de la "ñ". 


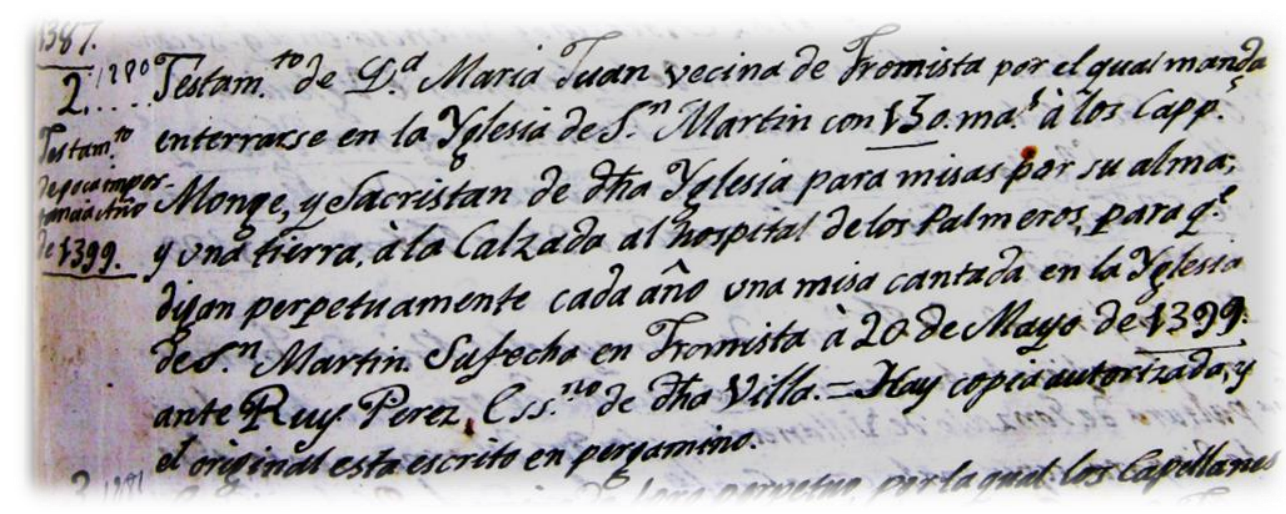

Escritura del "escriba Frómista 2"

La tercera escritura, de trazo más fino y rápido que las anteriores, muestra dos rasgos peculiares: la incurvación del astil de la " $\mathrm{d}$ " uncial hasta formar un gran ojo o lazo, y el alargamiento en forma de espiral del trazo vertical de algunas mayúsculas. Se alterna con el escriba principal desde el folio 225 al 252, los cuales estaban destinados a registrar los cinco legajos que ocupaban en el archivo los documentos del Barrio de San Martín y los pleitos por su posesión ante los señores de Frómista. Ambos escriben de manera coetánea, hasta el punto que mientras uno redacta los resúmenes al margen el otro se encarga del texto principal o se alternan en su escrituración ambos amanuenses ${ }^{352}$.

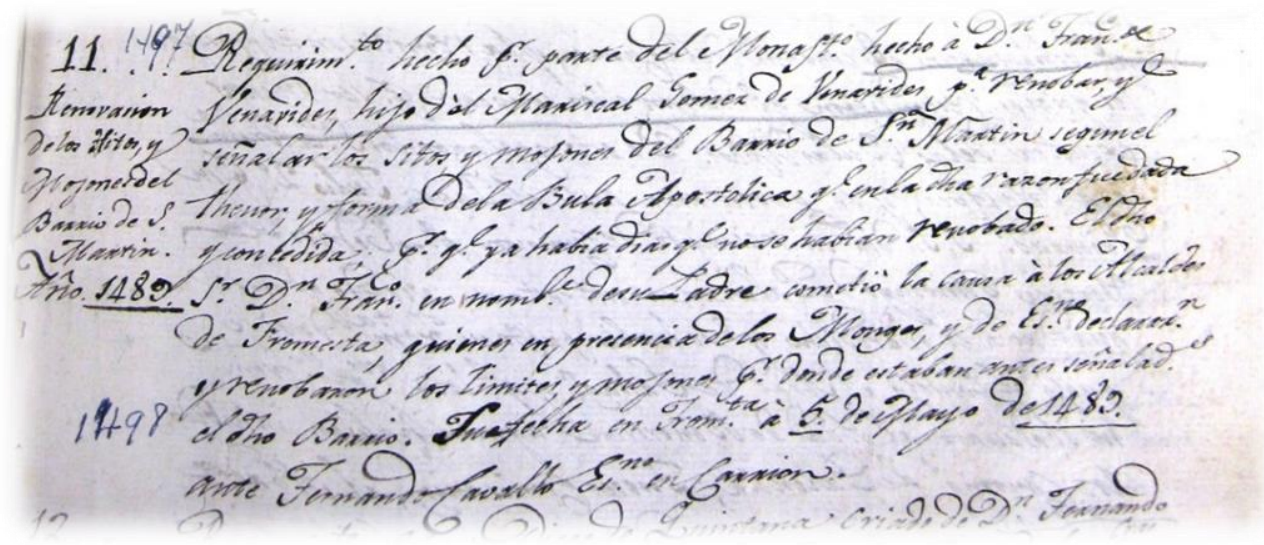

Escritura del "escriba Frómista 3"

Esa evidencia indica la posibilidad de que el "escriba A", como archivero principal, como artífice de la estructura del libro, se valiese de tres ayudantes

352 AHPP, Desamortización, legajo 112, ff. 239r-242r. 
para agilizar y repartir las tareas de lectura o dictado de los documentos -especialmente los más amplios y complejos, como es el caso del ejemplo anterior, al abordar un asunto tan importante para el monasterio como el pleito por la posesión del barrio de San Martín- con el registro de los resúmenes en el códice.

- La escritura del segundo amanuense con más volumen documental registrado, el llamado "escriba B", comienza en el folio 283 alternándose con el "escriba A" hasta el folio 322, a partir del cual continuará su trabajo de manera individual hasta finalizar la descripción de los documentos del archivo con el cajón 27.

Hace una letra humanística cursiva, con una inclinación hacia la derecha muy pronunciada que aumenta a medida que progresa en la redacción del libro, con desarrollo más generoso de astiles y caídos, trazando una " $\mathrm{g}$ " más estilizada y abierta que la del escriba $\mathrm{A}$, con un desarrollo del caído, que sube por la izquierda del trazo descendente en busca de la línea del renglón. Es una escritura más cursiva que la de A, y menos cuidada, como prueban las numerosas palabras tachadas a modo de corrección, trazada con un instrumento de corte más amplio, lo que hace que contrasten los trazos finos y gruesos de las letras.

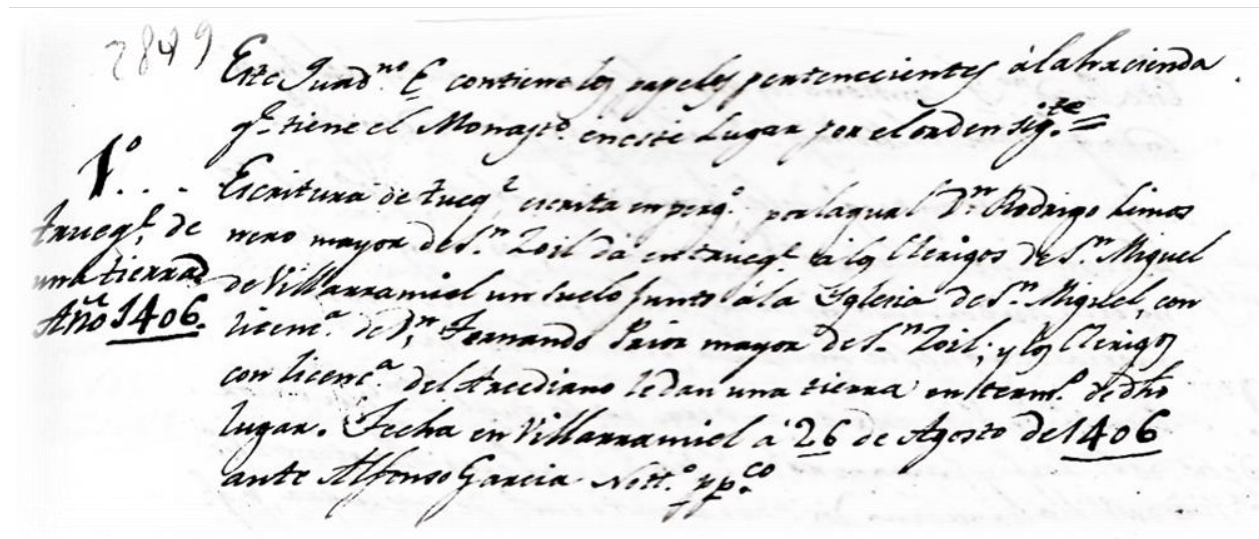

\section{Escritura del "escriba B"}

Como ya indicamos, la disposición de los diferentes elementos en el folio se mantendrá a lo largo de todo el códice; con la excepción de los folios en los que el margen inferior apenas existe porque el escriba apura casi hasta el límite en algunas ocasiones. 
La cronología de sus asientos llega hasta $1809^{353}$, fecha en la que la desamortización napoleónica detiene la producción documental, que no volverá a retomarse hasta 1814. El inicio de su redacción coincide con el final del trabajo del "escriba A", hecho que tal vez se habría producido por un cambio de escribano principal o fruto de una simple reorganización de funciones dentro del archivo.

Esta mano también realizaría algunas de las notas marginales del Índice; así como las remisiones de cada uno de los nuevos epígrafes que registra, incluyendo las correspondientes a aquellos cajones que hasta ese momento estaban incompletas, al no conocerse la ubicación final de todos los diplomas en el momento de su redacción, como ya habíamos indicado.

- No obstante, el hecho de que el códice abarque cronológicamente hasta el año 1818, hace que aquellos documentos ${ }^{354}$ producidos o recibidos por el monasterio con posterioridad a 1814 fueran asentados por un nuevo escriba (el llamado “escriba C"), cuya escritura se caracteriza por trazar unas letras excesivamente inclinadas hacia la derecha, con caídos y astiles pronunciados e incurvados en el caso de la "d" uncial (muy inclinado hacia la izquierda), destacando la duplicación de los caídos de "p" y “f”, el trazo abierto y alargado de la " $g$ ", y el alargamiento y la inclinación a la izquierda de los trazos verticales de algunos números, caso del 4.

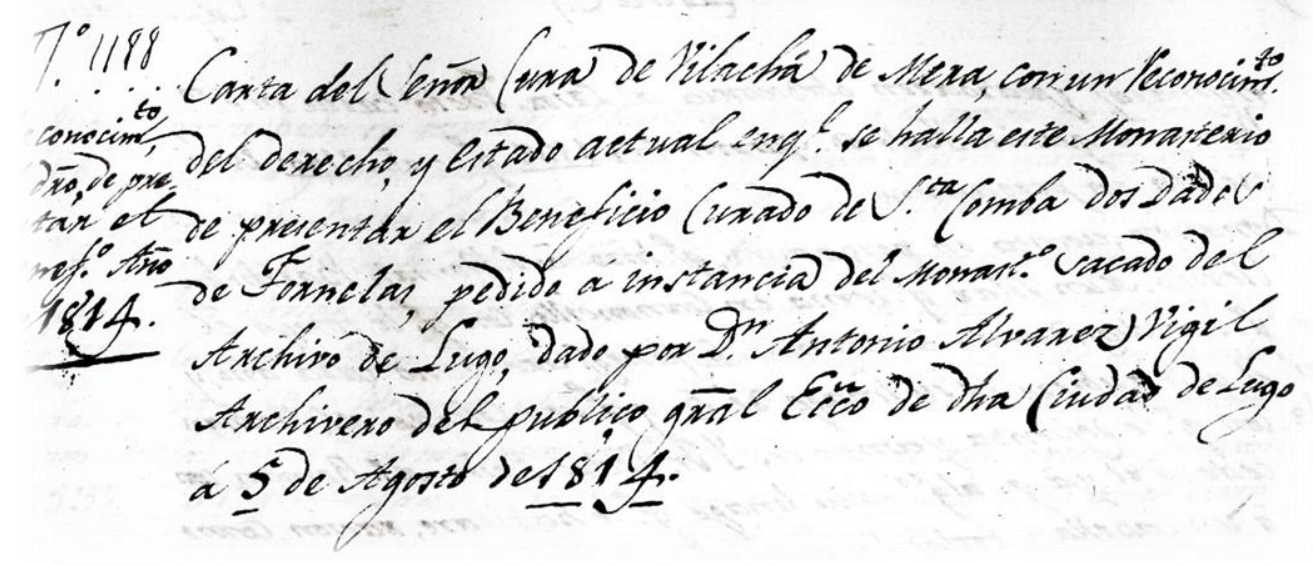

Escritura del "escriba C"

353 AHPP, Desamortización, legajo 112, f. 438r.

354 AHPP, Desamortización, legajo 112, f. 119v, f. 182r, f. 101v, f. 7v, f. 275 r. 
Tal y como habíamos apuntado, carecemos de evidencia alguna que nos acerque a la identidad del que sin duda fue uno de los cargos de mayor relevancia en la vida de la comunidad monástica, el archivero, en lo que atañe a las ocupaciones no espirituales ${ }^{355}$; hasta el punto de acometer una empresa tan compleja como la que suponía la reorganización del archivo, la conservación de los títulos de propiedades y derechos y la elaboración de un instrumento clave tanto para el control de los documentos en el archivo y del archivo mismo como para la administración y la gestión del patrimonio monástico.

La falta de esta información podría suponer un obstáculo infranqueable que nos impidiera, al margen de unas primeras meditaciones, aportar datos objetivos en torno a esta cuestión; si no fuese por la existencia de una somera, aunque no por ello menos importante, noticia que nos proporciona el Índice de San Zoilo al situar como archivero del cenobio, en el año 1798, al monje fray Benito Sabido ${ }^{356}$.

355 Taurino Burón nos indica al respecto que en muchas ocasiones la labor de organizar los archivos fue anónima, puesto que pocas veces constan los archiveros con su nombre. Esta reflexión se encuadra dentro de una acertada y completa aproximación a lo que era la figura del archivero y sus funciones, así como de la evolución en la concepción y ordenación de los archivos de diversos monasterios, ejemplificándolo con el Manual de Cisneros compuesto en 1635. BURÓN CASTRO, Taurino, "Archivología: una mirada hacia atrás": Boletín de la $A N A B A D, 43-1$ (1993), pp. 7-30, especialmente p. 17.

356 El registro nos indica: "Extracto substancial del pleito litigado por el fiscal general eclesiástico de la ciudad y obispado de Palencia contra este real monasterio de San Zoil de Carrión, [...] Sacado de los autos originales que se hallan en el legajo 539 del archivo de la catedral de dicha ciudad de Palencia, por el padre fray Benito Sabido, monge y archivero de este monasterio, en el año de 1798 [...]”. AHPP, Desamortización, legajo 112, f. $448 \mathrm{v}$, n. $^{\circ} 24$.

El Índice nos aporta el nombre de algunos de los que fueron archiveros de San Zoilo en diferentes épocas, a través de referencias directas y noticias indirectas:

Fray Pedro Merino: nombrado como archivero en un documento de 1744 (AHPP, Desamortización, legajo 112, f. 369r, n. ${ }^{\circ}$ 38). Natural de Mota de Toro, tomó el hábito antes de 1721 y murió en 1761, tal y como señala ZARAGOZA PASCUAL, Abadologio San Zoilo, p. 313. Fray Mauro Fuertes: archivero y profeso en él (AHPP, Desamortización, legajo 112, f. 371r, n. ${ }^{\circ}$ 5); El Abadologio únicamente reseña a un monje llamado Mauro Fuentes, aunque la inexistencia de una fecha concreta en el códice hace difícil certificar que fuese el mismo monje; ZARAGOZA PASCUAL, Abadologio San Zoilo, p. 314.

- Monje Rodulfo: no hay constancia de que fuese archivero pero sí escriba, al menos copia "Vn quaderno que contiene la vida, martirio, traslación, milagros y rezo de nuestro patrono San Zoil. Es copia de un libro mui antiguo escrito en pergamino por el monge Rodulfo" (AHPP, Desamortización, legajo 112, f. 117r, n. ${ }^{\circ}$ 1) y una "Historia de este monasterio muy antigua, escrita en pergamino, por un mozo llamado Rodulfo" (AHPP, Desamortización, legajo 112, f. 471r, n. ${ }^{\circ}<10>$ ).

Padre Juan de Cisneros: elaboró el Manual del Archivo de San Zoilo de Carrión en 1635 (AHN, Clero, Libro 9552). Las fuentes le nombran como natural de Loja, monje profeso del monasterio de San Zoilo, al que dio hábito el abad Barrantes, y escritor de obras cronológicas e histórico-monásticas; además fue archivero de la Congregación de San Benito y catalogó su archivo junto con el de Carrión, Valvanera y El Espino (monasterio donde fue abad). Véase BECERRO DE BENGOA, Ricardo, "El Monasterio de Carrión”, pp. 77 y 84; ZARAGOZA PASCUAL, Ernesto, "Cronistas generales de la Congregación de San Benito de Valladolid": Boletín de la Real Academia de la Historia, 189-1 (1992), pp. 89-126, especialmente pp. 92 y 112.

En el Índice aparece como notario apostólico (AHPP, Desamortización, legajo 112, f. 59r, n. ${ }^{\circ}$; f. $82 \mathrm{v}$, n. ${ }^{\circ}$ 23; f. 118 r, n. ${ }^{\circ} 12$; f. 123 r, n. ${ }^{\circ} 16$; f. $130 \mathrm{v}$, n. ${ }^{\circ} 15$; f. $134 \mathrm{v}$, f. $295 \mathrm{v}$, n. ${ }^{\circ}$ 7; f. 333, n. ${ }^{\circ} 1$ ); abad del monasterio de Nuestra Señora del Espino (AHPP, Desamortización, legajo 112, f. 73r, n. ${ }^{\circ}$ 17); escritor de los Milagros de Nuestra Señora y la regla de Nuestro Padre San Benito 
Antes de exponer las evidencias documentales y cronológicas que situarían a este archivero como posible artífice e ideólogo del Índice, resulta fundamental contextualizar su obra a través de algunas fuentes que lo situarían como un hombre que consideró indispensable, para el ejercicio de tan importante misión, estar en contacto con las nuevas tendencias archivísticas, las cuales empezaban a revelarse ya como una necesidad a finales del siglo XVIII.

Fray Benito Sabido, natural de Celorrio (Asturias), entró a formar parte de la orden benedictina el $18 \mathrm{~d}$ noviembre de $1782^{357}$. El Índice nos pone en conocimiento que, junto con el cargo de archivero, desempeñó además otras funciones relacionadas con el ámbito administrativo, como apoderado del monasterio en 1796 y secretario del abad tanto en 1794 como en $1800^{358}$. Estos cargos evidencian la preponderante posición que este monje habría ocupado dentro de la comunidad, al otorgarle la capacidad jurídica para representar al monasterio y actuar en su nombre ante posibles pleitos e incluso en representación del abad, cuestión esta lógica si consideramos que el archivero era la persona más adecuada al ser quien mejor conocía la documentación que requerían los tribunales para sentenciar los procesos.

En 1795, y con motivo de los trabajos archivísticos que llevaba a cabo ${ }^{359}$, Gaspar Melchor de Jovellanos visita San Zoilo y, como ilustrado interesado en los archivos y en la documentación que estos albergaban, inspecciona su archivo y entra en contacto con su archivero, quedando tal y como él mismo explicaba “[...] amigos el archivero, fray Benito Sabido, asturiano, de Selorio, y yo"360. Quizá este contacto, esta relación estimulara al padre

\footnotetext{
(AHPP, Desamortización, legajo 112, f. 73r, n. ${ }^{\text {17 }}$; f. 471r, n. ${ }^{\text { }}$ ) y conocedor del trabajo de archivo al realizar una memoria de algunas escrituras que hay en el archivo de la catedral de Palencia pertenecientes a este monasterio de san Zoil (AHPP, Desamortización, legajo 112, f. 59r, f. 119r).

- Algunos de estos nombres y otros nuevos aparecen en un registro que indica "Las demás historias modernas están seguidas a esta por el padre Cisneros, padre Fonseca y padre Fuertes" (AHPP, Desamortización, legajo 112, f. 471r). Zaragoza Pascual nos indica la existencia de un monje llamado Diego de Fonseca que fue abad de Carrión entre 1689 y 1693; ZARAGOZA PASCUAL, Abadologio San Zoilo, p. 300, 301.

357 ZARAGOZA PASCUAL, Abadologio San Zoilo, p. 318.

358 AHPP, Desamortización, legajo 112, f. 200v, n. ${ }^{\circ}$ 48; f. 299r, n. ${ }^{\circ} 24$; f. 311v, n. ${ }^{\circ} 19$.

359 Para más información acerca del interés y el impulso surgidos en torno a los archivos desde el siglo XVIII véase ABELLA, Manuel, Noticia y plan de un viage para reconocer archivos y formar la colección diplomática de España, encargada por el rey. Madrid, 1795; GÓMEZ GÓMEZ, Margarita, "Crítica histórica y archivos. El caso de España en el siglo XVIII”: Historia. Instituciones. Documentos, 12 (1985), pp. 199-232.

${ }^{360}$ Esta visita forma parte de una serie de viajes realizados por Jovellanos plasmados en sus Diarios, a través de los cuales se puede inferir el creciente interés por los archivos, al considerar los documentos como el instrumento imprescindible para iluminar la historia de España. La noticia de la visita a San Zoilo y su archivo quedó registrada en su Diario $2^{\circ}$ y puede verse en JOVELLANOS, Gaspar Melchor, Obras completas. Tomo VII. Diario $2^{\circ}$, Cuadernos V, conclusión; Tomo VII. Diario $2^{\circ}$ Cuadernos V, conclusión, VI y VII (desde el 1 de setiembre de 1794 hasta el 18 de agosto de 1797). Oviedo, 1999.
} 
Sabido, conocedor de la valoración de documentos y archivos del momento, conocedor del valioso archivo de San Zoilo, a dotarle de una nueva organización, más simple, y de un instrumento que asegurase el acceso a la documentación en él custodiada.

Todos estos testimonios redundan en la afirmación de que en el momento en el que se escribió el Índice, fray Benito Sabido era el archivero principal del monasterio; no obstante, únicamente podríamos identificar al monje como el "escriba A" si al comparar la escritura del códice con la del propio Sabido resultaran una misma.

Pero solo contamos con coincidencias cronológicas y con algún testimonio documental que prueba que la misma mano que comenzó a escribir el códice (el "escriba A") también escribía en los dorsos de los documentos la nota de su localización en el archivo $^{361}$ hacia 1802, y que se diferencia de la mano que lo hacía en 1794 y de la que lo hará después de la invasión napoleónica.

Esta labor únicamente habría sido realizada por una persona entendida en el archivo de San Zoilo hasta el punto de poder efectuar este tipo de referencias cruzadas con solvencia, y que no era otra figura que el archivero del monasterio; cargo que, desde $1795 \mathrm{y}$ hasta comienzos del siglo XIX, ostentó el padre fray Benito Sabido.
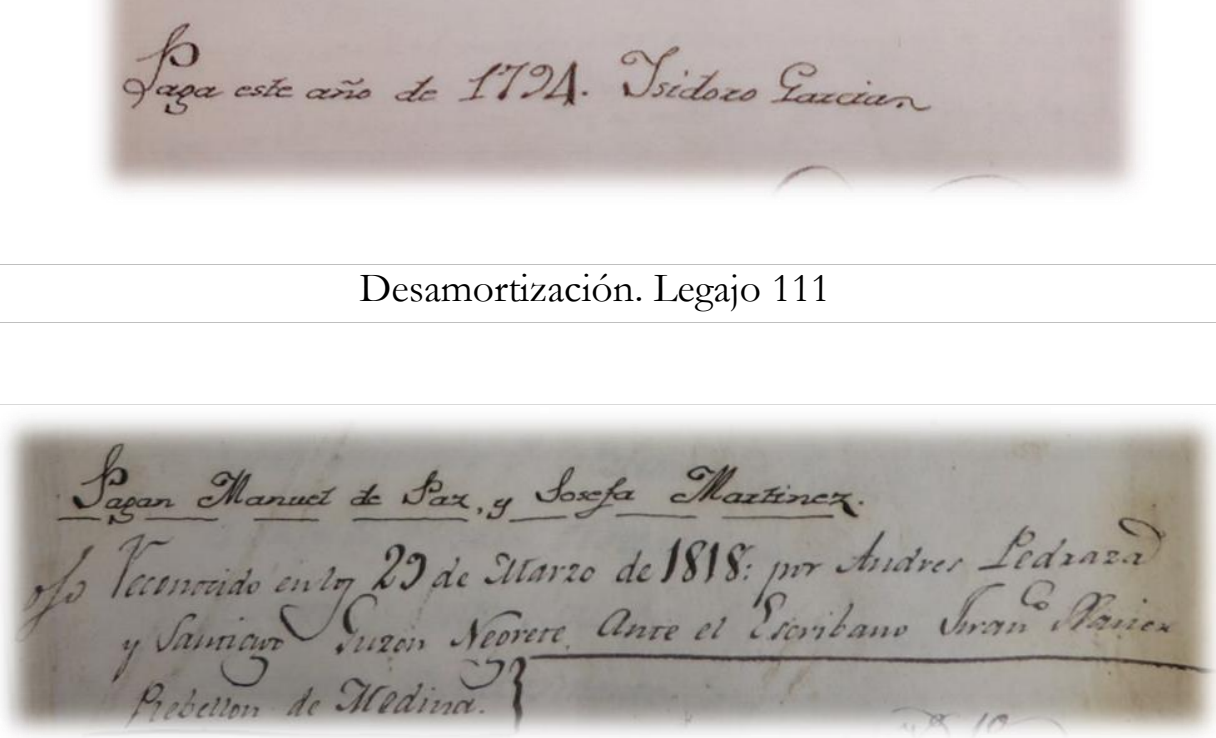

Desamortización. Legajo 111

Consultable en formato digital en: http://www.jovellanos2011.es/web/biblioteca-virtual-ficha/?cod=4481, http://www.jovellanos2011.es/web/biblioteca-virtual-ficha/?cod=4527 [fecha de las últimas consultas: 29 de marzo de 2017].

Una reseña puede encontrarse en SASTRE SANTOS, Eutimio, Una instrucción de Jovellanos para el arreglo del monasterio santiaguista del Sancti Spiritus. Salamanca, 1790. Madrid: Instituto Salazar y Castro, 1995, p. 27.

361 AHPP, Desamortización, legajo 111. 

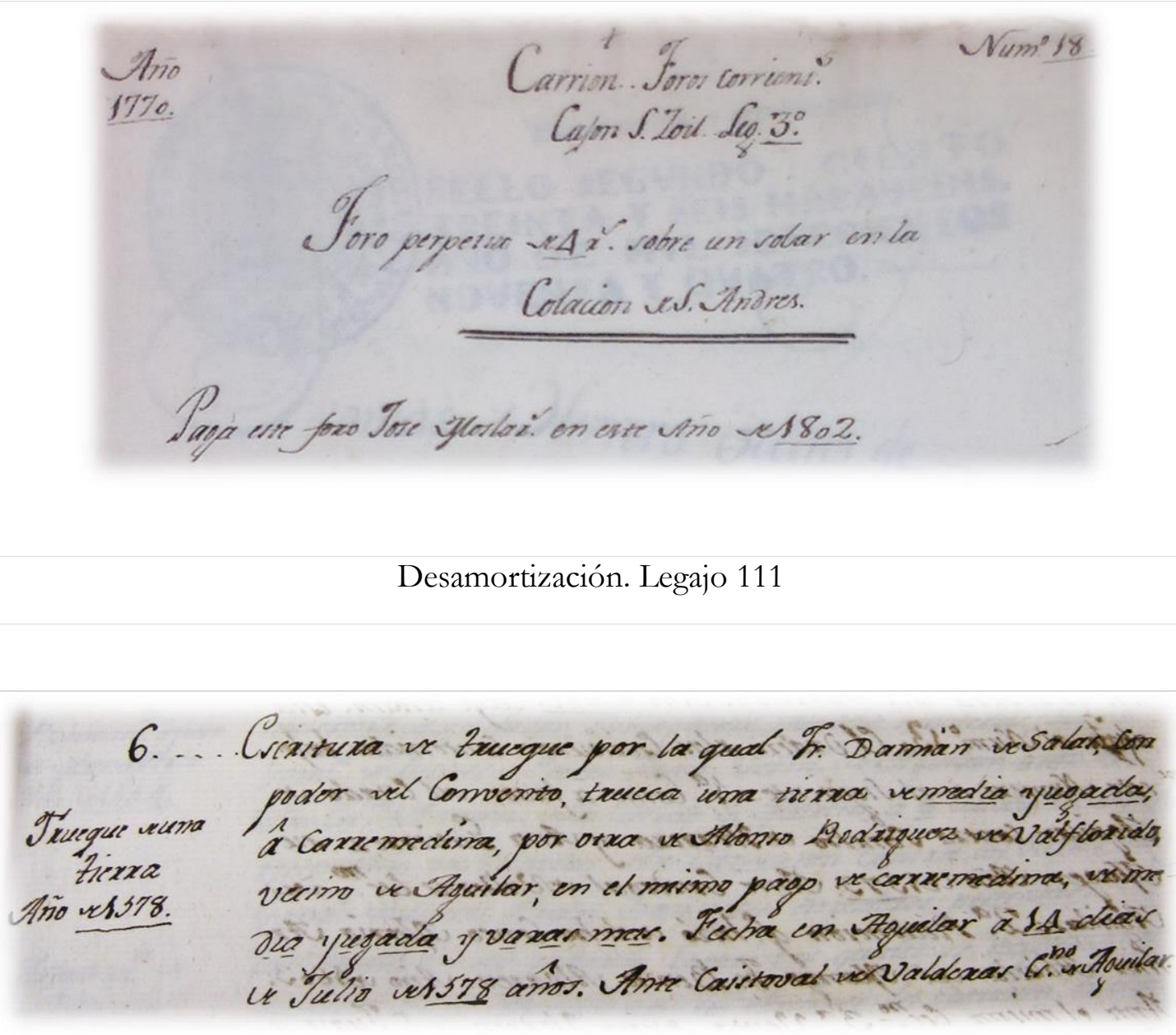

Índice de San Zoilo f. 2r (Mano del "escriba A")

\subsection{La construcción de los mensajes referenciales o labor sintetizadora}

Es precisamente en este aspecto donde encontramos otro de los indicios que nos llevan a relacionar la figura del archivero del monasterio con el escriba principal del libro, el "escriba A"; el cual debía ser un hombre con una amplia formación, versado en escrituras y papeles, y capaz de leer documentos con letra antigua, tal y como lo explicitaban las Constituciones de la Congregación ${ }^{362}$.

Estas características se tornan evidentes a través del análisis de algunos elementos presentes en el Índice, la suma de los cuales estaba pensada para facilitar la comprensión y

362 PORRAS HUIDOBRO, Facundo, Disertación sobre archivos, pp. 76-83, dedica un epígrafe a señalar la "Instrucción y cualidades que necesitan" aquellas personas que sean archiveros.

El padre Cisneros en su Manual del Archivo de San Zoilo expresaba también unas recomendaciones acerca de las características que debía poseer aquella persona que quisiera optar al cargo de archivero: "El primer aviso es que nunca se fíe este archivo de quien no tuviere este habito. El 2 que sea buen lector, buen latino y tenga buena pluma, que sepa leer letras antiguas, góticas, romanas y francesas y tenga afición a ello y mucha paciencia". PALACIO, Colección San Zoil. II, pp. 516. 
el acceso al contenido de los documentos; permitiéndonos así vislumbrar cómo escribían, cómo resumían, a qué recursos recurrían para conseguirlo y, en definitiva, la importancia y servicio que dieron a este tipo de registros fundamentados en una resuelta conciencia documental y archivística.

La escritura es de bastante calidad y muy esmerada, así como la separación de las palabras en el texto y la distribución en el folio de cada uno de los apartados, desde el encabezado hasta los resúmenes informativos y analíticos, reservando el margen derecho para escribir una serie de anotaciones a las que nos referiremos a continuación. Aunque se observa una cierta uniformidad a lo largo de la primera mitad del manuscrito -coincidiendo con la redacción del escriba principal-; la caligrafía cambia a medida que se avanza en la escrituración haciéndose cada vez más inclinada y menos agradable de leer. Poco se deja a la ornamentación, puesto que carece el códice de todo tipo de dibujos, figuras, letras miniadas y tintas de otros colores que no sean el negro u ocre. Su característica más notable era la practicidad, y su elaboración y estructura así deberían permitirlo, sin ornatos y añadidos que pudieran despistar o dificultar la localización de los documentos y que hubieran prolongado su redacción limitando su pronto manejo, que tan necesario se hacía para el monasterio.

El carácter referencial del manuscrito queda patente en los resúmenes de los documentos, medio para presentar la información contenida en las escrituras. Realizados en base a la previa lectura de los documentos, reflejan fielmente el contenido del diploma, alejándose de la transcripción literal aunque sin alterar el contenido documental ${ }^{363}$; máxime cuando eran conscientes de que cualquier error e intromisión podría suponer un menoscabo en la correcta gestión tanto del archivo como de su hacienda.

Todos estos aspectos denotan que su autor era una persona conocedora del latín y habituado al manejo de las escrituras antiguas, condiciones que difícilmente podría reunir otra persona que no fuese el archivero. La técnica para hacer las descripciones es como sigue:

Comienza los resúmenes analíticos con la expresión de la tipología documental, para pasar a continuación a señalar los elementos más propios del documento. En este

\footnotetext{
${ }^{363}$ TROCHE Y ZÚÑIGA, Froilán, El archivo cronológico-topográfico. Arte de Arcbiveros, pp. 37-38, dedica un capítulo al "arte de estractar", definiéndolo como "[...] definir en pocas palabras o escribir en pocas líneas el contenido más interesante de un documento, reasumiendo todos los puntos que abraza o son necesarios para conocer a primera vista lo que es [...], a saber: la clase de documento según el verdadero nombre que deba aplicársele, los sujetos por quien haya sido otorgado o jueces que hayan hecho oficio de actores, la cosa o suceso sobre que lo hicieron en bosquejo, el lugar y el día de su fecha y el escribano o sugeto que lo haya autorizado $[\ldots] "$.
} 
sentido, si está regestando una compra, venta, trueque o censo indica las personas implicadas en el negocio jurídico -informando sobre su vecindad o dignidad: vecino de Aviñante, prior de San Zoil, etcétera- así como de la calidad de los bienes que se están vendiendo, intercambiando..., y el dinero pagado por la operación (generalmente expresado en maravedís $\left.{ }^{364}\right)$, y finaliza con la data tópica y crónica, señalando, por último, ante qué escribano pasó la escritura ${ }^{365}$.

Mención aparte requieren los privilegios y las donaciones en los que describe pormenorizadamente las características del documento, desde la materia escriptoria hasta los sellos que portaba, indicando el rey o particular que lo concedió y los bienes o privilegios concedidos. Para terminar señalando la data tópica y crónica y la posible existencia de copias recientes que asegurasen su existencia en caso de deterioro del original $^{366}$. Una construcción muy similar es la que emplea para regestar las bulas ${ }^{367}$.

Las presentaciones y colaciones muestran un esquema muy singular y nos proporcionan los nombres de muchos de los prelados, monjes y abades, difíciles de conocer y situar cronológica y espacialmente sin la noticia de estos documentos. Las presentaciones ${ }^{368}$ comienzan con el nombre del monje electo a dicho curato y el de aquel que realiza la presentación; continúa con el nombre del anterior poseedor del beneficio y el

${ }^{364}$ Conocían los equivalencias de las monedas antiguas que se utilizaban en los diferentes reinos tal y como lo indica al expresar "Y assimismo les dan poder para que les puedan obligar [...] a dar y pagar al prior y convento de San Zoil en cada un año para siempre jamás hasta el fin del mundo, por la transación del barrio, 50 mill maravedís de la moneda que entonces corría en Castilla o, si dicha moneda se mudare, 1 mill florines de oro del cuño de Aragón de justo peso y valor, o 25 mill maravedís de la moneda antigua de los reynos de Castilla y León" (AHPP, Desamortización, legajo 112, f. 239r, n. ${ }^{\circ} 7$ ).

365 " $<$ Compra de unas casas con su corral en el barrio de San Zoles. Año de 1456>. Compra que hizo el monasterio a Juan López Moro, vecino de Carrión, de unas casas con su corral en el barrio de San Zoles, linderos: la calle pública y el Camino Francés, por precio de 1400 maravedís, con carga de 9 maravedís y una gallina de fuero. Su fecha, en San Zoil, a 11 de febrero de 1456, ante Álvar González, escribano de Carrión” (AHPP, Desamortización, legajo 112, f. 148v, n. ${ }^{\circ}$ 6).

366 “<Donación del rey don Alonso a Pedro Muñoz del lugar de Santa Cruz de Ventosilla. Era 1216. Año $1178>$. Privilegio del rey don Alonso, escrito en pergamino, con sello de plomo pendiente, por el qual hace merced y donación a Pedro Muñoz y sus hijos y herederos de toda la heredad que el rey tenía en Santa Cruz de Ventosilla, en el valle de Pero, con todos sus derechos y pertenencias, por el buen servicio que en mucho tiempo le había hecho. Diose este privilegio rodado en la villa de Arévalo, tertio kalendas januarii, era 1216, que es año de 1178” (AHPP, Desamortización, legajo 112, f. 183v, n. . 1).

367 " $<$ Bula original de Eugenio $4^{\circ}$ que confirma el contrato del barrio por 1 mill florines annuales. Año 1431>. Bulla original del papa Eugenio $4^{\circ}$, escrita en pergamino, con sello de plomo pendiente en filos de seda colorada y amarilla, que es confirmación de la sentencia del cardenal de San Pedro ad vincula puesta en el número antecedente[...]. Luego inserta de verbo ad verbum el instrumento y sentencia del cardenal de San Pedro. Fue dada esta bulla en Roma, apud Sanctum Petrum, a $1^{\circ}$ de octubre año de 1431 , en el año primero de su pontificado" (AHPP, Desamortización, legajo 112, f. 241v, n. ${ }^{\circ}$ 9).

368 “<Presentación de una cappellanía en don Antonio Pérez. Año 1707>. Presentación de una capellanía de San Martín hecha por el padre maestro fray Jacinto Díez, abad de San Zoil, en el licenciado Antonio Pérez, natural de la villa de Castrogerid, por resignación que de ella hizo don Juan Antonio de Godoy, último poseedor (cuya resignación y aceptación están aquí insertas). Su fecha, en San Zoil, a 27 de abril de 1707, ante Santiago Duque de Estrada, esscribano y notario de Carrión”. (AHPP, Desamortización, legajo 112, f. 209v, n. $\left.{ }^{\circ} 24\right)$. 
motivo de la vacante, y finaliza con la alusión a la data y el escribano ante quien pasó el documento. Las colaciones ${ }^{369}$ indican quién ha recibido ya la posesión del beneficio curado así como la persona que realizó la presentación.

Sin embargo, ninguna tipología refleja mejor el trabajo y esfuerzo que realizaron los escribas del Índice que los pleitos. Una ingente tarea que requería la lectura de los cientos de folios que en ocasiones ocupaban los procesos, la cual realizaban a la perfección, dando debida cuenta de quienes eran los contendientes y el motivo del pleito, para pasar a reseñar la presentación de pruebas, la relación de alegatos así como las sentencias y apelaciones; en definitiva, todos y cada uno de los documentos que testimonian los autos del proceso y que se unieron formando parte del todo que es el pleito, necesario para la acreditación de los fallos favorables pronunciados en los litigios motivados por la defensa de posesiones y privilegios. De cada una de las fases y testimonios del proceso se ofrece la data, que permite seguir el orden natural de la producción documental y el procedimiento, y seguirlo en los diferentes tribunales en los que pudo litigarse ${ }^{370}$.

Con unos resúmenes informativos tan detallados pero concisos, resulta complicado imaginar la información que se reservaba para los resúmenes analíticos situados en el margen izquierdo. No obstante, y haciendo gala de la maestría ya demostrada, va a reservar para estos la información correspondiente a la tipología documental, la localización (no en todos los casos), la calidad del bien, el derecho, la contienda, el privilegio contenido en el documento, y la data crónica, expresada en eras y años según apareciera en el documento.

- Resumen analítico: “<Compra de una casa en Las Heras. Año 1708>”.

- Resumen informativo: "Compra que hizo este monasterio al licenciado Bartolomé González Donis, clérigo de menores órdenes, de una casa en el lugar de Las Heras, junto a la yglesia, que linda con casa de Favián Valle y calles reales, por precio de 1.044 reales. Otorgose esta escritura en el lugar de Las

\footnotetext{
369 “<Colación en Matías Melendro. Año 1615>. Colación dada por el provisor de Palencia al bachiller Matías Melendro, en virtud de presentación del abad de San Zoil, por fin y muerte del bachiller Juan Pérez. Dada en Palencia, a 5 de octubre de 1615, ante Juan de Noriega, nottario; y tomó la posesión quieta y pacíficamente ante Pablo de Aedo, esscribano de Villasirga, en 19 de dicho mes y año" (AHPP, Desamortización, legajo 112, f. 436v, n. ${ }^{\circ}$ 6).

370 "Habiendo llegado a noticia del monasterio de San Zoil las diligencias arriba expresadas, la parte del monasterio pidió ante el señor don Miguel Antonio Franco y Villalba, juez de Valdíos, que dicho lugar de Valcavado y el de Revilla, inmediato a él y también despoblado, se declarase[n] por proprios del dicho monasterio; para lo qual exhivió el pleyto que está en la pieza B del quaderno C de este legajo, en que está compulsado el privilegio del señor rey don Alonso el $9^{\circ}$, al folio 144 de dicho pleito" (AHPP, Desamortización, legajo 112, f. 347v, n. ${ }^{\circ}$ ).
} 
Heras, a 4 de mayo de 1708, ante Lorenzo Luis, escribano y vecino del lugar de Villanueva de Muñeca"371.

Hemos indicado cómo construye los resúmenes, aportando la cantidad de información y detalles necesarios e imprescindibles; pero, ¿es objetiva y fiable la información que proporcionan? Para responder a esta pregunta nos vamos a remitir a aquellos datos históricos que, por su accesibilidad, nos van a proporcionar una fuente fiable que nos permita establecer su comparación con datos objetivos. Nos referimos a las alusiones que hace a los monarcas, sus fechas y genealogía, y a los pontífices con su ordinal y cronología.

El Índice contiene numerosas alusiones a reyes y pontífices, puesto que su proceso de conformación patrimonial se sustenta en los privilegios, donaciones y bulas que concedían aquellos al monasterio. Si bien resultan correctas las alusiones realizadas a los pontífices; analizadas todas las referencias alusivas a reyes, comprobamos cómo el escriba que redacta la primera parte del códice conoce a la perfección los detalles relacionados con las biografías, puesto que las referencias que hace encajan a la perfección con los datos históricos ${ }^{372}$. Únicamente encontramos un error en los resúmenes que comete el que denominamos "escriba B", confusión que se va a ver también reflejada en los resúmenes realizados al dorso de los documentos.

371 AHPP, Desamortización, legajo 112, f. 261r, n. ${ }^{\circ} 14$.

372 Señalamos un ejemplo de ese rigor histórico a través del "<Privilegio del rey don Fernando el Santo. Libra a los vassallos del barrio de todo pecho y pedido. Era 1258, año de 1220>.

Privilegio rodado, escrito en pergamino, con sello de plomo pendiente, del rey don Fernando el Santo el qual, por reverencia del venerable G[erard], abad de Cluni, su amigo, y atendiendo al gratíssimo servicio que le había hecho Juan, prior de San Zoil y camarero de España, trhaiendo de Alemania a la reyna doña Beatriz, su muger, hija de Filipo, rey de romanos, y con beneplácito de doña Berengaria, su madre, y del ynfante don Alonso, su hermano, hace libres de todo pecho y pedido a todos los vasallos del barrio de San Zoles, assí christianos como moros y judíos, y de todo gravamen y tributo, reservando para sí 100 maravedís que le habían de pagar cada año. Facta carta Vallisoleti, $8^{\circ}$ idus ianuari, era 1258, que es año de Christo 1220. Hay aquí tres copias authorizadas, una en pergamino y dos en papel” (AHPP, Desamortización, legajo 112, f. 91r, n. 3$)$.

Zaragoza Pascual nos da noticia de este abad y nos informa de lo siguiente: "Yepes dice que por encargo del rey Fernando III viajó a Alemania para traer a la que sería su esposa, la reina Beatriz de Suabia". ZARAGOZA PASCUAL, Abadologio San Zoilo, p. 281.

Esta noticia la encontramos reflejada en YEPES, Coronica de San Benito, p. 89; "Don Juan por la era de mil y dozientos y cincuenta y ocho, fue juntamente Prior de San Zoil, y Camerario de San Pedro de Cluni. Este floreció en los tiempos del Rey don Fernando llamado el Santo, el cual le hizo diferentes mercedes, y en una escritura da por razón, lo que contienen las palabras siguientes: Ego Ferdinandus Dei grattia, Rex Caftelle y Toleti , ob reverentiam venerabilis amici mei, N. Abbatis Cluniacensis necnon et intustu gratissimi seruitii, quod vos, Ioannes Prior Carrionenfi et Hispaniae Camerarius, cundo in Alemaniam, pro charisima uxore mea Regina Béatrice, filia Phihppi quonda Regis Romanorum nobis exitbuistis, etc. En que seda á entender claramente el seruicio que este Prior de Carrión don Juan hizo al Rey don Fernando yendo à Alemania por la Reyna doña Beatriz hija de Filipo, que se llamava Rey de los Romanos". 
Nos referimos a los datos confusos que aporta el escriba al extractar dos privilegios realizados por los reyes Alfonso IX y Fernando II, respectivamente. Sendos registros nos aportan la siguiente información:

" $<$ Privilegio del rey don Fernando el $2^{\circ}$. Era 1222. Año 1184>. Privilegio del rey don Fernando el $2^{\circ}$, hermano del rey don Sancho el Deseado, hijo del rey don Alonso el $8^{\circ}$ (sic) llamado el Emperador [... $]^{3373}$.

“<Privilegio del rey don Alonso el 9. Era 1234. Año 1196>. Privilegio $3^{\circ}$ del rey de Castilla y de Toledo don Alonso el $9^{\circ}$, hijo de don Fernando el $2^{\circ}$, es rodado, escrito en pergamino y en latín, con sello de plomo pendiente, por el qual el rey don Alonso, junto con su muger, la reyna doña Leonor, y su hijo don Fernando"374.

Antes de señalar las confusiones que se producen en estos documentos, resulta más significativo explicar el problema dinástico que puedo llevar al escriba a cometer dichos errores. Alfonso VII, conocido como "El Emperador” (1105-1157), es hijo de la reina doña Urraca I, hija de Alfonso VI y nieta de Fernando I "El Grande", primer rey de León en aglutinar bajo su mandato el condado de Castilla. Al morir Alfonso VII, vuelve a dividir el reino en dos, otorgando León al que será el futuro Fernando II (1137-1188) y Castilla a Sancho III (1133-1158). El sucesor de Fernando II, Alfonso IX de León (1171-1230) contrae matrimonio con Teresa de Portugal y Berenguela de Castilla, en segundas nupcias, de cuya unión nacerá Fernando III “El Santo”, que será rey de Castilla y de León y el padre de Alfonso X "El Sabio". A Sancho III, fruto de su unión con Leonor Plantagenet, le sucede Alfonso VIII de Castilla (1155-1214), cuyo sucesor será Enrique I, padre de la reina Berenguela de Castilla, antes mencionada.

La confusión entre estos dos monarcas, Alfonso VIII de Castilla y Alfonso IX de León, estriba en el hecho de que sus reinados coinciden en el tiempo, aunque en diferentes reinos, y lo que hace el escriba es mezclar sus consortes y títulos, al atribuir a Alfonso IX la esposa de Alfonso VIII y el título de rey de Castilla y León, cuando únicamente era de León. Lo mismo ocurre cuando nombra a Alfonso VIII como "El Emperador", título que había recibido su abuelo Alfonso VII.

373 (AHPP, Desamortización, legajo 112, f. 358r, n. ${ }^{\circ}$ 1).

374 (AHPP, Desamortización, legajo 112, f. 359r, n. ${ }^{\circ}$ 5). 
Este desarreglo da lugar a que en el reverso del documento original correspondiente al privilegio de Alfonso IX ${ }^{375}$, se haga una modificación al escribir sobre el número 9, un número 8 , tal y como indicábamos en el capítulo dedicado a la organización del archivo monástico. No obstante, desconocemos las motivaciones que llevaron a este cambio puesto que, si tenemos en cuenta los privilegios anteriores que reafirman la relación de padre e hijo de Fernando II y Alfonso IX ${ }^{376}$ también registrados en el Índice, la confusión no se habría producido en el nombre del monarca, sino en algunos datos de su biografía, lo cual haría innecesaria dicha corrección.

Reseñado y fundamentado el error, conviene enumerar algunas de las especificidades que hacen de este manuscrito un instrumento de referencia fiable para conocer el contenido de los documentos y como instrumentos de control del archivo:

- En los documentos cuya data está expresada en era cristiana, el mismo escriba realiza la conversión cronológica a años sin cometer errores que pudieran obrar en detrimento de sus privilegios ${ }^{377}$.

- Las reseñas a documentación y libros existentes en otros archivos es constante, como se observa para el caso concreto del Becerro de las Behetrías ${ }^{378}$ (al que se refiere como el Becerro de Valladolid, que está en la Chancillería), así como el libro Becerro de la Catedral de Palencia o el Archivo General de Simancas ${ }^{379}$. Destacan por su relevancia las alusiones al archivo del monasterio de San

375 Colegio de San Estanislao (Salamanca), Archivadores del Fondo Antiguo, Sala 2, Caja 11. El tercer documento del Colegio de San Estanislao resume: "Era 1234, año 1196. Villafrechós. Número 5. Priuillegio del rrey D. Alonso el $8^{\circ}$, en que concede al m[onasterio] las tercias de todas las Iglesias de Villafrechós, [saluo] una del obispo de León y otra de los Templarios. Quaderno A, Legajo 3, Cajón San Gregorio". "San Zoil”. 376 (AHPP, Desamortización, legajo 112, f. 359r).

377 Desde el año 1383 deja de utilizarse la datación por la era cristiana, fecha a partir de la cual se impone el estilo del nacimiento para fechar los documentos, que se empleará hasta el reinado de Felipe II. Este cambio se observa en el Índice, puesto que en los documentos a partir de esa cronología únicamente se expresa la data en años. Véase el epígrafe titulado "Cómo se reducen las eras al año cristiano" en TROCHE Y ZÚÑIGA, Froilán, El archivo cronológico-topográfico. Arte de Archiveros, pp. 2-3.

${ }^{378}$ Los datos que nos proporciona el manuscrito revelan como ese Becerro de Valladolid era el Becerro de las Behetrías, que permitió a Pedro I conocer «las behetrías quales e quantas son e quales e quantos son los naturales della» y «ver las tierras e rentas [de realengo] como están», y, de ahí las numerosas alusiones a dicho libro. Sirva como ejemplo la siguiente: “<Cláusulas del Becerro de Valladolid. Hecho en la era de 1390, año de 1352>. Papel simple que contiene las cláusulas sacadas del libro Becerro hecho por mandato del rey don Alfonso en la era de 1390, que está en poder del chanciller de la Chancillería de Valladolid. Estas cláusulas son pertenecientes a los derechos y señorío que tenía este monasterio en el lugar de Arconada, las quales se hallan al folio 49 de dicho libro, en la merindad de Carrión." (AHPP, Desamortización, legajo 112, f. 34v, n. ${ }^{\circ}$ 4). Otras referencias en AHPP, Desamortización, legajo 112, f. 270r, f. 421r, f. 430r, f. 445r).

Véase sobre el Libro de las Behetrías: Becerro: libro famoso de las Behetrías de Castilla, que se custodia en la Real Chancillería de V alladolid: manuscrito del siglo XIV en el cual se espresan detalladamente la naturaleza y orígen de la noble za de España y se describe en todo su esplendor el feudalismo nacional en el último tercio de la Edad Media, $1^{\mathrm{a}}$ ed., Santander: Librería de Fabián Hernández, 1866; MARTÍNEZ DIEZ, Gonzalo, Libro Becerro de las Behetrías. 1 y 2 Estudio y texto crítico, 3 Índices y mapas. León, 1981.

${ }^{379} \mathrm{La}$ relación a estos archivos se incluyen en el marco de cobro de diezmos y otras rentas, así como los beneficios de algunas iglesias (AHPP, Desamortización, legajo 112, ff. 40v-41r, f. 196v). 
Claudio de León, en el proceso sobre la congrua de un cura en San Juan de Aguilar ${ }^{380}$. Estas indicaciones redundan en la idea de que el artífice de este manuscrito era una persona que conocía y manejaba su archivo y conocía aquellos otros en los que el monasterio pudiera concentrar documentos y argumentos para defensa de sus derechos en los pleitos que contendía.

- Es notorio cómo los escribas buscan refrendar sus anotaciones en base a otros personajes ilustres que ya trabajaron en el archivo como el padre Cisneros y el padre Yepes $^{381}$.

\begin{abstract}
380 San Claudio de León fue un ilustre monasterio que desarrolló su existencia desde la Edad Media hasta la Desamortización, fecha a partir de la cual será desmantelado y sus piedras utilizadas para otros fines. El Índice señala al respecto de su relación con San Zoilo lo siguiente: " $<$ Proceso compulsado en Astorga para Roma, sobre la congrua de un cura en San Juan de Aguilar. Año de 1568>. < Concordia antigua. Año de $1247>$.
\end{abstract}

Llevose el proceso, y habiendo conocido de la causa y oído las partes (salieron a ella el convento de San Claudio y el cavildo de la yglesia de León, por lo que les tocaba), se presentó en este proceso la concordia antigua que se hizo entre el obispo de León Martino y el cavildo de su yglesia, de una parte; y Gaufrido, prior de San Zoil y camarero de Cluni, con su convento, de la otra, en la era de 1285, que es el año del Señor de 1247. Y estando al parecer conclusa esta causa, el dicho provisor de Astorga pronunció en ella sentencia, a 5 de febrero de 1568, por la qual confirmó la sentencia del provisor de León y le remitió la executión de ella. Apelaron de nuevo los monasterios de San Zoil y San Claudio, y no habiéndoles admitido la apelación, se llevó por vía de fuerza a la Chancillería, [...] Y se compulsó este proceso en Astorga, a 31 de agosto de 1568, ante Antonio Ocáriz, escribano y notario público. Esta causa se ventiló y sentenció en Roma y se sacaron executoriales, que están en el Archivo de San Claudio de León, y el trasunto está adelante, en el número $6^{\circ}$ de este mismo quaderno" (AHPP, Desamortización, legajo 112, f. 9r, n. ${ }^{\circ}$ 3).

$<$ Sentencia dada en Roma contra los curas de Aguilar sobre la congrua. Año de 1574>.

Trasumto simple de una sentencia dada en Roma contra quatro curas de Aguilar, y en favor de los monasterios de San Claudio y San Zoil y de la fábrica de la yglesia de León, en razón de la compra que los clérigos les pedían; por la qual parece que, habiendo cometido el conocimiento de esta causa la Santidad de Pío $5^{\circ}$ a Cristóval Robuste, auditor de la Cámara Apostólica, con consejo de sus colegas, dio en ella sentencia definitiva. Por la qual revoca las sentencias de los provisores de León y Astorga y absuelbe de la demanda puesta por los curas a los abades y conventos de San Claudio y San Zoil y a la fábrica de la yglesia de León y les da por libres de ella; dando por injustas, temerarias, ilícitas y presuntas las molestias que sobre esta razón se les habían echo. Pone perpetuo silencio a los curas en razón de la dicha congrua y les condena en las costas echas por dichos conventos y fábrica en esta tercera instancia de Roma. Dada y publicada en San Pedro de Roma, en el palacio apostólico de las causas, a 9 de julio de 1574, [...]" (AHPP, Desamortización, legajo 112, f. $9 \mathrm{v}, \mathrm{n}^{\circ}$ 6).

Esta misma referencia la encontramos en un manual confeccionado en el año 1620 y que recoge la Historia de San Claudio, y que comienza con estas palabras: "Fundación de la iglesia antigua y Martyrio de San Vicente, San Ramiro i sus doce compañeros", y termina así: "Yo también doy por concluido este manualico, que he acabado con infatigable trabajo, porque no he dejado papel en el archivo, grande ni pequeño, que no haya leído [...]". En el apartado dedicado a Aguilar de Campos se puede leer: "No sólo nos pertenecen las tercias deste lugar en las quatro parroquias de Nuestra Señora y S. Pedro y S. Andrés y S. Esteuan, sino también en la de S. Juan, que es priorato de S. Zoil de Carrión. Está la escritura desto en el dicho 2 tomo de la A, a folio 29. No pueden los curas pedirnos cóngruas porque ay executoriales contra ellos en que se les pone perpetuo silencio. Fol. 137”. Ambas reseñas en sus respectivos manuales coinciden a la perfección, lo que indica que el interés económico de ambos monasterios, lo que hizo que San Claudio poseyera la documentación y San Zoilo hiciera referencia a la existencia de dichos documentos en el archivo de este monasterio leonés".

El estudio y transcripción del manual puede verse en DÍAZ-JIMÉNEZ Y MOLLEDA, Eloy, "Real Monasterio benedictino de San Claudio de Léon, 1885": Revista Erudición ibero-ultramarina, Descripciones bibliográficas, [s.n]. Madrid, 1930-1932, pp. 6-7 y 114-115.

381 La confianza en el padre Cisneros hace que se feche un documento en el Índice en base a las aproximaciones realizadas por él, aun indicando que la escritura no permite determinarlo: "Donación que hizo doña María, hija de los condes, a Bononomen, abad de San Román, y a los monges que están en aquel 
- La identificación de los topónimos es bastante precisa, detallando cuando es necesario si el lugar está despoblado o si ha cambiado de nombre ${ }^{382}$. Además puntualiza los límites de cada una de las propiedades que cambia en los trueques e incluso señala la calle exacta en la que se encuentran algunas de las casas que adquiere, puesto que estaba al tanto de los beneficios que dicho grado de precisión aportaría al monasterio, por cuanto proporcionaba la localización y dimensiones de casas y tierras.

- El archivero incluía en el texto advertencias para que los sucesivos archiveros que consultasen y trabajasen en el archivo estuvieran prevenidos sobre el contenido de algunos de los documentos. Para ello indica cómo esa escritura “es perjudicial” o "es necesario cuidado"383; diferenciando además cuándo un documento era de utilidad para el monasterio o cuándo no ${ }^{384}$, e incluso dando a entender que consulta otros manuscritos con descripciones de los documentos para hacer los regestos de algunas de las piezas de archivo que que no se encuentran en él, como puede interpretarse de la siguiente anotación: “[...]

monasterio de ciertos solares en el lugar de Las Heras, y una heredad en San Martín junto a Villalveto, que ya está despoblado. Facta carta era 1116 (según el padre Cisneros), que es año de Christo 1078. Adviértase que esta casa puede estar equivocada pues ni hay figura de mil ni en los numerales góticos se encuentra el cinco antes del diez como se ve en esta escritura" (AHPP, Desamortización, legajo 112, f. 259r, n. . 1).

Para elaborar el manuscrito consulta otras fuentes como puede verse en el siguiente caso: " $<$ Censo perpetuo de 2 mill monedas de oro que concedió el rey don Alonso el $6^{\circ}$ al monasterio de Cluni. Año 1090>. A folio $3^{\circ}$ está una escritura del rey don Alonso el $6^{\circ}$ (que la trae el maestro Yepes en el tomo $4^{\circ}$, p. 453), hijo de don Fernando el $1^{\circ}$, por el qual confirma un censo anual de mil monedas de oro (que él llama methales), que su padre había concedido al monasterio de Cluni [...]” (AHPP, Desamortización, legajo 112, f. 189r, n. ${ }^{\circ}$ 1).

382 "Escritura de trueque en pergamino, partida por ABC, por la qual Pedro Fernando, prior de San Román, y su convento dan al convento de San Zoil toda la parte que tenían en la casa e yglesia de San Vicente de Otello (oy Autillo) con sus pertenencias [...]". (AHPP, Desamortización, legajo 112, f. 301v, n. 2); "Donación de unos censos hecha por nuestro reverendísimo padre maestro Juan Díaz, general de San Benito, hijo de esta casa, por sí y en nombre de su hermana Cathalina Díaz, difunta, beata que fue en el recogimiento de el lugar de Torre (oy despoblado con el título del Cristo de Torre), jurisdición de la villa de Astudillo [...]" (AHPP, Desamortización, legajo 112, f. 32r, n. ${ }^{\circ}$ 1); "Escritura de donación que hizo Enderquina Rodríguez a San Román y a su prior Gómez de toda quanta heredad tenía en Arenillas de Mazool, oy de Mazuecos” (AHPP, Desamortización, legajo 112, f. 30v, n. $\left.{ }^{\circ} 1\right)$.

383 “ $<$ Nota $>$. Esta sentencia es traslado de traslado y así, quando llegue el caso que tal vez sea necesario compulsarse, tenga presente el archivero el traslado o instrumento primordial que está en el libro $5^{\circ}$ de vitas,

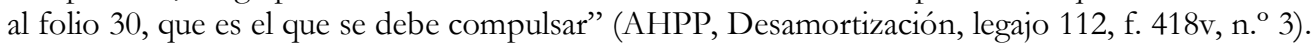

“ $<$ Nota $>$. Este ynstrumento es mui perjudicial al derecho de esta casa, y assí a nadie se muestre" (AHPP, Desamortización, legajo 112, f. 104r, n. ${ }^{\circ}$ ).

"Repárese en este proceso, que así como tiene cosas que aprovechan, tiene otras que dañan, y así es necesario cuidado" (AHPP, Desamortización, legajo 112, f. 376r, n. ${ }^{\circ}$ 3).

${ }^{384}$ El redactor describe una escritura que no está relacionada con el monasterio y lo advierte escribiendo: "Compra que hizo Pedro Sánchez, vecino de Población, a Sancho de Barreda de una tierra en término de dicho lugar, a do dicen a las Cascajeras, [...]. Esta escritura no habla con el monasterio (AHPP, Desamortización, legajo 112, f. 289v, n. ${ }^{\circ}$ 2).

La posible utilidad del documento llevó al archivero a copiarlo, tal y como indica en la siguiente anotación: "Al último de los papeles de Terradillos está una copia simple de la donación que hizo don Bernardo Martín, [...], que se trajo para ciertos asumptos con otros papeles; de la qual hice dos copias, y la una está en la cámara para lo que se pueda ofrecer [...]" (AHPP, Desamortización, legajo 112, f. 337v, n. ${ }^{\circ}$ 2). 
Falta esta escritura del archivo y por tanto no puede ponerse con más indivualidad" 385 .

- Muchas de las escrituras se mencionan a través de la existencia de uno o varios traslados o incluso únicamente por la copia -simple o autorizada- o trasunto que de ellas se conserva ${ }^{386}$. Estas copias y traslados, que llevaban el signo de validación del notario, se convertían en un recurso fundamental para el monasterio, al permitirles por su fidelidad y autenticidad servirse de ellos como documentos con autoridad en sustitución del documento original que se custodiaba en el archivo.

- Otro recurso empleado en el Índice fueron las notas o aclaraciones de diversa índole. Ensambladas en el margen derecho de los folios, su registro resultaba útil para el archivero que las anotó, quien también lo hizo con el objetivo de transmitir esta utilidad a sus sucesores, destacando la nota que indica "perjudicial"387 . Otras notas fueron añadidas por un escriba posterior a modo de aclaraciones al texto principal.

En ellas se va glosando el contenido de los documentos a través de palabras clave con el nombre de la tipología documental o de las poblaciones a las que afectan los diplomas ${ }^{388}$, y que estaban escritas por la misma mano que redacta los resúmenes.

Una de las palabras más recurrentes es la que indica la "falta" quizás de esos documentos a los que se refiere. Al ser escritas por una mano que no redacta ninguna parte del códice, aludimos a la posibilidad de que estas anotaciones se hicieran con posterioridad a la Desamortización de 1820; puesto que, cuando tras la vuelta de la comunidad al monasterio en 1823 le fueron devueltas sus

\footnotetext{
385 AHPP, Desamortización, legajo 112, f. 289v, n. ${ }^{\circ} 3$.

386 Los ejemplos resultan tan abrumadores que señalamos algunos de los más significativos: "Sacose este testimonio, que concuerda con su original, por Gerónimo López Labrador, notario" (AHPP, Desamortización, legajo 112, f. 181v, n. ${ }^{\circ}$ 3), "Hay copia authorizada y el original está escrito en pergamino" (AHPP, Desamortización, legajo 112, f. 196r, n. ${ }^{\circ}$ 2), "Que el monasterio les dé traslados authorizados de todas las escrituras y privilegios del barrio y quede obligado a mostrar los originales quando fuere necesario" (AHPP, Desamortización, legajo 112, f. 238v, n. 20), "Hay un original y un traslado autoriza[do] por Juan de Castrillo, y de ambos copia autorizada por don Antonio Martín García, traductor” (AHPP, Desamortización, legajo 112, f. 436r, n. ${ }^{\circ}$ 1).

387 "Nota: Bajo este número se halla también una consulta y parecer de un abogado sobre la reedificación de la yglesia de San Saturnino de Barajores, que pretendía hacer el mismo penitenciario don Juan Abad. Léase pues sirve mucho para lo perteneciente a esta yglesia" (AHPP, Desamortización, legajo 112, f. 60v, n. ${ }^{\circ}$ 12).

388 Esta peculiaridad también se observa en el repertorio de las escrituras de la Catedral de León redactado en el siglo XV; aunque estas anotaciones se añaden con posterioridad en el siglo XVIII, a diferencia del Índice de San Zoilo en el que se realizan de manera coetánea a su redacción. Un estudio detallado de dicho repertorio puede encontrarse en HERRERO JIMÉNEZ, Mauricio, "Una llave para el tesoro de la catedral de León: el códice 17”, pp. 197-216.
} 
maltrechas posesiones, y siendo el archivo uno de los bienes más perjudicados, llevarían a cabo el intento de reestructuración, utilizando el Índice como herramienta para revisar aquellos documentos que se hubieran extraviado.

No podríamos finalizar esta enumeración sin aludir a un recurso necesario en un manuscrito, el Índice, que pretendía guiar en la localización de los documentos, y que no es otro que las remisiones. Introducidas al final de los epígrafes, daban referencia exacta y precisa del lugar -cajón, cuaderno, legajo y número- en el que se encontraban los documentos en el archivo (y por tanto en el Índice, representación de aquel), junto a otros documentos referentes a la población cuyos documentos eran regestados en el cajón donde se escribían las remisiones, reseñas necesarias puesto que poca utilidad tendría un diploma si era imposible su localización ${ }^{389}$.

Todas estas estrategias nos proporcionan la idea de una preocupación constante por la documentación, puesto que de su cuidado y de la administración del patrimonio dependía el mantenimiento de la casa común y con ella el sustento material y espiritual de la comunidad. Sin ninguna duda fue esta necesidad lo que motivó la elaboración de un instrumento de referencia, el Índice, que permitiera localizar los documentos, rastrear el contenido de los mismos y controlar la organización del archivo con eficacia y que, aún en la actualidad, sigue siendo una fuente fundamental para conocer la realidad de lo que fue el archivo de San Zoilo hasta el momento de su desamortización.

\subsection{La fortuna de los documentos}

Como ya venimos señalando desde el comienzo de este capítulo, la Desamortización de 1835 así como las sucesivas legislaciones marcadas al amparo de una forzada conciencia artística y archivística, fijaron el destino de todos aquellos bienes catalogados como no enajenables que habían sido sustraídos de los monasterios clausurados. La documentación, tan importante para las Delegaciones de Hacienda como para un recién creado Archivo Histórico Nacional, sufrió las consecuencias de esa disparidad de fines que, en muchas ocasiones, prestaba especial atención a su contenido por los beneficios que de este pudieran obtener, alejándose de todo el cuidado y protección al que habían sido sometidos en su anterior ubicación.

$389<$ Remisiones $>$. $<$ Diezmos $>$. Despacho del prior de San Román sobre los diezmos y obladas de Barajores. Año de 1233. Cajón San Juan, legajo $3^{\circ}$, quaderno B, número $2^{\circ}$. <Yantar $>$. Carta executoria contra el cura de Barajores sobre el yantar que debe pagar a San Román. Año de 1655. Cajón San Juan, legajo $3^{\circ}$, quaderno B, número 9. (AHPP, Desamortización, legajo 112, f. 61r, n. ${ }^{\circ}$ 14) 
La dispersión de la documentación alteró el orden original del archivo y, al no seguir dicha disgregación ningún criterio archivístico lógico ni quedar asentada en ningún registro, resulta una empresa si no inviable sí muy compleja la reconstrucción de lo que alguna vez fue el conjunto documental del archivo de San Zoilo y cuál era el patrimonio del monasterio que a través de él podía asimismo recomponerse. Es por ello precisamente que el Índice se muestra como una fuente indispensable para conocer cuántos documentos custodiaba en su archivo el archivo a las puertas de la Desamortización y, a través de su contenido, poder determinar el volumen de su patrimonio y valorar el alcance económico del cenobio y la labor espiritual que merced y ello pudo llevar a cabo.

Dos han sido los trabajos que hasta el momento han pretendido dar a conocer algunos de los diplomas que formaron parte del archivo, el publicado por M. ${ }^{a}$ Luisa Palacio Sánchez-Izquierdo y el de Julio Pérez Celada. Sus colecciones documentales abarcan desde la consolidación del monasterio en el siglo XI hasta principios del siglo XV -Palacio Sánchez-Izquierdo publica los documentos datados hasta 1419 y Pérez Celada los fechados hasta 1400-. Dejaron fuera de sus trabajos la documentación de época Moderna, motivado en parte por el amplio volumen documental producido en esta etapa, y se ocuparon de los documentos medievales porque su instalación en el Archivo Histórico Nacional hace más fácil su localización y consulta, de un lado; y de otro, por el interés porque en los siglos medievales muchos de los diplomas documentan el proceso de conformación patrimonial y, por ende, una de las épocas más atractivas de la historia del monasterio. Pero esa historia será incompleta si no se construye, al menos, con la totalidad de los documentos de archivo. El Índice es por eso una fuente de especial valor al dar noticia de los documentos archivados hasta los años inmediatamente anteriores a los del proceso desamortizador.

En el Índice de San Zoilo se describen 3118 registros comprendidos entre los siglos $\mathrm{X}$ y XIX. Estableciendo una división ficticia entre los documentos medievales y los modernos, comprobamos como hasta principios del siglo XV (940-1419) se registraron 433 documentos, que suponen el 14\% del total de los documentos descritos. El grueso de estos se encuentran fechados entre los siglos XV-XIX (1419-1818), con 2685 registros, que representan el 86\% del total de los documentos. Esto supone que, a igualdad de extensión temporal -5 siglos-, el volumen de la producción/recepción de documentos en el monasterio fue aproximadamente 6 veces mayor a partir de 1419, motivado sobre todo por una más activa administración de un patrimonio que se había acrecentado merced a las anexiones que se produjeron en los siglos anteriores. 
Para evaluar la representatividad del Índice hasta 1419 -es decir, en cuánto se aproxima ya no tanto su estructura (cambiante en el tiempo) como su contenido al del propio archivo para esa época- se hacía necesario comparar los asientos del Índice con los documentos de San Zoilo del Archivo Histórico Nacional publicados en las colecciones diplomáticas de Pérez Celada y Palacio Sánchez-Izquierdo. Para ello, hemos elaborado unas tablas - recogidas en el anexo 2 de este capítulo- que permiten relacionar todos y cada uno de los documentos que estos autores han publicado con los asientos del Índice. Discriminando aquellos diplomas cuya referencia en el Índice tiene su correspondencia con la existencia real del documento en algún archivo, dichas tablas se centran en relacionar, a través de tres criterios: la no descripción del documento en el Índice, la única descripción del Índice, y, por último, la existencia solamente de referencias bibliográficas y no documentales.

En la siguiente tabla ofrecemos un resumen de los datos recogidos en las tablas que ofrecemos completas en el anexo 2:

\begin{tabular}{|l|c|c|}
\hline \multicolumn{1}{|c}{ Número de documentos } & $\begin{array}{c}\text { Pérez Celada } \\
(1047-1400)\end{array}$ & $\begin{array}{c}\text { Palacio Sánchez- } \\
\text { Izquierdo (1047-1419) }\end{array}$ \\
\hline Documentos editados & 343 & 214 \\
\hline Coincidencias con el Índice & 200 & 155 \\
\hline Documentos no registrados en el Índice & 143 & 59 \\
\hline Coincidencias entre ambas publicaciones & 14 & 14 \\
\hline
\end{tabular}

Una vez analizada la información, pasamos a centrarnos en los 433 registros correspondientes al intervalo 940-1419, para calcular las intersecciones con los documentos editados en los trabajos de los autores citados. En base a ese cálculo, se pueden extrapolar los siguientes datos:

- De los 433 recogidos en el Índice hasta 1419, 277 registros (64\%) han sido editados porque existe tanto el documento (original o copia) como la noticia del Índice.

- Otros 50 documentos (un 12\%) fueron editados a partir de la noticia del Índice porque no existe documento, ni original ni copia.

- Por último, 106 registros (24\%) aparecen regestados en el Índice pero no se incluyeron en ninguna de las dos colecciones diplomáticas y hasta el momento 
no tenemos constancia de que se hayan editado las noticias en ninguna publicación sobre el archivo del monasterio.

Como complemento, es posible estimar un cociente de representatividad del Índice hasta 1419. Si asumimos que las publicaciones anteriores suponen una colección exhaustiva de la producción documental del monasterio hasta 1419, tenemos que en conjunto (eliminando duplicados entre autores) el número de documentos diferentes asciende a 529. Por lo tanto, calculando:

$$
\text { Representatividad }=\frac{\text { Número de registros del Índice }}{\text { Número total de documentos }}=\frac{433}{529} \cong 0.81
$$

Esto significa que, de forma ideal, el Índice contendría un $80 \%$ el contenido del Archivo original hasta 1419. No obstante, esta estimación presenta un conjunto de limitaciones:

a) 106 registros $(1 / 4$ del total) aparecen únicamente en el Índice.

b) Del total de documentos editados por los autores mencionados, 202 no figuran en el Índice.

c) Los editores siguieron criterios diferentes de selección y edición y sus colecciones pueden no incluir (y así es) el total de documentos del archivo hasta 1419.

d) Entre esta fecha y el momento de escrituración del Índice algunos documentos se perdieron y no pudieron ser descritos en el mismo.

No hay dudas en la gran ventaja que supone utilizar el Índice del monasterio como reflejo de su archivo, pues proporciona un marco unificado a partir del cual extraer información e independiza el proceso de extracción de criterios subjetivos del investigador. La ausencia de registros correspondientes a 202 documentos en el Índice es un indicador potencial de que existía un filtro previo a la inclusión de un documento en el mismo, posiblemente con un criterio de practicidad y utilidad para el control del archivo del monasterio y la administración de este.

No obstante, en conjunto, los documentos de los siglos medievales, como he dicho, representa tan sólo el 14\% del total de los documentos que contiene el Índice, lo cual hace resaltar la abrumadora cantidad de documentos e información no editada hasta el momento 
en su totalidad, aunque se haya hecho de forma parcial, y sobre todo destaca las posibilidades del Índice como fuente para conocer la historia del monasterio.

Concluimos el capítulo representando lo que hemos dicho en estos dos gráficos:
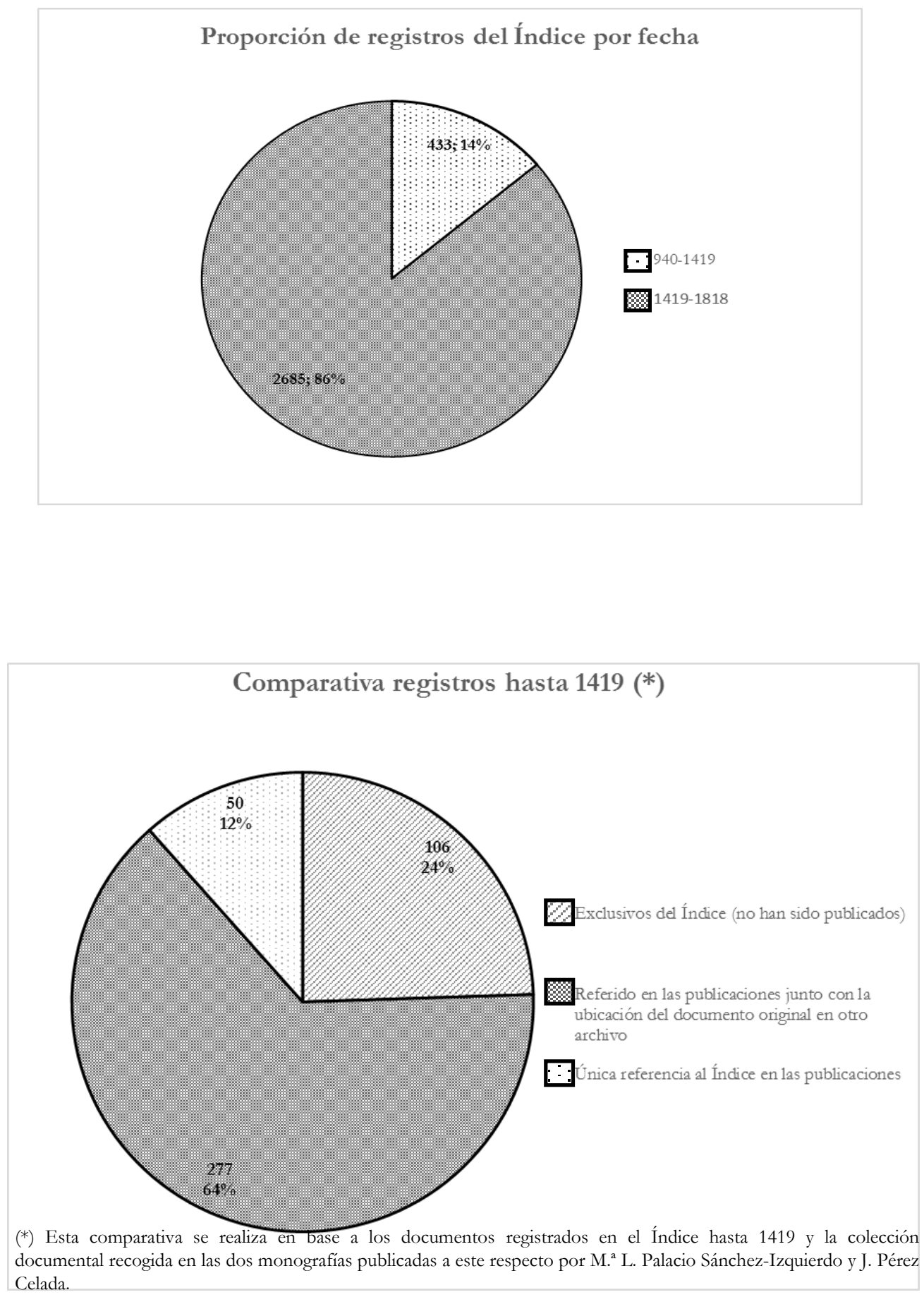
ANEXO 1. Inventario de bienes muebles del Monasterio de San Zoilo de Carrión, confeccionado entre el 19 de octubre y el 24 de noviembre de 1835 (AHPP, Desamortización, Legajo 435)

"Ymbentario que los infrascritos Ss[eñores] R[everendísimo] P[adre] Abad fray Plácido Trebijano; el Padre Granero, fray Joaquín Rodríguez; don Ylario Girón, subdelegado de rentas; don Justo Martínez Davalillos, contador de las mismas; y en representación del de arbitrios de amortización de la provincia, don Francisco San Martín, comisionado de dichos arbitrios de este partido, forman de todos los efectos y muebles pertenecientes a este suprimido monasterio de San Zoilo, con arreglo a la Real Orden Circular de doce de agosto de este año, habiendo dado principio a este ymbentario el día 19 de octubre de este año, según se nos prebino con fecha 18 del mismo, en esta forma:

Primeramente la casa combento con sus habitaciones altas y bajas, huerta y demás pertenencias.

Yd. Vn relox de torre que está en la misma.

Yd. Vn libro titulado Granería.

Yd. Otro titulado Rentaería.

Yd. Otro id. de Coplillas.

Yd. Otro titulado Borrador.

Yd. Otro de lo mismo, que da principio en 1834.

Yd. Otro Manual de bodega.

Yd. Otro titulado de Depósito.

Yd. Otro titulado de Molinos.

Yd. Otro de encabezo y cuentas de sacristía.

Yd. Otro del Priorato de las Heras.

Yd. Otro del Priorato de San Román.

Yd. Otro del Priorato del Brezo.

Yd. Otro del Priorato de Villaberde.

Archibo

Primeramente vn manual que contiene el índice general de los papeles y demás documentos pertenecientes a este Monasterio.

Yd. Cajón $1^{\circ}$. Legajo $1^{\circ}$. Donaciones, trueques, compras y otros papeles de hacienda de Santa María de Aguilar de Campos, Colecturías de Lázaro Gutiérrez y papeles de la yglesia de San Juan de esta villa.

Yd. Legajo $2^{\circ}$. Donaciones, compras, trueques y papeles del mismo priorato de Aguilar y pleitos con el Cabildo Ecclesiástico de dicha villa.

Yd. Legajo $3^{\circ}$. Proceso compulsado en Chancillería, ganado en el 1601.

Yd. Legajo $4^{\circ}$. Concordias, papeles, memoriales, apuntaciones y pareceres del letrados sobre la misma causa.

Yd. legajo $5^{\circ}$. Proceso sobre la resunción de San Juan y Confirmación de las concordias.

Yd. Cajón $2^{\circ}$. Legajo $1^{\circ}$. Papeles de los pueblos de Añora, Arenillas, Mazuecos, Arenillas de San Pelayo, Arenillas de Nuño Pérez y Astudillo. 
Yd. Legajo $2^{\circ}$. Donaciones, papeles de hacienda, jurisdicción antigua y derechos de señorío, Yglesia de San Facundo y Santa María de Arconada, tercias y nobeno de Santa / María, visitas antiguas de la misma y capellanes de Juan Fernández de Arconada.

Yd. Legajo $3^{\circ}$. Abiñante, hacienda que tiene San Román en este pueblo, yglesia, presentación de beneficios y hacienda que tiene el Brezo en este pueblo.

Yd. Cajón $3^{\circ}$. Legajo $1^{\circ}$. Papeles pertenecientes a los pueblos de Baillo, Baños, Barajores, Bárcena y Valsurbio.

Yd. Legajo $2^{\circ}$. Yd. de Becerril San felices, Puerto del Val, Bolaños y Bustillo de Cea.

Yd. Legajo $3^{\circ}$. Papeles y documentos del Priorato del Brezo.

Yd. Legajo $4^{\circ}$. Yd. de Calzada y demás pueblos que contiene.

Yd. Cajón $4^{\circ}$. Legajo $1^{\circ}$. Privilegios concedidos a este monasterio.

Yd. Legajo $2^{\circ}$ y $3^{\circ}$. Privilegios Reales y egecutorias del mismo.

Yd. Legajo $4^{\circ}$. Sobre lo mismo.

Yd. Cajón $5^{\circ}$. Legajo $1^{\circ}$. Papeles sobre diezmos de esta parroquia.

Yd. Legajo $2^{\circ}$. Papeles sobre las reliquias de los Santos Mártires.

Yd. Legajo $3^{\circ}$. Sobre el hospital de la O.

Yd. Legajo $4^{\circ}$. Sobre el hospital de San Lázaro y la Herrada.

Yd. Yd. $5^{\circ}$. Sobre la capilla de Santa Constanza.

Yd. Cajón $6^{\circ}$. Legajo $1^{\circ}$. Donaciones.

Yd. Legajo $2^{\circ}$. Compras y adjudicaciones.

Yd. Yd. $3^{\circ}$. Foros corrientes.

Yd. Yd. $4^{\circ}$. Foros no corrientes.

Yd. Cajón $7^{\circ}$. Legajo $1^{\circ}$. Papeles pertenecientes a Castrillo y Cerbatos de la Cueza.

Yd. Legajo $2^{\circ}$. Yd. sobre Cestillos.

Yd. Legajo $3^{\circ}$. Sobre Cisneros y demás pueblos que contiene.

Yd. Cajón $8^{\circ}$. Legajo $2^{\circ}$ y $3^{\circ}$. Papeles al Pueblo de Frómista.

Yd. Cajón $9^{\circ}$. Legajo $1^{\circ}$ hasta en $5^{\circ}$. Papeles del mismo Pueblo.

Yd. Cajón 10. Legajo $1^{\circ}$. Papeles del Pueblo de Lobera.

Yd. Legajo $2^{\circ}$. Yd. de Lobera, San Mamés y otros Pueblos.

Yd. Yd. $3^{\circ}$. Sobre el Priorato de San Román.

Yd. $4^{\circ}$. Papeles de hacienda del mismo priorato.

Yd. Cajón 11. Legajo 1․ Papeles de Fuentes de Naba y otros pueblos.

Legajo $2^{\circ}$. Yd. de Recueba y otros pueblos.

Yd. $3^{\circ}$. Sobre el priorato de San Román.

Yd. Cajón 12. Legajo $1^{\circ}, 2^{\circ}$ y $3^{\circ}$. Sobre el mismo Priorato de San Román.

Yd. Vn legajo sin número de compras, trueques, obras hechas en esta Casa y unas escrituras sueltas de este Monasterio.

Yd. Cajón 13. Legajo $1^{\circ}$. Papeles del Pueblo de Valcabado.

Yd. Legajo $2^{\circ}$. Papeles de Valcobero y otros Pueblos.

Yd. 3․ Sobre Villafrechós.

Yd. $4^{\circ}$. Yd. pertenecientes a Toro.

Yd. Cajón 14. Libros de granería y mayordomía antiguos y documentos de informaciones de monjes.

/ Yd. Cajón 15. Legajo $1^{\circ}$. Papeles pertenecientes a Villamayor.

Yd. Legajo $2^{\circ}$. Yd. a Villafría. 
Yd. $3^{\circ}$. a Villalpando.

Yd. $4^{\circ}$. a Villamayor.

Yd. $5^{\circ}$. a Villamuriel y otros pueblos.

Yd. Cajón 16. Legajos $1^{\circ}$ hasta el $4^{\circ}$. Papeles pertenecientes a Villamuera.

Yd. Cajón 17. Legajo $1^{\circ}$. Villaoliba y otros pueblos.

Yd. Legajo $2^{\circ}$. Papeles pertenecientes a Villaturde.

Yd. Yd. $3^{\circ}$. Yd. a Villaumbrales y otros Pueblos.

Yd. Cajón 18. Legajo $1^{\circ}, 2^{\circ}$ y $3^{\circ}$. Pertenecientes al Priorato de Villaberde.

Yd. Cajón 19. Dos apeos de San Román.

Yd. Cajón 20. Dos libros de visitas y arriendos y generales, vn libro de apeo de esta villa y varios papeles e instrumentos sobre juros.

Yd. Cajón 21. Cuatro libros sobre censos y tres legajos de Yd.

Yd. Cajón 22. Arriendos del Brezo.

Yd. Yd. Papeles sobre el censo de Autol, en la Rioja.

Yd. Cajón 24. Vn libro de profesiones.

Yd. Yd. Otro libro de arriendos del Brezo.

Yd. Otro de lo mismo de esta villa.

Yd. Otro de Yd. y otros Pueblos.

Yd. Vn legajo de obligación de misas y anibersarios.

Yd. Cajón 25 y 26. Catorce libros manuscritos de varios folios.

Yd. vn arquetón de pino viejo

Yd. vna mesa de lo mismo.

\section{Hospedería}

Primeramente vna mesa de pino.

Yd. Dos camas viejas.

Yd. Tres colchones, quatro sábanas, quatro fundas, dos mantas, dos colchas de cotón y quatro almohadas, todo mediano.

Yd. Dos cortinas de lona con sus barras de hierro.

Yd. Tres sillas de paja mediana.

Yd. Vn vellón de ojadelata viejo.

Yd. Otra cama con dos colchones, dos fundas, dos sábanas, dos almohadas, una manta y una colcha, todo usado.

Yd. Otra mesa de pino.

Yd. Una almofra de Talabera.

Yd. Vnas cortinas de lona con su barra de hierro.

Cocina

Primeramente un perol de cobre aljofarado, bastante vsado.

Yd. Otro más pequeño muy biejo.

Yd. Vna caldera de cobre buena.

/ Yd. Vna caldera mediana.

Yd. Otra pequeña vieja.

Yd. Tres tarteras de cobre viejas. 
Yd. Vna muy grande.

Yd. Vn almirez.

Yd. Dos cazos pequeños biejos.

Yd. Dos sartenes de hierro grandes.

Yd. Seis coberteras de lo mismo viejas.

Yd. Vna cacilla y una espumadera viejas.

Yd. Vn velón mediano.

Yd. Veinte platos de talavera ordinaria.

Yd. Docena y media escudillas de lo mismo.

Yd. Dos medias cántaras y una cuartilla de pajas.

Yd. Seis ollas y quatro cazuelas de Perihuela grandes.

Yd. Vna paleta y unas tenazas de hierro.

Yd. Dos tarteras pequeñas.

Yd. Vn cazo pequeño viejo.

Yd. Vnas parrillas grandes y otras pequeñas.

Yd. Vna tartera pequeña muy vieja.

Yd. Vna cuchilla.

Cillerería

Primeramente vna mesa pequeña forrada en vle de pino.

Yd. Quatro sillas de paja malas.

Yd. Vn arcón mediano para meter el pan.

Yd. Diez tablas de manteles usados y algunos rotos.

Yd. Veinte y dos servilletas medianas.

Refectorio

Primeramente seis mesas de nogal grandes viejas.

Yd. Siete bancos de pino.

Yd. Otra mesa pequeña.

Yd. Vn velón con quatro mecheros sin pie.

Yd. Catorce vasos con sus platos pequeños.

Yd. Tres saleros de talabera.

Chopete

Yd. Cinco tinajas grandes vacías.

Yd. Otra pequeña.

Yd. Vna romana grande y otra pequeña.

Yd. Once pellejos de carnero.

Yd. Vna soga carretal de esparto.

Yd. Un caldero de milar.

\section{/ Ante Bodega}

Primeramente siete carrales con arcos de madera vacíos.

Yd. Otro como de 30 cántaros con quatro arcos de hierro.

Yd. Diez maderos de frutales viejos. 
Yd. Tres aldabias para meter los carrales.

Yd. Vn pozal con arcos de madera.

Yd. Vnos serones de mimbre para verdura.

Yd. Un cesto de lo mismo.

Yd. Dos pares de aguaderas de lo mismo.

Yd. Seis pedazos de vn arco de yerro para cuba.

Yd. Dos caballetes de madera para otra.

\section{Bodega}

Yd. Vna carral con cinco arcos de hierro.

Yd. Vna pequeña con arcos de madera.

Yd. Otra como de 40 cántaras.

Yd. Vna cuba como de 80 cántaros con cinco arcos de hierro.

Yd. Otra con seis arcos de hierro.

Yd. Una como de 70 cántaros con seis arcos de hierro.

Yd. Vna carral pequeña.

Yd. Otra con quatro arcos de hierro.

Yd. Otra como de 30 cántaros.

Yd. Otra como de 26 id.

Yd. Otra como de 30.

Yd. Once tenajas para agua.

Yd. Ocho zarras pequeñas de mimbre.

Cuadra

Yd. Tres trillas viejas.

Yd. Vna porción de madera para quemar.

\section{Sacristía}

Primeramente dos juegos de epistolario.

Yd. Sin misales.

Yd. Vn Ritual romano y un Pon $<$ ti $>$ ifical.

Yd. Vn terno blanco con capa, quatro casullas, bolsas y paños de corporales correspondientes y un paño de hombros.

Yd. Cuatro casullas blancas con sus bolsas y paños.

Yd. Vn terno encarnado común como el anterior.

Yd. Vn terno rico encarnado, medio triu, con capa, dos dalmáticas y tres casullas.

Yd. Otro morado, de capa, dalmáticas, tres casullas y un paño de hombros.

Yd. Vna capa, tres casullas verdes, con sus bolsas y paños correspondientes.

Yd. Vn terno de terciopelo negro viejo, con capa, casulla y dalmáticas.

Yd. Otro negro común, de capa, dalmáticas, tres casullas y sus paños correspondientes.

/ Yd. Vn dosel de damasco con su cubierta de lo mismo.

Yd. Vn paño de hombro de bayeta ordinaria.

Yd. Vn pontifical blanco, con capa, casullas, quatro dalmáticas y paños de hombro.

Yd. Dos mitras, dos tunicelas blancas y dos encarnadas. 
Yd. Vn palio.

Yd. Catorce albas.

Yd. Veinte y dos amitos.

Yd. Doce juegos de corporales.

Yd. Catorce manteles de altar.

Yd. Tres roguetes.

Yd. Veinte y quatro libras de cera en achas y velas.

Yd. Cinco cálices de plata completos.

Yd. Vn viril de lo mismo.

Yd. Tres ampollas de id.para los Santos Óleos.

Yd. Tres juegos de vinageras de plata.

Yd. Vn incensario con su nabir de id.

Yd. Vna llabe para el sagrario de id.

Yd. Vn copón de lo mismo.

Yd. Vna cruz de procesiones de cobre dorada.

Yd. Vn báculo abacial de cobre dorado.

Yd. Otro de ojadelata.

Yd. Vn acetre de metal con el hisopo.

Yd. Vna mesa de jaspe.

Yd. Dos ciriales de ojadelata y una cruz de lo mismo.

Yd. Vos niños de Jesús bestidos.

Yd. Cuatro crucifijos de peana con sus vrnas.

Yd. Dos espejos grandes con marcos de color, alcuba y llabes romanos.

Yd. Otro pequeño con la luna bastante deteriorado con marco negras.

Yd. Dos vrnitas con el Nacimiento de Nuestro Señor Jesu Cristo.

Yd. Vna pila de cobre pequeña.

Yd. La cajonería de nogal completa.

Yglesia

Primeramente vn altar mayor de los Santos Mártires con dos uvrnas de ojadelata y otra de plata, donde están las reliquias de los mismos.

Yd. Otro de Nuestra Señora.

Yd. Otro de San Benito.

Yd. Otro de San Leandro.

Yd. Otro de San Gregorio.

Yd. Otro del Santo Cristo.

Yd. Otro de Santa Gertrudis.

Yd. Otro de la Magdalena.

Yd. Cuatro confesionarios.

/ Yd. Seis bancos de terciopelo encarnado y un canapé.

Yd. Otros quatro de pino.

Yd. Dos vanquillos de terciopelo encarnado llameados.

Yd. Dos almoadones de terciopelo encarnados.

Yd. Dos púlpitos de pino pintados.

Yd. Tres atriles de latón y tres de madera. 
Yd. Ocho acheros dorados y quatro negros.

Yd. Dos alfombras grandes.

Yd. Veinte candeleros de metal para los altares.

Yd. Cuatro lámparas de ojadelata.

Yd. Vna pila de piedra con su caldera de cobre.

Coro Viejo

Yd. Vna sillería de nogal con 39 asientos.

Yd. Dos atriles de pino.

Yd. Un facistol.

Yd. Dos cortinas de paño de seda encarnadas.

Yd. Dos id. blancas de raso.

Yd. Seis id. pequeñas de carro de oro floriado.

Coro Alto

Yd. Vn órgano con dos órdenes de teclas.

Yd. Vna sillería de nogal con dos órdenes de asientos.

Yd. Vn facistol

Yd. Tres atriles.

Yd. Vna linterna de ojadelata.

Yd. Once libros corales.

Sala Capitular

Yd. Cinco bancos de respaldo de pino viejos.

Cuadros en la misma

Yd. Vna Santa Getrudis.

Yd. Vna Santa Teresa.

Yd. Vna Santa Escolástica.

Yd. Vn San Benito.

Yd. Ocho paisages con los Reuerendos Padres.

Yd. Vn Santo Domingo.

En el Claustro

Yd. Vna Efigie de Nuestra Señora, de medio cuerpo.

Yd. Vn cuadro de San Yldefonso.

Yd. Otro de San Gregorio.

Yd. Otro de san Bernardino.

/ Yd. Otro de San Yldefonso.

Yd. Otro de Santa Getrudis.

Yd. Otro de San Benito.

Yd. Otro de San Anselmo.

Yd. otro de Santa Getrudis.

Yd. Otro de San Benito.

Yd. Vna Dolorosa. 
Yd. Otro cuadro de San Juan Ebangelista.

En la Sacristía

Yd. Vn Descendimiento.

Yd. Vna cara de Dios.

Yd. Vn San Pedro ad vínculam.

Yd. Vn San Gregorio el Magno.

Yd. Vn San Francisco de Paula.

Yd. Vn San Bruno.

Yd. Vn Santo Domingo.

Yd. Vn San Rafael y Tobías.

Yd. Vn San Lorenzo Justiniano.

Yd. Vna Santa Getrudis con el Salbador.

Yd. Vn San Benito.

Yd. Vn San Canuto de Celis.

Yd. Vn San Benito con los Ángeles.

Yd. Dos San Gerónimos.

Yd. Vn San José.

Yd. Vn Santo Tomás.

Yd. Vn Niño Jesús con el cordero.

Biblioteca

Yd. Doscientos libros de pasta de obras incompletas en varios folios.

Yd. Ciento sesenta libros en pergamino de obras incompletas en varios folios.

Yd. En otros estantes, seiscientos libros en pergamino de obras incompletas.

Panera

Primeramente vna carga de yeros.

Yd. Vna carga de titos redondos.

Yd. Tres cargas, tres celemines de garbanzos.

Yd. Tres quartos de titos esquinados o muelas.

Yd. Vna fanega de abas verdes.

Yd. Tres quartos de lentejas.

Yd. Dos cargas, quatro quartos de alubias.

Yd. Cuatro cargas, diez quartos de abena.

Yd. Once cargas y seis quartos de trigo.

Yd. Vna id., seis quartos y quatro celemines de centeno.

/ Yd. Trece cargas, seis quartos y cinco celemines de cebada.

Yd. Doce aarobas de manzanas que se vendieron a cinco reales arroba, cuyo importe se encuentra en poder del comisionado.

En esta forma se finalizó este ymventario el 24 de noviembre de 1835, que firmaron el subdelegado de rentas, Don Hilario Girón; contador de las mismas, Don Justo Martínez Davalillo; el comisionado del ramo de amortización, Don Francisco San Martín; el Reverendísimo abad fray Plácido Trebijano y Fray Joaquín Rodríguez Granero. 
Justo Martínez Davalillo (rúbrica). Plácido Trevijano (rúbrica). Francisco San Martín (rúbrica). Joaquín Rodríguez (rúbrica). Hilario Girón (rúbrica).

Nota

Adbierte que en la casilla de corrientes se espresa lo que pagan anualmente y en la de atrasos todos los débitos, tanto por corrientes quanto por atrasos.

Nota

Todos los muebles que constan en este ynventario fueron vendidos en almoneda pública en cantidades de 1109 reales, según la relación pasada a estas oficinas, en 9 de noviembre de 1836, por el comisionado del Partido de Carrión, intervenida por el contador de rentas de aquel partido, con asistencia del Provisor Síndico, quedando únicamente [...]istentes en dicha fecha por falta de licitadores los efectos que a continuación se espresan:

Vna mesa de pino.

Tres cortinas de lana con su varrita.

Vn belón de ojadelata.

Vna mesa.

Vna amofia de Talavera.

Dos sartenes de hierro grandes.

Seis coverteras.

Vna cacilla y una espumadera.

/ Veinte platos de Talavera.

Docena y media de escudillas.

Dos medias cántaras y una fuentilla de varro.

Seis oyas y quatro cazuelas.

Vna paleta y vnas tenazas.

Vna mesa de pino forrada en ule.

Cuatro sillas de pajas.

Vn arcón mediano.

Seis mesas de nogal.

Siete bancos de pino.

Vna mesa pequeña.

Tres saleros de Talavera.

Cinco tinajas grandes.

Otra pequeña.

Once pellejos de carnero.

Vna soga de esparto.

Vn caldero de melar.

Vn pozal y tres aldabias.

Vn cesto de mimbre.

Seis pedazos de aros de cuba.

Palencia, 22 de noviembre de 1836. 
ANEXO 2. Tablas comparativas de los documentos descritos en el Índice de San Zoilo hasta 1419 y los publicados en las colecciones documentales publicadas por M. ${ }^{a}$ Luisa Palacio Sánchez-Irquierdo y Julio A. Pérez Celada.

\section{TABLA A. COMPARATIVA CON JULIO A. PÉREZ CELADA}

\begin{tabular}{|c|c|c|c|c|}
\hline \multirow[b]{2}{*}{$\begin{array}{l}\text { Documentos } \\
\text { Colección } \\
\text { Pérez Celada }\end{array}$} & \multicolumn{3}{|c|}{ Criterio de selección de los documentos } & \multirow[b]{2}{*}{$\begin{array}{c}\text { Documentos publicados } \\
\text { también por Palacio Sánchez- } \\
\text { Izquierdo }\end{array}$} \\
\hline & $\begin{array}{l}\text { Docs. solo } \\
\text { descritos en el } \\
\text { Índice }\end{array}$ & $\begin{array}{l}\text { Docs. no } \\
\text { descritos } \\
\text { en el Índice }\end{array}$ & $\begin{array}{l}\text { Docs. con } \\
\text { solo } \\
\text { referencia } \\
\text { bibliográfica }\end{array}$ & \\
\hline 1 & & & & $\mathrm{X}$ \\
\hline 2 & $\mathrm{X}$ & & & \\
\hline 4 & & & & $\mathrm{X}$ \\
\hline 5 & $\mathrm{X}$ & & & \\
\hline 6 & & $\mathrm{X}$ & $\mathrm{X}$ & \\
\hline 7 & & $\mathrm{X}$ & $\mathrm{X}$ & \\
\hline 8 & & $\mathrm{X}$ & $\mathrm{X}$ & \\
\hline 10 & $\mathrm{X}$ & & & \\
\hline 11 & & $\mathrm{X}$ & & \\
\hline 13 & $\mathrm{X}$ & & & \\
\hline 16 & & $\mathrm{X}$ & $\mathrm{X}$ & \\
\hline 17 & & $\mathrm{X}$ & & \\
\hline 19 & & $\mathrm{X}$ & & \\
\hline 20 & $\mathrm{X}$ & & & \\
\hline 28 & & $\mathrm{X}$ & & \\
\hline 29 & & $\mathrm{X}$ & & \\
\hline 33 & & & & $\mathrm{X}$ \\
\hline 34 & & $\mathrm{X}$ & & \\
\hline 35 & & $\mathrm{X}$ & $\mathrm{X}$ & \\
\hline 38 & & $\mathrm{X}$ & $\mathrm{X}$ & \\
\hline 39 & $\mathrm{X}$ & & & \\
\hline 40 & $\mathrm{X}$ & & & \\
\hline 41 & & $\mathrm{X}$ & $\mathrm{X}$ & \\
\hline 42 & & $\mathrm{X}$ & & \\
\hline 43 & $\mathrm{X}$ & & & \\
\hline 49 & & & & $X$ \\
\hline 51 & & $X$ & & \\
\hline 54 & & & & $X$ \\
\hline 57 & & & & $\mathrm{X}$ \\
\hline 58 & & & & X \\
\hline
\end{tabular}


EL ÍNDICE DE SAN ZOILO DE CARRIÓN

\begin{tabular}{|c|c|c|c|c|}
\hline 63 & & & & $\mathrm{X}$ \\
\hline 69 & & $X$ & & \\
\hline 70 & $\mathrm{X}$ & & & \\
\hline 72 & & & & $\mathrm{X}$ \\
\hline 73 & & & & $\mathrm{X}$ \\
\hline 75 & & $\mathrm{X}$ & & \\
\hline 77 & & $X$ & & \\
\hline 78 & & $\mathrm{X}$ & & \\
\hline 80 & & $\mathrm{X}$ & & \\
\hline 82 & & & & $\mathrm{X}$ \\
\hline 83 & & & & $\mathrm{X}$ \\
\hline 85 & $\mathrm{X}$ & & & \\
\hline 87 & & $\mathrm{X}$ & & \\
\hline 88 & $\mathrm{X}$ & & & \\
\hline 89 & & $\mathrm{X}$ & & \\
\hline 91 & & $\mathrm{X}$ & $\mathrm{X}$ & \\
\hline 94 & & $\mathrm{X}$ & & \\
\hline 96 & & $\mathrm{X}$ & $\mathrm{X}$ & \\
\hline 99 & $\mathrm{X}$ & & & \\
\hline 100 & & $\mathrm{X}$ & & \\
\hline 101 & & & & $\mathrm{X}$ \\
\hline 102 & & $\mathrm{X}$ & & \\
\hline 103 & & $\mathrm{X}$ & $\mathrm{X}$ & \\
\hline 104 & & $\mathrm{X}$ & $\mathrm{X}$ & \\
\hline 105 & $\mathrm{X}$ & & & \\
\hline 107 & $\mathrm{X}$ & & & \\
\hline 109 & $\mathrm{X}$ & & & \\
\hline 112 & $\mathrm{X}$ & & & \\
\hline 114 & & $\mathrm{X}$ & & \\
\hline 115 & & $\mathrm{X}$ & & \\
\hline 116 & & $X$ & & \\
\hline 117 & & $\mathrm{X}$ & & \\
\hline 118 & & $\mathrm{X}$ & & \\
\hline 119 & & $\mathrm{X}$ & & \\
\hline 120 & & $\mathrm{X}$ & & \\
\hline 121 & & $\mathrm{X}$ & & \\
\hline 122 & & $\mathrm{X}$ & & \\
\hline 123 & & $\mathrm{X}$ & & \\
\hline 124 & & $\mathrm{X}$ & & \\
\hline 125 & & $\mathrm{X}$ & & \\
\hline 126 & & $\mathrm{X}$ & & \\
\hline 130 & $\mathrm{X}$ & & & \\
\hline 131 & & $\mathrm{X}$ & & \\
\hline 132 & & $\mathrm{X}$ & & \\
\hline
\end{tabular}


EL ÍNDICE DE SAN ZOILO DE CARRIÓN

\begin{tabular}{|c|c|c|c|}
\hline 140 & & $X$ & $X$ \\
\hline 142 & & $X$ & $\mathrm{X}$ \\
\hline 143 & $\mathrm{X}$ & & \\
\hline 144 & $\mathrm{X}$ & & \\
\hline 145 & & X & \\
\hline 148 & & $\mathrm{X}$ & $X$ \\
\hline 149 & $\mathrm{X}$ & & \\
\hline 151 & & $\mathrm{X}$ & \\
\hline 153 & & $X$ & \\
\hline 154 & $\mathrm{X}$ & & \\
\hline 155 & & $\mathrm{X}$ & $\mathrm{X}$ \\
\hline 157 & $X$ & & \\
\hline 158 & & X & $X$ \\
\hline 159 & & $\mathrm{X}$ & $X$ \\
\hline 160 & & $\mathrm{X}$ & \\
\hline 161 & & $\mathrm{X}$ & $\mathrm{X}$ \\
\hline 161 & & $\mathrm{X}$ & $X$ \\
\hline 163 & & $X$ & \\
\hline 164 & $\mathrm{X}$ & & \\
\hline 172 & & $\mathrm{X}$ & $\mathrm{X}$ \\
\hline 174 & & $\mathrm{X}$ & $\mathrm{X}$ \\
\hline 175 & & $\mathrm{X}$ & $X$ \\
\hline 176 & & $\mathrm{X}$ & $\mathrm{X}$ \\
\hline 178 & & $\mathrm{X}$ & $X$ \\
\hline 179 & & $X$ & $X$ \\
\hline 184 & & $X$ & \\
\hline 185 & & $\mathrm{X}$ & \\
\hline 188 & & $\mathrm{X}$ & \\
\hline 190 & $\mathrm{X}$ & & \\
\hline 192 & & $X$ & $X$ \\
\hline 195 & & $\mathrm{X}$ & \\
\hline 196 & $\mathrm{X}$ & & \\
\hline 199 & $\mathrm{X}$ & & \\
\hline 200 & $\mathrm{X}$ & & \\
\hline 208 & & $\mathrm{X}$ & \\
\hline 209 & & $\mathrm{X}$ & \\
\hline 210 & & $\mathrm{X}$ & \\
\hline 213 & & $\mathrm{X}$ & $\mathrm{X}$ \\
\hline 214 & & $X$ & $X$ \\
\hline 215 & & $X$ & \\
\hline 216 & & $\mathrm{X}$ & $\mathrm{X}$ \\
\hline 218 & & $X$ & $\mathrm{X}$ \\
\hline 220 & & X & \\
\hline 221 & & $X$ & \\
\hline
\end{tabular}


EL ÍNDICE DE SAN ZOILO DE CARRIÓN

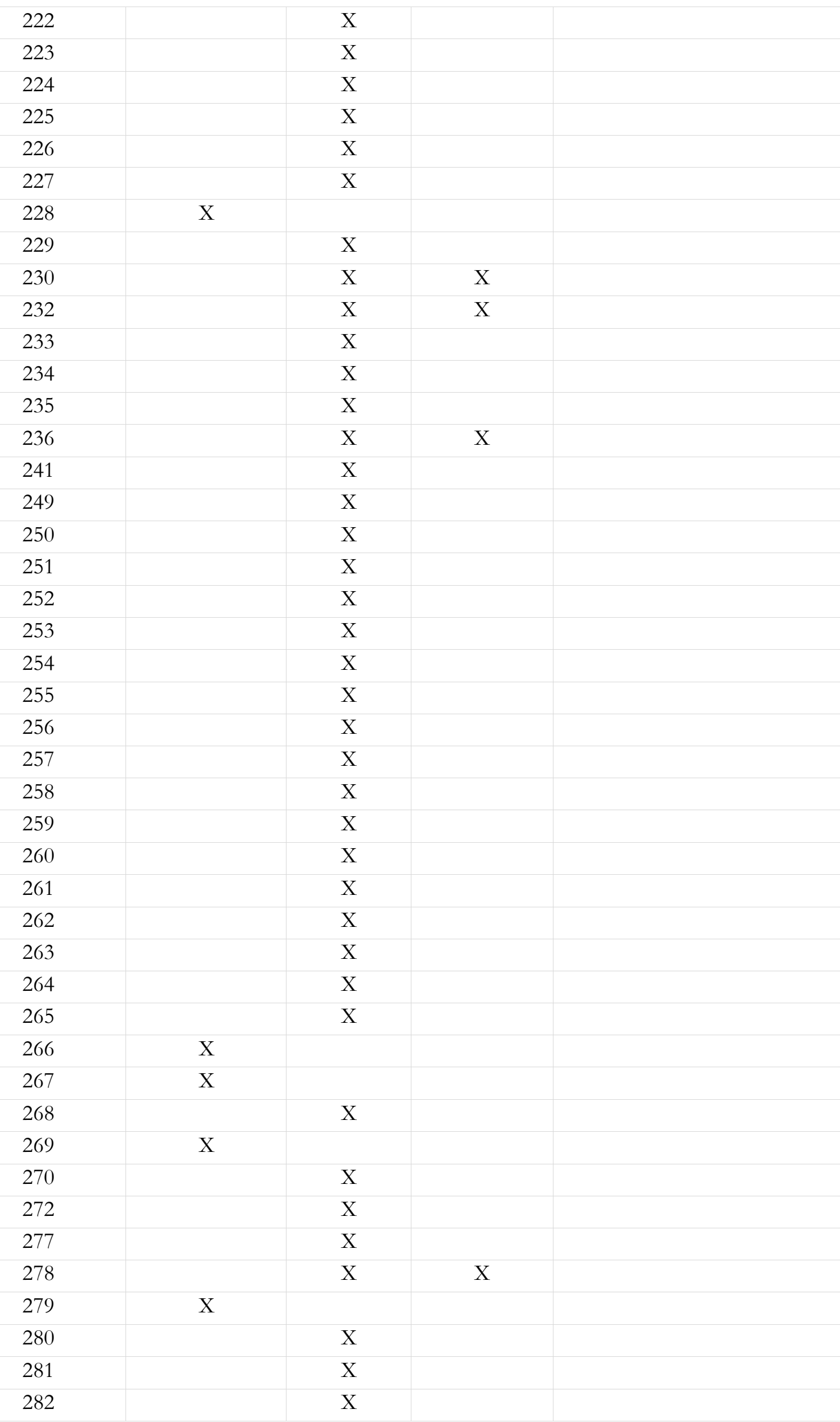


EL ÍNDICE DE SAN ZOILO DE CARRIÓN

\begin{tabular}{|c|c|c|c|c|}
\hline 284 & & $\mathrm{X}$ & & \\
\hline 287 & $X$ & & & \\
\hline 288 & $\mathrm{X}$ & & & \\
\hline 289 & & $\mathrm{X}$ & & \\
\hline 291 & & $\mathrm{X}$ & $\mathrm{X}$ & \\
\hline 292 & & $\mathrm{X}$ & & \\
\hline 293 & $\mathrm{X}$ & & & \\
\hline 295 & & $\mathrm{X}$ & & \\
\hline 297 & & $\mathrm{X}$ & & \\
\hline 300 & $\mathrm{X}$ & & & \\
\hline 301 & $\mathrm{X}$ & & & \\
\hline 302 & $\mathrm{X}$ & & & \\
\hline 304 & & $\mathrm{X}$ & $\mathrm{X}$ & \\
\hline 305 & $\mathrm{X}$ & & & \\
\hline 306 & $\mathrm{X}$ & & & \\
\hline 309 & & $\mathrm{X}$ & & \\
\hline 310 & & $\mathrm{X}$ & & \\
\hline 311 & & $\mathrm{X}$ & & \\
\hline 313 & $\mathrm{X}$ & & & \\
\hline 314 & & $\mathrm{X}$ & & \\
\hline 315 & $\mathrm{X}$ & & & \\
\hline 317 & & $\mathrm{X}$ & & \\
\hline 318 & & $\mathrm{X}$ & & \\
\hline 319 & $\mathrm{X}$ & & & \\
\hline 321 & $\mathrm{X}$ & & & \\
\hline 323 & $\mathrm{X}$ & & & \\
\hline 324 & & $\mathrm{X}$ & $\mathrm{X}$ & \\
\hline 325 & $\mathrm{X}$ & & & \\
\hline 327 & & $\mathrm{X}$ & & \\
\hline 329 & & $\mathrm{X}$ & & \\
\hline 330 & & $\mathrm{X}$ & & \\
\hline 331 & & $\mathrm{X}$ & $\mathrm{X}$ & \\
\hline 332 & $X$ & & & \\
\hline 333 & & $\mathrm{X}$ & & \\
\hline 336 & $\mathrm{X}$ & & & \\
\hline 337 & $\mathrm{X}$ & & & \\
\hline 338 & & & & $\mathrm{X}$ \\
\hline 339 & $\mathrm{X}$ & & & \\
\hline 340 & & $\mathrm{X}$ & & \\
\hline 342 & & $\mathrm{X}$ & & \\
\hline 343 & & $\mathrm{X}$ & & \\
\hline TOTAL & 50 & 143 & 38 & 14 \\
\hline
\end{tabular}


TABLA B. COMPARATIVA CON M. ${ }^{a}$ LUISA PALACIO SÁNCHEZ-IZQUIERDO

\begin{tabular}{|c|c|c|c|c|}
\hline \multirow[b]{2}{*}{$\begin{array}{l}\text { Documentos } \\
\text { Colección } \\
\text { Palacio Sánchez- } \\
\text { Izquierdo }\end{array}$} & \multicolumn{3}{|c|}{ Criterio de selección de los documentos } & \multirow[b]{2}{*}{$\begin{array}{l}\text { Documentos publicados } \\
\text { también por Pérez Celada }\end{array}$} \\
\hline & $\begin{array}{l}\text { Docs. solo } \\
\text { descritos en el } \\
\text { Índice }\end{array}$ & $\begin{array}{c}\text { Docs. no } \\
\text { descritos } \\
\text { en el } \\
\text { Índice }\end{array}$ & $\begin{array}{l}\text { Docs. con } \\
\text { solo } \\
\text { referencia } \\
\text { bibliográfica }\end{array}$ & \\
\hline 1 & & & & $\mathrm{X}$ \\
\hline 3 & & & & $\mathrm{X}$ \\
\hline 4 & & $\mathrm{X}$ & $\mathrm{X}$ & \\
\hline 5 & & $\mathrm{X}$ & $\mathrm{X}$ & \\
\hline 7 & & $\mathrm{X}$ & $\mathrm{X}$ & \\
\hline 10 & & $\mathrm{X}$ & & \\
\hline 11 & & $\mathrm{X}$ & & \\
\hline 24 & & & & $\mathrm{X}$ \\
\hline 27 & & $\mathrm{X}$ & $\mathrm{X}$ & \\
\hline 33 & & $\mathrm{X}$ & & \\
\hline 34 & & & & $\mathrm{X}$ \\
\hline 35 & & $\mathrm{X}$ & & \\
\hline 38 & & & & $\mathrm{X}$ \\
\hline 40 & & & & $\mathrm{X}$ \\
\hline 41 & & $\mathrm{X}$ & & \\
\hline 42 & & $\mathrm{X}$ & $\mathrm{X}$ & $\mathrm{X}$ \\
\hline 45 & & & & $\mathrm{X}$ \\
\hline 47 & & $\mathrm{X}$ & & \\
\hline 50 & & $\mathrm{X}$ & & \\
\hline 51 & & $\mathrm{X}$ & & \\
\hline 55 & & & & $\mathrm{X}$ \\
\hline 56 & & & & $\mathrm{X}$ \\
\hline 57 & & $\mathrm{X}$ & & \\
\hline 59 & & & & \\
\hline 61 & & $\mathrm{X}$ & & \\
\hline 63 & & $X$ & & $X$ \\
\hline 64 & & & & $\mathrm{X}$ \\
\hline 67 & & $\mathrm{X}$ & & \\
\hline 73 & & $X$ & & \\
\hline 74 & & $\mathrm{X}$ & & $\mathrm{X}$ \\
\hline 76 & & $\mathrm{X}$ & & \\
\hline 77 & & $\mathrm{X}$ & & \\
\hline 78 & & $\mathrm{X}$ & $\mathrm{X}$ & \\
\hline 80 & & $\mathrm{X}$ & & \\
\hline 81 & & $\mathrm{X}$ & & \\
\hline 82 & & $\mathrm{X}$ & & \\
\hline 93 & & $\mathrm{X}$ & & \\
\hline 94 & & $\mathrm{X}$ & & \\
\hline
\end{tabular}


EL ÍNDICE DE SAN ZOILO DE CARRIÓN

\begin{tabular}{|c|c|c|c|c|}
\hline 96 & & X & & \\
\hline 98 & & $\mathrm{X}$ & & \\
\hline 100 & & $\mathrm{X}$ & & \\
\hline 101 & & $\mathrm{X}$ & & \\
\hline 111 & & $\mathrm{X}$ & & \\
\hline 114 & & $\mathrm{X}$ & & \\
\hline 116 & & $\mathrm{X}$ & & \\
\hline 122 & & $\mathrm{X}$ & & \\
\hline 123 & & $\mathrm{X}$ & & \\
\hline 125 & & $\mathrm{X}$ & & \\
\hline 127 & & $\mathrm{X}$ & & \\
\hline 128 & & $\mathrm{X}$ & & \\
\hline 129 & & $\mathrm{X}$ & & \\
\hline 130 & & $\mathrm{X}$ & & \\
\hline 131 & & $\mathrm{X}$ & & \\
\hline 136 & & $\mathrm{X}$ & & \\
\hline 137 & & $\mathrm{X}$ & & \\
\hline 138 & & $\mathrm{X}$ & & \\
\hline 142 & & $\mathrm{X}$ & & \\
\hline 146 & & & & $\mathrm{X}$ \\
\hline 147 & & $\mathrm{X}$ & & \\
\hline 149 & & $\mathrm{X}$ & & \\
\hline 168 & & $\mathrm{X}$ & & \\
\hline 173 & & $\mathrm{X}$ & & \\
\hline 175 & & $\mathrm{X}$ & & \\
\hline 176 & & $\mathrm{X}$ & & \\
\hline 177 & & $X$ & & \\
\hline 178 & & X--- & & \\
\hline 179 & & $\mathrm{X}$ & & \\
\hline 190 & & $\mathrm{X}$ & & \\
\hline 209 & & $\mathrm{X}$ & & \\
\hline 212 & & $\mathrm{X}$ & & \\
\hline 214 & & $\mathrm{X}$ & & \\
\hline TOTAL & 0 & 59 & 6 & 14 \\
\hline
\end{tabular}




\section{LA FORMACIÓN DEL PATRIMONIO Y SU ADMINISTRACIÓN A TRAVÉS DEL ÍNDICE}

La historia económica de todo monasterio, la que da cuenta de los bienes y actividades que conforman su riqueza, se define en base a dos momentos vitales perfectamente diferenciados: aquel en el que se produce la formación del patrimonio, en el que sus fundadores, reyes y nobles, lo dotan tan prolijamente que el devenir histórico los guía, pasados los primeros siglos, hacia la segunda etapa, en la que la comunidad debe encargarse de conservar y administrar ese patrimonio que se convertirá en la fuente de su sustento material y espiritual.

El monasterio de San Zoilo participó, como no podría ser de otra manera, de esta realidad y su Índice así lo refleja, al convertirse en testimonio de todas aquellas acciones jurídicas en las que el cenobio se vio inmerso durante su dilatada existencia y cuya principal finalidad basculó entre la adquisición de propiedades y derechos, y la posterior gestión y defensa de los mismos.

En San Zoilo, el desarrollo de este proceso va a transcurrir indisolublemente unido y en paralelo a dos circunstancias determinantes; su acontecer histórico, marcado por las sucesivas incorporaciones a Cluny y a la Congregación Benedictina de Valladolid; y la anexión bajo su órbita de influencia de una serie de prioratos, cuyas posesiones se convertirán en uno de los cimientos económicos más firmes al asegurar la prosperidad del monasterio en algunos momentos de crisis que hicieron peligrar una estabilidad difícil de conservar, tal y como lo atestiguan los numerosos pleitos en los que el cenobio se vio envuelto fundamentalmente a partir del siglo XVI.

El estudio de las distintas tipologías de los documentos descritos en el Índice nos va a proporcionar una amplia y nítida perspectiva de la evolución jurídico-administrativa experimentada por el monasterio desde su fundación. $\mathrm{Y}$ hacerlo a través de aquellos documentos custodiados en el archivo hasta la fecha en que se produjo la Desamortización nos revelará, como si de una "foto fija" se tratase, la situación experimentada por la abadía carrionense en los momentos previos a su supresión definitiva. 
La amplitud del territorio controlado por San Zoilo, unida a la variable y voluble coyuntura económica e histórica en que desarrolló sus funciones, trajo como consecuencia el acopio de una ingente producción documental, hecho este que se tradujo en la proliferación de tipologías documentales ${ }^{390}$. Será precisamente esta amplitud tipológica la que obligue a centrar nuestro estudio en aquellas acciones jurídicas que fueron, por su peso a nivel cuantitativo y cualitativo, más decisivas y fundamentales tanto para la creación de su dominio como para la gestión, explotación y defensa del mismo.

\subsection{La formación del dominio}

El proceso de configuración patrimonial se fundamentó a partir de diversos actos de concentración de propiedades, consistentes casi íntegramente en donaciones, compras y permutas. La abrumadora mayoría de estos tipos hace que cualquier mención a otros posibles modos de concentración resulte intrascendente para un análisis de conjunto, más aún cuando algunos de esos negocios en nada modificaban la estructura y disposición del señorío. El monasterio de San Zoilo prolongó dicho proceso a lo largo de toda su existencia -la documentación representa un 23,9\% del total de la producción-; no obstante es necesario advertir que las características y finalidad de esas concentraciones variará en función de un versátil y quebradizo contexto económico y social.

Una primera aproximación al número de donaciones y compras pone en evidencia cómo las primeras representaron una cantidad sensiblemente inferior respecto a las segundas. Si bien este dato nos revela la manifiesta predisposición del monasterio a ampliar y consolidar sus dominios, hecho este que se produce a partir del siglo $\mathrm{XV}$, no va a significar un retroceso en la importancia de las donaciones, al ser estas - por la calidad de lo donado- las principales artífices de la composición del patrimonio desde el siglo XI hasta el XIII; hacienda que San Zoilo reajustó a través de las operaciones de permuta en función del beneficio que dicho negocio reportara.

Las frecuencias absolutas representadas en la siguiente tabla muestran el notable incremento del número de transacciones a partir del siglo XVI, con un marcado descenso

\footnotetext{
${ }^{390} \mathrm{Al}$ final de este capítulo puede consultarse una relación de las principales tipologías registradas en el Índice; la distribución cronológica por siglos de cada uno de esos negocios o actividades proporciona una visión de conjunto que nos permite seguir paso a paso la formación del patrimonio y su administración por esta institución monástica, así como su capacidad de adaptación a las diferentes vicisitudes acaecidas en cada una de las épocas.
} 
en el último siglo motivado por el cese de la actividad ante las sucesivas experiencias desamortizadoras y la definitiva supresión de la comunidad en 1836.

\begin{tabular}{c|c|c|c|c|c|c|c|c|c|c}
\hline & $\mathbf{1 0 0 0 -}$ & $\mathbf{1 1 0 0 -}$ & $\mathbf{1 2 0 0 -}$ & $\mathbf{1 3 0 0 -}$ & $\mathbf{1 4 0 0 -}$ & $\mathbf{1 5 0 0 -}$ & $\mathbf{1 6 0 0 -}$ & $\mathbf{1 7 0 0 -}$ & $\mathbf{1 8 0 0 -}$ & Total \\
\hline PERMUTA & $\mathbf{1 1 0 0}$ & $\mathbf{1 2 0 0}$ & $\mathbf{1 3 0 0}$ & $\mathbf{1 4 0 0}$ & $\mathbf{1 5 0 0}$ & $\mathbf{1 6 0 0}$ & $\mathbf{1 7 0 0}$ & $\mathbf{1 8 0 0}$ & $\mathbf{1 9 0 0}$ & \\
\hline DONACIÓN & 15 & 4 & 4 & 6 & 16 & 28 & 14 & 52 & 1 & 126 \\
\hline COMPRA & 2 & 5 & 22 & 5 & 28 & 15 & 8 & 1 & 0 & 128 \\
\hline
\end{tabular}

No obstante, el sentido de estas cifras quedaría vacío de contenido sin una interpretación temporal de dichos datos que nos permita conocer, de un lado, la evolución en la tendencia hacia los diferentes negocios por siglos; y de otro, analizar las posibles causas y motivaciones que incidieron de manera decisiva en dicha predisposición.

La siguiente gráfica nos ofrece una visión precisa de dicha evolución y evidencia la existencia de dos momentos perfectamente definidos en el proceso de formación patrimonial, que a su vez están en directa relación con las circunstancias históricas y la situación económica que atravesaba el monasterio en cada etapa ${ }^{391}$.

Así, durante los primeros siglos de existencia el monasterio iniciará su andadura merced a la recepción de un importante número de donaciones que, en función de la posición social del donante y de las motivaciones que guíen sus ofrendas, dotarán al monasterio de un considerable ámbito de influencia en el que ejercer su dominio, tanto a nivel territorial como económico.

Esta importante captación patrimonial, que se prolonga hasta mediados el siglo XIII, se ve reforzada por la concesión de una serie de privilegios por parte de los reyes, disposiciones que estaban orientadas a la consecución de determinadas exenciones y a la protección y defensa de los derechos de la comunidad. Esta transferencia de heredades y derechos será clave para que el monasterio pueda soportar los envites de la gran crisis que

\footnotetext{
391 Pérez Celada incide en la decisiva influencia de los priores y abades en el cambio de tendencia económica del monasterio, destacando el siglo XII y principios del siglo XIII como la época "dorada" a raíz de las importantes acciones jurídicas emprendidas por el prior Humberto y su sucesor don Pedro. Véase PÉREZ CELADA, Julio A. El monasterio de San Zoilo de Carrión, pp. 291-292.

Este hecho se refuerza en el siglo XV aunque con un marcado carácter negativo, al sufrir el monasterio reiteradamente las desastrosas e interesadas administraciones de los abades comendatarios y consistoriales.
} 
asoló el territorio de Castilla durante el siglo XIV ${ }^{392}$, la cual obligó al monasterio a efectuar una serie de cambios significativos en sus hábitos tanto gestores como espirituales.

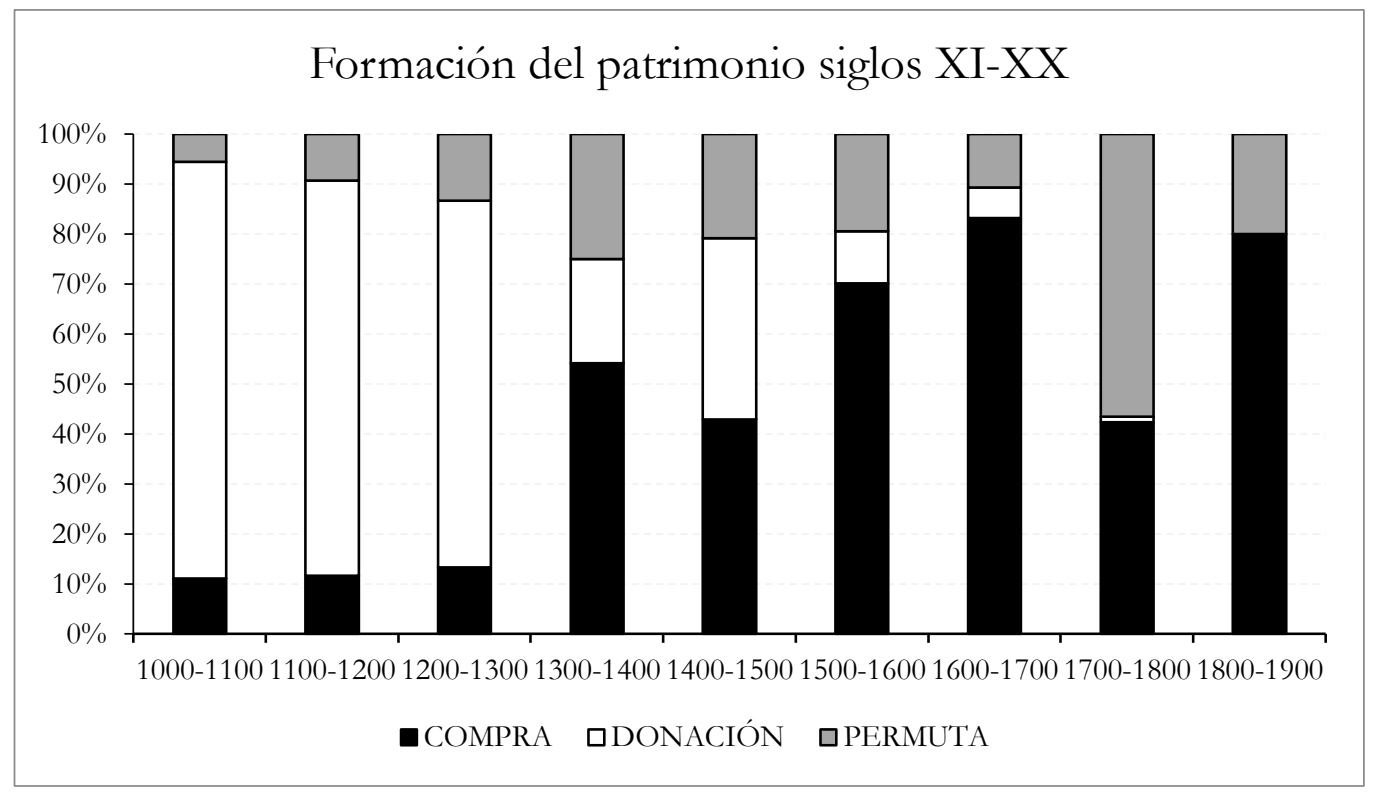

El siglo XV se presentará para el cenobio como una etapa de transición. Heredero de la problemática de la centuria anterior, experimentará progresivamente una lenta

392 La entidad de "la crisis del siglo XIV" en la historiografía ha provocado la proliferación de un amplio número de monografías dedicadas a este tema. Por ello aludimos únicamente a aquellas que consideramos de obligada consulta para completar la comprensión de dicho fenómeno y su manifiesta incidencia en la Corona de Castilla. Véase al respecto VALDEÓN VARUQUE, Julio, Los conflictos sociales en el Reino de Castilla en los siglos XIV y XV. Madrid, 1975; IDEM, "La crisis del siglo XIV en la Corona de Castilla”, en HIDALGO DE LA VEGA, María José (ed. lit.), Homenaje a Marcelo Vigil Pascual: la historia en el contexto de las ciencias humanas y sociales. Salamanca, 1989, pp. 217-236.

Asimismo conviene reseñar algunos de los trabajos publicados sobre la economía monástica en estos momentos de recesión, entre los que destacan MORETA VELAYOS, Salustiano, Rentas monásticas en Castilla: Problemas de método. Salamanca, 1974; GARCÍA GONZÁLEZ, Juan José, Vida económica de los monasterios benedictinos en el siglo XIV. Valladolid, 1972.

Este último autor fundamenta su obra en base al Libro de Cuentas de 1338, un informe en el que el papa Benedicto XII encarga en 1336 a los abades de los monasterios de Silos y Cardeña un informe sobre la situación económica de los nueve monasterios benedictinos de la provincia de Toledo, entre los que se encontraba San Zoilo. En él se detallan los ingresos y gastos de cada uno de ellos y el balance, en su mayoría, es negativo. La transcripción ha sido publicada en su integridad por García González, utilizando para ello una copia del mismo libro realizada en 1639 por el padre Juan de Cisneros, puesto que el original, custodiado en Cardeña, desapareció tras la Desamortización. 
recuperación que, si bien estuvo marcada por la venta de algunas propiedades y la cesión injustificada de otras de gran importancia y peso económico, como la casa de San Pelayo en Toro, posibilitó a la recién nombrada abadía - tras su separación definitiva de Cluny reparar su malograda situación iniciando así un cambio de tendencia en las características de las transacciones efectuadas.

Este viraje quedará reforzado por la anexión a la Congregación de San Benito en 1532, hecho que supuso la liberación de una considerable cuantía de las rentas, las cuales se habían visto embargadas por el pago de los elevados intereses que reclamaban al monasterio los abades externos en concepto de pago por el "ejercicio de sus funciones". Esta nueva situación, unida al repunte de la religiosidad popular fruto de las reformas impulsadas por el Concilio de Trento, abre al monasterio la posibilidad de conciliar las tradicionales formas de adquisición de bienes, con aquellas que hasta el momento no habían ofrecido especial trascendencia.

Las donaciones experimentan un ligero repunte, que se ve potenciado por las concesiones que hacen los particulares a través de sus testamentos; sin embargo, la independencia administrativa conseguida a comienzos del siglo XVI pone a disposición del monasterio el efectivo necesario con el que poder invertir en la compra de nuevas heredades que, sin llegar a ostentar la calidad de las primeras donaciones, le permiten ampliar su territorio de influencia e incluso modificarlo en su beneficio por medio de las numerosas permutas y trueques que, una vez estabilizado su patrimonio, proliferaron en el siglo XVIII en aras de la posesión de un dominio más estable y consolidado.

Toda esta evolución favoreció la conformación de una nueva realidad en la que el monasterio abandonará su tradicional papel como elemento pasivo receptor de propiedades y privilegios, para convertirse en el agente conformador y organizador de su propio patrimonio. Esta circunstancia ocasionará la aparición de una necesidad de autogestión y conservación que llevará al cenobio a iniciar una etapa que, alejada ya de la inestabilidad política medieval, no quedará exenta de los problemas derivados de una conciencia administrativa que determinará el rumbo de su actividad y ocupación, la cual se prolongará hasta la disolución de la comunidad y la consiguiente enajenación de todos sus bienes y propiedades a comienzos del siglo XIX.

La importancia que reviste este fenómeno para la comprensión de la historia global del monasterio, convierte en imprescindible el hecho de efectuar una detallada aproximación al mismo. Sin embargo, resultaría cuanto menos incongruente y desacertado 
focalizar el estudio en la gestión del patrimonio de San Zoilo, no sin antes realizar una exposición de cuáles eran las propiedades susceptibles de ser administradas y cuáles fueron los cauces por lo que las referidas haciendas quedaron bajo la órbita de influencia del monasterio carrionés ${ }^{393}$.

El dominio del monasterio comienza a articularse en el entorno más próximo a la abadía y su coto monástico. Así, durante los siglos XI, XII y hasta mediados del siglo XIII la comunidad va a recibir un conjunto de donaciones que configurarán el núcleo inicial de su patrimonio. La donación se convirtió, por tanto, en el elemento básico de adquisición de bienes y derechos por parte del monasterio de San Zoilo en otros siglos. Este hecho se vio favorecido por la existencia de una nobleza laica entre la que primaban unas motivaciones de índole piadoso, en consonancia con la elevada espiritualidad que caracterizó a la época medieval. El Índice nos reseña como entre sus cláusulas incluirían fórmulas tan frecuentes como "por remedio de su alma" referida al donante pero que podía hacerse extensiva a sus padres e incluso a otros parientes ${ }^{394}$, o la petición de que los monjes rogasen perpetuamente por ellos ${ }^{395}$; apelando así a la eficacia de las oraciones de los monjes como intercesores ante Dios por la salvación de su alma.

393 Las monografías publicadas por Julio Pérez Celada y M. ${ }^{a}$ Luisa Palacio Sánchez-Izquierdo refieren con detalle cómo se produjo la configuración del dominio a lo largo de los siglos medievales, en base a los diplomas incluidos en sus respectivas colecciones documentales. Véase PÉREZ CELADA, Documentación San Zoilo. I; IDEM, Documentación San Zoilo. II; IDEM, El monasterio de San Zoilo de Carrión; PALACIO, Colección San Zoil. I; IDEM, Colección San Zoil. II; IDEM, San Zoil de Carrión (siglos XI-XIV.

El presente trabajo pretende mostrar la visión que, de dicho proceso de formación patrimonial, nos ofrecen los documentos regestados en el Índice de San Zoilo; ampliando el ámbito cronológico abarcado en las publicaciones referidas anteriormente, al incluir la producción documental de Época Moderna generada por el monasterio hasta 1818, fecha en la que se describe el último de los diplomas.

394 “Donación escrita en pergamino, por la qual doña Elvira Sánchez, por remedio de su alma y la de sus padres, hace donación a Dios, a San Juan, a los Santos Zoil y Felices y al prior don Pedro y a todos los ancianos de San Zoil, de aquella porción que tenía en Santa María de Trigueros, en el monasterio [...]”. AHPP, Desamortización, Legajo 112, f. 291v, n. 2.

395 “Testamento de doña María Juan, vecina de Frómista, por el qual manda enterrarse en la yglesia de San Martín, con 150 maravedís a los cappellanes, monge y sacristán de dicha yglesia para misas por su alma, y vna tierra, a la Calzada, al hospital de Los Palmeros para que digan perpetuamente cada año vna misa cantada en la yglesia de San Martín”. AHPP, Desamortización, Legajo 112, f. 196r, n. ${ }^{\circ} 2$. 
En otras ocasiones los donantes podían especificar la celebración de aniversarios a cambio del beneficio obtenido por el bien donado ${ }^{396}$ e incluso solicitar el derecho a ser admitidos formando parte de la comunidad ${ }^{397}$ o enterrados en el mismo centro religioso, como ocurrirá en el caso de los condes don Gómez Díaz y doña Teresa así como con sus hijos, todos ellos sepultados en el monasterio. Lo frecuente de estas situaciones no exime, sin embargo, de la posibilidad que en algunas de las donaciones y privilegios concedidos por los monarcas estuviera implícita la conveniencia y el beneficio político del negocio que realizaban ${ }^{398}$ e incluso que, en el caso de los donantes de menor posición social y económica, primasen con carácter no siempre manifiesto, las motivaciones materiales por encima de las simplemente espirituales ${ }^{399}$.

La procedencia inicial de esas dotaciones la encontramos en el linaje de los condes fundadores del monasterio, puesto que tanto ellos como sus descendientes proveyeron a los monjes de una amplia base patrimonial. Si bien el Índice no recoge la referencia a la donación del monasterio hecha por la condesa doña Teresa a la abadía de Cluny en $1076^{400}$, las noticias registradas previas a esta fecha nos indican que ya con anterioridad, los condes se preocuparon por facilitar el acceso del cenobio a un conjunto de bienes a través de diferentes operaciones, entre las que destacaron la donación realizada en 1047 por el conde don Gómez de la iglesia de San Facundo y Primitivo en Arconada ${ }^{401}$, así como el acceso a

396 “[...] Estas 7 tierras con estos maravedís lo dio con carga de 6 aniversarios [...]". AHPP, Desamortización, Legajo 112, f. 145v, n. ${ }^{\circ} 16$.

397 “Donación, escrita en pergamino, por la qual doña María, vecina de Bárcena, da a este monasterio una tierra, en la vega de Carrión, [...] Todo esto porque se la admita como hermana de la orden. Fue otorgada a 2 de diciembre de 1412, ante Fernando Rodríguez de Castellanos, notario de Palencia”. AHPP, Desamortización, Legajo 112, f. 144r, n. ${ }^{\circ} 7$.

398 “Privilegio rodado y partido por ABC, escrito en pergamino con sello de plomo pendiente en filos de seda, por el qual el rey don Alonso el $9^{\circ}$, para vtilidad de su reyno, toma para sí la villa de Castromayor (que ahora es Aguilar de Campos), [...] y le hace merced de los lugares de Gañinas, Revenga y Golpejara, según consta de este privilegio y de los que se hará remisiones”. AHPP, Desamortización, Legajo 112, f. 443v, n. ${ }^{\circ} 1$.

399 “Donación, escrita en pergamino, por la qual Mencía Ruiz, vecina de Frómista, en el Barrio de San Martín, da a este monasterio de San Zoil todos quantos vienes tiene en el dicho lugar de Frómista y en sus términos, en Población , cerca de Frómista, y en sus términos; en Villasarracino y sus términos; en Piña y sus términos, con condición que el monasterio la sustente, vista y calce por toda su vida y la digan dos treintenarios de misas y un aniversario [...]”. AHPP, Desamortización, Legajo 112, f. 190r, n. ${ }^{\circ}$.

400 Para más información acerca de la controversia surgida en torno a este diploma véase el capítulo dedicado a la Historia del monasterio.

${ }^{401}$ AHPP, Desamortización, Legajo 112, f. 35v, n. ${ }^{\circ} 1$. 
las tercias de un conjunto indefinido de lugares tras la concordia ajustada con el Obispo de Palencia en $1051^{402}$. A esto se une la inmunidad y exención del pago de rentas que el rey Alfonso VI concedió al barrio de San Zoles -centro del dominio- en 1073, lo cual será ratificado por sus sucesores hasta que se lleve a cabo la venta del mismo y de su jurisdicción a la villa de Carrión en $1564^{403}$.

El establecimiento del cenobio bajo la órbita de influencia de la abadía borgoñona, supondrá un punto de inflexión que hará que San Zoilo se convierta en el foco receptor de la piedad de numerosos donantes. La complejidad y el volumen de las operaciones de adquisición de derechos y propiedades efectuadas por el monasterio durante sus casi nueve siglos de existencia, hace que la representación gráfica de la localización de cada una de los lugares donde el cenobio ostentó su hacienda se convierta en un instrumento de referencia clave para facilitar y agilizar el proceso de comprensión íntegra de su territorio de influencia.

El mapa adjunto evidencia cómo en los primeros años del siglo XIX, el dominio de San Zoilo se extendía por un amplio territorio de orientación Norte-Sur que comprendía casi toda la actual provincia de Palencia, así como algunas posesiones en torno al actual límite de las provincias de Valladolid y Zamora ${ }^{404}$.

El coto monástico de San Zoilo, perfilado por su ámbito de influencia jurídica, espiritual y económica del núcleo del dominio, nos viene definido por el propio Índice a lo largo de los tres cajones $-4^{\circ}$ (San Pedro), $5^{\circ}$ (San Andrés) y $6^{\circ}$ (San Zoilo) - en los que se organiza la documentación dentro del propio archivo.

A nivel jurídico se observa el interés por la custodia de aquellos diplomas que abalasen y justificasen una serie de privilegios y exenciones concedidos al monasterio por los pontífices y los reyes. Así, las bulas nos informan tanto del beneficio que supuso para la comunidad su dependencia respecto a Cluny -al quedar por asimilación bajo la protección directa de la Sede Apostólica ${ }^{405}$-, como del menoscabo económico y moral que implicó la

\footnotetext{
402 AHPP, Desamortización, Legajo 112, f. 107r, n. ${ }^{\circ} 1$.

403 AHPP, Desamortización, Legajo 112, f. 95v, n. 38.

404 Para la elaboración de este mapa se han utilizado las siguientes fuentes MARTÍNEZ DÍEZ, Gonzalo, Libro Becerro de las Behetrías, y las imágenes de mapas que ofrece el servidor Google Maps: https://www.google.es/maps [Fecha de la última consulta: 25 de abril de 2017].

405 AHPP, Desamortización, Legajo 112, f. 80r, n. ${ }^{\circ} 1$.
} 
etapa de gobierno de los abades consistoriales y comendatarios hasta su anexión definitiva a la Congregación de San Benito en $1532^{406}$.

Por otra parte, los privilegios reales tendrían una visible connotación económica en 1226 Fernando III exime al monasterio del pago de portazgo, lo cual será confirmado por sus sucesores ${ }^{407}-\mathrm{y}$ nos proporcionan una idea del apoyo dispensado por parte de la corona hacia esta institución tanto durante su etapa dependiente como después de su adhesión a San Benito.

Jurisdiccionalmente, el monasterio se encontraba dentro del barrio de San Zoles, junto con una serie de casas y vecinos a los que el rey Alfonso VI había otorgado una serie de libertades y exenciones ${ }^{408}$. Esta filiación se mantuvo, aunque no exenta de problemas, hasta 1564 cuando, tras muchos años de pleitos y reivindicaciones por parte de la villa de Carrión, el monasterio concluya la venta de dicho barrio. Además incluye un cuaderno en el que recoge los sucesivos requerimientos por el incumplimiento de los pactos adoptados en el reparto del agua del Cuérnago -a San Zoilo le correspondía una tercera parte- y los pactos adoptados con la villa de Carrión por el uso del Arroyo Forero ${ }^{409}$.

En 1476, las graves privaciones por las que atravesaba el mantenimiento espiritual de la parroquia de San Zoles - carecían de rentas para pagar las cosas del culto divinollevan al sacristán mayor, fray Zoil de Nogal, a solicitar al para Sixto IV la anexión de la capellanía de la Magdalena, situada dentro de la iglesia, para que con sus rentas pudiera servir el curato, unión que será aprobada dos años después, en $1478^{410}$.

Al monasterio le pertenecían íntegramente los diezmos y las tercias de las parroquias de San Zoles y San Martín de Frómista, con la obligación de "dar al capellán de la yglesia de San Zoil 20 áureos cada año para su sustento y provisión; y en la yglesia de San Martín den a cada capellán 22 áureos cada año sin comida, o 12 con comida en el monasterio, a elección de ellos" ${ }^{\text {411 }}$; además de corresponderle la percepción de una tercera parte de las tercias, así como el derecho de presentación en algunas iglesias dispersas por el dominio monástico, a las que aludiremos más adelante.

\footnotetext{
406 AHPP, Desamortización, Legajo 112, f. 87v, n. ${ }^{\circ} 40$.

407 AHPP, Desamortización, Legajo 112, f. 88r, n. 2.

408 AHPP, Desamortización, Legajo 112, f. 91r, n. ${ }^{\circ} 1$.

409 AHPP, Desamortización, Legajo 112, f. 97v-102r.

${ }^{410}$ AHPP, Desamortización, Legajo 112, f. 102v, n. ${ }^{\circ} 2$.

411 AHPP, Desamortización, Legajo 112, f. 107v, n. 3.
} 


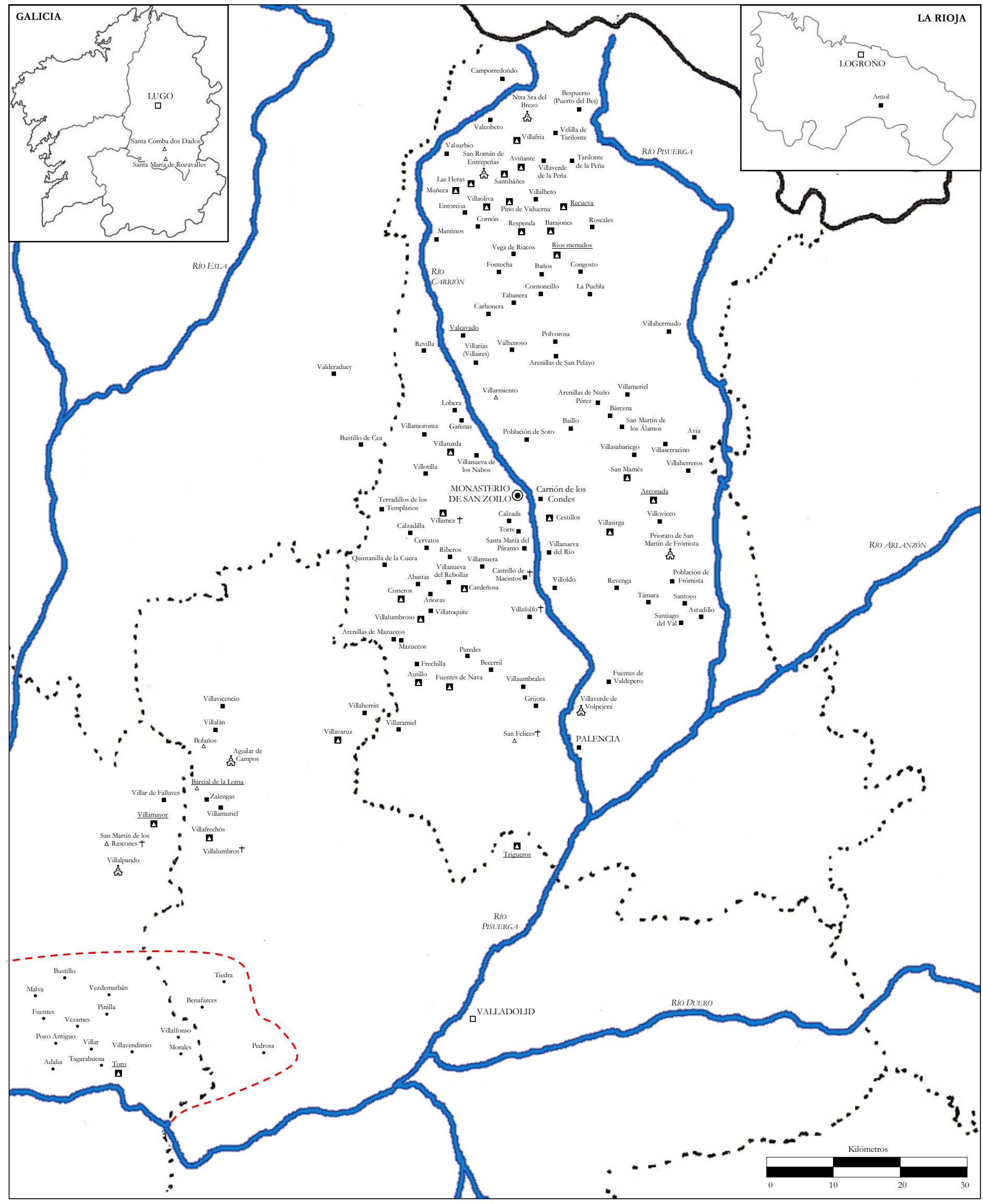

(-) Centro del dominio monástico

解 Prioratos dependientes de San Zoilo en 1818

Capital de provincia

Lugares donde el monasterio ostenta derechos de propiedad

$\triangle \quad$ Lugares donde el monasterio ostenta derechos sobre iglesias

$†$ Despoblado

Lugar Antiguo priorato / monasterio dependiente (reseñado por el Padre Yepes)

----. Límite de provincia actual

---. Priorato de San Pelayo de Toro y sus dependencia

- Dependencias pertenecientes al Priorato de San Pelayo de Toro 
Además, dentro del monasterio se encontraba la Cofradía de Santa María Magdalena ${ }^{412}$, el Hospital de Nuestra Señora de la $\mathrm{O}^{413}$ - fundado por el abad comendatario Luis Hurtado de Mendoza y cuya administración generó numerosos pleitos por la negativa al pago de un "alquiler" en concepto de uso del suelo monástico-; y la Capilla de doña Constanza ${ }^{414}$, sita en la sacristía desde su fundación en 1591 por don Antonio Doro Campoo y doña Constanza Enríquez hasta su anulación en 1774. Los Hospitales de San Lázaro y La Herrada, aunque no pertenecían a San Zoilo, se encontraban bajo su influencia, al ser el cura del monasterio el encargado de cubrir el oficio de la capellanía en el de San Lázaro ${ }^{415}$ y de administrar los Santos Sacramentos en el de La Herrada ${ }^{416}$, tarea por la cual recibiría una necesaria manutención.

Ya en el ámbito estrictamente económico el monasterio acogió un conjunto de propiedades en Carrión y San Zoles ${ }^{417}$, donadas en su mayoría por parte de los mismos vecinos entre el siglo XI y el XVII; las cuales, al no ser su dotación patrimonial muy elevada, incluían unidades como casas, huertas, herrenes, tierras e incluso dinero a cambio del establecimiento de aniversarios. El monasterio incrementó estas propiedades a través de compras, trueques y alguna cesión, entre las que destacan las operaciones para la posesión de los molinos del Huerto, de la Tapia ${ }^{418}$-cedidos al monasterio en 1480 por Francisco Girón- y de Guzmán, adquirido este entre 1701 y $1704^{419}$. Para gestionar estas propiedades se valió del establecimiento de foros, contratos que implicaban la cesión de las posesiones que el monasterio había ido adquiriendo a cambio del pago de una renta; los cuales reportarían unos beneficios muy provechosos fundamentalmente en aquellos momentos en los que se vieron más azuzados por la difícil crisis económica ${ }^{420}$.

Mas el ámbito de influencia de San Zoilo no se limitó únicamente a su área circundante más próxima, puesto que, cómo ya venimos advirtiendo, el cenobio fue

\footnotetext{
412 AHPP, Desamortización, Legajo 112, f. 125r.

413 AHPP, Desamortización, Legajo 112, f. 126r.

${ }^{414}$ AHPP, Desamortización, Legajo 112, f. 137r.

415 AHPP, Desamortización, Legajo 112, f. 131r.

416 AHPP, Desamortización, Legajo 112, f. 133r.

417 AHPP, Desamortización, Legajo 112, f. 143r-148r.

418 AHPP, Desamortización, Legajo 112, f. 156r, n. ${ }^{\circ} 1$.

419 AHPP, Desamortización, Legajo 112, f. 156v, n. 3.

${ }^{420}$ AHPP, Desamortización, Legajo 112, ff. 157r-168v.
} 
ampliamente dotado durante los primeros siglos mediante concesiones que incluían ocasionalmente la posesión de núcleos bastante alejados.

Cada una de las heredades que le fueron donadas al monasterio constituía un pequeño dominio por sí misma, sin que ello supusiera la percepción del señorío íntegro o la propiedad de una aldea, villa ${ }^{421}$, barrio o monasterio; siendo una constante desde finales del siglo XIII la mera posesión sobre determinadas tierras, casas, prados, viñas o solares en base a las donaciones provenientes de un amplio grupo de "particulares" ${ }^{422}$. Con el cierre del siglo XII, se pone fin a la etapa de mayor captación patrimonial que convirtió a la nobleza en la principal protagonista de la aportación al patrimonio monástico de una gran cantidad de bienes y derechos ${ }^{423}$.

La existencia de haciendas en las zonas no inmediatas al centro de dominio provocará que estas queden fuera de la jurisdicción propia del coto monástico y que, por lo tanto, se haga necesaria su gestión a través de una serie de unidades de administración territorial con las que organizar y controlar el territorio dependiente: los prioratos ${ }^{424}$. Su presencia como elementos básicos de la articulación se produjo como consecuencia natural de la incorporación -mediante donación o anexión- de dichos monasterios al de San Zoilo, y con ellos de todas sus propiedades asociadas, generándose así una relación de

${ }^{421}$ Destaca la donación de la villa de San Mamés "Donación, escrita en pergamino, que hizo a este monasterio la condesa doña Sancha por el remedio de su alma y la de sus padres, de la villa de San Mamés, junto al arroyo Ozeza, con todo quanto allí tiene y le pertenece, divisas de vasallos, solares poblados y despoblados, tierras, viñas, huertos, prados, etcétera, con la obligación de que hagan todos los años un aniversario principal por dicha condesa, el día de la Asunción de Nuestra Señora den de comer aquel día a doce pobres, y después de su muerte la escrivan en la regla Cluniacense para que nunca falte el aniversario". AHPP, Desamortización, Legajo 112, f. 271 r, n. ${ }^{\circ} 1$.

422 "Donación que hizo a San Román Alonso cano, vecino de Ríos Menudos, de una casa paxiza, para ser vasallo del dicho convento [...]. AHPP, Desamortización, Legajo 112, f. 300r, n. ${ }^{\circ} 4$.

423 Recibirá posesiones y derechos en Arconada, Avia, Becerril, Cervatos, Cestillos, Cisneros, Congosto, Frechilla, Fuentes de don Bermudo, Gañinas, Lobera, Paredes de Nava, Quintanilla de la Cueza, Revilla, Riberos, Villameriel, Villamez, Villamuriel, Villanueva de los Nabos, Villarramiel, Villaturde, Villarsirga, entre otros.

424 PÉREZ CELADA, Julio A. El monasterio de San Zoilo de Carrión, pp. 230-235, establece una diferencia entre los "prioratos" y las "casas", al considerar estas como las únicas unidades de articulación del dominio por la existencia de un terrazgo y unos campesinos sobre los que realizar la gestión. Así señala como domos a San Martín de Frómista y San Pelayo de Toro, en contraposición al prioradgo de Aguilar de Campos, que no se ajustaba a los requisitos explicados. 
dependencia manifiesta a través del traspaso del propio archivo del priorato al archivo central de San Zoilo, encargado ahora del control y manejo de su documentación.

El Padre Yepes, en su Corónica, señalaba lo siguiente sobre esta cuestión: "Fue el Monasterio de San Zoil de Carrión muy rico antiguamente, y tuvo muchos monasterios sugetos". [...] “Assímismo en todos los lugares donde el Monasterio de San Zoil de Carrión tenía filiaciones y Monasterios menores sugetos, [...] tuuo gruesíssimas haciendas que se le anexaron a los mismos Monasterios, con que vino à ser este vno de los poderosos de España, y fue por muchos años riquíssimo" ${ }^{425}$. Una somera aproximación al Índice del archivo nos permite ponernos al corriente de la fiabilidad de estas palabras, al poder contrastar y constatar a través de los documentos regestados en sus casi quinientos folios una realidad que, sin distar en demasía de lo ya apuntado por Yepes, nos ofrece los matices pertinentes que requieren los casi doscientos años que separa la redacción de ambos libros.

De los catorce monasterios que Yepes señalaba como sujetos a San Zoilo a comienzos del siglo XVII -San Román de Entrepeñas, San Pedro de Recueva, San Facundo y San Primitivo de Arconada, San Pelayo de Toro, Valcavado, San Martín de Frómista, San Martín de Villamayor, San Pelayo de Barcial, Santa María de Trigueros, San Juan de Aguilar, San Lorenzo de Villalpando, San Miguel de Ríosmenudos, San Salvador de Villaverde y Nuestra Señora del Brezo- únicamente seis de ellos aparecen reflejados en el Índice como prioratos dependientes del cenobio: San Román de Entrepeñas, San Martín de Frómista, San Juan de Aguilar, San Lorenzo de Villalpando, San Salvador de Villaverde y Nuestra Señora del Brezo. El resto, a excepción de San Pelayo de Toro, permanece vinculado no ya como monasterio, sino como iglesias sobre la que ostenta la presentación y colación de su beneficio curado o simplemente como heredades en las que detenta algún tipo de derecho o propiedad.

Al margen de esta inevitable salvedad, esos monasterios se convirtieron para San Zoilo en una prolongación de su influencia en aquellos lugares en ocasiones muy distantes del espacio carrionés. Es por ello que, establecer cronológicamente los momentos de anexión de cada uno de ellos, nos va a proporcionar una imagen precisa de cómo se fue conformando el dominio progresivamente.

- Como ya habíamos señalado con anterioridad, en el año 1047 el conde don Gómez Díaz edifica un monasterio en Arconada para dar limosna a los pobres

425 YEPES, Coronica San Benito, p. 83. 
y dona la iglesia San Facundo y San Primitivo al monasterio de San Zoilo ${ }^{426}$. Tras esta noticia, el Índice sitúa en el siglo XVI los derechos de presentación del monasterio sobre el beneficio curado de dicha iglesia.

- Situado entre Tierra de Campos y Campo de Toro, el priorato de San Pelayo de Toro será donado en algún momento del siglo XI aún en vida de los fundadores ${ }^{427}$. Comprendía un territorio muy extenso que incluía las iglesias de Santa María y San Martín de Benafarces, San Martín de Vezdemarbán y San Salvador de Pozo Antiguo, y proporcionaba cuantiosas rentas al monasterio. En 1443 el abad Gonzalo de Cerbatos permutó la hacienda con Pedro de Vivero por un juro de 11.000 maravedís. El incumplimiento de dicho pago dará como resultado un pleito que se prolongará hasta 1591 con la pérdida definitiva de dicho priorato ${ }^{428}$.

- No existe ninguna noticia en el Índice que nos sitúe bajo la pista de la posible fecha de anexión del monasterio de San Andrés de Valcavado ${ }^{429}$; únicamente

426 AHPP, Desamortización, Legajo 112, f. 35v, n. ${ }^{\circ} 1$.

427 "Es tan antigua que no parece memoria cierta de dónde la hubo el monasterio o quién se la donó, porque como no tenemos cosa cierta de la primera fundación de este monasterio tampoco se halla del origen de su priorato de San Pelayo de Toro, ni de esta hacienda que siempre estubo anexa a él. Sólo hay por tradición que como a esta casa la reedificaron los infantes que llamaron de Carrión (y nosotros nuestros fundadores), el cónsul don Gómez Díaz, la señora condesa doña Theresa, su muger, y los infantes, sus hijos; así entró esta hacienda de Toro con otras que dieron a este monasterio en su dotación y, como ni de aquellos nos han quedado esscrituras con ser tan constante en tradición, tampoco de esto. Sólo se halla memoria cierta de haber gozado el convento esta hacienda desde antes de los años de 1210 hasta el de 1443 en que se enagenó, que son 233 años, en que por lo menos consta haberla gozado quieta y pacíficamente". AHPP, Desamortización, Legajo 112, f. 339r.

${ }^{428}$ AHPP, Desamortización, Legajo 112, ff. 338r-344v. Véase PÉREZ CELADA, Julio A., "La casa de San Pelayo de Toro y sus dependencias entre los siglos XI y XIV. Una aproximación al señorío cluniacense en la provincia de Zamora”, en Actas del I Congreso de Historia de Zamora. T. III. Zamora, 1988, pp. 223-231; IDEM, "Sobre la toma de posesión feudal en la Baja Edad Media castellana. El lugar de Benafarces en el año 1435", en Actas de las I Jornadas sobre Fuentes y Métodos de la Historia Local. Zamora, 1990, pp.89-95.

${ }^{429}$ AHPP, Desamortización, Legajo 112, ff. 345r-349r. La única noticia a la existencia de la iglesia de San Andrés de Valcavado aparece regestrada en el siguiente asiento "Apartamiento que hizo Fernando Álvarez, clérigo de Frómesta, del pleito sobre el beneficio curado de la Magdalena, en el que confiesa estar anexo dicho beneficio al oficio de la sacristanía de San Zoil, por bulla de la Santidad de Sixto $4^{\circ}$ cometida al abad de Benevivere; y que por haberle dado el monasterio el beneficio curado de San Andrés de Valcavado y conocer que no tenía entero derecho al de la Magdalena, le renuncia y cede al dicho sacristán, jurando no molestarle ahora ni en tiempo alguno. Su fecha, en Carrión, a 22 de julio de 1488, ante Fernando Cavallo, escribano de dicha villa". AHPP, Desamortización, Legajo 112, f. 105r, n. 12. 
aparecen regestados aquellos documentos relacionados con la administración de la hacienda en este lugar a partir del siglo XV.

- Ya en el siglo XII, y en consonancia con la política de donaciones que prosiguieron los descendientes de los condes fundadores, la condesa doña Aldonza dona en 1110 la tercera parte de la hacienda que tenía en San Juan de Tarador, en la villa de Castromayor (actual Aguilar de Campos) ${ }^{430}$; y aunque en 1181 el rey Alfonso IX trueque dicha villa por otras heredades, argumentado para ello motivos políticos, respetará los derechos sobre las iglesias que le pertenecían al monasterio ${ }^{431}$.

- En esta misma línea se sitúa la donación que en 1118 realiza doña Mayor Gómez de la mitad del monasterio de San Martín de Villamayor, con todo lo que en él la pertenecía, y en Barcial de la Loma el monasterio de San Pelayo con su ración entera ${ }^{432}$. Esta donación traerá consigo la anexión de otros lugares como Villarramiel, Frechilla, Fuentes de don Bermudo y Cardeñosa, entre otros.

- La reina doña Urraca va a poner a disposición del monasterio el que será uno de los prioratos más importantes, al donar en 1118 la iglesia de San Martín de Frómista ${ }^{433}$, que traerá anexo el barrio homónimo merced a la donación que de él hizo en 1066 la reina doña Mayor; la disputa por la posesión de su señorío traerá acarreado el inicio de un pleito con los señores de Frómista que se iniciará en 1414, llegando sin solución hasta el siglo XIX ${ }^{434}$. En 1537 se produjo una fallida tentativa de venta de dicho priorato al monasterio de San Benito de la misma villa.

\footnotetext{
${ }^{430}$ AHPP, Desamortización, Legajo 112, f. , n. ${ }^{\circ} 1$.

431 "Privilegio rodado y partido por ABC, escrito en pergamino con sello de plomo pendiente en filos de seda, por el qual el rey don Alonso el $9^{\circ}$, para vtilidad de su reyno, toma para sí la villa de Castromayor (que ahora es Aguilar de Campos), y entonces era del monasterio, < con toda su heredad>, al qual deja todas las yglesias <que hay y hubiere> de aquella villa, con sus derechos y dominio, como las había tenido antiguamente". AHPP, Desamortización, Legajo 112, f. 443v, n. ${ }^{\circ} 1$.

432 AHPP, Desamortización, Legajo 112, f. 1v, n. ${ }^{\circ} 2$.

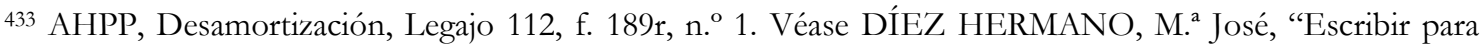
conservar. El priorato de San Martín de Frómista a través del índice de San Zoilo de Carrión”, en Ramón BALDAQUÍ ESCANDELL (coord.), Lugares de escritura: el monasterio. Alicante, 2016, pp. 427-443.

434 AHPP, Desamortización, Legajo 112, f. 234r-251v. Véase PÉREZ CELADA, Julio A., "Los conflictos jurisdiccionales en el barrio de San Martín de Frómista en los siglos XIV y XV” en Cuadernos burgaleses de historia medieval, n. ${ }^{\circ}$. 3, 1995, págs. 155-185.
} 
- Como ya indicamos al mencionar la anexión del priorato de San Juan de Aguilar, en 1181 el rey Alfonso $9^{\circ}$ permuta la villa de Castromayor por los lugares de Gañinas, Revenga y Golpejera (actual Villaverde), pasando así el priorato de San Salvador de Villaverde a formar parte del dominio monástico. En el año 1603 el Índice nos habla de este lugar como la "granja de Villaverde". $\mathrm{Y}$ aun dedicando dos cuadernos al nombramiento de alcaldes mayores de Villaverde hechos por los abades de San Zoil desde el año de 1600 adelante, así como a los pleitos criminales sobre la jurisdicción en razón de los pastos, no proporciona noticia alguna acerca de la participación de San Zoilo en la vida eclesiástica de dicha comunidad.

- Santa María de Trigueros ${ }^{435}$ se unirá al monasterio a partir de la donación que de sus respectivas porciones realizarán Mayor Pétriz y Elvira Sánchez en 1129 y 1136, respectivamente.

- En 1199, don Pedro, abad de San Zoilo y camarero de Cluny, compra toda la heredad de San Miguel de Riosmenudos a Sancha Sogni por precio de 30 maravedís ${ }^{436}$. En 1228, y por razones de proximidad, San Zoilo permutará con San Román esta iglesia por la de San Vicente de Otello (Autillo) ${ }^{437}$.

- Con una única noticia explícita del momento en el que se produjo la incorporación de San Lorenzo de Villalpando, este antiguo priorato donado por el rey Fernando III el Santo en $1226^{438}$, recobra su visibilidad en el Índice a

435 AHPP, Desamortización, Legajo 112, f. 291v-292r. El Índice de San Zoilo incluye los documentos relacionados con el monasterio de Santa María de Trigueros en un quaderno al que denomina "Quintanilla de Trigueros" (municipio de la actual provincia de Valladolid). No obstante, dicho monasterio, actualmente desaparecido, estaba localizado en la población de Trigueros del Valle (municipio próximo a Quintanilla de Trigueros), tal y como demuestra la referencia precisa del Índice a su localización junto a un castillo "[...] Santa María de Trigueros, en el monasterio, que está en El Castillo [...]”, construcción sita en este lugar de Trigueros del Valle. Pensamos que dicha confusión pudo producirse a raíz de la única mención al lugar de Quintanilla en uno de los tres documentos que componen el cuaderno.

Para más información acerca de esta cuestión puede consultarse la página web del Archivo Municipal de Trigueros del Valle: http://censoarchivos.mcu.es/CensoGuia/fondoDetail.htm?id=70229 [Fecha de la última consulta: 30 de abril de 2017].

436 AHPP, Desamortización, Legajo 112, f. 300r, n. ${ }^{\circ} 1$.

${ }^{437}$ AHPP, Desamortización, Legajo 112, f. 301v, n. ${ }^{\circ} 2$.

438 "Donación del rey don Fernando el Santo, escrita en pergamino, con sello de plomo pendiente en filos de seda, por la qual da al prior y monasterio de San Zoil del orden cluniacense los monasterios de San Estevan de Villamayor y San Lorenzo de Villalpando”. AHPP, Desamortización, Legajo 112, f. 397r, n. ${ }^{o} 1$. 
partir del siglo XV a través de la gestión de la hacienda del priorato y del beneficio de la iglesia de San Lorenzo ${ }^{439}$.

- El proceso de anexión medieval cimenta la expansión del monasterio de una manera casi íntegra por toda la Tierra de Campos. El proceso podría haberse dado por finalizado en este momento de no ser por la unión que se produjo en 1443 del priorato de San Román de Entrepeñas ${ }^{440}$. A petición del abad de San Zoil don Gonzalo, a raíz del "tan miserable estado" en que se hallaba el dicho priorato, el Papa Eugenio $4^{\circ}$ autoriza mediante bula a Miguel de Echarri, arcediano de Valdonsella, a llevar a cabo las pesquisas pertinentes, las cuales finalizan con la adhesión de San Román al cenobio y la facultad al abad para nombrar al prior. Su anexión supondrá, de una parte, la llegada al monasterio de todo su archivo - entre cuyos documentos destaca la espléndida dotación realizada en el 940 por Diego Moñiz y Tigridia a la casa de San Román, escritura más antigua registrada en el Índice ${ }^{441}-$; y de otra, la inclusión de todas aquellas haciendas y derechos que hasta ese momento habían constituido el dominio monástico del recientemente incorporado priorato, entre los que se encontraban Mazuecos, Arenillas, San Cristóbal de Aviñante, Santiago de Villaoliva, San Saturnino de Barajores -los tres donados en 1226 a San Román por Fernando III El Santo ${ }^{442}$-, San Felices, Bespuerto, Cornón, Cornoncilllo, Villalveto, Villabermudo, Velilla de Tarilonte, Villafría y Fontecha, junto con la iglesia de Santa María Madre en Santibáñez.

- Esta incorporación acarreará la unión del monasterio de San Pedro de Recueva, donado a San Román en 1115 por el conde Pedro Ansúrez ${ }^{443}$, pasando a San Zoilo los beneficios existentes sobre dicha iglesia como señores que eran del priorato sanromaniego.

- La expansión por la Montaña y el Páramo palentinos se completará con la afiliación en 1519 del priorato del Nuestra Señora del Brezo por bula de León

\footnotetext{
439 AHPP, Desamortización, Legajo 112, f. 392r-397r.

440 AHPP, Desamortización, Legajo 112, f. 326r, n. ${ }^{\circ}$ 2. La colección documental ha sido publicada por RUIZ ASENCIO, José Manuel-RUIZ ALBI, Irene-HERRERO JIMÉNEZ, Mauricio, Colección documental del monasterio de San Román de Entrepeñas (940-1608). León, 2000.

${ }^{441}$ AHPP, Desamortización, Legajo 112, f. 312r, n. ${ }^{\circ} 1$.

${ }^{442}$ AHPP, Desamortización, Legajo 112, f. 47r, n. ${ }^{\circ} 1$.

443 AHPP, Desamortización, Legajo 112, f. 292v, n. ${ }^{\circ} 1$.
} 
$\mathrm{X}^{444}$, incorporando sus propiedades en Basurbio, Las Heras, Barajores, Aviñante, Bárcena, Santibáñez o Villafría.

Este prolijo panorama de dádivas, llena de sentido la aseveración de Ricardo Becerro de Bengoa al expresar: "Llegó el monasterio de San Zoil a su mayor esplendor al finalizar el siglo XVI" ${ }^{45}$. Y no erraba en su declaración, pues precisamente esta centuria se va a convertir junto con el siglo XVII, en protagonistas de excepción del resurgimiento de esta abadía, tanto en el ámbito económico como en el espiritual.

La evidente disponibilidad de excedentes monetarios va a impulsar al monasterio a emprender lo que será un claro ejemplo de consolidación y concentración de su ámbito de influencia. A través de más de doscientas compras, conseguirá hacerse con un selecto conjunto de propiedades rurales y urbanas -tierras, viñas, corrales, herrenes, bodegas, prados y solares-; las cuales, además de quedar integradas de manera homogénea junto a otras heredades ya preexistentes, se convertirán en unidades de explotación susceptibles de ser arrendadas a cambio del cobro de una asequible renta o censo; conveniente negocio en el cual, como podrá comprobarse más adelante, nunca le van a faltar interesados.

Con una clara preeminencia de las adquisiciones en torno al área controlada por sus prioratos -Aguilar, Frómista, Nuestra Señora del Brezo en Bárcena y Tarilonte, y San Román en Santibáñez-, la cifra de compras más abundante se registra en Carrión y San Zoles, en un acertado intento por afianzar y fortalecer posiciones en su coto de influencia adyacente. Únicamente observamos dos casos peculiares: de una parte, en la compra de la vecindad en el barrio de Otero en Villamayor, aprovechando con sus ganados los pastos del pueblo a cambio del pago de 100 reales al año para ayuda de sus gastos ${ }^{446}$; y de otra, en Villamuera, donde el acopio de compras se hizo en respuesta a los sucesivos intentos del concejo de Carrión por arrebatarle la jurisdicción sobre dicha villa ${ }^{447}$.

La permuta será la actividad a la que menos recurrirá el monasterio pues, al no ser su política el desprenderse de posesiones, los cambios de propiedades únicamente se

\footnotetext{
444 AHPP, Desamortización, Legajo 112, f. 70v, n. ${ }^{\circ} 4$.

445 BECERRO DE BENGOA, El Monasterio de Carrión, p. 77.

446 "Escritura de venta por la qual el convento compró a los vecinos del barrio de Otero la vecindad, con todas las preeminencias de vecino eclesiástico, con calidad que sólo pueda traer un ato de ganado. Y en pago y satisfacción se obligó a dar cada año al concejo 100 reales para ayuda de sus gastos y repartimientos" AHPP, Desamortización, Legajo 112, f. 398r, n. ${ }^{\circ} 8$.

${ }^{447}$ AHPP, Desamortización, Legajo 112, f. 414r, n. ${ }^{\circ} 4$.
} 
concebían cuando dicho trueque iba a realizarse por algo más ventajoso. Será en el siglo XVIII cuando, una vez estabilizado su patrimonio, opten por su puesta en práctica de una manera más frecuente.

\subsection{Las rentas de la iglesia}

Si bien predominó la posesión de heredades, bienes y derechos señoriales como elementos más relevantes para la articulación del dominio; también las iglesias y monasterios se convirtieron en una sustanciosa fuente de ingresos puesto que, al hecho de ostentar la propiedad y titularidad sobre los mismos -e incluso sin que esto fuese un requisito imprescindible ${ }^{448}$ - se anexaba la percepción de toda una suerte de rentas eclesiásticas en función de los derechos que sobre ellas poseyera el monasterio.

El componente más común de la retribución de los eclesiásticos eran el diezmo, y más concretamente la tercia decimal concedida a los servidores de las iglesias; a este se unían la renta por la administración de posesiones asignadas al beneficio, las ofrendas recibidas de los fieles y la remuneración por la celebración de determinados servicios de culto, sobre todo los aniversarios.

La necesidad de preservar la recepción de dicha tercia hizo que San Zoilo se viera inmerso en numerosos pleitos por la defensa de aquellos derechos parroquiales que consideraba le pertenecían. El Índice de San Zoilo se hace buen eco de esta conflictividad en tanto que muy abundante era el número de iglesias anexionadas a la mesa del abad. Entre ellos cabría destacar la disputa en la que se vieron envueltos los monasterios de San Zoilo de Carrión, San Román de Entrepeñas y San Isidro de Dueñas ${ }^{449}$ ante la pretensión del obispo de Palencia Tello Téllez de Meneses por consolidar sus derechos en diversas iglesias de su diócesis.

En 1220, el monasterio de San Zoilo buscó consolidar de una manera factible la defensa de la prescripción al monasterio de diferentes parroquias y sus tercias, para lo cual

\footnotetext{
$448 \mathrm{Al}$ monasterio le pertenecían íntegramente las parroquias de San Zoles y San Martín de Frómista “[...] monasterio y de la parroquia de San Zoles (en que dicho monasterio está sito, y de quien es toda la parroquia por privilegio) [...]"; "Copia authorizada de vna información antigua que hizo el monasterio de San Zoil con 38 testigos, de que la yglesia de San Martín era plenamente de dicho monasterio, que el obispo de Palencia no tenía jurisdicción [...]”. AHPP, Desamortización, Legajo 112, f. 109r, n. ${ }^{\circ}$ 7; f. 197r, n. ${ }^{\circ} 12$.

${ }^{449}$ Esta concordia ya había sido reseñada en REGLERO DE LA FUENTE, Carlos M., El Monasterio de San Isidro de Dueñas en la Edad Media, pp. 163-168.
} 
encargó al monje procurador, el padre Gunsalvo, elaborar una información que recogiese una lista de las parroquias con las pruebas que justificaban la posesión de dichas prescripciones, sus diezmos y sus tercias ${ }^{450}$. El índice reseña que dicha información es antigua y tiene diez hojas aunque le faltan otras y que en ellas están notados los siguientes lugares: San Martín de Frómista, San Facundo de Arconada, Villamez, San Mamés, San Román de Fuentes de don Bermudo, San Pedro de Villasirga, San Martín de Villavaruz, San Salvador de Villalumbroso y San Miguel de San Felices.

En 1228 dicha disputa concluyó con una concordia por la que el cabildo concedía "que el monasterio de San Zoil tenga las yglesias parroquiales de San Zoil y San Martín de Frómesta con todos los diezmos, primicias y ofrendas de vivos y muertos, posesiones y demás pertenencias; y el obispo y sus vicarios tengan en dichas yglesias parroquiales la institución de los capellanes a presentación de los monges, visita y corrección de los clérigos y parroquianos" $\$ 451$.

Además otorgaba el derecho de presentación de los clérigos y la tercera parte de las tercias de las iglesias de San Andrés de Villagonzalo, San Pedro de Villasirga, San Facundo de Arconada, Santa María de Villamez, Santa María de Villaturde, San Juan de Cestillos, Santa María de Cardeñosa, San Salvador de Villalumbroso, San Román de Fuentes de don Bermudo, San Martín de Villavaruz y Santa María de Trigueros.

Por último, entregaba la iglesia de San Vicente de Autillo con todas sus pertenencias, diezmos y el derecho a presentar clérigos y, a cambio, el monasterio renunciaba a favor del obispo a la mitad de la tercia episcopal que recibía de las iglesias de San Mamés, Villaturde y Villamez.

Las rentas obtenidas de dichas iglesias se convirtieron en una importante fuente de ingresos para el monasterio durante los sucesivos siglos. Además, el derecho de presentar el beneficio eclesiástico ${ }^{452}$ en esas parroquias otorgó al monasterio una serie de ventajas

\footnotetext{
450 AHPP, Desamortización, Legajo 112, f. 107r, n. ${ }^{\circ} 2$.

451 AHPP, Desamortización, Legajo 112, f. 107v, n. 3.

452 Para más información acerca de esta cuestión véase MARTÍN MARTíN, José Luis, "El clero rural en la Corona de Castilla", en MARTÍNEZ SAN PEDRO, María Desamparados-SEGURA DEL PINO, María Dolores (coords.), La iglesia en el mundo medieval y moderno. Almería, 2004, pp. 55-82.
}

BARRIO GOZALO, Maximiliano, "El sistema beneficial en la España del siglo XVIII: Pervivencias y cambios": Cuadernos Dieciochistas, 2 (2001), pp. 73-107. 
económicas y la posibilidad de tejer un entramado de estrategias clientelares y familiares en torno al cenobio.

A partir del siglo XVI, el Índice registra la noticia de numerosas iglesias sobre las que el monasterio ostentaba algún tipo de beneficio (principalmente presentación y colación): San Juan de Aguilar, San Facundo de Arconada, Santa Bárbara de Barajores, San Pedro de Bolaños, San Juan de Cardeñosa, San Juan de Cestillos, Santa María de Barriofalda de Cisneros, Santa Comba dos Dados, Santa María de Rozavalles, San Martín de Frómista, San Martín de los Rascones, Muñeca, Pino de Viduerna, San Pedro de Recueva, Respenda, Santibáñez de la Peña, San Román de Entrepeñas, San Salvador de Villalumbroso, San Justo de Villafría, San Lorenzo de Villalpando, San Miguel de Villarmienzo, San Pedro de Villasirga, Santa María de Villaturde y San Salvador de Villaverde.

Estimar una evolución cuantitativa de los derechos de patronazgo que pertenecieron al monasterio a través del Índice es una tarea compleja, puesto que debemos considerar la existencia de un factor variable como lo es el hecho de que el códice no registra únicamente aquellas iglesias en las que detentaba estos beneficios, sino que además indica los cambios que se producían cada vez que un puesto quedaba vacante. No obstante, la evolución cronológica advierte de cómo, a causa de la tardía consolidación del sistema parroquial en Castilla, hecho este que no se produjo hasta comienzos del siglo XIII ${ }^{453}$, los importantes cambios acontecidos en el monasterio durante el siglo XVI -prosperidad económica, unión a la Congregación de San Benito y anexión de los prioratos de San Román de Entrepeñas y Nuestra Señora del Brezo, junto con sus respectivas propiedades e iglesias- provocaron una reconversión en positivo de sus funciones eclesiásticas; todo ello en consonancia con esa nueva situación que experimentó el cenobio coincidiendo con el paso hacia la Época Moderna.

\footnotetext{
${ }^{453}$ MARTÍN MARTÍN, José Luis, "Beneficios y oficios del clero rural castellano (siglos XIII-XV)": Anuario de Estudios Medievales, 35-2 (2005), pp. 693-736, especialmente p. 696, señala al respecto: "Pero quizás sea más importante, a estos efectos, la extensión y fijación de las costumbres sobre el pago de la población de la décima parte de sus ingresos a la iglesia. Es verdad que la normativa es muy anterior, pero también que se fue aplicando con lentitud y que, al menos en Castilla, fue entonces cuando se desarrolló una contabilidad que ha trasmitido una información algo más precisa sobre las iglesias, los beneficios y las peculiaridades de estos".
} 


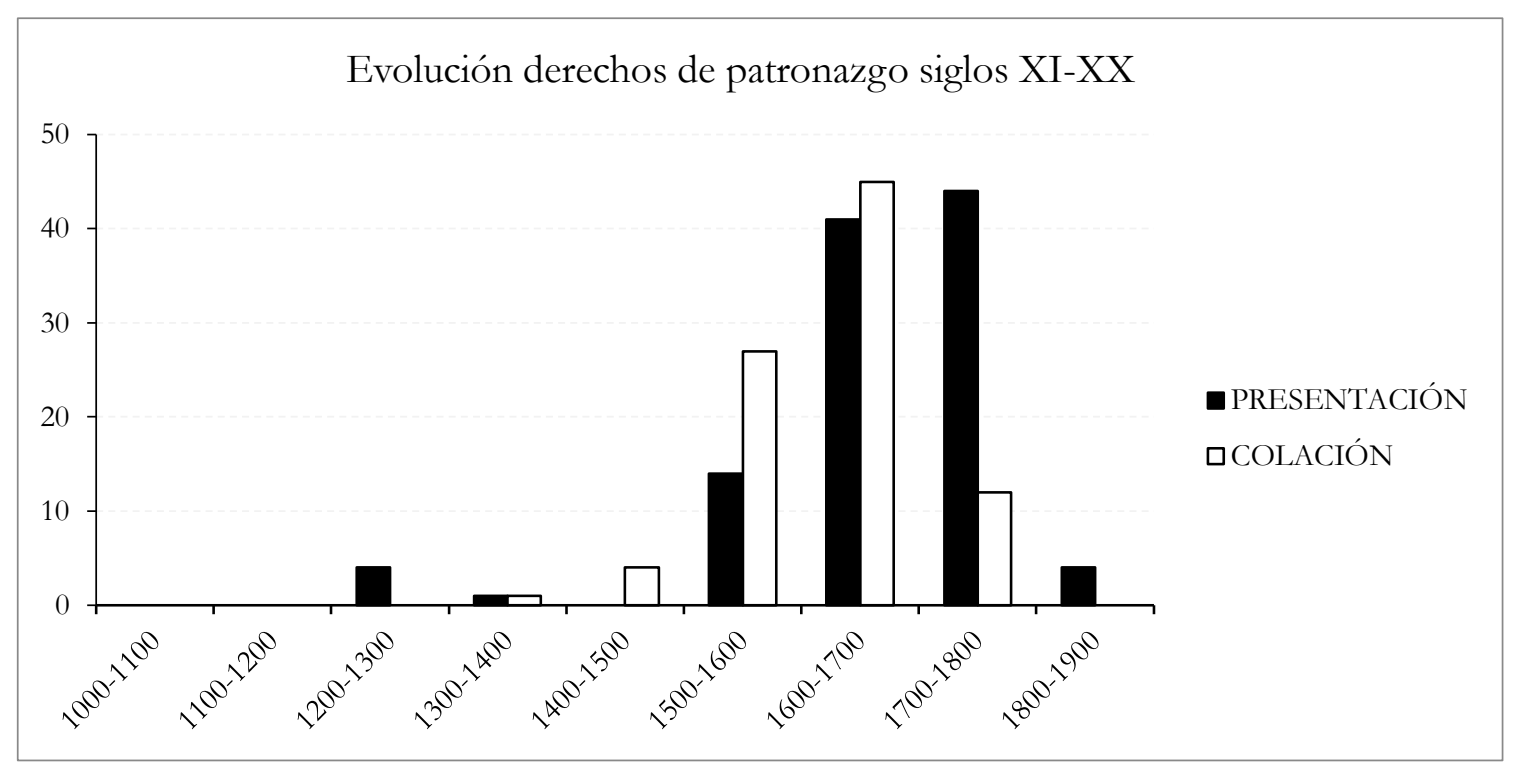

\subsection{La administración y defensa del patrimonio}

El acceso de San Zoilo a los siglos de la Edad Moderna vendrá determinado por un cambio de concepto en las funciones que, sobre un reciente consolidado patrimonio, habría de adquirir el monasterio a la hora de abordar las nuevas necesidades gestoras de administración y defensa, evidenciadas a partir de un giro en el cariz de las operaciones jurísdiccionales que definirían y caracterizarían de ahora en adelante su futuro desenvolvimiento socio-económico.

En lo referente a la gestión, un considerable número de los documentos a los que hace referencia el Índice nos remiten a los sistemas de explotación y aprovechamiento de esas propiedades -más del 11\% del total-, lo cual se iba a traducir en una serie de contratos de diversa índole que implicaban en su mayoría la cesión de posesiones por parte del monasterio a un particular a cambio del pago de una renta.

El proceso de transición temporal que experimenta la actividad económica del monasterio, se explica en base a un conjunto de relaciones causa-efecto entre un contexto histórico que no siempre le fue favorable y un innato instinto de supervivencia que le llevó a optimizar al máximo aquellos recursos que estuvieron a su disposición en cada uno de las etapas de su existencia. 


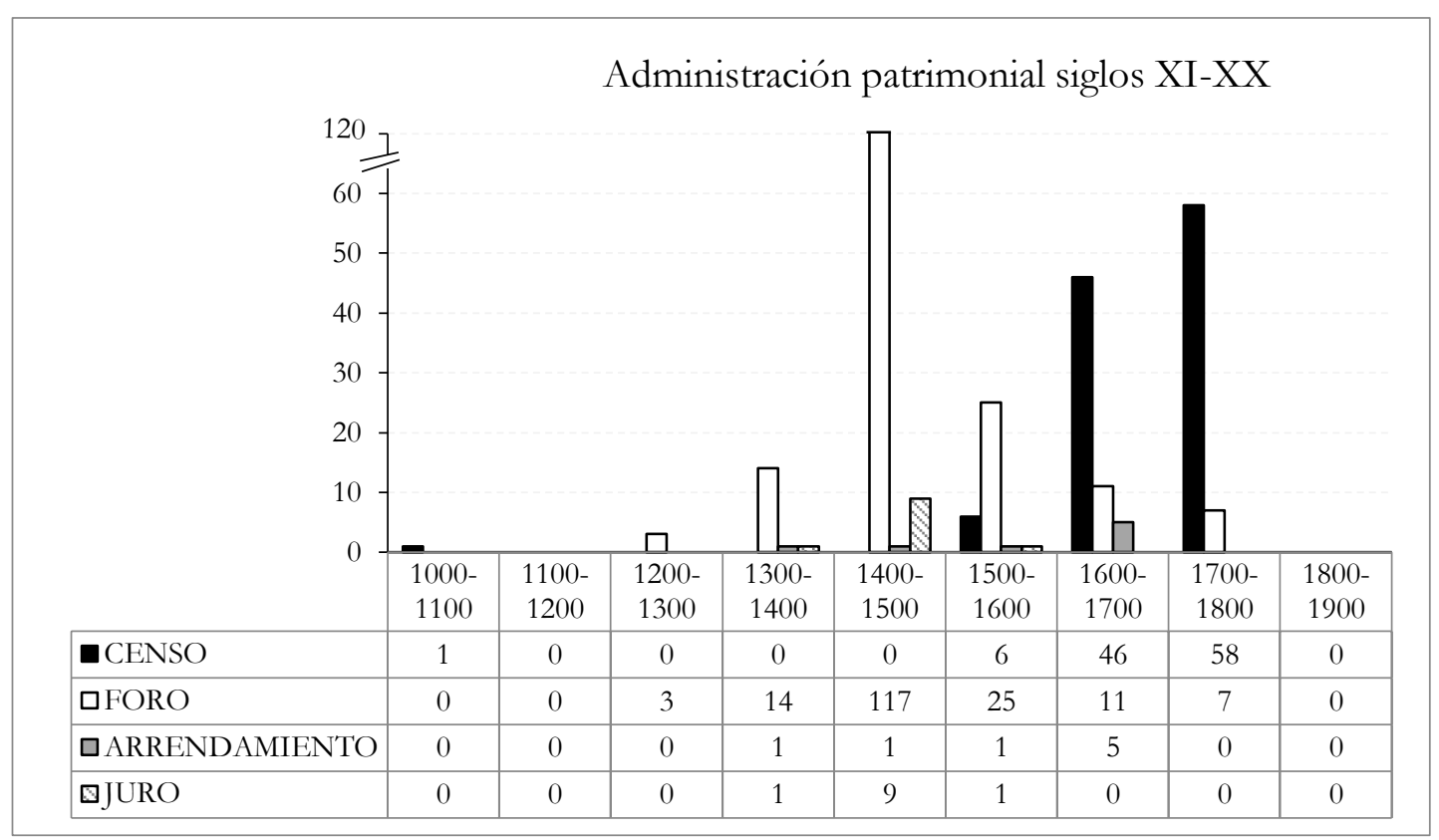

Así, trascurridos los tres primeros siglos desde su fundación, fructíferos en cuanto las cuantiosas donaciones en su beneficio así lo atestiguan, y, una vez apartada la lobreguez en la que el turbulento siglo XIV le había sumido, San Zoilo afronta el tránsito hacia la modernidad con el impulso que le insuflan las renovadas fuerzas de saberse ya liberado de las pesadas cargas que el yugo de la dependencia había impuesto sobre su maltrecha y descalabrada economía.

A comienzos del siglo XVI contaba el monasterio con un contundente patrimonio inmueble, merced a la amplia dotación siglos antes recibida. Sin embargo, le acuciaba disponer del efectivo necesario que le facilitase el desempeño de la función espiritual, sin que ello supusiera la pérdida por negligencia de importantes haciendas, como había sucedido en la centuria anterior al desprenderse del próspero priorato de San Pelayo de Toro y su comarca por permuta -"que así la llamaron"454_ cedida por el primer abad

\footnotetext{
${ }^{454}$ En Cajón 12 San Facundo estaba destinado para guardar la información relativa a la pérdida de la hacienda de Toro y su comarca. Lo daños que causó dicha pérdida para el monasterio y lo fraudulento del proceso de enajenación pueden deducirse a partir de los comentarios que el archivero incorpora al regestar su documentación. Así expresa cómo consiguió el abad don Gonzalo de Cervatos, “convencer” a los monjes de San Zoilo para que consintieran la permuta del priorato: "Estaban los monges prevenidos con que (como consta de las informaciones del convento) Pedro de Vivero había dado a Pedro García, prior del convento, cuarenta doblas de oro para que hablandase y consintiese; a los juniores y novicios los había alagado con razones sophísticas y dineros (que los más de los nombrados en la escritura eran mozos, juniores y novicios sin noticia y sin experiencia). Pero no se pudo conquistar por este camino un monge llamado don Luis de la Varguilla, pues, no habiendo consentido en la primera proposición, le mandó el abad comer pan y agua y, viendo que ni esto bastaba para que diese su consentimiento, le metió en la cárcel, donde le tubo hasta este
} 
comendatario Gonzalo de Cervatos a Pedro de Vivero, vecino de Toro y guarda del rey don Juan II, por la cantidad de 11000 maravedís anuales de juro, insuficiente renta que nuca se llegó a cubrir y que derivó al monasterio en muchos y costosos pleitos.

El mecanismo que van a poner en práctica para conseguir la liquidez que tanto necesitaban va a ser una suerte de "alquiler" de la época, al ceder el dominio útil de algunas de sus numerosas posesiones, por un período de tiempo determinado o bien indefinido, a cambio del pago de un canon que se recibía en especie o en dinero. El foro se convertirá por ello en la principal unidad de explotación durante el siglo XV y en menor medida en el XVI. Sin embargo, esta inicial euforia se va diluyendo con el discurrir de los siglos. ¿Había dejado entonces de ser rentable esta operación? La respuesta la encontramos en la misma temporalidad del concepto de foro que, por su frecuente carácter de "a perpetuidad", provocaba que una vez hecha efectiva la transacción sobre el bien inmueble, este pudiera heredarse o venderse, pero no repetirse, puesto que cada bien inmueble sólo podía corresponderse unívocamente con un contrato de alquiler. Su frecuencia fue mayor en Carrión, San Zoles, San Martín de Frómista y San Román, territorios donde más arraigada estaba la presencia del monasterio debido a las numerosas compras realizadas con anterioridad en estos lugares ${ }^{455}$.

Los arrendamientos ${ }^{456}$, sobre propiedades de cómoda imposición censual y por un período limitado de tiempo, y los juros ${ }^{457}$, en concepto de pensión perpetua sobre las rentas

día fatal del desacierto del otorgamiento de la escritura, que, sacando al monge de la cárcel para que asistiese al contrato con los demás después de haber propuesto el abad y dado su consentimiento los demás, le dixo a este: “¿Y vos, don Luis, que decís a esto? , ¿dais vuestro consentimiento?”. Respondió el monge: "Yo consiento a pesar de Dios. ¡Notable confusión!”. AHPP, Desamortización, Legajo 112, ff. 338v- 344v.

455 "Escritura de foro por la qual Juan Alfonso, prior de San Román, da a Juan Rodrigo de Villaverde el suelo del molino de la Lastra, en el río de Aviñante, para que le hiciere moler y correr, pagando cada año a San Román una fanega de trigo y un par de gallinas”. AHPP, Desamortización, Legajo 112, f. 45v, n. 6.

456 “Arrendamiento que hizo el convento de San Zoil a Juan González Patudo, cura de San Lorenzo de Villafrechós, de las tercias de pan y vino pertenecientes al monasterio en aquel lugar y en Villalumbrós de Campos por tiempo de seis años, por precio de ciento y treinta cargas de trigo bueno, limpio, etcétera, puesto en San Zoil a su costa. Su fecha, en Carrión, a 23 de septiembre de 1417, ante Fernán Rodríguez de Castellanos, esscribano de Carrión”. AHPP, Desamortización, Legajo 112, f. 160r, n. 9.

457 "Privilegio, escrito en pergamino con sello de plomo pendiente, de 11 mill 000 maravedís de juro situados en esta forma: en las alcavalas de Villamuera, merindad de Carrión, 4 mill 000 maravedís; en las alcabalas de Arconada , merindad de Carrión, 600 maravedís; y en las alcavalas de Santoyo , merindad de Castrojeriz, 6 mill 400. Este privilegio de 11 mill maravedís de juro/perpetuo concedió al monasterio el rey don Juan el $2^{\circ}$, año 1447 [...]”. AHPP, Desamortización, Legajo 112, f. 454r-454v, n. ${ }^{\circ} 3$. 
públicas cedidas por la monarquía, representaron un porcentaje escaso en el ámbito de la gestión del patrimonio.

Esta actividad le reportó cuantiosas ganancias al monasterio que, una vez agotado en gran medida el aprovechamiento de sus posesiones, encontró una nueva forma de rentabilidad en el préstamo a particulares de los ingresos acumulados con los foros, a cambio del pago de una serie de réditos por cada año acumulado en la demora de su devolución. Los siglos XVII y XVIII convertirán al censo en la tipología documental más frecuente, tal y como lo atestigua la dedicación en exclusiva del cajón $21^{\circ}$ del archivo para custodiar los documentos acreditativos de dichas transacciones ${ }^{458}$.

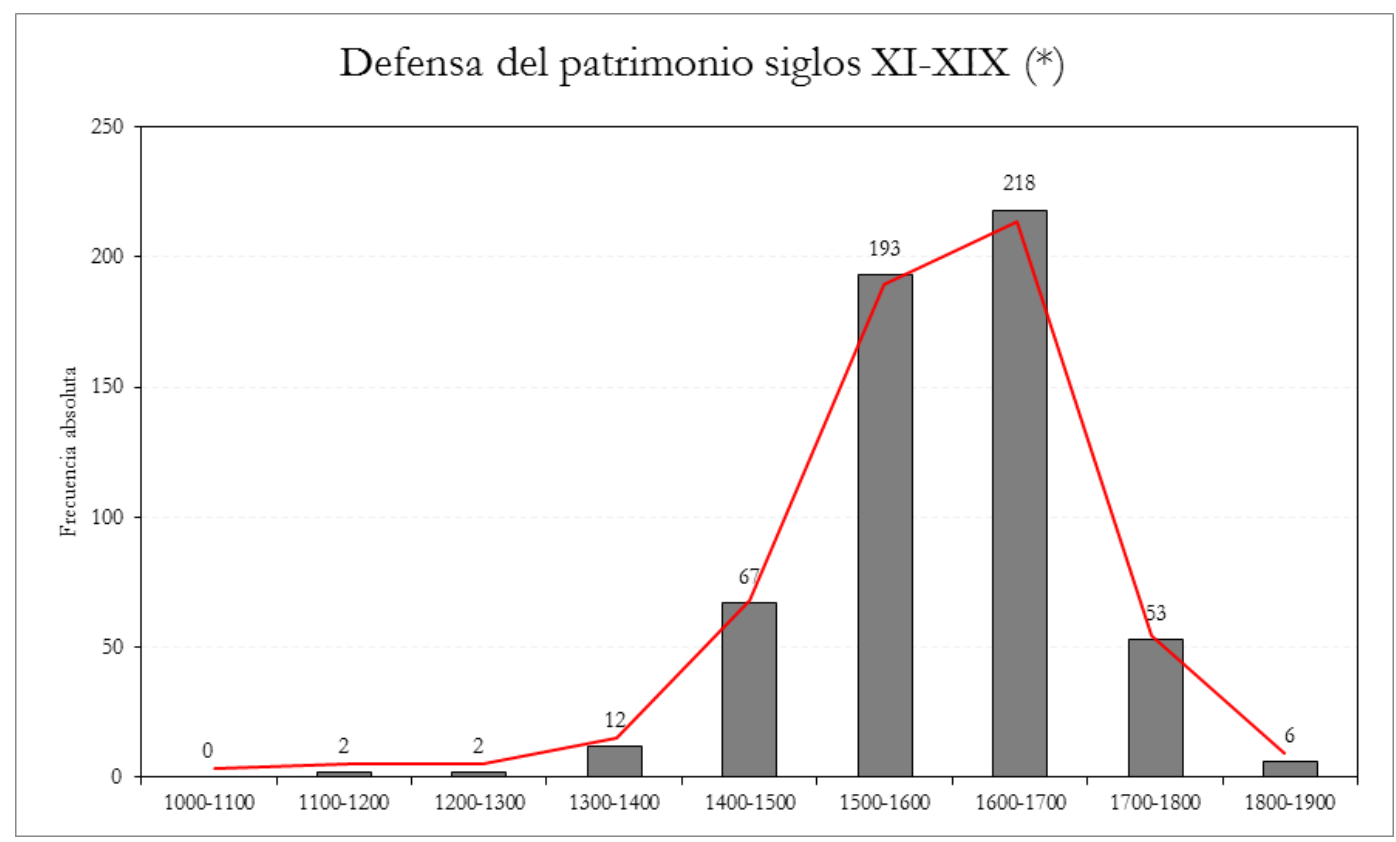

(*) Tipologías incluidas bajo el calificativo defensa patrimonial: pleitos, autos, documentos judiciales, requerimientos y sentencias.

A causa del elevado incumplimiento de las condiciones de estos contratos de arrendamiento, el monasterio se vio obligado a buscar en los tribunales la defensa de unos derechos que consideraba vulnerados ${ }^{459}$, hecho que explica el ascenso en paralelo de la

\footnotetext{
458 AHPP, Desamortización, Legajo 112, f. 459r.

459 “ $<$ Pleito sobre este foro $>$. Y últimamente está el reconocimiento de este mismo foro hecho por Manuel Pérez Ruiz, vecino de dicha villa, con el testimonio del pleito (que) contra él y Manuel Carrillo, en que fueron condenados a pagar los cánones recibidos”. AHPP, Desamortización, Legajo 112, f. 159r, n. ${ }^{\circ} 9$.
} 
explotación del dominio y el surgimiento de numerosos conflictos jurisdiccionales en un intento de defensa de su inestimable patrimonio.

A esto se unían los percances heredados a raíz de la crisis del siglo XIV cuando, ante la grave situación de pobreza, San Zoilo se vea obligado a ceder en encomienda señorial alguna de sus posesiones más valiosas, entre ellas la jurisdicción del Barrio de San Martín de Frómista, a raíz del cual, el cenobio quedará inmerso en un extenuante pleito que se prolongará hasta el siglo XIX. Las palabras originales del Índice así lo registraban:

"Escritura de arrendamiento por modo de encomienda del barrio de San Martín, por el qual don Juan, prior de San Zoil, dio en renta por diez años a Juan Fernández de Padilla, señor de Frómesta, el barrio de San Martín con jurisdicción, nombramiento de oficiales, diezmos mayores y todo quanto allí tenía el monasterio, salvo los diezmos menores y todos los derechos de la yglesia, como ofrendas, pie de altar, mandas de testamentos, heredades, casas, solares, todo lo qual quedó libre al monasterio para que lo llevase y gozase. Todo lo demás se arrendó por precio de 30 mill maravedís cada año, con condición que el dicho Juan Fernández de Padilla no solicite que ningún vasallo del barrio de San Martín se pase a vivir a su lugar de Frómesta ni a otro alguno suyo, que mantenga a los vasallos del barrio en sus fueros y privilegios y que los defienda y ampare y no les cause daño alguno. La causa de hacer este arrendamiento y dar el varrio en encomiendo a Juan Fernández de Padilla dice esta escritura que fue porque este cavallero, como poderoso, les ofreció 30 mill maravedís adelantados de la renta para que pagasen sus deudas y en particular una que debían los monges al abad de Cluniago y para que desempeñasen y quitasen de la judería de Carrión un vaso de oro del monasterio que tenían empeñado para sustentarse, por la mucha necesidad/en que se hallaban a causa de no haber cogido fruto ninguno el año anterior por los malos temporales y plaga de la langosta. Y para asegurar los vasallos y los frutos del barrio, aunque con gran pérdida del monasterio, diole en encomienda, de que se siguió la destrucción y pérdida del barrio y aún de la hacienda de toda la orden en España. Otorgose la escritura en Palencia, a 30 de abril, era de 1363, que es año de 1325, ante Domingo Pérez, escribano de dicha ciudad. Y este traslado fue sacado y signado de Fernando Pérez, escribano de Carrión" ${ }^{\prime 460}$.

Para sustentar este complejo entramado de relaciones económicas, el monasterio de San Zoilo, como señor que fue del territorio sobre el que se extendía su dominio, impuso una no siempre moderada fiscalidad sobre sus vasallos, y lo hizo a través del cobro de una

También fueron muy numerosos los pleitos por el impago de tributos, como el diezmo, y aquellos relacionados con la presentación de clérigos.

${ }^{460}$ AHPP, Desamortización, Legajo 112, ff. 225v-226r, n. 4. 
serie de rentas o prestaciones como la infurción ${ }^{461}$-a cambio de la ocupación de un lugar-, la serna ${ }^{462}$-para los solariegos que trabajaban la tierra- el yantar o la martiniega ${ }^{463}$, entre otras; las cuales aparecen reflejadas a lo largo del Índice ${ }^{464}$, al permitir este instrumento un sencillo acceso a la información que contenían los documentos en caso de reclamación por impago de alguno de estos impuestos.

Mas no fue este códice el único libro con el los monjes contaron para la administración de su señorío. Las disposiciones emanadas de las Actas de los Capítulos Generales y de las Constituciones establecían, que en el archivo del monasterio debían custodiarse, junto con las escrituras, una colección de libros gestores; todo ello en aras de preservar la tan valiosa información relacionada con la administración de sus propiedades $^{465}$.

La consulta de varias fuentes nos ha permitido reconocer la lógica existencia en San Zoilo de una importante colección de estos libros considerados imprescindibles para el monasterio. Así, el "Inventario de Desamortización" ${ }^{466}$ de 1835 señalaba que en el archivo había un libro titulado Granería - donde se inscribirían las rentas que cobraba cada año en grano-, otro Raentería - para otras rentas de la casa-, uno de Coplillas, un Borrador -en el

461 “Escritura en pergamino, por la qual Domingo Yváñez, prior de San Román, recive por familiar a don Matheo y a doña Marina, su muger, por lo qual prometen ser leales vasallos de San Román y dar de infurción cada año un sueldo y una quarta de pan de trigo”. AHPP, Desamortización, Legajo 112, f. 313v, n. 10.

462 "Por lo tocante al señorío y vasallaje pondré aquí una relación breve de lo que hoy se cobra y está en vso, y es lo siguiente. $\left\langle 1^{\circ}>\right.$. Por razón de sernas debe percibir el monasterio dos cántaras de mosto de qualquier vecino que sea cosechero; y de las viudas, sólo un cántaro, llegando a coger treinta”. AHPP, Desamortización, Legajo 112, f. 469r, n. ${ }^{\circ} 1$.

463 “<Martiniega y yantar>. También tenía el monasterio martiniega y yantar, que le pagaban todos los vecinos del barrio, y aún el mismo adelantado lo pagaba”. AHPP, Desamortización, Legajo 112, f. 230 r, n. ${ }^{\circ} 1$. 464 Sirva como ejemplo de todas aquellas rentas anexas a un barrio como el de San Martín de Frómista el siguiente asiento: "Por esta escritura parece que [...]don Gerónimo de Venavides, marqués de Frómesta, [...] vende, funda y constituye nuevamente al abad y convento de San Zoyl 100 mill maravedís de renta y censo en cada un año para siempre jamás sobre el barrio de San Martín y sobre la villa de Frómesta, y sobre el señorío, vasallaje y jurisdición civil y criminal, y sobre sus términos, montes y prados, aguas estantes y manantes, exidos y abrevaderos, rentas, pechos y derechos, yantares, fonsadera y martiniega, sernas, portazgos y alcabalas, oficios de alcaldías y escribanías, pregonerías, merindad y diezmos, y sobre el molino que dicen del abad y sobre las otras rentas [...]”. AHPP, Desamortización, Legajo 112, f. 247v, n. ${ }^{\circ} 3$.

465 MATÉ SADORNIL, Archivo San Benito, p. 319-321; nos ofrece una relación de aquellos libros que estarían custodiados en los archivos de los monasterios benedictinos.

466 AHPP, Desamortización, Legajo 435. 
que asentar detalladamente el gasto ordinario de la semana-, un Manual de bodega-para anotar las rentas que el monasterio cobra en vino-, un libro de Depósito- en el que se escribe todo el dinero que la casa recibe así como el que sale del arca del depósito-, otro de Molinos, de encabezo y cuentas de sacristía y otros de los prioratos de Las Heras, San Román, el Brezo y Villaverde.

Por su parte, el Índice de San Zoilo registra la existencia de un libro de encabezo o renta cisa ${ }^{467}$, un libro de apeos ${ }^{468}$, otro de compras y ventas ${ }^{469}$, de visitas ${ }^{470}$, de gradas ${ }^{471}$ - con los nombres de los que toman hábito y su fecha-, un libro del Depósito ${ }^{472}$, otro del Consejo $^{473}$ y uno de Misas de $1701^{474}$. Además el cajón $25^{\circ}$ San Claudio se reservó para custodiar diez "libros antiguos y curiosos" antiguo de las escrituras del archivo.

Completarían esta recopilación dos libros que recoge el Padre Cisneros en su Manual $^{476}$ : un libro de obras - para anotar el dinero recibido y el gastado en ellas- y un libro de los conocimientos de las escrituras que se sacan del archivo, el cual estaría a cargo del archivero y en el que se indicaba a quién se habían prestado, en qué fecha y el contenido de dichas escrituras.

467 “Todos los demás censos que están en este quaderno no los pongo aquí por estar algunos ya redimidos, y todos los demás perdidos e incobrables hace muchos años, como consta de los libros de encabezo o renta cisa". AHPP, Desamortización, Legajo 112, f. 469r, n. ${ }^{\circ}$ 1; f. 270v, n. 11.

468 AHPP, Desamortización, Legajo 112, f. 457r. El Índice dedica el cajón 20 San Millán a custodiar once libros de apeos.

469 AHPP, Desamortización, Legajo 112, f. 452r, n. ${ }^{\circ} 8$.

470 AHPP, Desamortización, Legajo 112, f. 43r.

471 AHPP, Desamortización, Legajo 112, f. 471r.

472 “[...] según consta del Libro de Depósito en las qüentas de estado del año de 1781”. AHPP, Desamortización, Legajo 112, f. 101v, n. 39.

473 En el que se anotaban las propuestas y decisiones del Consejo de la Comunidad, destacando informaciones como las obras y la aprobación de cuentas. AHPP, Desamortización, Legajo 112, f. 123v, n. ${ }^{\circ}$ 19; f. $270 \mathrm{v}$, n. ${ }^{\text {o }} 11$.

474 Para inscribir las misas que hay obligación de decir por aniversarios y capellanías. AHPP, Desamortización, Legajo 112 , f. $164 \mathrm{v}$, n. $^{\circ} 41$.

475 AHPP, Desamortización, Legajo 112, f. 471r. Destacamos aquí la interesante noticia que nos aporta Ricardo Becerro de Bengoa cuando, al hablar de cómo conoció al último abad de San Zoilo, fray Plácido Trevijano, nos informa de que "Él guardaba los libros curiosos de la Orden, y retenía en su memoria grandes recuerdos de la abadía, transmitidos por sus antecesores”. BECERRO DE BENGOA, El Monasterio de Carrión, p. 93.

476 PALACIO, Colección San Zoil. II, pp. 560 y 561, respectivamente. 
Los distintos aspectos abordados en este capítulo constituirían la base fundamental del proceso de formación, gestión y administración del patrimonio monástico de San Zoilo, hasta el punto de representar su documentación un 65\% del total de diplomas asentados en el Índice. No obstante, como ya señalamos al iniciar este apartado, lo dilatado de su producción documental hace que se hayan quedado fuera de nuestro estudio, por razones estrictamente cuantitativas, numerosas tipologías para nada desdeñables relativas a cuestiones tales como los apeos que acreditaban deslindes y establecían las demarcaciones de los lugares que eran posesión del cenobio, las bulas pontificias, las cédulas reales, las tazmías o los documentos notariales, abundantes sí, pero imprescindibles todos para dar a conocer la realidad material y espiritual de lo que fue el patrimonio del insigne monasterio de San Zoilo de Carrión de los Condes.

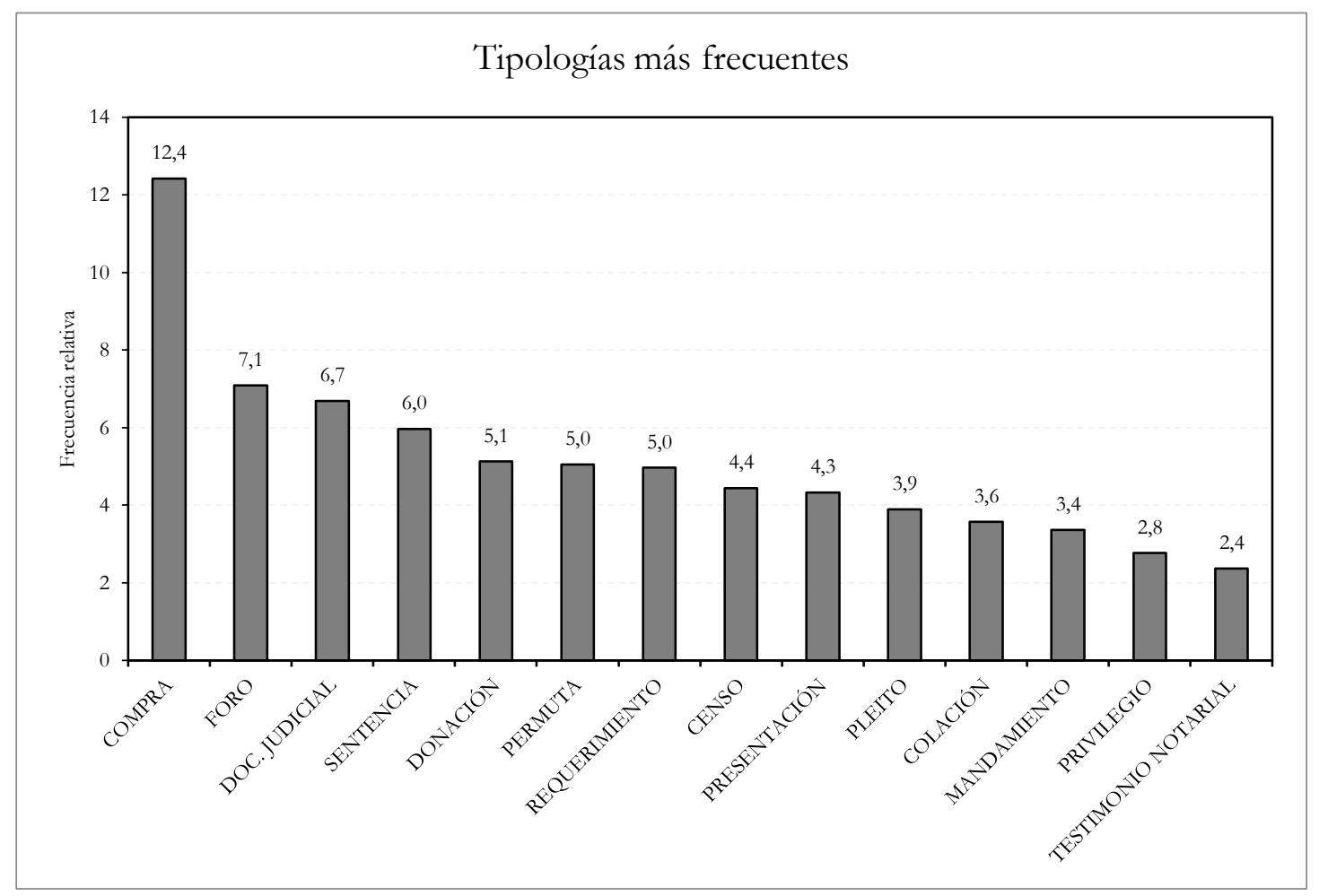


TABLA1. TIPOS DOCUMENTALES EN EL ÍNDICE DE SAN ZOILO

\begin{tabular}{|c|c|c|c|c|c|c|c|c|c|c|}
\hline TIPOLOGÍA AÑOS & $\begin{array}{c}1000- \\
1100\end{array}$ & $\begin{array}{c}1100- \\
1200\end{array}$ & $\begin{array}{l}1200- \\
1300\end{array}$ & $\begin{array}{l}1300- \\
1400\end{array}$ & $\begin{array}{l}1400- \\
1500\end{array}$ & $\begin{array}{c}1500- \\
1600\end{array}$ & $\begin{array}{l}1600- \\
1700\end{array}$ & $\begin{array}{l}1700- \\
1800\end{array}$ & $\begin{array}{l}1800- \\
1900\end{array}$ & TOTAL \\
\hline ANIVERSARIO & 0 & 0 & 0 & 0 & 0 & 1 & 1 & 0 & 0 & 2 \\
\hline APEO & 0 & 0 & 0 & 0 & 2 & 19 & 8 & 1 & 0 & 30 \\
\hline ARRENDAMIENTO & 0 & 0 & 0 & 1 & 1 & 1 & 5 & 0 & 0 & 8 \\
\hline BULA & 0 & 2 & 11 & 3 & 21 & 11 & 9 & 0 & 0 & 57 \\
\hline C. EJECUTORIA & 1 & 0 & 5 & 6 & 5 & 11 & 26 & 2 & 1 & 57 \\
\hline COLACIÓN & 0 & 0 & 0 & 1 & 4 & 27 & 45 & 12 & 0 & 89 \\
\hline COMPRA & 2 & 5 & 4 & 13 & 33 & 101 & 109 & 39 & 4 & 310 \\
\hline CONCORDIA & 1 & 4 & 8 & 0 & 10 & 12 & 6 & 2 & 0 & 43 \\
\hline CUENTAS & 0 & 0 & 0 & 0 & 1 & 3 & 4 & 4 & 0 & 12 \\
\hline DESPACHO & 0 & 0 & 1 & 0 & 0 & 0 & 4 & 14 & 0 & 19 \\
\hline FUNDACIÓN & 0 & 0 & 0 & 0 & 0 & 0 & 3 & 0 & 0 & 3 \\
\hline INDULGENCIA & 0 & 0 & 0 & 0 & 0 & 0 & 3 & 1 & 1 & 5 \\
\hline INFORMACIÓN & 0 & 0 & 0 & 1 & 7 & 16 & 5 & 0 & 0 & 29 \\
\hline JURO & 0 & 0 & 0 & 1 & 9 & 1 & 0 & 0 & 0 & 11 \\
\hline LICENCIA & 0 & 0 & 0 & 0 & 1 & 8 & 31 & 8 & 3 & 51 \\
\hline MANDAMIENTO & 0 & 0 & 0 & 0 & 3 & 30 & 47 & 4 & 0 & 84 \\
\hline MEMORIA & 0 & 1 & 0 & 0 & 1 & 3 & 8 & 3 & 0 & 16 \\
\hline MEMORIAL & 0 & 0 & 0 & 0 & 1 & 4 & 18 & 2 & 0 & 25 \\
\hline OBLIGACIÓN & 0 & 0 & 0 & 0 & 3 & 3 & 6 & 1 & 0 & 13 \\
\hline OTROS $^{478}$ & 0 & 3 & 4 & 7 & 37 & 107 & 143 & 46 & 4 & 351 \\
\hline PROVISIÓN REAL & 0 & 0 & 0 & 0 & 2 & 12 & 14 & 3 & 0 & 31 \\
\hline RECONOCIMIENTO & 0 & 0 & 1 & 1 & 0 & 4 & 15 & 4 & 0 & 25 \\
\hline REQUERIMIENTO & 0 & 0 & 1 & 6 & 28 & 45 & 40 & 4 & 0 & 124 \\
\hline SENTENCIA & 0 & 1 & 1 & 4 & 24 & 49 & 42 & 26 & 2 & 149 \\
\hline TAZMÍA & 0 & 0 & 0 & 0 & 0 & 0 & 0 & 0 & 1 & 1 \\
\hline TESTAMENTO & 2 & 2 & 0 & 2 & 3 & 8 & 10 & 0 & 0 & 27 \\
\hline $\begin{array}{l}\text { TESTIMONIO } \\
\text { NOTARIAL }\end{array}$ & 0 & 0 & 0 & 1 & 4 & 18 & 27 & 8 & 1 & 59 \\
\hline TRASPASACIÓN & 0 & 0 & 0 & 0 & 10 & 0 & 2 & 0 & 0 & 12 \\
\hline VENTA & 1 & 0 & 0 & 0 & 10 & 9 & 5 & 4 & 0 & 29 \\
\hline VISITA & 0 & 0 & 0 & 0 & 0 & 4 & 2 & 0 & 0 & 6 \\
\hline
\end{tabular}

477 Bajo la denominación de documento judicial se incluyen las siguientes tipologías: alegación, apartamiento, apelación, apuntamiento, auto procesal, declaración, demanda, interrogatorio, probanza y proceso.

478 La inclusión del resto de tipologías bajo la denominación común de "Otros" se ha realizado principalmente en base a un criterio de representatividad cuantitativa. Se incluyen en esta categoría: absolución, aceptación, acuerdo, adjudicación, admisión, advertencia, agravatoria, amojonamiento, amparo, apelación, apresamiento, aprobación, arrendamiento, asiento, breve, capitulación, carta de amparo, carta de entrega, carta de pago, carta de unión, carta de vecindad, censura, cesión, citatoria, codicilo, colecturía, comisión, compromiso, concierto, conservatoria, consulta, contrato, contribución, convenio, decreto, definitorio, dejación, demanda, despacho, depósito, desembargo, diligencia, dotación, edicto, ejecutorial, elección, embargo, emplazamiento, excomunión, exención, inhibitoria, interrogatorio, juramento, libramiento, liquidación, manda testamentaria, misas, monitorio, nombramiento, notificación, ofrenda, ordenanza, parecer, partición, patronato, pedimiento, pesquisa, petición, postura, prenda, préstamo, probanza, pronunciamiento, propuesta, prorrogación, provisión, querella, ratificación, recaudo, reclamación, recudimiento, recusación, redención, relación, renuncia, repartimiento, representación, súplica, requisitoria, resignación, resolución, respuesta, restitución, revocación, subrogación, súplica, tasación, traspaso. 


\section{CONCLUSIÓN}

Toda Tesis Doctoral requiere unas conclusiones que contengan las ideas a las que se llega tras considerar toda la información y los datos manejados a lo largo de su elaboración, en mi caso las proposiciones que he deducido tras esa consideración y con las que pretendo probar que el Índice de San Zoilo de Carrión no es solo un índice entendido como una lista ordenada de documentos, sino expresión de una realidad que gira en torno al archivo monástico.

Para poder exponer esa proposición ha sido preciso considerar varias circunstancias, distintos elementos, diversa información. Para hacerlo, y en ello está la base de la Tesis doctoral, o lo que es lo mismo, el origen de lo que pueda ser la proposición deducida, la aplicación de la metodología archivística ha resultado fundamental. Y lo ha sido porque el documento de archivo (y el Índice es un instrumento para el archivo y de archivo) testimonia negocios jurídicos y administrativos en los que, en nuestro caso, San Zoilo es parte interviniente como autor, destinatario, productor o conservador. Se hace entonces necesario conocer al productor, puesto que sólo conociendo al productor (también productor por acumulación) de los documentos podrían valorarse estos en un contexto real y diacrónico. La historiografía del monasterio de San Zoilo de Carrión nos permite hacer una primera consideración: se han publicado trabajos, sobre todo en el ámbito diplomático, centrados en los siglos medievales, pero a partir del siglo XV hay unos vacíos de información documental que el Índice puede llenar y llena porque en él se describen más de 3000 documentos de los cuales se desconocen la práctica totalidad de los datados en la Edad Moderna, y que además constituyen la mayoría de los que habían sido descritos en él hasta el momento en que se redactó, convirtiéndose así en una fuente indispensable para un mejor conocimiento de la historia del monasterio carrionense en los siglos bajo medievales y de la modernidad.

Consideración la que acabo de hacer que ha de ser matizada doblemente: la transcripción del Índice, por un lado, permite saber cuántos documentos medievales y modernos han desaparecido y cuántos se describieron; y por otro, la ordenación de los diplomas códice en el Índice proporciona una imagen de lo que el archivo de San Zoilo era en 
el siglo XIX, o lo que es igual: proporciona la organización que tenía el archivo del monasterio.

¿Y qué organización era esa? No distinta a la que impera en el viejo continente desde la aparición de la escritura, el documento y el archivo, necesitados el tercero del segundo y el segundo del primero. La escritura se hizo necesaria para no perder la información; el documento, para fijar lo que era preciso conocer para la administración; el archivo es la consecuencia de la suma de un documento tras otro. Y en él desde el inicio de la historia y la aparición de la escritura y hasta las revoluciones burguesas se organizaron los documentos para que fuera más fácil y seguro la administración y el cuidado del patrimonio. En unas ocasiones se impuso más esta segunda preocupación que la primera, pero en otras fue al contrario. El repaso bibliográfico que hicimos para conocer la evolución del concepto diacrónico de archivo fue menos efectivo que el Índice para mostrar el concepto de archivo que tenía el monasterio de San Zoilo cuando se copió el Índice entre paso del siglo XVIII al XIX. Y esta consideración permite concluir una realidad innegable: sin un perfecto control de los documentos y sin una óptima organización de los mismos se hace imposible la administración de las propiedades y la memoria de fundadores y beneficiarios.

El Índice (imagen del archivo) y el archivo mismo debían permitir la recuperación de los documentos que posibilitaban no sólo una óptima administración del patrimonio sino también su defensa, además de la de los privilegios, exenciones y libertades conseguidas a lo largo de siglos. De ahí que su organización responda a un concepto administrativo-patrimonial del archivo. La disposición, la ordenación de las descripciones de los documentos en el Índice, concebido para hacer más fácil y rápido el acceso a la información, se hacen a partir de la organización del archivo en cajones, legajos y cuadernos. Y en esa organización hay dos claves: una clasificación a partir de los lugares en los que el monasterio tenía propiedades (ordenación topográfica) para la documentación del monasterio de San Zoilo; y una separación de la documentación que procedía de los prioratos que fueron anexionándose al monasterio carrionés.

No hay archivos de un solo diploma, siempre estará formado por un conjunto orgánico de documentos. Y conocer el archivo requiere el análisis de esos documentos. Naturalmente en el Índice lo hicimos a partir de los resúmenes que se hicieron de los mismos. El conjunto permite conocer todo lo concerniente al tiempo de formación del patrimonio del cenobio benedictino y la defensa que del mismo hizo el monasterio, así como delimitar el territorio en el que San Zoilo tuvo sus heredades y las razones que explican su pertenencia al 
mismo. El Índice se convierte así, y es conclusión trascendental, en una fuente primordial para construir la historia del patrimonio documental de San Zoilo. Un patrimonio con orígenes diversos y distintos, llegado al monasterio por vía directa, la principal, puesto que San Zoilo fue también destinatario principal; o indirecta, ya que a él se unieron los diversos monasterios que, como prioratos, se fueron incorporando progresivamente, como hemos dicho, al monasterio de San Zoilo.

No puede faltar la consideración de la materialidad del Índice, que fue un libro, como muestra la preparación de los folios, concebido desde el principio para cumplir con su función de permitir el acceso a la información de los documentos y a su localización y control. Se puso en práctica una práctica documentaria de resúmenes analíticos e informativos hechos con un gran rigor, atendiendo fundamentalmente a las unidades informativas esenciales de los documentos, sin desatender a fechas, tipologías, autores y destinatarios. Actividad delicada que se encomendó a peritos en letras y documentos, es decir, a los encargados del archivo de San Zoilo en los momentos en que escribió, por dos escribas principales y otros secundarios, muy secundarios. Todos aplicados en la tarea de un libro que tiene una historia archivística compleja, tanto que ha sido necesario considerar para conocer las razones que explican que el manuscrito no esté hoy en el Archivo Histórico Nacional de Madrid y lo esté en el Archivo Histórico Provincial de Palencia.

La suma de estas consideraciones pormenorizadas y la contemplación de conjunto que proporciona la transcripción del manuscrito, nos ha permitido certificar la idea que proporciona el repaso de la bibliografía archivística, y concluir de forma rotunda que el concepto administrativo-patrimonial del archivo determina la forma de organizar y describir los documentos en el Índice de San Zoilo. El archivo es memoria y, como tal, garantía de privilegios, exenciones y libertades, sin los cuales se hace imposible la defensa del patrimonio necesario para la vida del monasterio. Y el Índice es una puerta de acceso a esa memoria de archivo. Puerta de imprescindible y necesaria apertura para garantizar un acceso rápido y seguro al contenido de los documentos, que son garantía y prueba de derechos y propiedades.

El Índice, pues, nos lleva al archivo, que nos ha permitido conocer al productor, de la misma manera que el conocimiento de este nos lleva a conocer su archivo. Un recorrido bidireccional que tiene el objeto de alcanzar, para ofrecerlo después, una visión del patrimonio documental del monasterio de San Zoilo de Carrión desde un manuscrito del siglo XIX. 
En síntesis, las consideraciones mencionadas y la contemplación del conjunto que es el Índice, nos permite hacer las siguientes conclusiones:

- La redacción del Índice se ajustó de forma precisa a la normativa que, sobre Archivos, establecía la Congregación de San Benito de Valladolid desde el siglo XVI y que se concretó en sucesivas Constituciones.

- San Zoilo fue autor, destinatario y productor-conservador de muchos de los documentos de su archivo; sin embargo, la posterior incorporación de algunos prioratos provocó que se incorporara al archivo de San Zoilo tantos fondos como monasterios anexionados, integrándose en la organización del mismo desde el momento en que monasterio se encargó de su gestión. En esa organización se respetó la singularidad de cada uno de los fondos, aunque nunca se perdió de vista el concepto administrativo-patrimonial de archivo. Se supo compaginar la individualidad de los fondos con la ordenación de los documentos siguiendo criterios topográficos.

- Al reflejar el Índice la ordenación física de los documentos en el Archivo en cajones, legajos y cuadernos, se convirtió en un instrumento clave para agilizar la búsqueda de documentos sin tener de manipular innecesariamente los originales. Para asegurar esta tarea se ideó un sistema de referencias cruzadas de la localización exacta en el archivo, estableciendo una correspondencia entre la ubicación que proporcionaba la noticia del Índice y el resumen que se escribió en el dorso de los documentos.

- Las nuevas concepciones archivísticas de finales del siglo XVIII e inicios del siglo XIX trajeron como consecuencia la reordenación del archivo monástico. En consecuencia, se vieron obligados a actualizar los instrumentos de gestión que tenían, como lo era el Manual del Padre Cisneros, y que se tornaron inoperantes, con el objetivo de optimizar y simplificar el trabajo de archivero. El resultado fue la elaboración de un libro Índice, el Índice, de las escrituras.

- Este fue además y después una herramienta para reestructurar el Archivo monástico tras la Desamortización liberal de 1820. La sustracción de la documentación trajo como consecuencia importantes pérdidas documentales y la alteración de la ordenación anterior. Cuando en 1823 el archivo vuelve al monasterio, el Índice será utilizado para reordenarlo, para determinar qué documentación había sido extraviada y cuál ni siquiera había sido devuelta. Su reflejo se observa por un lado, en las anotaciones hechas al margen de los regestos en el propio Índice, y por otro en el hecho de que la fecha del último documento asentado en el Índice sea 1818, aunque la supresión de la comunidad Monasterio no ocurriera hasta 1835. 
- El Índice siempre conservó su función administrativa, tal como lo demuestra el hecho de que cuando a finales del siglo XIX el Archivo Histórico Nacional reclama a las Delegaciones Provinciales de Hacienda el trasvase de una documentación que consideraba histórica, la mayor parte fue transferida a Madrid, excepto aquella que seguía cumpliendo un papel de control administrativo para el nuevo propietario de todos los bienes enajenados, el Estado.

- La redacción del Índice se hizo a principios del siglo XIX. Aportamos pruebas que permiten asignar la autoría intelectual y material del códice a fray Benito Sabido, archivero principal del monasterio en esa época.

- Evidentemente él no trabajó solo. Hemos determinado la presencia de hasta seis escribas diferentes en la redacción del Índice. La representación mayoritaria de una de las manos, lo cuidado de su escritura y lo preciso en la construcción de los mensajes referenciales, lleva a identificarlo con el archivero principal. El amplio volumen de documentación producida por el monasterio explica la posible necesidad de implicar a otros monjes que ayudaran al archivero en la tarea de lectura y resumen de los documentos, así como su registro en el Índice.

- A partir del conocimiento que se tiene de los documentos medievales ya publicados en diferentes colecciones documentales y tras computar el número de documentos resumidos en el Índice en el siglo XIX, se puede concluir que la representatividad del Índice hasta el siglo XV está en torno al 80\%. A esto se suman el conjunto de documentos de Época Moderna, todavía sin publicar, para los cuales el Índice supone una fuente de información privilegiada.

- El análisis de los contenidos de la documentación resumida en el Índice nos ha permitido establecer dos etapas claramente diferenciadas en la vida económica del monasterio. Una primera, de formación del patrimonio, hasta mediados del siglo XIII, teniendo como base fundamental las donaciones; la segunda, de administración y gestión del patrimonio, que se inicia en el siglo XV y que se traduce en el aprovechamiento de los bienes reunidos a través de censos y foros. Los numerosos documentos judiciales y pleitos registrados ponen de relieve la importancia que para la comunidad tuvo la documentación, al ser esta presentada como acreditación de sus derechos y posesiones en los numerosísimos litigios en que se vio envuelto. Todo un conjunto de ocupaciones materiales que transcurrían en el plano terrenal, sin las cuales se hacía imposible el desarrollo de la función espiritual para la que había sido fundado el monasterio. 

SEGUNDA PARTE.

EDICIÓN DEL ÍNDICE DE SAN ZOILO DE CARRIÓN 



\section{NORMAS DE EDICIÓN Y TRANSCRIPCIÓN}

Las normas de edición y transcripción que hemos utilizado en el trabajo son las del Tratado de Paleografía española publicado de Agustín Millares Carlo, con la colaboración de José Manuel Ruiz Asencio479.

En aplicación de las normas mencionadas, se ha respetado la grafía original que aparece en el manuscrito, aun siendo esta errónea o defectuosa; sin embargo, y para hacer más fácil la compresión del texto, hemos puntuado el mismo de acuerdo a lo establecido por la Real Academia Española de la Lengua en su Ortografía480, y otro tanto hemos hecho en el uso de mayúsculas y minúsculas y en lo que atañe a la separación de palabras, por lo que se han unido las letras y sílabas las palabra que en el manuscrito se escribieron de forma separada y hemos separado las que debieran estarlo aun habiendo sido escritas como una sola. Se ha hecho, sin embargo, la excepción de mantener las contracciones (hoy en desuso) "deste” (de este), “quel” (que el) y otras, y colocar un apóstrofo en contracciones como d'España.

El mencionado respeto a la grafía original hace que se haya mantenido la grafía u y v, al margen de que haya sido empleada en el códice para representar de manera indistinta los fonemas de u vocal y v consonante (auía). Lo mismo hemos hecho en los casos en que la y griega se empleó en sustitución de una i (tenýa) o en aquellos otros en que se duplicó el uso de consonantes (ottros, esscriuano).

Para una mejor intelección del contenido, no solo hemos desarrollado las palabras abreviadas, sino que hemos incluido en la transcripción una serie de anotaciones con el mismo propósito. Y así, donde faltaba, por rotura o falta del soporte u omisión del escriba, se ha advertido mediante tres puntos suspensivos entre corchetes [...]; y en caso de haber podido reconstruir el texto que faltaba, se ha transcrito entre también corchetes [ventas de].

Otra de las anotaciones que, como editora, he hecho es la de advertir los errores o repeticiones innecesarias del amanuense mediante la palabra sic escrita entre paréntesis:

479 MILLARES CARLO, Agustín, con la colaboración de J. M. RUIZ ASENCIO, Tratado de Paleografía española. 3 volúmenes, $3^{\text {a }}$ ed. Madrid, 1983, vol. II, pp. IX-XXIII.

480 Ortografía de la Lengua Española. Real Academia Española y Asociación de Academias de la Lengua Española, 2010. 
rerunciación (sic); así como indicar de la presencia de elementos validatorios, rúbricas y firmas: Antonio Fernández Escudero (rúbrica), y los añadidos al texto entre renglones o en los márgenes del folio, que he identificado escribiendo la palabra añadida entre paréntesis angulares $<>$ : $<$ de $>$ dos prados en término.

Para no distraer la lectura del texto, hemos advertido en nota a pie de página que hay una palabra o varias tachadas o que fueron corregidas: sigue tachado: y una quarta más, corregido sobre 1466 .

Se ha indicado el paso de un folio a otro en el códice empleando una línea oblicua y a continuación y entre paréntesis el número del folio escrito en caracteres cursivos: / (fol. 201r), / (f. 304v); y lo mismo se ha hecho para advertir del paso del recto al vuelto de un mismo: / (f. 128r), / (f. 128v).

Puesto que reproducir la disposición de la página del manuscrito habría supuesto dificultar la edición del Índice, se ha optado por colocar entre paréntesis angulares y en renglón independiente el resumen analítico que se coloca en el margen izquierdo del folio: “<Requirimiento al mariscal para que pague los 5 mill maravedís. Año 1515>”; para transcribir a continuación y debajo de este el resumen informativo: "Requirimiento hecho por parte de este monasterio al mariscal don Gómez de Venavides, señor de Fromista, para que pague a la mesa conventual los 5 mill maravedís contenidos en la donación y escrituras de arriva. El mariscal responde que se allana a pagarlos. Su fecha, en Frómista, a 9 de agosto de 1515, ante Hernando Sánchez, beneficiado de San Pedro de Frómista, notario apostólico”.

Las notas aclaratorias del margen derecho se han llevado a pie de página, con la previa advertencia del lugar de ubicación: Al margen derecho: Veáse atrás número 22 compra. 


\section{/ $(f .1 r)^{1}$ CAJÓN I ${ }^{\circ}$. SANTA MARÍA. LETRA A. AGUILAR DE CANPOS ${ }^{2}$.}

El primer cajón del Archivo de este Real Monasterio de San Zoil tiene por título: Santa María, y en él hay cinco legajos de diferentes papeles y escrituras, pertenecientes todos al Priorato de San Juan de Aguilar de Campos.

\section{Legajo primero}

Este legajo contiene tres quadernos, que son los siguientes: Quaderno A: Hacienda; Cuaderno B: Colecturía de Lázaro Gutiérrez; Quaderno C: Yglesia de San Juan.

\section{Quaderno A}

Donaciones, compras, trueques, y otros papeles Hacienda. / (f. $1 v)$ Las escrituras que contiene este quaderno A son las siguientes, puestas por orden cronológico:

1. <Testamento de la condesa doña Aldonza, hija de los fundadores de San Zoil>.

La primera escritura es un testamento y donación de la condesa doña Yldoncia, hija del cónsul (sic) don Gómez Díaz, y de la condesa doña Teresa (a quienes tenemos por fundadores y primeros bienechores de este monasterio de San Zoil). Por este testamento y carta de donación, que está escrito en pergamino, hace donación la dicha señora condesa doña Aldonza a los religiosos que sirven a Dios y a la Regla de San Benito en el monasterio de San Juan Baptista y de San Zoil Mártir, para la sacristía, de la tercera parte de hacienda que tenía en Pharayones, en Fontezua, en San Juan de Tarador (que es Aguilar), en Villavera, en Villamaurel, en Villagonzalo, y en Villamayor ${ }^{3}$; y si sus hijos no tubiesen sucesión, manda toda su hacienda al dicho monasterio de San Zoil. También manda al monasterio de San Pedro de Cluni un lagar y cuba que tenía en San Juan de Tarador. Dice en dicho testamento que la hacienda que manda al monasterio fue de la parte que la cupo de sus padres y de su abuelo Munio Fernández. Y se la da para que todos tengan parte en los sacrificios y oraciones de sus religiosos. Otorgose este testamento vndécimo kalendas januarii, era 1148, que es año de Cristo 1110, ante Raymundo, escribano.

\section{[2]. [ $<$ Donación de Mayor García, muger de don Gómez>].}

La segunda escritura de este quaderno es una donación de Mayor García, muger de don Gómez, por la que, juntamente con sus hijos don García, Pelayo, Diego, y Vrraca Gómez, hace donación al monasterio de San Juan Baptista y de los Mártyres San Zoil y San Felices, de la orden de Cluni, de la mitad del monasterio de San Martín de Villamayor, con todo lo que en él la pertenecía; en Celengas toda su porción entera; en Villavela y en Tarador (Aguilar) toda su porción entera; en Barcial de la Loma el monasterio de San Pelayo con su ración entera; en Villarramiel su porción entera; en Frechilla su porción entera; en Fuentes de don Bermudo su ración entera; en Cardeñosa su porción entera; y en el monasterio de San Román de Peñas ${ }^{4}$ su ración. Otorgose esta escritura quinto décimo kalendas junii, era 1156, que es año de Cristo $1118^{5}$. Reynando en Aragón el rey don Alfonso el $1^{\circ}$, la reyna doña Vrraca en León. De esta escritura hay un traslado en pergamino.

\section{/ (f. 2r) 3. < Posesión de 56 jugadas de tierra de San Juan de Aguilar. Año de 1530>.}

Escritura de restitución que hizo Diego de Castañeda, cura que fue de San Juan de Aguilar, por mandado del Obispo de León, para descargo de su conciencia, de cincuenta y seis yugadas de tierra que tenía de la yglesia de San Juan; y posesión que tomó de ellas fray

\footnotetext{
$1 /(f .1 r)]$ en el folio de guarda se anotó: Folio 118 buelto. El año de 1682 se trasladaron las indulgencias de San Mauro y San Plácido a los día[s] de San Zoil y San Félix. Cajón de San Andrés, legajo ${ }^{\circ}$.

${ }^{2}$ CAJÓN I ${ }^{\circ}$... CANPOS] enmarcado en un rectángulo.

3 Villamayor] al margen iqquierdo: en Pharayones, Fontezua, Aguilar, Villavera, Villamaurel, Villagonzalo, Villamayor.

${ }^{4}$ San Román de Peñas] al margen izquierdo: [en monasterio de San Martín de Villamayor, Celengas, Villavela, Tarador, Barcial de la Loma, Villarramiel, Fr] echilla, [Fuentes] de don Bermudo, [Cardeño]sa, San Roman [de] Peñas.

5 1118] al margen iqquierdo: [Er]a 1156, [añ]o 1118.
} 
García de Mazuelas, mayordomo de San Zoil, en los términos de la villa de Aguilar. A 19 días de julio de 1530, ante Bernardino de Valderas, escribano de Aguilar.

4. $<$ Trueque de una tierra. Año 1530>.

Escritura de trueque por la qual fray Diego de Canales, presidente, y en convento de San Zoil truecan con Diego de Castañeda, cura de San Juan de Aguilar, una heredad que el dicho cura havía plantado de viña y era del convento, a Las Quintanas, término de Aguilar, por otra tierra a Valleluengo, de una yugada y tres quartos de sembradura. Fecha en San Zoil, a 6 días de julio de 1530 años, ante Juan de Castrillo, escribano de Carrión.

5. < Trueque de una tierra. Año de 1545>.

Escritura de trueque por la qual fray Juan de Santa María, abad de San Zoil, premisa información de utilidad, trueca una tierra que el monasterio tenía en término de Aguilar, a Pago Nuevo, por otra tierra de Diego de Pernía en el mismo término, a Las Frieras, que hace una yugada poco más o menos. Fecha en Aguilar, a 3 días de marzo de 1545 años, ante Lope de Valderas, escribano de Aguilar.

6. <Trueque de una tierra. Año de 1578>.

Escritura de trueque por la qual fray Damián de Salas, con poder del convento, trueca una tierra de media yugada a Carremedina, por otra de Alonso Rodríguez de Valflorido, vecino de Aguilar, en el mismo pago de Carremedina, de media yugada y varas más. Fecha en Aguilar, a 14 días de julio de 1578 años, ante Cristóval de Valderas, escribano de Aguilar.

7. <Trueque de una tierra. Año de 1588>.

Escritura de trueque por la qual fray Benito de Camino trueca un majuelo del convento, que hace 170 varas de tierra, en término de Aguilar, a do dicen a la Puente de San Juan, por otra tierra del comisario Juan Martínez, beneficiado de Aguilar, a Oteros de Rey, en el mismo término, que hace una yugada y ocho palos, poco más o menos. Fecha en Aguilar, a 17 días del mes de febrero de 1588 años, ante Cristóval de Valderas, escribano de Aguilar.

8. <Obligaciones, libranzas y cartas de pago $>$.

Escrituras diversas de obligación, libranzas y cartas de pago tocantes / (f. 2v) a la administración de la hacienda de Aguilar y de Campos, que no sirven más que de memoria de aquellas cosas, y conseqüencia para las de adelante.

9. $<$ Pregones y posturas de la hacienda $>$.

Escrituras de pregones y posturas en los arrendamientos de la hacienda de Aguilar y de Campos, desde el año de 1564 hasta el de 1617, que sólo sirven de memoria.

10. <Venta de 100 cargas de trigo. Año de 1584>.

Testimonios y despachos de 100 cargas de trigo que vendió el monasterio al licenciado Tejada para las Armadas de Su Magestad. Año de 1584.

11. <Apartamiento de un arrendamiento de los diezmos menudos. Año de 1600>.

Apartamiento que hizo Juan Magarzo de una arrendamiento que havía echo de los diezmos menudos de San Juan de Aguilar y de las tercia[s] de las yglesias de aquella villa. Año de 1600, ante Cristóval de Valderas, escribano de Aguilar.

\section{2. <Qüentas de Aguilar y Campos>.}

Qüentas que se tomaron a fray Plácido de Venavides de la administración de Aguilar y de Campos desde el año 1621 hasta el de 1624.

13. $[<[$ Escritur] as de [ventas de] tierras, [herrenes, c]asas, etcétera, [a favor de] Pedro [Álvarez], padre [de Benito Alvarez, quien después de sacerdote se metió] monge [en esta casa, e] hizo [donación al monasterio de algunos bienes]>]. 
Escrituras de ventas de tierras, herrenes, casas, etcétera, a favor de Pedro Álvarez, vecino de Aguilar de Campos y padre del licenciado Pedro (sic) Álvarez, quien después de sacerdote se metió monge en esta casa, y antes de profesar hizo donación al monasterio de algunos bienes, por testamento otorgado ante Norberto de Sandoval y Guevara, escribano de Carrión, año de 1686. Cuyo testamento está aquí ${ }^{6}$ al número 13. El orden de las escrituras contenidas bajo este número es el siguiente:

$1^{a}$. Censo a favor del Estado de Aguilar contra Sancho de Herrera y Ana Gutiérrez, su muger. Año de 1573, ante Cristóval de Valderas, escribano de Aguilar.

$2^{a}$. Redención que hizo de dicho censo María Armia, abuela del monge fray Benito Álvarez. Año de 1603, ante el mismo escribano.

$3^{a}$. Venta de una herrén a San Juan, a favor del referido Pedro (sic) Álvarez. Año de 1614, ante Juan Ysidro, escribano de dicha villa.

4a. Venta a favor del mismo de una cueva al quarto de San Estevan. Año de 1613, ante Juan Freile, escribano de dicha villa.

$5^{\text {a }}$ Venta a favor del mismo de un pajar al quarto de San Martín. Año de 1623, ante Antonio de San Martín, escribano de la dicha villa.

$6^{a}$. Venta a favor del mismo de una herrén a San Juan. Año de 1623, ante el mismo escribano.

$7^{\text {a }}$ Venta a favor del mismo de otras dos herrenes a San Juan. Año de 1623.

8. Venta a favor del mismo de unas casas a la puerta de / (f. 3r) San Martín. Año de 1636, ante Juan de Vrones, escribano de Barcial.

$9^{a}$. Venta que la cofradía del Santísimo Sacramento otorgó a favor de Pedro Álvarez, padre del dicho monge, de una herrén a las de San Juan, con carga de un aniversario de 200 reales y de una tierra a Las Frieras. Pasó ante Antonio de San Martín. Año de 1624.

10. Donación que el padre fray Benito Álvarez, quando vino a tomar el hábito, otorgó de parte de su hacienda, a favor de Felipe Cifuentes, con carga de algunos censos y aniversarios que contra sí tenía. Pasó ante Santiago Facón, escribano de dicha villa. Año de 1685.

11. Testamento que el dicho padre fray Benito Álvarez otorgó antes de su profesión, por el qual mandó a este monasterio dos viñas, dos herrenes y diez tierras. Pasó este testamento ante Norberto de Sandoval y Guevara. Año de 1686.

12. Escritura de redención de los 200 reales que el cavildo eclesiástico de Aguilar tenía de principal para el aniversario contra dicho padre fray Benito Álvarez sobre dicha her[r]én y tierra, los quales redimió este convento, ante Santiago Facón. Año de 1691.

14. <Censo a favor del licenciado Fernández. Año de 1615>.

Escritura de censo otorgado por Lucas de Santiago y Leonor González, su muger, a favor del licenciado Juan Fernández Rodríguez, vecinos todos de Aguilar. Año de 1615, ante Lope de Valderas, escribano de la misma villa. Sacó su copia por decreto judicial Antonio de

\footnotetext{
${ }^{6}$ aquí] escrito sobre al fo.
} 
Laverde San Martín. Año de 1647. Este censo recayó en el monasterio aunque no se sabe por qué título.

$<$ Reconocimiento a favor del monasterio. Año de 1654>.

Reconociéronle a su favor, subrogando nuevas hipotecas, Juan González de Lucas y Pedro Juan, vecinos de Aguilar, ante el dicho escribano Antonio de Laverde San Martín. A 6 de octubre de 1654.

$<$ Adjudicación de las hipotecas. Año de 1662>.

Testimonio en relación de la execución contra los dichos Juan González de Lucas, Pedro Juan, y sus herederos, poseedores de las hipotecas del referido censo; las quales se adjudicaron judicialmente al monasterio, no obstante la oposición hecha por los executados, para la satisfacción del capital y réditos, y de ellas tomó posesión, en 2 de junio de 1662, como todo más largamente consta de dicho testimonio, dado por Cristóval López, escribano de la dicha villa de Aguilar.

15. <Censo a favor de Juan de Olea. Año de 1616>.

Escritura de censo a favor de Juan de Olea el Mozo, otorgado por Francisco Fernández y María de Lózar, su muger, vecinos de Aguilar, ante Lope de Valderas, escribano en la misma villa, a 8 de octubre de 1616. Este censo recayó en el monasterio y, habiendo / (f. 3v) executado por los réditos, el año de 1618 tomó posesión de una casa y 20 quartas de viña, hipotecas suyas. Gozolas el monasterio once años, y habiendo ajustado qüenta con el heredero, salió el monasterio condenado y alcanzado, por lo que tubo que volver las hipotecas, quedando corriente el censo.

$<$ Reconocimiento a favor del monasterio. Año de 1654>.

Reconociéronle Juan García y Juana Rodríguez, su muger, vecinos de Tamariz, ante Antonio de Laverde San Martín, a 6 de septiembre de 1654. Este censo no se paga, ni consta haberse redimido, ni haberse adjudicado al monasterio sus hipotecas; pero por quanto una anotación que tiene al principio, dice: "que goza el priorato algunas hipotecas", se ha dexado aquí este ynstrumento para noticia de ellas.

16. <Compra de un corral. Año de 1643>.

Escritura de compra de un corral en el quarto de San Estevan, que hizo el monasterio a Antonio de Cifuentes, vecino de Aguilar. Pasó la escritura ante Gaspar Crespo, escribano de Barcial de la Loma, a 30 de marzo de 1643.

17. Bajo este número están las escrituras siguientes:

$<$ Compra de la casa del priorato. Año de 1662>.

$1^{\text {a }}$. Compra que hizo este monasterio a Don Bernardino Miguel de Prado, vecino de Mayorga, como padre y administrador de los hijos que le quedaron de doña Ysabel de Villarroel, su muger, de la casa principal del priorato, en la calle de Valflorido, con otra casilla que llaman el Molino y un corral, en precio todo ello de 1950 reales de vellón, ante Cristóval López, escribano en Aguilar, a 4 de febrero de 1662. De todas las quales tomó posesión el monasterio a 17 días del mismo mes y año.

<Depósito de los 1950 reales. Año de 1662>.

$2^{\text {a }}$. Depósito de los 1950 reales, por quanto la villa y su procurador executaron al dicho don Bernardino por los réditos de un censo y para el pago embargaron dicha 
cantidad, a 24 de febrero de 1662, por testimonio del mismo escribano Cristóval López.

$<$ Venta de una ronda a favor de Juan Cavallero. Año de 1614>.

$3^{\text {a }}$. Venta de una ronda a favor del licenciado Juan Cavallero, en precio de 200 reales, otorgada por Antonio González, como procurador de la villa de Aguilar, ante Antonio de San Martín, escribano de la misma, a 28 de enero de 1614. Esta casa la compró el monasterio, como se dirá luego.

$<$ Venta de otra ronda a favor del mismo. Año de 1625>.

$4^{a}$. Venta de otra ronda a favor del mismo licenciado Juan Cavallero, en precio de 120 reales, otorgada por Antonio de San Martín, como procurador general de la villa de Aguilar, ante el mismo escribano, a 19 de junio de 1625.

$<$ Demanda, tasación. Venta judicial y posesión que tomó el convento de dichas casas. Año de 1662>.

$5^{a}$. Demanda por razón de los daños que causaban las casas anteriores y otras de la villa; tasación de su valor por Alarifes; venta judicial de ellas / (f. $4 r)$ y posesión que tomó de ellas el convento, en 4 de mayo de 1662, ante Cristóval López, escribano de Aguilar.

<Compra de dos sitios de corrales y de otras casas. Año de 1664>.

$6^{a}$. Compra de dos sitios de corrales y de unas casas viejas, en la calle de Valflorido, por precio de 400 reales, que hizo este monasterio a Francisco Cavallero de Luna, vecino de la villa de Cuenca de Campos, con poder que tenía de su madre, doña Úrsula del Yerro. Pasó esta escritura ante el referido Cristóval López, escribano, a 11 de ,ulio de 1664.

$<$ Compra de dos suelos de dos casas caídas. Año de 1665>.

$7^{\mathrm{a}}$. Compra que hizo el monasterio al licenciado Juan Antonio de Olea y don Cristóval de Olea, su hermano, vecinos de Aguilar, de dos suelos de dos casas caídas en la calle de Valflorido, en precio de 450 reales, ante el mismo escribano Cristóval López, a 17 de junio de 1665.

18. Bajo este número están las escrituras siguientes:

$<$ Dote de doña Petronila Freile. Año de 1619>.

$1^{\mathrm{a}}$. Tasación de los bienes muebles que llevó doña Petronila Freile quando casó con Pablo Cifuentes. Año de 1619, ante Antonio de San Martín, escribano en Aguilar.

$<$ Carta de pago del dote. Año de 1630>.

$2^{a}$. Testimonio en relación de la carta de pago que otorgó Pablo de Cifuentes de los bienes que recivió en dote doña Petronila Freile, su muger. Año de 1630, ante el mismo escribano.

$<$ Censo contra Pablo de Cifuentes. Año de 1628>.

$3^{a}$. Censo otorgado por Pablo de Cifuentes a favor de la obra pía que en el convento de San Pedro Martín de la ciudad de Rioseco fundó María Fernández, cuyo 
derecho compró después este monasterio. Año de 1628, ante Juan Rodríguez Escudero, escribano en esta ciudad.

$<$ Otro censo contra el mismo. Año de 1630>.

$4^{\mathrm{a}}$. Censo otorgado por Pablo de Cifuentes a favor de José Serrano. Año de 1630, ante Francisco Moro de Saldana, escribano en Carrión.

$<$ Donación de este censo al monasterio. Año de 1630>.

$5^{a}$. Donación que hizo a este monasterio del censo anterior José Serrano. Año de 1630, ante el mismo escribano.

$<$ Declaración de las hipotecas de este censo. Año de 1630>.

6 ${ }^{a}$. Declaración que hizo Pablo de Cifuentes de las hipotecas de este censo con expresión de las que pertenecían a bienes gananciales. Año de 1630, ante el mismo escribano.

$<$ Hijuela de Pablo de Cifuentes. Año de 1615>.

$7^{\text {a }}$. Hijuela y adjudicación de todos los bienes que le tocaron a Pablo Cifuentes por legítima herencia. Año de 1615, ante Lope de Valderas, escribano en Aguilar.

$<$ Convenio entre el monasterio y doña Petronila. Año de 1665>.

$8^{a}$. Convenio entre este monasterio y doña Petronila Freile, con cesión y poder en causa propia, porque se la compró el derecho. Año de 1665, ante Antonio Magarzo, escribano en Aguilar.

$<$ Venta de un censo a favor de este monasterio. Año de 1665 $>$.

$9^{a}$. Venta, cesión y poder en causa propia que otorgó el convento de San Pedro Mártir de Rioseco a favor de este monasterio de San Zoil, del censo que tenía contra Pablo de Cifuentes. Año de 1665, ante / (f. 4v) Mathé Díez, escribano en dicha ciudad.

$<$ Concurso contra los bienes de Pablo de Cifuentes, tasación de ellos; adjudicación al monasterio y posesión que de ellos tomó. Año de 1665>.

10. En virtud de estos convenios, ventas, cesiones y poderes, sólo quedó por único acreedor a los bienes concursados de Pablo Cifuentes este monasterio, quien, prosiguiendo la demanda, pidió tasación de todos los que se hallasen ser suyos y que se ajustase qüenta de todo lo que se debía, con citación del defensor nombrado en esta causa; y hechas todas las diligencias, se tasaron y se le adjudicaron por bienes de dicho Pablo de Cifuentes dos viñas y diez tierras en término de la villa de Aguilar, quedando sólo dos tierras por no tener certeza si eran suyas. Con todo, faltó mucho para satisfacer enteramente al monasterio, como consta de este proceso o testimonio en relación, signado y firmado de Antonio Magarzo, escribano de la misma villa. Año de 1665 .

19. <Compra de una herrén. Año de 1682>.

Compra de una herrén en la calle de Valflorido que hizo el monasterio a Antonio Pérez Menayo y María Fernández, su muger, vecinos de Aguilar, en precio de 100 reales. A 20 de noviembre de 1682, ante Cristóval López, escribano en la misma villa.

20. Bajo este número estas (sic) las escrituras siguientes: 
$<$ Compra de una herrén. Año de 1682>.

$1^{\text {a }}$. Compra de una herrén a San Juan, en precio de 180 reales, que otorgaron Santiago Alonso y doña María Escudero, su muger. A 26 de noviembre de 1682, ante Miguel Curto, escribano de la villa de San Miguel del Valle, de donde eran también vecinos los vendedores.

$<$ Compra de otra herrén. Año de 1683>.

$2^{\text {a }}$. Compra de otra herrén a San Juan, en precio de 100 reales, que otorgó, por sí y ante sí, Santiago Facón, escribano en Aguilar, a 18 de diciembre de 1683.

$<$ Trueque de una tierra por una herrén. Año de 1684>.

$3^{\text {a }}$. Trueque entre este monasterio y Juan López, vecino de Aguilar, por el qual el dicho Juan López da al monasterio una herrén a San Juan, de media quarta ${ }^{7}$, y el monasterio le da una tierra a Valleluengo, de cinco quartas y media, con más 15 reales en dinero por la mejoría. Pasó esta escritura a 10 días del mes de marzo de 1684, ante Cristóval López Ramírez, escribano en Aguilar.

$<$ Compra de una tierra herrén. Año de 1684>.

$4^{a}$. Compra de una tierra herrén a San Juan, en precio de 50 reales, que otorgaron Miguel González de Lucas, menor en días, y Paula García, su muger, con hipotecas de una tierra y una viña a su seguridad. A 20 de marzo de 1684, ante el mismo escribano.

21. <Compra de unas casas. Año de 1684>.

Compra de unas casas a Valflorido, en precio de 330 reales, que otorgaron Cristóval, José y Antonio de Robles, a 3 de abril de 1684, ante Antonio Magarzo. Y por quanto dicha casa tenía quarta parte Escolástica Fernández, su hermana, se obligaron a darla satisfacción hipotecando, para seguridad de la venta, dos tierras.

/ (f. 5r) 22. Bajo este número estas (sic) las escrituras siguientes:

$<$ Memoria de dos compras de tierras. Año de $1692^{8}>$.

1. $^{\text {a }}$ Memoria firmada de Facon, escribano de Aguilar, de dos compras de tierras a favor de este monasterio: la primera, de dos tierras, a Pedro Momo, y la otra, de tres tierras, a Francisco Fernández Martínez. Año de 1692.

$<$ Memoria de otras dos compras de una viña y de una tierra. Año de 1692>.

$2^{\text {a }}$. Memoria firmada de Alonso Porrero de otras dos compras: la una, de una viña, a Santiago de Rey, y la otra, de una tierra, a Pedro Zapata. Año de 1692.

$<$ Memoria de otra compra de una tierra. Año de 1692>.

$3^{a}$. Otra memoria, firmada del mismo escribano, de otra compra de una tierra a Miguel de Herreras y Ana María de León, su muger. Año de 1692.

\footnotetext{
${ }^{7}$ quarta] sigue tachado: y una quarta más.

8 Año de 1692] al margen derecho: Nota: En este año se 1692 redimió el cavildo de Aguilar el censo de los 20 ducados que pagaba para la obra de la yglesia de San Juan, y dio para ello 10 yugadas de herrenes. Véase adelante el Legajo $4^{\circ}$; quaderno A; número 37.
} 
$<$ Trueque de 4 tierras por dos. Año de 1693>.

$4^{\text {a }}$. Trueque entre el monasterio y Santiago Facon, vecino de Aguilar, por el qual da el monasterio a dicho Santiago Facon quatro tierras por dos que éste le dio a Carregatón. A 31 de marzo de 1693, ante el mismo escribano otorgante.

$<$ Trueque de una herrén por otra. Año de 1693>.

$5^{a}$. Trueque de una herrén por otra a San Juan con don José de Laverde San Martín, vecino de Aguilar. Firmado por el mismo y el padre Morán, prior de Aguilar, a 6 de abril de 1693.

$<$ Compra de una tierra. Año de 1694>.

$6^{a}$. Compra de una tierra, a camino de Berruezes, a Juan López, vecino de Aguilar. Pasó ante Alonso Porrero, escribano de Aguilar, a 3 de febrero de 1694?

$<$ Compra de una hera. Año de 1695>.

$7^{a}$. Compra de una hera, a las de San Juan, a María de Lózar, viuda de Lucas Fernández, vecinos de Aguilar. A 2 de abril de 1695, ante Alonso Porrero, escribano de la dicha villa.

$<$ Compra de otra tierra. Año de 1695>.

8 a Compra de otra tierra, al Torrejón, a Juan López, vecino de Aguilar. Pasó ante Santiago Facon, escribano de la dicha villa. A 18 de abril de 1695.

$<$ Compra de dos tierras. Año de 1695>.

9a. Compra de dos tierras, la una al Gamonal y la otra a Los Valles, a Alonso Ximénez y Andrea de Cifuentes, su muger, vecinos de Aguilar. Ante Alonso Porrero, escribano de la dicha villa, a 24 de abril de 1695.

$<$ Compra de dos tierras. Año de 1695>.

10. Compra de dos tierras, a los tesos de Las Atalayas, a Juan López, vecino de Aguilar. Ante Santiago Facón, escribano de dicha villa, a 8 de diciembre de 1695.

$<$ Compra de una tierra. Año de 1698>.

11. Compra de una tierra, a Buenavista, a Pedro de Girón, vecino de Aguilar. Ante Santiago Facón, escribano de dicha villa, a 12 de diciembre de 1698.

$<$ Compra de dos tierras. Año de 1698>.

12. Compra de dos tierras, la una al Gramadal y la otra a Villotis, a Diego de Sedano y María Sánchez Gorgojo, su muger, vecinos de Villafrechós. Ante Luis de Salazar, escribano de Villafrechós, a 20 de diciembre de 1698.

$<$ Compra de una hera. Año de 1699>.

13. Compra de una hera, a las de San Juan, a Lázaro Juárez y Jacinta Guerra, su muger, vecinos de Aguilar. Ante Santiago Facón, escribano de dicha villa, a 6 de febrero de 1699.

\footnotetext{
9 1694] al margen derecho: Se trocó ésta, véase el número 32.
} 
$<$ Compra de una tierra y una herrén. Año de 1699>.

14. Compra de una tierra, a Carregatón, y una herrén, a San Juan, a Santiago Facón y Antonio Facón, su hijo, vecinos de Aguilar. Ante el mismo / (f. 5v) Santiago Facón, escribano de dicha villa, a 14 de febrero de 1699.

$<$ Compra de una tierra. Año de 1699>.

15. Compra de una tierra, a Orcilla, a Francisco Fernández Martínez, vecino de Aguilar. Ante Alonso Porrero, escribano de Villamuriel, a 3 de abril de 1699.

$<$ Compra de otra tierra. Año de 1699>.

16. Compra de una tierra, al último camino travieso, a Manuel Pérez, vecino de Aguilar. Ante Santiago Facón, escribano de dicha villa, a 6 de abril de 1699.

$<$ Compra de otra tierra. Año de 1700>.

17. Compra de una tierra, a Las Bodeguillas, a Francisco Raldo y Ana del Rey, su muger, vecinos de Aguilar. Ante Alonso Porrero, escribano de Villamuriel, a 12 de febrero de 1700 .

$<$ Compra de quatro tierras. Año de 1707>.

18. Compra de quatro tierras en término de Aguilar, a don José Herreras y Francisco Casado, como testamentarios de Petrona Alonso, vecina que fue de Aguilar. Pasó ante Francisco Núñez de Prado, escribano de dicha villa, a 20 días del mes de diciembre de 1707.

$<$ Compra de una tierra. Año de 1709>.

19. Compra de una tierra, al Pasadero, a Francisco Pérez y Catalina Guerra, vecinos de Aguilar. Ante el mismo escribano, a 25 de febrero de 1709.

$<$ Compra de una tierra. Año de 1710>.

20. Compra de una tierra, a Las Quintanas, a María Ramírez, viuda de Juan de Soto, y Alonso Martínez, su yerno. Ante el mismo escribano, a 19 de marzo de 1710 .

23. < Adjudicación de una tierra y una viña. Año de 1713>.

Testimonio de la adjudicación de una tierra y una viña, al Arenal, dado por Manuel Sebastián de Cevallos, escribano en Aguilar. Año de 1713. Estas tierras eran de Francisco Collantes y Juana Magarzo, su muger, cuya hacienda estaba concursada. Y no habiéndose hallado más que dos tierras y dos viñas, se adjudicaron, por acto de justicia, se adjudicaron al monasterio las dos posesiones arriba referidas; y las otras dos, al licenciado don Alonso Antonio Villarroel por otro crédito que tenía contra los mismos. La tierra al Arenal la gozaba don Diego Cid, médico de Aguilar, he hizo obligación de dexarla libre al monasterio para el año de 1715.

24. Bajo este número están las escrituras siguientes:

$<$ Venta de una casa a favor del licenciado Guerra. Año de 1691>.

$1^{\text {a }}$. Venta de una casa, silos y corral, en la calle de Vaflorido, otorgada por Juan López a favor del licenciado Antonio Guerra Fernández, cura de San Estevan, 
en precio de 1 mil reales, con carga de 10 reales de aniversario. A 31 de enero de 1691, ante Santiago Facon, escribano de Aguilar.

$<$ Redención de un aniversario de 10 reales. Año de 1700. $>$.

$2^{a}$. Redención que hizo el licenciado Antonio Guerra Fernández de los 10 reales de aniversario situados sobre la dicha casa. A $1^{\circ}$ de febrero de 1700 , ante el mismo escribano.

$<$ Compra de la anterior casa. Año de 1714>.

$3^{\text {a }}$. Compra que hizo el monasterio del suelo de la anterior casa, cueva, silos y materiales que quedaron cuando se quemó, al licenciado / (f. $6 r)^{10}$ Antonio Guerra Fernández, cura de San Estevan, como curador de los hijos de Miguel Guerra, su hermano. Hízose esta compra por precio de 900 reales, en que se remató judicialmente, como consta de esta escritura y actos que pasaron ante Manuel Sebastián de San Andrés Cevallos, escribano de Aguilar, a 5 de agosto de 1714.

25. <Compra de una tierra herrén. Año de 1716>.

Compra de una tierra herrén, de cinco quartas, a Gregorio Núñez, en precio de 550 reales, con los que redimió un censo que contra sí tenía a favor de este monasterio. Pasó esta escritura ante Francisco Núñez de Prado, escribano en Aguilar, a 15 de noviembre de 1716. Está unida a esta escritura la de censo, que se otorgó a 6 de junio de 1704, ante el mismo escribano.

26. <Compra de un suelo corral y un pedazo de bodega. Año de 1746>.

Compra de un suelo corral, de dieciséis pies en quadro, con un pedazo de bodega, a Tomás Pérez y Francisco Pérez Olea, en precio de 47 reales. Pasó la escritura a 20 de marzo de 1746, ante Manuel Torices, escribano de Aguilar.

27. <Compra de una casa con la redención de un foro y un censo. Año de 1755>.

Compra de una casa, a Valflorido, a Jacinta Guerra, vecina de Aguilar, por precio de 300 reales, a 29 de mayo de 1755, ante Manuel de Torices, escribano de Aguilar. A esta escritura están unidas otras tres: las dos primeras son un censo y un reconocimiento de él que contra dicha casa tenían las monjas de Santa Clara de la Villa de Cuenca de Campos, el qual censo redimió la referida Jacinta Guerra el mismo año de 1755; la tercera escritura es la redención que hizo el monasterio de un foro de 40 maravedís que contra la misma casa tenía el cavildo de Aguilar, a 25 de abril de 1755, ante el mismo escribano Manuel Torices.

28. <Compra de una cueva, lagar y pajar. Año de 1760>.

Compra de una cueva, lagar y pajar que hizo este monasterio a los herederos de don Manuel de Villarroel, por precio de 1000 reales. A 5 de marzo de 1760, ante Francisco de Estrada, escribano de Aguilar.

29. <Representación del padre Noblino sobre la exención de carruajes y decreto del capitán general. Año de 1762>.

Representación ${ }^{11}$ que hizo el padre Noblino, prior de Aguilar, al capitán general de Zamora, sobre la exención de no concurrir con ganados ni carruajes al trasporte de víveres

10 / (f. 6r)] entre el folio $5 v$ y el folio 6r se adjunta la siguiente nota: Nota: Paga de diezmos por los beneficiados de las tierras nuevamente adquiridas, número 17; por las fábricas y cofradías, número 18; por el monasterio, año de 1772, número 25; por la huerta de la yglesia de San Pedro. En el vuelto de la nota se escribe: Para los.

11 Al margen derecho: Falta. 
para el exército de Su Magestad, a que le quería obligar la justicia de Aguilar. Y decreto del mismo capitán general en que manda a la justicia no $/(f .6 v)$ incluya dicho ganado y carruajes para la condución de trasportes. Dado en Zamora, a 11 de octubre de 1762. Ynsistió de nuevo la villa y no se sabe en qué paró.

30. $<$ Cesión de varias tierras. Año de 1787>

Cesión que hizo Miguel Alonso, vecino de Aguilar, de varias tierras que llevava en arriendo, para que el monasterio las pudiese arrendar y disponer de ellas. Hecha a 3 de febrero de 1787. el de $1714>$.

31. $<$ Memoria de la hacienda raíz del priorato de Aguilar desde el año de 1692 hasta

Memoria de la hacienda raíz que tiene el monasterio en término de la villa de Aguilar de Campos, assí de la que consta del apeo del año de 1692 como de otras posesiones que se compraron después hasta el año de 1714. En esta memoria se advierte que faltan algunas escrituras, assí de compras como de trueques, que hizieron los priores de San Juan de Aguilar.

32. <Trueque de una tierra por otra. Una al camino de Berruecas (sic) y la otra a Villobera. Año $1818>^{12}$.

Escritura ${ }^{13}$ de trueque hecha entre este monasterio y el coronel don Ángel Castellanos de una tierra que el monasterio tenía en Aguilar, al camino de Berrueces, de quatro yugadas y 27 estadales, por otra en la misma villa, a Villobera, de cinco yugadas y 27 estadales, que el dicho señor Castellanos dio al monasterio. Su fecha: en Aguilar, a 21 de diciembre de 1818. Ante Francisco Antonio de Estrada, escribano de dicha villa, por quien es da (sic) esta copia, cuyo original se executó en los 15 de diciembre de 1817, ante el mismo.

\section{/ (f. $7 r)$ Remisiones.}

Trueque que hizo este monasterio con el rey don Alonso el $9^{\circ}$ de la villa de Castromayor (hoy Aguilar). Véase el Cajón San Yldefonso. Legajo $1^{\circ}$, número $1^{\circ}$.

\section{/ (f. 8r) Quaderno B del Legajo $1^{\circ}$}

33. Este quaderno B, que es el segundo del primer legajo, que está en el cajón Santa María, consta de papeles de qüentas y memoriales de deudas antiguas de la hacienda del priorato de Aguilar de campos, y particularmente los papeles tocantes a los pleytos, trampas y enredos de la colecturía de Lázaro Gutiérrez, que fue muchos años colector de la hacienda del priorato; y la tubo con tanta confianza del monasterio que, quando se le llegaron a tomar qüentas, ni las dio ni las pudo dar, ni se halló claridad alguna ni resguardo, por lo que no hubo más que cerrar los ojos a una mui gran pérdida que tubo el monasterio con la administración perjudicial de este hombre. Sólo sirven estos papeles de abrir los ojos para huir de colectores seculares para la administración de haciendas, por ser esto su total ruina. No hay aquí cosa singular de más advertencia que lo dicho, pues este hombre murió en el hospital, sin que el monasterio, ni en vida ni en muerte, hallase cosa alguna de que cobrar algo de tanto como había perdido. Y por lo mismo no se ponen aquí por menor estos papeles.

\footnotetext{
$12<$ Trueque ... 1818>] Este asiento fue escrito por otra mano diferente, que también escribió la nota de remisiones del folio $7 r$.

13 Al margen derecho: Veáse atrás número 22 compra $6^{a}$ titulada hoy la gloria.
} 


\section{/ (f. $8 v)$ Quaderno C del Legajo $1^{\circ}$}

Este quaderno $\mathrm{C}$, que es el tercero del legajo $1^{\circ}$, contiene papeles y escrituras tocantes a la yglesia de San Juan de Aguilar, que son las siguientes: $1495>$.

$1^{\text {a }}$. < Colación del curato de San Juan de Aguilar en Diego de Castañeda. Año de

Trasumto authorizado de una colación del beneficio curado de San Juan de Aguilar, echa por don Alonso de Valdivieso, obispo de León, en Diego de Castañeda, clérigo del obispado de Palencia, en virtud de presentación en él echa por don Luis Hurtado de Mendoza, administrador perpetuo de la abadía de San Zoil. Su fecha: en Villacarralón, a 17 de noviembre de 1495, ante Francisco de Valderas, su secretario.

$2^{a}$. <Sentencia en la colación del beneficio de San Juan. Año de 1558>.

Sentencia dada por el bachiller García de la Vandera, provisor de León, por la qual declara el título y colación echa en Alonso de Represa del beneficio curado de San Juan de Aguilar, por presentación de los mismos feligreses, ser ninguna y de ningún valor y efecto, y ampara a Francisco Pardo en la posesión que tenía del dicho beneficio por virtud de la colación que le había sido echa por presentación del abad y convento de San Zoil, a quien declara por verdadero patrono del beneficio; y condena en costas a Alonso de Represa. Pronunciose en León, a 18 de noviembre de 1558, ante Andrés Pérez de Madrid, notario público.

$3^{\mathrm{a}}$. $<$ Proceso compulsado en Astorga para Roma, sobre la congrua de un cura en San Juan de Aguilar. Año de 1568>.

Proceso actuado y compulsado en Astorga, en grado de apelación para Roma, ante el licenciado Antonio de Ormaza, provisor de Astorga, sobre que, habiendo puesto el monasterio cura en San Juan de Aguilar y señalándole de congrua 20 cargas de trigo, 5 de zebada y la mitad del pie de altar, no contento con esto, el cura Francisco Pardo pidió al monasterio más congrua ante el provisor de León, el qual, sin embargo de la apelaciones interpuestas de parte del convento, dio sentencia en esta causa, por la qual asignó de / (f. 9r) congrua al dicho Francisco Pardo otras 10 fanegas de trigo además de las 20 cargas que el monasterio le tenía señaladas, con otras 5 de zevada y mitad del pie de altar. Apeló el monasterio y sacó breve del nuncio para que el provisor de Astorga conociese en grado de apelación. Yntimose el breve al licenciado Antonio Ormaza, que lo era a la sazón, y, habiendo acetado la comisión, en virtud de ella despachó mandamiento de inhibitoria, citatoria y compulsoria.

\section{$<$ Concordia antigua. Año de 1247>.}

Llevose el proceso, y habiendo conocido de la causa y oído las partes (salieron a ella el convento de San Claudio y el cavildo de la yglesia de León, por lo que les tocaba), se presentó en este proceso la concordia antigua que se hizo entre el obispo de León Martino y el cavildo de su yglesia, de una parte; y Gaufrido, prior de San Zoil y camarero de Cluni, con su convento, de la otra, en la era de 1285, que es el año del Señor de 1247. Y estando al parecer conclusa esta causa, el dicho provisor de Astorga pronunció en ella sentencia, a 5 de febrero de 1568, por la qual confirmó la sentencia del provisor de León y le remitió la executión de ella. Apelaron de nuevo los monasterios de San Zoil y San Claudio, y no habiéndoles admitido la apelación, se llevó por vía de fuerza a la Chancillería, donde se dio auto y provisión, declarando que los provisores de León y Astorga hacían fuerza en no haber otorgado las apelaciones interpuestas; y se les mandó otorgar y reponer, a 2 de abril de 1568; y no habiendo obedecido, se despachó sobrecarta de provisión, en cuia virtud el provisor de Astorga otorgó la apelación y repuso lo actuado después de ella. Y se compulsó este proceso en Astorga, a 31 de agosto de 1568, ante Antonio Ocáriz, escribano y notario público. Esta causa se ventiló y sentenció en Roma y se sacaron executoriales, que están en el Archivo de San Claudio de León, y el trasunto está adelante, en el número $6^{\circ}$ de este mismo quaderno. 


\section{$4^{\circ}$. $<$ Requerimiento al provisor de Astorga. Año de 1568>.}

Requerimiento echo por parte del monasterio al provisor de Astorga para que conceda un año de término para la apelación a Roma, en atención a que para traerla y mejorarla no havía señalado más que 60 días de término. A 4 de mayo de 1568, ante Francisco de Bajo, notario.

\section{5. < Notificación de ynibitoria. Año de 1568>.}

Notificación de unas letras de ynibición de Roma, echa por el padre fray Juan de Corcuera, abad de San Zoil, al provisor de Astorga, quien se dio por inhibido. A 28 de marzo de 1569, ante Antonio de Ocáriz, escribano y notario de Astorga.

/ (f. 9v) 6. < Sentencia dada en Roma contra los curas de Aguilar sobre la congrua. Año de 1574>.

Trasumto simple de una sentencia dada en Roma contra quatro curas de Aguilar, y en favor de los monasterios de San Claudio y San Zoil y de la fábrica de la yglesia de León, en razón de la compra que los clérigos les pedían; por la qual parece que, habiendo cometido el conocimiento de esta causa la Santidad de Pío $5^{\circ}$ a Cristóval Robuste, auditor de la Cámara Apostólica, con consejo de sus colegas, dio en ella sentencia definitiva. Por la qual revoca las sentencias de los provisores de León y Astorga y absuelbe de la demanda puesta por los curas a los abades y conventos de San Claudio y San Zoil y a la fábrica de la yglesia de León y les da por libres de ella; dando por injustas, temerarias, ilícitas y presuntas las molestias que sobre esta razón se les habían echo. Pone perpetuo silencio a los curas en razón de la dicha congrua y les condena en las costas echas por dichos conventos y fábrica en esta tercera instancia de Roma. Dada y publicada en San Pedro de Roma, en el palacio apostólico de las causas, a 9 de julio de 1574, año tercero del pontificado del Papa Gregorio 13, ante Nicolás Ponsevir, notario de La Rota.

El original de esta sentencia y sus executoriales están en el Archivo de San Claudio de León, y este monasterio pagó de las costas de este pleito 368 maravedís el año de 1578.

7. $<$ Mandamiento del obispo de León en que pone sirviente en San Juan y seqüestra los bienes. Año de 1582>.

Auto dado por don Francisco Trujillo, obispo de León, en la villa de Aguilar, en que dice que, atento a que los monges llevaban los diezmos de San Juan y tenían obligación de poner un monge o clérigo que sirviese aquella yglesia y administrase los Santísimos Sacramentos y había dos o tres años que no le ponían, en perjuicio de muchos feligreses que había, el dicho obispo nombraba y nombró un clérigo que sirviese en tanto que el convento ponía sirviente, y seqüestró los frutos y diezmos de la yglesia de San Juan. Dio poder al licenciado Ramos, su vicario, para que nombrase un clérigo que lo sirviese; y por estar fuera de la villa de la yglesia de San Juan y no acudir a ella los feligreses, dice el obispo que la pretendía unir a otra yglesia de las que están dentro, y que esto se publicase en tres días de fiesta, para que el que pretendiese agravio acudiese a dar razón de él ante el mismo obispo. Dado en Villagarcía, a 3 de abril de 1582. En virtud de este mandamiento el vicario Ramos nombró a Martín Aparicio para que sirviese la yglesia de San Juan, y en lugar del monge que había de residir para ayudarle nombró a Pedro Val, clérigo de Aguilar, y para pagarle seqüestró los frutos de la yglesia pertenecientes a San Zoil. A 16 de mayo de 1582, / (f. 10) ante Juan Alonso, escribano de Aguilar.

$<$ Desembargo de los frutos. Año de 1582>.

Después de esto, contándole al obispo que el monasterio había puesto el correspondiente servicio en la yglesia de San Juan, dio mandamiento de desembargo de los frutos, para que se acudiese con ellos al monasterio, y suspendió la anexión de la yglesia a otra del lugar. A 27 de junio de 1582, ante Diego de Peñaranda, notario de León.

$<$ Testimonio de cómo el monasterio puso sirviente. Año de 1582>.

Está aquí el testimonio de cómo fray Sebastián de Ávila asistía y servía en la yglesia de San Juan la semana que le tocaba y dixo la misa cantada y predicó los días de Pascua, de 
Espíritu Santo y Trinidad. Dado en Aguilar, a 10 de junio de 1582, por Juan Alonso, escribano de Aguilar.

8. $<$ Mandamiento para que el monasterio pague unas costas. Año de 1594>.

Mandamiento del provisor de Palencia para que el monasterio pague las costas que le tocaban de un pleito que había litigado junto con los clérigos de Aguilar y el almirante contra los clérigos de Barcial, sobre los diezmos de las heredades que labraban en término de Aguilar los vecinos de Barcial. Dado en Valladolid, a 8 de febrero de 1594.

9. <Muerte del padre Nájara y fundación de 4 misas rezadas. Año de 1595>.

Dos cartas escritas ambas por $^{14}$ el cura Juan Morán de Castañeda y Pablo de Cifuentes, a 8 de marzo y 10 del mismo mes de 1595, en que avisan al general de la muerte del padre fray Ambrosio de Nájera, prior de Aguilar, el qual les había dexado en confianza cierta cantidad de dinero para que lo entregasen a San Román y este lo diese al monasterio de San Zoil para que, con este dinero y los capitales de los censos que dexó, se fundasen quatro misas rezadas, anuales y perpetuas por su intención ${ }^{15}$.

10. $<$ Requirimiento al nombramiento de primiciero. Año de 1599>.

Requirimiento hecho por fray Hernando de Caniego, procurador de San Zoil, a Juan Cavallero, cura de San Juan, que no pare perjuicio al monasterio el nombramiento de primiciero por él echo en Aparicio Franco, feligrés de San Juan. A 21 de noviembre de 1599, ante Cristóval de Collantes, escribano de Aguilar.

11. < Carta en razón de los ornamentos de San Juan. Año de 1611>.

Carta ${ }^{16}$ del licenciado Juan Cavallero, cura de San Juan, en razón de la restitución que se le pide de los ornamentos, cruz y cáliz de la yglesia de San Juan. En ella expone a nuestro padre fray Alonso Barrantes, abad de San Zoil, lo que siente el desamparo que hizo el monasterio de aquella yglesia. Su fecha, a 30 de abril de 1611. de $1628>$.

12. $<$ Carta executoria de la Chancillería en razón de las campanas de San Juan. Año

Carta executoria ganada por el monasterio en la Chancillería de Valladolid sobre la restitución de las campanas de la yglesia de San Juan. Por ella parece que, en Aguilar, a 29 de agosto de 1619, el alcalde Juan Magarzo hizo cabeza de proceso diciendo que, teniendo la yglesia de San Juan en su torre dos campanas buenas, unos carpinteros de Villafrechós las quitaban ocultamente y las habían bajado de la torre para llevarlas y las tenían / (f. 10v) desarmadas en la yglesia. Hizo información sumaria visitando personalmente la yglesia, donde halló las campanas desarmadas. Formó inventario de sus materiales y los depositó en Juan de Olea. Prendió los oficiales que trabajaban en la torre y les tomó su declaración. Estando en este estado, salió el monasterio pidiendo se volviesen las campanas, atento que tenía compuesta la yglesia y reparada la torre para ponerlas en ella. Opúsose a esto la villa por medio de su procurador general, diciendo entre otras cosas que la yglesia no era del monasterio, que pedía las campanas para engañarles, no ponerlas en la torre sino llevárselas, etcétera. Alegaron de nuevo ambas partes, recibiose la causa a prueba, hizo el convento la suya y se hizo publicación de testigos. Apelaron ambas partes a la Chancillería, donde se llevaron los autos originales por no haberles sentenciado el alcalde. Presentó el procurador del monasterio su poder y pidió restitución de las campanas en atención a que la justicia de Aguilar no lo había querido hacer, dilatando la causa 11 años. Querellose el procedimiento y despojo de las campanas que había bajado de la torre para componerla porque se estaba cayendo, y, habiendo notificado a la misma justicia de Aguilar tres provisiones de la Chancillería para que determinase la causa, no lo había hecho; por lo que pidió se procediese contra los autos perjudiciales echos por la justicia ordinaria, que era parte formal contra el monasterio. Diose traslado a la villa y, habiendo presentado poder su procurador, alegó de su justicia y excepción con que se dio la causa por conclusa. Y en Relaciones, a 17 de junio

14 Al margen derecho: Falta.

15 Al margen derecho: 4 misas rezadas.

${ }^{16}$ Al margen derecho: Falta. 
de 1628, dio la sala auto por el qual mandó que el concejo de Aguilar pusiese las campanas en la yglesia de San Juan a costa del monasterio. Notificose a los procuradores y ninguno suplicó. Pasose en cosa juzgada, pidió el monasterio se le librase executoria del dicho auto, lo qual assí se estimó en $1^{\circ}$ de julio de 1628 , ante Pedro de Carandona, escribano de Cámara. Está aquí un requirimiento a la villa de Aguilar sobre lo mismo y un acuerdo de la villa del año 1647. $1653>$.

13. < Parecer para no contribuir a los reparos de las obras de las yglesias. Año de

Consulta y parecer de un abogado sobre que ${ }^{17}$ ni este monasterio ni el de San Claudio deben contribuir a los reparos de obras ni ornamentos de las yglesias de Aguilar aunque lo mande el ordinario; y que los vecinos, como presenteros de los beneficios, deben concurrir a dichos pastos en caso de necesidad. Año de 1653.

14. <Disputa en derecho sobre el oratorio de Aguilar. Año de 1676>.

Escrito del obispo de León sobre haber puesto oratorio en la casa de Aguilar sin licencia ni consentimiento suyo. Síguese la respuesta que dio el maestro / (f. 11r) González, abad de San Zoil, la que vista por el obispo dio licencia para que se usase dicho oratorio. Año de 1676. $1690>$.

15. <Despacho del señor obispo para que se diezme según costumbre. Año de

Despacho de don Juan Aparicio Navarro, obispo de León, para ${ }^{18}$ que en todo el obispado se diezme según los Sinodales de él y prevenido por los Sagrados Cánones. A 8 de agosto de 1690, ante Juan de Salinas Jove, escribano y notario de León.

16. <Despacho contra el anterior, del mismo señor obispo. Año de 1693>.

Contradespacho de el mismo obispo de León para que en Aguilar ${ }^{19}$ se observe la costumbre antigua de diezmar, declarando que, en quanto al rasero tirado se entienda pasándole por encima de la medida, de manera que no lleve copete o colmo; y suspende qualesquiera censuras discernidas en esta razón en quanto a dicha villa de Aguilar y los interesados en sus diezmos. Su fecha, en León a 9 de julio de 1691, ante Antonio Carvajo, su secretario.

17. < Concordia sobre diezmos con los beneficiados de Aguilar. Año de 1705>

Concordia entre los monasterios de San Zoil y San Claudio de León con el cavildo eclesiástico de la villa de Aguilar, por la que se obliga éste a pagar diezmo de todas las posesiones nuevamente adquiridas para sus beneficios; con declaración de las personas que se las habían donado y otras a quienes las habían comprado. Y assimismo se obliga a pagar diezmo de qualesquiera posesiones que por qualquier título se les agregase en lo sucesivo. Su fecha, en Aguilar, a 20 de noviembre de 1705, ante Santiago Facón, escribano en Aguilar.

18. <Despacho sobre diezmos de fábricas, cofradías, etcétera. Año de 1706>

Despacho del provisor de León notificado a los curas y mayordomos de las yglesias, fábricas, cofradías y villa para que declaren los frutos que habían cogido; lo[s] quales declararon lo que habían cogido de sus senaras y confesaron deber pagar diezmo de todo ello por no tener razón, título ni privilegio para lo contrario. Dado en León, 2 de octubre de 1706, ante Francisco Álvarez, notario de la misma ciudad. Notificole don Ysidoro Sánchez Gorgojo, cura de Santa María, a 6 de octubre del mismo año.

19. Bajo este número están los papeles siguientes:

$<$ Reclamo simple de los privilegios sobre los tercios de Aguilar, Arconada, Villafrechós y Villalumbrós, despoblado>.

\footnotetext{
${ }_{17}$ Al margen derecho: Falta.

18 Al margen derecho tachado: Falta.

19 Al margen derecho tachado: Falta.
} 
$1^{\circ}$. Una relación simple de los privilegios, executorias, concordias y demás títulos que tiene el monasterio tocantes a percivir las tercias de Santa María de Arconada, de Villafrechós y su despoblado de Villalumbrós y las de la villa de Aguilar. $1707>$.

$<$ Desembargo de las tercias por el superintendente de Valladolid. Año de

$2^{a}$. Desembargo de las tercias de Aguilar por el superintendente y administrador general de rentas reales de la ciudad de Valladolid. / (f. 11v) Su fecha, en la dicha ciudad, a 11 de marzo de 1707. Este desembargo no tubo efecto porque este señor administrador no era juez competente para esta causa respecto de éstar formando en Madrid un consejo que conociese de la dicha causa.

$<$ Orden del mismo para la cobranza de los novenos. Año de 1707>.

$3^{\circ}$. Copia simple de una orden del mismo superintendente a las xusticias de su provincia sobre la cobranza de los dos novenos pertenecientes a Su Magestad. A 26 de junio de 1707.

$<$ Carta del mismo para que se retengan los novenos. Año de 1707>.

$4^{\circ}$. Carta del mismo a la xusticia de Aguilar para que retenga y dé qüenta de los novenos, y para que los embargue de la tercia perteneciente a San Claudio de León. A 11 de julio de 1707.

$<$ Copia simple de la real cédula de Felipe $5^{\circ}$ por la que desembarga las tercias de Aguilar, Arconada, Villafrechós y su despoblado Villalumbrós. Año de 1708>.

$5^{\circ}$. Copia simple de la real cédula del señor Felipe $5^{\circ}$ por la se sirve desembargar las tercias pertenecientes al monasterio en los tres lugares de Arconada, Aguilar y Villafrechós, con su despoblado de Villalumbrós. Por la misma cédula aprueba, confirma y ratifica Su Magestad las donaciones echas a este monasterio de las tercias, novenos y diezmos que goza, mandando que los perciva y posea como hasta allí. Dada en Madrid, a 10 de enero de 1708. La cédula original está entre los papeles de Villafrechós, cajón San Gregorio, legajo Q, número (sic).

$<$ Notificación de la anterior cédula. Año de 1708>.

$6^{\circ}$. Requerimiento echo al dicho superintendente de Valladolid con la anterior cédula de Su Magestad. Obedecimiento del mismo y mandamiento de él para que se guarde y cumpla. En 13 de febrero de 1708. El qual se notificó a la justicia de Aguilar en 26 del mismo mes y año.

20. $<$ Real cédula de Felipe $5^{\circ}$ para que no se impida la entrada libre de las tercias y rentas. Año de 1746>.

Real cédula del señor Felipe $5^{\circ}$, librada a petición de este monasterio, para que la justicia de Aguilar no impida la entrada libre de las tercias y las rentas en dicho priorato. Dada en El Pardo, a 8 de febrero de 1746. Notificose y obedeciose por la villa en 21 del mismo mes y año; en testimonio de Tomás de Azebedo, escribano de Su Magestad y del número de la villa de Cabreros del Monte.

21. <Despacho para que don Francisco Sahagún pague 24 fanegas, celemín y medio de granos que estaba debiendo al priorato. Año de 1764>.

Despacho del provisor de León contra don Francisco Sahagún, abad del cavildo eclesiástico de Aguilar, para que pague 24 fanegas, celemín y medio de granos que estaba debiendo al priorato, y no quería entregarlas mientras el prior de San Juan no le satisfaciese 3 fanegas y media de trigo que suponía corresponderle del diezmo de unas tercias que el priorato tenía arrendadas, siendo assí que estaban exentas de diezmo. Su fecha, en León, a 26 de mayo de 1764. Al pie de este despacho está el recivo de dicha cantidad.

22. < Apartamiento de una demanda sobre diezmos y declaraciones de el mismo. Año de $1764>$. 
Apartamiento de una demanda que hizo un arrendatario de los diezmos pertenecientes al cavildo de León, en el término de Pajares, y declaración / (f.12r) de el mismo del derecho que tienen las parroquias de Aguilar a los diezmos menudos que se adeudan en dicho término de Pajares. Su fecha, en Aguilar, a 6 de diciembre de 1764, ante Manuel Castellanos, notario.

23. <Despacho contra el cavildo de Aguilar para que guarde la exención que ha tenido el monasterio para no pagar diezmos de las heredades. Año de 1769>.

Despacho del provisor de León, a petición del monasterio, contra el cavildo eclesiástico de Aguilar para que, bajo la pena de 20 ducados, guarde la exención y libertad que siempre ha tenido el monasterio de no contribuir con diezmo alguno de las heredades pertenecientes al priorato de San Juan, lábrelas por sí o por los colonos. Dado en León, a 29 de julio de 1769, ante Fernando de Villalón Gil. Notificose al cavildo y arrendatarios el mismo año.

24. <Auto y despacho contra los arrendatarios de una huerta para que paguen todo el diezmo. Año de 1775>.

$(\text { Crus })^{20}$ Auto y despacho del provisor de León, a instancia de este monasterio, contra los arrendatarios de una huerta propia de la yglesia de San Pedro de la villa de Aguilar, para que dentro de tercero día pague todo el diezmo que adeudaren en dicha huerta con las costas que se causasen. Dado en León, a 22 de diciembre de 1775, ante Fernando de Villalón Gil. Requiriose con este despacho a Francisco de Estrada, notario y escribano de Aguilar, quien hizo información sumaria. Y, constando por ella la costumbre de diezmar de dicha huerta, dio auto para que pagasen diezmo y costas. Y así lo executaron, como consta del testimonio de el mismo, dado a 16 de agosto de 1779.

25. <Convenio entre el prior de San Juan y el cavildo de Aguilar sobre el diezmo. Año de $1772>$.

Convenio echo por el padre prior de San Juan con el cavildo de Aguilar por el que, para contar diferencias, se obliga el prior a dar cada año al cavildo de Aguilar quatro cargas de pan, mediado trigo y zevada, para razón del diezmo que pretendía de sus heredades. Su fecha, a 25 de marzo de 1772, ante Manuel Castellanos, escribano en Aguilar.

26. $<$ Sobre la exención de diezmos>.

Papeles simples sobre la exención de diezmos de las haciendas de San Juan de Aguilar.

27. $<$ Sentencia contra el cavildo de Aguilar para que pague los nuevos diezmos. Año de $1797>$.

Testimonio en relación del pleito seguido entre monasterio y el de San Claudio de León contra los curas y beneficiados de la villa de Aguilar, sobre los diezmos de que estaban exentos antes del brebe de Su Santidad de 18 de enero de 1796, a que fueron condenados por el señor provisor de León en 7 de octubre de 1797, ante Ramiro Rodríguez Blanco, notario de León, quién sacó este testimonio en 19 de julio.

/ (f. 12v) Remisiones.

Tercias. Desembargo de las tercias. Véase el cajón San Gregorio, legajo 3º, quaderno A, número 25.

\section{/ (f. 13r) Legajo $2^{\circ}$ del cajón Santa María}

Este legajo $2^{\circ}$ consta de escrituras y papeles tocantes a los pleitos que ha tenido este monasterio de San Zoil con el cavildo eclesiástico de la villa de Aguilar de Campos, en razón de los 120 feligreses que pertenecían a la parroquia e yglesia de San Juan, al modo como se habían de nombrar unos quando morían otros; sentencias y concordias antiguas y modernas

${ }^{20}$ (Cruq)] al margen derecho: (Cruq) Nota. Este número se pondrá después del siguiente. 
que ha habido sobre este particular. No tiene quadernos este legajo, sino escrituras y papeles sueltos por el orden siguiente:

\section{$1^{\circ}$. < Concordia antigua. Era de 1285, año de 1247>.}

Concordia original escrita en pergamino partido por A B C, con quatro sellos de cera pendientes en filos de seda coloreada, otorgada entre el obispo de León don Martín y el cavildo de su yglesia, de una parte; y de la otra, don Gaufrido, prior mayor de San Zoil y camarero de Cluni en España, y su convento. Entre los quales havía pleito sobre los diezmos de todas las yglesias de Aguilar que el monasterio pretendía serle debidos por la donación que de ellos havía echo el rey don Alonso el $9^{\circ}$, en la era de 1218, que es año de Cristo de 1180, quando tomó por trueque la villa y castillo de Castromayor (que ahora se llama Aguilar), como consta de su privilegio que está en el cajón San Ildefonso, entre los papeles de Villaverde, legajo $1^{\circ}$, quaderno A, número $1^{\circ}$; y por la posesión que tenía de más de 40 años de llevar los diezmos dando una parte voluntariamente a la yglesia de León, y el obispo y el cavildo pretendían los dichos diezmos por el derecho común de que no les pudo despojar el rey para darlo al monasterio.

Este pleito se compuso con esta concordia, por la qual se determinó que la yglesia de San Juan tenga perpetuamente 120 parroquianos de suerte que, faltando alguno por muerte o por otro accidente, se subrrogue y nombre otro de las demás yglesias en su lugar, el qual tenga las mismas calidades y hacienda que el que faltó; de suerte que en todo tiempo esté completo el número de los 120 feligreses, cuyos diezmos se habían de partir en esta forma: que el obispo y cavildo de León lleven la tercera parte de los diezmos de pan, vino y legumbres; y las otras dos terceras partes las lleve el monasterio con todo el diezmo de todos los ganados y menudos de todos los 120 feligreses, con todas las ofrendas quotidianas / ( $f$. 13v) y distribución de vivos y difuntos de la yglesia de San Juan. En quanto a los diezmos de las demás yglesias, se determinó que el obispo lleve una tercia de los diezmos del pan, vino y legumbres; las fábricas otra tercia; y que la otra tercia lleven los clérigos la mitad y el monasterio la otra mitad. Y además de estas tercias, que lleve la yglesia de San Juan una tercia del ganado y de los diezmos menudos de todas las demás yglesias, que es la que solía llevar el obispo de León; y que el monasterio quede con el foro o censo que le solían pagar <las yglesias o $>^{21}$ los clérigos. Prometen el obispo y la yglesia de León conservar al monasterio en la posesión perpetua y pacífica de todo lo dicho y ampararle en todos sus negocios; y lo mismo promete el monasterio al obispo y cavildo. Otorgose esta concordia en Villalpando, tertio ydus julii, era 1285, que es año de Cristo 1247, ante Domingo de Ramos, notario de Villalpando, estando presentes don Guillelmo Olim, abad de Sahagún, Gonzalo Pérez, prior de San Román, Juliana, priora, y Marina de Juan, monja de San Miguel de Villalpando, y otros muchos.

$2^{\circ}$. <Trasumto legalizado de la misma concordia. Año de 1423>.

Trasumto legalizado en Roma por el doctor Domingo de San Geminiano, auditor general de la Cámara Apostólica, de la concordia anterior. Está escrito en pergamino con sello de cera pendiente en filos de cáñamo. Su fecha, a 5 de julio de 1423, ante Juan Valiar de Vico, notario. Aquí hay otros dos trasumtos.

$3^{\circ}$. Bajo este número están los papeles siguientes:

$<$ Nombramiento de los 120 feligreses y modo de repartirlos. Años de 1382 y $1422>$.

$1^{\circ}$. Testimonio y requerimiento echo por Alfonso Fernández, cura de San Juan, en virtud de poder de don Guido de la Cusol, prior mayor de San Zoil, para que el dicho cura recibiese en su nombre los 120 feligreses que se daban cada año a la yglesia de San Juan; de los quales, había de haber y cobrar del rector de Santa María 40 feligreses, del rector de San Estevan ${ }^{22}$ otros 40 y del de San Pedro otros 40 . Y el dicho Alfonso Fernández, cura de San Juan, requirió al retor de San Estevan que le diere y señalase los dichos 40 feligreses que le tocaban como estaba obligado; el qual

$21<$ las yglesias o>] escrito al margen izquierdo, y indicado con señal de (Cruz) dónde se ha de colocar.

${ }^{22}$ San Estevan] sigue tachada ta detras de San, y escribe la E de Estevan sobre M. 
confesó estarlo como sus antecesores, y así los nombró y señaló con efecto y juró que estaban bien nombrados. Su fecha, a 6 de noviembre, era de 1420, año de Cristo 1382, ante Pedro Ruiz, escribano público en Palazuelo.

$2^{\circ}$. Requerimiento echo de don Guido de la Cusol, prior mayor de San Zoil, al retor de la yglesia de San Pedro para que le diere y nombrare los 40 feligreses que le tocaban de los 120 que pertenecían a la yglesia de San Juan. Y el dicho retor confesó estar obligado y los nombró. A 15 de noviembre, era 1420, año de / (f. 14r) Cristo de 1382, ante Álvar Rodríguez, escribano público de Villalpando.

$3^{\circ}$. Requerimiento y protesta echa por Fernando González de Velforado, en nombre de su señor don Pedro ${ }^{23}$, prior mayor de San Zoil (capellán mayor del ynfante don Juan), a los clérigos y cavildo de la villa de Aguilar para que nombraren 7 feligreses que faltaban al cumplimiento de los 120 feligreses a que estaban obligados por la concordia que está puesta arriba en el número $1^{\circ}$. Su fecha, a 13 de septiembre de 1422, ante Gonzalo Alfonso de León, escribano en Aguilar. A esta concordia respondieron los clérigos que no sabían de tal concordia y, que si la había, no se debía entender con ellos sino con los que la hicieron. Por esto y otras razones que alegaron, se negaron al nombramiento.

$4^{\circ}$. $<$ Sentencia del obispo Eugubino para que se guarde la concordia. Año de 1444>.

Sentencia original, escrita en pergamino con sello de cera pendiente en filos de ilo colorado, dada por el obispo Eugubino, en virtud de comisión del papa Eugenio $4^{\circ}$, por la que manda guardar la concordia del año 1247, quanto a los 120 feligreses de San Juan de Aguilar; y condena a los clérigos y cavildo a pagar al monasterio los corridos de los feligreses que no se habían nombrado, y las costas. Dada en Roma, a 12 de agosto de 1444. Ante Juan Ratingh de Holsten, notario de la curia romana.

$5^{\circ}$. $<$ Bulla de Eugenio $4^{\circ}$, confirmatoria de la sentencia anterior. Año de 1444>.

Bulla del Papa Eugenio $4^{\circ}$, escrita en pergamino con sello de plomo pendiente, por la que confirma la sentencia anterior del obispo Eugubino a favor de este monasterio y da comisión a los obispos de Burgos, León y Ancona para que la hagan executar y guardar. Su data, décimo kalendas octobris, anno 1444, pontificatus anno 14.

\section{$6^{\circ} .<$ Otra bulla como la anterior $>$.}

Otra bulla del mismo papa que contiene lo mismo que la anterior, y está en la misma forma y estilo y con el mismo sello y fecha.

7. < Executoriales de Roma dadas por el obispo de Ancona. Año de 1444>.

Dos bullas (duplicadas) executoriales de Roma, escritas en pergamino con sellos de cera pendientes en cuerdas de cáñamo colorado, dadas por el obispo de Ancona, juez executor por el papa Eugenio $4^{\circ}$, de la sentencia que en el pleito de los 120 feligreses de San Juan de Aguilar dio a favor de este monasterio el obispo Eugubino, que es la que queda puesta en el número $4^{\circ}$. Su fecha, en Roma, a 23 de septiembre de 1444. Ante Juan Ratingh de Holsten, notario de la curia romana.

8. <Trasumtos de los executoriales anteriores y su obedecimiento por el cavildo de Aguilar. Año de 1445>.

Dos trasumtos, el uno autorizado y el otro simple, de las executoriales anteriores del obispo de Ancona. Con estos executoriales fue requerido / (f. 14v) Juan González de Ravanal, canónigo de Palencia, por don Pedro de To(sa)santos, abad de San Zoil. Yntimáronse a los curas y clérigos de Aguilar, los quales le obedecieron y en su cumplimiento nombraron 30 feligreses que faltaban para el número de los 120 que debía de haber; y asimismo obedecieron y cumplieron lo demás que se les mandaba por los dichos executoriales. En 15 de junio de 1445 años, ante Diego Gómez de Saldaña, clérigo de la diócesis de León y notario apostólico.

9. <Requirimiento para que se cumplan los 120 feligreses. Año de 1451>.

23 Pedro] al margen derecho: Don Pedro, prior mayor de San Zoil, capellán mayor del ynfante don Juan. 
Requerimiento echo por Pedro García, de Villasur de Ferreros, en nombre de don Pedro de Tosantos, abad de San Zoil, a los clérigos de Aguilar para que nombrasen los feligreses que faltaban al cumplimiento de los 120, los quales lo cumplieron, aunque mal porque nombraron a una mujer debiendo ser un varón. Su fecha, en Aguilar, a 24 de septiembre de 1451, ante Gonzalo Alfonso de León, escribano de Aguilar.

10. < Requirimiento para lo mismo. Año de 1505>.

Otro requirimiento echo por el prior de San Juan de Aguilar a los clérigos para el mismo nombramiento de feligreses y se cumplió. A 22 de julio de 1505, ante Cristóval de Barriales, escribano en Aguilar.

11. <Escrituras de nombramientos de feligreses. Año de 1539>.

Un quaderno de escrituras de demandas puestas ante el prior de Escalada, juez conservador. Requirimientos echos a los clérigos de Aguilar y otros papeles sobre el nombramiento de los 120 feligreses. Hechos en el año de 1539. $1541>$.

12. <Súplica a Su Santidad sobre el nombramiento de los 120 feligreses. Año de

Súplica a Su Santidad en razón del nombramiento de los 120 feligreses que no querían cumplir los clérigos, sin embargo de la sentencia dada por el prior de Escalada a favor del monasterio, y confirmada por Lope Castañón, canónigo de León, que está adelante en el número 14. Esta súplica no tiene fecha, parece ser del año de 1541.

13. $<$ Requirimiento para que se cumplan los 120 feligreses a que se negaron los curas. Año de 1541>.

Requirimiento con protesta echo por Fray Miguel de Velorado, prior de San Juan, a los curas y clérigos de Aguilar para que cumplan el número de los 120 feligreses según están obligados. Su fecha, en Aguilar, a 12 de agosto de 1541, ante Lope se Valderas, escribano en dicha villa. Respondieron los curas que estaba pleito pendiente sobre esta causa, que por culpa del monasterio no se sentenciaba, y que hasta que se determinase no tenían obligación de cumplir lo que se les pedía. $1542>$.

14. $<$ Carta executoria a favor del monasterio en razón de los 120 feligreses. Año de

Carta executoria a favor del monasterio en el pleito de los 120 feligreses de San Juan de Aguilar, por la qual parece que, en la ciudad de León, a 22 de mayo de 1542, por ante Diego de Peñafiel, escribano y notario de León, fue requirido por parte del monasterio Lope Castañón, canónigo de León, / (f. 15r) con una comisión y subdelegación en él echa por don Alonso Fernández de Madrid, arcediano del Alcor y canónigo de Palencia, juez principal por breve apostólico de la Santidad del [papa] Paulo $3^{\circ}$; el qual acató la comisión por muerte del arcidiano de Valdemiriel, canónigo de León, que primero en virtud del mismo breve había empezado a conocer en esta causa.

$<$ Narrativa echa por el monasterio al papa Paulo $3^{\circ}>$.

Con este requirimiento se presentó al dicho Lope Castañón una súplica echa por el monasterio a Su Santidad, en la que le hace relación de lo contenido en la concordia del año 1247, que queda puesta en el número $1^{\circ}$, y asimismo de la sentencia dada por el obispo Eugubino. Dada año de 1444, confirmada por Eugenio $4^{\circ}$ y mandada observar por las executorias del obispo de Ancona el mismo año de 1444, cuyos instrumentos quedan puestos arriba en los números $4^{\circ}, 5,6$.

$<$ Sentencia del prior de escalada, juez conservador. Año de 1541 $>$.

Y si bien las dichas sentencias y executorias se guardaron por espacio de más de 100 años, con todo eso había como más de tres años que, faltando 13 feligreses del número de los 120, requirió el monasterio a los clérigos para que completasen dicho número. Y por no quererlo hacer acudió a pedir el cumplimiento ante el prior de Escalada, su juez conservador, el qual, en conformidad a las sentencias y executorias sobredichas, condenó a los clérigos a que nombrasen luego a los 13 feligreses que faltaban. De esta sentencia apelaron los clérigos, 
y el conservador les negó la apelación de los que se quejaron por vía de fuerza a la chancillería de Valladolid, donde se mandó que otorgase, y por obedecerles otorgó la apelación.

$<$ Presentación de instrumentos por parte del monasterio $>$.

De este mandamiento se sintió agraviado el monasterio y acudió a Su Santidad pidiéndole remedio y desagravio. Dio Su Santidad comisión para ello al prior de Santa María de Trianos y a los arcedianos de Villameriel en León y del Alcor en Palencia. El de Villameriel fue requerido, acetó, procedió, murió. Fue requerido el del Alcor para que procediese y prosiguiese, acetó y después se escusó; subdelegó en el referido Lope Castañón, quien acetó la subdelegación y, en virtud del brebe de Paulo $3^{\circ}$, dado a 30 de enero de 1542 , procedió al conocimiento de esta causa y despachó compulsa citatoria e ynibitoria. Presentó el monasterio la sentencia dada por don Santiago de los Ríos, prior de Escalada, en Carrión, a 27 de agosto de 1541, ante Juan de Castillo, escribano en Carrión. Y asimismo presentó el requerimiento que hizo don Pedro de Tosantos, abad de San Zoil, al cavildo de Aguilar, año de 1445; que queda puesto arriba en el número $8^{\circ}$ con los demás instrumentos arriba citados.

$<$ Sentencia de Castañón, juez executor. Año de 1542>.

Estando la causa en este estado, hubo competencia de jurisdicción porque los clérigos habían apelado al nuncio de la sentencia del prior de Escalada, y sacaron / (f. 15v) breve de comisión para el arcediano de Montenegro, quien procedió a inhibir al canónigo Lope Castañón; y este inhibió a Montenegro, el qual subdelegó en el provisor de León. Sin embargo, la causa fue conclusa para prueba ante el canónigo Castañón, quien dio auto para ella, en 11 de julio de 1542, del qual apeló la parte de los clérigos. Hiciéronse probanzas y, pasado el término, el monasterio pidió publicación de ellas y se notificó a las partes. Pidió el monasterio sentencia en atención a que la causa estaba conclusa; y el dicho canónigo Lope Castañón, juez apostólico, dio sentencia definitiva por la qual, con acuerdo del licenciado Mayorga, su asesor, confirmó la sentencia dada por el prior de Escalada. La qual mandó se llevase a debida execución hasta que por el cavildo de Aguilar fuese cumplida y executada, satisfaciendo al monasterio y priorato de San Juan los 120 feligreses diezmeros, dando los que faltasen al cumplimiento de dicho número, equivalentes en diezmería, que diezmen, primicien y ofrenden en San Juan según está mandado y que, atento que litigaron mal los clérigos, paguen al monasterio lo que habían de haberle diezmado y ofrecido los feligreses que faltaban al cumplimiento de los 120 . Y los condenó en las costas, reservando en sí la tasación de uno y otro, mandando que todo lo cumplan dentro de 9 días después del pronunciamiento de la sentencia, so pena de excomunión. $1544>$.

$<$ Acetan y cumplen los clérigos la sentencia y se apartan de la apelación. Año de

De esta sentencia apelaron los clérigos, en 18 de agosto de 1542. Presentó el monasterio un memorial jurado de las costas para que se tasasen y pidió carta executoria de la sentencia. Tasáronse las costas en 5870 maravedís y se mandó librar mandamiento con censura para que se pagasen, como también la carta executoria de cuyo auto apeló la parte contraria. Libró el juez mandamiento de execución con censura para que se guardase la sentencia del prior de Escalada y la suya, y se pagasen las costas; lo qual se cumplió y executó y se bolbieron al juez los despachos notificados. Y los clérigos, al requerimiento que se les hizo con las sentencias, respondieron que ya las habían cumplido y echo nombramiento de los feligreses que faltaban, y que habían pagado las costas y, que si otra cosa faltaba, que lo dixesen y lo cumplirían luego, como lo / (f.16r) hicieron en 2 de abril de 1544. Y aprobaron y dieron por buenas las dichas sentencias apartándose de la apelación que tenían interpuesta ante el dicho Lope Castañón, lo que así se cumplió. Y, habiéndolo acetado la parte del monasterio, pidió que todo se le diese por testimonio; y se le dio firmado del juez y signado de Diego de Peñafiel, notario y escribano de León, ante quien todo ello pasó, a 25 de junio de 1544 .

15. < Poder del convento para el cumplimiento de los 120 feligreses. Año de 1562>.

Poder del monasterio dada (sic) a fray Juan de Ayala, mayordomo, y a Francisco Gómez, solicitador de causas de Valladolid, para que pidan a los clérigos de Aguilar el 
cumplimiento de los 120 feligreses y los diezmos. Su fecha, en San Zoil, a 17de junio de 1562, ante Andrés Sánchez, escribano de Carrión.

16. <Requirimiento a los clérigos para que nombren feligreses calificados para el priorato de San Juan. Año de 1577>.

Requirimiento echo por parte del monasterio a los clérigos de Aguilar sobre que, debiendo tener el priorato 120 feligreses calificados como lo que solía tener antes, que le daban más de 120 cargas de pan sin otros aprovechamientos, los clérigos habían nombrado los más pobres, de suerte que no diezmaban 6 cargas de trigo; siendo así que el priorato daba al cura de San Juan 20 cargas de trigo, 5 de zebada y 108 maravedís porque sirviese el beneficio. Por tanto, se les requirió que nombrasen de nuevo los 120 feligreses de la calidad, cantidad y aprovechamiento que habían sido los de los tiempos pasados y que satisfaciesen lo que hasta allí había perdido el priorato. Los curas respondieron que estaban prontos a nombrar los feligreses que faltaban, y con efecto nombraron 11 personas que entregaron al prior fray Antonio de Molina. En Aguilar, a 13 de julio de 1577, ante Cristóval de valderas, escribano en la misma villa. Este requirimiento está duplicado.

17. <Requirimiento para que se cumplan los 120 feligreses. Año de 1578>.

Otro requirimiento echo por fray Damián de Salas, mayordomo de San Zoil, a los curas de Aguilar para que nombrasen los feligreses que faltaban al número de los 120. Obedecieron y nombraron 7 que faltaban. En 13 de junio de 1578, ante Cristóval de Valderas, escribano en Aguilar.

18. $<$ Dos brebes de Roma duplicados. Año de 1578>.

Brebe original, duplicado, de Roma, con sello de cera pendiente, escrito en pergamino, dado por Gaspar Gropero, año de 1578. Es compulsorio, inhibitorio y citatorio.

19. <Demanda para el cumplimiento de los 120 feligreses. Año de 1578>.

Demanda puesta por el monasterio ante el ordinario de León, a los curas y clérigos de Aguilar por el mal nombramiento que hacían de los 120 feligreses de San Juan, escogiendo siempre los más pobres, de modo / (f.16v) que apenas diezmaban, entre todos, al monasterio 3 ó 4 cargas. Acusáronse las reveldías a los clérigos. No hay aquí más autos. Púsose esta demanda año de 1572.

20. < Requirimiento y nombramiento de feligreses en San Juan. Año de 1584>

Requirimiento echo por fray Francisco Undona, prior de San Juan, a los clérigos de Aguilar para que nombrasen los feligreses que faltaban al cumplimiento de los 120. Obedecieron y nombraron 38. En Aguilar, a 11 de julio de 1584, ante Cristóval de Valderas, escribano de dicha villa.

21. < Parecer de un abogado. Año de 1592>.

Ynstrucción de un abogado para poner la demanda a los clérigos de Aguilar y copia simple del primer pedimiento de demanda. Año de 1592.

22. <Copias simples de seis sentencias desde el año de 1592 hasta el de 1599>.

Copias simples de seis sentencias que ha habido en el pleito de los 120 feligreses dadas por diversos jueces, y algunos autos del nuncio, Consejo y chancillería sobre lo mismo. Desde el año de 1595 hasta el de 1599.

23. < Censuras contra los que ocultaban los bienes del monasterio. Año de 1597>.

Censuras del provisor de León, en virtud de una paulina del nuncio, contra los que ocultaban los bienes del monasterio y contra los que señalaban diezmeros de poco provecho en Aguilar. Sus fechas, en León, a 24 de abril de 1597, ante Buenaventura de Madrid, secretario.

24. $<$ Duda en apelación de la sentencia $>$.

Duda y respuesta de letrados sobre si un tercero puede apelar de la sentencia de otro tercero quando le es perjudicial, y cómo se ha de portar el tal apelante. No tiene fecha. 


\section{5. $<$ Ynterrogatorio de los clérigos $>$.}

Ynterrogatorio de los clérigos de Aguilar para la liquidación de los frutos de los 120 feligreses. No tiene fecha. $1600>$.

26. $<$ Padrones de los vecinos y pechería de Aguilar. Desde el año de 1558 hasta el de

Padrones de los vecinos y pechería de Aguilar para el nombramiento de los 120 feligreses desde el año de 1558 hasta el de 1600. La mayor parte de estos papeles no tienen autoridad alguna; sólo hay de consideración uno, mandado sacar a instancia del monasterio por el licenciado Gallego de Robles, juez executor, por comisión del provisor de León, de la carta executoria de los 120 feligreses. Sacó este padrón Cristóval de Valderas, escribano de Aguilar, año de 1598. Por tener esta formalidad se pasó el primero.

27. < Recivo del proceso original. Año de 1598>.

Recivo del proceso original en remisión del nuncio al provisor de León, dado por nuestro padre fray Alonso Barrantes, en Madrid, a 27 de febrero de 1598; y remitido por el mismo a Gerónimo de la Serna, notario de Valladolid, a 23 de abril del mismo año de 1598.

28. < Testimonio de un auto de remisión del nuncio. Año de 1598>.

Testimonio de un auto de remisión del nuncio al ordinario de León, mandándole que oyga a la parte del señor almirante por lo que / $(f .17 r)$ toca a su interés y no más y haga justicia. Dado en Madrid, a 26 de febrero de 1598, authorizado de Juan Obregón, oficial de la justicia del nuncio. Hai aquí un traslado autorizado de el mismo.

29. < Provisión Real original. Año de 1598>.

Provisión del Consejo Real para que, si el provisor de León no executare, se lleve el proceso a Valladolid para declarar la fuerza. Dada en Madrid, a 24 de febrero de 1598, ante Miguel de Ondozea, escribano de cámara de Su Magestad. Es original. $1598>$.

30. $<$ Comisión del provisor de León para que se executen las tres sentencias. Año de

Comisión del doctor Francisco del Pozo, provisor de León, dada a Sebastián Martínez, clérigo de León, y a Juan de Quiroga, escribano de la misma ciudad, para que executen las tres sentencias conformes. Y carta executoria de ellas sobre el nombramiento de los 120 feligreses de San Juan de los Medianos. Dadas, la primera por don Luys Niño, chantre de Valladolid, a 27 de enero de 1596; la 2a , por el maestro fray Luis de Calatayud, ministro de la Trinidad de Valladolid, a 3 de abril de 1596; y la tercera, por fray Gerónimo de Bustamante, comendador de la Merced de Valladolid, a 19 de marzo de 1597; el qual, por su auto, cometió la execución de las referidas sentencias al dicho provisor de León. Todo está inserto en esta comisión. Las sentencias son las que están atrás, número 22 , y el auto de nuncio en el número 28. Esta comisión, que fue dada en León, a 13 de marzo de 1598, ante Andrés Ortiz, escribano y notario, está authorizada del referido escribano Juan de Quiroga. $1598>$.

31. < Poder general para cobranzas y para notificar al almirante de Castilla. Año de

Poder general para cobranzas y pleitos dado por el monasterio a su abad fray Pedro de Torrecilla y a fray Antonio de los Ríos, mayordomo, otorgado a 26 de marzo de 1598, ante Andrés Sánchez, escribano en Carrión, y substitución en don Francisco de Paz de la Serna; y a Nicolás Muñoz, procurador del Consejo de Su Magestad, para notificar, especialmente al almirante de Castilla, una provisión real tocante al pleito de Aguilar. Su fecha, en Carrión, a 26 días del mismo mes y año, y ante el mismo escribano.

32. < Provisión real para la execución de las tres sentencias. Año de 1598>.

Provisión de la real chancillería de Valladolid para que el ordinario de León mande executar la comisión que dio para la execución de la (sic) tres sentencias, y carta executoria acerca del nombramiento de los feligreses. Dada en Valladolid, a 18 de julio de 1598, ante Pedro Martínez Carranza, escribano de Su Magestad. Es original. 
/ (f. 17v) 33. < Provisión de la Chancillería para la execución de la carta executoria. Año de $1598>$.

Otra provisión de la chancillería, inserto un auto contra el ordinario de León, para que guarde y execute la comisión que había dado, en 13 de marzo, para la execución de la carta executoria y nombrar feligreses. Dada en Valladolid, a 12 de agosto de 1598, ante Juan de Villafranca, escribano de cámara de Su Magestad. Es original.

34. $<$ Mandamiento para que se pague al monasterio lo que se ha dejado de diezmar. Año de $1598>$.

Mandamiento del licenciado Robles, juez executor de las tres sentencias, para que se junten los clérigos a la compulsa de las tazmías para el nombramiento de los 120 feligreses, y que se pague al monasterio lo que se ha dejado de diezmar. Su fecha, a 22 de agosto de 1598, ante Juan de Quiros, escribano.

35. < Brebe del nuncio para que se le lleven los autos originales. Año de 1598>.

Brebe del nuncio Camilo Caetano para que se le lleven los autos originales sobre el nombramiento de los 120 feligreses. Dado en Madrid, a $1^{\circ}$ de septiembre de 1598 , autorizado por Bartolomé Gutiérrez, notario apostólico. Hay aquí dos copias simples de este breve.

36. < Dudas sobre la execución. Año de 1598>.

Dudas sobre la execución de las tres sentencias que estaba haciendo el licenciado Gallego de Robles, y pareceres de algunos letrados sobre este particular. Año de 1598.

37. < Escritura de suspensión del término de 40 días. Año de 1598>.

Escritura de suspensión y prorrogación del tiempo y término de 40 días, que había dado el nuncio en un breve para que se inhibiese de la execución de la carta executoria el licenciado Gallego de Robles; y que el escribano enviase los autos. Y los clérigos, de una parte, y nuestro padre fray Alonso Barrantes, de la otra, acordaron que se tomasen 20 días más de término, en los quales no corriese el que había dado el nuncio. Su fecha, en Aguilar ,a 16 de septiembre de 1598, ante Cristóval de Valderas, escribano en dicha villa.

38. <Mandamiento para que el provisor guarde el auto de remisión. Año de 1599>.

Mandamiento del nuncio para que el provisor de León guarde el acto de remisión, sin embargo de otras letras de inhibición que se le hayan notificado. Dado en Madrid, a 30 de enero de 1599, ante Juan de Obregón, notario apostólico. Es original.

39. < Sentencia dada por el licenciado Robles para la execución de las tres sentencias sobre el nombramiento de los 120 feligreses. Año de 1599>.

Sentencia dada por el licenciado Gerónimo Gallego de Robles, juez comisionado por el licenciado Pozo, provisor de León, para la execución de las tres sentencias conformes; y carta executoria a favor del monasterio sobre el nombramiento de los feligreses que faltaban al número de los 120 que debía tener la parroquia de San Juan. Por esta sentencia declara que los curas no habían calificado el nombramiento de 45 parroquias que habían echo, el qual era injusto y contra derecho, contra la (sic) tres sentencias. Y concordia antigua, assí en calidad como en cantidad, / (f. 18r) por que las viudas de parroquianos muertos que lo havían sido de la parroquia de San Juan no pudieren suplir ni subrogar a sus maridos, ni tampoco los desavecindados, desterrados y ausentes que de propósito hacen ausencia. Por lo qual, revocó el dicho nombramiento y le hizo de nuevo conforme a las dichas sentencias, sacando para nombrarles, minuta de todos los feligreses de todas las parroquias; graduando los más ricos y los más pobres por su orden y sacando y nombrando los que eran medianos en calidad y diezmería, y a éstos declaró por sus nombres por parroquianos de San Juan. Y les mandó con censura se tengan por tales y acudan con los diezmos, primicias y oblaciones enteramente al prior de San Juan, y de allí reciban los sacramentos. Y a todos mandó guardar esta sentencia que se les notificó. Su fecha, en Aguilar, a 3 de abril de 1599, ante Alonso del Vado, notario de León. 

$1599>$.

40. <Provisión de la Chancillería para la execución de las tres sentencias. Año de

Provisión de la Chancillería contra el ordinario de León para que otorgue y reponga lo acetuado cerca de retardar la execución de las tres sentencias; y carta executoria y absuelva, etcétera. Dada en Valladolid, a 5 de mayo de 1599, ante Juan de Villafranca, escribano de cámara de Su Magestad.

41. <Brebe del nuncio para que se lleven a él los autos originales. Año de 1599>.

Brebe del nuncio, a petición de los clérigos de Aguilar, para inhibir al provisor de León, citar, compulsar y llevar los autos, a él, originales. Dado en Madrid, a 12 de mayo de 1599, ante Bartholomé Gutiérrez, notario apostólico. $1599>$

42. <Provisión de la chancillería para la execución de las tres sentencias. Año de

Provisión de la Chancillería contra el ordinario de León porque retardaba la execución de las tres sentencias, y carta executoria. Dada en Valladolid, a 14 de mayo de 1599, ante Juan de Villafranca, escribano de cámara de Su Magestad.

43. $<$ Requirimiento echo al licenciado Pozo para que entregue los autos al escrivano. Año de 1599>.

Requirimiento echo por parte del monasterio al licenciado Pozo, provisor de León, con una provisión y auto de la chancillería para que entregue los autos de execución de la carta executoria al escrivano, para que se prosiga en ella y no se retarde. Su fecha, en León, a 25 de mayo de 1599, ante Juan Fernández de Vega, escribano y notario de León.

44. <Requirimiento a los curas para que nombren 5 feligreses. Año de 1599>.

Requirimiento a los curas para que nombrasen 5 feligreses que faltaban al cumplimiento de los 120 feligreses, iguales a los 5 que habían muerto. Respondieron que cumplirían lo que tenían obligación. Su fecha, en Aguilar, a 10 de julio de 1599, ante Cristóval de Valderas, escribano en dicha villa. Está duplicado. $1599>$.

/ (f. $18 v)$ 45. <Mandamiento para que el monasterio pague a un escribano. Año de

Mandamiento del provisor de León para que el monasterio pague a un escribano los derechos que le debía de la execución de la carta executoria. Dada en León, a 20 de julio de 1599, ante Antonio de Cafra Arguelles, notario de León.

46. <Mandamiento para que no se notifiquen censuras. Año de 1599>.

Mandamiento del provisor de León para que prendan a qualquiera que notificare algún mandamiento o censuras del juez conservador del monasterio. Su fecha, en León, a 9 de agosto de 1599, ante Victorio Vado, notario en León.

47. <Copia simple de un brebe del nuncio para que no se proceda contra los clérigos de Aguilar. Año de 1599>.

Copia simple de una ynhibitoria del nuncio para que ni el provisor de León, ni el licenciado Gallego de Robles, ni el bachiller Domingo de los Ríos, juez conservador, procedan contra los clérigos de Aguilar en ciertas causas a que se habían quejado tocantes a los pleitos de los diezmos y feligreses de San Juan. Dado en Madrid, a 13 de octubre de 1599.

48. <Requirimiento a los curas para que nombren 10 ó 12 feligreses que faltaban. Año de 1600>.

Requirimiento a los curas para que nombrasen 10 ó 12 feligreses que faltaban al cumplimiento de los 120. Respondieron que había pleito pendiente en la nunciatura y, hasta que se sentenciase, no querían nombrarlos. Su fecha, en Aguilar, a 11 de julio de 1600, ante Cristóval de Valderas, escribano en dicha villa. 
49. <Requirimiento al mayordomo de la yglesia de San Juan para que no nombre diezmero. Año de 1600>.

Requirimiento del monasterio al mayordomo de la yglesia de San Juan para que no nombre diezmero ni primiciero a ninguno de los 120 feligreses nuevamente nombrados por dicha yglesia. Su fecha, en Aguilar, a 10 de enero de 1600, ante Cristóval de Collantes, escribano de la dicha villa.

50. < Copia simple de un brebe del nuncio para que ningún juez conozca de la causa de los 120 feligreses. Año de 1600>.

Copia simple de un brebe inhibitorio de nuncio para que don Pedro del Campo, juez conservador, abad de Benevívere, ni otro ningún juez, conozca de la causa que estaba pendiente en la nunciatura entre el monasterio de San Zoil y los clérigos de Aguilar. Su fecha, en Aguilar, a 11 de julio de 1600. $1600>$.

51. <Mandamiento del provisor para que no se obedezcan las censuras. Año de

Mandamiento del doctor pozo, provisor de León, para que no se obedezcan las censuras que embiare el juez conservador del monasterio. Su fecha, en León, a 29 de agosto de 1600 . $1600>$.

52. < Otro mandamiento de el mismo y para lo mismo, y auto al pie de él. Año de

Otro mandamiento del mismo provisor para lo mismo, y auto y declaración al pie de él para que no se entienda en lo tocante al pleito pendiente ante el nuncio de que está inhibido, ni en lo que fuere conforme a derecho y al santo concilio de Trento. Dados en León, a 23 de agosto de 1600 y 2 de septiembre del mismo año, ante Pedro Álvarez, notario. de $1600>$.

53. < Provisión de la chancillería al provisor de León para que embíe los autos. Año

Provisión de la chancillería contra el provisor de León para que otorgue y reponga o embíe los autos sobre impedir los mandatos del juez conservador. Dada en Valladolid, a 5 de septiembre de 1600, ante Juan de Villafranca, escribano de cámara de Su Magestad. Está aquí otra provisión sobre lo mismo. Dada en 30 de septiembre del mismo año y ante el mismo escribano. $1600>$.

/ (f. 19r) 54. <Certificación de entrega del proceso sobre los 120 feligreses. Año de

Certificación y fe de Gerónimo de la Serna, notario de Valladolid, de cómo entregó a Andrés Gutiérrez, cura de Aguilar, el proceso original del nombramiento de los 120 feligreses en 1323 ojas, en virtud de un mandamiento compulsorio del nuncio, dado a instancia de los clérigos de Aguilar, para llevarlo y presentarlo en aquel tribunal en grado de apelación. Su fecha, en Valladolid, a 21 de octubre de 1600.

55. <Provisión Real para que el provisor embíe el proceso. Año de 1600>.

Provisión del Consejo Real para que el provisor de León otorgue y reponga o embíe el proceso al Consejo. Su fecha, en Madrid, a 18 de noviembre de 1600, ante Juan Gallo de Andrada, escribano de cámara de Su Magestad.

56. <Apelación del auto de execución para la sentencia del nuncio. Año de 1600>.

Testimonio de apelación, interpuesta por parte del monasterio, de un auto que dio el provisor de León en que mandaba se executase la sentencia que havía dado el nuncio en la causa del nombramiento de los 120 feligreses, que es la $6^{a}$ de las que dan puestas atrás en el número 22 de este legajo, la qual era contra las tres sentencias conformes, y carta executoria de ellas que tenía el monasterio, el qual havía apelado de la sentencia del nuncio y también de este auto de su execución. Su fecha, en León, a 28 de noviembre de 1600, ante Andrés Ortiz, escribano y notario de la dicha ciudad. 
57. < Compulsoriales de pleito de los 120 feligreses. Año de 1600 y 1601>.

Mandamiento para hacer la compulsa del pleito de los 120 feligreses de San Juan de Aguilar, en virtud de un mandamiento compulsorial de Roma, dado para este efecto por el doctor Francisco Peña, auditor de Rota, cuyo trasumto autorizado está aquí. Su fecha, en Roma, a 20 de diciembre de 1600 . Y los mandamientos en virtud de él y la notificación al nuncio se hicieron año de 1601.

58. <Mandamiento inhibitorio del nuncio. Año de 1601>.

Mandamiento original del nuncio en el qual inhibe, al provisor de León, y a otros qualesquiera jueces, del conocimiento de la causa y execución de la carta executoria librada por el mismo nuncio. Su fecha, en Valladolid, a 23 de junio de 1601. $1601>$.

59. <Mandamiento del mismo para que ningún juez conozca en la causa. Año de

Trasumto autorizado de otro mandamiento del mismo nuncio, dado a instancia de los clérigos de Aguilar, por el qual manda a los jueces conservadores y a otros qualesquiera que no conozcan de la causa de los 120 feligreses inmortales durante inhibitione. Su fecha, en Valladolid, a 27 de junio de 1601. Está signado de Cristóval de Valderas, escribano de Aguilar.

60. $<$ Requirimiento para que nombren los feligreses que faltaban. Año de 1601>.

Requirimiento echo por parte del monasterio a los curas de Aguilar para que nombren los feligreses que faltan al cumplimiento de los 120 immortales. Su fecha, en Aguilar, a 11 de julio de 1601, ante Álvaro Freile, escribano en dicha villa.

$/(f .19 v) 61 .<$ Requirimiento para que ciertos feligreses paguen los diezmos mayores y menores y para que los curas de Aguilar no administren los sacramentos a los feligreses nuevamente nombrados. Año de 1601>.

Dos requerimientos echos por parte del monasterio: el primero a ciertos feligreses de San Juan para que le paguen los diezmos mayores y menores, los quales respondieron estar requiridos por el cavildo de Aguilar con un mandamiento del nuncio para que no los paguen al monasterio sino al cavildo, pero que los retendrían y pagarían a quien los huviere de haver; el segundo es echo a los curas de Aguilar, para que no se metan en administrar sacramentos, baptizar, casar, ni velar a los feligreses de nuevo nombrados por la yglesia de San Juan. Dados en Aguilar, a 15 de septiembre de 1601, ante el bachiller Montero de Castañeda, notario apostólico.

62. $<$ Brebe original de Roma, por el qual se inhibe al notario del conocimiento de esta causa. Año de 1600 y su notificación el (sic) de 1601>.

Brebe original de Roma, escrito en pergamino con sello de cera colorade pendiente, dado por el doctor Francisco Peña, auditor de Rota, a instancia de este monasterio en grado de apelación de la sentencia que contra él havía dado el nuncio; el qual se inhibió del conocimiento de este pleito y se compulsó para llevar a Roma el proceso que está adelante; y es todo el legajo $3^{\circ}$ de este cajón. Diose este brebe en Roma, año de 1600, y se notificó al nuncio en Valladolid, a 20 de junio de 1601, por Francisco Martínez de Luna, clérigo y notario apostólico.

63. < Provisión de la chancillería para que el provisor remita los autos. Año de 1601>.

Provisión de la chancillería al provisor de León para que remita los autos. Dada en Valladolid, a 24 de octubre de 1601, ante Juan de Villafranca, escribano de cámara de Su Magestad. $1601>$

64. <Copia simple de un auto del nuncio para que se cobren los diezmos. Año de

Copia simple de un auto del nuncio por el qual, a instancia del monasterio, alza el embargo que había puesto para que no se cobrasen los diezmos y da licencia para que se cobren; y al provisor de León, facultad para que pueda dar mandamientos para ello y remita 
la causa a La Rota. Dado en Valladolid, a 29 de octubre de 1601, ante Juan de Obregón, oficial mayor del nuncio.

65. < Sobrecarta para que el provisor cumpla lo mandado. Año de 1601>.

Sobrecarta de la chancillería para que el provisor de León cumpla lo que le estaba mandado por la anterior provisión. Dada en Medina del Campo, a 13 de diciembre de 1601, ante Juan de Villafranca, escribano de cámara de Su Magestad.

66. < Requirimiento a los curas para que den las tazmías. Año de 1602>

Requirimiento echo por parte del monasterio a los curas de Aguilar para que den las tazmías de los años 1600 y 1601. Su fecha, en Aguilar, a 19 de enero de 1602, ante Álvaro Freile, escribano en dicha villa.

\section{/ (f. 20r) Legajo $3^{\circ}$ del Cajón Santa María}

$<$ Aquí consta todo el derecho del monasterio y todos los pleitos que ha tenido sobre los 120 feligreses. Es mui de notar por la inteligencia que de todo se ha de tomar de aquí>.

Este legajo $3^{\circ}$ es un proceso que se compulsó para llevar a Roma en grado de apelación, el año 1601, del pleito tan reñido y costoso que tubo este monasterio de San Zoil con los curas y beneficiados de las quatro yglesias de la villa de Aguilar, principales litigantes, y con el Almirante de Castilla, la fábrica mayor y el cavildo de la yglesia de León, las fábricas de las yglesias y concejo de Aguilar, y con particulares feligreses de San Juan. Que todos salieron a la causa en el discurso del pleito sobre el nombramiento de los 120 feligreses de la yglesia de San Juan, si habían de ser de los equivalentes a los muertos y otros que faltaban, o de los medianos de las demás yglesias, de suerte que ni fueren de los más ricos ni de los más pobres en diezmería y hacienda. Lo que este proceso tiene digno de advertencia para inteligencia de esta materia es lo siguiente:

$<$ Privilegio del rey don Alonso el $9^{\circ}$. Año de 1180>.

A folio 128 de este proceso está compulsado el privilegio del rey don Alonso El $9^{\circ}$, dado en el año del Señor 1180, confirmado por el rey don Alonso el Sabio, año de 1256, por el rey don Fernando el $4^{\circ}$, año de 1304, y por el rey don Alonso el $11^{\circ}$, año de 1316. Cuyos originales están en el cajón San Ildefonso, legajo $1^{\circ}$, quaderno $\mathrm{A}$, número $1,2,3,4$.

$<$ Concordia antigua con el obispo y cavildo de León. Año de 1247>.

A folio 100 y 158 está compulsada la concordia antigua entre don Martín, obispo de León, y su cavildo, de la una parte, y Gaufrido, prior mayor de San Zoil y camarero de Cluni, con su convento, de la otra. Año de 1247. Cuyo original está en el número $1^{\circ}$ de legajo $2^{\circ}$ de este cajón.

$<$ Legalización de la anterior concordia. Año de 1423>.

A los mismos folios 100 y 158 está compulsada la legalización de la anterior concordia hecha por el doctor Domingo de San Germiniano, auditor general de la Cámara Apostólica. Año de 1423. Que está puesta en el número $2^{\circ}$ del mismo legajo $2^{\circ}$.

$<$ Sentencia del obispo Eugubino. Año de 1444>.

A los folios 124 y 162 están los auttos procesales y sentencia que dio el obispo Eugubino Caleme, por comisión del papa Eugenio $4^{\circ}$. Año de 1444. Que está en el número $4^{\circ}$ del dicho legajo $2^{\circ}$.

$/(f .20 v)<$ Bulla de Eugenio $4^{\circ}$ y executoriales de Roma, que confirman la sentencia anterior. Año de 1444>. 
A folio 101 esta la bulla de Eugenio $4^{\circ}$ dirigida a los obispos de Burgos, León y Ancona, para que executen la sentencia del obispo Eugubino. Año de 1444. Y al mismo folio y a los folios 115 y 159 están los executoriales de Roma dados por el obispo de Ancona, juez executor. Año de 1444. Estas bullas están en los números 5, 6 y 7 del mismo legajo $2^{\circ}$.

$<$ Proceso y sentencia del juez conservador. Año de 1541. Y carta executoria de Lope Castañón. Año de 1544>.

A folio 17 está el proceso y sentencia del prior de Escalada, juez conservador. Año de 1538. Y al folio 108 está otro proceso y sentencia del mismo juez conservador. Dada año de 1544. Con la sentencia y carta executoria del canónigo Lope Castañón. Año de 1544. La carta executoria está en el número 14 del dicho legajo $2^{\circ}$.

$<$ Proceso ante el provisor de León. Año de 1593>.

A folio 65 y 157 empieza la compulsa del pleito que puso el monasterio al cavildo de Aguilar ante el ordinario de León, a 27 de septiembre de 1593, sobre que los feligreses que le havían nombrado no eran equivalentes en diezmería. A folio 66 está el poder de los clérigos, la negativa y excepción que pusieron; y al 67, los alegatos de ambas partes.

$<$ Ynformación por parte del convento y compulsa de tazmías $>$.

$\mathrm{Al}$ folio 68 está la comisión, para hacer las informaciones, con la que fue requerido el cura de Zainos, quien aceptó la comisión al folio 69, y por el interrogatorio, que está a folio 70, hizo la información por parte del monasterio con 16 testigos y 5 calumnias, la que llega hasta el folio 81 . A folio 82 está la compulsa de las tazmías de Aguilar desde el año de 1592 hasta el año de 1594.

$<$ Compulsa de ynstrumentos $>$.

Al folio 99 y siguientes está la compulsa de las escrituras del archivo de San Zoil que son las que quedan puestas al principio de este proceso.

$<$ Ynformación por parte de los clérigos $>$.

Al folio 129 está la comisión del provisor para hacer la información por parte de los clérigos, a la que sigue el interrogatorio y provanza que hicieron con 14 testigos, ante el mismo juez y notario que la de el monasterio.

$<$ Sentencia del provisor de León. Año de 1595>.

A folio 149 recibiose la causa a prueba de tachas, y la información de seis testigos a folio 150. A folio 153 se dio la causa por conclusa, y a folio 154 está la sentencia dada por el licenciado Aparicio de Ortega, provisor de León, a 22 de febrero de 1595; por la que condena a los clérigos de Aguilar a que cumplan, dentro de 20 días, el número de los 120 feligreses subrogando equivalentes; pero les absuelve del sesmo de vino que les pedía el monasterio. Acetó éste la sentencia en lo favorable y apeló en lo perjudicial. $1596>$.

$<$ Proceso y sentencia del chantre de Valladolid, juez apostólico. Año de

A folio 2 está el requirimiento que hizo el monasterio a don Luis Niño, chantre de Valladolid, con un brebe del nuncio para que conociese de la causa. Acetado la comisión, despachó el chantre mandamiento inhibitorio / (f.21r) contra el provisor de León, quien se dio por inhibido en $1^{\circ}$ de junio de 1595.

A folio 4 está el poder del cavildo de Aguilar. Oídas las partes, dio su sentencia el mismo chantre, que está a folio 6, en 27 de enero de 1596; por la qual confirma la sentencia del provisor de León, con tal que los feligreses que faltan se nombren de los medianos. Comintieron ambas partes esta sentencia en lo que les era favorable y apelaron de ella en lo que les era contrario. 

$1596>$

$<$ Proceso y sentencia del ministro de La Trinidad de Valladolid. Año de

$\mathrm{Al}$ folio 7 está un requirimiento echo por el cavildo de Aguilar a fray Luis de Calatayud, ministro de La Trinidad de Valladolid, con un brebe del nuncio en que le da comisión para conocer de esta causa. Citó las partes e inhibió al chantre.

Al folio 10 está la sentencia dada por el ministro de La Trinidad, en 3 de abril de 1596, por la que confirma la anterior del chantre con algunas restricciones. Se confirmó el monasterio con esta sentencia en lo favorable y apeló de lo contrario.

$<$ Auto de la Chancillería sobre una fuerza. Año de 1596>.

Al folio $11^{24}$ consta que se llevó el pleito a la Chancillería, por no otorgar el juez la apelación de los clérigos donde se declaró que no otorgársela no hacía fuerza. A 4 de mayo de 1596.

$<$ Proceso ante el prior de la yglesia de Valladolid. Año de 1596>.

$\mathrm{Al}$ folio 12 fue requerido don Francisco de Recalde, prior de la yglesia colejial de Valladolid, con un brebe del nuncio, ganado a instancia del monasterio, para que conociese de esta causa en grado de apelación.

Al folio 15 está un auto de dicho prior en que recibe la causa a prueba.

A los folios 16 y 17 están los ynterrogatorios de ambas partes para la prueba.

$<$ Presentación del proceso antiguo del año de 1536>.

$\mathrm{Al}$ mismo folio 17 está presentado por el monasterio el proceso antiguo ante el prior de Escalada del año de 1536.

Al folio 28 está la comisión del prior de Valladolid para la información por parte de los clérigos y un interrogatorio por parte del monaterio.

Al folio 29 está un memorial de los feligreses de San Juan que habían muerto en los 50 años antecedentes, los que se havían nombrado en su lugar y los que entonces vivían.

Al folio 30 está la información de los clérigos con 9 testigos.

$<$ Bulla de exención. Año de 1434>.

Al folio 39 está compulsada la bulla de exención del Papa Eugenio $4^{\circ}$, concedida a la congragación de Santa Justina. Año de 1434.

$<$ Bulla de extensiva. Año de 1533>.

Al folio 40 está la bulla del Papa Clemente $7^{\circ}$, confirmatoria de la de León 10, que son extensivas de los privilegios concedidos a la congregación de Santa Justina. Año de 1533.

Al folio 43 empieza la compulsa de las tazmías de los feligreses de San Juan desde el año de 1564 hasta el de 1594.

A los folios 46 y 49 están presentados algunos pa/ (f. 21v) drones y repartimientos de la pechería de Aguilar.

$<$ Sentencia del prior de la yglesia de Valladolid. Año de 1596>.

A folio 60 está la sentencia dada por dicho don Francisco Recalde, en 29 de noviembre de 1596, por la qual confirmó la sentencia del ministro de La Trinidad, con tal que los feligreses que faltaban se nombraren de los equivalentes a los muertos en hacienda y diezmería etcétera. Las partes acetaron la sentencia en lo favorable y apelaron de lo perjudicial.

${ }^{24} \mathrm{Al}$ folio 11] sigue tachado: se. 
<Proceso y sentencia del comendador de La Merced. Año de 1597>.

A folio 60 está un brebe del nuncio, dado a instancia del monasterio, para que el comendador de La Merced de Valladolid conozca de esta causa.

A folio 63 está la sentencia dada por el mismo comendador, en 19 de marzo de 1597, por la qual confirma la sentencia del prior de Valladolid en unos puntos, y en otros la del ministro de La Trinidad. Pidió el monasterio carta executoria de las tres sentencias conformes, del chantre de Valladolid, del ministro de La Trinidad y del comendador de La Merced. Este mandó librarla y es la que está a folio 156.

$<$ El almirante sale a la causa. Año de 1597>.

A folio 64, el almirante de Castilla sale a la causa. Año de 1597.

A folio 154 está un brebe del nuncio para que no se execute la carta executoria del comendador de La Merced, a quien se inhibió, y también al provisor de León. $1597>$.

$<$ Execución de la carta executoria del comendador de La Merced. Año de

A folio 156 comienza la execución de la carta executoria remitida por el comendador de La Merced al provisor de León, el qual dio comisión para executarla al licenciado Gerónimo Gallego de Robles.

$<$ Presentación de instrumentos por parte del monasterio $>$.

A folio 180 sale el almirante oponiéndose a la execución de la carta executoria. A folio 158 está la concordia antigua del año de 1247 con su legalización. A folio 159 los executoriales de Roma del año de 1444. A folio 162 el proceso y sentencia del obispo Eugubino. A folio 164 la sentencia del licenciado Aparicio, provisor de León. A folio 167 la sentencia del chantre de Valladolid. A folio 169 la sentencia del ministro de La Trinidad de Valladolid. A folio 172 la bulla de exención de Eugenio 4을 año de 1434. A folio 173 la bulla de Clemente $7^{\circ}$ de participación y extensión de los privilegios de la congregación de Santa Justina a la de España, año de 1533. A folio 174 la sentencia del prior de la yglesia de Valladolid. A folio 176 la sentencia del comendador de La Merced. Diose esta carta executoria en Valladolid, a 7 de junio de 1597. conformes $>$.

$<$ Provisión de la Chancillería para que se executen las tres sentencias

A folio 183 está un auto del provisor de León por el que manda se nombren los feligreses equivalentes que faltaban y se averigüe lo que / (f. 22r) havía perdido el monasterio. A folio 183 está una provisión de la Chancillería para que el provisor otorgue y reponga. A folio 184 apela al almirante de Castilla y hay aquí otro auto de la Chancillería sobre otra fuerza. A folio 185 está la comisión dada por el provisor de León, a instancia del monasterio, al licenciado Robles para que, conforme a la carta executoria y una provisión real, execute las tres sentencias conformes que están al folio siguiente.

$<$ Ynhibitorio del nuncio $>$.

Desde aquí adelante comenzó el licenciado Robles a conocer de esta causa y llegan sus autos de execución hasta el folio 215 y, sin concluir la execución de la carta executoria, se sacó inhibitorio del nuncio que está al mismo folio 215, el que se notificó al dicho Robles y al provisor de León.

$<$ Brebe del mismo para que se prosiga el execución $>$.

A folio 216 está un brebe del nuncio para que el provisor de León prosiga la execución y al folio 217 se prosiguió. A folio 218 están presentadas algunas tazmías. A folio 253 y 260 está la prueba del monasterio. A folio 274 está la de los clérigos.

$<$ Sentencia del juez executor $>$. 
A folio 349 el licenciado Gallego de Robles, juez executor, dio su sentencia, en 3 de abril de 1599, que es la que queda puesta en el legajo $2^{\circ}$, número 39 . Afolio 321 los clérigos y algunos parroquianos de San Juan apelaron desta sentencia. A folio 332 se llevó la causa a Valladolid por vía de fuerza, en se (sic) declaró que el juez executor en unos puntos de su sentencia hizo fuerza y en otros no. A folio 333 está un mandamiento del provisor de León para que se lleve el proceso y el juez sobresea en la causa.

<Salen a la causa el almirante, la yglesia de León y el concejo de Aguilar>.

A folio 334 está la tazmía del vino del año de 1581. A folio 335 está una querella del monasterio de los agravios que se hicieron en la execución de la carta executoria. A folio 338 están unos autos echos por el provisor de León contra el proceder del juez executor a instancia de los clérigos. A folio 339 salió de nuevo a la causa el almirante. A folio 340 salió también el concejo de Aguilar. A folio 343 salió la yglesia y cavildo de León.

$<$ Prosigue la execución el licenciado Robles>.

A folio 348 está un auto del provisor de León por el qual, en virtud de una provisión de la Chancillería, buelbe de nuevo el proceso y execución al licenciado Gallego de Robles, a quien al mismo folio recusaron los clérigos, poniéndole tachas, y el monasterio le defiende. A folio 349 está una provisión real para que el provisor de León otorgue, reponga y absuelba a todos los que de nuevo havían salido a la causa / (f. 22v) o que embiase los autos a la Chancillería. Lleváronse. A folio 350 se dio auto en que se declara que, mandando el provisor executar lo que falta de la carta executoria, no haze fuerza.

$<$ Mandamiento del obispo de León>.

Al mismo folio está un mandamiento del obispo de León para se lleve una licencia que había dado su provisor sobre la administración de sacramentos a los feligreses de San Juan.

$<$ Auto para que se siga la execución>.

A folio 351 requirió el monasterio al licenciado Robles que prosiguiese la execución, quien dio auto para su cumplimiento a folio 352, de que apeló el convento en lo perjudicial. Al mismo folio se recivió la causa a prueba.

$<$ Posesión de los feligreses de San Juan. Año de 1599>.

A folio 354 está un mandamiento del juez executor para que los nombrados se tengan por feligreses de San Juan; y siguen los autos de posesión que tomó de ellos el padre fray Alonso Barrantes, que fue el que solicitó y dio la gran batería de esta execución y lo más de todo este pleito. A folio 366 está el ynterrogatorio del convento. A folio 367 presentación de testigos. A folio 368 provanza del convento con 9 testigos, la que a folio 375 se remitió a León. A folio 375 ynterrogatorio de los clérigos. A folio 376 provanza de los clérigos.

$<$ Dos brebes ynhibitorias del nuncio. Año de 1599>.

A folio 382 está un mandamiento ynhibitorio del nuncio dirijido al provisor de León. A folio 383 otro brebe del nuncio, dado a instancia de los clérigos de Aguilar, en grado de apelación de la execución. Fue requerido con él Gerónimo de la Serna, notario de Valladolid, para que entregase el proceso original, y obedeció. Ynhibiose al provisor de León y citose al monasterio. Año de 1599.

A folio 384 está un auto del nuncio en que remite el proceso al Ordinario de León para que oyga al almirante. Y al mismo folio está la respuesta que dio el juez executor a la notificación que se le hizo del brebe del nuncio.

$<$ Mandamiento agravatorio del nuncio. Año de 1599>. 
A folio 385 está otro mandamiento agravatorio del nuncio, dado a instancia de los clérigos, a 3 de julio de 1599, para que se lleve el proceso y se inhiba el juez executor. Obedeció éste y el notario dixo que daría el proceso original, y pagándole la saca de la mitad de 38 ojas que tenía. A folio 386 alegan los clérigos ante el nuncio. A folio 387 está un mandamiento de Domingo de los Ríos, arcipreste de Cervera, juez comendador, para que los feligreses de San Juan acudan con todos los diezmos al monasterio / (f. 23r) y que ni los clérigos ni otro lo impida, a 23 de julio de 1599. A folio 388 el nuncio, oídas las partes, evocó a sí la causa.

$<$ Sentencia definitiva del nuncio de Clemente $8^{\circ}$. Año de 1600>.

A folio 390 está la sentencia definitiva, dada por Dominico Gimnasio, nuncio de Clemente $8^{\circ}$. Dada a 2 de agosto de 1600 . Por la que confirma la sentencia del licenciado Aparicio, provisor de León, y las demás que confirman ésta, especialmente la de don Francisco Recalde, prior de la yglesia de Valladolid, y revoca las demás en quanto se oponen a éstas y pone perpetuo silencio al monasterio.

$<$ Apela el monasterio. Brebe ynhibitorio de Roma. Año de 1600>.

Apeló éste de esta sentencia a Su Santidad y sacó brebe ynhibitorio, compulsorio, etcétera, del doctor Francisco Peña, auditor de La Rota, que está a folio 390 , y en la primera oja de este proceso, en cuya virtud se compulsó para llevarle a Roma, donde fue dado el brebe, a 20 de diciembre de 1600.

$<$ Requirimiento al nuncio. Año de 1601>.

Con él fue requirido el nuncio, en 20 de junio de 1601, ante Francisco Martínez de Luna, clérigo de la diócesis de Pamplona, notario del nuncio, el qual compulsó y authorizó este proceso en Valladolid, donde estaba la Corte, a 9 de julio de 1601.

\section{Legajo $4^{\circ}$ del Cajón Santa María}

Este legajo, que es el quarto del cajón Santa María, consta de dos quadernos tocantes a las concordias y diferencias que ha tenido este monasterio con los clérigos de Aguilar sobre la feligresía, priorato e yglesia de San Juan, que son los siguientes:

\section{Quaderno A del legajo $4^{\circ}$}

Este quaderno contiene concordias con el cavildo y villa / (f. 23v) de Aguilar sobre los 120 feligreses de San Juan por el orden siguiente:

$1^{\circ}$. <Capítulos de concordia hechos en Cisneros. Año de 1602>.

Escritura de concierto y capítulos de concordia, otorgada en la villa de Cisneros, a 5 de enero de 1602, ante Diego Pérez, escrivano de dicha villa, entre nuestro padre fray Alonso Barrantes, abad de San Zoil, y fray Antonio de los Ríos, mayordomo, con poder del monasterio y el bachiller Alonso Franco, arcipreste y beneficiado de la villa de Aguilar, y Andrés Gutiérrez del Pozo, cura de San Estevan, y el licenciado Juan Fernández Rodríguez, abogado, vecinos ambos de la dicha villa, y con poder del cavildo eclesiástico de ella. Estos capítulos se ponen por escrito en la misma escritura de concordia que está adelante. Con esta escritura está otra authorizada.

2. <Ratificación de los capítulos. Año de 1602>.

Escritura de ratificación de los capítulos concordados en la villa de Cisneros. Hecha por los clérigos de Aguilar, a 11 de enero de 1602, ante Cristóval de Valderas, escribano de dicha villa.

$3^{\circ} .<$ Pareceres del convento. Año de 1602>.

Pareceres del convento para la ratificación de los capítulos de concordia. Dados a 11 de enero y 26 de marzo de 1602 , el $1^{\circ}$ ante el abad de este monasterio y el $2^{\circ}$ ante el general. 
4. <Testimonio del recivo de los capítulos. Año de 1602>.

Testimonio del recivo y ratificación de los capítulos de concordia entregados a los clérigos de Aguilar. Dado por Álvaro Freile, escrivano en la misma villa, en 19 de enero de 1602 .

5. $<$ Cartas del general. Año de 1602>.

Cartas del general fray Alonso del Corral y de los visitadores de nuestra religión, escritas al abad de San Zoil en orden a los conciertos de Aguilar. Año de 1602.

6. <Poder del monasterio para otorgar de nuevo los capítulos. Año de 1602>.

Poder que dio el monasterio a nuestro padre fray Alonso Barrantes, abad de él, para otorgar de nuevo los capítulos de concordia con el cavildo de Aguilar. Su fecha, en San Zoil, a 27 de abril de 1602, ante Andrés Sánchez, escribano de Carrión.

7. $<$ Requirimiento del padre Huércanes y respuesta del convento. Año de 1602>.

Requirimiento hecho por su paternidad fray Plácido de Huércanes a nuestro padre fray Alonso Barrantes, abad de esta casa, para que no pase a hacer la concordia de Aguilar, a 28 de mayo de 1602, ante Andrés Sánchez, escribano de Carrión. los monges.

Respuesta que dio la comunidad al precedente requirimiento. Está firmada de todos

Hai aquí otro papel de su paternidad Huércanes y una protesta del padre Cavallero contra la concordia.

/ (f. 24r) 8. < Mandato del general para efectuar la concordia. Año de 1602>.

Mandato del general para que se efectúe la concordia de Aguilar y la de la capilla de doña Constanza. Dado en San Juan de Corias, a 23 de junio de 1602, ante fray Diego de Marquina, secretario de la religión.

9. <Petición al general para hacer la concordia. Año de 1602>.

Petición de los padres del Consejo de esta casa a nuestro padre general para hacer la concordia, y licencia de el mismo para que se efectúe. Dada en Bergondo, a 20 de julio de 1602, ante fray Diego de Marquina, secretario de la religión.

10. <Licencia del general $>$.

Otra licencia del general para lo mismo y con la misma fecha.

11. <Concordia sobre los 120 feligreses. Año de 1602>.

Escritura de concordia entre este monasterio y los comisarios del cavildo de Aguilar sobre los 120 feligreses immortales de la yglesia de San Juan. Otorgada en el mismo monasterio, a 29 de julio de 1602, ante Pedro de Cervantes, escribano de la villa de Carrión, cuyo signo está comprobado por tres escrivanos de la misma villa, que son Pascual López, Alonso Zapata y Antonio Orejón. Esta conocordia está hecha con las 16 condiciones siguientes:

$<$ Condición $>1^{\text {a }}$. Que el monasterio renuncia y traspasa el derecho que tiene a los 120 feligreses en la forma que al dicho monasterio le pertenecen, que son dos tercias de pan y vino y los diezmos menudos enteramente, para que de allí adelante no lo lleve el monasterio sino que lo lleve y sea del cavildo, curas y beneficiados de Aguilar para siempre jamás en la forma que se declara en los capítulos de adelante.

$2^{a}$. Que en satisfacción y trueque, el cavildo cede y traspasa la sesta parte y sesmo de pan que tiene en los feligreses de todas las yglesias de Aguilar, entrando en esto el sesmo de los 120 feligreses de San Juan que el monasterio cede y traspasa. Y para la seguridad de la cobranza, desde luego, el cavildo da todo su poder cumplido al monasterio para cobrar el dicho sesmo por su authoridad como suyo propio. Y para mayor seguridad obliga, por especial hipoteca, los dichos 120 
feligreses de San Juan con sus diezmos y el derecho que el monasterio tenía a ellos sin reclamar el cavildo que, por esta renunciación, no tiene congrúa suficiente ni ${ }^{25}$ pedirá jamás < para ella, ni por la administración de sacramentos ni por otra razón ni título que agora ni en los tiempos venideros se siguieren e recrecieren cosa alguna ${ }^{26}$.

$3^{\text {a }}$. Que el cavildo declara que, fuera de este sesmo que da al monasterio / (f. 24) por los 120 feligreses, tiene este también en Aguilar otro sesmo de pan y una tercia de diezmos menudos de todos los vecinos de la villa; lo qual ha llevado de tiempo immemorial a esta parte y lo ha de llevar de allí adelante, assí de los feligreses que traspasa que son al presente y de los que por ellos en adelante se subrrogaren, si hubiese subrogación, como de los demás parroquianos de las otras yglesias de Aguilar. De suerte que, con el sesmo que el cavildo le da, ha de tener el monasterio en Aguilar una tercia de pan igual a la que lleva el de San Claudio de León y una tercia entera de menudos de todos los vecinos de dicha villa excepto lo que se declara en el capítulo 11 que trata del diezmero.

4a. Que si el cavildo y fábrica de León y las de las yglesias de Aguilar, el almirante y el concejo quesieren venir con el cavildo en este contrato con los requisitos y escrituras necesarias, se han de incorporar los 120 feligreses de San Juan y sus diezmos con los feligreses de las demás yglesias, para ser feligrés de ellas y diezmar en ellas como los demás. Y en tal caso, el monasterio hace la dejación y traspaso a favor del cavildo y de los demás interesados. En todos los quales feligreses ha de tener el monasterio de San Claudio una tercia entera de pan y vino; el monasterio de San Zoil otra tercia de pan y otra de menudos; el cavildo de Aguilar otra tercia de vino y otra de menudos y un noveno de pan; la fábrica de la yglesia de León un sesmo de vino y un noveno de pan, de lo qual ha de dar un ochavo a las yglesias parroquiales según costumbre; y el almirante ha de llevar otro sesmo de vino y un noveno de pan, del qual ha de dar el tercio a las yglesias como lo acostumbra. Las fábricas de las yglesias de Aguilar llevan un tercio de menudos (cada una de sus feligreses) y demás del ochavo y tercia de fábrica y almirante, sacados de todos el diezmero, como se dice en el capítulo 11. Y si los dichos terceros o qualquiera otra persona que pretendan alguna acción al pleito que se concuerda y a lo que el monasterio traspasa en el cavildo en algún tiempo pusieren sobre ello algún pleito, el monasterio no tenga obligación a defenderle, sino el cavildo, sin que al monasterio se le desqüente cosa alguna de lo que el cavildo le da por esta permuta.

$5^{\mathrm{a}}$. Que el monasterio se quede con la yglesia de San Juan, sus retablos, / (f. 25r) ornamentos, cruces, cálices, campanas, plata y demás cosas que en ella están. Y para su reparo se ha de quedar con los censos y doce obradas de tierra que tiene la yglesia; y las fábricas de las yglesias han de dar, cada año, al monasterio 1 mill maravedís para el dicho reparo, por razón de las heminas de las primicias que han de llevar de los feligreses que eran de San Juan. Todo lo qual no pueda enagenar el monasterio, so pena que todo ello quede para el cavildo con la yglesia y lo a ella perteneciente. Y en la yglesia de San Juan pueda el cavildo hacer y decir los aniversarios, misas, sufragios y procesiones que están fundados y se acostumbran hacer por los difuntos de ella y los que hace la villa en ella por su devoción ${ }^{27}$.

$6^{a}$. Que si en el priorato de San Juan huviere monges, el cavildo señale asientos al prior y companero que assistieren a los oficios de mortuorios y honrras, $y$ se les den sus distribuciones como hasta allí; y el asiento del prior sea luego consecutivamente delante de los curas de las quatro parroquias y al compañero le cubran los dos clérigos más modernos del cavildo.

\footnotetext{
25 ni] sigue tachado: la.

26 alguna] sigue tachado: por causa alguna.

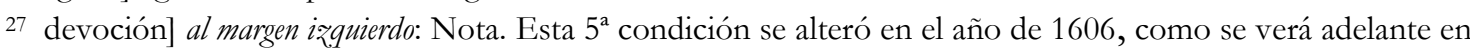
el número 26.
} 
$7^{\mathrm{a}}$. Que el cavildo se obliga a que el concejo de Aguilar remitirá al monasterio los 3 mill maravedís que este le pagaba cada año, y el monasterio remita al concejo las 3 fanegas de trigo que este le pagaba cada año a él.

$8^{a}$. Que el monasterio queda sin la obligación de poner cura, capelán y sacristán para los 120 feligreses, a los quales el cavildo haya de administrar los santos sacramentos a su disposición, sin que por ello el monasterio le dé cosa alguna, quedando el curato extinguido e incorporado en el cavildo.

$9^{a}$. Que el cavildo queda obligado a satisfacer al cura Juan Cavallero, por los días de su vida, las 20 cargas de trigo y 5 de zevada que el monasterio le daba. Y para ayuda de esta satisfacción ha de dar el monasterio al cavildo 8 cargas de trigo de cada año por la vida del dicho Juan Cavallero, de las quales quede libre el monasterio muerto él.

10. Que las heminas de trigo y zevada que los feligreses dan ${ }^{28}$ en nombre de primicias a la yglesia de San Juan sean para las demás yglesias parroquiales, donde han de recivir los sacramentos los 120 feligreses y han de dar los molletes el Jueves Santo, y para paga de los 1 mill maravedís que han de dar para reparo de la yglesia de San Juan.

/ (f. 25v $11^{\mathrm{a}}$. Que el primiciero que se solía escoger para la yglesia de San Juan quede para el cavildo, el que escogiere, el qual sea equivalente en diezmería a Aparicio Franco, último diezmero. Con que de todo el diezmo que este diezmero y primiciero diezmare, lleve el monasterio la sexta parte solamente del pan que diezmare; y lo demás, enteramente el cavildo.

$12^{\mathrm{a}}$. Que por quanto por las sentencias dadas en este pleito por el ordinario de León y jueces apostólicos ha havido diversas condenaciones de frutos a favor del monasterio, lo renuncia y remite en el cavildo, con el derecho de poder pedir esto mismo a otros terceros, para que en su nombre los haya y cobre; y para ello le da poder bastante.

$13^{\mathrm{a}}$. Que de los tres años de 1599, 1600 y 1601 el convento cobre enteramente los frutos corridos de los años de 99 y 600 de los feligreses de San Juan que nombró el licenciado Gallego de Robles, juez executor, y los diezmos del año de 601 los covre también, quedando para el cavildo un sesmo de pan y una tercia de vino y otra tercia de menudos, y que el dicho cavildo dé luego las tazmías de pan y vino de los años de 600 y 601 para que el convento cobre por ellas los diezmos que le pertenecen conforme a este capítulo.

$14^{\mathrm{a}}$. Que el monasterio dexa en el estado en que está el pleito que tiene compulsado para Roma, en apelación de la sentencia del nuncio. Y, cumpliendo el cavildo los capítulos de esta concordia, el monasterio no ha de proseguir en el dicho pleito, so pena de las costas, etcétera. Y si el cavildo en algún tiempo no cumpliere lo contratado, el trascurso de tiempo no perjudique al monasterio para proseguir la dicha su apelación sin embargo de qualquier remedio que pueda tener el cavildo para alegar las sentencias por pasadas en cosa juzgada, pues desde luego suspenden los términos de la apelación y la dexan en el estado que tiene.

$15^{\mathrm{a}}$. Que además de las licencias y confirmaciones de esta concordia dadas por los ordinarios, para que sea más firme se apruebe y confirme por $\mathrm{Su}$ Santidad. Y para ello ambas partes den poder bastante, y para que nombre executor que la execute, y el costo de la confirmación sea a qüenta de ambas partes por igual.

$16^{a}$. Que ninguna parte pague a la otra las costas en que hubiere / ( $f$. 26r) sido condenada en el pleito, sino que cada qual pague las que hubiere hecho; $y$ en razón de los capítulos contenidos en las demandas del dicho pleito no pida ni demande la una parte contra la otra cosa alguna; porque todo cerá (sic) con la observancia de lo aquí capitulado.

${ }^{28}$ dan] sigue tachado: sean. 
12. <Requirimiento para que se entreguen las llaves. Año de 1602>.

Requirimiento hecho por parte del monasterio al cura Cavallero para que entregase las llaves y ornamentos de la yglesia de San Juan. En 13 de agosto de 1602, ante Âlvaro Freile, escribano en Aguilar.

13. $<$ Ratificación de la concordia. Año de 1602>.

Ratificación de la escritura de concordia hecha por los clérigos de Aguilar. A 14 de agosto de 1602, ante Cristóval de Valderas, escribano en dicha villa.

14. <Confirmación de la concordia. Año de 1602>.

Confirmación de la concordia por don Juan Alonso de Moscoso, obispo de León. En 27 de agosto de 1602. Firmado con su sello y de Tomás de la Cuesta, su secretario.

15. $<$ Renuncia del curato de San Juan. Año de 1602>.

Renuncia del curato de San Juan hecha por el cura Juan Cavallero, y consentimiento de el mismo en la concordia. A 2 de septiembre de 1602, ante Cristóval de Valderas, escribano en Aguilar. de $1602>$

16. $<$ Poder del monasterio para pedir al nuncio la confirmación de la concordia. Año

Poder del monasterio para pedir al nuncio confirmación de la concordia. Otorgado en S. Zoil, a 21 de septiembre de 1602, ante Pedro de Cervantes, escrivano en Carrión.

17. <Confirmación del nuncio de la última concordia. Año de 1602>.

Brebe del nuncio Dominco Gignasio, escrito en pergamino, con sello de cera colorada, pendiente en cuerda de cáñamo, por el qual confirma la concordia que se hizo entre monasterio y el cavildo de Aguilar, en el año de 1602, ante Pedro de Cervantes, escribano de Carrión. Su fecha, en Valladolid, quinto ydus octobris, anno 1602. Está aquí una copia authorizada del mismo brebe, sacada por el bachiller Lorenzo Montero de Castañeda, notario en Carrión, a 5 de julio de 1603.

18. <Ynformación que la concordia se hizo libremente. Año de 1602>.

Ynformación hecha por comisión que dio nuestro padre fray Alonso Barrantes, abad de San Zoil, al padre maestro fray Diego de Venegas, predicador de esta casa, por la qual se prueba que la concordia de Aguilar se hizo libremente. A 18 de noviembre de 1602.

19. <Ynformación contra los que la impedían. Año de 1602>.

Ynformación que hizo nuestro padre fray Alonso Barrantes, por comisión del reverendísimo general contra los que impedían que se llevase a efecto la concordia. Año de 1602.

20. < Poder para la confirmación. Año de 1602>.

Poder del monasterio para pedir a Su Santidad la confirmación de la concordia. Otorgado en San Zoil, a 29 de diciembre de 1602, ante Alonso Zapata, escribano en Carrión.

/ (f. 26v) 21. <Testimonio que se consumió el Santísimo. Año de 1603>.

Testimonio dado por Cristóval de Valderas, escribano de Aguilar, de que se consumió el Santísimo Sacramento en la yglesia parroquial de San Juan con licencia del ordinario de León, y consentimiento del monasterio. A 24 de junio de 1603.

22. <Ynventario de bienes. Año de 1603>.

Ynventario de los bienes que se hallaron en la yglesia de San Juan. Hecho en 8 de julio de 1603, ante Álvaro Freile, escribano de Aguilar. 


\section{3. < Petición para que se apruebe la concordia. Año de 1604> .}

Petición original hecha por el monasterio al Capítulo General para que aprobase la concordia de Aguilar y el concierto de la capilla de doña Constanza ${ }^{29}$, en 11 de mayo de 1604. $Y$ decreto del capítulo, en $1^{\circ}$ de junio del mismo año, en que se confirman. Firmado de fray Balthasar Guerrero, relator del capítulo. $1605>$.

24. <Ynformación de utilidad para reformar la $5^{\text {a }}$ condición de la concordia. Año de

Petición de su paternidad Barrantes, abad de San Zoil al general fray Antonio Cornejo; comision de este e información de utilidad hecha en virtud de ella por fray Mauro de Otel, difinidor, para reformar la $5^{a}$ condición de la concordia. Todo esto se autuó año de 1605. Hay aquí pareceres de letrados cerca de la utilidad.

25. < Capítulos de la concordia. Sacados año de 1606>.

Copias literales de los capítulos contenidos en la concordia del año de 1602, sacados por Juan de Villafrades, escribano en Carrión, a 17 de junio de 1606; y por Alonso Zapata, escribano también de Carrión, en el mismo mes y año.

26. < Alteración de la $5^{a}$ condición de la concordia, por la qual en lugar de lo que allí se estipulaba ha de dar el cavildo 20 ducados para reparos de la yglesia de San Juan. Año de $1606>$.

Testimonio dado por Juan de Villafrades, escribano en Carrión, a 16 de junio de 1616, de la alteración de la $5^{\text {a }}$ condición de la concordia anterior del año de 1602. De este testimonio consta que el monasterio de San Zoil y el cavildo de Aguilar, con licencia de sus superiores y poder del cavildo, otorgaron una escritura ante Alonso Zapata, escribano en Carrión, a 19 de julio de 1606. En ella se dice que, haviéndole parecido al monasterio ser poca la cantidad que el cavildo da para el reparo de la yglesia de San Juan en los censos, yugadas de tierra y 1 mill maravedís que dan de renta en cada un año, como se contiene en la $5^{a}$ condición de la dicha concordia, se convinieron en que la dicha escritura de concordia y transación se guarde y lleve a debida execución para siempre jamás; obligándose el cavildo a que pagaran cada año perpetuamente para el reparo y fábrica de la yglesia de San Juan de Aguilar 20 ducados, de que harán la primera paga desde el día que se trajere la confirmación de Su Santidad de esta escritura en un año y assí sucesivamente, etcétera ${ }^{30}$. Con que todos los censos, yugadas de

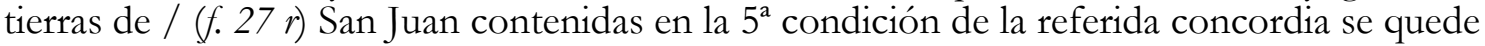
para el cavildo y que en esta conformidad se entienda la $5^{\text {a }}$ condición de ella. De esta escritura (cuyo original pasó ante Alonso Zapata) sacó este testimonio Juan de Villafrades, como queda dicho.

\section{7. $<$ Recivo de la concordia. Año de 1606>.}

Recivo de la escritura de concordia otorgada ante Alonso Zapata, escribano en Carrión, año de 1606, por Andrés Gutiérrez del Pozo, cura de San Andrés de Aguilar, para embiarla a confirmar a Roma. Su fecha: a 13 de julio de 1606.

\section{8. < Poder del cavildo. Año de 1611>.}

Poder del cavildo de Aguilar, para pedir a Su Santidad confirmación de la concordia. A 24 de diciembre de 1611, ante Juan Freile, escribano en Aguilar.

29. <Bulla de Paulo $5^{\circ}$ en la que se da comisión al provisor de León para que confirme la concordia. Año de $1617>$.

Bulla de la Santidad de Paulo $5^{\circ}$, escrita en pergamino, con sello de plomo pendiente en cuerdas de cáñamo, dada a instancia del monasterio de San Zoil y cavildo de Aguilar, por la qual parece que se le hizo relación del pleito que entre estas partes hubo en razón del nombramiento de los 120 feligreses de San Juan; si los que faltaban se havían de nombrar de

\footnotetext{
${ }^{29}$ Constanza] al margen derecho: Capilla de doña Constanza.

30 etcétera] al margen derecho: Nota. Este foro de los 20 ducados le redimió el cavildo año de 1692. Véase adelante el número 37.
} 
los equivalentes a los muertos en hacienda y diezmería o de los medianos; y de las sentencias y carta executoria que sobre esta causa se dieron. Y como aún después de esto, habiéndose apelado de la última sentencia dada por el nuncio y estando el proceso compulsado para llevarse a la Rota, las partes, por escusar pleitos, costas e inquietudes, se havían concordado y hecho escritura de transación, con licencia y aprobación de sus superiores, en la forma y con las 16 condiciones que están atrás en la escritura de concordia, número 11 de este quaderno, y también en esta bulla. Lo qual, visto por Su Santidad y no constándole con certeza la verdad de este caso de que se le hizo relación, da por esta bulla comisión al ordinario de León para que, haviéndose informado de la verdad de la narrativa y hallando ser cierta, confirme con authoridad apostólica la dicha concordia con sus capítulos y mande que se guarde inviolablemente para siempre jamás. Dada en Roma, apud Santam Mariam Mayorem, anno Domini 1617, pontificatus anno decimo. Presentose en León ante el provisor y se admitió la concordia y dio auto sobre ello, como se verá adelante, en los números 32 y 33. de $1623>$.

30. $<$ Bulla de Vrbano $8^{\circ}$ en la que se da la misma facultad al provisor de León. Año

Bulla de la Santidad de Vrbano $8^{\circ}$, escrita en pergamino, con sello de plomo pendiente en cuerdas de cáñamo, dada a instancia del monasterio de San Zoil y cavildo de Aguilar, por la qual declara y confirma la bulla anterior / (f. $27 v)$ dada por el papa Paulo $5^{\circ}$ y declara la $5^{a}$ condición de ella que se alteró por la escritura que está atrás, número 26 de este quaderno. De suerte que el cavildo de Aguilar se quede con las doce obradas de tierra de San Juan que pertenecían al monasterio, y el cavildo pague a éste, cada año, 20 ducados de foro perpetuo para reparos de la yglesia de San Juan. Es per inde valere y por ella da Su Santidad comisión al provisor de León para que averigüe la verdad de la narrativa, y, verificada, apruebe la concordia. Dada en Roma, apud Santam Mariam Mayorem, anno Domini 1623, ydibus octobris, pontificatus Anno $1^{\circ}$. Presentose ante el provisor de León y se confirmó la concordia, como se verá adelante en los números 32 y 33. Están aquí dos copias authénticas de estas bullas, una en latín y otra en romance.

31. $<$ Coste de las bullas $>$.

Carta y qüenta del padre fray Pedro Marín, procurador de Roma, en razón de las bullas de la confirmación de la concordia de Aguilar y su coste. Año de 1625. $1625>$.

32. <Aprobación y confirmación de la concordia por el provisor de León. Año de

Testimonio de la aprobación que hizo el licenciado Diego Garcia de Tineo y Llano, provisor de León por el obispo don fray Gregorio de Pedrosa, de la narrativa que se hizo a Su Santidad para la confirmación de la concordia hecha entre el monasterio de San Zoil y el cavildo de Aguilar y aprobación y confirmación que hizo de ella el mismo provisor en virtud de la comisión a él dada por las bullas de Paulo $5^{\circ}$ y Vrbano $8^{\circ}$. Diole Juan Baptista de Torres, escribano y notario de León, a 16 de julio, digo junio, de 1625.

33. < Otro testimonio de lo mismo. Año de 1629>.

Otro testimonio en relación de todos los autos de la confirmación de la concordia, insertas en él las bullas y el auto de confirmación dado por el ordinario de León en virtud de ellas, y de la información con que se verificó la narrativa que también está inserta. Dado por Juan Baptista de Torres, escribano de la causa, en León, a 20 de octubre de 1629. Al fin de este testimonio está una execución contra el cavildo sobre la paga del foro de los 20 ducados. Año de 1654.

34. < Apartamiento del pleito sobre la paga de los 20 ducados. Año de 1629>.

Testimonio authorizado del apartamiento que hizo el monasterio del pleito pendiente en León, sobre la paga de los 20 ducados que da el cavildo al monasterio para reparos de la yglesia de San Juan, por estar obligados a ello por las bullas de confirmación y per inde valere de la concordia. Dado en León, a 30 de enero de 1629, por Ysidro Álvarez de Ferreras, escribano y notario en dicha ciudad. 
35. $<$ Mandamiento contra el cavildo. Año de 1629>.

Mandamiento del ordinario de León para que el cavildo pague al monaterio 528 reales de plata, que le tocaron pagar del coste de las bullas. A 13 de octubre de 1629, ante / (f. 28r) Juan Baptista de Torres, notario de León.

36. <Mandamiento para que se paguen los 20 ducados. Año de 1636>.

Mandamiento y autos del ordinario de León para que el cavildo de Aguilar pague al monasterio los 20 ducados de los reparos de la yglesia de San Juan. A 7 de junio de 1636. No está authorizado.

37. < Redención de los 20 ducados de foro. Año de 1692>.

Redención que hizo el cavildo eclesiástico de Aguilar de los 20 ducados que por concordia pagaba de foro a este monasterio, computando su capital a cinco por ciento. Hicieron el pago en 10 yguadas de herrenes, a precio de 450 reales cada yguada, precediendo informaciones de utilidad y licencias del reverendísimo general y provisor de León. Pasó esta escritura ante Santiago Facón, escribano en Aguilar, a 3 de octubre de 1692. Está aquí una execución ${ }^{31}$ contra dicho cavildo, año de 1654, por 180 ducados correspondientes a 9 Años. Ante Damián de Torres.

\section{Quaderno B del legajo $4^{\circ}$}

Este quaderno, que es el $2^{\circ}$ y último de este legajo, contiene papeles de poca importancia, como son memoriales, pareceres de letrados, apuntamientos y razones en pro y en contra de la concordia sobre los 120 feligreses de San Juan. Contiene también otros papeles sobre los asientos del prior en las Juntas con el cavildo de Aguilar y sobre la permuta del priorato. Son pocos los que están authorizados. Los más notables son los siguientes:

$1^{\circ}$. <Concordia sobre entierros, asientos del prior, etcétera. Año de 1498>.

Concordia original hecha entre don Luis Hurtado de Mendoza, abad de esta casa, y los curas de Aguilar sobre entierros, ofrendas, procesiones, asientos, y feligreses equivalentes. Su fecha: en Aguilar, a 8 de octubre de 1498, ante Álvaro de la Vega, escribano en dicha villa.

2. <Copia de la anterior concordia. Año de 1566>.

Copia authéntica de la anterior concordia, sacada en 18 de enero de 1566 por Andrés Sánchez, escribano de Carrión.

3. <Apartamiento del pleito. Año de 1568>.

Apartamiento que hizo del pleito el cura Francisco Pardo sobre la congrua que pedía al monasterio. En 7 de junio de 1568.

$4^{\circ}$. < Parecer de abogados. Año de 1634>.

Parecer de dos abogados de Valladolid sobre el asiento del prior de San Juan y su companero en las Juntas con el cavildo. Dado en 11 de marzo de 1634.

/ (f. 28v) 5. <Licencia del general. Año de 1568>.

Licencia del general para permutar los 120 feligreses de San Juan y hacer sobre ello concordia con la villa y cavildo de Aguilar. Dada en Valladolid, a 5 de junio de 1568, ante fray Cristóval de Agüero, su secretario.

6. $<$ Comisión e información. Año de 1569>.

Comisión del general e información de si convendría o no al monasterio desacerse del priorato de San Juan de Aguilar. Hecha año de 1569.

\footnotetext{
31 execución] al margen izquierdo: Execución contra el cavildo.
} 
7. <Memoriales, apuntamientos, pareceres de letrados, etcétera $>$.

Bajo este número están memoriales, apuntamientos, poderes, pareceres de letrados, informaciones en derecho, capítulos de concordia, disputas sobre la utilidad de ella entre su paternidad Huercanos y Barrantes, etcétera. Estos papeles no se entienden por menor, por ser de poca importancia y de ninguna authoridad.

\section{Legajo $5^{\circ}$ del cajón Santa María}

Este legajo, que es el $5^{\circ}$ y último del cajón Santa María, consta de dos ynstrumentos: el $1^{\circ}$ es una ynformación hecha por el provisor de León para la resuncion de la yglesia de San Juan Extramuros de la villa de Aguilar, ante Juan Fernández de Vega, su notario, año de 1575. Esta resunción no pudo tener efecto porque los 120 feligreses, sus primicias y diezmos, no se incorporaron a las demás yglesias de la villa hasta la concordia del año de 1602, que es la que queda puesta en el legajo $4^{\circ}$, quaderno $\mathrm{A}$, número 11.

El segundo ynstrumento es un proceso que contiene la ynformacion que hizo el provisor de León, año de 1625, ante Juan Baptista de Torres, escribano de León, de la verdad y legitimidad de las concordias otorgadas entre el monasterio de San Zoil y cavildo de Aguilar en los años de 1602 y 1606. Esta ynformación fue hecha por comisión de las Santidades de Paulo $5^{\circ}$ y Vrbano $8^{\circ}$, cuyas bullas están en este proceso / (f. 29r) compulsadas, como también las dos referidas concordias, cuyos contenidos no se ponen aquí por estenso por estar ya hecho en el quaderno A, del legajo $4^{\circ}$, en los números 11, 26, 29, 30, 32 y 33. 


\section{/ f. 30r) Cajón $2^{\circ}$. San Juan. Letra A.}

Este cajón San Juan, que es el segundo del archivo, contiene tres legajos pertenecientes a diversos lugares: legajo 1: Añozas, Arenillas de Mazuecos, Arenillas de Nuño Pérez, Arenillas de San Pelayo, Astudillo ${ }^{32}$; legajo $2^{\circ}$ : Arconada; legajo $3^{\circ}$ : Aviñante.

\section{Legajo $1^{\circ}$} siguientes:

Este legajo, que es el $1^{\circ}$ del cajón San Juan, contiene 5 quadernos, que son los
Quaderno A. Añozas
D. Arenillas de San Pelayo.
B. Arenillas de Mazuecos.
C. Astudillo ${ }^{33}$.
C. Arenillas de Nuño Pérez

\section{Quaderno A del legajo $1^{\circ}$}

\section{Añozas}

En este quaderno A están los papeles pertenecientes a la hacienda que tiene el monasterio en este lugar, por el orden siguiente:

$1^{\circ} .<$ Convenio sobre una viña. Año de 1696>.

Escritura de convenio entre este monaterio y el licenciado Manuel Rodríguez, vecino de Añozas, sobre una viña plantada en tierra propia del monasterio, a los Linares, término de dicha villa, sobre la cual le puso demanda el monasterio y por evitar gastos le dio éste 20 ducados y el dicho Manuel Rodríguez cedió la viña. Su fecha: en Añozas, a 3 de mayo de 1696, ante Josef Guzmán, escribano en dicha villa.

/ (f. 30v ) 2. < Adjudicación de 5 tierras y una viña. Año de 1745>.

Testimonio de los concursos formados contra los bienes de Santiago Rodríguez e Ysabel Durántez, su muger, y contra los de Juan de Capillas, por los capitales y réditos de dos censos. Del primer concurso se adjudicaron al monasterio 5 tierras y vna viña en término de Añozas; y del segundo, nada. Diose este testimonio en 3 de marzo de 1745, por Mauricio Martínez de Chirueches, escribano de Villalumbroso.

\section{Quaderno B del Legajo $1^{\circ}$. \\ Arenillas de Mazuecos}

Este quaderno B, que es el segundo del legajo $1^{\circ}$, contiene una escritura de donación perteneciente al lugar de Arenillas de Mazuecos, que es la siguiente:

$1^{\circ}$. <Donación de Enderquina Rodríguez a San Román. Era de 1165, año de 1127>.

Escritura de donación que hizo Enderquina Rodríguez a San Román y a su prior Gómez de toda quanta heredad tenía en Arenillas de Mazool, oy de Mazuecos, assí solares como divisas, montes, tierras, etcétera, por remedio de su alma. Facta carta $\mathrm{X}^{\mathrm{o}}$ kalendas junii, era M C LX V, anno Domini $1127^{34}$.

\footnotetext{
32 Astudillol sigue tachado: y Avia.

${ }^{33}$ Astudillo] sigue tachado: E. Avia.

34 1127] al margen izquierdo: Remisiones. Véase el trueque que hizo el prior de San Román con el de San Zoil, cajón San Martín, legajo1 ${ }^{\circ}$, quaderno B, número $3^{\circ}$.
} 
Quaderno C del legajo $1^{\circ}$.

Arenillas de Nuño Pérez

Este quaderno $\mathrm{C}$, que es el tercero del legajo $1^{\circ}$, contiene escrituras pertenecientes al lugar de Arenillas de Nuño Pérez, que son las siguientes:

$1^{\text {a }}$. < Compra de la hacienda que doña Vrraca tenía en Arenillas de Nuño Pérez, por precio de 100 maravedís. Era de 1234, año de 1196>.

Escritura de donación que hizo doña Vrraca Martínez, muger de don Assur, por remedio de su alma; por la qual da para la obra de la yglesia de San Román toda quanta heredad tiene en Arenillas de Nuño Pérez, que está en el río de Avia, solares, tierras, viñas, etcétera, y con la divisa de su hermana María Martínez, muger de Munio González Palomino, y la mitad de un molino, con todo quanto le pertenece en la dicha villa, fuera de un solar / (f. 31r) con su divisa que estaba junto al castillo de dicha villa, junto a la puerta de ella y fuera del mismo castillo. Y fray Martín, por cuya qüenta corría la obra de San Román, la dio en precio, 100 maravedís. Facta carta in anno que fuit arrancata de Alarcos, era 1234, anno Domini 1196.

2. <Donación de Martín Fernández. Era de 1239, año de 1201>.

Escritura de donación por la qual Martín Fernández da a San Román la heredad que compró de doña Vrraca de Midorda en Arenillas de Nuño Pérez, solares, viñas, tierras, parada de molino, con la divisa de doña Vrraca; con que él lo goze por sus días y después de ellos no se venda, sino que lo ponga en renta para comprar azeyte y pitanza, para que todos los años le hagan un ${ }^{35}$ aniversario y se acuerde de él don Pablo, prior, por cuyo consejo hizo esta escritura. Facta era 1239, anno Domini $1201^{36}$. Gonzalvo Roiz, teniente Castello Santi Romani.

3. <Donación de don Manuel de la Vega hecha a Nuestra Señora del Brezo de 500 maravedís. Año de 1546>.

Escritura de donación por la qual don Manuel de la Vega, vecino de Bárcena, nieto de doña Francisca Henrríquez de Tobar y del governador Diego Hurtado de la Vega, dice que, por el cargo que él y sus antecesores son a la casa de Nuestra Señora de Brezo y servicios que la debe, la hace donación de 500 maravedís de renta sobre la huerta y renta que de ella tiene en Arenillas de Nuño Pérez, como uno de los herederos de la dicha doña Francisca Henrríquez, su abuela, para siempre jamás. Fecha en Bárcena, a 5 de octubre, año de 1546, ante Juan Vélez, escribano y notario público ${ }^{37}$. Esta donación pertenece a San Román, por el trueque que hizo con el Brezo, y se halla entre los papeles de Villafría, cajón San Plácido, legajo $1^{\circ}$, quaderno A, número 23 .

4. $<$ Demanda y emplazamiento contra don Francisco de Colmenares sobre la paga de 2 mill maravedís de foro, situados sobre < una> huerta de este lugar: Año de 1666>.

Remisiones. Donación de 1500 maravedís sobre esta huerta. Cajón San Benito, legajo $3^{\circ}$, quaderno $\mathrm{A}$, número 8 .

\section{Quaderno D del legajo $1^{\circ}$. \\ Arenillas de San Pelayo}

Este quaderno D, que es el tercero del mismo legajo, contiene escrituras pertenecientes al lugar de Arenillas de San Pelayo, que son las siguientes:

$1^{\circ}$ Bajo este número están las escrituras siguientes:

\footnotetext{
35 un] al margen derecho: Aniversario.

36 1201] sigue tachada palabra ilegible.

${ }^{37}$ público] al margen izquierdo: Esta donación pertenece a San Román por el trueque que hicieron.
} 
$1^{\text {a }}$. $<$ Venta de una tierra a María Ruiz, madre de fray Felipe, hijo de este monasterio, por precio de 60 ducados. Año de 1595>.

Escritura de venta por la qual Santiago del Río, cura de Renedo de Valdavia, / (f. 31v) vende a María Ruiz, su ama, madre de fray Felipe Ruiz, fraile lego, hijo de este monasterio, vna tierra de dos obradas, poco más, en Arenillejas, término de Arenillas de San Pelayo, Villoheles y Villabasta, con carga de media cántara de vino y seis tortas, que sobre la tercia parte de ella tenía la letania de Renedo y Polvorosa cada año, por precio de 60 ducados. Su fecha: en Renedo de Valdavia, a 2 de mayo de 1595, ante Toribio del Campo, escribano del mismo lugar.

$2^{\text {a }}$. < Codicilio y testamento de Santiago del Río, cura de Renedo. Año de 1595>.

Escritura de codicilio y testamento por la qual Santiago del Río, cura de Renedo de Valdavia, manda toda su hacienda a Maria Ruiz, su ama, madre de fray Felipe, y a Llorenta, su criada, para que ambos la partan por igual. Su fecha: en Renedo, a 14 de febrero de 1595, ante Pedro Rodríguez, escribano del número del Valle de Valdavia.

$3^{a}$. <Testamento de María Ruiz. Año de 1607>.

Testamento de María Ruiz por el qual dexa por heredero de sus bienes y hacienda a fray Felipe Ruiz, su hijo, fraile lego de este monasterio; y éste la heredó del dicho religioso. Su fecha: en Renedo de Valdavia, a 13 de noviembre de 1607, ante Toribio del Campo, escribano del mismo lugar. Síguense dos codicilios de mandas particulares de la misma, ante el mismo escribano.

$4^{a}$. <Ynventario de los bienes de María Ruiz. Año de 1607>.

Ynventario de los bienes que dexó María Ruiz, madre del dicho religioso. Hecho en Renedo de Valdavia, a 12 de diciembre de 1607, ante el mismo escribano.

$5^{\mathrm{a}}$. <Requirimiento a los testamentarios de María Ruiz. Año de 1608>.

Requirimiento hecho por fray Antonio de los Ríos, mayordomo de San Zoil, a los testamentarios de María Ruiz, para que no gasten por su alma más que el $5^{\circ}$ de su hacienda. Su fecha: en Renedo de Valdavia, a 14 de abril de 1608, ante el dicho escribano.

6 ${ }^{a}$. <Qüentas de María Ruiz. Año de 1611>.

Qüentas que dio María Ruiz a los curadores de Llorenta de Cumillas de la herencia que tubo del cura de Renedo. Cartas de pago de la renta que pagó el monasterio y otras cartas al abad sobre lo mismo. Las qüentas son del año de 1605; y las cartas de pago, de 1611.

\section{Remisiones a otro cajón}

$<$ Remisiones $>$.

Esta hacienda se trocó por la que el monasterio tiene en Población del Soto. Véase el cajón San Estevan, legajo $1^{\circ}$, quaderno D, número $3^{\circ}$. número $6^{\circ}$.

Donación de una carga de trigo en este lugar: Véase el cajón San Benito, legajo $3^{\circ}$,

/ (f. 32r) Quaderno E del legajo $1^{\circ}$.

Astudillo, por su despoblado de Torre.

Este quaderno, que es el $5^{\circ}$ de este legajo, contiene escrituras pertenecientes a la hacienda que este monasterio tiene en término de esta villa, que son las siguientes:

$1^{\mathrm{a}}$. <Donación de unos censos por nuestro reverendísimo Díez (sic). Año de 1629>.

Donación de unos censos hecha por nuestro reverendísimo padre maestro Juan Díaz, general de San Benito, hijo de esta casa, por sí y en nombre de su hermana Cathalina Díaz, difunta, beata que fue en el recogimiento de el lugar de Torre (oy despoblado con el título 
del Cristo de Torre), jurisdición de la villa de Astudillo; y fundación ${ }^{38}$ de una misa rezada cada día por sus almas y las de sus parientes difuntos. Son dos escrituras, otorgadas ambas a 24 de agosto de 1629, ante Francisco Moro de Saldaña, escribano de Carrión. Los demás papeles pertenecientes a estos censos y a la fundación de esta misa están en el cajón San Veremundo con los testamentos de los monges.

2. < Posesión de las hipotecas de un censo. Año de 1655>.

Donación que hizo Cathalina Ruesga, viuda, vecina de Bobadilla del Camino, de las hipotecas de un censo que contra sí tenían Juan y Clara Pérez, vecinos de Torre, junto a Astudillo; y posesión que tomó de ellas el monasterio, en 8 de marzo de 1655, ante Pedro Espinosa, escribano de Astudillo. Está aquí un juramento que hizo Francisco Pérez, declarando el tiempo que havía gozado las anteriores hipotecas. Su fecha, el mismo día, mes y año, y ante el mismo escribano. También se halla aquí la escritura de un censo de 10 mill maravedís de principal, otorgada por los referidos Juan Pérez y Clara Pérez, su muger, a favor de Cathalina Díaz, hermana del reverendísimo Díaz, a 10 de noviembre de 1614, ante Francisco Fernández, escribano de Santoyo.

3. <Execución por los réditos de dos censos que recayeron en este monasterio>.

Pleito executivo contra los vecinos de Torre, jurisdición de Astudillo, por los réditos de dos censos que contra sí tenían dichos vecinos a favor de / (f. 32v) Cathalina Díaz, y recayeron en este monasterio por donación que de ellos le hizo el reverendísimo Díaz, hermano de ella, cuya donación es la que queda puesta en el número $1^{\circ}$ de este quaderno. Están cosidos en este proceso los dos censos: el $1^{\circ}$ a folio $2^{\circ}$; y el segundo, a folio 10.

$<$ Sentencia a favor de este monasterio. Año de 1658>.

A folio 193 está la sentencia dada en el adelantamiento de Campos, a 18 de marzo de 1658, por don Diego González de Castro, teniente de alcalde mayor en la ciudad de Palencia, ante Hernando Suárez, escribano. Síguense los pregones que de dicha hacienda se dieron.

$<$ Posesión que tomó el monasterio de las hipotecas de estos censos. Año de 1658>.

Al folio 200 está la posesión que de las hipotecas de estos censos dio al monasterio Juan Gutiérrez Campuza, escribano recetor, en 3 de abril de 1658. A las últimas ojas están puestas en limpio las heredades de que tomó posesión el monasterio.

\section{Remisiones a otro cajón}

$<$ Remisiones $>$.

La donación de un majuelo (por fray José Cornejo) en este despoblado de Torre está en el cajón San Martín, legajo $4^{\circ}$, quaderno B, número único.

\section{Legajo $2^{\circ}$ del cajón San Juan.}

\section{Arconada}

Este legajo, que es el $2^{\circ}$ del cajón San Juan, contiene los papeles pertenecientes al lugar de Arconada, divididos en los 7 quadernos siguientes: quaderno A: hacienda; quaderno B: jurisdición y derechos; quaderno C: yglesia y beneficio de San Facundo; quaderno D: yglesia y beneficio de Santa Maria; quaderno E: tercias y noveno de Santa María; quaderno F: visitas de los abades de la ygleisa de Santa María; quaderno G: capellanía intitulada de Majo Mora.

\footnotetext{
38 fundación] al margen derecho: Fundación de una misa rezada cada día por el reverendísimo Díez y su hermana.
} 


\section{/ (f. 33r) Quaderno A del legajo $2^{\circ}$}

En este quaderno están los papeles pertenecientes a la hacienda que este monasterio tiene en el lugar de Arconada, por el orden siguiente:

$1^{\circ}$. $<$ Donación de la reyna doña Vrraca de toda la heredad que tenía en el lugar de Arconada. Era de 1158, año de 1120>.

Donación de doña Vrraca, reyna de España, hija del rey don Alonso el $6^{\circ}$ y de la reyna de (sic) doña Constanza, escrita en pergamino, por la qual da al monasterio cluniacense de San Zoil y a su prior don Estevan y a los monges de este monasterio, y a sus sucesores para siempre jamás, toda la heredad que tenía de la parte real en Arconada, con tierras, viñas, prados, pastos, huertas, árboles, solares poblados y despoblados, montes, etcétera, con todo lo que a esto pertenece donde quiera que esté. Facta carta $16^{\circ}$ kalendas maii, era 1158 , que es año de Cristo 1120. Ay aquí dos copias authorizadas de esta donación, la una de Rodrigo de Asus[...], notario apostólico, sacada en Valladolid, año de 1513, a 16 de agosto; la segunda, por don Martín García, traductor, año de 1783.

2. $<$ Requirimiento al concejo de Arconada para que pague 600 maravedís situados sobre sus alcavalas. Parte de un Juro Real perteneciente de la hacienda antigua de Toro. Año de $1462>$.

Requirimiento hecho al concejo de Arconada por Juan de Alarcón y Diego de Herrera, escuderos y criados de Fernando de Fonseca, Rodrigo de Vlloa y Cathalina de Melo, muger de Pedro de Vivero, los quales, como procuradores de don Pedro de Carrión, abad de San Zoil, requirieron al dicho concejo con un privilegio real de 600 maravedís de renta cada año situados sobre las alcavalas de Arconada, para que pagasen los réditos corridos de ciertos años y se allanasen a pagar los que cayesen en los sucesivo. El concejo respondió que havía pagado los corridos hasta allí a los recaudadores del rey, de que tenía cartas de pago; pero que pagaría de allí adelante al dicho abad o a quien lo huviese de haber, dándole traslado del privilegio y carta de pago de lo que en virtud de él pagase. Su fecha: en Villamuera, año de 1462, ante Álvar González de Carrión, escribano de esta villa. Este juro se halla con los demás en el cajón San Leandro.

3. $<$ Donación de Pedro de Lerones de toda la heredad que tenía en Arconada. Está aquí la compra a favor de él mismo. Año de 1473>.

Donación que hizo a este monasterio Pedro de Lerones, pellejero, vecino de Carrión, de toda la heredad que tenía en los términos de Arconada, por las obligaciones que tenía al convento, y encarga que le encomienden a Dios. / (f. 33v) Su fecha: en Carrión, a 19 de enero de 1473, ante Juan Martínez de Carrión, escribano de la dicha villa. Ay una copia authorizada, sacada año de 1783. Está Aquí la compra de esta heredad que hizo Pedro de Lerones a Juan Laso, monge de este monasterio.

4. $<$ Trueque de una tierra por otra en este lugar. Año de 1588>.

Escritura de trueque entre el monasterio de San Zoil y el concejo de Arconada, por la qual da el monasterio al concejo una tierra en término de este lugar, a la Huerta, de tres heminas de sembradura, por otra que el dicho concejo le dio, a Carredavia, término del mismo lugar, que haze una obrada. Y el concejo y vecinos de Arconada se obligan a dar al monasterio toda la teja y ladrillos que necesitase para el reparo de la yglesia de Nuestra Señora del dicho lugar, y para la casa y granero que allí tiene el monasterio, como a un vecino y al mismo precio. Su fecha: en San Zoil, a 31 de marzo de 1588, ante Andrés Sánchez, escribano de Carrión.

\section{Remisiones a otro cajón}

Juro sobre las alcavalas de este lugar, de 600 maravedís. Véase el cajón San Leandro.

Sentencia sobre una tierra en Arconada a favor de este monasterio. Año de 1363. Cajón San Benito, legajo $2^{\circ}$, quaderno $\mathrm{B}$, número $2^{\circ}$. 


\section{/ (f. 34r) Quaderno B del legajo $2^{\circ}$}

En este quaderno están las escrituras y papeles pertenecientes a la jurisdición y derechos que tubo el monasterio en este lugar, además de los que se hallan entre los papeles de San Zoles y Villamuera. Los que hay aquí están por el orden siguiente:

$1^{\circ}$. < Privilegio del rey don Alonso $11^{\circ}$ a favor del lugar de Arconada. Era de 1373, año de $1335>$.

Privilegio del rey don Alonso $11^{\circ}$ por el qual parece que el concejo de Arconada se quejó de que, teniendo privilegio del rey don Sancho, abuelo, y del rey don Fernando, padre del dicho rey don Alonso $11^{\circ}$, para no ser presos por deudas agenas en las guerras, pusieron fuego a la yglesia del dicho lugar y se quemó el dicho privilegio confirmado por el rey don Alonso en las cortes de Madrid. Por lo qual a los vecinos se les hacía muchos agravios y se despoblaba el lugar. Y para remediar estos males pidieron confirmación de dicho privilegio.

$<$ En estos privilegios dicen los reyes que el lugar de Arconada era del monasterio $>$.

El dicho rey don Alonso $11^{\circ}$ se le concedió para que no pudiesen ser prendados por las deudas, del camarero de San Zoil y prior de San Román, que debiesen al rey, ni por la mula y vaso que solían pagar a su merino mayor. Este privilegio que está escrito en pergamino, sellado con sello de plomo pendiente en filos de seda, fue dado en Valladolid, a 29 de abril de la hera de 1373, que es año de Cristo de 1335, ante Juan Gutiérrez, escribano del rey.

$2^{\circ}$. < Exención del concejo de Arconada. Era de 1385, año de 1347>.

Escritura por la qual consta que un alcalde compelía a los vecinos de Arconada a que comprasen ciertos bienes (no los señala) del prior de San Román; y los de Arconada alegan razones y privilegios para no lo hacer ni pagar de los bienes del camarero de San Zoil y prior de San Román, vaso ni mula, al adelantado, que era cierto tributo que en aquel tiempo se pagaba. Su fecha: a 16 de junio, era de 1385, que es año de Cristo de 1347.

3. < Privilegio del rey don Enrique $3^{\circ}$. Año de 1391>.

Privilegio del rey don Enrique $3^{\circ}$ (que llamaron el enfermo), escrito en pergamino, con sello de plomo pendiente en filos de seda, / (f. 34v) por el qual confirma otro privilegio de su padre, el rey don Juan el $1^{\circ}$, dado en Burgos, a 25 de agosto, era de 1417, que es año de 1379. El qual es confirmación del privilegio del rey don Alonso el $11^{\circ}$, su visabuelo, padre del rey don Pedro, dado en Valladolid, a 29 de abril, era de 1373, año de Cristo 1335, y es el privilegio de arriba número $1^{\circ}$, el qual confirma este rey don Enrique $3^{\circ}$ por este privilegio. Dado en las Cortes de Madrid, a 23 de abril de 1391.

\section{4. <Cláusulas del Becerro de Valladolid. Hecho en la era de 1390, año de 1352>.}

Papel simple que contiene las cláusulas sacadas del libro Becerro hecho por mandato del rey don Alfonso en la era de 1390, que está en poder del chanciller de la Chancillería de Valladolid. Estas cláusulas son pertenecientes a los derechos y señorío que tenía este monasterio en el lugar de Arconada, las quales se hallan al folio 49 de dicho libro, en la merindad de Carrión.

5. <Nombramiento de merino. Año de 1453>.

Copia simple de un nombramiento de merino hecho por don Pedro de Tosantos, por la gracia de Dios y de la Santa Yglesia de Roma abad de San Zoil, en Gómez Pérez, vecino de Arconada. Su fecha: en San Zoil, a 30 de julio de 1453.

6. < Poder del convento para cobrar de Arconada 1.148 maravedís. Año de 1471>.

Poder para cobrar del concejo de Arconada 1.148 maravedís dado por Pedro de Astorga, vecino de Medina del Campo, a Juan de Argüello, vecino de Castromocho, por libramiento de Francisco de Madrid y Pedro de Ávila, recaudadores del rey. Su fecha: en Palencia, a 15 de mayo de 1471, ante Pedro de Porras, notario apostólico. 
7. < Obligación del concejo de Arconada. Año de 1485>.

Escritura por la qual el concejo de Arconada se obliga a pagar a doña Orosol, vecina del dicho lugar, 14.500 maravedís que el concejo debía de alcavalas a Fernando de Madrid, recaudador de ellas. Su fecha: en Arconada, a 25 de enero de 1485, ante Pedro de San Zoles, escribano de Carrión.

8. $<$ Querella del monasterio. Año de 1508>.

Querella del monasterio ante el provisor de Palencia contra la justicia de Carrión, porque, haviendo el monasterio mandado prender y teniendo presos en San Zoles ciertos vasallos de Arconada, vino la justicia de noche y los sacó de la cárcel. El provisor admitió la querella y dio comunión al cura de Belén, para que hiciese información del caso. Año de 1508.

9. $<$ Mandamiento para vender Arconada. Año de 1512>.

Mandato del Capítulo General que se celebró en Sagún, año de 1512, siendo general fray Juan de Amusco y presidiendo en él don Alonso Carrillo de Albornoz, obispo de Ávila, en el qual se determinó / (f. 35r) que, atentos los pleitos e incomodidades, muchas costas y poco provecho que traían a la religión algunos vasallos que tenían los monasterios de Arlanza, Nájera, Salamanca, y los de Arconada del de San Zoil, los tales vasallos se vendiesen, trocasen, empeñasen, o enagenasen. Está firmado este mandato del dicho obispo de Ávila, el general y de los difinidores. Su fecha: en Sagún, a 7 de mayo de 1512.

10. $<$ Requirimiento de un merino. Año de 1525>.

Requirimiento que hizo un merino de Arconada, estando preso en la cárcel de Carrión, al corregidor y teniente para que le soltasen. Año de 1525.

11. $<$ Vrciones de Arconada $>$.

Memoria simple de las personas que pagaban vrciones en Arconada y quánto pagaba cada vecino. No tiene fecha.

12. <Provanzas del yantar. Año de 1544>.

Traslado authorizado y sacado con provisión de la Chancillería de unas probanzas que hizo el monasterio para justificar que el concejo de Arconada le debía dar un yantar que éste le negaba, las quales se hicieron por comisión de fray Blas de Pedrosa, abad de San Claudio de León, juez conservador. Año de 1544, ante Pedro Vacas, clérigo y notario apostólico.

13. < Carta executoria contra el concejo y vecinos de Arconada sobre las sernas, martiniega y vrciones. Año de 1558>.

Carta executoria contra el concejo y vecinos de Arconada, vasallos de este monasterio de San Zoil y de San Román, sobre la paga de sernas, martiniega y vrciones que como tales vasallos debían pagar cada año a esta casa. Consta por esta carta que, haviendo tenido pleito esta casa sobre la paga de las referidas pensiones con el referido concejo y vecinos, reconociendo estos su poca justicia y que el monasterio tenía a su favor vna sentencia arbitra del año de 1451, con posesión actual continuada de cobrar, otra sentencia en Carrión, y otra en la sala, dadas en este último litigio, no quisieron esperar a la revista del pleito.

$<$ Redimieron las sernas $>$

Y assí trataron de redimir las sernas pagándolas de una vez, las quales se ajustaron en 178.125 maravedís, que pagaron a la casa; y la sala aprobó este contrato y transación, a 4 de agosto de 1558, ante Juan de Gauna, escribano de cámara de Su Magestad. Se advierte que el concejo y vecinos no redimieron martiniega ni vrciones.

\section{Remisiones}

Provisión para que no se innove en la jurisdicción. Véase el cajón San Mauro, legajo $1^{\circ}$, quaderno $\mathrm{B}$, número 9. 


\section{/ (f. 35v) Quaderno C del legajo 2o.}

En este quaderno $C$ están las escrituras tocantes a la yglesia y beneficio curado de San Facundo de Arconada, presentaciones y colaciones de él, por el orden siguiente:

$1^{\mathrm{a}}$. <Donación de la yglesia de San Facundo por el conde don Gómez Díaz. Era de 1085, año de 1047>.

Donación, escrita en pergamino, del conde don Gómez Díaz, marido de doña Teresa, a quienes tenemos por reedificadores y fundadores de este monasterio. Por esta escritura consta que el dicho conde don Gómez Díaz edificó un monasterio para dar limosna a los pobres que iban y venían a visitar a los apóstoles San Pedro y Santiago, en honor de san Facundo y Primitivo y de San Cristóval y de todos los santos, en la villa de Arconada, fundada en tiempos antiguos; la qual yglesia de San Facundo y Primitivo (que estaba consagrada por dos obispos llamados Cipriano y Pedro) la da a Dios y a la yglesia de San Juan Baptista y de San Zoil y San Felices y a los monges de la orden de Cluni que sirven a Dios en ella, para que ellos y sus sucesores la tengan y posean perpetuamente. Facta carta donaciones era 1085, que es el año de Christo de 1047, feria sexta, ydibus martii. Reynando en León y Castilla el rey don Fernando y su muger, doña Sancha.

Confirman esta carta Cipriano, obispo de León, don Miro, obispo de Palencia, el abad don Diego y otros. de $1531>$.

2. <Ynformación de la presentación y patronato del beneficio de San Facundo. Año

Ynformación original y su copia autorizada, hecha por parte del monasterio ante el licenciado Ximénez de Sobrarbe, arcipreste de Carrión, en que se prueba pertenecer al monasterio el patronato de la yglesia de San Facundo de Arconada y la presentación de su beneficio todas las veces que vacare. Su fecha: en Carrión, año de 1531, ante Juan de Castrillo, escribano y notario.

3. <Carta executoria a favor de este monasterio sobre la presentación del beneficio curado de San Facundo de Arconada. Año de 1586>.

Carta executoria de la presentación del beneficio curado de San Facundo de Arconada, por la qual, a pedimiento del monasterio, el licenciado don Francisco de Rivadeneyra, deán y provisor en sede vacante del obispado de Palencia, dio mandamiento contra Francisco y Rodrigo de Guinea, notarios de la audiencia episcopal, para que diesen a la parte del convento ciertas presentaciones y colocaciones del beneficio de San Facundo; / (f. 36r) en cuyo cumplimiento del dicho Francisco de Guinea compulsó y sacó del proceso que estaba en su poder las escrituras siguientes:

$<$ Presentación en Juan Ordóñez. Año de 1585>.

Vna presentación hecha por fray Antonio Perroto, abad de San Zoil, en el bachiller Juan Ordóñez, vecino de Cavañas, diócesis de Palencia. A 16 de marzo de 1585, ante Andrés Sánchez, escribano en Carrión.

Carta de edicto sobre la presentación anterior dada por el licenciado Juan Rodríguez de Santa Cruz, provisor de Palencia. A 21 de marzo de 1585, ante Francisco de Guinea, notario.

$<$ Colación en Juan Blanco. Año de 1558>.

Colación del beneficio de San Facundo dada por el licenciado Gómez de Mora, provisor de Palencia, a Juan Blanco, clérigo de Arconada, en virtud y presentación en él hecha por fray Juan Vaca, abad de San Zoil. Su fecha: en Palencia, a 28 de enero de 1558, ante Fernando Montero, notario. Síguese la posesión que tomó del curado el dicho Juan Blanco. A 6 de febrero de 1558, ante Andrés de Buelna, escribano de población. 
<Colación en Pedro Ximénez. Año de 1531>.

Colación de dicho beneficio, hecha por el licenciado Bartolo Sánchez de Tórtoles, arcediano de Zerrato y provisor de Palencia, en Pedro Ximénez, clérigo de la diócesis de Calahorra, en virtud de la presentación que de él hizo este monasterio. Su fecha: en Palencia, a 20 de noviembre de 1531, ante Francisco Fernández, notario.

Síguese el asiento del libro Becerro de la yglesia de Palencia, del qual consta que la presentación de este curato pertenece a este monasterio.

$<$ Sentencia. Año de 1586>.

Presentados estos ynstrumentos, el licenciado Juan Rodríguez Santa Cruz, provisor, pronunció sentencia, en 29 de marzo de 1586, ante Rodrigo de Guinea, notario de la audiencia, por la qual declara estar vaco el beneficio curado de San Facundo de Arconada, por fin y muerte de Juan Blanco, su último poseedor, al abad y convento de San Zoil, por presentero del beneficio, y al bachiller Juan Ordóñez, por bien presentado.

$<$ Colación en Juan Ordóñez. Año de 1586>.

Sin embargo, de lo pedido por el concejo de Arconada y del fiscal del obispado y de las oposiciones hechas al beneficio por Miguel de Carrión, Pedro Pérez y Melchor Fernández en virtud de esta sentencia, los provisores de Palencia en sede vacante, precedido examen, dieron título de colación del dicho beneficio al bachiller Juan Ordóñez. Esta executoria está authorizada y firmada de Francisco de Guinea, notario. Después de esta executoria están las colaciones originales en Pedro Ximénez, año de 1531, y en Juan Blanco, año de 1558, con la posesión quieta y pacífica que éste tomó del referido beneficio.

\section{/ (f. 36v 4. <Colación en Francisco Andrés. Año de 1593>.}

Colación del beneficio de san Facundo de Arconada hecha por el licenciado Oteo de Angulo, provisor de Palencia, en Francisco de San Andrés, natural de Vioño, diócesis de Burgos, en virtud de presentación que en él hizo fray Toribio de San Andrés, abad de San Zoil. Su fecha: en Palencia, a 26 de enero de 1593, ante Francisco de Guinea, notario.

\section{5. <Colación en Juan Díez de Miranda. Año de 1597>.}

Colación del beneficio de San Facundo hecha por el licenciado don Francisco de Rivadeneira, deán, y el doctor Tomás López, canónigos y provisores de Palencia en sede vacante, en Juan Díaz de Miranda, en virtud de presentación que en él hizo el padre fray Juan de Palacios, presidente de San Zoil. Opúsose a esta colación Francisco Marcos, a título de patrimonial; y sin embargo, en Palencia, a 2 de mayo de 1597, los dichos provisores dieron sentencia definitiva por la que declararon estar bien echa la presentación en Juan Díaz de Miranda, de la que le despacharon título colación el mismo día, mes y año, ante Fernando Chocán, notario apostólico, tomó la posesión quieta y pacíficamente. A 13 de mayo de 1597, ante Juan de Revenga, escribano de Arconada.

\section{6. < Colación en Bernardino Jijón. Año de 1622>.}

Colación del beneficio de San Facundo hecha por el licenciado Antonio Ramírez, provisor de Palencia, en Bernardino Jijón, en virtud de presentación que en él hizo el padre fray Juan Díaz, abad de San Zoil, por ingreso en religión de Luis Pastor (cuyo título falta), su último poseedor. Opúsose Laurencio Melendro, clérigo capón, a título de patrimonial, el qual se apartó de la oposición. Declarose por bien hecha la presentación en Bernardino Jijón, y se le dio la colación del beneficio, a 11 de enero de 1622, ante Balthasar de Bero, notario; y tomó la posesión de él en 17 del mismo mes y año, ante Pedro Baíllo, escribano de Arconada.

7. <Colación en Francisco de Terán. Año de 1638>.

Colación hecha por don Fernando Rodríguez, maestreescuela y provisor de Palencia, en Juan de Terán, natural del lugar de Terán, en el valle de Cabuérniga, por presentación que le hizo el maestro fray Francisco de Lemos, abad de San Zoil. Opúsose Laurencio Melendro como patrimonial; sin embargo, declarose por bien echa la presentación en el referido Terán. 
Despachósele colación en 24 de marzo de 1638, ante Francisco Pedrero, notario. Tomó la posesión del beneficio quieta y pacíficamente en 27 del mismo mes y año, ante José de San Estevan, cura de Santa María de Arconada y notario apostólico.

\section{/ (f. 37r) 8. <Empetra del curato por Laurencio Melendro. Año de 1649>.}

Por resignación que hizo en manos de Su Santidad el licenciado Francisco Terán del curato de San Facundo, le impetró y sacó bulla de Roma el licenciado Laurencio Melendro, patrimonial de Arconada, con la que requirió al provisor de Palencia, quien le despachó título de colación. La bulla fue dada en Roma, año de 1649; en ella se hace relación de que la presentación del beneficio pertenece a este monasterio y de que pro hac vice le presenta $\mathrm{Su}$ Santidad. Está aquí una carta del concejo de Arconada al abad de esta casa en la que da parte de la muerte de Laurencio Melendro y pide el curato para Gaspar Melendro, a quien parece no se dio, sino al licenciado Estevan Díez, cuyos títulos faltan.

9. <Colación en Mathías del Valle. Año de 1684>.

Colación hecha por don Martín González Panniagua, arcediano del Alcor y provisor de Palencia, en el licenciado Mathías del Valle, en virtud de presentación que le hizo el maestro fray Bernardo de Estúñiga, abad de San Zoil. Su fecha: en Palencia, a 8 de noviembre de 1684, ante Fernando Aguado Pardo Ruiz, notario. Está aquí una copia authorizada de esta colación y de la posesión, y también la resignación que hizo del curato en manos del abad y la acetación de éste, en 22 de octubre de 1693, ante Norberto de Sandoval y Guevara, escribano de Carrión.

10. <Acetación en Juan de Ruiloba. Año de 1694>.

En virtud de la resignación que hizo Mathías del Valle y acetación del abad, que también se halla aquí, se hizo la presentación del beneficio por el maestro fray Gregorio Ruiz, abad de esta casa, en el licenciado Juan de Ruiloba, a 4 de enero de 1694, ante Norberto de Sandoval y Guevara, escribano de Carrión. Está aquí la colación hecha al mismo por don Jacinto de Arana y Cuesta, provisor de Palencia, a 13 de marzo de 1694, ante Marcos Ruiz.

\section{1. < Colación en Francisco Gutiérrez de la Vega. Año de 1708>.}

Colación y posesión del curato de San Facundo que tomó don Francisco Gutiérrez de la Vega, en virtud de presentación que de él le hizo el abad de esta casa. La colación fue hecha en 6 de junio de 1708, ante Marcos Ruiz, notario de Palencia; y la posesión se tomó a 15 de julio del mismo año, ante Francisco Ruiz de Sandoval, escribano y notario de Carrión ${ }^{39}$.

/ (f. 37v) 12. <Colación en Juan Carrillo. Año de 1717>.

Por renuncia que hizo don Francisco Gutiérrez de la Vega en manos del maestro fray Jacinto Díez, abad de San Zoil, presentó el curato de San Facundo en el licenciado don Juan Carrillo, a quienes despacharon los provisores de Palencia, en sede vacante, el título de colación, a 18 de septiembre de 1717, ante Marcos Ruiz, notario; y tomó la posesión en $1^{\circ}$ de noviembre del mismo año, ante Norberto Salomón, notario apostólico. Este don Juan Carrillo renunció el curato, en 26 de marzo de 1722, ante Santiago Duque de Estrada, notario; y el maestro Flórez, abad, le presentó en don Ysidro Vélez Bracho, a 6 de julio de 1722, ante el mismo notario.

\section{3. < Colación en Sebastián del Campo>.}

Colación hecha por el licenciado don Manuel González Benito, provisor de Palencia, del curato de San Facundo, en don Sebastián del Campo Navarro, en virtud de presentación que le hizo el maestro Flórez, abad. Su fecha: en Palencia, a 7 de junio de 1725, ante José Meléndez, notario. Tomó la posesión en 25 de junio del mismo año, ante Alonso Cabeza, notario de Carrión.

\footnotetext{
${ }^{39}$ Carrión] sigue tachado: 12. Renuncia que hizo del curato don Francisco Gutiérrez, en manos del abad, el maestro fray Plácido Flórez, a 26 de marzo de 1722, ante Santiago Duque de Estrada, escribano de Carrión. Presentación del mismo abad en el licenciado don Ysidro.
} 


\section{4. < Presentación y colación en Antonio Rodríguez. Año de 1734>.}

Presentación del curato de San Facundo hecha por el maestro fray Jacinto Díaz, abad de San Zoil, en el licenciado don Antonio Martín Rodríguez. A 3 de octubre de 1734. Está aquí la colación y posesión del mismo beneficio.

15. $<$ Renuncia de el mismo. Año de 1735>.

Renuncia que hizo del curato el mismo don Antonio Martín Rodríguez en manos del abad. A 26 de noviembre de 1735, ante Agustín Díez de Castro, escribano y notario de Carrión.

16. <Presentación en Andrés de Soto. Año de 1735>.

Presentación que hizo del curato el maestro fray Jacinto Díez de Angulo, abad, en el licenciado don Andrés de Soto. A 28 de noviembre de 1735, ante su secretario fray Zoil Fernández; authorizada por Agustín Díaz de Castro, escribano de Carrión.

17. < Presentación en José Fierro. Año de 1777>.

Presentación del curato de San Facundo hecha por el padre maestro fray Martín Basco, abad, en don José Fierro. A 19 de enero de 1777, ante su secretario fray Yldefonso Hidalgo.

$<$ No tubo efecto $>$.

Esta presentación no tubo efecto por no haber acaecido la vacante en ninguno de los quatro meses ordinarios, marzo, junio, septiembre y diciembre, según lo dispuesto en el concordato. Moviose pleito sobre esta presentación. El monasterio certificó varios instrumentos, tanto de este archivo como del de la cathedral de Palencia, cuya copia simple está aquí. De resulta de este pleito se declaró por nula esta presentación que correspondía a Su Magestad, quien le presentó en don Felipe Garnica.

\section{/ (f. 38r) 18. < Presentación en don Juan Orejón. Año de 1796>.}

Presentación del curato de San Facundo hecha por el maestro fray Leandro Pérez, abad, en don Juan orejón. A 22 de septiembre de 1796, haviendo precedido concurso y propuesta del señor obispo con arreglo a reales órdenes.

\section{Remisiones}

Ynformación sobre los diezmos de esta yglesia de San Facundo, hecha año de 1220. Cajón San Andrés, legajo $1^{\circ}$, quaderno B, número $2^{\circ}$.

\section{Quaderno D del legajo $2^{\circ}$}

En este quaderno D están las escrituras tocantes a la yglesia y beneficio curado de Santa María de Arconada, presentaciones y colaciones de él por el orden siguiente ${ }^{40}$ :

La donación de esta yglesia hecha a San Román por Diego Monniz y su muger, doña Tigridia, (condes de Saldaña), en el año de 940, está entre los papeles de San Román, Cajón San Martín, legajo $1^{\circ}$, quaderno A, número $1^{\circ}$.

1. $<$ Bullas de Alexandro $6^{\circ}$ y posesión del curato de Santa María de Arconada dada al sacristán mayor de San Zoil. Año de 1500>.

Posesión que tomó del curato de Santa María de Arconada don Sebastián de Rivera, sacristán mayor de San Zoil, en virtud de unas bullas del papa Alexandro $6^{\circ}$, cuya súplica y decreto original está aquí refrendado por el cardenal de Santa Práxedes. De estas bullas consta que Toribio Aparicio, cura de Santa María de Arconada, resignó libremente el beneficio en manos de Su Santidad; y aceptada hizo colación y gracia de él a don Sebastián de Rivera, sacristán mayor de San Zoil, en $1^{\circ}$ de julio de 1500. Y el mismo día dio comisión al prior y

\footnotetext{
${ }^{40}$ siguiente] al margen entre paréntesis: Nota.
} 
prouisor de Palencia y otros, para que pusiesen en la posesión del dicho beneficio al dicho sacristán; y el auditor de la Cámara Apostólica despachó comisión executoria en forma, insertas en ella las dichas bullas, a 8 de julio del mismo año. De todo lo qual se sacó esta copia authorizada a instancia del mismo sacristán, ante Andrés de Colmenares, cura de San Andrés y vicario / (f. 38v) de Carrión, a 15 de enero de 1502, de que dio fe Pedro Fernández de Carrión, clérigo y notario apostólico. En 14 de agosto de 1500, el dicho sacristán mayor de San Zoil Sebastián de Rivera requirió con las referidas bullas a Toribio Aparicio, para que dexase el beneficio curado de Santa María de Arconada y le diese la posesión real y actual de él, como Su Santidad lo mandaba, el qual las obedeció y dio la posesión en forma de curato al dicho Sebastián de Rivera, ante Pedro Fernández de Carrión, clérigo y notario apostólico.

\section{2. < Presentación de Álvaro de Mendoza. Año de 1531>.}

Presentación del curato de Santa María de Arconada hecha por el prior y monasterio de San Zoil en Álvaro de Mendoza, clérigo. A 11 de septiembre de 1531, ante Juan de Castrillo, escribano de Carrión.

$<$ Renunció el curato $>$.

Este Álvaro de Mendoza renunció el curato en manos de Su Santidad, a efecto y no de otra manera que el dicho curato recayese en el monasterio de San Zoil, con la condición de que éste le havía de dar de pensión en cada un año 24 mill maravedís. Acetó el monasterio, como consta de la escritura de concordia otorgada a 30 de noviembre de 1542, ante Juan de Castrillo, notario apostólico, que se halla aquí con otros papeles sobre lo mismo.

\section{3. <Qüentas de la yglesia. Año de 1577>.}

Qüentas que dio Juan Gutiérrez, mayordomo de la yglesia de Santa María de Arconada, de algunos gastos que havía echo en ella por los años de 1577.

4. <Cartas de Roma, etcétera, desde 1602 hasta 1605>.

Cartas de Roma y otras partes y papeles tocantes al beneficio de Santa María de Arconada. Háblase en ellas de Frómesta, Aguilar y otras cosas. Son de los años de 1602 hasta 1605.

\section{5. $<$ Colación en Gonzalo de Colmenares. Año de 1603>.}

Colación del beneficio de Santa María hecha por don Gaspar de Peralta, canónigo y provisor de Palencia, por la qual consta que estando vaco dicho beneficio por muerte de Antonio de Colmenares, su último poseedor, fray Plácido de Huércanos, abad de San Zoil, le presentó en el licenciado Santiago de Colmenares. Opusiéronse a esta presentación el bachiller Santiago Martínez y otros; salió a la causa el fiscal por la dignidad episcopal, de la qual conoció el nuncio a pedimento del licenciado Gonzalo de Colmenares, por haver sido provehído el dicho beneficio en Martín Sierra de Juvero, clérigo de la diócesis de Calahorra. El nuncio remitió el pleito al ordinario, el qual dio carta de edicto; y dentro del término parecieron / (f. 39r) los opositores, alegaron y presentaron sus probanzas y, conclusa la causa, el dicho provisor dio sentencia definitiva, por la qual declara al abad de San Zoil por verdadero presentero de dicho beneficio y manda que Gonzalo de Colmenares, presentado por el dicho abad, califique su persona y parezca a ser examinado, sin embargo de las oposiciones de los demás opositores y de lo alegado por el fiscal. Y siendo examinado y aprobado se le hizo la presente colación del beneficio, en Palencia, a 17 de mayo de 1603, ante Pedro de Arana Ozerín, notario; y tomó posesión quieta y pacífica a 19 días del mismo mes y año, ante Francisco Moro de Saldaña, escribano de Carrión.

\section{6. < Colación en Juan de Jijón. Año de 1607>.}

Colación del curato de Santa María hecha por don Francisco de Valverde Aldrete, deán y provisor de Palencia en sede vacante, en Juan de Jijón, por presentación que hizo en él fray Juan Díaz, abad de San Zoil, a quien se declaró por verdadero presentero por sentencia definitiva. Diose esta colación en Palencia, a 14 de noviembre de 1607, ante Fernando Chucán, notario; tomó la posesión en 18 del mismo mes y año ante Luys de Revenga, escribano de Arconada. 
7. < Muerte de Juan de Jijón. Año de 1535>.

Fe y testimonio dado por Fernando Bállo, escribano de Arconada, de la muerte de Juan de Jijón, cura de Santa María, acaecida a 5 de octubre de 1535.

8. <olación en José de San Estevan. Año de 1635>.

Colación del curato de Santa María hecha por el doctor Santiago Roxo, penitenciario y provisor de Palencia, en el licenciado José de San Estevan, por presentación que de él hizo el maestro fray Bernardo de San Estevan, abad de san Zoil, a quien se declaró por verdadero presentero, por sentencia definitiva. Diose la colación en Palencia, a 27 de octubre de 1635, ante Juan Pérez, notario; tomó la posesión en $1^{\circ}$ de noviembre del mismo año, ante Francisco Moro de Saldaña, escribano de Carrión.

9. <Licencia para resignar el curato. Año de 1639>.

Consentimiento que dio el maestro fray Francisco de Lemos, abad de San Zoil, al licenciado José de San Estevan, cura de Santa María, para que resignase el curato en manos de Su Santidad a favor de Juan Moral de la Guerra pro hac vice tantum et salvo jure pratonatus (sic) et presentationis al monasterio. Su fecha, en San Zoil, a 20 de mayo de 1639, ante Andrés Martínez, notario.

10. <Presentación, colación y posesión que tomó del curato Juan de Cisneros, con obligación de no permutarle, pena de 500 ducados. Año de 1651>.

Presentación del curato de Santa María hecha por el maestro fray Plácido del Río, abad de San Zoil, en el licenciado Juan de Cisneros, a 13 de septiembre de 1651, / (f. 39v) ante Francisco Moro de Saldaña, authorizado por Norberto de Sandoval y Guevara, escribanos y notarios de Carrión. En el mismo día, mes y año se obligó el dicho Juan de Cisneros ${ }^{41}$ a no permutar el curato, bajo la pena de 500 ducados, por escritura otorgada ante el mismo notario Francisco Moro de Saldaña. Síguese la colación hecha por el yllustrísimo señor obispo de Palencia, a 15 de septiembre de 1651, ante Matheo de Villar, su secretario, y la posesión del curato a 16 días del mismo mes y año.

11. <Proceso en el pleito que huvo sobre la presentación que hizo el abad en Hernando Melendro. Año de 1664>.

Por muerte del licenciado Juan de Cisneros, año de 1664, vacó el curato de Santa María. Pretendió la presentación de él el licenciado Hernando Melendro, beneficiado de Villovieco, el qual, para poderla conseguir, hizo información de que no era patrimonial de Arconada; hízola también el abad de San Zoil. Y constando de una y otra ser assí, presentó el curato en él. Opusiéronse los vecinos, citose al monasterio quien salió a la defensa, hizo sus probanzas de que no estaba obligado a presentar en patrimoniales; y vistos los autos, el licenciado don Luys Díez de León, provisor de Palencia, dio sentencia definitiva, por la qual declara estar bien echa la presentación en el licenciado Melendro, a 24 de abril de 1665, ante Lázaro Montoya, notario. En el mismo día y año se le despachó título de colación y tomó la posesión en 25 días del mismo mes y año, ante Juan de la Hera, notario apostólico. Este cura renunció al curato en manos del abad el mismo año.

12. <Presentación y colación en Juan Fernández Cevallos. Año de 1665>.

Presentación y colación del curato de Santa María en el licenciado Juan Fernández de Zevallos hechas por el maestro Estúñiga, abad de San Zoil, y el provisor de Palencia. Año de 1665. Tomó posesión en 24 de diciembre del mismo año, ante fray Francisco de Molina, monge de San Zoil y notario apostólico.

13. <Pleito sobre la presentación en don Vicente de la Torre y Riva. Año de 1669>.

Por dexación que hizo en manos del abad el licenciado Juan Fernández de Zevallos, año de 1667, presentó el curato el maestro Estúñiga en don Vicente de la Torre y Riva, sobre cuya presentación hubo pleito en el tribunal de Palencia con el fiscal, el qual se llevó por vía de fuerza a Valladolid y últimamente, en grado de apelación, a Burgos, donde se dio sentencia

\footnotetext{
${ }^{41}$ Cisneros] sobrescrito y tachado: se obligó.
} 
a favor del monasterio; y los provisores en sede vacante despacharon título de colación a favor del referido don Vicente de la Torre y Riva, a 21 de febrero de 1669, ante Matheo / ( $f$. $40 r$ ) de la Canal, notario apostólico, y tomó posesión de él a 24 días de febrero del mismo año, ante Francisco de Dueñas, notario.

$<$ Permiso del abad para permutar el curato $>$.

Está aquí ${ }^{42}$ el permiso del abad para que el dicho don Vicente permutase el curato con don José de la Peña por una capellanía que éste tenía en Benavente. Dado a 17 de noviembre de 1695, ante Francisco Ruiz, notario apostólico; falta la colación y posesión de don José [de la] Peña. $1722>$.

14. <Presentación y colación en don Antonio de los Bueis Larreategui. Año de

Por justos motivos que tenía don José de la Peña renunció el curato en manos del maestro Hórez, abad de San Zoil, con la condición de que se le asignase congrua sustentación. Acetó el abad y le presentó en don Antonio Bueis Larreategui. Opúsose el fiscal a la renuncia y presentación y no obstante el provisor por sentencia definitiva, dada a 5 de mayo de 1722, ante José Meléndez, notario, declaró la sentencia por suficiente y la presentación por bien echa, señalando al dicho don José de la Peña para la congr[u]a sustentación durante su vida 15 cargas de trigo y 12 de zevada. Diósele la colación el mismo día, mes y año, y tomó la posesión a 9 días del mismo mes y año, ante Santiago Duque de Estrada, notario.

\section{5. < Colación en don Narciso Martínez Quijano. Año de 1750>.}

Colación del curato de Santa María hecha por el proviso de Palencia en don Narciso Martínez Quijano, en virtud de presentación que le hizo el maestro fray Jacinto Díez, abad de San Zoil. Su fecha, en Palencia, a 23 de octubre de 1750, ante Pedro López Navarroel, notario. Tomó posesión a 26 de octubre del mismo año, ante Bernardino de Villalón, notario. Se halla aquí la renuncia que hizo el mismo del curato en manos del abad, año de 1756.

16. <Cartas sobre la presentación del curato $>$.

Cartas del obispo de Palencia y abad de San Zoil sobre la presentación del curato de Santa María en don Sebastián Manjón de San Miguel, cuyos títulos faltan.

17. <Presentación en don Agustín de la Serna. Año de 1788>.

Presentación del curato de Santa María hecho por el maestro fray Leandro Pérez, abad de San Zoil, en don Agustín de la Serna, a 13 de enero de 1788, ante José Tablares, escribano de Carrión, haviendo precedido concurso y propuesta del señor obispo, con arreglo a reales órdenes.

18. $<$ Declaración de que una casa nueva de Arconada pertenece a la yglesia de Santa María. Año de 1795>.

Despacho del señor provisor de Palencia, por el que hace saber a don Felipe Garnica, cura de San Facundo de Arconada, y a Vicente Gonzalo, vecino del mismo lugar, el auto dado en 10 de julio de 1795, por el que, a petición de este monasterio, del cura y mayordomo de la yglesia de Santa María, se declara que la casa nuevamente fabricada por dicho Vicente Gonzalo pertenece a esta parroquia de Santa María y no a / (f. 40v) la de San Facundo, a cuyo cura prohíbe el que por su parte impida y se oponga a dicha declaración. Pasó ante José Patricio de Retes, notario; y la notificó José Tablares, escribano de Carrión, el día 13 del mismo mes y año.

\footnotetext{
42 aquí] sigue tachado: La permuta que en.
} 


\section{Quaderno E del legajo $2^{\circ}$}

En este quaderno están los papeles tocantes a las tercias y noveno de la yglesia de Santa María de Arconada por el orden siguiente:

$1^{\circ}$. < Memoria del libro Becerro de Palencia $>$.

Copia simple de unas claúsulas del libro Becerro de la Cathedral de Palencia, de los diezmos que corresponden a este monasterio en el barrio de San Zoles, Cestillos, San Facundo y Santa María de Arconada. Ay aquí otra memoria de los derechos de esta casa en las referidas yglesias.

\section{2. <Carta executoria de las tercias de Santa María de Arconada. Año de 1642>.}

Carta executoria por la qual consta que el emperador Carlos $5^{\circ}$ y sus contadores mayores, en el año de 1541 dieron comisión a Francisco Gómez de Espinosa, vecino de Carrión, para que arrendase y cobrase las tercias de Arconada y otros lugares, con la qual requirió al corregidor de Carrión, quien, sin citar al monasterio, despachó un aguacil a Arconada y embargó los diezmos que el monasterio tenía en su granero y, hallándole cerrado, puso otro candado, mandando a los regidores no los permitiesen sacar. En vista de esto, pidió el monasterio al corregidor desembargo de ellos, alegando la posesión a que se opuso el recaudador, sobre lo qual se hicieron ciertas probanzas; y el monasterio se presentó en grado de apelación ante los contadores mayores de Valladolid por vía de nulidad y agravio, los cuales avocaron a sí la causa y dieron traslado al fiscal.

\section{$<$ Auto $>$.}

Allegó éste de su derecho y el monasterio hizo su pribanza, en cuya vista, en $1^{\circ}$ de diciembre de 1642, dichos contadores mayores / (f. 41r) dieron un auto por el que mandaron que, sin perjuicio del derecho de Su Magestad, se levantase el embargo y no se innovase en adelante, mientras otra cosa no se mandase. Notificose este auto al fiscal a que no replicó, con que se despachó esta carta. Y con ella fue requirido el corregidor, el qual obedeció y levantó el embargo. De este auto se originó el pleito que se verá adelante en la executoria del año de 1612.

3. $<$ Relación del Archivo de Simancas. Provisión real para compulsar el Becerro de Palencia. Año de 1609>.

Relación simple de lo que se halla en los libros reales que están en los Archivos de Simancas, sobre las tercias del lugar de Arconada: Provisión real para compulsar unas partidas del libro Becerro de la cathedral de Palencia sobre las tercias de Arconada. Su fecha, en Madrid, a 28 de noviembre de 1609, ante Martín Pradeda, secretario de cámara de Su Magestad. En virtud de esta provisión compulsó lo que se pedía Blas de Saagún, escribano de Palencia, a 10 de diciembre del mismo año, por quien están firmadas estas cláusulas que se hallan aquí insertas.

4. $<$ Papeles en derecho sobre las tercias $>$.

Papeles en derecho que hizieron los licenciados don Antonio de la Cueva y Silva y don Alonso Seijas de la Carrera sobre el pleito acerca de las tercias de Arconada, en la propiedad. $1612>$

5. <Segunda carta executoria sobre las tercias de Santa María de Arconada. Año de

Executoria en propiedad de las tercias de Santa María de Arconada librada por el presidente y oydores de la Contaduría Mayor de Hacienda a favor de este monasterio. En ella se hace relación de las instancias del pleito de la executoria puesta atrás hasta que se dio el auto en ella contenido; después de lo qual consta que en Madrid, a 24 de enero de 1587, el doctor Villagómez, fiscal de Su Magestad, pidió en el Consejo de Hacienda se volviese a ver el dicho pleito, y alegó a favor de Su Magestad. Fue emplazado el monasterio, quien salió a la causa y alegó de su justicia presentando la carta executoria de 1542, la que pidió el monasterio se le devolviese original.

$<$ Auto $>$ 
Opúsose el fiscal por no ser executoria de sentencia, sino de auto que no había pasado en cosa judgada; y conclusa la causa sobre este artículo, los contadores mayores dieron un auto, a 26 de octubre de 1590, en que dixeron que por entonces no havía lugar a dar al monasterio la executoria que pedía hasta que se ordenase otra cosa. Suplicó el monasterio de este auto y la causa quedó este estado hasta que el fiscal Melchor de Molina pidió nuevo emplazamiento, que se despachó en 27 de octubre de 1607, para que el monasterio fuese en seguimiento de la causa; y haviendo parecido Jilimón de la Mota, fiscal, alegó contra el monasterio, a quien se dio traslado, y respondió alegando su justicia. / (f. 41v) Reciviose la causa a prueba, hizo el monasterio y presentó su información con otras escrituras y, haviéndolas redarguido el fiscal, se recevió nuevamente a prueba sobre este artículo.

$<$ Sentencia de vista. Año de 1612>.

Hízola el monasterio y la presentó dentro del término, y publicada y dada la causa por conclusa. Vista por los señores presidentes y oydores, dieron su sentencia definitiva en Madrid, a 22 de mayo de 1612, por la qual absolvieron al monasterio del pedimento y demanda contra él puesta por el fiscal sobre las tercias de la yglesia de Santa María de Arconada, y mandaron que en el aprovechamiento de ellas no se le ponga impedimento sino que las goze como hasta allí, con que se tenga cuidado que en las vecindades que se hicieren de los vecinos de la dicha yglesia y de la de San Facundo, de que Su Magestad lleva las tercias, no se haga fraude, etcétera. Suplicó el fiscal de esta sentencia y alegó contra ella, diose traslado al monasterio y, evacuado, se dio por conclusa la causa.

$<$ Sentencia de revista. Año de 1612>.

Y en 3 de julio del dicho año los referidos presidente y oydores dieron sentencia de revista por la qual confirmaron la de vista. De las quales, a instancia del monasterio, se dio esta carta executoria, en Madrid, a 14 de julio de 1612, ante Pedro Guadrón de Herrera, escribano de Cámara.

Notificose esta carta executoria al fiscal de Su Magestad en 23 días del mismo mes y año, el qual respondió que las sentencias contenidas en ella son comunes a las partes; y assí pidió se pasaren por los libros de la Contaduría Mayor y contadores de rentas, para que en ellos haya noticia que estas tercias las ha de gozar el monasterio y para que no se haga fraude a Su Magestad en las vecindades. Notificose al monasterio y pidió lo mismo que el fiscal. Mandó el Consejo que assí se cumpliese, y a 31 de julio de 1612 se dio fe por los contadores de que esta carta executoria quedaba asentada en los libros de la Escrivanía Mayor de Rentas de Su Magestad.

6. <Sentencia contra un cura sobre diezmos. Es copia simple>.

Copia simple de una sentencia dada por el provisor de Palencia, año de 1638, en un pleito que este monasterio y el cavildo de Palencia tubieron con el licenciado Laurencio Melendro, sobre que pagase diezmo de los frutos que cogiere, a que fue condenado.

7. < Noveno de Santa María y concordia con el concejo. Año de 1645>.

Concordia hecha entre este monasterio y el concejo y vecinos de Arconada por la que, y otros papeles que van aquí cosidos, consta que en el año de 1645 se presentaron dichos vecinos ante el provisor de Palencia, de quien sacaron mandamiento de embargo del noveno de Santa María para ornamentos, reparos y demás necesario para adorno de aquella yglesia. Salió el monasterio a la causa, haciendo antes depósito de algunos ornamentos ante Gerónimo Laso, y dando fianzas (f. 42r) logró se desembargase el noveno; pero aunque se notificó a los regidores, se resistieron, por lo que se pasó a dar queja. Tratose después de concordia, la que se otorgó a 21 de noviembre de 1645, ante Francisco Moro de Saldaña, escribano de Carrión, y la ratificó el concejo de Arconada, a 27 días del mismo mes y año y ante el mismo escribano.

Entre varios puntos en que se concordaron los principales son los siguientes:

$1^{\circ}$. Apartamento del pleito por ambas partes, con obligación de no seguirle. 
$2^{\circ}$. El monasterio cede y traspasa en el concejo y vecinos de Arconada la tercera parte del noveno de la parroquia de Santa María, quedando a cargo del concejo todas las obras y reparos de la dicha yglesia y proveherla de los ornamentos necesarios con inclusión de azeyte y cera, etcétera.

$3^{\circ}$. Que el abad y convento de San Zoil como patrono in solidum y presentero no sólo de los curatos de las dos yglesias, sino también de la capellanía del licenciado Juan Fernández, las haya de presentar siempre que vacaren en hijos patrimoniales de dicho lugar.

$<$ Nota $>$.

Esta concordia no tubo efecto por que el monasterio dejó después a la yglesia medio noveno para ornamentos y reparos; y por lo que toca a las presentaciones las ha hacho y las hace libremente en quien quiere.

\section{8. <Embargo del noveno de Santa María. Año de 1667>.}

Por comisión del señor obispo de Palencia fue a visitar a Arconada el doctor don Gregorio de Velasco en el año de 1667, y dio un auto por el qual embargó todo el noveno de Santa María; recurrió el monasterio al abad de Benevivere, juez conservador, el qual despachó sus censuras para que se trajesen los autos y proveher justicia. Hizo el monasterio su información y el juez dio auto de desembargo, dejando el monasterio a la yglesia la mitad de dicho noveno y en este estado se quedó la causa que pasó ante Norberto de Sandoval, escribano de Carrión, año de 1668.

Renovose este pleito en el año de 1691 porque el provisor de Palencia mandó observar el auto de visita del doctor Velasco y embargó todo el noveno, para lo qual dio comisión a don Vicente de la Torre, cura de la parroquia de Santa María.

$<$ Desembargo del noveno. Año de 1691>.

Salió el monasterio a la defensa, alegó de su derecho y de cómo dejava cada año a la yglesia medio noveno y que también debían contribuir los demás interesados en los diezmos, a sueldo por libra, y otras cosas; por lo que pidió desembargo y se le dio, con condición de que prosiguiese dejando el medio noveno y perciviese el otro medio con la tercia entera, según consta del auto dado en Palencia, a 7 de noviembre de 1691, ante Lucas Díez Paniagua, el qual auto fue notificado al referido don Vicente de la Torre por Gonzalo del Valle, / ( $f$. 42v) escribano de Villasirga, quien le obedeció. Y en este estado prosigue la casa.

9. <Pareceres de abogados sobre reparar la yglesia de Santa María. Año de 1759>.

Haviendo mandado el señor obispo de Palencia que se reparase la yglesia de Santa María, pretendió este monasterio que concurriese a estos gastos el cavildo de Palencia, como interesado en los diezmos de dicha yglesia. Respondió el cavildo que esto tocaba al monasterio según la concordia otorgada entre los dos y el obispo de Palencia, en el año de 1228 (esta concordia está en el cajón San Andrés, legajo $1^{\circ}$, quaderno C, número $3^{\circ}$ ). Habiéndose consultado este punto en Valladolid y Madrid con varios abogados, fueron de dictamen, excepto uno, que por razón del noveno que concede al monasterio dicha concordia, estaba éste obligado a todos los reparos de la dicha yglesia. Están aquí estos pareceres, que son del año de 1759.

Remisiones de este quaderno

$<$ Remisiones $>$.

Concordia entre este monasterio, el de San Ysidro y San Román de Entrepeñas con el obispo y cavildo de Palencia sobre diezmos y presentaciones de beneficios de(l) este obispado. Cajón San Andrés, legajo $1^{\circ}$, quaderno B, número $3^{\circ}$.

Desembargo de las tercias de Santa María de Arconada y confirmación que hizo de ellas el Señor Felipe $5^{\circ}$, año de 1708 . Véase el cajón San Gregorio, entre los papeles de Villafrechos, legajo $3^{\circ}$, quaderno A, número 25. 
$<$ Donación $>$.

La donación de esta yglesia hecha a San Román por don Diego Monniz y su muger, doña Tigridia. Véase el cajón San Martín, legajo $1^{\circ}$, quaderno A, número $1^{\circ}$.

\section{/ (f. 43r) Quaderno F del legajo $2^{\circ}$}

$<$ Libro de visitas desde el año de 1556 hasta el de 1680>.

Este quaderno es un libro que contiene las visitas que hicieron los abades de San Zoil de la yglesia de Santa María de Arconada, desde el Año de 1556 hasta el de 1680, inclusive. Al último de este libro están unas consultas y pareceres sobre la visita de los abades y del arcipreste, cuyo contenido no se pone aquí por menor por no conservar el monasterio el derecho de visitar esta yglesia.

\section{Quaderno $G$ del legajo $2^{\circ}$}

En este quaderno están los papeles tocantes a la capellanía del licenciado Juan Fernández, clérigo, sus presentaciones y colaciones, por el orden siguiente:

1. <Testamento e ynstitución de la capellanía de Arconada hecha por Juan Fernández, cura del mismo lugar. Año de 1400>.

Testamento e ynstitución de capellanía que otorgó Juan Fernández, cura de Arconada, por el qual manda a San Román de Entrepeñas una tierra de obrada y media en término de Arconada, sobre la huelga de Fojos. Ynstituie una capellanía en esta forma: manda y ordena que todos sus bienes raíces, assí casas como tierras, viñas, herrenes y el palomar que tiene en Arconada y en sus términos, fuera del palomar que mandó a su madre y fuera de las tierras que mandó al concejo y a la yglesia de San Facundo y al monasterio de San Román de Entrepenas, toda la demás heredad que tenía en Arconada, en Villasirga y dos tierras en término de Carrión, sea para cantar una capellanía perpetua, la qual dota y ordena en remisión de sus pecados y por las almas de sus generaciones; y esta capellanía se ha de cantar en las yglesias de Arconada, y la ha de tener por su vida Pedro Fernández Calvo, su sobrino; si no quisiese ser monge / (f. 43v) de San Zoil, como lo era, y si él fuere monge y no la pudiere cantar, sus parientes más cercanos, dos o tres de ellos o los que huviere, presenten un capellán, si le huviere de su linaje, ante el prior de San Zoil y ${ }^{43}$ el arcipreste de Carrión, para que cante la dicha capellanía y le hagan colación de ella. A los quales, prior y arcipreste, hace e ynstituye por executores y mayorales para facer la dicha colación para siempre jamás. Y el capellán que sus parientes presentaren tenga la dicha capellanía mientras viviere si fuere de su linaje; y si no lo fuere, que la tenga hasta que haya clérigo de su linaje, porque su intención es que el de su linaje sea preferido al extraño; y no le haviendo, que lo puedan poner y disponer todos los dichos prior y arcipreste a su albedrío y poner persona suficiente para ello. Hace ynventario de todos sus bienes. Su fecha, en Arconada, a 13 de julio de 1400, ante Fernando González, notario público de la ciudad de Palencia. Sacose este ynstrumento de su original en San Zoil, a 26 de octubre de 1531, por Juan de Castrillo, escribano y notario de Carrión.

2. <Presentación y colación en Gaspar de Castrillo hecha por el abad y arcipreste de Carrión. Año de 1546>.

Presentación y colación original de la capellanía de Juan Fernández hecha por fray Juan de Santa María, abad de San Zoil, y el licenciado Ximénez de Sobrarbe, arcipreste de Carrión, en Gaspar de Castrillo, clérigo, por renuncia que de ella había hecho Pedro de la Carrera en manos de los dichos abad y arcipreste. Su fecha, en San Zoil, a 30 de julio de 1546,

\footnotetext{
$\left.{ }^{43} \mathrm{y}\right]$ escrito sobre para.
} 
ante Juan de Castrillo, escribano de Carrión. Tomó la posesión a $1^{\circ}$ de agosto del mismo año y ante el mismo escribano.

\section{3. < Presentación y colación en García Díez. Año de 1555>.}

Copia autorizada de la presentación y colación de la capellanía de Juan Fernández hecha por fray Rodrigo de Corcuera, abad de San Zoil, y el licenciado Ximénez de Sobrarbe, arcipreste de Carrión, en García Díez, clérigo, por renuncia que de ella hizo Gaspar de Castrillo. Su fecha, en Carrión, a 28 de junio de 1555, ante(s) Andrés Sánchez, escribano de Carrión. Tomó la posesión a 2 de diciembre de 1552, ante Francisco Guijarro, escribano de Villasirga. Sacó esta copia Gerónimo de la Serna, notario apostólico de Valladolid, por mandado del prior de la yglesia de dicha ciudad, a 22 de agosto de 1596.

$<$ Nota $>$.

Hasta este tiempo el abad de San Zoil y arcipreste de Carrión presentaron y colaron esta capellanía, absolutamente sin recurso, al ordinario de Palencia, en virtud de la authoridad y poder que les da el fundador por la escritura de testamento e ynstitución que queda puesta en el número $1^{\circ}$. De aquí adelante se advierte que todas las colaciones las han echo los ordinarios de Palencia.

\section{/ (f. 44r) 4. <Colación en Domingo Majo de Mora. Año de 1608>.}

Colación de la capellanía de Juan Fernández hecha por el licenciado Miranda, provisor de Palencia, en Domingo Majo de Mora, provisor de San Millán, en virtud de presentación que de ella le hicieron el abad de San Zoil y arcipreste de Carrión, quienes fueron declarados por verdaderos presenteros. Su fecha, en Palencia, a 19 de diciembre de 1608, ante Lucas Gallardo, notario, por el secretario Pedro de Arana. Tomose la posesión a 24 días del mismo mes y año, ante Luis de Revenga, escribano de Arconada.

\section{5. <Colación en Antonio Díez (sic) Montero. Año de 1637>.}

Colación de la capellanía de Juan Fernández hecha por el provisor de Palencia en el licenciado Antonio Díaz Montero, canónigo de la santa yglesia de Palencia, en virtud de presentación que de ella le hicieron el abad de San Zoil y arcipreste de Carrión, quienes fueron declarados por verdaderos presenteros por sentencia definitiva dada en Palencia, a 29 de julio de 1637, ante Francisco Pedrero, escribano. Tomose la posesión en las yglesias de Santa María y San Facundo, a 9 de agosto del mismo año, ante el licenciado José de San Estevan, cura de Santa María y notario apostólico. de $1638>$.

6. < Pleito entre el licenciado Montero y Alonso Agúndez sobre esta capellanía. Año

Después de haver tomado posesión el licenciado Montero, tubo pleito con Alonso Agúndez, natural de Zaratán, quien estando en Roma obtubo bullas, en el mes de octubre de 1637, de la tesorería de Covarrubias y de un beneficio simple de la yglesia de San Juan del Mercado de Carrión, o de otra; y porque en estas yglesias no havía tal beneficio vaco, recurrió con su bulla al juez apostólico de Palencia pretendiendo con ella esta capellanía de Arconada, fundado en que la bulla dice que havía vacado por muerte de Domingo Majo. Y, haviendo echo su información, mandó el juez apostólico darle la posesión de dicha capellanía. A este tiempo salió a la causa el licenciado Díaz Montero, alegando su derecho y posesión con el título de colación de la capellanía en él echa por el abad y arcipreste, verdaderos presenteros. En vista de los autos y que toda la narrativa de Agúndez era falsa, el licenciado don Francisco García Gil Ramírez, deán y juez apostólico de Palencia, revocó el auto dado a favor de Alonso Agúndez, mantuvo en la posesión al licenciado Montero, dexando su derecho a salvo a las partes para que sigan la causa donde les convenga, con lo que se acabó esta causa, que pasó ante Antonio de Palenzuela, notario. Año de 1638.

\section{7. < Presentación y colación en Andrés Lucas. Año de 1651>.}

Presentación y colación hechas por el abad de San Zoil y arcipreste de Carrión y el obispo de Palencia en el licenciado Andrés Lucas, año de 1651. Tomose la posesión a 4 de diciembre del mismo año, según todo consta de este testimonio sacado por Francisco de 
Diego Lobo, arcipreste de Castrejón y secretario de cámara de dicho señor obispo, a 20 de diciembre del mismo año.

/ (f. 44v) 8. < Resignación de la capellanía. Año de 1658>.

Resignación que hizo el licenciado Andrés Lucas de la capellanía de Juan Fernández en manos del abad y arcipreste, para que la presentasen en quien quisiesen, a 27 de marzo de 1658, ante Álvaro de Santa Cruz, notario apostólico.

9. <Presentación en Francisco González. Año de 1658>.

Presentación que, en virtud de la anterior renuncia, hicieron el abad de San Zoil y el arcipreste de Carrión de la misma capellanía en el licenciado Francisco González de la Haya, a 30 de marzo de 1658, ante Andrés Martínez de Aguilar, notario de Carrión.

10. <Presentación en don Agustín de la Serna. Año de 1796>.

Presentación de la capellanía de Juan Fernández hecha por el maestro fray Leandro $<$ Pérez $>^{44}$, abad de San Zoil, y don Pedro Ybáñez de la Madrid, arcipreste de Carrión, en don Agustín de la Serna, cura párroco de la yglesia de Santa María de Arconada, a 22 de junio de 1796, ante Ysidoro Ruiz de Colmenares, notario de Carrión.

$<$ Pleito sobre esta presentación $>$.

Opusiéronse a esta presentación algunos vecinos de San Facundo y después el cura don Juan Orejón, por suponerla unida y agregada a su curato. Contradijo esta pretensión el referido don Agustín y también el abad y arcipreste, que salieron a la causa como patronos de dicha capellanía; intervino también en la causa el fiscal eclesiástico.

$<$ Sentencia, Año de 1797>.

Diose la posesión interina de esta capellanía al cura de San Facundo, tratose después la causa en el juicio petitorio y plenario posesorio, en el qual, después de haverse alegado por las partes litigantes y certificado varios instrumentos, el doctor don Gregorio Ceruelo de la Fuente, chantre y provisor de Palencia, dio sentencia, por la que declara al abad de San Zoil y arcipreste de Carrión por verdaderos presenteros y a don Agustín de la Serna por bien presentado, y se la adjudica en el concepto de eclesiástica colativa; y condena a don Juan Orejón, cura de San Facundo, a que restituya y deje las heredades propias de la capellanía desde el día en que contestó la demanda. Manda assimismo que dentro de dos meses haga el referido don Agustín apeo formal de las heredades. Diose esta sentencia en Palencia, a 15 de diciembre de 1797, ante Tomás Díaz de Basurto, notario. Apeló el cura de San Facundo de esta sentencia y, no haviéndola mejorado, se dio la causa por desierta y la sentencia pasada en authoridad de cosa juzgada. Sacose este testimonio por el mismo notario, a 5 de diciembre de 1798.

Se hallan en este testimonio algunas presentaciones compulsadas del Archivo de la cathedral de Palencia que no se hallan aquí, y assimismo una memoria de las fincas propias de la capellanía, las quales se apearon el año de 1800 ante José Tablares, escribano de Carrión.

\section{/ (f. 45r) Legajo $3^{\circ}$ del cajón San Juan \\ Aviñante}

Este legajo, que es el tercero del cajón San Juan, contiene los papeles pertenecientes al lugar de Aviñante, divididos en los quatro quadernos siguientes: quaderno A: papeles pertenecientes a la hacienda que tiene San Román en este lugar; quaderno B: yglesia, presentaciones del beneficio de este lugar y derecho del yantar; quaderno C: hacienda que tiene Nuestra Señora del Brezo en este lugar; quaderno D: hacienda que tiene San Zoil en este lugar.

$44<$ Pérez>] escrito al margen derecho por una mano posterior. 


\section{Quaderno A del legajo $3^{\circ}$}

En este quaderno están los papeles pertenecientes a la hacienda que tiene San Román en este lugar de Aviñante por el orden siguiente:

$1^{\circ}$. <Donación de un solar y su divisa por Belliz Gutiérrez>.

Carta de donación, escrita en pergamino, hecha a San Román por Belliz Gutiérrez y su muger, María Cídez, de un solar de la fuente con su divisa, por remedio de sus almas. Facta carta octavo kalendas aprilis, sabato Pasquae. No tiene fecha ni firma. año $1159>$.

2. $<$ Donación de un prado, un barrial y una divisa por Gil Díaz, etcétera. Era 1197,

Donación, escrita en pergamino, hecha a San Román por Gil Díaz, Toda Díaz y María Díaz, hijos de Diago Gómez, del prado de los Arroyales en término de Villaverde ${ }^{45}$ y un barrial en Robredo y una divisa en Aviñante, que era de García Díaz. Esta donación fue hecha a Pedro Roiz (que tenía el castillo de San Román) por dos añales que cantó por el padre y hermano de los referidos y cinco maravedises que les dio. Facta carta mense maio, era 1197, que es año de Cristo 1159, regnante rege Alfonso, parvulo filio regis Santii, in Toleto et in Castella; rex Ferandus in Leon, episcopus Raymundus in Palencia, episcopus Joanes in Leon, prior Sancti Romani Achardus, senior yn castello Sancti Romani Petrus Roiz, sub manu ejus; Tel Petrez senior yn Carrione, et in Saldania don Bueso.

\section{/ (f. 45v) 3. <Contrato sobre un solar. Año 1163>.}

Contrato entre Pedro Fernández y Elvira Núñez, su muger, y Pedro Domínguez y Marina, su muger, sobre un solar en Aviñante, que lindava con otro de San Román. Facta carta mense junii, era 1201, año de Cristo 1163. Regnante etcétera, como las primeras firmas de arriba.

4. <Donación de heredades por don Gonzalo Fernández y su muger, doña Sancha. Era 1230, año 1192>.

Escritura en pergamino, partida por letras de A, B, C, por la qual don Gonzalo Fernández (que tenía el castillo de San Román) y su muger, doña Sancha, en presencia y con consentimiento de sus hijos, dan a San Román y a una capellanía que allí havían fundado todas las heredades que tenían en Aviñante, Villacorta y Villaverde ${ }^{46}$, pobladas y por poblar, con tal que no se puedan enagenar sino que sean para el sustento del capellán que sirviese la capellanía, el qual ha de nombrar el prior quando alguno muriere. Facta carta quinto ydus martii, era 1230, año de Cristo 1192.

5. $<$ Donación de un solar. Era 1242, año 1204>.

Donación hecha a San Román por García Pérez y su mujer, doña Toda, de un solar en Aviñante que compraron de Juan Cortés, clérigo. Facta carta quinto kalendas augusti, era 1242, que es año de Christo 1204.

6. $<$ Foro sobre un molino de una fanega de trigo y un par de gallinas. Año de 1396>.

Escritura de foro por la qual Juan Alfonso, prior de San Román, da a Juan Rodrigo de Villaverde el suelo del molino de la Lastra, en el río de Aviñante, para que le hiciere moler y correr, pagando cada año a San Román una fanega de trigo y un par de gallinas. Por esta escritura da el mismo Juan Rodrigo un prado en Fondón de Valle. Su fecha, a 8 de abril de 1396, ante Juan Pérez, escribano público. de $1418>$.

7. $<$ Foro sobre un molino, un prado y una tierra de 20 maravedís y dos gallinas. Año

Escritura de foro por la qual don Juan de Ortega, prior de San Román, da a Francisco García, cura de Villafría y Villalveto, y a Juan de Guardo, vecino de Villafría, un molino, un prado y una tierra en Aviñante, por 20 maravedís y dos gallinas de foro cada año. Su fecha,

45 Villaverde] al margen derecho: Villaverde.

46 Villaverde] al margen derecho: Villacorta y Villaverde. 
en San Román a 8 de enero de 1418, ante Juan Martínez de Moñeca, notario público de Palencia. $1532>$.

8. $<$ Foro de media carga de trigo y dos gallinas sobre el molino de encima. Año de

Bajo este número están las escrituras siguientes:

$1^{\text {a. }}$ Escritura de foro por la que Juan de Ponga, vecino de Aviñante, se obliga a pagar perpetuamente a San Román media carga de trigo y dos gallinas cada año sobre el molino de encima que antes llevava en una fanega; y el prior le dio 1.700 maravedís por la fanega que cargó de más y el dicho Juan de Ponga hipotecó un prado y una tierra para mayor seguridad. Su fecha, en San Román, a 13 de junio de 1532, ante Alonso Fernández, escribano. de $1788>$.

$<$ Sentencia sobre el mismo molino, un prado y una tierra hipotecados. Año

$2^{\mathrm{a}}$. Testimonio en relación del pleito / (f. 46r) y sentencia dada por el correxidor de Saldaña a favor del priorato de San Román sobre el dominio pleno de dicho molino, prado y tierra hipotecados, que antes havía declarado por bienes mostrencos, por su auto dado a 13 de noviembre de 1786. Diose esta sentencia en 18 de abril de 1788, ante Ygnacio de la Puente, escribano de Saldaña, quien sacó este testimonio en 21 de junio del mismo año.

$<$ Copia de la sentencia dada en Madrid, que confirma la anterior en quanto al molino y la revoca en quanto al prado y tierra. Año de 1791>.

Copia simple de la sentencia dada en Madrid por el señor don Francisco Pérez de Lema, subdelegado general de bienes mostrencos, etcétera, por la que confirma la sentencia anterior de Saldaña en quanto al dominio pleno del molino de encima y la revoca en quanto al prado y tierra hipotecados, declarándoles por bienes mostrencos y los manda vender prefiriendo al monasterio. Diose en Madrid, a 20 de septiembre de 1791 .

9. $<$ Compra de un prado por precio de 4 ducados y carga de una misa. Año de 1536>.

Compra del prado de las Camuñas en Aviñante hecha por fray Diego de Sagún, prior de San Román, a Juan de Caso, vecino de Santiváñez, en precio de 4 ducados con carga de una misa ${ }^{47}$ cada año, día de San Martín. Su fecha, en San Román, a 25 de enero de 1536, ante Pedro de Estrada, escribano.

10. <Poder para el repartimiento de galeotes. Año de 1541>.

Poder del concejo de Aviñante para oponerse a un repartimiento de galeotes que se hacía por orden de Su Magestad en Santa María del Campo, por no ser de veletría (sic) sino solariegos y de señores particulares en cuyos solares vivían. Su fecha, en Aviñante, a 14 de enero de 1541, ante Alfonso Fernández, escribano.

11. <Trueque de varias posesiones, de dos tierras y tres prados. Año de 1550>.

Escritura de trueque entre fray Pedro de Porras, prior de San Román, y Francisco Mantilla, vecino de Aviñante, por la qual éste da a San Román una tierra a la Lancha, de dos quartos y tres zelemines de sembradura, un prado al Valle, de dos carros de yerva, otro en Soles, de cinco carros, otro a las Heras del Valle, de un carro, y una tierra a la fuente de las Salinillas, de tres quartos de sembradura, por otras posesiones que el prior le dio en el mismo término de Aviñante, precedida la licencia del abad de San Zoil. Su fecha, en San Román, a 15 de octubre de 1550, ante Francisco de Carranza, escribano público.

12. <Trueque de varios prados y heredades por un prado. Año de 1551>.

Escritura de trueque entre fray Pedro de Porras, prior de San Román, y Cristoval Gómez, cura de Aviñante, por la qual éste da a San Román un prado en término de Aviñante,

${ }^{47}$ misa] al margen derecho: Aniversario. 
a do llaman a las Heras, por otros prados y heredades que San Román le da a él. Su fecha, en Aviñante, a 7 de marzo de 1551, ante Agustín de Medina, escribano público.

13. <Trueque de un linar con licencia del provisor de San Román. Año de 1555>.

Escritura de trueque de un linar otorgada por Hernando de Colmenares, vecino de Aviñante, con licencia que pidió para ello al prior de San Román / (f. $46 v)$ por ser el linar de un préstamo de San Román. Su fecha, en San Román, año de 1555, ante Juan Rodrigo, escribano de Su Magestad.

14. <Trueque de una casa por 3 tierras y 2 prados. Año de 1791>.

Escritura de trueque entre el padre maestro fray José Fierro, prior de San Román, y Francisco Antón y Benito Antón, con sus mugeres, vecinos de Aviñante, por la que éstos dan a San Román 3 tierras y 2 prados, en término de Aviñante, por una casa que el prior les dio en el mismo lugar. Su fecha, en San Román, a 6 de octubre de 1791, ante Manuel Luis París, escribano de Su Magestad y vecino de Villanueba de Arriba.

15. <Compra de 3 tierras por precio de 825 reales. Año de 1796>.

Compra de 3 tierras en término de Aviñante hecha por fray Pedro de Castro, prior de San Román, a Manuel de Villegas, vecino del mismo lugar, por precio de 825 reales. Su fecha, en Guardo, a 16 de abril de 1796, ante Rafael de Medina Maudes, escribano de Guardo. $1797>$.

16. $<$ Trueque de una casa por una tierra en Aviñante y otra en Villaverde. Año de

Escritura de trueque entre fray Pedro de Castro, prior de San Román, y Matheo Antón, vecino de Villaverde de la Peña, por la que éste da a San Román una tierra en el término de Aviñante y otra en término de Villaverde ${ }^{48}$ por una casa con su corral y huerto que le dio el prior en este mismo lugar de Villaverde. Su fecha, en San Román, a 10 de mayo de 1797, ante Bernardo Valbuena, escribano de Su Magestad y vecino de Respenda.

\section{Remisiones}

\section{$<$ Donación $>$}

La donación que hizo don Gómez García a San Román de todo lo que tenía en este lugar. Véase el cajón San Lorenzo, legajo 4, número 1, entre los papeles de Muñeca.

$<$ Donación $>$

Yttem la donación de doña Vrraca Martínez para la obra de San Román de toda la heredad que tenía en este lugar. Véase el cajón San Lorenzo, legajo $2^{\circ}$, número $3^{\circ}$, entre los papeles de las Heras.

$<$ Trueque $>$.

Trueque de una casa por una tierra en Aviñante, a do llaman los Milanos, para el priorato de San Román. Véase el cajón San ${ }^{49}$ Martín, legajo 1º ${ }^{\circ}$ quaderno B, número 36.

$<$ Donación $>$.

Donación de toda la heredad que tenía Pelarrubio en Aviñante. Cajón San Martín, legajo $1^{\circ}$, quaderno A, número $6^{\circ}$.

$<$ Trueque $>$.

Trueque entre el prior de San Zoil y el de San Román de toda la hacienda de este lugar. Véase el cajón San Martín, legajo $1^{\circ}$, quaderno B, número $3^{\circ 50}$.

\footnotetext{
48 Villaverde] al margen derecho: Villaverde de la Peña.

${ }^{49}$ San] sigue tachado: Lorenzo.

${ }^{50}$ número $3^{\circ}$ ] a continuación se canceló: <Tierra>. Vna tierra en Aviñante para San Román. Cajón San Martín, legajo $1^{\circ}$, quaderno $\mathrm{B}$, número 37 .
} 
$<$ Tierras, etcétera $>$.

Un prado en Aviñante para San Román. Cajón San Gregorio, legajo 2ª quaderno D, número $2^{\circ}$. Véase el cajón San Plácido, legajo $1^{\circ}$, quaderno A, número $3^{\circ}$

\section{/ (f. 47r) Quaderno B del legajo $3^{\circ}$}

En este quaderno $B^{51}$ están los papeles tocantes a la yglesia de San Cristóval (oy Santa María Magdalena) de Aviñante, presentaciones de su beneficio y derechos del yantar, por el orden siguiente: $1226>$.

1. <Donación de la yglesia de Aviñante por don Fernando el Santo. Era 1264, año

Donación hecha a San Román por el rey don Fernando el Santo de las yglesias de San Cristóval de Aviñante, Santiago de Villaoliva ${ }^{52}$ y San Saturnino de Barajores, con todos sus derechos y obladas de vivos y difuntos. Da assimismo las casas, solares poblados y por poblar, tierras, prados, molinos, ríos, montes y todo lo demás que tenía en dichos lugares. Esta donación, que está escrita en pergamino, con sello de plomo pendiente, fue fecha en Palencia, a 18 de marzo era 1264, que es año de Cristo 1226. Está aquí una copia de esta donación sacada por don Antonio Martín, traductor y notario, año de 1783. $1233>$.

2. <Despacho del prior de San Román sobre diezmos y obladas. Era 1271, año

Despacho escrito en pergamino por el qual don Pedro, prior de San Román, juntamente con sus monges, encargan y mandan a don Fernando y don Guillén, sus hermanos, que al parecer eran curas de Aviñante y Barajores ${ }^{53}$, entreguen a don Fausto Clavero, del monasterio, los diezmos y obladas que pertenecían al monasterio de San Román. Su fecha, en San Román, a 15 de agosto, era 1271, que es año de Cristo 1233, ante don Estevan Tornay, clérigo de Villaoliva y notario apostólico.

3. CConcordia sobre el primer clérigo en la yglesia. Era 1280, año 1242>.

Concordia escrita en pergamino hecha entre don Fernando, prior de San Román, y don Pelay Yncola con el concejo de Aviñante sobre la yglesia de San Cristóval, por la qual concordia establecen que de los clérigos que huviere de haver en aquella yiglesia, el primero sea de San Román y el segundo de don Pelay Yncola o de sus herederos; y si los huviere naturales del lugar, sean éstos preferidos a los que no lo fueren y si el concejo no quisiere recivir los clérigos que pusieren el prior o don Pelay y sus sucesores, el prior nombre un hombre, otro don Pelay o sus herederos, otro el concejo $/(f .47 v)$ y otro de mancomún, y en quien viniere la mayor parte le admita el concejo. Facta carta domingo, día de los Ynocentes, sub era 1280, año de Cristo 1242. Es perjudicial.

4. <Presentación en Cistóval Gómez. Año de 1509>.

Presentación del beneficio curado de San Cristóval de Aviñante hecha por don Luis Hurtado de Mendoza, administrador perpetuo de la abadía de San Zoil, en Cristóval Gómez de Valderrávano por ascenso de Juan Ruiz, clérigo, su último poseedor, al curato de Santa María Madre en el monasterio de San Román. Su fecha, en Covarruvias, a 13 de octubre de 1509, ante Pedro de Castro, notario. de $1613>$.

5. $<$ Pleito sobre la presentación del curato y sentencia a favor del monasterio. Año

\footnotetext{
$\left.{ }^{51} \mathrm{~B}\right]$ escriita sobre es.

52 Villaoliva] al margen derecho: Villaoliva y Barajores.

${ }^{53}$ Barajores] al margen derecho: Barajojes.
} 
Autos originales del pleito litigado sobre el curato de San Cristóval (oy Santa María Magdalena) de Aviñante entre el licenciado Agustín de Medina, presentado por el abad de San Zoil, y Pedro Monte de Colmenares, Hernando Monte de Colmenares y Juan Recio de la Vega, en la audiencia eclesiástica de León, en cuyo pleito se dio sentencia a favor del dicho Agustín de Medina (que no era patrimonial) y se declaró por único presentero al abad y prior de San Román. Dada en León, a 5 de diciembre de 1613, ante Juan Martínez Ocón, notario de la misma ciudad.

6. <Colación en Agustín de Medina. Año de 1613>.

Colación hecha por el provisor de León, en virtud de la anterior sentencia, del beneficio curado de Santa María Magdalena de Aviñante en Agustín de Medina. Su fecha, en León, a 5 de diciembre de 1613, ante Juan Martínez Ocón, notario. Tomó posesión a 11 días del mismo mes y año.

7. $<$ Parecer sobre la presentación del curato $>$.

Parecer del licenciado Solartoraya contra este monasterio y a favor de los patrimoniales e hijosdalgo y mayor de la casa de Mantilla sobre la presentación del curato y posesión de él dada a Agustín de Medina.

8. <Colación en Antonio Medina. Año de 1644>.

Colación del curato de Santa María Magadalena de Aviñante hecha por el doctor don Francisco Gallo de Zevallos, provisor de León, en el licenciado Antonio de Medina, en virtud de presentación hecha por el abad de San Zoil, quien fue declarado por verdadero y único presentero en juicio contradictorio de Estevan de Vega, presentado por el concejo como patrimonial. Dada en León, a 9 de septiembre de 1644, ante Felipe Escobar, notario. Tomó la posesión a 11 de octubre del mismo año, ante Diego de Vega, notario.

\section{9. <Jantar del prior de San Román. Año de 1655>.}

Testimonio de la sentencia dada por el provisor de León a favor del priorato de San Román contra los curas de Aviñante, Villafría, Barajores y Riosmenudos ${ }^{54}$, sobre los jantares que estos curas se resistían a pagar / f. 48r). Diose esta sentencia en León, a 23 de febrero de 1655, ante Pedro Pasqual, notario. Notificose esta sentencia a los curas por Francisco Quijano, notario apostólico y vecino de Tabanera, quien sacó este testimonio en el mismo año. Los curas consintieron en la sentencia.

10. < Copia de un alegato sobre el derecho del monasterio a la presentación>.

Copia de un alegato en derecho sobre el que tiene este monasterio a la presentación perpetua, y en todo tiempo, del curato de Santa María Magdalena de Aviñante, en el qual se hace mención de muchos papeles antiguos presentados en el pleito que se suscitó con motivo de la presentación hecha por el abad en don Francisco Junquera, que es la del número siguiente. de $1680>$.

11. < Seis papeles sobre el pleito de la presentación en don Francisco Junquera. Año

Bajo este número están los papeles siguientes:

$1^{\circ}$. Presentación del curato de Santa María Magdalena de Aviñante hecha por el abad de San Zoil en don Francisco Junquera, a 22 de mayo de 1680.

$2^{\circ}$. Un alegato contra la pretensión del fiscal de León.

$3^{\circ}$. Testimonio de una petición hecha por parte del monasterio con la protesta de que no le pare perjuicio si alguno sacare bulla de ympetra de Su Santidad durante el pleito, por ser contra el derecho del monasterio y del patrimonio real.

\footnotetext{
${ }^{54}$ Riosmenudos] al margen derecho: Villafría, Barajores y Riosmenudos.
} 
$4^{\circ}$. Despacho de los provisores de León en sede vacante para compulsar papeles, assí en este archivo como en León y en la nunciatura.

$5^{\circ}$. Testimonio de la sentencia que dichos provisores, sede vacante, dieron, a 9 de agosto de 1680, ante Alonso Pacheco, notario, a favor de este monasterio y del referido cura don Francisco Junquera, contra el fiscal de León y el arcediano de Saldaña, que pretendía ser juez de esta causa.

$6^{\circ}$. Agravatoria del nuncio con prorrogación de término, inhibiendo al arcediano de Saldaña que intentaba ser juez en primera instancia y mandando al escrivano que remita los autos originales.

12. < Copia de una[s] letras apostólicas. Año de 1684>.

Copia authorizada por Manuel de Villegas, notario apostólico, vecino de Carrión, de las letras apostólicas que el licenciado Andrés González Roldán ganó para llevar el pleito en grado de apelación a la curia romana. Año de 1684. Sacose este testimonio a 31 de agosto de 1685.

\section{3. $<$ Relación del pleito con Roldán en $\operatorname{Roma}^{55}>$.}

Relación del pleito con Roldán en la corte de Roma, desde que se llevó a ella en grado de apelación. En ella se hace un resumen de las dudas y fundamentos por una y otra parte, que sirven de dirección en esta causa, y aunque no está firmada, está bien trabajada.

14. $<$ Bullas y papeles de Roma y nueva elección y presentación del curato en don Álvaro García Tuñón. Año de 1689>.

Bajo este número están los papeles siguientes:

$1^{\circ}$. Presentación del curato de Santa María Magdalena, hecha por el abad de San Zoil en don Álvaro García Tuñón, a 10 de marzo de 1689, ante Norberto de Sandoval y Guevara / (f. $48 v)$, notario.

$2^{\circ}$. Brebe de Alexandro $8^{\circ}$ dirigido al deán de León y penitenciario de Palencia, para que pongan en posesión del curato de Aviñante a don Álvaro García Tuñón. Dada en Roma, año de 1689. Está dentro una copia simple.

$3^{\circ}$. Relación de cómo Su Santidad proveyó el curato de Villamarco en el licenciado Andrés Rodríguez Roldán, con condición de que renunciase en sus manos el derecho que pretendía tener al de Aviñante. Contiene este papel una ynstrucción de un abogado de Valladolid para hacer nueva presentación, copia de la narrativa del pleito desde que el monasterio presentó el curato en don Francisco Junquera hasta que Roldán le renunció en manos de su Santidad, papel del procurador de Roma en que dice que remite las letras de la gracia del curato hecha por Su Santidad a don Alvaro García Tuñón.

$4^{\circ}$. Bulla de la Santidad de Alexandro $8^{\circ}$ en que hace relación de las reservas de beneficios y curatos que hicieron a la Sede Apostólica los pontífices Juan 22 e Ynocencio $11^{\circ}$, sus predecesores, y de cómo este, stante reservatione, poco tiempo antes de morir havía echo gracia del curato de Aviñante a don Álvaro García Tuñón; pero por la muerte de Su Santidad no se le había despachado bulla y assí ahora se la manda dar. Que está dada en Roma, año de 1689, decimo septimo kalendas novembris. En esta bulla se hace relación de todo el pleito desde el año de 1680. Hai aquí una copia simple y un resumen de esta bulla.

15. <Licencia del abad para permutar el curato. Año de 1697>.

Permiso que dio el abad de San Zoil a don Álvaro García Tuñón para permutar el curato de Santa María Magdalena de Aviñante y el beneficio simple de San Andrés de Canduela ${ }^{56}$ por el de Robledo y sus anexos, en el obispado de Astorga, que gozaba don Juan

\footnotetext{
${ }^{55}$ Roma] sigue tachado A.

${ }^{56}$ San Andrés de Canduela] al margen derecho: San Andrés de Canduela.
} 
Fernández de Ladreda. Su fecha, en San Zoil, a 19 de marzo de 1697, ante Gregorio García de Miranda, notario de Carrión.

$<$ Nota $>$

Este don Juan Fernández de Ladreda permutó el curato de Aviñante con don Tomás de Bedoya, que gozaba el de Vega de Rioponce, junto a San Terbás. Faltan los papeles tocantes a estas permutas.

16. <Licencia del abad para renunciar el curato. Año de 1725>.

Permiso que dio el abad de San Zoil a don Tomás de Bedoya para renunciar el beneficio curado de Aviñante en don Simón de Bedoya, su sobrino. Su fecha, en San Zoil, a 19 de diciembre de 1725, ante Francisco Cano Núñez, notario y escribano de Carrión.

17. <Despacho contra el cura sobre el jantar. Año de 1783>.

Despacho del provisor de León contra don Juan Francisco Martínez, cura de Aviñante, para que pague el jantar al prior de San Román, compañero, criado, una cavallería y dos perros; según el auto por él dado, a 12 de septiembre de 1783, ante Diego Ybáñez, notario. Librose el despacho a 25 del mismo mes y año.

/ (f. 49r) 18. < Pleito sobre la presentación del curato de Aviñante>.

Testimonio en relación del pleito sobre la presentación del curato de Aviñante seguido en León, año de 1796, dado por Ramiro Rodríguez Blanco, notario de León, a 6 de octubre del mismo año. De este testimonio consta que, haviendo vacado el curato de Santa María Magdalena de Aviñante en el mes de marzo del año de 95, por muerte de don Juan Francisco Martínez, su último poseedor, se formó pleito sobre la provisión de él, a instancia del fiscal eclesiástico de la ciudad de León, el que se siguió con los estrados de la audiencia. Y en 13 de julio de 1795 se dio sentencia por el provisor de León, declarando pertenecer la presentación de este curato a Su Magestad en los ocho meses apostólicos; y en los quatro ordinarios, al obispo.

$<$ Sentencia a favor del monasterio. Año de 1796>.

Noticioso el monasterio de esta sentencia, salió a la causa en 30 de julio del mismo año, siguiola con el fiscal, presentó varios instrumentos para calificar el derecho de patronato y presentación; y, en vista de ellos, a 6 de septiembre de 1796, el licenciado don Dionisio Pérez Lózar, provisor de León, dio sentencia por la qual declara que las vacantes de dicho curato que sucedan en los quatro meses ordinarios corresponde la presentación a este monasterio, revocando en quanto a esto la anterior sentencia y dejándola en su fuerza en todo lo demás que comprende. Esta sentencia se pasó en authoridad de cosa juzgada a 27 de septiembre del mismo año.

19. < Presentación en don Joaquín Zevallos. Año de 1796>.

Presentación del curato de Santa María Magdalena de Aviñante hecha por el maestro fray Leandro Pérez, abad de San Zoil, en don Joaquín Zevallos Vélez, a 12 de noviembre de 1796, ante fray Luis Palencia, su secretario, haviendo precedido concurso y propuesta del señor obispo de León con arreglo a reales órdenes.

\section{Remisiones}

Acerca de algunas presentaciones, etcétera, véase el cajón Plácido, legajo $2^{\circ}$, quaderno A, número 15 , título Villafría.

\section{/ (f. 49v) Quaderno C del legajo $3^{\circ}$}

Este quaderno contiene los papeles pertenecientes a la hacienda que tiene Nuestra Señora del Brezo en este lugar de Aviñante, por el orden siguiente: 
$1^{\circ}$. <Compra de 3 prados. Año de 1494>.

Compra que hizo para Nuestra Señora del Brezo fray Juan, prior de San Román, a Pedro de Roxas, vecino de Pino, de tres prados en término de Aviñante, dos a Fuente Salmillas y el otro más arriba, en precio de 1.150 maravedís. Su fecha, en Viduerna a 18 de enero de 1494, ante Gonzalo de Valderrábano, escribano público y notario apostólico.

$<$ Compra de otros 3 prados. Año de 1494>.

Está unida a este instrumento otra escritura de compra que hizo el mismo prior de San Román para Nuestra Señora del Brezo a Toribio Marcos, vecino de Santiváñez, de otros 3 prados en término de Aviñante: el uno al Valle, el otro junto a Santa María del Valle y el otro a los Maderos, por precio de 500 maravedís. Su fecha, en Santiváñez, a 22 de enero de 1494, ante Gonzalo de Valderrábano, escribano y notario. Está aquí una copia de estas dos escrituras, sacada por don Antonio Martín García, traductor y notario, año de 1783.

2. $<$ Sentencia arbitra sobre unos prados. Año de 1523>.

Sentencia arbitra, dada en virtud de cierto compromiso, por el licenciado Antonio Ruiz de Modoya, vecino de Carrión, por la qual condena a Diego de Colmenares, vecino de Aviñante, a que vuelva a la casa del Brezo dos prados que la tenía usurpados en este lugar, con la yerva que había cogido de ellos el año de 1521, y también unos salces y mochas que havía cortado de otro prado; y en quanto a la tierra de la Zevada y Prado del Río, declara ser del dicho Diego de Colmenares y pertenecer al Brezo en empeño de 5 mill 200 maravedís que dio sobre ellas fray Juan de la Masón, prior que havía sido del Brezo, y manda las tenga el Brezo hasta que se le paguen los dichos maravedís. Diose esta sentencia en Carrión, a 7 de marzo de 1523, ante Floristán de la Serna, escribano de Carrión. Ai aquí una copia de este ynstrumento, sacada por don Antonio García, traductor, año de 1783.

3. < Concordia de los pastos comunes con Aviñante y Villaverde. Año de 1527>.

Concordia entre fray Juan de Villoldo, prior del Brezo, y los concejos de Aviñante y Villaverde, por la qual convienen en que el prior / (f. 50r) del Brezo, siendo vecino de Villafría, pueda pastar con 140 cavezas de ganado menor en los términos comuneros que pastan los de los lugares de Villafría, Aviñante y Villaverde ${ }^{57}$, desde el día de Santa Cruz de septiembre hasta primero de marzo de cada año; y que si algún vecino de Aviñante o Villaverde trajere más ganado de las 140 cavezas, pueda el prior del Brezo traher tanto como él y que pueda traher 10 cavezas del ganado que dieren de limosna en los días que la dieren, y después las saque; y si más trajere ${ }^{58}$ puedan prendarlas los concejos o vecinos de los dichos lugares. Su fecha, en Aviñante, a 22 de enero de 1527, ante Alonso Fernández de Respenda, escribano de Su Magestad.

4. < Concordia sobre los pastos de Aviñante. Año de 1536>.

Concordia entre fray Bartholomé de Zaldívar, prior del Brezo, y el concejo de Aviñante sobre los pastos, por la qual consta que haviendo prendado los de Aviñante el ganado que trahía el Brezo en el término de este lugar, se querelló de ellos el prior del Brezo, y por escusar pleitos se concordaron en nombrar un letrado que resolviese este punto; y en efecto nombraron al doctor Guillén de Carrión, y en el ínterin se convinieron en que se bolvieren las prendadas al prior, pudiendo pastar con sus ganados donde pastan los ganados de Villafría por el tiempo que quisiere el consejo de Aviñante, sin que por esto adquiera posesión la casa del Brezo, hasta que el letrado lo determine. Su fecha, en Aviñante, a 11 de diciembre de 1536, ante Antonio de San Román, escribano de Su Magestad.

57 Villafría y Villaverde] al margen derecho: Villafría y Villaverde.

58 trajere] sigue tachada: $\mathrm{n}$. 
5. <Donación de un prado. Año de 1596>.

Donación hecha a la casa de Nuestra Señora del Brezo por Diego de Vega, vecino de Tarilonte, de un prado en término de Aviñante, a Prapóstigo y al Molino, que hace una carretada de yerva. Su fecha, en Villafría, a 8 de diciembre de 1596, ante García de Cosío, escribano de Su Magestad.

6. < Compra de una tierra en precio de 4 ducados. Año de 1596>.

Compra que hizo fray Cristóval de Matienzo, prior del Brezo, para la casa de Nuestra Señora, a Juan Mayordomo, vecino de Villafría, de una tierra en término de Aviñante, a las Huertas, que hace un quarto de pan de sembradura, en precio de 4 ducados. Su fecha, en Villafría, a 8 de diciembre de 1596, ante García de Cosío, escribano de Su Magestad.

7. <Compra de dos linares. Año de 1598>.

Compra que hizo fray Francisco de Villafuerte, prior del Brezo, para la casa de Nuestra Señora, a Francisco Hidalgo, vecino de Aviñante, de dos linares en término del mismo lugar; uno en Avefría, que hace quarto y medio de linaza, y el otro a la Riva, bajo de la puente vieja, / (f. 50v) que hace una fanega de linaza de sembradura, en precio de trece ducados y medio. Su fecha, en el Brezo, a 9 de octubre de 1598, ante García de Cosío, escribano de Su Magestad.

8. < Compra de un linar. Año de 1598>.

Compra que hizo fray Francisco de Villafuerte, prior del Brezo, para la casa de Nuestra Señora, a Diego Puente, vecino de Aviñante, de un linar al Campo, término de dicho lugar, que hace 8 zelemines de linaza de sembradura, en precio de 50 reales sencillos. Su fecha, en Santiváñez, a 10 de diciembre de 1598, ante García de Cosío, escribano de Su Magestad.

9. <Compra de una tierra y un linar. Año de 1598>.

Compra que hizo el mismo prior del Brezo, para la casa de Nuestra Señora, a Bartholomé García, vecino de Aviñante, de una tierra y una linar, en término de dicho lugar; la tierra atrás el río, que hace una fanega de linaza de sembradura, y el linar a Navefría, que hace una fanega de linaza de sembradura, en precio de catorce ducados y medio. Su fecha, en Santiváñez, a 14 de octubre de 1598, ante García de Cosío, escribano de Su Magestad.

10. < Compra de una tierra y un prado. Año de 1598>.

Compra que hizo el mismo prior del Brezo para la casa de Nuestra Señora a Francisco Díaz, vecino de Aviñante, de una tierra y un prado en término de dicho lugar; la tierra a la Horca, que hace media carga de trigo de sembradura, y el prado a Navefría, que hace carro y medio de yerva, en precio de 22 ducados y medio. Su fecha, en Aviñante, a 31 de octubre de 1598, ante García de Cosío, escribano de Su Magestad.

11. < Compra de una tierra. Año de 1598>.

Compra que hizo el mismo prior del Brezo, para la casa de Nuestra Señora, a Francisco Hidalgo, vecino de Aviñante, de una tierra a Portillo, término de dicho lugar, que hace quarto y medio de trigo de sembradura, en precio de 3 mill maravedís. Su fecha, en el Brezo, a 5 de noviembre de 1598, ante García de Cosío, escribano de Su Magestad.

12. < Compra de una tierra. Año de 1599>.

Compra que hizo el prior del Brezo, para Nuestra Señora, a Hernando Sánchez, cura de Pino de Viduerna, de una tierra a Soles, término de Aviñante, que hace más de dos quartos de sembradura, en precio de 12 ducados. Su fecha, en Viduerna, a 24 de enero de 1599, ante Blas Ordóñez, escribano de Su Magestad. 
13. <Compra de una tierra. Año de 1599>.

Compra que hizo el prior del Brezo, para la casa de Nuestra Señora, a Cathalina Montes, de una tierra a la Garganta del Valle, término de dicho lugar, que hace una fanega de trigo de sembradura, en precio de 13 ducados. Su fecha, en Aviñante, a 17 de septiembre de 1599, ante Blas Ordóñez, escribano de Su Magestad.

/ (f. 51r) 14. <Compra de una tierra y un prado. Año de 1599>.

Compra que hizo fray Cristóval de Matienzo, prior del Brezo, para la casa de Nuestra Señora, a Diego de Vega, vecino de Aviñante, de una tierra y un prado; este en término de dicho lugar, a la Garganta del Valle; y la tierra en término de Villafría, a la Lingorda, en precio de 91 reales. Su fecha, en Viduerna, a 6 de diciembre de 1599, ante Blas de Ordóñez, escribano de Su Magestad.

15. <Compra de un prado. Año de 1599>.

Compra que hizo el mismo prior del Brezo, para la casa de Nuestra Señora, a Juan de las Heras, vecino de Velilla de Tarilonte, de un prado a Navefría, término de Aviñante, en precio de 50 reales. Su fecha, en Velilla de Tarilonte, a 17 de noviembre de 1599, ante Blas de Ordóñez, escribano de Su Magestad.

16. <Compra de una tierra, Año de 1599>.

Compra que hizo el prior del Brezo, para la casa de Nuestra Señora, a Pablo Alonso, vecino de Pino de Viduerna, de una tierra al Campo, término de Aviñante, que hace tres quartos de trigo de sembradura, en precio de 15 ducados. Su fecha, en Pino de Viduerna, a 28 de septiembre de 1599, ante Blas Ordóñez, escribano de Su Magestad.

17. <Compra de un linar. Año de 1600>.

Compra que hizo fray Cristóval de Matienzo, prior del Brezo, para la casa de Nuestra Señora, a Ana Sotil, viuda de Diego de Vega, vecina de Aviñante, de un linar, a los Huertos, término de dicho lugar, en precio de 3 ducados y medio. Su fecha, en Aviñante, a 4 de diciembre de 1600, ante Blas Ordóñez, escribano de Su Magestad.

18. <Compra de dos prados y una tierra. Año de 1664>.

Compra que hizo fray Félix de Noriega, prior del Brezo, para la casa de Nuestra Señora, al licenciado Diego Alcalde, cura de Villafría, de un prado, a la Sernilla, término del lugar de Aviñante, que hace un carro de yerva; y de otro prado y una tierra en término del lugar de Villafría ${ }^{59}$, el prado a la Serna y la tierra a la Requejada, en precio todo de 295 reales. Su fecha, en San Román, a 13 de marzo de 1664, ante Marcos de la Vega, escribano de Su Magestad y vecino de Villanueva de Muñeca.

\section{Remisiones}

Donación de un solar y vasallo, con todas sus posesiones, y una casa en este lugar. Año de 1530. Cajón San Benito, legajo $3^{\circ}$, número 8.

$<$ Compra $>$.

Vna tierra en este lugar por compra. Véase el cajón San Martín, legajo $1^{\circ}$, quaderno C, número 7.

\footnotetext{
${ }^{59}$ Villafría] al margen derecho: Villafría.
} 


\section{/ (f. 51v) Quaderno D del legajo $3^{\circ}$}

En este Quaderno están los papeles pertenecientes a la hacienda que tiene este monasterio de San Zoil en este lugar, por el orden siguiente:

1. <Compra de una tierra. Año de 1765>.

Compra que hizo (con su dinero) el padre fray Zoil Trigo a favor de este monasterio, a Melchor de Ravanal y Francisca de Vega, su muger, vecinos de el lugar de Villaverde de la Peña, de una tierra en término de Aviñante, a la Zelada, que hace 5 zelemines de trigo, en precio de 144 reales. Su fecha, en Pino de Viduerna, a 5 de febrero de 1765, ante José Luis de Cantoral, escribano de Su Magestad y vecino de Villanueva de Muñeca.

2. $<$ Compra de una tierra. Año de 1765 $>$.

Compra que hizo el mismo padre Trigo a Ysabel Antón, viuda, vecina de Velilla de Tarilonte, de una tierra en término de Aviñante, al Campo, que hace una fanega y medio quarto de trigo, en precio de 412 reales. Su fecha, en el Brezo, a 10 de mayo de 1765, ante el mismo escribano.

3. $<$ Compra de dos tierras. Año de 1765>.

Compra que hizo el mismo padre Trigo a José de la Cuesta Terán, vecino de Villafría, de dos tierras, la una en término de Aviñante, a el Bardalillo, que hace más de una fanega de trigo, y la otra en término de Villafría ${ }^{60}$, a Trollán, que hace cinco zelemines de pan; las dos tierras en precio de 350 reales. Su fecha, en Villafría, a 26 de abril de 1765, ante el mismo escribano.

\section{Remisiones}

Compra de una tierra para San Zoil. Véase el cajón San Martín, legajo 4º quaderno $\mathrm{D}$, número $5^{\circ}$.

\footnotetext{
${ }^{60}$ Villafría] al margen derecho: Villafría.
} 


\section{/ (f. 55r $)^{61}$ Cajón $3^{\circ}$ San Benito \\ Letras B y C}

Este cajón San Benito, que es el tercero del archivo, contiene quatro legajos pertenecientes a diversos lugares: Legajo $1^{\circ}$ : Baillo, Baños, Barajores, Bárcena, Barsubio. Legajo $2^{\circ}$ : Becerril, BesPuerto, Bolaños, Bustillo de Cea. Legajo $3^{\circ}$ : Brezo. Legajo $4^{\circ}$ : Calzada, Calzadilla, Camporredondo, Carbonera, Cardeñosa.

\section{Legajo $1^{\circ}$} siguientes:

Este legajo, que es el $1^{\circ}$ del cajón San Benito, contiene 8 quadernos que son los

$$
\begin{array}{ll}
\text { Quaderno A Baillo } & \text { E Hacienda del Brezo en este lugar. } \\
\text { B Baños } & \text { F Bárcena: Hacienda de San Zoil. } \\
\text { C Barajores. Hacienda de } & \text { G Hacienda del Brezo en este lugar. } \\
\text { San Román. } & \\
\text { D Yglesia y beneficio de este } & \text { H Basurbio: Hacienda del Brezo. } \\
\text { lugar. } &
\end{array}
$$

\section{Quaderno A del legajo ${ }^{\circ}$}

\section{Baillo}

Este quaderno A contiene los papeles pertenecientes a la hacienda que tiene el monasterio en este lugar, por el orden siguiente:

$1^{\circ}$. $<$ Memoria de las heredades $>$. Baillo.

Memoria simple y antigua de las heredades que el monasterio de San Zoil tine en

$2^{\circ}$. $<$ Trueque de una tierra. Año de 1429>.

Trueque que el monasterio de San Zoil (con licencia de don Gonzalo, prior de San Román de Entrepeñas y provisor de don Pedro, prior mayor de San Zoil) hizo con Rodrigo Ybáñez, vecino de Baillo, de una tierra en término de este lugar, por otra en el mismo término a Carremercado. Su fecha, en San Zoil, a 28 de diciembre de 1429, ante Fer/ (f. 55v) nando Rodríguez de Castellanos, escribano y notario público.

$3<$ Mandamiento para apear. Año de 1529>.

Mandamiento del licenciado Álvarez, teniente correxidor de Carrión, para apear las heredades que el monasterio de San Zoil tiene en Baillo. Dado a 4 de junio de 1529, ante Hipólito de Rozas, escrivano de Carrión.

\section{/ (f. 56r) Quaderno B del legajo $1^{\circ}$ \\ Baños}

Este quaderno B contiene los papeles pertenecientes a la hacienda que tubo el Brezo en este lugar, y oy pertenece a San Román, por el trueque que hicieron los dos prioratos en

$61 /(f .55 r)]$ Los folios 52 a 54 se dejaron en blanco. 
el año de 1581, y se halla entre los papeles de Villafría, cajón San Plácido, legajo $1^{\circ}$, quaderno A, número 23 .

$<$ Nota $>$

La donación de tres cargas de trigo en este lugar hecha a Nuestra Señora del Brezo (para la dotación de la capilla) por don Gonzalo Ruiz de la Vega, año de 1518, está en este cajón, legajo $3^{\circ}$, número $6^{\circ}$. Los demás papeles están por el orden siguiente:

$1^{\circ}$. $<$ Sentencia en favor de don Manuel de la Vega del señorío, vasallaje y vrción de este lugar. Año de 1558>.

Testimonio de una sentencia dada por Antonio Sánchez de Villanuño, teniente correxidor de Saldaña, con acuerdo del licenciado Guerra, su asesor, por la que declara el lugar de Baños ser solariego en propiedad y señorío de don Manuel de la Vega, nieto de doña Francisca Henrique de Thobar, y tener de él justo título de venta y causa, y estar en posesión inmemorial de llevar un real, un quarto de trigo y un par de gallinas de fuero y vrción en cada un año de cada vecino del lugar de Baños; y condena a ciertos vecinos del dicho lugar a que le paguen lo que le havían dejado de pagar, y paguen de allí adelante perpetuamente. Pronunciose esta sentencia en Saldaña, a 18 de junio de 1558, ante Felipe Gómez, escribano de dicha villa. Apelaron de esta sentencia los vecinos de Baños y no haviendo seguido la apelación, pidió dicho don Manuel un tanto authorizado de dicha sentencia y se le dio, que es éste.

$2^{\circ}$. $<$ Carta executoria de tres cargas de trigo en favor del Brezo contra los vecinos de Baños>.

Traslado sacado con authoridad de la justicia del lugar de la Puebla de una carta executoria librada por la chancillería de Valladolid / (f. 56v) a favor del monasterio de Nuestra Señora del Brezo y de doña Chatalina de Cieza, muger de Garcilaso de la Vega, vecinos de Tablares, contra los vecinos del lugar de Baños. Por esta executoria consta que doña Cathalina de Cieza puso demanda a los vecinos de Baños, año de 1564, ante la justicia de Saldaña, por un real y dos gallinas de urción que por razón de su dote debía pagar cada vecino, como lo pagaban a don Manuel de la vega, a lo qual se opuso el concejo. En 3 de abril de 1565, el monasterio del Brezo puso demanda al mismo concejo, ante la misma justicia, por tres cargas de trigo que havía dejado al dicho monasterio Gonzalo Ruiz de la Vega, señor del dicho lugar, las quales tenía sobre los vecinos de él, y las donó al Brezo para dotación de una capellanía de una misa diaria que se le decía en dicho monasterio, y hacía 4 años que no la pagaban dichas tres cargas de trigo. Negó el concejo la demanda, y éste la presentó en Valladolid en grado de apelación, donde pidió se retubiese la causa e hiciese justicia a las partes, en lo que todas convinieron, por lo que en 17 de julio de 1565 se dio auto de retención de la causa en la chancillería.

$<$ Sentencia definitiva $>$.

Alegaron las partes de su derecho, hicieronse pruebas, etcétera; y conclusa la causa, en 10 de mayo de 1569 se dio sentencia definitiva, por la qual amparan al monasterio del Brezo y a doña Cathalina de Cieza en la posesión de cobrar en cada un año del concejo y vecinos de Baños, el prior, monges y convento del Brezo, 3 cargas de trigo en cada un año, y la dicha doña Cathalina 46 gallinas y un real de cada vecino, etcétera.

$<$ Sentencia de revista. Año de 1570>.

De esta sentencia apeló el concejo, y sin embargo, en 27 de enero de 1570 se pronunció sentencia en grado de revista, por la qual se confirmó la de vista, con la condición que el dicho trigo, gallinas y maravedís se cobren de los vecinos de dicho lugar por el orden que se solían cobrar, y no del concejo. El Brezo y dicha doña Cathalina pidieron y se les dio esta 
carta executoria contra dicho concejo, a 6 de mayo de 1570, ante Hernando de Villafranca, escribano de cámara, de la que sacó este traslado Juan Pérez, escribano de Su Magestad, a 28 de mayo de 1573.

$$
\text { / (f. 57r) Remisiones }
$$

$<$ Donación $>$.

Donación de una heredad hecha a este monasterio de San Zoil (en este lugar de Baños) por Sancha Ýñiguez. Año de 1123. Véase el cajón San Gregorio, entre los papeles de Villalumbroso, número $1^{\circ}$.

$<$ Linar $>$.

El trueque que hizo el prior de San Román con Thomás de Cosgaya, de una casa con su huerto por un linar en este lugar de Baños etcétera. Año 1793. Véase el cajón San Estevan, legajo $2^{\circ}$, quaderno $\mathrm{D}$, título Riosmenudos, número 7 ; ídem legajo $3^{\circ}$, quaderno $\mathrm{A}$, número 13.

\section{/ (f. 57v) Quaderno C del legajo $1^{\circ}$ \\ Barajores}

Hacienda de San Román en este lugar

Este quaderno C contiene los papeles pertenecientes a la hacienda que tiene San Román en este lugar, por el orden siguiente:

$1^{\circ}$. $<$ Donación de la condesa doña Aldonza y sus hijos. Era 1125, año 1087>.

Escritura en pergamino, por la qual la condesa doña Aldonza, con sus hijos Ferrando Ferrández y Elvira Monioz, da a San Román tres casas, con todas las heredades y prados con sus olmos, que tenía en el lugar de Barajores, en el territorio de San Román, cerca del lugar de Respenda, con carga de un aniversario ${ }^{62}$ cada año. Manda que los vasallos que habiten en las tres casas sean vasallos de San Román. Facta carta décimo sexto kalendas septembris, era 1125, que es año de Christo 1087. Regnante rex Aldefonsus in Toletula et in Leone, et in Castella; et commite domino Gómez Gonzálvez in Avia etcétera.

2. <Donación de Miguel, clérigo, de un solar. Era 1209, año 1171>.

Donación que hizo a San Román Miguel, clérigo, de un solar que tenía en Barajores, con que él lo goze por sus días y pague a San Román por el agosto de cada año 6 fanegas de zenteno, y 5 el que le sucediere; y el que viviere en él sea collazo de San Román y que no se pueda vender. Y fray Acardo, prior de San Román, concede a qualquiera que viviere en el solar libertad de ciertos pechos y tributos, y concede al dicho Miguel ración en San Román siempre que la quisiere, como se le daba a uno de los capellanes, con tal que guarde obediencia al prior. Facta carta Sancto Romano, $1^{\circ}$ die februarii, era 1209 , que es año de Cristo 1171. Regnante rege Yllefonso in Toleto et Castella. Rege Ferrando in Galicia, etcétera.

/ (f. $58 r)$ 3. <Foro de unos suelos. Era 1286, año 1248>.

\footnotetext{
62 aniversario] al margen derecho: Aniversario.
} 
Escritura de foro que otorgó don Gonzalo Pérez, prior de San Román, a don Domingo, don Miguel y don Joan, nietos de don Miguel de Barajores, de unos suelos que ellos edificaron a su costa en término y suelo de San Román, para ellos, sus hijos y nietos, con que den senos quarteros de pan de zenteno en agosto. Facta carta in era 1286, año de Christo 1248.

4. $<$ Donación de una casa. Era 1291, año 1253>.

Escritura por la qual Domingo Martínez, prior de San Román, recive por familiares a Pedro Martínez y a su mujer, doña Mari González, y ellos hacen donación a San Román de sus cuerpos y de una casa que tenían en Barajores, con condición de que todos los que vivieren en ella sean vasallos de San Román y le den cada año una libra de cera. Facta carta decimo sexto kalendas julii, era 1291, que es año de Cristo 1253.

5. < Trueque de un solar en Riosmenudos y una tierra en Barajores. Año de 1782>

Escritura de trueque entre el priorato de San Román y don Manuel García Ramos, cura de Riosmenudos, por la que éste da a San Román una tierra en término de este lugar, al Maello, que hace tres quarteros de sembradura, por un pedazo de solar que le dio el priorato en el lugar de Riosmenudos, de medio quarto de sembradura. Su fecha, en San Zoil, a 23 de octubre de 1782, ante Martín García Gatón, escribano de Carrión. Están cosidas con esta escritura de trueque tres escrituras pertenecientes a la seguridad de la tierra que se dio al priorato.

6. <Trueque de una casa por dos tierras y un linar. Año de 1782>.

Escritura de trueque entre el priorato de San Román y Agustín Roldán, vecino de Riosmenudos, por la que éste da a San Román dos tierra y un linar, la una tierra en término de Barajores, a el Molinillo, de 3 quartos de trigo de sembradura; la otra tierra en término de Roscales $^{63}$, a los Roderos, de un quarto de trigo de sembradura; y el linar en término de Riosmenudos, al Cascarón, de 3 quartos de linaza, por una casa que el priorato le dio en Riosmenudos. Su fecha, en San Zoil, a 23 de octubre de 1782, ante Martín García Gatón, escribano de Carrión.

\section{Remisiones}

Trueque de una casa. Véase el cajón San Gregorio, legajo $2^{\circ}$, quaderno D, número $2^{\circ}$.

\section{/ (f. 58v) Quaderno D del legajo $1^{\circ}$ \\ Barajores \\ Yglesia, curato y yantar}

En este quaderno D están los papeles pertenecientes a la yglesia de San Saturnino (oy Santa Bárbara) de Barajores, presentaciones de su beneficio y derechos del yantar, por el orden siguiente:

$<$ Nota $>$

La donación de esta yglesia hecha a San Román por el rey don Fernando el Santo, año de 1226, está entre los papeles de Aviñante, en el cajón San Juan, legajo $3^{\circ}$, quaderno B, número $1^{\circ}$. También se halla compulsada en la executoria que está en el número $6^{\circ}$ de este quaderno, al folio 15.

\footnotetext{
${ }^{63}$ Roscales] al margen derecho: Roscales. Riosmenudos.
} 
$1^{\circ}$. < Concesión de la yglesia de San Saturnino a don Pedrabat por sus días. Era 1279, año $1241>$.

Escritura en pergamino por la qual don Fernando, prior de San Román, por consejo del convento y de Gonzalvo Gonzálvez, que tiene la Mampusta, da a don Pedrabat la yglesia de San Zadornín de Barayosos, con todas sus pertenencias, con libros, con vestimentas y con campanas, por todos sus días, con que la tenga y guarde lealmente para la casa de San Román y dé una procuración (yantar ${ }^{64}$ ) al prior de San Román, e tres omes e dos bestias, y que después de sus días vuelva la yglesia libre a San Román, y entregue al prior la clave y el tesoro. Facta carta día de San Marcos Evangelista, seis días por andar de abril, era 1279, que es año de Cristo 1241. Regnate rex Fernandus in Castella et in Leone et in Toleto, et Regina dona Joan, etcétera.

2. Concordia sobre la yglesia de San Saturnino. Era 1283, año 1245>.

Concordia, escrita en pergamino, entre Guillén Pérez y el concejo de Barajores, de la una parte, y el prior de San Román, de la otra, por la qual se convivieron y concordaron en que la mitad de la yglesia de San Satutrnino fuese de Guillén Pérez, / ( f. 59r) y la otra mitad de don Fernando, prior de San Román, y de sus sucesores, poniendo cada una de las partes un clérigo; y si huviese más de los dos, los pongan por mitad; y que de los dos clérigos, el uno sea solariego de San Román y el otro de don Guillén y paguen las ynfurciones por mitad; y que estos clérigos den qüenta, cada año, de las alajas de la yglesia a los merinos de San Román y de don Guillén y que estén sujetos al ordinario y al arcediano en lo que les toca. Facta carta en el mes de enero, era 1283, que es año de Cristo 1245. Esta concordia es perjudicial $^{65}$ por ser contraria a la donación.

3. < Colación en Rodrigo de Espinosa. Año 1485>.

Colación del curato de San Saturnino de Barajores hecha por el licenciado Pedro de Vega, provisor de León, en Rodrigo de Espinosa, en virtud de presentación que de él le hizo don Luis Hurtado de Mendoza, abad comendatario de San Zoil. Su fecha, en León, a 27 de julio de 1485, ante Juan Ramírez, notario. Tomó la posesión a 4 de agosto del mismo año, ante Juan González de Ravanal, clérigo de Congosto y notario.

\section{4. <Presentación en Juan Fernández. Año de 1642>.}

Presentación del curato de Santa Bárbara (antes San Saturnino) hecha por el maestro fray Plácido del Río, abad de San Zoil, en Juan Fernández, a 13 de julio de 1642, ante fray Juan de Cisneros, notario apostólico. Está aquí un tanto simple de la sentencia dada por el proviso de León a favor del dicho Juan Fernández, como patrimonial del dicho lugar.

$<$ Nota $>$

Adviértase que esta claúsula de ser patrimonial, no tubo efecto en las presentaciones siguientes.

5. $<$ Testimonio de una sentencia sobre la presentación del curato de Barajores. Año de $1680>$.

Testimonio dado por Juan de Cavredo, notario de la nunciatura, de la sentencia a favor de este monasterio sobre la presentación libre del curato de Barajores, aprobando la

\footnotetext{
64 yantar] al margen izquierdo: Yantar.

${ }^{65}$ perjudicial] al margen izquierdo: Perjudicial.
} 
que se havía hecho en Roque Miguel. El contenido de esta sentencia se pondrá por extenso en el número siguiente. Diose este testimonio a 17 de julio de 1680.

6. <Executoria sobre la presentación del curato de Barajores $>$.

Executoria a favor de este monasterio sobre la presentación libre y en todo tiempo del curato de Barajores contra el concejo y vecinos de dicho lugar, ganada en la nunciatura. Año de 1680.

$<$ Presentación del curato en Roque Miguel $>$.

$\mathrm{Al} /(f .59 v)$ principio de esta executoria está la presentación que hizo la comunidad en Roque Miguel, natural del lugar de Gañinas, a 16 de marzo de 1679, ante fray Francisco de Molina, notario apostólico. En esta ocasión, el concejo y vecinos de Barajores pretendieron tocarles la presentación del curato, y deber ser en patrimoniales; y así presentaron en el licenciado Andrés Martín, natural de Respenda, sobre la qual se litigó pleito en León, ante el provisor don Diego Fernández de Humada, donde se alegó por ambas partes. Compulsó el monasterio todos los papeles que tenía, como se anotan al principio de esta carta executoria.

$<1^{\mathrm{a}}$ sentencia, en León, a favor del monasterio. Año de 1679 $>$.

Estando la causa en estado, a 4 de agosto del mismo año, dio sentencia el provisor, por la qual declaró tocar privativa y libremente la presentación y patronato del dicho beneficio curado al abad, monasterio y priorato de San Román, en todo tiempo, mes y forma que vaque, negando a las partes contrarias la manutención introducida por sus artículos y declarándoles por no partes, y adjudicando dicho curato al referido Roque Miguel.

$<2^{\mathrm{a}}$ sentencia, que revoca la primera $>$.

De esta sentencia apelaron el concejo y vecinos; y por quanto luego entró por nuevo provisor don Rodrigo de Prado, alegaron agravios contra él, quien, en $1^{\circ}$ de septiembre del mismo año, revocó en todo y por todo la sentencia dada por su antecesor, poniendo el pleito en el mismo estado que tenía antes de la tal sentencia.

$<3^{a}$ sentencia en la nunciatura, a favor del monasterio. Año de 1680 $>$.

De esta sentencia apeló el convento, y porque el provisor no la quiso conceder en ambos efectos, se llevó a Valladolid por vía de fuerza, de donde se volvió luego al notario, porque aquellos señores dixeron que no iba en estado. Con que se llevó al señor nuncio, y nuevamente se alegó por ambas partes, y su Yllustrísima, en 5 de abril de 1680, dio auto por el qual confirmó en todo y por todo el que havía dado el doctor don Diego Fernández de Humada en 4 de agosto de 1679, el qual se notificó al dicho licenciado Andrés Martínez, quien no apeló de él; por lo qual se dio la causa por pasada en cosa juzgada, y se mandó despachar esta carta executoria ante don Balthasar Montero, secretario / (f. 60r) de la nunciatura, la qual no se sacó por entonces por poco cuidado; y assí se estubo hasta 4 de julio de 1695, que huvo el mismo pleito con los vecinos, a que coadyubó don Tomás Enrríquez.

7. <Presentación y colación del curato en el licenciado Francisco Miguel. Año de 1680>.

Presentación del curato hecha por el maestro fray Juan González, abad de San Zoil, en el licenciado don Francisco Miguel, a 7 de mayo de 1680, ante fray Francisco de Molina, notario apostólico. Está aquí un traslado, signado y firmado del licenciado Alonso Díez, notario apostólico y cura de Tarilonte, en 11 de agosto de 1680, de la colación que los provisores de León, sede vacante, hicieron en el dicho Francisco Miguel, a 8 de agosto del mismo año, ante Ramiro Ordóñez, notario, por la qual confirman las dos sentencias contenidas en la carta executoria antecedente. 
8. $<$ Colación en don Miguel de Guardo. Año de 1687>.

A la presentación que hizo el abad, convento y prior de San Román, en el licenciado don Miguel de Guardo, natural de Carrión, se opuso el fiscal de León, pretendiendo hacerle de concurso, atento a que la vacante havía sido en mes apostólico. Acudió el presentado al nuncio, quien mandó se le hiziese colación, en virtud de nombramiento en él hecho por el abad de San Zoil y prior de San Román, reservando el derecho a salvo a dicho fiscal. Fue requerido con este auto el provisor de León, quien en su cumplimiento mandó parecer a examen al dicho don Miguel de Guardo, y le despachó título de colación del curato, en 31 de (sic) 1687, ante Luys Díaz de la Rocha, escribano y notario de León; y en su virtud tomó la posesión de él, como todo consta de este traslado authorizado de Miguel de la Vega, escribano y notario apostólico, vecino de Aviñante, a 3 de septiembre de 1690.

9. Bajo este número están los papeles siguientes:

$<$ Resignación del curato. Año de 1694>.

Resignación que hizo el licenciado Miguel de Guardo del curato de Barajores en manos del maestro fray Gregorio Ruiz, abad de San Zoil, ante Norberto de Sandoval y Guevara, escribano y notario de Carrión, a 11 de septiembre de 1694.

$<$ Aceptación del abad $>$.

Aceptación del abad ante el mismo notario, dicho día, mes y ano. Está duplicado.

$<$ Presentación del curato en don Miguel Pérez>.

Presentación que hizo el mismo abad en el licenciado don Miguel Pérez de la Vega,/ (f. 60v) ${ }^{66}$ ante el mismo notario, a 14 de septiembre de 1694.

Barajores $>$.

$<$ Petición por parte del monasterio contra el concejo y vecinos de

Copia simple de una petición que hizo el licenciado Bedoya por parte del monasterio contra el concejo y vecinos de Barajores, que en esta ocasión nuevamente pretendieron tocarles la presentación del curato. En esta petición se hace relación de todo lo alegado por las partes contrarias en las dos vacantes antecedentes, y responde

$\left.{ }^{66} /(f .60 v)\right]$ Entre elf. 59 y elf. 60 se incluye una carta escrita en un papel de tamaño cuarto.

(Crus)

Mi Reverendo Padre fray Gregorio Calderón.

En vista de lo acordado, en que vuestro padre remitiría a esta ciudad, a poder del señor magistral doctor Melchor Pico, la concordia que se celebró por esa comunidad y el dueño y señor de Frómista, me he detenido, como prometí a vuestro padre, en responder a el traslado que se me ha dado. Y se halla la novedad de que por su procurador se me está apremiando para que debuelba los autos, y este señor yntendente no da más tregua que quatro días; y que en respuesta de ésta remita dicha concordia, porque de no haverla imbiado, se sospecha no tenerla o no ser favorable. Espero respuesta a la maior brebedad, / como el que disponga vuestro padre a su placer, de la insuficiencia de éste su verdadero y fino servidor, que sus manos besa.

Antonio Fernández Escudero (rúbrica).

Palencia y febrero 19, de 1791.

Quaderno D. Legajo $1^{\circ}$, número 7.

Aprovechando los especios en blanco del papel se hicieron las siguientes operaciones:

$1000+50+41=1091 ; 1285-38=1247$.

Subsidio y escusado los dos tercios 2882,1

$1618,87+1618,17=3237$.

1214.

$3581,31+782,5=3364,2$ (sic).

$1500,150[\ldots]$. 
a ello concluyendo estar executoriado a favor del monasterio, como consta de la executoria que queda puesta en el número 6 de este quaderno.

$<$ El provisor concede a la parte contraria más término $>$.

Testimonio dado por Gerónimo de Canseco, notario de León, en 8 de junio de 1695, de cómo estando el pleito en estado de sentenciarse, concedió el provisor a la parte contraria restitución de la mitad del término probatorio, contradiciéndolo el monasterio.

$<$ Petición del monasterio ante el nuncio de Su Santidad $>$.

Copia simple de una petición presentada por parte del monasterio ante el nuncio de Su Santidad, quexándose del provisor de León por la prorrogación de término y pidiendo que se llevasen los autos a la nunciatura.

$<$ Testimonio de la sentencia dada en León a favor del monasterio sobre la presentación libre del curato. Año de 1695>.

Testimonio authorizado de Francisco Álvarez, notario de León (ante quien pasó este pleito), a 24 de noviembre de 1695, de la sentencia dada en dicho pleito por el licenciado don Antonio Martín Granizo, provisor de León, por la qual ampara al monasterio en la posesión en que está de presentar libre y absolutamente el curato en quien quisiere, aunque no sea patrimonial del dicho lugar de Barajores, en todo tiempo, mes y forma que vaque; y manda comparecer a examen al dicho licenciado don Manuel Pérez de la Vega.

10. $<$ Papeles sobre la presentación libre del curato $^{67}>$.

Memoria de los papeles, fundamentos y razones que tiene el monasterio para la presentación libre y absoluta del curato de Barajores, en todo tiempo, mes y forma que vaque, fundados en la donación del rey don Fernando el Santo, año de 1226, de los quales se ha valido en todos los pleitos que ha tenido hasta el año de 1695.

11. $<$ Papeles simples sobre lo mismo>.

Papeles simples pertenecientes al curato de Barajores, y una carta del reverendísimo Mier, procurador en la corte de Roma, escrita al abad de esta casa, sobre lo que debía de hacer en el caso que alguno impretrase el curato de Su Santidad.

/ (f. 60v) 12. <Demanda para que no se prosiga la obra de una capilla en la yglesia de Barajores. Año de 1717>.

Despacho del provisor de León, a petición de este monasterio, para que cesase la obra de una capilla que estaban construyendo don Pedro Fernández de la Calle, provisor de Ciudad Rodrigo, y don Juan Abad, canónigo penitenciario de la misma santa yglesia ${ }^{68}$. Su fecha, en León, a 29 de julio de 1717, ante Francisco Álvarez, secretario.

Requisitoria despachada por el provisor contra dichos señores para que, si tubieren algo que exponer, comparezcan ante él dentro de doce días. Su fecha, en León, el mismo día, mes y año y ante el mismo escribano.

\footnotetext{
${ }^{67}$ curatol sigue tachado. Año de.

${ }^{68}$ yglesi] al margen derecho: Nota: Bajo este número se halla también una consulta y parecer de un abogado sobre la reedificación de la yglesia de San Saturnino de Barajores, que pretendía hacer el mismo penitenciario don Juan Abad. Léase pues sirve mucho para lo perteneciente a esta yglesia.
} 
Notificación del primer despacho al maestro y oficiales de la obra, quienes la obedecieron.

$<$ Súplica al abad y consentimiento de éste para que se haga la capilla. Año de 1717>.

Súplica de don Juan Abad de la Calle, penitenciario de Ciudad Rodrigo, al abad de esta casa, para que permita la construcción de la nueva capilla, poniendo sus armas dentro de ella, y consentimiento que dio el dicho Abad para que se hiciese según pedía, no perjudicando a la yglesia ni a sus derechos parroquiales. Su fecha, en San Zoil, a 4 de agosto de 1717, ante Agustín García, notario de Carrión.

13. <Presentación del curato de don Bernardo Llamazares. Año de 1722>.

Presentación del curato de Barajores hecha por el maestro fray Plácido Flórez, abad de San Zoil, en don Bernardo Fernández de Llamazares, natural de Sahagún. A 10 de marzo de 1722, ante Agustín Díez de Castro, escribano y notario de Carrión ${ }^{69}$.

14. $<$ Propuesta de la terna para la presentación del curato. Año de 1770>.

Testimonio dado por Francisco Rodríguez, notario mayor de la audiencia eclesiástica de León, a 21 de mayo de 1770, de la propuesta hecha por los gobernadores y vicarios generales de aquel obispado, sede vacante, al abad de esta casa, para que haga el nombramiento de cura de Barajores en uno de los tres comprendidos en la propuesta. Ésta es la primera terna con arreglo a Reales Órdenes.

$<$ Remisiones $>$

$<$ Diezmos $>$.

Despacho del prior de San Román sobre los diezmos y obladas de Barajores. Año de 1233. Cajón San Juan, legajo $3^{\circ}$, quaderno $B$, número $2^{\circ}$.

$<$ Yantar $>$.

Carta executoria contra el cura de Barajores sobre el yantar que debe pagar a San Román. Año de 1655. Cajón San Juan, legajo 3º quaderno B, número 9.

\section{/ (f. 61v) Quaderno E del legajo $1^{\circ}$ \\ Barajores \\ Hacienda del Brezo en este lugar}

Este quaderno contiene los papeles pertenecientes a la hacienda que tiene Nuestra Señora del Brezo en este lugar, por el orden siguiente:

$1^{\circ}$. <Compra de 15 tierras, 5 prados y un día de molino de veinte días. Año de 1591>.

Compra que hizo fray Francisco de Villafuerte, prior del Brezo, para la casa de Nuestra Señora, a Joan Díaz y María de Guardo, su muger, vecinos de las Heras, de 15 tierras, 5 prados, y un día de molino, que es de veinte días uno. Vna tierra a do dicen encima de la Varga, dos a la Huerta, otra al Casar, otra a las Hontanillas, dos a la Horca, dos al Llano de Vega, otra a las Coronas, término de Barajores, otra a carrera de Rorcales ${ }^{70}$, otra que está junto a ella, otra a Malrasca, otra a Valde Barajores, en término de Recueva, otra a Valdecobo, término de Roscales. Los prados: el uno al Ríal, otros dos pradillos en la vega de arriva, y los otros dos más abajo en la dicha vega. El molino es el que llaman Bajero, que está en término

\footnotetext{
${ }^{69}$ Carrión.] al margen derecho: Falta.

${ }^{70}$ Rorcales] al margen derecho: Recueva, Roscales, Vega.
} 
de Barajores. Todo por precio de 68 ducados y 2 reales. Su fecha, en las Heras, a $1^{\circ}$ de noviembre de 1591, ante García de Cosío, escribano de la Puebla.

2. $<$ Donación de hacienda. Año de 1594>.

Donación hecha a la casa de Nuestra Señora del Brezo por Cathalina Martínez, hija de Pedro Martínez y Francisca de Roscales, de todos los bienes y hacienda, muebles y raízes, que la pertenecían de la herencia de su padre. Su fecha, en Barajores a 12 de septiembre de 1594, ante García de Cosío, escribano real y de la audiencia de la Puebla.

3. $<$ Compra de dos linares. Año de 1598>.

Compra que hizo fray Francisco de Villafuerte, prior del Brezo (para la casa de Nuestra Señora), a Cathalina de la Fuente, viuda de Juan Valle, vecina de las Heras, de dos linares en término de Barajores, vno a do dicen a la Vega de Barajores, que hace quarto y medio de linaza, / (f. 62r) y el otro a la misma Vega, que hace un quarto de linaza, por precio de 10 ducados. Su fecha, en las Heras, a 5 de noviembre de 1598, ante García de Cosío, escribano de la Puebla.

\section{4. <Compra de un linar. Año de 1598>.}

Compra que hizo el mismo fray Francisco de Villafuerte, para la casa de Nuestra Señora del Brezo, a Juan Díaz y María de Guardo, su muger, vecinos de las Heras, de un linar en término de Barajores, a do dicen a la Huerta, de tres suertes; la que aquí se compra haze 4 zelemines de linaza de sembradura, por precio de 3 ducados y medio. Su fecha, en las Heras, a 5 de noviembre de 1598, ante García de Cosío, escribano de la Puebla.

$$
\begin{gathered}
\text { / (f. 62v) Quaderno F del legajo } 1^{\circ} \\
\text { Bárcena } \\
\text { Hacienda de San Zoil en este lugar }
\end{gathered}
$$

En este quaderno están los papeles pertenecientes a la hacienda que tiene este monasterio de San Zoil en este lugar, por el orden siguiente:

$1^{\circ}$. <Trueque de una tierra por otra. Año de 1416>.

Escritura de trueque entre García Fernández, sacristán mayor de San Zoil, y Juan Fernández, vecino de Bárcena, por la que éste le da una tierra en el término de Bárcena, a do dicen el Subaco, por otra tierra que el dicho sacristán le da en el mismo término de Bárcena, a do dicen Vallizonuño. Su fecha, en San Zoil, a 22 de octubre de 1416, ante Ferrand Rodríguez de Castellanos, escribano de Carrión.

\section{/ (f. 63r) Quaderno G del legajo $1^{\circ}$. Bárcena.}

Hacienda del Brezo en este lugar.

En este quaderno están los papeles pertenecientes a la hacienda que tiene Nuestra Señora del Brezo en este lugar, por el orden siguiente:

$$
1^{\circ} \text {. <Posesión de } 4 \text { viñas. Año de 1539>. }
$$

Testimonio de la posesión que tomó el prior del Brezo de quatro viñas en término de Bárcena, como mansesor y testamentario que fue de doña Francisca Henríquez de Tobar, que fue la que mandó estas viñas al Brezo con la demás hacienda, como consta por su testamento, que está en el legajo $3^{\circ}$ de este cajón, número 8. Pasó este testimonio a 12 de marzo de 1539, ante Pedro López, escribano y vecino de Bárcena.

$2^{\circ}$. <Compra de una viña. Año de 1542>.

Compra que hizo fray Pedro de Porras, prior del Brezo, para la casa de Nuestra Señora, a Alonso Ximón y Toribio Caro, clérigos, vecinos de Bárcena, de una viña, a do dicen a so la Cuesta, término del mismo lugar, que ay en ella tres obreros y medio, por precio de 8 ducados de oro, que hacían 3 mill maravedís de la moneda usual. Su fecha, en Bárcena, a 14 de septiembre de 1542, ante García de la Puente, escribano de Castrillo de Villavega. 


\section{/ (f. 63v) Quaderno H del legajo $1^{\circ}$ \\ Basurbio}

Hacienda del Brezo en este lugar

En este quaderno están los papeles pertenecientes a la hacienda que tiene Nuestra Señora del Brezo en este lugar, por el orden siguiente:

$1^{\circ}$. $<$ Compra de un prado. Año de 1556>.

Compra que hizo el prior del Brezo, para la casa de Nuestra Señora, a Gutierre de Soa, vecino de Basurbio, de un parado, a do dicen la Fuenfría, término de dicho lugar, por precio de 2.244 maravedís. Su fecha, en Villafría, a 2 de diciembre de 1556, ante Juan Rodrigo, escribano y vecino de Villaverde.

$2^{\circ}$. <Compra de dos prados. Año de 1559>.

Compra que hizo el mismo prior, para la casa del Brezo, a Juan Rebanal, vecino de Basurbio, <de $>$ dos. prados en término de dicho lugar; vno a do dicen al Prado Pendo, y el otro al Molino Caýdo, por precio de 5 ducados. Su fecha, en Camporredondo, a 8 de mayo de 1559, ante Francisco Gómez, escribano de Camporredondo

3. <Compra de un prado. Año de 1560>.

Compra que hizo el prior del Brezo, para la casa de Nuestra Señora, a Pero Pellón, vecino de Basurbio, de un prado, a do dicen Calamaca, término de dicho lugar, por precio de 12 ducados. Su fecha, en Villafría, a 5 de diciembre de 1560, ante Agustín de Medina, escribano.

4. <Compra de una tierra. Año de 1592>.

Compra que hizo el prior del Brezo, para la casa de Nuestra Señora, a Pedro de Ravanal y Alonso de Ravanal, vecinos de Basurbio, de una tierra a la Fu[e]ntexa, término del dicho lugar, que hace una carga de centeno de sembradura, por precio de 17 ducados y dos reales. Su fecha, en el Brezo, a $1^{\circ}$ de mayo de 1592, ante García de Cossío, escribano de la Puebla.

5. <Compra de una tierra. Año de 1592>.

Compra que hizo el prior del Brezo, para la casa de Nuestra Señora, a García Gutiérrez, vecino de Basurbio, de una tierra a la Fuentexa, que hace quarto y medio de sembradura, por precio de 4 ducados. Su fecha, en el Brezo, a postrer día de agosto de 1592, ante García de Cossío, escribano de la Puebla.

\section{/ (f. 64r) 6. <Compra de un prado. Año de 1592>.}

Compra que hizo el prior del Brezo, para la casa de Nuestra Señora, a Antón Martínez, vecino de Basurbio, de un prado, a do dicen a Hontalar Mayor, en término de dicho lugar, que hace tres entuertas de yerva, por precio de 32 reales. Su fecha, en el Brezo, a último día de agosto de 1592, ante García de Cosío, escribano de la Puebla.

\section{7. <Compra de un prado y una tierra. Año de 1592>.}

Compra que hizo el prior del Brezo, para la casa de Nuestra Señora, a Juan de Rabanal, vecino de Basurbio, de un prado, a do dicen los Picones, que hace cinco entuertas de yerva, y una tierra, a do dicen Posadillas, que hace un quarto de centeno de sembradura; todo en término de dicho lugar, por precio de 35 reales. Su fecha, en el Brezo, a 18 de septiembre de 1592, ante García de Cosío, escribano de la Puebla.

\section{8. <Compra de un prado. Año de 1592>.}

Compra que hizo el prior del Brezo, para la casa de Nuestra Señora, a Alonso de Rabanal, vecino de Basurbio, de un prado, a do dicen a la Fonfría, término del dicho lugar, que hace medio carro de yerva, por precio de 4 ducados. Su fecha, en el Brezo, a 12 de noviembre de 1592, ante García de Cosío, escribano de la Puebla.

9. <Compra de un prado. Año de 1598>. 
Compra que hizo el prior del Brezo, para la casa de Nuestra Señora, a Simón Cardo y María de Guardo, su muger, vecinos de Basurbio, de un prado, a do dicen a las Paradejas, término del dicho lugar, por precio de 9 ducados. Su fecha, en el Brezo, a 5 de noviembre de 1598, ante García de Cosío, escribano de la Puebla.

10. <Compra de un prado. Año de 1598>.

Compra que hizo el prior del Brezo, para la casa de Nuestra Señora, a Gerónima de Mier, viuda de García Gutiérrez, vecina de Basurbio, de un prado, a do dicen a las Peñas, término del dicho lugar, que hace carro y medio de yerva, por precio de 8 ducados y 7 reales. Su fech,a en Basurbio, a 10 de diciembre de 1598, ante García de Cosío, escribano de la Puebla.

11. < Compra de un prado. Año de 1598>.

Compra que hizo el prior del Brezo, para la casa de Nuestra Señora, a Ynés Crespa de Caso, viuda de Pedro de Guardo, vecina de Basurbio, de un prado, a do dicen a la Lamaza, término del dicho lugar, que hace un carro de yerva, por precio de 84 reales. Su fecha, en el Brezo, a 5 de noviembre de 1598, ante García de Cosío, escribano de la Puebla.

12. < Compra de un prado. Año de 1598>.

Compra que hizo el prior del Brezo, para la casa de Nuestra Señora, a Ynés Crespa de Caso, viuda de el mismo, y vecina de Basurbio, de un prado a Hontanar Mayor, término del dicho lugar, que hace un carro de yerva, por precio de 7 ducados. Su fecha, en el Brezo, a 10 de diciembre de 1598, ante García de Cosío, escribano de la Puebla.

/ (f. 64v) 13. <Compra de un prado y una tierra. Año de 1598>.

Compra que hizo el prior del Brezo, para la casa de Nuestra Señora, a María de Guardo, viuda de Antón Martínez, vecina de Basurbio, de un prado a los Picones, que hace medio carro de yerva, y una tierra a la Picuda, que hace dos carros de pan, los dos en término del dicho lugar, por precio de 7 ducados y medio. Su fecha, en el Brezo, a 10 de diciembre de 1598, ante García de Cosío, escribano de la Puebla.

14. <Compra de un prado. Año de 1598>.

Compra que hizo el prior del Brezo, para la casa de Nuestra Señora, a Juan de Miguel y María Pérez, su muger, vecinos del lugar de Vidrieros, de un prado al Carnizal, término del lugar de Basurbio, por precio de 80 reales. Su fecha, en Vidrieros, a 18 de noviembre de 1598, ante Juan Gutiérrez de Santiváñez, escribano de Cerbera.

15. < Compra de un prado. Año de 1599>.

Compra que hizo el mismo prior, para la casa de Nuestra Señora, a Marina Gómez, viuda de Santiago de la Torre, vecina de Camporredondo, de un prado al Hontanar, término de Basurbio, que hace un carro de yerva, por precio de 73 reales. Su fecha, en Camporredondo a 30 de enero de 1599, ante Diego de Vega, escribano de Camporredondo.

16. < Compra de dos prados. Año de 1599>.

Compra que hizo el mismo prior, para la casa de Nuestra Señora, a Pedro de Ravanal, vecino de Basurbio, de dos prados, el uno a la Fonfrida, que hace tres entuertas de yerva, y el otro al Redondillo, que hace otras tres entuertas de yerva, los dos en término de dicho lugar, por precio de 66 reales. Su fecha, en Basurbio, a 8 de mayo de 1599, ante Diego de Vega, escribano y vecino de Camporredondo.

17. <Compra de un prado. Año de 1599>.

Compra que hizo el mismo prior, para la casa de Nuestra Señora, a Juan de Guardo, vecino de Basurbio, de un prado a las Llanas del Río, término del dicho lugar, por precio de 22 ducados. Su fecha, en Camporredondo, a 11 de mayo de 1599, ante Diego de Vega, escribano de Alva y Camporredondo.

18. <Compra de un prado. Año de 1599>. 
Compra que hizo el mismo prior, para la casa de Nuestra Señora, a Ynés Crespa de Casso, vecina de Basurbio, de un prado a Badregamal, término del dicho lugar, que hace un carro de yerva, por precio de70 reales. Su fecha, en Camporredondo, a 27 de abril de 1599, ante Diego de Vega, escribano de Alba y Camporredondo.

19. <Compra de tres tierras y quatro prados. Año de 1599>.

Compra que hizo el mismo, prior para la casa de Nuestra Señora, a Juan de Rabanal y Gerónima de Mier, su muger, vecinos de Basurbio, de una tierra a los Barriales, término del dicho lugar, que hace 7 carros de paja; otra en el Soto al Brezal, que hace dos carros de paja; otra en Posadillas, a do llaman a las Qruletas, que hace tres carros de paja; yten un prado, a Badregamal, que hace carro y / (f. 65r) y medio de yerva; otro prado a las Costanas, con la llana de la Fonfrida, que hace carro y medio de yerva; otro prado al Carnizal, que hace medio carro de yerva; otro prado al de Picones, que hace medio carro de yerva, términos de Basurbio; todo ello por precio de 41 ducados y medio. Su fecha, en Basurbio, a 11 de hebrero de 1599, ante Diego de Vega, escribano de Camporredondo.

20. < Compra de una tierra y un prado. Año de 1599>.

Compra que hizo el mismo prior, para la casa de Nuestra Señora, a Simón Cardo y María de Guardo, vecinos de Basurbio, de una tierra a los Veneros, que hace un carro de paja; y un prado a los Picones, que hace un carro de yerva, ambos a dos en término de dicho lugar, por precio de 7 ducados. Su fecha, en Basurbio, a 11 de hebrero de 1599, ante Diego de Vega, escribano de la Puebla.

21. <Donación de un prado. Año de 1599>.

Escritura de donación por la qual Gaspar de Cordaves y Juan de Cordaves, vecinos de Camporredondo, mandan y hazen donación a la casa de Nuestra Señora del Brezo: un prado al Carrizal, en término de Basurbio, que hace un carro de yerva, el qual prado havía mandado a Nuestra Señora Pedro Merino, vecino de Camporredondo, estando enfermo de peste; y estos que hacen la donación cumplen su voluntad, como marido el uno, y el otro curador de sus hijos. Su fecha, en Camporredondo, a 20 de junio de 1599, ante Diego de Vega, escribano de Alva y la Puebla. $1600>$.

22. <Redención de un censo que estaba sobre las heredades de Basurbio Año de

Redención de un censo que tenía Alonso García, vecino de Pisón, de 500 maravedís de réditos sobre las heredades de Basurbio, que compró fray Francisco de Villafuerte a García Gutiérrez y Gerónima de Mier, su muger, cuyo principal quitó y pagó con 32 ducados fray Cristóval de Matienzo, siendo prior del Brezo, como consta del recivo que está junto y al fin de este censo. Su fecha, a 13 de enero de 1600.

\section{/ (f. 66r) Legajo $2^{\circ}$ del cajón San Benito} siguientes:

Este legajo que es el $2^{\circ}$ del cajón San Benito contiene quatro quadernos, que son los
Quaderno A Becerril y San Felices.
C Bolaños.
B Bespuerto.
D Bustillo de Cea.

Quaderno A del legajo $2^{\circ}$

Becerril y su despoblado de San Felices

Este quaderno A contiene los papeles pertenecientes a la hacienda y derechos que tiene el monasterio en Becerril y su despoblado de San Felices, por el orden siguiente:

$1^{\circ}$. < Donación de Elvira Téllez. Era 1175, año 1137>.

Donación, escrita en pergamino, por la qual Elvira Téllez, por el remedio de su alma y de las de sus padres, da a la sacristía de San Juan, San Zoil y San Félix, toda quanta hacienda 
tenía en la villa de San Felices, en el Alfoz de Palencia (esta villa estaba junto a Becerril y se despobló e incorporó en Becerril), con las yglesias, divisas, solares, poblados y despoblados, tierras, viñas, prados, huertas, pastos, molinos, montes, ríos, fuentes etcétera. De todo esto hace donación porque los ancianos de este monasterio hagan un aniversario ${ }^{71}$ y encomienden a Dios su alma y las de sus padres. Facta charta sub notura (sic) die VII feria, $3^{\text {a }}$ kalendas novembris, era 1175, que es año de Christo 1137. Regnante ymperator Adefonsus, pariter cum vxor sua, Berengaria ymperatrice, in Leone et in Toletula et in Ceragoze. Comes Rodericus Martínez in Campos. Guter Ferrández, mayordomoo. Dieg Muñiz, mayorino in Carrione et in Saldanie etcétera. Está aquí una copia authéntica.

$$
2^{\circ} \text {. <Donación de Pedro Rey. Era 1178, año 1140>. }
$$

Donación, escrita en pergamino, por la qual Pedro Rey y su muger, Sancha Pérez, dan a Dios y al monasterio de San Juan Baptista y San Zoil y San Felices, y al prior don Bernardo, toda la hacienda que tenían en Becerril, en San Martín de los Alamos, Avia, Cassillas, Támara y en toda la Liébana ${ }^{72}$, con sus divisas, / (f. 66v) solares, collazos, tierras, viñas, huertos, prados, ríos, molinos, pastos etcétera. Facta Carta VI feria, XV kalendas. novembris, era 1178, que es año de Christo 1140. Regnante ymperator Yldefonsus, pariter cum ymperatrice Berengari a, in Legione et in Toledo et in Saragoza, etcétera. Está aquí una copia authéntica. $1200>$.

3. < Concordia entre este monasterio y el cavildo de San Felices. Era 1238, año

Concordia, escrita en pergamino y partida por ABC, hecha entre fray Pedro, prior de San Zoil, con consentimiento del sacristán y toda la comunidad, y el concejo y el cavildo de San Felices, por la qual el dicho prior concede al concejo de San Felices y a los clérigos, hijos y nietos de él y sus sucesores, para siempre, que puedan poner clérigos en las yglesias de San Felices, con consejo y consentimiento del sacristán de San Zoil; los quales clérigos lleven la mitad de una tercia de los diezmos de pan y vino y de las demás cosas que se diezmen, y la mitad de las primicias, derechos de difuntos ofrendas u otros aprovechamientos que en ellas huviere. Que los clérigos lleven las obladas todos los días del año, excepto ocho, que son: la Natividad del Señor, la Epifanía, la Purificación de Nuestra Señora, Domingo de Ramos, Pasqua, Pentecostés, Todos Santos y el día siguiente de los difuntos. En los quales ocho días ha de percivir el sacristán de San Zoil la mitad de las obladas y del vino. Que el sacristán tenga una tercia entera y la mitad de otra tercia del pan y del vino y de todas las cosas que se suelen diezmar en que los clérigos no tengan parte alguna. Este pacto se hizo con condición que el concejo y clérigos estén en paz con el convento, y los clérigos assistan a las yglesias de manera que el monasterio no pueda quejarse de su asistencia, y que sean vasallos del monasterio y no de otro, y vivan en los solares del convento, y el servicio que se debe al obispo, arcediano y arcipreste u otras qualesquiera personas eclesiásticas le hagan de sus propios bienes, excepto el foro acostumbrado a la yglesia de Palencia que se pagará del común; y que los clérigos no tengan parte en las heredades que mandare qualquiera por su alma, sino que todas sean del sacristán sin contradicción alguna. Que ningún clérigo tenga ración en las dichas yglesias, sino fuere vasallo del monasterio y jurare primero en el capítulo guardarle fidelidad; y que cada año reconocerán al prior dándole un yantar de sus bienes, y al sacristán dos veces cada año. Y si algún clérigo fuere contra lo ordenado en esta escritura o tomare alguna cosa de lo que no le pertenece, pierda su ración. El sacristán de / (f. 67r) San Zoil presentará al obispo el que más idóneo le pareciere de dichos clérigos para que haga oficio de cura, y muerto uno, presente otro. Facta carta in claustro Sancti Zoili, tertio idus septembris, era 1238, que es año de Christo 1200. Está aquí una copia.

\section{$<$ Nota $>$}

Esta concordia se alteró por la del año 1228 celebrada entre este monasterio, el de San Ysidro, San Román, y el obispo y cavildo de Palencia, que está en el cajón San Andrés, legajo $1^{\circ}$, quaderno $\mathrm{B}$, número $3^{\circ}$. Por esta última concordia quedó el monasterio con una

\footnotetext{
71 aniversario] al margen derecho: Aniversario.

${ }^{72}$ Liébana] al margen derecho: San Martín de los Álamos, Avia, Cassillas, Támara, Liébana.
} 
tercia entera; pero en el día sólo percibe 6 cargas de pan, mediado trigo y cebada, y 16 cántaras de vino. No hay ynstrumento que acredite esta alteración, aunque se supone que fue por posterior concordia con los clérigos de Becerril.

\section{4. $<$ Dos foros de 2 y 3 maravedís. Año de 1409>.}

Dos escrituras de foro, en pergamino, por las quales Garci Fernández, sacristán mayor de San Zoil, da a Fernando García Ferrejón, vecino de Becerril, una viña a Yuntar, término de la misma villa, por 2 maravedís de foro cada año, y una tierra al mismo, a Valdelacaraza, en el mismo término, por 3 maravedís de foro cada año. Sus fechas, en Becerril, a 26 de enero de 1409, ante Pedro García, notario público de Palencia. Hay copia authéntica de estos foros.

\section{5. $<$ Dos foros de 1 y 7 maravedís. Año de 1409>.}

Dos escrituras de foro, en pergamino, por las que el mismo sacristán da a Juan de Congosto, vecino de Becerril, una viña a los Teruelos, término de dicho lugar, por 1 maravedí de foro cada año, y dos tierras a Antón Fernández, vecino del mismo lugar, por 7 maravedís de foro cada año. Sus fechas, en Becerril, a 27 de enero de 1409, ante Pedro García, notario de Palencia. Hay copia de estos foros.

6. < Contrato para plantar de viña una tierra. Año de 1417>.

Escritura de contrato, en pergamino, por la que don Fernando, prior mayor de San Zoil, da a Juan Pérez, vecino de Becerril, 2 obradas de tierra, para que en 7 años las tenga plantadas de viña, y al cabo de ellos sea la mitad para él y la mitad para el monasterio. Su fecha, en San Zoil, a 23 de diciembre de 1417, ante Gonzalo González de Cervatos, escribano de Su Magestad.

7. $<$ Contrato para plantar ${ }^{73}$ de viña una tierra a medias. Año de $1417>$.

Escritura de contrato, en pergamino, por la que el mismo don Fernando da a Juan García y consortes, vecinos de Becerril, una tierra en término de este lugar, para plantarla de viña a medias. Su fecha, en Becerril, a 13 de diciembre de 1417, ante el mismo escribano.

8. $<$ Foro de 4 maravedís sobre una heredad. Año de 1420>.

Escritura de foro, en pergamino, por la qual don Fernando, prior mayor de San Zoil, da a Fernando Pérez, vecino de Becerril, una tierra picón, puesta majuelo, de 2 quartos, a Refoyo, término del mismo lugar, / (f. 67v) por 4 maravedís de foro cada año. Su fecha, en San Zoil, a $1^{\circ}$ de diciembre de 1420 , ante Diego González de Cervatos, escribano real. Hay copia authéntica de este foro.

9. $<$ Dos foros de 2 (sic) [y 7] maravedís. Año de 1426>.

Dos escrituras de foro, en pergamino, por las quales Juan de Ortega, sacristán mayor de San Zoil, da a Fernando Muñoz, vecino de Becerril, 3 majuelos en término del mismo lugar; uno a carre Monzón, otro a San Felices, cerca de la yglesia de San Pedro, y otro al Rabo de la Fesa, por 6 maravedís de foro cada año; y a Juan García de Cervatos, vecino del mismo lugar, 2 Majuelos, el uno a San Felices y el otro al camino del Pozo, en el mismo término, por 10 maravedís de foro cada año. Sus fechas, en Becerril, a 6 de noviembre de 1426, ante Diego Díez, escribano en Becerril. Ay copia.

10. $<$ Memoria de heredades. Año de 1427>.

Memoria de las tierras y viñas que tiene la sacristía de San Zoil en los términos de la villa de Becerril. Hecha a $1^{\circ}$ de noviembre de 1427 , ante Pedro González, notario público de Palencia.

\footnotetext{
${ }^{73}$ plantar] sigue tachado: una.
} 
11. <Censura del abad de Sahagún para que los clérigos de Becerril paguen 6 cargas de trigo y 16 cántaras de vino. Año de 1433>.

Censura dada por don Domingo, abad de Sahagún, juez conservador, inserta la bulla conservatoria del papa Clemente $6^{\circ}$, $a^{74}$ favor de los monasterios cluniacenses de España, por la que manda a los curas y clérigos de Becerril paguen a la sacristía de San Zoil 6 cargas de pan, mediado trigo y cevada, y 16 cántaras de vino, que la debían cada año por razón de los diezmos de las heredades que los vecinos de Becerril sembraban en término de San Felices. Su fecha, en Sahagún, a 27 de octubre de 1433. Está aquí un requirimiento echo al prior del cavildo de Becerril, para que pague el pan y vino. Su fecha, a 8 de marzo de 1644, ante Andrés Gallo, escribano en la misma villa.

12. < Foro de 18 maravedís de dos pedazos de viña. Año de 1456>.

Escritura de foro, en pergamino, por la qual Fernando González de San Román, sacristán mayor de San Zoil, con licencia de don Pedro, abad del monasterio, da a Diego Alfonso, carpintero, vecino de Becerril, dos pedazos de viñas cerca del término de Becerril, una de 5 quartas, a Salaíces, junto al Pozo Salso, y otra de 13 quartas, a Valde Palencia, por 18 maravedís de foro cada año. Su fecha, en San Zoil, a 13 de noviembre de 1456, ante Álvar González de Carrión, escribano público. Esta escritura está en papel. Ay copia de ella.

\section{3. $<$ Memoria de hacienda $>$.}

Memoria simple de las heredades que tenían antiguamente de este monasterio y sacristía algunos vecinos de Becerril y lo que cada uno pagaba por ellas.

14. <Escritura de la casa de Becerril. Año de 1660>.

Bajo este número están varias escrituras pertenecientes a la casa ${ }^{75}$ y corral que tiene este monasterio en la villa de Becerril, las quales / (f. 68r) se anotan en la primera oja por su orden, por tanto no se ponen aquí por extenso. La $5^{a}$ escritura es la principal compra de la casa, que se hizo a 28 de febrero de 1660, ante Antonio Buey, escribano en Becerril. La $8^{a}$ escritura es otra compra de un suelo hundido contiguo a otra casa. Su fecha, a 28 de abril de 1660, ante Diego Ruiz Martínez, escribano de la misma villa. La 9a es otra compra de un quarto alto y bajo de la misma casa, a 12 de octubre de 1711, ante Bernardo Buey Valle, escribano de la misma villa.

\section{5. <Compra de 2 viñas. Año de 1662>.}

Compra que hizo este monasterio a Simón Pedraza y María Dorado, su muger, vecinos de Becerril, de 2 viñas, la una en término de Paredes de Valleluengo ${ }^{76}$, de 4 quartas, y la otra en término de Becerril, al prado de las Fuentes, de otras 4 quartas, por precio de 730 reales. Su fecha, en Becerril, a 22 de enero de 1662, ante Diego Ruiz Martínez, escribano de la misma villa.

16. <Compra de 4 pedazos de viña. Año de 1672>.

Compra que hizo este monasterio a Hernando González y María Gastán, su muger, vecinos de Aguilar de Campos, de 4 pedazos de viña en término de la villa de Becerril, por precio de 22 mill marvedís. Su fecha, en Aguilar de Campos, a 29 de noviembre de 1672, ante Cristóval López Ramírez, escribano en Aguilar.

17. <Trueque de una viña por otra. Año de 1698>.

\footnotetext{
74 a] escrita sobre en.

75 casa] al margen derecho: Se vendió esta casa en 12.000 reales a Fernando Peláez, vecino de Becerril, en 27 de abril de 1819.
}

\footnotetext{
${ }^{76}$ Paredes de Valleluengo] al margen derecho: Paredes.
} 
Trueque que hizo este monasterio con Claudio Autillo, vecino de Becerril, por el que éste da al monasterio $1^{\mathrm{a}}$ viña, a Estrella Blanca, de 2 quartas y media, por otra que el monasterio le dio de igual cabida a Guadaña, en término de Villaumbrales; y por el mayor valor que tenía la que recivió el monasterio, le dio éste 250 reales. Su fecha, en Becerril, a 28 de noviembre de 1698, ante Bernardo Buey Valle, escribano de la misma villa.

\section{Remisiones}

Concordia con el obispo y cavildo de Palencia sobre diezmos. Año de 1228. Cajón San Andrés, legajo $1^{\circ}$, quaderno B, número $3^{\circ}$.

Licencia del general para vender algunas casas. Cajón San Bernardo, legajo $3^{\circ}$, quaderno A, número $3^{\circ}$.

\section{/ (f. 68v) Quaderno B del legajo $2^{\circ}$ \\ Bespuerto} siguiente:

En este quaderno B están los papeles pertenecientes al Puerto del Bes, por el orden

$1^{\circ}$. $<$ Donación de doña Vrraca Díaz. Era 1265, año 1227>.

Donación que hizo a San Román y a su prior don Geraldo, doña Vrraca Díaz, del Puerto del Bes, en las montañas de Liébana, de un límite a otro, con la obligación de que rueguen a Dios perpetuamente por su alma y la de sus padres. Su fecha, en San Román, kalendas novembris, era 1265, que es año de Cristo 1227, ante Domingo Abad de Cornonzillo, quien la escrivió y signó.

2. < Sentencia en desempeño del Puerto del Bes. Era 1403, año 1365>.

Sentencia arbitra que dieron Guillén Pérez, Francisco González y Domingo Fernández, juezes arbitros, vecinos de Carrión, en un pleito que hubo entre Benito Pérez, prior de San Román, y Domingo Martínez de Ynojal, sobre que por cierta deuda que el dicho prior tenía a los padres de Ynojal, tenía éste como en empeño el Puerto del Bes y una tierra so el Sendero, en término de Arconada ${ }^{77}$. Y sobre el desempeño de estas posesiones y paga del deuda se comprometieron en dichos juezes arbitros, los quales determinaron por esta sentencia difinitiva que, dando el dicho prior al dicho Domingo Martínez 15 cargas de pan, mitad trigo y mitad zebada, dexase éste libre y desembarazado para San Román y su prior el Puerto del Bes y la heredad de so el Sendero en Arconada. Su fecha, en Carrión, a 25 de marzo de era de 1403, que es año de Cristo 1365, ante Juan García, escribano de Carrión.

3. Memoria antigua de los términos y mojones del Puerto del Bes.

4. < Sentencia sobre la propiedad del Puerto del Bes. Año 1739>.

Sentencia definitiva dada por el señor don Pablo Cárdenas y Badillo, corregidor de la villa de Carrión y juez privativo de lugares, despoblados, valdíos y heredades usurpadas a la Real Hacienda, en virtud de real cédula, con parecer de asesor, a favor de este monasterio y contra el promotor fiscal de Su Magestad, sobre la propiedad, uso y aprovechamiento del Puerto del Bes, su dehesa y pastos, en cuya posesión manda que nadie le perturbe, pena de 100 ducados. Su fecha, en Carrión, a 16 de octubre de 1739, ante Santiago Duque de Estrada, escribano de la misma villa.

\footnotetext{
77 Arconada] al margen derecho: Arconada.
} 


\section{/ (f. 69r) Quaderno C del legajo $2^{\circ}$ \\ Bolaños}

En este quaderno C están los papeles pertenecientes al beneficio de San Pedro de Bolaños y al patronato que tiene el abad de este monasterio, a quien pertenece su presentación, por el orden siguiente:

$1^{\circ}$. $<$ Edicto para la colación del beneficio de Bolaños. Año de 1547>.

Carta de edicto y fe de su fijación dada por el licenciado Toro, provisor de León por el obispo don Juan Fernández de Temiño, para la colación del beneficio de San Pedro de Bolaños, en virtud de presentación hecha por el abad de San Zoil en Martín de Santa María, clérigo de la diócesis de Burgos. Su fecha, en León, a 13 de abril de 1547, ante Francisco de Valderas, escribano y notario.

2. <Autos originales de la sentencia a favor de este monasterio sobre las 5 cargas de pan mediado de patronato del beneficio de Bolaños. Año de 1610>.

Autos originales del pleito que este monasterio litigó contra el licenciado Nicolás de Lera, cura de San Pedro de Bolaños, sobre la paga de las 5 cargas de pan, mediado trigo y cebada, de patronato cada año, en que fue condenado por sentencia dada por el provisor de León, a 27 de abril de 1610; y aunque apeló de la sentencia, reconociendo después que no tenía justicia, se apartó de la apelación, consintió la sentencia y pagó. Al último de estos autos están dos mandamientos de un mismo tenor contra el cura de San Pedro, con inserción de la sentencia antecedente, para que pague las referidas 5 cargas de pan mediado. Su fecha, en León, a 7 de marzo de 1618, ante Juan Baptista de Torres, escribano y notario de León.

3. <Testimonio en relación de la sentencia anterior>.

Testimonio en relación del pleito y sentencia, apelación y apartamiento de ella en la causa referida en el número antecedente. Dado por Norberto de Sandoval y Guevara, notario y escribano de Carrión, a 13 de marzo de 1687.

\section{4. $<$ Mandamiento del provisor sobre las 5 cargas del patronato. Año de 1636>.}

Mandamiento del provisor de León, con inserción de la sentencia puesta en el número $2^{\circ}$, para cobrar de los herederos del licenciado Matheo de San Marcos, cura que fue de San Pedro de Bolaños, el pan que quedó debiendo por razón del patronato. Sus fecha, en León, a 4 y 5 de junio de 1636, ante Juan Baptista de Torres, notario en dicha ciudad.

5. $<$ Colación del beneficio de Bolaños. Año de 1649>.

Colación del beneficio curado de San Pedro de Bolaños en el licenciado Alonso García Ruano, en virtud de presentación que en él hizo el abad de San Zoil. Su fecha, en León, a 12 de agosto de 1649, ante Bernardino Alonso, notario en dicha ciudad. Sacó el testimonio de $/(f .69 v)$ esta colación Gaspar Ferrer, cura de Valdunquillo y notario apostólico, en $1^{\circ}$ de octubre del mismo año. $1668>$.

6. < Sentencia del provisor por la que declara vacante el curato de Bolaños. Año

Testimonio de la sentencia dada por el provisor de León, a instancia del fiscal eclesiástico, por la que declara vacante el curato de San Pedro de Bolaños, por no residir en él el licenciado Alonso García, su actual poseedor, mandando que se haga saber al patrono y presentero que de él fuere para proveherle de nuevo. Su fecha, en León, a 5 de diciembre de 1668, ante Francisco González de Reyero, notario.

7. <Presentación en [el licenciado] Tomás Pérez. Año de 1669>.

Presentación del curato de San Pedro de Bolaños hecha por el maestro fray Bernardo de Estúñiga, abad de San Zoil, en el licenciado Tomás Pérez. Su fecha, en San Zoil, a 8 de enero de 1669, ante fray Francisco de Molina, notario apostólico. 


\section{8. <Presentación en Felipe Ybáñez. Año de 1669>.}

Presentación hecha por el mismo abad del curato de San Pedro de Bolaños, en el licenciado Felipe Ybáñez, clérigo de menores órdenes, el mismo día, mes y año y ante el mismo notario.

9. < Presentación en Juan de Almirante y sentencia del provisor en que confirma. Año de 1678 y $1679>$.

Presentación del curato de San Pedro hecha por el maestro fray Juan González, abad de San Zoil, en el licenciado Juan de Almirante y Linares, clérigo de menores órdenes. Su fecha, en San Zoil, a 8 de diciembre de 1678, ante fray Francisco de Molina, notario apostólico. Está aquí una sentencia del provisor de León, en que confirma esta presentación, hecha en el referido Juan Almirante, y manda se le despache título de colación. Su fecha, a 22 de junio de 1679, ante Pedro Ybáñez, notario en León.

10. $<$ Fe de la muerte [del cura] Almirante. Año de 1680>.

Fe de la muerte del licenciado Juan Almirante y Linares, cura de San Pedro de Bolaños, dada por el licenciado Martín García de Bárcena, racionero de la santa yglesia de León, en 18 de septiembre de 1680.

11. <Presentación en Marcos Díaz. Año de 1680>.

Presentación del curato de San Pedro de Bolaños hecha por el maestro fray Juan González, abad de San Zoil, en el licenciado Marcos Díaz, clérigo de menores órdenes. Su fecha, en San Zoil, a 20 de septiembre de 1680, ante Francisco de Dueñas, notario apostólico.

12. < Presentación en Juan de Ruiloba. Año de 1693>.

Presentación del curato de San Pedro hecha por el maestro fray Gregorio Ruiz, abad de San Zoil, en Juan de Ruiloba, clérigo de menores órdenes. Su fecha, en San Zoil, a 2 de octubre de 1693.

13. <Presentación en Fabián Panero. Año de 1694>.

Presentación del curato de San Pedro hecha por el maestro fray Gregorio Ruiz, abad de San Zoil, en Fabián Panero, presbítero, natural de Velilla de Guardo. Su fecha, en San Zoil, a 9 de enero de 1694, ante Norberto de Sandoval y Guevara, notario apostólico.

14. $<$ Despacho del provisor contra el cura de Bolaños, para que pague el patronato. Año de 1714>.

Despacho del provisor de León contra don Juan González, cura de San / (f. 70r) Pedro de Bolaños, para que pague 7 cargas de pan que estaba debiendo por razón del patronato. Su fecha, en León, a 19 de diciembre de 1714, ante Francisco Álvarez, notario apostólico. Notificósele este despacho y pagó.

15. <Copia simple de una sentencia del provisor sobre la presentación de este beneficio. Año de 1730>.

Copia simple de la sentencia dada por el provisor de León por la que declara pertenecer al abad de San Zoil la presentación del beneficio curado de San Pedro de Bolaños, sede pontificia vacante, y da por bien hecha la presentación que hizo dicho abad en don Manuel Ybáñez. Su fecha, en León, a 18 de agosto de 1730, ante Miguel González de Quevedo, notario.

16. <Papeles sobre el derecho de la presentación del curato de Bolaños>.

Bajo este número están unos papeles sobre el derecho que este monasterio tiene al patronato y presentación del curato de Bolaños, sede pontificia vacante, con sus preguntas y respuestas, escritos por el maestro fray Anselmo Pérez Cos, abad de San Zoil. 


\section{Quaderno D del legajo $2^{\circ}$ \\ Bustillo de Cea}

En este quaderno D están los papeles pertenecientes a la hacienda del monasterio en el lugar de Bustillo de Cea, por el orden siguiente: $1567>$.

$1^{\circ}<$ Adjudicación de los bienes de Antón Barba, lego de este monasterio. Año de

Sentencia dada por Juan de Rebenga, teniente de governador de la villa y jurisdicción de Cea, por la qual ampara y adjudica al monasterio en la posesión de los bienes que quedaron por muerte de Toribio Barba y pertenecieron a Antón Barba, fraile lego de este monasterio. Su fecha, en Cea, a 23 de mayo de 1567, ante Pedro de Tejerina, escribano de Su Magestad. Notificó esta sentencia a los testamentarios de Toribio Barba, Roco Muñoz, escribano y notario. Está aquí el ynventario y tasación de bienes que pertenecieron al dicho fraile lego.

\section{/ (f. 70v) Legajo $3^{\circ}$ del cajón San Benito \\ Nuestra Señora del Brezo}

Este legajo $3^{\circ}$ contiene los papeles pertenecientes a la vnión del Brezo con este monasterio; dotación de la capilla de Nuestra Señora, sus milagros, licencia para pedir limosna etcétera, por el orden siguiente:

$1^{\circ}$. <Posesión que tomó del Brezo fray Juan de la Masón, Año de 1484>.

Posesión que tomó del Brezo fray Juan de la Masón, monge de San Zoil, a 12 de marzo de 1484, en virtud de nombramiento que del dicho priorato y del de San Román hizo en él don Luis Hurtado de Mendoza, abad de San Zoil, a 3 de marzo del mismo año. Sacó este testimonio Gonzalo de Valerrábano, escribano de Su Magestad, a 7 de agosto de 1507.

\section{2. < Posesión que tomó del Brezo Fernando de Bustamante. Año de 1487>.}

Posesión que tomó del Brezo Fernando de Bustamante, monge y enfermero de San Zoil, por comisión y nombramiento de don Luis Hurtado de Mendoza, administrador de San Zoil, a 17 de enero de 1487, ante Juan de Villegas, escribano de Su Magestad. Está aquí por menor el ynventario de quanto halló en el Brezo, que era mui poco, por haberle robado su antecesor fray Juan de la Masón, a quien por lo mismo quitaron el priorato; y queriéndole prender se escapó a Roma, e impetró bullas de Su Santidad, para bolber a tomar la posesión del priorato, el que resignó después en manos de Su Santidad, como consta de la bulla que está abajo en el número $4^{\circ}$. de1508>.

3. <Mandamiento para dar la posesión del Brezo a fray Juan de la Masón. Año

Mandamiento de Gerónimo de Contreras, canónigo de Burgos, juez apostólico por comisión de la Santidad de Julio $2^{\circ}$, para poner en la posesión de la casa de Nuestra Señora del Brezo a fray Juan de la Masón, y que se le acuda con los frutos y rentas de ella, en virtud de una bulla que para ella havía alcanzado de Su Santidad. Su fecha, en Burgos, a 22 de diciembre de 1508, ante Juan Cortés, notario apostólico.

\section{4. <Bulla de vnión del Brezo a San Zoil. Año de 1519>.}

Bulla de León $\mathrm{X}^{\mathrm{o}}$, por la que haviendo resignado libremente fray Juan de la Masón, en manos de Su Santidad el priorato e yglesia de Nuestra Señora del Brezo, Su Santidad, a instancia de don Juan Rodríguez de Fonseca, arzobispo Rosano, obispo de Burgos y administrador perpetuo de la abadía de San Zoil, une y anexa la dicha casa y priorato del Brezo a la mesa abacial de San Zoil. Datum Malleam, Portuensis diocesis, anno yncarnationis Domini 1519 , tertio idus maii, pontificatus anno $7^{\circ}$. Ay aquí dos copias authorizadas de esta bulla.

\section{/ (f. 71r ) 5. < Posesión que tomó del Brezo Francisco de Nevantes. Año de 1520>.}

Posesión que tomó de la casa de Nuestra Señora del Brezo Francisco de Nevantes, en nombre y con poder de don Juan Rodríguez de Fonseca, arzobispo de Rosano, obispo de 
Burgos y administrador perpetuo de la abadía de San Zoil, en virtud de la bulla anterior de León Xo. Su fecha, en el Brezo, a 18 de agosto de 1520, ante Diego de San Zoles, notario apostólico.

6. <Dotación de la capellanía del Brezo por Gonzalo Ruiz de la Vega en 4.900 maravedís y 7 cargas de trigo. Año de 1518>.

Escritura de dotación de la capellanía de Nuestra señora del Brezo hecha por Gonzalo Ruiz de la Vega, como patrono que dice ser de ella, por la que en descargo de su conciencia y en cumplimiento de lo que mandó por su testamento el governador Diego Hurtado de la Vega, su padre, da para la dicha capellanía sobre 4 mill maravedís, que al tiempo de las partijas de la hacienda del governador se situaron en un censo del lugar de Carbonera ${ }^{78}$, y sobre otros 900 maravedís más que el dicho Gonzalo Ruiz de la Vega tenía sobre el mismo lugar de Carbonera, 3 cargas de trigo en su lugar de Baños, otra en Arenillas de San Pelayo, y otras 3 cargas de trigo en Villameriel, puestas en Arenillas de Nuño Pérez. Y en caso de que él o sus hijos dieren diez cargas de trigo puestas y situadas más cerca de la casa de Nuestra Señora, que le suelten por ellas las 7 cargas de trigo y los 900 maravedís de Carbonera, dando las 10 cargas de trigo en parte que valgan la mitad más y más cerca de la dicha casa. Todo lo qual cede y traspasa en fray Juan de la Masón, prior del Brezo, en nombre de la casa. Su fecha, en Nuestra Señora del Brezo, a 9 de septiembre de 1518, ante Alfonso Fernández, escribano y notario público. Ay copia authorizada. Hay aquí una nueva obligación del mismo señor sobre las 7 cargas de trigo. Año de 1539. molino $>$.

7. <Tanto simple de la escritura de arriba, de una sentencia y de la donación de un

Bajo este número está un ynstrumento sin authoridad, que contiene un tanto de la escritura de dotación anterior y de una sentencia contra el lugar de Carbonera, sobre los 4.900 maravedís de dicha dotación que pasó ante Jorje de Escovedo, escribano de Saldaña, año de 1519, a la qual falta una oja. Assimismo contiene la donación de un molino en el término de Castrillo de Renedo, en el valle y ribera de Valderadue, con el tributo de 3 fanegas de trigo a favor del marqués de Denia, que hizo a la casa del Brezo doña Ysabel Enrríquez, vecina de Santa María del Río, junto a Cea, año de 1491; también le falta una oja. El original se halla en el cajón San Gregorio, legajo $2^{\circ}$, quaderno B, número (sic).

/ (f. 71v) 8. <Testamento de doña Francisca Henrríquez de Tobar, muger del governador. Año de 1530>.

Testamento de doña Francisca Henrríquez de Tobar, señora de Vega de Riacos, muger del governador Diego Hurtado de la Vega, por el qual manda a la casa de Nuestra Señora del Brezo 1.500 maravedís de renta perpetua, situados sobre la renta que resultare de la venta de Arenillas de Nuño Pérez ${ }^{79}$, y más las viñas que esta señora tenía en el lugar de Bárcena, y una carga de trigo y otra de cebada de la renta que tenía de aforado en la yglesia de Muñeca, con carga de que digan una misa cada viernes ${ }^{80}$ de cada semana perpetuamente en la capilla de Nuestra Señora, donde se manda enterrar; y que en ella arda una lámpara todos los días de Nuestro Señor y de Nuestra Señora. Manda que se le digan algunas misas y treintenarios en el Brezo, para los quales señala limosna y ofrendas. Y por quanto confiesa haber recivido de fray Mauro de Ybarra, prior del Brezo, 5 mill maravedís en dinero, cede y traspasa en él y en la casa de Nuestra Señora todo el fuero y dominio que tenía en un solar y vasallo en Aviñante ${ }^{81}$, con todas sus posesiones, tierras, prados, casas, casares, molinos, árboles etcétera, que pertenecían al dicho solar y vasallo; y una casa en que vivía Pedro Fernández, con todos sus heredamientos. Nombra por testamentario principal al abad de San Zoil y manda que la comunidad de este monasterio vaya a su entierro y la den todo

\footnotetext{
${ }^{78}$ Carbonera] al margen derecho: Carbonera, Baños, Arenillas de San Pelayo, Villameriel.

${ }^{79}$ Arenillas de Nuño Pérez] al margen derecho: Arenillas de Nuño Pérez, Bárcena, Muñeca.

80 viernes] al margen derecho: Vna misa cada viernes.

81 Aviñante] al margen derecho: Aviñante
} 
quanto huviere menester. Su fecha, en Nuestra Señora del Brezo, a 4 de octubre de 1530, ante Cristóval Gómez de Valderrábano, clérigo, vecino de Aviñante y notario apostólico.

$<$ Ratificación del testamento. Año de 1533>.

Ratificacón que hizo la misma doña Francisca del anterior testamento ante el mismo notario, en Nuestra Señora del Brezo, a 13 de septiembre de 1533.

$<$ Codicilio de la misma señora. Año de 1537>.

Codicilio y última voluntad de la misma señora, por el qual revoca todo lo que mandó en el primer testamento, excepto lo mandado a Nuestra Señora del Brezo, que todo esto lo dexa en su fuerza y valor y lo ratifica de nuevo. Su fecha, en Vega de Riacos, a 27 de marzo de 1537, ante Diego Fernández de Congosto, escribano y notario público.

$<$ Declaración de los bienes que dio a sus hijos. Año de 1537>.

Síguese una declaración de los bienes que esta señora había dado a sus hijos, ante el mismo escribano, a 27 de agosto de 1537. Ay una copia authorizada del testamento, su ratificación y codicilio.

9. <Ynventario de alhajas $>$.

Memorial e ynventario de las alhajas que tenía la casa de Nuestra Señora del Brezo, visitándola fray Gaspar de Villarroel, presidente de San Zoil, y siendo prior del Brezo fray Francisco de Buitrón, a 26 de noviembre de 1535.

/ (f. 72r) 10. <Ynformación sobre el paso del ganado por Guardo. Año de 1550>.

Ynformación hecha por parte de fray Diego de León, prior del Brezo, ante Cristóval Gómez de Valderrábano, juez de comisión, por don Antonio de León, prior de Escalada, juez conservador, en un pleito contra Toribio Gutiérrez Escribano y Juan del Río, vecinos de Guardo, sobre que haviendo embiado el prior del Brezo su ganado a los páramos de Cea, y pasando por término de Guardo, los sobredichos salieron a la puente del dicho lugar y prendaron el ganado, tomándole un carnero y dos corderos, y llevaron presos a los pastores sin authoridad de justicia; de lo qual se querelló el dicho prior ante su juez conservador y se hizo esta información en el mes de diciembre de 1550, ante Juan Gutiérrez de Villanueva, clérigo y notario apostólico. Consta aquí que se restituió el ganado.

11. < Colación de las reliquias que dio Francisco Santoyo. Año de 1562>.

Licencia que dio fray Juan de Corcuera, abad de San Zoil, a fray Bernardo de los Ríos, prior del Brezo, para colocar en aquella casa unas reliquias que havía dado para ella Francisco de Santoyo, contador de la Cruzada de Su Magestad, con aprobación e ynformación hecha por don Pedro de Lagasca, obispo de Palencia, año de 1562. Estas reliquias que trajo el dicho Santoyo de Colonia, estaban en una caja redonda, guarnecida de oro y seda de colores, y debajo tafetán verde, cubiertas las reliquias con un viril de vidrio, y son las siguientes:

De la Magdalena.

De San Pedro mártir.

De San Blas obispo.

De Santa Ynés.

De diez mil mártires.

De Santa Vtilia Virgen.

De San Clemente papa.

De Santa Marta Virgen.

De la Cruz de Nuestro Señor.
De San Cristóval.

De las once mil vírgines.

De San Agustín obispo.

De Santa Bárbara Virgen.

De San Pablo mártir.

De San Juan mártir.

De Santo Domingo.

De Santa Catharina Virgen y mártir.

De San Alexo. 
De San Bartholomé. Y otras que no se pueden leer por estar escritas en lengua tudesca.

12. $<$ Concierto de los aniversarios de Valcobero. Año de 1582>.

Concierto que hizo fray Damián de Salas, prior del Brezo, con Alonso Santos de Arce, cura de Valcobero, sobre unos aniversarios que tenía el Brezo en la yglesia de este lugar, y se le debían al cura, los que satisfizo el prior, a 2 de febrero de 1582.

/ (f. $72 v)$ 13. $<$ Bulla de Paulo $5^{\circ}$ que concede varias yndulgencias a los cofrades de Nuestra Señora. Año de 1607>.

Bulla de Paulo $5^{\circ}$, escrita en pergamino, por la qual concede yndulgencia plenaria a los cofrades de Nuestra Señora del Brezo en el día que entraren a serlo, en el artículo de la muerte, y en la fiesta de la Natividad de Nuestra Señora, cofesando y comulgando, etcétera; y en el artículo de la muerte si no pudieren confesar y comulgar, estando verdaderamente contritos, si invocaren el dulce nombre de Jesús con el corazón si no pudieren con la boca. Ytem concede Su Santidad a los mismos cofrades, si contritos, confesados y comulgados visitaren la yglesia de aquel santuario en los días de la Anunciación de Nuestra Señora, Santa Cruz, San Matheo y San Miguel, 7 años y 7 seságenas de perdón de las penitencias por las culpas cometidas. Vltimamente concede a los dichos cofrades todas las veces que asistieren en dicha yglesia a los divinos oficios y misas rezadas o cantadas, o a juntas particulares o secretas de la dicha cofradía, o dieren posada a pobres, o hicieren paces con sus enemigos o de otros, o asistieren a los entierros de los difuntos, o a las procesiones que con licencia del ordinario hiciere dicha cofradía, o acompañaren el Santísimo Sacramento quando se lleva a los enfermos y en otras ocasiones, o si estando impedidos, oyendo la campanilla, rezaren una vez las oraciones del Padrenuestro y Ave María, o dijeren cinco veces la oración del Padrenuestro y otras tantas el Ave María por las ánimas de los difuntos de dicha cofradía, o redujeren alguna persona a carrera de salvación, o enseñaren a los ignorantes lo que deben saber para salvarse. Todas las veces que esto executaren y qualquiera cosa de ellas, les concede 60 días de yndulgencias y perdón de las penitencias impuestas por sus culpas. Datum Rome, apud San Petrum, anno 1607, kalendas martii, pontificatus anno tertio. Hay copia simple de esta bulla y de otra de Clemente Nono, que se hallara adelante al número 22.

14. <Fundación de la cofradía del Rosario. Año de 1609>.

Testimonio de la fundación de la cofradía del Rosario en Nuestra Señora del Brezo, hecha por el padre fray Domingo Daza, de la Orden de Santo Domingo, a $1^{\circ}$ de mayo de 1609, ante Diego de Cosío Bustamante, notario.

15. <Consulta sobre misas. Año de 1612>.

Consulta hecha en Roma y pareceres del doctor Roa Dávila y del maestro Salazar, sobre la rebaja de misas y sacar altar privilegiado. Año de 1612.

/ (f. $73 r)$ 16. <Fundación de 2 misas por el padre Perea. Año de 1619>.

Petición que presentó al abad de San Zoil el padre fray Plácido Perea, prior que havía sido de Nuestra Señora del Brezo, para que se depositase el alcance que havía hecho a la casa en sus qüentas finales, y que añadiendo él hasta 4.500 reales se emplease todo y se le dixesen por su intención 2 misas $^{82}$ perpetuamente, vna el día de nuestro padre San Benito y otra el día de San Plácido. El abad da su licencia y declara se funden las dos misas. Dada a $1^{\circ}$ de octubre de 1619, ante fray Benito de Aragón, su secretario.

17. <Calificación de los milagros de Nuestra Señora del Brezo. Año de 1621>.

Calificación de 29 milagros hechos por la gloriosíssima Virgen María Nuestra Señora del Brezo en diversos años, entre los inumerables que ha hecho desde el año de 1478 en que fue Dios servidose apareciese a unos pastores de Cáceres llamados Diego y Pedro del Brezo, estando en la ciudad de Cáceres, donde les avisó por tres veces que viniesen a las montañas de Liébana, a la parte donde llamaban la fuente del Brezo etcétera. Estos milagros están

822 misas] al margen derecho: 2 misas. 
aprobados y calificados por don Juan de Llano y Valdés, obispo de León, a instancia del padre fray Juan de Cisneros, precediendo las informaciones, juntas y consultas que dispone el Santo Concilio de Trento. Y hecha la dicha calificación, dio licencia el mismo obispo para que dichos milagros se publicasen, predicasen e imprimiesen. Su fecha, en León, a 26 de abril de 1621, ante Juan Baptista de Torres, escribano y notario de la audiencia episcopal de León. En virtud de esta calificación, el dicho fray Juan de Cisneros, siendo abad del monasterio de Nuestra Señora del Espino, escrivió los dichos milagros en cinco tablas que están en la yglesia de Nuestra Señora del Brezo ${ }^{83}$. Año de 1621.

18. <Ynformación original y calificación de milagros. Año de 1621>.

Ynformación y calificación de los milagros hechos por Nuestra Señora del Brezo. Hízose esta información, que es la original, por comisión del señor obispo de León, quien los calificó y aprobó en 24 de abril de 1621, ante Juan Baptista de Torres, notario de León.

19. <Sumario de los milagros de Nuestra Señora del Brezo>.

Bajo este número están tres sumarios o recopilaciones de los milagros de Nuestra Señora: el primero, que es de santo padre Cisneros, contiene 34 milagros; el segundo, firmado del reverendísimo Barrantes, contiene 40, los que certifica estar aprobados por los señores obispos de León en 12 de septiembre de 1623; y el tercero, que es anónimo, refiere 43 milagros.

/ (f. 73v) 20. < Auto para que el Brezo no pague sisa. Año de 1645>.

Auto de la justicia y comisarios de Millones, de la villa de Carrión, para que no se pague sisa del vino que se consumiere en el priorato de Nuestra Señora del Brezo. Su fecha, en Carrión, a 11 de octubre de 1645, ante Tomás Pérez, escribano en dicha villa.

21. < Fundación de la cofradía de Nuestra Señora del Brezo. Año de 1668>.

Fundación de la cofradía de Nuestra Señora del Brezo, condiciones y obligaciones que han de cumplir los cofrades. Su fecha, en el Brezo, a 15 de agosto de 1668, ante Diego Ruiz Martínez, escrivano de Becerril y notario apostólico. de $1668>$.

22. $<$ Copia simple de la bulla de Clemente $9^{\circ}$ de yndulgencias para los cofrades. Año

Copia simple de la bulla de Clemente $9^{\circ}$ por la qual concede a los cofrades de Nuestra Señora yndulgencia plenaria, en el día que entraren cofrades, en el artículo de la muerte, invocando el nombre de Jesús con el corazón si no pudieren con la boca, o dando alguna señal de penitencia; y en el día de la Asunción de Nuestra Señora confesando y comulgando etcétera. Expidiose la bulla original en Roma, idibus junii, anno 1668.

23. <Licencia para bendecir la hermita de San José. Año de 1763>.

Licencia dada por don Juan Álvarez Osorio, obispo de León, para bendecir la ermita de San José, que havía edificado a sus expensas el padre prior fray Matheo de Raigadas, junto al priorato de Nuestra Señora del Brezo, erigir altar y celebrar en ella el santísimo sacrificio de la misa. Su fecha, en San Román, a $1^{\circ}$ de julio de 1673, ante don Francisco Ferrer, su secretario.

\section{4. < Súplica para sacar a Nuestra Señora en procesión. Año de 1691>.}

Carta de los 24 concejos en que piden licencia para sacar a Nuestra Señora en procesión. Su fecha, en Castrejón, a 18 de mayo de 1691.

\section{5. <Licencia para pedir limosna para Nuestra Señora del Brezo>.}

Bajo este número están las licencias siguientes para pedir limosna: dos del Consejo Real, para pedir limosna en los obispados de León y Oviedo; tres de los comisarios de Cruzada; una del arzobispo de Burgos, quatro de los obispos de Palencia y dos de León. Dadas todas en varios años.

\footnotetext{
${ }^{83}$ Brezo] escrito sobre Espino.
} 
26. $<$ Relación de la hacienda de Nuestra Señora del Brezo $>$.

Dos relaciones simples en las que se da noticia de la hacienda que tiene el santuario de Nuestra Señora del Brezo en varios lugares.

27. <80 días de yndulgencia. Año 1803>.

Yndulgencia que concedió el arzobispo de Burgos. Año 1803.

\section{Remisiones} quaderno B.

Hacienda del Brezo en el lugar de las Heras. Véase el cajón San Lorenzo, legajo $2^{\circ}$,

Testamento de don Diego de Colmenares que puede pertenecer al Brezo. Cajón San Estevan, legajo $1^{\circ}$, quaderno $\mathrm{E}$, número $1^{\circ}$.

$8^{\circ}$

Compra de prados, casa y huerta. Cajón San Estevan, legajo $3^{\circ}$, quaderno A, número

Compra de tres prados en el lugar de Valcovero. Cajón San Gregorio, legajo $2^{\circ}$, $<$ quaderno $\mathrm{A}>$, números $1^{\circ}, 2^{\circ}$ y $3^{\circ}$.

Otra compra. Véase el mismo cajón y legajo, quaderno C.

Hacienda del Brezo en Santiváñez. Cajón San Martín, legajo 1º quaderno C.

\section{/ (f. 74r) Legajo $4^{\circ}$ del cajón San Benito}

Este legajo, que es el $4^{\circ}$, contiene 5 quadernos, que son los siguientes:

Quaderno A Calzada.

Quaderno B Calzadilla.

Quaderno C Camporedondo.

Quaderno D Carbonera.

Quaderno E Cardeñosa.

Quaderno A del legajo $4^{\circ}$

\section{Calzada}

Este quaderno A contiene los papeles pertenecientes a la hacienda que este monasterio tiene en este lugar, por el orden siguiente:

$1^{\circ}<$ Foro de 15 maravedís sobre 3 tierras. Año de 1408>.

Escritura de foro perpetuo por la qual el monasterio da a Juan Fernández de Relea, vecino de Carrión, 3 tierras, una en término de Calzada, a la fuente que dicen de Baíllo, y dos en término de San Mamés, en el pago que llaman de Azedo ${ }^{84}$, por 15 maravedís de foro cada año. Su fecha, en San Zoil, a 25 de enero de 1408, ante Garcí Fernández, escribano de Carrión. Hay copia authorizada.

${ }^{84}$ Azedo] al margen derecho: San Mamés. 
2. <Requirimiento para apreciar el molino de Palacios. Año de 1424>.

Requirimiento que hizo el monasterio a Diego Sánchez, tundidor, vecino de Carrión y arrendatario de los molinos de Palacios y de la Serna, para que nombrase apreciador de los aparejos del molino de Palacios, que estaba cayéndose y se quería hacer de nuevo. Su fecha, en Carrión, a 5 de mayo de 1424, ante Rui García, escribano de Carrión.

\section{/ (f. 74v ) 3. < Requirimiento para apreciar el molino de Palacios. Año de 1425>.}

Requirimiento que hizo el monasterio al mismo Diego Sánchez para que nombrase un apreciador que, junto con el del monasterio, apreciasen el molino de Palacios, nuevamente compuesto. Su fecha, en Carrión, a 31 de enero de 1425, ante Rui García, escribano de Carrión.

\section{4. $<$ Compra de 6 tierras por 6.200 maravedís. Año de 1449>.}

Compra que hizo el monasterio a Pedro de Argüello, vecino de Carrión, de 6 tierras en término de Calzada, la $1^{\text {a }}$ cerca del molino de Antequina, de 5 obradas, otra a Carre Herreros, de $1^{a}$ obrada, otra al Pumar, de obrada y media, otra a Mojarrabas, de obrada y media, y otra linde de ésta, de poco más de media obrada, y otra a los Tejadillos, por precio de 6.200 maravedís. Su fecha, en San Zoil, a 24 de marzo de 1449, ante Gómez González de Carrión, escribano público. Hay copia authorizada.

\section{5. <Compra de 2 tierras por 2.300 maravedís. Año de 1476>.}

Compra que hizo el monasterio a Pedro Calahorra, vecino de Calzada, de 2 tierras en término del mismo lugar, junto al molino de la Serna, hacia el Páramo, que hacen 4 obradas, poco más o menos, por precio de 2.300 maravedís. Su fecha, en San Zoil a 12 de diciembre de 1476, ante Fernando Cavallo, escrivano de Carrión. Hay copia authorizada.

\section{6. <Trueque de una tierra por un prado. Año de 1477>.}

Trueque que hizo el monasterio con Alfonso García de Villasur, limosnero mayor del mismo monasterio, de una tierra de media obrada en término de Carrión, junto al molino del Pisón, por un prado que dicho limosnero le dio en término de Calzada, junto al molino de Palacios. Su fecha, en San Zoil a 20 de abril de 1477, ante Fernando Cavallo, escribano de Carrión.

\section{7. $<$ Requirimiento sobre la libertad de unas tierras. Año de 1477>.}

Requirimiento que hizo el monasterio al concejo de Calzada sobre la libertad de las heredades que havía comprado a Pedro de Calahorra, que son las del número $5^{\circ}$. Su fecha, en Calzada, a 30 de diciembre de 1477, ante Fernando Cavallo, escribano de Carrión.

8. <Compra de una tierra por 850 maravedís. Año de 1478>.

Compra que hizo Zoil de Nogal, sacristán mayor de San Zoil, a Pedro Escudero, vecino de Calzada, de una tierra en término del mismo lugar, al camino de Villotilla, de 3 obradas, poco más o menos, por precio de 850 maravedís. Su fecha, en San Zoil, a 12 de marzo de 1478, ante Fernando Cavallo, escribano de Carrión.

\section{/ (f. 75r) 9. < Memoria simple>.}

Memoria simple de los gastos hechos por un molinero en el molino de la Serna, sito en la rivera de Calzada. Año de 1570.

10. <Compra de 6 tierras por 9 mill maravedís y extinción de un foro de 6 quartos de trigo y 4 gallinas. Año de 1583>.

Compra que hizo el monasterio a Alonso Merino, vecino de Calzada, de 6 tierras, la una de 5 quartas y 34 palos, al camino de Abanciles, otra de 2 obradas y 48 palos, al Sotillo, otra de media obrada y 33 palos, a la laguna de don Pedro, otra de media obrada y 10 palos, al Hierro, otra de 5 quartas y 70 palos, al Oyo, y otra de 120 palos a la cavaña que llaman de la Lámpara de San Zoil, por precio de 9 mill maravedís; y con la extinción de un foro de 6 quartos de trigo y 4 gallinas que tenía contra sí el dicho Alonso Merino. Su fecha, en San Zoil, a 16 de junio de 1583, ante Andrés Sánchez, escribano de Carrión. 
11. < Requisitoria para cobrar la renta del molino de Palacios. Año de 1607>.

Requisitoria despachada por el licenciado don Leonardo de Quevedo, alcalde mayor de Carrión, para prender y cobrar de un molinero de Palacios la renta que debía al monasterio por el molino y tierras. Su fecha, en Carrión, a 11 de julio de 1607, ante Alonso Zapata, escribano de Carrión.

12. <Querella contra los de Calzada sobre el daño de una tierra y porte de zéspedes. Año de 1673>.

Proceso original de una querella dada por parte del monasterio contra el concejo y vecinos de Calzada porque no limpiaban el cuérnago, de que se seguía destruir una tierra junto al molino de Palacios, pretendiendo por este medio hacerla pastiza, y assimismo porque impedían a los criados del monasterio y a sus obreros cortar zéspedes y portearles para sus molinos, con otras cosas que se acumularon y consta de dicho pleito. Hízose probanza por ambas partes ante Norberto de Sandoval y Guevara, escribano de Carrión, en los años de 1673 y 1674 . A este pleito le falta la sentencia.

13. Compra de una casa por 520 reales. Año de 1732>.

Compra que hizo el monasterio a Santiago Carnizero, vecino de Calzada, de una casa en el mismo lugar, por precio de 520 reales. Su fecha, en Carrión, a 17 de mayo de 1732, ante Agustín Díez de Castro, escribano de Carrión. Está unida a esta escritura la de compra que hizo el mismo Santiago Carnicero a Francisco Álvarez, vecino de Carrión, otorgada en el mismo día, mes y año, y ante el mismo escribano.

14. <Pleito sobre concurrir a la monda y repartimiento de aguas del cauce de Benevivere $>$.

Testimonio en relación del pleito seguido a instancia de Santos $<$ Blanco $>$ y Gregorio Melendro, regidores de la Rivera de Benevivere, a quienes se agregaron los demás molineros de dicha rivera y el monasterio de Santa María de Benevivere, contra Pedro Miguel, arrendatario del molino de la Serna, / (f. 75v) propio de este monasterio de San Zoil, que también salió a la causa, sobre la paga de 108 reales y 2 maravedís en que había sido multado, según ordenanzas de aquella rivera, por no haber concurrido a los puertos y corta de obas; y assimismo por los repartamientos del saco de aguas para su cauce en los años de 1790 y 91, y también sobre que a dicho molinero de la Serna se le obligase a concurrir a dichas cargas en lo sucesivo.

\section{$<$ Compromiso $>$.}

Siguiose la causa hasta la definitiva y antes de darse la sentencia, las dos referidas comunidades comprometieron la causa en los licenciados don José y don Juan Fernández de Toledo, abogados de esta villa de Carrión, obligándose ambos monasterios a no reclamar de su sentencia, pena de 1 mill ducados que se habían de dar a la parte obediente.

$<$ Sentencia contra este monasterio y el arrendatario del molino. Año de 1798>.

Acetado el compromiso por dichos abogados, dieron su sentencia arbitraria, en 8 de mayo de 1798, por la que, sin embargo de declarar que el dicho molino se halla situado en la rivera de Calzada, es parte integrante de la de Benevivere, y por lo mismo condenan a dicho molinero y a este monasterio en todo lo contenido en la demanda. Pasó este pleito ante Miguel López, escribano de Carrión, quien sacó este testimonio a 21 de junio de 1800.

\section{Remisiones}

$<3$ tierras en Calzada $>$.

Trueque que hizo el monasterio con el concejo de Villarramiel, por el qual le dieron al monasterio 3 tierras en término de Calzada. Año de 1464. Véase el cajón San Plácido, legajo $5^{\circ}$, quaderno $\mathrm{G}$, número $3^{\circ}$. 
$<$ Compra de tierras en Calzada $>$.

Compra de tierras en Calzada. Año de 1649. Véase el cajón San Zoil, legajo 2º quaderno $\mathrm{A}$, número (sic).

$<$ Foro de una tierra en término de Calzada $>$.

Foro de 32 maravedís sobre una tierra en término de Calzada, a favor del hospital de San Lázaro. Véase el cajón San Andrés, legajo 4º quaderno A, número $5^{\circ}$.

$<$ Foro sobre una tierra en término de Calzada $>$.

Foro sobre una tierra en término de Calzada. Véase el cajón San Lorenzo, legajo $3^{\circ}$, quaderno $\mathrm{B}$, número $5^{\circ}$.

\section{/ (f. 76r) Quaderno B del legajo $4^{\circ}$ \\ Calzadilla}

Este quaderno B contiene los papeles pertenecientes a la hacienda que tiene este monasterio en este lugar, por el orden siguiente:

$1^{\circ}$. $<$ Restitución de un pedazo de tierra. Año de 1406>.

Escritura por la qual Gonzalo Campos, vecino de Calzadilla del Camino, restituye a don Rodrigo, limosnero mayor de San Zoil, un pedazo de tierra en que se havía intrusado. Su fecha, en Carrión, a $1^{\circ}$ de abril de 1406, ante Gutierre Fernández, escribano de Carrión.

2. < Foro perpetuo de 6 maravedís y 2 gallinas. Año de 1407>.

Escritura por la qual don Rodrigo, limosnero mayor de San Zoil, con licencia de don Fernando, prior mayor de él, da a foro perpetuo a Gonzalo Pérez, vecino de Calzadilla del Camino, una tierra en término del mismo lugar, cerca de la aldea, por 6 maravedís y 2 gallinas de renta cada año. Su fecha, en San Zoil, a 10 de abril de 1407, ante García Fernández, escribano de Carrión. $1673>$.

3. <Trueque de un pedazo de campo por una herrén y un poco de prado. Año de

Trueque entre este monasterio y el licenciado Mathías Gómez, cura de Calzadilla, por el qual éste dio al monasterio una herrén en dos pedazos y un poco de prado, a los Campillos, por un pedazo de campo que el monasterio le dio junto a la fuente del dicho lugar. Su fecha, en San Zoil, a 8 de abril de 1673, ante Norberto de Sandoval y Guevara, escribano de Carrión.

\section{/ (f. 76v) Quaderno C del legajo $4^{\circ}$ \\ Camporredondo}

Este quaderno $\mathrm{C}$ contiene los papeles pertenecientes a la hacienda que tiene el priorato de San Román en este lugar, por el orden siguiente:

$<$ Nota $>$

La donación de hacienda en este lugar hecha a San Román por don Gómez García, en la era 1260, que es año de 1222 , está en el cajón San Lorenzo, legajo $4^{\circ}$, número $1^{\circ}$.

$1^{\circ}<$ Compra de un prado por precio de 1.500 maravedís. Año de 1545>.

Compra que hizo fray Pedro de Sahagún, prior de San Román, a Juan Escudero, de un prado en término de Camporredondo, al Rivero, por precio de 1.500 maravedís. Su fecha, en Camporredondo, a 12 de junio de 1545, ante Cristóval Gómez, notario apostólico. Hay copia authorizada. 
2. $<$ Compra de un prado por precio de 66 reales. Año de 1611>.

Compra que hizo fray Juan Díez, prior de San Román, a Gutierre de Herrera, vecino de Camporredondo, de un prado en término de Santa Ofemia, al término de Camporredondo, por precio de 66 reales. Su fecha, en Velilla, a 29 de noviembre de 1611, ante Francisco Valiente, escribano de Guardo. Hay copia authorizada.

\section{/ (f. 77r) Quaderno D del legajo $4^{\circ}$ Carbonera}

Este quaderno contiene los papeles pertenecientes a la hacienda que tiene San Román en este lugar, por el trueque que hizo con el Brezo en el año de 1581, y se halla entre los papeles de Villafría, cajón San Plácido, legajo $1^{\circ}$, quaderno A, número 23.

$<$ Nota. Donación de hacienda. Año de 1518>.

La donación de 4.900 maravedís hecha en este lugar por don Gonzalo Ruiz de la Vega, año de 1518, está en esta cajón, legajo $3^{\circ}$, número $6^{\circ}$. Los demás papeles se hallan por el orden siguiente:

\section{$1^{\circ} .<$ Demanda del prior del Brezo. Año de 1561>.}

Carta executoria ganada en el Adelantamiento de Campos por la casa de Nuestra Señora del Brezo contra el concejo de Carbonera, por la qual consta que en la villa de Cuenca de Campos, a 26 de febrero de 1561, se presentó ante el licenciado Arriega, alcalde mayor de Adelantamiento, fray Juan Argadero, prior del Brezo, querellándose criminalmente del concejo de Carbonera porque, estando en posesión inmemorial dicha casa del Brezo de percivir en cada un año del concejo y vecinos 4.900 maravedís, y estando assimismo en posesión dicha casa de que no pagándole esta cantidad, nombraba el prior una persona que le sacase prendas por ella, vsando de esta posesión, por no haberle pagado en dos años continuos, les prendó cinco vacas y las llevó al priorato. Quejáronse los vecinos de los criados del prior al alcalde de la Hermandad y por fuerza volvieron las vacas a sus casas. Por esto pidió el prior que, declarando estar la casa del Brezo en quieta y pacífica posesión de cobrar los dichos 4.900 maravedís del dicho concejo y vecinos y poder prender, sea amparada y defendida en ella, condenando a los contrarios en las penas de derecho y a que paguen los dos años que debían. Admitiose la querella; hízose la información por parte del prior, en virtud de la qual fueron presos Rodrigo González y Pedro de Villareal, vecinos de Carbonera, quienes negaron la demanda y se quejaron de haberles tomado las vacas. Citose al concejo, hizo su probanza, y pidió / (f. $77 v)$ se le declarase no ser parte en esta causa.

$<$ Donación de don Gonzalo Ruiz de la Vega $>$.

Hizo el priorato su probanza y presentó la escritura de dotación de la capilla de Nuestra Señora del Brezo hecha por don Gonzalo Ruiz de la Vega, hijo del governador Diego Hurtado de la Vega, por la que hace donación, entre otras cosas, de 4.900 maravedís, que tenía sobre los vecinos de Carbonera, cuya escritura está en el legajo $3^{\circ}$ de este cajón número $6^{\circ}$, y se halla también compulsada en esta executoria a folio $5^{\circ}$ vuelto.

$<$ Sentencia definitiva a favor del Brezo. Año de 1563>.

Y conclusa la causa en 29 de abril de 1563, el dicho alcalde mayor, pronunció sentencia definitiva, por la qual condena al concejo y vecinos de Carbonera a que dentro de 6 días, de cómo sean requeridos con la carta executoria, paguen al prior y casa del Brezo en cada un año para siempre jamás los 4.900 maravedís que tiene de censo y tributo sobre los vecinos de dicho lugar; y que consientan que el prior y quien su poder huviere, les prende en sus ganados y bienes por la dicha cantidad quando no la pagaren; y ampara al prior en la posesión de hacer las dichas prendas por su authoridad sin pena alguna. De esta sentencia apeló el concejo y por no haber mejorado la apelación le requirió el prior para que trajese la provisión, y el concejo dio poder para apartarse, consintiendo en que la sentencia dada se guarde y lleve a pura y debida execución y se diese carta executoria de ella, en cuya virtud el procurador del concejo hizo el apartamiento en forma ante el dicho alcalde mayor. 


\section{$<$ Carta executoria. Año de 1564>.}

El priorato pidió se le diese carta executoria y se le dio la presente, en la villa de Cuenca, a 15 de abril de 1564, firmada del licenciado Ruiz, ante Juan de Torizes, escribano. Siguen a esta executoria algunos mandamientos executorios de la justicia de Saldaña sobre la paga de los mismos maravedís, y una sentencia del año 1681.

2. < Sentencia a favor de San Román sobre la paga de los 4.900 maravedís de Carbonera. Año de 1797>.

Testimonio en relación del pleito contra el concejo y vecinos de Carbonera sobre haberse(n) negado a la paga de los 4.900 maravedís, que hacen 144 reales y 4 maravedís, y que cada año deben satisfacer al priorato de San Román, a lo que fueron condenados con costas por auto definitivo dado por el licenciado don Mathías Morales, correxidor de Saldaña, a 6 de septiembre de 1797, ante Ygnacio de la Puente, escribano de la misma villa. Y por el mismo fue dado este testimonio en 16 de julio de 1798.

3. <Carta executoria a favor de San Román sobre los 144 reales y 4 maravedís. Año de $1802>$.

De esta sentencia apeló el concejo de Carbonera, diciendo que, sin embargo de la posesión inminente en que se hallaba el priorato de San / (f. $78 r$ r) Román de percivir la cantidad de 4.900 maravedís, que componen 144 reales y 4 maravedís, se encuentran en la sospecha de ser su contribución infundada; y que para cerciorarse de la verdad necesitan se les manifieste el ynstrumento primordial en que se funde el censo o foro perpetuo, porque se hallan sin hipotecas que le aseguren. Se contestó por la parte de San Román, y habiendo expuesto ambas partes sus razones y presentado documentos, se hizo ver el derecho que el priorato de San Román tiene de percibir los citados 144 reales y 4 maravedís por donación que de ellos hizo al priorato del Brezo don Gonzalo Ruiz de la Vega, señor de Bárcena y Carbonera, como así consta de los instrumentos compulsados en el proceso, igualmente que una escritura de venta presentada por dicho concejo hecha por el licenciado don Gonzalo, por la qual vende a Juan de Cosío y doña Juana de Mier, su muger, cinco cargas de pan que él tenía en el referido Carbonera, y para asegurárselo hipoteca especialmente seis carneros nuebos, doce gallinas bibas, dos docenas de quesos asaderos, dos matas de leña, 100 maravedís en dinero, que así mismo tiene so $<$ bre $>^{85}$ el lugar de Carbonera y varios vecinos de él, una suerte de tierra y las tercias de los diezmos de pan de la yglesia de dicho lugar. Por lo qual es bien de conocer que dicho don Gonzalo tenía señorío y propiedades en el referido Carbonera, lo que no ignoraban los vecinos de éste; pero alegaban que dichas propiedades y señorío había sido vendido, según otra escritura de venta presentada por su parte, hecha por don García Manrrique de la Vega, en que hace cesión al concejo de Carbonera de este lugar, sus términos, montes, pastos y abrebaderos etcétera. Y contestando la parte del priorato de San Román, se hizo conocer el error que padecían, pues aunque don García había enagenado parte de sus fincas y derechos, no se registraba ni se hallaba el de el citado canon; y aunque se hallase, nada le favorecía, porque en tal caso estaba bien manifiesto el estelionato que habría cometido el dicho don García por haber vendido lo que no era suyo. Por lo que habida la causa por conclusa por ambas partes, el licenciado don Mathías Morales, corregidor de Saldaña, en 17 de diciembre de 1800 dio i pronunció sentencia difinitiva, condenando al concejo y vecinos de Carbonera a la paga de los 144 reales y 4 maravedís y en todas las costas, imponiéndoles perpetuo silencio, y amparando en la quieta y pacífica posesión y propiedad al prior de san Román. De esta sentencia apeló el concejo a la Real Chancillería de Valladolid, y vistos los autos y méritos del proceso por los señores presidentes y oidores de ella, pronunciaron sentencia difinitiva, pasada en cosa juzgada, por la qual confirman en todo y por todo la dada por el corregidor de Saldaña. Fue dada por don Francisco María Fita, don Manuel María Cambronero y don Manuel María de Junco, presidente e oidores, en Valladolid, a 9 de abril de 1802, en que fue librada esta executoria, ante don Manuel Hortega Álbarez, escribano de cámara.

\footnotetext{
${ }^{85}$ so $<$ bre $>$ ] so escrito sobre en
} 


\section{/ (f. 78v) Quaderno E del legajo $4^{\circ}$ Cardeñosa}

Este quaderno $\mathrm{E}$ contiene los papeles pertenecientes a la hacienda y diezmos que tiene este monasterio en este lugar, por el orden siguiente:

$<$ Nota. Donación de la yglesia. Año de 940>.

La donación de la yglesia de San Juan de este lugar por Diego Moñíz y su muger, doña Tigridia, (condes de Saldaña), en el año 940, está con los papeles de San Román, cajón San Martín, legajo $1^{\circ}$, quaderno A, número $1^{\circ}$.

$<$ Donación de hacienda. Año de 1118>.

La donación de hacienda hecha a San Zoil por doña Mayor García, año de 1118, está en el cajón Santa María, legajo $1^{\circ}$, quaderno A, número $2^{\circ}$.

\section{$1^{\circ}<$ Foro 25 maravedís y una gallina. Año de 1417>.}

Escritura, en pergamino, por la qual don Fernando, prior mayor de San Zoil, da a Martín Fernández, vecino de Cardeñosa, una tierra de obrada y media, a tras San Pedro, para plantarla de viña, y dos suelos para edificar casas, todo en término de Cardeñosa, por 25 maravedís y una gallina de foro perpetuo cada año. Su fecha, en Cardeñosa, a 30 de noviembre de 1417, ante Gonzalo Gómez, escribano y notario público.

\section{2. <Demanda sobre el sesmo de los diezmos de Cardeñosa $>$.}

Sentencia sobre el sesmo de los diezmos mayores y menores que el monasterio de San Zoil tiene en el lugar de Cardeñosa y sus términos, por la qual parece que Juan García, mayordomo de San Zoil, puso demanda ante Gonzalo García de Antezo, vicaro del arcipreste de la Cueza, a Fernán Martínez y Pedro Alfonso, porque habiendo cogido los diezmos mayores y menores del lugar de Cardeñosa, el año de 1436, y teniendo en su poder el sesmo de ellos que pertenecía al monasterio, no se le querían dar; los quales respondieron ser cierto que estaba en su poder el dicho sesmo pero que no les constaba que perteneciese al monasterio, que probase como se le debía y se le entregarían. El mayordomo probó con escrituras y testigos que pertenecía al monasterio dicho sesmo, y le había llevado de tiempo inmemorial.

\section{$<$ Sentencia a favor del monasterio. Año de 1437>.}

Alegaron / (f. 79r) las partes, y conclusa la causa, en conformidad y consentimiento de ambas, el dicho vicario dio sentencia definitiva, por la qual declaró ser debido al monasterio de San Zoil cada año el sesmo de todos los diezmos mayores de pan, vino y ganado e menudos que huviese de los frutos que se cogiesen en todos los términos del lugar de Cardeñosa; y mandó a los dichos colectores le acudan con los frutos tocantes al sesmo de dicho año de 1436 que estaban en su poder, y les condenó en las costas, y mandó a los colectores que fuesen de allí adelante que acudan al monasterio con dicho sesmo libremente y sin pleito alguno. La qual sentencia se dio con acuerdo de buenos letrados, en presencia de las partes, en el barrio de San Zoles, a 20 de junio de 1437, ante Gutierre Fernández de San Zoles, escribano de Carrión, a quien fueron entregados los registros de Gonzalo González de Cisneros, escribano público de Raveros, ante quien havía pasado. Está unida a esta escritura una copia authorizada por fray Francisco de Molina, notario apostólico, a 31 de julio de 1663.

\section{3. $<$ Carta sobre el noveno $>$.}

Carta de Bernardo Clemente escrita al padre fray Antonio del Valle sobre el noveno de Cardeñosa. Año de 1614.

\section{4. $<$ Desembargo del noveno de Cardeñosa. Año de 1669>.}

Proceso y autos originales ante el abad de Benevivere, juez conservador, sobre el desembargo del noveno de los diezmos que havía embargado el señor obispo de Palencia, prohibiendo que se entregase al monasterio. Éste hizo su información, con varios testigos, de la posesión en que se hallaba de percivir dicho noveno y compulsó la concordia con el obispo y cavildo de Palencia, hecha año de 1228 (que está en el cajón San Andrés, legajo 1º, 
quaderno B, número $3^{\circ}$ ). En vista de estos ynstrumentos y el Libro de Oro de la Cathedral de Palencia, el señor obispo desembargó dicho noveno, mandando que de allí adelante se acudiese con él al monasterio. Su fecha, en Palencia, a 13 de diciembre de 1669, ante don Bernardo de Rezola, su secretario.

\section{5. <Presentación en el licenciado Lucas Antón. Año de 1673>.}

Presentación del beneficio curado de San Juan de Cardeñosa, hecha por el maestro fray Bernardo de Estúñiga, abad de San Zoil, en el licenciado Lucas Antón. Su fecha, en San Zoil, a 30 de septiembre de 1673, Ante fray Francisco de Molina, notario apostólico.

\section{Remisiones}

Concordia entre este monasterio, el de San Ysidro y San Román / (f. 79v) de Entrepeñas, con el señor obispo de Palencia y cavildo de esta santa yglesia, sobre diezmos y presentaciones de beneficios de este obispado. Cajón San Andrés, legajo $1^{\circ}$, quaderno B, número $3^{\circ}$. De esta concordia consta que en este lugar había dos yglesias, una intitulada Santa María, que pertenecía a San Zoil, con la presentación del beneficio y un noveno; otra, San Juan, que pertenecía al priorato de San Román de Entrepeñas, con la presentación de su beneficio y un noveno.

Trueque de heredades. Véase el cajón San Yldefonso, legajo $3^{\circ}$, número $13^{\circ}$ y siguientes. Ydem. Amojonamiento etcétera ${ }^{86}$, adelante.

86 etcétera] sigue tachado: legajo. 


\section{/ (f. 80r) Cajón $4^{\circ}$ San Pedro \\ Letra C}

Este cajón San Pedro, que es el $4^{\circ}$ del archivo, contiene quatro legajos pertenecientes todos a este monasterio de San Zoil: Legajo $1^{\circ}$ : Bullas pontificias y vnión a la Congregación; legajo $2^{\circ}$ : Privilegios reales tocantes a este monasterio; legajo $3^{\circ}$ : Privilegios reales sobre la jurisdición del barrio de San Zoles; legajo $4^{\circ}$ : Privilegios reales y señorío del Agua del Cuérnago.

\section{Legajo $1^{\circ}$}

Este legajo contiene los dos quadernos siguientes: Quaderno A: Bullas y concesiones pontificias y otros papeles pertenecientes a este monasterio como miembro de Cluni; quaderno B: Bullas de nombramientos de abades comendatarios de este monasterio hasta su vnión inclusive a la Congregación de San Benito de Valladolid.

\section{Quaderno A del legajo $1^{\circ}$}

Este quaderno contiene bullas pontificias y otros papeles tocantes a este monasterio, por sí y como miembro de Cluni, por el orden siguiente:

$1^{\circ}$ Bulla del cardenal Jacinto. Recive al monasterio baxo la protección de la Sede Apostólica. Año 1173>.

Bulla ${ }^{87}$ del cardenal Jacinto, legado del papa Alexandro $3^{\circ}$, escrita en pergamino, con sello de cera pendiente, por la qual admite a Humberto, prior de San Zoil y camarero de Cluni, con el monasterio y sus bienes, bajo la protección de la Sede Apostólica; y manda bajo graves penas que si algún arzobispo, obispo, prelado entrare en el monasterio y quisiere celebrar, las ofrendas que se hizieren sean para los monges y el tal prelado no pueda disponer de ellas sin licencia del superior del monasterio. Datum Palentie, 12 kalendas decembris, anno ab Yncarnatione Domini 1173.

/ (f. $80 v)$ 2. $<$ Bulla del papa Clemente $3^{\circ}$. Protección y gracias concedidas a Cluni y a sus anexos. Año de 1187>.

Copia authorizada por Juan, arzobispo de Viena, y Juan, obispo Bellicense, escrita en pergamino, con dos sellos de cera pendientes, de una bulla original del papa Clemente $3^{\circ}$, por la qual admite al monasterio de San Pedro de Cluni, con todos sus anexos y filiaciones, personas y bienes, bajo la protección de la Sede Apostólica; hace libres y confirma los territorios de los monasterios con todos los bienes y posesiones que les han dado los príncipes y otras personas; que no paguen diezmo de los Novales y de lo que cultivaren por sí o a sus expensas; que puedan recivir a los que huyan del siglo, assí clérigos como legos; que los profesos no puedan dexar la religión sino por otra más estrecha, con licencia del abad, y que nadie los reciba; que qualquiera se pueda enterrar en los monasterios y nadie lo contradiga; que nadie perturbe ni agravie a los monasterios ni les quite sus bienes y hacienda. Datum Laterani, $5^{\circ}$ kalendas martii, Yncarnationis Dominice anno 1187, pontificatus anno $1^{\circ}$. Esta copia se dio año de 1260. $1200>$.

3. $<$ Bulla de Ynocencio $3^{\circ}$. Que los familiares traigan las llaves de San Pedro. Año de

Bulla ${ }^{88}$ del papa Ynocencio $3^{\circ}$, escrita en pergamino, con sello de plomo pendiente, por la qual concede al monasterio de San Zoil, como miembro de Cluni, que sus conversos y criados puedan trhaer las llaves de San Pedro. Datum Laterani, nonas iunii, pontificatus anno $3^{\circ}$, que es año de Christo 1200. Ay una copia al número 11.

\footnotetext{
${ }^{87}$ Bulla] al margen derecho: falta.

${ }^{88}$ Bulla] al margen derecho: Falta, pero hay una copia simple: Legajo de bulas.
} 
4. $<$ Bulla de Gregorio 9 ${ }^{\circ}$. Que sólo los visitadores nombrados por el capítulo visiten los monasterios de Cluni. Año de 1236>.

Copia authorizada, escrita en pergamino, de una bulla ${ }^{89}$ del papa Gregorio $9^{\circ}$, por la qual concede al monasterio de San Pedro de Cluni, que, atento a que en los capítulos que celebraban anualmente nombraban visitadores que visitasen su monasterio y anexos, no estén obligados a admitir otros visitadores sino los elegidos por su capítulo, sin especial licencia de la Sede Apostólica. Datum Interamni (sic), idus yanuarii, pontificatus anno decimo, que es año de Christo 1236. Sacose esta copia año de1391.

5. $<$ Bullas de Ynocencio $4^{\circ}$ para que ningún arzobispo, obispo, excomulgue a los monges y a los que contrataren con ellos. Año de 1246>.

Dos bullas ${ }^{90}$ del papa Ynocencio $4^{\circ}$, ambas de un tenor, escritas en pergamino, con sello de plomo pendiente, en que concede al abad de Cluni y a todos sus monasterios que ningún arzobispo, obispo, etcétera, pueda excomulgar a sus monges, poner entredicho, llamarlos a juicio ni conocer de sus causas; y manda que se guarde la bulla de Gregorio $9^{\circ}$ para que nadie excomulgue a los que fueren a moler a los molinos de los monasterios o a cocer a sus hornos, a tratar / (f.81r) o comunicar, comprar o vender con los monges, etcétera. Datum Lugduni, $11^{\circ}$ kalendas octobris, pontificatus anno $3^{\circ}$, que es el de Cristo de 1246.

6. < Bulla de Ynocencio 4․ Que los arzobispos no lleven procuración. Año de 1246>.

Bulla ${ }^{91}$ del mismo Ynocencio $4^{\circ}$, escrita en pergamino, con sello de plomo pendiente, por la que prohíbe a los arzobispos que quando anden las visitas de sus obispados y lleguen a las casas y prioratos de Cluni, no exijan de ellos procuración. Datum Lugduni, $6^{\circ}$ kalendas octobris, pontificatus anno $3^{\circ}$, año de 1246.

7. $<$ Bulla de Ynocencio $4^{\circ}$. Que no vayan a juicio ultra duas dietas. Año de 1246>.

Bulla del mismo Ynocencio $4^{\circ}$, escrita en pergamino, por la qual manda que ningún monge de Cluni pueda ser llamdo a juicio, fuera de dos dietas, desde el monasterio donde viviere para ninguna causa, aunque sea por comisión apostólica, si en ella no hace expresa mención. Datum Lugduni, $6^{\circ}$ kalendas octobris, pontificatus anno $3^{\circ}$, que es año de 1246.

8. $<$ Bulla de Ynocencio $4^{\circ}$. Que ninguno tenga jurisdicción en los monges de Cluni. Año de 1246>.

Bulla ${ }^{92}$ del mismo Ynocencio $4^{\circ}$, escrita en pergamino, por la qual prohíbe, en la forma que su predecesor Gregorio $9^{\circ}$, que ninguno tenga jurisdicción sobre los monges de Cluni aunque sacare letras apostólicas contra ellos, si no se hiciere expresa mención del Orden Cluniacense. Datum Lugduni, $6^{\circ}$ kalendas octobris, pontificatus anno $3^{\circ}$, que es año de 1246.

9. $<$ Bulla de Ynocencio $4^{\circ}$. Que los arzobispos y obispos no excomulguen a los que contrataron con los monges. Año de 1246>.

Bulla del mismo Ynocencio $4^{\circ}$, escrita en pergamino, con sello de plomo pendiente, por la qual a los arzobispos, obispos en cuyos obispados haya monasterios, prioratos, granjas, casas y posesiones sujetas al monasterio de Cluni, guarden la bulla de su predecesor Gregorio $9^{\circ}$ que les prohíbe excomulgar a los que vienen a vender o contratar a los monasterios, prioratos, etcétera, y a los que vinieren a moler a sus molinos o a cocer a sus hornos. Datum Lugduni, $6^{\circ}$ kalendas octobris, pontificatus anno $3^{\circ}$, año 1246.

\footnotetext{
${ }^{89}$ bulla] al margen derecho: falta.

90 bullas] al margen derecho: falta.

${ }^{91}$ Bulla] al margen derecho: falta.

92 Bulla] al margen derecho: falta.
} 
10. $<$ Bulla de Ynocencio $4^{\circ}$ sobre la provisión de las yglesias de Cluni. Año de 1246>.

Bulla ${ }^{93}$ del mismo Ynocencio $4^{\circ}$, escrita en pergamino, con sello de plomo pendiente, por la qual declara no estar obligados el abad y monasterios de Cluni a proveer yglesia alguna de su orden a sujeto alguno, aunque haya impetrado letras apostólicas, si en ellas no se hiciere mención del orden de Cluni. Datum Lugduni, kalendas octobris, pontificatus anno $3^{\circ}$, que es año de 1246.

11. $<$ Bulla de Ynocencio $4^{\circ}$. Que los monges de San Zoil obedezcan al abad de Cluni. Año de 1248>.

Bulla del mismo Ynocencio $4^{\circ}$, escrita en pergamino, con sello de plomo pendiente, dirijida al prior y convento de San Zoil, por la que les manda obedecer al abad de Cluni, supuesto confesaban / (f. $81 v$ ) haberle prometido obediencia. Datum Lugduni, $\mathrm{X}^{\mathrm{o}}$ kalendas nobembris ${ }^{94}$, pontificatus anno $3^{\circ}$, que es año de 1248 . Ay aquí un tanto authorizado de esta bulla y de la que queda puesta arriba en el número $3^{\circ}$.

12. $<$ Bulla de Ynocencio $4^{\circ}$. Que nadie impetre pensiones sobre la orden de Cluni. Año de $1250>$.

Bulla ${ }^{95}$ del mismo Ynocencio $4^{\circ}$, escrita en pergamino, con sello de plomo pendiente, por la qual concede que ninguna persona pueda impetrar pensión alguna sobre los monasterios, prioratos, granjas, yglesias y beneficios sujetos a Cluni, aunque sea por bullas apostólicas, si en ellas no se hace expresa mención de esta bulla de verbo ad verbum. Datum Lugduni, $9^{\circ}$ kalendas novembris, pontificatus anno $8^{\circ}$, que es el de Christo 1250.

13. <Bulla de Alexandro $4^{\circ}$. Exención de los obispos y otros jueces. Año de 1255>.

Bulla del papa Alexandro $4^{\circ}$, escrita en pergamino, con sello de plomo pendiente, por la qual confirma todo lo contenido en las bullas de su predecesor Ynocencio $4^{\circ}$, y exime a los monges, familiares y criados de los monasterios, prioratos, granjas e yglesias de Cluni, con todos sus bienes, de la jurisdición de los ordinarios y otros jueces; prohíbe a estos de poderlos excomulgar, citar, llamar, conocer de sus causas, visitarles a ellos y a sus monasterios, etcétera. Datum Laterani, $15^{\circ}$ kalendas februarii, pontificatus anno $2^{\circ}$, que es año de 1255 . Hay aquí una copia authorizada de esta bulla y de otra de Clemente $6^{\circ}$ que está adelante en el número 16.

14. <Bulla de Juan 22 conservatotia para los monges de Cluni. Año de 1319>.

Bulla ${ }^{96}$ conservatoria dada por el para Juan 22, escrita en pergamino, en la qual nombra por jueces conservadores de los monasterios, prioratos, granjas y religiosos sujetos a Cluni existentes fuera del reyno de Francia a los abades de Oña, Exlonza y Samos, para que los defiendan y amparen contra qualesquiera personas que los agraviaren o les detubieren sus bienes y hacienda, etcétera. Datum Avinión, $15^{\circ}$ kalendas augusti, pontificatus anno $3^{\circ}$, que es año de 1319.

15. <Traslado de una bulla para que los monges de Cluni puedan ordenarse con qualquier obispo. Año de 1329>.

Traslado de una bulla ${ }^{97}$ del papa Alexandro, escrito en pergamino, por la qual se concede a los monges cluniacenses que puedan ser ordenados por qualquier obispo, sin que preceda más examen que el de sus prelados, y que no puedan ser excomulgados por los obispos y sus vicarios, y manda a estos que les guarden las exenciones que les están concedidas por otros pontífices. Sacose este traslado a 8 de diciembre, era de 1367, que es año de Christo 1329.

\footnotetext{
93 Bulla] al margen derecho: falta.

${ }^{94}$ nobembris] no escrito sobre octo.

95 Bulla] al margen derecho: falta.

${ }^{96}$ Bulla] al margen derecho: falta.

${ }^{97}$ bulla] al margen derecho: falta.
} 
/ (f. 82r) 16. < Bulla de Clemente $6^{\circ}$ por la que exime al monasterio de Cluni y a sus anexos de toda jurisdicción a los ordinarios. Año de 1342>.

Bulla ${ }^{98}$ del papa Clemente $6^{\circ}$, escrita en pergamino, con sello de plomo pendiente, por la qual exime a todas las personas, monasterios, prioratos, decanías, granjas y demás cosas, mediate vel immediate, sujetas a Cluni, de qualquiera jurisdicción ordinaria y extraordinaria de todos los obispos y otros jueces, y los hace immediatos a la Sede Apostólica, los admite en su protección y amparo, y da por nulo quanto en contrario se hiciere. En quanto a la visita de las parroquias no deroga la costumbre que huviese de visitarlas, ni de pagar la procuración debida por visita o por otro qualquier título. Datum Avinione, kalendas aprilis, pontificatus anno $1^{\circ}$, que es el de Christo 1342.

17. <Testimonio de la contribución que esta casa pagaba a Cluni. Año de 1377>.

Testimonio ${ }^{99}$, escrito en pergamino, que contiene varias cartas de pago de las contribuciones que este monasterio pagaba a Cluni, siendo prior de él don Juan Germán, y estas contribuciones las cobraba don Guido, prior mayor de Santa María de Náxera, camarero y vicario general de Cluni en España. Estas pagas llegan hasta la era de 1415, que es año de 1377, en el que se sacó este testimonio por Juan Martínez, notario de Palencia

$<$ Nota. En este número 18 están dos sentencias dadas por los señores obispos de Ávila y Barcelona, por las que declaran deber guardar al monasterio un entredicho que el señor obispo de Palencia tenía puesto a la villa de Carrión en los años de 1403 y $1415>>^{100}$.

19. <Definición de Cluni para que los sujetos a su congregación pagasen cierto tributo. Año de 1422>.

Testimonio, escrito en pergamino, de una difinición hecha en San Pedro de Cluni por los difinidores del Capítulo General, celebrada a 22 de junio del año de 1422, en la Dominica Jubilate, en que se hace mención de los agravios y molestias que por aquellos tiempos hacían algunas personas eclesiásticas y seglares a los monasterios, prioratos y personas inmediatamente sujetos a Cluni, en sus privilegios, libertades, exenciones, yndultos y haciendas, para cuya defensa se determinó que todos los interesados contribuyesen con cierta cantidad de dinero, que se juntase y pusiese en un depósito común, para sacar de allí lo que fuese necesario para la defensa de todos. Se asigna en él la cantidad que havían de pagar cada monasterio, cada priorato, oficiales y otras personas. Dado por el prior mayor de Cluni, a 27 de junio del mismo año. $1422>$.

$20<$ Media Annata que se pidió a don Pedro, prior de San Zoil y la negó. Año de

Testimonio ${ }^{101}$ signado de Juan González de Amusco, notario público, el qual da fe de que Martín Fernández de Porras, su colector apostólico en el obispado de Palencia, por los años de 1422 embargó los frutos/ (f. 82v) del monasterio y dio censuras contra don Pedro, prior de San Zoil y capellán del ynfante don Juan, para obligarle a que pagase 500 florines por su elección, pretendiendo haberla hecho el Sumo Pontífice Martino $5^{\circ}$. Respondió el prior por sus procuradores no deber tal contribución a la Sede Apostólica por no haber sido él electo por el papa, sino por el abad de Cluni, a quien se había de pagar la media annata, caso que se debiese pagar, y por otras razones. Sin embargo de esto, procedió el subcolector, apelose, no concedió la apelación, volvió a proceder, volviose apelar, tampoco otorgó la apelación; protestose y socose (sic) de todo este testimonio.

21. < Citatoria del abad de Sahagún, juez conservador, contra los retenedores de los bienes de este monasterio. Año de 1450>.

Citatoria de don Pedro, abad de Sahagún, juez conservador de los monasterios y personas sujetas a Cluni, en virtud de una bulla del papa Clemente $6^{\circ}$, dada en Aviñón idibus

\footnotetext{
${ }^{98}$ Bulla] al margen derecho: falta.

99 Testimonio] al margen derecho: falta.

$100<$ Nota ...... 1415>] escrito al margen izquierdo.

${ }^{101}$ Testimonio] al margen derecho: falta.
} 
aprilis, pontificatus anno $2^{\circ}$, que es el de Christo 1343 , por la qual nombra por conservador de cluniacenses a los abades de Leomar, en la diócesis de Braga, en Portugal, al de Sahagún y al de Oña; la qual bulla no está en este archivo y puede ser que esté en el de Sahagún, por haverse llevado a aquella casa para requirir al abad, quien usó de ella en pleitos que tubo este monasterio con los marqueses de Frómesta y clérigos de Aguilar y otros. Diose esta citatoria contra los vsurpadores de la hacienda de los monasterios de San Zoil, San Román y San Ysidro, en la villa de Sahagún, a 25 de marzo de 1450, ante Joan Alfonso de Zamora, escribano de Su Magestad y de dicho señor abad.

22. <Conservatoria subdelegada por el abad de Sahagún. Año de 1486>.

Subdelegación ${ }^{102}$ que hizo don Rodrigo, abad de Sahagún, del oficio de juez conservador en el chantre y tesorero de la yglesia de Santa María de Vsillos y en el abad de Castro, para ciertas causas de este monasterio. Está aquí inserta la bulla de Clemente $6^{\circ}$ en la que nombra al abad de Sahagún por juez conservador. Su fecha, en Sahagún, a 13 de octubre de 1486, ante Sancho de Escobar, notario.

23. <Requirimiento para no sacar del monasterio un soldado que se refugió en él. Año de 1635>.

Testimonio $^{103}$ de una protesta y requirimiento que hizo el abad de San Zoil a un aguacil de Carrión para que no llevase preso a un soldado que se havía refugiado en este monasterio. Su fecha, en San Zoil, a 26 de abril de 1635, ante fray Joan de Cisneros, notario apostólico.

\section{/ (f. 83r) Quaderno B del legajo ${ }^{\circ}$}

Este quaderno contiene bullas de nombramientos de abades consistoriales y comendatarios de este monasterio, con otros papeles, hasta su vnión inclusive a la Congregación de San Benito de Valladolid, por el orden siguiente:

$1^{\circ}<$ Bulla del papa Eugenio $4^{\circ}$. Constituye al prior de San Zoil en abad, con todas las exenciones y privilegios abaciales. Año de 1435>.

Bulla ${ }^{104}$ del papa Eugenio $4^{\circ}$, escrita en pergamino, con sello de plomo pendiente, por la qual, a instancia del rey don Juan el $2^{\circ}$ y de la reyna doña María, su muger, atento que el monasterio sustentaba 25 monges, extingue el oficio y dignidad de prior de él y le erije en abadía, y al superior de él en abad, con todas las preeminencias, honores, immunidades ${ }^{105}$, libertades, exenciones y privilegios de que vsen perpetuamente, y elige por abad a don Pedro, que a la sazón era prior de San Zoil, y da facultad a qualquier obispo para que le bendiga; y assí bendito use de todas las insignias, indultos y privilegios abaciales, y goze de las mismas gracias que el abad de Sahagún y los demás abades de la religión. Datum Florentie, $4^{\circ}$ idus ianuarii, anno Domini 1435, pontificatus anno $3^{\circ}$.

2. $<$ Bulla de Eugenio $4^{\circ}$. Confirma la pasada y que el abad goze de los privilegios que los abades de Cluni. Año de 1435>.

Bulla del mismo Eugenio $4^{\circ}$, escrita en pergamino, con sello de plomo pendiente, es perinde valere, y confirmación de la de arriba. Concede al abad de San Zoil todas las gracias, privilegios y exenciones que tenían los demás abades de Cluni. Datum Florentie, anno Domini 1435 , pontificatus anno $5^{\circ}$. Hay dos copias, una authorizada y otra simple.

\footnotetext{
102 Subdelegación] al margen derecho: falta.

103 Testimonio] al margen derecho: falta.

${ }^{104}$ Bulla] al margen derecho: faltan casi todos.

105 immunidades] imm escrito sobre dig.
} 

de $1438>$.

3. $<$ Bulla de Eugenio $4^{\circ}$. Provisión de la abadía en don Gonzalo de Cervatos. Año

Bulla ${ }^{106}$ de Eugenio $4^{\circ}$, escrita en pergamino, con sello de plomo pendiente, por la qual consta que, haviendo vacado la abadía de San Zoil por muerte de su abad don Pedro, el convento, conforme a la Santa Regla, eligió por su abad a don Gonzalo de Cervatos, que era prior de San Román de Entrepeñas, no constándoles de una constitución apostólica de el papa Eugenio $4^{\circ}$ en que reservaba para sí la provisión de las abadías, dando por nullo quanto se hiciese en contrario. De esta constitución tubo noticia el convento después de hecha la elección, y assí dio qüenta de ella al papa para / (f. 83v) que la confirmase; pero el mismo Eugenio $4^{\circ}$ la declaró por nulla en su consistorio, con acuerdo de los cardenales; y constándole por testimonio de la capacidad del mismo don Gonzalo, le eligió de nuevo por abad de San Zoil y le dio esta bulla dirijida a don Juan, rey de Castilla y León. Dada en Ferrara, pridie nonas iunii, anno Domini 1438, pontificatus anno $8^{\circ}$.

4. $<$ Bulla de Eugenio $4^{\circ}$ para que los súbditos obedezcan a don Gonzalo de Cervatos. Año de 1438>.

Bulla ${ }^{107}$ de Eugenio $4^{\circ}$, escrita en pergamino, con sello de plomo pendiente, por la qual consta que, habiendo elegido consistorialmente a don Gonzalo de Cervatos por abad de San Zoil, como queda dicho, manda a todos los súbditos y vasallos que le obedezcan y guarden los derechos que como a tal le pertenecen. Datum Ferrarie, pridie nonas iunii, anno Domini 1438, pontificatus anno $8^{\circ}$.

5. $<$ Bulla de Eugenio $4^{\circ}$ al señor obispo de Palencia para que a don Gonzalo, abad de San Zoil, se le guarden todos los derechos. Año de 1438>.

Bulla ${ }^{108}$ del mismo Eugenio $4^{\circ}$, escrita en pergamino y dirijida al señor obispo de Palencia, en la que, después de referir la elección que había hecho Su Santidad en don Gonzalo de Cervatos por abad de San Zoil y los motivos que había tenido para ella, manda al señor obispo guarde y haga guardar todos los derechos que le competen por abad y le favorezca en lo necesario para el buen govierno del monasterio. Datum Ferrarie, pridie nonas iunii, anno Domini 1438, pontificatus anno $8^{\circ}$.

6. $<$ Bulla de Eugenio $4^{\circ}$. Para que los novicios no vayan a profesar a Cluni y profesen en San Zoil. Año de 1439>.

Bulla de Eugenio $4^{\circ}$, escrita en pergamino, con sello de plomo pendiente, por la qual, haciendo mención de lo concedido en las bullas antecedentes y a instancia del rey don Juan el $2^{\circ}$ y de la reyna doña María, su muger, atendiendo a los graves inconvenientes que resultaban de ir los novicios de San Zoil a profesar al monasterio de San Pedro de Cluni como habían ydo hasta allí, da facultad al abad don Gonzalo y a sus sucesores para que de allí adelante, perpetuamente, den la profesión a los novicios que tomaren el hábito en San Zoil y no vayan a hacerla a Cluni. Datum Florentie, idibus junii, anno Domini 1439, pontificatus anno $9^{\circ}$. $1444>$.

7. $<$ Bulla de Eugenio $4^{\circ}$. Provisión de la abadía en don Pedro de Tossantos. Año de

Bulla de Eugenio $4^{\circ}$, escrita en pergamino, con sello de plomo pendiente, por la qual, habiendo vacado la abadía de San Zoil por muerte del abad don Gonzalo de Cervatos, elige en ella por consistorio a don Pedro de Tosantos, que era limosnero mayor de San Zoil, y manda al obispo de Palencia que le ampare en la abadía. Dada en Roma, apud Santum Petrum, $3^{\circ}$ nonas septembris, anno Domini 1444, pontificatus anno 14.

\footnotetext{
106 Bulla] al margen derecho: está.

107 Bulla] al margen derecho: está.

108 Bulla] al margen derecho: está.
} 
/ (f. 84r) 8. < Bulla de Eugenio $4^{\circ}$. Provisión del oficio de limosnero mayor de San Zoil en Pedro García. Año de 1445>.

Bulla de Eugenio $4^{\circ}$, escrita en pergamino, con sello de plomo pendiente, por la qual consta que, estando vaco el oficio de limosnero mayor de San Zoil por promoción de don Pedro de Tossantos que le tenía, él y el convento eligieron por limosnero a un monge del mismo monasterio que se llamaba Pedro García, el qual, no teniendo seguridad en la tal elección, pidió al papa que la confirmase o la hiciese de nuevo. Su Santidad dio esta bulla dirijida al arcediano de Carrión, para que se informase de la persona y, hallando ser idóneo el dicho Pedro García, le confirmase y amparase en el oficio de limosnero. Datum Rome, idibus augusti, anno Domini 1445, pontificatus anno $15^{\circ}$.

9. <Bulla de Pío 2ª Elección de abad en Pedro García. Año de 1461>.

Bulla ${ }^{109}$ de Pío $2^{\circ}$, escrita en pergamino, con sello de plomo pendiente, por la qual consta que, habiendo vacado la abadía de San Zoil por muerte del abad don Pedro de Tossantos, el convento eligió a don Pedro García, que era prior mayor y limosnero de San Zoil, y le presentó al papa Pío $2^{\circ}$, el qual, en virtud de la elección y presentación del convento, le nombró por esta bulla por abad de San Zoil. Datum Rome, apud Santum Petrum, anno Domini 1461, sexto decimo kalendas augusti, pontificatus anno $3^{\circ}$.

10. $<$ Bulla de Pío $2^{\circ}$ para que qualquier obispo bendiga al abad don Pedro García. Año de 1461>.

Bulla ${ }^{110}$ de Pío $2^{\circ}$, escrita en pergamino, con sello de plomo pendiente, por la qual da comissión apostólica a qualquier obispo para que pueda bendecir y tomar juramento de fidelidad a don Pedro García, a quien había dado la abadía de San Zoil. Datum Rome, apud Santum Petrum, anno Domini 1461, kalendas augusti, pontificatus anno $3^{\circ}$.

11. $<$ Bulla de Paulo $2^{\circ}$ para que los vasallos obedezcan a don Pedro González de Mendoza, abad comendatario. Año de 1469>.

Bulla de Paulo $2^{\circ}$, escrita en pergamino, con sello de plomo pendiente, por la qual consta que, habiendo dado Su Santidad en encomienda la abadía de San Zoil (vacante por muerte de don Pedro García) a don Pedro González de Mendoza, obispo de Sigüenza (después cardenal de España y arzobispo de Toledo), para que la administrase todo el tiempo que fuese obispo de Sigüenza, manda Su Santidad a los vasallos de San Zoil que le obedezcan, respeten y guarden fidelidad, acudiéndole con los derechos ordinarios. Datum Rome, apud Santum Petrum, anno Domini 1469, pridie idus februarii, pontificatus anno $6^{\circ}$. $1507>$.

12. $<$ Bulla de Julio $2^{\circ}$. Provee el oficio de limosnero en Diego de las Heras. Año de

Bulla de Julio $2^{\circ}$, escrita en pergamino, con sello de plomo pendiente, por la qual da comisión al tesorero de la yglesia de Palencia para que, informándose y hallando capaz a Diego de las Heras, monge de San Zoil, le dé el oficio de limosnero mayor, que estaba vaco por muerte de Juan Lasso. Datum Rome, anno Domini 1507, tertio idus augusti, pontificatus anno $4^{\circ}$.

/ (f. $84 v)$ 13. < Cédula de la reyna doña Juana para desencastillar al monasterio de San Zoil. Año de 1507>.

Cédula real de la reyna doña Juana, firmada de su mano, sellada con su sello, refrendada de Lope de Conchillos, su secretario, por la qual manda que la companía de a cavallo del capitán don Pedro del Castillo vaya a desencastillar el monasterio de San Zoil, a disposición del alcalde Ronquillo. Dada en Santa María del Campo, a 20 de septiembre de 1507.

109 Bulla] al margen derecho: está.

${ }^{110}$ Bulla] al margen derecho: está. 
14. <Testimonio de cómo el monasterio de San Zoil se sujeta a la reforma de la Congregación de San Benito de Valladolid. Año de 1507>.

Testimonio dado por Julián Martínez de Cortes, escrivano real, por el qual consta que, habiendo llegado al monasterio de San Zoil el abad de San Benito de Valladolid, reformador y visitador general de la Orden, requirió al alcalde Ronquillo, que estaba presente, con una bulla apostólica y cédulas de la reyna, para que le diese favor y ayuda para reformar este monasterio y unirle a la Congregación. El dicho alcalde se ofreció y requirió al convento para que diese la obediencia al dicho abad, para lo qual se leyeron las bullas y provisiones reales que para ello tenían; y el convento, habiendo consultado entre sí sobre el caso, dio la obediencia al abad de Valladolid y se sujetó a la reforma y visita, en 28 de septiembre de 1507, que es la fecha de este testimonio, siendo prior de San Zoil fray Diego de las Heras.

15. $<$ Traslado de un poder de don Bernardino de Carvajal, para tomar posesión de este monasterio. Año de 1509>.

Traslado del poder que dio don Bernardino de Carvajal, cardenal de Santa Cruz, para tomar la posesión de este monasterio, su yglesia parroquial y otras, de que le había hecho merced el papa Julio $2^{\circ}$, por su bulla dada el año de 1508, y se halla aquí inserta. Fue sacado este traslado en la villa de Frómesta, a 12 de octubre de 1509, ante Gonzalo García, escribano de Su Magestad.

16. $<$ El marqués de Aguilar ofrece administrar la hacienda de San Zoil y dar mil ducados al abad comendatario don Bernardino de Carvajal. Año de 1510>.

Escritura por la qual don Luys Fernández Manrique, marqués de Aguilar, ofrece dar personas en Carrión que administren la hacienda del monasterio de San Zoil y den cada año mil ducados de oro al cardenal don Bernardino de Carvajal, sólo porque los monges queden en la observancia y no vengan en poder de otro comendatario después de los días de don Bernardino; propone ciertas condiciones para lo que ofrece. Su fecha, en Carrión, a 28 de noviembre de 1510.

17. < Proceso de embargo y qüentas de la renta de San Zoil que perteneció a don Bernardino de Carvajal, después de que fue privado de todo. Año de 1511>.

Bajo este número está un proceso acerca de las rentas que pertenecían a don Bernardino de Carvajal, abad comendatario de este monasterio, después que el papa Julio $2^{\circ}$ le confiscó todos / (f. 85r) sus bienes, le privó de la dignidad de cardenal y de todos sus oficios, beneficios y rentas (por cismático), que fue el año de 1511. Los ynstrumentos de este proceso son los siguientes:

$1^{\circ}$. Carta del nuncio escrita al subcolector apostólico de Palencia, en que le da qüenta cómo Su Santidad privó al cardenal don Bernardino de Carvajal, embía un tanto de la bulla de Julio $2^{\circ}$ acerca de esto y manda que se recojan las rentas que pertenecían al dicho don Bernardino de la abadía de San Zoil, para la Cámara Apostólica. Su fecha, a 10 de diciembre de 1511.

2. Embargo que hizo el canónigo Matilla, subcolector apostólico, de los frutos de la abadía de San Zoil que pertenecían al cardenal, en 23 de diciembre de 1511.

3. Respuesta al embargo de arriba, dada por el teniente que cobraba las rentas y frutos del monasterio. No tiene fecha ni firma.

4. Provisión de la reyna doña Juana para que Hernando de Herrera cobre en nombre de Su Alteza la hacienda del convento y acuda con ella el mayordomo de él para su sustento. Dice en esta provisión que este monasterio fue fundado y dotado por los reyes, sus progenitores. Su fecha, en Burgos, a 6 de diciembre de 1511. No está authorizada.

5. Cédula del rey don Fernando para que los cobradores de las rentas de los monasterios de San Zoil de Carrión, Santa María de Nájera, Exlonza y San Claudio de León, paguen los repartimientos que les echaba el abad de San Benito de Valladolid, que era visitador general. Este traslado se sacó en San Zoil, a 30 de noviembre de 1511, ante Floristán de la Serna, escribano de Carrión. 
6. Libranza del general de San Benito de 160 ducados que pagó el administrador de San Zoil por el repartimiento. Año de 1511.

7. Poder del canónigo Matilla, subcolector apostólico, para cobrar los frutos de San Zoil pertenecientes al cardenal don Bernardino. Año de 1512.

8. Cédula del rey don Fernando para que el administrador de la hacienda de San Zoil cobre su salario de la mesa abacial y no de la conventual. Su fecha, a 7 de septiembre de 1511.

9. Cédula del rey don Fernando para que la renta de la mesa conventual de San Zoil se entregue al convento, y la que pertenecía a la mesa abacial se dexe a la disposición del nuncio. Su fecha, a 23 de diciembre de 1511.

10. Carta del nuncio para que se le entregue lo que pertenecía a / (f. $85 v)$ don Bernardino de Carvajal. Su fecha, a 24 de diciembre de 1511.

11. Requirimiento del canónigo Matilla a Fernando de Herrera, teniente de la abadía de San Zoil por su Alteza, para que pague a la Cámara Apostólica lo que perteneció a don Bernardino de Carvajal. Su fecha, en San Zoil, a 28 de diciembre de 1512. No está authorizado.

12. Qüentas que dio Fernando de Herrera al canónigo Matilla de lo que tocó a don Bernardino de Carvajal. Su fecha, a $1^{\circ}$ de enero de 1512, ante Floristán de la Serna, escribano de Carrión.

18. < Suspensión de la paga del subsidio. Año de 1519>.

Carta firmada y sellada por don Pedro Ruiz de la Mota, obispo de Badajoz, por la qual manda a los colectores del subsidio que no cobren este presente año del obispo de Burgos, abad comendatario de San Zoil, la parte de subsidio que le tocaba por la abadía de San Zoil hasta que el emperador mande lo que se ha de hacer. Dada en Molina, a 11 de diciembre de 1519.

19. <Cédula del emperador. Que ninguno tome posesión de la abadía de San Zoil en virtud de letras apostólicas. Año de 1524>.

Copia simple de una cédula del emperador Carlos $5^{\circ}$ para que ninguno tome posesión de la abadía de San Zoil, aun en virtud de letras apostólicas, sin pasarlas antes por su consejo, por ser, como dice, de fundación y patronato real. Su fecha, en Valladolid, a 10 de noviembre de 1524. Año de 1524>.

20. $<$ Bulla de Clemente $7^{\circ}$. Provisión de la abadía de San Zoil en don Pedro Stroci.

Bulla, escrita en pergamino, con sello de plomo pendiente, del papa Clemente $7^{\circ}$, por la qual, habiendo vacado las abadías de Párace[s], diócesis de Segovia, la de San Ysidro de León y la de San Zoil de Carrión, por muerte de don Juan Rodríguez de Fonseca, obispo de Burgos, que las tubo en encomienda (cuyo título de nombramiento falta), hace merced de estas tres abadías a su sobrino don Pedro Stroci, clérigo florentino, de 15 años de edad, para que las goze por toda su vida, para su congrua sustentación, y las concede motu propio, con tal que al tiempo de la expedición de esta bulla no estubiesen provistas canónicamente. Datum Rome, apud Santum Petrum, anno 1524, quarto nonas decembris, pontificatus anno $2^{\circ}$.

21. < Letras citatoriales para poner en la posesión a don Pedro Stroci. Año de 1524>.

Letras cetatoriales, escritas en pergamino, con su sello pendiente, dirijidas y expedidas por don Juan Baptista Casertaneo, juez executor, de la bulla anterior de Clemente $7^{\circ}$, para que se ponga en posesión de las tres abadías antes nombradas a don Pedro Stroci y se le contribuia con todos los derechos y emolumentos a ellas pertenecientes. Datum Rome, anno 1524, pontificatus anno $2^{\circ}$. 
22. $<$ Poder a don Juan Francisco de Vgochoni para que tome posesión de la abadía de San Zoil. Año de 1525>.

Poder, escrito en pergamino, dado por don Pedro Stroci a don Juan Francisco de Vgochoni, clérigo florentino y abad de la colejiata de Castroxeriz, para que tome posesión de las abadías de Párace[s], San / (f. 86r) Ysidro de León y San Zoil, en nombre de él, y las rija y govierne en lo espiritual y temporal. Datum Florentie, anno 1525.

23. $<$ Brebe de Clemente $7^{\circ}$. Que se dé la posesión de la abadía a Stroci. Año de 1525>.

Brebe del papa Clemente $7^{\circ}$, escrito en pergamino, dirijido a los monges de San Zoil, en que les manda, en virtud de santa obediencia, den la posesión de la abadía a los procuradores de su sobrino don Pedro Stroci. Datum Rome, apud Santum Petrum, die $5^{\text {a }}$ aprilis, anno 1525.

24. < Citatoria contra Diego de Fonseca. Año de 1525>.

Mandamiento monitorio y citatorio, escrito en pergamino, con sello pendiente, dado por Martín de Spínola, juez de causas del Sacro Palacio y comisionado del papa Clemente $7^{\circ}$, a instancia de Pedro Stroci, contra Diego de Fonseca, intruso en la abadía de San Zoil, para que parezca a dar razón de sí. Datum anno 1525.

25. $<$ Executoriales de Clemente $7^{\circ}$ en favor de Stroci. Ano de 1525>.

Executoriales dadas por Juan Copis, obispo Tarracinense, escritos en pergamino, con su sello pendiente, para que se cumpla y execute la bulla que dio el papa Clemente $7^{\circ}$ a Pedro Stroci, su sobrino, de las abadías de Párace[s], San Ysidro y San Zoil. Datum Rome, die $5^{\text {a }}$ aprilis, anno 1525.

\section{$<$ Nota $>$.}

Sin embargo de esta bulla y de todos los mandamientos anteriores, los monges no dieron la posesión de la abadía a Stroci, por ser a tiempo que trataba de unirse a la Congregación de San Benito de España. Aquí acabaron los abades comendatarios y empezaron los monges a nombrar abad según dispone la Santa regla, y nombraron a fray Francisco de Atienza, por muerte de don Juan Rodríguez de Fonseca, obispo de Burgos, como consta por el número 27 , que está adelante.

26. < Concordia sobre los bienes de Fonseca. Año de 1525>.

Concordia entre Antonio de Fonseca, señor de Coca y Alahejos, y fray Diego de Sahagún, presidente de San Zoil, sobre los bienes que quedaron por muerte de don Juan Rodríguez de Fonseca, obispo de Burgos y abad comendatario de San Zoil. Su fecha, en Madrid, a 10 de abril de 1525, ante Hernando de Cuéllar, escribano de Su Magestad.

27. <El emperador aprueba la elección de abad de San Zoil. Año de 1525>.

Cédulas del emperador Carlos $5^{\circ}$ por las quales, como patrono de este monasterio, aprueba y confirma la elección de abad que hizieron los monges en el padre fray Diego de Sahagún, por muerte de fray Francisco de Atienza, que había sido elegido por muerte de de don Juan Rodríguez de Fonseca, obispo de Burgos, último abad comendatario. Su fecha, en Toledo, a 13 de octubre de 1525. Sacose (sic) estos traslados en Carrión, por Miguel de Cisneros, escribano, a 7 de noviembre del mismo año. Está unida a ésta otra cédula del mismo emperador por la qual aprueba otra elección que habían hecho los monges de abad. Año de 1524.

28. <Cédula al corejidor de Carrión en virtud de las bullas de impetra de la abadía de San Zoil. Año de 1525>.

Cédula del mismo emperador, firmada de su mano, dirijida al correjidor de Carrión, por la que le manda que, si alguno pretendiere / (f. $86 v)$ tomar posesión de la abadía de San Zoil en virtud de bullas apostólicas, el corejidor las recoja y embíe al concejo. Su fecha, en Toledo, a 13 de octubre de 1525. Hay un tanto authorizado. 

$1525>$.

29. <El emperador desembarga los bienes del monasterio de San Zoil. Año de

Cédula del mismo emperador, firmada de su mano, por la qual manda desembargar los bienes y rentas de el monasterio de San Zoil que estaban embargados por el canónigo Ayala, como procurador de don Pedro Stroci, y por el maestreescuela de León, como subcolector de la Cámara Apostólica. Su fecha, en Toledo, a 13 de octubre de 1525.

30. <El emperador manda a las justicias guarden las cédulas de arriba. Año de 1525>.

Copia authéntica de una cédula del emperador Carlos $5^{\circ}$ en la que hace mención de las cédulas anteriores sobre la eleccion de abad en fray Diego de Sahagún, y manda a todos los correjidores y justicias que las guarden y cumplan como en ellas se contiene. Su fecha, en Toledo, a 13 de octubre de 1525. Sacose esta copia en Carrión, a 7 de noviembre del mismo año, por Miguel de Cisneros, escribano.

31. <Provisión real para que no se impetren beneficios, etcétera, que fueren de patronato real. Año de 1525>.

Provisión del emperador, con inserción de una real pracmática, para que no se impetren las yglesias, beneficios, etcétera, que fueren de patronato real. Su fecha, en Toledo, a 19 de octubre de 1525. Es traslado sacado por Francisco Catalán, escribano de Carrión, año de 1526.

32. <Proceso contra los agentes de Pedro Stroci que querían tomar posesión de la abadía de San Zoil, en la que se amparó a fray Diego de Sahagún. Año de 1526>.

Proceso fulminado contra con los agentes de Pedro Stroci, clérigo florentino, el qual, después de la muerte del señor Fonseca, obispo de Burgos, impetró la abadía de San Zoil y embió las bullas de ella a ciertos agentes para que tomasen la posesión en su nombre. Yntentaron éstos entrar en el monasterio a notificar las bullas al padre fray Diego de Sahagún, que era abad electo por los monges. Presentó el monasterio las cédulas que tenía del emperador, notificolas al correjidor, y éste le amparó; cogió las bullas, las embió al consejo, puso presos a los que las quisieron intimar y fijaron censuras a las puertas de la yglesia y los embió al consejo, donde se vieron las bullas y la información que hizo el monasterio de ser de patronato real, por lo que ampararon a fray Diego de Sahagún en la posesión de la abadía y dieron las bullas por surrecticias y ganadas con siniestra relación y mandaron que no se vsase de ellas. Todo esto sucedió en el año de 1526.

33. $<$ Bulla de Clemente $7^{\circ}$. Provisión de la abadía en Juan Francisco de Vgochoni. Año de 1527>.

Bulla del papa clemente $7^{\circ}$, escrita en pergamino, con sello de plomo pendiente, por la qual da en encomienda la abadía de San Zoil a Juan Francisco de Vgochoni, clérigo de Burgos, que dice estaba vaca por haberse resistido el convento a dar la posesión que quería tomar de ella Pedro Stroci. Este Vgochoni / (f. 87r) no tomó posesión de ella y sólo logró por concierto una pensión y la renunció en la Congregación el año de 1530, como se verá adelante. Datum Rome, decimo kalendas septembris, anno 1527, pontificatus anno $4^{\circ}$.

34. <Executoriales de la bulla anterior. Año de 1527>.

Executoriales, escritas en pergamino, con sello pendiente, para que se cumpla lo contenido en la bulla antecedente, dados por Juan Baptista, obispo Casertáneo, en Roma, a 27 de agosto de 1527. de $1530>$.

35. < Súplica de Vgochoni a Su Santidad para renunciar la abadía de San Zoil. Año

Súplica que Juan Francisco Vgonochi, abad de Castro, dignidad de Burgos, hizo a la Santidad de Clemente $7^{\circ}$, de quien había impetrado la abadía de San Zoil, para renunciar la acción que por dicho nombramiento tenía a ella en la Congregación de San Benito de España, con tal que la casa de San Zoil le diese por sus días cierta pensión. Hízose esta súplica año de 1530. 
36. < Concierto sobre la pensión y bullas. Año de 1530>.

Concierto que hizo el general fray Alonso de Toro con Hernando de Escobar sobre la pensión que pagaba este monasterio al abad de Castro y sobre la expedición de las bullas del monasterio de San Zoil. Su fecha, en San Ysidro de Dueñas, a 30 de septiembre de 1530. Está duplicado ${ }^{111}$.

37. Bajo este número están los ynstrumentos siguientes: $1^{\circ}$ : Vn poder de don Juan Francisco Vgochoni a su hermano Hernando de Escobar para cobrar las rentas y pensiones a él pertenecientes, dado a 21 de abril de 1530. $2^{\circ}$ : Traslado de una bulla de Clemente $7^{\circ}$ en la que pone de pensión 850 ducados de oro a la abadía de San Zoil a favor de Vgochoni. Su fecha, en Roma, año de 1532. Está authorizado este traslado por Fernando de la Vega, notario apostólico. $3^{\circ}:<$ Carta de pago de 3580 ducados de oro de las pensiones del abad de Castro. Año de 1532>. Carta de pago que dio Fernando de Escobar al mayordomo de San Zoil de las pensiones que tenía el abad de Castro, Vgochoni, sobre esta abadía. Dada en Burgos, a 15 de noviembre de 1532, ante Francisco de Llerena, notario en esta ciudad.

38. < Cartas de Roma sobre la composición con el abad de Castro. Año de 1532>.

Cartas del procurador de Roma y abad de Castro, escritas al abad de San Benito de Valladolid, sobre la composición, bullas y resignación de la abadía de San Zoil y pensiones que se le habían de dar, conforme a la orden y concierto que había hecho el emperador Carlos $5^{\circ}$, para que, estando libre esta abadía, se uniese a la Congregación. Sus fechas, en Roma, año de 1532.

39. < Carta del General sobre la pensión del abad de Castro. Año de 1532>.

Carta del General al mayordomo de San Zoil en que le declara el concierto que tiene hecho con Hernando de Escobar sobre las pensiones que este monasterio había de pagar al abad de Castro. Su fecha, a 27 de junio de 1532. Este número y el antecedente se pondrán después del número $36^{112}$.

/ (f. 87v $40 .<$ Trasumto de la bulla de Clemente $7^{\circ}$ de la vnión de este monasterio a la Congregación de San Benito de Valladolid. Año de 1532>.

Trasumto, escrito en pergamino y authorizado por Gerónimo de Glimiciis, auditor de la Cámara Apostólica, de la bulla que concedió Clemente $7^{\circ}$ por el mes de julio del año de 1532, para que el monasterio de San Zoil se vniese a la Congregación de San Benito de España, dada a instancia del emperador Carlos $5^{\circ}$, mediante el apartamiento que hizo de la acción que tenía a esta abadía don Juan Francisco de Vgochoni, abad de Castro, a quien la casa se obligó a dar anualmente la pensión que queda dicha. Este trasumto fue sacado a 17 de agosto de 1532, por Felipe de Quintillies, notario en la corte de Roma y de la Cámara Apostólica. Hay aquí dos copias de la bulla, la una authorizada y la otra simple, escritas en papel.

41. <Carta sobre la bulla de vnión. Año de 1532>.

Carta de Hernando de Escobar, escrita al mayordomo de San Zoil, en que le da parte del despacho de la bulla de unión y le pide dinero por el concierto que havía hecho con el General. Su fecha, en Burgos, a 10 de agosto de 1532.

\section{2. <Qüenta del coste de las bullas. Año de 1532>.}

Qüenta de los gastos que hizo el abad de Castro en la expedición de las bullas de unión que montó 1.164 ducados, 3 julios y 38 quatrines, lo qual pagó el monasterio de San Zoil. Hízose a 18 de agosto de 1532. Está firmada del dicho abad de Castro y de los dos procuradores de la Congregación.

111 duplicado] al margen derecho: Nota. Sigue el número $8^{\circ}$ y $9^{\circ}$.
112 36] al margen derecho: "Nota. 
43. < Consentimiento del emperador y de su madre para que haga la vnión de San Zoil a la Congregación. Año de 1532>.

Cédula del emperador Carlos $5^{\circ}$ y de la reyna doña Juana, su madre, firmada de la misma reyna, los quales, (en virtud de la bulla de Clemente $7^{\circ}$ para la vnión de este monasterio a la Congregación y mediante el apartamiento que había hecho don Juan Francisco Vgochoni de esta abadía) dan su consentimiento para que, en efecto, se haga la dicha vnión. Dada en Madrid, a 30 de diciembre de 1532. adelante.

44. Lista de los superiores que ha tenido este monasterio desde el año de 948 en

\section{/ (f. 88r) Legajo $2^{\circ}$}

Este legajo, que es el $2^{\circ}$ del cajón San Pedro, contiene privilegios reales concedidos a este monasterio sobre varias materias, por el orden siguiente: $1188>$.

$1^{\circ}<$ Privilegio para que ninguno prenda los collazos de San Zoil. Era 1226, año de

Privilegio del rey don Alonso, escrito en pergamino, con sello de plomo pendiente, por el qual prohíbe a sus merinos y a otra qualquier persona prendar a los collazos de los monasterios de San Zoil y San Román ${ }^{113}$, sino por deuda propia de ellos. Su fecha, en Carrión, era 1226, que es año de Christo $1188^{114}$. Hay dos copias, una authorizada y otra simple.

2. <Privilegio del rey don Fernando el Santo. Exime al monasterio de pagar portazgo de quanto trajere para su vso. Era 1264, año de 1226>.

Privilegio rodado, escrito en pergamino, con sello de plomo pendiente, por el qual el rey don Fernando el Santo, con su muger, la reyna doña Beatriz, y sus hijos, Alfonso, Frederico y Ferrando (en conformidad de un privilegio dado por el rey don Alonso, su abuelo), concede para siempre jamás al monasterio de San Zoil que de todas las mercaderías y demás cosas que trajeren para su propio vso y el de todas sus granjas no pague portazgo alguno en ninguna parte de su reyno. Su fecha, en Palencia a 19 de marzo, era 1264, que es año de 1226. Hay dos copias authénticas y una certificación del abad de esta casa fray Matheo Quijano, del año de 1721, de lo que necesitaba este monasterio para alimento y vestuario de los monges.

3. < Privilegio de don Alonso el Sabio. Confirma el anterior. Era 1292, año 1254>.

Privilegio rodado, escrito en pergamino, con sello de plomo pendiente, por el qual el rey don Alonso el Sabio confirma a la letra el privilegio antecedente del rey don Fernando el Santo, su padre. Su fecha, en Burgos, a 29 de diciembre, era 1292 que es año de Cristo 1254. Hay copia authorizada.

4. $<$ Privilegio de don Alonso. Confirma el anterior y le extiende a los vasallos de San Zoles. Era 1315, año de 1277>.

Privilegio del mismo rey don Alonso, escrito en pergamino, con sello de cera pendiente, por el qual confirma de nuevo el privilegio de su padre, don Fernando, de la exención de portazgo, y la extiende a los vasallos de San Zoles ${ }^{115}$, excepto en Toledo, Sevilla y Burgos. Su fecha, en Burgos, a 20 de diciembre, era 1315, que es año de 1277. Hay aquí una copia simple.

\footnotetext{
113 San Román] al margen derecho: San Román.

114 1188] segundo 1 escrito sobre 2.

${ }^{115}$ San Zoles] al margen derecho: San Zoles.
} 
/ (f. 88v) 5. < Privilegio del rey don Sancho. Exime al monasterio de pagar mula y vasso. Era 1323, año de $1285>$.

Privilegio, escrito en pergamino, con sello de cera pendiente, por el qual el rey don Sancho el Brabo exime al monasterio de San Zoil de pagar al merino mayor la mula y vaso de plata que se le pagaba; y además confirma al monasterio todas las franquezas que tubo en tiempo de los reyes sus antecesores. Su fecha, en Toledo, a 8 de junio, era 1323, que es año de 1285. Hay copia simple.

6. <Privilegio del rey don Sancho. Hace libre de todo pecho la hacienda de San Zoil y San Román. Era 1325, año de 1287>.

Privilegio del rey don Sancho el Brabo, escrito en pergamino, con sello de cera pendiente, por el qual hace libre de todo pecho al camarero de San Zoil y al prior de San Román ${ }^{116}$ de todos los heredamientos que compraron, ganaron o tubieron de qualquiera manera, desde el tiempo de su abuelo don Fernando el Santo. Su fecha, en Toro, a 18 de agosto, era 1325, que es año de 1287 . Hay copia simple.

7. <Privilegio del rey don Fernando el $4^{\circ}$. Exime al monasterio de pagar portazgo. Era 1338, año de 1300>.

Privilegio del rey don Fernando el $4^{\circ}$, escrito en pergamino, con sello de cera pendiente, por el qual confirma el privilegio del rey don Alonso (que es el del número $4^{\circ}$ ), en que hace libre de portazgo al monasterio de San Zoil, sus granjas y vasallos. Su fecha, en Valladolid, a 18 de mayo, era de 1338, que es año de Christo de $1300^{117}$.

8. <Testimonio de un carta de amparo del rey don Alonso. Era 1366, año de 1328>.

Testimonio, escrito en pergamino y signado de Gonzalo Pérez, escribano de Carrión, de una carta de amparo que el rey don Alonso dio al prior de San Zoil contra algunas personas que sin derecho tenían bienes y posesiones del monasterio. Dada en Villalpando, a 8 de agosto, era de 1366, que es año de 1328. Hay copia simple.

9. < Carta de la reyna doña María, por la que concede que el ganado del monasterio ande por todo su reyno sin pagar tributo, era 1369, año de 1331>.

Traslado, escrito en pergamino y signado de Alfonso Juanes, escribano de Carrión, de una carta de la reyna doña María, por la que ampara a este monasterio, sus vasallos y bienes; y concede que todo el ganado pueda andar por todas las tierras del rey don Alonso, su señor, sin pagar tributo alguno, salvo por alguna deuda conocida que ellos mismos hayan hecho. Su fecha, en Trojiello, era de 1369, que es año de Christo 1331. Hay una copia simple.

10. <Privilegio del rey don Pedro. Que el monasterio no pague vaso ni mula. Era 1389, año $1351>$.

Privilegio del rey don Pedro, escrito en pergamin, con sello de plomo pendiente, por el qual confirma el privilegio del rey don Alonso, su padre, y otro del rey don Fernando sobre que este monasterio no pague al adelantado, ni a los merinos, vaso, ni mula, ni dinero por razón de entrada. Dado en Valladolid, / (f. 89r) a 18 de septiembre, era de 1389, que es año de 1351. Hay copia simple.

11. $<$ Privilegio del rey don Pedro. Confirma todos los privilegios del monasterio de San Zoil, de sus prioratos, yglesias y vasallos. Era de 1389, año de 1351>.

Privilegio del rey don Pedro, escrito en pergamino, con sello de plomo pendiente, por el qual confirma al monasterio de San Zoilo, a sus prioratos, yglesias y vasallos todos los privilegios, franquezas, libertades, gracias y donaciones que tenían desde el tiempo de los reyes sus antepasados, y manda a todas las justicias que amparen y defiendan al dicho

\footnotetext{
${ }^{116}$ San Román] al margen derecho: San Román.

117 1300] al margen derecho: Nota. Después de este número se ha de poner otro privilegio del mismo don Fernando, por el que confirma el quinto de las mediduras del pan que se vendiere en Carrión, y se ha puesto aquí.
} 
monasterio en los referidos privilegios. Dado en las Cortes de Valladolid, a 13 de octubre, era de 1389, que es año de 1351.

12. < Privilegio del rey don Henrique $2^{\circ}$. Confirma todos los privilegios de San Zoil. Era de 1409, año de 1371>.

Privilegio del rey don Enrrique $2^{\circ}$, escrito en pergamino, con sello de plomo pendiente, por el qual confirma todos los privilegios, gracias, donaciones, etcétera, que (de) tenían de uso y costumbre, desde el tiempo de los reyes sus antepasados; y manda a todas las justicias que los guarden y hagan guardar. Dado en las Cortes de Toro, a 22 de septiembre, era de 1409, que es año de 1371.

13. $<$ Privilegio del rey don Henrrique $3^{\circ}$. Confirma todos los privilegios de San Zoil. Año de 1403>.

Privilegio del rey don Henrrique $3^{\circ}$, escrito en pergamino, con sello de plomo pendiente, por el qual confirma el privilegio de arriba del rey don Henrrique, su abuelo, inserto en éste, y manda se guarden al monasterio todos los privilegios según se habían guardado en tiempo del rey don Juan, su padre; y a las justicias que le amparen y defiendan. Dado en Palencia, a 28 de agosto, año de 1403. de $1408>$.

14. $<$ Privilegio del rey don Juan el $2^{\circ}$. Confirma los dos privilegios antecedentes. Año

Privilegio del rey don Juan el $2^{\circ}$, escrito en pergamino, con sello de plomo pendiente, por el qual confirma el privilegio antecedente de don Henrrique $3^{\circ}$, su padre, y el de don Henrrique $2^{\circ}$, inserto en éste, y manda que al monasterio de San Zoil se le guarde y conserve en sus privilegios, vsos, costumbres, etcétera, como hasta allí. Dado en Alcalá de Henares, a 18 de marzo, año de 1408.

15. $<$ Privilegio del rey don Juan el $2^{\circ}$. Confirma el antecedente y los de don Henrique $2^{\circ}$ y $3^{\circ}$. Año de $1420>$.

Privilegio del mismo rey don Juan el $2^{\circ}$, escrito en pergamino, con sello de plomo pendiente, por el qual confirma el privilegio antecedente que él mismo había dado estando bajo de tutor; y manda guardar todo lo en él contenido con los privilegios de confirmación de los reyes don Henrrique $2^{\circ}$ y $3^{\circ}$ insertos en éste. Dado en Valladolid, a 20 días de abril, año de 1420. Año 1456>.

/ (f. $89 v)$ 16. $<$ Privilegio del rey don Henrrique $4^{\circ}$. Confirma los privilegios anteriores.

Privilegio del rey don Henrrique $4^{\circ}$, escrito en pergamino, con sello de plomo pendiente, por el qual confirma el antecedente de don Juan el $2^{\circ}$, su padre, y los de don Henrrique $2^{\circ}$ y $3^{\circ}$ insertos en éste, y manda guardar todos los privilegios, exenciones, gracias, etcétera, que el monasterio de San Zoil había tenido hasta allí. Dado en la ciudad de Segovia, a 21 de mayo, año de 1456. $1587>$.

17. <Testimonio de la libertad del ganado de este monasterio de San Zoil. Año de

Testimonio authorizado de una provisión real, dada a 14 de octubre de 1583, a Christóval de Grajal, arrendador del servicio y montazgo real, en la que se manda que todos los señores de ganados y sus pastores le paguen de sus ganados los derechos que están obligados conforme a las leyes de estos reynos, exceptuando de pagar estos derechos de servicio y montazgo algunas comunidades y personas particulares, entre las quales entra este monasterio de San Zoil, por privilegiado para no pagar, de 400 bacas, 5 mil ovejas, 20 yeguas y 200 puercos, servicio ni montazgo. Sacose este testimonio (con authoridad del doctor Roque de Saavedra, juez de comisión del servicio y montazgo) en la villa de Carrión, a 27 de enero de 1587, por Pedro de Cisneros, escribano de dicha villa. 
18. $<$ Sentencia en que se declara que el monasterio no debe pagar 12 mil maravedís para la obra de la puente, por ser vecino y parroquiano de la villa. Año de 1610>.

Testimonio de una sentencia dada por don Juan Ramírez Freile y Arellano, correjidor de Carrión, en el pleito que tubo el convento con el procurador del fiscal de los negocios de la puente de Carrión, en razón de no pagar 12 mil maravedís que se le habían repartido, de los que en esta sentencia se da por libre al convento por ser vecinos y parroquianos de la villa, los quales han de ser comprehendidos en el repartimiento de la puente que a esta villa le toca. Diose este testimonio por Alonso García, escribano de Carrión, a 9 de hevrero de 1610, que es el mismo mes y año en que se dio la sentencia.

19. Bajo este número están los papeles siguientes: $1611>$.

$<$ Testimonio de que el monasterio no paga montazgo por el ganado. Año de

$1^{\mathrm{o}}$ Tres testimonios dados por Francisco Moro de Saldaña, escribano de Carrión, los dos en el año de 1611 y el otro en el 1635, por los que declara ser cierto el privilegio de arriba, número 17, para que el monasterio no pague servicio ni montazgo de las cavezas de ganado que allí se expresan.

$<$ Declaración de la libertad del ganado $>$.

$2^{\circ}$ Declaración que hizieron los portazgueros de la villa de Saldaña por el duque, su señor, de haber pasado libres / (f. 90r) de portazgo los ganados de San Zoil y granja de Villaverde con el mandamiento del administrador del dicho señor duque para lo mismo.

$<$ Carta sobre lo mismo $>$.

$3^{\circ}$ Carta del mismo administrador al abad de San Zoil, en la que le dice que tiene orden del duque, su señor, para no hacer novedad sobre el paso del ganado de este monasterio. Su fecha, a 12 de diciembre de 1716.

20. <Auto para que el monasterio no pague sisa de 2 mil cántaras de vino que necesita para su gasto. Año de 1657>.

Bajo este número están varios testimonios y dos autos dados por don Prudencio de Meneses y Riaño, administrador general de millones de la ciudad de Toro, a favor de este monasterio, en que manda que no pague sisa del vino que encerrare y cojiere de sus rentas, diezmos y cosecha, hasta en cantidad de 2 mil cántaras que el monasterio ha menester para su consumo. Dados en Carrión, a 10 y 11 de febrero de 1657, ante Manuel de Orejón, escribano en dicha villa.

$<$ Otro auto para lo mismo $>$.

Síguese un traslado de la ynformación que hizo el monasterio, en razón de 210 cántaras de vino que tenía embargadas en la villa de Becerril por el corregidor de Palencia, y de cómo necesitaba 2 mil cántaras para el consumo de todo el año. Vistos estos autos y demás diligencias, el señor don Francisco de Angulo, correjidor de Carrión, dio sentencia a favor de este monasterio, por la qual manda el desembargo de dichas cántaras y que no pague sisa de las dos mil que necesita para su gasto. Dada en Carrión, a 23 de octubre de 1656, ante Norberto de Sandoval, escribano de dicha villa.

Finalmente hay varios despachos de los correjidores de Carrión, dirijidos al de Palencia, para que dexen sacar libremente al monasterio la cantidad de vino que tenía en Becerril, Villaumbrales y Grijota.

21. <Acuerdo de las villa de Carrión para que el estado eclesiástico no pague arbritrios. Año de 1755>.

Copia authorizada del acuerdo celebrado por los señores justicia y regimiento de la villa de Carrión en el que, a representación del estado eclesiástico de esta villa y para guardar su inmunidad, se determinó no pagasen arbitrios y se le abonasen a cada individuo 2 maravedís en cada libra de carnero y baca que consumiese, 4 maravedís en cada azumbre de 
vino tinto y 8 en la de vino blanco generoso, cesando la villa de pagar los 550 reales que por razón del arbitrio de carnes se daba anualmente al cavildo eclesiástico, quedando éste con la obligación de pagar al médico el salario correspondiente al dicho cavildo; y manda que dicho estado eclesiástico, assí secular como regular, acuda con zédulas firmadas / (f. 90v) de sus superiores, vicarios, etcétera, a las carnicerías públicas, tabernas de vino tinto y blanco. Se acordó a 18 de septiembre de 1755, ante Andrés Núñez Castelo, escribano de Carrión.

22. $<$ Copias simples de los privilegios $>$.

Bajo este número están dos copias simples de privilegios. La $1^{\text {a }}$ de los contenidos en este legajo $2^{\mathrm{o}}$ y uno a favor de San Román; la $2^{\mathrm{a}}$ contiene los privilegios de este legajo y los pertenecientes a sus prioratos y curatos que se hallan en sus respectivos lugares y títulos.

\section{$<$ Nota $>$}

Vn privilegio del rey don Felipe $2^{\circ}$, dado en Madrid, a 12 de diciembre de 1562, por el que confirma los previlegios, donaciones, libertades, etcétera, de este monasterio, según estaban confirmados por los Reyes Cathólicos don Fernando y doña Ysabel, y otros señores reyes; se halla presentado en el pleito que sigue el monasterio con la villa de Villamuera en el juicio de propiedad sobre las sernas y demás derechos de señorío en la Real Chancillería de Valladolid y oficio de don Matheo Vaquero, secretario de cámara.

\section{/ (f. 91r) Legajo $3^{\circ}$}

Este legajo $3^{\circ}$ del cajón San Pedro contiene los privilegios, reales executorias y otros papeles pertenecientes a la jurisdicción antigua que tubo el monasterio en el barrio de San Zoles, y su venta a la villa de Carrión, por el orden siguiente:

$1^{\circ}<$ Privilegio del rey don Alonso. Libra de todo tributo la hacienda de don Gómez Cidiz. Era 1167, año de 1129>.

Privilegio del emperador don Alonso, escrito en pergamino, por el qual concede a don Gómez Cidiz y su muger, Elo Galiz (dicen ser estos señores nietos de los fundadores de este monasterio), que no pueda entrar ningún sayón, ni por homicidio, ni por género de tributo real o particular, en la heredad que entonces tenían ni en la que adquiriesen de allí adelante. Facta carta $13^{\circ}$ kalendas maii, era 1167, que es año de Christo 1129. año $1142>$.

2. $<$ Privilegio del emperador don Alonso. Libertad del barrio de San Zoles. Era 1180,

Privilegio del emperador don Alonso y su muger, la reyna doña Berengaria, por el qual confirma otro del rey don Alonso el $6^{\circ}$, su abuelo, y de la reyna doña Vrraca, su madre, los quales concedieron a todos los vecinos del barrio de San Zoles (le dan título de villa), libertad y exención de todo pecho real y mandan que ninguno entre en el barrio a prender ni hacer daño alguno. Dio este privilegio de confirmación el emperador, en Burgos, en presencia y a instancia de su amigo don Pedro, abad de Cluni, $7^{\circ}$ idus septembris, era 1180 , que es año de Christo 1142. Hay copia authorizada.

3. <Privilegio del rey don Fernando el Santo. Libra a los vassallos del barrio de todo pecho y pedido. Era 1258, año de 1220>.

Privilegio rodado, escrito en pergamino, con sello de plomo pendiente, del rey don Fernando el Santo el qual, por reverencia del venerable G[erard], abad de Cluni, su amigo, y atendiendo al gratíssimo servicio que le había hecho Juan, prior de San Zoil y camarero de España, trhaiendo de Alemania a la reyna doña Beatriz, su muger, hija de Filipo, rey de romanos, y con beneplácito de doña Berengaria, su madre, y del ynfante don Alonso, su hermano, hace libres de todo pecho y pedido a todos los vasallos del barrio de San Zoles, assí christianos como moros y judíos, y de todo gravamen y tributo, reservando para sí 100 maravedís que le habían de pagar cada año. Facta carta Vallisoleti, $8^{\circ}$ idus ianuari, era 1258, que es año de Christo 1220. Hay aquí tres copias authorizadas, una en pergamino y dos en papel. 


\section{/ (f. 91v) 4. <Concordia de los 25 criados excusados de pecho. Año de 1240>.}

Concordia, escrita en pergamino, hecha entre don Gui, prior de San Zoil, camarero de Cluni, y los vecinos del barrio de San Zoles, por la que se convinieron que 25 vecinos del barrio, criados del monasterio, sean libres de todo pecho y repartimiento. Su fecha, en el mes de mayo, año de 1240.

5. < Privilegio del rey don Alonso el Sabio. Libra de todo pecho a los vecinos del barrio. Era 1292, año 1254>.

Privilegio rodado, escrito en pergamino, con sello de plomo pendiente, del rey don Alonso el Sabio por el qual confirma el que dio el rey don Fernando el Santo, que es el número $3^{\circ}$, en que hace libres de todo pecho, pedido y tributo a los vecinos del barrio de San Zoles. Su fecha, en Burgos, a 28 de diciembre en la era de 1292, que es año de Christo 1254. Hay copia authorizada.

6. $<$ Privilegio del rey don Sancho para que los del barrio de San Zoles puedan entrar y vender vino. Era 1330, año de 1292>.

Privilegio del rey don Sancho el Brabo, escrito en pergamino, con sello de cera pendiente, por el qual, a instancia del prior y convento de San Zoil, da por nulas otras cartas que havía dado a instancia del concejo de Carrión para que los vecinos del barrio de San Zoles no pudiesen entrar vino seis meses del año; y por este privilegio da facultad para que compren y vendan vino en todo tiempo sin que nadie se lo pueda impedir. Dado en Burgos, a 25 de febrero, era de 1330, que es año de 1292.

7. < Privilegio del rey don Alonso 11 de la libertad y exenciones del barrio de San Zoles. Era 1354, año de 1316>.

Privilegio rodado del rey don Alonso 11, escrito en pergamino, con sello de plomo pendiente, por el qual, a instancia de don Juan de Lodosa, prior de San Zoil y camarero de Cluni, confirma y manda se guarde el privilegio de las exenciones del barrio de San Zoles que concedió a este monasterio el emperador don Alonso, que es el que está en el número $2^{\circ}$. Dado en Toro, a 15 de agosto, era de 1354, que es año de 1316.

8. < Privilegio del rey don Alonso 11. Que los del barrio no paguen las deudas del monasterio. Era de 1373, año de 1335>.

Privilegio del rey don Alonso 11, escrito en pergamino, con sello de plomo pendiente, por el qual libra a los vasallos y moradores del barrio de San Zoles de pagar y ser prendados por las deudas del monasterio, porque los de la villa de Carrión, quando el monasterio tenía alguna deuda que no podían cobrar con facilidad, prendaban a los del barrio para cobrarsen (sic). Dado en Valladolid, a 15 de febrero en la era de 1373, que es año de 1335.

9. <Traslado authorizado de un privilegio de don Juan el $2^{\circ}$ y sus antecesores en que hacen libre de portazgo a la villa de Carrión y barrio de San Zoles. Año de 1408>.

Traslado authorizado de un privilegio del rey don Juan el $2^{\circ}$ por el qual exenta y hace libre de portazgo a la villa de Carrión y barrio de San Zoles. Este privilegio es confirmación de los privilegios de Henrrique $3^{\circ}$, don Juan el $1^{\circ}$, don Henrrique $2^{\circ}$ y don Alonso 11 , insertos en este traslado, que se sacó a 14 días / (f. 92r) de mayo, año de 1408, que es el mismo año en que el sobredicho don Juan $2^{\circ}$ dio el privilegio de confirmación. Sobre la misma exención de portazgo para el barrio de San Zoles véase el legajo $2^{\circ}$ de este cajón, número $4^{\circ}$, donde está el privilegio de don Alonso, dado en la era de 1315, que es año de 1277.

10. $<$ Privilegio del Rey don Juan el $2^{\circ}$ por el qual hace libre de todo tributo a los bienes del monasterio y a doce escusados del barrio de San Zoles. Año 1410>.

Privilegio del rey don Juan el $2^{\circ}$, escrito en pergamino, por el qual confirma y hace salvar en sus libros otro privilegio del rey don Henrrique, su visabuelo, dado año de 1405, por el qual nombra por su capellán a don García, prior de San Zoil, y a él y a los bienes, assí espirituales como temporales del monasterio, los recibe en su guarda y amparo; y manda a los obispos y justicias de la jurisdición de Palencia, Burgos, León y Zamora les amparen y defiendan; hace assimismo libres de todo pecho y tributo a sus bienes y a doce vasallos 
escusados del barrio de San Zoles. Diose este privilegio de confirmación en Tordesillas, a 11 de febrero de 1410.

11. <Protesto de un preso de la cárcel de San Zoles. Año 1435>.

Protesta que hizo don Juan, prior mayor de San Zoil, para que un judío que estaba en la cárcel de San Zoles se entregase a la justicia real del Adelantado para evitar escándalos y alborotos. Su fecha, en Frómesta, a 22 de agosto de 1435, ante Gonzalo Fernández, notario público de Palencia.

12. < Ynformación de las exenciones del barrio de San Zoles. Año de 1438>.

Ynformación hecha por parte del monasterio sobre el señorío, vasallaje y exenciones del barrio de San Zoles que tubo por sus privilegios reales, por comisión que dio a un cura de San Andrés el señor provisor de Palencia para el pleito que tenía el monasterio con Pedro Sánchez, bachiller, alcalde de Carrión, sobre la guarda de dichas exenciones del barrio. Su fecha, en Carrión, a 25 de septiembre de 1438, ante Juan Sánchez, escribano y notario de Carrión.

13. <Testimonio de un preso que tomó el abad de San Zoil. Año de 1445>.

Testimonio dado por Fernando González, escribano de Carrión, de cómo el abad don Pedro de Valdivieso tomó al merino de Carrión un preso que sacaba del barrio de San Zoles para llevarle a la cárcel de Carrión. Su fecha, en la dicha villa, a 28 de enero de 1445.

14. < Testimonio de un preso vuelto de la villa al varrio. Año de 1457>.

Testimonio dado por Gutierre Fernández de San Zoles, escribano de Carrión, de cómo Francisco de Chaves, correjidor de Carrión, mandó volber al barrio de San Zoles un preso que tenía en la cárcel de la villa y le había sacado del barrio. Su fecha, a 7 de noviembre de 1457.

/ (f. 92v) 15. <Compromiso y sentencia sobre la jurisdicción del barrio de San Zoles, y otros derechos. Año de 1460>.

Escritura de compromiso, escrita en pergamino, por la qual parece que este monasterio y la villa de Carrión, por evitar pleitos y contiendas que tenían sobre la jurisdicción del barrio y otras regalías, se convinieron en nombrar por jueces árbitros, con todo su poder, a el licenciado Rodrigo Álvarez, alcalde de Carrión, Diego Álvarez de Vozmediano, don Pedro, prior mayor y limosnero de San Zoil, y Fernando González, sacristán del monasterio, los quales, a 14 de agosto de 1460, dieron y pronunciaron sentencia por la que mandaron que se guarde y cumpla por ambas partes lo siguiente:

$1^{\circ}$. Que el merino de Carrión no entre en el barrio de San Zoles a exercer su oficio, sino que el merino del barrio execute en él los mandamientos de los alcaldes de la villa.

2. Que el merino del barrio, nombrado por el abad, vaya al concejo de Carrión a hacer juramento como el merino de la villa.

3. Que los alcaldes de Carrión en las causas civiles remitan sus mandamientos al merino de San Zoles que los execute en el barrio; y si no lo hiciere por negligencia, los mismos alcaldes en persona puedan entrar a executarlos. $\mathrm{Y}$ si en el varrio estubiere algún vecino de Carrión u de otra parte que deba algo, y el alcalde teme que el merino le avisará o no le querrá prender, el alcalde de Carrión pueda entrar a prenderlo y embargar sus bienes, dejándolos en poder del merino del barrio.

4. Que en las causas criminales puedan los alcaldes de Carrión, por si mismos, entrar a buscar y prender los delinqüentes, dexándolos presos en la cárcel del barrio en poder del merino de él, y que de allí sean condenados o absueltos; y que si el reo fuere condenado a muerte o pena corporal, sea entregado al merino de la villa a la puerta de la torre de la puente o a los alcaldes en el dicho barrio.

5. Que los alcaldes de la villa puedan entrar en el varrio a hacer pesquisas de qualquier delito; pero si los vecinos del barrio tubieren entre sí algunas palabras 
injuriosas, la justicia de la villa no pueda entrar a hacer pesquisa sobre ello si no fuere a pedimento de parte.

6. Que los fieles de la villa puedan entrar en el barrio a exercer su oficio en pesas y medidas, y para esto vaya con ellos el merino del barrio o algún otro vecino; y las penas que hecharen por las pesas y medidas falsas sean para el abad.

$<$ Clavera $>$.

7. Que en la clavera de encima de la puente puedan pacer los / (f. 93r) ganados de los vecinos de la villa y los del barrio; que la villa lleve erazgo de lo que en ella se trillare, salvo del limosnero de San Zoil, si trillare pan o cogiere lino en la dicha clavera, cerca de la huelga e fontanilla que está cabe la huerta de la limosna; y assimismo, si por parte del convento fuere hechado lino en la dicha clavera y en el mismo sitio, que no paguen erazgo; que si alguno quesiere edificar casas en la dicha clavera sea vasallo del monasterio.

$<$ Salzeda $>$.

8. Que la salzeda de las alisas e salzes que divide la caba nueva se guarde desde Nuestra Señora de marzo hasta Nuestra Señora de agosto, y lo demás del tiempo sea pastiza común; y la otra salzeda de abajo, con toda la clavera, sea pastiza común, y los salzes que sean del monasterio.

9. Que el monasterio pueda cercar la huerta del convento, dexando libre el arroyo forero, por donde puedan entrar y salir por el dicho arroyo a sacar el agua del Cuérnago para regar.

Mandan los dichos jueces que ambas partes guarden y cumplan esta sentencia, bajo la pena de mil doblas de oro castellanas de la banda, que no la guardare a la otra según en el compromiso se que ha de pagar la parte $<$ Traslado authorizado de esta sentencia $>$.

Hay aquí un traslado de esta sentencia, escrito en papel, sacado en San Zoil, a 3 de mayo de 1511 años, y signado de Floristán de la Serna, escribano de Carrión.

16. $<$ Escritura de la villa de Carrión para que el monasterio no pague alcavala del pan que vendiere. Año de 1482>.

Escritura por la qual el concejo de la villa de Carrión da por libre al monasterio para siempre de pagar alcavala del pan que vendiere, por la gracia que le hizo el año de 82 y 90 de darle mil maravedises para ayuda de las necesidades de dicho concejo. Su fecha, en Carrión, a 27 de agosto de 1482, ante Pedro de San Zoles, escribano de Carrión.

17. <Ynformación que el abad puede prender sus vasallos. Año de 1495>.

Ynformación hecha por parte del monasterio ante la justicia de Carrión, en que prueba que el abad de San Zoil puede prender y encarcelar a los vasallos de San Zoles, Villamuera, Arconada ${ }^{118}$ y otros lugares y, ponerles presos en el monasterio. Su fecha, en Carrión, a 30 de septiembre de1495, ante Álvaro de Cisneros y García de Avia, escrivanos de la misma villa.

18. $<$ Concordia sobre la jurisdición de los tres lugares $>$.

Capítulos de concordia hechos entre don Luys Hurtado de Mendoza, administrador perpetuo de la abadía de San Zoil, y la villa de Carrión ${ }^{119}$, en razón de las diferencias que

\footnotetext{
118 Arconada] al margen derecho: Villamuera y Arconada

${ }^{119}$ Carrión] al margen derecho: Villamuera y Arconada
} 
había sobre la jurisdicción del / (f. 93v) barrio de San Zoles, Villamuera y Arconada. No tienen fecha ni están authorizados.

19. < Protesta contra la concordia anterior. Año de 1501>.

Protesta que hizo don Luis Hurtado de Mendoza contra una sentencia que habían pronunciado unos jueces árbitros, de resulta de la concordia anterior, por ser perjudicial al monasterio y a la jurisdición de los lugares de San Zoles, Villamuera y Arconada. Su fecha, en Carrión, a 8 de agosto de 1501, ante Francisco Martínez, escribano en dicha villa.

20. < Estatuto para que sólo el tabernero del barrio de San Zoles pueda vender vino, con prohibición a los vecinos. Año de 1518>.

Estatuto de los vecinos del barrio de San Zoles para que se guarde la costumbre immemorial de que haya taberna en el barrio, y que sólo el tabernero pueda vender vino; que ningún particular pueda tener más de una cántara para el gasto de la semana, bajo la pena de perder el vino y mil maravedís para la Cámara de Su Magestad. Su fecha, en San Zoil, a $1^{\circ}$ de enero de 1518, ante Floristán de la Serna, escribano de Carrión.

\section{1. < Ordenanzas del barrio de San Zoles. Año de 1523>.}

Ordenanzas de los vecinos de San Zoles en las que ordenan que, de allí adelante, el día de Año Nuevo se junten en presencia del abad, y ellos nombren diez hombres, de los quales escoja el abad dos para rejidores, quatro para jurados y uno para diputado, los quales ordenen los demás oficios y arrienden la taberna. Fueron hechas estas ordenanzas en la hospedería de San Zoil, a 28 de diciembre de 1523, ante Floristán de la Serna, escribano de Carrión. de $1523>$.

22. <Testimonio de cómo se bolvió un preso de la villa al barrio de San Zoles. Año

Testimonio dado por Juan de Avia, escribano de Carrión, de cómo el aguacil de la villa bolvió un hombre que había puesto preso, tomándole de la parte de la torre que estaba en la puente hazia el barrio y le entregó al prior de San Zoil. Dado en la puente de Carrión, a 2 de febrero de 1523.

\section{3. < Poder que dio un correjidor de Carrión a un aguacil. Año de 1523>.}

Poder que dio un correjidor de Carrión a un aguacil de la misma villa para que fuera su teniente y exerciera su jurisdición en todos los actos, assí civiles como criminales, dentro y fuera del lugar. Su fecha, en Carrión, a 14 de agosto de 1523, ante Christóval Oro, escribano de la misma villa. $1527>$.

24. < Testimonio de cómo se trajo al barrio un preso que estaba en la villa. Año de

Testimonio dado por Alonso Sánchez, escribano de Carrión, de cómo el aguacil de Carrión bolvió un preso que estaba en la cárcel de la villa y que havía tomado al merino del barrio. Su fecha, en Carrión, a 3 de agosto de 1527.

\section{/ (f. 94r) 25. < Testimonio de otro preso. Año de 1529>.}

Otro testimonio, dado por Polite de Roxas, escribano de Carrión, de cómo se bolbió al barrio un preso que el aguacil de Carrión había llevado a la cárcel de la villa y se entregó al merino de San Zoles. Su fecha, en Carrión, a 28 de marzo de 1529.

26. $<$ Testimonio de que el merino forastero no puede entrar con vara en San Zoles. Año de 1529>.

Testimonio dado por Francisco Catalán, escribano de Carrión, de cómo un merino de la merindad de fuera de Carrión, después de haber entrado con vara en el barrio de San Zoles, confesó haberlo hecho por ignorancia y que no debía entrar de esta manera. Su fecha, en Carrión, a 7 de abril de 1529. 

$1529>$.

27. < Testimonio de una execución con licencia del merino de San Zoles. Año de

Testimonio, dado por Polite de Roxas, escribano de Carrión, de cómo el licenciado Álvarez, teniente de correjidor de esta villa, confiesa haver hecho una execución en el barrio de San Zoles, porque se lo pidió el merino puesto por el abad, a quien tocaba hacerla y no se atrevió. Da satisfacción al monasterio para guarda de su derecho. Su fecha, en Carrión, a 2 de abril de 1529. $1539>$.

28. < Poder del merino del barrio de San Zoles contra la villa de Carrión. Año de

Poder que dio Juan Delgado, merino del barrio de San Zoles, para seguir un pleito en Valladolid contra la villa de Carrión, porque su justicia dio mandamiento para prenderle por haver él puesto preso a un vecino del barrio. Dado en San Zoil, a 3 de diciembre de 1539, ante Juan de Castrillo, escribano de Carrión.

29. <Proceso sobre el encabezamiento de las alcavalas del barrio de San Zoles con las de la villa de Carrión. Año de 1547>.

Proceso hecho en razón del encabezamiento de las alcavalas del barrio de San Zoles que pretendían los vecinos de él que se hiciese aparte y no con el de la villa de Carrión, y por la ynformación que se hizo por parte de la villa parece no hubo lugar; pero consta que sobre las alcavalas del barrio estaban 7.500 maravedís de juro, a los que salió la villa haciendo buenos, y con esta condición se admitió el encabezamiento todo junto. Esta advertencia importa para la seguridad del juro que tiene este monasterio sobre las alcavalas de San Zoles $^{120}$. Este proceso pasó en Carrión, a $1^{\circ}$ de marzo de 1547 , ante Thomás Sánchez, escribano de dicha villa.

30. $<$ Carta para que se suelte un preso del barrio y se guarde la carta executoria de la jurisdición. Año de 1547>.

Carta de la Real Chancillería de Valladolid para que la justicia de Carrión suelte al alcalde de San Zoles, que le tenía preso por haberle hallado con vara visitando un mesón del varrio, y para que se guarde la carta executoria sobre la jurisdicción del barrio dada a favor del monasterio, año de 1538, que es la que está entre los papeles de Villamuera, / (f. 94v) cajón San Mauro, legajo $1^{\circ}$, número (sic). Fue dada esta carta en Valladolid, a 26 de octubre de 1547, ante Pedro Palacios, escribano de cámara.

31. <Petición para que se quite un alcalde reboltoso. Año de 1549>.

Petición que hicieron los vecinos del barrio de San Zoles al abad de San Zoil para que quitase un alcalde reboltoso y pusiese otro a propósito para conservar la paz. Fue presentada a 7 de septiembre de 1549, firmada del procurador general y de Juan de Santa María, escribano del concejo de San Zoles.

32. < Proceso sobre querer el teniente de Carrión residenciar a los alcaldes de San Zoles. Año de 1551>.

Bajo este número se halla una información que hizo el monasterio en razón de la jurisdición del barrio de San Zoles porque un teniente de correjidor de la villa de Carrión quiso residenciar a los alcaldes del dicho barrio y quitarles las varas de justicia. Está firmada ${ }^{121}$ de Juan de Castrillo, escribano de Carrión. Síguese el poder y requerimiento que hizo el monasterio al mismo teniente sobre lo mismo, al que respondió que nuestra carta executoria le daba jurisdición acumulativa con los alcaldes del barrio y que, mientras no se le prohibiese el tomar residencia a dichos alcaldes, que protestaba e protestó no le parase perjuicio el dicho requerimiento. Su fecha, en Carrión, a 25 de enero de 1551, ante Gregorio Movilla, escribano público.

${ }^{120}$ San Zoles] al margen derecho: Véase nuestro legajo $1^{\text {o }}$ del cajón San Leandro, letra G.
${ }^{121}$ firmada] escrito sobre signada. 
33. < Executoria a favor del Barrio de San Zoles para que haya carnicería, pescadería y taberna $>$.

Executoria, escrita en pergamino, con sello de plomo pendiente en filos de seda, del emperador Carlos $5^{\circ}$, por la qual consta que en la Chancillería de Valladolid, a 19 de julio de 1547, la parte de este monasterio y los vecinos del barrio de San Zoles se querellaron de los vecino de Carrión porque les prohibían poner en el dicho barrio carnicería, pescadería, panadería, taberna y otros oficios necesarios para su abasto, sobre que se dio traslado a la parte de la villa. Se alegó y probó por ambas partes: el monasterio pressentó los privilegios que tiene del barrio, Villamuera y Arconada y otras confirmaciones de los privilegios del monasterio, que todos están insertos, de verbo ad verbum, en esta carta executoria.

$<$ Sentencia definitiva $>$.

Y habida la causa por conclusa, en la Real Chancillería de Valladolid, a $1^{\circ}$ de marzo del año de 1547 se pronunció sentencia definitiva, por la qual declaran que los vecinos del barrio para siempre puedan poner en él carnicería, pescadería y taberna, en que se pueda vender libremente carne, pescado y vino conforme a la postura de los alcaldes del barrio, con que no excedan de los precios de la villa; y en castigar los excesos guarden los alcaldes las ordenanzas de Carrión, y que los vecinos de la villa no les perturben. En quanto / (f. 95r) al castigo de los pescaderos, carniceros y taberneros que excedieren, y visita de pesos y medidas, y en lo demás perteneciente a la jurisdicción del barrio, haya lugar prevención entre la justicia de Carrión y los alcaldes del barrio, conforme a las cartas executorias que hay en este particular de la Chancillería; y que las justicias de Carrión no se entrometan en los casos que previnieren y conocieren los alcaldes de San Zoles. Que los vecinos de Carrión buelvan a los del barrio las pesas, medidas, pescado, etcétera, que les huviesen quitado y suelten los presos.

$<$ Sentencia de revista. Año 1551>.

De esta sentencia apeló la villa de Carrión y, conclusa la segunda instancia, en Valladolid, a 10 de septiembre de 1549, se pronunció sentencia de revista, confirmando la primera, de que se despachó esta carta executoria a 2 de marzo de 1551 . Está bajo este número esta misma carta executoria, escrita en papel, que se sacó el año de 1554 por haverse perdido la anterior.

34. < Ynformación sobre el pasto de los ganados de San Zoles. Año 1551>.

Ynformación hecha [por] el alcalde de San Zoles y Gregorio de Movilla, escribano, en el año 1551, sobre haber los vecinos de la villa prendado y comido tres carneros de la carnicería del barrio y haber prendido al pastor, y sobre el pasto de los carneros.

35. <Executoria sobre que el ganado de la carnicería de San Zoles pueda pastar en los términos de Carrión>.

Executoria ganada en la Real Chancillería de Valladolid, por la que consta que este monasterio de San Zoil, concejo, alcaldes y rejidores del barrio de San Zoles, a 13 de octubre de 1551, se querellaron de los vecinos de la villa de Carrión porque no les dexaban pastar el ganado de la carnicería del barrio en los pastos de Carrión, como lo tenían de costumbre, sobre que se dio traslado a la villa. Alegaron ambas partes y probaron lo que les pareció.

$<$ Sentencia de vista $>$.

Y conclusa la causa, se pronunció sentencia definitiva en Valladolid, a 5 de diciembre de 1553, por la que se declara que los vecinos del barrio de San Zoles pueden trhaer por los términos de la villa de Carrión todo el ganado que necesitaren para el servicio y abasto de la carnicería del dicho barrio, y poder pacer en los dichos términos en la misma forma que el de los obligados de la carnicería de Carrión.

$<$ Sentencia de revista. Año de 1555>.

Suplicó la villa de esta sentencia y, conclusa la causa en segunda instancia, se pronunció sentencia definitiva en grado de revista, a 10 de septiembre de 1555 , por la que se confirmó la primera de vista y se mandó librar esta carta executoria, a 13 de septiembre del mismo año, ante Gerónimo de Vega, escribano de cámara de Su Magestad. 

Año de $1556>$.

/ (f. 95v) 36. < Requirimiento al correjidor para que suelte al alcalde de San Zoles.

Requirimiento hecho por parte del monasterio a la justicia de Carrión para que soltase al licenciado Flores, alcalde mayor del barrio de San Zoles, que estaba preso en la villa. Obedeció el correjidor, como consta de testimonio dado por Thomás Sánchez, escribano de Carrión, a 10 de diciembre de 1556.

37. <Que no se impida la taberna del barrio. Año de 1557>.

Requirimiento a la villa de Carrión para que no impida la taberna del barrio de San Zoles. Está signado de Francisco Sánchez de Valbuena, escribano de Carrión, a 2 de marzo de 1557.

38. < Venta del barrio, su jurisdición y el molino de la tapia a la villa. Año de 1564>.

Escritura de venta del barrio de San Zoles y su jurisdición y del molino de la tapia, propio todo del monasterio de San Zoil. Por esta escritura parece que el monasterio, por evitar pleitos y disensiones que todos los días tenía (sobre la jurisdición del barrio) con la villa de Carrión y los mismos vecinos del barrio y de la villa entre sí, se empezó a tratar de la enagenación de él, el año de 1561; para lo qual se practicaron en este año y siguientes todas las diligencias necesarias y se sacaron las licencias competentes por parte del monasterio y de la villa. En virtud de esto, el año de 1564 el monasterio otorgó en favor de la villa de Carrión dicha venta, traspasando en ella para siempre jamás el barrio de San Zoles con toda la jurisdición y preeminencias que sobre él tenía, incorporando sus vecinos por propios de la villa, con las mismas exenciones que estos tienen y con las condiciones siguientes, que están al folio 14:

$<1^{\text {a }}$ Condición $>$.

Que el dicho barrio de San Zoles y los vecinos de él se incorporen en la villa y se hagan vecinos de ella, renunciando el monasterio la jurisdición en la villa, en todo y por todo.

$<2^{\mathrm{a}}>$.

Que por razón de dicha jurisdición y por los gastos que el dicho monasterio tubo en sacarla, y la taberna, carnicería y otras preeminencias, ha de darle la villa 500 mil maravedís en tres plazos.

$<3^{\mathrm{a}}>$.

Que el monasterio pueda trhaer perpetuamente 100 carneros immortales por los términos de la villa de Carrión, que muertos unos se subrroguen otros, para gasto del monasterio y no para venderlos, los quales puedan entrar en todos los pastos que entran los de los obligados de la villa.

$<4^{\mathrm{a}}>$.

Que los 387 mil 500 maravedís de las dos últimas pagas lo haya de emplear el monasterio en un juro perpetuo o en comprar alguna hacienda para que siempre haya memoria de que la / (f. 96r) tiene por la jurisdición del barrio.

$<5^{\mathrm{a}}>$.

Que los vecinos del barrio se incorporen con los de la villa y hagan un cuerpo con ella, gozando las mismas preeminencias que ellos.

$\left.<6^{\mathrm{a}}\right\rangle$.

Que la villa haya de recivir por vecino a qualquiera que se quisiere avecindar en el barrio; y si la villa le negare la vecindad sólo la pueda dar el abad de San Zoil. $<7^{\mathrm{a}}>$.

Que haya perpetuamente taberna en el barrio, de vino, de cinco leguas al contorno de donde lo trhae la villa; y si ésta lo trajere de Toro, se pueda trhaer y vender en el 
barrio. Y si la villa no pusiere esta taberna pasados quince días después de requerida, que la ponga el abad, y que por aquel año que le pusiere no le pueda quitar la villa; y que assimismo pueda haber y haya en el barrio panaderas, tenderas y mal cocinado.

$<8>$.

Que los 300 maravedís de martiniega que tiene el monasterio sobre los vecinos del barrio de San Zoles los cobre de los mismos vecinos.

$<9>$.

Que la villa ha de pagar al monasterio los 7 mil 51 maravedís que tiene por privilegio de Su Magestad sobre las alcavalas del barrio (Véase el juro en el cajón San Leandro).

$<10>$.

Que la villa buelva al monasterio cierta cantidad de vigas que este tenía cortadas, y la propiedad del sitio donde se cortaron quede para la villa.

11. <Venta del molino de la tapia y sus tierras $>$.

Que el monasterio vende y da a foro perpetuo al concejo y vecinos de la villa de Carrión el molino de la tapia, propio del monasterio, con dos paradas molientes y corrientes y todos sus aparejos, juntamente con las heredades del mismo molino, que son hasta 5 obradas de tierra, por precio de nueve cargas de trigo en cada un año, seco, limpio de dar y tomar, medido por la medida de Ávila, puesta en el monasterio el día de Nuestra Señora de septiembre, con la condición de que si no pagaren este día paguen doblado y bajo otras condiciones que se pueden ver al folio 79 vuelto.

$<12>$.

Que si la villa en algún tiempo fuere contra estos capítulos, pierda todos los maravedís que huviere dado al monasterio; y si éste fuere contra ellos, buelva a la villa todo lo que huviere percivido de ella.

$<13>$.

Que para efectuar este concierto, la villa saque licencia de Su Magestad y el monasterio de su General.

/ (f. $96 v)<14>$.

Vltimamamente, que si fuere necesario sacar confirmación de Su Santidad, se saque dentro de un año y el coste que tubiere le satisfagan ambas partes por mitad.

Para cumplimiento de estas condiciones hipotecaron ambas partes varios bienes generales y especiales. Otorgose la escritura en San Zoil, a 15 de febrero de 1564, ante Andrés Sánchez, escribano de Carrión. Al día siguiente tomó la villa posesión del barrio y su jurisdición, con todo lo demás que les cedió el monasterio por esta escritura; y en 28 de febrero del mismo año tomó posesión el monasterio del hervaje de los 100 carneros en los términos de la villa de Carrión. Todo pasó ante el mismo escrivano.

39. <Consulta sobre el ganado del pastor de San Zoil. Año de 1602>.

Consulta que se hizo a dos letrados sobre haber prendado la villa el ganado del pastor del monasterio que no podía trhaerlo según las ordenanzas de la villa; por lo que parece le condenaron en Carrión en la pérdida de un carnero y en las costas del proceso; pero no se sabe en qué paró esta causa. Año de 1602.

40. <Mandamientos sobre la martiniega a los vecinos del barrio $>$.

Bajo este número está una información hecha por el monasterio el año de 1562 sobre los 300 maravedís de martiniega que le deben pagar cada año los vecinos del barrio de San 
Zoles, y varios mandamientos y requerimientos hechos a los mismos vecinos sobre la misma paga desde el año de 1613 hasta el de 1686.

41. <Provisión real sobre los pastos del ganado del monasterio. Año de 1767>.

Provisión real de la Chancillería de Valladolid, dirijida a la justicia de la villa de Carrión, para que no se perturbe al monasterio en la posesión en que está de trhaer sus ganados mayores y menores por los términos de la villa como qualquier vecino de ella, y además los 100 carneros inmortales. Su fecha, en Valladolid, a 22 de septiembre de 1767, ante Juan Antonio de Cos, secretario de cámara. $1779>$.

42. <Executoria ganada por el monasterio por el pasto de sus ganados. Año de

Carta executoria ganada en la Chancillería de Valladolid contra la justicia, regimiento y procuradores, síndico y personero de la villa de Carrión, sobre que el monasterio pueda trhaer por los términos de la villa, no sólo los 100 carneros immortales (que por la venta del barrio le fueron concedidos ${ }^{122}$ ), sino también los demás que quisiere trhaer en la misma forma y manera / (f. 97r) que los otros vecinos más hacendados de ella, en cuya posesión fue manutenido y amparado el monasterio por las sentencias de vista y revista, dadas a 23 de marzo de 1779 y a 15 de junio del mismo año; y condenan a la villa a que no perturbe ni inquiete al monasterio en dicha posesión, pena de 50 mil maravedís para la cámara de Su Magestad. Fue despachada esta carta executoria a 18 de junio de 1779, por testimonio de don Manuel Luis de Vitoria, secretario de cámara de Su Magestad. $1796>$.

43. < Carta executoria a favor del monasterio sobre unos ganados infestados. Año de

Carta executoria ganada en la Chancillería de Valladolid contra don Antonio Jofre de Villegas, don Juan José Colderón (sic) y otros consortes, vecinos de Carrión, por la que se confirman dos autos dados por el correjidor de Carrión, en dos expedientes que siguió el monasterio el año de 1794, sobre que dos ganados que se habían manifestado contagiados en la loma, y que por disposición de los ganaderos habían bajado a la vega, se removiesen a la loma, por el daño que se podía seguir al ganado del monasterio. Diose la sentencia en Valladolid, condenando en costas a las partes contrarias, en 27 de enero de 1796, y sacose esta carta executoria a 12 de abril del mismo año, por testimonio de don Joaquín Piquot y Serrador, secretario de cámara de Su Magestad.

\section{Remisiones.}

Executoria y posesión de la jurisdición del barrio. Véase el cajón San Mauro, legajo $1^{\circ}$, quaderno $\mathrm{A}$, números $4^{\circ}$ y $5^{\circ}$; en éste está el districto de la jurisdición del varrio de San Zoles.

\section{/ (f. 97v) Legajo $4^{\circ}$}

Este legajo, que es el $4^{\circ}$ del cajón San Pedro, contiene los privilegios y otros papeles pertenecientes al agua del Cuérnago y al arroyo forero, por el orden siguiente:

$1^{\circ}<$ Previlegio y pesquisa ${ }^{123}$ del agua del Cuérnago. Era de 1241. Año de 1203>.

Previlegio ${ }^{124}$ del Rey Don Alonso por el qual consta que, estando Su Magestad en la Cámara de San Zoil y habiéndosele quejado los monges que se les quitaba el agua del

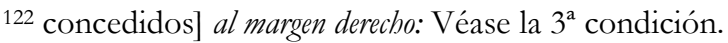

123 pesquisa] s corregida sobre $\mathrm{r}$.

124 Previlegio] al margen derecho: Nota. Bajo este número está una relación de los fundamentos que tiene este monasterio para gozar la $3^{a}$ parte del agua del Río Mayor; y un plan de él con los cuérnagos y boquetas que salen de ellos.
} 
Cuérnago, dio su comisión y authoridad a don Pelayo, abad de Sahagún, y a Rodrigo Martín para hacer pesquisa e información con mucho número de testigos; y hecha, resultó que los de Nogal cegaban la presa del Nido del Cuervo y que no había sopresa, que en Nogal había una presa y que los vecinos iban y la desacían sin ser prendados ni castigados por ello. Algunos testigos dixeron que el emperador había mandado que el agua de río Carrión se dividiese en tres partes, que la dos vengan a Carrión y la otra a San Zoil y que no haya sopresa alguna de Nogal abajo. Presentada esta pesquisa ante el rey don Alonso y don Martín, arzobispo de Toledo, mandó el rey a un portero suyo que fuese a Nogal y quebrantase la presa estando presente Pelayo, abad de Sahagún; mandó también quebrantar la presa de Carrionzillo y que no huviese sopresa ninguna desde el Nido del Cuervo hasta Carrión. Confirma y aprueva lo hecho y manda que le valga al monasterio de San Zoil y que de esto se hagan tres cartas, vna para que esté en poder del rey, otra en Sahagún y otra en San Zoil. Diose este privilegio, escrito en pergamino, en el claustro de San Zoil, día de la vigilia de la Asunción de Nuestra Señora, era 1241, que es año de Christo de 1203. Hay copia authorizada de este privilegio.

2. Dos copias authorizadas, escritas en pergamino, de un privilegio del rey don Fernando el $4^{\circ}$, por el que confirma y manda que se guarde el privilegio anterior del rey don Alonso. Sacose la / (f. 98r) primera por Juan Mache, escribano de Carrión, a 5 de julio, era de 1346, que es año de Christo 1308; y la segunda por Guillén Pérez, escribano de la misma villa, a 9 de enero, era de 1369, que es año de 1331.

3. <Privilegio a favor de las Huelgas de Burgos y repartimiento del agua del río. Era 1323. Año de 1285>.

Copia authorizada de un privilegio del rey don Sancho el Brabo, confirmado por su nieto el rey don Alonso 11, dado a instancia de la ynfanta doña Blanca, hermana del rey don Sancho y señora de las Huelgas de Burgos, y de la abadesa de aquel monasterio, por el qual conceden dichos reyes el agua del río Carrión a los molinos que tenía en su rivera el monasterio de las Huelgas, y ponen el repartimiento y presas del agua del río desde Saldaña hasta el Nido del Cuervo, y mandan a los monges de San Zoil no quiten el agua de la presa de doña Sancha que va a los molinos de las Huelgas. Diose el privilegio en Burgos, a 17 de abril, era de 1323, que es año de 1285; y el de confirmación, en la misma ciudad, a 22 de septiembre, era de 1343, que es año de 1305. Sacose esta copia del original que está en dicho monasterio de las Huelgas en virtud de provisión de la Real Chancillería de Valladolid, por José de Castellanos, escribano de Su Magestad, del número de la referida ciudad de Burgos y del juzgado de las Huelgas, a 12 de enero de 1724. Hay dos copias simples, una antigua y otra moderna. de $1331>$.

4. < Privilegio del rey don Alonso 11, confirma los del número $1^{\circ}$ y $2^{\circ}$. Era 1369. Año

Copia authorizada, escrita en pergamino, de un privilegio del rey don Alonso 11, por el que confirma y manda guardar los dos privilegios de los números $1^{\circ}$ y $2^{\circ}$ de arriba, insertos en éste. Diose el privilegio de confirmación en Sevilla, a 14 de febrero, era de 1369, que es año de 1331. Sacose esta copia en Carrión, por Fernando González, escribano de la misma villa, a 20 de julio de 1398. Hay otra copia authorizada sacada año de 1780, y otra simple de letra antigua.

\section{5. <Testimonio del repartimiento del agua del río. Año de 1375>.}

Testimonio authorizado por Francisco Pérez, escribano de Carrión, en 31 de julio de 1411, a instancia de don Fernando, prior mayor de San Zoil, el qual es copia de otro testimonio dado por Gómez Rodríguez, escribano de la misma villa, a 2 de agosto de 1375, del repartimiento que se hizo por la justicia de Carrión del agua del río, / (f. 98v) hechando las dos partes a Población del Soto y la otra a San Zoil. 

de $1398>$.

6. $<$ Requirimiento a los de Población del Soto sobre el repartimiento del agua. Año

Testimonio de un requirimiento hecho por parte de este monasterio a los arrendadores del agua, molinos y campo de Población del Soto ${ }^{125}$ por la abadesa de las Huelgas de Burgos, con el privilegio del agua, al qual obedecieron, dando la tercera parte del agua a San Zoil como la había tenido siempre. Su fecha, a 10 de agosto de 1398, ante Gómez García de Saldaña, escribano y notario público. Hay copia authorizada.

7. <Testimonio del repartimiento del agua. Año de 1412>.

Testimonio de cómo se partieron las aguas del Río Mayor en Población del Soto y se dio la tercera parte a San Zoil, en virtud del privilegio real que para ello tiene, y las otras dos partes a la villa de Carrión. Su fecha, en Población del Soto, a 31 de julio de 1412, ante Fernando Alfonso de Carrión, notario de Palencia. Hay copia authorizada.

8. <Requirimiento sobre el repartimiento del agua. Año de 1412>.

Otro testimonio de un requirimiento con el privilegio de las aguas, hecha al merino y molineros de Población del Soto, sobre el repartimiento de la tercera parte del agua, el qual obedecieron. Su fecha, a 31 de julio de 1412, ante Fernando Alfonso de Carrión, notario de Palencia. Hay copia authorizada.

$9^{126}$. < Provisión contra los alcaldes de Carrión para que paguen los daños por haber quitado el agua. Año de 1416>.

Copia authorizada de una provisión real de don Juan el $2^{\circ}$, por la qual manda a los alcaldes de Carrión hagan pagar al monasterio de San Zoil los daños que se le han seguido por haberle quitado la tercera parte del agua del río, y les emplaza para que dentro de nueve días acudan ante él a exponer las causas que tubieren para no hacerlo. Su fecha, en Valladolid, a 16 de septiembre de 1416. Notificose esta provisión a los alcaldes de Carrión por Rui García, escribano de la misma villa, quien sacó esta copia.

$10^{127}$. <Requirimiento a la sentencia de Carrión para que quite una sopresa del Cuérnago. Año de 1416>.

Requirimiento hecho por pate del monasterio a los alcaldes de Carrión para que guarden y hagan guardar el privilegio del agua, y en su cumplimiento manden deshacer una sopresa del Cuérnago. Está inserto en este requirimiento el privilegio del agua y la respuesta de los alcaldes. Su fecha, en Carrión, año de 1416, ante Gonzalo Fernández, escribano en dicha villa.

11. <Testimonio cómo el comendador de la Herrada juró no hacer sopresa en el Cuérnago. Año de 1416>.

Testimonio, escrito en pergamino, por el qual consta que don frei Sancho, comendador del hospital de don Gonzalo, que es el de la Herrada, habiendo hecho una sopresa en el Cuérnago para sacar agua para regar su huerta, confiesa que el monasterio / ( $f$. $99 r$ ) tiene privilegios para que no se pueda hacer y que erró; pide perdón humildosamente al monasterio, promete y jura que no lo hará otra vez. El monasterio le perdonó el yerro por haberlo pedido afincadamente don García Fernández Manrrique y doña Aldonza,su muger, con tal que de allí adelante cumpliese lo prometido y jurado. Su fecha, en San Zoil, a 18 de octubre de 1416, ante Rui García, escribano de Carrión. Hay copia authorizada.

12. < Requirimiento a la villa para que entregue el privilegio del agua. Año de 1441>.

Requirimiento hecho por parte del monasterio de San Zoil al concejo y regimienmto de la villa de Carrión, para que le buelban el privilegio del agua concedido al monasterio que tenía el concejo en el arca o archivo común, habiendo sido otorgado al monasterio y no a la

\footnotetext{
${ }^{125}$ Población del Soto] al margen derecho: Población del Soto.

126 9] al margen derecho: Nota. Este número debe ser el 10.

127 10] al margen derecho: Este número debe ser el 9.
} 
villa por los reyes de Castilla. Respondió el concejo que tenía el privilegio y que no le entregaba porque era común al monasterio y a la villa, pertenecía más a ésta porque en él se le concedía dos partes de agua y al monasterio sólo una. Su fecha, en Carrión, a 4 de abril de 1441, ante Luis Fernández, escribano en dicha villa.

\section{3. <Licencia para regar. Año de 1477>.}

Licencia que dio Alfonso García de Villasur, limosnero de San Zoil, a ciertos hombres para que en el año de 1477, que hubo gran falta de agua, pudiesen regar sus heredades tomando el agua del Cuérnago por encima de las canales del molino del pisón, los quales conocieron que no podían hacerlo sin dicha licencia y que regarían por aquella vez y no más, sin pretender por ello adquirir posesión por ello. Su fecha, en San Zoles, a 2 de junio de 1477, ante Fernando Cavallo, escribano de Carrión.

14. < Concordia entre el monasterio de San Zoil y el de Santa Clara sobre una presa que éste había hecho en el Río Mayor. Año de 1482>.

Escritura de concordia y obligación que hicieron las monjas y convento de Santa Clara de Carrión de satisfacer y pagar a este monasterio todos los daños que se le siguiesen de las aguas y avenidas del Río Mayor en el molino de la tapia y huertas, por haber hecho las monjas una presa en el Río Mayor para sacar agua para su molino del temple; y si no satisfacieren dichos daños pueda el monasterio de San Zoil, por su authoridad, derribar la dicha presa. Su fecha, en Santa Clara, a 22 de octubre de 1482, ante Fernando Cavallo, escribano de Carrión.

15. $<$ Repartimiento de aguas $>$.

Copia simple de un repartimiento de las aguas que van a Villanueba, Villaturde y Benevívere, hecho año de 1483. $1522>$.

/ (f. 99v) 16. < Requirimiento a la villa que guarde el privilegio del agua. Año de

Requirimiento hecho por el monasterio a la justicia de Carrión para que guarde los privilegios del agua y no consienta sopresa en el Cuérnago ni en el río contra lo ordenado en los privilegios, y que se parta el agua dando la tercera parte enteramente a San Zoil. Su fecha, en Carrión, a $1^{\circ}$ de agosto de 1522, ante Francisco Catalán, escribano en la misma villa. Están unidos a éste otros requirimientos del año de 1560.

17. < Provisión sobre el arroyo forero. Año de 1527>.

Provisión del emperador Carlos $5^{\circ}$ para que el arroyo forero se heche por fuera del monasterio o se ponga una red en el sitio por donde sale el agua, de suerte que por él no pueda entrar ni salir nadie. Fue dirijida esta provisión a la justicia de Carrión. Su fecha, en Burgos, a 10 de diciembre de 1527, ante Francisco de Campo, escribano de Su Magestad.

18. <Licencia del General para concordar sobre el arroyo forero. Año de 1527>.

Licencia del General fray Alonso de Toro para que el monasterio pueda concertar con la villa sobre el sitio del arroyo forero. Su fecha, en San Zoil, a 25 de septiembre de 1527, ante Francisco Catalán, escribano de Carrión.

19. <Concordia con la villa sobre el arroyo forero. Año de 1528>.

Concordia y capitulaciones del arroyo forero hechas entre este monasterio y la villa de Carrión. Son las siguientes:

$1^{\text {a }}$. Que el arroyo forero y su agua vaya por donde fue siempre, que sea del mismo ancho y que los monges no lo impidan.

$2^{a}$. Que el bocadero y entrada del agua del Cuérnago en el arroyo forero sea por donde fue siempre, llano y del mismo tamaño, sin que se le ponga impedimento.

$3^{\mathrm{a}}$. Que al fin del arroyo forero y salida de la huerta pueda el monasterio hacer una puente de madera, sobre la qual se puedan hacer tapias para cerrar el monasterio y que por 
debajo la puente haya una reja de yerro abierta para que el agua salga libremente y no pueda entrar por ella persona alguna.

$4^{\mathrm{a}}$. Que todas las veces que fuere necesario entrar a limpiar el dicho arroyo, o ver si va bien el agua, el monasterio dé entrada y puerta abierta para ello, y quiten los impedimentos so pena de 20 mil maravedís y pagar los daños que se siguieren a los dueños de las heredades que se habían de regar.

$5^{a}$. Que si los monges no abrieren las puertas a los que vinieren a tomar el agua o limpiar el arroyo, puedan derribar / (f. 100r) las tapias que estuvieren sobre la puente del dicho arroyo y entrar a lo que huviere menester.

Otorgose esta escritura en el mes de abril del año de 1528, ante Juan Sánchez, escribano de Carrión.

20. <Testimonio de una querella por haber regado sin licencia. Año de 1530>.

Testimonio de la querella que dio el monasterio ante el prior de Escalada, juez conservador, de la muger de Juan de Ortega, por haber sembrado un linar y sacado agua del Cuérnago para regarle sin pedir licencia al monasterio. Confiesa ésta que no pudo hacerlo y pide licencia para regarlo por aquella vez. Su fecha, en Carrión, a 18 de junio de 1530, ante Juan de Castrillo, escribano en dicha villa. Hay copia authorizada.

21. < Sentencia sobre cortar zéspedes. Año de 1551>.

Copia simple de una sentencia dada por la Chancillería de Valladolid a favor de la villa de Carrión y contra este monasterio para que no corte zéspedes de la Clavera de arriba sino conforme a las ordenanzas de la villa. Su fecha, en Valladolid, a 27 de octubre de 1551.

22. <Nombramiento de regidor del agua. Año de 1553>.

Nombramiento de regidor del agua que hicieron los molineros de la rivera de San Zoles en presencia de fray Rodrigo de Corcuera, abad de San Zoil, los quales aprobaron las ordenanzas de esta rivera y juraron de guardarlas. Su fecha, en San Zoil., a 11 de junio de 1553, ante Andrés Sánchez, escribano de Carrión. Hay copia authorizada.

23. <Licencia para regar. Año de 1567>.

Confesión que hace Antonio Núñez de Alameda de haberle concedido fray Juan de Corcuera, abad de San Zoil, licencia para regar un linar. A 18 de agosto de 1567.

24. $<$ Mandamiento para la partición de las aguas. Año de 1570>.

Mandamiento de la justicia de Carrión para la partición de las aguas entre las riveras de Calzada, Torre y Carrión, conforme al privilegio que tiene este monasterio. Su fecha, en Carrión, a 22 de junio de 1570. Hay copia authorizada.

25. < Relación en derecho sobre el agua. Año de 1573>.

Relación en derecho, en lengua latina, del repartimiento del agua $<$ en un pleito $>$ que tubo este monasterio con los vecinos del lugar de la Serna, llamados Nogalenses. Año de 1573.

26. < Ordenanzas de la rivera de San Zoles. Año de 1574>

Copia simple de las ordenanzas de la rivera, molinos y agua de San Zoles, hechas siendo abad de este monasterio fray Sebastián de Encinas, en Carrión, a 14 de diciembre de 1574, ante Andrés Sánchez, escribano en la misma villa.

27. <Licencia para regar. Año de 1587>.

Confesión que hizo Juan Galarán de haber sacado licencia de nuestro padre abad para regar un pedazo de huerta. Año de 1587. 
/ (f. 100v $) 28 .<$ Requirimiento a la villa para que no arrime el río al monasterio y barrio. Año de 1600>.

Requirimiento hecho por parte del monasterio a la justicia de Carrión para que, con motivo de una estacada que iba a hacer en el Río Mayor junto al puente, no arrime el agua al monasterio ni al barrio de San Zoles por el gran daño que de ello se podría seguir. Su fecha, en Carrión, a 2 de octubre de 1600, ante Pedro de Cervantes, escribano de la dicha villa. Hay aquí dos requirimientos y una provisión real sobre lo mismo del año 1608.

29. <Mandamiento para que se dé el agua al monasterio. Año de 1624>.

Mandamiento del correjidor de Carrión a los molineros de la rivera de San Zoles para que den al monasterio el agua que le pertenece. Su fecha, en Carrión, a 16 de septiembre de 1624, ante Francisco Moro de Saldaña, escribano en dicha villa. Hay copia authorizada.

30. <Información en un pleito sobre el agua del Cuérnago. Año de 1626>.

Provisión real y provanza hecha por parte de este monasterio en el pleito que seguía contra doña María Gallinas y sus hijos, sobre el agua que tomaba del Cuérnago para un molino suyo. Hízose esta información año de 1626, ante Francisco Moro de Saldaña, escribano de Carrión.

31. <Licencia para sacar zéspedes. Año de 1647>.

Licencia que dio el correjidor de Carrión al rejidor y molineros de la rivera de San Zoles para cortar zéspedes para el servicio de la presa y conducir el agua a los molinos y riegos. Dada en Carrión, a 10 de agosto de 1647, ante Andrés Martínez, escribano en dicha villa.

32. <Licencia para romper el campo que fuere necesario para conducir el agua para el Cuérnago. Año de 1649>.

Licencia que dio el correjidor de Carrión a los molineros y pisoneros de la rivera de San Zoles para que, por el sitio que les señalaren, puedan romper el campo y sitio que fuere necesario para conducir el agua para el Cuérnago, molinos, prado de la villa y demás heredades de riego, atento que por la justicia y regimiento de ella se ha dado licencia para dicho rompimiento. Dada en Carrión, a 20 de marzo de 1649, ante Gerónimo López, escribano de dicha villa. $1659>$.

33. < Manuel Magdaleno confiesa no poder poner manta ni zarzo para regar. Año de

Escritura que otorgó Manuel Magdaleno, vecino y rejidor perpetuo de Carrión, por la que confiesa no poder poner manta ni zarzo en el Cuérnago para regar una tierra junto al molino de la Salzeda, y que sólo lo puede hacer por la boqueta que tiene el Cuérnago, sin impedir el curso natural del agua. Su fecha, en Carrión, a 12 de agosto de 1659, ante Norberto de Sandoval y Guevara, escribano en dicha villa.

34. <Licencia al regidor de la rivera de San Zoles para tener juntas. Año de 1663>.

Licencia que dio don Bentura López de Arriaga, correjidor de Carrión, al rejidor de la rivera de San Zoles, para que pueda juntar cavildos / (f. 101r) y acordar lo que conviniese para el mejor réjimen de dicha rivera. Su fecha, en Carrión, a 12 de julio de 1663, ante Gerónimo Laso, escribano en la misma villa.

35. < Auto de oficio contra unos de Nogal porque cerraron una presa. Año de 1665>.

Compulsa, en virtud de provisión real, de una querella y auto de oficio formado por el correjidor de Carrión contra algunos vecinos de Nogal porque cerraron la presa y impedían venir el agua por el Río Mayor y a la rivera de San Zoles. Fue sacada esta compulsa por Norberto de Sandoval y Guevara, a $1^{\circ}$ de septiembre de 1665.

$<$ Nota. Sentencia contra Sahagún y Nogal sobre una presa $>$.

Este mismo año se siguió pleito por parte de este monasterio y la villa de Carrión contra en el monasterio de San Benito de Sahagún, su priorato de Nogal y el licenciado 
Francisco de los Cuetos, vecino de Carrión, sobre una presa que había hecho el prior de Nogal. Diose sentencia de vista y revista en Valladolid a favor de este monasterio y la villa de Carrión, ante Domingo de la Madrid, secretario de cámara de Su Magestad, en cuyo oficio se hallarén estos autos, como consta de la nota que se halla a lo último de este papel. Se concluyó el pleito año de 68.

36. < Repartimiento y cobranza del coste del pleito de las aguas. Año de 1668>.

Repartimiento hecho por la justicia de Carrión, en virtud de reales provisiones, entre los interesados en el agua del Cuérnago, del coste que tubo el pleito referido en el número antecedente, cuya cantidad había satisfecho enteramente este monasterio por sí y por la villa. Año de 1668.

37. <Acuerdo de la villa para deshacer una pradera que había cercado en la clavera de arriba. Año de 1758>.

Testimonio de un acuerdo celebrado por la villa de Carrión, a 15 de julio de 1758, por el que confiesa el ayuntamiento el derecho que tiene el monasterio para que no se extraiga agua del Cuérnago para riego de huertas ni otra cosa, en virtud de lo qual mandó suspender y reducir a su antiguo estado un pedazo de pradera que había mandado cercar para huerta en la clavera de arriba, entre los molinos de la Salzeda y San Martineja, de lo que se había quejado el monasterio ante el correjidor. Sacose este testimonio a 8 de agosto de 1758, por Manuel Francisco Blanco, escribano de Carrión.

38. <Licencias para regar.>.

Bajo este número están varias licencias para regar concedidas por el padre abad, y en su ausencia por el presidente de este monasterio, desde el año de 1768 hasta el de 1780.

39. <Provisión real en el pleito con don Vicente Ruiz sobre el agua del Cuérnago. Año de $1782>$.

Provisión real para que quatro individuos de la cofradía de Nuestra Señora de la O juren y declaren, al tenor de un pedimiento en ella inserto, presentado por el abad y monges de este monasterio en / (f.101v) un pleito que seguía contra don Vicente Ruiz Ramos, vecino de esta villa, sobre haber extraído agua del Cuérnago para regar una tierra propia del Hospital de la $\mathrm{O}$, detrás de las cercas de la huerta de este monasterio. Su fecha, en Valladolid, a 7 de junio de 1782, ante don Gregorio Núñez de Arce, escribano de cámara de Su Majestad. Este pleito se comenzó en Carrión por vía criminal, en donde fue condenado en todo dicho don Vicente, de cuya sentencia interpuso apelación a Valladolid, según consta del Libro de Depósito en las qüentas de estado del año de 1781. Está pendiente este pleito en el oficio del referido escribano de cámara, don Gregorio Núñez de Arce.

40. $<$ Licencias para regar $>$.

Tres licencias concedidas a varias personas por los abades de esta casa para sacar agua del Cuérnago a fin de regar varias heredades en los años de 1787, 1790 y 1793.

41. <Auto para que nadie lave en el Cuérnago. Año de 1795>.

Testimonio de un pedimento por parte de este monasterio y auto dado a su continuación por el correjidor de Carrión, por el que prohíbe a toda persona de qualquiera clase que sea, el lavar en el Cuérnago, bajo la multa de 4 ducados por la primera vez y doble por la segunda, cuyo auto se hizo saber a voz de pregón al vecindario. Su fecha, en Carrión, a 23 de diciembre de 1795, ante José Tablares, escribano en dicha villa, quien sacó este testimonio en 15 de abril de 1797.

42. <Licencia para regar. Año 1802>.

Licencia que dio nuestro padre maestro fray Leandro Pérez para regar una tierra con el agua del Cuérnago, en el año de 1802.

43. $<$ Licencia para regar. Año 1807>.

Licencia que dio nuestro padre maestro fray Plácido Esnelgo, abad de San Zoil, para sacar agua del Cuérnago parar regar el plantío que está junto a la calzada, en el año de 1807. 
44. $<$ Licencia para regar. Año 1816>.

Licencia que dio nuestro padre maestro fray Fulgencio Campo, abad de San Zoil, para regar el plantío que está junto a la calzada sacando el agua del Cuérnago. Su fecha, en San Zoil, a $1^{\circ}$ de mayo de 1816. 


\section{/ (f. 102r) Cajón 5o San Andrés \\ Letra C}

Este cajón san Andrés, que es el $5^{\circ}$ del archivo, contiene cinco legajos que son los siguientes: $1^{\circ}$ : Parroquia, diezmos y visita de yglesia; legajo $2^{\circ}$ : Cuerpos de los Santos Mártires y diferencias con los clérigos y villa de Carrión sobre la preferencia en los asientos; legajo $3^{\circ}$ : Hospital de la O; legajo $4^{\circ}$ : Hospitales de San Lázaro y la Herrada; legajo $5^{\circ}$ : Capilla de doña Constanza y su extinción.

\section{Legajo $1^{\circ}$ \\ Parroquia}

Este legajo contiene los tres quadernos siguientes: Quaderno A: Papeles pertenecientes a la parroquia de San Zoles o Santa María Magdalena; quaderno B: Diezmos de dicha parroquia; quaderno C: Papeles sobre la visita de la parroquia.

\section{Quaderno A del legajo $1^{\circ}$}

Este quaderno contiene los papeles pertenecientes a la vnión de la capellanía de Santa María Magdalena a la sacristía de San Zoil, y sobre derechos parroquiales, por el orden siguiente:

$<$ Nota $>$.

La parroquia de San Zoles, sita en este real Monasterio de San Zoil, solía antiguamente tener por cura un clérigo, por presentación y nombramiento del abad de esta casa; y en esta forma se governó hasta el año de 1476, en que fray Zoil de Nogal, sacristán mayor de San Zoil, logró de la Santidad de Sixto $4^{\circ}$, se uniese a la sacristía de San Zoil la capellanía de la Magdalena, para servir el curato por sí o por otro monge, como consta de los papeles siguientes:

$1^{\circ}<$ Bulla del papa Sixto $4^{\circ}$, dirigida al abad de Benevivere, para que vniese la capellanía de la Magdalena a la sacristía de este monasterio. Año de 1476>.

Bulla del papa Sixto $4^{\circ}$, escrita en pergamino, con sello de plomo pendiente, por la qual consta que fray Zoil de Nogal, monge y sacristán mayor de este monasterio de San Zoil $^{128}$, / (f. 102v) representó a Su Santidad que la sacristía de este monasterio, estaba tan pobre por aquellos tiempos que sus rentas no alcanzaban para el reparo de sus ornamentos y demás cosas pertenecientes al culto divino; que si a la dicha sacristía se uniese e incorporase perpetuamente la capellanía perpetua que estaba fundada en el altar de la Magdalena, dentro de la yglesia del mismo monasterio, se podría acudir con más comodidad a dichas obligaciones; que el cuidado de veinte y cinco almas que estaba anejo $a^{129}<$ la sacristía $>$, solían tener clérigos seculares; que quando vacaba pertenecía su presentación al abad del monasterio por una antigua y aprobada costumbre; que los frutos de esta capellanía no escedían del precio de diez y seis libras de moneda turonense. Vistas estas razones por Su Santidad, comete, por esta bulla, la verificación de esta narrativa al abad de Nuestra Señora de Benevivere, para que hallando ser assí, vna e incorpore perpetuamente la dicha capellanía a la sacristía de dicho monasterio, con consentimiento expreso de su abad, y dé la posesión corporal de ella al dicho Zoil de Nogal, el qual y otro qualquiera monge que le suceda en la sacristanía pueda tener y exercer lícitamente el cuidado de dicha capellanía por su propia authoridad y gozar de los frutos y réditos de ella y emplearlos en utilidad de la sacristía y capellanía. Diocesani loci et cuiusvis alterius licencia super hoc minime requisita, non obstantibus pię memorię Bonifacii pappe VIII et aliis appostolis constitutionibus et cetera. Datum Romę, apud Sanctam Mariam, anno yncarnationis Dominicę millessimo quadrigentessimo septuagessimo sexto, nonas iunii, pontificatus nostri anno quinto.

\footnotetext{
128 Zoil] al margen derecho: Falta.
}

129 a] sigue tachado: ella. 
2. <Vnión de la capellanía de la Magdalena a la sacristía de San Zoil. Año de 1478>.

Testimonio, escrito en pergamino, con sello de cera pendiente, por el qual consta haber acetado el abad de Benevivere la comisión que se le da por la bulla anterior de Sixto $4^{\circ}$ (que está inserta de verbo ad verbum en este testimonio), y en su cumplimiento procedió a la ynformación de la narrativa de dicha bulla y, hallando ser verdad, pareció en su presencia Alonso Ybáñez, clérigo beneficiado de San Pedro de Carrión y capellán perpetuo de la capellanía de la Magdalena, y resignó en sus manos la dicha capellanía con / (f. 103r) juramento que no havía intervención de pacto, simonía etcétera, y acetando el dicho abad de Benevivere esta resignación, con licencia de don Pedro González de Mendoza, administrador perpetuo de este monasterio, y vsando de la facultad apostólica que le estaba concedida por dicha bulla, vnió, anexó e incorporó la dicha capellanía de la Magdalena a la sacristía de San Zoil, dando en quanto puede, la posesión de ella a fray Zoil de Nogal, con todas las prerrogativas y condiciones que tiene la bulla; y manda al señor obispo de Palencia (a quien dirije este escrito), en virtud de santa obediencia, que pasados seis días después que fuere requirido con la bulla y esta letras de su execución, reciba al dicho Zoil de Nogal a la corporal y actual posesión de la dicha capellanía, y haga acudir con todas las rentas y frutos a ella pertenecientes. Su fecha, en el monasterio de Benevivere, a 8 de enero de 1478, ante Joan de Vivero, clérigo notario apostólico. Hay dos copias, una simple y otra traducida del latín al castellano y authorizada por Antonio de Guzmán, notario apostólico y vecino de Frómesta.

3. Bajo este número están los papeles siguientes:

<Sentencia sobre la capellanía de la Magdalena, contra Vicente Álvarez, clérigo, y a favor del sacristán de San Zoil. Año de 1478>.

$1^{\circ}$. Vna sentencia ${ }^{130}$ que dio don Joan de Carrión, abad de Benevivere, juez apostólico, en un pleito que pasó entre Zoil de Nogal, sacristán de San Zoil (después de haver tomado posesión de la capellanía de la Magdalena) y Vicente Álvarez de la Carrera, clérigo de la diócesis de Palencia, que pretendía pertenecerle la dicha capellanía y los frutos de ella, por lo que inquietaba al dicho fray Zoil en su posesión. Y vistos los autos por el dicho juez, declaró que este clérigo no tiene derecho alguno a dicha capellanía y pertenecer al dicho sacristán y a sus sucesores; y que por bien de paz y concordia condena y manda que el dicho Vicente Álvarez, oy, día de esta sentencia, ceda y renuncie todo derecho que pretende tener a dicha capellanía, y que jure en pública forma de no pedir ni demandar, ahora ni en ningún tiempo, en juicio ni fuera de él, por sí o por otra persona, contra dicho sacristán. Y por quanto (dice el juez) avemos atraído al dicho Vicente Álvarez a que renuncie todo el derecho suyo, y a que faga y cumpla todo lo contenido en esta sentencia, condenamos y manda/ ( $f$. 103v)mos (y mandamos) a fray Zoil de Nogal, que le pague 40 cargas de pan, mitad trigo y mitad zevada, por los gastos que se le havían originado en la prosecución de esta causa; y no condena en costas por ciertas causas que a ello le movieron. Dada esta sentencia en Santa María de Benevivere, a 20 de julio de 1478, ante Fernando Cavallo, escribano de Carrión.

$<$ Juramento que hizo Vicente Álvarez de guardar la sentencia>.

$2^{\circ}$. Juramento que hizo Vicente Álvarez de guardar todo lo contenido en esta sentencia y de no molestar más, ni en juicio ni fuera de él, al dicho fray Zoil de Nogal, por razón de qualquier derecho que tubiere a esta capellanía. Su fecha, en Benevivere, en el mismo día, mes y año de la sentencia, y ante el mismo escribano.

sentencia $>$.

$<$ Carta de pago de 20 cargas de pan que recivió Vicente Álvarez por la

$3^{\circ}$. Carta de pago y finiquito de 20 cargas de trigo, de las que se le adjudicaron a Vicente Álvarez de la Carrera, por la sentencia de arriba. Su fecha, en el barrio de San Zoles, a 22 de agosto de 1478, ante Fernando Cavallo, escribano de Carrión.

${ }^{130}$ sentencia] al margen derecho: Falta. 
4. $<$ Relación simple de una demanda que puso el sacristán de San Zoil a Vicente Álvarez de la Carrera>.

Papel simple ${ }^{131}$ en el que se declara que el sacristán sucesor de fray Zoil de Nogal hizo una representación contra Vicente Álvarez por no haber guardado la sentencia anterior. Antes bien, marchando a Roma, ganó el beneficio para un primo suyo; litigose pleito en Palencia y en Roma por más de 7 años y en este intermedio murió fray Zoil de Nogal. Concertáronse los dos, y uno de los capítulos fue que el sacristán le havía de dar de pensión cada año 2000 maravedís, hasta tanto que le diesen otro beneficio a él o a su primo. Lo qual y todo lo contenido en los demás capítulos (que pasaron según dice ante Fernando Cavallo) cumplió el sacristán por haberlo jurado. Pide también las 40 cargas de pan, supuesto que no cumplió la sentencia y juramento.

5. < Sobrecarta para que se lleven al Consejo los autos del pleito sobre la capellanía de la Magdalena. Año de 1482>.

Sobrecarta de los Reyes Cathólicos, dada a instancia de fray Zoil de Nogal, sacristán de San Zoil, para que, por vía de fuerza, se llevasen los autos que havía hecho el abad de San Salvador, provisor de Palencia, en virtud de una bulla de impetra que havía ganado de Su Santidad Fernando Álvarez, clérigo de Frómesta, cometida al dicho provisor, para que le pusiese en possesión del beneficio curado de Santa María Magdalena, a causa de que fray Zoil de Nogal, quando sacó la bulla de Sixto $4^{\circ}$ no havía hecho verdadera narrativa del justo valor de la dicha capellanía. / (f. 104r) Fue dada esta sobrecarta (inclusa en esta la primera carta) en Valladolid, a 2 de septiembre de 1482, por mandado del Almirante de Castilla y ante Juan Sánchez, escribano de Cámara. Está aquí inserta la notificación que se hizo al provisor de Palencia y su obedecimiento en el mismo mes y año, y ante Alfonso de Camiedes, escribano y notario público.

6. < Requirimiento al concejo de Carrión para que dé por inhibido al provisor de Palencia. Año de 1483>.

Requirimiento que hizo al concejo de Carrión Alfonso García de Villasur, limosnero de San Zoil, como procurador de Zoil de Nogal, sacristán y cura de esta parroquia, con un testimonio de un proceso pendiente ante el auditor de la Cámara Apostólica, y letras de inhibición, para que el provisor de Palencia no conozca del pleito entre Zoil de Nogal y Fernando Alvarez, clérigo de Frómesta, sobre la posesión del beneficio curado de la Magdalena, por estar pendiente en Roma; y requiere al concejo haya por inhibido al dicho provisor. Su fecha, en Carrión, a 27 de mayo de 1483, ante Juan Martínez de Carrión, escribano en la misma villa.

7. <Executoriales a favor de Fernando Álvarez, sobre el beneficio curado de la Magdalena. Año de 1484>.

Executoriales $^{132}$ de Roma a favor de Fernando Álvarez, clérigo de Frómesta, contra Zoil de Nogal, sobre el beneficio curado de la Magdalena. Este Fernando Álvarez impetró de Su Santidad dicho beneficio curado a título de que Zoil de Nogal, que le poseía, no había hecho verdadera narrativa del valor de sus rentas. Trajo bullas cometidas al provisor de Palencia, el qual amparó a Fernando Álvarez; apeló dicho Zoil de Nogal y el provisor no le admitió la apelación; recurrió al Consejo por vía de fuerza ${ }^{133}$, donde se le otorgó la apelación. Llevose a Roma la causa y Su Santidad la cometió a Guillelmo de Porrerii, auditor del Sacro Palacio, quien condenó a dicho Zoil y amparó a Fernando Álvarez; apeló nuevamente dicho Zoil y se confirmó la sentencia anterior. De estas dos sentencias suplicó, y cometida la causa a Juan, obispo Nucerino, confirmó las sentencias pasadas, condenando en costas a Zoil de Nogal. Pasada esta sentencia en authoridad de cosa juzgada, y tasadas las costas por el referido obispo, mandó Su Santidad que se pusiese en execución; y se despacharon estas executoriales a favor del dicho Fernando Álvarez, en las quales están insertas las súplicas, comisiones y sentencias de este pleito. Su fecha, año de 1484.

\footnotetext{
131 Papel simple] al margen derecho: Falta.

132 Executoriales] al margen derecho: Falta.

133 fuerza] al margen izquierdo: Perjudicial.
} 
$<$ Nota $>$.

Este ynstrumento es mui perjudicial al derecho de esta casa, y assí a nadie se muestre.

/ (f. 104v) 8. $<$ Brebe de Ynocencio $8^{\circ}$ en que ampara a Zoil de Nogal en la capellanía de la Magdalena. Año de 1485>.

Brebe de la Santidad de Ynocencio $8^{\circ}$, dirijido, según el sobrescrito) (sic), a los abades de San Zoil y Benevivere, para que en cumplimiento de otro brebe del papa Sixto $4^{\circ}$, su antecesor, (que no llegó acá por haber muerto Su Santidad), amparen y defiendan a Zoil de Nogal en la posesión de la capellanía de la Magdalena. Datum Romę apud Sanctum Petrum, die vigessima nona ianuarii, 1485 , pontificatus anno primo.

\section{9. < Embargo de diezmos del beneficio curado de la Magdalena. Año de 1485>.}

Mandamiento ${ }^{134}$ de los provisores de Palencia a todos los diezmeros y parroquianos del beneficio curado de Santa María Magdalena, sito dentro del monasterio de San Zoil, para que no entreguen los diezmos a Zoil de Nogal ni a Fernando Álvarez, litigantes, hasta que conste a quién de los dos pertenece el beneficio. Su fecha, en Palencia, a 7 de julio de 1485.

10. <Entredicho del abad de Sa[ha]gún contra Vicente Álvarez. Año de 1487>.

Requirimiento a los clérigos de Carrión para que guardasen un entredicho que había puesto el abad de Sahagún contra Vicente Álvarez de la Carrera, que seguía el pleito de Fernando Álvarez, su primo, sobre el beneficio curado de la Magdalena. Su fecha, en Carrión, a 28 de julio de 1487, ante Fernando Cavallo, escribano en la misma villa.

11. <Concordia entre el sacristán de San Zoil y Vicente Álvarez, sobre el beneficio curado de la Magdalena. Año de 1488>.

Concordia hecha entre Fernando de Bustamante, sacristán de San Zoil, y Vicente Álvarez de la Carrera, por sí y en nombre de Fernando Álvarez, en el pleito sobre el beneficio curado de la capellanía de Santa María Magdalena, por la que Carrera se obliga a hacer resignación y apartamiento del derecho que Fernando Álvarez y él tenían al beneficio, y depositar las escrituras, sentencias, executoriales y demás papeles del pleito (jurando no ocultar nada) en poder del Guardián de San Francisco de Carrión, que por las costas y gastos del pleito dé el sacristán a Vicente Álvarez 2000 maravedís de pensión cada año por su vida; y que para esto saque Carrera bulla a su costa, dentro de cierto término y, no lo cumpliendo, entregue el guardián al sacristán todos los papeles depositados. Que los monges diesen a Carrera o a Fernando Álvarez la presentación del beneficio de Valcabado o de Villaturde y, desde entonces, cesase la pensión, aunque ellos no admitiesen la presentación, y que den fianzas de no molestar al sacristán, etcétera. Otorgá/ (f. 105r)ronse estas Capitulaciones, juráronse y se firmaron por ambas partes, a $1^{\circ}$ de febrero de 1488, ante Fernando Cavallo, escribano de Carrión, y Gerónimo de Hermosilla, clérigo y notario apostólico.

12. <Apartamiento jurado que hizo Fernando Álvarez del pleito del beneficio curado de la Magdalena. Año de 1488>.

Apartamiento que hizo Fernando Álvarez, clérigo de Frómesta, del pleito sobre el beneficio curado de la Magdalena, en el que confiesa estar anexo dicho beneficio al oficio de la sacristanía de San Zoil, por bulla de la Santidad de Sixto $4^{\circ}$ cometida al abad de Benevivere; y que por haberle dado el monasterio el beneficio curado de San Andrés de Valcavado y conocer que no tenía entero derecho al de la Magdalena, le renuncia y cede al dicho sacristán, jurando no molestarle ahora ni en tiempo alguno. Su fecha, en Carrión, a 22 de julio de 1488, ante Fernando Cavallo, escribano de dicha villa.

13. $<$ Reconocimiento de Diego de San Zoles, que el beneficio de la Magdalena está anejo a la sacristía de San Zoil. Año de 1512>.

Juramento que hizo Diego de San Zoles, capellán de Nuestra Señora de Belén, de esta villa de Carrión, (que servía el beneficio curado de la Magdalena por nombramiento del

${ }^{134}$ Mandamiento] al margen derecho: Falta. 
monasterio) de que no havía hecho ni haría auto alguno contra el monasterio en el pleito que seguía, en grado de apelación, ante el vicario del señor cardenal arzobispo de Toledo, contra Valenzuela, secretario del obispo de Palencia, sobe dicho beneficio curado de la Magdalena. Confiesa del dicho Diego de San Zoles que este beneficio es propio del monasterio y que está anexo a la sacristía de él, en cuyo nombre le sirve. Su fecha, en San Zoil, a 14 de febrero de 1512.

14. <Colación del curato de la Magdalena en Francisco de Valenzuela, hecha por el obispo de Palencia como abad de San Zoil. Año de 1512>.

Colación del beneficio curado de la Magdalena, hecha por don Juan Rodríguez de Fonseca, obispo de Palencia y abad comendatario de San Zoil, en Francisco de Valenzuela, canónigo de Palencia, y su secretario. Esta colación dice que la da por pertenecerle como abad y por estar vaco dicho beneficio, sea por estar extinguido el oficio de sacristán, sea por muerte o resignación de Fernando Álvarez. Su fecha, en Burgos, a 12 de junio de 1512, ante Sebastián Gorbalera, notario. Síguese la posesión que tomó Diego Aries Sabariego, en nombre de dicho Valenzuela, la qual no tiene fecha. También hay un mandamiento del mismo señor obispo a todos los vasallos y feligreses del barrio de San Zoles, bajo graves penas, que acudan al dicho Valenzuela con las rentas y frutos del referido beneficio. Su fecha, en Burgos, a 17 de junio de 1512. Y de todo / (f. 105v) da testimonio Alonso Álvarez, notario apostólico. Este nombramiento le resistió el monasterio como consta del papel siguiente.

15. < Poder del monasterio contra Valenzuela. Año de 1512>.

Poder que dieron el prior y monges de san Zoil a fray Gaspar de Villarroel, presidente del monasterio, para todos sus pleitos y causas, y especialmente para el pleito que seguían ante el vicario del cardenal arzobispo de Toledo contra Francisco de Valenzuela, sobre el beneficio curado de la Magdalena. Su fecha, en San Zoil, a 11 de agosto de 1512, ante Floristán de la Serna, escribano de Carrión.

16. Querella y sentencia contra <uno> que administró el viático a un feligrés del barrio, sacándole de la O. Año de 1512>.

Querella que dio el monasterio contra el bachiller Antonio Sedano, clérigo de Carrión, ante el comendador de la Herrada, juez conservador, por haber administrado el Santísimo Sacramento a un feligrés del barrio, sacándole del Hospital de la O; el qual confesó ser assí, pero que no lo había hecho por perjudicar el derecho del monasterio, sino por ser medianoche, estar el feligrés mui apurado, y hacer él oficio de cura por el abad. El juez le condenó en cierta pena pecuniaria y le puso otras para que no lo hiziese de allí adelante. Pasó todo en el mes de noviembre de 1561, ante Andrés Sánchez, escribano de Carrión.

17. $<$ Declaración del provisor que el monasterio puede hacer procesiones por la parroquia. Año de 1623>.

Mandamiento y declaración del licenciado Antonio Ramírez, provisor de Palencia, de que el monasterio puede hacer procesiones por el término de su parroquia, y que los que asistieren a ellas no incurran en censura alguna; y manda a los clérigos, bajo excomunión mayor y pena de 20 ducados, no vayan contra esta declaración. Su fecha, en Palencia, a 7 de abril de 1623, ante Balthasar de Belo, notario. Notificose a todos los clérigos de Carrión, los quales por entonces le obedecieron. $<$ Está aquí una licencia que dio el señor nuncio para que la condesa de Lemos entrase en una procesión por los claustros de San Zoil. Año de 1612>.

18. <Nombramiento de cura en el padre fray Gerónimo Gracián. Año de 1627>.

Nombramiento que hizo el abad de San Zoil, con parecer de los padres del consejo, en el padre fray Gerónimo Gracián para que, por el tiempo que fuere su voluntad, haga oficio de cura de esta parroquia. Su fecha, en San Zoil, a 2 de abril de 1627, ante Francisco Moro de Saldaña, escribano de Carrión. Síguese la aprobación y licencia para exercer dicho oficio, dada por el licenciado Juan Baptista de la Rigada, provisor de Palencia, a 8 de mayo del mismo 
año, ante Sebastián Díaz, notario en la misma ciudad ${ }^{135}$. Este es el primer monge para quien se sacó licencia del ordinario para hacer de cura.

/ (f. 106r) 19. Bajo este número, están los papeles siguientes:

$1^{\circ}$. Poder que dio el abad de San Zoil a fray Juan de Cisneros para querellarse de los clérigos de Carrión que habían publicado estar excomulgadas las personas que habían asistido a una procesión que había hecho el monasterio por su parroquia. Su fecha, en San Zoil, a 16 de junio de 1635, ante Francisco Moro de Saldaña, escribano de Carrión.

$<$ Declaración del provisor de Palencia, que el monasterio puede hacer procesiones por la parroquia. Año de 1635>.

$2^{\circ}$. Declaración del provisor de Palencia, que el monasterio puede hacer procesiones por su parroquia, y que los que asisten a ellas no incurren en excomunión; y manda a los curas que no las impidan bajo graves penas. Su fecha, en Palencia, a 17 de junio del mismo año, ante Martín de la Cantera, notario. Esta declaración del provisor, se notificó a todos los curas de Carrión y está duplicada.

$3^{\circ}$. Testimonio que contiene la declaración anterior y la que queda puesta en el número 17 de este quaderno, y assímismo el motivo, forma y orden con que se zelebró la dicha procesión. Dio este testimonio (que está duplicado) Francisco Moro de Saldaña, escribano de Carrión, a 27 días de junio del mismo año.

20. <Mandamiento para que se embíen las matrículas. Año de 1635>.

Copia simple de un mandamiento del provisor de Palencia para que se embíen las matrículas de los feligreses que habían cumplido con la yglesia por la Pasqua. Su fecha, en Palencia, a 12 de julio de 1635, ante Martín de la Cantera, notario.

$$
\text { 21. <Entrega de un difunto en medio del puente. Año de 1667>. }
$$

Testimonio de cómo el monasterio con su cruz y ciriales entregó, en el medio del puente de esta villa, a los curas de San Andrés, un difunto, vecino del barrio de San Zoles. Dado en la misma puente, a 24 de octubre de 1667, por Diego Ruiz Martínez, notario y vecino de Becerril.

22. <Despacho del provisor para cobrar los derechos de una difunta. Año de 1692>.

Despacho del provisor de Palencia, a petición de este monasterio, para que los testamentarios y herederos de una muger de Torre, que pasó por esta parroquia para enterrarse en el convento de San Francisco, paguen los derechos debidos a esta parroquia; y manda a los curas de Carrión no perturben ni inquieten al monasterio en los derechos de su parroquia. Dado en Palencia, a 11 de enero de 1692, ante Marcos Ruiz, notario.

23. <Diligencias sobre un ahogado. Año de 1778>.

Testimonio $^{136}$ en relación de las diligencias practicadas en favor del derecho parroquial de esta yglesia, sobre un ahogado en el Río Mayor. Diole este testimonio Manuel Ydquierdo, escribano de Carrión, a 7 de octubre de 1778. Hay aquí un parecer de un abogado sobre esto.

\section{/ (f. 106v) Remisiones}

\footnotetext{
135 ciudad] al margen izquierdo: Nota.

136 Testimonio] al margen derecho: Falta.
} 


\section{/ (f. 107r) Quaderno B del legajo $1^{\circ}$}

Diezmos

Este quaderno B contiene papeles pertenecientes a los diezmos de la parroquia de San Zoles, por el orden siguiente:

$1^{\circ}$. $<$ Concordia entre los condes y don Miro, obispo de Palencia, sobre las tercias de sus heredades. Era de 1089. Año de 1051>.

Concordia ${ }^{137}$, escrita en pergamino, hecha entre el conde don Gómez Díaz, su muger, doña Theresa, y el obispo de Palencia don Miro, sobre las tercias de sus heredades, por la que habían tenido grandes barajas y diferencias ante don Fernando el $1^{\circ}$, rey de León. Juntáronse en Santa María (oy Carrión) y concordaron que se dividiesen las tercias de sus hombres o vasallos por mitad, de suerte que la una mitad se diere al dicho obispo para la yglesia de San Antolín y la otra mitad quedase al conde para San Juan de la Puente (que es este monasterio). Facta cartula tertio nonas augusti, era 1089, que es año de Christo 1051.

2. <Ynformación de la prescripción de la parroquia de San Zoles y sus tercias, y la de otras yglesias. Año de 1220>.

Ynformación ${ }^{138}$ antigua, escrita en pergamino (que tiene diez ojas y la faltan otras), hecha por el padre Gunsalvo, monge procurador de este monasterio, en la qual prueba contra el obispo de Palencia la prescripción de esta parroquia de San Zoles y sus tercias, que se halla al folio $3^{\circ}$ vuelta, y assimismo la prescripción de otras yglesias, diezmos y tercias de otros lugares del obispado, que son los siguientes:

San Martín de Frómesta, folio $1^{\circ}$.

San Facundo de Arconada folio, $4^{\circ}$ vuelto.

Villamez, folio $5^{\circ}$.

San Mamés, folio $6^{\circ}$.

San Román de Fuentes de don Bermudo, folio $6^{\circ}$ vuelto.

San Pedro de Villasirga, folio $7^{\circ}$ vuelto.

San Martín de Villavaruz, folio $8^{\circ}$.

San Salvador de Villalumbroso, folio $8^{\circ}$ vuelto.

San Miguel de San Felices, folio 10.

Esta Ynformación, parece haberse hecho el año de 1220. < En el cajón San Agustín, legajo $2^{\circ}$, quaderno A, número 12 , hay un trasumto authorizado desta información, hecha para la yglesia de San Martín de Frómesta>.

/ (f. 107v) 3. < Concordia entre el obispo y cavildo de Palencia y los monasterios de San Zoil, San Román y San Ysidro, sobre diezmos y presentaciones de beneficios. Era 1266. Año 1228>.

Concordia escrita, en pergamino, con ocho sellos de cera pendientes (oy tiene quatro), por la qual consta que, habiendo dado licencia el padre abad de Cluni, este monasterio, el de San Román de Entrepeñas y el de San Ysidro de Dueñas concordaron con el obispo y cavildo de Palencia sobre los diezmos y presentaciones de beneficios del obispado en la forma siguiente:

$<$ San Zoil $>$.

Primeramente el obispo y cavildo quieren y conceden que el monasterio de San Zoil tenga las yglesias parroquiales de San Zoil y San Martín de Frómesta ${ }^{139}$ con todos los diezmos, primicias y ofrendas de vivos y muertos, posesiones y demás pertenencias; y el obispo y sus

${ }^{137}$ Concordia] al margen derecho: Falta.

138 Ynformación] al margen derecho: Falta.

${ }^{139}$ Frómesta] al margen derecho: San Martín de Frómesta. 
vicarios tengan en dichas yglesias parroquiales la institución de los capellanes a presentación de los monges, visita y corrección de los clérigos y parroquianos, la procuración acostumbrada y conforme a derecho y los demás derechos episcopales, salvo los privilegios del monasterio cluniacense que por derecho deben valer. Los monges sean obligados a dar al capellán de la yglesia de San Zoil 20 áureos cada año para su sustento y provisión; y en la yglesia de San Martín den a cada capellán 22 áureos cada año sin comida, o 12 con comida en el monasterio, a elección de ellos.

En las yglesias de San Andrés de Villagonzalo, San Pedro de Villasirga, San Facundo de Arconada, Santa María de Villamez, Santa María de Villaturde, San Juan de Cestillos, Santa María de Cardeñosa, San Salvador de Villalumbroso, San Román de Fuentes de don Bermudo, San Martín de Villavaruz y Santa María de Trigueros tenga el obispo y sus vicarios la institución de los clérigos, a presentación ${ }^{140}$ de los monges, visita, corrección, procuración y demás derechos episcopales; y el monasterio tenga en cada yglesia de todas éstas una tercera parte de la tercia de todos los diezmos de ellas, sin carga alguna; y las otras dos partes de esta tercia las lleven los clérigos, con todas las ofrendas de vivos y muertos. En las yglesias en que el monasterio percive las tercias de la fábrica provea a las yglesias de lo necesario y lo restante lo convierta en sus vsos.

En la yglesia de San Martín de Villavaruz ${ }^{141} /(f .108 r)$ conceden al monasterio el cavildo y el obispo la tercia pontificial, dándoles de foro cada año dos carneros y dos cargas de zebada.

En la yglesia de San Felices ${ }^{142}$ tengan el obispo y el cavildo una tercia de todos los diezmos y los clérigos y la yglesia otra, con todas las ofrendas de vivos y muertos; y el monasterio tenga otra tercia sin carga alguna; y los clérigos estén obligados a los derechos episcopales y a proveer las yglesias. El obispo y el cavildo renuncian el foro que allí tenían, y el monasterio perdona las procuraciones y oblaciones que solía percivir de los clérigos por razón de la yglesia.

En la yglesia de Villamuera ${ }^{143}$ guárdese la composición hecha entre el monasterio y la yglesia de Palencia.

Que la yglesia de San Vicente de Autillo ${ }^{144}$ sea del monasterio, con todas sus pertenencias y con los diezmos que percive de las yglesias de Autillo; y el obispo y sus vicarios tengan la institución de los clérigos, a presentación de los monges, y la procuración y derechos episcopales. Y últimamente conceden el obispo y el cavildo al monasterio que tenga las heredades de todas las dichas yglesias que entonces tenían.

Y el prior y el monasterio de San Zoil dexan para el obispo y cavildo la mitad de las tercias pontificales que llevavan en las yglesias de San Mamés, Villamez y Villaturde ${ }^{145}$. Y el obispo y cavildo se obligan a que ni ellos ni clérigo alguno pedirá jamás al monasterio cosa alguna de lo que en esta concordia se le concede, en juicio ni fuera de él.

\section{$<$ San Román $>$.}

Por esta misma concordia conceden el obispo y cavildo, al prior de San Román de Entrepeñas, que tenga la presentación de los clérigos en las yglesias de Santa María de Arconada, San Juan de Cardeñosa y San Pedro de Recueva ${ }^{146}$; y el obispo y sus vicarios tengan la institución de los clérigos, visita, corrección, procuración y demás derechos episcopales; que los clérigos lleven dos partes de una tercia de los diezmos, con todas las ofrendas de vivos y muertos, y paguen las cargas episcopales; y el monasterio lleve la tercera parte de aquella tercia sin carga alguna.

\footnotetext{
140 presentación] al margen derecho: Presentaciones: Villagonzalo, Villasirga, San Facundo de Arconada, Villamez, Villaturde, Cestillos, Santa María de Cardeñosa, Villalumbroso, Fuentes de don Bermudo, Villavaruz, Trigueros. ${ }^{141}$ Villavaruz] al margen derecho: Villavaruz.

${ }^{142}$ Felices] al margen derecho: San Felices, junto a Becerril.

143 Villamuera] al margen derecho: Villamuera.

144 Autillo] al margen derecho: San Vicente de Autillo. .

145 Villaturde] al margen derecho: San Mamés, Villamez, Villaturde.

146 Recueva] al margen derecho: Santa María de Arconada, San Juan de Cardeñosa, Recueva.
} 
En las yglesias en que dicho monasterio tiene las tercias de las fábricas, provea a las yglesias / (f. 108v) de lo necesario, y lo demás lo convierta en su vso.

Conceden también que dicho monasterio tenga las yglesias de San Cipriano y Santa María del Páramo ${ }^{147}$ y, si en algún tiempo tubieren parroquianos, hágase en ellas lo mismo que en las demás yglesias parroquiales, y tenga el monasterio todas las heredades de las dichas yglesias. Oblíganse el obispo y el cavildo a que ni ellos ni clérigo alguno pedirán, en juicio ni fuera de él, cosa alguna de lo que en esta concordia se concede al monasterio de San Román.

$<$ San Ysidro $>$.

Al monasterio de San Ysidro se le concede la yglesia parroquial del monasterio y la de Santiago ${ }^{148}$ de Valde ${ }^{149}$ y la presentación de los capellanes, curas, y beneficios con ciertas partes de diezmos, en la forma y con las condiciones que se conceden a San Zoil y San Román las yglesias y diezmos arriba dichos.

También se le concede la presentación del beneficio de San Cancellato de Bobadela y de San Miguel de Medina, y las tercias pontificales en las yglesias de Santa Eugenia y Santa Columba y Santa María de Remolinos, con todas las heredades de dichas yglesias.

En Santa María de Autela se le dan 8 áureos; en la yglesia de Baños 2 áureos, un carnero y 30 panes. Y el monasterio de San Ysidro da al obispo y cavildo la villa de Santa Cecilia con su yglesia y todas sus pertenencias, Villaejiga y San Pedro de Summarripa, con todos sus términos y pertenencias, y la yglesia de San Pelayo de Fuentes de don Bermudo con todo lo que la pertenece.

Se obligan los concordantes a guardar todo lo estipulado en esta concordia bajo la pena de 1000 marcos de plata etcétera. Facta carta mense februario, era 1266, que es año de Christo 1228. Hay copia simple.

4. $<$ Memoria de los diezmos que tiene este monasterio en varios lugares $>$.

Memoria ${ }^{150}$ simple, sacada del libro que tiene la cathedral de Palencia, de los diezmos que tiene este monasterio en algunos lugares del obispado, y modo de repartirlos en sus cillas entre los interesados. Los lugares son los siguientes: Frómesta, Cardeñosa, Villamuera, Villaverde, Villaturde, Villamez, Castellanos, San Zoles, San Juan de Cestillos, Arconada, Becerril, Fuentes de Nava, Recueva. monasterio $>$.

/ (f. 109r) 5. $<$ Memoria de algunas escrituras del archivo de Palencia tocantes a este

Otra memoria ${ }^{151}$, firmada de fray Juan de Cisneros, de algunas escrituras que hay en el archivo de la cathedral de Palencia pertenecientes a este monasterio de san Zoil; algunas de ellas las hay en este archivo. También contiene esta memoria unas partidas sacadas del libro Becerro de dicha cathedral sobre los diezmos y presentaciones de las yglesias de San Zoil, San Juan de Cestillos y Arconada. $1287>$.

6. <Sentencia sobre los diezmos prediales y sacramentales de San Zoles. Año de

Sentencia árbitra ${ }^{152}$, escrita en pergamino, dada por Ibán Ibáñez, canónigo de Palencia, en un pleito que el sacristán de este monasterio puso a los clérigos de Carrión sobre diezmos, por la qual se determinó que los vecinos del barrio de san Zoles pagasen enteramente a este monasterio el diezmo de lo que cogiesen del puente acá en término de San Zoil, tanto de huertas como de tierras; y assimismo que los vecinos de Carrión pagasen a este monasterio la mitad del diezmo de todo lo que cogiesen del puente acá por razón del territorio, y la otra mitad a las yglesias donde son parroquianos. Fue dada esta sentencia en

\footnotetext{
147 Páramo] al margen derecho: San Cipriano, Santa María del Páramo.

${ }^{148}$ Santiago] tiago escrito sobre palabra ilegible.

149 Valde] sigue tachado: San Boal.

150 Memoria] al margen derecho: Falta.

151 Memoria] al margen derecho: Falta.

152 árbitra] al margen derecho: Está compulsada en el número 19, es 18.
} 
Palencia, lunes, 23 de junio, anno Domini 1287, ante Pedro Ramón y Gonzalo García, escribanos de los pleitos del señor obispo. Sacó este traslado Pedro Fernández, escribano de Carrión, a 27 de noviembre, era 1341, que es año de 1303. Hay dos copias authorizadas escritas en papel.

7. $<$ Concordia entre el cavildo de Palencia y este monasterio en la que se obliga el cavildo a dar al monasterio 6 cargas de pan mediado por los diezmos que adeudaren los vecinos de Carrión en término de esta parroquia de San Zoles. Año de 1405>.

Concordia, escrita en pergamino, con dos sellos de cera pendientes, hecha entre el cavildo de la santa yglesia de Palencia y este monasterio de San Zoil por la que, para evitar varias contiendas y debates que havía entre una y otra parte sobre los diezmos prediales de los vecinos de Carrión que labraban las heredades del monasterio y de la parroquia de San Zoles (en que dicho monasterio está sito, y de quien es toda la parroquia por privilegio), porque el monasterio decía pertenecerle la mitad de los dichos diezmos, y el deán y cavildo decían que era todo el diezmo suyo y de los clérigos e yglesias de Carrión; por tanto concordaron y convinieron en que el deán y cavildo de la yglesia de Palencia dé al monasterio cada año para siempre jamás / (f. 109v) 6 cargas de pan (son 5 de la medida nueva), mitad trigo y mitad zevada, pagadas en la villa de Carrión, del pan que en ella se cogiere y tocare al tercio del cavildo, y que todos los demás diezmos, así mayores como menores, que se adeudaren por dichos vecinos de Carrión sean todos del cavildo, en quanto a la tercia que de ellos llevan. Dexa el deán y cavildo su derecho a salvo al monasterio para demandarle y seguirle contra los curas, clérigos e yglesias de Carrión, o concertarse con ellos sobre esto mismo, pues por esta concordia no se perjudica al derecho que unos u otros tubieren. Oblíganse ambas partes a cumplir esta concordia bajo la pena de 1000 doblas de oro castellanas que ha de pagar la parte que no la guardare por cada vez a la parte obediente. Su fecha, en Palencia, dentro del mismo cavildo, a 17 de julio de 1405, ante Alfonso García de Villagarcía, clérigo del obispado y notario apostólico. Hay copia authorizada.

8. <Mandamiento del cavildo de Palencia para que se paguen a San Zoil las 6 cargas de pan. Año de 1405>.

Recudimiento, escrito en pergamino, con su sello pendiente, otorgado por el cavildo de Palencia, en el que, haciendo mención de la anterior concordia, manda a sus arrendadores y administradores den y paguen al monasterio de San Zoil las 6 cargas de pan mediado contenidas en dicha concordia para siempre jamás, entregándolas en Carrión del pan que allí se cogiere de la tercia del cavildo, tomando carta de pago del monasterio. Su fecha, en Palencia, a 22 de julio de 1405, ante Alfonso García de Villagarcía, clérigo y notario apostólico.

9. $<$ Mandamiento a los vecinos y clerecía de Carrión para que paguen la quarta parte del tercio de todos los diezmos. Año de 1406>.

Mandamiento ${ }^{153}$, escrito en pergamino, de los curas de Santiago, San Pedro y Santa María del Camino de la villa de Carrión, jueces árbitros nombrados por la clerecía de la misma villa, en el pleito y contienda que tenían con este monasterio sobre diezmos, por el que mandan y ruegan (a todos los parroquianos de las yglesias de Carrión, assí clérigos como legos, judíos y moros, que labran las heredades que a dicho monasterio pertenecen) que / ( . 110r) den y paguen al monasterio la quarta parte de todos los diezmos que pertenecen al tercio de la dicha clerecía, assí pan como vino, y todas las demás cosas que en las dichas heredades cogieren, por estar assí avenidos con el prior, sacristán y clavero del dicho monasterio. Su fecha, en San Zoil, a 21 de agosto de 1406, ante Gonzalo Fernández, clérigo y notario apostólico. Hay una copia simple.

10. <Ynformación que todos los diezmos y primicias del barrio de San Zoles son del monasterio. Año de 1496>.

Ynformación hecha con once testigos a pedimento del sacristán y monasterio de San Zoil ante la justicia de Carrión, en la que se prueva la posesión immemorial que tenía el sacristán de percivir todos los diezmos y primicias de los vecinos del barrio de San Zoles

${ }^{153}$ Mandamiento] al margen derecho: falta. 
para gastos de cera, azeite para 9 lámparas, ornamentos y otras cosas necesarias para el culto divino; también se prueba que los vecinos del barrio eran vasallos del monasterio y la costumbre que tenían de diezmar quando alguno se pasaba a vivir a la villa que era la misma de ahora. Hízose esta ynformación el año de 1496, ante Juan de Berrio, escribano de Carrión ${ }^{154}$. En esta ynformación se da título de Bienhabenturada a la condesa doña Theresa.

11. <Provisión real para que se diezme en la era, antes de alzar el pan. Año de 1518>.

Provisión real ${ }^{155}$ de los reyes doña Juana y su hijo don Carlos, dada a petición de este monasterio para que, conforme a la pramática en ella inserta, se diezme del montón en la era, antes de alzar el pan, en las villas de Villafrechós, Fuentes de don Bermudo, Villalumbroso, Cardeñosa, Barrio de San Zoles y demás lugares donde este monasterio tiene rentas de diezmos y tercias. Dada en Toro, a 23 de agosto de 1518, ante Francisco Hernández Alderete, escribano de Cámara.

12. <Executoria de las tercias de San Zoles, a favor de este monasterio. Año de $1542>$.

Carta executoria ${ }^{156}$ de las tercias del barrio de San Zoles, de la qual consta que, estando el monasterio en quieta y pacífica posesión de llevar enteramente los diezmos de esta parroquia, la villa de Carrión presentó memorial en la Contaduría de Su Magestad pidiendo se encabezasen por del rey las tercias decimales del dicho barrio, como se había hecho por los años de 1539 y 1540, hasta el de 1544. Diose recudimiento para que se / (f. 110v) acudiese con dichas tercias a los arrendatarios de las tercias reales de Carrión, los quales embargaron los diezmos. El monasterio se querelló en el Consejo de Hacienda donde se litigó esta causa con el fiscal de Su Magestad y con la villa de Carrión. Probó el monasterio la immemorial que tenía de llevar todos los diezmos de San Zoles, sin que en ellos tubiese parte alguna el rey, el obispo, ni el cavildo de Palencia, e hizo ver que era malicioso el encabezamiento nuevamente hecho en los libros de Su Magestad. Conclusa la causa se dio sentencia ${ }^{157}$ en Valladolid, a 4 de noviembre de 1542, por la qual se declaró que dicho encabezamiento de las tercias de San Zoles y el arrendamiento de ellas hecho por la villa de Carrión, y el embargo executado el año de 1541, todo era en sí nullo y de ningún valor y efecto. Mandase alzar el seqüestro y que se acuda con todo al monasterio libremente y sin costas; y por no apelar de esta sentencia ni el fiscal ni la villa, se despachó al monasterio esta carta executoria, a 28 de noviembre de 1542, ante Alonso de Frías ${ }^{158}$, escribano de cámara de Su Magestad. de $1687>$

13. < Execución contra el cavildo de Palencia por las 5 cargas de pan mediado. Año

Execución puesta por parte de este monasterio ante el correjidor de Carrión contra Antolín Herrero, colector de los diezmos del cavildo de Palencia, por las 6 cargas de pan mediado de la medida vieja o cinco de la nueva. Resistiose a pagarlas por no tener orden del cavildo, le puso el juez preso, y embargó y depositó las 5 cargas de pan en Juan Abril, vecino de Carrión. Hízose esta execución en el mes de noviembre de 1687, ante Norberto de Sandoval y Guevara, escribano de Carrión.

14. <Sentencia contra el monasterio sobre los diezmos del Parque, labrándose por forasteros. Año de 1689>.

Bajo este número se halla primeramente un testimonio ${ }^{159}$ dado por Francisco Sánchez, notario recetor de Palencia, en 13 de septiembre de 1689, de una sentencia dada por el provisor de dicha ciudad en el pleito que pusieron a este monasterio los señores deán y cavildo y los curas y beneficiados de las yglesias de Carrión sobre los diezmos que en el término del Parque adeudaba don Pedro Calderón, vecino de la villa de Sa[ha]gún, por la que

\footnotetext{
154 Carrión] al margen izquierdo: Nota.

155 Provisión Real] al margen derecho: falta.

156 Carta executoria] al margen derecho: Falta (tachado). Maltratada.

157 sentencia] al margen derecho: Esta sentencia está compulsada en el número 19. Es 18.

158 Frías] al margen derecho: Frías.

159 testimonio] al margen derecho: Falta.
} 
mantiene y ampara a dichos señores deán y cavildo, / (f. 111r) curas y beneficiados de Carrión en la posesión en que han estado y están de percivir y cobrar todos los diezmos que causan todos los forasteros de lo que labran y siembran, assí en el término del Parque como en los demás de dicha villa, cuyos diezmos declara tocar y pertenecer a dichos señores y no al monasterio, a quien manda no les inquiete en dicha posesión, pena de excomunión mayor y 200 ducados de plata; y que restituya dentro de 6 días todos los diezmos que por esta causa huvieren percivido; y le reserva su derecho a salvo para que, en el juicio petitorio, plenario y posesorio, pida lo que le convenga. Diose esta sentencia en Palencia, a 4 de julio de 1689.

$<$ Sentencia del nuncio. Confirma la anterior $>$.

De esta sentencia apeló el monasterio al nuncio quien, en 31 de marzo de 1693, confirmó la sentencia antecedente del provisor de Palencia en todo y por todo, según y como en ella se contiene. Assí consta del memorial ajustado que se halla entre estos papeles; y del mismo memorial consta que el monasterio también apeló de esta sentencia pero no siguió la apelación. Hay aquí varios papeles pertenecientes a esta causa y dos planes de la villa de Carrión y sus lugares rayanos.

15. < Cartas y consulta sobre los diezmos de un forastero. Año de 1733>.

Cartas del cavildo de Palencia al abad de este monasterio sobre los diezmos de Bernardo del Campo, vecino de Amusco, que vivío por algún tiempo en el barrio de San Zoles, por lo que pretendía el monasterio sus diezmos, sobre los que hai aquí un parecer de un abogado, que manifiesta no pertenecer al monasterio sino al cavildo y clérigos de Carrión, en calidad de foráneos. Todos estos papeles son del año de 1733.

16. <Sentencia a favor del monasterio sobre diezmos de huertas reducidas a tales desde el año de 1710. Año de 1762>.

Copia simple de una sentencia dada en Palencia, a 12 de mayo de 1762, en el pleito que este monasterio, el cavildo de Palencia y comunidad eclesiástica de Carrión siguieron contra la justicia, rejimiento y otros particulares de dicha villa, sobre el diezmo de todas las huertas sitas en su término, por la que se declara que todas las heredades que antes fueron lavrantías y sembradas de trigo y demás especies, y ahora se han reducido a huertas / (f. 111v) y linares, diezmen íntegramente de todos los frutos que en ellas sembrasen, plantasen, produjesen y recogiesen, bien en especie, bien en dinero, según se conviniese con los interesados en ellos.

$<$ Sentencia de Burgos. Confirma la anterior $>$.

De esta sentencia apeló la villa a Burgos donde, en 24 de octubre de 1763, se dio sentencia por la que, amparando a la villa en la posesión de no diezmar de la ortaliza y demás especies expresadas en el proceso de aquellas heredades que de inmemorial tiempo hayan sido huertas, confirma la sentencia de Palencia, declarando deberse pagar el diezmo de todas las heredades que se justifiquen haverse(n) reducido a huertas desde el año de 1710. Este pleito pasó ante Francisco García, notario de Palencia. $1768>$.

17. < Cartas del cavildo y monasterio sobre las 5 cargas de pan mediado. Año de

Cartas del cavildo de Palencia que manifiestan la resistencia de pagar al monasterio las 5 cargas de pan mediado a que está obligado por la concordia del año de 1405, puesta atrás, número $7^{\circ}$, mientras el monasterio no les satisfaciese un tercio entero de los diezmos de los feligreses de San Zoles, que juzgaba pertenecerle por dicha concordia. Respuestas del monasterio a estas cartas, que todas son de los años de 1768 y 69. Síguense dos relaciones de los documentos que hacen al derecho del monasterio sobre la parroquia y diezmos de San Zoles, y varios dictámenes de unos abogados de Valladolid sobre lo mismo. Parece que el cavildo no se conformó con esto y assí se puso el pleito siguiente. 
18. $<$ Testimonio del pleito que tubo este monasterio con el cavildo de Palencia, sobre las 5 cargas de pan mediado $>$.

Testimonio ${ }^{160}$ en relación del pleito que siguió este monasterio con el deán y cavildo de Palencia en razón de las 5 cargas de pan mediado, en los tribunales de Palencia y Burgos.

Este pleito tubo principio en 13 de noviembre de 1770, por pedimento que se presentó por parte del monasterio ante el provisor de Palencia, solicitando despacho, que se libró contra don Ygnacio Yzquierdo, colector eclesiástico de Carrión, para que le entregase las 15 cargas de pan que se le estaban debiendo de los años de 1768, 69 y 70. No queriendo el colector cumplir con lo mandado, pidió el monasterio segundo despacho, que no tubo efecto por haver salido oponiéndose el deán y cavildo. Formalizó el monasterio su demanda presentando un testimonio del libramiento general, que queda puesto atrás, número $8^{\circ}$, y un certificado de los libros de tazmías por lo que acreditó haverse pagado las dichas cargas de pan / (f. 112r) mediado hasta el año de 1767 inclusive.

$<$ Sentencia en la posesión a favor del monasterio $>$.

Compulsose también por parte del monasterio la concordia que queda puesta atrás, en el número $7^{\circ}$, y, recivida la causa a prueba y hecha por ambas partes la que les convino, dándose la causa por conclusa se dio sentencia definitiva por la que, sin perjuicio del derecho de las partes en el juicio de propiedad, mantubo y amparó al monasterio en la quieta y pacífica posesión que se hallaba antes del año de 1768 de percivir en cada año en la cilla de Carrión 5 cargas de pan, por mitad trigo y zebada, por razón de los diezmos de la parroquia de San Zoles; y manda se le satisfaga al monasterio todas las cargas de pan que se le debían desde dicho año de 1768. Fue dada eta sentencia en Palencia, a 10 de marzo de 1772, ante Pedro León de Santotis, notario en dicha ciudad.

$<$ Demanda del cavildo en el juicio de propiedad $>$.

Después de esta sentencia, en 19 de mayo de 1772, el deán y cavildo pusieron demanda en el juicio de propiedad pidiendo que, conforme a lo pactado en la concordia de 17 de julio de 1405, se declarase corresponder a dicho cavildo un tercio entero de todos los diezmos que adeudasen los parroquianos de San Zoles, tanto de las heredades del monasterio como de las de otro qualquiera y por qualquiera otro que se cultiven, y de lo contrario que no perciva el monasterio las 5 cargas de pan mediado. Esta demanda se hizo saber al monasterio, quien salió oponiéndose a ella, en 26 de junio del mismo año, diciendo no debía de contestar a la demanda del cavildo, y formó artículo sobre que le pagase las 1 mil doblas de oro castellanas, pena convencional de la expresada concordia. Desestimose este artículo por el señor provisor. Apeló el monasterio, protestó el real auxilio contra la fuerza, sacó provisión real, se notificó al provisor y, llevados los autos a Valladolid, se declaró por la sala, no hacía fuerza el provisor. Contestó después de esto a la demanda el monasterio y, recivida la causa a prueba, hizo el monasterio la suya con muchos testigos y compulsó los ynstrumentos de este quaderno, números $6^{\circ}$ y 12 , con otros varios pertenecientes al barrio de San Zoles.

$<$ Sentencia en Palencia a favor del monasterio. Año de 1774>.

Conclusa la causa se dio sentencia en Palencia por la que se declaró deber subsistir / (f. 112v) válida y firme la concordia de 17 de julio de 1405, sin haber lugar ni términos a su rescisión o anulación, ni a lo demás pedido por parte de los señores deán y cavildo; y en su conseqüencia se les condena a la continuación de su observancia y cumplimiento para ahora y siempre jamás, con la paga del situado anual de 5 cargas de pan mediado, en el interín y hasta tanto que no justifiquen en bastante forma no labrarse por vecinos del casco de la villa de Carrión heredades en los términos de la parroquia de San Zoil, cuyos diezmos no equivalgan a compensar dichas 5 cargas de pan mediado; y declárase no haber incurrido dichos señores en la pena de las 1 mil doblas castellanas de la concordia, respeto de la probable causa que han tenido para litigar. Diose esta sentencia a 10 de octubre de 1774.

160 Testimonio] al margen derecho: Falta (tachado); está muy deteriorado y es vtil. 
$<$ Sentencia en Burgos. Confirma la anterior $>$.

De esta sentencia apeló el cavildo al metropolitano de Burgos, donde se dio sentencia confirmando la de Palencia; y, aunque apelaron después al nuncio, se apartaron de la apelación. Sacó el testimonio de esta causa José Patricio de Retes, notario mayor de Palencia, a 19 de enero de 1783. Síguense unos despachos de los provisores para que se observen estas sentencias que están aquí insertas.

19. <Despachos del provisor para que se paguen los nuevos diezmos de todas las huertas. Año de 1798>.

Tres despachos originales del provisor de Palencia para que, en virtud del breve de Su Santidad de 8 de enero de 1796, todos los vecinos de Carrión y barrio de San Zoles que tubieren huertas en los términos de San Zoles, Cestillos y Villamez contribuian al monasterio con el diezmo de todos los frutos que en ellas cogieren. Hay aquí un testimonio dado por José Tablares, escribano de Carrión, de haberse allanado todos a la paga de los diezmos después de notificado el tercer despacho. Su fecha, a 26 de marzo de 1798.

20. $<$ Sentencia contra este monasterio sobre las tercias reales de los nuevos diezmos. Año 1802>.

Copia ${ }^{161}$ simple de una sentencia dada por el Consejo de Hacienda contra este monasterio por la que se declaran comprehendidas en la derogación de ${ }^{162}$ breve apostólico de ocho de enero de 1796 las tercias de los nuevos diezmos que este monasterio percibiese de los feligreses de la parroquia de Santa María Magdalena; y se acu/ (f. 113r)da para el monasterio al administrador de tercias reales de la dicha villa de Carrión con todas las que correspondiesen de los referidos nuevos diezmos que hubieren percibido desde la publicación del indicado breve y perciba en adelante en virtud de él; y lo acordado a consulta con Su Majestad los señores de su Real Consejo de Hacienda en justicia, así lo proveyeron y rubricaron. Madrid y octubre, diez y seis, de 1802.

\section{Remisiones}

Diezmos pertenecientes a la parroquia de San Zoles por los hospitales de San Lázaro, la Herrada y Nuestra Señora de la O, véanse sus títulos en este cajón.

\section{/ (f. 113v) Quaderno C del legajo $1^{\circ}$ \\ Visita}

Este quaderno contiene los papeles pertenecientes a la visita de la parroquia de San Zoles o Santa María Magdalena, por el orden siguiente:

$1^{\circ}$. <Testimonio de cómo el arcediano de Campos desiste de pedir derechos de procuración para la visita de la parroquia de San Zoles. Año de 1519>.

Testimonio dado por Diego de San Zoles, cura de Nuestra Señora de Belén y notario apostólico, de cómo el mayordomo de San Zoil, en nombre del monasterio, requirió al tesorero de Vssillos, juez conservador del cavildo de Palencia, con las bullas de Eugenio $4^{\circ}$ y Julio $2^{\circ}$, para que diese por nullas unas censuras que había fulminado contra el monasterio para que éste pagase los derechos de procuración y visitación al arcediano de Campos. El tesorero de Husillos hecho cargo de las bullas, dio por nullas dichas censuras ante notario que dio fe de ello. Notificáronse estas bullas al arcediano de Campos, quien respondió que si el pedía estos derechos de procuración era porque él y sus antepasados los havían llevado hasta entonces, mas porque las dichas bullas hazían exempto al monasterio que se apartaba

${ }^{161}$ Copia] al margen derecho: Falta.

162 del] sigue tachado: nuevo. 
de la demanda y de qualquiera acción que pudiese tener. Fue dado este testimonio en la villa de Vssillos a 19 de febrero de 1519.

2. Contra el arcediano de Campos, que intentó visitar la parroquia de San Zoles. Año de 1519>.

Letras de citación, inhibición y compulsorio, dadas por el auditor ${ }^{163}$ del Sacro Palacio por la Santidad de León X $\mathrm{X}^{\mathrm{o}}$ contra Fernando López de Valmarinos, arcediano de Campos, que intentó visitar la parroquia de Santa María Magdalena, sita dentro de este monasterio, en el ínterin o hasta tanto que se dé sentencia definitiva, amparando al monasterio en la posesión que se hallaba. Su ${ }^{164}$ fecha, en Roma, a 25 de febrero de 1519. Hay aquí copia authéntica escrita en papel.

3. <Requirimiento al visitador para que no visite al cura puesto por el monasterio. Año de 1552>.

Requirimiento hecho por parte del monasterio de San Zoil al licenciado Barahona, visitador del obispado de Palencia, para que no visite al cura y capellán que el monasterio tenía nombrado para administrar los santos sacramentos. Hízose en el hospital de La Herrada, a 15 de mayo de 1552, ante Andrés Sánchez, escrivano de Carrión.

/ (f. 114r) 4. < Parecer sobre la visita. Año de 1578>.

Consulta y parecer del doctor Campoo para que no se admita ni consienta la visita de la parroquia de San Zoles. Año de 1578.

5. < Consulta y parecer sobre la visita y despacho del nuncio. Año de 1748>.

Conculta y pareceres de dos abogados de Madrid acerca de la visita que intentó hacer en esta parroquia de San Zoles el Yllustrísimo ${ }^{165}$ señor don Josef Rodríguez Cornejo, obispo de Palencia, y despacho que se sacó del nuncio, en que manda se haga saber al señor obispo la petición del monasterio aquí inserta para los efectos que convenga. Dado en Madrid, a 10 de julio de 1748.

6. <Despacho del señor obispo de Palencia para que el cura de la parroquia de San Zoles, nombrado por el abad, no exerza su oficio de cura sin aprobación especial de su Yllustrísima. Año de 1761>.

Copia de un despacho del señor obispo de Palencia por el qual consta ${ }^{166}$ que su Yllustrísima hizo presente al padre abad de este monasterio lo mucho que le importaba saber con qué facultades se administraban los Santos Sacramentos en esta parroquia de Santa María Magdalena y se exercía la cura de almas. A lo que se le respondió que se hacía y exercía por varios y distintos monges ad nutum de dicho reverendo padre abad con solas las licencias de confesar de Su Ylustrísima; y como éstas no se habían pedido con la expresión y fin de con ellas exercer en dicho barrio la cura de almas, se opuso su Ylustrísima diciendo que le correspondía, en la actual visita que se hallaba, visitar el sagrario, pila baptismal y demás perteneciente a la parroquialidad. No asintió a ello el padre abad, fundándolo en los privilegios que decía tener de Cluni; y Su Yllustrísima, para evitar pleitos y sosegar su conciencia, propuso que el padre abad junto con Su Yllustrísima expusiesen todas las razones y fundamentos que asistían al derecho y regalía de uno y otro y con ellas se consultase a Su Santidad. Aunque el abad pidió un mes de término para deliberar sobre el asunto, se negó absolutamente a ahacer dicha consulta; por lo que mandó Su Yllustrísima, por este auto, que el padre abad presente dentro de quince días, ante Su Yllustrísima o su vicario, una persona que, precedida la correspondiente aprobación, pueda exercer de su consentimiento la cura de almas, pena de excomunión mayor late sententie, absteniéndose el que haze de cura de exercer su ministerio y de las licencias de confesar en el ínterin y hasta tanto que Su

\footnotetext{
163 auditor] al margen derecho: Falta.

$164 \mathrm{su}$ ] u escrita sobre: e.

165 yllustrísimo] al margen derecho: Falta.

166 consta] al margen derecho: Falta.
} 
Yllustrísima hace por sí la citada consulta y Su Santidad lo declara. Fue dado este auto en Palencia, a 8 de enero de 1761, ante Fernando López de Mena, secretario.

$/(f .114 v) 7 .<$ Despacho del nuncio para que el monge nombrado por el abad y con sola la aprobación de confesor, pueda exercer la cura de almas en esta parroquia. Año de $1761>$.

Copia authorizada de un despacho del señor nuncio de España ${ }^{167}$, por el que manda al señor obispo de Palencia no altere ni innove cosa alguna que perjudique a la posesión immemorial en que se halla este monasterio de exercer la cura de almas, en esta parroquia, por su abad o por un monge nombrado por él con sola la aprobación para oír confesiones; y que si el señor obispo tubiere alguna razón para impedirlo, la exponga y alegue dentro de quince días después de la notificación de este despacho. Que fue dado en Madrid, a 16 de febrero de 1761, y sacada esta copia en el mismo año por Manuel Francisco Blanco, notario y escribano de Carrión. Están aquí las notificaciones que se hizieron de este despacho al señor Yllustrísimo, al administrador de La Herrada, a los feligreses del barrio, al cura de San Andrés, etcétera.

8. $<$ Representación del señor obispo de Palencia a Su Santidad sobre la visita de esta parroquia de San Zoles. Año de 1761>.

Representación que hizo el señor Bustamante, obispo de Palencia, a Su Santidad, en la que, después de alegar brebemente los motivos que tiene para visitar esta parroquia y hacer presente a Su Santidad que el monge nombrado por el abad exerce la cura de almas sin su licencia ni especial aprobación para ella, y que el padre abad se había negado a hacer la consulta sobre este particular, suplica a Su Santidad se sirva mandar que este monasterio consulte a la Sagrado (sic) Congregación del Concilio sobre sus derechos, para que, comparados éstos con el decreto del Concilio de Trento y la constitución Firmandis de Benedicto 14, contrarios a la pretensión del monasterio, resuelvan y confirmen lo que fuere justo. Su fecha, en Palencia, a 25 de febrero de 1761. Está en latín.

La decisión de esta duda la cometió Su Santidad a la Congregación del Concilio, como consta de los dos papeles adjuntos.

9. <Despacho del nuncio a favor de los feligreses de esta parroquia que havían cumplido en ella con el precepto anual. Año de 1761>.

Despacho del nuncio para que a los feligreses de esta parroquia que ${ }^{168}$ habían cumplido en ella con el precepto anual no se les moleste por don Antonio Pérez, teniente de cura de la parroquia de San Andrés, ni por otro alguno, como intentaba Su Yllustrísima por su decreto puesto atrás en el número $6^{\circ}$ de este Quaderno. Su fecha, en Madrid a 20 de mayo de 1761, ante Francisco Agustín de Lorza Aguirre, secretario de la nunciatura.

10. $<$ El señor nuncio confirma el decreto del señor obispo de Palencia contra este monasterio. Año de 1762>.

Copia simple de un testimonio escrito en latín dado por Francisco Agustín de Lorza y Aguirre, notario de la nunciatura, en el que después ${ }^{169} /(f .115 r)$ de hacer relación de la causa que se seguía entre el señor obispo de Palencia y este monasterio sobre la visita de su parroquia e insertar el decreto de Su Yllustrísima, puesto atrás, número $6^{\circ}$, dice que, vistos por el señor nuncio los instrumentos y demás deducido y alegado por ambas partes, concluida la causa y citadas las partes, dio decreto, a 5 de febrero de 1762, por el que, atendida la clara disposición de la Bulla Firmandis de Benedicto 14, declaraba y declaró no haber lugar al artículo de manutención introducido por parte del monasterio, y confirmaba y confirmó el decreto proveído por el señor obispo de Palencia de 8 de enero de 1761, y que para su execución se librase la correspondiente provisión. Aunque apeló el monasterio de este decreto del nuncio, se mandó llevar a debida execución por provisión despachada a favor de Su Yllustrísima en 6 de marzo del mismo año de 62.

\footnotetext{
${ }^{167}$ España] al margen derecho: Falta.

168 que] al margen derecho: Falta.

169 después] al margen derecho: Falta.
} 
11. <Licencia del señor obispo para exercer la cura de almas. Año de 1762>.

Testimonio dado por Manuel Francisco Blanco, escribano de Carrión, en 9 de enero de 1764, de la licencia que dio el señor Bustamante, obispo de Palencia, al padre Moreira para exercer la cura de almas en esta parroquia, precedido examen, todo en conformidad de su decreto atrás referido y mandado guardar por el señor nuncio. Diose esta licencia en Palencia, a 22 de marzo de 1762, ante don Antonio Gómez de Cos, pro-secretario.

12. $<$ Cartas del procurador de Roma sobre la visita de esta parroquia $>$.

Cartas del maestro fray Bernardo Salazar, procurador de Roma $y^{170}$ residente en aquella corte, dirijidas al abad de esta casa, en las que no sólo habla del derecho que puede tener este monasterio para no ser visitada su parroquia (sobre lo que estaba pleito pendiente), sino también del modo de seguirle, tanto en los tribunales de Madrid como en Roma. Dice en la primera carta que hizo mal el monasterio en consentir la sentencia del nuncio, puesta arriba, número $10^{\circ}$. Estas cartas son de los años de 1762 y 63.

13. $<$ Decisiones de la Congregación del Concilio sobre la visita de esta parroquia. Año de 1764>.

Copia simple de la declaración dada por la Sagrada Congregación de Ynt(r)érpretes del Concilio a las dos dudas que se le propusieron sobre la visita y cura de almas de esta parroquia, que son las siguientes:

$1^{\text {a }}$. Si la yglesia parroquial de Santa María Magdalena vnida a este monasterio bajo el título de San Zoil, del orden de Cluni, está sujeta a la jurisdición ordinaria, y si su visita y todos los actos pertenecientes a ella corresponden al ordinario de Palencia.

/ (f. $115 v) 2^{\text {a }}$. Si es lícito al abad de dicho real monasterio hacer que se exerza la cura de almas de la sobredicha yglesia parroquial de Santa María Magdalena por presbítero secular o regular ad ejus nutum amovilem sin licencia, aprobación ni examen del ordinario de Palencia.

A estas dudas respondió la Sagrada Congregación en 18 de febrero de 1764, a la primera afirmativamente en todas aquellas cosas que pertenecen a la cura de almas y administración de sacramentos, a la segunda negativamente. Assí dice se halla en los libros 113, folio $1^{\circ}$, y 114, folios 45 y 63, existentes en la secretaría de dicha Sagrada Congregación.

14. <Pedimiento para que no se dé paso a un brebe sobre la visita $>$.

Pedimiento presentado en la Cámara de Castilla por José Sanz García ${ }^{171}$, procurador de este monasterio, por el que, en nombre de éste, suplica a la Cámara se sirva mandar suspender el pase de un brebe que había sacado el obispo de Palencia, para visitar esta parroquia.

15. $<$ Respuesta del fiscal sobre la visita. Año de 1781>.

Copia simple de la respuesta dada por el señor conde de Campomanes ${ }^{172}$, fiscal del Consejo, en el expediente sobre la visita de esta parroquia. Es contra el monasterio. Dio esta respuesta el señor fiscal en 30 de noviembre de1781.

16. <Pedimientos por parte del monasterio sobre la visita a esta parroquia>

Bajo este número están tres copias de unos pedimientos ${ }^{173}$ presentados por parte del monasterio a la Cámara de Castilla, sobre la visita de esta parroquia. En ellos, especialmente en el tercero, se exponen las razones y fundamentos para no ser visitada por el señor obispo de Palencia.

\footnotetext{
170 y] al margen derecho: Falta.

${ }^{171}$ García] al margen derecho: Falta.

172 Campomanes] al margen derecho: Falta

173 pedimientos] al margen derecho: Falta.
} 
17. $<$ Requirimiento y protesta que hizo el monasterio sobre la visita de esta parroquia. Año de $1781>$.

Requirimiento hecho por parte del monasterio al Yllustrísimo señor don José Luis de Mollinedo, obispo de Palencia, para que se abstenga de visitar esta parroquia, no obstante lo resuelto por la Congregación del Concilio. Su Yllustrísima, sin hacer caso del requirimiento ni querer tomar el pedimiento, respondió que a lo que venía, venía; por lo que, por parte del monasterio, se protestó quanto obrase Su Yllustrísima en orden a la visita y lo pidió por testimonio; pero, sin embargo de esto, se executó la visita. Dio este testimonio Miguel Calvo Luengo, escribano de Su Magestad y recetor de la Chancillería de Valladolid, a 2 de octubre de 1781.

18. $<$ Protesta de la visita del año de 1788>.

Requirimiento y protesta como la anterior, hecha por parte del monasterio a don Bernardo García Martín, visitador general ${ }^{174} /$ (f. 116r) de este obispado de Palencia, por el señor Mollinedo, obispo de él. Fue dado este testimonio por José Tablares, escribano de Carrión, a 2 de julio de 1788.

19. < Protesta de la visita de 1799>.

Otra protesta como las anteriores de la visita que hizo de esta ${ }^{175}$ parroquia don Vicente Vbago, visitador general de este obispado, por el Yllustrísimo Mollinedo. Su fecha, en San Zoil, a 12 de septiembre de 1799, ante José Tablares, escribano de Carrión.

\section{/ (f. 117r) Legajo $2^{\circ}$}

Este legajo, que es el $2^{\circ}$ del cajón San Andrés, contiene los quatro quadernos siguientes: Quaderno A: papeles pertenecientes a los cuerpos de los santos mártires, reliquias e yndulgencias que hai en esta yglesia; Quaderno B: pleitos y diferencias con la villa y clérigos de Carrión sobre la precedencia de assientos; Quaderno C: obra pía de don Francisco Barrio, y otras de Carrión; Quaderno D: Cofradía de la Magdalena y otras.

\section{Quaderno A del Legajo $2^{\circ}$}

\section{Reliquias}

Este quaderno A contiene los papeles pertenecientes a los quadernos de los santos mártires, reliquias e yndulgencias que hay en esta yglesia, por el orden siguiente:

$1^{\circ}$. $<$ Historia de San Zoil $>$.

Vn quaderno que contiene la vida, martiro, traslación, milagros ${ }^{176}$ y rezo de nuestro patrono San Zoil. Es copia de un libro mui antiguo escrito en pergamino por el monge Rodulfo. El qual se halla en el cajón San Claudio.

$2^{\circ}$. $<$ Historia de San Félix $>$.

Otro quaderno que contiene la historia de la vida, muerte y traslación de nuestro compatrono San Félix monge y mártir, y un sermón ${ }^{177}$ que predicó el padre fray Félix Dávila, del Orden de Predicadores en la traslación de una reliquia de este monasterio a Alcalá de Henares. Este quaderno está impreso y con él se halla manuscrito el oficio de dicho santo.

\footnotetext{
174 general] al margen derecho: Falta.

175 esta] al margen derecho: Falta.

176 milagros] al margen derecho: Falta.

177 sermón] al margen derecho: Falta.
} 
3. < Yndulgencia plenaria para el altar del Crucifixo. Año de 1580>.

Bulla del papa Gregorio 13, escrita en pergamino, con sello de plomo pendiente, por la qual concede Su santidad yndulgencia plenaria ${ }^{178} a^{179}$ qualquiera alma por quien se dixere misa de difuntos en el altar del Santo Crucifixo. Datum Rome, apud Sanctum Petrum, anno 1580 , nonis septembris, pontificatus anno nono. Está aquí la facultad del comisario general de Cruzada, dada en Madrid, a 15 de junio de 1581, ante Martín de Salvatierra, su secretario.

/ (f. 117v) 4. <Cartas de Córdova en que piden reliquias de San Zoil y testimonio de lo que se halló en el arca. Año de 1600>.

Bajo este número se hallan 9 cartas relativas a la pretensión que hizo la ciudad de Córdova para que se le diesen unas reliquias de San Zoil; por la última de estas cartas consta que no tubo efecto la petición por entonces. Hay entre estas cartas, al número $4^{\circ}$, un testimonio de cómo en 19 de septiembre de 1600 se abrió el arca de San Zoil y se registraron las reliquias que en ella había en presencia del reverendísimo padre maestro fray Juan de Los Arcos, general de la congregación, abad de San Zoil y otros padres ancianos. Otro testimonio cómo este se halla en el libro $3^{\circ}$ del Cajón San Claudio, al folio 106.

5. <Cartas del rey Felipe $3^{\circ}$ y de Alcalá de Henares en que piden reliquias de San Félix; y memoria simple de las reliquias que se hallaron en la vrna. Año de 1606>.

Bajo este número se hallan 8 cartas, entre ellas dos del señor rey Felipe $3^{\circ}$ y otras dos de su secretario de Estado, para que este monasterio diese a la villa de Alcalá de Henares unas reliquias de San Félix, y al número $7^{\circ}$ está la determinación de esta comunidad para dar una, la que se entregó en 21 de diciembre de 1606, con testimonio signado de Pedro Cervantes, escribano y notario de Carrión. Este testimonio no le hay en este archivo. También hay aquí una memoria simple de las santas reliquias que se hallaron en la vrna de San Félix; y en ella, dice, que se halla la ynscripción siguiente: Aquí jace San Felices, parte de sus huesos e sus cenizas, e la vestidura en que fue quemado, que le trajeron los Cuendes. Era 1068 que es año de 1030.

6. <Calificación de las reliquias de San Félix. Año de 1606>.

Ynformación y calificación de las reliquias de San Félix que están en este monasterio, hecha para dar una a Alcalá de Henares, en 19 de diciembre de 1606 por don Gaspar de Peralta, provisor de Palencia, ante Lucas Gallardo, notario, por comisión del cardenal Milino, nuncio apostólico de España, que se halla aquí original.

7. < Testimonio de unas reliquias. Año de 1609>.

Testimonio authorizado ${ }^{180}$ por Francisco de Solórzano, notario apostólico, de unas reliquias que fueron del padre fray Juan de San Pelayo, monge de nuestra orden. Su fecha, en Madrid a 8 de agosto de 1609. Estas reliquias se entregaron, según dice el rótulo de este pergamino, a nuestro reverendísimo Barrantes, y se pusieron en las medallas del relicario.

8. $<$ Yndulgencia plenaria por 7 años, para el día de San Félix. Año de 1616>.

Yndulgencia plenaria ${ }^{181}$ concedida por la santidad de Paulo $5^{\circ}$ por 7 años, para el día de San Félix. Datum Rome, apud Sanctam Mariam Mariorem, die tertia februarii, anno 1616, pontificatus anno undécimo. Está aquí la licencia del comisario general de Cruzada para vsarla. Su fecha, en Madrid a 30 de marzo del mismo año.

\footnotetext{
178 plenaria] al margen derecho: Falta.

179 a] sigue tachado: la.

180 authorizado] al margen derecho: Falta.

181 plenaria] al margen derecho: Falta.
} 

$1619>$.

9. < Carta de gracias de la ciudad de Burgos por una reliquia de San Zoil. Año de

Carta ${ }^{182}$ de la ciudad de Burgos escrita a nuestro reverendísimo padre fray Alonso Barrantes, a 6 de diciembre de 1619, en la que le da gracias / (f.118r) por una reliquia que la dio de San Zoil, la que se colocó en la parroquia de su advocación sita en la dicha ciudad.

10. < Carta de Palencia en que piden el rezo de San Zoil. Año de 1620>.

Carta ${ }^{183}$ del cavildo de Palencia en que pide el rezo propio de San Zoil, y en caso que no lo huviere que le den las razones más authénticas de su vida, martirio y traslación a este monasterio para incorporarle con los demás santos en el nuevo rezo que iban a hacer. Esta carta es del año de 1620. de $1622>$

11. $<$ Yndulgencia plenaria por 7 años para el día de nuestro padre San Benito. Año

Brebe de Gregorio 15 por el que concede yndulgencia plenaria por 7 años a los que visitaren esta yglesia el día de nuestro padre San Benito, y assimismo a los que asistieren a la oración de las 40 horas, que se zelebraba en dicha yglesia, una vez cada año. Datum Rome, apud Sanctum Petrum, die 22 novembris, anno 1622, pontificatus anno secundo. Está aquí la licencia del comisario de Cruzada, para vsar de esta yndulgencia. Su fecha, en Madrid, a 25 de enero de 1623.

12. $<$ Voto de celebrar a San Bartholomé como patrono hecho por esta comunidad. Año de 1640>.

Escritura original del voto que este monasterio hizo al glorioso San Bartholomé, obligándose a tenerle por patrono y celebrar su oficio como doble de $1^{a}$ clase, con sermón y las demás solemnidades que se acostumbran en los demás patronos, haciendo commemoraciones de él en las commemoraciones comunes, en atención a haber experimentado por su intercesión el favor del cielo, dando salud a los monges, librándoles de las enfermedades que desde el día de su festividad solían molestarles. Su fecha, en San Zoil, a 26 de agosto de 1640, ante fray Juan de Cisneros, notario apostólico.

13. <Elección que hizo la villa de Carrión de nuestro mártir San Zoil, por único patrón suyo. Año de 1643>.

Testimonio de la elección que hizo la villa de Carrión y el cavildo eclesiástico de ella de único patrón suyo al glorioso mártir San Zoil, en conformidad del decreto de la Santidad de Vrbano $8^{\circ}$, sobre la reformación de fiestas en toda la Christiandad, en atención a que ya era antes su patrono, junto con San Félix, por estar en ella sus cuerpos. Su fecha, en Carrión, a 5 de octubre de 1643, ante Gerónimo López, escribano de Ayuntamiento y del número de dicha villa. Está legalizado por Gerónimo de Letrán, Francisco Moro de Saldaña y Thomás Pérez, escribanos de la misma villa.

14. < La villa de Sangüesa pide una reliquia de San Zoil. Año de 1651>.

Carta de la villa y cavildo de Sangüesa en la que piden a éste / (f.118v) una reliquia de San Zoil, y para obligarle a darla refieren la tradición antigua de su aparición en aquella villa, fundación de su yglesia y muchos milagros. Escriviose esta carta a 6 de abril de 1651. No consta que se haya dado esta reliquia.

15. <Testimonio de un milagro de los Santos Mártires. Año de 1681>.

Testimonio de cómo Francisco Ordás de la Vega, vecino de esta villa de Carrión, tirando a las palomas y rebentándosele totalmente la escopeta, quedó libre y sin daño alguno, habiendo invocado al mismo tiempo el auxilio de San Zoil y San Félix, según que él mismo lo declaró bajo juramento ante Norberto de Sandoval y Guevara, escribano en Carrión, a 13 de enero de 1681.

${ }^{182}$ Carta] al margen derecho: Falta.

183 Carta] al margen derecho: Falta. 

$1682>$.

16. < Yndulgencia plenaria y perpetua para los días de San Zoil y San Félix. Año de

Yndulgencia plenaria y perpetua concedida por la Santidad de Ynocencio 11 a petición de este monasterio para los días de sus patronos San Zoil y San Félix, la qual es comutación de la yndulgencia concedida a toda nuestra congregación en los días de San Mauro y San Plácido por Clemente décimo. Datum Rome, apud Sanctam Mariam Mayorem, die vigessima quarta augusti, 1682, pontificatus anno $6^{\circ}$. Hay aquí dos copias impresas de este brebe original; y también la licencia del comisario de cruzada para publicar y ganar dichas indulgencias. Dada en Madrid, a 11 de mayo de 1683.

17. <Yndulgencia plenaria para la traslación de los cuerpos de los Santos Mártires. Año de 1697>.

Yndulgencia plenaria concedida por la Santidad de Ynocencio 12 para los tres días primeros de la Pasqua de Pentecostés del año de 1697, en que se celebró en este monasterio la traslación de los cuerpos de los Santos Mártires San Zoil y San Félix de las vrnas viejas en que estaban antes a las que ahora tienen de plata; las que pagó de su depósito (le costaron 1 mill doblones) nuestro reverendo padre maestro fray Alonso de Mier, procurador de Roma. La relación de las fiestas de esta traslación consta largamente y se halla en el libro $3^{\circ}$ del Cajón San Claudio, al foilo 108 vuelto. Hay una razón de la plata que pesan las vrnas.

18. < Sermones en la traslación de los cuerpos de los Santos Mártires. Año de 1697>.

Dos sermones, en un quaderno impreso, que predicaron, el uno nuestro padre maestro fray Jacinto Díaz, predicador general de nuestra religión y abad actual de esta casa; y el otro, el padre maestro fray Bernardo Caravés, predicador mayor de esta casa, quando se trasladaron los cuerpos de los Santos Mártires San Zoil y San ${ }^{184}$ Félix a las nuevas vrnas de plata que hizo el reverendísimo Mier. Año de 1697.

19. < Sermón a la colocación de la ymagen de Santa Gertrudis. Año de 1700>.

Sermón ${ }^{185}$ que predicó nuestro padre maestro fray Jacinto Díez, predicador general de nuestra religión y abad de esta casa, en la función de la colocación / ( f. 119r) de la ymagen de Santa Gertrudis la Magna, trahída de Nápoles, y de las de Santa Escolástica y Santa Metildis, trahídas de Madrid, en el altar nuevo que se hizo para ese efecto, y en ocasión que se acababa de concluir la yglesia y el choro, a expensas de nuestro yllustrísimo don fray Anselmo de la Torre, obispo de Tuy. Ymprimiose este sermón el año de 1700.

20. $<$ Memoria de las reliquias que hay en la vrna del Sagrario. Año de 1704>.

Memoria simple de las santas reliquias que se metieron en la vrna de plata que está encima de la custodia, en 16 de noviembre de 1704. Esta relación original se halla en el libro $3^{\circ}$ del Cajón San Claudio, al fol. 109; y assimismo otra relación de las que se metieron en los años de 1705 y 1717, con un papel de las que se hallaron en dicha vrna en el año de 1737.

21. <Testimonio de cómo se abrió la vrna de San Zoil, para entregar una reliquia a la ciudad de Córdova. Año de 1708>.

Bajo este número están varias cartas de la ciudad y obispo de Córdova, por las que buelben a pedir una reliquia de San Zoil, y entre ella está un testimonio signado de Agustín García de Miranda, Gregorio García de Miranda y Santiago Duque de Estrada, escribanos y notarios de Carrión, de cómo en su presencia se bajó y abrió la vrna de San Zoil, con toda solemnidad, y de ella se sacó un hueso, al parecer canilla de un brazo, del santo de un jeme de largo y se entregó al comisario de dicha ciudad de Córdova. Todo lo qual se executó en 21 de diciembre de 1708.

\footnotetext{
${ }^{184}$ San] sigue tachado: Agapio

185 Sermón] al margen derecho: Falta.
} 
22. < Sermón predicado en Córdova por la reliquia de San Zoil. Año de 1714>.

Sermón ${ }^{186}$ impreso que predicó el reverendo padre fray Antonio Ventura de Prado, Orden de la Santísima Trinidad, en la función que zelebró la ciudad de Córdova a la colocación de la santa reliquia de San Zoil que le dio este monasterio. Esta función se zelebró según consta de este sermón en el año de 1714.

23. < Yndulgencia de 40 días rezando un Credo al Santo Christo. Año de 1763>

Concesión ${ }^{187}$ de 40 días de yndulgencia a todos los que asistiesen a la colocación del Santísimo Christo, y a los que rezaren de rodillas un Credo delante de su santa ymagen, hecha por el señor obispo de Sigüenza, a 11 de diciembre de 1763, a petición de santo Padre Morante, abad de esta casa.

24. < Los beneficiados de Cardeñosa piden una reliquia. Año de 1775>.

Memorial ${ }^{188}$ de los beneficiados y vecinos del lugar de Cardeñosa, en que piden alguna reliquia para colocarla en su parroquia. Concedioseles / (f.119v) un hueso de cinco dedos de largo de San Fructuoso, obispo de Braga, que estaba en el relicario; según consta del recivo adjunto, dado por don Antonio Manzanedo y Santiago, a 13 de septiembre de 1775.

25. <Testimonio de la translación de las reliquias. Año de 1814>.

Testimonio ${ }^{189}$ de la translación de las reliquias de los Santos Mártires San Zoil y San Félix con otros muchos santos, como en él se expresa, a la parroquia de Santa María del Camino de esta villa, por la invasión de los franceses, en mayo de 1810; hasta que por la misericordia del Todopoderoso permitió y quiso se volviesen a trasladar y colocar en su yglesia. Fue dado a 13 de agosto de 1814, por José Tablares del Val, escribano de esta villa de Carrión. Hay copia autorizada por el mismo en el libro $6^{\circ}$ del archivo, titulado Martirologio: Cajón 25. San Claudio.

\section{/ (f. 120r) Quaderno B del Legajo $2^{\circ}$ \\ Diferencias con los clérigos}

Este quaderno B contiene los papeles pertenecientes a los pleitos y diferencias que ha tenido este monasterio con los clérigos y villa de Carrión sobre la precedencia de asientos, por el orden siguiente:

$1^{\circ}$. < Hermandad con los 12 capellanes de Carrión. Era de 1314. Año de 1276>.

Carta de hermandad, escrita en pergamino, con dos sellos pendientes, hecha entre don Juan Germán, prior de San Zoil, y el convento con el común de los doce clérigos de la villa de Carrión, por la qual ordenaron que los capellanes viniesen al monasterio a las vísperas y misa de San Zoil y San Félix; y que después de vísperas, el convento les diese vino para beber. Que quando algún monge muriese, viniesen los capellanes a decirle una vigilia y el convento les diese de beber; y que otro día habían de venir a enterrarle y decirle la misa con ministros; y que quando muriese algún capellán fuesen allá los monges e hiciesen otro tanto. Los monges hacen a los clérigos participantes de sus oraciones, sacrificios, buenas obras etcétera, como igualmente los clérigos a los monges. Su fecha, a 8 de marzo, era del 1314, que es año de Christo de 1276.

2. <Vnión de la Cofradía de San Zoil y San Felices a la de los 25 clérigos de Carrión. Capítulos de la Concordia>.

Concordia que hizieron los cofrades de la cofradía de San Zoil y San Felices con la cofradía de los 25 clérigos de Carrión; los quales comprometieron esta vnión y sus capítulos

\footnotetext{
186 Sermón] al margen derecho: Falta.

${ }^{187}$ Concesión] al margen derecho: Falta.

188 Memorial] al margen derecho: Falta.

189 Testimonio] al margen derecho: Nota. Antes de este número debe ponerse otro instrumento que se executó antes que éste y está en el mismo quaderno de don Bernardo Soto Casielles, vecino de Oviedo.
} 
en dos jueces árbitros, y por tercero al padre fray Diego de Canales, presidente del monasterio de San Zoil. Estos dieron por vnidas las dos cofradías con ciertas condiciones y capítulos, algunos de los quales son: Que el hospital de San Zoil, que estaba en el barrio, se conserve siempre y esté en pie con dos camas para pobres y se repare por qüenta de la cofradía; y los cofrades entierren los pobres que murieren en él. Que acudan todos a vísperas y misa de San Zoil y San Felices, y tengan velas encendidas en las manos. Que entierren a los cofrades de San Zoil, lo quales sólo paguen una libra de cera en su muerte y no otra entrada ni salida. Que para que siempre se conserve / (f. 120v) la memoria de la cofradía de San Zoil y San Felices, haya siempre 12 cofrades que se llamen de San Zoil. Que no se puedan vender ni enagenar las heredades de esta cofradía, y que la regla de ella se guarde siempre. Que las colaciones y juntas que se solían hazer en la cofradía de San Zoil, se hagan en el hospital. Que siempre se elija un mayordomo de los cofrades de San Zoil que cuide de los reparos y administración del dicho hospital. Que el prelado de San Zoil sea cofrade y cuide de que no se enagene la hacienda de la cofradía y de que esté en pie y reparado el dicho hospital de San Zoil; y en quanto a éste sea juez de los cofrades. Que si los cofrades de los 25 no cumplieren los capítulos de esta concordia, los de San Zoil puedan desunirse y gozar su hospital y todo lo que antes tenían; y para esto y todo lo demás sea su juez el prelado de San Zoil.

$<$ Año de 1531>.

Otorgose esta concordia a 25 de junio de 1531 ante Juan de Castrillo, notario apostólico, y la confirmó el señor provisor de Palencia. Está aquí el registro de esta escritura y una memoria de las heredades de la cofradía.

\section{3. <Diferencias con los clérigos sobre el lugar de las procesiones. Año de 1576>.}

Relación de lo que ha habido acerca de la innovación que hubo sobre el lugar que debía guardar el cavildo de Carrión en las procesiones que debía guardar el cavildo de Carrión en las procesiones que venían a este monasterio y de algunos alborotos y escándalos que pasaron en la yglesia el día de San Zoil del año de 1576.

4. <Testimonio de un requerimiento hecho al padre abad sobre las procesiones del día de San Zoil. Año de 1576>.

Testimonio dado por Cristóval Verde de Castilla, escrivano de Carrión, de una protesta y seguimiento que hizo la villa y clerecía de Carrión al padre abad de este monasterio, porque no les dexó entrar en la yglesia a hacer su procesión el día de San Zoil, como lo tenían de costumbre; y respuesta que dio el padre abad de que estaba pronto a recivirles y darles entrada, siempre que guardasen la costumbre antigua en lo tocante al orden que debían guardar en las procesiones. Su fecha, en Carrión, a 27 de junio de 1576.

\section{5. < Poder del monasterio para querellarse de la villa y clerecía. Año de 1576>.}

Poder del monasterio para querellarse de la justicia y clerecía de Carrión por el atropellamiento y escándalo que dieron en esta yglesia el día de San Zoil, con relación de lo que sucedió. Su fecha, en San Zoil, a 29 de junio de 1576, ante Cristóval Luis Rodríguez, escribano de Carrión. de $1577>$.

6. $<$ Concierto entre el cabildo de Carrión y el monasterio sobre las procesiones. Año

Concierto y capitulación hecha entre este monasterio y la clerecía / (f. 121r) de Carrión, sobre salirles a recivir quando vinieren en procesión y de los lugares que unos y otros han de ocupar. Su fecha, en San Zoil, a 14 de mayo de 1577. Están aquí las condiciones que para esto pide el cavildo con la respuesta que a ellas dio el monasterio.

7. <Que los regulares no precedan a los clérigos en las procesiones. Año de 1602>.

Comisión que dio el provisor de Palencia a un beneficiado de San Andrés de esta villa, para que requiriendo a este monasterio y demás comunidades de Carrión, execute y haga cumplir lo provehído por el motu propio de Clemente $8^{\circ}$, en que manda que los regulares no precedan a los clérigos en los entierros y procesiones. Dada en Palencia, a 28 de mayo de 1602, ante Lucas Gallardo, notario apostólico. Está aquí una copia simple del referido motu propio. 
8. $<$ Diferencias entre el abad y correjidor sobre la silla que debía ocupar en los días en que la villa solía asistir a los oficios divinos. Año de 1611>.

Bajo este número hay varias protestas, requerimientos, cartas y otros papeles sobre las diferencias y pesadumbres que hubo en este monasterio el año de 1611, en razón de que haviendo en el choro bajo bancos de respaldo en que se sentaban los monges a los oficios divinos y sermón, y se ponía a la cabezera del lado derecho una silla para el abad (era entonces santo padre Barrantes), los días en que por voto la villa de Carrión venía en procesión a esta casa, que eran víspera de la Ascensión, día de San Felix y San Zoil y algunos otros días solemnes, el correjidor o su teniente pretendían que o esta villa no havía de estar allí ni el abad sentarse en ella, o que el correjidor había de sentarse al lado derecho y el abad al idquierdo. Con esta injusta pretensión, día de nuestro padre San Benito de marzo, diziendo la misa mayor el padre guardian de San Francisco, el correjidor y su teniente mandaron poner otra silla junto a la del abad, y los dos sin otra cortesía se sentaron en ellas. Visto esto por el abad por evitar alborotos se salió de la yglesia y no volbió. Continuando estos desórdenes en la víspera de la Ascensión. Octava del Corpus y día de San Bernabé del mismo año, el día 14 de junio propuso y embió este monasterio a la justicia y rejidores seis medios por los que quería evitar toda inquietud. Se presentaron en ayuntamiento y no los admitieron, como consta del testimonio que se halla aquí, dado por Gerónimo López, escribano de Carrión, en el que se inserta un decreto del Consejo en que manda al correjidor y abad de San Zoil / ( $f$. $121 v)$ que informen sobre el asunto y que en el interin nada se innove. No obstante este día de San Félix por la mañana, un alguacil entró y puso los bancos del rejimiento en la yglesia, estando el convento en contemplación, y con él varios soldados con armas haciendo un grande ruido. Salió el convento del choro y el abad encargó a la comunidad con precepto y censuras que en qualquier ocasión de inquietud ninguno hablase palabra. La madre Luisa, monja de Santa Clara, de conocida virtud y santidad tubo noticia de estos alborotos y embió a llamara al abad, correjidor y rejidores y juntos determinaron que por aquella vez se estubiese a lo la dicha madre resolviese acerca del asiento del abad, sin perjuicio de las partes. Este parecer y resolución de la madre Luisa, firmado de los regidores, se entregó al abad, el qual con otra carta de la misma se halla aquí original; y haviendo todos convenido en lo que en él se ordenaba al tiempo del sermón todo se deserdenó: mandó el abad proseguir la misa, se dejó el sermón, se alborotó toda la gente que había en la yglesia y la procesión se volvió a la villa. Hai aquí a las últimas ojas un parecer de los padres del Consejo para hacer una sillería en el choro bajo y componer los alborotos que pasaron el día de San Zoil del mismo año, como se reza en el número siguiente.

9. <Relación de los alborotos entre este monasterio y la villa de Carrión sobre el asiento del abad, particularmente de lo que sucedió el día de San Zoil con fray Diego de Olea. Año 1615>.

Bajo este número están los papeles siguientes:

$1^{\circ}$ Vna relación hecha por el abad y padres del Consejo y firmada de sus nombres, de lo sucedido en las diferencias que este monasterio tenía con el correjidor y rejimiento de esta villa, sobre querer quitar el choro bajo la silla que se solía poner para el abad.

$2^{\circ}$ Vna copia simple de un memorial que nuestro padre abad fray Alonso Barrantes embió a Su Majestad en cumplimiento de un decreto del Consejo en que se le mandaba que informase de lo que había acerca del assiento, y de las razones que tenía contra lo que solicitaba la villa.

$3^{\circ}$ Relación simple de los alborortos que sucedieron en la yglesia el día de San Zoil, y es como se sigue: Habiendo el Padre Abad embiado dos monges a tratar con don Juan Ramírez de Arellano, correjidor de Carrión, acerca del asiento y silla del abad, para evitar inquietudes en un día tan solemne, no se convinieron, según parece. Hasta las diez dadas aguardó el abad y convento a que / (f. 122r) llegase la procesión de la villa para comenzar los oficios divinos. Viendo que no venía, se comenzaron: estando en la epístola llegó la procesión de la villa, anduvo por los claustros, y el rejimiento y justicia se sentaron en los bancos. Preguntó el correjidor para quién era una silla que estaba a la cabezera de los del convento. Respondió un monge que era para el abad, y el corejidor la mandó quitar, el monge 
la tubo con la mano, requirió al corejidor y pidió por testimonio cómo el dicho corregidor le hazía fuerza y despojaba al convento de su posesión.

Estando en estos requerimientos y protestas de ambas partes, se levantó en la yglesia gran ruido y alboroto a causa de que habían entrado unos soldados en la cozina del monasterio y habían sacado de ella mucha parte de la comida que se estaba aderezando; y habiendo llegado la voz del choro alto donde estaba mucha gente, y entre ella fray Diego de Olea, fraile lego, cocinero, a cuyo cargo estaba la comida y cozina; salió de dicho choro, se fue a la cozina y halló que estaba llorando un muchacho a quien él había dexado para su guarda y, preguntándole por qué lloraba, halló y vio ser verdad que los soldados habían quitado la comida. Alborotado con esto cogió un asador, y diciéndole que los soldados habían salido por la yglesia fue tras ellos; y muchos desenbainando las espadas contra él, quebrando la reja de la yglesia y aprovechándose de sus baluartes para lo mismo, llegaron correjidor, aguaciles y escrivanos y echaron mano del religioso diciéndole mil oprobios, a que ayudaron algunos clérigos haciendo lo mismo con el abad que estaba revestido en el altar mayor, no perdonando a los demás monges que estaban en la yglesia y choro; y quitando con afrenta al dicho fraile lego el escapulario se le hizieron pedazos, y de esta manera le sacaron de la yglesia, tirándole de las orejas y dándole golpes le llevaron a la cárcel pública y le pusieron con grillos en el calabozo donde estubo algunos días, como consta del proceso que sigue a este número. Todo esto pasó el día 27 de junio de 1611. Síguese a esto ciertos medios de composición por parte de la villa y monasterio que parece no se observaron. de $1611>$

10. $<$ Mandamiento del juez correxidor para que se suelte a fray Diego de Olea. Año

Querella que dio el monasterio de la justicia de la villa de Carrión sobre la prisión de fray Diego de Olea, ante el abad de Benevivere, juez / (f. 122v) conservador de este monasterio, por la qual parece que habiéndose hecho la información de testigos que declararon ser verdad lo sucedido en el día de San Zoil, y con las circunstancias que quedan declaradas en el número antecedente, el juez conservador dio varios mandamientos con censuras para que se soltase al dicho fray Diego de Olea, y se bolbiese al monasterio; pero no queriendo obedecer, el correjidor y alcalde mayor dio otro mandamiento declarándoles por excomulgados, y a los curas y beneficiados la cesación a divinis. En vista de este mandamiento, la justicia de Carrión sacó el preso de la cárcel y le entregó al padre abad, como consta del testimonio dado por Miguel de Terán, escribano de Carrión, a 30 de junio de 1611, ante quien pasó todo el proceso.

\section{1. <Mandamiento para que no entren seglares en el choro. Año de 1611>.}

Mandamiento con censuras del nuncio de Su Santidad para que durante el oficio divino no entren seglares en nuestro choro, ni tomen asiento en él, para evitar los inconvenientes que quedan referidos y de que el monasterio hizo relación. Dado en Madrid, a 28 de junio de 1611.

12. < Carta del procurador de Roma con un monitorio del auditor contra la justicia y rejimiento de Carrión. Año de 1611>.

Carta del procurador de Roma con dos traslados de un monitorio del auditor de la Cámara Apostólica, ganado a instancia de este monasterio, por el qual se dexa a disposición del padre abad el admitir o no a la justicia y rejimiento de esta villa en los días que solía venir en procesión a esta yglesia, y en caso que se les admita ha de ser tomado el asiento que se le señalare. Esto se les manda con precepto y censuras y con la pena de 4 mill escudos para la Cámara; y en caso que tengan algún derecho para lo que pretenden, se les manda que lo escriban en Roma en el término de 60 días, contados desde el día de la notificación de este monitorio, que fue dado en Roma, a 13 de septiembre de 1611, en el año 7 del pontificado de nuestra Santidad papa Paulo $5^{\circ}$.

13. < Copia autorizada del monitorio contra la justicia de Carrión sobre los asientos. Año de 1612>.

Copia authorizada del mismo monitorio del auditor de la Cámara Apostólica, por Antonio Bohón de Bustamante, escribano y notario de Carrión. Están aquí las notificaciones 
que se hicieron por parte del monasterio al alcalde mayor, rejidores, arcipreste y demás curas de Carrión, que todo se executó en el mes de febrero de 1612, ante el referido escribano y notario.

14. $<$ Requirimiento para que no vengan en procesión. Año de 1612>.

Bajo este número están quatro requirimientos:

El $1^{\circ}$ hecho por parte del monasterio al arcipreste y clérigos de Carrión, para que no vengan en procesión a esta yglesia. Su fecha, a 30 de mayo de 1612.

El $2^{\circ}$ hecho por parte del rejimiento de Carrión a este monasterio / (f. 123r) para que no impida dichas procesiones por razón de la posesión immemorial que decían tener. Fue hecho en 13 de junio del mismo año ante Gerónimo López, escribano de Carrión.

El $3^{\circ}$ es de la parte del monasterio hecho a la justicia y rejimiento de Carrión sobre lo mismo, haciéndoles presente el privilegio de Eugenio $4^{\circ}$ y el monitorio que queda dicho. Su fecha, a 15 de junio del mismo año, ante Pedro de Carrión, escribano de dicha villa.

15. <Mandamiento para que los seglares no entren en el choro. Año de 1614>.

Mandamiento del nuncio, a petición de este monasterio, para que los seglares no puedan entrar en el choro mientras se celebran los divinos oficios, sin licencia del abad u otro superior. Dado en Madrid, a 24 de julio de 1614.

16. <Testimonio de un acuerdo entre el Ayuntamiento, clérigos y este monasterio, sobre una procesión que no tubo efecto. Año de 1635>.

Testimonio dado por fray Juan de Cisneros, notario apostólico, de cómo el ayuntamiento y clérigos de Carrión pidieron licencia a este monasterio para llevar en procesión a la parroquia de Santa María los cuerpos de los Santos Mártires por una necesidad que había de agua; y habiéndola concedido el abad y padres del Consejo con el orden y manera que se había de guardar en la procesión; sin embargo de estar firmado de todos, el cavildo eclesiástico de Carrión no convino en esta disposición por lo que no tubo efecto. Pero consta de este mismo testimonio de cómo el día de San Félix por la tarde, el convento, con la justicia y rejimiento de Carrión, hizo su procesión con los cuerpos de los Santos Mártires a San Lázaro, bolbiendo por el puente al monasterio. Todo pasó en el mes de junio de 1635, ante el referido notario.

17. <Licencia que dio el abad para venir en procesión. Año de 1635>.

Licencia que pidieron los cofrades de la Veracruz para venir en procesión por voto que habían hecho y licencia que dio el abad por aquella vez tan solamente, firmada de Santo Padre, a 11 de junio de 1635, ante fray Juan de Cisneros, notario apostólico.

18. <Acuerdo del cavildo de Carrión sobre las procesiones de los Santos Mártires. Año de 1754>.

Copia simple de un acuerdo que hizieron los clérigos de Carrión, en el que se ordena el modo y forma que se debía observar en las procesiones que por razón de alguna necesidad se hubiesen de hacer con los cuerpos de los santos mártires San Zoil y San Félix, cuya disposición se propuso al padre maestro fray Yldefonso de Bárcena, abad de este monasterio, pero no consta lo que se resolvió. Su fecha, en Carrión, a 15 de noviembre de 1754.

19. <Acuerdo del cavildo y consentimiento del monasterio con el parecer del señor obispo de Palencia contra él>.

Otra copia simple del mismo acuerdo, en el que según su contexto se resolvió últimamente por el clero y monges de este monasterio, en presencia del visitador general de este obispado, guardar / (f. 123v) en las procesiones el methodo y orden en él contenido. Hay aquí una relación simple de este y otros acuerdos con expresión de que el señor Bustamante, obispo que era de Palencia, los tubo por inválidos para estar (dice) hechos sin consentimiento de los obispos antecesores; pero se responde que los señores obispos dieron su tácito consentimiento por haberles constado de el hecho, y de haber pedido la villa licencia 
a Sus Yllustrísimas para que el padre abad celebrare de pontifical, como consta de los acuerdos y de los libros de Consejo de este monasterio.

\section{/ (f. 124r) Quaderno C del Legajo $2^{\circ}$ \\ Obras Pías en Carrión}

Este quaderno $\mathrm{C}$ contiene los papeles pertenecientes a algunas obras pías de que es patrono el abad de este monasterio y la de don Antonio Pastor (que llaman de los Veinte) por el orden siguiente:

$1^{\circ}<$ Obra Pía del comendador de La Herrada. Año de 1561>.

Copia authorizada por Francisco Moro de Saldaña, escribano de Carrión, del testamento y codicil(i)o que hizo don Juan Rodríguez de Castañeda, comendador del Hospital de La Herrada, en el que inserta una cláusula de la obra pía que fundó para dotes de casadas y monjas, en la que nombra al abad de este monasterio por uno de los patronos de ella; y manda que el dinero se ponga en el arca del depósito de este monasterio; en una arca aparte con las tres llaves que dice en su testamento. Otorgado en el dicho hospital, a 18 de noviembre de 1561, ante Gregorio Movilla, escribano de Carrión. < Hay aquí otra copia autorizada por Andrés Sánchez, escribano de Carrión>.

2. < Renuncia que hizo el abad de San Zoil del patronato de la obra pía del comendador de La Herrada. Año de 1601>.

Testimonio dado por Pedro de Cervantes, escribano de Carrión, de la renuncia que hizo el abad de este monasterio del patronato de la obra pía del referido comendador de La Herrada, por haber nombrado los otros patronos un mayordomo sin su consentimiento y por otras causas que para para ello tubo. Requirió a los patronos y dieron por respuesta que el haber nombrado otro mayordomo fue porque lo dexó mandado con censuras el señor visitador del obispado. Su fecha, en Carrión, a 31 de marzo de 1601.

3. <Licencia del General para que el abad sea patrono. Año de 1673>.

Licencia que pidió nuestro padre maestro fray Juan González, abad de esta casa ${ }^{190}$, a nuestro reverendísimo Padre General para admitir el patronato de la obra pía que fundó en esta villa Francisco de Barrio, vecino de ella, y concesión de su reverendíssima. Su fecha, en Salamanca, a $1^{\circ}$ de marzo de 1673.

4. $<$ Fundación de dos misas cada día en el convento de San Francisco por Francisco Barrio. Año de 1676>.

Traslado simple de la escritura de fundación de dos misas cada día que Francisco Barrio de la Vega hizo en el covento de San Francisco de Carrión; su limosna de dos reales por cada una. Y para ello dexan 1460 reales en los censos que en este papel se expresan. Hay aquí también una copia simple de un memorial del padre guardián de San Francisco al señor obispo de Palencia, en el que suplica que las misas se le paguen a razón de 4 reales por cada una, y al pie / (f. 124v) de él está el decreto de Su Yllustrísima en que manda se les paguen como lo piden y como ya lo tenía mandado por otro decreto; y assimismo 2 ducados por una memoria que se hacía en dicho convento, día de San Buenaventura, por el referido Francisco Barrio. Su fecha, en Palencia, año de 1676.

5. $<$ Cláusulas del testamento sobre las dos misas $>$.

Cláusulas del testamento y última voluntad que otorgó Francisco Barrio de la Vega ante Norberto de Sandoval y Guevara, escribano de Carrión, y razones para probar que el convento de San Francisco no tiene fundamento para pedir que las dos misas referidas se le paguen a 4 reales, ni que su limosna se pague de las rentas de la obra pía, por haber sido fundadas en distintos tiempos y con distintos caudales. Todo esto fue sacado por Francisco Mauro Fuertes, hijo de este monasterio.

\footnotetext{
190 casa] al margen derecho: Aquí corresponde el número $7^{\circ}$.
} 
6. $<$ Pleito que puso el convento de San Francisco sobre las dos misas de a dos reales para que se le pagasen a 4 . Año de 1714>.

Relación del pleito que el convento de San Francisco de esta villa de Carrión movió contra esta obra pía y sus patronos, pretendiendo que de los bienes de ella se le debía aumentar la limosna de las dos misas que el mismo Francisco Barrio havía fundado, aunque con censos señalados para su satisfacción. Este pleito comenzó en Palencia el año de 1714, y el año de 1715 se llevó a Burgos en grado de apelación, en donde según aquí se dice está detenido. Hay aquí una memoria de todo lo alegado por una y otra parte, y un memorial del hecho para claridad del derecho de la obra pía.

7. <Fundación de la obra pía de los Veinte. Año de 1655>.

Fundación del Patronazgo Monte de Piedad Christiana que ${ }^{191}$ en la yglesia Mayor de Santa María del Camino de la villa de Carrión dotó y fundó don Antonio Pastor (que llaman de los Veinte), natural de dicha villa y vecino de la ciudad de Sevilla, en el día 10 de julio de 1655, por testimonio de Francisco López Castelar, escribano público de dicha ciudad.

\section{/ (f. 125r) Quaderno D del legajo $2^{\circ}$ \\ Cofradía de la Magdalena y otras}

Este quaderno D contiene los papeles pertenecientes a la Cofradía de la Magdalena sita en este monasterio, la del Santísimo Sacramento y otras, por el orden siguiente:

$1^{\circ}<$ Venta de una herrén que hizo la cofradía de San Zoil. Año de 1420>.

Venta que hizo la cofradía de San Zoil a Juan de Toledo, converso, de una herrén, lindante con el río de Carrión, en precio de 400 maravedís. Su fecha, en el Hospital de la cofradía de San Zoil, a 6 de agosto de 1420, ante Fernando Rodríguez de Castellanos, escribano y notario público. Esto sólo sirve para memoria de la cofradía que hubo de san Zoil.

2. < Regla de la cofradía de San Juan. Año de 1485>.

Regla y estatutos de la cofradía de San Juan Baptista, fundada en la yglesia de San Andrés de esta villa de Carrión, aprobada por el señor obispo de Palencia, a 22 de junio de 1485.

3. < Regla de la cofradía de Santa María Magdalena. Año de 1585>.

Regla y estatutos de la cofradía de Santa María Magdalena, fundada en la yglesia de este monasterio de San Zoil. Su fecha, parece ser del año de 1530. Fue aprobada por el ordinario de Palencia, a 29 de junio de 1585, ante Juan de Virtus, notario de la misma ciudad.

4. $<$ Bulla del papa Clemente $8^{\circ}$. Concede varias yndulgencias a la cofradía de Santa María Magdalena. Año 1604>.

Bulla del papa Clemente $8^{\circ}$, escrita en pergamino, con sello de plomo pendiente, por el qual concede a todos los fieles vtriusque sexus que contritos, confesados y comulgados, entraren en la cofradía de la Magdalena, sita en el monasterio de San Zoil, en el primer día de su entrada, yndulgencia plenaria y también en el artículo de la muerte, diciendo el dulce nombre de Jesús con el corazón si no pudieren con la boca. Concede también a los mismos que contritos, etcétera, visitaren la yglesia de San Zoil del día de santa María Magdalena, yndulgencia plenaria de todos sus pecados; y a los que no fueren cofrades, siete años y siete quarentenas de yndulgencia. Y assimismo, a los mismos cofrades que con las mismas disposiciones visitaren la yglesia en los días de San Juan Evangelista, San Gregorio el Magno, la Ynvención de la Cruz y San Zoil y rezaren por ${ }^{192}$ / (f. 125v) la Exaltación de la Santa Fe,

191 que] al margen derecho: Este número ha de ser el 3.

192 por] sigue tachado: los. 
etcétera, por cada vez que lo hicieren en cada día de los dichos siete años y siete quarentenas de indulgencia. Y todas las veces que los dichos cofrades assistieren en forma de cofradía a los Divinos Oficios que se celebran en la dicha yglesia o en las congregaciones públicas o secretas para exercer qualquiera obra pía, o a las procesiones ordinarias y extraordinarias, assí de la cofradía como otras, o fueren a enterrar a los muertos o acompañaren el Santísimo Sacramento quando se lleva a los enfermos y los que estubieren impedidos, quando oyeren tocar la campana, puetos de rodillas, rezaren un Pater noster y una Ave María por el enfermo, o fueren a consolar al que estubiere en adversidad u hospedaren los pobres peregrinos y les ayudaren con limosnas y oficios de charidad o pusieren paz entre los enemigos o rezaren cinco veces el Pater noster y el Ave María por las almas de los cofrades o enseñaren a los ignorantes los preceptos de la ley de Dios y lo demás necesario para su salvación o exercitaren qualquier otro oficio de charidad. Por cada vez que qualquiera de estas cosas hicieren se les relajan 60 días de las penitencias impuestas por sus pecados, o que de qualquiera otra manera tubieren que cumplir. Datum Tusculi, anno 1604, nonas octobris, pontificatus anno $13^{\circ}$. Está aquí la licencia del comisario de Cruzada para vsar de dichas yndulgencias. Su fecha, en Valladolid, a 15 de enero de 1605, ante Juan de Talavera, su secretario.

\section{5. <Fundación de la cofradía de la Minerva. Año de 1648>.}

Fundación, regla y estatutos de la cofradía del Santísimo Sacramento en la yglesia de San Zoil, su aprobación e indulgencias concedidas por Paulo $3^{\circ}$ a la Minerva de Roma, con extensión, comunicación y participación a todas quantas cofradías se fundasen en la Christiandad con el título y nombre del Santísismo Sacramento. Su fecha, en San Zoil, a 17 de diciembre de 1648.

\section{/ (f. 126r) Legajo $3^{\circ}$}

\section{Hospital de Nuestra Señora de la O}

Este legajo, que es el $3^{\circ}$ del cajón San Andrés, contiene los papeles pertenecientes al Hospital de la $\mathrm{O}$ (sito dentro de esta parroquia) y a las diferencias que con él ha tenido este monasterio sobre diezmos y administración de sacramentos por estar el Hospital fundado en suelo suyo, por el orden siguiente:

\section{$1^{\circ}<$ Testamento de don Luys Hurtado de Mendoza. Año de 1507>.}

Testamento que hizo don Luis Hurtado de Mendoza, abad comendatario de este monasterio y fundador del Hospital y cofradía de Nuestra Señora de la O (que él llama de San Zoil), en el qual hace varias mandas a San Zoil, a San Román y a los monges de este monasterio y dexa por patrono del referido hospital al conde de Castro, su sobrino, y después de él a los que le sucedieren en el mayorazgo. Fue hecho el ${ }^{193}$ testamento en Villamuera; y este traslado, en Paredes de Nava, a 24 de junio de 1507, ante Pedro González de Quevedo, escribano de la misma villa y notario público. Hay copia simple.

2. <Partición de los juros que dexó don Luys Hurtado. Año de 1508>.

Partición de los juros que dexó en su testamento don Luis Hurtado de Mendoxa, hecha por los procuradores de las yglesias y comunidades a quienes dexó estos juros, de los quales tocaron a San Zoil 5 mill 154 maravedís. Su fecha, en Valladolid, a 29 de octubre de 1508, ante Luis de Lucerna, escribano de la reyna.

3. $<$ Bulla del papa Julio $2^{\circ}$. Aprueba y confirma las tres capellanías del Hospital de la O. Año de 1508>.

Bulla del papa Julio $2^{\circ}$, escrita en pergamino, con sello de plomo pendiente, por la qual aprueba y confirma las tres capellanías que fundó en el Hospital de la $\mathrm{O}$ don Luys Hurtado de Mendoza, para tres capellanes que digesen misa a los peregrinos y les administren

193 el] escrito sobre: este. 
los Santos Sacramentos, cuya execución viene cometida al arzobispo Sipontino, al abad de San Juan de Burgos y al de Benevivere. Dada en Roma, año de 1508.

4. $<$ Censuras del juez conservador para que se guarden las dos bullas del papa Julio $2^{\circ}$. Año de 1509>.

Letras y censuras de Pedro de Carrión, abad de Benevivere, juez executor por comisión apostólica, dirijidas al obispo, deán y cavildo de la yglesia de Palencia, para que guarden y no impidan / (f. 126v) el cumplimiento de dos bullas de Julio $2^{\circ}$, aquí insertas, dadas a instancia de los testamentarios de don Luis Hurtado de Mendoza, a favor del Hospital de la O. En la primera concede Su Santidad indulgencia a los que hizieren limosnas al dicho hospital, etcétera; y en la segunda confirma las tres capellanías que instituyó du fundador para tres capellanes que digan misa, confiesen y administren los sacramentos a los peregrinos que llegaren al dicho Hospital. Dadas en el monasterio de Benevivere, año de 1509. la $\mathrm{O}>$.

5. $<$ Parecer de quatro letrados sobre pagar diezmos a este monasterio el Hospital de

Parecer de quatro letrados sobre que el Hospital de la $\mathrm{O}$ debe pagar diezmo a la parroquia de San Zoil, de los frutos y ganados del mismo hospital. Parece que los cofrades confesaban entonces que el dicho hospital era miembro de este monasterio y que como tal havía de gozar de sus privilegios, exenciones y libertades; y que como el monasterio era esento de pagar diezmo de los frutos que coge en sus propias heredades que labran con sus manos e a sus propias expensas, assí lo debía ser el mismo hospital por tener yglesia nuevamente fundada por authoridad apostólica. Hay copia authorizada, sacada por don Antonio Martín García, traductor, año de 1783. El parecer original no tiene fecha.

6. <Sentencia del juez conservador para que se vuelba un preso a la Casa de la Limosna. Año de 1523>.

Sentencia ${ }^{194}$ que dio el prior de Escalada, juez conservador, a favor del monasterio contra un teniente de la villa de Carrión, para que volbiese a la Casa de la Limosna (que dicen ser el Hospital de la O) un preso que de allí había sacado. Diose esta sentencia a 13 de abril de 1523, ante Juan de Castrillo, escribano y notario apostólico. Está aquí el mandamiento del juez para llevar a execución dicha sentencia y la notificación hecha al teniente con la respuesta que dio de que se había marchado dicho preso, y que siempre y quando que le que le cogiese estaba pronto a obedecerla, lo qual pasó ante Diego de San Zoles y Pedro Hortiz, escrivanos. de $1536>$.

7. $<$ Requirimiento del monasterio para que le paguen el suelo del dicho hospital. Año

Requirimiento hecho por parte del monasterio al abad y cofrades del Hospital de la O para que le paguen el suelo donde está fundado dicho hospital y no prescrivan derecho sobre él. Su fecha, a 19 de diciembre de 1536, ante Juan de Castrillo, escribano de Carrión. gallinas $>$.

8. $<$ Foro perpetuo a favor de este monasterio de una carga de trigo, 8 reales y dos

Foro ${ }^{195}$ perpetuo que otorgaron el abad, rejidores y cofrades del Hospital de la $\mathrm{O}$ a favor de este monasterio, por el que se obligan / (f. 128r) a pagar por el suelo de dicho hospital una carga de trigo. 272 maravedís, que son 8 reales, y dos gallinas, la mitad de los maravedís y las dos gallinas día de Navidad y los 136 restantes el día de San Juan de junio ${ }^{196}$. La carga de trigo se revaja porque el hospital tiene a su favor otra carga de trigo sobre una casa del barrio que este monasterio compró al de San Andrés de Arroyo con dicha pensión, cuya escritura de compra con su recivo está en el Cajón de San Zoil, legajo $2^{\circ}$, número 25. Esta escritura de foro se otorgó a 6 de diciembre de 1552, ante Andrés Sánchez, escribano de Carrión. Hay aquí copia authorizada de esta escritura.

\footnotetext{
194 Sentencia] al margen derecho: Falta.

${ }^{195}$ Foro] al margen derecho: Falta.

196 junio] al margen iqquierdo: Nota: año de 1552.
} 


\section{9. <Reclamación del monasterio por el suelo del Hospital de la O. año de 1556>.}

Reclamación ${ }^{197}$ que hizo el monasterio por el suelo del Hospital de la $\mathrm{O}$, por quanto dicen que su fundador hizo este hospital sin licencia ni consentimiento de los monges y por necesitar el suelo para hacer otro hospital para dar limosna, y porque los cofrades invertían sus rentas en comidas y otras cosas indecentes, y aunque exponen otras razones, citando el testamento de don Luis Hurtado de Mendoza, su fundador, a la verdad no de hallan en él, como se puede ver según queda puesto en el número $1^{\circ}$ de este quaderno. Fue hecha esta reclamación a 31 de diciembre de 1556, ante Andrés Sánchez, escribano de Carrión.

10. < Pleito entre este monasterio y los cofrades del Hospital de la O, sobre la administración de sacramentos en dicho hospital>

Proceso en grado de apelación que este monasterio tubo con el abad y cofrades del Hospital de la $\mathrm{O}$, con motivo de la administración de los sacramentos a los peregrinos que a él concurren. Por estos autos parece que, habiendo el monasterio nombrado por cura de esta parroquia de San Zoles a don Juan Díaz de Miranda, el qual como tal cura administraba los sacramentos a los peregrinos, criados y ochavín de la $\mathrm{O}$, y promovido éste al curato de Nuestra Señora de Belén, de esta villa, no pudo acudir al servicio del curato de San Zoles, por lo que nombró el abad a un monge que le sirviese, y al mismo tiempo los cofrades nombraron al licenciado Guadiana para que exerciese el oficio de cura en dicho hospital; y habiendo muerto en este tiempo un peregrino, Guadiana le enterró en el hospital, a puertas cerradas. Querellose el monasterio ante el provisor de Palencia / (f. 128v) y el provisor mandó que ni Guadiana no otro exerciese el oficio de cura en dicho hospital sin tener nombramiento del abad o monasterio, o si tubiesen alguna razón para ello que alegasen de su justicia. En efecto, lo hizieron. Ofreció el monasterio información y pidió compulsa de papeles, se admitió esta información, la qual se hizo por catorce testigos, quienes declararon que el hospital es de la parroquia de San Zoles y que esta se estiende hasta el lugar de Calzada; que el cura de esta parroquia administra los sacramentos a todos los moradores de ella y que este $^{198}$ siempre ha sido nombrado por el abad de San Zoil y que ha administrado siempre los santos sacramentos en el Hospital de la $\mathrm{O}$ a los peregrinos, ochavín y demás personas de él; y que ha enterrado a los muertos en él, a los peregrinos en el cementerio de san Zoil y al administrador y demás oficiales en el cuerpo de la yglesia del mismo monasterio, sin que en esto se entrometiese otro ninguno; y aunque en dicho hospital está el Santísimo Sacramento y sagrados óleos, no hay pila baptismal ni otros recaudos para administrar los demás sacramentos, y que nunca ha sido tenido por yglesia parroquial sino por una hermita etcétera. Compulsó el monasterio la bulla de unión de la capellanía de la Magdalena a la sacristía de San Zoles, y otras escrituras de este quaderno.

$<$ Sentencia del provisor de Palencia a favor del monasterio $>$.

Se presentó ante el provisor esta ynformación y compulsa; acusó el monasterio las rebeldías, diose la causa por conclusa, alegó el convento de su justicia, y en 24 de julio de 1627 pronunció el provisor sentencia, por la que restituye in integrum al convento y cura por él nombrado en la parroquia de San Zoles y le manutiene y ampara en la posesión en que ha estado de administrar los sacramentos a los peregrinos, caseros y criados del Hospital de la O como feligreses de la parroquia de San Zoles, y en la percepción de los diezmos que coje y demás cosas que se debieren, y enterrar a los que en dicho hospital murieren, sin que se puedan entrometer en ello los cofrades, capellanes, etcétera, de la O. Y contra ellos da su mandamiento para que no inquieten ni perturben al convento en la dicha posesión bajo ciertas penas; y a Guadiana, por haber / (f. 129r) enterrado al peregrino, le condena con dos días de reclusión; y en quanto al artículo de la propiedad sigan su justicia donde y como les convenga; y que todo se cumpla sin perjuicio de la jurisdicción ordinaria. Diose mandamiento, inserta esta sentencia cometiendo al vicario de Carrión, el qual dio la posesión al convento.

\footnotetext{
${ }^{197}$ Reclamación] al margen derecho: Falta.

198 este] e escrita sobre: que.
} 
$<$ El provisor concede la restitución a los cofrades $>$.

Los cofrades apelaron de esta sentencia y pidieron restitución; alegó el convento estar finalizado el pleito, y sin embargo de esto, el 31 de julio el provisor de Palencia dio auto en que concedió la restitución que habían pedido los cofrades y dio por presentada su ynformación y compulsa de papeles, y se dio traslado al convento.

Hicieron los cofrades su ynformación con cinco testigos. Compulsaron varias visitas de los señores obispos y algunas partidas de qüentas de los mayordomos del dicho hospital. El convento presentó su petición al dicho provisor sobre que habiendo dado auto en favor del convento les concedió la restitución que pedían los cofrades en perjuicio suyo, y protextó el auxilio de la fuerza. La parte de los cofrades sacó la ordinaria contra el provisor de Palencia, y en 4 de agosto se presentó el convento en grado de apelación ante el metropolitano de Burgos y pidió letras inhibitorias, compulsorias, contra el provisor de Palencia, el qual se dio por inhibido y se llevó el proceso a Burgos.

$<$ Los provisores de Burgos dan por nulo este auto del provisor de Palencia $>$.

Alegaron allí ambas partes de su derecho, y en 17 de septiembre los provisores de Burgos dieron auto por el que declararon que el auto dado por el provisor de Palencia en 31 de julio, en que concedía la restitución a los cofrades de la $\mathrm{O}$, de que apeló el convento, le daban y dieron por nulo y de ningún valor y efecto y mandaron que las partes alegasen de su justicia para el artículo que haya lugar de derecho, en razón de la restitución pedida por parte del dicho hospital, contra la sentencia que dio el ordinario a favor del monasterio en 24 de julio. De este auto apelaron los cofrades y notificaron a los provisores de Burgos una provisión inhibida de la Chancillería de Valladolid. Se dieron por inhibidos y se llevaron los autos a Valladolid.

\section{/ (f. 129v) < Auto de la Chancillería $>$.}

La Chancillería dio un auto en 15 de octubre, en que dice que el provisor de Palencia en su otorgar a la parte de los cofrades la apelación que ante él por su parte fue interpuesta no hizo fuerza, y se la remitieron.

$<$ Otro auto de la Chancillería. Año de 1627>.

Parece que los cofrades se querellaron de nuevo en la Chancillería del auto de los provisores de Burgos, dado en 17 de septiembre, y visto el proceso en la Chancillería, en 26 de octubre de 1627 (ante Diego Gómez Ossorio, escribano de Cámara) dieron sentencia en que dicen que los provisores de Burgos, reponiendo el auto por ellos dado, en que dieron por ninguno el dado por el provisor de Palencia, en que dio por nulo el auto de ínterin pronunciado a favor del monasterio de San Zoil; y oyendo de nuevo a las partes sobre la apelación ante ellos interpuesta del dicho auto por parte del dicho monasterio, no hicieron fuerza y se lo remitieron. Y no lo haciendo y cumpliendo, assí lo hacen. La qual alzando y quitando, mandaron dar carta y provisión del rey a la parte de dicha cofradía y hospital, para que dichos provisores les otorguen su apelación para que la puedan seguir y proseguir ante quien y como deban; repongan y den por ninguno todo lo después de ella, y en el término en que pudieron y debieron apelar, fecho y procedido; y absuelban los excomulgados y alzen las censuras y entredicho que sobre ello hubieren dado, y puesto libremente y sin costa alguna.

\section{$<$ Nota $>$.}

En este estado se quedó el pleito, pues no se siguió más. Fue sacado este proceso por Sebastián Díez, notario de Palencia, del original que está en el oficio de Fausto Martínez, notario en la misma ciudad.

\section{1. <Memoriales y advertencias para el pleito del Hospital de la $\mathrm{O}>$.}

Dos memoriales ajustados y advertencias en el pleito que en grado de apelación ${ }^{199}$ ante el metropolitano de Burgos tiene este monasterio con el abad y cofrades del Hospital

\footnotetext{
199 apelación] al margen derecho: Falta.
} 
de la $\mathrm{O}$ de esta villa de Carrión, sobre el nombramiento de cura que administre los santos sacramentos a los peregrinos que vienen a dicho hospital.

12. $<$ Requirimento del monasterio para que el obispo buelva las llaves del sagrario del dicho Hospital, y respuesta del señor obispo>.

Requirimento hecho por parte del monasterio de San Zoil al señor obispo de Palencia para que vuelba las llaves de la custodia del Hospital de la $\mathrm{O} /(f .130 r)$ que había quitado jurídicamente al monge que el abad tenía nombrado para el oficio de cura, y las había dado a un cura para que las tubiese y administrase los santos sacramentos, no pudiéndolo hacer por estar la causa en grado de apelación ante el metropolitano y estar inhibido in totum el ordinario de Palencia. Está aquí la respuesta del señor obispo, en la que declara que habiendo visitado el hospital fue informado de que en el tiempo que le habían administrado los monges avían muerto algunos peregrinos sin sacramentos por no saber diversidad de lenguas, y para evitar estos daños y sin perjuicio del derecho de las partes ni del estado de la causas que ante el metropolitano está pendiente, avía nombrado dos sacerdotes que sabían diversidad de lenguas por el tiempo e ínterin que la causa principal se fenecía y acababa. Dada en Palencia, a $1^{\circ}$ de diciembre de 1627, ante Joán Ruiz Ynfante, notario y secretario de Su Yllustrísima.

13. < Provisión de Valladolid sobre las llaves del Sagrario. Año de 1627>.

Provisión ${ }^{200}$ de la Chancillería sobe la fuerza que hizo el señor obispo en quitar las llaves del Hospital de la $\mathrm{O}$, por la qual se manda que dentro de ocho días vayan los autos a Valladolid. Dada en esta ciudad, a 10 de diciembre de 1627, ante Diego Gómez de Osorio, escribano de Cámara de Su Magestad. $1628>$.

14. <Letras de ynhibición de los provisores de Burgos a los de Palencia. Año de

Letras ordinarias de los provisores de Burgos dirijidas a los provisores de Palencia por las que les inhiben para que no entiendan en esta causa de haber quitado las llaves el señor obispo, y que se remitan a Burgos los autos que esto hubiere. Su fecha, en dicha ciudad de Burgos, a 12 de agosto de 1628, ante Juan Pérez Calahorra, notario.

15. < Cartas de fray Juan de Cisneros sobre el pleito de las llaves. Año de 1628>.

Cartas de fray Juan de Cisneros y del procurador de Burgos en razón del pleito que ya se hallaba en Burgos, sobre las llaves que nos había quitado el obispo de Palencia y dádolas a un cura para que administrase los sacramentos en el Hospital de la O. Sus fechas son el mes de agosto y septiembre de 1628.

16. $<$ Requirimento del convento para que no se entierre en el cementerio a un peregrino. Año de 1629>.

Requirimiento hecho por parte del monasterio a Pedro López Moro, cofrade del Hospital de la O, para que sin licencia y consentimiento / (f. 130v) del padre abad, no se enterrase en el cimenterio que está enfrente del convento a un francés que había muerto en dicho hospital. Su fecha, a 9 de junio de 1629, ante Gerónimo López, escribano del ayuntamiento de Carrión.

17. < Otro requirimiento sobre lo mismo. Año de 1635>.

Requirimiento hecho por el presidente y teniente de cura de la parroquia de este monasterio a Melchor de la Rúa, cura de la parroquia de Santa María de esta villa, para que no enterrase en el mismo cementerio a un peregrino que había muerto en el Hospital de la $\mathrm{O}$, por estar el pleito pendiente sobre la administración de sacramentos a los peregrinos y tener el monasterio dos sentencias a su favor, una del ordinario de Palencia y otra del

200 Provisión] al margen derecho: Falta. 
metropolitano de Burgos. Fue hecho en el cementerio, a 23 de septiembre de 1635, ante fray Juan de Cisneros, notario apostólico.

18. <Testimonio de la quarta funeral que recivió el monasterio por un morador del hospital. Año de 1637>.

Testimonio dado por Francisco Moro de Saldaña, escribano de Carrión, de haber recivido el padre fray Gerónimo Gracián, teniente de esta parroquia de San Zoles, tres ducados por la quarta funeral de Melchor Santos, que aunque no murió en esta parroquia fue morador en el Hospital de la O. Su fecha, en Carrión, a 12 de agosto de 1637.

19. <Consentimiento que se pidió al padre abad para enterrar a uno que había muerto en el dicho hospital. Año de 1647>.

Dos testimonios dados por Francisco Ochoa, notario apostólico, de la súplica, petición y consentimiento que se pidió al padre abad de este monasterio para llevar de secreto el cuerpo de don Antonio Calderón, que murió en el Hospital de la $\mathrm{O}$ y se mandó enterrar en la yglesia de Santa María de Carrión; y de cómo se pagó la quarta funeral por el mismo. Su fecha, en Carrión, a 9 de enero de 1647.

\section{/ (f. 131r) Legajo $4^{\circ}$ \\ Hospitales de San Lázaro y La Herrada}

Este legajo, que es el $4^{\circ}$ del Cajón San Andrés, contiene dos quadernos: en el primero están los papeles pertenecientes al Hospital de San Lázaro; en el segundo, los pertenecientes al Hospital de La Herrada, que son los siguientes:

\section{Quaderno A}

Este quaderno contiene los papeles pertenecientes al Hospital de San Lázaro por el orden siguiente:

$1^{\circ}$. <Confiesan los lazerados del Hospital de San Lázaro el derecho de este monasterio al dicho hospital. Era de 1359. Año de 1321>.

Vna carta de contrato, escrita en pergamino y sellada con dos sellos de cera pendientes, otorgada entre don Joán, prior de San Zoil y camarero de Cluniago en España, y don Alonso, su mayordomo, y los malados o lazerados del Hospital de San Lázaro, en la que estos confiesan haber recivido por merced el permiso del dicho prior para hacer un altar y oratorio y que no consentirán que clérigo alguno diga misa, entierro o haga oficio alguno de cura, salvo el de la Capellanía de San Zoil, o a quien él mandare. Que no tomarán diezmo alguno, tanbien de las sus tierras como de las otras, mas que sea el diezmo todo del dicho monasterio, assí como siempre fue; que no pondrán esquila, campana, ni pila sin consentimiento del dicho prior; y finalmente que las ofrendas que allí se hicieren mientras la misa sean para el clérigo del dicho monasterio y para el sacristán. Fue hecha esta carta a 8 de julio, era de 1539, que es año de 1321, ante Francisco Pérez, escribano de Carrión.

2. <Compra de una tierra para San Lázaro. Año de 1412>.

Compra ${ }^{201}$ que hizo un racionero del Hospital de San Lázaro a Joana Fernández, vecina de Carrión, de una tierra a Odra, por precio de trescientos y veinte maravedís. Su fecha, en Carrión, año de 1412, ante Rui García, escribano de Carrión.

/ (f. 131v $) 3 .<$ Privilegio del rey don Juan el $2^{\circ}$ para que no se impida pedir limosna para los de San Lázaro. Año de 1420>.

Privilegio ${ }^{202}$ del rey don Juan el $2^{\circ}$, escrito en pergamino, por el que confirma otro privilegio del rey don Enrrique, que es confirmación de otro del rey don Juan el $1^{\circ}$, por el

${ }^{201}$ Compra] al margen derecho: Falta.

202 Privilegio] al margen derecho: Falta. 
qual manda que ninguna persona impida a los que van a pedir limosna para los pobres de San Lázaro de Carrión, y que no les obliguen a pagar pecho ni portazgo, etcétera, porque de todo les hace libres, y pone penas a los contraventores. Su fecha, en Valladolid, a 5 de febrero de 1420 .

4. <Foro de 150 maravedís sobre once tierras a favor de San Lázaro. Año de 1421>.

Foro $^{203}$ perpetuo, escrito en pergamino, por el qual el mayordomo y racioneros de San Lázaro dan a Juan Benito, de San Vicente de la Varquera, vecino de San Zoles, once tierras $^{204}$, por precio de 150 maravedís en cada un año de la moneda que corriere al tiempo de las pagas. Está en la misma escritura la licencia que, después de otorgada esta escritura, pidieron al prior de San Zoil para evitar la nulidad que podría resultar de su falta. Su fecha, en la casa de San Lázaro, a $1^{\circ}$ de abril año de 1421, ante Ferrando Rodríguez de Castellanos, escribano y notario de Palencia. Hay copia authorizada por don Antonio Martín, traductor.

5. < Sentencia sobre un foro de 32 maravedís a favor de San Lázaro. Año de 1460>.

Demanda que puso el monasterio (como administrador del Hospital de San Lázaro) ante el prior de Escalada, contra Pedro García de Palenzuela, sobre la paga de un foro perpetuo de 32 maravedís que tenía a su favor dicho hospital sobre una tierra en término de Calzada ${ }^{205}$, al molino de la Dueña, cuyo foro hacía más de 40 años que no se pagaba, por lo que el dicho juez dio sentencia adjudicando la dicha tierra al referido hospital. Está aquí la carta de compromiso que hicieron Pedro García de Palenzuela y Blas Mercadero, compradores de dicha tierra, y la sentencia de los juezes árbitros en la que adjudican la tierra a Palenzuela con la obligación de pagar este foro al hospital. Su fecha, en Carrión, año de 1460, ante Juan González de Castellanos, escribano y notario público.

6. < Sentencia sobre un foro de 10 maravedís a favor de San Lázaro. Año de 1483>.

Sentencia ${ }^{206}$ que dio el arcipreste de Carrión a favor del mayordomo del Hospital de San Lázaro, por la qual manda que Sancha de Ledantes, vecina de Robradillo ${ }^{207}$ pague un foro de 10 maravedís que tenían contra sí una viña y una tierra que ella llevaba, perteneciente al dicho hospital. Su fecha, en Carrión, a 18 de febrero de 1483, ante Fernando Cavallo, escribano de Carrión.

\section{/ (f. 132r) 7. <Ynformación de las heredades de San Lázaro. Año de 1528>.}

Testimonio ${ }^{208}$ dado por Francisco Catalán, escribano de Carrión, de una información que hizo el teniente de San Zoil, de las heredades y ventas que tiene el hospital de San Lázaro. Su fecha, en el barrio de San Zoles, a 26 de hebrero de 1528. de $1596>$.

8. $<$ Vn libro authorizado de las visitas, ordenamientos, etcétera, de San Lázaro. Año

Vn libro ${ }^{209}$ en quartilla, escrito en pergamino y authorizado por Andrés Sánchez, escribano de Carrión, que contiene una memoria de las heredades, rentas, visitas de los abades de este monasterio y ordenanzas del Hospital de San Lázaro, etcétera, desde el año de 1529 hasta el 1596.

9. <Privilegio del rey don Felipe $3^{\circ}$, que es confirmación de otros, para que los de San Lázaro puedan pedir limosna y los esenta de todo tributo. Año de 1603>.

Privilegio ${ }^{210}$ del rey don Felipe $3^{\circ}$ por el qual confirma todos los privilegios de los reyes don Juan el $1^{\circ}$, don Enrrique $3^{\circ}$, don Juan el $2^{\circ}$ y don Felipe $2^{\circ}$, en que conceden a los

\footnotetext{
203 Foro] al margen derecho: Falta.

204 tierras] al margen derecho: Dos tierras en Calzada y una en Villámez.

${ }^{205}$ Calzada] al margen derecho: Calzada.

206 Sentencia] al margen derecho: Falta.

${ }^{207}$ Robradillo] al margen derecho: Robradillo.

208 Testimonio] al margen derecho: Falta.

209 libro] al margen derecho: Falta.

210 Privilegio] al margen derecho: Falta.
} 
lazerados y lazeradas del Hospital de San Lázaro que puedan pedir limosna por todo el reyno y les esenta de pagar pecho, fosadera, diezmo y de otro qualquier tributo. Dado en Valladolid, a 8 de junio, año de 1603, firmado de don Luis de Velasco y Faxardo, escribano mayor de los privilegios del rey, y de don Pedro de Contreras, regente de la escrivanía mayor de los privilegios. Están escritos en pergamino, con sello de plomo pendiente.

10. <Trasunto authorizado de los mismos privilegios. Año de 1608>.

Trasumto authorizado por Alonso de Zapata, escribano de Carrión, de los privilegios del número antecedente, y sacado a petición del procurador racionero del Hospital de San Lázaro, y con authoridad de justicia. Su fecha, en Carrión, a 22 de marzo de 1608.

11. <Otro trasumto simple de los mismos privilegios $>$.

Otro trasunto simple de la confirmación de los privilegios de San Lázaro que dio el señor don Felipe $3^{\circ}$, y es el de arriba, número 9, con inserción de los privilegios de los mencionados reyes.

12. $<$ Trasumto authorizado de una sobrecarta del rey don Felipe $3^{\circ}$, para que los de San Lázaro puedan pedir limosna. Año de 1615>.

Trasunto autorizado por don Francisco Moro de Saldaña, escribano de Carrión, de una sobrecarta del rey Felipe $3^{\circ}$, para que los de San Lázaro puedan pedir limosna por todo el reyno sin que ninguno les impida; se inserta aquí una provisión del emperador Carlos $5^{\circ}$, y se hace mención de otro privilegio de los Reyes Cathólicos para lo mismo. Su fecha, en Madrid, a 3 de diciembre de 1611, y el de esta copia el de 1615. Está duplicado este trasumto.

13. <Licencia de la Cruzada para pedir limosna. Año de 1620>.

Dos licencias de los señores comisarios de Cruzada para que los de San Lázaro puedan pedir limosna en todo el reyno. Dadas en Madrid en los años de 1620 y 1635.

/ (f.132v) 14. <Cédula real del rey don Felipe $4^{\circ}$, prorroga la licencia por 4 años para pedir limosna. Año de 1642>.

Cédula real del rey don Felipe $4^{\circ}$ en la que prorroga la licencia por otros quatro años para que los de San Lázaro puedan pedir limosna en todos sus reynos y señoríos. Dada en Madrid, año de 1642, firmada de los de su Consejo y de don Gaspar Sánchez, canciller mayor del rey.

\section{Remisiones}

$<$ Privilegio de los Reyes Cathólicos>.

Vna copia authorizada de un privilegio de los Reyes Cathólicos para que los de San Lázaro puedan pedir limosna por todo el reyno, que es confirmación de otros. Véase el Cajón San Agapio, legajo $2^{\circ}$, quaderno E, en San Lázaro de Frómesta.

Foro de 15 maravedís para la casa de San Lázaro de tres pedazos de tierra con su huerto. Véase el Cajón San Lorenzo, legajo $3^{\circ}$, quaderno C, número $4^{\circ}$.

\section{/ (f. 133r) Quaderno B del legajo $4^{\circ}$ \\ Hospital de la Herrada}

Este quaderno B contiene los papeles pertenecientes al Hospital de La Herrada por el orden siguiente:

$1^{\text {o }}$. <Donación del Hospital de La Herrada. Era de 1260. Año de 1222>.

Copia simple de la donación del Hospital de La Herrada, con todas sus pertenencias, hecha a don Tello, obispo de Palencia, y a sus sucesores, por don Gonzalo Ruiz y su muger, doña Marquesa, con sus hijos, con condición que el obispo de Palencia dé a los pobres la renta que hubiere del hospital, menos 10 maravedís que tome el cavildo de Palencia en cada 
un año por un aniversario que manda se le diga cada año; que haya en dicho hospital quatro clérigos misacantantes que digan todos los días misa por su ánima. Su fecha, en Palencia, a 8 de mayo era 1260, que es año 1222. Sacose esta copia del pleito que el monasterio trahía con el comendador de La Herrada y que se compulsó para llevar a Burgos en grado de apelación.

2. <Compromiso sobre los diezmos de La Herrada>.

Compromiso, escrito en pergamino y authorizado por Alfonso Fernández de Paredes, escribano de Carrión, por el qual parece que don Pedro, sacristán mayor de San Zoil, en nombre del convento, puso en pleito a frei Miguel, comendador del Hospital de La Herrada, sobre los diezmos que decía debían pagar los collazos, quinteros, hortelanos, mancebos, mesqueros e apaniguados del dicho comendador u hospital de las cosas que ganaren, labraren, trabajaren o criaren, e otrosí sobre el diezmo que el dicho sacristán dice se le debe de la huerta del dicho hospital.

$<$ Sentencia arbitra. Era de 1403. Año de 1635>.

Las dos partes, de común consentimiento, se comprometieron en Toribio González, limosnero mayor de San Zoil, y Martín Fernández, cura de Santa María de Carrión, quienes, vistas las razones de una y otra / (f. 133v) y, habiendo consultado con letrados, dieron sentencia definitiva, por la que mandaron que el dicho don Pedro, sacristán mayor, ni los otros sacristanes que vinieren después de él, que no demande diezmo alguno de la huerta del dicho hospital, de ninguna ni alguna cosa que sea, ni el dicho comendador ni los otros que vinieren después de él no estén obligados a dárselo, ahora ni en ningún tiempo, salvo si vassalo o feligrés del dicho monasterio de San Zoil la labrare, que mandamos que él dé el diezmo al dicho sacristán de aquello que al dicho vassallo o feligrés cupiere.

Otrosí mandamos que los quinteros, mancebos e mesqueros que moraren con el dicho comendador en el dicho hospital den la mitad del diezmo de lo que ganaren al dicho sacristán; y si moraren en el barrio de San Zoles, que es del dicho monasterio, que den todo el diezmo al dicho sacristán de San Zoil.

E otrosí mandamos que todos los otros heredamientos que diezmen al dicho sacristán según suelen hasta aquí. Y mandan que las otras partes paguen 70 maravedís para dárselos a los que los aconsejaron. La qual sentencia fue consentida por ambas partes. Fue dada esta sentencia a $1^{\circ}$ de marzo, era de 1403, que es año de 1365 . Hay dos copias, una authorizada y otra simple.

3. < Pleito sobre los diezmos personales de los criados de La Herrada>.

Pleito que puso el monasterio a Juan ${ }^{211}$ y Pedro, criados del Hospital de La Herrada, sobre los diezmos personales que debían pagar de sus soldadas al dicho monasterio ante el prior de Escalada, juez conservador, el qual, vistos los autos, dio sentencia, por la qual condenó a Juan de Soña y Pedro Lomilla a que pagasen al convento los diezmos personales de las soldadas que ganaron en el servicio del comendador; y en quanto a los diezmos personales que los dichos ganaron después de la dicha demanda, reserva al monasterio su derecho a salvo, para que lo pueda pedir si viere que le cumple.

$<1^{a}$ sentencia a favor del monasterio. Año de 1526>.

Fue dada esta sentencia a 18 de enero de 1526 ante el bachiller Santos; y el pleito, ante Floristán de la Serna, escribano de Carrión.

$<2^{a}$ sentencia, confirmación de la $1^{\mathrm{a}}>$.

Parece que, habiendo muerto el comendador de La Herrada y los criados contra quienes se había puesto esta demanda, y habiendo / (f. 134r) en este monasterio muchas diferencias por la elección de abad, se detubo la causa hasta el año de 1543 en que el monasterio bolbió a poner la demanda ante el mismo juez y, hecha la notificación a don Juan Rodríguez de Castañeda, comendador de La Herrada, en 19 de mayo de 1544, el dicho juez pronunció sentencia, en la que buelbe a condenar a los criados de dicho hospital a que paguen

211 Juan] sigue tachado: Toribio. 
el diezmo personal de las soldadas que ganaren y sementera que hicieren. Pasó ante Francisco López, asesor.

Hay aquí un trasumto simple de este pleito. Año de 1527>.

4. <Testimonio de la ofrenda que llevó el monasterio por el comendador difunto.

Testimonio $^{212}$ dado por Francisco Catalán, escribano de Carrión, por el qual consta que, habiendo muerto el comendador de La Herrada y enterrádose en San Andrés de Carrión, se pidió de parte del monasterio la parte que le correspondía de la ofrenda que se llevava a su sepultura, como parroquiano que era de esta parroquia de San Zoil, y los clérigos confiesan aquí serle debida. Su fecha, en Carrión, a 30 de julio de 1527. $1527>$.

5. $<$ Provisión del señor Carlos $5^{\circ}$ para visitar el Hospital de La Herrada. Año de

Quatro copias simples de dos provisiones del emperador Carlos $5^{\circ}$, por las quales consta que, habiéndose quejado algunas personas de la mala administración del Hospital de La Herrada que no se daba limosna y que no se cumplía con la voluntad del fundador, mandó $\mathrm{Su}$ Magestad a los bachilleres Villota y Boniel que visitasen dicho hospital, y que, informándose de la verdad, le diesen razón de todo para poner remedio. Por aquí consta el derecho de Su Magestad al referido Hospital. Dadas en Burgos, en los años de 1527 y 1528, ante Francisco de los Cobos, secretario de Su Magestad. $1575>$.

6. <Testamento de don Hernando Ximénez, comendador de La Herrada. Año de

Testamento de don Hernando Ximénez, comendador de La Herrada, que murió en Carrión y mandó enterrarse en La Herrada y que los monges de San Zoil le hiciesen allí los sufragios, si los clérigos no quisieren hacerlos. Nombró por testamentario a fray Ambrosio de Nájera, monge de San Zoil. Otorgose en 25 de noviembre de 1575, ante Juan de Cantoral, escribano de Carrión, por quien se sacó esta copia authorizada.

7. <Letras ynhibitorias del señor nuncio contra el obispo de Palencia sobre la administración de sacramentos en el Hospital de La Herrada. Año de 1635>.

Testimonio dado por Francisco Mozo de Saldaña, escribano de Carrión, de unas letras del nuncio de Su Santidad, por las quales consta que, estando este monasterio en quieta y pacífica posesión de administrar los sacramentos / (f. 134v) en el Hospital de La Herrada y de llevar todos los diezmos prediales y personales de los habitantes en él, el señor don Cristóval Guzmán y Santoyo, obispo de Palencia, nombró un administrador, dándole, contra todo derecho, título de cura, para que administrase los sacramentos a las personas del dicho hospital, substrayéndose de acudir a esta parroquia. Por lo que, siendo el señor obispo parte interesada en esta causa, el monasterio recurrió ante el señor nuncio y sacó estas letras de ynhibición, las quales se notificaron al señor obispo, quien respondió que, como ordinario, le tocaba las primeras instancias, y que iba prosiguiendo en ella como se reza por los papeles siguientes.

Fueron dadas en Madrid, a 9 de julio de 1635, y este testimonio en 1536. Hay copia.

8. <Ynformación del comendador de La Herrada>.

Memoria simple de la ynformación de ocho testigos que hizo el comendador de La Herrada contra el derecho del monasterio, y preguntas por las que deben examinarse los testigos que presente el monasterio.

9. <Testimonio de que en La Herrada no hay pila baptismal. Año de 1636>.

Testimonio dado por fray Miguel Preciado y fray Juan de Cisneros, notarios apostólicos, de que en el Hospital de La Herrada no hay pila baptismal ni señal de haberla habido. Dado en el monasterio de San Zoil, a 25 de marzo de 1636.

212 Testimonio] al margen derecho: Falta. 
Hay aquí dos declaraciones simples sobre lo mismo de Francisco Moro de Saldaña, escribano de Carrión, y de Eugenio de Guzmán, escribano de Villamuera.

10. <Pedimento del monasterio en el pleito de La Herrada>

Pedimento presentado por parte del monasterio ante el señor nuncio, suplicando se dé por nullo el procedimiento del señor obispo por haber procedido en la causa contra el tenor de las letras ynhibitorias de arriba, haber mandado hacer ynformación de testigos; y, sin conclusión ni citación, dio auto a favor del comendador de La Herrada, que era hermano del señor obispo, y por tanto, que no debía entender en la causa.

11. $<$ Mandamiento del señor nuncio en que da por atentado un auto del obispo de Palencia. Año de 1636>.

Mandamiento executivo del señor nuncio, inserto un auto en que da por atentado el auto que dio el obispo de Palencia a favor del comendador de La Herrada, y manda que las cosas buelban al estado que tenían antes del auto del provisor, y assimismo que el comendador pague al monasterio cien reales de plata y cinqüenta de vellón. Dado en Madrid, a 28 de abril de 1636, ante Francisco Gutiérrez / (f. 135r) Zorrilla, su secretario.

Hay copia authorizada por Francisco Moro de Saldaña, escribano de Carrión, sacada en el mismo año.

12. $<$ El comendador de La Herrada pagó de costas 100 reales de palta y 50 de vellón. Año de 1636>.

Testimonio $^{213}$ dado por Francisco de los Cuetos, escribano de Carrión, de cómo el referido comendador de La Herrada, don Juan de Guzmán y Santoyo, pagó al monasterio los 100 reales de plata y 50 de vellón por las costas en que fue condenado por el señor nuncio, con la aceptación que de ellos hizo toda la comunidad. Su fecha, en San Zoil, a 36 de mayo de 1636.

13. < Executoria a favor de este monasterio en el pleito de La Herrada sobre la administración de sacramentos en dicho hospital>.

Executoria despachada por el señor nuncio don Laurencio Campeje, a petición del monasterio, contra don Juan de Guzmán y Santoyo, comendador de La Herrada, por la qual consta que, en virtud del mandamiento executivo puesto arriba, en el número 11, el comendador de La Herrada y el convento alegaron de su derecho y, conclusa la causa, dio auto el nuncio en que dice que se retenía este pleito en su tribunal; y que sobre el artículo de manutención intentado por las partes, aleguen de su justicia para la segunda audiencia. De lo qual apeló la parte del comendador al Consejo Real, el que dio auto en que declara que el nuncio no hacía fuerza en no remitir esta causa al ordinario o en no otorgar la apelación del auto en que la retubo.

$<$ Sentencia del nuncio. Año de 1637>.

$\mathrm{Y}$, haviendo hecho ambas partes su provanza, alegaron de bien probado. $\mathrm{Y}$, conclusa la causa, en Madrid, a 11 de marzo de 1637, dio auto el señor nuncio, por el qual dixo que, sin perjuicio del derecho de las partes en el juicio petitorio, posesorio y plenario, y en el ínterin y hasta que otra cosa se provea y mande, manutenía y amparaba al abad de San Zoil, como cura propio, en la posesión en que ha estado y está, por sí y sus vicarios y tenientes, de administrar los Santos Sacramentos en el dicho Hospital de La Herrada, y a las personas de él, como sus parroquianos y feligreses, en la qual posesión el dicho abad no sea inquietado, molestado ni perturbado por persona alguna, y para ello se den los mandamientos de manutención necesarios; y manda que los jueces competentes pongan este auto en execución. Pasaron estos autos ante Francisco Gutiérrez Zorrilla, su secretario.

Está aquí el requirimiento que se hizo al abad de Benevivere, como juez, para que pusiese en execución este auto y su aceptación con las notificaciones que se hicieron al comendador y sus criados por Jacinto Rubín de Celis, notario apostólico.

${ }^{213}$ Testimonio] al margen derecho: Falta. 
/ (f. 135v) 14. < Testimonio de que el comendador vino a este monasterio a cumplir con la parroquia. Año de 1637>.

Testimonio que dio Francisco Moro de Saldaña, escribano de Carrión, de cómo el licenciado don Juan Guzmán y Santoyo, presbítero y morador en La Herrada, dixo misa en el relicario de este monasterio día de Jueves Santo, a 9 de abril de 1637, para cumplir con la dicha parroquia como tal parroquiano. Su fecha, en el monasterio de San Zoil, dicho dia, mes y año.

15. $<$ Licencia que pidió el comendador para casar en La Herrada a un hermano suyo. Año de $1647>$.

Un papel firmado de don Juan Guzmán y Santoyo, comendador de La Herrada, en que confiesa haber pedido licencia al padre fray Francisco de Lemos, abad de esta casa, para que otro sacerdote casase a un hermano suyo. Su fecha, en San Zoil, a 19 de noviembre de 1647.

16. <Testamento de don Félix de Guzmán, comendador de La Herrada, y quarta funeral que se pagó a este monasterio. Año de 1651>.

Testamento de don Félix de Guzmán y Santoyo, comendador de La Herrada, por el qual manda enterrarse en la parroquia de Santiago, y que se pague la quarta funeral a esta parroquia como feligrés de ella. Fue otorgado en 21 de marzo de 1651, ante Francisco Ochoa, escribano de Carrión.

Está aquí un testimonio que dio Francisco Moro de Saldaña, en 28 de marzo de 1651, de cómo este mismo día el cura de Santiago entregó al procurador del monasterio una fanega de trigo y diez y seis panecillos, que fue la mitad de la ofrenda que se llevó al entierro del referido comendador.

\section{7. <Licencia para casar en La Herrada. Año de 1674>.}

Licencia que dio nuestro padre maestro fray Bernando de Estúñiga para que don Manuel López del Molino se pudiese casar en La Herrada. Su fecha, en San Zoil, a 19 de noviembre de 1674 .

18. <Declaración jurada de un cura que administró el Viático en La Herrada, sin ánimo de usurpar ${ }^{214}$ el derecho parroquial. Año de 1687>.

Testimonio dado por Juan Cano, notario y recetor de Palencia, de la querella criminal que dio fray Francisco de Turzeta, abad de este monasterio, del licenciado Matheo del Río, cura de Santa María de Carrión, por haber administrado el Viático a don Miguel Gutiérrez, capellán del Hospital de La Herrada, sin licencia del padre abad como cura propio; y declaración jurada del mismo cura don Matheo del Río de cómo lo hizo por la grande necesidad del enfermo y no con ánimo de usurpar el derecho parroquial. Y con esto quedaron todos en paz. Su fecha, en Carrión, a 10 de septiembre de 1687, ante el mismo notario.

19. < Otra licencia para casar. Año de 1725>.

Licencia ${ }^{215}$ que pidió don Gabriel Obejero al abad de esta casa para que el padre prior casase a una criada suya en la yglesia del Hospital / (f. 136r) de La Herrada. Su fecha, en La Herrada, a 12 de febrero de 1725.

20. $<$ Fundamentos que tiene el monasterio para el pleito de La Herrada>.

Memoria simple de las razones que tiene este monasterio para administrar los Santos Sacramentos a las personas que viven en el Hospital de La Herrada, y para percivir los diezmos personales de ellos; con la relación de los papeles que se embiaron al procurador de Corte para el pleito de que se habla en este quaderno.

214 usurpar] usur escrito sobre: pertur.

${ }^{215}$ Licencia] al margen derecho: falta. 
21. < Parecer sobre los diezmos de La Herrada. Año 1802>.

Parecer $^{216}$ del licenciado don Pablo Merino y Olmo, sobre que no debe seguirse la apelación que este monasterio tenía interpuesta ante el metropolitano de Burgos en el pleito sobre los diezmos del Hospital de La Herrada. Dado en Burgos, a 30 de julio de 1802.

\section{/ (f. 137r) Legajo $5^{\circ}$ \\ Capilla de doña Constanza}

Este legajo $5^{\circ}$ del Cajón San Andrés contiene los papeles pertenecientes a la erección, dotación y extinción de la capilla que se llamaba de doña Constanza, por el orden siguiente:

$1^{\circ}$. $<$ Provisión de los Reyes Cathólicos para que no se impida la obra de la capilla que ahora se llama de doña Constanza. Año de 1490>.

Vna ${ }^{217}$ provisión de los Reyes Cathólicos, don Fermando y doña Ysabel, firmada del condestable de Castilla, por la qual mandan que ninguna persona de la villa de Carrión impida la obra de sacristía y casa que estaba haciendo el monasterio (en lo que ahora se llama capilla de doña Constanza, por haberse vendido después a dicha señora) con el fin de guardar la plata y or[na]mentos, porque el año anterior nos habían quitado una custodia que valía 30 mill maravedís, y para que el sacristán que hacía oficio de cura en esta parroquia pudiese salir con comodidad a la administración de los Santos Sacramentos. Dada en Burgos, a 2 de diciembre de 1420, ante Juan Sánchez, escribano de cámara de Sus Altezas.

2. <Licencia del General para la escritura de fundación de la capilla. Año de 1602>.

Licencia ${ }^{218}$ que pidió al General nuestro padre maestro fray Alonso Barrantes, para otorgar con doña Constanza Enrríquez y su hijo la escritura de fundación y dotación de la capilla, insertas las condiciones para ella y la concesión de Su Reverendísima. Dada en la Granja de Villaverde, a 26 de marzo de 1602.

3. $<$ Parecer del monasterio para que se otorgue la escritura. Año de 1602>.

Parecer firmado de todos los monges para que se haga la escritura de fundación y dotación de esta capilla, excepto fray Leandro ${ }^{219}$ Caballero y fray Benito de Pedrosa, que dieron algunas razones porque no convenía. Su fecha, en San Zoil, a 22 de abril de 1602.

4. $<$ Escritura de dotación de la capilla de doña Constanza. Año de 1602. Testamento de don Antonio d'Oro Campoo>.

Traslado authorizado por Juan de Villafrades, escribano de Carrión, de la escritura de dotación de la capilla que era sacristía del monasterio, y ahora se llama de doña Constanza Enrríquez, otorgada entre este monasterio y la dicha doña Constanza, como tutora y curadora de don Antonio d'Oro Enrríquez, su hijo mayor, en la qual está inserto el testamento de don Antonio d'Oro Campoo, marido y padre de los referidos, alférez mayor y rejidor de Carrión, otor/ (f. 137v) gado en 24 de agosto de 1591, ante Melchor de la Rúa, escribano de Carrión, y su codicilo, hecho a 6 de diciembre del mismo año, ante el mismo escribano.

Tiene esta escritura tres tratados:

En el primero están insertas las condiciones y capítulos de la dotación con la licencia del General para ella, la curaduría y tutoría de los hijos con la ynformación de utilidad y licencia que dio la justicia de Carrión a la referida doña Constanza para otorgarlas y obligar la persona y bienes del mayorazgo de su hijo don Antonio d'Oro Enrríquez, ante Pedro de Cervantes, escribano de Carrión.

\footnotetext{
216 Parecer] al margen derecho: falta.

$217 \mathrm{Vna}$ al margen derecho: Falta.

${ }^{218}$ Licencia] al margen derecho: Falta.

${ }^{219}$ Leandro] escrito sobre: Benito.
} 
Las condiciones de esta dotación son las siguientes:

$<$ Condiciones de esta escritura $>$.

$1^{\mathrm{a}}$. Da el monasterio la capilla para la dicha doña Constanza, hijos y sucesores, con propiedad, señorío y patronazgo, para que puedan enterrarse, hacer altar con gradas, poner retablo, asientos, reja, puerta, llaves, escudos de armas dentro de la capilla y en la reja della, etcétera, sin que otra persona pueda tener asientos, enterrarse ni hacer cosa alguna en dicha capilla sin licencia de los patronos, los quales puedan hacer en ella lo que quisieren.

$2^{\text {a }}$. Que si la yglesia se mudare, haya de quedar esta capilla conjunta a la capilla mayor por el lado del Evangelio; y si fuere de tres naves, la capilla de Nuestra Señora corra adelante, de suerte que los patronos puedan abrir arco en su capilla de 20 pies de largo para poner reja, sin que delante pueda haber altar ni embarazo. Y caso que para la obra de la yglesia le pareciere al monasterio mudar esta capilla, haya a su costa otra tal y tan buena y del mismo tamaño. Y no habiendo mudanza en la yglesia, el monasterio no pueda vender ni enagenar la capilla de Nuestra Señora de la grada arriba, ni en ella se pueda enterrar nadie salvo los monges de dicho convento, porque en toda la dicha capilla de Nuestra Señora ni en lo que se alargare ha de haber sepultura ni embarazo, para que los patronos entren y salgan en su capilla, y puedan abrir el arco por aquella parte; y que el monasterio reteje siempre a su costa la dicha capilla de doña Constanza, y que los demás repasos corran por qüenta de los patronos.

$3^{\mathrm{a}}$. Que los patronos, para que entren sus mujeres, hijas, etcétera, a oír misa en su capilla, puedan abrir una puerta en la reja de la nave que cae donde está su capilla, por donde puedan entrar / (f. 138r) en todas las horas que la yglesia estubiese abierta, sin que se lo estorve el convento; y estando la yglesia cerrada, queda a la voluntad del abad el dar la licencia para que entren, y que pueda[n] trhaer consigo quatro criadas y dos señoras con que se entren derechas en su capilla sin tomar asiento fuera de ella, excepto para oír sermón o a los oficios que se dixeren en la Capilla Mayor, que en tal caso, por no poder oírlos desde su capilla, se les permite asiento desde el boltalete del primer arco del lado del Evangelio sobre que está fundado el cimborio, para que allí puedan poner su estrado de alfombras, almoadas, etcétera, en espacio de ocho o nueve pies en quadro. Y para que desde allí puedan oír sermón ha de consentir el convento que la dicha doña Constanza pueda mudar el púlpito al lado de la Epístola. Y esta señora, por sus días, pueda entrar a rezar sus devociones devajo del arquillo que está en la capilla de Nuestra Señora, frontero a su capilla.

$4^{\mathrm{a}}$. Que todas las veces que se hubiere de sepultar en dicha capilla algún patrón, muger, hijos o descendientes de él, ha de salir el convento en procesión con cruz y ministros a recivir el cuerpo hasta la última grada de la puerta de la yglesia; y la cruz salga fuera de las goteras y los ministros sin salir de ellas; y a los cuerpos de otros deudos que se enterraren en dicha capilla, el convento salga a recivirlos hasta la reja de la yglesia, y la cruz y ministros hasta la puerta de la yglesia; y en tales entierros puedan entrar en dicha capilla los descendientes del patrón con las señoras que los acompañaren. Y por el entierro, honras y cabo de año y el recivimiento de los patronos, mugeres, hijos y descendientes de ellos han de pagar 60 ducados por cada uno, y por los demás parientes 25 , y en esto entra el tañer; por los criados lo que los demás feligreses, y que no se pague ataúd, ni paños si el difunto no lo mandare.

\section{$<$ Misas $>$.}

$5^{\text {a }}$. Que el convento diga una misa perpetuamente por los patronos y sus familias haciendo conmemoración de ellos, assí vivos como difuntos, de las quales se han de cantar dos cada semana, la una el miércoles de Nuestra Señora y la otra el viernes del día, las quales / (f. 138v) se podrán decir en el altar mayor, con que en la capilla se digan otras dos rezadas, aunque sean por la intensión del convento, de suerte que ningún día se dexe de decir misa en esta capilla; y después de las dos misas cantadas se ha de ir con responso cantado a dicha capilla; las demás misas rezadas se han de decir en esta capilla con responso rezado. Además de estas misas, se han de decir en dicha capilla otras diez misas cantadas con ministros y órgano, vna otro día de Todos los Santos, día de San Antonio de Padua, lunes primero después de la Trinidad, las otras tres en las tres Pasquas de Navidad, Resurrección y 
Espíritu Santo o los primeros días después de ellos, y las quatro restantes en las quatro fiestas de Nuestra Señora: Purficación, Anunciación, Asunción y Natividad, con responso cantado en las cantadas y rezado en las rezadas, y para todas ha de dar el convento vino y cera y ornamentos hasta tanto que los patronos los manden hacer. Y, queriendo los patronos o sus mujeres oír las misas, avisando, se les aguardará en verano hasta las nueve y en invierno hasta las diez.

$6^{a}$. Que el convento dé sitio para hacer sacristía a la capilla sin perjuicio de la yglesia, donde puedan tener cajones y ornamentos, donde se vistan los sacerdotes que allí dixeren misa, y los fundadores puedan poner sus armas en los cálices y demás servicio de plata, todo lo qual puedan tener cerrado, y una llave tendrá el pastor y otra el sacristán.

$7^{a}$. Que si para validación y firmeza de esta escritura de patronato, además de la licencia del General, fuere necesario traher bulla de Su Santidad para que la apruebe y confirme, la haya de traher el convento a su costa dentro de un año del otorgamiento de esta escritura. Y el convento se obliga a no empeñar, vender ni enagenar los bienes y rentas de esta dotación, aunque haya urgente necesidad y evidente utilidad y aunque intervenga licencia del patrono y especial facultad de Su Santidad.

$<$ Dotación de la capilla. 200 ducados de un juro para el convento $>$.

$8^{\mathrm{a}}$. La octava y última condición es que por ${ }^{220}$ razón de la capilla, patronato, misas, memorias y otras obligaciones a que el monasterio se obliga por esta escritura, los dichos señores doña Constanza Enrríquez y don Antonio d'Oro Enrríquez, su hijo, (en conformidad de la que don Antonio d'Oro Campoo, marido y padre de los / (f. 139r) referido[s], dexó ordenado en su testamento y codicilio) dan y transpasan al dicho convento 200 ducados de renta de un juro, a razón de 20 mill maravedís el millar, que el dicho don Antonio d'Oro Campoo dexó destinados para este efecto, situados sobre las alcavalas de la villa de Carrión, por privilegio de Su Magestad, dado en Madrid, a 22 de febrero de 1591. El qual, desde luego, entregan al convento y suplican a Su Magestad y Consejo le despachen en su cabeza para que le goze desde el día de la fecha de esta escritura para siempre jamás. Además de esto, se obligan a dar al convento 1600 ducados pagados dentro de seis meses después de otorgada esta escritura y, no pagando dentro de este término, cumplan con fundar censo por ellos al convento con seguridad y a contento suyo.

Assimismo, se obligan a dar al convento otros 1500 ducados pagados en la vida de los dos sucesores, los primeros que sucedieren en el mayorazgo después de la vida del dicho don Antonio, pagando el primer sucesor los mil ducados y el segundo los quinientos restantes un año después que heredaren el dicho mayorazgo. Y para la seguridad y saneamiento de los 1600 ducados y de los 500 que debe pagar el último sucesor obligan las rentas del mayorazgo y los bienes libres de madre e hijo. Y para lo demás contenido en esta escritura obligan todo lo que conforme al testamento y codicilio del señor don Antonio d'Oro Campoo pueden y deben obligar con rerunciación (sic) de las leyes, etcétera.

Juraron ambas partes de guardar todo lo contenido en esta escritura, que fue hecha en San Zoil, a 22 de julio de 1602, ante Andrés Sánchez, escribano de Carrión. Y luego, el dicho día, mes y año, estos señores tomaron posesión de esta capilla.

Fue sacado este traslado a 2 de marzo de 1620.

5. $<$ Mandamiento para que no se saquen de Santa María los huesos de don Antonio d'Oro Campoo. Año de 1602>.

Copia simple de un mandamiento dado por don Gaspar de Peralta, provisor de Palencia, a petición del convento de Santo Domingo de Carrión, para que los huesos de don Antonio d'Oro Campoo no se saquen de la parroquia de Santa María de dicha villa, donde estaban depositados, y se lleven a San Zoil. Su fecha, en Palencia, a 5 de deziembre de 1602, ante Lucas Gallardo, por el notario Arana.

${ }^{220}$ por] sigue tachado: la. 
/ (f. 139v 6. < Poder de doña Constanza para seguir este pleito. Año de 1602>.

Poder de doña Constanza Enrríquez para seguir el pleito ante el provisor de Palencia contra el convento de Santo Domingo en razón de sacar de ${ }^{221}$ Santa María los huesos de su marido y llevarlos a enterrar a San Zoil. Dado en Carrión, a 12 de octubre de 1602, ante Pedro Guerra de Cervantes, escribano de esta villa. de $1602>$.

7. $<$ Requirimiento al prior de Santo Domingo para que dexe la capilla mayor. Año

Requirimiento hecho por parte de doña Constanza al prior de Santo Domingo para que dexe libre la capilla mayor de su convento si quiere que se trasladen a ella los huesos de su marido. Su fecha, en Carrión, a 19 de octubre de 1602, ante Pedro de Cervantes, escribano de la misma villa.

8. Confirmación del Reverendísimo de la capilla de doña Constanza. Año de 1602>.

Confirmación ${ }^{222}$ del Reverendísimo fray Alonso del Corral, general de San Benito, de la escritura de dotación de la capilla de doña Constanza. Su fecha, en Sahagún, a 24 de noviembre de 1602.

9. <Pleito entre Gabriel de Mantilla y doña Constanza sobre qüentas. Año de 1602>.

Proceso entre Gabriel de Mantilla, testamentario de don Antonio d'Oro Campoo, y doña Constanza Enrríquez, viuda del mismo, sobre las qüentas y fianzas que la pedían de la curaduría de sus hijos. Pasó año de 1602 y 1604 ante Pedro de Cervantes.

Está aquí una copia authorizada del mismo escribano del testamento de don Antonio d'Oro Campoo.

10. <Licencia del nuncio para trasladar a este monasterio los huesos de don Antonio d'Oro Campoo. Año de 1602>.

Licencia que dio el señor nuncio, escrita en pergamino, con su sello pendiente, a doña Constanza para trasladar los huesos de su marido, don Antonio d'Oro, de la yglesia de Santa María a la capilla de su nombre sita en este monasterio, cometida al abad de La Vega, quien mandó hacer información y dio su mandamiento con censuras para que no molesten a dicha señora. Y el corregidor y alcalde mayor no obedecieron.

$<$ Testamento $>$.

Está aquí el testamento de don Antonio d'Oro sacado por Francisco Moro de Saldaña, escribano de Carrión.

La licencia del nuncio fue dada en Valladolid, ano de 1602. Hay copia authorizada por fray Antonio de San Román, notario apostólico.

11. $<$ Fe del entierro de los huesos de don Antonio. Año de 1603>.

Testimonio $^{223}$ dado por Alonso Zapata, escribano de Carrión, de cómo, en virtud de la licencia dada por el señor nuncio, la dicha doña Constanza trajo los huesos de su marido a esta capilla, y de haverlos visto. Dio fe en 31 de enero de 1603. de $1603>$

12. $<$ Confesión de doña Constanza de haber sacado los huesos de su marido. Año

Testimonio dado por don Pedro de Cervantes, escribano de Carrión, de la confesión que hizo doña Constanza de haber sacado de noche los huesos de su marido, valiéndose para esto de un capellán suyo que ayudó a dicha señora. Su fecha, en Carrión, a 5 de febrero de 1603.

\footnotetext{
221 de] escrito sobre: los.

${ }^{222}$ Confirmación] al margen derecho: Falta.

223 Testimonio] al margen derecho: Falta.
} 
/ (f. 140r) 13. < Poder para el pleito de la traslación de los huesos. Año de 1603>.

Poder $^{224}$ que dio Alonso de Aguilar, curador ad litem de los hijos de doña Constanza, para defensa de la querella ${ }^{225}$ que dio Gabriel Mantilla por haber sacado los huesos de don Antonio d'Oro Campoo de la yglesia de Santa María. Su fecha, en Carrión, a 7 de febrero de 1603, ante Pedro de Cervantes, escribano de la misma villa.

14. <Querella contra doña Constanza por la traslación de los huesos. Año de 1603>.

Testimonio dado por Pedro de Cervantes de la querella que dio Gabriel de Mantilla, testamentario de don Antonio d'Oro, de doña Constanza Enrríquez, por la traslación que se hizo de los huesos. Dado en Carrión, a 8 de febrero de 1603.

15. $<$ Petición de doña Constanza para que el provisor de Palencia la absuelva de las censuras ad cautelam. Año de 1603>.

Testimonio dado por Pedro de Arana Ozerín, notario de Palencia, de una petición presentada ante el provisor de Palencia por doña Canstanza Enrríquez, suplicando se la absuelva de las censuras que escrupulosa haber incurrido por haber sacado los huesos de su marido; y auto del provisor en que manda que dé la causa porqué tiene otro escrúpulo, para que hecho esto se la pueda absolver, y que si quiesiere seguir la apelación se la dé traslado con inserción de la confesión que ella hizo, y se halla aquí. Su fecha, en Palencia, a 18 de febrero de 1603. $1603>$.

16. <Absolución y confirmación del nuncio de la traslación de los huesos. Año de

Brebe $^{226}$ del nuncio por el qual absuelve a doña Constanza de las censuras en que pudo haber incurrido por haber sacado los huesos de su marido de la yglesia de Santa María y llevádoles a San Zoil, y confirmación de esta traslación. Está escrito en pergamino, con su sello pendiente. Dado en Valladolid, en el mes de marzo del año de 1603.

Están en este número insertos los pareceres de unos teólogos de Salamanca sobre si quando doña Constanza sacó los huesos de su marido de la yglesia de Santa María incurrió en alguna censura; y si incurrió, si está segura en conciencia, con la absolución ad cautelam del nuncio. Dados en Salamanca, año de 1603.

17. < Confirmación de la dotación de la capilla. Año de 1604>.

Confirmación ${ }^{227}$ del General y difinitorio de la dotación de la capilla de doña Constanza. Dada en Valladolid, a 10 de junio de 1604, y firmada de los difinidores y secretario del Capítulo.

18. < Brebe de Clemente $8^{\circ}$. Confirmación de la dotación de la capilla. Año de 1605>.

Brebe de La Santidad de Clemente $8^{\circ}$, escrito en pergamino, por el qual confirma las escrituras y contratos que el monasterio hizo con doña / (f. 140v) Constanza Enrríquez y don Antonio d'Oro Campoo, su hijo (sic), en razón de la dotación de su capilla. Datum Romę, apud Sanctum Petrum, die $3^{\mathrm{a}}$ iunii, anno Domini 1605, pontificatus anno $13^{\circ}$.

Hay aquí un trasumto authorizado del auditor de la Cámara Apostólica que es confirmación de esta bulla de Clemente $8^{\circ}$, escrito en pergamino.

19. $<$ Pleito executivo contra doña Teresa de Cárdenas y sus hijos por los réditos del censo de la dotación de la capilla. Año de 1620>.

Pleito executivo contra doña Teresa de Cárdenas y Toledo, viuda de don Antonio Enrríquez d'Oro, y contra sus hijos, herederos y sucesores del mayorazgo y bienes que quedaron de don Antonio d'Oro Campoo y Doña Constanza, su muger, ya difuntos, por 112.500 maravedís de réditos corridos del censo aquí presentado de 37 mill 500 en cada año,

\footnotetext{
224 Poder] al margen derecho: Falta.

${ }^{225}$ querella] sigue tachado: de la defensa.

${ }^{226}$ Brebe] al margen derecho: Falta

${ }^{227}$ Confirmación] al margen derecho: Falta.
} 
que debe pagar a este monasterio el mayorazgo de don Antonio d'Oro Enrríquez por los 1 mill 600 ducados de principal por la dotación de la capilla. En este pleito dio un auto el teniente correjidor de Carrión, en que declaró que en quanto a los bienes de doña Constanza que estaban obligados a este censo no se entendía esta deuda con el pleito de acreedores, pero sí en quanto a los bienes libres del mayorazgo, y que las partes acudan donde les convenga. Su fecha, en Carrión, desde el año de 1620 hasta el de 1622, ante Francisco Moro de Saldaña, escribano de la misma villa.

Está aquí la escritura de censo.

20. $<$ Requirimiento a doña Teresa de Cárdenas para que pague los 1 mill ducados de la dotación de la capilla. Año de 1622>.

Requirimiento hecho por parte del monasterio a doña Teresa de Cárdenas como tutora de Antonio Francisco d'Oro, sucesor del mayorazgo, para que pagase a este monasterio los 1 mill ducados que le pertenecen por la dotación de la capilla; la qual respondió que, sin perjuicio del mayorazgo y por evitar pleitos, estaba pronta a pagarlos. Su fecha, en Carrión, a 14 de marzo de 1622, ante Francisco Moro de Saldaña, escribano de esta villa.

21. < Provisión Real para seguir el pleito de los rréditos del censo. Año de 1622>.

Provisión Real, sacada a petición de este monasterio, para seguir el pleito en la Chancillería de Valladolid, acerca de los réditos del censo de la dotación de la capilla de doña Constanza, contra doña Teresa Cárdenas, su nuera. Dada en Valladolid, a 13 de abril de 1622, ante Diego Gómez Osorio, escribano real.

22. <Compromiso entre el monasterio y doña Teresa de Cárdenas sobre los réditos del censo de 1.600 ducados. Año de 1622>.

Escritura de compromiso otorgada entre el monasterio y doña Teresa de Cárdenas como tutora de don Antonio Francisco d'Oro Enrríquez, su hijo, sobre la demanda que el monasterio le puso de los réditos corridos del censo de 1.600 ducados de principal y seguridad de él, juntamente con la seguridad del juro de 200 ducados de renta cada año / $(f$. 141r) sobre las alcabalas de Carrión, por ser finca mui vaja y, assimismo <por la seguridad> que pide el convento de los 500 ducados que le debe pagar el segundo sucesor del mayorazgo de don Antonio d'Oro Campoo, según lo concertado en la fundación y dotación. Y para este compromiso nombró el monasterio al licenciado Gaspar de Celis, abogado y escribano de Saldaña, y doña Teresa, al licenciado Bernardo Lezana, vecino de Carrión, a los quales dieron poder bajo ciertas condiciones. Su fecha, en Carrión a 9 de agosto de 1622.

$<$ Testamento $>$. Saldaña> .

Está aquí el testamento de don Antonio d'Oro. <Todo ante Francisco Moro de

23. <Nombramiento de juez árbitro para el compromiso. Año de 1628>.

Nombramiento que hizo el monasterio de juez árbitro para el compromiso en el dotor Soto de Acuña, abogado de Paredes, por muerte del licenciado Gaspar de Celis, con el licenciado Lezana. Su fecha, en Carrión, a 19 de septiembre de 1628, ante Francisco Moro de Saldaña, escribano de dicha villa. Parece que se murieron los dos jueces y no tubo efecto el compromiso.

24. <Memorial del pleito con doña Teresa de Cárdenas. Año de 1(sic) >

Memorial en relación del pleito que tubo este monasterio con doña Teresa de Cárdenas, muger de don Antonio d'Oro Enrríquez, curadora de sus hijos, y pareceres de letrados a las consultas que se hicieron sobre la paga de los maravedís que señalaron los fundadores de la capilla para su dotación.

25. <Petición del monasterio para que se componga la capilla. Año de 1651>.

Petición que presentó el monasterio ante el correjidor de Carrión, en virtud de estar la capilla hundiéndose y necesitar repararse. Se notificó a los maestros de cantería, pero no 
está aquí el auto del correjidor. Hai aquí una copia simple del requirimiento que se hizo por parte del monasterio al sucesor del mayorazgo, que se hallaba en Ávila, a quien pertenecía el dicho reparo por la escritura de dotación. En Carrión, a 11 de agosto de 1651, ante Francisco Moro de Saldaña, escribano en dicha villa.

26. $<$ Diligencias hechas por parte del monasterio para executar a doña Leonor de Quiñones por 3 mill reales. Año de 1658>.

Diligencias hechas por parte del monasterio para executar a doña Leonor de Quiñones, viuda de don Antonio Francisco Enrríquez, por 3 mill reales que estaba debiendo del resto de los 500 ducados que debía pagar el segundo poseedor del mayorazgo de don Antonio d'Oro Campoo y doña Constanza Enrríquez por la escritura de dotación de la capilla. Pasaron en los años de 1658, 1661 y 62, ante Norberto de Sandoval y Guevara, escribano de Carrión.

No consta de lo que el monasterio cobró.

27. < Provisión Real y emplazamiento por los réditos del censo. Año de 1667>.

Provisión de la Chancillería de Valladolid, con inserción de la demanda / (f. 141v) que puso este monasterio a doña Leonor de Quiñones por los réditos y seguridad del censo de 1.600 ducados de la escritura de la dotación, por hacer más de 48 años que no se habían pagado; y notificación que se hizo a dicha señora de esta provisión. Dada en Valladolid, a $1^{\circ}$ de diciembre de 1667, ante Francisco de Castro y Taboado (sic), escribano de Cámara.

28. <Auto del correjidor de Carrión para que el monasterio componga provisionalmente la capilla. Año de 1757>.

Auto $^{228}$ de don Juan Antonio del Río, correjidor de Carrión, notificado al señor padre Bárcena, abad de este monasterio, por el que manda que, por vía de providencia y por ignorarse por entonces el patrono de la capilla de doña Constanza, se haga saber al monasterio para que la componga en virtud de la declaración hecha por un maestro de obras, que un paredón de dicha capilla estaba desplomándose y para evitar qualquier daño que podía originarse a los pasajeros. Dado en Carrión, a 27 de marzo de 1757, ante Manuel Francisco Blanco, escribano en dicha villa. de $1772>$.

29. $<$ Cartas entre este monasterio y el conde de Superunda acerca de la capilla. Año

Cartas entre este monasterio y el conde de Superunda, sucesor del mayorazgo de don Antonio d'Oro Campoo, en las que se hace presente la necesidad de componer la capilla y el poder que da el monasterio para rescindir la escritura de dotación y patronato. Todas son de los años de 1772 y 73.

30. <Traslado authorizado del testamento y dotación de la capilla. Año de 1773>.

Traslado ${ }^{229}$ authorizado y sacado por Andrés Núñez Castelo, escrivano de Carrión (a petición del padre maestro fray Agapio Franco, abad de San Zoil), del testamento, tratados y dotación de la capilla de doña Constanza Enrríquez. Su fecha, en Carrión, a 8 de marzo de 1773.

31. <Escritura de rescisión y anulación del patronato, fundación y dotación de la capilla de doña Constanza. Año de 1774>.

Traslado $^{230}$ authorizado de la escritura de rescisión y casación que otorgaron entre partes: de la una, el monasterio de San Zoil; y de la otra, el conde de Superunda, poseedor actual del mayorazgo y patronato que fundaron don Antonio d'Oro Campoo y doña Constanza Enrríquez. Por esta escritura, hecha con facultad real, se anulan todas las escrituras que se han hecho en razón de la fundación y dotación de esta capilla, quedando el monasterio con el mismo dominio y propiedad que tenía a dicha capilla antes que se otorgase la primera

\footnotetext{
228 Auto] al margen derecho: falta.

229 Traslado] al margen derecho: Falta.

230 Traslado] al margen derecho: Falta.
} 
escritura y sin pensión ni carga alguna de misas. Fue otorgada esta escritura a 25 de febrero de 1774, ante Martín García Gatón, escribano de Carrión; y sacado este traslado a 10 de marzo del mismo año y por el mismo escribano.

32. < Relaciones simples de lo perteneciente a la capilla de doña Constanza $>$.

Dos relaciones simples de las cosas pertenecientes a la capilla de doña Constanza desde su fundación, y razón de lo que debía percivir y no percivió el monasterio, habiendo cumplido con todas las cargas y pensiones de misas.

\section{Remisiones}

$<$ Subsidio $>$.

Subsidio que se debía pagar por el juro de la capilla de doña Constanza. Véase el Cajón San Prudencio.

$<$ Proceso contra doña Constanza $>$.

El proceso formado contra doña Constanza Roxas como señora de la huerta de don Gaspar (que hoy llaman la huerta grande) sobre la paga de dos foros, uno de 80 maravedís y el otro de 85, que sobre ella tenía este monasterio. Véase el Cajón San Zoil, legajo 3º número $5^{\circ}$.

$<$ Juro $>$.

Juro de 75 mill maravedís que dio doña Constanza por esta capilla. Véase el Cajón San Leandro, legajo $1^{\circ}$, número 9. 


\section{/ (f. 143r) Cajón $6^{\circ}$ San Zoil}

Este cajón San Zoil, que es el $6^{\circ}$ del archivo, contiene cuatro legajos que son los siguientes: $1^{\circ}$ Donaciones hechas a este monasterio en Carrión y San Zoles; $2^{\circ}$ Compras, trueques, adjudicaciones hechas a este monasterio ${ }^{231} ; 3^{\circ}$ Foros corrientes en Carrión; $4^{\circ}$ Foros antiguos que no se cobran.

\section{Legajo $1^{\circ}$ del cajón San Zoil}

Este legajo contiene las donaciones hechas a este monasterio en el término de Carrión y San Zoles, por el orden siguiente:

$1^{\circ}$. <Donación de Mayor Gómez de la tercera parte de su ganado. Era 1115. Año $1077>$.

Donación que hizo a este monasterio Mayor Gómez de la tercera parte de su ganado. En esta donación hace a su marido heredero de su hacienda y su marido, Joán Gómez, hace heredera a su muger. Facta carta era 1115, que es año de Cristo de 1077. Está escrita en pergamino. $1097>$.

2. $<$ Donación de Mayor Gómez de la $3^{\text {a }}$ parte de sus bienes y ganado. Era 1135. Año

Donación, escrita en pergamino, hecha a este monasterio por Mayor Gómez de la tercera parte de sus bienes y ganado y las otras dos restantes a su marido, Fernando Velázquez. Esta señora parece sea la misma del número <antecedente>, aunque distinto marido. Facta carta era 1135, que es año de 1097.

3. $<$ Donación de don Juan Galindo del huerto de Los Arenales y de 9 casas con carga de un aniversario. Año de 1234>.

Donación, escrita en peramino y partida por $\mathrm{ABC}$, que hizo a este monasterio don Juan Galindo del huerto de Los Arenales, que linda, por una parte con el cuérnago que va a los molinos de Pedro Núñez; de la segunda parte, el huerto de Sancha Payán; de la tercera parte, el huerto de la enfermería; y de la $4^{a}$ parte, el huerto de doña Mayor. Y en el varrio de San Zoles da 5 casas con su huerto: $1^{\mathrm{a}}$ : linderos: de $1^{\mathrm{a}}$ calleja de Juan Remón; de $2^{\mathrm{a}}$ parte, casas de los hijos de Fernán Núñez; de $3^{a}$ parte, casas de los hijos / (f. 143v) de Guillén de Cavanolas; de $4^{a}$ parte, el huerto V(V)illemboso. Otras dos casas en el barrio de Francos: linderos: de $1^{\mathrm{a}}$ parte camino de Santiago; de $2^{\mathrm{a}}$ parte, la calle que va al río; de $3^{\mathrm{a}}$ parte, el camino que va a los molinos de La Puente; de la $4^{a}$ parte, casas de Juan Galindo. Otra casa a la Pontezuela con su huerto: linderos: de $1^{a}$ parte el camino; de $2^{a}$ parte, el huerto que fue del conde; de $3^{a}$ parte, el huerto de don Pedro de la Tapia; de $4^{a}$ parte, el huerto de doña Hurraca. Otra casa con su huerto: linderos: de $1^{a}$ parte la viña del camarero; de $2^{a}$, el camino; de $3^{a}$, el huerto de Pela García; de 4a , el huerto de don Laurencio el Monge. Cuyas rentas se repartan en esta forma: 5 maravedís se den al principio de la Quaresma por su aniversario ${ }^{232}$ y de su muger, María Ferrández, y de sus hijos y doce pobres; y de lo que restase de las rentas se dé extraordinario al convento en la Quaresma. Facta carta era 1272, que es año 1234. Hay una copia authorizada y otra simple escrita en pergamino.

4. $<$ Donación de la renta de unas casas en el barrio para alumbrar tres lámparas. Era 1296. Año de 1258>.

Donación, escrita en pergamino, con sello de cera pendiente, por la qual Domingo Martínez, sacristán menor de San Zoil, con licencia de Goinchart ${ }^{233}$, prior de este monasterio y camarero de Cluni, da a este monasterio toda la renta que redituaren unas casas que había comprado en el barrio de San Zoles para alumbrar dos lámparas, una a Nuestra Señora y otra

\footnotetext{
231 monasterio] al margen derecho: Y molinos de la tapia y del huerto y de Guzmán.

232 aniversario] al margen derecho: Aniversario.

233 Goinchart] por Guichart, prior de Carrión y camarero.
} 
en el cavildo, para siempre. Su fecha, en el mes de febrero, era de 1296, que es año de 1258. Hay copia authorizada.

5. <Donación de una casa corral en el barrio de San Pedro. Año de 1388>.

Donación, escrita en pergamino, que hizo Marina Álvarez a Juan de Ortega de una casa y corral en el barrio de San Pedro, la qual dicha casa parece vino a ser del monasterio, aunque no parece el título de pertenencia. Su fecha, en Carrión, a 3 de agosto de 1388. (Hay copia authorizada), ante Rodrigo Alfonso, escribano de dicha villa.

6. $<$ Donación de la huerta de Orbaneja con su casa, corral y hera y la casa y corral de Ferreros, con carga de 2 aniversarios. Año de 1399>.

Donación, escrita en pergamino, por la qual Ferrand González de la Varguilla y Teresa Sánchez, su muger, vecinos de Carrión y familiares de este monasterio, le dan la huerta de Orbaneja, en la vega de Carrión, con sus árboles, casa, corral y hera, y la casa y corral de Ferreros, con la carga de 2 aniversarios ${ }^{234}$. Fue otorgada en San Zoil, a 14 de diciembre de 1399, ante Francisco Pérez, escribano de dicha villa. Hay copia authorizada.

\section{/ (f. 144r) 7. <Donación de una tierra ${ }^{235}$. Año de 1402>.}

Donación, escrita en pergamino, por la qual doña María, vecina de Bárcena, da a este monasterio una tierra, en la vega de Carrión, lindero el arroyo mediano, por que el monasterio quitase 3 maravedís de foro que la misma señora había puesto a favor del dicho monasterio en unas casas huerta que ella tenía en el barrio de San Zoles. Todo esto porque se la admita como hermana de la orden. Fue otorgada a 2 de diciembre de 1412, ante Fernando Rodríguez de Castellanos, notario de Palencia. Y el foro, escrito en pergamino, a 11 de julio de 1402, ante Rodrigo Alfonso, escribano de Carrión. Hay copia authorizada de la donación de la tierra.

8. $<$ Donación de 40 maravedís y de una tierra. Año de 1405>.

Donación, escrita en pergamino, por la qual Guiomar Pérez, por una cláusula de su testamento, manda a este monasterio 40 maravedís en la tierra de la cerca, en la vega de Carrión; e Ysabel Fernández, hija de la referida Guiomar, con licencia de su marido, García Álvarez, da tierra al monasterio con la carga de los mismos maravedís y con carga de un aniversario $^{236}$ en cada año. Su fecha, en San Zoil, a 31 de julio de 1405, ante Pedro Fernández, escribano de Carrión. Hay copia authorizada.

9. <Donación de una herrén a Sobrepeña. Año de 1405>.

Copia authorizada, escrita en pergamino, de una cláusula de testamento por la qual Fernando González de la Varguilla manda a este monasterio una herrén a Sobrepeña, cave la cerca. Fue sacada esta copia en Carrión, a 31 de agosto de 1405, ante Francisco Pérez, escribano de dicha villa ${ }^{237}$. Hay copia authorizada de la cláusula del testamento escrita en papel.

10. $<$ Donación de unas casas a la Puerta del Canto. Año de 1410>.

Donación, escrita en pergamino, por la que Álvar Galindo, vecino de Carrión, da a este monasterio unas casas mejoradas que el mismo monasterio le había dado a foro, cerca de la Puerta del Canto, con carga de un aniversario ${ }^{238}$ el primer domingo de Quaresma. Su fecha, en San Zoil de Carrión, a 27 de junio de 1410, ante Gutierre Fernández, escribano de Carrión. Hay copia authorizada.

\footnotetext{
234 aniversarios] al margen derecho: Dos aniversarios.

235 tierra] precede tachado: foro y.

236 aniversario] al margen derecho: Aniversario.

${ }^{237}$ villa] Sigue tachado: Está aquí la escritura de foro de 25 maravedís sobre esta herrén a favor de este monasterio escrita en pergamino.

238 aniversario] al margen derecho: Aniversario.
} 
11. $<$ Donación de los generales, leña, sal y salsa pertenecientes a la mesa del prior. Año de 1412>.

Donación, escrita en pergamino, que hizo al convento y monasterio de San Zoil don Fernando, prior mayor de este monasterio, de los generales, leña, sal y salsa y de todos los derechos que pertenecían a su mesa de la cozina del convento. Su fecha, en San Zoil, a 12 de octubre de 1412, ante Francisco Pérez, escribano de Carrión. Esta donación la confirmó en Santo Domingo de la Calzada, Domingo Fernández, bachiller en decretos, monge de Santa María de Náxera, como visitador y reformador de los / (f. 144v) monasterios sujetos a Cluni por comisión del Papa Benedicto 13, cuyo brebe está aquí inserto. $1420>$.

12. <Donación de una huerta a la Piqueta y de unas casas en la Calle Mayor. Año de

Donación, escrita en pergamino, que hizo Alfonso Ximón, vecino de Carrión, a su hijo Pedro Díaz, monge de San Zoil y a su hija Juana Rodríguez, de una huerta en término de dicha villa, a la Piqueta, linderos: huerta de Sancho Ruiz del Peso y huerta de Toribio Rejo. $\mathrm{Y}$ assimismo hace donación de unas casas en la Calle ${ }^{239}$ Mayor, linderos: casas de Juan Fernández y la calle pública, con la condición de que un hermano se herede al otro. Su fecha, en Carrión, a 16 de enero de 1420, ante Rui García Pachistre, escribano en ella. $1431>$.

13. <Donación de 2 tierras, vna a Carre Villacuende y otra a la Palomilla. Año de

Donación, escrita en pergamino, que hizo Juan Fernández Relea, vecino del varrio de San Zoles, de dos tierras que fueron de la cofradía de San Miguel, sita dentro de este monasterio, las quales son en la vega y término de Carrión: la una a Carre Villacuende, do dicen a Piedra Alva, que ha por lindero de la dicha carrera; y la otra tierra es do dicen la Palomilla, que ha por lindero el arroyo. Estas dichas tierras las da a la sacristía de San Zoil con la carga de alumbrar la lámpara de la capilla de San Miguel y que arda mientras se dixeren las horas en este monasterio. Su fecha, en el varrio de San Zoles, a $1^{\circ}$ de marzo de 1431, ante Fernando Rodríguez de Castellanos, escribano y notario de Palencia. Hay copia authorizada.

14. <Donación de unas casas en el barrio de Dentro Castro con carga de 2aniversarios. Año de 1432>.

Donación, escrita en pergamino, que hizo a este monasterio María Fernández, vecina de Carrión, de unas casas en el barrio de Dentro Castro, que han por linderos: la calle pública, con carga de dos aniversarios ${ }^{240}$, el uno por el ánima de doña Mayor, su madre, y el otro por su ánima. Su fecha, en el monasterio de San Zoil, a 17 de marzo de 1432, ante Fernando Rodríguez de Castellanos, escribano y notario de Palencia. Hay copia authorizada.

15. $<$ Donación de unas casas con su corral en el barrio, sobre las quales tenía el monasterio 50 maravedís y 2 gallinas. Año de 1433>.

Donación, escrita en pergamino, que hizo a este monasterio Ferrand Pérez, vecino de Cangarna ${ }^{241}$, de unas casas con su corral en el barrio de San Zoles, linderos: camino real que va a Villomez y el Camino Francés, sobre las quales casas tenía el monasterio 50 maravedís y 2 gallinas. Su fecha, en San Zoil, a 23 de septiembre de 1433, ante Fernando Rodríguez de Castellanos, escribano de Palencia.

Bajo este número están los papeles siguientes:

$1^{\circ}$. Vna escritura simple en papel de este foro que dio el monasterio a Rui González, año de 1423, ante el mismo escribano.

$2^{\circ}$. La escritura / (f. 145r) de venta de estas casas que hizo Rui González al dicho Ferrand Pérez por precio de 900 maravedís, año de 1425, ante Alfonso Niño.

\footnotetext{
239 Calle] Sigue tachado: Pública.

240 aniversarios] al margen derecho: Dos aniversarios.

${ }^{241}$ Cangarna] por Congarna (Cantabria).
} 
$3^{\circ}$. Vna escritura del mismo foro y sobre las mismas casas que dio el monasterio al mismo Ferrand Pérez, año de 1434, ante Fernando Rodríguez de Castellanos.

$5^{\circ}$. La notificación que hizo Ferrand Pérez al monasterio para que las comprase, si quería, por el tanto.

$6^{\circ}$. La venta que hizo Ferrand Pérez a Alfonso Fernando, cocinero del convento, con la carga de los 50 maravedís y 2 gallinas, año de 1435, ante Fernando Rodríguez de Castellanos, escribano y notario de Palencia.

Hay copia authorizada de la donación.

16. <Donación de Juan Fernández Benito de 7 tierras, de vna salzeda, de 175 maravedís y de una pradera con carga de 7 aniversarios. Año de 1439>.

Donación escrita en pergamino, que hizo a este monasterio Juan Fernández Benito, natural de San Vicente de La Varquera, de 7 tierras, en la vega de Carrión, 2 a do dicen el Paramillo de Ferreros, lideros: de la una, el Arroyo Viejo; de la otra, tierra la carreruela que va de Ferreros a Calzada; otra tierra a do dicen la Palomilla, que ha por linderos la carrera que va de Calzada a Villomez; otra tierra a do dicen a Odra, lindero: el arroyo que dicen Río Mediano, que la cerca enderredor; otra tierra que llaman Redonda de la Hera, linderos: la hera del comendador del hospital de don Gonzalo y el Camino Francés; otras dos tierras juntas a la salzeda del dicho monasterio, linderos: de la una, el cuérnago; de la otra, el cuérnago y la huelga que sale al camino de Villamez.

Ytten dio una salzeda, linderos: el arroyo y las dichas tierras de la salzeda.

Ytten 150 maravedís en una huerta en el barrio de San Zoles, cerca del monasterio, linderos: el cuérnago del río; y en dos tierras, la vna llamada del Bodegón, y la otra del Olmillo.

Ytten otros 25 maravedís en un solar de casas en el barrio de San Zoles.

Estas 7 tierras con estos maravedís lo dio con carga de 6 aniversarios ${ }^{242}$ perpetuamente. Su fecha, en San Zoil, a 14 de noviembre de 1439, ante Fernando García Pachistre el Mozo, escribano y notario público. papel.

Hay dos copias authorizadas de esta donación, una escrita en pergamino y otra en

Bajo este número se halla otra donación del mismo de una pradera en la vega de Carrión, que ha por linderos: la salzeda del convento, según viene el Arroyo del Aventadero, la qual recivió él, a fuero del convento, sin árboles, y la da poblada de ellos, con carga de un aniversario $^{243}, /(f .145 v)$ y de esta donación hay copia authorizada.

$<$ Nota $>$.

Están aquí todos los ynstrumentos pertenecientes al derecho que tenía el referido Juan Fernández Benito en dichas posesiones, que se han puesto juntas para mayor claridad. $1439>$.

17. <Donación de una tierra a los Camillos y de la huerta de los Nogales. Año de

Donación, escrita en pergamino, que hizo a este monasterio Ysabel Fernández, vecina de Carrión, de una tierra en término de dicha villa cerca del barrio de San Zoles, a do dicen los Camillos, que ha por linderos: el arroyo de la huerta de los Nogales e la carrera que va a Villamez, con carga de una aniversario ${ }^{244}$. Su fecha, en Carrión a 15 de enero de 1439, ante Luis Fernández, escribano en dicha villa. Hay copia authorizada.

18. $<$ Donación de una tierra a Salze Redondo. Año de 1453>.

Donación que hizo a este monasterio Alonso Gañinas, vecino de Carrión, de una tierra en término de dicha villa, a do dicen Salze Redondo, de obrada y media. Su fecha, en

\footnotetext{
242 aniversarios] al margen derecho: Seis aniversarios.

243 aniversarios] al margen derecho: $\mathrm{Vn}$ aniversario.

244 aniversarios] al margen derecho: $\mathrm{Vn}$ aniversario.
} 
San Zoil, a 2 de abril de 1453, ante Álvar González, escribano de Carrión. Hay copia authorizada.

19. <Donación de un suelo corral en el barrio. Año de 1457>.

Donación que hizo a este monasterio María González, vecina del barrio de San Zoles, de un suelo corral sito en el mismo barrio, linderos: de la una parte, el Camino Francés; de la otra, camino que va a Villamez, con carga de un aniversario ${ }^{245}$. Su fecha, en el mes de febrero, año de 1457, ante Álvar González, escribano de Carrión.

20. $<$ Donación de 40 maravedís sobre una tierra en la Clavera. Año de 1462>.

Donación que hizo a este monasterio Gonzalo Pérez de Moslares, vecino de Carrión, de 40 maravedís sobre una tierra en la Clavera, con carga de un aniversario ${ }^{246}$, como consta de una cláusula de su testamento, inserta en esta escritura, que fue otorgada a 22 de mayo de 1462, <ante Ruy Fernández de Villamoronta> y ante Fernando Cavallo, escrivano de Carrión. Esta copia (sic).

21. <Donación de una tierra a la Vega. Año de 1463>.

Donación que hizo a este monasterio Teresa García, vecina de Carrión, de una tierra en la Vega, debajo de la puente de río mediano, con carga de un aniversario ${ }^{247}$. Su fecha, en Carrión, a 16 de febrero de 1463, ante Ferrand García Pachistre el Mozo, escribano de Carrión.

22. <Donación del Cardenal de España de la mitad de los bienes de los monges difuntos. Año de 1480>.

Donación que hizo a este monasterio don Pedro González de Mendoza, Cardenal de España, etcétera, de la mitad de los bienes de los monges que fallecían y que le pertenecían como administrador perpetuo de este monasterio ${ }^{248}$. Su fecha, en Medina del Campo, a 31 de octubre de 1480 .

23. $<$ Donación de un esclavo. Año de 1521>.

Donación que hizo a este monasterio Die[g]o de Olea y Reynoso, vecino de Melilla, de un esclavo suyo llamado Diego, para el servicio de este / (f. 146r) monasterio. Su fecha, a 15 de diciembre de 1521.

24. $<$ Donación de 8 mill maravedís con carga de 3 misas rezadas cada semana y un aniversario. Año de 1573>.

Donación que hizo a este monasterio $<$ María del Brezo $>$, vecina del barrio de San Zoles, de 8 mill maravedís situados en su favor, los 4 mill sobre varios particulares de Villamuera y los otros 4 mill sobre varios vecinos de Carrión, con cargo de un aniversario y 3 misas rezadas cada semana ${ }^{249}$, como consta de su testamento, que pasó ante Juan de Cantoral, escribano de Carrión, cuya copia authorizada es ésta, sacada por el mismo escribano. Su fecha, a 14 de junio año de 1573.

$<$ Posesión que tomó el monasterio de una casa con su huerta en el barrio $>$.

En el año de 1577 este monasterio puso execución contra Benito de Villapún, heredero de María del Brezo, por los maravedís que estaba debiendo y, con authoridad de juez, se sacó a vender una casa con su huerta en el barrio de San Zoles, y el monasterio tomó posesión de ella, como consta de las diligencias cosidas con esta escritura de testamento.

\footnotetext{
245 aniversarios] al margen derecho: $\mathrm{Vn}$ aniversario.

246 aniversarios] al margen derecho: $\mathrm{Vn}$ aniversario.

247 aniversarios] al margen derecho: $\mathrm{Vn}$ aniversario.

248 monasterio] al margen derecho tachado: Después de este superior responde el número 32.

${ }^{249}$ semana] al margen derecho: 3 misas rezadas cada semana.
} 
Hay aquí una escritura de convenio con ciertas condiciones sobre el cumplimiento de las misas de María del Brezo, que pasó entre este monasterio y Juan de Avendaño, testamentario de dicha señora. Año de 1587, ante Andrés Sánchez, escribano de Carrión.

$<$ Nota $>$.

En el día se dicen 15 misas rezadas cada año y un aniversario ${ }^{250}$ día de San Antonio.

25. <Donación de 32 mill 622 reales de réditos de varios censos con carga de 12 misas cantadas cada año y una rezada cada día. Año de 1633>.

Donación que hizo a este monasterio José Serrano, vecino de Carrión, de 800 ducados, los quales, viviendo él, los había dado a censo a este monasterio con carga de 12 misas cantadas ${ }^{251}$ con sus responsos en cada un año, como consta de esta escritura, otorgada en este monasterio, a 5 de enero de 1625, ante Francisco Moro de Saldaña, escribano de Carrión. Además de estos 800 ducados, donó al monasterio 23 mill 822 reales en los réditos de varios censos, como consta de su testamento, inserto aquí, con la carga de una misa rezada cada día perpetuamente. Su fecha, en San Zoil, a 13 de octubre de 1633, ante Francisco Moro de Saldaña, escribano de Carrión.

$<$ Nota $>$.

En el día sólo se dicen 144 misas cada año, como consta del número siguiente.

26. $<$ Reducción de misas. Año de 1659>.

Reducción de misas y aniversarios hecha por nuestro reverendísimo padre fray Diego de Silva, general de San Benito, a petición de este monasterio. A 15 de septiembre de 1659.

27. $<$ Donación de 15 reales por 5 misas anuales, los que se señalaron en una casa en el barrio. Año de 1687>.

Donación que hizo a este monasterio Felipa González, vecina de Carrión, de 15 reales por 5 misas anuales ${ }^{252} \mathrm{y}$, por no haber dejado situado y señalado en cosa segura y firme la fundación de las dichas cinco misas. Manuel González de Villegas y Francisco González tes/ (f. 146v)tamentarios de la referida, señalaron la fundación de las cinco misas rezadas en una casa que la dicha Felipa González tenía en el barrio de San Zoles. Como consta todo de esta escritura otorgada en San Zoil, a 6 de abril de 1687, ante Norberto de Sandoval y Guevara, escribano de Carrión.

Está aquí un tanto de algunas cláusulas del testamento de la dicha Felipa, firmado de Blas Vela y Álvarez, ante quien pasó el testamento. de $1689>$.

28. $<$ Donación de 600 ducados con carga de 4 misas cantadas perpetuamente. Año

Donación que hizo a este monasterio Balthasar de Vega y Cathalina Blanco, su muger, de 600 ducados, para que se digan por sus almas 6 misas cantadas perpetuamente, las quales, por su codicilio, se rebajaron a $4^{253}$, como consta de este testamento, otorgado en Carrión, a 24 de abril de 1689, ante Agustín García de Miranda, escribano en dicha villa.

Está aquí la petición del monasterio al general por la que parece que en el codicilio sólo dejaron los sobredichos 400 ducados y las 4 misas.

29. $<$ Relación de los aniversarios antiguos y modernos que esta casa tiene obligación de cumplir $>$.

Quaderno en que están escritos los aniversarios antiguos y modernos que esta casa tiene obligación a cumplir cada año, con la razón y noticia que hay para cada uno de ellos, sacada de los papeles que están esparcidos en distintos cajones del archivo. A lo último de

\footnotetext{
250 aniversarios] al margen derecho: $\mathrm{Vn}$ aniversario.

251 cantadas] al margen derecho: 12 misas rezadas cada semana cantadas y una misa rezada cada día.

252 anuales] al margen derecho: 5 misas rezadas.

253 4] al margen derecho: 4 misas cantadas.
} 
esta memoria está una tabla de los meses con las misas que a cada uno corresponde. Están mezclados los de San Román y de Frómesta.

30. < Carta del reverendísimo Barrantes a la abadesa Calense, en la que hace relación de los ynstrumentos principales que faltan de este archivo $>$.

Carta que escrivió el reverendísimo Barrantes, año de 1613, a la yllustrísima María de Lotaringia, abadesa del monasterio calense, en la qual hace relación de que la Santa Congregación había escrito otra, de que no había tenido respuesta. En esta añade la falta de algunas escrituras tocantes a esta casa que fueron llevadas a Cluni desde que fue miembro de él este monasterio. Pide y suplica la remisión de ellas, para lo que la pone la relación de los ynstrumentos. También de esta carta se infiere que el convento calense tenía alguna sujeción a la Congregación de España, pues en ella da licencia a dicha abadesa para gozar y obtener un priorato.

31. <Trasumto simple de la visita que hicieron los abades de Silos y Cardeña y relación de la hacienda antigua de este monasterio>.

Trasumto simple de una visita que hicieron en esta casa los abades de Santo Domingo de Silos y San Pedro de Cardeña, por comisión del Sumo Pontífice, en el año de 1338, en que consta los monges que tenía este monasterio, su hacienda y gastos.

Es papel curioso que se sacó de un libro antiguo de estas visitas, que está en el archivo de Cardeña.

/ (f. 147r) 32. <Donación de 200 maravedís de un foro sobre el mesón de Merlín. Año $1490>254$.

Donación que hizo a este monasterio Zoil de Saldaña, monge y limosnero de él, de 200 maravedís de un foro que había comprado en las casas y mesón de Juan Merlín, linderos: las dos calles públicas, la una que va al monasterio y la otra que va al molino de la Tapia, y ellas junto al puente. De estos 200 maravedís, los 150 deja dicho Zoil de Saldaña con carga de 2 aniversarios ${ }^{255}$ cantados, y los 50 restantes los deja para el cantor que es o fuere del monasterio, a quien nombra por patrono para que cuide de que se cumpla lo que manda. $\mathrm{Y}$ en caso de que el monasterio no cumpliere con los dichos aniversarios, que pueda el cantor quitar al convento los 150 maravedís y mandar a quien quisiere que haga los dichos aniversarios con ellos. Su fecha, en San Zoil, a 17 de enero de 1490. Escribano, Juan de Berrio, del número de Carrión. Hay copia authorizada de la donación, y la escritura de compra de los 200 maravedís que envió Zoil de Saldaña con su copia authorizada, por el mismo escribano, de 1488. También están bajo este número otros papeles pertencientes al derecho que tenían los sucesores de Juan Merlín, con una provisión real sobre varios debates que entre los acreedores había por este foro.

\section{Remisiones}

La donación que hizieron Juan Laso y María Herrera, su muger, de varias casas en la parroquia de San Pedro, de varias tierras y viña que no señalan el término (Véase este cajón, legajo $2^{\circ}$, quaderno $\mathrm{B}$, número $2^{\circ}$ ), a Juan Laso, monge de este monasterio.

La donación que hizo Zoil de Saldaña de 200 maravedís de foro sobre la casa mesón junto al puente. Véase el legajo $2^{\circ}$, quaderno $\mathrm{B}$, número $8^{\circ}$. Está en el número $11^{\circ}$.

$254<$ Donación... 1490>] todo este asiento aparece invalidado con cuatro lineas que forman un aspa a modo de tachado.

2552 aniversarios] al margen derecho: 2 aniversarios. Nota: Este yntrumento se puso con los demás papeles pertenecientes a es[ta]casa mesón, en el legajo $2^{\circ}$ deste Cajón, número 8; pero está en el número 11. 


\section{/ (f. 148r) Legajo $2^{\circ}$}

Compras, trueques y molinos del Huerto, de la Tapia y de Guzmán

Este legajo $2^{\circ}$ del cajón San Zoil contiene los 3 quadernos siguientes: Quaderno A: Compras hechas en Carrión y San Zoles; Quaderno B: Trueques en idem; Quaderno C: Molinos del Huerto, de la Tapia y de Guzmán.

\section{Quaderno A}

Este quaderno contiene los papeles pertenecientes a compras hechas por este monasterio en Carrión y San Zoles y algunas adjudicaciones y cesiones a favor de este monasterio, por el orden siguiente:

$1^{\circ}$. <Compra de unas casas en el barrio de la Tejada. Era 1409. Año de 1371>.

Compra $^{256}$ que hizo Beneito Pérez, prior de San Román, a Gonzalo Fernández y Juana Gutiérrez, su muger, vecinos de Carrión, de unas casas en dicha villa, en el barrio de la Tejada, linderos: la calle pública y la cárcaba de la cerca de San Julián, por precio de 40 cargas de trigo. Su fecha, en Carrión, a 28 de enero, era de 1409, que es año 1371, ante Guillén Pérez, escribano público de dicha villa. Hay copia authorizada.

2. < Compra de unas casas con su corral en el barrio de San Pedro. Año de 1398>.

Compra que hizo Juan de Ortega, monge de San Zoil, de unas casas en el barrio de San Pedro a los testamentarios de Marina Álvarez, por precio de 200 maravedís. Su fecha, en Carrión, a 3 de mayo, año de 1398, ante Rodrigo Alonso, escribano de dicha villa.

3. <Posesión que tomó el monasterio de unas casas a la Varquilla. Año de 1409>.

Posesión que tomó el monasterio de unas casas en Carrión, en la calle de la Varquilla, linderos: casa del monasterio y la calle pública, porque Fernando Blanco, vecino de dicha villa, que las tenía a foro, se había ausentado y hacía dos años que no pagaba. Su fecha, en Carrión a $1^{\circ}$ de marzo de 1409, ante Rodrigo Alfonso, escribano de dicha villa. $1455>$.

/ (f. 148v) 4. <Compra de la $3^{\text {a }}$ parte de unas casas en el barrio de San Zoles. Año de

Compra que hizo el monasterio a fray Andrés, fraile de San Pablo de Palencia, de la tercera parte de unas casas en el barrio de San Zoles, lindero: carrera que va a Villamez, por precio de 850 maravedís, sobre la qual tercera parte tenía el monasterio un foro como consta de dicha escritura. Su fecha, en San Zoil, a 29 de junio de 1455, ante Álvaro González de Carrión, escribano de dicha villa.

5. <Compra de la $3^{\text {a }}$ parte de unas casas en el barrio de San Zoles. Año de 1456>.

Compra que hizo el monasterio de la $3^{a}$ parte de unas casas en el barrio de San Zoles, lindero: la calle pública, por precio de 1000 maravedís y con carga de 22 maravedís de fuero. Su fecha, en San Zoil, a 25 de enero de 1456, ante Álvar González, escribano de Carrión.

6. <Compra de unas casas con su corral en el barrio de San Zoles. Año de 1456>.

Compra que hizo el monasterio a Juan López Moro, vecino de Carrión, de unas casas con su corral en el barrio de San Zoles, linderos: la calle pública y el Camino Francés, por precio de 1400 maravedís, con carga de 9 maravedís y una gallina de fuero. Su fecha, en San Zoil, a 11 de febrero de 1456, ante Álvar González, escribano de Carrión.

Está aquí la posesión que tomó el monasterio de dichas casas y la escritura de foro a favor del referido monasterio. Año de 1416, ante Fernand Rodríguez de castellanos, escribano de Palencia.

7. < Compra de dos pedazos de tierra en el barrio de San Zoles. Año de 1459>.

Compra que hizo el monasterio a Hamete, moro, vecino del barrio de San Zoles, de dos pedazos de tierra que estaban dentro de la cerca de la huerta nueva, que el monasterio

${ }^{256}$ Compra] al margen derecho: San Román. 
había cercado, por precio de 480 maravedís. Su fecha, en San Zoil, a 23 de agosto de 1459, ante Álvar González de Carrión, escribano en dicha villa.

8. <Cesión de una tierra huerta en el barrio de San Zoles. Año de 1459>.

Cesión que hizo al monasterio Alonso García, vecino de Carrión, de una tierra huerta en el barrio de San Zoles, cerca del molino del huerto, linderos: el camino real que va de Carrión a Calzada y los dos arroyos que riegan las huertas de abajo; y de otro, pedazo de tierra que entraba en ésta, los quales había comprado él por precio de 2 mill 90 maravedís. $\mathrm{Y}$, porque el monasterio tenía aforadas las dichas tierras, se las cedió por el mismo precio. Su fecha, en San Zoil, a 15 de septiembre de 1459, ante Álvar González de Carrión, escribano de dicha villa.

9. <Cesión al monasterio de unas casas a la puente. Año de 1467>.

Cesión que hizo al monasterio Álvar García de Palenzuela, vecino de Carrión, de unas casas al puente, linderos: la calle pública, las quales él había comprado a Vrraca González por precio de 9 mill maravedís, y, porque el monasterio tenía un foro sobre ellas, se / (f. 149r) las cedió por 4500 maravedís. Su fecha, en el barrio de San Zoles, a 17 de junio de 1467, ante Gutierre Fernández, escribano de Carrión.

Está aquí la escritura de compra que hizo el referido Palenzuela a Vrraca González, y la posesión que tomó el monasterio de dichas casas y de cómo bolvió a poner en ellas a dicha Vrraca. Todo lo qual pasó en el mismo año y ante el mismo escribano.

10. <Compra de una casa y corral en el barrio de San Zoles. Año de 1467>.

Compra que hizo el monasterio a Juan de Carrión, clérigo de Villavega, de una casa con su corral en el barrio de San Zoles, con la tercera parte de un foro que sobre ella tenía el monasterio, linderos: la calle pública, por precio de 1 mill maravedís. Su fecha, en San Zoil, a 7 de abril de 1467, ante Juan González Catalán, escribano de Carrión.

11. <Declaración de que un valladar pertenece el monasterio. Año de 1472>.

Declaración que hizo Juan Fernández, cura de San Pedro, con varios testigos de que el valladar de una tierra en el término de esta villa, a las huertas de allende el río, que tenía por linderos: tierra del monasterio y tierra de la capellanía de los clérigos de San Pedro, era del monasterio. Su fecha, en San Zoil, a 5 de abril de 1472, ante Juan Martínez de Carrión, escribano de dicha villa.

12. < Adjudicación al monasterio de una huerta a la Clavera. Año de 1474>.

Adjudicación, que por sentencia de Martín de Modoya, juez árbitro, se hizo al monasterio de una huerta a la Clavera, que ha por linderos: huerta del convento y las calles públicas, sobre la qual tenía el monasterio un foro de 20 maravedís y una gallina. Esta huerta la vendió Juan Sánchez a Lope de Ávila sin notificar como debía al monasterio. Y por esta razón manda el juez se adjudique dicha huerta al monasterio por el mismo precio que el dicho Lope de Ávila la había comprado, con obligación de pagar el monasterio a Cathalina López, hija de Juan Sánchez, 4 cargas de trigo por las pérdidas que decía haber tenido en el depósito del dinero para la compra y otras costas. Su fecha, en Carrión, a 10 de noviembre de 1474, ante Fernando Cavallo, escribano de dicha villa.

Está aquí la escritura de venta de esta misma huerta que hizo Juan Sánchez a Lope de Ávila, a 21 de mayo de 1470, ante Gutierre Fernández de San Zoles, escribano de Carrión.

13. $<$ Compromiso sobre unas tierras $>$.

Compromiso hecho entre el monasterio y Juan Merlín el Mozo en un pleito que estaba pendiente ante los provisores de Palencia / ( $f .149 v)$ sobre ciertas tierras que, por la información, parece ser tres tierras: vna a do dicen el Manzano, que ha por linderos: el arroyo de los Linares y la Huelga; otra a Carrevieja, que ha por linderos: la carrera y dos huertas del monasterio; otra a la Clavera de Abajo, que se llama la tierra de la Canal, que ha por linderos: la dicha Clavera y el Cuérnago.

$<$ Sentencia a favor del monasterio. Año de 1475>. 
Y, habiendo nombrado ambas partes por jueces árbitros a Diego Martínez Sedeño, prelado de la yglesia de Santiago de Carrión, y Diego Fernández de San Zibrián, cura de Santa María de Belén, precedida información de ambas partes (que están bajo este número), dieron sentencia por la qual mandan que las dichas tierras las goze el dicho Juan Merlín por su vida y la de su muger, y que dé al monasterio 850 maravedís de foro perpetuo cada año; que después de la vida de los dos, queden las tierras para el monasterio y que la sementera la pierda el monasterio. Fue dada esta sentencia a 4 de mayo de 1475, ante Fernando Cavallo, escribano de Carrión.

Está aquí la posesión que tomó el monasterio de la tierra a Carrera Vieja y la escritura de foro duplicada, escrita en pergamino, que hizo este monasterio de estas tierras a Juan Merlín, padre de Juan Merlín, que aquí se nombra. Su fecha, en San Zoil, a 22 de septiembre de 1423, ante Ferrand Rodríguez de Castellanos, escribano de Palencia.

14. < Posesión que tomó el monasterio de una casa, huerta en el barrio de San Zoles y tierra del Bodegón. Año de 1475>.

Testimonio dado por Fernando Cavallo, escribano de Carrión, de la posesión que tomó el monasterio de las casas y huerta que tenía a vita Cathalina, muger de Lope Fernández Vaynero, vecino de San Zoles, las quales han por linderos: de dentro, huerta y el Cuérnago y la huerta de la Limosna; y por delante, la calle del Camino Francés. Su fecha, en el barrio de San Zoles, a 27 de septiembre de 1475.

Está aquí el apartamiento que hizieron Lope Fernández Vaynero, y sus yernos de la dicha casa, huerta y tierra del Bodegón. Su fecha, en el año de 1476, ante el mismo escribano.

15. < Compra de unas casas y corral en el barrio de San Zoles. Año 1475>.

Compra que hizo el monasterio a Pedro Sánchez, merino, vezino de Villamuera, de unas casas y corral en el barrio de San Zoles, que han por linderos: casas de la sacristanía del monasterio; y de otra parte, el Cuérnago del molino; por detrás, tierra que llaman de la Monja, que es del monasterio; y por delante, la calle pública; por precio de 5500 maravedís, con el foro de 50 maravedís y un par de gallinas que tenía / (f. 150r) el monasterio a su favor sobre dichas casas. Su fecha, en San Zoil, a 27 de septiembre de 1475, ante Fernando Cavallo, escribano de Carrión.

\section{6. < Posesión que tomó el monasterio de dos tierras. Año 1475>.}

Testimonio dado por Fernando Cavallo, escribano de Carrión, del apartamiento que hizo García Pachistre, vecino de dicha villa, de dos tierras en la Vega, la una que dicen de la Fuente del sapo; y la otra (sic), que son en término de Villamez ${ }^{25}$, las quales tierras había tomado su abuelo del monasterio a foro por seis quartos de trigo, para cuya paga había hipotecado una tierra suya que llaman de Talabado de doce obradas, poco más o menos. Y por este testimonio consta que García Pachistre dexó libres estas tierras para el monasterio y éste le bolbió la tierra de Talabado, por concierto que dice haber habido entre ellos. Su fecha, en San Zoil, a 4 de julio de 1475, ante Fernando Cavallo, escribano de Carrión.

Están aquí tres testimonios dados por Álvar González y Diego González, escribanos de Carrión, de la posesión que tomó el monasterio en los años de 1455, 56 y 57 de la tierra de Talabado, como especial hipoteca, por no haber pagado en varios años el foro de los 6 quartos de trigo de las tierras arriba referidas.

$<$ Sentencia a favor del monasterio $>$.

También se halla aquí una sentencia árbitra, dada año de 1430, en la que es condenada María Alfonso, muger de García Fernández Pachistre, y su hijo Fernand García Pachistre a que paguen los 6 quartos de trigo que parecen ser los mismos del foro que pagaba por las referidad tierras, aunque esta sentencia supone otra que no hay. Está signada de Fernand Rodríguez de Castellanos, escribano de Palencia.

17. < Posesión que tomó el monasterio de un solar. Año de 1477>.

257 Villamez] al margen derecho: Villamez. 
Testimonio dado por Fernando Cavallo, escribano de Carrión, de la posesión que tomó el monasterio de un solar en el barrio de San Zoles, linderos: por una parte casas de Rodrigo Blas; y por otra, casas de Álvar García de Palenzuela, vecino de Carrión. Su fecha, a 2 de enero de 1477. Sobre este solar tenía el monasterio un foro y, porque no se le pagaban, tomó dicha posesión.

\section{8. <Compra de un corral cercado en San Zoles. Año 1478>.}

Compra que hizo fray Zoil de Nogal, sacristán mayor de San Zoil, de un corral cercado en el barrio de San Zoles, linderos: camino real de Carrevillanueva; y por detrás, tierras del mismo sacristán, por precio de 1500 maravedís. Su fecha, en el barrio de San Zoles, a 29 de septiembre de 1478, ante Fernando Cavallo, escribano de Carrión.

19. <Sentencia a favor del monasterio sobre la posesión de tres tierras. Año 1482>.

Compromiso y sentencia árbitra entre el monasterio y la parte de doña Fátima, muger de maestre Hamete, moro, y de sus hijos, sobre la posesión y propiedad de unas tierras que tenían a foro / (f. 150v) del dicho monasterio, que son dos pedazos cerca de la huerta de Rodrigo de Gozón, junto al arroyo, y de la otra parte cercada de las tapias, linderos: la Carrera Vieja; e la otra tierra, que es la Zapata, la otra tierra es en Fuente del hospital de don Gonzalo, linderos: el Camino Francés. Esta diferencia se comprometió en el bachiller Martín de Modoya, el qual mandó dar la posesión de las dichas tierras al monasterio, reservando a las partes el derecho de propiedad. Su fecha, en Carrión, a 4 de septiembre de 1482, ante Pedro de San Zoles, escribano en dicha villa.

20. $<$ Compra de un corral y una herrén y de un foro de 15 maravedís y una polla en el barrio de San Zoles. Año 1482>.

Compra que hizo fray Zoil de Nogal, monge de este monasterio, a fray Juan Cuba, fraile de San Francisco de Carrión, de un corral y una herrén en el barrio de San Zoles, junto al camino que va de San Zoles a Villomez, linderos: tierra de Santa Clara de Carrión, tierra del dicho fray Zoil y calle y camino de Villamez; por precio de 41 reales de plata y con carga de 15 maravedís y una polla de foro, a favor de Juan López Moro, vecino de San Zoles. Su fecha, en Carrión, a 23 de septiembre de 1482, ante Pedro de San Zoles, escribano de dicha villa.

Bajo este número está la escritura de compra que hizo el referido Zoil de Nogal al mismo Juan López Moro de los 15 maravedís y la polla de foro que tenía sobre el dicho corral y herrén, por precio de 850 maravedís. Su fecha, en Carrión, a 4 de marzo de 1484, ante el mismo escribano. $1485>$.

21. <esión de unas casas para el monasterio en el barrio de San Pedro. Año de

Cesión que hizo Elvira, muger de Rodrigo de Calzadilla, a su hijo Juan de Calzadilla, monge de San Zoil, de unas casas pequeñas con su corralejo en el barrio de San Pedro, lindero la calle pública. Por razón de que este monge había pagado la mayor parte de los 1800 maravedís que habían costado las dichas casas (como consta de la escritura de venta que está aqui) con carga del foro que en ellas tenían la Hermandad de los 20 clérigos de Carrión. Su fecha, en Carrión, a 18 de julio de 1485, ante Fernando Cavallo, escribano de Carrión.

\section{2. <Compra de unas casas en San Zoles. Año 1497>.}

Compra que hizo el monasterio a Álvaro Aveja el Viejo, de unas casas en el barrio de San Zoles, linderos: las calles públicas, sobre las quales tenía el monasterio 43 maravedís de foro perpetuo, por precio de 17 mill maravedís. Su fecha, en San Zoil, a 23 de junio de 1497, ante Fernando Cavallo, escribano de Carrión.

23. < Compra de unas casas en San Zoles. Año 1512>.

Compra que hizo el monasterio a Hernando Santos, vecino de Carrión, / (f. 151r) de unas casas en el barrio de San Zoles, linderos: la calle pública, por precio de 3 mill maravedís. Su fecha, en San Zoil, a 24 de mayo de 1512, ante Floristán de la Serna, escribano de Carrión. 
24. < Compra de una casa, huerta y palomar en el barrio de San Zoles. Año 1519>.

Compra que hizo el monasterio a Diego de Olea, vecino de Carrión, de una casa, huerta y palomar en el varrio de San Zoles, linderos: el cuérnago y la calle pública, por precio de 17500 maravedís, que es el tanto en que la compró este Diego de Olea a Álvar Arrayaz, con cargo de 70 maravedís de foro que sobre la dicha casa, huerta y palomar tenía el monasterio. Su fecha, en San Zoil, a 7 de enero de 1519, ante Alonso Gómez de San Román, escribano de Carrión.

25. < Compra de unas casas en San Zoles. Año 1532>.

Compra que hizo este monasterio al de San Andrés de Arroyo de unas casas ${ }^{258}$ en el barrio de San Zoles, linderos: las calles públicas (las quales había heredado María de la Serna, freila del dicho convento de San Andrés, hija de Lope de Aveja), por precio de 11 mill maravedís, con la pensión de una carga de trigo que sobre estas casas tenía de foro perpetuo el Hospital de la O.

Esta carga de trigo no se paga porque el monasterio tenía otra a su favor sobre el suelo del dicho hospital. Véase el Cajón San Andrés, legajo $3^{\circ}$, número $8^{\circ}$. Su fecha, en San Andrés de Arroyo, a 31 de agosto de 1532, ante Pedro de Herreros Gallego, escribano de Su Magestad.

Está aquí el recibo de los 11 mill maravedís que dio este monasterio por dichas casas, a 5 de septiembre del mismo año, y firmando del mismo escribano.

26. < Compra de unas casas en el barrio de San Zoles. Año 1541>.

Compra que hizo este monasterio a Juan Aveja, vecino de San Zoles, de unas casas en el barrio de San Zoles, linderos: por delante la calle pública, por precio de 3750 maravedís y con cargo de 11 maravedís de fuero que sobre ellas tenía el monasterio. Su fecha, en San Zoles, a 22 de abril de 1541, ante Juan de Castrillo, escribano de Carrión.

\section{7. <Compra de unas casas en San Zoles. Año 1545>.}

Compra que hizo este monasterio a Beatriz de Aveja, muger de Diego Sedeño, vecinos de San Zoles, de unas casas en el dicho barrio, que han por linderos la calle pública, por precio de 6 mill maravedís, y con carga de 3 maravedís de foro perpetuo que el monasterio tenía sobre ellas. Su fecha, en San Zoles, a 28 de abril de 1545, ante Juan de Castrillo, escribano de Carrión.

28. <Compra de la mitad de unas casas en San Zoles. Año 1545>.

Compra que hizo el monasterio a María, muger de Lope de Guadalajara, vecina del barrio de San Zoles, de la mitad de unas casas con su corral en el dicho barrio, linderos: la calle pública que va al Molino de la tapia, por precio de 4 mill maravedís, y con carga de 3 maravedís / (f. 151v) que sobre dicha mitad de casas tenía este monasterio. Su fecha, en San Zoles, a 18 de mayo de 1546, ante Juan de Castrillo, escribano de Carrión.

29. <Compra de una casa en el barrio de San Zoles. Año 1546>.

Compra que hizo el monasterio a Juan de Aveja y Leonor Rodríguez, su muger, vecinos de San Zoles, de una casa en dicho barrio, a la plazuela de la Picota, por precio de 4500 maravedís y con cargo de 3 maravedís de fuero que sobre ella tenía el monasterio. Su fecha, en San Zoles, a 25 de enero de 1546, ante Francisco de Oviedo, escribano de Su Magestad.

Está aquí la escritura de redención de un censo de 6 mill maravedís de principal que tenía sobre esta casa Cathalina Gómez, muger de Alonso Gómez de San Román, cuya cantidad pagó el dicho Juan de Aveja y su muger. Otorgada el mismo día, mes y año y ante el mismo escribano.

258 casas] al margen derecho: Nota. Sobre esta casa litigó el monasterio pleyto con don Antonio Jofre, vecino desta villa, que pretendía ser ipoteca de un censo suyo y fue condenado en costas por sentencia dada año de 1796, ante Manuel Álvarez, escribano de Carrión. 
30. <Compra de unas casas en el barrio de San Zoles con el derecho de un foro de 700 maravedís y 4 gallinas. Año 1548>.

Compra que hizo este monasterio a Alonso Oro, mercadero, vecino de Carrión, de unas casas y del derecho de un foro de 700 maravedís y 4 gallinas, por precio de 25 maravedís cada maravedí y 2500 por las gallinas, que montan 20 mill maravedís, las quales casas son en el barrio de San Zoles, linderos: huerto y casa de don García Fernández Manrique y la calle pública. Su fecha, en San Zoil, a 9 de mayo de 1548, ante Juan de Castrillo, escribano de Carrión.

Está aquí una escritura de foro sobre estas casas y la donación que hizo a Alonso Oro su madre de las dichas casas. Su fecha, en Osorno, a 30 de septiembre de 1547, ante Juan Martínez, escribano de dicho lugar. Y últimamente la posesión que tomó el referido Alonso Oro de las dichas casas ante Christóval Oro, escribano de Carrión.

31. <Confesión de que una casa en el barrio era propia del monasterio. Año 1549>.

Testimonio dado por Juan de Santa María, escribano de Carrión, de haber confesado Alonso Vida el Viejo, vecino de San Zoles, que una casa en que él vivía en dicho barrio, a la bajada del puente, era propia de este monasterio; y por lo mismo se apartaba del pleito que con él tenía pendiente sobre la dicha casa. Su fecha, en San Zoles, a 5 de febrero de 1549.

32. < Compra de unas casas en San Zoles. Año 1550>.

Compra que hizo este monasterio a la cofradía de los 25 clérigos de Carrión [de] unas casas que fueron de la cofradía de los Santos Mártires San Zoil y San Félix (la qual se incorporó con la de los 25), que han por linderos: de una parte, casa del monasterio; por parte de atrás, tierra del Hospital de la O; por delante, la calle pública; y por otra parte, la calle e carrera que va a Carrevieja, por precio de 12 mill maravedís. Su fecha, en San Zoil, a 25 de abril de 1550, ante / (f. 152r) Juan de Castrillo, escribano de Carrión. Está aquí el poder de los 25 clérigos para esta renta, ante Tomás Sánchez, escribano en dicha villa.

\section{3. < Compra de 11 salzes en la Clavera. Año 1563>.}

Compra que hizo este monasterio a don Gaspar de la Serna y doña Antonia, su muger, de 11 salzes en la Clavera, cabe la huerta de la Limosna, que han por linderos: la dicha clavera y salzes del dicho monasterio, por precio de 2 mill 40 maravedís. Su fecha, en Carrión, a 7 de mayo de 1563, ante Andrés Sánchez, escribano en dicha villa.

34. <Compra de 14 salzes cerca del monasterio. Año 1612>.

Compra que hizo este monasterio a Juan de Lomas, vecino de Carrión, de 14 salzes, los once junto a la casa de los santos, cerca del dicho monasterio, y los otros tres a la puerta de las Carretas del dicho monasterio, por precio de 21 reales. Su fecha, en Carrión, a 7 de octubre de 1612, ante Gerónimo Laso, escribano en dicha villa.

35. <Compra de un lámpara de plata. Año 1631>.

Compra que hizo este monasterio a la cofradía de Nuestra Señora de la Piedad de Valladolid [de] una lámpara de plata que pesaba 31 marcos de plata y una onza, por precio de 2023 reales de plata dobles. Su fecha, en Valladolid, a 23 de septiembre de 1631, ante Juan Ruiz, escribano en dicha ciudad.

36. < Testimonio de 170 ducados que pagó el monasterio por la huerta de Andrés Gallo en el barrio de San Zoles. Año 1635>.

Testimonio dado por Antón Ruiz, escribano de Becerril, del pago que hizo este monasterio de 170 ducados a Andrés Gallo por una tierra huerta de obrada y media en San Zoles, enfrente del corral del ganado del monasterio, linderos: el cuérnago y tierra del dicho convento y el camino que va a la Herrada, cuya escritura de venta pasó ante Gerónimo López, escribano de Carrión (no está aquî). Su fecha, en Becerril, a 28 de marzo de 1635.

Está aquí el reconocimiento de dos foros del monasterio que hizo el dicho Andrés Gallo, uno de 357 maravedís sobre la huerta arriba deslindada, con su casa dentro de ella, que compró a Juan de Lomas, vecino de Carrión; y otro de 54 maravedís sobre una herrén 
que compró de los herederos de Alonso Marcos, que linda con la tierra de la Zapata, con el camino que va a la Zapata y con la dicha huerta de Andrés Gallo; y éste para cercar su huerta parece hicieron los monges con él el trueque de un corral caído que junto a la dicha huerta tenían, por otro pedazo de tierra, linde de la tierra de la Zapata, del otro lado de dicha huerta, para lo que precedió información de utilidad y licencia del general, que todo está bajo este número.

/ (f. 152v) 37. < Compra que hizo este monasterio al de San Pedro de Cardeña. Año $1649>$.

Compra que hizo este monasterio al de San Pedro de Cardeña de 36 tierras en términos de esta villa, Cestillos, San Mamés y Calzada ${ }^{259}$ y de 5 censos y un foro perpetuo de 680 maravedís sobre una casa a la calle de los Caldereros, en Carrión, por precio de 10758 reales de vellón. Su fecha, en San Zoil, a 15 de febrero de 1649, ante Francisco Moro de Saldaña, escribano de Carrión.

Están aquí juntamente los papeles de partijas y entrega hecha al padre fray Plácido de Guzmán, hijo de la casa de Cardeña, que es por donde le vino esta hacienda a dicha casa.

Adviértase que la casa del fuero arriba dicho se cayó, y habiéndose vendido los materiales por 200 reales que puso a censo este monasterio quedó el suelo por suyo.

38. < Compra de unas casas y viña para pagar a este monasterio. Año 1677>.

Compra de unas casas a la Puente a favor de Gabriel de Prado, linderos: la cárcaba que cae al río; y por delante, la calle que va al dicho puente; y una viña que compró él mismo en Villovieco, donde llaman a la Pradera Larga, de 6 quartas poco más o menos. Esta hacienda, según dice el padre Fuentes, se vendió judicialmente para pagar a este monasterio las rentas de los molinos y 700 reales que le había prestado fray Juan Díaz, monge de este monasterio, cuyos autos pasaron ante Gregorio García de Miranda, por los años de 1677 en adelante.

39. <adjudicación al monasterio de una casa a las pradillas del Puente Mayor, en San Zoles. Año 1679>.

Auto dado por don Francisco Zapata, correjidor de Carrión, para el que adjudica a este monasterio, contra los curadores de los nietos que quedaron de Andrés Gutiérrez, vecino de dicha villa, unas casas arrimadas a las pradillas del Puente Mayor, en el barrio de San Zoles, linderos: las dichas pradillas, el río mayor y la calle pública, sobre la que tenía el monasterio 510 maravedís y 2 gallinas de foro perpetuo. Fue dado este auto a 5 de mayo de 1679, ante Norberto de Sandoval y Guevara, escribano en dicha villa.

Está aquí la escritura de foro de esta misma casa, otorgada año de 1569, ante Andrés Sánchez, y el reconocimiento que hizo de este foro Andrés Gutiérrez, año 1647, ante Francisco Moro de Saldaña, escribano de Carrión.

40. <Que la piedra de la fuente que está en la Calzada es del monasterio. Año 1697>.

Testimonio signado de Agustín García Miranda, escribano de Carrión, por el qual da fe de que toda la piedra de la fuente que hizo esta villa al último de la calzada del Puente Mayor es de este monasterio, por si se arruinare o no corriere pueda tomarla y llevarla como suya propia que es. Su fecha, en Carrión, a 24 de abril de 1697.

/ (f. 153r) 41. <Compra de una casa en la calle de la Rúa. Año 1725>.

Compra que hizo este monasterio a José Fontán y Josefa Reynoso, vecinos de Carrión, de una casa en la calle de la Rúa, con su bodega, corral, cavalleriza y pajar, frente a las carnizerías, linderos: por la puerta principal, con casas de Andrés Ruiz y de don Antonio Orejón, y con la calle de la Rúa; y por la puerta de atrás, con panera de don José de Medina de los Ríos Campoo, y con casas de los acreedores a los bienes de Francisco Simón de Aguilar, por precio de 2 mill 800 reales, con carga de 1100 reales del principal de un censo que contra dicha casa tenía el cura y beneficiador de la yglesia de San Andrés de esta villa, y

${ }^{259}$ Calzada] al margen derecho: Cestillos, San Mamés y Calzada. 
un foro de 260 maravedía y 4 gallinas a favor de dicho cura y beneficiados. Su fecha, en Carrión, a 6 de mayo de 1725, ante Santiago Duque de Estrada, escribano en dicha villa.

Bajo este número, a folio 52, está la redención del censo de 1100 reales que hizo fray Zoil de Pedroso, monge de este monasterio, y varias diligencias y execuciones y las advertencias que deben considerarse sobre el foro que tenía contra sí esta casa. Pueden verse en la primera y segunda oja de este papel, que no se ponen aquí por no molestar ${ }^{260}$. Esta casa se vendió en 19 de febrero de 1793 a Vicenta Muñoz, viuda, cuya escritura de venta pasó ante José Tablares, escribano de Carrión ${ }^{261}$.

\section{2. < Compra de una casa en el barrio de San Zoles. Año de 1764>.}

Compra que hizo este monasterio a Ysidro Cantero y Josefa Vicente, su muger, vecinos de Carrión, de una casa con su habitación alta y baja en el barrio de San Zoles, linderos: por parte del poniente con casa que fue de Escolástica Meriel (la qual recayó en el monasterio); de la del norte, con corral $<$ de ella $>$; de la de levante, con casa del mismo monasterio; y por parte de adelante, con la calle pública que sale al campillo y cuérnago del molino que llaman del Huerto, por precio de 900 reales. Su fecha, en Carrión, a 12 de junio de 1764, ante Manuel Francisco Blanco, escribano de dicha villa. Está aquí una escritura de venta que hizo Ysidro Cantero y su muger a Escolástica Meriel, de una casa en el barrio de San Zoles, linderos: por parte de levante con la calle real de dicho varrio; por parte del norte, con casa de los otorgantes; por poniente, con reguera que sale de Cuérnago y riega la huerta grande; y por parte de atrás, con huerta de herederos de Carlos Rebuelta, por precio de 1860 reales. Su fecha, en Carrión, a $1^{\circ}$ de marzo de 1758, ante Gabriel Zeano Vivas, escribano en dicha villa. ${ }^{262}$. Esta casa recayó en el monasterio por el testamento de Escolástica Meriel y por la aceptación que hizo el padre Castro, que pasó ante Manuel Blanco, escribano de Carrión, como consta de un papel que está dentro de esta escritura.

$$
\text { / (f. 153v ) 43. < Compra de unas quadras en la calle de la Mejorada. Año 1792>. }
$$

Compra que hizo este monasterio a don Buenavista Olea, como apoderado de su hermano don José Olea (Guardia de Corps de la Compañía Flamenca) de unas quadras a la colación de Santiago, en el casco de esta villa, en la calle que llaman de la Mejorada, por otro nombre callejuela de Jirón, linderos: casa de este monasterio y casa de doña Ynés Ruiz y otros que dice son bien notorios, por precio de 2000 reales de vellón. Su fecha, en Carrión, a 30 de junio de 1792, ante Pedro Martínez León, escribano de dicha villa ${ }^{263}$. Estas quadras se vendieron juntamente con la casa que compramos en la calle de la Rúa, que es la que está en este Quaderno, número 41.

44. <Adjudicación de una casa en la calle de la Castillería. Año 1792>.

Testimonio dado por Ángel Gutiérrez, escribano de esta villa de Carrión, del pleito seguido por este monasterio contra Jacinto Elizes y Engracia del Campo, su muger, vecinos de dicha villa, sobre la paga de más de 70 cargas de trigo que debían a dicho monasterio por renta del molino arinero que habían tenido en arrendamiento, cuya causa tubo principio el año de 1776, ante Andrés Núñez Castelo, escribano que fue de dicha villa; y, no habiéndoseles encontrado a los referidos más bienes propios que una casa que tenían en dicha villa, en la calle que llaman de la Castillería ${ }^{264}$ (sobre esta casa tenía el monasterio un foro de 119 maravedís, cuya escritura foral y reconocimiento está cosida con este ynstrumento), por auto dado por el señor licenciado don Francisco Roxo Gómez, correjidor de esta villa, en 22 de diciembre de 1792, ante el referido escribano Ángel Gutiérrez Pérez, se mandó adjudicar al citado real monasterio la mencionada casa en qüenta y pago de la referida deuda. Fue dado este testimonio a 20 de enero de 1793.

\footnotetext{
260 molestar] al margen derecho: Nota.

261 Carrión] al margen derecho: Véase el número 43.

262 villa] al margen derecho: Nota.

263 villa] al margen derecho: Nota.

264 Castillería] al margen derecho: Nota.
} 


\section{Remisiones}

$<$ Molinos del Huerto y de la Tapia $>$.

La compra que hizo este monasterio de las terceras partes de los molinos del Huerto y de la Tapia y de la $3^{a}$ parte de quatro tierras a ellas anejas: véase el Quaderno $C$ de este legajo $2^{\circ}$, número $1^{\circ}$.

La compra de dos foros, el uno de 136 maravedís y el otro de 100, sobre unas casas en la calle de San Pedro y calle de Santa Eulalia: véase este cajón, legajo $3^{\circ}$, números $6^{\circ}$ y $7^{\circ}$ ,y el número 10 sobre la huerta de Henar.

Yttem La compra de un foro de 100 maravedís sobre unas casas en la calle de Santa Olalla: véase el cajón San Zoil, legajo $4^{\circ}$, número 57.

Otra compra de un foro de 50 maravedís sobre una tierra en Carrión: véase el mismo legajo $4^{\circ}$, número 58 .

\section{/ (f. 154r) Quaderno B del Legajo $2^{\circ}$ \\ Trueques en Carrión y San Zoles}

Este quaderno contiene los papeles pertenecientes a los trueques hechos por este monasterio en Carrión y San Zoles, por el orden siguiente:

$1^{\circ}$. < Trueque de la tierra de la Monja por otros dos pedazos de tierra. Año 1477>.

Trueque que hizo este monasterio con fray Zoil de Nogal, sacristán mayor de este monasterio, de la tierra que llaman de la Monja, en el barrio de San Zoles, linderos: de una parte, el Cuérnago del molino; y de la otra, casas del monasterio y tierra de las monjas de Santa Clara, por otros dos pedazos de tierra que el dicho Zoil de Nogal había comprado a Juan López Moro, vecino de San Zoles (cuya escritura de compra está bajo este número), linderos: la dicha tierra de la Monja y tierra pequeña de la de Juan de la Cosa. Su fecha, en San Zoil, a 20 de abril de 1477, ante Fernando Cavallo, escribano de Carrión. Está aquí duplicada este misma escritura de trueque y la de posesión que tomó fray Zoil de Nogal de la tierra de la Monja, todo ante el mismo escribano.

$2^{\circ}$. $<$ Trueque de unas casas por otras en la parroquia de San Pedro. Año 1481>.

Trueque que hizo Juan Laso, monge de este monasterio, con García de la Serna Herrero, vecino de Carrión, de unas casas en dicha villa, a la parroquia de San Pedro, lindero: por delante la calle pública, por otras que el dicho García le dio, las quales estaban en la misma parroquia con el mismo lindero; y sobre ellos 4500 maravedís que valían más las casas de Juan Laso; y además de esto la obligación de pagar un foro que tenían sobre sí las referidas casas de Juan Laso. Su fecha, en Carrión, a 28 de junio de 1481, ante Fernando Cavallo, escribano de dicha villa ${ }^{265}$. Bajo este número están los testamentos de Juan Laso y María Herrera, padres del referido monge, en los años de 1445 y 470, ante Fernando García Pachistre el Mozo y Juan Martínez, escribano de dicha villa.

También están aquí las qüentas entre María Herrera y sus hijos para las partijas, año 1449, ante García Fernández de San Zoles, escribano de la misma villa. Yttem una escritura de arrendamiento de la mitad de unas casas, tierras y una viña que hizo el curador del dicho monge, año de 1460, ante Gómez González de Carrión, escribano de la misma villa. Yttem una sentencia árbitra sobre los bienes que quedaron de los padres del referido monge, dada a 27 de febrero de 1468, ante Fernando Cavallo, escribano de Carrión.

\footnotetext{
265 villa] al margen derecho: Nota.
} 
3. $<$ Trueque de 5 blancas viejas por 12 maravedís y medio y una gallina sobre unas casas. Año 1490>.

Trueque que hizo este monasterio con Pedro Fernández de Carrión, cura de la parroquia de San Andrés, de 5 blancas viejas que tenía de foro el monasterio sobre unas casas en que el dicho cura vivía por 12 maravedís y medio y una gallina / (f.154v) de foro perpetuo que él tenía sobre unas casas en que vivía Pedro Quijano que estaban en la parroquia de Santa Olalla, linderos: la calle pública, con condición de que le digan en este monasterio dos misas cada año por su alma. Su fecha, a 21 de octubre de 1490, ante Fernando Cavallo, escribano de dicha villa. Año 1497>.

4. $<$ Trueque de tres pedazos de tierras huertas por una huerta en término de Carrión.

Trueque que con licencia de don Luis Hurtado de Mendoza, abad comendatario de San Zoil, hizo este monasterio con Rui Fernández de Grijalva, escribano de Carrión, de tres pedazos de tierras huertas a los Arenales, en término de dicha villa, linderos: el uno cerca de Carrera Herreros, los Arroyos y tierra de la Capellanía de Santiago; los otros dos pedazos son cerca el uno del otro, que han por linderos: tierra de la Capellanía de Santiago, que está en medio de ellos, y tierra de los clérigos de Santa María del Camino, por otra huerta que el dicho Rui Fernández tenía en término de dicha villa, cerca de Carrera Vieja, que ha por linderos: de la una parte, tierra de la limosna de San Zoil; y de las otras partes, tierras del monasterio y huerta que tenía Pedro González. Su fecha, en San Zoil, a $1^{\circ}$ de marzo de 1497, ante Fernando Cavallo, escribano de Carrión.

5. < Trueque de una tierra en Cestillos por otras dos bajo de la puente de Río Mediano. Año 1519>.

Trueque que hizo este monasterio con Juan Díaz Mercader, de una tierra en Cestillos por otras dos tierras en término de Carrión, bajo de la puente de Río Mediano; la una de obrada y media, poco más o menos, que ha por linderos: de la una parte, tierra de María Martínez; y de la otra, tierra de Campo, vecino de dicha villa; y de la otra parte, el arroyo. La otra tierra es bajo de las Vargas, que ha por linderos: de la una parte, tierra de los 20 clérigos; y de la otra parte, el Cuérnago Viejo, que se perdió, que era de Santa Clara. Su fecha, en San Zoil, a 31 de diciembre de 1519, ante Floristán de la Serna, escribano de Carrión.

6. <Trueque de una tierra en la Loma por otra en la Vega. Año 1546>.

Trueque que hizo este monasterio con Francisco Gómez de Espino, vecino de Carrión, de una tierra en término de dicha villa, a carre San Andrés del Aldea, de media obrada, poco más o menos, lindero: el caminillo Canpudo, por otra tierra en la Vega de Carrión, carre los Exidos, de más de media obrada, que ha por linderos: de la una parte, el camino de los Exidos que va a la abadía de Benevivere; y de la otra parte, tierra de Fernando de la Carrera y el arroyo entremedias, e tierra del mismo Francisco Gómez de Espinosa, e el camino que va a la calzada entremedias. Su fecha, en San Zoil, a 10 de mayo de 1546, ante Juan de Castrillo, escribano de Carrión.

$<$ Auto a favor del monasterio ${ }^{266}$.

Está aquí cosido a esta escritura el testimonio del pleito que ganó el monasterio sobre esta tierra en ambos juicios en los años de 1793 y 94, ante José Tablares, escribano de dicha villa.

7. $<$ Trueque de un camino desde la esquina de la Herrada por una tierra a Piedra Alva. Año 1594>.

Trueque que hizo este monasterio con la villa de Carrión de un camino / (f. 155r) que empieza desde la esquina de la huerta de la Herrada, arroyo arriba, desde el arroyo hasta la tierra de Piedra Alva (y el dicho camino ha de tener dos estadales de ancho), que linda desde la esquina de la huerta de la Herrada con tierra del monasterio y tierra de Francisco Campoo, vecino de Carrión, por una tierra que llaman a Piedra Alva, que hace 8 quartas, poco más o

266 monasterio] al margen derecho: Nota. 
menos, que linda con tierra de la Herrada y el arroyo en medio; y de la otra parte, tierra de los herederos de Santiago Ramos y tierra de Vázquez de Rueda y la Huelga de Odra. Su fecha, en San Zoil, a 327 de enero de 1594, ante Pedro de Yguña, escribano de Carrión.

$$
8^{267} \text {. }
$$
$1676>$.

9. <Trueque de una tierra en término de San Mamés por otra a los Enjidros. Año

Trueque que hizo este monasterio con Pedro Herrero y doña Juana de Menoyo y Murga, vecinos de Carrión, de una tierra en término de San Mamés, donde llaman San Lázaro y la Tripilla, de 5 obradas, linderos: el camino que va de dicho lugar al molino del Ayante y el camino real que va a Villaherreros, por otra tierra a los Enxidros, en término de dicha villa, de 2 obradas y media, poco más o menos, linderos: tierras de don Manuel de los Ríos Campoo, y con tierra de este monasterio, arroyo en medio; con información de utilidad y licencia de Su Reverendísima. Su fecha, en Carrión, a 19 de junio de 1676, ante Blas Vela Álvarez, escribano de dicha villa. $1785>$.

10. <Trueque de 4 tierras en término de Carrión por otras en el mismo término. Año

Trueque que con licencia de Su Reverendísima hizo este monasterio con el de Santa María de Benevivere, de quatro tierras en término de Benevivere: la $1^{a}$ está al pago que llaman de la Cañada, de 2 quartas, poco más o menos, linderos: a la parte del zierzo, con el arroyo del campo de las Viñas y con el campo y término de Benevivere; y de parte de abajo y de arriba, con tierras de dicho Benevivere. La $2^{\mathrm{a}}$, en el dicho término a la Junquera, de 4 quartas, poco más o menos, linderos: de parte de abajo, con el camino que va de Villotilla a Villanueba de los Nabos; y de parte de ábrego, con tierra del convento de Benevivere; y de parte de zierzo, el arroyo. La $3^{\mathrm{a}}$ otra en dicho término, a la Laguna de don Pedro, que hace media obrada, poco más o menos, linda: de parte del cierzo, con dicha laguna; y de parte de arriba, con tierra de herederos de Toribio Merino, vecino de Bustillo; y de parte de ábrego, con tierra de Benevivere. La $4^{\mathrm{a}}$, en dicho término, al Campo de Pedralva, que hace una obrada, poco más o menos, linda: de parte de abajo, con tierra de Benevivere; y de arriba, con tierra de San Torquato, por otras dos tierras que el referido Benevivere dio a este monasterio: La $1^{\mathrm{a}}$ en término de Carrión, al camino de Villaturde, que hace 14 quartas, poco más o menos, linda por el oriente con el camino real que va a Villaturde; por el norte, con tierra del Beneficio de Evangelio de la yglesia de San Andrés; por el poniente, con tierra que hoy lleva don / (f. 155v) José Díaz de Castro, vecino y rejidor de esta villa; por el sud, con otra del Beneficio, que goza don Pedro Martínez, cura en dicha yglesia. La $2^{\mathrm{a}}$, en dicho término, a do llaman Odra, que hace 5 quartas, linda por el oriente con tierra de los 20 de dicha villa; por el norte, con tierra del mayorazgo titulado de los Bustamantes, arroyo regadío en medio; por el poniente, con tierra del monasterio de San Zoil, arroyo en medio; y por el sud, con el arroyo madre llamado de Odra. Fue otorgada esta escritura en San Zoil, a 22 de febrero de 1785, ante Martín García Gatón, escribano de Carrión.

11. $<$ Trueque de 450 maravedís y 2 gallinas de foro sobre unas casas en el Mercado por otro de 40 reales sobre una casa mesón en San Zoles. Año 1658>.

Trueque que con las licencias necesarias hizo este monasterio con los patronos y curas de la capilla mayor de la yglesia de Santiago de la villa de Carrión de un foro de 450 maravedís y 2 gallinas que este monasterio tenía sobre unas casas en el Mercado de dicha villa, linderos: por una parte la plaza de dicho Mercado; y por otra, la calle principal que va a las Tenerías; y por detrás, la callejuela que va a las Heras de carre Palencia, por 40 reales de foro perpetuo que la dicha yglesia de Santiago tenía sobre una casa mesón en el barrio de San Zoles, junto al Puente Mayor (que por haberse quemado estaba hecho solar), linderos: las calles que van la una al dicho convento y la otra al molino de la Tapia, sobre las que y una huerta contigua a ellas tenía el monasterio dos foros, el uno de 200 y el otro de 600 maravedís,

267 8] al margen derecho: Nota. En este número $8^{\circ}$ se debe poner el número 11, por corresponderle aquí por el año. 
cuya casa, mesón y huerta (hecha herrén) ceden al monasterio por el foro arriba expresado que éste les dio. Su fecha, en San Zoil, a 2 de enero de 1658, ante Norberto de Sandoval y Guevara, escribano de Carrión. Están aquí todos los instrumentos pertenecientes a esta casa mesón.

\section{/ (f.156r) Quaderno C del legajo $2^{\circ}$}

Molinos del huerto de la Tapia y de Guzmán

Este quaderno $\mathrm{C}$ contiene los papeles pertenecientes a los molinos del huerto de la Tapia y de Guzmán, por el orden siguiente:

$1^{\text {o }}$. < Compra de la tercera parte de los molinos de la Tapia y del huerto, y de la $3^{\text {a }}$ parte de 4 tierras. Año 1465>.

Bajo este número está primero la venta que otorgó Rui Díaz, hijo de Ximón Díaz, a favor deste monasterio, de la tercera parte que tenía y le pertenecía en los molinos de la Tapia y huerto, y de la tercera parte de 4 tierras: la $1^{a}$ que ha por linderos: tierra de la muger de Juan de Valle; la $2^{a}$ la tierra del molino de la tapia; la $3^{a}$ está a la carrera de San Cristóval, en término de Carrión, linderos: el camino real y tierra de Santa Clara y los arroyos; y la $4^{a}$ tierra, que llaman del Pisón; por precio de 8 mill maravedís, y con carga de los foros que el monasterio tenía sobre dichos molinos y tierras. Su fecha, en San Zoil, a 16 de diciembre de 1465, ante Juan González Catalán, escribano de Carrión.

$<$ Testamento de Rui Díaz>.

Síguese el testamento que otorgó el dicho Rui Díaz, por el qual manda todos sus bienes a este monasterio después de la muerte de Guiomar de Herrera, su muger.

Después de esto se sigue una donación que, en perjuicio de este monasterio, hizo la referida Guiomar de Herrera de todos sus bienes a su hermano Alonso de Rueda, lo qual, sabido por este monasterio, se opuso assí por razón de la venta que había hecho Rui Díaz, su marido, de las terceras partes de estos molinos y tierras, como por el testamento. Este pleito, por consentimiento de ambas partes, se comprometió en un juez árbitro y, por su sentencia, mandó entre otras cosas que la dicha Guiomar pudiese disponer a su arbitrio de las otras dos partes del molino de la Tapia, las quales dos partes las vendió a este monasterio por precio de 10 cargas de trigo y 1.800 maravedís cada año durante su vida.

$<$ Cesión del derecho de estos dos molinos a favor de este monasterio $>$.

Y, por último, después de varios enredos de la dicha Guiomar, en 10 de julio de 1480, Francisco Girón, religioso gerónimo y hermano de la dicha Guiomar de Herrera, estando en este monasterio de San Zoil, por ante Fernando Cavallo, escribano de Carrión, otorgó escritura de cesión, traspasación y donación y de qualquier derecho que pudiese tene, a los dichos molinos del huerto (y) de la Tapia y tierras a ellos anejas; y consintió, ratificó y aprobó todas las escrituras que en este punto habían otorgado a favor de este monasterio, assí el dicho Rui Díaz como la dicha Guiomar de Herrera, su hermana, y otros qualesquiera interesados. Todo lo qual se puede ver con más extensión en las dos primeras ojas de este papel.

\section{/ (f.156v) 2. <Proceso sobre el molino de Guzmán. Año 1629>.}

Parte de un proceso antiguo, sin autoridad, en el que se da noticia de quién fue el molino de Guzmán, por qué se vendió judicialmente a Juan de Mediavilla, familiar del Santo Oficio y vecino de Carrión, en qué cantidad se remató en él, y qüentas que pasaron desde el año de 1628 hasta el de 1629. Que todo pasó ante Gerónimo Laso, en cuyo oficio sucedió Santiago Duque de Estrada, donde se halla el original.

3. < Papeles sobre el molino de Guzmán, desde el año de 1649>.

Bajo este número están los papeles siguientes pertenecientes al molino de Guzmán:

$1^{\circ}$. El testamento del licenciado Felipe Martínez, cura del lugar de Velilla, junto a Saldaña, por el qual manda a los hijos de Juan de Reynoso y Lucía de 
Villamediana, su muger, y sucesores de éstos, el referido molino; y, si faltaren todos, manda a este monasterio que le posea como suyo, con la carga de que se diga cada mes una misa cantada, con ministros y órgano, perpetuamente. Fue otorgado en Velilla, a 16 de diciembre de 1649, ante Antonio Ramos, escribano de Saldaña.

$2^{\circ}$. Vn tanto simple del codicilio que otorgó el susodicho, en que confirma las manas del testamento, el mismo año y ante el mismo escribano.

$3^{\circ}$. Vn tanto simple de la escritura de capitulaciones, que otorgó el susodicho quando trató de casar a su sobrina Lucía de Mediavlla, año 1637, ante Gerónimo Laso.

$4^{\circ}$. Testimonio de Norberto de Sandoval y Guevara de los hijos e hijas de Reynoso y Mediavilla, y un parecer de un abogado de Valladolid.

$<$ Compra que hizo este monasterio de la $4^{a}$ parte del dicho molino $>$.

$5^{\circ}$. Vna escritura de venta que otorgó Juan de Reynoso a este monasterio de la quarta parte del dicho molino y de la de una tierra junto a él que, por ser un de los herederos, le pertenecía, por precio de 800 reales. Otorgada en Villamuera, a 19 de marzo de 1690, ante Francisco Herrero, escribano de dicha villa.

$6^{\circ}$. Escritura de obligación que otorgó el dicho Juan de Reynoso a favor del padre Fuertes de 2420 reales, 7 céntimos, 4 quartas y 3 zelemines de trigo que le había prestado para seguir el pleito que le habían puesto sobre el mismo molino. Su fecha, a 13 de julio de 1701, ante Gregorio García de Miranda.

$<$ Compra de las tres partes restantes del dicho molino $>$.

Vltimamente está una escritura de venta que otorgó el dicho Juan Reynoso, a favor del dicho monge, de las tres partes restantes del molino y tierra para satisfacer a la deuda arriba dicha, con la que se acabó de comprar el dicho molino y tierra. Su fecha, en Carrión, a 30 de marzo de 1704, ante Blas Vela Álvarez, escribano de Carrión.

En estas dos ventas se hace mención de un foro ${ }^{268}$ de 50 maravedís que tiene este monasterio sobre el mismo molino. Véase este cajón, legajo 32, número $1^{\circ}$.

4. $<$ Parecer de un abogado sobre este molino. Año 1718>.

Parecer de don Juan de Valbuena, abogado de Palencia, en el que dice que ninguno de los herederos de Lucía de Mediavilla puede enagenar este molino. Dado en Palencia, a 3 de julio de 1718.

\section{/ (f. 157r) Legajo $3^{\circ}$ \\ Foros corrientes en Carrión y San Zoles}

Este legajo contiene los papeles pertenecientes a los foros corrientes que este monasterio tiene en Carrión y San Zoles, por el orden siguiente:

$1^{\circ}$. <Foro de 50 maravedís sobre el molino de Guzmán o San Martineja. Año 1399>.

Escritura de foro, en pergamino, por la qual Pedro Díaz, prior de la claustra, con licencia de don Toribio, prior mayor de este monasterio, da a Juan Sánchez Armero, vecino de Carrión, la mitad del molino que dicen de Ybanades (oy San Martineja y de Guzmán), en el Cuérnago del río de Carrión, por 50 maravedís de foro perpetuo en cada año, los quales maravedís se cargaron sobre unas casas en Carrión, en la calle de la Frenería, que han por linderos la calle pública, y con la condición que el dicho Juan Sánchez pagase cada año 18 maravedís al capellán que sirviere la capellanía de Ximón Díez, la qual capellanía está en Santa María de Beldén, en Carrión, y assimismo con la condición de que si no pagare en los plazos

268 foro] Al margen derecho: El foro de 50 maravedís sobre este molino a favor deste monasterio. Véase este cajón, legajo $3^{\circ}$, número $1^{\circ}$. 
señalados esté obligado a pagar a este monasterio un maravedí por cada día de tardanza. Su fecha, en San Zoil, a 26 de marzo de 1399, ante Gómez García de Saldaña, escribano de Carrión. Hay copia authorizada.

$<$ Reconocimiento de este foro $>$.

También está aquí el reconocimiento de este foro hecho por Juan de Reynoso Labrador, vecino de Carrión, año de 1639, ante Francisco Moro de Saldaña, escribano de dicha villa.

2. < Foro de 26 maravedís sobre unas casas en la colación de San Pedro y después sobre una tenería. Año 1410>.

Bajo este número están tres escrituras de foro sobre unas mismas casas:

La $1^{a}$, escrita en pergamino, por la qual este monasterio da a Fernan Rodríguez de Castellanos, vecino de Carrión, unas casas y corral en la colación de San Pedro, que han por linderos la calle pública, por 26 maravedís de foro perpetuo. Su fecha, en San Zoil, a 26 de febrero de 1410, ante Francisco Pérez, escribano de Carrión.

La $2^{a}$, también en pergamino, por la qual este monasterio dio las mismas casas a Fernando Aparicio, vecino de Carrión, por los mismos 26 maravedís de foro perpetuo. Su fecha, en San Zoil a 13 de enero de 1438, ante Fernando García Pachistre, / (f.157v) escribano de Carrión.

La $3^{\mathrm{a}}$, vna escritura en papel, por la qual consta que, habiendo vendido estas casas Alonso Ruiz del Agua y María de Castro, su muger, libres del foro que sobre ellas tenía este monasterio, éste les obligó a que le afianzasen, como en efecto lo hizieron, imponiendo de nuevo este foro sobre una tenería con quatro pidas y su bodega, a las tenerías de San Juan. Su fecha, en Carrión, a 8 de marzo de 1641, ante Gerónimo de Terán, escribano de dicha villa; cuya escritura de imposición acetó el monasterio en 9 días del mismo mes y año y ante el mismo escribano.

3. <Foro de 160 maravedís sobre unas casas en la calle de la Rúa, a la Puerta del Canto. Año 1424>.

Escritura de foro perpetuo, en pergamino, por el qual este monasterio da a Juan Alegre, vecino de Carrión, unas casas en la calle de la Rúa Alta, a la Puerta del Canto, por 160 maravedís y un par de gallinas. Su fecha, en San Zoil, a 25 de enero de 1424, ante Fernando Rodríguez de Castellanos, escribano de Carrión. Hay copia authorizada.

Está aquí una escritura de reconocimiento de este mismo foro hecho por Pedro Pérez de Fresneda, procurador del número de esta villa, año de 1663, ante Norberto de Sandoval y Guevara, escribano de esta villa; y otro reconocimiento de los herederos del mismo Pedro Pérez, año de 1680, ante Blas Vela Álvarez, escribano de dicha villa.

Síguese otro reconocimiento del mismo foro que hizo Santiago Duque de Estrada, escribano de esta villa, a 20 de mayo de 1745, ante Agustín Díez de Castro, escribano de Carrión.

$<$ Demanda sobre este foro $>$.

Después de esto está una demanda que puso el monasterio contra el mismo Santiago Duque por hacer nueve años y medio que no pagaba dicho foro. Y por auto dado por don José de los Ríos Campoo, correjidor de Carrión, se travó execución en los bienes del referido Santiago Duque, a 30 de abril de 1744, ante Gabriel de Zeano Vivas, escribano de dicha villa. A esta causa salió el procurador de la parte de Santiago Duque, diciendo que, en pago de los maravedís y gallinas, había dado al padre fray Benito Cantero, prior de Villaverde, unas fanegas de sal; y para esto presentó tres recivos del mismo prior, los quales dieron por finjidos y de ninguna authoridad tres secretarios nombrados por la justicia para su reconocimiento. Lo qual pasó en el mismo año y ante el mismo escribano. 
4. $<$ Foro de 35 maravedís y un par de gallinas sobre un suelo junto a la Puerta de San Juan. Año 1460>.

Escritura de foro perpetuo, por la qual este monasterio, con licencia de su abad, dio a Alfonso de Castañón, vecino de Carrión, un suelo junto a la Puerta de San Juan, por 35 maravedís y un par de gallinas de / (f. 158r) foro perpetuo en cada año. Su fecha, en San Zoil, a 7 de junio de 1460, ante Álvar González de Carrión, escribano de Carrión. Hay copia authorizada.

Están aquí dos reconocimientos de este mismo foro, el $1^{\circ}$ hecho por Juan de la Vega, vecino de Carrión, a 2 de enero de 1639, ante Francisco Moro de Saldaña, escribano en dicha villa. Hay copia authorizada; el $2^{\circ}$ reconocimiento hecho por don Lorenzo Sánchez, cura de la yglesia parroquial de San Juan, en 25 de abril de 1785, ante Martín García Gatón, escribano de dicha villa. $1470>$.

5. $<$ Dos foros de 80 y 85 maravedís y un par de gallinas sobre la Huerta Grande. Año

Bajo este número está $1^{\circ}$ una escritura de foro, por la qual este monasterio da a Lope de Ávila, vecino e morador de San Zoles, una huerta en el dicho barrio, junto al molino del Huerto, por 80 maravedís y un par de gallinas de foro perpetuo, con la condición y obligación que, dentro de dos años, ha de hacer una casa dentro de la misma huerta. Su fecha, en San Zoil, a 15 de abril de 1470, ante Juan Martínez de Carrión, escribano en dicha villa. Hay copia authorizada.

\section{$<$ Pleito sobre la paga de lo devengado de este foro $>$.}

$2^{\circ} \mathrm{Vn}$ proceso formado contra doña Constanza de Rosas, como señora de la dicha huerta, llamada de don Gaspar (oy la Huerta Grande) en el que, a folio 96 y 98 vuelta, por auto dado por don Juan de Solórzano, correjidor de Carrión, se manda executar a dicha doña Constanza para la paga del referido foro y de otro de 85 maravedís (cuya escritura está a folio 13 del dicho proceso) que tenía el monasterio a su favor sobre la misma huerta. Estos autos pasaron desde el año de 1662 hasta el de 1665, ante Norberto de Sandoval y Guevara, escribano de Carrión.

6. $<$ Foro de 136 maravedís sobre una casa en la calle de San Pedro, oy en la colación de San Andrés. Año de 1501>.

Escritura de foro perpetuo, en pergamino, por la qual consta que Marina la Cordera puso a favor de este monasterio 136 maravedís de foro perpetuo situados en unas casas en la calle de San Pedro de esta villa, por 80 reales que la dio el monasterio. Su fecha, en San Zoil, a 10 de noviembre de 1501, ante Alonso de Guadiana, escribano de dicha villa. Están aquí dos reconocimientos de este mismo foro, el $1^{\circ}$ hecho por Martín de la Vega y Ana de Montes, su muger, año de 1646, ante Francisco Moro de Saldaña, escribano de Carrión; y el $2^{\circ}$ por Diego Fernández y Francisca Fernández, su muger, vecinos de Carrión, como consta de la aceptación que hicieron los referidos del mismo foro por esta escritura de venta de la referida casa, año de 1765, ante Manuel Francisco Blanco, escribano de Carrión, y la copia año de 1794, ante Ygnacio Gutiérrez, escribano de dicha villa.

/ (f. 158v) 7. < Foro de 100 maravedís sobre una casa en el barrio de Santa Olalla. Año de $1503>$.

Escritura de foro perpetuo de 100 maravedís que, a favor de la cofradía de San Pedro, puso Toribio de Membrillar, vecino de Carrión, sobre una casa en el barrio de Santa Olalla. Su fecha, en Carrión, a 4 de septiembre de 1503, ante García de Avia, escribano de dicha villa.

Está aquí la escritura de venta que otorgó la referida cofradía a favor de este monasterio del mismo foro, por precio de 2500 maravedís, a 16 de febrero de 1548, ante Pedro López Moro, escribano en dicha villa.

Vltimamente está un reconocimiento de este mismo foro sobre esta misma casa (que ahora es herrén) hecho por Ysabel Montes, vecina de esta villa, a 18 de marzo de 1641, ante Gerónimo de Terán, escribano de dicha villa. 
8. $<$ Dos foros de 4 gallinas sobre unas casas a las Tenerías. Año 1516 y 1529>.

Dos escrituras de foro perpetuo de 4 gallinas sobre unas casas a las Tenerías y calle que vaja del Mercado Viejo al río, sobre las quales fundó estos dos foros Juan Pando, el $1^{\circ}$ a favor de Miguel de Villaherreros, a 14 de julio de 1516, ante Rodrigo de Santa Olalla, escribano de Carrión; el $2^{\circ}$ a favor de Toribio del Campo, a 6 de julio de 1520, ante Pedro López Moro, escribano de dicha villa.

Sucedió en estos foros Francisco Sánchez Cavallero, quien, habiendo tomado a foro perpetuo de otras 4 gallinas otras casas de este monasterio, en la calle de la Tejada, pudo dexar estas libres, situó las 4 gallinas de foro sobre las referidas casas a las Tenerías, como resulta más por estenso de la renta y traspasación de foro. Que pasó ante Alonso Zapata, escribano de dicha villa, a 17 de mayo de 1603, cuya copia sacó Ysidoro Ruiz de Colmenares, sucesor en su oficio y papeles, a 7 de julio de 1794.

Reconoció este foro a favor del monasterio Juan de Vega Ortelano, a 16 de marzo de 1651, ante Francisco Moro de Saldaña, escribano de Carrión. $1546>$.

9. $<$ Foro de 6 reales y 2 gallinas sobre una casa en la calle de Sancti Spiritus. Año

Escritura de foro perpetuo por la qual este monasterio da a Francisco de Oropesa, vecino de Carrión, una casa en la calle de Sancti Spiritus, que va de San Francisco a Santa Clara, por 6 reales y 2 gallinas de foro perpetuo. / (f. 159r) Su fecha, en San Zoil, a 7 de agosto de 1546, ante Juan de Castrillo, escribano de Carrión.

Está aquí el reconocimiento de este mismo foro hecho por Miguel Poza, vecino de Carrión, a 22 de enero de 1642, ante Francisco Moro de Saldaña, escribano en dicha villa.

Síguese una escritura de venta que otorgó Diego de Plada y Juana de Gil, su muger, a favor de Manuel Carrillo, de la mitad de esta casa, dividiendo el foro. Su fecha, en Carrión, a 30 de noviembre de 1770, ante Gabriel de Zeano Vivas, escribano de Carrión; y está copia, a 11 de junio de 1794, ante Manuel Álvarez, escribano de dicha villa.

$<$ Pleito sobre este foro $>$.

Y últimamente está el reconocimiento de este mismo foro hecho por Manuel Pérez Ruiz, vecino de dicha villa, con el testimonio del pleito (que) contra él y Manuel Carrillo, en que fueron condenados a pagar los cánones recibidos. Su fecha, en Carrión, a 21 de septiembre de 1800, ante José Tablares, escribano de dicha villa. $1561>$.

10. $<$ Foro de 68 maravedís sobre una tierra huerta que hoi se llama de Enao. Año de

Escritura de foro perpetuo por la (la) qual consta que María de Setién, vecina del barrio de San Zoles, puso a favor de este monasterio 68 maravedís de foro perpetuo sobre unas casas (que hoy son huerta) por 2 mill 40 maravedís que el monasterio la dio. Su fecha, en Carrión, a 6 de agosto de 1561, ante Andrés Sánchez, escribano de dicha villa.

Está aquí la vía executiva seguida contra don Fernando de Enao, vecino de Madrid, poseedor de dicha huerta, año de 1663, ante Norberto de Sandoval y Guevara, escribano de dicha villa.

11. < Foro de 450 maravedís sobre una casa en el barrio de San Zoles. Año 1646>.

Escritura de reconocimiento de un foro de 450 maravedís (cuya escritura principal falta) a favor de este monasterio sobre una casa con su corral hecho por Andrés Gutiérrez el Viejo, vecino de Carrión, la qual casa compró a la cofradía de San Juan y la Magdalena. Su fecha, en Carrión, a 13 de abril de 1646, ante Francisco Moro de Saldaña, escribano en dicha villa.

Síguese la escritura de venta que hizo María Gutiérrez, vecina de Villanueva de los Nabos, de la referida casa, a favor del licenciado Juan Brabo de la Torre, presbítero, vecino de dicha villa, a 24 de abril de 1664, ante Gerónimo Laso, escribano de dicha villa. 
Vltimamente está aquí el reconocimiento de dicho foro que hizo Alonso Brabo, vecino de San Zoles, a 24 de noviembre del mismo año, ante Norberto de Sandoval y Guevara, escribano en dicha villa.

12. $<$ Foro de 4 reales sobre un solar en la calle de la Castillería. Año 1748>.

Escritura de foro perpetuo por la qual este monasterio da a Gregorio Mínguez, vecino de Carrión, ocho varas de solar en quadro en / (f. 159v) la calle de la Castillería, por 4 reales de foro perpetuo cada año. Su fecha, a 12 de mayo de 1748, ante Gabriel Zeano Vivas, escribano de dicha villa.

\section{3. < Foro de 4 reales sobre un solar en la calle de la Castillería. Año 1748>.}

Escritura de foro perpetuo por la qual este monasterio da a Juan Callejo, vecino de Carrión, 11 varas en quadro de solar, en la calle de la Castillería, por 4 reales de foro perpetuo en cada año. Su fecha, en Carrión, a 12 de mayo de 1748, ante Gabriel de Zeano Vivas, escribano de dicha villa.

\section{4. $<$ Foro de 5 reales y $1 / 2$ sobre un solar en la calle de la Castillería. Año 1752>.}

Escritura de foro perpetuo por la qual este monasterio da a Miguel Blanco, vecino de Carrión, un solar de 11 varas y media de solar, para una casa y corral en la calle de la Castillería, por 4 reales de foro perpetuo cada año. Su fecha, en Carrión, a $1^{\circ}$ de octubre de 1752, ante Andrés Núñez Castelo, escribano en dicha villa. Por haberse intrusado el dicho otorgante en mayor parte de terreno, se le obligó a que pagase real y medio más de foro perpetuo, como consta de la escritura de obligación que está aquí firmada de su nombre, a 20 de septiembre de 1759. $1760>$.

15. < Foro de 4 reales sobre un solar en la colación de San Juan del Mercado. Año

Escritura de foro perpetuo por la qual este monasterio da a Manuel Cantero Romo, vecino de Carrión, un pedazo de solar en la colación de San Juan del Mercado, a las Tenerías, por 4 reales de foro perpetuo. Su fecha, en Carrión, a 30 de abril de 1760, ante Manuel Francisco Blanco, escribano de dicha villa. Y está copia, a 4 de octubre de 1784, ante Ygnacio Gutiérrez, escribano de la misma villa.

Está aquí el reconocimiento que hizo de este foro Zoil Cantero, vecino de dicha villa, a 18 de enero de 1780, ante Martín García Gastón, escribano en dicha villa.

16. <Foro de 4 reales sobre un solar en la calle de la Tejada. Año 1761>.

Escritura de foro perpetuo por la qual este monasterio da a Andrés de la Barga, residente en Renedo, un solar en la calle de la Tejada, por 4 reales de foro perpetuo. Su fecha, en Carrión, a 8 de febrero de 1761, ante Manuel Francisco Blanco, escribano de dicha villa. Y está copia, a $1^{\circ}$ de octubre de 1784, ante Ygnacio Gutiérrez, escribano de la misma villa.

17. $<$ Foro de 2 reales sobre un solar en la calle de la Tejada. Año de 1761>.

Escritura de foro perpetuo por la qual este monasterio da a Santiago Barba, vecino de Carrión, un solar en dicha villa, en la colación de la parroquia de San Andrés y calle de la Tejada, por 2 reales de foro perpetuo cada año. Su fecha, en Carrión, a 8 de febrero de 1761, ante Manuel Francisco Blanco, escribano de dicha villa. Y está copia por Ygnacio Gutiérrez, / (f. 160r) escribano de dicha villa, a 2 de octubre de 1784.

Síguese una escritura de venta que otorgó Matheo Santos y Josefa Pérez, su muger, vecinos de Carrión, a favor de Melchor Merino, del mismo solar hecho corral, a 5 de enero de 1768, ante Antonio de Zeano Vivas, escribano de dicha villa.

$<$ Sentencia a favor de este monasterio sobre el mismo solar $>$.

Vltimamente está aquí un testimonio dado por José Tablares, escribano de Carrión, del pleito que este monasterio tubo sobre el dicho solar en el que, por sentencia dada por don Manuel Carpintero y Eraso, correjidor de dicha villa, declaró al dicho monasterio el dominio directo del terreno contenido en el dicho foro; y condena a Benito Tejo a la paga del referido foro con todo lo devengado; y a la señora Marquesa de Villasante, residente en 
Valladolid, como partes contrarias, a las costas causadas en dicho pleito. Cuya sentencia fue pronunciada a 18 de diciembre de 1800, ante el referido escribano.

18. $<$ Foro de 4 reales sobre un solar en la colación de San Andrés. Año 1770>.

Escritura por la qual este monasterio, después de admitir la cesión de un solar que había dado a foro en la colación de la parroquial de San Andrés a Thomas Herrero, vecino de Carrión, da el mismo solar, para edificar casa, a Francisco Magdaleno, de la misma vecindad, en 4 reales de foro perpetuo. Su fecha, en dicha villa, a 6 de noviembre de 1770, ante Andrés Núñez Castelo, escribano en dicha villa. Y está copia, a 22 de mayo de 1794, ante Ángel Gutiérrez Pérez, escribano de la misma villa.

\section{/ (f.161r) Legajo $4^{\circ}$}

Foros no corrientes en Carrión y San Zoles

Este legajo contiene los papeles pertenecientes a los foros que este monasterio tenía en Carrión y San Zoles, pero en el día no son corrientes, por el orden siguiente:

$1^{\circ}$. $<$ Dos foros, el uno de 5 maravedís y el otro de 47 , sobre una casa con su huerta en San Zoles y sobre unas casas en la colación de San Andrés. Año 1387>.

Escritura de foro perpetuo, en pergamino, por la qual este monasterio da a Francisco Pérez, vecino de Carrión, unas casas con su huerto, linderos: el río mayor y la calle pública, por 5 maravedís de foro perpetuo. Y el mismo Francisco Pérez puso a favor del mismo monasterio otros 47 maravedís de foro perpetuo sobre unas casas suyas, en que él vivía, en la quadrilla de San Andrés. Su fecha, en Carrión, a 15 de abril de 1387, ante Francisco Pérez, escribano en dicha villa. Hay copia authorizada y un reconocimiento, año de 1664.

2. < Foro de 15 maravedís sobre un huerto en San Zoles. Año 1387>.

Escritura de foro perpetuo, en pergamino, por la qual este monasterio da a Pedro García, vecino del barrio de San Zoles, un huerto, lindero: la calle pública, por 15 maravedís de foro perpetuo. Su fecha, en San Zoil, a 20 de octubre de 1387, ante Diego Perea, escribano de Carrión.

3. < Foro de 4 maravedís sobre un suelo en San Zoles. Año 1387>.

Escritura de foro perpetuo, duplicada y escrita en pergamino, por la qual este monasterio da a Toribio Fernández, vecino de San Zoles, un suelo en el mismo barrio, linderos: la calle pública, por 4 maravedís de foro perpetuo. Su fecha, en San Zoil, a 20 de octubre de 1387, ante Diego Pérez, escribano de Carrión.

4. <Foro de 40 maravedís sobre una huerta en San Zoles. Año 1387>.

Escritura de foro perpetuo, en pergamino, por la qual este monasterio da a Simón Díaz Moro, vecino de Carrión, una huerta en el barrio de San Zoles, lindero: la carrera que va al molino del Huerto, por 40 maravedís de foro perpetuo. Su fecha, en San Zoil, a 18 de septiembre de 1387, ante Diego Pérez, escribano de Carrión.

el mismo año.

Está aquí otra escritura, en papel, no authorizada, del mismo foro y hecha en

/ (f.161v) 5. <Foro de 5 maravedís sobre unas casas en Carrión, en el barrio de dentro de Castro. Año 1388>.

Escritura de foro perpetuo, en pergamino, por la qual Antonio Fernández, vecino de Carrión, confiesa que él y otros pagaban al monasterio 50 maravedís de foro perpetuo sobre unas casas en el barrio de San Zoles. Y por quanto el rey (que entonces era don Juan el $1^{\circ}$ ), por la guerra que hubo en el reyno, mandó derribar los barrios de San Zoles, del Mercado y de San Vicente, y el dicho Antonio Fernández había llevado parte de la teja y madera de las referidas casas, puso a favor del monasterio 5 maravedís que le pertenecían de foro perpetuo 
sobre unas casas que él tenía en Carrión, en el barrio de dentro de Castro. Su fecha, en San Zoil, a 25 de abril de 1388, ante Rodrigo Alfonso, notario de Palencia.

6. < Foro de 5 maravedís sobre unas casas en el barrio de la Tejada. Año 1388>.

Escritura de foro perpetuo, en pergamino, por la qual consta que García Fernández, vecino de Carrión, con otros compañeros pagaba a este monasterio 50 maravedís de foro perpetuo situado sobre unas casas en el barrio de San Zoles; y, por haberse derribado el barrio por orden del rey, puso a favor del referido monasterio 5 maravedís que le pertenecían sobre unas casas suyas en que él moraba, en la quadrilla de la Tejada. Su fecha, en San Zoil, a 25 de abril de 1388, ante Rodrigo Alfonso, notario de Palencia.

7. $<$ Foro de 20 maravedís sobre una tierra en San Zoles. Año 1389>.

Escritura de foro perpetuo, en pergamino, por la qual este monasterio da a Alfonso Fernández, vecino de Carrión, una tierra en el barrio de San Zoles, por 20 maravedís de foro perpetuo. Su fecha, en San Zoil, a 29 de agosto de 1389, ante Rodrigo Alfonso, escribano de Carrión.

8. < Foro de 38 maravedís sobre un solar en San Zoles. Año 1392>.

Escritura de foro perpetuo, en pergamino, por la qual este monasterio da a García Fernández, escribano de Carrión, un solar en el barrio de San Zoles, por 38 maravedís de foro perpetuo. Su fecha, en San Zoil, a 12 de enero de 1392, ante Gutiérre Fernández, escribano de Carrión. Hay copia authorizada escrita en pergamino.

9. <Foro de 15 maravedís sobre una tierra en término de Carrión. Año 1393>.

Copia authorizada por Rui González, escribano de Carrión, y escrita en pergamino, de una escritura de foro perpetuo, por la qual el limosnero de San Zoil, con licencia del vicario general de Cluni en España, da a Alfonso Fernández del Pozo, vecino de Carrión, una tierra de 3 obradas, cerca de las viñas de Cestillos, en término de Carrión, por 15 maravedís de foro perpetuo. Su fecha, a 14 de abril de 1393.

/ (f.162r) 10. <Foro de 2 libras de cera sobre una tierra. Año 1397>.

Escritura de foro perpetuo, en pergamino, por la qual el sacristán de San Zoil, con licencia del prior mayor, da a Pedro Fernández, vecino de Carrión, una tierra con ciertas zepas de viña por 2 libras de cera de foro perpetuo cada año. Su fecha, en San Zoil, a 27 de septiembre de 1397, ante Sancho Fernández, escribano de Carrión.

11. <Foro de 25 maravedís sobre una herrén a Sobrepeña. Año 1401>.

Escritura de foro perpetuo, en pergamino, por la qual este monasterio da a Gonzalo Fernández de San Zoles una herrén a Sobrepeña por 25 maravedís de foro perpetuo. Su fecha, en Carrión, a 19 de enero de 1401, ante Francisco Pérez, escribano de Carrión.

Esta herrén la donó a este monasterio Fernando González de la Varguilla, como consta de una cláusula de testamento que está en este cajón, legajo $1^{\circ}$, número 9.

12. $<$ Foro de 20 maravedís sobre una tierra a Prado Fierro. Año de 1403>.

Escritura de foro perpetuo, en pergamino, por la qual este monasterio da a Pedro Mateo, vecino y morador de San Zoles, una tierra en la vega de Carrión, a Prado Fierro, por precio de 20 maravedís de foro perpetuo. Su fecha, en San Zoil, a 20 días de febrero, año de 1403, ante Gutierre Fernández, escribano de Carrión,

13. <Foro de 18 maravedís y una gallina sobre unas casas en San Zoles. Año 1403>.

Escritura de foro perpetuo, en pergamino, por la qual este monasterio da a Juan Dent y a María Ferrández, su muger, moradores en el barrio de San Zoles, unas casas en el dicho barrio, por 18 maravedís y una gallina de foro perpetuo. Su fecha, en San Zoil, a 12 de enero de 1403, ante Gómez García de Saldaña, escribano en Carrión. 
14. <Foro de 16 maravedís sobre una tierra en Carrión. Año 1405>.

Escritura de foro perpetuo, en pergamino, por la qual este monasterio da a Pedro de Villamuera y a Juan, su hermano, vecinos de Carrión, una tierra en término de dicha villa, que ha por linderos: la carrera que va a Palencia y carrera que va a Santa María de Villasirga, por 16 maravedís de foro perpetuo. Su fecha, en San Zoil, a 6 de diciembre de 1405, ante Francisco Pérez, escribano de Carrión.

15. < Foro de 7 maravedís sobre una pradera en San Zoles. Año 1405>.

Escritura de foro perpetuo, en pergamino, por la qual este monasterio da a Ferrando Ybáñez, vecino de Carrión, una pradera que es cerca de la salceda del dicho monasterio, que ha por linderos: la huerta de la Limosna, el Cuérnago y la Huelga, por 7 maravedís de foro perpetuo. Su fecha, en San Zoil, a 13 de marzo de 1405, ante Francisco Pérez, escribano de Carrión.

16. $<$ Foro de 80 maravedís sobre el huerto de don Galindo. Año de 1405>.

Escritura de foro perpetuo, en pergamino, por la qual este monasterio da a Alfonso Cavallero, vecino de Carrión, una tierra el (sic) los huertos de dicha villa, que se llama Huerto de don Galindo, que ha por linderos: la Huelga y el Río Mayor, por 80 maravedís de foro perpetuo. Su fecha, en San Zoil, a 21 de abril de 1405, ante Francisco Pérez, escribano de Carrión.

Está aquí un requirimiento que hizo este monasterio a Alfonso Ordóñez, hortelano, para que dejase libre la dicha huerta por pertenecerle a este monasterio. No tiene fecha.

17. $<$ Foro de 5 maravedís sobre una tierra. Año 1407>.

Escritura de foro perpetuo, en pergamino, por la qual este monasterio da a Alfonso Rodríguez, hortelano, vecino de Carrión, una tierra en dicho tér/ $(f .162 v)$ mino por 5 maravedís de foro perpetuo. Su fecha en San Zoil a 28 de diciembre de 1407, ante García Fernández, escribano de Carrión. Hay copia authorizada.

18. <Foro de 40 maravedís sobre unas casas en la Barguilla. Año 1409>.

Escritura de foro perpetuo, en pergamino, por la qual este monasterio da a Juan Martínez, monge de este monasterio, unas casas en Carrión, en el barrio de la Barguilla, por 40 maravedís de foro perpetuo. Su fecha, en San Zoil, a $1^{\circ}$ de marzo de 1409 años, ante Rodrigo Alfonso, escribano en Carrión. Hay copia authorizada.

19. < Foro de 20 maravedís y una gallina sobre unas casas en Carrión. Año 1415>.

Escritura de foro perpetuo, en pergamino, por la qual este monasterio da a Pedro García de Robradillo, vecino de Carrión, unas casas en dicha villa, a do dicen a Valera, por 20 maravedís y una gallina de foro perpetuo. Su fecha, en Carrión, a 21 de marzo de 1415, ante Gutierre Fernández, escribano de Carrión.

20. < Foro de 6 maravedís sobre una tierra a Paramillo de Ferreros. Año 1416>.

Escritura de foro perpetuo, en pergamino, por la qual este monasterio da a Juan de Ralea, vecino de Carrión, una tierra en término de Ferreros, a do dicen a Paramillo, por 6 maravedís de foro perpetuo. Su fecha, en San Zoil, a 16 de agosto de 1416, ante Gómez García de Saldaña, escribano de Carrión.

Esta escritura está multiplicada y sacada en mismo día, mes y año, y signada del mismo escribano.

21. < Foro de 9 maravedís sobre un solar en San Zoles. Año 1416>.

Escritura de foro perpetuo, en pergamino, por la qual este monasterio da a Juan de Calzadilla, vecino de Carrión, un solar en el barrio de San Zoles, lindero: el Camino Francés, por 9 maravedís de foro perpetuo. Su fecha, en San Zoil, a 16 de marzo de 1416, ante Ferrand Rodríguez de Castellanos, escribano de Palencia. 
22. < Foro de 130 maravedís sobre una tierra en San Zoles. Año 1417>.

Escritura de foro perpetuo, en pergamino, por la qual este monasterio da a Alfonso Fernández Gallego, vecino de Carrión, una tierra en el barrio de San Zoles, linderos: la Clavera y la calle pública, por 130 maravedís de foro perpetuo. Su fecha, en San Zoil, a 14 de enero de 1417, ante Gómez García de Saldaña, escribano de Carrión.

Hay dos copias authorizadas desta misma escritura.

23. <Foro de 6 maravedís sobre unas casas y solar en San Zoles. Año 1418>.

Escritura de foro perpetuo, en pergamino, por la qual este monasterio da a Gonzalo Fernández, cappellán de San Andrés, unas casas y solar en el barrio de San Zoles, linderos: huerta de la dicha capellanía y el Camino Francés, por 6 maravedís de foro perpetuo. Su fecha, en San Zoil, / (f.163r) a 2 de abril de 1418, ante Ferrando Rodríguez de Castellanos, esribano y notario de Palencia.

24. < Foro de 140 maravedís sobre una tierra en San Zoles. Año 1418>.

Escritura de foro perpetuo, en pergamino, por la qual este monasterio da a Alfonso García Garzón, vecino de Carrión, una tierra cerca del molino del Huerto, linderos: las carreras que van de Carrión a Torre y de Carrión a Calzada y al Cuérnago, por 140 maravedís de foro perpetuo y con condición de que la ha de regar como se riegan las otras tierras del monasterio. Su fecha, en San Zoil, a 2 de agosto de 1418, ante Fernando Rodríguez de Castellanos, escribano y notario de Palencia.

25. < Foro de 25 maravedís sobre una tierra en la vega de Carrión. Año 1419>.

Escritura de foro perpetuo, en pergamino, por la qual este monasterio da a Juan Fernández de Relea, vecino de Carrión, una tierra en la vega de dicha villa, a Castro Calzada, lindero: la carrera que va de Carrión a dicha villa, por 25 maravedís de foro perpetuo. Su fecha, en San Zoil, a 9 de abril de 1419, ante Fernando Rodríguez de Castellanos, escribano de Palencia.

Hay copia authorizada, en pergamino, sacada en mismo día, mes y año, y por el mismo escribano. $1419>$.

26. <Foro de 140 maravedís sobre 4 pedazos de tierra en la vega de Carrión. Año

Escritura de foro perpetuo, en pergamino, por la qual este monasterio da a Francisco Sánchez, vecino de Carrión, cuatro pedazos de tierra en la vega de dicha villa: uno encima del monasterio, que ha por linderos: la Salceda, el Cuérnago y el Río Mayor; y los otros tres pedazos en los huertos de Carrión, linderos: el molino de la Tapia y la carrera que va de dicha villa a Ferreros, por 140 maravedís a foro perpetuo. Su fecha, en San Zoil, a 6 de septiembre de 1419, ante Ferrando Rodríguez de Castellanos, escribano de Palencia.

27. <Foro de 70 maravedís sobre la huerta y casa de Orbaneja. Año 1421>.

Escritura de foro perpetuo, en pergamino, por la qual este monasterio da a Pedro García Truchero, vecino de Carrión, una huerta que se dice de Orbaneja con su casa en la vega de la dicha villa, lindero: huerta del monasterio de Benevivere, por 70 maravedís de foro perpetuo. Su fecha, en San Zoil, a 21 de diciembre de 1421, ante Ferrando Rodríguez de Castellanos, escribano de Palencia.

Este foro parece que se vendió al abad y cofrades de la O. Año de 1584, ante Andrés Sánchez, escribano de Carrión.

28. <Foro de 40 maravedís sobre una casa y corral en San Zoles. Año 1421>.

Escritura de foro perpetuo, en pergamino, por la qual este monasterio da a Alfonso Doncel, carnicero, vecino de Carrión, una / (f.163v) casa sin techo y un corral cercado de tapias en el barrio de San Zoles, lindero: el Camino Francés, por 40 maravedís de foro perpetuo. Su fecha, en San Zoil, a 6 de otubre de 1421, ante Ferrando Rodríguez de Castellanos, escribano de Palencia. 
29. <Foro de 6 maravedís sobre una herrén en San Zoles. Año 1421>.

Escritura de foro perpetuo, en pergamino, por la qual este monasterio da a Ferrando Alfonso Bueno, vecino de Carrión, una herrén en el barrio de San Zoles, linderos: la calle que viene desde el puente mayor al monasterio y el sendero que viene desde la misma puente al referido monasterio, por 6 maravedís de foro perpetuo. Su fecha, en San Zoil, a 9 de octubre de 1421, ante Ferrando Rodríguez de Castellanos, escribano de Palencia.

Está aquí la escritura de venta que de la misma herrén otorgó el referido Ferrando Bueno a Juan de Toledo, ferrador, con la carga de los 6 maravedís a favor del mismo monasterio. Año de 1426, ante Alfonso Fernández, escribano de Carrión.

\section{0. < Foro de 30 maravedís sobre una herrén en San Zoles. Año 1422>.}

Escritura de foro perpetuo, en pergamino, por la qual este monasterio da a Juan de Toledo, vecino de Villavega, una herrén cerca deste monasterio, lindero: la calle que viene de la puente mayor al referido monasterio, por 30 maravedís de foro perpetuo. Su fecha, en San Zoil, a 8 de julio de 1422, ante Ferrando Rodríguez de Castellanos, escribano de Palencia. Está multiplicada. $1423>$.

31. <Foro de 160 maravedís sobre 3 pedazos de tierra en la vega de Carrión. Año

Escritura de foro perpetuo, en pergamino, por la qual este monasterio da a Juan Merlín, ferrador, vecino de San Zoles, tres pezados de tierra, el uno a carrera de Villamez, y los otros dos pedazos en la vega de Carrión, por 160 maravedís de foro perpetuo $<y 2$ gallinas $>$. Su fecha, en San Zoil, a 19 de noviembre de 1423, ante Ferrando Rodríguez de Castellanos, escribano de Palencia. Hay copia authorizada.

32. <Traspasación de 3 maravedís sobre la mitad de unas casas. Año 1425>.

Traspasación que hizo Juan Fernández, clérigo de Santa María, de 3 maravedís de foro perpetuo que tenía este monasterio sobre una viña en término de Cestillos, en la mitad de unas casas en Carrión, cerca de la Calleja Vieja, por haber vendido la dicha viña libre de foro. Su fecha, en Carrión, a 27 de enero de 1425, ante Ferrando García de la Serna, escribano de dicha villa.

33. < Foro de 210 maravedís sobre dos tierras y una herrén en Carrión. Año 1425>.

Escritura de foro perpetuo, en pergamino, por la qual este monasterio da a Juan de Toledo, ferrador, vecino de Villavega, dos tierras y una herrén en término de Carrión: la una, lindero: la Car/ (f.164r)rera Vieja y la carrera que va a Calzada; y la otra tierra y herrén, linderos del Camino Francés y el camino que va a Villamez, por 210 maravedís de foro perpetuo. Su fecha, en San Zoil, a 16 de agosto de 1425, ante Rui García, escribano de Carrión. Hay copia authorizada.

34. <Traspaso de 8 maravedís sobre la mitad de unas casas en Carrión. Año 1427>.

Traspaso que hizo Pedro Fernández de Lerones, vecino de Carrión, de 8 maravedís de foro perpetuo que tenía este monasterio sobre una tierra en término de Cestillos, en la mitad de unas casas en Carrión, al barrio de la Calleja Vieja, por no poder labrar la dicha tierra. Su fecha, en San Zoil, a 8 de agosto de 1427, ante Rui García, escribano de Carrión.

35. <Traspaso de 20 maravedís de foro en unas casas en Carrión. Año 1428>.

Traspaso que hicieron Juan Fernández Blanco y Fernando Sánchez de Población, vecinos de Carrión, de 20 maravedís y una gallina de foro perpetuo que este monasterio tenía sobre un solar de casas en Carrión, en la calle de la Barguilla, en otras casas que los referidos tenían en dicha villa, las unas en el barrio de dentro Castro y las otras en el barrio de la Ferrería. Su fecha, en San Zoil, a 25 de marzo de 1428, ante Ferrando Rodríguez de Castellanos, escribano de Palencia.

36. < Foro de 20 maravedís sobre un pedazo de tierra a Ferreros. Año de 1428>.

Escritura de foro perpetuo, en pergamino, por la qual este monasterio da a Hamete, moro, vecino de Villavega, un pedazo de tierra, carrera Ferreros, cerca del molino de la tapia, 
linderos: el Cuérnago y el aventadero de dicho molino, por 20 maravedís de foro perpetuo. Su fecha, en San Zoil, a 15 de septiembre de 1428, ante Ferrando Rodríguez de Castellanos, escribano de Palencia.

\section{7. <Foro de 70 maravedís sobre unas casas en Carrión. Año 1434>.}

Escritura de foro perpetuo, en pergamino, por la qual este monasterio da a García Alfonso, vecino de Carrión, unas casas con su corral en dicha villa, al barrio de la Barguilla, por 70 maravedís de foro perpetuo. Su fecha, en San Zoil, a 15 de enero de 1434, ante Alfonso Fernández, escribano de Carrión.

38. < Foro de 12 maravedís sobre una tierra en la Vega. Año 1447>.

Escritura de foro perpetuo, en pergamino, por la qual este monasterio da a Pedro Fernández de San Zoles, vecino de Carrión, una tierra que llaman del Moro, junto al monasterio de Benevivere, linderos: la huelga de los exidos de la abadía, por 12 maravedís de foro perpetuo. Su fecha, en San Zoil, a 4 de febrero de 1447, ante Álvaro González, escribano de Carrión.

39. <Foro de 3 maravedís sobre un huerto en San Zoles. Año 1448>.

Escritura por la qual Gonzalo Fernández, arcipreste de la Oxeda, da a Alfonso de Vado, vecino de Carrión, un huerto en el barrio / (f.164v) de San Zoles, con la pensión de pagar a este monasterio 3 maravedís de foro perpetuo. Su fecha, en Carrión, a 18 de junio de 1448, ante García Fernández de San Zoles, escribano de Carrión. Año 1449>.

40. $<$ Foro de 10 maravedís sobre un solar que fue tabla de partir carne en Carrión.

Escritura de foro perpetuo, en pergamino, por la qual este monasterio da a Pedro López, moro, vecino de Carrión, un suelo en dicha villa, que fue tabla de carnicería, por 10 maravedís de foro perpetuo. Su fecha, en San Zoil, a 10 de diciembre de 1449, ante Álvar González de Carrión, escribano de dicha villa. Hay copia authorizada.

También está aquí la escritura de venta que $<$ de $>$ dicha tabla de cortar carne otorgó Señorina Alfonso a Alfonso Sánchez, carnicero, con la carga de los 10 maravedís de foro perpetuo a favor deste monasterio. Año de 1424, ante Juan de la Caba, escribano de Carrión.

Vltimamente se halla aquí un testimonio dado por Norberto Sandoval y Guevara, escribano de Carrión, de un requirimiento que se hizo a Thomás Vallejo para que pagasen 90 maravedís que debía de atrasos del dicho foro. Su fecha, en Carrión, a 11 de diciembre de 1662.

41. $<$ Foro de 70 maravedís y 3 gallinas sobre 2 solares y una tierra y herrén en San Zoles. Año 1451>.

Escritura simple de foro perpetuo, por la qual este monasterio da a Ruy López Catalán, vecino de San Zoles, dos solares y una tierra herrén en dicho barrio por 70 maravedís y 3 gallinas de foro perpetuo. Su fecha, en San Zoil, a 27 de septiembre de 1451, ante Fernando García Pachistre, escribano de Carrión ${ }^{269}$.

Estos solares y herrén los posee el monasterio por cesión que hizo don Diego García de la Llana, por escritura que se otorgó año de 1417, ante Agustín García, escribano de Carrión, como consta del libro de misas de 1701 que está en el estante de fuera de este archivo.

42. < Foro de 15 maravedís sobre unas casas en Carrión. Año 1451>.

Escritura de foro perpetuo, en pergamino, por la qual consta que este monasterio, haviendo dado a Pedro Fernández de San Zoles la tierra que llaman del Moro (como consta del número 38 deste legajo) por 12 maravedís de foro perpetuo y con la condición de no poderla vender ni enagenar, por esta escritura se le deja esenta y libre. Y él, en recompensa y satisfacción, da al monasterio 3 maravedís más de foro, que en todo son 15, que los sitúa en

${ }^{269}$ Carrión] al margen derecho: Nota. 
unas casas suyas en Carrión que están a la Puentecilla, cerca de la yglesia de Belén, y asimismo da una tierra en término de dicha villa, a do dicen a Acedillo, de 3 obradas, lindero: el arroyo de Río Mediano. Su fecha, en San Zoil, a 26 días defebrero de 1451, ante Álvar González de Carrión, escribano en dicha villa.

43. <Traspaso de 10 maravedís en una herrén. Año 1452>.

Traspaso que hicieron Mayor Alfonso e Ysabel González de 10 maravedís de foro perpetuo que este monasterio tenía sobre un mesón en el barrio de San Zoles, en una hera al camino de San Pedro, lindero: la / (f.165r) carrera que va a la Torre del Requejo. Su fecha, en Carrión, a 25 de septiembre de 1452, ante Juan García de la Rúa, escribano de Carrión. $1453>$.

44. $<$ Foro de 12 maravedís y medio y media blanca sobre un suelo en San Zoles. Año

Escritura escrita en pergamino por la qual Cathalina Sánchez y Teresa, su hermana, vecinas de Palencia, venden a Blas Caminero, vecino de San Zoles, un suelo de casas en el dicho barrio, con la carga de 12 maravedís y medio y media blanca que sobre el dicho suelo tenía este monasterio. Su fecha, en San Zoles, a 14 de abril de 1453, ante Gómez González, escribano de Carrión.

45. < Traspaso de 6 maravedís en una tierra en Carrión. Año 1456>.

Traspaso que hizo Cathalina García, vecina de Carrión, de un foro de 6 maravedís que este monasterio tenía sobre unas casas en el barrio de San Pedro, en una tierra de 2 obradas, a la fuente de los Olmos, en término de dicha villa. Su fecha, en San Zoil, a 25 de enero de 1456, ante Álvar González, escribano de Carrión. Hay copia authorizada.

46. <Foro de 6 maravedís sobre un suelo en San Zoles. Año 1475>.

Escritura de venta, en pergamino, por la qual Lope de Ávila, vecino de San Zoles, vende a Mahoma Ginete, moro, vecino de dicho barrio, un pedazo de un suelo de una huerta y casas, con la carga de 6 maravedís de foro perpetuo que sobre él tenía este monasterio. Su fecha, en San Zoles, a 26 de abril de 1475, ante Fernando Cavallo, escribano de Carrión.

47. < Foro de 6 maravedís sobre un solar en San Zoles. Año 1476>.

Escritura de venta, en pergamino, por la qual Lope de Ávila, vecino de San Zoles, vende a Rodrigo Baynero un pedazo de solar en dicho barrio, con la carga de 6 maravedís de foro perpetuo que sobre él tenía este monasterio. Su fecha, en San Zoil, a 30 de julio de 1476, ante Fernando Cavallo, escribano de Carrión.

48. < Sentencia a fabor deste monasterio de 200 maravedís sobre unas casas a Sobrepeña. Año 1484>.

Sentencia dada por Juan Ruiz de Colmenares, arcipreste de Carrión y comendador del Hospital de don Gonzalo, por la qual condena a María García, muger de Diego Treceño, y Alonso de San Mamés, su sobrino, a que paguen 200 maravedís de foro perpetuo que este monasterio tenía sobre unas casas en que ellos vivían, que fueron de la legítima de don Luis de la Barguilla, y están cerca de Sobrepeña, linderos: casas del monasterio de Benevivere y la ronda que va de Sobrepeña. Su fecha, en Carrión, a 20 de julio de 1484, ante Fernando Cavallo, escribano de Carrión. $1648>$.

49. $<$ Redención de 500 maravedís por 500 reales a favor deste monasterio. Año

Traspaso que hizo Fernando de Madrid, vecino de Palencia, a Juan de la Torre y a su muger, vecinos de Carrión, de 500 maravedís que él tenía sobre unas casas en Carrión, a la Puerta del Canto, por las dos terci(ci)as partes de las casas y mesón que ellos tenían en el barrio de San Zoles. Su fecha, en Carrión, a 16 de noviembre de 1485, ante Pedro San Zoles, escribano de dicha villa.

Este foro tenía el monasterio / $(f .165 v)$ a su fabor y lo redimió el licenciado Miguel Ortiz, cura de dicha villa, con 500 reales de vellón, como consta de la licencia del general e información que se hizo para admitir la redemción de dicho foro que está aquí, aunque no 
hay otros papeles que lo acrediten. Redimiose en 13 de febrero de 1648, ante Francisco Moro de Saldaña, escribano de Carrión.

50. <Foro sobre una huerta en San Zoles. Año 1486>.

Escritura de foro perpetuo, por la qual Mencía Álvarez, muger de Diego Álvarez de Monterroso, vecina de Carrión, da a Rodrigo Alcaller, vecino en el barrio de San Zoles, una huerta en dicho barrio, linderos: la calle pública y al Clavera, por 500 maravedís y un par de gallinas; y con la carga de otro foro (no dice el precio) que sobre la dicha huerta tenía este monasterio. Su fecha, en Carrión, a 3 de abril de 1486, ante Pedro de San Zoles, escribano de dicha villa; y este traslado fue sacado por Hernán Gómez de Linares, escribano de dicha villa, a 3 de marzo de 1514.

51. <Foro sobre una huerta en San Zoles. Año 1487>.

Escritura de venta por la qual Martín Laso de la Vega, vecino de Carrión, vende a Lope Ras, vecino del barrio de San Zoles, una huerta en dicho barrio , lindero: la calle que va al Huerto, con la carga del foro que sobre ella tiene qualquier yglesia o monasterio. No hace mención de San Zoil ni dice más que esto. Su fecha, en Carrión, a 26 de noviembre de 1487, ante García Fernández de San Zoles, escribano de dicha villa.

52. < Foro de 21 maravedís sobre unas casas en San Zoles. Año 1489>.

Sentencia árbitra por la qual Juan de Berrio, vecino de Carrión, juez árbitro, manda que se pague al monasterio 21 maravedís y medio de foro perpetuo que le pertenecían sobre unas casas que García Pachistre, vecino de Carrión, tenía en el barrio de San Zoles. Fue dada esta sentencia en Carrión, a 27 de julio de 1489, ante Fernando Cavallo, escribano de dicha villa.

53. <Foro de 23 maravedís sobre unas casas en San Zoles. Año 1490>.

Escritura de venta, en pergamino, por la qual Pedro García y María Fernández, su muger, vecinos de San Zoles, venden a Alfonso Fernández de San Vicente unas casas en dicho barrio, con la carga de 23 maravedís de foro perpetuo a fabor deste monasterio; los 8 maravedís de la moneda vieja y los 15 de la moneda que se usare al tiempo de las pagas. Su fecha, en Carrión, a 29 de julio de 1490, ante Francisco Pérez, escribano de dicha villa. Hay copia authorizada.

\section{4. < Foro de 40 maravedís sobre una tierra huerta en San Zoles. Año 1498>.}

Escritura por la qual Juan Martín de Villanueba del Río, vecino de Carrión, sitúa 40 maravedís de foro perpetuo a fabor de este monasterio sobre un[a] tierra huerta junto al molino de la Tapia, de una quarta de obrada, con los que dotó Gonzalo Pérez de Moslares un aniversario ${ }^{270}$ en cada año que ha de decir el monasterio el día de San Bartholomé. Su fecha, en Carrión, a 25 de octubre de 1498, ante Fernando Cavallo, escribano de dicha villa.

/ (f.166r) 55. <Traspaso de 30 maravedís de foro en unas casas bajo la cuesta del Trigo. Año 1498>.

Traspaso que hizo Pedro García de Minañes, bachiller de la gramática de Carrión, de 30 maravedís de foro perpetuo que este monasterio tenía sobre un solar en unas casas suyas que llamaban la Escuela, en la quadrilla de la Tejada de la Cuesta del Trigo, por razón de que este monasterio le dio el dicho solar que estaba contiguo a las referidas casas. Su fecha, en San Zoil, a 18 de enero de 1498, ante Fernando Cavallo, escribano de Carrión. Año 1500>.

56. $<$ Foro de 20 maravedís y gallina y media de foro sobre una huerta en San Zoles.

Escritura de venta por la qual Ysavel de San Zoles, vecina de Calzada, vende a Juan de Villasaña, vecino del barrio de San Zoles, una huerta con sus corrales en el dicho barrio, con carga de 20 maravedís y gallina y media de foro perpetuo que sobre la dicha huerta tenía

270 aniversario] al margen derecho: Aniversario. 
este monasterio. Su fecha, en Calzada; a 18 de febrero de 1500, ante Juan de San Zoles, escribano de Carrión. $1501>$.

57. <Foro de 100 maravedís sobre unas casas en el barrio de Santa Olalla. Año

Escritura de foro perpetuo, en pergamino, por la qual Juan de la Parra, vecino de Carrión, puso a fabor de este monasterio 100 maravedís de foro perpetuo sobre unas casas suyas en el barrio de Santa Olalla, por 2000 maravedís que este monasterio le dio. Su fecha, en San Zoil, a 8 de noviembre de 1501, ante Alonso Guadiana, escribano de Carrión.

58. < Foro de 50 maravedís sobre una tierra en Carrión. Año 1501>.

Escritura de foro perpetuo, en pergamino, por la qual Maribuesa, vecina de Carrión, pone a fabor de este monasterio 50 maravedís de foro perpetuo sobre una tierra en término de dicha villa, a do dicen a la Veguilla de Calzada, de media obrada, poco más o menos, por 1000 maravedís que el referido monasterio la dio. Su fecha, en San Zoil, a 4 de octubre de 1501, ante Alonso Guadiana, escribano de dicha villa. $1501>$.

59. < Foro de 150 maravedís sobre unas casas en el barrio de Santa Olalla. Año

Escritura de foro perpetuo por la qual Thoribio de Menbrillar, vecino de Carrión, pone y sitúa a fabor deste monasterio 150 maravedís de foro perpetuo sobre unas casas suyas en dicha villa, en el barrio de Santa Olalla, por 3 mill maravedís que el referido monasterio le dio. Su fecha, en Carrión, a 9 de diciembre de 1501, ante García de Avia, escribano de dicha villa.

60. $<$ Foro de 50 maravedís sobre unas casas en Carrión. Año 1504>

Escritura de venta por la qual Diego Ortegón, vecino de Carrión, vende a Fernando de Balderrábano, unas casas con su corral en dicha villa, a Sobrepeña, con carga de 70 maravedís de foro perpetuo; los 50 a fabor de este monasterio y los 20 restantes a fabor de los 20 clérigos de Carrión. Su fecha, en Carrión, a 20 de abril de 1504, ante Rui Fernández de Grijalba, escribano de dicha villa.

Está aquí la posesión que de dichas casas tomó el referido Fernando de Balderrábano, en 25 de junio del mismo año, y ante el mismo escribano.

61. < Foro de 400 maravedís sobre unas casas en la Plaza de San Andrés. Año 1507>.

Escritura de foro perpetuo, por la qual Pedro Alfonso de la Plaza, vecino / (f.166v) de Carrión, vende a Juan de la Torre 400 maravedís de foro perpetuo situado sobre unas casas suyas en dicha villa, en la Plaza de San Andrés. Por esta escritura consta que Juan de la Torre vendió el dicho foro a Diego Diez de Rojas por 10 mill maravedís; y inserta en esta escritura está la venta que el referido Rojas hizo a este monasterio del dicho foro y por el mismo precio. Su fecha, en San Zoil, a 22 de abril de 1507, ante Francisco Catalán, escribano de Carrión. Síguense los autos formados contra el referido Diego Díez de Rojas por 3.600 maravedís de los réditos corridos de 9 años sobre la paga de dicho foro, que pasaron ante Gerónimo Laso, escribano de Carrión ${ }^{271}$.

${ }^{271}$ Carrión] sigue tachado: 62. <Foro de 600 maravedís sobre una casa, mesón y huerta cerca del Puente de esta villa. Año $1511>$.

Bajo este número está una escritura de foro perpetuo, por la qual Gregorio Ponce, vecino de Carrión, da a Pedro Sedeño, vecino de San Zoles, 2.150 maravedís de foro perpetuo sobre unas casas, mesón y huerta, cerca de la Puente de dicha villa, linderos: las calles públicas; con la carga de 600 maravedís de foro perpetuo que sobre ellas tenía el monasterio. Su fecha, en Carrión, a 11 de abril de 1511, ante Juan de Roxas, escribano de Carrión.

Síguese la execución que, a petición de este monasterio, <se hizo $>$ contra Miguel Ponce, Pedro Sedeño, sus hijos y herederos, por 6.800 maravedís de los corridos de dos foros, el uno de 200 maravedís y el otro de 600. Parece que Julián Ponce, curador de los hijos de Gregorio Ponce, por recompensa de los 600 maravedís de foro que el monasterio tenía sobre esta y otra casa, porque los menores no podían pagar, la cedió 

$1518>$.

62. < Foro de 70 maravedís sobre una casa huerta y palomar en San Zoles. Año

Escritura de venta por la qual Álvaro Arrayaz, vecino de San Zoles, vende a Diego de Olea de Reynoso una casa con su huert $<\mathrm{a}>$ y palomar en el dicho barrio, linderos: el Cuérnago y calle pública, con la carga de 70 maravedís de foro perpetuo que sobre ella tenía este monasterio. Su fecha, en Carrión, a 15 de diciembre de 1518, ante Alonso Gómez de San Román, escribano de dicha villa.

Está aquí la posesión que de dicha casa tomó el referido Diego de Olea ante Juan de Castrillo, escribano de dicha villa.

63. < Foro de 68 maravedís sobre un suelo en San Zoles. Año 1519>.

Escritura de foro perpetuo, por la qual este monasterio da a Alonso Oro, vecino de Carrión, un suelo en el barrio de San Zoles, linderos: de las dos partes el Camino Francés y el camino que va a Villamez y Villaturde, por 68 maravedís de foro perpetuo. Su fecha, en San Zoil, a 23 de mayo de 1519, ante Floristán de la Serna, escribano de Carrión.

64. $<$ Reconocimiento de un foro de 80 maravedís sobre unas casas y huerta en San Zoles. Año 1524>.

Escritura de reconocimiento, por la qual Diego de Olea Reynoso, vecino de Carrión, se obliga a pagar 80 maravedís y 4 gallinas de foro perpetuo que este monasterio tenía sobre unas casas y huerta en el barrio de San Zoles, / (f.167r) linderos: de una y otra parte, las calles y camino que ban al dicho monasterio. Su fecha, en San Zoil, a 29 de agosto de 1524, ante Floristán de la Serna, escribano de Carrión.

Este mismo día, mes y año y ante el mismo escribano este monasterio hizo gracia y donación al referido Diego de Olea, por su vida solamente, de las dichas 4 gallinas.

65. <Foro de 417 maravedís y 2 gallinas sobre unas casas en Carrión, calle de la Tejada. Año 1527>.

Escritura de foro perpetuo, en pergamino, por la qual este monasterio da a Thorivio del Campo, vecino de Carrión, unas casas con su corral en dicha villa, en la calle de la Tejada, lindero: casa y cueva del dicho monasterio, y entra un pedazo de la cueva por debajo de la dicha casa, por 485 maravedís y 2 gallinas de foro perpetuo. Su fecha, en San Zoil, a 8 de noviembre de 1525 .

Desta escritura reclamó el monasterio porque le abían faltado las solemnidades y licencias del General, por lo que se comprometió en un letrado, el qual mandó que de la dicha casa aforada se quedase para el monasterio una sala que estaba sobre la bodega que allí tenemos, y que de allí adelante sólo pagasen de foro 417 maravedís y las 2 gallinas, como consta de la nueba escritura de foro inserta aquí, que fue otorgada en San Zoil, a 9 de octubre de 1527, ante Francisco Catalán, escribano de Carrión.

66. <Foro de un real sobre una tierra en la Vega, a carre el Abadía. Año 1546>.

Escritura de venta, por la qual Luisa de Saldaña, vecina de Carrión, vende a Francisco Roxo, vecino de dicha villa, una tierra en la Vega, de 2 obradas, poco más o menos, camino de carre el Abadía, que ha por linderos: tierra del Hospital de la Herrada y el Camino Real, con la carga de 1 real de foro perpetuo que sobre ella tenía este monasterio. Su fecha, en Carrión, a 26 de diciembre de 1546, ante Juan Alonso, escribano de dicha villa.

Está aquí la execución que a petición deste monasterio se hizo contra don Manuel de Castañeda, rexidor de Carrión, actual poseedor de dicha tierra, por 1.558 maravedís de los

\footnotetext{
al monasterio, cuya escritura de cesión falta deste archibo, que fue otorgada en San Zoil, a 30 de enero de 1534, ante Juan de Castrillo, escribano de Carrión.

Al margen: Nota. Este ynstrumento se puso en el legajo 2 deste Cajón, con los demás papeles pertenecientes a esta casa mesón y el troque que últimamente se hizo con los curas de la yglesia de Santiago, año de 1658, en el número 11, Quaderno B.
} 
corridos de dicho foro. A 22 de octubre de 1689, ante Norberto Sandoval y Guevara, escribano de Carrión.

67. < Foro de 32 maravedís sobre una casa en Carrión. Año 1562>.

Sentencia dada por el licenciado Francisco de Busto, teniente de corregidor de Carrión, por la qual condena a Juan de Torres, vecino de dicha villa, a que pague 32 maravedís de foro perpetuo que este monasterio tenía sobre un corral y una casa que se llamaba el Estudio Viejo; y además 192 maravedís de atrasos del dicho foro. Su fecha, en Carrión, a $1^{\circ}$ de septiembre de 1562, ante Andrés Sánchez, escribano de dicha villa.

68. <Foro de 15 reales sobre unas casas y un suelo en San Zoles. Año 1569>.

Escritura de foro perpetuo con sus tres tratados y licencia del General, por la qual este monasterio da a Alonso Garzón, vecino del barrio de San Zoles, unas casas junto a la Puente y un suelo hecho corral en el dicho barrio, por 15 reales de foro perpetuo. Su fecha, en San Zoil, a 21 de abril de 1569, ante Andrés Sánchez, escribano de Carrión.

Esta escritura está duplicada y authorizada.

69. < Foro de 375 maravedís y 2 gallinas sobre unas casas en San Zoles. Año 1570>.

Escritura de foro perpetuo con sus tres tratados y licencia del General, / (f.167v) por la qual este monasterio da a Alonso Gutiérrez, vecino del barrio de San Zoles, unas casas en dicho barrio, lindero: la calle y plaza pública, cave el molino del Huerto, por un ducado (que vale 375 maravedís) y 2 gallinas de foro perpetuo. Su fecha, en San Zoil, a 21 de mayo de 1570, ante Andrés Sánchez, escribano de Carrión.

70. <Foro de real y medio sobre un suelo en Carrión. Año 1572>.

Escritura de foro perpetuo, por la qual este monasterio da a Julián Baýllo, vecino de Carrión, un suelo en dicha villa, en la parroquia de Santa Olalla, por real y medio de foro perpetuo. Su fecha, en San Zoil, a 11 de enero de 1572, ante Andrés Sánchez, escribano de dicha villa.

71. <Foro de 425 maravedís y 2 gallinas sobre una casa en San Zoles. Año 1601>.

Escritura de venta, por la qual Thomás Pérez y María Sánchez, su muger, vecinos de Carrión, venden a Juan de Cisneros una casa en el barrio de San Zoles, con la carga de 425 maravedís y 2 gallinas de foro perpetuo que sobre ella tenía este monasterio. Su fecha, en Carrión, a 16 de diciembre de 1601, ante Diego Arias de Miranda, escribano de dicha villa; y este traslado fue sacado por Laurencio López, escribano, a petición de Juan de Cisneros y por mandamiento de la justicia, año 1617.

72. < Execución por un foro sobre unas casas y huerta en San Zoles. Año 1615>-

Execución pedida por este monasterio contra Lope Rufiano y Ana Rodríguez, su muger, vecinos de Carrión, por 2.700 maravedís, de los corridos de un foro que tenía este monasterio sobre unas casas con su huerta. Su fecha, en Carrión, a 9 de enero de 1615, ante Francisco Moro de Saldaña. A esta execución se opuso Domingo Brabo, en nombre de Antonio Boon, a quien el señor corregidor por su auto acusó la reveldía; y desto no consta más.

73. $<$ Reconocimiento de un foro de 80 maravedís y 2 gallinas sobre un huerto en San Zoles. Año 1626>.

Reconocimiento que hizo el bachiller Román de Villamartín, clérigo de la yglesia de Santiago, de un foro de 80 maravedís y 2 gallinas que este monasterio tenía sobre un huerto cercado en el barrio de San Zoles, lindero: huerta de don Gerónimo de Guevara, vecino de Carrión. Su fecha, en dicha villa, a 26 de hebrero de 1626, ante Francisco Moro de Saldaña, escribano de la misma. 
74. $<$ Reconocimiento de un foro de 500 maravedís y 2 gallinas sobre unas casas a la Cuesta del Trigo. Año 1647>.

Reconocimiento que hicieron doña Ysavel Calderón de Carranza y don Francisco de los Ríos Campoo, vecinos de Carrión, de un foro de 500 maravedís y 3 gallinas (y por esta escritura se rebaja una gallina) que este monasterio tenía sobre unas casas en dicha villa, a la Cuesta del Trigo, que hacen esquina a la calle de la Texada. Su fecha, en Carrión, a 2 de abril de 1647, ante Francisco Moro de Saldaña, escribano en dicha villa.

Está aquí la escritura de venta que el referido don Francisco de los Ríos Campoo y doña Eufrasia Velarde de Santillana, su muger, otorgaron de las mismas casas y con la carga del mismo foro a fabor deste monasterio a don Francisco de Santiago Pemental, vecino de la misma villa, a 28 de agosto de 1663, ante Andrés / (f.168r) Simón de Aguilar, escribano de Carrión; y sacada esta copia a 19 de noviembre de 1707, por Agustín García de Miranda, escribano de la misma villa.

\section{5. $<$ Foros antiguos $>$.}

Vn quaderno, escrito en pergamino y sin authoridad, que contiene los foros antiguos que tenía este monasterio sobre muchas casas de Carrión, del barrio de San Zoles, y sobre algunas heredades. 


\title{
/ (f. 169r) Cajón $7^{\circ}$. San Felices \\ Letras C, E y F
}

Este Cajón San Felices, que es el séptimo del archivo, contiene tres legajos pertenecientes a diversos lugares: Legajo $1^{\circ}$ : Castrillo de Macintos y Cerbatos; Legajo $2^{\circ}$ : Cestillos; Legajo $3^{\circ}$ : Cisneros, Santa Comba dos Dados, Cornón y Cornoncillo, Santa Cruz de Ventosilla, Entorcisa, Fontecha, Frechilla.

\section{Legajo $1^{\circ}$}

Este legajo, que es el primero del Cajón San Felices, contiene dos quadernos, que son los siguientes:

\author{
Quaderno A. Castrillo de Macintos \\ Quaderno B. Cerbatos
}

\section{Quaderno A Castrillo de Macintos}

Este quaderno A contiene los papeles pertenecientes a la hacienda y vecindad que este monasterio tiene en dicho lugar de Castrillejo, por el orden siguiente:

$1^{\circ}$. < Foro de 3 maravedís y 2 gallinas sobre un huerto en Castrillejo. Año 1428>.

Escritura de foro perpetuo, en pergamino, por la qual Juan Alfonso, limosnero del monasterio de San Zoil, da a Juan, vecino de Castrillo, cerca de Macintos, un huerto en dicho lugar, que ha por linderos: huerto de la Orden de Santiago en la calle pública, por 3 maravedís y 2 gallinas de foro perpetuo. Su fecha, en San Zoil, a 2 de octubre de 1428, ante Fernando Rodríguez de Castellanos, escrbano y notario de Palencia.

\section{2. $<$ Compra de una tierra. Año 1519>.}

Escritura de venta, por la qual el concejo de Castrillo vende a Juan de Cea, vecino de dicho lugar, una tierra en dicho término, a donde dicen al Bal, lindero el arroyo del Val, por precio de 170 maravedís. Su fecha, en Castrillo, a 15 de hebrero de 1519, / (f. 169v) ante Alonso Quadros, escribano de Su Magestad. No consta si el monasterio compró después esta tierra.

\section{3. <Compra de una casa con su corral y herrén. Año 1626>.}

Compra que hizo este monasterio a Thoribio Barbán, Mencía de Lombraña, su muger, y Juan de Castro, vecinos todos de Guaza, de una casa con su corral y herrén todo junto en el lugar de Castrillejo, linderos: las calles públicas del dicho lugar, por precio de 200 reales. Su fecha, en Villamuera, a 28 de enero de 1626, ante Eugenio de Guzmán, escribano de Villamuera.

4. <Compra de una casa texada y corral. Año 1627>.

Compra que hizo este monasterio a Antonio García y María de la Cruz, su muger, vecinos de Castrillejo, de una casa texada con su corral en dicho lugar, lindero: el Camino Real que va a Palencia, por precio de 300 reales. Su fecha, en Carrión, a 18 de agosto de 1627, ante Francisco Moro de Saldaña, escribano de dicha villa.

5. <Mandamiento para que no se dé la vecindad a Bartholomé Macho. Año 1627>.

Mandamiento del doctor Tobar, corregidor de Carrión, para que el concejo de Castrillejo no dé la vecindad de dicho lugar a Bartholomé Macho, vecino de Villamuera, sino es estando todo el concejo y vecinos juntos. Dado en Carrión, a 27 de octubre de 1627, ante Juan Díez Pajaza, escribano. Notificose este mandamiento a un rexidor del dicho lugar ante Santos de Guzmán, escribano de Villamuera.

6. $<$ Compra de una casa. Año 1629>.

Compra que hizo este monasterio a Juan Rey, vecino de Castrillejo, de una casa en dicho lugar, lindero: casa deste monasterio y las calles públicas, por precio de 3.858 
maravedís. Su fecha, en Carrión, a 13 de abril de 1629, ante Francisco Moro de Saldaña, escribano de dicha villa. $1630>$.

7. <Provisión real para confirmar ciertas ordenanzas del lugar de Castrillejo. Año

Provisión real del Consejo, a petición del lugar de Castrillejo, para que el corregidor de Carrión con su ayuntamiento haga información sobre la utilidad de ciertas ordenanzas que el referido lugar havía hecho para la guarda y conservación de sus panes, viñas y demás heredades, y hecha esta información dé su parecer para que se confirmen en el Consejo. Dada en Madrid, a 30 de julio de 1630, ante Marcos de Prado y Velasco, escribano de Cámara de Su Magestad. de $1631>$

8. < Carta executoria a favor deste monasterio sobre la vecindad de Castrillejo. Año

Carta executoria a fabor deste monasterio, por la qual, y por los autos que están baxo este mismo número, consta que este monasterio pidió en concejo público la vecindad del lugar de Castrillejo y éste se la dio, de que tomó posesión quieta y pacífica, dando al concejo doce cargas de trigo para sus necesidades. Y por / (f. 170r) ser este lugar de la jurisdicción de Carrión, el concejo hizo relación a la justicia de dicha villa $\mathrm{y}$, haciendo información de utilidad, se aprobó y dio licencia por la justicia de Carrión. No obstan[te] esto, en 21 de diciembre de 1625, Juan Téllez, provisor general de Carrión, contradijo la dicha vecindad y alegó contra el convento, el qual salió a la causa ante la justicia de Carrión; y, recibida la causa a prueba ${ }^{272}$, el licenciado don Fernando Altamirano de las Cavezas, corregidor de Carrión, en 13 de marzo de 1627, dio sentencia a fabor deste monasterio, amparándole en la posesión de dicha vecindad. Desta sentencia apeló el provisor general de la villa y se llevó el pleyto a la Chancillería de Valladolid, donde el convento alegó y declinó jurisdición, la qual no se le admitió y, sin concluir en este artículo, salió sentencia en el pleyto principal contra el monasterio. Por lo que se quedó en este estado el pleyto hasta el año de 1630, en que la villa de Carrión y concejo de Castrillejo convinieron y consintieron (precedía información y las licencias necesarias) que el este monasterio gozase quieta y pacíficamente la posesión de la vecindad de Castrillejo como hasta allí la havía tenido, y que se apartaban y apartaron del pleyto que estaba pendiente, como el monasterio guarde y cumpla las condiciones siguientes:

$<$ Capítulos de concordia $>$.

$1^{a}$. Que el monasterio acuda como un vecino a las sernas y senaras del concejo y, no lo haciendo, pueda ser penado como los demás vecinos, y para ello han de tener una persona seglar que le compela a ello.

$2^{\text {a }}$. Que el monasterio no ha de tener en Castrillejo más aprovechamientos de los pastos y demás cosas dél que tiene uno de los demás vecinos y, si más ganado tregere ha de ser pagando el erbaxe a satisfacción del concejo y por arrendamiento, queriéndoselo dar, y no de otra manera; y de lo que así traxere erbajado ha de pagar los diezmos, y no de lo que traxere como vecino. Y, no cumpliéndolo así, podrá ser compelido a ello por la justicia seglar sustanciando la causa con la persona que el dicho convento ha de tener en el referido lugar.

$3^{\mathrm{a}}$. Que el monasterio por sí ni por tercera persona no pueda comprar el dicho lugar de Castrillejo ni cosa de él ni eximirle / (f. 170v) de la jurisdición de Carrión; y, si lo hicieren, la villa pueda salir al tanto y litigarlo, pagando el monasterio las costas del pleyto, además que la compra sea nula.

$4^{\mathrm{a}}$. Que en qualquier tiempo que qualquier vecino de Carrión o de otra parte se quisiere avencidar en Castrillejo, no lo pueda estorbar ni contradicir el monasterio; y que el concejo de Castrillejo a de benir en estas condiciones.

5 . Que, no cumpliendo el monasterio con estas condiciones y qualquiera de ellas, sea visto quedar el dicho pleyto sobre la dicha vecindad en su fuerza y vigor; y la villa le pueda proseguir en el estado en que está.

\footnotetext{
272 prueba] al margen izquierdo: Sentencia.
} 
General.

$6^{a}$. Que, para otorgar esta escritura, el monasterio ha de sacar licencia del

Las quales condiciones fueron hechas en este monasterio, a 7 de febrero de 1630, ante Gerónimo López, escribano de Carrión.

Esta escritura de concordia, con sus condiciones y con los poderes necesarios se presentó en la Chancillería de Valladolid y por todas las partes se pidió se confirmase por sentencia y se diese carta executoria. Los señores mandaron llebarla al fiscal para que lo viese y alegase, el qual contradixo la dicha concordia.

$<1^{\text {a }}$ sentencia $>$.

Concluido el pleyto, salió sentencia contra lo alegado por el fiscal de Su Magestad y, de pedimento de las demás partes, confirmaron la dicha escritura de transacción y concordia, y condenaron a las partes a que pasen por lo en ella contenido.

Pronunciada la dicha sentencia, se llebó el pleyto al fiscal, el qual suplicó y alegó de nuebo contra esta sentencia.

$<$ Sentencia de revista $>$.

Las partes concluyeron sin embargo y, en once de febrero de 1631, salió sentencia de revista, por la qual se confirmó la primera de vista y se mandó despachar esta carta executoria. Que fue dada en Valladolid, a 18 de hebrero del mismo año, ante Diego Gómez Osorio, escribano de Cámara de Su Magestad.

Síguese la notificación que se hizo al concejo de Castrillejo y villa de Carrión desta carta executoria, en la que convinieron y mandaron se guarde y cumpla en todo y por todo. Por testimonio de Santos de Guzmán y Gerónimo López, escribanos de Villamuera y Carrión.

9. $<$ Pareceres de abogados sobre los diezmos de Castrillejo $>$.

Consultas y pareceres de dos letrados, por los que parece que de la concordia antecedente resultó que el cavildo de Palencia puso demanda al monasterio sobre la paga de diezmos de todo el ganado y frutos de tierras que el convento tuviese en el lugar de Castrillejo. Después se trató de concordia y para esto se consultaron abogados. Pero no consta en lo que las partes se convinieron.

$<$ Carta de pago del erbaje. Año 1636>.

Hay aquí dos cartas de pago de los años de 1630 y 1636 de los maravedís que este monasterio pagó al concejo de Castrillejo / (f. 171r) por el erbaje del ganado que trahían en dicho lugar. Por testimonio Gerónimo Laso y Francisco Moro de Saldaña, escribanos de Carrión. Año 1659>.

10. $<$ Testimonio de cómo el ganado de San Zoil pastaba en el término de Castrillejo.

Testimonio dado por Norbeto Sandoval y Guevara, escribano de Carrión, por el que consta que, estando él en el término del lugar de Castrillejo, vio pastar un atajo de ganado ovejuno propio deste monasterio y, haviéndole preguntado al pastor sobre este ganado le respondió que, aunque con él habían estado algunos vecinos de dicho lugar y reconocido el dicho ganado por del monasterio, no le havían dicho se saliese del dicho término ni hechado pena alguna. Y para que conste dio el presente testimonio en el priorato de Villaverde, a 29 de abril de 1659.

\section{Remisiones}

Amojonamientos y ordenanzas con Villaverde. Cajón San Yldefonso, legajo $3^{\circ}$, número (legajo $3^{\circ}$, número) 13 y siguientes.

Ídem sobre un molino. Cajón San Gregorio, legajo $2^{\circ}$, quaderno B. 


\section{/ (f. 171v) Quaderno B del legajo $1^{\circ}$ \\ Cerbatos}

$<$ Nota $>$.

La donación que hizo Sancha Ýñiguez de las heredades que tenía en Cerbatos, que fueron de Pedro Velázquez y de su muger, doña Ocenda, era 1161, que es año de Christo de 1123. Véase el cajón San Gregorio, título Villalumbroso, quaderno último, número $1^{\circ}$.

Este quaderno contiene los papeles pertenecientes a la hacienda y vecindad que este monasterio tiene en este lugar, por la orden siguiente:

$1^{\circ}$.

Reconocimiento que hicieron los clérigos y beneficiados de las yglesias del lugar de Cerbatos de un foro perpetuo de 30 maravedís que este monasterio tenía sobre una viña en el término de dicho lugar, a do dicen a Perales, lindero: el campo de Perales. Su fecha, en Cerbatos, a 26 de noviembre de 1522, ante Miguel Roxo, escribano de Su Magestad.

\section{Remisiones}

Donación y arrendamiento de una tierra y una viña en Cerbatos. Véase el cajón San Estevan, legajo $2^{\circ}$, quaderno $\mathrm{F}$, número $1^{\circ}$.

\section{/ (f. 172r) Legajo $2^{\circ}$ del Cajón San Felices}

Cestillos

Este legajo, que es el segundo del cajón San Felices, contiene los papeles pertenecientes al término de Cestillos, divididos en los dos quadernos siguientes: Quaderno A: Hacienda que este monasterio tiene en dicho término; Quaderno B: Yglesia y presentación del beneficio de Cestillos.

\section{Quaderno A del legajo $2^{\circ}$}

En este quaderno están los papeles pertenecientes a la hacienda que este monasterio tiene en el término de Cestillos, por el orden siguiente:

$1^{\circ}$. <Compra que hicieron don Gómez Dídaz y su muger, doña Theresa, de muchas heredades en Cestillos. Era 1095, año 1057>.

Escritura de venta, en pergamino, por la qual los vecinos de Villanueva, de Torre, de Ferreirolos, de Cestillos y de otras villas de Santa María ${ }^{273}$ (que así se llamaba en aquel tiempo Carrión) venden al conde don Gómez Dídad y a la condesa doña Theresa, su muger, reedificadores deste monasterio, muchas heredades y molinos en dichos lugares. Otorgose esta escritura $6^{\circ}$ idus novembris era 1095, que es año de Christo 1057, reynando en Castilla y León don Fernando; y el conde don Gómez Dídaz, en Santa María y en Saldaña.

2. <Privilegio del rey don Alonso por el que confirma ciertos vasallos y heredades que donaron a este monasterio en Cestillos. Era 1241, año 1203>.

Privilegio rodado, escrito en pergamino, con su sello de plomo pendiente, por el qual don Alonso, rey de Castilla y de Toledo, con su muger, doña Leonor, y su hijo don Fernando, conceden y confirman a don Pedro, camarero de España y prior de San Zoil, y al convento

\footnotetext{
${ }^{273}$ Santa María] al margen derecho: Villanueba, Torre, Ferreirolos, Cestillos y Santa María.
} 
deste monasterio la donación que le hizo Fernando Sánchez (repostero del rey) y doña Vrraca, su muger, por la qual concedieron al monasterio, para después de su muerte, los collazos, solares, poblados y por poblar, que tenían en Cestillos, con sus tierras y viñas, que dieron de limosna; y los collazos, huertas, tierras y viñas que donó al monasterio don Walcio, hermano de don Fortunio. Facta carta apud Carrionem, era 1241, año de Christo 1203, pridie nonas novembris.

3. <Trueque de toda la heredad que tenía San Román en Loma de Foyos por la mitad de un molino en Cestillos. Era 1244, año 1206>.

Escritura de trueque, en pergamino, partida por $A B C$, por la qual / (f. 172v) don Guillén, prior de San Román, con licencia de don Pedro, prior de San Zoil, y con consentimiento de los monges, clérigos y legos que vivían en San Román, da a doña María Pétriz toda la heredad que tenía en Loma de Foyos: collazos, solares, poblados y despoblados, prados, pastos, montes, fuentes, etcétera (como lo había donado a San Román ${ }^{274}$ doña Sancha García, madre de Gonzalvo Fernández); y la referida doña María Pétriz, con sus hijos e hijas, da en cambio al dicho don Guillén la mitad de un molino que ella tenía en Cestillos, que estaba en el Quérnago de San Cipriano, que era de San Román; y la otra mitad del molino que dice era de los hijos de don Florencio de Villaovieco y, $<$ si $>$ no quisieren trabajar en él de manera que por su culpa se pierdan las maquilas, pueda el referido prior entrar y poseer todo el molino. Además de la mitad deste molino le dio dos tierras immediatas a él, de la parte de la carrera que viene de Cestillos, linderos: los molinos y el Cuérnago. Facta carta in Casteion, era 1244, que es año de 1206.

4. <Donación de una parada de molino en Cestillos. Era 1253, año 1215>.

Donación, escrita en pergamino, partida por ABC, que hizo don Juan Díaz, hijo de don Armengot, a don Juan de Beganola y a su muger, doña Ana, de la mitad del molino de Cestillos, que está entre los molinos de San Cipriano y de Sotiello, es a saber: aquella parada que dio doña María d'Almenara, mi abuela, a don Laurencio de Villaovieco. No hace mención deste monasterio. Facta carta era 1253, que es año 1215.

5. < Foro de 4 maravedís sobre una tierra en Cestillos. Año 1404>.

Escritura de foro perpetuo, en pergamino, por la qual don Rodrigo, limosnero mayor de San Zoil, da a Alfonso, vecino de Carrión, una tierra de una obrada en término de Cestillos, que ha por linderos: la carrera que va a Palencia y la carrera que va al molino del Arena, por 4 maravedís de foro perpetuo. Su fecha, en San Zoil, a 6 de diciembre de 1404, ante Francisco Pérez, escribano de Carrión.

6. $<$ Foro de 4 maravedís sobre una tierra en Cestillos. Año 1404>.

Escritura de foro perpetuo, en pergamino, por la qual el mismo don Rodrigo da a Fernando de Villavildo, vecino de Carrión, una obrada de tierra en término de Cestillos, que ha por lindero: la carrera que va a Palencia, por 4 maravedís de foro perpetuo. Su fecha, en San Zoil, a 6 de diciembre de 1404, ante Francisco Pérez, escribano de Carrión.

7. $<$ Foro de 4 reales sobre una tierra en Cestillos. Año 1404>.

Escritura de foro perpetuo, en pergamino, por la qual el mismo don Rodrigo da a Juan de la Laguna, vecino de Carrión, una obrada de tierra en término de Cestillos para plantarla de viña, por 4 reales de foro perpetuo. Su fecha, en San Zoil, a 6 de diciembre de 1404, ante Francisco Pérez, escribano de Carrión.

Está aquí el reconocimiento que deste mismo foro y sobre la misma tierra hecha viña hizo Santiago Reynoso, / (f.173r) vecino de Carrión, a favor deste monasterio, a 20 de marzo de 1647, ante Francisco Moro de Saldaña, escribano de Carrión.

Hay copia authorizada de la escritura del foro.

\footnotetext{
${ }^{274}$ San Román] al margen derecho: San Román.
} 


\section{8. $<$ Foro de 4 maravedís sobre una tierra en Cestillos. Año 1404>.}

Escritura de foro perpetuo, en pergamino, por la qual el mismo don Rodrigo, con licencia del prior mayor de San Zoil, da a Salvador Fernández de Ledigos, vecino de Carrión, una obrada de tierra para plantarla de viña en término de Cestillos, que ha por lindero: el arroyo que va a Vallejo, por 4 maravedís de foro perpetuo. Su fecha, en San Zoil, a 18 de diciembre de 1404, ante Francisco Pérez, escribano de Carrión.

9. <Foro de 6 maravedís sobre una tierra en Cestillos. Año 1404>.

Escritura de foro perpetuo, en pergamino, por la qual el mismo don Rodrigo, con la misma licencia, da a Rodrigo de San Mamés, vecino de Carrión, una tierra para plantarla de viña en término de Cestillos, por 6 maravedís de foro perpetuo. Su fecha, en San Zoil, a 18 de diciembre de 1404, ante Francisco Pérez, escribano de Carrión.

10. $<$ Foro de 20 maravedís sobre una tierra en Cestillos. Año 1405>.

Escritura de foro perpetuo, en pergamino, por la qual el mismo don Rodrigo, con la misma licencia, da a Miguel Sánchez Alfajeme, vecino de Carrión, una tierra que dicen del Prado, en término de Cestillos, para plantarla de viña, que ha por lindero: el arroyo Forero, por 20 maravedís de foro perpetuo. Su fecha, en Carrión, a 18 de enero de 1405, ante Francisco Pérez, escribano de dicha villa.

11. $<$ Foro de 4 maravedís sobre una tierra en Cestillos. Año 1405>.

Escritura de foro perpetuo, en pergamino, por la qual el mismo don Rodrigo, con la misma licencia, da a Alfonso de Burgos, vecino de Carrión, una tierra para plantarla de viña, en término de Cestillos, que ha por lindero: un camino que llega a par de la dicha tierra, por 4 maravedís de foro perpetuo. Su fecha, en Carrión, a 19 de enero de 1405, ante Francisco Pérez, escribano de dicha villa.

12. <Foro de media libra de cera sobre una viña en Cestillos. Año 1405>.

Escritura de foro perpetuo, en pergamino, por la qual el sacristán de San Zoil, con la misma licencia, da a Marina, vecina de Carrión, una viña, en término de Cestillos, por media libra de cera de foro perpetuo. Su fecha, en San Zoil, a 27 de noviembre de 1405, ante Gutierre Fernández, escribano Carrión.

13. <Foro de 4 maravedís sobre una tierra en Cestillos. Año 1405>.

Escritura de foro perpetuo, en pergamino, por la qual el mismo don Rodrigo, y con la misma licencia, da a Fernando de Mañueco, vecino de Carrión, una obrada de tierra, en término de Cestillos, para plantarla de viña, que ha por lindero: la carrera que va a Lomas, por 4 maravedís / (f. 173v) de foro perpetuo. Su fecha, en San Zoil, a 26 de diciembre de 1405, ante Francisco Pérez, escribano de Carrión. Hay copia authorizada.

14. $<$ Foro de 4 maravedís sobre una tierra en Cestillos. Año 1406>.

Escritura de foro perpetuo, en pergamino, por la qual el mismo don Rodrigo, con la misma licencia, da a Pedro, vecino de Carrión, una tierra <eria>, en término de Cestillos, para plantarla de viña, que ha por linderos: la carrera que va a Palencia y la carrera que va al molino del Arena, por 4 maravedís de foro perpetuo. Su fecha, en San Zoil, a 5 de abril de 1406, ante García Fernández, escribano de Carrión.

15. $<$ Foro de 10 maravedís sobre una tierra en Cestillos. Año 1406>.

Escritura de foro perpetuo, en pergamino, por la qual el mismo don Rodrigo, con la misma licencia, da a Juan de Lerones, vecino de Carrión, una tierra eria, en término de Cestillos, a do dicen a la Cabra, para plantarla de viña, que ha por lindero: la carrera que va a la Cabra, por diez maravedís de foro perpetuo. Su fecha, en San Zoil, a 7 de febrero de 1406, ante García Fernández, escribano de Carrión. Hay copia authorizada.

16. <Foro de 10 maravedís sobre una tierra en Cestillos. Año 1406>.

Escritura de foro perpetuo, en pergamino, por la qual el mismo don Rodrigo, con la misma licencia, da a Alfonso Martínez, vecino de Cestillos, una tierra eria, en dicho término, 
a do dicen a Val de Helipe, para plantarla de viña, que ha por lindero: la carrera que va a Fuente Muño, por 10 maravedís de foro perpetuo. Su fecha, en San Zoil, a 18 de marzo de 1406, ante García Fernández, escribano de Carrión.

17. $<$ Foro de 8 maravedís sobre una tierra en Cestillos. Año 1406>.

Escritura de foro perpetuo, en pergamino, por la qual el mismo don Rodrigo, con la misma licencia, da a Juan Jacob, vecino de Carrión, una tierra eria, en término de Cestillos, que es entre las viñas, por 8 maravedís de foro perpetuo, para plantarla de viña. Su fecha, en San Zoil, a 5 de abril de 1406, ante García Fernández, escribano de Carrión.

18. < Foro de 5 maravedís sobre una pradera en Cestillos. Año 1406>.

Escritura de foro perpetuo, en pergamino, por la qual el mismo don Rodrigo, con la misma licencia, da a Pedro Martínez de Becerril, vecino de Carrión, una pradera, en término de Cestillos, carrera Villanueba, por 5 maravedís de foro perpetuo. Su fecha, en San Zoil, a 4 de julio de 1406, ante García Fernández, escribano de Carrión.

19. < Foro de 20 maravedís y una gallina sobre dos tierras en Cestillos. Año 1406>.

Escritura de foro perpetuo, en pergamino, por la qual el mismo don Rodrigo, con la misma licencia, da a Rodrigo Alfonso, linacero, vecino de Carrión, dos tierras erias, en término de Cestillos, de / (f. 174r) yuso de los Barreros, lindero de la una tierra: la carrera que viene de Villasirga a la era primera de Cestillos; lindero de la otra: la dicha carrera y la dicha era, por 20 maravedís de foro perpetuo y una gallina. Su fecha, en San Zoil, a 24 de octubre de 1406, ante García Fernández, escribano de Carrión.

20. < Foro de 5 maravedís sobre una tierra en Cestillos. Año 1407>.

Escritura de foro perpetuo, en pergamino, por la qual el mismo don Rodrigo, con la misma licencia, da a Juan Aparicio de Lagunilla, vecino de Carrión, una tierra eria, en término de Cestillos, para plantarla de viña, por 5 maravedís de foro perpetuo. Su fecha, en San Zoil, a 28 de diciembre de 1407, ante García Fernández, escribano de Carrión

21. <Foro de 13 maravedís sobre dos tierras en Cestillos. Año 1407>.

Escritura de foro perpetuo, en pergamino, por la qual el mismo don Rodrigo, con la misma licencia, da a Juan Fernández de Quintanilla, vecino de Carrión, dos tierras erias, en término de Cestillos, para plantarlas de viña, por 13 maravedís de foro perpetuo. Su fecha, en San Zoil, a 28 de diciembre de 1407, ante García Fernández, escribano de dicha villa.

22. < Foro de 7 maravedís sobre una tierra en Cestillos. Año 1407>.

Escritura de foro perpetuo, en pergamino, por la qual el mismo don Rodrigo, con la misma licencia, da a Rui Fernández, vecino de Carrión, una tierra en término de Cestillos, para plantarla de viña, por 7 maravedís de foro perpetuo. Su fecha, en San Zoil, a 28 de diciembre de 1407, ante García Fernández, escribano de Carrión.

23. <Foro de 12 maravedís sobre una tierra en Cestillos. Año 1407>.

Escritura de foro perpetuo, en pergamino, por la qual el mismo don Rodrigo, con la misma licencia, da a Thoribio, vecino de Carrión, una tierra eria, con el rastrojo, en término de Cestillos, a do dicen a Bal de la Ega, por doce maravedís de foro perpetuo. Su fecha, en San Zoil, a $1^{\circ}$ de febrero de 1407, ante García Fernández, escribano de Carrión.

24. <Traspaso de un foro de 21 maravedís sobre una tierra en Cestillos. Año 1407>.

Traspaso que, con licencia deste monasterio, hizo Gonzalo González Guadiana, en nombre de Ysavel Alfonso, su muger, vecinos de Carrión, de un foro de 20 maravedís que el referido monasterio tenía sobre unas casas en Carrión, en el barrio de la Frenería, en una tierra de la dicha Ysabel, en término de Cestillos, cerca del molino de la calle, que ha por lindero: el Cuérnago en derredor, con la mejoría de un maravedí de foro sobre los 20 maravedís a fabor deste monasterio. Su fecha, en San Zoil, a 15 de febrero de 1407, ante Gómez García de Saldaña, escribano de Carrión. Hay copia authorizada. 
Está aquí el reconocimiento que deste mismo foro hizo Ysavel Díaz a favor deste monasterio, en 14 de julio de 1510, ante Ximeno de San / (f. 174v) Zoles, escribano de Carrión. En este reconocimiento le llama huerta y añade por lindero el camino.

25. < Foro de 4 maravedís sobre una tierra en Cestillos. Año 1407>.

Escritura de foro perpetuo, en pergamino, por la qual el mismo don Rodrigo, con la misma licencia, da a Pedro, vecino de Carrión, una tierra, en término de Cestillos, encima de la Barga, que ha por lindero: el arroyo del concejo, por 4 maravedís de foro perpetuo y con la obligación de plantarla de viña. Su fecha, en San Zoil, año de 1407, ante García Fernández, escribano de Carrión.

\section{6. $<$ Foro de 15 maravedís sobre una tierra en Cestillos. Año 1408>.}

Escritura de foro perpetuo, en pergamino, por la qual el mismo don Rodrigo, con la misma licencia, da a Peydro, vecino de Carrión, una tierra en término de Cestillos, a do dicen a los Barros, por 15 maravedís de foro perpetuo. Su fecha, en San Zoil, a $1^{\circ}$ de abril de 1408, ante García Fernández, escribano de Carrión.

Está aquí el reconocimiento que deste mismo foro y sobre esta misma tierra, con los linderos del Sotillo y camino que va a Villanueba del Río, hizo Christóval Castrillo, vecino del referido lugar de Villanueba, a fabor deste monasterio. A 17 de diciembre de 1662, ante Bartholomé González, escribano de Carrión. Hay copia authorizada $1408>$.

27. < Foro de 20 maravedís de foro perpetuo sobre una tierra en Cestillos. Año

Escritura de foro perpetuo, en pergamino, por la qual el mismo don Rodrigo, con la misma licencia, da a Juan Fernández Jacob, vecino de Carrión, una tierra en término de Cestillos, que ha por lindero: la carrera que va a Villanueba del Río, por 20 maravedís de foro perpetuo. Su fecha, en San Zoil, a $1^{\circ}$ de abril de 1408, ante García Fernández, escribano de Carrión.

Está aquí un auto dado por el corregidor de Carrión para que reconozca este foro Miguel Magdaleno, y la respuesta que este dio de cómo había vendido la dicha tierra por no saber que tenía la carga del foro. A 19 de junio de 1663, ante Norberto Sandoval y Guevara, escribano de la misma villa

\section{8. < Foro de 2 maravedís sobre una tierra en Cestillos. Año 1409>.}

Escritura de foro perpetuo, en pergamino, por la qual Alfonso de Burgos, vecino de Carrión, da a Juan, vecino de la misma villa, una tierra en término de Cestillos, que él tenía a foro deste monasterio, que ha por linderos: la carrera que va a Otero de Cantos y el arroyo, por 2 maravedís de foro perpetuo. Su fecha, en Carrión, a 4 de enero de 1409, ante Rodrigo Alfonso, escribano de dicha villa.

29. <Foro de 25 maravedís sobre una tierra en Cestillos. Año 1410>.

Escritura de foro perpetuo, en pergamino, por la qual el mismo don Rodrigo, con la misma licencia, da a Pedro Poza, vecino de Carrión, una tierra en término de Cestillos, cerca del molino del Arrena, que ha por linderos: la carrera vieja que va a Villanueba y la Carreruela que va al dicho molino, por 25 maravedís de foro / (f. 175r) perpetuo. Su fecha, en San Zoil, a 18 de marzo de 1410, ante Rui García, escribano de Carrión. Hay copia authorizada

30. < Foro de 4 maravedís sobre una viña en Cestillos. Año 1421>.

Escritura de venta, en pergamino, por la qual Marina Rodríguez, vecina de Carrión, vende a Alfonso y Juan Bubiller, sus hijos, la mitad de unas casas en dicha villa, en la colación de San Pedro, en media obrada de tierra, y una viña majuelo, en término de Cestillos, esta viña con carga de 4 maravedís de foro perpetuo que sobre ella tenía este monasterio. Su fecha, en el convento de San Francisco de Carrión, a 2 de octubre de 1421, ante Ferrand Rodríguez de Castellanos, escribano de Palencia. 
31. < Foro de 10 maravedís sobre una tierra en Cestillos. Año 1423>.

Escritura de foro perpetuo, en pergamino, por la qual don Thorivio, limosnero mayor de San Zoil, da a Pedro Belasco, vecino de Carrión, una tierra que llaman la Cascajera, en término de Cestillos, que ha por linderos: el Cuérnago y huerta de la Limosna de San Zoil, por 10 maravedís de foro perpetuo. Su fecha, en San Zoil, a 22 de marzo de 1423, ante Ferrand Rodríguez de Castellanos, escribano de Palencia.

32. <Foro de 2 maravedís sobre una tierra en Cestillos. Año 1425>.

Escritura de foro perpetuo, en pergamino, por la qual don Gonzalo Martínez de Cerbatos, limosnero mayor de San Zoil, da a Juan de Vilamuera, vecino de Carrión, una tierra eria en término de Cestillos, a do dicen a Val de la Trigera, que ha por lindero: la carrera, por 2 maravedís de foro perpetuo, y con condición de plantarla de viña. Su fecha, en San Zoil, a 10 de abril de 1425, ante Ferrand Rodríguez de Castellanos, escribano de Palencia.

33. <Foro de 5 maravedís sobre una tierra en Cestillos. Año 1434>.

Escritura de reconocimiento, en pergamino, que otorgó Gonzalo, vecino de Carrión, de un foro de 15 maravedís que este monasterio tenía sobre una tierra en término de Cestillos, que ha por linderos: la laguna y la carrera que va a Villanueva del Río. Su fecha, en San Zoil, a 5 de febrero de 1434, ante Ferrand Rodríguez de Castellanos, escribano de Palencia.

34. <Donación de una tierra en Cestillos. Año 1438>.

Donación, en pergamino, que hizo a este monasterio María García, vecina de Carrión, una tierra en término de Cestillos, a do dicen al Hoyal, cerca del molino del Campo, que ha por linderos: el arroyo y el sendero que va de Cestillos al dicho molino, con carga de un aniversario ${ }^{275}$ perpetuo cantado con su misa el día de San Andrés Apóstol. Su fecha, en San Zoil, a 21 de noviembre de 1438, ante Gonzalo González de Carrión, escribano de Su Magestad. $1404>$.

35. <Posesión que tomó este monasterio sobre una tierra viña en Cestillos. Año

Testimonio dado por Alfonso Fernández de San Cibrián, escribano público, de la posesión que tomó don Pedro, prior mayor y limosnero de San Zoil, / ( f. 175v) de una tierra viña en término de Cestillos, que ha por lindero: la carrera que va a Palencia, porque hacía muchoa años que no le pagaban los réditos de un foro de 4 maravedís que tenía a su favor sobre la dicha tierra. Fue dado este testimonio a 24 de septiembre de 1448.

Está aquí la escritura de foro, en pergamino, sobre esta misma tierra, otorgada a 6 de diciembre de 1404, ante Francisco Pérez, escribano de Carrión.

36. <Venta de un foro de 35 maravedís. Año 1462>.

Escritura de venta, en pergamino, por la qual Leonor Ruiz de Reynoso, vecina de Carrión, vende a Juan García de la Serna, escribano y vecino de dicha villa, 35 maravedís de foro perpetuo que ella tenía sobre una huerta en término de Cestillos, que ha por linderos: de las dos partes las carreras que van a Villanueba del Río. Su fecha, en Carrión, a 23 de septiembre de 1462, ante Juan Martínez, escribano de dicha villa.

Está aquí el reconocimiento que deste mismo foro hizo Blas Ybáñez, vecino de dicha villa, a favor deste monasterio, el qual parece le heredó de Juan de la Serna, monge profeso desta casa e hijo del referido Juan García de la Serna. Su fecha, en Carrión, a 23 de enero de 1647, ante Francisco Muro de Saldaña, escribano de dicha villa.

37. <Compra de una huerta en Cestillos. Año 1465>.

Compra que hizo este monasterio a Juan de Palacios, vecino de Carrión, de una tierra en término de Cestillos, <al Moratejo>, que ha por linderos: el Cuérnago; y de las otras partes cercada de arroyos, por precio de 2.500 maravedís; y sobre esta huerta tenía ya el referido

\footnotetext{
275 aniversario] al margen derecho: Aniversario.
} 
monasterio 60 maravedís y un par de gallinas de foro perpetuo. Su fecha, en San Zoil, a 7 de enero de 1465, ante Juan González Catalán, escribano de Carrión.

38. <True[que] de una tierra por otra en Cestillos. Año 1465>.

Trueque que hizo este monasterio con Juan González, vecino de Carrión, de una tierra en término de Cestillos, a do dicen carre la Loma, por otra tierra que el referido Juan Santiago <le dio $>$ en el mismo término de carre la Loma. Su fecha, en San Zoil, a 24 de febrero de 1465, ante Juan González Catalán, escribano de Carrión.

39. <Foro de 220 maravedís y un capón en Cestillos. Año 1497>.

Escritura de foro perpetuo por la qual Zoil de Sadaña, monge limosnero de San Zoil, con licencia de don Luis Hurtado de Mendoza, administrador perpetuo deste monasterio, da a Juan Frayle y a Juan de Villanueba una tierra en término de Cestillos, a la Loma, que ha por lindero: el camino, por 220 maravedís y un capón de foro perpetuo. Su fecha, en Carrión, a 13 de septiembre de 1497, ante Fernando Caballo, escribano de dicha villa. Está multiplicada esta escritura.

\section{0. <Sentencia sobre una tierra a favor deste monasterio. Año 1529>.}

Proceso y sentencia dada por don Santiago de los Ríos, prior de Escalada, juez conservador, por la qual condena a Ysabel González Cerera, vecina de Carrión, a que restituya a este monasterio una tierra que ella tenía a vita por 250 maravedís y dos gallinas, en término de Cestillos, que ha por linderos: la huelga y el camino, por razón de que hacía algunos años que no pagaba la renta. Fue dada esta sentencia en Carrión, a 5 de octubre de 1529.

Síguense dos mandamientos del dicho juez a los curas y clérigos de Carrión para que excomulguen a la referida Ysabel por no querer / (f. 176r) obedecer a la sentencia pronunciada por él. Que todo pasó ante Juan de Castrillo, escribano de Carrión.

En este proceso están las escritura de vita y transpasación de la dicha tierra. Ante Fernando Caballo, Polite de Rojas y Floristan de la Serna, escribanos de dicha villa.

41. <Compra de una viña. Año 1540>.

Compra que hizo este monasterio a Fernando de la Vega, vecino de Carrión, de una viña de tres quartas y media, a do dicen los Arenales, que ha por lindero: el caminillo que va a Villanueba, por precio de 1.500 maravedíes. Su fecha, en San Zoil, a 24 de hebrero de 1540, ante Juan de Castrillo, escribano de Carrión. Esta escrita en pergamino.

42. $<$ Sentencia a favor deste monasterio sobre la entrada y serbicio de una tierra por la era y prado en Cestillos. Año 1543>.

Bajo este número hay dos sentencias a favor deste monasterio: la $1^{\text {a }}$ dada por Gómez Catalán, juez árbitro, en un pleyto entre el limosnero mayor de San Zoil y Pedro Argadero, vecino de Carrión, sobre que, habiendo comprado este del concejo una era y prado, que después hizo huerta, junto a una tierra del dicho limosnero en término de Cestillos, pretendía tener entrada a su era y prado por la referida tierra, y el limosnero pretendía tenerla para su tierra por la dicha era y prado. Y por esta sentencia declara el juez que el limosnero tenga entrada y servidumbre para su tierra por la era y prado del referido Argadero, y que este no la tenga para las suyas. Fue dada esta sentencia en Carrión, a 28 de marzo de 1480, ante Fernando Cavallo, escribano de dicha villa.

La $2^{a}$ sentencia sobre lo mismo fue dada a fabor deste monasterio por el bachiller Brasa, theniente de corregidor, en la villa de Carrión, a 9 de enero de 1543, ante Thomás Sánchez, escribano de dicha villa.

43. <Requirimiento y renuncia de un molino en Cestillos. Año 1576>.

Requirimiento que hizo a este monasterio Agustín de Poza, como curador de Pedro Marcos, vecino de Carrión, soldado que murió en Flandes, el qual tenía a vita el molino de la Paradilla, en término de Cestillos, por 8 cargas de trigo y 6 gallinas; y, haviendo el referido 
Poza renunciado esta vita, el monasterio la acetó. A 24 de septiembre de 1576, ante Antonio López Moro de Colmenares, escribano de Carrión.

\section{Remisiones}

Compra de varias tierras que hizo este monasterio / (f. 176v) al de San Pedro de Cardeña. Véase el Cajón San Zoil, legajo $2^{\circ}$, quaderno A, número 37.

\section{/ (f. 177r) Quaderno B del legajo $2^{\circ}$ \\ Yglesia de San Juan de Cestillos}

En este quaderno A están los papeles pertenecientes a la yglesia y presentación del beneficio de S. Juan de Cestillos, por el orden siguiente:

$1^{\circ}$. $<$ Concordia entre este monasterio y el concejo de Cestillos sobre la presentación del curato de San Juan de Cestillos y sus diezmos. Era 1223, año 1185>.

Concordia escrita en pergamino, partida por $\mathrm{ABC}$, hecha en presencia de don Lupo, merino mayor del rey, entre don Humberto, prior y camarero, y el convento de San Zoil, de una parte, y el concejo de Cestillos, de la otra, por la qual se convinieron en que siempre los ancianos de San Zoil pongan de su mano clérigo en la yglesia de San Juan de Cestillos como en heredad propria de San Zoil. Y después que el clérigo que al presente la administra, viviendo o muriendo, la dejase si huviese algún clérigo de la parentela del concejo en la villa o fuera de ella que sea idónio para servirla, tanto por tanto sea puesto en aquella yglesia. Pero esto sea por mano de los ancianos de San Zoil, y para que siempre les sea obediente y vasallo sin dominio de otro. $Y$ tengan los ancianos con su clérigo un $<a>$ tercia de todos los diezmos con todas las ofrendas, y asimismo el obispo tenga episcopalmente su tercia, y el concejo tenga su tercia enteramente como siempre la tubo. Y si el clérigo, por su culpa o neglijencia, no cumpliere con las obligaciones de su oficio, el concejo tenga potestad de prendarle según el foro de la tierra y no le valga el palacio. Fue hecha esta carta era 1223, que es año de 1185.

$2^{\circ}$. < Colación del curato de Cestillos. Año 1478>.

Colación del beneficio curado de San Juan de Cestillos hecha por el bachiller Juan Sánchez de Castromocho, provisor de Palencia, en el bachiller García González, clérigo de preste de la yglesia de Santa Olalla de la villa de Carrión, por virtud de la presentación en él hecha por el limosnero de San Zoil inserta aquí. Su fecha, en Palencia, a 28 de julio de 1478, ante Fernando Pérez, notario apostólico.

$3^{\circ}$. <Presentación y colación del curato de Cestillos. Año 1528>.

Presentación y colación del beneficio curado de Cestillos hecha por este monasterio y el provisor de Palencia en Alonso Gutiérrez, clérigo de la yglesia de San Andrés de Carrión, por muerte de Pedro de Santa Olalla, último poseedor. Fue hecha esta presentación a 14 de julio de 1528, ante Juan de Castrillo, notario y vecino de Carrión; y la colación: en Palencia, a 17 del mismo mes y año, ante Francisco Fernández, notario en dicha ciudad. Esta colación esta multiplicada. Síguese la posesión que el referido Alonso Gutiérrez tomó del dicho beneficio. Año 1528>.

$4^{\mathrm{o}}$. $<$ Apelación del monasterio por unos beneficios menores de San Juan de Cestillos.

Testimonio dado por Francisco Fernández, notario público de Palencia, de una apelación interpuesta por parte deste monasterio ante el provisor de de Palencia / (f. 177v) por haber hecho nombramiento y colación de un beneficio diaconal y tres acolitatos en Pedro Martínez de Landecho, fiscal, no haviendo tales beneficios en la yglesia de San Juan de Cestillos. Su fecha, en Palencia, a 29 de julio de 1528. 
$5^{\circ}$. $<$ Sentencia en que se declara la yglesia de Cestillos ser parroquial, sus límites y diezmos. Año 1587>.

Sentencia ${ }^{276}$ dada por don Francisco de Ribadeneyra, provisor de Palencia, por la qual declara la yglesia de San Juan de Cestillos ser parroquial y tener sus límites de por si, que son los que van del primer molino de los Badillos por el sendero y la carrera que para el dicho molino va arrimado a la huerta de Juan de Cantoral y al molino que dicen de las Monjas, por el caminillo de carre Palencia a la mira de las viñas hasta entrar en el camino de carre Nabos, y va cerca del corral de la Manrrica, una tierra en medio, y por el corral de Francisco Oxero hasta el camino que va a Amusco y a los mojones de Villasirga; y de allí a los Arenales; en el qual termino entra el pago de los Barreros y lo que alcanza conforme a estos itos del pago de la Espada. Declara asimismo que los que labran en este termino siendo parroquianos de la dicha yglesia de San Juan han de pagar todo el diezmo a la dicha parroquia y los que tienen parte en el dicho diezmo; y, labrándolo los vecinos de Carrión, pertenece la mitad a la yglesia de Cestillos, y la otra mitad a la yglesia donde son parroquianos; y en esta posesión, uso y costumbre declara estar la yglesia de Cestillos y en ella la ampara. Pone pena que nadie la inquiete, alza los embargos y reserva el conocimiento del derecho de la propiedad. Dada en Palencia, a 13 de enero de 1587, ante Juan Brabo de Sobremonte, notario de aquella ciudad.

$6^{\circ}$. <Colación del beneficio curado de Cestillos. Año 1595>.

Colación del beneficio curado de San Juan de Cestillos hecha en sede vacante por los provisores de Palencia por sentencia definitiba, en Gerónimo González de Saldaña, clérigo de Carrión, por muerte de Thorivio Requejo, último poseedor del dicho beneficio, y en virtud de la presentación que en el referido Gerónimo González hizo fray Thorivio Santandrés, abad de San Zoil. Dada en Palencia, a 20 de septiembre de 1595, ante Lucas Gallardo, notario de aquella audiencia. Síguese la posesión que el sobredicho tomó del referido beneficio, ante Sebastián García, escribano y notario de Carrión.

$7^{\circ}$. <Colación del beneficio curado de Cestillos. Año 1634>.

Colación del beneficio curado de Cestillos hecha por el licenciado don Fernando Rodríguez, provisor de Palencia, en Gabriel Antonio de Yglesias, clérigo, natural del lugar de Cuerno, jurisdición de Saldaña, por muerte del licenciado Francisco Sánchez d’Oro, último poseedor, y en virtud de la presentación hecha por fray Antonio del Valle, abad de San Zoil. Dada en Palencia, a $1^{\circ}$ de septiembre de 1634, ante Sebastián Díez, notario de / (f. 178r) aquella audiencia. Síguese la posesión que el referido tomó del dicho beneficio, ante Francisco Moro de Saldaña, escribano y notario de Carrión.

$8^{\circ}$. $<$ Consulta y parecer sobre consumir el obispo de Palencia el Santísimo Sacramento de la yglesia de Cestillos $>$.

Consulta sobre si el señor obispo de Palencia, por su authoridad y sin dar parte al patrono, puede consumir el Santísimo Sacramento que está en la yglesia de San Juan de Cestillos, y si esta consunción perjudicará al monasterio quanto a la percección del noveno y demás derechos que tiene. Resuelve el doctor Vecilla que, no haviendo feligreses, puede el señor obispo ý hacer el beneficio rural, mas no por esto perderá el monasterio ni el cura los derechos que tiene. Hay aquí varias cartas del señor obispo de Palencia al abad de San Zoil, en las que se ve haber mandado Su Yllustrísima volber el Santísimo a la parroquia de San Juan de Cestillos.

$9^{\circ}$. $<$ Colación del beneficio curado de Cestillos. Año 1639>.

Colación hecha por don Christóval de Guzmán y Santoyo, obispo de Palencia, en Cristóval, Marqués, clérigo de menores órdenes, por ascenso del licenciado Gabriel Antonio de Yglesias, último poseedor del beneficio curado de San Juan de Cestillos, y en virtud de la presentación hecha por el padre maestro fray Francisco de Lemos, abad de San Zoil. Dada en Piña, a 19 de mayo de 1639, ante el licenciado Hernando de Salceda, secretario del obispo. Síguese la posesión que el referido tomó del dueño beneficio, ante el bachiller Balthasar Rojo, clérigo y notario apostólico.

\footnotetext{
276 Sentencia] al margen derecho: Falta este instrumento.
} 
10. $<$ Memorial de las alajas de San Juan de Cestillos. Año 1639>.

Memorial firmado de Christóval Marqués, cura de San Juan de Cestillos, de las alhajas, ornamentos que tenía la dicha yglesia, según se las avia entregado este monasterio en el año de 1639.

11. < Colación del beneficio curado de San Juan de Cestillos. Año 1659>.

Colación del beneficio curado de San Juan de Cestillos hecha por el licenciado don Juan Francisco Maldonado, provisor de Palencia, en el licenciado Francisco Fernández de Mier, subdiácono, por muerte de Christóval Marqués, último poseedor de dicho curato, y en virtud de la presentación hecha por el padre maestro fray Plácido de Quirós, abad de San Zoil. Dada en Palencia, a 3 de octubre de 1659, ante Lázaro de Montoya, notario en dicha ciudad. Síguese la posesión que el sobredicho tomó del referido curato, ante Norberto Sandoval y Guevara, notario en Carrión. $1696>$.

12. <Presentación y colación del beneficio curado de San Juan de Cestillos. Año

Presentación ${ }^{277}$ y colación del mismo beneficio curado hecha por el padre maestro fray Gregorio Ruiz, abad de San Zoil, y el señor don fray Alonso Laurencio de Pedraza, obispo de Palencia, en el licenciado don Juan de Herrera, cura de la iglesia de San Bartholomé de Carrión, por muerte del licenciado Francisco Fernández de Mier, su último poseedor. Fue hecha la presentación en San Zoil, a 2 de diciembre de 1696, ante Agustín García de Miranda, notario; y la colación fue dada en Carrión, a 18 del / (f. 178v) mismo mes y año, ante don Francisco Alfonso, secretario del obispo. Síguese la posesión que el sobredicho tomó del referido beneficio, a $1^{\circ}$ de enero de 1697, ante Agustín García de Miranda, notario.

13. <Colación del beneficio curado de San Juan de Cestillos. Año 1703>.

Colación del mismo beneficio curado hecha por el señor don fray Alonso Laurencio de Pedraza, obispo de Palencia, en el licenciado don Sevastián Campoo Martínez, presvítero, por muerte del licenciado don Juan de Herrera, último poseedor, y en virtud de la presentación hecha por el padre maestro fray Pedro de Granda, abad de San Zoil. Dada en Palencia, a 12 de diciembre de 1703, ante don Francisco Alfonso, secretario de Su Yllustrísima. Síguese la posesión que el sobredicho tomó del referido curato, ante Agustín García, notario appostólico.

14. <Presentación del beneficio curado de San Juan de Cestillos. Año 1737>.

Presentación del mismo beneficio curado hecha por el padre maestro fray Juan Baca, abad de San Zoil, en el licenciado don Felipe Obejero, administrador actual del Hospital de la Herrada, por muerte de don Sevastián de los Ríos Campoo (cuya fe de muerto esta aquî), su último poseedor. Dada en San Zoil, a 21 de agosto de 1737, ante Francisco Núñez, notario en Carrión.

15. <Licencia para ir en rogatiba. Año 1753>.

Licencia ${ }^{278}$ que pidió el concejo del lugar de Villanueba del Río, al abad de San Zoil para ir en rogatiba a la yglesia de San Juan < de> Cestillos, en 12 de mayo de 1753.

16. $<$ Colación del mismo beneficio curado. Año 1753>.

Colación del mismo beneficio curado hecha por el licenciado don Manuel Rubin de Celis, provisor de Palencia, en don Bernardo Diaz de Castro, presvítero en la parroquia(l) de Nuestra Señora de Belén, por muerte de don Felipe Obejero, último poseedor, y en virtud de la presentación hecha por el padre maestro fray Manuel Ordoñez, abad de San Zoil. Dada en Palencia, a 23 de agosto de 1753, ante Manuel de las Bárcenas, notario en dicha ciudad. Síguese la posesión que el sobredicho tomó del referido beneficio, ante Salvador de la Fuente, notario en Carrión.

277 Presentación] al margen derecho: Falta.
${ }^{278}$ Licencia] al margen derecho: Falta. 

$1795>$.

17. <Presentación y colación del beneficio curado de San Juan de Cestillos. Año

Presentación y colación del mismo beneficio curado hecha por el padre maestro fray Leandro Pérez, abad de San Zoil, y por el doctor don Gregorio Ceruelo de la Fuente, provisor de Palencia, en don Simón Pérez, clérigo de menores ordenes y cappellán en esa villa de Carrión, por renuncia que del referido beneficio hizo don Bernardo Diaz de Castro, como consta de las diligencias aquí insertas con el auto definitibo dado por dicho señor provisor, a 9 de septiembre de 1795, ante Vicente Antonio de Vrrabieta, notario mayor. Y este testimonio fue sacado de su original por Ysidoro Ruiz de Colmenares, notario deste obispado y escribano desta villa de Carrión, en 25 del mismo mes y año.

\section{/ (f. 179r) Remisiones}

La concordia entre el obispo y cavildo de Palencia y este monasterio sobre diezmos y presentaciones de beneficios en Cestillos y otros lugares. Véase el cajón de San Andrés, legajo $1^{\circ}$, quaderno $\mathrm{B}$, número $3^{\circ}$.

La tercia de los diezmos en Cestillos que dio el obispo de Palencia (don Raymundo) a este monasterio. Véase el cajón San Agapio, legajo $1^{\circ}$, quaderno A, número $1^{\circ}$, en un quaderno al folio $5^{\circ}$.

\section{/ (f. 179v) Legajo $3^{\circ}$ del Cajón San Felices}

Este legajo $3^{\circ}$ contiene los quadernos siguientes:

$\begin{array}{ll}\text { Quaderno A Cisneros } & \text { E Entorcisa } \\ \text { B Santa Comba dos Dados } & \text { F Fontecha } \\ \text { C Cornón y Cornoncillo } & \text { G Frechilla } \\ \text { D Santa Cruz de Ventosilla } & \end{array}$

Quaderno A del legajo $3^{\circ}$

\section{Cisneros}

En este quaderno A están los papeles pertenecientes a la presentación del beneficio curado de Santa María de Barriofalda, extramuros de la villa de Cisneros, por el orden siguiente:

$1^{\circ}$. $<$ Concordia entre este monasterio y los feligreses de la yglesia de Santa María de Barriofalda sobre la presentación de su beneficio curado. Año 1533>.

Concordia hecha entre este monasterio y Alonso Andrés, vecino de Cisneros, en nombre de los feligreses y parroquianos de la yglesia de Santa María de Barriofalda, sita extramuros de dicha villa, en razón de la presentación de su beneficio curado. Por esta escritura parece que, estando este monasterio en quieta e inmemorial posesión de presentar dicho beneficio siempre y quando que vacase, para que esta presentación fuese firme y segura, ambas partes se concordaron en que el dicho beneficio se presentase en hijos patrimoniales de la dicha yglesia con las condiciones siguientes:

$1^{a}$. Que este beneficio curado, que entonces estava vaco por muerte de Diego Guerra, último poseedor, le tenga y posea Alonso Estévanez, clérigo y retor que havía sido de la dicha yglesia a quien los mismos feligreses habían nombrado, y que el monasterio, como único patrón y presentero, apruebe la presentación en él hecha. 
$2^{a}$ Que cuando el año beneficio vacare, los feligreses que fueren de la dicha parroquia estén obligados dentro de tercer día a hacerlo saber al monasterio y éste hacer la presentación del dicho beneficio en hijo patrimonial de la dicha yglesia, para que en virtud de ella el ordinario haga la estación; y no lo haciendo así incurran en la pena de 20.000 maravedís, mitad para el ordinario y mitad para la fábrica de San Zoil; y ésto sea para que el drecho que este monasterio tiene de presentan no se pierda.

$3^{\text {a }}$ Que si el ordinario hiciere colación deste beneficio sin la presentación del monasterio, sea en sí ninguna y el referido / (f. 180r) monasterio pueda presentar de nuebo en quien quisisere y el clérigo que recibiere la colación sin la dicha presentación incurra en la misma pena.

$4^{\mathrm{a}}$ Que quando vacare el dicho beneficio y viniere hijo patrimonial a pedir la presentación luego que la recibiere los feligreses de la dicha yglesia sean obligados a dar al monasterio un marco de plata y más un jantar al abad o presidente y dos monges que con ellos fueren y a sus criados y mulas que llevaren en esta manera: la noche que fueren a la dicha villa de Cisneros su cena y otro día su comida y cena; y este jantar se dé cada y quando el abad le pidiere y le rediman a dinero como se concertaren; y no lo cumpliendo y pasando el día que se huviere de dar incurran en pena de 5 mill maravedís, la mitad para la cámara del obispo y la otra mitad para la lámpara de los Santos Mártires; y todavía quedan obligados a dar el jantar como queda dicho.

$5^{a}$ Que si sucediendo la tal vacante no hubiere hijo patrimonial de la dicha yglesia, el monasterio le pueda presentar en quien quisiere y esté así probeído hasta que haiga hijo patrimonial a quien se dé.

$6^{\text {a }}$ Que el dicho Alonso Estévanez en quien fue presentado dicho beneficico, dé al monasterio el marco de plata y el jantar por razón de la presentación.

$7^{a}$ Que si en algún tiempo se aumentare la feligresía de la dicha yglesia y fuere necesario multiplicar más prevendas, el clérigo que huviere de entrar en la tal prebenda sea obligado a tomar la presentación del dicho monasterio, con que los feligreses le paguen el dicho marco y jantar según que por los otros obligan y bajo las mismas penas.

$8^{\mathrm{a}}$ Que todo lo dicho sea guardado y cumplido por los feligreses y parroquianos presentes y futuros de la dicha yglesia; y el referido monasterio quedó obligado a guardar todo lo contenido en esta concordia, que fue hecha en San Zoil, a 2 de mayo de 1533, ante Juan de Castrillo, escribano de Carrión.

Hay copia simple desta concordia.

$2^{\circ}$. $<$ Carta del obispo de León sobre la presentación de este beneficio. Año 1560>.

Carta del señor obispo de León al abad de San Zoil, en la que confiesa que la presentación del beneficio de Santa María de Barriofalda pertenece a este monasterio y le pide por un licenciado benemérito y virtuoso. Su fecha, en León, a 5 de noviembre de 1560.

$3^{\circ}$. < Presentación y colación en Martín Tristán. Año (año) 1566>.

Presentación y colación hecha por el padre maestro fray Benito de Sahagún, abad de San Zoil, y el licenciado Juan Sierra, provisor de León, en Martín Tristán, clérigo y vecino de Cisneros. Por esta colación consta que siendo cura de la yglesia de Santa María de Barriofalda el licenciado de Astudillo, no residía ni / (f. 180v) servía el dicho beneficio hacía quatro o cinco años; y a instancia del fiscal fue citado para que pareciese y diese razón de sí; y no lo haciendo fue acusado de rebeldía y privado del curato. Pusiéronse edictos y se opusieron el referido Martín Tristán y Antonio Frechoso; y por no haver éste parecido a examen fue aprobado el primero y se le dio la colación, en León, a 3 de abril de 1566, ante Pedro de Belasco, notario, en virtud de la presentación hecha por el abad deste monasterio, a 5 de febrero del mismo año, ante Andrés Sánchez, escribano de Carrión.

Está aquí la posesión que el dicho Martín Tristán tomó del referido beneficio, ante Antonio Roiz, escribano de Cisneros. 
$4^{\circ} .<$ Propuesta de los feligreses en Alonso Martínez para este beneficio. Año 1600>.

Propuesta que hicieron los feligreses de Santa María de Barriofalda en Alonso Martínez, clérigo de menores órdenes, hijo patrimonial de la dicha yglesia, para que el abad deste monasterio presentase en él el referido beneficio, que estaba vaco por muerte del licenciado Martín Tristán, último poseedor. Su fecha, en Cisneros, a 16 de noviembre de 1600, ante Melchor Fernández de la Peña, escribano de Cisneros.

Está aquí la acectación del abad, ante Pedro de Cerbantes, escribano de Carrión.

$5^{\circ}$. $<$ Carta del licenciado Robles. Año 1600>.

Carta del licenciado Robles de la Puerta al abad de San Zoil, en la que decidiera que la presentación deste beneficio se ha de hacer conforme a la concordia que queda puesta en el número $1^{\circ}$ deste quaderno. Su fecha, en Cisneros, a 18 de noviembre de 1600.

$6^{\circ}$. <Testimonio de cómo la presentación pertenece al abad. Año 1604>.

Testimonio dado por Pedro de Cerbantes, escribano de Carrión, a petición de fray Alonso Barrantes, abad de San Zoil, por el que consta que el abad deste monasterio es único presentero del beneficio curado de la yglesia de Santa María de Barriofalda y de haverle visto presentar y en virtud de la presentación el provisor de Palencia dar el título y colación. Su fecha, en San Zoil, a 19 de marzo de 1604.

$7^{\circ}$. < Obligación de dar un jantar al abad de San Zoil $>$.

Escritura de obligación por la qual Bartholomé Matheo se obliga a dar un jantar al abad desta casa por la presentación del beneficio curado de Santa María de Barriofalda, que había hecho en su hijo el bachiller Pedro Matheo. Pasó esta obligación ante Andrés Sánchez. No tiene fecha.

\section{Remisiones}

$<$ Nota $>$.

La hacienda y demás derechos deste lugar pertenecen a este monasterio por el trueque que hizo con el de San Román, año de 1406. Véase el cajón San Martín, legajo 1º quaderno $\mathrm{B}$, número $3^{\circ}$.

\section{/ (f. 181r) Quaderno B del legajo $3^{\circ}$ \\ Santa Comba dos Dados}

En este quaderno B están los papeles pertenecientes a la presentación y colación del beneficio curado de Santa Comba dos Dados, del lugar de Fornelas, obispado de Lugo, por el orden siguiente:

$1^{\circ}$. <Colación de Santa Comba dos Dados en Diego Pérez. Año 1529>.

Trasunto sin authoridad de una colación del beneficio curado de Santa Comba dos Dados, hecha por don Pedro de Rivera, obispo de Lugo, en Diego Pérez, clérigo, por muerte de Juan Fernández de Varines, último poseedor, y en virtud de la presentación que en él hicieron el presidente y conbento de San Zoil. Su fecha, en Lugo, a 14 de diciembre de 1529, ante Francisco Hontiveros, notario.

$2^{\circ}$. <Colación del mismo beneficio en Diego Díaz de la Ayuela. Año 1630>.

Colación del mismo beneficio hecha por el licenciado don Pedro Caveza Vela, arcediano de Neyra, provisor de Lugo, en Diego Díaz de la Ayuela, clérigo. Por esta colación consta que, haviendo vacado el dicho beneficio por muerte del licenciado Diego Gómez Valcárcel, último poseedor, Diego Pérez Sanjurjo pidió el dicho beneficio por de libre colación, la qual se le dio, y tomó la posesión haviendo calificado su persona. Ésta se contradijo por parte deste monasterio por ser este beneficio de su presentación insolidum, por haver vacado en el mes de diciembre de 1629 y tener seis meses en que se havía de hacer 
concurso y remitir al abad los aprobados para que escojiese uno de ellos y, en virtud de la presentación, darle el título de colación. Desto apeló el referido Sanjurjo y se opuso el sobredicho Diego Díaz de la Ayuela y, haviendo provado su intento, diose sentencia en que se declaró ser el dicho beneficio de presentar del abad de San Zoil y de su convento. Fue llamado a examen y aprovado Diego Díaz de la Ayuela y, en este estado, desistió Sanjurjo de la oposición y apelación. Despachose mandamiento, inserta la sentencia, para el padre fray Mauro Deza, abad de Samos, el qual, en virtud del poder que tenía del abad y monges de San Zoil, presentó el dicho beneficio en el referido Ayuela. Y se le dio este título de colación en la ciudad de Lugo, a 12 de junio de 1630, ante Juan de Villar, notario.

Está aquí la posesión que el referido tomó del dicho beneficio el mismo mes y año ante Benito Rodríguez Pillado, notario. $1631>$

/ (f. 181v) $3^{\circ} .<$ Colación del mismo beneficio en Álvaro de Torres Castellanos. Año

Colación del mismo beneficio hecha por don Diego Vela, obispo de Lugo, a Álvaro de Torres Castellanos, clérigo de menores órdenes, por la qual parece que, haviendo vacado este beneficio por muerte de Diego Díaz de la Ayuela, último poseedor, se opuso insolidum el dicho Álvaro de Torres; y, haviendo calificado su persona, se dio traslado al fiscal. Diose sentencia en que se declaró al referido por legítimo opositor y ser el beneficio de presentación del abad y convento de San Zoil, por haver vacado en el mes de junio de 1630, que es uno de los quatro reservados. Examinado y aprobado el dicho Álvaro de Torres, se despachó mandamiento (que está aquí inserto), para el abad y convento de San Zoil. Y éste, con poder que dio al padre fray Mauro Deza, abad de Samos, hizo presentación del dicho beneficio en el referido Álvaro de Torres Castellanos. Y en virtud de ella se le dio este título de colación en la ciudad de Lugo, a 10 de enero de 1631, ante Álvaro de Aguiar, secretario, y la posesión ante Pedro Sal, clérigo, notario.

Sacose este testimonio, que concuerda con su original, por Gerónimo López Labrador, notario.

$4^{\circ}$. < Carta del obispo del Lugo al abad de San Zoil. Año 1631>.

Carta del señor don Diego Vela, obispo de Lugo, al abad de San Zoil, en la que confiesa pertenecer a éste la presentación del referido beneficio y le da las gracias por la acertada elección de la persona del sobredicho Álvaro de Torres. Su fecha, en Lugo, a 11 de febrero de 1631. $1678>$.

$5^{\circ}$. <Testimonio de la presentación del mismo beneficio en Andrés González. Año

Testimonio dado por Norverto de Sandoval y Guevara, escribano de Carrión, de la presentación que del referido beneficio hizo fray Juan González, abad de San Zoil, en el licenciado Andrés González, cura de la parroquia de Santa Olalla, del lugar de las Heras. Su fecha, en Carrión, a 4 de noviembre de 1678.

Está aquí la acetación que desta presentación hizo el referido Andrés González ante Thorivio Martín, cura del lugar de Pino de Viduerna, notario apostólico.

$6^{\circ}$. <Testimonio del derecho que tiene el abad de San Zoil a la presentación deste beneficio. Año 1769>.

Testimonio dado por Thomás Varela, notario de la ciudad de Lugo, de la sentencia pronunciada por el fiscal de aquella audiencia, en la que se declara el derecho del abad deste monasterio a la presentación del beneficio curado de Santa Comba dos Dados en los quatro meses ordinarios, y que al presente estaba vaco por muerte de don Gabriel Varela, último poseedor. Su fecha, en Lugo a 10 de abril de 1769, que es el mismo año en que se dio la sentencia.

/ (f. 182r) $7^{\circ}$. $<$ Reconocimiento del derecho de presentar el beneficio. Año de 1814>.

Carta del señor cura de Vilachá de Mera, con un reconocimiento del derecho y estado actual en que se halla este monasterio de presentar el beneficio curado de Santa Comba dos 
Dados de Fornelas, pedida a instancia del monasterio, sacado del archivo de Lugo, dado por don Antonio Álvarez Vigil, archivero del público general eclesiástico de dicha ciudad de Lugo, a 5 de agosto de 1814.

\section{/ (f. 182v) Quaderno C del legajo $3^{\circ}$ Cornón y Cornoncillo}

En este quaderno $\mathrm{C}$ están los papeles pertenecientes a los lugares de Cornón y Cornoncillo, por el orden siguiente:

$1^{\circ}$. $<$ Donación de dos solares en Cornoncillo. Era 1093. Año 1055>.

Donación que hizo a San Román una muger llamada Lootracia de dos solares en el lugar de Cornoncillo, al arroyo de Cornone. Facta carta era 1093, que es año de Christo 1055, reunante (sic) rex Ferdinando in Legione; et comite Gaumit Didat, in Sancti Romani; et in Saldania; episcopus Ciprianus, in sedis Legionis Sancta María. Apas Bonomen. Hay copia simple.

$2^{\circ}$. <Donación de un solar en Cornón. Era 1198. Año 1160>.

Donación que hizo a San Román Estévan Clérigo de un solar que él había comprado en Cornón, con la condición de vivir en él, y se ofrece a pagar cada año 8 fanegas de zenteno; y sus sucesores que paguen seis. Y que sus parientes que vivieren en dicho solar que sean collazos de San Román, con que los mantenga y defienda el prior con justicia y honor. Y después de sus días manda la mitad de su hacienda a San Román. Y fray Achardo, prior de San Román, que otorga esta escritura, le concede a él y a sus sucesores ración en San Román / (f. 182v) mientras guardaren obediencia al prior. Facta carta in Sancto Romano, quinto kalendas martii, era 1198, que es año 1160. Está escrita en pergamino.

\section{3. <Donación de un solar en Cornonzillo. Era 1210. Año 1172>.}

Donación, escrita en pergamino, que hizo a San Román Bartholomé Clérigo de un solar que tenía en Cornoncillo, con que le tenga él por sus días dando a San Román 6 fanegas de centeno cada año; y el que le tubiere de su linage dé 5, y que sea collazo de San Román, con que le defienda y ampare. Y fray Pedro, prior de San Román, concede a él y a qualquiera de su linage que le habitare ración como a un capellán todas las veces que la quisiere, como guarden obediencia al prior. Facta carta in Sancto Romano, XVII kalendas septembris, era 1210, que es año 1172.

4. <Donación de Elvira Fernández de toda la hacienda que tenía en Cornón. Era 1267. Año 1229>.

Donación, escrita en pergamino, por la qual Elvira Fernández da a Pedro Fernández, prior, y al monasterio de San Román, toda quanta hacienda tenía en Cornón de Pedro Martínez, su palacio con las yglesias y vasallos, posesiones, solares, tierras, prados, montes, etcétera, porque rueguen a Dios por ella. Se entra monja del orden cluniacense, promete al prior obediencia según la regla de San Benito y perseverar hasta la muerte en el monasterio de San Román, y el prior la admite y recibe por monja de aquel monasterio. Facta carta era 1267 , que es año de 1229.

Hay copia authorizada.

5. <Apartamiento de una demanda por un suelo en Cornón. Era 1274. Año 1236>.

Apartamiento, escrito en pergamino, que hizo Guier Sánchez de una demanda que había puesto a don Pedro, prior de San Román, por la mitad de un suelo en el lugar de Cornón, por cierta satisfacción que el referido prior le había dado. Facta carta era 1274, que es año 1236.

6. <Donación de unas casas en Cornoncillo. Era 1297. Año 1259>.

Escritura en pergamino, por la qual don Juan, prior de San Román, junto con su convento, recibe por familiares a don Guijelmo y a su muger, doña Yllana, y les da por sus 
días el prado del Pollo y otro prado en Muñeca ${ }^{279}$, y que después buelban a San Román; y el referido don Guigelmo y su muger, en agradecimiento desta merced, dan a San Román las casas que tenían en Cornoncillo y los prados de Villaoliva ${ }^{280}$, y obligan a todos los que habitaren dichas casas a que paguen de furción 20 dineros y una gallina. Facta carta XIII días andados de marzo, en la era de 1297, que es año de 1259.

Hay copia authorizada.

7. < Donación de unas casas en Cornón. Era 1306. Año 1268>.

Donación escrita en pergamino, partida por ABC, por la qual Fernán Ruiz y su muger, doña Marina, dan a San Román las casas que tenían en Cornón, con dos losas, por la merced que don Guín, prior de San Román, les / (f. 183r) había hecho en recivirles por familiares, darle a él ración en San Román y a ella quatro maguilas de trigo, dos pozales de vino y un tozino cada año. Facta carta era 1306, que es año 1268.

8. <Compra de unos casares, 4 olmos y 2 tierras en Cornón. Año 1537>.

Compra que hizo fray Diego de Sahagún, prior de San Román, a Rodrigo Lloréntez, clérigo, de unos casares, quatro olmos y dos tierras en el lugar de Cornón, de Pedro Martínez, por precio de 1.200 maravedís. Su fecha, en Villaoliva, a 13 de hebrero de 1537, ante Christóval Gómez de Valderrábano, escribano y notario.

Están aquí dos escrituras de venta de las mismas posesiones. La $1^{a}$ que hizo García Pérez a Pedro de Las Heras, año 1535, ante Juan de Nieves, escribano y vecino de Guardo. La $2^{\text {a }}$ que hizo Pedro de Las Heras a Rodrigo LLoréntez, año 1536, ante Diego de Bustillo, escribano público.

9. < Posesión de una casa y préstamo en Cornón. Año 1567>.

Testimonio dado por Agustín de Medina, escribano real, de la posesión que tomó fray Antonio de Grijalva, prior de San Román, de una casa con sus tierras y prados a ella pertenecientes, en el lugar de Cornón, por muerte de Bartholomé González, vecino de dicho lugar. Su fecha, en Cornón, a 17 de septiembre de 1567. $1797>$.

10. $<$ Trueque de un solar en Cornonzillo por una tierra en el mismo término. Año

Trueque que, con las licencias necesarias, hizo fray Pedro de Castro, prior de San Román, con Antolín Herrero de un solar (que actualmente está reducido a cultura y hace 4 celemines de zenteno) en el lugar de Cornonzillo, por una tierra en el referido lugar, a do llaman a el Mazo, que hace 8 zelemines de sembradura, poco más o menos; linderos, al oriente: con el Camino real que va al barrio de la Puebla; al poniente, con el monte. Su fecha, en San Román, a 10 de mayo de 1797, ante Bernando Valbuena, escribano de la ciudad de Burgos y vecino de Respenda, en cuyo lugar se sacó este testimnio, en el mismo año y por el mismo esscribano. $1797>$.

11. <Trueque de un solar en Cornonzillo por una tierra en el mismo término. Año

Trueque que, con las licencias necesarias, hizo fray Pedro de Castro, prior de San Román, con José Largo García, vecino del lugar de Cornonzillo, de un solar (actualmente reducido a cultura y hace dos zelemines y medion de trigo) en el referido lugar, por una tierra en dicho término, a do llaman encima de las Heras, que hace 7 zelemines de morcajo. Su fecha, en Respenda, a 12 de mayo de 1797, ante Bernando Valbuena, escribano de la ciudad de Burgos y vecino del dicho lugar, en el que se sacó este testimonio, en el mismo año y por el mismo escribano.

\footnotetext{
279 Muñeca] al margen derecho: Muñeca.

280 Villaoliva] al margen derecho: Villaoliva.
} 


\section{Reminiones}

La donación de don Gómez García de todo lo que tenía en el lugar de Cornón. Véase el cajón San Lorenzo, legajo $4^{\circ}$, número $1^{\circ}$, entre los papeles de Muñeca.

\section{/ (f. 183v) Quaderno D del legajo $3^{\circ}$ Santa Cruz de Ventosilla}

En este quaderno D están los papeles pertenecientes al lugar despoblado de Santa Cruz de Ventosilla, jurisdición de Cea, y a la presentación de su beneficio simple, por el orden siguiente:

$1^{\circ}$. <Donación del rey don Alonso a Pedro Muñoz del lugar de Santa Cruz de Ventosilla. Era 1216. Año 1178>.

Privilegio del rey don Alonso, escrito en pergamino, con sello de plomo pendiente, por el qual hace merced y donación a Pedro Muñoz y sus hijos y herederos de toda la heredad que el rey tenía en Santa Cruz de Ventosilla, en el valle de Pero, con todos sus derechos y pertenencias, por el buen servicio que en mucho tiempo le había hecho. Diose este privilegio rodado en la villa de Arévalo, tertio kalendas januarii, era 1216, que es año de 1178.

2. < Confirmación del rey don Alonso a Pedro Gutiérrez de Santa Cruz de Ventosilla. Era 1221. Año 1183>.

Privilegio del mismo rey don Alonso, escrito en pergamino, con sello de plomo pendiente, por el qual concede y confirma a Pedro Gutiérrez y a sus sucesores toda la heredad que había sido del rey en Santa Cruz de Ventosilla y que él había comprado a Pedro Muñoz por unas casas que le dio en Palencia. Fua dado este privilegio rodado en Cuéllar, $2^{\circ}$ kalendas martii, era 1221, que es año 1183.

3. <Pleito sobre la hermita y término de Santa Cruz de Ventosilla a favor deste monasterio. Año 1445>.

Proceso y sentencia dado a favor deste monasterio por el bachiller Fernan Gonzáez de Frómesta, alcalde mayor del adelantamiento y juez en esta causa, por comisión del conde de Castro, señor de Cea, ante quien parece se querelló don Pedro de Tosantos, abad de San Zoil, de que siendo suyo el término de Santa Cruz de Ventosilla, que está en la jurisdición de Cea, los vecinos de San Pedro, aldea junto a Cea y Santa Cruz, entraron en un monte de su término y se le talaron y destruyeron. Por lo qual el conde dio la dicha comisión al referido alcalde mayor, quien, habiendo citado las partes, hizo averiguación de los términos y mojones de la hermita de Santa Cruz de Ventosilla como perteneciente a este monasterio. Los quales términos partió el dicho juez habiendo hecho publicación de testigos de las informaciones hechas por parte del monasterio de la villa de Cea y del lugar de Villacaco, y se alzaron y renovaron los mojones, deslindando los términos entre los dichos lugares y Santa Cruz, y se hizo división de la Mata del término de Santa Cruz y del término de Villavelasco, San Pedro y Valderadue.

\section{$<$ Sentencia $>$.}

Y conclusa la causa, el dicho alcalde mayor pronunció / (f. 184r) sentencia definitiva por la qual declara que la hermita de Santa Cruz de Ventosilla y sus términos, que está en la jurisdición de Cea, es y ha sido de (de) tiempo immemorial a aquella parte de los abades y priores de San Zoil y que dicha hermita parte términos con la villa de Cea, con San Pedro de Valderadué, con Villavelasco, con Villacaco, Carvajal, Villadiego, con la hermita de San Llorente, con Valderaniego, con la hermita de Santo Andrés. Nombra todos los linderos y mojones que tiene Santa Cruz por todos estos términos de lugar a lugar, todo alrededor, y dize que renovó todos los mojones y puso de nuevo los que fueron necesarios. Declara los prados, tierras, matas y heredades que están dentro del término de Santa Cruz y que 
pertenecen al monasterio. Declara assimismo el modo que han de tener de pastar con sus ganados los vecinos de los otros lugares en el término de Santa Cruz y que nadie pueda pastar, rozar ni cortar leña en la Mata y señala las penas de los que lo quebrantaren y que éstas sean para el abad o la persona que por él estubiere allí. Y que los renteros de Santa Cruz puedan apacentar sus ganados en los términos de los otros lugares fura de las matas y cotos de ellos. Fue dada esta sentencia en la villa de Cea, a 16 de febrero de 1445, ante Fernando López de Carrión, escribano público. $1445>$.

4. <Copia authorizada de la sentencia de arriba, sentencia sobre el Estepal. Año

Copia authorizada de la sentencia de arriba y otra sentencia dada por el mismo juez sobre el Estepal, en término de Santa Cruz, en la que declara que los vecinos de Cea y de San Pedro de Valderadué están en posesión de pazer y rozar con sus ganados brabos y mansos, sin pena ni coto alguno, en dicho Estepal y por tanto deben hacerlo. Dada en la villa de Cea, a 17 de Febrero de 1445, ante Fernando López de Carrión, escribano público.

5. < Copia authorizada de la sentencia de arriba. Año 1504>.

Copia authorizada por Pedro Fernández de Carrión, clérigo y notario apostólico, de la sentencia que dio el alcalde mayor del adelantamiento en razón de la hermita y términos de Santa Cruz de Ventosilla, con el testimonio dado por el mismo notario de el arrendamiento que del dicho término hizo este monasterio a los vecinos de San Pedro de Valderadué el año de 1502. Fue sacada esta copia año de 1504.

6. $<$ Querella contra los vecinos de las casas de Cea. Año 1517>.

Querella dada por parte deste monasterio ante el prior de Escalada, juez conservador, contra los vecinos de las aldeas de Cea, porque sin licencia del monasterio entraban con sus ganados a pastar en los términos de Santa Cruz de Ventosilla. Año de 1517.

7. < Colación del beneficio simple de Santa Cruz en Fernán González. Año 1556>.

Colación del beneficio simple de Santa Cruz de Ventosilla hecha por Lope Castañón, canónigo de León, por don Pedro de Marquina, arcediano de Cea, / (f. 184v) en Fernán González, clérigo, vecino de Castromudarra, por simple resignación que de él hizo Hernando de Prado, vltimo poseedor, y en virtud de la presentación que en el referido Fernán González hizo el maestro fray Rodrigo de Corcuera, abad de San Zoil. Dada en León, a 19 de henero de 1556, ante Andrés Pérez, notario apostólico.

Está aquí inserta la posesión que el sobredicho tomó del referido beneficio en el mismo mes y año, ante Pedro Constancio, escribano y notario público.

8. <Foro a favor deste monasterio de 7.500 maravedís y 4 cabritos. Año 1570>.

Escritura de foro perpetuo, por la qual consta que, habiendo este monasterio otorgado otra escritura de foro perpetuo al concejo de Villavelasco de todo el término de Santa Cruz de Ventosilla con todo lo a él perteneciente y deslindado conforme a la sentencia de arriba, número $3^{\circ}$, fuera de la presentación del beneficio simple de la yglesia o hermita de Santa Cruz (que esta la reservó el monasterio para sî) por precio de 4.500 maravedís, de 2 cabritos de foro perpetuo, con condición de que el monasterio pudiese trhaer y pastar en el dicho término de Santa Cruz 350 cabezas de ganado. Pero, ya porque nunca los pastaba ya por otros respetos, el monasterio se llamó a engaño, dándose por enormísimamente lesso; atento lo qual, ante la justicia de Cea, puso demanda al concejo de Villavelasco por el dicho término. Más por escusar pleitos y gastos, el monasterio y el concejo de Villavelasco se convinieron en que el referido concejo pagase al monasterio, de foro perpetuo 3 mill maravedís y 2 cabritos más de los que pagaba por la primera escritura. De suerte que pagase cada año 7.500 maravedís y 4 cabritos; los 4 mill día de Navidad y los 3 mill y 4 cabritos en la Pasqua de Espíritu Santo, y que con esto el monasterio renunciase la acción que tenía a pastar en el dicho término. Hiciéronse los tres tratados y, precedida la licencia del general con las demás solemnidades, otorgose esta escritura de foro perpetuo según va referido, ratificando y aprobando la primera, que pasó ante Juan de Castrillo, escribano de Carrión, quedando en cabeza del monasterio la presentación del referido monasterio y los diezmos de 
la yglesia y tierras a ella pertenecientes para el beneficio de ella, y con condición que el concejo de Villavelasco renueve esta escritura cada diez años, so pena de incomisso y con las demás condiciones ordinarias de los foros perpetuos. A todo lo qual se obligaron, en nombre y con poder del concejo de Villavelasco, los regidores y procuradores de dicha villa. Fecha en San Zoil, a 10 de diciembre de 1570, ante Andrés Sánchez, escribano de Carrión.

\section{/ (f. 185r) 9. <Colación del mismo beneficio en Gerónimo González. Año 1603>.}

Colación del mismo beneficio dada por el licenciado don Antonio Ramírez, provisor de León, a Gerónimo González Pajuela por dejación que de él hizo el licenciado Estevan Calvo y en virtud de la presentación hecha por el padre maestro fray Alonso Barrantes, abad de San Zoil. Dada en León, a 20 de septiembre de 1603, ante Antonio de Zafra Argüelles, notario.

Está aquí la posesión que tomó el mismo ante Francisco Muñoz, escribano de Cea. Y este testimonio sacado a petición deste monasterio, por Juan de Santa María, notario y vecino de Cisneros.

\section{0. <Colación en Justo González. Año 1656>.}

Colación del mismo beneficio dada por el licenciado don Leonel de Abreu y Azebedo, provisor de León, a Justo González, natural deVillabasta, por renuncia que de él hizo Gerónimo González Pajuela y en virtud de la presentación hecha por el abad de este monasterio. Dada en León, a 12 de enero de 1656, ante Pedro de Espinosa y Conchés, notario. Y este testimonio, que concuerda con su original, fue sacado, a petición del monasterio, por Antonio de Fresnedo, notario público, año 1657.

11. <Presentación y colación en don Juan de la Calle Santos. Año 1691>.

Testimonio dado por Bernardo González de Córdova, escribano de Guardo, de la presentación y colación hecha por el maestro fray Diego de Fonseca, abad de San Zoil, y por el licenciado don Blas Gutiérrez del Campo, provisor de León, en el licenciado don Juan de la Calle Santos, natural de Guardo, por resignación que hizo del referido beneficio José Sebastián (cuyo título falta). Fue dada la presentación en el monasterio de San Zoil, a 12 de noviembre de 1691, ante Norberto de Sandovsl y Guevara, escribano y notario de Carrión; y el título de colación, en León el mismo mes y año, ante Juan Rodríguez Mayo, escribano de León.

Está aquí la posesión que tomó él mismo del referido beneficio, ante Manuel de Villaverde, cura de Villavelasco y notario apostólico.

12. <Presentación en don Juan Carrillo. Año 1716>.

Presentación del mismo beneficio hecha por el padre maestro fray Jacinto Díez, abad de San Zoil, en el licenciado don Juan Carrillo, natural de Villalón, por muerte de don Juan de la Calle Santos, vltimo poseedor. Su fecha, en San Zoil, a 28 de junio de 1716, ante Gregorio García de Miranda, notario público y vecino de Carrión.

13. <Presentación y colación en don Juan de Montenegro. Año de 1734>.

Presentación y colación del mismo beneficio hecha por el reverendo padre maestro fray Jacinto Díez, abad de San Zoil, y por licenciado don Fernando Antonio de Herrera, provisor de León, en el licenciado don Juan de Montenegro, presbítero, natural de León, por muerte de don Sebastián del Campo,su último poseedor (cuyo título falta). Fue dada la presentación en San Zoil, a 24 de octubre de 1734, ante Agustín Díez de Castro, escribano y notario de Carrión; y el título de colación, ante Felipe Margolle Robles; y este testimonio de la colación ante José Espinosa, notario apostólico.

\section{/ (f. 185v ) 14. <Ordenanzas de Villavelasco. Año 1737>.}

Traslado autorizado por Francisco Cano Núñez, escribano de Carrión, de las ordenanzas del lugar de Villavelasco, confirmadas por el consejo, en 29 de abril de 1737, y sacado este traslado en 26 de junio del mismo año, a petición deste monasterio. 
15. < Auto definitivo en que se declara pertenecer a este monasterio el término de Santa Cruz de Ventosilla. Año de 1739>.

Testimonio dado por Gerónimo de la Mata y Puerta, escribano de Sahagún, del auto definitivo dsdo a favor deste monasterio por don Juan Pérez de la Lastra, alcalde mayor de la villa de Sahagún, juez privativo de despoblados, en virtud de cédula real, en el que declara tocar y pertenecer a este monasterio el término despoblado de Santa Cruz de Ventosilla y que no ha lugar de incorporarle en el Real Patronato, sin embargo de no constar donación expresa hecha a este monasterio del referido término y de lo delegado por el fiscal de Su Magestad, que todo se haya inserto aquí. Dado en Sahagún, a 16 de septiembre de 1739, ante el referido Gerónimo de la Mata y Puerta.

\section{/ (f. 186r) Quaderno E del Legajo $3^{\circ}$}

Entorcisa

En este quaderno E están los papeles pertenecientes al lugar de Entorcisa, por el orden siguiente:

$1^{\circ}$. $<$ Foro de 30 maravedís, un par de gallinas, otro par de cabritos y dos pares de perdices sobre un suelo en Entorcisa. Año 1403>.

Escritura de foro perpetuo, escrita en pergamino, por la qual don Beltrán de San Basille, prior mayor de San Zoil, da a Alfonso Fernández, vecino de Muñeca, un suelo para poblar casas en el lugar de Entorcisa ${ }^{281}$ y toda la heredad de pan llevar y todos los prados que pertenecían al dicho priorato de San Zoil en el lugar de Muñeca ${ }^{282}$, por 30 maravedís, un par de gallinas, otro par de cabritos y dos pares de perdizes de foro perpetuo. Su fecha, en San Zoil, a 12 de enero de 1403, ante Gómez García de Saldaña, escribano de Carrión. Hay copia authorizada y duplicada.

\section{2. $<$ Requirimiento para que se entregase un proceso. Año 1552>.}

Testimonio dado por Juan de Hinojedo, escribano de Saldaña, de un requirimiento que se hizo por parte del monasterio de San Román a Juan Díaz, escribano de dicha villa, para que entregase un proceso del pleito que tenía San Román con Fabián de la Fuente, vecino de Entorcisa, en virtud de una provisión que se había traído para ello. Su fecha, en Saldaña, a 20 de septiembre de 1552.

\section{Remisiones}

$<$ Trueque $>$.

La hacienda deste lugar pertenece a San Román por el trueque que hizo con este monasterio, año de 1406. Véase el cajón San Martín, legajo $1^{\circ}$, quaderno B, número $3^{\circ}$.

$<$ Donación $>$.

La donación de doña Vrraca Martínez, para la obra de San Román, de toda la heredad que tenía en Entorcisa, año de 1196. Véase el cajón San Lorenzo, legajo $2^{\circ}$, quaderno A, número $3^{\circ}$, entre los papeles de las Heras.

$<$ Donación $>$.

La donación de don Gómez García, de todo lo que tenía en Entorcisa, año de 1222. Véase el cajón San Lorenzo, legajo $4^{\circ}$, número $1^{\circ}$, entre los papeles de Muñeca.

\footnotetext{
${ }^{281}$ Entorcisa] al margen derecho tachado: Entorcisa.

${ }^{282}$ Muñeca] al margen derecho: Muñeca.
} 
$<$ Trueque $>$.

Trueque de dos solares por una tierra. Véase el cajón San Bernado, legajo $1^{\circ}$, quaderno $\mathrm{A}$, número $6^{\circ}$.

\section{/ (f. 186v) Quaderno F del Legajo $3^{\circ}$ \\ Fontecha}

En este quaderno F están los papeles pertenecientes al lugar de Fontecha, por el orden siguiente:

$1^{\circ}$. $<$ Donación de un solar y préstamo. Era 1171, año 1133>.

Donación, escrita en pergamino, que hizo Martín Gonzálvez y su muger, Vrraca Muñoz, de un solar y préstamo en el lugar de Fontecha, término de San Román, a Monio Velítez y su muger, Cete Anayaz, para que funden y vivan en él. No habla nada de San Román. Facta carta era 1171, que es año 1133.

2. <Compra de toda la heredad en el alfoz de San Román y en Fontecha. Era 1233, año $1195>$.

Compra que hizo el maestro Juan, prior de San Román, a Alfonso López, hijo de Lope López y de Vrraca Petriz, de toda la heredad que le pertenecía de su madre y de su abuelo el conde don Pedro, en el alfoz de San Román, poblado y por poblar, montes, prados etcétera, con todo lo que tenía en Fontecha, en Villanueva, en Varrio y en Pino ${ }^{283}$, por 40 maravetinos. Facta carta era 1233, que es año 1195. Concilium de Carrión auditores et confirmatores. Está en pergamino.

3. < Compra de una heredad en Fontecha. Era 1253, año 1215>.

Compra, escrita en pergamino, que hizo don Hugo, prior de San Román, a don Fernando Petri y su muger, doña Vrraca, una heredad que había sido de Domingo Petri, en la villa de Fontecha, por 5 morabetinos que el referido prior le dio, con que se da por pagado. Facta carta era 1253, que es año 1215.

4. <Requirimiento a Vitorio de la Calle, para que dexe una casa y lo anexo a ella, en Fontecha. Relación de los mismos bienes en manos del prior de San Román. Año 1695>.

Bajo este número están los papeles siguientes:

$1^{\circ} \mathrm{Vn}$ testimonio dado por Miguel de la Vega, notario público del lugar de Aviñante, de un requirimiento que el prior de San Román hizo a Vitorio de la Calle, vecino de Fontecha, para que dexase libre una casa, tierras y prados a ella anejas, propios de dicho monasterio, en que se había metido sin título alguno; a que se sigue la respuesta que dio el referido Vitorio de la Calle. Parece que por inadvertencia se olvidó poner la fecha.

$2^{\circ}$ Testimonio dado por el sobredicho escribano y Andrés de la Calle, escribano de Fontecha, de las declaraciones que hizieron Juan de la Fuente, Toribio Lobato y otros vecinos de Fontecha, de cómo gozaban una casa de San Román, dividida en diversos poseedores por enagenación de Toribio de la Calle y sus herederos, con que parece ser la misma de arriba. Su fecha, en Fontecha, a 11 de abril de 1680.

$3^{\circ}$ Testimonio dado por el mismo escribano, Miguel de la Vega, de cómo ante él se había apeado la hacienda que el priorato de San Román tenía en Fontecha; y en este testimonio hace relación de tres casas y solares, dos prados y un huerto / (f. 187r) y en común de todo lo perteneciente a los préstamos de las tres casas. Su fecha, en Aviñante, a 10 de marzo de 1680.

Vltimamente está otro testimonio dado por Andrés de la Calle, escribano y vecino de Fontecha, de la dejación que doña Lorenza de Vega, viuda de don Juan de la Calle Santos, vecina del mismo lugar, hizo del préstamo de casa, prados y tierras que dicho su

\footnotetext{
${ }^{283}$ Pino] al margen derecho: Villanueva, Varrio y Pino.
} 
marido había gozado como hijo de Vitorio de la Calle, contra quien se hizo el requirimiento de arriba. Su fecha, en Fontecha, a 8 de mayo de 1695.

5. <Trueque de una casa, corral y huerto por dos tierras y un prado. Año 1789>.

Trueque que hizo el padre fray Gregorio Calderón, prior de San Román, con Felipe García, vecino de Fontecha, de una casa, corral y huerto que el dicho priorato tenía en el dicho lugar, por dos tierras y un prado en el término del referido lugar; que la $1^{a}$ está a do llaman los Cerojales, a la Lorenza, y hace una fanega de zenteno; la $2^{\mathrm{a}}$, a la loma de Fonlada, hace medio quarto de sembradura; y el prado, al molino de Miguel Fuentes, y hace una carretada de yerva. Su fecha, en San Román, a 19 de mayo de 1789, ante Manuel París, escribano real y vecino de Villanueba de Arriba.

6. <Trueque de un solar por un prado. Año 1789>.

Trueque que hizo el mismo prior de San Román, con don José de Zevallos, vecino de Fontecha, de un solar en el casco de dicho lugar, perteneciente a dicho priorato, por un prado en el término del referido lugar, encima de la Puente y bajo de la hermita de Nuestra Señora de Fonlada. Su fecha, en Fontecha, a 22 de febrero de 1789, ante Manuel Luis París, escribano real y vecino de Villanueba de Arriba.

\section{Remisiones}

$<$ Nota $>$.

La hacienda de este lugar pertenece a San Román por el trueque que hizo con este monasterio, año de 1406. Véase el cajón San Martín, legajo $1^{\circ}$, quaderno B, número $3^{\circ}$.

$<$ Trueque $>$.

Trueque. Véase el cajón San Gregorio, legajo $2^{\circ}$, quaderno Y, número $2^{\circ}$.

\section{/ (f. 187v) Quaderno G del Legajo $3^{\circ}$ \\ Frechilla}

Este quaderno $G$ contiene los papeles pertenecientes a la hacienda que tiene este monasterio en el lugar de Frechilla, por el orden siguiente:

$1^{\circ}$. $<$ Foro de 45 maravedís por un solar. Año 1393>.

Escritura de foro perpetuo, en pergamino, por la qual Juan Alfonso, prior de claustra, con licencia de don Toribio, prior mayor de San Zoil, da a Pedro Fernández Havero, vecino de Frechilla, dos suertes de un solar, dividido en cinco suertes; otra a Juan García, otra a García Galiano, y otra suerte a Juan Ferrero, para que edifiquen casas en él, por 9 maravedís de foro perpetuo que cada uno debe pagar. Su fecha, en San Zoil, a $1^{\circ}$ de mayo de 1393, ante Rodrigo Alfonso, escribano de Carrión.

2. < Foro de 1.500 maravedís y 18 gallinas por las heredades de Frechilla. Año 1518>.

Escritura de foro perpetuo, por la qual este monasterio precediendo los tres tratados y licencia del General dan al concejo y vecinos de la villa de Frechilla 24 tierras que están deslindadas en esta escritura, unas casas con su corral y 45 maravedís de foro perpetuo sobre otras cinco casas, por 1.500 maravedís y 18 gallinas de foro perpetuo, puesto en San Zoil a costa del concejo y vecinos del dicho lugar. Su fecha, en San Zoil, a 5 de octubre de 1518, ante Floristán de la Serna, escribano de Carrión.

$<$ Reconocimiento $>$.

Está aquí el reconocimiento que deste mismo foro hizo la justicia deste lugar por sí y en nombre del concejo de él, en el que confiesan la obligación que tienen a su paga, sin embargo de una orden que recibieron del real y supremo Consejo, en que les mandaba no satisficieren dicho foro de los propios desta dicha villa. Su fecha, en Frechilla, a 16 de marzo 
de 1770, ante Santiago García Bartholomé, escribano de dicha villa. Hay copia authorizada del foro.

3. <Amojonamiento de Frechilla y Fuentes. Año 1552>.

Testimonio signado de Juan Racho, escribano de Frechilla, de cómo se alzaron y renovaron los mojones entre los términos de Frechilla y Fuentes de don Vermudo. El primer testimonio (de los dos que aquí hai sobre lo mismo) fue dado a 20 de mayo de 1523 ; y el $2^{\circ}$, a 21 de noviembre de 1552.

\section{Remisiones}

La donación de doña Mayor García de toda su porción entera en Frechilla hecha año de 1118. Véase el cajón Santa María, legajo $1^{\circ}$, quaderno A, número $2^{\circ}$.

La donación de un vasallo que hizo don Pedro Ansúrez, por el trueque que con él hizo este monasterio, año de 1095 . Véase el cajón San Plácido, legajo $5^{\circ}$, entre los papeles de Villamez, quaderno $\mathrm{B}$, número $1^{\circ}$.

La ynformación y entrega de una tierra, parte de ella en Frechilla y parte en Fuentes de don Vermudo. Véase el cajón San Lorenzo, legajo $1^{\circ}$, quaderno A, número $3^{\circ}$.

/ (f. 188r) En el legajo de papeles sueltos se hallan 3 escritos de vitas, en pergamino, de varias casas, tierras y viñas en Frechilla. 


\section{/ (f. 188v) Cajón $8^{\circ}$ San Agapio \\ Frómesta}

Este cajón San Agapio, que es el $8^{\circ}$ del archivo, contiene quatro legajos pertenecientes todos al priorato de San Martín de Frómesta: El legajo $1^{\circ}$ contiene donaciones, compras, trueques y foros; legajo $2^{\circ}$ : yglesia de San Martín y esención de diezmos, Santísimo Milagro, qüentas de la fábrica, sacristía e yglesia de San Lázaro; legajo $3^{\circ}$ : presentación y colaciones de capellanías, congrua y rezo de los Capellanes, diferencias sobre la visita y otras cosas; legajo $4^{\circ}$ : cartas de pago y qüentas.

\section{Legajo $1^{\circ}$}

Este legajo contiene los dos quadernos siguientes: quaderno A: donaciones hechas a San Martín de Frómesta y algunas a este monasterio; quaderno B: compras, trueques y foros.

Quaderno A del legajo $1^{\circ}$

Este quaderno contiene las donaciones hechas a San Martín de Frómesta y algunas a este monasterio en dicho lugar, por el orden siguiente:

$1^{\text {o }}$. $<$ Donación de San Martín de Frómesta y sus tercias por la reyna doña Mayor. Era 1104, año 1066>.

Vn quaderno de nueve ojas, escritas en pergamino de letra antigua, en el qual hay las escrituras siguientes:

$\mathrm{Al}$ folio $1^{\circ}$ está el testamento y donación de la reyna doña Mayor, hija del conde don Sancho, por la qual manda al monasterio de San Martín de Frómesta que ella había comenzado a edificar junto a Frómesta de sus heredades lo siguiente: toda la población que ella había poblado junto a la misma yglesia, las viñas y tierras que habían servido a la casa de San Martín, para ella y los que allí sirvieren, más otras posesiones de las quales una está en la villa de Bobadilla ${ }^{284}$, y en otra villa que se llama Agero, que ella había comprado de su haber; también da las tercias de Frómesta y de Población medio prado y una serna en Villota. Y dice que nadie se atreva a hacerles injuria porque no es decente que tal género de hombres / $(f$. 189r) como los monges esté sujeto a ningún hombre, sino a solo Dios. Divide las ovejas, bacas y yeguas que tenía en Frómesta. Y las vacas que tenía en Asturias las divide en tres partes: la primera da al lugar donde fuere sepultado su cuerpo; la segunda parte a San Martín, para que los sirvientes, legos y clérigos que día y noche sirven allí, tengan de qué sustentarse; y la tercera da a los tres monges que allí asisten, para que digan por ella oraciones, vigilias, oficios de difuntos, canten misas y hagan por su alma el bien que pudieren. Fue hecha esta donación en los ydus de junio, era 1104, que es año de Christo 1066. Hay copia authorizada.

$<$ Concordia entre el Zebrero y el Hospital de Villafranca. Era 1227, año 1189>.

A folio $2^{\circ}$ hay una concordia entre Oliverio, prior del Zebrero, y el Hospital de Villafranca, en la que el del Zebrero dexa lo que tenía en Villafranca con unos molinos, y el de Villafranca dexa lo de Perexe y cierta cantidad de maravedís. Su fecha, en Villafranca, era 1227, que es año de 1189. No pertenece en cosa alguna a este monasterio.

$<$ Censo perpetuo de 2 mill monedas de oro que concedió el rey don Alonso el $6^{\circ}$ al monasterio de Cluni. Año 1090>.

A folio $3^{\circ}$ está una escritura del rey don Alonso el $6^{\circ}$ (que la trae el maestro Yepes en el tomo $4^{\circ}$, página 453), hijo de don Fernando el $1^{\circ}$, por el qual confirma un censo anual de mil monedas de oro (que él llama methales), que su padre había concedido al monasterio de Cluni, por la hermandad que tenía con dicho monasterio, y añade al dicho censo otras misl monedas de oro (que son dos mil) por la misma hermandad. Su fecha, en Burgos, en el año de 1090 .

$<$ Donación de la reyna doña Vrraca del monasterio de San Martín de Frómesta con toda la heredad que a ella le pertenecía. Era 1156, año 1118>.

${ }^{284}$ Bobadilla] al margen derecho: Bobadilla, Agero, Población, Villota. 
A folio $4^{\circ}$ está la donación de la reyna doña Vrraca, hija del rey don Alonso el $6^{\circ}$, en la que dice que hace su testamento a Dios y a los bienaventurados Apóstoles San Pedro y San Pablo de Cluni, y al monasterio de San Juan Baptista y de los Santos Mártires Zoil y Felices de Carrión, y al prior don Esteban, su fidelísimo amigo, de su heredad propia que tiene de su padre y de sus abuelos por juro de heredad, esto es: el monasterio de San Martín de Frómesta con su foro y con sus yglesias o tercias, tierras, viñas, pobladas y no pobladas, y todas sus heredades donde quiera que se hallaren, para que los religiosos de Cluni que viven en el dicho monasterio de Carrión lo posean quietamente y por juro de heredad para que el Señor Omnipotente, por la intercesión de los dichos Apóstoles y oraciones de los monges de Cluni, le perdone sus pecados y los de sus padres. Fue hecho este testamento en la era de 1156, que es año de 1118, $2^{\circ}$ nonas ianuarii. Hay dos copias authorizadas. Cestillos $>$.

/ (f. 189v) <Aniversario por don Raymundo, obispo de Palencia, que dio la tercia de

A folio $5^{\circ}$ está una escritura otorgada por don Humberto, prior y camarero, y todo el convento de Carrión, en la que ofrecen hacer un aniversario por don Raymundo, obispo de Palencia, y que este se haga por el limosnero que tuviere el hospital de pobres, de la tercia del diezmo que pertenece al obispo en Cestillos ${ }^{285}$; y que este día (que ha de ser el lunes primero de Quaresma) dé una comida al convento y a 12 pobres, mientras tubiere la dicha tercia. Esto mismo, dice, concedió don Pedro, abad de Cluni, y todo el convento en su capítulo pleno, quando hizo profesión en él el referido don Raymundo. Esta escritura no tiene fecha.

\section{$<$ Donación de 4 güertos para zamarros de los viejos de San Zoil $>$.}

A este mismo folio está una donación que hizo al monasterio de San Zoil el mismo fray Humberto, de quatro huertos para zamarras de los viejos; y el monasterio se ofrece hacerle un aniversario ${ }^{286}$ perpetuamente, y cada sacerdote decirle una misa; y el camarero les ha de dar una comida y assimismo a 12 pobres. Esta donación la confirmó Radulfo, abad de Cluni, como se ve al folio $5^{\circ}$ vuelta deste mismo quaderno; pero ni una ni otra tiene fecha. Frómesta>.

$<$ Sentencia del obispo de Palencia a favor deste monasterio sobre las tercias de

A folio $6^{\circ}$ está una relación que hizo Alderico, obispo de Palencia, a G[onzalo Pérez ${ }^{287}$, arzobispo de Toledo, ante quien pendía, en grado de apelación, un pleito que este monasterio tenía con los clérigos y vecinos de Frómesta sobre la tercia de los diezmos de aquella villa, que solía gozar la iglesia de San Martín, que es miembro de San Zoil. Pone las razones de una y otra parte, las quales, vistas con diligencia, dice el señor obispo de Palencia: absolvimos al señor camarero de la demanda que le pusieron quanto a la dicha tercia de los diezmos; y moderamos la procuración según lo que oýmos de ambas partes, de suerte que todos los que dan diezmos sean admitidos a la dicha procuración, con tal que no vaya a ella sino sola una persona de cada casa. La parte del concejo apeló a vuestra audiencia sobre ambos artículos: el camarero aunque quiso obedecer nuestra sentencia si la parte contraria no apelara; pero esta supuesta apeló sobre el artículo de la procuración. Yo dándoos debida reverencia señalé a ambas partes día determinado, que es la dominica que se canta Misericodia Domini, para que se presenten ante vuestra presencia a oýr lo que vuestra santidad determina sobre esto. No tiene fecha.

Este pleyto le concordaron año 1186, como consta de un privilegio del rey don Alonso el nono, que está en el cajón San Román, legajo $1^{\circ}$, número $1^{\circ}$.

/ (f. 190r) <Confirmación de Humberto en prior de San Zoil y camarero de España de la donación de los zamarros>.

A este mismo folio buelta está una escritura por la qual fray Radulfo, abad de Cluni, confirma a Hunberto en prior perpetuo de San Zoil y Camarero de España, y asimismo

\footnotetext{
285 Cestillos] al margen derecho: Cestillos.

286 aniversario] al margen derecho: Aniversario.

${ }^{287}$ G[onzalo Pérez]: arzobispo de Toledo entre 1182 y 1191.
} 
confirma la donación que el mismo Hunberto había hecho para zamarros de los viejos de San Zoil que es la que está al folio $5^{\circ}$ deste quaderno.

$<$ Memoria de las alhajas de la yglesia de San Zoil $>$.

$\mathrm{Al}$ folio $7^{\circ}$ está una memoria de las alhajas y tesoro que había en la yglesia de San Zoil. Estas escrituras no tienen fecha.

$<$ Pesquisa sobre el agua del Cuérnago y su presa. Era 1241 (sic), año 1103>.

$\mathrm{Al}$ mismo folio vuelta está la pesquisa que hicieron don Pelayo, abad de Sahagún, y Rodrigo Martín, por $<$ mandado $>$ del rey don Alonso el $6^{\circ}$, sobre el agua del Cuérnago y su presa, que viene a entrar en San Zoil, de la qual se hace mención en el privilegio original del mismo rey, que está en el cajón San Pedro, legajo $4^{\circ}$, número $1^{\circ}$. Facta carta in claustro beati Zoili, era 1241 (sic), que es año de 1103.

$<$ Pesquisa sobre los pastos y riego del lugar de Gañinas $>$.

Al folio $8^{\circ}$ está una pesquisa que hizieron don Juan, abad de Benevivere, Álvaro Lazareno y Fernando Núñez, soldados, por comisión del rey don Alonso, en razón de los pastos y riego del lugar de Gañinas ${ }^{288}$. Esta escritura está cortada por abajo y sólo puede servir de memoria.

$2^{\circ}$. <Donación de un suelo a un cappellán de San Martín. Era 1354, año 1316>.

Donación, escrita en pergamino, por la qual don Juan de la Dosa, prior de San Zoil y camarero, da a Juan Fernández, capellán de la yglesia de San Martín de Frómista, un solar que es en el corral de dicho monasterio de San Martín, para poblar y hacer casas en él y que sea vasallo del monasterio, y como tal pague todos los fueros y derechos. Su fecha, a 20 de octubre, era de 1354, que es año de 1316, ante don Loreynte, escribano público de Frómista.

$3^{\circ}$. <Comisión pontificia a petición deste monasterio $>$.

Comisión pontificia dada al prior de Santa María de Burgos para que al retor de Santa María del Castillo de Frómista y a otros vecinos de Burgos, Palencia y León se les compela, aunque sea por censuras, a que no impidan al prior de San Martín la percepción de sus rentas y emolumentos. Datum Lugduni, quinto idus aprilis, pontificatus nostri anno octavo.

$4^{\circ}$. <Donación de Mencía Ruiz a este monasterio de San Zoil. Año 1410>.

Donación, escrita en pergamino, por la qual Mencía Ruiz, vecina de Frómista, en el Barrio de San Martín, da a este monasterio de San Zoil todos quantos vienes tiene en el dicho lugar de Frómista y en sus términos, en Población ${ }^{289}$, cerca de Frómista, y en sus términos; en Villasarracino y sus términos; en Piña y sus términos, con condición que el monasterio la sustente, vista y calce por toda su vida y la digan dos treintenarios de misas y un aniversario ${ }^{290}$ cada año día de Santa Cruz de mayo. Su fecha, en el monasterio de San Zoil, a 3 de febrero de / (f. 190v) 1410, ante Francisco Pérez, escribano de Carrión.

Está al pie desta escritura el juramento que hizo la dicha Mencía Ruiz de cumplir esta donación; en el mismo día, mes y año y ante el mismo escribano.

Véase el quaderno B deste legajo desde el número $3^{\circ}$.

5. <Executoriales de Roma a foros del priorato de San Martín>.

Executoriales de Roma, escritos en pergamino, por los quales parece que don Juan de Fonseca, obispo de Burgos y administrador perpetuo de la abadía de San Zoil, se quejó al Papa León $X^{\circ}$ de Hipólito Delgadillo, clérigo, de haberse alzado con el priorato de San Martín de Frómesta, sus frutos y rentas.

$<1^{\text {a }}$ Sentencia $>$.

\footnotetext{
${ }^{288}$ Gañinas] al margen derecho: Gañinas.

289 Población] al margen derecho: Población, Villasarracino, Piña.

290 aniversario] al margen derecho: Aniversario.
} 
Su Santidad cometió la causa al auditor de la Rota y dio sentencia definitiva, por la qual condenó a Hipólito Delgadillo a que restituyese el priorato y no molestase más al obispo de Burgos, que restituyese los frutos que había llevado, y le condena en las costas.

\section{$<2^{a}$ Sentencia $>$.}

Desta sentencia apeló Delgadillo ante su Santidad, y en segunda sentencia cometió la causa a Jacobo Simoneta quien confirmó la $1^{\mathrm{a}}$ sentencia.

$<3^{a}$ Sentencia, que confirma la $1^{\mathrm{a}}$ y $2^{\mathrm{a}}$, a favor del priorato de San Martín. Año 1519>.

Desta $2^{a}$ sentencia bolbió apelar Delgadillo ante el mismo papa, el qual cometió la causa a Camilo Valionibus, auditor de la Cámara Apostólica, el qual confirmó la $2^{a}$ sentencia dada por Simoneta. Y habiendo tres sentencias conformes en favor de don Juan de Fonseca, no hubo lugar a más apelación; y assí por parte del obispo se sacó comisión para executar las tres sentencias. Cometiose al mismo Camilo, el qual tasó las costas de Delgadillo en 60 florines de oro de Cámara y otros quatro más para la expedición de los executoriales, y le condenó a que los pagase juntamente con los frutos recividos del priorato dentro de 30 días. Sacáronse estas executoriales de Roma, a 9 de mayo de 1519, signadas y authorizadas de Remigio Gerardo, notario y substituto de Bernardo de Miranda, notario de la Rota. Hay copia simple de estos executoriales escrita en papel.

$<$ Absolución de censuras $>$.

También se halla aquí la absolución de unas censuras que el referido Hipólito Delgadillo había sacado de Roma contra fray Rodrigo Laso, monge de San Martín de Frómesta, y Gonzalo Gutiérrez, cura de aquella yglesia; la qual absolución fue dada por Diego de Espinosa, canónigo de Palencia, por comisión que para ello tenía del penitenciario de Roma. Dada en Palencia, a 27 de febrero de 1515, ante Alonso de Paz, notario de Palencia.

/ (f. 191r) 6. < Memoria antigua de la hacienda y más cosas pertenecientes al priorato de San Martín. Año 1532>.

Un quaderno, en quartilla, de diez y seis ojas, que contiene una memoria antigua de la hacienda que tenía el priorato de San Martín, derechos y prerrogativas del prior, lo perteneciente a la yglesia, capellanes, Hospital de San Lázaro, y otras cosas curiosas, ordenado por el padre fray Juan de Amayuelas, prior de San Martín, después de aver sido ocho años prior y tener más de 30 de noticia de las cosas de aquel priorato por los monges de la claustra. Escriviole y firmole de su nombre, a 4 de noviembre de 1532.

7. $<$ Venta que hizo este monasterio al de San Benito de Frómesta del priorato de San Martín. Año 1537>.

Escritura de venta, por la qual el abad y monasterio de San Zoil vende (con licencia del General) el priorato de San Martín de Frómesta al monasterio de Santa María de aquella villa (que oy se llama San Benito) con el Patronato, yglesia, hacienda y todo quanto este monasterio tenía allí, excepto los 15 mill maravedís de censo que pagaban a esta casa los mariscales de Frómesta por el varrio de San Martín, por precio de 20 mill maravedís de censo en cada un año, que había de dar el monasterio de Frómesta a este de San Zoil. Pero habiéndose quejado los de San Benito de Frómesta que la hacienda y renta de San Martín no era tanta como se les había prometido, se hizo rebaja del censo y quedó en 16 mill maravedís; sin embargo parece que nada desto tubo efecto. Otorgose esta escritura en Frómesta, a 30 de julio de 1537, ante Juan de Castrillo, escribano de Carrión.

\section{8. $<$ Memoria del priorato de Frómesta $>$.}

Vn quaderno manuscrito que contiene el estado que tenía antiguamente el priorato de San Martín de Frómista y los pleitos y disensiones que ha habido sobre el barrio, yglesia etcétera. Sin fecha. 


\section{/ (f. 191v) Quaderno B del Legajo 1 \\ Compras, trueques y foros}

Este quaderno B contiene los papeles pertenecientes a las compras, trueques y foros hechos por los priores de San Martín y algunos por este monasterio, por el orden siguiente:

$1^{\circ}$. <Trueque se dos pares de casas en Carrión por doce alanzadas y media de viñas y tierras en Frómesta. Era 1366, año 1328>.

Escritura de trueque, escrita en pergamino, con sello de cera pendiente, por la qual don Juan, prior de San Zoil y camarero de Cluni, con el convento dan a Juan Lorenzo, alcalde de Frómesta, dos pares de casas en Carrión por doce lanzadas $<y$ media $>$ de viñas y tierras que él dio al monasterio en término de Frómesta y Población ${ }^{291}$, a carrera de Palencia; y las seis de tierras, a la Pedrera. Su fecha, a 24 de febrero, era de 1366, que es año de 1328, ante Catarino Fernández, escribano de Carrión.

2. <Compra de una tierra. Año 1330>.

Compra, escrita en pergamino, que hizo Estevan García a Pedro Martínez, vecino de Frómesta, de una tierra en Valdefontanas. Su fecha, en el varrio de San Martín de Frómesta, a 6 de marzo de 1330, ante Sancho López de Frómesta.

3. <Compra de un prado. Año 1365>.

Compra, escrita en pergamino, que hizieron Estevan González y Mencía Ruiz a María Juan, vecinos todos de Frómesta, de un prado que es a la presa de Bragadón, por precio de 15 maravedís. Su fecha, en Frómesta, a 30 de septiembre, era de 1403, que es año de 1365.

4. <Compra de una viña. Año 1369>.

Compra, escrita en pergamino, que hizo Mencía Ruiz ${ }^{292}$, vecina de Frómesta, a Diego Martínez, vecino del mismo lugar, de una viña en Villota, que es término del mismo lugar, por precio de 440 maravedís. Su fecha, en Frómesta, a 17 de diciembre, era de 1407, que es año de 1369, ante Juan Martínez, escribano público.

Esta Mencía Ruiz parece ser la misma que donó a este monasterio todo quanto tenía. Véase la escritura de donación deste legajo, quaderno A, número $4^{\circ}$.

5. <Compra de una tierra. Año 1381>.

Compra que hizo Estevan García y su muger, Mencía Ruiz, a Toribio Fernández, vecino de Frómesta, de una tierra a la fuente de la manera, por precio de 140 maravedís. Su fecha en Frómesta a 15 de diciembre. Era de 1419 que es año de 1381, ante Toribio Sánchez, escribano de dicho lugar. Está escrita en pergamino.

6. < Compra de unas casas con su bodega y corral. Año 1381>.

Compra, escrita en pergamino, que hizieron Estevan García y Mencía Ruiz, su muger, vecinos de Frómesta a Martín Bedija, de unas / (f. 192r) casas con su bodega y corral en el barrio de san Martín, por precio de 300 maravedís. Su fecha en Frómesta a 14 de enero. Era de 1419 que es año de 138, ante Toribio Sánchez, escribano de dicho lugar.

7. < Foro de 4 maravedís sobre un suelo en el barrio de San Martín. Año 1389>.

Escritura de foro perpetuo en pergamino por la qual don Thoribio, prior mayor de San Zoil, da a Domingo Fernández de Piña, vecino del barrio de San Martín un suelo de casas en el dicho barrio por 4 maravedís de foro perpetuo. Su fecha en San Zoil a 19 de mayo de 1389, ante Juan Martínez de Frómista, notario de Palencia. Este traslado se sacó en el barrio de san Martín, ante Juan Martínez Alcalde, en el barrio por la orden de San Zoil de Carrión, estando en audiencia en el portal de la yglesia de San Martín, en presencia de Fernando Martínez, notario de la misma ciudad, a 4 de enero de 1419.

\footnotetext{
291 Población] al margen derecho: Población.

292 público] al margen derecho: Nota.
} 
$8^{\circ} .<$ Compra de dos tierras. Año 1390>.

Compra escrita en pergamino que hizo Estevan García, vecino del barrio de san Martín, a Theresa, vecina de Frómista, de dos tierras, la una a Vontidiel. Linde el camino francés y ambas por precio de 120 maravedís. Su fecha en el dicho barrio a 9 de diciembre de 1390, ante Juan García, escribano de Frómista.

9. <Compra de dos suelos. Año 1398>.

Compra escrita en pergamino que hizo don Thoribio, prior del monasterio de San Zoil a Juan Rascón y Ferrando, su hermano, de dos suelos de casas en el abrrio de San Martín a las puertas de Carremonzón, por precio de 110 maravedís. Su fecha en Frómista a 15 de septiembre de 1398, ante Thoribio Fernández, escribano de dicha villa.

10. $<$ Foro de 12 maravedís sobre un suelo. Año 1410>.

Escritura de foro perpetuo en pergamino por la qual don Fernando, prior mayor de San Zoil da a Juan Fernández, vecino de Frómista, un solar que el dicho monasterio de san Zoil tenía en el barrio de San Martín, que ha por linderos de las dos partes huerto y corral del dicho monasterio y de la otra parte la calle que dicen de los Cerones, por 12 maravedís de foro perpetuo. Su fecha en San Zoil a 8 de mayo de 1410, ante Francisco Pérez, escribano de Carrión.

11. $<$ Foro de 48 maravedís para San Zoil sobre 4 obradas de tierra y los diezmos para San Martín. Año 1417>.

Escritura de foro perpetuo en pergamino por la qual don Fernando, prior mayor de San Zoil da a Juan Martínez, notario de Palencia y vecino del barrio de san Martín quatro obradas de tierra en término de Frómesta, que es a do dicen prado Rabi Estubero, para que las plante de viña y de los frutos de ella dé el diezmo a la yglesia de San Martín, viva o no en el barrio, y que pague de foro al referido monasterio de San Zoil 48 maravedís en cada un año. Su fecha en San Zoil a 18 de marzo de 1417, ante Alfonso Rodríguez, notario de Palencia.

12. <Foro de 29 maravedís para San Zoil sobre dos obradas de tierra y los diezmos para San Martín. Año 1418>.

Escritura de foro perpetuo en pergamino por la qual don Fernando, prior mayor de San Zoil da a Diego de Palencia, vecino del barrio de San Martín, dos obradas de tierra en término de Frómesta, a do dicen Revilla Escobedo, con condición que las plante de viña y que ha de dar / (f. 192v) el diezmo a la yglesia de San Martín y que pague por las dos obradas 29 maravedís de foro perpetuo al dicho prior de san Zoil. Su fecha en San Zoil a 19 de diciembre de 1418, ante Ferrando Rodríguez de Castellanos, escribano y notario de Palencia.

13. <Foro de 29 maravedís para San Zoil sobre 2 obradas de tierra y el diezmo para San Martín. Año 1418>.

Escritura de foro perpetuo en pergamino por la qual don Fernando, prior mayor de San Zoil, da a Juan Ponce, vecino del barrio de San Martín, dos obradas de tierra de su priorato, en término de Frómesta, a do dicen Revilla Estovedo, para que las plante de viña, y el diezmo sea para la yglesia de san Martín y que pague por las dos obradas 29 maravedís de foro perpetuo al prior de san Zoil. Su fecha en San Zoil a 19 de diciembre de 1418, ante Ferrando Rodríguez de Castellanos, escribano y notario de Palencia.

14. <Compra de unas casas en Frómesta. Año 1418>.

Compra, (escrita en papel) que hizo Juan de Nogal, vecino del barrio de san Martín, a los concejos de Frómesta y del dicho barrio, de unas casas en Frómesta por precio de 55 maravedís y un dinero. Su fecha en Frómista a 25 de septiembre de 1418, ante García Fernández de Frómesta, escribano de dicha villa y notario de Palencia. 
15. <Foro de 24 maravedís para San Zoil sobre 2 obradas de tierra y el diezmo para San Martín. Año 1419>.

Escritura de foro perpetuo en pergamino, por la qual don Fernando, prior mayor de San Zoil, da a Diego Franco, vecino del barrio de San Martín, 2 obradas de tierra que antes avía dado a Diego Ponce y las dexó, las quales están en término de Frómesta a do dicen la Loma, y se las da con condición que las plante de viña y dé el diezmo de ella a la yglesia de San Martín, y que pague al prior que es o fuere de San Zoil 24 maravedís de foro perpetuo. Su fecha en San Zoil a 6 de diciembre de 1419, ante Ferrando Rodríguez de Castellanos, escribano y notario de Palencia.

16. $<$ Requirimiento deste monasterio a unos vecinos de Frómesta que se entraron en unas heredades propias de él. Año 1438>.

Requirimiento que hizo don Juan, prior de la Claustra de San Zoil a unos vecinos de Frómesta porque sin orden y contra justicia se entraron en unas heredades propias deste monasterio de San Zoil, y quebrantaron las puertas de una herrén que estaba junto a la yglesia de san Martín, arando en ella y en las demás heredades. No hay otra cosa notable en esta escritura que fue hecha a 27 de noviembre de 1438, ante Alvar Martínez de Frómesta, escribano de dicha villa y notario de Palencia.

Están insertos en este requirimiento dos poderes que dio este monasterio al referido don Juan, el uno para pleitear y el otro para arrendar. $1530>$.

/ (f. 193r) 17. < Posesión de unas casas y heredades en Frómesta para San Zoil. Año

Posesión que tomó fray Juan de Villoldo, procurador de San Zoil, de unas casas en la calle de la Yedra en Frómesta y de otras heredades y viñas pertenecientes a este monasterio, por cesión y renunciación que de ellas hizo Diego de Nogal, la qual cesión está con esta escritura de posesión. Su fecha en Frómesta a 27 de hebrero de 1530, ante Juan Pardillo, escribano de Su Majestad.

18. <Trueque de una tierra por otra. Año 1567>.

Trueque que hizo este monasterio y fray Antonio Osorio, prior de san Martín de Frómista con Alonso Santiago, de una tierra del dicho priorato en término de la dicha villa que está junto a la Puerta de Carremonzón, por otra tierra que el referido Alonso Santiago dio al dicho priorato en el mismo término a do dicen a carrecamino y más 1200 maravedís en dinero. Su fecha en San Zoyl a 29 de agosto de 1567, ante Andrés Sánchez, escribano en Carrión.

\section{9. <Compra de dos pedazos de corrales. Año 1592>.}

Compra que hizo este monasterio para el de San Martín de Frómista a don Luis de Venavides, marqués de dicha villa, de dos pedazos de corrales que el uno fue cavalleriza y el otro errén y están juntos, y lindan con la yglesia de San Martín, con corrales de dicho priorato y con la calle pública, que hoy están dentro de su cerca, por precio de 160 reales. Su fecha en Frómista a 13 de enero de 1592, ante Antonio Laso, escribano de dicha villa.

\section{0. < Tasación de un corral en 4404 maravedís. Año 1593>.}

Tasación de un corral para el priorato de San Martín hecha entre la justicia de Frómista y premisso Iuramento por Juan de la Fuente y Pedro Morejón, vecinos de Frómista, que le tasaron en 150 reales, de los quales se rebajó un censo de 12 maravedís que tasado a maravedí el real montó 408, y de los réditos de 24 años, en que los menores estaban condenados 288 marevedís que todo hace 696, de manera que resta que han de haber libremente dichos menores 4404 maravedís, los quales debía de dar el prior de San Martín para quedar con el corral. Su fecha en Frómista a 15 de septiembre de 1593, ante Francisco Obeso de Buelna, escribano de dicha villa.

\section{1. <Compra de una cueba con su casa y lagar. Año 1597>.}

Compra que hizo fray Plácido de Huércanos, prior de San Martín, a Gabriel arcador y Antonia de Frómista, su muger, vecinos de Frómista, de una cueba en dicha villa en la calle 
de Grajal, barrio del dicho priorato, con su casa, lagar, piedra, viga y con todos los demás aparejos, con carga de 10000 maravedís de principal de un censo y 21 reales de réditos que sobre la dicha cueba tenía Diego Martínez, vecino de Bobadilla del Camino, y por precio de 31 ooo maravedís que con 315 reales que pagó por la redención y réditos del censo importó todo 41.7oo maravedís. Fue otorgada esta escritura en Frómista a 5 de enero de 1597, ante Juan Redondo de Reoyo, escribano de dicha villa.

Está aquí cosida la escritura de censo que estaba sobre dicha cueba y al pie de ella la redención de él.

\section{2. <Compra de una era. Año 1598>.}

Compra que hizo el prior de San Martín de Frómista a Juan Pastor, el Mozo e Ysavel de la Fuente, su muger, vecinos de dicha villa, de una era / (f. 193v) en término desta dicha villa a do dicen al Hoyo de Pedro hijo, que ensina y media poco más o menos, linde el camino que viene de las Eras, por precio de 6204 maravedís que pagó de contado el padre fray Zoil de Escobar por el dicho priorato. Su fecha en Frómista a 14 de julio de 1598, ante Juan Redondo de Reoyo, escribano de dicha villa.

\section{3. <Compra de una era. Año 1602>.}

Compra que hizo fray Plácido Huércanos, prior de San Martín, a Bastián Lozano, vecino de Frómista, de una era en término de dicha villa a do dicen el hoyo de Pedro hijo, que hará media hensina poco más o menos, por precio de 10 ducados que por ella pagó el referido prior. Su fecha en Frómista a 14 de septiembre de 1602, ante Juan Redondo de Reoyo, escribano de dicha villa.

\section{4. $<$ Requirimiento para vendimiar unos días antes. Año 1603>.}

Requirimiento hecho por fray Diego de Ortigosa como prior de San Zoil, y en nombre del prior de San Martín a Lucas de la Fuente, alcalde ordinario y a Juan Fernández de Villohetes, prior general de Frómista, para que no impidan a la casa de San Martín el vendimiar dos días antes que los demás vecinos. Ha esto respondieron que jamás oyeron decir que el dicho priorato tubiese privilegio expreso ni costumbre inmemorial para hacerlo; y con esta respuesta se quedó la causa sin concluir. Fue hecho este requirimiento a 18 de septiembre de 1603, ante Juan Redondo de Reoyo.

25. < compra de varias heredades para San Martín de Frómista hechas desde el año de 1641 hasta el de 1661>.

Bajo este número están varias compras de eredades que hizo para el priorato de san Martín de Frómista el padre fray Juan Aguado, su prior, que son las siguientes:

$1^{a}$ Compra de una huerta frontera de las puertas de Carremonzón por precio de 3000 maravedís. Su fecha en Frómista a 30 de agosto de 1641, ante Alonso Pérez del Campo, escribano de dicha villa.

$2^{a}$ Compra de un corral en la misma villa por precio de 34 reales. Su fecha en Frómista a 13 de enero de 1643, ante el mismo escribano.

$3^{\text {a }}$ Compra de una Era a los Barriales, por precio de 3000 maravedís. Su fecha en la misma villa a 25 de febrero de 1644, ante el mismo escribano.

$4^{a}$ Compra de otra era, en las eras nuebas, por 44 reales. Su fecha en la misma villa a 21 de julio de 1649, ante Alonso Rodríguez, escribano della.

$5^{a}$ Traspasación de un censo perteneciente a la cofradía del Santísimo Milagro, que entre otras ipotecas estaba sobre una tierra a Carretuerta, y le puso sobre otras dos tierras y entre partes de una casa en la calle del Buey, en lo que convinieron los jueces de dicha cofradía como consta desta escritura hecha en Frómista a 17 de abril de 1651, ante Alonso Rodríguez, escribano de dicha villa.

$6^{a}$ Compra de una tierra en el mismo término a donde llaman a Vuela, por precio de 55 reales. / (f. 194r) Su fecha en Frómista a 12 de septiembre de 1651, ante el mismo escribano. 
$7^{\text {a }}$ Compra de una tierra en el mismo término a carretuerta, por precio de 21 ducados. Su fecha en la misma villa a 20 de abril de 1651, ante el mismo escribano.

$8^{a}$ Compra de una tierra en el mismo término, al sendero de Ladrones, por precio de una carga de cebada y cinco quartos de trigo. Su fecha en la misma villa a a 16 de marzo de 1656, ante el mismo escribano.

$9^{a}$ Compra de dos tierras en el mismo término, la una a Balle los rubios, y la otra a Carrepozuelo, por precio de 448 reales. Su fecha en la misma villa a 13 de agosto de 1657, ante el mismo escribano.

$10^{a}$ Compra de una viña en el mismo término, a Buela, por precio de 75 reales. Su fecha en la misma villa a 28 de marzo de 1659, ante el mismo escribano.

$11^{a}$ Compra de una tierra en el mismo término a fontanillas, por precio de 400 reales. Su fecha en la misma villa a 18 de diciembre de 1660, ante el mismo escribano.

$12^{\mathrm{a}}$ Compra de una tierra en el mismo término, a Cariavilla, por precio de 6000 maravedís. Su fecha en dicha villa a 28 de mayo de 1661, ante el mismo escribano.

26. $<$ Memorial de deudas del Padre Aguado. Año 1666>.

Memorial ${ }^{293}$ simple de las deudas sueltas, sin los censos, que se hallaron por fin y muerte del padre fray Juan Aguado, prior que fue de San Martín de Frómista, en 27 de enero de 1666.

\section{7. $<$ Mandamiento para reconocer una deuda del Padre Aguado. Año 1667>.}

Mandamiento librado por el alcalde mayor del adelantamiento de campos, a petición deste monasterio contra Manuel de Lomas y Pedro Briones, vecinos de Frómista para que reconozcan una deuda que tenían contra sí de 3000 reales a fabor del Padre fray Juan Aguado, prior de San Martín. Dado en Palencia a 24 de marzo de 1667, ante Lucas Muñiz de Castro. Al pie deste mandamiento está la satisfacción que dio Pedro de Briones de los 1500 reales que le tocaban, ante Antonio Rojo Pérez, escribano de Su Majestad, y un ajuste de cuentas entre el padre fray Juan Aguado y Antonio de la Fuente, vecino de Frómista, del qual resultan 569 reales a fabor del dicho Antonio de la Fuente, que pasó ante Alonso Rodríguez, escribano de dicha villa.

28. <Compra de una cueba con su granero alto y bajo. Año 1668>.

Compra que hizo fray Juan de Vega, prior de San Martín, a Ana Fernández, vecina de Frómista, de una cueba con su jaraíz, piedra, biga, rarauso y granero alto y bajo en la calle de Grajal, por / (f. 194v) precio de 800 reales. Su fecha en Frómista a 12 de septiembre de 1668, ante Pedro Briones Saco de Somoza, escribano de dicha villa.

29. <Compra de ocho tierras y quatro viñas para San Zoil. Año de 1726>.

Compra que hizo para este monasterio fray Zoil de Pedroso a Atanasio García y a doña María de Miranda, su muger, vecino de Frómista, de las heredades siguientes:

$1^{a}$. Una tierra en término de dicha villa a do llaman a las Hazas de una obrada poco más o menos.

$2^{a}$. Otra tierra en el mismo término, a Tajagrano, de nueve eminas poco más

o menos.

$3^{a}$. Otra tierra a do llaman Arroyo de diez eminas poco más o menos.

$4^{a}$. Otra tierra en el mismo término, a Balcabado, de tres eminas y media.

5 . Otra tierra a do llaman al Canto Blanco, de tres eminas y media.

6 . Otra tierra a la Cabaña de Puente-Itero de diez eminas poco más o menos.

${ }^{293}$ Memorial] al margen derecho: Falta. 
menos.

$7^{a}$ Una viña a do llaman a carre la Esa de dos aranzadas y media poco más o

$8^{a}$. Otra viña a carre Támara de siete quartas.

9a. Otra viña a do llaman a Rebilla Manzano, que está perdida, de cinco quartas poco más o menos.

$10^{a}$ Otra viña, también perdida, a do llaman a Cespedosa, de siete quartas.

$11^{\text {a }}$. Otra tierra a do llaman a Villitán de una obrada.

$12^{\text {a }}$. Otra tierra a carre las Arenillas de cinco eminas.

Las quales compró el referido por precio de 1500 reales. Su fecha en Población de Campos a 26 de noviembre de 1726, ante Antonio Rebuelta, escribano de dicha villa.

Está aquí otra escritura de compra que hizo el dicho fray Zoil de otra tierra en el mismo término de Frómista, a carre las Arenillas, de cinco eminas (la qual es mitad de la última tierra puesta en la primera venta) por precio de 40 reales. Su fecha en Támara a 30 de diciembre del mismo año, ante Pedro Chico, escribano de Su Magestad.

30. < Auto para que se siga el camino antiguo. Año de 1772>.

Testimonio dado por Esteban Cortijo, escribano de Frómista, de un auto dado por el correjidor de Carrión, a petición de este monasterio, por el qual manda suspender el nuevo camino / (f. 195r) que había delineado el arquitecto mayor del Real Canal y que se use el antiguo como de inmemorial tiempo a esta parte se había executado, porque de los contrario era perjudicial no sólo al priorato de San Martín si no a otros particulares interesados. Dado en Carrión a 29 de noviembre de 1772, ante Diego del Val Cornejo. Sacose este testimonio en Frómista a $1^{\circ}$ de mayo de 1773.

\section{1. <Compra de una casa. Año 1802>.}

Compra que hizo el padre fray Yldefonso, hidalgo prior actual de San Martín, a Santos Frechilla, vecino de Frómista, de una casa en dicha villa en la calle del Toro, por precio de 800 reales. Su fecha en Frómista a 14 de marzo de 1802, ante pedro Rodríguez Antón, escribano de dicha villa.

32. <Compra de una casa. Año de 1802>.

Compra que hizo el padre fray Yldefonso, hidalgo prior de San Martín de Frómista, de una casa con su piedra, viga y para uso, en la calle del Toro de dicha villa, propia de la capellanía que al presente goza don Bernardo Díez, presbítero capellán en ella, en virtud de información de utilidad recibida a instancia del mismo don Bernardo y aprobada por el señor provisor de Palencia por precio de 10200 reales, en cuya cantidad fue rematada la que entregó el dicho padre prior. Fue otorgada esta escritura en la villa de Frómista a 20 de mayo de 1802, ante Pedro Rodríguez Antón, escribano de dicha villa.

\section{/ (f. 195v) Remisiones}

Compra de una tierra y una viña en población de Frómista. Véase el cajón San Estevan, legajo $1^{\circ}$, quaderno C, números 1 y $2^{\circ}$.

Compra de una viña en el mismo lugar de población. Cajón San Estevan, legajo 1º, quaderno $\mathrm{C}$, número $4^{\circ}$.

Donación de Balthasar de Nogal de varias tierras en Frómesta. Cajón San Estevan, legajo $1^{\circ}$, quaderno $\mathrm{C}$, número $6^{\circ}$.

\section{/ (f. 196r) Legajo $2^{\circ}$ del Cajón San Agapio}

Este legajo contiene los cinco quadernos siguientes: Quaderno A: Yglesia de San Martín y esención de diezmos; quaderno B: Santísimo milagro; quaderno C: Qüentas de la fábrica de la yglesia; quaderno D: Sacristía; quaderno E: Hospital de San Lázaro y su yglesia. 


\section{Quaderno A}

Este quaderno contiene los papeles pertenecientes a la yglesia de San Martín y esención de diezmos, por el orden siguiente:

$1^{\circ}$. $<$ Testamento de muy poca importancia. Año de 1387>.

Testamento de doña María, vecina del barrio de San Martín de Frómesta, por [el] qual manda enterrarse en la yglesia de San Martín, y la hace algunas mandas de poca consideración en dinero. Su fecha: en el dicho barrio, a 21 de abril de 1387, ante Toribio Fernández, notario público de la ciudad de Palencia.

2. <Testamento de poca importancia. Año de 1399>.

Testamento de doña María Juan, vecina de Frómista, por el qual manda enterrarse en la yglesia de San Martín, con 150 maravedís a los cappellanes, monge y sacristán de dicha yglesia para misas por su alma, y vna tierra, a la Calzada, al hospital de Los Palmeros para que digan perpetuamente cada año vna misa cantada en la yglesia de San Martín. Su fecha, en Frómista, a 20 de mayo de 1399, ante Ruy Pérez, esscribano de dicha villa.

Hay copia authorizada y el original está escrito en pergamino.

3. < Foro de 12 maravedís y media cántara de vino. Año de 1411>.

Escritura, en pergamino, de foro perpetuo, por la qual los capellanes de San Martín dan a Fernando Mazo el mozo, vecino de Frómista, cinco tierras en término de dicha villa por 12 maravedís y media cántara de vino de foro perpetuo. Estas tierras fueron de doña Juana, muger de Toribio Fernández, la qual las mandó a dichos capellanes con carga de cinco misas por su alma perpetuamente. Su fecha, en Frómista, a 28 de diciembre de 1411, ante Toribio Fernández, esscribano de dicha villa.

/ (f. 196v) 4. < Traspasación de un foro. Año de 1461>.

Traspasación de vn foro de 7 maravedís y medio que tenían los monges y capellanes de la yglesia de San Martín sobre vnas casas en corro de San Martín, que eran de Pedro Fernández, esscribano, en otras casas dentro de la misma villa. Su fecha, en Frómista, a 7 de abril de 1461, ante Álvar Martínez, esscribano de dicha villa y notario de Palencia.

5. <Traspasación de un foro. Año de 1470>.

Traspasación que hizo Juana, muger de Juan García Redondo, vecina de Marcilla, de vn foro de 6 maravedís que tenía el cura, clérigos y monge de la yglesia de San Martín sobre vn majuelo a Villota en dos viñas de 6 quartas, vna a la Nava y la otra a Carretuerta. Su fecha, en Frómista, a 21 de marzo de 1470, ante Gonzalo García, escribano de dicha villa. $1473>$.

$6^{\circ}$. $<$ Testamento en que se manda 25 maravedís sobre la tierra a los Barriales. Año

Testamento de Pedro Martínez Acero, vecino de Frómesta, en el que manda a la yglesia de San Martín (donde quiere ser enterrado) 25 maravedís sobre la tierra de los Barriales, con carga de un aniversario ${ }^{294}$ perpetuo cada año, día de Nuestra Señora de marzo, con su vigilia la víspera. Su fecha, en Frómista, a 22 de octubre de 1473, ante Gonzalo García de Burgos, esscribano de dicha villa.

$7^{\circ}$. <Cláusula del Becerro de Palencia. Año 1529>.

Testimonio sacado por Alonso Paz, notario de Palencia, en el que se contiene vna cláusula del libro Becerro de los beneficios e yglesias del obispo de Palencia, que dice así: En Frómesta hay otra yglesia que llaman San Martín y es toda y todos los diezmos del monasterio de San Zoil de Carrión. Fue sacada a 25 de febrero de 1529, en dicha ciudad.

$8^{\circ}$. $<$ Recibo de 10 ducados de oro por vna sepultura. Año 1531>.

Recibo firmado de fray Juan de Amayuelas, prior de Frómista, en el que confiesa haber recibido 10 ducados de oro, los ocho de la sepultura de Gonzalo de Villanueba y los

294 aniversario] al margen derecho: Aniversario. 
dos del ornamento que se le dio para sepultarle como capellán que era de la yglesia de San Martín. Su fecha, a 17 de noviembre de 1531. de $1546>$.

9. $<$ Sentencia para que salga la procesión del Corpus de la yglesia de San Martín. Año

Sentencia dada por Pedro Ruiz, beneficiado de Amusco, juez de comisión por el señor obispo de Palencia, por la qual se manda que perpetuamente salga de la yglesia de San Martín la procesión del día del Corpus y que tome en ella la capa y diga la misa mayor deste día el monge o capellán de San Martín que fuere semanero y, si éste estubiere impedido, la dirá el semanero que se sigue y así sucesibamente. A esta sentencia / (f. 197r) precedió información por parte de la justicia, y el cabildo y clérigos. Habiendo sido citados, no quisieron alegar cosa alguna. Fue pronunciada esta sentencia <en Frómesta $>$, a 28 de julio de 1546, ante Juan Laso, esscribano de dicha villa. $1547>$.

10. <Testamento en que se manda decir 12 misas por 6 reales sobre una casa. Año

Testamento de Baltasar de Anaya, vecino de Frómesta, por el qual ordena vna capellanía de 12 misas cada año ${ }^{295}$ en la yglesia que se enterrare, y deja para ellas 6 reales que tenía de censo a su fabor sobre vna casa en la plaza de Frómista. Sacose la copia de dicho testamento a 30 de agosto de 1547, ante Juan Laso, esscribano de Frómista.

Hay aquí vn papel simple que declara los días en que se han de decir las dichas misas y que se digan en la yglesia de San Martín.

11. <Sentencia a fabor de San Martín en razón de las ofrendas>.

Sentencia ${ }^{296}$ dada por don Gaspar de Salazar, tesorero y canónigo de Cuebasrubias, juez conservador contra Juan Palomino, vecino de Frómista, porque inducía a los feligreses a que no ofreciesen a la yglesia de San Martín y, por haber confesado su culpa y pedido perdón sólo le condena en 2 libras de aceite para dicha yglesia. Fue dada esta sentencia en la villa de Cuebasrubias, ante Rodrigo de Rozas, clérigo de la diócesis de Burgos y notario apostólico. No tiene fecha este instrumento.

12. < Copia avthorizada de una información sobre la propiedad de la yglesia de San Martín. Año 1551>.

Copia ${ }^{297}$ authorizada de vna información antigua que hizo el monasterio de San Zoil con 38 testigos, de que la yglesia de San Martín era plenamente de dicho monasterio, que el obispo de Palencia no tenía jurisdición alguna en ella, ni diezmos ni ofrendas y sólo ordenaba a los capellanes, daba los santos óleos, etcétera. Sacose esta copia por mandado del prior de Escalada, juez conservador, por Juan de Castrillo esscribano de Carrión, a 9 de junio de 1551, de la información original, que queda puesta en el cajón San Andrés, legajo1 ${ }^{\circ}, 2^{\circ} \mathrm{B}$, número $2^{\circ}$. $1551>$.

13. < Pleito sobre decir la misa de los días solemnes con el cura de San Martín. Año

Bajo este número se contienen los papeles siguientes:

$1^{\circ}$. Vna petición que hizo Bernardino González, cura de San Martín, ante los provisores de Palencia para que se le mantubiese en la posesión de decir las misas mayores los días de Pascuas y demás festibos, de la que ofreció información, la que hizo en virtud de despacho librado por los dichos señores provisores, a 25 de febrero de 1551, con 10 testigos, ante Hernando de Marquina, recetor de la audiencia episcopal de Palencia. Presentada dicha información, dieron auto los señores provisores de manutención y amparo de posesión a fabor dicho cura, según se infiere de la petición presentada después por él mismo. Querellose el monasterio de San Zoil y pidió justicia ante el señor / (f. 197v) tesorero de Covarrubias, juez conservador, quien procedió contra dicho cura. Fueron los autos a la Chancillería por

\footnotetext{
295 año] al margen derecho: 12 misas cada año.

296 Sentencia] al margen derecho: falta.

297 Copia] al margen derecho: falta.
} 
vía de fuerza, donde se mandó que el juez conservador no conociese en la causa y se remitió al ordinario de Palencia, ante quien pidió dicho Bernardino González se citase al monasterio. Y así se hizo en 7 de diciembre del mismo año. Declinó el monasterio jurisdición y apeló, replicó Bernardino González y acusó algunas rebeldías. Está signada esta petición y demás papeles por Estevan de Huerta los vnos y Fernando Montero los otros, notarios de la ciudad de Palencia, año de 1551.

$2^{\circ}$. Ynformación original hecha a instancia deste monasterio por fray Domingo de Comonte, prior de Santa María de Frómesta, juez comisionado por don García Salazar, tesorero y canónigo de Covarrubias y juez conservador, en la que se prueba con siete testigos los siguiente: que la yglesia y priorato de San Martín es plenamente del monasterio de San Zoil y sus abades ponen allí prior y vicario monge, y que a este, y no al obispo, toca el tomar las qüentas de la yglesia, que los diezmos de la yglesia y priorato son de dicho monasterio, los que por contrato gozan los señores de Frómesta con cierta pensión, que la presentación de las capellanías toca a los señores abades de San Zoil, que los priores de San Martín están en posesión de celebrar las misas mayores todos los días solemnes, que en ella les intentaba perturbar Bernardino González con título de cura de San Martín, cometiendo graves tropelías y causando grandes escándalos a todos los feligreses y vecinos de Frómesta, como largamente consta de los once capítulos contenidos en dicha información. Que pasó ante Juan de Castrillo, esscribano de Carrión, año de 1551.

$3^{\circ}$. Copia de la anterior probanza, autorizada por el mismo esscribano. Su fecha, en Frómesta, a 23 de febrero del mismo año.

$4^{\circ}$. Poder general dado por Bernardino González a Pedro de Ríosmenudos y a otros para todos sus pleytos y cobranzas. Su fecha, en Frómesta, a 30 de abril de dicho año, ante Juan Laso, esscribano de dicha villa. Al pie deste poder consta la paga que hizo este monasterio a dicho Pedro de Ríosmenudos de 2.600 maravedís, importe de las costas de vn pleyto que tubo este monasterio contra Bernardino. Su fecha, a 7 de mayo del año arriba dicho, ante el mismo esscribano.

$5^{\circ}$. Mandamiento citatorio, compulsorio e inivitorio de don Francisco de Lorenzana, arecediano de Mayorga, juez apostólico en virtud de un brebe del nuncio de Su Santidad, inserto en él, dirigido / (f. 198r) al ordinario de Palencia, para que se le remita el pleito que va expuesto. Su fecha, en León, a 5 de diciembre de 1551, ante Pedro de Soto, notario, el qual mandamiento se notificó a Bernardino González por Juan Laso, esscribano sobredicho, en 14 de diciembre del repetido año.

14. < Protesta sobre la misa de Juebes Santo. Año de 1551>.

Testimonio ${ }^{298}$ dado por Juan Laso, esscribano de Frómesta, de la protesta que hizo fray Rodrigo de Corcuera, prior de San Martín, para que no $<$ le $>$ parase perjuicio el no decir la misa el día de Jueves Santo, a instancia del señor marqués de dicha villa. Su fecha, en ella, a 26 de marzo de 1551.

15. < Foro de 60 maravedís a fabor de la yglesia de San Martín. Año 1558>.

Foro de 60 maravedís a fabor de la yglesia de San Martín contra Gonzalo de Castro y María, su muger, sobre dos viñas en término de Frómesta. Su fecha, en Frómesta, a 27 de enero de 1558, ante Pedro Martínez Calderón, escrivano.

16. <Testimonio de que la yglesia y coro de San Martín es de San Zoil. Año 1566>.

Testimonio dado por Andrés Sánchez de vna cláusula contenida en un apeo de Frómesta que se hallaba en San Zoil, por la que consta que la yglesia y cor $<$ o de $>$ San Martín de Frómesta es deste monasterio de San Zoil. Su fecha, a 3 de marzo, de 1592; y la del apeo, a 28 de enero de 1566, ante Melchor Laso, esscribano de Frómesta.

298 Testimonio] al margen derecho: falta. 
17. < Testimonio a fabor de vn arrendatario de San Martín. Año 1568>.

Testimonio ${ }^{299}$ dado a petición de Hernando de la Vega por Melchor Laso, esscribano de la villa de Frómesta, de cómo, llevando él en arrendamiento vnas heredades propias del priorato de San Martín, le pedía la renta de ellas el cura de dicha yglesia llamado Bernardino González. Su fecha, en dicha villa, a 18 de febrero de 1568.

18. < Petición de querella contra Bernardino González. Año 1578>.

Querella ${ }^{300}$ contra Bernardino González, cura de San Martín, de muchos agravios que hacía a aquel priorato y a sus priores. Está firmada del doctor Campo y parece ser del año 1578.

19. < Absolución de censuras a Thomas González. Año 1591>.

Dispensación apostólica y absolución de censuras dada al bachiller Thomás González, capellán de la yglesia de San Martín, por habe enterrado en ella con solemnidad vna criatura en tiempo de entredicho. Su fecha, año de 1591.

20. < Protesta sobre la misa mayor del día de Resurrección. Año 1598>.

Protesta ${ }^{301}$ hecha por el padre fray Plácido de Huércanos, prior de San Martín, contra Thomás González, capellán de San Martín, por haberse revestido y puesto en el altar mayor para decir la misa solemne el día de Pascua de Resurrección, contraviniendo a la concordia que ordena la diga el prior. Su fecha, en Frómesta, a 22 de marzo de 1598, ante Juan Redondo de Reoyo, esscribano de dicha villa.

/ (f. 198v) 21. < Pleyto sobre la limosna de misas. Año 1602>.

Proceso <sobre> la limosna de ciertas misas que habían dicho los monges del priorato de San Martín por vn difunto y no se las pagaban los testamentarios, por haber mandado el provisor de Palencia, a instancia del capellán Thomás González que no se las diesen a dichos monges sino al cura y capellanes de San Martín. No se concluyó este pleyto. Está autorizado de Andrés Sánchez, esscribano de Carrión, año 1602.

Está aquí cosida la escritura de censo que estaba sobre dicha cueba y al pie de ella la redención de él.

22. <Pleito sobre la limosna de misas. Año 1602>.

Proceso sobre la limosna de otras misas que se debía[n] a ${ }^{302}$ los monges de San Martín; se alegó e hizo prueba, pero no se concluyó. Ante Andrés Sánchez, esscribano de Carrión, y Juan Redondo Reoyo, esscribano de Frómesta, año de 1602.

23. <Requirimiento sobre limosna de misas. Año 1602>.

Requirimiento que hizo Thomás González, cura de San Martín, al prior para que recibiese la limosna de las misas que los monges de San Martín hubiesen dicho en vn mes. Ante Juan Redondo Reoyo, esscribano de Frómesta, año de 1602. Le falta el signo.

24. < Resolución de vender todo lo que hay en Frómesta. Año 1602>.

Resolución ${ }^{303}$ que tomó este monasterio de San Zoil de vender la yglesia de San Martín con el priorato, tierras, viñas, etcétera, que tiene en la villa de Frómesta, excepto lo que paga el señor Marqués, por precio de 12.000 ducados o 600 de renta anual. Su fecha, en San Zoil, a 24 de abril de 1602.

Está aquí la petición del abad al general para tratar de la venta y la comisión para la información de vtilidad. A 17 de mayo del mismo año.

\footnotetext{
299 Testimonio] al margen derecho: falta.

300 Querella] al margen derecho: falta.

${ }^{301}$ Protesta] al margen derecho: falta.

302 a] escrita sobre $\mathrm{n}$.

${ }^{303}$ Resolución] al margen derecho: falta.
} 
Hay también cartas del señor obispo de Palencia y señor Marqués sobre este asunto.

25. $<$ Mandamiento del señor obispo de Palencia para que nadie predique en San Martín sin su licencia. Año 1603>.

Mandamiento de don Martín de Axpe y Sierra, obispo de Palencia, para que ningún predicador religioso ni seglar predicase en San Martín sin expresa licencia y consentimiento suyo. Notificole el bachiller Antonio Redondo a los padres fray Plácido de Huércanos, prior, y a fray Juan Marín, predicador de San Zoil. Su fecha, en Palencia, a 18 de abril de 1603, ante Andrés de Rozas, secretario de Su Señoría Yllustrísima.

Síguese la respuesta que a este mandamiento dio el padre prior, a 10 de noviembre del mismo año, ante Juan Redondo de Reoyo, esscribano de Frómesta.

Bajo este número se halla vnida vna licencia, dada <por> don Gaspar de Peralta, provisor de Palencia, para que Antonio Redondo pueda servir vna capellanía y el curato de San Martín por sólo el término de vn año. Su fecha, en Palencia, a 30 de septiembre de 1603, ante Lucas Gallardo, notario. Año 1603>.

/ (f. 199r) 26. < Requirimiento para que no predicase en San Martín vn fraile francisco.

Requirimiento ${ }^{304}$ hecho por el padre fray Ambrosio Matute, residente en San Martín, al padre fray Melchor Arias, guardián de Villasilos, para que no predicase en la yglesia de San Martín. Su fecha, en Frómesta, a 23 de noviembre de 1603, ante Juan Redondo de Reoyo, esscribano de dicha villa.

27. $<$ Requirimiento sobre decir la misa y predicar. Año 1603>.

Requirimiento hecho por fray Plácido de Huércanos, prior de San Martín, a Thomás González, cura capellán de San Martín, para que no digese la misa el día de Resurrección y que no predicase el mismo día el bachiller Penche en dicha yglesia, pues sólo tenían licencia del obispo y no del prior de San Martín. Su fecha, en Frómesta, a 30 de marzo de 1603, ante Juan Redondo de Reoyo, esscribano de dicha villa.

28. <Querella por los agrabios que hacía a San Martín Antonio Redondo. Año 1603>.

Ynterrogatorio $^{305}$ y apuntamientos para querellarse de los insultos y agrabios que cometía Antonio Redondo, cura de San Martín, contra el prior, monges y criados de dicho priorato. Púsose esta querella ante el provisor de Palencia, año de 1603.

29. <Testimonio de la disposición del claustro de San Martín. Año 1603>.

Testimonio de la forma y disposición del claustro de San Martín, puertas de la yglesia y sus cerraduras con las demás que caen al claustro, dado a instancia de fray Plácido Huércanos, prior de San Martín de Frómesta, a 24 de noviembre de 1603, por Juan Redondo Reoyo, esscribano de dicha villa.

30. <Testimonio de vna cláusula de testamento por que se manda vna tierra a San Martín. Año 1605>.

Testimonio de vna cláusula del testamento de Juan Pérez el Viejo, vecino de Frómesta, por el que fundó un aniversario ${ }^{306}$ en la yglesia de San Martín; y para su cumplimiento dejó un quarto de trigo sobre vna tierra a carre Marcilla. Sacó este testimonio Juan Redondo Reoyo, esscribano de Frómesta, a 12 de diciembre de 1605, y el testamento fue otorgado año $15<5>0^{307}$, ante Melchor Laso, esscribano de dicha villa.

\footnotetext{
304 Requirimiento] al margen derecho: falta.

305 Ynterrogatorio] al margen derecho: falta.

306 aniversario] al margen derecho: Aniversario.

$30715<5>0$ ] escrito sobre 1650 .
} 
31. < Licencia del provisor de Palencia para predicar en San Martín al bachiller Penche y no otro. Año 1605>.

Licencia ${ }^{308}$ dada por don Gaspar de Peralta, provisor de Palencia, al bachiller Penche, beneficiado de Támara, para que él y no otro predique en San Martín y, caso que alguno pretenda perturbarle, da a Thomás González comisión para que proceda con censuras. Su fecha, en Palencia, a 5 de abril de 1605, ante Lucas Gallardo, notario. Confirmó esta licencia el licenciado Manuel García de Miranda, provisor de Palencia, a 3 de abril de 1609. En virtud de la dicha comisión, Thomás González mandó con censuras a Penche aceptase los sermones y predicase el de Resurreción, y al prior de San Martín que no le perturbase; a lo que respondió dicho prior y apeló, en 19 de abril / (f. 199v) de 1609, ante Juan Redondo de Reoyo, esscribano de dicha villa.

32. <Testamento de Catalina Martínez que mandó enterrarse en San Martín y 200 misas. Año 1608>.

Testamento $^{309}$ de Catalina Martínez, viuda, vecina de Castrojerid ${ }^{310}$, por el que manda enterrarse en la yglesia de San Martín de Frómista y que se la digan en ella 200 misas. Su fecha, en Castrojerid ${ }^{311}$, a 27 de enero de 1608, ante Gerónimo Artacho, escribano en dicha villa. Hace codicilio ante el mismo escribano el día siguiente, en que declara que si hay inconveniente en llebarla a enterrar a donde dispuso en su testamento, la entierren en San Juan de Castrojerid.

33. <Apelación deste monasterio sobre la misa mayor y sermón de Pascua en San Martín. Año 1609>.

Apelación ${ }^{312}$ interpuesta por el monasterio de San Zoil en el tribunal ecclesiástico de Palencia por haber nombrado Thomás González a Francisco Pérez para que hiciese oficio de cura en San Martín y digese la misa de Resurrección el año 1609, y al bachiller Penche para que predicase. Desta apelación da fee Lucas Gallardo, clérigo palentino, notario público appostólico y de la audiencia episcopal de Palencia y oficial mayor de Pedro Arana Ocerín ${ }^{313}$, notario en dicha ciudad, a 30 de abril de 1609.

34. < Carta del obispo de Palencia sobre enterrar a vn difunto en San Martín ${ }^{314}>$.

Carta del padre fray Juan de Cisneros al obispo de Palencia en que le suplica castigue a los curas de la parrochia de San Pedro de Frómesta por haber quitado con escándalo vn cadáber que debía enterrarse en la de San Martín. En la misma carta está la respuesta del obispo y ambas sin fecha.

35. <Compra de vna tierra para la yglesia de San Martín. Año 1619>.

Compra que hizo el mayordomo de la yglesia de San Martín para su fábrica de vna tierra de media emina en término de Frómesta' por precio de 44 reales' a Francisco Macho, vecino de la misma villa. Su fecha' 11 de noviembre de 1619, ante Alonso Pérez del Campo, esscribano público de dicha villa.

36. <Trueque que hizo la yglesia de San Martín de vna hera y 4 herrenes por dos tierras. Año 1635>.

Trueque celebrado entre la yglesia de San Martín por medio de su mayordomo Juan Santos y Francisco Sánchez de Aranda por el que aquella da a éste vna hera a San Lázaro y quatro herrenes a las Puertas de Grajal por dos tierras, vna a do dicen la Costilla, de vna obrada, y la otra a San Lázaro, de tres eminas. Su fecha' en Frómesta' a 29 de noviembre de 1635, ante Alonso Pérez del Campo, esscribano de dicha villa.

\footnotetext{
308 Licencia] al margen derecho: falta.

309 Testamento] al margen derecho: falta.

310 Castrojerid] d escrita sobre $\mathrm{z}$.

311 Castrojerid] d escrita sobre z.

312 Apelación] al margen derecho: falta.

313 Ocerín] c escrita sobre z.

314 San Martín] sigue tachado: Año.
} 
37. < Petición de los bienes del licenciado Brasa. Año 1649>.

Compromiso, sentencia y partición de los bienes que dejó el licenciado Brasa entre sus herederos, lo que de ningún modo pertenece al monasterio. / (f. 200r) Diose esta sentencia de compromiso a 29 de julio de 1649, ante Alonso Rodríguez, esscribano de Frómesta.

38. $<$ Testamento de Juan Santos. Año 1649>.

Testamento $^{315}$ de Juan Santos, vecino de Frómesta, en el que deja por albacea y testamentario al padre fray Juan Aguado, prior de San Martín de Frómesta. Su fecha' a 28 de septiembre de 1649' en dicha villa, ante Alonso Rodríguez, esscribano de la misma.

39. < Pleyto sobre vnas casas de vna capellanía de San Martín. Año 1649>.

Pleyto entre el licenciado Antonio Sánchez, capellán de la capellanía que fundó Hernando Sánchez del Corro en la yglesia de San Martín de Frómesta, de la vna parte; y de la otra, Antonio de la Fuente, Pedro de San Martín y otros, sobre vnas casas sitas en el corro de dicha yglesia, las quales fueron de dicho fundador y capellanía y después se vendieron con licencia del ordinario para comprar vna tierra. Diose la sentencia en Palencia, a 9 de agosto de 1649, ante Matheo del Villar, notario de dicha ciudad.

40. <Testamento y codicilio de María Pérez. Año 1661>.

Testamento y codicilio de María Pérez, residente en la villa de Frómesta, en el que deja por testamentario al padre fray Juan Aguado, prior de dicho priorato. Su fecha, en dicha villa, a 20 de diciembre de 1661, ante Alonso Rodríguez, esscribano en la misma.

41. <Mandamiento del provisor. Año 1662>.

Diligencias y mandamiento del provisor de Palencia para que se paguen las deudas a la yglesia de San Martín. Su fecha, en Palencia, a 27 de marzo de 1662, ante Lázaro de Montoya, notario.

42. < Carta del padre Modoya al abad. Año 1662>.

Carta $^{316}$ de fray Lorenzo de Modoya en que da cuenta al señor abad deste monasterio de San Zoil de lo que pasó en la visita que hizo el provisor de Palencia, a 29 de septiembre de 1662.

43. <Cuentas de vn testamento. Año 1666>.

Cuentas que dio el padre prior de San Martín como testamentario de Antonio de la Fuente, año 1666.

44. $<$ Requirimiento para que se quite vna reja de vna capilla de la yglesia de San Martín. Año 1680>.

Requirimiento que hizo el padre fray Leandro de la Madrid, prior de San Martín de Frómesta, al licenciado Carabaza, cura desta yglesia, para que quitase vna reja que sin su licencia ni authoridad alguna había puesto en vna capilla de ella. Su fecha, en dicha villa, a 17 de enero de 1680, ante Joaquín Pérez de la Madrid, esscribano en la misma.

45. <Licencia para dotar vna sepultura de la yglesia de San Martín. Año 1686>.

Petición del mayordomo de la yglesia de San Martín, licencia y comisión del abad de San Zoil para hacer la información de vtilidad que podía resultar a la fábrica de dicha yglesia el conceder al licenciado Juan de la Fuente dotase vna sepultura, por lo que ofrecía 130 reales. Pasó ante Marcos de la Fuente, esscribano / (f. 200v) y notario en dicha villa, año 1686.

46. $[<$ Memoria de vnos aniversarios $>]$.

Memoria de los aniversarios que había en la yglesia de San Martín y qüentas entre el padre prior y cura.

\footnotetext{
315 Testamento] al margen derecho: falta.
}

316 Carta] al margen derecho: falta. 
47. < Sentencia a fabor deste monasterio sobre la esención de diezmos de las heredades del priorato de Frómesta. Año 1770>.

Testimonio dado por Pedro León de Santotís, notario de Palencia, a 31 de enero de 1771, de la sentencia dada por el licenciado don José Martín de Recalde, provisor de Palencia, a fabor deste monasterio de San Zoil y contra los señores deán y cabildo de dicha ciudad por la que ampara al priorato de San Martín en la posesión de no pagar diezmos de sus heredades, lábrelas por sí o por los colonos o arrendatarios. Fue dada esta sentencia en Palencia, a 28 de noviembre de 1770 , ante el dicho notario.

Está aquí la información que se hizo con diez testigos por parte del monasterio de la posesión en que estaba de no pagar diezmo alguno de dichas heredades y asimismo vnos pedimentos y apuntaciones antiguas sobre el mismo derecho que tiene este monasterio.

48. < Protesta sobre la esención de diezmos del priorato de San Martín. Año 1798>.

Escritura otorgada por el padre fray Benito Sabido, monge de San Zoil, como apoderado de dicho monasterio, con motivo de que, habiendo concurrido a la ciudad de Palencia a la cobranza de 400 ducados que en cada vn año debe percibir este monasterio del estado concursado de la villa de Frómesta, y estando mandádosle entregar por la yntendencia, don Joaquín Díez, administrador por Su Magestad de dicho estado, quería rebajarle de dicha cantidad 150 reales por el diezmo del mosto, que dicía corresponder a Su Magestad por las viñas que el priorato de San Martín tiene en la villa de Frómesta, suponiendo no estaban esentas de él por la bula o brebe de Su Santidad de 8 de enero de 1796 y; por redimir dicho padre Sabido la vejación que en esto se le hacía, se allanó a la paga de dichos 150 reales con la protesta de que no le pare perjuicio a dicho monasterio por esto y de hacer ver en juicio la esención que tiene este priorato de semejante contribución. Su fecha, en Palencia, a 8 de marzo de 1798, ante Juan Rodríguez Bocos, esscribano en dicha ciudad.

49. <Declaración de la esención de diezmos del priorato de San Martín sin embargo del brebe de Su Santidad de 1796. Año 1801>.

Testimonio de la demanda puesta por este monasterio ante el señor yntendente de Palencia contra don Joaquín Díez, administrador por Su Magestad del estado seqüestrado de la villa de Frómesta, sobre que éste le devolbiese los diezmos que había percibido de todos los predios esentos que pertenecen a este monasterio y a su priorato de / ( $f$. 201r) San Martín de Frómesta, por la mala inteligencia del brebe de Su Santidad Pío $6^{\circ}$ (que de Dios goce). Remitió esta demanda a instancia del dicho administrador, el señor yntendente al excelentísimo señor don José de Godoi, gobernador del Consejo de Hacienda, quien, habiendo tomado el parecer de varios letrados con vista de los autos e instrumentos que presentó el monasterio, declaró y mandó al dicho señor yntendente que se reputasen por esentas las heredades dichas respecto no estar derogada su esención por el brebe de Su Santidad de 1796, y que por tanto obligase al referido administrador del estado seqüestrado devolbiese imediatamente los frutos que hubiese recogido, y de la ejecución desto manda se le dé aviso. Su fecha, en Madrid, a 7 de marzo de 1801.

Está aquí la liquidación que se hizo en la contaduría de Palencia de las cantidades de trigo, cebada, etcétera, que había percibido dicho administrador, las que se devolvieron al monasterio en dinero. Sacó este testimonio Manuel Casado Plaza, esscribano de Su Magestad, del número de Palencia y titular de rentas de la misma, a 28 de abril de 1801.

\section{Remisiones}

Dos requerimientos hechos el año de 1411 por parte de este monasterio para que se dexen libres los diezmos del barrio de San Martín. Véase el cajón siguiente: San Román, legajo $1^{\circ}$, número 25 .

\section{/ (f. 201v) Quaderno B del legajo 2}

Este quaderno contiene los papeles pertenecientes al santísimo milagro, por el orden siguiente: 
$1^{\circ}$. <Testimonio del santísimo milagro de la eucharistía. Año 1565>.

Copia autorizada por Antonio Laso, esscribano de Frómesta, de vna ynformación y testimonio que se dio a petición de Bernardino González, cura de San Martín, del suceso del santísimo sacramento de la eucharistía. Su fecha, en Palencia, a 7 de agosto de 1565, ante Miguel Montero, notario público por autoridad apostólica. Esta copia no tiene fecha. Hay asimismo otra copia autorizada hecha por don Antonio Martín, traductor, año 1783. $1550>$.

2. <Testimonio de cómo el prior de San Martín mostró el santísimo milagro. Año

Testimonio de cómo el padre fray Pedro de Soto, prior de San Martín, abrió vna ventana que había en la cantería de la yglesia de dicho pr[i]orato y mostró el santísimo milagro que estaba allí custodiado. Su fecha, en Frómesta, a 18 de henero de 1550, ante Juan Laso, esscribano de dicha villa.

3. <Ynformación sobre haber vn visitador quitado el santísimo milagro del poder de los monges de San Martín. Año 1550>.

Ynformación hecha con seis testigos, a instancia deste monasterio, y con authoridad del prior de Escalada, juez conservador, de que, habiendo visitado la yglesia de San Martín el licenciado Varahona, visitador comisario por [el] señor obispo de Palencia, pidió en el mismo acto de la visita se le manifestase el santísimo milagro; lo que reusó fray Pedro de Soto, prior de San Martín, no queriendo entregar las llabes con que le tenía custodiado. Enojado el visitador por esto y por varias razones que el padre Quintanilla, compañero de dicho prior, alegaba para no permitir se visitase el santísimo milagro, hizo esfuerzos y ademanes de prender a dicho monge. Visto lo qual por el prior, para evitar tan grave escándalo, entregó las llabes y el visitador registró el santísimo milagro y lo hizo colocar en el sagrario del altar mayor, entregando las llabes dél al cura de San Martín que presente estaba. Su fecha, en Carrión, año 1550, ante Juan de Castrillo, notario.

/ (f. 202r) 4. $<$ Brebe del nuncio por el que concede indulgencias por el santísimo milagro. Año 1565>.

Brebe del nuncio de Su Santidad en España, escrito en pergamino, en el que concede algunas quarentenas de indulgencias, <en> algunos días del año, a todos los que confesados $^{317}$ y comulgados rezaren vn Padre Nuestro y Ave María delante del santísimo milagro. Datum in oppido de Madrid, anno millésimo quingentésimo sexagésimo quinto, quarto ydus novembris. Hay copia autorizada. $1592>$

$5^{\circ}$. <Protesta para enseñar el santo milagro al rey un visitador de Palencia. Año

Prtotesta que hizo el abad de San Zoil al licenciado Vega, visitador comisario por el señor obispo de Palencia, para que $<$ no $>$ para $<$ se $>$ perjuicio al priorato de San Martín el acto de enseñar dicho visitador, en compañía del abad, el santísimo milagro a Su Magestad don Felipe $2^{\circ}$, a su hijo don Felipe ya la ynfanta. Su fecha, en la sacristía de San Martín de Frómesta, a 3 de septiembre de 1592, ante Antonio Laso, esscribano de dicha villa.

6. <Carta sobre enseñar el santísimo milagro. Año 1603>.

Carta $^{318}$ del reverendísimo Barrantes al prior de Frómesta en que le pone los inconvenientes que tiene para ir a dicho priorato y enseñar el santo milagro a los reyes. Su fecha, en Carrión, a $1^{\circ}$ de julio de 1603.

7. < Testimonio sobre que no se presten las alajas del santísimo milagro. Año 1678>.

Testimonio dado por Norberto de Sandoval y Guebara, esscribano del número de Carrión, de haber leído vna carta de la señora condesa de Medellín escrita a don Luis de Miranda, su fecha, en Madrid, a 9 de julio de 1678, en que declara que es su voluntad que las alajas que se ha dado para el santísimo milagro no se presten a yglesia alguna que no sea la

317 confesados] precede tachado re.

318 Carta] al margen derecho: falta. 
de San Benito de Frómesta, y eso en ciertos días; y que duchas alajas estén custodiadas en la sacristía de San Martín en vna arca de dos llabes, vna del[1]as que tenga el padre prior y la otra el abad de la cofradía. Su fecha, en Carrión, a 17 de julio de 1678.

8. <Licencia del abad de San Zoil para colocar el altar en que está el santísimo milagro. Año 1761>.

Licencia que pidió don Manuel Calbo al abad de San Zoil para la colocación del altar en que se puso el santísimo milagro y distribución de los viejos, sin perjuicio de la fábrica de la yglesia. Su fecha, en Frómesta, a 9 de julio de 1761. Está aquí la respuesta del abad en que concede esta petición sin perjuicio de las regalías de su abadía. En San Zoil, a 13 de julio de dicho año.

9.

Qüentas que se tomaron a Manuel Revolledo, mayordomo de la cofradía, en el año de 97 en 98.

\section{/ (f. 202v) Remisiones}

\section{Quaderno C del legajo 2}

Este quaderno $\mathrm{C}$ contiene los papeles pertenecientes a las qüentas de fábrica de la yglesia de San Martín, por el orden siguiente:

$1^{\circ}$. $<$ Requirimiento a los mayordomos de la yglesia de San Martín para que vayan a dar las cuentas a San Martín. Año 1551>.

Requirimiento que hizo fray Lorencio de Modoya, prior de San Martín, a los mayordomos de aquellas yglesia para que fuesen a dar las cuentas a San Martín y, que de lo contrario, las protestaba; a lo que respondieron dichos mayordomos que las tenían dadas y cerradas por orden de los feligreses en sus mismas casas, como era costumbre, y que ya habían avisado a dicho padre prior para que asistiese y que ninguna más obligación tenían. Su fecha, en Frómesta, a 28 de septiembre de 1551, ante Melchor Laso, esscribano en dicha villa.

2. <Memorial de partidas de qüentas. Años 1552 hasta 1600>.

Memorial de partidas sacadas de los libros de qüentas que presentaron los clérigos y mayordomos de la yglesia de San Martín, desde el año 1552 hasta 1600.

3. <Requirimentos a los mayordomos de la yglesia para que no den dinero a los capellanes. Años 1588 y 1601>.

Seis requirimientos hechos por los priores de San Martín a los mayordomos de aquella yglesia para que no den dinero a los capellanes de ella para pleitear con este monasterio. Los 5 primeros en los años de 1588, 1591 y 1592, ante Antonio Laso; y el vltimo, año 1601, ante Alonso Pérez, ambos esscribanos de Frómesta.

4. <Memorial de los pleitos de los gastos de la fábrica de la yglesia. Año 1600>.

Memorial del pleito, ante el ordinario de Palencia, entre el monasterio y los capellanes y mayordomos de la yglesia de San Martín, sobre los gastos hechos de la fábrica de la yglesia en pleitos y cosas que no eran en vtilidad de ella. Año 1600.

/ (f. 203r) 5. <Autos en el pleito de qüentas. Años 1600 y 1601>.

Dos autos, sin autoridad, dados por don Gaspar de Peralta, provisor de Palencia, por los quales manda que el fiscal salga a la causaen el pleito de las qüentas de la yglesia de San Martín y que la siga hasta su conclusión. Dados, el uno a 17 de octubre de 1600, y el otro a 12 de enero de 1601. 


\section{6. < Gastos del cura Calleja en el pleito de la yglesia. Año 1601>.}

Testimonio dado por Alonso Pérez, escribano de Frómesta, de un mandamiento del señor provisor de Palencia, para que el mayordomo de la yglesia de San Martín pague al cura Calleja 200 reales que había gastado por su mandado en los pleitos de la misma yglesia. Está al pie de este mandamiento la carta de pago firmada del mismo cura. Su fecha, en Frómesta, a 29 de febrero de 1601.

7. $<$ Requirimiento para nombrar mayordomo. Año 1602>.

Requirimiento hecho por el padre fray Plácido Huércanos, prior de San Martín, al cura Calleja y feligreses de aquella parroquia, para que se juntasen con él a elegir y nombrar mayordomo de dicha yglesia conforme a la concordia y carta executoria del año de 1556 y, no lo haciendo, que él, por sí solo, le nombraría. Su fecha, en Frómesta, a 31 de enero de 1602, ante Juan Redondo Reoyo, esscribano de dicha villa.

8. $<$ Sentencia sobre que la fábrica de la yglesia no contribuya más que con 2 ducados para la luminaria del santísimo. Año 1798>.

Testimonio en relación, dado por Tomás Díaz de Basurto, notario mayor de la audiencia ecclesiástica de Palencia, del pleito litigado contra este monasterio y priorato de San Martín por don Ygnacio Maté, presbítero beneficiado de preste en la yglesia parroquial de Nuestra Señora del Castillo de la villa de Frómesta, abad de la cofradía del Santísimo Milagro, Manuel Vallejo revilla y Clemente Fernández, jueces de dicha cofradía, sobre que por la fábrica de la yglesia se contribuyese con lo necesario para luminaria del santísimo sacramento. En cuyo pleito se dio sentencia por el señor provisor por la que ampara a la fábrica en la posesión de no contribuir más que con 2 ducados para la referida luminaria, y declara deber satisfacer todo el más costo de ella la cofradía del Santísimo Milagro; y condena en las costas a los contrarios. Diose esta sentencia en Palencia, a 23 de marzo de 1798.

\section{/ (f. 203v) Quaderno D del legajo 2}

Este quaderno D contiene los papeles pertenecientes a la sacristía de San Martín de Frómesta, por el orden siguiente:

$1^{\circ}$. < Colación de la sacristía de San Martín. Año 1539>.

Colación que hizo de la sacristía de San Martín de Frómesta fray Gaspar de Villarroel, abad de San Zoil, en fray Diego de Pinedo, monge de nuestra orden. Fecha en San Zoil, a 11 de septiembre de 1539, ante Juan de Castrillo, escribano y notario de Carrión.

2. < Recibo y qüenta de los bienes de la sacristía de San Martín. Año 1544>.

Recibo ${ }^{319}$ que dio Bernardino González, cura de San Martín, en el que confiesa haber recibido de mano del padre fray Juan de Santa María, abad de San Zoil, la plata y bienes de la sacristía de San Martín. Y al pie deste recibo está un escrito del mismo abad en el que declara haber tomado qüenta de dichos bienes al referido cura y habérselos entregado al padre fray Miguel de Villoria, prior de San Martín, a 9 de julio de 1544. Está firmado del mismo abad.

3. < Comisión del nuncio en un pleito de la sacristía. Año 1550>.

Comisión dada por Juan, arzobispo sipontino, nuncio de Su Santidad, a los arcedianos de Valderas, Bribiesca y Lara para que conozcan en cierta causa y pleito que tubo un capellán de la sacristía de San Martín con un provisor de Palencia. Dada en Valladolid, en los ydus de agosto, año de 1550. Está escrita en pergamino.

${ }^{319}$ Recibo] al margen derecho: falta. 
4. <Bulla de vnión de la sacristía de San Martín y su beneficio a la mesa abacial y convento de San Zoil. Año 1553>.

Bulla $^{320}$ escrita en pergamino, con su sello pendiente, dada por Pompeyo Rambicario, obispo valdense y sulmonense, legado a latere de la Santidad de Paulo $3^{\circ}$, cerca del rey don Juan de Portugal, por la qual consta que, teniendo la sacristía de San Martín y el benefício o capellanía de ella Francisco Tamayo, clérigo de la diócesis de Palencia, hizo voluntariamente resignación de ella en manos del dicho legado, el qual la aceptó y dio por vaca la dicha sacristía y su beneficio. $\mathrm{Y}$, habiéndole hecho relación este monasterio que la referida sacristía le pertenecía, con authoridad propia e inmemorial de poderla dar a quien quisiese, por temor que tenían que en los tiempos de adelante los que entonces les inquietaban y molestaban podrían dudar del derecho que a ella tenían y moverles pleitos, el referido monasterio le / ( . 204r) suplicaba que, para mayor seguridad y quietud, le hiciese gracia y concesión de ella; la qual le concede el dicho legado y une la dicha sacristía y su beneficio a la mesa abacial y convento de San Zoil y da facultad para que tomen posesión de ella. Da comisión al arcediano de Saldaña, al prior de San Miguel de Escalada y al comendador de la Herrada para que les pongan en posesión de ella y les defiendan. Dada en Burgos, año 1553, ydibus martii, pontificatus Summi Sanctitatis domini Iulii $3^{\circ}$ ano $5^{\circ}$.

5. < Poder para que el monasterio goze los bienes de la sacristía. Años 1554>.

Poder irrebocable dado en causa propia por Francisco Tamayo, clérigo de Palencia, al abad, monges de San Zoil y priores de San Martín de Frómesta, para que, en su nombre y para ellos mismos y por todos los días de la vida del referido clérigo, puedan tener y gozar, cobrar y arrendar todos los frutos, rentas mayores y menores y los demás derechos pertenecientes al oficio de sacristán de San Martín que él tenía, y para que puedan poner y quitar el sacristán para que sirva la dicha sacristanía todas las veces que quisieren y se obliga a no contradecirlo jamás. Su fecha, en Palencia, a 23 de diciembre de 1554, ante Francisco Vchoa, clérigo palentino, notario appostólico. Año 1599>.

6. $<$ Requirimiento al mayordomo para que no dé dinero para el pleito de la sacristía.

Requirimiento hecho en nombre deste monasterio al mayordomo de la yglesia de San Martín para que no dé dinero a los capellanes para seguir el pleito de la sacristía contra el monasterio, con protesta que, dándole, será por qüenta del mayordomo y no de la fábrica ni sacristía. Su fecha, en Frómesta, a 13 de septiembre de 1599, ante Alonso Pérez, escribano de dicha villa. Año 1600>.

7. < Sentencia en la presentación de la sacristía dada a favor de fray Alonso Barrantes.

Sentencia dada por don Gaspar de Peralta, provisor de Palencia, en el pleito que ante él pendía entre el abad de San Zoil, fray Alonso Barrantes (presentado al beneficio de la sacristía de San Martín), de la una parte; y de la otra, Thomás González y el bachiller Calleja, cura y capellanes de aquella yglesia, por la qual falló estar vaco el dicho beneficio por fin y muerte del licenciado Gil Rodríguez, su último poseedor, y declara al abad de San Zoil por verdadero presentero del beneficio y sacristía de San Martín y al padre fray Alonso Barrantes por bien presentado para el dicho beneficio. Y, para que la sacristía sea mejor servida, manda que el dicho fray Alonso Barrantes en su lugar ponga una persona eclesiástica o seglar que en su nombre sirva la sacristía y cumpla con las cargas de ella y, poniendo el servicio en esta forma, manda que se le acuda con los frutos y rentas del dicho beneficio y sacristía, etcétera. / (f. 204v) Pronunciose esta sentencia a 21 de marzo de 1600, ante Lucas Gallardo, notario de Palencia.

\section{$<$ Colación de la sacristía a fray Alonso Barrantes $>$.}

Está aquí la colación del dicho beneficio y sacristía dada por el mismo provisor a fray Alonso Barrantes, en que está inserta la sentencia de arriba. Diose la colación a Martín Nieto, procurador de Barrantes, a 4 de marzo de 1600, ante Lucas Gallardo. Martín Nieto sostituyó

${ }^{320}$ Bulla] al margen derecho: falta. 
el poder que tenía de Barrantes en fray Martín de Sahagún, prior de San Martín, para que en su nombre tomase la posesión.

Al pie desta sostitución está el requirimiento que desta colación se hizo al cura Calleja para que diese la posesión, el qual la protestó y dixo que no la daba por voluntad sino por obedecer a su prelado. El abad de San Zoil, que estaba presente, dixo que, atento que no tenía la posesión por quieta y pacífica con aquellas protestas, para que lo fuese requirió a Francisco Pérez, cura de Nuestra Señora del Otero de Frómesta, para que diese la posesión de la dicha sacristía, el qual la dio quieta y pacíficamente al padre fray Martín de Sahagún, en nombre del padre fray Alonso Barrantes, en 25 de marzo de 1600, ante Juan Redondo de Reoyo, escribano de Frómesta.

$8^{\circ}$. < Bulla de impetra a favor de Juan Nieto. Año 1602>.

Copia simple de una bulla de Clemente $8^{\circ}$ dada en favor de Juan Nieto de Villaviudas, assistente en Roma, por la qual Su Santidad le hace gracia de la sacristía de San Martín y su beneficio, que había vacado por muerte de Gil Rodríguez, su último poseedor. Dada en Roma, año de 1602. Año 1603>.

9. <Provisión real para recoger las bullas de impetra de Juan Nieto y entrega de ellas.

Provisión real para recoger y llevar al Consejo las bullas con que impetró Juan Nieto de Villaviuda la sacristía de San Martín contra la posesión inmemorial del monasterio y patronato Real. Dada en Valladolid, a 28 de enero de 1603, ante Juan Gallo de Andrada, escribano de Cámara.

Está aquí un requirimiento hecho al teniente de correjidor de Palencia para que obligue a los escribanos ante quien pasan los autos para que los entreguen, por mandarlo assí la sala, ante Blas de Sahagún, escribano de Palencia.

Vltimamente está un testimonio dado por el mismo escribano de cómo se entregaron los autos y las bullas de impetra de Juan Nieto, a 29 de enero del mismo año.

10. < Mandamiento para que se dé la posesión de la sacristía a Juan Nieto. Año 1603>.

Mandamiento dado por don Bartholomé de Quesada, canónigo penitenciario de Palencia, inserta la bulla de impetra de Juan Nieto de la sacristía de San Martín, por la qual (sic) manda se le dé la posesión de ella. Dado en Palencia, a 21 de enero de 1603, ante Juan Brabo Guerra, notario.

$\mathrm{No}^{321}$ se tomó esta posesión ni tubieron efecto las bullas porque en Chancillería se declaró la fuerza que hacía este juez en no otorgar al monasterio la apelación.

/ (f. 205r) 11. < Protesta del monasterio sobre la posesión que se mandó hacer de la sacristía. Ã̃o 1603>.

Testimonio dado por Lucas Gallardo, notario de Palencia, del pedimiento presentado en nombre del prior de San Martín, atento de que si ser citado ni oýdo el monasterio, se había dado mandamiento por el provisor de Palencia para dar la posesión de la sacristía. Pídese se revoque lo autuado y de no hacerlo assí se protesta el auxilio real de la fuerza. Su fecha, en Palencia, a 25 de octubre de 1603.

12. < Provisión del Consejo para quel dotor Quesada otorgue y reponga lo autuado sobre la sacristía. Año 1604>.

Provisión real y sobrecarta del Real y Supremo Consejo, dada a instancia de fray Alonso Barrantes, contra el canónigo Quesada de Palencia, juez apostólico, para que se cumpla otra provisión (que está inserta en ésta, dada en 8 de noviembre de 1603), por la qual le manda que otorgue y reponga y que mande embiar los autos para ver si hace fuerza en conocer y proceder en la execución de las bullas con que Juan Nieto avía impetrado el

$\left.{ }^{321} \mathrm{No}\right]$ al margen derecho: Nota. 
beneficio de la sacristía de San Martín. Dada en Valladolid, a 21 de febrero de 1604, ante Miguel de Ondarza Zavala, escribano de Cámara.

$<$ Otra provisión de la Chancillería para el mismo Quesada y un auto de la misma>

Hay aquí también otra provisión de la Chancillería, que estaba en Medina del Campo, para que el doctor Quesada, juez de comisión, guarde un auto dado en la dicha Chancillería por el qual declaran que el dicho doctor Quesada, reponiendo lo hecho por él y oyendo de nuevo a fray Alonso Barrantes en la causa de la sacristía de San Martín, en no otorgarle la apelación que ante él interpuso, no hizo fuerza y se lo remitieron y, no lo haciendo, hazía fuerza. Dada en Medina del Campo, a 19 de marzo de 1604, ante Juan Gonzalo Deza, escribano de Cámara.

Al pie desta provisión está el testimonio dado por Juan Brabo Guerra, notario de Palencia, de cómo el referido Quesada obedeció y mandó que las partes alegasen de nuevo por su auto dado en el mismo mes y año. Año 1627>.

13. <Nombramiento de sacristán hecho por el abad de San Zoil en el padre Carrera.

Nombramiento y colación de la sacristía de San Martín hecha por el padre maestro fray Juan Cortés, abad de San Zoil, en el padre fray Mauro de la Carrera, prior deste monasterio, en 23 de mayo de 1627, ante Francisco Moro de Saldaña, escribano de Carrión. Al pie está la posesión quieta y pacífica que de la dicha sacristía dio fray Miguel de Castro, prior de San Martín, al referido fray Mauro en el mismo mes y año, ante Alonso Pérez del Campo, escribano de Frómesta.

$<$ Aprobación del provisor de Palencia>.

Hay aquí un mandamiento del licenciado don Juan Baptista de la Rigada, provisor de Palencia, por el qual, habiendo visto la posesión tomada por fray Mauro, le da licencia (si es necesario) para exercer el oficio de sacristán, ratifica y aprueba la da/ (f. 205v)da por el abad de San Zoil y manda con censuras a los clérigos y feligreses le reconozcan por tal y le acudan con los diezmos y emolumentos de la dicha sacristía. Dado en Palencia, a 23 de junio de 1627, ante Sebastián Díez, notario y vecino de Palencia.

14. $<$ Memoriales del hecho y derecho del monasterio en el pleito de la sacristía $>$.

Bajo este número están primeramente un memorial del hecho para el pleito de la sacristía con Juan Nieto de Villaviudas.

$2^{\circ}$. Vn memorial del derecho que el monasterio tiene a la sacristía de San Martín y sobre que el obispo, sin oýr a nadie, está obligado a amparar al monasterio.

$3^{\circ}$. Otro memorial del hecho en este pleito. Que las capellanías y sacristía son de Patronato Real y fundaciones legas con los bienes de los patronos fundadores, como consta de las donaciones de los mesmos, etcétera.

\section{/ (f. 206r) Quaderno E del legajo 2. \\ Hospital de San Lázaro.}

Este Quaderno E contiene los papeles pertenecientes al hospital de San Lázaro de Frómesta y su yglesia, por el orden siguiente: $1412>$.

$1^{\circ}$. $<$ Concordia entre los cofrades de San Lázaro y los capellanes de San Martín. Año

Escritura $^{322}$ en pergamino por la qual los cofrades de San Lázaro concuerdan con los capellanes de San Martín que, obligándose a decir cada año perpetuamente una vigilia y misa, día de la Epifanía, por el alma de doña María Juana la Montora, que en su testamento había dexado a los cofrades una tierra en el término de Frómesta, ellos se obligaban a dar cada año

322 Escritura] al margen derecho: falta. 
a los dichos capellanes 12 maravedís y media cántara de vino. Su fecha, en Frómesta, a 12 de junio de 1412, ante Toribio González de Frómesta, notario de Palencia, que la escrivió por Gonzálo Martínez, escribano de dicha villa.

\section{2. < Donación de 1500 maravedís para San Lázaro de Frómesta. Año 1445>.}

Testamento de García Fernández, vecino de Frómesta, por el que manda a San Lázaro 1500 maravedís para emplearlos en hazienda, con carga de 2 misas cada semana que se han de decir en dicho hospital. Su fecha, en Frómesta, a 7 de enero de 1445, ante Gonzalo Fernández de Sanfagún, escribano de dicha villa.

\section{3. < Posesión que se tomó de San Lázaro y todas sus heredades. Año 1507>.}

Testimonio dado por Gonzalo García, escribano de Frómesta, de la posesión que, a voz de pregón, se dio a fray Juan de Calzadilla (en nombre del abad de San Benito de Valladolid, general reformador) de la casa y hospital de San Lázaro, como anejo que dice ser del monasterio de San Zoil, y de todas sus heredades y rentas. Su fecha, en Frómesta a 8 de octubre de 1507. $1507>$.

4. < Obligación que hizo Gonzalo de Anieva a favor del prior de San Martín. Año

Escritura $^{323}$ de obligación que hizo Gonzalo de Anieva, vecino y morador de la casa de San Lázaro, de pagar a fray Juan de Calzadilla, prior de San Martín, 4 cargas, 3 quartos y 2 zelemines de trigo y más 2 cargas de zebada que el dicho prior había pagado, como constaba de la qüenta que le habían tomado de la hazienda y rentas de San Lázaro. Su fecha, en Frómesta, a 21 de octubre de 1507, ante Gonzalo García, escribano de dicha villa.

/ (f. 206v) 5. <Qüentas de la hacienda de San Lázaro. Año 1507>.

Testimonio dado por Gonzalo García, escribano de Frómesta, de las qüentas que dio fray Juan de Calzadilla, prior de San Martín, de la administración que había tenido de la hacienda de San Lázaro. Su fecha, en Frómesta, a 19 de octubre de 1507.

6. <Privilegio de los Reyes Cathólicos para que los de San Lázaro puedan pedir por todo el reyno. Año 1538>.

Traslado authorizado por Juan Laso, escribano de Frómesta, de un privilegio de los Reyes Cathólicos, dado año de 1477, que es confirmación de los de don Juan y don Enrrique insertos en éste, para que los de San Lázaro de Frómesta y los de Carrión puedan pedir limosna libremente por todo el reyno y para que no paguen portazgo ni otros pechos. Fue sacado este traslado a 20 de diciembre de 1538.

\section{7. <Visitas de San Lázaro hechas por el abad de San Zoil. Año 1544>.}

Testimonio dado por Alonso García, clérigo, de la visita que hizo Bernardino González, administrador de la casa y hospital de San Lázaro, por el reverendo padre fray Juan de Santa María, abad de San Zoil, señor de dicha casa y hospital. Dado en Frómesta, a 13 de marzo de 1544.

Hay aquí otro papel firmado del sobredicho abad en el que declara haber él mismo visitado dicha casa y hospital, con relación de las alhajas que encontró en él, en 28 de febrero del mismo año.

8. < Concierto sobre el retablo de San Lázaro de Frómesta. Año 1558>.

Vna escritura de concierto sobre el retablo de San Lázaro de Frómesta hecha entre Francisco Pérez el Mozo, pintor, y fray Juan Argadero, prior de San Martín, con poder de fray Juan Vaca, abad de San Zoil, a 12 de agosto de 1558, ante Melchor Laso, escribano de Frómesta. Síguese un mandamiento de fray Francisco Arias, abad de la Misericordia de Frómesta, por comisión del general fray Alonso Zorrilla del año de 1568, por el qual requiere a fray Juan de Corcuera, abad de San Zoil, para que haga tasar y pagar el dicho retablo. En

${ }^{323}$ Escritura] al margen derecho: falta. 
virtud del qual se tasó en 36 mill 370 maravedís. Hay aquí otros papeles en orden a la paga del dicho retablo del año de 1570.

\section{/ (f. 207r) Legajo $3^{\circ}$ del Cajón San Agapio}

Este legajo, que es el $3^{\circ}$ del cajón San Agapio, contiene los tres quadernos siguientes: quaderno A: Presentaciones y colaciones de las capellanías de San Martín, quaderno B: Congrúa y rezo de los capellanes, quaderno C: Pleytos y diferencias sobre la visita de la yglesia de San Martín.

\section{Quaderno A}

En este quaderno están los papeles pertenecientes a las presentaciones y colaciones de las capellanías de San Martín de Frómista, por el orden siguiente: $1487>$.

$1^{\circ}$. $<$ El Papa Ynocenzio $8^{\circ}$ da una capellanía de San Martín a Alonso Fernández. Año

Trasunto simple de un motu proprio del Papa Ynocencio $8^{\circ}$ por el qual consta que, entre otros beneficios, había hecho gracia de una capellanía de San Martín a Alonso Fernández, su familiar y continuo comensal y beneficiado de Santiago; y, sin embargo desta provisión apostólica, se intrusaron en los demás beneficios y juntamente en la capellanía de San Martín Diego Pérez, Gonzalo Muñoz y Fernando de Vanicias, con agravio del dicho Alonso Fernández y menosprecio de la silla apostólica. Por lo qual Su Santidad dio este motu proprio contra ellos mandándoles con censuras y graves penas, dejanse libres al dicho Alonso Fernández los dichos beneficios y capellanía; y manda asimismo a los arrendadores y colonos que tienen a su cargo los frutos no acudan con ellos a los intrusus sino al dicho Alonso Fernández. Dado en Roma, año de 1487, en los ydus de octubre.

\section{$2^{\circ}$. < Colación de la capellanía de San Martín a Pedro Martínez. Año 1505>.}

Colación de una capellanía de San Martín hecha por el licenciado Alonso Bázquez, vicario general de Palencia por el obispo don Juan Rodríguez de Fonseca, a Pedro Martínez, clérigo de Cobarrubias, presentado por don Luis Hurtado de Mendoza, administrador perpetuo de la abadía de San Zoil, por fin y muerte de Rodrigo de Espinosa, último poseedor de dicha capellanía. Dada en Palencia, a 13 de noviembre de 1505, ante Rodrigo Paz, esscribano y notario de dicha ciudad.

Está aquí la posesión que tomó el referido de dicha cappellanía en el mismo año, ante Juan Bedija, clérigo y notario de Frómista. $1507>$.

/ (f. 207v $3^{\circ}$. $<$ Colación de una cappellanía de San Martín a Gonzalo Gutiérrez. Año

Copia autorizada de una colación de una capellanía de San Martín hecha por Juan, obispo Vritonoriense, nuncio apostólico, a Gonzalo Gutiérrez, clérigo de Santa Marina, diócesis de Burgos, por muerte de Gonzalo Galabaza, último poseedor, y en virtud de la presentación que en él hizo don Luis Hurtado de Mendoza, administrador perpetuo de San Zoil. Dada en Torquemada, undécimo kalendas martii, año de 1507. Sacose esta copia a 15 de marzo de 1529, ante Francisco Fernández, notario de la ciudad de Palencia.

$$
4^{\circ} \text {. <Presentación de una cappellanía en Thorivio Lagunilla. Año 1529>. }
$$

Presentación de una capellanía de San Martín hecha por fray Diego de Canales, presidente deste monasterio de San Zoil, en Thorivio de Lagunilla, vecino de Pino del Río, por muerte de Luis Hurtado de Mendoza. Hecha en San Zoil, a 14 de enero de 1529, ante Francisco Catalán, esscribano y notario apostólico.

$5^{\circ}$. < Colación de una cappellanía de San Martín a Thorivio de Lagunilla. Año 1529>.

Colación, escrita en pergamino, con sello de cera pendiente en una cinta de seda berde, por la qual consta que ante el licenciado Bártulo Sánchez de Tórtoles, provisor de Palencia, fray Diego Canales, presidente de San Zoil, presentó a Thorivio de Lagunilla para 
la capellanía de San Martín, que vacó por muerte de Luis Hurtado de Mendoza, su último poseedor. A esta presentación se opuso Alonso Pérez, clérigo de Frómista, a título de patrimonial, alegando que como a tal se le debía dar la colación y no al presentado por el monasterio. Recibiose la causa a prueba, presentaron ambas partes sus informaciones, después de las quales el provisor dio sentencia a favor del monasterio, por la qual declara la dicha capellanía ser de presentación deste monasterio, y dio por bien presentado al referido Thorivio de Lagunilla, al qual admitió a examen, le aprobó y dio la colación desta cappellanía en 19 de marzo de 1529, ante Francisco Férnandez, esscribano y notario de Palencia.

Hay copia, authorizada por el mismo escribano y escrita en papel, desta colación y sentencia sacada el mismo mes y año; y al pie de ella está la posesión que tomó el referido Lagunilla de dicha cappellanía, a 20 de marzo del mismo año, ante Bernaldino de Carrión, notario apostólico.

$6^{\circ}$. <Colación de una cappellanía en Diego Guillén. Año 1531>.

Colación de una cappellanía de San Martín hecha por el bachiller Francisco Valverde, provisor de Palencia, a Diego Guillén, clérigo de Carrión, en virtud de la presentación hecha por el presidente y monges deste monasterio por muerte de Thorivio de Villanueba, último poseedor. Dada en Palencia, a 20 de junio de 1531, ante Francisco Fernández, esscribano y notario de Palencia.

/ (f. 208r) $7^{\circ}$. $<$ Copia simple de una bula de Gregorio 13 sobre una cappellanía de San Martín. Año 1584>.

Copia simple de una bula de Gregorio 13 por la qual parece que, haviendo resinnado en manos de Su Santidad Alonso de Pardo, cura de Nuestra Señora del Castillo de Frómista, una cappellanía de San Martín, y haviéndola pedido Pedro Calleja, beneficiado de la referida yglesia de Nuestra Señora del Castillo, haciendo relación falsa que la cappellanía no es servidera y que su valor no pasaba de 24 ducados de cámara, Su Santidad da comisión al ordinario de Palencia para que, hallando que Alonso de Pando sin la dicha capellanía tenía congrúa suficiente y ser cierta la narratiba, hiciese colación y diese la posesión de ella a Pedro Calleja. Dada en Roma, a 21 de julio de 1584.

$8^{\circ}$. $<$ Parecer sobre que haya monjes en los beneficios. Año 1598>.

Parecer del doctor Valdés, letrado de Valladolid, en el que prescribe los medios que deben de thomarse para poner monges en los beneficios de Frómista, San Lorenzo de Villalpando y San Juan de Aguilar y cómo se escusara el que los clérigos sirvan dichos beneficios. Dado en dicho (sic) ciudad, a 16 de julio de 1598.

$9^{\circ}$. <Pareceres que haya clérigos en los beneficios de San Martín. Año 1602>.

Dos pareceres de dos letrados de Valladolid, en los que declaran que, en los beneficios de San Martín, el abad y monges deste monasterio deben presentarlos a clérigos seculares para que el obispo les haga colación y no ser justo el que se haga novedad sobre esto, sin embargo del motu proprio de Clemente $8^{\circ}$. Dados en Valladolid, a 22 de junio de 1602.

10. <Mandamientos en pro y contra el licenciado Brasa sobre el servivio de una cappellanía de San Martín. Año 1602>.

Requirimientos y mandamientos en pro y contra el licenciado Brasa, beneficiado de San Pedro de Frómista, porque, usando de un mandamiento del provisor de Palencia, dado a instancia de Thomás González, cappellán de San Martín, pretendía serbir la cappellanía de aquella yglesia, que estaba vacante por muerte del cappellán Calleja, para lo que procedió el provisor con mandamientos y censuras contra los monges; y fray Gaspar Madruga, abad de la Vega, juez conservador, contra los clérigos, sobre que ubo muchos escándalos, hasta que el maestro fray Diego Venegas alcanzó del obispo de Palencia que mandase a don Gaspar de Peralta, su provisor, que absolviese a los monges y mandase a Brasa que no sirbiese la cappellanía, como lo hizo por el mandamiento que está aquí original, dado en Palencia, a 27 de octubre de 1602, ante Lucas Gallardo, notario de dicha ciudad. Pasaron los requerimientos 
ante Juan Redondo de Reoyo, esscribano de Frómista; y el mandamiento del juez conservador, ante Alonso Zapata, esscribano de Carrión, todo en el mismo año.

[11]. <Está aquí una petición del licenciado Brasa y la licencia que le dio el padre maestro Barrantes, abad de San Zoil, para servir la capellanía que tenía Thomás González. Dada en Frómesta, a 8 de noviembre de $1606^{324}>$. $1603>$.

12325. <Colación de una cappellanía de San Martín a Juan Madagleno (sic). Año

Colación de una cappellanía de San Martín hecha por don Gaspar de Peralta, provisor de Palencia, a Juan Madaleno, clérigo natural de Carrión, por fin y muerte de Pedro Calleja, último poseedor, y en virtud de la presentación hecha para el abad de San Zoil. Dada en Palencia, a 10 de marzo / (f. 208v) de 1603, ante Pedro de Arana Ocerín, notario de dicha ciudad. Tomó la posesión a 16 del mismo mes y año, ante Juan Redondo de Reoyo, esscribano de Frómista.

Está aquí la licencia que dio fray Alonso Barrantes, abad de San Zoil, al referido Juan Magdaleno, cura de Arconada, para que pueda nombrar persona hábil que sirva por él la dicha capellanía, sin perjuicio del derecho del monasterio. Dada a 13 de mayo del mismo año.

$13^{326}$. < Colación de una cappellanía a Juan Sánchez. Año 1604>.

Colación de una capellanía de San Martín hecha por don Gaspar de Peralta, provisor de Palencia, a Juan Sánchez, clérigo de Frómista, por resignación que de ella hizo Juan Magdaleno, último poseedor, y en virtud de la presentación hecha por el padre maestro fray Alonso Barrantes, abad de San Zoil. Dada en Palencia, a 24 de marzo de 1604, ante Lucas Gallardo, notario de dicha ciudad.

Tomó la posesión a 31 días del mismo mes y año, ante Juan Redondo de Reoyo, esscribano de Frómista. $1605>$.

14 ${ }^{327}$. $<$ Proceso sobre nombrar substituto de una cappellanía de San Martín. Año

Un proceso sin authoridad por el qual parece que Thomás González, cappellán de San Martín (que también lo era del número de la santa yglesia de Palencia), se concertó con Juan Gutiérrez, clérigo de Frómista, para que sirbiese por él la dicha cappellanía; y para esto sacó mandamiento del provisor y licencia por un año, que se notificó al cura y monges, y haviéndole admitido por algún tiempo después le escluyeron, de que se quejó el referido Thomás González al provisor y dio comisión al licenciado Brasa, el qual hizo información a favor de los clérigos y citó a los monges para que alegasen contra ella, pero la causa se quedó en este estado; y pasó año de 1605, ante Alonso Pérez, esscribano de Frómista. Año 1608>.

$15^{328}$. $<$ Carta de los feligreses, que no consienten sea monge sacristán de San Martín.

Carta que escriben los feligreses de San Martín en respuesta de otra que les había escrito el abad de San Zoil para que diesen su consentimiento sobre la presentación de las capellanías y sacristía a los monges y no a seglares. Dicen en ella los fundamentos que tienen para no dar su consentimiento y los inconvenientes grandes que se siguen de que sirban religiosos en aquella yglesia, especialmente de que el sacristán lo sea. Fue escrita a 16 de enero de 1608.

324 1606] al margen inferior: Nota <Este número 11 debe ser una licencia que dio el padre maestro Barrantes a Antonio Martínez para que sirviese la capellanía que tenía Thomás González en su ausencia. Dada en San Zoil, a 13 de mayo de 1603, ante Alonso Zapata, escribano y notario de Carrión>.

$32512]$ corregido sobre 11.

326 13] corregido sobre 12.

327 14] corregido sobre 13.

328 15] corregido sobre 14. 


\section{329 . < Colación de una cappellanía a Francisco Pérez. Año 1609>.}

Traslado authorizado por Alonso Pérez, esscribano de Frómista, de una colación de una cappellanía de San Martín hecha por el licenciado don Manuel García de Miranda, provisor de Palencia, al bachiller Francisco Pérez, clérigo de Frómista, por muerte de Juan Sánchez, último poseedor, y en virtud de la presentación hecha por el abad de San Zoil. Dada en Palencia, a 2 de junio de 1609, ante Lucas Gallardo, notario de dicha ciudad. Fue sacado este traslado a 13 del mismo mes y año.

$17^{330}$. < Carta del procurador de Roma. Año 1612>.

Carta del padre fray Andrés de Salazar, procurador de Roma, escrita al abad de San Zoil sobre lo que debe hacerse para presentar los beneficios de / (f. 209r) San Martín en monges y sobre la unión de los beneficios de San Román y el Brezo. Su fecha, en Roma, a 26 de marzo de 1612. $1623>$.

$18^{331}$. < Parecer sobre poner monges o clérigos en la yglesia de San Martín. Año

Parecer del licenciado don Diego de Quiñones Lorenzana, letrado de León, por el qual declara que el padre abad de San Zoil puede poner en la yglesia del priorato de San Martín de Frómista, siendo unida al monasterio de San Zoil, un monge o clérigo secular aprobados por el ordinario y amobiles ad nutum de Santo Padrev conforme al motu proprio de Clemente $8^{\circ}$. Y en otro parecer del mismo, que está aquí, encarga sobre todo el que se hagan todas las diligencias posibles en buscar la bula de unión antes de comenzar el pleyto sobre esta razón. Dados en León, a 3 de mayo y 29 de marzo de 1623.

1932. < Colación de una cappellanía a Josef de Sancti Estevan. Año 1634>.

Colación de una cappellanía de San Martín hecha por el doctor Santiago Roxo, provisor de Palencia, a Josef de Sancti Estevan, clérigo de Melgar, por fin y muerte de Matheo Marcos, último poseedor, y en virtud de la presentación hecha por el abad de San Zoil. Dada en Palencia, a 2 de diciembre de 1634, ante Francisco Pedrero, notario de dicha ciudad. Tomó la posesión con poder Juan de Estrada, clérigo de Frómista, que le dio Juan Pérez, presvítero, vecino de dicha villa, a 27 de diciembre del mismo año, ante Alonso Pérez del Campo, esscribano de Frómista.

\section{$20^{333}$. < Colación de una cappellanía a Francisco de Santa Cruz. Año 1635>.}

Colación de una cappellanía de San Martín hecha por el doctor Santiago Roxo, provisor de Palencia, a Francisco de Santa Cruz, clérigo de Frómista, por dejación que de ella hizo Francisco Pérez, último poseedor, y en virtud de la presentación que en él hizo el padre maestro fray Bernardo de San Estevan, abad de San Zoil. Dada en Palencia, a 23 de abril de 1635, ante Francisco Pedrero, notario de dicha ciudad. Tomó la posesión a 28 del mismo mes y año, ante Alonso Pérez del Campo, esscribano de Frómista.

21. < Presentación de una cappellanía a Thomás de la Torre. Año 1662>.

Testimonio dado por fray Francisco Molina, monge de San Zoil y notario apostólico, de una presentación de una capellanía de San Martín hecha por el padre maestro fray Juan González, abad deste monasterio en el licenciado Thomás de la Torre, clérigo de menores órdenes y natural de Cumillas, arzobispado de Burgos, por fin y muerte del licenciado Domingo García, último poseedor. Dada en San Zoil, a 24 de agosto de 1662.

22. <Nombramiento interino de cura de San Martín en el padre fray Leandro de la Madriz y mandamiento a los curas para que le tengan por tal. Año 1683>.

\footnotetext{
329 16] corregido sobre 15.

$33017]$ corregido sobre 16.

331 18] corregido sobre 17.

$33219]$ corregido sobre 18.

333 20] corregido sobre 19.
} 
Licencia que dio el obispo de Palencia al padre fray Leandro de la Madrid, prior de San Martín de Frómista, para que hiciese el oficio de cura en el ínterin que el padre abad de San Zoil hacía el nombramiento de cappellán cura de dicho priorato. Dada en Palencia, a 20 de diciembre de 1683, ante Thomás Francisco Torres, secretario de Su Yllustrísima.

Síguese un mandamiento del mismo señor obispo a los curas y beneficiados / (f. 209v) de las yglesias de San Pedro y Nuestra Señora del Castillo de la villa de Frómista, para que hagan enteramente con el dicho prior, como tal cura de ínterin, aquello mismo que se ha hecho y debido hacer con el cura secular sin alterar ni innobar en cosa alguna. Dado en dicha ciudad, a 13 de febrero de 1684, ante el mismo secretario. Notificose este mandamiento a los dichos curas, a 8 de marzo del mismo año, por Gonzalo del Valle, notario y esscribano de Villasirga.

23. < Colación de una cappellanía a Juan Antonio Godoy. Año 1684>.

Colación de una capellanía de San Martín hecha por el licenciado don Pedro Rodríguez Mogrovejo, provisor de Palencia, al licenciado Juan Antonio de Godoy, natural de la filegresía de Tenorio, en el reyno de Galicia, por muerte del licenciado Bernardo Martínez Carabaca, y en virtud de la presentación que en él hizo el padre maestro fray Bernardo de Estúniga, abad de San Zoil. Dada en Palencia, a 3 de febrero de 1684, ante Francisco Sánchez, notario de dicha ciudad. Tomó la posesión a 9 días del mismo mes y año, ante Gonzalo del Valle, notario y esscribano de Villasirga.

\section{4. <Presentación de una cappellanía en don Antonio Pérez. Año 1707>.}

Presentación de una capellanía de San Martín hecha por el padre maestro fray Jacinto Díez, abad de San Zoil, en el licenciado Antonio Pérez, natural de la villa de Castrogerid, por resignación que de ella hizo don Juan Antonio de Godoy, último poseedor (cuya resignación y aceptación están aquí insertas). Su fecha, en San Zoil, a 27 de abril de 1707, ante Santiago Duque de Estrada, esscribano y notario de Carrión.

\section{$<$ Renuncia $>$.}

Está aquí la renuncia que de dicha capellanía hizo el referido don Antonio Pérez, en 20 de agosto de 1716, ante Pedro Castaño, esscribano y notario de Castrogeriz. $1720>$.

25. < Presentación de una cappellanía de San Martín en don Felipe Martínez. Año

Presentación de una capellanía de San Martín hecha por el padre maestro fray Matheo Quijano, abad de San Zoil, en el licenciado don Felipe Martínez Carabaza, clérigo de menores órdenes y natural de Frómista, por renuncia que de ella hizo don Pedro Montes del Castillo, último poseedor, por un auto dado por el señor fiscal de Palencia por ausencia del señor provisor. Dado en Palencia, a 15 de noviembre de 1720, ante Josef Meléndez, notario mayor de dicha ciudad. Fue dada esta presentación a 26 del mismo mes y año, ante Alonso Caveza, notario y vecino de Carrión.

26. < Presentación y colación de una cappellanía de San Martín en don Fernando Quadros. Año 1729>.

Presentación y colación de una capellanía de San Martín hecha por el padre maestro fray Josef de Yglesias, abad de San Zoil, y el licenciado don Lorenzo Bernardo Pereyra de Ocampo, provisor de Palencia, en el licenciado don Fernando Quadros, clérigo de prima tonsura, natural de Frómista, por renuncia que de ella hizo don Felipe Carabaza, último poseedor. Fue dada la presentación en San Zoil, a 15 de noviembre de 1729, ante Agustín Díez de Castro, notario; y la colación, en Palencia, a 27 de enero de 1730, ante Josef Meléndez, notario mayor de dicha ciudad. Al pie de ella está la posesión que, en nombre del referido Quadros, tomó don Felipe Carabaza, a 2 de febrero del mismo / (f. 210r) año ante Pedro Téllez, notario. 

$1743>$.

27. <Presentación de una cappellanía de San Martín en don Manuel Calbo. Año

Presentación de una capellanía de San Martín hecha por el padre maestro fray Manuel Ordóñez, abad de San Zoil, en el licenciado don Manuel Calbo, natural de dicha villa, clérigo de menores órdenes, por muerte de don Ambrosio Caxigas, último poseedor. Dada en San Zoil, a 10 de junio de 1713, ante Agustín Díez de Castro, notario y esscribano de Carrión. $1757>$.

28. <Presentación de una cappellanía de San Martín en don Josef Caxigas. Año

Testimonio dado por Pedro Chico Escobar, notario y esscribano de Frómista, de la presentación de una cappellanía de San Martín hecha por el padre maestro fray Yldefonso de la Bárcena Mier, abad de San Zoil, en don Josef Caxigas, presbítero, natural de dicha villa, por muerte de don Fernandon Quadros, último poseedor. Dada en San Zoil, a 27 de enero de 1757 , en cuyo mes y año fue sacado este testimonio.

29. <Edicto del señor obispo en que manda suspender la presentación de las cappellanías. Año 1769>.

Copia simple de un edicto del señor don Josef Cayetano de Loaces, obispo de Palencia, por el que manda a los patronos de las capellanías no pasen a presentarlas hasta tanto que hagan constar del derecho que tienen a su presentación y de que su renta, inclusas las cargas, asciende a 200 ducados de vellón, en conseqüencia de una orden ${ }^{334}$ espedida por la Cámara de Castilla. Dado en Palencia, a 13 de maro de 1769, ante don Alonso Aguiar, secretario de Su Yllustrísima. $1784>$.

30. <Presentación de una cappellanía de San Martín en don Lorenzo Chico. Año

Copia autorizada por Martín García Gatón, esscribano y notario de Carrión, de la presentación de una capellanía de San Martín hecha por el padre maestro fray Martín Basco, abad de San Zoil, en don Lorenzo Chico, beneficiado de Nuestra Señora del Otero, y residente en la espresada villa, por muerte de don Manuel Calbo, su último poseedor. Dada en San Zoil, a 11 de febrero de 1784, en cuyo día, mes y año se sacó esta copia.

\section{1. < Protesta sobre la provisión del curato de San Martín. Año 1789>.}

Protesta que hizo el padre fray Anastasio Moreyra, prior de San Martín de Frómista, de la provisión del curato de San Martín hecha por el señor obispo de Palencia en don Antonio González Caxigas. Su fecha, en Frómista, a 18 de octubre de 1789, ante Pedro Rodríguez Antón, esscribano de dicha villa.

/ (f. 210v) 32. < Presentación de una capellanía de San Martín en don Josef Carabaza Téllez. Año 1803>.

Copia authorizada por Ysidoro Ruiz de Colmenares, esscribano y notario de Carrión, de la presentación de una capellanía de San Martín hecha por el padre maestro fray Leandro Pérez, abad de San Zoil, en don Josef de Carabaza Téllez, natural de Frómista, vacante por renuncia que de ella hizo don Pedro Alcántara Sendino y Calbo ante Pedro Nolasco Calbo, notario público y vecino de la ciudad de Burgos (que se halla aquí adjunta con la certificación dada por el mismo notario de que el referido don Pedro Alcántara es capellán del reximiento provincial de dicha ciudad). Dada en San Zoil, a 4 de enero de 1803, en cuyo día, mes y año se sacó esta copia.

33. < Apuntaciones sobre el derecho deste monasterio en San Martín de Frómista>

Memoriales y apuntaciones sobre el derecho que tiene el monasterio de San Zoil en su priorato e yglesia de San Martín de Frómista y sobre la pretesión de que los monges sirviesen las capellanías de la dicha yglesia y de los medios que se deben de poner para su consecución.

\footnotetext{
334 orden] sigue tachada de.
} 


\section{4. $<$ Fundación de una capellanía $>$.}

Fundación de una capellanía que hizo don Gómez Manrique, adelantado de Castilla, en las yglesias de Frómesta y privilegios que concedieron los reyes a su casa. Todo está sin authoridad y no pertenece al monasterio más que por curiosidad.

\section{/ (f. 211r) Quaderno B del legajo $3^{\circ}$ \\ Congrua y rezo de los cappellanes}

Este quaderno B contiene los papeles pertenecientes a la congrua y rezo de los capellanes de San Martín y pleytos que sobre esto ha tenido este monasterio, por el orden siguiente:

$1^{\circ}$. <Ynformación sobre la congrua de los capellanes. Año 1550>.

Ynformación en derecho, sin authoridad, hecha según parece el año de 1550, en razón del pleyto que este monasterio tenía con los capellanes sobre un estipendio y congrua. $1552>$.

$2^{\circ}$. $<$ Monitorio de Roma sobre el estipendio de los capellanes de San Martín. Año

Mandamiento monitorio librado por Pablo Emilio Verallo, juez de la curia romana y auditor de la Cámara Apostólica, escrito en pergamino, con sello de cera colorada pendiente, contra el canónigo Andrés de Llano, para que se inhiba, y contra Alonso Álvarez, arcipreste de Población, Bernardino González y los demás capellanes de San Martín, para que acudan a Roma en siguimiento de la causa sobre el estipendio de sus capellanías, pendiente ante el dicho juez, y de que el convento apeló a Roma y sacó este mandamiento para seguirla en aquella curia. Dado año de 1552, ante Arcángelo Raimundo, clérigo de la diócesis de Tricariense, notario apostólico.

Está aquí otro monitorio compulsorial, dado en Roma por el mismo juez y en la misma razón, ad contumaciam, y contra los mismos, y ante el mismo notario, escritos los dos en pergamino, y asimismo la notificación, escrita en papel, hecha a 25 de junio por Antonio Amigo, notario de la ciudad de Palencia.

/ (f. $211 v) 3^{\circ} .<$ Provisión Real para recoger y llevar a la Chancillería el mandamiento monitorio del número anterior. Año 1552>.

Traslado authorizado por Andrés de la Riva, esscribano de Frómista, de una provisión real dada en la Chancillería de Valladolid, a 28 de junio de 1552, por la qual parece que Bernardino González, capellán de San Martín, Francisco de Tamayo, sacristán de dicha yglesia, y Alonso Álvarez, arcipreste de Población, se quejaron en la Chancillería de que, haviendo traído pleyto con el monasterio ante el ordinario de Palencia y ante los jueces apostólicos en grado de apelación, sobre el estipendio de sus capellanías y, haviendo tenido tres sentencias conformes en su favor, habían sacado carta de executoria dada por Andrés de Llano, canónigo de Palencia y último juez apostólico. Y, habiendo acudido a la Chancillería por vía de fuerza, habían remitido la causa al referido Andrés de Llano, y que estando la causa en este estado, como el monasterio había trahído de Roma un breve monitorio e inibitorio que intimaron al dicho canónigo y temían ser citados los interesados, pidieron que se mandase guardar la dicha carta executoria y que se enviase a la Chancillería el referido mandamiento monitorio e inhibitorio, como en efecto por esta provisión se mandó llebar con los demás autos que por virtud de ella se hubiesen hecho. Fue sacado este traslado en Valladolid, a 16 de julio de 1552. Está duplicado. $1553>$.

$4^{\circ}$. <Mandamiento de comparendo contra Bernardino González y companeros. Año

Mandamiento de personaliter comparendo dado por Francisco Alverico, auditor general de la curia Romana y juez comisionado para esta causa, en el qual se hace relación de la desovediencia y reveldía a las letras appostólicas cometida por Bernardino González, Francisco de Tamayo y Alfonso Álvarez que se les habían intimado para que fuesen a seguir 
la causa pendiente en Roma en grado de apelación hecha por este monasterio en razón del estipendio y congrua que los capellanes de San Martín pedían de sus capellanías. Antes, sin embargo, de la dicha apelación habían acudido a tribunales seglares para impedir la execución de las letras appostólicas de arriba y hacían otras / (f. 212r) muchas vexaciones y molestias al monasterio y sus monges. Por lo qual se les manda comparecer personalmente en Roma bajo graves penas y censuras, y se da comisión a los prelados y dignidades de España para que les compelan a ello. Dado en Roma, a 6 de enero de 1552, ante Gaspar Pagano, público notario de la curia de la Cámara Appostólica.

$5^{\circ}$. $<$ Mandamiento $2^{\circ}$ de personaliter comparendo contra Francisco Tamayo sobre la misma razón. Año 1554>.

Otro mandamiento de personaliter comparendo, escrito en pergamino, con sello de cera pendiente, contra los mismo y Juan de Luzeta, beneficiado de la yglesia de Yscaray, y especialmente contra Francisco de Tamayo, sacristán de San Martín, dado por el mismo auditor a instancia del fiscal de la Cámara Appostólica, por no haber obedecido el mandamiento anterior, y porque el referido Tamayo no pudo ser habido ni tenía casa donde notificarle, se manda publicar, a modo de edicto, en la audiencia de Roma, en la yglesia de San Pedro y en las yglesias de San Juan y Santa María de Paredes y en otros lugares, para que venga a su noticia y parezca personalmente en Roma a purgarse de los agravios que hizo al convento en impedir la execución de los breves de arriba. Dado en Roma, a 5 de mayo de 1554, ante Gaspar Pagano, notario de la Curia Appostólica, en el año $5^{\circ}$ del pontificado de Julio $3^{\circ}$.

$6^{\circ}$. $<$ Mandamiento del provisor de Palencia para que los capellanes recen el rezo romano. Año 1597>.

Petición de los capellanes de San Martín y mandamiento del provisor de Palencia, en sede vacante, en que manda con censuras que en San Martín se rece el rezo romano por los capellanes y monges del dicho priorato. Síguese la apelación que de este mandamiento hizo el padre fray Plácido Huércanos, ante los provisores de Palencia, a 25 de febrero de 1597, ante Pedrosa de Villegas, notario de dicha ciudad. Hay aquí otros papeles sobre lo mismo pero todos están sin authoridad.

$7^{\circ}$. $<$ Sentencia de Cornelio Cataneo que condena a los cappellanes a que residan y recen el rezo en el monasterio o no se les dé el vestuario. Año 1600>.

Traslado simple de una sentencia dada por el doctor Cornelio Cataneo, protonotario y juez appostólico, contra los capellanes de San Martín en razón del vestuario y rezo. Por esta sentencia da por libre al convento por haber pagado las cargas de pan que pedían los capellanes y declara que el convento no está obligado / (f. 212v) a pagarles el vestuario si no fuere guardando el modo y orden de rezar de los monges conforme a la concordia hecha el año 1556 (que está delante en el quaderno $C$ número $8^{\circ}$ ), a cuya observancia condenó a los capellanes, y en su execución y posesión manutenía al convento para que, si los capellanes no la guardaren, no les dé nada y, guardándola, esté obligado a darles el vestuario conforme a la referida concordia y $\mathrm{ca}<\mathrm{r}>$ ta executoria y conforme a ella pueda el abad y convento multar al cura y capellanes quando no acudieren a las horas y rezo en que les ampara y mantiene. Que los referidos cura y capellanes restituyan al convento los maravedises en que les huvieren multado por no haber residido a las horas canónica. Y, en quanto a esto, revoca la sentencia dada en esta causa por don Gaspar de Peralta, provisor de Palencia. Dada a 26 de agosto de 1600, ante Francisco de Santander, notario appostólico.

$<$ Sentencia del nuncio en $3^{\mathrm{a}}$ instancia que confirma la de Cataneo. Año 1601>.

Está aquí un tanto simple de una sentencia que dio en la misma causa don Gimnasio, arzobispo sipontino, nuncio de Su Santidad, por la qual, en tercera instancia, confirma la sentencia que dio el doctor Cataneo y manda que se guarde. Dada en Valladolid, a 7 de julio de 1601, ante Francisco Núñez de Luna, notario.

Asimismo está aquí un requirimiento hecho por parte del monasterio al referido provisor de Palencia para que se hinibiese en la causa. Ante Martín Pérez Escalante, notario de Palencia. 
8. $<$ Mandamiento del provisor de Palencia para que el monasterio comparesca ante él en seguimiento desta causa. Año 1602>.

Mandamiento, sin authoridad, del doctor don Miguel Santos de San Pedro, arcediano del Alcor, en la santa yglesia de Palencia, juez appostólico nombrado para esta causa por la Santidad de Clemente $8^{\circ}$ por un breve inserto aquí y expedido a instancia del obispo de Palencia, cura y capellanes de San Martín, en grado de apelación, por el que se le da comisión para que entienda en esta causa de la congrua. Y el referido provisor manda notificar el referido breve al monasterio para que dentro de nuebe días comparezcan ante él en seguimiento de dicho pleyto y alegar lo que les convenga. Dado en Palencia, a 13 de mayo de 1602, ante Lucas Gallardo, notario de dicha ciudad. Fue sacado este traslado en Carrión.

/ (f. 213r $)$ 9. < Mandamiento de Roma en la causa con el obispo y capellanes de San Martín sobre el estipendio y rezo monástico. Año 1603>.

Mandamiento de citación e inhibición, escrito en pergamino, dado por Alexandro Lita, auditor de la Cámara Appostólica juez ordinario de causas en Roma, por el qual parece que en la causa tocante al trigo y estipendio que pedían los capellanes al monasterio y que se sustrajo de pagarles por no querer, conforme a la concordia, acudir a las horas canónicas y rezar el rezo monástico, haviéndose ventilado esta causa ante muchos jueces, alega el obispo y capellanes haver tenido tres sentencias conformes en su favor y el monasterio haver tenido en el suyo la última ante el nuncio de Su Santidad. Y por haverse cometido al arcediano y jueces sinodales de Palencia la execución y tenerlos por sospechosos (por ser súbditos y dependientes del obispo, que era parte formal en este pleyto), apelaron ante Su Santidad y pidieron retención desta causa en la Rota. Admitiose la apelación, retúbose la causa y diose este monitorio citando al obispo, capellanes y demás interesados, inhibiendo a todos los jueces que desta causa hubiesen conocido. Dado en Roma, a 20 de agosto de 1603, ante Quirino Cabarto, notario de las causas del Sacro Palacio. Notificose este mandamiento monitorio a don Miguel Santos, arcediano del Alcor, juez de comisión en esta causa, a 3 de diciembre de 1603, ante Juan Brabo Guerra, notario de dicha ciudad; y, en 26 de enero de 1604 y ante el mismo notario, se le notificó al mismo como provisor que era y se le dio por inhibido.

10. $<$ Mandamiento del provisor para que el monasterio pague por el estipendio a los cappellanes de San Martín ciertas cargas de pan. Año 1603>.

Traslado authorizado por Alonso Pérez, esscribano de Frómista, de una sentencia dada contra el monasterio por don Gaspar de Peralta, provisor de Palencia, por la qual manda que, en execución de la carta executoria del cura y capellanes de San Martín, los renteros que el monasterio tiene en Frómista, y a falta destos los colectores de las tercias y diezmos de Arconada, paguen a qüenta del monasterio 28 cargas de pan por mitad a Thomás González, 25 al cura al cura Calleja por el estipendio de sus capellanías, y 3 cargas de trigo a Juan de Yerro, arcipreste / (f. 213v) de Población, por la visita de la pila de San Martín, en que era condenado el monasterio por la dicha carta executoria. Y manda dar sus cartas declaratorias y agravatorias contra los dichos renteros y colectores del monasterio. Dada en Palencia, a 11 de marzo de 1603, en cuyo año fue sacado este traslado, el qual está aquí multiplicado.

Síguese un mandamiento del mismo provisor, sin authoridad, para que los referidos renteros y colectores del monasterio paguen a los contenidos en esta sentencia el pan que pretendían y que por ella está mandado pagar. Dado en Palencia, a 14 de marzo del mismo año, ante Pedro de Arana, notario de dicha ciudad, ante quien fue pronunciada la sentencia del provisor. $1603>$.

11. <Mandamiento del juez conservador, que no se obedezca al provisor. Año

Mandamiento de fray Hernando de Ayala, abad del monasterio de la Vega, juez conservador, para que los renteros y colectores del monasterio no obedezcan la sentencia ni mandamientos del provisor de Palencia, ni paguen a los clérigos las referidas cargas de pan que piden. Dado en Carrión, a 15 de marzo de 1603, ante Alonso Zapata, esscribano en dicha villa. Notificose este mandamiento por Luis de Revenga, esscribano de Arconada, al mayordomo de las rentas que este monasterio tenía en dicho lugar en el mismo mes y año. 
12. < Auto del provisor contra el prior de San Martín. Año 1603>.

Copia simple de un auto del provisor de Palencia en el que reincluye en las censuras dadas en sus mandamientos al padre fray Plácido de Huércanos, prior de San Martín de Frómista, y a Juan Gutiérrez, vecino de Arconada, para que guarden lo proveído por él. Dado en Palencia, a 26 de abril de 1603, ante Lucas Gallardo, notario de dicha ciudad.

13. <Mandamiento de absolución de las censuras de arriba dado por el provisor de Palencia. Año 1603>.

Auto dado por don Gaspar de Peralta, provisor de Palencia, (a instacia de la parte del prior de Frómista, inserta aquí su petición) el qual, por estar inhibido por juez superior del conocimiento desta causa, repone lo que había hecho después de la inhibición y manda absolver al prior de Frómista y a los que estaban declarados. Dado en Palencia, a 23 de mayo de 1603, ante Pedro de Arana, notario en dicha ciudad.

/ (f. 214r) 14. <Mandamiento de inibición de un juez appostólico de León contra el provisor de Palencia. Año 1603>.

Mandamiento citatorio, ynibitorio y compulsorio dado por don Pedro de Henao Osorio, canónigo de León y juez appostólico en esta causa, en virtud de un breve y comisión del nuncio de Su Santidad, inserto aquí, dado a 26 de septiembre de 1603 a instancia del abad de San Zoil y prior de San Martín, en grado de apelación, de los autos y sentencias dadas por el ordinario de Palencia en la causa de los capellanes, en razón de las cargas de pan que pedían por el estipendio de sus capellanías. Fue dado este mandamiento en León, a 14 de octubre de 1603, <ante Diego García, notario>. Notificose al provisor de Palencia a 10 de diciembre del mismo año; el qual respondió que procedía a execución de la carta executoria que hay en esta causa, dada en virtud de tres sentencias conformes y que, haviendo apelado el monasterio a la Chancillería y al nuncio, declararon no hacer fuerza y se lo remitieron, y así requiría al dicho juez y de lo contrario apelaba.

Hay aquí otro mandamiento del mismo juez contra el mismo provisor de Palencia agravando las censuras para que se inhiba desta causa. Dado en León, a 8 de enero de 1604, ante Diego García, notario.

15. $<$ Mandamiento de citación de partes para compulsar el proceso en la causa de los capellanes. Año 1604>.

Mandamiento de citación de partes dado por don Luis de Orduña, canónigo de Palencia, juez apostólico (nombrado en virtud de ciertas letras appostólicas de monseñor Alexandro Lita, auditor del Sacro Palacio), para compulsar el proceso o procesos en la causa contra el obispo de Palencia, cura y capellanes de San Martín, que pretendían que el abad y prior de dicho priorato les señalasen el trigo con que se les había de contribuir y sobre si habían de observar el rezo monacal o clerical. Dado en Palencia, a 4 de marzo de 1604, ante Juan Brabo Guerra, notario de dicha ciudad. Al pie de él están las notificaciones hechas al fiscal, cura y cappellanes.

16. <Auto del provisor de Palencia para que un capellán de San Martín pague al que hizo de cura en dicha parroquia siete cargas de pan por cada año. Año 1729>.

Testimonio dado por Pedro León de Santotis, notario mayor de Palencia, de un auto difinitibo dado por el provisor de dicha ciudad en el pleyto y causa entre el licenciado don Francisco de Saldaña, beneficiado en la villa de Frómista y cura theniente que fue en la parroquial de San Martín de ella, y el licenciado don Felipe Carabaza, cura en dicha villa / (f. 214r) y cappellán de la citada parroquia, por el qual auto condena al referido don Felipe a que pague al dicho don Francisco de Saldaña siete cargas de pan por cada uno de los años que ha exercido el ministerio de cura en la referida parroquia. Consta deste testimonio no haber pagado este monasterio, o el priorato de San Martín en su nombre, 12 cargas de pan como quiso un cappellán de San Martín, fundado en que las pagaron tres padres priores por equivocación. Fue dado este auto en Palencia, a 20 de julio de 1729, ante Josef Meléndez, notario mayor de dicha ciudad, y este testimonio fue sacado en 26 de octubre de 1768. 
17. $<$ Parecer de dos letrados sobre las 6 cargas de pan que se dan al cura de San Martín. Año 1768>.

Parecer del licenciado don Pedro Mazedo y Estrada, abogado de Valladolid, en el que declara que las seis cargas y una fanega de pan mediado que anualmente paga el prior de San Martín al capellán que hace el oficio de cura, no deben darse al otro cappellán, sin embargo de que alguno de los priores cometió el herror de contribuir con seis cargas al uno y con otras 6 cargas al otro, haciéndolas iguales, lo que manifiesta ser un introducido abuso. Dado en Valladolid, a 28 de octubre de 1768. Al pie está otro parecer del licenciado don Manuel Martínez Merino, abogado de la misma ciudad, que confirma el anterior.

18. <Azvertencias para los pleytos con los capellanes>.

Memoriales de advertencias y otros papeles simples tocantes a los pleytos sobre la congrúa y rezo de los capellanes de San Martín, todos sin authoridad.

\section{/ (f. 215r) Quaderno C del legajo $3^{\circ}$ \\ Visita de San Martín}

En este quaderno $C$ están los papeles pertenecientes a los pleytos que ha tenido este monasterio con los obispos de Palencia y sus visitadores sobre la visita de la parroquia de San Martín de Frómista, sus derechos y procuraciones, por el orden siguiente:

$1^{\circ}$. $<$ Proceso del juez conservador contra el obispo y sus provisores que prendieron al prior de San Martín. Año 1550>.

Proceso fulminado por Francisco Moro, prior de Benevivere, juez conservador subdelegado por el prior de San Agustín de Valladolid, juez principal conservador de los monasterios de la Congregación de San Benito de España, por el qual parece que, haviendo sido requirido el dicho prior de Benevivere con la comisión y subdelegación del prior de San $^{335}$ Agustín, inserta la bula conservatoria de la religión y habiéndola acetado en 23 de agosto de 1550 por ante Juan de Castrillo, notario de Carrión, dio un mandamiento contra don Luis Cabeza de Baca, obispo de Palencia, y contra sus provisores, por el qual dice haverse crellado ante él la parte del monasterio de San Zoil, de que siendo el prior de San Martín y sus monges sugetos al abad y esentos de la jurisdición del obispo, en oprobio de la religión y en contravención de las bulas de esención de ella, havía dado un mandamiento para que fuese preso el prior de San Martín, como en efecto lo fue, y puesto en la cárcel episcopal, y asimismo para que fuesen seqüestrados sus bienes y rentas. Por lo qual el dicho juez, a instancia deste monasterio, mandó con censuras y penas reponer y anular los dichos mandamientos, que los da por nulos, y manda a Bernardino González, cappellán de San Martín, que no use más de los tales mandamientos sino que los rasgue bajo de censuras, etcétera. Manda asimismo a los renteros acudan al prior con las rentas y quita los embargos puestos. Recibe en su amparo a los monges que vivieren en San Martín y a sus bienes. Pide de parte de Su Santidad a las justicias seglares no permitan le sea hecha fuerza ni violencia, que les releva de qualquier / (f. 215v) censuras que por esto fueren contra ellos dadas por el obispo y sus oficiales. Este mandamiento se notificó en Frómista a los contenidos en él.

Síguense dos poderes, el uno de los capellanes y feligreses y el otro del obispo, provisor y vicario, para salir a la defensa desta causa.

En 30 de agosto del mismo año alegó Bernardino González, en nombre de los demás, contra este mandamiento y apeló de sus censuras. Contra lo qual volvió el monasterio alegar ante el conservador y pidió procediese contra el obispo, alegando no ser juez en esta causa, mandando soltar al preso y alzar el seqüestro de los bienes, etcétera, a 3 de septiembre del dicho año. No haviendo respondido los contrarios, se recibió la causa a prueba y se dio

\footnotetext{
335 San] sigue tachado: Martín.
} 
comisión a Juan de Castrillo, notario desta causa, para que hiciese información por el monasterio.

$<$ Ynformación del monasterio $>$.

A 9 de septiembre del mismo año, la parte del monasterio articuló y probó con cinco testigos lo siguiente:

$1^{\circ}$. Que San Martín es filiación de San Zoil, sugeto a su visita y correpción.

$2^{\circ}$. Que de tiempo immemorial el abad visita el Santísimo, el Santo Milagro, pila y olios, y por su orden se manda gastar los vienes de la fábrica, sin que el obispo se meta en esto, por no tener opción a ello en la visita alternativa que hace y ser la principal la del abad.

$3^{\circ}$. Que la yglesia y heredades son de San Zoil y como tal las arriendan los priores de San Martín y cobran los derechos de sepulturas. Y en esta posesión han estado de tiempo immemorial.

$4^{\circ}$. Que tienen arrendadas las dichas heredades a N. y N. etcétera.

$5^{\circ}$. Que por mandamiento del obispo está mandado prender el prior de San Martín, porque cumple los mandamientos de su abad, y de hecho tienen seqüestrados los bienes y rentas del monasterio y los renteros no quieren acudir con ellas.

$6^{\circ}$. Que todo lo dicho es pública voz y fama.

$<$ Sentencia del juez conservador $>$.

En 12 de septiembre de 1550 se presentó ante el juez conservador esta probanza por el monasterio y se pidió se proveyese conforme a lo probado y actuado. En cuya virtud el dicho juez declaró ser así lo probado y mandó dar sus censuras contra el obispo y sus provisores hasta que se iniban del conocimiento desta causa y anulen todos y qualesquier mandamientos que tengan dados y mandó alzar todos los seqüestros que / (f. 216r) tengan hechos y se proceda con censuras contra los renteros para que paguen al monasterio. Y que el obispo y sus provisores juren que en ningún tiempo procederán contra los monges y sus bienes. En cuya virtud y cumplimiento de lo mandado en esta sentencia del dicho juez conservador dio su mandamiento de benignidad contra el obispo, provisores y demás conortes, por el qual les manda cumplir lo contenido en dicha sentencia. Dado este mandamiento en Benevivere, a 18 de septiembre de 1550, ante Juan de Castrillo, notario de Carrión.

Notificose en Frómista a los renteros ante Juan Laso, notario en dicha villa. Y a 23 del mismo mes y año, se notificó en Palencia al bachiller Llanos, vicario, el qual dijo que apelaba y apeló de lo mandado por dicho juez ante Antonio de Ayala, notario de la ciudad de Palencia.

$<$ Sentencia de la Chancillería $>$.

Se vio esta causa en Chancillería y los señores declararon hacer fuerza el dicho juez conservador e dieron por ninguno todo lo por él provehido y remitieronla causa a juez competente. En Valladolid, a 23 de diciembre del mismo año. $1551>$.

$2^{\circ}$. $<$ Mandamiento monitorio contra el obispo sobre la visita de San Martín. Año

Mandamiento monitorio y citatorio, escrito en pergamino, con sello de cera pendiente, dado por Peregrino Fabio, obispo Bescano, auditor general de la Cámara Apostólica y juez de las causas de la curia romana, contra el obispo de Palencia y consortes, para que acudan a Roma en siguimiento de la causa introducida por el abad de San Zoil quejándose del dicho obispo, de que siendo el monasterio y sus anejos esentos de la jurisdición ordinaria, quería visitar y visitaba la yglesia de San Martín de Frómista y hacia otros agravios etcétera. Dado en Roma, a 27 de abril de 1551, ante Balthasar Molleii, genovés, notario appostólico. Está duplicado este mandamiento con dos copias simples. 
$3^{\circ}$. $<$ Mandamiento citatorio y compulsorio del maestreescuela de Valladolid al obispo de Palencia y consortes. Año 1551>.

Mandamiento citatorio y compulsorio dado por el licenciado don Alonso de Miranda, maestreescuela y canónigo de Valladolid, dirigido al obispo de Palencia y consortes, por el qual parece haver sido requirido que el dicho maestreescuela por parte del monasterio con el breve monitorio y compulsorio del número antecedente / (f. 216v) para que le executase. Y en virtud de él dio este mandamiento para que las partes contrarias se hallasen presentes a la compulsa de varias escrituras tocantes a esta causa. Dado en Valladolid, a 9 de octubre de 1551, ante Christóval de Villanueba, notario.

No está notificado este mandamiento.

$4^{\circ}$. <Protesta que hizo el prior de San Martín a un visitador de Palencia. Año 1551>.

Requirimiento y protesta que hizo fray Lorenzo de Modoya, residente en el priorato de San Martín, al licenciado Gómez de Mora, provisor de Palencia y visitador nombrado por Su Yllustrísima, en virtud de un mandamiento dado por él, para que el referido monge entregase los libros de la yglesia y de sus bienes. Al que responde que no tiene obligación a obedecerle por no ser su juez el provisor, que está pronto a guardar una concordia una concordia hecha entre el obispo y cabildo de la yglesia de Palencia con algunos monasterios de dicha orden y sus abades (Véase esta concordia en el cajón San Andrés, legajo $1^{\circ}$, quaderno 13, número $3^{\circ}$ ). Su fecha, en Frómista, a 24 de septiembre de 1551, ante Juan Lasso , esscribano de dicha villa.

$5^{\circ}$. <Ynterrogatorio para el pleyto de la visita, etcétera. Año 1551>.

Pedimiento, poderes e interrogatorio para hacer información sobre la costumbre de visitar el abad la yglesia de San Martín y para los pleytos que tenía este monasterio con los obispos de Palencia, capellanes de San Martín, etcétera. Año 1551.

$6^{\circ}$. $<$ Poder del monasterio y licencia del general para concordarse con el obispo de Palencia. Año 1554>.

Bajo este número están los papeles siguientes:

$1^{\circ}$. Un poder que otorgó este monasterio al padre fray Rodrigo de Corcuera, abad de él, para que en virtud de los pleytos que había con los obispos de Palencia, sus provisores, capellanes y feligreses de San Martín sobre las visitas de dicho priorato y sobre las misas mayores que se habían de decir en los días festivos, pudiese hacer concordia con don Pedro Gasca, obispo de Palencia, y comprometer los pleytos y diferencias en los letrados o personas que le parecieren. Su fecha, en San Zoil, a 27 de abril de 1554, ante Andrés Sánchez, escribano de Carrión.

$2^{\circ}$. Petición que en virtud de dicho poder presentó el dicho abad ante el General de la orden fray Bartholomé de Alvear, pidiendo licencia para hacer la dicha concordia, ofreciendo información de utilidad, la qual, acetada por el General, se hizo; y en virtud de ella dio su licencia para que dicho abad efectuase la concordia. En San Benito de Valladolid, a 8 de septiembre de 1554, ante el abad de Arlanza.

\section{$/(f .217 r) 7^{\circ} .<$ Mandamiento para sacar unas informaciones. Año 1555>.}

Mandamiento conpulsorio del provisor de Burgod, juez apostólico, para sacar unas informaciones para presentar en un pleyto de San Martín contra el obispo de Palencia. Dado en Burgos, a 8 de marzo de 1555, ante Fernando de Huidobro, notario.

$8^{\circ}$. $<$ Carta executoria de la sentencia dada por los provisores de Burgos sobre la visita de la yglesia de San Martín. Año 1556>.

Carta executoria original dada por el licenciado Diego García de Torres y el doctor Diego Ramiro, provisores de Burgos por el cardenal don Francisco de Mendoza, obispo de dicha ciudad, los quales conocieron de la causa y pleyto que había entre este monasterio y el obispo de Palencia por un breve (inserto aquî) de Juan, arzobispo Sipontino, nuncio de Su 
Santidad. Dado en $1^{\circ}$ de septiembre de 1550, a instancia del obispo de Palencia, apelante de $^{336}$ cierta sentencia dada por un juez conservador.

Por esta carta executoria consta que, de parte del abad y monasterio de San Zoil, fue presentada crella ante don Sancho de Herrezuelo, arcediano de Valladolid, juez conservador, contra don Luis Caveza de Baca, obispo de Palencia, y el licenciado Baraona, su visitador, por razón de que siendo los monges esentos inmediatos a la sede appostólica y a los prelados de su religión, el dicho obispo dio mandamiento para prender a fray Andrés de Quintanilla, monge de San Martín, y el referido visitador, con gente armada, le prendió en Arconada y le llevó preso a Magad. La causa desta prisión fue porque en 14 de enero de 1550, después de haber visitado el licenciado el licenciado Baraona en San Martín y haviendo puesto el Santo Milagro en el sagrario del altar mayor, donde está el Santísimo Sacramento, fray Pedro de Soto y fray Andrés de Quintanilla, que a la sazón vivían en San Martín, rompieron el retablo por detrás y sacando del sagrario el Santo Milagro le pusieron en el lugar donde antes estaban y de donde le había sacado el visitador. A las 9 de la noche le sacaron de allí y, tomándole el uno debajo de los hábitos y el otro acompañándole con un montante, le llevaron al monasterio de San Benito de Frómista; y, antes que el caso llegase a noticia de todos, le volvieron a San Martín, por lo que mandó el señor obispo hacer dicha prisión. Y, sin embargo de lo alegado por él, parece que el juez conservador dio sentencia en que declarándose por juez mandó soltar el preso y absolvió a los excomulgados. Desta sentencia apelaron el obispo de Palencia, su visitador y demás consortes, ganaron el brebe del nuncio arriba dicho para los provisores de Burgos, los quales le acetaron y dieron su mandamiento citatorio, compulsorio e inibitorio, en cuya virtud se llevó el proceso a Burgos, en donde alegaron las partes de su derecho. Fue recibida esta causa a prueba, hiciéronse / $(f .217 v)$ y se presentaron las informaciones, se hizo publicación de testigos y el pleyto se dio por concluso.

Estando la causa en este estado, los procuradores de las partes presentaron ante los dichos juezes una escritura de compromiso hecho por don Pedro Gasca, obispo de Palencia, y fray Rodrigo de Corcuera, abad de San Zoil, en Villamuriel, a 8 de enero de 1555, ante Fernando Montero, notario, y asimismo una sentencia firmada del doctor Saldaña y el doctor Flórez. En esta escritura de compromiso dicen las partes que, atento al pleyto entre ellos pendiente y concluso ante los provisores de Burgos, que se convenían en que los jueces enviasen el proceso concluso a Palencia para que allí lo viesen por asesores el doctor Saldaña, de parte del obispo, y el doctor Flórez, de parte del monasterio. Y lo que ellos determinasen y diesen firmando de sus nombres, aquello se determinase por sentencia de los provisores de Burgos, jueces en esta causa, y aquello mismo se obligaban las partes a guardar; y que si los dichos doctores no se concordaban, pudiesen por sí nombrar otro tercero para concordar. $\mathrm{Y}$ así concordado, aquello mismo pidieron que sentenciase los dichos jueces de Burgos, y para guardarlo prometieron y dieron palabra de no reclamar contra ello. En virtud de lo qual los dichos doctores Saldaña y Flórez, asesores y compromisarios, dieron y firmaron la sentencia con once capítulos de declaración acerca de las dichas diferencias y pleytos sobre la yglesia de San Martín de Frómista, que son los siguientes:

$$
1^{\circ} \text {. <La yglesia de San Martín es parroquial y visita el obispo y el abad>. }
$$

Que la yglesia del priorato de San Martín es parroquial, con filegresía, parroquianos, sacramento, olio y crisma y todo lo demás necesario; que el obispo de Palencia y su visitador tengan visitación del Santísimo Sacramento, Santo Misterio, olio, crisma, pila bautismal para siempre jamás, en lo qual no sean perturbados por el abad de San Zoil, el qual pueda visitar cada año lo suso dicho conque por su visitación no se impida la del obispo ny de sus oficiales.

\section{$2^{\circ} .<$ Visita el obispo, a los clérigos $>$.}

Que los obispos y sus visitadores tengan la visitación y corrección de los clérigos, cura y capellanes legos de la yglesia de San Martín, y de los feligreses de su parroquia, y que el abad y prior de San Martín no se entrometan / (f. 218r) en la dicha visitación de los dichos capellanes y feligreses por no les pertenecer.

336 de] sigue tachado: dicha. 


\section{$3^{\circ} .<$ Hay dos capellanes y un sacristán $>$.}

Que en la yglesia de San Martín hay tres beneficios perpetuos, dos capellanes y un sacristán, y que haya para siempre, cuya presentación es del abad de San Zoil y su convento y la colación pertenece a los obispos de Palencia y sus oficiales en su nombre. Que los tales dos capellanes sean clérigos legos y que el abad y convento puedan presentar para sacristán un religioso o donado del dicho monasterio, el qual sea suficiente y, siéndolo, el obispo o su provisor tenga obligación a colarle el dicho beneficio; y si el sacristán fuere clérigo o persona lega, le pueda castigar el obispo o su provisor como a los clérigos y sacristanes del obispados.

$$
4^{\circ} \text {. }<\text { El cura se nombre de los capellanes }>\text {. }
$$

Que el obispo y sus provisores, y no el abad ni el convento, nombre al cura que huviere de administrar los sacramentos en San Martín y que haya de nombrar a uno de los dichos capellanes o a ambos y no a otro, como de tiempo immemorial se ha hecho, sin innobar cosa alguna.

\section{$5^{\circ} .<$ Las cuentas las tome el abad o el prior $>$.}

El prior de San Martín o los abades de San Zoil, estando en el priorato, tomen las qüentas de la fábrica y de todas las limosnas, conque a ello estén presentes dos feligreses de la dicha parroquia y el cura de ella, y hagan gastar la hacienda en las cosas más útiles a la yglesia y culto divino; que el obispo y sus visitadores no se metan en tomarlas, salvo que en sus visitas las podrán rever y mandar en ellas lo que convenga y enmendar lo mal gastado, sin revocar lo que por el prior estuviere mandado gastar.

$6^{\circ}$. <Nombra mayordomo el abad o el prior>.

Que el prior o el abad de San Zoil, estando en dicho priorato, com parecer de los feligreses y cura, nombre cada año, o de dos en dos, un mayordomo lego de los feligreses de San Martín, a quien se acuda con las rentas y limosnas de la fábrica, el qual lo gaste en lo que el prior y abad le mandaren, y el visitador las pueda reveer como arriba está dicho.

\section{$7^{\circ} .<$ El obispo pueda visitar la sacristía $>$.}

Que el obispo y sus visitadores puedan entrar en la sacristía y ver los cálices y ornamentos y mandar reparar y hacer de nuebo lo que fuere necesario, si el prior o abad no lo huvieren mandado.

$/(f .218 v) 8^{\circ} .<$ Jurisdición del obispo y del abad acumulativa para castigar a los religiosos que no guardaren esta sentencia $>$.

Que si el prior o monges o sacristán monge o donado que estuvieren en dicho priorato delinquieren contra lo ordenado en esta sentencia, o el sacristán en lo tocante a su oficio, el castigo toque acumulative y a prevención al abispo y abad de San Zoil, de tal suerte que si fueren denunciados ante el obispo, haya de conocer y castigar sin que el abad le perturbe, y si el abad previniere la causa, o fueren denunciados ante él, conozca y castigue sin que el obispo se entrometa en ello ni lo pueda impedir; y que en solos estos casos pueda conocer el obispo y castigar a estos religiosos en la forma dicha y no en los demás que delinquieren, por ser esentos de su jurisdición.

$9^{\circ}$. <Los cappellanes canten la misa y recen el rezo monástico>.

Que el prior y capellanes de San Martín sean obligados para siempre jamás a decir los días que se acostumbra a decir misa cantada en dicha yglesia, y que ésta, la tercia y vísperas sean conforme a la Regla de San Benito y de San Zoil de Carrión, excepto que en las fiestas de guardar o de voto se han de acomodar con la yglesia de Palencia, y sean obligados a cantar las dichas horas conforme se cantan en todo el obispado.

$$
10^{\circ} .<\text { El prior multa a los cappellanes }>\text {. }
$$

Que el prior de San Martín pueda multar y multe en la ración a los clérigos y capellanes que no asistieren a los oficios divinos como siempre lo han hecho. 
Resurrección>.

11․ $<$ El obispo o prior puedan decir la misa los días de Navidad y

Que el prior de San Martín o el abad pueda decir las misas mayores de los días de Navidad y Resurrección, y la de Pascua del Espíritu Santo la diga el cura; y las demás misas solemnes y de las otras fiestas del año las diga el que fuere semanero como le cupiere por su semana, sin que en esto haya prelación alguna.

Da por libres de las acusaciones al doctor Barahona, visitador, y a otra qualquiera persona, así clérigo como monge, y se pone perpetuo silencio a las partes.

Esta sentencia la firmó el doctor Flórez, juez por el monasterio, a 30 de mayo de 1556, de que da fee Andrés Sánchez, escribano de Carrión. Y el doctor Saldaña, juez por el obispo y consortes, la firmó a 30 de mayo del mismo año, de que da fee Lorenzo de Baldés, esscribano de Palencia.

$<$ Pronunciación desta sentencia $>$.

Presentada esta sentencia por los procuradores de las partes ante los provisores de Burgos Diego García de Torres y el doctor Ramiro, jueces en esta causa, y haviéndoles / ( $f$. $219 r$ ) pedido que en la misma forma la dieren y pronunciaren, los dichos jueces dieron y pronunciaron la dicha sentencia a 6 de junio de 1556.

Notificose a los procuradores de las partes y la consintieron en todo y pidieron que de ella se les diese carta executoria, la qual se dio y mandó cumplir so pena del ingreso de la yglesia al obispo y sus oficiales; y a los monges, capellanes y feligreses so pena de excomunión y de mil ducados de oro, la mitad para la parte obediente y la otra mitad para pobres y obras pías. Dada en Burgos, a 6 de junio de 1556, ante Lope de Allende, notario público de la audiencia episcopal.

$<$ Notificación en Frómesta $>$.

Notificose esta carta executoria en la yglesia de San Martín a la mayor parte de los feligreses, a 6 de octubre del mismo año, ante Andrés Sánchez, escribano de Carrión.

$<$ Notificación al señor obispo $>$.

En Astudillo, al señor don Pedro Gasca, obispo de Palencia, a 2 de abril de 1557, ante Juan Fernández del Campo, notario.

$<$ Notificación a los cappellanes y al cura de San Martín>.

En la villa de Frómista, a los capellanes de San Martín y a Bernardino González, cura de dicha parroquia, a 5 de abril del mismo año, ante Melchor Laso, escribano de Frómista.

Después de estas notificaciones está una copia authorizada de esta sentencia, sacada por Norberto de Sandoval y Guevara, escribano de Carrión, a 23 de enero de 1680.

9. $<$ Copia autorizada de la misma carta executoria ${ }^{337}>$.

Traslado authorizado de la carta executoria del número antecedente, escrito en pergamino, y sacado con authoridad del ordinario de Palencia a instancia del padre fray Plácido Huércanos, abad de San Zoil. Está firmado del licenciado don Gaspar de Peralta, provisor de Palencia, y sinnado de Lucas Gallardo, notario en la ciudad de Palencia, a 20 de noviembre de 1600 .

$<$ Confirmación de ella por don fray Josef González, obispo de Palencia ${ }^{338}>$.

Al pie desta carta executoria está un auto, dado en Carrión, a 19 de octubre de 1625, por don fray Josef González, obispo de Palencia, en el qual dice que, haviendo visto y pasado por los ojos toda esta carta executoria (que llama concordia) y constándole que las partes no la cumplen en algunas cosas, por oviar pleytos y diferencias y que no se falta a nada, la confirma en todo como en ella se contiene; manda al prior y religiosos de San Martín y al

337 executoria] sigue tachado: Año 1600.

338 Palencia] sigue tachado: 1625. 
cura y cape/ (f. 219v)[la]nes de aquella yglesia la guarden y cumplan en todo como en ella se contiene debajo de las penas señaladas y, siendo necesario, lo manda con excomunión mayor late sententie y de 50 ducados para la fábrica de la dicha yglesia, y que debajo de las mismas censuras se le dé cuenta de lo que se faltare en su cumplimiento; manda asimismo al prior la promulgue y haga notoria a todos en un día de fiesta al ofertorio de la misa mayor. su secretario.

Está del señor obispo firmado, sellado con su sello, y refrendado de Pedro de la Peña,

10. <Copia simple de la carta executoria $>$. folio 15.

Copia simple de la carta executoria anterior y de la concordia que comienza desde el

11. < Poder y copia authorizada de los capítulos de la concordia. Año 1559>.

Bajo este número están los papeles siguientes:

Lo primero está la compulsa que, a pedimiento de esta casa por auto del arcediano de Mayorga, juez apostólico en virtud de letras del nuncio, se sacó del oficio de Pedro de Villaverde, escribano de la ciudad de León, donde paraban los autos del pleyto que esta casa tubo con los capellanes y parroquia de San Martín de Frómesta sobre los derechos que este monasterio tenía en dicha yglesia. Contiene algunas nuledades que están notadas a las márgenes.

Lo segundo un traslado (sacado del oficio de Melchor Laso, escribano de la villa de Frómesta y a petición de este convento, presentada ante la justicia de dicha villa) de los capítulos de concordia hecha entre fray Juan Vaca, abad de San Zoil, el cura Bernardino González con otros seis clérigos y los feligreses de San Martín. Sacose este traslado año de 1590.

Vltimamente está una carta de Antonio Laso, escribano en dicha villa, en la qual da noticia al padre fray Plácido de Huércanos de los defectos y nulidades que se contienen en la compulsa hecha por Melchor Laso, su hermano, para que procurase poner el remedio más conveniente a este monasterio.

\section{2. <Visita hecha por el abad en San Martín de Frómista. Año 1564>.}

Escritura por la qual consta que el padre fray Benito de Sahagún, abad de San Zoil, visitó solemnemente el Santísimo Sacramento, Santo Misterio, pila baptismal, ornamentos, etcétera, de la yglesia de San Martín / (f. 220r) de Frómesta, <en presencia > de los capellanes especialmente de Bernardino González, que entonces hacía el oficio de cura (el mayor contrario que tubo esta casa), al qual, juntamente con los mayordomos, pidió el abad los libros de qüentas y por venirse a San Zoil las dexó cometidas al prior y le dio comisión para que acerca de ellas hiciese lo que le pareciese más conveniente. Su fecha, en Frómesta, a 23 de abril de 1564, ante Andrés Sánchez, escribano de Carrión. Está aquí el ynventario de las alhajas de la yglesia.

13. <Visita que hizo el abad de San Zoil de la yglesia de San Martín de Frómesta y de la sacristía de ella y de sus ornamentos y alajas. Año 1566>.

Testimonio dado por Francisco Obeso Buelna, esscribano de Carrión, por el que consta que, a quince días del mes de enero de 1566, habiendo visitado el padre fray Benito de Sahagún, abad de San Zoil, el Santísimo Sacramento, Santo Misterio, pila bautismal, etcétera, quiso visitar la sacristía y lo que en ella había, para lo qual mandó a Bernardino González, cura, y a Alonso Pando, capellán de dicha yglesia de San Martín de Frómesta, que le presentasen los libros de las visitas y cuentas, con el inventario de las alajas de ella.

Respondieron que no querían presentárselos, pues en quanto a la sacristía no tenía el abad derecho alguno de visitar. Requirioles el abad con la carta executoria y capítulos de su sentencia, para que los guardasen, bajo las penas en ella contenidas; requirió asimismo a los mayordomos de la yglesia, para que le entregasen los libros de las cuentas de ella, los que respondieron que lo oían. 
En 17 de enero del mismo año se quejó el abad ante el provisor de Palencia de que los capellanes, cura y mayordomos de San Martín de Frómesta no le obedecían ni cumplían los capítulos de la concordia y carta executoria, pidiendo cumplimiento de todo. A lo que el licenciado Navarro, comendador de La Herrada y provisor de Palencia por don Christóbal Baltodano, obispo de ella, dio auto, por el qual mandó con censuras al cura de San Martín que, dentro de tercero día, haciendo el abad la visita ante Buelna (a quien nombra por notario), le dé la visita de la sacristía, conforme al capítulo séptimo de la sentencia arbitraria, y que el cura y las personas a cuyo cargo está dar las cuentas se las den, conforme al capítulo quinto de dicha sentencia y al capítulo cuarto de la sentencia apostólica; y que el abad dé cuenta de lo que hubiere hecho dentro de un mes, conforme al dicho decreto. Notificose este mandamiento al abad y se conformó con el decreto del concilio, en el canon tercero, sesión 24 , sin perjuicio de su derecho, y en hacer la visita ante el notario nombrado por dicho señor provisor.

Después de lo qual, a 27 de enero del mismo año, el mismo padre abad, habiendo hecho algunas propuestas para que no perjudicase a su derecho el haberle nombrado el provisor notario ante quien hiciese la visita, después de la misa mayor se vistió de capa y visitó, en presencia del cura, capellanes y feligreses / (f. 220v) el Santo Misterio, Santísimo Sacramento, pila bautismal, sagrados óleos y la sacristía con los ornamentos y alajas de ella. Todo lo qual pasó ante el dicho escrivano.

\section{4. <Requirimiento a Bernardino González. Año 1586>.}

Bajo este número están los papeles siguientes:

$1^{\circ}$. Vn requirimiento que se hizo por parte del monasterio con vna Pavlina a Bernardino González, pretenso cura de San Martín, para que volviese al monasterio ciertas escrituras que tenía vsurpadas como lo confiesa en su respuesta. Ante Antonio Laso, escribano de Frómesta. Su fecha, en Frómesta, a 14 de febrero de 1586.

$2^{\circ}$. Dos interrogatorios en el pleito con dicho Bernardino González sobre si había de ser cura de San Martín no siendo capellán de esta yglesia.

Están firmados del licenciado Pedro Díaz y del licenciado Cano, y la sentencia sobre esto dada por don Christóbal Rodríguez de Lorenzana, dada el año de 1589. Véase en el número 16 deste quaderno.

15. <Requirimiento a Bernardino González para que entregue las llaves. Año 1587>.

Requirimiento y protesta hecha por fray Martín de Sahagún, abad de San Zoil, a Bernardino González, cura de San Martín, para que le diese las llaves del Sagrario, pila baptismal, sacristía y demás necesario para hacer la visita de aquella yglesia. El qual respondió a las dos veces que fue requerido, que no daría las llaves sin orden de su prelado, y en efecto ni las dio ni se hizo la visita. Su fecha, en Frómesta, a 26 de noviembre de 1587, ante Andrés Sánchez, escribano de Carrión.

16. <Sentencia a favor del monasterio contra Bernardino González. Año 1589>.

Testimonio dado por Pedro de Villaverde, escribano y notario de León, de una sentencia dada en grado de apelación a favor de este monasterio por don Cristóval Rodríguez de Lorenzana, canónigo de León, juez apostólico por comisión del nuncio, contra Bernardino González, clérigo y capellán de San Martín, por la qual revoca la sentencia de los provisores de Palencia y declara que Bernardino González no puede ser cura por haber renunciado la capellanía que ha de tener, el que ha de ser cura conforme a la concordia del año de 1556. La qual sentencia fue pronunciada a 31 de octubre de 1589. Síguense dos mandamientos del mismo juez para que los referidos pagasen seis ducados de la mitad de las asesorías, dados en el mismo año y ante el mismo escribano.

17. <Mandamiento para que se paguen los derechos del pleito. Año 1589>.

Mandamiento dado por don Christóbal Rodríguez de Lorenzana contra los beneficiados de San Martín para que paguen la mitad de las assesorías y los derechos ocasionados en el pleito contra el cura de la parroquia de San Martín. Su fecha, en León, a 
13 de noviembre de 1589, ante el Pedro de Villa/ (f. 221r)verde, escribano y notario de dicha ciudad. Está al pie la carta de pago.

$18^{339}$. <Depósito del registro de Melchor Laso. Año 1590>.

Testimonio dado por Francisco Oveso de Vuelna, escribano en Frómesta, de cómo el padre fray Martín de Sahagún, abad de San Zoil, pidió ante Francisco de Rozas, alcalde mayor de Frómesta, se depositase el registro de Melchor Laso en que estaban las escrituras de arriba y estaba en poder de Antonio Laso, su hijo, para seguridad de ellas, que estaban sospechosas y era necesario comprobarse, entre tanto que se terminase el pleito que el monasterio tenía pendiente con los cappellanes ante el juez de León. El juez de Frómesta mandó exivir el dicho registro con citación del cura Bernardino González y le mandó depositar en Juan de la Peña, vecino de dicha villa. Su fecha, a 31 de enero de 1590.

19. <Mandamiento para que paguen el cura y capellanes ciento y cincuenta reales de asesorias. Año 1592>.

Mandamiento del provisor de Burgos, juez apostólico, contra los capellanes de San Martín, para que paguen ciento cinqüenta reales que les tocaron de la mitad de las asesorías por la sentencia dada en el pleito que había entre ellos y el monasterio. Su fecha, a 17 de marzo de 1592, ante Baltasar Gutiérrez, notario.

Al pie deste instrumento está vna notificación deste mandamiento al cura y capellanes de San Martín, ante Antonio Laso, escrivano.

20. <Requirimiento al obispo de Palencia para que guarde la concordia. Año 1592>.

Requirimiento hecho por el padre fray Plácido Huércanos, abad de San Zoil, a don Fernando Miguel de Prado, obispo de Palencia, para que guarde y haga guardar la concordia hecha entre el monasterio y obispos de dicha ciudad, año de 1556, como en ella se contiene sin añadir ni quitar cosa alguna por combenir así a a la paz. A la qual respondió el dicho obispo que, por ser algunos capítulos de la concordia contra la dignidad episcopal, derecho y cánones del concilio y que de guardarla se seguirían algunos inconvenientes, y no haber tomado resolución en lo que se debe hacer en esto, que procurará informarse con brebedad del derecho y pretensión del monasterio y de los capellanes y parroquianos y que entre tanto requiere al abad que no siga el pleito y si lo hiciere protesta los daños por su cuenta. Su fecha, en Palencia, a 5 de junio de 1592, ante Gómez de Ávila, escribano y notario de dicha ciudad.

$<$ Requirimiento al cura y capellanes para que guarden la concordia. Año de 1597>.

Bajo este número está vn requirimiento hecho de orden de fray Plácido de Huércanos, abad de San Zoil, al cura, capellanes y mayordomo de la yglesia de San Martín para que guarden y cumplan la concordia del año de 1556, con las moderaciones del año 1595. A lo que respondieron no obedecían interin no se le manifestasen los capítulos de moderación. Su fecha, en Frómesta, a siete de enero de 1597, ante Juan Redondo de Reoyo, escribano en dicha villa.

/ (f. 221v) 21. $<$ Carta executoria del ordinario de Zamora a favor deste monasterio que el cura de San Martín ha de ser nombrado de los cappellanes actuales. Año 1598>.

Carta executoria ganada en tercera instancia a fabor del monasterio ante el ordinario de Zamora, por comisión del nuncio contra la dignidad episcopal de Palencia, los capellanes y feligreses de San Martín, en razón de que el cura de aquella parroquia ha de ser nombrado de los capellanes de ella presentados por el abad de San Zoil. Por esta carta executoria consta que, habiendo Bernardino González renunciado la capellanía que tenía y no siendo capellán pretendió el monasterio que no había de ser cura.

$<1^{\text {a }}$ sentencia de Palencia $>$.

339 18] al margen derecho: Nota: En este número 18 debe estar el número 26 de este quaderno que está ya colocado en su orden. 
Sobre lo que hubo pleyto ante el ordinario de Palencia en primera instancia, en la qual el doctor Cañamero, juez de comisión por el señor obispo de Palencia, a 26 de septiembre de 1586, pronunció sentencia en esta causa, por la qual declara que Bernardino González fue nombrado por cura de San Martín siendo capellán de aquella yglesia, y que como cura había exercido el oficio de tal más de cuarenta años, y no haber lugar a removerle del oficio; y declara que, conforme a la concordia, el que hubiere de ser cura de San Martín ha de ser nombrado vno de los dos capellanes de aquella yglesia como fue el referido González.

\section{$<2^{\mathrm{a}}$ sentencia del juez de León $>$.}

De esta sentencia se apeló y el convento sacó brebe del nuncio para los jueces sinodales de León. Y con él fue requerido don Christóbal Rodríguez de Lorenzana, arcediano de Mayorga, canónigo de León y juez sinodal, el qual, habiendo citado y oído las partes y conociendo en esta causa, en 31 de octubre de 1589, con acuerdo del doctor Salazar y Benavides, pronunció sentencia en ella, por la cual revoca la del ordinario de Palencia y declara (conforme a la concordia firmada del licenciado Diego García de Torres, el doctor Ramiro y los doctores Saldaña y Flores, y conforme a otro[s] capítulos) que no puede ser elegido por cura de San Martín el que no fuere capellán de aquella yglesia natural y perpetuo y, atento a que Bernardino González renunció la capellanía perpetua que tenía y que al presente no era capellán que no podía ser cura. Deja su derecho a salbo al ordinario de Palencia para que pueda nombrar por cura a vno de los capellanes que eran actualmente de San Martín, conforme a la dicha concordia.

\section{$<$ Sentencia del juez de Zamora $>$.}

De esta sentencia se apeló por parte del fiscal de Palencia, cura, capellanes y feligreses de San Martín. Sacaron brebe del nuncio para que conociese en esta causa el licenciado Diego Mateos de Laguna y Miedes, provisor de Zamora; y, por haber muerto el nuncio antes de aceptar la comisión, habiéndose dado traslado a las partes contrarias, sacaron brebe del sucesor, el qual fue aceptado por el doctor don / (f. 222r) Juan Rodríguez, provisor de Zamora. Y, en virtud de esto, conocida la causa, pronunció sentencia definitiba, por la qual confirma in totum la sentencia dada por el arcediano de Mayorga, reservando las partes su derecho a salvo para que en las demás causas deducidas en esta tercera instancia sigan su justicia como les convenga. Fue dada esta sentencia a 17 de marzo de 1592.

De esta sentencia fue apelado por parte del obispo, cappellanes y feligreses. Otorgose la operación y, pasado el término de ella, el monasterio pidió deserción.

Acusáronse las rebeldías, diéronse más plazos, los quales pasados, el provisor don Diego Matheos de Miedes dio auto < de $>$ deserción y la sentencia pasada en cosa guzgada y mandó dar carta egecutoria al monasterio, de que apeló el obispo y consortes, y sin embargo se dio esta carta egecutoria en la ciudad de Zamora, a 22 de septiembre de 1598. Está firmada del mismo señor provisor ante Balthasar Gutiérrez, notario de dicha ciudad. Al pie están las notificaciones hechas al cura y cappellanes de San Martín.

$<$ Mandamiento inhibitorio del provisor de Palencia $>$.

Sin embargo de lo dicho parece, por un traslado simple que está en esta carta egecutoria que, habiendo las partes del obispo y cappellanes sacado nuevo breve del nuncio para los sinodales de Palencia y habiendo requirido con él al doctor Thomás Díez de Modoya, arcediano de Cerrato y canónigo de Palencia, a istancia de las partes contrarias, y dio mandamiento por el qual manda que don Gaspar de Peralta, provisor de Palencia, se hinhiva del conocimiento de esta causa en que procedía a egecución de la carta egecutoria arriba contenida, al qual la había cometido el provisor de Zamora como al ordinario immediato. Diose este mandamiento en Palencia, a 7 de enero de 1604, ante Lucas Gallardo, notario de dicha ciudad.

22. $<$ Recusación del chantre de Valladolid, juez, por el nuncio en el pleito sobre la visita. Año 1598>.

Proceso, maltratado, en que está inserta la sentencia dada por los provisores de Burgos en el pleito que este monasterio tenía en grado de apelación con el señor obispo de 
Palencia sobre la visita de San Martín, rezo y misas y otras cosas tocantes a los capellanes, que es la que está en la carta executoria del número $8^{\circ}$ deste quadreno $\mathrm{C}$. Y está sacado y signado este proceso por Gerónimo de la Serna.

En él hay varios poderes, protestas, hechas por las partes contrarias contra el chantre de Valladolid don Luis Niño, juez nombrado por el nuncio en esta causa, sobre varios artículos. Todo pasó el año de 1598, ante el mismo Gerónimo de la Serna, notario en Valladolid.

/ (f. 222v) 23. < Comisión apostólica para que se guarde la concordia. Año 1602>.

Brebe apostólico de comisión dado sub anulo Piscatoris por la santidad del papa Clemente $8^{\circ}$ para que los abades de Nuestra Señora de la Vega, Benevivere y el ordinario de Burgos hagan guardar la concordia y carta executoria de arriba con todo rigor de censuras, y siendo necesario con invocación del brazo secular. Fue dado a instancias del monasterio porque, no sólo no se guardaba lo contenido en la carta executoria y los capítulos de su concordia y sentencia, sino que en esto mismo le hacían las partes contrarias muchas vejaciones y molestias. Está escrito en latín y pergamino. Su fecha, en Roma, a 26 de junio de 1602.

24. $<$ Mandamiento del nuncio para que se exiban los papeles pertenecientes al pleito con los curas y capellanes de San Martín. Año 1603>.

Mandamiento dado por don Dominico Gimnasio, nuncio de Su Santidad, para que los escribanos que tubieren los papeles que el monasterio ha menester para presentar en la causa pendiente ante Su Yllustrísima acerca de multar a los capellanes en su estipendio porque no acudían a las horas del oficio divino, los exiban. En virtud del qual Alonso Zapata, escribano y notario de Carrión, sacó y compulsó de los libros de cuentas del priorato de San Martín cuatro partidas por las que consta no haberse pagado el trigo que se da de estipendio a los capellanes por la asistencia a dichos oficios.

$<$ Información del monasterio $>$.

Asimismo hay vna información hecha por el monasterio con autoridad de fray Hernando de Ayala, abad de la Vega, juez conservador, ante el mismo escribano y notario, con citación de los capellanes, por la que prueba el monasterio, con cinco testigos, que los capellanes no acudían al coro con los monges a cantar ni rezar las horas que tenían obligación según el rezo monástico, sino que vnas veces las decían los clérigos solos ${ }^{340}$ por su rezo y otras los monges por el suyo, sin que juntasen vnos y otros; por lo qual los priores les detenían a los capellanes el pan de sus capellanías y no se lo habían pagado. de visita $>$.

$<$ Mandamiento del conservador para que se pague al arcipreste de Población derecho

Asimismo hay aquí otro mandamiento del mismo juez conservador para que el provisor de Palencia y su vicario revoque vn mandamiento que había dado contra el prior de Frómesta porque no pagaba tres cargas de pan que le pedía el arcipreste de Población y Frómesta por la visita de las pilas, que decía serle debido; y les manda se iniban del conocimiento de la causa, y al mismo arcipreste le manda no vse del dicho mandamiento, ni moleste al prior de San Martín, ni pida ante el provisor cosa contra él. Dado en Carrión, a 23 de octubre de 1602, ante Andrés Sánchez, escrivano y notario de dicha villa.

/ (f. 223r) 25. < Requirimiento hecho al obispo de Palencia para que guarde las bulas de concordia. Año 1603>.

Requirimiento hecho por parte del monasterio a don Martín de Aspe y Sierra, obispo de Palencia, y a su provisor para que guarden y hagan guardar las bulas de esención que tiene la religión y la carta executoria y concordia del año de 1556. Los quales respondieron que las guardarían en lo que tocase a la conservación de su jurisdición y autoridad episcopal, y que en lo que les fuese perjudicial apelaban. Su fecha, en Palencia, a 19 de julio de 1603, ante Hernando de Castro, escribano y notario de dicha ciudad.

${ }^{340}$ solos] sigue tachada $\mathrm{y}$. 
$26^{341}$. $<$ Mandamiento para compulsar vn monitorio que había en el Archivo de San Millán. Año 1589>.

Mandamiento dado por fray Juan de Segovia, prior de Santo Domingo de Carrión, a petición deste monasterio, como juez conservador, para que se saque del archibo de San Millán vn traslado autorizado de vn monitorio inivitorio dado por Alexandro Riario, avditor general de la Cámara Apostólica, contra los obispos de Burgos, Calahorra y Palencia, para que guarden las bulas, privilegios y esenciones de la orden, de que se habían quejado los monasterios ante él; y, no haciéndolo, sean citados para dar cuenta de sí en Roma, donde fue dado año 1573. Y este traslado se sacó de su original a 22 de noviembre de 1589, con autoridad de Andrés de Arenzana, provisor de San Millán, ante Gonzalo de Placencia, escribano de dicha villa de San Millán.Hay dos copias simples deste monitorio.

\section{7. <Mandamiento inivitorio del provisor de Palencia. Año 1603>.}

Mandamiento citatorio e inivitorio dado por fray Hernando de Ayala, abad de Santa María de la Vega, juez apostólico (en virtud de letras apostólicas aquí insertas), dado a instancia deste monasterio, para que el provisor de Palencia don Gaspar de Peralta de iniva del conocimiento desta causa y para que el prior de San Martín no dé congrua ni ingreso de yglesia al bachiller Redondo ni a otra persona alguna que no fuere capellán perpetuo de dicha yglesia, ni a los tales tengan por verdaderos curas hasta tanto que por él sea determinada esta causa en justicia. Su fecha, en el monasterio de la Vega, a 8 de marzo de 1603, ante Alonso Zapata, escribano de Carrión.

\section{8. < Requirimiento para que no paguen derechos de visita. Año 1603>.}

Requirimiento hecho por parte del monasterio a don Gaspar de Peralta, provisor de Palencia, con los executoriales que ganaron los monasterios de nuestra orden contra el arzobispo, cabildo y arciprestes del arzobispado de Burgos, para que los guarde igualmente dicho señor provisor y revoque vn mandamiento que había dado para que el prior de San Martín pagase al arcipreste de Población tres cargas de trigo que pretendía debérsele a título de visitación de la pila. El dicho provisor responde que los executoriales se entienden y hablan sólo con Burgos no con Palencia, y que así no le comprenden, y siempre que La Rota declarare otra cosa obedecerá. Su fecha, en Palencia, a 26 de septiembre de 1603, ante Hernando de Castro, notario y escribano de dicha ciudad.

\section{9. <Mandamiento del nuncio al abad de la Vega. Año 1603>.}

Mandamiento dado por don Dominico Gimnasio, nuncio de Su Santidad, por el qual manda con censuras al abad de la Vega que preceda a la execución / (f. 223v) del brebe de Su Santidad que es el del número 23 de este quaderno, sin embarbo (sic) del mandamiento que tenía de su general para no hacerlo. Dado en Valladolid, a 9 de mayo de 1603, firmado: Dominicus Jenin, abbrebiator.

30. $<$ Requirimiento del provisor para no pagar derecho de visita. Año 1603>.

Requirimiento hecho por parte del monasterio al doctor don Miguel Santos de San Pedro, provisor de Palencia, con los executoriales que ganaron algunos monasterios de nuestra orden contra el arzobispo de Burgos sobre no pagar derechos de visita, alegando que las palabras formales de dichos executoriales hablan con todos los monasterios de nuestra orden que tubiesen pila. Este provisor dio la misma respuesta que el pasado, que es la del número 28. Dada en Palencia, a 29 de octubre de 1603, ante Hernando de Castro, notario en dicha ciudad.

\section{1. < Parecer de licenciado Vázquez. Año 1603>.}

Consulta hecha al licenciado Vázquez sobre varios puntos de la sentencia, carta executoria, brebe de Clemente $8^{\circ}$ y comisión dada al abad de la Vega (que todo está inserto aquî) y respuesta del mismo, dada a 2 y 3 de mayo de 1603.

$34126]$ al margen derecho: Nota: Este pago debe ser el número 18 deste quaderno. 
32. <Declaración de los capítulos de la concordia. Año 1605>.

Declaración de los capítulos de la concordia hecha año de 1556, para lo que se juntaron don Martín de Aspe y Sierra, obispo de Palencia, y nuestro excelentísimo padre fray Alonso Barrantes, abad de San Zoil, con el poder del convento aquí inserto. Esta declaración de los capítulos no tiene(n) fuerza alguna, pues sólo están firmados del abad del monasterio.

Síguese vna carta del padre fray Plácido Huércanos, escrita al reverendísimo, en que le advierte no convenir las declaraciones y capitulaciones dichas a los intereses del monasterio y por tanto que no diese su licencia para ello. Año de 1605.

33. < Requirimiento al abad de la Vega. Año 1606>.

Requirimiento hecho por parte deste monasterio al padre fray Gaspar Madruga, abad de Nuestra Señora de la Vega, con el brebe de comisión puesto en el número 23 deste quaderno, dado por Clemente Octabo, para que le accepte y haga guardar la carta executoria, quien respondió que la aceptaba y cumpliría según pedía la justicia. Su fecha, en dicho monasterio de la Vega, a 11 de octubre de 1606, ante Alonso Zapata, escribano en Carrión.

34. <Mandamiento del provisor de Palencia y visita del abad. Año 1680>.

Mandamiento dado por el licenciado don Pedro Rodríguez Mogrobejo, provisor de Palencia, en virtud de vna petición presentada por este monasterio, por el qual manda se lleben a execución las executoriales y sentencias dadas en razón de la visita que el señor obispo de Palencia y el padre abad de San Zoil deben hacer en la yglesia de San Martín. Su fecha, en Palencia a 9 de enero de 1680, ante Francisco Sánchez, notario.

Síguese vn testimonio dado por Norberto de Sandobal y Guevara, escrivano de Carrión, de cómo el padre maestro fray Juan González, abad de San Zoil, visitó solemnemente la yglesia de San Martín el día 22 de enero de 1680. quaderno $>$.

/ (f. 224r) 35. <Advertencias para la mejor inteligencia de los papeles deste

Memorial de las razones que este monasterio de San Zoil tiene para fundar su derecho sobre el priorato, jurisdición, diezmos y visita de la yglesia de San Martín, con otros papeles simples que dan luz a lo perteneciente a dicho priorato, en especial a lo tocante a este quaderno.

\section{Legajo $4^{\circ}$ del Cajón San Agapio}

Este legajo ${ }^{342}$, que es el cuarto del cajón San Agapio, contiene dos quadernillos; el uno de papeles pertenecientes a las cuentas del priorato, y el otro de cartas de pago tocantes a la misma hacienda; que no se expresan aquí por menor por ser de poca consideración.

\footnotetext{
342 legajo] al margen derecho: Falta todo.
} 


\section{/ (f. 225r) Cajón 9 San Román \\ Frómesta}

Este cajón San Román, que es el $9^{\circ}$ del archivo, contiene cinco legajos pertenecientes todos al barrio de San Martín de Frómesta: Legajo $1^{\circ}$ : Señorío antiguo del barrio de San Martín; Legajo $2^{\circ}$ : Capítulos de concordia y dos informaciones; Legajo $3^{\circ}$ : Pleito con los señores de Frómesta desde el año de 1414 hasta el de 1462; Legajo $4^{\circ}$ : Estado de los pleitos desde el referido año hasta el de 1572; Legajo $5^{\circ}$ : Estado de los pleitos desde el año de 1572 hasta el presente, donde se halla la escritura de censo perpetuo de cien mil maravedís sobre el dicho Barrio.

\section{Legajo $1^{\circ}$}

Este legajo, que es el $1^{\circ}$ del cajón San Román, contiene los privilegios y otros papeles pertenecientes al señorío antiguo del barrio de San Martín de Frómesta, por el orden siguiente:

$1^{\circ}$. <Privilegio del rey don Alonso que confirma la concordia entre el prior y el concejo de Frómesta sobre diezmos y una comida. Era 1224. Año 1186>.

Vn privilegio, escrito en pergamino, con sello de plomo pendiente en filos de seda colorada, por el qual el rey don Alonso el $9^{\circ}$ confirma una concordia hecha entre Humberto, prior de San Zoil, camarero de Cluni, y el concejo de Frómesta, en presencia del rey, del arzobispo de Toledo y de otros prelados y grandes, en la que el camarero da al concejo la quinta parte de la tercia de los diezmos que tenía la yglesia de San Martín en las demás yglesias de Frómesta dos años consecutivos; y el tercer año, la quarta parte, para los ornamentos de las demás yglesias, y así de allí adelante para siempre, y el concejo perdone la comida que decía deberle dar la casa de San Martín el día de este santo, con lo demás que pretendía deberle dar el prior de San Martín para la fábrica de las demás yglesias, de todo lo qual dexa libre para siempre a la casa de San Martín. / (f. 225v) Facta carta apud Ágredam, décimo séptimo kalendas februari, era 1224, que es año de Christo 1186. Confirman el rey, don Gonzalo, arzobispo de Toledo, y otros obispos.

$2^{\circ}$. $<$ Partición de la villa de Frómesta entre quatro hermanos. Era 1329. Año 1291>.

Escritura de partición de la villa de Frómesta hecha entre quatro hermanos: Rodrigo Yáñez, doña Vrraca, Fernando Yáñez y doña Teresa, hijos de Juan Díaz, que era señor de Frómesta; pero esto sin tocar al barrio de San Martín, que era del monasterio, aunque hace mención de los barrios que lindaban con él, pero esto no entró en la partición. Fueron testigos el prior de San Martín y su compañero y fray Diego, prior de la yglesia de Población. Su fecha, en Frómesta, a 20 de marzo, era 1329, año 1291.

$3^{\circ}$. < Privilegio del rey don Sancho. Cofirma un título de escribano del barrio de San Martín. Era 1330. Año 1292>.

Privilegio, escrito en pergamino, con sello de cera pendiente, por el qual el rey don Sancho confirma un título de escrivano de christianos y judíos del barrio de San Martín que la ynfanta doña Juana (muger del ynfante don Luys), con consentimiento del concejo del barrio, había dado a Domingo Fernández para que vse del oficio de escrivano como los demás de Frómesta entre los christianos y judíos vecinos del barrio, que la dicha doña Juana dice eran sus vasallos porque los tenía en encomienda. La fecha de la carta de doña Juana y la del concejo es a último de agosto, era 1329, año de Christo 1291, y la confirmación del rey fue dada en Carrión, a 3 de abril, era 1330, año 1292.

4. <Arrendamiento por modo de encomienda del barrio de San Martín en 30 mill maravedís por diez años. Era 1363. Año 1325>.

Escritura de arrendamiento por modo de encomienda del barrio de San Martín, por el qual don Juan, prior de San Zoil, dio en renta por diez años a Juan Fernández de Padilla, señor de Frómesta, el barrio de San Martín con jurisdicción, nombramiento de oficiales, diezmos mayores y todo quanto allí tenía el monasterio, salvo los diezmos menores y todos los derechos de la yglesia, como ofrendas, pie de altar, mandas de testamentos, heredades, casas, solares, todo lo qual quedó libre al monasterio para que lo llevase y gozase. Todo lo 
demás se arrendó por precio de 30 mill maravedís cada año, con condición que el dicho Juan Fernández de Padilla no solicite que ningún vasallo del barrio de San Martín se pase a vivir a su lugar de Frómesta ni a otro alguno suyo, que mantenga a los vasallos del barrio en sus fueros y privilegios y que los defienda y ampare y no les cause daño alguno. La causa de hacer este arrendamiento y dar el varrio en encomiendo a Juan Fernández de Padilla dice esta escritura que fue porque este cavallero, como poderoso, les ofreció 30 mill maravedís adelantados de la renta para que pagasen sus deudas y en particular una que debían los monges al abad de Cluniago y para que desempeñasen y quitasen de la judería de Carrión un vaso de oro del monasterio que tenían empeñado para sustentarse, por la mucha necesidad / (f. 226r) en que se hallaban a causa de no haber cogido fruto ninguno el año anterior por los malos temporales y plaga de la langosta. Y para asegurar loa vasallos y los frutos del barrio, aunque con gran pérdida del monasterio, diole en encomienda, de que se siguió la destrucción y pérdida del barrio y aún de la hacienda de toda la orden en España. Otorgose la escritura en Palencia, a 30 de abril, era de 1363, que es año de 1325, ante Domingo Pérez, escribano de dicha ciudad. Y este traslado fue sacado y signado de Fernando Pérez, escribano de Carrión.

5. < Privilegio del rey don Alonso que los del varrio de San Martín no paguen más de 4 mill maravedís de fonsadera. Era 1369. Año 1331>.

Privilegio, escrito en pergamino, con sello de plomo pendiente en filos de seda blanca, verde y amarilla, por el qual el rey don Alonso confirma otro privilegio del rey don Fernando, su padre, que es confirmación de otro del rey don Sancho dado era de 1329, año de 1291, por el qual, a instancia de la infanta doña Juana, muger del ynfante don Luys (que juntamente con Arconada y Población ${ }^{343}$ tenía el barrio de San Martín en encomienda), concede que los vecinos de dicho varrio no paguen más de 4 mill maravedís de la guerra por todo lo que les tocare de fonsadera en los repartimientos de ella. Dado en Valladolid, a 28 de noviembre, en la era de 1369, que es año de 1331.

6. <Carta de doña Leonor para que el merino de Frómesta no lleve un dezmero. Era 1386. Año 1348>.

Carta de doña Leonor, madre del conde don Tello, que entonces era señor de Frómesta, por la qual parece que don Tello, a título de la encomienda del barrio, ponía alcalde, merino y los demás oficiales; y el merino que ponía don Tello llevaba el dezmero que el monasterio daba a su merino quando le nombraba. De lo qual se quejó el camarero y convento a esta señora, y ella escrivió esta carta al merino que había puesto su hijo, para que no llevase el dezmero al convento, pues este no le había nombrado a él sino don Tello. Esta carta fue escrita en papel con sello de cera a las espaldas, en Medina de Rioseco, a 5 de junio, era de 1386, que es año de 1348.

7. <Carta del rey don Pedro: que los vasallos del convento le paguen lo que había gastado por ellos. Era 1389. Año 1351>.

Carta, escrita en papel, con sello de cera a las espaldas, del rey don Pedro el Cruel a Juan García Manrique, su merino mayor, para que haga que los vasallos que el monasterio tenía en Frómesta paguen al convento la costa que había hecho, y ellos se habían obligado a pagarle porque los sacase como les sacó del poder del conde don Tello, que se los había dado en encomienda y les hacía vexaciones. Dada en Valladolid, a 6 de octubre, era de 1389, que es año de 1351.

8. < Carta del rey don Pedro: que los vasallos obedezcan al prior de San Zoil. Era 1390. Año 1352>.

Carta del rey don Pedro el Cruel, escrita en papel, con sello de cera a las espaldas, por la qual manda a los vasallos del barrio de San Martín que reconozcan al prior de San Zoil por su señor y le paguen los derechos y rentas que como tales vasallos están obligados a pagarle, como / (f. 226v) lo habían hecho siempre con otros priores, sus antecesores. Dada en León, a 8 de mayo, era de 1390, que es año de 1352.

\footnotetext{
${ }^{343}$ Población] al margen derecho: Arconada, Población.
} 
9. <Ynformación hecha por comisión de don Tello de lo que el monasterio tenía en el barrio de San Martín. Era 1390. Año 1352>.

Ynformación, escrita en pergamino, por la qual consta que en 13 de mayo de la era de 1390, año de 1352, ante Garci Fernández de Carrión, escribano de Palencia, y de Juan Fernández, escribano de Frómesta, don Yugo Carite, vicario y procurador de don Pedro Carite, prior de San Zoil, requirió a Fernán Gutiérrez de Camargo, merino de Frómesta por don Tello, con una carta y comisión del mismo don Tello, hijo del rey don Alonso, señor de Aguilar, por la qual le manda que haga información con diez hombres buenos debajo de juramento sobre los evangelios y averigüe las cosas que el prior y convento tienen en su barrio de San Martín; y, averiguadas, se las desembargue y entregue para que lo goze libremente y sin impedimento alguno de persona que se lo quiera estorvar. Dada en Burgos, a 4 de mayo era 1390, que es año de 1352. En virtud de esta comisión el merino hizo información como se le mandaba y por ella prueba con muchos testigos que todo el barrio de San Martín es del monasterio y los vecinos de él sus vasallos, salvo siete suelos que compró Juan Fernández de Padilla, y otro[s] siete de don Tello, pero que los vasallos que vivían en ellos diezmaban al convento; que el prior de San Zoil nombraba y ponía alcalde, merino, escribano, sayón y pregonero, los quales exercían sus oficios por mandado del prior hasta que don Tello entró en la encomienda del barrio; que el prior tenía las llaves de las puertas de la cerca que llaman de Grajal y Carremonzón; que la jurisdición y señorío era del prior salvo lo criminal, de que conocían los alcaldes puestos por don Tello; que del yantar no llevaba cosa el prior y de la martiniega llevaba la quarta parte y don Tello las tres partes por la encomienda; que las calumnias, omecillos y entregas que acaecían en el barrio las llevaba el prior; que Juan Fernández Padilla y doña Teresa, su muger, tomaron en encomienda del prior de San Zoil el barrio de San Martín con todos sus derechos, salvo los de la yglesia, que quedó el monasterio con ellos.

$<$ Dos copias de la misma ynformación $>$.

Bajo este mismo número están dos copias de la misma información y escritas en pergamino authorizadas y signadas, la una de Luys González y Juan Alfonso, notarios de la ciudad de Palencia, y la otra sacada de su original con authoridad de la justicia de Carrión y signada de Sancho Fernández, escribano de dicha villa, a 30 de mayo del año de 1386.

10. $<$ Requirimiento al merino de Frómesta para que no use de su oficio en el barrio de San Martín. Era 1390. Año 1352>.

Requirimiento hecho por don Hugo Caray, prior de San Juan de Burgos, vicario general por don Pedro Caray, prior de San Zoil, a Juan Fernández/ (f. 227a) de Castro, merino del concejo de Frómesta, para que no usase el oficio de merino en el barrio de San Martín y dexase vsar el oficio al merino nombrado por el prior, y que no llevase rentas ni derechos de los dichos vasallos; y protestó lo que protestar debía. El merino respondió que él era nombrado para vsar el dicho oficio por Juan Fernández de Hinestrosa, el qual tenía para ello cédula del rey don Pedro, que está inserta en este reqirimiento. Su fecha, en el Real de sobre Jijón, a 4 de julio, era de 1390, que es año de 1352, que es el mismo mes y año, que fue hecho este requirimiento ante Juan Fernández, escribano de Frómesta.

11. $<$ Querella de los agravios que hacía el merino de Frómesta a los vecinos del barrio de San Martín. Era 1390. Año 1352>.

Querella que dieron siete vecinos del barrio de San Martín ante su señor don Hugo Caray, vicario general de don Pedro Caray, prior de San Zoil, contra Juan Fernández, merino de Frómesta, por Juan Fernández de Hinestrosa porque les sacaba prendas y tomaba el pan de las heras y les hacía otras extorsiones para cobrar los derechos de merino y del dezmero que pretendía deberle pagar los vecinos del barrio, siendo contra justicia y costumbre, porque los vasallos del barrio no reconocían para esto sino al merino nombrado por el prior de San Zoil. Diose esta querella a 22 de agosto, era de 1390, que es año de 1352, ante Gonzalo Martínez, escribano de Frómesta.

Estando en el barrio de San Martín respondió el dicho prior y vicario que los oýa y que él pediría justicia al rey para que no les hiciesen semejantes agravios. 
12. < Requirimiento a don Fernán Sánchez de Tovar con una cédula del rey para que cese de hacer agravios al varrio de San Martín. Era 1417. Año 1379>.

Requirimiento que hicieron García Fernández y Torivio González, en nombre del monasterio y de los vecinos del barrio de San Martín, a don Fernand Sánchez de Tovar, almirante mayor de la mar, con una cédula del rey don Juan el $1^{\circ}$, dada a 8 de mayo, era de 1417, que es año de 1379 , en ${ }^{344}$ la qual dice a dicho almirante que el convento y vecinos del barrio de San Martín se querellaron de él por los grandes agravios que les hacía, especialmente que el año de 1372, cuando Su Alteza le había hecho merced del lugar de Frómesta, llevó del barrio 3 mill doblas, 350 cargas de pan que hizo que le diesen de diezmo y 20 cántaras de vino, y que les cupó a pagar por una fortaleza que el almirante había hecho en la yglesia de San Martín 20 mill maravedís, y que desde el dicho año hasta entonces, que fueron siete años, había llevado de ellos 55 mill maravedís, y que había tomado de la yglesia de San Martín una cruz y un cáliz de plata, que podía valer hasta 1500 maravedís, y que hacía que sus omes posasen en su varrio y no el vuestro. Y se maravilla de que hiciese unas cosas como éstas a los del varrio de San Martín. La qual cédula fue intimada al dicho almirante en Burgos, a 17 de mayo, era de 1417, que es año de 1379, ante Ruy Fernández, escribano y notario del rey.

El almirante respondió que el barrio y Frómesta habían andado juntos y reconocían a sólo un señor al qual pagaban sus derechos, y al monasterio solos 150 maravedís de martiniega (y es verdad, pero lo demás lo había quitado él). $1384>$.

/ (f. 227v $)$ 13. < Requirimiento a doña Mencía para que no cobre martiniega. Año de

Requirimiento hecho de(l) parte del monasterio a doña Mencía Ruiz, senora de Frómesta, para que bolviese ciertas cavalgaduras que había prendado a los vecinos del barrio porque no le pagaban la martiniega que pretendía debérsele. Su fecha, en Frómesta, a 10 de octubre del año de 1384, ante Toribio Sánchez, escribano de dicha villa.

14. <Carta del rey don Juan para que el adelantado mayor desagravie al monasterio y restituya los derechos del barrio de San Martín. Año 1384>.

Carta del rey don Juan, escrita en papel, con sello grande de cera a la espalda, dirigida a Diego Gómez Manrique, adelantado mayor de Castilla, y a los merinos y justicias de Frómesta, en la [que] se les manda que no hagan agravios a los vecinos del barrio de San Martín, en atención a que se le había quexado don Toribio, prior mayor de San Zoil, diciendo que estando él en posesión del priorato, sus filiaciones y granjas, por gracia que le había [hecho] el papa Clemente $7^{\circ}$ por muerte de don Guido, su antecesor, algunos hombres poderosos y otros por su mandado, contra razón y derecho, les habían tomado el barrio de San Martín con sus vasallos, jurisdicción y derechos de un año a aquella parte; y pidió que se lo restituyesen. Para lo qual se dio esta carta al adelantado y justicias para que hiciesen que el convento fuese restituydo en sus derechos y que fuesen castigados los que le hubiesen agraviado. Dada en Madrigal, a 26 de octubre de 1384, ante Pedro Alfonso, escribano del rey.

15. $<$ Requirimiento hecho a doña Elvira y doña Mencía para que dexen el barrio de San Martín. Año 1385>.

Requirimiento hecho por parte del alcalde mayor del adelantamiento de Castilla (en nombre de Día Gómez Manrique, adelantado mayor) a doña Elvira Ruiz de Tobar, muger de Gutierre González Quixada, y a doña Mencía Ruiz, hijas ambas de Fernán Sánchez de Tobar, por el qual se les hace presente que, siendo así que por orden del rey don Alonso el $11^{\circ}$ y del rey don Juan el $1^{\circ}$ se mandó que todos los monasterios, filiaciones y granjas suyas estubiesen en encomienda del rey y de los adelantados del reyno donde les cupiese; y supuesto $\mathrm{de}^{345}$ que don Guido, prior que había sido de San Zoil, y don Toribio, que a la sazón lo era, habían dado la encomienda del dicho monasterio de San Zoil al dicho Día Gómez Manrique, en cuya posesión estaba, y que el barrio de San Martín era del dicho monasterio, por lo qual era en encomienda del rey; que requería a dichas señoras porque habiendo venido al barrio

344 en] escrito sobre por.

345 de] escrito sobre: es. 
posaban en él y hacían muchas molestias a sus vecinos tomándoles el pan, vino, paja, dineros y otras cosas contra su voluntad, y así se le desembarazasen y se pasasen a Frómesta y bolviesen a los vasallos todo lo que les habían tomado. Su fecha, en el barrio de San Martín, a 22 de abril año de 1385, ante Juan Fernández, notario público. $1387>$.

/ (f. 228r $)$ 16. < Sentencia a favor del monasterio sobre el yantar y martiniega. Año

Escritura de compromiso y sentencia arbitraria, escrita en pergamino, por la qual don Toribio, prior de San Zoil, y el concejo del barrio de San Martín comprometen las deferencias que tenían sobre los derechos que había de llevar el prior se San Zoil de la martiniega y yantar que le debían de dar cada año los vasallos de San Martín. Comprometiéronse en el bachiller Domingo Fernández, el qual pronunció sentencia, condenando a dicho concejo a que pagase cada año al prior de San Zoil 1200 maravedís de yantar y martiniega. Fue dada esta sentencia a 17 de junio, año de 1387, ante Francisco Pérez, escribano de Carrión.

17. < Sentencia a favor del monasterio sobre el molino de Frómesta. Año 1388>.

Sentencia dada por Juan Martínez Calabaza, vecino de Frómesta, nombrado juez por don Toribio, prior de San Zoil, y por los herederos de Martín Pérez, vecino de dicha villa, en razón del pleyto que tubieron sobre el molino que tenía el monasterio en la rivera del barrio de San Martín. Por esta sentencia manda el dicho juez que se buelva el molino al prior y convento y que prueve lo que se le debe de renta para que se le mande pagar, y que los contrarios prueben lo que han gastado y se les debe de reparos para que del mismo modo se les pague. Dada en el portal de San Martín de Frómesta, a 14 de diciembre de 1388, ante Toribio Fernández, escribano y notario público.

18. <Testimonio que había merino en el barrio. Año 1390>.

Testimonio dado por Sancho López, notario de Palencia y vecino de Frómesta, por el qual consta que había merino en el barrio de San Martín. Dado en el dicho barrio, a 8 de marzo de 1390.

19. $<$ Requirimiento para que se paguen los diezmos de San Martín al monasterio. Año 1410>.

Requirimiento hecho por Fernán García, monge de San Zoil (en nombre de su señor, el prior), a Alfonso García, escribano, para que como había pagado el diezmo de la cebada que había cogido aquel año, le pagase el de trigo y vino que había cogido. El qual respondió ser verdad que había pagado el diezmo de cevada y que le debía el del trigo y vino, pero que se le había embargado al merino y, que sacándole a salvo, que él estaba pronto a pagárselo. Su fecha, en Frómesta, a $1^{\circ}$ de noviembre de 1410, ante Toribio Fernández, escribano de dicha villa.

20. $<$ Nombramiento de oficiales del barrio de San Martín por el prior mayor de San Zoil. Año 1410>.

Nombramiento que hizo don Fernando, prior mayor de San Zoil, de alcaldes del barrio de San Martín, de merino, de escrivano de Sayón y pregonero, todos vasallos y vecinos del dicho barrio. Manda que tengan los derechos y rentas que les pertenecen por sus oficios y les nombra por el tiempo que la su merced fuere. Póneles pena para que vsen bien sus oficios y aplica la mitad para la Cámara de la Reyna, bajo cuya encomienda está el barrio, y la otra mitad para la Cámara de la reyna, bajo cuya encmienda está el barrio, y la otra mitad para su Cámara. Dado en San Zoil, a 25 de noviembre, año de 1410. Está sellado con cera verde a la espalda.

21. $<$ Requirimiento al alcalde mayor del adelantamiento con una carta del rey don Juan. Año 1410>.

Requirimiento hecho por Alfonso González de Escobar, criado de la reyna doña Cathalina (madre, turora y governadora del rey don Juan el $2^{\circ}$ ) a Fernán / (f. 228v) Ruiz Herrezuelo, alcalde mayor del del adelantamiento de Castilla, por ante Lope Fernández de Castroverde, notario público del rey, a 26 de noviembre de 1410, por el qual parece que se le intimó al dicho alcalde mayor una carta del rey, firmada de la reyna, sellada con su sello 
mayor, inserta aquí, dada en Segovia, a 15 de noviembre del mismo año, en la que dice que había un mes que la parte del convento había presentado ante el dicho alcalde mayor una carta suya por ante Toribio Fernández, escribano de Frómesta, la qual era de seguro que ponía el rey ent[r]e Gómez Manrique, adelantado mayor, su muger, doña Sancha, y el prior y convento de San Zoil y sus vasallos del barrio de San Martín. Y, habiéndole pedido que la cumpliese e hiciese pregonar, no lo había hecho. Por lo qual le manda que la cumpla y pregone en Frómesta y donde fuese necesario para escusar los daños y agravios que recevían el convento y sus vasallos del adelantado y de otras personas y, que pregonada, castigue a los que fueren contra ella y que pague al monasterio las costas. Requerido el dicho alcalde mayor con esta carta, la obedeció y la hizo pregonar; y a lo de las costas respondió que no las debía pagar por haber cumplido y pregonado la primera carta.

22. $<$ Requirimiento al alcalde mayor del adelantamiento para que cumpla una carta del rey a favor del prior y vasallos de San Martín. Año 1410>.

Requirimiento hecho por Alfonso González de Escobar, criado de la reyna doña Cathalina a Fernán Ruiz Herrezuelo, alcalde mayor del adelantamiento de Castilla, por ante Lope Fernández de Castroverde, escribano y notario público del rey, estando en el palacio del prior de San Zoil, que es junto a la yglesia de San Martín, a 26 de noviembre de 1410. Por el qual parece que se le intimó al dicho alcalde mayor una carta del rey, firmada de la reyna doña Cathalina, su madre, en que había un mes que la parte del convento había presentado ante el dicho alcalde mayor una carta suya por ante Toribio Fernández, escribano de Frómesta, firmada de la dicha reyna, la qual era de seguro que ponía el rey entre Gómez Manrique, su adelantado mayor, doña Sancha, su muger, y el prior y convento de San Zoil con sus vasallos del barrio de San Martín. Y, habiéndole pedido que la cumpliese e hiciese pregonar, no lo había hecho. Por lo qual le manda que la cumpla y la haga pregonar en Frómesta y donde fuere necesario para escusar los daños y agravios que recivía el convento y sus vasallos del dicho adelantado y otras personas y que pague al monasterio las costas. Dada en Segovia, a 15 de noviembre de 1410. Y, requerido el dicho alcalde mayor con esta carta, la obedeció; y a lo de las costas respondió que no las debía pagar por haber cumplido y pregonado la primera carta.

/ (f. 229r) 23. < Requirimiento al concejo con una carta de la reyna para que no obedezcan al adelantado ni a sus ministros. Año 1410>.

Requirimiento hecho por Alfonso González de Escobar al concejo del barrio de San Martín con una carta dela reyna doña Cathalina, governadora y madre del rey don Juan el $2^{\circ}$, firmada de su mano y hecha a 18 de noviembre de 1410. Por la qual les manda que, atento a que ella los tiene en encomienda y son vasallos del monasterio, no obedezcan a Gómez Manrique, adelantado, ni a doña Sancha de Roxas, su muger, ni acudan en sus pleytos civiles ni criminales y otros negocios, a los ministros que el adelantado tenía en Frómesta, sino a los que el prior de San Zoil, como señor, les nombrase en el barrio en primera instancia; y en grado de apelación acudiesen a las justicias Reales. Hízose este requirimiento al concejo a 28 de noviembre de 1410, ante Lope Fernández de Castroverde, escribano y notario del rey.

24. <Requirimiento a doña Sancha, señora de Frómesta, para que dege al convento el barrio y le buelva 100 mill maravedís que había llevado de él. Año 1410>.

Requirimiento hecho por don Rodrigo, limosnero mayor de San Zoil, a doña Sancha de Rojas, muger de el adelantado don Gómez Manríquez, con una carta de la reyna doña Catalina, madre de el rey don Juan el segundo, dada en Segovia, a quince de noviembre de 1410, ante Martín González. Por esta carta parece que el prior y convento de San Zoil se querellaron ante dicha reyna que el adelantado y su muger se habían alzado con el barrio de San Martín y en él hacían todos los oficios. Por lo que les manda la reyna que dejen y desembarguen al monasterio la jurisdicción del barrio que les tenían usurpada y les dejen libres los oficios y derechos dél y le buelvan cien mil maravedís que le habían llebado de los derechos que en él tenía el monasterio y lespaguen las costas que con este motivo habían causado a los monges. Con esta carta fue requerida y emplazada doña Sancha en la villa de Frómesta, a 26 de noviembre de 1410, ante López Fernández de Castroverde, escribano y notario de la reyna. 
25. $<$ Requirimiento para que un merino desembargue los diezmos de San Martín. Año 1411>.

Requirimiento hecho por parte del monasterio a Alfonso Crespo, merino de Frómesta, para que dexase libres los diezmos de los vecinos del barrio de San Martín que tenía embargados a instancia de los clérigos terceros del cavildo de Palencia y de las demás parroquias de Frómesta que pretendían pertenecerles. Hecho en Frómesta, a 8 de agosto de 1411, ante Toribio Fernández, escribano de Frómesta. $1411>$.

26. $<$ Carta de la reyna para que doña Sancha no agravie a los vecinos del barrio. Año

Carta de la reyna doña Catalina, tutora y governadora del reyno, escrita a doña Sancha de Rojas, viuda del adelantado don Gómez Manrríquez, en que la dice y manda que, por haber pleito pendiente sobre el barrio de San Martín entre su marido y el monasterio de San Zoil (que le llama su encomienda), no les haga agravio alguno ni les heche huéspedes y que suelte los presos que tubiere vecinos del barrio vasallos de el monasterio. Dada en Aillón, a 12 de agosto de 1411, ante Fernando Alfonso, escribano de la reyna, de cuya mano esta firmado.

/ (f. 229v) 27. < Requirimiento para que no se vendan las casas del barrio. Año 1411>.

Requirimiento hecho por parte de don Fernando, prior de San Zoil, a Juan Fernández Barba, vecino de Valladolid, para que unas casas que tenía en el barrio de San Martín no las vendiese como quería a doña Sancha de Rojas, señora de Frómesta. Fue hecho en Frómesta, a 20 de agosto de 1411, ante Gonzalo Martínez, escribano de dicha villa.

28. < Carta de la reyna en que llama algunos vecinos. Año 1411>.

Carta de la reyna doña Catalina, firmada de su mano, por la qual manda llamar a ciertos vecinos del barrio de San Martín para que bayan a la Corte a cosas tocantes al servicio del rey, su hijo, y suyo. Dada en Aillón, a $1^{\circ}$ de septiembre de 1411.

A la espalda está la notificación de esta carta que hizo don Rodrigo, limosnero de San Zoil, a Toribio Fernández, escribano de Frómesta, para que la cumpliese.

29. < Carta de la reyna para que Gómez de Benavides y los del concejo cambien los papeles pertenecientes al barrio $>$.

Carta de la reyna de Castilla y León, escrita en papel, con sello de cera a la espalda, a los vecinos y concejo del barrio de San Martín, en la que les dice haber escrito una carta a don Gómez de Venavides y a su muger, doña María Manrique, para que embíen los recabdos y acción que tenían al barrio de San Martín; y que el concejo embíe un procurador con sus papeles para que la causa se determine por justicia. Y la reyna embía con esta carta a Juan Bravo, su escudero de a cavallo, para que acompañe al procurador y nadie le haga daño. Dada en Madrid, a 28 de marzo. No tiene año.

30. <Testimonio de una carta de amparo de la reyna doña María a favor del monasterio, sus filiaciones y vasallos. Año 1419>.

Testimonio dado por Fernando Martínez, del barrio de San Martín, notario de la ciudad de Palencia, por el qual consta que Juan de Ortega, monge de San Zoil, queriendo notificar a doña María Manríquez, muger de don Gómez de Venavides, una carta de la reyna doña María, huyó dicha señora, por cuyo motivo se leyó públicamente; la qual, según está inserta en este testimonio, contenía lo siguiente:

Que el prior la había suplicado por su petición que reciviese el convento y monasterio de San Zoil en su encomienda para ampararlos y defenderlos, como lo había hecho la señora reyna doña Cathalina. Y que ella los recivía en su encomienda con su monasterio, lugar y filiaciones y granjas suyas, y a sus vasallos y hacienda y que los recevía bajo su protección y amparo para que de allí adelante todo fuese salvo y seguro por todo el reyno y para que nadie les haga daño alguno ni los prendan ni tomen cosa alguna por deudas ni otro respeto, salvopor las rentas reales, si no es siendo primero llamados a juicio y convencidos por razón y derecho. Lo qual les sea guardado, so pena de su merced y del rey y de 1000 doblas cruzadas 
castellanas, de fino oro y de justo precio, para la real Cámara. Y manda a todas las justicias de Castilla y León guarden y hagan guardar esta carta que estaba firmada de la reyna y sellada con sello real de cera colorada. Dada en Valladolid, a 20 días de noviembre de 1419.

Y porque la dicha doña María Manrique no había querido oýr dicha carta, el monge Juan de Ortega lo pidió por testimonio, que fue dado en Frómesta a 26 de noviembre del mismo año por el notario arriba dicho.

$$
<[\ldots]>\text {. }
$$

Copia authorizada por Gonzalo García, escribano de Cámara, de la confirmación de los privilegios del barrio de San Martín hecha por los Reyes Católicos; hecho año 1496 y sacada esta copia el de 1500.

\section{/ (f. 230r) Legajo $2^{\circ}$ del Cajón San Román}

Este $2^{\circ}$ legajo contiene dos informaciones y un proceso (todo sin autoridad) del pleito que tuvo este monasterio con el adelantado don Gómez Manrrique y su muger, doña Sancha, por los años 1410 y siguientes sobre el señorío, vasallage, etcétera, del barrio de San Martín. Lo que contiene[n] estas dos informaciones es lo siguiente: Año 1411>.

$1^{a}$. $<$ Información del monasterio en defensa de el barrio de San Martín de Frómesta.

La primera información, que no tiene principio, fue hecha en Palencia por el mes de abril del año de 1411, por parte del monasterio de San Zoil, ante Juan Rodríguez Bachiller, receptor de la Audiencia Real, y Gonzalo Ruiz, por acompañado, y Juan Esteban, escribano ante quien se hizo esta información, que tiene 10 testigos $^{346}$.

$<$ Señorío del barrio $>$.

Lo que se prueba en ella a favor del monasterio es que el prior y convento de San Zoil era señor absoluto del barrio de San Martín; y los vecinos, sus vasallos. Que el barrio de San Martín era por sí separado del lugar de Frómesta en jurisdicción, señorío y fuero distinto. Que el prior y convento de San Zoil ponían un monge que asistiese en San Martín y fuese prior con otro compañero o dos. Que el día de San Martín iva el prior de San Zoil o enviaba cinco ó seis monges que asistían a vísperas y misa del Santo, y a las vísperas daban a cada feligrés de los que se hallaban en ellas una pera y dos veces de vino y el día siguiente convidaban a comer a 30 feligreses de los más principales, unas veces más y otras menos, a voluntad del prior. El de San Zoil tomaba residencia a los oficiales y llamaba a concejo a los vecinos del barrio y ellos acudían y se juntaban en el palacio que tenía el prior en ${ }^{347}$ San Martín y allí trataban de las cosas tocantes al buen govierno.

$<$ Posesión del barrio que tomaba el prior nuevo de San Zoil $>$.

Quando entraba prior nuevo en San Zoil (como sucedió al prior don Toribio, y a don Beltrán, que le sucedió) iva a Frómesta y tomaba posesión del barrio y los vecinos le ivan a dar la obediencia, reconociendo al prior por su señor y confesando ser sus vasallos. Esto sucedió a don Beltrán estando en Frómesta el adelantado, quando pretendía ser el señor absoluto del barrio.

$<$ Diezmos del barrio $>$.

Tenía el monasterio y llebaba en el barrio de San Martín todos los diezmos mayores de pan y vino enteramente, y asimismo los menores, que tocaban a todos los vecinos del barrio de San Martín, y por orden del prior se recogían y se llebaban a San Zoil o se guardaban en el priorato.

$<$ Martiniega y yantar $>$.

346 testigos] al margen derecho: Falta todo.

347 en] infrascrito y tachado: de. 
También tenía el monasterio martiniega y yantar, que le pagaban todos los vecinos del barrio, y aún el mismo adelantado lo pagaba también de las heredades que tenía. Pagaba cada vecino 6 maravedís de martiniega si tenía casa, y si no la tenía, pagaba 3.

\section{$<$ Otros derechos $>$}

Tenía también el monasterio otros derechos que llamaban penas, calumnias, omecillos, entregas, etcétera, y éstos cobraba el merino del prior.

\section{/ (f. 230v)<Oficios que provehía el prior de San Zoil >.}

Proveía y nombraba cada año el prior de San Zoil en el barrio de San Martín los oficios de alcaldes, merino, escribano, pregonero, sayón y otros. Después el prior don Toribio hizo gracia a los vecinos del barrio del nombramiento de estos oficios y así de allí adelante los nombraban ellos a nombre del prior.

$<$ Llaves de las puertas $>$.

Había llaves de las puertas del barrio, que una llamaban de Monzón y otra de Gragal. Éstas las tenían los vecinos del barrio a quienes las encargaban los alcaldes y éstos tenían el cuidado de cerrar de noche y abrir por la mañana.

$<$ Encomienda y arrendadores del barrio de San Martín>.

Consta también por esta información que don Juan Germán, prior mayor de San Zoil, fue el primero en dar el barrio en encomienda al conde don Tello, que en aquel tiempo era hombre poderoso y mui valido del rey don Enrrique $3^{\circ}$. Después de éste tubo el barrio en encomienda Pedro López de Padilla, a quién se siguió Lope Fernández de Padilla. Después del qual entró en la encomienda el almirante Fernán Sánchez de Tovar, que hizo harto daño, en cuya oposición pretendió la encomienda Gutierre González ${ }^{348}$ Quijada y, porque no le quisieron los del barrio en la oposición, mató a un hombre; por lo qual se dio la encomienda a don Gómez Manrrique, adelantado, por cuyas extorsiones el prior don Toribio dio la encomienda al duque de Venavente, que no tomó la posesión porque se la resistió el adelantado con gente armada; y así el adelantado se lebantó con todo porque, habiéndosele dado la encomienda antes que fuese señor de Frómesta, la compró después y quiso juntar el barrio de San Martín con el lugar de Frómesta y hacerse señor de todo.

$<$ Agravios de los comendadores del barrio de San Martín>.

Luego que el adelantado compró a Frómesta de los herederos del Almirante y entró por señor de ella con la ocasión de tener el barrio de San Martín en encomienda, quiso juntarle y confundirle con el lugar. Y así lo primero que hizo fue quitar los alcaldes y oficiales del barrio que habían nombrado los vecinos, nombrando otros no vecinos del barrio, como lo debían ser, sino, del lugar de Frómesta. Por éstas y otras extorsiones y tiranías el prior don Toribio quitó la encomienda del barrio al adelantado y la dio segunda vez al duque de Benavente; pero el adelantado se lo defendió con gente armada y su muger, doña Sancha, quitó las llaves de las puertas a los vecinos del barrio porque no dejase entrar en él al Duque y de allí tuviese ocasión para tomar a Frómesta. Viéndose el ade/ (f. 231r)lantado en estas contingencias, sacó bula apostólica del Papa, de permuta, para que el monasterio le diese el barrio de San Martín con todo lo perteneciente a él por un lugar que el adelantado tenía en la frontera de Aragón llamado Arcos.

Con esta bula vino a San Zoil doña Sancha de Rojas, muger del adelantado, a pedir al prior y convento que, en virtud de ella, hiciesen el contrato y permuta. Viose la bula que venía cometida al obispo de Palencia y respondió el convento que sin su intervención no se podía executar ni otorgar el contrato.

El adelantado hizo instancia para que la executase el obispo de Palencia, el qual cometió las diligencias y execución al deán de aquella ciudad; pero esta permuta nunca tuvo efecto. Sin embargo de estas diligencias, el adelantado poco a poco se iva adelantando de todo lo que el monasterio tenía en el barrio, y así cobraba cada año diez mil maravedís del derecho de señorío fuera de los carros de paja y leña y otras cosas que solía llebar el

348 González] sigue tachado: de. 
monasterio. Arrendaba el oficio de merino en cinco mil maravedís y el de escribano en otro tanto. Los vecinos del barrio se hicieron fuertes y no quisieron pechar al adelantado como los de Frómesta y así pagaban al monasterio el yantar y martiniega y 150 maravedís de la moneda vieja y al adelantado los derechos referidos y los de su encomienda.

Con tantas tiranías como el adelantado hacía con el monasterio y sus vasallos justamente pudo temer que también se levantase con los diezmos y demás derechos que le quedaban; y así, para poner remedio a tantos males, el monasterio se querelló ante el rey don Juan el $2^{\circ}$, el qual mandó a los oidores de su Consejo que hiciesen justicia; para lo qual se introduxo este pleito, en que se hizo la información dicha, de que consta todo lo que va referido con otras cosas que no son de este intento. La Audiencia citó algunos vecinos del barrio para que fuesen a decir su parecer y declarar la justicia del monasterio en Valladolid, como en efecto lo hicieron, a pesar de la resistencia que les hizo el adelantado, cerrándoles las puertas del barrio, como todo consta en las deposiciones de esta información y de la que se sigue.

$2^{a}$. <Información del pleyto del barrio con don Gómez Manrique. Año 1411>.

Esta segunda información, aunque menos defectuosa, / (f. 231v) tampoco está autorizada. Tiene 16 testigos con que el monasterio prueba su intento. El orden que guarda es como se sigue:

$1^{\circ}$. Vn poder dado por don Fernando, prior mayor, y el monasterio de San Zoyl a don Rodrigo, limosnero mayor, a García Fernández, Alfonso Sánchez y Juan Sánchez, todos monges del monasterio, y a Fernán García de la Serna, vecino de Carrión, para seguir el pleyto con don Gómez Manrrique y doña Sancha de Rojas, su muger. A 4 de diciembre de 1410, ante Francisco Pérez, escribano de Carrión.

$<$ Proceder de la audiencia hasta la prueba $>$.

Síguese una provisión, despachada en nombre del rey don Juan el $2^{\circ}$ por los oidores de la Audiencia de Valladolid, en que está inserto el estado del pleyto del barrio de San Martín con el adelantado. Se hace relación de la querella que ante ellos puso el monasterio al adelantado por haberse ${ }^{349}$ lebantado con todo lo que tenía en el dicho barrio de San Martín. Pidió restitución de todo lo que se le había quitado y de 200 mill maravedís que había llevado el dicho adelantado de los derechos del barrio pertenecientes al monasterio, de todo lo qual ofreció información. El adelantado respondió que los oidores no eran jueces en esta causa y negó todo lo que el monasterio había propuesto y lo contenido en su querella.

Concluso el pleyto, los oidores dieron sentencia interlocutoria, por la qual se declararon por jueces en esta causa y la recibieron a prueba. El monasterio, para hacer su probanza, señaló los lugares de el obispado de Palencia. Dieron a las partes 60 días de término para las pruebas y se despachó esta carta de receptoría y comisión al bachiller Juan Rodríguez de Burgos, receptor, y que llebase al escribano para dar fe a Juan Estevan de Salamanca. Dada en Valladolid, a 30 de marzo ${ }^{350}$ de 1411, ante Alfonso Peláis de Oviedo, escribano de la Audiencia.

Requiriose con esta provisión al receptor, aceptola; pero el adelantado le recusó por sospechoso. Diósele por acompañado para hacer la información Gonzalo Ruiz, ante los quales y de el escribano dicho se hizo como está en este quaderno. Para la qual se presentó un ynterrogatorio de 45 preguntas en la Chancillería y los oidores lo remitieron al receptor. Lo que por él articuló el monasterio y probó por esta información es lo siguiente:

$<$ Artículos $>$.

$1^{\circ}$. Conocimiento del barrio que siempre se llamó de San Martín.

/ (f. 232r < Q Qué probó el monasterio en esta segunda ynformación>.

$2^{\circ}$. Que siempre fue el barrio distinto de Frómesta.

\footnotetext{
349 haberse] sigue tachada: $\mathrm{d}$.

350 marzo] escrito sobre: mayo.
} 
$3^{\circ}$. Que siempre fue el barrio de San Zoil.

$4^{\circ}$. Que el prior y convento siempre estuvieron en posesión del barrio y de sus vecinos como vasallos suyos.

$5^{\circ}$. Que el convento estuvo en posesión de llebar de los vecinos martiniega y yantar, penas, calumnias, derechos y entregas.

$6^{\circ}$. Que el convento estaba en posesión de poner alcalde, merino, escribano, sayón y pregonero, que usaban sus oficios en el barrio.

$7^{\circ}$. Que todo esto era pública voz y fama.

barrio.

$8^{\circ}$. Que tenían en su poder, o de otros por ellos, las llaves de las puertas del yantar.

$9^{\circ}$. Que poseían y llebaban cada año 600 maravedís de martiniega y 600 de

10. Que todo era pública voz y fama.

11. Que estando el convento y sus predecesores en posesión de todo lo dicho de 200 años aquella parte, les había despojado de todo don Gómez Manrrique, adelantado mayor de Castilla.

convento.

12. Que el adelantado cometió lo dicho por fuerza y contrala voluntad del

13. Que el adelantado tomó y se apoderó de las penas y calumnias, yantar y martiniega y todos los demás derechos, salvo 150 maravedís de martiniega que le dexó al convento, habiendo éste de haber 600 maravedís de ella cada año y otro tanto del yantar.

14. Que el adelantado apremiava a los vasallos del monasterio, vecinos del barrio, a que pareciesen ante sus alcaldes del lugar de Frómesta.

15. Que el adelantado no consentía que los monges pusiesen en su barrio los dichos oficiales para que exerciesen sus oficios.

los monges.

16. Que el adelantado quitó y tenía las llaves del barrio, despojando de ellas a

17. Que todo lo dicho es público y notorio, pública voz y fama.

18. Que los priores de San Zoil acostumbraban dar al barrio en encomienda a quien ellos querían, para que los vecinos de él fuesen amparados y defendidos en sus necesidades.

19. Que los señores que eran de Frómesta tenían el barrio de San Martín en encomienda en nombre de los priores que por tiempo eran de San Zoil, sin tener otro algún título en él.

20. Que Fernán Sánchez de Tobar, Almirante, fue señor de Frómesta.

21. Que el Almirante tuvo en su vida el barrio de San Martín en encomienda por mano del prior de San Zoil que entonces era.

22. Que el adelantado don Gómez tuvo el barrio en encomienda por mano de don Toribio, prior de San Zoil, y quanto tiempo tuvo la encomienda.

23. Que habría tres años que Gómez Manrrique había ganado una bula del Papa para permutar con el convento de San Zoil el barrio de San Martín y el señorío temporal de él y sus derechos.

24. Que / (f. 232v) la dicha bula vino cometida a don Sancho de Rojas, obispo de Palencia, para que diese licencia para hacer la dicha permuta.

25. Que el obispo cometió esta diligencia al deán de Calahorra, su provisor, y a Rodrigo Rodríguez de Torquemada para que lo tratasen con las partes. 
26. Que el adelantado y doña Sancha de Rojas, su muger, daban al convento de San Zoil el señorío y derechos de el barrio 6000 maravedís en cada año perpetuos y 20 mill maravedís luego por lo que havían llebado de los vecinos del barrio pertenecientes al monasterio.

27. Que Juan Fernández de Padilla fue señor de Frómesta y como tal llebaba los derechos de aquel lugar.

28. Que Juan Fernández de Padilla arrendó del monasterio el barrio de San Martín con sus derechos y diezmos, y que pusiese por el prior y convento alcaldes y merino en el dicho barrio, y que tuviese las llaves de la cerca del barrio por ellos y por cierto tiempo determinado.

29. Que lo dicho era pública voz y fama, etcétera.

30. Que Fernán Sánchez de Tobar, Almirante, mandó en su testamento que, por lo que había llebado de los vecinos del barrio y de los derechos del monasterio, diesen sus herederos 20 mill maravedís en satisfacción.

31. Que quando murió este Almirante dejó el lugar de Frómesta a sus hijas doña Elvira y doña Mencía y mandó que fincase a salvo el barrio de San Martín para el prior y convento, por quanto era suyo y le pertenecía.

32. Que doña Elvira y doña Mencía, después de la muerte de su padre, partieron entre sí el lugar de Frómesta, y dejaron aparte el barrio como cosa de la orden.

33. Que todo lo dicho es pública voz y fama.

34. Que Sancho Fernández de Tovar tuvo la parte del lugar de Frómesta que cupó en la partición a doña Elvira, por compra o trueque que con ella hizo.

35. Que el adelantado Gómez Manrrique compró del dicho Sancho Fernández la parte de Frómesta que hubo de doña Elvira.

36. Que el adelantado compró de doña Mencía la parte de Frómestaque le había cabido en la partición, sin el barrio de San Martín, que siempre quedó al prior de San Zoil como cosa suya propia.

37. Que los derechos, yantar y martiniega y los derechos de la alcaldía, escribanía, merindad, sayonería, pregonería, entregas, penas y homecillos del barrio que pertenecían al convento, con lo demás que llebó el adelantado, así en dinero que hechó a los vecinos cada año de pedido, como en paja y leña y otros servicios que de ellos llebó, pudieron montar en cada año 10 mill maravedís, y más todo el tiempo que lo llebó.

38. Que antes que el adelantado comprase a Frómesta tuvo en encomienda el barrio por el padre prior.

39. / (f. 233r) Que el tiempo que doña Elvira y doña Mencía tuvieron a Frómesta, o quando fue de doña Mencía y de Sancho Fernández de Tobar, tuvo el adelantado el barrio en encomienda por el prior de San Zoil.

40. Que todo lo dicho era pública voz y fama.

41. Que Fernán Sánchez de Tobar, quando era señor de Frómesta, tomaba juramento a los vecinos del barrio que no acogerían por las puertas de él a persona alguna que quisiese hacerle daño.

42. Que quando doña Elvira y doña Mencía eran señoras de Frómesta habían rogado a los vecinos del barrio que no acogiesen a Juan de Tobar.

43. Que al tiempo que el prior de San Zoil venía nuevamente al monasterio por prior los vecinos del barrio le recibían por su señor y como a tal le besaban la mano.

44. Que los vecinos del barrio besaron la mano y recibieron por sus señores al prior don Toribio y al que entonces era, don Fernando, quando vinieron de nuevo por priores. 
45. Que todo lo sobredicho era público y notorio, pública voz y fama.

Todo lo qual se prueba en esta información, además de lo que queda dicho en la antecedente, que resultó de las preguntas que hacían el receptor, su acompañado y escribano $^{351}$ a los testigos. Que fue hecha a 3 de abril del año de 1411.

$3^{\circ}$.

Vn proceso, sin authoridad, copiado del original, fulminado en el pleyto que este monasterio tubo sobre la jurisdicción, derechos y exenciones del barrio de San Martín con don Gómez Manrique, adelantado de Castilla, señor de Frómesta, y después de su muerte con doña María Manrique, su hija, que fue muger de don Gómez de Venavides. En este proceso está primeramente la querella que dio don Rodrigo, limosnero mayor de San Zoil, ante los oydores de la Audiencia del rey don Juan el $2^{\circ}$, en Valladolid, a 26 de enero de 1411, quexándose de don Gómez y de doña Sancha, su muger, por haberse alzado con todas las exenciones, señorío, vasallaje y derechos que el prior y convento de San Zoil tenía en el varrio de San Martín, y haber hecho los agravios y estorsiones que quedan referidos en las informaciones antecedentes; que todos están referidos en esta querella, en la qual se pide restitución de todo lo que el adelantado había llevado y de 200 mill maravedís que había tenido de aprovechamiento de los derechos del barrio pertenecientes a este monasterio.

Luego está la sentencia que dieron los oidores, a 4 de marzo de 1411, en que se declaran por jueces de la causa, sin embargo de lo que en contrario había alegado la parte del adelantado, y mandan dar recetoría para que las partes prueben lo que habían ofrecido probar.

Síguese el poder del convento, alegatos de las partes, ynterrogatorio de 45 artículos presentado por el convento para su probanza y la presentación que hizo de cinco informaciones, cerradas y selladas, en su favor, alegato en su favor, tachas de los testigos del adelantado y proceder de la Audiencia (que estubo el tiempo que duró el pleyto en Valladolid, Sepúlveda y Simancas) hasta la / (f. 233v) conclusión del pleyto para sentencia definitiva, que fue por agosto de 1412. Todo lo qual y lo demás hasta el fin de este pleyto consta de la carta executoria que se dio a favor del monasterio; la qual, aunque se halla copiada en este proceso, pero por estar sin authoridad y hallarse la original en el legajo siguiente, se dexa para aquel lugar el estenderla, donde se podrá ver.

Después de la carta executoria se sigue una ynformación hecha por parte del monasterio en la villa de Piña, por el mes de agosto de 1411, ante el bachiller Juan Rodríguez de Burgos, receptor de la Real Audiencia, y por autoridad y fe de Juan Estevan de Salamanca, escribano público, en la qual articula y prueba el monasterio, con trece testigos, todo lo qual queda dicho en la primera ynformación. Hízose por las 40 preguntas y artículos del ynterrogatorio que está en el número $2^{\circ}$ de este legajo $2^{\circ}$.

\section{/ (f. 234r) Legajo $3^{\circ}$ del Cajón San Román}

Este legajo $3^{\circ}$ contiene los pleytos que ha tenido este monasterio con los señores de Frómesta desde el año de 1414 hasta el de 1462 inclusive, por el orden siguiente:

$1^{\circ}$. <Carta executoria a favor del monasterio. Año 1414>.

Carta executoria, escrita en pergamino, con sello de plomo pendiente, dada por lo oydores de la Audiencia del rey don Juan el $2^{\circ}$ en favor del monasterio de San Zoil y contra el adelantado don Gómez Manrique y su hija doña María Manrique, heredera del señorío y estado de Frómesta. Por esta carta executoria consta que, después de la sentencia interlocutoria dada por los oydores (de la que se habló en el número antecedente), por la qual se declararon jueces de la causa, se recivió a prueba, diose término para ella, señalaron las partes los lugares donde se había de hacer y se despachó recetoría. Presentaron las partes, dentro del término, algunas probanzas cerradas, el monasterio presentó cinco. Pidieron más

351 escribano] sigue tachado: como. 
plazo, dióseles el quarto a instancia del adelantado, consintiendo el convento y dentro de este término presentaron nuevas informaciones.

A este tiempo murió el adelantado y dexó por señora de Frómesta a su hija doña María Manrique, que después casó con don Gómez de Venavides. Presentose el procurador de esta señora en la Audiencia, hizo oposición a este pleyto como heredera del señorío de Frómesta. Alegó ser de menor edad y que no había podido presentar dentro del quarto término 140 testigos que tenía en ciertos lugares que señaló, y que los vecinos de San Martín habían hecho liga y monopolio contra el adelantado para ser contra él en dicho y en hecho. Pidió el quinto plazo para sus pruebas y restitución in integrum, sobre lo qual alegaron ambas partes. Diose el pleyto por concluso y, visto sobre este artículo por los dichos oydores, dieron sentencia interlocutoria, por la qual otorgaron la restitución pedida por parte de doña María Manrique y mandaron despachar recetoria para sus pruebas con asignación de cierto plazo. Ambas partes presentaron sus escrituras, las del monasterio fueron 41, las 35 en papel y las seys en pergamino. A instancia del monasterio se abrieron las probanzas y se hizo publicación de testigos, contra los quales protestaron las partes decir sus excepciones. Dióseles traslado y alegaron de su derecho y el monasterio dixo las tachas de los testigos / (f. 234v) del adelantado y de doña María. Concluyeron las partes y fue dado el pleyto por concluso.

$<$ Sentencia definitiva $>$.

Y, haviéndose visto por los oydores con gran diligencia y habiendo tenido su acuerdo, dieron en el dicho pleyto su sentencia definitiva, por la qual condenaron a don Gómez Manrique y a su hija doña María a que restituyesen al prior y convento de San Zoil la posesión de poner alcaldes, merino, escribano, pregonero $<y>$ sayón en el varrio de San Martín y les dexasen vsar libremente de la posesión en el dicho nombramiento de oficiales y que éstos vsasen sus oficios, llevando cada uno sus derechos. Ytem condenaron al dicho Gómez Manrique a que restituyese al dicho prior y convento la posesión de llevar los derechos y penas, calumnias, omecillos y derechos de entregas y les dexasen vsar libremente de ellas. En quanto a lo que pudieran redituar los dichos derechos fallaron que, según la naturaleza y calidad de este negocio, diferían al prior y convento el juramento pedido por su parte y que jurasen, por sí o por su procurador, con especial(dad) mandado para ello, quánto podrían redituar dichos derechos con buena diligencia en los 20 años antes que la demanda se pusiese, y desde ésta, hasta el día de la data de esta sentencia, que conforme las probanzas se podían tasar en 4 mill maravedís de la moneda que entonces corría, en cada un año de los 20 hasta que se puso la demanda, y desde ella hasta la data de la sentencia.

$<$ El convento no fue despojado del señorío del barrio $>$.

Ytem declararon haber tenido el convento en el dicho tiempo la posesión y no haber sido despojado de la del varrio de San Martín y de su señorío y vecinos, y en quanto a este artículo absolvieron al adelantado de la demanda.

$<$ Martiniega y yantar $>$.

Ytem quanto a la martiniega y yantar, de que pretendía el monasterio haberles despojado el adelantado, fuera de 150 maravedís que les comintió llevar por ello, absolvieron al adelantado de la demanda contra él puesta, por no parecer que habían sido despojados de ello, y dexaron su derecho a salvo al monasterio quanto a la propiedad y posesión de llevar todos los maravedises del yantar y martiniega además de los 150 que llevaba como señor en cada un año, etcétera.

$<$ Llaves del barrio $>$.

Y en quanto a la demanda de las llaves de las puertas del barrio, absuelben al adelantado y dicen que, en quanto a esto, no es su intención hacer agravio a ninguna de las partes en razón de la propiedad; y en quanto a ella les reservaron su derecho a salvo para que lo pidiesen donde debiesen. No hicieron condenación de costas.

$<$ Sentencia de revista, confirma la $1^{\text {a }}$ de vista $>$.

De esta sentencia fue suplicado por parte de Gómez Manrique y de su hija doña María en lo que era contra ellos y en lo favorable la consintieron. Lo mismo hizo la parte del 
monasterio. La parte de doña María / (f. 235r) dixo de nulidad de la sentencia y alegó sus razones. Pidió ciertas restituciones y sobretodo ser desagraviada.

Después de haber replicado ambas partes, diose la causa por conclusa; y dentro de cierto término para ello señalado, dieron los oydores su sentencia de revista, por la qual negaron la restitución pedida por parte de doña María Manrique y dixeron no haber lugar. Y, sin embargo de lo alegado, confirmaron la sentencia de vista y condenaron a la parte de doña María a las costas que el monasterio había hecho en esta instancia.

$<$ Sentencia de los derechos $>$.

Después de esto, la parte del monasterio presentó una petición, diciendo que estaba pronto a hacer el juramento que en la sentencia se había diferido acerca de los 4 mill maravedís en cada un año de los derechos que había llevado el adelantado en los 20 años antecedentes a la demanda puesta por el convento y de ella a la data de la sentencia; y, habiendo hecho el juramento y siendo preguntado, respondió que administrados por el convento los derechos del barrio hubieran valido en cada un año 4 mill 500 maravedís o más.

Por lo qual dieron los oydores sentencia en que fallaron que debían condenar y condenaron a Gómez Manrique en 4 mill maravedís cada año de los 20 antecedentes a la demanda puesta por el monasterio, que todo importaba 93 mill 915 maravedís y 2 dineros, en los quales condenaron a adelantado. Y mandaron dar esta carta executoria, que fue dada en Rámaga, aldea de Arévalo, a 4 de julio de 1414, ante Alfonso Peláez de Oviedo, escribano de la Audiencia Real. Hay aquí una copia simple de esta carta executoria, escrita en papel.

\section{2. <Escritura de posesión y execución de la carta executoria. Año 1414>.}

Escritura en pergamino por la qual parece que, en la villa de Becerril, a 6 de octubre de 1414, en presencia de Luys Sánchez de Aranda, escribano y notario del rey, Juan Martínez de Castro, monge de San Zoil, requirió al bachiller Juan Martínez de Burgos, alcalde mayor de dicha ciudad, con la carta executoria de arriba (inserta en esta escritura) y con otra carta y provisión real a él dirigida y firmada de la reyna doña Cathalina, madre y tutora del rey don Juan el 2 y governadora del reyno, dada en Valdenebro a 5 días de octubre del mismo año; por la qual dice que el prior y convento de San Zoil se había querellado de que, habiendo requerido con la carta executoria de arriva a Ruy Díaz de Roxas, lugarteniente de Diego Gómez de Sandoval, adelantado mayor de Castilla, para que la executase y cumpliese, había ido para ello a Frómesta y le cerraron las puertas por mandado de Gómez de Venavides y, que según los privilegios del lugar, respondieron que no podía entrar / ( f. 235v) en él el adelantado ni su teniente a hacer tales execuciones. De lo que había tomado testimonio la parte del convento, que la presentó a la reyna con la querella y que no dexaron los del lugar que se hiciese la dicha execución. Por lo qual el rey y la reyna, su madre, en su nombre, mandó al dicho Juan Martínez de Burgos que, siendo requerido con la carta executoria, la execute como en ella se contiene; y, si para ello hubiere menester favor y ayuda, manda al adelantado y su teniente, a los vecinos de Frómesta y a todos los concejos y justicias de las ciudades, villas y lugares del reyno que se la den y hagan dar y que vayan con él, si es necesario, al dicho lugar o a otros qualesquiera donde la necesidad lo pidiere. La qual carta, aceptada y obedecida por el dicho juez, en cumplimiento de ella y de la carta executoria, fue a Frómesta el día 8 de octubre del referido año y, estando junto al concejo de la villa en la yglesia de San Pelayo, les hizo saber la dicha carta executoria y su comisión y les requirió con ellas para que las obedeciesen y les pidió el favor y ayuda que para ello fuese menester. El concejo respondió que obedecía las cartas reales y que se le diese traslado para responder.

$<$ Posesión que tomó el prior de San Martín>.

Después de lo qual, el dicho Juan Martínez de Castro, monge, y don Fernando, prior mayor, que se hallaron presentes, presentaron los poderes que tenían del convento para recivir la posesión del barrio. En 9 del dicho mes, estando junto el concejo del barrio y con él don Fernando, prior de San Zoil, y otros monges, en el palacio de San Martín, el prior requirió de nuevo al juez para que executase la carta executoria y la orden que para ello tenía. El juez, en cumplimiento de su comisión y carta executoria, restituyó al prior en nombre del convento y le dio quieta y pacífica posesión de poner alcaldes, merinos, escribano, pregonero 
y sayón entre los vecinos del barrio, sus vasallos, los quales vsaron libremente de sus oficios llevando cada uno sus derechos.

Lo $2^{\circ}$, le restituyó y dio posesión de llevar libremente las penas, calumnias, omecillos y derechos de entregas que sucedían entre los vecinos del barrio. El prior, como señor del barrio, se dio por entregado de todo y nombró para los oficios dichos a los vecinos del barrio, para que los vsasen libremente como solían desde el día de San Martín primero venidero hasta el de el año siguiente, etcétera. Ellos aceptaron e hicieron juramento de fidelidad en manos del prior.

Y para hacer execución en los bienes del adelantado por 95 mill 921 maravedís de costas que mandaba la carta executoria se pagasen al monasterio, nombró el prior por herederos y bienes del adelantado a doña María Manrique, muger de Gómez de Venavides, que 1500 maravedís de la moneda vieja en cada un año en las / (f. 236r) alcavalas de Frómesta y que esta villa es suya ${ }_{s}$ nombró a doña Teresa, muger de Juan de Avendaño, que tenía la villa de Losas; y a doña Juana, muger de don Pedro, que tenía el fos de La Piedra y el castillo de Ovirva junto a Burgos; y a doña Sancha de Roxas y a doña Elvira y a doña Mencía. Y la dicha doña Sancha, en nombre de doña Elvira y doña Mencía, como su tutora y curadora, que tiene la mitad de Requena y la mitad de la casa de Villalaco con la mitad de la heredad de allí y de sus vasallos de Santillana, y la mitad de la heredad de Villaviudas y la mitad de los vasallos de Piña, la mitad de los vasallos de Manquillos. Todo lo qual nombró para hacer la execución. El juez dixo que lo vería y haría lo que fuese justicia. Luego el prior mandó al pregonero que había nombrado que diese un pregón en el barrio por mandado de su señor don Fernando, prior de San Zoil, en que mandaba que todos los vecinos de él que tubiesen algunas causas, acudiesen a librarlas a los alcaldes que el prior había nombrado y a los demás oficiales, bajo de ciertas penas que les puso. Todo lo qual consta de esta escritura que pasó ante el dicho Luys Sánchez, escribano, de quien está signada y authorizada.

3. <Proceso de la quexa de doña María Manrrique al papa Martino $5^{\circ}$ por la restitución que la negó la Audiencia>.

Proceso de la quexa y apelación que presentó doña María Manrique y su marido, don Gómez de Venavides, por haberle negado los oydores de la Real Audiencia la restitución que pidió como menor, la qual se interpuso ante e papa Martino $5^{\circ}$. De este proceso y de los papeles que están con él consta que, después que los oydores de Valladolid dieron la sentencia de revista, confirmando la de vista, en favor del monasterio, como queda notado arriba, la dicha doña María apeló ante el rey con las 1.500 doblas, ofreciéndose a depositarlas o a dar fiador de ellas. Y, por no haberlo cumplido, los oydores declararon esta apelación por desierta y las sentencias por pasadas en cosa juzgada, según estilo de la Audiencia y leyes del reyno. $\mathrm{Y}$, en virtud de esto y de la carta executoria, fueron restituydos el prior y convento, y la dicha doña María pidió ante el juez que se la diese curador ad litem por haber muerto su madre; el qual, habiéndosele concedido, pidió ante el executor restitución contra las sentencias, la qual se la negó. Y de esta negación apeló el curador ante el rey. Acudió el procurador del convento alegando declinatoria de jurisdicción y nombrando por su juez conservador al abad de Oña, ante el qual protestaba responder y no ante los oydores, los quales, sin embargo, procedieron y se concluyó la causa.

\section{$<$ Violencia de don Gómez de Venavides>.}

Estando el convento en quieta y pacífica posesión por espacio de quatro años (pendiente el pleyto) / (f. 236v) fue violentamente despojado del barrio, y con mano armada entró don Gómez de Venavides en San Martín y con su gente y criados lo destrozó todo y derribó el campanario de la yglesia. De esta enormíssima lesión y despojo tan violento recurrió el convento al abad de Sahagún, como juez conservador, el qual procedió contra los dichos invasores que habían despojado al monasterio de la posesión que tenía en San Martín y su barrio, dio sus monitorios para que restituyesen al convento lo que le habían quitado. De estas censuras apeló doña María Manrique, su marido y criados ante la Santidad del Papa Martino $5^{\circ}$, el qual cometió la causa a Artungo de Capel, auditor del Santo Palacio, quien sentenció que los oydores del rey debieron haber restituydo in integrum a doña María Manrique y en esto condenó al monasterio con costas. 
$<$ Doña María Manrrique apela al papa y saca executorias de Roma. Año 1425>.

De esto apeló el monasterio ante Su Santidad y, habiéndose cometido la causa a dos auditores del Santo Palacio, confirmaron la sentencia pasada y condenaron al monasterio, el qual bolvió apelar y se cometió de nuevo la causa a Pedro, diácono cardenal, y después, por ciertos motivos, a Guillermo, presbítero cardenal de San Marcos, el qual revocó las sentencias pasadas y declaró que el convento había apelado justamente y le absolbió de la demanda de doña María Manrique; la qual apeló al papa que cometió la causa a Jordán, obispo Albanense, quien por sí solo dio sentencia, revocando la de Guillermo y confirmando las dos primeras, despachó executoriales a favor de doña María, cometidos a Pedro Cleteyns, el qual mandó restituyr a doña María en el estado en que se hallaba antes de dar los oydores las dos sentencias a favor del monasterio y dio despacho para ello, insertos los executoriales, que fueron dados año $8^{\circ}$ del pontificado del papa Martino $5^{\circ}$, que fue el del Señor de 1425. Mandó asimismo que el convento no vsase de la executoria de la Audiencia y que restituyese a doña María Manrique y a Gómez de Venavides en el barrio como estaba el adelantado antes de las dichas sentencias, y que el convento pagase a doña María 15 florines de oro que le habían costado los executoriales.

Como este juez executor estaba en Roma, cometió la execución de las executorias y su mandato vniversis et singulis, etcétera, (Datum Rome, a 6 de marzo de 1426) en España. Requirió con estas letras la parte de doña María al bachiller Juan Rodríguez de Castro, canónigo de Palencia, para que las executase. Pidió la restitución del barrio y que se le bolviesen 143 mill 900 maravedís que había llevado el convento de la condenación de la Chancillería y de los derechos del barrio que había gozado doce años después de sacada la carta executoria de la Real Audiencia.

$$
/(f .237 r)<\text { Nota }>\text {. }
$$

Este juez subexecutor hizo presente su comisión (que es donde comienza este proceso) insertando las letras del obisbo (sic) de Elete para que el monasterio restituyese a doña María el barrio y le pagase los maravedís de la demanda dentro de cierto término. En el qual se presentó la parte del convento ante el dicho juez, dixo nulidades, apeló de todo y pidió testimonio; de lo qual se mandó dar traslado a la parte contraria, la qual presentó poder y contradixo lo alegado por parte del convento y bolvió a pedir que el juez procediese a la execución de los executoriales de Roma. Contra lo qual bolvió la parte del convento alegar contra el juez y su comisión más en forma, diciendo que esta causa no era eclesiástica ni pudieron conocer de ella en Roma sino ante el rey y sus consejeros que habían conocido primero de ella y assí que el juez subexecutor no debía conocer, etcétera. Después de varias réplicas y alegatos de ambas partes, en 26 de octubre del año de 1426, el canónigo Juan Rodríguez dio sentencia declarándose por juez para la execución de lo que en las letras le había cometido el executor principal, y mandó a las partes viniesen concluyendo y tragesen sus letrados para que se disputase el caso principal. El procurador del convento dixo que en lo que era a favor de su parte, consentía y, en lo contrario, apelaba. El procurador contrario consintió; el del convento apeló por escrito y presentó la apelación en forma.

$<$ Se recive la causa a prueba y se queda en este estado. Año 1426>.

En 15 de noviembre del mismo año el juez pronunció auto en que recivió la causa a prueba con término de 30 días, de que apeló el procurador del convento y pidió testimonio.

En este estado quedó esta causa sin pasar adelante ni tener efecto la execución de los executoriales. Y el monasterio quedó en posesión del barrio y le tubo hasta que le aforó al mariscal por 1 mill florines, como se dirá adelante. de Palencia.

Este proceso está authorizado de Alfonso García de Villagarcía, escribano y notario

Hay aquí otros papeles de memoriales e informaciones en derecho tocantes a esta misma instancia.

4. $<$ Requirimiento a don Gómez de Venavides para que vuelba las llaves del barrio. Año 1426>. 
Requirimiento hecho por Gonzalo González, monge de San Zoil, a don Gómez de Benavides, señor de Frómesta, para que volbiese las (las) llaves de la puerta de Carre Monzón, que es en el barrio de San Martín, las quales había quitado a Alfonso de Gomeda, vecino del dicho barrio, que las tenía por el prior y sus vasallos. El procurador de don Gómez respondió que el barrio no era del prior y así que no le pertenecían las llaves ni se las había de dar. Su fecha, en Frómesta, a 2 de enero de 1426, ante Fernando Sánchez de Frómesta, escribano y notario de dicha villa.

$5^{\circ}$. < Excomunión contra el prior de San Zoil. Año 1426>.

Denunciación hecha por los provisores de Palencia para comisión apostólica, dada a instancia de don Gómez de Venavides y de doña María Manrrique, su / (f. 237v) muger, en que declara por escomulgado a don Pedro, prior mayor de San Zoil, por no haber ${ }^{352}$ obedecido ciertas letras de Roma en los pleitos del barrio. Dada y leída en la yglesia de San Martín, a 29 de junio de 1426.

6. $<$ Concordia hecha en presencia de don Juan, rey de Navarra, entre este convento y don Gómez de Venavides. Año 1427>.

Concordia hecha en la ciudad de Toro, a 21 de febrero del año de 1427, en presencia de Diego Gómez de Medina, escribano y notario público, por compromiso que hicieron don Pedro, prior de San Zoil (cappellán del rey de Navarra), don Gómez de Venavides y doña María Manrrique, su muger, señores de Frómesta, en manos de don Juan, rey de Navarra, ynfante de Aragón, etcétera, teniendo por asesores al licenciado Pedro Martínez de Astudillo y Juan García de Villasur, con cuyo acuerdo asentó el dicho rey de Navarra entre la dichas partes los capítulos de concordia siguientes:

$1^{\circ}$. Que sean amigos y se hagan buenas obras.

$2^{\circ}$. Que el convento quede libre de la condenación de las sentencias de Roma, y don Gómez y doña María de la condenación de las sentencias de Valladolid y su carta executoria.

$3^{\circ}$. Que don Gómez, doña María y sus herederos sean obligados a dar al convento cada año para siempre jamás 50 mil maravedís, mitad a San Juan y mitad a Navidad.

$4^{\circ}$. Que los cinco primeros años no pagasen más de 40 mill maravedís cada uno y de allí adelante para siempre los 50 mill.

$5^{\circ}$. Que don Gómez y doña María den cartas de pago al convento de quanto les debieren así de costas como de principal y que las dichas cartas sean dadas el día que el dicho convento traspasare el señorío del dicho barrio en los dichos don Gómez y doña María.

$6^{\circ}$.Que para la paga de los 50 mill maravedís se otorguen escrituras a contento del convento, con parecer de letrados, y para la paga se obligue toda la villa de Frómesta y el barrio, y quando se nombre(s) alcaldes y oficiales cada año hagan juramento de pagar al convento los dichos maravedís, so pena de perjuros e infames y que puedan ser excomulgados por el conservador del monasterio y que no sean absueltos hasta que paguen a sus plazos.

$7^{\circ}$. Que don Gómez y doña María, para pagar los dichos maravedís, obliguen la villa de Frómesta y barrio con los derechos que en ella tuvieren y con todos los demás bienes, muebles y raízes. Y si por casos fortuitos el lugar o barrio se perdiese o despoblase, que todavía estén obligados a la paga.

$<$ Mil florines de oro del cuño de Aragón>.

$8^{\circ}$. Que si la moneda blanca que entonces corría se mudase, la villa y barrio, con los diezmos y demás derechos, quede acensuado para pagar al convento mil

352 haber] sigue tachado: le. 
florines de oro del cuño de Aragón de peso, o por ellos 25 mill maravedís de la moneda vieja, qual más quisiere el convento.

$9^{\circ}$. Que se ponga censo y tributo perpetuo de la moneda en la forma dicha para siempre jamás con toda firmeza y libre de todo tributo real y concejil, o en qualquiera manera, salvo si el tributo le hechare el papa, que, en tal caso, le había de pagar el convento.

$10^{\circ}$. Que en diez (en diez) años los dichos señores y sus subcesores, siendo requeridos por el convento, estén obligados a confesar por ante escribano público qué tiene el barrio acensuado para el convento.

/ (f. 238r $11^{\circ}$. Que el convento, a su costa, saque licencia del papa o del abad de Cluni para otorgar este censo y contrato.

$12^{\circ}$. Que los dichos don Gómez y doña María tengan todos los derechos temporales y todas las décimas de pan y vino y menudos que al convento pertenecen del varrio de San Martín y de sus vecinos de él, assí de derechos como de diezmos, con el yantar, martiniega, alcaldía y demás oficios, penas y derechos, llaves de las puertas, fueros de los suelos, con todas las demás cosas pertenecientes al señorío del barrio y que tengan el señorío de él y de todos sus vecinos y toda la jurisdición civil y criminal, mero mixto imperio, y que tengan por suyo el molino del abad en el término de Frómesta y del barrio, con todo lo demás que el convento tenía en la villa y barrio de San Martín, salvo el monasterio e yglesia de San Martín, que esto quedó para el convento con sus corrales y huertas, y que tengan todas las ofrendas, derechos de entierros, oblaciones de vivos y muertos, con las colaciones y presentaciones de oficios y beneficios de capellanías y sacristanía, y esto mismo de la casa de San Lázaro cerca de Frómesta, afueras de los dichos diezmos y de lo sobredicho, que sea de los dichos don Gómez y doña María y de sus sucesores.

$<$ Presentación y colación de beneficios para el monasterio $>$.

$13^{\circ}$. Que las heredades, así de tierras como de casas y suelos, despoblados y viñas, tierras, prados, heras, herrenes y huertas que hoi tiene el convento en Frómesta, en el barrio y en sus términos, sean suyas libres y aún las que hubiere de aquí adelante por donación o mandas, y si el dicho convento labrare por sí las dichas heredades o por sus quinteros, que no esté obligado a pagar diezmo alguno de todos los frutos que en ellas cogieren; pero que si las dieren a renta o a medias a otras personas paguen diezmo a los señores de Frómesta, salvo de lo que hubiere de haber de ellas el convento, que esto sea libre.

14. Que si el convento tuviere de allí adelante otras heredades fuera de las sobredichas que pague el diezmo de los frutos que en ellas cogiere a los dichos señores, exceptuando a aquellas heredades que les fueren mandadas o dadas por el amor de Dios o por carga de conciencia sin precio alguno; y que de los frutos de las tales heredades se pague el diezmo en la forma y manera que va declarado.

15. Que el convento pueda tener en la yglesia y monasterio de San Martín y en su suto (sic) dos quinteros para que labren sus heredades, los quales no paguen tributo alguno a los señores de Frómesta por las dichas heredades; pero si otras heredades labraren o compraren de otras qualquier personas, que paguen sus tributos y diezmos como los demás vecinos del barrio. Que estos quinteros no se nombren de los vecinos del barrio.

16. Que tomen don Gómez y doña María el señorío del barrio de manos del prior y convento.

17. Que don Gómez y doña María juren de pagar y cumplir todo lo sobredicho so pena de perjuros y que puedan ser excomulgados por el conservador del monasterio, por el obispo de Palencia, y que no sean absueltos hasta que lo guarden y hagan guardar todo. Que sus subcesores hagan el mismo juramento y, que si no le quisieren hacer, se buelva al monasterio el señorío del barrio con todo lo sobredicho. 
18. Que si los dichos señores no pagaren los dichos maravedís a los dichos plazos dentro del dicho monasterio, paguen por cada día que tardaron en la / $(f$. $238 v$ ) paga 500 maravedís de la moneda corriente por vía de interese convencional.

19. Que, si no obstante las dichas penas, pasaren tres plazos de tres pagas sin pagar los dichos maravedís, quede a la elección del convento o llebar las dichas penas con el censo principal o bolver a su poder el dicho barrio con todo lo demás de él, además que los señores de Frómesta paguen 1 mill doblas para el convento.

20. Que el monasterio les dé traslados authorizados de todas las escrituras y privilegios del barrio y quede obligado a mostrar los originales quando fuere necesario.

21. Que si los señores de Frómesta cometiren algún delito de heregía, como lesae majestatis u otro, por donde pierdan el lugar y barrio de manera que no puedan pagar el dicho censo, el convento pueda recobrar el dicho barrio con todo lo sobredicho o cobrar el dicho censo de aquel o de aquellos en quien la dicha villa y barrio fueren traspasados.

22. Que cuando el dicho barrio se entregare a los dichos señores, que se amojone para que se sepa en quanto se carga el censo.

23. Que don Gómez y doña María sean obligados a sacar licencia y confirmación de el rey para hacer lo sobredicho.

24. Que los dos quinteros del convento sean exentos de todo tributo real como de el tributo al señor por las heredades que labraren de el convento; pero si tuvieren bienes raízes propios, que paguen por ellos como los demás vecinos y que los tales quinteros no sean vecinos del barrio. María.

25. Que el convento traspase todos sus derechos en don Gómez y doña

26. Que el prior y convento pueda pone su vino y pan que cogiere de sus heredades en el barrio y en la villa quando quisiere, sin pagar tributo alguno, sino el alcabala de el rey o tributo papal, y que no(s) los estorben los vecinos de Frómesta labrar sus heredades.

27. Que los dichos señores no puedan vender ni enagenar el dicho barrio sin hacerlo saber primero al convento, y que si lo quisiere ${ }^{353}$ por el tanto se le trespase.

28. Que de todo lo dicho, sin mudar la substancia, se hagan contratos por ambas partes, con consejo de letrados, con toda firmeza y que a todo se obligue la villa y barrio concejilmente con licencia de sus señores. Todo lo qual pronunció el rey don Juan de Navarra a modo de sentencia y mandó que de todos se otorgasen escrituras para que se guardasen por ambas partes.

$<$ Parecer antiguo contra esta concordia $>$.

Hay aquí un parecer antiguo contra esta concordia en que prueba haber sido perjudicial al monasterio y que no se pudo hacer ni tuvo fuerza por falta de mucha[s] solemnidades y, en particular, por ser enagenación de diezmos y de bienes eclesiásticos en persona secular sin licencia y confirmación del papa o del abad de Cluni, que era el prelado inmediato a quien estaba subjeto el convento de San Zoyl. Y así, esta concordia ni se guardó ni tuvo el efecto que de ella se promete.

7. < Poder de don Gómez de Venavides para obligarse a pagar los 1 mill florines por la transación del barrio de San Martín. Año 1430>.

Trasumto authorizado en Roma, escrito en pergamino, del poder que dieron don Gómez de Venavides y su muger, doña María, señores de Frómesta, a don Álvaro / (f. 239r) Monroy, deán de Plasencia, a Frustos Montes, arcediano de Segovia, a Pedro González de Roa y a Juan Monte, notario del rey, a los quales y a cada uno, in solidum, dan poder cumplido

353 quisiere] sigue tachada: $\mathrm{n}$. 
para que en su nombre y de sus herederos, con licencia y confirmación del papa, puedan admitir y acetar del prior y convento de San Zoil y de quien su poder hubiere el barrio de San Martín, que es del dicho convento, con todas sus pertenencias, derechos de nombrar oficios, martiniega, yantar, diezmos mayores y menores, el molino del abad, las llaves de Grajal y Carremonzón, la jurisdición alta y baja, civil y criminal, mero mixto imperio, con todos los derechos, penas y demás cosas pertenecientes al dicho barrio como lo tenían y poseýan el prior y convento de San Zoil. Y assimismo les dan poder para que les puedan obligar, a ellos y a sus sucesores, con todos sus bienes muebles y raíces, en especial con la villa de Frómesta, a dar y pagar al prior y convento de San Zoil en cada un año para siempre jamás hasta el fin del mundo, por la transación del barrio, 50 mill maravedís de la moneda que entonces corría en Castilla o, si dicha moneda se mudare, 1 mill florines de oro del cuño de Aragón de justo peso y valor, o 25 mill maravedís de la moneda antigua de los reynos de Castilla y León, como el convento escogiere, puestos en el monasterio en dos pagas, mitad por San Juan y mitad por Navidad de cada año, so pena de 10 mill florines del mismo oro, mitad de ellos para la Cámara Apostólica y la otra mitad para el convento. Lo qual puedan admitir por sentencia de juez competente y obligarlos al cumplimiento de todo ello, so pena de excomunión y entredicho eclesiástico en la villa de Frómesta, en que ipso facto incurran. A todo lo qual se obligan ellos, por sí y en nombre de sus sucesores, con otras muchas condiciones y cláusulas muy favorables al convento. Otorgose este poder en Frómesta, a 5 de octubre de 1430, ante Diego Gómez de Astudillo, escribano público y real. Sacose este trasumto por authoridad y mandato de Luys de García, canónigo de Bolonia, en Roma, a 19 de noviembre de 1431, ante Ángelo Pérez, notario apostólico de la Cámara Apostólica, y de Ventura Pauluty, notario ymperial de la misma curia y cámara.

8. < Sentencia y concordia de los 1 mill florines, dada por el cardenal de San Pedro ad Vincula. Año 1431>.

Sentencia original, escrita en pergamino, con sello grande de cera pendiente en filos de seda colorada, dada por Juan, presbítero cardenal de San Pedro ad Víncula, por la qual consta que, a instancia de don Juan el $2^{\circ}$ y de sus grandes y señores de su Corte y assimismo del prior, monges y convento de San Zoil y de Gómez de Venavides y doña María Manrrique, su muger, la santidad del papa Martino $5^{\circ}$ cometió la averiguación del pleito que había entre el convento y los dichos señores en razón del barrio de San Martín con su jurisdicción, derechos y diezmos y el molino que llaman del Abad, para que, informado de todo, hiciese relación de ello a Su Santidad en público consistorio, en presencia del colegio de los cardenales para, según ella, proveer en esta causa del remedio conveniente. Y procediendo el dicho cardenal a execución de su comisión, parecieron ante él don Pedro Pérez de Velforado, prior mayor de San Zoil / (f. 239v) que había ido a Roma a este pleito en nombre del convento, y Pedro González de Roa, procurador de dichos señores, con sus poderes correspondientes. Habiendo información de la utilidad de las partes, llebó Dios al papa Martino $5^{\circ}$, y en su lugar fue electo Eugenio $4^{\circ}$, a 3 de mayo de 1431, el qual, viva vocis oráculo, dio comisión al mismo cardenal para que hiciese relación de la causa y estado de ella. Y los dichos don Pedro Pérez de Velforado y Pedro González de Roa, procuradores de ambas partes, para que el cardenal los admitiese concordaron entre sí que el barrio con su jurisdicción y lo demás a él perteneciente lo diese el prior y convento a censo perpetuo enfiteusi a dichos señores de Frómesta y a sus herederos i subcesores y se les hiciese escritura de transación, que ambas partes se perdonasen mutuamente todas y qualquier penas, gastos y costas que hubiesen hecho en qualquier tribunal, que fuesen amigos prometiendo guardar paz perpetua entre sí. De todo lo qual el dicho cardenal hizo relación al papa Eugenio $4^{\circ}$ en presencia de los cardenales. El papa volvió a cometer la causa al mismo cardenal y le mandó que recibiese información de la utilidad que a las partes se seguía de hacer transación, concordia y enfiteusi de las dichas cosas.

$<$ Que paguen 1 mill florines de oro del cuño de Aragón>.

Poco después parecieron ante el señor cardenal el dicho prior don Pedro y Frutos Monte, arcediano de Segovia, procurador de dichos señores, los quales, con licencia del cardenal, otorgaron que el prior don Pedro, en nombre del convento, hizo cesión y transación en dichos señores y sus herederos del barrio de San Martín con su jurisdicción alta y baja, mero mixto imperio, civil y criminal, con todos los diezmos y cosas que son de diezmar 
dentro de los términos del barrio, con los yantares, acaydías, notaría, pregonería, sayonería, oficios de merindad, martiniega, fonsadera, portazgo, con sus haberes, con las llaves de las puertas de Gragal y Carremonzón, con todas las demás pertenencias y con todo señorío y acción directa y mixta, como el convento lo tiene y le pertenece, por precio cada año de 1 mill florines de oro del cuño de Aragón, de bueno y justo precio, perpetuamente para siempre jamás, los quales paguen al monasterio, los 500 por San Juan de junio y los otros 500 por Navidad, los quales se paguen por los dichos señores, so pena de 10 mill florines de la misma calidad, la mitad para la Cámara Apostólica y la otra mitad para el convento, y que los hayan de pagar tantas quantas veces dexaren de hacer las dichas pagas; y que los dichos señores y sucesores hayan de pasar en la tasación por el dicho y juramento del prior del convento, sin que sea necesaria otra provanza; y devajo de las censuras eclesiásticas de excomunión y so pena de entredicho, al qual se someta la villa de Frómesta ipso facto, en que incurran dichos señores tantas quantas veces no pagaren al monasterio dicho censo, penas y costas, de las quales censuras no puedan ser absueltos si no fuere pagando y satisfaciendo todo lo sobredicho.

$<$ Bienes que no entraron en el cenco y quedaron libres para el monasterio $>$.

Pero con condición que no entren en esta censión, sino que queden libres y que goze el convento / (f. 240r) los demás bienes que tenía espirituales y temporales, como son la yglesia de San Martín y la yglesia de San Lázaro Extramuros de Frómesta, con sus cortes, casas, huertos, dos suelos, uno edificado y otro por edificar, con sus pertenencias y todas las tierras, viñas y heredades del campo labrado y no labrado, lo qual poseía y gozaba el monasterio dentro de los términos de Frómesta y de el barrio. En lo qual consintió el dicho procurador Fructos Monte. Y asimismo que goze el monasterio todas las posesiones y heredades que le fueren mandadas por testamento o donadas en qualquiera manera, las quales pueda el monasterio labrar, y para ello tener dos labradores extraños y no vecinos del barrio, y que esto no se les pueda prohibir ni estorbar, los quales labradores o fámulos puedan habitar libremente con sus familias en las casas de la yglesia de San Martín y que éstos sean libres de todo tributo, diezmo, censo, gavela e imposición de los señores de Frómesta y que no puedan ser oprimidos ni obligados a pagarlo.

Yten que los monges y convento puedan entrar libremente en todos tiempos, de día y de noche, en el dicho barrio y sin contradicción alguna estar y vivir en él, vender y comprar los frutos de sus heredades, encerrarlos y guardarlos en el lugar, aunque sean comprados de otros vecinos del lugar de Frómesta, sin pagar por ello tributo, imposición alguna a dichos señores salvo el derecho real, que se llama comúnmente alcabala del rey, o el tributo que los sumos pontífices pusieren por razón de las heredades sobredichas.

Yten que si el monasterio tuviere o adquiriere más heredades de las que pudieren labrar los dos sobredichos labradores las puedan arrendar o dar a vita o a censo infiteusi a los vecinos del barrio; pero que las dichas heredades no se puedan dar a renta ni a censo (a los señores de Frómesta) por los vasallos del barrio ni por otra interpósita persona, ni el convento las pueda arrendar ni a dar a censo a los dichos señores, ni ellos las puedan admitir en ninguna manera, so pena de excomunión ipso facto incurrenda. Y que si los dichos labradores o fámulos tuvieren o labraren otras heredades suyas propias o de otros vecinos de Frómesta que no sean del monasterio, paguen de ellas el diezmo y tributo que los demás vecinos tienen obligación de pagar.

Las quales donaciones, transaciones y concesiones, con sus pactos y condiciones, pidieron al dicho cardenal de San Pedro que las admitiese y diese para ellas su licencia por la authoridad apostólica a él concedida, según que las admitió por el tenor de las presentes letras. Pero dice que ordena, quiere y determina que los dichos señores reciban el dicho / $f$. 240v) barrio con todo lo demás de que el monasterio le hace cesión a censo infiteusi, reconociendo el contrato de 10 en 10 años, yendo para ello el monasterio, por sí o por sus procuradores, y que reconozcan tener el barrio señorío, etcétera, en nombre del monasterio, aunque lo posean por sí o por otro, y hagan y reciban de nuevo esta escritura de contrato inphitéutico con todo lo que arriba está declarado y abajo irá expresado según la forma y tenor de estas presentes letras. 
Y que antes que los dichos señores tomen posesión del barrio, llamen al concejo y pueblo de la villa de Frómesta y del barrio de San Martín y, estando juntos, unos y otros reconozcan estas escrituras y se obliguen con los mismos señores a cumplirlas y pasar por las penas y censuras de ellas, y prometan pagarlas quantas veces fueren cometidas, y que cumplan esto todas las veces que los señores reconocieren las escrituras de emfiteusi.

Assimismo quiere y manda el dicho cardenal, y de consentimiento de los procuradores, que los oficiales de la villa y barrio que se han de poner por los dichos señores hagan juramento, en manos del prior y convento o en las de su procurador, de guardar todas las cosas dichas y que abajo se dirán y pagar las dichas penas quando quiera que él faltare en ello. Y si los dichos oficiales faltaren a este cumplimiento después de haber prestado al juramento, fuera de incurrir en las penas de infamia, los declara suspensos de oficio y exercicio, y declara en tal caso los dichos señores y sus subcesores haber incurrido en la pena concordada de los 10 mill florines en que incurran quantas veces dexaran de hacer la paga.

Después de lo qual, el dicho Fructus Monte, en nombre de sus partes, prometió y se obligó a cumplir todo lo sobredicho y para su cumplimiento hipotecó todos los bienes de los dichos señores, en especial la villa de Frómesta con todo los perteneciente a ella, y se obligó a que, si por dos años continuos se dejase de pagar el censo, emphiteusi, caiga en in comisso el dicho barrio y que en tal caso los señores se aparten del señorío en propiedad, derecho y posesión de la villa de Frómesta y de el barrio de San Martín con las demás cosas sobredichas que le pertenecen, y todo ello se apropie y adjudique al monasterio sin necesitar del consentimiento de los dichos señores ni de otra persona alguna, sin que por ello el convento incurra en algún daño o pena y, que si los señores de Frómesta se lo impidieren de qualquiera manera, incurran en la pena de 10 mill florines y en las censuras sobredichas.

$<$ Se somete al obispo de Palencia y a los conservadores del convento para el cumplimiento de este contrato $>$.

Y el dicho Fructos Monte sometió a sus partes y toda su hacienda con los bienes del imphiteusi a jurisdicción del obispo de Palencia y su vicario general y al juez conservador del convento como es al abad de Sahagún y de Oña, a los quales obispo y conservadores se da poder y authoridad, licencia y jurisdicción plenísima para conocer y proceder en todo lo sobredicho sin estrépito de juicio, atendiendo solamente a la verdad del hecho, sumariamente quitadas y pospuestas las solemnidades del derecho y con invoc[ac]ión del brazo seglar, siendo necesario.

Los procuradores renunciaron todas exenciones, dolo, fuerza, ley y todo / (f. 241r) quanto les pueda favorecer contra lo aquí ordenado y determinado. Y juraron voluntariamente en manos del cardenal, tocadas las Sagradas Escrituras (para quitar escrúpulos), que en nada de lo sobredicho había intervenido, fraude, ni mal trato, sino que la escritura de cesión y imphiteusi era en evidente utilidad de las partes, y que guardarán y cumplirán todo lo sobredicho y que obedecerán todos y qualesquier mandamientos de la Santa Yglesia de Roma.

$<$ Que se divida la villa del barrio por ciertos límites $>$.

Que dividirán el barrio de la dicha villa de Frómesta por ciertos límites, poniendo mojones entre uno y otro, de suerte que perpetuamente conste la división, que de año en año se renueben bajo las dichas penas y trasgresión del juramento hecho.

$<$ Que se confirme el contrato por el rey dentro de 3 años $>$.

Con lo qual, y bajo de las condiciones dichas y las de abajo,el dicho cardenal admitió el dicho contrato y dio licencia para él por autoridad apostólica. Y manda a los dichos Gómez de Venavides y doña María Manrrique y sus subcesores, bajo las dichas penas ipso facto incurrendas lo contrario haciendo, que dentro de ocho días después de haber tomado la posesión del dicho barrio con todo lo demás a él perteneciente, juren en manos del prior y convento o de su procurador que guardarán y cumplirán todas las cosas aquí contenidas; y, asimismo debajo de las mismas penas, les manda que hagan que el rey aprueve y confirme estos contratos, lo qual hagan dentro de 3 años primeros siguientes y, en otra manera, los declara por insursos en las sobredichas penas. 
Determina que el convento sea obligado, todas las vezes que para ello fuere requerido por parte de los señores de Frómesta, a darles los privilegios y escrituras tocante[s] a la hacienda del barrio que entra en este contrato quando las hubiere menester para su defensa.

$\mathrm{Y}$ asimismo determina que, por razón de este censo imphiteusi, el convento no sea obligado a pagar censo, gavela, imposición y tributo a rey, señor, obispo o comunidad ni al señor del lugar, ni puedan ser apremiados a pagarlo, antes declara tener y deber gozar quanto a esto de entera y perfecta libertad, salvo si la sede apostólica impusiere algo por razón del barrio.

$<$ Que no se enagene el barrio sin licencia del convento $>$.

Prohive a los señores de Frómesta poder vender o enagenar el barrio o cosa de lo perteneciente a él sin voluntad y consentimiento del convento.

Determina, por autoridad apostólica y consentimiento de los procuradores, que los señores de Frómesta y sus herederos estén obligados a pagar al convento los 1 mill florines cada año en dos pagas en la forma dicha, de que no puedan ser libres por algunos casos fortuitos que en qualquiera manera vengan y caigan sobre el dicho barrio y sus cosas. Declara asimismo que el dicho barrio no pueda ser confiscado ni pasar a otro poder por delitos cometidos por los señores o sus herederos y, que si tal vez succediese haber de pasar a otro poder, sea con voluntad y consentimiento del convento, y que siempre vaya con el barrio y sus cosas el dicho censo con sus cláusulas, penas y gravámenes y que de otra manera no se enagene.

Cerca de lo qual, supuesta la dicha trasación y censo y en su cumplimiento, el dicho cardenal de San Pedro por / (f. 241v) (por) autoridad apostólica, da licencia a los dichos señores de Frómesta y sus herederos para que puedan tener, poseer y gozar de la jurisdicción, señorío, barrio y demás cosas contenidas en el contrato imphitéutico por virtud de las presentes letras.

En fe de lo qual mandó darlas, refrendadas de su secretario y selladas con su sello pendiente, junto a Santa María Transtiberim de Roma, en las casas de su morada, a 22 días de noviembre de 1431, en el primer año del pontificado del señor Eugenio $4^{\circ}$, ante Rodrigo González de Mazuelos, clérigo del obispado de Burgos y notario apostólico.

Hay aquí dos copias simples de esta sentencia, la una escrita en pergamino y la otra en papel, y asimismo un requirimiento simp[le he]cho a dichos señores sobre el cumplimiento desta sentencia.

9. $<$ Bula original de Eugenio $4^{\circ}$ que confirma el contrato del barrio por 1 mill florines annuales. Año 1431>.

Bulla original del papa Eugenio $4^{\circ}$, escrita en pergamino, con sello de plomo pendiente en filos de seda colorada y amarilla, que es confirmación de la sentencia del cardenal de San Pedro ad vincula puesta en el número antecedente. Por esta bulla consta que el prior y convento de San Zoil y los dichos don Gómez de Venavides y doña María Manrique suplicaron a Su Santidad que se dignase con especial gracia conceder fuerza y firmeza, por su confirmación apostólica, a la dicha concesión, donación, transación, penas, pactos, condiciones, modos, formas, mandamientos, estatutos y decretos del mismo cardenal y a todas las demás órdenes y cosas contenidas en el mismo instrumento y a cada cosa de ellas. Lo qual, teniendo todo Su Santidad por bueno y grato, lo confirmó con authoridad apostólica de cierta sciencia, y las da valor y fuerza con el patrocinio de estas letras, supliendo con la misma authoridad apostólica todos los defectos, si algunos hubieren intervenido en este en este contrato. Luego inserta de verbo ad verbum el instrumento y sentencia del cardenal San Pedro. Fue dada esta bulla en Roma, apud Sanctum Petrum, a $1^{\circ}$ de octubre año de 1431, en el año primero de su pontificado.

Bajo este mismo número hay $<$ tres $>{ }^{354}$ copias autoriçidadas $(s i c)$ y una simple. La $1^{\text {a }}$ escrita en pergamino con sello de cera pendiente y sacada a instancia de fray Zoyl de Nogal, monge de San Zoyl, de esta bula de Eugenio $4^{\circ}$. Sacose con autoridad y mandato del doctor

$354<$ tres $>$ ] infrascrito y tachado: quatro. 
Juan del prior, canónigo de Santa María la Mayor, auditor general de la curia de la Cámara Apostólica, en Roma, a 16 de julio de 1485, por ante Pedro Landino, clérigo Vultuariens[e], notario de la curia apostólica. Las otras dos están escritas en papel y sacadas en este monasterio, a 30 de mayo de 1707, por Antonio Fernández de Guzmán, vecino de Frómesta y notario latino apostólico. Vna de ellas está en latín y la otra en castellano.

\section{0. <Requirimiento de los señores de Frómesta al prior de San Boal. Año 1431>.}

Requirimiento que hizo un escudero de don Gómez de Venavides y doña María Manrrique (como protectores que dicen ser del monasterio de San Zoyl) al prior de San Boal, vicario y receptor del abad de Cluni, para que cesase de ciertas diligencias que hacía contra el prior de San Zoyl, para que pagase los florines que tenía obligación a Cluni por la defensa que aquella casa hacía en Roma a todos los monasterios que le estaban sugetos. El prior de San Bual (sic) responde que se ponga en juicio de dos letrados y que se esté a lo que ellos / (f. 242r) determinaren. Hecho en Carrión, a 9 de junio de 1431, ante Gutierre García de San Zoles, escribano de dicha villa.

\section{1. $<$ Cartas de pago. Año de 1474>}

Cartas de pago que daba el convento y sus mayordomos a los señores de Frómesta de lo que recibían del censo del barrio de San Martín, con protesta de ser a qüenta de paga y no por paga entera, desde el año de 1452 hasta el de 1474.

12. $<$ Requirimiento para que jurasen los oficiales de Frómesta guardar las bullas, etcétera. Año 1462>.

Requirimiento hecho por Alfonso García de Villasur, monge de San Zoyl, a Gómez de Venavides, señor de Frómesta, estando presentes los alcaldes, regidores y oficiales de ella, para que el dicho don Gómez hiciese jurar a los dichos oficiales que guardarían los privilegios, bullas y concordias del monasterio tocantes al barrio, el qual mandó que lo jurasen y juraron en forma de guardarlo y hacerlo guardar. Hecho en Frómesta, a 4 de noviembre de 1462, en el monasterio de Santa María de Misericordia, ante Alonso García de Dueñas, escribano y notario de el rey.

\section{/ (f. 242v) Legajo $4^{\circ}$ del Cajón San Román}

Este legajo $4^{\circ}$ contiene los papeles pertenecientes a los pleytos que ha tenido este monasterio con los señores de Frómesta desde el año de 1483 hasta el de 1563 inclusive, por el orden siguiente:

$1^{\circ}$. $<$ Requirimiento y paga de 25 mill maravedís del mariscal, y protesta de don Luys Hurtado. Año 1483>.

Requirimiento hecho de parte del mariscal don Gómez de Venavides, señor de Frómesta, a don Luys Hurtado de Mendoza, administrador perpetuo de la abadía de San Zoil, para que reciva 25 mill maravedís de la paga de Navidad del año de 1483 por el censo del barrio de San Martín y que dé carta de pago y finiquito. Don Luys recive el dinero y da carta de pago; y después requiere que, de aquella misma paga, se le paguen 500 florines de oro de Aragón que se le deben por el mismo barrio, so pena de incurrir en las censuras de la bula apostólica y de la sentencia dada en esta razón, y protesta cobrarlos con daños y costas. Su fecha, en San Zoil, a 24 de diciembre de 1483, ante Rodrigo de Santolalla, escribano de Carrión.

2. $<$ Provisión real para hacer información en el pleyto de los 1 mill florines contra el mariscal. Año 1484>.

Provisión real de los Reyes Cathólicos para hacer información en el pleyto y demanda que puso don Luys Hurtado de Mendoza, administrador de la abadía de San Zoil, al mariscal Gómez de Venavides porque no pagaba el censo de los 1 mill florines confirmado por authoridad apostólica, el qual censo tampoco había pagado su tío don Gómez, habiendo pasado treinta años sin que unos ni otros pagasen al monasterio lo que debían del barrio de San Martín. Don Luys Hurtado pidió 30 mill florines de las pagas que habían dexado de 
hacer y otros tantos por las penas en que habían incurrido conforme a la institución del censo y la bula de confirmación y, assimismo, haber incurrido el barrio en in comisso y pertenecer al monasterio. Dada en Valladolid, a 20 de julio de 1484, ante Pedro Sedano, escribano de Cámara.

3. < Requirimiento para que los testigos vayan a Valladolid. Año 1484>.

Requirimiento hecho con la provisión real de parte de don Luys Hurtado de Mendoza a la justicia de Carrión, para que compeliese a los testigos por él nombrados a que fuesen a Valladolid a decir sus dichos en la información del pleyto con el mariscal; y notificación a los testigos para que lo cumplan. Su fecha, en Carrión, a 29 de julio de 1484, ante Juan de Torralba, esscribano de dicha villa.

\section{4. $<$ Ynterogatorio de tachas $>$.}

Ynterrogatorio y provanza de tachas que puso don Luys Hurtado de Mendoza a los testigos de la información que había hecho el mariscal don Gómez de Benavides, y alegato de don Luis Hurtado contra el dicho mariscal en el pleyto del barrio de San Martín, por los años de 1484. Está sin authoridad.

\section{5. <Memorial del pleyto del barrio de San Martín. Año 1484>.}

Bajo este número están los memoriales que se han hecho en los pleytos que el monasterio ha tenido con los señores de Frómesta don Gómez de Venavides el Viejo, con el mariscal Gómez de Venavides, su nieto, y con don Gerónimo de Venavides, en el pleyto nuevo de la demanda que el monasterio le puso por 150 mill maravedís de censo perpetuo cada año por la jurisdicción, señorío ${ }^{355}$, etcétera, del barrio de San Martín y de seis qüentos, 800 mill maravedís de las pagas devengadas de dicho censo. Su fecha, a 14 de marzo de 1484. Son copias simples.

\section{/ (f. 243r) 6. < Compromiso del Cardenal de España y el conde de Castro. Año 1488>.}

Escritura de compromiso otorgada por don Luis Hurtado, administrador de abadía (sic) de San Zoyl, por sí y en nombre del convento, y el mariscal don Gómez de Venavides, por sí y en nombre de sus subcesores, por la qual parece que, estando entre ellos pleyto pendiente ante el presidente y oidores de la Chancillería de Valladolid, en razón del censo de los 1 mill florines de oro por el barro de San Martín, y habiendo muchos años que no se pagaban el monasterio puso demanda por ellos, y por otro tanto de las penas puestas en el mismo censo y en la bula de confirmación. Y, habiendo ambas partes gastado mucho y recibido otros daños, de común consentimiento, comprometieron la determinación de esta causa en don Pedro González de Mendoza, cardenal de España, arzobispo de Toledo, y en don Álbaro de Mendoza, conde de Castro, hermano de don Luis Hurtado, y les dieron authoridad y poder para que ambos juntos la sentenciasen; $y$ se obligaron con toda firmeza a pasar por la sentencia que ellos diesen. Púsose de pena en este compromiso 20 mill doblas a la parte que no cumpliese esta sentencia arbitraria, que había de pagar a la parte obediente. Su fecha, en Valladolid, a 3 de noviembre de 1488, ante Pedro de Sedano, escribano y notario de Cámara, estando presentes y aceptando el compromiso los dichos Cardenal de España y conde de Castro. Hay aquí dos copias simples de esta escritura. Año 1488>.

7. $<$ Escritura de juramento de guardar el compromiso y la sentencia que se diere.

Escritura de juramento que otorgaron como caballeros don Luis Hurtado y don Gómez de Benavides en manos del conde de Castro de que cumplirán y guardarán el compromiso de arriba y todo lo en él contenido, y la sentencia que en virtud dél diesen el Cardenal de España y el conde de Castro para siempre jamás por sí en nombre de sus subcesores, y que sobre ello y su cumplimiento no moverán más pleytos la una parte a otra ni se llamarán a engaño aunque la elesión (sic) fuese enorme o enormísima, ni pidirán restitución in integrum ni en otra manera. Su fecha, en Valladolid, a 3 de noviembre de 1488, ante Pedro de Sedano, escribano de Cámara y notario.

355 señorío] sigue tachado: $\mathrm{y}$. 
8. <Sentencia arbitraria del Cardenal de España y de el conde de Castro, en la que reducen los 1 mill florines a 150 mill maravedís. Año 1488>.

Sentencia arbitraria original que dieron, en virtud del compromiso y juramento de arriba, don Pedro González de Mendoza, arzobispo de Toledo y cardenal de España, y don Álbaro de Mendoza, conde de Castro, jueces árbitros nombrados por don Luis Hurtado de Mendoza, abad comendatario de este monasterio de San Zoyl, y Gómez de Venavides, mariscal de Frómesta, en el pleyto que esta casa litigaba contra el dicho mariscal sobre la paga de los mil florines de oro del cuño de Aragón del censo y fuero ${ }^{356}$ enfitéctico por el barrio de San Martín, sus diezmos, jurisdición, etcétera, que cada año dicho mariscal debía pagar conforme a la escritura de transación, sentencia del cardenal de San Pedro ad vincula y bula de confirmación de Eugenio $4^{\circ}$. Todo lo qual visto por los dichos jueces árbitros, fallaron que para ajustar estas diferencias debían reducir y tasar los mil florines de oro a que el dicho / (f. 243v) mariscal y sus subcesores pagasen cada año 150 mill maravedís en esta manera: los 50 mill $^{357}$ maravedís que los pagasen cada año el dicho mariscal y sus subcesores en la moneda corriente al tiempo de las pagas; y los 100 mill maravedís restantes por juro de heredad para siempre jamás situados en las jurisdiciones de Carrión y Saldaña o en qualquiera de ellas. Y que entre tanto que se libra el privilegio de este juro, el mariscal y sus subcesores paguen los dichos 100 mill maravedís en cada un año al convento, otorgando de uno y de otro dicho mariscal (dentro de seis días después que se firmase esta sentencia) obligación, asegurándola con la dicha villa de Frómesta y con los demás bienes suyos y los de sus herederos. Ytem mandaron que el dicho mariscal, dentro de seis meses, pagase al dicho don Luis Hurtado 1 mill florines de oro así por razón de los años que había dexado de pagar el censo, por los gastos que se habían hecho en el pleyto.

$<$ Que se guarde y cumpla la sentencia del cardenal de San Pedro ad vincula y la bula de Eugenio $4^{\circ}>$.

Asimismo mandaron se guarde y cumpla la sentencia del cardenal de San Pedro ad vincula y la bulla de confirmación de Eugenio $4^{\circ}$ con todas sus cláusulas, firmezas, vínculos, etcétera, como en ellas se contiene, con la tasación y redución de los 1 mill florines a los 150 mill maravedís hecha en esta sentencia. Y para que los oidores de la audiencia den sentencia de vista y revista, en confirmación de esta sentencia, dan por libre al mariscal de qualquier penas en que haya incurrido, pone[n] en perpetuo silencio a las partes y mandan que guarden y cumplan esta sentencia bajo las penas contenidas en dicho compromiso, etcétera. Fue dada esta sentencia por los dichos señores en la villa de Valladolid, a 26 de noviembre de 1488, en presencia de don Luis Hurtado y del mariscal, los quales dixeron que consentían y la aprobaban, ante Diego de Muros, canónigo de Santiago, notario apostólico y secretario del Cardenal, y ante Diego González de Guadalajara, notario y secretario del mismo señor.

Hay aquí tres copias de esta sentencia, la primera escrita en pergamino, sacada a 4 de agosto de 1501 y authorizada por Pedro Fernández de Carrión, notario público; la segunda, escrita en papel, fue sacada a 20 de septiembre de 1783 y autorizada por don Antonio Martín García, notario apostólico y traductor de lenguas antiguas; la tercera es una copia simple.

9. <Declaración de los 100 mill maravedís de juro y obligación de pagarlos mientras se sacare el dicho juro. Año 1488>.

Escritura otorgada entre don Luis Hurtado y don Gómez de Venavides en declaración de la condición de la sentencia árbitra dada por el cardenal de España y el conde de Castro, en que dicen que el mariscal sea obligado a dar, dentro de un año primero siguiente, 100 mill maravedís de juro puestos en las merindades de Carrión o Saldaña y que entregase los privilegios y despachos de ello a su costa.

/ (f. 244r) Por esta escritura se declara que por quanto podría ser que el dicho señor mariscal no pudiese dar los dichos privilegios del dicho juro dentro del dicho año y que, por no hacerlo así, podría incurrir en las penas contenidas en el dicho compromiso, ambas partes,

\footnotetext{
356 fuero] sigue tachado: $\mathrm{y}$.

35750 mill] sigue tachado: mil.
} 
de común consentimiento, asientan y otorgan que el dicho mariscal se obliga y obligó de dar los dicho[s] 100 mill maravedís de juro situados en las dichas merindades, aceptado y expedido a su costa el dicho privilegio dentro del dicho año como en la dicha sentencia se contiene. Y si caso fuere que no le pudiere dar el dicho juro situado dentro del dicho año, que en tal caso el dicho mariscal y sus herederos hayan de dar y den al dicho administrador, prior, monges y convento que ahora son o serán de aquí adelante (hasta tanto que den el dicho juro según la dicha sentencia se contiene) los dichos 100 mill maravedís en cada un año pagados en los términos contenidos en la dicha sentencia arbitraria, bajo las penas, condiciones, censuras y juramentos contenidos en el contrato y sentencia del cardenal de San Pedro in vincula y en la bula de confirmación de Eugenio $4^{\circ}$; a las quales penas se obliga de nuevo el mariscal a tener y guardar todo lo contenido en esta escritura. Que fue fecha en Valladolid, a 3 de diciembre de 1488, ante Pedro de Sedano, escribano y notario público de la Audiencia Real.

Hay aquí copia authorizada de esta escritura por don Antonio Martín, notario y traductor de letras antiguas.

10. < Requirimiento del mariscal para que guarde la sentencia árbitra. Año 1489>.

Requirimiento hecho por parte del monasterio al mariscal Gómez de Benavides para que guardase lo contenido en la sentencia árbitra del cardenal de Toledo y del conde de Castro y la respuesta del señor mariscal en que dice que, por evitar penas y hachaques, que está presto a cumplir lo contenido en la dicha sentencia arbitraria según y en la forma que en ella se contiene, y pide se le dé por testimonio. Su fecha, en Frómesta, a 6 de abril de 1489, ante Pedro García de Frómesta, escribano y notario público.

11. <Renovación de los hitos y mojones del barrio de San Martín. Año de 1489>.

Requirimiento hecho por parte del monasterio hecho a don Francisco de Venavides, hijo del mariscal Gómez de Venavides, para renobar y señalar los sitos (sic) y mojones del barrio de San Martín según el thenor y forma de la bula apostólica que en la dicha razón fue dada y concedida, porque ya había días que no se habían renovado. El dicho señor don Francisco, en nombre de su padre, cometió la causa a los alcaldes de Frómesta quienes, en presencia de los monges y de escribano, declararon y renobaron los límites y mojones por donde estaban antes señalados [d]el dicho barrio. Fue ${ }^{358}$ fecha en Frómesta, a 5 de mayo de 1489, ante Fernando Cavallo, escribano en Carrión.

12. $<$ Requirimiento de las escrituras y censos del Barrio. Año 1501>.

Reconocimiento que hizo Diego de Quintanilla, criado de don Fernando Venavides (con poder del mariscal Gómez de Venavides) de las escrituras / (f. 244v) que el monasterio tiene tocantes al censo del barrio de San Martín, especialmente la sentencia del cardenal de España y el conde de Castro y la bula de confirmación dada por Eugenio $4^{\circ}$. El qual reconocimiento se hizo en virtud de la condición puesta en los contratos, que de en 10 en 10 años se hiciese de las escrituras, y del censo que pagaban al monasterio los señores de Frómesta. Hecho en San Zoyl, a 4 de agosto de 1501, ante Gonzalo García, escribano, y ante Pedro Fernández, clérigo y notario apostólico. $1506>$.

13. <Proceso eclesiástico sobre la paga de los 150 mill maravedís de censo. Año

Bajo este número están dos procesos de varias escrituras presentadas en una causa eclesiástica ante el abad de Sahagún don fray Alonso de Grijota, juez conservador y executor de la bula de Eugenio $4^{\circ}$, ante el qual puso demanda don Juan Hurtado, administrador de la abadía de San Zoyl, a Gómez de Venavides (hijo del mariscal) y a doña Leonor de Velasco, su madre, por las pagas del censo de 150 mill maravedís cada año que tenían obligación de pagar; y ni él ni su padre había algunos años que no habían pagado. Por lo qual, el dicho abad de Sahagún nombró por juez subdelegado a don Pedro de Carrión, abad de Venevívere, para que conociese esta causa y mandase hacer pago a don Luis Hurtado e hiciese guardar la concordia y sentencia árbitra del cardenal de España y del conde de Castro, según que los

358 Fue] escrito sobre: Fe. 
señores de Frómesta tenían obligación de guardarla, bajo las penas y censuras allí contenidas. En virtud de esta subdelegación y de las escrituras que presentó don Luis, procedió el abad de Benevívere con censuras y declaración de las de la bula de Eugenio $4^{\circ}$ en que habían incurrido dichos señores de Frómesta, los quales declinaron jurisdicción y se quexaron al rey; y en el ínterin el abad de Benevívere fue agrabando las censuras y puso entredicho en Frómesta. El rey, con acuerdo de los de su Consejo, escribió al abad de Sahagún y al de Benevívere para que sobreseyesen el conocimiento de la causa y la remitiesen al Consejo. Los quales respondieron que debían ellos conocer por ser meros executores delas bulas apostólicas. De esto apelaron los señores de Frómesta a la Sede Apostólica y se presentaron ante el papa Julio $2^{\circ}$ por su procurador; Su Santidad dio su rescripto de comisión para Rodrigo de Herrera, canónigo de Palencia. Entre tanto, viendo que no se guardaba el entredicho que se había puesto en Frómesta, de que se quejó el concejo al abad de Sahagún, y que los señores de Frómesta no obedecían al abad de Benevívere, a quien habían inhibido los canónigos de Palencia, jueces comisarios, el abad de Sahagún avocó así la causa y dio comisión subdelegatoria / (f. 245r) a don Ýñigo del Castillo, canónigo y capiscol de la yglesia colegial de Santa María de Almazán, el qual apretó el entredicho; y, porque aún no le querían guardar, remitió los culpados entredichos al brazo seglar. Los canónigos de Palencia despachaban letras inhibitorias para y contra el abad de Sahagún y éste las despachaba contra ellos con tanto aprieto que finalmente, con acuerdo de muchos letrados, se declararon por no jueces de esta causa. Si embargo de todo esto, no consta que estos señores pagasen el dicho censo como debían, por lo qual el convento hubo de pedir execución al Consejo Real, como queda dicho atrás, que se denegó, y no hubo punto fixo hasta que se hizo la concordia de los 100 mill maravedís, de que se hablará en adelante. Todo esto succedió desde el año de 1501 hasta el de 1506. Véase la primera oja del primer proceso donde se halla el contenido de los principales papeles y el folio donde están.

14. $<$ Requirimiento a doña Leonor para que pague los 150 mill maravedís de censo. Año 1508>.

Requirimiento hecho por parte de el cardenal de Santa Cruz don Bernardino de Carvajal, abad comendatario de San Zoyl, a doña Leonor de Velasco, como tutora de don Gómez de Venavides, su hijo, y nieto del mariscal, para que paguen los 150 mill maravedís del censo del barrio de San Martín y cumpliese la sentencia del cardenal de España, etcétera. Su fecha, en Frómesta, a $1^{\circ}$ de febrero de 1508, ante Juan Luis, clérigo y notario apostólico.

15. <Sentencia árbitra dada por tres letrados de Valladolid en el pleyto con el mariscal. Año 1538>.

Trasumpto autorizado del compromiso que hizo el convento y el mariscal en tres letrados de Valladolid y sentencia que ellos dieron. Por este instrumento parece que, sin embargo de la sentencia árbitra dada por el cardenal de España y el conde de Castro, en que mandaban que el mariscal y sus subcesores diesen al convento 150 mill maravedís de censo en cada un año por los 1 mill florines que había determinado la concordia de Roma y sentencia del cardenal de San Pedro confirmada por el Papa Eugenio $4^{\circ}$, el mariscal no quería pagar al convento lo que ordenaba dicha sentencia árbitra y, a lo sumo, confesaba haber de pagar cada año 50 mill maravedís de censo. Por lo qual el convento se quexó en el Concejo (sic) Real y pidió juez executor; y, no habiéndosele concedido, se acordaron ambas partes conprometer esta causa en tres letrados de Valladolid, que fueron el licenciado Gonzalo González de Burgos y el doctor Juan Bueno, por jueces árbitros, y por tercero en discordia al doctor don Juan de Valencia, para que viesen y determinasen esta diferencia. En virtud de lo qual el abad y convento hicieron escritura de compromiso en los dichos tres letrados, insertos los tres / (f. 245v) tratados, comisión del general, ynformación de utilidad y licencia del prior de San Benito, para que, dentro de dos meses primeros, la determinasen quanto al principal del censo y los réditos caídos de lo que había dexado de pagar el mariscal; y se obligó el convento a guardar lo que los dichos jueces arbitrasen y mandasen, etcétera. Está inserto aquí el compromiso del mariscal don Gómez de Venavides en los mismos letrados, y en la misma forma que el de el convento inserto en él la facultad real que para ello obtuvo del emperador Carlos $5^{\circ}$ y de su Consejo. 


\section{$<$ Sentencia $>$.}

En virtud de los dichos compromisos que aceptaron, los referidos letrados habiendo visto los procesos ante ellos comprometidos sobre los 100 mill maravedís de renta que al monasterio le son debidos por la sentencia árbitra, el cardenal de España, además de 50 mill maravedís que el monasterio tiene de censo cada año sobre el barrio de San Martín y sobre las pagas devengadas y lo pagadas, dieron y pronunciaron todos tres sentencia árbitra por la qual fallaron que debían de condenar y condenaron al mariscal Gómez de Venavides que instituya, sitúe en favor del monasterio 10 mill maravedís de censo perpetuos sobre el barrio de San Martín, además de los $50^{359}$ mill maravedís de censo que el mariscal y sus antecesores han pagado y sus subcesores han de pagar perpetuamente al monasterio a los plazos que se pagan los dichos $50^{360}$ mill maravedís; y para la situación de ellos saque el mariscal facultad real dentro de un año primero siguiente y en el ínterin pague los 10 mill maravedís con que, si él o sus subcesores dentro de 10 años dieren y situaren al monasterio 12 mill maravedís de juro viejo 12 leguas alrededor de Carrión por los dichos 10 mill maravedís de censo o de censo perpetuo seguro a contento del convento cinco leguas alrededor de Carrión que, en tal caso, entregando al convento los privilegios del dicho juro, el mariscal y sus subcesores queden sin obligación de pagar los dichos 10 mill maravedís y sólo con la de pagar cada año al monasterio los 50 mill maravedís en la forma que los han pagado.

Asimismo condenan al mariscal a que dentro de cuatro meses pague al convento 100 mill maravedís en dinero por las pensiones decursas y no pagadas, con lo que dan por libre la mariscal de todas las demandas puestas por el monasterio, a quien ponen ${ }^{361}$ perpetuo claudio en esta causa. En esta sentencia no vino el doctor Juan Bueno aunque la firmó, por haber sido acuerdo entre los tres jueces que lo que los dos determinasen lo firmasen todos. Fue dada en Valladolid, a 5 de junio de 1538, ante Domingo de Santa María, escribano y notario público, el qual sacó este trasumpto en virtud de mandamiento dado, a instancia del convento, por el licenciado Francisco de Lerma, alcalde / (f. 246r) de Chancillería en Valladolid, a 22 de noviembre de 1541.

Está aquí una petición del monasterio por la que reclamó de la sentencia arbitraria dada por estos letrados y nueva demanda que puso en el pleyto nuevo a don Gerónimo de Venevides, marqués de Frómesta, por los 150 mill maravedís de censo en cada un año por el barrio de San Martín conforme a la sentencia del cardenal de España y el conde de Castro. Asimismo puso el monasterio demanda por 6 qüentos, 800 mill maravedís que le estaba debiendo el marqués de las pagas que habían pasado y no se las había pagado ni el mariscal ni él. Luego se sigue la respuesta y excepciones que puso el marqués a esta demanda y tras ella otra réplica del convento. Por último están dos interrogatorios, lo mismo uno que otro, que presentó el monasterio para probar el derecho de su justicia que tenía la nueva demanda.

\section{6. <Revocación del poder hecho por el monasterio. Año 1551>.}

Revocación que hizo el monasterio del poder que había dado al mariscal y a otra qualesquier persona para que impetrasen del papa confirmación de la sentencia árbitra que habían dado los tres letrados de Valladolid, por ser la tal sentencia en perjuicio del monasterio, el qual la quería contradecir sin pasar por ella. Su fecha, en San Zoyl, a 13 de noviembre de 1551, ante Juan de Castrillo, escribano de Carrión. Notificolo Juan de Cantoral, notario apostólico, a don Luis de Venavides, señor de Frómesta, a 15 días del mismo mes y año.

17. <Cartas de pago con protesta. Año 1560>.

Cartas de pago y recibo dadas por el monasterio de los 60 mill maravedís que pagaban los señores de Frómesta de censo por el Barrio, protesta de no perjudicar por ello el derecho que el monasterio tenía a maior ${ }^{362}$ cantidad y al dicho barrio. Sus fechas, por los años de 1560

\footnotetext{
359 50] sigue tachado: 0.

$36050]$ sigue tachado: 0.

361 ponen] sigue tachado: en.

362 maior] corregido sobre: más.
} 
y 1563, ante Andrés Sánchez y Diego de Gobeo, escribanos. Hay algunas cuentas de los gastos que se hacían por el monasterio en estos pleytos del Barrio.

18. <Compulsa de los valores de los diezmos de San Martín. Año 1563>.

Compulsa, a pedimiento del monasterio, con provisión real de la Chancillería, de algunos padrones, tazmías y memoriales sacados de libros y memoriales de los criados de los señores de Frómesta, de que consta lo que valieron algunos años los diezmos de San Martín, así de pan como de vino. Esta compulsa se hizo para presentarla en Valladolid en el pleyto con el marqués de Frómesta, que decían no valían los frutos del barrio los 100 mill maravedís de censo que él pagaba. Su fecha, en Frómesta, a 3 de noviembre de 1563, ante Juan Pérez de Santillana, escribano y receptor de la Chancillería.

19. <Relaxación del juramento. Año 1592>.

Brebe de Pedro Millino, nuncio de España, por el qual relaja el juramento que de parte el convento se había hecho en la escritura de compromiso y sentencia del cardenal de España, para que, sin embargo, pueda pedir su justicia, y desagrado de la segunda sentencia que dieron los letrados de Valladolid, y seguir el pleyto contra el marqués de Frómesta. Dado en Madrid, año 1592.

\section{/ (f. 246v) Legajo $5^{\circ}$ del Cajón San Román}

Este legajo $5^{\circ}$ contiene los papeles pertenecientes a los pleytos que ha tenido este monasterio con los señores de Frómesta desde el año de 1572 hasta el presente, por el orden siguiente:

$1^{\circ}$. <Acuerdo del monasterio para hacer la concordia con el Marqués. Año 1572>.

Acuerdo y resolución hecha por el abad fray Sebastián de Encinas y demás monges de este monasterio para que se haga concordia con el marqués de Frómesta por 100 mill maravedís que ofrecía dar en censo por el barrio de San Martín y sus derechos, para evitar más pleitos. Está firmado de diez y ocho monges. Su fecha, en San Zoil, a 2 de enero de 1572. Hay aquí un memorial de advertencias para el otorgamiento de dicha escritura.

\section{2. < Escritura de transación del barrio de San Martín. Año 1574>.}

Escritura de concierto y transación del barrio de San Martín hecha entre el abad y monges de San Zoil y don Gerónimo de Venavides, marqués de Frómesta, por la qual parece que, después de haber reclamado el monasterio de la sentencia árbitra de los tres letrados de Valladolid y haber alegado el Marqués que el monasterio no tenía derecho a reclamar, etcétera, el monasterio replicó contra esto y, estando el pleyto concluso y para sentenciarse, como consta del proceso que pasó ante Pedro Alemán, secretario de la Chancillería, en el mes de diciembre de 1573, el monasterio, de una parte, y el dicho don Gerónimo de Venavides, de la otra, por escusar pleytos y costas, trataron de concertarse entre sí; para lo qual, habiendo el monasterio sacado licencia del general y observado las demás formalidades, dio su poder para otorgar esta escritura de concierto al padre fray Benito de Camino, mayordomo de este monasterio. Assimismo, habiendo don Gerónimo de Venavides conferido con el abad y convento y sacado facultad del rey para hacer este contrato y obligar su estado y mayorazgo, dio su poder a Francisco de Castro, vecino de Valladolid. Juntos ambos procuradores en dicha ciudad, en virtud de las dichas licencias y poder, otorgaron esta escritura de concordia y transación con los capítulos y condiciones siguientes:

$$
<1^{\text {a }} \text { condición }>\text {. }
$$

Primeramente que ambas partes se apartan del pleyto con renunciación de leyes, etcétera, y dan por ningunas las escrituras, probanzas, sentencias, etcétera, en él presentadas y todo lo contenido y fulminado en el proceso del pleyto y que ellos ni sus sucesores no bolverán a este pleyto para siempre jamás. 


$$
<2^{\mathrm{a}}>\text {. }
$$

Que el Marqués y sus sucesores se obligan a dar y pagar cada año para siempre jamás al abad y convento de San Zoil 100 mill maravedís de censo y renta / (f. 247r) que comenzó a correr desde principio del año pasado de 1572 en adelante, pagados la mitad por San Juan de junio y la otra mitad por Navidad del dicho año, y así sucesivamente en adelante, fundados en virtud de la dicha licencia y facultad sobre la villa de Frómesta y varrio de San Martín, rentas y diezmos y todo lo demás a ello anexo y perteneciente, y que sobre ello se haya de hacer y otorgar, en favor del convento, escritura de censo bastante con las condiciones de los censos y con las obligaciones y censuras que hasta allí habían pagado los 60 mill maravedís.

$$
<3^{\mathrm{a}}>\text {. }
$$

Que se obliga el Marqués a que, dentro de seis meses siguientes, pagará al monasterio 500 ducados en dinero para un ornamento, o el valor de ellos, en brocado, cenefas, seda, oro y forros para el dicho ornamento, del color que el abad gustare. En el qual ornamento se han de poner las armas del Marqués.

$$
<4^{\mathrm{a}}>\text {. }
$$

Que si acaso los parroquianos de San Martín pidieren más servicio para la yglesia, a los curas y clérigos más congrua, sea obligado a todo ello el dicho Marqués y sus subcesores a defenderlo, pues lleba los diezmos de la dicha yglesia.

$$
<5^{\mathrm{a}}>\text {. }
$$

Que si el Marqués quisiere traher a su costa confirmación de Su Santidad de esta escritura lo pueda hacer, para lo qual la parte del convento da todo su poder cumplido al Marqués.

$$
<6^{\mathrm{a}}>\text {. }
$$

Que con lo susodicho el abad y convento quedan contentos y pagados de todo el derecho y acción que tenían al barrio de San Martín y a su jurisdicción civil y criminal, términos, yantares, fonsadera, martiniega, sernas y portazgos, alcaldía y escrivanías, pregonerías y diezmos de él, y molino que dicen del abad, con todo lo demás que pretendían ser suyo y que se les debía de pagas decusas del censo que se pagaba por el Barrio al monasterio y a toda otra qualquiera cosa que por esta razón pretendiese tener acción. De todo lo qual da por libre al Marqués y sus subcesores y desde luego se aparta de todo ello y cede y traspasa en él todo derecho y acción, y que lo gozen y tengan por suyo propio como si fuese de su mayorazgo con todas las cláusulas, subcesiones y llamamientos de él. Que ningún tiempo el monast[eri]o irá contra esta escritura ni pedirá lesión, ni restitución in integrum, que con lo de arriba se contenta el convento y, si hubiere demasía en el valor del Barrio y censos corridos, lo cede y renuncia. Y los procuradores se obligan a que las partes ratificarán y tendrán por buena esta escritura que está otorgada con todas las firmezas y cláusulas necesarias, insertos los poderes, súplicas, ynformaciones de utilidad, licencias y facultades del rey y de el general de San Benito. Fue otorgada en Valladolid, a 13 de marzo de 1574, ante Juan de Rozas, escribano de Su Magestad y del número de dicha villa.

\section{/ (f. 247v) $<$ Ratificación de esta escritura $>$.}

Síguese la escritura de ratificación y aprobación hecha por don Gerónimo de Venavides, marqués de Frómesta, en la qual dice que, habiendo visto, leído y entendido la dicha escritura de transación y concordia, por sí y sus subcesores aprueba, ratifica y la tiene por buena y útil y se obliga a todo lo contenido en ella, que lo guardará y cumplirá como en ella se contiene, etcétera. Fue otorgada a 26 de marzo del mismo año, en la villa de San Moñoz, ante Rodrigo Álbarez, escribano de dicha villa.

3. <Escritura de censo de 100 mill maravedís de renta que paga el marqués a el monasterio. Año 1574>.

Escritura de censo perpetuo de 100 mill maravedís de renta y censo perpetuo en cada un año que deben de pagar al monasterio los señores que fueren de Frómesta por razón del 
barrio de San Martín con su jurisdición, diezmos y derechos, de que hizo el monasterio cesión como de cosa suya propia. Por esta escritura parece que don Francisco de Castro, como procurador y en nombre de don Gerónimo de Venavides, marqués de Frómesta, y de sus subcesores en su casa, estado y mayorazgo, y usando del dicho poder, licencia y facultad real, incorporado todo en esta escritura, vende, funda y constituye nuevamente al abad y convento de San Zoyl 100 mill maravedís de renta y censo en cada un año para siempre jamás sobre el barrio de San Martín y sobre la villa de Frómesta, y sobre el señorío, vasallaje y jurisdición civil y criminal, y sobre sus términos, montes y prados, aguas estantes y manantes, exidos y abrevaderos, rentas, pechos y derechos, yantares, fonsadera y martiniega, sernas, portazgos y alcabalas, oficios de alcaldías y escribanías, pregonerías, merindad y diezmos, y sobre el molino que dicen del abad y sobre las otras rentas, pechos y derechos de la villa de Frómesta y barrio de San Martín, etcétera. El qual dicho censo comenzó a correr desde principio del año de 1572 en adelante, pagado la mitad día de San Juan y la otra mitad el día de Navidad, puesto y pagado a costa del Marqués, en el monasterio de San Zoyl, a los dichos plazos. Debajo de las penas y censuras y gravámenes con que hasta allí había pagado el marqués los 60 mill maravedís, y so pena de pagar costas, daños, intereses y menoscabos que se siguieren. El qual dicho censo se fundó, y los marqueses quedan obligados a él, con las condiciones siguientes:

$$
\text { / (f. 248r) }<1^{\mathrm{a}} \text { condición }>\text {. }
$$

Que el marqués y sus subcesores han de pagar cada año para siempre jamás los dichos 100 mill maravedís a los dichos plazos al abad, prior, monges y convento de San Zoyl que son y por tiempo fueren, so pena del doblo y costas y so las penas y censuras de las bulas que tiene el dicho monasterio, por virtud de las quales cobraba los dichos 60 mill maravedís.

$$
<2^{\mathrm{a}}>\text {. }
$$

Que por ningún caso de peste, guerra, etcétera, que suceda en Frómesta o en el barrio de San Martín y en las rentas de ello no pueda haber descuento alguno de esta renta y censo de los dichos 100 mill maravedís en cada un año, sino que se hayan de pagar enteramente sin descuento alguno.

$$
<3^{\mathrm{a}}>\text {. }
$$

Que si acaso con facultad real o de otra manera se vendiere la villa de Frómesta y barrio de San Martín y sus rentas o se sacare alguna cosa de ello por pleyto, o en otra qualquiera manera se enagenare, que todos aquellos que sucedieren en ello por título de mayorazgo, venta, donación o renunciación sean obligados a pagar al convento los dichos 100 mill maravedís de censo, por los quales se pueda executar en cada uno de ellos.

$$
<4^{\mathrm{a}}>\text {. }
$$

Que si acaso el cura y clérigos de la yglesia de San Martín, por pleyto o en otra qualquiera manera, sacaren más congrua o se les diere más servicio, el Marqués y sus subcesores sean obligados a se avenir con ellos, y que no por eso se descuente nada de los 100 mill maravedís de censo que ha de haber el monasterio en cada un año.

$$
<5^{\mathrm{a}}>\text {. }
$$

Que todos los subcesores de la villa de Frómesta y barrio de San Martín, rentas y diezmos de ello, en qualquiera manera que en ellos subcedan, se ha visto subceder con esta carga e hipoteca de los dichos 100 mill maravedís de censo para pagarlos en cada un año para siempre jamás a los dichos plazos y a cada uno de ellos. Con las quales condiciones y las demás cláusulas de los censos y las que son necesarias a éste en particular, se otorgó esta escritura de consumisión (para su execución y cumplimiento) a todas y a qualquier justicias, y en especial a los alcaldes de la Chancillería. Fue otorgada en la villa de Valladolid, a 13 de marzo de 1574, ante Juan de Rozas, escribano público y del número de dicha villa.

$<$ Ratificación de esta escritura de censo $>$.

Síguese una escritura por la qual don Gerónimo de Venavides, marqués de Frómesta, ratifica, aprueba y otorga de nuevo la escritura de censo arriba referida y obliga a todo lo 
contenido en ello. Su fecha, en la villa de San Moñoz, a 26 de marzo de 1574, ante Rodrigo Álbarez, escribano de dicha villa. $1574>$.

$/(f .248 v) 4^{\circ} .<$ Requirimiento al Marqués para que pague lo que debía del censo. Año

Requirimiento hecho por parte del monasterio a don Gerónimo de Venavides, marqués de Frómesta, para que pague al monasterio lo que le debe del censo del barrio conforme a la nueva concordia y escritura de los 100 mill maravedís en cada un año. Respondió el Marqués que tiene por bien que esto se pague como deuda más antigua de los bienes que él tenía en poder del depositario general de la Chancillería de Valladolid. Su fecha, en San Moñoz, a 26 de marzo de 1574, ante Rodrigo Álbarez, escribano de dicha villa.

\section{5. <Requirimiento al Marqués para lo mismo. Año 1580>.}

Requirimento hecho por parte del monasterio al marqués de Frómesta para que pague las pagas decusas del censo y lo contenido de dicha escritura. A lo que respondió el Marqués que estaba pronto a cumplir el contrato y a dar libranza para que el depositario general, a costa de su hacienda, lo pague todo. Su fecha, en Frómesta, a 4 de julio de 1580, ante Andrés Sánchez, escribano en Carrión.

$6^{\circ} .<$ Carta executoria a favor del monasterio para que el marqués pague los 100 mill maravedís de censo en plata. Año 1625>.

Carta executoria ganada en la Chancillería de Valladolid a favor del monasterio de San Zoyl contra el marqués de Frómesta y el administrador de su estado para que los 100 mill maravedís de censo que el monasterio tiene sobre la villa de Frómesta y barrio de San Martín se paguen en moneda de plata. Por esta carta executoria parece que, habiendo pleyto en Valladolid entre don Luis de Venavides, marqués de Frómesta, y sus acreedores a sus bienes y rentas sobre la paga de lo que se les debía, se nombró por administrador del estado del Marqués a Cosme de Mallagara, vecino de Valladolid, el qual, en 5 de junio de 1625, presentó petición ante el presidente y oidores de la Chancillería, diciendo que el estado del Marqués paga cada año al monasterio de San Zoyl 100 mill maravedís de censo en plata en dos pagas, la una por Navidad y la otra por San Juan de junio, puestos en dicho monasterio, y que este fuero es por razón de un barrio que el convento tenía en Frómesta y, que faltando la dicha paga en esta forma, luego se puede(n) bolver a tomar el dicho barrio, el qual vale más de 500 ducados cada año y que el administrador, por hacer la paga, no halla plata para cumplir al precio de la prammática. Suplica se mande dar forma como haya cumplido y no le pare perjuicio el no hacer la paga en plata y que cumpla en hacerla en quartos con el premio conforme a la prammática de Su Magestad. Mandose dar traslado al monasterio, el qual fue citado con provisión real y respondió que, sin embargo de lo confesado y pedido por la parte contraria, lo que debía al / (f. 249r) monasterio en cada un año eran 150 mill maravedís en plata sin otras cantidades que debía y que el pedimiento no se debía hacer ante los oidores siendo el convento reo y monasterio, por lo qual declinó jurisdición y pidió declaración en este artículo.

\section{$<$ Auto de vista $>$.}

Y, habiéndose visto lo alegado, en 4 de julio de 1625 se dio auto en el qual se declaró que el administrador cumplía con pagar en quartos, pagando asimismo el premio de los 100 mill maravedís conforme a la prammática de Su Magestad. Del qual auto la parte del convento suplicó y dixó de nulidad por no se haber declarado sobre la declinatoria, por lo qual no se había podido declarar sobre lo pedido por la parte contraria. Pidió asimismo que, pronunciando por nulo el dicho auto, se viese y pronunciase sobre la declinatoria y, caso que no hubiese lugar, protestó alegar y probar con escrituras que la hacienda que llebaba la parte contraria por el censo valía más de 3 mill ducados cada año. De este alegato se mandó dar y dio traslado a la parte contraria, y la del convento bolvió alegar en forma de su justicia y caso que no hubiese lugar la declinatoria, pidió la paga en plata. Diose traslado a la otra parte y ambas presentaron sus poderes. Estando el pleyto concluso se mandó substanciar con el marqués de Frómesta el segundo pedimiento del monasterio. Diose provisión para el Marqués, inserto el pedimiento del convento, el qual se le notificó en Madrid por Juan de Medina, escribano de Su Magestad, quien respondió que su administrador cumple con pagar 
conforme a la prammática, en vellón con el premio, y que el censo no procede de dineros entregados en plata ni oro sino de venta de tierras, y que por su parte se acudirá a responder. La parte del convento acusó la rebeldía del Marqués por no haber venido a responder y el pleyto fue concluso.

\section{$<$ Auto de revista $>$.}

Y, visto por el presidente y oidores, dieron auto contra él y su administrador, a 5 de noviembre de 1625, por el qual dixeron que, sin embargo del auto de vista en este pleyto dado, mandaron que el administrador del Marqués pague al dicho monasterio los 100 mill maravedís de renta que tiene sobre el estado de Frómesta en plata, conforme a la escritura sobre lo susodicho otorgada.

Notificose a las partes y la del convento pidió carta executoria y, llebado el proceso al doctor Pichardo Semanero, / (f. 249v) y por él visto, mandó dar y se dio esta carta executoria de los dichos autos de vista y revista, en efecto y cumplimiento del de revista, a favor del monasterio. Que fue dada en Valladolid, a 12 de diciembre de 1625, ante Matheo de Bársena, escribano de Cámara. Chanciller, don Diego de Villagómez. Refrendada, Luis Fernández.

$<$ Testimonio autorizado de varios autos en que es condenado el administrador del Marqués a cumplir el auto de la carta executoria y es repelida su petición del proceso. Año $1628>$.

Síguese un testimonio autorizado por el qual parece que el administrador del estado de Frómesta, en 13 de octubre de 1628, presentó petición en la Chancillería, pidiendo se le diese forma como había de cumplir la paga del censo de los 100 mill maravedís, atento que después del auto de revista de la carta executoria de arriba en que se mandaba pagar en plata, había salido prammática rigurosa en razón del premio de ella, por lo qual no se podía hallar para hacer la dicha paga. Diose traslado a la parte del monasterio y alegó obstar exempción de cosa juzgada sobre que se había dado carta executoria al convento. Salió auto en 27 de octubre del mismo año en que en discordia se remitió a otra sala, en la qual visto, declararon obstar al administrador excepción de cosa juzgada y que su petición se quite del proceso. Suplicó el administrador y pidió rebocación del dicho auto y se ordene lo que debe hacer para que las costas y daños no sean por su cuenta. Notificose a la parte del convento, y concluso sin embargo, en 24 de noviembre se dio auto en que se mandó que el administrador se (sic) qüenta al Marqués del estado del pleyto y haga con él diligencia. Despachose este auto a instancia del administrador para intimarle al Marqués, a quien se notificó en Madrid el mismo año. Y respondió que su estado estaba en pleyto de acreedores, del qual sólo le tocaban los alimentos y que lo demás pende de los señores de la sala donde pasa el dicho pleyto y donde pertenece el remedio de esta paga y lo demás tocante a dicha hacienda. Después de lo qual el administrador pidió se declarase haber cumplido con la obligación que tiene de tal administrador y se provea lo que conviene en este pleyto. A 15 de diciembre de 1628 se dio auto en que se mandó cumplir lo proveído. De todo lo qual dio este testimonio Domingo de la Madrid, escribano de Cámara ante quien pasó, en Valladolid, a $1^{\circ}$ de marzo de 1629.

$<$ Provisión real con inserción de autos para que se guarde lo provehido $>$.

Síguese finalmente una provisión real, con inserción de / (f. 250r) (de) autos para que el administrador del estado de Frómesta le pague al monasterio en especie de plata los maravedís que se le estubieren debiendo del censo perpetuo de 100 mill maravedís que el dicho estado paga al dicho convento. Dada en Valladolid, a 17 de febrero de 1665, ante Domingo de la Madrid, escribano de Cámara.

7. <Mandamiento de desembargo para que se pague al monasterio los 100 mill maravedís de censo. Año 1636>.

Bajo este número están los papeles siguientes: 
1. Vna consulta y parecer del doctor Bonilla sobre el modo de proceder a la cobranza del censo de Frómesta habiendo de por medio la paga de las lanzas a ${ }^{363} \mathrm{Su}$ Magestad. Año 1636.

2. Mandamiento de desembargo dado por don Francisco de Alarcón, del Consejo de Guerra de Su Magestad, para que se le paguen al convento los 100 mill maravedís de censo y lo que se le debiese en adelante, sin obstar para esto el ambargo de las rentas del Marqués. Dado en Madrid, a 16 de octubre de 1636.

3. Testimonio dado por Ysidro González, escribano en Frómesta, de cómo el juez de lanzas cobró para Su Magestad los dos tercios del año de 1636 y reservó el tercero para pagar a este monasterio. Su fecha, en Frómesta a 15 de diciembre del mismo año.

8. <Mandamiento del provisor de Palencia contra los de Frómesta. Año 1637>.

Trasunto autorizado de la bula de Eugenio $4^{\circ}$ con el qual se requirió al provisor de Palencia, el qual le obedeció y, en virtud dél, dio mandamiento para que los de Frómesta pagasen los 50 mill maravedís que debían del plazo de San Juan del año de 1637. Los quales pagaron con efecto y se quedaron con el original del mandamiento para su resguardo. Está aquí su traslado autorizado por Jacinto Gallego, notario apostólico, vecino de Carrión, quien lo sacó a 14 de julio del dicho año.

9. <Auto dado por don Francisco de Alarcón para que los de Frómesta paguen la renta caída en plata doble. Año 1637>.

Auto dado por don Francisco de Alarcón, de los consejos de Su Magestad, para que la justicia ordinaria de la villa de Frómesta cumpla y execute la sobrecarta dada por Su Magestad a favor del monasterio de San Zoyl para que se le haga pago de la renta caída del censo perpetuo de 100 mill maravedís en plata doble que el estado de Frómesta está obligado a pagar en cada un año. Dado a 22 de enero de 1637.

Está al pie de este auto el requirimiento que hizo el padre fray Manuel de Lemos al señor don Antonio de la Peña y Villagómez, corregidor en la villa de Frómesta, para que haga cumplir lo contenido en él.

10. <Auto sobre los 100 [mill] maravedís del censo. Año 1659>.

Testimonio en relación de la petición, autos y provisión real despachada en la sala para que los mayordomos o recaudadores de la renta de Frómesta paguen a esta casa los 100 mill maravedís que se la debían del año de 1659, en atención a que no había administrador en dicho estado. Dado en el mismo, ante Norverto de Sandoval y Guevara, escribano de Carrión. Año 1669>.

/ (f. 250v) 11. < Proceso apostólico sobre la paga de 50 mill maravedís de el fuero.

Proceso apostólico contra el Marqués, justicia y regimiento de la villa de Frómesta sobre la paga de 50 mill maravedís de plata doble del plazo de Navidad de 1668. También se halla aquí un testimonio en relación de las condiciones del fuero hecho con facultad real, y asimismo de las executorias reales ganadas sobre las pagas de él hasta este año de 1669; juez de esta causa, el abad de San Salvador de Oña.

12. $<$ Mandamiento con censuras contra el Marqués. Año 1685>.

Mandamiento de censuras dado por el señor abad de Sahagún contra el Marqués y justicia de Frómesta sobre la paga de los 50 mill maravedís de plata doble que deben a este monasterio correspondiente al plazo de San Juan de junio del año de 1685 por razón del barrio de San Martín.

13. < Proceso apostólico sobre la paga de 50 mill maravedís del censo. Año 1686>.

Proceso apostólico contra el Marqués, justicia y regimiento de Frómesta sobre la paga de los 50 mill maravedís de plata doble del plazo de Navidad de 1685, de cuyos autos fue

363 a] Escrito sobre: de. 
juez apostólico el padre abad de Sahagún como delegado de la sede apostólica. Y porque en esta causa se procedió no sólo contra la justicia y regimiento de dicha villa de Frómesta sino también contra vecinos particulares de ella, lo apelaron por vía de fuerza a la Chancillería de Valladolid, donde se declaró el padre abad no hacía fuerza y se le bolvieron a remitir los autos. Lo mismo declaró el nuncio de España, mandando que por ahora procediese solamente contra el theniente, corregidor, justicia, regimiento de dicha villa; de lo qual apelaron los susodichos al Consejo Real, pero no se les concedió la apelación en la nunciatura, con que se detubo el pleyto hasta que se hallanaron a dar satisfacción a este monasterio de las rentas que pertenecían al señor Marqués. Y, en el mes de octubre del año de 1687, se despachó mandamiento contra dicha justicia y contra los arrendadores y recaudadores de la renta del Marqués; pero por ser mucha la deuda no pudieron acabar de dar satisfacción de lo atrasado, por lo que en adelante se bolvió a pedir de nuevo como se verá después. $1687>$.

14. $<$ Desembargo de las rentas del Marqués para pagar a este monasterio. Año

Auto dado por el licenciado don Pedro Gamarra y Arriaga, caballero de la orden de Santiago, para que se desembarguen las rentas del estado del señor marqués de Frómesta hasta en cantidad de lo que está debiendo de atrasado a este monasterio y, que en adelante, se debiere del censo y fuero de 100 mill maravedís de plata de renta en cada un año / ( $f$. $251 r$ ) y que a la parte del monasterio se le acuda y pague libremente lo corrido y que corriere del dicho censo y para ello se le dé el despacho necesario. Dado en Valladolid, a 6 de septiembre de 1687, ante Ysidro Calderón, escribano de Cámara.

Hay aquí otro auto dado por el doctor don Pedro Sarmiento y Toledo, caballero de la misma orden, sobre lo mismo, a favor de este monasterio, en el mismo año y ante el mismo escribano.

15. < Proceso contra el marqués sobre la paga de 167 mill maravedís de censo. Año $1688>$.

Proceso apostólico contra el Marqués, justicia y regimiento de la villa de Frómesta sobre la paga de 167 mill maravedís que se estavan debiendo hasta la paga de San Juan el año de 1688, con la protexta de otros 50 mill maravedís. También se halla en este quaderno la prammática real del año de 1686 sobre el premio de la plata y oro, en la que se declara como se había de recibir en estas pagas sobre las que había pleyto pendiente, y así se daban las cartas de pago con protexta. Pasó todo en los años de 1688, 89 y 90, siendo juez de sta causa el padre abad de Sahagún.

16. <Despacho con censuras contra el Marqués para que pague 252 mill 172 maravedís de plata doble de los atrasos. Año 1691>.

Despacho con censuras, librado por don Gaspar de Quincozes, provisor de Palencia, contra el Marqués, justicia y regimiento de la villa de Frómesta sobre la paga de 252 mill 172 maravedís de plata doble que se estaban debiendo de atrasos del dicho foro hasta la paga de San Juan de junio de 1691; y testimonio dado por Norberto de Sandoval y Guevara, notario apostólico, de cómo el administrador de Frómesta vino al monasterio a pagar y con efecto entregó a los depositarios de dicho monasterio 364287 reales y medio de a ocho del cuño antiguo, computados a 8 reales cada uno, en cuya moneda dixeron los padres priores que debía hacerse la paga como siempre se había hecho. Pero el administrador respondió que, hasta que lo declarare la sala y le sea mandado, no debe pagarles si no es computados a 10 reales cada real de a ocho, como lo pretende dicho estado. Su fecha, en San Zoyl, a 24 de enero de 1692.

17. <Despacho contra el Marqués para que pague 500 florines de oro devengados con las costas, etcétera. Año 1707>.

Despacho librado por don Melchor Ángel Gutiérrez, provisor de Palencia, para que el administrador, oficiales de justicia y regimiento de la villa de Frómesta den y paguen a este monasterio 500 florines de oro que estaban debiendo del foro de medio año, con más 342

364 monasterio] Sigue tachado: los. 
reales que importan las costas causadas en el litijio de este tribunal y de las dos instancias de fuerza en que entran los 50 reales en que fue multado dicho administrador por la sala. Y, no pagando dicha cantidad, manda a los curas y clérigos de dicha villa que los declaren por excomulgados. Dado en Palencia, a 29 de octubre de 1707, ante Marcos Ruiz, notario. Año 1718>.

/ (f. $251 v)$ 18. < Testimonio de 400 ducados que se pagan a este monasterio de censo.

Testimonio dado por Manuel Santos Aparicio, secretario de Cámara, de cómo el administrador del estado de Frómesta siempre había pagado al monasterio 400 ducados en cada un año por el foro, sin obstar para esto el concurso de acreedores que había a dicho estado. En Valladolid, en 28 de diciembre de 1718.

Hay aquí otro testimonio dado por José González Ochoa, escribano de Cámara, sobre lo mismo y en el mismo año. $1718>$.

19. $<$ Libramiento contra el Marqués para que pague 200 ducados de un tercio. Año

Libramiento despachado por los oidores de la Chancillería, a petición de este monasterio, para que el administrador de Frómesta le pagase 200 ducados de lo corrido de un tercio que había cumplido en San Juan de junio de 1777, sin embargo de qualesquiera embargos. Fecho en Valladolid, a 5 de febrero de 1718, ante Antonio Goitiz Arana, secretario de Cámara.

20. <Libramientos despachados por los corregidores de Palencia para cobrar los réditos del censo. Año 1719 hasta el de 1751>.

Autos dados por los corregidores de Palencia a pedimiento de este monasterio y en virtud de carta orden del yllustrísimo señor marqués de Campo Florido, del Consejo de Su Magestad y su presidente en el Real de Hacienda, para que el administrador del real valimiento y de las rentas concusadas del estado de Frómesta, dé satisfacción y pague al dicho monasterio lo que costare estársele debiendo de los réditos del censo de 400 ducados en cada un año, por ser crédito privilegiado. Fueron dados desde el año de 1719 hasta el de 1751, inclusive.

21. <Cuentas de los administradores y respuesta que dio este monasterio $>$.

Papel tocante a las cuentas que se han tomado a los administradores y razón de las cantidades de maravedís que el monasterio de San Zoyl ha recibido del estado de Frómesta desde el año de 1716 hasta el de 1732, por las que parece haber recibido el dicho monasterio. Al fin de este papel se hallará la respuesta que dio, después de la qual nada se ha hablado sobre esta materia, y el monasterio prosigue cobrando pacíficamente los 400 ducados como antes.

22. <Consulta y parecer sobre el valor de los maravedís del censo. Año 1799>.

Consulta hecha al padre fray Liciniano Sáez, hijo del monasterio de Santo Domingo de Silos, sobre el valor de ${ }^{365} 100$ mill maravedís que tiene en este monasterio de foro sobre el estado de Frómesta y respuesta del mismo padre en que dice estar este monasterio perjudicado, por lo menos en 50 mill maravedís.

También hay aquí un formulario de como se ha de dar la carta de pago para la cobranza de dicho foro.

365 de] Sigue tachado: los. 


\section{/ (f. 251v) Cajón 10: San Lorenzo}

Este cajón San Lorenzo, que es el décimo del archivo, contiene quatro legajos pertenecientes a diversos lugares, que son: Legajo $1^{\circ}$ : Fuentes de Nava o de don Bermudo, Fuentes de Valdepero, Gañinas y Grijota; legajo $2^{\circ}$ : Las Heras; legajo $3^{\circ}$ : Lobera, San Mamés, Santa María del Páramo, Santa María de Rozavales, San Martín de los Álamos, San Martín de los Rascones y Mazuecos; legajo $4^{\circ}$ : Muñeca.

\section{Legajo $1^{\circ}$} los siguientes:

Este legajo, que es el $1^{\circ}$ del cajón San Lorenzo, contiene quatro quadernos, que son

Quaderno A Fuentes de Nava o de don Bermudo

B Fuentes de Valdepero

\author{
C Gañinas \\ D Grijota
}

\section{Quaderno A del legajo $1^{\circ}$}

Fuentes de Nava o de don Bermudo

Este quaderno A contiene los papeles pertenecientes a la hacienda e yglesia de San Román de este lugar por el orden siguiente:

$1^{\circ}$.

Trasumto sin autoridad de una sentencia árbitra dada en un pleyto que traxeron los feligreses de la yglesia de San Román de Fuentes de Nava con los curas y clérigos de otra villa en razón del servicio de dicha yglesia. Por esta sentencia consta que, haviendo pasado este pleyto / (f. 252r) en la audiencia episcopal de Palencia, los provisores de ella, en 15 de marzo de 1468, dieron sentencia difinitiva, en que dicen constar por las probanzas que la yglesia de San Román con sus emolumentos y servicio pertenece a la limosna y limosnero de San Zoil y que los curas y clérigos de Fuentes no son beneficiados ni intitulados en la dicha yglesia por serlo en la de San Pedro de la dicha villa, según las constituciones del obispado y costumbre inmemorial. Y que asimismo que el limosnero puesto por el abad y convento de San Zoil hizo con los clérigos de Fuentes un concierto y condiciones, como patrono de la yglesia de San Román, cerca del servicio de ella; el qual, con ciencia y paciencia de los clérigos, no guardó el limosnero. Y, siendo así que por razón del servicio tenía obligación de dar a los clérigos (como les había dado) los menudos de los 25 maravedís de estimación y ahora se había substraýdo de dárselos, no estaban obligados al dicho servicio. Y, perteneciendo como pertenece al limosnero la propiedad de la dicha yglesia y que los clérigos la servían por razón de los dichos menudos de los 25 maravedís de estimación y no por otro respeto, y por no haber tenido los feligreses acuerdo con los clérigos en la concordia y posesión de ella, no se pudo decir ser despojados por los clérigos sino por el limosnero. Y así declararon los provisores que la restitución pedida por lo[s] feligreses contra los curas y clérigos no tenía lugar en la forma que la pidieron; y en esta razón les impone perpetuo silencio. Y en quanto a la vexación en testimonio por ellos hecha, reservan su derecho a salvo a los feligreses para que puedan pedir el servicio de la yglesia al limosnero o a quien derecho tubieren, y les condenan en costas. De esta sentencia apelaron los feligreses ante el arzobispo de Toledo y después, por escusar pleitos, lo comprometieron en el bachiller Fernando de Benavente y con comisión que tubo del marqués de Astorga, señor de Fuentes, conoció en esta causa. Y, vistos los autos de ella, en 4 de mayo de 1469 dio esta sentencia árbitra por la qual confirma la de los provisores de Palencia, salvo quanto a las costas, que las remite a los felegreses. Pasó ante Fernando Sánchez de Paredes, escribano de esta villa.

2. <Capítulos de concordia entre el limosnero de San Zoil y los clérigos de Fuentes sobre el servicio de su yglesia $>$.

Capítulos de concordia entre el limosnero de San Zoil y los clérigos de Fuentes en los que se dice que los clérigos han de servir con toda puntualidad la yglesia de San Román de la dicha villa y parroquianos de ella, en la forma que se sirven las otras yglesias del mismo 
lugar. Que / (f. 252v) por esto lleven la sesta parte de los diezmos de pan y vino de menudos de esta yglesia como de las demás y el pie de altar y primicias y qualesquier emolumentos a ello pertenecientes. Que los clérigos estén obligados a solemnizar las vocaciones y fiestas de la yglesia de San Román como las de las otras yglesias y haya sermón quando fuere vso y costumbre. Que el limosnero no pueda quitar el dicho servicio y emolumentos a los clérigos ni ellos dexarlo por ningún caso. Que sobre estos capítulos se ordene un instrumento de concordia. Esta debe de ser la que se cita en la sentencia de arriva, que después no se guardó, ni estos capítulos tienen más authoridad que la de un papel simple, que son si fecha ni año.

3. <Ynformación y entrega que se hizo a este monasterio de una tierra en término de Fuentes. Año 1575>.

Ynformación hecha por parte del monasterio de San Zoil ante Alonso de Arenillas, alcalde ordinario de Frechilla, por la qual prueba el monasterio ser suya una tierra que está donde dicen a Tejadillo, parte de ella en el término de Frechilla ${ }^{366}$ y parte en el de Fuentes, de tres obradas, poco más o menos, para presentarla el monasterio en un pleyto que tubo sobre dicha heredad en el adelantamiento con el concejo de Fuentes. Hízose a 28 de noviembre de 1574, ante Toribio de Guaza, escribano de Frechilla.

Está aquí la escritura de apartamiento y entrega que el concejo de Fuentes hizo a este monasterio de la referida tierra, reconociéndola por propia del monasterio y restituyéndole el pan que habían segado y cogido de ella. Fue otorgada en esta villa de Fuentes a 20 de marzo de 1575, ante Juan Herrero, escribano de dicha villa.

4. $<$ Sentencia contra este monasterio para que alze el embargo que había hecho por la renta de 25 maravedís de estimación que tiene sobre los diezmos de Fuentes de Nava. Año $1600>$.

Copia simple de una sentencia difinitiva dada por el doctor don Thomás López, doctoral de la Santa Yglesia de Palencia, por don Gaspar de Peralta, provisor de ella, por la qual condena al abad y monges de este monasterio en el pleyto que trahía con Juan Roxo de Salinas, vecino de la ciudad de Burgos, que salió a la causa por su hijo fray Juan Roxo, religioso trinitario en dicha ciudad; y manda alzar el seqüestro y embargo que de pedimiento de este monasterio se hizo en los frutos y diezmos pertenecientes a la renta de 25 maravedís de estimación que tiene en los diezmos mayores y menores de la villa de Fuentes de Nava y que se acuda libremente con ellos al dicho Juan Roxo; y le amparan en la posesión de la dicha renta por la tercera vita que en el dicho fray Juan, su hijo, se puso por fin y muerte de Luys Núñez, canónigo de Palencia, su último poseedor. Fue dada en Palencia, a 28 de abril de 1600.

\section{/ (f. 253r-254r) Remisiones a otros cajones}

$<$ Donación $>$.

La donación que hizo a este monasterio doña Mayor García de su ración entera, en Fuentes de don Bermudo, año de 1118. Véase el cajón Santa María, legajo $1^{\circ}$, número $2^{\circ}$.

$<$ Trueque $>$.

El privilegio y carta de trueque del rey don Alonso el Emperador, año de 1129, y confirmación del rey don Fernando $4^{\circ}$, año de 1304, por el qual nos da a Lobera por todo quanto teníamos en Fuentes de Nava. Véase el legajo $3^{\circ}$ de este cajón, número $1^{\circ}$, título Lobera.

$<$ Diezmos, tercias y presentación del beneficio $>$.

Los diezmos, tercias y presentación del beneficio de la yglesia de San Román de este lugar de Fuentes. Véase el cajón San Andrés, legajo $1^{\circ}$, quaderno B, número $2^{\circ}, 3^{\circ}$ y $4^{\circ}$.

${ }^{366}$ Frechilla] al margen derecho: Frechilla. 
$<$ Amojonamiento $>$.

Testimonio del amojonamiento de los términos de Frechilla y Fuentes. Véase el cajón San Felices, legajo $3^{\circ}$, quaderno G, número $3^{0367}$.

\section{/ (f. 253v-254v) Quaderno B del legajo $1^{\circ}$ Fuentes de Valdepero}

Este quaderno D (sic) contiene los papeles pertenecientes a la hacienda que tiene este monasterio en este lugar, por el orden siguiente:

$1^{\circ}$. $<$ Carta executoria contra el concejo de Fuentes en razón de no pagar pecho de la heredad que allí tiene el monasterio. Año 1542>.

Carta executoria ganada en la Chancillería de Valladolid contra el concejo de Fuentes de Valdepero, por la qual parece que, en Carrión, a 16 de enero de 1535, ante don Santiago de los Ríos, prior de la Escalada, juez conservador, este monasterio se querelló del concejo de Fuentes de Valdepero porque, siendo las heredades y bienes raýzes que el monasterio tenía en dicho lugar libres y exentos de todo derecho y tributo, el concejo les pedía cierta martiniega y habían dado mandamiento para cobrarla de Gonzalo de Camargo, vecino de Palencia, que tenía a renta las dichas heredades. De lo que el monasterio se dio por agraviado, pidió justicia y que se diesen por nulos los mandamientos que contra esto hubiese dado el dicho concejo y que no los diese de allí adelante.

Contradixo la parte del concejo, alegó de su justicia y declinó jurisdicción. Presentose en la Chancillería y, habiéndose quexado del juez conservador, sacó ynhibitoria y compulsoria y en virtud de ella se llevó el proceso a Valladolid, donde se presentó la parte del monasterio y, a instancia y consentimiento de ambas partes, se retubo la causa en la Chancillería. Ratificó el monasterio su demanda y pidió justicia; negola el concejo, sobre que se concluyó, se recivió la causa a prueba y se alegó de bien probado.

$<$ Sentencia difinitiva $>$.

Visto el pleyto por el presidente y oydores, en 11 de julio de 1542, dieron sentencia difinitiva, por la qual declaran haber probado el monasterio la intención de su demanda y condenan al concejo, alcaldes, rejidores, procuradores, oficiales y hombres buenos de la villa de Fuentes de Valdepero a que ahora ni de aquí adelante no repartan pechos algunos a la persona y personas que tubieren arrendados los bienes que el monasterio tiene en la villa de Fuentes de Valdepero por razón de los dichos bienes, ni sean obligados a pagar cosa alguna por los dichos bienes. Notificose a los procuradores de las partes y ninguno suplicó y pasó la sentencia en cosa juzgada. Y, de pedimiento de la parte del monasterio, se / (f. 255r) (se) dio esta carta executoria en Valladolid, a 21 de octubre de 1542, ante Alonso de Santiestevan, escribano de Cámara.

$<$ Copia de la executoria $>$.

Hay aquí una copia authorizada de esta carta executoria, sacada en Palencia, a 9 de diciembre de 1542, ante el licenciado Juan de la Villa, juez de residencia, y signada de Hernando de Castrillo, escribano y notario de dicha ciudad. $1648>$.

2. <Execución y posesión que tomó el monasterio de 5 tierras en este lugar. Año

Escritura de venta judicial a favor de este monasterio de los bienes raýzes de Antonio Marcos, vecino de esta villa de Fuentes, por nueve cargas y media de trigo y quatro y media de cevada que estaba debiendo, por que fue executado. Y, hechas todas las diligencias ante el licenciado Pedro Sanz, alcalde mayor del adelantamiento, tomó el monasterio posesión de cinco tierras expresadas en este proceso, a 20 de abril de 1648, ante Toribio de Porras Villadiego, escribano del adelantamiento.

$3673^{\circ}$ ] sigue tachado: Entrega de una tierra. 
3. <Adjudicación de 5 tierras a favor de este monasterio. Año 1701>.

Adjudicación que se hizo a este monasterio de cinco pedazos de tierra y farrenales de pan llebar de los bienes que quedaron por muerte de Fernando Aragón, vecino de Fuentes de Valdepero, por un censo y réditos de él que tenía este monasterio contra el sobredicho. $\mathrm{Y}$, aunque las dichas posesiones importaban más 112 reales, los pagó y entregó el padre fray Mauro Fuertes, mayordomo de dicho monasterio, con lo que se le otorgó carta de pago. Fue fecha en dicha villa de Fuentes, a 18 de marzo de 1701, ante Francisco de la Torre, escribano de dicha villa.

\section{/ (f. 255v) Quaderno C del Legajo $1^{\circ}$ Gañinas}

Este quaderno $\mathrm{C}$ contiene los papeles pertenecientes a la hacienda y señorío de este lugar y algunos de los lugares de Lobera y Villarmienzo, por el orden siguiente:

$1^{\circ} .<$ Escritura de trueque del rey don Alonso el $9^{\circ}$ con este monasterio. Era 1218. Año 1180>.

Copia authéntica del privilegio y carta de trueque del rey don Alonso el $9^{\circ}$ en que para bien de su reyno toma para sí la villa de Castromayor (oy Aguilar de Campos) y da en cambio al monasterio las villas de Gañinas, Revenga ${ }^{368}$ y Golpejera $^{369}$ (oy Villaverde). Dado en Castroxeriz, era MCCXVIII, que es año de Christo 1180, quarto nonas aprilis. Hay aquí una copia simple de este privilegio. El original, escrito en pergamino, está en el cajón San Yldefonso, legajo $1^{\circ}$, número $1^{\circ}$, entre los papeles de Villaverde.

2. < Compra de todos los bienes que tenía Gómez Pérez en Gañinas. Año 1399>.

Compra que hizo Diego Fernández, monge enfermero de San Zoil (para la enfermería del monasterio) a Gómez Pérez de Valderrábano y Sancha López, su muger, de todos quantos bienes raýces tenían y les pertenecían en Gañinas y sus términos, casas, suelos, tierras, prados, pastos, dehesas, salces, árboles, molino, cespederas, heras, etcétera, por precio de 600 maravedís. Fecha en Castellanos, a 22 de marzo de 1399, ante Gómez García de Saldaña, escribano real.

3. < Foro de 2 maravedís y dos pares de pollas sobre un solar. Año 1414>.

Escritura de foro perpetuo, en pergamino, por la qual don Fernando, prior mayor de San Zoil, da a Fernando, hijo de Toribio Marchicón, vasallo del monasterio, morador en Gañinas, un solar en el dicho lugar para edificar casa, por 2 maravedís de la moneda vieja de foro perpetuo en cada un año; y en el que se hizo la escritura le había de dar dos pares de pollas. Su fecha, en Gañinas, a 19 de marzo de 1414, ante Diego González de Cervatos, escribano y notario público y real.

4. <Compra que hizo el monasterio de 10 cargas de pan mediado. Año 1442>.

Compra que hizo este monasterio a Men Rodríguez de Cornado, vecino de Carrión, criado de doña Leonor de la Vega, de 10 cargas de pan $^{370}$ mediado, trigo y cevada, medido por la medida Avilesa, de foro y censo perpetuo para siempre jamás, las quales son de las 20 cargas de pan que al dicho Men Rodríguez le pertenecían por la heredad que tenía / (f. 256r) en Gañinas, Lobera ${ }^{371}$ y sus términos, las quales llevaba en censo y foro perpetuo Arias de Cantoral, morador en Gañinas. Estas heredades habían sido de doña Leonor de la vega y sus hijos; hicieron donación de ellas al referido Men Rodríguez por los buenos servicios que había hecho a su madre, y el monasterio le compró las 10 cargas de foro y censo perpetuo por 14 mill maravedís que dio por ellas. Su fecha, en este monasterio, a 28 de diciembre de 1442, ante Álvar González de Carrión, escribano de esta villa.

\footnotetext{
${ }^{368}$ Revenga] al margen derecho: Revenga.

${ }^{369}$ Golpejera] al margen derecho: Golpejera.

${ }^{370}$ pan] escrito sobre trigo.

${ }^{371}$ Lobera] al margen derecho: Lobera.
} 
$<$ Testimonio de doña Leonor de la Vega $>$.

Está aquí el testamento de la dicha doña Leonor de la Vega, muger del Almirante don Diego Hurtado de Mendoza, y el poder que dio a sus hijos para que hagan y cumplan su testamento con la manda y donación que hicieron al referido Men Rodríguez de todas las heredades que dicha señora tenía en Gañinas y de los molinos que llaman del Prado de Calzada en la rivera de la[s] Huelgas.

5. $<$ Mandamiento para que los vecinos vengan a segar. Año 1525>.

Mandamiento que dio fray Ysidro Pérez, monge y mayordomo de San Zoil, para que los merinos y regidores de Gañinas, Lobera y Villarmienzo ${ }^{372}$ embíen los vecinos de estos lugares para ayudar a segar los panes del monasterio, so pena de 600 maravedís a cada uno. Dado en San Zoil, a 8 de julio de 1525.

6. <Provisión real para que la justicia de Saldaña suelte unos presos. Año 1527>.

Provisión real del emperador don Carlos para el alcalde mayor de Saldaña, suelte unos presos de Villarmienzo ${ }^{373}$ y Gañinas y que les pague las costas de la prisión en que les tenía porque obedecían los mandamientos del abad de San Zoil, siendo de su jurisdicción civil, como dice el mismo emperador, por privilegios de los reyes, sus antepasados. Dada en Valladolid, a 22 de mayo de 1527, ante Ramiro del Campo, escribano de Cámara.

Está aquí el mandamiento del correjidor de Saldaña para que se obedezca y cumpla la dicha real provisión y se suelten los presos. Ante Christóval del Valle, notario.

7. $<$ Consentimiento de una sentencia del juez conservador a favor del monasterio. Año 1528>.

Escritura por la qual Fernando Palomeque, en nombre y con poder de Juan de Céspedes, su padre, consiente una sentencia que contra él había dado Diego de los Ríos, juez conservador del monasterio, por[que] el dicho Juan de Céspedes había hecho cierto agravio a los vasallos de Villarmienzo y Gañinas en prenderlos y dar sentencia contra ellos porque habían obedecido al abad o su teniente del monasterio. Fecha en San Zoil, a 5 de abril de 1528.

8. $<$ Foro de 28 cargas de pan mediado y 12 gallinas. Año 1531>.

Escritura de foro perpetuo por la qual fray Diego de Canales, presidente, y el monasterio de San Zoil dan al concejo y vecinos del lugar de Gañinas, a foro perpetuo, todas las heredades y posesiones que el monasterio tiene en aquel lugar por 28 cargas de pan, mediado trigo y cebada, y 12 gallinas en cada / (f. 256v) un año para Nuestra Señora de agosto. Otorgose en el monasterio de San Zoil, a 14 de marzo de 1531, ante Juan de Castrillo, escribano de Carrión.

$<$ Proceso en la vía executiva sobre la paga de este foro $>$.

Está vnido a esta escritura un proceso formado por la vía executiva, por el qual consta que en el año de 1641 el concejo y vecinos de Gañinas se substrajo de pagar las 28 cargas de pan mediado y las 12 gallinas que por la referida escritura de foro deben pagar cada año a este monasterio, diciendo se les había de mostrar por dónde se le debía al convento esta renta. El convento pidió execución en el adelantamiento de Campos ante el secretario Miguel Martínez y presentó para ello la escritura de foro. El concejo se opuso a la execución redarguyendo de falsa dicha escritura. El convento alegó en su defensa, pidió requisitoria para la justicia de Carrión, ante la qual comprobó dicha escritura de legal y, conforme con otras de Juan de Castrillo que están en el archivo, hizo información de que de tiempo inmemorial a esta parte los de Gañinas habían pagado este foro. Compulsó 4 privilegios reales por donde consta que el lugar de Gañinas con su jurisdicción es del monasterio y asimismo otras escrituras por donde consta la hacienda que el monasterio tiene en aquel lugar, que es la misma que dio a foro al concejo; las quales escrituras están copiadas y

372 Villamienzo] al margen derecho: Lobera y Villarmienzo.

373 Villamienzo] al margen derecho: Villarmienzo. 
authorizadas en este proceso y se presentaron en esta instancia en el tribunal del adelantamiento.

\section{$<$ Sentencia a favor del monasterio $>$.}

Los de Gañinas recusaron al alcalde mayor del adelantamiento y su teniente, trajeron provisión de la Chancillería para que se acompañase el teniente con el doctor don Francisco de Villarroel, abogado de Valladolid, el qual, visto los actos, dio sentencia a favor del monasterio condenando al concejo y vecinos de Gañinas a pagar principal, décima y costas; y don Francisco de Liorri y Cisneros, teniente de corregidor y alcalde mayor, se conformó con la dicha sentencia en la suya, que se pronunció a 20 de mayo de 1642, ante Miguel Martínez, escribano del adelantamiento. Y en virtud de estas sentencias los de Gañinas pagaron con efecto principal, décima y costas. $1531>$.

9. <Ynformación que estos lugares no entran en el repartimiento de galeotes. Año

Ynformación hecha ante la justicia de Saldaña por parte y con poderes de los lugares de Gañinas, Lobera, Villarmienzo, Pedrosa y Villota del Páramo ${ }^{374}$, por la qual consta que, haviendo don Juan Manrique, alcalde mayor de Burgos, convocado en Santa María del Campo a todos los lugares de vehetría para hacerles repartimiento de galeotes para las armadas reales, estos lugares probaron en esta información que no eran de vehetría, y los del monasterio que por sus privilegios estaban libres del dicho repartimiento, con que fueron dados por libres por dicho alcalde mayor y diputados, re/ (f. 257r)partidores. En Santa María del Campo, a 20 de marzo de 1531, ante Diego Pérez de Leguetio, escribano del repartimiento. La ynformación se hizo el mismo año ante Andrés de Baltanás, escribano de Saldaña.

10. < Proclama de calumnia en el pleyto de los tres lugares sobre el yantar y dos obreros. Año 1595>.

Ynformación y juramento de calumnia hecho por el convento de San Zoil en virtud de una real provisión dada en la Chancillería de Valladolid, a 6 de diciembre de 1594, ante Bartholomé Furtado, escribano de cámara, para el pleyto que el convento puso a los concejos de Gañinas, Lobera y Villarmienzo ${ }^{375}$, en que articuló que de tiempo y costumbre inmemorial estaba en convento en posesión de llevar un yantar de cada uno de los tres concejos y dos obreros de cada vecino para la siega de(l) agosto. Y, negándolos estos concejos, les puso el convento demanda y siguió el pleyto en la Chancillería. Y, estando recivido a prueba además de la información plenaria que hizo el convento ante Juan de Ache, recetor de ella, hizo ésta de calumnia ante Andrés Sánchez, escribano de Carrión, por la qual, habiendo sido requerido el concejo de Villarmienzo con la real provisión, nombró y dio su poder para hacer el juramento de calumnia a Pedro Bustillo, Juan Marcos y Pedro Ybáñez, vecinos de dicho lugar, ante el mismo recetor Juan de Ache el qual, devajo de juramento, les tomó sus deposiciones al tenor de cierto interrogatorio; y todos tres se remitieron a lo que habían dicho en la información hecha por el monasterio en este pleyto ante el dicho recetor. Hízose esta información de calumnia en Villarmienzo por el mes de septiembre de 1595, ante Juan de Ache, recetor de la Chancillería. Dirijiose al secretario Zarandona, escribano de Cámara, ante quien pasaba este pleyto.

\section{1. < Testimonio de el libro bezerro de Valladolid. Año 1595>.}

Testimonio de las cláusulas que se hallan en el libro beçerro de la Chancillería de Valladolid, por donde consta que este lugar de Gañinas es abadengo y que es del camarero de San Zoyl de Carrión con otros derechos. Fueron sacadas estas cláusulas por Martín Ruiz de Mitarte, chanciller, en Valladolid, a 28 de noviembre de 1595.

Hay aquí una copia simple de estas mismas cláusulas y de los lugares de Lobera y Villarmienzo ${ }^{376}$.

\footnotetext{
374 Villota del Páramo] al margen derecho: Lobera, Villarmienzo, Pedrosa y Villota del Páramo.

375 Villarmienzo] al margen derecho: Lobera y Villarmienzo.

376 Villarmienzo] al margen derecho: Lobera y Villarmienzo.
} 
12. $<$ Ttestimonio de jurisdicción. Año 1596>.

Testimonio de cómo fray Alonso Barrantes, monge de San Zoil, con poder del convento, en señal de jurisdicción, llamó al merino de Gañinas y le pidió copia de los vecinos del lugar y le mandó tocar a concejo, y de cómo le obedeció. En 6 de septiembre de 1596, ante Mateo de Cosío, escribano de Saldaña.

\section{3. $<$ Nombramiento de merino. Año de 1623>.}

Testimonio dado por Francisco Moro de Saldaña, escribano de Carrión, del nombramiento de merino mayor del lugar de Gañinas que el padre fray Juan Díez, abad de San Zoyl, hizo en la persona de Gabriel Díez, / (f. 257v) vecino de dicho lugar. Su fecha, en San Zoyl, a 7 de enero de 1625.

limosna>.

$<$ Sentencia difinitiva para que el merino de Gañinas no sea mayordomo de la

Está aquí una sentencia difinitiva dada por don Pedro Vallejo, alcalde mayor del adelantamiento de Campos, por la qual consta que, habiendo el concejo de Gañinas nombrado a Gabriel Díaz, merino de dicho lugar, por mayordomo de la limosna que dexó don Pedro Vaca, arzobispo que fue de Granada, el dicho merino se quexó ante el licenciado don Juan de Saravia, correjidor de Saldaña, el qual, oýdas las partes, sentenció y condenó al merino a que acetase el oficio de mayordomo; el qual apeló al adelantamiento donde se llevó el proceso; y, vista la causa por el alcalde mayor, dio esta sentencia difinitiva en que da por libre al merino y manda al concejo que nombre otro mayordomo para la limosna y que el correjidor de Saldaña la mande executar y, aviéndosele notificado, la obedeció y en su cumplemiento dio mandamiento para el concejo, nombrase otro mayordomo. Fue dada esta sentencia en Villalón, a 25 de enero de 1627, ante Alonso Pérez, escribano.

14. $<$ Nombramientos de merinos para los tres lugares. Año 1633>.

Nombramientos de merinos para Gañinas, Lobera y Villarmienzo ${ }^{377}$ hechos por los abades de San Zoil en un solo sujeto para los tres lugares, desde el año de 1633 hasta el de 1680; pero se advierte que en los títulos de estos lugares hay otros nombramientos más antiguos, especiales para cada lugar.

\section{5. <Memorias y papeles en derecho para el pleyto del foro $>$.}

Memoriales, papeles en derecho y otras advertencias para el pleyto que este monasterio de San Zoil litigó con el concejo de Gañinas sobre la paga de 28 cargas de pan mediado y 12 gallinas que cada año pagaba de foro perpetuo al dicho monasterio por las tierras, prados, sotos, etcétera, que es el del número $8^{\circ}$ de este quaderno.

16. $<$ Executoria a favor de este monasterio sobre la paga del foro de 28 cargas de pan y 12 gallinas. Año 1644>.

Executoria ganada en la Chancillería de Valladolid a favor de este monasterio contra el concejo y vecinos de Gañinas sobre la paga de 28 cargas de pan, mediado trigo y cevada, y 12 gallinas que pagaban cada año de foro perpetuo por la hacienda que tenía allí el monasterio. Fue dada en Valladolid, a 14 de septiembre de 1644, ante Martín Gallo, escribano de Cámara de Su Magestad. Véase el número $8^{\circ}$ de este quaderno, donde se halla la escritura del foro y una relación de este pleyto. $1651>$.

17. <Sentencia a favor del monasterio por los 300 maravedís de martiniega. Año

Sentencia difinitiva a favor de este monasterio dada por el alcalde mayor de Palencia contra el concejo y vecinos de Gañinas, por la qual les condena a pagar los 300 maravedís de martiniega que debían pagar cada año al monasterio de los ocho años que estaban debiendo, amparándole en la posesión immemorial en que siempre había estado y reservando el / ( $f$. 258 r) derecho a salvo a la parte del dicho concejo, para que, en razón de la propiedad, pidan

377 Villarmienzo] al margen derecho: Lobera y Villarmienzo. 
y sigan su justicia donde les convenga. Fue dada en Palencia, a 16 de diciembre de 1651, ante Hernando Xuárez, escribano.

Está cosida con esta sentencia la carta de pago que dio el monasterio al concejo de Gañinas de 2.700 maravedís de la dicha martiniega de nueve años corridos hasta el de 1651 inclusive, a razón de 300 maravedís en cada uno, según la sentencia antecedente; ante Francisco Moro de Saldaña, escribano de Carrión.

18. $<$ Nombramiento de merino para los tres lugares. Año 1731>.

Testimonio dado por Agustín Díez de Castro, escribano de Carrión, del nombramiento de merino mayor de Gañinas, Lobera y Villarmienzo ${ }^{378}$ que el padre fray Plácido de Iglesias, abad de San Zoil, hizo en la persona de Christóval Herrero, vecino de Gañinas, para que lo fuese de los tres lugares. Su fecha, en San Zoil, a 27 de marzo de 1731.

19. <Papeles sobre el derecho del monasterio en los tres lugares>.

Papeles simples que contienen una razón de los ynstrumentos que tiene el monasterio por donde consta que los lugares de Gañinas, Lobera y Villarmienzo son suyos y tiene en ellos jurisdicción, martiniega, peones, etcétera. Y, assimismo se hace relación de que per non vsum perdió el monasterio lo más de esto y cómo se podrá intentar restituyrlo.

\section{Remisiones a otros cajones}

$<$ Trueque $>$.

El privilegio original y carta de trueque de don Alonso $9^{\circ}$ en que da a Gañinas por la villa de Aguilar de Campos. Véase el cajón de San Yldefonso, legajo $1^{\circ}$, número $1^{\circ}$.

$<$ Confirmación $>$.

El privilegio del rey don Alonso el Sabio, que es confirmación del de don Alonso el $9^{\circ}$. Véase el mismo cajón y legajo, número $2^{\circ}$.

$<$ Confirmación $>$.

El privilegio del rey don Fernando el $4^{\circ}$, que es confirmación del de don Alonso el Sabio. Véase el mismo cajón y legajo, número $3^{\circ}$.

$<$ Confirmación $>$.

El privilegio del rey don Alonso $11^{\circ}$, que es confirmación del de don Fernando el $4^{\circ}$, su padre. Véase el mismo cajón y legajo, número $4^{\circ}$.

$<$ Pesquisa $>$.

Pesquisa sobre los pastos y riego del lugar de Gañinas. Véase el cajón San Agapio, legajo $1^{\circ}$, quaderno $\mathrm{A}$, número $1^{\circ}$, en el quaderno al folio $8^{\circ}$.

$<$ Foros $>$.

Dos foros, el uno de 4 maravedís y el otro 2 maravedís y medio, sobre unas casas en este lugar de Gañinas. Véase el libro $5^{\circ}$ de vistas y arrendamientos, a los folios 73 y 74.

\section{/ (f. 258v) Quaderno D del Legajo $1^{\circ}$ \\ Grijota}

Este quaderno D contiene los papeles pertenecientes a la hacienda que tiene este monasterio en este lugar, por el orden siguiente:

$1^{\circ}$. <Compra de 5 tierras para redimir un censo. Año 1656>.

378 Villarmienzo] al margen derecho: Lobera y Villarmienzo. 
Compra que hizo este monasterio a Pedro Caballero y María Gato, su muger, vecinos de Grijota, de cinco tierras en término de dicha villa, que hacen 12 hobradas, las quales venden al monasterio para redimir un censo que contra sí tenían, que llaman de Villafrechós. Se tasaron estas tierras en 42 mill maravedís, que son 1.235 reales, de los quales los 912 eran de la parte del principal y los 323 restantes de los réditos devengados. Otorgose esta escritura en Grijota, a 16 de julio de 1656, ante Pedro Caballero, escribano de dicha villa.

$2^{\circ}$. <Compra de una cueba y 10 tierras para redimir 3 censos. Año 1657>.

Compra que hizo este monasterio a Hernando Becerro y consortes, vecinos de Grijota, de una cueba con dos bastos de cubas y 10 tierras, las 7 en término de Grijota y las 3 en el de Villaumbrales ${ }^{379}$, con las quales redimieron 3 censos (cuyas escrituras están cosidas aquî que contra sí tenían. Ymportaban los censos con principal, réditos, costas y salarios, 4.937 reales; y las heredades se tasaron en 4.268 reales, con que se les perdonaron 669 reales. Fue otorgada esta escritura en el monasterio de San Zoil, a 21 de septiembre de 1657, ante Norberto de Sandoval y Guevara, escribano de Carrión.

\section{/ (f. 259r) Legajo $2^{\circ}$ del Cajón San Lorenzo \\ Las Heras}

Este legajo, que es el $2^{\circ}$ del cajón San Lorenzo, contiene quatro quadernos pertenecientes al lugar de Las Heras, que son los siguientes: Quaderno A: papeles pertenecientes a la hacienda que tiene San Román y San Zoil en este lugar; Quaderno B: hacienda que tiene Nuestra Señora del Brezo en este lugar; Quaderno C: yglesia, presentaciones del beneficio de este lugar y diezmos; Quaderno D: hermita del Santo Christo de este lugar.

\section{Quaderno A del legajo $2^{\circ}$}

Este quaderno A contiene los papeles pertenecientes a la hacienda que tiene San Román y San Zoil en este lugar de Las Heras, por el orden siguiente:

$1^{\circ}$. <Donación de doña María. Era 1116. Año 1078>.

Donación que hizo doña María, hija de los condes, a Bononomen, abad de San Román, y a los monges que están en aquel monasterio de ciertos solares en el lugar de Las Heras, y una heredad en San Martín ${ }^{380}$ junto a Villalveto, que ya está despoblado. Facta carta era 1116 (según el padre Cisneros), que es año de Christo 1078.

Adviértase que esta casa puede estar equivocada pues ni hay figura de mil ni en los numerales góticos se encuentra el cinco antes del diez como se ve en esta escritura.

/ (f. 259v) 2. <Donación de Scetha Ferre de una casa y su heredad. Era 1162. Año $1124>$.

Donación, escrita en pergamino, que hizo Scetha Ferre a San Román y a los monges que allí servían a Dios día y noche, de una casa con toda su heredad porque la recivan en su hermandad. Su fecha, era 1162, que es año de Christo 1124. Regnante rex Aldefonsus in Castro et in Carrione et in Burgos, etcétera.

3. <Donación de Vrraca Martínez de toda su heredad. Era 1234. Año 1196>.

Donación, escrita en pergamino, que hizo Vrraca Martínez para la obra de San Román de toda la heredad que tenía en Entorcisa y Las Heras, y la heredad que tenía en Aviñante ${ }^{381}$, prados, tierras y exidos y solares en Villanueva. Y el maestro de la obra, el prior

\footnotetext{
379 Villaumbrales] al margen derecho: Villaumbrales.

380 Martín] al margen derecho: San Martín, junto a Villalveto.

381 Aviñante] al margen derecho: Aviñante, Entorcisa y Villanueva.
} 
y todo el convento lo reciben y aceptan. Su fecha, en el mes de mayo, era de 1234, año 1196. Regnate Rex Alfonsus in Castella et in Toleto, cum regina Leonor, etcétera.

4. <Compra de un solar. Era 1380. Año 1342>.

Compra que hizieron García Fernández y Juana Gómez a María Fernández, de un solar que tenía en el lugar de Las Heras, cuya escritura por no poderse leer toda no se sabe si este solar le donaron o vendieron a San Román. Su fecha, era 1380, que es año de 1342, ante Juan Pérez, escribano de Guardo.

5. <Sentencia de división de términos de Las Heras y Villanueva. Año 1453>.

Sentencia que dio don Pedro de Tosantos, abad de San Zoil, como señor de los lugares de Las Heras y Villanueva ${ }^{382}$, por la qual dividió los términos, pastos, mojones y aguas de estos dos lugares, y manda que ninguna parte de los dos concejos no vaya en contra dicha sentencia, so pena de 28 maravedís a cada una de las partes. Fue dada a 28 de abril de 1453 , ante Juan González de Villalveto, escribano y notario público.

6. <Sentencia a favor de San Román sobre pastar, rozar y cortar en término de Las Heras. Año 1539>.

Sentencia árbitra dada por el padre fray Diego de Covarrubias, prior de Nuestra Señora del Brezo, por compromiso del padre fray Diego de Sahagún, prior de San Román, y el concejo y vecinos del lugar de Las Heras en el pleyto y diferencia que había entre las dos partes sobre pastar, rozar y cortar en el término de dicho lugar.

Por esta sentencia se declara que el prior de San Román y sus antecesores habían mandado pacer, rozar y cortar con bueno y justo título en el dicho término de Las Heras; y manda que de allí adelante en (sic) dicho prior y sus subcesores./ (f. 260r) en nombre del monasterio de San Román lo puedan hacer libre y desembargadamente donde y quando el concejo de Las Heras pace, roza y corta en la forma dispuesta en cierta escritura y apeo del monasterio; y si en esto escedieren los criados del monasterio, el concejo envíe a él por la pena que estubiere puesta, y que el prior sea obligado a satisfacerles; y que el prior les perdone el exceso de ciertas prendas que los de Las Heras habían tomado a sus criados, pero las habían vuelto y todo lo habían hecho ignorante e inocentemente. Pronunciose esta sentencia en el monasterio de San Román, a 27 de abril de 1539, ante Christóbal Gómez, cura de Santa María Madre (que es en el dicho monasterio), notario apostólico. La qual sentencia se notificó al prior y al concejo de Las Heras y todo[s] la aceptaron y admitieron.

Hay copia autorizada de esta sentencia. $1568>$.

7. <Testimonio de que los de Las Heras predaron el ganado de San Román. Año

Testimonio dado por Agustín de Medina, escribano real, de cómo los de Las Heras prendaron el ganado de San Román, se lo maltrataron y lo llebaron prendado; y requirimiento que les hizo el padre fray Antonio de Grijalba, prior de San Román, para que se le volviese. Su fecha, en Las Heras, a 13 de octubre de 1568.

8. < Sentencia a favor de San Román en la posesión de pastar, etcétera. Año 1571>.

Copia simple de una sentencia dada por el licenciado Veltrán de Guevara, alcalde mayor del adelantamiento de Campos, por la qual amparó al monasterio de San Román en la posesión en que ha estado de gozar con sus ganados mayores y menores de los pastos y aguas de los términos de Las Heras, y cortar leña de sus montes como uno de los vecinos de él, y condena a los vecinos a que no inquieten al prior en esta posesión, so pena de 50 mill maravedís, y les reserva su dicho (sic), salvo en la propiedad. Pronunciose a 16 de febrero de 1571.

/ (f. 260v) 9. < Sentencia para que los de Las Heras no rompan ni enagenen las tierras de su término. Año 1571>.

382 Villanueva] al margen derecho: Villanueva. 
Copia simple de una sentencia dada por el mismo licenciado Beltrán de Guevara, por la qual condena al concejo y vecinos del lugar de Las Heras a que no empeñen, vendan ni enagenen tierras algunas del término de dicho lugar contra lo dispuesto por las leyes del reyno; y si algunas están aradas y rompidas no las aren más sino que las dexen para pasto comun, etcétera. Pronunciose esta sentencia a 16 de febrero de 1571. Año 1571>.

10. $<$ Provisión de la Chancillería para llevar el proceso de las dos sentencias de arriva.

Provisión real de la Chancillería, en la qual se hace relación que el concejo de Las Heras apeló de las dos sentencias de arriva y se presentó, y porque no siguió la apelación ni llevó el proceso se manda por esta provisión, sacada a instancia del prior de San Román, que se lleve el proceso y autos del pleyto a costa del concejo y vecinos de Las Heras. Dada en Valladolid, a 30 de septiembre de 1571, ante Pedro Alemán, escribano de cámara. A la espalda está la notificación de esta provisión hecha al concejo y vecinos de dicho lugar, a 1 de noviembre del mismo año, por Agustín de Medina, escribano real.

11. <Apartamiento de la apelación y consentimiento de la sentencia del adelantamiento dada a favor de San Román. Año 1572>.

Testimonio dado por Agustín de Medina, escribano real, por el qual consta que el concejo y vecinos de Las Heras en forma de concejo se apartan del pleyto que tenían con el prior y monges de San Román sobre la vecindad y ciertas prendas que habían hecho al monasterio, en el qual pleyto fueron condenados por el alcalde mayor del adelantamiento; y conociendo ahora que no tienen justicia, de un acuerdo y voluntad se apartan de la apelación y apelaciones que tenían hechas de la dicha sentencia y consienten en ella; piden y suplican al dicho alcalde mayor libre carta executoria de la dicha sentencia en quanto hubiese lugar de derecho, y que ellos desde luego la consienten y dan por buena; y si no hubiese lugar de darla el alcalde mayor, se saque de los señores oidores de la chancillería. Y lo pidieron por testimonio en el lugar de Las Heras, a 28 de abril de 1572.

\section{2. < Adjudicación de una casa para San Román>.}

Copia simple de una sentencia dada por el licenciado Peralta en un pleyto entre Juan García, vecino de Las Heras, y García del Varruelo, vecino de Villanueba, el qual es dado por libre de la demanda y se adjudica a San Román por suya propia una casa sobre que fue la demanda. No hay más razón que esta.

/ (f. 261r) 13. < Consulta y parezer sobre la contribución del prior de San Román como vecino de Las Heras. Año 1596>.

Bajo este número están los papeles siguientes:

$1^{\circ} \mathrm{Vn}$ memorial de lo que pretendían los vecinos de Las Heras sobre que el prior de San Román contribuyese como vecino en sus repartimentos.

$2^{\circ}$ Vna consulta hecha por fray Antonio Perroto, prior de San Román, al licenciado Ordóñez de la Real, en la qual, tocando los pleytos sobre la vecindad de Las Heras, dice que el monasterio tiene carta executoria (la qual no parece en el archivo) y assimismo que los de Las Heras pretendían que el prior como vecino de aquel lugar contribuyese en los repartimientos penales; y el prior se escusa por exento y le nombra por juez árbitro por su parte, en 28 de abril de 1596.

$3^{\circ}$ Parecer del licenciado Hinojedo, que San Román debe gozar los aprovechamientos de Las Heras como vecino de este lugar.

Síguense unas advertencias sobre esta vecindad.

14. <Compra de una casa en Las Heras. Año 1708>.

Compra que hizo este monasterio al licenciado Bartolomé González Donis, clérigo de menores órdenes, de una casa en el lugar de Las Heras, junto a la yglesia, que linda con casa de Favián Valle y calles reales, por precio de 1.044 reales. Otorgose esta escritura en el lugar de Las Heras, a 4 de mayo de 1708, ante Lorenzo Luis, escribano y vecino del lugar de Villanueva de Muñeca. 
15. < Trueque de dos solares por un prado en Las Heras. Año 1789>.

Trueque que hizo el padre fray Gregorio Calderón, prior de San Román, con José Roldán, vecino de Riosmenudos, de dos solares de casa que el dicho priorato tenía en dicho lugar, por un prado en término del lugar de Las Heras, a do llaman Garganta del Valle y presa de Los Molinos, que haze un carro de yerba; linda a poniente con prado de dicho priorato; al norte, con prado y tierra de Bernardo de la Cuesta; al oriente, con prado del mismo Bernardo; y a medio día, con el río y presa. Otorgose esta escritura en el priorato de San Román, a 16 de marzo de 1789, ante Manuel Luis París, escribano y vecino de Villanueva de Arriba.

16. <Trueque de una casa y solar con su corral y huerto por 2 prados y 3 tierras en Las Heras. Año 1791>.

Trueque que hizo el padre maestro fray José Fierro, prior de San Román, con Leonardo Macho y Magdalena Pérez, su muger, vecinos del lugar de Las Heras, de una casa y solar con su corral y huerto que el dicho priorato tenía en dicho lugar, a el Barrio de Medio, por un prado en el término de dicho lugar, <que hace medio carro de yerva $>$, a do llaman Prado Llano, que linda al poniente con prado de/ (f. 261v) don Francisco Enrríquez; al norte, con prado de don Manuel García Ramos; al oriente, con prado de dicho priorato; y al mediodía, con tierra libre de Manuel Macho.

Más por otro prado en el término de dicho lugar, a Fuente Frayle, que hace una carretada de yerva, linda al oriente con tierra del dicho Manuel Macho; a poniente, con tierra de dicho priorato; a mediodía, con tierra también de dicho priorato; y al norte, con prado de Francisco Alcalde.

Más por una tierra linar, término de Villanueva ${ }^{383}$, a do llaman Socasa, que hace una fanega de linaza; linda al oriente con linar de José de la Calle; a mediodía, con la Regadera; a poniente, con linar de Josefa García; y al norte, con Prado de don Francisco Zevallos.

Más por una tierra en el mismo término de Villanueva, a do llaman Pedraza, que hace tres quartos de trigo; linda a poniente y mediodía con tierra de Josefa García; al norte, con tierra de Bartholomé Luys; al oriente, con tierra de las Ánimas; y al mediodía, con el campo del Concejo.

Más por otra tierra en término del lugar de Las Heras, a do llaman Ontana, que hace diez celemines de morcajo; linda al norte con el Monte; al poniente, con tierra de José Alcalde; a mediodía, con la lindera gorda; al oriente, con tierra que se ignora su dueño. Y el padre prior de San Román pagó 30 reales por el esceso y más valor de dichas heredades. Fue otorgada esta escritura en el lugar de Las Heras, a 4 de octubre de 1791, ante Manuel Luys París, escribano y vecino de Villanueva de Arriba. $1791>$.

17. <Trueque de una casa con su parte de corral por 2 prados y una tierra. Año

Trueque que hizo el padre maestro fray José Fierro, prior de San Román con Santiago Roldán, menor, y Bárbara de el Amo, su muger, vecinos del lugar de Las Heras, de una casa sitio y solar en el casco de dicho lugar, a el barrio del Peral, con su parte de corral, que el dicho priorato tenía en el referido lugar; por un prado en el término del mismo lugar, a do llaman Río de Oro, que hace una carretada de yerva; linda a mediodía con prado de Francisco Alcalde y con otro de dicho priorato; al norte, con tierra de Manuel Luys Díez y con la lindera gorda; y a poniente, con prado de Juan Fernández, y hace pico a saliente.

Más por otro prado en dicho sitio de Río de Oro, que hace una carretada de yerva; linda a poniente con prado de dicho priorato; a mediodía, con el río; al oriente, con prado de las Amayuelas; y al norte, con tierra del ya citado Manuel Luys.

Más por una tierra en término de Santiváñe ${ }^{384}$ a la Sopeña de Mattemala, que hace un quarto de trigo; linda a poniente con tierra de José Alcalde; al norte, con la Peña; al oriente,

383 Villanueva] al margen derecho: Villanueva.

384 Santiváñez] al margen derecho: Santiváñez. 
con tierra de la yglesia de Las Heras; y a mediodía, con una lindera. El padre prior pagó los 20 reales por el más valor que tienen dichas heredades. Fue otorgada esta escritura en el lugar de Las Heras, a 7 de diziembre de 1791, ante Manuel Luys París, escribano de Villanueva de Arriba. Año 1791>.

/ (f. 262r) 18. < Trueque de una casa con su huerto y corral por una tierra y un prado.

Trueque que hizo el padre maestro fray José Fierro, prior de San Román, con Froylán Aparicio y Eulalia Gracía, su muger, vecinos de Las Heras, de una casa, sitio y solar con su huerto y corral, que el dicho priorato tenía en el casco de dicho lugar, a el barrio del Peral, por una tierra en el término del dicho lugar, a do dicen Rebanal, que hace quarto y medio de trigo; linda al oriente con tierra de Agustín de Medina; a mediodía, con una lindera; a poniente, con tierra que goza Thomas García; y al norte, con el arroyo.

Yttem por un prado en término de dicho lugar, bajo de la fuente a el Zalde de la Carrera, que hace un carro de yerva; linda al norte con el prado grande de San Román; a poniente, con prado de José González; al mediodía, con el dicho prado grande del priorato; y al oriente, con prados de San Vicente y herederos de Balthasar de Aguilar. Y el padre prior <pagó> 269 reales por el mayor valor de las dichas heredades. Fue otorgada esta escritura en el lugar de Las Heras, a 25 de noviembre de 1791, ante Manuel Luys París, escribano y vecino de Villanueva de Arriba.

19. <Trueque de una casa con su corral y huerto por 4 tierras y un prado. Año 1791>.

Trueque que hizo el padre maestro fray José Fierro, prior de San Román, con Pedro Calvo y su muger, Bernarda de la Cuesta, vecinos de Las Heras, de una casa con su corral y huerto que el dicho priorato tenía en medio del dicho lugar, por una tierra en término de Las Heras, a do llaman la Valleja, que hace medio quarto de centeno; linda al mediodía con mata del concejo; al oriente, con tierra de Juan Fernández; al norte, el mismo; y al poniente, tierra del mismo.

Más por otra tierra en el mismo término y sitio de la Valleja, que hace medio quarto de centeno; linda al poniente con tierra de herederos de Manuel García; al norte, con tierra de Ángel García; al oriente, con tierra de Simón Rojo; y al mediodía, con tierra de Manuel Rebanal.

Más por otra tierra en término de Las Heras, sobre Mata Caleros, que hace un quarto de trigo; linda al mediodía con una lindera; al poniente, con un pizcarral; al norte, con una lindera y con tierras de Hipólito Roxo etcétera; y al oriente, con tierra de Mathías García.

Más por otra tierra en el mismo término, a las Tenébrigas, que haze cinco zelemines de trigo; linda al norte con una lindera; al mediodía, con otra lindera; al oriente, con tierra de Antonio Barrero; y al poniente sale a pico.

Más por un prado en el término del mismo lugar, a do llaman Río de Oro, a el lado de la loma, que hace más de medio carro; linda al norte con el río; al oriente, con prados de los herederos de Phelipe Díez; al mediodía, con la loma; y al poniente, lindando a mediodía con prado de dicho Phelipe Díez. Y el padre prior recivió 60 reales por el esceso y mayor valor que tenía la casa a las heredades que recivió. Fue otorgada esta escritura en el lugar de Las Heras, a 25 de noviembre de 1791, ante Manuel Luys París, escribano y vecino de Villanueva de Arriba.

\section{/ (f. 262v) 20. <Trueque de un solar con su huerto por un (sic) tierra. Año 1797>.}

Trueque que hizo el padre fray Pedro de Castro, prior de San Román, con Santiago Santos, vecino del lugar de Pino de Viduerna, de un solar con su huerto, que todo está unido, y que el dicho priorato tenía en el casco de dicho lugar de Pino, en su barrio de la Yglesia, por una tierra en término del lugar de Las Heras, a do llaman la Torre, que hace quatro celemines y medio de trigo; linda al norte con tierra de Vita deste dicho priorato, que gozan los herederos de Francisco Díez; al mediodía, con otra de la capilla del Santísimo Christo 
intitulado de Las Heras; al poniente, con tierra de Miguel de Liévana; y al oriente, con tierra de don José Alonso. Fue otorgada esta escritura en el priorato de San Román, a 11 de mayo de 1797, ante Bernardo Valbuena, escribano y vecino del lugar de Respenda.

21. <Compra de una casa en Las Heras. Año 1805>.

Compra que hizo el padre fray Silvestre Palacios, cura del lugar de Las Heras, a Atanasio Casares, vecino del lugar de Aviñante, de una casa en el dicho lugar de Las Heras, linderos, casa de este monasterio y herederos de Ventura Díez, vecino que fue de dicho lugar, y calles reales, por 550 reales de vellón. Su fecha, en Guardo, a 18 de septiembre de 1805, ante Diego Manuel González de Córdova, escribano de dicha villa.

\section{Remisiones}

$<$ Donación $>$.

La donación que hizo Pela Rubio de las heredades que tenía en Las Heras. Véase el cajón San Martín, legajo $1^{\circ}$, quaderno A, número $6^{\circ}$.

$<$ Trueque $>$.

Trueque de una casa por un linar en el lugar de Las Heras, a do llamana Encima del Campo. Véase el cajón San Martín, legajo $1^{\circ}$, quaderno B, número (sic).

$<$ Tierra. Linares $>$.

Vna tierra y dos linares en Las Heras. Cajón San Martín, legajo $1^{\circ}$, quaderno B, número 34.

$<$ Linar. Tierras $>$.

Vn linar en Las Heras para San Román. Cajón San Martín, legajo $1^{\circ}$, quaderno B número 37. Dos tierras para San Román. Véase el cajón San Gregorio, legajo $2^{\circ}$, quaderno $\mathrm{D}, \mathrm{n}^{\mathrm{o}} 2$.

$<$ Linar. Prado $>$.

21.

Vn linar y prado. Véase el Cajón San Plácido, legajo 5º quaderno E, números 16 y

\section{/ (f. 263r) Quaderno B del legajo $2^{\circ}$}

Este quaderno B contiene los papeles pertenecientes a la hacienda que tiene Nuestra Señora del Brezo en este lugar de Las Heras, por el orden siguiente:

$1^{\mathrm{o}}$. < Foro de seis quartos de trigo y tres reales por el Monte del Rey. Año 1579>.

Escritura de foro perpetuo por la qual don Diego de Colmenares y doña Juana Enrríquez de la Vega, su muger, dan a Toribio Merino y a Toribio Macho, vecinos del lugar de Las Heras, <y a Martín Macho>, el monte que llaman del Rey, por seis quartos de trigo y tres reales de foro perpetuo en cada un año. Su fech,a en la villa de la Puebla, a $1^{\circ}$ de abril de 1579, ante Juan Pérez, escribano de Su Magestad.

Este monte le donaron los referidos al priorato del Brezo, como se verá abajo.

$2^{\circ}$. <Compra de una tierra en Las Heras. Año 1592>.

Compra que hizo fray Francisco Villafuerte, prior del Brezo, a Pedro Casa, vecino de Santiváñez de la Peña, como testamentario de Mencía Díez, su muger, de una tierra en término del lugar de Las Heras, a do llaman a Curial, que hace quarto y medio de sembradura, 
por precio de quince ducados, que pagó el dicho prior. Su fecha, en el lugar de Cornoncillo, a 6 de mayo de 1592, ante García de Cosío, escribano de la Audiencia de la villa de la Puebla.

3. <Donación del Monte del Rey para Nuestra Señora del Brezo. Año 1599>.

Donación que hicieron a la casa de Nuestra Señora del Brezo don Diego de Colmenares, doña Juana Enrríquez, su muger, y don Pedro Enrríquez y Colmenares, vecinos del lugar de la Puebla, del monte que llaman del Rey, en el término del lugar de Las Heras, con carga de que se les diga una misa rezada el primer sábado de cada mes; y con condición que ningún prior ni abad ni otra persona alguna pueda vender, dar ni trocar dicho monte; y si lo hicieren, que en tal caso no valga y que sus herederos lo puedan pedir y sacar como suyo; y lo mismo si no se digeren las doce misas. Fue otorgada en la Hoz del Brezo, a 9 de septiembre de 1599, ante Blas Ordóñez, escribano natural de Cervera y vecino de Viduerna.

$<$ Ratificación $>$.

Síguese la ratificación que hizo la dicha doña Juana Enrríquez de la Vega de la donación de arriba, en que declara que por ser/ (f. 263v) muchas las doce misas que ordena se le digan en la escritura de arriva, las reduce a solas tres cada año perpetuamente ${ }^{385}$ : la primera cantada, que se digere en la casa de Nuestra Señora, día de Santa María de septiembre; la segunda cantada, día de la Cruz; y la tercera rezada, día de Santa Ana. Su fecha, en la Puebla, a 8 de noviembre de 1599, ante el mismo escribano.

$<$ Ratificación de la donación $>$.

Vltimamente está aquí otra ratificación que hizo de la dicha donación don Pedro Enrríquez de Colmenares, vecino de la Puebla, residente en Tablares, en la misma forma y con la misma declaración y redución de misas que la que hizo doña Juana Enrríquez, su tía. Hecha en Viduerna, a 26 de noviembre de 1599, ante el mismo escribano.

\section{4. <Cesión de varias hipotecas para Nuestra Señora del Brezo. Año 1668>.}

Escritura de cesión que hicieron Damián Díez y Escolástica Cordero, su muger, vecinos del lugar de Santiváñez de la Peña, y Juan Merino de el de Barajores como curador de la persona y bienes de María Cordero, de una casa, tres tierras, un prado en el lugar de Las Heras, y otro en el término de Santiváñez, como hipotecas afectas al censo que en favor del santuario del Brezo otorgaron Pedro Cordero y Catalina Barriosuso de 500 reales de principal, en 19 de julio de 1668, cuya cesión hicieron con autoridad de justicia por las crecidas cantidades que estaban debiendo de los réditos de dicho censo. Fue otorgada esta escritura en el priorato del Brezo, a 11 de octubre de 1784, ante Ygnacio de la Puente, escribano de Saldaña. Está aquí la escritura de censo.

\section{5. <Trueque de una tierra por un prado. Año 1796>.}

Trueque que hizo el padre fray Yldefonso Hidalgo, prior del Brezo, con Simón de Arriba, vecino de Las Heras, de un solar de casa que tenía el dicho santuario en el casco del mismo lugar, al barrio porquero, por un prado en el término de dicho lugar, a Las Herras, a Puente la Veguilla, que hace una carretada de yerbas; linda al oriente con prado de Felipe Martín; al mediodía, con el río; a poniente, con exidos y tránsito de las haciendas; y al norte, con las linderas. Y el padre prior entregó al dicho Simón 45 reales por el exceso y más valor que tenía el dicho prado. Fue otorgada esta escritura en la villa de Guardo, a 7 de enero de 1796, ante Rafael de Medina Mandes, escribano de dicha villa.

\section{/ (f. 264r) Remisiones}

$<$ Compra $>$.

Compra de una tierra en este lugar para el Brezo. Véase el cajón San Martín, legajo $1^{\circ}$, quaderno $\mathrm{C}$, número $7^{\circ}$.

\footnotetext{
385 perpetuamente] al margen derecho: Dos misas cantadas y una rezada.
} 
$<$ Compra $>$.

Compra de un huerto cercano en este lugar. Véase el mismo cajón, legajo y quaderno, número 10.

\section{Quaderno C del legajo $2^{\circ}$}

Este quaderno $\mathrm{C}$ contiene los papeles pertenecientes a la yglesia, presentaciones del beneficio y diezmos del lugar de Las Heras, por el orden siguiente:

$1^{\circ}$. <Concordia entre el prior de San Román y concejo de Las Heras sobre poner clérigo. Era 1278. Año 1190>.

Concordia antigua, escrita en pergamino, y partida por ABC, la qual dice como en el tiempo del prior don Fernando ovo discusion entre el concejo de Las Heras y la casa de San Román sobre la yglesia de Las Heras. El concejo decía que bien avría nueve años que ellos metieran clérigo e sacaran. E el prior decía que donde él avía cimiterio e fonte e tercia, él debía a meter clérigo e elos non. E sobre tales razones como aquestas fecimos tal composición: que el prior e el concejo metan clérigo en aquella yglesia de mancomún, e el clérigo o los clérigos que cantaran la yglesia sean vasallos de San Román; e todo clérigo que fore natural de la villa ordénese por mandado del prior o del convento para aquella yglesia, e si ovier ibi naturale de que plega al concejo e al prior que sea e otro non. Et aquellos homes delas no se entierren ni se bapticen si non en San Román, e San Román sos derechos, así como ovo siempre cimiterio/ (f. 264v), baptismo e V maquilas de pan ${ }^{386}$ de la yglesia, la tercia de trigo, la tercia de centeno, la tercia de ordio. Facta carta feria III ${ }^{\mathrm{a}}$, die nominato VI kalendas julii, era 1278, que es año de 1190. Regnante Rege Ferdinando et cetera.

2. < Sentencia árbitra en favor de San Román del modo como había de servir el capellán en San Román, Las Heras y Santiváñez, y como los feligreses habían de ir a San Román. Año 1433>.

Sentencia árbitra dada por Alfonso Pérez de Castejón y Juan Martín, clérigo de Tarilonte, jueces árbitros nombrados por parte de don Pedro Martínez, prior de San Román, de la una parte, y Juan Fernández, capellán del dicho monasterio, de la otra, sobre las contiendas que había en razón de cómo había de serbir el dicho capellán en el dicho monasterio y cómo le había de pagar el prior y qué cosa había de hacer cada una de las partes. Vistas las razones de una y otra, y usando del compromiso y poder a ellos dado, que pasó ante Alfonso Fernández de Tarilonte, beneficiado en Santa María de Regla en León, notario apostólico; y habiéndose informado de la verdad y de lo que habían usado los priores pasados con los capellanes, por quitar pleytos y diferiencias, de común acuerdo determinaron y dieron la sentencia siguiente:

Primeramente mandan que el dicho Juan Fernández, clérigo, sirva por sí en el monasterio de San Román como capellán en todas las fiestas de Nuestro Señor, Nuestra Señora, apóstoles y otros principales y domingos del año, asistiendo a los maytines, misa y vísperas cantadas en la forma que se cantaren y digeren en el dicho monasterio.

$2^{\circ}$ Que el dicho capellán diga dos días misas de las feriales en el dicho monasterio en cada semana, y que cada semana diga un día misa en Las Heras y otro en Santiváñez, hermitas e hijuelas del dicho monasterio, y que estos días así festivos como feriales los sirva de todas las horas canónicas, así en San Román como en la hijuelas.

$3^{\circ}$ Que si no fuere a las vísperas de los días que hubiere de decir misa en San Román pague un maravedí; si no fuere a los maitines pague otro maavedí, y si no dixere la misa pague tres maravedís para el que la digere; y si no dixere misas sea para reparación del monasterio y de las hermitas, salvo si lo dejare por enfermedad, o con licencia del prior.

$4^{\circ}$ Que venga a las procesiones que se hicieren, pena de un maravedí.

\footnotetext{
${ }^{386}$ pan] sigue tacahada: $\mathrm{o}$.
} 
$5^{\circ}$ Que si alguna de las dichas fiestas viniere en día ferial de los que ha de servir el capellán que se le cuente por fiesta y por feria.

$6^{\circ}$ Que celebre y administre todas las veces que se ofreciere al año a los vecinos de los dichos lugares, y que el prior le dé libros y ornamentos; y que si quisiere el capellán tener el Santíssimo Sacramento en San Román, en el altar de Santa María Madre, el prior le dé una arquita en que le ponga. Que el capellán/ (f. 265r) entre por la puerta del claustro como el prior y los monges y cante y reze por los libros del monasterio.

$7^{\circ}$ Que el día que dixere misa en el monasterio no lleve ofrenda sino pitanza o treintenario, según se mandare.

$8^{\circ}$ Que quando dixere misa en Las Heras o Santiváñez sea suya toda la ofrenda y que no lleve ofrenda de Santa María del Valle.

$9^{\circ}$ Que el prior dé al capellán por el servicio la mitad de los diezmos de Santiváñez y todos los diezmos de Las Heras; y todos los dichos días que dixere misa en el monasterio que el prior le dé de comer y de beber como a un monge. Y si no quisiere comer con los monges le dé el prior cada año carga y media de trigo en grano y tres maravedís por cada día que dixere misa; y cada año, cien maravedís para vestuario. Y si no se los diere para Santa María de agosto haya el capellán las cinco maquillas de pan que tiene el prior del patronazgo de Las Heras.

10 Que se le dé en el monasterio una cámara donde tenga su cama, y si quisiere vivir en Santiváñez le dé el prior un suelo de los que allí tiene con sus préstamos sin tributo alguno.

11 Que quando el prior fuere a comer los yantares haga llamar al capellán y le lleve consigo; y si no le llamare que le dé por cada yantar cinco maravedís y otros cinco por cada yantar que le prior tomare en dinero.

12 Que las penas en que incurriere el capellán sean acusadas por el monge o dos hombres buenos, uno de Santiváñez y otro de Las Heras, nombrados por ambas partes, y sean creýdos por sus verdades; y las penas en que cayere el prior sean acusadas por el capellán y sea creýdo por su juramento.

13 Que todas estas penas sean executadas por el arcipreste de San Román o por su vicario si él no viviere en el arziprestazgo; $y$ que las partes vayan a verlas notificar otro día después de San Juan Baptista de cada año. Y que el arcipreste execute dichas penas a cada una de las partes en los diezmos de Santiváñez que cada uno de ellos ha de haber. Con esto se puso fin a todos los debates. Fue dada esta sentencia, y consentida por ambas partes, en Tarilonte, a 13 de enero de 1433, ante Juan Pérez de la Torre de Pisón, notario de la ciudad de Palencia. Esta sentencia está sin authoridad.

La qual dicha sentencia así presentada ante el dicho juez conservador, el dicho Pedro de Quintanilla, en nombre del monasterio de San Zoyl y del prior de San Román, pidió traslados autorizados de ella; y dicho juez los mandó sacar, interponiendo su autoridad, y entregar al dicho Quintanilla, y que lo signase y firmase Juan de Castrillo, / (f. 265v) escribano y notario de Carrión.

$<$ Mandamiento del provisor de León para que se cumpla la sentencia. Año 1532>.

Al pie de esta sentencia está un mandamiento del provisor de León para que Christóval Gómez, capellán de San Román, para que haga el servicio en el altar de Santa María Madre, según se contiene en dicha sentencia. Síguese la notificación y cumplimiento deste mandamiento, que todo está sin autoridad.

3. <Capítulo sobre el servicio del curato $>$.

Capitulaciones, concierto ${ }^{387}$ hecho entre el prior de San Román y los vecinos de Las Heras en razón de cómo se les había de servir el curato, asistir a los divinos oficios y

${ }^{387}$ concierto] al margen derecho: Falta. 
administrar los Santos Sacramentos; el qual no tuvo efecto ni se executó. No tiene fecha ni autoridad.

4. $<$ Brebe del nuncio contra el obispo de León por haber hecho curato la hermita de Las Heras. Año 1570>.

Proceso que sólo tiene un poder de fray Gerónimo de Chaves, prior de san Román, para los procuradores de Valladolid, y un brebe, escrito en pergamino, de Juan Baptista Castaneo, nuncio de la Santidad de Pio $5^{\circ}$, para los ordinarios de Palencia y Valladolid, con una súplica introclusa, por la que consta que, habiendo el abad de San Zoil, como señor patrono, puesto por cura a Juan Merino del curato de Santa María Madre, al qual estaba anexo el de Las Heras, vsando en esto de la costumbre y posesión inmemorial en que estaban los abades de San Zoil de nombrar tal cura, y no debiendo ser molestados en esta posesión, el ordinario de León sin causa legítima, a instancia de algunos vecinos de Las Heras, dio sentencia difinitiva, por la qual declaró que la dicha yglesia de Santa María Madre no era parroquial y erigió en yglesia parroquial la hermita de Las Heras; y mandó al dicho Juan Merino que no celebrase más los divinos oficios en la dicha yglesia de Santa María Madre, ni administrase los Santos Sacramentos sino en la dicha hermita; y que los vecinos de Las Heras no acudiesen de allí adelante a San Román para lo sobredicho. De esta sentencia se apeló y dixo de nulidad y la parte del convento se presentó por esta súplica ante el nuncio y pidió esta comisión, que se le concedió en Madrid, a 28 de junio de 1570. No hay más que esto.

\section{5. $<$ Colación a Gonzalo Montes de Colmenares. Año 1573>.}

Colación que hizo el licenciado Guerra, provisor de León, del beneficio curado de Santa Eulalia de Las Heras, con consentimiento del padre fray Sebastián de Encinas, abad de San Zoil, en Gonzalo Montes de Colmenares, beneficiado de Cornón, por permuta que hizo con Ruy González de Carbonera, que era cura de Las Heras. Su fecha, en León, a 9 de diciembre de 1573, ante Juan de Valduvielso, notario de aquella audiencia.

$\mathrm{Al}$ pie está la posesión que tomó el dicho Gonzalo Montes de Colmenares, ante Andrés Serrano, escribano y vecino de Guardo.

/ (f. 266r) 6. < Yantar que paga el cura de Las Heras. Año 1574>.

Testimonio dado por Andrés Sánchez, escribano de Carrión, de la obligación que hizo Hernando de Vega, cura de Viduerna y de Las Heras, de pagar al prior de San Román ${ }^{388}$ cada año por el día de santa Olalla 4 reales, por razón del yantar que paga el cura de Las Heras al prior de San Román. Su fecha, en Carrión, a 7 de mayo de 1574.

7. <Colación a Hernando de Vega. Año 1574>.

Colación que hizo el licenciado Guerra, provisor de León, del beneficio curado de Santa Eulalia de Las Heras, con consentimiento del padre fray Sebastián de Encinas, abad de San Zoil, en Hernando de Vega, cura de Viduerna, por permuta que hizo con Gonzalo Montes de Colmenares, que era cura de Las Heras. Su fecha, en León, a 17 de mayo de 1574, ante Juan de Valdivielso, notario.

Está duplicada esta colación y a la espalda está la posesión.

8. < Proceso sobre la colación del curato de Las Heras. Año 1606>.

Proceso sobre la colación del curato de Santa Eulalia de Las Heras, por el qual consta que en el mes de diciembre del año de 1605 se opusieron a dicho curato, que estaba vaco por muerte de Hernando Vega, su último poseedor, Diego García Barr[an]tes y el bachiller Juan Moreno de Vedoya, cura de Villalafuente, ante el provisor de León, que mandó fijar edictos. En 19 de enero de 1606, el concejo de Las Heras pretendió ser presentero: dio su presentación para el dicho beneficio al dicho Juan Moreno de Vedoya el qual la presentó en León. El doctor Gonzalo de Vega Rabanal, provisor de León, dio comisión para que las partes hiciesen sus informaciones. A 17 de marzo del mismo año, el cura de Villalveto hizo

388 San Román] al margen derecho: San Román. 
la información de Juan Moreno que está presentada en el proceso. En 21 de abril del mismo, Alonso del Vado, procurador, presentó poder del concejo y salió por él a la causa, pidiendo que el concejo fuese declarado por presentero del beneficio de Las Heras y para ello se mostró parte en este pleyto. Mandose dar traslado a la otra parte.

A 5 de mayo se dio la causa por conclusa difinitivamente, se mandaron citar las partes para sentencia y que padeciesen a examen; y habiendo comparecido ante los examinadores sinodales aprobaron a Juan Moreno y reprobaron a Diego García. El mismo día se presentó petición de parte de este monasterio y pidió ser amparo en la posesión de presentar persona para este beneficio y pidió traslado del auto de examen para elegir de los aprobados a quien se haga colación y de lo contrario apela etcétera. Mandose dar este traslado.

El procurador de Moreno pidió que se diesen censuras para manifestar la presentación que hizo el monasterio en Diego García, que no estaba en el proceso ni parecía. Mandaronse(se) dar y el mismo día apeló Diego Barrantes del auto de examen y su reprobación.

/ (f. 266v) Llebose el pleyto [a] la Chancillería por vía de fuerza y los señores dieron auto en que declararon que no iba el pleito en estado y lo bolvieron al ordinario. La parte del convento pidió para presentar y que en el ínterin no se prosiga a la provisión ni colación del beneficio; y de lo contrario apela. Moreno requirió al provisor con el auto de la Chancillería para que le guardase y pidió colación al beneficio.

$<$ Sentencia de León>

En 22 de mayo del mismo año, el licenciado Antonio Ramírez, provisor de León, pronunció sentencia, por la que declaró el beneficio vaco por muerte del referido Hernando de Vega; y haber sido y ser de presentar del convento y abad de San Zoil y como tales haber presentado en Diego García Barrantes para ser proveído de él. Y que por el auto de examen pareció no ser idóneo y serlo el bachiller Juan Moreno de Vedoya, le hizo título, colación y provisión y el mismo día le despachó la colación del beneficio inserta a la ${ }^{389}$ dicha sentencia.

El bachiller Moreno presentó las censuras y declaraciones de cómo el abad de San Zoyl había dado a Diego García la presentación deste beneficio, que no parecía, y se mandaron juntar al proceso.

En 20 de mayo del mismo año, se presentó Diego García en grado de apelación ante Juan García Millino, nuncio de Su Santidad, y sacó breve de comisión para el abad de Sahagún o su provisor, para que conociesen de esta causa. Se notificó al provisor de Sahagún quien dio sus letras, inserto el brebe, con inhivición citatoria y compulsoria.

$<$ Sentencia del provisor de Sahagún a favor de este monasterio $>$

Llebose el proceso de León a Sahagún, y en él constó que Moreno se había ya aparta[do] del pleyto, con que conoció la causa el provisor de Sahagún; concluyó, llamó a examen a Diego García, fue examinado en su presencia por los examinadores sinodales y aprobado por todos ellos, nemine discrepante, con que sentenció la causa a su favor y del monasterio, y le dio la colación, cuyo título está abajo. Este proceso que se fulminó en León ante Pedro Álbarez, notario y escribano, y su letrado que se llebó a Sahagún, y los autos del proceso que allí se hicieron por el provisor han de estar en los papeles de Simón de los Ríos, notario de Sahagún, ante quien pasaron.

9. < Poder para oponerse al curato de Las Heras. Año 1606>.

Poder que dio Fernando de Colmenares, cura de Villalveto y vicario en todo el arciprestazgo de San Román, para que en su nombre puedan hacer oposición al curato de Santa Eulalia de Las Heras, que estaba vaco por muerte de Hernando de Vega, su último poseedor, en virtud de presentación del abad de/ (f. 267r) San Zoil como único presentero,

389 la] sigue tachado: dicha. 
atento que Diego García Barrantes por no capaz fue reprobado. Su fecha, en Viduerna, a 17 de julio del año de 1606, ante Blas Ordóñez, escribano y vecino del dicho lugar.

Esta fue prevención por si en Sahagún tampoco salía aprobado Diego García poner a uno de los nombrados por el abad.

\section{0. <Colación de Diego García Barrantes. Año 1606>.}

Colación del curato de Las Heras hecha por el licenciado Hernando Núñez, provisor en la villa de Sahagún y en toda su abadía, a Diego García Barrantes, natural de la villa de La Cumbre, en virtud de presentación hecha por el padre abad de San Zoil y del brebe y comisión del nuncio, para que entendiese en esta causa, según consta del proceso que está en el número $8^{\circ}$. Su fecha, en Sahagún, a 2 de agosto de 1606, ante Simón de los Ríos, secretario de la abadía. Tomó la posesión a 6 de agosto del mismo año, ante Pedro Montes de Colmenares, cura de Viduerna.

11. <Proceso original sobre la presentación del curato de Las Heras. Año 1641>.

Proceso original por el qual consta que habiendo sacado el curato de Las Heras en el mes de mayo del año de 1640 por muerte de Diego García Barrantes, su último poseedor, se opusieron a el dicho curato el licenciado Gerónimo Rozadilla, con presentación del obispo y después de la del abad de San Zoil, y el licenciado Diego Alcalde, como patrimonial y con presentación del concejo de Las Heras, sobre que hubo pleyto, porque el provisor de León le hizo de concurso, diciendo que había vacado en uno de los meses reservados a Su Santidad, despachó testimoniales a Roma a favor de Rozadilla para el título de colación; y aunque hubo apelación por parte de Alcalde y de este monasterio, se le despachó el título de colación, se le dio la posesión y murió cura según consta de los papeles de este proceso. El título de colación y el testimonio de la posesión están a la séptima oja de este proceso.

A las primeras ojas se hallan dos relaciones más circunstancias de este pleyto.

12. < Poder y consentimiento para poner cura monge. Año 1653>.

Poder que otorgó el concejo y vecinos del lugar de Las Heras y ratificación de él, en que pretenden que el abad de San Zoil, como único presentero que dicen ser del curato del dicho lugar, les ponga un monge por cura, para evitar los daños e inconvenientes que se les habían seguido con los clérigos que habían tenido. Su fecha, en Las Heras, a 31 de enero de 1653, ante Francisco Quixano, escribano y vecino de Respenda.

\section{3. < Sentencia contra el cura de Las Heras sobre el yantar. Año 1655>.}

Sentencia dada por el licenciado don Leones de Abreu y Azevedo, provisor de León, por la qual consta que en aquel tribunal había pleyto / (f. 267v) pendiente entre el prior de San Román y el cura de Las Heras sobre el yantar; y por esta sentencia se le condena al cura a que pague al prior de San Román, como siempre ha sido vso y costumbre. Dada en León, a 23 de febrero de 1655, ante Pedro Pasqual. Al pie están las notificaciones ante Francisco Quixano. $1657>$.

14. <Carta executoria del nuncio para poner monge que haga oficio de cura. Año

Carta executoria a favor de este monasterio ganada en la nunciatura, por la qual parece que el año de 1653, estando vaco el curato de Las Heras, por muerte del licenciado Gerónimo de Rozadilla, que murió en el mes de enero del mismo año, habiendo fixado edictos el ordinario de León, sin atender a las presentación del abad, que la había hecho en el licenciado Juan Antón, dio el curato al licenciado Andrés González, sobre que se siguió pleyto en dicho tribunal, en que condenó a este monasterio, despachando título y colación al dicho Andrés González, en virtud de bula de gracia que ganó de Santo Padre, de lo qual se apeló por parte del monasterio; y en virtud del brebe del señor nuncio se siguió ante el señor don Gabriel Martínez, protonotario y juez apostólico en la nunciatura, quien revocó lo actuado y obrado por el provisor, declarando por nula la colación y título dado al dicho Andrés González y pertenecer, en todo tiempo, al abad de esta casa el derecho de presentar dicha vicaría. De la qual sentencia fue apelado por parte del fiscal de León y del dicho Andrés González por ante el señor nuncio, el qual declaró dicha yglesia de Las Heras ser vicaría 
perpetua vnida a San Román e hijuela suya y como tal pertenecer al abad de San Zoil nombrar vicario que la sirva en qualquier tiempo que vaque. Pero en quanto a la ynstitución hecha en el dicho Andrés González la confirmó y aprobó, mandando despachar carta executoria en quanto a lo que dichas tres sentencias son conformes. Dada en Madrid, a 10 de marzo de 1657. La qual sentencia se notificó al señor obispo, provisor fiscal y al dicho Andrés González, quienes la obedecieron.

Después de lo qual, el año de 1700 se pidió por parte del convento el que respecto que dicho curato estaba declarado por vicaría, se declarase ${ }^{390}$ por el ordinario de León que podía el abad poner monge que la sirviese, el qual lo negó, mandando cumplir la sentencia del señor nuncio pronunciada a 10 de marzo del año de 1657. Del qual auto se apeló por ante Su Eminencia y en virtud de letras apostólicas se llevó el pleyto a la nunciatura, donde Su Yllustrísima declaró que el abad de / (f. 268r) San Zoil pudiese poner vicario secular o regular que exerza oficio de cura, con tal que siendo regular haya de estar con compañero regular de la misma orden ${ }^{391}$. Este auto fue dado en Madrid, a 25 de agosto de 1701, con el que se requirió al ordinario de León para que repusiese él por sí, dado en 26 de junio de 1700, y se cumpla con éste, quien lo aceptó y obedeció como en él se contiene.

$<$ Posesión que tomó del curato el padre fray Mauro Ordóñez $>$.

Por muerte del licenciado Andrés González, que fue año de 1707, en virtud de la carta executoria referida y del auto del señor nuncio, nuestro padre maestro fray Jacinto Díez, abad de San Zoil, nombró por vicario de cura del lugar de Las Heras al padre fray Mauro Ordóñez, el qual con dicha carta executoria y con el nombramiento se presentó ante el obispo de León, fue examinado y aprobado, trajo los despachos necesarios, requirió al concejo con ellos y, en presencia del padre abad, de otros monges y seglares tomó posesión en 14 de septiembre de 1707, ante José García de Guadiana, escribano de Respenda.

Pasó luego a tomar posesión de la hermita del Santo Christo, pero no lo pudo conseguir, como consta de los papeles que están aquí cosidos con esta carta executoria. $1708>$.

15. <Despachos del provisor de León sobre la vecindad del cura de Las Heras. Año

Despacho del provisor de León para que el concejo de Las Heras nombre dos persona ancianas que declaren si los curas antecesores al monge gozaron de la vecindad y de los repartimientos útiles que gozan los demás vecinos; el qual se les notificó y aunque declararon que sí no dieron cumplimiento, por lo que se sacó segundo despacho agravado con censuras; se les notificó en público concejo y se allanaron a cumplir con lo que se les mandaba por no tener qué responder. Dados en León, en el mes de junio de 1708, ante Francisco Álvarez, notario de la Audiencia.

16. < Convenio del concejo de Las Heras para que al padre cura se le guarde la vecindad. Año 1751>.

Testimonio dado por José Luys de Cantoral, escribano y vecino de Villanueva de Muñeca, del convenio y compromiso que hicieron el padre fray Rosendo Carrera, cura de Las Heras, y el concejo del mismo lugar en don Santiago Román, cura de Respenda, y don Mathías Cacharo, oficial mayor de la única contribución, quienes declararon que al dicho padre cura se le debe dar el vso de cierto molino (sobre que había pleyto) y otros qualesquiera aprovechamientos ygual con los demás vecinos. Pero advirtiendo que si la administración de estos y su conservación tubiese algunos costos, tenga dicho padre cura obligación a la contribución de ellos como cada uno de dicha vecindad; y en lo demás se le guarde las regalías y derechos que se guardan en aquel arziprestazgo. Su fecha, en Villanueva de Muñeca, a 6 de mayo de 1751.

\footnotetext{
390 declarase] sigue tachado: por el ordinario.

391 orden] al margen derecho: Nota.
} 


\section{/ (f. 268v) 17. < Parecer sobre el diezmo de fruta. Año 1757>.}

Consulta y parecer del licenciado don Miguel Alonso sobre que los vecinos del lugar de Las Heras deben de pagar diezmo de camuesa o de otra qualesquiera especie a que se negaban, por ser frutos nuevos, en aquel pueblo; pero esto, dice, no induce derecho de no deberse el diezmo por la causa de no haberse pagado, por faltar el supuesto que debía constituir costumbre, etcétera. Dado en León, a 26 de marzo de 1757.

18. <Apartamiento y obligación del concejo de Las Heras sobre los diezmos de pabos, fruta y hortaliza. Año 1786>.

Testimonio dado por don Antonio Leonardo López, notario de la audiencia de León, del apartamiento que hizo el concejo y vecinos de Las Heras del pleyto que había entre dicho concejo y el padre cura del dicho lugar, sobre la paga de diezmos de pabos, fruta y hortaliza; y auto dado por don Thomás Sanz Carpintero, provisor de León, por el que aprueba dicho apartamiento y la obligación que hacen de pagar el diezmo de las referidas tres especies. Dado en León, a 10 de enero del año de 1786.

\section{Remisiones}

El cura de las Heras era al mismo tiempo cura de Santiváñez y Santa María Madre. Véase el cajón San Martín legajo $2^{\circ}$, quaderno C, número $3^{\circ}$.

\section{/ (f. 269r) Quaderno D del legajo $2^{\circ}$}

Este quaderno D contiene los papeles pertenecientes a la hermita del Santo Christo del Valle del lugar de Las Heras, por el orden siguiente:

$1^{\circ}$. <Fundación de la hermita y capellanía del Santo Christo del Valle. Año 1650>.

Carta authorizada por José Gallo, notario y vecino de Saldaña, de la fundación de la hermita y capellanía del Santo Christo del Valle, sito en el lugar de Las Heras. Por esta escritura parece que Juan Valle, vecino de Las Heras, había hecho una ermita junto al mismo lugar con sus propios bienes y hacienda, que se llama del Santo Christo del Valle, donde con licencia del ordinario de León se celebraba y decía misa. Esta ermita, dice el mismo Juan valle que la hizo con ánimo y propósito de fundar una capellanía de presentación y patronato real, lo que puso en execución con las condiciones siguientes:

Primeramente que los capellanes que fueren de dicha capilla, cada uno y en su tiempo, sean obligados perpetuamente para siempre decir 12 misas rezadas en cada un año, una en cada mes, viernes o sábado, y los demás subcesores las puedan decir adonde quisieren las dichas misas, y han de recivir los dichos capellanes las limosnas de las misas, 24 reales en moneda de vellón conveniente; y si no hubiere capellán, es nuestra voluntad la pueda gozar y llevar el patrono de ellos, mandando decir las dichas misas a donde quisiere para perpetualidad de la dicha memoria y capellanía. Después de referir las hipotecas que agrega a esta capellanía, nombra por primer capellán a su hijo Manuel Valle, y después de sus días juntos nombraron por patrono a Juan Valle, hijo de Fabián Valle, nieto de dicho fundador, y que del dicho nombrado descienda el dicho patronazgo por línea recta de los Valles y que los patronos siempre sean de la casa de los Valles, los parientes más cercanos. Y en caso que faltare la línea recta o transversal de los Valles, nombra por patrono de dicha capellanía al concejo y vecinos de Las Heras, con obligación de presentarla en hijos, patrimoniales, etcétera. Fue otorgada esta escritura en el lugar de Las Heras, a 14 de octubre de 1650, ante Francisco Quixano, escribano y vecino de Respenda. 
2. <Que la llave del archivo no la tenga el cura. Año 1691>.

Memorial $^{392}$ del mayordomo de la hermita del Santo Christo del Valle presentado al Yllustrísimo señor don Juan de Aparicio y Navarro, obispo / (f. 269v) de León, contra el padre cura de Las Heras, porque pretendía tener una de las tres llaves del archivo donde se echara la limosna y respuesta de Su Yllustrísima en que manda que las tres llaves las tengan por ahora una el vicario de la dignidad, otra el mayordomo y otra el rejidor más antiguo. Dada en León, a 21 de octubre de 1694.

3. <Mandamiento del señor obispo sobre las procesiones a la hermita. Año 1755>.

Mandamiento del señor don Alfonso Fernandez de Velasco y Pantoja, obispo de León, dado en la santa visita, por el qual declara el derecho del padre cura en la hermita del Santo Christo, lo que se debe obserbar por los curas y por el mayordomo quando van en procesión a dicha hermita y assimismo para las funciones que tiene fixas en el discurso del año. Dado en León, a 2 de octubre de 1755.

4. < Testimonio de cómo se hizo una procesión alrededor de la hermita. Año 1766>.

Testimonio dado por Bartholomé González de Velasco, notario y nuncio de Cervera, de cómo concluyda la misa que se celebró el día 14 de septiembre del año de 1766, se ordenó e hizo una procesión alrededor de la hermita del Santo Christo, sin salir de su ámbito más que lo preciso, y en la citada procesión llevaron las insignias de cruz y pendón. Fue dado este testimonio en Las Heras en el dicho día, mes y año, de pedimiento del padre fray Félix Oñate, vicario de cura del dicho lugar.

Nota: En esta procesión no debían llevar, según lo mandado en el auto de visita del señor Pantoja, que es el del número antecedente.

5. $<$ Sentencia del provisor de León sobre el derecho del padre cura en la hermita del Santo Christo. Año 1766>.

Copia authorizada por Ramiro Rodríguez Blanco, notario de la audiencia de León, de una sentencia dada por don José Antonio Xaramillo, provisor, en el pleyto que había entre el padre cura de Las Heras y los curas párrocos y regidores de los 24 lugares, sobre la vsurpación del derecho parroquial en las funciones que se celebraban en la hermita del Santo Christo. Por esta sentencia se declara que el padre cura siempre que quisiere decir misa en dicha hermita o exercer otro acto de devoción se le franqueen las llaves. Que en las procesiones, rogativas, etcétera, se observe el auto de visita del señor Pantoja, que es el del número $3^{\circ}$ deste quaderno. Su fecha, en León, a 18 de agosto de 1766.

6. <Alegaciones sobre el derecho parroquial en la hermita>.

Alegatos de una y otra parte sobre el derecho parroquial que pretendía tener el padre cura de Las Heras en la hermita del Santo Christo. Están aquí insertos los autos de visita de los señores obispos y de los provisores con las provanzas hechas por una y otra parte. Pero todo sin authoridad.

\section{/ (f. 269r) Legajo $3^{\circ}$ del cajón San Lorenzo}

Este legajo $3^{\circ}$ contiene los 7 quadernos siguientes:

Quaderno A. Lobera.

B. San Mamés.

C. Santa María del Páramo .

D. Santa María de Rozavalles.
E. San Martín de los Álamos.

F. San Martín de los Rascones.

G. Mazuecos.

392 Memorial] al margen derecho: Falta. 


\section{Quaderno A del legajo $3^{\circ}$ \\ Lobera}

Este quaderno A contiene los papeles pertenecientes a la hacienda y señorío que tiene este monasterio en este lugar, por el orden siguiente:

$1^{\circ}$. <Privilegio y carta de trueque del emperador don Alonso. Era 1167. Año 1129>.

Privilegio y carta de trueque del emperador don Alonso, por el que da a este monasterio a Lobera, Castromuza, San Millán junto a Quintanilla, una parte de Cabañas ${ }^{393}$ con todas sus heredades, jurisdición y derechos, y el monasterio le da en cambio la porción que tenía en Fuentes de don Bermudo ${ }^{394}$, con sus términos y divisiones, fuera de la yglesia de San Román con sus solares, que dexa para el monasterio. Concede con su authoridad imperial el que en todo su reyno ningún monge del orden de Cluni ni sus prioratos y decanías paguen portazgo de sus propias haciendas o mercadurías. Su fecha, en Carrión, en la era de 1167, que es año de 1129, quarto decimo kalendas decembris. Hay copia simple.

\section{/ (f. 269v) 2. <Privilegio del rey don Fernando el 4. Era 1341. Año 1304>.}

Privilegio del rey don Fernando el $4^{\circ}$, que es confirmación del privilegio anterior del emperador don Alonso. Dado en Carrión, a 6 de febrero, era de 1342, que es año de 1304. Está escrito en pergamino, con sello de plomo pendiente; y hay tres copias simples.

3. < Privilegio del rey don Alonso 11, para que en Lobera no haya más que 6 pecheros. Era 1353. Año 1315>.

Privilegio del rey don Alonso 11, por lo qual parece que el camarero de San Zoil hizo relación al ynfante don Juan, tío y tutor del rey, de que en Lobera había poca vecindad y eran muchos los pechos que se pagaban y pidió por merced que se exentasen a los vasallos que tenía en aquel lugar de pagar pecho. El rey con consejo de su tío dio comisión al alcalde de Carrión para que hiciese información de los que podían pagar pecho en Lobera; y hecha, remitida, cerrada y sellada, costó por ella que no había más que seis vecinos que pudiesen pagar pecho. $\mathrm{Y}$ visto por el ynfante, a instancia del camarero, mandó despachar este privilegio, escrito en pergamino, con sello de cera pendiente, por el qual el rey manda a los cogedores de los pechos de la merindad de Saldaña que para que este lugar se pueble no pongan en el encabezamieno de los pecheros de él más que seis vecinos que paguen pecho y los demás queden libres de todo pecho. Dado en Burgos, a 24 de mayo, era de 1353, que es año de 1315.

Hay copia de este privilegio autorizado por don Antonio Martín García, notario y vecino de la villa de Ribas.

\section{4. $<$ Carta del Concejo de Lobera al abad de Benevivere $>$.}

Carta ${ }^{395}$ que el concejo de Lobera escribió al abad de Benevivere, juez conservador, quexándose de que procedía contra ellos con rigor, pretendiendo que no tenía jurisdicción contra ellos y haciéndoles gastar en pleitos; proponen vuscar su remedio como pudieren. No tiene fecha, pero está firmada por Juan González, escribano de los fechos del concejo de Saldaña.

5. < Testimonio de unas prendas que se bolvieron a los de Lobera. Año 1486>.

Testimonio dado por Juan de Torralba, escribano de Carrión, de cómo Alonso de la Puerta, alcalde de Saldaña, ofreció que otro día bolvería unas prendas que había mandado sacar a unos vecinos de Lobera, quedando a salvo el derecho de los vecinos de Saldaña y del monasterio. Fue dado a instancia de él en Carrión, a 8 de agosto de 1486.

\footnotetext{
393 Cabañas] al margen derecho: Lobera, Castromuza, San Millán junto a Quintanilla, Cabañas.

${ }^{394}$ Fuentes de don Bermudo] al margen derecho: Fuentes de don Bermudo.

${ }^{395}$ Carta] al margen derecho: Falta.
} 


\section{6. < Entrega que se hizo el (sic) monasterio de unos presos. Año 1502>.}

Testimonio dado por Juan de San Vicente, escribano y notario de Saldaña, de cómo Antonio de Heredia, alcalde de dicha villa, y Diego González, merino, por reberencia de los monges de San Zoyl y de don Luis Hurtado de Mendoza, / (f. 270r) su abad, entregaron en Lobera unos presos, vecinos de este lugar, a Juan de Carrión, monge del dicho monasterio, en guarda de un privilegio con que les requirió. El monge recibió a dichos presos, los puso en la cárcel, les hechó una cadena de hierro, los cerró con un candado y los entregó a Bartolomé Díez, merino de Lobera, para que los guardase y diese cuenta de ellos. Su fecha, en Lobera, a 31 de mayo de 1502.

\section{7. <Requirimiento para que la justicia de Saldaña bolviese un preso. Año 1514>.}

Requirimiento que hizo Bartolomé Díez merino de Lobera, a Bartolomé García, vecino de Saldaña, para que le bolviese un preso que había sacado una noche de su casa. Su fecha, en Saldaña a $1^{\circ}$ de octubre de 1514, ante Pedro Díaz, escribano de dicha villa.

\section{8. < Testimonio de las cláusulas del libro Becerro de Valladolid. Año 1595>.}

Testimonio dado por Martín Ruiz de Mitarte, chanciller, de las cláusulas que se hallan en el Libro Bezerro de la Chancillería de Valladolid, sacadas por mandado de su acuerdo y a petición de este monasterio, por las que costa que el lugar de Lobera es de San Zoyl de Carrión y demás derechos que tiene en este lugar. Se sacaron en Valladolid, a 28 de noviembre de 1595.

\section{9. $<$ Nombramiento de merino. Año 1639>.}

Nombramiento de merino del lugar de Lobera hecho por el padre maestro fray Francisco de Lemas, abad de San Zoyl, en Antón Pérez el Mozo, vecino de dicho lugar. Su fecha, en San Zoyl, a 27 de agosto de 1639, ante fray Diego de Sandobal, secretario. $1646>$.

10. $<$ Requisitoria para que este monasterio responda a la demanda del concejo. Año

Requisitoria liberada por el adelantamiento de Palencia para que este monasterio, por sí o por su procurador, compareciese a responder a la demanda puesta por el concejo y regidores del lugar de Lobera, que se negaban a pagar las ocho cargas de pan mediado, doce gallinas y trescientos cincuenta maravedís de martiniega en cada un año, por la posesión en que estaba el monasterio hacía muchos años. Notificose a esta comunidad, en 5 de marzo de 1646, por Tomás Pérez, escribano en Carrión.

11. $<$ Petición y licencia del General para vender las 8 cargas de pan, 12 gallinas y 350 maravedís del foro de Lobera. Año 1648>.

Petición de los padres priores del consejo deste monasterio de San Zoyl al reverendo padre maestro fray Juan de Espinosa, General de San Benito, en que exponen la utilidad que este dicho monasterio tenía en vender al concejo de / (f. 270v) Lobera las ocho cargas de pan mediado, doce gallinas y trescientos cincuenta maravedís que cada año pagaban de foro y martiniega por mil ducados que ofrecían pagar de presente. Dio Su Reverendísima comisión para hacer esta información de utilidad al padre prior fray Juan de Cisneros, quien la hizo mui cumplida; y en su vista Su Reverendísima dio licencia para la dicha venta. En San Vicente de Oviedo, a 15 de mayo de 1648.

Véanse ${ }^{396}$ los libros de encabezos de este año y el libro de consejos que empieza el año de 1636, al folio 105 y 147, donde consta que se resolvió por los padres priores de consejo el que se vendiese todo lo de Lobera, Gañinas y Villarmienzo.

12. $<$ Memoriales simples y relación del pleyto con los de Lobera sobre el foro y martiniega $>$.

Memoriales simples de los papeles, instrumentos y razones que tenía este monasterio para el pleyto que en el año de 1645 movieron los de Lobera, substrayéndose de pagar las 8 cargas de pan mediado, las 12 gallinas y los 350 maravedís de foro y martiniega. A lo último

396 Véanse] al margen derecho: Nota. 
está la memoria de dicho pleyto, en la qual se refiere la demanda puesta por el monasterio en el mismo año y la sentencia de posesión a mío favor dada en Palencia; assimismo las de vista y revista confirmadas en la Chancillería de Valladolid.

\section{Remisiones}

$<$ Señorío $>$.

Otros papeles pertenecientes al señorío que tenía este monasterio en este lugar, yantar y nombramientos de merinos para los tres lugares: Lobera, Gañinas y Villarmienzo en un solo sugeto. Véase este cajón, legajo $1^{\circ}$, quaderno $C$, números $4^{\circ}, 5^{\circ}, 9^{\circ}, 10,11,14$ y 18.

Vna copia de los privilegios del señorío de este lugar. Véase el cajón San Yldefonso, legajo $1^{\circ}$, número $1^{\circ}$, entre los papeles de Villaverde.

\section{/ (f. 271r) Quaderno B del Legajo $3^{\circ}$ \\ San Mamés}

Este quaderno B contiene los papeles pertenecientes a la hacienda que este monasterio tiene en el lugar de San Mamés, por el orden siguiente: $1160>$.

$1^{\circ}$. $<$ Donación de la condesa doña Sancha de la villa de San Mamés. Era 1198. Año

Donación, escrita en pergamino, que hizo a este monasterio la condesa doña Sancha por el remedio de su alma y la de sus padres, de la villa de San Mamés, junto al arroyo Ozeza, con todo quanto allí tiene y le pertenece, divisas de vasallos, solares poblados y despoblados, tierras, viñas, huertos, prados, etcétera, con la obligación de que hagan todos los años un aniversario ${ }^{397}$ principal por dicha condesa, el día de la Asunción de Nuestra Señora den de comer aquel día a doce pobres, y después de su muerte la escrivan en la regla Cluniacense para que nunca falte el aniversario. Fue hecha esta carta de donación y confirmación en el primer día de diciembre, era 1198, que es año de 1160.

2. <Compra de una viña por 16 maravedís y quarta. Era 1239. Año 1221>.

Compra que hizo el prior don Martín de Santa María del Castillo de Carrión a Morán Anáez y su muger, doña Loba, de una viña en término de San Mamés, a las Quintanas, por 16 maravedís y quarta. Su fecha, en el mes de noviembre, era 1259, que es año de 1221.

3. <Trueque de 2 tierras por una en San Mamés. Año 1407>.

Trueque que hizo este monasterio con Gonzalo Fernández, vecino de Carrión, de dos tierras que tenía el dicho monasterio en término de San Mamés, a Llanillos, por una tierra en dicho término, a do dicen a la Encrucijada. Su fecha, en San Zoil, a 11 de junio de 1407, ante García Fernández, escribano de Carrión.

4. <Foro de 3 maravedís, 5 dineros y dos tierras. Año 1408>.

Foro perpetuo, escrito en pergamino, por el qual este monasterio da a Gonzalo Fernández, vecino de Carrión, dos tierras en el término de San Mamés, a Llanillos, por 3 maravedís y 5 dineros de foro perpetuo en cada un año. Su fecha, en San Zoil, a 25 de enero de 1408, ante García Fernández, escribano de Carrión.

\section{5. $<$ Foro de 15 maravedís sobre 3 tierras. Año 1408>.}

Foro perpetuo, escrito en pergamino, por el qual este monasterio da a Juan Fernández Relea, vecino de Carrión, tres tierras: una en / (f. 271v) término de Calzada ${ }^{398}$, a la fuente de Vaýllo, que ha por lindero el arroyo. Las otras dos en término de San Mamés, en el pago que llaman Asedo; que la una tierra ha por lindero la carrera que va a Villasabariego, por 15

397 aniversario] al margen derecho: Aniversario.
${ }^{398}$ Calzada] al margen derecho: Calzada. 
maravedís de foro perpetuo en cada un año. Su fecha, en San Zoil, a 25 de enero de 1408, ante García Fernández, escribano de Carrión.

6. <Foro de 6 maravedís por quatro pedazos de viña. Año 1410>.

Foro perpetuo, escrito en pergamino, por el qual este monasterio da a García, vecino de San Mamés, quatro pedazos de viña, yrias, en término de dicho lugar y a San Andrés; que la una de ellas es a do dicen Algares, y las otras tres son en Fondón de Arenas, que han por linderos de una parte la carrera que va a Villasirga, por seis maravedís de foro perpetuo en cada un año. Su fecha, en San Zoyl, a 28 de diciembre de 1410, ante Ruy García, escribano en Carrión.

7. $<$ Foro de 4 maravedís y medio por 3 tierras viñas. Año 1410>.

Foro perpetuo, escrito en pergamino, por el qual este monasterio da a Alfonso de Ayuela, vecino de San Mamés, tres tierras viñas en término de dicho lugar, a do dicen a las Quintanas, que han por linderos de una parte la Carrera de Nogal, por 4 maravedís y medio de foro perpetuo en cada un año. Su fecha, en San Zoyl, a 28 de diciembre de 1410, ante Ruy García, escribano en Carrión.

8. < Foro de 10 maravedís por tres viñas. Año 1410>.

Foro perpetuo, escrito en pergamino, por [el qual] este monasterio da a Juan Blanco, vecino de Carrión, tres viñas yrias en el término de $<$ San Mamés $>^{399}$, que las dos de ellas son a do dicen Asedo, que han por linderos de una parte la carrera que va a Villasavariego; y la otra viña es en el pago de Arenas, por 10 maravedís de foro perpetuo en cada un año. Su fecha en San Zoil, a 28 de diciembre de 1410, ante Ruy García, escrivano en Carrión.

9. $<$ Foro de 2 maravedís por tres tierras viñas. Año $1410>$.

Foro perpetuo, escrito en pergamino, por el qual este monasterio da a Domingo Fernández, vecino de Carrión, dos tierras viñas en término de San Mamés, a do dicen Asedo, que han por linderos de una parte la carrera que va a Villasavariego, por 2 maravedís de foro perpetuo en cada un año. Su fecha, en San Zoil, a 28 de diciembre de 1410, ante Ruy García, escribano en Carrión.

10. $<$ Foro de 6 maravedís por una viña. Año 1416>.

Foro perpetuo, escrito en pergamino, por el qual este monasterio da a Domingo García de Gozón, vecino de Carrión, una viña en término de San Mamés, a do dicen a Llanillos, por 6 maravedís de foro perpetuo en cada un año. Su fecha, en San Zoil, a 16 de agosto de 1416, ante Gómez García de Saldaña, escribano de Carrión ${ }^{400}$.

/ (f. 272r) 11. < Foro de 8 maravedís por una viña tierra. Año 1448>.

Foro ${ }^{401}$ perpetuo, escrito en pergamino, por el qual este monasterio da a Juan García, vecino de Carrión, un viña tierra en término de San Mamés, a do dicen a LLanillos, que ha por lindero de una parte la Carrera, por 8 maravedís de foro perpetuo en cada un año. Su fecha, en San Zoil, a último día de febrero de 1448, ante Álvar González de Carrión, escribano de esta villa.

12. <Posesión de una viña tierra. Año 1445>.

Testimonio dado por Gutierre Fernández de San Zoles, escribano y notario, de la posesión que tomó Fernando de San Román, mayordomo de San Zoil, de una viña tierra en

\footnotetext{
399 < San Mamés>] infrascrito y tachado: dicho lugar.

${ }^{400}$ Carrión] sigue tachado: Remisiones: Foro de 10 maravedís. Véase el cajón San Benito, legajo 4º quaderno A, número $1^{\circ}$. Tercias, cajón San Andrés, legajo $1^{\circ}$, quaderno B, número $3^{\circ}$. Compra de tierras, cajón San Zoil, legajo $2^{\circ}$, quaderno $\mathrm{A}$, número 37 .

${ }^{401}$ Foro] al margen derecho: Nota: Este número debe ser el siguiente, por su año.
} 
término de San Mamés, a do dicen a Llanillos, que ha por lindero de una parte la Carrera, porque el que la tenía a foro no pagaba la renta de ella. Su fecha, a 21 de diciembre de 1445.

13. <Trueque de una tierra por otra. Año 1454>.

Trueque que hizo este monasterio y su abad don Pedro con Fernando de Riomoroso, vecino de Carrión, de una tierra que el dicho monasterio tenía en término de San Mamés, por otra tierra que el referido Fernando tenía en el término de dicho lugar, que ha por lindero de una parte el río Vseza; y de otra parte, los Prados. Su fecha, en San Zoil, a 17 de abril de 1454, ante Álvar González de Carrión, escribano y notario.

14. < Foro de 2 maravedís por dos pedazos de viña y una herrén. Año 1455>.

Foro perpetuo por el qual Fernando González de San Román, sacristán mayor de San Zoil, da a Pedro Domínguez, vecino de San Mamés, dos pedazos de viña y una herrén, que es todo ello en término de dicho lugar, a do dicen al Paquillo, por 2 maravedís de foro perpetuo en cada un año para la sacristanía de este monasterio. Su fecha, en San Zoil, a 2 de marzo de 1455, ante Álvar González de Carrión, escribano y notario.

15. <Compra de una quarta de tierra por 200 maravedís. Año de 1485>.

Compra que hizo este monasterio a Sancha Díaz Barahona, monja del monasterio del Moral, y a Alfonso de la Fuente, vecino de San Mamés, como testamentario de María Díaz, de una quarta de tierra en el dicho, lugar junto al Palomar, por precio de 200 maravedís. Su fecha, en San Mamés, a 30 de mayo de 1485, ante Alfonso Fernández de Sancibrián, escribano y notario público.

16. <Trueque de una herrén por una tierra. Año 1495>.

Trueque que hizo este monasterio con Rodrigo de Santolalla, escribano, vecino de Carrión, de una herrén que el dicho monasterio tenía en el lugar de San Mamés, por una tierra que el dicho Rodrigo tenía en término del dicho lugar, a do dicen la Calzada, que ha por lindero de una parte el camino que va a Villaherreros. Su fecha, en San Zoyl, a 30 de diciembre de 1495, ante Fernando Caballo, escribano de Carrión.

/ (f. 272v) 17. <Foro perpetuo de 2 gallinas por un suelo con su herrén. Año 1505>.

Foro perpetuo por el qual este monasterio da a Juan Barrio, vecino de San Mamés, un suelo con su herrén en el dicho lugar, que ha por lindero de una parte el Camino, por un par de gallinas vivas de foro perpetuo en cada un año, con condición que dentro de dos años había de hacer casa en la dicha herrén. Su fecha, en San Zoyl, a 5 de febrero de 1505, ante Juan de Sanzoles, escribano de Carrión.

18. <Compra de una casa con 40 maravedís de foro por este monasterio. Año 1648>.

Compra que hizo Pedro Cembrero, vecino de Villasarracino, a Lope Gutiérrez, vecino de Villasirga, de una casa en el lugar de San Mamés, que linda con la calle pública, con la carga y pensión de 40 maravedís de foro perpetuo que sobre ella tenía este monasterio. Su fecha, en Villasirga, a 8 de febrero de 1648, ante Alonso Álbarez de Alcebedo, escribano de dicha villa.

19. <Reconocimiento de un foro de 60 maravedís sobre una casa. Año 1650>.

Reconocimiento que hizo Bartolomé Herrero, vecino de San Mamés, de un foro de 20 maravedís, que es la parte de los 60 maravedís que tenía este monasterio a su fabor sobre una casa que el referido Bartolomé había comprado en el dicho lugar, que está detrá de la yglesia, y linda con la calle pública. Su fecha, en Carrión, a 22 de febrero de 1650, ante Francisco Ochoa, escribano de dicha villa.

La escritura del foro está en el libro $5^{\circ}$ de vitas y arriendamientos, al folio 75 vuelta. 


\section{Remisiones}

$<$ Foro, tercias, compra $>$

Foro de 15 maravedís sobre 2 tierras. Véase el cajón San Benito, legajo 4º quaderno A, número $1^{\circ}$.

Tercias. Cajón San Andrés, legajo 1º, quaderno B, número $3^{\circ}$.

Compra de tierras. Cajón San Zoil, legajo $2^{\circ}$, quaderno A, número 37.

\section{/ (f. 273r) Quaderno C del legajo $3^{\circ}$ \\ Santa María del Páramo}

Este quaderno $\mathrm{C}$ contiene los papeles pertenecientes a la hacienda que tiene $<$ San Román> y este monasterio en Santa María del Páramo, término del lugar de Torre, por el orden siguiente:

$1^{\circ}$. <Trueque de hacienda por la de Santa María del Páramo. Era 1202. Año 1175>.

Escritura de trueque, en pergamino, por la qual Dominicus 111 (sic), abas Dominis Sanctis (que parece ser abad de Sahagún), con todo su monasterio, da en trueque y cambio a Achardo y al monasterio de San Román de Entrepeñas ${ }^{402}$ toda la heredad que hubo de Osorio Osóriz en Santa María del Páramo, entre Calzada y Torre, con todos sus fueros, términos, divisas, casas, solares, prados, corrales, tierras, viñas, montes, fuentes, molinos, aguas, y con todas sus pertenencias, para siempre jamás; y además le dio unas luvas, una mula y doce monedas de oro. Y él recive en cambio del dicho prior de San Román todo quanto pertenecía a San Román en Bobadilla de Aratoi, junto a San Andrés de San Facundo, y en Rioseco y en Población de Gordaliza, y todo lo que tenía por juro de heredad en Berzianos y en su territorio. Facta carta era 1202, que es año de Christo 1175.

\section{2. <Carta de Arras a Vrraca. Era 1242. Año 1204>.}

Carta de Arras, escrita en pergamino, por la qual Rodrigo Fernández da a Vrraca García, su muger, la mitad de toda la hacienda que tenía en la villa de León. Su fecha, era 1242, que es año de 1204. Esta escritura no dice más, por lo que parece no pertenecer ni a San Román ni a San Zoil.

3. <Compra de tres prados. Era 1303. Año 1265>.

Compra que hizo don Gui, prior de San Román de Entrepeñas ${ }^{403}$, a don Pero Juan, clérigo de San Julián, de tres prados en los exidos de Torre, por precio de 25 maravedís. Facta carta era 1303, que es año de 1265, ante Juan Pérez, notario público de Carrión.

\section{/ (f. 273v) 4. <Foro de 15 maravedís sobre tres tierras y un huerto. Año 1410>.}

Foro perpetuo, escrito en pergamino, por el qual Martín Ruiz, mayordomo de la Orden de San Lázaro de Carrión, por nombramiento y con licencia de don Fernando, prior mayor de San Zoil, y los racioneros de San Lázaro dan a foro perpetuo a Martín Ervejón, vecino de Torre, tres pedazos de tierra con su huerto que la dicha Orden tenía en dicho término, por 15 maravedís de foro perpetuo en cada año. Su fecha, en Carrión, a 3 de abril de 1410, ante Ruy González, escribano de dicha villa.

5. <Compra de un prado por 300 maravedís. Año 1446>.

Compra en pergamino que hizo don Pedro, abad de San Zoil, a María Gutiérrez, viuda de Juan Ferreros, de un prado junto a Santa María del Páramo, que ha por lindero de una parte el arroyo que está entre medias de los prados, por precio de 300 maravedís. Su fecha, en Carrión, a $1^{\circ}$ de junio de 1446, ante Álvaro González de Carrión, escribano de dicha villa.

402 San Román de Entrepeñas] al margen derecho: San Román.

${ }^{403}$ San Román de Entrepeñas] al margen derecho: San Román. 


\section{6. <Compra de un prado por 120 maravedís. Año 1447>.}

Compra, en pergamino, que hizo don Pedro de Tosantos, abad de San Zoyl, a Marina, muger de Toribio Alcalde, vecina de Calzada, de un prado, a do dicen a los Prados de Santa María del Páramo, que ha por linderos: de la una parte el camino que va de Carrión a Santa María del Páramo; y de otra parte, el arroyo, por precio de 120 maravedís. Su fecha, en San Zoyl, a 23 de febrero de 1447, ante García Fernández de San Zoles, escribano de Carrión.

7. <Donación de la granja y molino de Santa María del Páramo, etcétera. Año 1458>.

Donación y traspaso que hizo don Pedro de Tosantos, abad de San Zoyl, al convento y su mesa de 5 mill maravedís de los 50 mill que tenía la mesa abadial sobre el barrio de San Martín; asimismo hace donación de la granja que dicen de Santa María del Páramo, cerca del lugar de Torre, con una casa de molino que es cerca de ella, con todos sus términos y derechos, prados, pastos, décimas, etcétera; y asimismo hace donación a la dicha mesa conventual de la mitad de los bienes, así muebles como raízes, que tubiesen los monges y hermanos quando murieren; todo lo qual lo da con condición de que se junten todas las rentas del convento, haciendo una bolsa común, y que se haga tabla de los oficios de obligación que ha tenido la casa desde su fundación. Su fecha, en San Zoil a 16 de noviembre de 1458, ante Álbaro González de Carrión, escribano de dicha villa.

8. < Posesión de los molinos, granja e iglesia de Santa María del Páramo. Año 1459>.

Posesión, que en virtud de la anterior donación, tomó Alfonso García de Villasur, prior de la claustra, de los molinos, granja e yglesia de Santa María del Páramo. Su fecha, a 14 de febrero de 1459, ante Álbaro González de Carrión, escribano y notario.

/ (f. 274r) 9. <Confirmación de la donación de arriba. Año 1466>.

Confirmación que hizo don Pedro de Carrión, abad de San Zoil, de la donación y traspaso que había hecho para la mesa conventual don Pedro de Tosantos, de los 5 mill maravedís de Frómista y del molino, granja, pastos y hacienda de Santa María del Páramo, con la mitad de las legítimas y espolio de los monges y hermanos. Su fecha, en San Zoil, a 7 de septiembre de 1466, ante Fernando Cavallo, escribano de Carrión.

10. $<$ Bulla de comisión para confirmar la donación de arriva. Año $1467^{404}>$.

Bulla del papa Paulo $2^{\circ}$, escrita en pergamino, con sello de plomo pendiente, por la qual da su comisión al deán y Alfonso de Gañinas, canónigo de Palencia, para que, hecha información de la narrativa que se le hizo por el abad don Pedro de Carrión y convento de San Zoil de las dos escrituras de arriva, y hallando ser cierta qualquiera de los dos, confirme la donación hecha a la mesa conventual. Dada en San Marcos de Roma, año de 1467, XI kalendas aprilis.

11. < Confirmación de la donación hecha a la mesa conventual. Año 1468>.

Escritura, en pergamino, con sello de cera pendiente con cintas de seda, por la qual Alfonso Fernández de Gañinas, canónigo de Palencia, en virtud de la comisión que le dio el papa Paulo $2^{\circ}$ por la bulla de arriva, habiendo hecho la información y hallado ser cierta la narrativa, confirma la donación hecha a la mesa conventual por las dos escrituras de arriva, números 7 y 9 . Su fecha, en San Zoil, a 4 de agosto de 1468, ante Pedro Ximón, clérigo de Villamuera, notario apostólico.

Hay copia simple.

12. <Copia simple de las escrituras de arriva. Año 1481>.

Trasumto simple de las escrituras de los ynstrumentos contenidos en los números 7 , 9, 10 y 11, sacados con authoridad de Juan Ruiz de Colmenares, arcipreste de Carrión y comendador del Hospital de don Gonzalo, a 7 de diciembre de 1481; pero el escribano Fernando Cavallo se descuydó en signarlo y assí está sin authoridad.

404 1467] corregido sobre 1466 
13. < Requirimiento al mariscal para que pague los 5 mill maravedís. Año 1515>.

Requirimiento hecho por parte de este monasterio al mariscal don Gómez de Venavides, señor de Fromista, para que pague a la mesa conventual los 5 mill maravedís contenidos en la donación y escrituras de arriva. El mariscal responde que se allana a pagarlos. Su fecha, en Frómista, a 9 de agosto de 1515, ante Hernando Sánchez, beneficiado de San Pedro de Frómista, notario apostólico.

14. <Foro de 22 cargas de trigo por todo lo de Santa María. Año 1581>.

Foro perpetuo por el qual este monasterio con licencia y cédula real da al concejo y vecinos de Torre el molino con sus quatro paradas, la hermita, tierras, prados, pastos de Santa María del Páramo por 22 cargas de trigo de foro perpetuo en cada un año. Su fecha, en San Zoil, a 31 de julio de 1581, ante Andrés Sánchez, escribano de Carrión.

/ (f. 274v) 15. < Provisión real para que los de Torre rediman un censo de 200 ducados. Año 1630>.

Provisión real dada en el Consejo de Castilla para que el concejo de Torre redima, dentro de dos años, un censo de 200 ducados que había tomado, con facultad y licencia del mismo Consejo, para la provisión del pósito. Dada en Madrid, a 24 de diciembre de 1630, ante Lázaro de los Ríos Angulo, escribano de Cámara. $1630>$.

16. $<$ Provisión real para que la justicia informe sobre un censo de 200 ducados. Año

Provisión real para que el correjidor de Carrión informe sobre la necesidad que tenía el lugar de Torre de sacar otro censo de 200 ducados, además del que ya tenía de igual cantidad. Dada en Madrid, a 24 de diciembre de 1630, ante Lázaro de Ríos Angulo, escribano de Cámara.

17. <Escritura de resguardo a favor del monasterio. Año 1634>.

Escritura de resguardo que otorgó el licenciado Bernardo Lezana, abogado de la Chancillería y vecino de Torre, a este monasterio de que no le pararía perjuicio el pleyto que trahía con los de Torre sobre la vecindad y pastos de dicho lugar. Su fecha, en Carrión, a 9 de febrero de 1634, ante Andrés Martínez, escribano de dicha villa.

18. <Convenio entre el concejo de Torre y este monasterio por el qual se hace dexación a este del molino, tierras y hermita de Santa María del Páramo. Año 1640>.

Bajo este número están los papeles siguientes:

$1^{\circ}$ Vna escritura de convenio por la qual consta que el monasterio executó al concejo de Torre por la renta de siete años del foro de las 22 cargas de trigo, y que después de muchos gastos trataron de convenio, haciendo el concejo dexación del término, molino, tierras y hermita de Santa María, obligándose a pagar lo que debían atrasado, assí del dicho foro como de los réditos de 3750 maravedís de un censo que dexó a este monasterio José Serrano (el que parece tienen aun en contra sí por este no le alteraron ni innovaron), que uno y otro valuado y ajustado montó 5380 reales. Se otorgó año de 1640, ante Francisco Moro de Saldaña, escribano de Carrión.

$2^{\mathrm{a}}$ Demanda puesta por el monasterio contra el concejo porque, al tiempo de la entrega, pareció el molino desmejorado y que le faltaba una parada. Pide el monasterio que se le entregue corriente y moliente como era de su obligación por el convenio antecedente. El concejo y vecinos por obiar pleytos se obligaron a pagar por esta última escritura 1100 reales en que se convivieron con el monasterio por las desmejoras del dicho molino. Fue otorgada esta escritura a $1^{\circ}$ de abril de 1642, ante el mismo escribano. 
19. $<$ Dexación de una tierra y un prado para el monasterio, pertenecientes al foro de arriva. Año 1658>.

Dexación que hicieron al monasterio el concejo y vecinos de Torre ${ }^{405}$ de una tierra y un prado con que se habían quedado quando se anuló el foro de las 22 cargas de trigo, que la tierra y el prado están a donde dicen, el / (f. 275r) parque de abajo, que también llaman las Praderas. Se obligaron a pagar diez y nueve cargas y un quarto de trigo que importaban las rentas del tiempo que habían gozado dicho prado y tierra, según la declaración de los nombrados por ambas partes. Fue otorgada en San Zoil, a 7 de julio de 1658, ante Norberto de Sandoval y Guevara, escribano de Carrión.

\section{0. <Amojonamiento de Santa María $>$.}

Papel simple que contiene una razón de las tierras y prados con el amojonamiento del término de Santa María del Páramo.

21. < Concierto con el señor cura de Torre, de pagarle una carga de pan mediado por la asistencia con los parroquianos de Santa María. Año 1818>.

Escritura de concierto hecha entre este monasterio y don Juan Merino, cura del lugar de Torre, en razón de lo que se le había de dar por administrar los Santos Sacramentos y exercer los demás oficios parroquiales a la casa y habitantes del molino de Santa María del Páramo, como parroquianos que son de este monasterio de San Zoil, a quien pertenece dicho molino, iglesia y despoblado de Santa María del Páramo, con todos los diezmos mayores y menores que el molinero y demás habitantes adeudasen, en cuya conformidad ambas partes se convinieron y concertaron en que el monasterio dará anualmente al dicho don Juan y sus subcesores una carga de pan, mediado trigo y cebada, por razón del trabajo y asistencia parroquial con los feligreses del citado Santa María, vajo las condiciones que en ella se expresan. Su fecha, en san Zoil, a 7 de enero de 1818, ante José Tablares del Val, escribano de Carrión.

\section{Remisiones}

$<$ Yglesia $>$.

La yglesia de Santa María del Páramo se concede al monasterio de San Román. Véase el cajón San Andrés, legajo $1^{\circ}$, quaderno B, número $3^{\circ}$.

\section{/ (f. 275v) Quaderno D del legajo $3^{\circ}$ \\ Santa María de Rozavalles}

Este quaderno D contiene los papeles pertenecientes a la presentación del beneficio curado de Santa María de Rozavalles en Galicia, obispado de Lugo, por el orden siguiente: Año 1601>.

$1^{\circ}$. <Presentación del curato de Santa María de Rozavalles en Gregorio Rodríguez.

Presentación del curato de Santa María de Rozavalles hecha por el padre maestro fray Alonso Barrantes, abad de San Zoil, en Gregorio Rodríguez, clérigo de menores, natural de la villa de Monforte, por muerte de Alonso García, su último poseedor. Su fecha, en Valladolid, a 28 de junio de 1601, ante Juan Ruiz, escribano y notario en dicha ciudad.

Está aquí el título de colación dado por don Pedro de Castro, obispo de Lugo, en el qual declara al abad de San Zoil y sus sucesores por patronos y únicos presenteros de dicho curato, sin embargo de la oposición que hizo Francisco Rodríguez, beneficiado de San Fiz de Villamarín, pidiendo se vniese a su beneficio el de Santa María de Rozavalles, quien fue

405 Torre] al margen derecho: Torre. 
condenado por sentencia del provisor. Dada en Lugo, a 22 de agosto del mismo año, ante Fernando Sanjurjo, notario.

En 23 de agosto del mismo año tomó posesión el dicho Gregorio Rodríguez, ante Domingo López de Labrada, notario apostólico. Del original de estos autos hay aquí una copia authorizada por Pedro de Valcárcel, escribano y vecino de Monforte.

\section{2. <Colación del curato a José González Herreros. Año 1642> .}

Colación del mismo curato hecho por Juan López de Ventosinos Gayoso, provisor en sede vacante por el cavildo, en José González Herreros, vecino de Monforte, en virtud de la presentación que hizo en él el padre maestro fray Plácido de Vrbina, abad de Monforte, mediante el poder que para ello le dio el padre maestro fray Plácido del Río, abad de San Zoil. Su fecha, en Lugo, a 12 de mayo de 1642, ante Asensio Pérez de Pintelos, secretario. A la vuelta está la posesión que tomó, a 13 del mismo mes y año, ante Antonio Rodríguez, notario.

\section{3. $<$ Carta para renunciar el curato. Año 1654>.}

Carta del licenciado José González Herreros en que pide al abad de este monasterio su consentimiento y el de toda la comunidad para renunciar el curato de Santa María de Rozavales a favor del licenciado Estevan de Castro. Su fecha, en Monforte, a 28 de septiembre de 1654.

\section{/ (f. 276r) 4. <Colación a don Antonio Candeda. Año 1635>.}

Colación al mismo beneficio curado dada por el señor don Antonio Medina Cachón, obispo de Lugo, al licenciado don Antonio Candeda, clérigo, en virtud de la presentación que en él hizo el padre abad de San Zoyl por fin y muerte al licenciado Andrés de Leys, su último posedor. Su fecha, en la ciudad de Lugo, a 12 de febrero de 1685, ante Lucas Sánchez de Fontecha, secretario.

Hay copia de la misma colación autorizada por Benito Rodríguez, notario apostólico.

5. <Presentación en don Francisco Yerro. Año 1728>.

Testimonio dado por Gregorio García a Miranda, escribano y notario de Carrión, de la presentación del mismo beneficio curado, hecha por el padre maestro fray Jacinto Díez, abad de San Zoyl, en el licenciado don Francisco Yerro, clérigo, por fin y muerte del licenciado don Antonio de Candeda, su último posedor. Su fecha, en Carrión, a 20 de junio de 1728.

Está aquí el despacho de aprobación a favor del referido don Francisco Yerro, dado por el Yllustrísimo señor don Manuel José de Santa María, obispo de Lugo, en el mismo mes y año.

6. $<$ Cartas del señor obispo de Lugo. Año 1728>.

Dos cartas del Yllustrísimo señor obispo de Lugo al padre abad de Carrión, en las que le da gracias por haber presentado el beneficio curado de Rozavales en un sobrino suyo. Su fecha, en la ciudad de Lugo, a 19 de abril de 1728.

\section{7. <Presentación del beneficio en don Domingo López. Año 1735>.}

Presentación ${ }^{406}$ del mismo beneficio curado hecha por el padre maestro fray José del Campo, predicador jubilado y conventual del monasterio de Samos (en virtud del poder que para ella tenía del padre abad de San Zoil), en don Domingo López, presbítero. Su fecha, en el monasterio de San Julián de Samos, a 21 de febrero de 1735, ante Pedro de la Torre, notario de la villa y jurisdición de Samos.

Está aquí el testimonio dado por Andrés Antonio del Prado, notario en la ciudad de Lugo, de cómo el referido don Domingo fue admitido, aprobado y se le despachó el título de colación del referido beneficio. Su fecha, en el mismo mes y año.

\footnotetext{
406 Presentación] al margen derecho: Nota: Este papel 7 debe ser el número 8 (tachado).
} 
8. <Testimonio de la vacante del mismo beneficio curado. Año 1751>.

Testimonio dado por José Fern[ande]z de Sanjurjo, notario de la ciudad de Lugo, de cómo el beneficio curado de Rozavales había vacado por muerte de don Domingo Fern[ande]z, su último poseedor, en el mes de febrero, uno de los reservados; y asimismo que los quatro meses ordinarios corresponde la nominación y elección de cura al reverendo padre abad y monges del convento de San Zoyl. Su fecha, en la ciudad de Lugo, a 5 de mayo de 1751.

/ (f. 276v) 9. < Poder que se dio al padre maestro Muñoz para presentar los dos beneficios curados de Santa María de Rozavales. Año 1766>.

Poder que dio el padre abad y monges del monasterio de San Zoyl al reverendo padre maestro fray Atilano Muñoz, abad de San Vicente de Monforte, para que pudiese presentar los dos beneficios curados de Santa María de Rozavales y de Santa Comba de Osdados, que se hallan dentro del obispado de Lugo, siempre y quando que vacasen en los meses ordinarios, y por seguir qualquier pleyto que se moviere sobre la propiedad y derecho de esta presentación. Dado en Carrión, a 19 de mayo de 1766, ante Andrés Núñez Castelo, escribano en Carrión.

\section{/ (f. 277r) Quaderno E del legajo 3 \\ San Martín de los Álamos}

Este quaderno E contiene los papeles pertenecientes a la hacienda que tiene este monasterio en este lugar de San Martín de los Álamos, es lo siguiente:

\section{1. $<$ Donación de Diego Muñiz. Era 1194. Año 1156>.}

Donación, escrita en pergamino, por la qual Diego Muñiz y su muger, Urraca Téllez, juntamente con sus hijos y nietos, dan a los Santos Mártires Zoyl y Felices y a don Poncio, prior y camarero de Cluni, y a los monges de él, para alumbrar la yglesia de los mismos santos, toda la hacienda que tenían en la villa de San Martín de los Álamos, junto al río de Avia, entre Bárcena y Villavega y Santa Cruz y Villalegido, con carga de un aniversario ${ }^{407}$ en cada un año. Fue hecha esta donación en la era de 1194, que es año de Christo de 1156, reynando en España el emperador don Alonso; y Raimundo, obispo de Palencia.

\section{Remisiones}

La donación que hizo Pedro Rey y su muger, Sancha Pérez, de toda la hacienda que tenían en San Martín de los Álamos. Véase el cajón San Benito, legajo $2^{\circ}$, quaderno A, número $2^{\circ}$.

\section{/ (f. 277v) Quaderno F del legajo $3^{\circ}$ \\ San Martín de los Rascones}

En este quaderno $\mathrm{F}$ están los papeles pertenecientes a las presentaciones y colaciones del beneficio simple rural de San Martín de los Rascones, por el orden siguiente:

$<$ Nota $>$

La donación de la mitad del monasterio de San Martín de Villamayor (oy de los Rascones) hecha por Mayor García, muger de don Gómez. Véase el cajón Santa María, legajo $1^{\circ}$, quaderno $\mathrm{A}$, número $2^{\circ}$.

\footnotetext{
407 aniversario] al margen derecho: Aniversario.
} 


\section{1. < Presentación en Christóval de Cisneros. Año 1576>.}

Presentación del beneficio simple de San Martín de los Rascones hecha por el padre maestro fray Christóval de Agüero, abad de San Zoyl, en Christóval de Cisneros, clérigo, por fin y muerte de Juan Calzada, su último poseedor. Su fecha, en San Zoyl, a 4 de abril de 1576, ante Andrés Sánchez, escribano de Carrión.

2. <Copia simple de una sentencia sobre la presentación deste beneficio. Año 1633>.

Copia simple de una sentencia dada en León, año 1633, ante Francisco González, en la que se declara que el beneficio simple de San Martín de los Rascones es de patronato y presentación del abad y convento de San Zoyl de Carrión, con relación de los descendientes de los Rascones que vivían y tenían derecho a presentar; asimismo hay aquí otro papel sobre el mismo drecho que alega esta familia.

3. < Carta del provisor de León sobre la presentación. Año 1639>.

Carta del doctor don Diego García Santos, provisor de león, en la que declara que todas las veces que toca la mitad de algún patronato y presentación a qualquiera patrono (como esta llano y ajustado le toca en el caso presente al convento de San Zoyl) es justicia llana el que debe ser preferido el apresentado por tal, siendo más benemérito y digno, como notoriamente sucede en el señor don Antonio de la Torre, apresentado por el convento. Su fecha, en León, a 15 de noviembre de 1639.

4. <Presentación en Toribio Díez, que no tuvo efecto. Año 1647>.

Presentación hecha por el padre maestro fray Francisco de Lemos, abad de San Zoil, en el licenciado Toribio Díaz Santos, por fin y muerte de don Antonio de la Torre, sobre que se prosiguió pleyto que estaba pendiente desde la presentación de Torre, y así esta no tuvo efecto. Fue hecha en Carrión, a 24 de diciembre de 1647, ante don Antonio Santos, arcipreste y notario apostólico.

Hay aquí una consulta sin parecer y una carta deste Toribio Díaz, que trata de las cosas del pleyto.

/ (f. 278r) 5. < Título y colación deste beneficio en Santiago Luengo. Año 1648>.

Traslado autorizado por Alonso Bázquez, notario apostólico del obispado de León, de la sentencia, título y colación dada por el licenciado fray Juan Bajino, prior de Villar de Fallaves, del hábito de San Juan, juez apostólico, a favor del licenciado Santiago Luengo, presentado por los Rascones para este beneficio, quando murió Francisco Ares, último poseedor; el qual juez revocó la sentencia que entonces dio el doctor don Diego García Santos, provisor, a favor de don Antonio de la Torre, presentado por el monasterio, desestimando asimismo la que por muerte de Torre se dio a Toribio Díaz Santos; y así tomó la posesión deste beneficio el dicho licenciado Santiago Luengo, en 31 de enero de 1648, ante el referido notario.

Pónense en esta sentencia todos Rascones.

6. < Presentación en Antonio Sánchez Basco. Año 1761>.

Presentación deste beneficio hecha por el padre maestro fray Juan González, abad de San Zoyl, del licenciado Antonio Sánchez Basco, clérigo, por fin y muerte del licenciado Santiago Luengo, último posedor. Su fecha, en San Zoyl a 20 de mayo de 1671, ante Norverto de Sandoval y Guevara, notario y vecino de Carrión.

Síguese un tanto simple del título de colación dado a favor del referido Antonio Sánchez, por sentencia árbitra entre él y los demás presentados, a $1^{\circ}$ de febrero de 1672 , ante Sebastián Calzas, secretario.

Síguense varias cartas en que piden la presentación para el referido Antonio Sánchez.

7. < Presentación en Francisco Gato Monjón (sic). Año 1675>.

Presentación hecha por el maestro fray Bernardo Estúñiga, abad de San Zoyl, en [e] licenciado Francisco Gato Monjón (sic), clérigo de menores órdenes, por fin y muerte de 
Antonio Sánchez Basco, su último posedor. Su fecha, en el priorato del Brezo, a 9 de septiembre de 1675, ante Miguel de la Vega, escribano y notario.

Síguese un tanto simple de la presentación que todo el convento hizo en el mismo licenciado Francisco Gato, pero falta el título de la colación.

\section{8. <Presentación en don Melchor Manjón. Año 1694>.}

Presentación del mismo beneficio hecha por el padre maestro fray Gregorio Ruiz, abad de San Zoil, en el licenciado don Melchor Manjón, presbítero, por fin y muerte del licenciado Francisco Gato Manjón, su último posedor. Su fecha, en San Zoil, a 21 de septiembre de 1694, ante Norberto de Sandoval y Guevara, escribano y notario de Carrión.

Síguese la aprobación y confirmación de esta presentación hecha por toda la comunidad de San Zoil, a 11 de diciembre del mismo año.

También hay aquí un tanto simple de la donación que hizo doña Mayor García, de que se hace mención al principio de este quaderno, y del referido don Melchor Manjón.

/ (f. 278v 9. < Presentación en don Francisco Rico Aguado. Año 1697>.

Aprobación y ratificación de la comunidad de San Zoil de la presentación de este beneficio hecha por el padre maestro fray Jacinto Díez, abad de San Zoil, en el licenciado Francisco Rico Aguado, clérigo de prima tonsura, por fin y muerte del licenciado Melchor Manjón, su último poseedor. Su fecha, a 18 de agosto de 1697, ante Santiago Duque de Estrada, escribano y notario de Carrión.

Síguese un testimonio dado por Pedro Martínez, notario de León, de la sentencia dada por el provisor a favor del dicho Francisco Rico Aguado, en la oposición que le hizo don Juan Treviño, año de 1698.

Vltimamente está el testimonio dado por Antonio López, oficial mayor y notario de la Audiencia de León, del título de colación despachado a favor del referido Aguado, en 17 de abril de 1698.

10. < Cartas al padre abad de San Zoil. Año 1752>.

Cartas escritas al padre maestro fray Manuel Ordóñez, abad de San Zoil, recomendándole la persona de un sobrino del señor Muñiz, para que presentase en él el beneficio de San Martín de los Rascones. Su fecha, 12 de julio de 1752.

11. $<$ Presentación en don Francisco Bariego. Año 1752>.

Presentación del mismo beneficio, con la ratificación del convento, hecha por el padre maestro fray Manuel Ordóñez, abad de San Zoil, en don Francisco Bariego, clérigo de primera tonsura, por fin y muerte de don Francisco Rico Aguado, su último poseedor. Su fecha, en San Zoil, a 19 de septiembre de 1752, ante Juan Cano Guijelmo, notario apostólico.

Está aquí el título de colación dado por los provisores de León, a 12 de diciembre del mismo año; y a la vuelta la posesión que tomó el mismo, en dicho mes y año, ante Manuel Gómez Serrano, notario.

12. <Presentación en don Cesáreo Villasante. Año 1784>.

Presentación del mismo beneficio hecha por el padre maestro fray Martín Basco, abad de San Zoil, con toda la comunidad, en don Cesáreo Villasante, clérigo de prima tonsura, por fin y muerte de don Francisco Bariego, su último poseedor. Su fecha, a 9 de febrero de 1784, ante Miguel López, escribano y notario de Carrión.

\section{Remisiones}

El decreto benefical dado por el señor obispo de León, y confirmado por la Cámara, año de 1790, para que el que tuviese este beneficio sirviese como beneficiado en la yglesia de Santa María de Villamayor. Véase el cajón San Plácido, legajo 4º título Villamayor. 


\section{/ (f. 279r) Quaderno G del legajo $3^{\circ}$ \\ Mazuecos}

Este quaderno $G$ contiene los papeles pertenecientes a la hacienda que tiene el monasterio en este lugar, por el orden siguiente:

$1^{\circ}$. $<$ Requirimiento al monasterio para que defienda 4 quartas de tierra. Año 1623>.

Requirimiento hecho a este monasterio por Gonzalo Ruiz, en nombre de Bernardino Vajo, vecino de Mazuecos, para que defienda 4 quartas de tierra que el referido Bernardino tenía a vita de este monasterio y el comendador de Vilela, del Orden de San Juan, por un mandamiento le obligó a que las dexase por decir pertenecían a la dicha Orden. Su fecha, en San Zoil, a 11 de mayo de 1623, ante Francisco Moro de Saldaña, escribano de Carrión.

Está aquí el poder.

2. <Testimonio de la dexación que hizo Bernardino Vajo de las 4 quartas de tierra y depósito de 28 celemines de trigo. Año 1623>.

Testimonio dado por Alonso Pasqual de Membrellar, escribano de Mazuecos, de la dexación que hizo Bernardino Vajo de las 4 quartas de tierra que tenía a vita de este monasterio, en término de dicho lugar, por evitar la vejación y la excomunión que había sacado el comendador de San Juan para que las dexase y entregase la renta de los siete años que hacía que las llevaba. Y porque el monasterio había salido a la causa, y hasta tanto que se averiguase si eran o no del monasterio, se depositaron 28 celemines de trigo que le parece debía dar de renta por los 7 años, como consta del testimonio adjunto, dado en la villa de Mazuecos a 13 de mayo de 1623, que es el mismo día, mes y año que el primero.

3. <Compra de 7 pedazos de tierra. Año 1692>

Compra que hizo este monasterio a Leonardo Salinas y María Aparicio, su muger, vecinos de Mazuecos, de 7 pedazos de tierras de pan llevar en término de dicha villa, por precio de 45 mill 600 maravedís. Su fecha en Mazuecos, a 3 de junio de 1692, ante Manuel Rodríguez, escribano de dicha villa.

\section{Remisiones}

$<$ Trueque $>$.

Trueque que hizo el prior de San Román con el de San Zoil, año de 1406, por el que da aquel a este toda la hacienda que tenía en Mazuecos. Véase el cajón San Martín, legajo ${ }^{\circ}$, quaderno $\mathrm{B}$, número $3^{\circ}$, por lo que pertenece a San Zoil.

\section{/ (f. 279v) Legajo $4^{\circ}$ del cajón San Lorenzo \\ Muñeca}

Este legajo $4^{\circ}$ del cajón San Lorenzo contiene los papeles pertenecientes a la hacienda que tiene San Román en este lugar, presentación de su beneficio y pleitos que ha habido sobre las dos cargas de pan de aforado que mandó doña Francisca Henríquez de Tobar, por el orden siguiente:

$1^{\circ}$. $<$ Donación de la $3^{\mathrm{a}}$ parte de todos los bienes que tenía don Gómez García en el lugar de Muñeca. Era 1260. Año 1222>.

Donación ${ }^{408}$, escrita en pergamino, por la qual don Gómez García hace donación a San Román y a la orden de Cluni de su alma y cuerpo, y hace pacto con el convento de San Román y con doña Vrraca Díaz, por el qual les da quanto tiene y le puede pertenecer en

${ }^{408}$ Donación] al margen derecho: Falta. 
Muñeca, Entorcisa ${ }^{409}$, Villanueba, Barrio, Aviñante, Villaverde, Villacorta, Cornón de Pedro Martínez, en Respenda, en Lores, Camporedondo, en Rodias y en Liébana. De suerte que da a San Román $<$ la $3^{\text {a }}$ parte $>$ de todos sus muebles y raíces, y las dos terceras partes a doña Vrraca; y el prior de San Román junto con su convento reciven al dicho don Gómez por hermano y familiar, y le hacen participante de sus sufragios. Fue hecha esta carta de donación en Muñeca, en la era 1260, que es año de 1222.

2. $<$ Concierto entre el cura de Muñeca y el prior de San Román sobre 2 cargas de cebada. Año 1557>.

Escritura de concierto hecha entre Juan de Vozmediano, cura de Muñeca, y fray Rodrigo de Corcuera, prior de San Román, por la qual parece que habiendo habido pleyto entre los dos sobre dos cargas de cebada que San Román pretendía pertenecerle sobre el patronato del beneficio de Muñeca; y que el cura decía estar las dichas cargas sobre otros bienes de doña Francisca Henríquez de Tobar, y de otros herederos de su marido, el governador Diego Hurtado de la Vega, y no sobre el dicho patronato. Habiendo habido quatro sentencias por ambas partes en pro y en contra se concertaron por esta escritura en que el cura Juan de Vozmediano se obliga a pagar a los priores de San Román en cada un año para siempre jamás 2 cargas de cebada para el día de Nuestra Señora de agosto, las quales pone sobre el patronato del beneficio de Muñeca, o en Arenillas o en otra parte que no sea más lejos de San Román, las quales dice que son por razón de cierto traspaso que hizieron los herederos del governador Diego Hurtado de la Vega al monasterio de San Román sobre el dicho patronato del beneficio de Muñeca. / (f. 280r) Y el prior de San Román le perdona y se da por pagado de todas las cargas de cebada que le debía haber pagado hasta allí, con que de allí adelante pague a San Román las dos cargas de cebada en cada un año a que se obliga por esta escritura; assimismo el dicho prior cede su derecho y da poder en causa propia al dicho cura, para que en su nombre las pueda haber, pedir y cobrar de los herederos de los dichos governador y doña Francisca Henríquez, su muger. Fue otorgada esta escritura en San Román, a 10 de mayo de 1557, ante Agustín de Medina, escribano de Su Majestad.

3. <Pleyto sobre las 2 cargas de pan que donó al Brezo doña Francisca Henríquez de Tobar. Año 1608>.

Pleyto que pasó entre los monasterios de San Román y el Brezo, de una parte, y el licenciado Juan Soto Velasco, cura de Muñeca, de la otra, en razón de las dos cargas de pan que mandó al Brezo doña Francisca Henríquez de Tobar, muger del governador Diego Hurtado de la Vega, como consta del testamento de esta señora, que está en el Cajón San Benito, legajo $3^{\circ}$, número $8^{\circ}$, de que hizo cesión la casa del Brezo a la de San Román, con otras haciendas por el lugar de Villafría, como consta de la escritura de trueque que está en el cajón San Plácido, legajo $1^{\circ}$, quaderno A.

Por este proceso, parece que los monasterios de San Román y el Brezo, pusieron demanda al dicho cura Soto Velasco, ante don Juan Baptista de Herrera, provisor de León, a 11 de diciembre de 1608, diciendo que de tiempo inmemorial a aquella parte los curas de Muñeca les habían pagado dos cargas de pan, centeno y cevada por mitad de la media vieja; y que había 15 o 16 años que el dicho Soto Velasco no las pagaba. Que las dichas 2 cargas eran aliende y fuera de otras 2 cargas de cevada que debía a San Román cada año por diferentes títulos, sobre los quales estaban condenados los curas de Muñeca. Piden que se mandasen pagar de allí adelante cada año las dichas 2 cargas de pan y todas las demás que hasta allí no se habían pagado; y protestaron poner la demanda más en forma. a prueba.

Fue citado Soto Velasco, el qual se opuso a la demanda y la negó. Reciviose la causa

$<$ Provanza de los monasterios $>$.

Articulan y prueban los monasterios ante Fernando de Colmenares, cura de Villalveto, juez de comisión por el provisor de León, la calificación de las personas de Juan

409 Entorcisa] al margen derecho: Entorcisa, Villanueva, Varrio, Aviñante, Villaverde, Villacorta, Cornón, Respenda, Lores, Camporedondo, Rodias, Liévana. 
de Vozmediano, del bachiller Mathías de Paredes y otros curas de Muñeca, y que no pagarían de sus diezmos y rentas cosa que no fuese justamente debida.

Que los dichos curas de Muñeca, sus antecesores y sucesores han pagado cada año a los dos monasterios 4 cargas de pan, centeno y cevada, dos a cada casa (de tiempo inmemorial) / (f. 280v) y que la yglesia de Muñeca debía y pagaba aforado.

Que los monasterios y sus priores han arrendado, con otras haciendas, las dichas 4 cargas de pan, como cosa propia; y que la yglesia o cura u otros en su nombre las han pagado a los arrendatarios.

Que a los monasterios se les reparte subsidio y escusado por el aforado de estas 4 cargas de pan, y consta de la colectura del subsidio.

Que arrendando los curas los frutos del beneficio, expresaban en los arrendamientos que los arrendadores habían de pagar aquellas 4 cargas de pan a los monasterios y ellos las pagaban.

Que todo es público y notorio etcétera. Prueban los cargos con 27 testigos. Presentose esta información en León, a 31 de marzo de 1609.

$<$ Provanza del licenciado Soto Velasco $>$.

El licenciado Soto Velasco articula y pretende probar que en el mes de noviembre de 1607, fray Alonso Barrantes, fray Gaspar de Montenegro, prior y presidente de San Román y del Brezo, fueron con mucha gente a Muñeca, y llevaron por fuerza y violencia del licenciado Velasco y sus diezmeros 39 fanegas y media de trigo y dos y media de cebada y centeno, maltratando a los diezmeros y a sus casas, etcétera.

\section{$<$ Compulsa del monasterio $>$.}

En 13 de junio de 1609 pidió el monasterio mandamiento para compulsar ciertos papeles para presentarlos en este pleyto, y compulsó los siguientes:

Vn entredicho de la Cruzada, porque San Román no había pagado el subsidio del pan que goza en Muñeca, que había sido de doña Francisca Henríquez, hecha el mismo año.

Cartas de pago de los colectores el subsidio.

Vna absolución del entredicho de arriba, etcétera. Se halla aquí compulsada una deposición de testigos que declaran que el patronato y presentación del beneficio curado de Muñeca pertenece a doña Francisca Henríquez de Tobar, vecina de Vega de Riacos; el testamento de dicha señora, el Libro de rentas de la yglesia de León, etcétera.

$<$ Sentencia del ordinario de León. Año 1610>.

Diose la causa por conclusa para difinitiva, y el doctor Juan Pérez de Grado, provisor de León, pronunció sentencia, por la qual declara que la casa y priorato de Nuestra Señora del Brezo tiene de foro perpetuo sobre los frutos y rentas del beneficio de Muñeca 2 cargas de centeno y cebada en cada un año, y estar obligados los curas que tubieren el dicho beneficio a pagarlas; mediante lo qual condena al cura a que dé y pague las dichas 2 cargas de pan de los diez y seis años que se había substraýdo de pagarlas; y se le manda que dentro de nueve días que esta sentencia se haya de executar y cumplir, dé y pague las 32 cargas de pan, mitad centeno y mitad cevada, procedidas de los dichos 16 años; y que / (f. 281r) de allí adelante, él y sus sucesores paguen las dichas 2 cargas de pan, mitad centeno mitad cevada, cada año al dicho priorato, so pena de excomunión mayor. Y en quanto al despojo opuesto por el licenciado Soto, le reserva su derecho a salvo para que siga su justicia, etcétera. Dada en León, a 12 de marzo de 1610, ante Pedro Álvarez, notario de dicha ciudad. En 13 de marzo apeló de esta sentencia el licenciado Soto, cura de Muñeca. Después de varios alegatos de una y otra parte, en 16 de enero de 1618, el dicho provisor Palacios de la Cruz dio auto por el qual declara la apelación del cura por desierta y la sentencia por pasada en cosa juzgada; y cómo tal mandó librar carta executoria a favor del monasterio (que se sacó y es la del número siguiente). 


\section{$<$ Auto de la Chancillería. Año 1618>.}

Parece que después de esto se llebó este pleyto por vía de fuerza a la Chancillería, donde, en 24 de julio de 1618, se dio auto en que se declaró que el provisor en no otorgar al cura la apelación por él interpuesta no hacía fuerza; y se lo remitieron ante Juan de Zamora Cabreros, escribano de Cámara. En virtud de este auto de la Chancillería, y en su cumplimiento, el dicho provisor a petición del monasterio mandó librar comisión para que el juez executor de la carta executoria (la qual estaba ya dada) la execute y proceda a hacer pago al convento de lo que constare debérsele.

Hasta aquí son los autos hechos en León.

$<$ Autos de Burgos $>$.

El Brebe del nuncio, con la súplica introclusa, dirigido al ordinario y jueces sinodales de Burgos se notificó a don Martín de Salinas, juez sinodal y canónigo de dicha ciudad; y habiéndole aceptado dio letras inhibitorias, compulsorias y citatorias; y dio algunos autos que están al principio del proceso, hasta que éste se compulsó en León y se llebó a Burgos, donde se presentó ante el dicho juez, a 4 de marzo de 1619. En 28 de marzo el juez remitió este pleyto al licenciado Francisco de Espinosa Alarcón, canónigo y abogado de Burgos, para con su parecer sentenciar y determinar esta causa; y habiendo alegado las partes de su justicia, dio la causa por conclusa y mandó citar las partes.

$<$ Sentencia del Juez Apostólico de Burgos $>$.

En $1^{\circ}$ de junio de 1619 el doctor don Martín de Salinas, juez de comisión por el nuncio, con acuerdo del dicho licenciado Alarcón, pronunció sentencia difinitiva, por la qual declara la apelación interpuesta por el licenciado Soto de la sentencia dada por el provisor de León a favor del monasterio, a 11 de marzo de 1610, haber estado y quedar desierta, y la dicha sentencia pasada en authoridad de cosa juzgada. En / (f. 281v) cuya conformidad confirma el auto dado por el provisor de León, en que declaró la apelación interpuesta por el dicho Soto por desierta y la dicha sentencia por pasada en cosa juzgada; y mandó se librase de él la carta executoria a favor del monasterio. Y declara no haber lugar la revocación de atentado pedida por el dicho Soto Velasco. Y alzando qualquier sobreseymiento, inhibición e inhibiciones en qualquiera manera dadas, remite la execución al provisor de León, y reserva en sí la de librar la carta executoria. Esta sentencia se notificó a las partes, y la de Soto Velasco apeló y protestó el auxilio real de la fuerza.

$<$ Auto de la Chancillería $>$.

Después de esto parece que se bolvió a llevar este pleyto por vía de fuerza a la real chancillería, y en ella, a 17 de marzo de 1620 años, se dio auto en que se declara que el doctor don Martín de Salinas, juez de esta causa, en no otorgar al licenciado Soto la apelación por él interpuesta, no hizo fuerza y se lo remitieron. Pasó ante Andrés Gallo, escribano de Cámara, que es todo lo que contiene este proceso.

4. < Carta executoria de las 2 cargas de pan. Año 1618>.

Carta executoria dada por el doctor Palacios de la Cruz, provisor de León, a favor de los monasterios de San Román y el Brezo, contra el licenciado Soto Velasco, cura de Muñeca, en el pleyto de las 2 cargas de pan, mediado centeno y cevada, de aforado, de que se hace mención en el número antecedente. Dada en León, a 26 de mayo de 1618, ante Pedro Álvarez, escribano de dicha ciudad.

Véase el número antecedente, donde se dice cómo después se siguió el pleyto en Burgos y que el monasterio tubo sentencia a su favor.

5. <Obligación de Antonio Henríquez, cura de Muñeca, de pagar todos los gastos del pleyto. Año 1630>.

Testimonio dado por Juan de Vega Salazar, notario y recetor del tribunal de la nunciatura, de la obligación que hizo Antonio Henríquez de Cisneros, cura de Muñeca, de pagar al padre fray Antonio del Valle, procurador de San Benito en Madrid, todo quanto se gastase en el pleyto que tenía pendiente con Juan de Narganes, sobre el curato de Muñeca; y 
que el dicho padre fray Antonio había remitido a Roma. Su fecha, en Madrid, a 29 de mayo de 1630.

6. <Petición del concejo de Muñeca contra un monge que servía el curato de este lugar. Año 1632>.

Petición presentada al provisor de León por parte del concejo y vecinos de Muñeca, para que se les dé cura que administre los Sacramentos, atento de que el monge que servía dicho curato por ausencia de Antonio Henríquez, actual cura, no acudía al servicio de la yglesia. El señor provisor dice que da licencia para que el cura de Entorcisa sirva dicho curato, siendo cierta esta relación, pero que antes de vsar de ella, se notifique al dicho monge. Dada en León, a 20 de febrero de 1632. No tiene authoridad.

Siguen dos cartas sobre lo mismo. $1633>$.

/ (f. 281v) 7. <Letras ynhibitorias de la nunciatura contra el ordinario de León. Año

Letras ynhibitorias del doctor don Pedro Testay, protonotario y juez de comisión por el nuncio de Su Santidad, ganadas a petición del licenciado Antonio Henríquez de Cisneros, cura de Muñeca, para inhibir al ordinario de León en el pleyto que tenía pendiente con el bachiller Juan de Nerganes, Francisco Valiente y consortes sobre el curato de dicho lugar. Dadas en Madrid, a 24 de octubre de 1633, ante Ygnacio de Velasco, notario de la nunciatura.

Síguense las notificaciones hechas en Madrid y León en el mismo año.

8. $<$ Carta executoria a favor de Juan de Narganes sobre la presentación del curato de Muñeca. Año 1636>.

Carta executoria por la qual parece que habiendo nuestro padre maestro fray Juan Díaz, abad de San Zoil, presentado el beneficio curado de Muñeca, Juan de Narganes no vsó de ella el dicho Narganes en la oposición que hizo al dicho beneficio contra Antonio de Medina, que tenía la presentación del concejo de dicho lugar; y constando al abad que el dicho Narganes había obrado tan mal, que había ocultado su presentación y que se valía de la presentación que le dio don García Manrique, vecino de Bárcena (como señor que dixo ser de la casa y torre de Vega de Riacos) que pretendía ser patrono del dicho beneficio; el dicho abad revocó la presentación que había hecho en el referido Narganes y la dio a Antonio Medina de Cisneros, el cual se valió de ambos derechos, del de el monasterio y del concejo. Sobre esto hubo un pleyto muy grande en León, en la nunciatura, etcétera. Finalmente se sacaron letras de Roma, y después de varios jueces vino últimamente cometida la causa a don Lorenzo Yturruzarra, chantre de Alcalá y vicario de Madrid, el cual confirmó las sentencias del provisor y nuncio, y revocó las de don Pedro Testay y don Miguel Cavallero, jueces in curia de esta causa, como consta de su sentencia dada en Madrid, a 24 de diciembre de 1635, ante Simón Ximénez Cortes, notario apostólico. Notificóse esta sentencia a las dos partes que se hayaron presentes, de la cual no se apeló y en su execución se mandó despachar esta carta executoria a favor de Narganes; y en virtud de ella se volvió a reintegrar en la posesión de este beneficio curado. Fue dada esta carta executoria en Madrid, a $1^{\circ}$ de febrero de 1636 , ante el mismo notario. Síguense las notificaciones de esta carta executoria.

Vltimamente está una relación sucinta de lo contenido y actuado en este pleyto.

9. <Apartamiento del pleyto de las 2 cargas de pan mediado que hizo el cura de Muñeca. Año 1786>.

Testimonio dado por Manuel Luys París, escribano y vecino de Villanueba de Arriba, del apartamiento que hizo don Bernabé Carrión, cura de Muñeca, de el / (f. 282r) pleyto que este monasterio tenía pendiente en el tribunal de León sobre la paga de 2 cargas de pan, mediado centeno y cevada, de la medida vieja (las mismas de que se hace mención en los números $3^{\circ}$ y $4^{\circ}$ de este legajo) y allanamiento del dicho cura a pagar enteramente las cargas caýdas desde que contestó al pleyto, y las 2 cargas que anualmente fueren cayendo, sin que él ni sus sucesores puedan oponerse a la tal satisfacción y paga. Su fecha, en Muñeca, a 27 de mayo de 1786. Este apartamiento fue aprobado por el señor don Thomas Sanz Carpintero, 
provisor de León, por su auto dado en la misma ciudad, a 22 de julio del mismo año, ante don Antonio Leonardo López, notario mayor.

\section{Remisiones}

$<$ Trueque $>$.

La Hacienda de este lugar pertenece a San Román por el trueque que hizo este monasterio con él, año de 1406: véase el cajón San Martín, legajo $1^{\circ}$, quaderno B, número $2^{\circ}$.

$<$ Donación $>$.

Donación de una carga de trigo y otra de cebada por doña Francisca Henríquez de Tobar: cajón San Benito, legajo $3^{\circ}$, número $8^{\circ}$.

$<$ Donación $>$. $6^{\circ}$

Donación de un prado en Muñeca: cajón San Felices, legajo 3', quaderno C, número

$$
<\text { Foro }>\text {. }
$$

Foro perpetuo de 30 maravedís, un par de gallinas, otro par de cabritos y dos pares de perdices, por toda la heredad y todos los prados que pertenecían a San Zoil en el lugar de Muñeca: cajón San Felices, legajo $3^{\circ}$, quaderno C, número $1^{\circ}$.

$<$ Tierras $>$.

Dos tierras: véase el cajón San Plácido, legajo 5º quaderno E, número 21.

\section{(f. 283r) Cajón 11 San Estevan} Palencia.

Véase a la vuelta legajo $1^{\circ}$, quaderno ídem, donde debe estar este ynstrumento y título

$1^{\circ}$. < Compra de una casa en Palencia, en la calle de los Soldados, por precio de 9000 reales. Año 1802>.

Compra que hizo el padre fray Gregorio Calderón, monge de este monasterio, de una casa $^{410}$, en el casco de la ciudad de Palencia, calle de los Soldados, a mano izquierda, como se entra en ella por la Mayor; que linda por Sur con dicha calle; por Poniente y Norte, casa y convento de las monjas Agustinas Canónigas; y por Oriente, con otra casa de la propia obra pía, de quien era esta; cuya venta fue otorgada por los señores comisionados del venerable deán y cavildo de la santa yglesia cathedral de la dicha ciudad,en virtud de Real Orden de Su Majestad, a favor del referido padre Calderón, por precio 9 mill 000 reales vellón; el qual la compró con condición que después de su fallecimiento quedase para este monasterio. Su fecha, en Palencia, a 19 de septiembre de 1802, ante Marcelino Nieto, escribano de dicha ciudad.

Tomada la razón de esta escritura en el oficio de hipotecas de la misma ciudad al folio 195 y siguientes del Libro Corriente, ante Thomás de las Bárcenas, escribano en ella.

${ }^{410}$ Casa] al margen derecho: Se vende en el año de 1818. 


\section{/ (f. 283v) Cajón 11 San Estevan}

Este cajón San Estevan, que es el vndécimo del archivo, contiene 3 legajos pertenecientes a diversos lugares, que son: Legajo $1^{\circ}$ : Paredes de Nava, Pino de Viduerna, Población del Soto, Población de Frómesta, $<\mathrm{La}>$ Puebla, Quintanilla de la Cueza, Quintanilla de Trigueros; Legajo $2^{\circ}$ : Recueba, Revenga, Ríos Menudos, Riveros.; Legajo $3^{\circ}$ : Respenda.

$$
\text { Legajo } 1^{\mathrm{o} 411}
$$

Este legajo, que es el primero del Cajón San Estevan, contiene siete quadernos, que son los siguientes:
Quaderno A..........Paredes
B..........Pino de Viduerna
C..........Población de Frómesta
D..........Población del Soto

\author{
E..... La Puebla \\ F......Quintanilla de la Cueza \\ G......Quintanilla de \\ Trigueros
}

\section{Quaderno A del legajo $1^{\circ}$ \\ Paredes}

Este quaderno A contiene los papeles pertenecientes a la hacienda que tiene este monasterio en este lugar, por el orden siguiente:

/ (f. $284 r) 1^{\circ}$. <Privilegio del rey don Alonso por el qual hace libre de todo pecho la hacienda de Paredes. Era 1222. Año 1184>.

Privilegio rodado, escrito en pergamino con sello de plomo pendiente, por el qual el rey don Alonso el 9, con su muger, la reyna doña Leonor, concede para siempre al monasterio de San Zoil y a don Humberto, su prior y camarero de Cluni en España, que de las casas y heredades que tubieron en Paredes no paguen fosadera ni facendera, ni pecho alguno, ni pedido, sino que para siempre quede libre de todo gravamen y exacción. Facta carta apud Carrionen (sic), era M CC XX II, que es año de Christo de 1184.

Hay copia autorizada por don Antonio Martín García, notario appostólico.

2. < Foro de 2 maravedís y medio sobre una tierra. Año 1406>.

Escritura de foro perpetuo, en pergamino, por la qual don Rodrigo, limosnero mayor del monasterio de San Zoil, con licencia de don Fernando, prior Mayor de él da a Alfonso Fernández, ferrero, vecino de Paredes de Nava, una tierra que es a Pozuel de Padre, término de dicha villa, lindero la carrera vieja, etcétera. Su fecha, en la villa de Paredes, a 27 de agosto de 1406, ante Martín García de Paredes, notario apostólico.

Hay copia authorizada por don Antonio Martín García, notario.

3. <Advertencias y cartas sobre un pleyto decimal. Año 1582>.

Advertencias, cartas y otros papeles sueltos acerca de un pleyto que pusieron los clérigos de Paredes ante el provisor de Palencia a un rentero del monasterio sobre que pagan diezmos de las heredades que tenía el dicho monasterio, no habiéndolo pagado antes otros arrendatarios que los habían llevado. Condenó el provisor al rentero, quien apeló al nuncio y sacó breve con que inhivió al provisor. Después a instancia de los clérigos, el provisor dio mandamiento contra el monasterio para que mostrase las diligencias que había echo en aquel pleyto. El monasterio respondió no ser su juez ni haberle citado para el pleyto. Sacó breve de Roma para que el obispo de Zamora conociese en esta causa, que se quedó así y que pasó por los años de 1582 y 83.

${ }^{411}$ Legajo $\left.1^{\circ}\right]$ al margen izquierdo: Nota: Véase al dorso título Palencia, que debe ser el $1^{\circ}$ de este legajo. 


\section{4. $<$ Sentencia sobre una tierra a favor del monasterio. Año 1651>.}

Sentencia a favor de este monasterio dada por don Gerónimo de la Torre, corregidor de Palencia, en el pleyto que el / $(f .284 v)$ referido monasterio tenía con un vecino de Villalumbroso, sobre una tierra, a do llaman los Olmos de Buenaventura, término de Paredes, y que el dicho vecino pretendía pertenecerle, para lo qual pidió contra el arrendatario la renta de los años que la havía gozado; y habiendo salido el monasterio a la defensa, hizo su probanza y el referido corregidor, en grado de apelación, dio esta sentencia por la qual declara la dicha tierra, de diez quartas poco más o menos, ser propia del dicho monasterio, y le ampara en la posesión que ha estado de percivir y llevar sus frutos. Y asimismo dio auto para que al dicho monasterio se le vuelban dos cargas de trigo que se habían depositado. Dada en Palencia, a 20 de junio de 1651, ante Hernando Juárez, escribano real. Notificose y fue consentida.

\section{5. <Compra de una viña ${ }^{412}$. Año 1662>.}

Compra que hizo este monasterio a Ángela de Bustillo, vecina de Villaumbrales, de una viña ${ }^{413}$ de cinco quartas, poco más o menos, a do dicen Valliluengo, término de Paredes, por precio de 20.000 maravedís. Su fecha, en Villaumbrales, a 22 de enero de 1662, ante José Asenjo, escribano de dicha villa.

6. < Compra de casas, bodega, viñas y tierras. Año 1691>.

Compra que hizo este monasterio al licenciado Mathías Calonge, beneficiado de la yglesia parroquial de Villalumbroso, y a otros vecinos del dicho lugar, de unas casas, una bodega y lagar en Villalumbroso ${ }^{414}$; de siete villas, las 2 en dicho lugar y 5 en término de Paredes; y de 6 tierras, las 5 en término de Paredes y la una en el de Villalumbroso, por precio de 13.820 reales. Otorgose esta escritura en Villalumbroso, a 4 de abril de 1691, ante Francisco Herrero, escribano y vecino de Villamuera.

\section{7. <Compra de viñas y tierras. Año de 1691>.}

Compra que hizo este monasterio a Manuel Moro, vecino de Castrillejo, de 2 viñas y una tierra en término de Paredes, y otra tierra en término de Villalumbroso ${ }^{415}$; todas por precio de 636 reales. Otorgose esta escritura en el monasterio de San Zoil, a 14 de junio de 1601, ante Norverto de Sandoval y Guevara, escribano de Carrión.

\section{/ (f. 285r) 8. <Desembargo de un carro de mieses de este monasterio. Año 1692>.}

Auto de desembargo, dado por le provisor de provisor de Palencia, de un carro de mieses que los beneficiados de Paredes habían embargado del fruto de una tierra que el monasterio tenía en dicha villa, a fin de que se les pagase diezmo de lo que en dichas tierras se cogiese; y por este auto se manda que, dando el monasterio fianza (como en efecto se dio), le entregasen los granos que de dichas mieses procedieron. Dado en Palencia, a 30 de octubre de 1691, ante Bernardo Rodríguez Palacios, notario.

De este pleyto se da relación en el título Villalumbroso, cajón San Gregorio, legajo 2, quaderno J, número 7.

9. <Compra de tierras y viñas. Años 1692 y 1693>.

Bajo este número están las compras siguientes:

$1^{\circ}$ Compra que hizo este monasterio a Pedro Pérez y María González, su muger, vecinos de Mazuecos, de 2 viñas en término de Paredes, a donde llaman Los Linos, por precio de 1.312 reales y $1 / 2$. Fue otorgada esta escritura en Mazuecos, a 5 de enero de $1692^{416}$, ante Alexandro García, escribano de dicha villa.

\footnotetext{
412 viña] infrascrito t tachado: tierra.

413 viña] infrascrito t tachado: tierra.

414 Villalumbroso] al margen derecho: Villalumbroso.

415 Villalumbroso] al margen derecho: Villalumbroso.

416 1962] sigue tachado y $1 / 2$.
} 
$2^{\circ}$ Compra que hizo este monasterio a Simón García, vecino de Villalumbroso, de una viña en el término de Paredes, donde llaman La Muñeca, por precio de 96 reales y medio. Ante Norverto de Sandoval y Guevara, escribano de Carrión, donde se otorgó, a 20 de abril de 1692.

$3^{\circ}$ Compra que hizo <el> monasterio a Marcos Cardenal, vecino de Villalumbros, de una viña, a donde llaman al Pasadero, término de Paredes, por precio de 1.634 reales y 8 maravedís, con la pensión de un censo de 300 reales y una obligación y fianza de 400 reales que contra dicha viña había. Su fecha, en Villalumbroso, a 30 de abril de 1692, ante Diego Lasso, escribano de dicha villa. Están aquí 2 papeles autorizados que conducen para la seguridad de esta venta.

$4^{\circ}$ Compra que hizo este monasterio a Santiago Martínez y María Nicolás, su muger, vecinos de Villalumbroso, de una viña en término de Paredes, al pago que llaman al Pasadero, por precio de 560 reales. Su fecha, en Villalumbroso, a 17 de enero de 1693, ante Diego Lasso, escribano de dicha villa.

$5^{\circ}$ Compra que hizo este monasterio a Alexandro Martínez, vecino de Villalumbroso, de una viña en término / (f.285v) de Paredes, donde llaman al Mijar de Arriba, por precio de 1.167 reales. Su fecha, en el monasterio de San Zoil, a 26 de marzo de 1693, ante Norverto de Sandoval y Guevara, escribano de Carrión.

$6^{\circ}$ Compra que hizo este monasterio a Gerónimo Correas, vecino de Villalumbroso, de una viña donde llaman Almijar de Abajo, término de Paredes, con un pedacico de tierra que es de dicha viña; ytem una tierra en dicho término y pago de Paredes, por precio de 5.111 reales. Su fecha, en el monasterio de San Zoil, a 28 de marzo de 1693, ante Norverto de Sandoval y Guevara, escribano de Carrión.

10. < Adjudicación de una tierra. Año 1745>.

Testimonio dado por Mauricio Mirañaz de Chirueches, escribano de Villalumbroso, de la adjudicación que se hizo a este monasterio de una tierra de 3 obradas en término de Paredes, por auto dado por don Diego Fernández de Herrezuelo, alcalde de dicha villa, en el pleyto que litigó el referido monasterio contra los bienes de Miguel Redondo, por el principal y réditos de un censo.

Su fecha, en Villalumbroso, a 22 de marzo de 1745.

11. $<$ Sentencia a favor del monasterio de una tierra. Año 1786>.

Testimonio dado por Norverto Gallego, escribano de Paredes, de la sentencia dada a favor de este monasterio por el licenciado don Antonio Ramón Calvo y Serrano, alcalde mayor de dicha villa, en el pleyto que había con los procuradores de ella sobre una tierra de 42 quartas, al pago que llaman la Caben o Corral de Magallón. Fue dada esta sentencia en la villa de Paredes, a 26 de abril de 1786. Tomó posesión el monasterio de dicha tierra a 11 de mayo del mismo año y ante el mismo escribano.

12. < Auto difinitivo a favor de este monasterio sobre una tierra. Año 1798>.

Testimonio dado por Norverto Gallego, escribano de Paredes, del auto difinitivo dado a favor deste monasterio por don Gaspar Chato González, teniente de alcalde mayor de dicha villa, contra Francisco Ynfante Lagunilla, desta vecindad, sobre la propiedad de una tierra que antes fue viña, de cavida de una quarta y 30 palos, en término de dicha villa, en donde dicen Pedrueco. Dado en Paredes, a 27 de agosto de 1798. Notificose este auto y en 10 de enero de 1799 se declaró por consentido y pasado en la autoridad de cosa juzgada; y se mandó que se llevase a execución.

\section{Remisiones}

$<$ Procesos, adjudicación, compra $>$.

Procesos contra los de Paredes en Villaverde. Véase el cajón San Yldefonso, legajo $1^{\circ}$ y $2^{\circ}, 3^{\circ}$. Amojonamientos. Adjudicación de 5 tierras en Paredes: c ajón San Gregorio, 
legajo $2^{\circ}$, quaderno J, número 12. Compra de una viña: cajón san Benito, legajo $2^{\circ}$, quaderno A, número 15 .

\section{/ (f. 286r) Quaderno B del legajo ${ }^{\circ}$ Pino de Viduerna}

Este quaderno B contiene los papeles pertenecientes a la yglesia de San Adrián de este lugar y yantar del cura, y préstamo que tiene San Román, a quien pertenece por el trueque que hizo con este monasterio, que se citará abajo en las remisiones. Las escrituras que contiene son las siguientes: Año $1280>$.

$1^{\circ}$. $<$ Reconocimiento de la yglesia de San Adrián de Pino de Viduerna. Era 1318.

Escritura en pergamino, por la qual parece los vecinos de Pino de Viduerna, haviendo trahído pleyto con el prior de San Román ante Fernando González, arcipreste de Villanueva, sobre la yglesia de San Adrián de dicho lugar de Pino, y con deseo de estar en paz con el prior de San Román don Pedro de Toro, fueron tres hombres de Pino a San Román, en nombre de su concejo, a tiempo que se les havía caído la yglesia y le dijeron que les mostrase el privilegio que tenía la casa de San Román, por donde pretendía pertenecerle la dicha yglesia de San Adrián; y el dicho prior les mostró el privilegio del conde don Pedro Ansures, que parece $^{417}$ dio dicha yglesia (no hay esta donación); los quales haviendo visto dicho privilegio se convencieron y dijeron al prior que hiciese de ella lo que quisiese y la requirieron que la mandase alzar; y el prior a ruego de hombres buenos lo hizo así. El prior dio de su mano la dicha yglesia a un clérigo para que la sirviese, con que le diese a él y a sus monges un yantar y los demás derechos que hera costumbre, a lo qual se obligó el clérigo.

Fue echa esta escritura viernes, a 12 de enero, en la era de 1318, que es año de 1280. No tiene autoridad.

$2^{\circ}$. <Reconocimiento del yantar para el prior de San Román. Año 1395>.

Reconocimiento que hizo Juan Martín, cura de Pino de Viduerna, de que debía dos yantares a Juan Alfonso, prior de San Román, y reconoce que se le debe dar en cada año según se había / (f. 286v) dado siempre. Su fecha, en Pino a 13 de septiembre de 1395, ante Juan Pérez, escribano de San Martín. antiguas.

Hay copia autorizada por don Antonio Martín García, notario y traductor de letras

Juntamente se hallan aquí otras dos copias de esta escritura; la una autorizada por Juan de Castrillo, y sacada a 11 de septiembre de 1529; y la otra por el referido Antonio Martín, escribanos y notarios públicos.

$3^{\circ}$. $<$ Requirimiento y posesión que tomó el prior de San Román de una casa, tierras y prados. Año 1557>.

Testimonio dado por Agustín de Medina, escribano de Su Magestad, del requirimiento y posesión que tomó el padre fray Rodrigo de Corcuera, prior de San Román, de un préstamo de una casa, tierras y prados, que estaba vaco por muerte de Pedro de Ponga, vecino de Pino de Viduerna, donde estaban dichas posesiones. Su fecha, en Pino de Viduerna, a 7 de marzo de 1557.

Hay aquí otros dos testimonios.

$4^{\circ}$. $<$ Compra de una tierra. Año 1792>.

Compra que hizo el padre maestro fray Josef Fierro, prior de San Román, a Francisco Baños y Teresa Mayor, vecinos del lugar de Abiñante, de una tierra en el término de Pino de Viduerna, a Soles, a so las Lomas, al duerno, que hace quarto y medio de trigo; linda con los

${ }^{417}$ parece] sigue tachado: le. 
prados y con tierra de Gerónimo Luis, vecino de Santiváñez, y con tierra de Santiago Santos, vecino de Pino, y con tierra de herederos de Francisco Martín, de dicho lugar, por precio de 310 reales vellón. Su fecha, en San Román, a 20 de septiembre de 1792, ante Manuel Luis París, escribano de Su Magestad y vecino de Villanueva de Arriba.

\section{Remisiones}

$<$ Trueque $>$.

Trueque entre San Román y el prior de San Zoil. Cajón San Martín, legajo 1º, quaderno $\mathrm{B}$, número $3^{\circ}$.

$<$ Compra $>$.

Compra que hizo el prior de San Román en Pino. Cajón San Felices, legajo 3º, quaderno $\mathrm{F}$, número $2^{\circ}$.

$<$ Donación $>$.

Donación del conde don Pedro Ansúrez. Cajón San Gregorio, legajo 2ª quaderno $\mathrm{Y}$, número $1^{\circ}$.

$<$ Prados $>$.

Quatro prados en Pino. Véase el Cajón San Martín, legajo 1 $^{\circ}$, quaderno B, número 34. Otro prado para San Román: cajón San Gregorio, legajo $2^{\circ}$, quaderno D, número $2^{\circ}$.

\section{/ (f. 287r) Quaderno C del legajo $1^{\circ}$ \\ Población de Frómesta}

Este quaderno $\mathrm{C}$ contiene los papeles pertenecientes a la hacienda que tiene este monasterio en el lugar de Población de Frómesta, por el orden siguiente:

$1^{\circ} .<$ Compra de una tierra. Año 1389>.

Escritura en pergamino, muy maltratada, por la qual parece que Martín Pérez, vecino de Población, vende al prior de San Martín de Frómesta una tierra en término de Población, cabe el arroyo. Su fecha, en Frómesta, a 28 de diciembre de 1389, ante Sancho López, escribano.

$2^{\circ}$. $<$ Compra de una viña. Año $1392>$.

Escritura en pergamino, muy maltratada, por la qual parece que este monasterio compró a Juan de Sevilla, vecino de Población, una viña, en el collazo de dicha villa. Su fecha, en el año de 1392, ante Sancho López de Frómesta, escrivano.

$3^{\circ}$. < Foro de 10 maravedís y 2 pollas por una tierra. Año 1404>.

Foro perpetuo, escrito en pergamino, por el qual don Fernando, prior mayor de San Zoil, da a Toribio Martínez, vecino de Piña, una tierra, a la Carrera que dicen de Viñaderos, en término de Población de Frómesta, por 10 maravedís y dos pollas en cada un año; y $<$ con $>$ condición que de todos los frutos que cogiere en la dicha tierra pague el diezmo a la yglesia de San Martín de Frómesta. Su fecha, en San Zoil, a 18 de diciembre de 1404, ante Francisco Pérez, escribano de Carrión.

$4^{\circ}$. <Compra de una viña. Año 1641>.

Compra que hizo fray Juan Aguado, prior de San Martín de Frómesta, a Juan Rasillo, vecino de Piña, de una viña al Pinchete, término de Población, que hace media alanzada, poco más o me nos, por precio de 35 reales. Su fecha, en Frómesta, a 10 de febrero de 1641, ante Alonso Pérez, escribano de dicha villa.

$5^{\circ}$. Bajo este número se hallan diversas escrituras de censo, testamentos, mandas, hijuelas de hacienda y compras que hicieron los ascendientes de Baltasar de Nogal y Osorio, 
quien vivió / (f. 287v) algunos años en este monasterio, en donde está enterrado; y nos dejó toda la hacienda que tenía en Población de Frómesta y en Frómesta. Las escrituras son desde el año 1592 hasta el de 1709, inclusive.

\section{$6^{\circ}$. <Donación de Baltasar de Nogal de viñas, tierras, bodega y casa. Año 1717>.}

Donación entre vivos que hizo a este monasterio Baltasar de Nogal y Osorio, vecino de Población de Frómesta (y murió en este monasterio) de toda su hacienda, conviene a saber: una bodega y lagar con sus aparejos, una hera, diez pedazos de viñas y majuelos, 14 tierras; todo ello en los términos de Población y en los de Frómesta; y asimismo una casa en Carrión, en el barrio que llaman de Santi Espíritus, frente del convento de San Francisco, con la carga de un censo de 300 reales de principal que sobre ella tenía la cofradía de San Roque y capellanía de los Palmeros; y por no haber pagado dicho Baltasar de Nogal en muchos años los réditos de este censo le executaron; y haviéndolos pagado redimió dicho censo (falta la escritura de este censo redimido), por lo qual recayó en él dicha casa, como todo consta de esta escritura de donación, que fue otorgada en la villa de Carrión, a 1 de marzo de 1717, ante Gregorio García de Miranda, escrivano de dicha villa.

Adviértase que las tres primeras viñas expresadas en esta donación tenían contra sí 250 reales de principal de un censo mancomunado con Josef Román a favor de la capellanía de Antolín Cayón; y la mitad de este censo le redimió el monasterio como heredero que fue del dicho Baltasar de Nogal, cuya escritura está aquí unida, como asimismo la ijuela de la legítima de Baltasar de Nogal, la compra que él mismo hizo de una casa y 3 viñas; y últimamente las diligencias de execución contra los herederos de Bartholomé Osorio, por los réditos del censo de la cofradía de San Roque.

$7^{\circ}$. $<$ Auto dado a favor de este monasterio sobre una tierra en término de Población. Año 1764>.

Auto dado por el licenciado don Manuel Rubín de Celis, provisor de Palencia, a favor de este monasterio contra don Diego Macho Antón, beneficiado de la yglesia de San Pedro de la villa de Frómesta, sobre una tierra en término de Población, una de / ( f. 288r) las que heredó el monasterio de Baltasar de Nogal, por el qual se mantiene y ampara al dicho monasterio en la posesión en que ha estado y estaba, al tiempo de la moción de este pleyto, de gozar, disfrutar y arrendar la deslindada tierra, en cuya posesión mandaba y mandó no sea inquietado, molestado ni perturbado por persona alguna; y que el referido beneficiado, por ahora, y sin perjuicio, vuelva y restituya a Christóval Ramos, arrendatario de dicha tierra, los frutos que recogió en ella en el año próximo pasado, satisfacciéndole éste el importe de la simiente que dicho eclesiástico había echado en ella. Dado en Palencia, a 10 de septiembre de 1764, ante Bernardo Facundo Bázquez, notario de la Audiencia.

$<$ Auto de los provisores de Burgos $>$.

El referido eclesiástico apeló a Burgos y parece desistió de dicha apelación, por lo que los provisores de dicha ciu(i)dad declararon la mencionada determinación por consentida y pasada en autoridad de cosa juzgada, y mandaron se procediese a la execución y cumplimiento del auto dado en Palencia. Su fecha, en Burgos, a 29 de noviembre del mismo año, ante Agustín Ladrón de Guevara, notario. $1794>$.

$8^{\circ}$. $<$ Trueque de un lagar y bodega por dos viñas en término de Población. Año

Trueque que hizo el padre fray Cayetano Tabohada, prior de San Martín de Frómesta, con Joaquín de Satolalla e Ysabel Hortega Frechilla, su muger, vecinos de la misma villa, por el qual dicho prior da a estos un lagar con su bodega en el barrio de Grajal, por dos viñas que estos le dieron en término de la villa de Población, al Oyal. Otorgose esta escritura en dicha villa de Frómesta, a 9 de septiembre de 1794, ante Pedro Rodríguez Antón, escribano de dicha villa.

9. <Relación de las donaciones antiguas, etcétera, de Población>.

Papel simple en que se expresan las donaciones antiguas, así de las tercias de diezmos que en esta villa de Población tubo este monasterio por privilegio y donación de la Reyna 
doña Vrraca, como de otras que hicieron Juan García Población y una señora llamada doña Mencía Ruiz, cuyas escrituras / (f. 288v) se hallan <en> otros cajones que se citarán abajo en las remisiones.

\section{Remisiones}

$<$ Donación $>$.

Donación de la reyna doña Mayor de las tercias de Población. Véase el cajón San Agapio, legajo $1^{\circ}$, quaderno $\mathrm{A}$, número $1^{\circ}$.

$<$ Donación $>$.

Donación de doña Mencía Ruiz de todo quanto tenía en Población. Véase el mismo cajón, legajo y quaderno número 4.

$<$ Trueque $>$. número $1^{\circ}$.

Trueque de viñas y tierras en Población. Véase el mismo cajón y legajo, quaderno B,

Que la ynfanta doña Juana tenía en encomienda el lugar de Población. Véase el Cajón San Román, legajo $1^{\circ}$, número $5^{\circ}$.

\section{/ (f. 289r) Quaderno D del legajo $1^{\circ}$ \\ Población de Soto}

En este quaderno D están los papeles pertenecientes a la hacienda que tiene este monasterio en este lugar, por el orden siguiente:

$1^{\circ}$. < Convenio entre este monasterio y el concejo de Población sobre el término y soto del dicho lugar. Año 1404>.

Escritura en pergamino por la qual parece que por quanto hacía mucho tiempo había grandes contiendas entre el concejo de Población y este monasterio sobre el término de dicho lugar y el soto inmediato a él, para evitar los daños que una a otra parte se hacían paciendo y rozando donde no los pertenecía, ambas partes se convinieron y preguntaron a hombres ancianos de dicho lugar, quienes bajo juramento dixeron que lo que pertenecía al dicho convento de San Zoil es esto según que aquí se dirá: según toma desde el arroyo nuevo e de la otra parte la huelga de Sarsaxal fasta los mojones, e desde la boca de la huelga como va fasta el arroyo de la Pachistra; e otrosí que pertenescía al dicho convento como toma desde el mojón de fondo e el cuérnago fasta la tierra que dicen de fixos de Fernando Ruis de Quadórniga. E de esto ficieron juramento los del dicho concejo de Población que era así verdad y que de allí adelante que lo guardarían, etcétera. Fue echa esta escritura cerca del soto de Población, a 22 de febrero año de 1404, ante Gómez García de Saldaña, esscribano de Carrión.

Hay copia autorizada de esta escritura para don Antonio Martín García, traductor y notario appostólico.

$2^{\circ}$. $<$ Compra de una tierra. Año 1517>.

Compra que hizo Pedro Sánchez, vecino de Población, a / (f. 289v) Sancho de Barreda de una tierra en término de dicho lugar, a do dicen a las Cascajeras, de una obrada poco más o menos, por precio de 650 maravedís. Su fecha, en Población del Soto, a 11 de marzo de 1517, ante Floristán de la Serna, esscribano de Carrión.

Esta escritura no habla con el monasterio.

$3^{\circ}$. <Trueque de tierras en Arenillas de San Pelayo por otras de este lugar. Año 1641>.

Trueque que hizo este monasterio con Toribio Cóbreces, vecino de Renedo, de varias tierras que el monasterio tenía en Arenillas de San Pelayo por otras que el dicho Toribio dio 
a este monasterio en este lugar de Población del Soto, y 2 en el término de Carrión. Otorgose la escritura en el año de 1641, ante Francisco Moro de Saldaña, esscribano de Carrión ${ }^{418}$.

Falta esta escritura del archivo y por tanto no puede ponerse con más individualidad.

\section{Remisiones}

Requirimiento echo por parte de este monasterio a los arrendadores del agua, molinos y campo de Población del Soto. Véase el cajón San Pedro, legajo $4^{\circ}$, número $6^{\circ}$.

\section{/ (f. 290r) Quaderno E del legajo 1 \\ La Puebla}

Este quaderno E contiene un testamento y codicillo cuya hacienda puede pertenecer en algún caso al Santuario de Nuestra Señora del Brezo, y es el siguiente:

\section{$1^{\circ}$. <Testamento de Diego Colmenares. Año 1614>.}

Testamento y codicillo de Diego de Colmenares, vecino de La Puebla, en el qual nombra por sus herederos a don Juan de Agueros, hijo de Juan de Agueros, su sobrino, y, en caso que este no acepte su herencia, sustituye a sus hermanos, uno en pos de otro, con condición que vivan en sus casas de La Puebla el que huviere de haber su hacienda, y que defienda la libertad e ydalguía de ella; y no lo cumpliendo sustituye en toda su hacienda y vínculo al monasterio de Nuestra Señora del Brezo con carga de 12 misas cada año ${ }^{419}$. Fue otorgado este testamento a 22 de junio de 1614, ante Matías de Treceño, esscribano y vecino de Buenavista.

\section{$<$ Codicillo $>$.}

En el codicillo y su cabeza dice que quiere añadir y quitar de su testamento y en él pone esta cláusula. Primeramente dixo que hera su voluntad, siendo Nuestra Señora servido, se hayan de casar y casen conforme lo manda la Santa Madre Yglesia, doña Beatriz, hija de don Pedro Enrríquez, difunto, su sobrino, con don Juan de Agueros, hijo de don Juan de Agueros, su sobrino, por quanto esta es su voluntad. Y no casándose la dicha doña Beatriz con el dicho don Juan, su sobrino, dijo hera su voluntad que la casa de Nuestra Señora del Brezo sea su heredera de sus bienes y hacienda y los lleve con la bendición de Dios y del / (f. 290v) abad de San Zoil de Carrión. Y sin otra revocación concluye el codicillo, que fue otorgado en la villa de San Salvador, a 18 de mayo de 1615, ante Diego de los Ríos, esscribano de dicha villa.

No se cumplió la condición del testamento en quanto a vivir en La Puebla don Juan de Agueros, ni la del cidicillo sobre el casamiento; sin embargo, doña Beatriz pretendió entrar en estos bienes por ser vinculados y ella sobrina y heredera del testador. Hay aquí una copia simple de este testamento y otra del testamento de Hernando Osorio, y últimamente está el inventario de todos los bienes muebles y raíces del referido Diego de Colmenares.

$2^{\circ}$. $<$ Pareceres sobre este testamento $>$.

Consulta y pareceres sobre el testamento de Diego de Colmenares y sobre si su hacienda pertenece a Nuestra Señora del Brezo.

\footnotetext{
${ }^{418}$ Carrión] al margen derecho: Nota.

419 año] al margen derecho: 12 misas cada año.
} 


\section{/ (f. 291r) Quaderno F del legajo 1 \\ Quintanilla de la Cueza}

Este quaderno F contiene los papeles pertenecientes al lugar de Quintanilla de la Cueza, por el orden siguiente:

1․ $<$ Población del barrio de San Millán de Quintanilla. Era 1215. Año 1177>.

Escritura en pergamino, partida por $\mathrm{ABC}$, por la qual parece que fray Vmberto, prior de San Zoil y camarero de España, concede a todos los pobladores que quisieren poblar nuestro barrio de San Millán de Quintanilla, con condición que el día de San Miguel de cada año paguen de censo doce dineros al camarero que tubiere el cargo del vestuario de los ancianos, y los clérigos entren en la yglesia por mano del concejo y tengan siempre las primicias y la tercia de los diezmos de pan y vino y de todo lo demás que pertenece a los diezmos de la yglesia; y la otra tercia que se parta igualmente entre el camarero y el concejo; y la otra tercia entera la lleve el obispo. Y los clérigos que entraren en la yglesia presten omenage y seguridad de que todo el tiempo que estubieren en la yglesia sean vasallos del prior y ancianos de San Zoil sin que reconozcan otro señor. En lo demás el concejo de San Millán tenga el mismo foro o reconocimiento que tiene el convento de San Zoil. Facta carta in era 1215, que es ano de Christo de 1177, regnante rege Aldefonso, cum vsore sua, regina Alienor, in Toleto et in Estremadura et in Castella; comité Fernando, senior in medietate de Carrione; Rodrigo Rodriguez, senior in altera medietate.

\section{$2^{\circ}$. $<$ Pleyto sobre un huerto herrén. Año 1654>.}

Pleyto que hubo entre este monasterio y el licenciado Gregorio Román, cura de Quintanilla de la Cueza, ante el señor obispo de Palencia y sus jueces de comisión, sobre un huerto cercado que después se abrió y quedó hecho herrén, sito en el dicho lugar, lindero: las calles públicas, en el que el dicho clérigo se había entrado en él sin causa ni razón, estando el monasterio en quieta y pacífica posesión; y para justificación del derecho se compulsaron los apeos así de Quintanilla como de Calzadilla y de Cerbatos, en virtud de los quales el concejo y vecinos de dicho lugar se apartaron e hicieron dexación de las heredades, viñas, etcétera, contenidas en el dicho apeo; y el señor corregidor de Carrión mandó dar al monasterio la posesión de todas ellas, pero el cura apeló y el pleyto se quedó así.

\section{/ (f. 291v) Quaderno G del legajo $1^{\circ}$ \\ Quintanilla de Trigueros}

Este quaderno $G$ contiene los papeles pertenecientes a la hacienda que tiene este monasterio en Quintanilla de Trigueros, por el orden siguiente: $1129>$.

$1^{\circ}$. $<$ Trueque entre este monasterio y la condesa doña Mayor Petriz. Era 1167. Año

Escritura de trueque, en pergamino, por la qual la condesa doña Mayor Petriz da en cambio a don Estevan, prior de San Zoil, y a todos los ancianos la porción que tenía en el monasterio de Santa María de Trigueros, con toda la heredad que pertenecía a aquel monasterio y la parte que había comprado de su sobrino el conde Ermengot y la parte que tenía en la Serna de Canlargo; y el convento la dio la porción que tenía en Villaciscla de la parte de los hijos del conde Sancho y la que tenía en Villabollo ${ }^{420}$ de parte de Martín Pétrez. Facta carta nonas aprilis, era 1167, que es año 1129.

Hay aquí copia de esta escritura sacada por autoridad de justicia, en el año de 1528, y autorizada por Francisco Catalán, esscribano de Carrión.

${ }^{420}$ Villabollo] al margen derecho: Canlargo, Villaciscla y Villalbollo. 


\section{$2^{\circ}$. $<$ Donación de doña Elvira Sánchez. Era 1174. Año 1136>.}

Donación escrita en pergamino, por la qual doña Elvira Sánchez, por remedio de su alma y la de sus padres, hace donación a Dios, a San Juan, a los Santos Zoil y Felices y al prior don Pedro y a todos los ancianos de San Zoil, de aquella porción que tenía en Santa María de Trigueros, en el monasterio, que está en El Castillo, con toda la heredad del mismo monasterio que enteramente la pertenecía; y de la heredad que ella tenía en la villa de Trigueros da la mitad a San Zoil y la otra mitad la reserva para sí durante su vida y después de su muerte la deja al dicho monasterio de San Zoil. Y el dicho prior con todos los ancianos la dan en préstamo por su vida quanto les pertenecía en Villa del Rey ${ }^{421}$ y que después vuelva al monasterio. Facta carta tercio nonas ianuari, era 1174, que es año de 1136.

Hay aquí copia de esta escritura sacada por autoridad de justicia en el año de 1528 y autorizada por Francisco Catalán, esscribano de Carrión.

/ (f. 292r) $3^{\circ}$. <Licencia del general para trocar unas tierras. Año 1629>.

Licencia que dio nuestro reverendísimo padre maestro fray Gregorio Parcero, general de San Benito, para trocar unas tierras, de obrada y media, por otras en término de Quintanilla. Dada en el monasterio de San Martín de Madrid, a 12 de marzo de 1629.

\section{Remisiones}

La presentación del beneficio de Santa María de Trigueros y la tercera parte de la tercia de todos los diezmos de dicha yglesia perteneciente a este monasterio. Véase la concordia, cajón San Andrés, legajo $1^{\circ}$, quaderno B, número $3^{\circ}$.

\section{/ (f. 292v) Legajo 2º del cajón San Estevan}

Este legajo $2^{\circ}$ contiene los 6 quadernos siguientes:
Quaderno A..........Recueba
B.......... Yglesia y beneficio deste lugar
C...........Revenga

D..........Ríos Menudos

E..... Yglesia de este lugar

F.......Riveros

\section{Quaderno A del legajo $2^{\circ}$ \\ Recueba}

Este quaderno A contiene los papeles pertenecientes a la hacienda que tiene el priorato de San Román en este lugar, por el orden siguiente:

$1^{\circ}$. <Donación de don Pedro Ansúrez de la yglesia de San Pedro de Recueba. Era 1153. Año 1115>.

Donación escrita en pergamino, por la qual el conde don Pedro Ansúrez Díaz, juntamente con su muger, la condesa doña Elvira Sangiz, dan a San Román la yglesia de San Pedro del lugar de Recueba (que la llama monasterio) con toda la heredad, con solares, tierras, prados y con quanto pertenecía a dicha yglesia, y de la manera que Herrand Annayaz la había dotado. Facta pagina donationis XVI kalendas maii, era 1153, que es año de 1115. apostólico.

Hay copia autorizada y sacada por don Antonio Martín García, antiquario y notario

${ }^{421}$ Rey] al margen derecho: Villa del Rey. 

$1120>$.

$2^{\circ}$. $<$ Donación de Ferrán Pérez de la hacienda que tenía en Recueba. Era 1158. Año

Donación escrita en pergamino, por la qual Ferrán Petrez, juntamente con su mujer, Elo Rodríguez, después de poner en esta escritura las mismas palabras que en la antecedente y confirmar la donación de la yglesia o monasterio de San Pedro de Recueba hecha por / ( $f$. 293r) el conde don Pedro Ansúrez, concede a San Román toda la hacienda, solares, tierras, prados y quanto les pertenecía en aquel lugar por concesión de doña Vrraca. Facta carta tercio kalendas maii, era 1158, que es año de 1120. $1537>$.

$3^{\circ}$. < Posesión que tomó el prior de San Román de un prado, carrera y sotillo. Año

Testimonio dado por Christóval Gómez, notario apostólico y vecino de Aviñante, de la renunciación y apartamiento que hicieron Juan Luis y Catalina, su muger, vecinos de Recueba, de un prado que se dice Carrera Mercado, y de la Carrera y Sotillo que tenía el dicho prado, todo lo qual dejaron por evitar pleytos al padre fray Diego de Sahagún, prior de San Román, para que hiciera de ello todo lo que quisiera; en virtud de lo qual fray Alonso de Villamuera, monge de San Román y su procurador, acetó el apartamiento y tomó posesión de estas fincas, como consta de esta escritura otorgada en el lugar de Recueba, a 15 de julio de 1537.

$4^{\circ}$. $<$ Carta executoria a favor de este monasterio de un prado y una tierra. Año $1540>$.

Carta executoria por la qual parece que este monasterio se querelló ante los alcaldes del crimen de Valladolid, de Pedro Martín y Juana, su muger, Miguel López y otros consortes, vecinos de Vega y Barajores, porque teniendo el priorato de San Román un prado y una tierra sembrada en el término de Recueba, el dicho Pedro Martín y consortes fueron una noche con armas, segaron el prado; y otro día con carros, para llevar la yerba; y estando los criados del monasterio segando el pan de la heredad, y dos monges con ellos, fueron armados a estorbarlo y quitarles la mies, acometiéndoles y diciéndoles palabras injuriosas. Se pidió que los reos fuesen castigados y volviesen al monasterio el pan y yerba que habían llevado y que amparasen al monasterio en la posesión del prado y tierra. Hízose información y fueron llevados presos los acusados. Litigose la causa ante dichos juezes, alegaron las partes, hiciéronse pruebas, y conclusa la causa en 22 de diciembre de 1539, se dio sentencia, por la qual dicho Pedro Martín y consortes fueron condenados en destierro de la Chancillería y cinco leguas alrededor y de los lugares de Vega y Barajores, su término y jurisdicción, por el tiempo que fuese la voluntad de Su Magestad, etcétera / (f. 293v) y a que dentro de tercero día restituyan al dicho monasterio el pan que habían llevado, y le amparan en la posesión del prado y tierra, reservando la propiedad a salvo. De esta sentencia suplicó la parte de Pedro Martín, dijo agravios y, sin embargo, en 12 de mayo de 1540 se dio sentencia de rebista, por la qual se confirmó la difinitiva de vista, y se mandó executar. De todo lo qual se sacó esta carta executoria, a 13 días del mismo mes y año, ante Gaspar Velas, escribano del crimen.

Síguese la notificación de esta sentencia hecha a Pedro Martín y consortes, a 3 de junio del mismo año, por Pedro Estrada, escribano y vecino de Villoheles.

\section{$5^{\circ}$. <Posesión que tomó el prior de San Román de un préstamo. Año 1561>.}

Testimonio dado por Agustín de Medina, escribano de Su Magestad, de cómo habiendo muerto Pedro Pérez, cura de Recueba, que tenía una casa y préstamo de San Román, el prior fray Lorenzo de Modoya tomó posesión de él y se le dio a Pedro Pérez, cura de Villafría, el qual se obliga a serle vasallo y a pagar las vnciones y entrada que los demás acostumbraban a pagar. Su fecha, en Recueba, a $1^{\circ}$ de julio de 1561.

Están aquí deslindadas las posesiones, que parecen ser una casa, cinco tierras, dos linares y dos prados y huerto.

$6^{\circ}$. $<$ Posesión que tomó el prior de San Román de un casa de préstamo. Año 1578>.

Testimonio dado por Pedro Rodríguez, escribano y vecino de Viduerna, de cómo el padre fray Benito del Camino, prior de San Román, tomó posesión de una casa, sita en el lugar de Recueba, que era de préstamo que había vacado por muerte de Alonso Guigelmo, 
cura de dicho lugar; y de cómo entró y metió en al dicha casa a Francisco Moreno, criado de dicho prior. Su fecha, en Recueba, a 22 de mayo de 1578.

$7^{\circ}$. <Trueque de 2 casas por 5 tierras y un prado. Año de 1792>.

Trueque que hizo el padre maestro fray José Fierro, prior de San Román, con Felipe de Arriba y María Bores, su muger, vecinos de Recueba, de dos casas con su corral y huerto, sitas en dicho lugar y propias de dicho priorato, por dos tierras, un prado y un linar en término de dicho lugar de Recueba, y otro linar en término del lugar de Vega de Riacos ${ }^{422}$ y una tierra en término de Tarilonte ${ }^{423}$, y más 872 reales que los referidos Felipe de Arriba y su muger dieron a dicho padre prior por las referidas casa. Fue otorgada esta escritura en el lugar de Recueba, a 16 / (f. 294r) de marzo de 1792, ante Manuel Luis París, escribano de Su Magestad y vecino de Villanueva de Arriba.

$8^{\circ}$. <Trueque de una casa por 4 tierras. Año 1792>.

Trueque que hizo el padre maestro fray José Fierro, prior de San Román, con Fernando Bores y María Martín, su muger, vecinos del lugar de Recueba, de una casa con su huerto, situada en dicho lugar y propia de dicho priorato, por 4 tierras en término de dicho lugar, que la primera está a do llaman el Río, la $2^{\mathrm{a}}$ a las Pradillas de Valde Sancho, la $3^{\mathrm{a}}$ a San Christóval y la $4^{\mathrm{a}}$ a do llaman la Cuesta del Buitre, a Abrogera; cuyas tierras dieron los referidos por la dicha casa. Fue otorgada esta escritura en el lugar de Recueba, a 29 de julio de 1792, ante Manuel Luis París, escribano de Su Magestad y vecino de Villanueva de Arriba.

$9^{\circ}$. $<$ Trueque de una casa por cinco tierras y un prado. Año 1797>.

Trueque que hizo fray Pedro Castro, prior de San Román, con Fernando del Hospital, vecino de Recueba, de una casa sita en el dicho lugar y propia del (del) dicho priorato, por un prado y una tierra en término de la villa de Castrejón ${ }^{424}$ más por otras dos tierras en término del lugar del Pisón ${ }^{425}$; y asimismo por otras dos tierras en término de este lugar de Recueba; que la $1^{\mathrm{a}}$ está a do dicen la Campeja de mal nombre, la $2^{\mathrm{a}}$ a do dicen Carrera de Mercado. Cuyas tierras y prado dio el referido Fernando por la dicha casa; como consta de esta escritura otorgada en el lugar de Recueba, a 14 de marzo de 1797, ante Christóval de Castresana y Torre, escribano de Castrejón.

\section{Remisiones}

Compra de una tierra en término de Recueba. Véase el cajón San Benito, legajo $1^{\circ}$, quaderno $\mathrm{E}$, número $1^{\circ}$.

\section{/ (f. 294v) Quaderno B del Legajo $2^{\circ}$}

Este quaderno contiene los papeles pertenecientes a la yglesia, presentaciones y colaciones de los beneficios de preste, evangelio y grados de este lugar de Recueba, por el orden siguiente:

$1^{\circ}$. <Ynformación a favor de San Román de cómo estos beneficios son de presentación del abad. Año 1579>.

Traslado autorizado por Francisco Gómez, escribano de Castrejón, de una información hecha a favor del monasterio de San Román, por comisión del licenciado don Prudencio de Armentia, provisor de Palencia, en el año de 1578, la qual hizo Alonso de Campó, cura y vicario, arcipreste de Castrejón, en el lugar de Recueba, en la qual se prueba con seis testigos que de tiempo inmemorial los abades de San Zoil, como señores del priorato de San Román, son verdaderos y únicos patronos de todos los beneficios que hay en la yglesia

\footnotetext{
422 Vega de Riacos] al margen derecho: Vega de Riacos y Tarilonte.

423 Tarilonte] al margen derecho: Tarilonte.

${ }^{424}$ Castrejón] al margen derecho: Castrejón.

425 Pisón] al margen derecho: Pisón.
} 
de Recueba y que siempre y en qualquiera manera que hayan vacado, han presentado en ellos persona a su voluntad; y que de qualquiera presentación presbiteral han llevado por razón del sello y firma un marco de plata; por el de evangelio a dos ducados y por el de grados a 12 y a 14 reales. Fue sacado este traslado en la villa de Castrejón, a 30 de enero de 1579.

$$
2^{\circ} \text {. < Presentación del beneficio de grados en Diego Luis. Año 1592>. }
$$

Presentación del beneficio de grados de la yglesia de San Pedro de Recueba, hecha por el padre maestro fray Plácido Huércanos, abad de San Zoil, en el licenciado Diego Luis, capellán del número de la yglesia de Palencia, por fin y muerte de Bartholomé Fernández, su último poseedor. Su fecha, en Palencia, a 3 de junio de 1592, ante Hernando de Castro, escribano de dicha ciudad.

$3^{\circ}$. <Colación del beneficio de preste de Recueba en Gonzalo Morante. Año 1597>.

Colación del beneficio de preste de la yglesia de Recueba, hecha por don Francisco de Rivadeneira, provisor en sede vacante del obispo de Palencia, en Gonzalo Morante, clérigo, por fin y muerte de Alonso González, su último poseedor; y en virtud de la presentación hecha por el prior y presidente de San Zoil. Su fecha, en Palencia, a 24 de enero de 1597. Morante.

A la vuelta está la posesión que tomó del dicho beneficio el referido Gonzalo $1605>$.

$/(f .295 r) 4^{\circ} .<$ Executoria sobre la vnión del beneficio de evangelio al de preste. Año

Carta executoria en razón de la vnión del beneficio de evangelio en el de preste de la yglesia de San Pedro de Recueba, por la qual parece que haviendo muerto Juan Luis, cura de dicho lugar, el padre fray Pedro de Santayana, abad de San Zoil, presentó los dos beneficios en el año de 1596 en Alonso de Gonzalo, en cuya virtud los provisores de Palencia le hicieron colación de ellos; y habiendo vacado por su muerte dichos beneficios, se hizo colación del de preste a Gonzalo de Morante de que tomó la posesión; y en 10 de octubre de 1602 pidió ante don Gaspar de Peralta, provisor de Palencia, declaración de la vnión de estos beneficios y que se le hiciese colación del de evangelio, a lo qual se opusieron el concejo de Recueba, Diego Luis, beneficiado de grados del dicho lugar y después el convento de San Zoil. Sin embargo, el dicho provisor, en $1^{\circ}$ de junio de 1604, dio sentencia por la qual declaró haber probado su intención el dicho Gonzalo de Morante, y que el dicho beneficio de evangelio se incluia en el de preste por la vnión hecha de ambos, como le tubo el dicho Alonso Gonzalo; y manda se le acuda con los frutos de ambos. De la qual sentencia apelaron las otras partes y se ganó el brebe del nuncio, con el qual fue requerido el licenciado Juan Rodríguez de Santa Cruz, canónigo y juez sinodal de Palencia, el qual conoció esta causa, y teniendo el pleyto concluso para difinitiva, se concertaron en cierta forma los dichos Diego Luis y Gonzalo Morante, e hicieron cierta concordia que pidieron al dicho juez la confirmase. Después de lo qual, en 25 de agosto de 1605, el dicho juez dio sentencia, por la qual confirmó la que había dado don Gaspar de Peralta, juntamente con la dicha concordia, para cuya execución se remitió al dicho provisor don Gaspar; y porque no lo hizo a instancias del dicho Morante, procedió el dicho juez a execución y desembargo de frutos en virtud de esta carta executoria, que fue librada en 26 de agosto de 1605, ante Pedro de Arana Ocerín, notario de Palencia.

Síguese la posesión que tomó el referido Morante del beneficio de evangelio vnido al de preste / (f. 295v) ante Fernando de Colmenares, notario apostólico.

Está aquí vnido un mandamiento con censuras del provisor de Palencia, para que el cura Morante pague a Diego Luis las costas del pleyto sobre la provisión del beneficio de evangelio de Recueba; y al pie está la carta de pago de ellas. Dada en Palencia, a 15 de diciembre del mismo año.

$5^{\circ}$. $<$ Declaración para que se desunan los dos beneficios. Año 1616>.

Certificación que con licencia del provisor de Palencia dio Juan de Rodrigo, cura de Recueba, de cómo el concejo de dicho lugar dixo que convenía se dividiese el beneficio de evangelio del de preste. Su fecha, en Recueba, a 24 de febrero de 1616. 

$6^{\circ} .<$
Año $1616>$.

$6^{\circ}$. $<$ Colación del beneficio de evangelio, preste y curado, en Bartolomé Gonzalo.

Colación del beneficio de evangelio, preste y curado hecha por el licenciado don Antonio Ramírez, provisor de Palencia, en Bartolomé de Gonzalo, clérigo, por fin y muerte de Gonzalo Morante, su último poseedor, que los tenía vnidos; y en virtud de la presentación que en él hizo el padre fray < Juan> Díez, abad de San Zoil. Dada en Palencia, a 21 de mayo de 1616, ante Juan de Noriega, notario.

A la espalda está la posesión que de dicho beneficio tomó el referido Bartolomé Gonzalo, ante Fernando Monte, notario.

$7^{\circ}$. <Sentencia del obispo de Palencia sobre la partición de diezmos. Año 1640>.

Traslado autorizado por el padre fray Juan de Cisneros, notario apostólico, de una sentencia dada por Christóval de Guzmán y Santoyo, obispo de Palencia, sobre el modo que se ha de observar en distribuir los diezmos entre los beneficiados mayores y menores y el curato del lugar de Recueba, en la qual se declara que el preste lleva seis partes, que hacen seis graderías, el curado tres, que es media ración, y el evangelio otras tres, y el gradero una, que es sesta parte de una razión entera. Dada en Palencia, a 11 de octubre de 1640, ante Hernando de Salzeda, secretario del señor obispo.

$8^{\circ}$. $<$ Presentaciones de los beneficios de preste y evangelio en Juan Enero y Pedro Díez. Año 1667>.

Bajo este número hay dos presentaciones, la $1^{\text {a }}$ del beneficio de preste curado, hecha por el padre maestro fray Bernardo de Estúñiga, abad de San Zoil, en el licenciado Juan Enero, clérigo, vecino del lugar de Baños, por muerte de Bartolomé Gonzalo, su último poseedor; dada en San Zoil, a 14 de agosto de 1667, ante fray Francisco de Molina, notario apostólico. La $2^{a}$ es del beneficio de evangelio / (f. 296r) del dicho lugar de Recueba, hecha por el mismo en el licenciado Pedro Díez, beneficiado de grados en dicha yglesia, por muerte del referido Bartolomé Gonzalo, su último poseedor, que los tenía vnidos; dada en San Zoil, a 15 días del mismo mes y año y ante el mismo notario. beneficios>.

$<$ Nota $><$ Sentencia a favor de este monasterio sobre la desunión de estos

Sobre la división y desunión que hizo este abad de estos dos beneficios hubo pleyto muy reñido con el obispo de Palencia; se llevó en grado de apelación a Burgos, en donde ganó este monasterio sentencia a su favor; y habiendo aprobado allí los dos presentados por el abad, se despacharon títulos de colación, en virtud de los quales tomaron la posesión quieta y pacíficamente. Pasó este pleyto en Burgos ante el notario Escalada. Faltan de este archivo estos títulos, y asimismo el tanto de la sentencia; y sólo se hallan aquí dos provisiones reales contra el fiscal de Palencia para que remita los autos originales con unas preguntas para la información.

9. < Presentación del beneficio de grados de Francisco de Pedrosa. Año 1669>.

Presentación del beneficio de grados de dicha yglesia de Recueba, hecha por el padre maestro fray Bernardo Estúñiga, abad de San Zoil, en el licenciado Francisco de Pedrosa, clérigo de menores órdenes, por ascenso de Pedro Díez, su último posedor, al beneficio de evangelio de dicha yglesia. Dada en San Zoil, a 2 de mayo de 1669, ante fray Francisco de Molina, notario apostólico.

10. < Colación del beneficio de evangelio al licenciado Diego de Treceño. Año 1679>.

Colación del beneficio de evangelio de dicha yglesia, hecha $<$ por $>$ el licenciado don Pedro Rodríguez Mogrovejo, provisor de Palencia, en el licenciado Diego Treceño, clérigo, por fin y muerte de Pedro Díez, su último poseedor; y en virtud de la presentación que en él hizo el padre abad de San Zoil. Dada en Palencia, a 2 de agosto de 1679, ante Francisco Lozano, notario.

A la espalda está la posesión que tomó de dicho beneficio. 
11. < Colación del beneficio de evangelio a Ambrosio Treceño. Año 1683>.

Colación del beneficio de evangelio, hecha por el mismo provisor, en el licenciado Ambrosio Treceño, por ingreso en religión de Diego Treceño, su último poseedor; y en virtud de la presentación que en él hizo el padre abad de San Zoil. Dada en Palencia, a 24 de marzo de 1683, ante Bernardo Rodríguez Palacios, notario.

A la espalda está el testimonio dado por Juan de Vega, escribano y notario, de la posesión que tomó el referido.

\section{/ (f. 296v) 12. <Colación del beneficio de grados en Matheo de Mata. Año 1690>.}

Testimonio dado por Miguel de la Vega, notario y vecino de Abiñante, de la colación hecha por don Gaspar de Quincozes, provisor de Palencia, en Matheo de Mata, natural de Barajores, del beneficio de grados de dicha yglesia, por muerte del licenciado Francisco de Pedrosa, su último poseedor; y en virtud de la presentación que en él hizo el padre abad de San Zoil. Dada en Palencia, a 18 de abril de 1690, ante Bernardo Rodríguez Palacios, notario; y este testimonio fue dado en la casa del Brezo, a 3 de septiembre del mismo año.

13. <Presentación y colación del beneficio de preste en Sebastián Abad. Año 1698>.

Presentación del beneficio de preste de dicha yglesia, hecha por el padre maestro fray Jacinto Díez, abad de San Zoil, en el licenciado Sebastián Abad, cura del lugar de Buedo, por fin y muerte del licenciado Juan Herrero, su último poseedor. Dada en San Zoil, a 23 de febrero de 1698, ante Gregorio García de Miranda, notario de Carrión.

Está aquí el título de colación dado por el licenciado don Francisco de Ceballos, provisor de Palencia, en 23 de abril del mismo año, ante Antonio Martínez Tamayo, notario en dicha ciudad, y asimismo un testimonio dado por el mismo del título original.

14. $<$ Dos presentaciones del beneficio de evangelio en don Toribio de Narganes y Pedro de Lezcano. Años de 1729 y 1732>.

Bajo este número están dos presentaciones del beneficio de evangelio de dicha yglesia. La $1^{a}$ hecha por el padre maestro fray Jacinto Díez en el licenciado don Toribio Narganes, natural de Castrejón, por renuncia que de él hizo don Juan Campero, beneficiado de preste de Camporedondo, como consta de la certificación que está aquí, dada por Ysidoro Meneses, notario apostólico, juntamente con el auto del señor provisor de la admisión de su renuncia. Fue dada esta presentación en San Zoil, a 6 de marzo de 1729, ante Santiago Duque de Estrada, notario y escribano de Carrión.

La $2^{\text {a }}$ fue hecha por el padre maestro fray José Yglesia, abad de San Zoil, en el licenciado don Pedro de Lezcano, natural de Barajores, clérigo de menores órdenes, por fin y muerte del licenciado don Toribio Narganes, su último poseedor. Dada en San Zoil, a 21 de abril de 1732, anta Agustín Díez de Castro, notario y escribano de Carrión.

Está aquí la colación dada a don Pedro de Lezcano por el doctor don Lorenzo Bernardo Pereyra, provisor de Palencia, en 13 de agosto del mismo año, ante Ysidoro Meneses, notario de dicha ciudad.

15. <Presentación del beneficio de grados en don Francisco Lezcano y renuncia del mismo. Año 1739>.

Presentación del beneficio de grados hecha por el padre maestro fray Juan Baca, abad de San Zoil, en el licenciado don Francisco Lezcano, natural de Barajores, por fin y muerte de don Juan de la Calle, su último / (f. 297r) poseedor. Dado en San Zoil, a 15 de abril de 1739, ante Gabriel de Zeano Vivas, notario y vecino de Carrión. En el año de 1744 hizo renuncia de dicho beneficio el referido don Francisco de Lezcano, como consta del testimonio dado por José García de Guadiana, notario; y del despacho dado por el señor provisor de Palencia, que todo está aquí vnido. 
16. $<$ Dos presentaciones, la una del beneficio de preste, en don Francisco Rodríguez; y la otra del beneficio de evangelio, en don Alonso Martínez. Año 1743>.

Presentación del beneficio de preste hecha por el padre maestro fray Manuel Ordóñez, abad de San Zoil, en el licenciado don Francisco Rodríguez, clérigo de menores órdenes, por fin y muerte de don Sebastián Abad, su último poseedor. Dada en San Zoil, a 10 de junio de 1743, ante Agustín Díez de Castro, notario y escribano de Carrión. Se halla aquí una carta escrita al señor obispo de Palencia por don Manuel Antonio Giménez Bretón, su provisor, en la que le dice ser muy justo el reparo del padre abad para no hacer la presentación en esta vacante en quien no sea patrimonial en la dicha yglesia de Recueba. Juntamente se halla aquí otra presentación del beneficio de evangelio, hecha por el mismo padre abad en el licenciado don Alonso Martínez, natural y patrimonial de dicho lugar de Recueba, por fin y muerte de don Pedro Lezcano, su último poseedor. Dada en San Zoil, en el mismo día, mes y año y ante el mismo notario.

17. <Dos presentaciones, la $1^{\mathrm{a}}$ del beneficio de evangelio, en don José de Hompanera; y la $2^{\mathrm{a}}$ del de preste, en don Antonio Rodríguez. Año 1778>.

Bajo este número están dos presentaciones: la $1^{\text {a }}$ del beneficio de evangelio hecha por el padre maestro fray Yldefonso de Mier, abad de San Zoil, en don José de Hompanera, presbítero y patrimonial de dicho lugar, por fin y muerte de don Alonso Martínez, su último poseedor. Dada en San Zoil, a 29 de octubre de 1778, ante Martín García Gatón, notario de Carrión.

La $2^{a}$ es del beneficio de preste de dicha yglesia, hecha por el mismo padre abad en don Antonio Rodríguez, patrimonial y clérigo de dicho lugar, por fin y muerte de don Francisco Rodríguez, su último poseedor. Dada en San Zoil, a 23 de diciembre del mismo año y ante el mismo notario.

18. < Presentación del beneficio de grados en don Pedro Revilla. Año 1784>.

Presentación del beneficio de grados de dicha yglesia hecha por el padre maestro fray Martín Basco en don Pedro Revilla, natural de Recueba, por fin y muerte de don Alonso Abad, su último poseedor. Dada en San Zoil, a 14 de octubre de 1784, ante Martín García Gatón, notario y escribano de Carrión.

\section{9. <Pleyto sobre los diezmos de Recueba> .}

Proceso de un pleyto que tubo este monasterio con don Francisco Rodríguez, cura del lugar de Recueba, por el qual parece que en el año de 1783 el monasterio demanda al dicho cura sobre que le entregase $<$ el diezmo $>$, los frutos de avena, fruta, queso, soldadas, vino y demás que legítimamente le correspondían, poniendo estos en la mesa común / ( $f$. $297 v$ ) con todos los demás diezmos mayores, para deducir el monasterio el noveno de todos los diezmos mayores y menores que se adeudan en dicho lugar, en su término y de los foráneos de trigo, centeno, cebada, avena, lino, hortaliza y de todas las demás cosas de las que en dicho lugar se deven pagar y pagan diezmos sin excepcionar cosa alguna y sin privar a dicho monasterio del diezmo de los frutos de avena (frutas, queso, soldadas, vino y otras cosas, sin apropiárselo dicho cura, como intentaba, alegando no había avido ni avía costumbre; y aún quando la hubiera, decía que hera notoria la incongruidad de los beneficios de aquel pueblo.

\section{$<$ Sentencia de Palencia contra este monasterio. Año 1786>.}

Alegaron ambas partes, hízose información de testigos, se compulsaron varias escrituras y algunas partidas de los apeos de San Román; y dándose la causa por conclusa, el doctor don Juan José Fernández Vallejo, provisor de Palencia, dio sentencia difinitiva, por la qual declara que la parte del referido monasterio de San Zoil no ha probado como debía su acción y demanda, y que sí lo ha hecho el citado don Francisco de su defensa y excepción, en cuya conseqüencia debía de absolver absolvía a éste de la propuesta demanda, y manda continúe en la percepción de dichos diezmos según y como hasta allí lo había executado, sin embargo de lo alegado y producido por el referido monasterio. Fue dada esta (esta) sentencia en Palencia, a 21 de enero de 1786, ante Baltasar Francisco Ybáñez, notario mayor. 
$<$ Sentencia de Burgos, confirmando la de Palencia $>$.

De esta sentencia apeló el monasterio al metropolitano de Burgos, y admitida la apelación, habiendo alegado ambas partes de su derecho, conclusa la causa, el licenciado don Bernardino López Baldivieso, provisor y vicario general interino de aquel arzobispado, dio sentencia confirmando la dada por el ordinario de Palencia, en Burgos, a 5 de octubre del mismo año.

De esta sentencia volvió a apelar el monasterio al tribunal de la Anunciatura, de donde sacó letras inhivitorias y compulsorias, dadas en Madrid, a 8 de diciembre ${ }^{426}$ del mismo año, las que notificadas al doctor Juan de Tobia, provisor de dicha ciudad, se dio inhivido del conocimiento de esta causa que parece se quedó, así como consta del traslado de este pleyto, sacado por José Julián García, notario mayor de dicha ciudad de Burgos, a 12 de febrero de 1787.

Hay aquí varios pareceres sobre que el monasterio debe seguir la $3^{a}$ instancia; sin embargo de haver muerto el cura y querer el nuevo desistir por conocer la justicia del monasterio.

(f. 298r) 20. <Ereción del beneficio de preste moderno, con supresión de los beneficios de evangelio y grados. Año 1786>.

Testimonio dado por Baltasar Francisco Ybáñez, notario mayor de Palencia, del expediente formado a pedimiento del concejo y vecinos del lugar de Recueba, en razón de que se vniesen las rentas de un beneficio de evangelio, vacante por muerte de don Alonso Martín, y las de otro de grados, por muerte de don Antolín Abad, y que se erigiese con ellas un beneficio presbiteral para proveerle en persona venemérita, sin perjuicio del derecho que ha tenido a presentarles en hijos patrimoniales del mismo pueblo el padre abad de San Zoil. De esta pretensión se comunicó traslado al fiscal, quien le evaquó, exponiendo ser vtil dicha vnión de beneficios y crear uno presbiteral. Opúsose don Francisco Rodríguez, cura en dicho pueblo, pidiendo se le congruase su beneficio con las rentas de las vacantes y se suspendiese la vnión intentada de éstos.

$<$ Auto a favor de este monasterio para la libre presentación del beneficio $>$.

Vltimamente, en 5 de septiembre de 1786, el doctor don Juan José Fernández de Vallejo, provisor de Palencia, dio auto por el qual dice que en atención a que los dos expresados beneficios de grado y evangelio, en su actual disposición para si sólo cada uno, es enteramente invtil al servicio de la yglesia. Desde luego uno agrega e incorpora entre sí las rentas, frutos y emolumentos de los dos expresados beneficios; y así unidas e incorporadas respecto de que el referido pueblo de Recueba es de rigurosa montaña, y que la congrua líquida y suficiente conforme a lo dispuesto por las sinodales, crea y erige un beneficio presbiteral moderno, cuyos poseedores hayan de tener y cumplir todas las cargas que corresponden a la clase de los demás de la diócesis. Manda asimismo que este supresión y nueva erección del beneficio presbiteral se haga saber al padre abad de San Zoil. A conseqüencia de este auto se expidieron los edictos y despacho que en él se acuerdan. Salió este monasterio oponiéndose enérgico a la fixación de edictos por pertenecerle in solidum la presentación; y habiendo alegado su derecho y presentado varios documentos, se dio auto por el dicho provisor, por el qual manutiene y ampara al referido monasterio y a sus abades en la quieta y pacífica posesión en que han estado de presentar libremente los beneficios de aquel pueblo en hijos patrimoniales en qualquier tiempo, mes y forma que vacasen sin la qualidad de que preceda fixación de edictos ni otro (f. 298v) requisito alguno judicial, más que tan solamente el que aquel que fuese provisto haya de manifestar la suficiencia necesaria y justificar su patrimonio antes de recivir la colación, con tal que la presentación sea hecha dentro del término legal, en cuya posesión manda su merced no sean inquietados ni perturbados por persona alguna. Fue dado este auto en el mismo año y ante el mismo notario ante quien pasaron los autos.

426 diciembre] Escrito tachado: noviembre. 


\section{1. < Primera presentación de preste moderno en don Pedro Revilla. Año 1787>.}

Primera presentación del beneficio de preste moderno de la yglesia de San Pedro del lugar de Recueba, hecha por el padre maestro fray Leandro Pérez, abad de San Zoil, en don Pedro Revilla, natural del mismo lugar, en virtud de la vnión de los dos beneficios de evangelio y grados, y de la nueva erección de éste, como consta del auto anterior del señor provisor. Fue dada esta presentación en San Zoil, a $1^{\circ}$ de febrero de 1787, ante Martín García Gatón, notario y escribano de Carrión.

Está aquí el título de la colación de este beneficio dado al mismo don Pedro por el doctor don Juan José Fernández de Vallejo, provisor de Palencia, en 9 de marzo del mismo año, ante Baltasar Francisco Ybáñez, notario mayor; y asimismo la posesión que tomó don Antonio Merino por el referido don Pedro Revilla, ante Benito de la Fuente, notario y vecino de Castrejón.

22. <Presentación del beneficio de preste curado en don Pedro Revilla. Año 1787>.

Presentación del beneficio de preste curado de la yglesia de Recueba, hecha por el padre maestro fray Leandro Pérez, en don Pedro Revilla, patrimonial, clérigo y beneficiado de dicha yglesia, por fin y muerte de don Francisco Rodríguez, su último poseedor. Dada en San Zoil, a 12 de junio de 1787, ante Josef Tablares, notario y escribano de Carrión.

Hay aquí un traslado autorizado por el mismo escribano de la misma presentación, y asimismo una carta del señor Mollinedo, obispo de Palencia, escrita al referido padre abad, con la propuesta de tres sujetos, a la que no se arregló por el auto de amparo dado a favor de este monasterio.

23. <Presentación el beneficio de preste menor en don José de Arriba. Año 1787>.

Testimonio dado por José Tablares, notario y escribano de Carrión, de la presentación del beneficio de preste menor nuevamente erigido de la yglesia de San Pedro de Recueba, hecha por el padre maestro fray Leandro Pérez, abad de San Zoil, en don José de Arriba, natural del dicho lugar, por promoción de don Pedro Revilla, que le tenía, al de preste / (f. 299r) mayor curado. Dado en San Zoil, a 8 de julio de 1787, ante el mismo notario, cuyo traslado fue sacado en el mismo día, mes y año.

24. < Presentación del beneficio de preste menor en don Basilio Campo. Año 1794>.

Presentación del beneficio moderno de preste menor, hecha por el padre maestro fray Leandro Pérez, abad de San Zoil, en don Basilio Campo, natural del lugar de Loma, vnico patrimonial legítimo por renuncia de don José de Arriba, que le obtenía. Dado en San Zoil, a 20 de abril de 1794, firmado de fray Benito Sabido, secretario, y en testimonio de José Tablares, notario y escribano de Carrión.

Está aquí el título de colación dado al mismo por el doctor don Gregorio Ceruelo de la Fuente, provisor de Palencia, en 14 de marzo de 1795, ante Baltasar Francisco Ybáñez, notario mayor de dicha ciudad. Al pie está la posesión que tomó el referido don Basilio del dicho beneficio ante Christóval de Castresana, escribano de Castrejón.

25. < Presentación del beneficio de preste menor en don Diego Martín. Año 1805>.

Presentación del beneficio moderno de preste menor de la yglesia de San Pedro de Recueba, hecha por el padre maestro fray Plácido Emelgo, abad de San Zoil, en don Diego Martín, natural del lugar de Villalveto, vnico patrimonial legítimo, por muerte de don Basilio Campo, su último poseedor. Dada en San Zoil, a 6 de agosto de 1805, firmada del padre fray Mauro Núñez, secretario; y sacado este traslado por Ysidoro Ruiz de Colmenares, notario y escribano de Carrión.

26. <Alegados sobre los diezmos de Recueba>.

Alegados de la parte del monasterio y de la de don Francisco Rodríguez, cura de la yglesia de San Pedro de Recueba, sobre el pleyto de los diezmos de aquella yglesia, de que se hace relación en este quaderno número 19. 


\section{Remisiones}

La donación de esta yglesia: Véase este Cajón y legajo, quaderno A, número $1^{\circ}$.

La presentación de este Beneficio: Véase la concordia, Cajón San Andrés, legajo 1º, quaderno $\mathrm{B}$, número $3^{\circ}$.

\section{/ (f. 299v) Quaderno C del legajo $2^{\circ}$ \\ Revenga}

Este quaderno $\mathrm{C}$ contiene los papeles pertenecientes a la hacienda que tiene este monasterio en este lugar, por el orden siguiente:

$1^{\circ} .<$ Compra de una tierra. Año de 1616>.

Compra que hizo este monasterio a Pedro García, vecino del lugar ${ }^{427}$ de Revenga, de una tierra en término de dicho lugar, a donde dicen a Carre Molinos, que hace una obrada, poco más o menos, por precio de 4.100 maravedís y en pago de dos cargas de trigo que el referido debía al monasterio, y sin el fuero que dicha tierra tenía. Fue otorgada esta escritura en el lugar de Villavieco, a 16 de noviembre de 1616, ante Bernabé Pérez, escribano y vecino de dicho lugar.

$$
2^{\circ} \text {. <Compra de dos tierras. Año de 1616>. }
$$

Compra que hizo este monasterio a Hernando Pérez de la Yglesia, vecino del lugar de Revenga, de dos tierras, la una a donde dicen a Hernandañal, término de dicho lugar, que hace más de obrada y media; y la otra a donde dicen a Carre Amusco, en el mismo término, que hace una obrada menos once palos, por precio de 11.926 maravedís. Fue otorgada este escritura en San Zoil, a 11 de diciembre de 1616, ante Gerónimo Laeso, escribano de Carrión.

$<$ Nota $>$

Adviértase que hubo otro Revenga cerca de Castromocho, en el alfoz de Torre Mormojón, que es el que nos dio el rey don Alonso por la villa de Aguilar: Véase el privilegio y carta de trueque en el cajón San Yldefonso, legajo $1^{\circ}$, número $1^{\circ}, 2^{\circ}, 3^{\circ}$ y $4^{\circ}$, entre los papeles de Villaverde.

\section{/ (f. 300r) Quaderno D del legajo $2^{\circ}$ \\ Ríos Menudos}

En este quaderno D están los papeles pertenecientes a la hacienda que tiene este monasterio, y que en el día parece pertenecer a San Román, en este lugar de Ríos Menudos, por el orden siguiente:

$1^{\circ}$. $<$ Compra de toda la heredad del monasterio de San Miguel de Ríos Menudos. Era 1237. Año 1199>.

Escritura en pergamino, por la qual don Pedro, prior de San Zoil y Camarero de Cluni en España, compra a Sancha Sogni, con voluntad y consentimiento de su hijo Gutierre García, toda la heredad que tenía o debía tener en el monasterio de San Miguel de Ríos Menudos, con todas sus pertenencias, solares, poblados y por poblar, tierras cultas e incultas, montes, valles, molinos, etcétera, por precio de 30 maravedís, con los que se da por bien pagada. Facta carta XVIII kalendas octobris, era 1237, que es año de Christo 1199.

${ }^{427}$ lugar] escrito sobre: Carre. 
2. $<$ El monasterio de San Zoil da temporalmente la yglesia de Ríos Menudos. Era 1232. Año 1199>.

Escritura en pergamino, por la qual don Pedro, prior de San Zoil, juntamente con el convento, dan a Fernando Petri la yglesia de Ríos Menudos, con todas sus pertenencias, el palacio, solares, poblados y por poblar, y demás hacienda que allí tenían, con condición que después de su muerte vuelba[n] todo al monasterio; y el dicho Fernando Petri, en recompensa de este beneficio da al referido prior y convento todos los solares y tierras que él tenía en dicho lugar, para que después de su muerte lo posean para siempre. Facta carta era 1237, que es año de 1199.

\section{3. <Foro y vasallage en Ríos Menudos. Era 1295. Año 1257>.}

Escritura en pergamino por la qual Domingo Ybáñez, prior de San Román, da a don Andrés y a su muger, doña Yllana, una heredad y una casa en Ríos Menudos, con condición que quantos la gozaren sean vasallos de San Román, y paguen ciertos tributos quantos allí vivieren. Facta carta era 1295, que es año de 1257

4. < Donación de una casa y préstamo de tierras. Año 1529>.

Donación que hizo a San Román Alonso cano, vecino de Ríos Menudos, de una casa paxiza, para ser vasallo del dicho convento; y el padre fray Diego de Sahagún y abad de San Zoil y prior de dicho convento le da un préstamo de tierras, linares y un prado en término de Vega de Riacos ${ }^{428}$, con obligación / (f. 300v) de pagarle en cada un año de vrción por los dichos préstamos una fanega de trigo y un par de gallinas. Su fecha, en Ríos Menudos, a 18 de febrero de 1529, ante Diego Fernández, cura de dicho lugar y notario apostólico. Año 1664>.

5. <Declaración de los vecinos de Ríos Menudos de los préstamos de San Román.

Auto dado por el corregidor de Saldaña a petición de fray Juan Fernández, prior de San Román, para que algunos vecinos de Ríos Menudos que gozaban préstamos de San Román declarase cada uno lo que gozaba; y declaración que hicieron los mismos bajo juramento de que heran proprios de San Román, como consta del testimonio dado por Lorenzo de la Vega, escribano. Asimismo hay aquí dos mandamientos de don Diego Docio de Venavivere, juez conservador contra Pedro Roldán, vecino de Ríos Menudos, y Catalina Gregorio, vecina de Barajores, para que dexasen un solar de casa que ya estaba hecho huerta en dicho lugar; y una tierra y linar, y que paguen los frutos que valieron en todo el tiempo que los han gozado. Dados en el convento de Venavivere, a 3 de abril y 12 de mayo de 1664, ante Norverto de Sandoval y Guevara, notario y escribano de Carrión.

\section{6. <Trueque de una casa y huerta por dos tierras. Año 1792>.}

Trueque que hizo el padre maestro fray José Fierro, prior de San Román, con Mathías Herrero y Antonia Roldán, vecinos de Ríos Menudos, de una casa y huerta propias de dicho priorato, por una tierra linar en término de dicho lugar, a do llaman la Quintanilla, que hace 8 celemines de linaza, más por otra tierra en el mismo término, a do llaman el Colmenar, a rastro de Llano, que hace quarto y medio de trigo; y que los referidos le dieron por la dicha casa y huerta. Fue otorgada esta escritura en 19 de abril de 1792, ante Manuel Luis París, escribano y vecino de Villanueva de Arriba.

7. < Trueque de una casa corral y huerto por 4 tierras y un prado. Año 1794 (sic) >

Trueque que hizo el padre maestro fray José Fierro, prior de San Román, con Thomás de Cosgaya, vecino de Ríos Menudos, de una casa, corral y huerto propias de dicho priorato, por una tierra linar en término del lugar de Baños, a do llaman las Llosas, que hace una fanega de linaza, más por tres tierras en término del lugar de Ríos Menudos, que la $1^{a}$ está a la Varga de Villanueva, y hace una cuarta de morcajo; la $2^{\mathrm{a}}$, en término de dicho lugar, a do llaman

${ }^{428}$ Vega de Riacos] al margen derecho: Vega de Riacos. 
Billoslero, y hace quarto y medio de morcajo; y la $3^{a}$ está a do llaman las Colgadas y hace 10 celemines de centeno. Y además un prado en término de dicho lugar, a Val de Roscales, que hace más de medio carro, cuyas heredades dio el referido por la dicha casa, corral y huerto. Fue otorgada esta escritura en San Román, a 2 de abril de 1793, ante Manuel Luis París, escribano y vecino de Villanueva de Arriba.

\section{/ (f. 301r) Remisiones}

Vn linar en término de Ríos Menudos, al Cascarón. Véase el Cajón San Benito, legajo $1^{\circ}$, quaderno $\mathrm{C}$, número 6.

Sentencia a favor de San Román sobre el yantar de este lugar. Véase el Cajón San Juan, legajo $3^{\circ}$, quaderno B, número 9. 13.

Trueque de un solar por un prado: Cajón San Estevan, legajo $3^{\circ}$, quaderno A, número

\section{/ (f. 301v) Quaderno E del Legajo $2^{\circ}$ \\ Yglesia}

Este quaderno E contiene los papeles pertenecientes a la yglesia de San Miguel de Ríos Menudos, sus diezmos, presentaciones y colaciones de su beneficio curado, por el orden siguiente:

$1^{\circ}$. <Donación de la yglesia de San Miguel de Ríos Menudos. Era 1237. Año 1199>.

Donación, escrita en pergamino, por la qual Ferrando Nunio y su muger, doña María Hermíllez, dan por sus almas a Dios y a don Pedro, prior de San Zoil, camarero de España, a su convento y sucesores toda la heredad que tenían en la villa de Ríos Menudos y en sus términos, tierras, viñas, prados, solares, etcétera, y la yglesia de San Miguel con su monasterio y todas las heredades que allí pertenecían a doña Sancha Somni; y asimismo hacen donación de toda la heredad que tenían en la villa de Villarías ${ }^{429}$. Por lo qual el prior de San Zoil les hace participantes de los sufragios del convento y les concede por sus días la hacienda que tenía allí el convento y la que ellos mismos le dieron, excepto la mitad de los diezmos de su trabajo y un solar con su préstamo de Martín Clérigo, con condición que después de la muerte de los dos toda la hacienda de dicha villa de Villarías vuelva al monasterio. Facta carta era 1237, que es año de 1199 . Año 1228>.

$2^{\circ}$. $<$ Trueque de la yglesia de San Miguel por la de San Vicente de Otello. Era 1266.

Escritura de trueque en pergamino, partida por $\mathrm{ABC}$, por la qual Pedro Fernando, prior de San Román, y su convento dan al convento de San Zoil toda la parte que tenían en la casa e yglesia de San Vicente de Otello (oy Autillo ${ }^{430}$ ) con sus pertenencias. Y el convento de San Zoil da a San Román la yglesia de San Miguel de Ríos Menudos con todas sus pertenencias y con toda la hacienda que allí tenía; para lo qual unos y otras tubieron licencia y veneplácito de los visitadores de Cluni, que aprobaron y confirmaron esta escritura, y el sacristán la selló. Facta carta era 1266, que es año de 1228.

$3^{\circ}$. < Provisión de la iglesia de San Miguel en don Guigelmo. Era 1214. Año 1239>.

Escritura en pergamino, partida por ABC, por la qual don Fernando, prior de San Román, con consejo de todo el convento, da a don Guigelmo por su vida la yglesia de Ríos Menudos, con toda la heredad que allí tenía San Román, fuera de los vasallos, y que lleva la ofrenda y funerales, / (f. 302r) y que la mitad del diezmo sea para San Román; y quede para don Guigelmo dos moyos, uno de cebada y otro de centeno, que labre a medias la heredad y que goze el palacio con sus casas y con su huerto, y que dé al prior de San Román un yantar

${ }^{429}$ Villarías] al margen derecho: (precede tachado: Villarias) Villarías.

430 Autillo] al margen derecho: Autillo. 
en cada un año con tres vestias y con cinco hombres, etcétera. Facta carta en el mes de junio, en el día de San Pedro, en los Archos, era 1277, que es año 1239.

$4^{\circ}$. < Provisión de la yglesia de San Miguel en Diago Pérez y Pedro Gómez. Era 1290. Año 1252>.

Escritura en pergamino, por la qual el prior de San Román, con consejo del convento, da a Diago Pérez y Pedro Gómez, por los días de ambos, la yglesia de San Miguel de Ríos Menudos, con su diezmo, heredades y derechos que allí tenía San Román; y todo lo que tenía en Riacos y en Vega, y que la presentación del clérigo sea del prior de San Román o por su mandado del obispo; y que después quede todo libre a la casa de San Román con todas sus mejoras, con que sigan el pleyto que tenía San Román con don Gillén, clérigo de Ríos Menudos. Y ellos dan a San Román dos solares con sus préstamos en Velasilo ${ }^{431}$, y de presente dan ciertas posesiones y prometen defender dicho convento en qualquiera parte que se hallaren. Facta carta a 15 de febrero, era 1290, que es año de 1252.

\section{$5^{\circ}$. < Licencia para resignar el beneficio de Ríos Menudos. Año 1531>.}

Licencia y consentimiento que dio fray Diego de Canales, presidente de San Zoil, al arcipreste Diego de Colmenares, vecino de la Puebla y cura de Ríos Menudos, para que resignase este beneficio en Juan López, clérigo, vecino de Roscales. En esta licencia confiesa el dicho arcipreste la acción que tiene dicho presidente a la presentación de este beneficio. Su fecha, en San Zoil, a 12 de agosto de 1531, ante Diego González, notario apostólico. $1604>$.

$6^{\circ}$. $<$ Arrendamiento ${ }^{432}$ de los diezmos menores y foráneos de Ríos Menudos. Año

Escritura de arrendamiento que hizo el padre fray Juan de Palacios, prior de San Román, al comisario Pedro Díaz de Valdeón, cura de Ríos Menudos, de todos los diezmos menudos y foráneos de dicho lugar, por dos gallinas buenas en cada un año durante su vida, con lo qual confiesa tener suficiente congrua y se aparta de toda acción a pedir más. Su fecha, en San Román, a 13 de enero de 1604.

Hay aquí un testimonio dado por Pedro de la Calle, escribano público, de otro arrendamiento que hizo el padre fray Plácido de Perea, prior de San Román, al mismo comisario, de los mismos diezmos menudos y foráneos, excepto / (f. 302v) el vino, por un quarto de trigo y dos gallinas en cada un año, por espacio de ocho años. Su fecha, en Ríos Menudos, a 16 de diciembre de 1604.

$7^{\circ}$. <Colación del beneficio a Pedro Díaz de Valdeón. Año 1594>.

Colación del beneficio de San Miguel de Ríos Menudos hecha por el doctor Juan García de Brizuela, provisor de León, a Pedro Díaz de Valdeón, clérigo, por fin y muerte de Alonso Fernández, su último poseedor; y en virtud de la presentación que en él hizo fray Toribio de San Andrés, abad de San Zoil, al qual se declara por único patrón presentero, en virtud de la qual se dio la dicha colación en León, a 15 de enero de 1594, ante Juan Fernández de Vega, notario.

A la vuelta está el testimonio dado por Francisco Robles, escribano y notario, de la posesión que el referido tomó del dicho curado.

8. $<$ Declaración que hizo el cura Pedro Díez de Valdeón sobre este curato y su congrua. Año 1635>.

Testimonio dado por Francisco Quijano, notario y vecino de Tabanera, de una declaración que hizo el comisario Pedro Díez de Valdeón, cura de San Miguel de Ríos Menudos, por la qual declara pertenecer el patronato y presentación del beneficio de dicho lugar al abad de San Zoil; y que en virtud de ella octubo la colación y posesión de dicho beneficio, arriba referida.

431 Velasilo] al margen derecho: Velasilo.

432 Arrendamiento] al margen derecho: Nota: este número debe ser el siguiente. 
El cura da en cada año un yantar al prior de San Román en reconocimiento de la dicha presentación; y que la casa de San Román tiene la mitad de todos los diezmos mayores y menores del dicho beneficio, y el diezmo del vino que pertenece al dicho beneficio; y que él paga por los diezmos menores y foráneos un quarto de trigo y una gallina cada año.

Que el prior de San Román pone merino que recoja los diezmos cada año. Que la yglesia de San Miguel con las primicias que lleva y con otros derechos que le pertenecen tiene suficientemente lo necesario para su fábrica. Que todo el tiempo que ha sido cura de dicha yglesia con la parte de diezmos que le toca y con el pie de altar ha tenido bastante congrua y que la tendrá qualquiera cura que sirviere el dicho beneficio como la tubieron todos sus antecesores y se aparta de pedir más congrua.

Que la dicha yglesia de San Miguel fue / (f.303r) antiguamente monasterial, que la servían religiosos, y que había convento sujeto al de San Román, cuyo prior solía poner capellán, monge o clérigo a su voluntad que sirviese la dicha yglesia. Todo lo qual así dicho y declarado juró in vervo sacerdotis ser cierto, público y notorio, pública voz y fama. Fue hecha esta declaración en Ríos Menudos, a 26 de noviembre de 1635, ante Juan de Vega, escribano y vecino de Vega de Riacos.

\section{9. <Cartas del obispo de León. Año 1637>.}

Cartas del obispo de León y arcediano de Saldaña, su sobrino, en que piden al abad de San Zoil la presentación de este beneficio. Su fecha, en León, a 2 de marzo de 1637.

\section{0. < Colación ${ }^{433}$ de este beneficio a Gaspar González Carbonera. Año 1646>.}

Traslado simple del título y colación del beneficio curado del lugar de Ríos Menudos que el provisor de León despachó al licenciado Gaspar González Carbonera, natural de dicho lugar, en virtud de la resignación que en manos de Su Santidad y a su favor hizo el licenciado Pedro Díez de Valdeón, último posehedor de dicho beneficio. Dado en León, a 22 de agosto de 1646, ante Felipe Escobar, escribano y vecino de dicha ciudad.

\section{1. <Provisión Real para recoger unas bulas de impetra del curato. Año 1645>.}

Provisión real del Consejo y fiscal de Su Magestad a petición de este monasterio, para recoger unas bulas de Su Santidad con que el licenciado Gaspar González Carbonera empetró el curado de Ríos Menudos, en perjuicio de la primera instancia del ordinario y de la quieta y pacífica posesión en que estaba el monasterio de presentar dicho beneficio curado. Dada en Madrid, a 8 de marzo de 1645, ante Francisco Arrieta, secretario de Su Magestad.

12. $<$ Demanda que puso el cura pidiendo congrua. Año 1658>.

Testimonio dado por Toribio Francisco, notario y vecino de Carrión, de la demanda que el licenciado Gaspar González Carbonera, cura que fue de Ríos Menudos, puso ante el provisor de León pidiendo a los interesados en los diezmos para que se le añadiese la congrua, para lo qual se despachó requisitoria, y aunque se notificó, año de 1658, parece que no se siguió.

13. <Papeles y cartas del procurador de Madrid sobre el pleito de los diezmos de Ríos Menudos. Año 1659>.

Bajo este número están los papeles siguientes: $1^{\circ}$ Mandamiento del provisor de León, a pedimiento de este monasterio, para hacer la información de los diezmos, yantar y presentación del curado.

$2^{\circ}$ Traslado autorizado por Toribio Francisco, notario, de unas / (f. 303v) letras del nuncio para llevar el pleyto a la anunciatura, con la notificación hecha al abad y convento.

$3^{\circ}$ Testimonio dado por Marcos de la Vega de cómo se notificaron dichas letras al cura Gaspar González Carbonera.

$4^{\circ}$ Cartas del procurador general de Madrid que tratan de este pleyto y de cómo salió la sentencia a nuestro favor, confirmando la del ordinario de León en quanto a la mitad de los

${ }^{433}$ Colación] al margen derecho: Nota: este número debe ser el siguiente. 
diezmos mayores; y que en quanto a los menores tenemos dos sentencias a nuestro favor. Su fecha, en Madrid a 23 de julio de 1659.

14. $<$ Executoria a favor de este monasterio sobre $<$ la mitad de $>$ los diezmos mayores y menores de Ríos Menudos. Año 1659>.

Carta executoria ganada por este monasterio en virtud de una sentencia dad en tercera instancia por el licenciado don Pedro Velasco, protonotario y juez apostólico, por brebe y comisión de monseñor señor nuncio, en el pleito y causa que pendía entre partes, de la una: el abad, monges y convento de San Zoil; y de la otra, Gaspar González Carbonera, cura de Ríos Menudos, por la qual confirma la sentencia dada por el doctor don Miguel Santos de San Pedro, provisor de León, en 12 de octubre de 1656, en quanto por ella mantubo y amparó al prior y convento de San Román de Entrepeñas en la posesión de percibir y cobrar la mitad de los diezmos mayores que se cogen y diezman en el dicho lugar de Ríos Menudos; y asimismo en la posesión de cobrar los diezmos del vino que se venden en la taberna del dicho lugar; pero en quanto por la dicha sentencia mantubo y amparó al dicho Gaspar González, cura, en la posesión de percivir enteramente todos los diezmos menores, sin dar parte alguna al dicho convento, la revoca y confirma la primera sentencia dada en el lugar de Viduerna, a 22 de julio de 1655, por el licenciado don Toribio Díez Santos, arcipreste del partido y comisionado para esta causa, por la qual manutubo y amparó al dicho convento, no sólo en la posesión de cobrar ${ }^{434}$ la mitad de los dichos diezmos mayores, sino también en la de todos los demás diezmos menores; y asimismo la confirma en todo lo demás en la dicha sentencia contenido, excepto en quanto el dicho juez de comisión manutubo y amparó al dicho convento en la proprie/ (f. 304r) dad de la mitad de los dichos diezmos mayores, y declaró pertenecerle, en lo qual la revoca, y reserva su derecho a salvo a las dichas partes para que en razón de la propiedad de los dichos diezmos, así mayores como menores, pidan y sigan su justicia ante quien y más les conviniere. Fue dada y pronunciada esta sentencia en Madrid, a 23 de julio de 1659, ante José Camerino, notario y secretario.

De esta sentencia apeló el dicho cura de Ríos Menudos y otorgada su apelación ante el señor nuncio por no haber dicho cosa en contrario le fue acusada y notificada la rebeldía; estando conclusa la causa se dio auto por el referido juez apostólico, por el qual se mandó dar esta carta executoria en Madrid, a 24 de septiembre del mismo año.

Síguense varios autos dados por el licenciado don Francisco Morante de la Madrid, canónigo de la colegial de Aguilar de Campó, y del señor Mogrovejo, provisor de Palencia, para que el referido cura Gaspar González pague la cantidad que montaren la mitad de los diezmos menores de 13 años debidos al prior de San Román; y asimismo los diezmos de Nobalios; y que cumpla y guarde todo lo contenido en la carta executoria. Dados en los años de 1660 y 1678.

15. $<$ Dos presentaciones y una colación del curado de Ríos Menudos. Años 1679, 1694 y $1698>$.

Bajo este número están los papeles siguientes.

$1^{\circ}$ Vna presentación del beneficio curado de San Miguel de Ríos Menudos, hecha por el padre maestro fray Juan González, abad de San Zoil, en el licenciado don Francisco de Junquera, por fin y muerte del licenciado don Gaspar González Carbonera, su último poseedor. Su fecha, en San Zoil, a 16 de junio de 1679, ante fray Francisco de Molina, notario apostólico. Síguese una copia simple de una sentencia dada por el provisor de León a favor del referido Junquera.

$2^{\circ}$ Otra presentación del mismo beneficio hecha por el padre maestro fray Gregorio Ruiz, abad de San Zoil, en el licenciado don Juan de la Calle Santos, por fin y muerte de don Francisco Junquera, su último posehedor. Su fecha, en San Zoil, a 9 de abril de 1694, ante Norberto Sandoval y Guevara, escribano y notario de Carrión.

$3^{\circ}$ Título y colación del dicho beneficio, hecha por el licenciado don José García, provisor de León, en el licenciado Andrés Fernández, y en / (f.304v) virtud de la presentación

\footnotetext{
434 cobrar] sigue tachado: los dichos.
} 
que en él hizo el padre abad de San Zoil, por fin y muerte del licenciado don Miguel de la Cruz, su último poseedor, por permuta que hizo con don Juan de la Calle. Dado en León, a 17 de junio de 1698, ante Bernardo García, escribano y notario de dicha ciudad. Es copia autorizada del título original. Síguese un memorial del abad y monges de este monasterio al señor obispo de León, representándole el derecho que tiene a la presentación del dicho beneficio.

16. <Carta executoria a favor de este monasterio sobre la presentación libre en todo tiempo del curato de este lugar. Año 1699>.

Executoria librada a favor de este monasterio contra el fiscal de León, en virtud de una sentencia dada en 9 de junio de 1698, por el licenciado don José García, provisor de dicha ciudad, por la qual declara dicho beneficio curado de la yglesia parroquial de Ríos Menudos haber vacado y estarlo al presente por fin y muerte del licenciado don Manuel de la Cruz, su último poseedor; y ser de patronato y presentación en todo tiempo, mes y forma que vaque sólo e in solidum del abad, monges y convento de San Zoil de Carrión. Y que vsando en esta vacante de su derecho le presentaron en el dicho licenciado Andrés Fernández, quien habiendo justificado como justificó para ser legítimo opositor, en virtud de dicha presentación, se le debía de adjudicar y adjudicó; y le mandó librar título y colación con mandamiento de posesión. Fue dada esta carta executoria por el doctor don Francisco Navarrete, provisor de León, a 14 de noviembre de 1699, ante Bernardo García, escribano y notario.

17. <Presentación y colación del beneficio curado en don Ygnacio Manganés. Año $1726>$.

Presentación y colación del beneficio curado de San Miguel de Ríos Menudos, hecha por el padre maestro fray Jacinto Díez, abad de San Zoil, y don José Porras, canónigo y vicario de León, en el licenciado don Ygnacio Manganés, clérigo de primera tonsura, por fin y muerte del licenciado don Andrés Fernández, su último poseedor. Su fecha, en san Zoil, a 7 de octubre de 1726, ante Gregorio García de Miranda, notario y vecino de Carrión. Está duplicada.

Está aquí la renuncia que el referido don Ygnacio Manganés hizo en manos del abad de San / (f. 305r) Zoil, de este curato, por haber obtenido el beneficio curado de Santa María del lugar de Villaturde. Su fecha, en Carrión, a $1^{\circ}$ de marzo de 1729, ante Santiago Duque de Estrada, notario y escribano de Carrión. $1729>$.

18. <Presentación y colación del beneficio curado en don Bentura González. Año

Presentación y colación del beneficio curado de la yglesia de San Miguel de Ríos Menudos, hecha por el padre maestro fray Jacinto Díez, abad de San Zoil, y por el licenciado Juan de Morales, canónigo y vicario de León, en el licenciado don Bentura González, clérigo de menores órdenes, por renuncia que hizo de dicho curato don Ygnacio Manganés, su último poseedor. Su fecha, en San Zoil, a 2 de marzo de 1729, ante Santiago Duque de Estrada, notario y escribano de Carrión.

\section{9. $<$ Sentencia sobre la provisión del curato. Año 1780>.}

Testimonio dado por Ramiro Rodríguez Blanco, notario mayor de León, de una sentencia dada por el (el) licenciado don Thomás Sanz Carpintero, provisor de dicha ciudad, por la qual declara haber vacado el beneficio curado del lugar de Ríos Menudos, por muerte de don Bentura González, su último poseedor, y que en los cuatro meses ordinarios pertenece su presentación al padre abad de San Zoil, previo concurso general y con remisión de terna, conforme al último concordato ajustado entre la Santa Sede y Su Magestad. Dada en León, a 10 de octubre de 1780.

20. <Despacho para que el cura dé copia de las tadmias. Año 1784>.

Despacho librado por el licenciado don Thomás Sanz Carpintero, prior de León, a petición de este monasterio, para que don Manuel García Ramos, cura del lugar de Ríos Menudos, dé copia autorizada de la tadmia que en cada un año $<$ ha $>$ debido y debe formar. 
Dado en León, a 18 de agosto de 178, ante Francisco Ballejo, notario de dicha ciudad. Se le notificó y se hallanó dicho cura a executar lo que se le mandaba.

21. <Sentencia sobre la provisión de este curato. Año 1792>.

Testimonio dado por Hipólito de Diego Pérez, notario mayor de la Audiencia eclesiástica de León, de una sentencia dada por el licenciado don Lorenzo Moratinos Garzón, provisor de dicha ciudad, por la qual se declara deberse proveer el dicho curato de Ríos Menudos en todas sus vacantes, por concurso general, y corresponder la presentación a Su Magestad en los 8 meses apostólicos, y en los 4 ordinarios / (f. 305v) al reverendo padre abad de San Zoil, precediendo siempre remisión de terna de los aprovados en dicho concurso. Fue dada esta sentencia en León, a 26 de junio de 1792.

22.

Memoria de los derechos que este monasterio de San Miguel tiene a la presentación del curato de la yglesia de San Miguel de Ríos Menudos.

\section{Remisiones}

$<$ Donación $>$.

Donación de don Pedro, prior de San Zoil, a Fernando Petri, por la vida de éste de la yglesia de Ríos Menudos. Véase este Cajón y legajo, quaderno $\mathrm{D}$, número $2^{\circ}$.

\section{/ (f.306r) Quaderno F del legajo $2^{\circ}$ \\ Riveros}

Este quaderno $\mathrm{F}$ contiene los papeles pertenecientes a la hacienda que tiene el monasterio en este lugar, por el orden siguiente.

$1^{\circ}$. <Contrato y donación de tierras y viñas. Era 1266. Año 1228>.

Escritura en pergamino, por la qual don Cantarino, señor de la cocina, y Pedro Gonzálvez, mayordomo de San Zoil, juntamente con el convento, dan a don Beneito, por su vida, tres viñas que son de la cocina: la $1^{\mathrm{a}}$ en término de Cerbatos ${ }^{435}$, a Oter de lobos; la $2^{\mathrm{a}}$ en término de Riveros, en Paramillos, tras San Salvador; la $3^{\mathrm{a}}$ en linde de ésta. Con condición que después de sus días vuelvan al monasterio; y en reconocimiento hace don Beneito donación al monasterio de cinqüenta maravedís y dos tierras, apreciadas en 30 maravedís; la una en término de Villavillo ${ }^{436}$, al Pozuelo; y la otra en Valbar, término de Cerbatos y de Cespedosa. El monasterio por esta limosna recibe a don Beneito por familiar y participante de la Orden de Cluniago. Facta carta in mense iulii, pridie nonas, sub era MCCLXVI, que es año de 1228.

\section{$2^{\circ} .<$ Donación de una viña y tres tierras $>$.}

Donación en pergamino, por la qual don Rodrigo Rodríguez, hijo de don Rodrigo y doña Ynés, da al monasterio la heredad que ganó a su vasallo don Beneito el Arcipreste. Esta heredad está en término de Riveros: la viña en la Cuesta; la tierra junto a los Prados de Riveros; otra tierra en Malvar; y la otra tierra en Pozuelos. No tiene fecha, mas parece del tiempo de la anterior escritura.

$3^{\circ}$. < Compra de 7 quartas y 9 palos de tierra. Año 1600>.

Compra que hizo este monasterio a Domingo Fernández, vecino de Riveros, de siete quartas y nueve palos de tierra a do dicen a la Nevilla, en el término de dicho lugar, por precio

435 Cerbatos] al margen derecho: Cerbatos.

436 Villavillo] al margen derecho: Villavillo. 
de 68 reales. Su fecha, en la villa de Villamuera, a 4 de enero de 1600, ante Santos de Guzmán, escribano de dicha villa.

$4^{\circ}$. <Trueque de 2 viñas por una y 3 cargas y media de trigo. Año 1681>.

Trueque que hizo el padre fray Francisco de Molina, prior de Villaverde, con Santos de Villegas y Bernarda Antón, su muger, vecinos de Riveros, por el qual estos le dan una viña de seis quartas, al / (f.306v) Pozuelo, término de dicho lugar, lindero: Juan Castrillo y viña de Juan Alcalde; y el referido padre prior les da una viña a Villa Toribio, de 3 quartas, y otra al Gerbal, término de Riveros, de dos quartas. Por la demasía les da asimismo 3 cargas y media de trigo. Su fecha, en Villamuera, a 30 de diciembre de 1681, ante Manuel de Orejón, escribano público.

\section{Remisiones}

Trueque i heredades. Véase el cajón San Yldefonso, legajo $3^{\circ}$, número $4^{\circ}$.

\section{/ (f. 307r) Legajo $3^{\circ}$ del cajón San Estevan \\ Respenda}

Este legajo $3^{\circ}$ del cajón San Estevan contiene 2 quadernos, que son: Quaderno A: papeles pertenecientes a la hacienda que tiene San Román en este lugar; Quaderno B: presentaciones y colaciones de los beneficios simples de San Andrés de Canduela, término del lugar de Baños, y de San Bool, junto a Respenda.

\section{Quaderno A del Legajo $3^{\circ}$}

Este quaderno A contiene los papeles pertenecientes a la hacienda que tiene San Román en este lugar, por el orden siguiente: $1022>$.

$1^{\circ}$. $<$ Donación de Gelvira del lugar de Villavermudo (oy San Bool). Era 1060. Año

Donación, escrita en pergamino, en letra gótica, por la qual doña Gelvira, hija de Fáfila Fernández, y de su muger, Adosinda, y muger de Munio Gómez, hace donación al monasterio de San Román del lugar de Villabermudo (que habiéndose $<$ des $>$ poblado, quedó con el nombre de San Bool, junto a Respenda, que oy día conserva), con todos sus términos y con yglesia determinada; y otra villa que llaman Aguirolo de Susano ${ }^{437}$, con todos sus términos. Otorgose esta donación y testamento XII kalendas septembris, era 1060, que es año de Christo 1022. Hay dos copias de esta escritura, la una autorizada por don Antonio Martín García, notario apostólico, la otra es simple.

$2^{\circ}$. < Admítese un familiar y se da un préstamo. Era 1324. Año 1286>.

Escritura en pergamino, por la qual don Domingo Pérez, prior del monasterio de San Román, admite por familiar a don Pedro, hijo de Ángel de Respenda, y le dan el préstamo que tenían sus padres después de los día de ellos; y que después de su muerte, lo deje libre para el monasterio; y que si no tubiere hijo, que deje al monasterio la quinta parte de sus bienes muebles, y si le tubiere que dé quince maravedís y la quinta parte de la casa de Villavermudo, que está cerca de la del convento, y dos pares de misas. / (f. 307v) Su fecha, a 18 de enero, era 1324, que es año de Christo 1286.

3. < Provisión ${ }^{438}$ Real de emplazamiento al monasterio de San Román. Año 1552>.

Copia simple de una provisión real de emplazamiento, ganada en la Chancillería de Valladolid por los vecinos del lugar de Respenda, porque el prior de San Román les prohibía pastar y aprovecharse del término de los Casares (que es lo mismo que Villavermudo y San Bool), que era del monasterio, para lo que mandó hacer una casa en el mismo término. Dada en Valladolid, a 9 de marzo de 1552.

\footnotetext{
437 Aguirolo de Susano] al margen derecho. Aguirolo de Susano.

438 Provisión] al margen derecho. Nota: este número debe ser el número $5^{\circ}$.
} 
4. $<$ Executoria a favor del monasterio de San Román sobre el término de San Bool. Año 1559>.

Executoria $^{439}$ ganada a favor del monasterio de San Román, en la Chancillería de Valladoli, por la qual parece que en 8 de marzo de 1552, la parte del concejo de Respenda puso demanda al dicho monasterio diciendo que, siendo suyo propio el término de los Casares, y vsando de él como de cosa propia y pastándole como tal, el prior de San Román intentara prohibirle el aprovechamiento de él, para lo qual había edificado una casa dentro del dicho término; y pidió se declarare el dicho término ser público y concejil para su vso y aprovechamiento común; y condenasen al prior a que no lo impidiese y que derribase la casa que había hecho. La parte del monasterio negó la demanda, reciviose la causa a prueba, puso el monasterio sus excepciones, las partes hicieron sus probanzas, pusieronse tachas, diose lugar a la prueba de ellas y abonos. El monasterio presentó la donación de Gelvira Fafile, que $<$ es $>$ la del número $1^{\circ}$, un apeo y una escritura de arrendamiento hecha al concejo de Respenda, que están aquí insertas; contra las quales escrituras se opuso el concejo y fue recivido a prueba y la causa por conclusa. Después de lo qual, en Valladolid, a 6 de septiembre de 1555, se dio sentencia, por la qual el convento de San Román fue absuelto de la demanda del concejo de Respenda; y fue dado por libre de ella, y al concejo se le puso perpetuo silencio. De esta sentencia suplicó la parte del concejo y dixo agravios a que satisfizo el convento; diose recetería al concejo para hacer información contra las escrituras del convento; hiciéronse nueva probanzas, y habida por conclusa la causa, en Valladolid, a 28 días del mes de abril de 1559 años, se dio sentencia de revista, por la qual se confirmó la primera difinitiva de vista. Y de ello se mandó dar y dio la carta executoria. Fecha en Valladolid, a 2 de junio del mismo año, ante Juan Ruiz, escribano de Cámara.

Notificose al concejo de Respenda de parte del monasterio de San Román, en 11 de junio del mismo año, ante Agustín de Medina, escribano.

\section{/ (f. 308r) 5. < Deslindamiento ${ }^{440}$ del término de San Bool. Año 1531>.}

Deslindamiento del término de San Bool de Respenda hecho por Cristóval Gómez, clérigo y notario apostólico, a 6 de marzo de 1531.

Está aquí una información que se hizo del término de San Bool y Villalveto, ante Vrbán Fernández, notario apostólico, pero no tiene authoridad.

$$
\text { 6. }<\text { Requirimiento }{ }^{441} \text { para que no talen el bosque de San Bool>. }
$$

Requirimiento hecho por fray Juan de Santa María, prior de San Román, al concejo y vecinos de Respenda, para que no rozen ni talen el monte de San Bool, llamado por nombre el Monte de Arriba, por ser propio de San Román y no tener el concejo propiedad ni señorío en él. No tiene fecha.

7. $<$ Escritura de censo y foro perpetuo de 25 mill maravedís y doce gallinas por el término de San Bool de Respenda. Año 1572>.

Escritura de censo y foro perpetuo del término y monte de San Bool de Respenda, por la qual consta que el monasterio de San Zoil, por el mes de septiembre de 1571, ante Andrés Sánchez, escribano de Carrión, habiéndose hecho los tres tratados y estando presentes los procuradores del concejo de Respenda, precedida ynformación de vtilidad en virtud de la licencia del General, el dicho monasterio dio a censo y foro enfiteusi perpetuo para siempre jamás al concejo y vecinos del lugar de Respenda el término redondo con el monte e cimenterio e yglesia que está en el mismo término, con todos sus prados, pastos, montes, exidos, heredades, aguas y derechos como le pertenecen al monasterio de San Román; y los prados que están en el término de Respenda, que solía tener a renta el concejo (el qual dicho término de San Bool tiene por términos y linderos el término de Respenda, el de Viduerna, Fontecha, Barajores, Villalbeto, Pino e Viduerna y Vega de Riacos), por precio

\footnotetext{
${ }^{439}$ Executoria] al margen derecho. Falta.

${ }_{440}$ Deslindamiento] al margen derecho. Nota: este número debe ser el número $3^{\circ}$.

${ }^{441}$ Requirimiento] al margen derecho. Falta.
} 
e quantía de 25 mill maravedís de la moneda corriente y una docena de gallinas, puesto en San Román a costa del concejo, la mitad para el día de Pasqua de flores, y la otra mitad con las gallinas para el día de San Martín; y con las condiciones siguientes:

$1^{a}$ Que si estubiere el concejo dos años, uno en pos de otro, sin pagar, cayga en incomiso, pierda la posesión del dicho término y vuelva al monasterio.

$2^{a}$ Que no entra en este contrato el derecho de la presentación del beneficio de la yglesia del dicho término de San Bool, porque ésta queda para el monasterio.

$3^{\text {a }}$ Que el concejo venga o embíe un procurador a San Zoil a renovar este contrato de diez en diez años.

$4^{a}$ Que de veinte en veinte años el concejo deslinde y amojone el dicho término a su costa.

/ (f. 308v) $5^{a}$ Que pasando los bueyes de San Román por el término de San Bool, quando se va a cobrar sus rentas, y no deteniéndose en ella de un día adelante puedan pacer en los cotos y desas del dicho término que estubieren dados por los bueyes de labor del concejo de Respenda.

$6^{a}$ Que tengan el dicho término guardado y que no le puedan dividir ni enagenar pero sí arrendar por tiempo limitado con licencia del monasterio.

Y los dichos procuradores de Respenda, con poder que tubieron y presentaron del concejo; y habiendo hecho información de vtilidad ante el corregidor de Saldaña, y con su licencia, otorgaron esta escritura y se obligaron al dicho foro en forma, por sí y sus sucesores. Que fue echa en el monasterio de San Zoil de Carrión, a 30 de diciembre de 1572, ante Andrés Sánchez, escribano de Carrión. Año 1621>.

8. Compra de prados, casa y huerta para Nuestra Señora del Brezo, la que se vendió.

Copia simple de dos escrituras de compra que hizo el santuario del Brezo en este lugar: la una de dos prados, ante Pedro de la Calle, escribano, año 1615; la otra de una casa con su corral y huerta, ante el mismo escribano, en el año de 1621. Después parece que estas fincas se dieron a vita a los mismos a quienes se había comprado. Y últimamente parece que en el año de 1626, siendo prior del Brezo fray Benito de Aragón, con licencia del abad de San Zoil, se vendió esta hacienda ante el mismo escribano; y el dinero se dio a censo, como consta de las executorias que están bajo este número.

9. < Executoria a favor de San Román sobre los préstamos de Respenda. Año 1660>.

Executoria a favor de este monasterio y del priorato de San Román de Entrepeñas, ganada en la Chancillería de Valladolid, contra algunos vecinos de Respenda que negaban la propriedad y señorío de los préstamos que allí tenía dicho priorato, por lo que la sala, confirmando la sentencia que había dado el Corregidor de Saldaña, les condenó a que las casas de los ocho préstamos, con sus tierras, linares y prados, eran proprios del priorato de San Román en propiedad y posesión, y mandó despachar esta carta executoria. Que fue dada a 30 días del mes de enero de 1660, ante Pedro de la Vega Colmenares, escribano de Cámara.

10. $<$ Execución de la carta executoria y reconocimiento de préstamos. Año 1663>.

Execución de la carta executoria antecedente, por la qual los poseedores de los préstamos reconocen todos los bienes de ellos espresados en esta escritura, los que se volvieron a dar nuevamente / (f. 309r) a los mismos sujetos por los días de sus vidas, y no más, como consta de esta escritura, que fue aprobada y executada por el corregidor de Saldaña en el año de 1663, ante Lorenzo de la Vega, escribano de dicha villa. $1664>$

11. <Provisión real contra algunos que retenían los bienes de los préstamos. Año

Provisión real y emplazamiento de la sala contra Francisco González y Pedro de Guadiana, porque no obstante la carta executoria y su execución se entrometían en una casa y linar de las pertenecientes a los préstamos de San Román. Dada en Valladolid, a 28 de 
marzo de 1664, ante Pedro de la Vega, escribano de Cámara. Notificose a las partes por Marcos de la Vega, escribano.

12. <Auto difinitivo a favor de San Román sobre el término de San Bool. Año $1739>$.

Testimonio dado por Santiago Duque de Estrada, escribano de Carrión, del auto dado por el señor don Pablo Francisco de Cárdenas, corregidor de Carrión, contra el promotor fiscal de la Real Acienda, por el qual declara tocar y pertenecer la propiedad, vso y aprovechamiento del término del lugar despoblado de San Bool o Villavermudo al priorato de San Román, y no ser compreendido en la real jurisdición. Dado en Carrión, a 15 de septiembre de 1739. Notificose a las partes por el mismo escribano.

13. <Trueque de un solar, prado y 60 reales por un prado. Año 1789>.

Trueque que hizo el padre fray Gregorio Calderón, prior de San Román, con Thomás Cosgaya, vecino de Ríos Menudos ${ }^{442}$, de un solar de casa, sito en dicho lugar, y un prado en término del lugar de Baños ${ }^{43}$, proprios de dicho priorato, por un prado que el referido le dio en término del lugar de Respenda, a do llaman la Barcenilla, con más 60 reales que el dicho prior dio al referido Cosgaya, por el esceso que había. Su fecha, en Ríos Menudos, a 5 de febrero de 1789, ante Manuel Luis París, escribano y vecino de Villanueva de Arriba. $1791>$.

14. $<$ Trueque de una casa con 40 reales por dos prados, una tierra y un linar. Año

Trueque que hizo el padre maestro fray José Fierro, prior de San Román, con Juan Martín, vecino de Respenda, de una casa sita en dicho lugar, propria del dicho priorato, por dos prados, una tierra y un linar en el término de dicho lugar, con más 40 reales que dio el padre prior por el esceso de las fincas que recivió. Su fecha, en Respenda, a 12 de septiembre de 1794, ante Manuel Luis París, escribano de Su Magestad. Año 1792>.

/ (f. 309v) 15. < Trueque de una casa y huerta y 235 reales por un prado y tres tierras.

Trueque que hizo el padre maestro fray José Fierro, prior de San Román, con Manuel García y Dionisia de Colmenares, vecinos de Respenda, de una casa y huerta sita en el dicho lugar, por un prado y dos tierras en el mismo término y una tierra en el término de Vega de Riacos ${ }^{444}$; y además 235 reales que dicho priorato pagó por esceso que tenían las heredades y que recivió. Su fecha, en Respenda, a 26 de enero de 1702, ante Manuel Luis París, escribano de Su Magestad.

16. <Trueque de un solar por una tierra. Año 1797>.

Trueque que hizo el padre fray Pedro de Castro, prior de San Román, con Manuel Martín de Pedrosa, vecino de Respenda, de un solar de casa sito en dicho lugar, proprio del dicho priorato, por una tierra en el mismo término, a do llaman la Cuesta de las Lozas, que hace ocho celemines de trigo de sembradura. Su fecha, en San Román, a 10 de mayo de 1797, ante Bernardo Balbuena, escribano y vecino de Respenda.

17. <Trueque de un solar por un prado. Año 1797>.

Trueque que hizo el padre fray Pedro Castro, prior de San Román, con don Juan Gavera de Gudiana, vecino de Respenda, de un solar de casa con su parte de huerto, sito en dicho lugar, propia del dicho priorato, por un prado en el mismo término, que está a do llaman las Quintas, que hace un carro de yerba. Su fecha, en San Román, a 10 de mayo de 1797, ante Bernardo Balbuena, escribano de Su Magestad.

18. <Trueque de un solar y huerto por un prado. Año 1797>.

Trueque que hizo el padre fray Pedro Castro, prior de San Román, con Pasqual González, vecino de Respenda, de un solar de casa y huerto, sito en dicho lugar y propio de

442 Ríos Menudos] al margen derecho: Ríos Menudos.

${ }^{443}$ Baños] al margen derecho: Baños.

444 Vega de Riacos] al margen derecho: Vega de Riacos. 
dicho priorato, por un pardo en el mismo término, a do llaman las Vallejas, que hace medio carro de yerba. Su fecha en San Román, a 10 de mayo de 1797, ante Bernardo Balbuena, escribano de Su Magestad.

\section{Remisiones}

Donación en este lugar. Véase el Cajón San Lorenzo, legajo $4^{\circ}$, número $1^{\circ}$.

Trueque del prior de San Zoil con el de San Román. Véase el cajón San Martín, legajo $1^{\circ}$, quaderno $\mathrm{B}$, número $3^{\circ}$.

\section{/ (f. 310r) Quaderno B del Legajo $3^{\circ}$}

En este quaderno B están las presentaciones y colaciones pertenecientes a los beneficios simples de San Bool de Respenda y San Andrés de Canduelas, por el orden siguiente: $1473>$.

$1^{\circ}$. < Colación del beneficio de San Andrés de Canduela a Juan Fernández. Año

Colación del beneficio curado de San Andrés de Canduela, hecha por don Rodrigo de Bergara, obispo de León, por la qual parece que habiendo hecho resignación de este beneficio Juan Fernández, clérigo, en manos de don Fernando Cabeza de Baca, arcediano de Saldaña; el dicho arcediano en virtud de esta resignación y de la presentación del reverendo señor don Pedro González de Mendoza, administrador perpetuo de la abadía de San Zoil de Carrión, le dio la colación de este beneficio a Juan Fernández, clérigo, vecino de Congosto. El señor obispo de León declara que la tal colación fue contra derecho, y que no la pudo hacer el arcediano; para que con mejor título pueda el dicho Juan Fernández obtener este beneficio le da este título y colación en forma, en la ciudad de León, a 3 de febrero de 1473. Hay copia autorizada de esta colación por don Antonio Martín García, traductor y notario.

$2^{\circ}$. $<$ Sentencia a favor de Juan Alonso. Año 1533>.

Sentencia dada por el provisor de León, en favor de Juan Alonso, beneficiado de San Andrés de Canduela, por la qual le ampara en la posesión de este beneficio contra Gaspar de las Casas, que pretendió ser promovido a él después de haber más de 25 años que el dicho Juan Alonso lo había sido. Dada en León, a 26 de junio de 1533, ante Diego García, notario.

$3^{\circ}$. <Provisión Real para dar <el título> [d]el beneficio de San Bool a Pedro Hernández de Hortega. Año $1556>$.

Provisión real para que Pedro de Velasco, notario, y el visitador del obispado de León diese un traslado del título y colación del beneficio de San Bool, que se había hecho a Pedro Hernández de Hortega; el qual título se pedía para presentarlo en el pleyto que tenía San Román con Respenda. Dada en Valladolid, a 26 de octubre de 1556, ante Juan de Sant Estevan, escribano de Cámara.

$4^{\circ}$. $<$ Presentación y colación del beneficio de San Bool en Francisco de Sant Andrés. Año $1594>$.

Proceso de la presentación y colación del beneficio simple de San Bool, hecha por el padre maestro fray Toribio de Sant Andrés, abad de San Zoil, y fray Martín de Sahagún, prior de San Román, en Francisco de Sant Andrés, clérigo, por fin y muerte de Diego / (f. 310v) de Quijano, su último poseedor, en virtud del qual el licenciado don Pedro de Canseco, Arcediano de Saldaña, le dio el título y colación, que fue dado en la ciudad de León, a 19 de octubre de 1594, ante Buenaventura de Madrid, notario. $1596>$.

5. Colación de los beneficios de San Bool y San Andrés en Francisco de la Paz. Año

Colación de los beneficios de San Bool de Respenda y San Andrés de Canduela, hecha por el licenciado Aparicio de Ortega, provisor de León, en virtud de la presentación hecha 
por el padre abad de San Zoil y prior de San Román, en don Francisco de Paz de la Serna, por fin y muerte de don Francisco de San Andrés, último poseedor. Fecha en León, a 23 de diciembre de 1596, ante Buenaventura de Madrid, notario de la audiencia

6. < Presentación de San Bool y San Andrés en Diego de Bargas. Año 1604>.

Presentación de los beneficios de San Bool y San Andrés, hecha por el padre maestro fray Alonso Barrantes, abad de San Zoil, en el licenciado de Bargas, residente en Valladolid, por haber mudado de estado don Francisco Paz de la Serna, último poseedor. Su fecha, en San Zoil, a 23 de enero de 1604, ante Alonso Zapata, escribano de Carrión.

\section{7. < Comisión para la ynformación del beneficio de San Andrés. Año 1606>.}

Comisión dada por el licenciado don Antonio Ramírez, provisor de León, a instancia de Diego de Bargas, beneficiado de San Andrés de Canduela, para que se haga información del valor de las rentas de este beneficio, para pagar la limosna de más misas y de más precio, que se solía pagar, como lo pretendía el cura de dicho lugar. Dada en la ciudad de León, a 17 de abril de 1606.

8. <Renuncia de los beneficios de San Bool y San Andrés. Año 1615>.

Renuncia ${ }^{445}$ que hizo Diego de Bargas en manos del abad de San Zoil de los beneficios de San Bool y San Andrés de Canduela, por haberse entrado religioso de la Compañía de Jesús. Fecha en el Colegio de Villagarcía, a 24 de diciembre de 1615. $1616>$.

9. < Colación de los beneficios de San Bool y San Andrés en Diego Barrantes. Año

Colación de los beneficios de San Bol y San Andrés de Canduela, hecha en sede vacante por el licenciado Centena de Valdés, en Diego Barrantes, cura de las Heras, en virtud de la presentación que en él hizo el padre abad de San Zoil, y por renuncia de Diego de Bargas, religioso de la Compañía de Jesús. Dada en León, a 30 de julio de 1616, ante Juan Bautista de Torres, notario de Audiencia. Está aquí la posesión que tomó de dichos beneficios, ante Pedro Monte de Colmenares, clérigo.

\section{/ (f. 311r 10. <Resignación de San Bool y San Andrés. Año 1641>.}

Resignación de los beneficio de San Bool y San Andrés de Canduela, hecha en manos del abad de San Zoil por el licenciado Felipe de la Fuente Colmenares, comisario del Santo Oficio y cura de la Villa de Campo Redondo. Fecha en dicha villa, a 3 de mayo de 1641, ante Juan Gonzalez de Solórzano, notario apostólico.

11. < Carta del señor obispo de León. Año 1676>.

Carta del señor don Juan Aparicio Navarro, obispo de León, en la que pide al padre abad de San Zoil la presentación de los beneficios de San Bool y San Andrés de Canduela, para don Alonso Sánchez Basco, natural de Villalpando. Su fecha, en León, a 30 de marzo de 1676.

12. < Presentación del beneficio de San Bool en Martín García Lasso. Año $1676>$.

Presentación del beneficio simple de San Bool, hecha por el padre maestro fray Bernardo Estúñiga, abad de San Zoil, en el licenciado Martín García Lasso, clérigo de menores órdenes, natural de Pino del Río, por fin y muerte del licenciado Diego Ruiz, y resignación que de dicho beneficio hizo don Alonso Sánchez Basco. Su fecha, en San Zoil, a 3 de septiembre de 1676, ante fray Francisco de Molina, notario apostólico.

13. < Presentación y colación del beneficio de San Andrés de Canduela. Año 1687>.

Copia autorizada por Alexandro de Salzeda, notario, de la presentación del beneficio de San Andrés de Canduela, hecha por el padre maestro fray Francisco Turceta, abad de San Zoil, en el licenciado don Álbaro García Tuñón, cura del lugar de Villaturde, por fin y muerte del

445 Renuncia] al margen derecho: Falta. 
licenciado don Bartolomé Gil, su último poseedor. Su fecha, en San Zoil, a 28 de septiembre de 1687, ante Norverto de Sandoval y Guevara, notario y vecino de Carrión.

Hay aquí dos testimonios dados por Antonio Ybáñez de la Madrid y Miguel de la Vega, notarios de la colación de dicho beneficio, dada al mismo por el licenciado don Pedro Santos de Bisoba, dignidad de la cathedral de León; y la posesión que tomó de dicho beneficio.

14. <Autos para que el beneficiado de San Andrés reedifique la hermita. Año 1704>.

Autos dados por el señor don Juan de la Calle Santos, vicario de la dignidad del partido de San Román, en virtud de la comisión dada por el señor obispo de León, para que el licenciado don Juan Fernández de Ladredo, beneficiado actual de San Andrés de Canduela, levantase la hermita que se había caýdo, por lo que se le mandó embargar todos los frutos de dicho beneficio. En vista de esto, dicho beneficiado se allanó a reparar dicha hermita, como consta del testimonio dado por Felipe Reliegos, notario público, en 20 de octubre de 1704.

(f. 311v) 15. <Presentación y colación del beneficio de San Andrés en don Juan González Arintero. Año 1708>.

Testimonio dado por Thomás González Arintero, notario mayor de León, de la presentación y colación del beneficio de San Andrés de Canduela, hecha por el padre maestro fray Jacinto Díez, abad de San Zoil, y don Antonio Horcasitas, penitenciario de León, en el licenciado don Juan González Arintero, clérigo de menores órdenes, por fin y muerte del licenciado don Juan Fernández de Ladrera, último poseedor. Dada en San Zoil, a 20 de abril de 1708, ante Francisco Ruiz de Sandoval, notario del número de Carrión; tomó posesión ante José García de Guadiano, escribano de Castrejón.

16. <Presentación y colación del beneficio de San Bool en don Francisco de Cabiedes. Año 1710>.

Presentación y colación del beneficio simple de San Bool, hecha por el padre maestro fray Anselmo Pérez, abad de San Zoil, y el licenciado don Diego de Torres, provisor de León, en el licenciado don Francisco de Cabiedes y Herrera, natural de Carrión, por fin y muerte de don Martín García Laso, su último poseedor. Dada en San Zoil, a 15 de abril de 1710, ante Pedro Martínez y Herrera, notario apostólico; tomó posesión ante Pedro Martínez, notario.

17. < Permuta del benficio de San Andrés por una capellanía de Mayorga. Año 1719>.

Testimonio dado por Francisco de Valcárcel, notario de León, del consentimiento y licencia que dio el padre maestro fray Matheo Quijano, abad de San Zoil, para que don Juan González de Arintero, beneficiado de San Andrés de Canduela, para permutar este beneficio con el licenciado don Juan de Montenegro, por una capellanía que éste gozaba en la parroquia de San Salvador de Mayorga. Dada en San Zoil, a 27 de noviembre de 1719.

Síguese el testimonio dado por Toribio Alonso, notario de León, el título y colación que hicieron a los referidos los señores provisores sede vacante. Dada en León, a 9 de diciembre del mismo año, ante Juan Crespo, notario mayor.

18. <Colación del beneficio de San Bool en don Juan de Montenegro. Año 1729>.

Testimonio ${ }^{446}$ dado por Toribio Alonso, notario de León, de la colación del beneficio simple de San Bool, hecha por don Enrrique de Vlloa, arcediano de Saldaña, juez ordinario, en el licenciado don Juan de Montenegro, natural de dicha ciudad, por fin y muerte de don Francisco Cabiedes, su último poseedor; y en virtud de la presentación que en él hizo el padre abad de San Zoil. Dada en León, a 4 de mayo de 1729, ante Dionisio Ybáñez, notario mayor de la Audiencia.

446 Testimonio] al margen derecho: Falta. 
19. $<$ Presentación de los beneficios de San Bool y San Andrés, en don José Balbuena. Año 1800>.

Presentación de los beneficios simples de San Bool y San Andrés de Canduela, hecha por el padre maestro fray Fulgencio Campo, abad de San Zoil, en don José Balbuena, cura párroco del lugar de Respenda, por fin y muerte de don José Díez Piñán, su último poseedor. Dada en el priorato de San Román, a 26 de agosto de 1800, firmada del padre fray Benito Sabido, su secretario.

\section{Remisiones}

$<$ Donación $>$. La donación de la yglesia de San Bool. Véase este cajón y legajo, quaderno $\mathrm{A}$, número $1^{\circ}$.

Donación de hacienda en San Andrés de Canduela. Véase el cajón San Martín, legajo $1^{\circ}$, quaderno $\mathrm{A}$, número 11. 


\section{/ (f. 312r) Cajón 12 San Martín}

Este cajón San Martín, que es el duodécimo del archivo, contiene cuatro legajos, los tres pertenecientes al priorato de San Román, y el quarto a diversos lugares, que son: legajo $1^{\circ}$ : donaciones, compras, trueques y foros hechos en Santiváñez; legajo $2^{\circ}$ : privilegios reales sobre la jurisdición, vnión de San Román a San Zoil, y curato de Santa María Madre; legajo $3^{\circ}$ : cartas de pago; legajo $4^{\circ}$ : Santoyo, Santiago del Bal, Soles, Tabanera, Tarilonte y Tarradillos.

\section{Legajo $1^{\circ}$}

Este legajo, que es el primero de este cajón, contiene los tres quadernos siguientes: quaderno A: donaciones hechas a San Román en Santiváñez y sus términos; quaderno B: compras, trueques y foros en el mismo lugar; quaderno C: hacienda que tiene el Brezo en Santiváñez.

\section{Quaderno A del legajo $1^{\circ}$}

\section{Donaciones}

Este quaderno A contiene las donaciones hechas a San Román en el lugar de Santiváñez y sus términos, por el orden siguiente:

$1^{\circ}$. $<$ Donación que hizo a San Román Diego Monniz y su muger, doña Tigridia. Era 978. Año 940>.

Donación, escrita en pergamino y letra gótica (la más antigua del archivo), por la qual don Diego Monniz y su muger, doña Tigridia, condes de Saldaña, dan a San Román y su abad, Lecinio, para sustento de los monges que están en su casa y de todos los que a ella vinieren, primeramente el lugar en que está sita la misma yglesia con todos sus alrededores y pertenencias, casas, cuebas, huertos, molinos, prados, montes, saltos, con todos sus productibles antiguos y aguas; cuyos términos de parte del oriente del término de Valcárcere (Nuestra Señora del Valle), de parte de la yglesia enteramente, con todas sus tierras y atrios, todo lo ofrece enteramente a la casa santa de San Román; y de parte del occidente, todo / $(f$. $312 v$ ) el sitio que discurre hasta el castillo, con todos sus límites y términos, lo concede perpetuamente a la misma yglesia. En Buardo concede a San Román la yglesia de San Quirce con todas sus casas, frutales, prados, huertos, pastos y dehesas con todo lo a ella perteneciente. Assimismo la yglesia que estaba sita en el arrabal de Dueñas, que llamaban de Santiago, con todo lo que le pertenecía de casas, prados, huertos, molinos, pastos, tierras, viñas, fuentes, con todos sus términos. Assimismo, en el lugar de Arconada da otra yglesia llamada Santa Marina (oy se llama Santa María) con todas sus pertenencias, casas, atrios, huertos, prados, pastos, tierras, con todos sus términos. Todo lo qual mandan y conceden al dicho abad Lecinio y a todos sus monges, por que cuyden del govierno del monasterio de San Román según la regla de San Benito, y les da facultad para edificar, plantar, procurar y governar a su voluntad. Fecha en la era de 978, que es año de 940.

Hay varias copias de esta donación, unas escritas en latín y otras en castellano; pero entre todas la que está metida dentro del original es la que está fielmente sacada, que las demás añaden lo que no hay y se advierte para lo sucesivo.

$$
2^{\circ} \text {. <Donaciones de dos curas, Pelayo y García. Era 1092. Año 1054>. }
$$

Donación escrita en pergamino, por la qual el cura Pelayo y un presvítero llamado García dan a San Román y a su abad la yglesia de Santa Marina de Comontes, sita junto al río llamado Comontes, para edificar en ella un monasterio. También hacen donación de un molino y otras heredades en Carapipos, junto al río Havia. Fecha en la era de 1092, que es año de 1054. Hay copia simple de esta donación.

3. <Donación de Natalia. Era 1116. Año 1078>.

Donación, escrita en pergamino, por la qual Natalia da a San Román y a su abad Bononomen todo quanto tenía. Fecha en la hera de 1116, que es año de 1078. 


\section{4. $<$ Donación de una tierra y un vasallo. Era 1158. Año 1120>.}

Donación, escrita en pergamino, por la qual Vida Bermúdez, con su hermano Salvador y su hijo Domingo, dan a San Román y a su prior Gómez, una tierra y un vasallo que sirva a San Román, la qual tierra está en su término, en la villa que llaman Tenestares, donde había de vivir el que tubiese esta tierra o en Belilla de Guardo o en Bárcena. Facta carta tercio kalendas maii, era 1158, que es año de 1120.

\section{/ (f. 313r) $5^{\circ}<$ Donación del palacio de Barrio. Era 1163. Año 1125>.}

Donación, escrita en pergamino, por la qual Mayor García, juntamente con sus hijos García Gómez, Pelayo Gómez, Diego Gómez, Teresa Gómez y Vrraca Gómez, da a San Román la parte que tenía en el palacio que fue de la condesa doña Teresa, llamado Barrio, cerca del castillo que llamaban de San Román, junto a la yglesia de San Miguel. Fecha, $6^{\circ}$ kalendas martii, era 1163, que es año de 1125.

\section{6. <Donación de Pelarrubio. Era 1218. Año 1180>.}

Donación, escrita en pergamino, por la qual Pelarrubio ofrece su cuerpo a la obra de San Román y hace donación de todas las heredades que tenía en Santiváñez, Aviñante, en Barrio, en Las Heras ${ }^{447}$ y en otros lugares por remedio de su alma y la de sus padres. Y fray Martín, maestro de obras de San Román, recive su cuerpo y todas sus heredades con la carga de cantar un aniversario ${ }^{448}$ después de sus días. Fecha $5^{\circ}$ ydus maii, era 1218, que es año 1180.

\section{7. <Donación de Domingo Abad de Aviñante. Era 1225. Año 1187>.}

Escritura en pergamino, por la qual Domingo Abad de Aviñante, haviéndose criado desde su niñez en San Román en servicio de don Hugo, prior, el qual le hizo ordenar de sacerdote y, en agradecimiento de este beneficio, se dona a San Román por todos los días de su vida, promete estabilidad y obediencia y servir toda su vida a San Román, a quien manda la mitad de toda su hacienda. Aceta el prior Polmo este ofrecimiento y donación y, en recompensa, le da la tercera parte de los diezmos de la villa de Santiváñez y los funerales, salvo la quinta parte de ellos, que pertenecía a la casa de San Román. También le concede ciertas heredades que habían sido de su padre, para que las goze por sus días y después vuelvan a San Román. Fecha XV kalendas aprillis, era 1225, que es año de 1187.

\section{8. <Donación de don Estevan, familiar de San Román. Era 1244. Año 1206>.}

Escritura en pergamino, por la qual don Juan, prior de San Román, con consentimiento del convento, recive por familiar de él a don Estevan y a su cilleriza Marina Pérez y a sus hijos, quantos fueren, vasallos de San Román, para que participen de los sufragios de la Orden de Cluni. Y el dicho don Estevan da en recompensa a San Román una tierra con sus suelos sobre la Fuente Mayor y que quantos allí moraren sean vasallos de San Román, paguen ciertas funciones cada año y den un yantar al prior desde Navidad hasta Antroydo; promete que todos sean fieles a San Román y que esta heredad no se venderá ni se empeñará. Fecha $6^{\circ}$ idus maii, era 1244, que es año de 1206. Año 1245>.

/ (f. 313v 9. 4 Donación de 6 moyos de pan sobre el molino de la Lastra. Era 1283.

Donación, escrita en pergamino, por la qual Pelay Micola da a San Román por su alma seis moyos de pan por la mitad de trigo y la mitad de centeno sobre el molino de la Lastra, con carga de un aniversario ${ }^{449}$ por él y su muger, doña Theresa; y manda que sus hijos y herederos no puedan vender ni empeñar esta renta si no que siempre quede libre para San Román. Su fecha, a 4 de febrero, en la era de 1283, que es año de 1245.

10. <Escritura de familiares de San Román. Era 1294. Año 1256>.

Escritura en pergamino, por la qual Domingo Yváñez, prior de San Román, recive por familiar a don Matheo y a doña Marina, su muger, por lo qual prometen ser leales vasallos

${ }^{447}$ Heras] al margen derecho: Aviñante, Barrio, Las Heras.

448 Aniversario] al margen derecho: Aniversario.

${ }^{449}$ Aniversario] al margen derecho: Aniversario. 
de San Román y dar de infurción cada año un sueldo y una quarta de pan de trigo; y que estos fueros les conserven a San Román sus hijos y nietos y quantos moraren en aquel suelo. Fecha en la era de 1294, que es año de 1256.

11. $<$ Donación de don Pedro Díaz y su muger, doña Mari Pérez, de hacienda, tercias e yglesia. Era 1296. Año 1258>.

Donación, escrita en pergamino, con sello de cera pendiente, por la cual don Pedro Díaz, hijo de don Diego Pérez de Melgar y doña Mari Pérez, su muger, dan a don Domingo Ybáñez, prior de San Román, quanto tenían en San Román y en todos sus términos, y particularmente quanto tenían en Viduerna, en Respenda, en Canduela ${ }^{450}$ y de Congosto arriba todo lo que les pertenece; y nombradamente dan la tercia de la yglesia de Viduerna y la tercia de la yglesia de San Lorent, y la yglesia de San Cosme y Damián, y todo quanto tenían en estas aldeas con todos sus solares poblados y por poblar, divisas, palacios, etcétera. Y el dicho prior, por esta merced, da al referido don Pedro Díaz y a su muger, doña Mari Pérez, por los días de ambos, una casa que tenía en Arenillas de Nuño Pérez, con condición que después de sus días vuelva a San Román. Su fecha, a 24 de febrero de la era 1296, que es año 1258.

Hay dos copias autorizadas de esta escritura, la una por Juan de Castrillo, esscribano de Carrión, y la otra por don Antonio Martín García, nottario y vecino de la villa de Rivas.

12. < Escritura de familiares de San Román. Era 1297. Año 1259>.

Escritura en pergamino, por la qual Domingo Ybáñez, prior de San Román, admite por familiares de aquella casa a Pedro Valle y a su muger, doña María, y les da una casa en que vivan, con que sean vasallos de San Román y paguen cierto tributo; y / (f. 314r) ellos hacen donación a San Román de ciertas cabezas de ganado y prometen a Dios ser leales y fieles vasallos. Fecha a 20 de abril, era 1297, que es año de 1259.

$<$ Hay aquí otra escritura en que el prior de San Román admite por racioneros a don Juan de Barrio, etcétera>.

13. <Donación de hacienda por una sepultura. Era 1376. Año 1338>.

Escritura en pergamino, por la qual el convento de San Román da una sepultura debajo del coro a Bras de Valderrábano y su muger, y se obligan a enterrarlos y sustentar un capellán que diga misa por ellos, por 300 maravedís que ellos dan en vida a San Román y después de ella toda su hacienda. Su fecha, en la era de 1376, que es año de 1338, ante Galindo Ruiz, esscribano público de Saldaña.

14. $<$ Donación de 5 maravedís de foro sobre unas casas. Año 1520>.

Donación que hizo a San Román Francisco de Espinosa, clérigo, de 5 maravedís de foro perpetuo sobre unas casas en Santibáñez, linderos: de las dos partes las calles públicas del dicho lugar, y de las otras dos partes: huertos de dicho monasterio de San Román. Su fecha, en el Hospital de la O, junto a Carrión, a 2 de abril de 1520, ante Floristán de la Serna, escribano de dicha villa.

\section{Remisiones}

$<$ Donación $>$.

La donación de Mayor García de su ración en San Román. Véase el cajón Santa María, legajo $1^{\circ}$, quaderno $\mathrm{A}$, número $2^{\circ}$.

Las donaciones hechas a San Román en otros lugares. Véase el título de cada lugar donde se hallarán.

$<$ Donaciones $>$.

Donaciones hechas a San Román. Véase el cajón San Gregorio, legajo $2^{\circ}$, quaderno Y, número $1^{\circ}$ y siguientes.

\footnotetext{
${ }^{450}$ Canduela] al margen derecho: Viduerna, Respenda, Canduela.
} 
$<$ Trueque $>$.

Trueque de la yglesia de Santiago o de Dueñas. Véase el mismo cajón y legajo y quaderno, número $2^{\circ}$.

$<$ Donación $>$. número $1^{\circ}$.

Donación del lugar de Villafría. Véase el cajón San Plácido, legajo $1^{\circ}$, quaderno A,

$<$ Trueque $>$.

Trueque entre San Román y El Brezo. Véase el mismo cajón y legajo y quaderno, número 23 .

\section{/ (f. 314v) Quaderno B del legajo $1^{\circ}$}

Compras, truques y foros

Este quaderno B contiene los papeles pertenecientes a las compras, trueques y foros hechos por el priorato de San Román en el lugar de Santiváñez y sus términos, por el orden siguiente:

$1^{\circ} .<$ Compra de un solar y divisa. Era 1186. Año 1148>.

Compra que hizo Martín Pérez a Gutierre González de un solar con su divisa en el lugar de Santiváñez. Fecha $7^{\circ}$ idus maii, era 1186, que es año de 1148. Está escrita en pergamino.

$2^{\circ}$. < Contrato de la obra de la yglesia y bodega de San Román. Era 1234. Año 1196>.

Escritura en pergamino, partida por $\mathrm{ABC}$, por la qual Bartolomé, prior de San Román, da al hermano Martín y a la obra de San Román cierta heredad que el maestro Juan había comprado en el alfoz de San Román; y asimismo le da un solar en Santiváñez, la serna de Fenar, y por dos años el diezmo de Barrio, la tercia de Santiváñez y un carral de vino y dos tocinos. Y el dicho hermano Martín se obliga a hacer el sobrado de la pared de la yglesia hasta la cocina, la bodega con las ventanas y paredes, etcétera. Su fecha, en la era de 1234, que es año de 1196. $1406>$.

$3^{\circ}$. < Trueque de hacienda entre el prior de San Zoil y el prior de San Román. Año

Trueque, escrito en pergamino, por el qual don Fernando, prior mayor de San Zoil, da a don Domingo Juan, prior de San Román, toda la hacienda, vasallos y derechos que le pertenecían en los lugares de Fontecha, Entorcisa, Villa Oliva, Santiváñez, Villalbeto, Respenda, Pino, Muñeca, Tabanera, Aviñante ${ }^{451}$. Y el prior de San Román da al de San Zoil en trueque toda la hacienda que tenía en Cisneros, en Arenillas, en Mazuecos, en Guaza ${ }^{452}$ y en todos los términos de estos lugares. Su fecha, en el monasterio de San Zoil, a 4 de octubre de 1406, ante Francisco Pérez, esscribano de Carrión. Hay copia autorizada por el mismo esscribano.

$/$ (f. 315r) 4. $<$ Foro de 3 carneros y 12 gallinas sobre las aguas y 3 tierras. Año $1451>$.

Foro perpetuo por el qual don Pedro de Tosantos, abad, junto con el convento de San Zoil, da a Pedro Puente y Pedro Asenxo, vecinos de Santiváñez, en nombre del concejo, todas las aguas que nacen alrededor de San Román para que las lleven por donde pudieren y se aprovechen de ellas para regar las heredades y prados; y asimismo les da 3 tierras que están en el dicho lugar, a do dicen desde el Huerto Viejo al Tejar hasta la huerta e la sernilla so la Penilla, por 3 carneros de dos dientes y una docena de gallinas de foro perpetuo en cada año, y con condición que otro ningún concejo no pueda a provecharse de estas aguas ni hacer

451 Aviñante] al margen derecho: Fontecha, Entorcisa, Villa Oliva, Santiváñez, Villalbeto, Respenda, Pino, Muñeca, Tabanera, Aviñante.

${ }^{452}$ Guaza] al margen derecho: Cisneros, Arenillas, Mazuecos, Guaza. 
molinos. Su fecha, en el monasterio de San Zoil, a 4 de abril de 1451 ante Álvar González, escribano de Carrión.

Hay dos copias authorizadas, la una por don Antonio Fernández de Guzmán, escribano y notario; y la otra, por don Antonio Martín García, notario y vecino de Rivas.

5. <Carta de amparo a favor de los vecinos de Santiváñez. Año 1519>.

Copia simple de una sobrecarta de amparo de la reyna doña Juana, a favor de los vecinos de Santiváñez, para que el prior de San Román no les impida el aprovechamiento de los pastos y aguas ni les maltraten, y que cumpla con la primera carta de amparo. Dada en la ciudad de Toro, a 11 de abril de 1519.

6. <Compra de un casar y tierra por 2.500 maravedís. Año 1521>.

Compra que hizo Juan Alonso, cura de Pino, a Mayor, viuda, de un casar y mitad de una tierra en término de Santiváñez, por precio de 2.500 maravedís. Su fecha, en Viduerna, a 22 de octubre de 1521, ante Alonso Fernández de Respenda, esscribano.

Esta hacienda parece que hera de San Román y que no pudo venderse y así la tiene dada en arrendamiento.

7. <Sentencia a favor de San Román sobre el Prado Cerrado. Año 1529>.

Testimonio dado por Juan de Valdés, esscribano de Saldaña, por el qual parece que Nuño Orejón, corregidor de dicha villa, en la visita que hizo en los lugares de la Montaña, visitando el lugar de Santiváñez; y, hecha cierta información de oficio con los vecinos de él, dio una sentencia en que declara que los vecinos de Santiváñez, según consta de la información, tienen y reparten entre sí cada año la yerba y fruto del Prado del Campo Cerrado. Decláralo por del concejo y condena a los vecinos a que de allí adelante arrienden la yerba del dicho prado a público pregón y que se deposite lo que por él dieren por propios del concejo. Publicada esta sentencia la aceptaron y obedecieron los vecinos de Santiváñez. / (f. 315v) Después de lo qual pareció ante el mismo corregidor y en presencia del dicho esscribano el padre fray Diego Méndez, monge de San Román, el qual se querelló de que, siendo de aquel priorato el Prado Cerrado, lo hubiese adjudicado al concejo sin oýr la parte del monasterio y pidió que lo revocase y diese por nulo. El corregidor, en 19 de noviembre de 1529, dio auto en que declara que su intención no era agraviar al monasterio de San Román, que el había sentenciado por la información que había hecho y que suspendía el efecto de la dicha sentencia y pena.

8. <Compra de una tierra por 12 ducados. Año 1543>.

Compra que hizo fray Alonso de Villamuera, prior de San Román, a Juan Alonso, cura de Pino, de una tierra en Santiváñez, a Sopeña, por precio de 12 ducados. Su fecha, en Pino, a 18 de abril de 1543, ante Alonso Rodríguez, escribano y vecino de Carrión.

Está aquí la escritura de trueque que hicieron Toribio y Hernando, vecinos de Las Heras, con el dicho cura de esta tierra por un linar y diez ducados. Hcha en el mismo año y ante el mismo escribano.

9. <Trueque de una tierra por otra en Santiváñez. Año 1546>.

Trueque que hizo fray Alonso de Villamuera, prior de San Román, con Juan Díez, en nombre de Juan Pérez y su muger, vecinos de Las Heras, de una tierra en término de Las Heras, propia del dicho priorato, por otra tierra que los sobredichos le dieron en término de Santiváñez, linderos: de una parte heredad de San Román; y de la otra, heredad del canónigo Colmenares y el río. Su fecha, en Las Heras, a 23 de marzo de 1546, ante Alonso Rodríguez, escribano y vecino de Carrión.

10. $<$ Revocación de una licencia para hacer ordenanzas. Año 1546>.

Testimonio dado por Agustín de Medina, escribano público, de la rebocación que hizo el prior de San Román, juntamente con el concejo de Santiváñez, de una licencia que habían dado a Garcilaso de La Vega, vecino de Colmerales, para hacer ciertas ordenanzas, 
por ser en perjuicio del dicho lugar de Santiváñez. Su fecha, en este lugar, a 16 de junio de 1546.

11. <Requirimiento a Alonso Martín para que no edifique una casa. Año 1547>.

Testimonio dado por Agustín de Medina, escribano público, del requirimiento que hizo el prior de San Román y el concejo de Santiváñez a Alonso Martín, vecino de dicho lugar, para que edifique una casa en egido del concejo; y él se allana a dar otro tanto y más de lo que toma del concejo. Su fecha, en Santiváñez, a 6 de junio de 1547.

/ (f. 316r) 12. <Sentencia a favor de San Román sobre un real de foro. Año 1553>.

Sentencia dada por don Antonio de León, prior de Escalada, juez conservador, a favor de San Román contra Alfonso Mayor para que pague un real de foro perpetuo por la tierra en que edificó una casa junto con la casilla del hospital. Dada en Carrión, a 17 de junio de 1553, ante Andrés Sánchez, esscribano y nottario de la villa.

Está aquí un testimonio dado por Miguel López, esscribano de Carrión, del reconocimiento que hizo de dicho foro Juan Mayor, nieto de Alonso Mayor, en el lugar de Santiváñez, a 4 de octubre de 1611, ante Juan de Vega, esscribano ppúblico.

13. <Mandamiento para no edificar casas en Santiváñez. Año 1554>.

Mandamiento del corregidor de Saldaña para que los vecinos de Santiváñez no edifiquen casas en perjuicio del monasterio de San Román. Dado en Saldaña, a 13 de abril de 1554, ante Diego Gómez, esscribano de dicha villa.

14. <Compra de un huerto con unos perales. Año 1559>.

Compra que hizo fray Lorenzo de Modoya, prior de San Román, a Bartholomé Fernández y Juana, su muger, de un huerto con unos perales dentro del lugar de Santiváñez, junto del solar y casas en que vivía Juan Montes, que eran de San Román, linderos: huerta y molino de Garcilaso de Colmenares, vecino de Tablares, por precio de 3.000 maravedís. Su fecha, en Villalbeto, a 11 de mayo de 1559, ante Jorge de Vega, esscribano ppúblico.

15. < Trueque de un prado por un exido. Año 1564>.

Trueque que hizo fray Francisco de la Serna, prior de San Román, con el concejo y vecinos del lugar de Santiváñez, de un pedazo de un prado propio del dicho priorato por otro pedazo de un exido en el dicho lugar, a do dicen la Redondilla. Su fecha, en Santiváñez, a 10 de febrero de 1564, ante Agustín de Medina, esscribano ppúblico.

16. $<$ Mandamiento para que no se edifique en Santiváñez. Año 1564>.

Mandamiento del licenciado Hernando Díez, corregidor de Saldaña, para que Miguel Martínez, vecino de Santiváñez, no edifique ni prosiga la obra que tenía comenzada sin consentimiento / (f. 316v) del prior de San Román. Dado en Saldaña, a 7 de febrero de 1564, ante Felipe Gómez, esscribano de dicha villa.

17. <Sentencia a favor de San Román de 3 blancas y una gallina de foro sobre un solar. Año 1573>.

Bajo este número están los papeles siguientes:

$1^{\circ}$. Vna escritura de venta que hizo el concejo de Santiváñez juntamente con el prior de San Román, a quien pidieron licencia para otorgarla, yen virtud de ella vendieron a Hernando Oreja, cura de Las Heras y Santiváñez, un solar en dicho lugar, detrás de la fragua, por precio de 1.500 maravedís. Su fecha, en Santiváñez, a 2 de enero de 1542, ante Alonso Rodríguez, esscribano.

$2^{\circ}$. Vna sentencia dada por el padre fray Bernardo de Lerma, prior de Santo Domingo de Carrión, juez conservador, por la qual parece que, habiendo muerto el dicho cura Hernando Oreja, heredó este solar con la casa que se edificó en él Bartholomé Santos, clérigo, vecino de Santiváñez, a quien puso demanda el monasterio para que pagase el tributo que debía por el solar en que había edificado la casa. Y el dicho juez, visto los autos, conclusa la causa, dio y pronunció este sentencia, por la qual condena al dicho Bartholomé Santos a que 
pague al dicho priorato de San Román 3 blancas y una gallina en cada un año perpetuamente por razón del solar en que había edificado la casa. Dada en Carrión, a 8 de noviembre de 1573, ante Andrés Sánchez, esscribano de dicha villa.

3. Vna carta executoria, dada por el dicho juez a instancias de este monasterio, y una requisitoria para que el prior de Sahagún, donde estaba el dicho Bartholomé Santos, se la mandase notificar, como en efecto se la notificó.

$<$ Obligación que hizo Hernando Oreja de pagar 3 gallinas $>$.

Vltimamente está aquí una obligación que hizo el mismo Bartholomé Santos de pagar al prior de San Román 3 gallinas en cada un año por razón del suelo de las casas que había heredado de Hernando Oreja. Su fecha, en San Zoil, a 11 de agosto de 1579. Está firmada de su nombre.

/ (f. 317r) 18. <Executoria a favor de San Román sobre una casa y préstamo de Santiváñez. Año 1574>.

Carta executoria dada en la Chancillería de Valladolid a favor de San Román contra Brígida García, vecina de Santiváñez, por la qual parece que la parte del convento se querelló en el adelantamiento de Campos de la dicha Brígida porque, siendo el dicho convento señor de Santiváñez y sus vecinos vasallos solariegos y tener facultad para darles casas, suelos y préstamos que vacaban, a quien, como y quando querían, teniendo en Santiváñez una casa con su préstamo y, habiéndosela dado el convento a Juan Puente el Viejo por su vida, muerto éste, se la dio a Juan Puente, su hijo; pero la dicha Brígida, por fuerza y contra la voluntad del prior, se entró en la dicha casa y préstamo y no la quería dejar. Puso demanda el convento ante el licenciado Alonso Fernández de Córdoba, alcalde maor del adelantamiento de Campos, y en 17 de abril de 1573 dio sentencia, por la qual condena a dicha Brígida en 200 maravedís y a que se salga de la dicha casa, dejándola libre con sus préstamos a Juan Puente, a quien se la había dado el prior. De esta sentencia apeló Brígida a la Chancillería donde se litigó; y en 13 de octubre de 1573 se dio sentencia, por la qual declararon por desierta la apelación de Brígida y la sentencia del adelantamiento por pasada en cosa juzgada, y que se llevase a debida execución, y la condenaron en costas. Suplicó la parte de Brígida y, en 5 de febrero de 1574, se dio sentencia de revista confirmando la pasada y volviendo a condenarla en costas. De lo qual se dio esta carta executoria ante Andrés de Yrizas, esscribano de Cámara, la qual se notificó al alcalde mayor del adelantamiento para que la mandase executar.

19. <Sentencia sobre el servicio y paso de unas tierras en San Román y sobre un palomar. Año 1603>.

Bajo este número hay dos sentencias en un pleyto que tubo el prior de San Román con Pedro Merino el Viejo, sobre el servicio y paso de unas heredades. La $1^{\text {a }}$ fue dada en el adelantamiento de Campos, a 25 de octubre de 1603, ante Bartholomé Torices, por la qual se confirma otra sentencia, dada por el alcalde mayor de Saldaña, y se declara que la prohibición de pasar por las tierras sobre que ha sido el pleyto sea y se entienda / (f.317v) desde que se comenzare a sembrarlas hasta que se haya alzado el fruto de ellas, y el demás tiempo del año pueda el dicho Pedro Merino pasar libremente por el camino que solía haber antes de ahora. Y se confirma en quanto a cerrar las ventanas de un palomar y en quanto a cerrar las demás ventanas de la dicha casa que caen a vista de las tierras del dicho convento por donde no puedan salir las palomas; declara que el dicho Pedro Merino las pueda tener libremente, con que por ellas no haga daño a las tierras y sementera del convento.

$<$ Año 1605>.

La $2^{a}$ sentencia fue dada en la Chancillería, estando en Burgos, a 29 de abril de 1605, ante Pedro de Angulo, esscribano de Cámara, por la qual se confirma la del adelantamiento.

20. <Amojonamiento de Santiváñez con Villanueva>.

Advertencias sobre la comunidad de pastos entre los de Santiváñez y el lugar de Villanueva, con el amojonamiento de los términos de estos lugares. Asimismo una memoria simple de las tierras y prados, con sus deslindes, que se concedieron a Pedro Merino para su hijo. 


\section{1. $<$ Pareceres sobre la sucesión de préstamos $>$.}

Parecer del doctor $\mathrm{Muñoz}$ sobre si en los préstamos de los vasallos suceden forzosamente sus hijos. $\mathrm{Y}$ es de parecer que, si los vasallos y sus hijos no prueban prescripción de tiempo immemorial que siempre se han aforado a los hijos de los vasallos los tales fueros y heredades, el prior podrá, quando vacaren, aforarlos a quien quisiere y más diere por ellas.

\section{2. $<$ Foro de 4 maravedís sobre un molino de concejo. Año 1640>.}

Testimonio dado por Andrés de Mansilla, esscribano de Saldaña, de una escritura de convenio entre el prior de San Román y el concejo y vecinos de Santiváñez, por la qual éstos se obligan a pagar al dicho priorato 4 maravedís de cada un año para siempre jamás por el molino que está fundado entre la dicha casa y el dicho lugar de Santiváñez (que es el último de abajo) y esto por razón de que el dicho convento goza en el dicho lugar como dos vecinos. Y por estos 4 maravedís dicho prior renunció al derecho que podía tener al dicho molino. $\mathrm{Y}$ se declara que si con el tiempo se perdieren o cayeren los dos molinos que el dicho priorato tiene en el río, encima del molino arriba referido, el dicho priorato aya de moler y muela en el molino que el concejo tiene edificado, / (f. 318r) y, moliendo en él, sea visto quitarse el dicho foro de los 4 maravedís y el prior tendrá obligación de pagar al dicho concejo 30 reales por la parte que le podía tocar en el gasto que el dicho concejo hizo en edificar dicho molino.

Asimismo se declara que, si en algún tiempo el dicho concejo quisiere edificar otro molino debajo o encima de este molino nuevo, que lo pueda hacer, pagando el priorato otros 4 maravedís en cada un año según y en la forma que va referido, no moliendo dicho priorato; y, moliendo, ha de pagar los dicho 30 reales según arriba está declarado, con que el molino que así hicieren no sea en perjuicio de los otros molinos que el dicho priorato tiene. Esta escritura fue aceptada por ambas partes y otorgada en el priorato de San Román a 19 de marzo de 1640.

\section{3. $<$ Foro de 8 maravedís sobre un suelo. Año 1655>.}

Escritura de foro de 8 maravedís que otorgó Andrés Díez, vecino de Santiváñez, a favor del dicho priorato de San Román por el suelo de una casa que había fabricado en el término del dicho lugar, a los Carcabales, y sobre la que el dicho prior le había puesto pleyto. Su fecha, en el lugar de Las Heras, a 14 de febrero de 1655, ante Marcos de la Vega, esscribano y vecino de Villanueva de Muñeca.

\section{4. < Foro de 3 maravedís sobre un suelo de una casa. Año 1661>.}

Escritura de foro perpetuo de 3 maravedís que otorgó el concejo y vecinos del lugar de Santiváñez a favor del priorato de San Román sobre el suelo de una casa en el dicho lugar, junto a la hermita de San Juan, y sobre la que, habiéndose querellado dicho padre prior porque la edificaban sin su licencia, confesaron todos los vecinos ser el dicho sitio y suelo de San Román y que los demás vecinos que han edificado en el dicho lugar y hecho casa, molinos, etcétera, ha sido siempre con licencia del prior. Ambas partes aceptaron esta escritura, que fue otorgada en el lugar de Santiváñez, a 20 de noviembre de 1661, ante Marcos de la Vega, esscribano y vecino de Villanueva de Muñeca.

\section{5. <Foro de 4 maravedís sobre el sitio del Pisón. Año 1662>.}

Escritura de foro perpetuo de 4 maravedís que otorgó Rafael Merino, vecino del lugar de Santiváñez, por el sitio del Pisón, / (f. 318v) que fundó en el río de San Román, que está entre dos molinos, y que confiesa ser propio del dicho priorato. Fue otorgada esta escritura en Carrión, a 17 de febrero de 1662, ante Norverto de Sandoval y Guebara, esscribano de dicha villa.

\section{6. <Foro de 2 maravedís sobre un pedazo de campo. Año 1663>.}

Escritura de foro perpetuo de dos maravedís que otorgó Bartholomé del Balle, vecino de Santiváñez, sobre un pedazo de campo cercado que compró al concejo de dicho lugar, y está junto a los molinos del dicho concejo y el río que baja de San Román, con quien linda, por quanto reconoce que el dicho suelo es proprio del priorato de San Román y que ninguna persona puede cercar ni edificar sin licencia del padre prior, y que los demás vecinos que lo 
han hecho han fundado foro en reconocimiento del señorío. Su fecha, en Santiváñez, a 16 de junio de 1663, ante Marcos de la Vega, esscribano de Muñeca.

27. <Compra de una casa, prado y seis tierras. Año 1664>.

Compra que hizo el padre fray Juan Fernández, prior de San Román, a Juan Martín y María del Valle, su muger, vecinos del lugar de Santiváñez, de una casa con sus corrales y huerto en dicho lugar, que linda con calles reales alrededor; de un prado en término de dicho lugar, a do dicen Prado Redondo, y seis tierras de pan llevar en el mismo término, por precio y quantía de 144 ducados. Su fecha, en San Román, a 21 de marzo de 1664, ante Marcos de la Vega, esscribano.

Y porque hubo yerro en una tierra se deshizo luego en el mismo año y ante el mismo esscribano, dando el dicho Juan Martín otra tierra y satisfaciendo el padre prior el exceso.

28. < Foro de 2 maravedís sobre un pedazo de exido. Año 1691>.

Escritura de foro perpetuo de 2 maravedís que otorgó Santiago Díez, vecino del lugar de Santiváñez, a favor del priorato de San Román, sobre un pedazo de exido en el dicho lugar, en el que edificó una casa, con licencia y consentimiento del prior de San Román, en reconocimiento del señorío que dicho priorato tiene en el dicho lugar. Su fecha, en San Román, a 6 de septiembre de 1691, ante Miguel de la Vega, escribano y vecino del lugar de Aviñante.

\section{/ (f. 319r) 29. <Compra de una tierra linar. Año 1471>.}

Compra que hizo fray Thomás Brabo, prior de San Román, a Diego de Vega, vecino de Santiváñez, de una tierra linar en término de dicho lugar, a las Vallejuelas, cerca de la cruz de la hera, que hará quasi una fanega de linaza de sembradura, por precio de 350 reales. Su fecha, en Villanueva de Muñeca, a 10 de febrero de 1471, ante José Luys de Cantoral, escribano de dicho lugar.

Está duplicada esta escritura.

30. <Trueque de una casa y huerto por 3 tierras. Año 1788>.

Trueque que hizo el padre fray Gregorio Calderón, prior de San Román, con Miguel Rebanal e Ysabel Villalba, su muger, vecinos de Santiváñez, de una casa con su huerto, sita en dicho lugar y propia del dicho priorato, por 3 tierras en término del mismo lugar, que la $1^{a}$ está a do llaman las Azas, que hace fanega y medio quarto de linaza; la $2^{a}$ está a do llaman al Frontal de Sobre Carrera, y hace un quarto de sembradura; y la $3^{a}$ está al exido de Botear, y hace una fanega de linaza. Fue otorgada esta escritura en el lugar de Santiváñez, a 20 de febrero de 1788, ante Manuel Luis París, esscribano y vecino de Villanueva de Arriba.

31. <Trueque de un solar y huerta por una tierra y prado. Año 1789>.

Trueque que hizo el padre fray Gregorio Calderón, prior de San Román, con Bernardo Luis, vecino de Entorcisa, de un solar de casa y huerta en el casco de dicho lugar, propio de dicho priorato, por una tierra y un prado en término de dicho lugar de Santiváñez, que la tierra está al frontal de Sobre Carrera y hace una fanega de centeno, y el prado está a do llaman la Ontanilla y hace una carretada de yerba. Su fecha, en San Román, a 22 de marzo de 1789, ante Manuel Luis París, esscribano ppúblico.

32. < Confesión y remisión de la roturación del monte. Año 1789>.

Testimonio dado por Manuel Luis París, esscribano público, de la confesión que hicieron José Merino e Ysidoro de Amo del exceso y delito que ambos cometieron en la violenta introducción y roturación del monte de San Román, llamado La Mata. Por lo que pidieron remisión y condenación al padre maestro fray José Fierro, quien se la concedió, como consta de esta escritura, que fue fecha en San Román, a 27 de julio de 1789.

$<$ Está duplicada $>$. 


\section{3. <Compra de un huerto. Año 1789>.}

Compra que hizo el padre maestro fray José Fierro, prior de San Román, a Manuel Gregorio, vecino de Santiváñez, de un huerto cercado con sus árboles frutales en el casco de dicho lugar, al Barrio del Río, de cabida de medio carro de yerba, poco más / (f. 319v) o menos, por precio de 725 reales. Su fecha, en Santiváñez, a 27 de noviembre de 1789, ante Manuel Luis París, esscribano ppúblico.

Está duplicada esta escritura.

34. $<$ Trueque de una casa por varias tierras y prados. Año 1792>.

Trueque $^{453}$ que hizo el padre maestro fray José Fierro, prior de San Román, con Francisco Díez y Josefa de Guzmán, su muger, vecinos de Santiváñez, de una casa corral y huerta en el dicho lugar, propia del dicho priorato, por un linar, dos prados y cuatro tierras en término de Santiváñez, más por 4 prados en término de Pino, y asimismo por un linar y una tierra en término de Viduerna, y últimamente por otra tierra y dos linares en término del lugar de Las Heras ${ }^{454}$. Cuyas heredades dio el referido Francisco Díez al dicho prior por la sobredicha casa y 125 reales, por el esceso del más valor de dichas heredades. Su fecha, en San Román, a 24 de marzo de 1792, ante Manuel Luis París, esscribano.

35. <Trueque de una casa y huerto por 3 tierras. Año 1792>.

Trueque que hizo el padre maestro fray José Fierro, prior de San Román, con Simón Roxo, vecino de Las Heras, de una casa corral y huerta, sita en el lugar de Las Heras, propia del dicho priorato, por tres tierras que el referido dio en término del lugar de Santiváñez, con más de 85 reales por el esceso y más valor de la casa al de las heredades. Su fecha, en San Román, a 24 de febrero de 1792, ante Manuel Luis París, esscribano.

36. <Trueque de una casa y huertos por varias heredades y prados. Año 1793>.

Trueque que hizo el padre maestro fray José Fierro, prior de San Román, con María Merino, Plácido y Vicente Montes, madre e hijos, vecinos de Las Heras, de una casa, corral y huertos, sitos en dicho lugar y propios de dicho priorato, por un linar en término de Las Heras $^{455}, 3$ prados y un linar en término de Santiváñez y una tierra en término del lugar de Aviñante ${ }^{456}$, con más 20 reales que los referidos entregaron al padre prior, por el esceso y más valor que tenía la casa que dio a las heredades que recivió. Su fecha, en San Román a 24 de abril de 1793, ante Manuel Luis París, esscribano ppúblico.

37. < Compra de una tierra linar. Año 1790>.

Compra que hizo el padre maestro fray José Fierro, prior de San Román, a Manuel Gregorio, vecino de Santiváñez, de una tierra linar en término de dicho lugar, a do llaman las Vallejas del Manzanillo, que hace media carga de linaza, po/ (f. 320r)co más o menos, por precio de 1.900 reales. Su fecha, en San Román, a 28 de julio de 1790, ante Manuel Luis París, esscribano ${ }^{457}$.

38. <Compulsa de las rentas repartidas de Santa María del Valle. Año 1793>.

Testimonio dado por Manuel Luis París, esscribano, de la compulsa de unas partidas de un libro en folio del priorato de San Román, que contiene la regla y estatutos de la Cofradía de Santa María del Valle, fundada en el año de 1426 en la hermita de este título, situada dentro del territorio de San Román; y las partidas compulsadas hablan de la renta de las tierras de la dicha cofradía aprobada por los yllustrísmos obispos de León y sus respectivos comisarios, que todo fue a petición del padre fray Pedro Castro, prior actual, y el padre fray Andrés Huidobro, teniente de cura del lugar de Santiváñez. Su fecha, en San Román, a $1^{\circ}$ de septiembre de 1793.

\footnotetext{
453 Trueque] al margen derecho: Este número ha de ser el 37.

${ }^{454}$ Las Heras] al margen derecho: Pino, Viduerna, Las Heras.

455 Las Heras] al margen derecho: Las Heras.

${ }^{456}$ Aviñante] al margen derecho: Aviñante.

457 esscribano] al margen derecho: Este número ha de ser el 34.
} 


\section{Remisiones}

$<$ Trueque $>$.

Trueque de toda la heredad que tenía San Román en Loma de Foyos por la mitad de dos molinos que tenía en Cestillos. Cajón San Felices, legajo $2^{\circ}$, quaderno A, número $3^{\circ}$.

$<$ Trueque $>$.

Toda la hacienda de Santa María del Páramo para San Román por trueque que hizo. Véase el cajón San Lorenzo, legajo $3^{\circ}$, quaderno C, número $1^{\circ}$.

$<$ Compra $>$. número $3^{\circ}$.

Compra de 3 prados en los exidos de Torre Véase el mismo cajón, legajo y quaderno,

$<$ Trueque $>$.

Vna tierra en término de Santiváñez por trueque. Véase el cajón San Lorenzo, legajo $2^{\circ}$, quaderno $\mathrm{A}$, número 17.

$<$ Trueque $>$.

Otro trueque. Véase el cajón San Gregorio, legajo $2^{\circ}$, quaderno Y, número $2^{\circ}$.

\section{/ (f. 320v) Quaderno C del legajo $1^{\circ}$}

Hacienda de Nuestra Señora del Brezo

Este quaderno C contiene los papeles pertenecientes a la hacienda que tiene el santuario de Nuestra Señora del Brezo en el lugar de Santiváñez por el orden siguiente:

$1^{\circ}$. $<$ Compra de una tierra. Año 1592>.

Compra que hizo fray Francisco de Villafuerte, prior del Brezo, a Santiago Román, vecino de Santiváñez, de una tierra en el término de dicho lugar, a Espinarejo, que hace 3 quartos de trigo de sembradura, con una barbacana de piedra que se obliga de hacer frontero del río, por precio de 34 ducados que pagó por ella. Su fecha, en el Brezo, a $1^{\circ}$ de mayo de 1592, ante García Cosío, escribano de La Puebla.

2. $<$ Compra de una tierra. Año 1592>.

Compra que hizo el mismo prior del Brezo a Bartholomé Martín, vecino de Santiváñez, de una tierra a Espinarejo, término de dicho lugar, que hace 3 quartos de trigo de sembradura, por precio de 38 ducados que dicho prior pagó por ella. Su fecha, en San Román, a 2 de abril de 1592, ante García de Cosío, escribano de la Puebla. Está duplicada esta escritura.

3. <Compra de una tierra. Año 1592>.

Compra que hizo el mismo prior del Brezo a Pedro de la Merina, vecino de Santiváñez, de una tierra a do dicen al Arroyal, término de dicho lugar, que hace 4 celemines de trigo de sembradura, por precio de 40 reales que pagó por ella dicho prior. Su fecha, en Santiváñez, a 11 de junio de 1592, ante García de Cosío, escribano de la audiencia de La Puebla.

\section{4. $<$ Compra de una tierra. Año 1596>.}

Compra que hizo fray Christóval de Matienzo, prior del Brezo, a Bartholomé de la Medina, vecino de Santiváñez, de una tierra al Espinalejo, término de dicho lugar, que hace un quarto de trigo de sembradura, por precio de 12 ducados que por ella pagó dicho prior. Su fecha, en San Román, a 3 de enero de 1596, ante el sobredicho escribano. 
/ (f. 321r) 5. <Compra de una tierra. Año 1598>.

Compra que hizo fray Francisco de Villafuerte, prior del Brezo, a Pedro Montes, vecino de Santiváñez, de una tierra a do dicen a Espinarejo, término de dicho lugar, que hace 4 celemines de trigo de sembradura, por precio de 4 ducados que por ella pagó dicho padre prior. Su fecha, en Santiváñez, a 25 de junio de 1598, ante el sobredicho escribano.

6. $<$ Compra de una tierra. Año 1598>.

Compra que hizo el mismo prior del Brezo, a Bartholomé Cordero, vecino de Las Heras, de una tierra en el término del lugar de Santiváñez, a donde llaman el Duxo, que hace quarto y medio de trigo de sembradura, por precio de once ducados que por ella pagó dicho padre prior. Su fecha, en El Brezo, a 14 de septiembre de 1598, ante el sobredicho escribano. $1598>$.

7. < Compra de seis tierras en Santiváñez, una en Aviñante y otra en Las Heras. Año

Compra que hizo el mismo prior del Brezo a Juan de Medina, vecino de Santiváñez, como principal, y a Francisco Méndez de Hevia, vecino de Cornón, como su fiador, de ocho tierras en los términos de Santiváñez, Aviñante y Las Heras, que son las siguientes:

La $1^{\text {a }}$ está a do dicen encima de Soles, que hace 5 quartos de trigo de sembradura ${ }^{458}$.

La $2^{\text {a }}$ está a do dicen al Convento, término de Santiváñez, que hace una fanega de trigo de sembradura.

La 3 está en término de Las Heras ${ }^{459}$, a do dicen a los Barriales, que hace media carga de trigo de sembradura.

La 4 está do dicen a Espinalejo, término de Santiváñez, que hace medio quarto de trigo de sembradura.

La $5^{\text {a }}$ está más arriba de ésta, de dos celemines de sembradura.

La 6 está en el término del lugar de Santiváñez, a do dicen a la Sopeña, que hace una fanega de trigo de sembradura.

La 7 está en el dicho término, a do dicen a Santa María, que hace una fanega de trigo de sembradura.

Y la $8^{a}$ está más abajo, que hace medio quarto de trigo de sembradura.

Por precio de 114 ducados que por ellas pagó dicho padre prior, a cuya seguridad los dichos principal y fiador ypotecaron ciertas posesiones. Su fecha, en Carrión, a 6 de noviembre de 1598, ante el sobredicho escribano. Está aquí una / (f. 321v) escritura de trueque que hizo el referido Juan de Medina con Bartholomé de Hernando de una tierra por otra en término de Santiváñez, las quales pertenecen a la compra de este número 7.

8. <Compra de una tierra. Año 1599>.

Compra que hizo el prior del Brezo a Domingo Fernández, vecino de Vega de Riacos, de una tierra a la Sopeña, término del lugar de Santiváñez, que hace una fanega de trigo de sembradura, por precio de 85 reales. Su fecha, en Viduerna, a 28 de febrero de 1599, ante Blas Ordóñez, escribano y vecino de dicho lugar.

9. <Compra de una tierra. Año 1599>.

Compra que hizo fray Cristóval de Matienzo, prior del Brezo, a Pedro Casa y María Díaz, vecinos de Santiváñez, de una tierra a do llaman a la Carrera de Botear, término de dicho lugar, que hace siete celemines de trigo de sembradura, por precio de 61 reales. Su fecha, en Santiváñez, a 21 de diciembre de 1599, ante Blas Ordóñez, escribano y vecino de Viduerna.

\footnotetext{
458 sembradura] al margen derecho: Aviñante.
}

${ }^{459}$ Heras] al margen derecho: Las Heras. 
10. $<$ Compra de un prado y un huerto. Año 1599>.

Compra que hizo el prior del Brezo a Juan García, vecino de Las Heras, de un prado, a do dicen a Botear, término de Santiváñez, que hace un carro de yerba, y de un huerto cercado en el lugar de Las Heras ${ }^{460}$ por precio de 13 ducados. Su fecha, en Aviñante, a 8 de agosto de 1599, ante el sobredicho escribano.

11. <Compra de un prado. Año 1599>.

Compra que hizo el prior del Brezo a Juan Macho, vecino de Las Heras, de un prado, a do llaman al Bamazal, al término de Santiváñez, que hace un carro de yerba, por precio de 60 reales. Su fecha, en el término de Viduerna, en la vega de tras del molino, a 16 de agosto de 1599, ante el mismo escribano.

12. $<$ Censuras para que se declaren las haciendas. Año 1608>.

Censuras de don Juan Bautista Herrera, provisor de León, para que en los ap[e]os y otras escrituras se declaren las heredades y mojones que en muchos lugares del obispado habían ocultado y vsurpado con grave perjuicio y daño del priorato de San Román. Dada en León, a 7 de junio de 1608.

\section{Remisiones}

$<$ Tierra $>$.

Véase el cajón San Plácido, legajo $1^{\circ}$, quaderno A, número $3^{\circ}$.

\section{/ (f. 322r) Legajo $2^{\circ}$ del Cajón San Martín}

Este legajo, que es el $2^{\circ}$ del cajón San Martín, contiene tres quadernos pertenecientes a San Román, que son: quaderno A: privilegios y jurisdición de San Román; quaderno B: bula y papeles de la unión de San Román a este monasterio de San Zoil; quaderno C: curato de Santa María Madre.

\section{Quaderno A del legajo $2^{\circ}$}

Este quaderno contiene los papeles pertenecientes a los privilegios y jurisdición de San Román, por el orden siguiente:

$1^{\text {o }}$. < Privilegio del rey don Alonso sobre los omicidios. Era 1292. Año 1255>.

Privilegio del rey don Alonso el Sabio, escrito en pergamino, por el qual concede al monasterio de San Román y su alfoz libertad para sus vasallos acerca de los omicidios, para que no sean condenados en ellos los que juraren que no los han cometido. Fecho en Vitoria, a 9 días andados del mes de diciembre, era de 1293, que es año de Christo de 1255.

$2^{\circ}$. < Privilegio del rey don Alonso sobre el yantar. Era 1376. Año 1338>.

Privilegio del rey don Alonso el 11, escrito en pergamino, por el qual manda al merino mayor de Castilla, que es el adelantado, que no lleve yantar al prior y convento de San Román, ni por ello le prenden, ellos ni sus sucesores; por quanto habiéndose querellado al rey dicho prior, costó por información que nunca le habían pagado. Dado en Burgos, a 30 de marzo, era de 1376, que es año de 1338.

3. <Privilegio del rey don Enrrique sobre el yantar. Era 1409. Año 1371>.

Privilegio del rey don Enrrique, escrito en pergamino, con sello de plomo pendiente en filos de seda de colores, por el qual confirma elrpivilegio de don Alonso, inserto aquí, para que el monasterio de San Román no pague yantar al adelantado mayor de Castilla ni a sus merinos. Dado en Toro, a 22 de septiembre, en la era de 1409, que es año de 1371.

${ }^{460}$ Heras] al margen derecho: Las Heras. 


\section{4. $<$ Traslado de una carta de amparo. Año 1406>.}

Traslado autorizado por Francisco Pérez, esscribano de Carrión, escrito en pergamino, de una carta de amparo que dio el rey don Enrrique $3^{\circ}$ en favor del prior y convento de San Román / (f.322v) para que a ellos ni a sus criados y vasallos no les tomen ni prenden los adelantados o sus merinos sus haciendas. Dada en la ciudad de Segovia, a 17 de agosto de 1396. Y este traslado fue sacado a 20 de julio de 1406.

5. < Poder para que no se repartan galeotes. Año 1531>.

Testimonio dado por Alonso Ruiz, esscribano ppúblico, del poder que dio fray Diego de Sahagún, prior de San Román, a otro monge de dicho monasterio para que no se haga repartimiento de galiotes a los vasallos de San Román, por ser solariegos del dicho monasterio. Su fecha, en el lugar de Viduerna, a 15 de marzo de 1531.

6. <Sentencia a favor de San Román sobre las alcabalas. Año 1534>.

Testimonio dado por Juan de Castrillo, esscribano de Carrión, de una sentencia dada por el prior de Escalada en favor del abad de San Zoil y fray Diego de Sahagún, prior de San Román, contra Fernando Méndez y consortes, los quales fueron condenados a volver 6 reales que habían llevado de alcabala por unos bueyes que el dicho prior vendió en la feria de Saldaña, siendo él y dicho monasterio exento de pagarla; y asimismo les condena en costas. Dada en Carrión, a 2 de marzo de 1534.

\section{7. $<$ Requirimiento para no pagar repartimiento del puente. Año 1556>.}

Requirimiento que hizo fray Rodrigo de Corcuera, prior de San Román, a un alguacil de León, para que no hiciese repartimiento para la puente de Villazente a los lugares de Las Heras y Santiváñez. Su fecha, en Las Heras, a 17 de noviembre de 1556.

8. $<$ Executoria contra el merino de Saldaña para que el prior de San Román pueda nombrar merino en Santiváñez. Año 1574>.

Carta executoria, a favor del prior de San Román, contra la justicia y merino mayor de la merindad real de Saldaña, ganada en el adelantamiento de Campos. Por la qual parece que, en 13 de enero de 1570, Bartholomé de Mendoza, merino mayor, se querelló ante el corregidor de Saldaña de Alonso Merino, vecino de Santiváñez, porque siendo éste nombrado por el prior de San Román para que hiciese el oficio de merino en el dicho lugar, sin orden de la justicia de Saldaña quitó a Brígida, viuda de Juan Puente, la posesión de una casa y préstamo que tenía de San Román y la dio a Juan Puente, su andado, por mandado de dicho prior, como consta del número 18 del legajo $1^{\circ}$, quaderno $\mathrm{B}$, de este cajón. $\mathrm{A}(\mathrm{a})$ cerca de lo qual el dicho corregidor de Saldaña, en 12 de junio del mismo año, dio sentencia, por la qual condenó al dicho Alonso Merino en 6 meses de / (f. 323r) destierro de Santiváñez y Saldaña y sus términos y en 600 maravedís de pena, y mandó que esta sentencia se pusiese en el archivo de Saldaña con inventario, para que costase que el prior de San Román no tenía jurisdición alguna, civil ni criminal.

$$
<1572>\text {. }
$$

De esta sentencia apeló la parte del monasterio, en 16 de junio del mismo año, ante el alcalde mayor del adelantamiento, donde se litigó la causa, en la qual el licenciado Alonso Fernández de Córdoba, alcalde mayor de dicho adelantamiento, en 30 de agosto de 1572, dio sentencia por la qual revocó la del corregidor de Saldaña y declaró que el prior y convento de San Román tiene derecho de poner merino en Santiváñez para cobrar las rentas y vrciones de sus vasallos y renteros y ponerlos en posesión de las dichas heredades y citarlos para ante el prior y convento; y absolvió al dicho Alonso Merino de lo contra él pedido y acusado. Manda que la parte del convento y prior sean amparados y reintegrados en la posesión y derecho de poder nombrar y tener el tal merino; y condena al dicho merino mayor y justicia de Saldaña a que sobre lo dicho no inquieten ni perturben al dicho Alonso Merino ni a otro alguno mientras tubiere poder del dicho prior, pena de 50.000 maravedís, mitad para la Cámara y mitad para el convento.

Notificose esta sentencia a las partes. Acusó al monasterio las rebeldías, y a su instancia el dicho alcalde mayor, por su auto declaró que, atento a haberse notificado su 
sentencia a las partes contrarias, no haber apelado, debía mandar dar y dio esta carta executoria en la villa de Palacios de Campos a 6 de marzo de 1574. La qual se notificó a la justicia y merino mayor de Saldaña y dixeron que la oían y, vsando de ella fray Diego Baca, prior de San Román, nombró por merino a Martín Macho, vecino de Santiváñez, en 27 de marzo de1575, ante Agustín de Medina, esscribano ppúblico.

\section{9. <Querella contra Medina y Macho, vecinos de Santiváñez. Año 1590>.}

Querella que puso este monasterio contra Juan de Medina y Martín Macho, vecinos de Santiváñez, y otros cómplices porque pretendieron afrentar a fray Thoribio de Sant Andrés, fray Zoil de Escobar y fray Juan de Mayorga, que estaban en San Román y El Brezo, con una petición que hicieron firmar contra ellos a diferentes personas, ofreciendo información de cosas infames / (f. 323v) para que el general les privase de voto; pero los que firmaron y concurrieron a esto se retrataron y desdigeron en estos papeles. Sucedió esto año de 1590.

\section{0. < Pleyto de maltratamiento del padre fray Zoil Escovar. Año 1606>.}

Información que mandó hacer el padre maestro fray Alonso Barrantes, siendo abad de San Zoil, de la vida y costumbres de fray Zoil de Escovar; y pleyto contra Diego de Vega y Francisco Díaz, vecino de Aviñante, que maltrataron al dicho fray Zoil. Año de 1606.

11. $<$ Declinatoria de jurisdicción $>$.

Declinatoria que hizo fray Juan, prior de San Román de la jurisdición de un provisor de León que dio un mandamiento contra él para que pareciese a satisfacer a ciertos capítulos que pusieron unos vecinos de Santiváñez.

12. <Nombramiento de merino. Año 1664>.

Bajo este número están tres testimonios dados por Marcos de la Vega y Lorenzo Luis, esscribanos, de tres nombramientos de merino hechos por los priores de San Román desde el año de 1664 hasta 1721 inclusive; y asimismo un auto del corregidor de Saldaña en que declara por bien hechos dichos nombramientos y manda a los merinos reales de dicha villa que, en los nombrados y que en adelante se nombraren por el convento de San Román y sus priores, no les perturben su vso y exercicio, según se manda por la carta executoria de arriba. Dado en Saldaña, a 12 de agosto de 1695, ante Manuel de Escandón, esscribano de dicha villa.

13. <Provisión real para que no entren ganados en los montes del Rey, Villafría y Santiváñez. Año 1671>.

Provisión de la sala a petición de este monasterio, despachada a los lugares de Las Heras, Santiváñez y Villafría, para que en los tres montes, el uno que llaman del rey, en el término de Las Heras, y otro pedazo y matas en el término de Villafría, y el otro en el lugar de Santiváñez, propio del priorato de San Román, no puedan entrar ganados, en particular los cabrunos; y que se puedan acotar los dichos montes por espacio de 20 años, para que en dicho tiempo se críen las plantas que en ellos había y las que se pusiesen nuevamente. Dada en Madrid, a 11 de julio de 1671, ante Gabriel de Aresti, esscribano de Cámara.

Al pie están las notificaciones hechas a los lugares de Santiváñez y Las Heras; pero no al de Villafría.

14. $<$ Requirimiento sobre prendas del monte. Año 1671>.

Testimonio dado por Miguel de la Vega, esscribano y vecino del lugar de Aviñante, de un requirimiento que el padre fray Francisco de Tezano, prior de San Román, hizo al regidor de Santiváñez, para que no se / (f. 324r) entrometiese a cotear la vellota del monte que dicho priorato tiene suyo propio en dicho lugar, ni a prendar a persona alguna que en dicho monte cogiese dichas vellotas por pertenecerle a él como dueño y señor dél. El regidor negó haberlo hecho en dicho monte. Su fecha, en el lugar de Santiváñez, a 29 de octubre de 1671. 


\section{5. < Testimonio del destrozo del monte. Año 1789>.}

Testimonio dado por Felipe de Balbuena, esscribano y vecino del lugar de Respenda, del destrozo y descortezo de árboles del monte llamado La Mata, propio y privativo de la casa y priorato de San Román, por reconocimiento de dos maestros que para el efecto se llamaron. Dado en San Román, a 22 de septiembre de 1789.

16. <Testimonio sobre diez carneros. Año 1789>.

Testimonio ${ }^{461}$ dado por Manuel Luis París, esscribano y vecino de Villanueva, de cómo Miguel de Liévana, vecino de Santiváñez, declaró no tener en su poder y con su proprio ganado lanar, oy día de la fecha, más que diez carneros propios del dicho priorato de San Román que allí dejó el padre fray Gregorio Calderón, prior anterior al padre maestro Fierro, por quien fue pedido este testimonio. Dado en Santiváñez a 4 de agosto de 1789.

17. $<$ Testimonio del nombramiento de merino. Año 1789>.

Testimonio dado por Manuel Luis París, esscribano de Su Magestad, del nombramiento de merino que hizo el padre maestro fray José Fierro en la persona de Manuel Villalba Mental, vecino de Santiváñez, para cobrar y recaudar las rentas, foros, etcétera, de todos los vasallos y renteros del priorato de San Román. Dado en dicho Priorato, a 14 de diciembre de $1789^{462}$.

18. < Consulta y parecer sobre el dominio territorial de Santiváñez. Año 1789>.

Consulta y parecer de dos letrados de Valladolid en que declaran que el priorato de San Román tiene muy acreditado el dominio territorial y solariego del término y lugar de Santiváñez, y como fruto vendido de esta propiedad y dominio nadie le puede disputar el vso y aprovechamiento de todos los pastos y demás vtilidades públicas de los dichos términos, no como un vecino sino como dos, sin que por esto se pueda entender ni se entienda la real cédula de 66 con el priorato de San Román, ni le pueda perjudicar en cosa alguna. Dado en Valladolid, a 29 de enero de 1789.

/ (f. 324v) 19. < Requirimiento del prior de San Román sobre 14 carneros. Año $1790>$.

Testimonio dado por Manuel García de Guadiana, esscribano y vecino de Viduerna, del requirimiento que el concejo y vecinos de Santiváñez hicieron al padre maestro fray José Fierro, prior de San Román, con 14 carneros que llevaron consigo los regidores y vecinos hasta las puertas del dicho priorato, para que les recogiese y no se propase a pastar con ellos en los términos de dicho lugar. A lo que respondió dicho padre prior que tenía hecho cierto contrato con Miguel de Liébana de tenerlos y alimentarlos hasta que dicho padre prior les llebase para matar, con otras muchas razones que expresan en este testimonio. Dado en San Román, a 29 de noviembre de 1790.

\section{0. < Pedimento del concejo contra los apeos de San Román. Año 1790>.}

Testimonio dado por Ygnacio de la Puente, esscribano de Saldaña y juez comisionado, de un pedimiento presentado por parte del regimiento y vecinos de Santiváñez sobre los muchos agravios que dice experimentaba el común en los últimos apeos practicados a solicitud del prior de San Román; que el priorato, vajo del amparo y posesión de su executoria, procura se le comuniquen las regalías y aprovechamientos de vecindad como antes las tenía, cuyo derecho protesta en nombre del común, la que fue admitida por dicho juez comisionado por su auto dado en Santiváñez, a 13 de diciembre de 1790.

\section{1. <Testimonio del destrozo del nuevo plantío. Año 1790>.}

Testimonio dado por Manuel Luis París, esscribano y vecino de Villanueva de Arriba, del reconocimiento que el padre maestro fray José Fierro, prior de San Román, hizo en

461 Testimonio] al margen derecho: Falta.

462 1789] sigue tachado: $<18>$. Testimonio dado por Manuel García de Guadiana, esscribano y vecino del lugar de Viduerna. 
compañía del padre cura y dos vecinos de Respenda del destrozo acaecido en el nuevo plantío, a el sitio intitulado la Cruz de Piedra.

22. <Sentencia y aprovación de los apeos de San Román. Año 1790>.

Testimonio dado por Ygnacio de la Puente, esscribano de Saldaña, del pleyto y sentencia de aprobación de los apeos del coto, monte, señorío, foros y regalías del priorato de San Román, dada por Alfonso de Astudillo, corregidor de Saldaña, a 9 de marzo de 1790, y confirmada por los señores de la Chancillería, con las costas en que se condena al concejo y vecinos de Santiváñez, a 25 de septiembre del mismo año, ante Zieza, esscribano de Cámara.

23. < Testimonios de los destrozos del coto de San Román. Año 1792>.

Bajo este número están cuatro testimonios dados por Ygnacio de la Puente y Manuel Luis París, esscribanos de Su Magestad, a pedimiento del padre maestro fray José Fierro, prior de San Román, de los destrozos / (f. 325r) que algunos vecinos de Santiváñez hicieron en el coto pastando en él y cortando árboles. Dados en San Román, en el año de 1792.

24. <Despacho a favor del prior de San Román sobre los aprovechamientos de Santiváñez. Año 1793>.

Despacho del corregidor de Saldaña, a favor del prior de San Román, por el qual se manda a los regidores, cocejo y vecinos del lugar de Santiváñez cumplan con lo mandado en un despacho anterior, contribuyendo a dicho padre prior y sus sucesores con todos los aprovechamientos comunes como dos vecinos de dicho lugar, reintegrándole de aquellos que no le hubiesen comunicado hasta el día de la fecha de este despacho. Dado en Saldaña, a 4 de febrero de 1793, ante Ygnacio de la Puente, esscribano de dicha villa.

\section{Remisiones}

$<$ Privilegio $>$.

Privilegio del rey don Alonso para que ninguno prenda los collazos de San Román. Véase el cajón San Pedro, legajo2 ${ }^{\circ}$, número $1^{\circ}$.

$<$ Privilegio $>$.

Privilegio del rey don Sancho por el qual hace libre de todo pecho al prior de San Román de toda la hacienda que hubiere comprado desde el tiempo de su abuelo don Fernando el Santo. Véase el mismo cajón y legajo número $6^{\circ}$.

Yantar que paga el cura de Las Heras a San Román. Cajón San Lorenzo, legajo 2, quaderno $\mathrm{C}$, número $6^{\circ}$.

$<$ Privilegio $>$.

Privilegio de un juro de 20 mill 000 maravedís. Véase el cajón San Leandro, legajo 1º, número $4^{\circ}$.

\section{/ (f. 325v) Quaderno B del legajo $2^{\circ}$}

Este quaderno B contiene las bulas y papeles pertenecientes a la vnión de San Román a este monasterio de San Zoil por el orden siguiente:

$1^{\circ}$. $<$ Bula de Eugenio $4^{\circ}$ por la que comete al arcediano de Valdonsella la vnión del priorato de San Román al monasterio de San Zoyl. Año 1443>.

Bula de Eugenio 4, escrita en pergamino, con sello de plomo pendiente, por la qual parece que don Gonzalo, abad de San Zoil, hizo relación a Su Santidad que, si bien el monasterio de San Román de Entrepeñas había sido fundado y dotado de rentas suficientes para el sustento de un prior y cinco monges que asistiesen en él para las divinas alabanzas; pero que había llegado ya a tan miserable estado y se hallaba tan destruydo que apenas se podían celebrar en él los divinos oficios, ya porque personas poderosas circumvecinas se habían alzado con sus bienes como porque hacía algunos días que había pleytos y diferencias 
entre Juan Martínez de Castro, prior de San Román, y Alonso Fernández, de una parte; y de otra, un tal Pedro Lechón, prior de Nogal, monge pretenso de dicho monasterio, en razón del dicho priorato. Y que si este se vniese al monasterio de San Zoil, siendo como era el abad poderoso, defendería los bienes de San Román y le restituyría a su antiguo ser. Y, porque de facto el dicho Pedro Lechón había despojado del dicho priorato al referido Alonso Fernández, se pidió remedio para todo. Su Santidad, por esta bula, cometió esta causa al arcediano de Valdonsella, dignidad de la yglesia de Pamplona, residente en Roma, para que, hallando ser cierta la narrativa, anexase, incorporase y vniese el priorato de San Román al monasterio de San Zoil; de suerte que, faltando su legítimo prior, o por muerte o por resignación, pudiese el abad tomar posesión de él; y que si (como se había insinuado) el dicho Alonso Fernández hiziese resignación del priorato en manos del arcediano, la admitiese y diese fin a los pleytos, poniendo perpetuo silencio, non obstantibus, etcétera; y que si la vnión se hiciere, hayan de asistir perpetuamente en San Román dos sacerdotes con sus sirvientes que se sutenten de los frutos del dicho priorato, al qual se le señalase el censo que había de pagar a Cluni como miembro suyo. Datum Rome, apud Santum Petrum, anno Domini 1443, pridie nonas decembris.

/ (f. 326r) $2^{\circ}$. $<$ Vnión del priorato de San Román al monasterio de San Zoil hecha por el arcediano de Valdonsella. Año 1443>.

Sentencia, escrita en pergamino, con sello de cera pendiente, dada por Miguel de Echarri, arcediano de Valdonsella, en virtud de la bula de comisión de Eugenio $4^{\circ}$, puesta arriba, la qual también está inserta en esta sentencia. Por la qual el dicho juez, habiendo hecho información y verificada la narrativa del abad de San Zoil, hace vnión, anexión e incorporación del priorato de San Román al monasterio de San Zoil, con todos sus frutos, rentas, etcétera. Da facultad al abad para que, dejando el priorato su prior legítimo, o por muerte o resignación, pueda libremente tomar posesión de él con todos sus derechos y pertenencias. Y, habiéndose presentado una resignación del dicho priorato hecha por Alonso Fernández, que a la sazón era prior de San Román, la aceta el dicho juez y pone fin a todos los pleytos movidos entre Juan Martínez de Castro, Alonso Fernández, priores de San Román, y Pedro Lechón, que pretendía el dicho priorato, y les pone perpetuo silencio en esta causa. Pone censuras a qualquiera que impidiere a don Gonzalo, abad de San Zoil, y sus sucesores la posesión de la dicha vnión y el vso de los frutos de dicho priorato. Dada en Roma, año de 1443, ante Guillelmo Lesne, nottario appostólico.

Hay dos copias de esta sentencia, la $1^{a}$ autorizada por Antonio Fernández de Guzmán, nottario y vecino de Frómesta; la $2^{\mathrm{a}}$ no está autorizada.

$3^{\circ}$. < Proceso de un pleyto entre Juan Martínez, Alonso Fernández y Pedro Lechón sobre el priorato de San Román y posesión de él que se dio a Pedro Lechón. Año 1443>.

Proceso en el qual está inserta una bula del Papa Eugenio $4^{\circ}$, dada a instancia de Pedro Lechón, monge y prior de Nogal, en cuya narrativa se hace mención que Alfonso Fernández, monge del monasterio de San Zoil, dio noticia a Su Santidad que Juan Martínez de Castro, prior de San Román, no atendiendo a su estado ni reputación, había destruido los bienes del monasterio, y los que habían quedado se consumían en vsos ilícitos, etcétera, Lo qual, advertido por Su Santidad, dio comisión al deán de León y a dos dignidades de aquella yglesia y les mandó hacer información del caso y conocer de él. Y si, citados y llamados los interesados, hallasen ser verdad lo sobredicho, privasen por sentencia al dicho Juan Martínez del dicho priorato de San Román y, caso que se efectuase la dicha privación, no habiendo legítimo impedimento, diesen el priorato al dicho Alfonso Fernández.

Siendo requerido con esta comisión appostólica, / (f. 326v) Juan de Grajal, canónigo y deán de León, conoció de esta causa y dio en ella sentencia, por la qual privó al dicho Juan Martínez del priorato y se le dio a Alonso Fernández. Apeló Juan Martínez y, por no haber seguido la apelación, quedó desierta. Estando la causa en este estado, los dichos Juan Martínez y Alonso Fernández la comprometieron en Gonzalo Ruiz de la Vega, lego, el qual les compuso dejando en el priorato para que le sirviese al dicho Juan Martínez y por súbdito suyo al dicho Alonso Fernández; pero con la obligación de dar a éste cierta pensión de pan. De todo lo qual hizo relación a Su Santidad el dicho Pedro Lechón, prior de Nogal, y alegó que la apelación interpuesta por Juan Martínez de la sentencia dada por el deán de León era 
desierta y la sentencia pasada en cosa juzgada. Por lo qual, y porque el dicho Alonso Fernández había renunciado y cedido su derecho y se había sujetado a ser súbdito de Juan Martínez, el priorato de San Román con efecto estaba vacante. Atento a lo qual y, a que de tener el dicho Juan Martínez el priorato se podían temer mayores daños que los pasados, Su Santidad dio bulla de comisión dirigida al arcediano de Valdemeriel, al maestro de escuela y provisor de León, para que conociesen de esta causa; y, hallando ser cierta la narrativa de Pedro Lechón, no habiendo impedimento de derecho (fuera de ser hijo de clérigo y soltera, en que estaba habilitado) le diesen dicho priorato.

$<$ Sentencia a favor de Pedro Lechón $>$.

Fue requerido con esta comisión appostólica el dicho arcediano de Valdemeriel, el qual halló por sus informaciones ser verdadera la narración de Pedro Lechón. Y así lo declaró por su sentencia, dada en 20 de mayo de 1443, e hizo provión (sic) y colación del priorato de San Román al dicho Pedro Lechón, mandando que se le acudiese con los frutos de él. En 5 de julio del mismo año tomó posesión de dicho priorato. Después de esto el mismo Eugenio $4^{\circ}$, a instancia del abad de San Zoil, don Gonzalo, dio la bulla que está en el número $1^{\circ}$ y el arcediano de Valdonsella vnió a San Zoil el priorato de San Román como consta del instrumento que está en el número $2^{\circ}$; pero este pleyto pasó adelante, como se verá en las bulas y escrituras siguientes.

/ (f. 327r) $4^{\circ} .<$ Sentencia del abad de Cardeña por la qual se declara ser canónica la vnión de San Román a San Zoil. Año 1446>.

Sentencia, escrita en pergamino, dada en Roma por don Pedro, abad de Cardeña, por comisión appostólica de la Santidad de Eugenio $4^{\circ}$, en virtud de la relación que hizo a Su Santidad don Pedro, abad de San Zoil, de los pleytos y resistencia que hacía Pedro Lechón por la vnión del priorato de San Román al monasterio de San Zoil. Por esta sentencia declara el dicho abad de Cardeña ser canónica y legítima la dicha vnión e incorporación del dicho priorato y que el dicho monasterio de San Román, con todos sus frutos, pertenecen al monasterio de San Zoil, conforme a derecho, y así se lo adjudicó; con que siempre asistan en San Román dos sacerdotes con sus sirvientes que se sustenten con los frutos de él, cumplan con las obligaciones de los divinos oficios; y que señalen para cada año el censo que han de pagar al monasterio de Cluni. Declara que Pedro Lechón no tenía derecho alguno al priorato y que injustamente le había impedido la posesión de él al abad y convento del monasterio de San Zoil. Pónele perpetuo silencio y le condena a pagar todos los frutos que había llevado del priorato desde que se puso el pleyto. Dada en Roma, a 12 de septiembre de 1446. Está autorizada, signada y refrendada de Juan Fernández de Medina, clérigo seguntino, nottario appostólico.

$5^{\circ} .<$ Bulla de Eugenio $4^{\circ}$ para que se execute la sentencia del abad de Cardeña y se vna San Román a San Zoil. Año 1446>.

Bulla de Eugenio $4^{\circ}$, escrita en pergamino, con sello de plomo pendiente, dirigida a los abades de Sahagún, Benevívere y al deán de la yglesia seguntina, en la qual se hace mención de la bula del mismo Eugenio, que es la del número $1^{\circ}$, y de la vnión que en virtud de ella hizo el arcediano de Valdonsella del priorato de San Román al monasterio de San Zoil, y que, no obstante, este Pedro Lechón se había entrado en dicho priorato e impedía al abad y convento de San Zoil la posesión de él. Por lo qual Su Santidad, a petición de don Pedro, abad de dicho monasterio, concedió esta bula de comisión para los dichos abades y deán, a los quales o a qualquiera de ellos manda que, expeliendo y quitando del dicho priorato a Pedro Lechón, ponga en verdadera, real y pacífica posesión de él al dicho abad y convento de San Zoil y de todas las pertenencias y derechos del dicho priorato y hagan que Pedro Lechón restituya los frutos del priorato, conforme a la sentencia del dicho abad de Cardeña; y que procedan contra los rebeldes, inobedientes, impedientes o contradicentes ${ }_{s}$ por censuras e invocación del brazo seglar, etcétera. Dada en Roma, en el año de 1446.

6. $<$ Renuncia de Pedro Lechón del priorato. Año 1446>.

Testimonio, escrito en pergamino, dado por Juan González de Ravanal, clérigo, notario apostólico, de la renuncia que hizo Pedro Lechón, prior intruso de San Román, en manos de don Pedro Tosantos, abad de San Zoil, del priorato de San Román, y 
consentimiento que dio para que se vniese perpetuamente / (f.327v) al monasterio de San Zoil. Su fecha, en este monasterio, a 7 de enero de 1446.

7. $<$ Declaración de la reforma de San Román. Año 1510>.

Declaración e ynformación por la qual consta que el monasterio de San Román admitió la reforma y vnión a la congregación, quando este de San Zoil, y que el abad de San Benito ponía allí prior y monges. Su fecha, en Valladolid, a 30 de enero de 1510, ante Francisco de Gerez, esscribano y nottario appostólico.

8. <Testimonio de cómo San Román es filiación de San Zoil. Año 1667>.

Testimonio dado por Norverto de Saldoval y Guevara, esscribano de Carrión, de cómo el priorato de San Román es filiación de este monasterio de San Zoil, y que así consta de bullas, privilegios y otros papeles. Su fecha, en Carrión, a 18 de septiembre de 1667.

\section{/ (f. 328r) Quaderno C del legajo $2^{\circ}$ Curato}

Este quaderno C contiene los papeles pertenecientes al curato de Santa María Madre, presentaciones y colaciones de él, por el orden siguiente: Año 1333>.

$1^{\circ}$. < Presentación de la yglesia de San Juan de Santiváñez en Martín Abad. Era 1371.

Escritura en pergamino por la qual el prior y convento de San Román dan la yglesia de San Juan de Santiváñez a Martín Abad, racionero de San Román, para que la sirva por todos los días de su vida, y por ello le dan todo el pie de altar, con todas las aventuras y el tercio de pan y de los diezmos y las tierras y prados que solía tener Martín Domínguez; y asimismo se obligan a darle ración por toda su vida en el dicho monasterio bien y cumplidamente. Su fecha, a 24 de marzo, en la era de 1371, que es año de 1333, ante Juan Pérez, esscribano de Guardo.

$2^{\circ}$. < Carta de racionero y vicario de Barrio y Santiváñez. Era 1386. Año 1348>

Escritura en pergamino por la qual don Estevan, prior de San Román, con el poder que tenía de la orden y del abad de Cluni, da ración de pan, vino y carne, como se daba a los monges, a Juan Abad, clérigo de Tarilonte, con condición que siga las horas del coro en San Román y que diga cada semana tres días misa en dicho monasterio y que los otros cuatro días diga misa en Barrio ${ }^{463}$ y en Santiváñez, y le concede la mitad de los diezmos del ganado y menudos de Barrio y Santiváñez. Su fecha, en la villa de Guardo, a 18 de octubre, en la era de 1386, que es año de 1348, ante Álbar González, esscribano de dicha villa.

De aquí consta que San Román llevava los diezmos.

$3^{\circ}$. $<$ Sentencia para que el cura de Las Heras, Santiváñez y Santa María Madre resida en San Román. Año 1456>.

Testimonio dado por Alfonso Moniz de Mieres, esscribano y nottario de León, de una sentencia dada por don Gutierre González de Quirós, arcediano de Saldaña, contra Juan de Prado, cura de Las Heras, de Santiváñez y Santa María Madre, en virtud de una querella que dieron contra él, el concejo y hombres buenos de San Román porque el dicho cura no residía en este lugar. Por esta sentencia se le manda pena de excomunión y de privación del beneficio de San Román, que viva y resida en el lugar de San Román, a cuyos parroquianos diga misa, horas canónicas y administre sacramentos, y que en Las Heras diga cada semana dos misas y de tres domingos diga el uno allí misa. Dada en Congosto, a 28 de junio de 1456.

${ }^{463}$ Barrio] al margen derecho: Varrio. 
$<$ Nota $>$.

Por estos dos papeles consta que San Román antes estaba poblado. Año 1485>.

/ (f. 328v $)$ 4. <Colación del curato de Santa María Madre en Rodrigo de Espinosa.

Colación del beneficio curado de Santa María Madre hecha por el licenciado don Pedro de la Vega, provisor de León, en Rodrigo de Espinosa, clérigo, por fin y muerte de Juan de Prado, su último poseedor, y en virtud de la presentación que en él hizo don Luis Hurtado de Mendoza, abad comendatario de San Zoil. Su fecha, en León, a 27 de julio de 1485, ante Juan Ramírez, nottario de dicha ciudad.

Está aquí la licencia que el dicho abad comendatario dio a Juan Fernández Cobo, beneficiado de la villa de Monzón y cura de Santa María Madre, para resignar este curato; y de la presentación que dicho señor hizo de él en el referido Rodrigo de Espinosa, su criado, ante Gonzalo Pérez de Tremello, clérigo y nottario appostólico.

\section{$5^{\circ}$. <Testamento y dotación del hospital de Santiváñez. Año 1501>.}

Testamento de Juan de Villalbeto, vecino de Santiváñez, marido de Mayor, por el qual manda al hospital que fundó fuera del dicho lugar diversas tierras para reparos del dicho hospital. Fue otorgado en dicho hospital, donde moraba el dicho Juan de Villalbeto, a 17 de febrero de 1501, ante Gonzalo de Valderrábano, esscribano y vecino de Viduerna.

6. <Presentación del curato de Santa María madre en Juan Ruiz. Año 1505>.

Presentación del beneficio curado de Santa María Madre hecha por don Luis Hurtado de Mendoza, abad comendatario de San Zoil, en Juan Ruiz, clérigo de la yglesia de San Estevan del lugar de Villalbeto, diócesis de Burgos, por fin y muerte de Rodrigo Espinosa, su último poseedor. Su fecha, en el lugar de Mezerrero, a 13 de octubre de 1505, ante Pedro de Castro, esscribano y nottario.

Está aquí un testimonio dado por Ýñigo del Castillo, clérigo y nottario appostólico, del poder que el referido Juan Ruiz dio a Alonso Gascón, clérigo del dicho lugar de Villalbeto, para que en su nombre tomase la posesión y reciviese la colación del dicho curato de Santa María Madre.

Asimismo está aquí la carta de edicto dada por el bachiller Diego de Huidobro, provisor de León, en virtud de esta presentación, para que acudiesen ante él todos los que tubiesen derecho al beneficio curado de Santa María Madre. Dada en León, a 21 del mismo mes y año.

\section{7. < Colación del curato de Santa María Madre en Alonso Gascón. Año 1518>.}

Colación del beneficio curado de Santa María Madre hecha por don Alonso Villarroel, provisor de León, en Alonso Gascón, clérigo, en virtud de la presentación que en él hizo don Juan Rodríguez de Fonseca, arzobispo rosano y abad comendatario de San Zoil, y por la resignación que hizo de dicho beneficio Juan Ruiz, su último poseedor. Su fecha, en León, a 10 de agosto de 1518, ante Juan de Vegas, nottario de dicha ciudad.

/ (f. 329r) $8^{\circ}$. < Licencias para permutar el curato de Santa María Madre. Año 1523>.

Dos licencias que dio don Juan Rodríguez de Fonseca, abad comendatario de San Zoil, a Juan Alonso, beneficiado de Canduela, y a Alonso Gascón, cura de Santa María Madre, para que mutuamente permutasen sus beneficios. Dadas en Valladolid y Burgos, a 29 de enero y 6 de julio de 1523, ante Gerónimo López, nottario appostólico.

\section{9. <Colación del curato de Santa María Madre en Juan Ibáñez. Año 1529>.}

Colación del beneficio curado de Santa María Madre hecha por don Pedro Manuel, obispo de León, en Juan Ybáñez, presvítero, en virtud de la presentación que en él hizo el presidente y convento de San Zoil por fin y muerte de Alonso Gascón, su último poseedor. Su fecha, en Zea, a 15 de octubre de 1529, ante Francisco Hortiz, nottario appostólico. 


\section{0. $<$ Renuncia del curato de Santa María Madre. Año 1533>.}

Testimonio dado por Juan de Castrillo, esscribano y nottario de Carrión, de la renuncia que hizo Juan Ybáñez del beneficio curado de Santa María Madre con sus anexos. Su fecha, en el monasterio de San Zoil, a 24 de septiembre de 1533.

Está aquí la licencia y consentimiento que, para esta renuncia a favor de Christóval Gómez, clérigo de la diócesis de León, dio el padre maestro fray Alonso de Virves, abad de San Zoil.

11. $<$ Recivo de varias presentaciones y colaciones. Año 1559>.

Recivo firmado de Alonso de Calzada, clérigo, vecino de Carrión, de varias presentaciones y colaciones que recivió del prior del monasterio de San Zoil para presentarlas ante el arcediano de Saldaña en el pleyto que había sobre el beneficio del lugar de Aviñante. Su fecha, en San Zoil, a 15 de junio de 1559.

\section{2. < Vnión del beneficio curado de Santiváñez a San Román. Año 1572>.}

Vnión del beneficio curado de Santiváñez al monasterio de San Román hecha por el licenciado Tehófilo Guerra, provisor de León, por la qual consta que, visitando el dicho provisor la yglesia parroquial de Santa María Madre, halló que el lugar de Santiváñez estaba anejo al beneficio de Las Heras, el uno al otro y el otro al otro, y ambos a la yglesia de Santa María Madre, y que sobre la división de los dichos lugares se trataba pleyto entre el prior de San Román y los vecinos de Las Heras, y que por evitar los dichos pleytos se hizo la desvnión con consentimiento de San Román, y que después de ella se les administraron los sacramentos y se les dijo misa por los monges de San Román conforme a la dicha visita. Asimismo le constó que de tiempo inmemorial a aquella parte pertenecían a San Román la mitad de todos los diezmos, frutos y rentas mayores y menores, oblaciones y emolumentos de los vecinos de Santiváñez, parroquianos de Santa María Madre, y que con la otra mitad de frutos no se podía susten/ (f. 329v)tar un clérigo que sirviese el beneficio de Santiváñez, y que a los vecinos de este lugar les estaba mejor ir a misa y a los demás oficios a San Román, donde está sita su propia parroquia, y recivir del prior y monges los santos sacramentos que no en otra parte. Los vecinos de Santiváñez tubieron por bien que su lugar y feligresía se anejase e incorporase de nuevo a San Román según lo había sido de tiempo inmemorial a aquella parte. Por lo qual el dicho provisor fue personalmente a visitar la dicha yglesia, y lo que resultó de dicha visita está escrito a la letra en esta escritura; la qual visita se hizo en San Román, a 8 de abril de 1572.

Por la ynformación que el dicho señor provisor hizo de seis personas que para el intento habían nombrado los vecinos de Santiváñez, conoció que convenía todo lo que queda dicho; y después de algunas órdenes que dio acerca de la policía de la yglesia, mandó que el dicho beneficio de Santiváñez se sirva y administre por un monge de la orden de San Benito que resida en el monasterio de San Román que no sea el prior de él, porque con más facilidad se confiesen los feligreses. El qual dicho monge ha de ser examinado y aprobado por el señor obispo de León y, así aprobado, administre los sacramentos a los dichos parroquianos; y, habiendo negligencia en esto, pueda ser multado en los frutos del beneficio. Y el tal religioso ha de poder ser amovido y quitado del dicho beneficio siempre que el ordinario lo mandare, con tal que en lugar de él pongan luego otro religioso que sirva el beneficio, aprobado también por el ordinario; el qual además de la administración de sacramentos ha de hacer lo siguiente:

Primeramente que el tal monge ha de decir misa cantada y oficiársela a los demás religiosos todos los domingos y fiestas de guardar, y los demás días rezada por los vecinos del lugar.

$2^{\circ}$. Que la semana en que no hubiere fiesta de guardar diga tres misas rezadas en la hermita de Santiváñez, las quales han de ser del día y por el pueblo. Y, si la semana tragere fiestas se ha de disminuir el número de las tres misas según las fiestas que hubiere.

$3^{\circ}$. Los días de fiesta que lloviere o nevare mucho ha de hir el monge a decir misa a la hermita y cumpla con decir la rezada; esto es, no pudiendo los feligreses ir a oírla a San Román. 
$4^{\circ}$. Que el tal monge esté / (f. 330r) obligado a obedecer los mandamientos del ordinario y sus visitadores en lo que tocare al servicio del dicho beneficio y cumplir con las demás obligaciones a que los demás curas del obispado están obligados. Asimismo mandó que los vecinos de Santiváñez estén y pasen por lo suso dicho y acudan al monasterio de San Román con todos los diezmos mayores y menores, obligaciones y emolumentos que están obligados y están en costumbre de dar al dicho monasterio y a las personas que antes servían el dicho beneficio.

Después de lo qual, en Santiváñez a 25 de abril de 1572, Agustín de Medina, esscribano real, leyó y notificó estos capítulos de visita al concejo, regidores y vecinos de Santiváñez, juntos en concejo a campana tañida, los quales dijeron que los abedecían y aceptaban y que estaban prontos a cumplir lo que por la dicha visita les hera mandado. Y pidieron y suplicaron al prior y monges de San Román lo aceptasen; quienes, notificados por el mismo esscribano, dijeron que cumplirían lo que se oredenaba y mandaba.

$<$ Vnión $>$.

Por lo qual, atenta la evidente utilidad del servicio en lo espiritual de los vecinos de Santiváñez y para que mejor sean servidos y se les administren los santos sacramentos, el dicho provisor, por la presente, en la mejor forma que en derecho pudo, anejó e incorporó la dicha feligresía de Santiváñez para siempre jamás al dicho monasterio de San Román e hizo de la dicha parroquia anexión e incorporación, título y colación al prior, monges y convento de dicho monasterio que ahora son y serán para siempre jamás; para que, con toda la otra mitad de frutos, diezmos y rentas, fueros y derechos que los dichos vecinos de Santiváñez solían pagar, diezmar y ofrecer a la persona que les administraba los sacramentos, los hayan y lleven los dichos prior y monges de San Román y con el cargo del servicio de misas y administración de sacramentos, conforme a lo dispuesto en la dicha visita. Y manda a qualquier clérigo o nottario que pongan a los dichos monges en posesión del dicho beneficio y feligresía de Santiváñez, y a los vecinos que tengan al prior y monges de San Román por su verdadero cura y rector, como a tal acudan con la otra mitad de los frutos, diezmos, etcétera, como queda dicho. Y que, si para más validación / (f.330v) y firmeza de esta anexión e incorporación fuere necesario el beneplácito y confirmación de Su Santidad, como tal ordinario de este obispado y en nombre del señor obispo cuyo vicario hera (y porque así convenía se hiciese porque lo había visto por vista de ojos), pide y suplica a Su Santidad lo confirme y apruebe, e interponga a ello su autoridad y decreto. Dada en León, a 12 de abril de 1573, ante Andrés Pérez de Madrid, esscribano y nottario de dicha ciudad.

Hay copia autorizada, por el mismo esscribano, de esta escritura.

$<$ Nota $>$.

En el año 1577 se trató de que esta vnión se confirmase en Roma y no efectuó por no haverse embiado la relación copiosa con las causas que hubo por esta vnión, como consta de una carta de los procuradores generales que entonces había en Roma, que lo heran fray Juan Guzmán y fray Diego Villar, escrita a fray Ambrosio de Nágera, abad de San Zoil, que está con esta vnión. Lo cierto es que con el título de ser pobre el beneficio de Santiváñez, pudo el ordinario hacer la vnión en la forma hecha, como consta del Concilio Tridentino De Reformationa, sessión 21, capítulo $5^{\circ}$, cuyo título es: Propter ecclesiarum paupertatem et in casibus a jure permissis faciat episcopus vniones perpetuas quarumcunque ecclesiarum parrochialium et aliorum beneficiorum etiam non curatorum cum curatis.

13. $<$ Libro de visitas de la parroquia de Santa María Madre desde el año de 1574 hasta el de $1608>$.

Libro de las visitas hechas por los ordinarios de León en la parroquia de Santa María Madre desde el año de 1574 hasta el de 1608; pero adviértase que antes de este tiempo se escribían estas visitas en el libro de ellas que estaba en Las Heras, por estar vnidos los dos curatos de Las Heras y Santiváñez. Pero después que se desvnieron estos dos beneficios y el de Santiváñez se vnió a San Román, se hizo este libro por mandado de los obispos y sus visitadores. Desde el año de 1608 hasta su desmembración se hacía la visita del Santísimo en el altar de Santa María Madre, que está fuera de la reja, visitábase la pila bautismal y óleos santos y no se escrivía nada ni se tomaban cuentas. 
14. < Bulla de Clemente VIII que es impetra del beneficio de Santiváñez. Año 1592>.

Bula de Clemente $8^{\circ}$ cometida al ordinario de Palencia (por estar vaco el obispado de Léon) concedida a instancia de Fernando Sánchez de Robles, el qual impetró de Su Santidad el beneficio de Santiváñez a título de estar vaco por muerte de Juan Bartholomé Oreja, cura que fue y murió en el mes de septiembre, y los monges de San Román, dice, haberse entrado en él sin título ni fundamento. Dada en Roma, IIII kalendas marzii, año 1592. (Perjudicial ${ }^{464}$ ). $1593>$.

/ (f. 331r 15. < Apartamiento de la impetra del beneficio de Santa María Madre. Año

Testimonio dado por Andrés Sánchez, esscribano de Carrión, del apartamiento y renuncia que hizo Fernando Sánchez de Ro(ro)bles del beneficio curado de Santa María Madre del lugar de Santiváñez; cuya provisión y presentación declara él mismo haber sido de tiempo immemorial a aquella parte del monasterio de San Zoil y del priorato de San Román. Su fecha' en San Zoil' a 22 de noviembre de 1593. Año 1598>.

16. $<$ Pleyto contra el cura de Villafría que se entró a servir el curato de Santiváñez.

Querella que dio fray Antonio Perroto, prior de San Román, ante el abad de Benevívere, juez conservador, contra Andrés de Espundia, cura de Villafría, porque se entró a servir el curato del lugar de Santiváñez' en virtud de un mandamiento dado por el licenciado Pozo, provisor de León, a título de que dicho beneficio estaba vaco. El juez conservador dio comisión al cura de Villaverde de la Peña para que hiciese información. Hízola y por ella consta la acción que tiene el monasterio a este curato y su posesión immemorial. Remitiose al juez conservador, no pasó adelante porque el cura conoció que no tenía justicia y se apartó del pleyto, que pasó año de 1598. $1620>$.

17. <Mandamiento para que se repartan los Santos Óleos desde San Román. Año

Mandamiento del provisor de León a petición del prior de San Román para que el arcipreste lleve allí los santos óleos y desde allí se repartan como de cabeza de arciprestadgo. Dado en León' a 8 de agosto de 1620' ante Pedro Álvarez, nottario. Síguese la notificación y el cumplimiento de dicho mandamiento hecho por el dicho arcipreste.

18. < Protestas para que no visiten los arcedianos de Saldaña. Año 1630>.

Dos protestas con requerimientos hechos por los priores de San Román a los arcedianos de Saldaña porque visitaron la parroquia de Santa María Madre. La una protesta es del año de 1588 y la otra de 1630, ante Juan Martínez de Ocón, esscribano y nottario de León.

19. $<$ Requirimiento para no poner la cruz de piedra. Año 1636>.

Requerimiento que hicieron los vecinos del lugar de Santiváñez al padre fray Gregorio Caballero por ausencia del padre prior de San Román para impedir el hacer y poner la cruz de piedra que está más abajo de la casa. Su fecha' en Santiváñez a 12 de agosto de 1636' ante Pedro de la Calle, esscribano y vecino de Fontecha.

20. $<$ Licencia para hacer oficio de cura. Año 1640>.

Licencia $^{465}$ que dio el señor don Bartholomé Santos, obispo de León, al padre fray Mauro Bázquez, para que aga el oficio de cura en el priorato de San Román por el tiempo que fuere la voluntad del abad, y asimismo para que administre el sacramento de la penitencia y predicar en todo el obispado por el tiempo de su voluntad. Dada en León' a 6 de junio de 1640' ante Juan Bautista Oyos, secretario. $1656>$.

/ (f. 331v $21 .<$ Escritura de patronato de San Román y revocación de la misma. Año

\footnotetext{
464 Perjudicial] al margen derecho: Perjudicial.

465 Licencia] al margen derecho: Falta.
} 
Bajo este número están los papeles siguientes:

$1^{\circ}$. Vna escritura de obligación ${ }^{466}$ por la qual el abad, monges y convento de San Zoil se convinieron con don Carlos Enrríquez Cisneros y Alvornoz y con doña Antonia Bázquez, su muger, señores de Mazuelas, sobre darles dos sepulturas encima de las gradas del altar mayor de San Román, y asimismo la capilla que está al lado de la epístola, bajo algunas condiciones perjudiciales a esta casa y a dicho priorato; según consta de esta escritura' otorgada en 26 de abril de 1646' ante Francisco Moro de Saldaña, esscribano de Carrión.

$2^{\circ}$. Nueva escritura por la qual el padre fray Juan Enrríquez, en virtud del poder que tenía de este monasterio, estando en el lugar de Mazuelas juntamente con dichos señores, revocaron en todo y por todo la escritura antecedente y se les volvieron los 75 mill maravedís que habían dado' según consta de esta escritura' que se otorgó en dicho lugar' en 3 de marzo de 1656' ante Juan de Calzada Bonifaz, esscribano de Saldaña.

22. <Memoria de aniversarios, obras pías y sus fincas. Año 1668>.

Bajo este número está un pedimiento del padre fray Gerónimo de la Sierra, cura de Santiváñez, ante el provisor de León, en que se queja de que los bienes y rentas de las yglesias de San Román y Santiváñez, sus fábricas y rectorías y los de aniversarios, etcétera, hacía mucho tiempo que no se apeaban ni se sabía quién las llevava' y pide que el señor provisor dé comisión a qualquiera cura para que ante esscribano o nottario hiciese la averiguación de todos los bienes pertenecientes así a la fábrica como a los aniversarios, etcétera. En virtud del qual pedimiento el licenciado don Diego Llano, provisor de León, dio su comisión para la dicha averiguación, que despachó en León' a 25 de mayo de 1667' ante Juan González de Armentero, secretario. Requiriose con este despacho a Juan de Escandón Bustamante, el qual aceptó y pasó a la averiguación.

Vltimamente está un testimonio dado por Francisco de la Vega, esscribano de Castrejón, de la entrega de los bienes que se hizo a Rafael Merino, vecino de Santiváñez, con la carga de misas que sobre ellos fundaron sus padres en Santa María Madre. Su fecha' en Castrejón' a 8 de abril de 1669.

23. <Testimonio de un aniversario. Año 1671>.

Testimonio dado por Miguel de la Vega, esscribano y vecino de Aviñante, de una claúsula sacada de la tabla de los aniversarios que se dicen en San Román en el mes de diciembre. Su fecha' en dicho priorato' a 31 de agosto de 1671.

24. <Despacho del provisor de León a favor de San Román sobre el repartimiento de los Santos Óleos. Año 1716>.

Despacho librado por el señor don Juan Lorenzo Rallol, provisor de León, en execución de una sentencia inserta aquí a favor del prior de San Román contra don Pedro López de Madriz, arcipreste de dicho arciprestadgo, por la qual se le manda que todos / (f. $332 r$ ) los años y en tiempo competente vaya personalmente al priorato de San Román a cebar las crismeras de la parroquia del priorato del dicho monasterio antes o después del repartimiento de las demás parroquias; y así lo cumplan dicho arcipreste o sus tenientes' pena de excomunión mayor y de diez ducados de apercibimiento. En conformidad de esta sentencia fue dado este despacho' en León' a 11 de diciembre de 1716' ante Estevan Álvarez, secretario.

25. $<$ Parecer sobre poner armas en San Román>.

Parecer $^{467}$ del doctor Flórez sobre que don Juan Enrríquez, señor de Campo Redondo, no puede poner sus armas en la yglesia de San Román.

26. $<$ Memorial de advertencias $>$.

Memorial de advertencias de algunas cosas tocantes al govierno de San Román y otros papeles pertenecientes a aniversarios, memorias, etcétera, todos de poca importancia.

466 obligación] al margen: Falta.

${ }^{467}$ Parecer] al margen derecho: Falta. 
27. <Libros de bautizados, etcétera $>$.

Libro de bautizados, casados y difuntos en San María Madre' que comienza en 23 de noviembre de 1572 y concluye en 5 de octubre de 1621.

28. <Testimonio sobre querer los vecinos de Santiváñez cura monge. Año 1793>.

Testimonio dado por Manuel Luis París, esscribano de Villanueva de Arriba, de haber declarado los regidores y procurador síndico general o personero del lugar de Santiváñez que la mayor parte del vecindario no querían otro párroco que a los monges benitos con quien habían vivido siempre bien vnidos y en buena armonía. Su fecha' en Santiváñez’ a 30 de enero de 1793.

/ (f. 332v) Legajo $3^{\circ}$ del Cajón 12 San Martín

Este legajo, que es el $3^{\circ}$ del cajón San Martín, contiene cartas de pago y conocimientos de subsidio i escusado, y otros papeles semejantes; pero no tiene otra cosa considerable.

\section{/ (f. 333r) Legajo $4^{\circ}$ del Cajón San Martín} siguientes:

Este legajo, que es el $4^{\circ}$ del cajón San Martín, contiene cinco quadernos, que son los

Quaderno A Santiago del Bal y Santoyo.

B Soles.

C Tabanera.

D Tarilonte.

E Terradillos.

\section{Quaderno A del legajo $4^{\circ}$ \\ Santiago del Bal y Santoyo}

Este quaderno A contiene los papeles pertenecientes a la hacienda que tiene este monasterio en estos lugares' por el orden siguiente:

$1^{\circ}$. <Testamento de fray José Cornejo. Año 1641>.

Testamento que otorgó el hermano fray José Cornejo, lego de este monasterio, por el qual, después de 113 misas que manda se digan por el alma de sus padres y su muger, deja por heredero a este monasterio de todos sus bienes, que son: vna casa con media huerta en el lugar de Santiago del Bal, siete tierras y un majuelo en el término de dicho lugar y un majuelo en término de Torre ${ }^{468}$. Fue otorgado en el monasterio de San Zoil' a 28 de julio de 1641, ante fray Juan de Cisneros, nottario appostólico.

$2^{\circ}$. <Adjudicación de 9 viñas y una tierra en Santoyo. Año 1742>.

Testimonio dado por Manuel de la Fuente, esscribano de Santoyo, de la adjudicación que se hizo a este monasterio de nueve viñas y una tierra en el término de dicho lugar, en el concurso que se formó a los bienes de María Sánchez, vecina de él, por el capital y réditos de un censo a favor de este monasterio. Su fecha' en Santoyo' a 4 de noviembre de 1742. 1771.

Hay aquí otro testimonio del mismo esscribano y sobre lo mismo, sacado año de Año 1742>.

$3^{\circ}$. $<$ Adjudicación de 4 tierras en Santiago del Bal y cinco tierras y un viña en Santoyo.

Testimonio dado por Manuel de La Fuente, esscribano de la villa de Santoyo, de la adjudicación que se hizo a este monasterio por la / (f. $333 v$ justicia ordinaria de dicha villa, a

468 Torre] al margen derecho: Torre. 
saber: de cuatro tierras en el término de Santiago del Bal y una viña en el término de Santoyo, en el concurso que se formó a los bienes de Juan Delgado y María Fernández, vecinos de Santoyo, por el capital y réditos de un censo que tenía este monasterio a su favor. Su fecha' en Santoyo' a 1 de diciembre de 1742.

Hay aquí otro testimonio sobre la misma adjudicación dado por Santiago Andrés Pérez Delgado, esscribano de dicha villa, en 20 de septiembre de 1771.

\section{/ (f. 334r) Quaderno B del Legajo ${ }^{\circ}$ \\ Soles}

Este quaderno B contiene los papeles pertenecientes a la hacienda que tiene Nuestra Señora del Brezo en el término de Soles por el orden siguiente:

$1^{\circ}$. <Escritura de censo de 2000 maravedís a favor de Beatriz del Puerto. Año 1578>.

Escritura de censo por la qual Bartholomé del Valle, cura de Pino de Viduerna, y consortes compraron un censo de 2 mil maravedís de renta en cada un año de Beatriz del Puerto, viuda, vecina de Saldaña, por 28 mil maravedís que de ella recivieron, los quales fundan sobre ciertas heredades. Su fecha, en Saldaña, a 4 de abril de 1578, ante Francisco Gómez, escribano de dicha villa. Los herederos de dicho Bartholomé del Valle redimieron y pagaron este censo al doctor Martínez, nieto de la dicha Beatriz, como consta de la carta de pago que está al fin de esta escritura, fecha en Saldaña, a 7 de marzo de 1619, ante Antonia Bedoya, escribano de dicha villa.

\section{$2^{\circ}$. <Censo de 4000 maravedís en favor de Beatriz del Puerto. Año 1583>.}

Escritura de censo que otorgaron Pedro Martín y Bartholomé del Valle, clérigo, vecinos de Pino, a favor de Beatriz del Puerto, de 4 mil maravedís de fuero y censo perpetuo al quitar, por precio de 56 mil maravedís que dio la dicha Beatriz. Y para seguridad se ypotecaron muchas heredades de las contrayentes y se pretendió que entre ellas estaba una tierra que había comprado El Brezo, más no parece en el censo por especial ypoteca. Su fecha, en Saldaña, a 30 de noviembre de 1583, ante Melchor Fernández, escribano de dicha villa.

$3^{\circ}$. <Compra de una tierra. Año 1592>.

Compra que hizo el padre fray Francisco Villafuertes, prior de Nuestra Señora del Brezo, de una tierra en los términos de Santiváñez y Aviñante, que está a do dicen a la Sopeña de Soles, que hace carga y media de trigo de sembradura, por precio de 114 ducados y horra de alcabala que por ella pagó dicho prior. Su fecha, en el monasterio del Brezo, a 28 de marzo de 1592, ante García de Cossío, escribano de la jurisdicción de la villa de La Puebla. Está duplicada esta escritura. $1612>$.

/ (f. 334v $) 4^{\circ} .<$ Execución y carta de gasto del censo de Beatriz del Puerto. Año

Execución judicial del doctor Pedro Ignacio Martínez, cura de San Miguel de Saldaña, por 4 mil maravedís, costas y décima de los réditos del censo de Beatriz del Puerto, su abuela; y carta de gasto del mismo para los fiadores de Bartholomé del Valle, que pagaron esta cantidad y ellos executaron, y se pagaron en ciertas heredades ypotecadas en el dicho censo. Todos son autos judiciales del corregidor de Saldaña hechos en los años de 1612 y 1618, ante Antonio Bedoya, escribano de dicha villa.

5. $<$ Renunciación de herencia. Año 1612>.

Escritura de renunciación que hicieron los hijos de Pedro Martín y Francisca Alonso, su muger (obligados al censo de Beatriz del Puerto), de la herencia de sus padres. Fecha en Carrión, a 18 de noviembre de 1612, ante Gerónimo López, escribano de dicha villa. 
6. <Cesión de estos censos a favor del monasterio. Año 1619>.

Escritura de cesión y traspaso que otorgó Roque Díaz de Rábago, como nieto y heredero de Beatriz del Puerto, en favor del abad, monges y convento de San Zoil, de 56 mil maravedís de principal de un censo contra Pedro Martín y Bartholomé del Balle, vecinos de Pino, con más 28 mil 800 maravedía de réditos, costas y décima que quedó a pagarle el convento. Su fecha, en Saldaña, a 7 de marzo de 1619, ante Antonio de Bedoya, escribano de dicha villa.

7. <Testimonio de 78 mil maravedís que pagó el monasterio. Año 1619>.

Testimonio dado por Antonio de Bedoya, escribano de Saldaña, de la carta de pago que otorgó Roque Díaz de Rábago, vecino de dicha villa, de 78 mil maravedís que recivió del monasterio de San Zoil por mano de fray Plácido Perea y Pedro Merino, vecino de Santiváñez, por la cesión que hizo de los censos, y de que le había hecho escritura de obligación el monasterio. Su fecha, en Saldaña, a 13 de abril de 1619. $1619>$.

8. <Carta judicial de los bienes ypotecados a los censos de Beatriz del Puerto. Año

Carta judicial actuada ante don Pedro de Mendoza, corregidor de Saldaña, ante quien executó Roque Díaz de Rábajo a los herederos de Pedro Martín y Bartholomé del Valle, vecinos de Pino de Viduerna, por 20 mil maravedís / (f. 335r) de los réditos corridos que debían pagar al dicho Roque Díaz como heredero de Beatriz del Puerto, su abuela, por un censo que ella había comprado a los dichos Bartholomé del Valle y consortes. Trabose la execución en los bienes executados y, hechos los autos, se opuso el prior del Brezo, diciendo que entre los demás bienes ypotecados estaba la tierra de Soles que hera de la casa del Brezo; y si bien se dio por libre en el mandamiento de remate y posesión; con todo eso, por asegurarla más, el monasterio de San Zoil compró el dicho censo a Roque Díaz de Rábago, como consta del testimonio antecedente, el qual cedió en el monasterio todo el derecho que tenía el principal el censo, y a sus réditos, junto con el derecho de la execución de ellos, la qual se adjudicó a la parte del monasterio y se le mandó dar y dio la posesión de los bienes ypotecados, que después vendió el prior del Brezo para pagar el censo de Roque Díaz, que montó principal y réditos 86 mil maravedís, que se pagaron en una obligación de 78 mil maravedís, dos ducados, que había cobrado de Juan de Medina por unas heredades ypotecadas al censo y los 7 mil y tantos maravedís restantes que remitió y dio de limosna para Nuestra Señora del Brezo. De toda esta historia no sacó nada la casa del Brezo, porque la tierra de Soles no estaba ypotecada, ni consta por el censo, y así no necesitó de asegurarse; y si en la posesión que tomó el prior del Brezo de las ypotecas, que heran muchas y de gran valor, hubo algún aprovechamiento fue para el dicho prior y no para la casa. Estos autos pasaron año de 1619, ante Antonio de Bedoya, escribano de Saldaña.

\section{Remisiones}

$<$ Prado $>$.

Trueque de un prado para San Román. Véase el cajón San Gregorio, legajo 2, quaderno $\mathrm{D}$, número $2^{\circ}$.

\section{/ (f. 335r) Quaderno C del legajo $4^{\circ}$ \\ Tabanera}

Este quaderno contiene los papeles pertenecientes a la hacienda que tiene San Román en este lugar por el orden siguiente:

$1^{\circ}$. < Posesión de la hacienda de Tabanera. Año 1412>.

Escritura por la qual Juan Gómez de Valderábano puso en posesión a don Fernando, prior mayor de San Zoil, de unos solares, heras y heredades que él tenía en el lugar de Tabanera y sus términos, la qual hacienda le había dado por la heredad y señorío que el dicho 
prior tenía en el lugar de Villaires (o Villarías) encima de Saldaña ${ }^{469}$. Y manda a los renteros que acudan con las rentas al dicho prior. Su fecha, a 20 de noviembre de 1412, ante Diego González de Cerbatos, escribano público.

$$
2^{\circ} \text {. <Apeos de Tabanera. Año 1646>. }
$$

Tres apeos de las tierras, linares y prados que hay en el lugar de Tabanera, hechos en los años de 1564, 1607 y 1646. Todos tres están sin autoridad.

\section{Remisiones}

Esta hacienda pertenece a San Román por el trueque que hizo el prior de San Zoil con el de San Román. Véase el trueque cajón San Martín, legajo $1^{\circ}$, quaderno B, número $3^{\circ}$.

\section{/ (f.336r) Quaderno D del legajo $4^{\circ}$ Tarilonte}

Este quaderno D contiene los papeles pertenecientes a la hacienda que tiene este monasterio por el orden siguiente: $1356>$.

$1^{\circ}$. $<$ Trueque de dos tierras o dos solares y una tierra en Tarilonte. Era 1394. Año

Escritura en pergamino por la qual don Estevan, prior de San Román, da a Juan Rodríguez de Valderábano, vecino de Villalbeto, dos tierras que el dicho monasterio de San Román tenía en Villanueva de Valdefuecha (o Fontecha) por dos solares ${ }^{470}$ y una tierra que el dicho Juan Rodríguez le dio en Tarilonte. Su fecha, en Guardo, a 3 de marzo, era de 1394, que es año de 1356, ante Fernán García, escribano ${ }^{471}$. Está duplicada esta escritura en pergamino, y asimismo hay copia autorizada de ella por Antonio Martín García, traductor y notario apostólico.

$2^{\circ}<$ Compra de dos tierra y un linar. Año 1765>.

Compra que hizo el padre fray Zoil Trigo, prior de Nuestra Señora del Brezo, a José Alonso y Manuel Gutiérrez, vecinos de Tarilonte, de dos tierras y un linar en término de dicho lugar; que las tierras están a do dicen el Camino del Oyo; y la una hace una fanega de trigo de sembradura y la otra cinco celemines; y el linar está a do dicen las Zarzas, que hace un quarto de linaza de sembradura, por precio de 796 reales que por ellas pagó dicho prior. Su fecha, en Tarilonte, a 29 de marzo de 1765, ante José Pérez de Salazar, escribano y vecino de Respenda.

\section{3. $<$ Compra de una tierra. Año 1765 $>$.}

Compra que hizo el padre fray Zoil Trigo, prior de Nuestra Señora del Brezo, a José Calbo, vecino de Tarilonte, de una tierra en término de dicho lugar, a do dicen las Canteras, que hace ocho celemines de trigo de sembradura, por precio de 209 reales que por ella pagó dicho prior. Su fecha, en Tarilonte, a 29 de marzo de 1765, ante José Pérez de Salazar, escribano y vecino de Respenda.

\section{/ (f. 336v) $4^{\circ} .<$ Compra de tres tierras. Año 1765>.}

Compra que hizo el mismo fray Zoil Trigo a Antonio Calbo, vecino de Tarilonte, de tres tierras en término de dicho lugar; que la una está a do dicen La Cubilla y hace 8 celemines de trigo de sembradura; la otra, a do dicen El Oyo y hace otros 8 celemines de trigo, y la otra está a do dicen La Mata de Juan García, y hace 8 celemines de centeno, por precio de 535 reales que por ellas pagó dicho padre prior. Su fecha, en Tarilonte, a 21 de marzo de 1765, ante José Pérez de Salazar, escribano público.

\footnotetext{
${ }^{469}$ Saldaña] al margen derecho: Villayres o Villarías.

470 solares] al margen derecho: Villanueva de Fontecha.

471 escribano] sigue tachado: público.
} 
5. $<$ Compra de dos tierras. Año 1765>.

Compra que hizo el mismo fray Zoil Trigo a Manuel Vallejo, vecino de Velilla de Tarilonte, de dos tierras; la una en término del lugar de Tarilonte, a do llaman el Turumbón, que hace quarto y medio de centeno, y la otra en término del lugar de Aviñante ${ }^{472}$, a do llaman San Andrés, que hace más de un quarto de morcajo, por precio de 233 reales que por ellas pagó dicho padre prior. Su fecha, en El Brezo, a 10 de mayo de 1765, ante José Luis París, escribano y vecino de Villanueva de Muñeca.

6. <Compra de dos tierras. Año 1765>.

Compra que hizo el mismo fray Zoil Trigo a Patricio Calbo, como curador de Juan Rodríguez, vecinos de Tarilonte, de dos tierras en término de dicho lugar; que la una está a do llaman so la Torre, que hace un quarto de trigo, y la otra a do llaman el Oyo, de la misma cavida, por precio de 460 reales que por ellas pagó dicho padre prior; las que se vendieron con autoridad de justicia, como consta de las diligencias practicadas insertas en esta escritura, que fue otorgada en la Villa de Saldaña, a 13 de mayo de 1765, ante José Quijano Duque, esctibano de dicha villa.

\section{7. $<$ Compra de una tierra. Año 1765>.}

Compra que hizo el mismo padre fray Zoil Trigo a María Alonso, viuda, vecina de Tarilonte, de una tierra linar en término de dicho lugar, a do dicen de la Carrera, que hace una fanega y medio quarto de linaza de sembradura, por precio de 615 reales que por ella pagó dicho padre prior. Su fecha, en Tarilonte, a 24 de mayo de 1765, ante José Pérez de Salazar, escribano público.

8. <Compra de una tierra. Año 1765>.

Compra que hizo el mismo fray Zoil Trigo a Manuel del Prado, menor en días, vecino de Tarilonte, de una tierra en término de dicho lugar, a do dicen el Revollo, que hace 5 celemines de trigo de sembradura, por precio de 150 reales que por ella pagó dicho padre fray Zoil. Su fecha, en Tarilonte, a 24 de mayo de 1765, ante José Pérez de Salazar, escribano y vecino de Respenda.

En la segunda pieza de este pleyto, que es lo actuado ante el alcalde mayor del adelantamiento, intitulada $\mathrm{B}$, está compulsado el título que el monasterio tiene del lugar de Valcabado y Revilla (véase dicha pieza al folio 144 vuelta), que, habiendo dado a foro este lugar al doctor Amaro Díaz de Flores, como consta atrás, le entregó el título que tenía de este lugar y él le presentó en el adelantamiento para el pleyto que tubo con la villa de Saldaña y el duque del Ynfantado, su dueño.

Al fin de estas cinco piezas están varios papeles sueltos, que los más no tienen ni principio ni fin y así tienen muy poca o ninguna autoridad; pero si de algo sirviesen, véase.

$$
\text { / (f. 337r) Remisiones }
$$

$<$ Tierra $>$.

Una tierra en Velilla. Véase el cajón San Gregorio, legajo 2 ${ }^{\circ}$, quaderno E, número $6^{\circ}$. $<$ Linar $>$.

Un linar de trueque. Cajón San Estevan, legajo 2 ${ }^{\circ}$ quaderno A, número 7.

\section{/ (f. 337r) Quaderno E del legajo $4^{\circ}$ \\ Terradillos}

Este quaderno E contiene los papeles pertenecientes a la hacienda que el monasterio tiene en este lugar, por el orden siguiente:

${ }^{472}$ Aviñante] al margen derecho: Aviñante. 
$1^{\circ} .<$ Demanda sobre unos suelos y casas. Año 1542>.

Demanda que puso el monasterio ante el prior de Escalada, juez conservador, a Toribio García y Juan Prieto, clérigos de Terradillos, porque pedían cierto aniversario sobre unos suelos y casas libres que tenía el monasterio en este lugar. $\mathrm{Y}$, siendo y compareciendo ante el dicho juez, confesaron no haber tal aniversario y digeron no le pedirían; y el juez conservador les puso perpetuo silencio para que no le pidiesen jamás. Su fecha, en Carrión a 12 de abril de 1542, ante Juan de Castrillo, escribano de dicha villa.

$2^{\circ}$. $<$ Sentencia y posesión de una tierra. Año 1790>

Sentencia dada por el corregidor de Saldaña a favor de este monasterio contra el concejo de Lagartos ${ }^{473}$ sobre una tierra de la qual tomó posesión el monasterio. Su fecha, en Saldaña, a 23 de diciembre de 1790, ante Ygnacio de la Puente, esscribano de dicha villa.

$$
\text { / (f. 337v) Las Tiendas }
$$

Al último de los papeles de Terradillos está una copia simple de la donación que hizo don Bernardo Martín, del Hospital de Santa María de Las Tiendas, de la Orden de Santiago, que se trajo para ciertos asumptos con otros papeles; de la qual hice dos copias, y la una está en la cámara para lo que se pueda ofrecer. Fue hecha en la era de 1228, que corresponde al año 1190.

\footnotetext{
${ }^{473}$ Lagartos] al margen derecho: Lagartos.
} 
/ (f. 338r) Cajón 13 San Facundo

Este cajón San Facundo, que es el décimo tercio del archivo, contiene seis legajos, todos pertenecientes a Toro y su comarca, que son: legajo $1^{\circ}$ : hacienda antigua; legajo $2^{\circ}$ : memoriales y informaciones sobre el pleyto; legajos $3^{\circ}, 4^{\circ}, 5^{\circ}$ y $6^{\circ}$ : lo mismo.

Toro y su comarca

Legajo $1^{\circ}$ del Cajón San Facundo

$<$ Foro perpetuo de 4000 maravedís de juro de doña Beatriz Rodríguez de Fonseca por la hacienda de Benafarces. Año 1448>.

El primer legajo de este cajón consta de escrituras antiguas de la hacienda que tubo el monasterio de San Zoil en Toro y su comarca por el priorato de San Pelayo de aquella ciudad. Por las quales constaba haber tenido y posehído el monasterio de San Zoil esta hacienda desde antes del año de 1210, pues desde entonces se hallan escrituras de ella. Las que hay en este legajo son 32, las quales están por su orden y no se ponen aquí porque, supuesto el estado de esta hacienda, no es necesario. Adviértase que la escritura del número 31, escrita en pergamino y otorgada en el año de 1448, es de foro perpetuo; por la qual don Pedro de Tosantos ${ }^{474}$, abad, el prior mayor y convento de San Zoil, con los requisitos necesarios y confirmación auténtica dan en foro perpetuo a doña Beatriz Rodríguez de Fonseca, viuda del doctor Juan Alfonso, toda la hacienda y heredades que el monasterio tenía en el lugar de Benafarces, jurisdicción de Toro y diócesis de Zamora, con su jurisdicción, vasallos y diezmos, por precio de 4 mill maravedís de juro de renta en cada año, cuya primera condición es que no entre en esta escritura el patronazgo y derechos de presentar que tenía el convento en las yglesias de Santa María y San Martín de Benafarces ${ }^{475}$ porque esto quedó para el monasterio. Cabían las heredades que dio el monasterio en este foro el año que se sembrasen 200 cargas de pan. Fue hecha el año de 1448, ante Juan Sánchez de Cantalapiedra, nottario appostólico y esscribano real.

Esta escritura es la confirmación con autoridad aapostólica que hizo don Juan Rodríguez de Toro, arcediano de Valderas, por comisión del Papa Eugenio $4^{\circ}$, inserto el proceder, autos, escritura de foro y todos los instrumentos que pasaron en este contrato.

\section{/ (f. 338v) Legajo $2^{\circ}$ Cajón 12 San Facundo}

El $2^{\circ}$ legajo de este cajón es de informaciones en derecho, memoriales y advertencias hechas en todas instancias para el pleyto que el monasterio tubo sobre la hacienda de San Pelayo de Toro y lugares de su comarca con Viveros, Fonsecas y Vlloas.

\section{Legajos $3^{\circ}, 4^{\circ}, 5^{\circ}$ y $6^{\circ}$ Cajón 12 San Facundo \\ Toro y su comarca}

Estos cuatro legajos de este cajón constan de las esscrituras de permuta y transación que hizo este convento de la hacienda de Toro con Pedro de Vivero el Viejo y después con su hijo Pedro de Vivero y Juan de Vlloa y Fernando de Fonseca. Y asimismo tienen también los memoriales y papeles de los pleytos que ha habido entre Fonsecas, Viveros y Vlloas y otras comunidades y personas en cuyo poder entró la hacienda que fue del monasterio en Toro y su tierra, litigados después que el monasterio. Vltimamente fue condenado en el consejo con las mil y quinientas doblas en que se toca toda la acción que este convento tubo a la hacienda y esscrituras que el monasterio, quando litigó, no pudo descubrir por la malicia de los interesados que las tubieron ocultas; y después, pleiteando entre sí, las sacaron y presentaron. Hay también trasumptos de los brebes appostólicos de comisión para el prior de San Benito de Valladolid para la confirmación de la primera escritura de transación y otros que ocultó Pedro de Vivero y no hubo noticia de ellos hasta que en estos años los sacó o trajo de Roma el Marqués de La Mota.

\footnotetext{
474 Pedro de Tosantos] al margen derecho: Abad don Pedro de Tosantos.

475 Benafarces] al margen derecho: Presentación de los beneficios de Benafarces.
} 


\section{Remisiones}

Foro perpetuo de ${ }^{476} 11$ mill maravedís, privilegios y juros. Véase el cajón San Leandro, legajo $1^{\circ}$, número $3^{\circ}$.

\section{/ (f. 339r) Relación de la hacienda que tubo el monasterio de San Zoil en Toro, su enagenación y pleytos}

$<1210>$.

La hacienda que este monasterio de San Zoil tubo y perdió en la ciudad de Toro y en veinte lugares de su comarca fue tan grande y lucida que, después que salió de su poder, se pudieron ilustrar con ella no solo tres familias de Viveros, Fonsecas y Vlloas, que constan ser en estos tiempos de las más prósperas y nobles de Castilla, sino también algunas comunidades principales y muchas personas particulares en quien se desmembró y dividió. Es tan antigua que no parece memoria cierta de dónde la hubo el monasterio o quién se la donó, porque como no tenemos cosa cierta de la primera fundación de este monasterio tampoco se halla del origen de su priorato de San Pelayo de Toro, ni de esta hacienda que siempre estubo anexa a él. Sólo hay por tradición que como a esta casa la reedificaron los infantes que llamaron de Carrión (y nosotros nuestros fundadores), el cónsul don Gómez Díaz, la señora condesa doña Theresa, su muger, y los infantes, sus hijos; así entró esta hacienda de Toro con otras que dieron a este monasterio en su dotación y, como ni de aquellos nos han quedado esscrituras con ser tan constante en tradición, tampoco de esto. Sólo se halla memoria cierta de haber gozado el convento esta hacienda desde antes de los años de 1210 hasta el de 1443 en que se enagenó, que son 233 años, en que por lo menos consta haberla gozado quieta y pacíficamente.

En el año de 1443, 24 días del mes de abril, don Gonzalo de Cerbatos, abad de San Zoil, juntó el convento en la Casa de la Limosna, que era extra claustra monasterii (en este tiempo el monasterio era claustral e inmediato a la Sede Appostólica) y les propuso a los monges dél (que tenían poca noticia del caso) la permuta de la hacienda que el monasterio tenía en la ciudad de Toro y su comarca por 11 mill maravedís de juro que ofrecía por ella Pedro de Vivero, vecino de Toro y guarda mayor del rey don Juan el $2^{\circ}$, hombre muy valido y poderoso en aquel tiempo y aún deudo del abad y amigo suyo; $y$, habiéndose propuesto al convento que la hacienda no valía más que 120 cargas de trigo de renta, de que sacando las cotas, gastos ${ }^{477}$, cobranzas y encargos, le venían a quedar al convento menos intereses, que no pasaban de 7 mill maravedís y a veces no eran más de 4 mill, con esta propuesta de un abad, mal entendida de un convento, respondió que con/ (f. 339v)venía el contrato y, si bien de mala, vinieron en ello. En 8 días de marzo del mismo año, estando presente el mismo Pedro de Vivero, se juntó el convento en su capítulo y, sin haver precedido más tratados ni licencia $<y$ consentimiento $>$ del superior, que era necesaria, el abad volvió a proponer al convento la misma permuta. Estaban los monges prevenidos con que (como consta de las informaciones del convento) Pedro de Vivero había dado a Pedro García, prior del convento, cuarenta doblas de oro para que hablandase y consintiese; a los juniores y novicios los había alagado con razones sophísticas y dineros (que los más de los nombrados en la escritura eran mozos, juniores y novicios sin noticia y sin experiencia). Pero no se pudo conquistar por este camino un monge llamado don Luis de la Varguilla, pues, no habiendo consentido en la primera proposición, le mandó el abad comer pan y agua y, viendo que ni esto bastaba para que diese su consentimiento, le metió en la cárcel, donde le tubo hasta este día fatal del desacierto del otorgamiento de la escritura, que, sacando al monge de la cárcel para que asistiese al contrato con los demás después de haber propuesto el abad y dado su consentimiento los demás, le dixo a éste: “¿Y vos, don Luis, que decís a esto? , ¿dais vuestro consentimiento?". Respondió el monge: "Yo consiento a pesar de Dios. ¡Notable confusión!". Pero estaban ciegos, unos con la pasión y otros con el interés. Al fin, sin embargo, se otorgó la escritura de permuta (que así la llamaron) ante Joán Ochoa de

\footnotetext{
476 de] sigue tachado: estos.

477 gastos] sigue tachado: $\mathrm{y}$.
} 
Marquina, esscribano de cámara del rey y su nottario ppúblico, que le trajo Pedro de Vivero para este efecto, y Álvaro González de Carrión, esscribano de esta villa; por la qual, en trueque y cambio de 11 mill maravedís de juro que se obligó a dar don Pedro de Vivero, librados por privilegio real en cabeza del monasterio de San Zoil, el convento le hizo cesión de todos los bienes y hacienda que tenía en la ciudad de Toro y lugares de su comarca, por mayor y sin expresarlos en particular ni decir todos los lugares ni señalar las heredades y posesiones de ellos ni nombrar las yglesias, beneficios, diezmos y jurisdicciones. Pero de las provanzas y escrituras que presentó el convento consta que la hacienda fue la siguiente:

Primeramente en Toro la yglesia de San Pelayo con su beneficio, diezmos y lo demás que le pertenecía, con vnas casas y corrales junto a ella, en que solía vivir el prior de San Pelayo y un monge compañero. La Aceña escrivana con seis quiñones, que rentavan a 2 mill maravedís, y todos 12 mill <maravedís>; la Aceña Troya, la de la Rivera del Puerto, la de la Rivera de la Peral, y en todas tenía el monasterio diversos quiñones, que en todas rentaba 30 mill maravedís, y su valor apreciado en venta era 490 mill 000 maravedís. Más tenía en Toro una hera y otras posesiones de viñas y heredades.

/ (f. 340r) Más en el lugar de Vez de Marbán ${ }^{478}, 192$ cargas de sembradura que rentavan 142 cargas de trigo, 3 cargas de cebada, doce carros de paja y 48 pares de gallinas.

En Pinillas ${ }^{479} 8$ cargas de sembradura y de renta 30 cargas de trigo, 9 pares de gallinas y tres carros de paja.

En Fuentes ${ }^{480} 45$ cargas de sembradura y un herrenal, renta de 20 cargas de trigo y 2 pares de gallinas.

En Villar ${ }^{481} 60$ cargas de sembradura, renta 28 cargas de trigo, 6 pares de gallinas y dos carros de paja.

En Pozo Antiguo ${ }^{482} 160$ cargas de sembradura, 4 foros, 2 heras, renta 60 cargas de trigo y 6 pares de gallinas.

En Vezames ${ }^{483} 92$ cargas de sembradura, otra heredad y una casa, renta 40 cargas de trigo y 12 pares de gallinas.

En Malva ${ }^{484} 20$ cargas de trigo de sembradura, renta 6 cargas de trigo ${ }^{485}$.

En Morales ${ }^{486} 80$ cargas de sembradura, renta 20 cargas de trigo, 3 pares de gallinas y 3 carros de paja.

En Pedrosa ${ }^{487} 20$ cargas de sembradura y una huerta, renta 8 cargas, 3 fanegas de trigo y 3 fanegas de zebada.

En Villavendimio ${ }^{488} 70$ cargas de sembradura y un herrenal, renta 2 cargas y una fanega de trigo.

Tenía también posesiones y heredades en los lugares de Bustillo, Tiedra, Villaveza, Tagarabuena, Villalfonso, Adalia, Castroquemado ${ }^{489}$ y otros.

$<$ Renta de la hacienda de Toro $>$.

\footnotetext{
478 Vez de Marbán] al margen derecho: Vez de Marbán.

479 Pinillas] al margen derecho: Pinillas.

${ }^{480}$ Fuentes] al margen derecho: Fuentes.

481 Villar] al margen derecho: Villar.

482 Pozo Antiguo] al margen derecho: Pozo Antiguo.

483 Vezames] al margen derecho: Vezames.

$\left.{ }^{484} \mathrm{Malva}\right]$ al margen derecho: Malva.

485 trigo] sigue tachado: 3 pares de gallinas, 3 carros de paja.

486 Morales] al margen derecho: Morales.

487 Pedrosa] al margen derecho: Pedrosa.

488 Villavendimio] al margen derecho: Villavendimio.

${ }^{489}$ Castroquemado] al margen derecho: Bustillo, Tiedra, Villaveza, Tagarabuena, Villalfonso, Adalia, Castroquemado.
} 
Los testigos dicen y es común opinión que, quando se permutó y enagenó esta hacienda, había en ella por lo menos mil cargas de sembradura, jurisdiciones, diezmos, yglesias, presentaciones de tres beneficios, casas, aceñas, quiñones, huertas, etcétera, y que todo rentaba mil cargas de trigo cada año, ciento de cebada, 30 mill maravedís en dinero, 300 pares de gallinas y 200 carros de paja, todo puesto en Toro a costa de los renteros, y sin que en esto tuviese costa considerable el convento.

$<24$ condiciones de la escritura de permuta $>$.

Esta escritura, con las circunstancias dichas, se otorgó por ambas partes, con las firmezas necesarias, a favor de Pedro de Vivero, pendiente de 24 condiciones que en ella están insertas, por falta de las quales o de qualquiera de ellas la escritura es nula, como de ella consta, y son:

Primera, que el convento hace traspaso de todos los dichos bienes; y Pedro de Vivero, de los 11 mill maravedís de juro.

$2^{a}$. Que se exceptúa y queda para el monasterio todo lo que doña Beatriz Rodríguez de Fonseca tiene en [d]el convento en Benafarces ${ }^{490}$.

$3^{\text {a }}$. Quede para el abad el patronazgo de la yglesia de San Pelayo de Toro, y en ella tenga derecho de presentación el clérigo que Pedro de Vivero o sus herederos le propusieren, y no otro, tanto que sea idóneo.

$4^{a}$. Queden para el monasterio las casas, corral y huerta que están junto a la yglesia de San Pelayo, y lo demás quede para Vivero y sus sucesores, habiendo para ello decreto de la Sede Áppostólica.

$5^{\mathrm{a}}$. Que con el dicho decreto haya Vivero todos los frutos y rentas de todos los bienes, y disponer de ello desde $1^{\circ}$ de enero pasado.

Gozó antes de la confirmación appostólica.

6. Que dé Vivero 11 mill maravedís de renta, situados en las afueras de los lugares que quisiere el monasterio. sacado a su costa.

$/(f .340 v) 7^{\mathrm{a}}$. Que dentro de dos años entregue Vivero al convento el juro

$8^{a}$. Que en tanto que saca el privilegio pague al monasterio los 11 mill maravedís de renta cada año.

$9^{a}$. Que Vivero asegure el juro si en algún tiempo faltare o no se cobrare.

$10^{\mathrm{a}}$. Que no se puedan vender ni enagenar las dichas heredades sin licencia del convento, el qual las pueda tomar por el tanto que otro diere si quisiere.

$11^{a}$. Si esta hacienda en algún tiempo volviere al monasterio, se vuelvan a Vivero y sus sucesores los 11 mill maravedís de juro.

$12^{a}$. Que no tengan esta hacienda más que uno o dos herederos y no se divida en más sin licencia del convento.

$13^{\text {a }}$. Que reciva Pedro de Vivero la posesión de esta hacienda interviniendo el procurador del convento por inventario, deslindamiento y apeo de todas las heredades para que en todo tiempo haya memoria de ellas.

No se cumplió.

14a. Que Vivero tenga por su cuenta el sustento de la yglesia de San Pelayo, clérigo de ella con todos los encargos de ésta y de todas las demás haciendas.

$15^{\mathrm{a}}$. Que todos bienes que cede el monasterio estén anexos e hipotecados a los 11 mill maravedís de juro para seguridad de ellos.

${ }^{490}$ Benafarces] al margen derecho: Benafarces. 
$16^{\mathrm{a}}$. Que el monasterio y sus bienes estén obligados a la seguridad de los bienes que se deslindaren en la posesión que de ellos tomare Vivero.

$17^{\mathrm{a}}$. Que Vivero saque de Su Santidad breve de confirmación para que, sin pena alguna, se pueda otorgar todo lo sobredicho; y hacen la traspasación de todo ello para que el contrato sea válido. Vivero gozó antes de la confirmación y la que hubo fue nula.

$18^{a}$. Que si el comisario de la confirmación hallare por información que la hacienda del monasterio merece más que los 11 mill maravedís de renta, Vivero añada a ellos lo que el comisario juzgare. No se cumplió.

19a. Que Vivero trayga a su costa el rescripto de la confirmación dentro de dos años, quedando Vivero con el rescripto y confirmación original y dando al convento trasumpto autorizado en forma.

de todos.

$20^{\mathrm{a}}$. Que ambas partes otorguen de todo escrituras con juramento a provecho

$21^{\mathrm{a}}$. Que fuera de lo dicho Vivero otorgue qualesquiera otros capítulos que por el abad le fueren dados antes de la execución del rescripto y confirmación para la seguridad y saneamiento del convento.

22a. Que si Pedro de Vivero no (no) traxere el rescripto appostólico dentro del dicho término, esté obligado a pagar al convento los 11 mill maravedís, puestos en San Zoil a su costa por sus tercios, hasta que trayga el rescripto y se execute.

$23^{\mathrm{a}}$. Que todas las escrituras, instrumentos y recaudos de esta permuta pasen por ante dos esscribanos.

$24^{a}$. Que el convento dé y entregue a Pedro de Vivero todas las esscrituras sacadas y autorizadas a costa de Vivero que fueren pedidas por él o sus sucesores para seguridad de la hacienda.

De estas 24 condiciones que están insertas en la dicha escritura de permuta son muy / (f. 341r) pocas lasque cumplió Pedro de Vivero, de las que le tocaban a favor del monasterio, y sólo atendió al gozo de la hacienda de que al punto tomó posesión, sin cumplir la $13^{\text {a }}$ condición de apear y deslindar las posesiones y heredades que recibió del monasterio.

$<$ Breve de confirmación de Eugenio $4^{\circ}$ papa. Año 1444>.

En 27 días del mes de enero de 1444, a instancia del monasterio ${ }^{491}$ y Pedro de Vivero, el papa Eugenio $4^{\circ}$ dio su breve de comisión para el arcediano de Náxera, en la yglesia de Calahorra, para que, constándole por información que el dicho contrato era en evidente vtilidad de este convento, lo aprobase y confirmase. En cuyo cumplimiento Diego Botello, arcediano de Náxera, estando residente en la ciudad de Salamanca (y con presumpta de prevendado de aquella yglesia y que no lo era ya de la de Calahorra) procedió e hizo sus autos, de los quales (aunque según la relación de su sentencia fue citada la parte del monasterio) no consta ni parece haber asistido la parte del convento a lo actuado y sentenciado por él. $1447>$.

$<$ Sentencia de confirmación de la escritura dada por el arcediano de Náxera. Año

Antes, según la dicha relación, con solas diligencias hechas por la parte de Pedro de Vivero, en 9 días del mes de agosto del año de 1447, cinco meses después de muerto el papa Eugenio $4^{\circ}$, que le dio la comisión y breve, y sin que conste haber aceptado ni comenzado a executar la dicha comisión durante la vida del dicho papa Eugenio $4^{\circ}$, el dicho Diego Botello dio y pronunció sentencia de confirmación, por la qual parece confirmar y aprovar el dicho contrato y escritura de permuta. Y, porque por ventura le constó que los bienes que daba el monasterio valían más de los 11 mill maravedís de juro que había ofrecido Pedro de Vivero, por ellos y para adelante el monasterio no pretendiese haber sido agraviado ni lesso, mandó que, además de los 11 mill maravedís de juro dichos, el dicho Pedro de Vivero añadiese otros

\footnotetext{
${ }^{491}$ monasterio] al margen derecho: Murió el abad don Gonzalo y le sucedió don Pedro de Valdevieso y a éste don
} Pedro de Tosantos. 
2 mill 000 maravedís de renta tales en cada un año, a satisfacción del monasterio, que por todos fuesen cada año 13 mill 000 maravedís de juro.

$<$ Apeló el convento de la sentencia del arcediano de Nágera>.

No quedó el convento satisfecho desta sentencia, antes pretendió estar por ella grandemente agraviado y, haviendo presumido este agravio a causa del poder grande y favor que tenía Pedro de Vivero, no compareció a lo actuado y sentenciado por el dicho arcediano. Por lo qual apeló el convento para ante Su Santidad de la dicha sentencia y confirmación.

$<$ Cométese la causa al maestro Guillelmo de Fondera $>$.

Aceptó la apelación el papa Nicolao $\mathrm{V}^{\mathrm{o}}$ y por su breve la cometió al maestro Guiliermo de Fondera, auditor de las causas del Santo Palacio, etcétera; el qual procedió haiendo algunos autos sin concluir ni decidir cosa alguna de esta causa. Año 1449>.

$<$ El convento ratifica el contrato con Vivero y la sentencia del arcediano de Náxera.

Estando en este estado y pendiente la causa en Roma, por escusarse el convento de las molestias y vexaciones que Pedro de Vivero y sus amigos le hacían, el abad don Pedro de Tosantos $^{492}$ y el convento de San Zoil (habiendo intervenido el arzobispo de Toledo y muchos y grandes señores) se convinieron con Pedro de Vivero y concordaron en ratificar (como de hecho ratificaron), confirmaron, aprovaron y juraron guardar el otro contrato y permuta / (f. 341v) y asimismo la dicha sentencia y confirmación del dicho arcediano de Náxera, en 7 de agosto de 1449 años. Y Pedro de Vivero dio y entregó al convento el juro de los 11 mill maravedís y el privilegio de él que hasta entonces (que fueron 6 años) no le había entregado ni el monasterio le había gozado por haber estado empeñado o embargado en poder de un esscribano de Carrión. Y asimismo, de consentimiento de ambas partes, Pedro de Vivero entregó al convento 41 mill maravedís en moneda corriente por los dos mil maravedís que el arcediano de Náxera había mandado en sentencia añadir a los 11 mill maravedís contenidos en la dicha escritura de permuta. Lo qual así hecho, el convento suplicó en forma a Su Santidad el mismo día que confirmase y aprovase todo lo hecho. La qual diha (sic) súplica aprobó Pedro de Vivero, estando en Valladolid, a 13 días de agosto del dicho año 1449. Esta escritura no tubo tratados, hízola un esscribano que embió Pedro de Vivero de la Corte.

En 29 de octubre de 1449 años, en virtud de la dicha súplica, el mismo papa Nicolao $\mathrm{V}^{\mathrm{o}}$ dio su breve y comisión al obispo de Palencia para que, precediendo información de evidente vtilidad en favor del monasterio, procediese en esta causa y la aprovase y confirmase o la absolviese. Este breve se dio sin haber hecho verdadera narrativa al pontífice, pues se dice que Pedro de Vivero había cumplido con el convento lo que tenía obligación; y esto era falso así en las condiciones y capítulos de la escritura de transación como en lo contenido en la sentencia del arcediano de Náxera, ni dio al monasterio los 2 mill maravedís de juro que había mandado el arcediano añadir a los 11 mill y, aunque en la escritura de ratificación suena que el monasterio recivió por ellos 41 mill maravedís, no consta la paga ni el monasterio los recivió dentro de 8 meses que mandó el arcediano. La súplica no la hicieron más que cinco monges, siendo 18 en el convento; fue diferente el esscribano de la súplica que el de la ratificación; no se hizo ante dos escrivanos conforme a las condiciones de la escritura de permuta. Por lo qual y otras razones este breve fue subrepticio, Vivero por sí solo le sacó, él solo le intimó al obispo sin dar parte de ello ni mostrársele al convento, que no lo vio ni le constó lo que contenía.

\section{$<$ Sentencia del obispo de Palencia. Año 1450>.}

Sin embargo, el obispo de Palencia, sin hacer información nueba de vtilidad como se le ordenó en el breve, porque no hubo tiempo para hacerla porque desde el día de la data hasta la execución de la sentencia no pasaron más que dos meses y 22 días, que heran menester para venir el breve de Roma, y los testigos que habían de decir estaban lejos y para ajustar el valor de las heredades hera menester mucho tiempo; por lo qual procedió el obispo

492 Pedro de Tosantos] al margen derecho: Don Pedro de Tosantos. 
atropelladamente, suponiendo (sin que conste más que en relación) haber citado a la parte del monasterio, / (f. 342r) y no se hallando a nada presente más que la parte de Pedro de Vivero, dio sentencia de confirmación de la escritura de ratificación, en 27 de enero de 1450, por la qual aprobó y confirmó la dicha escritura de ratificación y la de permutación y la sentencia de confirmación dada por el arcediano de Náxera.

$<$ Apela el convento de la sentencia del obispo de Palencia $>$.

Por todo lo qual, y por haberse hecho la escritura de ratificación y la súplica de ella al papa por solos cinco monges y sin expreso consentimiento y voluntad de los demás, apeló el convento del proceder y sentencia del dicho obispo de Palencia para ante Su Santidad y presentaron su apelación en Roma el mismo año 1450.

El mismo papa Nilocao $\mathrm{V}^{\mathrm{o}}$ aceptó la apelación y advocó así la causa y la cometió por su breve para veer decidir y fenecerla al maestro Pedro Martín de Cuebasrubias, capellán del papa y auditor del Sacro Palacio, el qual procedió en ella y como juez hizo algunos autos judiciales, sin determinación empero de la causa. La qual, pendiente en este tribunal y estando en el estado dicho, no obstante la dicha apelación, el obispo de Palencia procedió contra el convento con censuras y entredicho, confiscándoles sus bienes y aún mandando que se acudiese con ellos a Pedro de Vivero porque el convento no cumplía lo que el obispo había mandado en su sentencia.

Viendo el monasterio, en estado tan trabajoso, tan agraviado y sin favor ni esperanzas de conseguir su justicia por lo favores y potencia de la parte contraria, por librarse de tantos males, trabajos, vexaciones, gastos y pleytos, hizo en Roma, ante el dicho auditor, con Pedro de Vivero y sus procuradores, el contrato siguiente:

Que Pedro de Vivero además de los 13 mill maravedís de renta añadiese al monasterio otros dos mil maravedís más de juro en cada un año, de suerte que por todos fuesen 15 mill 000 maravedís, con tal condición que si los procuradores de ambas partes hallasen por verdad que alguna persona daba más cantidad por los dichos bienes del monasterio, el dicho Pedro de Vivero la diese asimismo; y porque constó que el dicho año de 1450 el conde de Castañeda y otras personas daban 19 mill 500 maravedís de juro en cada un año por ellos, atendiendo a que la causa de esta puja hera por haberlos mejorado Pedro de Vivero en el tiempo que los había tenido, no se pudieron concordar los procuradores, por lo qual eligieron por tercero concordante al dicho auditor Cuebasrubias, y junto con ellos concordaron que Pedro de Vivero debía dar y diese al monasterio de allí adelante en cada un año 16 mill 000 maravedís de juro perpetuo a satisfacción del monasterio, la qual concordia se hizo por el mes de agosto del año de 1451.

$<$ Suplica el monasterio se confirme la concordia $>$.

Hecha esta concordia, la parte del monasterio suplicó a Su Santidad que ${ }^{493}$, atento que si se hubiesen de llevar a Roma los recaudos necesarios para confirmar esta concordia con la información de vtilidad necesaria, era fuerza hacerse muy grandes gastos y pasarse mucho tiempo en daño de los religiosos que estaban excomulgados y contra la reputación de su honrra, Su Santidad se / (f. 342v) sirviese cometer la dicha confirmación en España a alguna persona o personas de satisfacción, para que constando ser vtil al monasterio la concordia, la confirmasen y aprobasen.

$<$ Breve y comisión al prior de San Benito de Valladolid $>$.

Presentada esta súplica ante Su Santidad, año 1451, 16 kalendas septembris, el mismo papa Nicolao $V^{o}$ dio su breve y comisión al prior de San Benito el Real de Valladolid, en el qual, haciendo relación de todo el caso desde el otorgamiento de la primera escritura de permuta hasta esta dicha súplica, da comisión al dicho prior de San Benito de Valladolid para que pueda absolver y absuelva a los monges y religiosos de San Zoil y otras qualesquier personas eclesiásticas de qualquier censura de excomunión o entredicho y de qualquiera penas y perjurios en que hayan incurrido y, advocando o reduciendo la causa a derecho, en caso que la aprobación y confirmación se hagan extinguiendo estas causas y por sí mismo,

493 que] sigue tachado: si. 
después que le constare de la relación legítimamente sobre que le encarga la conciencia, si hallare que el trueque o cambio y el decreto y ordinación celebrado por los procuradores y por Pedro, auditor, son en evidente vtilidad del monasterio, de consentimiento del abad y convento y de Pedro de Vivero, quitando qualesquier embargos, apruebe y confirme el dicho trueque y cambio y la concordia últimamente hecha; y el decreto y ordenación por el auditor y procuradores hecho, y las condiciones según que proceden razonablemente, y todo lo contenido en el dicho y otros instrumentos sobre las dichas cosas hechos, declare que tengan firmeza supliendo los defectos que tubieren, y, teniendo efecto esta confirmación por la autoridad appostólica, haga poner en debida execución la concordia y trueque y que lo guarden perpetuamente ambas partes como les tocare, refrenando a los contraditores por censuras, etcétera, non obstantibus constitutionibus, ordinationibus, etcétera. Dado en San Pedro de Roma, ut supra. Sacose del registro de las bulas appostólicas por Juan Ávila, maestro del dicho registro, con autoridad de Luis de Ayala y de Juan Domingo Espínola, protonottario appostólico auditor general de la curia de las causas de la Cámara Appostólica y juez ordinario de la Romana Curia, en Roma, a 29 de octubre de 1614.

$<$ Vivero oculta el breve y no cumple la concordia de Roma. Requiérele el convento que la cumpla. Año 1454>.

Nunca se vsó este breve ni llegó jamás a manos del prior de San Benito porque, después de expedido y haber entrado en poder de Pedro de Vivero, nunca le quiso exhivir; y aunque el convento, en 3 de diciembre de 1454, le requirió que le pagase los 16 mill maravedís de juro en cada un año que le habían mandado dar en el contrato hecho en Roma con los corridos hasta entonces, que según consta del requirimiento eran más de 70 mill maravedís, y que exhiviese el breve cometido al prior de San Benito de Valladolid o que volviese al monasterio sus heredades y hacienda, respondió a muchas cosas con equivocación sin cumplir ninguna de las que se le pedían, alegando que no tenía obligación hasta que el Santo Padre diese su confirmación a pagar al monasterio los maravedís que le pedía y, que en lo tocante al breve que se le pedía, no le tiene, aunque, si alguno hay, a noticia que tiene algunas / (f. 343r) rasguras o defectos por donde no se puede vsar dél; pero que escrivirá a sus procuradores de Roma que se le embíen sin los tales defectos para que se vse dél. Pero nunca más se trajo ni pareció hasta que después, el año de 1454, el marqués de La Mota, para presentar en su pleyto, hizo sacar de los archivos el trasumpto del autorizado, que es el que atrás y el año de 1620 le tubo el padre Cisneros y le hizo traducir y copiar por el secretario del rey Thomás Gracián Danrisco; con lo qual parece que ahora no sólo el dicho contrato y concordia hecha en Roma está sin confirmar, pero también la primera escritura de permuta que se hizo el año de 1443.

Después de lo qual el convento, por librarse de Pedro de Vivero que como tan poderoso y favorecido en la Corte tenía alas para hacer muchas vexaciones y le hacía extraordinarios agravios y molestias, teniéndole y gozando tiránicamente su hacienda sin pagarle por ella lo que había concertado, y que tenía obligación, pues ni aún le aseguraba ni se cobraba el juro de los 11 mill maravedís, por haberle tomado el rey don Henrrique y mandado a sus tesoreros que no acudiesen al monasterio con los réditos dél ni menos los maravedís que se aumentaron en la concordia hecha en Roma.

\section{$<$ Concierto del monasterio con Juan de Vlloa. Año 1456>.}

Y finalmente el monasterio, por escusar pleytos y gastos, siendo abad don Pedro de Tosantos ${ }^{494}$, en 17 de agosto de 1456, se concertó con Juan de Vlloa y Hernando de Fonseca, caballeros poderosos y rejidores de la ciudad de Toro, de darles la dicha hacienda que posehía Pedro de Vivero, porque ellos diesen al monasterio 16 mill maravedís de renta perpetua en cada un año, según lo acordado en la concordia de Roma. Pero aparte, con pretesto que sacando estos caballeros la hacienda de poder de Pedro de Vivero, quedasen ellos con la mitad y el convento con la otra mitad. De lo qual se otorgó escritura en forma por ambas partes, qual consta de la $2^{a}$ escritura de ratificación que llamaron de emphiteusi.

\footnotetext{
${ }^{494}$ Pedro de Tosantos] al margen derecho: Don Pedro de Tosantos.
} 
De aquí resultaron muchas y muy grandes pesadumbres entre Pedro de Vivero y Vlloa y Fonseca, sin quedar libre de ellas el convento, que como todos heran poderosos trahían medio rebuelta a Castilla.

\section{$<$ Concordia entre Vivero, Vlloas y Fonsecas. Año 1459>.}

$\mathrm{Y}$, tomando personas de consideración la mano en concertarlos, en 22 de septiembre de 1459 se concordaron y convinieron en que el monasterio diese la dicha hacienda a todos tres en esta forma: que se hiciese quatro partes y Pedro de Vivero quedase con las dos, Juan de Vlloa con una parte y con la otra Fernando de Fonseca; y que todos diesen al monasterio por su hacienda 12 mill maravedís de renta cada año, los 6 mill Pedro de Vivero, 3 mill Vlloa y 3 mill Fonseca, y que de ellos se hiciese censo perpetuo.

$<$ Escritura de emphiteusi>.

Y así se otorgó la escritura de emphiteusi por todas las partes.

$<$ Bolvió el monasterio el juro de los 11 mill maravedís $>$.

Con que el monasterio volviese el juro de los 11 mill maravedís, como de hecho le volvió, para que se partiese entre los tres, qual consta entre la partición de bienes que se hizo entre los hijos de Pedro de Vivero, pues señaladamente mandaron adjudicar a / (f. 343v) los dos de ellos la mitad de este juro. Fue también condición que, siendo necesario, esta escritura se confirmase, y que los tres caballeros pidiesen y tragesen por su cuenta la confirmación; aunque no parece haberse cumplido esta condición, y así esta escritura como la primera está sin confirmar, y sin haber precedido licencia del superior para la transacción de los bienes. Y aún después se revocó esta escritura por los que la otorgaron, andando el tiempo.

$<$ Ratificación de la escritura de enfiteusi $>$.

Hecha esta escritura murió Pedro de Vivero, dejando nombrados por herederos de la hacienda que le cupo del monasterio en esta $2^{a}$ escritura de unfiteusi a Diego y Gabriel de la Zorera, sus hijos. Y en el mismo año de 1459 doña Catalina de Merlo, su madre, y muger de Pedro de Vivero, como tutora de sus hijos, y los dichos Vlloa y Fonseca dieron poder a sus procuradores para que viniesen al monasterio y, junto con el abad y convento, ratificasen y confirmasen (como de facto se hizo) la dicha escritura de enfiteusi; y en la ratificación todas las partes suplicaron a Su Santidad confirmase la dicha escritura de enfiteusi y ésta su ratificación, y que Su Santidad se sirviese de anexar al monasterio de San Zoil la yglesia de San Martín de Vez de Marbán ${ }^{495}$ y la de San Pelayo de Toro ${ }^{496}$, habiendo el monasterio los frutos y rentas del beneficio de la dicha yglesia de San Martín, 20 cargas de trigo por la de San Pelayo y su reparo; aviendo, para mejor efecto, hecho el cura que entonces hera de San Martín renunciación de su beneficio y curato a favor del monasterio. $\mathrm{Y}$, aunque en la escritura se hizo esta súplica a Su Santidad, no se presentó en Roma ni consta haberse confirmado cosa de lo en ella contenido.

$<$ El monasterio pone el pleyto en la Chancillería de Valladolid. Año 1492>.

Después de lo qual, sintiéndose el monasterio en demasía gravado y enormísimamente lesso en todos estos contratos y escrituras, por los años del Señor de 1492 puso demanda de estos bienes en la Chancillería de Valladolid a los herederos de Pedro de Vivero y Hernando de Fonseca.

$<$ Valor de la hacienda $>$.

Que por lo menos en qualquier tiempo valía la hacienda del monasterio 150 mill 000 maravedís de renta en dinero; pues, como constó de la información que en este pleyto hizo el monasterio, tomada la mitad de los testigos que más dixeron y de los que menos, sólo de tierras de pan llevar había más de 960 cargas de sembradura, sin yglesias, diezmos, rentas, jurisdiones, vasallos, viñas, molionos, aceñas, huertas, casas, prados, heras y otras cosas.

$<2^{\mathrm{a}}$ Demanda. Año 1494>.

\footnotetext{
495 Vez de Marbán] al margen derecho: San Martín de Vez de Marbán.

${ }^{496}$ San Pelayo de Toro] al margen derecho: San Pelayo de Toro.
} 
Fuera de esta demanda, en 17 de junio de 1494 el monasterio puso otra demanda por la hacienda que le tenían los hijos de Vlloa y doña Aldonza de Castilla, su madre, los quales declinaron jurisdición en la Chancillería y pidieron se remitiese la causa a Toro. Contradijo el monasterio y la Chancillería se declaró por juez, con lo qual corrió esta demanda con el pleyto principal, en la qual se dio sentencia que las partes comprometiesen en ciertos oidores, lo qual contradixeron el convento y las partes de Pedro de Vivero y Fonseca.

$$
<1501>\text {. }
$$

Viose el pleyto y el año de 1501 se dio auto para que se arbitrase en Chancillería esta causa por las / (f. 344r) partes y el monasterio apeló dél.

$<$ Confirmación del privilegio de los 11 mill maravedís. Año 1539>.

Andando el pleyto que duró muchos años, el monasterio ni gozaba su hacienda ni cobraba el privilegio de los 11 mill maravedís de Vivero ni se le pagaban los 12 mill maravedís con lo contratado en la ratificación de la escritura de enfiteusi. Y, abiendo pasado muchos años con estos inconvenientes tan grandes, el año de 1539 pidió al emperador don Carlos y a la reyna doña Juana, su madre, le confirmasen en su cabeza el privilegio que se había perdido, o le tenían ocultado los contrarios con los pleitos, y no gozaba el convento el juro de los 11 mill maravedís que le había dado Pedro de Vivero. Y, constando que esta cantidad estaba salvada en la Contaduría Real y sus libros a favor del monasterio, se despachó nuebo privilegio por perdido el primero; y ahora le tiene y goza el monasterio, confirmado por el rey Felipe $2^{\circ}$ en el año de 1562.

$<$ Sentencia de vista contra el convento. Año de 1542>.

Siguió el convento en muchos trances y con extraordinarios achaques y gastos el pleyto de su hacienda con Viveros, Vlloas y Fonsecas, favorecidos de todo el mundo y atropellada injustamente la justicia del monasterio, que hera la que se puede conocer por esta ajustada y verdadera relación. Por lo qual se vio finalmente condenado en el tribunal de la Chancillería por sentencia difinitiva de vista, en el año de 1542, y absueltos de su demanda Pedro de Vivero y Hernando de Fonseca y sus herederos.

$<$ Sentencia de revista en que es condenado el monasterio. Año 1586>.

Apelló el convento, siguió la apelación con alegatos, informaciones y escrituras, si bien no pudo jamás hallar auténtica la de enfiteusi y su ratificación citadas atrás, en qué consistía la justicia del monasterio, en que provaba estar revocada por consentimiento de las partes la escritura primera de permuta hecha con Pedro de Vivero el año de 1443, que pareció después de condenado el convento $3^{a}$ vez con las mil y quinientas, quando ya no tubo remedio ni se podía aprovechar de ella. Y así, en el año de 1586, fue condenado $2^{\mathrm{a}}$ vez el convento con la sentencia de revista, por la qual se confirmó la primera de vista en la Chancillería. De la qual apelló el convento con las mil y quinientas doblas.

$<$ Sentencia de las 1 mill 500 contra el monasterio. Año 1591>.

Siguiose el pleyto en el Consejo en el qual, en 14 de enero de 1591, se dio sentencia difinitiva, por la qual se confirmaron las sentencias de vista y revista dadas por la Chancillería, por no tener el monasterio persona inteligente y qual era menester informar, por haberse muerto y estar ausentes los letrados que habían mirado y enterádose de este pleyto y de la justicia del monasterio.

Después han tenido grandes pleytos sobre esta hacienda Viveros, Fonsecas y Vlloas y otros interesados, de que no ago relación por no importar al monasterio.

Lo que importa es advertir lo siguiente: (vuelta).

$<1$ Recla[mación] $>$.

/ (f. 344v) De lo dicho consta que, yendo el monasterio reclamando en todos tiempos así de la primera escritura de permuta como de la de enfiteusi y su ratificación y las demás, especialmente desde la sentencia confirmatoria que dio el arcediano de Náxera y de la del obispo de Palencia hasta que dio el breve para [que] el prior de San Benito de Valladolid confirmase la concordia hecha en Roma, por sentirse el convento agraviado en las dichas 
sentencias y confirmaciones del arcediano de Náxera y obispo de Palencia, que habían procedido en ellas contra derecho, como queda advertido, no admitió el convento las dichas confirmaciones por injustas y gravantes, y debiendo ser dadas en conformidad de ambas partes, según el tenor de los breves, no las admitiendo más; antes re $<$ cla $>$ mando y apelando la parte del convento, parece faltar la conformidad y consentimiento de las partes y consiguientemente no haber tenido fuerza las dichas confirmaciones. Y, supuesto que el breve del prior de San Benito no se executó ni se sacó breve de confirmación para la $2^{a}$ escritura de enfiteusi y su ratificación, parece constar de primo ad ultimum que esta causa, en quanto al punto de la confirmación, está indecisa y que consiguientemente la escritura de permuta, la concordia hecha en Roma y la $2^{\mathrm{a}}$ escritura de enfiteusi con su ratificación están sin confirmar y que la transación de bienes eclesiásticos está hecha sin licencia, sin confirmación y sin autoridad del superior, y consiguientemente es inválida y nulla.

Este pleyto, conforme a los pareceres de letrados que se consultaron año de 1620, está desauciado de remedio dificultoso, dudoso y largo, más que por falta de justicia (de justicia) del convento, pues todos los contratos por falta de solemnidad son nullos, si bien los contrarios purgaron con las sentencias y cartas executorias de Chancillería y del Consejo qualquiera mala fee. Y porque en estos tribunales sólo se conoció de la enormísima lessión del convento y no de la falta de confirmación y solemnidad, cuya causa está introducida y pendiente en La Rota, se podría entrar por aquí y proseguir con lo actuado, pidiendo de nuebo por falta de confirmación y solemnidad. Y, caso que esto se intentase, sería bien prevenirse con sacar permiso del rey por vía de conciencia, para proseguir esta causa en Roma por no confirmada, con cuyo beneplácito ganado de antemano quedaba llano el paso en el Consejo, para que no detubiese qualquiera sentencia o executoriales favorables al convento que se ganasen en Roma, sin embargo y contra sentencia de las mil y quinientas. 


\section{/ (f. 345r) Cajón 14 San Gregorio}

Este cajón San Gregorio, que es el décimoquarto del archivo, contiene tres legajos pertenecientes a diversos lugares, que son: legajo $1^{\circ}$ : Valcabado; legajo $2^{\circ}$ : Valcovero, Valderadue, Valhenoso, Vega de Riacos, Velilla de Tarilonte, Villaherrín, Villaherreros, Villaibáñez, Villalveto, Villalumbroso; legajo $3^{\circ}$ : Villafrechós.

$$
\text { Legajo } 1^{\circ}
$$

Este legajo, que es el primero del cajón San Gregorio, contiene los tres qu[a]dernos siguientes: quaderno A: escrituras de censo y foro perpetuas hechas en favor del monasterio por las heredades que tenía en el lugar de Valcavado; quaderno B: pleytos que tubo el doctor Flores en nombre del monasterio; quaderno C: proceso en cinco piezas que litigó el dicho Flores en razón de los términos, tierras, pastos y jurisdición de dicho lugar, con otros papeles sueltos.

\section{Quaderno A del legajo ${ }^{\circ}$}

\section{Valcavado}

Este quaderno A contiene las escrituras de censo pertenecientes a la hacienda que tiene el monasterio en este lugar, por el orden siguiente:

$1^{\circ}$. $<$ Foro de 450 maravedís por las heredades de Valcavado y Revilla con más 12 gallinas y 6 gansos. Año 1415>.

Escritura de foro, escrita en pergamino, por la qual el convento de San Zoil da a foro perpetuo a Alfonso Fernández de Sotillo, Toribio Domínguez de San Martín, Juan de los Varrios y Toribio Martínez de Valcabadillo, vecinos todos de Valcabado, todas las heredades, montes, pastos, etcétera, que el monasterio tiene en Valcabado y Revilla ${ }^{497}$ y sus términos por 450 maravedís, doce gallinas y seis ansarones de renta en cada año. Su fecha, en San Zoil, a 12 días del mes de enero de 1415, ante Fernando Rodríguez de Castellanos, esscribano y nottario de Palencia.

$2^{\circ}$. <Censo perpetuo de la hacienda de Valcavado y Revilla al licenciado Amaro Díaz de Flores por 6 mill 000 maravedís. Año 1548>.

Escritura de censo perpetuo, por la qual el abad fray Juan de Santa María ${ }^{498}$ y el convento de San Zoil dan a foro y censo perpetuo al bachiller Amaro Díaz de Flores, vecino de Carrión, para él y sus herederos, el lugar / (f. 345v) de Valcavado, términos y vasallos dél, y el término de Revilla ${ }^{499}$ con todo lo a él perteneciente, con las tierras de lino y pan llevar, prados, términos, pastos, éxidos, dehesas, cotehados y por cotehar, montes, árboles, aguas, molinos, riveras, casas, solares, pechos y derechos, vrciones y martiniegas y los diezmos ${ }^{500}$ mayores y menores como los han tenido y llevado los vasallos de Valcavado por el censo que tenían hecho, y como pertenece al monasterio de San Zoil, señor del dicho lugar, con la jurisdición ${ }^{501}$ civil y criminal mero mixto imperio, que le fue concedido al monasterio en ambos lugares por privilegios reales, con el patronazgo y presentación de beneficios ${ }^{502}$ curados y simples que tien[e] el monasterio en la yglesia de San Andrés del dicho lugar, por precio de 4 mill 500 maravedís, 12 gallinas vivas y 15 libras de truchas cada año para siempre jamás. Los 2.250 maravedís pagados el día de San Juan de junio, las 15 libras de truchas el día de Nuestra Señora de agosto y los otros 2.550 maravedís y gallinas el día de Navidad. Con las condiciones siguientes:

$1^{\mathrm{a}}$. Que si pasaren dos años sin pagar, se entre el monasterio en la hacienda con sus mejoras por incomiso.

\footnotetext{
497 Revilla] al margen derecho: Revilla.

498 abad fray Juan de Santa María] al margen derecho: abad fray Juan de Santa María.

${ }^{499}$ Revilla] al margen derecho: Revilla.

500 diezmos] al margen derecho: Diezmos.

501 jurisdición] al margen derecho: Jurisdición.

502 presentación de beneficios] al margen derecho: Presentación de beneficios.
} 
$2^{\text {a }}$. Que el censuatario y vecinos de Valcavado reconozcan al abad como a señor y al que en su nombre fuere al lugar siendo monge le besen la mano y le den los mantenimientos como están obligados a sus señores.

$3^{\text {a }}$. Que el censuario no sea contra el monasterio sino en su favor y ayuda quando le fuere mandado.

$4^{a}$. Que si los vasallos juraren vasallaje al censuario se especifique que no será contra el abad de San Zoil, so pena de incomiso.

$5^{\text {a }}$. Que lo contenido en este censo no se pueda enagenar, etcétera, sino avisando al monasterio si lo quiere por el tanto, sopena de incomiso.

$6^{a}$. Que dentro de un año como hubiere tomado la posesión Amaro Díez del lugar, esté obligado a poner el pleyto y demanda en nombre del monasterio sobre la jurisdición a la villa de Saldaña y la siga y, sacándola, acuda al monasterio con las penas de Cámara, sin poder hacer gracia de ellas después de aplicadas, so pena de pagar las de su casa; y no poniendo la demanda dentro del dicho tiempo, caiga en incomiso.

Con estas condiciones pueda disponer de todo, etcétera. Y es también condición que esta hacienda no se pueda dividir. También es obligado a dar un yantar ${ }^{503}$ cada año al abad y dos monges, cena y comida y, que si no le fueren a tomar que le pierdan, y el convento avise tres días antes que le vaya a tomar.

Esta escritura se otorgó sin licencia del general; pero con sus tres tratados, a título de ser vtil al monasterio (si bien no se hizo información de vtilidad) y de que el bachiller Amaro Díaz de Flores se obligó a seguir a su costa el pleito de Toro ${ }^{504}$ por el convento, lo qual no cumplió. Fue otorgada esta escritura en San Zoil, a último día / (f. 346r) de febrero de 1548, ante Juan de Castrillo, esscribano ppúblico de Carrión.

$<$ Escritura de comutación de las gallinas, truchas y yantar a dinero. Año 1551>.

Después de esto, en San Zoil, a 21 días de enero de 1551, el dicho abad fray Juan de Santa María ${ }^{505}$ y el convento de San Zoil, con licencia de fray Rodrigo de Vadillo, general de San Benito, habiendo precedido información de vtilidad, otorgaron escritura de comutación, por la qual hicieron comutación de las 15 libras de truchas por otros tantos reales, a real la libra, y por cada gallina de las doce quarenta maravedís, que por todo son 990 maravedís, la mitad para el día de San Juan y la otra mitad para el día de Navidad, junto con los 4 mill 500 maravedís del contrato principal. Otorgose ante el mismo esscribano Juan de Castrillo.

$3^{\circ}$. < Obligación del doctor Flores que (sic) no presentar sino el que quisiere el abad para el beneficio $>$.

Cédula de letra y firma de don Amaro Díaz de Flores en que dice que ni él ni sus sucesores no presentarán en ningún tiempo el beneficio curado de la yglesia de Valcavado sino al que le señalare el abad de San Zoil, so pena que la tal presentación sea nulla. Su fecha, en 5 de junio de 1549 .

$4^{\circ}$. $<$ Escrituras de foros, vitas, vasallajes y arrendamientos. Año de 1549 hasta 1600>.

Bajo este número están las escrituras de foros, vitas, vasallajes y arrendamientos hechas en favor del doctor Flores, de la hacienda que tubo del monasterio en Valcavado y Revilla a foro perpetuo, por el qual pagaba al monasterio seis mil maravedís cada año. Son todas 19 escrituras ante diferentes esscrivanos.

$5^{\circ}$. $<$ Arriendo de 8 tierras, una huerta y solares por una fanega de trigo y cebada y una gallina. Año 1638>.

Escritura de arriendo que otorgaron los padres fray Mauro de la Carrera y fray Pedro de Velasco, monges profesos del monasterio de San Zoil, a Martín Pérez, vecino de Valcavado, en favor del dicho monasterio, de ocho tierras, una huerta y los suelos que suelen

\footnotetext{
503 yantar] al margen derecho: Yantar.

504 Toro] al margen derecho: Toro.

505 abad fray Juan de Santa María] al margen derecho: Abad fray Juan de Santa María.
} 
andar con las dichas tierras: la $1^{a}$ en el término de Valcavado, a sso el Sendero, que hace celemín y medio de sembradura, lindero: el dicho convento; otra tierra en dicho término, sobre el sendero, de cinco celemines de sembradura, lindero: tierras del dicho monasterio; otra tierra en término, a los Holmillos, de un quarto de sembradura, lindero: tierras del dicho monasterio; otra tierra en dicho término: a Las Canalejas, de un quarto de sembradura, lindero: tierras del dicho monasterio; otra tierra en dicho término, al Canto, de dos celemines de sembradura, lindero: el río y tierras del dicho monasterio; otra tierra en dicho término, a voca de Vecilla, de quatro celemines de sembradura, lindero: tierras del dicho monasterio; otra tierra en dicho término: a La Campera del Molino, de un quarto de sembradura, lindero: tierras del dicho monasterio; otra tierra en dicho término, a Las Casas, de medio celemín de sembradura, lindero: tierras del dicho monasterio; vna huerta en dicho término, junto a Las Casas, de dos celemines de sembradura, lindero: tierras del dicho monasterio, con más los suelos. Por las quales ha de dar y pagar una fanega de trigo y cebada, por mitad, en cada un año, por nuebe años que está el arriendo, bueno, seco, limpio, con más una gallina. / (f. 346v) Fue hecha en Carrión, a 29 de diciembre de 1638, ante Francisco Moro de Saldaña, esscribano de Carrión.

$6^{\circ}$. $<$ Arriendo de 8 tierras y los suelos que andan con ellas por una fanega de trigo y cebada y una gallina. Año 1638>.

Escritura de arriendo que otorgaron los dichos padres fray Mauro de la Carrera y fray Pedro de Velasco, monges del monasterio de San Zoil, a Francisco Santos, vecino del lugar de Los Varrios, en favor del dicho monasterio, de ocho tierras y los suelos que el dicho monasterio tiene en el lugar de Valcavado, por precio de una fanega de trigo y cebada, por mitad, bueno, seco y limpio, con más una gallina en cada año, fasta nueve que está el arriendo. Fue otorgada en Carrión, a 29 de diciembre de 1638, ante el mismo esscribano.

$7^{\circ}$. <Arriendo de 17 tierras y dos huertas por 33 celemines de pan mediado y dos gallinas. Año 1638>.

Escritura de arriendo que otorgaron los dichos padres fray Mauro de la Carrera y fray Pedro de Velasco, monges del monasterio de San Zoil, a Toribio Pérez, vecino del lugar de Valcabado, en favor del dicho monasterio, de diez y siete tierras de pan llevar y dos muertas, por tiempo y espacio de 9 años, por precio de 33 celemines de pan, mediado trigo y cebada, seco, limpio y bueno, con más dos gallinas vivas, por cada uno de los dichos años. Fue otorgada en Carrión, a 29 de (de) diciembre de 1638, ante el mismo esscribano. $1647>$.

8. <Escritura de obligación contra Hernando de la Cuesta y Toribio Casa. Año

Escritura de arriendo y obligación que hizo el abad y convento de San Zoil a Hernando de la Cuesta y Toribio Casa, vecinos de Valcavado, en favor del dicho monasterio, de todas las tierras que el dicho convento tiene y los susodichos han tenido y gozado en renta en el dicho lugar y sus términos, contenidas y declaradas en los arrendamientos y apeos que de ellos tenemos a que nos referimos, para que las tengan y gozen por tiempo de 9 años, por precio de carga y media de trigo y cebada, por mitad, bueno, seco y limpio, en cada uno de los dichos 9 años, con más quatro gallinas buenas y vivas. Fue otorgada en el monasterio de San Zoil, a12 días del mes de abril de 1647, ante Francisco Moro de Saldaña, esscribano de Carrión.

\section{/ (f.347r) Quaderno B del legajo $1^{\circ}$}

Este quaderno B contiene los papeles pertenecientes a los pleytos que litigó el doctor Flores en nombre del monasterio, por el orden siguiente:

$1^{\circ}$. <Provanza que hizo el licenciado Flores de averiguación. Año 1551>.

Provanza que hizo el licenciado Flores en el pleyto que tubo con los concejos de Saldaña y su tierra y los lugares de Santa Olaja, Los Barrios, Poza y Valcavadillo, para averiguar las heredades y términos del lugar de Valcavado que el monasterio dio a foro a Amaro Díaz de Flores. Hizo esta probanza el año de 1551, en virtud de <una> receptoría de la Chancillería de Valladolid, ante Alonso de Satisteban, esscribano de Cámara, dada en 
13 de enero de 1551. La provanza que se hizo original pasó ante Rodrigo de Cantoral, esscribano de Carrión.

$2^{\circ}$. <Pleyto con Valcabadillo sobre la Mata Castillo de Revilla. Año 1553>.

Proceso de un pleyto que tubo el doctor Flores, en nombre del monasterio de San Zoil y suyo, con los vecinos de Valcavadillo sobre la Mata Castillo, en el monte de Revilla ${ }^{506}$, en el qual sentenció el prior de Escalada, juez conservador, en favor del monasterio; de que se dieron por agraviados los de Valcavadillo. Y se comprometió esta causa en Alonso del Campo y Pedro Téllez, juezes árbitros, vecinos de Carrión; los quales condenaron al monasterio, a 29 de febrero de 1552. De cuya sentencia se apeló para ante el teniente corregidor de Carrión, el qual sentenció en favor del monasterio, adjudicándole la Mata, y condenando a los contrarios en los frutos corridos, en 23 de junio de 1553, ante Thomás Sánchez, esscribano de Carrión.

Es proceso original.

$3^{\circ}$. < Execución contra el licenciado Flores. Año 1625>.

Execución que se pidió contra el licenciado Flores y sus herederos ante la justicia de Carrión y Francisco Moro de Saldaña, esscribano de dicha villa, en virtud de la escritura de foro perpetuo que hizo con el monasterio y obligación de pagar 6 mill maravedís por el lugar de Valcavado y sus términos. Y habiendo muerto el sucesor, se fue a Las Indias y no volvió a haber más memoria dél. Por lo qual, habiendo hecho información (la que sestá aquî) de su ausencia y no pagando los dichos maravedís, el monasterio se volvió a ello. Pasó ante el dicho esscribano Francisco Moro de Saldaña, año de 1625.

/ (f. 347v) $4^{\circ}$. < Executoria, posesión y deslinde de los lugares despoblados de Valcavado y Revilla. Año 1740>.

Carta executoria ganada en la audiencia de valdíos, que el señor rey Fhelipe $5^{\circ}$ puso en la villa de Carrión, en favor del monasterio de San Zoil, contra el promotor fiscal de la dicha audiencia y el procurador síndico general de la villa de Saldaña y de toda su tierra; por la qual parece que en Carrión, a 21 de agosto de 1739, Andrés Pardo de Salas, en nombre del concejo de Valcavadillo, respondió a un autto del señor don Pablo Francisco de Cárdenas y Vadillo, corregidor de la villa de Carrión y juez privativo de despoblados y valdíos, por el qual mandaba que dentro de cierto tiempo el concejo de Valcavadillo exhiviese los instrumentos de pertenencia del lugar despoblado de Valcavado, como usufructuario de sus pastos, montes, etcétera. Y en su pedimiento alegó consonidad de pastos común a los 25 lugares de la tierra y jurisdición de la villa de Saldaña, de que se dio traslado al dicho promotor fiscal, y en su escrito insistió en la denuncia, pidiendo se declarase dicho despoblado por del real patrimonio y que para ello se hiciese reconocimiento de su términos con toda claridad, teniendo presentes los apeos antiguos de los lugares confinantes a dicho despoblado; cuyo reconocimiento y vista ocular se executó en los 3 de agosto de 1740 sin haber exivido dichos apeos. Habiendo llegado a noticia del monasterio de San Zoil las diligencias arriba expresadas, la parte del monasterio pidió ante el señor don Miguel Antonio Franco y Villalba, juez de Valdíos, que dicho lugar de Valcavado y el de Revilla, inmediato a él y también despoblado, se declarase[n] por proprios del dicho monasterio; para lo qual exhivió el pleyto que está en la pieza B del quaderno $C$ de este legajo, en que está compulsado el privilegio del señor rey don Alonso el $9^{\circ}$, al folio 144 de dicho pleyto. De cuyo instrumento y del dicho privilegio incluso en él informó dicho promotor fiscal ser suficiente para el título de pertenencia, y que para su determinación se citase al procurador general de la villa y tierra de Saldaña, lo que se executó, y en su pedimiento pidió la consonidad de pastos de la villa y tierra de Saldaña, la que se admitió por la parte del monasterio con la mutua. Y conclusa la causa en Carrión, a 15 de septiembre de 1740, el dicho don Miguel Franco, con parecer de asesor, dio sentencia difinitiva, en que se ampara a dicho monasterio en el dominio, propiedad y vsufruto de los enunciados lugares de Valcavado y Revilla ${ }^{507}$, dejando la

\footnotetext{
506 Revilla] al margen derecho: Revilla.

${ }^{507}$ Revilla] al margen derecho: Revilla.
} 
consonidad de los pastos en la costumbre antigua. Y en los $23<$ de septiembre $>$ de dicho año se despachó dicha executoria, mediante la qual el dicho juez de valdíos con toda su audiencia, en los 8 de octubre, dio la posesión al apoderado del monasterio, con asistencia del procurador general de la villa de Saldaña, su nombrado, y los nombrados por parte del monasterio, y fueron presentes al deslinde y amojonamiento de dichos términos, que está a continuación de dicha executoria; aunque no conforme al deslinde que está en la dicha pieza $\mathrm{B}$, en la pregunta $8^{\mathrm{a}}$, al folio $10, /(f .348 r)$ y en la pieza $\mathrm{C}$ de la séptima pregunta, por haberse hecho de estendidos de los pagos en que dan dichas provanzas los mojones, los dichos nombrados como partes interesadas. Pasó ante Santiago Duque de Estrada, esscribano de Carrión.

Están aquí los apeos que se hicieron en el año de 1759 ante José de Ceano Vivas, esscribano de dicha villa. 
$<$ Año de $1550>$.

\section{(f. 348v) Quaderno C del legajo $1^{\circ}$ Valcavado}

Este quaderno $\mathrm{C}$ es un proceso en cinco piezas del pleyto que litigó don Amaro Díaz de Flores en la Chancillería de Valladolid por los años de 1550 contra la villa de Saldaña, en razón de los términos, tierras, pastos de Valcavado y Revilla ${ }^{508}$ y la jurisdición civil y criminal mero mixto imperio de Valcavado. Lo que pedía el doctor Flores es lo siguiente:

$1^{\circ}$. Toda la heredad, prados y campos que están desde la punta del soto que dicen del Castillo, que está en el término de Revilla ${ }^{509}$, junto a los prados pregoneros, viniendo el río avajo, hasta do dicen los Prados de la Majada por el calze viejo, por donde antiguamente solía ir el Río Mayor, desde el dicho calze viejo hasta el lugar de Valcavado en todo el circuito susodicho, con la hera que estaba al Prado de la Majada.

$2^{\circ}$. Pide la hera grande que comienza del Portillo de las tierras y linda con los prados de Palacios, que llega hasta los Prados de la Majada con sus regueras.

Valdecelasco.

$3^{\circ}$. Pide las matas y carrascales de Vililla y de Valdecarril, de Bustillo y de

$4^{\circ}$. Pretende deslindar los términos entre la villa de Saldaña y el lugar de Valcavado y otros lugares, declarando los mojones.

$5^{\circ}$. Pide tener los vecinos de Valcavado pasto común en todos los términos de la villa y tierra de Saldaña.

de este lugar.

$6^{\circ}$. Pide la mata de Valdehavina, que es el monte de Valcavado, y está dentro

$7^{\circ}$. Pide el soto de Revilla, que está en el término de Revilla.

$8^{\circ}$. Pide los prados que dicen pregoneros de Saldaña.

Valcavado.

$9^{\circ}$. Pide la jurisdicción civil y criminal mero mixto imperio en el lugar de

Este pleyto se puso primero en el adelantamiento, y lo actuado allí está en la pieza B, y sin concluirse ni sentenciarse de un auto interlocutorio que dio el alcalde mayor. Apeló Saldaña y se llevó a la Chancillería donde se ventiló mucho, y tampoco se sentenció definitivamente por ser pleyto muy entrincado y de grandes dificultades, con muchos cabos, que cado uno necesita de mucho tiempo y gran cuidado. Así por estas dificultades como porque aunque están aquí las cinco piezas de este proceso falta mucho más dél y mucho de ello muy maltratado.

/ (f. 349r) En la segunda pieza de este pleyto, que es lo actuado ante el alcalde mayor del adelantamiento, intitulada $\mathrm{B}$, está compulsado el título que el monasterio tiene del lugar de Valcavado y Revilla (véase dicha pieza al folio 144 vuelta), que habiendo dado a foro este lugar al doctor Amaro Díaz de Flores, como consta atrás, le entregó el título que tenía de este lugar y él le presentó en el adelantamiento para el pleyto que tubo con la villa de Saldaña y el duque del Ynfantado, su dueño.

Al fin de estas cinco piezas están varios papeles sueltos, que los más no tienen principio ni fin y así tienen muy poca o ninguna autoridad; pero si de algo sirvieren, véase.

\footnotetext{
508 Revilla] al margen derecho: Revilla.
}

${ }^{509}$ Revilla] al margen derecho: Revilla. 
/ (f. 349v) Legajo $2^{\circ}$ del cajón San Gregorio

Este legajo, que es el segundo del cajón San Gregorio, contiene 10 quadernos pertenecientes a diversos lugares, que son los siguientes:

Quaderno A Valcovero

$B$ Valderradue

C Valhenoso

D Vega de Riacos

E Velilla de Tarilonte
F Villaherrín

$G$ Villaherreros

H Villaibáñez

Y Villalveto

J Villalumbroso

Quaderno A del legajo ${ }^{\circ}$

Valcovero

Este quaderno A contiene los papeles pertenecientes a la hacienda que (que) tiene Nuestra Señora del Brezo en este lugar, por el orden siguiente:

$1^{\circ}$. $<$ Compra de un prado. Año 1542>.

Escritura de venta por la qual Juan Macho, vecino de Valcovero, vende a fray Pedro de Porras, prior del Brezo, para el dicho priorato un prado al Arroyo de Hontanares, término de dicho lugar, por precio de dos mil maravedís. Su fecha, en Valcovero, a 24 de abril de 1542, ante Juan Fernández, escribano de la jurisdicción de Alva Camporredondo, etcétera.

$2^{\circ} .<$ Compra de un prado. Año 1544>.

Escritura de venta por la qual Juan Macho, vecino de Valcovero, vende al padre fray Pedro de Porras, prior del Brezo, para el dicho priorato, un prado a la Fuente del Asno, término de dicho lugar, por precio de mil maravedís. Su fecha, en Valcovero, a 31 de octubre de 1544, ante Juan Fernández, escribano público.

$3^{\circ}$.

Escritura de venta por la qual Sebastian Pérez, vecino de Valcovero, vende a la casa del Brezo un prado a Piedras Hitas, término de dicho lugar, que hace un carro de yerba, por precio de diez ducados que por él pagó el padre fray Francisco de Villafuerte, prior del Brezo. Su fecha, en Villafría, a 7 de abril de 1591, ante García de Cossío, escribano de la jurisdición de La Puebla. Está multiplicada.

\section{Remisiones}

Esta hacienda pertenece al Brezo por el trueque que hicieron los priores. Cajón San Plácido, Legajo 1, quaderno A, número 23.

$$
\begin{gathered}
\text { / (f. 350r) Quaderno B del Legajo } 2^{\circ} \\
\text { Valderradue }
\end{gathered}
$$

Este quaderno contiene las escrituras siguientes:

$1^{\circ}$. < Venta del molino a Pernía, marido de doña Ysabel Enrriquez. Año 1466>.

Escritura de venta por la qual Diego de Juara, vecino de Castrillo de Valderadue, y María Fernández, su muger, venden a Juan de Pernía, criado del conde de Castro, cinco cargas de trigo de la medida nueva situadas en la renta de un molino que tenían en el dicho lugar de Castrillo ${ }^{510}$, y en otro molino que se obligaron a hacer debajo de aquel en el mismo calze, por precio de mil maravedís. Fecha en 2 de julio de 1466, ante Juan $<$ González $>$ de Robles, escribano de Cea.

$2^{\circ} .<$ Donación del molino. Año 1490>.

Escritura de donación que hizo a la casa del Brezo doña Ysabel Enrríquez, vecina de Santa María del Páramo, junto a Cea, y muger que fue de Juan de Pernía, de un molino en el término de Castrillo ${ }^{511}$, con el tributo de tres fanegas de trigo que sobre él tenía el marqués de Denia; el qual dio esta señora para la obra y edificios de aquella casa. Fecha en Santa María del Río, a 19 de noviembre de 1490, ante Juan Alfonso, escribano. Sacose esta escritura y se autorizó en Carrión, a 19 de junio de 1491, ante Fernando Caballo, escribano de Carrión.

$3^{\circ}$. $<$ Donación de tres fanegas de trigo en el molino. Año 1501>.

Escritura de donación por la qual don Bernardo de Rojas y de Sandoval, mayordomo mayor del rey, marqués de Denia, por devoción que tenía con Nuestra Señora del Brezo, hace donación a su casa de tres fanegas de trigo que tiene de fuero en cada un año en el molino

${ }^{510}$ Castrillo] al margen derecho: Castrillo.

511 Castrillo] al margen derecho: Castrillo. 
de Castrillo ${ }^{512}$, su lugar que es, en la rivera de Valderradue, que era de Ysabel Enrríquez. Fecha en la villa de la Cea, a 8 de agosto de 1501, ante Alonso de la Peña, escribano de dicha villa.

$<$ Nota $>$.

Este molino se vendió porque, habiendo edificado otros molinos próximos a él en la misma rivera, no había quien le tomase en arriendo y se iba perdiendo todo. Pasó esto año 1755.

$$
\begin{gathered}
\text { / (f. 350v) Quaderno C del legajo } 2^{\circ} \\
\text { Valhenoso }
\end{gathered}
$$

Este quaderno $\mathrm{C}$ del legajo $2^{\circ}$ contiene la escritura siguiente: Año 1512>.

$<$ Compra que hizo el padre fray Juan de Lamasón para Nuestra Señora del Brezo.

Escritura de venta por la qual parece que Diego Hurtado de la Vega, hijo legítimo del gobernador Diego Hurtado de la Vega, vecino de Vega de Riacos, vende a fray Juan de Lamasón, prior del Brezo, para la casa de Nuestra Señora, su lugar de Valhenoso, con ocho cargas de pan terciado que tenía en él en cada un año, y una docena de gallinas, media docena de ansarones y dos cabritos con todo lo demás que le pertenecía a él y a su hermano, Pedro González de Tovar, según que le huvieron y heredaron del governador, su padre, con todas sus casas, olmedas, tierras, prados y otros heredamientos y derechos etcétera, por precio de quarenta mil maravedís. Fecha en el lugar de Vega de Riacos, a 9 de noviembre de 1512, ante Alonso Fernández de Respenda, escribano de la reyna. Hay copia de esta escritura pero no tiene autoridad.

$$
\begin{gathered}
\text { / (f. 351r) Quaderno D del legajo } 2^{\circ} \\
\text { Vega de Riacos }
\end{gathered}
$$

Este quaderno D contiene los papeles pertenecientes a la hacienda que tiene San Román en este lugar, por el orden siguiente:

$1^{\circ}$. <Trueque de un linar. Era 1277. Año 1239>.

Escritura, escrita en pergamino, partida por $\mathrm{ABC}$, por la qual parece que don Fernando, prior ${ }^{513}$, y el convento de San Román dan a don Pedro Juan Domínguez y Domingo Domínguez, de Vega de Riacos, un medio linar sobre ${ }^{514}$ Espinar para que hagan solares para San Román, dando en cada año en oforción dos quartos de pan, mediado trigo y cebada, y otros tributos; y ellos dan a San Román una losa, que es en camino que es a la yglesia de San Cosme y Damián. Facta carta era 1277' que es año 1239.

Está multiplicada.

$2^{\circ}$. $<$ Trueque de una casa y huerto por varias tierras. Año 1792>.

Trueque que hizo el padre maestro fray José Fierro, prior de San Román, con Juan Merino y Escolástica Cordero, vecinos del lugar de Barajores, de una casa, sitio, solar, con su corral, huerto y árboles' sitos en dicho lugar de Barajores ${ }^{515}$ y proprios del dicho priorato, por una tierra linar en término de Vega de Riacos, otras dos tierras en término de Las Heras ${ }^{516}$, 4 prados en término de Pino ${ }^{517}$, Aviñante ${ }^{518}$ y Soles ${ }^{519}$, con más 200 reales que los referidos entregaron al padre prior por el esceso y más valor que tenía la casa' corral y huerto que dio a las heredades que recivió. Su fecha' en Barajores a 16 de marzo de 1792' ante Manuel Luis París, esscribano y vecino de Villanueba de Arriba.

\footnotetext{
${ }^{512}$ Castrillo] al margen derecho: Castrillo.

513 Prior] sigue tachado: De San Román, junto.

514 sobre] sigue tachado: el.

515 Barajores] al margen derecho: Barajores.

${ }^{516}$ Las Heras] al margen derecho: Las Heras.

517 Pino] al margen derecho: Pino.

518 Aviñante] al margen derecho: Aviñante.

519 Soles] al margen derecho: Soles.
} 


\section{Remisiones}

$<$ Prado $>$.

Vn prado. Véase el cajón San Estevan, legajo $2^{\circ}$, quaderno D, número $4^{\circ}$.

$<$ Tierra $>$.

Vna tierra. Véase el mismo cajón, legajo $3^{\circ}$, quaderno A, número 15.

$<$ Linar $>$.

Vn linar. El mismo cajón, legajo $2^{\circ}$, quaderno A, número $7^{\circ}$.

Dos tierras. Cajón San Benito, legajo $1^{\circ}$, quaderno E, número $1^{\circ}$.

\section{/ (f. 351v) Quaderno E del legajo $2^{\circ}$ Velilla de Tarilonte}

Este quaderno E contiene los papeles pertenecientes a la hacienda que tiene San Román en este lugar, por el orden siguiente:

$1^{\circ}$. $<$ Donación de dos salares (sic) y un quinto para San Román>.

Donación que hizo don Nicolás Gil a San Román de dos solares en Velilla y el quinto de todos sus bienes y su cama para después de sus días. Ofrécese por familiar y se manda enterrar en San Román. Y don Hugo, prior, con consentimiento del superior de Cluni y de su convento, le admite por familiar y le da en préstamo dos solares en Castrejón ${ }^{520}$ y en Traspeña ${ }^{521}$, otro en Villalveto ${ }^{522}$, otro en Velilla y otro en Villaverde ${ }^{523}$ con sus barriales y prados. Todo lo qual y los dos solares en Velilla y una serna y la heredad de Celada ${ }^{524}$, manda vuelva libremente a San Román después de sus días Confirma doña Mayor, su muger, y su hijo Pelay Íncola, que es el de la concordia ${ }^{525}$ de Aviñante. No tiene fecha esta donación.

$2^{\circ}$. $<$ Donación de Juan Domínguez. Era 1402. Año 1364>.

Donación que hizo a San Román Juan Domínguez de todos sus bienes muebles y raíces que tenía en Velilla de Tarilonte porque le den de comer, beber, vestir, y calzar lo que buenamente hubiere de menester toda su vida, y el vestido cada dos años, una saya y una capa de sayal. Fecha en Carrión, a 18 de marzo, era de 1402, que es año de 1364, ante Garci Fernández, esscribano de Palencia.

$3^{\circ}$. $<$ Compra de dos tierras. Año 1765>

Escritura de venta otorgada por Manuel Díez y María Heras, vecinos de Villanueva de la Peña, de dos tierras para San Zoil en el término de Velilla de Tarilonte. Su fecha, en Respenda, a 11 de abril de 1765, ante José Pérez de Salazar, esscribano de dicha villa.

$4^{\circ} .<$ Compra de dos tierras. Año 1765>.

Escritura de venta otorgada por Ángel de Prado, Ángel y Santos García de dos tierras en el término de Velilla para San Zoil. Su fecha, en Velilla de Tarilonte, a 26 de abril de 1765, ante José Luis de Cantoral, esscribano de Villanueva de Muñeca.

$5^{\circ} .<$ Compra de siete tierras. Año 1766>.

Escritura de venta otorgada por Andrés Vallejo, vecino de Velilla de Tarilonte, de siete tierras en término de dicho lugar para San Zoil. Su fecha, en la villa de Cerbera, a 9 de agosto de 1766, ante Bartholomé González de Velasco, esscribano de Cervera.

\footnotetext{
${ }^{520}$ Castrejón] al margen derecho: Castrejón.

521 Traspeña] al margen derecho: Traspeña.

522 Villalveto] al margen derecho: Villalveto.

523 Villaverde] al margen derecho: Villaverde de la Peña.

${ }^{524}$ Celada] al margen derecho: Celada.

525 concordia] al margen izquierdo: De la yglesia.
} 


\section{/ (f. 352r) 6. <Compra de varias tierras. Año 1766>.}

Escritura de venta otorgada por Lorenzo de las Heras, vecino de Velilla de Tarilonte, de varias tierras en los términos de dicho lugar y en Tarilonte ${ }^{526}$ para San Zoil. Su fecha, en Cervera, a 9 de agosto de 1766, ante Bartholomé González de Velasco, esscribano de dicha villa.

Está junto con esta escritura otra de subrogación de heredades, porque dos posesiones de esta escritura no heran libres. Pasó ésta de subrogación ante Manuel García de Guadiana, esscribano de Castrejón, a 20 de mayo de 1767.

\section{Remisiones}

$<$ Tierra $>$.

Vna tierra en término de este lugar para San Zoil. Véase el cajón San Bernardo, legajo $3^{\circ}$, quaderno $\mathrm{B}$, número $8^{\circ}$.

\section{/ (f. 352r) Quaderno F del legajo $2^{\circ}$}

Villaherín

Este quaderno F contiene los papeles siguientes:

$1^{\circ}$. $<$ Memorial $>$.

Memorial de la hacienda que tiene el monasterio en Villaherín y sus términos según está deslindado. No tiene fecha.

$2^{\circ}$. $<$ Despacho para que paguen doce cargas de trigo. Año 1651>.

Despacho librado por el licenciado don Estevan de Malalana, arcipreste de Villalpando y juez conservador, contra Antonio Ravanales y Susaña González, vecinos de Villaherrín, para que pagasen doce cargas de trigo y cebada que debían de renta por las tierras que llevavan en dicho lugar. Dado en Villalpando, a 7 de julio de 1651, ante Juan Redondo, nottario appostólico.

$<$ Nota $>$.

En el legajo 4 del cajón San Plácido, quaderno A, número 11, hay una memoria antigua de esta hacienda que es título Villamayor, después de la dicha villa.

$$
\begin{gathered}
\text { / (f. 352v) Quaderno G del legajo } 2^{\circ} \\
\text { Villaherreros }
\end{gathered}
$$

Este quaderno $G$ contiene los papeles pertenecientes a la hacienda que tiene el monasterio en este lugar, por el orden siguiente:

$1^{\circ}$. $<$ Donación. Era 1206. Año 1168>.

Donación, escrita en pergamino, por la qual Peláez y Vrraca Peláez dan a Gómez Peláez, su hermano, toda la hacienda que tienen en Villaherreros y en Patella Inferior ${ }^{527}$. Facta carta era 1206, que es año 1168. No tiene cosa considerable.

$2^{\circ} .<$ Año $1409>$.

Escritura de cierta heredad a Paramillo de Ferreros. Año 1409. No se hizo al monasterio.

\section{$3^{\circ}$. $<$ Venta de una herrén. Año 1616>.}

Escritura de venta por la qual Alonso de Reoyo vende al convento de san Zoil una herrén a Somavilla, término de Villaherreros, por precio de quatro mil maravedís. Su fecha, en Villaherreros, a 17 de octubre de 1616, ante Ysidoro de la Serna, esscribano de dicho lugar.

\footnotetext{
526 Tarilonte] al margen derecho: Tarilonte.

${ }^{527}$ Patella Inferior] al margen: Padilla de Avajo.
} 


\section{$4^{\circ}$. $<$ Licencia del general para vender una cueva. Año 1631>.}

Petición del concejo y licencia del reverendísimo fray Mauro de Villarroel, general de la congregación, pa[ra] vender una cueva en Villaherreros. Ãño 1631.

\section{/ (f. 353r) Quaderno H del legajo $2^{\circ}$ Villaibáñez}

Este quaderno $\mathrm{H}$ consta de una sola escritura, que es la siguiente:

$<$ Escritura sobre la hacienda que tenía San Zoil en Villaibáñez. Era 1273. Año 1235>.

Escritura, escrita en pergamino y partida por ABC, por la qual dice don Gui, camarero de San Zoil, junto con el convento, que habían puesto demanda a toda la hacienda que don Diego Ýñiguez tenía en Villa Ybáñez, del monasterio de San Zoil, por tenerla a tuerto. Y le pusieron la demanda con carta del apostóligo (breve del papa) que dio comisión a don Mauricio, obispo de Burgos, el qual nombró por jueces al deán maestre Pedro y al arcediano maestre Aparicio, los quales oyeron las partes y dieron sentencia, en que mandaron que don Diego Ýñiguez tuviese todo lo que tenía enVillaibáñez que pertenecía al monasterio de San Zoil por toda su vida, según la escritura hecha entre él y el camarero, y que dé cada año de censo al camarero veinte maravedís. $\mathrm{Y}$ ambas partes vinieron en ello y otorgaron esta escritura con el convento, que fue hecha en el mes de marzo era 1273, que es año 1235. El convento no tenía sello y pidió prestado para sellar el del concejo de Carrión, que es el carro; y el camarero selló con el suyo, que es el castillo.

\section{$<$ Nota $>$.}

Este lugar fue de la diócesis de León y oy está despoblado. Hay memoria que tubo el monasterio en él hacienda, como consta de la escritura arriba dicha, que está sellada con un sello de cera pendiente, que de una parte tiene un castillo, que son las armas y sello del camarero de San Zoil, que hera su prior mayor; y de la otra, un carro, que son las armas de la villa de Carrión, con que selló esta escritura el convento de San Zoil.

\section{/ (f. 353v) Quaderno Y del legajo $2^{\circ}$ Villalveto}

Este quaderno Y contiene los papeles pertenecientes a la hacienda y calidades que tiene San Román en este lugar, por el orden siguiente: $1096>$.

$1^{\circ}$. $<$ Donación del conde don Pedro Ansures y su muger, Ailoni. Era 1134. Año

Donación y testamento, escrita en pergamino, en letra gótica, por la qual el conde don Pedro Ansúrez, siendo conde de Saldaña, concede a la aula de San Adrián, San Miguel, Santa María y otras reliquias que estaban en la yglesia del lugar de Recueva; y a Fernando, presvítero, y sus sucesores libertad de ciertos pechos, y concede ciertos prados y tierras, que todo ello parece lo que San Román goza en este lugar. Facta carta sabato, tertio nonas februari, era 1134, que es año 1096.

Está duplicada en letra vulgar y en latín. Año 1153>.

$2^{\circ}$. $<$ Trueque de la condesa doña Aelo, hija del conde don Pedro Ansuúres. Era 1191.

Escritura de trueque, escrita en pergamino, por la qual consta que Ancardo, prior de San Román, con consentimiento del capítulo de San Ysidro y el de Carrión, dio a la condesa doña Aelo, hija del conde don Pedro Ansúrez, la yglesia de Santiago de Quileta ${ }^{528}$, junto a Dueñas, con todo lo que le pertenecía, como se lo había dado a San Román el conde don Diego Monnio hacía 222 años. Y la condesa le da en trueque dos solares en Villalveto, con todo lo que le pertenece (que oy los goza San Román), y todo lo que esta condesa tenía en Villanueva de Sotronca, en Fontecha, en Santivánez, y lo que tenía en la yglesia o monasterio

\footnotetext{
${ }^{528}$ yglesia de Santiago de Quileta] al margen derecho: Iglesia de Santiago junto a Dueñas.
} 
de San Saturnino de Vega y en la villa de Cuerno de Tablar ${ }^{529}$. Facta carta en San Ysidro, nonas septembris, era 1191, que es año 1153.

$3^{\circ}$. $<$ Donación de un solar en San Martín. Era 1210. Año 1172>.

Donación que hizo a San Román Domingo Velázquez y a su prior don Achar de un solar en la villa de San Martín ${ }^{530}$, que era junto a Villalveto, cuyas heredades labran oy los vecinos de Pino; y el dicho Domingo y sus hijos e hijas lo otorgan a San Román por sus almas, con foro y cargo que qualquiera de sus hijos u otro que allí morare dé en furción a San Román doce panes, medio tocino; y si trajere carral de vino, un quartegón y una asadura. Facta carta mense decembris, era 1210 , que es año $1172^{531}$.

/ (f. $354 r) 4^{\circ}$. $<$ Donación de dos solares que hizo don Gómez Payar y su muger, doña Juliana. Era 1235. Año 1197>.

Escritura, escrita en pergamino, por la qual Bartolomé, prior de San Román, con asenso de su convento, admite por familiares de aquel monasterio a don Gómez Payar y a su muger, Juliana Gutiérrez; y ellos mandan enterrar sus cuerpos en San Román y que lleve todos sus bienes muebles después de sus días y dos solares con sus préstamos que tenían en Villalveto; y el prior les concede por sus días los solares que tenía el monasterio en Castrejón, en Traspeña, en Velilla y en Villaverde ${ }^{532}$, con sus préstamos. Facta carta in die aparitio Domini, sub era 1235, que es año 1197.

$5^{\circ}$. < Colación de la yglesia de Villaoliva y Villalveto. Era 1356. Año 1318>.

Colación ${ }^{533}$ que hizo un arcediano de Saldaña, de la yglesia de Villaoliva ${ }^{534}$ y de Villalveto por presentación y consentimiento del prior de San Román ${ }^{535}$. Era 1356, que es año 1318.

$6^{\circ}$.

Escritura ${ }^{536}$ de un préstamo(mo) que dio fray Bernardino Argadero, en nombre de fray Juan de Corcuera, prior de San Román, a Pedro Guixelmo, vecino de Recueba; es el préstamo en Villalveto. Su fecha, en San Román, a 21 de octubre de 1566, ante Agustín de Medina, esscribano.

Esta escritura es el original.

$7^{\circ} .<$ Executoria de un préstamo en Villalveto. Año 1570>.

Carta executoria de un préstamo en Villalveto, por la qual parece que, en 16 de enero de 1557, se querelló el padre fray Juan de la Corcuera, prior de San Román, ante el licenciado Marcos Rodríguez, alcalde mayor del adelantamiento de Campos, de Catalina de Paredes, porque, teniendo el monasterio en Villalveto una casa y préstamo en que solía vivir Antón Fernández, su marido, yendo a tomar posesión el dicho prior del préstamo que había vacado por fin y muerte del dicho Antón Fernández, la dicha Catalina había tomado un asador y salido a matarle, diciendo que la había querido forzar y otras palabras feas, etcétera; y pidió que fuese castigada y que le dexase libre el préstamo. Sobre lo qual se hizo información y fue presa la dicha Catalina. De parte del monasterio se presentó un memorial de las casas y heredades de este préstamo, para que por él fuesen examinados los testigos de su información, que está aquí inserto.

$$
<1557>\text {. }
$$

\footnotetext{
${ }^{529}$ Cuerno de Tablar] al margen derecho: Villanueva de [Sotronca], Fontecha, Santiváñez, San Saturnino de [Vega], Cuerno de Tablar.

530 San Martín] al margen derecho: San Martín.

531 1172] sigue tachado: Remisiones. <Trueque>. Véase el trueque, cajón.

${ }^{532}$ Villaverde] al margen derecho: Castrejón, Traspeña, Velilla, Villaverde.

533 Colación] al margen derecho: Falta.

534 Villaoliva] al margen derecho: Villaoliva.

535 San Román] sigue tachado: Su fecha, en San Román, a 21 de octubre de 1566.

${ }^{536}$ Escritura] al margen derecho: Falta.
} 
$\mathrm{Y}, /(f .354 v)$ hecha la información y conclusa la causa, el licenciado Sotomayor, alcalde mayor, dio sentencia, en Cuenca de Campos, a 14 de julio de 1557, por la qual condenó a la dicha Catalina de Paredes a que dexase al monasterio el dicho préstamo con los frutos y rentas corridos y más en doscientos maravedís de pena.

$$
<1567>\text {. }
$$

De la qual dicha sentencia apeló la dicha Catalina a la Chancillería de Valladolid para ante los alcaldes del crimen de ella, los quales mandaron soltar a la dicha Catalina, que estaba presa, y remitieron la causa a los oydores. Los quales, por su sentencia, dada en Valladolid, a 28 de febrero de 1567, confirmaron la sentencia dada por el alcalde mayor del adelantamiento y mandaron se llevase a devida execución. De que suplicó la parte de Catalina de Paredes y, sin embargo, se confirmó en revista la dicha sentencia y la del alcalde mayor del adelantamiento, a 13 de junio de 1570 . De todo lo qual se mandó dar y dio en la Chancillería carta executoria, a 21 de julio de 1570, ante Hernán de Villafranca, esscribano de Cámara de Su Magestad. préstamo.

Al último de esta carta está un memorial de las heredades anejas a este mismo

$8^{\circ}$. <Trueque de una casa, etcétera, por varias heredades. Año 1797>.

Trueque que hizo el padre fray Pedro Castro, prior de San Román, con Tomás Martín, vecino de Villalveto, de una casa con su corral, huerto y pradilla proprio del dicho priorato, por dos prados y tres tierras en término de dicho lugar de Villalveto. Su fecha, en San Román, a 10 de mayo de 1797, ante Bernando (sic) Balbuena, esscribano y vecino de Respenda.

\section{Remisiones}

\section{$<$ Donación $>$.}

A.

Las donaciones hechas a San Román. Véase el cajón San Martín, legajo $1^{\circ}$, quaderno

La donación de la yglesia de Santiago junto a Dueñas. Véase el mismo cajón, legajo y quaderno, número $1^{\circ}$.

$<$ Trueque $>$.

Véase el trueque. Cajón San Martín, legajo $1^{\circ}$, quaderno B, número $3^{\circ}$.

$<$ Solar $>$.

Vn solar. Véase este cajón y legajo, quaderno E, número $1^{\circ}$.

\section{/ (f. 355r) Quaderno J del legajo $2^{\circ}$ \\ Villalumbroso}

Este quaderno J contiene las escrituras pertenecientes a este lugar de Villalumbroso, presentación del curato de San Salvador de dicho lugar y noveno de diezmos, por el orden siguiente:

$1^{\circ}$. <Donación de Sancha Ýñiguez y sus hijos. Era 1161. Año 1123>.

Testamento y donación, escrita en pergamino, que otorgó Sancha Ýñiguez y sus hijos e hijas, por la qual ofrecen al monasterio de San Juan, San Zoil y San Felices, que está fundado junto al río de Carrión iuxta cives Sanctæ Mariæ, que en aquel tiempo Carrión hera ciudad y se llamaba Santa María ${ }^{537}$, y le hacen donación, por remedio de sus almas y de las de sus

\footnotetext{
537 Santa María] al margen derecho: Carrión se llamaba en este tiempo la ciudad de Santa María.
} 
padres, de las heredades que tenían en la villa de Fredolfo, que devió de ser lo que ahora Villoldo o Villafolfo, despoblado, y en Villanueba del Revollar y en Cerbatos, que fueron de Pedro Velázquez y de su muger, doña Ocenda, y las heredades que tenían de su patrimonio en Villalumbroso y en Santa María de Villaverde, y otra heredad en San Andrés de Congosto, y otra heredad en Vaños ${ }^{538}$, que fue de Elvira Ýñiguez, y otra heredad en el mismo lugar, que fue de Pedro Velázquez. Facta seriens testamenti kalendas maii, die sabato, era 1161, que es año de Christo de 1123, reynando en Castilla y León el rey don Alonso $8^{\circ}$ (sic), a quien llamaron el Emperador, y don Estevan, prior de San Zoil ${ }^{539}$.

$2^{\circ}$. $<$ Venta de un corral. Año 1692>.

Escritura de venta otorgada por Ygnacio Ybáñez, vecino de Villalumbroso, de un corral tapiado en dicha villa para este (este) monasterio por precio de 190 reales. Su fecha, en Villalumbroso, a 21 de febrero de 1692, ante Diego Laso, esscribano de dicha villa.

$3^{\circ}$. $<$ Venta de un corral. Año 1692>.

Escritura de venta a favor de este monasterio otorgada por Francisco Nicolás y María Antón, vecinos de Villatoquite, de un corral tapiado <en Villalumbroso $>$ por precio de 90 reales. Su fecha, en Villalumbroso, a 21 de marzo de 1692, ante el dicho esscribano.

/ (f. 355v) $4^{\circ} .<$ Compra de una bodega, etcétera. Año 1692>.

Venta a favor del monasterio que otorgó Gerónimo Correas, vecino de Villalumbroso, de una bodega en dicha villa, con más dos cubas y dos carralones, por precio de 500 reales. Su fecha, en Villalumbroso, a 31 de octubre de 1692, ante Santiago de la Huerta, esscribano y rector en Palencia.

$5^{\circ}$. < Compra y trueque de un casa. Año 1693>.

Venta de una casa a favor de Paula de Poza, viuda. Esta casa la cedió Paula de Poza al monasterio y la trocó el monasterio después por otra que linda con la casa que dicho monasterio compró a Matías Calonge y sus hermanos. Véase Título Paredes, cajón San Estevan, legajo $1^{\circ}$, quaderno A, número 6. Su fecha, en Villalumbroso, a 13 de septiembre de 1693, ante Diego Laso, escribano de dicha villa.

\section{$6^{0540}$. < Carta executoria sobre las aguas, fragua, etcétera. Año 1698>.}

Carta executoria a favor de este monasterio de San Zoil por la qual parece que, habiéndose puesto el monasterio a labrar y cultivar la hacienda antigua y nuevamente comprada en el lugar de Villalumbroso, para lo qual se puso monge que la administrase (lo que causó no pocos y graves daños) por octubre de 1691, siendo abad el maestro fray Diego de Fonseca, pareciéndole sería de mucha vtilidad para la casa el trabajar la hacienda de Villalumbroso, Paredes, Villatoquite, Añoza, etcétera; pero la experiencia ha acreditado que aunque sobre esto no se hubieran originado pleytos siempre saldríamos condenados en muchos reales; por querer cultivar dichas haciendas, se suscitaron los pleitos de diezmos, el de la vecindad y aguas que consumieron a esta casa.

$<$ Demanda. $1^{\text {a }}$ sentencia $>$.

En virtud de lo qual, el concejo, justicia, regimiento y vecinos de Villalumbroso no nos permitían gozar de las aguas, de la fragua, carnicería, abacería, ni que las labranzas pastasen con las del lugar en los pastos comunes. Sobre lo qual se puso demanda en Palencia, año de 1696, donde solamente nos concedieron aguas, fragua y yerbas para un par de labranza, pero no como a vecinos.

$<2^{\mathrm{a}}$ sentencia de vista y revista $>$.

De esta sentencia apeló el monasterio y fue el pleyto a Valladolid, donde en vista y revista extendieron la sentencia a dos pares de mulas y no más. Para lo qual se mandó dar y

\footnotetext{
538 Vaños] al margen derecho: Fredolfo o Villoldo, Villanueba del Revollar, Cerbatos, Santa María de Villaverde, Congosto, Baños.

539 San Zoil] al margen derecho: Prior de San Zoil don Estevan.

$5406^{\circ}$ ] al margen derecho: Debe ser el 9 (precede tachado: Nota. Este número debe ser el $9^{\circ}$ ).
} 
se dio esta carta executoria por los señores de la sala a favor del monasterio. Dada en Valladolid, a 20 de junio de 1698, ante Pedro Martínez de Sicilia, esscribano de Cámara.

No se notificó a la justicia.

En el año de 1705 se volvió a quitar la labranza y arrendar la hacienda.

/ (f. 356r $7^{\circ}$. <Executoria de manutención que no se pagase diezmo. Año 1699>.

Executoria por la qual parece que, habiéndose suscitado el segundo pleito, el qual se litigó con el cabildo de León, curas de Villalumbroso y Paredes, éstos, pues viendo que el monasterio trabajaba las tierras y viñas, pusieron demanda ante el provisor de León, en agosto de 1692, sobre que les pagase los diezmos de uno y otro; a lo que se opuso el monasterio, alegando sus exenciones y privilegios.

$<1^{a}$ sentencia $>$.

$\mathrm{Y}$, hechas las provanzas por una y otra parte, dio el provisor sentencia, en 23 de diciembre de 1697, por la qual mandó que el monasterio no pagase diezmo de las heredades antiguas cultivándolas a nuestras expensas; pero que de todo lo nuevamente adquirido lo pagásemos, ora sea trabajándolas a nuestras expensas o por colonos.

$<$ Apela el manasterio (sic) $>$.

De esta sentencia apeló el monasterio y sacó las ordinarias de la nunciatura a donde se llevó el pleito.

$<2^{\mathrm{a}}$ sentencia de manutención $>$.

$\mathrm{Y}$, en 5 de febrero de 1699, se dio auto de manutención y amparo a favor del monasterio de la posesión en que estaba de no pagar diezmo de lo que trabajábamos a nuestras expensas. Con lo qual se despachó esta carta executoria y con ella fue requerido el abad de Benavívere para que la hiciese guardar, el qual aceptó la comisión y dio auto para que se guardase.

Fue requerido el provisor de León y se notificó a las partes contrarias, como consta de las notificaciones puestas al pie de ella.

$<$ Apelación de parte del cavildo de León del auto del nuncio>.

De este auto o executoria del nuncio apeló el cavildo de León, como consta del testimonio que se sigue en este número, y ganó breve de Su Santidad para jueces sinodales de Palencia, Astorga y Oviedo; el qual aceptó la comisión y despachó letras citatorias y, habiéndolas notificado, se siguió la causa.

$<$ Sentencia confirmatoria de la del provisor. 1700.>

Y, en junio de 1700 , dio sentencia confirmando en todo la que avía dado el provisor de León (que es la arriba dicha); y sin dilación alguna despachó ministro que ajustase qüentas y la executase, el qual vino y la notificó al monasterio, en 22 de dicho mes de junio, y se respondió que se había apelado e implorado el auxilio de la fuerza.

$<$ Embargo $>$.

No obstante, el ministro pasó a Villalumbroso, hizo la qüenta como le pareció y emba[r]gó lo que quiso, entre algunas cosas cogió las labranzas y carros y los llevó a León, donde se vendieron, / (f. 356v) saliendo la casa a la compra por tercera persona.

$<$ Recurre el monasterio a la sala $>$.

Mientras tanto, se sacaron las provisiones reales para la fuerza y fueron notificadas al juez apostólico, notario de la causa, y a los demás, y se llevó el pleito a la sala, donde ganamos la fuerza.

$<$ Restitución $>$.

Y en su cumplimiento, el juez appostólico mandó restituir todo lo embargado y vendido, con lo qual fueron requeridos los ministros y cavildo de León y se restituyó todo 
después de los muchos gastos y daños. Pero siempre quedó la causa pendiente de la apelación y así fue necesario recurrir a Roma y traher letras para sacar el pleito y seguir la causa, las quales se notificaron al juez appostólico y al nottario de la causa para que sacase y cmpulsase el pleito, el que se compulsó y al presente está en Roma, donde no nos quisieron oír hasta que pagásemos la condenación y ajuste de qüentas que había hecho el ministro del juez appostólico, que pasaron de 400 ducados. Todos éstos y otros muchos daños, que bien ajustadas las qüentas pasaron de 3000 ducados, fue la causa el haber tomado en hacienda el principal y réditos de un censo y comprado lo demás con ánimo de poner o hacer allí priorato, como se efectuó, como dije al principio, hasta que el año de 1705 se arrendó todo a los vecinos de esta villa y a los de Añoza. Todo lo litigado se halla vajo este número, que puede servir para qualquier pleito de diezmos que suceda.

\section{8. <Compra de una hera. Año 1696>.}

Venta de una hera en las de abajo a favor del monasterio otorgada por Santiago Martínez, vecino de Villalumbroso, por precio de 100 reales; la hera está en término de dicho lugar. Su fecha, en Añoza, a 3 de mayo de 1696, ante José de Guzmán, esscribano de la villa de Añoza.

\section{9. <Compra de una hera. Año 1697>.}

Venta a favor el monasterio otorgada por Nicolás Correas, vecino de Villalumbroso, de una hera en las de abajo, término de dicho lugar, por precio de 110 reales. Su fecha, en Villalumbroso, a 3 de junio de 1697, ante Diego Lasso, esscribano de dicha villa ${ }^{541}$.

10. <Compra de una hera. Año 1698>.

Venta $^{542}$ a favor del monasterio otorgada por Alonso Thomé, Sebastián González y Marcelo Thomé, vecinos de Villalumbroso, de una hera en término de dicha villa, que llaman de avajo, de tres quartejones, por precio de 110 reales. Su fecha, en Villalumbroso.

\section{/ (f. 357r) 11. <Compra de una casa corral. Año 1701>.}

Venta otorgada por don Carlos Barba y doña Feliciana Santoyo Pimentel, regidor perpetuo de la villa de Carrión, de una casa corral, que fue texado de ganado lanar, y una herreneja herial, lindero della, por precio de 550 reales. Su fecha, en San Cebrián, a 20 de enero de 1701, ante Miguel López, escrivano de San Cebrián.

El papel siguiente es una confesión de los otorgantes, en que declaran haber ecivido el dinero y se obligan a hacer otra escritura, 2 de febrero de 1702.

12. < Adjudicación de hacienda en Villalumbroso y Paredes. Año 1743>.

Escritura de adjudicación de un solar, bodega y once tierras en los términos de Villalumbroso y Paredes ${ }^{53}$, hipotecadas de un censo que contra sí tenía Miguel Redondo a favor del monasterio, por lo que se nos adjudicaron dichas heredades por sentencia de don Diego de Herrezuelo, alcalde ordinario en Villalumbroso, a 6 de octubre de 1742. Pasó ante Mauricio Martínez de Chirueches ${ }^{544}$, de dicha villa, a 22 de diciembre de 1743.

13. <Dexación de una tierra y posesión que tomó el monasterio. Año 1797>.

Dexación de una tierra en término de Villalumbroso, la qual llevava Vicente Correas. $\mathrm{Y}$, habiendo dexado de pagar algunos años, cuya cantidad llegava a 92 fanegas, tres celemines y un quartillo de trigo, se le condenó por sentencia difinitiva dada por don Eugenio de Guzmán a que dejase la dicha tierra; y el monasterio, vsando de benignidad, le perdonó dicha cantidad y tomó posesión de la dicha tierra, que <es $>$ a do dicen a la Caven del Canto. Pasó ante Pedro Matanza, esscribano de Villalumbroso, a 19 de septiembre de 1797.

\footnotetext{
541 villa] al margen derecho: mal borrado, refiriéndose a la nota que está tachada que aparece a continuación.

542 Venta] al margen derecho: Nota (sigue texto borrado).

543 Paredes] al margen derecho: Paredes.

${ }^{544}$ Mauricio Martínez de Chirueches] al margen derecho está tachado: esscribano en Carrión.
} 


\section{Remisiones}

$<$ Adjudicación $>$.

Adjudicación de tierras. Véase título Paredes, cajón San Estevan, legajo $1^{\circ}$, Quaderno A, número $10^{0545}$. $<$ Y también véase el número $6^{\circ}$ y $7^{\circ}>$.

En el mismo cajón, legajo y quaderno, número 11, hay un testimonio que hace relación de la tierra del número 13 de este quaderno.

$<$ Concordia $>$.

Concordia. Véase el cajón San Andrés, legajo $1^{\circ}$, quaderno B, número $3^{\circ}$.

\section{/ (f. 358r) Legajo $3^{\circ}$ del Cajón San Gregorio}

Este legajo, que es el tercero de este cajón San Gregorio, contiene los dos quadernos siguientes: quaderno A: privilegios y executorias tocantes a las tercias y diezmos; quaderno B: hacienda que tiene el monasterio en Villafrechós.

\section{Quaderno A del legajo $3^{\circ}$}

\section{Villafrechós}

Este quaderno A contiene los privilegios, cartas executorias y escrituras tocantes a las tercias y acción que tiene el monasterio de San Zoil a la hacienda de Villafrechós y Cabañas, por el orden siguiente:

\section{$1^{\circ}$. < Privilegio del rey don Fernando el $2^{\circ}$. Era 1222. Año 1184>.}

Privilegio del rey don Fernando el $2^{\circ}$, hermano del rey don Sancho el Deseado, hijo del rey don Alonso el $8^{\circ}$ (sic) llamado el Emperador, por el qual dice que, para la seguridad, fortaleza y defensa de su reyno, toma para sí toda la heredad que el monasterio de San Zoil tinía (sic) en Villafructuoso (ahora Villafrechós), la qual dio a los pobladores de aquella villa quando la pobló, excepto dos yugadas de tierras, quanto pudiesen arar para un año dos yugadas de bueyes, y excepto todas las viñas que tenía Estevan, procurador de la casa de San Salvador en su palacio quando el rey tomó esta hacienda, y tres huertas, todas las herrenes y una hera. Y en trueque da al monasterio dos yglesias en la dicha villa, que son la de San Christóval y la de San Pelayo ${ }^{546}$, con sus viñas, heredades y parroquianos, con todo lo que les pertenece por derecho, y todas las demás yglesias que adelante se fundasen en la dicha villa, fuera de la yglesia del obispo, quæ venit cum parrochianis suis de Coreses ${ }^{547}$. La qual / ( $f$. $358 v$ ) manda que no reciva ningún parroquiano de las demás yglesias de los monges. Y para que esto sea firme y se guarde invi $<\mathrm{O}>$ lablemente, manda que se confirme por el obispo y cavildo y que se selle con su sello. Concede también que los monges posean perpetuamente juro hereditario todos los solares que el rey tenía y había dado a los vasallos que el monasterio tenía en el lugar de Cabañas ${ }^{548}$, los quales havían venido a poblar a Villafrechós, y de allí adelante ser ayan y quiten del derecho real, y los monges tengan en tales solares el mismo servicio que en lo demás que tenían en Cabañas y tengan en ellos todo servicio, sumazga (sic) $\mathrm{y}$ pedido enteramente, $\mathrm{y}$ los monges hayan y cobren por su merino la mitad de los derechos que allí tenía el rey de pedidos, fonsecas (sic) y calumnias. Y si los vasallos que allí tuviere el monasterio no le quisieren servir y acudir como a sus señores con el pan, vino, pedidos y otros servicios, los monges tengan poder para quitarles los préstamos y darlos a quien quisieren. Manda que el concejo de Villafrechós no haga violencia alguna a los monges en las cosas que fueren necesarias para sus yglesias, si conforme al tiempo y posibilidad ellos las administraren. Concede que los capellanes y clérigos de los monges, los hombres de su

\footnotetext{
545 número $10^{\circ}$ ] sigue tachado: La misma. Título Añoza. Cajón San Juan, legajo $1^{\circ}$, quaderno A, número $2^{\circ}$.

546 Pelayo] al margen derecho: Dos yglesias del monasterio, que son San Christóval y San Pelayo.

${ }^{547}$ Coreses] al margen derecho: Yglesia del obispo, la que se trasladó de Coreses.

${ }^{548}$ Cabañas] al margen derecho: Cabañas lugar del monasterio. Para esto de Cabañas véase el cajón San Lorenzo, legajo $3^{\circ}$, quaderno $\mathrm{A}, \mathrm{n} .^{\circ}$, vn privilegio del rey don Alonso el $7^{\circ}$.
} 
palacio y los que se les hubieren encomendado por familiares, sean libres de todo derecho de concejo, de castillo, pedido, pecho y de toda hacienda, así del concejo como del rey. Y que la yglesia de San Lorenzo de Cabañas ${ }^{549}$ se haga en Villafrechós en buen lugar; y las yglesias de Santa María, que es de los herederos, y la del Obispo, les da una sentencia: que miren los sacerdotes de ellas no embían sus hombres por las heras y lagares a cobrar los diezmos de los monges; que se den 20 obradas de bueyes al señor que fuere del lugar o a quien tuviere la voz del rey, y los que dieren y los que recivieren vuelban doblado a los monges lo que tomaren de $\operatorname{los}^{550}$ muertos, de las ofrendas de diezmos y primicias y de qualquiera otra cosa que sea del derecho de la yglesia. Si en este trueque los monges recivieren alguna mejora, el rey se lo concede por remedio de su alma y la de sus padres y parientes. Concede ${ }^{551}$ que si en la población de Villafrechós reciviere algún disgusto, recivan los monges enteramente todas las heredades que tenían en Villafrechós y sus vasallos de Cabañas vuelvan a su lugar, y las yglesias / (f. 359r) de Villafrechós queden al derecho del rey. Prohive que los préstamos de Cabañas los tengan otros sino los vasallos de este monasterio y que no los puedan dividir si no fuere con voluntad de los monges. Las mejoras que dice el rey que hace a los monges son: que embíen por merino a sus vasallos de Cabañas a quien quisieren y sea merino todo el tiempo que los hombres quisieren; yten que ninguno de Cabañas tenga sino sólo un préstamo de 20 obradas de bueyes, y les manda que no vendan ni empeñen las tierras ni viñas de sus préstamos, ni tengan préstamo de que no den un par de bueyes para la serna. Facta carta en Zamora, VII kalendas novembris, era 1222 que es año de Christo de 1184. Este privilegio está escrito en pergamino, con sello de cera pendiente en correas de cuero y forrado en pergamino.

Hay copia traducida por don Antonio Fernández de Guzmán, nottario appostólico.

$2^{\circ}$. < Privilegio del rey don Alonso el $9^{\circ}$. Era 1226. Año 1188>.

Privilegio original del rey don Alonso el $9^{\circ}$, escrito en pergamino, con sello de cera pendiente en filos de seda de varios colores y forrado en pergamino, por el qual confirma el privilegio pasado del rey don Fernando el $2^{\circ}$, su padre, a Humberto ${ }^{552}$, prior de San Zoil y camarero de Cluni, y a los monges y convento de San Zoil. Está en latín y refiere en relación todo lo contenido en él. Fecho en Carrión, V kalendas iullii, era 1226, que es año 1188.

3. <Trasumptos de los privilegios $>$.

Trasumptos ${ }^{53}$ simples en papel de los privilegios arriba dichos y del infraescriptio, el uno de ellos está autorizado, si bien está maltratado. Mejor están los originales de todos ellos.

$4^{\circ}$. <Privilegio del rey don Alonso el $9^{\circ}$. Era 1229. Año 1191>.

Privilegio del rey don Alonso el $9^{\circ}$, por el qual confirma el de el rey don Fernando el $2^{\circ}$, su padre, y manda al concejo y vecinos de Villafrechós que le guarden quanto a las yglesias $<y$ derechos $>$ de dicho lugar y vasallos y derechos de Cabañas. Dado en Palencia, III kalendas aprilis, era 1229 que es año de Christo de 1191. Está escrito en pergamino y en latín, con sello de plomo pendiente en filos de seda.

$5^{\circ}$. <Privilegio del rey don Alonso el $9^{\circ}$. Era 1234. Año 1196>.

Privilegio $3^{\circ}$ del rey de Castilla y de Toledo don Alonso el $9^{\circ}$, hijo de don Fernando el $2^{\circ}$, es rodado, escrito en pergamino y en latín, con sello de plomo pendiente, por el qual el rey don Alonso, junto con su muger, la reyna doña Leonor, y su hijo don Fernando, concede y confirma a Dios y al monasterio de San Zoil y a don Pedro ${ }^{554}$, su prior y camarero de Cluni, y a todos sus sucesores las tercias de los diezmos de todas las yglesias de Villafrechós que enton/ (f. 359v) ces heran y que de allí adelante se fundasen, las quales ayan todos los años

\footnotetext{
${ }^{549}$ la yglesia de San Lorenzo de Cabañas] al margen derecho: La yglesia de Cabañas se haga en Villafrechós en buen lugar.

$\left.{ }^{550} \mathrm{los}\right]$ sigue tachado: monges.

551 Concede] al margen derecho: Condiciones.

552 Humberto] al margen derecho: Don Humberto, prior de San Zoil.

553 Trasumptos] al margen derecho: Nota: este número a de ser el siguiente al $5^{\circ}$ privilegio.

554 don Pedro] al margen derecho: Don Pedro, prior de San Zoil.
} 
enteramente sin diminución alguna, excepto una yglesia del obispo que vino de Coreses $^{555} \mathrm{y}$ otra de los templarios que vino de Zalengas ${ }^{55}$. Y por estas tercias y los derechos de los muertos no estén obligados a cosa alguna en las dichas yglesias. Fecha en Palancia, nonas februarii, era 1234, que es año 1191. Hay copia traducida por Antonio Fernández de Guzmán, nottario appostólico.

$6^{\circ} .<$ Concordia entre el concejo de Villafrechós y Villalumbroso y el convento. Era 1283. Año 1245>.

Escritura de concordia, escrita en pergamino y partida por ABC, con sello de cera pendiente forrado en pergamino, en la qual el concejo y vecinos de Villafrechós ( y el de Villalumbroso) dicen que, habiéndose informado en el pleyto que trahían con el convento de San Zoil del derecho que éste tenía en tiempo de los reyes don Alonso y don Fernando y de sus padres y avuelos, hallaron que al convento le pertenecía enteramente la tercia de los diezmos de pan, vino y mortuorios de Villalumbroso ${ }^{557}$ y así quieren y vienen en que la aya el convento perpetuamente, sin contradición alguna; y por la buena voluntad que mostraron se les ofrece don Juan López, sacristán de Santa María de Náxera, en nombre del convento y como $<$ su $>$ procurador, tres cargas de pan de limosna para la lámpara en cada año de la dicha tercia, una de trigo, otra de centeno y otra de cebada. Y los del concejo ofrecen amparar y defender al convento sus tercias y demás cosas de su hacienda para siempre. Entre los testigos de esta escritura está don Martín Pérez, prior de Toro ${ }^{558}$. Fecha día de Santa María Magdalena de julio, era 1283, que es año 1245. Escriviola Domingo Bartholomé, monge de San Ysidro, por mandado del concejo. Hay copia autorizada por don Antonio Martín García, traductor y nottario.

$7^{\circ}$. < Carta del obispo de Zamora, inserta otra del rey don Alonso, para que se desembarguen la $3^{\text {a }}$, etcétera. Era 1295. Año 1257>.

Carta de don Suero, obispo de Zamora, nottario del rey don Alonso el Sabio, escrita en pergamino, sellada con su sello de cera pendiente, por la qual dice el obispo que por mandado del rey había mandado a Miguel Pérez de Toro, alcalde de Villafrechós por el rey, que hiciesen pesquisa si el camarero de Carrión había tercias en Villafrechós o Villalumbroso, que se las contradecía Fernán Martín, portero del rey. Y el dicho alcalde hizo información y se la embió cerrada y sellada y constó de ella que nunca el rey, ni otro por él, había llevado tercias de aquellos lugares, sino que los clérigos llevan la una tercia, otra el obispo de León y otra el / (f. 360r) camarero de Carrión, y que nunca se cogieron dezmeros sino un año por fuerza. Y la reyna doña Berenguela mandó que se les entregase.

$<$ Era 1294. Año 1256>.

Asimismo dice que vio una carta del dicho rey don Alonso el Sabio, que se pone a la letra ${ }^{55}$ en la del obispo, dirigida a los colectores de las tercias que el rey tenía en el obispado de León, a los quales dice que el convento de San Zoil se le había querellado que le quitaban las tercias de Villalumbrós ${ }^{560}$, que le pertenecían por privilegio que mostraron del rey don Alonso, su < vis>abuelo, y que las habían tenido en $<$ los $>$ tiempos del rey don Alonso y el rey don Fernando, su padre, y manda a los dichos colectores que no se las contradigan ni se las embarguen y que les vuelvan lo que de ellas hubieren tomado. Diose esta carta del rey en Segovia, a 8 días de septiembre, era 1294, que es año 1256. Y el obispo dice que leída la carta se la dé y que en esto no haya duda. Y en testimonio da esta carta abierta en Toro, tres días antes de San Juan Bautista, era 1295, que es año 1257.

Hay copia autorizada por don Antonio Martín García, traductor y nottario ppúblico. $8^{\circ} .<$ Carta de desembargo. Era 1296. Año 1258>.

\footnotetext{
555 Coreses] al margen derecho: Yglesia de Coreses.

556 Zalengas] al margen derecho: Yglesia de Zalengas.

557 Villalumbroso] al margen derecho: Villalumbroso.

558 prior de Toro] al margen derecho: Prior de Toro don Martín Pérez.

559 letra] sigue tachado: Que se pone.

${ }^{560}$ Villalumbrós] al margen derecho: Villalumbroso.
} 
Carta de desembargo que hizo Domingo Andrés, colector de las tercias reales en el obispado de León, de las tercias que el monasterio tiene en Villalumbrós ${ }^{561}$ y diezmos de Villafrechós, en virtud de la carta arriba dicha que dio don Suero, obispo de Zamora, la qual con la del rey don Alonso el Sabio, está inserta ${ }^{562}$, obedecida y executada en esta de desembargo, que está escrita en pergamino, con sello de cera pendiente. Dada en Valladolid, a 20 de enero, era 1296, que es año 1258. Hay copia autorizada por don Antonio Martín García, traductor y nottario ppúblico.

9. <Arrendamiento de las tercias en 130 cargas de trigo. Año 1417>.

Arrendamiento que hizo el convento de San Zoil a Juan González Patudo, cura de San Lorenzo de Villafrechós, de las tercias de pan y vino pertenecientes al monasterio en aquel lugar y en Villalumbrós ${ }^{563}$ de Campos por tiempo de seis años, por precio de ciento y treinta cargas de trigo bueno, limpio, etcétera, puesto en San Zoil a su costa. Su fecha, en Carrión, a 23 de septiembre de 1417, ante Fernán Rodríguez de Castellanos, esscribano de Carrión.

Hay copia autorizada por don Antonio Martín García, nottario.

10. < Obligación de 700 maravedís. Año 1429>.

Obligación hecha por Juan González Patudo, cura de San Lorenzo de Villafrechós, al monasterio por setecientos maravedís por / (f.360v) los diezmos de vino de Villafrechós y Villalumbrós ${ }^{564}$. Año 1429.

11. < Provanza de los préstamos de Santa María de Torices. Año 1454>.

Trasumpto de una provanza de las heredades de los préstamos de Santa María de Torices que pretendían los renteros que las tenían estar libres de diezmo y no deber contribuir en las tercias del monasterio. Está hecha con autoridad de don Álvaro de Nogales, abad del monasterio de Nuestra Señora de La Vega, juez subconservador por subdelegación del abad de Sahagún, juez principal conservador de los monasterios sujetos a Cluni. Hízose en Villafrechós, ante Ruy González, clérigo, y Alfonso López, vecinos de Villalpando, y ante Diego Fernández de Villalpando, esscribano y nottario de Villafrechós, a 4 de julio de 1454.

12. $<$ Diezmos de garvanzos y legumbres. Año 1480>.

Declaración hecha y firmada por el arcipreste y cavildo de Villafrechós, en que convienen en que el monasterio lleve la tercia enteramente de los garvanzos y demás legumbres que se cogieren en dicho lugar. Su fecha, sábado, 7 días de octubre de 1480.

13. < Concordia sobre los diezmos de capellanías. Año 1483>.

Carta de concordia hecha entre el covennto de San Zoil y Juan de la Rúa, monge dél y con su poder, y el cabildo y clérigos de Villafrechós y Alfonso González Francés, cura de San Christóval y abad de dicho cavildo, en su nombre y con su poder, por la qual parece que habiendo trahído pleito en razón de los diezmos de las capellanías de algunos clérigos de dicho lugar, que pretendían no deberlos al monasterio ni a otra persona, y el convento serle devidos conforme a derecho, y habiéndose informado de personas de ciencia y conciencia, y constando a los dichos clérigos que debían pagar los tales diezmos, por escusar pleitos y costas, se concordaron con el convento en que el dicho Juan de la Rúa en su nombre les perdona los diezmos de dos años que se habían subtrahído de pagar; y el dicho Alfonso González, en nombre del cavildo, se obliga y allana que de allí adelante para siempre jamás se pagará al monasterio la parte de los diezmos que huviere de haber de las capellanías llanamente y sin pleitos. Su fecha, en Villafrechós, a 9 de diciembre de 1483, ante Juan Rodríguez de Torre, esscribano de Villafrechós.

\footnotetext{
561 Villalumbrós] al margen derecho: Villalumbroso.

562 inserta] sigue tachado: $\mathrm{y}$.

563 Villalumbrós] al margen derecho: Villalumbroso.

564 Villalumbrós] al margen derecho: Villalumboso (sic).
} 

$1502>$.

/ (f. 361r $)$ 14. < Carta executoria de las tercias de Villafrechós y Villalumbrós. Año

Carta executoria de los Reyes Católicos don Fernando y doña Ysabel librada por sus contadores, escrita en pergamino, con sello de cera encarnada, en una caja de madera, pendiente en filos de seda encarnada y verde, por la qual parece que Alonso de Arévalo, vecino de Tordesillas, arrendador de las medias tercias pertenecientes al rey en las tierras del condado de Vrueña, en que caen los lugares de Villafrechós y Villalumbrós, puso demanda a estos concejos ante el corregidor de Tordesillas y su teniente y después ante Francisco Martínez, alcalde y comisario de cuentas por el rey en Tordesillas, por las medias tercias que pretendía haber tocado en los dichos lugares los años de $1499^{565}, 1500$ y 1501 en que fue arrendador. Citados los concejos, negaron la demanda por no pertenecer en aquellos lugares al rey cosa alguna de las medias tercias y que a ellos no se les debía pedir sino a los que gozaban y llevavan ${ }^{566}$ tercias. Reciviose el negocio a prueba, hicieron las partes sus provanzas, alegaron y presentaron escrituras. Conclusa la causa, el dicho Francisco Martínez dio sentencia en favor de Alonso de Arévalo y condenó a los concejos en la mitad de las tercias de aquellos tres años y las costas, reservándoles su derecho a salvo para que cobrasen de las personas a quien habían pagado las tercias. De que apelaron los concejos y, sin embargo, se alegó ante el dicho alcalde, el qual condenó a los concejos en ciertas penas por no haber entregado las tadmías de aquel tiempo, de lo qual apelaron. Alonso de Arévalo pidió declaración de deserción de la apelación de los concejos y mandamiento de execución para que se les pagase lo contenido en la sentencia. Diose el mandamiento y con él se hizo execución y remate en ciertos bienes de los concejos. De que apelaron ellos y el monasterio de San Zoil como tercero interesado, y se presentaron en grado de $<$ a $>$ pelación ante los nottarios reales de rentas de Valladolid, donde se llevó el proceso, y se alegó de la injusticia y nulidad de la sentencia y lo en virtud de ella hecho y executado, y pidieron se revocase todo ello y se diese por nulo. A que respondió Alonso de Arévalo en su defensa. Estando en este estado, se dio cédula para que este pleito se llevase ante los contadores mayores de Su Magestad para verlo y determinarlo. De esta cédula apeló el monasterio y los concejos y se presentaron con / (f.361v) el proceso ante el presidente e oidores de Valladolid, ante quienes alegaron las partes hasta que se dio el pleito por concluso; y se dio sentencia en la qual se remitió el pleito a los contadores mayores de Su Magestad ante quienes se presentó el proceso, y el convento y los concejos alegaron sus agravios y que el convento no había sido citado en la primera instancia porque no le paró perjuicio la sentencia, que las tercias eran una de los clérigos, otra de la yglesia de León y otra del monasterio, en que el rey no tenía cosa alguna, que el monasterio estaba en posesión inmemorial por privilegios que tenía de los reyes. Que el recurrimiento que se dio a Alonso de Arévalo de la mitad de las tercias fue por razón que al conde de Vrueña le quedaron la mitad de las tercias en sus tierras por las Cortes de Toledo del año de 80 y de la otra mitad se dio el recudimiento, creyendo que las llevava el conde, y era claro que las tercias de Villafrechós las llevava el monasterio, y así no tenía parte en ellas el conde ni el rey, y así se le debía deshacer el agravio hecho en la dicha sentencia, etcétera. Alonso de Arévalo respondió en su defensa. Las partes alegaron y el monasterio presentó los privilegios y escrituras en guarda de su derecho. Concluso el pleito, los contadores mayores dieron sentencia de restitución en favor del monasterio y concejos para lo que la havían pedido y se recivió el negocio a prueba de lo alegado. Los concejos hicieron y presentaron su provanza, y en reveldía de Alonso de Arévalo se hizo publicación y se concluyó la causa. Los contadores mayores del rey dieron sentencia por la qual revocaron y dieron por nula e injusta la sentencia, mandamientos y autos del alcalde y contador Francisco Martínez y dieron por libres a los concejos y al monasterio de los contra ellos pedido por Alonso de Arévalo y mandaron que, libremente y sin costas, les fueren vueltas qualesquiera prendas que les fuesen tomadas. Dada en 5 de noviembre de 1502. Notificose a las partes, la de Alonso de Arévalo no suplicó y la del convento pidió carta (carta) executoria, y se le dio ésta en Madrid, a 17 de noviembre de 1502, ante Diego Sánchez Ortiz, esscribano de los Reyes Católicos y de la Audiencia de sus contadores mayores. Están aquí

\footnotetext{
565 1499] sigue tachado: $\mathrm{y}$.

566 llevavan] sigue tachado: aquellas.
} 
un traslado autoriza/ (f. 362r)(za)do $\mathrm{do}^{567}$ de esta confirmación de la reyna doña Juana, un requirimiento ${ }^{568}$ a los alcaldes de Villafrechós, con una carta de desembargo de la reyna doña Juana, y una carta de recudimiento y provisión real de los Reyes Católicos, don Fernando y doña Ysabel, para que los oficiales $<$ y vecinos $>$ de Villafrechós y Villalumbrós y otros lugares acu(n)dan con la mitad de las tercias a Juan Rodríguez de Medina.

15. <Desembargo de la $3^{\mathrm{a}}$. Año 1507>.

Desembargo de pan y vino que el monasterio tiene en Villafrechós y Villalumbrós. Su fecha, en Villalfrechós, a 7 de octubre de 1507, ante Bernardino de Olmos, esscribano ppúblico.

16. $<$ Requirimiento y secresto de la tercia. Año 1508>.

Requirimiento que hizo Alonso de Camudio, alguacil de la reyna, a los alcaldes y regidores de Villafrechós para que le diesen cuenta con pago de la media tercia de pan y vino perteneciente a la reyna por los años de 1506, 1507 y 1508, los quales respondieron no haber cosa perteneciente a la reyna más que una tercia depan y vino del monasterio de San Zoil que le pertenecía por dos sentencias que había tenido en su favor de los Reyes Católicos. Sin embargo, el alguacil secrestó el trigo y vino que había del monasterio en Villafrechós, a 18 de septiembre de 1508, ante Pedro de Villafranca, esscribano de la reyna.

17. <Confirmación de la dicha executoria dada por los contadores de la reyna doña Juana. Año 1510>.

Confirmación de la carta executoria del número 14 de los Reyes Católicos dada a modo de privilegio, escrita en pergamino, con sello de plomo pendiente en un cordón de seda encarnada, verde, azul y color de naranja, por la qual la reyna doña Juana y sus contadores mayores confirman dicha executoria de los Reyes Católicos y la sentencia dada por sus contadores mayores a favor del monasterio, que todo está inserto a la letra en esta escritura. Dada en Madrid, a 23 de octubre de 1510.

Está con esta escritura un traslado autorizado de la executoria de los Reyes Católicos.

18. < Requirimiento para la cobranza de las tercias. Año 1512>.

Requirimiento que hizo fray Diego de Lilio, monge de San Zoil, a los alcaldes y procuradores de Villafrechós con un privilegio y cartas de la reyna doña Juana, para que en su cumplimiento desembargasen las tercias del monasterio, que las tenían embargadas unos colectores de la media tercia real, que después se desembargó y cobró el monasterio. Su fecha, en Villafrechós, a 21 de agosto de 1512, ante Bartholomé Pérez, esscribano de Aguilar.

/ (f. 362v) 19. <Desembargo de diezmos. Año 1614>.

Desembargo de los diezmos que tocaban al monasterio por el despoblado de Villalumbrós. Su fecha, en la villa de Santofimia, a 26 de agosto de 161, ante Juan Martín, esscribano de dicha villa.

20. $<$ Cuentas de la tercia. Año 1616>.

Averiguación que hizo el padre fray Antonio del Valle y el licenciado Juan Delgado, cura de Villalumbrós, como colector que era, de las cuentas del pan, trigo y cebada de las tercias de Villalumbrós. Pasó año 1616, ante Pedro d’Olmos, esscribano ppúblico.

21. <Comisión para los novales. Año 1633>.

Comisión del provisor de León, dada a instancia de la yglesia de Regla y convento de San Zoil, para hacer información que ciertas heredades que habían sido huertas no eran novales y así debían diezmo a la yglesia de León y al convento de San Zoil. Pasó año de 1633, ante Antonio de Vega, esscribano.

\footnotetext{
567 autoriza/ (f. 362r)(za)do] entre autoriza y do está tachado: de esta carta executoria de los Reyes Católicos, está también autori.

568 requirimiento] al margen derecho: Esto hace relación al número 16 infraescrito.
} 


\section{2. $<$ Sentencia de los zalengones. Año 1638>.}

Sentencia árbitra dada por don Juan de Galarza y Mallea, letrado de Villabrájima, en la diferencia que hubo entre este convento y el de Santa Clara de Villafrechós sobre los diezmos de la hacienda de Pedro Tomillo Zalengón, difunto, en que se declaró pertenecer a San Zoil. Pasó en 20 de septiembre de 1638.

\section{3. $<$ Sentencia sobre diezmos a favor de las monjas $>$.}

Tanto de una sentencia a favor de las monjas de Santa Clara de Villafrechós, en que las hace libres de pagar diezmo. No tiene fecha.

24. <Papel simple>.

Papel simple sacado de las razones que tienen las monjas para no pagar diezmos.

Está aquí un parecer que remitieron dichas monjas, al que se respondió y se dio la práctica de diezmar. También en papel simple.

25. <Desembargo de las tercias de Villafrechós, Aguilar y Santa María de Arconada por cédula del señor rey Felipe V. Año 1708>.

Desembargo de las tercias de Villafrechós y su partido, Aguilar de Campos y Santa María de Arconada ${ }^{569}$, en vista de privilegios y cartas executorias que presentó el monasterio habiendo la Magestad de nuestro rey Felipe V, mandado embargar a todos los diezmos por razón de los novenos que tocan a la corona por dos decretos despachados en los años de 1706 y 1707; con que confirmó Su Magestad dichos privilegios y cartas executorias en el año de 1708 por su cédula real de 10 de enero, firmada de su real mano y de los del su Concejo de Hacienda. Requiriose con dicha cédula real de confirmación a las justicias de Villafrechós y Aguilar. Y para más claridad en este título, la cédula real referi/ (f. 363r) da y en cada título de los otros lugares recordados, se hace mención de ella para que se valgan de ella quando fuere necesaria y sepan donde se halla para no multiplicar papeles. En Madrid, a 6 de enero de 1708. Año 1774>.

26. $<$ Despacho para que se repartan los diezmos de las legumbres a los interesados.

Despacho del provisor de León, a pedimiento del cavildo de dicha ciudad y el abad de San Zoil, para que los diezmos de las legumbres que se sembraren en Aguilar y Villafrechós se lleven a la cilla común y se repartan a todos los interesados. Dado en León, a 24 de septiembre de 1774.

Está aquí una copia de este despacho.

27. <Despacho sobre los diezmos de los beneficios de Villafrechós. Año 1797>.

Despacho librado por don Dionisio Pérez, provisor de León, a los curas y beneficiados de Villafrechós, para que, inmediatamente y vajo de pena de 50 ducados, juren y declaren cada uno de por sí, y conforme a su estado, qué diezmos adeudaron en la anterior cosecha las heredades de sus respectivos beneficios, para que juntos, etcétera, se reintegren al venerable deán y cavildo de León la parte que le corresponde de los diezmos y a los demás interesados. Dado en León, a 4 de julio de 1797. Año 1799>.

28. <Auto para que se paguen las tercias y diezmos de las yglesias de Villafrechós.

Pedimiento que puso el monasterio ante los señores del Consejo de Hacienda de Su Magestad por el qual parece que, habiendo gozado el monasterio de las tercias y diezmos del lugar de Villafrechós, Cabañas y Villalumbrós por el trueque que hizo la Magestad del señor rey don Fernando el $2^{\circ}$, etcétera, esta permuta se confirmó en forma especial, como todo consta de este instrumento, en la era de 1226, año 1188, por el señor rey don Alonso $9^{\circ}$ el de León. Véase el número $2^{\circ}$ de este quaderno, en que hace relación al $1^{\circ}$ y dice expresamente que hubiese de tener y percivir el monasterio para siempre, íntegramente y sin disminución

${ }^{569}$ Arconada] al margen derecho: Aguilar, Santa María [de] Arconada. 
alguna, las tercias de todos los diezmos de las yglesias que había entonces en Villafrechós y aún de todas las que hubiese en ella en los sucesivo. Lo mismo sucedió con las tercias relativas a los que oy se dicen nuebos diezmos o de exentos, a los quales se resistían pagar, como consta de este proceso en virtud de las cédulas reales, etcétera. A todo lo qual respondió el fiscal y proveyose por los señores del Consejo auto por el qual, en vista de este recurso y de los testimonios que le acompañan, dice: que al monasterio de / (f. 363v) San Zoil corresponde, por privilegio del señor rey don Fernando el $2^{\circ}$, confirmado por el rey don Alonso el $9^{\circ}$, su hijo, las yglesias de San Pelayo, San Christóval y San Lorenzo de Villafrechós y las demás yglesias que pudiese haber en dicha villa, con las tercias de las yglesias que había y hubiese en lo subcesivo, excepto la del obispo y de los Templarios. Todo lo qual declara ser así y pertenecer al monasterio las tercias y diezmos dichos, para lo qual manda ${ }^{570}$ librar para ello despacho o certificación correspondiente. En Madrid, 19 de diciembre de 1798. Licenciado Santa María.

$<$ Este auto se dio en Valladolid por don Cayetano de Vrbina, corregidor de (de) dicha ciudad, a 12 de enero de $1799>$.

En virtud de los qual se dio el auto que se sigue por el señor Vrbina, en que manda se obedezca esta certificación, se guarde y cumpla con el respeto devido en todo y por todo según y cómo en él se contiene. Notificose esto a las partes, con todos los requisitos que aquí se siguen, y al último está el recivo que hizo el (el) padre fray Ramón Durán de cinco mil quinientos $^{571}$ seis reales y 27 maravedís, que le entregó el tesorero de rentas reales, en 29 de octubre de 1799.

29. <Carta executoria a favor del monasterio sobre las $3^{\text {s }}$ de los diezmos de Villafrechós. Año 1799>.

Carta executoria de los señores del Consejo de Hacienda en sala, expedida contra el fiscal a favor de este monasterio de San Zoil, por la que se declara corresponderle las tercias de todos los diezmos pagados de Villafrechós y que se paguen en lo sucesivo en dicha villa, con devolución de lo que la parte de la Real Hacienda hubiese percivido. En virtud de lo qual, los señores del Consejo expidieron esta carta executoria por la qual mandan que luego que la recivan o con ella fueren requeridos, vean el auto proveído por los del dicho Consejo, en 19 de diciembre de 1798, para que le guarden y cumplan. Dada en Madrid, a 27 de marzo de 1799, ante don Simón de Rozas y Negrete, esscribano de Cámara.

No se hizo saber a las partes por haberse <notificado> (practicado que) la certificación sacada al afecto, en 23 de diciembre de 1798, del auto en ella inserto, dado en 19 del mismo / (f. 364r) mes y año, que es la del número antecedente.

\section{/ (f. 364v) Quaderno B del legajo $3^{\circ}$ \\ Villafrechós}

Este quaderno B contiene los papeles pertenecientes a la hacienda que tiene el monasterio en este lugar, por el orden siguiente:

$1^{\circ}$. $<$ Trueque de dos tierras por otra. Año 1419>.

Escritura de trueque, escrita en pergamino, por la qual San Juan Ortiz de Caraus y María Gómez, su muger, vecinos de Villalumbrós, dan en trueque a don Fernando, prior de San Zoil, dos tierras, la una a Carre Asno, de 4 obradas; y la otra en la Vega, do dicen a los Diezgos, de media obrada, en término de Villalumbrós ${ }^{572}$, por otra tierra a San Christóval, en dicho término, en que el dicho Ortiz había empezado a plantar majuelo, siendo ella del convento. Su fecha, en Villalumbrós, a 22 de enero de 1419, ante Gonzalo González, esscribano de dicho lugar.

\footnotetext{
570 manda] sigue tachado: manda.

${ }^{571}$ quinientos] sigue tachado: $\mathrm{y}$.

572 Villalumbrós] al margen derecho: Villalumbros.
} 
$2^{\circ}$. <Donación de unas casas y corral. Año 1423>.

Donación de unas casas y corral en Villafrechós hecha al convento de San Zoil por Juan González Patudo, cura de San Lorenzo de Villafrechós. Su fecha, en Carrión, a 13 de octubre de 1423, ante Fernán Rodríguez de Castellanos, esscribano de Carrión.

$3^{\circ}$. <Ynformación antigua de las heredades de Villafrechós $>$.

Provanza antigua, escrita en una tira de papel muy larga, hecha a instancia del padre fray Zoil de Saldaña, monje de este monasterio, ante Luis Fernández, arcipreste de Villafrechós, de las heredades que el monasterio tenía en ${ }^{573}$ este lugar. La falta un pedazo y así ni está cumplida ni tiene fecha ni fee ni autoridad de esscribano.

$4^{\circ}$. $<$ Recudimiento del rey don Juan el $2^{\circ}$. Año 1448>.

Carta de recudimiento del rey don Juan el $2^{\circ}$ para que los deVillafrechós acudan con todas las alcavalas, tercias y pedidos a Pedro Alonso de Madrid paralos gastos de las guerras. Año 1447.

$5^{\circ} .<$ Venta de unas cubas. $1447>$.

Escritura y carta de venta de unas casas, corral, cueva, lagar, cubas, tinajas, pajar y pozo que tenía en Villafrechós Ana / (f. 365r) de León, viuda de Sancho de Zayas, la qual las vendió a Rodrigo Alfonso de Barcial, vecino de Villameriel, el qual después las vendió al monasterio. Su fecha, en Villafrechós, a 30 de diciembre de 1447, ante Juan Pérez de Villameriel, esscribano de dicho lugar.

$6^{\circ} .<$ Venta de la misma casa. Año 1450>.

Escritura de venta por la qual Fernando de Zayas vende a Rodrigo Alfonso de Barcial la parte que tenía en vnas casas en Villafrechós, que son las de arriba, que después las hubo el monasterio. Su fecha, en Villafrechós a 9 de hebrero de 1450, ante Juan Pérez, esscribano de Villameriel.

$7^{\circ} .<$ Venta de las mismas casas al monasterio. Año 1450 $>$.

Escritura de venta, escrita en pergamino, por la qual el bachiller Rodrigo Alfonso de Barcial vende al monasterio las casas de arriba, con todas sus pertenencias, por precio de siete mil maravedís. Su fecha, en Villafrechós a 30 < de diciembre> de 1453, ante Juan Pérez, esscribano y nottario ppúblico.

$8^{\circ} .<$ Venta de un suelo. Año 1742>.

Escritura de venta, escrita en pergamino, por la qual Francisco de Zayas, vecino de Villafrechós, vende al monasterio un suelo de 30 pies de largo y seis de ancho, que caýa dentro del corral y portal de las casas que compró el monasterio, el qual pidió por él seiscientos maravedís. Fecha en dicha villa, a 24 de agosto de 1472, ante Juan Rodríguez de Torre, esscribano ppúblico.

9. $<$ Dexación que hicieron los interesados de las casas. Año 1479>.

Escritura de dexación (escrita en pergamino) y apartamiento de la acción y derecho que pretendían tener a las casas que el monasterio tenía en Villafrechós Fernando de Zayas y Elvira de Zayas, su hermana, y Cifuentes, su marido, los quales se apartaron por doce cargas de trigo que les dio el convento. Fecha en Villafrechós, a 14 de octubre de 1479, ante Juan Rodríguez de Torre, esscribano ppúblico.

10. $<$ Ynformación de un hastial. Año 1479>.

Ynformación hecha en razón de cuya era un hastial de la casa que el monasterio tiene en Villafrechós. Fecha a 12 de noviembre de 1479, ante Juan Rodríguez de Torre, esscribano de Villafrechós.

\footnotetext{
573 en] sigue tachado: a.
} 
11. $<\mathrm{Co}[\mathrm{n}]$ cierto sobre un rincón de la casa. Año 1479>

Concierto entre el monasterio y Fernando Zayas y su muger, los quales, por parecer de dos jueces árbitros, se apartaron de la / (f. 365v) acción que tenían a un rincón que lindaba con las casas del monasterio por dos cargas de trigo que les dio el padre fray Zoil en nombre del monasterio. Fecho en Villafrechós, a 14 de octubre de 1479, ante Juan Rodríguez de Torre, esscribano ppúblico.

12. < Testimonio de la donación de Álvaro Rodríguez. Año 1480>.

Testimonio dado por Juan Rodríguez de Torre, esscribano de Villafrechós, de que ante él pasó una donación que hizo al monasterio Álvaro Rodríguez y su muger de todos sus bienes, muebles y raíces. Dado en Villafrechós, a 14 de diciembre de 1480 (véase el número 14). Está inserta en este testimonio la donación.

13. $<$ Venta de una casa. Año 1484>.

Escritura de venta por la qual Pedro García, vecino de Villafrechós, vende al convento unas casas con su corral y pozo junto a la yglesia de Villalumbrós ${ }^{574}$ por precio de 5.500 maravedís. Su fecha, en San Zoil, a 3 de junio de 1484, ante Fernando Caballo, esscribano de Carrión.

14. $<$ Poder para tomar posesión de la hacienda de una donación. Año 1486>.

Poder que dio el prior Pedro Ruiz y el convento de San Zoil a fray Zoil de Saldaña, cantor, y a fray Juan de Lamasón, monges de este monasterio, para que tomasen posesión, cobrasen y arrendasen la hacienda y bienes que dexaron y donaron a dicho mnasterio de San Zoil Álvar Rodríguez y su muger en Villafrechós. Fecho en San Zoil, a 3 de julio de 1486, ante Fernando Caballo, esscribano arriba dicho (véase el número 12).

15. <Venta de un pedazo de casa. Año 1494>.

Escritura de venta por la qual Juan de Herrera, vecino de Villafrechós, vende al convento un pedazo de casa que juntaba con la del monasterio, entrando por el corral a mano izquierda, por precio de 700 maravedís. Su fecha, en Villafrechós, a 7 de mayo de 1494, ante Alexo de Olmos, esscribano de dicho lugar.

16. < Testamento y compra de una casa. Año 1505>.

Testamento de María de Castilla en que deja por sus testamentarios a Luis Fernández, arcipreste, y a Francisco Alonso, cura de San Salvador de Villafrechós, ante Alexo de Olmos, esscribano de dicho lugar, a 28 de noviembre de 1505. Los quales testamentarios vendieron a este monasterio una casa que era de la dicha María de Castilla, al quarto de San Lorenzo, para cumplimiento de su alma, por precio de 2.900 maravedís. Fecha la escritura de venta en Villafrechós, a 28 de noviembre del mismo año y ante el mismo esscribano.

Hay copia de todo, autorizada por don Antonio Martín García, traductor.

/ (f. 366r) 17. <Escritura de vecindad. Año 1510>.

Escritura de vecindad por la qual el concejo, justicia y regimiento de Villafrechós, en su ayuntamiento y en presencia del padre fray Gaspar de Villarroel, presidente de San Zoil, confiesan que la casa y tercia y demás bienes que el monasterio tiene en aquel lugar de tiempo atrás siempre ha tenido vecindad en dicho lugar, y porque las veces que el monasterio había de sacar el trigo o vino de allí para traherlo a San Zoil, o a otro lugar, las guardas de Villafrechós prendaban las cabalgaduras que el convento llevava para este efecto porque pacían en los términos de dicho lugar. Y sobre ello y el entrar los frutos que el monasterio tenía en Villalumbrós había havido algunas diferencias, desde luego dan la vecindad de Villafrechós al monasterio, para que goze de todo lo que los demás vecinos y que puedan entrar y vender los frutos que tubieren en Villalumbrós, y que sus cabalgaduras puedan pacer en todos los términos que las del lugar, guardando panes y viñas; y por las contribuciones que los demás vecinos están obligados a hacer, se obligó por el convento el padre fray Gaspar de Villarroel a dar y pagar al concejo en cada un año veinte reales de plata,

574 Villalumbrós] al margen derecho: Villalumbros. 
de a treinta maravedís cada uno. Fue echa en Villafrechós, a 28 de agosto de 1510, ante Alexo de Olmos, esscribano de dicha villa.

18. $<$ Venta de unas casas. Año 1519>.

Escritura de venta de una casa junto a la del monasterio que vendió Gonzalo Ochoa, vecino de Villafrechós, al convento de San Zoil, por precio de 2.210 maravedís. Su fecha, en San Zoil, a 13 de abril de 1519, ante Floristán de la Serna, esscribano de Carrión.

19. <Dexación de una viña que hace dos alanzadas. Año 1560>.

Escritura de dexación y posesión de una viña a Carre Veguilla, término de Villafrechós, por la qual Alonso de la Vega, vecino de dicho lugar, habiendo trahído pleito con el convento por la dicha viña que había comprado de Bernardino Choya y su muger, siendo del convento, hace dexación de ella en el monasterio porque el dicho Bernardino Choya y sus hijos le dieron porque dexase la viña una yugada de tierra y quatro ducados. Pasó esta escritura ante Gómez de Pernía, esscribano de Villafrechós, a 16 de noviembre de 1560.

$<$ Posesión de una viña $>$.

Tomó posesión de esta viña por el convento fray Juan de Ayala, mayordomo de San Zoil, a 21 días de noviembre de 1560, ante Francisco de Pernía, esscribano de Villafrechós.

/ (f. 366v) 20. <Venta de unas casas. Año 1582>.

Escritura de venta por la qual Alonso de María, como curador de Felipa Roxo, con autoridad de la justicia de Villafrechós, vende al monasterio unas casas en Villalumbrós ${ }^{575}$, por precio de 16 ducados. Su fecha, en Villafrechós, a 14 de agosto de 1582, ante Francisco de Varrio San Miguel, esscribano de dicho lugar.

21. <Donación de una tierra. Año 1593>.

Claúsula del testamento que hizo Francisco de Qüenca, vecino de Villafrechós, en que manda al monasterio de San Zoil yugada y media de tierra a la Enfestilla, donde está apeada, término de Villafrechós. Su fecha, en dicho lugar, a 7 de mayo de 1593, ante Alonso de Ramos, esscribano del mismo lugar.

22. < Licencia para dar 600 ducados para el desempeño de los de Villafechós. Año 1603 y $1604>$.

Petición de los padres del Consejo, comisión del general fray Alonso de Corral a fray Pedro de Agüero y fray Gregorio de Criales, información de vtilidad y licencia del mismo general para que el convento de San Zoil, como interesado en los diezmos de Villafrechós, contribuya con seiscientos ducados para comprar heredades que se den a renta a los de Villafrechós y las labren, para pagar un tributo que deben al duque de Osuna, porque no se despueble el lugar, que no puede pagar el tributo. Fecho todo año de 1603 y 1604.

23. <Venta de 13 yugadas de tierra. Año 1604>.

Escritura de venta por la qual Francisco Alonso, por sí y en nombre y con poder de María Domínguez, vecinos de Villabráxima, venden al convento trece yugadas de tierra en cinco tierras en los términos de Villafrechós, por precio de 68 mill 333 maravedís para el efecto del desempeño y paga del tributo que el estado de los hombres buenos de Villafrechós debía y tenía obligación de pagar al duque de Osuna. Su fecha, en Villafrechós, a 24 de diciembre de 1604, ante Alonso Ramos, esscribano de dicho lugar.

24. <Testimonio de la contribución del cavildo de León. Año 1605>.

Fee y testimonio de que por parte del deán y cavildo de la yglesia de León se depositaron doscientos treinta y tres ducados, que son la $3^{\text {a }}$ parte de los setecientos en que habían de contribuir para comprar heredades para el desempeño del tributo de los hombres buenos de Villafrechós. Dado en dicha villa, a 13 de mayo de 1605, por Alonso de Ramos, esscribano de ella.

575 Villalumbrós] al margen derecho: Villalumbrós. 


\section{5. $<$ Venta de una tierra. Año 1605 $>$.}

Escritura de venta por la qual Juan Vinagrero, Juan Pérez y Juan Garrote, sus yernos, vecinos de Villafrechós, venden al convento de San Zoil una tierra al Val, término de dicho lugar, que hace cinco yugadas y media y ochenta y tres palos, por precio de / (f. 367r) (de) 16 mill 900 maravedís para el desempeño y paga del tributo de los hombres buenos de Villafrechós. Su fecha, en dicha villa, a 4 de enero de 1605, ante Alonso Ramos, esscribano ppúblico.

\section{6. $<$ Venta de 3 pedazos de tierra. Año 1609>.}

Escritura de venta por la qual Á[1]varo Girón y Sabina de Olmos, su muger, vecinos de Villafrechós, venden al convento de San Zoil tres pedazos de tierra en término de dicho lugar: $1^{\circ}$ vna tierra a la senda de Tordehumos, junto al Marrandiel, que hace once yugadas, ci[n]co quartas y sesenta y seis palos; $2^{\circ}$ otra tierra al acabar de la senda de San García, junto al Marrandiel, que hace una yugada, cinco quartas y ochenta estados; $3^{\circ}$ otra tierra a la Puente Vieja, antes del prado, a la mano derecha, y es el corral que llaman de Juan de Olmos, que hace tres yugadas. Que todas hacen veinte y seis yugadas, cinco quartas y media, a cinco mil maravedís cada yugada, que todas montaron 134 mill 580 maravedís, que pagó por ellas el convento. Su fecha, en Villafrechós, a 18 de enero de 1609, ante Juan Pérez, esscribano de dicho lugar.

$<$ Escritura de cesión y carta de pago de 600 ducados. Año 1614>.

Está vajo este mismo número y juntamente cosida una escritura de entrega, cesión y traspaso que otorgaron a favor del convento los licenciados Pedro Ramos, Santiago Ochoa, Francisco Alonso y Francisco González, curas de las parroquias de Villafrechós, como patronos del proprio de los buenos hombres pecheros de aquella villa, y Francisco Díez y Antonio Pérez, mayordomos del dicho proprio. Por la qual dicen que, por quanto el monasterio de San Zoil hizo merced a los hombres buenos para el dicho proprio instituido para efecto de redimir el pan de palacio que pagan al duque de Osuna, señor de Villafrechós, seiscientos ducados para que se comprasen de heredades en el término de la dicha villa, que se habían de dar a renta a los hombres buenos de ella para aprovechamiento del proprio en un precio vajo por el tiempo que fuese a voluntad del convento, y si iba adelante había de ser para siempre; y no siendo para el dicho efecto, o deshaciéndose el dicho proprio, se quedasen las dichas heredades para el convento, el qual acordó que se le hiciese venta de las tierras que se comprasen con los dichos 600 ducados, para que las pudiese arrendar conforme a lo capitulado en la dicha fundación, que está escrita en el libro de fundación del dicho proprio; que pasó ante Alonso Ramos, esscribano de Villafrechós. Y porque el dicho proprio había / (f. 367v) comprado tres pedazos de tierras de Álvaro Girón y Sabina de Olmos, su muger, vecinos de Villafrechós, que son las de la escrit[ur]a de atrás, que montaron 134.580 maravedís, cuyas escrituras se hicieron a favor del convento para que diese al proprio de los hombres buenos lo que le havían mandado. Y porque aún no se había hecho entrega de los 600 ducados, tampoco se había entregado al convento la escritura de las tierras hasta ${ }^{576}$ que pasó fray Antonio del Valle a Villafrechós con resolución de hacer la paga de los 600 ducados.

$<$ Son tres tierras éstas que vendió Francisco Patudo $>$.

Y porque el dicho proprio había comprado a Francisco Patudo y a doña María de Cárdenas, su muger, vecinos de Villafrechós, otras tierras por escritura que pasó ante el esscribano de ésta, a 14 de enero de 1609, para cumplimiento de la cantidad de los 600 ducados, que son tres pedazos de tierra en término de Villafrechós ${ }^{577}$ : vno a carrera Villamuriel, sobre mano izquierda como se va a Villamuriel, la reguera del Castro avajo, que hace dos tres quartas y 33 palos; y el otro pedazo más avajo, al corral de la de Juan Pérez, la

\footnotetext{
576 hasta] sigue tachada palabra ilegible.

577 Villafrechós] al margen derecho: Estas seis tierras son las que goza el Estado, por las que paga una fanega de trigo y dos huebos.
} 
tierra de la misa del alva en medio de la de arriba, que la parte la dicha reguera del Castro, que hace seis yugadas, cinco quartas y 42 palos; y el otro pedazo que está a la senda de los palomares de Mayorga, a la reguera de Carrecueva, vajo de los álamos de Juan d'Olmo, que la parte la reguera, y hace seis yugadas, tres quartas y 60 palos, a razón de 5.600 maravedís la yugada; que todas montan 88.816 maravedís, que con lo de arriba montan los 600 ducados, menos mil que se embeven en estas últimas tierras por ser mejores que las de Girón. Entregaron al convento la escritura de las primeras tierras compradas a Girón y se le hace cesión y traspaso de los tres pedazos que se compraron a Francisco Patudo y doña María de Cárdenas, su muger, y, siendo necesario, se las venden en venta real y confiesan haber recibido del convento los 600 ducados y dan carta de pago de ellos. Fecha en Villafrechós, a 19 de marzo de 1614, ante Juan Pérez, esscribano ppúblico.

$<$ Posesión de las tierras ${ }^{578}$ dichas. Año 1614>.

Está $<$ ta $>$ mbién la escritura de posesión que tomó el padre fray Antonio del Valle, en nombre del convento, de las seis tierras dichas con autoridad de la justicia, a 19 de marzo del mismo año y ante el dicho esscribano. Año 1614>.

$<$ Obligación de los patronos del proprio para quitar un censo de 400 mill maravedís.

Asimismo hay también una escritura por la qual los patronos y mayordomos del proprio de los hombres buenos se obligan a quitar dentro de quatro años un censo de 400 mill maravedís que tiene Álvaro Girón sobre los bienes del dicho proprio, para que las heredades que compró el convento queden libres. Fecha a 19 de marzo del dicho año y ante el dicho esscribano.

$<$ Carta de pago de los 600 ducados. Año 1615>.

Vltimamente está / (f. 368r) la carta de pago que otorgaron los mayordomos del proprio de los hombres buenos de Villafrechós de los seiscientos ducados con que ayudó este monasterio para su desempeño. Los quales se recibieron en noventa cargas de trigo y cinco ducados que entregó Lázaro Gutiérrez, y 26 cargas de trigo que entregó Luis González, las 10 a cinco ducados y las 16 a 69 reales, que fueron las valías de(l) mayo y junio pasados, de que se dieron por contentos y pagados, etcétera. Fecha en Villafrechós, a 13 de abril de 1615, ante Juan Rodríguez, esscribano de Villafrechós.

\section{7. < Testimonio de posesión de tierras. Año 1615>.}

Testimonio de cómo, por mandamiento de pago del alcalde mayor del adelantamiento, el padre fray Antonio del Valle, mayordomo de San Zoil, tomó posesión de ciertas heredades de Pedro de Olmos, vecino de Villafrechós, y de Gonzalo Vinayo, vecino de Villamuriel, por cierto trigo que debían al monasterio; que son un majuelo a Nuestra Señora de Cavo, al camino de Carremedina, de tres alanzadas por bienes de Pedro de Olmos y por bienes de Gonzalo Vinayo; una tierra al humilladero de Santa Eufemia, de cinco yugadas; otra tierra a Carrevillar, de quatro yugadas; otra en el velaxe de Villamuriel a carre Castroverde, de cinco yugadas, linderos: el camino y las viñas; otra tierra a carre Zalengas; otra tierra al Val, que hace casi siete yugadas. Dado en Villafrechós, a 29 de septiembre de 1615, ante Juan Pérez, esscribano de dicha villa.

28. $<$ Memorial de deudas de pan. Año 1616>.

Memorial de deudas y obligaciones que se debían en pan al monasterio de San Zoil en Villafrechós, Villalumbrós y Villameriel, en 12 de febrero de 1616.

\section{9. < Pago de tres cargas y media de trigo. Año 1616>.}

Proceso en que está un auto y mandamiento del adelantamiento para que se paguen al monasterio siete cargas y media de trigo del arrendamiento de unas tierras que cedió al monasterio María de Prado, vecina de Villafrechós, por una deuda que debía, las quales estaban embargadas por otra deuda que se debía al licenciado Represa, el qual se concertó con fray Antonio del Valle, mayordomo de San Zoil, el qual recivió tres cargas y media de

\footnotetext{
578 tierras] sigue tachado dichas tierras.
} 
trigo, y otro tanto Represa. Pasó ante Gómez de Pernía, esscribano de Villafrechós, y Diego Pérez, esscribano del adelantamiento. Año de 1616.

30. $<$ Carta judicial de bienes executados. Año 1617>.

Carta judicial librada en el adelantamiento de Campos, por seis cargas de trigo que debían de resto de una obligación, diez / (f. 368v) cargas prestadas, Pedro Girón el Mozo y Catalina de Ysla, viuda de Luis de Olmos, contra quienes pidió execución el monasterio en el adelantamiento, y en virtud del mandamiento de remate della, no habiendo positor a los bienes, salió a pagarse en ellos Martín Garrido, procurador del convento, y los cedió en él. Aceptó la cesión fray Antonio del Valle, mayordomo, y tomó la posesión en dos casas en nombre de los demás bienes executados, que fueron los siguientes: vnas casas en el quarto de San Salvador con su huerto, un brasero, mantas, cabezales, colchones, etcétera; una tierra a la Mata, de quatro yugadas; otra a la Fuente, de cinco yugadas, todos de Catalina de Ysla, con otra tierra que heredaba de su madre, Leonor de Prado, a la Fuente, de cinco yugadas, y unas casas a la Vtasara con su huerto y una tierra a Mazarancón, de tres yugadas, que eran de Pedro Girón. Y el mayordomo, en nombre del convento, dio y pagó la décima, costas y salarios por qüenta de estos bienes. Pasó ante Bartholomé Torices, esscribano mayor del adelantamiento, año 1617.

31. < Venta de una casa. Año 1618>.

Escritura de venta por la qual Mariana de Melgar, viuda de Lope de Olmos, vecina de Villafrechós, vende al monasterio una casa en el quarto de San Christóval, por precio de ciento y treinta ducados que por ella pagó el convento, por mano del padre fray Gregorio de Santoyo. Tiene hipotecadas a la seguridad buenas tierras. Su fecha, en Villafrechós a 28 de octubre de 1618, ante Pedro de Olmos, esscribano de dicha villa.

Vn pedazo de esta casa se trocó, véase el número 39 y 40.

32. <Compra de la panera de Villafrechós. Año 1672>.

Compra que hizo el monasterio de la panera que tiene en Villafrechós a don Alexo d'Olmos, arcediano de Zea y canónigo de León, por precio de 8.800 reales. Pasó la venta ante Ysidro Fernández Barreda, esscribano de la ciudad de León, a 23 de mayo de 1672.

Está aquí otra venta de $(\mathrm{dos})<\mathrm{los}>$ suelos de dicha panera a favor del dicho Alexo.

33. <Venta de tres tierras a favor del padre fray Zoil Ortiz. Año 1684>.

Escritura de venta por la qual Juan Tomillo, vecino de Villalán, vende al padre fray Zoil Ortiz, prior de Aguilar, tres tierras en término de Villafrechós por precio de 282 reales que por ellas pagó dicho padre prior. Su fecha, en Aguilar a 4 de ogosto de 1684, ante Santiago Facón, esscribano de dicha villa.

Está aquí una memoria de las posesiones que faltan en este campo según apeos.

/ (f. 369r) 34. <Venta dos tierras a favor del padre fray Zoil Ortiz. Año 1684>.

Escritura de venta por la qual Lázaro Gutiérrez, vecino de Villafrechós, vende al padre fray Zoil Ortiz, prior de Aguilar, dos tierras en término de Villafrechós, por precio de 300 reales que por ellas pagó dicho padre prior. Su fecha, en Aguilar, a 4 de agosto de 1684, ante Santiago Facón, esscribano ppúblico.

35. <Ventas de tierras para esta casa desde el año de 1684>.

Quaderno en que están cosidas diez escrit[ura]s de ventas de tierras a favor de este monasterio desde el año de 1684 hasta el de 1703, cuya tabla está puesta en la primera oja de dicho quaderno, año y esscribano ante quien se otorgaron, por escusar aquí tan larga historia.

36. <Compra de la casa con su bodega, etcétera, en Villafrechós. Año 1703>.

Escritura de venta por la qual el licenciado don Antonio Ampuero Delgado y Pedro Ampuero, su hermano, vecinos de Villalpando y testamentarios que quedaron del licenciado don Antonio Asensio Calbiche, vecino de dicha villa, para cumplir lo que les ordenó en su testamento, vendieron a este monasterio una casa con su bodega, vasijas, caballeriza, pajar, 
pozo, etcétera, y corral que dicho Antonio Asensio tenía en Villafrechós, en la colación de San Pelayo, y enfrente de la dicha yglesia, lindero: casas de la labranza del convento de Santa Clara de dicha villa y calles públicas porque hace esquina a ellas dicha casa. Su fecha, en Villalpando, a 25 de junio de 1703, ante Francisco González, esscribano de ésta.

37. <Trueque de una tierra por otra. Año 1704>.

Escritura de trueque de una tierra que el monasterio tenía a donde llaman Coruñeses por otra que Froylán Gutiérrez tenía a la raya de Tordehumos, una y otra en término de Villafrechós. Su fecha, en Aguilar, a 6 de junio de 1704, ante Francisco Núñez de Prado, esscribano ppúblico.

38. $<$ Certificación de una escritura. Año 1744>.

Certificación que dio el padre fray Pedro Merino, archivero de este monasterio, de cómo en el archivo se hallaba una escritura de venta de unas casas que sirven de panera en Villafrechós a favor del monasterio. Su fecha, en San Zoil, a 10 de marzo de 1744.

39. <Compra de un herrén. Año 1764>.

Compra de un arreñal que el monasterio compró a las monjas de Villafrechós para hacer allí una casa y el monasterio las vende allí unos suelos. Fecha en Villafrechós, a 18 de febrero de 1764, ante Blas Rodríguez, esscribano de dicha villa.

40. $<$ Trueque de un solar por una tierra. Año 1765>.

Trueque y venta de un pedazo de solar y pajar fundado en él, que es parte del que este monasterio tiene al quarto de San Christóval (vide número 31), / (f. 369v) a don Gerónimo de Represa, beneficiado de Villafrechós, por una tierra que éste vendió y cedió a este monasterio, que hace tres yugadas $y^{579} 36$ palos, en término de dicha villa. Su fecha, en Villafrechós, a 8 de mayo de 1765, ante Felipe González, esscribano de ésta.

\section{1. <Trueque de 5 reales por un pedazo de solar. Año 1765>.}

Escritura por la qual se da a foro el restante solar arriba dicho a Francisco Xavier Aguado por cinco reales que anualmente debe pagar. Su fecha, en Villafrechós, a 25 de marzo de 1765, ante Felipe González, esscribano de dicho.

\section{2.}

Escritura por la qual se dio a foro un solar que el monasterio tiene en Villafrechós, al quarto de San Lorenzo, a Manuel de Loya, vecino de dicha villa, por 4 reales cada año. Su fecha, en Villafrechós a 15 de marzo de 1765, ante Felipe González, esscribano ppúblico.

43. < Memoriales de la justicia de Villafrechós para que contribuyan con alguna cosa para el pleito. Año 1772>.

Bajo este número hay quatro cartas, la una del cabildo de León en que la justicia, reximiento y vecinos de Villafrechós les piden alguna contribución como partícipes en los diezmos para el pleito que tenían con el duque de Osuna; la otra de los señores de Villafrechós en que piden al padre abad o convento les contribuya con algo; y las otras dos avisando en particular el estado en que está el pleito y de las cosas más necesarias para él. Año 1772.

44. <Papeles de Villafrechós contra el duque de Osuna. Año de 1776>.

Alegato que puso Narciso Francisco Blázquez, en nombre del concejo, xusticia y regimiento de Villafrechós, sobre la pertenencia del despoblado de Villalumbrós, que don Luis de Pernía y consortes pretendían vsurparlo, a lo qual respondió satisfaciendo dicho Blázquez. No tiene fecha.

Está aquíun folleto impreso en que condena al duque de Osuna a que reintegre a la villa de Villafrechós y sus hacendados respectivamente en la quieta y pacífica posesión del despoblado de Villalumbrós, sus tierras, pastos y demás aprovechamientos de que fueron

$\left.{ }^{579} \mathrm{y}\right]$ sigue tachado: $\mathrm{y}$. 
despojados en el año de 1771, con indemnización de todos los daños y perjuicios que les ocasionó el despojo. Madrid, 21 de octubre de 1776.

/ (f. 370r) Remisiones. 


\section{/ (f. 370v) Cajón 15 San Plácido}

Este cajón San Plácido, que es el decimoquinto del archivo, contiene cinco legajos pertenecientes a diversos lugares, que son: legajo $1^{\circ}$ : Villafría; $2^{\circ}$ : lo mismo; $3^{\circ}$ : Villalpando; $4^{\circ}$ : Villamayor; $5^{\circ}$ : Villameriel, Villamez, Villamuriel, Villanueva de Fontecha o de Abajo, Villanueva de Muñeca o de Arriba,Villanueva de los Navos, Villanueva del Revollar y Villanueva del Río.

\section{Legajo $1^{\circ}$}

Este legajo, que es el primero del cajón San Plácido, contiene los dos quadernos siguientes: quaderno A: donación que hizo el rey don Alonso del lugar de Villafría a San Román y hacienda que tiene Nuestra Señora del Brezo en este lugar; quaderno B: curato y pleytos.

\section{Quaderno A del Legajo $1^{\circ}$ \\ Villafría}

Este quaderno A contiene la donación de Villafría y los papeles pertenecientes a la hacienda que tiene Nuestra Señora del Brezo en este lugar, por el orden siguiente: Año 1255>.

$1^{\circ}$. $<$ Donación de Villafría y San Justo a San Román por el rey don Alonso. Era 1293.

Donación escrita en pergamino, con sello de plomo pendiente en filos de seda encarnada y atavacada, por la qual el rey don Alonso el Sabio da a San Román el lugar de Villafría con su yglesia monasterial de San Justo y Pastor, con todo lo demás perteneciente en dicho lugar, sin exceptuar cosa alguna. Fecha en Victoria en la era de 1293, que es año de 1255. Hay copia autorizada por don Antonio Martín García, traductor.

$$
\text { / (f. 371r } 2^{\circ} \text {. <Privilegio del rey don Alonso. Era 1293. Año 1255>. }
$$

Privilegio del rey don Alonso, escrito en pergamino, que es un tanto de la donación antecedente, en que hace libre de todo pecho, omicilio a los vasallos de Villafría y San Román, pero está tan borrado que no se puede leer, sólo si hay un traslado autorizado y sacado con todas sus firmas de confirmación, que son muchas. Fecho en la era de 1293, que es año de 1255.

\section{$3^{\circ}$. $<$ Donación que hizo Alonso Pérez de toda su hacienda al Brezo. Año 1503>.}

Donación que hizo Alonso Pérez, vecino de Villafría, de todos sus bienes, muebles y raíces, a Nuestra Señora del Brezo y de todas las heredades que tiene en Villafría, Villaverde, Aviñante y Santiváñez ${ }^{580}$ y en todos sus términos, lo qual manda por su alma y porque no tiene hijos ni herederos forzosos, siendo prior el padre fray Juan de Lamasón. Fecha en Viduerna, a 11 de abril de 1503, ante Gerónimo de Valderrábano, escribano y notario público. Están aquí otras dos escrituras de ventas de ciertas heredades que compró en Villafría el dicho Antonio Pérez, que entraron en esta donación. Año de 1499.

$4^{\circ}$. $<$ Venta de dos heredades para el Brezo en Villafría. Año 1503>.

Carta de venta de dos heredades que Juan de Bartholomé, vecino de Villafría, como mansesor de Juana, su hermana, vende al padre fray Juan de Lamasón, prior del Brezo, (dos heredades), una en la Lingorda y otra al Bravedo, por precio de 160 maravedís. Su fecha, en Villafría, a 14 de septiembre de 1503, ante Bernabé García, notario apostólico.

\section{$5^{\circ} .<$ Copias de unas ventas a favor del Brezo $>$.}

Copias de unas ventas a favor del santuario del Brezo que otorgaron diversas personas de La Mata que llaman de Trichorro, en término de Villafría. Están por el padre fray Mauro Fuertes, archivero de este monasterio, y profeso en él.

${ }^{580}$ Santiváñez] al margen derecho: Aviñante, Santiváñez, Villaverde de la Peña. 


\section{6. $<$ Venta de La Mata de Trichorro y una tierra junto al Molino. Año 1521>.}

Escritura de venta por la qual Diego Ferrero, vecino de Villafría, vende al padre fray Pedro Valbanera, prior del Brezo, una mata de madera y leña en término de Villafría, a donde llaman Trichorro, linderos Mata de Pedro Fernández, cura de Avinante; $2^{\circ}$, las Guaresas del lugar; $3^{\circ}$, el exido del concejo como se encierra dentro de sus mojones, con más la tierra del cabe el Molino, por precio de 2800 maravedís. Fecha en Nuestra Señora del Brezo, a 19 de diciembre de 1523, ante Alonso Fernández, escribano público. Hay copia autorizada por don Antonio Martín García, traductor de letras antiguas, vecino de la villa de Rivas.

\section{/ (f. 371v) $7^{\circ} .<$ Compra de una Mata. Año de 1524>.}

Escritura de venta por la qual Pedro de Ramos, vecino de Villanueva de Muñeca, y Bartolomé González, vecino de dicho lugar, por sus hijos venden al padre fray Pedro de Valvanera, prior del Brezo, todo lo que les pertenecía en la Mata de Río de Villafría, linderos: Pedro Fernández, cura de Aviñante, con las Guaresas y el concejo de Villafría, por precio de 750 maravedís. Su fecha, en Viduerna, a 2 de enero de 1524, ante Alfonso Fernández, escribano de Respenda. Hay copia autorizada por don Antonio Martín García, traductor de letras antiguas.

\section{8. $<$ Compra de 4 tierras en Villafría. Año 1525>.}

Escritura de venta por la qual Diego Herrero, vecino de Villafría, vende al padre fray Juan de Villoldo, prior del Brezo, quatro tierras en término de Villafría, por precio de 800 maravedís. Su fecha, en Viduerna, a 28 de marzo de 1525, ante Alfonso Fernández, escribano dicho.

9. <Compra de una tierra. Año 1527>.

Escritura de venta por la qual Diego Ferrero, vecino de Villafría, vende al padre fray Juan de Villoldo, prior del Brezo, una tierra al Picón de la Vega, término de Villafría, por precio de 306 maravedís. Su fecha, en Aviñante, a 22 de enero de 1527, ante Alfonso Fernández, escribano.

10. $<$ Compra de un prado. Año de 1527>.

Escritura de venta por la qual María, muger de Toribio de Guardo, vecino de Villafría, vende(n) al padre fray Juan de Villoldo, prior del Brezo, un prado a Sovilla, por precio de 375 maravedís. Su fecha, en Viduerna, a $1^{\circ}$ de febrero de 1527, ante el escribano arriba dicho.

11. <Compra de un prado. Año 1527>.

Escritura de venta por la qual María de Peral, muger de Toribio Pérez, vecina de Villafría, vende al padre fray Juan de Villoldo, prior del Brezo, < un prado > encima de Sovilla, término de dicho lugar, con fuero de un quarterón de cera que sobre él tiene la yglesia de San Justo de Villafría, por precio de 375 maravedís. Su fecha, en dicho lugar, a 7 de septiembre de 1527, ante Juan de Castrillo, escribano de Carrión.

12. <Compra de la Mata de Trichorio. Año de 1535>.

Escritura de venta por la qual Pedro Fernández, clérigo, vecino de Aviñante, vende a fray Francisco de Buytrón, prior del Brezo, una mata en término de Villafría, a do tienen a Trichorio, linderos: $1^{\circ}$ : Mata de la casa del Brezo, $2^{\circ}$ : Mata de las Guaresas, $3^{\circ}$ : Mata del concejo de Villafría, por precio 3.000 maravedís. Su fecha, en Aviñante, a 12 de junio de 1535, ante Christóval Gómez de Valderrábano, clérigo y notario apostólico. Hay copia autorizada por don Antonio Martín García, traductor de letras antiguas.

\section{/ (f. 372r ) 13. <Compra de 54 maravedís de martiniega. Año 1536>.}

Escritura de venta por la qual don Juan Enrríquez de Cisneros, señor de la villas de Alva y Valcovero y Casa de Campo Redondo, vende al padre fray Diego de Sahagún, prior de San $<$ Román ${ }^{581}, 54$ maravedís de martiniega que él y sus pasados tenían sobre el concejo

${ }^{581}$ San $<$ Román>] al margen derecho: San Román. 
y vecinos de Villafría. Su fecha, en San Román, a 23 de mayo de 1536, ante Antón Sánchez, escribano y vecino de Camporedondo. Costó esta martiniega 1500 maravedís.

14. <Donación del préstamo de Juan Ferrero. Año 1541>.

Escritura de donación y préstamo por la qual Juan Ferrero, vecino de Villafría, a la casa de San Román ${ }^{582}$ hace donación de un solar que tenía en dicho lugar; y luego el prior de San Román, fray Diego de Sahagún, le dio en préstamo el mismo solar para que en él edifique una casa; y juntamente le dio unas heredades, prados y huerto para que lo gozase por sus días, y el dicho Juan de Ferrero se obliga de ser vasallo y obediente al precepto y manda $<$ do $>$ del prior y pagarle el tributo que los demás vasallos, que es una fanega de trigo, diez celemines de centeno, una gallina y tres blancas. Fecha en San Román, a 21 de abril de 1541, ante Juan de Nieves, escribano público.

15. <Repartimiento del molino de Villafría. Año 1541>.

Declaración y concierto hecho entre fray Diego de Cuebarrubias, prior del Brezo, y Alonso Toribio de Villacorta, vecino de Villaverde, sobre el repartimiento del tiempo de moler en el molino de Villafría, y se declaró que de cada 60 días de molienda le caben a la casa del Brezo once días, los primeros del mes que comenzare la tanda. Fecha a 25 de noviembre de 1541.

16. <Trueque de 4 pedazos de prados. Año 1546>.

Escritura de trueque por la qual fray Pedro de Porras, prior del Brezo, da en trueque a Alonso de Palacios, clérigo, vecino de Congosto, un prado que tenía la casa del Brezo en término de Villafría, a la Portilla, que hacía un carro de yerba, por 4 pedazos de prados que tenía el dicho Alonso a Sovilla, de tres entuertas de yerba; otro en el mismo término y pago arriba del otro, que tiene medio carro de yerba; otro pedazo en el mismo término y pago de una entuerta de yerba; y el otro pedazo más avajo al Esperón. Su fecha, en Villafría, a 10 de noviembre de 1546, ante Juan Gutiérrez, clérigo y notario apostólico, vecino de Villanueva de Guardo.

\section{/ (f. 372v $)$ 17. <Sentencia árbitra sobre sacar agua para regar. Año 1546>.}

Sentencia árbitra entre el prior de San Román y concejo de Villafría, de una parte, y el de Aviñante ${ }^{583}$, de la otra, sobre sacar este el agua del término de Villafría para regar, en que condenaron al prior y concejo de Villafría. Dada año de 1546.

18. $<$ Trueque de prados y tierras. Año 1547>.

Escritura de trueque por la qual fray Pedro de Porres, prior del Brezo, con licencia de fray Juan de Santa María, abad de San Zoil, da a la iglesia de San Justo, y para ella a Juan Terrías, su mayordomo, quatro prados de quatro carros de yerba, en término de Villafría a la Portilla de la Sernilla larga y al Vallejo de ésta; otro a las hazas de Llorezbe, a la Fuente, y otro al valle de Villafría; y una tierra a la Penilla, los quales heran de Nuestra Señora del Brezo, para quien dio al dicho prior el mayordomo de San Justo, con licencia del licenciado Toro, provisor de León; tres prados con un picón en término de Villafría, donde llaman a Sovilla, que hacen quatro carros de yerba poco más o menos, linderos de todas partes con prados de la casa del Brezo; y más una tierra que es de la yglesia de Villafría, que está al Valle, linderos: prados de Nuestra Señora del Brezo. Su fecha, en El Brezo, a 17 de marzo de 1547, ante Juan Gutiérrez, clérigo y notario apostólico, vecino de Villanueva de Guardo.

19. $<$ Trueque de prados y tierras. Año 1548>.

Escritura de trueque por la qual fray Pedro de Porres, prior del Brezo (digo de San Román), da a Pedro Herrero, vecino de Villafría, un prado a la Portilla, y otro en término de Aviñante ${ }^{584}$, encima de Cortinas, y una tierra en el mismo término, a la Laguna de entramos ríos; y el dicho Herrero dio En trueque para San Román ${ }^{585} 3$ prados en término de Villafría,

\footnotetext{
582 San Román] al margen derecho: San Román.

583 Aviñante] al margen derecho: Aviñante.

584 Aviñante] al margen derecho: Aviñante.

585 San Román] al margen derecho: San Román.
} 
encima de Sovilla, todos tres juntos, que tienen por lindes de todas partes prados de Nuestra Señora del Brezo, y una tierra allí junto en el mismo término. Su fecha, en San Román, a 25 de febrero de 1548, ante Agustín de Medina, escribano público.

\section{0. $<$ Trueque de prados y tierras. Año 1548>}

Escritura de trueque por la qual fray Pedro de Porres, prior de San Román, da a Alonso Terán, vecino de Villafría, un prado a la Paredeja de (de) Monequilla y una tierra a la Canal y otro pedazo de tierra a la Barguilla, junto al camino; y el dicho Alonso da al prior un prado (un prado) en término de Villafría, junto con la casa de Nuestra Señora del Brezo, y una tierra allí mismo. Su fecha, en San Román, a 25 de febrero de 1548, ante el dicho escribano.

\section{$/(f .373 r) 21 .<$ Trueque de prados y tierras. Año de 1548>.}

Escritura de trueque por la qual fray Pedro de Porres, prior de San Román, da en trueque a Alonso Rodríguez, vecino de Villafría, un prado a la Callejuela, otro al Revolledo, otro junto a este y una tierra a Ondón de la Labrada, otra al Oyo, otra a los Arenales, otra al Oyal y otra a la Paradeja bajo de la Abregisilla, todas en término de Villafría. Y el dicho Alonso da al prior un prado encima de Sovilla, otro pradillo al huerto Nocal, otro al Cascajar del huerto Nocal, otro al Esperón, otro allí luego, otro al Cascajar de Sovilla, otro más abajo, otro allí luego bajo del huerto de Pedro Herrero y una tierra al Requejuelo, otra en el valle y otra encima de Sovilla, todas en término de Villafría, y deslindadas. Su fecha, en San Román, a 25 de febrero de 1518, ante el mismo escribano.

22. $<$ Donaciones de tierras y prados para Nuestra Señora del Brezo, con un reconocimiento de la Mata del Río. Año de 1578>.

Bajo este número están tres donaciones de tierras y prados, y un reconocimiento de la Mata del Río, hechos a la casa del Brezo: la $1^{\text {a }}$ de Juan Rodríguez, escribano, en que da una tierra que tenía en Villafría de 4 celemines de trigo de sembradura, al Revollar; la $2^{a}$ de Toribio de Villacorta, en que da una tierra que tenía en término de Villafría, junto a la Cruz; la $3^{a}$ de Martín Macho, en que da una haza de prado en término de Villafría a Sovilla; y trueque de una haza de prado a Sovilla, que era de Alonso Crespo, por una aria del Brezo; y últimamente un reconocimiento que hizo Alonso Herrero, regidor y vecino de Villafría, de que la Mata que llaman del Río era de Nuestra Señora del Brezo. Están ante diferentes escribanos, y por los años de 1567, 1570 y 1578.

23. <Trueque que entre San Román y el Brezo del lugar de Villafría, etc. Año 1581>.

Escritura de trueque otorgada entre fray Francisco de Vndona, prior de San Román, y fray Benito del Camino, prior del Brezo, los quales en nombre de sus prioratos y con poder de fray Ambrosio de Náxera, abad de San Zoil, y el convento, otorgaron esta escritura por la qual parece que la casa de San Román ${ }^{586}$ da a la del Brezo la propiedad y señorío que tiene en Villafría y sus términos, con todos los montes, cotos, pastos y preminencia de gozar como señor y vecino en todos los términos, montes, cotos y aprovechamientos, y todas las casas, solares, prados, tierras, linares y huertas que llevaban de San Román los vecinos de Villafria, sus vasallos; y todos los prados que San Román tiene en dicho lugar y su término, que andan a venta, fuera de los que gozan los vasallos de Villafría; y todas las tierras que trae / ( f. $373 v)$ en venta, fuera de las que gozan dichos vasallos en término de dicho lugar y de Aviñante ${ }^{587}$, que gozaba entonces Pasqual de Guardo, vecino de Villafría, y Martín Pérez, de dicho lugar, por su renta. Y asimismo las gallinas que cada vasallo debe a San Román, con los maravedís y yantar, o trescientos maravedís que el concejo de Villafría debe cada año, y con los 54 maravedís de martiniega que el concejo debe al monasterio con todo el derecho y preminencias que pertenecen a San Román en Villafría y sus términos de pacer, rozar y gozar todos los aprovechamientos, excepto la presentación del beneficio y el yantar que cada año da el cura, y el derecho que tienen el monasterio de San Zoil ${ }^{588}$ y priorato de San Román de apacentar sus ganados hasta los términos de Villafría, que esto se reservó para los

586 San Román] al margen derecho: San Román.

587 Aviñante] al margen derecho: Aviñante.

${ }^{588}$ San Zoil] al margen derecho: San Zoil. 
monasterios de San Zoil y San Román. Y asimismo le da todos los prados y tierras que San Román tenía en término de Valcovero ${ }^{589}$ que llevaba a renta Hernando de Onís, y los prados y tierras que tenía en término de Barsurbio ${ }^{590}$ que tenía a renta Santiago Martínez, vecino de Campo Redondo, y no entra aquí la renta de Santa Eufemia de este lugar, que quedó para San Román ${ }^{591}$. Por lo qual el prior del Brezo dio al de San Román para aquella casa 4 mil 900 maravedís de censos que tiene sobre el lugar de Carbonera ${ }^{592}$ perpetuamente, más tres cargas de trigo de censo perpetuo sobre el concejo de Vaños ${ }^{593}$, más 44 reales de censo perpetuo sobre una huerta en Arenillas de Nuño Pérez ${ }^{594}$, con más una carga de trigo y otra de cebada que paga cada año de patronazgo sobre los diezmos < de la yglesia $>$ de Muñeca ${ }^{595}$ el cura de aquel lugar, con más la renta de pan, gallinas y dineros ${ }^{596}$ que debían Juan del casar, vecino de Villanueva de Muñeca, y Hernán Puente y Juan< $<$ > Fernández, su muger, vecinos de Aviñante ${ }^{597}$, vasallos del Brezo, con todas las casas, solares, tierras, prados, huertas, montes, etcétera, a las dichas casas pertenecientes. Fecha en San Román, a 30 de marzo de 1581, ante Juan Rodríguez, escribano y notario. Hay copia autorizada por don Antonio Martín García, traductor de letra antigua.

24. $<$ Requerimiento a Toribio Merino para que pague y reconozca la renta de un prado. Año 1585>.

Requirimiento hecho por fray Damián de Salas, prior del Brezo, a Toribio Merino, vecino de Villafría, el qual violentamente y sin licencia del prior se entró en un prado que tenía Alonso Terán, / (f. 374r) vecino de Villafría, en el que armó una casa y, habiendo querido acusarle el prior, se compusieron que pagase al Brezo un quarto de centeno cada año, y no queriéndolo pagar, le requirió el prior que pagase, reconociese y asegurase, o lo pidiría por justicia; y Toribio Merino respondió confesando la teni(i)ta del prado, pero que se llamaba a engaño y así no pagaría de allí adelante. Fecho en Villafría, a 11 de abril de 1585. Después se le puso pleito y demanda a él y a Toribio de Guardo, en el adelantamiento, donde fueron condenados, y reconocieron como se ve en el número siguiente.

25. <Reconocimiento de Toribio Merino por una casa y un prado. Año de 1586>.

Reconocimiento que hicieron Toribio Merino y Toribio de Guardo, vecinos de Villafría, en virtud de una sentencia del doctor Pérez Manuel, alcalde mayor del adelantamiento de Campos, pasada en cosa juzgada, por el qual Toribio Merino reconoce que tiene una casa y solar en Villafría, linderos solar y préstamo que tenía Alonso Tarán y la calle pública, y un pedazo de prado con lo edificado en él, por lo qual se obliga a pagar un quarto de centeno, una gallina y tres blancas cada un año como lo pagan los demás vecinos de Villafría.

$<$ Reconocimiento de Toribio de Guardo por un préstamo. Año 1586>.

Y Toribio de Guardo reconoce que tiene del Brezo una casa y solar en Villafría, lindero préstamo de Alonso Tarán por una parte, y por otra Diego Martín, con el préstamo y heredades a ella anexo; por lo qual se obliga a pagar luego de entrada un carnero de dos dientes, o un ducado, y en cada un año, una fanega de trigo, diez celemines de centeno, una gallina y tres blancas, como los demás vecinos. Fecho en Palacios de Campos, a 16 de marzo de 1586, ante Gonzalo Méndez, escribano de Su Magestad y del numerario de la villa de Palacios y su concejo.

\footnotetext{
589 Valcovero] al margen derecho: Valcovero.

${ }^{590}$ Barsurbio] al margen derecho: Barsurbio.

${ }^{591}$ San Román] al margen derecho: San Román.

${ }^{592}$ Carbonera] al margen derecho: Carbonera.

${ }^{593}$ Vaños] al margen derecho: Vaños.

594 Pérez] al margen derecho: Arenillas de Nuño Pérez.

595 Muñeca] al margen derecho: Muñeca.

596 dineros] al margen derecho: dineros.

597 Aviñante] al margen derecho: Aviñante.
} 


\section{6. $<$ Venta de un prado. Año 1592>.}

Escritura de venta, por la qual Alonso Rodríguez, vecino de Villafría, vende a la casa del Brezo, siendo prior el padre fray Francisco de Villafuerte, un prado de tres entuertas de yerba, en término de dicho lugar, donde llaman a los Prados Cimeros del Valle, por precio de 24 reales. Su fecha, en Villafría, a 2 de mayo de 1592, ante García de Cossío, escribano de La Puebla.

27. < Venta de una tierra. Año 1592>.

Escritura de venta por la qual Juan González de Mental, vecino de Villafría, vende a la casa de Nuestra Señora del Brezo una tierra en término de dicho lugar, a la Hebreguilla, por precio de 18 reales que por ella pagó fray Francisco de Villafuerte, prior del Brezo. Su / (f. 374v) fecha, en el Brezo, a 21 de febrero de 1592, ante García de Cossío, escribano de La Puebla.

28. <Venta de una tierra. Año 1592>.

Escritura de venta por la qual Froylán Merino, vecino de Villafría, vende una tierra a término de este lugar, a do dicen al Oyo, que hace un quarto de trigo de sembradura, por precio de 50 reales, que por ella pagó el padre fray Francisco de Villafuerte, prior del Brezo. Su fecha, en el Brezo, a 28 de marzo de 1592, ante el mismo escribano.

29. $<$ Venta de una tierra. Año 1592>.

Escritura de venta por la qual Pasqual de Guardo, vecino de Villafría, vende a la casa del Brezo una tierra en término de dicho lugar, donde dicen a la Cotera, por precio de 30 reales, que por ella pagó el padre fray Francisco de Villafuerte, prior del Brezo. Su fecha, en San Román, a 2 de abril de1592, ante García de Cossío.

30. $<$ Donación de una tierra. Año 1599>.

Donación que hizo a la casa del Brezo Pedro Herrero, vecino de Villafría, y su hija María, de una tierra en término de dicho lugar, al Oyo, que linda con dos tierras del Brezo. Su fecha, en el Brezo, a 21 de septiembre de 1599, ante Blas Ordóñez, escribano de Cerbera.

31. $<$ Venta de una tierra. Año 1600>.

Escritura de venta por la qual Pedro Herrero el Mozo, vecino de Villafría, vende a la casa del Brezo una tierra a la Hebrequilla, término de dicho lugar, por precio de 32 reales. Su fecha, en Aviñante, a 5 de abril de 1600, siendo prior fray Cristóval de Matienzo, ante Blas Ordóñez, escribano.

\section{2. $<$ Venta del préstamo de Alonso Terán. Año 1600>.}

Escritura de venta por la qual Toribio Merino, vecino que fue de Villafría y al presente de Aviñante, como mansesor y testamento de Alonso Terán, vecino de dicho lugar, para cumplir su alma vende a fray Cristóval de Matienzo, prior del Brezo, para aquel priorato, una casa con las tierras y prados a ella anexos, que heran del préstamo que tenía el dicho Alonso y son de la casa del Brezo, con el tributo que se le paga perpetuamente, que es una fanega de trigo, diez celemines de centeno, una gallina, y tres blancas. Cuyas casas lindan con las que tenía el dicho Toribio Merino y casas de los herederos y muger de Toribio de Guardo, todo en Villafría, y con las calles públicas de este lugar, por precio de seis mil maravedís. Su fecha, en Aviñante, a 5 de abril de 1600, ante el dicho escribano.

33. $<$ Venta de una tierra. Año 1600>.

Escritura de venta de una tierra que vendió a la casa del Brezo, a do dicen Oyo, término de Villafría, Pedro Herrero, vecino de este lugar, que linda con tierras de la casa del Brezo, por precio de 33 reales, que por ella / (f. 375r) pagó el padre fray Cristóval de Matienzo, prior del Brezo. Su fecha, en Pino de Viduerna, a 18 de junio de 1600, ante el sobredicho escribano. 

$1638>$.

34. $<$ Venta de una casa y corral para Ciprián Merino con el tributo que les toca. Año

Escritura de venta de una casa y corral en Villafría que otorgó Pedro del Hospital el Viejo, vecino de Castrejón, a favor de Ciprián Merino, vecino de Villafría, con el tributo de infurción y otro que pareciere tener y deverse sobre dicha casa. Pasó ante Francisco de La Vega, escribano de Castrejón, año 1638. Esta casa parece la compró después Andrés Herrero, ante Gregorio de La Vega, escribano de Saldaña, por los años de 1650, y se negó a pagar el tributo siendo cierto que la compró con él.

35. < Foro de un pollo sobre el sitio de un colmenar. Año 1664>.

Escritura de foro perpetuo por la qual el padre fray Juan Fernández, prior de San Román, dio al licenciado Diego Alcalde, cura de Villafría, el sitio en que había levantado un colmenar en dicho lugar, con pensión de un pollo cada año para la casa del Brezo. Pasó ante Marcos de la Vega, escribano de Villanueva de Muñeca, año 1664.

\section{6. < Escrituras de foros y reconocimientos de los mismos. Años 1692 y 1795>.}

Bajo este número hay seis escrituras de foros sobre varias casas y solares a favor de Nuestra Señora del Brezo, en el lugar de Villafría, con sus reconocimientos pegados a ellas, ante Manuel Luis París. Y juntamente con éstas, y vajo el mismo número, están 8 reconocimientos de foros sobre casas en el mismo lugar y a favor del Brezo, y por último un foro de una gallina para Nuestra Señora, ante Manuel Luis París, escribano y vecino de Villanueva de Arriba. Las primeras escrituras por los años de 1690 y 1692, y los reconocimientos por los de 1783 y 1795.

37. <Trueque de una casa, solar, etcétera, por tres tierras para El Brezo. Año 1796>.

Trueque que hizo el padre fray Yldefonso Hidalgo, prior del Brezo, con Agustín Pelaz, vecino de Villafría, de una casa, sitio y solar, con su corral y huerto, en el casco de Villafría, que dio dicho padre prior al dicho Agustín; y éste dio en recompensa a la casa del Brezo y su prior tres tierras en término de (de) dicho lugar. Su fecha, en Guardo, a 7 de enero de 1796, ante Rafael de Medina Mandes, escribano de ésta. Está aquí un tanto de esta escritura.

\section{Remisiones}

La hacienda y señorío de este lugar pertenece al Brezo, por el trueque que hicieron los priores. Véase atrás número 23 , vuelta.

/ (f. 375v) Compra de una tierra y un prado en este lugar. Véase el cajón San Juan, legajo $3^{\circ}$, número 18, quaderno $\mathrm{C}$, para El Brezo.

Etcétera, otra tierra, quaderno D, número $3^{\circ}$.

\section{Quaderno B del legajo $1^{\circ}$}

Villafría

Este quaderno B contiene los papeles pertenecientes al curato y pleitos que ha habido sobre él en este lugar por el orden siguiente:

$1^{\circ}$. $<$ Memorial de un pleito sobre la yglesia de San Justo de Villafría $>$.

Memorial, bien maltratado y antiguo, por el qual parece que un clérigo llamado Vrbán, alcanzó del provisor de León collación del beneficio de la yglesia de San Justo de Villafría sin tener para ello presentación del prior de San Román, a quien pertenecía. Y en virtud de esta collación fue a Villafría a tomar la posesión de la yglesia y, hallándola cerrada, quitó la cerradura que había en las puertas y entró y tomó la posesión y puso otra cerradura nueva, con que dejó la yglesia cerrada. Tubo noticia de esto el prior de San Román y fue con sus criados a la dicha yglesia y, quitando la cerradura, se entró dentro con su gente, que cerraron fuertemente por dentro, tratando de resistir la entrada al clérigo, el qual vino de noche con veinte hombres armados y, hallando la puerta cerrada por dentro, rompieron las 
puertas a golpes y entraron y dieron al prior muchos empellones y le hicieron otros malos tratamientos, a él y a los criados que tenía consigo, con que los echaron de la yglesia sin hacerles notoria la colación ni otro despacho que tuviesen para ello. No dice en qué paró este pleito ni en qué año.

$$
\text { / (f. 376r }) 2^{\circ} \text {. <Licencia del provisor para servir el curato. Año 1539>. }
$$

Licencia que dio el licenciado Ballesteros, prior de León, a Hernando Oreja, clérigo, para que sirviese el beneficio curado de Villafría para un año. Dada en León, a 4 de marzo de 1539.

$3^{\circ}$. $<$ Proceso sobre el curato de Villafría que estaba vaco. Año 1590>.

Proceso original, vacante el beneficio de Villafría por muerte de Martín Pérez, en que presentó el convento a Pedro Ramos, provó su título, el concejo presentó al mismo que pretendió a título de patrimonial en que fue condenado. La sentencia salió a favor de Hernando Sánchez de Robles, por más hábil y haber sido la vacante en el mes de mayo. Se remitió la collación a quien tocase. Repárese en este proceso, que así como tiene cosas que aprovechan, tiene otras que dañan, y así es necesario cuidado. Pasó año de 1590.

$4^{\circ}$. <Parecer a los vecinos de Villafría sobre la posesión del curato. Año 1632>.

Parecer que dio el licenciado Mier y Terán, letrado de Cerbera, a los vecinos de Villafría en razón de la concordia con el abad de San Zoil sobre la presentación del beneficio en monge o en clérigo secular. Dado en 25 de marzo de 1632.

$5^{\circ}$. $<$ Maltratamiento del cura fray Vicente. Año 1634>.

Relación del desacato que cometieron el cura de Villaoliva, Pedro Martín, y otros, contra fray Vicente Llánez, cura de Villafría, quitándole los ornamentos y maltratándole acabando de decir misa. En 8 de abril de 1634>.

$6^{\circ}$. <Testimonio de una fuerza en la yglesia de Villafría. Año 1634>.

Requerimiento de fray Vicente Llánez y testimonio de Diego de Vega, notario, cómo Pedro Martín entró por fuerza en la yglesia de Villafria e hizo que contra voluntad del dicho fray Vicente, cura, dixese misa Andrés Valle, beneficiado de Pisón, diócesi de Palencia. En 9 de abril de 1634, Domingo de Ramos.

$7^{\circ} .<$ Requirimiento de fray Vicente a Pedro Martín. Año 1634>.

Requirimiento que hizo fray Vicen $<$ te $>^{598}$ de Llánez ante Diego de Vega, notario, a Pedro Martín y Toribio de Gonzalo, capellán suyo, que no le impidan hacer los oficios divinos; y de lo contrario apela y protesta, etcétera. Jueves de la Cena, 13 de abril de 1634.

8. < Requirimiento de Roque González a fray Vicente. Año 1634>.

Requirimiento hecho ante Agustín de Medina, notario y cura de Aviñante, por Roque González, cura de Velilla, a fray Vicente de Llánez para que a él y a Pedro Monte, cura de Villaverde, les entregase las llaves y ornamentos $<$ de la yglesia $>$ de Villafría para decir misa y administrar los sacramentos en cumplimiento del orden que tenían para ello del obispo de León. Y la respuesta de fray Vicente supuesta la apelación de la causa ante el nuncio, en 27 de abril de 1634.

9. <Provisión del auto de fuerza contra el provisor y obispo. Año 1634>.

Tanto autorizado de la provisión de la Chancillería, inserto el auto de fuerza contra el ordinario de León dado en esta (ca)/ (f. 376v) causa, y fee de las notificaciones y reposiciones. Dado en 12 de mayo de 1634, ante Juan Pita de Andradey, escribano de Cámara.

598 Vicen $<$ te $>$ ] escrito sobre Diego. 
10. $<$ Mandamiento de reposición del provisor y reintegración del monasterio en su posesión. Año 1634>.

Tanto autorizado del mandamiento del provisor de León, dado en virtud del auto y provisión de la Chancillería y con su inserción, por el qual da por repuesto y nulo todo [lo] precedido contra la posesión que el monasterio tenía en el beneficio y le reintegra en ella, a 29 de julio de 1634. Está notificado en Villafría a Pedro Martín y Pedro Monte.

11. <Memorial del pleito sobre la presentación en monge. Año 1631 y 1632>.

Memorial del pleyto que tuvo esta casa en razón de haber presentado monge para el beneficio de Villafría, del qual consta que, habiendo muerto el cura Alonso del Hospital, su último poseedor, el concejo de Villafría hizo presentación del beneficio en Roque González, clérigo de Tarilonte, en 23 de diciembre de 1631, el qual se opuso en 9 de enero de 1632.

En 20 de abril se opuso Pedro de Meras en nombre del convento y, atento que la presentación pertenece in solidum al abad, pidió se diese el beneficio a religioso o a la persona que el abad nombrase. Y en 15 de mayo el abad de San Zoil hizo presentación en fray Gerónimo Gracián, y se presentó y opuso en 27 ídem. Concertose con el abad el concejo de Villafría el qual, en 26 de marzo, confiesa que la presentación es del abad y da consentimiento para que por entonces y para siempre presente en monge y lleve los frutos del beneficio la casa del Brezo. Oblíganse a no lo contradecir y piden al ordinario lo confirme. Presentose esta escritura en León, a 18 de junio de 1632, y en 28 de septiembre el procurador del concejo alega haber sido engañado su parte en esta escritura y pide relaxación del juramento y se le concedió. En 29 de noviembre se apartó Roque González de la presentación hecha en él y el mismo día se opuso Francisco de la Escalera, con presentación del concejo y no la hay en el proceso. En 23 de septiembre otorgó el concejo una escritura por la qual revoca la otra que había hecho consintiendo que el abad presente en monge y pide que el obispo dé el beneficio al clero que quisiere y no a monge y se presentó en el proceso. Estos autos se hicieron siendo provisor el doctor Coronel y de aquí adelante con el doctor Navedas, provisor en sede vacante.

\section{$<$ Año de 1633>.}

Desde 31 de enero de 1633 se pidieron y dieron comisiones / (f. 377r) y se hicieron las provanzas de Francisco de la Escalera, a las quales puso tacha el convento en 14 de mayo, y en 30 pide la posesión de presentar en religioso. Hízose la información de convento y se presentó a 19 de julio. En 15 de junio compulsa el convento autos del prior de Escalada, juez conservador, en que declara que Villafría es de San Román y los vecinos sus vasallos solariegos, y que de solares y heredades pagan tributo como tales etcétera, consentido por los vecinos de Villafría. Vna partida del libro nuevo de registraciones de los beneficios del arciprestadgo de San Román, fol. 272, título del beneficio de San Justo y Pastor de Santa Lucía de Villafría fecho a Martín Pérez, cura de ella, de presentación del abad de San Zoil, fecha por el provisor Sierra, a 13 de diciembre de 1566, por ante Andrés Ortiz, escribano. Proceso y autos de la provisión de este beneficio en Alonso del Hospital, año de 1600, su colación está avajo. Del registro de Juan de Pedrosa, que pasó año de 1508, hay una compulsa en este proceso de Alonso del Hospital, siendo obispo de León don Francisco de Alerosi, cardenal de Pavía, y su provisor doctor Felipe de Hurias, de los títulos de los beneficios del arciprestadgo de San Román; y en 26 de mayo de dicho año dice que consta haberse registrado el curado de Villafría y dice de esta manera: Arciprestadgo de San Román, año 1508. Este dicho día ante el señor provisor Fronioso Sánchez fue presentado un título de collación del su beneficio curado de Villafría, fecho por el provisor del señor obispo, don Ýñigo Manrrique, de presentación del abad de San Zoil de Carrión, fecho en 25 de julio de 1485. Sacose a 22 de septiembre de 1600. Aquí entra la colación de Alonso del Hospital. En 8 de octubre se dio por conclusa la causa a instancia de la parte contraria, y la del convento contradixo a 10 , y pidió pareciesen los testigos contrarios a ratificarse ante el provisor por ser perjuros o no haber dicho lo que estaba escrito.

En 20 de junio de 1632 el concejo de Villafría hace presentación en Pedro de Palacios, clérigo de Congosto, y le procrean por hijo patrimonial de aquel lugar, por no tenerle. Opónese Pedro de Palacios al beneficio, en virtud de la pre/ (f. 377v)sentación dicha, en 19 
de noviembre de 1633. Pide posesión del beneficio y contradice la oposición de Escalera y la del convento. El convento contradice la oposición de Palacios y alega contra el concejo y su provanza, en 29 de noviembre, y, en $1^{\circ}$ de diciembre, pide que atento [que] no hay clérigo que sirva el beneficio, en tanto que se concluye la causa, se dé licencia para que el abad de San Zoil nombre religioso que sirva. Diose el servicio a religioso en el ínterin que se concluye la causa.

En 5 de diciembre Antonio de la Vega, clérigo, vicario de Villacintor, se opone a este beneficio por haber presentado el abad en religioso debiendo presentar en clérigo, porque perdió la presentación en esta vacante y se devolvió al ordinario y se dio por puesto. Este día se dio auto de examen sin perjuicio de las partes y del estado de la causa. Pídese término para Escalera, ausente, y consiente Antonio de Vega, en 10 de diciembre. En 12 del mismo, el convento apela y protesta el auxilio real de la fuerza por el auto de examen, haber hecho el beneficio de concurso, no haber declarado pertenecer la presentación in solidum al abad y que los testigos contrarios se fuesen a rarificar a León. Palacios apela del auto de examen por haber llamado a todos los opositores.

$<$ Buena $>$.

En 22 de diciembre se apartó Escalera de la oposición y presentación al beneficio.

$<$ Sentencia de Navedas $>$.

En 20 de diciembre sentenció el doctor Navedas, provisor ${ }^{599}$ en sede vacante, y declara ser el beneficio de Villafría, de patronazgo y nominación amovilem ${ }^{600}$ ad nutum in solidum del abad de San Zoil y, atento en que esta vacante nombró por cura dél a fray Gerónimo Gracián, y que Francisco de la Escalera y Roque González se apartaron de la oposición y derecho que pretendían al beneficio y que Pedro de Palacios no pareció a examen y que aunque pareció Antonio de la Vega no mostró suficiencia, sin perjuicio de la jurisdición ordinaria hubo por nombrado, elegido y presentado a fray Gerónimo Gracián por el abad de San Zoil amovilem ${ }^{601}$ ad nutum para que sea cura del beneficio curado de Villafría y en su defecto a Vicente Lláñez a los quales, por constar de su suficiencia, y a cada uno in solidum, da licencia y facultad en forma para que sirvan el dicho curato etcétera, y se les adjudican los frutos, diezmos, etcétera del beneficio. Mándaseles acuda con ello y se despache mandamiento de posesión con recudimiento de frutos. Con que los religiosos que el abad nombrare de allí adelante para / (f. 378r) el dicho curato estén sujetos, en lo tocante al curato, a la jurisdición ordinaria de aquel tribunal y sus visitadores, y lo mismo la yglesia y su fábrica. El mismo día se notificó al procurador contrario y al fiscal.

$$
<1634>\text {. }
$$

En 31 de marzo de 1634, entrando por obispo don Bartolomé Santos de Ruisoba y siendo su provisor Diego García Santos, el doctor Gerónimo Sánchez de Roa, nuevo fiscal, salió a esta causa, contradixo la sentencia de Navedas y todo lo en orden a ella actuado, puso tachas y pidió se excluyesen del beneficio de Villafría los religiosos nombrados y se pusiese cura clérigo etcétera. Y, en primero de abril, se opuso al beneficio Pedro Martín, natural de Villafría, y el obispo le dio por opuesto en lo que hubiese lugar de derecho.

$<$ Auto de Diego García, provisor>.

El mismo día el provisor dio un auto (sin citar ni oír al convento) por el qual dice que, atentos los defectos y nulidades que halla en los autos del pleyto, declara por nulla la sentencia que el doctor Naveda, provisor en sede vacante, dio en favor del convento y de los monges Gracián y Llánez, y como tal la revocaba y anullaba con todo lo en virtud de ella fecho y executado; y mandó con precepto y censura latæ sentenciæ y quinientos ducados de pena a los dicho Gracián y Llánez, y otras qualesquier personas no vsen de la dicha sentencia ni de los mandamientos en su virtud librados, y mandó al concejo no les admita por curas so las dichas penas y censuras. Y mandó executar el auto de examen dado por el doctor

\footnotetext{
${ }^{599}$ provisor] escrito sobre procurador.

600 amovilem escrito sobre ad movilem.

601 amovilem escrito sobre ad movilem.
} 
Navedas, atento no estaba executado, y que en su execución parezcan a examen los opositores seculares. Martín.

En 4 de abril, ante el obispo y examinadores, fue examinado y aprovado Pedro

\section{$<$ Sentencia del obispo $>$.}

En 5 de abril el obispo pronunció sentencia, en que declara ser el beneficio de Villafría, de presentar, del abad de San Zoil en los cuatro meses que tiene fuerza su presentación en clérigos seculares y que, atento que en esta vacante no presentó, conforme a derecho, en clérigo secular dentro del término que debía y que algunos de los opositores al beneficio se apartaron y que al examen sólo pareció Pedro Martín, clérigo de menores órdenes, que fue examinado y aprovado por suficiente. Por cuanto por iure devoluto tocaba al dicho obispo la provisión del beneficio, se le adjudica a Pedro Martín y le hace título y collación dél y le manda librar título de ello en forma y ma[n]damiento de posesión con recudimiento de frutos que se dio dicho día.

El mismo día apela de esta sentencia y auto del provisor la parte del convento y protesta el auxilio real de la fuerza y se le otorga la / (f. $378 v$ ) apelación quanto al efecto debolutibo, no quanto al suspensivo. Lo mismo en 6 de abril con poder nuevo.

En 8 de abril Palacios apela de las sentencias de Navedas y del obispo y protesta etcétera. Concédesele en devolutivo, no en suspensivo.

Llevose por vía de fuerza el proceso a la Chancillería a instancia del convento y, en 12 de mayo, salió auto en que se declaró que el obispo de León y su provisor, reponiendo lo hecho y procediendo contra el convento y oyéndoles de nuevo, no hacían fuerza; y no lo haciendo así la hacían. Y mandaron dar provisión para esto al convento, ante Martín Gallo, escribano de Cámara.

En 17 de julio el fiscal, en conformidad del auto de la Chancillería, pide sea citada la parte del convento; para que no se haga nullidad mandose dar traslado, y el procurador del convento responde que se le acabó el poder que se notifique a su parte.

En 24 de julio el provisor, por su auto, declara ser bastante el poder del convento dado a su procurador Pedro de Meras y que ponía el pleyto en el estado que tenía quando el fiscal salió a la causa, y se dé traslado a Meras para que alegue de su justicia. Por el convento alega, en 27 de julio, que el provisor no cumple ni executa el auto de fuerza en la Chancillería en que la hace de nuevo al convento, porque no otorga la apelación ni repone lo hecho ni remite la causa al juez superior. Pide que el provisor cumpla el auto de Chancillería y se iniba del conocimiento de la causa, otorgue y responda, etcétera. Y, salvo la nullidad, apella, protesta, etcétera. Y en 28 de julio se le requirió al provisor con esta petición y la provisión de Chancillería. Respondió haber cumplido reponiendo y dando por nullo lo actuado y lo buelve a hacer de nuevo y manda se despachen para su cumplimiento los mandamientos necesarios.

En 29 de julio da el provisor por conclusa la causa para sentencia y manda se citen las partes. La parete del convento contradice este auto, afírmase en sus apelaciones y pide sobresea el provisor el conocimiento de la causa y la remita al superior y revoque todo lo por él actuado; de lo contrario, apela y protesta, etcétera. El provisor responde que se ha cumplido la reposición y, siendo necesario, la hace de nuevo y revoca el auto de concusión de la causa y se dé traslado a las partes. El breve del doctor don Pedro Testay, comissario de nuncio en esta causa, se dio en Madrid a 26 de abril de 1634, para que se cite al fiscal y a los vecinos de Villafría y para que el provisor se iniba por 30 días y se remita la causa.

La provisión de Chancillería de dio a 24 de julio y responde a ella el provisor, a $1^{\circ}$ de agosto, que ha obedecido y repuesto y de nuevo / ( f. 379r) obedece y repone y vuelbe la causa al estado que tenía antes de sus autos, y para ello se despachen los mandamientos necesarios, Y quanto al breve del nuncio dixo que no ha pronunciado difinitivamente, sino que va conociendo de nuevo como se le manda por la provisión y se dé testimonio de todo y sin él no se vuelva la provisión a la parte del monasterio. 
Pedro Martín consiente la reposición del provisor y pide se revoque la sentencia de Navedas dada a favor del convento y religiosos, y se dé el beneficio al clérigo. A 31 de julio y a $1^{\circ}$ de agosto hasta $12 \mathrm{del} \mathrm{mismo} \mathrm{alegaron} \mathrm{y} \mathrm{pidieron} \mathrm{la} \mathrm{parte} \mathrm{del} \mathrm{convento} \mathrm{que} \mathrm{el} \mathrm{provisor}$ no debía conocer de ésta sino remitirla al nuncio y, los contrarios, que había de conocer y sentenciar en virtud del auto de Chancillería para que conociese y oyese de nuevo.

En 18 de diciembre el provisor dio nuevo auto de reposición muy en forma y manda dar mandamiento para que se execute y al monasterio se reintegre en su posesión del beneficio y se vuelban las cosas al estado en que estaban quando al convento se le dio la posesión en virtud de la sentencia de Navedas. Diose este mandamiento en forma a 19 de diciembre y, requiriendo al procurador del convento que reciviese el mandamiento, no le recivió diciendo no tenía poder para ello. Sin embargo, le recivió un religioso y se llevó a Villafría donde se notificó y se volvieron los monges a su posesión.

A 20 de diciembre la parte del convento alega que el provisor no es juez ni debe proceder en esta causa, pide se iniba y, obedeciendo a las letras del nuncio, se le remita por estar ya allí pendiente por vía de apelación de la sentencia que él había dado en favor de Pedro Martín y contra el monasterio y de lo contrario apela, protesta, etcétera.

$$
<1635>\text {. }
$$

Y en 25 de enero de 1635 pide lo mismo, atento que la causa está pendiente en el tribunal de justicia del nuncio, donde se había prorrogado el término de la inibición del provisor por otros 30 días más. Diose a 8 de enero esta prorrogación de término, otra se dio por otros 30 días a 14 de febrero.

A ocho de enero, a instancia del monasterio, el nuncio, habiendo advocado a sí la causa, dio sus letras para que se llevase el proceso. En 26 y 27 de enero se notificaron al fiscal y a Pedro Martín.

En 15 de marzo se hizo la compulsa de este pleito en virtud de las dichas letras por Felipe Martínez Ocón, escribano y notario, ante quien pasó esta causa.

Letras del nuncio por las quales se cita al fiscal de León, a Pedro Martín, al concejo y vecinos de Villafría que vayan en seguimiento de esta causa, y se manda al / (f.379v) (al) juez don Pedro de Testay y a otros qualesquier juezes, no conozcan de esta causa y al notario que embíe los autos originales. Dado a 20 de junio de 1635.

Otras letras del nuncio dadas a 18 de agosto de 1635 por las quales parece que el convento se quexó de que, sin embargo de estar inibido el provisor de León por su sentencia, procedía en esta causa y había dado mandamiento para que se embargasen los frutos del mandamiento de Villafría. Y, en virtud de esta petición, se dieron estas letras agravatorias para que el notario embíe tanto de los autos innovados, y al provisor y fiscal se les manda no innoven, y que dentro de un día se inhiba del conocimiento de esta causa. Trae fee de los últimos autos del proceso que se había llevado a Madrid para que se compulsasen los que hubiere de allí adelante. A 6 de septiembre de 1635 se notificaron al provisor, el qual se inhibió en el ínterin que se ordena otra cosa por el nuncio o otro juez; también se notificó a Pedro Martín. Lo que contiene esta vltima compulsa es: vna petición del fiscal en que pide se determine y sentencie la causa por el provisor. Mandose dar traslado sin perjuicio y el notario da fee que aunque la petición suena de 3 de agosto de 1634, no se trajo a su oficio hasta 23 de marzo de 1635, y parece ser todo petición y decreto de letra del provisor, y lo llevó el fiscal al oficio.

En 22 de junio pide el fiscal que se embarguen los frutos del beneficio, el convento lo contradice y pide se inhiba el provisor. Prorrogación del nuncio por 40 días de la inhibición del provisor, en 31 de marzo.

En 26 de junio auto del provisor para que se embarguen los frutos del beneficio de Villafría y se dé mandamiento para ello, el qual se dio y se embargaron los frutos.

En 14 de diciembre de 1635 el nuncio dio letras de desembargo, inserto el mandamiento de embargo del provisor y un auto dado por el mismo nuncio en que mandó 
que, dando el monasterio fianzas, se desembarguen los frutos. Y hecho esto se remite la causa al ordinario para que proceda y haga justicia a las partes.

$<$ Advertencia $>$.

Este pleito se concordó con el obispo de León en que el monasterio le daba la presentación que tenía en el curato de Las Heras, con que dejase libre al monasterio el curato de Villafría para que le sirva un monge del Brezo y aquella casa lleve los frutos dél. Y se pidió a Su Santidad confirmación de esta concordia. Véase donde se trata de la licencia que para hacer esta concordia se pidió al reverendísimo General, y la información de vtilidad que se hizo. Véase el número 31.

Pero con todo eso no parece tubo efecto, ni se sacó bulla confirmatoria de Su Santidad, como conta del pleito sobre el curato de Las Heras. Año 1640.

12. $<$ Mandamiento del nuncio para que se desembarguen los frutos del beneficio. Año 1635>.

Letras del nuncio, inserto un auto de el mismo contra un mandamiento de embargo que mandó hacer el provisor de León en los frutos del beneficio de Villafría, y por este manda el nuncio que se / (f. 380r) desembarguen y alza el embargo y manda se acuda con ellos a quien pertenecían antes del embargo, y en el auto alza (no se entiende en el negocio principal más en el artículo del embargo) la inhibitoria puesta (puesta) por el ordinario para que proceda y haga justicia en esta causa a las partes. Dado en Madrid, a 14 de diciembre de 1635.

13. Consentimiento del concejo y vecinos de Villafría para que sirva monge del Brezo el curato de este lugar, a 14 de febrero de $1628^{602}$.

14. Presentación del beneficio hecha por el padre maestro fray Bernando de San Estevan, abad de San Zoil, en el padre fray Gerónimo Gracián. Ante Francisco Moro, a 15 de mayo de $1632^{603}$.

15. Prorrogación del provisor de León para que fray Gerónimo Gracián sirva el curato de Villafría. Ante Juan de Torres, a 20 de mayo de $<1632>$.

16. Presentación del beneficio de Villafría hecha por el presidente de San Zoil en Gabriel Antón. Ante Francisco Moro, a 12 de junio de <1632>.

17. Mandamiento del provisor de León para compulsar las escrituras para el pleito del curato. Ante Felipe Martínez Ocón, a 1 de junio de $<1633>$.

18. Título y colación del cura $<$ to $>$ de Villafría dado por el doctor Navedas, provisor de León, al padre fray Gerónimo Gracián. En 23 de diciembre de $<1633>$.

$<\mathrm{Y}$ autos de la posesión que se tomó del curato. Ante Francisco de los Cuetos, escribano de Carrión, 13 de enero de $<1634>$.

19. Testimonio en que el concejo confiesa que el patronato y presentación del beneficio es del abad de San Zoil y San Román. Consiente que sea monge cura de Villafría y se aparta del pleito. Ante Francisco de los Cuetos, escrivano de Carrión, en 16 de enero de $<1634>$.

20. Testimonio autorizado de los autos, sentencia y colación que dio el obispo de León a Pedro Martín contra la posesión que tenía el convento del curato de Villafría. En 5 de abril de 1634, ante Felipe de Ocón. Dado por Diego de Vega, notario, a 07 de abril de $<1634>$.

21. Copia de la ordinaria de la Chancilleria de Valladolid para llevar el pleito por vía de fuerza. Ante Domingo de la Madrid, 10 de abril de $<1634>$.

22. Requirimiento hecho contra Toribio de Gonzalo, clérigo de Roscales, que dijo misa en Villafría sin licencia. Ante Diego de Vega, notario, en 16 de abril de <1634>.

602 1628] al margen derecho: 1628.

603 1632] al margen derecho: 1632. 
23. Citación a Pedro Martín para que vaya a Valladolid en seguimiento del pleito. Ante Diego de Vega, notario, en 22 de abril de $<1634>$.

24. La ordinaria en apelación dada en Madrid por don Pedro Testay, juez apostólico, comisario del nuncio. Ante Sebastián Martínez de Zaldivia, en 26 de abril de $<1634>$.

25. Testimonio cómo el provisor de León no obedecía lo que le mandó la Chancillería. Ante Diego de Vega, notario, a 3 de mayo de $<1634>$.

26. La ordinaria de la Chancillería para que el ordinario de León otorgue y reponga etcétera. Ante Juan Pita de Andradei, 12 de mayo de $<1634>$.

/ (f. 380v) 27. Mandamiento del provisor de León en que repone sus autos y manda poner al convento en posesión del curato. Ante Felipe Martínez Ocón, 9 de julio, <1634>.

28. Original y traslado de una sobrecarta de la Chancillería para que el ordinario de León obedezca la ordinaria, otorgue y reponga. Secretario Heras, 24 de julio de $<1634>$.

29. Sobrecarta con mayores penas para que el ordinario de León obedezca, otorgue y reponga, y autos. Secretario don Prado de León, en 8 de agosto de $<1634>$.

30. Provisión del Consejo Real para llevar las bulas de impetra del beneficio de Villafría. Secretario Lázaro de Ríos Angulo, a 11 de septiembre de <1634>.

31. Ynformación de vtilidad, comisión y licencia del General para la permuta del beneficio de Las Heras por el de Villafría. Año de <1636>.

32. Legajo de memoriales, cosas y advertencias en razón del pleito sobre el beneficio de Villafría sobre servirle monge. Año 1642 hasta <1654>.

33. <Auto del nuncio para que sirva monge el beneficio. Año 1634>.

Tanto simple del auto del nuncio en que mandó fuese restituido el monge al curato y se le acuda con los frutos del beneficio, el qual se notificó al provisor, que obedeció. Faltan las notificaciones al concejo y el auto de posesión que se tomó. Año de 1643 (sic).

34. <Carta executoria ganada en el nuncio sobre poner monge que sirva el curato de Villafría. Año 1672>.

Carta executoria ganada en el nuncio a favor de este monasterio y contra el concejo de Villafría, fiscal de León y Diego Alcalde sobre poner monge que sirva el curato de Santa Lucía de Villafría, como consta de la memoria de papeles puestos atrás. Este pleito se comenzó el año de 1631 y duró hasta el de 1672, en que esta casa ganó esta carta executoria en el nuncio contra los suso dichos, declarando dicho curato por vicaría vnida a San Román y que el abad de San Zoil, en todo tiempo, pueda poner y ponga monge o clérigo nutum a(d)movile que sea vicario de dicho curato. Pasó ante don Ysidro Jacinto Pau, en Madrid, en 25 de noviembre de 1671. Están aquí juntamente todos los autos hechos por el ordinario de León en cumplimiento de dicha carta, los quales pasaron ante Juan Álvarez, escribano y notario de la Audiencia Episcopal de aquella ciudad, donde están los originales, así de la dejación que de dicho curato hizo Diego Alcalde, que le tenía en virtud de bulas que había ganado de Su Santidad con relación siniestra durante el pleito, como la posesión que de él tomó el padre maestro fray Juan González, abad de San Zoil, por ante Miguel de la Vega, escribano y vecino de Aviñante, en 28 de abril de 1672.

/ (f. 381r) 35. < Nombramientos de vicarios de cura. Año 1683>.

Nombramientos que han hecho los abades en monges para vicarios de cura de Villafría, junto con las licencias y aprovaciones de los obispos de León, desde el año de 1672 hasta el de 1683.

36. < Razón del estado de los pleitos sobre la vicaría de Villafría. Año 1671>.

Bajo este número hay una razón del estado de los pleitos sobre la vicaría de Villafría: pedimiento para la retención de bulas y compulsa de varios instrumentos, mandamiento del provisor de León para la manifestación de ellos, provisión del consejo para la compulsa de 
privilegios y otros papeles, y últimamente está la provanza e información de testigos que acreditan el derecho que se hizo en el ano de 1671.

37. <Diezmo de verdura y hortaliza. Año 1794>.

Apartamiento del concejo y vecinos de Villafría del pleito que sobre la contribución con el diezmo de verdura y hortaliza litigó con el monasterio en el tribunal eclesiástico de León, bajo ciertas condiciones insertas en la escritura de apartamiento, que fue aprovada por el señor provisor de dicha ciudad por su auto de 10 de octubre de 1794, y testimonio de Ramiro Rodríguez Blanco, notario mayor, por quien fue dada esta certificación como originario de la causa, en 14 de octubre de dicho año.

38. < Carta executoria a favor de San Román y el Brezo, filiaciones de San Zoil sobre el yantar y martiniega que deben pagar los vecinos de Villafría. Año 1800>.

Carta executoria, ganada en la Chancillería de Valladolid, en favor de los prioratos de San Román y El Brezo, filiaciones de este de San Zoil, y contra el concejo de Villafría y sus vecinos, por la qual parece que el priorato de San Román y el de Nuestra Señora del Brezo se hallaban en la legítima posesión de percivir, de las personas que componen el vecindario de Villafría, el del Brezo por razón de martiniega 54 maravedís, en virtud de la cesión que el de San Román le hizo, y éste con título de yantar, en la de percivir del referido común una comida anual en el día once de noviembre para tres personas y dos caballerías. Y, sin embargo, de constar al expresado común de esta legitimidad de estos derechos que pertenecían a dichos prioratos, se opusieron a pagarlos, como consta de esta carta executoria; y habiéndose seguido el pleito, se dio auto por don Alonso Astudillo López, corregidor de Saldaña, en 18 de mayo de 1790, en que condena al concejo y sus / (f. 381v) vecinos a el pago del yantar y maravedises de martiniega, en la forma que está determinado por los señores presidentes y oydores de la Real Chancillería, de sus haberes particulares y no de los caudales de proprios. Del qual auto apeló el concejo de Villafría a la Chancillería de Valladolid, en donde fue condenado por varias sentencias de vista y revista, y últimamente se dio esta carta executoria en Valladolid, a 20 de mayo de 1800, ante don Francisco Javier Recio y Ramos, secretario de Cámara. Se notificó a las partes y aquí mismo siguen las notificaciones, diligencia y fee del pago de los derechos de martiniega etcétera. Encima de este legajo está un libro de cuentas y visitas de la yglesia de este lugar.

\section{/ (f. 382r) Legajo $2^{\circ}$}

Este legajo, que es el segundo del cajón San Plácido, contiene un solo quaderno perteneciente al vasallaje de Villafría. Consta de papeles, escrituras, cartas executorias pertenecientes a los pleitos y diferencias que han tenido la casa de San Román y la del Brezo con el concejo de Villafría, en razón del vasallaje y tributos de este lugar y sus vecinos.

\section{Quaderno A del legajo $2^{\circ}$ \\ Villafría}

Este quaderno A, que es el vnico del legajo $2^{\circ}$, contiene los papeles pertenecientes al vasallaje de este lugar por el siguiente:

$1^{\circ}$. <Foros de Villafría. Era 1317. Año 1279>.

Escritura escrita $<$ en $>$ pergamino, partida por ABC, por la qual don Pedro de Toro, prior de San Román, da a sus vasallos de Villafría los foros que el monasterio tiene en aquel lugar, con que paguen cierto tributo. Facta carta era 1317, año 1279.

$2^{\circ}$. $<$ Querella y sentencia contra los vecinos de Villafría en razón de los términos y vasallaje. Año 1531>.

Escritura y sentencia por la qual parece que por los años de 1531 fray Diego de Sahagún, prior de San Román, trató de apear la hacienda y derechos que el monasterio tenía en el lugar de Villafría, cuyos vecinos lo negaron y resistieron. De que se querelló el dicho prior ante Santiago de los Ríos, prior de Escalada, juez conservador, el qual dio sus letras citatorias contra los de Villafría que, habiéndoseles notificado, parecieron ante el dicho juez 
ciertos vecinos en nombre del concejo de Villafría y le pidieron les pusiese demanda, la qual puso por escrito la parte del dicho prior, diciendo que apeando los prados, tierras, heredades y términos pertenecientes a San Román que están en término de Saldaña, había venido a Villafría, cámara de San Román, para apear todos los términos, prados y exidos quél tenía en el dicho lugar, para lo qual fueron llamados los vecinos dél para que declarasen por dónde se dividían los términos del lugar pertenecientes a San Román de los otros lugares y, siendo todo del dicho priorato de tiempo inmemorial a aquella / (f. 382v) parte, haciendo los priores dél de todo ello como de cosa suya propia, admitiendo en las casas dél o repeliendo de ellas a los vasallos que han querido y poniendo en ellas quando alguno muere a otro a su voluntad, y que los vecinos del dicho lugar, que son todos vasallos de San Román, no habían querido declarar la verdad que sabían en el dicho apeo, ni decir los términos del dicho lugar a causa de molestar a la dicha casa; y pidió que fuesen apremiados a reconocer al prior de San Román por señor del dicho lugar declarando que los suelos, prados, exidos, heredades, términos y pastos que los gozan < como vasallos> de San Román y no en otra manera. El dicho juez mandó a los procuradores de Villafría que respondieran a la dicha demanda y alegaron de su derecho. Visto lo que alegaron, el dicho juez declaró que el lugar de Villafría con sus casas y solares heran de San Román y los vecinos dél ser vasallos solariegos del dicho monasterio y como tales tienen posesión en las heredades, prados, exidos y rozarlo y pacerlo como sus pasados en nombre del dicho monasterio; y mandó que los vecinos de Villafría señales los hitos y mojones del dicho término salvo lo que constare ser suyo proprio de los dichos vecinos. Y los dichos procuradores de Villafría, por sí y en nombre de los demás vecinos, aceptaron esta sentencia y se obligaron a cumplirla. Dada en Carrión, a 12 mayo de 1531, ante Juan de Castillo, escribano y notario de Carrión.

$3^{\circ}$. $<$ Memorial de escrituras antiguas. Año 1531>.

Memorial de lo que se halla en escrituras antiguas sobre el señorío y otras cosas que tiene el monasterio de San Zoil y sus prioratos de San Román y el Brezo en Villafría. Año 1531.

$$
4^{\circ} \text {. <Compromiso y sentencia contra los de Villaverde. Año } 1536 \text { y 1537>. }
$$

Escritura de compromiso y sentencia árbitra por la qual parece que, habiendo entrado algunos vecinos del lugar de Villaverde ${ }^{604}$ de la Peña a pastar en los términos del lugar de Villafría, salieron los monges de San Román con sus criados a defenderlo y prendaron a los pastores, en cuya defensa salieron algunos vecinos de Villaverde y les quitaron las prendas y maltrataron de obra y de palabra a los monges; de lo que se querelló en la Chancillería de Valladolid fray Diego de Sahagún, prior de San Román, y pidió juez contra los de Villaverde, y con efecto vino receptor a hacer la información. Y, estando la causa en este estado, se trató de composición para excusar pleitos y gastos y se tomó por medio comprometerla en jueces árbitros. Para lo qual por ambas partes se otorgó escritura de compromiso en San Román, a 15 de hebrero de 1536, ante Juan Gutiérrez, / (f. 383r) escribano.

$<$ Deslindamiento de los términos de Villafría y Villaverde $>$.

$\mathrm{Y}$ por esta escritura se nombraron por jueces árbitros y se dio poder en forma por ambas partes para esta causa a Christóval Gómez, cura de Santivánez y Las Heras, y a Alonso Delgado, cura de Valcovero, los quales en San Román, a 9 marzo (del) de 1536, dieron y pronunciaron sentencia árbitra por la qual declaran el prior de San Román por señor de Villafría y sus términos y declaran y deslindan por menor los límites, términos y mojones que parten y dividen los términos entre Villafría y Villaverde.

$<$ Condenación criminal contra los de Villaverde $>$.

Mandaron que dentro de 60 días el prior se apartase de la querella que tenía dada ante los alcaldes del crimen y trajesen testimonio de ello y perdone a los que le injuriaron.

Que el consejo dé al prior, en satisfacción de las costas que había echo en querella, información, etcétera, seis mil maravedís.

${ }^{604}$ Villaverde] al margen derecho: Villaverde. 
Condenaron a ciertos vecinos de Villaverde por el error que cometieron a ciertas penitencias dignas de leerse, etcétera, y por último mandaron que el prior, para seguridad, traiga dentro de 60 días confirmación de sus prelados de esta sentencia; la qual se notificó a las partes y la aceptaron y cumplieron, y se trajo confirmación del padre fray Gaspar de Villarroel, abad, y del convento de San Zoil. Fecha en él, a 20 hebrero de 1537, ante Juan de Castrillo, escribano de Carrión, y asimismo la confirmó fray Alonso de Toro, general, a 29 de julio del mismo año, y ante el mismo escribano.

$5^{\circ}$. <Repartimiento de martiniega. Año 1536>.

Repartimiento de la martiniega de los vecinos de Villafría, hecho por el prior de San Román a consentimiento del concejo, echando a cada millar de valor de las heredades una blanca. (Y adviértase que la pagó la casa del Brezo, cuya heredad se valoreó en 20 mill maravedís, y así le cupieron $<10>$ maravedís. Año 1536.

$6^{\circ}$. $<$ Mandamiento para que no arrienden ni rompan lo común. Año 1552>.

Mandamiento del corregidor de Saldaña con audiencia para que los vecinos de Villafría no arrienden los pastos, ni rompan los exidos comunes. Dado año de 1552 ante Diego Gómez, escribano. Diose a instancia del prior del Brezo.

$7^{\circ}$. < Compromiso y sentencia arbitra contra Villafría sobre el vasallaje, préstamos y términos. Año 1553>.

Escritura de compromiso y sentencia árbitra por la qual consta que, habiéndose quejado el concejo de Villafría en la Chancillería de que siendo los términos de aquel lugar públicos y concejiles, el mo/(f.383v)nasterio de San Román les quitaba sus aprovechamientos y que no los pudiesen arrendar y que los monasterios de San Zoil y San Román meten en ellos sus ganados y que el prior lleva cada año un yantar al concejo o un real a cada vecino, por el que era imposición, y una fanega de trigo cada vecino y ciertas güebras y diez celemines de centeno, una gallina y tres blancas a cada vecino. A que respondió el monasterio de San Román que los términos de Villafría son suyos y serle devido todo lo que los vecinos le pagan por ser sus vasallos solariegos e que los puebla y despuebla poniendo y quitando a quien quiere en el dicho lugar, sin que pueda haber en aquel lugar más vecinos de los que pone el prior, ni puede nadie gozar de los términos sino el solariego que fuere puesto por mano del prior, y que el concejo no es parte para dar vecindad ni aprovechamiento del lugar, y que lo que dicen que pagan es por los suelos, heredades y términos que gozan, siendo todo proprio del monasterio; y las tres blancas, de vrción y vasallaje; y el yantar, en reconocimiento del señorío y aprovechamiento del término, y que los que entran a ser vecinos por mano del prior pagan cierto tributo que llaman entrada y que todo lo que poseen los vecinos se llama préstamo de San Román por tenello prestado y de voluntad del prior, que se lo puede quitar siempre que quisiere, etcétera, sobre que hicieron ambas partes sus provanzas. Cuyo proceso pasó ante Palomino, escribano de Cámara de la Chancillería. Y, por excusar pleitos y gastos, el dicho concejo de Villafría y fray Rodrigo de Corcuera, prior de San Román, con poder del abad y convento de San Zoil, dado ante Juan de Castillo, escribano de Carrión, comprometieron esta causa en Juan de Vozmediano, cura de Muñeca; el doctor Flores, vecino de Carrión; en Pedro Montes, cura de Aviñante, y fray Pedro de Porras, monge de San Zoil, a los quales dieron poder para determinar y sentenciar esta causa, en Villafría, a 2 hebrero de 1553.

Y a 17 de hebrero del mismo año la parte del concejo pidió en Carrión a los jueces que antes de determinar la causa fuesen a ver por vista de ojos los términos de Villafría. El prior pidió lo mismo y se obligó a pagar lo que le cupiese de costa.

En Villafría, a 26 de hebrero dicho año, estando allí los jueces ante Andrés Sánchez, escribano de Carrión, los mandaron a las partes depositar para las costas y ellos hicieron el depósito. Mandaron los jueces a las partes que presentasen las escrituras y contratos que tubieren en su favor y se informaron de personas inteligentes cerca de esta causa.

En Villafría, a 26 del dicho mes y año, el concejo de Villafría y prior de San Román /(f. 384r) ratificaron el compromiso hecho y le juraron ante Andrés Sánchez, escribano dicho; y el día siguiente, 27 del dicho mes, dieron nuevo poder a los jueces para que, fuera de lo 
pedido y procesado, pudiesen declarar el señorío y lo que tiene San Román y lo que ellos habían de tener y les prorrogan la jurisdición y les dan poder para que, aunque esté confirmada la sentencia que dieren, puedan declarar las dudas que se ofreciesen de los casos de ella dentro de dos años primeros siguientes y para que cerca de ello puedan sentenciar, arbitrar, etcétera. El mismo día en Villafría presentaron las partes sus escrituras.

Después de lo qual, en el monasterio de Nuestra Señora del Brezo a 28 días de hebrero de 1553, estando juntos el doctor Amaro Díaz de Flores, el bachiller Joan de Vozmediano, fray Pedro de Porras y Pedro Montes, jueces árbitros, dieron y pronunciaron sentencia en este caso, por la qual mandaron y ordenaron las cosas siguientes:

$1^{\circ}$. Declaran que el lugar de Villafría con todos sus términos en posesión, propriedad y señorío, con todos los vecinos que en él viven, ser vasallos solariegos y ser todo, y los dichos vasallos y préstamos, del priorato de San Román, y a él anejo e perteneciente, y por tal se lo adjudican, declarando los vecinos de Villafría que son y fueron como tales vasallos solariegos no poder arrendar el término de Villafría ni parte dél en ningún tiempo, fuera de lo que aquí irá declarando, sin licencia del prior de San Román y del abad de San Zoil, concertándose con el uno de ellos.

$2^{\circ}$. Que por estar muy pobres y necesitados los vecinos de Villafría, puedan arrendar por 4 años primeros siguientes un pedazo de término que señalaren fray Pedro de Porras y Joan de Vozmediano y, no concordando entre uno de los otros dos jueces, con que para reconocimiento del señorío y de las costas que el prior había hecho le den cada año tres ducados, y que pasados los 4 años no arrienden sin la dicha licencia, y en los quatro años no puedan entrar ningún ganado de San Zoil ni San Román en el pedazo que arrendaren.

$3^{\circ}$. Que el prior de San Román como señor, por virtud del poder que tiene de San Zoil, pueda quitar y poner quando quisiere según la costumbre que tiene provada a los vecinos del dicho lugar, sus vasallos solariegos, de los solares y préstamos que les tiene dados. Y que por causas que a ellos les movían por los días de los que entonces eran vecinos en el dicho lugar de Villafría no pudiesen ser quitados de los solares y préstamos, sino que los tubiesen y gozasen por todos los días de sus vidas, pagando sus fueros y derechos como aquí irán ${ }^{605}$ declara(n)dos, no haciendo ellos cosa contra /(f. 384v) el señor de desobediencia e ingratitud y delito por donde los vasallos puedan ser quitados por sus señores, que en tal caso pueden ser quitados los que tal cosa cometieren.

Y que después de acabadas las vidas de los que entonces eran vivos, si el prior o abad de San Zoil no quisieren dar el préstamo al hijo heredero del difunto, que en tal caso, sea obligado a pagarle los edificios e mejoras que en tal solar el difunto hubiese echo, y hasta que se los pague pueda vivir en el solar por prenda, y que para la tasación de las mejoras se nombren personas y con pagar el prior la tasación le quede desembarazado sin contradición alguna y pueda tomar libremente el solar y préstamo y hacer de ello lo que quisiere como suyo que es, y con que ninguno pueda edificar casa ni hacerla de nuevo en el dicho término sin licencia del prior de San Román.

$4^{\circ}$. Que por ser estrechos y estériles de invierno los términos de Villafría y moderado el ganado que pueden caber, pueda o el monasterio de San Zoil o el de San Román, uno de ellos, entrar a pacer con 400 cabezas de ganado obejuno en los términos de dicho lugar en el verano y no en el invierno, con que el año que ${ }^{606}<$ comenzare a $>$ entrar el de San Zoil no pueda entrar el de San Román, y comenzando el de San Román no entre el de San Zoil, y que ni uno ni otro entre por aquellos dos primeros años.

\section{$5^{\circ} .<$ Yantar $>$.}

Que el concejo de Villafría dé un yantar al prior, como se le solían dar, o por él 300 maravedís cada año, por el tiempo que él le quisiere tomar, qual más el concejo quisiere escoger.

\footnotetext{
605 iran] precede tachado: se.

${ }^{606}$ que] sigue tachado: pueda.
} 


\section{$6^{\circ} .<$ Martiniega $>$.}

Que cada año dé al prior de San Román cada vecino de Villafría por razón de los solares y préstamos que tienen del monasterio, los que los tubieren, diez celemines de centeno, una gallina, tres blancas y una fanega de trigo por las huebras, como y al plazo que hasta allí habían pagado.

$7^{\circ}$. Que los cotos que se suelen cotear cada año por dehesas, báyales para los ganados de labor desde primero de marzo hasta día de San Martín, no los puedan pacer de fuera ni los dichos monasterios con sus ganados obejunos o brabos, sino que sólo sea pasto para los ganados de labor de los vecinos de Villafría, y como ellos pueda el prior de San Román meter sus ganados de labor; y, quanto a esto, se guarden al concejo sus ordenanzas y conforme a ellas puedan prendar y penar.

$8^{\circ}$. Que quanto a la jurisdición y merino de prendar, se guarde la costumbre que hasta allí se había tenido sobre cobrar los fueros, derechos y otras cosas que según derecho los señores pueden hacer y acostumbra el prior.

/ (f.385r) $9^{\circ}$. Que los dichos juezes prorrogaron en sí la jurisdición conforme al poder que se les dio para que dentro de dos años pudiesen declarar las dudas que entre las dos partes se ofreciesen cerca de lo contenido en los capítulos de esta sentencia y cada parte de ellos. Y con esto dieron por apartadas las partes una de otra y se les absuelven de qualquiera otra demanda y se les pone perpetuo silencio. Condenaron al concejo en el salario de dos días de la vista de ojos de los juezes y al prior en lo demás y cada parte pague sus asesorías y costas procesales.

El dicho día que se pronunció esta sentencia se mandó notificar y se notificó a las partes, los quales, unos y otros, dixeron que la consentían y la consintieron ante Andrés Sánchez, escribano de Carrión. El mismo día el concejo y fray Juan de Santa María, abad de San Zoil, y fray Rodrigo de Corcuera, prior de San Román, dieron poder a Gonzalo de Oviedo y Gregorio de Treceño, procuradores de la Chancillería, para que en ella presentasen el compromiso y esta sentencia consentida por las partes y pidiesen aprovación y confirmación de ella, pronunciándolo por su sentencia difinitiva y de ello den carta executoria para que se guarde.

8. < Poder de los vasallos de San Román y del Brezo contra estos prioratos sobre las vrciones de sus préstamos. Año 1580>.

Poder que otorgaron los vasallos de San Román y del Brezo, vecinos de los lugares de Entorcisa, Villanueva de Arriba, Villaoliva, Las Heras, Santiváñez, Villafría, Villaverde y Villalveto, para seguir un pleito contra los dichos prioratos, en razón de las vrciones que pagaban por los préstamos que tenían de ellos. Fecho año de 1580, ante Juan Rodrigo, escribano de Villaverde, sacado con mandamiento de la justicia de Saldaña, dado a instancia de los priores de los dichos prioratos.

9. $<$ Concordia entre el Brezo y Villafría sobre las contribuciones y aprovechamientos del concejo. Año 1581>.

Concordia hecha entre fray Benito del Camino, prior del Brezo, y el concejo y vecinos de Villafría, en razón de que éstos prendaban a los familiares y criados del Brezo porque no acudían a los aderezos de los caminos, guardas de términos y demás penalidades y contribuciones de concejo, y no daban parte de los aprovechamientos dél al prior como a vecino, debiendo estar libre de aquello y participar de esto. Sobre que se querelló el prior ante fray Juan de Salvatierra, prior de Santo Domingo de Carrión, juez conservador, el qual dio sus letras contra ellos, y se notificaron, juntamente con la querella, al concejo y vecinos de Villafría; los quales, conociendo la justicia del prior y por escusar pleitos y gastos, hicieron juntamente con el prior una con/ (f. 385v)cordia que contiene los capítulos siguientes:

$1^{\circ}$. Que todos los vecinos y concejo de Villafría para siempre jamás sean obligados a guardar todo lo contenido en la Bula Eugeniana concedida al Orden de San Benito en la forma siguiente: 
$2^{\circ}$. Que el prior (prior) del Brezo, sus familiares y criados para siempre sean libres de todas derramas reales y concejiles, que no contribuyan en ningún repartimiento ni en aderezo de caminos, ni de fuentes, puentes, defendimiento de caminos, conforme a los privilegios y bulas concedidas a la Orden de San Benito, principalmente la Bula Eugeniana citada.

$3^{\circ}$. Que el prior del Brezo que fuere para siempre pueda ahorrar y libertar en cada un año a su pastor 28 reses de ganado ovejuno y cabrano, andando siempre con el ganado del priorato, y que las crías de estas 28 reses no se cuentan, ni se haga caudal de ellas hasta el día de San Pedro de cada año, y de allí adelante se cuenten por cabezas de maná, y no se le pueda ahorrar más; y si más traxere, pueda el concejo libremente prendarle como quisiere y dar la parte de tales prendas al prior del Brezo que fuere.

$4^{\circ}$. Que en ningún tiempo del año pueda haber en Villafría coto alguno para las bacas de huelga más que para el ganado ovejuno, así del lugar como del priorato, sino que siempre ande el ganado ovejuno por donde andubiere el bacuno de huelga.

$5^{\circ}$. Que siempre que los de Villafría se juntaren a concejo y se hallaren a hacer algunos cotos como lo acostumb[r]an, o a soltar los cotos o parte de ellos, o para echar leña, madera o carbón, o qualquiera otro aprovechamiento, los rejidores sean obligados a hacerlo saber a los familiares, donados o criados del Brezo que asisten en la casa de Villafría para que guarden los cotos, montes y cosas, y cosas coteadas, so las penas que les fueren puestas como a los demás vecinos, lo qual hagan saber y avisen la noche antes en la casa que tiene El Brezo en Villafría, y no habiendo persona en ella a quien se dé el aviso, se le dé a un vecino de Villafría, a quien el prior del Brezo ha de tener nombrado para esto y que avise al prior para que lleve el aprovechamiento como un vecino de Villafría.

Y que por cada vez que los rejidores fueren negligentes en dar este aviso, paguen dos reales de pena aplicados para cera para el Santísimo Sacramento del priorato del Brezo. Y si haciendo saber los cotos a los familiares o criados del Brezo no los guardaren, pueda el concejo prendarlos libremente, o al vecino de Villafría nombrado co a su fiador, el qual sea obligado a pagar las penas que justamente debiere el ganado del Brezo y sus familiares y criados, con que el concejo pueda prendar al pastor del Brezo siempre que rompiere algún / (f. 386r) coto o entraren en panes o prados, de suerte que le puedan prendar sus ganados proprios y no los del priorato, executándole las penas en que incurriere y haciéndole pagar los daños en forma que suelen pagar los vecinos de Villafría.

A todo esto se obligaron ambas partes en forma y pusieron ciertas penas a quien lo quebrantase. Fecha en Villafría, a 8 de marzo de 1581, ante Juan Rodrigo, escribano de Villaverde.

10. <Mandamiento para no apear. Año 1581>.

Mandamiento del prior de Santo Domingo de Carrión, juez conservador, para que no se entrometan los de Villafría a apear los términos de dicho lugar, y da por nulo el que hicieron en este año de 1581. Hay copia simple.

11. <Parecer acerca de la sentencia árbitra. Año 1582>.

Parecer del licenciado Herrera, abogado de Valladolid, acerca de la execución y fuerza que tiene la concordia o sentencia árbitra del año de 1553, que está aquí, en el número $7^{\circ}$ de este legajo, dado en Valladolid, año de 1582. Año 1585>.

12. $<$ Mandamiento que no se tomen las cuentas sin asistir a ellas el prior del Brezo.

Mandamiento con audiencia de Pérez Manuel, alcalde mayor del Adelantamiento de Campos, para que los vecinos de Villafría no tomen las cuentas a los oficiales sin asistir a ellas el prior del Brezo, como su señor. Dado en Palacios, a 13 de mayo de 1585, ante Sancho García, escribano público.

13. $<$ Sentencia de la Chancillería en el pleito sobre el vasallaje y caminos. Año 1585>.

Sentencia dada en la Chancillería de Valladolid, a 19 de noviembre de 1585, de que parece que, no queriendo los vecinos de Villafría pasar por lo determinado en la sentencia 
árbitra que se dio en el año de 1553 , que es la que está en el número $7^{\circ}$ atrás, puso demanda en la Chancillería al prior y convento de San Román y al del Brezo, que tenía ya la posesión de Villafría desde el año de 1581 que se hizo la permuta. Pretendió el concejo ciertos capítulos por los qua (sic) se dio esta sentencia. Esta demanda y excepciones se pusieron año de 1552, un año antes que se diese la sentencia árbitra de que se apartaron en virtud del compromiso. Después, por los años de 1585, volvieron los de Villafría al pleito, hicieron ambas partes sus provanzas, y el convento presentó entre otras escrituras la sentencia árbitra de 1553, y pidió se mandase guardar. Y conclusa la causa en la Chancillería se dio sentencia difinitiva que contiene los capítulos siguientes:

$<$ Sentencia de vista en La Chancillería $>$.

Quanto a la ${ }^{607}$ demanda del primer artículo condena al convento a que no impida al concejo aprovecharse de los términos, con que no los puedan arrendar a forasteros.

Quanto al segundo, declara poder el convento aprovecharse de los términos con sus ganados como dos vecinos del concejo.

Quanto al tercero declara / (f. 386v) que el convento puede meter en las dehesas el mismo ganado de labor que dos vecinos y que no meta otro ganado de alguno.

Quanto al $4^{\circ}$ condena al convento no exerza en este lugar jurisdición alguna civil ni criminal, y declara la jurisdición pertenecer a Su Magestad.

Quanto al $5^{\circ}$ manda que yendo los monges a recivir el yantar se les dé, y no yendo no se les dé nada por él.

Quanto al $6^{\circ}$ absuelve al convento del pedimiento que había hecho el concejo de que no tenían obligación a pagar una gallina, tres blancas, una fanega de trigo y diez celemines de centeno.

14. <Provisión de emplazamiento contra El Brezo. Año 1586>.

Provisión Real de la Chancillería, inserta una petición del concejo en que apeló de la sentencia de vista y pidió lo contenido en estos artículos.

$<$ Artículos de la apelación del concejo de Villafría $>$.

$1^{\circ}$ Que no se les impida arrendar los pastos a forasteros y se allanan a dar al prior su parte del aprovechamiento como a un vecino.

$2^{\circ}$ Que el monasterio no pueda entrar sus ganados en las dehesas Boyales coteadas, sino donde entraren los ganados de los vecinos.

$3^{\circ}$ Que sólo vayan a tomar el yantar los dos monges y un criado, y no lleven más gente, y que le vayan a tomar día de San Martín, y no yendo entonces el concejo no tenga obligación a darle.

$4^{\circ}$ Que se allanan a pagar cada año una gallina, tres blancas, una fanega de trigo y diez celemines de centeno; pero que los que tienen y labran tierras y prados lo paguen todo, y los que no labran que sólo paguen las tres blancas y una gallina.

$5^{\circ}$ Que puedan disponer de las casas a su voluntad en vida y en muerte, y las puedan dejar a sus hijos, nietos, mugeres y herederos. Suponen que son suyas.

$6^{\circ}$ Que el prior del Brezo, so color de la permuta con San Román, se llame señor de Villafría, que goza los pastos de 60 años a aquella parte, porque ellos le dieron la vecindad, que fue en 3 de junio de 1515, porque les diese 300 maravedís cada año que durase por el tiempo que los vecinos quisiesen. Y, so color de la dicha permuta, embían un familiar con los ganados, que si hacen daño, maltrata a los guardas que los van a prendar y se nombran señores del término, que prendan a los que llevan leña o carbón con licencia del concejo; que, llegando los ganados de los vecinos cerca del monasterio, siendo dentro de los términos del lugar, los corren los del monasterio y maltratan los pastores que no contribuyen en las cosas de la vecindad, aunque antes de la permuta lo hacían. Piden que el prior del Brezo no

${ }^{607}$ la] sigue tachado: primera. 
entre con sus ganados a pacer sus términos, ni hagan otro aprovechamiento, / (f. 387r) porque declaran que no quieren que sean vecinos de Villafría; y que si entraren los puedan prendar como a forasteros, y que traigan pastores legos que puedan ser prendados, y los condenen a que no se nombren señores de Villafría, ni de sus términos, ni les estorben dar leña ni carbón, y que les dejen pacer a sus ganados y no los corran ni maltraten los pastores.

$7^{\circ}$ Piden emplazamiento para que el prior del Brezo vaya en seguimiento de esta causa y les pare perjuicio lo que en él se hiciere. $1586>$.

$<$ Prior de San Román, fray Ambrosio de Náxera; y del Brezo, fray Damián de Salas.

En virtud de este ${ }^{608}$ pedimento se dio esta provisión de emplazamiento, inserto el dicho pedimento, para que el prior del Brezo fuese o embiase en seguimiento de este pleito. Sacó este traslado Juan Rodrigo, escribano de Villaverde, por mandado de fray Ambrosio de Náxera, prior de San Román, y fray Damián de Salas, prior del Brezo, a 26 de marzo de 1586. No respondió el del Brezo.

\section{$<$ Respuesta del convento $>$.}

El convento respondió a estos capítulos como a los primeros, y además al quinto de éstos, que las casas y todo los demás que está en el término de Villafría, y las heredades que tienen los vecinos y vasallos, todas son proprias del convento, de suerte que sólo se concedieron para que los vecinos las gozasen por sus vidas y que no pudiesen disponer de ellas en persona alguna, vecino ni forastero. Y que quando muriesen pudiese el convento nombrar y poner en ellas otra persona qual quisiere, y que contra su voluntad ninguno puede ser admitido por vecino, aunque sean herederos o sucesores de los que faltan, y mucho menos si son personas extrañas, porque ninguno pueda ser admitido por vecino sino el que admitiere el convento. $\mathrm{Al} 6^{\circ}$, que no se ha seguido esto con parte legítima y que no es cierta la relación de que el priora $<$ to $>$ del Brezo entró en la vecindad por orden del concejo, porque no se la pudo dar, y que el priorato está dentro de los términos de este concejo, y del priorato de San Román, y que allí tiene este priorato heredades proprias, y no el concejo, que no tiene más de las que le ha dado el prior de San Román, y así tiene más propriedad en la vecindad que el concejo; y lo que allí tienen ambos prioratos se lo ha dado el convento de San Zoil como superior suyo. Y que no se han hecho malos tratamientos a los vecinos y sus ganados, antes han vsado de su derecho y con mucha modestia y todo buen proceder.

15. < Cuaderno de escrituras para el pleito de Villafría etcétera. Año 1586>.

Quaderno de escrituras y apeos que se presentaron en la Chancillería de Valladolid para el pleito de Villafría, y juntamente están aquí los apeos de este lugar y los de Aviñante, con algunos otros papeles sustanciales, como se ve al principio dél, en un especie de índice que tienen. Es del año 1531 hasta el de 1586.

\section{/ (f. 387v) 16. <Memorial del pleito hecho. Año 1592>.}

Memorial del pleito hecho año de 1592 por parte del monasterio, que entonces parece se volvió a tratar de esta diferencia. Hay otro memorial con éste, del mismo tiempo.

17. $<$ Memorial de hacienda y préstamos. 1630>.

Quaderno en que están puestos y dividos los préstamos y las personas que han ido sucediendo en ellos; y asimismo memoria de la hacienda y de la parte que El Brezo tiene en el molino. Desde el año de 1530 hasta 1630.

18. $<$ Memorial hecho. Año 1631>.

Memorial, escrito de mano, hecho por el procurador general de Valladolid y solicitador, para la vista de este pleito en grado de revista. Año 1631. Contiene toda la sustancia del ${ }^{609}<$ proceso $>$ desde sus principios y el derecho de ambas partes ${ }^{610}$.

\footnotetext{
${ }^{608}$ este] sigue tachada palabra ilegible.

${ }^{609}$ del] sigue tachado: Pleyto.

${ }^{610}$ Partes] sigue tachado: Informaciones y compulsa de papeles del convento.
} 


\section{9. $<$ Memorial impreso. Año 1632>.}

Otro memorial del pleito, impreso, hecho por el relator para la vista de este pleito. Año de 1632. Contiene la sustancia de los pleitos desde sus principios y el derecho de ambas partes, informaciones y compulsa de papeles del convento.

\section{0. < Primera carta executoria dada. Año de 1632>.}

Carta executoria ganada en la Chancillería de Valladolid a favor del monasterio de San Román contra el concejo de Villafría, por la qual consta la demanda que puso el concejo en la Chancillería de los 6 capítulos que están en el número 13 atrás y las excepciones y respuesta del convento, que está en el mismo número, que todo fue año de $1552^{611}$, un año antes que se diese la sentencia árbitra atrás dicha, número $7^{\circ}$. Después de lo qual, por los años de 1584, el convento volvió al pleito porque los de Villafría no querían guardar lo contenido en la sentencia árbitra, y sacó emplazamiento para que los de Villafría fuesen a seguir el pleito. Y el año 1585 en la Chancillería se dio en este pleito la sentencia de vista que está en el número 13, de la qual se apeló por ambas partes y el concejo puso además de los capítulos primeros otros nuebos que son los contenidos en el número 14. Esto se quedó en este estado hasta que el año de 1622 el convento dio poder para volver a seguir este pleito, el qual se presentó año de 1628. Pidió el convento emplazamiento para que el concejo fuese en seguimiento de esta causa, y el año de 1631 dio el concejo poder para ello y fue en seguimiento del pleito. El compromiso y sentencia ${ }^{612}$ árbitra del año de 1553 , que está en el número 7 ya dicho, está inserto en esta executoria, desde folio 82 hasta 124. Vistos los autos, informaciones antiguas y modernas, compulsas del monasterio, escrituras, sentencias, etcétera, en 3 días del mes de marzo de 1632, en la Chancillería se pronunció sentencia de revista por la qual se revoca la de vista y se manda guardar la sentencia árbitra, número $7^{\circ}, \mathrm{y}$ en 17 marzo del mismo año se libró esta carta executoria que no tuvo efecto por pura desgracia de no llevarla a devida execución. Ante Diego Gómez Oso<rio $>$.

\section{/ (f. 388r) 21. < Memorial del pleito. Año 1634>.}

Memorial de este pleito para verle en otra nueva instancia después de la primera carta executoria. Año 1634.

22. $<$ Segunda carta ${ }^{613}$ executoria en el pleito con Villafría sobre el vasallaje, términos y tributos. Año 1635>.

Segunda carta executoria librada en la Chancillería de Valladolid a pedimiento del monasterio de San Zoil y del de San Román en el pleito atrás referido contra el concejo y vecinos que Villafría, la qual contiene todo lo que la primera executoria del número 20 en relación, y consta que, después de librada dicha executoria al convento, la parte del concejo suplicó de la sentencia última en lo que podía ser de vista, en quanto por ella se había mandado guardar la sentencia arbitraria del año 1553, sobre que dixo agravios y ser nula la dicha escritura de compromiso y falta de solemnidad, por no haberse juntado a concejo precediendo citación y llamamiento de todos con voz de campana, no haber asistido la justicia ordinaria, no haber intervenido información de vtilidad, ni dado decreto judicial de licencia.

$<$ Alegato del concejo contra la sentencia de revista y la arbitraria $>$.

Porque los vecinos no pudieron comprometer los derechos que tenían deducidos en el pleyto que se comprometió, ni aprobar la sentencia arbitraria sin tener la facultad real que era necesaria por contener los más capítulos de la sentencia arbitraria, enagenación de los términos proprios y rentas del concejo y de algunos derechos pertenecientes al Patrimonio Real, por haberse concedido al monasterio que los vecinos de Villafría fuesen sus vasallos solariegos siendo el lugar de Su Magestad y otros derechos y tributos de yantares y otros tributos, sin que el prior hubiese mostrado título alguno, ni razón legítima. Porque el derecho les favorecía para gozar los pastos libres, sin dependencia del convento, y que éste no tubiese

\footnotetext{
611 1552] sigue tachado: el convento volvió al pleito porque los de Villafría; al margen derecho: 1552.

${ }^{612}$ sentencia] sigue tachado: que.

613 carta] escrito sobre sentencia.
} 
aprovechamiento alguno en ellos y para que ellos quedasen libres de los yantares y tributos e imposiciones que pretendía el convento. Porque la sentencia arbitraria jamás había sido vsada, ni guardada. Y que ninguno del concejo tenía bienes ni solares del convento. Y pidió revocación de la sentencia, declarando por ninguno el compromiso y sentencia arbitraria, absolviendo al concejo de todo lo pedido por el convento, etcétera. Otrosí pidió que el pleito se llevase al fiscal por tocar al Patrimonio y jurisdición Real, para que saliese a la defensa de la causa. Mandose dar traslado de este alegato a la parte del convento, que no dijo ni alegó cosa. Fue conclusa la causa y en 24 de julio de 1532 se dio auto en que se mandó repeler del proceso la dicha petición de suplicación. De este auto volvió a suplicar por parte del concejo afirmándose en lo que tenía alegado. Mandose dar traslado a la parte del convento, el qual, negando lo perjudicial, concluyó / (f. 388v) sin embargo. Después de lo qual, en relaciones, a 2 de agosto de 1632, se dio auto en que se mandó que, sin embargo del auto de vista, respondiese el monasterio derechamente a la petición de súplica del concejo.

$<$ Respuesta del convento $>$.

En cuyo cumplimiento el convento pidió se confirmase la sentencia de revista en que se había mandado guardar el compromiso, afirmándose en lo que antes tenía alegado porque, siendo el compromiso concordante con la sentencia de vista, a lo menos en lo que lo fuese, obstaba excepción de cosa juzgada al concejo de la sentencia de revista que le oponía en fuerza de perentoria. Que quando esto cesara, el compromiso se había de guardar como se mandaba en la sentencia de revista, por haberse otorgado con todas las solemnidades necesarias, y quando alguna faltara, se presumía por el transcurso de tan largo tiempo. Y porque de las provanzas y escrituras del proceso constaba la justificación con que habían procedido los jueces árbitros; y porque el concejo no tenía más derecho del que el convento le había dado por las escrituras de foro y arrendamiento y licencias presentadas en el proceso, sin lo qual no tenían en los términos derecho alguno; y porque así en los pastos como en los yantares y en todo lo demás por el compromiso se les daba, el convento se fundaba por las escrituras, provanzas y calumnias de pleito; y porque la sentencia arbitraria, en lo que miraba al derecho del convento, se había siempre guardado y algunos derechos que le daba no le competían hasta después de muertos < los> vecinos, contenidos en el compromiso que ya eran acabados; y que quando no hubiera el compromiso por los demás autos del pleito estaban justificados sus derechos, especialmente siendo como eran reos. Y pidió, en virtud de la cosa juzgada la escritura de compromiso, por los demás autos se mandase hacer lo que tenía pedido. Mandose dar traslado a la parte del concejo, que no dijo ni alegó cosa. Reciviose a prueba, hiciéronse y se presentaron provanzas y escrituras y el pleito fue concluso a difinitiva. En este estado pidió el concejo se llebase el pleito al físcal. Contradíxolo la parte del convento y concluso en relaciones. A 9 de marzo de 1633 se dio auto en que se manda llevar el proceso al fiscal. Llevósele y no dijo cosa alguna.

$<$ Sentencia de vista. Año 1633>.

Después de lo qual, en Valladolid, a 8 de julio de 1633, se pronunció sentencia por lo qual revocaron la sentencia difinitiva que manda se cumpla la escritura de compromiso y sentencia árbitra / (f. 389r) del año de 1553 y dan por ninguna la sentencia árbitra y escritura de transación y reservaron al convento su derecho a salvo para que, en razón de lo sobre que es este pleito, pida y siga su justicia como le convenga. Después de lo qual la parte del convento, en relación de las sentencias y actuando y afirmá[n]dose en lo que tenía alegado en todas instancias, pidió lo que tenía pedido en su favor. Diose traslado a las partes del concejo, que lo contradijo. Concluyose en lo principal.

$<$ Sentencia de revista. Año 1634>.

Después de lo qual, en la Chancillería de Valladolid, a 28 de septiembre de 1634, se pronunció sentencia de revista, por la qual confirmaron la de vista, con las enmiendas y declaraciones siguientes:

$<$ Aprovechamiento de los términos $>$.

$1^{\circ}$. En quanto por la dicha sentencia condenan al monasterio a que dexe pastar y aprovechar al concejo en todos sus términos para hacer en ellos los aprovechamientos que quisiesen y vsar de ellos como quisiesen, confirman la dicha sentencia y declaran ser proprios 
del concejo de Villafría todos los términos dél, sobre que ha sido este pleito, y como tales se los adjudican para que puedan aprovecharse de ellos como de cosa suya propria.

$<$ Yantar>.

$2^{\circ}$. En quanto por la dicha sentencia se manda que, yendo los monjes a recivir el yantar, se les dé y no yendo no se les dé nada por él, lo confirman, con que el yantar se dé día de San Martín de cada año a dos monjes y un criado del convento de San Román y no más.

$3^{\circ}$. En quanto por la dicha sentencia es absuelto el convento del pedimiento hecho de parte concejo en razón de pagar en cada un año cada vecino del dicho lugar tres blancas y diez celemines de trigo y diez de centeno, quanto a lo suso dicho confirman la dicha sentencia, con que esto se entienda quanto a los vecinos que tubieren tierras y casas aforadas del dicho convento, y con que los que tubieren solamente casas paguen una gallina y tres blancas al convento cada un año, y con que los que no tubieren casas, ni tierras, ni foro, no paguen nada.

$<$ Disposición de casas y heredades $>$.

$4^{\circ}$. En quanto al nuevo pedimiento hecho por parte del concejo cerca de que el convento no les impida el disponer de sus casas así en vida como al tiempo de su muerte libremente, declaran los vecinos de Villafría que son y fueren que puedan disponer en vida y en muerte libremente de las casas y heredades que tubieren aforadas del convento entre sus hijos y descendientes, y a falta de ellos o de no vivir en el dicho lugar y yéndose a vivir a otras partes buelvan al monasterio.

E de las demás casas e tierras / (f. 389v) que no fueren aforadas del dicho convento disponga libremente así entre sus herederos y parientes como con otras qualesquier personas como quisiesen.

$5^{\circ}$ Quanto a que el concejo pretende que el prior y monges del Brezo no metan sus ganados en los términos del concejo, ni hagan aprovechamientos en él como vecinos y que tengan pastor lego a quien puedan prendar, condena al prior y monges del Brezo que son y fueren a que no entren a pastar con sus ganados en los términos del concejo en manera alguna.

$6^{\circ}$ En quanto el concejo pretende que el prior del Brezo no se intitule prior de Villafría ni de sus términos, condenan al prior del Brezo a que no se llame tal señor ni les impida a sus vecinos el vso y aprovechamiento de sus términos.

\section{$<$ Declaración $>$.}

Después de pronunciada esta sentencia pidió la parte del monasterio que, habiendo reconocido la parte contraria tener derecho a una fanega de trigo y una gallina, se habían puesto en la sentencia por error de pluma diez celemines de trigo solamente, y así se mandase enmendar, y en relaciones se mandó hacer así, a 13 junio 1635. Y a instancia de la parte del convento se mandó despachar esta carta executoria en lo que son las sentencias en revista y contra quien son. Diose en Valladolid a 21 de junio de 1635, ante Francisco de Cardeña, escribano de Cámara.

$<$ Posesión y execución de esta carta executoria. Año 1636>.

Autos de posesión y execución de esta carta executoria hechos ante Gregorio de Valerón, escribano de Su Magestad y receptor de la Chancillería de Valladolid, en virtud de la provisión real y comisión que tubo para ello, año 1636, en que se averiguan y prueban los préstamos y hacienda que tiene el monasterio en Villafría y algunos vecinos los reconocen y se da posesión de todo al convento. Estos autos están aquí con la carta executoria y asimismo las dos vecindades.

23. <Executoria a pedimiento del concejo de Villafría. Año 1642>.

Después de todo esto, el año de 1642, los vecinos y concejo de Villafría pidieron se les despachase carta executoria, cuya execución se cometió a Pedro de Oteros, alcalde mayor de Tavanera, por ser la justicia realenga más cercana, el qual la admitió y en su cumplimiento 
mandó citar al abad de esta casa y a los priores de San Román y el Brezo, a quienes se notificó el auto, y el procurador de dicho concejo pidió al juez executor mandase a los monasterios guardasen la sentencia y executoria, y que el concejo fuese reintegrado en los términos para vsar de ellos a su albedrío, de los quales sean espe/ (f. 390r) lidos los ganados mayores y menores del Brezo y que San Román sólo entre en ellos como dos vecinos quando los demás. $\mathrm{Y}$ asimismo que las casas que no tienen fuero sean libres, y que las casas y tierras aforadas sólo pagasen tres blancas, diez celemines de trigo y diez de centeno; y las sin tierras, tres blancas y una gallina, y que de unas y otras pudiesen disponer entre sus hijos y descendientes en vida y en muerte. Que el yantar se diese día de San Martín sólo a dos monges y a un criado. Que no se nombren señores de dicho lugar ni sus términos. De todo lo dicho se mandó dar traslado a la parte del convento y, habiéndosele hecho saber, respondieron los priores no debían observar dicha carta executoria por necesitar declaración, la qual tocaba al presidente y oidores. Después de esto y de haber precedido varias réplicas de una y otra parte, el juez executor tercero de Oteros, alcalde mayor de Tabanera, a pedimiento el concejo de Villafría, con acuerdo del licenciado Juan de Narganes, vecino de Muñeca, y por ante Matías de Treceño, escribano y vecino del lugar de Buenavista en 6 de octubre de 1642, dio auto en mando que se diese posesión a dicho concejo de los términos como de cosa suya propia, etcétera, como llevó referido ${ }^{614}$.

$<$ Apelación del convento y alegato $>$.

De todo lo qual apeló el convento y alegó agravios en lo actuado ${ }^{615}$ por el juez executor, así en haber dado posesión a las partes contrarias de los términos de dicho lugar proprios de este monasterio, apeándolos y deslindándolos, como en la limitación de entrar los ganados en los cotos, en que no se diese cebada para las mulas quando fuesen a cobrar yantar, en que pudiesen disponer de las casas siendo del monasterio, y otras cosas.

$<$ Respuesta del concejo $>$.

A que se respondió por parte del concejo que el juez executor no había hecho agravio alguno en dar la posesión de los términos a su parte, como ni en lo demás actuado, y que de lo actuado por Gregorio Valerón en perjuicio de sus partes pedía destitución in integrum.

$<$ Sentencia de vista. Año 1634>.

En vista de lo qual, en Valladolid, a 13 de octubre de 1643, se declaró ${ }^{616}$ que, en haber el juez executor mandado dar a concejo la posesión de los términos del dicho lugar y en mandar que los vecinos pudiesen vender las casas que eran de fuero, juzgó mal; por lo qual lo revocaron y dieron por nulo. Y asimismo revocaron y dieron por nulo el haber mandado que entrasen ocho bueyes en las dehesas del dicho lugar y que no diesen de comer a las mulas de los religiosos, dejando su derecho al concejo, para que en quanto a estos dos capítulos últimos digan su apelación / (f. 390v) donde les conviniere. La qual se notificó a las partes y aunque se suplicó de ellas por ambas partes en lo que les era contrario, no contienen los pedimientos cosa de sustancia fuera de lo ya alegado, y sólo el concejo pidió acomulación de autos executados por Gregorio Valerón; y el convento, condenación de costas.

$<$ Sentencia de revista. Año de 1644>.

Con que se dio la sentencia de revista siguiente:

En Valladolid, a 22 de abril de 1644, se confirmó la sentencia antecedente como en ella se contiene sin addición ni limitación ${ }^{617}$ alguna.

$<$ Execución de esta carta executoria. Año 1657 y 1658>.

Con lo qual por parte de este convento se pidió carta executoria de lo sentenciado en vista y revista a su favor, la qual se mandó despachar, si bien no se sacó entonces y se dilató hasta el año de 1657 siguiente, como consta y pasó en el oficio de Agustín de las Heras,

\footnotetext{
614 referido] al margen derecho: folio 115 de esta executoria.

615 actuado] al margen derecho: folio 134.

${ }^{616}$ declaró] al margen derecho: fojas 144.

${ }^{617}$ limitación] al margen derecho: fojas 153.
} 
escribano de Cámara de Su Magestad. Después de lo qual, el año de 1657 se volvió a pedir por parte del convento el despacho de dicha carta executoria, citando para ello al dicho concejo, cuya execución se cometió a don Antonio de Varreda y Yebra, corregidor de Saldaña, quien la aceptó y en su cumplimiento pasó a Villafría y mandó citar y notificar al concejo su comisión para que, si tenían que responder, pareciesen ante Su Magestad.

$<$ Sentencia del juez $>$.

Y, habiendo alegado y protestado algunas cosas y respondídose a ellas por parte de la casa y prioratos, la executó en la forma siguiente:

Primeramente dijo que en cumplimiento de dicha carta executoria debía ${ }^{618}$ mandar y mandó se notifique al concejo y un vecinos de Villafría no se entrometan en la propriedad de dichos términos ni en vender ni arrendar los pastos y aprovechamientos y que sólo tengan el vso de pastos para sus ganados. Yten que no puedan vender ni enagenar ni dividir las casas que fueren de fuero sin licencia del prior de San Román, y lo mismo mandó de las que tienen fuero. Y que para proceder con claridad en todo, que el día siguiente se juntasen y pareciesen ante el suso dicho y su escribano a reconocer y declarar y ajustar si tienen o no pagadas las rentas. Yten que en quanto a los ocho bueyes, yantar ${ }^{619}$ y dar de comer a las mulas, respecto que dicho concejo tiene interpuesta apelación la siga si le pareciese, y mientras tanto se les notifique no innoven. Y lo mismo en quanto a la vecindad del Brezo que al presente goza, mediante que por dicha carta executoria consta estar apelado por parte del prior, no molesten a sus criados, pastores y ganados mientras otra cosa no sea mandada por los señores de la sala. Todo lo qual pasó ante Antonio Ramos, escribano / (f. 391r) y vecino de Saldaña. Fue notificada a los vecinos y concejo de Villafría, los quales apelaron de dicho auto para donde les conviniese, y asimismo protestaron que el hacer los reconocimientos era fuerza y que lo hacían por temor de las penas impuestas, con que las pasaron a hacer, las quales están al folio 35 siguientes con sus declaraciones, que todo pasó por testimonio del dicho Antonio Ramos.

$<$ Apelación del concejo $>$.

Después de lo qual el concejo, en virtud de la apelación interpuesta, se presentó en Valladolid y sacó provisión, con la qual se quiso mantener en la posesión sin seguir la apelación. Con que fue preciso que el convento recurriese para obligarles a que llevasen los autos originales, y habiéndoseles notificado provisión por parte del convento, el año de 1663, para que compareciesen allá, lo consultaron y, hallando quien les desengañase, se apartaron de la apelación interpuesta e hicieron la escritura siguiente:

$<$ Apartamiento del concejo. Año 1663>.

En Villafría, a 24 agosto 1663, habiendo tocado la campana y juntádose a concejo dichos vecinos por ante Marcos de la Vega, escribano y vecino de Villanueva de Muñeca, hicieron apartamiento de la apelación que tenían interpuesta a la execución de la carta executoria antecedente, y consintieron no sólo en la sentencia del juez executor sino también en todo lo demás en ella contenido y aún más en los artículos apelados, confesando tocarle y pertenecerle todo ello al convento y ser suyo proprio. Consta de dicha escritura que ésta también en el quaderno de dicha carta executoria.

24. < Parecer sobre la vecindad. Año 1654>.

Consulta y parecer sobre la vecindad respecto la sentencia de la sala. Dado por Juan González, a 5 de enero de 1654.

25. $<$ Reconocimiento sobre la vecindad. Año 1662>.

En 20 de diciembre de 1662 el concejo y vecinos de Villafría, por ante Marcos de la Vega, escribano dicho, reconocieron y confesaron que el monasterio del Brezo tenía en dicho lugar de immemorial tiempo una vecindad y como tal se debía aprovechar de todos los emolumentos, así de pastos como de catar hoja, etcétera.

618 debía] al margen derecho: fojas 30.

${ }^{619}$ yantar] al margen derecho: yantar. 
26. $<$ Querella contra el concejo porque hipotecaron los bienes de San Román a un censo. Año 1663>.

En 24 de diciembre de 1658 el concejo y vecinos de Villafría contraviniendo a la carta executoria tomaron un censo de 600 reales de principal y, al seguro de él, hipotecaron los bienes y préstamos de San Román, como consta de la esscritura que pasó ante Marcos de la Vega, escribano de Villanueva de Muñeca, por la qual se dio querella contra ellos ante Toribio de Villadiego, escribano de Palencia, en la misma ciudad, y salió la sentencia año 1663 con ciertas penas. Está aquí la querella. Año 1663>.

/ (f. 391v) 27. <Compulsa sobre los derechos que tiene este convento en Villafría.

En 16 de agosto de 1663, Norverto de Sandoval, escribano de Carrión y de esta casa, compulsó diversos papeles y sentencias de cartas executorias tocantes a los derechos que este convento y sus prioratos de San Román y El Brezo tenían en Villafría ${ }^{620}$.

28. <Licencia que pidió el concejo para cerrar un pedazo de campo, pagando 4 maravedís. Año 1664>.

En $1^{\circ}$ de abril de 1664, el concejo y vecinos de Villafría, siendo prior de San Román fray Juan de Fernández, pidieron les permitiese cerrar un pedazo de prado para socorro del concejo, por el tiempo que gustase el convento. Lo qual se les concedió, con pensión de 4 maravedís cada año, en la qual confiesan que el prior es señor solariego de dicho lugar y sus términos y que sin su licencia ni pueden arrendar, ni cerrar, ni edificar cosa alguna en ellos. Como todo consta de la escritura, que pasó por testimonio de Marcos de la Vega, escribano público.

29. < Licencias que ha pedido el concejo para arrendar la Peña de Robrra. Año 1678>.

Bajo esté número están varios papeles que son pedimientos, requerimientos ${ }^{621}$, mandamientos ${ }^{622}$ para que los vecinos de Villafría no arrienden los pastos ni otras cosas sin licencia de esta casa y que salgan de los términos unos ganados que habían admitido sin licencia, con la consulta y parecer que sobre esto se dio. Asimismo están algunas licencias que ha pedido el concejo en diversos años para arrendar las peñas y pastos de dichos términos.

30. <Copia del privilegio del rey don Alonso. Año 1671>.

Copia del privilegio del rey don Alonso el Sabio, que fue el 10 de este nombre (véase el cajón San Martín, legajo $2^{\circ}$, quaderno A, número $1^{\circ}$ ), y de las cartas executorias tocantes al señorío de Villafría. Autorizado por Norverto de Sandoval y Guevar, escribano de Carrión, a 12 de abril de 1671.

31. <Mandamiento sobre el yantar. Año 1771>.

Mandamiento executorio expedido por la justicia de Saldaña, en favor del priorato de San Román, en el pleito con el concejo y vecinos de Villafría, en razón de la continuación al derecho del yantar que deben pagar día de San Martín en cada un año, en que fueron condenados a pagarle y las costas. Año 1771.

32. <Mandamiento para que no se edifique, etcétera. Año 1792>.

Despacho que dio el corregidor de Saldaña para que los de Villafría no se propasen a levantar edificio alguno de casas, etcétera, sin licencia del prio de San Román. Dado en Saldaña, a 31 de mayo de 1792, ante Ygnacio de La Puente.

\footnotetext{
${ }^{620}$ Villafría] sigue tachado: Y asimismo está cosida aquí.

${ }^{621}$ requerimientos] sigue tachado: $\mathrm{y}$.

${ }^{622}$ mandamientos] sigue tachado: $\mathrm{y}$ licencias.
} 


\section{Remisiones}

$<$ Concordia $>$.

Concordia sobre poder pastar. Véase el cajón San Juan, legajo $3^{\circ}$, quaderno C, número $3^{\circ}$.

$<$ Testimonio $>$.

Testimonio sobre el yantar. Ýdem, quaderno B, número 9.

\section{/ (f. 392r) Legajo $3^{\circ}$ del Cajón San Plácido}

Este legajo, que es el tercero del cajón San Plácido, contiene los dos quadernos siguientes: quaderno A: papeles y escrituras tocantes a la hacienda que tiene el monasterio en el priorato de Villalpando; quaderno B: beneficio y curato de San Lorenzo de este lugar.

\section{Quaderno A del legajo $3^{\circ}$ \\ Villalpando}

Este quaderno A contiene los papeles pertenecientes a la hacienda que el monasterio tiene en este lugar, por el orden siguiente:

$1^{\circ}$. <Foro perpetuo de una gallina sobre un suelo. Año 1470>.

Escritura de foro perpetuo por la qual $<$ fray $>$ Diego Fernández de Respenda, prior de San Zoil, y Pedro Conde, prior de San Lorenzo de Villalpando, dan a fuero perpetuo a Alonso Marrache, vecino del arrabal de dicho lugar, un suelo junto a la yglesia de San Lorenzo por una gallina de foro perpetuo cada año. Su fecha, en Villalpando, a 26 de febrero de 1470, ante Alfonso Rodríguez de Tordesillas, esscribano de dicha villa.

$2^{\circ}$. $<$ Venta de casas y otros papeles, etcétera. Año 1610 $>$.

Venta de unas casas del doctor Bricianos, vecino de Villalpando, en virtud de licencia del general y demanda puesta sobre ella. Síguense después las cesiones que sobre ellas se hicieron del derecho que tenía el licenciado Miguel Fernández y licencia que se pidió por este convento para venderlas, y un despacho del provisor de León para la venta de una casa pequeña junto a Nuestra Señora la Nueva. Año 1610.

$3^{\circ}$. $<$ Pleito sobre la paga de 60 mill maravedís para una casa y la escritura de venta de la misma. Año 1633>.

Proceso y demanda de 60 mill maravedís que puso el abad y cavildo de Sati Spiritus de Villalpando ante el abad de San Zoil / (f. 392v) al padre fray Benito de Aragón, prior de Villalpando, en virtud de una escritura de obligación en que se obliga a pagar esta cantidad por una casa que compró, año 1633, que es la siguiente escritura de venta, por la qual el cavildo de Santi Spiritus de Villalpando vende al padre fray Benito de Aragón, prior de San Lorenzo, una casa en que vive, a la parroquia de San Lorenzo, por precio de 60 mill maravedís. Fecha a 24 de diciembre de 1633, ante Hernando Gutiérrez, esscribano de Villalpando.

$4^{\circ}$. $<$ Demanda sobre la paga de una gallina y 15 maravedís. Año 1716>.

Demanda puesta por el monasterio contra don Sebastián Cornejo, vecino de Villalpando, para el pago de un foro de dos gallinas y 15 maravedís, a que se opuso. Año de 1716.

\section{Remisiones}

$<$ Donación $>$.

La donación de San Lorenzo de este lugar. Está en el legajo $4^{\circ}$ de este cajón, quaderno A, número $1^{\circ}$, título Villamayor. 


\section{/ (f. 393r) Quaderno B del legajo $3^{\circ}$ Villalpando}

Este quaderno B contiene los papeles pertenecientes al beneficio y curato de San Lorenzo de este lugar, por el orden siguiente:

$1^{\circ}$. < Colación del nuncio hecha del beneficio de San Lorenzo a Gonzalo de Capillas. Año 1512>.

Trasunto autorizado por el provisor de León ante Andrés Pérez de Capillas, esscribano de León, dado a 2 de agosto de 1530, a instancia del monasterio de San Zoil, de una colación hecha por Juan, electo arzobispo Cusentino, nuncio apostólico, del beneficio de San Lorenzo, a favor de Gonzalo Capillas, cura de San Miguel de Villalpando, por renunciación libre que hizo Diego Fernández de Capillas, cura de San Lorenzo, cuya presentación dice pertenecer al abad de San Zoil, derogando por hac vice tantum el derecho de presentar del dicho abad. Dada en Burgos, $5^{\circ}$ kalendas aprilis, año 1512.

\section{$2^{\circ}$. < Poder del vicario de Villalpando. Año 1545>.}

Poder de Francisco de Robles, vicario de Villalpando, para seguir un pleito ante el prior de Escalada, juez conservador; véase adelante. Fecho año 1545, ante Pedro Morejón, nottario appostólico.

\section{$3^{\circ} .<$ Poder del obispo. Año 1545>.}

Poder de don Estevan de Almeyda, obispo de León, para seguir el pleyto de la visita de San Lorenzo ante el juez conservador. Fecho año de 1545, ante Juan de Varrientos, nottario appostólico.

$4^{\circ}$. $<$ Requirimiento que no se pague una sepultura. Año 1545>.

Requirimiento hecho por fray Juan de la Irnela ${ }^{623}$, prior de San Lorenzo, para que se retengan los (los) derechos de una sepultura y no se pague la licencia de abrirla al vicario, atento el pleito pendiente. Año 1545, ante Pedro Morejón, nottario appostólico.

$5^{\circ}$. <Proceso y sentencia contra el obispo de León, que no visite en San Lorenzo ni lleve derechos de visitación. Año 1546>.

Proceso original hecho ante Santiago de los Ríos, prior de Escalada, juez conservador, por el qual consta que, siendo prior de San Lorenzo de Villalpando fray Gaspar de Becerril, se subtrajo de pagar al obispo de León los derechos de la visitación de aquella yglesia, por los quales pretendía serle debido un yantar, un carnero y otros fueros y tributos; a cuya causa Francisco de Robles, vicario de Villalpando, embargó ciertos bienes pertenecientes al dicho prior. Por lo qual el convento se querelló ante el dicho juez conservador, el qual dio mandamientos y censuras para que se alzase el ambargo.

$<$ Este derecho está perdido per non vsum y omisión de esta casa $>$.

La parte del obispo respondió ante el juez y alegó su derecho, lo mismo hizo el convento hasta que la causa se recivió a aprueba y, dentro del término, ambas partes hicieron sus informaciones; el convento presentó escrituras y entre otras una sentencia en / (f.393v) (en) favor de la casa de Exlonza ${ }^{624}$ contra Diego de Muros, obispo de Oviedo, condenado en la visita y derechos del priorato de Santa María de Algadefe por el prior y convento de León, juez conservador, y en cierta pena pecuniaria por el desacato cometido contra los monges. Y, conclusa esta causa, el dicho prior de Escalada, en 10 de junio de 1546, dio sentencia, por la qual condena al obispo de León a que en ningún tiempo visite la yglesia de San Lorenzo y que por razón de la visitación no lleve derechos algunos y vuelva lo que hubiere llevado, y se alze qualquier embargo. Dada ante Juan de Castrillo, esscribano de Carrión. De esta sentencia apeló la parte del obispo; pero no siguió la apelación, con que se dio por desierta, y se despachó la executoria que está cosida en este proceso y sólo faltan las notificaciones hechas al obispo y sus oficiales.

\footnotetext{
${ }^{623}$ fray Juan de la Irnela] al margen derecho: fray Juan de la Yrnela.

${ }^{624}$ Exlonza] al margen derecho: San Pedro de Exlonza.
} 
$6^{\circ} .<$ Concordia de dos caridades resumida en 60 rreales. Año 1558>.

Escritura de concordia hecha entre Antonio Zamorano, cura de San Lorenzo de Villalpando, y los feligreses de aquella parroquia, de una parte; y fray Diego de Málaga, prior de San Lorenzo, por sí y en nombre y con poder del convento de San Zoil, < de la otra >; por la qual dicen que por quanto el priorato de San Lorenzo estaba obligado a dar en cada un año a los parroquianos dél, perpetuamente, dos caridades de pan, vino, queso, higos ${ }^{625} \mathrm{y}$ castañas, la una víspera de Nuestra Señora de La O y otra el día de San Estevan, en cuya execución se quebrantaba el ayuno de la Virgen Nuestra Señora y se experimentaban otros inconvenientes, se concertaron que, en lugar de las dichas caridades y por ellas, el prior que fuese diese cada año a los dichos feligreses 60 reales por Antroydo (sic) para una comida o para lo que ellos quisiesen; con que se apartaron de la acción a las dichas caridades y el dicho prior se obligó a dar los 60 reales cada año en la forma dicha perpetuamente. Fecha en Villalpando, a $1^{\circ}$ de mayo de 1558, ante Juan de Villacorta, esscribano.

$7^{\circ}$. <Ynterrogatorio de los feligreses. Año 1568>.

Ynterrogatorio de preguntas para la información que hizo el cura y feligreses de San Lorenzo en el pleito en que pedían un monge que ayudase al cura y un sacristán. Año 1568. $1568>$.

$8^{\circ}$. < Sentencia que el convento ponga monge y sacristán en San Lorenzo. Año

Sentencia dada por el licenciado Sierra, provisor de León, en que condena al convento a que ponga monge sacerdote en San Lorenzo que ayude al cura a los divinos oficios, y un sacristán hábil y suficiente y les dé el estipendio necesario. Diose a instancia del cura y feligreses de San Lorenzo, año 1568, ante Andrés Ortiz, esscribano.

\section{/ (f. 394r) 9. <Relevación de fianza. Año 1567>.}

Escritura por la qual fray Bernardino de Argadero, mayordomo de San Zoil, se obliga a que el convento relevará de una fianza que hizo Juan Luengo, cura de Villamayor, en un pleito en que los feligreses de Villalpando pedían les diese el convento monge que ayudase al cura de San Lorenzo. Año 1567.

\section{0. < Proceso antiguo sobre la provisión del beneficio. Año 1568>.}

Proceso antiguo y maltratado, por el qual se colige que, a 15 de julio de 1568, ante Andrés Sanches, esscribano de Carrión, fray Juan de Corcuera, abad de San Zoil, dio la presentación del beneficio curado de San Lorenzo de Villalpando a Miguel Sánchez, clérigo de la misma villa, el qual beneficio estaba vaco por fin y muerte de Antonio Zamorano, de cuya muerte se hizo información y se presentó en León, donde se dieron y se fixaron edictos. Opúsose el doctor Belver, alegaron los opositores, uno contra otro. El concejo de Villalpando dio poder para pedir por cura y pidió en León a Miguel Sánchez; los opositores hicieron sus informaciones y las presentaron. Llamaron a examen en que fue aprovado el doctor Belver y reprovado Miguel Sánchez. Al doctor se le dio nombramiento para que pidiese en Roma la colación del beneficio que vacó en mes del papa; y el licenciado Sierra, que era provisor, le nombró por vicario de San Lorenzo para que en el interim sirviese el beneficio. Apeló y dijo agravios Miguel Sánchez y ante el obispo pidió que le examinase por habérsele atropellado el examen y estar aprovado por el obispo para hacer oficio de cura, como le había hecho tres años que estuvo enfermo el licenciado Zamorano, su antecesor. Oyéronse sus peticiones y se mandaron poner en el proceso, que no pasa adelante, y no es de provecho por mal tratado, y no tiene acto favorable más que el de la presentación y está rota. Pasó el proceso, que es original, ante Andrés Ortiz, esscribano de León, año de 1568.

11. <Proceso original sobre la provisión del beneficio de San Lorenzo en Miguel Fernández. Año 1597>.

Proceso original por el qual parece que, habiendo muerto el bachiller Alonso Rodríguez Cotán, vltimo cura, fray Pedro de Torrecilla, abad de San Zoil, dio la presentación

625 higos] al margen derecho: higos. 
al bachiller Miguel Fernández, clérigo de Villalpando, en 13 de marzo de 1597, ante Andrés Sánchez, esscribano de Carrión.

\section{$<$ Colación de Alonso Rodríguez Cotán. Año 1594>.}

Este hizo la ${ }^{626}$ oposición en virtud de la presentación, y se despacharon y pusieron edictos. Opúsose también Antonio de Bricianos, clérigo de Villalpando. Miguel Fernández hizo su información y con ella presentó la colación que se dio a Alonso / (f. 394v) Rodríguez Cotán, último cura, por presentación del abad de San Zoil, y dada por el licenciado Aparicio de Ortega, provisor de León, a 19 de agosto de 1594, ante Gaspar Álvarez, esscribano; la qual se le dio por resignación y permuta del licenciado Gaspar Maldonado, cura de San Lorenzo, que ermutó el curato por una capellanía llamada de los Cotanes de Nuestra Señora de la Antigua de Villalpando que poseía el dicho Alonso Rodríguez, la qual colación y posesión original está en este proceso. El dicho Miguel Fernández pidió conclusión y renunció los términos; y el doctor Francisco del Pozo, provisor de León, dio auto de examen a 7 de mayo de 1597, para que ambos opositores pareciesen a él. Y pareciendo, Miguel Fernández fue aprobado para el dicho beneficio; y, en 9 de mayo del dicho año, el provisor dio auto por el qual declaró el beneficio de San Lorenzo estar vaco en el mes de marzo pasado por fin y muerte de Alonso Rodríguez Cotán, último poseedor, y declaró por legítimo opositor a él, al dicho Miguel Fernández, y por no parte a Antonio de Bricianos. Y que, atento que el curato vacó en el mes de marzo que es de Su Santidad, le remitía la colación para que le proveyese de ella, de consentimiento de presentación del abad de San Zoil, presentero verdadero, solo, in solidum, del dicho beneficio cada y quando que vacare. El mismo día dio el despacho en forma don Juan Alonso de Marcos, obispo de León, ante Andrés Ortiz, esscribano ante quien pasaron los demás autos de este despacho.

12. <Escritura de obligación del resto de los diezmos de San Lorenzo. Año 1612>.

Escritura de obligación, por la qual Álvaro Forienzo, Francisco Pardo y Alonso Álvarez, vecinos de Villalpando, seobligan de pagar al monasterio de San Zoil cinco cargas, siete celemines y medio de trigo y diez cargas, tres fanegas y tres celemines y medio de cebada que debía Juan Díaz, difunto, y sus herederos de alcance de la colecturía que tubo de los diezmos de San Lorenzo los años de 1610 y 1611. Fecha en Villalpando, a 6 de hebrero de 1612, ante García de León, esscribano de Villalpando.

13. < Posturas de los diezmos. 1612, etcétera $>$.

Posturas de los diezmos y rentas que el monasterio tiene en Villalpando por los años de 1612, 1613 y en los de adelante.

14.

Cartas de pago de los curas de San Lorenzo y otras personas.

15. $<$ Memorial de bienes y congrua $>$.

Memorial antiguo de los bienes y heredades del priorato de San Lorenzo, de su yglesia y del curato y lo que le toca por / (f.395r) su congrua y encargos, etcétera. Y la que se ha de dar al cura monge por auto del abad.

16. <Pleito sobre poner monge cura en San Lorenzo. Año 1633>.

Proceso original contra el obispo de León, su fiscal, la villa de Villalpando y feligreses de San Lorenzo sobre poner monge en dicha yglesia que sea prior y cura por el tiempo que gustare el abad, en que fueron condenados los suso dichos, y ahora le pone la casa. Pasó ante Juan Bautista de Torres, en León, año de 1633. Este es el pleito que litigó el padre prior fray Benito de Aragón y le faltan algunas ojas.

17. < Título y colación hecha en el padre fray Benito de Aragón. Año 1632>.

Título y colación del curato < de San Lorenzo $>$ de Villalpando, dado por el doctor Gerónimo Coronel Velázquez, provisor de León, al padre fray Benito de Aragón, en 23 de septiembre de 1632, ante Juan Bautista de Torres, esscribano y nottario de León; y los autos

${ }^{626}$ la] Sigue tachado: present. 
de posesión que le dio del dicho curato el licenciado Juan Borrego Aguado, cura de Santa María de Villalpando, quieta y pacíficamente, ante Francisco Hurtado, nottario, en 28 de octubre del mismo año, y asimismo están otros nombramientos para monges con las licencias del obispo.

18. < Provisión real y mandamiento del provisor para recoger una bula. Año 1633>.

Provisión real a pedimiento del fiscal de Su Magestad y por esta casa para que se recojan y lleven a Consejo unas bulas de Su Santidad, ganadas a pedimiento del licenciado Antonio Gutiérrez, cura de Tábara, para serlo de San Lorenzo. Asimismo un testimonio de la apelación interpuesta ante el provisor de León para ante Su Santidad, en orden a la calificación de dicha bula por narratiba. Pasó todo esto en los años de 1632 y 1633 que duraba el pleito principal (número 16), sobre poner monge.

19. $<$ Quaderno sobre dos pleitos, por los quales, su sentencia y autos, se justificó más el derecho del curto (sic). Año 1634>.

Este es un quaderno en que se contienen las razones de dos pleitos con su sentencia a favor de esta casa, el uno sobre que el padre fray Benito de Aragón hacía oficio de cura en San Lorenzo sin bastantes títulos, el otro sobre decir que había destrozado un archivo que estaba en dicha yglesia. Todo lo qual procedió de un auto de vista que hizo el canónigo Roxas de Robles, en sede vacante, y después prosiguió el fiscal en los años de 1633 y 1634, ante Bernardino Alonso y Pedro de Bárcena. Tocan a la justificación del curato y su sentencia.

\section{0. < Auto en favor del cura monge. Año 1634>.}

Auto dado por el licenciado Diego García Santos, provisor de León, en que declara el padre fray Benito de Aragón, prior de San Lorenzo de Villalpando, tener justo título para exercer oficio de cura de San / (f. 395v) Lorenzo en virtud de la sentencia del doctor Coronel, provisor de León, y que parece estar pasada en autoridad de cosa juzgada, y le da por libre de las demandas que contra él había puesto el fiscal del obispado. Dado en León, a 25 de marzo de 1634, ante Pedro de Bárcena, esscribano de León, ante el qual está presentado el título y colación con la sentencia que dio el doctor Coronel a favor del monasterio para que pueda servir este curato monge ad nutum a mobile, y en virtud de ello se dio este auto.

\section{1. <Carta de pago de 20 mill maravedís. Año 1634>.}

Escritura por la qual José de Soba da carta de pago y confiesa haber recibido 20 mill maravedís que ganó de prometido en las posturas de los diezmos de San Lorenzo el año de 1629. Fecha año de 1634, ante Lorenzo Salgado, esscribano de Villalpando.

22. <Nombramiento de sacristán para San Lorenzo. Año 1637>.

Título y nombramiento de sacristán de San Lorenzo de Villalpando dado por el padre fray Benito de Aragón, prior y cura de dicha parroquia, a José Martínez de Hortega, en $1^{\circ}$ de mayo de 1637, el qual está signado del licenciado Pedro Luengo, nottario appostólico, clérigo y vecino de aquella villa, el qual da testimonio de cómo tomó la posesión y servía dicho oficio.

\section{3. <Mandamiento citatorio sobre el curato de San Lorenzo. Año 1647>.}

Mandamiento citatorio al provisor de León a pedimiento de don Fausto de Muro sobre que qualquier monge o clérigo que hiciese oficio de cura en San Lorenzo compareciese con los títulos que tubiese, a que su paternidad Aragón no asistía, que era quien les podía tener. Hace relación este papel de otra demanda puesta sobre lo mismo, año de 1637. Notificósele al padre Aragón, el qual dio poder para la causa, y no parecen más autos. Pasó ante Bernardino Santos, año de 1647.

24. $<$ Quaderno sobre a quién toca poner cappellán en San Lorenzo, salario que le da esta casa y ofrendas, y lo que se le añadió de las cappellanías desde el año de 1633 hasta el de 1650 , con otras advertencias $>$.

Quaderno en que se hallan un auto del provisor de León por testimonio de Juan Bautista de Torres, con relación copiosa de los derechos que esta casa tiene en San Lorenzo de Villalapando, y de cómo puede poner su teniente regular o secular y sacristán, año 1633. 
Vn nombramiento de capellán y teniente que hizo el padre Aragón, año 1634.

Vn testimonio de la cláusula de visita que hizo don Bartolomé Santos de Risova, obispo de León, año 1635. Por la qual confiesa que el nombrar capellán de San Lorenzo toca al monge cura que allí pone San Zoil y pagarle salario, y para que pueda pasar le señala 12 mill maravedís de las capellanías fundadas en dicha yglesia. Está signado del licenciado Estevan de Lerma, nottario appostólico, año 1647.

Asimismo un testimonio en relación de los autos hechos por don Bartolomé Santos de Risova sobre quexa que dio la yglesia de San Lorenzo, año 1640, de que no había capellán; con que mandó embargar los diezmos y frutos de esta casa, y entonces fue nombrado por capellán don / (f. 396r) (don) Martín Navarro; con que se alzó el depósito y embargo según consta de dicho testimonio, signado del licenciado Estevan de Lerma, año de 1640.

Vn poder de José Martínez, capellán que era de San Lorenzo, año de 1642, por el qual da facultad al padre cura para que, en su ausencia nombre otro capellán, administre y cobre las rentas que le pertenecieren. Pasó ante Juan de Mongastón, nottario appostólico. Y siguen otros dos testimonios, etcétera, en los años de 1643 y 1650, y últimamente un papel firmado de su paternidad Aragón, en que se hace cargo de las razones que algunos monges daban para que se quitase el capellán, y responde a ellas conformándose con la carta executoria ganada contra esta casa, año de 1572.

25. < Petición de los feligreses para no admitir teniente secular. Año 1656>.

Carta de los feligreses de San Lorenzo en que se quejan al abad de que el padre cura admite por su teniente un clérigo secular, no lo necesitando la yglesia ni habiendo razón para admitirle. Está decretada esta petición y mandado al padre prior que no la haga, junto con la notificación. Pasó año 1656.

26. $<$ Nombramiento de curas y tenientes con las aprovaciones de los obispos. Año 1645 et sequentibus $>$.

Nombramientos de curas y tenientes suyos desde que se venció el pleito y comenzó a exercerle monge, junto con las aprovaciones de los señores obispos. Está también aquí una memoria de los curas seculares que se halla haber habido en el tiempo que faltaron monges en dicho oficio; pero parece no está cumplida por defecto de noticias y papeles. Año de 1645 hasta 1677.

\section{7. <Visitas hechas por los obispos desde el año de 1635 hasta el de 1657>.}

Trasumptos de visitas hechas por los señores obispos de León en San Lorenzo desde el año de 1635 hasta el de 1657, algunos están autorizados y todos ellos tienen algunas cosas notables tocantes al govierno de la yglesia, derechos de esta casa y de los padres curas que allí fueren. Todas estas visitas y las demás han sido mal permitidas respecto del pleito y sentencia del prior de Escalada, juez conservador. Dada el año de 1546, como queda dicho en el número $5^{\circ}$ atrás dicho. etcétera $>$.

28. $<$ Quaderno de los derechos de la yglesia de San Lorenzo, su hacienda y cuentas,

Bajo este número está un quaderno de varios papeles que estaban sueltos, y se ha[n] juntado, tocantes a los derechos de la yglesia de San Lorenzo y su hacienda y a las capellanías, memorias y aniversarios fundados en ella, junto con alguna razón de cuentas de uno y otro que sirven para noticias de lo pasado; véase al principio su contenido.

29. $<$ Testimonio en relación de un pleito sobre los réditos de un censo e imposición de otro. Año 1650>.

Autos contra los mayordomos de San Lorenzo sobre que entreguen al padre Aragón los 3.000 maravedís de los réditos del censo de 75 mill maravedís de principal que él impuso como cura; de los quales, / (f. 396v) parte procedieron de la manzana de la cruz de plata, etcétera. En este papel se da relación de cómo los dos mil maravedís que San Zoil daba para un refresco o comida a la parroquia se aplicaron para réditos de este censo, que su padre Aragón redimió con su depósito. Pasó ante Estevan de Lerma, año 1648 y 1650. 
30. $<$ Pleitos sobre los diezmos de corderos $>$.

Autos sueltos y relaciones de unos pleitos que hubo sobre los diezmos de corderos en diversos tiempos. Y porque las razones del uno conducen para la justificación del otro, se ponen aquí juntos.

31. $<$ Memoria de pleitos $>$.

Quaderno en que su paternidad Aragón hace una memoria de los pleitos que tuvo mientras fue cura de San Lorenzo, cuya lista pone en la última oja de él.

32. $<$ Escritura de transación. Año 1743>.

Escritura de transacción entre los curas párrocos de Villalpando, hecha año de 1743, ante Gregorio Panero, nottario appostólico y vecino de dicha villa.

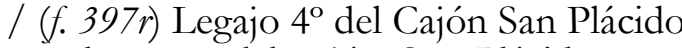

Este legajo, que es el cuarto del cajón San Plácido, contiene los tres quadernos siguientes: quaderno A: donaciones y ventas de este lugar; quaderno B: presentaciones, títulos, colaciones, posesiones de la vicaría de San Estevan, carta executoria contra la dignidad de León y posesión que tomó el monge para vicario; quaderno C: pleitos sobre congruas de los vicarios de cura, salarios de sacrista (sic) y pertenencias de diezmos.

\section{Quaderno A del legajo $4^{\circ}$ \\ Villamayor}

Este quaderno A contiene las donaciones y ventas de este lugar pertenecientes al monasterio, por el orden siguiente:

$1^{\circ}$. <Donación del rey don Fernando el Santo. Era 1264. Año 1226>.

Donación del rey don Fernando el Santo, escrita en pergamino, con sello de plomo pendiente en filos de seda, por la qual da al prior y monasterio de San Zoil del orden cluniacense los monasterios de San Estevan de Villamayor y San Lorenzo de Villalpando ${ }^{627}$, con todos sus diezmos y obladas así de vivos como de muertos. Facta carta era 1264, que es año de Christo de 1226.

$2^{\circ}$. $<$ Venta de una tierra. Año 1567>.

Venta de una tierra para el monasterio, de dos yeras, que otorgó Bernabé Roxo, vecino del barrio de Otero, en término de éste, a do llaman la Vintera, por precio de 8.000 maravedís. Pasó ante Álvaro López, esscribano de Villamayor, a 2 de diciembre de 1567. Dice la venta: "término de Otero", que es señal que los términos del barrio son distintos de los de la villa.

$3^{\circ} .<$ Venta de dos tierras. Año 1585>.

Venta de dos tierras a favor de este monasterio que otorgó Álvaro García, vecino del barrio de Otero, la una a las Hiruelas y la otra a la Brutera, por precio de ${ }^{628} 9.375$ maravedís. A $1^{\circ}$ de diciembre de 1585, ante Hernando Alonso, esscribano de Villamayor.

$/(f .397 v) 4^{\circ} .<$ Venta de dos tierras. Año 1617>.

Venta de dos tierras que otorgaron Juan Muñiz y Catalina Manjón, su muger, vecinos de Villamayor, a favor de este monasterio, la una atrás de San Salvador y la otra en la Vega, término de ${ }^{629}$ Villa Rey o Villar de Fallaves ${ }^{630}$, por precio de 381 reales. A 19 de julio de 1617, ante Antonio de Rueda, esscribano de Villamayor.

\footnotetext{
${ }^{627}$ San Lorenzo de Villalpando] al margen derecho: San Lorenzo de Villalpando.

${ }^{628}$ de] sigue tachado: un.

${ }^{629}$ de] sigue tachado: dicha villa.

${ }^{630}$ Villar de Fallaves] al margen derecho: Villar de Fallaves.
} 


\section{$5^{\circ}$. $<$ Testimonio de vtilidad. Año 1621>.}

Testimonio en relación de la declaración que hicieron los testigos en una información sobre la vtilidad que se seguía al monasterio en el trueque y cambio de una herrenal junto a Villamayor por otra tierra en la Vega, a la reguera de San Zoles, que era de Alonso Luengo. Pasó ante Antonio de Rueda, esscribano de dicha villa, en ella y octubre, 1, de 1621.

$6^{\circ} .<$ Trueque de una herrén por una tierra. Año 1621>.

Trueque y cambio de una herrén por una tierra que este monasterio hizo con Alonso Luengo, vecinos de Villamayor, para lo qual se hizo la información arriba dicha. Pasó año de $1621 \mathrm{y}$ ante el esscribano arriba dicho.

$7^{\circ}$. $<$ Executoria del pleito contra los bienes del licenciado Pedro Aguado por el censo que tenía, que se recivió en bienes raíces. Año 1663>.

Bajo este número está un proceso muy grande, pero corto en la sustancia, en el que se dice que esta casa compró el rédito de un censo que Pablo de Cifuentes tenía contra el licenciado Pedro Aguado, vecino de Villamayor, de 2.700 reales de principal. Que muerto este sacerdote le sucedió Santiago Aguado, su hermano, quien admitió la herencia y reconoció el censo; pero porque no pagaba las deudas, le executaron diversos sugetos, con que formaron pleito de acreedores, sin citar a esta casa. A esto se opuso Ana María Conejo, su muger, por el adote. Diose sentencia en Villamayor sin hacer memoria de esta casa, y en revista la graduaron en $7^{\circ}$ lugar; de que se apeló a Palencia, donde se revocaron las sentencias de Villamayor y graduaron a esta casa en primer lugar, mandando que así se cumpliese. Sobre la execución de esta sentencia se dio queja en Palencia, diciendo que el alcalde excedía; pero se verificó lo contrario, porque sólo dio la posesión como se le mandaba por la sentencia, haciendo tasación y pago de todo lo que se debía a esta casa, así de principal como de réditos, costas y salarios. Y, porque para hacer este pago se quitaron algunos bienes que estaban enagenados, Fabián Borrego y el licenciado García González, su yerno, recurrieron a la sala donde, estando para sentenciarse, lo pusieron en jueces árbitros, los quales mandaron que se les volviesen las posesiones que tenían compradas y que ellos pagasen el exceso que constase de qüentas y así se executó y se les requirió con esta carta executoria.

Parece ser que al convento se le hizo pago en bienes raíces, aunque no lo dice este proceso, ni en qué piezas. Conmenzose este pleito año de 1649 y duró hasta el de 1663.

/ (f. 398r) $8^{\circ}$. <Compra de la vecindad de Otero, año de 1670, y carta de pago del dinero de la vecindad. Año 1673>.

Escritura de venta por la qual el convento compró a los vecinos del barrio de Otero la vecindad, con todas las preeminencias de vecino eclesiástico, con calidad que sólo pueda traer un ato de ganado. Y en pago y satisfacción se obligó a dar cada año al concejo 100 reales para ayuda de sus gastos y repartimientos, como consta de la escritura que pasó ante Santiago Facón, esscribano y vecino de Aguilar, en 16 de agosto de 1670. Después se sigue un poder que los vecinos del dicho barrio dieron a Alonso Canillas, vecino dél, para que tratase con el convento el que redimiese los dichos 100 reales, dándoles 2 mill que les correspondían de principal por hallarse empeñados, el qual pasó ante Christóval Salgado, esscribano de Villalpando, en 12 de febrero de 1672; y últimamente está la redención de los dichos 2 mill reales y sus réditos corridos, otorgada por la justi[ci] a y vecinos del dicho lugar, ante el mismo esscribano, a 6 de marzo de 1672.

Quando se compró esta vecindad no había buelto monge a ser cura, con que ahora tenemos dos vecindades, la una comprada y la otra por cura de San Estevan.

9. <Venta de casa y herrén para Antonio García, quien después la vendió a este convento. Año 1673>.

Venta de una casa con su herrenal a favor de Antonio García Velasco (que después la vendió a esta casa), y pasó la venta ante Luis Bázquez, en 5 de noviembre de 1664.

Petición, ynformación de vtilidad y licencia del general para vender la casa antigua que teníamos en Villamayor y comprar otra más a propósito para vivir los monges y conservar la labranza, despachado todo esto año de 1673. 
Venta a favor de esta casa otorgada por Antonio García Velasco, vecino de Villamayor, de la misma casa y herrenal que él había comprado, según queda referido. Pasó esta venta ante Thomás de Caramazana, esscribano de dicha villa, a 25 de noviembre de 1673.

10. <Trueque de una tierra por otra. Año 1677>.

Petición, comisión, información de vtilidad y licencia del general para trocar una tierra por otra con don Alonso Luengo, vecino de Villamayor, año de 1677. Y asimismo el trueque y cambio que de dicha tierra se hizo en virtud de dichos despachos. Pasó ante el esscribano arriba dicho, en 5 de marzo de 1677.

11.

Memorial simple de la hacienda que el convento tenía en Villamayor, barrio de Otero, y sus términos. Este memorial no tiene fecha y así no se sabe por él lo comprado después. A lo último de él está la hacienda de Villaherrín, la de Villavicencio y la de Quintanilla del Monte.

12.

Compra de dos silos en Villamayor. Año de 1720.

13. < Sentencia sobre la paga de 1 mill 80 maravedís, etcétera. Año 1793>.

Tanto de una sentencia a favor de este monasterio y contra Agustín y Baltasara Lorenzo, vecinos del varrio de Otero / (f. 398v) sobre la paga de mil y ochenta maravedís. Ante Santiago de Moro y Aguado, esscribano de Villalpando, a 10 de mayo de 1793.

14. <Apartamiento de los vecinos en virtud de la sentencia de arriba. Año 1793>.

Apartamiento que hicieron Baltasara y Agustín Lorenzo, vecinos del barrio de Otero, en virtud de la sentencia de arriba, por el qual se apartan de la apelación que habían hecho y prometen no seguirla ahora ni en ningún tiempo. Dado en Valladolid a 28 de junio de 1793 ante don Ramón de Flores.

\section{Remisiones}

$<$ Donación $>$.

La donación de Mayor García de la mitad del monasterio de San Martín de Villamayor. Véase el cajón Santa María, legajo $1^{\circ}$, quaderno A, número $1^{\circ}$ y $2^{\circ}$.

\section{/ (f. 399r) Quaderno B del legajo $4^{\circ}$ Villamayor}

Este quaderno B contiene presentaciones, títulos, colaciones y posesiones de la vicaría de San Estevan, etcétera, por el orden siguiente:

$1^{\circ}$. <Memorial de papeles que faltan del archivo pertenecientes a este quaderno $>$.

Memorial de los papeles que faltan y se presentaron en el pleito que litigó el monasterio de San Zoil con el señor obispo de León sobre proveer en concurso la vicaría de San Estevan de Villamayor de Campos, cuyos papeles faltan del archivo y no sé dónde habrán hido a parar, que fue buen descuido. Año 1525>.

$2^{\circ}$. $<$ Poder que dio Alonso González para el pleito del curato, y sentencia a su favor.

Poder que otorgó Alonso González al padre fray Juan de Miranda y fray Andrés Salado, procuradores que eran en Roma, para que le defendiesen en el pleito que le puso Juan Delgado, clérigo de Villamayor, sobre el beneficio de San Estevan de Villamayor. Fecho en dicha villa, ante Diego de San Zoles, nottario appostólico, año de 1525. 
De esto parece ser que resultó que el pleito salió a favor de Alonso González y le despacharon en Roma nuevo título de colación, el qual no tiene fecha; pero del contesto ${ }^{631}$ de otros papeles parece ser que era pontífice Clemente $7^{\circ}$.

$3^{\circ}$. <Presentación hecha en Thomás de Ávila. Año 1575>.

Presentación de curato de San Estevan hecha por su padre fray Sebastián de Encinas, abad de San Zoil, en Thomás de Ávila, clérigo, vecino de Valladolid, por fin y muerte del bachiller Cristóval Salinas, último poseedor. Dada en San Benito de Sahagún, en 28 de junio de 1578, ante Pedro Fernández, esscribano. Falta la colación. $1658>$.

$4^{\circ}$. <Título, colación y posesión que tomó el licenciado Estevan de Lerma. Año

Título y colación despachado por don Miguel Santos, provisor de León, al licenciado Estevan de Lerma, ante Antonio de Burgos, en 10 de enero de 1658, en virtud de presentación del abad de San Zoil, conforme a lo dispuesto por el Concilio de Trento. Y asimismo la posesión que el suso dicho tomó dicho año ante Pablo de Caramazana, nottario appostólico y vecino de Villamayor. Signado todo de Francisco de Quintanilla, en 8 de mayo de 1568.

Desde la muerte del licenciado Juan Borrego Aguado, que el año de 1657 comenzó el pleito principal de San Estevan sobre si era vicaría, y así y todo fue después litigioso.

/ (f. 399v) $5^{\circ}$. <Testimonio y protesta contra la posesión que tomó el licenciado Facón. Año 1674>.

Protesta hecha por el padre fray Alonso Martínez, prior de Villamayor, contra la posesión que tomó de San Estevan el licenciado Juan Facón, en quien no presentó la casa porque estaba el pleito pendiente sobre declararla por vicaría vnida. Dio este testimonio Marcos Fernández, nottario appostólico y cura de San Nicolás de Castroverde, en dicha villa, a 2 de noviembre de 1674 .

$6^{\circ} .<$ Papeles tocantes al pleito de la vicaría $>$.

Papeles sueltos de consultas, pareceres, alegatos y cartas tocantes al pleito de la vicaría de San Estevan de Villamayor, el qual comenzó en el mes de julio de 1657 y duró hasta fin de diciembre de 1680, que se ganó la carta executuria (sic).

$7^{\circ}$. < Carta executoria a favor del monasterio sobre la vicaría de San Estevan de Villamayor y poner monge que la sirva. Año 1680>.

Carta executoria a favor del monasterio de la vicaría de San Estevan de Villamayor en juicio contradictorio contra los fiscales de la dignidad de León. Comenzose este pleito año 1657 ante el ordinario de aquel obispado, sobre declararla por vicaría unida perpetuamente a la mesa abacial, el qual le declaró de concurso y despachó título de colación a Estevan de Lerma. Apeló el convento, sacó letras del nuncio, llevose allá el pleito, citose al fiscal, hiciéronse provanzas, compulsáronse papeles, y en 15 de diciembre de 1672 dio el señor nuncio auto a nuestro favor, revocando el de el ordinario y declarando ser vicaría vnida y poder el abad poner clérigo seglar o regular que sirva la dicha vicaría. Des este auto apeló el fiscal, ganó letras de Su Santidad para juezes sinodales de Astorga, León y Oviedo, recusáronse algunos y últimamente concordaron en el de Oviedo, donde se siguió la causa y, en 23 de julio de 1680, confirmó la sentencia del nuncio como en ella se contiene. De esta sentencia apeló la parte del fiscal, pero no mejoró la apelación; con que pasados los términos, la dio el juez por desierta y la sentencia por pasada en cosa juzgada, y mandó despachar esta carta executoria signada de Francisco Cano, nottario appostólico, en 12 de diciembre de 1680.

${ }^{631}$ contesto] sigue tachado: parece. 

Año 1681>.

$8^{\circ}$. < Título, colación y posesión que tomó el monge de la vicaría de San Estevan.

Título y colación despachado por los provisores de León en virtud de la carta executoria al padre fray Agustín de Cuebas ante Juan Álvarez, nottario appostólico de dicha ciudad, en 31 de enero de 1681. Y al pie de ella las diligencias y posesión que de dicha vicaría le dio el licenciado Juan Olgado, arcipreste de Aguilar, ante Antonio Magarzo Rodríguez, nottario y vecino de dicha villa.

/ (f. 400r) 9. <Traslado de la posesión y colación. Año 1685>.

Traslado autorizado de la colación y posesión que tomó el dicho padre fray Agustín de Cuebas y de los demás autos y requerimientos que sobre esto se hicieron, signado del dicho Antonio Magarzo, en 9 del dicho mes y año de 1681.

10. $<$ Razón del hecho del pleito $>$.

Razán (sic) del hecho del pleito de San Estevan de Villamayor de Campos que este monasterio litigó contra el fiscal de León desde el año de 1657 hasta el de 1680. Véase atrás número $7^{\circ}$.

11. < Nombramiento de cura en monge. Año 1805>.

Nombramiento de cura de San Estevan de Villamayor hecho por el padre maestro fray Plácido Emeldo, abad de San Zoil, en el padre fray Zoil Medina, monge de este monasterio. Dado en él, a 9 de junio de 1805, firmado del padre fray Leandro Díaz, su secretario.

Faltan infinitos títulos o nombramientos de curas de este lugar hechos en monges, ya por falta de (de) cuidado en dejar el original, o un tanto de ellos, en el archivo, o ya por otros motivos y poca actividad en esto.

En el cajón San Vicente, legajo $2^{\circ}$ al último, hay varios títulos ${ }^{632}$, colaciones y posesiones de curatos en monges de diferentes lugares, etcétera.

632 títulos] sigue tachado: $\mathrm{y}$. 


\section{(f. 400v) Quaderno C del legajo $4^{\circ}$ Villamayor}

Este quaderno $\mathrm{C}$ contiene los pleitos sobre las congruas de los vicarios de cura, salarios de sacristán, pertenencias de diezmos y modos de diezmar, por el orden siguiente:

$1^{\circ}$. <Sentencia de congrua al cura de San Estevan. Año 1450>.

Sentencia que dio don Gonzalo, abad de San Zoil, sobre la congrua que don Rodrigo de Tablares, prior de San Estevan de Villamayor y de San Lorenzo de Villalpando, monge de esta casa, había de dar a don Guillén, cura de San Estevan y monge también de este monasterio, signada de Luis Fernández de Carrión, en 13 de mayo de 1450. Hay copia autorizada por don Antonio Martín García, traductor.

$2^{\circ}$. < Testimonio de embargo de frutos. Año 1507>.

Testimonio de un embargo que, en virtud de una provisión de $1<\mathrm{a}>$ reyna doña Juana y mandamiento del alcalde Ronquillo, hizo un esscribano de los frutos que el monasterio tenía en Villamayor, año de 1507. Año 1588>.

$3^{\circ}$. $<$ Pleito sobre el salario del sacristán, apartamiento y carta de pago del mismo.

Pleito sobre que el sacristán de San Estevan ganó mandamiento de León para que el convento le pagase salario, y el monasterio recurrió al prior de Santo Domingo como a juez conservador, el qual mandó no se vsase del tal mandamiento, ante Andrés Sánchez, esscribano de Carrión, en 7 de septiembre de 1588. Notificose a las partes y después Francisco Manso (que era el sacristán) se apartó de la demanda y por vía de limosna se le dieron tres cargas de trigo, de que otorgó carta de pago ante el mismo esscribano en 13 de octubre del mismo año.

$4^{\circ}$. $<$ Sentencia executoriada de los diezmos de los que vivían en la casa de Ana Manjón. Año 1600>.

Proceso y carta executoria en un pleito que ante el provisor de León puso doña Magdalena de Vlloa, señora de Villamayor, pretendiendo que Ana Manjón y los que viviesen en su casa eran parroquianos de Santa María y le habían de pagar los diezmos. Hiciéronse las provanzas y el provisor dio sentencia en que mandó que pagasen a San Estevan las primicias y mitad de diezmos, y a Santa María la otra mitad de diezmos. De esta sentencia apeló doña Magdalena; pero no mejoró la apelación, con que se despachó esta carta executoria ante Pedro Álvarez, esscribano, en Madrid, año de 1600.

Después de esto, el año de 1604, el monasterio, en cumplimiento de dicha carta executoria, pidió execución contra ladicha Ana Manjón sobre que pagase los diezmos causados durante dicho pleito y, para liquidarlos, despachó el alcalde mayor de Palencia, ministro de aquel tribunal, Francisco Díez, el qual los ajustó. A la execución se opuso la dicha Ana Manjón e hizo sus / (f. 401r) provanzas ante Lorenzo García, esscribano de dicha villa, y al parecer la suso dicha entrampó la paga por no haberlo embargado y depositado en ella y haberlo entregado a doña Magdalena.

Vltimamente está un parecer de cómo se erró la execución en no haberla pedido ante el ordinario de León como juez legítimo de esta causa.

$5^{\circ}$. <Colecturía de Hernando Palacios. Año 1610>.

Escritura por la qual Hernando Palacios se obligó a recoger todos los diezmos y rentas y a entregar todas las creces que tubiese, y por su trabajo se le habían de dar seis mil maravedís. Pasó ante Nicolás de Humilla, año 1610, y la sacó Antonio de Rueda, año 1616.

$6^{\circ} .<$ Desembargo de los diezmos. Año 1664>.

Mandamiento del abad de Venavívere (sic), juez conservador, contra la justicia y regimiento de Villamayor porque embargaron los granos que el convento tenía en dicha villa, diciendo los necesitaban para su sustento, año de 1664. Notificóselos Molina y obedecieron al segundo. 
$7^{\circ}$. $<$ Pleito sobre pastar los corderos del diezmo. Año 1670>.

Pleito compulsado a pedimiento de este monasterio por el alcalde mayor de Palencia contra la justicia de Villalpando ${ }^{633}$ y procuradores de su tierra y jurisdicción, que intentaron hecharnos de ella los corderos del diezmo de San Estevan, año de 1670, ante Luis Bázquez, esscribano de dicha villa. Este pleito parece no se prosiguió.

$8^{\circ}$. $<$ Sentencia de que los corderos de diezmo tocan a este monasterio. Año 1676>.

Auto y sentencia del provisor de León a favor del monasterio en el pleito que movió Juan Facón, vicario introducido en San Estevan, pretendiendo que se le habían de dar los corderos que hubiese de diezmo. Despachada ante Juan Álvarez, nottario de aquella episcopal, en 28 de marzo de 1676, y notificada en dicha año. $1677>$.

9. < Sentencia contra el monasterio sobre la congrua del vicario de San Estevan. Año

Sentencia contra el monasterio en el pleito de las 20 cargas de pan de congrua cada año al licenciado Juan Facón, a quien no se las queríamos pagar, así por no haber entrado con presentación de la casa como porque su asistencia personal la hacía en Castroverde y no en Villamayor, sobre que puso la demanda ante el provisor de León y dio sentencia, ano (sic) de 1675; y, dando el susodicho fianza y cartas de pago, se le entregaron en los años 1676 y 1677.

10. $<$ Papeles sueltos de diezmos $>$.

Bajo este número hay varios papeles tocantes a diezmos y modos de diezmar corderos como se ve al principio en la hoja $1^{\mathrm{a}}$, y son de diferentes años. $1680>$.

11. <Pleito sobre diezmos de corderos compulsado y proseguida la apelación. Año

Pleito compulsado en Zamora a pedimiento de esta casa contra la de Sahagún, priorato de Belver y cura de cañizo, para seguir la apelación interpuesta ante el provisor de Palencia, juez appostólico de esta causa, que consiste en que las partes contrarias embargaron y cogieron el diezmo de los corderos de Antonio / (f. 401v) García de Villamayor, parroquiano de San Estevan, por haber emparejado sus ganados en términos de aquellas villas el año de 1671. Siguiose la causa en Zamora, hiciéronse provanzas por todas partes y nos condenaron. Pasó el pleito ante Felipe López de Porras, quien lo compulsó el año de 1680; pero no hallo que se siguiese la apelación.

Antes de la compulsa están otros papeles tocantes al dicho pleito.

Hay también unas letras que se sacaron de Roma para la apelación de éste.

12. <Embargo de diezmos a pedimiento del monasterio. Año 1699>.

Mandamiento del provisor de León para que se embarguen los diezmos de lo que Andrés García, vecino de Villamayor, cogiese en Villalán, año de 1699, hasta que se declarase a quién los debía pagar. Hízose el ambargo; pero la causa no parece se siguió, que el cura de Villalán se quedó con todo.

13. $<$ Diligencias hechas sobre si unas casas que se edificaron en Villamayor son de la parroquia de San Estevan. Año 1754>.

Poder de la comunidad que se dio al padre maestro fray Manuel Ordóñez para las diligencias sobre si unas casas que se edificaron en Villamayor son de la parroquia de San Estevan.

Protestas que se hicieron.

Delineación de las casas de las dos parroquias que hay en Villamayor.

Consulta y dictamen de los abagados (sic) de Villalpando y Bolaños que dieron a favor de San Estevan en quanto al derecho parroquial en la propiedad. No se hicieron más

${ }^{633}$ Villalpando] al margen: Villalpando. 
diligencias sobre esto y así prosiguió el cura de Santa María en la posesión de dichas casas. También hay otro papel para probar que los < diezmos $>$ donde estubo la hermita de San Juan Evangelista pertenecen a la parroquia de San Estevan. $1777>$.

14. <Mandamiento para que se junte a cuentas y dé recivo final un párroco. Año

Mandamiento de los provisores generales en sede vacante de $<$ la $>$ ciudad de León para que don Juan Manuel Martínez, cura de Quintanilla del Monte, concu $<\mathrm{r}>$ ra a liquidar cuenta con el padre fray Gregorio Calderón, prior de Villamayor, para pagar colecturías, etcétera. Dado en León, a 30 de mayo de 1777.

15. $<$ Decreto beneficial. Año 1790>.

Decreto beneficial dado por el señor obispo de León y confirmad[o] por la cámara, promulgado en León, a 20 de junio de 1790, y despachado al monasterio en la visita de Villadangos, a 20 de octubre del dicho año. Hay otra copia con él y asimismo una representación de $<\mathrm{e}>1$ de la villa de Villamayor y San Martín de los Rascones.

16. $<$ Sentencia sobre diezmos (de) de forasteros. Año 1790>.

Sentencia difinitiva del señor provisor de León sobre que los vecinos de fuera de Villamayor que entraren a sembrar en términos de dicha villa paguen el diezmo de pan y vino, por mitad, al monasterio / (f. 402r) de San Zoil y marqués de Valdecarzán. Dada en dicha ciudad, a 25 de agosto de 1790, y executada en 7 de septiembre del mismo año, son dos.

17. <Copia de la sentencia sobre diezmos. Año 1804>.

Copia simple de la sentencia difinitiva a favor de este monasterio contra los párrocos y colectores de los diezmos de Villamayor. Año 1804.

\section{/ (f. 402v) Legajo $5^{\circ}$ del cajón San Plácido}

Este legajo, que es el quinto del cajón San Plácido, contién ocho quadernos pertenecientes a diversos lugares que son los siguientes:

Quaderno A... Villameriel

B... Villamez

C... Villamuriel

D... Villanueva de Fontecha
E... Villanueva de Muñeca

F... Villanueva de Los Navos

G... Villanueva del Rebollar

H... Villanueva del Río

Quaderno A del Legajo $5^{\circ}$

Villameriel

Este quaderno A contiene los papeles pertenecientes a un censo y tributo que paga a la casa del Brezo este lugar, por el orden siguiente:

$1^{\circ}$. <Declaración de 3 cargas de trigo de renta. Año 1579>.

Declaración que hicieron algunos de los vecinos de Villameriel, en virtud de una paulatina del nuncio que se leyó en aquel lugar, por la qual declaran y conocen que la casa de Nuestra Señora del Brezo tiene en aquel lugar tres cargas de trigo de renta en cada un año. Fecha en el dicho lugar, a 3 de agosto de 1579, ante Juan Díaz, escribano y vecino de Villanuño.

$2^{\circ}$. <Ynformación del Brezo de 3 cargas de trigo de renta. Año 1579>.

Traslado de una ynformación hecha por la casa de Nuestra Señora del Brezo en el pleito con Toribio Calvo y consortes, en razón de tres cargas de trigo cada año de censo y 
tributo que debían a la dicha casa, de que se sacó carta executoria en la Chancillería de Valladolid a favor del Brezo, que es la del número siguiente. Hízose esta información en Villanuño, por agosto de 1579, ante Juan Díaz, escribano. Sacose esta provanza para hacer apeo de la hacienda que tiene la casa del Brezo en este lugar.

$3^{\circ}$. < Carta executoria de tres cargas de trigo. Año 1580>.

Carta executoria ganada en la Chancillería de Valladolid a favor de Nuestra Señora del Brezo por la qual parece que, a 16 días de diciembre de 1578, puso demanda la parte del monasterio de San Zoil y El Brezo por tres cargas de trigo de renta. A los poseedores de la casa de Pedro García, tres fanegas; a los de la casa de Pedro Alonso, tres quartos; de la casa de Alonso García, tres fanegas; de la casa de Juan Rodrigo, tres quartos; y de la casa de Juan Fernández, tres fanegas; que / (f. 403r) hacen las dichas tres cargas de trigo. Pidiose que les mandasen pagar lo cornido (sic) y que pagasen de allí adelante.

A esta demanda se opuso Alonso Pérez, cura de Villameriel, que era uno de los contenidos en la demanda y declinó jurisdición y sobre este artículo se vio el pleito; y, en 5 de junio de 1579, se dio auto admitiéndole la declinatoria y remitiendo, quanto a cura, esta causa al juez eclesiástico para que conociere de ella. Los demás pusieron sus excipciones y, recivido a prueba, se hicieron provanzas por ambas partes.

$<$ Sentencia de vista $>$.

Conclusa la causa para difinitiva, en Valladolid, a 19 de diciembre de 1579, se pronunció sentencia difinitiva por la qual amparan al convento en la posesión de cobrar de Pedro García y demás contenidos en la demanda las fanegas y (y) quartos de trigo dichos, que hacen las tres cargas de la demanda, y se les condenan a que se las den y paguen cada año para siempre jamás desde que se subtraxeron de pagar, excepto la parte que de ello tenía Alonso Pérez, cura; que quanto a esto, reservaron su derecho a salvo al monasterio para que siga su justicia quando y como bien le estuviere.

$<$ Sentencia de revista $>$.

De esta sentencia suplicaron los de la parte contraria y alegaron ellos y la parte del convento. Y, conclusa en revista, a 30 de agosto de 1580 , se dio sentencia de revista contra Toribio Calvo, etcétera, y en favor del monasterio. Se confirmó por esta sentencia la de vista. De las quales sentencias se dio carta executoria a la parte del convento, en Valladolid, a 5 de septiembre de 1580, ante Alonso de Santisteban, escribano de Cámara. Notificose a las partes a 9 de octubre del mismo año; y al corregidor de Herrera, a $24 \mathrm{de} \mathrm{h}<\mathrm{e}>$ nero de 1581.

$4^{\circ}$. $<$ Reconocimiento del fuero y consignación de las heredades. Año 1581>.

Escritura de concordia y reconocimiento, por la qual Toribio Calvo y María Herrera, su muger, y otros vecinos, todos de Villameriel, y Alonso García, vecino de Arenillas de la Huerta siendo executados por 33 cargas de trigo de los corridos del foro perpetuo en que fueron condenados en la Chancillería y, habiéndose opuesto, y, sin embargo, habiéndose dado contra ellos y sus bienes mandamiento de trance y remate, se concordaron el padre fray Benito del Camino, prior del Brezo, en que por losdichos corridos le pagasen 15 cargas de trigo y las costas y décima de la execución. Y el prior les perdonó las otras 18 cargas con que hiciesen, como hicieron, escritura y renovación del dicho censo y tributo / (f. 403v) señalando y declarando las casas y demás heredades y posesiones a ellas anexas sobre que estaba cargado el dicho foro y de nuevo señalasen bienes bastantes para el dicho foro. Con lo qual reconocieron deber el dicho censo y tributo de dos cargas y una fanega de trigo en cada un año perpetuamente; y para mayor firmeza decla $<\mathrm{r}>$ aron los bienes que hipotecaban a él para que siempre estubiesen con la carga, no innovando en el derecho antiguo e immemorial ni en el de la carta executoria que tenía el monasterio, sino añadiendo más fuerza a la antigua. Nombraron las dichas heredades de hipoteca y las obligaron a la seguridad del dicho tributo, las quales están aquí especificadas y deslindadas. Fecha en el lugar de Villameriel, jurisdicción de Herrera, a 3 de junio de 1581, ante Andrés Sánchez, escribano de Carrión. Hay dos copias de esta escritura.

$5^{\circ}$. <Carta executoria de tres fanegas de trigo contra Alonso Pérez, cura de Villameriel. Año 1584>. 
Carta executoria ganada ante el provisor de Palencia a favor del Brezo, por la qual parece que, en Palencia, a 10 de enero de 1582, en la audiencia episcopal, fue puesta demanda de parte del abad, monges y convento de San Zoil y fray Damián de Salas, prior del Brezo, a Alonso Pérez, cura de Villameriel, como poseedor de unas casas y sus anejos en el dicho lugar, linderos corrales de Juan Calvo y las calles públicas. Porque, perteneciendo al Brezo 3 fanegas de trigo de vrción y foro perpetuo cada año sobre las dichas casas y sus anejos, y estando en posesión de cobrarlo de tiempo immemorial, y habiendo el cura comprado estas posesiones con el mismo tributo y obligación a reconocer el fuero, se había substraído algunos años de pagarle y no quería reconocerle, y pidió le amparase en la posesión de gozar y cobrar las dichas tres fanegas de trigo de fuero, condenando al cura a pagar lo corrido que no había pagado y a que él o quien tubiere las dichas casas y posesiones pague de allí adelante para siempre jamás dicho tributo y le reconozca. El dicho Alonso Pérez, cura, se opuso por su procurador a esta demanda y alegó / (f. 404r) sus excepciones, sobre que fue recibido a prueba. Y el dicho cura, alegando de su justicia, presentó ciertas escrituras de renta de las dichas casas y posesiones.

\section{$<$ Sentencia $1^{\mathrm{a}}>$.}

Y, conclusa la causa en 2 de agosto de 1583, el licenciado Santa Cruz, provisor de Palencia, pronunció sentencia en este pleito, por la qual ampara al monasterio en la posesión de cobrar al dicho cura Alonso Pérez tres fanegas de trigo en cada un año; y le condena a que las pague desde el día que se subtraxo de pagar y de allí adelante cada año para siempre jamás.

De la qual dicha sentencia apeló la parte del dicho cura y por frívola no le fue admitida su apelación. Y pasados los diez días de la apelación, la parte del convento pidió carta executoria y se le concedió la presente en Palencia, a 28 de septiembre de 1584, firmada del licenciado Santa Cruz, ante Francisco de Guinea, notario.

La qual dicha carta se notificó al dicho cura Alonso Pérez de parte del prior del Brezo, en Villanuño, a 20 de mayo de 1584, ante Juan Díaz, escribano de dicho lugar; el qual dicho cura dijo que la oýa y que vaya por el trigo que por la dicha sentencia se le mandaba pagar, que está presto de se lo dar, y esto dio por su repuesta.

\section{Remisiones}

$<$ Donación $>$.

La donación de las tres cargas de trigo de foro que tiene Nuestra Señora del Brezo en este lugar. Véase el cajón San Benito, legajo $3^{\circ}$, número 6.

\section{/ (f. 404v) Quaderno B del legajo $5^{\circ}$ \\ Villamez}

Este quaderno B contiene los papeles pertenecientes a la hacienda de este lugar < oy despoblado $>$ y a la presentación del beneficio simple de su yglesia, por el orden siguiente:

$1^{\circ}$. <Trueque con don Pedro Ansúrez y la condesa Eloni con don Hugo, prior de San Zoil. Era 1133. Año 1095>.

Escritura de trueque y cambio, escrita en pergamino y de letra gótica, por la qual el conde don Pedro Ansúrez y su muger, la condesa doña Eloni, dan al monasterio de San Zoil y a Hugo, su prior, en su nombre, la mayor parte de Villamez según que a ellos les pertenecía, con vasallos y heredamientos presentes y futuros. Más dan una divisa o vasallo en Frechilla ${ }^{634}$ que era partible con el conde don Diego Ansúrez, hermano de don Pedro; más en (en) Villovieco de Sabariego ${ }^{635}$ dan las heredades que fueron de la vieja; y el prior y convento les dan en trueque la hacienda que tenía en Poza y Poutez. Facta escritura VIII kalenndas januarii, era M C XXX III, que es año del señor de 1095.

${ }^{634}$ Frechilla] al margen derecho: Frechilla.

${ }^{635}$ Villovieco de Sabariego] al margen derecho: Villovieco de Sabariego. 


\section{$2^{\circ}$. $<$ Foro perpetuo de 2 cargas y una fanega de trigo por un prado. Año 1404>.}

Escritura de foro perpetuo por la qual el convento de San Zoil con licencia de don Fernando, prior mayor, dan a fuero y censo perpetuo a Pedro Fernández de Villanueva de Senadre (oy de los Navos) y Juan García de Olmillos, vecinos de Carrión, un prado que llaman del Camarero, en término de Villamez, por dos cargas y una fanega de trigo de renta en cada un año. Fecha en San Zoil, a 26 de octubre de 1404, ante Francisco Pérez, escribano de Carrión. Hay copia autorizada por don Antonio García, traductor.

$3^{\circ}$. $<$ Foro perpetuo de dos suelos. Año 1410>.

Escritura de fuero perpetuo por la qual el convento de San Zoil da a foro perpetuo a Velasco Rodríguez, vecino de Carrión, dos suelos en Villamez, y una pastiza que está delante de ellos, por 25 maravedís de renta cada año. Fecha en San Zoil, a 22 de junio de 1410, ante García Fernández, esscribano de Carrión.

$4^{\circ}$. <Sentencia arbitra de una carga de trigo de renta sobre una tierra. Año 1413>.

Sentencia arbitra en virtud de un compromiso hecho por Juan Alfonso, prior de la claustra y el convento de San Zoil, en un pleito que tubieron con María Alfonso, vecina de Carrión, viuda de García Fernández Pachistre, y Fernando García, su hijo, en razón de la paga de una carga de trigo de foro perpetuo en cada un año sobre una tierra junto a las heras de Villamez, término de Carrión. Comprometiose el pleito en Alfonso Fernández, bachiller, vecino / (f. 405r) de Carrión, el qual, habiendo visto la causa, dio sentencia a favor del monasterio y condenó a los contrarios a que pagasen. Dada en Carrión, a 13 de junio de 1413, ante Ruy González, esscribano de Carrión.

$5^{\circ}$. < Foro perpetuo de 25 maravedís sobre dos tierras. Año 1424>.

Escritura de fuero perpetuo por la qual Garci Rodríguez, enfermero mayor de San Zoil, da a fuero perpetuo a Juan Merlín, herrador y vecino de San Zoles, dos tierras en término de Villamez, una entre las dos huelgas y otra a las Truxillas, por precio de 25 maravedís de renta en cada un año, que había de gozar el monasterio por sus días, por haber sido estas tierras de sus padres y después del monasterio. Fecha a 5 de septiembre de 1424, ante Gutierre Fernández, esscribano de Carrión.

Hay copia autorizada por don Antonio Martín Garzía, traductor.

$6^{\circ}$. <Querella ante el conservador en razón de los pastos. Año 1435>.

Querella dada por parte del monasterio ante don Pedro, abad de Oña, juez conservador, contra Fernán García Pachistre, esscribano de Carrión, porque, estando el monasterio en quieta y pacífica posesión immemoril de gozar todos los términos de Villamez aquí deslindados y pacer en ellos con sus ganados y los de sus renteros, el dicho Fernán García prendó unos bueyes y ovejas de ciertos renteros del monasterio que andaban paciendo en el prado del Camarero, que es del monasterio, en término de dicho lugar; quéjase del agravio y pide proceda el dicho juez contra los culpados y los castigue. Lo qual pasó en el año de 1435. Es papel simple y sin autoridad ni auto del juez.

$$
7^{\circ} \text {. < Requirimiento en razón de los pastos. Año 1435>. }
$$

Requirimiento hecho por parte del monasterio de San Zoil a Fernán García Pachistre para que no inquiete la posesión inmemorial que el monasterio tiene de gozar los términos y pastos de Villamez, y vuelva las prendas que había tomado a unos renteros del monasterio que pastaban en el prado del Camarero. Fecho en Carrión, a 26 de agosto de 1435, ante Sancho González de Carrión, clérigo y nottario appostólico.

\section{$8^{\circ}$. $<$ For $[0]$ perpetuo de una tierra. Año 1437>.}

Escritura en pergamino, por la qual don Gonzalo Martínez de Cerbatos, prior de San Román de Entrepeñas y prior de la claustra de San Zoil, y el convento dan a fuero perpetuo a Juan de Hortega de la Serna, vecino de Carrión, una tierra que llama el Exido, en término de Villamez, por una carga de trigo de renta cada año. Fecha en San Zoil, a 14 de febrero de 1437, ante Ruy García Pachistre, esscribano de Carrión. 


\section{/ (f. 405v) 9. <Donación de una tierra. Año 1442>.}

Escritura de una donación, por la qual María García, habitante en el hospital de la Limosna de San Zoil, madre de Juan García Pachistre, monge de este monasterio, hace donación al convento de una tierra de tres obradas, que llaman la tierra de Toral, en término de Villamez, con cargo de un aniversario ${ }^{636}$ perpetuo con vigilia y misa cantada cada año perpetuamente, otro día después de Nuestra Señora de agosto, por su alma y la de sus difuntos. Fecha en el dicho hospital, a 14 de agosto de 1442, ante Garci Fernández de San Zoles, esscribano de Carrión.

Hay copia autorizada por don Antonio Martín García, traductor de letras antiguas.

10. $<$ Requirimiento para hacer arrendamientos. Año 1472>.

Requirimiento hecho por Juan Manrrique a los renteros que tenían las heredades de Villamez para que parezcan ante él a hacer arrendamientos por tenerlas él arrendadas al monasterio, año 1472. Puede servir este papel de memoria de estas heredades y sus arrendamientos.

11. <Testimonio del rompimiento de una tierra. Año 1679>.

Bajo este número se hallan:

Vn testimonio de cómo este convento, quieta y pacíficamente, rompió y aró la tierra del prado Camarero. Dado por Francisco Santos, esscribano de Carrión, en 13 de abril de 1679. Está multiplicado.

Vna razón de lo que dicen los apeos tocante a la tierra que se intenta arar.

Medidas de las tierra y prado Camarero y tierra de la Zarzosa, y otras de Villaturde ${ }^{637}$ y Villotilla ${ }^{638}$.

12. < Colación del beneficio simple de Villamez en Pedro Andrés de los Silos. Año $1600>$.

Colación del beneficio simple de la yglesia de Villamez, por la qual consta que, habiendo vacado por muerte de Gil Rodríguez, clérigo, último poseedor, fray Plácido de Huércanos, abad de San Zoil, hizo presentación en Pedro Andrés de los Silos, clérigo de menores órdenes, vecino del lugar de Huércanos. Dada en Palencia, a 18 de abril de 1600, ante Lucas Gallardo, nottario.

13. <Colación del beneficio a Marcos Pérez. Año 1611>.

Colación del beneficio simple de Villamez hecha sin contradición por el licenciado Manuel García de Miranda, provisor de Palencia, en virtud de la presentación hecha en Marcos Pérez por dejación que hizo del beneficio Pedro Andrés de Silos, sobre que dio el provisor sentencia en que declara al dicho abad por verdadero presentero y al dicho Marcos Pérez por bien presentado y capaz; y manda se le dé colación, y la dio en Palencia, a 26 de mayo / (f. 406r) de 1611, ante Juan de Noriega, nottario. Está aquí la posesión que tomó en $1^{\circ}$ de junio del mismo año.

14. <Colación del beneficio al licenciado Juan Delgado Terán. Año 1668>.

Colación del beneficio hecha en el licenciado Juan Delgado Terán por dejación del licenciado Andrés de San Juan, en virtud de presentación del abad de San Zoil contra el licenciado Manuel Blas, quien apeló a Burgos y sacó letras. Fue el pleito al nuncio y, habiéndose apartado el dicho Blas, se confirmó la sentencia de Palencia. Duró el pleito desde el año de 1665 ente el de 1668, como parece de estos autos y sentencias.

\footnotetext{
636 aniversario] al margen derecho: Vn aniversario. Nuestra Señora de Agosto.

${ }^{637}$ Villaturde] al margen derecho: Villaturde.

${ }^{638}$ Villotilla] al margen derecho: Villotilla.
} 
15. $<$ Diligencias para apear del apeo del término. Año 1670 $>$.

Diligencias por parte de la casa, en virtud de provisión real para apear el término de Villamez y deslindarle de los demás lugares rayanos. Copia simple sacada al pie de la letra del apeo que se hizo de dicho término, año de 1670, ante Norverto de Sandoval y Guevara, esscribano de Carrión.

16. $<$ Mandamiento de Palencia contra los colectores de Carrión por los diezmos de Villamez. Año 1688>.

Mandamientos con censuras contra los arrendadores y colectores de los diezmos de $^{639}$ Villamez y Carrión de los anos (sic) de 86 y 87, para que declaren y entreguen al convento lo que le tocaba por Villamez, de que eran deudores por haberlo recogido y vsurpado y detenido. Notificóseles y se allanaron a pagárselos según consta de estos autos, ante Norverto de Sandoval, esscribano de Carrión, año 1688.

Hay aquí un papel en que prueba los derechos que tiene el monasterio a la presentación del beneficio de Villamez.

17. < Colación a don Juan Gómez de la Torre. Año 1693>.

Colación hecha en don Juan Gómez de la Torre por el ordinario de Palencia, en virtud de presentación del abad de San Zoil por muerte del licenciado Juan Delgado Terán. Pasó ante Marcos Díez, nattario mayor de Palencia, año de 1693.

18. < Collación en don Bernardo Díaz de Castro. Año 1744>.

Título colación del beneficio de Villamez hecha en don Bernardo Díaz de Castro, en virtud de presentación en él hecha por el maestro fray Manuel Ordóñez, abad de San Zoil, año de 1744, ante Manuel López, nottario.

19. <Título hecho en don (don) Simón Pérez. Año 1796>.

Tútulo (sic) del beneficio de Villamez hecho en don Simón Pérez Prieto, en virtud de presentación que en él hizo el padre maestro fray Leandro Pérez, abad de San Zoil. Dado en Palencia, / (f. 406v) a 22 de septiembre de 1796, ante Thomás Díaz de Basurto, nottario mayor de asiento.

\section{Remisiones}

$<$ Concordia $>$.

Concordia sobre la presentación del beneficio. Véase el cajón San Andrés, legajo $1^{\circ}$, quaderno $\mathrm{B}$, número ${ }^{640} 2^{\circ}, 3^{\circ}$ y $4^{\circ}$. Vna tierra, ídem, legajo 4 , quaderno $\mathrm{A}$, número $4^{\circ}$.

$<$ Tierras $>$.

Dos tierras. Cajón San Zoil, legajo 2ª quaderno A, número 16.

\section{/ (f. 407r) Quaderno C del legajo $5^{\circ}$ Villamuriel}

Este quaderno $\mathrm{C}$ contiene los papeles pertenecientes a la hacienda que tiene el monasterio en este lugar, por el orden siguiente:

$1^{\circ}$. <Posesión de unas tierras que fueron de Francisco Rodríguez. Año 1623>.

Posesión y reintegración de unas tierras que fueron de Francisco Rodríguez, vecino de Villamuriel, en donde están dichas tierras; sobre las quales hubo pleito con Santiago Morejón, su primo, por decir que estaba ausente y le tocaban por ser el pariente más cercano. Diéronle la posesión los alcaldes de Villafrechós, desposeyendo al monasterio; de lo qual

\footnotetext{
639 de] escrita sobre: $y$.

${ }^{640}$ número] sigue tachado: $1^{\circ}$.
} 
apeló a Palencia, y el alcalde mayor revocó el auto y mandó volvernos a ellas, como se hizo ante Antonio de Argüello, esscribano de Villafrechós, año de 1623.

\section{Remisiones}

$<$ Donación $>$

La donación que hizo doña Aldonza de lo que tenía en este lugar. Véase el cajón Santa María, legajo $1^{\circ}$, quaderno A, número $1^{\circ}$.

\section{/ (f. 407v) Quaderno D del legajo 5 ${ }^{\circ}$}

Villanueva de Fontecha

Este quaderno D contiene la hacienda que tiene San Román en este lugar, por el orden siguiente:

$1^{\mathrm{o}}$. $<$ Donación del conde don Pedro Ansúrez de un solar, torre y prestamera. Era 1153. Año 1115>.

Escritura de donación, escrita en pergamino, que hizo y otorgó el conde don Pedro Ansures con su muger, la condesa doña Ervira (sic), de un solar con su torre y prestamera en el lugar de Villanueva de Fontecha, a Dios y al glorioso mártir San Román y al abad don Estevan. Facta carta donationis in die Sancti Joannis Evangelistæ, in era M C L III, anno Domini 1115, regnante regina Vrraca in Toleto et Leone; et comite Petrus Ansúrez, in Sancto Romano et in Saldania.

$2^{\circ}$. <Concordia con Villanueva de Fontecha sobre los montes de Aguirolo, de Susano, Matallana y Santa Colomba. Era 1290. Año 1252>.

Concordia, escrita en pergamino y partida por ABC, bien maltratada y apolillada, hecha entre don Gonzalo Pérez, prior de San Román, y el concejo de Villanueva de Fontecha sobre el término de la villa de Aguirolo de Suso (que es lo mismo que Susano) en la donación que hizo a San Román Fáfila Fernández de este término y del de Villavermudo (oy San Bool de Respenda). Véase el cajón San Estevan, legajo $3^{\circ}$, quaderno A, número $1^{\circ}$. Por esta escritura consta haber traído pleito sobre este término la casa de San Román con el concejo de Villanueva de Fontecha y sobre los montes de Matallana, que eran de San Román, pertenecientes a su yglesia de santa Columba; y después de 4 años de pleito el prior fue puesto en posesión de los montes por el deán de Salamanca, juez appostólico, con carta del rey don Fernando, para que lo executase Ferrán González, merino mayor del rey de Castilla. Fecha domingo, 7 días del mes de julio, sub era M C LXXXX, que fue año 1252. Tiene las cintas de los dos sellos que tubo y sin duda fue de mucha autoridad y grande importancia.

\section{Remisiones}

$<$ Compra $>$.

Compra de heredades. Véase el cajón San Felices, legajo $3^{\circ}$, quaderno A, número $2^{\circ}$.

$<$ Trueque $>$.

Trueque de dos tierras por dos salarios, etcétera. Cajón San Martín, legajo $4^{\circ}$, quaderno $\mathrm{D}$, número $1^{\circ}$.

\section{/ (f. 408r) Quaderno E del legajo $5^{\circ}$ \\ Villanueva de Muñeca}

Este quaderno E contiene las donaciones de este lugar hechas a San Román, por el orden siguiente: 
$1^{\circ}$. $<$ Donación de la condesa doña Aldonza. Era 1125. Año 1087>.

Escritura de donación, escrita en pergamino, hecha y otorgada por la condesa doña Aldonza, que fue hija de los fundadores de San Zoil, juntamente con sus hijos Fernando Fernández y Elvira Moniz; los quales dan o venden por veinte sueldos a Pedro Rodríguez, y a su muger, un solar con su era y exido, etcétera, y un fuero que esta señora tenía sobre esta posesión que dice está en Villanueva de Muñeca, en término de San Román. Facta carta feria $6^{a}$ X6 (sic) kalendas septembris, era 1125, que es año 1087.

$2^{\circ}$. <Donación del conde don Pedro Ansúrez y su muger. Era 1134. Año 1096>.

Escritura de donación, escrita en pergamino, por la qual el conde don Pedro Ansúrez, y su muger, doña Aeloni, y sus hijos, hacen donación al monasterio de San Román de las iglesias de Santa María de Villanueva de Muñeca, y la de San Miguel de Varrio ${ }^{641}$, y que los clérigos de ellas sean vasallos de San Román. Facta carta Era 1134, que es año de Christo 1096. Hay copia simple.

\section{$3^{\circ}$. $<$ Donación de Sancha Fernández. Era 1163. Año 1125>.}

Donación, escrita en pergamino, que hizo Sancha Fernández a San Román y a Gómez, prior, y a sus monges, de un solar y una tierra en Villanueva, en el territorio de San Román, por la qual dice que recivió del prior tres lienzos. Facta carta $5^{\mathrm{a}}$ feria, II kalendas maii, era 1163, que es año 1125.

$$
4^{\circ} \text {. <Testamento a favor del conde don Pedro Ansures. Era 1135. Año 1097>. }
$$

Escritura de testamento que Salvador, abad del monasterio de Santa María de Fitero, otorgó a favor del conde don Pedro Ansúrez, su muger e hijos, y éste le concede algunas exenciones al dicho abad para su monasterio. Facta carta testamenti $8^{\circ}$ idus marci, era 1135 , que es año 1097.

\section{$5^{\circ}$. <Donación de Gonzalo Fernández. Era 1200. Año 1162>.}

Carta de donación que hizo Gonzalo Fernández a Martín Domínguez, de un solar y una heredad en Villanueva de Muñeca. Fecha era 1200, que es año 1162.

$6^{\circ} .<$ Donación o venta de un solar. Era 1211. Año 1173>.

Carta de donación o venta que hizo Álvar Martínez a Pelay Pétrez, y a su muger ,Dominga, de un solar en Villanueva de Muñeca por dos maravedís. Facta carta mense junio, era 1211, que es año de Christo de 1173.

/ (f. 408v) 7. <Donación de Sol Díez. Era 1244. Año 1206>.

Donación que hizo a San Román Sol Díez, con voluntad y consentimiento de su hijo Juan y de su hija María, de un solar con su préstamo, un huerto, un prado en alongar y quatro tierras en término de Villanueva de Muñeca, siendo prior de San Román don Guillén. Facta carta era 1244, que es año de 1206. Está escrita en pergamino y partida por ABC.

\section{$8^{\circ}$. < Carta de venta de Garci Álvarez. Era 1282. Año 1244>.}

Escritura de venta, escrita en pergamino, muy mala de leer, por la qual Garci Álvarez, y su muger, doña María, venden a don Estevan, Marina Pédrez y sus hijos, ciertos prados y heredades en Villanueva de Muñeca, y pone que lindan por una parte con posesión de San Zoles $^{642}$, por precio de ocho maravedís y un yantar. Era 1282, que es año 1244.

9. <Trueque de heredades. Era 1374. Año 1336>.

Trueque hecho por Ruy García de Valdefontecha y Mencía Díaz, su muger, de ciertas heredades que ellos tenían en Villanueva de Muñeca, con otras de Santiváñez y otras partes, que habían heredado de un clérigo capellán de San Román. Fecho era 1374, que es año 1336.

\footnotetext{
${ }^{641}$ San Miguel de Varrio] al margen derecho: Yglesia de San Miguel de Varrio.

${ }^{642} \mathrm{San}$ Zoles] al margen derecho: San Zoles.
} 
10. $<$ Memorial de heredades de un préstamo $>$.

Memorial de las tierras y heredades de un préstamo y casa que tenía Bartolomé González, vecino de Villanueva de Muñeca.

11. <Trueque de un prado. Era 1419. Año 1381>.

Trueque de un prado en Villanueva de Muñeca. Fecho era de 1419, que es año de Christo de 1381.

12. <Donación de don Pedro, hijo del conde don Tello. Año 1400>.

Escritura de donación que hizo al monasterio de San Román don Pedro, hijo del conde don Tello, de todas las tierras, prados y casas que él hubo de haber y quedaron de Diosdado Fernández, vecino de Villanueva de Muñeca, por una deuda de 1.500 maravedís que éste le debía, con condiciones que sus testamentarios los pagasen, quedasen con las posesiones y San Román con los 1.500 maravedís. Fecha en Tablares, a 21 de mayo de 1400, ante Alfonso Muñoz de Camargo, esscribano.

Está aquí el original y un tanto dél autorizado por la justica de Saldaña ante Juan de Hinojedo, esscribano, a 27 de julio de 1574.

13. < Papeles de las aguas y términos con Santibáñez y San Román. Año 1527>.

Papeles que contienen un tanto de una información que se hizo y de una sentencia árbitra que dio fray Diego de las Heras, prior de San Román, en razón de la diferencia que había entre el monasterio de San Román y Santiváñez, de una parte, y los vecinos de Villanueva de Muñeca, de la otra, en razón del sitio por donde vajava el agua al dicho lugar de Villanueva y los términos de Fuente los Mures, y otros; y pastos de ellos, a quiénes pertenecen. Año 1527.

\section{/ (f. 409r) 14. < Pleito $^{643}$. Año 1557>.}

Papeles en razón de un pleito que tubo el monasterio de San Román con Toribio del Valle, vecino de Villanueva de Muñeca, porque vendió un suelo del monasterio sin licencia del prior, y se dio querella contra él en el adelantamiento de Campos. Año de 1557.

15. <Apelación de una sentencia. Año 1554>.

Apelación hecha por parte del monasterio de San Román, de una sentencia que dio contra él el licenciado Peralta, corregidor de Saldaña, en un pleito con unos menores que pretendían se les diese un préstamo que había tenido su padre, y que el prior no le podía dar libremente a quien quisiese. Año 1554, ante Felipe Gómez, esscribano de Saldaña. Este papel no tiene claridad de quiénes eran estos menores y parece ser los hijos de Juan Ramos, de que consta en el número siguiente.

16. < Pleito sobre el préstamo de Juan Ramos. Año 1554>.

Papeles tocantes a un pleito que tubo el monasterio de San Román con los hijos de Juan Ramos, en razón de un préstamo que tubo su padre en Villanueva, y vacó por su muerte, y los hijos pretendieron que se les había de dar a ellos, y el prior que le había de dar libremente a quien quisiese, en que fue condenado por sentencia del prior, año 1554.

17. < Trueque de una casa por tres prados y 1 tierra. Año 1791>.

Trueque que hizo el padre maestro fray José Fierro, prior de San Román, con Juan Luis González, vecino de Villanueva, de una casa, sitio y solar, con su corral, y un pedazo de huerta propios de de dicho monasterio, por tres prados y una tierra en término de Villanueba que dio el referido Juan. Su fecha, en Villanueba, a 4 de octubre de 1791, ante Manuel Luis Paris, esscribano de dicho lugar.

${ }^{643}$ Pleito] sigue tachado: con Toribio del Valle. 
18. <Trueque de una casa por dos prados. Año 1791>.

Trueque que hizo el padre maestro fray José Fierro, prior de San Román, con Matías García, vecino de las Heras ${ }^{644}$, de una casa con su corral, huerto y frutales, en término de dicho lugar, proprio del dicho priorato, por dos prados que el dicho Matías dio a dicho padre prior en término de Villanueva. Su fecha, en las Heras a 7 de octubre de 1791, ante el dicho esscribano.

19. <Trueque de una casa por varias heredades. Año 1791>.

Trueque que hizo el padre maestro fray José Fierro, prior de San Román, con Thomás Gutiérrez, vecino de Villanueva, de una casa con su corral, pozo y dos huertos, proprio de dicho priorato, por 4 prados y siete tierras, con más 35 reales que dio Thomas por el exceso/ (f. 409v) y más valor de la casa al de las heredades. Su fecha, en dicho lugar (todo en término de dicho lugar), a 4 de agosto de 1791, ante el esscribano sobredicho.

20. $<$ Trueque de una casa por varias heredades. Año 1791>.

Trueque hecho entre el padre maestro fray José Fierro, prior de San Román, de la una parte, y Manuel Luis Paris, Manuel Luis Villalba, don Matías y doña Paula de Hompaneda, de la otra, vecinos todos de Villanueba, de una casa con su corral y huerto en dicho lugar, y proprio de dicho priorato, por cinco prados, dos tierras y un pedazo de casa, todo en término de dicho lugar, con más 25 reales que dieron los susodichos al padre prior, por el exceso y más valor de la casa, al de las heredades. Su fecha, en (en) Villanueva, a 4 de agosto de 1791, ante Manuel Luis Paris, escribano sobredicho.

21. <Trueque de una casa por varias heredades. Año 1791>.

Trueque que hizo el padre maestro fray José Fierro, prior de San Román, con Juan Gutiérrez y Lorenza Pérez, su muger, vecinos de Villanueva de Arriba, de una casa con su corral y huerto en dicho lugar, propia de dicho priorato, por un prado y una viña en término de dicho lugar, dos tierras en Muñeca, otras dos en término Villaoliva, un linar y prado en término de las $\operatorname{Heras}^{645}$, con más 30 reales que dieron los susodichos al padre prior por el exceso y más valor de la casa al de las heredades. Su fecha, en San Román, a 12 de noviembre de 1791, ante el mismo esscribano ppúblico.

\section{2. <Trueque de una casa por varias heredades. Año 1792>.}

Trueque hecho entre el padre maestro fray José Fierro, prior de San Román, de la una parte, y Eduardo Luis y Manuela Luis, su muger, Manuel Laurencio y María Gutiérrez, su muger, de la otra, vecinos de Villanueva de arriba, de una casa, sitio y solar con su corral y las ofi[ci]nas correspondientes y huerta con árboles frutales, proprio de dicho priorato, por siete tierras y un prado en término de San Pedro de Guantes y Villanueva, con más 164 reales, que los susodichos pagaron al dicho padre prior por el exceso y más valor de la casa al de las heredades. Su fecha, en Villanueva a 13 de abril de 1792, ante Manuel Luis Paris, esscribano de dicho lugar.

\section{/ (f. 410r) Remisiones}

$<$ Donación $>$

Donación de Vrraca de los solares. Véase el cajón San Lorenzo, legajo $2^{\circ}$, quaderno A, número $3^{\circ}$ y $5^{\circ}$.

$<$ Donación $>$.

Donación de don Gómez García. Cajón San Lorenzo, legajo 4º número $1^{\circ}$.

${ }^{644}$ las Heras] al margen derecho: las Heras.

${ }^{645}$ las Heras] al margen derecho: Muñeca, Villaoliva, las Heras. 


\section{/ (f. 410v) Quaderno F del legajo $5^{\circ}$ \\ Villanueva de los Navos}

Este quaderno $\mathrm{F}$ contiene los papeles pertenecientes a la hacienda que tiene el monas[terio] de San Zoil en este lugar, por el orden siguiente:

\section{$1^{\circ}$. <Donación de don Munio Díaz y doña María, su muger. Era 1246. Año 1208>.}

Escritura de donación, escrita en pergamino y partida por ABC, por la qual Munio Díaz de Robradrillo y doña María, su muger, hacen donación a don Pedro, prior de San Zoil y camarero de Cluni en España, y al monasterio de San Zoil y a su hospital (que es lo mismo que a la hospedería) todas las heredades, foros, collazos, tierras, viñas, solares, poblados y despoblados, que tenían en Villanueva de Senadre, junto a Villamez (que oy se llama de los Navos), con toda la demás hacienda que tenían en el mismo lugar y la parte que tenían en la yglesia de $<e ́>1$ y en los molinos, con todo su derecho y dominio. Y el prior de San Zoil ${ }^{646}$ acepta la donación y en agradecimiento le da por sus días la hacienda que el monasterio tenía en Robradillo, para que junta con la que ellos dan al monasterio en Villanueva de Senadre la gozen por sus días, y después de ellos vuelva al monasterio; y ofrecieron estos señores dar de censo al monasterio dos libras de pimienta cada año. Facta carta era 1246, que es año de Christo de 1208.

$2^{\circ} .<$ Trueque de una cespedera. Era 1353. Año 1315>.

Escritura de donación, escrita en pergamino, por la qual don Guillén, prior de la claustra y el convento de San Zoil, con licencia de don Juan de Lodosa, prior mayor y camarero de San Zoil, dan en trueque a Simón Pérez de Carrión una tierra en Villanueva de Senadre, por una cespedera que él dio al convento, en término del mismo lugar. Fecha en 17 de noviembre, era 1353, que es año 1315, ante Ruy Pérez, esscribano de Carrión.

\section{$3^{\circ}$. <Foro de 9 quartos de trigo. Año 1424>.}

Escritura de fuero perpetuo, escrita en pergamino, por la qual María Fernández, muger de Pedro Lasso, vecino de Carrión, da a fuero a Juan García, vecino de Villlanueva de Senadre, las heredades que tenía en este lugar, por 9 quartos de trigo de renta cada año. Fecha en Carrión, a 6 de marzo de 1424, ante Gutierre Fernández, esscribano de Carrión. Fue reconocido este foro año 1642, ante Francisco Moro de Saldaña, por Juan Fernández de Porras.

$/(f .411 r) 4^{\circ} .<$ Foro de 10 maravedís sobre una ttierra. Año 1425>.

Escritura de foro, por la qual Gonzalo Martínez, prior de la claustra, y el convento de San Zoil, dan a fuero perpetuo a Rodrigo, vecino de Villanueva de Senadre, una tierra en término de este lugar, por 10 maravedís de renta en cada año. Fecha en San Zoil, a 17 de septiembre de 1425, ante Ruy García, escribano de Carrión.

\section{$5^{\circ}$. < Venta de 3 tierras. Año 1636>.}

Venta de tres tierras de la casa, que otorgaron Gregorio Herrero, etcétera, a favor de Ana de Virtus, viuda de Juan de Navarrete, vecina de Carrión, ante Francisco de los Cuetos, esscribano de dicha villa, en 28 de enero de 1636.

$<$ Dejación de dichas tierras. Año 1645>.

Después que el convento supo de esta venta se querelló del dicho Gregorio Herrero, vendedor, etcétera y de la dicha Ana de Virtus, compradora; la qual siendo cierta que era del convento hizo apartamiento y dejación de ellas, ante Gerónimo Lasso, esscribano de Carrión, año de 1645.

\section{$6^{\circ} .<$ Venta de una tierra para este monasterio. Año 1726>.}

Venta que otorgaron Toribio Porro y María Ramos, su muger, vecinos de Villanueva de los Navos, de una tierra que hace tres quartas y dos palos, poco más, en términos de dicho

${ }^{646}$ San Zoil] sigue tachado: la. 
lugar, a favor de este monasterio y del padre fray Zoil de Pedroso, por sus días. Pasó ante Santiago Duque de Estrada, esscribano de Carrión, a 9 de abril de 1726.

\section{Remisiones}

$<$ Consultas $>$.

Consultas sobre la tierra del Prado Camarero. Véase atrás quaderno B, número $11^{\circ}$.

\section{/ (f. 411v) Quaderno G del legajo $5^{\circ}$ \\ Villanueva de Rebollar}

Este quaderno $G$ contiene los papeles pertenecientes a la hacienda que tiene el monasterio en este lugar, por el orden siguiente:

$1^{\circ}$. $<$ Venta de casa y herrenes. Año 1524>.

Escritura de venta sacada por autoridad de justicia, por la qual Juan Alcalde, vecino de Villanueva del Rebollar, vende a Pedro García Tendero, vecino de Paredes, unas casas, huerta y herrenes en dicho lugar y en otras heredades por 3 mill 400 maravedís. Fecha a 4 de marzo de 1524, ante García Alonso, esscribano de Carrión.

$2^{\circ}$. $<$ Posesión de casas y heredades. Año 1445>.

Proceso de la posesión de unas casas, herrenes y viñas en Villanueva del Rebollar que tomó García Álvarez de Carrión, vecino desta villa, en nombre de Pedro de Carrión, su hijo, racionero de León, que las había comprado. Fecho a 5 de octubre de 1445, ante García Alonso, esscribano de Carrión.

$3^{\circ} .<$ Trueque de tierras. Año 1464>.

Escritura de trueque, por la qual Alfonso García de Villasur, limosnero mayor de San Zoil, con licencia de don Pedro de Carrión, abad del dicho monasterio, da en trueque a Pedro Martínez Serrano y Pedro Rogel, vecinos de Villarramiel ${ }^{647}$, todas las heredades que la limosna del dicho monasterio tenía en el dicho lugar de Villarramiel por otras heredades que los dichos Pedro Martínez y Pedro Rogel, en nombre y con poder del concejo de dicho lugar, dieron a la dicha limosna, que son tres tierras que compraron de Rodrigo de Colmenares, vecino de Carrión, las dos en término de Calzada ${ }^{648}$ a Mojarabos, otra al montón de Cascajo, otra en la loma de Carrión, a carre Castrillo, y otra tierra que compraron de Diego Álvarez de Carrión en término de Calzada, a Mojarabos; y por otras tierras en Villanueva del Rebollar que habían comprado de Diego Álvarez de Carrión. Fecha en San Zoil, a 19 de hebrero de 1464, ante González Catalán, esscribano de Carrión.

\section{Remisiones}

$<$ Donación $>$.

La donación que hizo doña Sancha de la hacienda que tenía en este lugar. Véase el cajón San Gregorio, legajo $2^{\circ}$, quaderno J, número $1^{\circ}$.

${ }^{647}$ Villarramiel] al margen derecho: Villarramiel.

${ }^{648}$ Calzada] al margen derecho: Calzada. 


\section{/ (f. 412r) Quaderno H del legajo $5^{\circ}$ \\ Villanueva del Río}

Este quaderno $\mathrm{H}$ contiene los papeles pertenecientes a la hacienda que tiene el monasterio en este lugar, por el orden siguiente:

$$
1^{\circ} \text {. <Trueque de } 4 \text { tierras. Era 1340. Año 1302>. }
$$

Escritura de trueque, por la qual Suer Pérez, sacristán mayor de San Zoil, da en trueque a Guiral Gusverte y Armitra Pérez, su muger, y Juan Sánchez, vecinos de Carrión, un suelo de un molino en término y cuérnago de Villanueva del Río, por quatro tierras en término de dicho lugar. Fecha en 12 días de mayo, era 1340, que es año de 1302. Hay copia, etcétera.

$2^{\circ}$. $<$ Foro de 3 tierras por 5 quarterones de cera. Año 1406>.

Escritura de fuero, escrita en pergamino, por la qual García Fernández, monge y sacristán mayor de San Zoil, da a foro perpetuo a Juan de Poza, vecino de Villanueva del Río, tres tierras en la vega de este lugar, por precio de cinco quarterones de cera cada año. Fecha en 21 de septiembre de 1406, ante Rodrigo Alfonso, esscribano de Carrión.

$3^{\circ}$. $<$ Foro de dos tierras por media libra de cera. Año 1406>.

Escritura de foro, escrita en pergamino, por la qual Garci Fernández, sacristán de San Zoil, da a foro perpetuo a Juan N., vecino de Carrión, dos tierras en término de Villanueva del Río, por precio de media libra de cera cada año. Fecha en San Zoil, a 24 de febrero de 1406, ante Rodrigo Alfonso, esscribano de Carrión.

$4^{\circ}$. $<$ Foro de una tierras por 3 quarterones de cera. Año 1406>.

Escritura de fuero, escrita en pergamino, por la qual García Fernández, sacristán de San Zoil, da a foro perpetuo a Juan Martín, vecino de Villanueva del Río, una tierra a la Talaya, término de dicho lugar, por precio de tres quarterones de cera cada año para la sacristía. Fecha en San Zoil, a 24 febrero de 1406, ante Rodrigo Alfonso, esscribano de Carrión.

$5^{\circ}$. $<$ Foro de un majuelo por media libra de cera. Año 1407>.

Escritura de fuero, escrita en pergamino, por la qual García Fernández, sacristán de San Zoil, da a foro perpetuo a Juan Relea, vecino de San Zoles, un majuelo en término de Villanueva del Río por media libra de cera cada año. Fecha en San Zoil, a 9 de enero de 1407, ante el mismo esscribano.

$6^{\circ} .<$ Foro de una viña por 5 quarterones de cera. Año 1422>.

Escritura de foro, escrita en pergamino, por la qual Juan Alonso, sacristán mayor de San Zoil, da a foro perpetuo a Alfonso Fernández de Revollera, vecino de Carrión, una viña en término de Villanueva del Río por cinco quarterones de cera en cada año. Fecha en San Zoil, a 27 de hebrero de 1422, ante Fernán Rodríguez de Castellanos, esscribano de Carrión.

$$
7^{\circ} .<\text { Foro de una viña. Año 1456>. }
$$

Escritura de venta, escrita en pergamino, por la qual Alfonso Martín, vecino de Villanueva del Río, vende a Pedro Manrrique, morador en Cestillos, una viña de dos quartas en término de dicho lugar con cargo de un quarterón de / (f.412v) cera que sobre ella tenía el sacristán de San Zoil. Fecha en Carrión, a 16 de abril de 1456, ante Pedro García de Carrión, esscribano de esta villa.

$$
8^{\circ} \text {. }<\text { Foro de una libra de cera sobre una tierra. Año 1497>. }
$$

Escritura de foro, escrita en pergamino, por la qual Fernán González, esscribano de San Zoil, da a fuero a Pedro Fernández de Valderrábano, vecino de Carrión, una tierra en término de Villanueva del Río por una libra de cera de renta cada año perpetuamente. Fecha en Carrión, a 25 de noviembre de 1497, ante Gutierre Fernández, esscribano de Carrión

Hay copia autorizada por don Antonio Martín García, traductor antiquario. 
EL ÍNDICE DE SAN ZOILO DE CARRIÓN

\section{Remisiones}

$<$ Compra $>$.

Compra que hicieron don Gómez Dídaz y su muger de varias heredades. Véase el cajón San Felices, legajo $2^{\circ}$, quaderno A, número $1^{\circ}$.

$<$ Trueque $>$.

Trueque de heredades en este lugar. Véase el cajón San Yldefonso, legajo $3^{\circ}$, número $12^{\circ}$, título Villaverde. 


\section{/ (f. 413r) Cajón 16 San Mauro \\ Villamuera}

Este cajón San Mauro, que es el décimo sesto del archivo, contiene quatro legajos pertenecientes todos a Villamuera, que son: legajo $1^{\circ}$ : Señorío y hacienda; legajo $2^{\circ}$ : Residencias que se tornan cada quadrienio a los alcaldes y ministros de justicia de este lugar; legajo $3^{\circ}$ : Pleitos y libros de qüentas; legajo $4^{\circ}$ : Propuestas para alcalde y demás ministros de justicia.

\section{Legajo $1^{\circ}$}

\section{Villamuera}

Este legajo, que es el primero del cajón San Mauro, contiene tres quadernos pertenecientes al lugar de Villamuera, que son los siguientes: quaderno A: Privilegios y cartas executorias de la posesión y propiedad de Villamuera, su jurisdición, señorío y vasallaje; quaderno B: Escrituras tocantes a la jurisdición; quaderno C: Hacienda de este lugar.

\section{Quaderno A del legajo $1^{\circ}$ \\ Villamuera}

Este quaderno A contiene los privilegios y cartas executorias de la posesión y propiedad, etcétera, por el orden siguiente:

$1^{\circ}$. $<$ Privilegio de ${ }^{649}$ don Alonso el XI, que ${ }^{650}$ confirma el de el rey don Alonso el Sabio, que confirmó el de el emperador don Alonso. Eras-Años: 1193-1155, 1293-1255, 1369-1331>.

Privilegio rodado original, escrito en pergamino con sello de plomo pendiente en filos de seda de colores, dado por el rey don Alonso el XI, en el qual confirma otro privilegio que había dado el rey don Alonso el Sabio, su visabuelo, fecho era 1293, que es año de 1255, el qual era confirmación de otro privilegio del rey don / (f.413v) don Alonso, emperador de España. Fecho era 1193, que año 1155, el qual emperador junto con la emperatriz doña Rica, su muger, y los reyes don Sancho y don Fernando, sus hijos, dicen que por amor de Dios y de almas de sus padres, y por remisión de sus pecados hacen donación a Dios y al monasterio de San Zoil de Carrión y a don Poymo, prior del dicho monasterio, y a todos sus sucesores, que ningún merino ni sayón ni hombre alguno se atreva a entrar en la villa de Villamuera, ni prendar por alguna calumnia, ni se atreva a prendar los hombres ni ganados de Villamoveira, que es Villamuera, ni los prenden por el alfoz de Carrión, ni se atreva ninguno a entrar a prendarlos en sus antiguos términos ni en algún otro lugar.

$<$ La reyna doña Vrraca dio a Villamuera al monasterio $>$.

Lo qual dice que hace por el alma de su madre, la reyna doña Vrraca, que dio la dicha villa a Dios y al monasterio de San Zoil. Fue confirmado el dicho privilegio y mandado guardar como hasta allí se había guardado por los reyes antecesores y dados por el dicho rey don Alonso el XI, regnante en uno con la reyna doña María, su muger, en Valladolid, a 7 días de diciembre, en la era de 1369, que es año de Christo de 1331.

Hay copia autorizada por don Antonio García, traductor; y otra simple.

$2^{\circ}$. <Privilegio del rey don Pedro en que confirma el de arriba. Era 1390. Año 1352>.

Privilegio original, escrito en pergamino con sello de plomo pendiente en filos de seda, del rey don Pedro, por el qual confirma al monasterio de San Zoil a instancia del concejo de Villamuera, el privilegio de arriba del rey don Alonso el XI, su padre, como en él se contiene; y está inserto en éste de verbo ad verbum, y manda que se guarde cumplidamente, como en él se contiene. Dado en León, a 23 días de junio, era 1390, que es año 1352. Mandolo escrivir, por mandado del rey, Sancho González.

\footnotetext{
$\left.{ }^{649} \mathrm{de}\right]$ sigue tachada: 1 .

${ }^{650}$ que] sigue tachado: es.
} 
Hay copia autorizada por don Antonio Martín García, traductor.

$3^{\circ}$. <Privilegio del rey don Juan el $2^{\circ}$, en que confirma los de arriba. Año 1446>.

Privilegio rodado, escrito en pergamino con sello de plomo pendiente en filos de seda de diversos colores, por el qual el rey don Juan el $2^{\circ}$, a instancia del monasterio de San Zoil, y porque el abad y monges dél sean obligados a rogar a Dios por su vida y del príncipe don Enrrique, su hijo, les confirma los privilegios de arriba, y en especial el privilegio del rey don Alonso el XI, su abuelo, que es el primero de arriba, y un alvalá del mismo rey don Juan el $2^{\circ}$. Lo qual, uno y otro, está inserto / $(f .414 r)$ de verbo ad verbum en este privilegio. Y por el alvalá manda a instancia de don Pedro de Tosantos, abad de San Zoil, que se confirme el dicho privilegio; sin embargo de haberse pasado el término que el dicho rey había señalado para la confirmación de todos los privilegios. Y por este privilegio, dado a instancia de don Pedro de Tossantos, dice que por la grande devoción que tiene con el glorioso mártir San Zoil, confirma el dicho privilegio del rey don Alonso y las mercedes y cosas en él contenidas; y manda que les valga y sea guardado de allí adelante como lo había sido hasta allí; y manda al príncipe don Enrrique, su hijo, y a todos los señores y justicias de sus reynos, y en particular a la de Carrión, que no se lo quebranten, sino que lo guarden y hagan guardar, etcétera. Dado en la villa de la Fuente del Saugo, a 5 días de enero de 1446. Juan Sánchez de Valladolid, esscribano del dicho rey, lo hizo escrivir por su mandado.

Hay copia autorizada por don Antonio Fernández de Guzmán, traductor y vecino de Frómesta, y otra por el padre fray Juan de Cisneros, la más fiel.

\section{$4^{\circ} .<$ Carta executoria de la jurisdicción de Villamuera y San Zoles. Año 1538>}

Carta executoria, escrita en pergamino con sello de plomo pendiente en filos de seda de colores, de la jurisdición privativa de Villamuera y de la acumulativa del varrio de San Zoles, ganada en la Chancillería de Valladolid por remisión de la reyna doña Juana y de su Consejo Real, en favor del monasterio de San Zoil contra la villa de Carrión y el fiscal de Su Magestad; por la qual parece que, en el barrio de San Zoles, a 9 de noviembre de 1513, la parte de don Juan Rodríguez de Fonseca, obispo de Palencia, abad perpetuo, comendatario de San Zoil, presentó ante el bachiller Martín de Espinosa una provisión de la reyna doña Juana, dada en Valladolid, a 28 de octubre de 1513, en que se hace relación que el Bachiller Sepúlveda, alcalde de Carrión, fue a visitar al lugar de Villamuera siendo de San Zoil, cuyo señorío pertenecía al dicho obispo de Palencia, abad del monasterio, y estando pleito pendiente sobre la jurisdicción del dicho lugar; y la dicha reyna había mandado por su carta que no se innovase durante el pleito.

$<$ Guerrilla de Villamuera sobre la visita del alcalde de Carrión $>$.

Y estando el dicho alcalde de Carrión mandó a los que con él estaban que hiriesen y matasen a Juan de Canillas, clérigo de Cordovilla, y poniéndolo en execución le dieron muchos golpes y heridas, de que le salió sangre y estaba a peligro de muerte. Y otro día siguiente el dicho Bachiller Sepúlveda fue a Villamuera, con 30 de a caballo y cien peones, y cercó la yglesia de la dicha villa, porque si quisiesen algunos vecinos acogerse a ella no pudiesen, y puso mucha gente armada por los cantones de las calles, porque ninguno se pudiese ir, y luego se fue en casa de Juan de la Torre, merino del obispo, con otra mucha gente armada / (f. 414v) y sacándole de su casa le puso en una borrica y con otros dos vecinos de Villamuera le llevó atadas las manos atrás y los puso en la cárcel de Carrión, con muchas amenazas que se lo habían de pagar, y que a esta causa muchos vecinos de Villamuera se fueron uyendo a Valladolid. El obispo pidió que fuesen castigados los que se hallasen culpados. Diose comisión al bachiller Martín de Espinosa para que sobre lo dicho hiciese información y la remitiese al Consejo para hacer justicia.

Martín de Espinosa, juez pesquisidor, aceptó la comisión e hizo la provanza y la remitió al Consejo, donde se presentó con otros autos y escrituras.

$<$ Demanda de Carrión $>$

La parte de la villa de Carrión puso demanda en el Consejo y alegó que, estando en costumbre inmemorial de vsar de la jurisdición de los lugares de Villamuera, Arconada y 
barrio de San Zoles ${ }^{651}$, un Cerbantes que residía en San Zoil por el obispo de Palencia, abad del monasterio, les impidía la dicha jurisdición y ponía penas a los vecinos de los dichos lugares para que no acudiesen a la justicia de Carrión en sus causas, y que oýa y libraba los pleitos civiles y criminales de los dichos lugares y prendía dentro del monasterio los vecinos de ellos; y uno embió preso a la fortaleza de Magaz y otro a Palencia; y, aunque se habían quejado al corregidor de Carrión, no lo había castigado por tocar al obispo de Palencia, y los que había llamado el corregidor para informarse no habían querido obedecer y no defendía la jurisdición real de los dichos lugares; y pidieron juez pesquisidor que conociese de estos y otros agravios y castigase a los que vsurpaban la jurisdición real y que fuese amparada la villa de Carrión en la posesión de la dicha jurisdición que tenían en nombre del rey. La parte del obispo respondió negando la demanda y que la jurisdicción de estos lugares fuese del rey, ni de la villa de Carrión, sino del monasterio de San Zoil; y pertenecía al obispo como su abad, la qual le pertenecía por privilegios reales, y por otros títulos y derechos; y que los abades habían vsado de ellas por sí y por sus ministros por tiempo immemorial, prendiendo y castigando a los vecinos de dichos lugares quando cometían algún delito y librando sus causas civiles y criminales, como señores de la dicha jurisdicción, en sciencia y consentimiento de la villa de Carrión, la qual si había hecho algún auto jurídico fue violento y oculto de que no pudo tener posesión immemorial; y alegó otras razones y derechos en su favor y contra los de la villa, etcétera. Contradijo el pesquisidor por estar apelado al Consejo y el pleito pendiente en él. Los privilegios que presentó la villa en que le da la jurisdición de los lugares de su alfoz no expresan a Villamuera, Arconada y San Zoles. Los privilegios del monasterio son más antiguos y los confirman los mismos reyes que dieron los privilegios de la villa, ni tampoco les pudieron aprovechar otras escrituras que presentaron, etcétera. Pidió ser absuelto de la demanda puesta por la villa y que se revocasen los autos hechos en perjuicio de su jurisdición y de sus vasallos, amparándole en la dicha jurisdición civil y criminal de los dichos lugares y vasallos, poniendo perpetuo silencio al concejo de villa de Carrión. Ambas partes volvieron a alegar de su justicia hasta que la causa fue conclusa y recivida a prueva. Las partes hicieron y presen/ (f. 415r)(sen)taron sus provanzas, escrituras y privilegios, y sobre ello alegaron de bien provado.

$$
<1514>
$$

Estando la causa en este estado el Consejo la remitió al presidente y oidores de Valladolid para que la viesen y hiciesen justicia; y para ello dieron su provisión real de la reyna doña Juana. Dada en Madrid, a 15 de febrero de 1514, ante Juan Ramírez, esscribano de cámara de la reyna. Presentada y obedecida en la Chancillería se despachó emplazamiento contra el obispo y concejos de dichos lugares, y a don Juan Rodríguez de Fonseca, obispo de Burgos, cappellán mayor de la reyna, abad de Párraces y de San Zoil. La parte de la villa de Carrión alegó de su justicia en la Chancillería, presentó ciertas escrituras y pidió lo que había pedido en el Consejo.

\section{$<$ Sale el fiscal a la causa $>$}

A esta sazón, el Católico rey don Fernando, con acuerdo de su Consejo, dio una cédula por la qual mandó al licenciado Juan de Salinas, su procurador fiscal, que asista a esta causa y la siga hasta fenecerla, el qual la obedeció. La parte del obispo y lugares se querelló de que estando el pleito pendiente y habiéndose mandado por carta y sobrecarta de la chancillería a la justicia y concejo de Carrión que no innovasen en el vso de la jurisdición; de estos lugares todavía innovaban y hacían vexaciones y extorsiones a los vecinos y vasallos de ellos, y pidió tercera carta y que con ella fuese juez a castigar los culpados; contra lo qual respondió la parte contraria que no había innovado, y el obispo sí. Y concluso este artículo se dio auto y carta por la qual mandaron a la justicia de Carrión que no innovase so graves penas, y que yría juez a executarlas a su costa.

El convento volvió a representar sus privilegios y escrituras presentadas por el obispo, haciendo mención de todos, y para ello pidió restitución. Diose el pleito por concluso en lo principal.

\footnotetext{
${ }^{651}$ Barrio de San Zoles] al margen derecho: Arconada, San Zoles.
} 
$<1536>$.

La parte contraria dijo contra los privilegios y escrituras presentadas por el obispo a 17 de agosto de 1536. Fray Gaspar de Villarroel, abad, y el convento de San Zoil dieron poder para proseguir este pleito que se había retardado y olvidado con la mudanza de la Abadía; con que viéndose don Juan Rodríguez de Fonseca en Burgos y arzobispo de Rosano, ni hizo caso de lo que importaba a este monasterio de donde era abad (sólo para coger el fruto dél y no para cuidar de su conservación). También dio poder el concejo de Villamuera, a 15 de septiembre de 1536; y el concejo de Arconada le otorgó también, a 19 del mismo mes y año, todos tres poderes ante Juan de Castrillo, esscribano de Carrión. A pedimiento del convento se dio emplazamiento contra la justicia y regimiento de Carrión, que fueron citados con él y no acudieron.

$<$ Sentencia de vista. Año 1537>.

Acusó el convento la reveldía, diose el pleito por concluso y en ausencia de la villa en la Chancillería se dio sentencia difinitiva en el negocio principal, por la qual / (f. 415v) ampararon a la justicia y concejo de Carrión en la posesión de vsar la jurisdición civil y criminal en el lugar de Arconada, y que el convento no les perturbe en ello. Y asimismo ampara a la dicha villa y su justicia en la posesión de vsar y exercer la jurisdición civil y criminal en el varrio de San Zoles, la qual use acumulative con los alcaldes puestos y nombrados por el abad y convento de San Zoil, los quales alcaldes así nombrados mandan que puedan vsar y exercer la dicha jurisdición civil y criminal acumulative con la justicia de Carrión en el barrio de San Zoles; y que entre los los dichos alcaldes y justicia de Carrión aya lugar prevención. Y quanto a la jurisdición de Villamuera pedida por la villa absuelven al abad y convento, y les dan por libres y ponen perpetuo silencio a la villa de Carrión para que en esta razón en ningún tiempo les pueda pedir cosa alguna. Dada a 23 de marzo de 1537. De esta sentencia suplicó la parte de la villa en lo que era contraria, y en lo favorable la aceptó y consintió, y alegó en forma sus agravios. Y el convento suplicó y alegó en forma contra la dicha sentencia sus agravios, suplicando de lo que era contraria y admitiéndola en lo favorable. Y ambas partes replicaron y alegaron de su justicia hasta que la causa fue dada por conclusa.

$<$ Sentencia de revista. Año de 1538>

Y, habiendo pedido el convento restitución de prueva para hacer información sobre los mismos artículos que había alegado, se le concedió y la causa se recivió a prueba y las partes hicieron y presentaron sus informaciones. Publicáronse y se alegó de bien provado, y sobre todo la causa fue conclusa. Y en 12 de abril de 1538 se dio en la Chancillería sentencia de revista, por la qual confirmaron la de vista.

Después de lo qual salió el licenciado Tapia a la causa y alegó contra las sentencias, contradijo el monasterio y pidió carta executoria; salió auto que se diese a 2 de agosto, la qual se dio y despachó a 3 de octubre de 1538, ante Gregorio de Setién, esscribano de cámara.

$5^{\circ}$. $<$ Posesión dada al monasterio de la jurisdición de Villamuera. Año 1538>.

Posesión dada al monasterio de San Zoil de las jurisdiciones de Villamuera y barrio de San Zoles, en execución de la carta executoria de atrás, por la qual parece que en la Chancillería de Valladolid, a 7 de octubre de 1538, se despachó a instancia de la parte del monasterio una provisión real por el emperador Carlos $\mathrm{V}^{\mathrm{o}}$ y la reyna doña Juana, su madre, por la qual se da comisión en forma para que el alcalde mayor del adelantamiento de Campos, en execución de la carta executoria de arriba y de sus sentencias, pusiese en posesión de las dichas jurisdiciones de Villamuera y barrio de San Zoles al / (f. 416r) abad y convento de San Zoil, de cuya parte fue requerido con la dicha comisión y carta executoria, en Frechilla, a 28 de noviembre de 1538, el doctor Thomas de Tobar, alcalde mayor del dicho adelantamiento, el qual la obedeció y aceptó la comisión. La parte de la villa de Carrión dio poder y se presentó ante el juez comisionado estando en Carrión donde, a 18 de diciembre de 1538, juntó a concejo la justicia, regidores y otras personas y les hizo patente su comisión y les citó y requirió para si quisiesen alegar algo contra los autos que se hiciesen. La villa pidió que en lo tocante a San Zoles no dé posesión al monasterio más que en lo que le tocase y quede la posesión acumulative dél a los dos alcaldes y merinos de Carrión y que no se dé jurisdición 
al monasterio en Villamuera, pues la executoria no se la da; y que el convento preste caución de no impedir la jurisdición de Arconada. El juez fue a Arconada y requirió a las partes pidiesen lo que les conviniese.

\section{$<$ Posesión de la jurisdicción de San Zoles $>$.}

La parte de la villa de Carrión pide se le dé posesión de la jurisdición civil y criminal de este lugar y que el abad dé las fianzas y quite el merino. El juez mandó que los vecinos de Arconada que de allí adelante no obedeciesen al abad de San Zoil ni a su merino, al qual mandó que no vsase más el oficio.

La villa pidió que si en San Zoles se hubiese de poner insignia de justicia fuese en suelo del monasterio y no de la villa, cuya justicia entrase en la posesión de jurisdición acumulative. Mandósele dar información de lo que había pedido.

$<$ Districto del barrio de San Zoles y su jurisdición $>$.

El convento presentó los privilegios que tiene del barrio y alegó contra lo que había alegado la villa y ofreció hacer la caución juratoria; ofreció e hizo información con trece testigos cómo el barrio de San Zoles y su jurisdición es desde la torre que estaba en medio de la puente del Río Mayor hasta San Lázaro y el molino de la tapia. Presentó también unos capítulos de una sentencia arbitra tocantes a la misma jurisdición. El juez dio la posesión civil y criminal de la jurisdición acumulative del barrio de San Zoles al monasterio con la villa de Carrión. Puso rollo y picota y dio tres varas: vna a un vecino de la villa y dos a dos vecinos del barrio, el uno en nombre de la villa y los dos en nombre del abad y convento de San Zoil, y les mandó vsar de sus oficios y jurisdición; e hicieron actos de ella a 10 de diciembre. El convento hizo obligación de no contravenir a lo contenido en las sentencias de la carta executoria, ni inquietar a la villa de Carrión en la jurisdición que por ella se le daba de Arconada y barrio de San Zoles en la forma en ella contenida y dio fianzas de cumplirlo. / (f. 416v) Fray Gaspar de Villarroel, abad de San Zoil, nombró alcaldes y merino y oficiales del barrio y les señaló lugar donde tubiesen audiencia y juzgasen las causas civiles y criminales, y les tomó juramento.

El juez mandó pregonar la jurisdición y posesión de ella que había dado y mandó que nadie fuese contra ella, ni se atreviese a quitar la picota que había puesto en San Zoles.

$<$ Posesión de la jurisdición de Villamuera. Año 1538>.

En 11 de diciembre de 1538 fue el dicho alcalde mayor del adelantamiento, juez de comisión, a Villamuera para dar la posesión al monasterio de su jurisdición. Señaló en la plaza sitio donde se pusiese una picota y la mandó poner y se puso con efecto. Dio dos varas de alcaldes y mandó vsasen de ellas e hiciesen justicia y se les tomó juramento en forma de los alcaldes, merino y escrivano, el que nombró el abad con los demás oficiales y él les tomó el juramento, y dijo que los alcades tubiesen las varas por el tiempo que fuese su voluntad y no más. El juez mandó poner y se puso una horca. Los alcaldes como tales vsaron sus oficios e hicieron autos de jurisdición y posesión que se había dado de ella al abad y convento y el juez mandó que nadie fuese contra ella, ni se atreviese a quitar el rollo ni la horca. Estos autos de posesión que se hicieron en diciembre de 1538 pasaron ante Juan de Obregón, esscribano de Su Magestad. Magestad.

Aquí falta una executoria del año 1556, ante Gerónimo de Vega, esscribano de Su 6. <Testimonio de las sentencias y executorias. Año 1676>.

Testimonio en relación de las sentencias de la executoria de atrás y cláusulas de concordias. Su fecha, en San Zoil, a 22 de junio de 1676, ante Blas Ysla Álvarez, esscribano de Carrión.

$7^{\circ}$. $<$ Executoria a favor del monasterio sobre nombrar alondiguero. Año 1769>.

Executoria ganada a favor de este monasterio en la Chancillería de Valladolid y contra el concejo, justicia y regimiento de Villamuera, sobre que propongan alondiguero para el pósito y lóndiga real de dicha villa, al modo que lo hacen de los demás oficios de justicia y concejiles, para que el abad que es o fuere de San Zoil nombre los que tenta (sic) por 
convenientes como dueño y señor que es de dicha villa. Controvertiose este pleito el año de 1769, y fueron condenados dicho concejo y vecinos de Villamuera en costas, de que se hizo paga y se allanaron en todo sin contradición alguna. Dada en ${ }^{652}$ Valladolid, a 7 de octubre de 1769, ante Gregorio Tabares, esscribano de Cámara.

\section{/ (f. 417r) Remisiones}

Ynformación y concordia sobre los lugares de Arconada y Villamuera. Véase el cajón San Pedro, legajo $3^{\circ}$, números 17 y 18.

Testimonio del pleito sobre la jurisdición. Véase el cajón San Yldefonso, legajo $1^{\circ}$, número $6^{\circ}$; y sobre los diezmos, ídem, número 21 y 24.

16.

Pleitos criminales contra los de Villamuera, etcétera. Ídem, legajo $2^{\circ}$, hasta número

\section{/ (f. 417v) Quaderno B del legajo $1^{\circ}$ \\ Villamuera}

Este quaderno B contiene las escrituras y concordias tocantes a la jurisdición de este lugar, por el orden siguiente: $1235>$.

$1^{\circ}$. <Concordia sobre la presentación del beneficio de Villamuera. Era 1273. Año

Escritura de concordia original, escrita en pergamino, entre el camarero de Cluni y el convento de San Zoil, de una parte; y el concejo de Villamuera, de la otra, en que dicen que si en Villamuera se hallase clérigo o cappellán natural e idóneo y el concejo rogase por <él>, el camarero le concederá de buena gana la cappellanía y le presentará al obispo o a sus vicarios; y, si entre ellos no se hallare tal clérigo, de común consentimiento el camarero y el concejo buscarán otra persona idónea que sea a gusto de ambos y el camarero le dará la cappellanía. Y el tal cappellán ha de ser vasallo del camarero y recivirá enteramente la ración de la cappellanía como se contiene en la escritura del obispo y cabildo de Palencia, que es la mitad de una tercia de pan, vino y menudos, y todos los dineros y ofrendas de los muertos y de las primicias y heredades de la yglesia lo que le pertenece. Por lo qual el dicho cappellán estará obligado a servir enteramente a la yglesia. Fecha era 1273, que es año de 1235, reynando en Castilla y Toledo el rey don Enrrique; y obispo en Palencia, don Tello.

$2^{\circ}$. $<$ Concordia sobre las dos cántaras de vino que paga cada vecino de Villamuera al monasterio. Año 1451>.

Escritura de concordia y sentencia por la qual parece que, en dos días del mes de marzo de 1451, ante Álvar González de Carrión, escribano de esta villa, habiéndose juntado en la capilla de Santa Catalina del monasterio de San Zoil, de la una parte, don Pedro Abad y el prior, monges y convento; y de la otra, Juan Fernández del Palomar y Fernán Sánchez y Juan Tagarro, vecinos de Villamuera, por sí y en nombre del concejo, y con su poder, que está aquí inserto; vnos y otros dijeron que, por quanto entre ambas las dichas partes había algunas diferencias en razón de las sernas que los vecinos de Villamuera habían pagado siempre y tenían obligación de pagar al monasterio, para escusar debates se habían convenido y concertado voluntariamente en que todos los vecinos de Villamuera que fueren casados en lugar de las dichas sernas dé cada uno al monasterio cada año dos cántaras de mosto,/ ( $f$. 418 r) y las viudas que cogieren de 50 cántaras de mosto arriba dé cada una dos cántaras, y las que cogieren de 50 abajo den cada una una cántara; y las viudas y viejos que no labraren ni cogieren vino ayuden a coger la leña los <que $>$ pudieren. Y que este mosto lo recoja el convento a las vendimias quando se cogen los diezmos hasta quince días después, y no lo cobrando a este tiempo, no haya obligación a darlo. Y esto se entienda ser a salvo de la serna de la vendimia. Todo lo qual quieren que valga por sentencia definitiva o como ley y ordenanza y como tal se obligan a guardallo.

\footnotetext{
${ }^{652}$ en] sigue tachado: Madrid.
} 
$3^{\circ}$. < Concordia y sentencia árbitra de las sernas en que el concejo hace dar al convento 20 peones para la siega de sus panes. Año 1530>.

Traslado simple de una concordia y sentencia árbitraria, por la qual parece que fray Diego de Canales, presidente, y el convento de San Zoil, con licencia del general fray Alonso de Toro; y Martín Velasco y Juan Alcalde el Viejo, vecinos de Villamuera, por sí y en nombre del concejo de dicho lugar, hacen escritura el convento en Juan Catalán, clérigo, y el concejo en el licenciado Valdivieso, para que ambos juntos determinen la diferencia que ambas partes tenían sobre las sernas de la siega fundadas en la vltima cláusula de la concordia de arriba, que dice que se entienda ser a salvo de la serna de la vendimia, en que se dudaba si los de Villamuera por esta cláusula eran libres de las sernas de la siega. Cerca de lo qual los dichos jueces compromisarios dieron sentencia en San Zoil, a 23 de agosto de 1530, ante Juan de Castrillo, esscribano de Carrión, por la qual mandan que en todo y por todo se guarde la concordia y sentencia de arriba quanto al mosto de que hace mención; y quanto a la dicha cláusula sobre que fue la duda declaran y mandan que el concejo de Villamuera den cada año perpetuamente veinte peones al monasterio de San Zoil para segar sus panes o para otra cosa que le sean pedidos, y les mantenga el convento el día que trabajaren por él; y con esto el concejo quede libre de otras obligaciones. Y que si los regidores, siendo requeridos de parte del convento, no dieren dentro de dos días los otros 20 peones esté obligado el concejo a darlos doblados, o que cada vecino del lugar sea obligado a dar un peón, qual más quisiere el monasterio. Esta sentencia la consintieron las partes y el general fray Alonso de Toro la / $f$. 418v) (la) aprovó y confirmó en San Zoil, a 29 de agosto de 1530, ante el mismo Juan de Castrillo, esscribano de Carrión.

\section{$<$ Nota $>$.}

Esta sentencia es traslado de traslado y así, quando llegue el caso que tal vez sea necesario compulsarse, tenga presente el archivero el traslado o instrumento primordial que está en el libro $5^{\circ}$ de vitas, al folio 30 , que es el que se debe compulsar.

$4^{\circ}$. $<$ Sentencia en razón de las alcavalas que pedían los arrendadores de Carrión a los vecinos de Villamuera. Año 1472>.

Sentencia dada por Alfonso Fernández de Burgo, chartre de Husillos y racionero de Palencia, por la qual parece que, habiendo el convento de San Zoil vendido cierto pan a unos vecinos de Villamuera, Juan Rodríguez, esscribano, y Gómez Catalán, arrendadores de las alcavalas de Carrión, quitaron prendas a los de Villamuera, y ante la justicia de Carrión pidieron les pagasen la alcavala del dicho pan que habían comprado. De que se querelló el convento ante el dicho juez conservador, el qual dio su mandamiento, citatorio y compulsorio, en virtud del qual parecieron los dichos arrendadores, y habiendo alegado de su justicia, dada la causa por conclusa, el dicho conservador dio en ella sentencia por la qual falló el convento de San Zoil ser exempto de pagar alcavala y las vexaciones hechas directe a los compradores del trigo e indirecte al monasterio ser temerarias, injustas e ilícitas; y por tales las declara y manda con excomunión a los arrendadores que dentro de seis día cesen de sus pedimentos y molestias y no las hagan de allí adelante, ni a los que compraren su pan; y dentro de otros diez día les buelvan las prendas que les habían tomado. Póneles perpetuo silencio y les condena en costas. Dada en Palencia, a 16 de enero de 1472, ante Per Álvarez de Tordelaguna, de la diócesis de Toledo, notario appostólico.

\section{$5^{\circ}$. $<$ Capítulos de concordia. Año 1501>.}

Capítulos de concordia, por jueces árbitros, entre don Luis Hurtado de Mendoza, administrador perpetuo de la abadía de San Zoil, y la villa de Carrión en razón del vso y administración de la jurisdición, pastos y aprovechamientos de los lugares de Villamuera, Arconada y barrio de San Zoles, y encerrar vino en la villa de Carrión, los quales sólo habían de durar por la vida de don Luis Hurtado. Fecha año de 1501. No está autorizado.

$6^{\circ} .<$ Requirimiento de la villa. Año 1505>.

Requirimiento hecho por Zoil de Saldaña, limosnero de San Zoil, en nombre de don Luis Hurtado de Mendoza, al corregidor y ayuntamiento de la villa de Carrión en razón de que algunos vecinos de ella / (f.419r) habían hechado peticiones en el Consejo de Su Alteza, 
quejándose de don Luis, que maltrataba y hacía violencias a sus vasallos, y que se alzaba con la jurisdición real, lo qual era falso porque él guardaba y quería guardar en paz lo contenido en las sentencias da (sic) entre el monasterio y la villa, y los requirió dijesen si era así verdad y quién había dado las peticiones para que al consejo constase la verdad. Respondieron que no sabían de tales peticiones y que las sentencias se guardaban sin que hubiese queja alguna. Fecho a $1^{\circ}$ de marzo de 1505, ante Juan de Varrio, esscribano. Año 1513>.

$7^{\circ}$. <Provisión contra un juez que sentenció ser Villamuera jurisdición de Carrión.

Provisión de la reyna doña Juana, compulsoria y de emplazamiento, dada en su Consejo, a instancia del concejo y hombres buenos de Villamuera, contra un mandamiento que había dado el licenciado de villa, juez de residencia de la villa de Carrión, en que declaró que la jurisdición de Villamuera pertenecía a la villa de Carrión. De que se querelló el convento en el Consejo y se le dio esta carta para citar a los de la villa de Carrión que fuesen a responder. Dada en Valladolid, a 8 de marzo de 1513, ante Juan Ramírez, esscribano de Cámara.

$8^{\circ}$. <Provisión real de prorrogación de término para pruebas. Año 1513>.

Provisión real de la reyna doña Juana, dada en su Consejo, con prorrogación del término que se había dado para hacer las informaciones en el pleito pendiente entre el obispo de Palencia, abad de San Zoil y el concejo de Villamuera, de una parte; y la villa de Carrión, de otra sobre la jurisdición de Villamuera. Dada en Valladolid, a 28 de octubre de 1513, ante Juan Ramírez, esscribano de Cámara.

9. < Provisión para que no se innove en la jurisdición de Villamuera. Año 1514>.

Provisiones reales de la reyna doña Juana, dadas en su Consejo, contra la justicia de Carrión para que no innove en lo tocante a la jurisdición de Villamuera, barrio de San Zoles y Arconada ${ }^{653}$, en tanto que estaba el pleito pendiente. Dadas en Valladolid, a 6 de mayo de 1514, ante Cristóval Palomino, esscribano de la audiencia de la reyna.

10. <Requirimiento para no obedecer. Año 1517>.

Requirimiento hecho por el merino de Villamuera para que los alcaldes y esscribano de aquel lugar no cumplan ni obedezcan los mandamientos dados por el teniente de Carrión. Fecho a 15 de junio de 1517, ante Francisco Martínez, esscribano y vecino de Santillana.

11. < Concordia con la villa de Carrión. Año 1517>.

Concordia hecha entre el arzobispo de Rosario, obispo de Burgos, abad comendatario de San Zoil, y el prior y convento, de una parte; y la villa de Carrión, de la otra, sobre el proceso que don Sebas/ (f. 419v)tián de Valera, provisor de León y juez conservador, hizo contra el bachiller Porras, alcalde de Carrión, y contra Pero López, esscribano, y otros, en razón de haber soltado un preso que estaba en el cepo y cárcel de Villamuera, sobre lo qual y jurisdición de Villamuera estaba pleito pendiente en el Consejo Real, y en tanto que se determinaba y sentenciaba para tener paz hicieron esta concordia con ciertas capitulaciones, que se habían de guardar sólo en quanto duraba el pleito y después se había de estar a lo que en él se sentenciase. Fecha año 1517, ante Juan Sánchez, esscribano de Carrión.

12. < Proceso e información contra el teniente de Carrión que executó un vecino de Villamuera. Año 1529>.

Proceso e información hecho por Pedro de la Carrera, cura de San Andrés y vicario de Carrión, juez subconservador, por comisión de fray Diego Liciniana, abad de Oña, juez conservador principal, contra el licenciado Alvarez, teniente de Carrión, por haber trahído por engaño al merino de Villamuera y haber hecho en su persona y bienes execución de cierta deuda, siendo abonado y no pudiéndolo hacer, como consta de la información que está aquí, por la qual le dio por libre y no se hizo la execución. Fecho en septiembre de 1529, ante Diego Caballero, notario appostólico.

${ }^{653}$ Arconada] al margen derecho: San Zoles, Arconada. 
13. <Auto del teniente en que suspende sus execuciones. Año 1529>.

Auto dado por el licenciado Álvarez, teniente de Carrión, por el qual suspende las execuciones y autos que había hecho en los vasallos de Villamuera y barrio de San Zoles, para que los juezes árbitros nombrados por la villa y convento determinen si lo pudo hacer y cómo se había de proceder de allí adelante cerca de las execuciones y jurisdición. Dado en Carrión, a 29 de octubre de 1529, ante Hipólito de Rojas, esscribano de Carrión.

14. <Requirimiento al teniente de Carrión. Año 1532>.

Requirimiento hecho al teniente de Carrión por el licenciado Villordón de parte del convento de San Zoil, porque mandase bolver el dinero que habían mandado depositar de unas execuciones hechas en Villamuera y que repusiese tres mandamientos que en orden a ello había dado en Villamuera y los remitiese al merino de allí nombrado por el convento. Fecho en Carrión, a 18 de enero de 1532, ante Hipólito de Rojas, esscribano de Carrión.

15. <Dudas y pareceres de los de Villamuera. Año 1560>.

Caso de dudas propuestas a los vecinos de Villamuera y pareceres del doctor Tamayo y del bachiller Antonio Marcos, en razón de que si pueden arrendar los pastos sin orden del abad; si éste ha de nombrar esscribanos, si ha de tomar qüentas y residencia, y si él o el concejo ha de pagar al juez y esscribano que toma las qüentas. Año 1560.

\section{/ (f. 420r) 16. < Recaudos para vender el lugar de Villamuera. Año 1568>.}

Licencia del general fray Alonso Zorrilla para vender a Villamuera y su jurisdición. Dada en San Benito de Valladolid, a 4 de junio de 1568. Parecer cerca de este punto, es en contrario.

$<1574>$.

Memorias de las calidades y hacienda que el monasterio tiene en este lugar y lo que se vendía y sus valo $<$ res $>^{654}$. Tratose de vender este lugar una vez a la villa de Carrión, y daba quatro mil ducados por él, por los años de 1574. Después a Antonio de Campo, y se valoreó en 1 qüento 390 mill 000 maravedís; y después a don Francisco Orense Manrrique. Hay memoria de los juros que se ofrecían por Villamuera de 4 mill ducados de principal con sus seguridades.

$$
<1582>\text {. }
$$

Hay un testimonio, cómo por los años de 1582, con facultad real, trataba de vender este lugar a los mismos vecinos dél Sinibaldo de Oria Ginovés, para pagarse de lo que el rey le debía de ciertos asientos que él y sus compañeros habían hecho con Felipe $2^{\circ}$.

17. <Cédula de diligencias del rey don Felipe $2^{\circ}$ para vender los lugares de las yglesias y monasterios. Año 1574>.

Cédula de diligencias y comisión del rey don Felipe $2^{\circ}$, dada al licenciado Castañiza, en virtud [d]el breve que concedió al dicho rey la Santidad del papa Gregorio XIII, para que pudiese desmembrar, partir y vender perpetuamente qualesquier villas y lugares, fortalezas, jurisdiciones, vasallos, etcétera, dándoles la justa recompensa y equivalencia que hubiesen de haber por las ventas que desmembraren y vendiesen. Y con esta cédula y su instrucción se dio al dicho licenciado $C a s<\mathrm{ta}>$ ñiza una memoria de lugares de yglesias y monasterios, en que están Villamuera y San Zoles por del monasterio de San Zoil, para que en todos se hagan las mismas diligencias que se hicieren en Magaz. Dada en San Lorenzo el Real, a 4 de septiembre de 1574, ante Juan Escovedo, secretario de Su Magjestad. Este trasumpto dio firmado y signado Juan de Sosa, esscribano de esta comisión.

18. < Poder para comprar las alcavalas de Villamuera. Año 1615>.

Poder que dio el convento de San Zoil a fray Francisco Gutiérrez, procurador general, y otros para que tratasen de comprar las alcavalas de Villamuera y memoriales que se hicieron en esta razón año 1685, ante Francisco Moro de Saldaña, esscribano de Carrión.

${ }^{654}$ valo $<$ res $>$ ] escrito sobre: vasallos. 
19. < Ordenanzas hechas el año de 1622>.

El año de 1622 se juntó el concejo de Villamuera para hacer ordenanzas y dieron comisión a seis vecinos para que las dispusiesen, los quales se juntaron y las compusieron según mejor les pareció, ante Santos de Guzmán; y habiéndolas trahído las aprobó y confirmó el padre maestro fray Juan Rey, abad de esta casa; y después de él, algunos juezes de residencia.

/ (f. 420v) 20. <Cédula real para contrar (sic) los soldados quintados. Año 1625>.

Trasumpto de una cédula para contar los soldados quintados de la jurisdición de Carrión, en cuya virtud quiso el licenciado Cabezas Altamirano, corregidor de Carrión, vsar de esta jurisdición en Villamuera; y quiso ir allá con gente de armas, y el convento salió a esta causa y no fue el corregidor porque la cédula dice que haga la diligencia en los lugares de su jurisdición, en que no se comprehende Villamuera. Dada a 10 de abril de 1625, ante Bartolomé de Anaya Villanueva, secretario de Su Magestad.

21. < Provisión y emplazamiento contra el corregidor de Carrión porque quiso quintar en Villamuera. Año 1625>.

Provisión de emplazamiento y compulsa, dada en la Chancillería de Valladolid, a instancia de fray Juan Cortés, abad de San Zoil, y de los alcaldes de Villamuera, contra el licenciado don Fernando Altamirano de las Cabezas, corregidor de Carrión, por ciertos autos que hizo en razón de ir a quintar los vecinos de Villamuera para la milicia. Dada en Valladolid, a 26 de agosto de 1625, ante Francisco de Valcárcel, esscribano de Cámara.

Está aquí una cédula real para que el corregidor de Carrión no diezme soldados en Villamuera; es original. Año 1625.

22. <Testimonio de la jurisdición de Villamuera. Año 1627>.

Testimonio de la jurisdición y señorío que el monasterio de San Zoil tiene en la villa de Villamuera. Dado por Eugenio de Guzmán, esscribano de Villamuera, a 9 de marzo de 1627. $1627>$.

23. $<$ Emplazamiento de que los vecinos se subtraen de reconocer la jurisdición. Año

Provisión de emplazamiento y compulsa dada en la Chancillería de Valladolid, a pedimiento del concejo y vecinos de Villamuera, que se quejaron de que el licenciado Lezana, alcalde mayor de Villamuera, había nombrado un teniente suyo, vecino del dicho lugar, el qual pretendía preferir a los alcaldes ordinarios en detrimento suyo y pretendían no deber el yantar ni haberse de tomar la residencia. Dada en Valladolid, a 26 de enero de 1627, ante Martín Gallo de Montoya, esscribano de Cámara. Es copia de Pedro Moro de Solórzano, esscribano.

24. < Parecer que se pueda poner alcalde mayor. Año 1627>.

Parecer de los letrados de Valladolid en que concuerdan que se puede nombrar y poner alcalde mayor en Villamuera que sea vecino del mismo lugar. A 17 de mayo de 1627.

25. <Cédula real para que se registren los lugares y registro de Villamuera, sus privilegios y executorias. Año 1635>.

Copia de una cédula real y orden de Su Magestad, para que se registren los lugares y jurisdicciones que gozan particulares por tolerancia o permisión de Su Magestad, para venderlos. Dada en Madrid, a 14 de enero de 1635, ante Francisco Gómez de Lasprilla, secretario de Su Magestad. Y fee de cómo el convento registró el lugar de Villamuera y presentó los títulos de privilegios y cartas executorias que tiene y por dónde le pertenece. En Carrión a 22 de febrero de 1635, ante Gerónimo López, esscribano de Carrión. 
/ (f. 421r) 26. < Concordia contra el convento y Villamuera sobre los derechos que toca a cada parte. Año $1647^{655}>$.

Concordia hecha entre el monasterio de San Zoil y el concejo y vecinos de Villamuera, precediendo para ello la información de vtilidad y licencias necesarias, por la qual parece que el año de $1647^{656}$, considerando los muchos pleitos que entre unos y otros estaban pendientes sobre las cántaras de sernas, peones, martiniega, yantar y derecho que tiene el convento para nombrar alcaldes ordinarios, regidores y demás oficios de concejo, conforme se acostumbra, y a poner libremente alcalde mayor, esscribano y alguacil, etcétera, y otros derechos, se ajustaron y concordaron en la forma que contiene dicha concordia, la qual contiene 13 capítulos, en que asientan los derechos que toca a cada parte y cómo se han de guardar. Pasó ante Francisco Moro de Saldaña, esscribano de Carrión, a 26 de marzo del dicho año de $1647^{657}$ (valga 1647).

27. <Cláusula del libro becerro de Valladolid. Año 1644>.

Cláusula del libro Becerro de Valladolid de lo que tiene el monasterio de San Zoil en Villamuera, y cómo este lugar es del monasterio. Hecha año de 1644.

28. $<$ Desembargo de sernas, peones, martiniega, etcétera. Año 1708>.

Por dos decretos del señor rey don Felipe $5^{\circ}$, los años de 1706 y 707 nos embargaron en Villamuera los maravedís de los peones, los de la martiniega, los del yantar o varas, las cántaras de mosto, de sernas, la fanega de cebada para mulas, la cántara de vino para mozos, etcétera, con que fue preciso recurrir a Madrid, al Consejo de Hacienda, y Junta del Real Valimiento, donde se declaró que estos derechos no heran comprehendidos en dicho real valimiento con que se presentó una petición por parte del monasterio pidiendo el desembargo de todo, ante don Alonso Carrillo Salzido y Rol, corregidor de Carrión, el qual, con su asesor, dio auto de desembargo y mandamiento contra los de Villamuera que pagasen pena de 50 ducados. Ante Pedro Martínez Herrera, en 21 de marzo de 1708.

$29^{658}$. < Testimonio de una provisión real. Año 1769>.

Testimonio y compra de una provisión real gana por el concejo de Villamuera, que pretendía eximirse de hacer pago de los derechos y sernas a que está obligado, y otras peticiones. Dado por Gabriel de Ceano y Vivas, a 17 de marzo de 1769.

30. < Sentencia contra dos vecinos de Villamuera para que paguen el mosto de las sernas. Año 1758>.

Sentencia ganada en el adelantamiento de Campos a favor de este monasterio, y contra Santiago y Francisco Martínez, vecinos de Villamuera, para que pagasen las cántaras de mosto que debían por razón de sernas, a cuya paga se habían opuesto los dos. Año de 1758.

/ (f. 421v) $31^{659}$. <Testimonio de diligencias practicadas. Año 1756>.

Testimonio ${ }^{660}$ en relación de las diligencias practicadas por este monasterio contra el concejo de Villamuera para el pago de maravedís, mosto, gallinas, etcétera, atrasados y corrientes. Ante Martín Hizquierdo, esscribano de Carrión, año 1756.

32. < Provisión para que los de Villamuera paguen los atrasos. Año 1783>.

Provisión real por la qual se manda que los vecinos y lugar de Villamuera paguen a este monasterio las contribuciones a que por concordias están obligados. Dada en Valladolid, a 21 de agosto de 1783, ante Matheo Baquero, esscribano de cámara.

\footnotetext{
655 1647] corregido sobre: 1643.

656 1647] corregido sobre: 1643.

657 1647] corregido sobre: 1643.

658 29] al margen derecho: Nota: este número debe ser el 31.

659 31] al margen derecho: Nota: este número debe ser el 29.

${ }^{660}$ Testimonio] sigue tachado: y copia.
} 


\section{3. $<$ Papeles simples de Villamuera $>$.}

Bajo este número está un papel simple del pleito entre el monasterio de San Zoil y la justicia, concejo y vecinos de Villamuera y el fiscal de Su Magestad, sobre la nulidad o balidación de ciertas escrituras y concordias, etcétera; otro ygualmente simple de los derechos que percibe el monasterio en Villamuera por razón de señorío.

\section{Remisiones}

$<$ Concordia $>$.

Concordia hecha entre el abad de Cluni, San Zoil, San Román, San Ysidro de Dueñas con el obispo y cavildo de Palencia sobre las yglesias, etcétera. Cajón San Andrés, legajo 1, quaderno $\mathrm{B}$, número 3 .

\section{/ (f. 422r) Quaderno C del legajo $1^{\circ}$ \\ Villamuera}

Este quaderno C contiene los papeles pertenecientes a la hacienda que tiene el monasterio en este lugar, por el orden siguiente:

$1^{\circ}$. < Foro de tres viñas por 30 maravedís. Año 1405>.

Escritura de foro, escrita en pergamino, por la qual Juan Alfonso, prior de la clausura, y el convento de San Zoil dan a foro y censo perpetuo a Juan Sánchez, vecino de Villamuera, tres viñas en término de dicho lugar, con ciertas tierras que con ellas solían andar; las dos viñas a do dicen a los Fondos; y la otra, al Manzanillo, por precio de 30 maravedís de renta cada año, su plazo por Navidad. Fecha en San Zoil, a 22 de abril de 1405, ante Francisco Pérez, esscribano de Carrión.

$2^{\circ}$. <Donación de una bodega con su lagar, etcétera. Año 1437>.

Donación, escrita en pergamino, por la qual Juan Fernández del Palomar y Fernán Martínez de las Puertas, vecinos de Villamuera, como mansesores y testamentarios de Juana Sánchez la Roja, vecina del mismo lugar, difunta, hacen donación al convento de San Zoil de una bodega con su jaraíz, viga, piedra, lagar y una cuba, que todo es en Villamuera, que fue de la dicha Juana Sánchez, porque la encomienden a Dios y que cada año embíe el convento 4 monges a Villamuera la víspera de San Felipe y Santiago, y digan una vigilia cantada y el día siguiente misa cantada con responso por la dicha Juana Sánchez ${ }^{661}$. Fecha en 6 de agosto de 1437, ante Fernán García Pachistre, esscribano de Carrión.

\section{$3^{\circ}$. $<$ Venta de unas casas por el monasterio. Año 1537>.}

Venta de unas casas en Villamuera a favor de Antón de la Torre que otorgaron Pedro de la Merina y María, su muger, las quales cedió y traspasó dicho Antón de la Torre a este monasterio por ocho mil maravedís en que les había comprado. Su fecha, en San Zoil, a 3 de noviembre de 1537, ante Juan de Castrillo, esscribano de Carrión.

$$
4^{\circ} \text {. }<\text { Venta de una casa. Año 1538>. }
$$

Escritura de venta por la qual Cristóval Antón, vecino de Villamuera, vende al convento de San Zoil una casa en dicho lugar, por precio de cinco mil maravedís y dos cargas de trigo. Fecha en Villamuera, a 26 de octubre de 1538, ante Antonio Adame, esscribano de Villamuera.

\footnotetext{
${ }^{661}$ Juana Sánchez] al margen derecho: Aniversario.
} 
$5^{\circ} .<$ Venta de vna casa. Año 1550>.

Escritura de venta por la qual Juan Texedor, vecino de Villamuera, vende al monasterio vna casa en dicho lugar, por precio de 7 mill 700 maravedís. Fecha en Villamuera, a 13 de enero de 1550, ante el dicho esscribano.

\section{/ (f. 422v) $6^{\circ} .<$ Venta de dos casas en Villamuera. Año 1543>.}

Escritura de venta por la qual Juan Merino y Francisca, su muger, venden al monasterio de San Zoil dos casas con un pedazo de portal y otro de corral en Villamuera por precio de 100 reales. Fecha en Villamuera, a 29 de enero de 1543, ante Antonio de Adame, esscribano de dicho lugar.

\section{$7^{\circ}$. $<$ Donación y venta de una casa en Villamuera. Año 1543>.}

Escritura de donación de unas casas en Villamuera que otorgó Ysabel de Pedrosa a Antonio de Villamartín, vecino de Carrión, y de una viña y una tierra. Fecha en Villanueva del Rebollar, a 22 de octubre de 1543, ante Pedro García, esscribano. Este Villamartín vendió al monasterio la casa contenida en esta donación por precio de 2 mill 250 maravedís. A 25 de octubre de 1542, ante Juan de Castrillo, esscribano de Carrión.

$8^{\circ}$. $<$ Venta de una vina (sic). Año 1573>.

Escritura de venta por la qual Julián Antón y Catalina del Pozo, su muger, venden al monasterio una viña en término de Villamuera, a Herreruela, que hace seis quartas y media, por precio de 8 mill 454 maravedís. Fecha en Villamuera, a 26 de julio de 1573, ante Juan Bravo, esscribano de Villamuera.

9. < Venta de una viña. Año 1574>.

Escritura de venta por la qual Pedro Fernández, vecino de Villamuera, vende al convento de San Zoil una viña en término de Villamuera, a Carre Valdoquite, que hace cinco quartas, por precio de 6 mill 120 maravedís. Fecha en Villamuera, a 13 de hebrero de 1574, ante el mismo esscribano.

10. < Proceso y demanda de cierta hacienda en Villamuera y Raveros. Año 1575>.

Proceso por el qual parece que el convento de San Zoil puso demanda ante el doctor Almanza, corregidor de Carrión, al capitán Antonio Núñez de Alameda, vecino y regidor de Carrión, y a doña Ynés de Robles, su muger, porque, habiendo <vendido> al monasterio por el mes de octubre de 1573 cierta hacienda de viñas, casas, lagar, heriales, etcétera, en término de Villamuera y Riveros, que habían sido de doña Francisca de Sandoval y ${ }^{662}$ de Gutierre Pérez Calderón, difunto, por precio de 94 mill maravedís, cuyas escrituras están presentadas en este proceso; parece que antes que se otorgase esta venta estaban estos bienes executados a instancia del marqués de Aguilar, por requisitoria del licenciado Álvar García de Toledo, alcalde de corte de Su Magestad; y por sentencia de remate se remataron estos bienes, por mayo de 1574, con los frutos de ellos y se dio la posesión al marqués. Y pidió que el dicho capitán y su muger, cumpliendo las escrituras de venta, hicieren ciertos al monasterio los dichos bienes o que pagasen el valor de ellos y las mejoras que el monasterio había hecho en ellos; de que pidió execución. El capitán Alameda respondió que los 94 mill maravedís que el convento había dado por los bienes se habían depositado y con su consentimiento se habían / (f. 423r) pagado al marqués a cuenta de la deuda porque había executado; y sobre su execución estaba pleito pendiente y no sentenciado, con que el monasterio no estaba despojado de los bienes.

En 25 de enero de 1575, el corregidor dio auto en que manda al capitán y a su muger que, dentro de nueve días, asegurasen al convento las heredades que le habían vendido ante Andrés Sánchez, esscribano de Carrión, ante quien pasó este pleito y escrituras. De este auto apeló Alameda, presentose ante la Chancillería y trajo provisión de emplazamiento, dada en Valladolid, a 11 de hebrero de 1575, ante Gonzalo Alemán, esscribano de Cámara. El

${ }^{662}$ y] al margen: Riveros. 
convento, sin embargo, pidió ante el corregidor prosiguiese con la causa y diese mandamiento de execución. Respondió que sigan su justicia, que no era juez en esta causa.

El proceso fue a Valladolid y aquí no hubo más.

11. < Proceso compulsado en la misma razón que el de arriba. Año 1575>.

Proceso compulsado ante Andrés Sánchez, esscribano de Carrión, para llebarlo en grado de apelación a la Chancillería de Valladolid. Esta compulsa que es del mismo proceso de arriba se hizo en virtud de la provisión que arriba se menciona. Año de 1575, ante Gonzalo Alemán, esscribano de Cámara.

12. $<$ Venta de una tierra y una viña. Año 1578 $>$.

Escritura de venta por la qual Juan García y María Martín, su muger, vecinos de Carrión, venden al convento de San Zoil una tierra y una viña en término de Villamuera; la viña que llaman de la Cuesta, y la tierra linde de ella, por precio de 16 mill 000 maravedís. Fecha en Carrión, a 12 de febrero de 1578, ante Andrés Sánchez, esscribano de dicha villa.

13. $<$ Venta de un corral. Año 1607>.

Escritura de venta por la qual Juan Roldán e Ysabel de Caballos, vecinos de Villamuera, venden al convento un corral en dicha villa, por precio de 680 maravedís. Fecha en Villamuera, a $1^{\circ}$ de mayo de 1607, ante Santos de Guzmán, esscribano de dicha villa.

14. $<$ Venta de una viña. Año 1615>.

Escritura de venta por la qual Juan Roldán, vecino de Villamuera, vende al convento de San Zoil una viña de una quarta y un quartejón, en término de dicho lugar, a Carre Villaverde, por precio de 2 mill maravedís. Fecha en Villamuera, a 9 de junio de 1616, ante el mismo esscribano.

15. <Venta de una viña. Año 1622>.

Escritura de venta por la qual Juan Aparicio Mozo, vecino de Villamuera, en virtud del poder que tiene aquí inserto de Pedro Hernández, vecino de la ciudad de Baeza, vende al monasterio de San Zoil una viña a Carre Valdes, término de Villamuera, que hace quarta y media, poco más o menos, por precio de 36 reales $^{663}$. Fecha en Villamuera, a 20 de diciembre de 1622, ante Eugenio de Guzmán, esscribano de Villamuera.

/ (f. 423v) 16. <Venta de una viña. Año 1623>.

Escritura de venta por la qual Juan de Hacebes, vecino de Villamuera, vende al convento de San Zoil una viña en el pago de Villaverde, término de Villamuera, que hace tres quartas, poco más o menos, por precio de 165 reales. Fecha en Villamuera, a 2 de mayo de 1623, ante Eugenio de Guzmán, esscribano de Villamuera.

17. $<$ Venta de una viña. Año 1623 $>$.

Escritura de venta por la qual Matías Adame, mozo habitante en Villamuera, vende al convento de San Zoil una viña a Carre Valdequite, término de dicho lugar, que hace seis quartas, poco más o menos, por precio de 100 reales. Fecha en Villamuera, a 27 de marzo de 1623, ante el mismo esscribano.

18. <Venta de una cueba. Año 1624>.

Escritura de venta por la qual Juan Alcalde, vecino de Villamuera, vende al convento de San Zoil una cueba con lagar, rodillo, espadilla y una cuba de 115 cántaras en Villamuera, por precio de 22 mill maravedís. Fecha en Villamuera, a 19 de enero de 1624, ante Santos de Guzmán, esscribano de Villamuera.

19. < Venta de una viña. Año 1634>.

Escritura de venta por la qual Domingo Calvo e Ysabel Roldán, su muger, vecinos de Villamuera, venden al convento de San Zoil una viña a Carre Villaverde, término de

66336 reales] al margen derecho: 36 reales. 
Villamuera, que hace tres quartas, poco más o menos, por precio de diez ducados. Fecha en dicho lugar, a 30 de marzo de 1534, ante Eugenio de Guzmán, esscribano.

20. <Venta de una tierra y después viña. Año 1633 y 1651>.

Escritura de venta de una tierra que compró el padre fray Gregorio Caballero, en nombre del convento de San Zoil, a Pedro Alonso, vecino de Villamuera, que la trocó por una viña. Fecha en Villamuera, a 10 de marzo de 1633 y 1651, ante Santos de Guzmán, esscribano de Villamuera.

21. $<$ Venta de viñas y cuebas y trueque de viñas por otras desde el año de 1680 hasta el de $1702>$.

Bajo este número está un quaderno de escrituras de compras de tierras, viñas, cuebas y trueques de unas viñas por otras desde al año de 1680 hasta el de 1702 . Véase el índice que trae al principio y al último del dicho quaderno, en que hace relación de todo lo contenido en él y con distinción.

22. <Venta de 3 viñas, 3 tierras, una herrén, cueba y panera. Año 1709>.

Escritura de venta de tres viñas; la una de 3 quartas, la otra de 2 y la otra de 4 , y un herrén de 2 quartas; una tierra de una obrada, otra de tres, una cueba con su tejada y panera, que otorgaron Santiago Rodríguez y Sebastiana Fernández, su muger, vecinos de Villamuera, y en término de dicho lugar, para redimir un censo de 1.100 reales a favor del maestro Fonseca. Pasó ante Alonso López, esscribano de Villamuera, año de 1709.

$$
/(f .424 r) 23 .<\text { Venta de tierras y viñas para redimir un censo. Año 1746>. }
$$

Escritura de venta por la qual Miguel Prieto, vecino de Villamuera, vende al monasterio una casa, corral, bodega, tres tierras y tres viñas, en término de dicho lugar, con las quales redimió un censo de 294 reales y 4 maravedís que tenía a favor de este monasterio. Pasó la escritura ante José Revollar Pérez, escribano de Palencia, año 1746. Está aquí el censo.

\section{4. <Compra de 10 viñas, 5 tierras, etcétera. Año 1745>.}

Escritura de venta por la qual Manuel Pérez, vecino de Villamuera, vende al monasterio 10 viñas, una casa, dos cuebas y cinco tierras en término de dicho lugar, con las que redimió dos censos que contra sí tenía, los quales están aquí pegados. Pasó ante Gregorio Boto Prieto, esscribano del número de la ciudad de Palencia, año 1745.

25. $<$ Pronunciamiento sobre poder el monasterio demoler una casa suya propia en Villamuera. Año 1773>.

Auto dado por el licenciado don Felipe Antonio Radillo, alcalde mayor del adelantamiento de Campos, a favor de este monasterio y contra don Antonio de la Pisa, vecino de Villamuera, en el pleito que trahían sobre que al monasterio no se le pudiese impedir el demoler una casa que tenía suya propria en dicho lugar y aprovecharse de la madera, en que fue condenado el dicho Antonio de la Pisa. Dado a 9 de agosto de 1773, ante Santiago González Morante, esscribano ppúblico.

\section{6. $<$ Medida de tierras. Año 1790>.}

Medida de tierras hecha por Santiago Facón Cadenas, agrimensor aprovado, vecino de Villamuera, a instancia del padre fray Bartolomé Villafañe y fray Mauro Recalde, granero y mayordomo de este monasterio ${ }^{664}$, consistentes dichas tierras en término de dicho lugar y proprias de dicho monasterio. Año 1790.

\section{Remisiones}

Amojonamientos y ordenanzas, etcétera. Cajón San Yldefonso, legajo 3º número 13 y siguientes, título Villaverde.

\footnotetext{
${ }^{664}$ monasterio] al margen derecho: Nota: San Zoles. La veintena y otras.
} 


\section{/ (f. 424v) Legajo ${ }^{\circ}$ del Cajón San Mauro Villamuera}

Este legajo, que es el segundo del cajón San Mauro, contiene diez y seis quadernos pertenecientes todos a las residencias que se tomaban cada quadrienio a los alcaldes y ministros de justicia de Villamuera, por o[r]den de años, que empiezan desde el año de 1553 y concluyen el de 1737; aunque en medio de éstos faltan las de algunos años que, por descuido, no trageron al archivo. Después del año de 1737 no se bolvieron a tomar más residencias, no sé porqué, pero supongo desde luego que no tendría mucha cuenta al monasterio y acaso menos utilidad.

\section{/ (f. 425r) Legajo $3^{\circ}$ del Cajón San Mauro Villamuera}

Este legajo, que es el tercero del cajón San Mauro, <contiene> tres quadernos pertenecientes al lugar de Villamuera, por el orden siguiente: quaderno A: pleitos como criminales por los alcaldes de este lugar puestos por los abades de San Zoil; quaderno B: lo mismo; quaderno C: libros de qüentas.

Quaderno A del legajo $3^{\circ}$

Villamuera siguiente:

Este quaderno A contiene pleitos criminales por lo alcaldes de este lugar, por el orden

$1^{\circ}$. $<$ Concordia entre el monasterio y la villa toca en las jurisdiciones en razón de un preso de Villamuera. Año 1517>.

Concordia entre la villa y este monasterio en razón de haber un teniente de Carrión entrado en Villamuera y, rompiendo el cepo de la cárcel y sacado de él un preso que llevó a la cárcel de Carrión, el convento pidió por el juez conservador que se bolvi<es $>$ e el preso; no obedeció la justicia, puso entredicho y no le guardaron los clérigos, antes apelaron y traxeron comisión de Roma para que el provisor de Palencia conociese del caso de las censuras, como consta de los papeles que están entre los de las diferencias de esta casa con los clérigos de Carrión, cajón San Andrés, legajo $2^{\circ}$, quaderno B. Y, estando en este estado, se hizo esta concordia que toca en las jurisdiciones del Varrio ${ }^{665}$ y Villamuera. Y don Juan Rodríguez de Fonseca, arzobispo de Rosano y obispo de Burgos y administrador perpetuo de la abadía de San Zoil, no quiso pasar por la dicha concordia como consta de un protesto que hizo (que está aquî) originalmente. Hízose año de 1517 ante Juan Ponce, esscribano de Carrión.

$2^{\circ}$. $<$ Censuras contra los clérigos de Carrión porque no guardaron el entredicho del juez conservador. Año 1517>.

Mandamiento y censuras hasta anatema, fulminado por don Sebastián Valera, maest $[\mathrm{r}]$ eescuela de Palencia, provisor de León y juez conservador de este convento, contra todos los clérigos de Carrión porque no guardaron el entredicho de arriba que había / ( $f$. $425 v$ ) puesto el juez conservador contra las justicias y esscribanos de Carrión. Suplicaron al mismo juez y, sin embargo, les condenó en las censuras y las cien doblas de oro de pena por no haber obedecido sus mandatos ni los del provisor de Palencia, que les había mandado que obedeciesen y guardasen el entredicho. Esto fue sobre que no querían entregar el preso de Villamuera dicho atrás. Pasó año 1517, ante Gregorio de Ordas, nottario appostólico.

$3^{\circ}$. < Procesos actuados por los alcaldes mayores de Villamuera. Año 1640>.

Bajo este número hay tres procesos hechos y actuados en primera y segunda instancia en diversas causas, así civiles como criminales, por los alcaldes mayores de Villamuera

${ }^{665}$ Varrio] al margen derecho: Barrio de San Zoles. 
puestos por los (sic) abad de San Zoil; el primero es un memorial que pusieron los vasallos de Villamuera en la audiencia del adelantamiento de Campos contra la elección de alcaldes ordinarios que hizo el padre maestro fray Francisco de Lemos, abad de San Zoil, por Año Nuevo de 1640.

\section{/ (f. 425v) Quaderno B del legajo $3^{\circ}$ Villamuera}

$<$ Papeles criminales $>$.

Este quaderno B consta de papeles criminales en Villamuera por varias contiendas que los vecinos tubieron entre sí y por esto están todos juntos, los quales se trageron de dicho lugar y pueden servir para atestiguar el derecho y jurisdición que tiene el monasterio en este lugar.

\section{/ (f. 425v) Quaderno C del legajo $3^{\circ}$ Villamuera}

Este quaderno $\mathrm{C}$ son dos de cuentas del concejo ${ }^{666}$ :

$<$ Libro de cuentas desde el año de 1576 hasta 1587>.

El primero es un libro de las cuentas de los proprios del concejo de la villa de Villamuera tomadas a los mayordomos por los alcaldes y regidores de la dicha villa, y remitidas por ellos a los alcaldes mayores y jueces de residencia, puestos y nombrados por los abades del monasterio de San Zoil para que las reviesen y aprobasen con las aprovaciones de ellos, desde el año de 1576 hasta el de 1587.

$<$ El $2^{\circ}$ de 1598 hasta $1609>$.

El segundo libro es lo mismo, desde el año de 1598 hasta el de 1609.

\section{/ (f. 426r) Legajo $4^{\circ}$ del Cajón San Mauro Villamuera}

$<$ Propuestas para alcaldes, algunos nombramientos de éstos y de escrivanos de Villamuera desde el año de 1560 adelante>.

Este legajo, que es el $4^{\circ}$ del cajón San Mauro, consta de nombramientos de escrivanos de Villamuera y nombramientos de justicia, hechos por los abades de San Zoil, junto con las propuestas de alcaldes, regidores, etcétera, que enbían los vecinos de dicho lugar. Primero están los nombramientos y títulos de los esscribanos y después las propuestas de alcaldes y algunos títulos, por orden de años, desde el año de 1560 adelante.

\footnotetext{
${ }^{666}$ concejo] al margen derecho: Falta todo.
} 
/ (f. 427r) Cajón 17 San Bernardo

Este cajón, que es el diez y siete del archivo, contiene tres legajos pertenecientes a diversos lugares que son: legajo $1^{\circ}$ : Villaoliva, Villardefallaves, Villarmienzo o Villavermudo, Villarramiel, Villaserracino, Villasabariego y Villovieco, Villasirga, Villatoquite; legajo $2^{\circ}$ : Villaturde, Villavaruz; legajo $3^{\circ}$ : Villaumbrales, Villaverde de la Peña y Villavicencio.

\section{Legajo $1^{\circ}$}

Este legajo, que es el primero del cajón San Bernardo, contiene nuebe quadernos, que son los siguientes:

Quaderno A... Villaoliva

$$
\begin{aligned}
& \text { B... Villardefallaves } \\
& \text { C... Villarmienzo } \\
& \text { D... Villavermudo } \\
& \text { E... Villarramiel }
\end{aligned}
$$

\author{
F... Villaserracino \\ G... Villasabariego y Villovieco \\ H... Villasirga \\ Y... Villatoquite
}

\section{Quaderno A del legajo $1^{\circ}$ \\ Villaoliva}

Este quaderno A contiene los papeles pertenecientes a la hacienda que tiene San Román en este lugar, presentaciones y colaciones del beneficio de él, por el orden siguiente:

$1^{\circ}$. $<$ Donación de un solar. Era 1273. Año 1235>.

Este quaderno A contiene los papeles pertenecientes a la hacienda que tiene San Román en este lugar, presentaciones y colaciones del beneficio de él, por el orden siguiente:

Donación escrita en pergamino y partida por ABC, por la qual don Estevano, clérigo de Villaoliva, por su alma y de sus parientes, hace donación a la casa de San Román de un solar sobre la fuente mayor, con condición que así el dicho don Estevan / (f. 427v) como sus hijos y sus nietos que en el dicho solar vivieren, que den cada año en la fiesta de San Román dos sueldos, y, si hí acaecier, 3 sueldos por vesas (sic), cinco sueldos de caloña, si acaecier que den a la casa de San Román la quarta parte de quanto for fuero e mi compaña que fincar después de mí, los que quisieren que sean familiares de San Román. Y don Estevan después de sus días da su cuerpo a San Román, con su lecho, con su boy e una baca o una media vestia, lo mejor que yo oviero, con que no se pueda enagenar este solar; y don Pedro de Razas, prior de San Román, y el convento, monjes, capellanes, frailes, etcétera, otorgaron esta carta a 15 días de junio, era 1273, que es año 1235, regnante el rey don Fernando, con la reyna doña Beatriz, en Toledo, Castilla y León y Galicia; obispo en León, don Arnaldo; tenente castellum Santi Romani, don Rodrigo González; so su mano, don Fernán Gutiérrez.

$$
2^{\circ} \text {. <Aceptación de dos familiares. Era 1320. Año 1282>. }
$$

Escritura, escrita en pergamino, por la qual don Pedro de Toro, prior de San Román, admite por familiares a don Cristóval y su muger, María Aparicio, que les dé Dios parte en quanto bien se ficiere en la orden de Cluniego, y ellos prometen ser leales a San Román y al prior toda la vida y ofrecen sus cuerpos a San Román y hacen algunas mandas. Era 1320, que es año 1282.

$3^{\circ}$. <Trueque de un solar por un prado. Año 1789>.

Trueque hecho entre el padre fray Gregorio Calderón, prior de San Román, con Andrés de la Cuesta, vecino de Villaoliva, de un solar en dicho lugar proprio de dicho priorato, por un prado en término del mismo lugar. Su fecha, en Villaoliva, a 24 de febrero de 1789, ante Manuel Luis París, esscribano de Villanueva de Arriba.

$4^{\circ}$. <Trueque de un solar y huerto por un prado. Año 1789>.

Trueque que hizo el padre fray Gregorio Calderón, prior de San Román, con Francisco Marcos, vecino de Villaoliva, de un solar y huerto proprio de dicho priorato, por 
un prado, todo en término de dicho lugar. Su fecha, en Villaoliva, a 24 de febrero de 1789, ante el dicho esscribano.

5. < Trueque de un solar por un prado. Año 1789>.

Trueque que hizo el padre fray Gregorio Calderón, prior de San Román, con Matías de Liébana, vecino de Villaoliva, de un solar proprio de dicho priorato por un prado, todo en término de dicho lugar. Su fecha, en Villaoliva, digo en San Román, a 24 de febrero de 1789, ante el sobredicho esscribano.

$/(f .428 r) 6^{\circ} .<$ Trueque de dos solares por una tierra. Año 1797>.

Trueque que hizo el padre fray Pedro de Castro, prior de San Román, con Martín Mayordomo, vecino de Entorcisa ${ }^{667}$, de dos solares en el casco del dicho lugar proprio de dicho priorato, por una tierra en término de Villaoliva, que era del dicho Martín. Su fecha, en Guardo, a 12 de abril de 1797, ante Rafael de Medina Maudes, esscribano de esta villa.

$7^{\circ}$. $<$ Trueque de un solar por una tierra. Año 1797>.

Trueque que hizo el padre fray Pedro de Castro, prior de San Román, con Tomás Martín, vecino de Villaoliva, de un solar proprio de dicho priorato, por una tierra que tenía dicho Thomás, todo en término de dicho lugar de Villaoliva. Su fecha, en Guardo, a 12 de abril de 1797, ante el mismo esscribano.

\section{$8^{\circ}$. < Colación en Diego de Herrera. Año 1522>.}

Colación del beneficio curado de la yglesia de Santiago de Villaoliva, por la qual consta que, habiéndose tratado pleito, de la una parte Diego de Herrera, clérigo presentado al dicho beneficio por fray Juan Román, prior de San Román; y de la otra, el concejo y vecinos de Villaoliva, y que, habiéndose dada (sic) y fijado en dicho lugar carta de edicto, y visto cómo el procurador del concejo no puso, diciendo ser padronero del dicho beneficio, y visto cómo ellos desistieron de la oposición, y cómo dijeron y confesaron no lo ser, según pareció por testimonio signado de esscribano público y todo lo demás, etcétera; Luis Alonso Moxino, arcipreste del Páramo, provisor de León, pronunció sentencia, por la qual falló, vistos los autos del proceso y escritos en él presentados, que debía de hacer e hizo colación, provisión y canónica institución del dicho beneficio al dicho Diego de Herrera, presvítero, a presentación del dicho fray Juan Román, prior de San Román, etcétera, y mandó a los vecinos del dicho lugar que le tubiesen por tal rector y cura; y en virtud de la otra sentencia le hizo colación en forma. Fecha en León, a 15 de abril de 1522, ante Juan de Quiros, nottario.

9. < Presentación en Sebastián de Villalpando. Año 1545>.

Traslado autorizado de una escritura de presentación que hizo fray Juan de Santa María, abad de San Zoil, por fin y muerte del bachiller Alonso Argadero, en Sebastián de Villalpando, clérigo de la diócesis de Palencia, para el beneficio curado de Santiago de Villaoliva. Fecha en San Zoil, a 2 de diciembre de 1545, ante Juan de Castrillo, esscribano y nottario de Carrión. León.

$\mathrm{Y}$ da fee y testimonio signado Juan de Herreras, esscribano y nottario de la ciudad de

/ (f. 428v) 10. <Colación a Sebastián de Villalpando. Año 1545>.

Colación del beneficio curado de Santiago de Villaoliva que dio el licenciado Luis Sánchez de Aguero, provisor de León, a Sebastián de Villalpando, clérigo de la diócesis de Palencia, en virtud de la presentación de atrás que le dio fray Juan de Santa María, abad de San Zoil. Fecha en León, a 7 de diciembre de 1545, ante Juan de Herreras, nottario.

\section{1. <Presentación en Juan Merino. Año 1555>.}

Presentación del beneficio curado de Santiago de Villaoliva que hizo fray Rodrigo de Corcuera, abad de San Zoil, en Juan Merino, clérigo, vecino del lugar de Baños, que estaba

${ }^{667}$ Entorcisa] al margen derecho: Entorcisa. 
vaco por resignación de Juan de los Ríos, cura del dicho lugar. Fecha en San Zoil, a 2 de abril de 1555. No está autorizado.

Ay un instrumento por el qual el dicho Juan Merino hace juramento de no resignar ni disponer del dicho beneficio sin licencia y permiso del abad de San Zoil, hecho el mismo día.

12. <Presentación en Alonso González. Año 1559>.

Presentación que hizo fray Lorenzo de Modoya, prior de San Román, del beneficio de Santiago de Villaoliva que resignó el doctor Antonio López, provisor de Salamanca, rector que era del dicho curato, cuya resignación admitió el dicho prior de San Román e hizo presentación del dicho beneficio en Alonso González, clérigo, presvítero, vecino de Villaoliva. Fecha en San Román, a 3 de enero de 1559, ante Juan Gutiérrez, nottario.

13. <Colación a Alonso González. Año 1559>.

Colación que hizo don García de la Bandera, provisor de León, del beneficio curado de Santiago de Villaoliva, en Alonso González, clérigo, presvítero, vecino de este lugar, en virtud de la resignación simple que de él hizo el doctor Antonio López, su último rector, y por la presentación que como patrón hizo fray Lorenzo de Modoya, prior de San Román. Fecha en León, a 22 de agosto de 1559, ante Pedro de Villasco, nottario.

Es traslado del original y no está autorizado.

14. < Testimonio de las colaciones de este beneficio. Año 1619>.

Testimonio dado por Francisco Moro de Saldaña, esscribano de Carrión, de las colaciones del beneficio de Santiago de Villaoliva que hay en el archivo de San Zoil, año 1619.

15. $<$ Presentaciones y colaciones $>$.

Bajo este número están varias presentaciones y colaciones del beneficio curado de la yglesia de Santiago de Villaoliva, desde al año 1647 hasta el de 1775.

16. < Concordia sobre el yantar. Año 1745>.

Concordia entre el prior de San Román y el cura de Villaoliva en razón del yantar que pertenece al priorato, por razón de patronazgo, el día de Santiago Apóstol en cada año. Hecha en San Román, a 8 de octubre de 1745.

\section{/ (f. 429r) Remisiones}

$<$ Donación $>$.

Donación del rey don Fernando el Santo de la yglesia de Santiago de Villaoliva. Véase el cajón San Juan, legajo $3^{\circ}$, quaderno B, número $1^{\circ}$.

$<$ Donación $>$.

Donación de unos prados en Villaoliva que hizo don Guijelmo y su muger. Véase el cajón San Felices, legajo $3^{\circ}$, quaderno C, número $6^{\circ}$.

$<$ Trueque $>$.

Trueque de dos tierras en Villaoliva. Cajón San Plácido, legajo $5^{\circ}$, quaderno E, número $21^{\circ}$.

$<$ Colación $>$.

Colación de la yglesia de Villaoliva. Cajón San Gregorio, legajo 2ª quaderno Y, número $5^{\circ}$.

$<$ Trueque $>$. número $3^{\circ}$.

Trueque entre San Zoil y San Román. Cajón San Martín, legajo $1^{\circ}$, quaderno B, 


\section{/ (f. 429v) Quaderno B del legajo $1^{\circ}$ \\ Villardefallaves}

Este quaderno B contiene las escrituras pertenecientes a la hacienda que tiene este monasterio en dicho lugar, por el orden siguiente:

$1^{\circ} .<$ Quaderno de escrituras a favor de este monasterio hechas en los años de 1582 y $1583>$.

Bajo este número está un quaderno de todas las escrituras de venta a favor de este monasterio, las quales contienen la hacienda y heredades que compró el monasterio en Villardefallaves, en Campos. Estas heredades las compró esta casa con el dinero que dio la villa de Carrión al monasterio por la jurisdición del barrio de San Zoles, por los años de 1582 y 1583, en que se hicieron dichas escrituras ante Juan Blanco, escrivano de Villardefallaves.

\section{$2^{\circ}$. $<$ Memoria de las ventas de arriba $>$.}

Memorial de todas las ventas, tierras y herrenales puestas en el quaderno de arriba, entre las quales tierras y herrenes se componen de treinta piezas compradas, las quales montaron 239 mill 202 maravedís, que hacen 7 mill 045 reales y 12 maravedís que por ellas pagó el monasterio. Está firmado este memorial por Andrés Sánchez, esscribano de Carrión.

\section{Remisiones}

$<$ Compra $>$.

Compra de una tierra en término de este lugar. Véase el cajón San Plácido, legajo $4^{\circ}$, quaderno $\mathrm{A}$, número $4^{\circ}$.

\section{/ (f. 430r $)$ Quaderno C del legajo $1^{\circ}$ \\ Villarmienzo}

Este quaderno $\mathrm{C}$ contiene los papeles pertenecientes a la jurisdición y derecho que tiene el monasterio a la presentación del beneficio curado de este lugar y pleitos que ha tenido, por el orden siguiente:

\section{$1^{\circ}$. <Colación del beneficio en Pedro García. Año 1478>.}

Trasumpto simple de una colación original, escrita en pergamino, que se sacó del archivo de San Zoil y se presentó en León, año 1619, en el oficio de Victorio Vázquez para un pleito, por la qual consta que, estando vaco el beneficio curado y el beneficio simple servidero a él anexo en la yglesia de San Miguel de Villarmienzo, por simple renunciación que de ellos hizo Juan García, cura de dicho lugar, último poseedor, y por presentación del convento de San Zoil fecho ante don Suero de Quiñones, arcediano de Saldaña, a quien pertenecía la canónica institución cada y quando que vacase y presentare el dicho convento, como vúnico y verdadero patrón y presentero; el dicho arcediano hace colación ${ }^{668}$ de los dichos beneficios a Pedro García, clérigo de Retuerto, y mandó se le acuda con los frutos y rentas de ellos, y porque los dichos beneficios curado y simple servidero son pobres, de suerte que cada uno no puede un clérigo tener congrua sustentación, de consentimiento y presentación del dicho convento, patrón verdadero cada y quando los dichos beneficios vacaren, le une y anexa los dichos beneficios en uno para que anden unidos. Fecha en Saldaña, a 10 de septiembre de 1478, ante Fernando García, nottario.

\footnotetext{
${ }^{668}$ colación] al margen derecho: Esta colación está inserta a la letra en la executoria de adelante número $4^{\circ}$.
} 

$1595>$.

$2^{\circ}$. <Asiento del libro becerro de Valladolid que Villarmienzo es de San Zoil. Año

Asiento de cómo el lugar de Villarmienzo es del monasterio de San Zoil, sacado del libro becerro de la Chancillería de Valladolid, por mandado de su acuerdo, a 28 de noviembre de 1595, de que da fee Martín Ruiz de Mitarte, chanciller, en cuyo poder estaba el dicho libro Becerro.

$3^{\circ}$. <Proceso sobre con el obispo de León y su fiscal. Año 1619 y 1620>.

Proceso sobre el pleito con el señor obispo de León y su fiscal sobre la presentación del beneficio curado de San Miguel de Villarmienzo, con algunas noticias antiguas tocantes a los derechos de esta casa. Véase al princi[pi]o dél la relación de su contenido desde el año de 1619 hasta el de 1620. Ante Francisco Moro de Saldaña (pasó este pleito), esscribano de Carrión.

/ (f. 430v) $4^{\circ}$. <Carta executoria contra el obispo y fiscal de León sobre la presentación del beneficio de Villarmienzo. Año 1620>.

Carta executoria en favor del abad y convento de San Zoil, dada por don Andrés Rodríguez, abad de Benavivere, prior de Mañino y comisario del Santo Oficio, otrosí juez appostólico en virtud de un breve y comisión del nuncio de Su Santidad contra el obispo y fiscal de León sobre la presentación del beneficio curado de San Miguel de Villarmienzo, por la qual parece que, en 9 de julio de 1618, fray Miguel de Castro, abad de San Zoil, hizo presentación para el dicho beneficio de Villarmienzo en Juan Fernández, clérigo de Carrión, por fin y muerte de Francisco Pérez de Velasco, último poseedor y cura del dicho beneficio. Y el dicho Juan Fernández hizo su oposición ante el provisor de León y se pusieron edictos; en cuya virtud se opusieron al dicho beneficio Gaspar Pérez, clérigo de menores órdenes, natural de San Martín del Obispo, y Diego Pérez de Sahabedra, su procurador, en su nombre. Juan Fernández hizo y presentó su información y con ella otros instrumentos y escrituras, y entre ellas el original de la colación de atrás, número $1^{\circ}$, sacada del archivo de San Zoil, que está aquí compulsada a la letra. En 20 de septiembre de 1618 el dicho Gaspar Pérez se apartó y fue dado por apartado de la oposición que había hecho, por entender que el beneficio era de presentación y no de concurso como él había pensado quando hizo la oposición.

\section{$<$ Sentencia del provisor $>$.}

Y, siendo conclusa la causa y examinado y aprovado el dicho Juan Fernández, el doctor Palacios, provisor de León, en 27 de octubre de 1618, pronunció sentencia difinitiva, por la qual declara el dicho beneficio de Villarmienzo ser libre, colativo y pertenecer su colación las veces que vacare a Su Santidad en sus meses y al obispo de León en los suyos. Y, por haber vacado esta vez en el mes de junio, que es de los meses del obispo, y haber sólo parecido el dicho Juan Fernández, etcétera, le debe hacer título y colación del dicho beneficio como libre colativo y no en otra forma; y mandó en virtud de esta sentencia librar título y colación en favor del dicho Juan Fernández, de lo qual por parte del convento fue apelado en tiempo y en forma y el provisor admitió la apelación. El convento se presentó en grado de apelación y dijo de agravios ante el nuncio; el qual, en Madrid, a 27 de julio de 1619, dio su breve de comisión para que el abad de Benavivere o prior de Escalada o qualquiera de los juezes sinodales de Palencia conociesen de esta causa; y con él fue requerido el dicho abad de Benavivere que aceptó la comisión y en virtud de ella dio letras ordinarias de citación y compulsoria, con que fue requerido en León Victorio Vázquez, nottario de la causa, para que diese y dio un tanto autorizado del pleito; y fue citado para que viniese en seguimiento de la causa del licenciado Pira de la Vega, fiscal general del obispado de León, y se notificó la inhibitoria / $(f .431 r)$ al licenciado don Diego Rubín de Celis, canónigo y provisor de León, y la obedeció y se inhivió del conocimiento de la causa. El convento, traído el proceso ante el abad de Benavivere, dijo y alegó agravios contra la sentencia del provisor de León y contra lo alegado en el proceso por los contrarios, cuya petición de agravios y fundamentos de la justicia del monasterio está aquí inserto a la letra, y pidió ser amparado y restituido por el remedio posesorio en la posesión de presentar el dicho beneficio como único y verdadero patrón, sólo insolidum de él; y que se revoque la sentencia y colación dadas por el ordinario de León con lo procedido y la posesión del dicho Juan Fernández y que así anulado y 
revocado, se declare deberse hacer y se haga título y colación del dicho beneficio de presentación del convento y se dé con efecto la posesión dél y en ella le ampare y defienda; y para todo conceda inhibición in totum para el provisor de León.

$<$ Testimonio de dos presentaciones (digo colaciones) hechas por presentación del convento. Año 1561>.

Presentó asimismo el convento un testimonio dado por Juan de Villafañe de Villavalter, nottario en León, a 16 de septiembre de 1561, en que da fee que ante el prior Bandera, provisor de León, y ante él como esscribano pende pleito entre Hernando de Lorenzana, clérigo de León, y el doctor Francisco Truxillo, canónigo de León, sobre el beneficio curado de San Miguel de Villarmienzo, en el qual fueron presentadas por el dicho Hernando de Lorenzana dos colaciones del dicho beneficio hechas, una en favor de Miguel de Poza y otra a favor de Alonso de Lobera, curas, que en virtud de estas colaciones fueron del dicho beneficio de presentación, de las quales consta haber hecho y colado el dicho beneficio de presentación del presidente y convento de San Zoil, como verdaderos patronos y presenteros de él; las presentaciones y colaciones quedaron en poder del dicho notario.

$<$ Sentencia del abad de Benavívere. Año 1620>.

De todo lo qual se dio traslado al fiscal y inhivición in totum para que el provisor de León se inhiviese in totum del conocimiento de la causa, la qual se notifico al doctor Palacios de la Cruz, provisor; y por no haber parecido el fiscal, se notificaron los autos en los estrados y se le acusaron las reveldías. Y conclusa la causa para difinitiva y citadas para ella las partes en $1^{\circ}$ de julio de 1620, el dicho abad de Benavivere, habiendo visto los autos con acuerdo de asesor, dio y pronunció sentencia difinitiva, por la qual declara el dicho provisor en su sentencia haber juzgado mal, por tanto la revoca y anula y da por ninguno todo lo en virtud de ella hecho, y declara al abad y convento de San Zoil por verdaderos patronos sólo e insolidum del dicho beneficio curado de San Miguel de Villarmienzo, y como tales haber podido presentar y presentado en él al licenciado Juan Fernández, y declara debérsele hacer nuebo título y colación del beneficio dicho, y ampara y siendo necesario restituye al abad y convento en el derecho, y posesión, de presentar el dicho beneficio como verdadero patrono, / (f. 431v) único, solo e insolidum dél; y anula el título y colación por el provisor dada en la forma en ella contenida, y la posesión en virtud de ella dada al licenciado Juan Fernández, etcétera; y condenan en costas al fiscal.

\section{$<$ El fiscal acepta la sentencia del abad de Benavívere $>$.}

Dio el dicho juez appostólico mandamiento, inserta la dicha sentencia, para que se notifique al obispo de León, a su provisor y fiscal y al dicho Juan Fernández, clérigo. Y habiendo Pedro Álvarez, esscribano de León, notificado al fiscal, en León, a 12 de agosto de 1620, respondió que había visto el mandamiento, sentencia, pleito y autos causados en primera y segunda instancia y los había consultado con el licenciado don Fernando de Valdeflores, y con el doctor Francisco de Collantes, abogado, y habiéndose enterado de la justicia que tiene el convento de San Zoil en esta causa y justificación de ella, consentía la dicha sentencia y está presto de pasar por ella como en ella se contiene.

$<$ Colación del juez apostólico en Juan Fernández. Año 1620>.

En Benavívere, a 12 de octubre de 1620, el dicho juez appostólico, a instancia de la parte del convento, dio auto en que, atento del consentimiento del fiscal, declaró su sentencia por consentida y pasada en cosa juzgada y la mandó executar; y en su cumplimiento pareció ante él Juan Fernández y le dio nuebo título y colación del beneficio de San Miguel de Villarmienzo, y mandó se le diese posesión; y mandó despachar para ello letras en forma. Y se despachó título y colación, inserta la dicha sentencia del juez appostólico, y haciendo relación de todo lo dicho, como consta de la colación que está aquí inserta a la letra, que fue dada a 2 de noviembre de 1620, ante Francisco Moro de Saldaña, esscribano de Carrión. Y en virtud de esta colación Juan Fernández tomó la posesión del dicho beneficio en Villarmienzo, a 8 de noviembre de 1620, ante Marcos de la Vega, nottario appostólico y vecino de Saldaña. Y en cumplimiento y execución de todo lo dicho, el dicho abad de Benavivere, juez appostólico, mandó dar y dio esta carta executoria, que fue hecha en el 
monasterio de Nuestra Señora y abadía de Benevivere, a 20 de diciembre de 1620, ante Francisco Moro de Saldaña, esscribano de Carrión.

$5^{\circ}$. $<$ Memoria del pleito de la presentación del beneficio $>$.

Memoriales y advertencias en el pleito de la presentación del beneficio de Villarmienzo que trató el convento con el fiscal y obispo de León, de que se tiene la carta executoria de arriba.

$6^{\circ} .<$ Nombramiento de merino. Año 1625>.

Nombramiento de merino de Villarmienzo hecho por el padre fray Juan Cortés, abad de San Zoil, en Santiago Juáñez, vecino de este lugar, en 15 de noviembre de 1625, ante Francisco Moro de Saldaña, esscribano de Carrión. $1672>$

$7^{\circ}$. $<$ Requirimiento y declaración sobre una bula de resignación o permuta. Año

Requirimiento hecho por parte del monasterio al licenciado Juan Fernández, cura de Villarmienzo, puesto por el abad de San Zoil, para que declare las bulas de resignación o permuta que había ganado con relación siniestra en perjuicio de esta casa, siendo vicaría vnida y que no vse (de ellas)/ (f. 432r) de ellas. Pidiose por testimonio y se le requirió con él ante Gaspar Lasso, esscribano de Carrión, a 11 de mayo de 1672; a lo qual dio por respuesta cómo había ganado la bula y que confesaba todo lo contenido en el requirimiento pero que no quería pleito quanto es de su parte.

8 . <Presentación de la vicaría de Villarmienzo en Francisco Gutiérrez. Año 1672>.

Presentación de la vicaría de San Miguel de Villarmienzo hecha por el maestro fray Juan González, abad de San Zoil, en el licenciado don Francisco Gutiérrez, natural de la villa de Saldaña, ante fray Francisco de Molina, nottario appostólico, en 15 de junio de 1672, en virtud de la qual se le despachó título de colación por el ordinario de León. Tomó posesión; año de 1709 la estaba gozando.

9. < Testimonio en relación del pleito del curato contra el arcediano de Saldaña y la sentencia que se dio. Año 1714>.

Presentación que hizo el abad de San Zoil en el licenciado don Manuel Díez Bargas por muerte del licenciado Francisco Gutiérrez, que murió en enero de 1712. Siguiose el pleito contra el arcediano de Saldaña en el oficio de Blas de la Llama, nottario mayor en aquella audiencia, y fue condenado por esta vez el convento, quien pretendía pertenecerle en todo tiempo; y así en este número se pone un testimonio en relación de dicho pleito con la sentencia en él pronunciada, signado de Francisco de Valcarce, nottario y vecino de León, en 4 de abril de 1714 .

10. $<$ Papeles sobre el pleito del beneficio $>$.

Bajo este número están varios papeles de consultas y pareceres pertenecientes al beneficio de San Miguel de Villarmienzo y jurisdición en diferentes años.

$<$ Asiento del becerro de la yglesia de León>.

En el archivo de Sahagún hay un traslado antiguo de más de 700 años del libro de Becerro viejo de la yglesia de León, de todas las yglesias y pilas del obispado, en el qual, al folio 32 vuelta, dice así:

En Villarmienzo: San Miguel, de el camarero de Carrión, da tercia a Reglas, et las duas a los clérigos, sacados dos dezmeros del rey, et en procuración 12 sueldos et un carnero, tres sueldos menos dos dineros, et dan tres maravedís en padronazgo. 


\section{Remisiones}

Papeles sobre el señorío de este lugar. Véase el cajón San Lorenzo, legajo $1^{\circ}$, quaderno $\mathrm{C}$, número $5^{\circ}, 6^{\circ}, 9^{\circ}, 10,11,14$ y 18 .

\section{/ (f. 432v) Quaderno D del Legajo $1^{\circ}$ \\ Villavermudo}

Este quaderno D contiene los papeles pertenecientes a la hacienda que tiene Nuestra Señora del Brezo en este lugar por el orden siguiente:

1. <Posesión que tomó Francisco de Colmenares, canónigo de León, de las heredades ${ }^{669}$ y tierras de Villa[ve]rmudo. Año 1531>.

Mandamiento de la justicia de Herrera y posesión que tomó, con consentimiento de las partes, Francisco Colmenares, canónigo de León, de ciertas posesiones y heredades que estaban hipotecadas a un censo perpetuo de media carga de trigo cada año que estaba obligado a pagarle Hernán Cantero, vecino de Villa[ve]rmudo; y de otras heredades ypotecadas a otro censo perpetuo de una carga de trigo cada año, que tenía obligación a pagar Alonso Martín, vecino de dicho lugar, los quales habían caído en incomiso por no haber pagado el dicho censo dos años, e hicieron cesión de las dichas heredades y consintieron se tomase esta posesión de ellas, a 18 de febrero de 1531, ante García de Lombraña, escribano de Herrera.

$2^{\circ}$. <Donación de las posesiones de Villa[ve]rmudo. Año 1607>.

Donación que hizo doña Juana Enrríquez de la Vega a la casa de Nuestra Señora del Brezo de las heredades que ella y su sobrino don Pedro Enrríquez tenían en Villa[ve]rmudo, junto a Herrera, consintiendo en ello el dicho don Pedro, con carga de decir cada año ${ }^{670}$ unas vísperas y misa cantada con diácono y subdiácono, día de Santa Ana en cada un año. Hay información y deslindamiento de estas heredades y la posesión que tomó de ellas el padre prior del Brezo, a 24 de noviembre de 1613, ante Miguel Lozano, escribano de Herrera. Hízose la manda a 12 de agosto de 1607, ante Diego de Treceño, escribano y vecino de Congosto.

Hay aquí un memorial de las tierras que tiene la casa del Brezo en este lugar y Santervás según parece dél.

\section{/ (f.433r) Quaderno E del legajo $1^{\circ}$ \\ Villarramiel}

Este quaderno $\mathrm{E}$ contiene los papeles pertenecientes a la hacienda que tiene el monasterio en este lugar, por el orden siguiente:

$1^{\circ} .<$ Trueque de una tierra. Año 1406>.

Escritura de trueque, escrita en pergamino, por la qual don Rodrigo, limosnero mayor de San Zoil, da en trueque a los clérigos de San Miguel de Villarramiel un suelo junto a la yglesia de San Miguel, con licencia de don Fernando, prior mayor de San Zoil; y los clérigos, con licencia del arcediano, le dan una tierra en término de dicho lugar. Fecha en Villarramiel, a 26 de agosto de 1406, ante Alfonso García, nottario appostólico.

\footnotetext{
${ }^{669}$ heredades] sigue tachado: de.

${ }^{670}$ año] al margen derecho: misa cantada y vísperas.
} 


\section{Remisiones}

$<$ Donación $>$.

Donación de la hacienda de este lugar que hizo al monasterio doña Mayor García. Véase el cajón Santa María, legajo $1^{\circ}$, quaderno A, número $2^{\circ}$.

$<$ Trueque $>$.

Trueque de heredades. Cajón San Plácido, legajo 5º quaderno G, número $3^{\circ}$.

\section{/ (f. 433v) Quaderno F del legajo ${ }^{\circ}$ \\ Villaserracino}

Este quaderno $\mathrm{F}$ contiene los papeles pertenecientes a la hacienda que tiene el monasterio en este lugar, por el orden siguiente:

$1^{\text {o. }}<$ Memoria de heredades $>$.

Apeo, escrito en pergamino, de las heredades que el monasterio de San Zoil tenía en el lugar de Villaserracino; es muy antiguo, no está autorizado ni tiene fecha; sólo puede servir de memoria de aquella hacienda, si bien confusa.

$2^{\circ}$. $<$ Vita de tierras para viñas. Era 1321. Año 1283>.

Escritura de vita, escrita en pergamino, por la qual don Gui, prior de San Zoil y camarero de Cluni, da a Pedro Martínez, vecino de Villaserracino, dos tierras en término de este lugar para que las plante y crie de viñas y las goze por sus días, y después de ellos que dé la mitad para la sacristía de San Zoil y la otra a sus herederos. Fecha a 12 días de febrero, era 1321, que es año de 1283, ante Juan Ferrán, esscribano de Carrión.

\section{Remisiones}

$<$ Donación $>$.

Donación que hizo doña Mencía Ruiz de la hacienda que tenía en este lugar. Véase el cajón San Agapio, legajo $1^{\circ}$, quaderno A, número $4^{\circ}$.

\section{/ (f. 434r) Quaderno G del legajo $1^{\circ}$}

Villasabariego y Villovieco siguiente:

Este quaderno $G$ contiene dos escrituras pertenecientes a estos lugares, por el orden

$1^{\circ} .<$ Venta de un huerto. Era 1119. Año 1081>.

Escritura de venta, escrita en pergamino, de letra gótica, por la qual Bermudo y su muger, Sol, venden a Muriel y doña Justa, su muger, un huerto por nueve sueldos de plata en Villavieja (que ahora es Villovieco), junto a Villasausariego. Facta carta era 1119, que es año 1081, reynando en Castilla y León el rey don Alonso el $6^{\circ}$; y el conde don Pedro Ansures, (conde), en Santa María de Carrión, que esta villa se llamaba entonces la ciudad de Santa María. 
$2^{\circ}$. < Carta de adopción. Era 1134. Año 1096>.

Escritura de adopción, escrita en pergamino, por la qual Flamo ${ }^{671}$, freiro, deja a su hermano Ciaz, pa<ra $>$ que haga oficio de padre de sus hijos, y sea honrra de su muger, Benita, hasta que él buelva del Santo Sepulcro, lo qual otorga con acuerdo de su muger y del concejo de Villasabariego. Era 1134, año 1096.

\section{Remisiones}

$<$ Trueque $>$.

Trueque entre don Hugo, prior, y el conde don Pedro Ansúrez en que da al convento lo que tenía la vieja en Villovieco de Sabariego. Véase el cajón San Plácido, legajo 5º, quaderno $\mathrm{B}$, número $1^{\circ}$.

\section{/ (f. 434v) Quaderno H del legajo $1^{\circ}$ Villasirga}

Este quaderno $\mathrm{H}$ contiene los papeles pertenecientes a la hacienda que tiene el monasterio en este lugar, por el orden siguiente:

$1^{\circ}$. $<$ Venta de un solar y hacienda. Era 1108. Año 1070>.

Escritura de venta, escrita en pergamino, con letra gótica, por la qual parece que la condesa doña Justa vende a Cide Morelez y su muger, María, un solar y hacienda en Villasirga, la qual había sido de Bermudo Bermúdez, y dio por esta hacienda un caballo castaño y ciertos sueldos de plata. Esta condesa doña Justa dice que era hija de Fernando. Facta cartula donacionis idus julias (sic), era 1108, que es año 1070.

$2^{\circ}$. <Foro perpetuo de 102 maravedís sobre una tierra. Año 1496>.

Escritura de foro perpetuo por la qual el convento de San Zoil, con poder de don Luis Hurtado de Mendoza, administrador perpetuo, da a foro perpetuo a Juan de Palacios, Alonso de Villarmienzo y Alonso Requena, vecinos de Villasirga, una tierra en término de este lugar, por precio de ciento y dos maravedís $<$ y dos gallinas $>$ de renta cada año. Fecha en San Zoil, a 27 de enero de 1496, ante Diego de San Zoles, clérigo de Carrión, nottario appostólico.

$<$ Con algunos reconocimientos dél $>$. de 1646.

Están pegados a este foro varios reconocimientos de él y una execución, hecha año

$3^{\circ}$. <Trueque de una tierra. Año 1523>.

Escritura de trueque por la qual fray Juan de Amayuelas, presidente de San Zoil, da en trueque a Antonio López, clérigo de Villasirga, una tierra de media obrada en término de este lugar, por otra media obrada en el mismo término. Fecha en San Zoil, a 4 de febrero de 1523, ante Floristán de la Serna, esscribano de Carrión.

$4^{\circ}$. <Trueque de heredades. Año 1580>.

Escritura de trueque, por la qual el convento da a Pedro López, vecino de Villasirga, quatro (digo tres) tierras y una heria en término de dicho lugar, por dos tierras que dio el dicho Pedro en el mismo término. Su fecha, en San Zoil, a 3 de febrero de 1580, ante Andrés Sanches, esscribano de Carrión.

${ }^{671}$ Flamo] siguen tachadas letras ilegibles. 


\section{/ (f. 435r) Remisiones}

$<$ Concordia $>$.

Concordia entre el obispo y cavildo de Palencia y este monasterio. Véase el cajón San Andrés, legajo $1^{\circ}$, quaderno $\mathrm{B}$, número $3^{\circ}$.

\section{/ (f. 435r) Quaderno I del legajo $1^{\circ}$ \\ Villatoquite}

Este quaderno I contiene los papeles pertenecientes a la hacienda que tiene el monasterio en este lugar, por el orden siguiente:

$1^{\circ}$. <Adjudicación de 3 tierras por los réditos y un censo. Año 1723>.

Adjudicación de tres tierras y una viña, en término de Villatoquite, para este monasterio en el concurso que se hizo o formó a los bienes de Francisco Nicolás, vecino de $<$ este $>$ lugar, a que este monasterio fue acreedor por un censo de mil reales de principal y 162 reales de réditos devengados. Pasó la escritura ante Rafael Roldán, esscribano y vecino de Villaleón, a 14 de diciembre de 1723; y la copia de la escritura, año 1724.

$2^{\circ}$. $<$ Medida de heredades. Año 1752 $>$.

Medida de $<$ las $>$ heredades que hay en Villatoquite; fueron apeadores Santiago Garrido y Santiago Regaliza, nombrados por la Real Hacienda, año de 1752.

\section{/ (f. 435v) Legajo $2^{\circ}$ del Cajón San Bernardo}

Este legajo, que es el segundo del cajón San Bernardo, contiene tres quadernos: los dos pertenecientes a Villaturde y el otro a Villavaruz, que son: quaderno A: curato y diezmos; quaderno B: hacienda; quaderno C: hacienda de Villavaruz.

Quaderno A del legajo $2^{\circ}$

\section{Villaturde}

Este quaderno A contiene los papeles pertenecientes al beneficio y diezmos de la yglesia de este lugar, por el orden siguiente:

$1^{\circ}$. <Sentencia arbitraria sobre los diezmos de Villaturde. Año 1433>.

Sentencia arbitraria dada por don Luis, limosnero mayor de San Zoil, y el bachiller Diego Álvarez de Carrión, juezes compromisarios árbitros en un pleito que hubo en razón de los diezmos de Villaturde, los quales pretendían el prior mayor de San Zoil y su convento pertenecer a su yglesia parroquial de Santa María de Villaturde, y el abad y convento de Sahagún y el prior de Nogal pretendían pertenecer a su yglesia parroquial de San Miguel del dicho lugar. Haviéndose comprometido esta causa en los dichos jueces, y habiendo visto las informaciones, escrituras y alegatos de ambas partes, los dichos jueces dieron sentencia, por la qual declaran estar provado ser la yglesia de San Miguel de Villaturde del monasterio de Sahagún y la parroquial de Santa María ser del monasterio de San Zoil; y que los vasallos de Sahagún que viven en Villaturde, parroquianos de San Miguel, que labran heredades del honor de Nogal, deben diezmar todo el diezmo al monasterio de Nogal del pan que cogieren en las tales heredades, y del pan que cogieren en otras heredades que no sean del honor de Nogal deben pagar la mitad a la yglesia de Santa María y al convento de San Zoil, y la otra mitad a la yglesia de San Miguel y al prior de Nogal. Y que los vasallos de San Zoil que vivieren en Villaturde, de las heredades que labraren del monasterio paguen todo el diezmo enteramente a la yglesia de Santa María y al convento de San Zoil. Y mandan que ambas las 
partes guarden / (f. 436r) este orden en coger los diezmos sin que la una perturbe a la otra. Dada en Carrión, a 5 de noviembre de 1433, ante Alfonso Fernández de Revenga, esscribano.

Hay un original y un traslado autoriza[do] por Juan de Castrillo, y de ambos copia autorizada por don Antonio Martín García, traductor.

$2^{\circ}$. <Colación del beneficio de Santa María en ${ }^{672}$ Alonso Gutiérrez. Año 1500>.

Colación ${ }^{673}$ del beneficio presviteral y curado de Santa María de Villaturde, que vacó por muerte de Pedro de Lomas, y por presentación de Sebastián de Rivera, sacristán mayor de San Zoil, se dio esta colación a Alonso Gutiérrez Gascón, capellán de don Luis Hurtado de Mendoza, administrador perpetuo de San Zoil. Diola el bachiller Justo de San Sebastián, provisor de Palencia, a 26 de agosto de 1500 años. Tomose la posesión quieta y pacíficamente.

\section{$3^{\circ}$. < Colación en García del Cubo. Año 1515>.}

Colación dada por Diego de Santander, canónigo de Palencia, sustituto de provisor, a García del Cubo, por resignación que hizo del beneficio Alonso Gutiérrez Gascón, el qual, con licencia y consentimiento de don Juan Rodríguez de Fonseca, obispo de Burgos y administrador de San Zoil, hizo la resignación y permutó este beneficio por una cappellanía en Nuestra Señora del Castillo en Saldaña, que tenía el dicho García del Cubo. Tomose la posesión quieta y pacíficamente en 25 de mayo de 1515, ante Rodrigo de Paz, esscribano de Palencia.

\section{$4^{\circ}$. < Colación en Pedro Martínez Landecho. Año 1529>.}

Colación del beneficio, dada en virtud de la presentación del presidente y convento de San Zoil como patrón y presentero, la qual dio el licenciado Bartolomé Sánchez de Tórtoles, provisor de Palencia, a Pedro Martínez de Landecho, fiscal de Palencia, presentado por el convento, por fin y muerte de García del Cubo, último poseedor. Fecha en 10 de mayo de 1529, ante Francisco Fernández, nottario.

\section{$5^{\circ}$. < Colación en el bachiller Juan Pérez. Año 1609>.}

Colación del beneficio de Santa María de Villaturde, por la qual parece que vacó por fin y muerte del bachiller Julián Ortiz, último poseedor; y estando vaco, el abad de San Zoil hizo presentación para él en el bachiller Juan Pérez, clérigo de Carrión; y se admitió la presentación y se pusieron edictos; y en el término de ellos, se opusieron el licenciado Santiago Pando, Francisco Catalán, el bachiller Francisco Martínez y el licenciado Juan Gregorio; y salió el fiscal por la dignidad episcopal, pretendiendo ser el beneficio de libre colación del obispo y no de presentación del abad. Salió el convento a la causa y las partes alegaron de su justicia, y hechas informaciones y presentadas escrituras, y hecha publicación de testigos, y dada la causa por conclusa, el licenciado Manuel García de Miranda, provisor de Palencia, en 12 de mayo de 1609, / (f. 436v) dio y pronunció sentencia difinitiva, por la qual declaró que el convento de San Zoil provó en el petitorio su intención por donde consumió y absolvió el posesorio de la dignidad episcopal, por cuya parte se provó su intención quanto a la posesión que tenía de proveher y colar en concurso el dicho beneficio; y atento que ambas partes habían deducido en este juicio el derecho que tenían, así en el posesorio como en el petitorio, declaró el fiscal en nombre de la dignidad episcopal quanto al petitorio y propiedad del (del) derecho de la elección de cura no haver provado su intención. Por lo que y en conseqüencia de ello, haciendo justicia, declaró al abad de San Zoil por verdadero presentero y al dicho bachiller Juan Pérez por bien presentado; y le mandó parecer a examen, y siendo aprovado le mandó dar y dio colación de él. Que fue fecha en Palencia, a 11 de mayo de 1609, ante Lucas Gallardo, nottario. Y tomó posesión quieta y pacíficamente, en 21 de dicho mes y año.

$$
6^{\circ} \text {. < Colación en Matías Melendro. Año 1615>. }
$$

\footnotetext{
672 en] sigue tachado: Pedro.

${ }^{673}$ Colación] al margen derecho: Está aquí junto la presentación hecha por Sebastián, limosnero.
} 
Colación dada por el provisor de Palencia al bachiller Matías Melendro, en virtud de presentación del abad de San Zoil, por fin y muerte del bachiller Juan Pérez. Dada en Palencia, a 5 de octubre de 1615, ante Juan de Noriega, nottario; y tomó la posesión quieta y pacíficamente ante Pablo de Aedo, esscribano de Villasirga, en 19 de dicho mes y año.

$$
7^{\circ} \text {. < Colación en el licenciado Pedro Pérez. Año 1618>. }
$$

Colación dada por el licenciado Antonio (Antonio) Ramírez, provisor de Palencia, al licenciado Pedro Pérez, en virtud de presentación del abad de San Zoil, por dejación que hizo el bachiller Matías Meléndez del beneficio de Villaturde. Dada en Palencia, a 4 de julio de 1618, ante Baltasar de Bergara; y tomó la posesión a 22 del dicho mes y año, que se la dio el bachiller Pedro Padillo, nottario.

\section{$8^{\circ}$. $<$ Mandamiento posesorio del beneficio de Villaturde. Año 1648>.}

Mandamiento de posesión del curato de Santa María de Villaturde, dado por el licenciado Matías Santos de San Pedro, provisor de León y juez appostólico por comisión de Su Santidad, a petición del licenciado José Pérez, quien por muerte del cura que era, lo impetró por Roma sacando bulas; las quales están aquí juntas con el dicho mandamiento. Dado en León, a 30 de enero de 1648. Dio la posesión el licenciado José ${ }^{674}$ Gómez, cura de Villanueva de los Navos, ante Santiago Conde, nottario, en 3 de febrero del dicho año.

/ (f. 437r) 9. <Presentación y colación del beneficio de Villaturde en el licenciado Francisco Fernández de Mier y dejación de él. Año 1663>.

Presentación del abad de San Zoil en el licenciado Francisco Fernández de Mier, por fin y muerte del licenciado José Pérez. Pusiéronse los edictos, salió el fiscal en nombre de la dignidad; siguiose la causa y, conclusa, despachó título de colación a favor del presentado el licenciado don Luis Díaz de León, provisor de Palencia, en 20 de marzo de 1663, ante Lázaro de Montoya. Y en 30 de mayo del mismo año el dicho Francisco Fernández renunció en manos del abad el dicho curato de Villaturde, por testimonio de Norverto de Sandoval y Guevara.

10. $<$ Presentación y colación en don Juan de Risova y sentencia contra patrimoniales. Año 1663>.

Presentación del curato de Villaturde hecha por el abad de San Zoil en don Juan Manso Santos de Risova, por renunciación que de él hizo el licenciado Francisco Fernández de Mier. Puestos los edictos, salieron el concejo y vecinos de dicho lugar pretendiendo tocar a patrimoniales; siguiose la causa alegando ambas partes de su derecho y se dio sentencia a favor del monasterio, amparándole en la posesión sin limitación alguna, como consta de su copia que está aquí cosida; y de la colación dada por el licenciado don Luis Díaz de León, provisor de Palencia, en 7 de diciembre de 1663, ante Lázaro de Montoya, con la cual requirió al licenciado Fernando García, cura de Santa María de Carrión, y le dio la posesión quieta y pacíficamente ante Norverto de Sandoval y Guevara, en 9 de diciembre de 1663, con que consta no tener razón los vecinos para alegar patrimonio.

\section{1. < Presentación y colación en don Álvaro García Tuñón. Año 1687>.}

Presentación del curato de Santa María de Villaturde hecha por el padre maestro fray Francisco Turceta, abad de San Zoil, por fin y muerte de don Juan Alonso Risova, en don Álvaro García Tuñón. Y colación dada sin contradición alguna por don Gaspar de Quincoces, privisor (sic)de Palencia, en 21 de junio de 1687, ante Lucas Díez Paniagua, en virtud de la qual le fue a dar y dio la posesión el licenciado José Rojo Sánchez, cura de Villotilla, ante Norberto de Sandoval y Guevara, en 29 del mismo mes y año.

\section{2. < Presentación y colación en don Pedro Merino. Año 1691>.}

Presentación y colación hecha por el padre maestro fray Diego de Fonseca, abad de San Zoil, del curato de Villaturde, por dejación que de él hizo don Álvaro García, el qual pasó a ser cura de Aviñante, en el licenciado Pedro Merino. Fue dada la dicha colación por el yllustrísimo señor don Alonso Laurencio de Pedraza, obispo de Palencia, en 3 de abril de

\footnotetext{
${ }^{674}$ José] sigue tachado: Gallego.
} 
1691, ante Lucas Díez Paniagua; y tomó posesión quieta y pacíficamente en 7 de abril del mismo año. $1713>$.

/ (f. 437v) 13. <Presentaciones y colaciones hechas por los años de 1707, 1710 y

Presentación y colación del curato de Santa María de Villaturde, hecha por el padre maestro fray Jacinto Díez, abad de San Zoil, en don Lorenzo García de Miranda, por muerte del licenciado Pedro Merino. Para lo qual despachó dicha colación el yllustrísimo señor don Alonso Laurencio de Pedraza, obispo de Palencia, en 11 de julio de 1707, ante don Francisco Alonso, nottario.

Hay aquí otros dos títulos del curato de Villaturde presentados por el abad de San Zoil, uno a favor de don Domingo Fernández de Orbexal, año de 1710, y el otro a favor de don Gregorio Gozón, año 1713.

14. < Presentación y colación en don Ygnacio Manganes. Año 1729>.

Título y colación hecha en don Ygnacio Manganes por el padre maestro fray Jacinto Díez, abad de San Zoil, por renuncia que hizo don Gregorio Gozón del curato de Villaturde, año de 1729.

15. < Presentación y colación en don Juan Antonio de los Ríos y sentencia sobre los patrimoniales contra Villaturde. Año 1758>.

Presentación y colación del curato de Villaturde hecha por el padre maestro fray Yldefonso de Mier en don Antonio González de los Ríos. En esta ocasión repitió el concejo de Villaturde el pleito de que el dicho curato se debía presentar en patrimoniales. Recurrió el monasterio a Palencia, alegando sus derechos, y dio el provisor sentencia a favor del monasterio, año 1758.

16. < Presentación en don Dámaso Martín. Año 1796>.

Presentación y colación del curato de Santa María de Villaturde hecha por el padre maestro fray Leandro Pérez, abad de San Zoil, y propuesta del señor obispo en don Dámaso Martín, año de 1796.

17. <Presentación y colación en don Pablo del Valle. Año 1809>.

Presentación, título y colación del curato de Santa María de Villaturde en don Pablo del Valle, por presentación que en él hizo el padre maestro fray Plácido Emelgo, abad de San Zoil, habiendo renunciado dicho curato don Antolín Gutiérrez Carretero, su último poseedor, en uno de los quatro meses ordinarios; por lo qual se despachó la colación en 11 de junio de 1809. Está junta la posesión que tomó quieta y pacíficamente ante Ysidoro Ruiz de Colmenares, esscribano de Carrión.

\section{Remisiones}

$<$ Concordia $>$.

Concordia entre el obispo y cavildo de Palencia y los monasterios, etcétera, sobre diezmos y presentaciones de beneficios. Cajón San Andrés, legajo $1^{\circ}$, quaderno B, número $3^{\circ}$.

\section{/ (f. 438r) Quaderno B del legajo $2^{\circ}$ Villaturde}

Este quaderno B contiene los papeles pertenecientes a la hacienda que tiene el monasterio en este lugar, por el orden siguiente: 
$1^{\circ} .<$ Trueque de una tierra por otra. Era 1263. Año 1225>.

Escritura de trueque, escrita en pergamino y partida por $\mathrm{ABC}$, por la qual don García, sacristán de San Zoil, da en trueque con licencia de don Juan, camarero y prior de este monasterio, al señor Castellano de Villaturde una tierra en término de este lugar por otra en el mismo, junto al camino que va a Calzada, y linda con tierra del prior de Nogal; y el sacristán da 2 maravedís por la mejora de la tierra que recive. Fecha en el mes de enero, era 1263, que es año de 1225.

\section{$2^{\circ}$. <Sentencia árbitra contra Mayor Sánchez ${ }^{675}$. Era 1357. Año 1319>.}

Sentencia árbitra dada por Fernán Ruiz y Miguel Ximénez, jueces árbitros, de un pleito entre don Gui, sacristán mayor de San Zoil, y Mayor Sánchez, vecina de Villaturde, los quales, en reveldía de ésta, dieron sentencia, por la qual adjudican al sacristán y mandan se le dé posesión de las tierras, viñas, casas, prados y otros bienes que contenía la demanda, y por lo que había dejado de pagar; y por los menoscabos mandan se le den ocho mil maravedís a diez dineros novenes el maravedí. Dada en Palencia, a 11 de mayo, era 1357, que es año 1319, ante Alfonso Ruiz, nottario appostólico.

Está escrita en pergamino.

$3^{\circ}$. $<$ Dejación de un préstamo de la casa. Era 1389. Año 1351>.

Escritura de dejación, escrita en pergamino, por la qual Fernán Álvarez deja y renuncia una casa con su préstamo que tenía en Villaturde en manos de don Pedro, sacristán mayor de San Zoil. Fue fecha en Carrión, a 24 de febrero de la era de 1389, que es año 1351, ante Pedro García, esscribano ppúblico.

$4^{\circ}$. <Sentencia de un préstamo contra Fernán Álvarez. Era 1410. Año 1372>.

Sentencia difinitiva dada por Fernán González (escrita en pergamino), alcalde ordinario en Carrión, por su señor el conde, a instancia de don Pedro, sacristán mayor de San Zoil, contra Fernán Álvarez, vecino de Villaturde, que se alzaba con un préstamo del monasterio; y por esta sentencia se le manda que le debuelva y desembaraze, condénale en las costas y le pone silencio. Están aquí declaradas y deslindadas las heredades de este préstamo. Fecha en Carrión, a 14 de julio, era 1410, que es año 1372, ante Pedro García, esscribano.

/ (f. $438 v) 5^{\circ}$. $<$ Foro perpetuo de vn solar herrén y dos tierras por una carga de trigo, dos capones y 20 maravedís. Año 1522>.

Bajo este número están tres escrituras de censo y foro perpetuo, las dos primeras están escritas en pergamino, estas no rigen; la otra, en papel, que es la que govierna, las quales son de un mismo foro. Por esta escritura parece que fray Juan de Amayuelas, presidente, y el convento de San Zoil, precediendo los tres tratados de la ley, dan a fuero perpetuo a Torivio Muñoz, vecino de Villaturde, unas casas con su corral, un huerto o herrén cercado de tapias en dicho lugar, lindero casa y corral, del hospital de don Gonzalo (que es la Herrada); y asimismo dos tierras, la una junto con <el> hastial de la yglesia de Santa María, de una obrada; y la otra de dos obradas, al Pradillo, todo en término de dicho lugar; y todo por una carga de trigo, dos capones y 20 maravedís de renta cada año. Fue fecha en San Zoil, a 27 de febrero de 1522, ante Floristán de la Serna, esscribano de Carrión.

6. < Aniversario de tres misas rezadas por Paula de Poza>

Aniversario de tres misas rezadas que ha de decir el padre maestro de novicios por Paula de Poza, en los días del tránsito de nuestro padre San Benito, día de San Zoil, de la Asumpción de Nuestra Señora y en sus altares. Su limosna, cinco reales por cada una que pagan de foro perpetuo sobre una tierra y un huerto José Porro y Manuela de Yllera, su muger, vecinos de Villaturde. Los papeles pertenecientes a la perpetuidad de estas misas, véase al principio de este instrumento, que está apuntado.

675 Sánchez] sigue tachado: Año. 
$7^{\circ} \cdot($ sic $)$.

\section{Remisiones}

Medida de tierras. Cajón San Plácido, legajo 5º quaderno B, número 11.

\section{/ (f. 439r) Quaderno C del legajo $2^{\circ}$}

Este quaderno $\mathrm{C}$ contiene los papeles pertenecientes a la hacienda que tiene el monasterio en este lugar, por el orden siguiente:

$1^{\circ} .<$ Carta executoria de 18 cargas de pan mediado y 9 gallinas. Año 1592>.

Carta executoria ganada a favor de este monasterio de San Zoil en la Chancillería de Valladolid, por la qual parece que a 10 de octubre de 1589, ante el presidente y oydores de Valladolid, puso demanda el convento al concejo de Villavaruz de Campos por 18 cargas de pan mediado y 9 gallinas vivas que estaba en costumbre inmemorial de cobrar y haber del dicho concejo, menos una carga de todo pan que se quedaba para el concejo por el cuidado de cobrar y recoger para el convento la dicha cantidad. Pidió justicia y manutención en la dicha posesión, o caso de despojo restitución, por haber dos años que se habían substrahído de pagar como solían, que pagasen lo que habían dejado de pagar, y se les mandase que pagasen de allí adelante, etcétera, siendo abad fray Antonio de Perroto. Diose emplazamiento y se notificó al concejo, el qual dio poder y se presentó por su procurador en la Chancillería, respondió y puso sus excepciones.

$<$ Sentencia de vista. Año de 1591>.

Reciviose la causa a prueba y las partes hicieron sus informaciones y las presentaron con otras escrituras; y, concluso y visto el pleito, en 21 de noviembre de 1591 se dio sentencia por la qual el convento fue amparado en la posesión de llevar del concejo de Villavaruz las diez y ocho cargas de pan mediado y nueve gallinas cada año, menos una carga, como dije arriba, y que el concejo no inquietase al monasterio en dicha posesión, so pena de 50 mill maravedís; y reservaron al concejo su derecho a salvo para que, en razón de la propriedad, siguiese su justicia, etcétera. Suplicaron ambas partes de esta sentencia, el concejo alegó en forma y se ofreció a probar, y recivido el pleito a prueba. La parte del convento alegó, consintió la sentencia en lo favorable y, en quanto no se había mandado que el concejo pagare lo que había dejado de pagar de los años pasados, suplicaba, y pidió cumplimiento de justicia quanto a esto, y que en lo demás se confirmase la sentencia dada.

$<$ Sentencia de revista. Año 1592>.

Replicó el concejo y la causa fue dada por conclusa y vista; a 20 de octubre de 1592 se dio sentencia difinitiva en revista, por la qual se confirmó la sentencia primera de vista, y se mandó que el con/ (f. 439v) (con)cejo pagase al monasterio lo que le hubiese dejado de pagar del pan y gallinas de los años pasados, tomando el convento en qüenta lo que de ello pareciese haber recivido. El convento pidió carta executoria y se le dio esta, fecha en Valladolid, a 4 de noviembre de 1592, ante Andrés de Frizar, esscribano de Cámara.

Requiriose con executoria al concejo y vecinos de Villavaruz de parte del convento, en 30 de marzo de 1593, ante Bartolomé Lozano, esscribano de Cuenca de Campos; y respondieron que la oýan y pidieron traslado de las sentencias. Este es traslado autorizado por Francisco Moro de Saldaña, esscribano de Carrión.

$2^{\circ}$. $<$ Executoria sobre 18 cargas de pan y 9 gallinas. Año 1695>.

Carta executoria ganada a favor de este monasterio de San Zoil en la Chancillería de Valladolid contra el concejo, justicia y regimiento de Villavaruz y el señor Almirante, sobre pagar diez y ocho cargas de pan mediado, trigo y cebada y nueve gallinas en cada un año. 
Dada en la Chancillería de Valladolid, a 9 de abril de 1695, ante Claudio Pita de Andrade y Montenegro, esscribano de Cámara.

$3^{\circ}$. <Testimonio de importe de las rentas. Año 1698>.

Testimonio dado por Santiago Cocho Paredes, de lo que importaron las rentas de las tierras, heras y prados de Villavaruz, en el concurso que hicieron de acreedores. Año 1698. gallinas $>$.

$4^{\circ}$. <Cuentas y otras diligencias que se practicaron sobre las 18 cargas de trigo y 9

Bajo este número está un borrón que se hizo para hacer la cuenta que dio el padre fray Anselmo Morán, de las rentas que cobró del concurso de Villavaruz; y se le tomaron por la justicia ordinaria. Está firmado por José Recio Ramos a 1º de diciembre de 1711.

Asimismo una razón de las diligencias que se practicaron con el concejo de Villavaruz sobre la carta executoria para el pago de las 18 cargas de trigo y 9 gallinas; y el concurso que hicieron los acreedores.

$5^{\circ}$. <Copias de despachos y libramientos. Año 1709>.

Copias de un despacho que dio el conde de la Estrella para la administración de los bienes concursados de Villavaruz, sus órdenes y libramientos para dicha administración, según se ve al principio de este instrumento, año 1709.

6. $<$ Cuentas. Año 1715>.

Cuentas que dio el padre prior de Aguilar, en virtud de despacho al administrador de los estados del Almirante del tiempo que dicho prior administró los bienes concusados de Villavaruz, año de 1715. $1797>$.

$/(f .440 r) 7^{\circ} .<$ Despacho y otros papeles para cobrar el pan y gallinas. Años $1719 \mathrm{y}$ de 1797.

Despacho de la yntendencia de Valladolid para que se paguen las gallinas, librado año

Y juntamente un traslado del libramiento que se debe sacar cada año en Madrid para cobrar el pan y gallinas de Villavaruz. Fecho en Madrid, año de 1719, con otras cartas.

\section{Remisiones}

$<$ Concordia $>$

Concordia entre el obispo de Palencia y este monasterio, etcétera, por la qual convienen en que este monasterio tenga la presentación del beneficio de San Martín de los Caballeros en Villavaruz y la $3^{\text {a }}$ pontifical, conque dé al obispo dos carneros y dos cargas de cebada de foro perpetuo. El monasterio no percibe hace muchos años los diezmos ni goza la presentación, sin embargo de esta concordia; y no se guardó por falta de curiosidad, o más digo de diligencia, en apuntar quando se pierde o gana un derecho. Véase el cajón San Andrés, legajo $1^{\circ}$, quaderno $\mathrm{B}$, número $3^{\circ}$.

\section{/ (f. 440v) Legajo $3^{\circ}$ del Cajón San Bernardo}

Este legajo, que es el tercero del cajón San Bernardo, contiene los (los) quatro quadernos siguientes: quaderno A: Villaumbrales; quaderno B: Villaverde de la Peña; quaderno C: Villavicencio; quaderno D: Villotilla.

Quaderno A del legajo $3^{\circ}$

Villaumbrales

Este quaderno A contiene los papeles pertenecientes a la hacienda que tiene el monasterio en este lugar, por el orden siguiente: 
$1^{\circ}$. $<$ Foro perpetuo de una tierra por 10 maravedís. Año 1417>.

Escritura de foro, escrita en pergamino, por la qual García Fernández, sacristán mayor de San Zoil, da a censo y foro perpetuo a Juan Martínez Cadón, vecino de Villaumbrales, una tierra de la sacristía a Vallejo, término de dicho lugar, por diez maravedís de renta cada año. Fecha en San Zoil, a 11 de diciembre de 1417, ante Fernán Rodríguez de Castellanos, esscribano de Carrión.

$2^{\circ}$. $<$ Execución de un censo y posesión que se tomó de hipotecas. Año 1638>

Proceso executivo contra Melchor García, Juan Díez y consortes de mancomún, etcétera. Executó este monasterio por los réditos de un censo de 12.600 reales que habían tomado los sobredichos arriba vecinos de Villaumbrales, y tomó poesesión el monasterio de hipotecas, año 1638, ante Alonso Remolino, esscribano de dicha villa. Parece faltan algunas ojas de dicha posesión, y la casa hace muchos años parece no goza toda la hacienda, ni aún la décima parte, sin constar la razón porqué. Pasó este proceso ante Juan Rodríguez, esscribano de Villaumbrales, a 20 de septiembre de 1614. La execución se puso año 1637.

$3^{\circ}$. < Licencia para vender los bienes de que se había tomado posesión. Año 1654>.

Petición del abad y padres del consejo al reverendísimo General, hecha año de 1654, para vender ciertas casas de que el monasterio tenía tomada posesión en Villaumbrales, Becerril $^{676}$ y otros lugares, el qual dio facultad para hacer información de vtilidad. Y, aprovándola, el maestro fray Plácido del Río dava su licencia para venderlas y emplear el dinero en haciendas raíz. Y aunque consta de la información y aprovación, falta razón de lo vendido que con efecto se executó.

/ (f. $341 r) 4^{\circ} .<$ Compra de 3 viñas con las que redimieron parte de un censo. Año $1706 \mathrm{y}$ $1671>$.

Escritura de venta de tres viñas en término de Villaumbrales, otorgada por Alonso Calvo y Catalina Calvo, hermanos, vecinos de Grijota, con las que redimieron la parte del censo de mancomunados que contra sí tenían. Para la seguridad de dicha venta entregaron otra venta hecha a su favor de las mismas viñas. Pasó ésta ante Andrés de la Torre, a 3 de febrero de 1671; y la otra ante Antonio de Palacios, esscribano de Grijota, a 26 de octubre de 1706.

\section{Remisiones}

$<$ Compra $>$.

Compra de tierras que hizo este monasterio para redimir 3 censos $^{677}$ en este lugar. Véase el cajón San Lorenzo, legajo $1^{\circ}$, quaderno D, número $2^{\circ}$.

$$
\text { Villavelasco }{ }^{678}
$$

Los papeles del término que disfrutan y pagan los vecinos de este lugar. Véase el cajón San Felices, legajo $3^{\circ}$, quaderno D, título Santa Cruz de Ventosilla.

\section{/ (f. 441v) Quaderno B del legajo $3^{\circ}$}

Villaverde de la Peña

Este quaderno B contiene los papeles pertenecientes a la hacienda que tiene San Román en este lugar, por el orden siguiente:

\footnotetext{
${ }^{676}$ Becerril] al margen derecho: Becerril.

677 censos] sigue tachado: 3 .

${ }^{678}$ Villavelasco] al margen derecho: Nota.
} 
$1^{\circ}$. <Donación de un préstamo de Osorio Ýñiguez. Era 1173. Año 1134>.

Donación ${ }^{679}$ que hizo a San Román Osorio Ýñiguez, con su noble muger, Guntroda Gonzálvez, por remedio de sus almas y de su hijo don Rodrigo, de un solar con su divisa y préstamo en Villaverde, en el término de San Román, según que le compraron de doña Juliana. Facta carta 3 nonas januarii, era 1172, que es año 1134.

$2^{\circ}$. $<$ Compra de dos prados. Era 1233. Año 1195>.

Escritura de venta, escrita en pergamino, por la qual María Martínez y su marido ,Alfonso Juan, venden a Martín, frayle de San Román, un prado en Villaverde de Golpejera (que parece que es este Villaverde de aquî), que fue del exido; y otro prado en Verrendillos, en seis maravedís. Facta carta era 1233, que es año 1195.

$3^{\circ}$. <Préstamo de Juan González. Año 1527>.

Memoria de un préstamo que dio fray Diego de Sahagún, prior de San Román, a Juan González de la Cuesta, vecino de Villaverde, año 1527.

$4^{\text {o. }}<$ Trueque de un suelo. Año 1450>.

Trueque de un solar o suelo que trocó Diego González, clérigo, cura de Aviñante, con Alfonso Fernández, monge de San Román. Fecho en Ríosmenudos, a 4 de julio de 1450, ante Juan Fernández de Ríosmenudos, esscribano de Palencia.

Hay copia autorizada por don Antonio Martín García, traductor.

$5^{\circ}$. $<$ Presentación del beneficio. Año 1525>.

Pres[en]tación del beneficio de Santa María de Villaverde, hecha en Alonso Delgado, clérigo, por fray Diego de Sahagún, presidente de San Zoil, año de 1525.

Está aquí una memoria de unas tierras que mandaron a Nuestra Señora del Brezo Alonso y Pedro de Villacorta, en Villaverde. No tiene autoridad ni claridad este papel. Año 1570. $1640>$.

$6^{\circ} .<$ Carta executoria de los bienes de un préstamo ypotecado a un censo. Año

Carta executoria ganada en la Chancillería de Valladolid a favor de San Román y contra la obra pía de misa de alva, situada en la yglesia de San Pedro de Saldaña, sobre haber ypotecado a un censo de dicha obra pía los bienes del préstamo que gozó Pasqual de la Cuesta, proprios de dicho/ (f.442r) priorato. Pasó ante Martín Gallo, esscribano de Cámara de Su Magestad; ganose y notificose a la parte, año de 1640.

$7^{\circ}$. <Compra de una tierra. Año 1765>.

Escritura de venta otorgada por Gregorio de Villacorta, vecino de Villaverde de la Peña, a favor de este monaterio, de una tierra en término de dicho lugar. Pasó ante Martín Yzquierdo, esscribano de Carrión, a 27 de mayo de 1765.

$8^{\circ} .<$ Compra de 4 tierras. Año 1765>.

Escritura de venta otorgada por Manuel de Villacorta, vecino de Villaverde de la Peña, a favor de este monasterio, de 4 tierras: la una en término de Velilla de Tarilonte ${ }^{680}$, a las Vegas, y las otras tres en término de Villaverde. Pasó ante José Luis de Cantoral, esscribano de Villanueva de Muñeca, a 10 de mayo de 1765.

\section{Remisiones}

$<$ Donación $>$.

Donación de un prado para San Román. Cajón San Juan, legajo $3^{\circ}$, quaderno A, número $2^{\circ}$. Ydem número $4^{\circ}$ y 16 . Ydem quaderno $\mathrm{C}$, número $3^{\circ}$.

${ }^{679}$ Donación] al margen derecho: Escrita en pergamino.

${ }^{680}$ Velilla de Tarilonte] al margen derecho: Velilla de Tarilonte. 
Ytem cajón San Lorenzo, legajo $4^{\circ}$, número $1^{\circ}$. Ydem cajón San Gregorio, legajo $2^{\circ}$, quaderno E, número $1^{\circ}$. Ydem cajón San Plácido, legajo $1^{\circ}$, quaderno A, número $3^{\circ}$.

$$
\text { / (f. 342v) Quaderno } C^{681} \text { del legajo } 3^{\circ}
$$

Este quaderno $\mathrm{C}^{682}$ contiene las escrituras pertenecientes a la hacienda que tiene el monasterio en este lugar, por el orden siguiente:

$1^{\circ}$. < Carta de venta para el convento de 67 heredades. Año 1642>.

Escritura de venta por la qual doña Gerónima de la Cerda, viuda de Cristóval Paniagua, vecina de Becerril, vende al abad y convento de San Zoil de Carrión 55 cargas y media de heredades que tenía en los términos de Villavicencio, Villagrá, Villalogan, Villalán, Becilla ${ }^{683}$, que son sesenta y siete heredades deslindadas en la dicha escritura, que hacen 54 mill 816 palos, por precio de 819 mill 123 maravedís que dio por ellas el convento, redimiendo algunos censos que contra sí tenían el dicho Cristóval Paniagua y la dicha Gerónima de la Cerda. De que la dicha Gerónima otorgó carta de pago en forma y carta de venta de las dichas heredades. Fecha en Becerril, a 10 de febrero de 1642, ante Andrés Gallo, esscribando del número de Becerril.

$2^{\circ}$.

Escritura de convenio y redención de censo y libertad de hipotecas del censo antecedente, por la qual don Antonio Paniagua de la Cerda, hijo de doña Gerónima de la Cerda, para hacer pago a don Francisco Francos, sus sobrino, del principal y réditos de un censo a que estaban hipotecadas las tierras que dicha señora vendió a esta casa; le da las contenidas en la escritura de este número $2^{\circ}$, con lo qual don Francisco se da por contento y pagado de todo ello, y otorgó la redención de dicho censo y libertad de lo vendido a esta casa de que había tomado posesión judicial. Pasó esta escritura ante Damián de Salas, esscribano real y vecino de Valladolid, en 30 de agosto de 1662; y sacó este traslado Antonio Buey, esscribano de Becerril, año 1663.

\section{Remisiones} número 11.

Memoria de la hacienda de este lugar. Cajón San Plácido, legajo $4^{\circ}$, quaderno A, Apeo de las heredades. Cajón San Millán.

\section{/ (f. 443r) Quaderno D del legajo $3^{\circ}$ \\ Villotilla}

Este quaderno D contiene los papeles pertenecientes a la hacienda que tiene el monasterio en este lugar, por el orden siguiente:

$1^{\circ} .<$ Donación de un solar. Era 1127. Año 1089>.

Escritura de donación, escrita en pergamino y de letra gótica, por la qual don Fernando Maurielid y sus hermanas Mayor Gómez, Aura Díaz, doña Sancha y doña Teresa y otro hermano, $<$ dan $>$ a doña Mayor Salvadores un solar en el lugar de Villautilla, y ella le dio después al monasterio de San Zoil. Facta carta en la era 1127, que es año de Christo 1089.

\footnotetext{
$\left.{ }^{681} \mathrm{C}\right]$ corregida sobre $D$.

$\left.{ }^{682} \mathrm{C}\right]$ corregida sobre $D$.

${ }^{683}$ Becilla] Al margen derecho: Villagrá, Villalogan, Villalán, Becilla.
} 
$2^{\circ}$. $<$ Foro perpetuo de un préstamo. Año 1455>.

Escritura de foro perpetuo por la qual Fernán González de San Román, sacristán mayor de San Zoil, da a foro perpetuo a Alfonso Pérez, vecino de Villotilla, una casa con su préstamo de quatro tierras, una a Laguna don Pedro, otra al Oyo, otra al molino de Sobradillo y otra al cascajo de Cabaña. Fecha en San Zoil, a 20 de febrero de 1455, ante Álvar González de Carrión, esscribano de esta villa.

Hay copia autorizada por don Antonio Martín García, traductor de letras antiguas.

$3^{\circ}$. $<$ Venta de casas y tierras. Año 1481 $>$.

Escritura de venta por la qual Alonso de Cardeñosa, vecino de Calzada, vende a Francisco Escudero, vecino de Villotilla, una casa y cuatro tierras en término de este lugar, con cargo de una fanega de trigo, una gallina de foro perpetuo que tiene el monasterio de San Zoil sobre esta hacienda. Fecha en Carrión, a 31 de mayo de 1481, ante Ruy Gutiérrez de Grijava, esscribano de Carrión.

$4^{\circ}$. $<$ Demanda de una tierra al concejo. Año 1572>.

Demanda del convento contra el concejo de Villotilla sobre una tierra; la qual se puso ante el prior de Santo Domingo, juez conservador, pero no resulta la determinación de ello. Pasó ante Andrés Sánchez, esscribano de Carrión, año 1572.

\section{Remisiones}

Medida de tierras. Cajón San Plácido, legajo 5º quaderno B, número 11. 


\section{/ (f. 443v) Cajón 18 San Yldefonso \\ Villaverde de Golpejera}

Este cajón San Yldefonso, que es el diez y ocho del archivo, contiene tres legajos pertenecientes al priorato de Villaverde de Golpejera, (que antes era Vulpejera): legajo $1^{\mathrm{o}}$ : privilegios y jurisdición; legajo $2^{\circ}$ : nombramientos de alcaldes y pl[e]itos criminales; legajo $3^{\circ}$ : hacienda y amojonamientos.

\section{Legajo $1^{\circ}$}

Este legajo, que es el primero del cajón San Yldefonso, contiene los privilegios y jurisdición pertenecientes al priorato de Villaverde, por el orden siguiente:

$1^{\circ}$. $<$ Privilegio del rey don Alonso el $9^{\circ}$ que toma a Aguilar al monasterio y da a Gañinas, Revenga y Golpejera. Era 1219. Año 1181>.

Privilegio rodado y partido por $\mathrm{ABC}$, escrito en pergamino con sello de plomo pendiente en filos de seda, por el qual el rey don Alonso el $9^{\circ}$, para vtilidad de su reyno, toma para sí la villa de Castromayor (que ahora es Aguilar de Campos ${ }^{684}$ ), y entonces era del monasterio, <con toda su heredad $>$, al qual deja todas las yglesias <que hay y hubiere $>$ de aquella villa, con sus derechos y dominio, como las había tenido antiguamente, y le hace merced de los lugares de Gañinas ${ }^{685}$, Revenga ${ }^{686}$ y Golpejara, según consta de este privilegio y de los que se hará remisiones. Este privilegio fue dado en Castroxeriz, 11 nonas aprilis, era 1219, que es año 1181. Magister Joannes, regis notarius; Petrus de Cardona, existente chancelario, scripsit.

Hay copia simple ${ }^{687}$.

/ (f. 444r) $2^{\circ}$. <Privilegio del rey don Alonso el Sabio, que confirma el de atrás, número $1^{\circ}$. Era 1294. Año 1256>.

Privilegio rodado original, escrito en pergamino, con sello de plomo pendiente en filos de seda, por el qual el rey don Alonso el Sabio confirma el de atrás, número $1^{\circ}$, con todo lo en él contenido. Dado en Victoria, a 20 días del mes de enero, en la era 1294, que es año de Christo 1256. Confirman este privilegio, con el rey y la reyna doña Iolani (sic), su muger, y con los prelados y señores del reyno, don Alfonso, etcétera.

Hay copia autorizada por don Antonio Martín García, traductor de letra antigua.

$3^{\circ}$. <Privilegio del rey don Fernando el $4^{\circ}$ en que confirma los dos privilegios de arriba. Era 1342. Año 1304>.

Privilegio rodado original, escrito en pergamino, con sello de plomo pendiente en filos de seda, por el qual el rey don Fernando el $4^{\circ}$, junto con la reyna doña Constanza, su muger, confirman el privilegio del rey don Alonso el Sabio, que es el de arriba, número $2^{\circ}$, que es confirmación del privilegio del rey don Alfonso el $9^{\circ}$, que es el número $1^{\circ}$, en que toma a Aguilar, fuera de las yglesias, y da el monasterio a Gañinas, Revenga y Golpejera. Dado en Carrión, a 28 días de enero, era 1342, que es año 1304.

Confirma don Mahomat Abe Nezar, etcétera. Hay copia autorizada por don Antonio Martín García, traductor. $1316>$.

$4^{\text {o }}$. <Privilegio del rey don Alonso el XI que confirma los 3 de arriba. Era 1353. Año

Privilegio rodado, escrito en pergamino, con sello de plomo pendiente en filos de seda encarnada, verde y blanca, dado por el rey don Alonso el XI en Toro, a 29 días de abril, era 1353, que es año de Christo de 1316, por el qual confirma otro privilegio del rey don Fernando el $4^{\circ}$, su padre, que es el de el número 3, el qual es confirmación de otro privilegio del rey don Alonso el Sabio, que es el número $2^{\circ}$, en que confirma el privilegio del rey don

\footnotetext{
684 Aguilar de Campos] al margen derecho: Aguilar.

685 Gañinas] al margen derecho: Gañinas.

686 Revenga] al margen derecho: Revenga.

${ }^{687}$ Hay copia] sigue tachado: autorizada por don Antonio Martín García, traductor de letra antigua.
} 
Alonso el $9^{\circ}$, que es el de el número $1^{\circ}$, por el qual, que aquí está inserto en latín, consta que el dicho rey don Alonso el $9^{\circ}$ con la reyna doña Leonor, su muger, por vtilidad de su rey no tomó todas las heredades que el monasterio de San Zoil de Carrión tenía en Castromayor (que así se llamaba Aguilar, a título de un gran castillo que tenía aquella villa y era del patrimonio de los fundadores de este monasterio, en que le dotaron), excepto las yglesias todas que en él había entonces y las que hubiese en él hasta el fin del mundo, con todos sus derechos esclesiásticos, que quedasen para el monasterio, excepto una tercia que allí tenía 1 concejo / (f. 444v) en todas yglesias de Castromayor; y que el dicho monasterio tenga el dominio de todas las yglesias que son y serán para siempre en la dicha villa, como siempre le había tenido antiguamente. $\mathrm{Y}$ asimismo dice el rey que toma toda la heredad que el monasterio tenía en el monasterio de San Juan de Taradui, fuera de quatro yugadas de tierra en buen lugar y veinte aranzadas de viña en buen lugar; y su huerto y herrenes que se quedasen para el monasterio de San Juan de Taradui, el qual no tubiese de allí adelante el concejo ninguna tercia. Asimismo tomó el rey toda la hacienda que el dicho monasterio tenía en Villatirso. Y por tanto el mismo rey don Alonso, junto con la reyna doña Leonor, su muger, determina conservar el dicho monasterio de San Zoil illeso e indemne; y deseando salvar su alma da y concede en cambio y precio de las dichas heredades al monasterio de San Zoil y a don Humberto ${ }^{688}$, su prior y camarero de Cluni en España, la villa de Gañinnes ${ }^{689}$, que es en el alfoz de Saldaña, en la rivera del río Carrión; y la villa de Revenga ${ }^{690}$, que es en el alfoz de Torre de Montinoyo o de Mormoyón; y todo lo que el rey tenía en Golpejera, excepto las encartaciones, que le había dado el emperador, lo qual dio todo al monasterio como el rey lo tenía, con todas sus entradas, salidas, pastos, aguas, montes, prados, vasallos y collazos etcétera, derechos y acciones que el rey tenía por derecho hereditario, etcétera, para siempre jamás, por derecho de heredad para que lo posea el convento, quieta y pacíficamente, sin que se pueda revocar, de tal modo que ni merino del rey, ni sayón, ni otro algún hombre entre allí por violencia para exercer ningún acto de jurisdición, ni tome de ellos himicidio (sic), ni calumnia, ni derecho de collazo o vasallaje, ni fonsadera, ni otro derecho alguno, ni paguen pedido alguno sino fuere al prior de San Zoil, al qual y a sus subcesores sirvan como a su especial señor, y ninguna de las dichas villa acuda a otra parte.

Esto es lo que contiene el primer privilegio, fecho en Castroxeriz, era 1219; y los demás, juntos con éste, son confirmación. Año 1739>.

$5^{\circ}$. $<$ Testimonio de una carta executoria y sobre el término redondo de Villaverde.

Testimonio de la real cédula de Su Magestad Fhelipe $5^{\circ}$, y copia de ella y demás autos, en que se confirma ser de este monasterio el término / ( $f .445 r)$ redondo de Villaverde de Golpejera con toda su jurisdición civil y criminal, etcétera. Sobre que se dio sentencia difinitiva a favor de este monasterio de San Zoil, en la villa de Carrión, a 6 de julio de 1739, ante Santiago Duque de Estrada, esscribano de Su Magestad y del número de esta villa de Carrión.

$<$ Jurisdición $>$.

6. <Testimonio del pleito de Valladolid con el concejo de Villamuera. Año 1561>.

Testimonio del pleito y demanda que puso el concejo de Villamuera ${ }^{691}$ a este convento, del desacato que hicieron a fray Juan de Corcuera sobre la jurisdición, pretendiendo eximiese de muchas tocantes al señorío que tiene el convento en este lugar; sobre esto hay cartas executorias. Dado en Valladolid, por Gerónimo de Vega, esscribano de Cámara, a 10 de noviembre de 1561.

$7^{\circ}$. $<$ Testimonio de prendar unos ganados. Año 1567>.

Testimonio dado por Pedro Adame, esscribano de Villamuera, de cómo la guarda de Villaverde prendó unos ganados ovejunos de Cardeñosa, que andaban en término de

\footnotetext{
${ }^{688}$ Humberto] al margen derecho: Don Humberto, prior de Cluni.

${ }^{689}$ Gañinnes] al margen derecho: Gañinas.

${ }^{690}$ Revenga] al margen derecho: Revenga.

${ }^{691}$ Villamuera] al margen derecho: Villamuera.
} 
Villaverde, y requirió a los dueños que fuesen por ellos y pagasen los daños. Dado en Cardeñosa, año 1567.

$8^{\circ}$. <Requirimiento al teniente de Carrión. Año 1568>.

Requirimiento que hizo fray Juan de Corcuera, abad de San Zoil, en el término de Villaverde, al licenciado Diego de Ávila, alcalde mayor de Carrión, para que allí no haga actos de jurisdición, y si los hiciere protesta no pare perjuicio al derecho del monasterio. Fecho a 4 de febrero de 1568, ante Juan de Cantoral, esscribano de Carrión.

$9^{\circ}$. < Parecer sobre tomar el rey el término de Villaverde. Año 1577>.

Parecer del licenciado Herrera, abogado de Valladolid, en razón del remedio que podía haber para que en las diligencias que el rey había mandado hacer para tomar y vender la jurisdición y vasallaje de Villamuera, no entrase ni se entendiese lo de Villaverde. Dado año de 1577.

10. < Testimonio de prendar en Villaverde. Año 1592>.

Testimonio dado por Matheo Rojo, esscribano de Villamuera, de cómo fray García de Santa María prendó unos ganados de Villamuera, que andaban dentro del término de Villaverde. Año 1592.

11. <Licencia para sacar cardos. Año 1600>.

Dos licencias que dio fray Plácido de Huércanos, abad de San Zoil, para que un vecino de Villamuera sacase cardos de una heredad que tenía a renta en término de Villaverde. Año 1600.

12. $<$ Fee del libro becerro de la Chancillería. Año 1602>.

Testimonio sacado del libro becerro de la Chancillería del asiento que en él tiene Villaverde de Golpejera, y cómo es del monasterio de San Zoil y lo que paga de derechos. Sacose con autoridad de la Chancillería, en Medina del Campo, a 5 de noviembre de 1602. Dio la fee el doctor Terán, chanciller de la chancillería, y lo firmó de su nombre.

/ (f. 445v) 13. <Sentencia sobre la jurisdición. Año 1605>.

Sentencia de la Chancillería, estando en Burgos, por la qual amparan al convento en la posesión de vsar la jurisdicción, civil y criminal, alta y vaja mero mixto imperio, en el término redondo de Villaverde de Golpejera, privatibamente, y es condenada la villa de Carrión a que no inquiete al monasterio en dicha posesión. Dada en Burgos, a 7 de septiembre de 1605.

14. <Papel simple del estado de este priorato $>$.

Papel simple del estado en que ha estado y está el priorato de San Salvador de Villaverde de Golpejera, anejo al Real Monasterio de San Zoil de Carrión.

15. $<$ Carta executoria de la jurisdición de Villaverde. Año 1607>.

Carta executoria de la jurisdición de Villaverde, ganada en la Chancillería de Valladolid, en favor de este monasterio de San Zoil y contra el fiscal de Su Magestad, justicia y regimiento de la villa de Carrión.

$<$ Comenzose el pleito el año 1602 ante el conservador de Santa María de la Vega>.

Por la qual parece que en San Zoil, a 23 de diciembre de 1602, ante fray Bernardo de Ayala, abad del monasterio de Nuestra Señora de la Vega, juez appostólico conservador, se querelló la parte del monasterio de don Fernando Avia de Castro, corregidor de Carrión, y del doctor Somonte, su teniente, porque estando el convento en vso y costumbre immemorial de la posesión de gozar la jurisdición civil y criminal de Villaverde, por ser la granja suya con su término redondo y jurisdición de él, los dichos corregidores y teniente se la impedían. Y de hecho y contraderecho, el dicho teniente había ido a Villaverde y, dentro de su término, había pretendido hacer autos de jurisdición y había derribado una horca que el monasterio tenía levantada en el dicho término por señal de su jurisdición, la qual le pertenecía por privilegios reales, en lo qual había hecho agravio y violencia al monasterio contra la bula de Eugenio $4^{\circ}$ y otras. 


\section{$<$ Auto del conservador $>$.}

Pidió se procediese contra ellos mandándoles que no inquietasen al monasterio en su jurisdición y que hiciesen bolver a levantar la horca como antes estaba; de lo qual ofreció al convento información, la qual admitida por el juez y hecha por el convento, el dicho abad de la Vega dio auto, por el qual mandó a los dichos corregidores y teniente de Carrión no impidiesen al convento el vso y costumbre en que estaban de administrar justicia, civil y criminal, en la granja de Villaverde y sus términos por sus ministros, y tener horca y picota, cárcel y prisiones para administrarla. Y que se notificase al teniente que, dentro de 9 días, buelva a poner la horca / ( $f .446 r)$ en la forma que estaba quando la derribó, so pena de 200 ducados, y que se procedería con censuras, etcétera. $\mathrm{Y}$, en caso que tubiesen que alegar, se les diese traslado de los autos para que dentro de tres días lo alegasen; assesor, el doctor Aguilar; esscribano, Alonso Zapata. Notificose este auto al corregidor y teniente, los quales respondieron con la protesta ordinaria declinando jurisdición, y negaron ser del convento la jurisdición de Villaverde, sino de Carrión y su justicia; y que siendo real, el convento la tenía vsurpada, etcétera, qual constaba por querella e información del procurador general; por la qual se había mandado derribar la horca que el convento había mandado levantar quatro años había y no más, porque siempre la justicia de Carrión había exercido allí su jurisdición. Presentaron la información que había hecho contra el monasterio el procurador general de Carrión, pidieron se pronunciase el conservador por no juez y que revocase el auto que había dado, apelaron y protextaron el auxilio real de la fuerza.

LLevose el proceso al dotor Aguilar, assesor, y mandó dar traslado al convento, el qual pidió, sin embargo, confirmación del auto dado, y alegó contra la justicia de Carrión. Pidió confirmación dél y agravación de censuras, y ser restituido y reintegrado en su posesión. Mandose dar este traslado y llevaron los autos.

$<2^{\circ}$ auto del conservador $>$.

El juez conservador, en 5 de marzo de 1604, dio otro auto en que mandó que, dentro de tres días, se pusiese la horca en el sitio de donde la habían quitado y no impidan al monasterio su jurisdicion y no buelvan a derribar la horca, ni inquieten al monasterio en la posesión de su jurisdición de allí adelante. Púsoseles pena de 200 ducados y excomunión mayor, etcétera.

\section{$<$ Pleito en la Chancillería en Medina del Campo>.}

Notificose este auto a las justicias y apelaron por vía de fuerza, y se quejaron en la Chancillería de los dos autos del conservador, y se llevó el proceso en vía de fuerza. Y la villa y su justicia pidió se retubiese allí y se conociese de esta causa, en que consintió la parte del convento; y por auto de la Chancillería se retubo allí para conocer de él. La parte del convento alegó en defensa de su jurisdición por títulos que tenía y por la posesión immemorial de haber vsado de ella civil y criminalmente en todas las ocasiones que se habían ofrecido dentro del término redondo de Villaverde, que es del monasterio y districto de los demás lugares con que confina. Y que siendo esto así, / (f. 446v) la justicia de Carrión, el año 1602 había entrado en el dicho término con varas altas, y vsando de jurisdición contra el derecho y posesión del monasterio habían derribado la horca que el convento tenía lebantada en el dicho término y habían pretendido hacer otros actos de justicia y jurisdición. Por lo qual pidió ser amparado en la posesión de vsar de la dicha jurisdición (como lo había hecho hasta alli), civil y criminal, alta y vaja, mero mixto imperio, en el dicho término redondo de Villaverde de Golpejera, privativamente, y en caso de despojo le restituyan en ella, condenando a los contrarios a que no les perturbasen en ella. Y en caso que los medios posesorios no hubiesen lugar, se declarase pertenecer al convento la dicha jurisdición privatiba, lo qual pidió se notificase a la parte contraria y al licenciado Bobadilla, procurador fiscal de Su Magestad. Diose emplazamiento y se notificó a la villa y al fiscal.

La causa fue conclusa sin alegar la villa ni el fiscal, y se recivió a prueba, que la hizo y presentó el monasterio y se hizo publicación de testigos. Después de esto la villa pidió restitución; concediósele.

Después de lo qual, el doctor don García de Navarrete, fiscal, y la parte de la villa de Carrión presentaron petición negando la demanda del convento; y alegando en su favor y 
contra lo alegado por el convento, pidieron ser dados por libres de la demanda del convento y amparados en la posesión de la jurisdición de Villaverde. Dentro del término de la restitución de prueba concedida a la villa se hicieron informaciones por las partes que, presentadas, se publicaron.

\section{$<$ Sentencia de vista. Año 1605>.}

Sobre que fue concluso el pleito. Y visto por los oydores de la Chancillería, en Burgos, a 20 de septiembre de 1605, dieron sentencia difinitiva, por la qual amparan al abad, monges y convento de San Zoil en la posesión en que han estado y están de vsar y exercer por sí y sus justicias la jurisdicción civil y criminal, alta y vaja, mero mixto imperio, en el término redondo de Villaverde de Golpejera, sobre que fue el pleito privativamente; y condenan al concejo, justicia y regimiento de Carrión y al fiscal del rey, a que no les inquieten ni perturben la dicha posesión, so pena de 20.000 maravedís por cada vez que lo contrario hicieren; y reservan su derecho a salvo a las partes quanto a la propiedad.

/ (f. 447r) De esta sentencia suplicaron la villa de Carrión y el fiscal, y alegaron contra ella, y pidieron restitución para hacer provanza por los mismos artículos en contrario. Diose traslado al convento y no alegó, con que se concluyó para prueba, y las partes hicieron y presentaron sus informaciones, de que se hizo publicación.

$<$ Sentencia de revista. Año 1606>.

El pleito fue concluso. Y visto por el presidente y oydores, en Valladolid, a 6 de octubre de 1606, dieron sentencia de revista, por la qual confirmaron la primera de vista. De las quales dichas sentencias la parte del convento pidió y se le dio esta carta executoria, en Valladolid, a 11 de enero de 1607, ante Pedro Angulo Toro, esscribano de Cámara.

$<$ Execución de la carta executoria y posesión de la jurisdicción de Villaverde de Golpejera. Año 1607>.

Execución de esta carta executoria y posesión de la jurisdición de Villaverde dada al convento de San Zoil, por la qual consta que, en Valladolid, a 10 de marzo de 1607, en la Chancillería, a instancia de la parte del monasterio se dio una real provisión de comisión a Pedro de Aulestia, receptor, para que en execución de las sentencias de la carta executoria, pusiese al convento en posesión de la jurisdición del término redondo de Villaverde. Y en su cumplimiento, el receptor requirió al corregidor de Carrión que le diese favor y ayuda, y se le ofreció.

El convento requirió al receptor que executase la carta executoria; mandó citar y citó a la villa y corregidor de Carrión, don Fernando de Linares, y a los regidores. El procurador general de la villa pidió los autos para responder, el qual pidió y requirió al receptor no excediese, etcétera.

El convento le requirió que diese la posesión, respondió que está presto y fue a Villaverde con nuestro padre maestro fray Alonso Barrantes, abad, al qual, en señal de posesión de jurisdición, le dio una bara de justicia y el abad la dio al licenciado Ordóñez, su alcalde mayor, para que exerza la jurisdición civil y criminal, alta y baja, mero mixto imperio. A pedimiento del abad el receptor mandó lebantar una horca en lo alto del otero, donde antes había estado, y mandó con penas que nadie la quite. Lebantose una picota en el campillo de la hera, junto a los caminos, y se mandó con penas que nadie la quite.

El procurador general de la villa de Carrión requirió no se innovase; sin embargo, en su presencia, se puso la picota. Diose posesión del término redondo por sus mojones, con que se concluyó, en marzo de 1607, ante el dicho Pedro de Aulestia, receptor.

\section{/ (f. 447v) 16. < Requirimiento que no se ponga la picota. Año 1607>.}

Requirimiento del procurador general de la villa de Carrión para que no se pusiese picota en el término de Villaverde. Fecho a 7 de marzo de 1607, ante Pedro de Aulestia, esscribano. 


\section{7. $<$ Capitulaciones con Paredes sobre los pastos. Año 1614>.}

Escritura de capitulaciones por quatro años, hechas entre el abad de San Zoil fray Juan Díaz, con licencia del general fray Alonso Barrantes, de una parte; y el licenciado Berdeces y los regidores y esscribano de Paredes, en nombre y con poder del concejo de la dicha villa, de la otra, en razón de las diferencias que había sobre pastar los ganados de Paredes en los términos de Villaverde, y los de esta granja en los de Paredes. Y para excusar mayores daños y tener paz, ambas partes otorgaron esta escritura con las capitulaciones que en ella se contienen. Fecha en Villaverde, a 11 de agosto de 1614, ante Santos de Guzmán, esscribano de Villamuera.

\section{8. < Cabeza de proceso contra la jurisdición. Año 1625>.}

Cabeza de proceso hecha por don Fernando Altamirano de las Cabezas, corregidor de Carrión, contra la jurisdición, horca y picota de Villaverde, el qual siendo requerido con la carta executoria, a 10 de febrero de 1625, mandó que se guardase y que diese testimonio de ello el convento, ante Antonio Orejón, esscribano de Carrión, el qual dio este testimonio.

19. <Licencia para sacar piedra. Año 1753>.

Licencia que pidió don José Calonge, cura y beneficiado de Riveros, para sacar piedra del priorato de Villaverde o su término. Año 1753.

20. $<$ Memorial ajustado entre don Tomás Machuca, cardenal, y otros hasta el número 14,que se titulan El Antiguo y capellanes de la congregación del número 40 de la catedral de Palencia, y también Colegio Real de Jacobitas, con el obispo y cavildo, etcétera. Año 1793>.

Bajo este número está un memorial ajustado, impreso en Madrid, hecho con citación y asistencia de las partes, en virtud de decreto de la Cámara del rey, que en ella siguen don Tomás Machuca y otros, hasta el número 14, que se titulan El Antiguo y capellanes de la congregación del número 40 de la catedral de Palencia, y también se titula Colegio Real de Jacobitas, con el reverendo obispo y con el deán y cavildo de la dicha santa yglesia, en que interbiene el señor fiscal don Benito Ramón de Hermida, sobre el patronato de dichas capellanías, derechos y preeminencias del cavildo de capellanes, distintivos con que se les deba tratar y el derecho a la parroquialidad absoluta de dicha ciudad de Palencia. Y juntamente otros varios escritos conducentes a esto mismo. Año 1793.

\section{/ (f. 448r) 21. <Proceso sobre los diezmos de Villaverde. Año 1603>.}

Proceso de un pleito decimal por el qual parece que el cavildo de la yglesia de Palencia puso demanda ante don Gaspar de Peralta, provisor de dicha ciudad, a tres vecinos de Villamuera por los diezmos de los frutos de ciertas heredades que tenían a renta del monasterio de San Zoil en el término de Villaverde, en que fue citado dicho monasterio. Y las parte alegaron de su justicia y hicieron sus informaciones hasta que, conclusa la causa, en Palencia, a 25 de septiembre de 1602, el dicho provisor dio sentencia por la qual declara el deán y cavildo de Palencia haber estado en posesión, vso y costumbre, quieta y pacífica, de llevar y gozar un tercio entero de los diezmos mayores y menores que se diezman en el término de la granja de Villaverde, y una quarta parte, asimismo, de los diezmos que se diezman en la villa y granero de Villamuera ${ }^{692}$, en esta forma: la mitad del diezmo de las dichas heredades en la cilla y granero de la dicha granja, y la otra mitad en la cilla de Villamuera, y les condena a que paguen los diezmos de allí adelante en esta manera, y que paguen lo que hasta allí habían dejado de pagar, ante Lucas Gallardo, nottario. La parte del convento apeló de esta sentencia y protestó el auxilio real de la fuerza y lo pidió por testimonio. Despachó el provisor mandamiento y comisión para que los de Villamuera pagasen el principal y costas en que habían sido condenados en la dicha sentencia. Notificose la comisión al bachiller Santos de Herrera, beneficiado de San Bartolomé, el qual, habiéndola aceptado, fue a Villamuera y hizo información y autos y procedió contra los que debían los diezmos y costas. Presentose el convento y los de Villamuera ante en nuncio en grado de apelación, el qual dio su breve de comisión para que conociese de esta causa el doctor don Marcos de la Caba, protonotario y juez appostólico, el qual dio su mandamiento, inhibitorio, citatorio y

${ }^{692}$ Villamuera] al margen derecho: Villamuera. 
compulsorio. Y, porque los de Villamuera tardaban en llevar el proceso, pidió el cavildo que el dicho juez les compeliese a ello, para lo qual dio su mandamiento, en Valladolid, a 14 de febrero de 1603. Y en virtud del dicho mandamiento sacó este proceso de su original Pedro de Arana Ocerín, nottario de audiencia en Palencia. Se apartó el convento de este pleito. Véase la escritura de apartamiento en el libre de escrituras, ante Alonso Zapata, que empieza el año 1603, al folio 97 hasta el 102, que está en el estante tras de la puerta de yerro, donde está la cajonería.

\section{/ (f. 448v) 22. <Obligación del prior de Villaverde. Año 1424>.}

Obligación que hizo don Juan, prior del monasterio de San Salvador de Villaverde, a Fernán González de Velforado, procurador de don Pedro, por la gracia de Dios prior mayor de San Zoil de Carrión, visitador, camarero y receptor del abad de Cluniego, de darle en nombre de su monasterio 30 florines o mil y quinientos maravedís para paga de las pensiones a que estaba obligado por los años de 1422, 23 y 24. Fecha y firmada a 26 de abril de 1424.

Hay aquí un papel simple que puede servir para alguna instrucción.

23. < Amojonamiento y deslinde [del] término de Villaverde. Año 1770>.

Amojonamiento circular y deslinde general del término de Villaverde, con asistencia de todos los concejos confinantes. Hecho año 1770, ante Antonio Francisco, esscribano real del número de Oteruelo.

24. <Extracto sobre que los criados de Villaverde cumplan con el precepto anual en la parroquia de Villamuera. Año 1774. Y sacado el de 1798>.

Extracto substancial del pleito litigado por el fiscal general eclesiástico de la ciudad y obispado de Palencia contra este real monasterio de San Zoil de Carrión, sobre que los criados y demás sirbientes de la granja de Villaverde, hijuela del dicho monasterio, hayan de cumplir con el precepto anual en la parroquia de Villamuera y no en la de San Zoil. Sacado de los autos originales que se hallan en el legajo 539 del archivo de la catedral de dicha ciudad de Palencia, por el padre fray Benito Sabido, monge y archivero de este monasterio, en el año de 1798. El precio fue por los años de 1773 y 1774.

\section{/ (f. 449r) Legajo $2^{\circ}$ del Cajón San Yldefonso \\ Villaverde}

Este legajo, que es el segundo del cajón San Yldefonso, contiene los nombramientos de alcaldes mayores de Villaverde hechos por los abades de San Zoil desde el año de 1600 adelante. Y los pleitos criminales sobre la jurisdición en razón de los pastos, etcétera, por el orden siguiente:

$1^{\circ}$. $<$ Nombramientos de alcaldes de Villaverde $>$.

Bajo este número $1^{\circ}$ están los nombramientos de alcalde hechos por los abades de San Zoil, por orden de años, que empiezan el año de 1600 y siguen hasta el presente.

$2^{\circ}$. $<$ Proceso y sentencia contra un pastor. Año 1599>.

Proceso fulminado por el teniente de alcalde de Villaverde contra un pastor que entró con su ganado en un monte recién plantado de Villaverde, y sentencia del licenciado Ordóñez en que le condena en 600 maravedís. Año 1599, ante Santos de Guzmán, esscribano de Villamuera.

\section{$3^{\circ}$. $<$ Proceso y sentencia contra un carretero. Año 1603>.}

Proceso de querella criminal que dio Diego Rodríguez, alguacil de Villaverde, ante Hernando de Mercado, alcalde ordinario de Villaverde, contra Pedro Martín Carretero, porque estando éste apacentando sus bueyes dentro del término de la granja, el dicho alguacil fue a tomarle una prenda y el carretero se la defendió y le dio de coces y palos. El alguacil le llevó preso y se querelló de él; hízose información y le sentenció el alcalde con su asesor, el 
licenciado Rojas de Arce, en 200 maravedís y seis meses de destierro de la jurisdición. Año 1603, ante Santos de Guzmán, esscribano.

$4^{\circ}$. < Proceso y sentencia contra los de Paredes. Año 1610>.

Proceso y sentencia contra ciertos vecinos de Paredes de $\mathrm{Nava}^{693}$, que habiéndoles prendado el ganado los guardas de Villaverde, cogieron las yeguas y mulas de la granja y las llevaron corriendo a Paredes, y murió una yegua que hiba preñada. El licenciado Ordóñez, alcalde mayor de Villaverde, les condenó por su sentencia en seis años / (f. 449v) de galeras y 60 ducados por la yegua y las costas. Año 1610, ante Santos de Guzmán, esscribano de Villamuera.

$5^{\circ}$. < Proceso y sentencia criminal contra los de Paredes. Año 1612>.

Proceso criminal y fulminado por Domingo Castrillo, alcalde o teniente de alcalde mayor de Villaverde, por querella criminal dada por parte del monasterio contra unos vecinos de Paredes, arrendadores y molineros del término de Paredes, que yendo a caza dentro del término de Villaverde, corrieron y maltrataron las yeguas y mulas de la granja, pretendiendo sacarlas del término; y a un pastor de Villaverde que salió a defenderlo le dieron de puntapiés y puñadas, de que le salió sangre. Acumulose el proceso de atrás y otros insultos que habían hecho los años atrás, de que se hizo información. Parece que éstos huyeron y dejaron un caballo, unas alforjas, una bota y un sombrero, lo qual mandó depositar el teniente de alcalde mayor. Actuose este proceso por marzo de 1612, ante Santos de Guzmán, esscribano por el abad de San Zoil.

\section{$6^{\circ}$. <Proceso contra un ladrón a quien azotaron en Villaverde. Año 1626>.}

Proceso criminal fulminado de oficio por Martín Alcalde, alcalde mayor de Villaverde, contra Juan Fernández, natural de Mérida, el qual fue convencido de ladrón por información y por su confesión, y fue condenado en cien azotes que le pegó Juan Francisco, berdugo de Carrión, alrededor de la granja, con toda solemnidad, y en diez años de destierro de la jurisdición precisos y las costas. Fecho en Villaverde, año de 1626, ante Eugenio de Guzmán, esscribano de Villamuera.

\section{$7^{\circ}$. < Proceso criminal contra unos de Carrión. Año 1632>.}

Proceso criminal fulminado en Villaverde por Tomás de Padierna, alcalde mayor de aquella granja, contra Martín de la Vega, Blas Callejo y Miguel Martínez, vecinos de Carrión, por querella que contra ellos dio Andrés Ruiz, pastor del convento, porque estando guardando el ganado y pasando por el camino de Paredes a Carrión, los sobredichos le maltrataron e hicieron sangre; y habiéndose hido a quejar a la granja, salió el alguacil de ella con otros mozos a prenderlos, llevando vara alta, y queriéndolos prender se resistieron, y uno dio un palo al alguacil, y ayudándoles otros que sobrevinieron quitaron a uno que estaba ya preso y todos se escaparon. El alcalde de Villaverde, en virtud de la querella, hizo información del caso y despachó / (f. 450r) requisitoria a la justicia de Carrión para que los prendiese y se los remitiese. Fue requerido con ella don Gaspar de los Reyes, teniente de Carrión, el qual aceptó la requisitoria y mandó que los delinqüentes fuesen presos y se remitiesen a Villaverde; y no pudiendo ser habidos, se les confiscasen sus bienes. Y todo se remitiese al alcalde de Villaverde. Y se dio mandamiento para que el teniente de alguacil mayor lo executase; después de lo qual los delinqüentes se presentaron ante el alcalde de Villaverde y pidieron les tomase su confesión, y vsase con ellos de misericordia. Tomóseles la confesión, sustanció el proceso y los sentenció en dos mil maravedís a cada uno, aplicados mitad para la Cámara del abad de San Zoil y mitad para el pastor, y las costas. Pasó en Villaverde, año 1632, ante Santos de Guzmán, esscribano.

\section{$8^{\circ} .<$ Proceso contra rabanal. Año 1639>.}

Proceso de oficio hecho por el alcalde de Villaverde contra Alonso de Rabanal, pastor, que hurtó sal, aves, palomas, lentejas, etcétera. No está sentenciado. Fecho en 22 de enero de 1639, ante Eugenio de Guzmán, esscribano de Villamuera.

${ }^{693}$ Paredes de Nava] al margen derecho: Paredes. 


\section{9. $<$ Requisitoria para prender un hombre. Año 1705>.}

Requisitoria despachada por un alcalde de la villa de Almanza para buscar y prender a un hombre; la qual presentaron y con ella requirieron a Ypólito del Valle, alcalde de Villaverde, quien la aceptó por ante Francisco Herrero, esscribano real y vecino de Villamuera; y mandó al teniente de alguacil andubiese y buscase el sugeto y le prendiese, en 27 de mayo de 1765.

10. < Apartamiento que hizo el monasterio de una querella. Año 1708>.

Apartamiento que otorgó el monasterio de una querella que había dado contra el corregidor de Paredes y otros vecinos, sobre haber pretendido sacar del término el ganado ovejuno y maltratado el pastor, como consta de los autos. Pasó este apartamiento ante Bernardo González, esscribano y vecino de Paredes, año de 1708.

\section{1. < Pleito criminal contra unos de Villamuera. Año 1726>.}

Pleito criminal contra unos hombres, vecinos y naturales de Villamuera, que se entraron cazando en el término de Villaverde y trataron mal de palabras a un religioso lego que asistía allí, haciendo de prior. Fue juez de la causa José de Astudillo, alcalde mayor de dicha granja, año 1726, ante Mauricio Martínez de Chirueches, esscribano de Carrión.

/ (f. 450v) 12. < Carta executoria contra unos vecinos de Paredes sobre prendadas y otros excesos. Año 1731>.

Carta executoria ganada a favor de este monasterio contra Andrés Galleo y Pedro Pajares, vecinos de la villa de Paredes de Nava, sobre unas prendadas y otros excesos en que fueron condenados en costas. Dada en Valladolid, a 4 de mayo de 1729, ante Francisco Antonio de Zamora y Salamanca, esscribano de Cámara. Notificose a las partes y la aceptaron ante Diego Ximénez, esscribano de Su Magestad, en Villaverde, a 16 de septiembre de 1731.

13. $<$ Executoria contra unos pastores y el procurador de Paredes sobre prendadas, etcétera. Año 1756>.

Carta executoria ganada en la Chancillería de Valladolid a favor de este monasterio, en el pleito que litigó contra unos pastores y el procurador de la villa de Paredes, sobre unas prendas y malos tratamientos hechos a los pastores de Villaverde que estaban pastando con el ganado de este monasterio en término de dicha granja; por la qual fueron condenados dichos pastores y procurador de Paredes en costas, bajo todo apercivimiento, como consta de esta carta executoria, que fue dada en Valladolid, a 3 de septiembre de 1755, ante Juan Antonio de Cos, esscribano de Cámara del rey. Fue notificada y aceptada por las partes y pagados los gastos causados, ante Manuel Francisco Blanco, esscribano de Carrión, en 4 de mayo de 1756.

\section{4. < Pleito criminal contra un pastor de Paredes. Año 1795>.}

Requirisitoria y pleito criminal contra Ysidro Bian, vecino de Paredes, pastor del ganado lanar de don Juan Lubiano, de la misma vecindad, que se handaba muy a deshora de la noche con el ganado dentro del término redondo de Villaverde, en que fue condenado en diez ducados por el alcalde mayor de dicho priorato Manuel de Viciosa. En 17 de febrero de 1795, ante José Tablares, esscribano de de Carrión.

15. < Pleito contra unos de Paredes que entraron a cazar en término de Villaverde. Año 1799>.

Pleito criminal o cabeza de proceso contra unos de Paredes (fulminado en Villaverde por Baltasar Prieto, alcalde mayor y ordinario de Villaverde) que se entraron cazando en el término de dicha granja, en tiempo de veda y en Sábado Santo, en que suplicaron al abad de San Zoil les perdonase, y así lo hizo y no se sentenció. Año 1799, ante Tablares.

$$
\text { / (f. 451r) 16. <Alegatos sobre la cilla de Villaverde y Villamuera. Año 1800>. }
$$


Alegatos entre este monasterio y la villa de Villamuera sobre la percepción de diezmos por razón de los predios que están sitos en el despoblado de Villaverde, y se lleven a la cilla común de Villamuera para repartirlos a los interesados. Año 1800.

\section{/ (f. 451v) Legajo $3^{\circ}$ del cajón San Yldefonso \\ Villaverde}

Este legajo, que es el tercero del cajón San Yldefonso, contiene las escrituras de venta de las heredades que ha comprado este monasterio en los términos de Villaverde, amojonamientos y demás hacienda, etcétera, por el orden siguiente:

$1^{\circ} .<$ Quaderno de escrituras de venta. Año 1568>.

Quaderno de escrituras de venta para este monasterio, en término de Villaverde. Véase al principio que trahe las que hay en este quaderno, excepto las anotadas que se pusieron en Villamuera por pertenecer allí. Año 1568 y siguientes.

$2^{\circ}$. <Trueques de tierras. Año 1568 y 1569>.

Otro quaderno de escrituras de trueque de heredades en los términos de Villaverde y Villamuera ${ }^{694}$, según consta al principio de este quaderno, hechas por los años de $1568 \mathrm{y}$ 1569.

$3^{\text {o. }}<$ Trueque de heredades. Año 1569>.

Quaderno de escrituras de trueque de heredades en los términos de Cardeñosa, Carrión y Villamuera ${ }^{695}$ por otras en Villaverde, según consta al principio de este quaderno; hechas en los años de 1568 y 1569.

$4^{\circ} .<$ Trueque de heredades. Año 1569>.

Otro quaderno de escrituras de trueque de heredades en los términos de Cardeñosa, Riveros y Villamuera ${ }^{696}$ por otras en término de Villaverde, véase al principio, hechas en los años de 1599.

$5^{\circ} .<$ Ventas de tierras. Año 1568 y 1575>.

Ventas de tierras para este monasterio en término de Villaverde, hechas en los años de 1568 hasta 1575, como consta al principio de este quaderno, en los términos de Villaverde, excepto lo anotado a la margen dél.

$6^{\circ} .<$ Ventas de tierras. Años 1577 y 1578>.

Ventas de tierras para este monasterio hechas por los años de 1577 y 1578, véase al principio de este quaderno, en los términos de Villaverde, excepto una que se puso en Villamuera y está anotada.

$7^{\circ} .<$ Ventas y trueques. 1533 y $1589>$.

Este quaderno consta de escrituras de venta y trueque de heredades en término de Villamuera ${ }^{697}$, por otras en término de Villaverde, véase al principio, que son bastantes. Años 1533 hasta 1589.

/ (f. 452r) $8^{\circ} .<$ Ventas de heredades. Año 1608 y $1623>$.

Quaderno de escrituras de venta para este monasterio en término de Villaverde, según consta al principio de este instrumento, hechas desde el año de 1608 hasta el de 1623, que son todas 15 escrituras.

\footnotetext{
${ }^{694}$ Villamuera] al margen derecho: Villamuera.

695 Villamuera] al margen derecho: Cardeñosa, Carrión, Villamuera.

${ }^{696}$ Villamuera] al margen derecho: Cardeñosa, Riveros, Villamuera.

${ }^{697}$ Villamuera] al margen derecho: Villamuera.
} 
9. <Ventas de tierras. Año 1620 y 1637>.

Otro quaderno de escrituras de venta para este monasterio de San Zoil, en término de Villaverde, véase al principio de él, hechas desde el año de 1620, 24, 25 y 27, que son todas 4 escrituras.

10. <Ventas, trueques, cesiones, etcétera. Año 1574 hasta 1696>.

Bajo este número está un libro de compras, ventas, trueques, cambios y cesiones en los lugares de Villasirga, Villamuera, Raveros y Calzada ${ }^{698}$, hechas desde el año de 1574 hasta el de 1696. Véase a la segunda oja de este libro, excepto las anotadas que se pusieron en sus respectivos lugares; las quales posesiones están en el término de Villaverde, y son con todas 48 heredades.

11. $<$ Venta de una tierra. Año 1739 $>$.

Escritura de venta por la qual Nicolás Velasco, vecino de Villamuera, vende a este monasterio una tierra a la cueba del Lobo, término de Villaverde, que hace siete quartas, poco más o menos, por prcio de setenta reales que por ella pagó dicho monasterio de San Zoil. Su fecha, en Carrión, a 8 de febrero de 1739, ante Gabriel de Ceano Vivas, esscribano de Carrión.

12. <Trueque de heredades entre el hospital de Santa María y San Zoil. Año 1770>.

Trueque de heredades que el hospital de pobres de Santa María de esta villa de Carrión ${ }^{699}$ tenía en el término de Villaverde, proprio de este monasterio de San Zoil, por otras que éste tenía en el término de Carrión y en Villanueva del Río ${ }^{700}$, con las correspondientes licencias de sus respectivos prelados, para tener la debida validación y firmez. Fue hecho en San Zoil, a $1^{\circ}$ de mayo de 1770, ante Andrés Núñez Castelo, esscribano del número y ayuntamiento de esta villa de Carrión.

De aquí adelante son amojonamientos, etcétera.

/ (f. 452v) 13. <Amojonamiento con Villamuera. Año 1553>.

Escritura simple de amojonamiento de los términos de Villaverde con Villamuera, hecho en virtud de una provisión real, a 21 de octubre de 1553, ante Andrés Sánchez, esscribano de Carrión. Está firmada de fray Rodrigo de Corcuera, abad de San Zoil.

14. <Provisión real y otros instrumentos. Año 1524 y 1561>.

Bajo este número está un instrumento que contiene lo siguiente:

$1^{\circ}$ Vna provisión real para compulsa de instrumentos en el pleito con los de Villamuera, y las diligencia[s] para este fin. $2^{\circ}$ Poderes respectivos. $3^{\circ}$ Dos arriendos hechos por el concejo de dicho lugar de todo el término de Villaverde, el uno por 6 años y el otro por 10, por 60 cargas de pan en cada un año, 24 gallinas y 10 mill 000 maravedís, sobre que era el pleito, en diferentes años, que son 1524 y 1561.

15. <Amojonamientos y ordenanzas de términos de varios lugares. Año 1552>.

Libro de amojonamientos y deslindamientos de términos de Villaverde con Villamuera, Paredes, Castrillejo y otros lugares y algunas ordenanzas. Las escrituras son las siguientes:

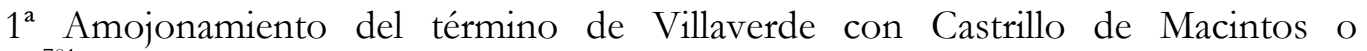
Castrillejo ${ }^{701}$, hecho año de 1552, ante Antonio Adame, esscribano de Villamuera, folio $1^{\circ}$.

$2^{\text {a }}$ Ordenanzas de pastos de términos entre Villamuera y Castrillo de Macintos ${ }^{702}$, hechas año de 1552, ante el mismo escribano, folio 4.

\footnotetext{
${ }^{698}$ Calzada] al margen derecho está tachado: Calzada.

${ }^{699}$ Carrión] al margen derecho: Hospital de Santa María de Carrión.

700 Villanueva del Río] al margen derecho: Villanueva del Río.

${ }^{701}$ Castrillejo] al margen derecho: Castrillejo.

${ }^{702}$ Castrillo de Macintos] al margen derecho: Villamuera, Castrillo.
} 
$3^{a}$ Amojonamiento de términos entre Paredes de Nava y Castrillo de Macintos ${ }^{703}$, hecho el año de 1552, ante Antonio de Vega, esscribano de Paredes, folio 8.

$<1559>$.

$4^{\mathrm{a}}$ Ordenanzas de términos y pastos entre Villoldo y Castrillo de Macintos ${ }^{704}$, hechas el año de 1559, ante Andrés Sánchez, esscribano de Carrión, folio 10.

$<1561>$.

$5^{\mathrm{a}}$ Amojonamiento de términos entre Villoldo y Castrillejo $^{705}$, hecho año de 1561, ante el mismo esscribano, folio 13; y otro, folio 14.

$<1569>$.

$\sigma^{a}$ Amojonamiento de términos entre Paredes y Castrillejo $^{706}$, hecho año de 1569. Hiciéronle los lugares entre sí y firmaron los presentes, no parece esscribano, folio 16.

$<1570>$.

$7^{\mathrm{a}}$ Amojonamiento de términos entre Castrillejo y Torre ${ }^{707}$, hecho en el año de 1570. Está firmado de algunos de los concejos, sin esscribano, folio 18.

$$
\text { / }(f .453 r)<1577>\text {. }
$$

$8^{a}$ Amojonamiento de términos entre Paredes y Castillejo $^{708}$, hecho año de 1577 , ante Francisco de Nogal, esscribano, folio 19 y 20.

$<1579>$.

$9^{a}$ Amojonamiento de términos entre Castrillo y Torre ${ }^{709}$, año 1579, ante Juan Bravo, esscribano de Villamuera, folio 21.

$<1591>$.

10. Amojonamiento de términos entre Villaverde y Castrillejo ${ }^{710}$, hecho año de 1591, ante Gaspar de Sahagún, esscribano de Becerril, folio 23.

$<1594>$.

11. Amojonamiento de términos entre Paredes ${ }^{711}$ y Villaverde, hecho año de 1594, ante Mateo Rojo, esscribano real, folio 28.

$<1606>$.

12. Amojonamiento de términos entre Villamuera ${ }^{712}$ y Villaverde, hecho año 1606, ante Santos de Guzmán, esscribano de Villamuera, folio 31.

$<1607>$.

13. Amojonamiento y apeo de todo el término redondo de Villaverde, con citación de los concejos, justicias y regimientos de Carrión, Paredes y Villamuera, hecho año de 1607, ante Antonio Orejón, esscribano de Carrión, y Santos de Guzmán, esscribano de Villamuera, folio 33 .

\footnotetext{
${ }^{703}$ Castrillo de Macintos] al margen derecho: Paredes, Castrillo.

704 Castrillo de Macintos] al margen derecho: Villoldo, Castrillo.

${ }^{705}$ Castrillejo] al margen derecho: Villoldo, Castrillo.

${ }^{706}$ Castrillejo] al margen derecho: Paredes, Castrillo.

707 Torre] al margen derecho: Torre, Castrillo.

${ }^{708}$ Castrillejo] al margen derecho: Paredes, Castrillo.

709 Torre] al margen derecho: Torre.

${ }^{710}$ Castrillejo] al margen derecho: Castrillo.

711 Paredes] al margen derecho: Paredes.

712 Villamuera] al margen derecho: Villamuera.
} 
16. <Apeo de la cofradía de Carrión. Año 1691>.

Apeo de las heredades que la cofradía de la villa de Carrión tiene en Villamuera, Cardeñosa y Villaverde. Ante Francisco Herrero, esscribano de Villamuera, año de 1691.

17. <Copias de dos apeos de la yglesia de Villamuera de las tierras que dice tener en Villaverde. Año 1615 y 1627>.

Bajo este número está un quaderno que contiene lo siguiente:

Primeramente están dos copias de los apeos que la yglesia de Villamuera ${ }^{713}$ hizo de las tierras que dicen tener en Villaverde; el uno de ellos es del año 1615, ante Santos de Guzmán, esscribano de Villamuera, y el otro del año 1627, ante Eugenio de Guzmán, receptor de Palencia, y esscribano de Añora. Pero adviértase que en el segundo apeo no sólo añadieron algo más de cavida en dos tierras, sino que pusieron 4 tierras más que en el antecedente, lo qual se advierte en la misma segunda copia.

$<$ Otras de la cofradía de San Julián. Año 1643 y 1691>.

Asimismo están aquí otras dos copias de apeos que la cofradía de San Julián de Carrión hizo de las tierras que supone tener en término de Villaverde; el uno de ellos, año 1643, ante Juan de Vega, esscribano de Villamuera; y el otro, año 1601, ante Francisco Herrero, esscribano del mismo lugar.

Esta copia es del número 16 de arriba.

$<$ Tierras del priorato de Villaverde $>$.

Después de esto está una memoria de todas las tierras que la casa ha adquirido en Villaverde, así por compras como por trueques.

18. <Tierras de la yglesia de Villamuera>.

Memoria de las tierras que la yglesia de Villamuera tiene en el término de Villaverde, y el curato, aniversarios, cofradías y beneficios. No tiene fecha.

$$
\text { / (f. 453v) } 19 .
$$

Tanto de un testamento que otorgó Juan del Campo, vecino de Carrión, sacado con autoridad de justicia, quien declara tener en los términos de Villamuera, Villaverde, Raveros y Cardeñosa, diferentes posesiones de tierras y viñas. Pasó ante Alonso Gómez de San Román, esscribano de de Carrión, año 1503.

\footnotetext{
713 Villamuera] al margen derecho: Villamuera.
} 


\section{/ (f. 454r) Cajón 19 San Leandro \\ Juros}

Este cajón, que es el 19 del archivo donde comienzan las cosas comunes, contiene los tres legajos siguientes: legajo $1^{\circ}$ : juros y sus privilegios reales; legajo $2^{\circ}$ : escrituras tocantes a los juros; legajo $3^{\circ}$ : censos redimidos.

\section{Legajo $1^{\circ}$}

Este legajo, que es el primero del cajón San Leandro, contiene los juros y sus privilegios reales, por el orden siguiente:

$1^{\circ}$. $<$ Juro de 4 mill maravedís, el rey don Juan el $2^{\circ}$, perpetuo. Año 1442>.

Privilegio, escrito en pergamino con sello de plomo pendiente en filos de seda, dado al monasterio de San Zoil por el rey don Juan el $2^{\circ}$ de 4 mill 000 maravedís de juro situados sobre las alcavalas del vino de la villa de Carrión ${ }^{714}$, los quales fueron de doña Beatriz Rodríguez de Fonseca y los dio a este monasterio por la hacienda que tenía en Benafarces ${ }^{715}$, como consta del foro perpetuo hecho el año de 1448; véase atrás, folio 338, cajón San Facundo, número $1^{\circ}$. Diose este privilegio en Arévalo, a 18 de octubre de 1442. Confirmaron después este privilegio la reyna doña Juana, el emperador Carlos $\mathrm{V}$ y el rey Felipe $2^{\circ}$, como consta por el privilegio siguiente, que es este mismo.

$2^{\circ}$. < Confirmación del juro de arriba. Años 1442, 1463, 1508 y 1563>.

Privilegio y confirmación del juro de 4 mill maravedís sobre la alcavala del vino de la villa de Carrión que dio a este monasterio doña Beatriz Rodríguez de Fonseca, que es el de arriba, escrito en pergamino, con sello de plomo pendiente, y en él la confirmación original de este privilegio, dada por la reyna doña Juana ${ }^{\not 16}$, año 1508 , que es confirmación de otro privilegio del rey don Enrrique $4^{\circ}$, año 1463 , en que confirma el de el rey don Juan el $2^{\circ}$, que es el de arriba. Vltimamente los confirma todos en este privilegio, nuevamente sellado, el rey don Felipe $2^{\circ}$. Dado en Madrid, a 4 de febrero de 1563.

$3^{\circ}$. <Juro de 11 mill maravedís perpetuo. Años 1447, 1461, 1537 y 1562>.

Privilegio, escrito en pergamino con sello de plomo pendiente, de 11 mill 000 maravedís de juro situados en esta forma: en las alcavalas de Villamuera ${ }^{717}$, merindad de Carrión, 4 mill 000 maravedís; en las alcabalas de Arconada ${ }^{718}$, merindad de Carrión, 600 maravedís; y en las alcavalas de Santoyo ${ }^{719}$, merindad de Castrojeriz, 6 mill 400 . Este privilegio de 11 mill maravedís de juro/ (f. 454v) perpetuo concedió al monasterio el rey don Juan el $2^{\circ}$, año 1447, por renunciación que Pedro de Vivero, vecino y regidor de Toro y guarda mayor del rey, hizo en el monasterio de San Zoil en trueque y cambio de la hacienda que desatentadamente le dio el monasterio en la ciudad de Toro y otros 18 lugares de su comarca, como consta por las escrituras de permuta citadas atrás, folio 338 vuelta, hechas en el año 1443. Este privilegio y juro está confirmado por el rey don Enrrique $4^{\circ}$, año 1461 . Perdiose este privilegio ya porque el monasterio cayó en abades comendatarios, poco cuidadosos de la hacienda de él, ya (y lo más cierto) porque el monasterio, en el contrato que hizo con Vivero, Vlloa y Fonseca, año 1459, les bolvió el privilegio de este juro porque se obligasen a darle 12 mill maravedís de censo perpetuo a su satisfacción, como consta en la relación de estos pleitos, folio 339. Perdido este privilegio, sacó el monasterio traslado autorizado de él, y le presentó al emperador don Carlos y la reyna doña Juana, su madre, y pidió nuebo privilegio y confirmación del pasado, que le concedieron y libraron en Valladolid a 10 de hebrero de 1531, cuyo original está en este privilegio. Después de lo qual, a instancia del convento, lo confirmó todo el rey don Felipe $2^{\circ}$, en Madrid, a 21 de diciembre de 1562.

\footnotetext{
${ }^{714}$ Carrión] al margen derecho: Carrión.

715 Benafarces] al margen derecho: Benafarces.

${ }^{716}$ Juana] sigue tachado: Dada.

717 Villamuera] al margen derecho: Villamuera.

718 Arconada] al margen derecho: Arconada.

${ }^{719}$ Santoyo] al margen derecho: Santoyo.
} 

$1510>$.

$4^{\circ}$. < Juro perpetuo de 20 mill maravedís, es de San Román. Años 1462, etcétera, hasta

Privilegio, escrito en pergamino con sello de plomo pendiente, de 20 mill 000 maravedís situados en la forma que se expresa al principio, que hacen justamente los dichos 20 mill maravedís, los quales son parte de los 106 mill 826 maravedís de juro perpetuo que tubo don Luis Hurtado de Mendoza, administrador perpetuo de San Zoil, por merced que de ellos le hizo el rey don Enrrique $4^{\circ}$, por tres cartas de privilegio; una dada en Segovia, a 6 de marzo de 1465; otra dada en Madrid, a 12 de octubre de 1462, y otra dada en Segovia, a 26 de marzo de 1463. De los quales mandó al monasterio de San Román ${ }^{720}$ los 20 mill 000 maravedís de juro perpetuo situados, como dije arriba, esto es: al principio de este privilegio, las dos partes para el sustento de los monjes de aquel monasterio, y la una parte para su fábrica, los quales habían confirmado a don Luis Hurtado los Reyes Católicos, año 1483; y mandaron confirmar al monasterio los 20 mill maravedís año 1510, en cuya virtud la reyna doña Juana mandó dar y dio su privilegio de los dichos 20 mill maravedís situados como dicho es en cabeza del monasterio de San Román./ (f. 455r) Dado en Madrid, a 14 de mayo de 1510 .

$<1530>$.

Este privilegio se perdió y por perdido le confirmaron y concedieron nuevo el emperador Carlos $5^{\circ}$ y la reyna doña Juana, su madre, en Madrid, a 12 de agosto de 1530.

$<1562>$.

Después le confirmó el rey don Felipe $2^{\circ}$, y dio este privilegio de nuevo inserto el original del emperador, y sellado de nuevo, en Madrid, a 12 de diciembre de 1562.

$<$ Fees de los contadores reales. Año 1537>.

Asimismo están aquí dos fees de los contadores mayores del rey del juro de San Román y otros tres juros, uno de 4 mill maravedís, otro de 5 mill 154 y otro de 11 mill maravedís, año 1537.

$5^{\circ}$. <Juro de 5 mill 154 maravedís que dio el monasterio a don Luis Hurtado de Mendoza. Año 1510 y 1562>.

Privilegio, escrito en pergamino, con sello de plomo pendiente, de 5 mill 154 $<$ maravedís $><$ de juro perpetuo $>$, situados en la forma que al principio se expresa, los quales mandó a este convento por su testamento don Luis Hurtado de Mendoza, administrador perpetuo de esta abadía, con cargo de que el convento le diga una misa de la cruz cantada en el altar mayor, con cruz, diácono y subdiácono, y un responso en medio de la capilla mayor todos los viernes ${ }^{721}$ de cada semana perpetuamente. Este juro ${ }^{722}$ era de los 106 mill 826 maravedís de juro que tenía don Luis por merced del rey don Enrrique el $4^{\circ}$, desde el año de 1462 , en la forma que se advierte en el privilegio de atrás, número $4^{\circ}$. En virtud de esta manda, el rey don Fernando el Católico mandó que al monasterio se le librase privilegio en su cabeza de los dichos 5 mill 154 maravedís por los años de 1509. Y de ellos libró privilegio en forma, sellado con sello de plomo, la reyna doña Juana. Dado en Valladolid, a 16 de enero de 1510, el qual está aquí original. Y por estar maltratado le mandó escrivir de nuevo y le confirmó el rey don Felipe $2^{\circ}$, en Madrid, a 30 de diciembre de 1562, y así hay dos privilegios de una misma cosa.

$6^{\circ}$. < Juro de Sevilla, de que toca el convento 19 mill 516 maravedís. Año 1535>.

Tres trasumptos autorizados de un privilegio dado por el emperador Carlos $5^{\circ}$ y la reyna doña Juana, su madre, a favor de Pedro Barrantes, vecino de Truxillo, señor de la Cumbre y padre de nuestro reverendísismo padre maestro fray Alonso Barrantes, de cantidad de 79 mill 184 maravedís de juro perpetuo en cada un año, a razón de 30 mill el millar,

\footnotetext{
${ }^{720}$ San Román] al margen derecho: San Román.

721 viernes] al margen derecho: Missa de la cruz cada viernes.

${ }^{722}$ Juro] al margen derecho: Villamayor, Bobadilla del Camino, Cerbatos, Villodrigo.
} 
situados sobre las rentas del alcavala y diezmo de las aceytes de la ciudad de Sevilla ${ }^{723}$ y su aljarafe, rivera y pesquerías, por razón de 2 qüentos 375 mill 543 maravedís de oro y plata, que Su Magestad <tomó> a Pedro Barrantes, el qual los trahía del Pira (sic); / (f. 455v) y el emperador los hubo menester para socorro de las guerras que tenía contra el turco y Barbarroja. Dado en Madrid, a 21 de diciembre de 1535. De este juro le tocan al convento de San Zoil 19 mill 516 maravedís por los legítimas de nuestro padre maestro Barrantes, los quales se le adjudicaron en las partijas que se hicieron de los bienes de sus padres, de que hay aquí todas las escrituras e instrumentos bastantes.

$7^{\circ}$. < Juro de 7 mill 051 maravedís en las alcavalas de San Zoles. Año 1556 y 1609>.

Privilegio del rey don Felipe $2^{\circ}$, dado en Madrid, a 19 de mayo de 1609, de cantidad de 7 mill 051 maravedís de juro al quitar, etcétera, como se expresa al principio. Está confirmado por el rey Felipe $3^{\circ}$, dicho año, y así cobra el monasterio, sin embargo de la pracmática del crecimiento de los juros los 7 mill 051 maravedís de juro enteramente.

$8^{\circ}$. < Juro de 8 mill 450 maravedís en las alcavalas de Sahagún. Año 1464 hasta 1575>.

Privilegio en pergamino, con sello de plomo pendiente, del rey don Felipe $2^{\circ}$, por el qual confirma para el monasterio de San Zoil 8.450 maravedís de juro perpetuo situados sobre las alcavalas de Sahagún, el qual compró el monasterio con ciertas heredades en Cisneros de Luis Bravo de Lagunas. Su primera concesión es del rey don Enrrique $4^{\circ}$, año 1464, y después le confirmaron los Reyes Católicos don Fernando y doña Ysabel, año 1481, y después de ellos la reyna doña Juana, año 1513, y el rey Felipe $2^{\circ}$, año 1566, y últimamente el mismo, en la cabeza del monasterio de San Zoil, año 1575. $1602>$

9. <Juro de doña Constanza en Carrión de 75 mill 000 maravedís. Años 1591 y

Privilegio en pergamino, con sello de plomo pendiente, de 75 mill 000 maravedís de juro al quitar, a razón de 2 mill 000 el millar, que compró Antonio Doro Campo, regidor y alférez mayor de Carrión, de que le concedió privilegio en su cabeza el rey Felipe $2^{\circ}$, en Madrid, a 22 de febrero de 1591; y le diputó en su testamento para la fundación o dotación de una cappellanía para su entierro; y después de él muerto, su muger, doña Constanza Enrríquez, y su hijo don Antonio Doro Enrríquez, tomaron para el dicho efecto la capilla de la yglesia de San Zoil que llamamos de doña Constanza, con ciertas fundaciones de misas y memorias que instituyeron; y en parte de pago dieron al monasterio este juro, como consta de los contratos que están atrás, folio 137, por lo qual el rey don Felipe $3^{\circ}$ dio su privilegio de este juro en cabeza del monasterio de San Zoil. Dado en Valladolid, a 19 de octubre de 1602.

Están situados sobre las alcavalas de Carrión.

\section{/ (f. 456r) Legajo $2^{\circ}$ del Cajón San Leandro}

Escrituras tocantes a los juros

Este legajo, que es el primero de este cajón San Leandro, contiene algunas escrituras y papeles tocantes a los juros, y en particular uno que es traslado de la relación por antelación de los juros que hay situados en la villa de Carrión y su alfoz desde el año de 1623 en adelante.

\section{/ (f. 456r) Legajo $3^{\circ}$ del Cajón San Leandro Censos redimidos}

Este legajo, que es el tercero del cajón San Leandro, consta de censos que ha tomado en diversos tiempos el monasterio y están redimidos.

\footnotetext{
${ }^{723}$ Sevilla] al margen derecho: Sevilla.
} 


\section{/ (f. 457r) Cajón 20 San Millán}

Apeos

Este cajón San Millán, que es el vei[n]te del archivo, contiene los apeos de las heredades que tiene el monasterio en diversos lugares, por el orden siguiente:

Primeramente está un legajo de apeos general de toda la hacienda que tiene el monasterio de San Zoil en diversos lugares, por orden alfabético, con varias provisiones reales para apear en diferentes años, y luego los libros siguientes:

Libro $1^{\circ}$ de apeos

Este libro, intitulado primero, contiene apeos hechos por los años de 1473 hasta 1481, en los lugares siguientes:

$<$ Apeos del año 1473>.

$<$ Arconada $>$.

42 у 118.

Apeo de este lugar; ante Fernando Díaz, esscribano de Villasirga, a folios 32,

$<$ Bárcena $>$.

Apeo ante Pedro de Colmenares, esscribano de Cámara, folio 37.

$<$ Becerril $>$.

Apeo ante Pedro Pérez Román, esscribano de Becerril, folio 138, 142 y 147.

$<$ Carrión y San Zoles $>$.

Apeo de Carrión y San Zoles; no está autorizado, folio 89, 103 y 133.

$<$ Castrillo de Macintos>

Apeo de Castrillo de Macintos; no está autorizado, folio $1^{\circ}$.

$<$ Cestillos $>$.

Apeo de Cestillos; no está autorizado, folio 88.

$<$ Frómesta $>$.

Apeo de Frómesta, sin autoridad, folio 128.

$<$ Ferreros $>$.

Apeo simple de Ferreros, folio 87.

$<$ Gañinas $>$.

Apeo ante Fernando Cavallo de Carrión, escribano, folio 75.

$<$ Tierras $>$.

Tierras de los Molinos de Calzada, folio 30.

$<$ Tierras $>$.

Tierras en la Vega de Carrión; esscribano, Alonso Sánchez, folio 103.

$<$ Villa $<$ sabariego $>>$.

Apeo ante Juan Martínez, esscribano de Carrión, folio 3.

$<$ Villamez $>$.

Apeo ante Juan Martínez de Carrión, esscribano de ésta, folio 7, 21 y 49.

$<$ Villanueva de Senadre $>$.

Apeo ante Fernando Cavallo, esscribano de Carrión, folio 50.

/ $(f .457 v)<$ Villanueva del Río $>$.

Apeo ante Fernando Cavallo, esscribano de Carrión, folio 68 y 80. 
$<$ Villasirga $>$.

Apeo ante Diego de San Zoles, nottario, folio 111.

$<$ San Zoles $>$.

Apeo simple de las heredades de San Zoles, folio 96 y 99.

\section{Libro $2^{\circ}$ de Apeos}

Este libro, intitulado segundo, contiene los apeos hechos por los años de 1410 hasta 1516, en diversos lugares; véase el índice de este libro, que está al principio, porque unas son sólo memorias de hacienda, y otros son apeos.

\section{Libro $3^{\circ}$ de Apeos}

Este libro, que es el tercero, contiene los apeos hechos por los años de 1508 hasta 1570, de la hacienda que tiene este monasterio de San Zoil en diversos lugares; los quales se hallan al principio de dicho libro, en el índice o tabla de lo que contiene.

\section{Libro $4^{\circ}$ de Apeos}

Este libro, que es el quarto, contiene los apeos hechos por los años de 1560 hasta 1571, de la hacienda que tiene este monasterio de San Zoil en diversos lugares, los quales se hallan al principio de este otro libro, en el índice de lo que contiene.

\section{/ (f. 458r) Libro $5^{\circ}$ de Apeos}

Este libro, que es el quinto, contiene los apeos hechos por los años de 1577 hasta 1692 de la hacienda que tiene este monasterio de San < Zoil > en diversos lugares, los quales se hallan anotados en el forro de este libro, en forma de índice.

Libro $6^{\circ}$ Apeos de Nuestra Señora del Brezo

Este libro, que es el sexto del legajo San Millán, contiene los apeos de la hacienda que tiene la casa del Brezo en diversos lugares anotados en el forro de este libro, hechos por los años de 1586, 1638 y 1784, que es el último apeo que se hizo del monte titulado Monte Rey. Libro $7^{\circ}$ Apeos de San Román

Este libro, que $\mathrm{e}^{724}<$ es el séptimo>, contiene los apeos de la hacienda y préstamos de San Román y es el más antiguo, aunque bien maltratado, y le faltan muchas ojas. Hechos por los años de 1544 y 1560. Desde el folio 136 se añadieron a este libro los apeos hechos por los años de 1526 hasta 1649.

\section{/ (f. 458v) Libro $8^{\circ}$ Apeos de San Román}

Este libro, que es el octavo, contiene los apeos de la hacienda y préstamos que tiene San Román en diversos lugares. Véase el índice que trahe al principio. Hechos por los años de 1581 y 1583. En el estante de esta primera sala según se entra, a la izquierda, cajón segundo, entre los libros de encabezo de San Román hay un libro de apeos que es copia de éste, pero no está autorizado.

\section{Libro $9^{\circ}$ de Apeos de San Román}

Este libro, que es el noveno, contiene los apeos de la hacienda y préstamos que San Román y El Brezo tienen en todos los lugares de aquella tierra. Hechos año de 1662, ante Lorenzo de la Vega, escribano de Saldaña.

Hay además unos apeos del Coto Monte y regalías del monasterio de San Román de Entrepeñas, en su lugar de Santiváñez y del despoblado de (de) San Bool, junto a Respenda. Hecho en los años de 1788 y 1789.

10. Apeo de Carrión y otros varios lugares executado en los años de 1655 y 1656, ante Norverto de Sandoval y Guevara, escribano de Carrión.

\footnotetext{
${ }^{724}$ que] sigue tachado: Es el segunda, ver sesto (por no alterar el orden de los apeos de San Román).
} 
11. Apeo de Arconada executado en el año de 1800, ante Jese Tablares, escribano de Carrión.

$<$ Frómesta $>$.

Ytem dos quadernos de apeos de Frómesta executados en diversos años, que son desde 1481 hasta 1664, etcétera. 


\section{/ (f. 459r) Cajón 21 Santo Toribio Censos}

Este cajón, que es el veinte y uno del archivo, contiene las escrituras y papeles pertenecientes a los censos que tiene este monasterio de San Zoil en diversos lugares, divididas en tres legajos de censos, y debajo de éstos están otros censos que parece que se cobran de los prioratos del Brezo, Frómesta, Aguilar, etcétera, con otras rentas judiciales a favor de este monasterio de Macintos, Boadilla de Rioseco y otros.

Legajo $1^{\circ}$ del Cajón Santo Toribio Censos siguientes:

Este legajo, que es el primero del cajón Santo Toribio, contiene los tres quadernos

\section{Quaderno A del legajo $1^{\circ}$ \\ Abastas ${ }^{725}$}

Este Quaderno A contiene las escrituras de censo de los lugares ${ }^{726}$ que aquí se expresarán por el orden siguiente:

$1^{\circ}$. $<$ Censo contra e licenciado Miguel Docio. 1678>.

Escritura de censo contra el licenciado Miguel Docio, de 1100 reales de (de) principal y 33 reales de réditos. A 14 de noviembre de 1678, ante Norverto de Sandoval y Guevara, escribano de Carrión.

$/(f .459 v) 2^{\circ} .<$ Censo contra Domingo y Francisco López. Año 1676>.

Escritura de censo contra Domingo y Francisco López, y sus mugeres, vecinos de Abastas, de 550 reales de principal y 16 reales y 17 maravedís de réditos en cada un año. Fue otorgada en 2 de septiembre de 1676, ante Norverto de Sandoval y Guevara, esscribano de Carrión.

\section{Añozas}

$3^{\circ}$. <Censo contra Juan Prieto y Lucía Poza. Año 1656>.

Escritura de censo contra Juan prieto y Lucía de Poza, su muger, vecinos de Añozas, de 500 reales de principal y 15 reales de réditos en cada un año. Fue otorgada en 20 de junio de 1656, ante Norverto de Sandoval y Guevara, esscribano de Carrión.

\section{Arconada}

$4^{\circ}$. <Censo contra el (el) concejo y vecinos de este lugar. Año 1765>.

Escritura de censo contra el concejo y vecinos de Arconada de 14 mill 000 reales de principal y 280 reales de réditos en cada un año. Fue otorgada en 14 de abril de 1765, ante Diego del Val y Cornejo, esscribano de Carrión.

\section{Autol} $1736>$.

$5^{\circ}$. < Censo contra don Diego Pérez y doña María Díez, vecinos de Autol. Año

Escritura de censo contra don Diego Pérez y doña María Díez, vecinos de la villa de Autol, obispado de Calahorra, de 33 mill 000 reales de principal y 825 reales de réditos en cada un año. Fue otorgada en 10 de marzo de 1763, ante Agustín Díez de Castro, esscribano de Carrión.

\section{Calzada} $1704>$.

$6^{\circ}$. <Censo contra Domingo Monje, José Aparicio, etcétera, vecinos de Calzada. Año

Escritura de censo contra Domingo Monge, José Aparicio y sus mugeres, vecinos de Calzada, de 400 reales de principal y 12 reales de réditos en cada un año. Fue otorgada en 4 de diciembre de 1704, ante Francisco Ruiz de Sandoval, esscribano de Carrión.

\footnotetext{
${ }^{725}$ Abastas] al margen derecho: Aguilar véase Quaderno C nº14.

${ }^{726}$ lugares] sigue tachado: siguientes.
} 


\section{Cardeñosa} Año 1679>.

$7^{\circ} .<$ Censo contra Juan Antón y el licenciado Lucas Antón, vecinos de Cardeñosa.

Escritura de censo contra Juan Antón y el licenciado Lucas Antón, beneficiado, vecinos de Cardeñosa, de 882 reales y 12 maravedís de principal y 26 reales y 10 maravedís de réditos en cada un año. Fue otorgada en 25 de enero de 1679, ante Norverto de Sandoval, esscribano de Carrrión. $1678>$.

$8^{\circ}$. < Censo contra Francisco Gallo y Francisca, su muger, vecinos de Cardeñosa. Año

Escritura de censo contra Francisco Gallo de Cevallos y Francisca de las Heras, su muger, vecinos de Cardeñosa, de 1.764 reales y 24 maravedís de principal y 52 reales y 32 maravedís de réditos en cada un año. Fue otorgada en 17 de noviembre de 1678, ante Norverto de Sandoval, esscribano de Carrión.

$$
9^{727} \text {. }
$$

$$
\text { / (f. 460r) Carrión }
$$

10. <Censo contra la Real Hacienda de la villa de Carrión. Año 1780>.

Escritura de censo contra la Real Hacienda y particularmente contra la venta de tabaco de esta villa, especial hipoteca de este censo donde se cobra, de 10 mill 300 reales de principal y 309 reales de réditos en cada un año. Fue otorgada en Toro, a 23 de mayo de 1780, por testimonio de José Vernal, esscribano de dicha ciudad.

11. <Censo contra Juan Pérez Pariente, vecino de Carrión. Año 1775>.

Escritura de censo contra Juan Pérez Pariente y Agustina Peláez, vecinos de Carrión, de 380 reales de principal y 11 reales y 12 maravedís de réditos en cada un año. Fue otorgada en 11 de junio de 1775, ante Andrés Núñez Castelo, esscribano de Carrión.

12. <Censo contra Blas Abastas y el licenciado Julián Abastas. Año 1673>.

Escritura de censo contra Blas Abastas y el licenciado Julián Abastas, beneficiado de San Cibrián, de 588 reales y 8 maravedís de principal y 17 reales y 22 maravedís de réditos en cada un año. Fue otorgada en 17 de septiembre de 1673, ante Norverto de Sandoval, esscribano de Carrión.

13. < Censo contra María Reynosa y consortes, vecinos de Carrión. Año 1762>.

Escritura de censos contra María Reynos, María Ana Fontán, viudas, Tomás González Reynoso y consortes, vecinos de Carrión, de 6 mill 000 reales de principal y 150 reales de réditos en cada un año. Fue otorgada en 8 de marzo de 1762, ante Manuel Francisco Blanco, esscribano de Carrión.

\section{Cerbatos de la Cueza}

14. $<$ Censo contra el licenciado Santos Caballero. Año 1706>.

Escritura de censo contra el licenciado Santos Caballero, beneficiado de Cerbatos. Otorgada en 23 de marzo de 1706, ante Agustín de Medina, esscribano de Carrión.

\section{Congosto}

15. $<$ Censo contra Alexo Vicente, vecino de Congosto. Año 1736>.

Escritura de censo contra Alexo Vicente y María González, su muger, vecinos de Congosto, de 3 mill 600 reales de principal y 108 reales de réditos en cada un año. Fue otorgada en 28 de julio de 1736, ante José García de Guadiana, esscribano de Castrejón.

727 9] sigue tachado: Cerbatos. Escritura de censo centra el licenciado Santos Caballero, beneficiado de Cerbatos de la Cueza. 


\section{Cuerno}

16. <Censo contra Pedro Cosgaya, vecino de Cuerno. Año 1770>.

Escritura de censo contra Pedro Cosgaya, vecino de Cuerno, de 905 reales de principal, y 4 maravedís, y de réditos: 27 reales con 5 maravedís en cada un año. Fue otorgada en 30 de abril de 1770, ante Andrés Núñez Castelo, esscribano de Carrión. 


\section{/ (f.460v) Cajón Santo Toribio \\ Quaderno B del legajo $1^{\circ}$ \\ Censos}

Este quaderno B contiene las escrituras de censo que tiene el monasterio de San Zoil en diver-sos lugares, por el orden siguiente:

\section{Fuentes de Don Bermudo}

$1^{\circ}$. <Censo contra Santiago Sevilla, vecino de Fuentes de Don Bermudo. 1721>.

Escritura de censo contra Santiago Sevilla Nieto y María de Cisneros, su muger, vecinos de Fuentes de don Bernardo, de 1.300 reales de principal y 39 reales de réditos en cada un año. Fue otorgada en $1^{\circ}$ de abril de 1721, ante Gregorio García de Miranda, esscribano de Carrión.

$2^{\circ}$.

$3^{\circ}$.

\section{Madrid}

$4^{\circ}$. $<220$ mill 300 reales $^{728}$. Caxa de amortización. Año 1538>.

En los gremios mayores de Madrid tenía el monasterio puestos 220 mill 300 reales, de lo que otorgó escritura en 27 de febrero de 1793, la qual se sacó y ${ }^{729},<$ habiéndose pasado el pago a la caxa de $<$ (se pasaron a la caxa de) amortización, como consta en la escritura que está en poder del padre fray Santiago Hermosilla, conventual de San Martín de Madrid e hijo desta casa $>$, como consta de los papeles que están bajo este número.

$4^{\circ}$. (sic) <Censo contra Juan Prieto (sic) y consortes, vecinos de Madrid. Año 1620>.

Escritura de censo contra Juan Preciado, Hernando Martín y Francisco López con sus mugeres, vecinos de Madrid, de 6.600 reales de principal, y 198 de réditos en cada un año. Fue otorgada la escritura en 8 de septiembre de 1620, ante Juan Gómez de la Quintana, esscribano real y vecino de Madrid.

\section{/ (f. 461r) Polvorosa}

$5^{\circ}$. $<$ Dos censos contra el concejo y vecinos de Polvorosa; el $1^{\circ}$ de 19 mill 000 reales de principal, año 1748; el $2^{\circ}$ de (de) acrecentación, es de 13 mill 500 reales de principal, año 1762 y $1765>$.

Dos escrituras de censo contra el concejo y vecinos de Polvorosa, de los quales el primero es de 19 mill 000 reales de principal y 475 reales de réditos en cada un año. Otorgose esta escritura en 28 de diciembre de 1748, ante Manuel García, esscribano de las diez villas de la Valdabia.

El segundo censo, otorgado ante el referido esscribano, en 23 de mayo de 1762, asciende por la adjunta escritura de acrecentamiento otorgada por los mismos en 29 de marzo de 1765, ante Manuel Francisco Blanco, esscribano de Carrión, a 13 mill 500 reales de principal y 337 reales y 17 maravedís de réditos en cada un año. Plazo de éste, 23 de mayo.

$$
\text { Roscales }^{730}
$$

$6^{\circ}$. <Censo contra don Antonio Merino, presbítero de Roscales. Año 1742>.

Escritura de censo contra don Antonio Merino, presvítero del lugar de Roscales, otorgada en 11 de junio de 1742, ante José Luis de Cantoral, esscribano de Villanueva de Muñeca.

\footnotetext{
728 reales] sigue tachado: Redimiose año 1798.

$\left.{ }^{729} \mathrm{y}\right]$ sigue tachado: y se [......] redimido los gremios el capital.

${ }^{730}$ Roscales] escrito sobre Santoyo.
} 


\section{Santoyo}

$7^{\circ}$. <Censo contra Blas Vallejo, vecino de Santoyo. Año 1642>.

Escritura de censo contra Blas Vallejo, vecino de Santoyo, de 1176 reales y 16 maravedís de principal y 35 reales con 10 maravedís de réditos en cada un año. Fue otorgada en 29 de diciembre de 1642, ante Francisco Moro de Saldaña, esscribano de Carrión.

\section{Santiváñez de la Peña}

8 . <Censo contra José Liébana, vecino de Santiváñez. Año 1761>.

Escritura de censo contra José de Liébana, vecino de Santiváñez, de 850 reales de principal y 25 reales y 17 maravedís de réditos en cada un año. Fue otorgada en 17 de julio de 1761, ante José Luis de Cantoral, esscribano de Villanueva de Muñeca.

9. <Censo contra Juan de Villalba, vecino de Santiváñez. Año 1775>.

Escritura de censo contra Juan de Villalba y Brígida Gutiérrez, su muger, vecinos de Santiváñez, de 400 reales de principal y 12 de réditos en cada un año. Fue otorgada en 30 de mayo de 1775, ante Manuel Luis París, esscribano de Villanueva de Muñeca.

10. <Censo contra Juan de Villalba, el mismo de arriba, aunque diferente>.

Escritura de censo contra Juan de Villalba y Brígida Gutiérrez, vecinos de Santiváñez, (tienen dos) de 1.000 reales de principal y 30 reales de réditos en cada un año. Fue otorgada en 25 de enero de 1766, ante José Luis de Cantoral, esscribano de Villanueva de Muñeca.

/ (f. 461v ) 11. <Censo contra Manuel Gregorio, vecino de Santiváñez. Año 1767>.

Escritura de censo contra Manuel Gregorio, vecino de Santiváñez, de 600 reales de principal y 18 reales de réditos en cada un año. Fue otorgada en 2 de noviembre de 1767, ante Manuel Luis París, esscribano de Villanueva de Muñeca.

\section{Torre de los Molinos}

12.

\section{Villanueva de Muñeca}

13. $<$ Censo contra José Luis de Cantoral, esscribano de Su Magestad, etcétera. Año 1767>. $<$ Redimiose $\mathrm{R}^{731}>$.

Escritura de censo contra José Luis de Cantoral, esscribano de Su Magestad, e Ysabel París, su muger, Manuel Luis París y Josefa Gonzalo, su muger, vecinos de Villanueva, de 3.400 reales de principal y 102 reales de réditos en cada un año. Fue otorgada en (en) 4 de abril de 1767, ante el referido esscribano; otorgante, José Luis de Cantoral.

\section{Villafría}

14. <Censo contra Gregorio García. Año 1765>.

Escritura de censo contra Gregorio García y Josefa Palaz, su muger, vecinos de Villafría, de 500 reales de principal y 15 reales de réditos en cada un año. Fue otorgada en 24 de abril de 1765, ante José Luis de Cantoral, esscribano de Villanueva de Muñeca.

15. < Censo contra el mismo Gregorio García. Año 1771>.

Escritura de censo contra el mismo Gregorio García, etcétera, vecino de Villafría, de 857 reales de principal y 25 reales con 24 maravedís de réditos en cada un año. Fue otorgada en 26 de octubre de 1771, ante Andrés Núñez Castelo, esscribano de Carrión.

\footnotetext{
$731<$ Redimiose> ] al margen derecho: Se redimió este censo en $1^{\circ}$ de agosto de 1815.
} 


\section{/ (f. 462r) Quaderno C del legajo $1^{\circ}$ \\ Censos}

Este quaderno C contiene las escrituras de censos que tiene el monasterio de San Zoil en diversos lugares, por el orden siguiente:

Villalán, véase número 13.

Villalumbroso

$1^{\circ}$. $<$ Censo contra el licenciado Matías Calonge, beneficiado. 1693>.

Escritura de censo contra el licenciado Matías Calonge, beneficiado de (de) Villalumbroso, de 800 reales de principal y 24 de réditos, otorgada en 20 de noviembre de 1693, ante Diego Lasso, esscribano de dicho lugar. Año 1691>.

$2^{\circ}$. $<$ Censo que compró este monasterio a los curas de Cisneros en Villalumbroso.

Escritura de censo otorgada en favor del cura y beneficiados de Cisneros, por Francisco Laso, etcétera, vecinos de Villalumbroso, los quales dichos curas y beneficiados le vendieron a este monasterio de San Zoil, por escritura otorgada en 5 de mayo de 1691, ante Sebastián de Hermosa, esscribano de Cisneros. Fue este censo en primera imposición de 1.102 reales y 32 maravedís de principal y oy, por haber redimido la mitad el licenciado Matías Calonge, sólo consiste su capital en 551 reales y 16 maravedís y 16 reales y 17 maravedís ${ }^{732}$ de réditos en cada un año.

\section{$3^{\circ}$. <Censo contra Matías Antón y consortes. Año 1729>.}

Escritura de censo contra Matías Antón e Ysabel Lasso, vecinos de Villalumbroso, y Josefa Durántez, viuda, y su hijo, vecinos de Villatoquite, de 850 reales de principal y 25 reales y 17 maravedís de réditos en cada un año. Fue otorgada en 19 de marzo de 1729, ante Mauricio Martínez de Chirueches, esscribano de Carrión.

$4^{\circ}$. $<$ Redimiose. Año 1794>.

El censo de este número $4^{\circ}$, que pagaba el mismo Manuel Díez Aparicio, se redimió en diciembre de 1794.

\section{$5^{\circ}$. <Censo contra Nicolás de Guzmán. Año 1736>.}

Escritura de censo contra don Nicolás de Guzmán, vecino de Villatoquite, Pedro Lasso y Ana Otero, su muger, vecinos de Villalumbroso, el qual en su primera imposición fue de 1.800 reales de principal y ahora, por haber redimido la mitad dél don Bernabé de Cuesta, vecino de Villatoquite, en 4 de/ (f. 462v) diciembre de 1769, sólo consta de 900 reales de principal y 27 reales de réditos en cada un año. Fue otorgada en 9 de marzo de 1763, ante Agustín Díez de Castro, esscribano de Carrión.

$\left[6^{\circ}.\right]$

$\left[7^{\mathrm{o}}.\right]$

\section{Villamorco}

$8^{\circ}$. $<$ Dos censos contra el concejo y vecinos de Villamorco; el $1^{\circ}$ de 1750 reales, el $2^{\circ}$ de 3.500 reales. Años 1754 y 1769>.

Dos escrituras de censo contra el concejo y vecinos particulares de Villamorco, de los quales el primero consta hoy (por haberse redimido la quarta parte dél en el año de 1762)

\footnotetext{
732 maravedís] al margen derecho: Los 16 reales y 17 maravedís q[ue resultan de este censo los pagó Manuel Díez Aparicio; que son los 25 reales y 17 maravedís que igualmente paga por el censo del número $3^{\circ}$ siguiente, y componen 42 reales, los mismos que paga dicho Aparicio.
} 
de 24.750 reales de principal y 495 reales de réditos en cada un año. Fue otorgada en 2 de septiembre de 1754, ante Manuel Francisco Blanco, esscribano de Carrión.

El $2^{\circ}$ es de 3.500 reales de principal y 105 reales de réditos en cada un año. Fue otorgado en 17 de enero de 1769, ante Juan Francés Brabo, esscribano en Villamorco.

\section{Villaumbrales}

9. $<$ Censo contra don Francisco Cabezudo y consortes. Año 1614>.

Escritura de censo contra don Francisco Cabezudo, beneficiado en Villaumbrales, Domingo Gato y consortes de 1000 reales de principal y 30 reales de réditos en cada un año. Fue otorgada en 12 de agosto de 1614, ante Juan Rodríguez, esscribano en Villaumbrales.

10. <Censo contra José Díez, vecino de Villaumbrales. Año 1680>.

Escritura de censo contra José Díez y Francisco García Monrroy, su muger, / (f. 463r) vecinos de Villaumbrales, de 764 reales y 24 maravedís de principal y 22 reales con 32 maravedís de réditos en cada un año. Fue otorgada en 8 de enero de 1680, ante Matheo Hortiz, esscribano de dicho lugar.

\section{1. <Censo contra Antón Aguado e Ysabel Herrero. Año 1676>.}

Escritura de censo contra Antón Aguado Porrío e Ysabel Herrero, su muger, vecinos de Villaumbrales, de 1.176 reales y 16 maravedís de principal y 35 reales y 10 maravedís de réditos en cada un año. Fue otorgada en 16 de septiembre de 1676, ante Norverto de Sandoval y Guevara, esscribano de Carrión.

12. < Censo contra Juan Moro y Alonso Moro. Año 1630>.

Escritura de censo contra Juan Moro Pérez y Alonso Moro Pérez, vecinos de Villaumbrales, de 588 reales y 8 maravedís de principal, y 17 reales y 22 maravedís de réditos en cada un año. Fue otorgada en 8 de enero de 1630, ante Santos de Guzmán, esscribano de Villamuera.

\section{Villalán}

13. <Censo contra Estevan Pardo. Año de 1664>.

Escritura de censo contra Estevan Pardo, vecino de Villalán, de 588 reales de principal y 17 reales y 22 maravedís de réditos en cada un año. Fue otorgada a 27 de septiembre de 1664, ante Norverto de Sandoval y Guevara, esscribano de Carrión.

$$
\text { Aguilar }
$$

14. $<$ Censo contra Pedro Pérez Minayo. Año de 1664>.

Escritura de censo contra Pedro Pérez Minayo, Ana Martínez, su muger, y Antonio Pérez, su hijo, vecinos de Aguilar, de 1.100 reales de principal y 33 de réditos en cada un año. Fue otorgada en 8 de diciembre de 1.664, ante Christóval López Ramírez, esscribano de Aguilar.

\section{/ (f. 463v) Legajo $2^{\circ}$ del Cajón Santo Toribio Becerril}

Este legajo, que es el segundo del cajón Santo Toribio, contiene las escrituras de censo que este monasterio de San Zoil tiene a su favor en el lugar de Becerril, por el orden siguiente:

$1^{\circ}$. <Censo contra el bachiller Francisco Berdeces y consortes. 1639>.

Escritura de censo contra el bachiller Francisco Berdeces y Morrondo, Gaspar Pérez, clérigos, y Santiago de Torres Villarroel, vecinos de Becerril, de 1.470 reales y 20 maravedís de principal y 44 reales de réditos en cada un año. Fue otorgada en 13 de mayo de 1639, ante Francisco Moro de Saldaña, esscribano de Carrión. 
$2^{\circ}$. <Censo contra Matías Buey y consortes. Año 1698>.

Escritura de censo contra Mathías Buey Carrión y Santiago Doncel y sus mugeres, vecinos de Becerril, de 1.100 reales de principal y 33 reales de réditos en cada un año. Fue otorgada la escritura en 29 de octubre de 1698, ante Bernardo Buey Valle, esscribano de dicho lugar.

\section{$3^{\circ}$. < Censo contra Ángel García y Josefa Pelaz. Año 1762>.}

Escritura de censo ${ }^{733}$ contra Ángel García y Josefa Palaz, su muger, vecinos de Becerril, de 1.500 reales de principal y 45 reales de réditos en cada un año. Fue otorgada en 24 de febrero de 1762, ante Manuel Pedrejón de San Juan, esscribano del mismo lugar.

\section{$4^{\circ} .<$ Censo contra Santiago Gutiérrez y su muger. Año 1709>.}

Escritura de censo contra Santiago Gutiérrez Martínez y Manuela Negrete Gallego, su muger, vecinos de Becerril, de 1.700 reales de principal y 51 reales de réditos en cada un año. Fue otorgada en 16 de enero de 1709, ante Bernardo Buey Valle, esscribano de dicho lugar.

5․ <Censo contra José Becerril y Águeda Garzía. Año 1725>.

Escritura de censo contra José Becerril Arias y Águeda Garzía, su muger, vecinos de Becerril, de 1.100 reales de principal y 33 reales de réditos en cada un año. Fue otorgada en 21 de marzo de 1725, ante José Buey, esscribano de dicho lugar.

$6^{\circ} .<$ Censo contra Santiago Fernández y Agustina, su muger. Año 1701>.

Escritura de censo contra Santiago Fernández Gutiérrez y Agustina Martínez Morrondo, vecinos de Becerril, de 2.200 reales de principal y 66 reales de réditos en cada un año. Fue otorgada en 13 de junio de 1701, ante Bernardo Buey Valle, esscribano de Becerril.

/ (f. 464r) $7^{\circ}$. <Censo contra Manuel de la Cuesta y Ana, su muger. Año 1698>.

Escritura de censo ${ }^{734}$ contra Manuel de la Cuesta y Ana Cuchilla, su muger, vecinos de Becerril, de 13.600 maravedís de principal y 680 maravedís de réditos en cada un año. Fue otorgada en 4 de diciembre de 1698, ante Bernardo Buey, esscribano de dicho lugar.

$8^{\circ}$. < Censo contra Santiago y Pedro García Galán. Año 1625>.

Escritura de censo contra Santiago y Pedro García Galán, y Cruz Rondabino, vecinos de Becerril, de 980 reales de principal y 29 reales y 14 maravedís de réditos en cada un año. Fue otorgada en 28 de noviembre de 1625, ante Francisco Moro de Saldaña, esscribano de Carrión.

9. <Censo contra Andrés de la Peña y consortes. Año 1739>.

Escritura de censo contra Andrés de la Peña y Thomasa Negrete, su muger, vecinos de Becerril, y consortes ${ }^{735}$, de 1.500 reales de principal y 45 reales de réditos en cada un año. Fue otorgada en 29 de abril de 1739, ante José Buey, esscribano de dicho lugar.

10. <Censo contra Francisco Revellón y Ana Garzía, su muger. Año 1734>.

Escritura de censo contra Francisco Revellón Villatoro y Ana García Cisneros, vecinos de Becerril, de 1000 reales de principal y 33 reales de réditos en cada un año. Fue otorgada en 30 de enero de 1734, ante José Buey, esscribano de Becerril.

11. <Censo contra Matías Olivares y Ángela LLorente. Año 1779>.

Escritura de censo contra Matías Olivares y Ángela Llorente Bezana, vecinos de Becerril, de 1.200 reales de principal y 36 reales de réditos en cada un año. Fue otorgada en 8 de julio de 1779, ante Baltasar Burgos, esscribano de Becerril.

\footnotetext{
733 censo] al margen derecho: Perdido.

734 censo] al margen derecho: Perdido.

735 consortes] sigue tachado: vecinos.
} 
12. $<$ Censo contra Juan Doncel y Antonia Buey. Año 1698>.

Escritura de censo contra Juan Doncel, y Antonia Buey Pérez, su muger, vecinos de Becerril, de 1.700 reales de principal y 51 reales de réditos en cada un año. Fue otorgada en 4 de noviembre de 1698, ante Andrés Pedrejón, esscribano de dicho lugar.

13. <Censo contra Matías Paredes y Ángela Hernando. Año 1724>.

Escritura de censo contra Matía Paredes y Ángela Hernando, su muger, vecinos de Becerril, de 700 reales de principal y 21 reales de réditos en cada un año. Fue otorgada en 31 de diciembre de 1724, ante José Buey, esscribano de dicho lugar.

14. <Censo contra Bernardo Arenas y Catalina Fernández, su muger. Año 1729>.

Escritura de censo contra Bernardo Arenas y Catalina Fernández, su muger, vecinos de Becerril, de 1.400 reales de principal y 42 reales de réditos en cada un año. Fue otorgada en 26 de agosto de 1729, ante Agustín Díez de Castro, esscribano de Carrión.

\section{/ (f. 464v) 15. <Censo contra Alonso Cabeza e Ysabel Ruiz. Año 1670>.}

Escritura de censo contra Alonso cabeza Brizón e Ysabel Ruiz, vecinos de Becerril, de 1.176 reales de principal y 35 reales y 10 maravedís de réditos en cada un año. Fue otorgada en 7 de enero de 1670, ante Norverto de Sandoval, esscribano de Carrión.

16.

Escritura de censo contra Matías Herrejón Calba y Catalina Díez Doncel, vecinos de Becerril, de 1.100 reales de principal y 33 reales de réditos en cada un año. Fue otorgada en 29 de octubre de 1698, ante Bernardo Buey Balle, esscribano de Becerril.

17. <Censo contra Simón Martín y Manuela Malanda. Año 1698>.

Escritura de censo contra Simón Martín Calvo y Manuela Malanda Gómez, vecinos de Becerril, de 1.000 reales de principal y 309 reales de réditos en cada un año. Fue otorgada en 2 de noviembre de 1698, ante Bernardo Buey, esscribano de Becerril.

18. <Censo contra Manuel Calva y María Herrón. Año 1729>.

Escritura de censo contra Manuel de la Calva, y María Herrón Ginete, su muger, vecinos de Becerril, de 1.100 reales de principal y 33 reales de réditos en cada un año. Fue otorgada en 18 de octubre de 1729, ante Agustín Díez de Castro, esscribano de Carrión.

19. <Censo contra José Rodríguez Carrancio y Ana, su muger. Año 1697>.

Escritura de censo contra José Rodríguez Carrancio y Ana de Torres Garzía, vecinos de Becerril, de 20 mill 400 reales de principal y 10 mill 20 reales de réditos en cada un año. Fue otorgada en 20 de julio de 1679, ante Bernardo Buey, esscribano de dicho lugar.

20. (sic).

21. <Censo contra Francisco Moro Remolino y Ana de los Bueyes. Año 1699>.

Escritura de censo contra Francisco Moro Remolino y Ana de los Bueyes, su muger, vecinos de Becerril, de 2.000 [reales] de principal y 60 reales de réditos en cada un año. Fue otorgada en 10 de septiembre de 1699, ante Bernardo Buey, esscribano de Becerril.

\section{/ (f. 465r) 22. <Censo contra Manuela Arenillas. Año 1774>.}

Escritura de censo contra Manuela Arenilla, viuda, vecina de Becerril, de 1.100 reales de principal y 33 reales de réditos en cada un año. Fue otorgada en 19 de julio de 1774, ante Andrés Pedrejón, esscribano de dicho lugar.

23. $<$ Dos censos contra Lorenzo de la Calva, el $1^{\circ}$ y el $2^{\circ}$ contra Bartolomé de la Calba. Año 1629>.

Escritura de censo contra Lorenzo de la Calva y Magdalena Perales, (son dos censos), su muger, el primero; y el segundo contra Bartholomé de la Calba y María Ruiz, su muger, vecinos de Becerril, de 600 reales de principal cada uno y 18 reales de réditos en cada un año, 
que todo componen 1.200 reales de principal y 36 de réditos. Fueron otorgadas ambas escrituras en 16 de diciembre de 1629, ante Santos de Guzmán, esscribano de Villamuera. $1698>$.

24. <Censo contra Ysabel <Díez> González, Manuel Trancho y su muger. Año

Escritura de censo contra Ysabel <Díez $>$ González, viuda, Manuel Trancho y su muger, vecinos de Becerril, de 1.600 reales de principal y 48 reales de réditos en cada un año. Fue otorgada en 10 de noviembre de 1698, ante Bernardo Buey Valle, esscribano de dicho lugar.

\section{5. <Censo contra Francisco Ceano, Sedano y su muger. Año 1695>.}

Escritura de censo contra Francisco Zedano Sedano y María Martín Calbo, su muger, vecinos de Becerril, de 3.000 reales de principal y 90 reales de réditos en cada un año. Fue otorgada en 3 de diciembre de 1695, ante Bernardo Buey Valle, esscribano dicho.

\section{6. <Censo contra Juan Pedrejones y Ángela Garzía. Año 1699>.}

Escritura de censo contra Juan Pedrejón y Ángela García Pedrosa, su muger, vecinos de Becerril, de 1.000 reales de principal y 30 reales de réditos en cada un año. Fue otorgada en 10 de septiembre de 1699, ante Bernardo Buey, esscribano sobredicho.

27. $<$ Dos censos contra Tomás García Negrete y su muger. Año 1766>.

Dos escrituras de censos contra Thomás García Negrete y Ángela de los Bueyes, vecinos de Becerril, cuyo principal de ambos es de 3.000 reales y 90 de réditos en cada un año. Fueron otorgadas dichas escrituras, la $1^{\mathrm{a}}$ en 20 de julio de 1763 y la $2^{\mathrm{a}}$ en 26 de noviembre de 1766, ambas ante Martín Yzquierdo, esscribano de Carrión.

28. <Censo contra Andrés Sánchez y su muger. Año 1699>.

Escritura de censo contra Andrés Sánchez y María Villorejo, su muger, vecinos de Becerril, de 2 mill 200 reales de principal, y hoy (por haberse redimido la mitad) sólo es de 1 mill 100 reales de principal y 33 de réditos en cada un año. Fue otorgada en 12 de septiembre de 1699, ante Bernardo Buey, esscribano de Becerril.

\section{/ (f. 465v) 29. <Censo contra Diego Herrejón y su muger. Año 1699>.}

Escritura de censo contra Diego Herrejón Revellón y Tersa Gallego, su muger, vecinos de Becerril, de 2.200 reales de principal y 66 reales de réditos en cada un año. Fue otorgada en 31 de marzo de 1699, ante Bernardo Buey, esscribano de Becerril.

30. <Censo contra Juan Gutiérrez y su muger. Año 1699>.

Escritura de censo contra Juan Gutiérrez Seguro y Jacinta Paniagua, su muger, vecinos de Becerril, de 1.000 reales de principal y 30 reales de réditos en cada un año. Fue otorgada en 9 de septiembre de 1699, ante Bernardo Nuey, esscribano dicho.

31. <Censo contra José Rodríguez Carrancio y su muger. Año 1701>.

Escritura de censo contra José Rodríguez Carrancio y Ana de Torres, su muger, vecinos de Becerril, de 1.000 reales de principal y 30 reales de réditos en cada un año. Fue otorgada en 9 de octubre de 1701, ante Bernardo Buey, esscribano del mismo lugar.

32. <Censo contra Lorenzo Ginete e Ysabel Garzía. Año 1769>.

Escritura de censo contra Lorenzo Ginete e Ysabel García, vecinos de Becerril, de 700 reales de principal y 21 de réditos en cada un año. Fue otorgada la escritura en 11 de enero de 1769, ante Manuel Pedrejón de San Juan, esscribano de dicha villa.

33. <Censo contra María Tubillo. Año 1778>.

Escritura de censo contra María Tubillo Moro, viuda, vecina de Becerril, de 4.400 reales de principal y 132 de réditos en cada un año. Fue otorgada la escritura en 4 de diciembre de 1778, ante Baltasar Burgos, esscribano de Becerril. 


\section{4. <Censo contra Matías Pérez y su muger. Año 1773>.}

Escritura de censo contra Matías Pérez Martínez y Ana de Lera Díez, su muger, vecinos de Becerril, de 1.100 reales de principal y 30 reales de rédito en cada un año. Fue otorgada en 30 de octubre de 1773, ante Baltasar Burgos, esscribano de Becerril.

\section{5. < Censo contra Ana Chamorro y consortes. Año 1709>.}

Escritura de censo contra Ana Chamorro, viuda de Juan Trancho, y de Santiago Moro, y Matías Trancho y Alexandra, su muger, vecinos de Becerril, de 1.000 reales de principal y 30 de réditos en cada un año. Fue otorgada en 16 de enero de 1709, ante Bernardo Burgos, esscribano.

36. <Censo contra Andrés de los Bueyes y María, su muger. Año 1724>.

Escritura de censo contra Andrés de los Bueyes Beatigui y María de Villanueva Guzón, vecinos de Becerril, de 2.200 reales de principal y 66 reales de réditos en cada un año. Hecha en 24 de enero de 1724, ante Santiago Duque de Estrada, esscribano de Carrión.

\section{/ (f. 466r) 37. <Censo contra Juan Pérez y su muger. Año 1773>.}

Escritura de censo contra Juan Pérez de la Calba y María Garzía Buey, su muger, vecinos de Becerril, de 1.100 reales de principal y 33 reales de réditos en cada un año. Fue otorgada en 30 de octubre de 1773, ante Baltasar Burgos, esscribano de dicho lugar.

\section{8. <Censo contra Santiago Díez Doncel y su muger. Año 1698>.}

Escritura de censo contra Santiago Díez Doncel e Ynés Gallego, su muger, vecinos de Becerril, de 2.500 reales de principal y 75 reales de réditos en cada un año. Fue otorgada en 22 de diciembre de 1698, ante Bernardo Buey, esscribano de Becerril.

\section{9. <Censo contra Francisco Garzía Sirgo y su muger. Año 1698>}

Escritura de censo contra Francisco García Sirgo y María Fernández Gutiérrez, vecinos de Becerril, de 1.200 reales de principal y 36 reales de réditos en cada un año. Fue otorgada en 22 de noviembre de 1698, ante Bernardo Buey, esscribano de dicho lugar.

40. <Censo contra Manuel Torres y su mujer. Año 1729>.

Escritura de censo contra Manuel de Torres Hernández e Ysabel Buey, vecinos de Becerril, de 1.100 reales de principal y 33 de réditos en cada un año. Fue otorgada en 12 de octubre de 1729, ante Agustín Díez de Castro, esscribano de Carrión.

41. <Censo contra Josefa de Castro. Año 1729>.

Escritura de censo contra Josefa de Castro, viuda, vecina de Becerril, de 2.000 reales de principal y 60 reales de réditos en cada un año. Fue otorgada en 11 de julio de 1729, ante Agustín Díez de Castro, esscribano de Carrión.

42. <Censo contra Agustín y Gregorio García, etcétera. Año 1698>.

Escritura de censo ${ }^{736}$ contra Agustín y Gregorio García, hermanos, y sus mugeres, vecinos de Becerril, de 750 reales de principal y 22 reales y 17 maravedís de réditos en cada un año. Fue otorgada en 3 de noviembre de 1698, ante Bernardo Buey Valle, esscribano del dicho lugar.

\section{3.}

Escritura de censo $^{737}$ contra Manuel Morante Díez y Manuel Olivares Fernández, vecinos de Becerril, de 1.800 reales de principal y 54 reales de réditos en cada un año. Fue otorgada en 22 de octubre de 1776, ante Baltasar Burgos, esscribano de Becerril.

\footnotetext{
736 censo] al margen derecho: Redimiose en 30 de enero de 1816.

${ }^{737}$ censo] al margen derecho: Véase el número 51 cómo están redimidos.
} 


\section{4. <Censo contra Juan Martín y María López. Año 1778>.}

Escritura de censo contra Juan Martín Roxo y María López Guzón, vecinos de Becerril, de 1.300 reales de principal y 39 reales de réditos en cada un año. Fecha en $1^{\circ}$ de diciembre de 1778, ante Baltasar Burgos, esscribano.

\section{5. <Censo contra Santiago y Juan Cubero. Año 1691>.}

Escritura de censo contra Santiago y Juan Cubero, vecinos de Becerril, de 391 reales y 6 maravedís de principal y 11 reales y 14 maravedís de réditos en cada un año. Otorgose en 9 de noviembre de 1691, ante Bernardo Buey, esscribano dicho.

$$
\text { / (f. 466v) 46. (sic). }
$$
Año 1628 y 1681>.

47. <Censo que compró Francisco Molina contra Agustín Gómez y María Rodríguez.

Escritura de censo contra Agustín Gómez y María Rodríguez, su muger, vecinos de Becerril, de 12.000 maravedís de principal y 10 reales con 20 maravedís de réditos en cada un año. Esta escritura la compró el padre fray Francisco Molina, prior de Villaverde, año 1681; la primera pasó en 7 de mayo de 1628, ante Pedro Buey, Gastán, esscribano de Becerril.

48. < Censo contra Francisco Merino y su muger. Año 1691>.

Escritura de censo contra Francisco Merino Cabeza y Francisca Ginete, su muger, vecinos de Becerril, de 1.000 reales de principal y 30 [reales] de réditos en cada un año. Fue otorgada en 13 de septiembre de 1691, ante Bernardo Buey, esscribano de Becerril.

49. <Censo contra Andrés Escobar y su muger. Año 1729>.

Escritura de censo contra Andrés de Escobar y Manuela Martínez, su muger, vecinos de Becerril, de 2.200 reales de principal y 66 reales de réditos en cada un año. Fue otorgada en 26 de agosto de 1729, ante Agustín Díez de Castro, esscribano de Carrión.

\section{0. <Censo contra Francisco Redondo. Año 1724>.}

Escritura de censo ${ }^{738}$ contra Francisco Redondo Cabeza, vecino de Becerril, de 1.000 relaes de principal y 30 reales de réditos en cada un año. Fue otorgada en 30 de abril de 1724, ante José Buey, esscribano de Becerril.

Tiene dos. Véase el número 52.

51. <Censo contra José Ybáñez y su muger. Año 1699>.

Escritura de censo ${ }^{739}$ contra José Ybáñez y Ana Cabeza Gatón, su muger, vecinos de Becerril, de 4.400 reales y 132 reales de réditos en cada un año. Fue otorgada en 16 de junio de 1699, ante Santiago Duque de Estrada, esscribano de Carrión.

52. <Censo contra Francisco Redondo. Año 1699>.

Escritura de censo contra Francisco Redondo Cabeza, vecino de Becerril, de 5.500 reales de principal y 165 reales de réditos en cada un año. Fue otorgada en 4 de diciembre de 1699, ante Gregorio García de Miranda, esscribano de Carrión.

53. <Censo contra don José Francisco Cid, presbítero. Año 1767>.

Escritura de censo contra don José Francisco Cid Villanuño, presbítero, vecino de Becerril, de 8.000 reales de principal y 200 reales de réditos en cada un año. Fue otorgada en 17 de marzo de 1767, ante Manuel Pedrejón de San Juan, esscribano de Becerril.

\footnotetext{
738 censo] al margen derecho: Redimiose en 5 de septiembre de 1815.

${ }^{739}$ censo] al margen derecho: Redimiose y se vnió con el número 42, que todo junto está en cabeza de Fernando Peláez, vecino de Becerril.
} 


\section{/ (f. 467r) 54. <Censo contra José de los Bueyes. Año 1766>.}

Escritura de censo contra José de los Bueyes y Bueyes, vecino de Becerril, de 1.500 reales de principal y 45 reales de réditos en cada un año. Fue otorgada en 8 de diciembre de 1766, ante Ygnacio Gutiérrez, esscribano de Carrión.

\section{/ (f. 467v) Legajo $3^{\circ}$ del Cajón Santo Toribio}

Este legajo, que es el tercero del cajón Santo Toribio, contiene dos quadernos de escrituras de censos en diversos lugares, que son los siguientes:

Quaderno A del legajo $3^{\circ}$

\section{Censos}

Este quaderno A contiene las escrituras de censo que tiene el monasterio en los lugares siguientes:

Villamayor de Campos

$1^{\circ}$. < Censo contra los vecinos del barrio de Otero en Villamayor. 1712>.

Escritura de censo contra los vecinos del barrio de Otero de Villamayor, de 3.000 reales de principal y 75 reales de réditos en cada un año. Fue otorgada en 23 de febrero de 1712, ante Francisco Gago, esscribano de Villamayor.

$2^{\circ}$. <Censo contra María del Castillo, vecina del barrio de Otero. Año 1664>.

Escritura de censo contra María del Castillo, vecina del mismo barrio, de 2.000 reales de principal y 60 reales de réditos en cada un año. Fue otorgada en 10 de septiembre de 1664, ante Luis de Salazar, esscribano de Villafrechós.

\section{$3^{\circ}$. <Censo contra Antonio Casquero y Juan González. Año 1675>.}

Escritura de censo contra Antonio Casquero y Juan González, vecinos del barrio de Otero, de 1.300 reales de principal y 65 reales de rédito en cada un año. Fue otorgada en 22 de enero de 1675, ante Thomás de Caramazana, esscribano de Villamayor.

$4^{\circ}$. <Censo contra el concejo y vecinos de Villamayor. Año 1697 y $1753>$.

Escritura de censo contra el concejo y vecinos de Villamayor, el qual fue en su primera imposición de 111.000 reales de principal, y en 30 de de marzo de 1700 redimió dicho concejo 18.500 , sesta parte de dicho capital, quedando este reducido entonces a 92.500 reales; pero hoy,/ (f. 468r) por la última escritura otorgada ante Andrés Núñez Castelo, esscribano de Carrión, en 14 de febrero de 1753, en que se le acrecentaron 4.000 reales más, consta de 96 mill 500 reales de principal; y sus réditos, a dos por 100, son 1.930 reales. Fue otorgada la primera escritura en 20 de enero de 1697, ante Tomás de Caramazana, esscribano de Villamayor.

\section{Mantinos}

$$
5^{\circ} .(\text { sic }) \text {. }
$$

\section{Ríos Menudos}

$6^{\circ}$. $<$ Dos censos contra el concejo y vecinos de Ríos Menudos en la Montaña. Años 1741 y $1743>$.

Dos censos contra el concejo y vecinos de Ríos Menudos; de los quales el $1^{\circ}$, que fue otorgado en 23 de abril de 1741, ante Santiago Duque de Estrada, esscribano de Carrión, es de 8.000 reales de principal y 200 reales de réditos en cada un año. El $2^{\circ}$ censo es de 3.000 reales de principal y 90 reales de réditos en cada un año. Fue otorgada la escritura en 20 de mayo de 1743, ante José García de Guadiana, esscribano y vecino de Respenda.

\section{Villamoronta}

$7^{\circ} .<$ Censo contra el concejo y vecinos de Villamoronta de 16.450 reales de principal y 329 reales de réditos. Año 1742 hasta 1768>. 
Escritura de censo ${ }^{740}$ contra el concejo y vecinos de Villamoronta, cuyo capital en su primera imposición ascendía a 20.000 reales, de cuya cantidad redimieron la mitad en 14 de abril de 1753; y en 3 de marzo de 1757 otorgaron escritura, por la qual acrecentaron la otra mitad de principal que había quedado con cinco mil reales más; y finalmente por otra escritura, otorgada ante el mismo esscribano Manuel Franco Blanco (esscribano de Carrión), en 15 de febrero de 1765, le añadieron otros cinco mil reales más; y en 18 de febrero de 1768 redimieron 3.550. Por lo qual hoy consta este censo de 16.450 reales de principal y sus réditos en cada un año son 329 reales, de los quales les pertenecen a la sacristía 91 reales y 17 maravedís, y a la casa 237 reales y 17 maravedís.

\section{Villanueva del Río} 1739 y $1742>$.

/ (f. $468 v) 8^{\circ} .<$ Dos censos contra el concejo y vecinos de Villanueva del Río. Año

Dos escrituras de censo contra el concejo y vecinos de Villanueva del Río, la $1^{\text {a }}$ otorgada en 9 de noviembre de 1739, ante Santiago Duque de Estrada, esscribano de Carrión, de 10.000 reales de principal y 250 reales de réditos en cada un año; el segundo censo, otorgado en 5 de agosto de 1742, ante Santiago Gil Villelga, es de 2.000 reales de principal y 60 reales de réditos en cada un año. Son a favor de la sacristía.

\section{Villaturde}

9. $<$ Censo contra el concejo y vecinos de Villaturde. Año 1740>.

Escritura de censo contra el concejo y vecinos de Villaturde de 10.000 reales de principal y 250 reales de réditos en cada un año. Fue otorgada en 26 de septiembre de 1740, ante Manuel Francisco Blanco, esscribano de Carrión. Sacristía.

\section{Villoldo}

10. $<$ Censo contra el concejo y vecinos de Villoldo. Año 1736>.

Escritura de censo contra el concejo y vecinos de Villoldo de 14.000 reales de principal y 350 reales de réditos en cada un año, de los quales corresponden a la sacristía 247 reales y 17 maravedís. Fue otorgada en 27 de marzo de 1736, ante Mauricio Martínez de Chirueches, esscribano de Carrión.

$$
\text { / (f. 469r) Censos }
$$

Quaderno B del legajo $3^{\circ}$

\section{Villamuera}

Este quaderno B contiene las escrituras de censo que tiene este monasterio de San Zoil a su favor en este lugar, por el orden siguiente:

$1^{\circ}$. $<$ Dos censos, el $1^{\circ}$ contra Miguel Calbo y el $2^{\circ}$ contra Domingo Montes y su muger. Años 1690 y 1716>.

Dos censos contra Miguel Calbo; el primero (y) es de 632 reales y 12 maravedís de principal y 18 reales con 33 maravedís de réditos en cada un año. Fue otorgada la escritura año 1690, ante Francisco Herrero, esscribano de Villamuera.

El segundo contra Domingo Montes y Ana Garrido, su muger, de 600 reales de principal y 28 reales de réditos en cada un año. Fue otorgada la escritura en 6 de septiembre de 1716, ante Christóval Martínez Medina, esscribano de dicha villa.

Todos los demás censos que están en este quaderno no los pongo aquí por estar algunos ya redimidos, y todos los demás perdidos e incobrables hace muchos años, como

740 censo] al margen derecho: Nota: Los censos que para tomar éste redimió este lugar, están seguidos a esta escritura.. 
consta de los libros de encabezo o renta cisa. Véase el de el año 1769 hasta 1792, al folio 134, en que comienza a poner lo de Villamuera aparte, con una nota en que solo sirve para saber lo que pagan los vecinos de este lugar, por ser partidas incobrables. Vltimamente, al fin de dicho libro, en la última partida, ya no pone sino lo que hoy se percibe en quanto a censos. Por lo tocante al señorío y vasallaje pondré aquí una relación breve de lo que hoy se cobra y está en vso, y es lo siguiente.

$$
<1^{\circ}>\text {. }
$$

Por razón de sernas debe percibir el monasterio dos cántaras de mosto de qualquier vecino que sea cosechero; y de las viudas, sólo un cántaro, llegando a coger treinta.

$<2^{\circ}>$.

Debe dar dicha villa de Villamuera veinte peones para segar los panes del monasterio o hacer otra cosa que se les mande; y el monasterio les ha de dar dicho día de comer; y no dando dichos peones, ha de pagar la villa quince reales el día de Nuestra Señora de agosto.

Nada de este segundo punto está en vso.

$/(f .469 v)<3^{\circ}>$. Pagan los vecinos de Villamuera sesenta y ocho maravedís por razón de martiniega y para gasto de la lámpara de San Zoil (antes pagaban ochenta y quatro).

$<4^{\circ}>$.

Quando el señor abad de este monasterio pasare personalmente a hacer el nombramiento de oficiales de justicia, debe darle la villa de comer y cenar, y a dos compañeros, criados y cavallerías que llevare; y no yendo, le da treinta reales por el dicho nombramiento, lo qual está en vso. Dichos derechos se pagaron al monasterio por la villa de Villamuera desde los más remotos tiempos de la antigüedad, como lo acreditan los documentos que están atrás, al folio 418 de este libro, cajón San Mauro, legajo ${ }^{\circ}$, quaderno $\mathrm{B}$, números $2^{\circ}, 3^{\circ}, 26$ y 32 .

\section{/ (f. 470r) Cajón 22 San Vicente}

Bulas comunes a la religión y cédulas reales siguientes:

Este cajón, que es el veinte y dos del archivo, contiene tres legajos, que son los

$$
\text { Legajo } 1^{\circ}
$$

Este legajo, que es el primero del cajón San Vicente, contiene las bulas comunes a la religión y privilegios que goza, las quales están sueltas, excepto el primer quaderno con su oja de lata pendiente, titulado Bullario auténtico de bulas y privilegios apostólicos de que goza la congregación de San Benito de España, sus monasterios y religiosos, por lo qual no se expresan las que son, pero se hallarán por orden de años si se ofreciere alguna vez.

$$
\text { Legajo } 2^{\circ}
$$

Este legajo, que es el segundo del cajón San Vicente, consta de papeles comunes a la religión y otros, que todos son sueltos, con algunas cartas de los Generales de la orden y un memorial de los Generales de la Orden que ha habido hasta hoy, con otros varios privilegios, etcétera, y varios títulos de posesión se curatos en monges de diferentes lugares.

$$
\text { Legajo } 3^{\circ}
$$

Este legajo, que es el tercero del cajón San Vicente, contiene las cédulas reales que se han podido recoger y otros papeles que, por no estar aquí completas, no se ponen con distinción ni por números, sólo sí por orden de años, para hallarse con más brevedad.

\section{/ (f. 471r) Cajón 23 San Rosendo}

En este cajón están las escrituras corrientes de arriendo de las heredades y hacienda que tiene el monasterio de San Zoil en varios lugares. 


\section{/ (f. 471r) Cajón 24 San Veremundo}

En este cajón están los libros de gradas e ynformaciones de monges y legos, e igualmente algunos testamentos de los mismos. Por razón de algunas de las escrituras de el legado de testamentos tiene el (el) convento obligación a decir ciertas misas y vigilias de aniversarios, como consta de dichos testamentos.

\section{/ (f. 471r) Cajón 25 San Claudio}

En este cajón están varios libros antiguos y curiosos, y son los siguientes:

$<$ Libro $1^{\circ}>$.

Papeles varios de Carrión, recopilación de las grandezas y antigüedad de la muy noble villa de Carrión, quiénes fueron sus verdaderos señores hasta que se incorporó en la Corona Real, etcétera.

$<2^{\circ}>$.

Ordenanzas de la villa de Carrión.

$<3^{\circ}>$.

Kalendario de bienhechores de Cluni y del monasterio de San Zoil y monges difuntos.

$<4^{\circ}>$.

El antiguo de las escrituras del archivo.

$/(f .471 v)<5^{\circ}>$.

Razón de la hacienda antigua.

$<6^{\circ}>$.

Martirologio, escrito en pergamino, regla, fundadores, bienhechores, hábitos y muertes de monges, con otras cosas antiguas.

$<7^{\circ}>$.

Varones ylustres, escrito también en pergamino.

$<8^{\circ}>$.

Regla de nuestro padre San Benito, escrita en pergamino, por el padre Cisneros.

$<9^{\circ}>$.

Psalterio escrito en pergamino.

$<10>$.

Historia de este monasterio muy antigua, escrita en pergamino, por un mozo llamado Rodulfo.

Las demás historias modernas están seguidas a ésta por el padre Cisneros, padre Fonseca y padre Fuertes.

\section{/ (f. 471v) Cajón 26 Santo Domingo \\ Tazmías}

En este cajón están las tadmías de todos los lugares pertenecientes a este monasterio de San Zoil y sus prioratos, etcétera.

\section{/ (f. 471v) Cajón 27 San Prudencio \\ Cartas de pago}

En este cajón 27 están algunos legajos pequeños e instrumentos de cartas de pago y qüentas particulares de mayordomos, de los tercios de colegiales y maestros y otras personas, etcétera. En este mismo cajón está la redención que se hizo del capital del quindenio, prorrata, condución y cambio, por medio del padre provisor fray Buenaventura Ordóñez. Año 1792. 

ÍNDICES 



\section{ÍNDICE DE PERSONAS}

Acardo, fraile: $57 \mathrm{v}$.

Achar: 353v.

Achardo: 182v, $273 \mathrm{r}$.

Adelantamiento de Campos, alcalde mayor: $354 \mathrm{r}$.

Aelo: 353v.

Agapio, fraile: $141 \mathrm{v}$.

Águeda García: 463v.

Aguilar de Campoo, arcipreste y beneficiado: $23 \mathrm{v}$.

Aguilar, doctor: 445v, 446r.

Agustín: 398r, 398v, 466r.

Agustín de Cuevas, fraile: 399v, 400r.

Agustín de la Serna: 40r, 44v.

Agustín de las Heras: 390v.

Agustín de Lorza Aguirre: $114 \mathrm{v}$.

Agustín de Medina: 46r, 47v, 63v, 260r, $260 \mathrm{v}, 262 \mathrm{r}, 286 \mathrm{v}, 315 \mathrm{v}, 316 \mathrm{r}, 323 \mathrm{r}, 329 \mathrm{v}$, 330r, 354r, 372v, 376r, 460r

Agustín de Poza: 176r.

Agustín Díez de Castro: 37v, 61r, 75r, $157 \mathrm{v}, 185 \mathrm{r}, 209 \mathrm{v}, 210 \mathrm{r}, 258 \mathrm{r}, 296 \mathrm{v}, 297 \mathrm{r}$, 459v, 462r, 464r, 464v, 466r, 466v.

Agustín García de Miranda: 119r, 146v, 152v, 167v, 168r, 178r, 178v.

Agustín García: 61r, 119r, 146v, 152v, $164 \mathrm{v}, 167 \mathrm{v}, 168 \mathrm{r}, 178 \mathrm{r}, 178 \mathrm{v}$.

Agustín Gómez: 466v.

Agustín Ladrón de Guevara, notario: 288r.

Agustín Lorenzo: 399.

Agustín Peláez, 375r.

Agustina Martínez Morrondo: 463v.

Agustina Peláez: 460r.

Ailoni: 353v.

Alderico: $189 \mathrm{v}$.

Aldonza: 98v, 99r.

Aldonza de Castilla, condesa: 1v, 57v, 98v, 99r, 343v, 344r, 408r.

Alejandra: $465 \mathrm{v}$.

Alejandro: 38r, 38v, 48v, 80r, 81v, 213r, 214r, 223r, 285r, 285v, 311r.

Alejandro III, legado de: 80r.

Alejandro IV: $81 \mathrm{~V}$.

Alejandro VI: 38r, 38v.

Alejandro VIII: 48v.

Alejandro de Salceda: 311r.
Alejandro García: 285r.

Alejandro Lita: 213r, 214r.

Alejandro Martínez: 285r, 285v.

Alejandro Riario: 223r.

Alejo de Olmos: 365v, 366r, 368v.

Alejo Vicente: 460r.

Alfonso: 1v, 13r, 13v, 14r, 14v, 15r, 16v, $17 \mathrm{v}, 18 \mathrm{r}, 20 \mathrm{r}, 23 \mathrm{v}, 24 \mathrm{r}, 26 \mathrm{r}, 26 \mathrm{v}, 27 \mathrm{r}, 32 \mathrm{v}$, $33 \mathrm{r}, 34 \mathrm{r}, 34 \mathrm{v}, 35 \mathrm{r}, 37 \mathrm{v}, 41 \mathrm{r}, 44 \mathrm{r}, 45 \mathrm{v}, 46 \mathrm{r}$, $48 \mathrm{r}, 49 \mathrm{v}, 50 \mathrm{r}, 60 \mathrm{r}, 63 \mathrm{r}, 63 \mathrm{v}, 64 \mathrm{r}, 65 \mathrm{r}, 66 \mathrm{r}$, $67 \mathrm{v}, 69 \mathrm{r}, 69 \mathrm{v}, 71 \mathrm{r}, 72 \mathrm{r}, 74 \mathrm{v}, 75 \mathrm{r}, 78 \mathrm{v}, 82 \mathrm{v}$, $87 \mathrm{r}, 88 \mathrm{r}, 88 \mathrm{v}, 89 \mathrm{r}, 89 \mathrm{v}, 91 \mathrm{r}, 91 \mathrm{v}, 92 \mathrm{r}$, $93 \mathrm{v}, 97 \mathrm{v}, 98 \mathrm{r}, 98 \mathrm{v}, 99 \mathrm{r}, 99 \mathrm{v}, 102 \mathrm{v}, 103 \mathrm{r}$, $103 \mathrm{v}, 104 \mathrm{r}, 105 \mathrm{r}, 105 \mathrm{v}, 109 \mathrm{r}, 109 \mathrm{v}, 110 \mathrm{r}$, $110 \mathrm{v}, 117 \mathrm{v}, 118 \mathrm{r}, 118 \mathrm{v}, 131 \mathrm{r}, 132 \mathrm{r}, 133 \mathrm{r}$, $139 \mathrm{v}, 140 \mathrm{r}, 143 \mathrm{v}, 144 \mathrm{r}, 144 \mathrm{v}, 145 \mathrm{r}, 148 \mathrm{r}$, $148 \mathrm{v}, 150 \mathrm{r}, 151 \mathrm{r}, 151 \mathrm{v}, 156 \mathrm{r}, 157 \mathrm{v}, 158 \mathrm{r}$, $158 \mathrm{v}, 159 \mathrm{r}, 161 \mathrm{v}, 162 \mathrm{r}, 162 \mathrm{v}, 163 \mathrm{r}, 163 \mathrm{v}$, $164 \mathrm{r}, 164 \mathrm{v}, 165 \mathrm{r}, 165 \mathrm{v}, 166 \mathrm{r}, 166 \mathrm{v}, 167 \mathrm{r}$, $167 \mathrm{v}, 169 \mathrm{r}, 172 \mathrm{r}, 172 \mathrm{v}, 173 \mathrm{r}, 173 \mathrm{v}, 174 \mathrm{r}$, $174 \mathrm{v}, 175 \mathrm{r}, 175 \mathrm{v}, 178 \mathrm{r}, 178 \mathrm{v}, 179 \mathrm{v}, 180 \mathrm{r}$, $180 \mathrm{v}, 183 \mathrm{v}, 185 \mathrm{r}, 186 \mathrm{r}, 186 \mathrm{v}, 187 \mathrm{v}, 189 \mathrm{r}$, $189 \mathrm{v}, 190 \mathrm{v}, 192 \mathrm{r}, 193 \mathrm{r}, 193 \mathrm{v}, 194 \mathrm{r}, 196 \mathrm{v}$, $199 \mathrm{v}, 200 \mathrm{r}, 202 \mathrm{v}, 203 \mathrm{r}, 204 \mathrm{r}, 204 \mathrm{v}, 205 \mathrm{r}$, $206 \mathrm{v}, 207 \mathrm{r}, 207 \mathrm{v}, 208 \mathrm{r}, 208 \mathrm{v}, 209 \mathrm{r}, 209 \mathrm{v}$, $210 \mathrm{r}, 211 \mathrm{r}, 211 \mathrm{v}, 212 \mathrm{r}, 213 \mathrm{v}, 216 \mathrm{r}, 216 \mathrm{v}$, 220r, 222v, 223r, 223v, 225r, 225v, 226r, $226 \mathrm{v}, 227 \mathrm{v}, 228 \mathrm{r}, 228 \mathrm{v}, 229 \mathrm{r}, 231 \mathrm{v}, 232 \mathrm{r}$, $232 \mathrm{v}, 233 \mathrm{r}, 234 \mathrm{r}, 234 \mathrm{v}, 235 \mathrm{r}, 237 \mathrm{r}, 242 \mathrm{r}$, $244 \mathrm{v}, 245 \mathrm{r}, 252 \mathrm{v}, 254 \mathrm{v}, 255 \mathrm{r}, 259 \mathrm{v}, 264 \mathrm{v}$, $265 \mathrm{r}, 265 \mathrm{v}, 269 \mathrm{v}, 271 \mathrm{v}, 272 \mathrm{r}, 273 \mathrm{v}, 274 \mathrm{r}$, 277r, 283v, 284r, 286r, 286v, 316r, 322r, $324 \mathrm{v}, 328 \mathrm{v}, 345 \mathrm{r}, 350 \mathrm{r}, 358 \mathrm{r}, 358 \mathrm{v}, 359 \mathrm{r}$, $359 \mathrm{v}, 360 \mathrm{r}, 360 \mathrm{v}, 363 \mathrm{r}, 363 \mathrm{v}, 364 \mathrm{v}, 365 \mathrm{r}$, $370 \mathrm{v}, 371 \mathrm{v}, 391 \mathrm{v}, 392 \mathrm{r}, 404 \mathrm{v}, 405 \mathrm{r}, 408 \mathrm{v}$, $411 \mathrm{v}, 412 \mathrm{r}, 412 \mathrm{v}, 413 \mathrm{r}, 413 \mathrm{v}, 414 \mathrm{r}, 418 \mathrm{v}$, 421r, 433r, 435v, 436r, 437r, 437v, 438r, $441 \mathrm{v}, 443 \mathrm{r}, 443 \mathrm{v}, 444 \mathrm{r}, 444 \mathrm{v}$.

Alfonso I de Aragón: 1v.

Alfonso IX: 13r, 13v, 20r, 189v, 225r, $255 \mathrm{v}, 283 \mathrm{v}, 284 \mathrm{r}, 359 \mathrm{r}, 359 \mathrm{v}, 363 \mathrm{r}, 363 \mathrm{v}$, $443 \mathrm{v}, 444 \mathrm{r}, 444 \mathrm{v}$.

Alfonso VI: 32v, 33r, 91r, 189r, 434r; hija de: $189 r$.

Alfonso VIII: 355r; hijo de: 358r, 358v, 359 r. 
Alfonso X: 20r, 88r, 91v, 322r, 360r, 370v, $391 \mathrm{v}, 413 \mathrm{r}, 413 \mathrm{v}, 444 \mathrm{r}, 444 \mathrm{v}$; notario de: 360 r.

Alfonso XI: 20r, 34r, 91v, 92r, 98r, 227v, $269 \mathrm{v}, 322 \mathrm{r}, 413 \mathrm{r}, 413 \mathrm{v}, 414 \mathrm{r}, 444 \mathrm{v}$.

Alfonso Aguiar: 210r.

Alfonso Agúndez: 44r.

Alfonso Álvarez de Acebedo: 272v.

Alfonso Álvarez: 105r, 105v, 211r, 211v, $212 \mathrm{r}, 394 \mathrm{v}$.

Alfonso Antonio Villarroel: 5v.

Alfonso Argadero: 428r.

Alfonso Astudillo López: 381r, 381v.

Alfonso Barrantes: 180v, 185r; fraile: 10r, $16 \mathrm{v}, 17 \mathrm{v}, 23 \mathrm{v}, 26 \mathrm{r}, 117 \mathrm{v}, 118 \mathrm{r}, 204 \mathrm{r}, 204 \mathrm{v}$, $205 \mathrm{r}, 208 \mathrm{v}, 223 \mathrm{v}, 257 \mathrm{r}, 275 \mathrm{v}, 280 \mathrm{v}, 310 \mathrm{v}$, 323v, 447r, 455r, 455v.

Alfonso Bravo: $159 \mathrm{r}$.

Alfonso Caballero: 162r.

Alfonso Cabeza Brizón: 464v.

Alfonso Cabeza: 37v, 209v, 464v.

Alfonso Calvo: 441r.

Alfonso Canillas: 398r.

Alfonso Cano: 300r, 300v.

Alfonso Carrillo de Albornoz: 34v, 35r.

Alfonso Carrillo Salcido y Rol: 421r.

Alfonso Crespo: 229r, 373r.

Alfonso de Aguilar: 140r.

Alfonso de Arenillas: 252v.

Alfonso de Arévalo: 361r, 361v, 362r.

Alfonso de Astudillo: $324 \mathrm{v}$.

Alfonso de Ayuela: 271v.

Alfonso de Burgos: 173r, 174v.

Alfonso de Calzada: 329r.

Alfonso de Camiedes: 103v, 104r.

Alfonso de Campoo: 294v.

Alfonso de Cardeñosa: 443r.

Alfonso de Castañón: 157v, 158r.

Alfonso de Corral, fraile: 366v.

Alfonso de Frías: 110r, 110v.

Alfonso de Gonzalo: 295r.

Alfonso de Grijota, fraile: 244v, 245r.

Alfonso de Guadiana: 158r.

Alfonso de la Fuente: 272r.

Alfonso de la Peña: 350r.

Alfonso de la Puerta: 269v.

Alfonso de la Vega: 366r.

Alfonso de Lobera: 431r.

Alfonso de María: 366v.

Alfonso de Mier, fraile: $118 \mathrm{v}$.

Alfonso de Miranda: 216r, 216v.
Alfonso de Pardo: 208r.

Alfonso de Paz: 190v.

Alfonso de Rabanal: 63v, 64r, 450r.

Alfonso de Ramos: 366v.

Alfonso de Reoyo: 352v.

Alfonso de Represa: 8v.

Alfonso de Rueda: 156r.

Alfonso de Santisteban: 254v, 255r, 347r, 403r.

Alfonso de Toro, fraile: 87r, 99v, 383r, 418r, 418v.

Alfonso de Valdivieso: 8v.

Alfonso de Villacorta: 441v.

Alfonso de Villamuera, fraile: 293r, 315v.

Alfonso de Villarmienzo: 434v.

Alfonso de Virués, fraile: 329r.

Alfonso de Zamudio: 362r.

Alfonso de Zapata: 132r.

Alfonso del Campo: 347r.

Alfonso del Corral: 139v; fraile: 23v.

Alfonso del Hospital: 376v, 377r, 377v.

Alfonso del Vado: 17v, 18r, 164r, 164v, 266r, 266v.

Alfonso Delgado: 383r, 441v.

Alfonso Díez: 60r.

Alfonso Doncel: 163r, $163 \mathrm{v}$.

Alfonso Estébanez: 179v, 180r.

Alfonso Fernández de Burgo: 418v.

Alfonso Fernández de Córdoba: 323r.

Alfonso Fernández de Gañinas: 274r.

Alfonso Fernández de Madrid: 14v, 15 r.

Alfonso Fernández de Paredes: 133r.

Alfonso Fernández de Rebollera: 412r.

Alfonso Fernández de Respenda: 49v, 50r, 315r, 350v.

Alfonso Fernández de Revenga: 435v, 436r.

Alfonso Fernández de San Cebrián: 175r, $175 \mathrm{v}, 272 \mathrm{r}$.

Alfonso Fernández de San Vicente: 165v.

Alfonso Fernández de Sotillo: 345r.

Alfonso Fernández de Tarilonte: 264v, 265r, 265v.

Alfonso Fernández de Velasco y Pantoja: $269 \mathrm{v}$.

Alfonso Fernández del Pozo: 161v.

Alfonso Fernández Gallego: 162v.

Alfonso Fernández, monje de San Zoilo: 326r, 326v.

Alfonso Fernández: 13v, 14v, 15r, 45v, $46 \mathrm{r}, 49 \mathrm{v}, 50 \mathrm{r}, 71 \mathrm{r}, 133 \mathrm{r}, 161 \mathrm{v}, 162 \mathrm{v}, 163 \mathrm{v}$, 
$164 \mathrm{r}, 165 \mathrm{v}, 175 \mathrm{r}, 175 \mathrm{v}, 186 \mathrm{r}, 207 \mathrm{r}, 264 \mathrm{v}$, $265 \mathrm{r}, 265 \mathrm{v}, 269 \mathrm{v}, 272 \mathrm{r}, 274 \mathrm{r}, 345 \mathrm{r}, 284 \mathrm{r}$, 315r, 323r, 325v, 326r, 326v, 350v, 371r , $371 \mathrm{v}, 412 \mathrm{r}, 418 \mathrm{v}, 435 \mathrm{v}, 436 \mathrm{r}, 441 \mathrm{v}$.

Alfonso Fernando: 145r.

Alfonso Franco: 23v.

Alfonso García de Dueñas: 242r.

Alfonso García de Villagarcía: 109r, 109v, $109 \mathrm{v}, 237 \mathrm{r}$.

Alfonso García de Villasur: 74v, 99r, 104r, 242r, 273v, 411v.

Alfonso García Garzón: 163r.

Alfonso García Ruano: 69r, 69v.

Alfonso García: 65r, 69r, 69v, 74v, 89v, 99r, 104r, 109r, 109v, 148v, 163r, 206v, 228r, 237r, 242r, 273v, 275v, 402v, 403r, $403 \mathrm{v}, 411 \mathrm{v}, 433 \mathrm{r}$.

Alfonso Garzón: 167r.

Alfonso Gascón: 328v, 329r.

Alfonso Gómez de San Román: 151r, $166 \mathrm{v}, 453 \mathrm{v}$.

Alfonso González de Escobar: 228r, 228v, 229 r.

Alfonso González Francés: 360v.

Alfonso González: 294v, 360v, 399r, 428v.

Alfonso González: 360v, 399r, 428v.

Alfonso Guadiana: 166r.

Alfonso Guijelmo: 293v.

Alfonso Gutiérrez Gascón: 436r.

Alfonso Gutiérrez: 167r, 167v, 177r, 436r.

Alfonso Herrero: 373r.

Alfonso Ibáñez: 102v, 103 r.

Alfonso Jiménez: $5 \mathrm{r}$.

Alfonso Juan: $88 \mathrm{v}, 441 \mathrm{v}$.

Alfonso López: 186v, 360v, 423v.

Alfonso Lorenzo de Pedraza: 178r, 178v, $437 \mathrm{r}, 437 \mathrm{v}$.

Alfonso Luengo: $397 \mathrm{v}$.

Alfonso Marrache: 392r.

Alfonso Martín: 5v, 173v, 180v, 297r, 298r, 315v, 399v, 412r, 412v, 432v.

Alfonso Martínez: 5v, 173v, 180v, 297r; fraile: $399 \mathrm{v}$.

Alfonso Mayor: 316r.

Alfonso Merino: 75r, 322v, 323r.

Alfonso Mojino: 428r.

Alfonso Moniz de Mieres: 328r.

Alfonso Moro Pérez: 463r.

Alfonso Muñoz de Camargo: 408v.

Alfonso Niño: 144v, $145 \mathrm{r}$.

Alfonso Oro, 151v, 166v.
Alfonso Pacheco: 48r.

Alfonso Palacios: 372r.

Alfonso Pando: 220r.

Alfonso Pascual de Membrillar: 279r.

Alfonso Paz: 196v.

Alfonso Peláez de Oviedo: 231v, 232r, $232 \mathrm{v}, 233 \mathrm{r}, 234 \mathrm{r}, 234 \mathrm{v}, 235 \mathrm{r}$.

Alfonso Pérez de Castejón: 264v, 265r, $265 \mathrm{v}$

Alfonso Pérez del Campo: 193v, 199v, 200r, 205r, 209r.

Alfonso Pérez: 193v, 199v, 200r, 202v, 203r, 204r, 205r, 207v, 208v, 209r, 257v, 287r, 371r, 402v, 403r, 403v, 404r.

Alfonso Pérez: 202v, 264v, 265r, 265v, $443 r$.

Alfonso Porrero, escribano Aguilar: 5r.

Alfonso Ramos: 366v, 367r, 367v.

Alfonso Remolino: 440v.

Alfonso Requena: $434 \mathrm{v}$.

Alfonso Rodríguez Cotán: 394r, 394v.

Alfonso Rodríguez de Tordesillas: 392r.

Alfonso Rodríguez de Valflorido: 2r.

Alfonso Rodríguez: 2r, 162r, 162v, 192r, 193v, 194r, 200r, 315v, 316v, 373r, 374r, $392 \mathrm{r}, 394 \mathrm{r}, 394 \mathrm{v}$.

Alfonso Ruiz del Agua: $157 \mathrm{v}$.

Alfonso Ruiz: 157v, 322v, 438r.

Alfonso Sánchez Vasco: 311r.

Alfonso Sánchez: 93v, 164v, 231v, 311r, $457 \mathrm{r}, 457 \mathrm{v}$.

Alfonso Santiago: 193r.

Alfonso Santos de Arce: 72r.

Alfonso Seijas de la Carrera: 41r.

Alfonso Simón: 63r, 144v.

Alfonso Terán: 372v, 374r.

Alfonso Tomé: 356v.

Alfonso Toribio de Villacorta: 372r.

Alfonso Vázquez: 207r, 278r.

Alfonso Vida el Viejo: 151v.

Alfonso Villarroel: 328v.

Alfonso Zapata, 24r, 26r, 26v, 27r, 75r, $139 \mathrm{v}, 158 \mathrm{v}, 208 \mathrm{r}, 213 \mathrm{v}, 222 \mathrm{v}, 223 \mathrm{r}, 223 \mathrm{v}$, $310 \mathrm{v}, 445 \mathrm{v}, 446 \mathrm{r}, 448 \mathrm{r}$.

Alfonso Zorrilla, fraile: 420r, 206v.

Almanza: 422v, 423r.

Álvar Arrayaz: 151r.

Álvar Galindo: 144r.

Álvar García de Palenzuela: 148v, 149r, $150 r$.

Álvar García de Toledo: 422v, 423r. 
Álvar González: 33r，67v，145v，148v, 150r, 164v, 165r, 255v, 256r, 272r, 328r, $417 \mathrm{v}, 418 \mathrm{r}, 443 \mathrm{r}$.

Álvar González de Carrión: 13v, 14r, 33r, $67 \mathrm{v}, 148 \mathrm{v}, 164 \mathrm{v}, 255 \mathrm{v}, 256 \mathrm{r}, 272 \mathrm{r}, 417 \mathrm{v}$, 418r, 443r.

Álvar Martínez: 196v, 408r.

Alvar Martínez de Frómista: 192v.

Alvar Rodríguez: 365v; mujer de: 365v.

Álvarez: $2 \mathrm{v}, 3 \mathrm{r}, 11 \mathrm{r}, 18 \mathrm{v}, 27 \mathrm{v}, 55 \mathrm{v}, 60 \mathrm{v}$, $61 \mathrm{r}, 69 \mathrm{v}, 70 \mathrm{r}, 73 \mathrm{v}, 75 \mathrm{r}, 77 \mathrm{v}, 78 \mathrm{r}, 92 \mathrm{v}, 93 \mathrm{r}$, $94 \mathrm{r}, 103 \mathrm{r}, 103 \mathrm{v}, 104 \mathrm{r}, 104 \mathrm{v}, 105 \mathrm{r}, 105 \mathrm{v}$, $143 \mathrm{v}, 144 \mathrm{r}, 146 \mathrm{r}, 146 \mathrm{v}, 155 \mathrm{r}, 156 \mathrm{v}, 157 \mathrm{v}$, $165 \mathrm{v}, 182 \mathrm{r}, 211 \mathrm{r}, 211 \mathrm{v}, 212 \mathrm{r}, 268 \mathrm{r}, 280 \mathrm{v}$, 281r, 281v, 331r, 331v, 332r, 394r, 394v, $394 \mathrm{v}, 399 \mathrm{v}, 400 \mathrm{v}, 401 \mathrm{r}, 408 \mathrm{v}, 411 \mathrm{v}, 416 \mathrm{v}$, $418 \mathrm{v}, 419 \mathrm{v}, 431 \mathrm{v}, 438 \mathrm{r}$.

Álvaro Abeja el Viejo: 150v.

Álvaro Arrabaz: 166v.

Álvaro de Aguiar: 181v.

Álvaro de Cisneros: 93r.

Álvaro de la Vega: 28r.

Álvaro de Mendoza: 243r, 243v.

Álvaro de Nogales: 360v.

Álvaro de Santa Cruz: 44v.

Álvaro de Torres Castellanos: 181v.

Álvaro Forienzo: 394v.

Álvaro Freile: 26r, 26v, 19r, 19v, 23v.

Álvaro García: 397r, 437r.

Álvaro García Tuñón: 48r, 48v, 311r, 437r.

Álvaro Girón: 367r, 367v.

Álvaro González: 164r.

Álvaro González de Carrión: 148v, 273v, 339r, 339v, 340r, 340v, 341r.

Álvaro Lazareno: 190r.

Álvaro López: 397r.

Álvaro Monroy: 239r.

Álvaro Rodríguez: 365v.

Amaro Díaz de Flores, doctor: 336v, 345r, 345v, 346r, 347r, 348v, 349r, 383v, 384r, $384 \mathrm{v}, 385 \mathrm{r}$.

Ambrosio Cajigas: 210r.

Ambrosio de Nájera, fraile: 10r, 134r, 330v, 373r, 373v, 386v, 387r.

Ambrosio Matute: $199 \mathrm{r}$.

Ambrosio Treceño: 296r.

Ana: 2r, 2v, 5r, 5v, 13r, 13v, 14r, 14v, 37r, $38 \mathrm{v}, 39 \mathrm{r}, 39 \mathrm{v}, 40 \mathrm{r}, 43 \mathrm{v}, 44 \mathrm{r}, 51 \mathrm{r}, 51 \mathrm{v}, 59 \mathrm{r}$, $63 \mathrm{v}, 64 \mathrm{r}, 64 \mathrm{v}, 65 \mathrm{r}, 77 \mathrm{v}, 78 \mathrm{r}, 84 \mathrm{v}, 85 \mathrm{r}, 98 \mathrm{r}$, $120 \mathrm{r}, 120 \mathrm{v}, 140 \mathrm{r}, 141 \mathrm{r}, 144 \mathrm{v}, 155 \mathrm{r}, 156 \mathrm{v}$, $158 \mathrm{r}, 166 \mathrm{r}, 167 \mathrm{v}, 168 \mathrm{r}, 172 \mathrm{v}, 174 \mathrm{r}, 182 \mathrm{v}$,
$186 \mathrm{v}, 194 \mathrm{r}, 194 \mathrm{v}, 196 \mathrm{r}, 196 \mathrm{v}, 197 \mathrm{r}, 197 \mathrm{v}$, 198r, 206r, 207v, 208r, 208v, 209r, 210r, $213 \mathrm{v}, 216 \mathrm{r}, 220 \mathrm{v}, 221 \mathrm{r}, 221 \mathrm{v}, 223 \mathrm{r}, 225 \mathrm{v}$, 226r, 235v, 236r, 246r, 251v, 256r, 256v, $259 \mathrm{v}, 262 \mathrm{r}, 262 \mathrm{v}, 263 \mathrm{r}, 263 \mathrm{v}, 266 \mathrm{r}, 266 \mathrm{v}$, 268r, 274v, 293r, 293v, 295r, 296v, 297r, 299r, 300r, 302r, 310r, 315r, 316r, 319r, $324 \mathrm{r}, 324 \mathrm{v}, 342 \mathrm{v}, 344 \mathrm{r}, 352 \mathrm{r}, 354 \mathrm{r}, 357 \mathrm{r}$, 362r, 364v, 365r, 368v, 371r, 373r, 373v, $397 \mathrm{v}, 398 \mathrm{r}, 399 \mathrm{r}, 400 \mathrm{v}, 414 \mathrm{r}, 415 \mathrm{r}, 415 \mathrm{v}$, 416r, 418r, 418v, 419r, 419v, 420v, 422r, $423 \mathrm{v}, 427 \mathrm{v}, 431 \mathrm{r}, 441 \mathrm{v}, 448 \mathrm{r}, 450 \mathrm{r}, 450 \mathrm{v}$, 454r, 454v, 455r, 455v, 460r, 460v, 461r, $462 \mathrm{r}, 463 \mathrm{r}, 464 \mathrm{r}, 464 \mathrm{v}, 465 \mathrm{v}, 466 \mathrm{v}, 467 \mathrm{v}$, 468r, 469r.

Ana Cabeza Gatón: 466v.

Ana Chamorro: 465v.

Ana Cuchilla: 464r.

Ana de León: 364v, 365r.

Ana de Lera Díez: 465v.

Ana de los Bueyes: 464v.

Ana de Montes: 158r.

Ana de Torres García: 464v, 465v.

Ana de Virtus: 411r.

Ana del Rey: 5v, 98r.

Ana Fernández: 194r, 194v, 373r, 373v, 423v.

Ana García Cisneros: 464r.

Ana Garrido: 469r.

Ana Gutiérrez: 2v, 354r.

Ana Manión: 400v, 401r.

Ana María Conejo: 397v.

Ana María de León: 5r.

Ana Martínez: 463r.

Ana Otero: 462r.

Ana Rodríguez: $167 \mathrm{v}$.

Ana Sotil: $51 \mathrm{r}$.

Anastasio Moreira, fraile: 210r.

Ancardo: $353 \mathrm{v}$.

Andrea de Cifuentes: $5 \mathrm{r}$.

Andrés: 300r; fraile: 148v, 208v, 209r, 217r, 320r, 399r.

Andrés Antonio del Páramo: 276r.

Andrés de Ampudia: 331r.

Andrés de Arenzana: 223r.

Andrés de Baltanás: 256v, 257r.

Andrés de Buelna: 36r.

Andrés de Colmenares: 38r, 38v.

Andrés de Escobar: 466v.

Andrés de Frizar: 439r, 439v.

Andrés de la Calle: 186v, 187r. 
Andrés de la Cuesta: 427v.

Andrés de la Peña: 464r.

Andrés de la Riva: $211 \mathrm{v}$.

Andrés de la Torre: 441r.

Andrés de la Varga: 159v.

Andrés de Lerys: 276r.

Andrés de Llano: 211r, 211v.

Andrés de los Bueyes Beategui: 465v.

Andrés de Mansilla: 317v, 318r.

Andrés de Rozas: 198v.

Andrés de Salazar, fraile: 208v, 209r.

Andrés de San Juan: 406r.

Andrés de Soto: $37 \mathrm{v}$.

Andrés de Yrizas: $317 \mathrm{r}$.

Andrés Díez: 318r.

Andrés Fernández: 304r, 304v.

Andrés Galleo: 450v.

Andrés Gallo: 67v, 281v, 442v.

Andrés García: 401v.

Andrés González: 48r, 181v, 267v, 268r.

Andrés González Roldán: 48r.

Andrés Gutiérrez: 19r, 23v, 27r, 152v, 159r.

Andrés Gutiérrez del Pozo: 23v, 27r.

Andrés Gutiérrez el Viejo: 159r.

Andrés Herrero: 375r.

Andrés Huidobro, fraile: 320r.

Andrés Lucas: 44r, 44v.

Andrés Martín: 44v, 59r, 59v, 60r, 100v, $274 \mathrm{v}$.

Andrés Martínez: 44v, 59v, 60r, 100v, $274 \mathrm{v}$.

Andrés Martínez de Aguilar: 44v.

Andrés Nuñez Castelo, 90r, 90v, 153v, $159 \mathrm{v}, 160 \mathrm{r}, 276 \mathrm{v}, 452 \mathrm{r}, 460 \mathrm{r}, 461 \mathrm{v}, 467 \mathrm{v}$, $468 \mathrm{r}$.

Andrés Ortiz, escribano: 376v, 377r, 377v, 393v, 394r, 394v, 17r, 19r.

Andrés Pardo de Salas: 347v, 348r.

Andrés Pedrejón: 464r, 465r.

Andrés Pérez: 184r, 184v, 330v, 333r, 333v, 393r.

Andrés Pérez de Capillas: 393r.

Andrés Pérez de Madrid: 8v, 330v.

Andrés Rodríguez Roldán: 48v.

Andrés Rodríguez: 430v.

Andrés Ruiz: 153r, 449v, 450r.

Andrés Salado, fraile: $399 \mathrm{r}$.

Andrés Sánchez: 36r, 43v, 75r, 96v, 100r, $105 \mathrm{v}, 113 \mathrm{v}, 124 \mathrm{r}, 127 \mathrm{v}, 128 \mathrm{r}, 132 \mathrm{r}, 137 \mathrm{r}$, $137 \mathrm{v}, 138 \mathrm{r}, 138 \mathrm{v}, 139 \mathrm{r}, 146 \mathrm{r}, 152 \mathrm{r}, 152 \mathrm{v}$, 159r, 163r, 167r, 167v, 180v, 184v, 193r, $198 \mathrm{r}, 198 \mathrm{v}, 216 \mathrm{v}, 218 \mathrm{v}, 219 \mathrm{r}, 219 \mathrm{v}, 220 \mathrm{r}$, 220v, 222v, 246r, 248v, 257r, 266r, 274r, $277 \mathrm{v}, 308 \mathrm{v}, 316 \mathrm{r}, 316 \mathrm{v}, 331 \mathrm{r}, 383 \mathrm{v}, 384 \mathrm{r}$, $384 \mathrm{v}, 385 \mathrm{r}, 394 \mathrm{r}, 400 \mathrm{v}, 403 \mathrm{r}, 403 \mathrm{v}, 422 \mathrm{v}$, $423 \mathrm{r}, 423 \mathrm{v}, 429 \mathrm{v}, 434 \mathrm{v}, 443 \mathrm{r}, 452 \mathrm{v}, 465 \mathrm{r}$, $16 \mathrm{r}, 17 \mathrm{r}, 23 \mathrm{v}, 23 \mathrm{v}, 28 \mathrm{r}, 33 \mathrm{v}$.

Andrés Simón de Aguilar: 167v, 168r.

Andrés Valle: 351v, 376r.

Andrés Vallejo: 351v.

Ángel Castellanos: 6v.

Ángel de Prado: 351v.

Ángel García: 262r, 351v, 463v.

Ángel Gutiérrez: 153v, 251r.

Ángel Gutiérrez Pérez: 160r.

Ángela de Bustillo: 284v.

Ángela de los Bueyes: 465r.

Ángela García: 465r.

Ángela Hernando: 464r.

Ángela Llorente Bezana: 464r.

Anselmo Morán, fraile: 439v.

Anselmo Pérez Cos, fraile: 70r.

Anselmo Pérez, fraile: 311v, 70r.

Antolín Cayón: 287v.

Antolín Gutiérrez Carretero: 437v.

Antolín Herrero: 110v, 183r.

Antón Aguado Porrío: 463r.

Antón de la Torre: 422r.

Antón Fernández: 67r, 354r.

Antón Martínez: 64r, 64v.

Antón Pérez el Mozo: 270r.

Antón Ruiz: 152r.

Antón Sánchez: 372r.

Antonia: 152r, 193r, 300v, 331v, 464r

Antonia Buey Pérez: 464r.

Antonia de Frómista: 193r.

Antonia Roldán: 300v.

Antonia Vázquez: $331 \mathrm{v}$.

Antonio: 40r, 41r, 44r, 47r, 47v, 49v, 50r, $56 \mathrm{r}, 60 \mathrm{v}, 67 \mathrm{v}, 68 \mathrm{r}, 79 \mathrm{r}, 86 \mathrm{r}, 96 \mathrm{v}, 97 \mathrm{r}, 102 \mathrm{v}$, $103 \mathrm{r}, 105 \mathrm{v}, 114 \mathrm{v}, 115 \mathrm{r}, 119 \mathrm{r}, 119 \mathrm{v}, 122 \mathrm{v}$, $124 \mathrm{v}, 127 \mathrm{v}, 130 \mathrm{v}, 131 \mathrm{v}, 137 \mathrm{r}, 137 \mathrm{v}, 138 \mathrm{r}$, $138 \mathrm{v}, 139 \mathrm{r}, 139 \mathrm{v}, 140 \mathrm{r}, 140 \mathrm{v}, 141 \mathrm{r}, 141 \mathrm{v}$, $153 \mathrm{r}, 156 \mathrm{v}, 160 \mathrm{r}, 161 \mathrm{v}, 167 \mathrm{v}, 169 \mathrm{v}, 176 \mathrm{r}$, $177 \mathrm{v}$, , 178v, 180v, 182r, 183r, 185r, 193r, $194 \mathrm{r}, 194 \mathrm{v}, 198 \mathrm{v}, 199 \mathrm{r}, 200 \mathrm{r}, 201 \mathrm{v}, 202 \mathrm{r}$, $202 \mathrm{v}, 209 \mathrm{v}, 210 \mathrm{r}, 211 \mathrm{r}, 216 \mathrm{r}, 219 \mathrm{v}, 220 \mathrm{v}$, $221 \mathrm{r}, 240 \mathrm{v}, 243 \mathrm{v}, 244 \mathrm{r}, 250 \mathrm{r}, 251 \mathrm{v}, 255 \mathrm{r}$, 260r, 261r, 262r, 268v, 269v, 270r, 275v, $276 \mathrm{r}, 277 \mathrm{v}, 278 \mathrm{r}, 278 \mathrm{v}, 281 \mathrm{v}, 282 \mathrm{r}, 283 \mathrm{v}$, $284 \mathrm{r}, 285 \mathrm{v}, 286 \mathrm{r}, 286 \mathrm{v}, 289 \mathrm{r}, 292 \mathrm{v}, 295 \mathrm{v}$, 
296v, 297r, 298r, 298v, 307r, 310v, 311r, $311 \mathrm{v}, 313 \mathrm{v}, 315 \mathrm{r}, 316 \mathrm{r}, 331 \mathrm{r}, 334 \mathrm{r}, 334 \mathrm{v}$, 335r, 336r, 336v, 347v, 348r, 352r, 358r, $358 \mathrm{v}, 359 \mathrm{r}, 359 \mathrm{v}, 360 \mathrm{r}, 362 \mathrm{v}, 365 \mathrm{v}, 367 \mathrm{r}$, $367 \mathrm{v}, 368 \mathrm{r}, 368 \mathrm{v}, 369 \mathrm{r}, 370 \mathrm{v}, 371 \mathrm{r}, 371 \mathrm{v}$, $373 \mathrm{r}, 373 \mathrm{v}, 390 \mathrm{v}, 393 \mathrm{v}, 394 \mathrm{r}, 394 \mathrm{v}, 395 \mathrm{r}$, $397 \mathrm{v}, 398 \mathrm{r}, 399 \mathrm{r}, 399 \mathrm{v}, 400 \mathrm{r}, 400 \mathrm{v}, 401 \mathrm{r}$, $401 \mathrm{v}, 404 \mathrm{v}, 405 \mathrm{r}, 405 \mathrm{v}, 407 \mathrm{r}$.

Antonio Abad: $298 \mathrm{r}$.

Antonio Adame: 422r, 452v.

Antonio Álvarez Vigil: 182r.

Antonio Amigo: 211r.

Antonio Ampuero Delgado: 369r.

Antonio Bedoya: 334r, 334v.

Antonio Bohón: 167v.

Antonio Bohón de Bustamante: 122v.

Antonio Buey: 67v, 68r, 442v.

Antonio Buey Larreategui: 40r.

Antonio Calderón: 130v.

Antonio Calvo: 336v.

Antonio Candeda: 276r.

Antonio Carvajo: 11r.

Antonio Casquero: $467 \mathrm{v}$.

Antonio Cornejo, fraile: 26v.

Antonio de Argüello: 407r.

Antonio de Ayala: 216r.

Antonio de Barreda y Yedra: 390v.

Antonio de Bedoya: 334v, 335r.

Antonio de Bricianos: 394r, 394v.

Antonio de Burgos: 399r.

Antonio de Campo: 420r.

Antonio de Ceano Vivas: 160r.

Antonio de Cifuentes: 3v.

Antonio de Fonseca: 86r.

Antonio de Fresnedo: 185r.

Antonio de Grijalva: 183r; fraile: 260r.

Antonio de Guzmán: 102v, 103r.

Antonio de Heredia: 269v, 270r.

Antonio de la Cueva y Silva: $41 \mathrm{r}$.

Antonio de la Fuente: 194r, 200r.

Antonio de la Peña y Villagómez: 250r.

Antonio de la Pisa: 424r.

Antonio de la Torre: $277 \mathrm{v}$.

Antonio de Laverde San Martín: 3r, 3v.

Antonio de León: 72r, $316 r$.

Antonio de los Ríos, fraile: 17r, 23v, 31v.

Antonio de Medina: 47v, 282r.

Antonio de Molina, fraile: 16r.

Antonio de Ocáriz: 9r.

Antonio de Ormaza: 8v, 9r.

Antonio de Palacios: 441r.
Antonio de Palenzuela: 44r.

Antonio de Rueda: 397v, 401r.

Antonio de San Martín: 2v, 3v, 4r.

Antonio de San Román: 50r; fraile: 139v.

Antonio de Vega: 452v.

Antonio de Villamartín: 422v.

Antonio de Zafra Argüelles, 185r.

Antonio del Valle, fraile: 79r, 177v, 178r, $281 \mathrm{v}, 362 \mathrm{v}, 367 \mathrm{r}, 367 \mathrm{v}, 368 \mathrm{r}, 368 \mathrm{v}$.

Antonio Díaz Montero: 44r.

Antonio Doró Campo Enríquez, regidor y alférez mayor de Carrión: 137r, 137v, 138r, 138v, 139r, 140r, 140v, 141v, 455v.

Antonio Enríquez de Cisneros: 281v, 282r.

Antonio Facón: 5r, 5v.

Antonio Fernández de Guzmán: 161v, 240v, 315r, 326r, 358r, 358v, 359r, 359v, $413 \mathrm{v}, 414 \mathrm{r}$.

Antonio Francisco: 140v, 141r, 448v.

Antonio Francisco Enríquez: 141r.

Antonio Frechoso: 180v.

Antonio García: 169v, 404v, 413r, 413v.

Antonio García de Villamayor: 401r, 401v.

Antonio García Velasco: 398r.

Antonio Goitiz Arana: 251v.

Antonio Gómez de Cos: 115r.

Antonio González: 437v, 3v.

Antonio González Cajigas: 210r.

Antonio González de los Ríos: 437v.

Antonio Guerra Fernández: 5v, 6r.

Antonio Gutiérrez: 395r.

Antonio Horcasitas: 311v.

Antonio Ibáñez de Madrid: 311r.

Antonio Jofre de Villegas: 97r.

Antonio Laso: 193r, 201v, 202r, 202v, $219 \mathrm{v}, 220 \mathrm{v}, 221 \mathrm{r}$.

Antonio Leonardo López: 268v.

Antonio López Moro de Colmenares: $176 r$.

Antonio López: 176r, 278v, 428v, 434v; doctor: 428v.

Antonio Magarzo Rodríguez: 4r, 4v, 399v, 400r.

Antonio Manzanedo y Santiago: 119r, $119 \mathrm{v}$.

Antonio Marcos: 255r, 419v.

Antonio Martín: 286v.

Antonio Martín García: 49v, 127v, 243v, $244 \mathrm{r}, 269 \mathrm{v}, 283 \mathrm{v}, 284 \mathrm{r}, 286 \mathrm{r}, 289 \mathrm{r}, 292 \mathrm{v}$, 307r, 310r, 313v, 315r, 336r, 359v, 360r, 
$365 \mathrm{v}, 370 \mathrm{v}, 371 \mathrm{r}, 371 \mathrm{v}, 373 \mathrm{r}, 373 \mathrm{v}, 400 \mathrm{v}$, $405 \mathrm{r}, 405 \mathrm{v}, 412 \mathrm{v}, 435 \mathrm{v}, 436 \mathrm{r}, 441 \mathrm{v}, 443 \mathrm{r}$, 444r.

Antonio Martín Granizo: 60v.

Antonio Martín Rodríguez: 37v.

Antonio Martín: 37v, 47r, 49v, 60v, 127v, $131 \mathrm{v}, 201 \mathrm{v}, 243 \mathrm{v}, 244 \mathrm{r}, 269 \mathrm{v}, 283 \mathrm{v}, 284 \mathrm{r}$, 286r, 286v, 289r, 292v, 296v, 307r, 313v, 315r, 336r, 359v, 360r, 365v, 370v, 371r, $371 \mathrm{v}, 373 \mathrm{r}, 373 \mathrm{v}, 400 \mathrm{v}, 405 \mathrm{r}, 405 \mathrm{v}, 412 \mathrm{v}$, 435v, 436r, 441v, 443r, 444r.

Antonio Martínez Tamayo: 296v.

Antonio Medina Cachón: 276r.

Antonio Medina de Cisneros: 282r.

Antonio Merino: 298v, 461r.

Antonio Núñez de Alameda: 422v, 423r.

Antonio Ocáriz: 9v.

Antonio Orejón: 24r, 153r, 447v, 453r.

Antonio Osorio: 193r.

Antonio Paniagua de la Cerda: 442v.

Antonio Pasto: $124 \mathrm{v}$.

Antonio Pérez: 114v, 209v, 367r, 367v.

Antonio Pérez Minayo: 4v.

Antonio Perroto, fraile: 36r, 261r, 331r, 439r.

Antonio Rabanales: 352r.

Antonio Ramírez: 105v, 185r, 295v, 310v, 36v.

Antonio Ramón Calvo y Serrano: 285v.

Antonio Ramos: 156v, 390v.

Antonio Redondo: 198v, 199r.

Antonio Revuelta: 194v.

Antonio Rodríguez: 275v, 297 r.

Antonio Rojo Pérez: 194r.

Antonio Ruiz: 180v.

Antonio Ruiz de Modoya: 49v.

Antonio Sánchez: 56r, 200r, 278r.

Antonio Sánchez de Villanuño: 56r.

Antonio Sánchez Vasco: 278r.

Antonio Santos: 277v.

Antonio Sedano: 105v.

Antonio Ventura de Prado, fraile: 119r.

Antonio Zamorano: 393v, 394r.

Aparicio: 9v, 10r, 11r, 20v, 21v, 23r, 25v, $38 \mathrm{r}, 38 \mathrm{v}, 157 \mathrm{r}, 157 \mathrm{v}, 174 \mathrm{r}, 251 \mathrm{v}, 262 \mathrm{r}$, 269r, 269v, 279r, 310v, 311r, 353r, 394r, $394 \mathrm{v}, 423 \mathrm{v}, 427 \mathrm{v}, 459 \mathrm{v}, 462 \mathrm{r}$.

Aparicio de Ortega: 20v, 310v, 394r, 394v. Aparicio Franco: 10r, 25v.

Aragón, fraile: 395v, 396r, 396v; infante de: $237 \mathrm{v}, 238 \mathrm{r}, 238 \mathrm{v}$.
Arcángelo Raimundo: 211r.

Arena: 139r, 464r.

Arias de Cantoral: 255v, 256r.

Armengol, conde: $291 \mathrm{v}$.

Armitra Pérez: 412r.

Arnaldo: 427r, 427v.

Asensio Pérez de Pintelos: 275v.

Astorga, provisor de: 8v, 9r.

Atanasio Casares: 262v.

Atanasio García: 194v.

Atilano Muñoz, fraile: 276v.

Aura Díaz: 443r.

Aviñante, cura de: $441 \mathrm{v}$; vecino: $371 \mathrm{v}$.

Ayala: 16r, 86v, 213v, 216r, 222v, 223r, $342 \mathrm{v}, 366 \mathrm{r}, 445 \mathrm{v}$.

Ballesteros: 376r.

Baltasar Burgos: 465v, 466r.

Baltasar de Aguilar, 262r.

Baltasar de Anaya: 197r.

Baltasar de Belo: 36v, 105v.

Baltasar de Nogal y Osorio: 287r, 287v, 288r.

Baltasar de Vega: 146v.

Baltasar de Vergara: 436v.

Baltasar Francisco Ibáñez: 297r, 297v, 298r, 298v, 299r.

Baltasar Guerrero, fraile: 26v.

Baltasar Gutiérrez: 221r, 222r.

Baltasar Molleus: 216r.

Baltasar Montero: 59v, 60r.

Baltasar Prieto: 450v.

Baltasar Rojo: 178r.

Baltasara Lorenzo: 398r, 398v, 399r.

Bandera: 428v, 431r.

Baños, vecino: 295v, 296r.

Barahona: 113v, 201v, 217r, 272r; doctor: 218v.

Bárbara del Amo: 261v.

Bárcena, fraile: $141 \mathrm{v}$.

Barrantes: 10r, 16v, 23v, 26r, 28v, 73r, $117 \mathrm{v}, 118 \mathrm{r}, 180 \mathrm{v}, 185 \mathrm{r}, 202 \mathrm{r}, 204 \mathrm{r}, 204 \mathrm{v}$, 205r, 208r, 208v, 223v, 257r, 266r, 266v, $267 \mathrm{r}, 275 \mathrm{v}, 280 \mathrm{v}, 310 \mathrm{v}, 323 \mathrm{v}, 447 \mathrm{r}, 455 \mathrm{r}$, $455 \mathrm{v}$; fraile: $121 \mathrm{r}, 121 \mathrm{v}, 146 \mathrm{v}$.

Bartolo Sánchez de Tórtoles: 36r.

Bartolomé: 17v, 261r, 269v, 270r, 272v, 295v, 296r, 311r, 314v, 354r, 371v, 378r, 395v, 396r, 408v, 420v, 424r, 436r, 439v; clérigo: $182 \mathrm{v}$.

Bartolomé Cordero: 321r. 
Bartolomé de Alvear, fraile: 216v.

Bartolomé de Anaya Villanueva: 420v.

Bartolomé de Gonzalo: 295v.

Bartolomé de Hernando: 321r, 321v.

Bartolomé de la Calva: 465r

Bartolomé de Medina: 320v.

Bartolomé de Mendoza: 322v, 323r.

Bartolomé de Quesada: 204v.

Bartolomé de Zaldívar, fraile: 50r.

Bartolomé del Valle: 218v, 334r, 334v, 335r.

Bartolomé Díez: 269v, 270r.

Bartolomé Fernández: 294v, 316r.

Bartolomé García: 50v, 270r.

Bartolomé Gil: 311r.

Bartolomé González, 174v, 183r, 261r, 351v, 352r, 371v, 408v.

Bartolomé González de Velasco: 351v, 352r.

Bartolomé González Donís: 261r.

Bartolomé Gonzalo: 295v, 296r.

Bartolomé Gutiérrez: 17v, 18r.

Bartolomé Herrero: 272v.

Bartolomé Hurtado: 257r.

Bartolomé Lozano: 439v.

Bartolomé Macho: 169v.

Bartolomé Martín: 320v.

Bartolomé Mateo: 180v.

Bartolomé Osorio: 287v.

Bartolomé Pérez: 362r.

Bartolomé Sánchez de Tórtoles: 436r.

Bartolomé Santos: 316v, 331r.

Bartolomé Santos de Risoba: 378r, 395v, 396r.

Bartolomé Torices: 317r, 317v, 368r, 368v.

Bartolomé Villafañe, fraile: 424r.

Bártulo Sánchez de Tórtoles: 207v.

Basilio Campo: 299r.

Beatriz: 88r, 91r, 151r, 290r, 290v, 334r, $334 v, 338 r, 339 r, 339 v, 340 r, 340 v, 341 r$, 454r; reina: 427r, 427v.

Beatriz de Abeja: 151r.

Beatriz del Puerto: 334r, 334v.

Beatriz Rodríguez de Fonseca, 338r, 339r, 339v, 340r, 340v, 341r, 454r.

Becerril, vecino: $442 \mathrm{v}, 466 \mathrm{v}$.

Bedoya: 48v, 60v, 334r, 334v, 335r.

Beltrán: 186r, 230r, 230v, 231r, 260v.

Beltrán de Guevara: 260r, 260v.

Beltrán de San Basilio: 186r.

Belver, doctor: 394r.
Benedicto XIII: 144r.

Benedicto XIV: 114v, 115r.

Benevívere, abad: 18v.

Benita: 434r.

Benito: 306r.

Benito Álvarez: 2v; fraile: $3 \mathrm{r}$.

Benito Cantero, fraile: $157 \mathrm{v}$.

Benito de Aragón, fraile: 73r, 308v, 392r, 392v, 395r, 395v.

Benito de la Fuente: 298v.

Benito de Pedrosa, fraile: 137r.

Benito de Sahagún: 180v; fraile: 219v, 220r.

Benito de Valladolid, juez principal conservador: 215r, 215v.

Benito de Villapún: 146r.

Benito del Camino, fraile: 2r, 247r, 293v, 373r, 373v, 385r, 385v, 386r, 403r, 403v.

Benito Pérez: 68v, 148r.

Benito Ramón de Hermida: 447v.

Benito Rodríguez Pillado: 181r.

Benito Rodríguez: 276r.

Benito Sabido, fraile: 200v, 311v, 448v.

Benito Tejo: 160r.

Berdeces, licenciado: $447 \mathrm{v}$.

Berenguela: 91r, 66r, 66v Berenguela, reina: 360r.

Bermudo Bermúdez: 434v.

Bermudo: 434r.

Bernabé Carrión: 282r, 282v.

Bernabé de Cuesta: 462r.

Bernabé García: 371r.

Bernabé Pérez: 299v.

Bernabé Rojo: 397r.

Bernarda Antón: 306r, 306v.

Bernarda de la Cuesta: 262r.

Bernardino Alonso: 69r, 69v, 395r.

Bernardino Bajo: 279r.

Bernardino Choy: 366r; mujer de: 366r.

Bernardino de Argadero, fraile: 354r, 394r.

Bernardino de Carrión: 207v.

Bernardino de Carvajal: 84v, 85r, 85v, $245 r$.

Bernardino de Olmos: 362r.

Bernardino de Valderas: 2r.

Bernardino de Villalón: 40r.

Bernardino Gijón: 36v.

Bernardino González, 197r, 197v, 198r, 201v, 203v, 206v, 211r, 211v, 212r, 215v, 218v, 219r, 219v, 220r, 220v, 221r, 221v. 
Bernardino González, capellán de San Martín: 211r.

Bernardino López Valdivieso: 297v.

Bernardino Miguel de Prado: 3v.

Bernardino Santos: 395v.

Bernardo: 37r, 39r, 46v, 61r, 66r, 66v, 67v, 68r, 69v, 72r, 79r, 111r, 115r, 115v, 116r, $118 \mathrm{v}, 135 \mathrm{r}, 141 \mathrm{r}, 178 \mathrm{v}, 183 \mathrm{r}, 190 \mathrm{v}, 195 \mathrm{r}$, 209r, 209v, 261r, 262v, 274v, 278r, 285r, $287 \mathrm{v}, 288 \mathrm{r}, 295 \mathrm{v}, 296 \mathrm{r}, 296 \mathrm{v}, 304 \mathrm{r}, 304 \mathrm{v}$, $309 \mathrm{v}, 311 \mathrm{r}, 316 \mathrm{v}, 319 \mathrm{r}, 337 \mathrm{v}, 350 \mathrm{r}, 354 \mathrm{v}$, 380r, 406r, 445v, 450r, 463v, 464r, 464v, 465r, 465v, 466r, 466v.

Bernardo Arenas: 464r.

Bernardo Buey Valle: 67v, 68r, 463v, 464r, 464v, 465r, 465v, 466r, 466v; escribano de Becerril: 465r.

Bernardo Burgos: 465v.

Bernardo Caravés, fraile: 118v.

Bernardo Clemente: 79r.

Bernardo de Ayala, fraile: 445v.

Bernardo de la Cuesta: $261 \mathrm{r}$.

Bernardo de Lerma, fraile: 316v.

Bernardo de los Ríos, fraile: 72 r.

Bernardo de Miranda: 190v.

Bernardo de Rezola: 79r.

Bernardo de Rojas y de Sandoval: 350r.

Bernardo de San Esteban, fraile: 39r, 209r, 380r.

Bernardo de Zúñiga, fraile: 37r, 69v, 79r, 135r, 209v, 278r, 295v, 296r, 311r.

Bernardo del Campo: $111 \mathrm{r}$.

Bernardo Díaz de Castro: 178v, 406r.

Bernardo Díez: 195r.

Bernardo Facundo Vázquez: 287v, 288r.

Bernardo Fernández de Llamazares: 61r.

Bernardo García: 304v.

Bernardo García Martín: 115v, 116r.

Bernardo González: 450r.

Bernardo Lezana: 141r, 274v.

Bernardo Luis: 319r.

Bernardo Martín: 337v.

Bernardo Martínez Caravaca: 209v.

Bernardo Rodríguez Palacios: 285r, 296r, 296v.

Bernardo Salazar, fraile: $115 \mathrm{r}$.

Bernardo Valbuena: 46v ,183r, 262v, 309v, $354 \mathrm{v}$.

Blanca: 98r.

Blas, mercader: $131 \mathrm{v}$.

Blas Abastas: 460r.
Blas Callejo: 449v, 450r.

Blas Caminero: $165 \mathrm{r}$.

Blas de la Llama: 432r.

Blas de Pedrosa, fraile: 35r.

Blas de Sahagún: 204v.

Blas de Valderrábano: 314r; mujer de: 314r.

Blas Gutiérrez del Campo: 185r.

Blas Ibáñez: 175v.

Blas Isla Álvarez: 416v.

Blas Ordóñez: 50v, 51r, 263r, 266v, 267r, $321 \mathrm{v}, 374 \mathrm{v}$.

Blas Rodríguez: 369r.

Blas Vallejo: 461r.

Blas Vela Álvarez: 146r, 146v, 155r, 156v, $157 \mathrm{v}$.

Blasa: 176r, 208r.

Bobadilla, licenciado: 446r, 446v.

Bonifacio VIII: 102r, 102v.

Bonilla: 250r.

Bonomen: 259r, 312v.

Bricianos, doctor: 392r.

Brígida: 317r, 322v, 323r, 461r.

Brígida García: 317r.

Brígida Gutiérrez: 461r.

Buenaventura de Madrid: 16v, 310r, 310v.

Buenaventura Ordóñez, fraile: 471v.

Buenavista Olea: 153v.

Burgos, arzobispo: 209r; dignidad: 87r; obispo de, administrador perpetuo de San Zoilo: 70v, 71r.

Bustamante: $17 \mathrm{r}, 70 \mathrm{v}, 72 \mathrm{v}, 104 \mathrm{v}, 105 \mathrm{r}$, $122 \mathrm{v}, 123 \mathrm{r}, 123 \mathrm{v}, 331 \mathrm{v}$.

Caballero: 158v, 162r, 282r, 3v, 4r, 10r, 26r.

Cabezas Altamirano: 420v.

Calleja: 203r, 204r, 204v, 208r, 208r, 208v, 213r, 213v.

Calzadilla, cura de: $76 \mathrm{r}$.

Cámara Apostólica: auditor: 13v, 19r, $240 \mathrm{v}$; auditor y juez de la curia romana: 216r, 342v.

Camilo Caetano: $17 \mathrm{v}$.

Camilo Valionibus: 190v.

Campo Redondo, cura de, comisario del Santo Oficio: $311 \mathrm{r}$.

Campo: 6r, 18v, 31r, 31v, 37v, 76r, 99v, $101 \mathrm{v}, 111 \mathrm{r}, 114 \mathrm{r}, 115 \mathrm{v}, 140 \mathrm{r}, 141 \mathrm{v}, 153 \mathrm{r}$, $153 \mathrm{v}, 154 \mathrm{v}, 155 \mathrm{r}, 157 \mathrm{v}, 158 \mathrm{v}, 167 \mathrm{r}, 167 \mathrm{v}$, 168r, 178v, 185r, 193v, 198r, 199v, 200r, 
205r, 209r, 209v, 210r, 218v, 219r, 256r, 276r, 299r, 311r, 311v, 347r, 354r, 420r, $453 \mathrm{v}, 455 \mathrm{v}$.

Campomanes, conde de: $115 \mathrm{v}$.

Cano: 28v, 38v, 39r, 48v, 135v, 185v, 193r, 193v, 198r, 198v, 199r, 203r, 212r, 213v, $219 \mathrm{r}, 219 \mathrm{v}, 220 \mathrm{v}, 221 \mathrm{r}, 223 \mathrm{v}, 278 \mathrm{v}, 294 \mathrm{v}$, 296v, 297r, 300r, 300v, 399v, 405v, 445r.

Cantarino: 306r.

Cañamero, doctor: $221 \mathrm{v}$.

Capellán, 103r, 103v, 198r, 198v, 200r, $237 \mathrm{v}, 238 \mathrm{r}, 238 \mathrm{v}, 294 \mathrm{v}, 295 \mathrm{r}, 415 \mathrm{r}$.

Carabaza: 200r, 209v, 210r, 210v, 214r, 214v.

Carlos: 256r, 331v, 344r, 357r.

Carlos Barba: 357r.

Carlos Enríquez Cisneros y Albornoz: 331v.

Carlos Revuelta: 153 r.

Carlos V: 40v, 85v, 86r, 86v, 87r, 87v, 94v, $99 \mathrm{v}, 132 \mathrm{r}, 134 \mathrm{r}, 245 \mathrm{r}, 245 \mathrm{v}, 246 \mathrm{r}, 344 \mathrm{r}$, $415 \mathrm{v}, 416 \mathrm{r}, 454 \mathrm{r}, 454 \mathrm{v}, 455 \mathrm{r}, 455 \mathrm{v}$.

Carrión, abogados: 75v; alcalde: 92r, 92v, 93r, 419r, 419v; alcalde mayor, 75r, 95v, $354 \mathrm{r}, 354 \mathrm{v}$, 420v; clérigo: $105 \mathrm{v}$; corregidor: $167 \mathrm{r}, 169 \mathrm{v}, 420 \mathrm{v}, 422 \mathrm{v}, 423 \mathrm{r}$; cura de: 165r, 165v; iglesia de San Bartolomé, cura de: 178r, 178v; notario: 26r; teniente de corregidor: $55 \mathrm{v}, 94 \mathrm{r}, 167 \mathrm{r}$; vecino: $153 \mathrm{v}$, $164 \mathrm{v}, 165 \mathrm{v}, 168 \mathrm{r}, 250 \mathrm{r}, 272 \mathrm{r}, 329 \mathrm{r}, 345 \mathrm{r}$, $345 \mathrm{v}, 346 \mathrm{r}, 347 \mathrm{r}, 410 \mathrm{v}, 411 \mathrm{r}$.

Castañeda, conde de: 341v, 342r.

Castañiza: 420r.

Castellano de Villaturde: 438r.

Castrejón, arcipreste: $294 \mathrm{v}$.

Castromudarra, vecino: $184 \mathrm{r}, 184 \mathrm{v}$.

Catalina: 32r, 32v, 33r, 50v, 56v, 61v, 62r, $146 \mathrm{v}, 149 \mathrm{r}, 149 \mathrm{v}, 165 \mathrm{r}, 228 \mathrm{r}, 235 \mathrm{r}, 235 \mathrm{v}$, 343r, 343v; reina: 228v, 229r, 229v.

Catalina Barriosuso: 263v.

Catalina Blanco: 146v.

Catalina Calvo: 441r.

Catalina de Cieza: 56r, 56v.

Catalina de Isla: 368r, 368v.

Catalina de la Fuente: 61v, 62r.

Catalina de Melo: 33r.

Catalina de Paredes: 354r, 354v.

Catalina del Pozo: 422v.

Catalina Díaz: 32r, 32v.

Catalina Díez Doncel: 464v.

Catalina Fernández: 464r.
Catalina García: 165r.

Catalina Gregorio: 300v.

Catalina Guerra: 5v.

Catalina López: 149r.

Catalina Manión: 397v.

Catalina Martínez: 61v, 199v.

Catalina Montes: 50v.

Catalina Ruesga: 32r.

Catalina Sánchez: 165r.

Catarino Fernández: 191v.

Cayetano de Urbina: 363v.

Cayetano Taboada, fraile: 288 r.

Cea, señor de: 183v, $184 \mathrm{r}$.

Cebrián: $35 \mathrm{v}$.

Cebrián Merino: 375r.

Centena de Valdés: 310v.

Cervatos, beneficiado: 460r.

Cesáreo Villasante: 278v.

Ciaz, 434r.

Cieza: $324 v$.

Cisneros: 39r, 39v, 59r, 73r, 78v, 79r, 82v, 86r, 86v, 89v, 93r, 106r, 109r, 118r, 123r, $130 \mathrm{r}, 130 \mathrm{v}, 134 \mathrm{v}, 167 \mathrm{v}, 199 \mathrm{v}, 256 \mathrm{v}, 270 \mathrm{r}$, $270 \mathrm{v}, 277 \mathrm{v}, 282 \mathrm{r}, 295 \mathrm{v}, 331 \mathrm{v}, 333 \mathrm{r}, 372 \mathrm{r}$, $455 \mathrm{v}, 460 \mathrm{v}, 464 \mathrm{r}, 471 \mathrm{v}$; fraile: $342 \mathrm{v}, 343 \mathrm{r}$, $471 \mathrm{v}$.

Cisneros de Luis Bravo de Lagunas: 455v.

Citi Anáyaz: 186v.

Citi Morález: 434v

Clara Pérez: 32r.

Claudia Pita de Andrade: 439v.

Claudio Autillo: 68r.

Clemente Fernández: 203r.

Clemente III: $80 \mathrm{v}$.

Clemente IX: 72v, 73v.

Clemente VI: 67v, 82r, 82v.

Clemente VII: 21r, 21v, 85v, 86r, 86v, 87r, $87 \mathrm{v}, 227 \mathrm{v}, 399 \mathrm{r}$.

Clemente VIII: 121r, 125r, 125v, 140r, $140 \mathrm{v}, 208 \mathrm{r}, 209 \mathrm{r}, 212 \mathrm{v}, 222 \mathrm{v}, 223 \mathrm{v}, 330 \mathrm{v}$.

Clemente X: $118 \mathrm{v}$.

Cluny, camarero: 91v, 225r, 225v; juez principal conservador: $360 \mathrm{v}$.

Santísimo Milagro, abad de la Cofradía del: $203 r$.

Comillas, clérigo de menores órdenes: 209r.

Congosto, vecino: $372 \mathrm{r}$.

Constanza: 158r, 455v; reina: 444r.

Constanza de Rosas: 158 r. 
Constanza Enríquez: 32v, 33r, 137r, 137v, $138 \mathrm{r}, 138 \mathrm{v}, 139 \mathrm{r}, 139 \mathrm{v}, 140 \mathrm{r}, 140 \mathrm{v}, 141 \mathrm{v}$, $455 \mathrm{v}$.

Cornelio Cataneo: 212r, 212v.

Coronel, doctor: 376v, 395r, 395v.

Cosme de Mallagara: 248v, 249r.

Covarrubias: 341v, 342r; canónigo: 197v.

Cristóbal: 4v, 427v.

Cristóbal Antón: 422r.

Cristóbal Baltodano: 220r.

Cristóbal Castrillo: 174v.

Cristóbal Collantes: 10r.

Cristóbal de Agüero, fraile: 28r, 28v, 277v.

Cristóbal de Barriales: 14v.

Cristóbal de Castresana: 299r.

Cristóbal de Cisneros: 277v.

Cristóbal de Collantes: 18v.

Cristóbal de Grajal: 89v.

Cristóbal de Guzmán: 178r, 295v.

Cristóbal de Matienzo, fraile: 50r, 51r, 65r, $320 \mathrm{v}, 321 \mathrm{v}, 374 \mathrm{v}, 375 \mathrm{r}$.

Cristóbal de Olea: 4r.

Cristóbal de Valderas: 2r, 2v, 16r, 16v, 17v, 18r, 18v, 19r, 23v, 26r, 26v.

Cristóbal de Villanueva: 216r, 216v.

Cristóbal del Valle: 256r.

Cristóbal Gómez: 76v, 259v, 260r, 265v, 293r, 308r, 329r, 383r.

Cristóbal Gómez de Valderrábano: 47v, 71v, 72r, 183r, 371v.

Cristóbal Guzmán: 134r, 134v

Cristóbal Herrero: 258r.

Cristóbal López Ramírez: 3r, 3v, 4r, 4v, 68r, 463r.

Cristóbal Luis Rodríguez: 120v.

Cristóbal Marqués: 178r.

Cristóbal Martínez Medina: 469r.

Cristóbal Oro: 93v, 151v.

Cristóbal Palomino: 419r.

Cristóbal Ramos: 287v, 288r.

Cristóbal Robuste: 9v.

Cristóbal Rodríguez de Lorenzana: 220v, 221r, 221v.

Cristóbal Salgado: 398r.

Cristóbal Salinas: 399r.

Cristóbal Verde de Castilla: 120v.

Cruz Rondavino: 464r.

Cuenca de Campos, monjas del monasterio de Santa Clara: 6r.

Dámaso Martín: 437v.
Damián de Salas: 442v; fraile: 2r, 16r, 72r, 373v, 374r, 386v, 387r, 403v, 404r.

Damián de Torres: 28r.

Damián Díez: 263v.

Denia, marqués de: $350 \mathrm{r}$.

Día Gómez Manrique: $227 \mathrm{v}$.

Diego: 105r, 106r, 113v, 127v, 129v, 130r, $140 \mathrm{v}, 145 \mathrm{v}, 149 \mathrm{r}, 149 \mathrm{v}, 150 \mathrm{r}, 151 \mathrm{r}, 158 \mathrm{r}$, 159r, 161r, 166r, 166v, 167r, 167v, 170v, $181 \mathrm{r}, 181 \mathrm{v}, 183 \mathrm{r}, 185 \mathrm{r}, 190 \mathrm{v}, 191 \mathrm{v}, 192 \mathrm{r}$, $192 \mathrm{v}, 193 \mathrm{r}, 193 \mathrm{v}, 194 \mathrm{v}, 195 \mathrm{r}, 207 \mathrm{r}, 209 \mathrm{r}$, $214 \mathrm{r}, 217 \mathrm{r}, 218 \mathrm{v}, 219 \mathrm{r}, 221 \mathrm{v}, 222 \mathrm{r}, 227 \mathrm{v}$, 235r, 235v, 237v, 238r, 238v, 239r, 243r, $243 \mathrm{v}, 244 \mathrm{r}, 244 \mathrm{v}, 246 \mathrm{r}, 249 \mathrm{r}, 249 \mathrm{v}, 255 \mathrm{r}$, $255 \mathrm{v}, 256 \mathrm{r}, 257 \mathrm{r}, 262 \mathrm{v}, 263 \mathrm{r}, 266 \mathrm{r}, 266 \mathrm{v}$, $267 \mathrm{r}, 269 \mathrm{v}, 277 \mathrm{r}, 277 \mathrm{v}, 278 \mathrm{r}, 279 \mathrm{v}, 280 \mathrm{r}$, $285 \mathrm{r}, 285 \mathrm{v}, 287 \mathrm{v}, 288 \mathrm{r}, 290 \mathrm{r}, 290 \mathrm{v}, 294 \mathrm{v}$, 295r, 295v, 296r, 299r, 305r, 305v, 310r, $310 \mathrm{v}, 311 \mathrm{r}, 311 \mathrm{v}, 312 \mathrm{r}, 312 \mathrm{v}, 313 \mathrm{r}, 315 \mathrm{v}$, 316r, 319r, 323v, 328v, 331v, 335r, 341r, 343r, 343v, 350r, 350v, 353r, 353v, 355r, 356v, 357r, 360v, 361r, 361v, 362v, 368r, 371r, 371v, 374r, 375r, 376r, 380r, 380v, $387 \mathrm{v}, 391 \mathrm{r}, 393 \mathrm{v}, 395 \mathrm{r}, 395 \mathrm{v}, 399 \mathrm{r}, 404 \mathrm{v}$; fraile: $24 \mathrm{r}, 26 \mathrm{r}, 46 \mathrm{r}, 72 \mathrm{r}, 84 \mathrm{v}, 86 \mathrm{r}, 86 \mathrm{v}$, $120 \mathrm{r}, 120 \mathrm{v}, 121 \mathrm{v}, 122 \mathrm{r}, 122 \mathrm{v}, 146 \mathrm{r}, 203 \mathrm{v}$, $207 \mathrm{v}, 208 \mathrm{r}, 225 \mathrm{v}, 256 \mathrm{r}, 256 \mathrm{v}, 259 \mathrm{v}, 260 \mathrm{r}$, 270r, 293r, 300r, 300v, 302r, 315r, 315v, $322 \mathrm{v}, 323 \mathrm{r}, 330 \mathrm{v}, 355 \mathrm{v}, 362 \mathrm{r}, 372 \mathrm{r}, 382 \mathrm{r}$, $382 \mathrm{v}, 383 \mathrm{r}, 392 \mathrm{r}, 393 \mathrm{v}, 408 \mathrm{v}, 418 \mathrm{r}, 418 \mathrm{v}$, $419 \mathrm{v}, 437 \mathrm{r}, 441 \mathrm{v}$.

Diego Alcalde: 51r, 267r, 375r, 380v.

Diego Alfonso: $67 \mathrm{v}$.

Diego Álvarez de Carrión: 411v.

Diego Álvarez de Vozmediano: 92v, 93r.

Diego Ansúrez: 404v.

Diego Arias de Miranda: 167v.

Diego Barrantes: 310v.

Diego Botello: 341r.

Diego Caballero: 419v.

Diego Cid: 5v.

Diego Colmenares: 49v.

Diego de Ávila: 445r.

Diego de Canales: 2r; fraile: 120r, 120v, 207v, 256r, 256v, 302r, 418r, 418v.

Diego de Castañeda: 2r, 8v.

Diego de Colmenares: 263r.

Diego de Cossío Bustamante: 72v.

Diego de Covarrubias, fraile: 259v, 260r, 372r.

Diego de Espinosa: 190v. 
Diego de Fonseca: 86r, 185r; fraile: 355v, 437r.

Diego de Gobeo: 246r.

Diego de Herrera: 33r, 428r.

Diego de Herrezuelo: 357r.

Diego de Huidobro: 328v.

Diego de Juara: 350r.

Diego de la Vega: 362v, 376r.

Diego de la Zoreda: 343r, 343v.

Diego de las Heras: $84 \mathrm{r}$; fraile: $84 \mathrm{v}$, $408 \mathrm{v}$.

Diego de León, fraile: 72r.

Diego de Lillo, fraile: 362r.

Diego de los Ríos: 256r, 290r, 290v.

Diego de Málaga, fraile: 393v.

Diego de Marquina, fraile: 24r, 24r.

Diego de Muros: 243r, 243v, 393r, 393v.

Diego de Nogal: 193r.

Diego de Olea: 151r; fraile: 121v, 122r, $122 \mathrm{v}$.

Diego de Olea de Reinoso: 145v, 146r, 166v, 167r.

Diego de Ortigosa: 193v.

Diego de Palencia: 192r, 192v.

Diego de Peñafiel: 14v, 15r, 15v, $16 r$.

Diego de Peñaranda: 10r.

Diego de Pernía: 2r.

Diego de Pinedo, fraile: 203v.

Diego de Prada: 159r.

Diego de Quintanilla: 244r, 244v.

Diego de Quiñones Lorenzana: 209r.

Diego de Respenda, fraile: 392r.

Diego de Sahagún: 183r; fraile: 46r, 86r, $86 \mathrm{v}, 259 \mathrm{v}, 260 \mathrm{r}, 293 \mathrm{r}, 300 \mathrm{r}, 300 \mathrm{v}, 322 \mathrm{v}$, 372r, 382r, 382v, 383r, 441v.

Diego de San Zoilo: 71r, 105r, 113v, 127v, 399r, 434v, 457r, 457v.

Diego de Sandoval, fraile: 270 r.

Diego de Santander: 436r.

Diego de Sedano: $5 r$.

Diego de Treceño: 432v.

Diego de Vargas: 310v.

Diego de Vega: 47v, 50r, 51r, 64v, 65r, 319r, 323v, 380r.

Diego de Venegas, fraile: 26r, 208r.

Diego de Villagómez: 249r, 249v.

Diego del Brezo: 73r.

Diego del Val Cornejo: 194v, 195r, 459v.

Diego Díaz de la Ayuela: 181r, 181v.

Diego Díez: 67v.

Diego Díez de Rojas: 166r, $166 v$.

Diego Docio de Benevivere: 300v.
Diego Fernández: 59r, 59v, 60r, 71v, 149r, $149 \mathrm{v}, 158 \mathrm{r}, 255 \mathrm{v}, 300 \mathrm{r}, 300 \mathrm{v}, 360 \mathrm{v}, 393 \mathrm{r}$.

Diego Fernández de Capillas: 393r.

Diego Fernández de Congosto: 71v.

Diego Fernández de Herrezuelo, 285v.

Diego Fernández de Humada: 59r, 59v, 60r.

Diego Fernández de San Cebrián: 149r, $149 \mathrm{v}$.

Diego Fernández de Villalpando: 360v.

Diego Ferrero: 371r, 371v.

Diego Franco: 192v.

Diego García: 27v, 214r, 217r, 218v, 219r, 221v, 266r, 266v, 267r, 310r.

Diego García Barrantes: 266r, 266v, 267r.

Diego García de Tineo y Llano: 27v.

Diego García de Torres: 217r, 218v, 219r, 221v.

Diego García Santos: 277v, 278r, 395r, 395v.

Diego Gómez: 1v, 14r, 14v, 45r, 129v, $130 \mathrm{r}, 140 \mathrm{v}, 170 \mathrm{v}, 181 \mathrm{r}, 227 \mathrm{v}, 235 \mathrm{r}, 235 \mathrm{v}$, $237 \mathrm{v}, 238 \mathrm{r}, 238 \mathrm{v}, 239 \mathrm{r}, 313 \mathrm{r}, 316 \mathrm{r}, 383 \mathrm{r}$, $387 \mathrm{v}$.

Diego Gómez de Astudillo: 239r.

Diego Gómez de Medina: 237v, 238r, 238v.

Diego Gómez de Osorio: 129v, 130r, $140 \mathrm{v}, 170 \mathrm{v}, 387 \mathrm{v}$.

Diego Gómez de Saldaña: 14r, 14v.

Diego Gómez de Sandoval: 235r, 235v.

Diego Gómez Manrique: 227v.

Diego Gómez Valcárcel: 181r.

Diego González: 32v, 67r, 67v, 150r, 243r,

243v, 255v, 269v, 270r, 302r, 335r, 441v.

Diego González de Castro: 32v.

Diego González de Cervatos: 67r, 67v, 335r, 255v.

Diego Guillén: 207v.

Diego Herrejón Revellón: 465v.

Diego Herrero: 371v.

Diego Hurtado de la Vega: 31r, 71v, 77v, $279 \mathrm{v}, 280 \mathrm{r}, 350 \mathrm{v}$.

Diego Hurtado de Mendoza: 71r.

Diego Ibáñez: 48v.

Diego Íñiguez: $353 \mathrm{r}$.

Diego Jiménez: $450 \mathrm{v}$.

Diego Lasso: 285r, 355r, 355v, 356v, 462r.

Diego Leciñana, fraile: $419 \mathrm{v}$.

Diego Llano: 331v.

Diego Luis: 294v, 295r, 295v. 
Diego Macho Antón: 287v, 288r.

Diego Manuel González de Córdoba: 262v.

Diego Martín: 191v, 193r, 299r, 374r.

Diego Martínez: 191v, 193 r.

Diego Mateos de Laguna y Miedes: 221v, 222r.

Diego Méndez, fraile: 315r, 315v.

Diego Muñiz: 66r, 78v, 277r, 312r, 312v, 353v; mujer de: $312 \mathrm{r}, 312 \mathrm{v}$.

Diego Ortegón: 166r.

Diego Perea: $161 \mathrm{r}$.

Diego Pérez: 23v, 161r, 181r, 207r, 256v, 257r, 302r, 305r, 305v, 368r, 430v, 459v.

Diego Pérez de Legutio: 256v, 257r.

Diego Pérez de Saavedra: 430v.

Diego Pérez Sanjurjo: 181r.

Diego Puente: 50v.

Diego Ramiro: 217r, 218v, 219r.

Diego Rodríguez: 449r.

Diego Rubín de Celis: 430v, 431r.

Diego Ruiz: 311r.

Diego Ruiz Martínez: 67v, 68r, 73v, 106r.

Diego Sánchez: 74r, 74v, 361r, 361v, 362r.

Diego Sánchez Ortiz: 361r, 361v, 362r.

Diego Sedeño: 151r.

Diego Silva, fraile: 146r.

Diego Torres: $311 \mathrm{v}$.

Diego Treceño: 296r.

Diego Vaca, fraile: 323 r.

Diego Vela: 181v.

Diego Villar, fraile: $330 \mathrm{v}$.

Dionisia de Colmenares: 309v.

Dionisio Ibáñez: 311v.

Dionisio Pérez Lózar: 49r.

Dionisio Pérez: 363r.

Diosdado Fernández: 408v.

Dominga: 408r.

Domingo: 13r, 18v, 20r, 22v, 23r, 43v, 44r, $58 \mathrm{r}, 67 \mathrm{v}, 68 \mathrm{v}, 101 \mathrm{r}, 143 \mathrm{v}, 144 \mathrm{r}, 167 \mathrm{v}$, $186 \mathrm{v}, 192 \mathrm{r}, 197 \mathrm{v}, 209 \mathrm{r}, 225 \mathrm{v}, 226 \mathrm{r}, 228 \mathrm{r}$, 245r, 245v, 246r, 249v, 250r, 271v, 273r, 275v, 276r, 300r, 306r, 307r, 307v, 312v, $313 \mathrm{r}, 313 \mathrm{v}, 314 \mathrm{r}, 314 \mathrm{v}, 321 \mathrm{v}, 342 \mathrm{v}, 351 \mathrm{r}$, $353 \mathrm{v}, 359 \mathrm{v}, 360 \mathrm{r}, 380 \mathrm{r}, 423 \mathrm{v}, 437 \mathrm{v}, 449 \mathrm{v}$, $459 \mathrm{v}, 462 \mathrm{v}, 469 \mathrm{r}$.

Domingo Andrés: 360r.

Domingo Bartolomé: 359v.

Domingo Bravo: $167 \mathrm{v}$.

Domingo Calvo: $423 \mathrm{v}$.

Domingo Castrillo: 449v.
Domingo de Comonte: $197 \mathrm{v}$.

Domingo de la Madrid: 101r, 249v, 250r, 380r.

Domingo de los Ríos: 18v, 22v, 23r.

Domingo de Ramos: 13r, 13v.

Domingo de San Geminiano: 13v, 20r.

Domingo de Santa María: 245r, 245v, 246r.

Domingo Domínguez: 351r.

Domingo Fernández: 68v, 144r, 192r, 225v, 228r, 271v, 276r, 306r, 321v, 437v.

Domingo Fernández de Arbejal: 437v.

Domingo Fernández de Piña: 192r.

Domingo García: 209r.

Domingo García de Gozón: 271v.

Domingo Gato: 462v.

Domingo Ibáñez: 300r, 313v, 314r.

Domingo Juan: $314 \mathrm{v}$.

Domingo López: 275v, 276r, 459v.

Domingo López de Labrada: 275v.

Domingo Majo: 43v, 44r.

Domingo Majo de Mora: 43v, 44r.

Domingo Martínez: 58r, 143v.

Domingo Martínez de Hinojal: 68v.

Domingo Monje: 459v.

Domingo Montes: 469r.

Domingo Pérez: 186v, 225v, 226r, 307r, $307 \mathrm{v}$.

Domingo Velázquez: 353v.

Dominico Gimnasio: 23r, 26r, 222v, 223r, 223v.

Dominicus Jenin: 223r, 223v.

Eduardo Luis: 409v.

Elio Rodríguez: 292v, 293r.

Elo Gáliz: 91r.

Elvira: 233r, 235v, 236r, 292v, 307r, 407v.

Elvira de Zayas: 365r.

Elvira Fáfila: 307v.

Elvira Fernández: 182v.

Elvira Íñiguez: $355 \mathrm{r}$.

Elvira Moniz: 408r.

Elvira Muñoz: 57v.

Elvira Núñez: 45v.

Elvira Ruiz de Tovar: $227 \mathrm{v}$.

Elvira Sánchez: 291v, 292v.

Elvira Téllez: 66r.

Enderquina Rodríguez: 30v.

Engracia del Campo: 153v.

Enrique: 89r, 89v, 91v, 92r, 131v, 132r, $140 \mathrm{r}, 140 \mathrm{v}, 206 \mathrm{v}, 230 \mathrm{r}, 230 \mathrm{v}, 231 \mathrm{r}, 311 \mathrm{v}$, 
$322 \mathrm{r}, 322 \mathrm{v}, 342 \mathrm{v}, 343 \mathrm{r}, 413 \mathrm{v}, 414 \mathrm{r}, 417 \mathrm{v}$, 454r, 454v, 455r, 455v; rey: 342v, 343r.

Enrique II: 89r, 89v, 91v, 92r.

Enrique III: 34r, 34v, 89r, 89v, 91v, 92r, 132r, 230r, 230v, 231r, 322r, 322v.

Enrique IV: 89v, 454r, 454v, 455r, 455v.

Enrique de Ulloa, 311v.

Escolástica Cordero: 263v, 351r.

Escolástica Fernández: 4v.

Escolástica Meriel: 153r.

España, cardenal de, arzobispo de Toledo: 84r; nuncio apostólico: $117 \mathrm{v}$.

Esteban: 5v, 6r, 32v, 33r, 36v, 37r, 39r, 44r, 47r, 47v, 185r, 191v, 192r, 197r, 197v, $209 \mathrm{r}, 231 \mathrm{v}, 232 \mathrm{r}, 232 \mathrm{v}, 233 \mathrm{r}, 233 \mathrm{v}, 254 \mathrm{v}$, 255r, 275v, 291v, 310r, 313r, 328r, 331v, 332r, 336r, 352r, 355r, 380r, 393r, 395v, 396r, 396v, 399r, 399v, 408v, 427r, 427v, 463r; abad, 407v; clérigo, 182v.

Esteban Álvarez: 331v, 332r.

Esteban Calvo: 185r.

Esteban Cortijo: 194v, 195r.

Esteban de Almeida: 393r.

Esteban de Castro: 275v.

Esteban de Huerta: 197r, 197v.

Esteban de Lerma: 395v, 396r, 396v, 399r, $399 \mathrm{v}$.

Esteban de Malalana: 352r.

Esteban de Vega: 47v.

Esteban Díez: 37r.

Esteban García: 191v, 192r.

Esteban González: 191v.

Esteban Pardo: 463r.

Esteban Tornay: $47 \mathrm{r}$.

Estrella, conde de la: 439v.

Eufrasia Velarde de Santillana: 167v, 168r.

Eugenio de Guzmán: 169v, 357r, 420v, $423 \mathrm{v}, 449 \mathrm{v}, 450 \mathrm{r}, 453 \mathrm{r}, 134 \mathrm{v}$.

Eugenio IV: 14r, 15r, 20r, 20v, 21v, 83r, $83 \mathrm{v}, 84 \mathrm{r}, 113 \mathrm{v}, 123 \mathrm{r}, 239 \mathrm{r}, 239 \mathrm{v}, 240 \mathrm{r}$, $240 \mathrm{v}, 241 \mathrm{r}, 243 \mathrm{r}, 243 \mathrm{v}, 244 \mathrm{r}, 244 \mathrm{v}, 250 \mathrm{r}$, 325v, 326r, 326v, 327r, 338r, 341r, 445v.

Eugubino Caleme: 20r.

Eulalia García: 262r.

Fabián Borrego: 397v.

Fabián de la Fuente: 186r.

Fabián Panero: 69v.

Fabián Valle, 261r, 269r.

Facón: 3r, 4v, 5r, 5v, 11r, 28r, 368v, 369r, 398r, 399v, 401r, 424r.
Fáfila Fernández: 407v.

Fátima: 150r, 150v.

Fausto Clavero: 47r.

Fausto de Muro: 395v.

Fausto Martínez: $129 \mathrm{v}$.

Federico: 88r.

Feliciana Santoyo Pimentel: 357r.

Felipa González: 146r, 146v.

Felipe: 3r, 11v, 31r, 31v, 37v, 40r, 40v, 47v, $56 \mathrm{r}, 69 \mathrm{v}, 87 \mathrm{v}, 90 \mathrm{v}, 117 \mathrm{v}, 132 \mathrm{r}, 132 \mathrm{v}, 178 \mathrm{v}$, $185 \mathrm{r}, 187 \mathrm{r}, 202 \mathrm{r}, 209 \mathrm{v}, 210 \mathrm{r}, 214 \mathrm{r}, 214 \mathrm{v}$, 293v, 294r, 303r, 311r, 316r, 316v, 324r, 344r, 362v, 363r, 369r, 369v, 376v, 377r, $377 \mathrm{v}, 378 \mathrm{r}, 378 \mathrm{v}, 379 \mathrm{r}, 380 \mathrm{r}, 380 \mathrm{v}, 401 \mathrm{r}$, $401 \mathrm{v}, 409 \mathrm{r}, 420 \mathrm{r}, 421 \mathrm{r}, 424 \mathrm{r}, 454 \mathrm{r}, 454 \mathrm{v}$, 455r, 455v.

Felipe II: 90v, 132r, 202r, 344r, 420r, 454r, $454 \mathrm{v}, 455 \mathrm{r}, 455 \mathrm{v}$.

Felipe III: 117v, 132r, 455v.

Felipe IV: $132 \mathrm{v}$

Felipe V: 11v, 347v, 348r, 362v, 363r, 421r, 444v, 445r

Felipe Antonio Radillo: 424r.

Felipe Carabaza: 209v, 210r, 214r, 214v.

Felipe Cifuentes: $3 r$.

Felipe de Arriba: 293v, 294r.

Felipe de Hurias: 376v, 377r, 377v.

Felipe de la Fuente Colmenares: 311r.

Felipe de Ocón: 380r.

Felipe de Quintillies: 87v.

Felipe de Valbuena: 324r.

Felipe Escobar: 303r, 47v.

Felipe García: 187r.

Felipe Garnica: 37v, 40r, 40v.

Felipe Gómez: 56r, 316r, 316v, 409r.

Felipe González: 369r, 369v.

Felipe Ibáñez: 69v.

Felipe López de Porras: 401r, 401v.

Felipe Margolle Robles: 185r.

Felipe Martín Ocón: 378r, 378v, 379r.

Felipe Martínez Carabaza: 209v.

Felipe Martínez de Ocón: 380r, 380v.

Felipe Ovejero: 178v.

Felipe Reliegos: 311r.

Felipe Ruiz, fraile: 31r, 31v.

Félix Dávila, fraile: $117 \mathrm{r}$.

Félix de Guzmán y Santoyo: 135r.

Félix de Noriega, fraile: $51 \mathrm{r}$.

Félix Oñate, fraile: $269 \mathrm{v}$.

Fernando: 12r, 14r, 20r, 33r, 34r, 34v, 36r, $36 \mathrm{v}, 37 \mathrm{r}, 39 \mathrm{r}, 43 \mathrm{r}, 43 \mathrm{v}, 47 \mathrm{r}, 47 \mathrm{v}, 58 \mathrm{v}, 67 \mathrm{r}$, 
$67 \mathrm{v}, 70 \mathrm{v}, 74 \mathrm{v}, 76 \mathrm{r}, 78 \mathrm{v}, 85 \mathrm{r}, 85 \mathrm{v}, 87 \mathrm{r}, 88 \mathrm{r}$, $88 \mathrm{v}, 89 \mathrm{r}, 90 \mathrm{v}, 91 \mathrm{r}, 91 \mathrm{v}, 92 \mathrm{r}, 92 \mathrm{v}, 93 \mathrm{r}, 97 \mathrm{v}$, $98 \mathrm{r}, 98 \mathrm{v}, 99 \mathrm{r}, 103 \mathrm{r}, 103 \mathrm{v}, 104 \mathrm{r}, 104 \mathrm{v}, 105 \mathrm{r}$, $137 \mathrm{r}, 175 \mathrm{v}, 176 \mathrm{r}, 177 \mathrm{r}, 177 \mathrm{v}, 178 \mathrm{r}, 183 \mathrm{v}$, 184r, 185r, 186v, 189r, 190r, 192r, 192v, 196r, 197r, 197v, 207r, 209v, 210r, 213v, $217 \mathrm{r}, 217 \mathrm{v}, 218 \mathrm{r}, 218 \mathrm{v}, 221 \mathrm{r}, 225 \mathrm{v}, 226 \mathrm{r}$, $228 \mathrm{r}, 229 \mathrm{v}, 231 \mathrm{v}, 235 \mathrm{v}, 236 \mathrm{r}, 237 \mathrm{r}, 251 \mathrm{v}$, $252 \mathrm{r}, 255 \mathrm{r}, 255 \mathrm{v}, 264 \mathrm{r}, 264 \mathrm{v}, 266 \mathrm{v}, 267 \mathrm{r}$, $269 \mathrm{v}, 272 \mathrm{r}, 273 \mathrm{v}, 274 \mathrm{r}, 275 \mathrm{v}, 280 \mathrm{r}, 280 \mathrm{v}$, 284r, 286r, 287r, 289r, 294r, 295r, 295v, $300 \mathrm{r}, 301 \mathrm{v}, 302 \mathrm{r}, 310 \mathrm{r}, 314 \mathrm{v}, 322 \mathrm{v}, 330 \mathrm{v}$, 331r, 335r, 338v, 343r, 343v, 345r, 350r, 351r, 353v, 358r, 358v, 359r, 359v, 360r, $361 \mathrm{r}, 361 \mathrm{v}, 362 \mathrm{r}, 363 \mathrm{r}, 363 \mathrm{v}, 364 \mathrm{v}, 365 \mathrm{r}$, 365v, 397r, 404v, 405r, 408r, 413r, 413v, 415r, 420v, 427r, 427v, 430r, 431v, 433r, $434 \mathrm{v}, 437 \mathrm{r}, 443 \mathrm{r}, 444 \mathrm{r}, 444 \mathrm{v}, 445 \mathrm{v}, 447 \mathrm{r}$, $447 \mathrm{v}, 455 \mathrm{r}, 457 \mathrm{r}, 457 \mathrm{v}$; prior: $264 \mathrm{r}, 264 \mathrm{v}$; rey: $226 \mathrm{r}, 427 \mathrm{r}, 427 \mathrm{v}$.

Fernando I de León: 107r, 131v, 132r.

Fernando II: 358r, 358v, 359r, 359v, 363r, 363v; hijo de: 359r, 359v.

Fernando III: 47r, 88r, 88v, 91r, 91v, 397r. Fernando IV: 20r, 88v, 97v, 98r, 269v, $444 \mathrm{r}, 444 \mathrm{v}$.

Fernando V: 90v, 137r, 361r, 361v, 362r, 455r.

Fernando Aguado Pardo: 37r.

Fernando Alonso Bueno: 163v.

Fernando Alonso de Carrión: 98v.

Fernando Altamirano de las Cabezas: $169 \mathrm{v}, 170 \mathrm{r}, 170 \mathrm{v}, 420 \mathrm{v}, 447 \mathrm{v}$.

Fernando Álvarez, 103v, 104r, 104v, 105r, 105v, 438r.

Fernando Antonio de Herrera: 185r.

Fernando Aparicio: 157r, 157v.

Fernando Aragón: 255r.

Fernando Avia de Castro: 445v.

Fernando Baíllo: 39r.

Fernando Blanco: 148r.

Fernando Bores: 294r.

Fernando Caballo: 74v, 99r, 103r, 103v, $104 \mathrm{v}, 105 \mathrm{r}, 131 \mathrm{v}, 145 \mathrm{v}, 149 \mathrm{r}, 149 \mathrm{v}, 150 \mathrm{r}$, $150 \mathrm{v}, 154 \mathrm{r}, 154 \mathrm{v}, 156 \mathrm{r}, 165 \mathrm{r}, 165 \mathrm{v}, 166 \mathrm{r}$, $175 \mathrm{v}, 176 \mathrm{r}, 272 \mathrm{r}, 274 \mathrm{r}, 350 \mathrm{r}, 365 \mathrm{v}, 457 \mathrm{r}$, $457 \mathrm{v}$.

Fernando Cabeza de Vaca: 310r.

Fernando Chocán: 36v, 39r.

Fernando Cuadros: 209v, 210r.

Fernando de Ayala, fraile: 213v.
Fernando de Banucias: 207r.

Fernando de Benavente: 251v, 252r.

Fernando de Bustamante: 70v, 104v, 105r.

Fernando de Colmenares: 266v, 267r, 280r, 280v, 295r.

Fernando de Escobar: 87r.

Fernando de Fonseca: 33r, 343r, 343v.

Fernando de Henao: 159r.

Fernando de Herrera: 85v.

Fernando de Huidobro: 217r.

Fernando de la Carrera: 154v.

Fernando de la Vega: 87r, 176r.

Fernando de Linares: 447r.

Fernando de Madrid: 34v, 165r.

Fernando de Mañueco: 173r.

Fernando de Riomoroso: 272r.

Fernando de San Román: 272r.

Fernando de Valdeflores: 431v.

Fernando de Valderrábano: 166r.

Fernando de Villalón Gil: 12r.

Fernando de Villavildo, 172v.

Fernando de Zayas: 365r.

Fernando del Hospital: 294r.

Fernando Díaz: 457r, 457v.

Fernando Fernández: 57v, 408r.

Fernando Fonseca: 338v, 343r.

Fernando García: 67r, 145r, 145v, 154r, $157 \mathrm{r}, 157 \mathrm{v}, 164 \mathrm{v}, 228 \mathrm{r}, 231 \mathrm{v}, 336 \mathrm{r}, 404 \mathrm{v}$, 405r, 422r, 430r, 437r.

Fernando García de la Serna, 163v, 231v. Fernando García de Pachistre: 145r, 145v, 150r, 154r, 157r, 157v, 164v, 405r, 422r.

Fernando García Errejón: 67r.

Fernando García Pachistre el Mozo: 145r, 145v, 154r.

Fernando González: 14r, 43r, 43v, 67v, 92r, 92v, 93r, 98r, 144r, 272r, 286r, 184r, $184 \mathrm{v}, 407 \mathrm{v}, 412 \mathrm{v}, 438 \mathrm{r}, 443 \mathrm{r}, 448 \mathrm{v}$.

Fernando González de Belorado: 14r, 448v.

Fernando González de Frómista: 183v, 184r.

Fernando González de la Varguilla: 143v, $144 r$.

Fernando González de San Román: 67v, 272r, 443r.

Fernando Gutiérrez: 427r, 427v.

Fernando Gutiérrez de Camargo: 226v.

Fernando Ibáñez: 162r.

Fernando López de Carrión: 183v, 184r.

Fernando López de Mena: 114r. 
Fernando López Valmarinos: 113v.

Fernando Martín: 360r, 422r, 78v.

Fernando Martínez de las Puertas: 422r.

Fernando Martínez: 78v, 192r, 229v.

Fernando Maurieli: 443r.

Fernando Mazo: 196r.

Fernando Méndez: 322v.

Fernando Miguel de Prado: 221r.

Fernando Monte: 197r, 197v, 217v, 218r, 218v, 295v, 36r.

Fernando Montero: 36r, 197r, 197v, 217v, $218 \mathrm{r}, 218 \mathrm{v}$.

Fernando Muñoz: 67v.

Fernando Núñez: 143r, 143v, 190r.

Fernando Nuño: 301v.

Fernando Pérez: 67r, 67v, 144v, 145r, 177r, 186v, 225v, 226r, 292v, 293r, 300r.

Fernando Rodríguez: 36v, 177v, 178r.

Fernando Rodríguez de Castellanos: 62v, $125 \mathrm{r}, 131 \mathrm{v}, 144 \mathrm{r}, 144 \mathrm{v}, 145 \mathrm{r}, 148 \mathrm{v}, 149 \mathrm{r}$, $149 \mathrm{v}, 150 \mathrm{r}, 157 \mathrm{r}, 157 \mathrm{v}, 162 \mathrm{v}, 163 \mathrm{r}, 163 \mathrm{v}$, 164r, 169r, 175r, 192r, 192v, 345r, 360r, $364 \mathrm{v}, 412 \mathrm{r}, 440 \mathrm{v}$.

Fernando Ruiz: 182v, 183r, 228v, 438r.

Fernando Ruiz de Cadórniga: 289r.

Fernando Ruiz Herrezuelo: 228v.

Fernando Sánchez: 164r, 172r, 237r, 251v, 252r, 330v, 331r, 417v, 418r.

Fernando Sánchez de Frómista: 237r.

Fernando Sánchez de Paredes: 251v, 252r.

Fernando Sánchez de Población: 164r.

Fernando Sánchez de Robles: 330v, 331r.

Fernando Sánchez de Tobar: 227r, 233 r.

Fernando Sanjurjo: 275v.

Fernando Velázquez: 143r.

Fernando Yáñez: 225v.

Fernando Zayas: 365r, 365v; mujer de: 365r, 365v.

Filipo: 91r.

Flamo: 434r.

Florencio de Villovieco: 172r, 172v.

Flores, doctor: 95v, 221v, 336v, 346r, 347r, 348v, 349r, 383v, 384r, 384v, 385r, 399r, 431v; licenciado: $347 \mathrm{r}$.

Flórez, doctor: 37v, 61r, 217v, 218r, 218v, 332r, 345r, 345v, 346r.

Floristán de la Serna: 49v, 85r, 85v, 93r, $93 \mathrm{v}, 105 \mathrm{v}, 133 \mathrm{v}, 134 \mathrm{r}, 150 \mathrm{v}, 151 \mathrm{r}, 154 \mathrm{v}$, $166 \mathrm{v}, 167 \mathrm{r}, 187 \mathrm{v}, 289 \mathrm{r}, 289 \mathrm{v}, 314 \mathrm{r}, 366 \mathrm{r}$, $434 \mathrm{v}, 438 \mathrm{v}$.
Fonseca: 33r, 70v, 71r, 86r, 86v, 105r, $105 \mathrm{v}, 185 \mathrm{r}, 190 \mathrm{v}, 207 \mathrm{r}, 328 \mathrm{v}, 329 \mathrm{r}, 338 \mathrm{r}$, $338 \mathrm{v}, 339 \mathrm{r}, 339 \mathrm{v}, 340 \mathrm{r}, 340 \mathrm{v}, 341 \mathrm{r}, 343 \mathrm{r}$, $343 \mathrm{v}, 344 \mathrm{r}, 355 \mathrm{v}, 414 \mathrm{r}, 415 \mathrm{r}, 423 \mathrm{v}, 425 \mathrm{r}$, 436r, 437r, 454r; fraile: 471v.

Francisca: 422v.

Francisca Alonso, hijos de: 334v.

Francisca Alonso: 366v.

Francisca de la Vega: 51v.

Francisca de las Heras: 459v.

Francisca de Roscales: 61v.

Francisca de Sandoval: 422v, 423r.

Francisca Enríquez de Tobar: 31r, 56r, 63r, 71v, 279v, 280r, 280v.

Francisca Fernández: 158r.

Francisca Jinete: 466v.

Francisco: 35v, 36r, 190r, 190v, 192r, 193r, $197 \mathrm{v}, 198 \mathrm{r}, 199 \mathrm{v}, 203 \mathrm{v}, 204 \mathrm{r}, 204 \mathrm{v}, 206 \mathrm{v}$, $207 \mathrm{v}, 208 \mathrm{v}, 209 \mathrm{r}, 209 \mathrm{v}, 211 \mathrm{v}, 212 \mathrm{r}, 214 \mathrm{r}$, $214 \mathrm{v}, 215 \mathrm{r}, 215 \mathrm{v}, 217 \mathrm{r}, 220 \mathrm{r}, 221 \mathrm{r}, 223 \mathrm{v}$, 228r, 231v, 244r, 245r, 245v, 246r, 247r, $247 \mathrm{v}, 248 \mathrm{r}, 250 \mathrm{r}, 255 \mathrm{r}, 256 \mathrm{v}, 257 \mathrm{r}, 257 \mathrm{v}$, 258r, 261r, 261v, 262v, 263r, 267r, 267v, 268r, 269r, 270r, 272v, 274v, 275v, 276r, $277 \mathrm{v}, 278 \mathrm{r}, 278 \mathrm{v}, 279 \mathrm{r}, 281 \mathrm{r}, 281 \mathrm{v}, 282 \mathrm{r}$, $284 \mathrm{v}, 285 \mathrm{v}, 286 \mathrm{v}, 287 \mathrm{r}, 289 \mathrm{v}, 291 \mathrm{v}, 293 \mathrm{v}$, $294 \mathrm{v}, 295 \mathrm{v}, 296 \mathrm{r}, 296 \mathrm{v}, 297 \mathrm{r}, 297 \mathrm{v}, 298 \mathrm{r}$, 298v, 299r, 302v, 303r, 303v, 304r, 304v, 305r, 306r, 306v, 309r, 310r, 310v, 311r, $311 \mathrm{v}, 314 \mathrm{r}, 314 \mathrm{v}, 316 \mathrm{r}, 319 \mathrm{v}, 320 \mathrm{v}, 321 \mathrm{r}$, $321 \mathrm{v}, 322 \mathrm{r}, 323 \mathrm{v}, 324 \mathrm{r}, 327 \mathrm{v}, 329 \mathrm{r}, 331 \mathrm{v}$, $334 \mathrm{r}, 346 \mathrm{r}, 346 \mathrm{v}, 347 \mathrm{r}, 347 \mathrm{v}, 348 \mathrm{r}, 349 \mathrm{v}$, 355r, 361r, 361v, 362r, 365r, 365v, 366r, $366 \mathrm{v}, 367 \mathrm{r}, 367 \mathrm{v}, 369 \mathrm{r}, 369 \mathrm{v}, 371 \mathrm{v}, 373 \mathrm{r}$, $373 \mathrm{v}, 374 \mathrm{r}, 374 \mathrm{v}, 375 \mathrm{r}, 376 \mathrm{v}, 377 \mathrm{r}, 377 \mathrm{v}$, 378r, 380r, 381r, 381v, 389r, 389v, 393r, $393 \mathrm{v}, 394 \mathrm{r}, 394 \mathrm{v}$.

Francisco Agustín de Lorza y Aguirre: $114 \mathrm{v}, 115 \mathrm{r}$.

Francisco Alberico: 211v, 212 r.

Francisco Alcalde: 261r, 261v.

Francisco Alonso: 178r, 178v, 365v, 367r, $367 \mathrm{v}, 437 \mathrm{r}$.

Francisco Altamirano: 420v.

Francisco Álvarez: 11r, 60v, 61r, 69v, 70r, 75r, 268r.

Francisco Antonio de Zamora y Salamanca: $450 \mathrm{v}$.

Francisco Antonio Estrada: 6v.

Francisco Ares: 278r.

Francisco Arias, fraile: 206v. 
Francisco Arrieta: 303r.

Francisco Baños: 286v.

Francisco Bariego: 278v.

Francisco Barrio de la Vega: 124r, 124v.

Francisco Berdeces y Morrondo: 463v.

Francisco Caballero de Luna: 4r.

Francisco Caballo: 244r.

Francisco Cabezudo: 462v.

Francisco Campoo: 154v, 155r.

Francisco Cano: 48v, 185v, 399v.

Francisco Cano Núñez: 48v, 185v.

Francisco Casado: 5v.

Francisco Catalán: 86v, 94r, 99v, 132r, 134r, 166r, 166v, 167r, 207v, 291v, 436r, 436v.

Francisco de Alarcón: 250r.

Francisco de Alerosi: 376v, 377r, 377v.

Francisco de Andrés: 310r, 310v.

Francisco de Angulo: 90r.

Francisco de Atienza, fraile: 86r.

Francisco de Bajo: 9r.

Francisco de Barrio: 124r.

Francisco de Barrio San Miguel: 366v.

Francisco de Benavides: 244r.

Francisco de Buitrón, fraile: 71v, 371v.

Francisco de Busto: 167r.

Francisco de Caviedes y Herrera: 311v.

Francisco de Campo: 99v.

Francisco de Cardeña: 389r, 389v.

Francisco de Carranza: 46r.

Francisco de Castro: 247r, 247v, 248r, 141r, 141v.

Francisco de Castro y Taboada: 141r, $141 \mathrm{v}$.

Francisco de Ceballos: 296v.

Francisco de Chaves: 92r.

Francisco de Collantes: 5v, 431v.

Francisco de Colmenares: 31r, 432v.

Francisco de Cuenca: 366v.

Francisco de Diego Lobo: 44r.

Francisco de Dueñas: 39v, 40r, 69v.

Francisco de Espinosa: 314r.

Francisco de Espinosa Alarcón: 281r, $281 \mathrm{v}$.

Francisco de Estrada: 6r, 12r.

Francisco de Guinea: 36r, 36v, 404r.

Francisco de Jerez: $327 \mathrm{v}$.

Francisco de Junquera: 304 r.

Francisco de la Escalera: 376v, 377r, 377v, 378r.

Francisco de la Serna, fraile: 316r.
Francisco de la Torre: 255r.

Francisco de la Vega: 331v, 375r.

Francisco de Lemos, fraile: 39r, 135r, 178r, 270r, 277v, 425v.

Francisco de Lerma: 245r, 245v, 246r.

Francisco de Liorri y Cisneros: 256v.

Francisco de Llerena: 87r.

Francisco de Lorenzana: 197v, 198r.

Francisco de los Cobos: 134r.

Francisco de los Cuetos: 101r, 135r, 380r, 411r.

Francisco de los Ríos Campoo: 167v, 168r.

Francisco de Madrid: 34v.

Francisco de Mendoza: 217r.

Francisco de Molina: 39v, 59r, 59v, 304r, 306r; fraile: $60 \mathrm{r}, 69 \mathrm{v}, 78 \mathrm{v}, 79 \mathrm{r}, 209 \mathrm{r}, 295 \mathrm{v}$, 296r, 306v, 311r, 432r, 437r.

Francisco de Nevantes: 71r.

Francisco de Nogal: 453r.

Francisco de Ondona, fraile: 16v, 373r, $373 v$.

Francisco de Oropesa: 158v, 159r.

Francisco de Oviedo: 151v.

Francisco de Paz de la Serna: 17r, 310v.

Francisco de Pedrosa: 296r, 296v.

Francisco de Pernía: 366r.

Francisco de Quintanilla: 399r.

Francisco de Recalde: $21 \mathrm{r}$.

Francisco de Ribadeneira: 35v, 36r, 36v, $177 \mathrm{v}, 294 \mathrm{v}$.

Francisco de Robles: 393r, 393v.

Francisco de Rozas: $221 \mathrm{r}$.

Francisco de Saldaña: 214r, 214v.

Francisco de San Andrés: 36r, 36v, 310v.

Francisco de Santa Cruz: 209r.

Francisco de Santander: 211v, 212r.

Francisco de Santiago Pimental: 167v, $168 \mathrm{r}$.

Francisco de Santoyo: 72r.

Francisco de Solórzano: $117 \mathrm{v}$.

Francisco de Tamayo: 211v, 212r.

Francisco de Tezano, fraile: 323v, 324r.

Francisco de Turceta, fraile: 135v, 311r.

Francisco de Valcárcel: 311v, 432r.

Francisco de Valderas: 8v, 69r.

Francisco de Valenzuela: 105r, 105v.

Francisco de Valverde Aldrete: 39r.

Francisco de Villafuerte: 50r, 349v; fraile:

$50 \mathrm{v}, 61 \mathrm{v}, 62 \mathrm{r}, 65 \mathrm{r}, 320 \mathrm{v}, 321 \mathrm{r}, 321 \mathrm{v}, 334 \mathrm{r}$, $374 \mathrm{r}, 374 \mathrm{v}$.

Francisco de Villarroel: 256v. 
Francisco de Zayas: 365r.

Francisco del Pozo: 17r, 394r, 394v.

Francisco Díaz: 50v, 323v.

Francisco Díez: 319v, 367r, 367v.

Francisco Enríquez: 261r, 261v, 141 r.

Francisco Escudero: 443r.

Francisco Fernández: 3r, 3v, 5r, 5v, 32r, 36r, 177r, 207v, 178r, 178v, 207v, 437r.

Francisco Fernández de Mier: 437r, 178r, 178v.

Francisco Fernández Martínez: 5r, 5v.

Francisco Ferrer: 73v.

Francisco Francos: 442v.

Francisco Gago: 467v.

Francisco Gallo de Cevallos: 47v, 459v.

Francisco García: 44r, 45v, 111v, 462v, 463r, 466r.

Francisco García Gil Ramírez: 44r.

Francisco García Monroy: 462v, 463r.

Francisco García Sirgo: 466r.

Francisco Gato Monjón: 278r.

Francisco Girón: 156r.

Francisco Gómez: 16r, 40v, 63v, 154v, $294 \mathrm{v}, 334 \mathrm{r}, 420 \mathrm{v}$.

Francisco Gómez de Espinosa: 40v, 154v.

Francisco Gómez de Lasprilla: 420v.

Francisco González: 44v, 68v, 69v, 146r, $146 \mathrm{v}, 277 \mathrm{v}, 367 \mathrm{r}, 367 \mathrm{v}, 432 \mathrm{r}$.

Francisco González de la Haya: 44v.

Francisco González de Reyero: 69v.

Francisco Guijarro: 43v.

Francisco Gutiérrez, fraile: 420r.

Francisco Gutiérrez de la Vega: 37r.

Francisco Gutiérrez Zorrilla: 37r, 134v, 135r, 420r, 432r.

Francisco Hernández Alderete: 110r.

Francisco Herrero: 156v, 284v, 450r, 453r, 469r.

Francisco Hidalgo: 50v.

Francisco Hierro: 276r.

Francisco Hontiveros: 181r.

Francisco Hurtado: 395r.

Francisco Infante Lagunilla: 285v.

Francisco Javier Aguado, 369v.

Francisco Javier Recio y Ramos: 381r, $381 \mathrm{v}$.

Francisco Junquera: 48r, 48v.

Francisco Lasso: 462r.

Francisco Lezcano: 296v, 297r.

Francisco López: 124v, 133v, 134r, 459v, $460 \mathrm{v}$.
Francisco López Castelar: 124v.

Francisco Lozano: 296r.

Francisco Macho: 199v.

Francisco Magdaleno: 160r.

Francisco Manso: 400v.

Francisco Mantilla: 46r.

Francisco Marcos: 36v, 427v.

Francisco María Fita: 77v, 78r.

Francisco Martínez: 19v, 23r, 48v, 49r, 93v, 361r, 361v, 362r, 419r, 421r, 436r, 436v.

Francisco Martínez de Luna: 19v, 23r.

Francisco Mauro Fuertes: 124v.

Francisco Méndez de Hevia: 321r, 321v.

Francisco Merino Cabeza: 466v.

Francisco Miguel: 60r.

Francisco Molina: 209r, 466v.

Francisco Morante de la Madrid: 304r.

Francisco Moreno: 293v.

Francisco Moro de Saldaña: 171r.

Francisco Moro de Saldaña: 4r, 32r, 38v, 39r, 39v, 41v, 42r, 89v, 100v, 105v, 106r, $118 \mathrm{r}, 124 \mathrm{r}, 130 \mathrm{v}, 132 \mathrm{r}, 134 \mathrm{r}, 134 \mathrm{v}, 135 \mathrm{r}$, $139 \mathrm{v}, 141 \mathrm{r}, 146 \mathrm{r}, 152 \mathrm{v}, 157 \mathrm{r}, 158 \mathrm{r}, 158 \mathrm{v}$, $159 \mathrm{r}, 165 \mathrm{r}, 165 \mathrm{v}, 167 \mathrm{v}, 169 \mathrm{v}, 171 \mathrm{r}, 172 \mathrm{v}$, $173 \mathrm{r}, 175 \mathrm{v}, 177 \mathrm{v}, 178 \mathrm{r}, 257 \mathrm{r}, 257 \mathrm{v}, 258 \mathrm{r}$, $274 v, 279 r, 289 v, 331 v, 346 r, 346 v, 347 r$, $410 \mathrm{v}, 420 \mathrm{r}, 421 \mathrm{r}, 428 \mathrm{v}, 430 \mathrm{r}, 431 \mathrm{v}, 439 \mathrm{v}$, 461r, 463v, 464r.

Francisco Moro: 215r, 215v, 380r.

Francisco Moro Remolino: 464v.

Francisco Navarrete: 304v.

Francisco Nicolás: 355r, 435r.

Francisco Núñez: 178v.

Francisco Núñez de Prado: 5v, 6r, 369r.

Francisco Obeso de Buelna: 193r, 220r, 221 r.

Francisco Ochoa: 130v, 135r, 204r, 272v.

Francisco Ojero: $177 \mathrm{v}$.

Francisco Ordás de la Vega: 118v.

Francisco Orense Manrique: 420r.

Francisco Ortiz: 329r.

Francisco Pardo: 8v, 9r, 28r, 394v.

Francisco Patudo, 367v.

Francisco Paz de la Serna: 310v.

Francisco Pedrero: 36v, 209r.

Francisco Peña: 19r, 19v, 23r.

Francisco Pérez: 5v, 6r, 32r, 45v, 46r, 98r, 98v, 131r, 143v, 144r, 144v, 157r, 161r, $162 \mathrm{r}, 165 \mathrm{v}, 172 \mathrm{v}, 173 \mathrm{r}, 173 \mathrm{v}, 175 \mathrm{v}, 190 \mathrm{r}$, $190 \mathrm{v}, 192 \mathrm{r}, 199 \mathrm{v}, 204 \mathrm{v}, 206 \mathrm{v}, 208 \mathrm{v}, 209 \mathrm{r}$, 
$228 \mathrm{r}, 231 \mathrm{v}, 287 \mathrm{r}, 314 \mathrm{v}, 322 \mathrm{r}, 322 \mathrm{v}, 404 \mathrm{v}$, 422r, 430v.

Francisco Pérez de Lema: 45v, 46r.

Francisco Pérez de Velasco: 430v.

Francisco Pérez el Mozo: 206v.

Francisco Pérez Olea: 6r.

Francisco Quijano: 47v, 48r, 267r, 267v, 269r, 302v, 303r.

Francisco Raldo: 5v.

Francisco Rebellón Villatoro: 464r.

Francisco Recalde: 21v, 23r.

Francisco Redondo Cabeza: 466v.

Francisco Rico Aguado: 278v.

Francisco Robles: 393r.

Francisco Rodríguez: 61r, 275v, 297r, 297v, 298r, 298v, 299r, 407r.

Francisco Rojo Gómez: 153v, 167r.

Francisco Ruiz: 40r.

Francisco Ruiz de Sandoval: 37r, 311v, $459 \mathrm{v}$.

Francisco Sánchez: 95v, 110v, 111r, 158v, 163r, 177v, 178r, 199v, 209v, 223v.

Francisco Sánchez Caballero: 158v.

Francisco Sánchez de Aranda: 199v.

Francisco Sánchez de Oro: 177v, 178r.

Francisco Sánchez de Valbuena: 95v.

Francisco Santos: 405v.

Francisco Sedano Sedano: 465r.

Francisco Simón de Aguilar: 153r.

Francisco Tamayo: 203v, 204r.

Francisco Terán: $37 \mathrm{r}$.

Francisco Trujillo: 9v, 10r, 431r.

Francisco Valiente: 76v, 282r.

Francisco Vallejo: 305r.

Francisco Valverde: 207v.

Francisco Villafuerte: 263r, 334r.

Francisco Zapata, 152v.

Froilán Aparicio: 262r.

Froilán Gutiérrez: 369r.

Froilán Merino: 374v.

Frómista, clérigo: 208v; señor de: 233r; vecino: 209 r.

Fronioso Sánchez: 376v, 377r, 377v.

Frutos Montes: 239r.

Fuente Fraile: 261r, 261v.

Fuertes, fraile: $156 \mathrm{v}, 471 \mathrm{v}$.

Fulgencio Campo, fraile: 101v, 311v.

Gabriel Antón: 380r.

Gabriel Antonio de Iglesias: 177v, 178r.

Gabriel Arcador: 193r.
Gabriel de Aresti, 323v.

Gabriel de Ceano y Vivas: 153r, 157v, 159r, 159v, 296v, 297r, 421r, 452r.

Gabriel de la Zoreda: 343r, 343v.

Gabriel de Prado: 152v.

Gabriel Díez: 257r, 257v.

Gabriel Mantilla: 140r.

Gabriel Martínez: 267v.

Gabriel Ovejero: 135v, $136 r$.

Gabriel Varela: 181v.

Galindo Ruiz: 314r.

Gallego de Robles: 16v, 17v, 18r, 18v, 21v, $22 \mathrm{r}, 22 \mathrm{v}, 25 \mathrm{v}$.

Gañinas, morador en: 255v.

García: 1v, 2r, 3r, 3v, 4v, 8v, 14v, 27v, 32v, $33 \mathrm{r}, 43 \mathrm{v}, 44 \mathrm{r}, 45 \mathrm{r}, 45 \mathrm{v}, 48 \mathrm{r}, 48 \mathrm{v}, 49 \mathrm{v}, 273 \mathrm{r}$, $275 \mathrm{v}, 276 \mathrm{r}, 277 \mathrm{v}, 278 \mathrm{r}, 279 \mathrm{v}, 282 \mathrm{r}, 283 \mathrm{v}$, $284 \mathrm{r}, 285 \mathrm{r}, 286 \mathrm{r}, 287 \mathrm{v}, 288 \mathrm{r}, 288 \mathrm{v}, 289 \mathrm{r}$, $292 \mathrm{v}, 296 \mathrm{v}, 297 \mathrm{r}, 297 \mathrm{v}, 299 \mathrm{v}, 300 \mathrm{r}, 302 \mathrm{v}$, 304r, 304v, 305r, 307r, 309v, 310r, 311r, $311 \mathrm{v}, 312 \mathrm{v}, 313 \mathrm{r}, 313 \mathrm{v}, 315 \mathrm{r}, 317 \mathrm{r}, 320 \mathrm{v}$, $321 \mathrm{v}, 324 \mathrm{v}, 334 \mathrm{r}, 336 \mathrm{r}, 337 \mathrm{r}, 339 \mathrm{r}, 339 \mathrm{v}$, 340r, 340v, 341r, 349v, 351v, 352r, 359v, 360r, 365v, 370v, 371r, 371v, 373r, 373v, $374 \mathrm{r}, 374 \mathrm{v}, 394 \mathrm{v}, 395 \mathrm{r}, 395 \mathrm{v}, 397 \mathrm{r}, 397 \mathrm{v}$, 398r, 400v, 401r, 401v, 402v, 403r, 403v, $404 \mathrm{v}, 405 \mathrm{r}, 405 \mathrm{v}, 406 \mathrm{r}, 408 \mathrm{v}, 409 \mathrm{r}, 410 \mathrm{v}$, $411 \mathrm{v}, 412 \mathrm{r}, 412 \mathrm{v}, 413 \mathrm{r}, 413 \mathrm{v}, 422 \mathrm{r}, 422 \mathrm{v}$, $423 \mathrm{r}, 423 \mathrm{v}, 428 \mathrm{v}, 430 \mathrm{r}, 432 \mathrm{v}, 433 \mathrm{r}, 435 \mathrm{v}$, 436r, 436v, 437r, 437v, 438r, 440v, 441v, 443r, 444r, 445r, 446r, 446v, 460r, 461r, $461 \mathrm{v}, 462 \mathrm{v}, 463 \mathrm{r}, 463 \mathrm{v}, 464 \mathrm{r}, 464 \mathrm{v}, 465 \mathrm{r}$, 465v, 466r, 466v, 468r.

García Alonso: 164r, 411v.

García Álvarez: 144r.

García Álvarez de Carrión: 408v, 411v.

García de Avia: 93r, 158v, 166r.

García de Cossío: 50r, 50v, 61v, 62r, 63v, 64r, 64v, 263r, 320v, 334r, 349v, 374r, $374 \mathrm{v}$.

García de la Bandera: 8v, 428v.

García de la Puente: 63r.

García de la Serna Herrero: 154r.

García de León: 394v.

García de Lombraña: 432v.

García de Mazuelas: 2r.

García de Navarrete, doctor: 446r, 446v.

García de Santa María, fraile: $445 r$.

García del Barruelo; 260v.

García del Cubo: 436r.

García Díaz: 43v, 45r. 
García Fernández: 67r, 74r, 76r, 98v, 99r, $151 \mathrm{v}, 154 \mathrm{r}, 161 \mathrm{v}, 162 \mathrm{r}, 162 \mathrm{v}, 164 \mathrm{r}, 164 \mathrm{v}$, $165 \mathrm{v}, 173 \mathrm{v}, 174 \mathrm{r}, 174 \mathrm{v}, 192 \mathrm{v}, 206 \mathrm{r}, 226 \mathrm{v}$, $227 \mathrm{r}, 231 \mathrm{v}, 259 \mathrm{v}, 271 \mathrm{r}, 271 \mathrm{v}, 272 \mathrm{r}, 273 \mathrm{v}$, 351v, 404v, 405r, 405v, 412r, 440v.

García Fernández de Carrión: 226v.

García Fernández de Frómista: 192v.

García Fernández de San Zoilo: 154r, $164 \mathrm{r}, 164 \mathrm{v}, 165 \mathrm{v}, 273 \mathrm{v}$.

García Fernández de San Zoilo: 405v.

García Fernández Manrique: 98v, 99r, $151 \mathrm{v}$.

García Fernández Pachistre, viuda de: 404v, 405r.

García Gómez: 313r.

García González: 177r, 397v.

García Gutiérrez: 63v, 64r, 65r.

García Hernández: 62v.

García Manrique: 226r, 282r.

García Manrique de la Vega: 77v, 78r.

García Pachistre: 144v, 145r, 145v, 150r, 154r, 157r, 157v, 164v, 405r, 422r, 165v.

García Pérez: 45v.

García Rodríguez: 405r.

García Salazar: 197v.

Garcilaso de Colmenares: 316r.

Garcilaso de la Vega: 56r, 56v, 315v.

Gaspar Álvarez: 394r, 394v.

Gaspar Chato González: 285v.

Gaspar Crespo: 3v.

Gaspar de Becerril, fraile: 393r, 393v.

Gaspar de Castrillo: 43v.

Gaspar de Celis: 141r.

Gaspar de Cordaves: 65r.

Gaspar de la Serna: 152r.

Gaspar de las Casas: 310r.

Gaspar de los Reyes: 449v, 450r.

Gaspar de Montenegro, fraile: 280v.

Gaspar de Peralta: 38v, 39r, 117v, 139r, $198 \mathrm{v}, 199 \mathrm{r}, 199 \mathrm{v}, 203 \mathrm{r}, 204 \mathrm{r}, 204 \mathrm{v}, 208 \mathrm{r}$, $208 \mathrm{v}, 211 \mathrm{v}, 212 \mathrm{r}, 213 \mathrm{r}, 213 \mathrm{v}, 219 \mathrm{r}, 219 \mathrm{v}$, 222r, 223r, 252v, 295r.

Gaspar de Quincoces: 251r, 296v, 437r.

Gaspar de Sahagún: 453r.

Gaspar de Salazar: 197r.

Gaspar de Villarroel, 383r; fraile: 71v, 105v, 203v, 366r, 415r, 416r, 416v.

Gaspar Ferrer: 69r, 69v.

Gaspar González Carbonera: 303r, 303v, 304r.

Gaspar Gropero: 16r.
Gaspar Laso: 431v, 432r.

Gaspar Madruga, fraile: 208r, 223v.

Gaspar Maldonado: 394r, 394v.

Gaspar Melendro: 37r.

Gaspar Pagano: 211v, 212r.

Gaspar Peralta: 448r.

Gaspar Pérez: 430v, 463v.

Gaspar Sánchez: 132v.

Gaspar Velas: 293r, 293v.

Gaufrido: 9v, 13r, 13v, 20r.

Gerardo: 68v, 190v.

Gil Díaz: 45r.

Gil Rodríguez: 204r, 204v, 405v.

Gilimón de la Mota: 41v.

Gimnasio: 23r, 212v, 222v, 223r, 223v.

Girón: 5r, 156r, 367r, 367v, 368r, 368v.

Goinchart: 143v.

Gómez: 1v, 14r, 14v, 16r, 30v, 34v, 35v, 36r, 40v, 41r, 45r, 47v, 56r, 63v, 64v, 71v, 72r, 74v, 76r, 76v, 78v, 91r, 98r, 98v, 107r, $115 \mathrm{r}, 129 \mathrm{v}, 130 \mathrm{r}, 140 \mathrm{v}, 143 \mathrm{r}, 151 \mathrm{r}, 153 \mathrm{v}$, $154 \mathrm{r}, 154 \mathrm{v}, 157 \mathrm{r}, 162 \mathrm{r}, 162 \mathrm{v}, 165 \mathrm{r}, 165 \mathrm{v}$, $166 \mathrm{v}, 170 \mathrm{v}, 172 \mathrm{r}, 174 \mathrm{r}, 176 \mathrm{r}, 181 \mathrm{r}, 183 \mathrm{r}$, $186 \mathrm{r}, 210 \mathrm{v}, 216 \mathrm{v}, 221 \mathrm{r}, 227 \mathrm{v}, 228 \mathrm{r}, 228 \mathrm{v}$, 229r, 229v, 230r, 230v, 231r, 231v, 233r, $234 \mathrm{r}, 234 \mathrm{v}, 235 \mathrm{r}, 235 \mathrm{v}, 236 \mathrm{r}, 236 \mathrm{v}, 237 \mathrm{r}$, $237 \mathrm{v}, 238 \mathrm{r}, 238 \mathrm{v}, 239 \mathrm{r}, 239 \mathrm{v}, 240 \mathrm{r}, 240 \mathrm{v}$, $241 \mathrm{r}, 241 \mathrm{v}, 242 \mathrm{r}, 242 \mathrm{v}, 243 \mathrm{r}, 243 \mathrm{v}, 244 \mathrm{r}$, $244 \mathrm{v}, 245 \mathrm{r}, 245 \mathrm{v}, 246 \mathrm{r}, 249 \mathrm{r}, 249 \mathrm{v}, 250 \mathrm{r}$, $255 \mathrm{v}, 259 \mathrm{v}, 260 \mathrm{r}, 265 \mathrm{v}, 271 \mathrm{v}, 274 \mathrm{r}, 278 \mathrm{v}$, 279v, 289r, 293r, 294v, 302r, 308r, 312v, 313r, 316r, 316v, 329r, 334r, 335r, 339r, $352 \mathrm{v}, 354 \mathrm{r}, 364 \mathrm{v}, 366 \mathrm{r}, 368 \mathrm{r}, 371 \mathrm{v}, 383 \mathrm{r}$, $387 \mathrm{v}, 406 \mathrm{r}, 408 \mathrm{r}, 409 \mathrm{r}, 418 \mathrm{v}, 420 \mathrm{v}, 436 \mathrm{v}$, $443 \mathrm{r}, 453 \mathrm{v}, 460 \mathrm{v}, 464 \mathrm{v}, 466 \mathrm{v}$.

González Catalán: 149r, 156r, 175v, 411v. Gómez Catalán: 418v, 176r.

Gómez Cidiz: 91r.

Gómez de Ávila: $221 \mathrm{r}$.

Gómez de Benavides: 229v, 233r, 234r, $234 \mathrm{v}, 235 \mathrm{r}, 235 \mathrm{v}, 236 \mathrm{r}, 236 \mathrm{v}, 237 \mathrm{r}, 237 \mathrm{v}$, 238r, 238v, 239r, 239v, 240r, 240v, 241r, $241 \mathrm{v}, 242 \mathrm{r}, 242 \mathrm{v}, 243 \mathrm{r}, 243 \mathrm{v}, 244 \mathrm{r}, 244 \mathrm{v}$, $245 \mathrm{r}, 245 \mathrm{v}, 246 \mathrm{r}, 274 \mathrm{r}$.

Gómez de Mora: 36r, $216 \mathrm{v}$.

Gómez de Pernía: 366r, 368r.

Gómez Díaz: 35v, 107r, 172r, 339r; conde: 1v.

Gómez García: 271v, 279v. 
Gómez García de Saldaña: 98v, 157r, 162r, 162v, 174r, 186r, 255v, 289r; escribano de Carrión: $271 \mathrm{v}$.

Gómez González: 165r.

Gómez González de Carrión: 74v, 154r.

Gómez Manrique, 210v, 227v, 228r, 228v, 229r, 230r, 230v, 231r, 233r, 234r, 234v, 235 r.

Gómez Payar: 354r.

Gómez Peláez: 352v.

Gómez Pérez de Valderrábano: 255v.

Gómez Pérez: 34v.

Gómez Rodríguez: 98r, 98v.

González: 3r, 3v, 4v, 10v, 11r, 13v, 14r, $14 \mathrm{v}, 30 \mathrm{v}, 31 \mathrm{r}, 32 \mathrm{v}, 33 \mathrm{r}, 37 \mathrm{r}, 37 \mathrm{v}, 43 \mathrm{r}, 43 \mathrm{v}$, $44 \mathrm{v}, 48 \mathrm{r}, 58 \mathrm{r}, 59 \mathrm{r}, 60 \mathrm{r}, 67 \mathrm{r}, 67 \mathrm{v}, 68 \mathrm{r}, 68 \mathrm{v}$, 69v, 70r, 74v, 77r, 77v, 78v, 79r, 82r, 82v, $84 \mathrm{r}, 92 \mathrm{r}, 92 \mathrm{v}, 93 \mathrm{r}, 98 \mathrm{r}, 102 \mathrm{v}, 103 \mathrm{r}, 124 \mathrm{r}$, $127 \mathrm{r}, 131 \mathrm{v}, 133 \mathrm{v}, 134 \mathrm{r}, 143 \mathrm{v}, 144 \mathrm{r}, 144 \mathrm{v}$, $145 \mathrm{v}, 146 \mathrm{r}, 146 \mathrm{v}, 148 \mathrm{v}, 149 \mathrm{r}, 150 \mathrm{r}, 154 \mathrm{r}$, $154 \mathrm{v}, 156 \mathrm{r}, 161 \mathrm{v}, 164 \mathrm{r}, 164 \mathrm{v}, 165 \mathrm{r}, 174 \mathrm{r}$, $174 \mathrm{v}, 175 \mathrm{r}, 175 \mathrm{v}, 176 \mathrm{r}, 177 \mathrm{r}, 177 \mathrm{v}, 181 \mathrm{v}$, $183 \mathrm{r}, 184 \mathrm{r}, 184 \mathrm{v}, 185 \mathrm{r}, 191 \mathrm{v}, 197 \mathrm{r}, 197 \mathrm{v}$, $198 \mathrm{r}, 198 \mathrm{v}, 199 \mathrm{r}, 199 \mathrm{v}, 201 \mathrm{v}, 203 \mathrm{v}, 204 \mathrm{r}$, 204v, 206r, 206v, 208r, 302r, 303r, 303v, $304 \mathrm{r}, 305 \mathrm{r}, 309 \mathrm{v}, 310 \mathrm{r}, 311 \mathrm{v}, 314 \mathrm{v}, 328 \mathrm{r}$, $331 \mathrm{v}, 335 \mathrm{r}, 339 \mathrm{r}, 339 \mathrm{v}, 340 \mathrm{r}, 340 \mathrm{v}, 341 \mathrm{r}$, 350r, 350v, 351v, 352r, 356v, 360r, 360v, $364 \mathrm{v}, 367 \mathrm{r}, 367 \mathrm{v}, 368 \mathrm{r}, 369 \mathrm{r}, 369 \mathrm{v}, 371 \mathrm{v}$, $374 \mathrm{r}, 374 \mathrm{v}, 376 \mathrm{r}, 376 \mathrm{v}, 377 \mathrm{v}, 378 \mathrm{r}, 380 \mathrm{v}$, $391 \mathrm{r}, 397 \mathrm{v}, 399 \mathrm{r}, 404 \mathrm{v}, 405 \mathrm{r}, 407 \mathrm{v}, 408 \mathrm{v}$, $409 \mathrm{r}, 411 \mathrm{v}, 412 \mathrm{v}, 413 \mathrm{v}, 417 \mathrm{v}, 418 \mathrm{r}, 424 \mathrm{r}$, $427 \mathrm{r}, 427 \mathrm{v}, 428 \mathrm{v}, 432 \mathrm{r}, 437 \mathrm{v}, 438 \mathrm{r}, 441 \mathrm{v}$, 443r, 448v, 450r, 460r, 465r, 467v.

González de Escobar, 228r, 228v, 229r.

Gonzalo: 13r, 13v, 14r, 14v, 31r, 40r, 40v, $42 \mathrm{r}, 42 \mathrm{v}, 45 \mathrm{v}, 49 \mathrm{v}, 55 \mathrm{r}, 55 \mathrm{v}, 56 \mathrm{r}, 56 \mathrm{v}, 58 \mathrm{r}$, 67r, 70v, 71r, 76r, 77v, 78r, 78v, 79r, 83r, $83 \mathrm{v}, 84 \mathrm{v}, 88 \mathrm{v}, 92 \mathrm{r}, 98 \mathrm{v}, 109 \mathrm{r}, 109 \mathrm{v}, 110 \mathrm{r}$, $133 \mathrm{r}, 145 \mathrm{v}, 148 \mathrm{r}, 162 \mathrm{r}, 162 \mathrm{v}, 163 \mathrm{r}, 164 \mathrm{r}$, $164 \mathrm{v}, 165 \mathrm{v}, 174 \mathrm{r}, 175 \mathrm{r}, 190 \mathrm{v}, 196 \mathrm{v}, 198 \mathrm{r}$, 205r, 206r, 206v, 207r, 207v, 209v, 223r, $225 \mathrm{r}, 225 \mathrm{v}, 227 \mathrm{r}, 229 \mathrm{v}, 230 \mathrm{r}, 230 \mathrm{v}, 231 \mathrm{r}$, 233r, 237r, 244r, 244v, 245r, 245v, 246r, $254 \mathrm{v}, 265 \mathrm{v}, 266 \mathrm{r}, 266 \mathrm{v}, 271 \mathrm{r}, 279 \mathrm{r}, 294 \mathrm{v}$, 295r, 295v, 296r, 325v, 326r, 326v, 328v, 339r, 339v, 340r, 340v, 341r, 364v, 366r, 368r, 374r, 376r, 380r, 383v, 384r, 384v, 385r, 393r, 400v, 405r, 407v, 408r, 411r, $422 \mathrm{v}, 423 \mathrm{r}, 461 \mathrm{v}$; fraile: $107 \mathrm{r}$.

Gonzalo Alemán: 422v, 423r.
Gonzalo Alfonso de León: 14r, 14v.

Gonzalo Calabaza: 207v.

Gonzalo Campos: 76r.

Gonzalo Capillas: 393r.

Gonzalo de Anievas: 206r.

Gonzalo de Camargo: 254v.

Gonzalo de Castro: 198r.

Gonzalo de Cervatos: 83r, 83v, 339r, 339v, 340r, 340v, 341r.

Gonzalo de Morante: 295r.

Gonzalo de Placencia: 223r.

Gonzalo de Valderrábano: 49v, 70v, 328v.

Gonzalo de Vega Rabanal: 266r, 266v.

Gonzalo de Villanueva: 196v.

Gonzalo del Valle: 42r, 42v, 209v.

Gonzalo Fernández: 45v, 92r, 98v, 109v, $110 \mathrm{r}, 162 \mathrm{r}, 162 \mathrm{v}, 163 \mathrm{r}, 164 \mathrm{r}, 164 \mathrm{v}, 172 \mathrm{r}$, 172v, 206r, 271r, 408r.

Gonzalo Fernández de Sahagún: 206r.

Gonzalo García: 84v, 109r, 206r, 206v, $244 \mathrm{r}, 244 \mathrm{v}$.

Gonzalo García de Burgos: 196v.

Gonzalo Gómez: 78v.

Gonzalo González: 58v, 237r, 364v.

Gonzalo González de Burgos: 245r, 245v, 246r.

Gonzalo González de Carrión: 175r.

Gonzalo González de Cervatos: 67r.

Gonzalo González de Cisneros: 78v, 79r.

Gonzalo González Guadiana: 174r.

Gonzalo Gutiérrez: 190v, 207v.

Gonzalo Martínez: 227r, 229v, 411r.

Gonzalo Martínez de Cervatos: 175r, 405r.

Gonzalo Méndez: 374r.

Gonzalo Montes de Colmenares: 265v, 266r; cura de Las Heras: 266r.

Gonzalo Morante: 294v, 295r, 295v.

Gonzalo Muñoz: 207r.

Gonzalo Ochoa: 366r.

Gonzalo Pérez: 13r, 13v, 58r, 76r, 88v, $145 \mathrm{v}, 148 \mathrm{r}, 165 \mathrm{v}, 328 \mathrm{v}, 407 \mathrm{v}$.

Gonzalo Pérez de Moslares: 145v, 165v.

Gonzalo Pérez de Tremello: 328v.

Gonzalo Ruiz: 31r, 133r, 230r, 230v, 231r, 233r, 279r, 326v.

Gonzalo Ruiz de la Vega, 56r, 56v, 71r, $77 \mathrm{v}, 78 \mathrm{r}, 326 \mathrm{v}$.

Gonzalo Viñayo: 368r.

Gracián y Yáñez: 378r.

Gregorio IX: 80v, 81r.

Gregorio XIII: 117r, 208r, 420r. 
Gregorio XV: 118r.

Gregorio Boto Prieto: 424r.

Gregorio Caballero, fraile: 331r, 423v.

Gregorio Calderón: 187r; fraile: 261r, 283r, 309r, 324r, 401v, 427v.

Gregorio Ceruelo de la Fuente: 44v, 178v, 299r.

Gregorio de la Vega: $375 r$.

Gregorio de Ordás: 425r, 425v.

Gregorio de Pedrosa, fraile: $27 \mathrm{v}$.

Gregorio de Setién: 415v.

Gregorio de Valerón: 389v, 390r, 390v.

Gregorio de Velasco: 42r.

Gregorio de Villacorta: 442r.

Gregorio García, vecino de Villafría: 461v.

Gregorio García de Miranda: 48v, 119r,

$152 \mathrm{v}, 156 \mathrm{v}, 185 \mathrm{r}, 276 \mathrm{r}, 287 \mathrm{v}, 296 \mathrm{v}, 304 \mathrm{v}$,

466r, 466v.

Gregorio Gozón: 437v.

Gregorio Herrero: 411r.

Gregorio Melendro: 75r, 75v.

Gregorio Mínguez: 159r, 159v.

Gregorio Miranda: 460v.

Gregorio Movilla: 94v, 124r.

Gregorio Núñez: 6r.

Gregorio Núñez de Arce: 101r, 101v.

Gregorio Panero: 396v.

Gregorio Parcero, fraile: 292r.

Gregorio Rodríguez: 275v.

Gregorio Román: 291r.

Gregorio Ruiz: 178r, 178v; fraile: 37r, 60r, 69v, 278r, 304r.

Gregorio Tabares: 416v.

Grijota, vecino: $441 \mathrm{r}$.

Guerra: 5r, 5v, 6r, 39r, 56r, 139v, 204v, 205r, 213r, 214r, 265v, 329r, 329v; licenciado: 266r.

Gui: 5r, 6v, 13r, 13v, 14r, 23v, 35v, 36r, 36v, 40r, 43v, 44v, 47r, 50r, 58v, 59r, 68v, $82 \mathrm{r}, 91 \mathrm{v}, 97 \mathrm{v}, 98 \mathrm{r}, 104 \mathrm{r}, 114 \mathrm{v}, 115 \mathrm{r}, 140 \mathrm{r}$, $143 \mathrm{r}, 143 \mathrm{v}, 144 \mathrm{r}, 153 \mathrm{r}, 156 \mathrm{r}, 167 \mathrm{v}, 168 \mathrm{r}$, $172 \mathrm{r}, 172 \mathrm{v}, 181 \mathrm{v}, 182 \mathrm{v}, 183 \mathrm{r}, 200 \mathrm{v}, 207 \mathrm{v}$, $210 \mathrm{r}, 227 \mathrm{v}, 236 \mathrm{v}, 262 \mathrm{r}, 273 \mathrm{r}, 278 \mathrm{v}, 279 \mathrm{r}$, 293v, 301v, 302r, 326r, 339r, 339v, 340r, 340v, 341r, 353r, 354r, 400v, 404r, 408v, $410 \mathrm{v}, 412 \mathrm{r}, 412 \mathrm{v}, 433 \mathrm{v}, 438 \mathrm{r}$.

Guido: $82 \mathrm{r}, 227 \mathrm{v}$.

Guido de la Cusol: 13v, $14 \mathrm{r}$.

Guijelmo: 182v, 278v, 293v, 301v, 302r.
Guillén: 47r, 50r, 58v, 59r, 68v, 97v, 98r, 143r, 143v, 172r, 172v, 207v, 302r, 400v, 408v, 410v.

Guillén de Carrión: 50r.

Guillén de Cavanolas: 143r, $143 \mathrm{v}$.

Guillén Pérez: 58v, 59r, 68v, 97v, 98r.

Guillermo: 341r, 236v.

Guillermo de Fondera: 341r.

Guillermo de Porreius: 104r.

Guillermo Lesne: 326r.

Guillermo Olín: 13r, 13v.

Guiomar de Herrera: 156r.

Guiomar Pérez: 144r.

Guiral Gusberti: 412r.

Guntroda Gonzálvez: 441v.

Gutierre de Herrera: 76v.

Gutierre de Soa: 63v.

Gutierre Fernández: 66r, 76r, 78v, 79r, 92r, 144r, 148v, 149r, 161v, 162r, 162v, 173r, 272r, 405r, 410v, 412v.

Gutierre Fernández de San Zoilo: 78v, 79r, 92r, 149r, 272r.

Gutierre García: 300r.

Gutierre García de San Zoilo: 241v, 242r.

Gutierre González: 314v, 230r, 230v, 231 r.

Gutierre González de Quirós: 328r.

Gutierre Pérez Calderón: 422v, 423r.

Gutierre Sánchez: 182v.

Heras: 51r, 84r, 84v, 261v, 262r, 266r, $319 \mathrm{v}, 351 \mathrm{v}, 352 \mathrm{r}, 380 \mathrm{v}, 390 \mathrm{v}, 408 \mathrm{v}, 459 \mathrm{v}$.

Hernando: $315 \mathrm{v}$.

Hernando Alonso: 397r.

Hernando Anayaz: 292v.

Hernando Becerro: 258v.

Hernando Cantero: 432v.

Hernando de Ayala, fraile: 222v, 223r.

Hernando de Caniego, fraile: 10r.

Hernando de Castrillo: 255r.

Hernando de Castro: 223r, 223v, 294v.

Hernando de Colmenares: 46r, 46v.

Hernando de Cuéllar: 86r.

Hernando de Escobar: 87r, 87v.

Hernando de Fonseca: 343v, 344r.

Hernando de Herrera: 85r.

Hernando de la Cuesta: 346v.

Hernando de Lorenzana: 431r.

Hernando de Mercado: 449r.

Hernando de Onís: 373r, 373v.

Hernando de Prado: 184r, 184v.

Hernando de Salceda: 178r, 295v. 
Hernando de Vega: 198r, 266r, 266v, 267 r. Hernando de Villafranca: 56v, 354v.

Hernando Díez: 316r, 316v.

Hernando Gómez de Linares: 165v.

Hernando González: 68r.

Hernando Gutiérrez: 392r, 392v.

Hernando Jiménez: $134 \mathrm{r}$.

Hernando Juárez: 32v, 257v, 258r, 284r, $284 \mathrm{v}$.

Hernando Martín: 460v.

Hernando Melendro: 39v.

Hernando Monte de Colmenares: 47v.

Hernando Núñez: 267r.

Hernando Oreja: 316v, 376r.

Hernando Osorio: 290r, 290v.

Hernando Palacios: 401r.

Hernando Pérez de la Iglesia: 299v.

Hernando Puente: 373r, 373v.

Hernando Sánchez de Robles: 376r.

Hernando Sánchez: 50v, 274r, 376r.

Hernando Santos: 150v, 151r.

Herrera: 2v, 5r, 5v, 33r, 41v, 76v, 85r, 85v, $154 \mathrm{r}, 156 \mathrm{r}, 178 \mathrm{r}, 178 \mathrm{v}, 185 \mathrm{r}, 244 \mathrm{v}, 245 \mathrm{r}$, $280 \mathrm{r}, 311 \mathrm{v}, 321 \mathrm{v}, 365 \mathrm{v}, 386 \mathrm{r}, 403 \mathrm{r}, 403 \mathrm{v}$, 428r, 428v, 448r; licenciado: 445r.

Hinojedo: 186r, 261r, 408v.

Hipólito de Diego Pérez: 305r, 305v.

Hipólito de Rojas: 419v.

Hipólito del Valle: 450r.

Hipólito Delgadillo: 190v.

Hipólito Rojo: 262r.

Huelgas de Burgos, señora de: 98r.

Huércanos: 28v, 38v, 39r, 193r, 193v, 198r, 198v, 199r, 203r, 212r, 213v, 219r, $219 \mathrm{v}, 221 \mathrm{r}, 223 \mathrm{v}, 294 \mathrm{v}, 445 \mathrm{r}$; vecino de: $405 \mathrm{v}$.

Hugo: 186v, 226v, 227r, 313r, 351v, 404v. Hugo Garay: 226v, 227 r.

Ignacio de la Puente: 45v, 46r, 77v, 263v, $324 \mathrm{v}, 325 \mathrm{r}, 337 \mathrm{r}, 391 \mathrm{v}$.

Ignacio de Velasco: 282r.

Ignacio Gutiérrez: 159v, 160r, 467r.

Ignacio Ibáñez: 355r.

Ignacio Izquierdo: $111 \mathrm{v}, 112 \mathrm{r}$.

Ignacio Manganés: 304v, 305r, 437v.

Ignacio Maté: 203r.

Ildefonso: 37v, 66r, 66v, 195r, 210r, 263v, 297r, 375r, 437v.

Ildefonso de Bárcena Mier, fraile: 123r, 210r, 297r, 437v.
Ildefonso Hidalgo, fraile: 37v, 263v, 375r.

Illana: $182 \mathrm{v}, 300 \mathrm{r}$.

Inés Crespa: 64r, 64v.

Inés de Robles: 422v, 423r.

Inés Gallego: 466r.

Inés Ruiz: 153v.

Inocencio III: $80 \mathrm{v}$.

Inocencio IV: $81 \mathrm{r}, 81 \mathrm{v}$.

Inocencio VIII: 104v, $207 \mathrm{r}$.

Inocencio XI: 48v, $118 \mathrm{v}$.

Ínigo del Castillo: 244v, $245 \mathrm{r}$.

Íñigo del Castillo: 328v.

Íñigo Manrique: 376v, 377r, 377v.

Iona Fernández: $131 \mathrm{r}$.

Isabel I: 90v, 137r, 361r, 361v, 362r, 455v.

Isabel Alfonso: 174r.

Isabel Antón: 51v.

Isabel Buey: 466r.

Isabel Calderón de Carranza: 167v.

Isabel de Caballos: 423v.

Isabel de la Fuente: 193r, 193v.

Isabel de Pedrosa: 422v.

Isabel de San Zoilo: 166r.

Isabel de Villarroel: 3v.

Isabel Díaz: 174r, 174v.

Isabel Durántez: 30v.

Isabel Enríquez: 71r, 350r.

Isabel Fernández: 144r, 145v.

Isabel García: 465v.

Isabel González: 164v, 165r, 175v, 176r, $465 r$.

Isabel González Cerera: 175v, 176 r.

Isabel Herrero: 463r.

Isabel Hortega Frechilla: 288r.

Isabel Lasso: 462r.

Isabel Montes: $158 \mathrm{v}$.

Isabel Roldán: 423v.

Isabel Ruiz: 464v.

Isabel Villalba: 319r.

Isidoro de Amo: 319r.

Isidoro de la Serna: 352v.

Isidoro Meneses: 296v.

Isidoro Ruiz de Colmenares: 158v, 178v, $210 \mathrm{v}, 299 \mathrm{r}, 437 \mathrm{v}$.

Isidoro Sánchez Gorgojo: 11r.

Isidro Álvarez de Ferreras: 27v.

Isidro Calderón: 250v, 251r.

Isidro Cantero: 153 r.

Isidro Fernández Barreda: 368v.

Isidro González: 250r.

Isidro Jacinto Pau: 380v. 
Isidro Pérez, fraile: 256r.

Isidro Ruiz de Colmenares: 44v.

Isidro Vélez Bracho: 37v.

Isidro Vián: 450v.

Jacinta Guerra: 5r, 6r.

Jacinta Paniagua: $465 \mathrm{v}$.

Jacinto: 80r, 118v, 119r, 135r, 185r, 209v, $380 \mathrm{v}$.

Jacinto de Arana y Cuesta: $37 \mathrm{r}$.

Jacinto Díaz, fraile: $118 \mathrm{v}, 119 \mathrm{r}$.

Jacinto Díez: 185r; fraile: 40r, 209v, 268r, 276r, 278v, 296v, 304v, 305r, 311v, 437v.

Jacinto Díez de Angulo, fraile: 37v.

Jacinto Elices: 153v.

Jacinto Gallego: 250r.

Jacinto Rubín de Celis: 135r.

Jerónima de la Cerda: 442v.

Jerónima de Mier: 64r, 64v, 65r.

Jerónimo Artacho: 199v.

Jerónimo Coronel Velázquez: 395r.

Jerónimo Correas: 285v, 355v.

Jerónimo de Benavides: 242v, 245r, 245v, 246r, 247r, 247v, 248r, 248v, 249r.

Jerónimo de Bustamante: $17 \mathrm{r}$.

Jerónimo de Canseco: 60v.

Jerónimo de Contreras: $70 \mathrm{v}$.

Jerónimo de Glimiciis: 87v.

Jerónimo de Guevara: 167v.

Jerónimo de la Mata y Puerta: $185 \mathrm{v}$.

Jerónimo de la Serna: 16v, 19r, 22v, 43v, $222 \mathrm{r}$

Jerónimo de la Torre: 284r, 284v.

Jerónimo de la Vega: 416v.

Jerónimo de Letrán: $118 \mathrm{r}$.

Jerónimo de Represa: 369r, 369v.

Jerónimo de Rozadilla: $267 \mathrm{v}$.

Jerónimo de Terán: 157v, 158v.

Jerónimo de Valderrábano: 371r.

Jerónimo de Vega: 95r, 445r.

Jerónimo Gallego de Robles: 17v, 18r, $21 \mathrm{v}$.

Jerónimo González de Saldaña: 177v.

Jerónimo González Pajuela: 185r.

Jerónimo Laso: 41v, 42r, 100v, 101r, 152r, 156v, 159r, 166r, 166v, 171r, 299v, 411r.

Jerónimo López: 100V, 118r, 121r, 121v, $122 \mathrm{v}, 123 \mathrm{r}, 130 \mathrm{r}, 130 \mathrm{v}, 152 \mathrm{r}, 169 \mathrm{v}, 170 \mathrm{r}$, $170 \mathrm{v}, 329 \mathrm{r}, 334 \mathrm{v}$.

Jerónimo López Labrador: 181v.

Jerónimo Luis: 286v.
Jerónimo Rozadilla: 267r.

Jerónimo Sánchez de Roa: 378r.

Jerónimo de Chaves, fraile: $265 \mathrm{v}$.

Jerónimo de la Sierra, fraile: 331v.

Jerónimo González Pajuela: 185r.

Jerónimo Gracián, fraile: 105v, 130v, 376v, 377v, 378r, 380r.

Jerónimo López: 170v, 420v.

Jiménez de Sobrarbe: $35 \mathrm{v}$.

Jimeno de San Zoilo: 174r, 174v.

Joaquín de Cevallos Vélez: 49r.

Joaquín de Santaolalla: 288r.

Joaquín Díez: 200v, 201 r.

Joaquín Orejón: 38r.

Joaquín Pérez de la Madrid: 200r.

Joaquín Piquot y Serrador: 97r.

Jordán: 236v.

Jorge de Escobedo: $71 \mathrm{r}$.

Jorge de Vega: 316r.

José: $75 \mathrm{v}$.

José Alonso: 336r, 262v.

José Antonio Jaramillo, provisor de León: $269 \mathrm{v}$.

José Antonio Robles: 4v.

José Aparicio: 459v; mujer de: 459v.

José Asenjo: $284 \mathrm{v}$.

José Becerril Arias: 463v.

José Bernal: 460r.

José Buey: 463v, 464r, 466v.

José Cajigas: $210 \mathrm{r}$.

José Calonge: 447v.

José Calvo: 336r.

José Camerino: 303v, 304r.

José Cayetano de Loaces: 210r.

José Cornejo, fraile: 333 r.

José de Arriba: 298v, 299r.

José de Astudillo: 450r.

José de Calabaza Téllez: 210v.

José de Castellanos: 98r.

José de Ceano Vivas: 347v, 348r.

José de Cevallos: 187r.

José de Godoy: 200v, 201r.

José de Hompanera: 297r.

José de Hortega: 395v.

José de Iglesias, fraile: 209v, 210r, 296v.

José de la Calle: 261r, 261v.

José de la Cuesta Terán: $51 \mathrm{v}$.

José de la Peña: 40r.

José de Liébana: 461r.

José de los Bueyes y Bueyes: 467r. 
José de Medina de los Ríos Campoo: 153r, $157 \mathrm{v}$.

José de San Esteban: 36v, 39r, 44r, 209r.

José de Soba: 395v.

José de Valverde San Martín: 5r.

José del Campo, fraile: 276r.

José Díaz de Castro: 155r, 155v.

José Díez: 462v, 463r.

José Díez Piñán: $311 \mathrm{v}$.

José Espinosa: 185r.

José Fernández de Sanjurjo: 276r.

José Fierro: 37v, 261v; fraile: 261r, 262r, 286v, 293v, 294r, 300v, 309r, 309v, 319r, $319 \mathrm{v}, 320 \mathrm{r}, 324 \mathrm{r}, 324 \mathrm{v}, 325 \mathrm{r}, 351 \mathrm{r}, 409 \mathrm{r}$, $409 \mathrm{v}$.

José Fontán: 153r.

José Francisco Cid Villanuño: 466v.

José Gallo: 269r.

José García: 304r, 304v.

José García de Guadiana: 460r, 468r, 296v, 297 r.

José Gómez: 436v.

José González: 262r; fraile: 219r, 219v.

José González Herreros: 275v.

José González Ochoa: 251v.

José Guzmán: 30r, 356v.

José Herreras: $5 \mathrm{v}$.

José Ibáñez: 466v.

José Julián García: 297v.

José Largo García: 183r.

José Luis de Cantoral: 51v, 319r, 351v, 442r, 461r, 461v.

José Luis de Mollinedo: 115v.

José Luis París: 336v.

José Martín de Recalde: 200v.

José Martínez: 396r.

José Melendez: 37v, 40r, 209v, 210r, 214r, $214 \mathrm{v}$.

José Merino: 319r.

José Olea: $153 \mathrm{v}$.

José Patricio de Retes: 40r, 40v, 112v.

José Pérez: 436v, 437r.

José Pérez de Salazar: 336r, 336v, 351v.

José Porras: 304v.

José Porro: 438v.

José Quijano Duque: 336v.

José Rebollar Pérez: 424r.

José Recio Ramos: 439v.

José Rodríguez Carrancio: 464v, 465v.

José Rodríguez Cornejo: 114r.

José Rojo Sánchez: 437r.
José Roldán: 261r.

José Román: $287 \mathrm{v}$.

José Sanz García: 115v.

José Serrano: 4r, 146r.

José Tablares: 40r, 44v, 101v, 112v, 115v, 116r, 153r, 154v, 159r, 160r, 298v, 299r, $450 \mathrm{v}, 458 \mathrm{v}$.

José Tablares del Val: 119v, 275r.

José Valbuena: 311v.

Josefa de Castro: 466r.

Josefa de Guzmán: 262v, 319v, 367r, 367v, 400v, 401r.

Josefa Durántez: 462r.

Josefa Gonzalo: 461v.

Josefa Palaz: 461v, 463v.

Josefa Pérez: 160r.

Josefa Reinoso: 153 r.

Josefa Vicente: 153 r.

Juan, 32r, 58r, 61v, 82v, 102v, 103r, 103v, $129 \mathrm{v}, 130 \mathrm{r}, 131 \mathrm{r}, 133 \mathrm{v}, 134 \mathrm{r}, 143 \mathrm{r}, 206 \mathrm{v}$, $227 \mathrm{r}, 227 \mathrm{v}, 228 \mathrm{r}, 228 \mathrm{v}, 230 \mathrm{r}, 230 \mathrm{v}, 231 \mathrm{r}$, $231 \mathrm{v}, 234 \mathrm{r}, 234 \mathrm{v}, 235 \mathrm{r}, 235 \mathrm{v}, 237 \mathrm{v}, 238 \mathrm{r}$, $238 \mathrm{v}, 239 \mathrm{r}, 239 \mathrm{v}, 240 \mathrm{r}, 240 \mathrm{v}, 241 \mathrm{r}, 241 \mathrm{v}$, 269v, 311r, 311v, 313r, 314r, 321v, 329r, $331 \mathrm{v}, 332 \mathrm{r}, 338 \mathrm{r}, 338 \mathrm{v}, 339 \mathrm{r}, 339 \mathrm{v}, 340 \mathrm{r}$, $340 \mathrm{v}, 341 \mathrm{r}, 342 \mathrm{v}, 343 \mathrm{r}, 343 \mathrm{v}, 344 \mathrm{r}, 345 \mathrm{r}$, $345 \mathrm{v}, 349 \mathrm{v}, 349 \mathrm{v}, 350 \mathrm{r}, 350 \mathrm{v}, 351 \mathrm{r}, 351 \mathrm{v}$, 352r, 354r, 359v, 360r, 360v, 361r, 361v, $362 \mathrm{r}, 362 \mathrm{v}, 362 \mathrm{v}, 364 \mathrm{v}, 365 \mathrm{r}, 365 \mathrm{r}, 365 \mathrm{v}$, 366r, 366v, 367r, 367v, 368r, 368v, 371r, $371 \mathrm{v}, 372 \mathrm{r}, 372 \mathrm{v}, 373 \mathrm{r}, 373 \mathrm{v}, 374 \mathrm{r}, 374 \mathrm{v}$, 375r, 376r, 376v, 377r, 377v, 380r, 380v, 382r, 382v, 383r, 383v, 384r, 384v, 385r, 385v, 386r, 386v, 387r, 390r, 391r, 391v, 393r, 393v, 394r, 394v, 395r, 395v, 396r, $397 \mathrm{v}, 399 \mathrm{r}, 399 \mathrm{v}, 400 \mathrm{v}, 401 \mathrm{r}, 401 \mathrm{v}, 402 \mathrm{v}$, 403r, 403v, 404r, 404v, 405r, 405v, 406r, $408 \mathrm{v}, 409 \mathrm{r}, 409 \mathrm{v}, 410 \mathrm{v}, 411 \mathrm{v}, 412 \mathrm{r}, 413 \mathrm{v}$, $414 \mathrm{r}, 414 \mathrm{v}, 415 \mathrm{r}, 415 \mathrm{v}, 416 \mathrm{r}, 416 \mathrm{v}, 417 \mathrm{v}$, 418r, 418v, 419r, 419v, 420r, 420v, 422r, $422 \mathrm{v}, 423 \mathrm{v}, 425 \mathrm{r}, 428 \mathrm{r}, 428 \mathrm{v}, 429 \mathrm{v}, 430 \mathrm{r}$, $430 \mathrm{v}, 431 \mathrm{r}, 431 \mathrm{v}, 437 \mathrm{r}, 438 \mathrm{r}, 448 \mathrm{v}, 450 \mathrm{v}$, 454r, 454v; doctor: 240v; fraile: 9r, 16r, $34 \mathrm{v}, 35 \mathrm{r}, 36 \mathrm{r}, 36 \mathrm{v}, 39 \mathrm{r}, 43 \mathrm{v}, 49 \mathrm{v}, 50 \mathrm{r}, 59 \mathrm{r}$, $60 \mathrm{r}, 69 \mathrm{v}, 70 \mathrm{v}, 71 \mathrm{r}, 72 \mathrm{r}, 73 \mathrm{r}, 76 \mathrm{v}, 77 \mathrm{r}, 77 \mathrm{v}$, $100 \mathrm{r}, 106 \mathrm{r}, 109 \mathrm{r}, 117 \mathrm{v}, 118 \mathrm{r}, 123 \mathrm{r}, 124 \mathrm{r}$, $130 \mathrm{r}, 130 \mathrm{v}, 134 \mathrm{v}, 150 \mathrm{v}, 152 \mathrm{v}, 203 \mathrm{v}, 205 \mathrm{r}$, 206r, 206v, 209r, 218v, 219v, 223r, 223v, $257 \mathrm{r}, 257 \mathrm{v}, 270 \mathrm{r}, 270 \mathrm{v}, 278 \mathrm{r}, 282 \mathrm{r}, 287 \mathrm{r}$, 295v, 296v, 297r, 300v, 302r, 304r, 308r, $323 \mathrm{r}, 323 \mathrm{v}, 330 \mathrm{v}, 331 \mathrm{v}, 333 \mathrm{r}, 345 \mathrm{r}, 345 \mathrm{v}$, 
346r, 350v, 354r, 365v, 366r, 371r, 371v, $372 \mathrm{v}, 375 \mathrm{r}, 380 \mathrm{v}, 383 \mathrm{v}, 384 \mathrm{r}, 384 \mathrm{v}, 385 \mathrm{r}$, 385v, 386r, 391v, 393r, 394r, 399r, 420r, $420 \mathrm{v}, 428 \mathrm{r}, 428 \mathrm{v}, 431 \mathrm{v}, 432 \mathrm{r}, 434 \mathrm{v}, 438 \mathrm{v}$, $445 \mathrm{r}, 447 \mathrm{v}$; obispo britonoriense, $207 \mathrm{v}$.

Juan II: 83r, 83v, 89r, 89v, 91v, 92r, 98v, $131 \mathrm{v}, 132 \mathrm{r}, 227 \mathrm{v}, 228 \mathrm{r}, 228 \mathrm{v}, 230 \mathrm{r}, 230 \mathrm{v}$, $231 \mathrm{r}, 231 \mathrm{v}, 234 \mathrm{r}, 234 \mathrm{v}, 235 \mathrm{r}, 235 \mathrm{v}, 239 \mathrm{r}$, $239 \mathrm{v}, 240 \mathrm{r}, 240 \mathrm{v}, 241 \mathrm{r}, 241 \mathrm{v}, 339 \mathrm{r}, 339 \mathrm{v}$, 340r, 340v, 341r, 364v, 413v, 414r, 454r, $454 \mathrm{v}$; madre y tutora de: $235 \mathrm{r}, 235 \mathrm{v}$.

Juan XXII: 48v, 81v.

Juan Abad: 328r.

Juan Abad de la Calle: 61r.

Juan Abril: 110v.

Juan Aguado: 193v, 200r; fraile: 287r.

Juan Alcalde: 411v, 418r, 418v, 423v, 306r, 306v.

Juan Alcalde el Viejo: 418r, 418v.

Juan Alegre: $157 \mathrm{v}$.

Juan Alfonso: 45v, 169r, 187v, 226v, 286r, 286v, 350r, 404v, 405r.

Juan Alfonso de Zamora: 82v.

Juan Alonso de Marcos: 394r, 394v.

Juan Alonso de Moscoso: 26r.

Juan Alonso: 9v, 10r, 26r, 167r, 310r, 315r, $315 \mathrm{v}, 329 \mathrm{r}, 394 \mathrm{r}, 394 \mathrm{v}, 412 \mathrm{r}$.

Juan Alonso Risoba: 437r.

Juan Álvarez: 399v, 401r.

Juan Álvarez Osorio: 73v.

Juan Antón: 267v, 459v.

Juan Antonio de Cos: 96v, 450v.

Juan Antonio de Godoy: 209v.

Juan Antonio de Olea: 4r.

Juan Antonio del Río: 141v.

Juan Aparicio de Lagunilla: 174r.

Juan Aparicio Mozo: 423v.

Juan Aparicio Navarro: 11r, 269r, 269v, 311 r.

Juan Argadero, fraile, prior del Brezo: 77r, $77 \mathrm{v}, 206 \mathrm{v}$.

Juan Bajino, fraile: $278 \mathrm{r}$.

Juan Bartolomé Oreja: 330v.

Juan Bautista: 87r.

Juan Bautista Cataneo: 85v, 265v.

Juan Bautista de Herrera: 280r.

Juan Bautista de la Rigada: 105v, 205r, 205v.

Juan Bautista de Torres: 27v, 28r, 28v, 29r, 69r, 73r, 395r, 395v, 310v.

Juan Bautista Herrera: 321v.
Juan Bautista Hoyos: 331r.

Juan Bedija: 207r.

Juan Blanco: 36r, 271v, 429v.

Juan Borrego Aguado: 395r, 399r.

Juan Bravo de la Torre: 159r.

Juan Bravo de Sobremonte: $177 \mathrm{v}$.

Juan Bravo Guerra: 204v, 205r, 213r, 214 r.

Juan Bravo: 229v, 422v, 453r.

Juan Bubiller: 175r.

Juan Bueno: 245r, 245v, 246r.

Juan Caballero: 3v, 10r, 25r, 26r.

Juan Callejo: 159v.

Juan Calvo: 403v, 404r.

Juan Calzada: $277 \mathrm{v}$.

Juan Calzada Bonifaz: 331v.

Juan Campero: 296v.

Juan Cano: $135 \mathrm{v}$.

Juan Cano Guijelmo: 278v.

Juan Carrillo: 37v, $185 \mathrm{r}$.

Juan Copis: 86r.

Juan Cortés: 45v, 70v; fraile: 205r, 420v, 431v.

Juan Cuba, fraile: 150v.

Juan Cubero: 466r.

Juan de Abeja: 151r, 151v.

Juan de Acebes: 423v.

Juan de Ache: $257 \mathrm{r}$.

Juan de Agüeros: 290r, 290v.

Juan de Alarcón: 33r.

Juan de Almirante y Linares: $69 \mathrm{v}$.

Juan de Amayuelas: 191r, 196v: fraile: $434 \mathrm{v}, 438 \mathrm{v}$.

Juan de Amusco, fraile: 34v, 35r.

Juan de Argüello: 34v.

Juan de Avendaño: 146r.

Juan de Ávila: 342v.

Juan de Ayala, fraile: 16r, 366r.

Juan de Barrientos: 393r.

Juan de Barrio, 272v, 314r, 418v, 419r.

Juan de Bartolomé: 371r.

Juan de Beganola: 172v.

Juan de Berrio: 110r, $147 \mathrm{r}$.

Juan de Cabredo: 59r.

Juan de Calzadilla: 162v; fraile: 206r, 206v. Juan de Canillas: 414r, 414v.

Juan de Cantoral: 134r, 146r, 246r, 445r.

Juan de Capillas: 30v.

Juan de Carrión: 103r, 103v, 149r, 269v, 270 r.

Juan de Caso: 46r. 
Juan de Castillo: 15r, 382r, 382v, 383v, 384r, 384v, 385r.

Juan de Castrillo: 2r, 35v, 38v, 43r, 43v, $94 \mathrm{r}, 94 \mathrm{v}, 100 \mathrm{r}, 120 \mathrm{r}, 120 \mathrm{v}, 127 \mathrm{v}, 151 \mathrm{r}$, $151 \mathrm{v}, 152 \mathrm{r}, 154 \mathrm{v}, 158 \mathrm{v}, 159 \mathrm{r}, 166 \mathrm{v}, 176 \mathrm{r}$, $177 \mathrm{r}, 179 \mathrm{v}, 180 \mathrm{r}, 184 \mathrm{v}, 191 \mathrm{r}, 197 \mathrm{r}, 197 \mathrm{v}$, $201 \mathrm{v}, 203 \mathrm{v}, 215 \mathrm{v}, 246 \mathrm{r}, 256 \mathrm{r}, 256 \mathrm{v}, 264 \mathrm{v}$, 265r, 265v, 286v, 306r, 306v, 313v, 322v, 329r, 337r, 345r, 345v, 346r, 371v, 383r, 393r, 393v, 415r, 418r, 418v, 422r, 422v, $428 \mathrm{r}, 435 \mathrm{v}, 436 \mathrm{r}$.

Juan de Cea: 169r, 169v.

Juan de Céspedes: 256r.

Juan de Cisneros: 39r, 39v, 167v, 199v; fraile: 59r, 73r, 82v, 106r, 109r, 118r, 123r, $130 \mathrm{r}, 130 \mathrm{v}, 134 \mathrm{v}, 270 \mathrm{r}, 270 \mathrm{v}, 295 \mathrm{v}, 333 \mathrm{r}$.

Juan de Congosto: 67r.

Juan de Corcuera, fraile: 9r, 72r, 100r, 206v, 354r, 394r, 428v, 445r.

Juan de Cordaves: 65r.

Juan de Cosío: 77v, 78r.

Juan de Escandón Bustamante: 331v.

Juan de Espinosa, fraile: 270r, 270v.

Juan de Estrada: 209r.

Juan de Fernández, fraile: 391v.

Juan de Fonseca: 190v.

Juan de Gauna: 35r.

Juan de Gijón, 39r.

Juan de Gil: 159r.

Juan de Grajal: 326v.

Juan de Guardo: 45v, 64v.

Juan de Guzmán y Santoyo: 135r.

Juan de Herrera: 365v, 428r, 428v, 178r, $178 \mathrm{v}$.

Juan de Hierro: 213r, 213v.

Juan de Hinojedo: 408v, 186r.

Juan de Hortega de la Serna: 405r.

Juan de Iruela, fraile: 393r.

Juan de la Calle Santos: 185r, 304r, 311r.

Juan de la Calle: 296v, 297r, 304v.

Juan de la Cava: 164v.

Juan de la Dosa: 190r.

Juan de la Fuente: 186v, 193r, 200r, 200v.

Juan de la Laguna: 172v.

Juan de la Parra: 166r.

Juan de la Peña: 221 r.

Juan de la Rúa: 360v.

Juan de la Serna: $175 \mathrm{v}$.

Juan de la Torre: 165r, 166r, 166v, 414r, $414 \mathrm{v}$; mujer de: $165 \mathrm{r}$.

Juan de la Villa: 255r.
Juan de Lamasón, fraile: 70v, 71r, 350v, $365 \mathrm{v}, 371 \mathrm{r}$.

Juan de las Heras: 39v, 51r.

Juan de Lerones: $173 \mathrm{v}$.

Juan de Llano y Valdés: 73r.

Juan de Lodosa: 410v, 91v.

Juan de Lomas: 152r.

Juan de los Arcos, fraile: 117v.

Juan de los Barrios: 345r.

Juan de los Ríos: 428v.

Juan de Luceta: 212r.

Juan de Mayorga, fraile: 323r, 323v.

Juan de Mediavilla: 156v.

Juan de Medina: 249r, 321r, 321v, 323r, $323 \mathrm{v}$.

Juan de Miguel: 64v.

Juan de Miranda, fraile: 323r, 323v.

Juan de Mongastón: 396r.

Juan de Montenegro: 185r, 311v.

Juan de Morales: 305r.

Juan de Narganes: 281v, 282r, 390r.

Juan de Nieves: 372r.

Juan de Nogal: 192v.

Juan de Noriega: 295v, 405v, 406r, 436v.

Juan de Obregón: 17v, 19v, 416v.

Juan de Olea: 3r, 3v, 10r, 10v.

Juan de Olea el Mozo: 3r, 3v.

Juan de Olmo: 367v.

Juan de Ortega: 45v, 67v, 100r, 148r, 229v

Juan de Palacios: $175 \mathrm{v}, 434 \mathrm{v}$; fraile: $36 \mathrm{v}$, $302 r$.

Juan de Pedrosa: 376v, 377r, 377v.

Juan de Pernía: 350r; mujer de: 350r.

Juan de Ponga: 45v.

Juan de Portugal: 203v, 204r.

Juan de Poza: 412r.

Juan de Prado: 328r, 328v.

Juan de Quiroga: 17r.

Juan de Quirós: 17v, 428r.

Juan de Rabanal: 64r, 64v, 65r.

Juan de Ralea: 162v.

Juan de Reinoso Labrador: 157r.

Juan de Reinoso: 156v.

Juan de Revenga: 36v.

Juan de Rodrigo: 295v.

Juan de Rozas: 247r, 247v, 248r.

Juan de Ruiloba: 37r, 69v.

Juan de Salinas Jove: $11 \mathrm{r}$.

Juan de Salinas: 415r.

Juan de Salvatierra, fraile: 385r, 385v, 386r.

Juan de San Esteban: 310r. 
Juan de San Pelayo, fraile: 117v.

Juan de San Vicente: 269v, 270r.

Juan de San Zoilo: 166r, 272v.

Juan de Santa María: 2r, 94v, 151v, 203v, 206v, 308r, 345r, 345v, 346r; fraile: 43v, 203v, 206v, 308r, 345r, 345v, 346r, 372v, $383 \mathrm{v}, 384 \mathrm{r}, 384 \mathrm{v}, 385 \mathrm{r}, 428 \mathrm{r}, 428 \mathrm{v}$.

Juan de Saravia: $257 \mathrm{v}$.

Juan de Segovia, fraile: 223r.

Juan de Sevilla: $287 \mathrm{r}$.

Juan de Solórzano: 158r, 311r.

Juan de Soña: 133v, 134 r.

Juan de Sosa: 420r.

Juan de Talavera: 125r, 125v.

Juan de Terán: 36v.

Juan de Tobía, 297v.

Juan de Toledo: 125r, 163v.

Juan de Torices: $77 \mathrm{v}$.

Juan de Torralba: 242v, 269v.

Juan de Torres: 167r, 380r.

Juan de Ulloa: 338v, 343r, 343v.

Juan de Urones: 3 r.

Juan de Valdivieso: 265v, 266r.

Juan de Valencia: 245r, 245v, 246r.

Juan de Vega: 194r, 194v, 302v, 303r, 316r, $328 \mathrm{v}, 453 \mathrm{r}$.

Juan de Vega Hortelano: 158v.

Juan de Villacorta: 393v.

Juan de Villafañe de Villabalter: 431r.

Juan de Villafrades: 26v, 27r, 137r, 137v, 138r, 138v, 139r.

Juan de Villafranca: 17v, 18r, 18v, 19v.

Juan de Villalba: 461r.

Juan de Villalbeto: 328v.

Juan de Villamuera: $175 \mathrm{r}$.

Juan de Villanueva: 175v.

Juan de Villar: $181 \mathrm{r}$.

Juan de Villasaña: 166r.

Juan de Villegas: 70v.

Juan de Villoldo: 193r; fraile: 49v, 50r, $371 \mathrm{v}$.

Juan de Virtus: $125 \mathrm{r}$.

Juan de Vivero: 102v, 103r.

Juan de Vozmediano: 279v, 280r, 280v, $383 \mathrm{v}, 384 \mathrm{r}, 384 \mathrm{v}, 385 \mathrm{r}$.

Juan de Zamora Cabreros: 281r.

Juan del Campo: 453v.

Juan del Casar: 373r, 373v.

Juan del Río: 72 r.

Juan Delgado: 94r, 333r, 333v, 399r, 362v.

Juan Delgado Terán: 406r.
Juan Dent: 162r.

Juan Díaz: 32r, 61v, 62r, 172v, 186r, 394v, $402 \mathrm{v}, 402 \mathrm{v}, 404 \mathrm{r}, 447 \mathrm{v}$; fraile: 36v, 39r, $152 \mathrm{v} 282 \mathrm{r}, 447 \mathrm{v}$.

Juan Díaz de Miranda: 36v, 128r, 128v.

Juan Díaz Mercader: 154v.

Juan Díez: 169v, 295v, 315v, 440v; fraile:

76v, 257r, 257v.

Juan Díez Pajaza: 169v.

Juan Domingo Espínola: 342v.

Juan Domínguez: 351r, 351v.

Juan Doncel: 464r.

Juan Enero: 295v, 296r.

Juan Enríquez, 332r; fraile: 331v.

Juan Enríquez de Cisneros: 372r.

Juan Enríquez de la Vega: 432v.

Juan Escobedo: 420r.

Juan Escudero: 76v.

Juan Esteban: 230r, 230v, 231r.

Juan Esteban de Salamanca: 231v, 232r, $232 \mathrm{v}, 233 \mathrm{r}, 233 \mathrm{v}$.

Juan Facón: 399v, 401r.

Juan Fernández: 3r, 18r, 23v, 28v, 39v, 40r, $41 \mathrm{v}, 42 \mathrm{r}, 43 \mathrm{r}, 43 \mathrm{v}, 44 \mathrm{r}, 44 \mathrm{v}, 48 \mathrm{v}, 59 \mathrm{r}, 62 \mathrm{v}$, $74 \mathrm{r}, 75 \mathrm{v}, 144 \mathrm{v}, 145 \mathrm{r}, 145 \mathrm{v}, 149 \mathrm{r}, 163 \mathrm{r}$, $163 \mathrm{v}, 164 \mathrm{r}, 174 \mathrm{r}, 174 \mathrm{v}, 181 \mathrm{r}, 190 \mathrm{r}, 192 \mathrm{r}$, $193 \mathrm{v}, 219 \mathrm{r}, 225 \mathrm{v}, 226 \mathrm{r}, 226 \mathrm{v}, 227 \mathrm{r}, 227 \mathrm{v}$, $229 \mathrm{v}, 233 \mathrm{r}, 261 \mathrm{v}, 262 \mathrm{r}, 264 \mathrm{v}, 265 \mathrm{r}, 265 \mathrm{v}$, $271 \mathrm{r}, 302 \mathrm{v}, 311 \mathrm{r}, 311 \mathrm{v}, 327 \mathrm{r}, 328 \mathrm{v}, 349 \mathrm{v}$, $375 \mathrm{r}, 402 \mathrm{v}, 403 \mathrm{r}, 410 \mathrm{v}, 417 \mathrm{v}, 418 \mathrm{r}, 422 \mathrm{r}$, $430 \mathrm{v}, 431 \mathrm{r}, 431 \mathrm{v}, 432 \mathrm{r}, 433 \mathrm{v}, 441 \mathrm{v}, 449 \mathrm{v}$; fraile: $218 \mathrm{v}, 300 \mathrm{v}$.

Juan Fernández Barba: 229v.

Juan Fernández Benito: 145r, $145 \mathrm{v}$.

Juan Fernández Blanco: 164r.

Juan Fernández Cobo: 328v.

Juan Fernández de Castro: 226v, 227r.

Juan Fernández de Cevallos: 39v, 40r.

Juan Fernández de Hinestrosa: 226v, 227 r.

Juan Fernández de Ladreda: 48v, 311r, $311 \mathrm{v}$.

Juan Fernández de Padilla: 225v, 226r, 226v, 233r.

Juan Fernández de Porras: 410v.

Juan Fernández de Quintanilla: 174r.

Juan Fernández de Relea: 74r, 163r.

Juan Fernández de Ríosmenudos: 441v.

Juan Fernández de Temiño: 69r.

Juan Fernández de Toledo: 75v.

Juan Fernández de Varines: 181r.

Juan Fernández de Vega: 18r, 28v, 302v. 
Juan Fernández de Villohetes: 193v. Juan Fernández del Campo: 218v, 219r. Juan Fernández del Palomar: 417v, 418r, 422r.

Juan Fernández del Palomar: 422r. Juan Fernández Jacob: 174v. Juan Fernández Medina: 327r. Juan Fernández Relea: 144v, 271r. Juan Fernández Rodríguez: 3r, 23v. Juan Ferrero: 187v, 372r.

Juan Fraile: $175 \mathrm{v}$.

Juan Francés Bravo: 462v.

Juan Francisco: 87v, 178r, 449v.

Juan Francisco de Uguccioni: 85v, 86r, $86 \mathrm{v}, 87 \mathrm{r}$.

Juan Francisco Maldonado: 178r.

Juan Francisco Martínez: 48v, 49r.

Juan Freile: 2v, 27 r.

Juan Galarán: 100r.

Juan Galiano: 187v.

Juan Galindo: 143r, 143v.

Juan Gallo de Andrada: 19r, 204v.

Juan García: 3r, 3v, 67r, 68v, 78v, 164v, $165 \mathrm{r}, 175 \mathrm{v}, 187 \mathrm{v}, 192 \mathrm{r}, 226 \mathrm{r}, 237 \mathrm{v}, 238 \mathrm{r}$, $238 \mathrm{v}, 260 \mathrm{v}, 266 \mathrm{v}, 272 \mathrm{r}, 288 \mathrm{r}, 288 \mathrm{v}, 302 \mathrm{v}$, $321 \mathrm{v}, 404 \mathrm{v}, 410 \mathrm{v}, 423 \mathrm{v}, 430 \mathrm{r}$.

Juan García de Antezo: 78v.

Juan García de Brizuela: 302v.

Juan García de la Rúa: 164v, 165 r.

Juan García de la Serna: 175v.

Juan García de Olmillos: 404v.

Juan García Manrique: 226r.

Juan García Millino: 266v.

Juan García Población: 288r, 288v.

Juan Garrote: 366v, 367r.

Juan Gavera de Gudina: 309v.

Juan Germán: 82r, 230r, 230v, 231 r.

Juan Gómez: 143r.

Juan Gómez de la Quintana: 460v.

Juan Gómez de la Torre: 406r.

Juan Gómez de Valderrábano: 335r.

Juan González: 3r, 14r, 14v, 59r, 70r, 82r, $82 \mathrm{v}, 131 \mathrm{v}, 149 \mathrm{r}, 156 \mathrm{r}, 175 \mathrm{v}, 181 \mathrm{v}, 259 \mathrm{v}$, $269 \mathrm{v}, 311 \mathrm{v}, 350 \mathrm{r}, 360 \mathrm{r}, 360 \mathrm{v}, 364 \mathrm{v}, 374 \mathrm{r}$, $374 \mathrm{v}, 391 \mathrm{r}, 441 \mathrm{v}, 467 \mathrm{v}$; fraile: $60 \mathrm{r}, 69 \mathrm{v}$, 124r, 209r, 223v, 278r, 304r, 380v, 432r.

Juan González Catalán: 149r, 156r, 175v.

Juan González de Amusco: 82r, 82v.

Juan González de Armentero: 331v.

Juan González de Castellanos: 131v.

Juan González de la Cuesta: 441v.
Juan González de Lucas: 3r.

Juan González de Mental: 374r, 374v.

Juan González de Rabanal: 14r, 14v, 59r.

Juan González de Robles: 350r.

Juan González de Villalbeto: 259v.

Juan González Patudo: 360r, 360v, 364v.

Juan Gonzalo Deza: 205r.

Juan Gregorio: 436r, 436v.

Juan Gutiérrez: 32v, 34r, 38v, 64v, 72r, 208v, 213v, 372r, 372v, 409v, 428v, 465v.

Juan Gutiérrez Campuza: 32v.

Juan Gutiérrez de Santibáñez: 64v.

Juan Gutiérrez de Villanueva: 72r.

Juan Gutiérrez Seguro: 465v.

Juan Guzmán y Santoyo: 135r; fraile: 330v.

Juan Herrero: 252v, 296v.

Juan Hurtado: 244v, 245r.

Juan I: 34r, 34v, 91v, 92r, 227r, 227v, 131v, $132 \mathrm{r}$.

Juan Ibáñez: 109r, 329r.

Juan Isidro: $2 \mathrm{v}$.

Juan Jacob: $173 \mathrm{v}$.

Juan José Calderón: 97r.

Juan José Fernández de Vallejo: 298r, $298 \mathrm{v}$.

Juan Laso: 33r, 33v, 154r, 196v, 197r, $197 \mathrm{v}, 198 \mathrm{r}, 201 \mathrm{v}, 216 \mathrm{r}, 216 \mathrm{v}$.

Juan López: 4v, 5r, 5v, 275v, 302r, 359v.

Juan López de Ventosinos Gavoso: 275v.

Juan López Moro: 148v, 150v.

Juan Lorenzo Rallol: 331v, 332r.

Juan Lorenzo: $191 \mathrm{v}$.

Juan Lubiano: 450v.

Juan Luengo: 394r.

Juan Luis: 245 r.

Juan Luis González: 409r.

Juan Luis y Catalina: 293r.

Juan Mache: 97v, 98r.

Juan Macho: 321v, 349v.

Juan Magarzo: 2v, 10r, 10v.

Juan Magdaleno, 208r, 208v.

Juan Manrique: 256v, 257r, 405v.

Juan Manso Santos de Risoba: 437r.

Juan Manuel Martínez: 401v.

Juan Marcos: 257r.

Juan Marín: 198v.

Juan Martín: 2r, 33r, 33v, 45v, 47v, 82r, 104r, 149r, 151v, 154r, 158r, 162v, 165v, $175 \mathrm{v}, 192 \mathrm{r}, 218 \mathrm{v}, 228 \mathrm{r}, 235 \mathrm{r}, 235 \mathrm{v}, 236 \mathrm{r}$, $264 \mathrm{v}, 265 \mathrm{r}, 265 \mathrm{v}, 286 \mathrm{r}, 286 \mathrm{v}, 309 \mathrm{r}, 218 \mathrm{v}$, 
$325 \mathrm{v}, 326 \mathrm{r}, 326 \mathrm{v}, 331 \mathrm{r}, 362 \mathrm{v}, 412 \mathrm{r}, 440 \mathrm{v}$, $457 \mathrm{r}, 457 \mathrm{v}, 466 \mathrm{r}$.

Juan Martín de Villanueba del Río: 165v. Juan Martín Rojo: 466r.

Juan Martínez: 2r, 33r, 33v, 45v, 47v, 82r, $104 \mathrm{r}, 149 \mathrm{r}, 151 \mathrm{v}, 154 \mathrm{r}, 158 \mathrm{r}, 162 \mathrm{v}, 175 \mathrm{v}$, 192r, 228r, 235r, 235v, 236r, 325v, 326r, $326 \mathrm{v}, 331 \mathrm{r}, 440 \mathrm{v}, 457 \mathrm{r}, 457 \mathrm{v}$.

Juan Martínez Alcalde: 192r.

Juan Martínez Cadón: 440v.

Juan Martínez Calabaza: 228r.

Juan Martínez de Burgos: 235r, 235v.

Juan Martínez de Carrión: 33r, 33v, 104r, 149r, 158r.

Juan Martínez de Castro: 235r, 235v, 236r, 325v, 326r, 326v.

Juan Martínez de Muñeca: 45v.

Juan Martínez de Ocón: 47v, 331r.

Juan Mayor: 50r, 316r.

Juan Mayordomo: 50r.

Juan Merino: 265v, 275r, 351r, 422v, 428v. Juan Merlín: 147r, 149r, 149v, 163v, 405r.

Juan Merlín el Mozo: 149r, 149v.

Juan Monte: 239r, 316r.

Juan Moral de la Guerra: 39r.

Juan Morán de Castañeda: 10r.

Juan Moreno: 266r, 266v.

Juan Moreno de Bedoya: 266r, 266v.

Juan Moro Pérez: 463r.

Juan Muñiz: 397v.

Juan Nieto de Villaviudas: 204v, 205v.

Juan Ochoa de Marquina: 339r, 339v, 340r, 340v, 341r.

Juan Olgado: 399v.

Juan Ordóñez: 36r.

Juan Orejón: 44v.

Juan Ortega: 143v.

Juan Pachistre: 405v.

Juan Palomino: 197r.

Juan Pando: 158v.

Juan Pardillo: 193r.

Juan Pastor el Mozo: 193r, 193v.

Juan Pedrejon: 465r.

Juan Pérez: 39r, 45v, 56v, 67r, 130r, 185v, 199r, 209r, 246r, 259v, 263r, 264v, 265r,

$265 \mathrm{v}, 273 \mathrm{r}, 280 \mathrm{v}, 281 \mathrm{r}, 286 \mathrm{r}, 286 \mathrm{v}, 315 \mathrm{v}$,

328r, 364v, 365r, 366v, 367r, 367v, 368r, 436r, 436v, 460r, 466r; mujer de: 315v.

Juan Pérez Calahorra: 130r.

Juan Pérez de Grado: 280v, 281r.

Juan Pérez de la Calva: 466r.
Juan Pérez de la Torre de Pisón: 264v, 265r, 265v.

Juan Pérez de Lalastra: 185v.

Juan Pérez de Santillana: 246r.

Juan Pérez de Villameriel: 364v, 365r.

Juan Pérez el Viejo: 199r.

Juan Pérez Vicente: 460r.

Juan Pita de Andrade: 376r, 376v, 380r.

Juan Ponce: 425r, 192v.

Juan Preciado: 460v.

Juan Prieto, 459v, 337r.

Juan Puente: 317 r.

Juan Rabanal: 63v.

Juan Racho: $187 \mathrm{v}$.

Juan Ramírez: 59r, 89v, 328v, 415r, 419r.

Juan Ramírez Freile y Arellano: 89v.

Juan Ramos: 409r.

Juan Rascón: 192r.

Juan Rasillo: 287r.

Juan Ratingh de Holsten: 14r.

Juan Recio de la Vega: 47v.

Juan Redondo: 193r, 352r.

Juan Redondo de Reoyo: 193v, 198r, 198v, 199r, 199v, 203r, 204v, 208r, 208v, 221r.

Juan Reinoso: $156 \mathrm{v}$.

Juan Relea: 412r.

Juan Remón: 143r, 143v.

Juan Rey: 156v, 169v; fraile: 420r.

Juan Rodrigo: 45v, 63v, 385r, 385v, 386r, 386v, 387r, 402v, 403r.

Juan Rodrigo de Villaverde: $45 \mathrm{v}$.

Juan Rodríguez: 3r, 3v, 4r, 36r, 46r, 46v, 70v, 71r, 86r, 105r, 105v, 124r, 133v, 134r, 185r, 207r, 221v, 222r, 230r, 230v, 231r, $231 \mathrm{v}, 232 \mathrm{r}, 232 \mathrm{v}, 233 \mathrm{r}, 233 \mathrm{v}, 236 \mathrm{v}, 237 \mathrm{r}$, 295r, 329r, 336r, 338r, 360v, 361r, 361v, 362r, 365r, 365v, 368r, 373r, 373v, 414r, $415 \mathrm{r}, 418 \mathrm{v}, 425 \mathrm{r}, 436 \mathrm{r}, 440 \mathrm{v}, 462 \mathrm{v}$.

Juan Rodríguez Bachiller: 230r, 230v, 231 r.

Juan Rodríguez Bocos: 200v.

Juan Rodríguez de Burgos: 231v, 232r, $232 \mathrm{v}, 233 \mathrm{r}, 233 \mathrm{v}$.

Juan Rodríguez de Castañeda: 124r, 133v, $134 r$.

Juan Rodríguez de Castro: 236v, 237r.

Juan Rodríguez de Fonseca: 70v, 71r, 86r, 105r, 105v, 207r, 329r, 414r, 415r, 436r.

Juan Rodríguez de Medina: 361r, 361v, 362r.

Juan Rodríguez de Santa Cruz: 36r, 295 r. 
Juan Rodríguez de Toro: 338r.

Juan Rodríguez de Torre: 360v, 365r, $365 \mathrm{v}$.

Juan Rodríguez de Valderrábano: 336r.

Juan Rodríguez Escudero: 4r.

Juan Rodríguez Mayo: 185r.

Juan Rodríguez Santa Cruz: 36r.

Juan Rojo de Salinas: 252v.

Juan Roldán: 423v.

Juan Román, fraile: 428r.

Juan Ruiz: 47v, 152r, 274r, 275v, 307v, $328 \mathrm{v}$.

Juan Ruiz de Colmenares: 274r.

Juan Ruiz de Fonseca: 328v.

Juan Ruiz Infante: $129 \mathrm{v}, 130 \mathrm{r}$.

Juan Sánchez: 92r, 103v, 104r, 137r, 149r, 157r, 177r, 208v, 231v, 338r, 413v, 414r, $419 \mathrm{r}, 419 \mathrm{v}, 422 \mathrm{r}$.

Juan Sánchez Armero: 157r.

Juan Sánchez Cantalapiedra: 338r.

Juan Sánchez de Castromocho: 177r.

Juan Sánchez de Valladolid: 413v, 414r.

Juan Santos: 199v, 200r.

Juan Sierra: 180v.

Juan Soto Velasco: 280r, 280v, 281r, 281v.

Juan Tagarro: 417v, 418r.

Juan Tejedor: 422r.

Juan Téllez: 169v, 170r, 170v.

Juan Terrías: $372 \mathrm{v}$.

Juan Tomillo: $368 \mathrm{v}$.

Juan Treviño: 278v.

Juan Vaca: 178v; fraile: 36r, 206v, 219v, 296v, 297r.

Juan Valiar de Vico: 13v.

Juan Valle: 61v, 62r, 269r.

Juan Vélez: 31 r.

Juan Vinagrero: 366v, 367r.

Juana: 5v, 77v, 78r, 84v, 85r, 144v, 155r, 196r, 196v, 206r, 225v, 226r, 235v, 236r, $259 \mathrm{v}, 263 \mathrm{r}, 263 \mathrm{v}, 293 \mathrm{r}, 293 \mathrm{v}, 315 \mathrm{r}, 316 \mathrm{r}$, 344r, 362r, 371r, 373r, 373v, 400v, 412r, 414r, 415r, 415v, 416r, 419r, 422r, 454r, $454 \mathrm{v}, 455 \mathrm{r}$; reina: $455 \mathrm{v}$.

Juana I: 315r, 344r, 362r, 400v, 454r, 454v, $455 \mathrm{r}, 455 \mathrm{v}$.

Juana de Menoyo y Murga: 155r.

Juana de Mier: 77v, 78r.

Juana Enríquez de la Vega: 263, 263v, 290r, 290v, 302r.

Juana Fernández: 373r, 373v.

Juana Gómez: 259v.
Juana Magarzo: 5v.

Juana Rodríguez: $144 \mathrm{v}$.

Juana Sánchez la Roja: 422r.

Juana, infanta: 225v, 226r.

Julián Abastas: 460r.

Julián Antón: 422.

Julián Baillo: 167v.

Julián Martínez de Cortes: $84 \mathrm{v}$.

Julián Ortiz: 436r, 436v.

Juliana: 13r, 13v, 354r, 441v.

Juliana Gutiérrez: 354r.

Julio II: 70v, 84r, 84v, 85r, 113v, 127r, $127 \mathrm{v}, 244 \mathrm{v}, 245 \mathrm{r}$; juez apostólico de: $70 \mathrm{v}$.

Justa: 434r, 434v.

Justo de San Sebastián: 436r.

Justo González: 185r.

La Herrada, comendador de, provisor de Palencia: 220r.

Las Heras, vecino: 261v, 262r, 319v.

Lázaro de los Ríos Angulo: 274v.

Lázaro de Montoya: 178r, 200r, 437r.

Lázaro de Ríos Angulo: 380v.

Lázaro Gutiérrez: 8r, 368r, 369r.

Lázaro Juárez: 5 r.

Lázaro Montoya: 39v.

Leandro Caballero, fraile: $137 \mathrm{r}$.

Leandro de la Madrid, fraile: 200r, 209r.

Leandro Díaz, fraile: 400r.

Leandro Pérez, 178v, 437v; fraile: 38r, 40r, $44 \mathrm{v}, 49 \mathrm{r}, 101 \mathrm{v}, 210 \mathrm{v}, 298 \mathrm{v}, 299 \mathrm{r}, 406 \mathrm{r}$, $406 \mathrm{v}, 437 \mathrm{v}$.

León Vistorio Vázquez: 430v, 431r.

León: 404v, 408r; escribano y notario:

220v; juez sinodal: 221v; juez comisionado: $280 \mathrm{r}, 280 \mathrm{v}$; provisor de: $17 \mathrm{r}$, $17 \mathrm{v}, 18 \mathrm{r}, 18 \mathrm{v}, 20 \mathrm{v}, 21 \mathrm{v}, 23 \mathrm{r}, 27 \mathrm{v}, 60 \mathrm{v}, 69 \mathrm{r}$, $269 \mathrm{v}, 280 \mathrm{r}, 280 \mathrm{v}, 310 \mathrm{r}, 393 \mathrm{v}, 425 \mathrm{r}, 425 \mathrm{v}$, 428r, 431r; visitador: 310r.

León X: 21r, 21v, 70v, 190v.

Leonardo de Quevedo: 75r.

Leonardo López: 268v, 282r, 282v.

Leonardo Macho: 261r, 261v.

Leonardo Salinas: 279r.

Leonel de Abreu y Acebedo, 185r, 267r, $267 \mathrm{v}$.

Leonor: 3r, 141r, 141v, 151v, 172r, 175v, 226r, 244v, 245r, 255v, 256r, 359r, 359v, 368r, 368v; reina: 283v, 284r, 444r, 444v; reina: $88 \mathrm{r}, 283 \mathrm{v}, 284 \mathrm{r}, 344 \mathrm{r}, 415 \mathrm{r}$. 
Leonor de la Vega: 255v, 256r; criado de: $255 \mathrm{v}, 256 \mathrm{r}$.

Leonor de Prado: 368r, 368v.

Leonor de Quiñones: 141r, 141v.

Leonor de Velasco: 244v, $245 \mathrm{r}$.

Leonor González: 3r.

Leonor Rodríguez: 151v.

Leonor Ruiz de Reinoso: $175 \mathrm{v}$.

Lezana: $141 \mathrm{r}, 274 \mathrm{v}, 420 \mathrm{v}$.

Liciano Sáez, fraile: $251 \mathrm{v}$.

Licinio: 312r, 312v.

Llanos: 6v, $11 \mathrm{v}, 12 \mathrm{r}, 55 \mathrm{r}, 55 \mathrm{v}, 62 \mathrm{v}, 98 \mathrm{r}$, $125 \mathrm{r}, 131 \mathrm{v}, 144 \mathrm{r}, 144 \mathrm{v}, 145 \mathrm{r}, 148 \mathrm{v}, 149 \mathrm{r}$, $149 \mathrm{v}, 150 \mathrm{r}, 157 \mathrm{r}, 157 \mathrm{v}, 162 \mathrm{v}, 163 \mathrm{r}, 163 \mathrm{v}$, 164r, 169r, 175r, 181v, 192r, 192v, 216r, 345r, 360r, 364v, 412r, 440v.

Loba, mujer de Morán Anáyez: 71r.

Lope: 177 r.

Lope Castañón: 14v, 15r, 15v, 16r, 20v, $184 \mathrm{r}, 184 \mathrm{v}$.

Lope Conchillos: 84v.

Lope de Abeja: 151r.

Lope de Allende: 218v, 219r.

Lope de Ávila: 149r, 158r, 165 r.

Lope de Guadalajara: 151r, 151v.

Lope de Valderas: 2r, 3r, 3v, 4r, 14v

Lope Fernández de Castroverde: 228r, 228v, 229r.

Lope Ras: $165 \mathrm{v}$.

Lope Rufiano: $167 \mathrm{v}$.

López Fernández de Castroverde: 229r.

Lorenza: $31 \mathrm{v}$.

Lorenza de Comillas: 31v.

Lorenza de Vega: 187r.

Lorenzo: 190r.

Lorenzo Bernardo Pereira: 296v.

Lorenzo Campeje: 135r.

Lorenzo Chico: 210r.

Lorenzo de la Calva: 465r.

Lorenzo de la Vega: 458v, 300v, 308v, 309r.

Lorenzo de las Heras: 352r.

Lorenzo de Modoya, fraile: 200r, 202v, 216v, 293v, 316r, 428v.

Lorenzo de Valdés: 218v.

Lorenzo de Villovieco: 172v.

Lorenzo Fernández Pereira de Ocampo:

$209 \mathrm{v}, 210 \mathrm{r}$.

Lorenzo García: 400v, 401r.

Lorenzo García de Miranda: 437v.

Lorenzo Iturruzarra: 282r.
Lorenzo Jinete: $465 \mathrm{v}$.

Lorenzo López: $167 \mathrm{v}$.

Lorenzo Luis: $261 \mathrm{r}$.

Lorenzo Melendro: 36v, 37r, 41v.

Lorenzo Montero de Castañeda: 26r.

Lorenzo Moratinos Garzón: 305r, 305v.

Lorenzo Pérez: 409v.

Lorenzo Ruiz: 323v.

Lorenzo Salgado: 395v.

Lucas Antón: 79r, 459v.

Lucas de la Fuente: 193v.

Lucas de Santiago: 3r.

Lucas Díez Paniagua: 42r, 42v, 437r.

Lucas Gallardo: 43v, 44r, 117v, 121r, 139r, $177 \mathrm{v}, 198 \mathrm{v}, 199 \mathrm{r}, 199 \mathrm{v}, 204 \mathrm{r}, 204 \mathrm{v}, 205 \mathrm{r}$, $208 \mathrm{r}, 208 \mathrm{v}, 212 \mathrm{v}, 213 \mathrm{v}, 219 \mathrm{r}, 219 \mathrm{v}, 222 \mathrm{r}$, 436r, 436v, 448r.

Lucas Muñiz de Castro: 194r.

Lucas Sánchez de Fontecha: 276r.

Lucía de Mediavilla: 156v.

Lucía de Poza: 459v.

Lucía de Villamediana: 156v.

Lugo, provisor de: $181 \mathrm{r}$.

Luis: 243r, 328v, 339r, 339v, 340r, 340v, $341 \mathrm{r}, 369 \mathrm{v}, 418 \mathrm{v}, 419 \mathrm{r}, 434 \mathrm{v}, 435 \mathrm{v}, 436 \mathrm{r}$, 437r, 455r.

Luis Cabeza de Vaca: 217r.

Luis de Ayala: 342v.

Luis de Benavides: 193r, 246r, 248v, 249r.

Luis de Calatayud, fraile: $17 \mathrm{r}, 21 \mathrm{r}$; fraile, ministro de la Trinidad de Valladolid: $21 \mathrm{r}$. Luis de García: 239r.

Luis de Lucerna: $127 \mathrm{r}$.

Luis de Miranda: 202r.

Luis de Orduña: 214r.

Luis de Revenga: 39r, 43v, 44r, 213v.

Luis de Salazar: 467v.

Luis de Varguilla: 339r, 339v, 340r, 340v, $341 \mathrm{r}$.

Luis de Velasco y Fajardo: 132r.

Luis Díaz de la Rocha: 60r.

Luis Díaz de León: 39v, 437r.

Luis Fernández de Carrión: 400v.

Luis Fernández: 99r, 145v, 249r, 249v, $364 \mathrm{v}, 365 \mathrm{v}, 400 \mathrm{v}$.

Luis Fernández Manrique: 84v.

Luis Gallardo: 405v.

Luis González: 226v, 368r, 409r.

Luis Hurtado, hermano de: 243 r.

Luis Hurtado de Mendoza: 8v, 28r, 47v, $59 \mathrm{r}, 70 \mathrm{v}, 93 \mathrm{r}, 93 \mathrm{v}, 127 \mathrm{r}, 127 \mathrm{v}, 128 \mathrm{r}, 154 \mathrm{v}$, 
$207 \mathrm{r}, 207 \mathrm{v}, 242 \mathrm{v}, 243 \mathrm{r}, 243 \mathrm{v}, 244 \mathrm{r}, 269 \mathrm{v}$, 270r, 328v, 418v, 419r, 328v, 418v, 419r, $434 \mathrm{v}, 455 \mathrm{r}$.

Luis Niño: 17r, 20v, 21r, 222r.

Luis Núñez: 252v.

Luis Palencia, fraile: $49 \mathrm{r}$.

Luis Pastor: 36v.

Luis Pernía: 369v.

Luis Salazar: 5 r.

Luis Sánchez de Agüero: 428v.

Luis Sánchez de Aranda: 235r, 235v, 236r.

Luis Vázquez: 398r, 401r.

Luisa: 121r, 121v.

Luisa de Saldaña: $167 \mathrm{r}$.

Lutracia: $182 \mathrm{v}$.

Magdalena de Ulloa: 400v, 401r.

Magdalena Perales: 465r.

Magdalena Pérez: 261r, 261v.

Mahoma Jinete, moro: $165 \mathrm{r}$.

Mahomat Abe Nazar: 444r.

Manuel Antonio Giménez Bretón: 297r.

Manuel Blas: 406r.

Manuel Calvo: 202r, 210r.

Manuel Cantero Romo: 159v.

Manuel Carpintero y Eraso: 160r.

Manuel Carrillo: 159r.

Manuel Casado Plaza: 201v.

Manuel Castellanos: 11v, 12r.

Manuel de Castañeda: 167r.

Manuel de Escandón: 323v.

Manuel de la Calva: 464v.

Manuel de la Cruz: 304v.

Manuel de la Cuesta: 464r.

Manuel de la Fuente: 333r, 333v.

Manuel de la Vega: 31r, 56r, 56v.

Manuel de las Bárcenas: 178v.

Manuel de Lemos, fraile: 250r.

Manuel de Lomas: 194r.

Manuel de Loya: 369v.

Manuel de Orejón: 90r, 306r, 306v.

Manuel de Torres Hernández: 466r.

Manuel de Viciosa: 450v.

Manuel de Villacorta: 442r.

Manuel de Villarroel: 6r.

Manuel de Villaverde: 185r.

Manuel de Villegas: 46v, 48r.

Manuel de Yllera: 438v.

Manuel del Prado: 336v.

Manuel Díez: 351v, 432r, 462r.

Manuel Díez Aparicio: 462r.
Manuel Díez Vargas: 432r.

Manuel Francisco Blanco: 101r, 114v, $115 \mathrm{r}, 141 \mathrm{v}, 153 \mathrm{r}, 158 \mathrm{r}, 159 \mathrm{v}, 160 \mathrm{r}, 450 \mathrm{v}$, 460r, 461r, 462v, 468v.

Manuel García: 58r, 199r, 199v, 208v, $261 \mathrm{r}, 261 \mathrm{v}, 262 \mathrm{r}, 305 \mathrm{r}, 309 \mathrm{v}, 324 \mathrm{v}, 352 \mathrm{r}$, 405v, 406r, 436r, 436v, 461r.

Manuel García de Guadiana: 324v, 352r.

Manuel García de Miranda: 199r, 199v, 208v, 405v, 406r, 436r, 436v.

Manuel García Ramos: 58r, 261r, 261v, $305 r$.

Manuel Gómez Serrano: 278v.

Manuel González Benito: 37v.

Manuel González de Villegas: 146r, 146v.

Manuel Gregorio: 319r, 319v, 320r, 461v.

Manuel Gutiérrez: 336r.

Manuel Hortega Álvarez: 77v, 78r.

Manuel Ibáñez: 70r.

Manuel Izquierdo: 106r.

Manuel José de Santa María: 276r.

Manuel López: 135r, 406r.

Manuel López del Molino: 135r.

Manuel Lorenzo: 409v.

Manuel Luis de Vitoria: 96v, 97r.

Manuel Luis Díez: 261v.

Manuel Luis París: 261r, 261v, 262r, 282r, $282 \mathrm{v}, 286 \mathrm{v}, 293 \mathrm{v}, 294 \mathrm{r}, 300 \mathrm{v}, 309 \mathrm{r}, 309 \mathrm{v}$, 319r, 319v, 320r, 324r, 324v, 325r, 332r, 351r, 375r, 409r, 409v, 427v, 461r, 461v.

Manuel Luis París: 324v, 325r.

Manuel Luis Villalba: 409v.

Manuel Macho: 261r, 261v.

Manuel María Cambronero: 77v, 78r.

Manuel María de Junco: 77v, 78r.

Manuel Martín de Pedrosa: 309v.

Manuel Martínez Merino: 214v.

Manuel Morante Díez: 466r.

Manuel Moro: 284v.

Manuel Olivares Fernández: 466r.

Manuel Ordóñez: 178v, 210r; fraile: 278v, 297r, 401v, 406r, 210r.

Manuel París: $187 \mathrm{r}$.

Manuel Pedrejón de San Juan: 463v, 465v, 466v.

Manuel Pérez: 5v, 60v, 159r, 424r.

Manuel Pérez de la Vega: 60v.

Manuel Pérez Ruiz: 159r.

Manuel Prieto: 424r.

Manuel Rabanal: 262r.

Manuel Rebolledo, 202r. 
Manuel Rodríguez, 30r, 279r.

Manuel Rubín de Celis: 178v, 287v, 288r.

Manuel Santos Aparicio: 251v.

Manuel Sebastián de Cevallos: 5v.

Manuel Sebastián de San Andrés Cevallos:

6r.

Manuel Torices: 6r.

Manuel Trancho: 465r.

Manuel Valle: 203r, 269r, 336v.

Manuel Vallejo: 203r, 336v.

Manuel Vallejo Revilla: 203r.

Manuel Villalba Mental: 324r.

Manuela Arenillas: 465r.

Manuela Luis: 409v.

Manuela Malanda Gómez: 464v.

Manuela Martínez: 466v.

Manuela Negrete Gallego: 463v.

Marcelino Nieto: 283r.

Marcelo Tomé: 356v.

Marcos Cardenal: 285r.

Marcos de la Cava: 448r.

Marcos de la Fuente: 200r, 200v.

Marcos de la Vega: 51r, 218v, 303v, 309r, 318r, 323v, 375r, 391r, 391v, 431v.

Marcos de Prado y Velasco: 169v.

Marcos Díaz: 69v.

Marcos Díez: 406r.

Marcos Fernández: 399v.

Marcos Pérez: 405v, 406r.

Marcos Rodríguez: 354r.

Marcos Ruiz: 37r, 37v, 106r, 251r

María: 2r, 3r, 3v, 4r, 4v, 5r, 5v, 30v, 31r, $31 \mathrm{v}, 39 \mathrm{r}, 43 \mathrm{v}, 45 \mathrm{r}, 61 \mathrm{v}, 62 \mathrm{r}, 64 \mathrm{r}, 64 \mathrm{v}, 65 \mathrm{r}$, $68 \mathrm{r}, 69 \mathrm{r}, 77 \mathrm{v}, 78 \mathrm{r}, 83 \mathrm{r}, 88 \mathrm{v}, 94 \mathrm{v}, 135 \mathrm{v}$, $144 \mathrm{r}, 144 \mathrm{v}, 145 \mathrm{v}, 146 \mathrm{r}, 146 \mathrm{v}, 150 \mathrm{r}, 151 \mathrm{r}$, $151 \mathrm{v}, 154 \mathrm{r}, 154 \mathrm{v}, 157 \mathrm{v}, 159 \mathrm{r}, 162 \mathrm{r}, 165 \mathrm{r}$, $165 \mathrm{v}, 167 \mathrm{v}, 169 \mathrm{v}, 172 \mathrm{r}, 172 \mathrm{v}, 175 \mathrm{r}, 191 \mathrm{v}$, 194v, 196r, 198r, 200r, 203v, 206r, 206v, $229 \mathrm{v}, 233 \mathrm{r}, 234 \mathrm{r}, 234 \mathrm{v}, 235 \mathrm{r}, 235 \mathrm{v}, 236 \mathrm{r}$, $236 \mathrm{v}, 237 \mathrm{r}, 237 \mathrm{v}, 238 \mathrm{r}, 238 \mathrm{v}, 239 \mathrm{r}, 239 \mathrm{v}$, $240 \mathrm{r}, 240 \mathrm{v}, 241 \mathrm{r}, 241 \mathrm{v}, 242 \mathrm{r}, 245 \mathrm{r}, 245 \mathrm{v}$, 246r, 259r, 259v, 263v, 273v, 276r, 279r, 285r, 293v, 294r, 301v, 308r, 218v, 319v, $321 \mathrm{v}, 328 \mathrm{r}, 333 \mathrm{r}, 333 \mathrm{v}, 336 \mathrm{v}, 345 \mathrm{r}, 345 \mathrm{v}$, 346r, 350r, 355r, 363r, 363v, 364v, 365v, $366 \mathrm{v}, 367 \mathrm{v}, 368 \mathrm{r}, 371 \mathrm{v}, 372 \mathrm{v}, 374 \mathrm{v}, 383 \mathrm{v}$, $384 \mathrm{r}, 384 \mathrm{v}, 385 \mathrm{r}, 397 \mathrm{v}, 403 \mathrm{r}, 403 \mathrm{v}, 404 \mathrm{v}$, $405 \mathrm{r}, 405 \mathrm{v}, 408 \mathrm{v}, 409 \mathrm{v}, 410 \mathrm{v}, 411 \mathrm{r}, 413 \mathrm{r}$, $413 \mathrm{v}, 422 \mathrm{r}, 423 \mathrm{v}, 427 \mathrm{v}, 428 \mathrm{r}, 428 \mathrm{v}, 434 \mathrm{v}$, $441 \mathrm{v}, 445 \mathrm{r}, 459 \mathrm{v}, 460 \mathrm{r}, 460 \mathrm{v}, 464 \mathrm{v}, 465 \mathrm{r}$, 465v, 466r, 466v, 467v; mujer de Pedro Valle: 313v, 314r; reina: 229v.

María Alonso: 150r, 336v, 404v, 405r.

María Ana Fontán: 460r.

María Antón: 355r.

María Aparicio: 279r, 427v.

María Armia: 2v.

María Bores: 293v, 294r.

María Buesa: 166r.

María Cárdenas: 367v.

María Castán: 68r.

María Cídez: 45r.

María Cordero: 263v.

María de Almenara: 172v.

María de Castilla: 365v.

María de Castro: 157v.

María de Cisneros: 460v.

María de Guardo: 61v, 62r, 64r, 65r; viuda de Antón Martínez: 64v.

María de la Cruz: 169v.

María de la Serna: 151r.

María de Lombraña: 169v.

María de Lotaringia: 146v.

María de Lózar: 3r, 3v, 5r.

María de Miranda: 194v.

María de Prado: 368r.

María de Setén: 159r.

María de Villanueva Guzón: 465v.

María del Brezo: 146r.

María del Castillo: 467v.

María del Peral, mujer de Toribio Pérez: $371 v$.

María del Valle: 218v.

María Díaz: 45r, 321v.

María Díez: 459v.

María Domínguez: 366v.

María Dorado: 68r.

María Escudero: 4v.

María Fernández: 4r, 4v, 144v, 259v, 162r, 165v, 333r, 333v, 350r, 410v.

María Fernández Gutiérrez: 466r.

María García: 165r, 175r, 405v.

María García Buey: 466r.

María Gómez: 364v.

María González: 58r, 285r.

María González: 145v, 460r.

María Gutiérrez: 159r, 273v, 409v.

María Hermíllez: 301v.

María Herrera: 154r, 403r, 403v.

María Herrón Jinete: 464v.

María Juan: 191v, $196 r$. 
María Juana la Montora, 206r.

María López Guzón: 466r.

María Manrique: 229v, 233r, 234r, 234v, 235r, 235v, 236r, 236v, 237r, 237v, 238r, $238 \mathrm{v}, 239 \mathrm{r}, 239 \mathrm{v}, 240 \mathrm{r}, 240 \mathrm{v}, 241 \mathrm{r}, 241 \mathrm{v}$, $242 \mathrm{r}$.

María Martín: 294r, 423v.

María Martín Calvo: 465r.

María Martínez: 30v, 31r, 154v, 441v.

María Merino: 319v.

María

Nicolás:

285 r.

María Pérez: 64v, 172r, 172v, 200r.

María Ramírez: 5v.

María Ramos: 411r.

María Reinoso: 460r.

María Rodríguez: 466v.

María Ruiz: 31r, 31v, 465r.

María Sánchez: 167v, 333r.

María Sánchez Gorgojo: 5r.

María Tubilla Moro: 465v.

María Villorejo: 465r.

Mariana de Melgar: 368v.

Mariano: 351v.

Marina: 13r, 13v, 64v, 143v, 158r, 173r, 175r, 182v, 183r, 273v, 313r, 313v, 408v.

Marina Álvarez: $143 \mathrm{v}$.

Marina de Juan: 13r, 13v.

Marina Gómez: 64v.

Marina la Cordera: 158r.

Marina Pérez: 313r.

Marina Pérez: 408v.

Marina Rodríguez: 175r.

Marquesa, mujer de Gonzalo Ruiz: 133 r.

Martín: 2r, 2v, 3r, 3v, 4r, 5r, 5v, 9v, 10r, $13 \mathrm{r}, 13 \mathrm{v}, 17 \mathrm{r}, 19 \mathrm{v}, 20 \mathrm{r}, 23 \mathrm{r}, 30 \mathrm{v}, 31 \mathrm{r}, 32 \mathrm{v}$, $33 \mathrm{r}, 33 \mathrm{v}, 37 \mathrm{r}, 37 \mathrm{v}, 38 \mathrm{v}, 39 \mathrm{r}, 40 \mathrm{r}, 41 \mathrm{r}, 44 \mathrm{v}$, $45 \mathrm{v}, 47 \mathrm{r}, 47 \mathrm{v}, 48 \mathrm{v}, 49 \mathrm{r}, 49 \mathrm{v}, 58 \mathrm{r}, 59 \mathrm{r}, 59 \mathrm{v}$, $60 \mathrm{r}, 60 \mathrm{v}, 61 \mathrm{v}, 64 \mathrm{r}, 64 \mathrm{v}, 66 \mathrm{r}, 67 \mathrm{v}, 68 \mathrm{r}, 69 \mathrm{r}$, $69 \mathrm{v}, 73 \mathrm{v}, 78 \mathrm{v}, 82 \mathrm{r}, 82 \mathrm{v}, 84 \mathrm{v}, 86 \mathrm{r}, 93 \mathrm{v}, 97 \mathrm{v}$, $100 \mathrm{v}, 104 \mathrm{r}, 106 \mathrm{r}, 115 \mathrm{v}, 116 \mathrm{r}, 117 \mathrm{r}, 127 \mathrm{v}$, $129 \mathrm{v}, 131 \mathrm{v}, 133 \mathrm{v}, 134 \mathrm{r}, 141 \mathrm{v}, 143 \mathrm{v}, 149 \mathrm{r}$, $150 \mathrm{r}, 150 \mathrm{v}, 151 \mathrm{v}, 153 \mathrm{v}, 154 \mathrm{r}, 154 \mathrm{v}, 155 \mathrm{r}$, $155 \mathrm{v}, 158 \mathrm{r}, 159 \mathrm{v}, 162 \mathrm{v}, 165 \mathrm{v}, 167 \mathrm{v}, 173 \mathrm{v}$, $175 \mathrm{r}, 175 \mathrm{v}, 177 \mathrm{r}, 177 \mathrm{v}, 178 \mathrm{v}, 180 \mathrm{v}, 181 \mathrm{v}$, $182 \mathrm{v}, 183 \mathrm{r}, 186 \mathrm{v}, 190 \mathrm{r}, 191 \mathrm{v}, 192 \mathrm{r}, 192 \mathrm{v}$, 193r, 196v, 198r, 198v, 199v, 200r, 200v, $201 \mathrm{v}, 204 \mathrm{v}, 207 \mathrm{r}, 209 \mathrm{v}, 210 \mathrm{r}, 211 \mathrm{r}, 214 \mathrm{v}$, $220 \mathrm{v}, 221 \mathrm{r}, 223 \mathrm{r}, 223 \mathrm{v}, 227 \mathrm{r}, 228 \mathrm{r}, 229 \mathrm{r}$, $229 \mathrm{v}, 235 \mathrm{r}, 235 \mathrm{v}, 236 \mathrm{r}, 236 \mathrm{v}, 237 \mathrm{v}, 238 \mathrm{r}$,
$238 \mathrm{v}, 239 \mathrm{r}, 239 \mathrm{v}, 240 \mathrm{r}, 240 \mathrm{v}, 241 \mathrm{r}, 241 \mathrm{v}$, $243 \mathrm{v}, 244 \mathrm{r}, 256 \mathrm{v}, 257 \mathrm{r}, 257 \mathrm{v}, 259 \mathrm{v}, 264 \mathrm{v}$, $265 \mathrm{r}, 265 \mathrm{v}, 267 \mathrm{v}, 269 \mathrm{v}, 460 \mathrm{v}, 462 \mathrm{r}, 463 \mathrm{r}$, $463 \mathrm{v}, 464 \mathrm{v}, 465 \mathrm{r}, 465 \mathrm{v}, 466 \mathrm{r}, 466 \mathrm{v}, 468 \mathrm{v}$, 469r; fraile: $37 \mathrm{v}, 210 \mathrm{r}, 220 \mathrm{v}, 221 \mathrm{r}, 278 \mathrm{v}$, 310r, 310v, 313r, 204v.

Martín V: 82r, 82v, 236r, 236v, 239r, 239v, 240r, 240v, 241r, 241v.

Martín Abad: 328r.

Martín Alcalde: $449 v$.

Martín Aparicio: 9v, 10r.

Martín Bedija: 191v, 192 r.

Martín Clérigo: 301v.

Martín de Aspe y Sierra: 198v, 223r, 223v.

Martín de Espínola: 86r.

Martín de Espinosa: 414r, 414v.

Martín de la Cantera: 106r.

Martín de la Vega: 158r, 449v, 450r.

Martín de Modoya: 149r, 150r, 150v.

Martín de Sahagún, fraile: 310r, 310v, $204 \mathrm{v}, 220 \mathrm{v}, 221 \mathrm{r}$

Martín de Salinas: 281r, 281v.

Martín de Salvatierra: $117 \mathrm{r}$.

Martín de Santa María: 69r.

Martín Domínguez: 328r, 408r.

Martín Errejón: 273v.

Martín Fernández: 31r, 78v, 133v, 134r.

Martín Fernández de Porras: 82r, 82v.

Martín Gallo: 257v, 378r, 378v, 379r, $441 \mathrm{v}, 442 \mathrm{r}$.

Martín Gallo de Montoya: 420v.

Martín García: 32v, 33r, 49v, 58r, 69v, $127 \mathrm{v}, 141 \mathrm{v}, 155 \mathrm{r}, 155 \mathrm{v}, 158 \mathrm{r}, 159 \mathrm{v}, 210 \mathrm{r}$, $243 \mathrm{v}, 244 \mathrm{r}, 269 \mathrm{v}, 283 \mathrm{v}, 286 \mathrm{r}, 289 \mathrm{r}, 292 \mathrm{v}$, 297r, 307r, 310r, 311r, 311v, 313v, 315r, 336r, 359v, 360r, 365v, 370v, 371r, 371v, $373 \mathrm{r}, 373 \mathrm{v}, 400 \mathrm{v}, 405 \mathrm{r}, 405 \mathrm{v}, 412 \mathrm{v}, 435 \mathrm{v}$, 436r, 441v, 443r, 444r.

Martín García de Bárcena: 69v.

Martín García Gatón, 58r, 141v, 155r, 155v, 158r, 159v, 210r, 297r.

Martín García Laso: 311r, 311v.

Martín García Paredes: 284r.

Martín Garrido: 368r, 368v.

Martín González: 37r, 229r.

Martín González Paniagua: 37r.

Martín Gonzálvez: 186v.

Martín Izquierdo: 421v, 442r, 465r.

Martín Laso de la Vega: 165v.

Martín Macho: 323r, 323v, 373r.

Martín Mayordomo: 428r. 
Martín Navarro: 395v, 396r.

Martín Nieto: 204v.

Martín Pérez: 228r, 287r, 291v, 314v, 346r, 346v, 359v, 373r, 373v, 376r, 376v, 377r, $377 \mathrm{v}$.

Martín Pradera: 41r.

Martín Ruiz: 257r, 270r, 273v, 430r.

Martín Ruiz de Mitarte: 257r, 270r, 430r.

Martín Sierra de Jubero: 38v, 39r.

Martín Tristán: 180v.

Martín Vasco, fraile: 37v, 210r, 278v, 297r.

Martín Velasco: 418r, 418v.

Martínez, doctor: 334r.

Martínez de Chiloeches: 30v, 357r, 450r, 462r, 468v.

Mateo: 313v.

Mateo Antón: 46v.

Mateo de Bárcena: 249r, 249v.

Mateo de Cosío: 257r.

Mateo de la Canal: 39v, 40r.

Mateo de Mata: 296v.

Mateo de Raigadas, fraile: $73 \mathrm{v}$.

Mateo de San Marcos: 69r.

Mateo de Villar: 39r, 39v.

Mateo del Río: $135 \mathrm{v}$.

Mateo del Villar: 200r.

Mateo Díez: 4r, 4v.

Mateo Marcos: 209r.

Mateo Ortiz: 462v, 463r.

Mateo Quijano, fraile: 88r, 209v, 311v.

Mateo Rojo: 445r, 453r.

Mateo Santos: 160r.

Mateo Vaquero: 90v, 421v.

Matías: 409v.

Matías Adame: 423v.

Matías Antón: 462r.

Matías Buey Carrión: 463v.

Matías Cacharo: 268r.

Matías Calonge: 284v, 355v, 462r.

Matías de Liébana: 427v.

Matías de Paredes: 280r, 280v.

Matías de Treceño: 390r.

Matías del Valle: 37 r.

Matías Errejón Calva: 464v.

Matías García: 262r, 409r.

Matías Gómez: 76r.

Matías Herrero: 300v.

Matías Meléndez: 436v.

Matías Melendro: 436v.

Matías Morales: 77v, 78r.

Matías Olivares: 464r.
Matías Paredes: 464r.

Matías Pérez Martínez: 465v.

Matías Santos de San Pedro: 436v.

Matías Trancho: 465v.

Matilla: $85 \mathrm{r}, 85 \mathrm{v}$.

Mauricio: 353r.

Mauricio Martínez de Chiloeches: 30v, 357r, 450r, 468v.

Mauricio Mirañar de Chiloeches: 285v.

Mauro de Ibarra, fraile: $71 \mathrm{v}$.

Mauro de la Carrera, fraile: 205r, 205v, 346r, 346v.

Mauro de Otel, fraile: 26v.

Mauro de Villarroel, fraile: 352v.

Mauro Deza: 181r, 181v.

Mauro Fuentes, fraile: 255 r.

Mauro Fuertes, fraile: 371r.

Mauro Núñez, fraile: 299r.

Mauro Ordóñez, fraile: 268r.

Mauro Recalde, fraile: 424r.

Mauro Vázquez, fraile: 331r.

Mayor: 1v, 15r, 15v, 50r, 55r, 55v, 75r, 78v, $95 \mathrm{v}, 103 \mathrm{r}, 103 \mathrm{v}, 143 \mathrm{r}, 164 \mathrm{v}, 165 \mathrm{r}, 188 \mathrm{v}$, $189 \mathrm{r}, 199 \mathrm{v}, 240 \mathrm{v}, 278 \mathrm{r}, 286 \mathrm{v}, 291 \mathrm{v}, 313 \mathrm{r}$, $315 \mathrm{r}, 316 \mathrm{r}, 323 \mathrm{r}, 323 \mathrm{v}, 328 \mathrm{v}, 351 \mathrm{v}, 354 \mathrm{r}$, $354 \mathrm{v}, 397 \mathrm{v}, 401 \mathrm{r}, 401 \mathrm{v}, 415 \mathrm{r}, 420 \mathrm{v}, 428 \mathrm{r}$, $438 \mathrm{r}, 443 \mathrm{r}, 455 \mathrm{v}$.

Mayor Alfonso: $164 \mathrm{v}, 165 \mathrm{r}$.

Mayor García: 1v, 78v, 278r, 313r.

Mayor Gómez: 143r, 443r.

Mayor Pérez: 291v.

Mayor Salvadórez: 443r.

Mayor Sánchez: 438r.

Mayorga: 15r, 15v, 323r, 323v.

Mazuelas, señores de: $331 \mathrm{v}$.

Melchor Ángel Gutiérrez: 251r.

Melchor Arias: 199r.

Melchor de la Rúa: 130v, 137r, 137v, 138r, $138 \mathrm{v}, 139 \mathrm{r}$.

Melchor de Molina: 41r, 41v.

Melchor de Rabanal: 51v.

Melchor Fernández: 36r, 180v, 334r.

Melchor Fernández de la Peña: 180v.

Melchor García: 440v.

Melchor Laso: 198r, 202v, 206v, 218v, 219r, 219v, 221r.

Melchor Manjón: 278r, 278v.

Melchor Merino: 160r.

Melchor Santos: 130v.

Men Rodríguez de Cornado: 255v, 256r. 
Mencía: 169v, 233r, 235v, 236r, 288r, $288 \mathrm{v}$.

Mencía Álvarez: 165v.

Mencía Díaz: 408v.

Mencía Díez: 263r.

Mencía Ruiz: 190r, 190v, 191v, 192r, 227v, 288r, 288v.

Mier y Terán, licenciado: 376r.

Miguel: 3v, 4v, 5r, 5v, 6r, 6v, 14v, 17r, 36r, $40 \mathrm{r}, 57 \mathrm{v}, 58 \mathrm{r}, 59 \mathrm{r}, 59 \mathrm{v}, 60 \mathrm{r}, 64 \mathrm{v}, 70 \mathrm{r}, 75 \mathrm{r}$, $75 \mathrm{v}, 86 \mathrm{r}, 86 \mathrm{v}, 115 \mathrm{v}, 122 \mathrm{r}, 122 \mathrm{v}, 133 \mathrm{r}$, $134 \mathrm{v}, 158 \mathrm{v}, 159 \mathrm{r}, 159 \mathrm{v}, 165 \mathrm{r}, 165 \mathrm{v}, 171 \mathrm{v}$, $173 \mathrm{r}, 174 \mathrm{v}, 186 \mathrm{v}, 187 \mathrm{r}, 201 \mathrm{v}, 203 \mathrm{v}, 212 \mathrm{v}$, $213 \mathrm{r}, 218 \mathrm{v}, 221 \mathrm{r}, 223 \mathrm{v}, 256 \mathrm{v}, 262 \mathrm{v}, 268 \mathrm{v}$, $278 \mathrm{r}, 278 \mathrm{v}, 282 \mathrm{r}, 285 \mathrm{v}, 293 \mathrm{r}, 293 \mathrm{v}, 296 \mathrm{v}$, $302 \mathrm{v}, 303 \mathrm{r}, 303 \mathrm{v}, 304 \mathrm{r}, 304 \mathrm{v}, 311 \mathrm{r}, 316 \mathrm{r}$, $316 \mathrm{v}, 319 \mathrm{r}, 323 \mathrm{v}, 324 \mathrm{r}, 324 \mathrm{v}, 326 \mathrm{r}, 331 \mathrm{v}$, $347 \mathrm{v}, 348 \mathrm{r}, 357 \mathrm{r}, 360 \mathrm{r}, 366 \mathrm{v}, 380 \mathrm{v}, 392 \mathrm{r}$, 394r, 394v, 399r, 430v, 431r, 432v, 438r, $449 \mathrm{v}, 450 \mathrm{r}, 459 \mathrm{r}, 469 \mathrm{r}$ : fraile: 14v, 133r, $134 \mathrm{v}, 203 \mathrm{v}, 430 \mathrm{v}$.

Miguel Alonso: 6v, 268v.

Miguel Antonio Franco y Villalba: 347v, 348 r.

Miguel Blanco: 159v.

Miguel Caballero: 282r.

Miguel Calvo: 469r.

Miguel Calvo Luengo: $115 \mathrm{v}$.

Miguel Curto: $4 \mathrm{v}$.

Miguel de Barajores: 58r.

Miguel de Belorado, fraile: $14 \mathrm{v}$.

Miguel de Carrión: 36r.

Miguel de Castro, fraile: $430 \mathrm{v}$.

Miguel de Cisneros: 86r, 86v.

Miguel de Echarri: 326r.

Miguel de Guardo: 60r.

Miguel de Herreras: 5r.

Miguel de la Cruz: 304r, 304v.

Miguel de la Vega: 60r, 186v, 187r, 278r, 296v, 218v, 323v, 324r, 331v, 380v.

Miguel de Liébana: 262v, 324r, 324v.

Miguel de Ondarza Zavala, 205 r.

Miguel de Ondarza: 17 r.

Miguel de Poza: 431r.

Miguel de Terán: 122r, $122 \mathrm{v}$.

Miguel de Vega: 311r.

Miguel de Villaherreros: 158v.

Miguel de Villoria, fraile: 203v.

Miguel Docio: 459r.

Miguel Fernández: 394r, 394v.

Miguel Fuentes: 187r.
Miguel González de Lucas: 4v.

Miguel González de Quevedo: 70r.

Miguel Guerra: 5v, 6r.

Miguel Hernández: 392r.

Miguel Jiménez: 438r.

Miguel López: 75v, 278v, 293r, 293v, 316r, $357 \mathrm{r}$.

Miguel Lozano: 432v.

Miguel Magdaleno: $174 \mathrm{v}$.

Miguel Martínez: 256v, 316r, 316v, 449v, 450r.

Miguel Montero: 201v.

Miguel Ortiz: 165r, 165v.

Miguel Pérez de Toro: 360r.

Miguel Poza: 159r.

Miguel Preciado, fraile: 203v.

Miguel Rabanal: 319r.

Miguel Redondo: 285v, 357r.

Miguel Rojo: 171v.

Miguel Sánchez: 394r.

Miguel Sánchez Alfajeme: 173r.

Miguel Santos: 399r

Miguel Santos de San Pedro: 212v, 223v, $303 v, 304 r$.

Miranda: 36v, 43v, 44r, 48v, 119r, 128r, $128 \mathrm{v}, 146 \mathrm{v}, 152 \mathrm{v}, 156 \mathrm{v}, 167 \mathrm{v}, 168 \mathrm{r}, 178 \mathrm{r}$, $178 \mathrm{v}, 185 \mathrm{r}, 190 \mathrm{v}, 194 \mathrm{v}, 199 \mathrm{r}, 199 \mathrm{v}, 202 \mathrm{r}$, $208 \mathrm{v}, 216 \mathrm{r}, 216 \mathrm{v}, 276 \mathrm{r}, 287 \mathrm{v}, 296 \mathrm{v}, 304 \mathrm{v}$, 399r, 405v, 406r, 436r, 436v, 437v, 460v, 466v.

Miro: 12r, 35v, 48v, 49r, 60r, 107r, 217r, 218v, 219r, 221v, 256r, 269v, 305r, 381r.

Mogrovejo: 209v, 296r, 304r.

Molina: 16r, 39v, 41r, 41v, 59r, 59v, 60r, 69v, 78v, 79r, 209r, 295v, 296r, 304r, 306r, 306v, 311r, 401r, 432r, 466v.

Mollinedo: 115v, 116r, 298v.

Montenegro: 439v.

Montero de Castañeda: 19v, 26r.

Morán, fraile: $5 r$.

Morán Anáyez: 271r.

Morante, fraile: $119 \mathrm{r}$.

Moreira, fraile: $115 \mathrm{r}$.

Mota, marqués de la: 338v, 342v, 343r.

Munio Díaz de Robladillo: 410v.

Munio Fernández: 1v.

Munio González Palomino: 30v, 31r.

Munio Velítez: 186v.

Muñoz, doctor: $317 \mathrm{v}$.

Muriel: 434r. 
Narciso Francisco Blázquez: 369v.

Narciso Martínez Quijano: 40r.

Natalia: 312v.

Navarra, capellán real: 237v, 238r, 238v.

Navarro: 11r, 37v, 40r, 220r, 269r, 269v, $311 \mathrm{r}, 395 \mathrm{v}, 396 \mathrm{r}$.

Navedas, doctor: 376v, 377v, 378r, 378v, 379r, 380r.

Nicolás V: 341r, 341v, 342v.

Nicolás Correas: 356v.

Nicolás de Guzmán: 462r.

Nicolás de Humilla: 401r.

Nicolás de Lera: 69r.

Nicolás Gil: 351v.

Nicolás Muñoz: 17r.

Nicolás Ponsevir: 9v.

Nicolás Velasco: 452r.

Noblino, fraile: 6r, 6v.

Norberto de Sandoval y Guevara: 3r, 37r, 39r, 39v, 42r, 48r, 48v, 60r, 60v, 69r, 75r, $76 \mathrm{r}, 90 \mathrm{r}, 100 \mathrm{v}, 101 \mathrm{r}, 110 \mathrm{v}, 118 \mathrm{v}, 124 \mathrm{v}$, $146 \mathrm{r}, 146 \mathrm{v}, 152 \mathrm{v}, 155 \mathrm{r}, 155 \mathrm{v}, 156 \mathrm{v}, 157 \mathrm{v}$, $158 \mathrm{r}, 159 \mathrm{r}, 164 \mathrm{v}, 167 \mathrm{r}, 174 \mathrm{v}, 178 \mathrm{r}, 185 \mathrm{r}$, 202r, 218v, 219r, 223v, 250r, 251r, 258v, $274 \mathrm{v}, 275 \mathrm{r}, 278 \mathrm{r}, 284 \mathrm{v}, 285 \mathrm{r}, 285 \mathrm{v}, 300 \mathrm{v}$, 304r, 311r, 327v, 391v, 406r, 437r, 458v, $459 \mathrm{r}, 459 \mathrm{v}, 460 \mathrm{r}, 463 \mathrm{r}, 464 \mathrm{v}$.

Norberto Gallego: 285v.

Norberto Salomón: $37 \mathrm{v}$.

Nuño Orejón: 315r, 315v.

Ocenda: 171v, 355r.

Oliveiro: 189r.

Ordóñez, licenciado: 447r, 449r, 449v.

Órez: 40r.

Orosol: 34v.

Osorio Íñiguez: $441 \mathrm{v}$.

Osorio Osóriz: 273r.

Oteo de Angulo: 36r, 36v.

Pablo Cárdenas y Badillo: 68v.

Pablo de Aedo: 436v.

Pablo de Caramanzana: 399r.

Pablo de Cifuentes: 4r, 10r, 397v.

Pablo del Valle: 437v.

Pablo Emilio Berallo: 211r.

Pablo Francisco de Cárdenas y Vadillo: 309r, 347v, 348r.

Pablo Merino y Olmo: 136r.

Pablo Ordóñez: 51r.
Palacios: 36v, 94r, 94v, 175v, 262v, 285r, 296r, 296v, 302r, 372r, 376v, 377r, 377v, $378 \mathrm{r}, 378 \mathrm{v}, 379 \mathrm{r}, 401 \mathrm{r}, 430 \mathrm{v}, 434 \mathrm{v}, 441 \mathrm{r}$; doctor: 430v, 431r.

Palacios de la Cruz: 280v, 281r, 281v, 431r, 431v.

Palencia: 36r, 36v, 37v, 39r, 40r, 43v, 44r, 49r, 113v, 178v, 192r, 192v, 196v, 197r, $199 \mathrm{v}, 200 \mathrm{v}, 202 \mathrm{r}, 207 \mathrm{v}, 220 \mathrm{r}, 294 \mathrm{v}, 295 \mathrm{r}$, 376r, 404r, 437r; capellán de la iglesia: 294v, 295r; juez comisionado: 196v, 197r; penitenciario y provisor: 39r; provisor de: 36r, 36v, 37v, 39r, 40r, 43v, 44r, 178v, $200 \mathrm{v}, 207 \mathrm{v}, 220 \mathrm{r}, 404 \mathrm{r}$; visitador: $113 \mathrm{v}$, 202r..

Palomino: 30v, 31r, 197r, 383v, 384r, 384v, 385r, 419r.

Párraces, abad: $415 \mathrm{r}$.

Pascual de Guardo: 373r, 373v, 374v.

Pascual de la Cuesta: 441v, 442r.

Pascual González: 309v.

Pascual López: 24r.

Patricio Calvo: 336v.

Paula de Hompaneda: 409v.

Paula de Poza: 355v, 438v.

Paula García: 4v.

Paulo II: 14v, 15r, 27r, 27v, 84r, 117v, $122 \mathrm{v}, 125 \mathrm{v}, 203 \mathrm{v}, 204 \mathrm{r}, 274 \mathrm{r}$.

Paulo III, juez de: $14 \mathrm{v}, 15 \mathrm{r}$.

Pavía, cardenal de: 376v, 377r, 377v.

Pedro, 2v, 3r, 5r, 9v, 10r, 10v, 13v, 14r, $14 \mathrm{v}, 15 \mathrm{r}, 18 \mathrm{v}, 24 \mathrm{r}, 26 \mathrm{r}, 31 \mathrm{v}, 32 \mathrm{r}, 33 \mathrm{r}, 33 \mathrm{v}$, $34 \mathrm{r}, 34 \mathrm{v}, 35 \mathrm{r}, 36 \mathrm{r}, 36 \mathrm{v}, 38 \mathrm{r}, 38 \mathrm{v}, 39 \mathrm{r}, 40 \mathrm{r}$, $41 \mathrm{v}, 43 \mathrm{r}, 43 \mathrm{v}, 44 \mathrm{r}, 45 \mathrm{r}, 45 \mathrm{v}, 46 \mathrm{r}, 47 \mathrm{r}, 47 \mathrm{v}$, $48 \mathrm{r}, 49 \mathrm{v}, 55 \mathrm{r}, 55 \mathrm{v}, 58 \mathrm{r}, 59 \mathrm{r}, 61 \mathrm{r}, 61 \mathrm{v}, 63 \mathrm{v}$, $64 \mathrm{v}, 66 \mathrm{r}, 67 \mathrm{v}, 69 \mathrm{r}, 69 \mathrm{v}, 71 \mathrm{v}, 72 \mathrm{r}, 73 \mathrm{r}, 74 \mathrm{v}$, $75 \mathrm{r}, 75 \mathrm{v}, 77 \mathrm{r}, 77 \mathrm{v}, 78 \mathrm{v}, 82 \mathrm{r}, 82 \mathrm{v}, 83 \mathrm{r}, 83 \mathrm{v}$, $84 \mathrm{r}, 84 \mathrm{v}, 85 \mathrm{v}, 86 \mathrm{r}, 86 \mathrm{v}, 87 \mathrm{r}, 88 \mathrm{v}, 89 \mathrm{r}, 89 \mathrm{v}$, 91r, 92r, 92v, 93r, 94r, 94v, 100v, 102v, $103 \mathrm{r}, 109 \mathrm{r}, 110 \mathrm{v}, 111 \mathrm{r}, 112 \mathrm{r}, 117 \mathrm{v}, 123 \mathrm{r}$, $124 \mathrm{r}, 127 \mathrm{r}, 127 \mathrm{v}, 130 \mathrm{r}, 130 \mathrm{v}, 131 \mathrm{v}, 132 \mathrm{r}$, $133 \mathrm{r}, 133 \mathrm{v}, 134 \mathrm{r}, 137 \mathrm{r}, 137 \mathrm{v}, 138 \mathrm{r}, 138 \mathrm{v}$, $139 \mathrm{r}, 139 \mathrm{v}, 140 \mathrm{r}, 143 \mathrm{r}, 143 \mathrm{v}, 144 \mathrm{r}, 144 \mathrm{v}$, $145 \mathrm{v}, 149 \mathrm{v}, 150 \mathrm{r}, 150 \mathrm{v}, 151 \mathrm{r}, 153 \mathrm{r}, 153 \mathrm{v}$, $154 \mathrm{r}, 154 \mathrm{v}, 155 \mathrm{r}, 155 \mathrm{v}, 157 \mathrm{r}, 157 \mathrm{v}, 158 \mathrm{v}$, $161 \mathrm{r}, 162 \mathrm{r}, 162 \mathrm{v}, 163 \mathrm{r}, 164 \mathrm{r}, 164 \mathrm{v}, 165 \mathrm{r}$, $165 \mathrm{v}, 166 \mathrm{r}, 166 \mathrm{v}, 171 \mathrm{v}, 172 \mathrm{r}, 172 \mathrm{v}, 173 \mathrm{v}$, $174 \mathrm{v}, 226 \mathrm{r}, 226 \mathrm{v}, 237 \mathrm{r}, 237 \mathrm{v}, 238 \mathrm{r}, 238 \mathrm{v}$, 272r, 273v, 274r, 286r, 292v, 293r, 300r, $307 \mathrm{r}, 307 \mathrm{v}, 310 \mathrm{r}, 313 \mathrm{v}, 315 \mathrm{r}, 327 \mathrm{r}, 327 \mathrm{v}$, $328 \mathrm{v}, 329 \mathrm{r}, 331 \mathrm{v}, 332 \mathrm{r}, 334 \mathrm{v}, 335 \mathrm{r}, 338 \mathrm{r}$, 
$341 \mathrm{r}, 341 \mathrm{v}, 343 \mathrm{r}, 353 \mathrm{v}, 359 \mathrm{r}, 359 \mathrm{v}, 380 \mathrm{r}$, $382 \mathrm{r}, 404 \mathrm{v}, 405 \mathrm{r}, 407 \mathrm{v}, 408 \mathrm{r}, 408 \mathrm{v}, 410 \mathrm{v}$, $411 \mathrm{v}, 413 \mathrm{v}, 414 \mathrm{r}, 417 \mathrm{v}, 418 \mathrm{r}, 427 \mathrm{v}, 432 \mathrm{v}$, 434r, 438r; fraile: $17 \mathrm{r}, 27 \mathrm{v}, 46 \mathrm{r}, 46 \mathrm{v}, 63 \mathrm{r}$, 66v, 67r, 76v, 201v, 217r, 262v, 294r, 295r, $309 \mathrm{v}, 320 \mathrm{r}, 346 \mathrm{r}, 346 \mathrm{v}, 349 \mathrm{v}, 354 \mathrm{v}, 366 \mathrm{v}$, 369r, 371r, 371v, 372r, 372v, 373r, 383v, 384r, 384v, 385r, 394r, 428r.

Pedro I: 226r, 226v.

Pedro Abad: 58v, 417v, $418 \mathrm{r}$.

Pedro Adame: 445r.

Pedro Aguado: $397 \mathrm{v}$.

Pedro Alcántara Sendino y Calvo: 210v.

Pedro Alemán: 247r, 260v.

Pedro Alfonso: 78v, 227v.

Pedro Alfonso de la Plaza: 166r, 166v.

Pedro Alonso: 402v, 403r, 423v.

Pedro Alonso de Madrid: 364v.

Pedro Álvarez: 2v, 18v, 266v, 280v, 281r, 281v, 331r, 400v, 401r, 431v.

Pedro Álvarez de Torrelaguna: 418v.

Pedro Andrés de los Silos: 405v, 406r.

Pedro Angulo Toro: 317v, 447r.

Pedro Ansúrez Díaz: 286r, 292v, 293r, 353v, 404v, 407v, 408r, 434r.

Pedro Arana Ocerín: 140r.

Pedro Argadero: 176r.

Pedro Asenjo: 315r.

Pedro Bahillo, escribano de Arconada: 36v.

Pedro Balvanera, fraile: $371 \mathrm{r}, 371 \mathrm{v}$.

Pedro Barrantes: 455r, 455v.

Pedro Briones Saco de Somoza: 194r, 194v.

Pedro Briones: 194r.

Pedro Buey Gastán: 466v.

Pedro Bustillo: 257r.

Pedro Caballero: 258r.

Pedro Cabeza Vela: 181 r.

Pedro Calahorra: $74 \mathrm{v}$.

Pedro Calderón: 110v, 111r.

Pedro Calleja: 208r, 208v.

Pedro Calvo: 262r.

Pedro Caray: 226v, $227 \mathrm{r}$.

Pedro Carite: 226v.

Pedro Casa: 263r, 321v.

Pedro Castaño, 209v.

Pedro Cervantes, $117 \mathrm{v}$.

Pedro Chico Escobar, 210r.

Pedro Chico: 194v.

Pedro Cleteyns: 236v.
Pedro Cordero: 263v.

Pedro Cosgaya: 460r.

Pedro de Agüero, fraile: 294r, 320r, 354v.

Pedro de Arana: 43v, 44r, 213v.

Pedro de Arana Ocerín: 38v, 39r, 208r, 208v, 295r, 448r.

Pedro de Argüello: 74v.

Pedro de Astorga: 34v.

Pedro de Aulestia: 447r, 447v.

Pedro de Ávila: 34v.

Pedro de Bárcena: 395r, 395v.

Pedro de Calahorra: 74v.

Pedro de Canseco: 310r, 310v.

Pedro de Carrión: 33r, 123r, 127r, 127v, 244v, 245r, 274r, 411v.

Pedro de Castro: 46v, 47v, 183r, 275v, $328 \mathrm{v}, 428 \mathrm{r}$; fraile: $262 \mathrm{v}, 294 \mathrm{r}, 309 \mathrm{v}, 320 \mathrm{r}$, $354 \mathrm{v}, 428 \mathrm{r}, 428 \mathrm{r}$.

Pedro de Cervantes, 24r, 26r, 100v, 124r, $137 \mathrm{r}, 137 \mathrm{v}, 138 \mathrm{r}, 138 \mathrm{v}, 139 \mathrm{r}, 139 \mathrm{v}, 140 \mathrm{r}$, 180v.

Pedro de Cisneros: 89v.

Pedro de Colmenares: 457r, 457v.

Pedro de Contreras: 132r.

Pedro de Criales, fraile: 366v.

Pedro de Enao Osorio: 214r.

Pedro de Espinosa y Conches: 185 r.

Pedro de Estrada: 46r.

Pedro de Girón: 5 r.

Pedro de Granda: 178v.

Pedro de Herreros Gallego: 151r.

Pedro de Iguña: $154 \mathrm{v}, 155 \mathrm{r}$.

Pedro de la Calle: 302r, 302v, 308v, 331r.

Pedro de la Carrera: 419v.

Pedro de la Merina: 320v, 422r.

Pedro de la Peña: 219r, 219v.

Pedro de la Tapia: 143r, 143v.

Pedro de la Torre: 276r.

Pedro de la Vega: 328v.

Pedro de la Vega Colmenares: 308v, 309r.

Pedro de Lagasca: 72r.

Pedro de Lerones: 33r, 33v.

Pedro de Lezcano: 296v.

Pedro de Lomas: 436r.

Pedro de Marquina: 184r, 184v.

Pedro de Mendoza: 334v, 335r.

Pedro de Meras: 376v, 378r, 378v, 379r.

Pedro de Olmos: 362v, 368r, 368v.

Pedro de Oteros: 390r.

Pedro de Ponga: 286v. 
Pedro de Porras, fraile: 46r, 63r, 349v, 372r, 372v, 373r, 383v, 384r, 384v, 385r.

Pedro de Quintanilla: 264v, 265r, 265v.

Pedro de Rabanal: 63v, 64v.

Pedro de Ramos: 371v.

Pedro de Razas: 427r, 427v.

Pedro de Riosmenudos, 197v.

Pedro de Rivera: $181 \mathrm{r}$.

Pedro de Rojas: 49v.

Pedro de Sahagún, fraile: $76 \mathrm{v}$.

Pedro de San Martín: 200r.

Pedro de San Zoilo: 34v, 93r, 150r, 150v, $165 r$.

Pedro de Santa Olalla: 177r.

Pedro de Santayana, fraile: 295r.

Pedro de Sedano: 243r, 243v, 244r.

Pedro de Soto: 197v, 198r; fraile: 201v, 217 r.

Pedro de Toro: 286r, 382r, 427v.

Pedro de Torrecilla, fraile: $17 \mathrm{r}, 394 \mathrm{r}$.

Pedro de Tosantos: 14r, 14v, 15r, 17r, 34v, $83 \mathrm{v}, 84 \mathrm{r}, 84 \mathrm{r}, 327 \mathrm{r}, 327 \mathrm{v}, 338 \mathrm{r}, 259 \mathrm{v}, 273 \mathrm{v}$, 274r, 286r, 315r, 341r, 341v, 343r, 382r, 394r, 413v, 414r, 427v.

Pedro de Valcárcel: 275v.

Pedro de Valdivieso: 92r.

Pedro de Vega: 59r.

Pedro de Velasco: 180v, 310r; fraile: 346r, 346v.

Pedro de Villa: 77r, 77v, 162r, 219v, 220v, 221r, 362r, 428v, 441v.

Pedro de Villacorta: 441v.

Pedro de Villafranca: 362r.

Pedro de Villamuera y Juan: 162 r.

Pedro de Villarreal: 77r, 77v.

Pedro de Villasco: 428v.

Pedro de Villaverde: 219v, 220v.

Pedro de Vivero: 338v, 339r, 339v, 340r, $340 \mathrm{v}, 341 \mathrm{r}, 341 \mathrm{v}, 342 \mathrm{r}, 342 \mathrm{v}, 343 \mathrm{r}, 343 \mathrm{v}$, 344r, 454r, 454v.

Pedro de Vivero el Viejo: 338v.

Pedro de Zarandona: 10r, 10v.

Pedro del Brezo: 73r.

Pedro del Campo: 18v.

Pedro del Castillo: 84v.

Pedro del Hospital el Viejo: 375r.

Pedro Díaz: 144v, 157r, 220v, 270r, 313v.

Pedro Díaz de Valdeón: 302r, 302v, 303r.

Pedro Díez: 295v, $296 r$.

Pedro Domínguez: 272r.

Pedro Enríquez: 432v.
Pedro Enríquez y Colmenares: 263r.

Pedro Escudero: $74 v$.

Pedro Espinosa: 32r.

Pedro Estrada: 293r, 293v.

Pedro Fernández: 38r, 38v, 43r, 43v, 71v, 109r, 144r, 154r, 154v, 162r, 164r, 164v, $182 \mathrm{v}, 184 \mathrm{r}, 187 \mathrm{v}, 196 \mathrm{v}, 243 \mathrm{v}, 244 \mathrm{r}, 244 \mathrm{v}$, 301v, 371r, 371v, 399r, 404v, 412v, 422v.

Pedro Fernández Abero: 187v.

Pedro Fernández Calvo: 43r, 43v.

Pedro Fernández de Carrión: 38r, 38v, 154r, 154v, 184r, 243v.

Pedro Fernández de Lerones: 164r.

Pedro Fernández de San Zoilo: 164r, $164 \mathrm{v}$.

Pedro Fernández de Valderrábano: 412v.

Pedro Gamarra y Arriaga: 250v, 251r.

Pedro García: 14v, 67r, 84r, 131v, 161r, $162 \mathrm{v}, 163 \mathrm{r}, 165 \mathrm{v}, 166 \mathrm{r}, 244 \mathrm{r}, 299 \mathrm{v}, 339 \mathrm{r}$, $339 \mathrm{v}, 340 \mathrm{r}, 340 \mathrm{v}, 341 \mathrm{r}, 365 \mathrm{v}, 402 \mathrm{v}, 403 \mathrm{r}$, 411v, 412r, 412v, 430r, 438r, 464r.

Pedro García de Carrión: 412r, 412v.

Pedro García de Frómista: 244r.

Pedro García de Minañes: 166r.

Pedro García de Palenzuela: 131v.

Pedro García de Robladillo: 162v.

Pedro García Galán: 464r.

Pedro García Tendero: 411v.

Pedro García Truchero: 163r.

Pedro Gasca: 216v, 217v, 218r, 218v, 219r.

Pedro Girón el Mozo: 368r, 368v.

Pedro Gómez: 302r.

Pedro González: 67v, 84r, 102v, 103r, $127 \mathrm{r}, 154 \mathrm{v}, 239 \mathrm{r}, 239 \mathrm{v}, 240 \mathrm{r}, 240 \mathrm{v}, 241 \mathrm{r}$, 241v, 243r, 243v, 310r, 350v.

Pedro González de Mendoza, cardenal: 84r, 102v, 103r, 145v, 243r, 243v, 310r.

Pedro González de Quevedo: $127 \mathrm{r}$.

Pedro González de Roa: 239r, 239v, 240r, 240v, 241r, 241v.

Pedro González de Tovar: 350v.

Pedro Gonzálvez: 306r.

Pedro Guadrón de Herrera: 41v.

Pedro Guerra de Cervantes: 139v.

Pedro Guijelmo: 354r.

Pedro Gutiérrez: 183v.

Pedro Hernández: 45v, 310r, 423v.

Pedro Hernández de Hortega: 310r.

Pedro Herrero: 155r, 372v, 373r, 374v, $375 r$.

Pedro Herrero el Mozo: 374v. 
Pedro Ibáñez: 69v, 257r.

Pedro Ignacio Martínez: 334v.

Pedro Jiménez: 36r.

Pedro Juan: 3r, 273r, 351r.

Pedro Juan Domínguez: 351r.

Pedro Lasso: 462r.

Pedro Lechón: 325v, 326r, 326v, 327r, $327 \mathrm{v}$.

Pedro León de Santotís: 112r, 200v, 214r, 214v.

Pedro Lezcano: 297r.

Pedro López: 40r, 63r, 130r, 130v, 158v, $164 \mathrm{v}, 230 \mathrm{r}, 230 \mathrm{v}, 231 \mathrm{r}, 331 \mathrm{v}, 332 \mathrm{r}, 419 \mathrm{r}$, $419 \mathrm{v}, 434 \mathrm{v}$.

Pedro López de Madrid: 331v, 332r.

Pedro López Moro: 130r, 130v, 158v.

Pedro Luengo: 395v.

Pedro Macedo y Estrada: 214v.

Pedro Manrique: 412r, 412v.

Pedro Manuel: 329r.

Pedro Marín, fraile: $27 \mathrm{v}$.

Pedro Martín: 17r, 58r, 61v, 153v, 155r, $155 \mathrm{v}, 173 \mathrm{v}, 177 \mathrm{r}, 177 \mathrm{v}, 182 \mathrm{v}, 183 \mathrm{r}, 191 \mathrm{v}$, $196 \mathrm{v}, 198 \mathrm{r}, 207 \mathrm{r}, 237 \mathrm{v}, 238 \mathrm{r}, 238 \mathrm{v}, 264 \mathrm{v}$, $265 \mathrm{r}, 265 \mathrm{v}, 278 \mathrm{v}, 293 \mathrm{r}, 293 \mathrm{v}, 311 \mathrm{v}, 334 \mathrm{r}$, $334 \mathrm{v}, 335 \mathrm{r}, 355 \mathrm{v}, 376 \mathrm{r}, 376 \mathrm{v}, 377 \mathrm{v}, 378 \mathrm{r}$, 378v, 379r, 379v, 380r, 411v, 436r, 449r; hijos de: 334v.

Pedro Martín Carretero: 449r.

Pedro Martínez: 17r, 58r, 61v, 153v, 155r, $155 \mathrm{v}, 173 \mathrm{v}, 177 \mathrm{r}, 177 \mathrm{v}, 182 \mathrm{v}, 183 \mathrm{r}, 191 \mathrm{v}$, $196 \mathrm{v}, 198 \mathrm{r}, 207 \mathrm{r}, 237 \mathrm{v}, 238 \mathrm{r}, 238 \mathrm{v}, 264 \mathrm{v}$, 265r, 265v, 278v, 311v, 355v, 411v, 436r.

Pedro Martínez Acero: 196v.

Pedro Martínez Calderón: 198r.

Pedro Martínez Carranza: 17r.

Pedro Martínez de Astudillo: 237v, 238r, 238v.

Pedro Martínez de Becerril: 173v.

Pedro Martínez de Landecho: 177r, 177v, 436r.

Pedro Martínez de Sicilia: 355v.

Pedro Martínez León: 153v.

Pedro Martínez Serrano: 411v.

Pedro Martínez y Herrera: 311v.

Pedro Matanza: 357r.

Pedro Mateo: 162r, 180v.

Pedro Merino: 317r, 317v, 334v, 437r, $437 \mathrm{v}$; fraile: $369 \mathrm{r}$.

Pedro Merino el Viejo: $317 \mathrm{r}, 317 \mathrm{v}$.

Pedro Miguel: 75r, 75v.
Pedro Minayo: 463r.

Pedro Momo: 5r.

Pedro Montes: 209v, 267r, 310v, 321r, 376r, 376v, 383v, 384r, 384v, 385r.

Pedro Montes de Colmenares: 47v, 267r, 310v.

Pedro Montes del Castillo: 209v.

Pedro Morejón: 193r, 393r.

Pedro Moro de Solórzano: 420v.

Pedro Muñoz: 183v.

Pedro Nolasco Calvo: 210v.

Pedro Núñez: 143r, 143v.

Pedro Ocerín: $199 \mathrm{v}$.

Pedro Ortiz: $127 \mathrm{v}$.

Pedro Padillo: 436v.

Pedro Pajares: 450v.

Pedro Palacios: 94r, 94v, 376v, 377r, 377v, 378r.

Pedro Pascual: 47v, 48r, 267r, 267v.

Pedro Pellón: 63v.

Pedro Pérez: 36r, 61r, 157v, 239r, 239v, 240r, 240v, 241r, 241v, 285r, 293v, 436v.

Pedro Pérez de Belorado: 239r, 239v, 240r, 240v, 241r, 241v.

Pedro Pérez de Fresneda: 157v.

Pedro Pérez de la Calle: 61r.

Pedro Porras: $34 \mathrm{v}$.

Pedro Poza: 174v, 175r.

Pedro Puente: 315r.

Pedro Quijano: 154r, 154v.

Pedro Ramón: 109 r.

Pedro Ramos, 367r, 367v, 376r.

Pedro Revilla: 297r, 298v, 299r

Pedro Rey: 66r, 66v.

Pedro Rodríguez: 31v, 195r, 288r, 293v, 408r.

Pedro Rodríguez Antón: 195r, 288r.

Pedro Rodríguez Antón: 210r.

Pedro Rodríguez Mogrovejo: 209v, 223v, $296 r$.

Pedro Rogel: 411v.

Pedro Roldán: 300v.

Pedro Ruiz: 13v, 45r, 196v, 197r, 365v.

Pedro Ruiz de la Mota: 85v.

Pedro Sal: 181v.

Pedro Sánchez: 92r, 149v, 150r, 289r, 289v.

Pedro Santos de Bisova: 311r.

Pedro Sanz: 255r.

Pedro Sarmiento y Toledo: 250v, 251r.

Pedro Sedano: 242v. 
Pedro Simón: 274r.

Pedro Strozzi: 85v, 86r, 86v, 87r; procurador de: $86 \mathrm{v}$.

Pedro Téllez: $347 \mathrm{r}$.

Pedro Testay: 282r, 378r, 378v, 379r, 380r.

Pedro Vaca: 35r, 257v.

Pedro Val: 9v, 10r, 257v, 313v, 314r, 371r, 371v.

Pedro Valle: 313v, 314r.

Pedro Vallejo: $257 \mathrm{v}$.

Pedro Velasco: 175r, 303v, 304r.

Pedro Velázquez: 171v, 355r.

Pedro Vivero: 33r.

Pedro Zapata: 5 r.

Pedrosa de Villegas, notario: 212r.

Pelayo: 1v, 97v, 117v, 190r, 312v, 313r.

Pelayo García: 143r, 143v.

Pelayo Gómez: 313r.

Pelayo Incola, 47r, 47v.

Pelayo Micola: $313 \mathrm{v}$.

Pelayo Onzola: 351v.

Pelayo Pérez: 408r.

Pelayo Rubio: 313r.

Penche, bachiller: 199r, 199v.

Peralta: 38v, 39r, 117v, 139r, 198v, 199r, 199v, 203r, 204r, 204v, 208r, 208v, 211v, 212r, 213r, 213v, 219r, 219v, 222r, 223r, 252v, 260v, 295r, 448r; licenciado: 409r.

Peregrino Fabio: 216r.

Pérez Manuel: 386r; doctor: 374r.

Petronila Freile: 4r.

Pichardo Semanero: 249r, 249v.

Pino, vecino: $334 \mathrm{r}$.

Pío II: 84r.

Pío VI: 200v, 201r.

Pira de la Vega: 430v, 431r.

Plácido: $319 \mathrm{v}$.

Plácido de Benavides, fraile: 2v.

Plácido de Guzmán, fraile: 152v.

Plácido de Huércanos: 193r, 193v, 198r, 198v, 199r; fraile: 23v, 38v, 39r, 203r, 212r, $213 \mathrm{v}, 219 \mathrm{r}, 219 \mathrm{v}, 221 \mathrm{r}, 223 \mathrm{v}, 294 \mathrm{v}, 405 \mathrm{v}$, 445r.

Plácido de Iglesias, fraile: 258 r.

Plácido de Perea, fraile: 73r, 302r, 302v, $334 \mathrm{v}$.

Plácido de Quirós, fraile: 178r.

Plácido de Urbina, fraile: $275 \mathrm{v}$.

Plácido del Río, fraile: 39r, 39v, 59r, 275v, $440 \mathrm{v}$.
Plácido Emeldo, fraile: 101v, 299r, 400r, $437 \mathrm{v}$.

Plácido Flórez, fraile: $61 \mathrm{r}$.

Polite de Rojas: 94r.

Polmo: 313r.

Pompeyo Rambicario: 203v, 204r.

Poncio: 277 r.

Porras, 34v, 46r, 63r, 82r, 82v, 255r, 304v, $349 \mathrm{v}, 372 \mathrm{r}, 383 \mathrm{v}, 384 \mathrm{r}, 384 \mathrm{v}, 385 \mathrm{r}, 401 \mathrm{r}$, $401 \mathrm{v}, 410 \mathrm{v}, 419 \mathrm{r}, 419 \mathrm{v}$.

Poymo: 413r, 413v.

Pozo: 17r, 17v, 18r, 18v, 23v, 27r, 161v, 394r, 394v, 422v; licenciado: 331r.

Prado de León: 380v.

Prudencio de Armentia: 294v.

Prudencio de Meneses y Riaño: 90r.

Puebla, vecino: 302 r.

Quesada: 204v, 205 r.

Quintanilla, fraile: $201 \mathrm{v}$.

Quirino Cabarto: 213r.

Radulfo: 189v, 190r.

Rafael de Medina Maudes: 263v, 46v, 428r.

Rafael Merino: 218v, 331v.

Rafael Roldán: 435r.

Raimundo: 1v, 189v, 211r, 277r.

Ramírez de Arellano: 121v, 122r.

Ramiro, doctor: 218v, 219r, 221v.

Ramiro del Campo: 256r.

Ramiro Ordóñez: 60r.

Ramiro Rodríguez Blanco: 12r, 48v, 49r, 269v, 305r, 381r

Ramón de Flores: 399r.

Ramón Durán, fraile: 363v.

Ramos: 9v, 10r, 13r, 13v, 58r, 101r, 101v, $154 \mathrm{v}, 155 \mathrm{r}, 156 \mathrm{v}, 261 \mathrm{r}, 261 \mathrm{v}, 287 \mathrm{v}, 288 \mathrm{r}$, 305r, 366v, 367r, 367v, 371v, 376r, 381r, $381 \mathrm{v}, 390 \mathrm{v}, 409 \mathrm{r}, 411 \mathrm{r}, 439 \mathrm{v}$.

Recueva, clérigo beneficiado: 298v, 299r.

Redondo, bachiller: 223r.

Remigio Gerardo: 190v.

Represa, licenciado: 368r.

Respenda, vecino: $307 \mathrm{v}$.

Reyes Católicos: 103v, 104r, 132r, 206v, $242 \mathrm{v}, 455 \mathrm{v}$.

Rica: 413r, 413v.

Riosmenudos, cura de: 302r, 302v, 303r.

Rivas, vecino: $371 \mathrm{r}$.

Roa Dávila: 72v. 
Robles: 4v, 16v, 17v, 18r, 18v, 21v, 22r, 22v, 185r, 330v, 331r, 350r, 376r, 393r, 393v, 395r, 422v, 423r.

Robles de la Puerta: $180 \mathrm{v}$.

Rodrigo: 32v, 33r, 35v, 36r, 43v, 45v, 55r, $55 \mathrm{v}, 59 \mathrm{r}, 59 \mathrm{v}, 63 \mathrm{v}, 68 \mathrm{v}, 76 \mathrm{r}, 77 \mathrm{r}, 77 \mathrm{v}, 82 \mathrm{v}$, $92 \mathrm{v}, 93 \mathrm{r}, 100 \mathrm{r}, 143 \mathrm{v}, 144 \mathrm{r}, 148 \mathrm{r}, 150 \mathrm{r}$, $150 \mathrm{v}, 161 \mathrm{v}, 162 \mathrm{v}, 165 \mathrm{r}, 165 \mathrm{v}, 172 \mathrm{v}, 173 \mathrm{r}$, $173 \mathrm{v}, 174 \mathrm{r}, 174 \mathrm{v}, 175 \mathrm{r}, 183 \mathrm{r}, 184 \mathrm{r}, 184 \mathrm{v}$, $187 \mathrm{v}, 190 \mathrm{r}, 190 \mathrm{v}, 197 \mathrm{r}, 198 \mathrm{r}, 207 \mathrm{r}, 216 \mathrm{v}$, $217 \mathrm{v}, 218 \mathrm{r}, 218 \mathrm{v}, 225 \mathrm{v}, 229 \mathrm{r}, 229 \mathrm{v}, 231 \mathrm{v}$, $233 \mathrm{r}, 242 \mathrm{v}, 244 \mathrm{v}, 245 \mathrm{r}, 247 \mathrm{v}, 248 \mathrm{r}, 248 \mathrm{v}$, 272r, 273r, 279v, 280r, 284r, 286v, 295v, 306r, 310r, 322v, 328v, 346r, 347r, 364v, $365 \mathrm{r}, 383 \mathrm{v}, 384 \mathrm{r}, 384 \mathrm{v}, 385 \mathrm{r}, 386 \mathrm{v}, 387 \mathrm{r}$, $400 \mathrm{v}, 402 \mathrm{v}, 403 \mathrm{r}, 411 \mathrm{r}, 411 \mathrm{v}, 412 \mathrm{r}, 427 \mathrm{r}$, $427 \mathrm{v}, 433 \mathrm{r}, 436 \mathrm{r}, 441 \mathrm{v}, 452 \mathrm{v}$.

Rodrigo Abad de Cornoncillo: 68v.

Rodrigo Alcaller: $165 \mathrm{v}$.

Rodrigo Alfonso: 143v, 144r, 148r, 161v, $162 \mathrm{v}, 173 \mathrm{v}, 174 \mathrm{r}, 174 \mathrm{v}, 187 \mathrm{v}, 412 \mathrm{r}$.

Rodrigo Alfonso de Barcial: 364v, 365r.

Rodrigo Álvarez: 92v, 93r, 247v, 248r, 248v.

Rodrigo Bainero: 165r.

Rodrigo Blas: 150r.

Rodrigo de Assus[...], notario apostólico: $32 \mathrm{v}, 33 \mathrm{r}$.

Rodrigo de Cantoral: 347r.

Rodrigo de Colmenares: 411v.

Rodrigo de Corcuera: 184r, 184v, 198r; fraile: 43v, 100r, 216v, 217v, 218r, 218v, $279 \mathrm{v}, 280 \mathrm{r}, 286 \mathrm{v}, 322 \mathrm{v}, 383 \mathrm{v}, 384 \mathrm{r}, 384 \mathrm{v}$, $385 \mathrm{r}, 452 \mathrm{v}$.

Rodrigo de Espinosa: 59r, 207r, 328v.

Rodrigo de Gozón: 150r, 150v.

Rodrigo de Guinea: 35v, 36r.

Rodrigo de Herrera: 244v, 245r.

Rodrigo de Paz: 436r.

Rodrigo de Prado: 59v.

Rodrigo de Rozas: $197 \mathrm{r}$.

Rodrigo de San Mamés: 173r.

Rodrigo de Santaolalla: 242v, 272r.

Rodrigo de Tablares: 400v.

Rodrigo de Ulloa: 33r.

Rodrigo de Vadillo, fraile: 346r.

Rodrigo de Vergara: 310r.

Rodrigo Díaz: 156r.

Rodrigo Díaz de Rojas, 235r, 235v.

Rodrigo Espinosa: 328v.

Rodrigo Fernández: 166r, 174r, 227r, 273 r.
Rodrigo Fernández de Grijalva, 154v, $166 r$.

Rodrigo Fernández de Villamoronta: $145 \mathrm{v}$.

Rodrigo García: 74r, 74v, 98v, 99r, 131r, $144 \mathrm{v}, 163 \mathrm{v}, 164 \mathrm{r}, 174 \mathrm{v}, 175 \mathrm{r}, 271 \mathrm{v}, 405 \mathrm{r}$, 408v, 411r.

Rodrigo García de Valdefontecha: 408v.

Rodrigo García Pachistre: 144v, 405r.

Rodrigo González: 77r, 77v, 144v, 161v, 265v, 273v, 360v, 404v, 405r, 427r, 427v.

Rodrigo González de Carbonera: 265v.

Rodrigo Gutiérrez de Grijalva: 443r.

Rodrigo Ibáñez: 55r, 55v.

Rodrigo Laso: $190 \mathrm{v}$.

Rodrigo Lloréntez: 183 r.

Rodrigo López Catalán: 164v.

Rodrigo Martín: 190r.

Rodrigo Martínez de Campos: 66r.

Rodrigo Paz: 207r.

Rodrigo Pérez: 196r, 410v.

Rodrigo Rodríguez: 306r.

Rodrigo Rodríguez de Torquemada: 233r.

Rodrigo Yáñez: 225v.

Rodríguez de Castellanos: 55r, 55v, 62v, $125 \mathrm{r}, 144 \mathrm{r}, 144 \mathrm{v}, 145 \mathrm{r}, 148 \mathrm{v}, 149 \mathrm{r}, 149 \mathrm{v}$, $150 \mathrm{r}, 157 \mathrm{r}, 157 \mathrm{v}, 162 \mathrm{v}, 163 \mathrm{r}, 163 \mathrm{v}, 164 \mathrm{r}$, 169r, 175r, 192r, 192v, 345r, 360r, 364v, 412r, 440v.

Rodulfo: $117 \mathrm{r}, 471 \mathrm{v}$.

Rojas de Arce: 449r.

Rojas de Robles: 395r.

Roldán: 48r, 48v, 261r, 261v, 300v, 423v, 435r.

Roma, juez ordinario: 213 r.

Román de Villamartín: 167v.

Ronquillo: 84v, 400v.

Roque de Saavedra: 89v.

Roque Díaz de Rábago: 334v, 335r.

Roque González: 376r, 376v, 377v, 378r.

Roque Miguel: 59r, 59v.

Roscales, vecino: 302r.

Rosendo Carrera, fraile: 268r.

Rota, auditor: $19 \mathrm{v}$.

Sabina de Olmos: 367r, 367v.

Sahagún, juez subconservador: $360 \mathrm{v}$.

Salazar: 5r, 72v, 115r, 197r, 197v, 208v, 209r, 336r, 336v, 351v, 467v.

Salazar y Benavides: $221 \mathrm{v}$. 
Saldaña, doctor: $217 \mathrm{v}, 218 \mathrm{r}, 218 \mathrm{v}, 221 \mathrm{v}$; vecino: $334 r$.

Salvador: 173r, 178v, 312v, 408r, 443r

Salvador de la Fuente: 178v.

Salvador Fernández de Ledigos: 173r.

San Agustín de Valladolid, juez conservador: $215 \mathrm{r}, 215 \mathrm{v}$.

San Cebrián, beneficiado: 460r.

San Esteban, cura de: $5 \mathrm{v}$, 6r.

San Juan de Aguilar de Campoo, priores: 6v.

San Juan Ortiz de Zarauz: 364v.

San Martín, capellán: 198r, 198v; cura de: 200r.

San Miguel de Ríos Menudos, cura de: 302v, 303r.

San Pedro de Bolaños, cura de: 69r.

San Román de Entrepeñas, prior: 55r, 55v, $307 \mathrm{v}$.

San Zoilo, abad comendatario: 10v, 11r, 39v, 40r, 49r, 69v, 117v, 245r; alcalde mayor del barrio de San Zoilo, 95v; predicador: 26r; vecino: $165 \mathrm{r}, 165 \mathrm{v}$.

Sancha: 45v, 228r, 228v, 231v, 233r, 235v, 236r, 271r, 301v, 443r.

Sancha de Ledantes: 131v.

Sancha de Rojas: 229r, 229v, 230r, 230v, 231r, 231v, 233r, 235v, $236 r$.

Sancha Díaz Barahona: 272r.

Sancha Fernández: 408r.

Sancha García: 172r, 172v.

Sancha Íñiguez: 171v.

Sancha López: 255v.

Sancha Payán: 143r, 143v.

Sancha Pérez: 66r, 66v.

Sancha Sogni: 300r.

Sancho: 2v, 34r, 82v, 88v, 91v, 98r, 144v, $162 \mathrm{r}, 188 \mathrm{v}, 189 \mathrm{r}, 191 \mathrm{v}, 217 \mathrm{r}, 225 \mathrm{v}, 226 \mathrm{r}$, 226v, 228r, 233r, 287r, 289r, 289v, 386r, 405r, 413r, 413v; fraile: 98v, 99r; hija de: $188 \mathrm{v}, 189 \mathrm{r}$.

Sancho IV: 88v, 91v, 98r, 226r.

Sancho Barreda: 289r, 289v.

Sancho de Escobar: 82v.

Sancho de Herrera: 2v.

Sancho de Herrezuelo: 217r.

Sancho de Rojas: 233r.

Sancho Fernández: 162r, 226v, 233 r.

Sancho García: 386r.

Sancho González: 413v.

Sancho González de Carrión: 405r.
Sancho López: 228r.

Sancho López de Frómista: 191v, 287r.

Sancho Ruiz del Peso: 144v.

Santa Cruz: 36r, 44v, 209r, 295r, 404r.

Santa Íñiguez: $355 \mathrm{r}$.

Santa María de Carrión, cura de: 39r, 135v.

Santa María de Nájera, monje de: $144 \mathrm{r}$.

Santa María la Mayor, canónigo: 240v.

Santa María, cura de: 328r.

Santa María, licenciado: 363r, 363v.

Santiago: 421r, 464r, 466r; clérigo de la iglesia de: $167 \mathrm{v}$.

Santiago Aguado: 397v.

Santiago Alonso: 4v.

Santiago Andrés Pérez Delgado: 333r, $333 \mathrm{v}$.

Santiago Barba: 159v, 160r.

Santiago Carnicero: 75r.

Santiago Cobo Paredes: 439v.

Santiago Conde: 436v.

Santiago de Colmenares: 38v, 39r.

Santiago de la Huerta: 355v.

Santiago de los Ríos: 15r, 175v, 176r, 254v, 382r, 382v, 393r, 393v.

Santiago de Moro y Aguado: 398r, 398v.

Santiago de Rey: 5 r.

Santiago de Torres Villarroel: 463v.

Santiago del Río: 31r, 31v.

Santiago Díez: 218v, 466r.

Santiago Doncel: 463v, 466r.

Santiago Duque de Estrada: 37v, 40r, 68v, 119r, 153r, 156v, 157v, 209v, 278v, 296v, $304 \mathrm{v}, 305 \mathrm{r}, 309 \mathrm{r}, 347 \mathrm{v}, 348 \mathrm{r}, 411 \mathrm{r}, 444 \mathrm{v}$, 445r, 465v, 466v, 468r, 468v.

Santiago Facón: 3r, 4v, 5r, 5v, 11r, 28r, 368v, 369r, 398r, 424r.

Santiago Facón Cadenas: 424r.

Santiago Fernández Gutiérrez: 463v.

Santiago García Bartolomé: 187v.

Santiago Garrido: 435r.

Santiago Gil Villelga: 468v.

Santiago González Morante: 424r.

Santiago Gutiérrez Martínez: 463v.

Santiago Juanes: 431v.

Santiago Luengo: $278 \mathrm{r}$.

Santiago Martínez: 285r, 356v, 373r, 373v.

Santiago Morejón: 407r.

Santiago Ochoa: 367r, 367v.

Santiago Pando: 436r, 436v.

Santiago Ramos: 154v, 155r.

Santiago Regaliza: 435r. 
Santiago Reinoso: 172v, $173 \mathrm{r}$.

Santiago Rodríguez: 30v, 423v.

Santiago Rojo: 39r, 209r.

Santiago Roldán: 261v.

Santiago Román: 268r, 320v.

Santiago Santos: 262v, 286v.

Santiago Sevilla Nieto: 460v.

Santibáñez de la Peña, cura de: 328r: vecino: 263v, 316v, 319r, 319v.

Santos: 14v, 15r, 34v, 72r, 75r, 75v, 83v, $84 \mathrm{r}, 130 \mathrm{v}, 133 \mathrm{v}, 134 \mathrm{r}, 150 \mathrm{v}, 151 \mathrm{r}, 160 \mathrm{r}$, $169 \mathrm{v}, 170 \mathrm{v}, 185 \mathrm{r}, 195 \mathrm{r}, 199 \mathrm{v}, 200 \mathrm{r}, 212 \mathrm{v}$, $213 \mathrm{r}, 223 \mathrm{v}, 251 \mathrm{v}, 259 \mathrm{v}, 262 \mathrm{v}, 273 \mathrm{v}, 274 \mathrm{r}$, 277v, 278r, 286v, 303v, 304r, 306r, 306v, $311 \mathrm{r}, 315 \mathrm{r}, 316 \mathrm{v}, 327 \mathrm{r}, 327 \mathrm{v}, 331 \mathrm{r}, 338 \mathrm{r}$, $341 \mathrm{r}, 341 \mathrm{v}, 343 \mathrm{r}, 351 \mathrm{v}, 378 \mathrm{r}, 395 \mathrm{r}, 395 \mathrm{v}$, 396r, 399r, 405v, 413v, 414r, 420r, 423v, 436v, 437r, 447v, 448r, 449r, 449v, 450r, 453r, 460r, 463r, 465r.

Santos Blanco: 75r, 75v.

Santos Caballero: 460r.

Santos de Guzmán, 169v, 170v, 420r, $423 \mathrm{v}, 447 \mathrm{v}, 449 \mathrm{r}, 449 \mathrm{v}, 450 \mathrm{r}, 453 \mathrm{r}, 463 \mathrm{r}$, 465 r.

Santos de Herrera: 448r.

Santos de Villegas: 306r, 306v.

Santos Frechilla: 195r.

Santos García: 351v.

Santoyo: 134r, 134v, 178r, 295v.

Scetha Ferre: $259 \mathrm{v}$.

Sebastián Abad: 296v, 297r.

Sebastián Calzas: 278r.

Sebastián Campoo Martínez; 178v.

Sebastián Cornejo: 392v.

Sebastián de Ávila, fraile: 10r.

Sebastián de Encinas, fraile: 100r, 246v, 265r, 266r, 399r.

Sebastián de Hermosa: 462r.

Sebastián de los Ríos Campoo: 178v.

Sebastián de Rivera: 38r, 38v, 436r.

Sebastián de Valera: 419r, 419v.

Sebastián de Villalpando: 428r, 428v.

Sebastián del Campo Navarro: $37 \mathrm{v}$.

Sebastián del Campo: 185 r.

Sebastián Díaz: 105v.

Sebastián Díez: 129v, 177v, 178r, 205r, $205 \mathrm{v}$.

Sebastián García: 177v.

Sebastián González: 356v.

Sebastián Gorbalera: 105r, 105v.

Sebastián Lozano: 193v.
Sebastián Manjón de San Miguel: 40r.

Sebastián Martínez de Valdivia: 380r.

Sebastián Martínez: 17r.

Sebastián Pérez: 349v.

Sebastián Valera: 425r, 425v.

Sebastiana Fernández: 423v.

Señorina Alfonso: $164 \mathrm{v}$.

Sepúlveda: 414r, 414v.

Sierra; 38v, 39r, 180v, 198v, 223r, 223v, $331 \mathrm{v}, 376 \mathrm{v}, 377 \mathrm{r}, 377 \mathrm{v}, 393 \mathrm{v}$; licenciado: $394 \mathrm{r}$.

Sigüenza, obispo de: 84 r.

Silvestre Palacios, fraile: 262v.

Simón Cardo: 64r, 65r.

Simón de Arriba: 263v.

Simón de Bedoya: 48v.

Simón de los Ríos: 266v, 267r.

Simón de Rozas y Negrete: 364r.

Simón Díaz Moro: 161r.

Simón Díez: 157 r.

Simón García: 285r.

Simón Jiménez Cortés: 282r.

Simón Martín Calvo: 464v.

Simón Pedraza: 68r.

Simón Pérez de Carrión: 410v.

Simón Pérez: 178v.

Simón Pérez Prieto: 406r, 406v.

Simón Rojo: 319v.

Simoneta: 190v.

Sinibaldo de Oria, genovés: 420r.

Sixto IV: 102r, 102v, 104v, $105 \mathrm{r}$.

Sol: $434 \mathrm{r}$.

Sol Díez: 408v.

Solartoraya, licenciado: $47 \mathrm{v}$.

Somonte, doctor: $445 \mathrm{v}$.

Soto de Acuña: $141 \mathrm{r}$.

Sotomayor: 354r, 354v.

Suero de Quiñones: 430r.

Suero: 360r.

Suero Pérez: 412r.

Susana González: 352r.

Támara, beneficiado: $199 \mathrm{r}, 199 \mathrm{v}$.

Tamayo: 203v, 204r, 211v, 212r, 296v, $419 \mathrm{v}$.

Tapia: 143r, 143v, 415v.

Tarilonte, cura de: 60r; vecino de: $336 \mathrm{v}$.

Tejada, licenciado: $2 \mathrm{v}$.

Tello: 133r, 226v, 230r, 230v, 231r, 341r, $417 \mathrm{v}$.

Teófilo Guerra: 329r, 329v. 
Terán, doctor: $445 \mathrm{r}$.

Teresa: 35v, 107r, 110r, 140v, 141r, 143v, $145 \mathrm{v}, 165 \mathrm{r}, 172 \mathrm{r}, 192 \mathrm{r}, 225 \mathrm{v}, 226 \mathrm{v}, 235 \mathrm{v}$, 236r, 286v, 313r, 313v, 339r, 443r; condesa: 1v; mujer de Gómez Díaz: 107r. Teresa de Cárdenas y Toledo: 140v, $141 \mathrm{r}$. Teresa Gallego: 465v.

Teresa García: 145v.

Teresa Gómez: 313r.

Teresa Mayor: 286v.

Tigridia, mujer de Diego Muñiz: 78v, 312r, $312 \mathrm{v}$.

Tobar: 31r, 56r, 63r, 71v, 169v, 233r, 279v, 280r, 280v, 415v, 416r.

Toda: $45 \mathrm{v}$.

Toda Día: 45r.

Toledo, arzobispo: 84r, 243r, 243v.

Tomás Bravo, fraile: 319 r.

Tomás de Acebedo: 11v.

Tomás de Ávila: 399r.

Tomás de Bedoya: 48v.

Tomás de Caramanzana: 398r, 467v, 468r.

Tomás de Cosgaya: 300v, 309r.

Tomás de la Cuesta: 26r.

Tomás de la Torre: 209r.

Tomás de las Bárcenas: 283r.

Tomás de Padierna: 449v, 450r.

Tomás de Tobar: 415v, 416r.

Tomás Díaz de Basurto: 44v, 203r, 406r, 406v.

Tomás Díez de Modoya: 222r.

Tomás Enríquez: 59v, 60r.

Tomás Francisco Torres: 209r.

Tomás García: 262r.

Tomás García Negrete: 464r, 465r.

Tomás González: 198r, 198v, 199r, 199v, 204r, 204v, 208r, 208v, 213r, 213v, 311v.

Tomás González Arintero: 311v.

Tomás González Reinoso: 460r.

Tomás Gracián Danrisco: 342v, 343r.

Tomás Gutiérrez: 409r, 409v.

Tomás Herrero: 160r.

Tomás López: 252v.

Tomás Machuca: 447v.

Tomás Martín: 428r.

Tomás Pérez: 6r, 69v, 73v, 118r, 167v, $270 r$.

Tomás Sánchez: 94r，95v，151v，152r, 176r, 347r.

Tomás Sanz Carpintero: 268v, 282r, 282v, $305 r$.
Tomás Vallejo: 164v.

Tomás Varela: $181 \mathrm{v}$

Toribio: 31r, 31v, 36r, 36v, 38r, 38v, 49v, $63 \mathrm{r}, 72 \mathrm{r}, 133 \mathrm{v}, 134 \mathrm{r}, 144 \mathrm{v}, 157 \mathrm{r}, 158 \mathrm{v}$, $161 \mathrm{r}, 166 \mathrm{r}, 169 \mathrm{v}, 174 \mathrm{r}, 175 \mathrm{r}, 186 \mathrm{v}, 187 \mathrm{v}$, 191v, 192r, 196r, 206r, 227v, 228r, 228v, 229r, 229v, 230r, 230v, 231r, 252v, 255r, $255 \mathrm{v}, 263 \mathrm{r}, 277 \mathrm{v}, 278 \mathrm{r}, 287 \mathrm{r}, 289 \mathrm{v}, 296 \mathrm{v}$, $302 \mathrm{v}, 303 \mathrm{r}, 303 \mathrm{v}, 304 \mathrm{r}, 310 \mathrm{r}, 310 \mathrm{v}, 311 \mathrm{v}$, $315 \mathrm{v}, 323 \mathrm{r}, 323 \mathrm{v}, 337 \mathrm{r}, 345 \mathrm{r}, 346 \mathrm{v}, 371 \mathrm{v}$, 372r, 373r, 373v, 374r, 374v, 376r, 380r, 391r, 403r, 409r, 411r.

Toribio Alonso: $311 \mathrm{v}$.

Toribio Aparicio: 38r, 38v.

Toribio Barbán: 169v.

Toribio Calvo: 402v, 403r, 403v.

Toribio Caro: $63 \mathrm{r}$.

Toribio Casa: 346v.

Toribio Cóbreces: 289v.

Toribio de Gonzalo: 376r, 380r.

Toribio de Guardo: 374r, 374v.

Toribio de Guaza: 252v.

Toribio de la Calle: $186 v$.

Toribio de Lagunilla: 207v.

Toribio de Membrillar: 166r.

Toribio de Porras Villadiego: 255r.

Toribio de San Andrés, fraile: 36r, 36v, 302v, 310r, 310v, 323r, 323v.

Toribio de Villacorta: 372r, $373 \mathrm{r}$.

Toribio de Villadiego: 391r.

Toribio de Villanueva: 207v.

Toribio del Campo: 31r, 31v, 158v, 167r.

Toribio del Valle: 409r.

Toribio Díaz Santos: 277v, 278r.

Toribio Díez Santos: 303v, 304r.

Toribio Domínguez de San Martín: 345r.

Toribio Fernández: 161r, 191v, 192r, 196r, 228r, 228v, 229r, 229v.

Toribio Francisco: 303r, 303v.

Toribio García: 337r.

Toribio González de Frómista: 206r.

Toribio González: 133v, 134r: 227r.

Toribio Gutiérrez Escribano: 72r.

Toribio Lobato: 186v.

Toribio Macho: 263r.

Toribio Marchicón: 255v.

Toribio Marcos: 49v.

Toribio Martín: $181 \mathrm{v}$.

Toribio Martínez: 287r.

Toribio Martínez de Valcabadillo: 345 r.

Toribio Merino: 263r, 373v, 374r, 374v. 
Toribio Muñoz: 438v.

Toribio Narganes: 296v.

Toribio Pérez: 346v, 371v.

Toribio Porro: $411 \mathrm{r}$.

Toribio Rejo: $144 \mathrm{v}$.

Toribio Requejo: $177 \mathrm{v}$.

Toribio Sánchez: 191v, 192r, 227v.

Toribio Santandrés: $177 \mathrm{v}$.

Toro: 69r, 87r, 99v, 286r, 338r, 360r, 382r, 383r，418r，418v，427v，447r，464r; licenciado: $372 \mathrm{v}$.

Umberto: 177r, 189v, 190r, 225r, 225v, 283v, 284r, 359r; fraile: 291r.

Urbano: 308r, 375v.

Urbano VIII: 27r, 27v, 28v, 29r.

Urbano Fernández: 308r.

Urraca: 30v, 31r, 32v, 33r, 68v, 91r, 148v, 149r, 172r, 186v, 189r, 225v, 259v, 273r, $277 \mathrm{r}, 279 \mathrm{v}, 313 \mathrm{r}, 413 \mathrm{r}, 413 \mathrm{v}$; reina: 1v, $288 \mathrm{r}, 288 \mathrm{v}$.

Urraca de Midorda: 31r.

Urraca Díaz: 68v, 279v.

Urraca García: 273r.

Urraca Gómez: 1v, 313r.

Urraca González: 148v, 149r.

Urraca Martínez: 30v, 31r, 259v.

Urraca Muñoz: 186v.

Urraca Peláez: 352v.

Urraca Téllez: $277 \mathrm{r}$.

Úrsula del Hierro: 4r.

Valdés, 73r, 208r, 310v.

Valenzuela: 105r, 105v.

Valladolid, vecino: 399r.

Vázquez de Rueda: 154v, 155r.

Vázquez, licenciado: 223v.

Vecilla: 178r.

Vega: 18r, 28r, 31r, 37r, 47v, 50r, 51r, 51v, 56r, 56v, 59r, 60r, 60v, 64v, 65r, 71r, 71v, $77 \mathrm{v}, 78 \mathrm{r}, 87 \mathrm{r}, 95 \mathrm{r}, 118 \mathrm{v}, 124 \mathrm{r}, 124 \mathrm{v}, 139 \mathrm{v}$, $146 \mathrm{v}, 158 \mathrm{r}, 158 \mathrm{v}, 165 \mathrm{v}, 176 \mathrm{r}, 186 \mathrm{v}, 187 \mathrm{r}$, $194 \mathrm{r}, 194 \mathrm{v}, 198 \mathrm{r}, 202 \mathrm{r}, 218 \mathrm{v}, 255 \mathrm{v}, 256 \mathrm{r}$, $263 \mathrm{r}, 263 \mathrm{v}, 266 \mathrm{r}, 266 \mathrm{v}, 267 \mathrm{r}, 278 \mathrm{r}, 279 \mathrm{v}$, 280r, 296v, 300v, 302v, 303r, 303v, 308v, 309r, 311r, 315v, 316r, 318r, 319r, 323v, $324 \mathrm{r}, 326 \mathrm{v}, 328 \mathrm{v}, 331 \mathrm{v}, 350 \mathrm{v}, 362 \mathrm{v}, 366 \mathrm{r}$, 375r, 376r, 380r, 380v, 391r, 391v, 416v, $430 \mathrm{v}, 431 \mathrm{r}, 431 \mathrm{v}, 432 \mathrm{v}, 445 \mathrm{r}, 449 \mathrm{v}, 450 \mathrm{r}$, $452 \mathrm{v}, 453 \mathrm{r}, 458 \mathrm{v}$.

Vega de Riacos, vecino: $350 \mathrm{v}$.

Velasco Rodríguez: 404v.
Vellido Gutiérrez: 45.

Ventura Díez: 262v.

Ventura González: 305r.

Ventura López de Arriaga: 100v, 101 r.

Vicenta Muñoz: 153r.

Vicente Álvarez de la Carrera: 103r, 103v, $104 \mathrm{v}, 105 \mathrm{r}$.

Vicente Antonio de Ubarrieta: 178v.

Vicente Correas: 357r.

Vicente de la Torre y Riva: 39v, 40r, 42r, $42 \mathrm{v}$.

Vicente Gonzalo: 40r, 40v.

Vicente Montes: 319v.

Vicente Ruiz Ramos: 101r, 101v.

Vicente Ubago: 116r.

Vicente Yáñez, fraile: 376r.

Victorio Vado: 18v.

Victorio Vázquez: 430r.

Vida Bermúdez: 312v.

Villacintor, vicario de: 376v, 377r, 377v.

Villafría, vecino: $371 \mathrm{v}$.

Villagómez: 41r, 249r, 249v, 250r.

Villalpando, clérigo, vecino: $395 \mathrm{v}$.

Villalumbroso, vecino: 462r.

Villamayor, vecino: $397 \mathrm{v}$.

Villamuera, alcalde mayor: 420v; vecino: $149 \mathrm{v}, 150 \mathrm{r}, 424 \mathrm{r}$.

Villanueva de Guardo, vecino: 372r, 372v.

Villanueva de los Nabos, 411r.

Villaoliva, vecino: $428 \mathrm{v}$.

Villordón: $419 \mathrm{v}$.

Villota y Boniel: 134r.

Vitorio de la Calle: 186v, 187r.

Walcio: 172r.

Yugo Carite: 226v.

Zafra Argüelles: 18v.

Zamora, capitán general: 6r, 6v.

Zarandona: $257 \mathrm{r}$.

Zoilo Cantero: $159 \mathrm{v}$.

Zoilo de Escobar, fraile: 323r, 323v.

Zoilo de Nogal: 74v, 102v, 103r, 104v, 154r; fraile: 102r, 103r, 103v, 104r, 150r, 150v, 240v; sacristán mayor de San Zoilo y capellán de la Magdalena: 103r, 103v.

Zoilo de Pedroso: 153r, 194v; fraile: 411r, $153 r$.

Zoilo de Saldaña; 175v, 418v, 419r; fraile: $364 \mathrm{v}, 365 \mathrm{v}$. 
Zoilo Medina, fraile: 400r. Zoilo Ortiz, fraile: 368v, 369r.

Zoilo Trigo, fraile: 51v, 336r, 336v.
Zúñiga: 37r, 39v, 40r, 69v, 79r, 135r, 209v, 278r, 295v, 296r, 311r. 


\section{ÍNDICE DE LUGARES}

Abastas: 459r, 459v

Abia de las Torres: 30v, 31r, 31v, 66r, 66v, 461 r.

Aguilar de Campoo: 1v, 2r, 2v, 3r, 3v, 4r, $5 \mathrm{r}, 5 \mathrm{v}, 6 \mathrm{v}, 8 \mathrm{r}, 8 \mathrm{v}, 9 \mathrm{r}, 9 \mathrm{v}, 10 \mathrm{r}, 10 \mathrm{v}, 11 \mathrm{r}, 11 \mathrm{v}$, $12 \mathrm{r}, 13 \mathrm{r}, 13 \mathrm{v}, 14 \mathrm{r}, 14 \mathrm{v}, 15 \mathrm{r}, 16 \mathrm{r}, 16 \mathrm{v}, 17 \mathrm{r}$, $17 \mathrm{v}, 18 \mathrm{r}, 18 \mathrm{v}, 19 \mathrm{v}, 20 \mathrm{r}, 20 \mathrm{v}, 21 \mathrm{r}, 21 \mathrm{v}, 22 \mathrm{r}$, $24 \mathrm{r}, 24 \mathrm{v}, 25 \mathrm{r}, 26 \mathrm{r}, 26 \mathrm{v}, 27 \mathrm{r}, 27 \mathrm{v}, 28 \mathrm{r}, 28 \mathrm{v}$, $29 \mathrm{r}, 38 \mathrm{v}, 68 \mathrm{r}, 82 \mathrm{v}, 84 \mathrm{v}, 226 \mathrm{v}, 304 \mathrm{r}, 362 \mathrm{r}$, $362 \mathrm{v}, 363 \mathrm{r}, 368 \mathrm{v}, 369 \mathrm{r}, 398 \mathrm{r}, 399 \mathrm{v}, 439 \mathrm{v}$, 463r.

Ayllón: $229 \mathrm{v}$.

Alaejos: 86r.

Alarcos: 30v, 31r.

Alba: 64v, 65r, 250v, 306r, 311v, 339r, $339 \mathrm{v}, 340 \mathrm{r}, 340 \mathrm{v}, 341 \mathrm{r}, 349 \mathrm{v}, 372 \mathrm{r}$.

Alcalá de Henares, 89r, 117r, 117v, 282r.

Alcor: $14 \mathrm{v}, 15 \mathrm{r}$.

Alemania: 91r.

Almanza: 450r.

Amusco: 111r, 177v, 196v, 197r.

Ancona: 14r, 20r, 20v.

Añora: 453r.

Añoza: 30r, 30v, 355v, 356v.

Aragón: 230r, 230v, 231r.

Arconada: 11r, 11v, 32v, 33r, 33v, 34r, $34 \mathrm{v}, 35 \mathrm{r}, 35 \mathrm{v}, 36 \mathrm{r}, 36 \mathrm{v}, 37 \mathrm{r}, 38 \mathrm{r}, 38 \mathrm{v}, 39 \mathrm{r}$, $39 \mathrm{v}, 40 \mathrm{r}, 40 \mathrm{v}, 41 \mathrm{r}, 41 \mathrm{v}, 42 \mathrm{r}, 43 \mathrm{r}, 43 \mathrm{v}, 44 \mathrm{r}$, $44 \mathrm{v}, 68 \mathrm{v}, 93 \mathrm{r}, 93 \mathrm{v}, 94 \mathrm{v}, 107 \mathrm{r}, 107 \mathrm{v}, 108 \mathrm{r}$, $108 \mathrm{v}, 109 \mathrm{r}, 213 \mathrm{r}, 213 \mathrm{v}, 217 \mathrm{r}, 226 \mathrm{r}, 312 \mathrm{r}$, $312 \mathrm{v}, 362 \mathrm{v}, 363 \mathrm{r}, 414 \mathrm{v}, 415 \mathrm{r}, 415 \mathrm{v}, 416 \mathrm{r}$, $416 \mathrm{v}, 418 \mathrm{v}, 454 \mathrm{r}, 454 \mathrm{v}, 457 \mathrm{r}, 457 \mathrm{v}, 458 \mathrm{v}$, 459v; (Santa María de Arconada): 362v, 363r.

Arcos: 30v, 31r, 230r, 230v, 231r.

Arenal: $5 \mathrm{v}$

Arenillas: 30v, 31r, 31v, 71r, 71v, 289v, $313 v, 314 v, 373 r, 373 v, 403 r, 403 v$.

Arenillas de la Huerta: 403r, 403v.

Arenillas de Mazol: 30v.

Arenillas de Nuño Pérez: 30v, 31r, 71r, 71v, 313v, 373r, 373v.

Arenillas de San Pelayo: 31r, 31v, 71r, $289 \mathrm{v}$.

Arévalo: 183v, 234r, 234v, 235r, 454r.

Arlanza: 34v, 35r.
Arroyo de Hontanares: 349v.

Astorga: 8v, 9r, 9v, 34v, 48v, 251v, 252r, $356 r$.

Astudillo: 32r, 32v, 180v, 218v, 219r.

Autela: $108 \mathrm{v}$.

Autilla del Pino: 443r.

Autillo de Campos: 107v, 108r.

Autol: $459 \mathrm{v}$.

Ávila: 34v, 35r, 82r, 96r, $141 \mathrm{r}$.

Aviñante de la Peña: 45r, 45v, 46r, 46v, $47 \mathrm{r}, 47 \mathrm{v}, 48 \mathrm{r}, 48 \mathrm{v}, 49 \mathrm{r}, 49 \mathrm{v}, 50 \mathrm{r}, 50 \mathrm{v}, 51 \mathrm{r}$, $51 \mathrm{v}, 60 \mathrm{r}, 71 \mathrm{v}, 186 \mathrm{v}, 187 \mathrm{r}, 218 \mathrm{v}, 259 \mathrm{v}$, $262 \mathrm{v}, 279 \mathrm{v}, 286 \mathrm{v}, 296 \mathrm{v}, 313 \mathrm{r}, 314 \mathrm{v}, 319 \mathrm{v}$, $321 \mathrm{r}, 321 \mathrm{v}, 323 \mathrm{v}, 324 \mathrm{r}, 329 \mathrm{r}, 331 \mathrm{v}, 334 \mathrm{r}$, 336v, 351r, 351v, 371r, 371v, 372v, 373r, $373 \mathrm{v}, 374 \mathrm{v}, 376 \mathrm{r}, 380 \mathrm{v}, 383 \mathrm{v}, 384 \mathrm{r}, 384 \mathrm{v}$, 385r, 387r, 437r, 441v. .

Aviñón: $82 \mathrm{v}$

Badajoz: $85 \mathrm{v}$

Baeza: 423v.

Baillo: 55r, 55v.

Baños de Cerrato: 56r, 56v, 71r, 108v, 295v, 296r, 300v, 309r, 355r, 373r, 373v, 428v.

Barajores de la Peña: 47r, 47v, 48r, 57v, 58r, 58v, 59r, 59r, 59v, 60r, 60v, 61r, 61v, $62 \mathrm{r}, 263 \mathrm{v}, 293 \mathrm{r}, 293 \mathrm{v}, 296 \mathrm{v}, 297 \mathrm{r}, 300 \mathrm{v}$, $308 \mathrm{v}, 351 \mathrm{r}$.

Barcelona, 82r.

Bárcena de Campos: 31r, 62v, 63r, 71v, $77 \mathrm{v}, 78 \mathrm{r}, 144 \mathrm{r}, 277 \mathrm{r}, 282 \mathrm{r}, 312 \mathrm{v}, 457 \mathrm{r}$, $457 \mathrm{v}$.

Barcial de la Loma: 3v.

Barrio: 179v, 180r, 180v, 186v, 279v, 313r, 328r, 346v, 347r, 408r.

Becerril del Carpio: 66r, 66v, 67r, 67v, 68r, 73v, 90r, 106r, 108v, 152r, 235r, 235v, $440 \mathrm{v}, 442 \mathrm{v}, 453 \mathrm{r}, 457 \mathrm{r}, 457 \mathrm{v}, 463 \mathrm{v}, 464 \mathrm{r}$, 464v, 465r, 465v, 466r, 466v, 467r.

Becilla: 442v.

Belver: 401r, 401v.

Benafarces: 338r, 454r.

Benavente: 40r.

Benevivere (Santa María de Benevivere): 42r, 75r, 75v, 79r, 99r, 102r, 102v, 103r, 
$103 \mathrm{v}, 105 \mathrm{r}, 122 \mathrm{r}, 122 \mathrm{v}, 127 \mathrm{r}, 127 \mathrm{v}, 154 \mathrm{v}$, $155 \mathrm{r}, 155 \mathrm{v}, 215 \mathrm{r}, 215 \mathrm{v}, 216 \mathrm{r}, 300 \mathrm{v}, 327 \mathrm{r}$, 331r, 356r.

Bergondo: 24r.

Berrueces: 5 r.

Bercianos del Real Camino 273r.

Boadilla del Camino: 32r, 108v, 188v, 189r, 193r, 273r.

Bolaños: 69r, 69v, 70r, 401v.

Bolonia: 239r

Braga: $119 \mathrm{r}, 119 \mathrm{v}$

Briviesca: $203 \mathrm{v}$.

Buedo: 296v

Buenavista de Valdavia: 5r, 290r, 390r.

Burgos: 14r, 20v, 34r, 34v, 36r, 36v, 39v, 40r, 69r, 70v, 71r, 85r, 85v, 86r, 86v, 87r, $87 \mathrm{v}, 88 \mathrm{r}, 91 \mathrm{r}, 91 \mathrm{v}, 92 \mathrm{r}, 98 \mathrm{r}, 98 \mathrm{v}, 99 \mathrm{v}, 105 \mathrm{r}$, $105 \mathrm{v}, 111 \mathrm{v}, 112 \mathrm{r}, 112 \mathrm{v}, 117 \mathrm{v}, 118 \mathrm{r}, 124 \mathrm{v}$, $127 \mathrm{r}, 129 \mathrm{r}, 129 \mathrm{v}, 130 \mathrm{r}, 130 \mathrm{v}, 133 \mathrm{r}, 134 \mathrm{r}$, 136r, 137r, 183r, 189r, 190r, 190v, 197r, $203 \mathrm{v}, 204 \mathrm{r}, 207 \mathrm{v}, 209 \mathrm{r}, 210 \mathrm{v}, 217 \mathrm{r}, 217 \mathrm{v}$, 218r, 218v, 219r, 221r, 222r, 222v, 223r, $223 \mathrm{v}, 226 \mathrm{v}, 227 \mathrm{r}, 235 \mathrm{v}, 236 \mathrm{r}, 252 \mathrm{v}, 256 \mathrm{v}$, $257 \mathrm{r}, 259 \mathrm{v}, 269 \mathrm{v}, 281 \mathrm{r}, 281 \mathrm{v}, 288 \mathrm{r}, 296 \mathrm{r}$, $297 \mathrm{v}, 317 \mathrm{v}, 322 \mathrm{r}, 328 \mathrm{v}, 329 \mathrm{r}, 353 \mathrm{r}, 393 \mathrm{r}$, 406r, 415r, 419r, 419v, 425r, 436r, 445v, 446v, 447r; diócesis: 207v.

Bustillo: 339r, 339v, 340r, 340v, 341r, 348v, 349r.

Bustillo de Cea: 70r

Cabañas: 36r, 358r, 358v, 359r, 363r, 363v. Cabreros del Monte: 11v.

Cáceres: 73 r.

Calahorra: 36r, 38v, 39r, 223r, 341r, 459v. Calzada de los Molinos: 74r, 74v, 75r, 75v, $100 \mathrm{r}, 131 \mathrm{v}, 144 \mathrm{r}, 145 \mathrm{r}, 145 \mathrm{v}, 148 \mathrm{v}, 152 \mathrm{v}$, $163 \mathrm{v}, 164 \mathrm{r}, 166 \mathrm{r}, 271 \mathrm{r}, 271 \mathrm{v}, 273 \mathrm{r}, 273 \mathrm{v}$, $411 \mathrm{v}, 438 \mathrm{r}, 443 \mathrm{r}, 452 \mathrm{r}, 457 \mathrm{r}, 457 \mathrm{v}, 459 \mathrm{v}$.

Calzadilla del Camino: 76r, $291 \mathrm{r}$.

Camporredondo de Alba: 63v, 64v, 65r, 76v, 279v, 296v, 311r, 332r, 349v, 372r, $373 \mathrm{r}, 373 \mathrm{v}$.

Canduela: 48v, 310v, 311r, 311v, 313v, 329 r.

Carbonera: 71r, 77v, 78r, 373r, 373v.

Cardeña: 35r, 35v, 36r, 36v, 323r, 323v, $325 \mathrm{v}, 326 \mathrm{r}, 326 \mathrm{v}, 327 \mathrm{r}, 328 \mathrm{r}, 328 \mathrm{v}, 329 \mathrm{r}$, $334 \mathrm{v}, 336 \mathrm{r}, 336 \mathrm{v}, 347 \mathrm{r}, 352 \mathrm{v}, 355 \mathrm{r}, 356 \mathrm{v}$, 359r, 359v, 361r, 361v, 362r, 363r, 363v, $364 \mathrm{v}, 365 \mathrm{v}, 366 \mathrm{r}, 366 \mathrm{v}, 367 \mathrm{r}$.
Cardeñosa: 35r, 35v, 36r, 36v, 78v, 79r, $107 \mathrm{v}, 108 \mathrm{r}, 108 \mathrm{v}, 110 \mathrm{r}, 119 \mathrm{r}, 119 \mathrm{v}, 323 \mathrm{r}$, $323 \mathrm{v}, 325 \mathrm{v}, 326 \mathrm{r}, 326 \mathrm{v}, 328 \mathrm{r}, 328 \mathrm{v}, 329 \mathrm{r}$, $334 \mathrm{v}, 336 \mathrm{r}, 336 \mathrm{v}, 347 \mathrm{r}, 352 \mathrm{v}, 355 \mathrm{r}, 356 \mathrm{v}$, $359 \mathrm{r}, 359 \mathrm{v}, 361 \mathrm{r}, 361 \mathrm{v}, 362 \mathrm{r}, 363 \mathrm{r}, 363 \mathrm{v}$, $364 \mathrm{v}, 365 \mathrm{v}, 366 \mathrm{r}, 366 \mathrm{v}, 367 \mathrm{r}, 367 \mathrm{v}, 445 \mathrm{r}$, $451 \mathrm{v}, 453 \mathrm{r}, 453 \mathrm{v}, 459 \mathrm{v}$.

Carregatón: $5 \mathrm{r}$.

Carremedina, 2r, 368r.

Carrevillanueva: 150r.

Carrión de los Condes: 15r, 16r, 17r, 23v, 26r, 26v, 27r, 32r, 33r, 33v, 34v, 35r, 35v, $36 \mathrm{r}, 37 \mathrm{r}, 37 \mathrm{v}, 38 \mathrm{r}, 38 \mathrm{v}, 39 \mathrm{r}, 39 \mathrm{v}, 40 \mathrm{r}, 40 \mathrm{v}$, $41 \mathrm{v}, 42 \mathrm{r}, 43 \mathrm{r}, 43 \mathrm{v}, 44 \mathrm{r}, 44 \mathrm{v}, 48 \mathrm{r}, 48 \mathrm{v}, 49 \mathrm{v}$, 50r, 58r, 60r, 61r, 62v, 66r, 68v, 69r, 73v, $74 \mathrm{r}, 74 \mathrm{v}, 75 \mathrm{r}, 75 \mathrm{v}, 76 \mathrm{r}, 78 \mathrm{v}, 79 \mathrm{r}, 82 \mathrm{r}, 82 \mathrm{v}$, $84 \mathrm{r}, 85 \mathrm{r}, 85 \mathrm{v}, 86 \mathrm{r}, 86 \mathrm{v}, 88 \mathrm{r}, 89 \mathrm{v}, 90 \mathrm{r}, 90 \mathrm{v}$, $91 \mathrm{v}, 92 \mathrm{r}, 92 \mathrm{v}, 93 \mathrm{r}, 93 \mathrm{v}, 94 \mathrm{r}, 94 \mathrm{v}, 95 \mathrm{r}, 95 \mathrm{v}$, $96 \mathrm{r}, 96 \mathrm{v}, 97 \mathrm{r}, 97 \mathrm{v}, 98 \mathrm{r}, 98 \mathrm{v}, 99 \mathrm{r}, 99 \mathrm{v}, 100 \mathrm{r}$, $100 \mathrm{v}, 101 \mathrm{r}, 101 \mathrm{v}, 102 \mathrm{v}, 103 \mathrm{r}, 103 \mathrm{v}, 104 \mathrm{r}$, $104 \mathrm{v}, 105 \mathrm{r}, 105 \mathrm{v}, 106 \mathrm{r}, 109 \mathrm{r}, 109 \mathrm{v}, 110 \mathrm{r}$, $110 \mathrm{v}, 111 \mathrm{r}, 111 \mathrm{v}, 112 \mathrm{r}, 112 \mathrm{v}, 113 \mathrm{v}, 114 \mathrm{v}$, $115 \mathrm{r}, 115 \mathrm{v}, 116 \mathrm{r}, 117 \mathrm{v}, 118 \mathrm{r}, 118 \mathrm{v}, 119 \mathrm{r}$, $120 \mathrm{r}, 120 \mathrm{v}, 121 \mathrm{r}, 121 \mathrm{v}, 122 \mathrm{r}, 122 \mathrm{v}, 123 \mathrm{r}$, $124 \mathrm{r}, 124 \mathrm{r}, 124 \mathrm{v}, 125 \mathrm{r}, 127 \mathrm{v}, 128 \mathrm{r}, 128 \mathrm{v}$, 129r, 129v, 130r, 130v, 131r, 131v, 132r, $133 \mathrm{r}, 133 \mathrm{v}, 134 \mathrm{r}, 134 \mathrm{v}, 135 \mathrm{r}, 273 \mathrm{r}, 316 \mathrm{r}$, 460r.

Carvajal: $183 \mathrm{v}, 184 \mathrm{r}$.

Casillas: 66r, 66v.

Castellanos: 108v, 255v.

Castilla: 17r, 20r, 21v, 22r, 35v, 83r, 83v, 99r, 103v, 104r, 115v, 172r, 210v, 227v, $229 \mathrm{v}, 233 \mathrm{r}, 239 \mathrm{r}, 259 \mathrm{v}, 274 \mathrm{v}, 322 \mathrm{r}, 339 \mathrm{r}$, $355 \mathrm{r}, 359 \mathrm{r}, 359 \mathrm{v}, 417 \mathrm{v}$.

Castrejón de la Peña: 44r, 73v, 172r, 172v, 294r, 294v, 296v, 298v, 299r, 311v, 351v, 352r, 354r, 375r, 460r.

Castrillejo de la Olma: 169v, 170r, 170v, 171r, 284v, 452v, 453r.

Castrillo de Macintos: 71r, 169r, 169v, 255r, 350r, 457r, 457v.

Castrillo de Renedo: 71r

Castrillo de Valderaduey: 350r.

Castrojeriz: 199v, 209v, 255v, 443v, 444r, $444 \mathrm{v}, 454 \mathrm{r}, 454 \mathrm{v}$.

Castromayor: 13r, 13v, 255v, 443v, 444r, 444v.

Castromocho: $34 \mathrm{v}$.

Castromudarra: 184r, 184v.

Castromuza: 269r. 
Castroverde: 399v, $401 \mathrm{r}$.

Cea: 71r, 72r, 183v, 184r, 184v, 329r, 350r. Cervatos de la Cueza: 171v, 291r, 306r, 355r, 460r.

Cervera de Pisuerga: 2r, 2v, 4r, 10r, 10v, $11 \mathrm{v}, 22 \mathrm{v}, 23 \mathrm{r}, 64 \mathrm{v}, 263 \mathrm{r}, 269 \mathrm{v}, 351 \mathrm{v}, 352 \mathrm{r}$, $360 \mathrm{r}, 360 \mathrm{v}, 361 \mathrm{r}, 361 \mathrm{v}, 362 \mathrm{r}, 364 \mathrm{r}, 364 \mathrm{v}$, $365 \mathrm{r}, 367 \mathrm{v}, 368 \mathrm{r}, 368 \mathrm{v}, 371 \mathrm{r}, 374 \mathrm{v}, 376 \mathrm{r}$, $380 \mathrm{r}, 380 \mathrm{v}, 381 \mathrm{r}, 381 \mathrm{v}, 387 \mathrm{v}, 389 \mathrm{r}, 389 \mathrm{v}$, $390 \mathrm{v}, 394 \mathrm{v}, 395 \mathrm{v}, 399 \mathrm{v}, 400 \mathrm{v}, 402 \mathrm{v}, 403 \mathrm{r}$, $403 \mathrm{v}, 404 \mathrm{r}, 408 \mathrm{r}, 414 \mathrm{r}, 414 \mathrm{v}, 415 \mathrm{r}, 415 \mathrm{v}$, $430 \mathrm{v}, 431 \mathrm{r}, 431 \mathrm{v}, 434 \mathrm{r}, 439 \mathrm{r}, 439 \mathrm{v}, 441 \mathrm{v}$, $442 \mathrm{r}, 442 \mathrm{v}, 444 \mathrm{v}, 445 \mathrm{r}, 445 \mathrm{v}, 446 \mathrm{r}, 446 \mathrm{v}$, 447r, 450v, 471v.

Cespedosa: 306r.

Cestillos: 107v, 108r, 108v, 109r, 112v, $152 \mathrm{v}, 154 \mathrm{v}, 163 \mathrm{v}, 164 \mathrm{r}, 172 \mathrm{r}, 172 \mathrm{v}, 173 \mathrm{r}$, $173 \mathrm{v}, 174 \mathrm{r}, 174 \mathrm{v}, 175 \mathrm{r}, 175 \mathrm{v}, 176 \mathrm{r}, 177 \mathrm{r}$, $177 \mathrm{v}, 178 \mathrm{r}, 178 \mathrm{v}, 189 \mathrm{v}, 412 \mathrm{r}, 412 \mathrm{v}, 457 \mathrm{r}$, $457 \mathrm{v}$.

Cisneros: 23v, 179v, 180r, 180v, 314v, 462r.

Ciudad Rodrigo: $61 \mathrm{r}$.

Coca: 86r.

Colmenares: $315 \mathrm{v}$.

Comillas: 31v, 209r.

Congarna: $144 \mathrm{v}$

Congosto: 59r, 310r, 313v, 328r, 355r, 372r, 376v, 377r, 377v, 432v, 460r.

Córdoba: $117 \mathrm{v}, 119 \mathrm{r}$.

Cordovilla: 414r, 414v.

Cornón: 182v, 183r, 265v, 279v, 321r, $321 \mathrm{v}$.

Cornoncillo: $182 \mathrm{v}, 183 \mathrm{r}$.

Covarrubias: 44r, 47v, 197r, 197v.

Cuéllar: 183v:

Cuenca de Campos: 4r, 77r, 77v, 354r, $354 \mathrm{v}, 439 \mathrm{v}$.

Cuerno de Tablar, juridicción de Saldaña: $353 \mathrm{v}, 460 \mathrm{r}$.

Denia, 71r, 350r.

Dueñas: 87r, 107v, 312r, 312v, 353v; (San Isidro de Dueñas): 87r.

El Brezo (Nuestra Señora del Brezo): 31r, $50 \mathrm{r}, 50 \mathrm{v}, 51 \mathrm{v}, 63 \mathrm{r}, 63 \mathrm{v}, 64 \mathrm{r}, 64 \mathrm{v}, 70 \mathrm{v}, 71 \mathrm{r}$, $71 \mathrm{v}, 72 \mathrm{r}, 72 \mathrm{v}, 73 \mathrm{r}, 73 \mathrm{v}, 263 \mathrm{r}, 278 \mathrm{r}, 320 \mathrm{v}$, $321 \mathrm{r}, 321 \mathrm{v}, 323 \mathrm{r}, 334 \mathrm{r}, 336 \mathrm{v}$.

El Espinarejo: 320v.

El Pardo: 11v.
El Pasadero: 5v.

Entrepeñas (San Román de Entrepeñas): 10r, 13r, 13v, 30v, 31r, 45v, 46r, 46v, 47r, $47 \mathrm{v}, 48 \mathrm{v}, 49 \mathrm{v}, 51 \mathrm{r}, 59 \mathrm{v}, 68 \mathrm{v}, 73 \mathrm{v}, 77 \mathrm{v}, 78 \mathrm{v}$, $88 \mathrm{r}, 107 \mathrm{v}, 108 \mathrm{r}, 108 \mathrm{v}, 146 \mathrm{v}, 172 \mathrm{r}, 172 \mathrm{v}$, $182 \mathrm{v}, 183 \mathrm{r}, 186 \mathrm{v}, 187 \mathrm{r}, 218 \mathrm{v}, 251 \mathrm{v}, 252 \mathrm{r}$, $252 \mathrm{v}, 259 \mathrm{v}, 260 \mathrm{r}, 260 \mathrm{v}, 261 \mathrm{r}, 261 \mathrm{v}, 262 \mathrm{r}$, $262 \mathrm{v}, 264 \mathrm{r}, 264 \mathrm{v}, 265 \mathrm{r}, 265 \mathrm{v}, 266 \mathrm{r}, 266 \mathrm{v}$, $267 \mathrm{r}, 267 \mathrm{v}, 273 \mathrm{r}, 279 \mathrm{v}, 280 \mathrm{r}, 280 \mathrm{v}, 286 \mathrm{r}$, $286 \mathrm{v}, 292 \mathrm{v}, 293 \mathrm{r}, 293 \mathrm{v}, 294 \mathrm{r}, 294 \mathrm{v}, 297 \mathrm{r}$, $297 \mathrm{v}, 300 \mathrm{r}, 300 \mathrm{v}, 301 \mathrm{v}, 302 \mathrm{r}, 302 \mathrm{v}, 303 \mathrm{r}$, $303 \mathrm{v}, 304 \mathrm{r}, 307 \mathrm{v}, 308 \mathrm{v}, 309 \mathrm{r}, 309 \mathrm{v}, 310 \mathrm{r}$, $310 \mathrm{v}, 311 \mathrm{v}, 312 \mathrm{r}, 312 \mathrm{v}, 313 \mathrm{r}, 313 \mathrm{v}, 314 \mathrm{r}$, $314 \mathrm{v}, 315 \mathrm{r}, 315 \mathrm{v}, 316 \mathrm{r}, 316 \mathrm{v}, 317 \mathrm{r}, 317 \mathrm{v}$, 318r, 319r, 319v, 320r, 320v, 321v, 322r, $322 \mathrm{v}, 323 \mathrm{r}, 323 \mathrm{v}, 324 \mathrm{r}, 324 \mathrm{v}, 325 \mathrm{r}, 325 \mathrm{v}$, 326r, 326v, 327r, 327v, 328r, 329r, 329v, 330r, 330v, 331r, 331v, 332r, 336r, 351r, $351 \mathrm{v}, 353 \mathrm{v}, 354 \mathrm{r}, 354 \mathrm{v}$.

Escalada (San Miguel de Escalada): 184r, 201v, 203v, 204r, 316r, 347r.

Eslonza (San Pedro de Eslonza): 81v. España: 13r, 13v, 21v, 32v, 33r, 82r, 84r, $86 \mathrm{r}, 87 \mathrm{r}, 87 \mathrm{v}, 91 \mathrm{r}, 114 \mathrm{v}, 117 \mathrm{v}, 131 \mathrm{r}, 145 \mathrm{v}$, 146v, 172r, 190r, 202r, 211v, 212r, 215r, $215 \mathrm{v}, 243 \mathrm{r}, 243 \mathrm{v}, 244 \mathrm{v}, 245 \mathrm{r}, 245 \mathrm{v}, 246 \mathrm{r}$, 250v, 277r, 283v, 284r, 291r, 342r, 342v.

Ferrara: 83r, 83v.

Ferreirolos: 172r

Fitero (Santa María la Real de Fitero): 408r.

Flandes: 176r.

Florencia: 83r, 83v, 85v, 86r.

Fontecha: 186v, 187r, 308v, 314v, 331r, 336r, 353v, 407v.

Fontezua: $1 \mathrm{v}$.

Francia: $81 \mathrm{v}$.

Frechilla: 187v, 252v, 404v.

Frómista: 38v, 82v, 84v, 92r, 102v, 103r, $103 \mathrm{v}, 104 \mathrm{r}, 107 \mathrm{r}, 107 \mathrm{v}, 108 \mathrm{r}, 108 \mathrm{v}, 146 \mathrm{v}$, $183 \mathrm{v}, 184 \mathrm{r}, 188 \mathrm{v}, 189 \mathrm{r}, 189 \mathrm{v}, 190 \mathrm{r}, 190 \mathrm{v}$, 191r, 191v, 192r, 192v, 193r, 193v, 194r, $194 \mathrm{v}, 195 \mathrm{r}, 196 \mathrm{r}, 196 \mathrm{v}, 197 \mathrm{r}, 197 \mathrm{v}, 198 \mathrm{r}$, 198v, 199r, 199v, 200r, 200v, 201r, 202r, $202 \mathrm{v}, 203 \mathrm{r}, 203 \mathrm{v}, 204 \mathrm{v}, 205 \mathrm{r}, 206 \mathrm{r}, 206 \mathrm{v}$, 207r, 207v, 208r, 208v, 209r, 209v, 210r, $210 \mathrm{v}, 211 \mathrm{v}, 213 \mathrm{r}, 213 \mathrm{v}, 214 \mathrm{r}, 215 \mathrm{r}, 215 \mathrm{v}$, 216r, 216v, 217r, 218v, 219r, 219v, 220r, $220 \mathrm{v}, 221 \mathrm{r}, 222 \mathrm{v}, 225 \mathrm{r}, 225 \mathrm{v}, 226 \mathrm{r}, 226 \mathrm{v}$, 
$227 \mathrm{r}, 227 \mathrm{v}, 228 \mathrm{r}, 228 \mathrm{v}, 229 \mathrm{r}, 229 \mathrm{v}, 230 \mathrm{r}$, $230 \mathrm{v}, 231 \mathrm{r}, 233 \mathrm{r}, 234 \mathrm{r}, 234 \mathrm{v}, 235 \mathrm{r}, 235 \mathrm{v}$, 236r, 237r, 237v, 238r, 238v, 239r, 239v, 240r, 240v, 241r, 241v, 242r, 242v, 243r, $243 \mathrm{v}, 244 \mathrm{r}, 244 \mathrm{v}, 245 \mathrm{r}, 245 \mathrm{v}, 246 \mathrm{r}, 246 \mathrm{v}$, $247 \mathrm{r}, 247 \mathrm{v}, 248 \mathrm{r}, 248 \mathrm{v}, 249 \mathrm{r}, 249 \mathrm{v}, 250 \mathrm{r}$, $250 \mathrm{v}, 251 \mathrm{r}, 251 \mathrm{v}, 274 \mathrm{r}, 287 \mathrm{r}, 287 \mathrm{v}, 288 \mathrm{r}$, 288v, 289r, 326r, 413v, 414r, 457r, 457v, $458 \mathrm{v}$.

Fuente del Saúco: 413v, 414r

Fuentes, 107r, 107v, 108r, 108v, 110r, $187 \mathrm{v}, 251 \mathrm{v}, 252 \mathrm{r}, 252 \mathrm{v}, 254 \mathrm{v}, 255 \mathrm{r}, 339 \mathrm{r}$, 339v, 340r, 340v, 341r, 460v .

Fuentes de Nava: 107r, 107v, 108r, 108v, $110 \mathrm{r}, 187 \mathrm{v}, 251 \mathrm{v}, 252 \mathrm{r}, 252 \mathrm{v}, 460 \mathrm{v}$.

Fuentes de Valdepero: 254v, 255r.

Galicia: 209v, 427r, 427v.

Gamonal: 5r

Gañinas de la Vega: 59r, 59v, 190r, 255v, 256r, 256v, 257r, 257v, 258r, 270r, 270v, $443 \mathrm{v}, 444 \mathrm{r}, 457 \mathrm{r}, 457 \mathrm{v}$.

Gijón: 226v, 227r.

Golpejera: 255v, 441v, 443v, 444r, 444v, 445r, 445v, 446r, 446v, 447r.

Gramadal: $5 \mathrm{r}$.

Granada: $257 \mathrm{v}$.

Grijota: 258v, 441r.

Guardo, 46v, 69v, 72r, 76v, 185r, 259v, $262 \mathrm{v}, 263 \mathrm{v}, 312 \mathrm{r}, 312 \mathrm{v}, 328 \mathrm{r}, 336 \mathrm{r}, 372 \mathrm{r}$, $372 \mathrm{v}, 375 \mathrm{r}, 428 \mathrm{r}$.

Guaza de Campos: 169v

Herrera, 403r, 432v, 432v.

Husillos: 82v, 113v, 418v.

Intorcisa: 186r, 259v, 279v, 281v, 314v, 319r, 385r, 428r.

La Cea: 350r.

La Cueza: 78v, 291r.

La Cumbre: $267 \mathrm{r}$.

La Hera: $312 \mathrm{v}$.

La Liébana: 66r, 66v, 73r, 279v.

La Loma de Santa Olaya: 3v, 172r, 172v, 299 r.

La Ojeda: 164r, 164v.

La Orcilla: 5v

La Puebla de Valdavia: 61v, 62r, 63v, 64r, $64 \mathrm{v}, 65 \mathrm{r}, 263 \mathrm{r}, 263 \mathrm{v}, 290 \mathrm{r}, 290 \mathrm{v}, 302 \mathrm{r}$, $320 \mathrm{v}, 334 \mathrm{r}, 349 \mathrm{v}, 374 \mathrm{r}, 374 \mathrm{v}$.
La Serna: $74 \mathrm{r}$

La Valdavia: 461r

Lara: 203v.

Las Bodeguillas: 4r, 4v, 5v, 6r.

Las Frieras: 2r, 3r.

Las Heras: 61v, 62r, 181v, 259v, 260r, $260 \mathrm{v}, 261 \mathrm{r}, 261 \mathrm{v}, 262 \mathrm{r}, 262 \mathrm{v}, 263 \mathrm{r}, 263 \mathrm{v}$, $264 \mathrm{r}, 264 \mathrm{v}, 265 \mathrm{r}, 265 \mathrm{v}, 266 \mathrm{r}, 266 \mathrm{v}, 267 \mathrm{r}$, $267 \mathrm{v}, 268 \mathrm{r}, 268 \mathrm{v}, 269 \mathrm{r}, 269 \mathrm{v}, 313 \mathrm{r}, 315 \mathrm{v}$, $316 \mathrm{v}, 318 \mathrm{r}, 319 \mathrm{v}, 321 \mathrm{r}, 321 \mathrm{v}, 322 \mathrm{v}, 323 \mathrm{v}$, $328 \mathrm{r}, 329 \mathrm{r}, 329 \mathrm{v}, 330 \mathrm{v}, 351 \mathrm{r}, 379 \mathrm{v}, 380 \mathrm{v}$, 383r, 385r, 409r, 409v.

La Puebla de Valdavia: 263r.

Las Quintanas: 5v.

Leomar (Braga): 82v.

León: 20v, 22r, 22v, 23r, 24r, 24v, 25v, 26r, $26 \mathrm{v}, 27 \mathrm{r}, 27 \mathrm{v}, 28 \mathrm{r}, 28 \mathrm{v}, 29 \mathrm{r}, 35 \mathrm{r}, 35 \mathrm{v}, 47 \mathrm{v}$, 48r, 48v, 49r, 59r, 59v, 60r, 60v, 61r, 66r, 69r, 69v, 70r, 73r, 73v, 83r, 83v, 85r, 85v, 86r, 86v, 92r, 107r, 172r, 180r, 184r, 184v, $185 \mathrm{r}, 190 \mathrm{r}, 197 \mathrm{v}, 198 \mathrm{r}, 209 \mathrm{r}, 214 \mathrm{r}, 219 \mathrm{v}$, $220 \mathrm{v}, 221 \mathrm{r}, 221 \mathrm{v}, 226 \mathrm{r}, 226 \mathrm{v}, 229 \mathrm{v}, 239 \mathrm{r}$, $265 \mathrm{v}, 266 \mathrm{r}, 266 \mathrm{v}, 267 \mathrm{r}, 267 \mathrm{v}, 268 \mathrm{r}, 268 \mathrm{v}$, $269 \mathrm{r}, 269 \mathrm{v}, 273 \mathrm{r}, 277 \mathrm{v}, 278 \mathrm{r}, 278 \mathrm{v}, 280 \mathrm{r}$, $280 \mathrm{v}, 281 \mathrm{r}, 281 \mathrm{v}, 282 \mathrm{r}, 282 \mathrm{v}, 302 \mathrm{v}, 303 \mathrm{r}$, $303 \mathrm{v}, 304 \mathrm{r}, 304 \mathrm{v}, 305 \mathrm{r}, 305 \mathrm{v}, 310 \mathrm{r}, 310 \mathrm{v}$, $311 \mathrm{r}, 311 \mathrm{v}, 321 \mathrm{v}, 322 \mathrm{v}, 323 \mathrm{v}, 326 \mathrm{r}, 326 \mathrm{v}$, $328 \mathrm{r}, 328 \mathrm{v}, 329 \mathrm{r}, 329 \mathrm{v}, 330 \mathrm{v}, 331 \mathrm{r}, 331 \mathrm{v}$, 332r, 355r, 356r, 356r, 360r, 362v, 363r, $363 \mathrm{v}, 368 \mathrm{v}, 369 \mathrm{v}, 372 \mathrm{v}, 375 \mathrm{v}, 376 \mathrm{r}, 376 \mathrm{v}$, $377 \mathrm{r}, 377 \mathrm{v}, 379 \mathrm{r}, 379 \mathrm{v}, 380 \mathrm{r}, 380 \mathrm{v}, 381 \mathrm{r}$, 393r, 393v, 394r, 394v, 395r, 395v, 396r, 399r, 399v, 400r, 400v, 401r, 401v, 402r, $413 \mathrm{v}, 419 \mathrm{r}, 419 \mathrm{v}, 425 \mathrm{r}, 425 \mathrm{v}, 427 \mathrm{r}, 427 \mathrm{v}$, 428r, 428v, 430r, 430v, 431r, 431v, 432r, $432 \mathrm{v}$.

Lobera de la Vega: 255v, 256r, 256v, 257r, $257 \mathrm{v}, 258 \mathrm{r}, 269 \mathrm{r}, 269 \mathrm{v}, 270 \mathrm{r}, 270 \mathrm{v}$.

Lores: $279 \mathrm{v}$.

Los Barrios, 346v, 347r.

Los Llanillos: 271r, 271v, 272r.

Los Rascones. 277v, 278v.

Los Tesos de las Atalayas: $5 \mathrm{r}$

Los Valles: $5 r$

Lugo: 181r, 181v, 182r, 275v, 276r, 276v.

Macintos: 169r, 457r, 457v.

Madrid: $11 \mathrm{r}, 11 \mathrm{v}, 16 \mathrm{v}, 17 \mathrm{r}, 17 \mathrm{v}, 18 \mathrm{r}, 18 \mathrm{v}$, 19r, 34r, 34v, 41r, 41v, 42v, 45v, 46r, 86r, $87 \mathrm{v}, 90 \mathrm{v}, 112 \mathrm{v}, 113 \mathrm{r}, 114 \mathrm{r}, 114 \mathrm{v}, 115 \mathrm{r}$, $117 \mathrm{r}, 117 \mathrm{v}, 118 \mathrm{r}, 118 \mathrm{v}, 119 \mathrm{r}, 122 \mathrm{v}, 123 \mathrm{r}$, 
$132 \mathrm{r}, 132 \mathrm{v}, 134 \mathrm{r}, 134 \mathrm{v}, 135 \mathrm{r}, 159 \mathrm{r}, 169 \mathrm{v}$, 200v, 201r, 202r, 229v, 246r, 249r, 250r, $267 \mathrm{v}, 268 \mathrm{r}, 274 \mathrm{v}, 281 \mathrm{v}, 282 \mathrm{r}, 292 \mathrm{r}, 297 \mathrm{v}$, 303r, 303v, 304r, 323v, 361r, 361v, 362r, $362 \mathrm{v}, 363 \mathrm{r}, 363 \mathrm{v}, 364 \mathrm{r}, 369 \mathrm{v}, 378 \mathrm{r}, 378 \mathrm{v}$, 379r, 379v, 380r, 380v, 400v, 401r, 415r, $420 \mathrm{v}, 421 \mathrm{r}, 430 \mathrm{v}, 431 \mathrm{r}, 440 \mathrm{r}, 447 \mathrm{v}, 454 \mathrm{r}$, $454 \mathrm{v}, 455 \mathrm{r}, 455 \mathrm{v}, 460 \mathrm{v}$.

Madrigal: $227 \mathrm{v}$

Magaz de Pisuerga: 8v, 217r, 414v, 415r, 420r 437v.

Malva: 339r, 339v, 340r, 340v, 341r

Manquillos: 235v, 236r

Mayorga: 3v, 197v, 198r, 219v, 221v, 222r, 311v; (San Salvador de Mayorga): 311v.

Mazuecos de Valdeginate: 30v, 279r, 285r, $314 \mathrm{v}$

Mazuelas: $331 \mathrm{v}$.

Medina de Rioseco: 2r, 108v.

Medina del Campo: 19v, 34v, 145v, 205r, 445r, 446r, 446v.

Melgar: 209r.

Melilla: 145v, 146r.

Mérida: 449v.

Mecerrero: 328v.

Molina: 85v.

Molinos de Calzada: 457r, 457v.

Monforte: 275v.

Montenegro: 15r, 15v.

Morales: 339r, 339v, 340r, 340v, 341r.

Muñeca: 51r, 51v, 71v, 186r, 218v, 261r, 268r, 279v, 280r, 280v, 281v, 282r, 282v, $314 \mathrm{v}, 318 \mathrm{r}, 319 \mathrm{r}, 336 \mathrm{v}, 351 \mathrm{v}, 371 \mathrm{v}, 373 \mathrm{r}$, $373 \mathrm{v}, 375 \mathrm{r}, 383 \mathrm{v}, 384 \mathrm{r}, 384 \mathrm{v}, 385 \mathrm{r}, 390 \mathrm{r}$, 391r, 408r, 408v, 409r, 409v, 442r, 461r, $461 \mathrm{v}$.

Nájera: 34v, 35r, 85r, 341r, 341v, 342r, $344 \mathrm{v}, 359 \mathrm{v}$.

Nápoles: 118v, 119r.

Navarra: 237v, 238r, 238v.

Nogal de las Huertas: 101r, 325v, 326v.

Oña (San Salvador de Oña): 81v, 82v, 236r, 236v, 239r, 239v, 240r, 240v, 241r, $241 \mathrm{v}, 250 \mathrm{v}, 405 \mathrm{r}, 419 \mathrm{v}$.

Osdados: 276v.

Osorno: $151 \mathrm{v}$.

Otello: 301v

Otero: 397r, 398r, 398v, 399r, 467v.

Oteros del Rey: $2 \mathrm{r}$.
Oteruelo: 448v.

Oviedo: 73v, 270r, 270v, 356r, 393r, 393v, 399v; (San Vicente de Oviedo): 270r, $270 \mathrm{v}$.

Pajares: 11v, 12r.

Palacios de Campos: 3v, 4r, 4v, 5r, 5v, 6r, $74 \mathrm{v}, 75 \mathrm{r}, 218 \mathrm{v}, 273 \mathrm{r}, 273 \mathrm{v}, 279 \mathrm{r}, 283 \mathrm{r}$, $284 \mathrm{v}, 285 \mathrm{r}, 285 \mathrm{v}, 286 \mathrm{v}, 287 \mathrm{r}, 287 \mathrm{v}, 289 \mathrm{r}$, 289v, 299v, 300r, 306r, 308v, 314v, 315r, 315v, 316r, 319r, 319v, 320r, 320v, 321r, $321 \mathrm{v}, 323 \mathrm{r}, 334 \mathrm{r}, 336 \mathrm{r}, 336 \mathrm{v}, 349 \mathrm{v}, 350 \mathrm{v}$, $351 \mathrm{v}, 352 \mathrm{r}, 355 \mathrm{v}, 356 \mathrm{v}, 357 \mathrm{r}, 365 \mathrm{v}, 368 \mathrm{v}$, 369r, 371v, 372r, 374r, 386r, 398r, 420r, 424r, 441r, 441v, 442r, 442r.

Palazuelo: $13 \mathrm{v}$

Palencia: 32v, 34v, 35v, 36r, 36v, 37r, 37v, 38r, 38v, 39r, 39v, 40r, 40v, 41r, 41v, 42r, $42 \mathrm{v}, 43 \mathrm{r}, 43 \mathrm{v}, 44 \mathrm{r}, 44 \mathrm{v}, 45 \mathrm{v}, 47 \mathrm{r}, 48 \mathrm{v}, 66 \mathrm{v}$, $67 \mathrm{r}, 67 \mathrm{v}, 72 \mathrm{r}, 73 \mathrm{v}, 79 \mathrm{r}, 82 \mathrm{r}, 83 \mathrm{v}, 85 \mathrm{r}, 88 \mathrm{r}$, $89 \mathrm{r}, 90 \mathrm{r}, 92 \mathrm{r}, 98 \mathrm{v}, 102 \mathrm{v}, 103 \mathrm{r}, 103 \mathrm{v}, 104 \mathrm{r}$, $104 \mathrm{v}, 105 \mathrm{r}, 105 \mathrm{v}, 106 \mathrm{r}, 107 \mathrm{r}, 107 \mathrm{v}, 108 \mathrm{r}$, $108 \mathrm{v}, 109 \mathrm{r}, 109 \mathrm{v}, 110 \mathrm{v}, 111 \mathrm{r}, 111 \mathrm{v}, 112 \mathrm{r}$, $112 \mathrm{v}, 113 \mathrm{v}, 114 \mathrm{r}, 114 \mathrm{v}, 115 \mathrm{r}, 115 \mathrm{v}, 116 \mathrm{r}$, $117 \mathrm{v}, 118 \mathrm{r}, 120 \mathrm{v}, 121 \mathrm{r}, 123 \mathrm{r}, 123 \mathrm{v}, 124 \mathrm{r}$, $124 \mathrm{v}, 125 \mathrm{r}, 127 \mathrm{r}, 127 \mathrm{v}, 128 \mathrm{r}, 128 \mathrm{v}, 129 \mathrm{r}$, $129 \mathrm{v}, 130 \mathrm{r}, 130 \mathrm{v}, 133 \mathrm{r}, 134 \mathrm{r}, 134 \mathrm{v}, 135 \mathrm{r}$, $135 \mathrm{v}, 139 \mathrm{r}, 139 \mathrm{v}, 140 \mathrm{r}, 144 \mathrm{r}, 144 \mathrm{v}, 145 \mathrm{r}$, $148 \mathrm{v}, 149 \mathrm{r}, 149 \mathrm{v}, 156 \mathrm{v}, 162 \mathrm{r}, 163 \mathrm{v}, 164 \mathrm{r}$, $165 \mathrm{r}, 169 \mathrm{r}, 170 \mathrm{v}, 172 \mathrm{v}, 173 \mathrm{v}, 175 \mathrm{r}, 175 \mathrm{v}$, $177 \mathrm{r}, 177 \mathrm{v}, 178 \mathrm{r}, 178 \mathrm{v}, 180 \mathrm{v}, 183 \mathrm{v}, 189 \mathrm{v}$, $190 \mathrm{r}, 190 \mathrm{v}, 191 \mathrm{v}, 192 \mathrm{r}, 192 \mathrm{v}, 194 \mathrm{r}, 196 \mathrm{r}$, $196 \mathrm{v}, 197 \mathrm{r}, 197 \mathrm{v}, 198 \mathrm{r}, 199 \mathrm{r}, 199 \mathrm{v}, 200 \mathrm{r}$, $200 \mathrm{v}, 201 \mathrm{r}, 201 \mathrm{v}, 202 \mathrm{r}, 202 \mathrm{v}, 203 \mathrm{r}, 203 \mathrm{v}$, $204 r, 204 \mathrm{v}, 205 \mathrm{r}, 205 \mathrm{v}, 206 \mathrm{r}, 207 \mathrm{r}, 207 \mathrm{v}$, 208r, 208v, 209r, 209v, 210r, 211r, 211v, 212r, 212v, 213r, 213v, 359r; diócesis: $376 r$.

Palenzuela: 44r, $131 \mathrm{v}$.

Pamplona: 325v, 23r.

Paramillo de Ferreros: 352v.

Paredes de Nava: 68r, 127r, 212r, 283v, 284r, 284v, 285r, 285v, 355v, 356r, 357r, $411 \mathrm{v}, 447 \mathrm{v}, 449 \mathrm{r}, 449 \mathrm{v}, 450 \mathrm{r}, 450 \mathrm{v}, 452 \mathrm{v}$, 453r.

Paredes de Valleluengo: 68r

Párraces (Santa María Real de Párraces): $85 \mathrm{v}, 86 \mathrm{r}$.

Pavía: 376v, 377r, 377v.

Pedrosa: 256v, 257r, 339r, 339v, 340r, $340 \mathrm{v}, 341 \mathrm{r}$. 
Perales: $171 \mathrm{v}$.

Farallones: $1 \mathrm{v}$

Pinillas: 339r, 339v, 340r, 340v, 341r.

Pino de Viduerna: 49v, 50v, 51r, 51v, $181 \mathrm{v}, 186 \mathrm{v}, 207 \mathrm{v}, 262 \mathrm{v}, 286 \mathrm{r}, 286 \mathrm{v}, 308 \mathrm{v}$, $311 \mathrm{r}, 314 \mathrm{v}, 315 \mathrm{v}, 319 \mathrm{v}, 334 \mathrm{r}, 334 \mathrm{v}, 335 \mathrm{r}$, $353 \mathrm{v}, 374 \mathrm{v}, 375 \mathrm{r}$.

Pino del Río: 207v, 311r.

Piña: 190r, 190v, 233v, 235v, 236r, 287r.

Pisón: 65r, 376r.

Población: 98r, 98v, 188v, 189r, 190r, $190 \mathrm{v}, 191 \mathrm{v}, 194 \mathrm{v}, 211 \mathrm{r}, 213 \mathrm{r}, 213 \mathrm{v}, 222 \mathrm{v}$, 223r, 225v, 226r, 273r, 287r, 287v, 288r, 288v, 289r, 289v.

Población de Campos: 194v.

Población de Frómista: 287r, 287v, 288r, 288v, 289r.

Población de Gordaliza: 273r.

Población del Soto: 98r, 98v, 289r, 289v.

Polvorosa de Valdavia: 31r, 31v, 461r.

Portugal: 203v, 204r

Poza: 347 r.

Pozo Antiguo: 339r, 339v, 340r, 340v, 341 r.

Pozuelos del Rey: 306r, 306v.

Puente de San Juan: 2r.

Puerto del Bes: 68v.

Quintanas de Hormiguera: 2r, 5v.

Quintanilla del Monte. 398r, 401v.

Quintanilla de la Cueza: 291r

Quintanilla de las Torres: 269r, 291r, 292r, 398r, 401v.

Rámaga: 234r, 234v, 235r.

Rascones: 277v, 278r, 278v, 401v.

Raveros: 78v, 79r, 452r, 453v.

Recueva: 61v, 108r, 108v, 292v, 293r, $293 \mathrm{v}, 294 \mathrm{r}, 294 \mathrm{v}, 295 \mathrm{r}, 295 \mathrm{v}, 296 \mathrm{r}, 297 \mathrm{r}$, 298r, 298v, 299r, 354r.

Remolinos: $108 \mathrm{v}$.

Renedo: 31r, 31v, 71r, 159v, 289v.

Renedo de Valdavia: 31r, 31v.

Requena: 235v, 236r.

Respenda de la Peña: 46v, 57v, 59r, 59v, 183r, 262v, 267r, 268r, 279v, 307r, 307v, 308r, 308v, 309r, 309v, 310r, 310v, 313v, $314 \mathrm{v}, 324 \mathrm{r}, 324 \mathrm{v}, 336 \mathrm{r}, 336 \mathrm{v}, 351 \mathrm{v}, 354 \mathrm{v}$, $371 \mathrm{v}, 407 \mathrm{v}, 458 \mathrm{v}, 468 \mathrm{r}$.

Retuerto: 430r.
Revenga de Campos: 255v, 299v, 443v, 444r.

Revilla: 150r, 336v, 345r, 345v, 346r, 347r, $347 \mathrm{v}, 348 \mathrm{r}, 348 \mathrm{v}, 349 \mathrm{r}, 350 \mathrm{v}, 351 \mathrm{r}$.

Ribas de Campos: 269v, 313v, 315r, 371r. Riosmenudos de la Peña: 3v, 4r, 4v, 5r, 6r, 6v, 8v, 9r, 9v, 11r, 16r, 17r, 23v, 24r, 26v, $31 \mathrm{v}, 36 \mathrm{r}, 47 \mathrm{v}, 48 \mathrm{r}, 58 \mathrm{r}, 261 \mathrm{r}, 300 \mathrm{r}, 300 \mathrm{v}$, $301 \mathrm{v}, 302 \mathrm{r}, 302 \mathrm{v}, 303 \mathrm{r}, 303 \mathrm{v}, 304 \mathrm{r}, 304 \mathrm{v}$, 305r, 305v, 309r, 441v, 468r.

Rioseco: 4r, 226r, 273 r.

Riberos de la Cueza: 306r, 306v, 422v, $423 \mathrm{r}, 447 \mathrm{v}, 451 \mathrm{v}$.

Robledo: 45r, 48v

Robladillo de Ucieza: 131v, 410v.

Rodias: $279 \mathrm{v}$.

Roma: 8v, 9r, 9v, 13r, 13v, 14r, 16r, 19r, $19 \mathrm{v}, 20 \mathrm{v}, 21 \mathrm{v}, 23 \mathrm{r}, 25 \mathrm{v}, 27 \mathrm{r}, 27 \mathrm{v}, 34 \mathrm{v}, 37 \mathrm{r}$, $38 \mathrm{v}, 44 \mathrm{r}, 48 \mathrm{r}, 48 \mathrm{v}, 60 \mathrm{v}, 70 \mathrm{v}, 72 \mathrm{v}, 73 \mathrm{v}, 82 \mathrm{v}$, $83 \mathrm{v}, 84 \mathrm{r}, 84 \mathrm{v}, 85 \mathrm{v}, 86 \mathrm{r}, 86 \mathrm{v}, 87 \mathrm{r}, 87 \mathrm{v}, 92 \mathrm{r}$, 102r, 102v, 103r, 103v, 104r, 104v, 107r, $107 \mathrm{v}, 108 \mathrm{r}, 108 \mathrm{v}, 113 \mathrm{v}, 115 \mathrm{r}, 122 \mathrm{v}, 125 \mathrm{v}$, $127 \mathrm{r}, 140 \mathrm{r}, 140 \mathrm{v}, 146 \mathrm{v}, 183 \mathrm{v}, 184 \mathrm{r}, 190 \mathrm{v}$, $204 \mathrm{v}, 207 \mathrm{r}, 208 \mathrm{r}, 208 \mathrm{v}, 209 \mathrm{r}, 211 \mathrm{r}, 211 \mathrm{v}$, 212r, 213r, 216r, 222v, 223r, 236r, 237r, 239r, 239v, 240r, 240v, 241r, 241v, 242r, $245 \mathrm{r}, 245 \mathrm{v}, 246 \mathrm{r}, 255 \mathrm{v}, 267 \mathrm{r}, 274 \mathrm{r}, 281 \mathrm{v}$, 282r, 284r, 325v, 326r, 327r, 330v, 338v, $341 \mathrm{v}, 342 \mathrm{r}, 342 \mathrm{v}, 343 \mathrm{r}, 343 \mathrm{v}, 344 \mathrm{v}, 356 \mathrm{v}$, 394r, 399r, 401r, 401v, 436v, 443v, 444r, $444 \mathrm{v}$.

Roscales de la Peña: 61v, 302r, 380r, 461r. Rota: 19r, 19v, 23r, 190v, 213r, 344v.

Rozabales: 3v, 4r, 4v, 5r, 5v, 6r, 6v, 8v, 9r, $9 \mathrm{v}, 11 \mathrm{r}, 16 \mathrm{r}, 17 \mathrm{r}, 23 \mathrm{v}, 24 \mathrm{r}, 26 \mathrm{v}, 31 \mathrm{v}, 36 \mathrm{r}$, $36 \mathrm{v}, 37 \mathrm{v}, 275 \mathrm{v}, 276 \mathrm{r}, 276 \mathrm{v}$.

Sabariego, 271r, 271v, 404v, 434r, 457r, $457 \mathrm{v}$.

Sahagún: 13r, 13v, 34v, 35r, 61r, 67v, 82v, $83 \mathrm{r}, 101 \mathrm{r}, 110 \mathrm{v}, 111 \mathrm{r}, 185 \mathrm{v}, 190 \mathrm{r}, 204 \mathrm{v}$, 236r, 236v, 239r, 239v, 240r, 240v, 241r, $241 \mathrm{v}, 244 \mathrm{v}, 245 \mathrm{r}, 250 \mathrm{v}, 251 \mathrm{r}, 266 \mathrm{v}, 267 \mathrm{r}$, 316v, 327r, 360v, 399r, 401r, 401v, 432r, 435v, 436r, 455v; (San Andrés de Sahagún): $273 \mathrm{r}$.

Salamanca: 34v, 35r, 124r, 140r, 341r, 428v.

Saldaña: 45v, 46r, 48r, 56r, 66r, 71r, 77v, $78 \mathrm{r}, 78 \mathrm{v}, 89 \mathrm{v}, 90 \mathrm{r}, 156 \mathrm{v}, 172 \mathrm{r}, 177 \mathrm{v}, 178 \mathrm{r}$, 186r, 243r, 243v, 244r, 256r, 256v, 257r, 
257v, 263v, 269r, 269v, 270r, 303r, 308v, 309r, 310r, 310v, 311v, 312r, 312v, 314r, $315 \mathrm{r}, 315 \mathrm{v}, 316 \mathrm{r}, 316 \mathrm{v}, 317 \mathrm{r}, 317 \mathrm{v}, 318 \mathrm{r}$, $322 \mathrm{v}, 323 \mathrm{r}, 323 \mathrm{v}, 324 \mathrm{v}, 325 \mathrm{r}, 328 \mathrm{r}, 329 \mathrm{r}$, $331 \mathrm{r}, 331 \mathrm{v}, 334 \mathrm{r}, 334 \mathrm{v}, 335 \mathrm{r}, 336 \mathrm{v}, 337 \mathrm{r}$, 345r, 345v, 346r, 347r, 347v, 348r, 348v, 349r, 353v, 354r, 375r, 383r, 385r, 390v, $391 \mathrm{v}, 408 \mathrm{v}, 409 \mathrm{r}, 430 \mathrm{r}, 431 \mathrm{v}, 432 \mathrm{r}, 432 \mathrm{r}$, 436r, 441v, 442r, 458v.

Samos (San Julián de Samos): 81v, 276r.

San Andrés: 273r, 310v, 311r, 311v, 355r.

San Andrés del Arroyo (Santa María y San Andrés del Arroyo): 151r.

San Andrés de Canduela: 310v, 311r, 311v. San Andrés de Congosto: 355r.

San Bol de Respenda: 308r, 308v, 310r, 310v, 311r, 311v, 407v.

San Cebrián de Campos: 357r, 460r.

San Esteban: 2v, 3v, 23v.

San Felices: 66r, 66v, 67r, 67v.

San Juan: 2r, 2v, 3r, 4v, 5r, 5v, 24r.

San Juan de Cestillos: 108v.

San Juan de Corias: 24r.

San Mamés de Campos: 74r, 152v, 155r, 271r, 271v, 272r, 272v.

San Martín: 2v, 66r, 66v, 277r, 277v, 286r, 286v, 353v, 401v, 430v.

San Martín de los Álamos: 66r, 66v, 277r. San Martín de los Rascones: 277v, 401v.

San Martín del Obispo: 430v.

San Miguel del Valle: $4 \mathrm{v}$.

San Millán, 269r.

San Muñoz: 247v, 248r, 248v.

San Pedro de Guantes: 409v

San Pedro de Valderaduey: 183v, 184r.

San Salvador: 250v, 306r, 311v.

Santervás de Campos: 48v, 432v.

San Vicente de la Barquera: 131v, 145r, $145 \mathrm{v}$.

San Zoilo de Carrión: passim.

Sangüesa: 118r, 118v.

Santa Cruz: 183v, 184r, 184v, 185v, 277r.

Santa María: 46r, 71r, 84v, 107r, 162r, 256v, 257r, 273r, 274r, 275r, 350r, 362v, 363 r.

Santa María del Campo: 46r, 84v, 256v, $257 \mathrm{r}$.

Santa María del Páramo: 273r, 273v, 274r, 275r, 350r.

Santa María del Río: 71r.

Santa Olaja de la Ribera: 347r.
Santiago: 108v, 243r, 243v, 333r, 333v.

Santiago del Val: 108v, 333r, 333v.

Santibáñez, 50v.

Santibáñez de la Peña: 46r, 49v, 50v, 218v, $261 \mathrm{v}, 263 \mathrm{r}, 263 \mathrm{v}, 264 \mathrm{v}, 265 \mathrm{r}, 265 \mathrm{v}, 286 \mathrm{v}$, 313r, 314r, 314v, 315r, 315v, 316r, 316v, $317 \mathrm{r}, 317 \mathrm{v}, 318 \mathrm{r}, 319 \mathrm{r}, 319 \mathrm{v}, 320 \mathrm{r}, 320 \mathrm{v}$, $321 \mathrm{r}, 321 \mathrm{v}, 322 \mathrm{v}, 323 \mathrm{r}, 323 \mathrm{v}, 324 \mathrm{r}, 324 \mathrm{v}$, $325 \mathrm{r}, 328 \mathrm{r}, 328 \mathrm{v}, 329 \mathrm{r}, 329 \mathrm{v}, 330 \mathrm{r}, 330 \mathrm{v}$, 331r, 331v, 332r, 334r, 353v, 371r, 383r, 385r, 408v, 458v, 461r, 461v.

Santillana: 419r.

Santo Domingo de la Calzada: 144r.

Santo Domingo de Silos: 251v.

Santa Eufemia: 362v.

Santoyo: 32r, 333r, 333v, 454r, 454v, 461r. Segovia: 85v, 89v, 228v, 229r, 239r, 322r, $322 \mathrm{v}, 360 \mathrm{r}$.

Sepúlveda: 233r, 233v.

Sevilla: 88r, 98r, 124v.

Sigüenza: $84 r, 119 r$.

Simancas: 41r, 233r, 233v.

Sobarriba: $108 \mathrm{v}$.

Sopeña: 315v.

Susano: 407v.

Tabanera de Valdivia: 47v, 48r, 302v, 303r, 314v, 335r, 390r.

Tábara: $395 \mathrm{r}$.

Tablares: 263v, 316r, 408v.

Támara de Campos: 66r, 66v, 199r, 199v.

Tamariz de Campos: 3r, 3v.

Tarador: $1 \mathrm{v}$.

Tarilonte de la Peña:, 50r, 51r, 51v, 60r, $264 \mathrm{v}, 265 \mathrm{r}, 265 \mathrm{v}, 293 \mathrm{v}, 294 \mathrm{r}, 328 \mathrm{r}, 336 \mathrm{r}$, 336v, 351v, 352r, 376v, 442r.

Terradillos: $337 \mathrm{r}, 337 \mathrm{v}$.

Tiedra: 339r, 339v, 340r, 340v, 341r.

Toledo: 84r, 86r, 86v, 88r, 88v, 172r, 225r, $225 \mathrm{v}, 251 \mathrm{v}, 252 \mathrm{r}, 259 \mathrm{v}, 341 \mathrm{r}, 341 \mathrm{v}, 359 \mathrm{r}$, $359 \mathrm{v}, 361 \mathrm{r}, 361 \mathrm{v}, 362 \mathrm{r}, 417 \mathrm{v}, 427 \mathrm{r}, 427 \mathrm{v}$.

Toledo: 66r, 66v.

Tordehumos: 367r, 369r.

Tordesillas: 92r, 361r, 361v, 362r.

Torices: $360 \mathrm{v}$

Toro: $88 \mathrm{v}, 89 \mathrm{r}, 90 \mathrm{r}, 91 \mathrm{v}, 96 \mathrm{r}, 110 \mathrm{r}, 237 \mathrm{v}$, 238r, 238v, 315r, 322r, 338r, 338v, 339r, $339 \mathrm{v}, 340 \mathrm{r}, 340 \mathrm{v}, 341 \mathrm{r}, 343 \mathrm{r}, 343 \mathrm{v}, 344 \mathrm{r}$, 345r, 345v, 346r, 359v, 360r, 444r, 444v; (San Pelayo de Toro): 338v.

Torquemada: $207 \mathrm{v}$. 
Torre: 5r, 32r, 32v, 100r, 106r, 172r, 273r, $273 \mathrm{v}, 274 \mathrm{r}, 274 \mathrm{v}, 275 \mathrm{r}, 333 \mathrm{r}, 452 \mathrm{v}, 453 \mathrm{r}$.

Torrejón: $5 \mathrm{r}$

Traspeña de la Peña: 351v, 354r.

Trigueros del Valle: 107v, 108r, $291 \mathrm{v}$.

Trujillo: 88v, 455r, 455v

Tuy: $118 \mathrm{v}, 119 \mathrm{r}$.

Urueña: 361r, 361v, 362r.

Valbar: 306r.

Valcárcer: 312r, 312v.

Valcavadillo: 347r, 347v, 348r.

Valcavado: 104v, 105r, 336v, 345r, 345v, 346r, 346v, 347r, 347v, 348r, 348v, 349r.

Valcobero: 72r, 349v, 372r, 373r, 373v, $383 r$.

Valdecarril: 348v, 349r.

Valdecarzana: 402r.

Valdecelasco: 348v, 349r.

Valdefontanas: 191v.

Valdemeriel: $14 \mathrm{v}, 15 \mathrm{r}$.

Valdenebro: 235r, 235v.

Valderaduey: 71r, 350r.

Valderaniego: 183v, $184 \mathrm{r}$.

Valderas: 203v, 338r.

Valedediós: $347 \mathrm{v}, 348 \mathrm{r}$.

Valdonsella: 325v, 326r, 327r.

Valdunquillo: 69r, 69v.

Valflorido: 4v, 6r.

Valhenoso: $350 \mathrm{v}$

Valladolid: 10r, 10v, 11r, 11v, 15r, 16r, $16 \mathrm{v}, 17 \mathrm{r}, 17 \mathrm{v}, 18 \mathrm{r}, 18 \mathrm{v}, 19 \mathrm{r}, 19 \mathrm{v}, 20 \mathrm{v}, 21 \mathrm{r}$, $21 \mathrm{v}, 22 \mathrm{r}, 23 \mathrm{r}, 26 \mathrm{r}, 28 \mathrm{r}, 28 \mathrm{v}, 32 \mathrm{v}, 33 \mathrm{r}, 34 \mathrm{r}$, $34 \mathrm{v}, 39 \mathrm{v}, 40 \mathrm{r}, 40 \mathrm{v}, 42 \mathrm{v}, 43 \mathrm{v}, 48 \mathrm{v}, 56 \mathrm{r}, 56 \mathrm{v}$, $59 \mathrm{v}, 60 \mathrm{r}, 77 \mathrm{v}, 78 \mathrm{r}, 84 \mathrm{v}, 85 \mathrm{r}, 85 \mathrm{v}, 87 \mathrm{r}, 87 \mathrm{v}$, $88 \mathrm{v}, 89 \mathrm{r}, 90 \mathrm{v}, 91 \mathrm{r}, 91 \mathrm{v}, 94 \mathrm{r}, 94 \mathrm{v}, 95 \mathrm{r}, 96 \mathrm{v}$, 97r, 98r, 98v, 100r, 101r, 101v, 103v, 104r, $111 \mathrm{v}, 112 \mathrm{r}, 115 \mathrm{v}, 125 \mathrm{r}, 125 \mathrm{v}, 127 \mathrm{r}, 129 \mathrm{r}$, $130 \mathrm{r}, 131 \mathrm{v}, 132 \mathrm{r}, 139 \mathrm{v}, 140 \mathrm{r}, 140 \mathrm{v}, 141 \mathrm{r}$, $141 \mathrm{v}, 152 \mathrm{r}, 160 \mathrm{r}, 169 \mathrm{v}, 170 \mathrm{r}, 170 \mathrm{v}, 203 \mathrm{v}$, $204 \mathrm{v}, 205 \mathrm{r}, 206 \mathrm{r}, 208 \mathrm{r}, 211 \mathrm{v}, 212 \mathrm{v}, 214 \mathrm{v}$, 215r, 215v, 216r, 216v, 217r, 222r, 223r, $223 \mathrm{v}, 226 \mathrm{r}, 229 \mathrm{v}, 230 \mathrm{r}, 230 \mathrm{v}, 231 \mathrm{r}, 231 \mathrm{v}$, $232 \mathrm{r}, 232 \mathrm{v}, 233 \mathrm{r}, 233 \mathrm{v}, 236 \mathrm{r}, 236 \mathrm{v}, 242 \mathrm{v}$, 243r, 243v, 244r, 245r, 245v, 246r, 247r, $247 \mathrm{v}, 248 \mathrm{r}, 248 \mathrm{v}, 249 \mathrm{r}, 249 \mathrm{v}, 250 \mathrm{r}, 250 \mathrm{v}$, $251 \mathrm{r}, 251 \mathrm{v}, 254 \mathrm{v}, 255 \mathrm{r}, 256 \mathrm{r}, 256 \mathrm{v}, 257 \mathrm{r}$, $257 \mathrm{v}, 260 \mathrm{v}, 265 \mathrm{v}, 270 \mathrm{r}, 270 \mathrm{v}, 275 \mathrm{v}, 293 \mathrm{r}$, 293v, 307v, 308v, 309r, 310r, 310v, 317r, $324 \mathrm{r}, 327 \mathrm{v}, 329 \mathrm{r}, 338 \mathrm{v}, 341 \mathrm{r}, 341 \mathrm{v}, 342 \mathrm{v}$, 343r, 343v, 344r, 344v, 347r, 348v, 349r, $354 \mathrm{v}, 355 \mathrm{v}, 360 \mathrm{r}, 361 \mathrm{r}, 361 \mathrm{v}, 362 \mathrm{r}, 363 \mathrm{v}$, 380r, 381r, 381v, 383r, 386r, 386v, 387r, $387 \mathrm{v}, 388 \mathrm{r}, 388 \mathrm{v}, 389 \mathrm{r}, 389 \mathrm{v}, 390 \mathrm{r}, 390 \mathrm{v}$, 391r, 399r, 402v, 403r, 413r, 413v, 414r, $414 \mathrm{v}, 415 \mathrm{r}, 415 \mathrm{v}, 416 \mathrm{r}, 416 \mathrm{v}, 419 \mathrm{r}, 420 \mathrm{r}$, $420 \mathrm{v}, 421 \mathrm{v}, 422 \mathrm{v}, 423 \mathrm{r}, 430 \mathrm{r}, 439 \mathrm{r}, 439 \mathrm{v}$, $440 \mathrm{r}, 441 \mathrm{v}, 442 \mathrm{r}, 442 \mathrm{v}, 445 \mathrm{r}, 445 \mathrm{v}, 447 \mathrm{r}$, $448 \mathrm{r}, 450 \mathrm{v}, 454 \mathrm{r}, 454 \mathrm{v}, 455 \mathrm{r}, 455 \mathrm{v}$.

Valle de Cabuérniga: 36v.

Valles de Valdavia: 31v.

Valleluengo: 2r, 4v, 68r.

Valsurbio: 63v, 64r, 64v, 65r.

Vega: 48v, 63r, 71v, 163v, 164r, 277r, $280 \mathrm{v}, 282 \mathrm{r}, 293 \mathrm{r}, 293 \mathrm{v}, 294 \mathrm{r}, 300 \mathrm{r}, 300 \mathrm{v}$, 302r, 302v, 303r, 308v, 309v, 316r, 321v, 350v, 351r, 353v, 457r, 457v.

Vega de Carrión: 457r, 457v.

Vega de Santa María: 353v.

Vega de Riacos: 71v, 280v, 282r, 293v, 294r, 300r, 300v, 302r, 302v, 303r, 308v, $309 \mathrm{v}, 321 \mathrm{v}, 350 \mathrm{v}, 351 \mathrm{r}, 351 \mathrm{r}$.

Vega de Ruiponce: 48v.

Velilla: 45r, 45v, 47r, 50r, 51r, 51v, 57v, $58 \mathrm{r}, 61 \mathrm{v}, 69 \mathrm{v}, 76 \mathrm{v}, 156 \mathrm{v}, 336 \mathrm{v}, 348 \mathrm{v}, 349 \mathrm{r}$, $351 \mathrm{v}, 352 \mathrm{r}, 354 \mathrm{r}, 376 \mathrm{r}, 442 \mathrm{r}$.

Velilla del Río Carrión: 69v, 312v.

Velilla de Tarilonte: 51r, 51v, 336v, 351v, 352r, 442r.

Ventosilla (Santa Cruz de Ventosilla): $183 \mathrm{v}, 184 \mathrm{r}, 185 \mathrm{v}$.

Verrendillos: 441v.

Vezdemarbán: 339r, 339v, 340r, 340v, 341r, 343r, 343v.

Vezames: 339r, 339v, 340r, 340v, 341r.

Vitoria: $370 \mathrm{v}$.

Vidrieros: 64v.

Viduerna de la Peña: , 49v, 50v, 51r, 51v, $181 \mathrm{v}, 262 \mathrm{v}, 263 \mathrm{r}, 263 \mathrm{v}, 266 \mathrm{r}, 266 \mathrm{v}, 267 \mathrm{r}$, 286r, 286v, 293v, 303v, 304r, 308v, 313v, $315 \mathrm{r}, 319 \mathrm{v}, 321 \mathrm{v}, 324 \mathrm{v}, 328 \mathrm{v}, 334 \mathrm{r}, 334 \mathrm{v}$, 335r, 371r, 371v, 374v, 375r.

Vilachá de Mera: 182r.

Vilela: $279 \mathrm{r}$

Villa del Rey: 291v.

Villabáñez: 353r.

Villabasta de Valdavia: 31r, 31v, 185r.

Villabermudo de Ojeda: 307r, 307v, 309r, 432v.

Villabollo: 291v.

Villabrágima: 366v. 
Villacaco: 183v, 184r.

Villacente: $322 \mathrm{v}$.

Villacintor: 376v, 377r, 377v.

Villaciscla: 291v.

Villacorta: 279v, 45v.

Villadangos: $401 \mathrm{v}$.

Villadiego: 183v, 184r

Villaejiga: $108 \mathrm{v}$

Villafranca: $189 \mathrm{r}$

Villafrechós: 10r, 10v, 11r, 11v, 110r, 258v, 358r, 358v, 359r, 359v, 360r, 360v, $361 \mathrm{r}, 362 \mathrm{r}, 362 \mathrm{v}, 363 \mathrm{r}, 363 \mathrm{v}, 364 \mathrm{r}, 364 \mathrm{v}$, 365r, 365v, 366r, 366v, 367r, 367v, 368r, $368 \mathrm{v}, 369 \mathrm{r}, 369 \mathrm{v}, 407 \mathrm{r}, 467 \mathrm{v}$.

Villafría: 31r, 45v, 47v, 48r, 49v, 50r, 51r, $51 \mathrm{v}, 63 \mathrm{v}, 280 \mathrm{r}, 293 \mathrm{v}, 323 \mathrm{v}, 331 \mathrm{r}, 349 \mathrm{v}$, $370 \mathrm{v}, 371 \mathrm{r}, 371 \mathrm{v}, 372 \mathrm{r}, 372 \mathrm{v}, 373 \mathrm{r}, 373 \mathrm{v}$, 374r, 374v, 375r, 376r, 376v, 377r, 377v, 378r, 378v, 379r, 379v, 380r, 380v, 381r, $381 \mathrm{v}, 382 \mathrm{r}, 382 \mathrm{v}, 383 \mathrm{r}, 383 \mathrm{v}, 384 \mathrm{r}, 384 \mathrm{v}$, 385r, 385v, 386r, 386v, 387r, 387v, 388r, 389r, 389v, 390r, 390v, 391r, 391v, 461v.

Villagarcía: 9v, 10r, 310v.

Villagonzalo: 1v, 107v, 108r.

Villagrá: $442 \mathrm{v}$.

Villaheles: 31r, 31v, 293r, 293v.

Villaherreros: 14v, 145r, 145v, 155r, 272r, $352 \mathrm{v}, 457 \mathrm{r}, 457 \mathrm{v}$.

Villaherrín: 352r, 398r

Villalaco: 235v, 236r

Villalán de Campos: 368v, 401v, 442v, 463r.

Villalbeto de la Peña: 45v, 266r, 266v, 280r, 280v, 299r, 308r, 308v, 314v, 316r, $328 \mathrm{v}, 336 \mathrm{r}, 351 \mathrm{v}, 353 \mathrm{v}, 354 \mathrm{r}, 354 \mathrm{v}, 385 \mathrm{r}$.

Villalcázar de Sirga: 42r, 42v, 43r, 43v, $107 \mathrm{r}, 107 \mathrm{v}, 108 \mathrm{r}, 162 \mathrm{r}, 173 \mathrm{v}, 174 \mathrm{r}, 177 \mathrm{v}$, 209r, 209v, 271v, 272v, 434v, 436v, 452r, 457r, 457v; (Santa María de Villasirga): $162 \mathrm{r}$.

Villalegidos: 277r.

Villaleón: 435r.

Villalafuente: 266r, 266v.

Villalogan: 442v.

Villalón: $185 \mathrm{r}, 257 \mathrm{v}$.

Villalpando: 13r, 13v, 14r, 88v, 311r, 352r, $360 \mathrm{v}, 392 \mathrm{r}, 392 \mathrm{v}, 393 \mathrm{r}, 393 \mathrm{v}, 394 \mathrm{r}, 394 \mathrm{v}$, 395r, 395v, 396v, 397r, 398r, 398v, 400v, $401 \mathrm{r}, 401 \mathrm{v}$.

Villalumbroso: 11r, 11v, 30v, 107r, 107v, $108 \mathrm{r}, 110 \mathrm{r}, 171 \mathrm{v}, 284 \mathrm{r}, 284 \mathrm{v}, 285 \mathrm{r}, 285 \mathrm{v}$, 355r, 355v, 356r, 356v, 357r, 359v, 360r, $360 \mathrm{v}, 361 \mathrm{r}, 361 \mathrm{v}, 362 \mathrm{r}, 362 \mathrm{v}, 363 \mathrm{r}, 363 \mathrm{v}$, $364 \mathrm{v}, 365 \mathrm{v}, 366 \mathrm{r}, 368 \mathrm{r}, 369 \mathrm{v}, 462 \mathrm{r}$.

Villalvillo: 306r.

Villamarco: $48 \mathrm{v}$.

Villamarín: $275 \mathrm{v}$

Villamaurel: $1 \mathrm{v}$.

Villamuriel: 368r.

Villamayor de Campos: 1v, 352r, 394r, 397r, 397v, 398r, 399r, 399v, 400r, 400v, 401r, 401v, 402r, 467v, 468r.

Villameriel: 15r, 71r, 364v, 365r, 368r, 402v, 403r, 403v, 404r.

Villamez: 107r, 107v, 108r, 108v, 112v, $144 \mathrm{v}, 145 \mathrm{r}, 145 \mathrm{v}, 148 \mathrm{v}, 150 \mathrm{r}, 150 \mathrm{v}, 163 \mathrm{v}$, $164 \mathrm{r}, 166 \mathrm{v}, 404 \mathrm{v}, 405 \mathrm{r}, 405 \mathrm{v}, 406 \mathrm{r}, 406 \mathrm{v}$, $410 \mathrm{v}, 457 \mathrm{r}, 457 \mathrm{v}$.

Villamorco: $462 \mathrm{v}$.

Villamoronta: $468 \mathrm{r}$

Villamuera: 33r, 90v, 93r, 93v, 94v, 108v, $134 \mathrm{v}, 146 \mathrm{r}, 149 \mathrm{v}, 150 \mathrm{r}, 156 \mathrm{v}, 169 \mathrm{v}, 274 \mathrm{r}$, $284 \mathrm{v}, 306 \mathrm{r}, 306 \mathrm{v}, 413 \mathrm{r}, 413 \mathrm{v}, 414 \mathrm{r}, 414 \mathrm{v}$, $415 \mathrm{r}, 415 \mathrm{v}, 416 \mathrm{r}, 416 \mathrm{v}, 417 \mathrm{v}, 418 \mathrm{r}, 418 \mathrm{v}$, $419 \mathrm{r}, 419 \mathrm{v}, 420 \mathrm{r}, 420 \mathrm{v}, 421 \mathrm{r}, 421 \mathrm{v}, 422 \mathrm{r}$, $422 \mathrm{v}, 423 \mathrm{r}, 423 \mathrm{v}, 424 \mathrm{r}, 424 \mathrm{v}, 425 \mathrm{r}, 425 \mathrm{v}$, $426 \mathrm{r}, 445 \mathrm{r}, 447 \mathrm{v}, 448 \mathrm{r}, 448 \mathrm{v}, 449 \mathrm{r}, 449 \mathrm{v}$ $450 \mathrm{r}, 451 \mathrm{r}, 451 \mathrm{v}, 452 \mathrm{r}, 452 \mathrm{v}, 453 \mathrm{r}, 453 \mathrm{v}$, 454r, 454v, 463r, 465r, 469r.

Villamuriel: 217v, 218r, 218v, 367v, 368r, $407 \mathrm{r}$.

Villanueva: 46v, 51r, 51v, 99r, 127r, 150r, $155 \mathrm{r}, 155 \mathrm{v}, 159 \mathrm{r}, 172 \mathrm{r}, 174 \mathrm{v}, 175 \mathrm{r}, 175 \mathrm{v}$, $176 \mathrm{r}, 178 \mathrm{v}, 186 \mathrm{v}, 187 \mathrm{r}, 259 \mathrm{v}, 259 \mathrm{v}, 260 \mathrm{v}$, $261 \mathrm{r}, 261 \mathrm{v}, 262 \mathrm{r}, 268 \mathrm{r}, 279 \mathrm{v}, 286 \mathrm{r}, 286 \mathrm{v}$, 293v, 294r, 300v, 309r, 317v, 318r, 319r, 324r, 324v, 332r, 336v, 351r, 351v, 353v, 355r, 371v, 372r, 372v, 373r, 373v, 375r, 385r, 391r, 404v, 407v, 408r, 408v, 409r, $409 \mathrm{v}, 410 \mathrm{v}, 411 \mathrm{r}, 411 \mathrm{v}, 412 \mathrm{r}, 412 \mathrm{v}, 422 \mathrm{v}$, $427 \mathrm{v}, 436 \mathrm{v}, 442 \mathrm{r}, 452 \mathrm{r}, 461 \mathrm{r}, 461 \mathrm{v}, 468 \mathrm{v}$.

Villanueva de Arriba: 46v, 51r, 51v, 187r, 261r, 261v, 262r, 268r, 286v, 293v, 294r, $300 \mathrm{v}, 309 \mathrm{r}, 318 \mathrm{r}, 319 \mathrm{r}, 324 \mathrm{v}, 332 \mathrm{r}, 336 \mathrm{v}$, $351 \mathrm{r}, 351 \mathrm{v}, 371 \mathrm{v}, 372 \mathrm{r}, 372 \mathrm{v}, 373 \mathrm{v}, 375 \mathrm{r}$, 385r, 391r, 408r, 408v, 409r, 409v, 409v, $427 \mathrm{v}, 442 \mathrm{r}, 461 \mathrm{r}, 461 \mathrm{v}$.

Villanueva de Fontecha: 407v.

Villanueva de la Peña: 351v.

Villanueva de los Nabos: 155r, 155v, 159r, $404 \mathrm{v}, 410 \mathrm{v}, 411 \mathrm{r}$, 436v. 
Villanueva del Río: 174v, 175r, 175v, 178v, $180 \mathrm{v}, 182 \mathrm{v}, 184 \mathrm{v}, 186 \mathrm{r}, 187 \mathrm{v}, 189 \mathrm{r}, 189 \mathrm{v}$, $191 \mathrm{r}, 191 \mathrm{v}, 192 \mathrm{r}, 192 \mathrm{v}, 196 \mathrm{r}, 206 \mathrm{r}, 217 \mathrm{v}$, $218 \mathrm{r}, 218 \mathrm{v}, 225 \mathrm{v}, 226 \mathrm{r}, 228 \mathrm{r}, 235 \mathrm{r}, 235 \mathrm{v}$, $243 \mathrm{r}, 243 \mathrm{v}, 244 \mathrm{r}, 247 \mathrm{r}, 247 \mathrm{v}, 248 \mathrm{r}, 252 \mathrm{v}$, $255 \mathrm{r}, 255 \mathrm{v}, 256 \mathrm{r}, 256 \mathrm{v}, 263 \mathrm{r}, 263 \mathrm{v}, 274 \mathrm{v}$, 284r, 286v, 287r, 287v, 291r, 300r, 308v, $313 \mathrm{v}, 314 \mathrm{r}, 316 \mathrm{v}, 331 \mathrm{v}, 334 \mathrm{r}, 334 \mathrm{v}, 335 \mathrm{r}$, 336r, 338v, 343r, 345r, 345v, 346r, 346v, $349 \mathrm{v}, 350 \mathrm{r}, 352 \mathrm{r}, 352 \mathrm{v}, 353 \mathrm{r}, 353 \mathrm{v}, 354 \mathrm{r}$, 355r, 359v, 364v, 365r, 365v, 366r, 366v, $367 \mathrm{r}, 367 \mathrm{v}, 368 \mathrm{v}, 369 \mathrm{r}, 371 \mathrm{r}, 371 \mathrm{v}, 372 \mathrm{r}$, $372 \mathrm{v}, 373 \mathrm{r}, 374 \mathrm{r}, 374 \mathrm{v}, 412 \mathrm{r}, 412 \mathrm{v}, 452 \mathrm{r}$, $468 \mathrm{v}$.

Villanueva de Sotronca: 353v.

Villanueva del Rebollar: 355r, 411v, 422v.

Villanuño de Valdavia: 402v, 404r.

Villaoliva de la Peña: 47r, 182v, 183r, 314v, 354r, 376r, 385r, 409v, 427r, 427v, 428r, $428 \mathrm{v}$.

Villar: 256r, 256v, 257r, 257v, 258r, 270r, 270v, 278r, 301v, 335r, 339r, 339v, 340r, $340 \mathrm{v}, 341 \mathrm{r}, 397 \mathrm{v}, 411 \mathrm{v}, 429 \mathrm{v}, 430 \mathrm{r}, 430 \mathrm{v}$, 431r, 431v, 432r, 433r.

Villar de Fallaves, 278r, 397v, 429v.

Villarías (Villaires): 301v, 335r.

Villarmienzo: 256r, 256v, 257r, 257v, 258r, 270r, 270v, 430r, 430v, 431r, 431v, 432r.

Villarramiel: $411 \mathrm{v}, 433 \mathrm{r}$.

Villasabariego: 271r, 271v, 434r.

Villasarracino: 190r, 190v, 272v, 433v.

Villasur de Herreros: 14v.

Villatirso: 444r, 444v.

Villatoquite: 355r, 355v, 435r, 462r.

Villaturde: 99r, 107v, 108r, 108v, 155r, $155 \mathrm{v}, 166 \mathrm{v}, 304 \mathrm{v}, 305 \mathrm{r}, 311 \mathrm{r}, 405 \mathrm{v}, 435 \mathrm{v}$, 436r, 436v, 437r, 437v, 438r, 438v, 468v . Villaumbrales: 68r, 258v, 284v, 440v, 441r, $462 \mathrm{v}, 463 \mathrm{r}$.

Villavaruz de Campos: 107r, 107v, 108r, $439 \mathrm{r}, 439 \mathrm{v}, 440 \mathrm{r}$.

Villavega: 63r, 163v, 164r, 277r.

Villavela: 1v, 183v, 184r, 184v, 185r, 185v. Villavelasco: 183v, 184r, 184v, 185r, 185v. Villavendimio: 339r, 339v, 340r，340v, 341 r.

Villavera: $1 \mathrm{v}$.

Villaverde: 13r, 45r, 45v, 46v, 49v, 50r, $51 \mathrm{v}, 63 \mathrm{v}, 89 \mathrm{v}, 90 \mathrm{r}, 108 \mathrm{v}, 137 \mathrm{r}, 157 \mathrm{v}, 171 \mathrm{r}$, 255v, 279v, 306r, 306v, 331r, 351v, 354r, 355r, 371r, 372r, 376r, 383r, 385r, 385v, 386r, 441v, 442r, 444v, 445r, 445v, 446r, $447 \mathrm{r}, 447 \mathrm{v}, 448 \mathrm{r}, 449 \mathrm{r}, 449 \mathrm{v}, 450 \mathrm{r}, 450 \mathrm{v}$, $451 \mathrm{r}, 451 \mathrm{v}, 452 \mathrm{r}, 452 \mathrm{v}, 453 \mathrm{r}, 453 \mathrm{v}$.

Villaverde de Volpejera: 441v, 445r, 445v, 446r, 446v, 447r.

Villaverde de la Peña: 46v, 51v, 331r, 351v, 383r, 385r, 442r.

Villavicencio: 398r, 442v.

Villaviudas: $235 \mathrm{v}, 236 \mathrm{r}$.

Villoldo: 355r, 371v, 452v, 468v.

Villota: 191v, 196v, 256v, 257r.

Villota del Páramo: 256v, 257r.

Villotilla: 155r, 155v, 405v, 437r, 443r.

Villotis: $5 r$.

Villovieco: 39v, 152v, 172r, 172v, 299v, $404 \mathrm{v}, 434 \mathrm{r}$.

Vioño: 36r, 36v.

Vitoria: 322r.

Zainos: 20v.

Zalengas: $1 \mathrm{v}$.

Zamora: 92r, 221v, 222r, 284r, 338r, 358r, $358 \mathrm{v}, 359 \mathrm{r}, 360 \mathrm{r}, 401 \mathrm{r}, 401 \mathrm{v}$.

Zaragoza: 66r, 66v.

Zaratán: 44r. 
